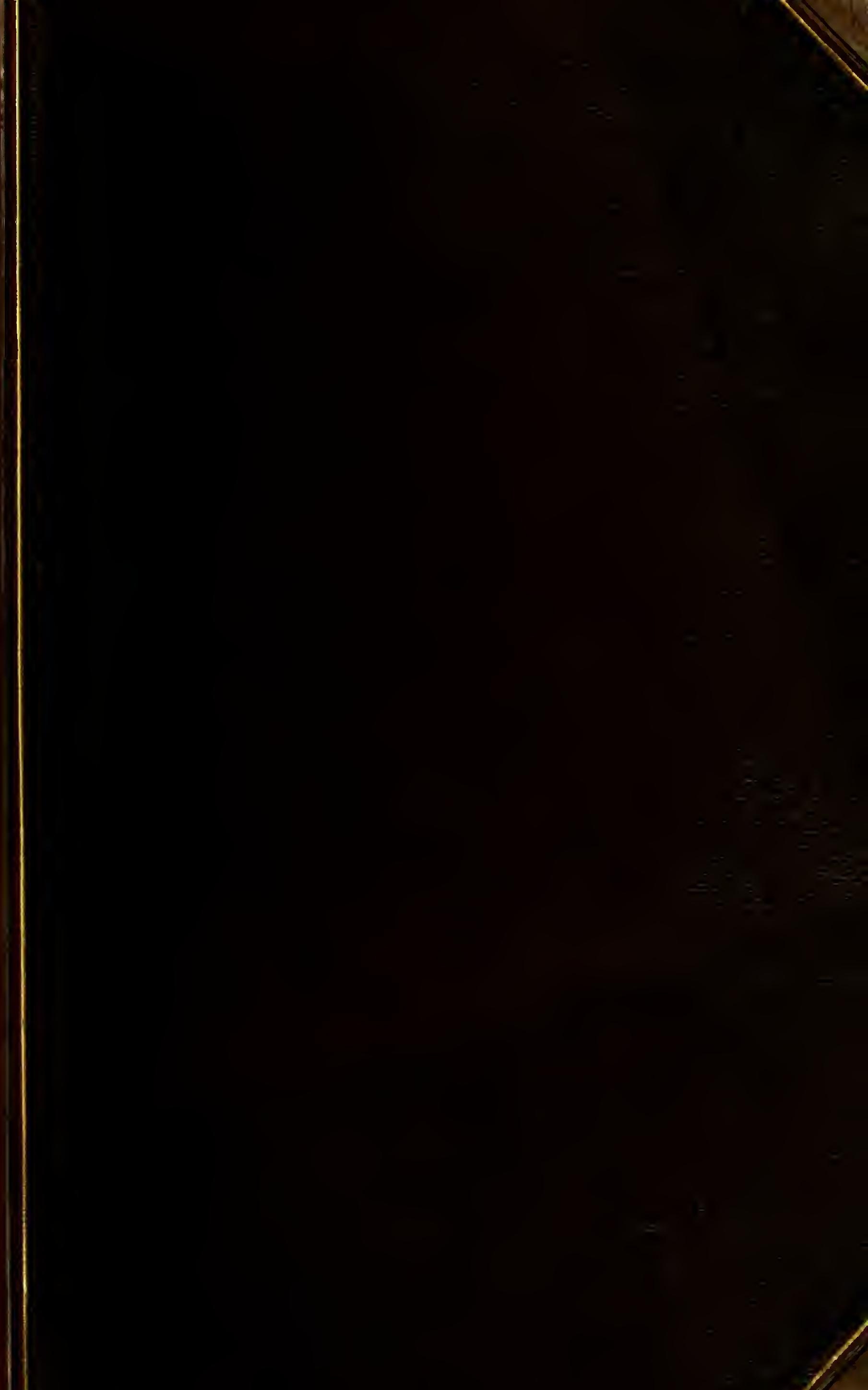




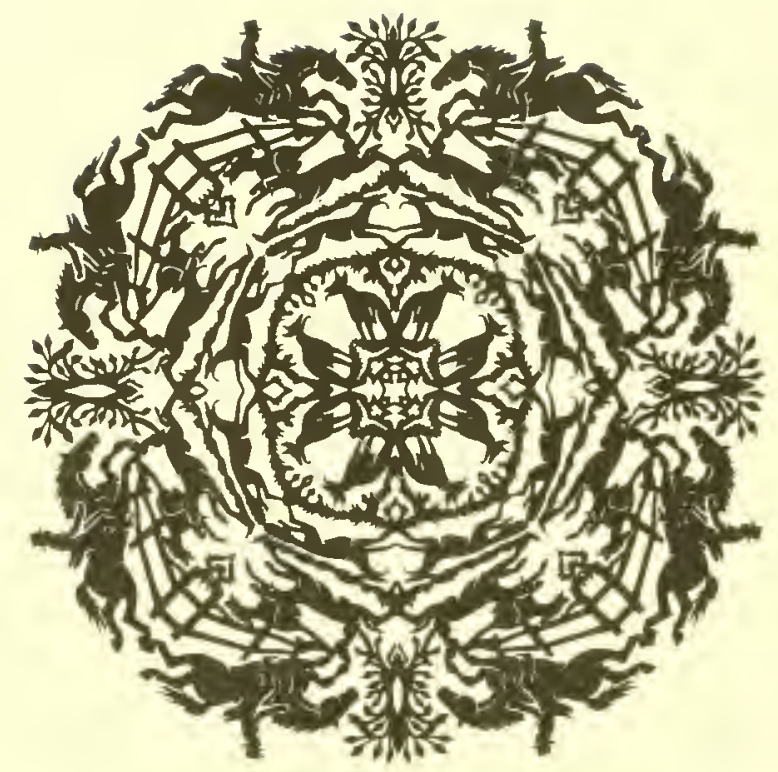

JOHN A.SEAVERNS 



\section{Digitized by the Internet Archive in 2009 with funding from \\ Boston Library Consortium Member Libraries}







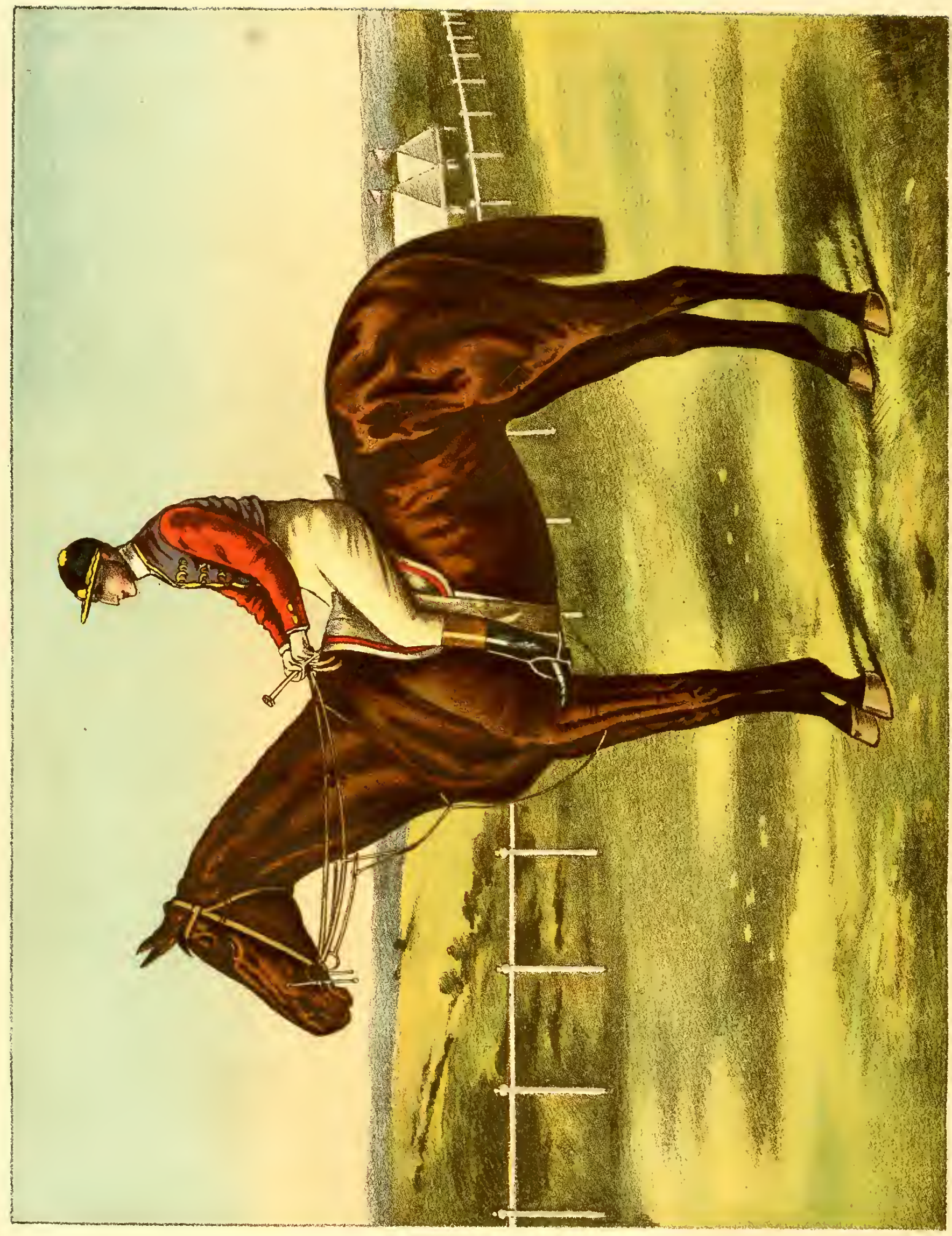

$Z$
0
$\Sigma$
$\Sigma$
$\Omega$
$\Omega$
$\square$
1 




\section{MODER N}

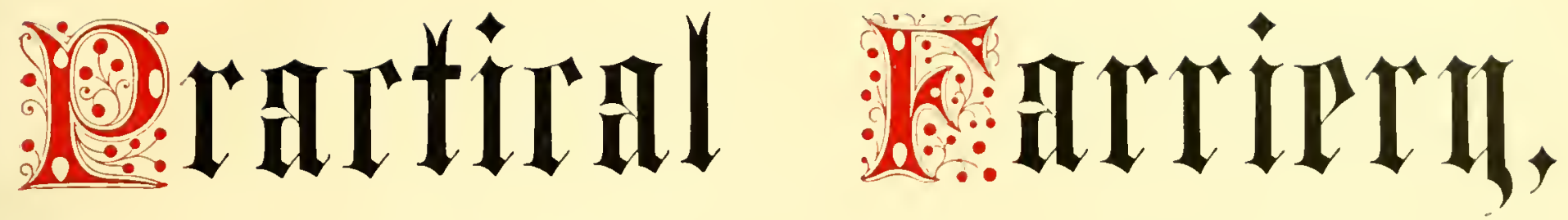

A COMPLETE SYSTEM OF THE VETERINARY ART' AS AT PRESENT

PRACTISED AT THE ROYAL VETERINARY COLLEGE, LONDON.

BY

W. J. MILES, M.R.C.V.S.L.

INCLUDING PRACTICAL TREATISES ON

CATTLE, THEIR MANAGEMENT IN DAIRY, FIELD, AND STALL. BY JOHN WALKER.

PASTURE GRASSES AND FORAGE PLANTS, By SAMUEL P. PRESTON.

TIIE PRACTICE OF SHEEP FARMING,

BY CHARLES SCOTT.

AND

THE DISEASES OF CATTLE, SHEEP, A N D PIG, By J. I. LU P TON, M.R.C.V.S.L.

L O N D O N

THE GRESHAM PUBLISHING COMPANY

34 SOUTHAMPTON STREET, STRAND 


\section{O D E R N}

\section{PRACTICAL FARRIERY,}

\section{A COMPLETE SYSTEM OF THE VETERINARY ART.}

\section{P R E F A E.}

No branch of husbandry and of the many allied industries in this country, has developed so great an importance of late years as the breeding and management of all descriptions of animals. England has long been known as the place of origin of the modern racehorse, but the knowledge and practical skill which produced that magnificent animal, have also been turned in more practical directions, and the various breeds of horses for riding and for light and heavy draught have been wonderfully increased in value by the intelligent application to them of the same principles of selection and continuous improvement. Even in these days of universal competition, other nations still look to Great Britain as their model in all that pertains to Horse Breeding and Management.

To England also belongs the honour of having first successfully applied the same principles to the improvement of the Breeds of Cattle and of Sheep. From the time of Robert Bakewell, who originated this movement in the middle of last century, progress has been steady and continuous. Other breeds than those to which his attention was directed have been developed and improved by the application of similar methods, until the chief English breeds have become celebrated throughout the world, and selected animals are eagerly purchased by foreign nations, that they may share the benefits enjoyed by the British farmer. Of late years, as is well known, the constantly increasing imports of grain into this country, due to the vast improvement in communication by railways and steam navigation, have more and more directed attention to our Live Stock and their means of support, as being probably in the near future the staple productions of our country.

In issuing a New Edition of Miles' "Modern Practical Farriery," which has long been accepted as a standard on its subject, the publisher has endeavoured still further to adapt it to the needs of the time, by important additions and extensions. The Origin and Varieties of the Horse in all parts of the world; his Breeding, Breaking, Training, Age as determined by the condition of his mouth; his treatment in Riding, Driving, and on a lengthened journey; the Stable and its Management; Vices in the Stable and on the Road; Warranty, Soundness, and Unsoundness-such are some of the leading topics treated of in the general and descriptive part of the Work.

In preparing the section of the Work specially devoted to Diseases of the Horse and Modern Veterinary Practice, the highest professional authorities have been carefully consulted, and the 
author has brought the results of his own wide and lengthened experience, and all available information regarding equi,e Anatomy, Medicine, and Surgery, to bear upon the elucidation of every subject which he has thought it necessary to consider.

In the section devoted to the Management of Cattle and Sheep, special treatises have been added by Messrs. John Walker and Charles Scott, writers of great practical experience in these departments, while the various Grasses and Forage Plants available for feeding cattle are fully described by Samuel P. Preston, and where necessary illustrated. The new systems of preserving grasses and green crops for winter use, as Ensilage, whether produced in Silos or in Stacks, are fully described and illustrated. A special section is devoted to the Diseases of Cattle, Sheep, and Pigs, and their Treatment according to the best veterinary practice of the day, by J. I. Lupton, M.R.C.V.S.L.

It is hoped that the whole will be found of the greatest importance to those engaged in the breeding, rearing, and management of stock, and will contribute not a little to render them their own Farriers. The Work is illustrated by numerous finely executed anatomical and other Engravings, possessing high value on the score of utility as well as of ornament, many of which are executed in colours. 


\title{
THE HISTORY OF THE HORSE.
}

\author{
CHAPTER I.
}

\section{THE ORIGIN AND ANCIENT HISTORY OF THE HORSR.}

The original country of the Horse is not known with certainty from any extant records of history or from reliable tradition. Buffon has asserted, and his thousand-and-one copyists-compilers of Natural Histories, Anecdotes of Animals, Select Readings, and the like-have echoed, that Arabia is the cradle of the race." More recent enquirers, searching and thinking for themselves, have shown this to be mere assumption. Certainly the nature of that country, its wide expanse of sandy plains, and its scanty herbage, offer no indication of a fit habitat for the wild horse to increase and multiply; and the conclusion is almost inevitable, that the Arab steed, like the thorough-bred of our own country, is indebted for the peculiar excellences which have made it celebrated, to the care, skill, and sedulous attention of its breeders and trainers: in short, that the Arab horse is not indigenous to that country, but the product of judicious cultivation during a long series of years-a process for which man is always rewarded by the development of the best, and often new and higher qualities, in the object of his care.

Nor are there wanting written proofs of this position. We shall first refer to the Bible, as the oldest historical record, to show that Arabia, notwithstarding its modern celebrity, has not the claim to number this noblest of quadrupeds among the native animals; and then proceed to notice those nations in which, at the earliest periods, the horse, as we know from their monuments, was used in war and in the arts of peace.

In those countries where the horse is indigenous, he appears to have been reduced to servitude from the earliest formation of human society. The first country in which we have proof of its domestication is in Africa. In Egypt, then, we have the testimony of history, both sacred and profane, as well as the marvellous monuments of this great community, which have survived the lapse of three thousand years, to attest the early subjugation of this valuable animal. In numerous sculptures, fresh as if yesterday from the chisel of the artist, the horse of the Egyptians appears harnessed to the chariots of warriors and kings; and the subsequent history of the same country shows how much it relied on the power of the horse in war. It is

- The late Mr. Youstt, in his agreeable and useful book of The Horse, compiled for the Society for the Diffision of Useful Knowledge; Professor Low, in his Domestic Quadrupeds of the British Islands; Blaine, and other authorities, sdopt this view. Mr. Karkeek, of Truro, in some clever papers in the Veterinarian (vol. ui. pp. 18 and 125), support. Buffon. Gibbon, and Niebuhr in their view of the original habitat of the horas. from the records of Jewish history that we receive the earliest written accounts of the subjugation of the horse in Egypt ; and, from the same source, we learn that the ancestors of the Israelites were not possessed of horses when they dwelt in the plains of Syria. When Abraham, more than 1,900 before Christ, sent his servant from Palestine to Mesopotamia, to bring a wife for his son Isaac, the messenger thus announced himself to Laban, the brother of Rebecca:- "I am Abraham's servant, and the Lord hath blessed my master greatly, and he is become great; and He hath given him flocks and herds, and silver and gold, and men-servants and maid-servants, and camels and asses." Observe, there is in this enumeration no mention of the horse; neither is it once spoken of in the subsequent recital of the wealth of Isaac. Again, when Jacob returned to his native land, he had oxen, sheep, goats, and asses, and camels, but no horses. In a later age, when the descendants of Jacob had multiplied in a district of Egypt which lies between the Nile and the Red Sea, and whence they were conducted to the Promised Land, they retained the habits of their ancestors in regard to the horse. In the Levitical law reference is made to the ass to denounce its flesh as "unclean;" and the sin of coreting "thy neighbour's ass" is denounced. Moreover, the duty of a seventh day's rest to that now despised but useful servitor is specially enjoined. Yet, all through, the horse is never spoken of as a part of the wealth or property of the people. On the other hand, there is an injunction that they shall not possess themselves of this animal, the pride of the Egyptians, in the land to which they are to be led. This

† The pre-eminently poetical picture of the war-hores in Job (c. Irrix. v. 19-25) is familiar to all :- "Hsat thou given the horse otrength P Hest thou clothed his neck with thunder $P$

"Canst thou make him afraid as a grasshopperp The glory of his nostrits is terrible," \&c.

In Berenger's Horsemanship is note on the nse of the word thunter in the shove quotation, which is worth transcribing:- "In this enume ration of the besuties and noble qualitie of the horse, it should be ro marked thst the English translators make Job say that the snimal's neck is clothed with thunder, an expression as falsw os it is sbsurd. Tho true rendering of this passage is, that his neck is clothed with a mane; thus Bochart, Le Clerc, Pstrick, and other commentators translate it. Bochart says that the word which in Hebrew signifes thunder is eynonymous for the mane of s horse; but this being so, it is astonishing that the translator should have set sside the just and natural signification, and have chosen to cover the horse's neck with thunder instesd of a mane; nor ib it less amaring that this nonsense should have been extolled by the author of the Gwardian (rol U. p. 26). and others. as an instance of the sublime." 
rocky and limited territory was then, as it is now, unsuited to the horse, and never could be so well defended by cavalry as by infantry. Indeed, we have the historical fact that the Jews were never so successful as when they trusted to their "footmen" in their earlier struggles, and in their subsequent wars under the glorious Maccabees.

Moses, well knowing the nature of the country to be supdued, discountenanced the use of cavalry. He counsels the people, when they go forth to the war, to have no fear of the "horses and chariots" of their enemies. He directs the future rulers of the land not " to multiply horses ;" and so closely was this command adhered to, that it was the practice to hamstring the horses made prizes of in the field. David, when he took seven hundred horses and one thousand chariots, houghed all the horses except one hundred of those trained for chariots. The Psalmist speaks with proud disdain of horses as used in war, exults in the overthrow of "the horse and his rider," and never mentions them, except as used by the enemies of his country. Is the commerce of Judea, and her intercourse with other nations, increased, these prejudices were broken down, and Solomon, his son, formed an army of chariots and cavalry ; nay, he established a trade for horses with Africa, and supplied the neighbouring countries with those animals from Egypt. It is farther remarkable, that when the Jews entered Palestine from the south, they encountered no horses; for no mention is made of horses in the first campaign of Joshua. The Philistines alone had horses, in the south of Syria; and they were an Egyptian colony. There is, therefore, every reason to conclude that Arabia, and all the countries southward of Palestine to the Persian Gulf, were, at that time, without horses.

Proofs multiply upon us. When the Midianites, an Arabian nation, were subdued, the spoil consisted of sheep, oxen, and slaves, but no horses. In the reign of Saul a war was carried on with Arabian nations on the Persian Gulf; the plunder consisted of slaves, camels, sheep, and asses. And, in an attack on Judea, by the Midianites, in an after age, we are told they came "with their cattle and their tents; and they came as locusts for multitude:" still no mention of horses. But although the Jews, on their first entrance to Palestine from the south, found no horses, no sooner did they come in contact with the nations of the north, than they were met by warlike people possessed of horses and chariots. These nations approached the Black Sea and the Caspian, the great region of what may be called the "Asiatic horse;" this being the source of supply, and not Africa, with which, at that time, they were cut off from intercourse; nor Arabia, as that country had no horses. If, then, historical record be of worth, we must conclude that Syria and Arabia, and the countries to the Persian Gulf, were not countries of the subjugated horse in early times, and that the horses which they possessed in later times came to them, not from the south, or from Africa, but from the great river-watered plains and wide steppes of the north, the original habitat of that species of the equine race which we shall call the Horse of Central Asia.

It was from their contiguity to this region that the Assyrians and the Medes became so early nations of conquering horsemen.
From other documents we learn that Asia Minor was a country of horses; and these again, we believe, came from the north, and not the south. An able writer, Professor Low, ${ }^{*}$ to whom we are much indebted for his researches, suggests an easy explanation of what might seem to suggest itself as a difficulty He says, we may beliere that the species was called into existence in more than one place, and was thence diffused as from different centres; and thus we may suppose one species existed in Africa, and another in eastern and northern Asia. Hence we conclude, from the testimony of history, that the Egyptians derived their horses from the vast continent which they inhabited, and not from a region from which they were separated by a tract of arid and sandy country, in which the horse did not exist in the first ages. On the contrary, this remarkable people procured the horses they so early possessed from regions where the African horse was as indigenous as those of Asia are to the plains of Tartary. The horse, then, appears to have been obtained by the Arab as his predatory habits took a more extended range; and his contact with Persia, and countries to the north, put it in his power to obtain them, and he acquired them and prized them, just as we see savages in modern times possess themselves of fire-arms for purposes of destruction or of defence. Though there is no precise record of when the Arabs began to use horses, it is clear that they had very little multiplied there till after the Christian era. Strabo states that in the time of Tiberius Cæsar, the south of Arabia, called Arabia Felix, had "neither horses nor mules," and that as regards Arabia Deserta, the north of Arabia, it had no horses, but the camel supplied its place. This is definite; and we find that though the warlike and aggressive followers of the Prophet became horsemen, and laid the original countries of the horse in the East under contribution, the horse in Arabia, in the time of Mahomet, was neither numerous nor generally possessed. When the Prophet of the Moslem advanced on Mecca, to wreak his vengeance on the enemies of the Koran, he had no more than two horses in his army; and in the list of plunder which he carried back with him after his victory there were oxen, sheep, and camels, but, as in more remote scripture times, not a mention of a single horse is made.

When once, however, the horse was adaed to the family of the Bedouin, in aid of the predatory purposes of this nation of robbers, the acquisition was treasured with un. ceasing care, and the condition of the horse looked to with unsleeping anxiety. To the wandering and plundering Ishmaelite the horse possessed a value that no other people could estimate. Not only did luxury and enjoyment depend upon their horse's goodness, his stoutness, his readiness, and his speed, but often the owner's liberty and life. Hence the love and regard for the horse acquired by this peculiar people; hence the warmth of esteem which leads to their hyperbolical Eastern praises; hence the cherished memory of their feats; hence their boastful pedigrees. Thus the Arab has formed for himself noble families of horses; and breeding from these, and

- Dormestic Animale of the British Islands. London: Longman \& Da 
preserving the purity of descent, this artificial product has distinguished them, above all the people of the East, as the possessors of a race of animals remarkable for many valuable properties, and suited, in an eminent degree, to the condition of the country and the uses of the people, who have brough ${ }^{4}$ them to a certain standard of perfection. The best horses are those of Nejd and Shomer, where the breed is maintained and jealously guarded in its greatest purity.

To Sesostris, fable and the poets attribute the subjugation of the horse among the Egyptians. We have already noticed that Egypt was the direct source of Solomon's supplies. The priee of a horse, we are then told, was 150 shekels, which, according to our scripture computation, would be about $£ 1710 \mathrm{~s}$., an immense sum if we estimate it by the price of food in those timen Six hundred years after Solomon, in the time of Xenophon, a good horse was $£ 2712$ s. ; at least, that is the price-fifty drachmæ- which Seuthis the Thracian paid for the steed on which he rode during the Retreat of the Ten Thousand.

Mr. Griffith, the ingenious annotator and translator of Cuvier's great work, Le Regne Animal, expresses his opinion that the horse is indigenous to Asia, and especially to the plains of Tartary, but that almost every district has its variety. These we shall note, at length, when we come to treat of Asiatic, African, and European horses in their varieties.

Upper Egypt, Ethiopia, Libya, Mauritania, Numidia, indeed, all the country north and west of Sahara, the Great Desert, doubtless abounded, even before the historic period, with numerous fleet and beautiful horses, the progenitors of the Barbs, of the stately horses of Dongola, and - throngh Palestine and Syria eastward to Persia, and westward into Asia Minormeeting most probably with oceasional crosses from the more northern breeds, whom they met roaming southwards, a migratory tendency remarkable not only in the northern races of man, and all animal creation, wild quadrupeds, as the deer, and in birds, but even in the innumerable slivals of the finny tribes

Colonel Hamilton Smith discusses the question as to whether the use of chariots, or the art of riding was the earliest service of the horse. It is a point of curiosity rather than of importance, and, perhaps, does not admit of a satisfactory conclusion. In Egypt, Palestine, and Grece, Colonel Smith supposes there were originally chariots only The monuments and anthorities do not, we think, negative the existence of riders. Job, with the exception of Genesis the most aneient extant writing, distinetly describes the horse as trained to battle; but he does not stop there. From a verse in the same chapter he shows that the horse was then, as now, employed in the chase of the ostrieh, (exelusively an Afriean bird), "what time she lifteth herself up on high, she scorneth the horse and his rider ;" and a still earlier intimation of the backing of this nolle animal is found in Genesis, chap xlix., v. 17. "An adder in the path, that biteth the horse's heels, so that his rider falleth backward." For ourselves we cannot see any valid reason for not accepting the opinion of Berenger," that, although either might be

- Heatory of Horsemanship, vol. i., p. 12. the more prevalent in particular countries, or at particulas periods, the one must have suggested and accompanied the other.

$I^{+}$appears most probable that the horse was subjugated in Central Asia from an ante-historic period, whence the know. ledge of his usefulness radiated to China and India. Another early region, perhaps of equal antiquity in the training of the horse, was Egypt and the adjacent conntries. That systematie attention was there paid to the breed of these animals the atunndanthistorical and scnlptured remains testify, and these seem to be designed from high bred types. In one or other of the countries of Western Europe the bridle, the true saddle, and probably the horse-shoe were invented; while with many of the Asiatic nations it horse, a mare, and a colt were fixed standards of value.

Next to the Egyptians, the Assyrians and Medes beeame, according to Strabo, the most celebrated horsemen of the ancient world. These people are often mentioned by the Jewish writers for the beauty of their horses and their skill as horsemen, and for the splendour of their equestrian trappings. They were at a later period imitated by the Persians, who decked and "clothed their horsemen most gorgeously." Although Persia became most renowned for its horse-riding, Xenophon says, that before the time of Cyrus, Persia had no horses; but that, from personal example, eneouragements, prizes, and recommendations of the king, every man in Persia rode on horseback. Indeed, the rery name of the people, by which their country afterwards became known, was taken from the Chaldee and Hebrew word peresh, a horseman. Immense droves of these animals were reared in the plains of Assyria and Persia; and one anthor speaks of 150,000 horses feeding in one vast plain near the Caspian gates. The Nysæan horses used by the kings of Persia are declared to hare been the finest horses in the world-a pre-eminence apparently claimed by every nation that erer possessed a horse; and we may also add, by most persons who hare orned one.

In Greece, the art of riding horses, and most probably the introduction of the horse himself, did not very long precede the Trojan war. Homer, who was some centuries after Joshua, frequently dwells on the beanty of the horses which drew the chariots of his heroes; although the fact is worthy of note, that he makes but two references to horse-riding in the Iliad, and but one in the Odyssey. The first in the Iliad (K 513), is where Ulysses and Diomed, haring stolen the horses of Rhesus, without the chariot, mount and gallop them to the Greciau camp. That in the Odyssey is merely as a simile (E 371), likeming Ulysses, after his shipwreek, bestriding a beam of wood, to a man on horseback. The reference in the 15th Book of the Iliad, however, as it gives an early instance of the Duerow feat of riding four horses, we will quote :-

\footnotetext{
"So when a horseman, from the watery mead, (Skilled in the manage of the bounding ateed) Drires four fair coursers, practised to obey, To oome great city, through the public way Safe in his art, as side by side they run, $\mathrm{He}$ shifts his seat, and rsult from one to one
} 
and now to this and now to that he flies; Admiring numbers follow with their eyes."

The horse formed a prominent feature in the beautiful mythologic fables of the ancients.

Neptune, we are told, created the horse by striking the earth with his trident :-

\section{" When Neptune his huge trident hurl'd Againat the sounding beach, the atroke Transfix'd the globe, and open broke The central earth, whence swift as light Forth rush'd the first-born borse."}

Eschylus, the tragedian, describes Prometheus as the first who taught man to render the horse obedient to the yoke (perhaps cultirating the earth is here alluded to).

Pluto carried off Proserpine in a chariot drawn by four horses (a quadriga); their names are preserved.

In Orid's beautiful fable of Phaeton, a description is given of the horses which were supposed to draw the chariot of the san, and which we find thus alluded to by our own immortal bard :-

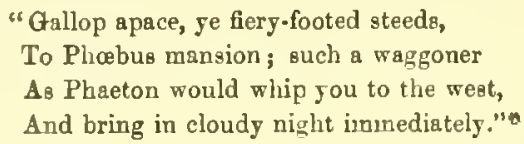

The goddess Aurora is represented, by the ancient poets, drawn in a rose-coloured chariot by milk-white horses, and preceding the sun at his rising.

It was the eighth of the labours of Hercules to destroy Diomedes, king of Thrace, a tyrant who fed his mares on human flesh. Mars, the god of war, "Was generally represented as riding in a chariot, drawn by furions horses, named Flight and Terror; and horses were offered up on his altars, to propitiate his warlike spirit.

The origin of the Centaurs, half man, half horse-a favourite fable of the ancients, some of whom, as Plutarch and even Pliny, hare actually maintained that these monsters existedis thus giren by Palæphatus, in his book, De Incredibilibus Historiis. This author relates, that in the reign of Ixion, king of Thessaly, a herd of mad bulls descended from Mount Pelion and ravaged the neighbouring country. In consequence of a large reward offered by Ixion for the destruction of the bulls, certain adventurous young men turned their attention to the training of horses for the saddle; before that time they having been only used in chariots. These men having attacked the bulls on horseback, and cleared the country of them, ravaged the plains of Thessaly, and evon attacked Ixion himself. At their departure from these exploits, the ignorant Lapithæ, as the inhabitants of that county were called, seeing only the tails of the horses and the upper parts of the men, delineated them as monsters, half man and half horse.

The "certain adventurous young men" here spoken of were a volony of Egyptians.t i Grecian tradition makes these Centaurs aetual beings, and fables that Philyre, the mother of the Centaurs, cohabited with Saturn in Philyres, an island near the south shore of the Euxine (this would point to

* Romeo and Juliet (Act iii. scene 2), + See Teunant's Shreds of Antiquity.
Asia Minor); and that from that island she emigrated to Thessaly and the country of the Pelasgi. This mother of the Centaurs gives a hint to Mr. Tennant, who, thereupon, takes a rapid glance at the probable migrations of the horse, which is so much in accordance with our views that we make no apology for quoting it:- "In this way one might amuse himself by attempting to trace, even by the few data afforded by history, the circuit by which horses, with the consequent art of equestrian exercise, passed from Egypt, the original and central riding-school of the world, into Greece and into Europe. From Egypt they passed into Assyria and Persia; from Assyria to Cappadocia, Amazonia, and Pontus-countries where horses were most reared, most admired, and, as the most admirable objects in animated nature, offered up as sacrifices to the sun. From Pontus they passed, with the streams of westwardrushing population, to Phrygia and the southern banks of the Propontis; and from thence, with 'horse-taming' Pelops and the Pelasgi, they migrated into Thessaly, and confounded with their novel and terrifying appearance, the simple and aboriginal inhabitants, to whom 'the horse and his rider' seemed a monster, outlandish and inscrutable!" The Thessalonians for many centuries continued the most celebrated of the Grecian cavalry.

Another colony of Egyptians appears to have landed somewhat later in Southern Greece, and to have introduced the horse to Athens. The leader of this migratory band was Erichthoneus.* This horse-breaker by profession, or prince and leader of a people, perhaps both, is celebrated by Virgil in his third Georgic. The lines are thus given in Dryden's version :-

$$
\begin{aligned}
& \text { "Bold Erichthoneus was the firat who joined } \\
& \text { Four horses for the rapid race design'd, } \\
& \text { And o'er the dusty wheels presiding sat: } \\
& \text { The Lapithe to chariots add the state } \\
& \text { Of bits and bridles; taught the steed to bound, } \\
& \text { To run the ring, and trace the airy round; } \\
& \text { To atop, to fiy, the rules of war to know, } \\
& \text { ' }{ }^{\circ} \text { obey the rider, and to dare the foe." }
\end{aligned}
$$

The most celebrated individual horse, of the Thessalian or an allied breed, was Bucephalus, the charger of Alexander tho Great. He was bought for sixteen talents from Philonieus,

- Mr. Bracy Clark, a scholar and a careful studier of all thungs pertaining to the horse, and to whom we owe one of the best and earliest essays on the horse's foot, observes-"Those err widely who derivr this name from the old Greek language, aince the Egyptian appeara the natural clue to it. Erictho - the ancient Egyptian word, of which the Greeks made Erictheus and Ericthonius, as of Apollo they made Apollonius-is composed of two words, er facere, vel rei alioujus auctorem esse, and chto, or ichto, equus, the horse; and hence Erictho, autor equitatus et equorum, the occupation ascribed to Ericthoneu8, in the lines of Virgil. Aristides and others confirm this by observing that he first tamed the horse, and then applied him to the chariot. On this account he was raised to heaven, and placed among the mnate'lation, as Auriga, Agitator, or Heniochus, the driver, or charioteer.

Chiron, poetically surnemed the Centaur-iulf man, half hus vo-was, it is conjectured, a Thessalian. His hybrid nature, signified hia medical akill wa६ equally directed to human and to brute medicine. Esculapius, to whom the establishment of rational principles in medicine is attributed, as well as Podaliriua and Machoan, were also his pupils. These early profeseors of th ars medendi and veterinary ucience were for centuries venersted as he oracle and fathers of medicine. 
out of his breeding pastures of Pharsalia. It is known he was a skevbald - that is white, clouded with large bay spots. IIe was, in short, a genuine and noble specimen of what moderns would call a circus horse, and his habits corresponded with this description. These parti-coloured horses were prized by the Parthians, but disliked by the Romans, who objected to them because so easily seen in partial darkness. Bucephalus was ridden by Alexander at the battle of the Hydaspes, and there received his death wound. Disobedient for once to the command of his master, he galloped from the heat of the fight, brought Alexander to a place where he was secure from danger, knelt, as was his custom, for him to alight, and having thus, like a good and faithful servant, discharged his duty to the last, he trembled, dropped down, and died.

Although, with the exception of the pastures of Thessaly, Greece was not a favourable country for the horse, he was soon found necessary in all parts of the country for the purposes of offence and defence Accordingly, in most of the states, particularly in Athens and Sparta, a new order of citizens was instituted, to be ranked second in the Commonwealth, and distinguished by certain honours and privileges, as owners of horses. The equites, or knights, of the Roman Republic, were instituted with the same view of keeping up the numbers and excellence of this noble animal.

Blundeville, in The Fover Chiefest Offices belonying to Horsemanship, speaks thus of the horses of Greece, and his description applies well to the animal we see figured on the frieze of the Parthenon and other temples. "The horses of Greece have good legges, great bodyes, comely heades, and are of high stature and verie wel made forwarde, but not backwarde, because they are pin-buttocked. Nutwithstanding they are very swifte, and of a bolde courage. But of alle the racys of Greece, both the horses and mares of Thessaly for their bewtie, bignes, and courage of al authors are most celebrated. For which cause Xerxes, on hys comming into Greece, made a runnyng of horses in chariots to be proclaymed in Thessalia, because hee wolde have hys owne horses to runne wyith the best in Greece. Julius Cæsar also beying dictatour of Rome, knowying the courage of the horses, was the first that ordeyned them as a spectacle before the people to fighte wyth wilde bulls, and-to kyll them."

-The caparisoning of the horse, and his part in the celebrated Olympic games will come more properly into the history of racing; whereto the two great works of Xenophon, "The Duties of the Master of the Horse," and "Of the Management of the Horse," will furnish prefatory matter.

On the decline of the Greek empire the Romans claim attention. It is clear that from the very building of their city they sedulously attended to the breeding and management of tho horse. Chariot and horse races were early introduced, but the chariot-race seems to have fallen into disfavour and horseraces to have advanced in esteem. Down to the times of the Cæsars the young men of the equestrian order were enthu. siastically devoted to horse exercise. Numerous writers describe or allude to these. They were either trials of speed, or more frequently exhibitions of dexterity in the manege, pacing and curvetting in intricate circles, a perfurnance in modern times limited to the circus. Standing upright on the back of the horse, lying along his back, vaulting off and on, picking up objects from the ground, and shifting from one horse to another, were among the favourite feats of these noble youths.

The knowledge of the horse now beeomes more accurate and generally diffused. The most eminent Roman writers on rural affairs introduce incidental notices of the breeds and the diseases of the horse and their remedies. Cornelius Celsus, whose veterinary works are lost, is stated to have witten excellently on this branch of the subject. Marcus Terentius Varro, (70 в. c.) MI. Portius Cato, (130 13. c.) Virgil, (10 B. c.), a few years later Columella and Palladius, also wrote on the horse and his diseascs. The two last copiously for the time. During this period the Roman emporors, busied in foreign wars, and maintaining a numerous cavalry, professional veterinarii were appointed to the several legions, and the horse and his diseases were systematically studied. Not much that is wortb preserving has come down to modern times from any of these "professionals."

About the middle of the fourth eentury, one of these, by name Vegetius, wrote the first work worthy of the name of a treatise on the Veterinary art. Ho begins systematieally with the diseases of the head and their treatment, and proceeds to those of the feet. He also gives extracts from the works of Chiron and of Hippocrates, which else had been totally lost.

The Romans seem to have learned the inhabitants of the southern Mediterranean coast, to place superior value on the mare. Their authors are of one accord in this. It may be in some degree attributable to the custom of the Romans to castrate all horses employed in traffic, for hire, or in agriculture. Oxen were used for the latter purpose in almost erery other country. The horse was rendered far more valuable and useful by these applications of his strength and docility. The practice spread from Italy, and this most admirable servant of man became a yet more general object of cultivation and attention. The irruption of the Goths, howerer, swept away almost every vestige of the civilization of the Romans, and the breeding of the horse and improvements in agriculture shared the general ruin.

Passing from Rome to Britain, we find in the 33rd chapter of the 4th book of Cresar's Commentaries, an accurate detail 0 ! the mode of equestrian warfare in Britain, as praetised in the century before Christ. This will, we think, add another corroboration to the fact that the "penitus toto divisos orbe Britannos" had their own indigenous horse, aye, and a horse of such size and vigour as to attract the eupidity of the con. querors. Cæsar carried many of them to Rome, and the British horse-we will presently speak of the mannii or ponies-was for a long time in request in many parts of the Roman Empire. It is impossible that Cæsar, who had horses of the full stature, tifteen hands and upwards, in his cavalry, could speak thus if his enemies had driven Welsh or Dartmoos 
ponies, as some have gratuitously assumed, not knowing how else to get rid of the difficulty of a special horse for these separated islands. The passage of Cæsar will speak for itself. "Their mode of fighting with their chariots is this : firstly, they drive about in all directions and throw their weapons, and generally break the ranks of the enemy with the very dread of their horses and the noise of their wheels; and when they have worked themselves in between the troops of horse, leap from their chariots and engage on foot.

"The charioteers meantime withdraw some little distance from the battle, and so place themselves with the chariots, that if their masters are overpowered by the number of the enemy they may have a ready retreat to their own troops. Thus they display in battle the speed of horse with the firmness of infantry; and by daily practice and exercise attain to such expertness, that they are accustomed, even on a declining and steep place, to check their horses at full speed, and manage and turn them in an instant, to run along the pole and stand on the yoke, and thence betake themselves with the greatest celerity to their chariots again."

How numerous these horses were at the time of Cæsar's invasion, we learn from the fact that when Cassibelaunus dismissed the main body of his army, he retained four thousand of his war chariots to harass the Roman army in their attempts to forage.

The Romans soun found it necessary to send a numerous cavalry into England, and at this period must have come the first cross in their breeding; horses from Gaul, Italy, Spain, and every province of the Roman empire being brought into the island. For hundreds of years we are without any record as to whether the British horse was thereby deteriorated or improved. We may presume that the neglect of breeding from selected parents must have led to a degeneration of the race.

Reverting to the ponies of Great Britain, these indigenous races were then as distinct as now, and contemporaneous with the British horse of Cæsar. Six centuries after, St. Augustine distinctly speaks of our Shetland, Welsh, New Forest, or Dartmoor breeds. Their diminutire stature is attested. The monk says:- "The mannii, or ponies that are brought from Britain, are those chiefly in use by jugglers and strollers, to exhibit the feats of their craft." They also fancifully shaved or clipped the upper parts of their shaggy bodies to add to their singularity of appearance.

The county of Argyle, in Scotland, is said to derive its name from Are-Gael-the breeding or horse-stud of the Gael; and in a superb work recently published, called the "Archæology of Scotland," there is a description of a truly remarkable discovery, throwing light on the charioteering of the Celts. There have been dug up, near the parallel roads of Glen Roy, two stone horse collars, the one formed of trap or whinstone, the other of a fine-grained red granite; these bear all the evidence of first-rate workmanship, are highly polished, and are of the full size of a collar adapted to a small highland horse, bearing a close imitation of the details of a horse collar of common materials in the folds of the leather, the nails, buckles, \&c. It has been suggested by antiquarians, that the amphitheatre of Glen Roy might have been the scene of ancient public games, and that these stone collars might be intended to commernorate the victor in the race.

Hengist, the name of the founder of the Saxon dynasty, signified an entire horse; and by the Saxons the horse was an object of superstitious veneration. Of this there remains an example which must be familiar to all who in the old coaching days rode through White Horse Vale, in Berkshire. The turf on the side of a hill has been cut away, displaying the chalk beneath in the figure of a gigantic horse, covering many hundred square feet. This is a genuine Saxon relic, and has, we believe, been preserved by a day being annually kept as high festival, on which all weeds are carefully cleared from the figure, and the outline restored.

The Anglo-Saxons are supposed to have first used the horse in ploughing about the latter part of the tenth century ; on the border of the Bayeux tapestry, representing the landing of William the Conqueror and the battle of Hastings (A.D. 1066), there is a representation of a man driving a harrow, the earliest instance we believe of horses thus used in field labour in this island.

Hugh the Great, head of the House of Capets, monarchs of France, presented to Athelstan, the natural son of Alfred the Great, whose sister Edelswitha he wooed and won, several running horses from Germany (equos cursores of the old Chronicle) magnificeutly caparisoned. Athelstan seems to have attached due importance to this upprovement upon the previous breed, since he issued a decree prohibiting the exporta. tion of horses without his licence. The most marked improvement, however, took place at the Norman Conquest, the martial barous bringing with them a large force of cavalry; and it was, by the way, to their superiority in that important arm that the victory of Hastings was in a great measure to be ascribed.

The office of the Master of the Horse dates back to the reign of Alfred the Great; the ancient Chronicles relate the attention paid by him to the breeding and improvement of the horse, to carry out which in the most efficient manner, an Officer was appointed, called Hors Thane-Master of the Horse; and during every succeeding reign this officer has held high rank, being near the royal person on all state occasions.

We may form an estimate of the value of a horse about that time, by an account bearing date A.D. 1000, which enacts that if a horse be destroyed or negligently lost, the compensation to be demanded was thirty shillings, for a mare or colt twenty shillings, and for a man one pound.*

* There were forty-eight slillings in the Anglo-Saxon pound, five pence in the shulling. The palue of a horse in eurrent money at that time would be about seventeen or eighteen pounds of nodern money-a remerkable coincidence with the earliest recorded value of a horse in distant lands of the East. Mr. M'Culloch estimates that there are now in Great Britain from $1,400,000$ to $1,500,000$ horses employed for various purposes of pleasure and utility : taking their arerage worth at from ten pounds to twelve, their total value would be from $14,000,000 l$. to $18,000,000 l$, exclusire of the young horses. 
The year of grace 1112 is important in equestrian annals, as witnessing the introduction into England of the first African horse; and about the same time another was presented by Alexander I., king of Scotland, to the Church of St. Andrews, though what relation a race-horse had to the church has been a knotty point for antiquaries. Both these animals were true Barbs from Morocco, procured doubtless through the agency of Jew dealers. Thers is no breed which has exercised so great an influence upon the stock of these islands as the Barb, and aone more leserving of kindness for the admirable qualities they possess. Kindness and forbearance towards animals is inculcated by the Koran, and it was a cutting satire upon our boasted civilization when, in allusion to this point, a Moor remarked to Colonel Hamilton Smith, "It is not in your book."

With this period we shall conclude uur historical retrospect; what is further to be said on the English horse will come when we treat of him in the perfection to which various crosses have brought him, as adapted for the different purposes of his master.

\section{OHAPTER II.}

THE NATURAL HISTORY OF THE HORSE: THE WILD HORSE: THY HORSES OF CENTRAL ASIA : THR PERSIAN HORSR: THB TOORKMIAN HORSE: THE CIRCASSIAN HORSE: HORSES OP INDIA: BIRMAN AND CHINESE HORSES: THE ARAB.-THE HORSES OP AFRICA:-THE BARB : THE DONGOLA HORSE: THE EGYPTLAN HORSE: THE HORSE OF THE CAPE OF GOOD HOPB.

\section{NATURAL HISTORY OF THE HORSE.}

IT is not our intention to enter into a disquisition as to the place of the horse in a systematic classification of quadrupeds. We shall merely note, incidentally, some of the more amusing results of that laborious brain-scattering which great naturalists have permitted themselves, while endeavouring rigidly to classify and catalogue the varieties of the horse and his affined races, and the absurdities into which they have been led by obstinately attempting to derive all the different species of the animal from one original pair.

The great Linnæus, in his last edition of Systema Natura, leaves the horse among his Belluce, the sixth order of Mammalia, in company with the hippopotamus, the hog, and the rhinoceros. Erxleben places him between the elephant and dromedary. Gmelin divides his horse genus into two sections: 1, Equus pedibus bisulcis (horse with split or double hoof), found in Chili (most probably a Llama), and Equus solidungulus (horse with a solid hoof). Jonston has figured a horse, called in German the Ethiopisches Pferd (Equus Ethiopicus) with a mane extending the whole length of his body from head to tail. This seems, probably, a sort of yak, of which there are two specimens in the Palace at Sydenham, and many live animals of this tribe have been recently introduced to France by the Societé d'Acclimatation. Jonston also figures a wild horse with a horn in the centre of his forehead. Though the unicorn has been abandoned by naturalists, some still cling to their bisulcus. Old Aldrovandus has some monstrous figures of horses with human faces, and hands at their hinder extremities. A horse of this sort, says that credulous author, belonged to Julius Cæsar, * teste Suetonius: "Julius Cæsar rode a horse with remarkable feet nearly like human ones: his hoofs being split after the manner of fingers, \&c." This malformed beast must have

* Caius Julius Cesar utebatur equo insigni pedibus prope humenis, et in modum digitorum ungulis fasis.-Suet. in Jul. cap. 81. been used merely to astonish the natives. The painter, however, was not content to give the animal split hoofs; he has drawn him, with as much veracity as the writer, with two human hands, four fingers and a thumb, and nails to each of them! Butler had this monster in his eye when he wrote of the steed of Sir Hudibras :-

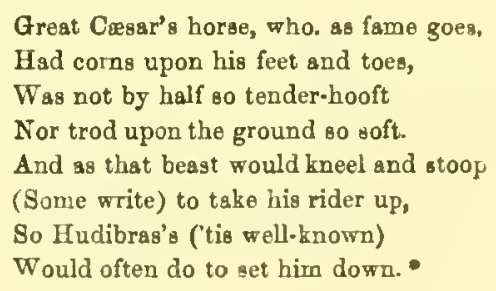

But we will quit these follies of the learned, and come tc Cuvier, who places the Solipedes (single-footed animals) at the end of his mammiferous Pachyderms (teat-bearing thick-skinned animals) and makes the family consist of only one genus Equus, with four varieties. $E$. Caballus (the horse). $\boldsymbol{E}$. Hemionus (the wild ass of Kertch and the Indus, dziggtal of Thibet and Tartary), $E$. Asinus (the wild ass of Africa, the Onager), E. Zebra, and E. Qungga. All of which, except the first (and here we have the support of MIr. Bell, in his British Quadrupeds, and Dr. Gray), we repudtiate and reject as horses; and maintain that, as a fruitful progeny cannot be obtained from their admixture, and as they always have been and alway: will be asses, demand for them, in future systems, a separate genus as Asinus, protesting against the Equus as misapplied We must quote some remarks of Mr. Bell on the structural differences of the two animals:- "The character of the tail is one of the most striking points upon which this distinction rests. In the horse the whole of this is covered with thick long hair, totally concealing its actual form; whilst in the whole of the others-the ass, the zebra, the quagga, the dziggtai, \&c.-it is

- Hudibras, part i. canto i. 4.35 
only clothed with long hair towards its extremity. The mane of the true horse is long and flowing, in the ass it is short and upright. In the horse the hind as well as the fore legs are furnished with those warty excrescences which in the ass are only found on the fore-legs. Waiving some other matters of minor importance, there is one character of some interest and value as a material distinction-I mean the general tendency of the coloration and markings in the two races. In the horse's coat there is an obvious disposition to the formation of small round spots of a different shade or hue to that of the ground, and this is the case whether the colour be black, chesnut, or grey; in the genus Asinus, on the contrary, the markings are invariably disposed in stripes. The zebra, the quagga, \&c., are examples too familiar to require more than this allusion; and in the common ass not only is the same tendency evinced in the cross-marks on the shoulders, but in the young ass there are frequently observed some small darker bands upon the legs. These tendencies to a peculiar character of colouring and marking are worthy of special note in the mammalia, among which will be found many instances bearing upon the distinction of approximating forms. In birds and insects it is still more marked, general, and striking, and has always attracted the attention of naturalists."

To this may be added the variations in the vocal organs of the two animals (which are mixed in various proportions in the mules), and the wide distinction between the playful whinny or proud neigh of the horse and the excruciating vocal performance of what, if it is to be retained as a horse, we would call Equus Hierosolymus. * With these acknowledged varieties of the ass, what but a determination to ignore the patent facts of natural history can induce writers to cling with superstitious awe to some myth of a single type of the horse, and refuse original habitats to the horses of Central Asia, of Africa, of Northern Tartary, of the continent of Europe, aye even to our own Welsh pony and Sheltie, who bear all the marks of genuine races? The facts of geology are admitted: right

- The following snstomical distinctions may interest some readers:In the horse the spertures of the lateral sacs are long and wide, snd bear some resemblance to the usual ventricles of the glottis. On the contrary, in the ass, the opening into each of the three sacs is a small round hole, and the snterior asc is a real bag of considersble size. Cuvier states that the mule, which in genersted by the male sas and the mare, has the openings into the laryngal sace wide, and the atructure of the organe of voice altogether spprosching that found in the horse; snd he therefore concludes that the account published by Herissant was taken from the dissection of the offepring of the atallion and the female ass. Blumenbsch has, however, followed many other anatomists in attributing similar organs of voice to the common mule snd the ses. Cuvier further sdds, that in the horse and the mule there is, at the commissure of the two cordse vocsles, s shight fold of the membrane, which is not visible in the sas. The size of this fold has been grestly exaggerated by Herisenat; he bas also attributed to it important offices, which it does not seem to perform. The peculiar sound called a bray is uttered by the ass in consequence of the extent of the laryngal sscs, and their being so much separsted from the cavity of the larynx by very contracted spertures. The bray seems indeed when beard to be a compound discordant sound, produced from the resonsnce of different sized csvities. Cuvier found in the quaggn the larynx organised es in the horse, except that the membrane extending from one corda vocalis to the other, did not exist.-Rees's Cyclopadia, srt. Maumanu. Majeratia's Comparative Physiology
Reverends, very Reverends, and Deans, uphold the centuries and myriads of years of preadamite history of fossils, rocks, and minerals; but the natural historian is afraid to whisper about there having been half a dozen original horses, or a dozen different dogs, as ancestors for the most distinct varieties of the family.

From this, we trust not altogether uninteresting digression, we return to method. The distinctive characters of the horse according to Linnæus, are :-

"The tail long, with hair all over; the mane long, without any humeral stripe. It is a generous, proud, and strong animal; fit for all the purposes of man; for draught, tho course, or the road; he is delighted with the freedom of open pastures; he is fearful of being touched on his hinder quarters; defends himself from the flies with his tail, scratches 'his fellow, defends his young, calls by neighing, sleeps after night-fall, fights by kicking and biting, rolls on the ground when weary and perspiring, bites the grass closer than the $0 x$, wants a gall-bladder, never vomits; the foal is produced with the legs stretched out; he is injured by being struck on the ear, or upon the stifle, by his being caught by the nose in barracks, by having his teeth rubbed with grease, and by various herbs. His diseases vary in different countries and climates. With us the glanders, a corruption of the ethmoid bones of the nose, is the most fatal and infectious disease. He eats hemlock without injury; he has no canine teeth till five years of age."

The teeth of the horse, fully treated hereafter, are incisors $\frac{6}{6}$; canines $\frac{1}{1} \frac{1}{1}$; molars $\frac{6}{6} \frac{6}{6}$; total 40 .

"Of all quadrupeds," says Buffon, "the horse possesses, along with grandeur of stature, the greatest elegance and proportion of parts. By comparing him with the animals above or below him, we find that the ass is ill-made, and that the head of the lion is too large; that the limbs of the ox are too slender, and too short in proportion to the size of the body; that the camel is deformed; and that the grosser animals - as the rhinoceros, hippopotamus, and elephantmay be considered as rude and shapeless masses.

"The great difference between the head of a man and that of a quadruped consists in the length of their jaws, which is the most ignoble of all characters. But though the jaws of a horse be very long, he has not, like the ass, an air of imbecility, nor like the ox of stupidity." The regularity and proportion of the parts of his head give him a light and sprightly aspect, being gracefully attached to his finely arched neck, which is well supported by the beauty of his chest; he elevates his head as if anxious to exalt himself above the condition of other quadrupeds. In this noble attitude he regards man face to face.

" His eyes are open, lively, and intelligent, his ears handsome and of a proper height, being neither too long like those of the ass, nor too short like those of the bull. His

- It need scarcely be observed thst this is rhetorical nonsenso. Each animal is perfect in its adsptation to itf place in the scale of creation, and to ito purposes. 
mane adorns his graceful neck, and gives him the appearance of strength and courage. His long bushy tail covers and terminates with advantage the extremity of his body. His tail, very different from the short tails of the deer, elephant, and hippopotamus, and from the naked tails of the ass, camel, and rhinoceros, is formed of long thick hairs, which seem to rise from his crupper, because the trunk from which they proceed is very short. He cannot, like the lion, elevate his tail; but though pendulous, it becomes him better, and as be can move it from side to side it serves him to drive off the flies which incommode him; for though his skin is very firm, and well garnished with close hair, it is nevertheless very sensible."

\section{THE WILD HORSE.}

No authentic record remains of the indigenous horse in his wild state. The dziggtai of Tartary, the kiang of Ladak and the Himalayas, the onager of Numidia, the zebra, and the quagga of Central and Southern Africa, are none of them the Equus Caballus, or true horse, of Buffon, Linnæus, Cuvier, Gray, \&c. ; they all belong to that second family of the Equida, the ass. Ialte Brun very rationally suggests that there was more than one original horse, varying in his different habitat. These would produce a fertile cross, partaking of the qualities and conformation of both sire and dam. This author specifies threp, original breeds of horse. The first indigenous to Bokhara, Persia, and Asia Minor; the second to Mongolia and Scythia, originated in the steppes of Central and Northern Asia; and third, the Arabian courser. The first two, as true indigenous varieties, we consider most probable, but in the third the great geographer adopted the current opinion of his time, and has assigned no true horse to North Africa-the original habitat of what we now know as the Barb-and has given to Arabia the eredit of the first horse of this noble variety. We trust we have already shown, that whatever celebrity the land of Ishmael may have acquired in comparatively modern times for the perfection of its horses - a perfection attained through many generations of careful breeding, training, and the "hard meat" system - it only possessed them at a period long since Africa owned its Barbs. To the laud now known as the Empire of Morocco, to Algeria, Tunis, Tripoli, and Lower Egypt, we transfer the claim of Arabia. From this variety too, we opine, the larger varieties of Persia, Armenia, Anatolia, Turkey, and Western Europe drew,- -at intervals, from the period of the Carthaginians and Romans until the Crusades, and thence to more modern times-that glorious attribute known as "blood ;" which gradually raised and gave fire and vigour to the heavier and more sluggish horses of the European continent and these islands, till the culminating point in speed, size, symmetry, and active strength, was realized in the British "thorough bred," such as we behold him in the son of Bay Middleton and Barbelle, a portrait of whom will be found in this volume.

As we have already said, the dziggtai or Tartary horse of Colonel H. Smith, (See Naturalist's Library) is not a horse strictly. He says-"The animal reccives its name trom the Mongolian Tartars on account of its large ears. The tail has hairs only at the extremity, and a black dorsal line which enlarges at the crupper. The general colour is a uniform bay or fawn colour, but the tint is redder in winter and lighter in summer. The ears, as already intimated, are longer than those of the horsc, but straighter and better formed than those of the mule. When undisturbed their character seems social and peaceable; they live in troops of from twenty to thirty, and often in much larger communities. The Mongols, Tungooses, and other nations bordering on the Great Desert hunt these animals for food, the flesh being considered a great delicacy."

The kiang, (Equus Hemionus) another of these pseudowild horses, was often seen by Col. MLarkham, who says :-

"The so-called wild horse is numerous throughout Chinese Tartary and Thibet. Several were seen to-day, and Coles killed one-he never killed another; and as for myself I could not have fired a shot after hearing the account of this one's death. The poor beast was badly wounded, and she (for it was a mare) feeling herself struck, walked up quictly within ten paces of Coles, and looked at him as much as to say, "What have I done to you that you should thus ill-treat me?" ".

"I could have shot as many as I pleased without any irouble, but never fired at one. In districts, however, where they have been disturbed and fired at, they become very dificult to approach. They are not at all like horses, but bear a wondrous similitude to a large donkey, being nearly of the same colour, and having a very big head with long ears. Their feet are remarkably good, shaped like those of a horse, and possessing great speed; their movements are easy and graceful, when seen at such a distance that their huge heads are not a prominent feature. Usually seen in companies of from two or three to ten or a dozen, large troops of thirty or forty are occasionally met with. When approached, they stand gazing at the intruder, urtil he gets within about three hundred yards, when they will trot off to a little distance, and then turn to look, standing as before, until their pursuer draws near, when they again move off. The Tartar name of the wild horse is kiang; young ones are occasionally caught by the Tartars, but I never heard of any attempt being made to break them for use."

We may remark, in concluding this branch of the subject, that the so-called wild horses of the steppes near the banks of the Don and Wolga, are the descendants of horses turned loose by the Russian army when suffering under scarcity of forage at the siege of Azof in 1657, and who have multiplied amazingly, though not so largely as the descendants of the horses taken over to South America by the Spaniards, myriads of whom roam over the Pampas, and of which more than 60,000 hides are imported yearly to this country.

We shall now proceed to consider the rarieties of the Horse. 


\section{1. -THE HORSE OF CENTRAL ASIA.}

The Tartar and Calmuck horses are perhaps the least cultivated or domesticated of any breed. They are small in stature, and by no means prepossessing in appearance, yet capable of undergoing long journeys, and of standing any amount of exposure. The colts are scarcely ever sheltered, and follow the tribe in its horseback movements. If a colt is weakly, a Calmuck quickly turns him into provender and feasts upon him; or, if of more mature age, subjects him, in the form of a steak-saddle, to a process intended to render the meat tender, which we find recorded in books of travels."

Linton, the author of a series of pleasant papers on "Russia and its Field Sports" in the Sporting Review, thus speaks of the endurance of this racc:-

"Although we did not halt on the high road to Moscow till we reached Ichondova, one hundred and ten versts, our horses did at least five leagues an hour. But subsequently, on arriving at Grovona-a place celebrated for the sumptuous building follies committed by Count Aratcheef, the detested favourite of the Emperor Alexander-we were obliged to change our sledges and reduce our horses to two in each, thus simply travelling at the pace of a mail; being finally obliged, when quitting the high roads, to submit to a simple villagesledge, drawn by a small active horse, whose harness was composed of cords I may here add with much truth that sixty versts are somewhat a long distance thus to travel during a night bitterly cold and dark, with a frozen wind which penetrates to the heart's core, and blinds you with frozen snow fine as salt. Ii is then, notwithstanding great-coats and furs, that the rigour of a Russian climate finds holes through which to penetrate.

"But it would be very unjust, even when frozen, to accuse the poor beast who drags you; on the contrary, we ought to give the greatest possible praise and consideration for showing the most unequalled patience and courage amid storms and danger, evincing an extraordinary instinct in reference to the snow-covered tracts which are daily re-covered by wind or fresh storms, however previously beaten and demarked; in fact, an unfortunate animal, without apparent form, nerve, or strength-in fact, a horse scarcely deemed sufficient to convey regetables to market-will trot sixty versts without halting, over snow-clad fields, through woods, over hedges and ravines, into which you descend like an avalanche, and rise again by a miracle; and yet, how are these poor beasts-so strong, so patient, so precious, notwithstanding their ugliness-treated when they arrive at their journey's end? Why, they are

- Butler (Hudibras, pt. 1, canto 2) alludes to this unsavoury custom, where he says hio bear was a "Muscovite," and "'mong the Cosarcks had been bred;"

"And though his countrymen the Huns, Did stew their meat between their bums And th' horses' backs whereon they itraddle, And every man eats up his saddle; He was not half so nice as they, But ate bis raw, when't osme in his wsg." permitted to suck up with their lips a little frozen snow to refresh themselves; and then turning their heads towards the sledge they have so patiently drawn, they are granted the happiness of eating the hay which has served as litter to warm the feet of its recent occupants. And thus horse and sledge are left generally in an open court-yard, where they are under the covering of heaven day and night. If it snows during the night, an apparently inanimate object may be seen standing immovable by the sledge in the morning. It is the gallant animal who yesterday drew you fifteen leagues, to return the same distance to-morrow."

These semi-wild animals range over the plains, each herd under the care of a stallion, who jealously prevents intrusion and the mingling of another herd with his own. As the stallion foals grow up they are expelled the herd, and wander till they succeed in forming a herd of their $0 \mathrm{wn}$.

The Ostraces, Urals, Mongols, Calmucks, Nogays, Visigoths, Ostrogoths, and Huns, who people the vast plains of Central Asia, seem to have been always horsemen. The nations known to antiquity as Scythians, Medes, and Parthians, were of common origin with one or other of these hordes, which fed the stream of invasion to the West, the South, and the East. Some of their leaders, from time to time, could bring three hundred thousand caralry into the field. The celerity of their marches, of their attacks and their retreats; the bardihood to which they brought themselves and their horses; their incursions and settlement-horde after horde-are the staple of the history of Asia, and of a large portion of Europe.

In the central steppes of Tartary there are, however, horses of a larger stature than those here spoken of. The Khirgese Tartars spear them and use them for food-the principal delicacy at high feasts being the horse's head, or a roasted foal.

The milk of the mare has from time immemorial been made by fermentation into a drink called kumiss. The process of its preparation is as follows:-To a gallon of fresh mare's milk about a quart of water and a pint of old kumiss, or sour milk, is added. The whole is then set in a warm place, covered with a thick cloth. At the end of twenty-four hours a clotted curd will have formed on the top, and the whole mixture will have become sour. It is then beaten up with a churn-staff, and again set by. Another churning completes the process, and the liquor is fit for consumption.

Dr. Clarke, in his Travels in Russia, gives the following account of the distillation of a spirit called rakee from this kumiss. The name will recall the vile brandy with which the Russian columns, who precipitated themselves on our brave Guards on the day of Inkermann, were maddened to the charge. The delicate process of production is thus detailed :"The still was composed of mud, or very close clay. For the neck of the retort a cane was used; and the receiver entirely covered by a coating of wet clay. The brandy had just passed over. The woman who had the management of the distillery, wishing to give me a taste of the spirit, thrust a small stick 
with a tuft of camel's hair into the receiver, dropped a portion of it on the retort, and, waving the instrument above her head, seattered the remaining liquor in the air. I asked the meaning of this ceremony, and was answered that it was a religious custom to give always the first of the brandy which they drew from the receiver to their god. The stick was then plunged into the liquor a second time, when more brandy adhering to the camel's hair, she squeezed it into the palm of her dirty band, and having tasted the liquor, presented it to our lips."

For two hundred and fifty years we are told that the Dukes of Muscovy, at their reception of Tartar ambassadors, made a ceremonial presentation of the milk of mares, after the fashion of coffee with Turks and Persians.

Berenger, in his excellent Treatise on Horsemanship, thus sketches the better breed of Tartar horse:- "Though but of a moderate stature, they are strong, nerrous, proud, full of spirit, bnld, and active. They have good feet, but somewhat narrow. Their heads are well-shaped and lean, but too small (?). Their forehand long and stiff, and the legs overlong. Yet, with all these imperfections, they are good and serviceable horses, being unconquerable by labour, and endowed with considerable speed. The Tartars live with them somewhat in the manner the Arabs do with their horses. When they are six or eight months old they make their children ride them, who exereise them in small excursions, dressing and forming them by degrees, and bringing them into gentle and early discipline; and, after awhile, making them undergo hunger and thirst, and many other hardships. The men, however, do not ride them until they are five or six years old, when they exact from them the severest service, and inure them to almost incredible fatigue, travelling two or three days almost without resting, and passing four or five days without better nourishment thas a handful of grass, and with nothing to quench thirst."

The Nogay Tartars have some of the tallest and strongest of the Tartar horses; and a variety that is used for draught. The Khan of Tartary uses these on state occasions. The Nogays can mount, it is said, one hundred tbousand men. Each Nogay has four horses when on an expedition: one for his own riding; a second as spare horse; and two more to carry his provision, his slaves, and his plunder.

We will elose this notice of the Cossack or Calmuck horse, by a transeript of an often printed account of a race, in which the question of superiority of the English racer in endurance, stoutness, and speed, was incontrovertibly established:-For this match the most celebrated Cossack horses from the Don, the Black Sea, and the Ural, were sent; and, after numerous trials, the best were seleeted. The English horses, on the other hand, were by no means of the first class. Their names were Sharper and Mina, and neither of them here would have ranked much above 'leather-platers.'

"On the 4th of August, 1825, on the challenge of the Cossacks, a race of the cruel distance of forty-seven miles, out and home, was agreed to. The four horses to start together; and the first in to take the whole stakes.

"On starting, the Cossacks took the lead at a moderate pace-the English horses following at the distance of three or four lengths; but before they had gone half-8-mile the stirrupleather of Sharper broke, and he ran avay with his rider, followed by Mina, and they went more than a mile, and up a steep hill, before they could be held in.

"Half the distance was run in an hour ano four minutes. Both the English horses were then fresh, and one of the Cossaeks. On their return Mina fell lame, and was taken away. The Cossack horse, likewise, began to flag, when the accompanying Russians began to drag him on by the bridle, throwing away the saddle, and putting a mere child on his back. Sharper, likewise, evidently shewed the effects of the pace at which he had gone when running away, and was much dis. tressed. The Cossacks then had recourse to foul play, and actually carried on their horse; some dragging him on by a rope, and the bridle at his head; and others pulling him on by the tail, and riding alongside of his quarters to support him, and relieving each other at this fatiguing work. Sharper did the whole distance in two hours and forty-eight minutes; and the Cossack horse was warped in eight minutes after him. At starting the English horses earried full three stone more than the Cossacks; and during the latter half of the race a mere child had ridden the Cossack."

The horses here engaged were of the breed, or a elosely allied one, to those of the Ukraine, which Byron so beautifully paints in Mazeppa:-

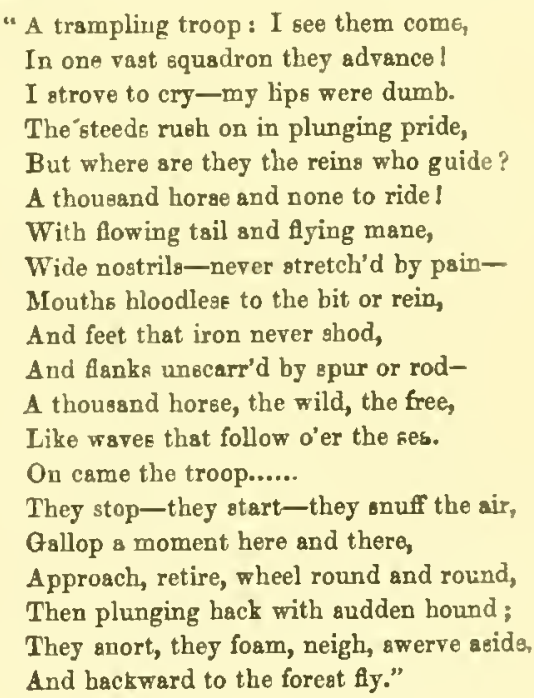

\section{1. - THE PERSIAN HORSE.}

The Persian horse is of high antiquity. His figure appears in the Assyrian sculptures. Alexander the Great received a Persian horse as a most valuable and acceptable present. From this, and the allied Toorkman horse, some of our earliest improvements of our breed are due. It may be observed, that an immense race of horses was early known in Dongols, in Africa; and that these, with a cross of the Barb, may have produced the more noble breed known as the Persian horse, par exeellence, for there were several breeds in that country.

It is by no means improbable that the ehariot of $\mathbf{X}$ erzes was drawn by Persian horses. We are told that they were from 
Armenia, and the noblest and stateliest which his extensive empire could furnish."

Under Cyrus the Persians became renowned for the beauty of their horses and the splendour of their caparisons; and in later days it was deemed unbecoming for a Persian of any pretension to rank to be seen in public except on horseback. Athenæus, the historian, however, tells us that they were more desirous of sitting at their ease than to prove themselves dexterous and bold horsemen. The stature of the Persian horse is often noted by ancient writers.

Down to the year 1800 no political mission had risited Persia for a century, but the fame of the English as soldiers had spread from India, and with a Persian until within the last twenty years a horseman and a warrior were convertible terms. An officer of one of the frigates which conveyed Sir John Malcolm's mission, who had gone on shore at Abusheher, and was there mounted on a spirited horse, afforded no small entertainment to the Persians by his bad horsemanship. The following day the man who supplied the ship with vegetables, and who spoke a little English, met him on board, and said, “Don't be ashamed, sahib: nobody knows you bad rider. I cell them you, all English, ride very well, but that time they see you, you very drunk." The worthy Persian thought it would have been an indelible reproach for a man of a warlike aation not to ride well, but none for an European to get drunk.

As a pendant to the Persian horse, we may give the following two anecdotes, from Sir John Malcolm's Sketches of Persia, premising that Sir John always applies the term Arab to all the horses of the territory washed by the Euphrates, and even those of Asia Minor :-

"When the envoy, returning from his former mission, was encamped near Bagdad, an Arab rode a bright bay mare of extraordinary shape and beauty before his tent, until he attracted his attention. On being asked if he would sell her; —'What will you give me?' was the reply: 'That depends upon her age; I suppose she is past five?' 'Guess again,' said he. 'Four ?' 'Look at her mouth,' said the Arab, with a smile. On examination she was found to be rising three. This, from her size and symmetry, greatly enhanced her value. The envoy said, 'I will give you fifty tomans' (a coin nearly of the value of a pound sterling). "A little more if you please,' said the fellow, apparently entertained. 'Eighty. A hundred.' He shook his head and smiled. The offer at last came to two hundred tomans! 'Well,' said the Arab, 'you need not tempt me further; it is of no use. You are a rich elchee (nobleman). You have fine horses, camels, and mules, and I am told, you have loads of silver and gold. Now,' added be, 'you want my mare, but you shall not bave her for all you have got." "

"An Arab sheik, who lived within fifty miles of Bussorah, had a farourite breed of horses. He lost one of his best mares, and could not for a long while discover whether she was stolen or had strayed. Some time after, a young man of a different tribe, who had long wished to marry his daughter, but had always been rejected by the sheik, obtained the lady's consent and eloped with her. The sheik and his followers pursued, but the lover and his mistress, mounted on one horse, made a wonderful march, and escaped. The old chief swore that the fellow was either mounted with the devil, or the favourite mare he bad lost. After his return he found the latter was the case; that the lover was the thief of his mare as well as of his daughter, and that he stole the one to carry off the other. The chief was quite gratified to find he had not been beaten by a mare of another breed; and was easily reconciled to the young man, in order that he might recover the mare, which appeared an object about which he was more solicitous than about his daughter."

Sir John Malcolm says-"A variety of horses are produced in Persia. The inhabitants of the districts which border on the Gulf still preserve pure those races of animals which their ancestors brought from the opposite shore of Arabia. In Fars and Irak they have a mixed breed from the Arabian, which, though stronger, is still a small horse compared with either Toorkman or Khorassan breeds, which are most prized by the soldiers of Persia. Both these latter races have also a great proportion of Arabian blood."

The Persian horse and its management is thus described by Sir Robert Ker Porter:- “The Persian horses never exceed 14 or $14 \frac{1}{9}$ hands high; yet certainly, on the whole, are taller than the Arabs. Those of the desert and country about Hillah seem very small, but are full of bone, and of good speed. General custom feeds and waters them only at sunrise and sunset, when they are cleaned. Their usual provender is barley and chopped straw, which, if the animals are picketed, is put into a nose-bag, and hung from their heads; but, if stabled, it is thrown into a lozenge-shaped hole, left in the thickness of the mud wall for that purpose, but much higher up than the line of our mangers, and there the animal eats at his leisure. Hay is a kind of food not known here. The bedding of the horse consists of his dung. After being exposed to the drying influence of the sun during the day, it becomes pulverized, and, in that state, is nightly spread under him. Little of it touches his body, that being covered by his clothing, a large nummud, from the head to the tail, and bound firmly round his body by a very large surcingle. But this apparel is only for cold weather ; in the warmer season the night clothes are of a lighter substance, and during the heat of the day the animal is kept entirely under shade.

"At night he is tied in the courtyard. The horses' heads are attached to the place of security by double ropes from their halters, and the heels of their hinder legs are confined by cords of twisted hair, fastened to iron rings and pegs driven into the earth. The same custom prevailed in the time of Xenophon, and for the same reason, to secure them from being able to attack and maim each other, the whole stud generally consisting of stallions. Their keepers, however, always sleep in their rugs amongst them, to prevent accident; and sometimes, notwithstanding all their care, they manage to break loose, and 
then the combat ensues. A general oeighing, screaming, kicking, and snorting, soon raise the grooms, and the scene for awhile is terrible. Indeed, no one can conceive the sudden aproar of such a moment, who has not been in Eastern countries to hear it; and then all who have must bear me witness that the noise is tremendous. They seize, bite, and kick each other, with the most determined fury; and frequently cannot be separated before their heads and haunches stream with blood. Even in skirmishes with the natives, their horses take parts in the fray, tearing each otber with their teeth, while their masters are in similar close quarters on their backs."

We have the following description of a Persian race, by the same author:

"My curiosity was fully on the spur to see the races, which I could not doubt must have been chosen from the best in the aation, to exhibit the perfections of its breed before the sovereign. The rival horses were divided into three sets, in order to lengthen the amusement. They had been in training several wecks, going very often over the ground during that time; and when I did sce them I found so much pains had been taken to sweat and reduce their weisht, that their bones were nearly cutting the skin. The distance marked for the race was a stretch of twenty-four miles; and that his Majesty might not have to wait when he had reached the field, the horses had set forward long before by three divisions from the starting point (a short interval of time passing between each set) so that they might have to come in a few minutes after the King had taken his seat. The different divisions arrived in regular order at the goal, but all so fatigued and exhausted, that their former boasted fleetness hardly exceeded a moderate canter when they passed before the royal eyes."

\section{III.-THE TOORKMAN HORSE.}

A beautiful breed of horses has long been known in Turkistan and South Tartary on the shores of the Caspian. They are large, stately, and strong, standing from fifteen to sixteen hands. The best breed of Turkish horses is descended from the Barb through the Arab and Persian horse; but these Toorkmans greatly exceed the horses of both those countries in point of size. The body is longer than the Arabian, and the croup more elevated. They have contributed materially to the improvement of the English breed.

This noble breed of horse appears to have been indigenous to Khorassan, thence westward through Mazanderan, to the south of the Caspian, in Armenia, Karamania, and Anatolia. He seems probably the progenitor of those Cappadocian horses so famed in ancient history for stature and stateliness. Vegetius expressly mentions that the horses of the Parthians were lighter and hardier than those of the Cappadocians or the Medes. Old Blundeville too says, from the inspection of many sculptures, these horses had larger heads than those of the Parthians. Oppian says of them, as is the case still with borses of large stature, "when young they are delicate and weak; but strength comes with years, and, contrary to other horses, they are better and more powerful when arlvanced in are." In which the ancient goes a little too far.
When, at the end of the eighth century, the Saraceno overrun a great part of Syria, Asia Minor, and Europe, they brought with them a force of two hundred thousand cavalry, far superior to the Goths and Huns of former ages. These horses, crossed with the Persian, seem to have given them size and weight.

Of the modern Toorkman horse we may observe that, right or wrong, since the Moslem faith and language have spread over the land, everything wonderful and beautiful is traced from the land of the Prophet; every first-rate animal to a dash of the blood of one of "the sucred mares," sanctified by the ownership of Mahomet himself. With how much historic truth the reader may easily imagine.

Captain Fraser thus relates the impression which they made upon him, in his Journey to Khorassan-tbe reader bearing in mind that the gallant Captain's ideal standard was our English blood horse. "They are deficient in compactness. Their bodies being long in proportion to their bulk." They are not well ribbed up. They are long on the legs-deficient in muscle-falling off below the knee†-narrow-chested, long. necked, head large and not well put on. Such was the im. pression I receired from the first sight of them, and it was not for some time that their superior valuable qualities became apparent to me."

Captain Fraser's experience in many a long ride subsequently convinced him of the truth that horses "go well in all forms."

Sir John Malcolm must again be our authority for the Toorkman's capabilities. He says, "This horse is regularly trained by the Toorkmans preparatory to their plundering expeditions. Before proceeding on a foray, these wild people knead a number of small hard balls of barley-meal, which, when wanted, they soak in water, and which serves as food both for themselves and their horses. It is a frequent practice with them in crossing deserts where no water is to be found, to open a vein in the shoulder of the horse and drink a little of his blood, which, according to their own opinion, benefits rather than injures the animal. It is confidently stated, that when in condition their horses have gone one hundred and forty miles within twenty-four hours; and it has been proved that parties of them were in the habit of marching from seventy to one bundred and five miles for twelve or fifteen days together without a halt."

During Sir John's first mission to Persia, be, when riding one day near a small encampment of Afshar families, expressed doubts to his Mehmander, a Persian nobleman, as to the reputed boldness and skill in horsemanship of their females. The Mehmander immediately called to a young woman of handsome appearance, and asked her in Turkish, if she was a soldier's daughter. She said she was. "And jou expect to be a mother of soldiers?" She smiled. "Mount that borse,"

- This is just the fsult an Arab cross would remedy. Rairon de plus f the originslity of the Toorkmsn rsce.

+ Bge dascription of Arsb, past. 
said be, pointing to one with a bridle, but without a saddle, " and show this European Elchee the difference between a girl of a tribe and a citizen's daughter." She instantly sprang upon the animal, and setting off at full speed, did not stop till she had reached the summit of a small hill in the vicinity, which was covered with loose stones. When there she waved her hand over her head, and came down the hill at the same rate at which she had ascended it. Nothing could be more dangerous than the ground over which she galloped; but she appeared quite fearless, and seemed delighted at having the opportunity of vindicating the females of her tribe from the reproach of being like the ladies of cities.

\section{IV. - THE TURISISH HORSE.}

This variety is one rather of admixture of breeds than having a distinct and indigenous origin. He partakes more or less of the Barb, the Arab, the Persian, the Toorkman, and, in some parts, of the Tartar horse in different localities. The Turkisb horse possesses valuable qualities. Some of our best blood is due to the Turkish horse. The Byerley Tirk, (brought from the Levant in 1685); the Acaster Turk; the Belgrade Turk (taken by General Mercée at the siege of that place in 1720); the Lister Turk (brought from Buda by the Marshal Duke of Berwick, temp. James II.); the Helmsley Turk, and others, will suggest themselves.

The author of Sylva, old Evelyn, thus enthusiastically paints a Turkish horse sent over to England in the second Charles's reign :-

"I never beheld so delicate a creature; somewhat of a bright bay, two white feet, a blaze; such a bead, eyes, ears, neck, breast, belly, baunches, legs, pasterns, and feet, in all respects beautiful, and proportioned to admiration; spirited, proud, nimble, making halt, turning with that swiftness, and in so small a compass, as was admirable."

The Turkish horses are likewise remarkable for their extreme docility, which is thus accounted for by Busbequius, who was ambassador at Constantinople in the seventeenth century; and it would be well, if botb masters and grooms would learn a lesson from the wisdom and humanity of this truly worthy and benevolent writer.

"Nothing," writes Busbequius, "can surpass the gentleness of the Turkish horses; and their obedience to their masters and grooms is very great. The reason is, they always treat them with great kindness. I myself saw when I was in Pontus, passing through a part of Bithynia called Axilos, towards Cappadocia, how gentle the country people were to young colts and how kindly they used them soon after they were foaled.

"They took them into their own habitations, cleansed, combed, and caressed them, with as much affection as they would their own children. They hang something like a jewel about their necks, and a broad ribbon which was full of amulets against poison, which they are most afraid of. They never strike them, the grooms that dress them being as gentle as their masters. In return for this treatment these animals naturally acquire a great attachment to man, and are always most tractable and assily managed.
"But, alas ! our Christian grooms' horses go on at another rate. They never think them rightly curried till they thunder at them with their voices, and let their clubs or horse-whips, as it were, dwell on their sides. This makes some horses even tremble when their keepers come into their stable; so that they hate and fear them too. But the Turks love to have their horses so gentle, that at the word of command they may fall on their knees, and in this position receive their riders.

"They will take up a staff or club upon the road with their teeth, which their rider has let fall, and hold it up to him again; and when they are perfect in this lesson, then, for credit, they have rings of silver hung on their nostrils as a badge of honour and good discipline. I saw some horses when their master was fallen from the saddle stand stock still without wagging a foot till he got up again. Another time I saw a groom standing at a distance in the midst of a whole ring of horses, and I saw some horses when their master was at dinner with me in an upper room prick up their ears to hear his voice, and when they did so they neighed for joy."

It may be worthy of note, that while the Arab horse is remarkable for uniformity of colour, and firm, flat, black legs; these larger horses, Persian, Toorkman, and Turkish have shown a disposition towards a white leg, and sometimes, as in the celebrated racer, Whitestockings, to a pair of them. We have already said Bucephalus was a skewbald; and a white leg -against which there is a traditional prejudice among English grooms-has often marked the finest of this race. A writer in the "Sporting Magazine" thus attacks this prejudice:-

"Turn to the banks of the Euphrates, to the decayed but once splendid seats of the Caliphs of the Black Banrer, to the cradle of the Arabian tales; to the queen of the east, Bagdad, the beloved capital of the great Haroun al Raschid, and there we have a breed of horses uniting the fire of the Persian witb the symmetry and enduring qualities of the Desert breed. Go further to the southward, cross the great river, roam among the settled tribes who have pitched their tents on the very verge of civilization, near unto the great cities, the dwellings of slaves, as they are not inaptly termed by the Bedouins, and you may lay your hand on the flowing manes of a race of horses - all chesnut, with the starting prominent eye, like an ember glowing; 'full of fire and full of bone,' and all singularly and invariably stamped with the peculiar distinctive marks of their caste; the white blazed face, and white legs (generally three) white up to the knee, perbaps the ancestors of the great Eclipse; a chesnut also with these remarkable marks, and which sometimes breaks forth in his most distinguished descendants-to wit, Sultan, his son Beiram, Harkaway, and a number of winners of our greatest stakes.

"The prejudice against white legs is strong; yet my experience, and it justifies me in the assertion, has proved that the chesnut horse with the white legs up to the knee is one of the hardiest, cleanest-limbed, fastest, and most honest of all the breeds; none bear so much rattling. I speak not of one, but of many of this kind."

We shall have more, however, to say of this ir another place. Grood authorities have much per contra. 


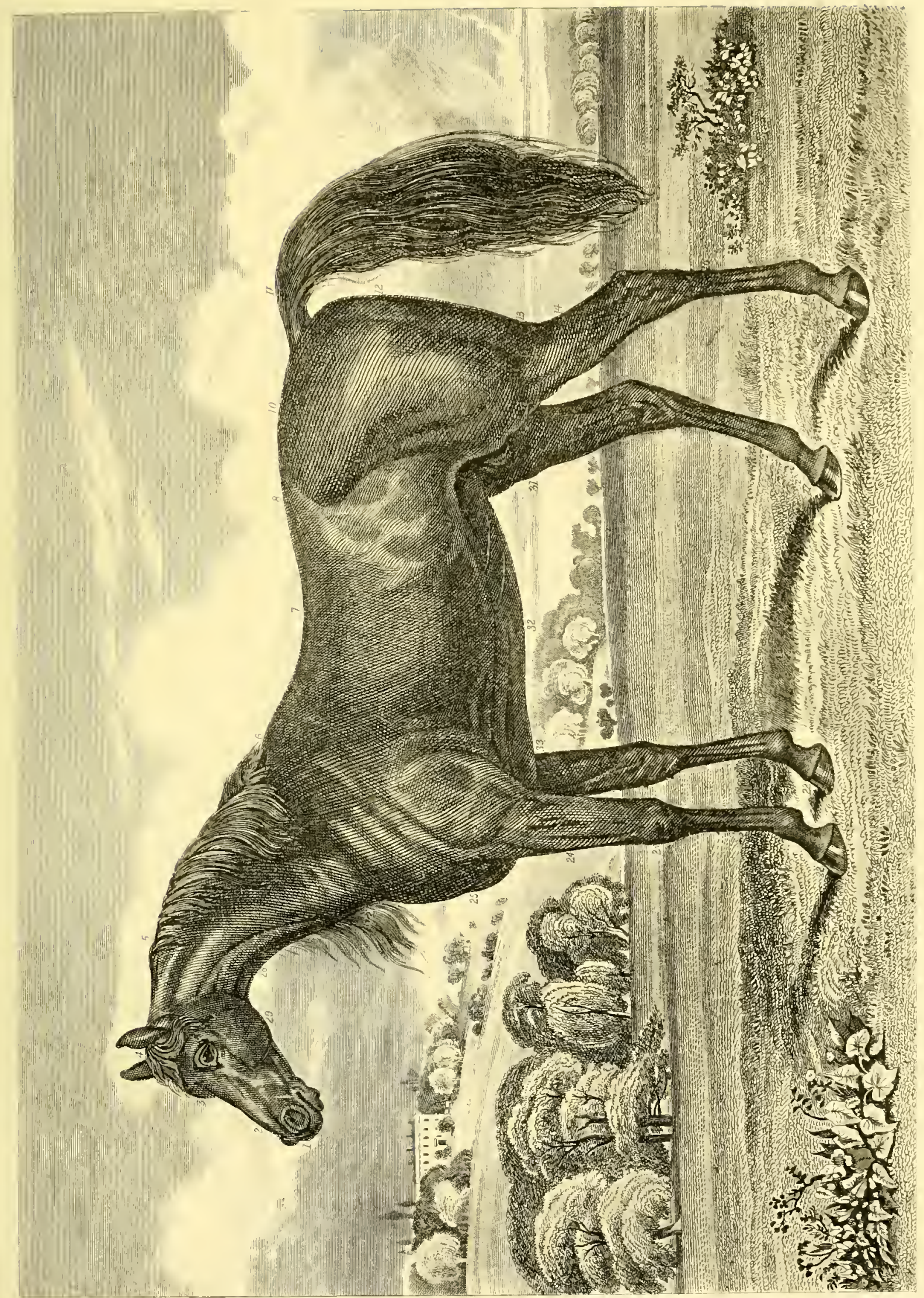





\section{v. - THE CIRCASSIAN HORSE.}

Therg is little to be said of this breed, except that it is smaller than the Persian, and somewhat larger than the northern Tartar breeds. Vast numbers of horses and sheep are reared in the valleys of the Tcherkesses, and they and the slaves which, up to a few years since, were a prime article of commerce with the Turks, formed the wealth of this bold nomadic race. The most valuable breed, marked with a pale horseshoe, was in the possession of the reigning familyreigning now no longer in the Caucasus; the fall and captivity of Schamyl, having placed the country in the power of the Russian invader. The Circassian horses have a good repute for stoutness and speed.

\section{VI. - THE HORSES OP INDIA.}

Retracing our steps to the far East and South, we come to the rast peninsula, the scene of so much glory, so much suffering, and so much triumph for England and Englishmen. The native horses of India are diminutive in size, so much so that the Persian or Arab cross is absolutely necessary to bring them up to the atandard of general utility. They are divided by writers on India into several slasses. The Tazee, the Toorkee, the Iranee, the Koakkee-the three last names suffsiently indicate their supposed origin; the Mahratta horse, so salled from that warlike people of Central Hindostan; and the Tattoo, or native Indian pony. Of these the Tazee seems to Lave the most claim to originality. It is low and rather hollow in the back, but easy in its paces, and has the drawback of being generally vicious and violent.

India is now well supplied with various breeds: many Arabian horses, bred for the purpose, are yearly imported from Muscat and the eastern coast of Arabia Thorough-bred English horses are often sent from England to Bombay, Calcutta, and Madras, as well as to Australia, where the East India Company formerly had a stud for the mounting of the cavalry in their service. Mr. Moorcroft, a veterinary surgeon of high reputation, undertook the management of this enterprise, and the result has been that the cavalry horses of India have rapidly improved.

To return. The second-named horse, the Toorkee, originally derived from a Toorkman or Persian strain, perhaps both, is the noblest race for spirit, size, and beauty. With an levated crest, lofty action, and withers quite or nearly fifteen bands high, they make showy horses for the parade. They are, however, what is called "tied in under the knee," showing a deficiency of volume in the flexor tendons, a fault seldom seen in the Arab or the Barb. There is also apparently a disproportionate smallness of bone below the knee ioint and about the hocks.

The Iranee is stouter and better limbed, has powerful loins and quarters, with the drawbacks of a coarsehead, lopping ears, and a sluggish temperament.

A writer on the horses of India, in the Sportsman's Magasine, says :-
"Those from Guzerat and Cutch" are certainly endowed with greater amiability of disposition, but are more calculated for purposes of display and parade than anything else The natives are very partial to this breed, and give long pri es for them, frequently as much as two or three thousand rupees. They blow them out to an enormous size, by feeding the $a$ or a composition which must be any thing but agreeable to the palate of the horse, viz., a kind of paste, made of pounded grain and sheep's head, wherewith the poor devil is crams ed like a turkey. The end of the flowing tail, geverally reach ng the ground, is dyed of a deep red colour, a cruelly sharp it is put into his mouth, he is buried under a ton of bedding covered with crimson cloth, doing duty for saddle, and, thus caparisoned, he is decmed fit to carry one of the 'Pillars of the State.' It is a pretty sight to see a procession, accompanied by a cavaleade thus mounted, and taking every opportunity of displaying their horsemanship, a cavalier occa. sionally darting from the cromd at the top of his speed, and as suddenly pulling his horse on his haunches in the midst of his headlong career, then wheeling about, and still at full speed, describe in an incredibly small space, the difficult figure of eight, with all the apparent ease of a graceful skaiter."

The Kozakee is a hardier and more patient animal. He has a deep girth and a good forearm, but betrays his origin by a large head and what are called "cat-hams." Nevertheless he is enduring, hardy, and capable of long journers.

Next we have the Mahratta horse, the product of halfblood Arab and the native Tazee. These horses are thus not vary complimentarily described by the writer wo have already quoted :-

"The Mahratta horse is an astive, serviceable little beast, but, in ten sases out of twenty, extremely vicious, but will often make a capital bunter, in fact, being the only horse in India worth his keep, the larger horses from Hindostan being adapted only for the capering of a native Sowar; they are leggy, under-limbed, and, as far as vice goes, regular man-eaters."

These were the horses who carried that formidable race who ruled in Central India from sea to sea, across the south of the Deccan, and whose rule was broken by the fall of Seringapatam and the death of Tippoo Sultaun. The MIahratta army consisted almost entirely of aavalry. The Mahratta, when not on horseback, may be said to be almost constantly employed in shampooing his horse." It is properly so called, for he rubs him violently with his wrists and elbows, as well as his hands, and moulds and bends his limbs in every direction. The Mahrattan way of riding is a singular and, according to European notions, a very ungraceful one His knees are as high as his horse's back; he holds on with his heels, and clings with his hands either to the mane or the peak of the saddle. With such aids, his seat is more secure than at first sight it would appear to be The peak of the saddle rises in the form of a crane's leck, and is said to have been

- These are Persian horses, or nearly 20, epoilt by unsstural trestment for purposes of pomp.-ED. 
borrowed from the Moguls. A crupper and a martingale are almost indispensable accompaniments of the Mahratta horserurniture It is a singular kind of crupper, however, not projecting from the centre of the saddle, but attached to both sides. The tobsa, or leathern vessel out of which the horse eats his corn, is also attached to the crupper; and this part of the trappings is generally ornamented with silver knobs, or with silk tassels or embroidery.

Their horses, like most of those of the East, are picketed, not only during the day, but very frequently in the night. A rope is carried from the headstall on each side to a peg driven into the ground. A rope, or thong, is also tied round the fetlocks behind, and carried backwards twenty or thirty feet, and fastened to a peg. This pulls the horse back, and keeps him, when standing, on the stretch, but does not prevent him from lying down. When they are thus tethered, their eyes are covered, that they may not be alarmed at any object that passes They are also clothed, in order that the beautiful, glossy appearance of their coat may be preserved.

They use the snaffle-bridle, but it is so jagged and pointed that the animal may be punished to the full content of any barbarian that may ride him. The headstall is usually ornamented, and from the rein a thong descends by which the horse may be occasionally reminded of his duty. The horseman has neither whip, switch, nor spur, but the horse is controlled, if he is disposed to rebel, by the cruel argument of the bit.

The breast of the Mahratta horse is more splendidly ornamented than any other part. Numerous coins, of different size and value-rupees and double rupees-are formed into plates more or less highly ornamented, and which in time of war form a rich booty for the conqueror. The mane, too, is generally plaited with silk-braids, and silver knobs attached to them, with a beautiful top-knot between the ears. If the rider has distinguished himself in war, some curious tails, said to be taken from the wild cow, dangle on either side.

The imported horses of India occupy a prominent place in a consideration of this subject. We have already alluded to the several sources of supply. Colonel Markham," in his lively volume, bears testimony to the goodness of the horses brought from Muscat and the Persian Gulf. He says:"The centre point of attraction (at Calcutta,) was the Arab stables of Sheik Ibrahim, who deserves to be commemorated were it only for his honesty. Filled with the best bred horses to be found in India, many an hour did I pass there; companionable as other horses may be, there are none to compare for sociality with high caste Arabs. Four thousand pounds did the old Sheik take from the regiment, with an air of the most perfect indifference, and wonderful to say, not a bargain was repented of in after times."

A writer who describes a sale of these horses, crossed with the Iranee, from the now defunct Company's stud at Bala

- Shooting in the Himalayas. A Journal of Sporting Adventures and Travel in Chinese Tartary, Ladak, Thibet, Cashmere, \&c., by Col. Fred. Markham, C.B. Bentley, 1854.
Hissar, is by no means so complimentary to this class of animal, in a second or third descent-"There were not less than one thousand horses shows. They were all above fourteen hands and a half in height, high-crested, and showylooking horses. The great defect seemed a want of bone below the knee, which is indeed general to all the native horses throughout India; and also so great a tendency to fulness in the hooks, that, in England, it would be thought half of them had blood spavins."

Both Arab and native crosses have, however, succumbed to the imported English horse. In 1829, Arab horses having previously been matched against English on race-courses at the various stations, Meerut, Cawnpore, Calcutta, Barrackpore, \&c., \&c., the question was thought to be brought to issue by the race of the English-bred horse Recruit, against Pyramus, a pure Arabian. The race was two miles over the Barrackpore course ; in this the English horse was an easy victor. Another English race-horse, Constance, however, was shortly after defeated by a selected Arab, and this balanced the account, say the advocates of the Arab. Why then place penalties on every imported horse on every race-course in India? the question answers itself.

Lest, however, we should seem to do mjustice to the Arab, un this point, we subjoin a table of time and distance, made by Captain Gwatkin, of the H. E. I. C. service, of the best performances of the $1 . \mathrm{ab}$ horses then in India :-

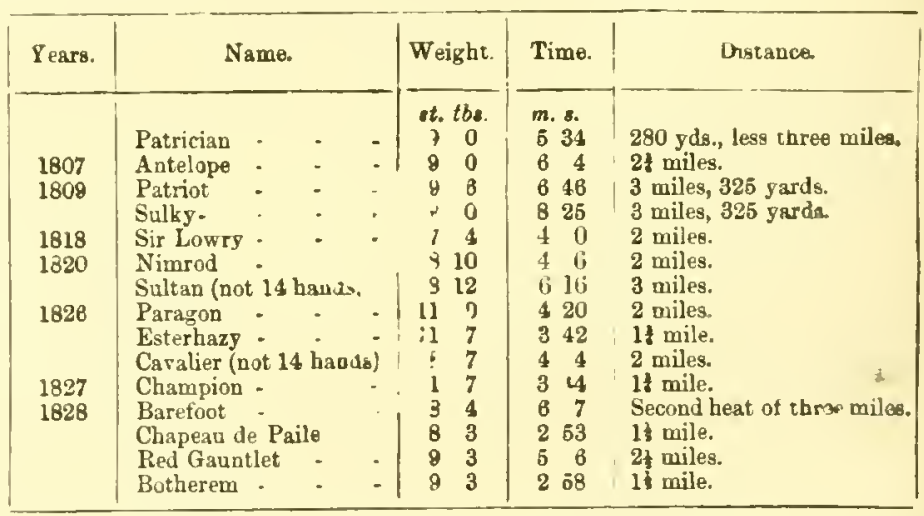

The speed and endurance in the Arabian therefore are not, according to the above report, diminished; and, as Captain Gwatkin observes, when we consider the average neight of these diminutive racers (fourteen hands, one inch), und the want of tenacity in the sandy soil of India. se cannot but be struck with their performances.

We may refer the reader who seeks further details to the pages of the Sporting Magazine and Astatic Journal, which from time to time contain accounts of Racung in India.

A remarkable instance of the confidence of a horse in a firm rider, and his native courage, was conspicuously evinced so the case of an Arab, mentioned by Colonel Hamilton Smith. General Sir Robert Gillespie happened, when mounted on this animal, to be present on the race-course of Calcutta during one of the great Hindoo festivals, when several hundred thousand people were assembled. On a sudden an alarm was given that a tiger had escaped from his keepers. Sir Rober 
immediately snatched a boar spear, and rode to attack this formidable enemy. The tiger was probably confounded by the crowd, but the moment he perceived Sir Robert, he crouched to spring at him. At that very instant, the gallant soldier, on his gallant steed, leapt right over him; Sir Robert striking the spear through the animal's spine! This was a small grey, but he possessed another horse who has become almost historical. It was a favourite black charger, bred at the Cape of Good Hope, and carried with him to India. When the noble soldier fell at the storming of Kalunga, this charger was put up for sale, and after great competition was knocked down to the privates of the 8th Dragoons, who actually contributed their prize-money, to the amount of $£ 500$, to retain this memorial of their beloved commander. The beautiful charger was always led at the head of the regiment on a march, and at the station at Cawnpore, took his ancient post at the colour stand, where the salute of passing squadrons were given at drill, and on reviows. When the regiment was ordered home, the funds of the privates running low, he was bought by a gentleman, who provided funds and a paddock for him, where he might pass the remainder of his days in comfort; but when the corps had departed, and the sound of the trumpet was heard no more, the gallant steed pined, refused his food, and on the first opportunity being led out for exercise, he broke from his groom, galloped to his ancient station on parade, neighed loudly again and again; and there, on the spot where he had so often proudly borne his beloved master, he dropped down and died!

Bishop Heber thus describes the docility of his IndoArabian horse. He says: "My morning rides are very pleasant. My horse is a nice, quiet, good-tempered little Arab, who is so fearless, that he goes, without starting, close to an elephant; and so gentle and docile that he eats out of my hand, and has almost as much attachment and as many coaxing ways as a dog. This seems the general character of the Arabian horses, to judge from what I have seen in this country. It is not the fiery, dashing animal I had supposed, but with more rationality about him, and more apparent confidence in his rider than the majority of the English horses."

\section{VII. - THE ARAB.}

The incomparable and improved breed of the noblest of $2^{n}$ aadrupeds, which takes its name from the country of the Ishmaelite, has certainly a high, if not the highest, claim to the admiration of every lover of the horse.

Mr. Youatt, in addition to many reasons which we have before given, as proving the Arab, like the British blood horse, a product of judicious crossing, training, and sedulous culture, notes that, "in a curious record of the commerce of the second century, among the articles exported from Egypt to Arabia, horses are mentioned, as presents to princes; while in the fourth centary the Roman Emperor sent two hundred Cappadocian horses as the most acceptable present he could offer to a powerful prince of Arabia."

- The peculating bacon-factor, and fraudulent army contractor, known as St. Georgs of Cappadocia, and distinguished as a horse-riding saint, is especially the tutelory patron of cavalry. When our Crueaders went to the
We have before noted the porerty of Mahomet in horses. and that at the close of the great campaign against the Koreish, though he drove off 24,000 camels and 40,000 sheep, and carried off 24,000 ounces of silver, horses are not in the list of plunder.

These and other circumstances sufficiently confute the notion of an original Arab horse, and show that he has been com paratively recently naturalized in that country. Indeed, the Arabs themselves lend countenance to this; for when, within the last hundred years, they found how eagerly their horses were sought, they pretended to no higher pedigree for their Kohlani than tracing the animal to one of the four mares on which Mahomet and his four immediate successors, fled from Mecca to Medina, in the night of the Hejira (July 15th, 622).

We will now say a few words on the country which gives birth to this beautiful animal.

The extensive country of Arabia, celebrated in all ages for its roving tribes, is situated at the south-western extremity of Asia. It is bounded on the south-west by the Red Sea and the Isthmus of Suez; on the north-east by the Persian Gulf and the lower course of the Euphrates; on the north-west by Syria, the Euphrates, and the intervening desert; and on the south-east by the Indian Ocean. The country may be described as a vast collection of rocky and precipitous mountains, encircled by a border of low, barren, and sandy plains, which differ widely in their climate, soil and productions. The plains consist either of bare rocks or of hard or loose sand, and suffer from an almost constant drought, there being no rivers; consequently the deep wells and springs scattered at distant intervals, and which are generally surrounded by a small margin of the most refreshing verdure, form the sole resource of the fainting traveller. The temperature of other tropical climates is moderate in comparison with the heat of these deserts, where the thermometer is frequently above $100^{\circ}$ during the night, in the sun $180^{\circ}$, and in the course of the day often rises to $110^{\circ}$ in the shade. The mountainous tracts immediately behind these dry and sandy deserts stretch backwards from the sea shore, and contain numerous valleys of remarkable fertility, forming the celebrated region called by the ancients Arabia Felix.

The dry air and soil of Arabia seem peculiarly adapted to produce hard muscular fibre; accordingly we find the Arabian horse in the highest, and other Eastern breeds in an inferior, degree, possess a firmness of anătomical organization unequalled except by the English thorough-bred horse. The nature and character of what is popularly called the horse of the desert particularly adapted him to beget an animal which, as in the case of the race horse, is called upon to put its physical power to the severest trial to which nature, aided by art, can

East in 1096, they found him in the Calendar as a warrior-saint, with tho title of "Victorious." It seems that, at the siege of Antioch, St. Grorge helped the English knights! Hence his adoption by Edward III. ac patron of the Garter, and the cry of "St. George for England!" so long the echo of the shout, "St. Denis for France!" The dragon is, according to one of the church-historians, merely the emblem of "the Incarnation of Eril," this not very reputable saint is fabled to have alsin. 
Bubmit. These advantages, which he derives from climate, and the great care exercised in breeding and rearing him by his Arab master, arise from the possession of larger muscles and zmaller, harder bones than any other horses-muscles and sinews constituting the powers of action; and on these depend the lasting qualities of an animal going at the top of his speed. Bones, being the weight to be lifted, serve only to extend the parts; and it is obvious that such as are small, but highly condensed, like those of the deer and the Arabian horse, are, by occupying less space, and containing less weight, more easily acted upon by muscular force than such as are large and porous, and for a greater duration of time, without fatiguing the active powers.

But the excellence of the horse of the border of the Desert does not end with his condensed bone and llat, wiry leg, so much valued by real judges. On reference to eminent writers on the anatomy of the horse, we find all the muscles, and fibres, and sinews of his framedescribed as driven into closer contact than those of any other breed-always excepting our own thorough-bred horse; and from the membranes and ligaments being composed of a firmer and thinner substance, be possesses the rare union of strength with lightness, so essential to the eudurance of fatigue in all quick motions; and when to these qualifications are added the peculiar and deerlike elegance, the broad squareness of forehead, the short fine muzzle, the prominent and brilliant eye, the small ear, and the beautiful course of the veins, he appears to furnish all the requisites of a race-horse.

The following tradition on the origin of the Kohlani, or Kailhani, the noblest race of horses, whose genealogy, with true Eastern exaggeration, has sometimes even been traced to the stud of Solomon, is from Burckhardt. The author relates that the Arabian prophet, wishing to set aside from his stud the best mares, in order to form a distinct and perfect breed, had them all kept for two entire days and nights without water. On a sudden, when almost mad with thirst, the mares are released, and gallop with the swiftness of the wind to the well-known spring. When in view of the refreshing waters, by a preconcerted signal, the trumpets sound a war charge. At this well-known sound five of the mares, forgetting in a moment the agonies of their thirst, leave untasted the waters of the spring, and gallop to the imagined war; and from these five mares the author fables the noblest breed to have descended.

Another writer, upon whose statements we shall hereafter remark, asserts that the greatest care is exercised in breeding the Kohlani, or Kailhani. Much ceremony takes place as well at the union of these animals as at the birth of the foal; and a certificate is made out and properly authenticated within seven days after that event." It is generally believed that pedigrees of the noble race of horses exist of not less than five hundred years, with sire and dam distinctly

- M. de Portes, who was sent by the French Government into Syria, seemingly contradicts this : but the custom of the tribes vary.-See pages 23-84 post. traced. The following pedigree is mentioned by Weston, in his Fragments of Oriental Literature: it was found hanging round the neck of an Arabian horse purchased by Colonel Ainslie during the English campaign in Egypt against the first Napoleon.

"In the name of God, the merciful and compassionate, and of Seyd Mohammed, agent of the High God, and of the companions of Mohammed and of Jerusalem. Praised be the Lord, the omnipotent Creator. This is a high-bred horse, and its colt's tooth is here in a bag about his neck, with his pedigree, and of undoubted authority, such as no infidel can refuse to believe. He is the son of Rabbaing, out of the dam Lahadah, and equal in power to its sire, of the tribe of Zazhalah. He is finely moulded, and made for running like an ostrich, and great in his stroke, covering much ground. In the honours of relationship he reckons Zaulah, sire of Mahat, sire of Kallack, and the unique Alket, sire of Manasseh, sire of Alshek, father of the race down to the famous horse the sire of Lakalala; and to him be ever abundance of green meat, and corn, and water of life, as a reward from the tribe of Zazhalah, for the fire of his cover; and may a thousand branches shade his carcase from the hyena of the tomb, from the howling wolf of the desert; and let the tribe of Zazhalah present him with a festival within an enclosure of walls; and let thousands assemble at the rising of the sun, in troops, hastily, where the tribe holds up, under a canopy of celestial signs within the walls, the saddle, with the name and family of the possessor. Then let them strike the hands with a loud noise incessantly, and pray God for immunity for the tribe of Zoab, the inspired tribe."

Burckhardt has some sensible remarks on the exaggeration of these pedigrees. In the interior the Bedouin does not trouble himself with them, as they know the genealogy of their horses as well, if not better, than that of their own families. The Arab horsedealer, however, with that acuteness which seems born of the profession, who goes with his stock to Damascus, or Bagdad, or eastward to Bussorah, supplies himself with a written pedigree, duly made out, for the edification of the purchaser. In these the animal is as gloriously furnished with an ancestry, as ever was parvenu by herald or king-at-arms. Some of these call on the credulity of the buyer to an immense extent. They trace the descent of the terrible high-bred animal, not only from one of the "four mares" of Mahomet, who figure like "the royal mares" in our stud-book, but might make paler Europeans blush, bringing them down in a direct line from the stud of Solomon, the son of David. This suggests a curious inference: the Arab, the child of tradition, with 2500 years of oral history, goes back to the stud of Solomon, who, we need hardly repeat, "brought up horses out of Egypt" a phrase equivalent to all Northern and Fastern Africa. The Bedouins of the Desert, unless, of course, they are "dealing," laugh at the idea of a horse's pedigree.

It is a prevalent error that the Arab is bred in the arid desert; and equally unphilosophical to suppose that he owes his undoubted powers of endurance in his adult state to the 
hardships inflicted upon hım in his youth. The real fact is, the Arabs select for their breeding places some of those beautiful spots, known only in such countries, where, though all may be dry and barren around, there is pasture, and the smaller sort of cereal grasses, saccharine dates, and various succulent herbs, remarkable for nutritious and sub-aromatic properties. The powers of the animal are developed in the natural way by exercise sufficient for health, and by hard work, when undergoing that exercise. Once only is a cruel, and sometimes ruinous exertion, imposed upon the animal, as we shall presently note.

In Nedjed the horses are regularly fed on dates, and the fragments of any provisions that may be used by the inhabitants; and some writers have even asserted, that flesh, raw, as woll as boiled, is given them by the wealthy people, a practice in the prevalence of which we are not inclined to place much faith. Very little water is given, as the Arabs conceive (and justly) that much liquid injures the horse's shape and affects his wind.

The colt is mounted after its second year, when the Arab, on all other occasions so kind to his horse, puts it to a cruelly severe trial. The colt, or filly, is led out to be mounted for the first time; its master springs on its back, and rides at full speed for perhaps forty miles, over sand and rock of the burning desert, without one moment's respite. He then plunges it into water enough to swim, and if immediately after this, it will eat as if nothing had happened, its purity of blood and staunchness are considered incontrovertible.

Count Reziousky gives the following account of the docility and sagacity of the Kohlan, translated by an English writer, which we give as curious, although extremely exaggerated both in style and matter :-

"Above all horses in the world," writes the Count, "the Kohlan is distinguished for the goodness of his quality and the beauty of his form. He possesses uncommon mildness of temper, an unalterable faithfulness to his master, a courage and intrepidity as astonishing as they are innate in his noble breast, an unfailing remembrance of the places where he has been, and of the treatment he has received. Not to be led, not to be touched but by his master, in the most dreadful confusion of battle cool and collected, he never forgets the place he came from, and, though mortally wounded, if he can gather up suffcient strength be carries back his desponding rider to his defeated tribe.

"His intelligence is wonderful; he knows when he is sold, or even when his master is bargaining to sell him. When the proprietor and purchaser meet for that purpose in the stables, the Kohlan soon guesses what is going on, becomes restless, gives from his beautiful eye a side glance at the interlocutors, scrapes the ground with his foot, and plainly shows his disconient. Neither the buyer nor any one else dares to come near him; but the bargain being struck, when the vendor, taking the Kohlan by the halter, gives him up to the purchaser with a slice of bread and some salt, and turns away, never more to look at him as his own-an ancient custom of taking leave of a horse, and his recognizing a new master-it is then that this generous and noble animal becornes tractable, mild, an! fasthful to another, and proves himself immediately attachod to him whom his passion, a few minutes before, might have laid at h1s feet, and trampled under his hoofs.

"This is not an idle story; I have been a witness of, and an actor in the interesting scene, having bought three Kohlan* from Turkish prisoners. I made the bargain in the stables, and received personally, and led off the most fierce but intelli. gent animals, which before the above mentioned ceremony 1 should not have dared to approach. The fact has been confirmed to me by all the Turkish and Arab prisoners, and by several rich Armenian merchants who deal in horses, and go generally to the desert to buy them. The Kohlans also evince great warlike qualities."

M. de Chateaubriand, in his Travels in the East, relates thr feat of an Arab mare, who died to save her master:-

"When I was at Jerusalem a feat of one of these steeds made a great noise. The Bedouin to whom the animal, a mare, belonged, being pursued by the governor's guards, rushed with her from the top of the hills that overlooked Jericho. The mare scoured at full gallop down an almost perpendicular declivity without stumbling, leaving the pursuers lost in admiration and astonishment. The poor animal, however, dropped down dead on entering Jericho, and the Bedouin, who would not quit her, was taken weeping over the body of his faithful companion. This mare," he continues, " has a brother in the desert who is so famous that the Arabs always know where he is what he is doing, and how he does."

Sir John Malcolm has two anecdotes to the same purpose, but of a more amusing nature.

"When the British envoy, returning from his former mission, was encamped near Bagdad, an Arab rode a bright bay mare, of extraordinary shape and beauty, before his tent, until he attracted his attention. On being asked if he would sell her-'What will you give me?' was the reply. 'That depends upon her age; I suppose she is five off?' 'Guess again,' said he. 'Four.' 'Look at her mouth,' said the Arab, with a smile. On examination she was found to be rising three. This, from her size and symmetry, greatly enhanced her value. The envoy said, 'I will give you fifty tomans' (a coin nearly of the value of a pound sterling. 'A little more, if you please,' said the fellow, apparently entertained. 'Eighty -a hundred.' He shook his head and smiled. The offer at last came to two hundred tomans. 'Well,' said the Arab, 'you need not tempt me further; it is of no use; you are a rich elchee (nobleman); you have fine horses, camels, and mules, and, I am told, you have loads of silver and gold. Now,' added he, 'you want my mare, but you shall not have her for all you have got." "*

"An Arab sheik, or chief, who lived within fifty miles of Bussorah, had a favourite breed of horses. He lost one of his best mares, and could not for a long while discover whether

- Sketches of Persia, vol. i. p. 49. 
she was stolen or had strayed. Some time after, a young man of a different tribe, who had long wished to marry his daughter, but had always been rejected by the sheik, obtained the damsel's consent and eloped with her. The sheik and his followers pursued, but the lover and mistress, mounted on one horse, made a wonderful march, and escaped. Upon this the old chief swore that the fellow was either mounted upon the devil, or the favourite mare he had lost. After his return he found the latter was the case ; that the lover was the thief of his mare, as well as of his daughter, and that he stole the one to enable him to carry off the other. 'The sheik was quite gratified to think he had not been beaten by a mare of another breed; and was easily reconciled to the young man, in order that he might recover the mare, about which he was more solicitous than about his daughter."*

Lieutenant Welstead relates an adventure in his Travels in Arabia which illustrates the importance of being well-mounted in that wild land:- " On my return from Obri to Suweit, contrary to the wish of the Bedouins, who had received intelligence that the Wahabees were lurking around, I left the village where we had halted, alone, with my gun, in search of game. Scarcely had I rode three miles from the walls, when suddenly turning an angle of the rocks, I found myself within a few yards of a group of about a dozen horsemen, who lay on the ground, basking listlessly in the sun. To turn my horse's head away was the work scarcely of an instant; but hardly had I done so, when the whole party were also in their saddles, in full cry after me. Several balls whizzed past my head, which Sayyid acknowledged by bounding forward like an antelope : he was accustomed to these matters, and their desire to possess him unharmed alone prevented my pursuers from bringing him dowr. As we approached the little town, I looked behind me; a sheik, better mounted than his followers, was in advance, his dress and long hair streaming behind him, while he poised his long spear on high, apparently in doubt whether he was sufficiently within range to pierce me. My good stars decided that he was not; for reining up his horse he rejonned his party, whilst I gained the walls in safety! The day before Sayyid came into my hands he had been presented to the Imaum by a Nedji sheik. Reared in domesticity, and accustomed to share the tent of some Arab family, he possessed, in an extraordinary degree, all the gentleness and docility, as well as the fleetness, which distinguish the pure breed of Arabia. To avoid the intense heat and rest their camels, the Bedouins frequently halted during my journey for an hour about midday. On these occasions Sayyid would remain perfectly still while I reposed on the sand, screened by the shadow of his body. My noon repast of dates he always looked for and shared. Whenever we halted, after unsaddling him and taking off his bridle with my own hands, he was permitted to roam about the encampment without control. At sunset he came for his corn at the sound of my voice; and during the night, without being fastened, he generally took up his

\footnotetext{
* Id. vol. i. p. $\mathbf{4 5}$.
}

quarters at a few yards from his master. During my coasting voyages along the shore, he always accompanied me; and even in a crazy open boat from Muscat to India My health having compelled me to return to England overland, I could not is consequence bring Sayyid with me. In parting with this attached and faithful creature, so long the companion of $\mathrm{my}$ perils and wanderings, I am not ashamed to acknowledge that I felt an emotion similar to what is experienced in being separated from a tried and valued friend."

M. de Chateaubriand, in his florid and poetic style, gives the subjoined apocryphal illustration of the affection of the Arab for his steed :-

"An Arab and his tribe had attacked in the desert the caravan from Damascus with complete success, and the Arabs were occupied in packing their booty, when the horsemen of the Pacha of Acre, who had come to meet the caravan, rushed suddenly on the victorious Arabs, of whom they killed a considerable number, and made the others prisoners; and, having tied them with cords, took them to Acre, as presents to the Pacha.

"Abon el Masseh, the hero of this story, had received a ball in his arm during the engagement, but as his wound was not mortal, the Turks had tied him upon a camel, taking his horse also with him.

"The evening of the day of their approach to Acre, the party encamped with their prisoners upon the Mountain of Safhadt. The legs of the wounded Arab were tied together by a leathern belt, and he was laid near the spot where the Turks slept. Kept awake during the night by the pain of his wound, he heard his horse neigh among others picketed round the tents, according to the Eastern custom. Recognising its voice, he could not resist the desire to go once more to the former companion of his life. He crawled with great diff. culty, with the help of his hands and knees, and reached his steed. 'My poor friend (addressing him), what canst thou do among these Turks? thou wilt be imprisoned under the roof of a khan, with the horses of an Aga or Pacha. The women and children will no longer bring thee camel's milk* or barley, or doura in their palms. Thou wilt no more course the desert like the wind from Egypt. No more wilt thou divide with thy chest the refreshing waves of Jordan. 0 that, if I remain a slave, I could reuder thee at least free! Let me try! There, go! return to our tents, tell my wife that Abon el Masseh returns to it no more, and lick the hands of my four children.'

"Thus speaking, Abon had gnawed with his teeth the goat's hair which had served to fasten the Arab horse, and the animal became free; but seeing his master parnacled and bound at his feet, the faithful and intelligent creature was taught by instinct what no language could have taught it. He bent his head, seized his master, and taking him up by his teeth by the leathern girdle round his body, set off in a gallop, and carried him to his tent. Arriving there, and

- See post. in "Horses of Africe" on this singular nutriment for the horre. 
throwing his master on the sand, at the feet of his wife and children, the horse expired from fatigue.

"The whole tribe wept his los $\tilde{3}$ - poets sang his merits, and bis name is constantly in the mouths of the Arabs who inhaioit the country ahout Jericho."

Of this interesting and wonderful account we can only say - "Si non è vero e ben trovato."

M. de Portes, another Frcnch writer, of a much earlier date than Chateaubriand, is much more prosaic and reliable. He tells us that although this nomadic people (the Arabs) possess the finest race of horses known to us, such a farrago of nonsense has been written, that it is difficult to clear the mists of uniruth, and separate the actual from the invented. Es tells us, that " the Arabian horses are commonly called Nedj." A more noble race is called Kohlan, divided into five different families, or noble sherifs, which five races, as the legend goes, originated from the five blessed mares of the prophet, and are named Tonaisse, Gilpha, Manegine, Seydie, and Seelani. Besides these, there are a number of other families too difficult to enumerate. I must own there are no certain signs by which one can ascertain whether a horse is Nedj or Kohlan, for I have conversed with many intelligent Arabs, and they all assured me they could not distinguish them unless the origin of the dam was known to them, and for that reason they kept their mares unstained by the leap of an inferior stallion, which is considered one of the principal sins of the Koran; and this command of their religion they at least follow to the very letter. If by chance the contrary should happen, the Bedouin does not value the foal the least, and, however handsome and promising it may be, he will part with it for a mere trifls If a Kohlan mare is stinted to a Nedj stallion, the foal is a Kohlan ; but if only to a Genesidek, the foal also is only Genesidek; and a foal only of a Nedj mare by a Kohlan stallion is Nedj, and for that reason you will meet amongst the latter, though an inferior race, many horses at least as handsome as the first, and even the Arabs cannot distinguish them without knowing the dam's race.

"The Arabs have no stud-book as is generally asserted, nor do they call together a number of witnesses when the covering act is performed, or when the foal is born: all this is false; for [ have often had opportunities to observe a leap in the night, where scarcely any and but casual witnesses were present. They choose the best horses among their own or a neighbouring tribe for a covering stallion, which travels about, as in Europe, and it is very difficult to purchase him, at least during the covering season-the horse serving three mares daily at about 5 s. (English currency) each, and travelling from tribe to tribe, sometimes to a great distance. They allow them to cover as early as two years old, and frequently the mares are not older. It happens, however, not unfrequently in this torrid climate that they are worthless at four or five years old Stallions, mares, and foals all graze together."

- This case, properly, only applies to the district of Jebel (the Hills), otherwire called Nejd, Nedj, or Nejed (the Highlsnds), the mountainous and centra! portion of Arabia.
The Arab generally rides without a bridle: a halter with a nose-band covered with iron like a cavesson, serves him for that purpose; and, instead of a saddle, these fiery coursere have merely a piece of wadded cloth, often ragged and always dirty, with itwo loops for stirrups attached on the back. They seldom have the hind-feet shod, an omission yet to be seen in some parts of Germany. The practice of firing is an oriental one: man and beast are subject to it, and complaints of th. most anomalous nature are subjected to the actual cautery.

In a work entitled Norse-buying in Syria, the writer of which went to Damascus via Beyrout, and thence to the borders of the Arabian Desert, for the purpose of purchasing remounts for our cavalry in the Crimea, we have an interesting account of the state of the Anaze horses and their owners at that time. M. de Portes, however, spcaks slightingly of them. He describes them as much inferior to the Nedji. The same writer states that the Arabs are indifferent about the formation and shape of their stallions: "if he runs well, is of the proper origin, and has no superstitious marks, they use him as such, and would put him without hesitation to their best mares; whereas, the most splendid stallion, if his origin is doubtful, and the marks ill-favoured, would not get the worst mare, I shall speak of their superstition-the Evil Eye -hereafter. In candour I must own, that though the stallions may possess great faults in their shape, they at the same time have extraordinary qualities, for as soon as they are mounted, all defects vanish: it would be almost impossible to detect any, so noble is their appearance. I saw many stallions with ugly hind quarters, the tail put on very low; but when mounted, they carry their tails erect, so that one doubted whether it was the same horse $\mathbf{A}$ few of the finest horses had much the appearance of English thorough-breds, but were much more active and pleasant to ride, when brokes in a little in the European fashion; for, raw from the Desert, not knowing bridle or spur, which latter is never used by the Arabs, they walk terrified on any pavement, and can only with difficulty be got into a trot, as they jump out of a walk into a full gallop, and stop as suddenly ; but being very docile, they are easily broken-in properly."

It has already been stated that the five principal races are said to originate from the five favourite mares of the Prophet, and these only deserve the name of Kohlan, and are mostly met with at Bagdad and Orfa. Those on the Euphrates are taller and stronger, but their muscles are not so finely developed. Some European judges prefer the Nedj to the Kohlan, as one often finds amongst them grander horses; but the Oriental prejudice always returns to the Kohlan, as their race is bred more in aud in, like our race-horses. It is difficult to say with any sort of certainty whether a horse is Nedj or Kohlan : the former havt somewhat of a Roman nose and high forehead: a true Kohlan, with a genuine certificate, has a nose drawn inwards, like a jact or pike, large eyes, wide nostrils, a broad front, and a beautiful head. One may buy without difficuity a stallion; but an Arat seldom parts with a mare, and, if pressed by necessity, they manage as follows. First, the price is agreed upon: the 
purchaser then begins to use the mare, and the first and second foal is delivered to the seller, who, if he likes, has the right to deliver in return one foal for the dam. These conditions often vary, for at times the owner will not sell above a fourth of the mare, which in the Arabian language is called purchasing "one foot."

We have alluded above to "superstitious marks ;" these vary with different tribes. The "Evil Eye" is as rife among the Arabs of the present day as with the Highlanders of two centurics or three centuries ago. In dread of this, many tribes are loth to show their horses-but more especially their mares-to strangers; and never omit to fortify the animal against it by a prayer to "Nashallah." If a horse falls ill after such a visit, they immediately call in a sort of wizard, who, uttering some cabalistical words, breaks an egg on the frontalbone of the patient, who, nevertheless, generally dies. The wizard then gravely says, "God ordained it so," or, "It was written so." But a French veterinary surgeon, uuder these circumstances, thought proper to administer a smart dose of physic, which saved his horse, whereas that attended by the Arab died in spite of the egg, the magical words, and the golden ring. Some of the prophecies of Mahomet are sheer nonsense, particularly those about colour: others coincide with observations of the present age. If Mahomet were inspired, our wives would do well never to permit their husbands to ride horses who carry the tail on one side, as they are sure to be soon repudiated; eind maidens ought to be in awe against bachelors on stallions with white spots on the thighs.

Burckhardt, the celebrated Asiatic traveller, says, in a letter to Professor Sewell-and this accords with the most recent travellers - that the "tribes richest in horses are those who dwell, during the spring of the year at least, in the fertile plains of Mesopotamia; for, notwithstanding all that is said of the desert horse, plenty of nutritious food is absolutely requisite for its reaching its full rigour and growth. The numerous tribes in the Red Sea, between Akaba and Necca, and as far as Yemen, have very few horses; but the Kurds and Bedouins in the East, and especially in Mesopotamia, possess more horses, and more valuable ones than all, the Arabian Bedouins; for the richness of their pastures easily nourishes the colts and fills their studs." These observations are very important, and evidently founded on truth. $\mathrm{He}$ adds, that "the number of horses in Arabia is not more than 50,000; a number far inferior to that found in any part of Europe or Asia on an equal extent of ground.

" During the Wahabce government, horses became scarcer every year among the Arabs. They were sold by their masters to foreign purchasers, who carried them to Yemen, Syria, and Bussora, which latter place supplies India with Arabian horses, because they were afraid of having them seized upon by their chiefs, it having become the custom, upon every slight pretext of disobedience or crime, to declare the nost valuable Bedouin mare forfeit to the public treasury.'

Such are the accounts handed down to us by respectable .uthorities, who in their turn received them from the Arabs themselves; but much allowance should be made for the prone ness to exaggeration for which all eastern nations are remarkable. especially the Arabians; and glorying, as they justly do, in the prowess of their beantiful steeds, it is not to be wondered at if they should sometimes enlarge upon their attributes and exploits.

The Imaum, or Sultan of Muscat, Syed Said, doubtless, during his long reign, from 1806 to 1856, sent to England the most genuine specimens of the Arab horse. His dominions, lying on the east of Nedjid, and south of the Persian Gulf, have, from their position, a more unadulterated Arab, pur sang, than the horse-dealing Anazes, Toorkmans, and the Syrian "copers," who are all interested in palming off their crossbreeds as Arabs. The monarch above mentioned, on more than one occasion, sent as royal presents to George IV., William IV., and her present Majesty, horses of surpassing beauty, according to the Arabian standard. One of these appears in our engraving of the "Barb and the Arabian," as a specimen of the contrasted qualities of the two races: the one the genuine North African horse-progenitor of some breeds of the Spanish, and many of our early racers-and the other the Oriental stock, to which also our turf owes deep obligations

It will be curious and interesting to the reader to peruse an accurate description of trro of these undoubted Arabs, written by a gentleman of unquestionable turf-experience; and to compare their points with those of an English race-horse, of which our frontispiece is a model:- "The first that was shown me was a black stallion, standing 14 hands i inches high, and branded ' $\mathrm{M}$ ' on the off-quarter. This horse is the more esteemed of the two, this colour in Arabs of the highest class being rarely or ever met with. Years, I was given to understand, were consumed in selecting the pair, and no limit put upon the price. Great as the difficulty has ever been to convey a just idea of the horse with the pencil, to put upon paper words to effect such a purpose is ten times a more hopeless affair. The first impression that the sight of this little unpretending animal made upon me was anything save in accordance with my anticipations as I entered his box. The issue was precisely such as we experience in contemplating a highly-finished picture; the more you gaze upon it, the more its beauties are developed. In this country we are by no means familiar with the Arab; many have not even seen one: I do not even think above a score have come within my own notice; but I must say, that if the portraits with which every sportsman is acquainted of the Darley and Godolphin Arabians be faithful delineations of the animals they profess to represent the whole model of the Arab horse, as I have seen it, differ, toto colo from them." Here I had before me one, selected by a Prince whose subjects have ever been celebrated for trafficking in the purest blood of the Desert: I could not doubt his claim to legitimacy. I have said his height is 14 hands 3 inches; his form so angular that at the first glance it seems

-We need hardly iterate that this proceeds upon the populsr assumption that those historical stallione were Arobo. They were both African horees. 
to defy all claim to symmetry. The whole character of shape and bearing is closely allied to that of the deer. When you come to a minuter examination of the parts, individually, then you are convinced how pure the fountain must have been whence such blood was obtained. The head of this horse can be likened to nothing but exquisitely chiselled marble; there is literally no flesh upon it; it is marble too to the touch. The eye is small, but clear to transparency; the cheek-bones are prominent; and there is a fixedness about the zars that helps you to think you are really looking upon the work of the sculptor. The jaws stand very far asunder; the nostrils are large and high; and the wind-pipe is of an extraordinary size. The neck is light, and set on similar to the deer's ; the shoulders more fleshy and epright than suits our taste; but below the knee the legs are perfection: you find quite as much bone as in the largest sized English blood-horse, and the tendons are in your grasp like iron. His carcase, without being very full of substance, is round and tolerably deep; his quarters what we express by vulgar. His thighs are very thin and sinewy, his loins narrow, the hocks perfectly clean, and slightly inverted; he is what we call 'cat-ham'd.' The tail is well set on, the dock small, the hair fine and scant, giving it the appearance of a mule's more than that of a horse. His shanks are short, and hard as adamant, the pasterns flexible, the hoofs singularly hard, but healthy, and the feet open and roomy. You read his temper in his eye; he is a light-hearted animal, without the slightest taint of rice."

The other stallion, a bright bay, is described aumost in the same words. "His head is less perfect, and his bone smaller, but his quarters are fuller and more softened down by the swell of the muscles. His back, which, like the other, is rather inclined to be hollow, is not more than eight or ten inches from hip to shoulder: I never saw a pony's so short. His beight is as near as possible the same as the black; in middle piece he has the advantage. They were both brought out for me, and I saw them in all their paces. In their action, as in their lean spare forms, you detect nothing superfluous: it is quiet and graceful, and entirely without any expression of exuberant exertion. Utility is the characteristic of the Arab horse. I can imagine them going for days together without fatigue: Nature intended them, and she has fitted them, for endurance. The impression of their extraordinary speed was long a vulgar error, which is now fast exploding. No Arab that ever trod the sand could live in company with an English race-horse, weight for inches, or after any fashion you will: with the size of a galloway you cannot have the stride essential to great velocity. Speed, regular and long sustained, no doubt they possess: the blight of degeneracy is yet unknown to the Desert-bred." A writer, who remarks upon the discrepancy here mentioned as to the Godolphin and Darley barbs, gravely suggests that these were "small Arabs;" the others, horses of "considerable size and power, whose immediate descendants becam6 racers;" which certainly leaves the matter just where it stood.

It is much to be regretted that at the death of William
IV., who, though himself no sportsman, lost no opportunity of promoting the national amusements of the turf and the chase, these beautiful specimens of the truo Arab should have been sold into the hands of foreigners. Mr. Christie Whyte, in his " History of the Turf," vol. ii., p. 389, thus notices the discreditable event.

"Nothing could exceed the general indignation of all parties throughout the kingdom, when it became publicly known that this noble appendage to royalty was to be broken up and sold off, for the benefit of foreigners. But, notwithstanding the remonstrances of members of both houses of the legislature, without distinction of political party, the sale was persevered in."

The following memorial on this subject was presented to her Majesty's government from the leading members of the Jockey Club.

"“We, the undersigned, have heard, with great concern, of the probability of a dissolution of the royal stud at Hampton Court. We think that the great and permanent attraction of the annual stud sale, by producing competition, enhances the value of thorough-bred horses, and thus promotes the improvement of the breed throughout the kingdom. We trust, therefore, that her Majesty's government may be induced to advise the Queen to retain the establishment; and we have the less scruples in expressing this hope, because we are persuaded that, under judicious management, the proceeds of the sale would be found, upon an average, to cover all the expense of maintaining the stud.

$\begin{array}{lll}\text { "Beaufort, } & \text { G. Anson, } & \text { G. Bentinck, } \\ \text { S. Batson, } & \text { Chesterfield, } & \text { H. Biggs, } \\ \text { Clarendon, } & \text { G. Byng, } & \text { Dorset, } \\ \text { C. C. Greville, } & \text { Richmond, } & \text { Wm. Hallett, } \\ \text { Suffield, } & \text { W. Powlett, } & \text { Tavistock, } \\ \text { G. Rush, } & \text { Uxbridge, } & \text { J. R. Udney, } \\ \text { Wilton, } & \text { H. S. Waddington, } & \text { Dorset, } \\ \text { Oxford, } & \text { C. Wilson." } & \end{array}$

The splendid stud was sold by Messrs. Tattersall, in the paddocks at Hampton Court, on Wednesday, the 25th of Cctober, 1837 ; and drew together an immense concourse, including many influential noblemen and gentlemen connected with the turf, agents from France, Germany, Russia, and Prussia, and an immense collection of trainers, breders, and others interested in the sale, or drawn thither by curiosity.

The general product of the sale was:-brood mares, 9,568 gs.; colt foals, 1,471 gs. ; filly foals, 1,109 gs. ; the stallions and two half-bred colts, 3,541 gs. ; total, 15,692 gs. Most of the lots were purchased by commission; Baron Maltzahn acting for the government of Prussia, and M. Lupin for that of France.

It would be irrelevant here to give the items of the sale. farther than the Arabians are in question:-

A Grey Arabian Mare of the purest caste; covered by the Colonel.

A Grey ditto of the purest caste, from the Imaum of Muscat; covered by the Colonel.
Guiness.

60

160 
A Grey ditto of the pareet caste, from the Imaum of Mlascat; covered by Actreon

Belvoirina, the dam of Elizabeth, Maria, \&c., by StamfordMercury-Herod, dec.; covered by the Black Arabian, horse untried .....

Brown Colt by the Colonel out of the first Arabian mare

A Chesnut Filly by Actron ont of the second Arabian mare, mare untried

A Bay Filly by the Colonel ont of the third Arabian mare, mare antried

The Black Arabian of the purest caste, from the Imaum of Muscat. The Bay Arabian of the purest caste, from the Imsam of Mnocat...

Of these the Black Arabian was bought for the king of Wurtemburg, and his stock have become celebrated in Germany. The others went to France and Prussia.

The following lines, supposed to be from the pen of Thomas Campbell, appeared in the Neu Monthly Magazine, suggested by a visit to Hampton Paddocks.

\section{THE ARABIAN. - S Sketch from Nature}

All bresthing things delight in the green world!

Behold in yon amall paddock a fair steed,

Arabian ohaped, sleok limbed, eyes that beam fire-

In action graceful as the ewimming owan-

The mould and model of his kind-as proud

And glorious a thing as eyes can see.

Fired, statue-like, he atands, like Parian stone,

Chiselled by art to the eimilitude

And attitude of life!-But greater bando

Than human hande have made him what he is-

The beautiful, the buogant thing, whose speed

Oould tire the obadows couroing o'er this ground;

A creature that we love, while to our will

Wa bend hie nature down, and teach him fear

-But he mut leave the field in which he fed,

And joyful run his own impulsive race.

Ses where the groom, with aiere thin epread with corn,

Presented oft oft вeen, as oft refused

(For the shy creature knows that the decoy

Corers the thralling rein, and more prefars

Ereedom uncurbed, and his own wanton play),

Comes now to anatch bim from his hasen of esse.

Ee stands a moment only, as if caught;

The coaxing groom believe his task is done,

And wonders where his freskishnes is fled.

Almost his hand he clutshed the dangiing mane-
Almost the rein is slipped upon his head,

When, ere an eye can turn, with playful prance,

Short, snuffing snort, snd instantaneous opring,

As if in mockery of the powers of man

A way he flies, swift so sn eagle ohoots

The ohrinking sir, and scours his prison bounds,

Till the air thunders as his frantic feet

Strike with atrong clatter on the hollow ground.

- Breathleas, but patient, still the dodging man

Follows the dodging besst, soothes the coy thing,

Calls him by name, whistles, and lastly, awears, -

"That first infirmity of noble grooms ;"

Now reddens with ferce rage, and now, once mora

Comes whispering wheedling words into his ear.

F 6 knows and hears him, and seems fairly won;

Too sure he has him, and too slow when sure-

He's gone again, straight as an srrow flies,

As hopeless to pursus. Down drop the sieve

And jingling rein; and now the asvage whip

With ahrilly threatanings thrillo along the air :

He heede it not, and stull his race he runs.

Now, tired of play, or else instinctive fesr,

Or more instinctive love, tames the wild thing,

And mskes him docile. He has had hio will

And now revigus the msstery to man;

For suddenly he turns in his mid flight.

And stando a prisoner, willing to be bound.

A writer in the Sportsman (vol. iii. p. 253) gives the follow ing summary of the divisions of Arabia and the character of their horses, which is, in the main, sufficiently accurate as a generalization :-

"Taking the comparative excellence of the different races, Nejed (between the desert of Syria and Yemen, and now in the possession of the Wahabees) is generally reckoned to produce the noblest, grandest horses; Hedjaz (extending along the Red Sea, from Mount Sinai to Yemen, and including in it Medina and Mecca) the handsomest; Yemen (on the coast of the Red Sea and the Indian Ocean, and the most fertile part of Arabia) the most durable; Syria the richest in colour; Mesopotamia the most quiet; Egypt the swiftest; Barbary the most prolific; and Persia and Koordistan the most warlike."

The Arab, in his influence on our thorough-bred stock, will receive due notice when we come to treat of the varieties of the English horse. 


\section{OHAPTER III.}

THE HORSES OF AFRICA.-1. THB BARB: 11. THE DONGOLA, NUBIAN AND ABYSSINIAN hORSE : III. THB RgYPTIAN hORSE: IV. THE HORSE OF THE CAPE OF GOOD HOPE.

THE HORSES OF AFRICA.

That this quarter of the globe possessed numerous distinct and original varieties of the horse, in form, size, and qualities is evident, despite the theory of a common origin for all breeds of that valuable quadruped-a theory which has led to such violent absurdities, in the endeavour to reconcile incongruous facts, and to force them into agreement with preconceived prejudices.

We have already shown that Media, Persia, and Assyria were not countries of the subjugated horse at a period long posterior to what is called the historic era; and that these countries manifestly derived the horses which multiplied therein in subsequent ages not from the South (or Arabia), but from the great "officina equorum," on the north. So also did the people of Northern Syria derive the horses with which they encountered Joshua from the same source: for there were then no horses in Southern Syria. Asia Minor, from the earliest times, was a country of horses, derived from the North and East; but Egypt, it is proved by all history, sacred and profane, derived its horses from the vast continent of which it forms a part, and not from a tract on which the horse did not exist in the first ages. "We may rather believe," says Professor Low, " that Egypt derived the horses she so early possessed from regions in which horses existed from the earliest times, and which we have as much reason to consider indigenous to Africa, as those which people the plains of Tartary are to Asia." To our minds this disposes of the claims of the Arabian, and transfers to the Barb, or true African horse, the patriarchal honours, as regards our own incomparable English breed, so long usurped by the Ishmaelitic parvenu. It appears to be the old case of an Americus Vesputius supplanting a Christopher Columbus. We need not resort to Scripture to show that the "Howden" or "Horncastle" of the Israelites and Egyptians was on the banks of the Nile, and that " the Ethiopians were a huge host with very many chariots and horsemen." The horse that drew their chariots yet exists in Abyssinia, Dongola, and Darfour, which possess a larger and a coarser horse than the finer breed of Arabia; while in various parts of North and Eastern Africa are breeds easily distinguishable from the Asiatic horse. Even at this day, deep in the interior, Major Denham tells us, " at Mandura a beautiful and powerful breed of horses is found;" and Mr. Tully further tells us "the horses of Bornou are excellent; they unite all the valuable properties of the Barb and the Arabian."

- 8 Ohron. chap. xri., r. 8
We will, however, quit general considerations, and confine ourselves to the leading specialties of the African breeds.

$$
\text { I. -THE BARB. }
$$

The country known as Barbary may be considered, for the purpose of the present enquiry, as comprising all North Africa, from Egypt westward along the coast of the Mediterranean; Tripoli, Tunis, Algeria, and Morocco, falling within its boundaries, which reach southward to the Sahara or Great Desert. Here was found that original breed known as the Barb, to which this island owes the early improvement of its coarse unwieldy horse, which we had derived, possibly, through the European continent from Central or Northern Asia-though we must confess we can see no solid reason against, but much strong presumption in favour, of an indigenous British horse.*

For the North African horse too may be claimed an improv. ing cross, which produced the handsomer breeds of Spain, still bearing the traces, in the Andalusian "barbs," and "jennets," of their Moorish original; while in yet earlier times, when Egypt was the granary of the Mediterranean countries, and Carthage held her head high against Rome, Africa gave "blood" to the horses of Thessaly, Italy, and the Northern shores of that inland sea.

In the historic period of English racing, the Barb ngures largely as the ancestor of our thorough-breds. The Godolphin Barb, (popularly and erroneously called the Godolphin " Ara. bian") was the origin of much of our best racing blood, while several of our greatest modern "flyers" trace their descent from the "African mares" imported by Charles II. This subject is treated in extenso in the Supplement on Horse Racing. The following are given by Berenger as the characteristic "points" of the Barb of Morocco, $\mathrm{Fez}$, and the interior of Tripoli.

"It seldom exceeds fourteen hands and a half in height. Its countenance is indicative of its spirit, and the facial line, in direct contradistinction to that of the Arabian, is often rounded : the eyes are prominent; the ears, though frequently small and pointed, are occasionally rather long and drooping; the crest is generally fine, but prominent, and not overladen with mane. The neck is of a good length; the shoulders flat and oblique; the withers prominent, and the chest almost invariably deep; the back is moderately curved and the carcase somewhat round; the arms and thighs are muscular and strongly marked; the knee and hock are broad and low-placed; the back-sinews singularly distinct and well-marked from the 
knee downwards; the pasterns rather long, the feet firm, and but moderately open at the bars. The croup, as compared with the Arab, is perhaps a little too long," but the quarters are muscular and well-developed.

The Barb is mounted at two years old, but never castrated, for "a Mussulman would not mutilate or sell the skin of the beast of the Prophet." The horses, with the Moors and Kabyles, are used for the saddle, and the mares kept for breeding. While no Arab mounts a stallion on his excursions, their descendants in Africa, and the Moors, never ride mares. The reason of this is, that the Arabs, constantly at war and plundering, endeavour to surprise their enemies in the grey of the morning or at the dawn of day. A stallion no sooner smells the stale of the mare in the enemies' quarters than he begins to neigh, which would, of course, give the alarm to the party to be surprised. This cannot happen when riding mares only. The African Arab, on the contrary, trusts to superior force. He fights in an open plain country, where an enemy can be discovered at many miles' distance: such stratagem is therefore useless to them. The Moorish method of cavalry exercise, and the training of their chargers, greatly consists in gallopping at the top of speed for a mile or more, then suddenly stopping while the rider hurls his lance, fires his musket, or goes through some other feat of assault or defence. By way of exercise, however, the lance is launched or the espingarda fired when at full gallop. The best-trained Barbary horses will stand still for hours when quitted by their riders. The usual food of the Barb is barley or chopped straw, and grass when to be found; hay as a winter feed, in our acceptation of the term, is unknown to him. The Barb requires more excitement to call out his powers than the Arabian, but when sufficiently stimulated his speed and endurance are equal, while the superior strength of loin and forehand makes him master of the greater weight of the two.

It would be unpardonable here to pass over the Godolphin Barb, whose blood ran through Cade-Matchem-ConductorTrumpator-Sorcerer-Doctor Syntax; through Eclipse, and a line of winners, by Bay Middleton to the Flying Dutchman; through Hambletonian, Highflyer, to his great opponent and Voltigeur; while Nutwith, West Australian, Sir Tatton Sykes, Tomboy, Melbourne, Surplice, Chanticleer, and a host of first class animals, trace their "blood" to this glorious Barb.

The Godolphin Barb, (whose figure accompanies the Royal Arab on Plate IV.) was sent, together with eight other horses, as a present from the Bey of Tunis to Louis XV. of France, on the conclusion of a treaty of commerce with that potentate by the Viscount de Manty, Admiral of the French fleet.

The Godolphin Barb was of a brown bay cosour, with some white on the off heel behind. He was supposed to have been foaled in 1724, but this is conjectural. He was above the stature of the Arab, standing 15 hands. So slight was

- This is a defect, if it be ona which is shared with the Barb by all our very best horses. the value set upon him in France, where his points were by no means understood, that he was degraded to the dradgery of drawing a wood-cart in Paris. There is a tradition that he was sold from the royal stables for ungovernable temper. He was brought to England by Mr. Coke, who presented him to Mr. Roger Williams, then proprietor of the St. James's Coffee House, near Charing Cross. As the most celebrated horses of modern times partake of his blood and that of the Darley "Arabian,"-a crossed Toorkman horse from Aleppowe shall have further occasion to refer to him in this respect. By Mr. Williams he was presented to Lord Godolphin, in whose possession, at Hog-Magog, in Cambridgeshire, he remained as a private stallion until his death.

In 1731, Hobgoblin, a then celebrated stallion, refusing to cover Roxana, she was sent to the Godolphin Barb, and from that leap came the celebrated Lath, the first horse from the socalled "Arabian."

Lath was one of the very best racers of his day, and superior to any horse preceding him except Flying Childers. The Godolphin Barb was sire to 38 colts and 20 fillies between 1732 and 1753, Lath being the first and Mr. Panton's Matchless the last of his stock.

The Godolphin Barb died at Hog-Magog, Cambridgeshire, in December, 1753, being supposed to be then in the 29 th year of his age. He lies buried in a covered passage, leading to the stables, with a flat stone over him without inscription. At his interment there was a gathering, and a gift of cakes and ale, as afterwards at that of his celebrated descendant Eclipse. There is an original portrait of this remarkable horse, by Seymour, in the collection of the Marquis of Cholmondeley, at Houghton Hall, Norfolk, and another picture of him with his favourite cat, in the Library at Gog-Magog, Cambridgeshire. He is represented in the prints of the day with his attendaut cat, between whom and himself a warm attachment for many years subsisted. So great indeed was it, on the part of poor puss, that we have it upon the best authority the cat pined away, refused its food, and died of grief at the loss of its companion. Mr. Holcroft, the celebrated dramatic writer, who in early youth was a Newmarket stable-lad, relates a similar mutuality of affection between a race-horse and a cat, which the horse would place on his back or in the manger, by taking her in his mouth without hurting her.

The crest of the Godolphin, preternaturally prominent, distinguishes him from every other horse. The Duke of Portland, however, had a Barb but little less lofty in this respect. It will be seen too, from the plate, which is a copy of his portrait, that his withers, from their almost humpish rise, give the effect of a sudden fall in the back, while there is a corresponding elevation of the spine towards the loins. Eclipse, with a straighter back, shared this peculiarity, almost to deformity. The Godolphin's muzzle was uncommonly fine, his head beautifully set on, his shoulders deep and oblique, his loins wide, and his quarters symmetrically powerful and well let down. The greater proportion of both colts and fillies from this celebrated horse were bay, like himself. His descendante. 


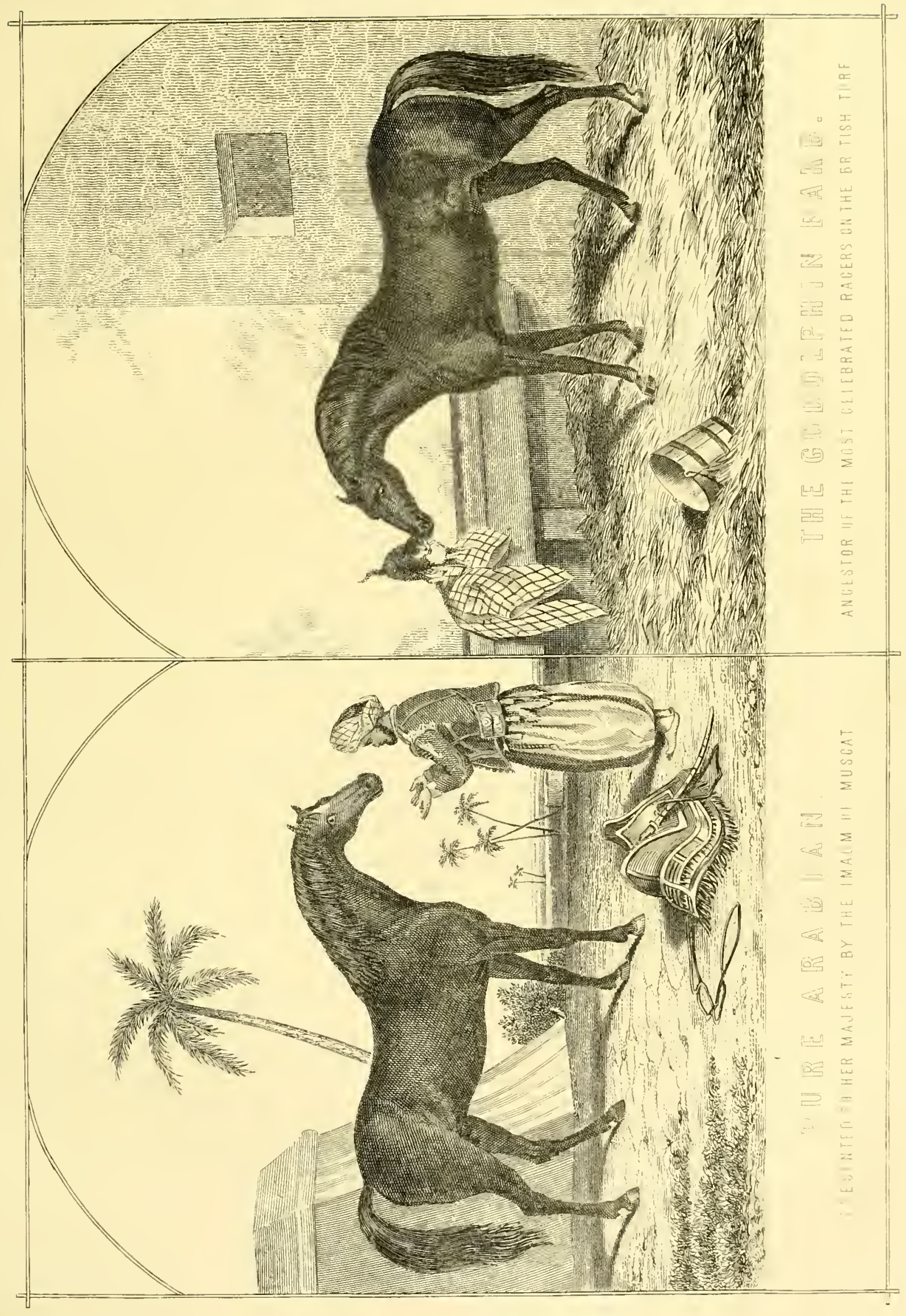



by orossing, have been of every colour. The Wellesley "Arabian" is neither Barb nor Arabian, but most probably a cross of Barb and Toorkman. "This horse," says Mr. Youatt, "has been erroneously selected as the pattern of a superior Arabian." The same remark will apply here as to the Darley Arabian. (See ante, p. 24.)*

The rullest and most interesting account of the Barb of modern Algeria has been written by General Daumas, and its value is greatly enhanced by containing a letter on the subject, written entirely by the celebrated Abd-el-Kader, and a very remarkable document it is. According to this high authority, a perfectly sound Barb horse can, without difficulty, travel nearly thirty miles daily for three or four months, without resting a single day; and such a horse can accomplish fifty parasangs-not less than two hundred miles-in one day. When Abd-el-Kader was with his tribe at Melonia, they made razsias in the Djeb-el-amur, pushing their horses at a gallop for five or six hours without drawing bridle, and they accomplished their expeditions in from twenty to twenty-five days. During all this time their horses ate only the corn carried by their riders, amounting to about eight ordinary meals. They often drank nothing for one or two days; and on one occasion were three days without water. The Arabic language is very epigrammatic, and the Arabs assign the

- Long aince the sbove views were formed and committed to prese by the writer, he had the gratification of finding them confirmed by the high authority of Admiral Rous, in a series of papers in Baily's Magazine of Sports and Pastimes, Nos. 1, 2, et seq., for March, April, and following months of 1860. The Admiral, though still adopting the looseness of epithet, which made our forefathers apply the term "Arabian" to almost all horses from the East or South, thus bears testimony to the deep obligstion we owe to that breed :-

"The Stud Book contains no horee's name which cannot prove e pure descent from Barbs, Arabians, Turkieh, or Persian stallions, and from Barb, Arabian, or Royal mares.

"With respect to Turkssh blood, I have no doubt that our pstriarche of this denomination, such ss Helmsley Turk, Byerley Turk, Place's White Turk, D'Areey's White Turk, the Selaby Turk, and others, were Arabian horses bought in Constantinople or Hungary, either captured in war or purchased from Turkish pechss.

"The Barbary atallions were very numerous and very successful, especially the Dodeworth, Ourwen and Bay Barb, Greyhound, the Compton Barb, the Thoulouse Berb; but the most prominent forefathers of the turf are the Darley Arshisn (?), eire of Flying Childers, end the Godolphin Arabian (Barb), whose blood hse been transmitted to every first clsss horse now in training. I can discover no Persian stallions on the register; but Bonny Blsck, the best mare of her day for a long distance in 1719, (whose owner, the Duke of Rutland, challenged sill the world to run sirteen miles for $£ 1000$ ), was by Black Hearty, a son of the Byerley Turk, out of a mare by a Peraian stallion.

"A great difference of opinion existe respecting the pedigrees of the Roysl mares. Some were purchesed in Hungary in the reign of Charles II. ; but $I$ have no doubt that a great majority of the Royal mares were imported from Moroceo when Tangiers was under the British flag, and that the superior Barbs were brought by the Saracens in the sirth century from Arabia, when they conquered northern Africa, and that they sre of the purest breed of the Desert."

In the last sentence the gallant Admiral, haring started from the false premise that the Arabian Deserts were well supplied with horses in the sixth century, has procoeded, as must needs follow, to an utterly false deduction. The historical slip is renial. Admirsl Roue's acumen perceived how much these snimals differed from the Arsb type, bat the popular traditional and accustomed phrase lod him to overlook the true African origin of the race. reasons for instructing their horses early, in these proverbs:"The lessons of infancy are graven in stone; but those of age disappear like the nests of birds." "The young branch without difficulty straightens itself; the large tree never." Accordingly the instruction of the horse begins in the first ycar. "If," says the Emir, "the horse is not mounted before the third year, at the best he will only be good for the course; but that he has no need of learning-it is his natural faculty."

The Arabs thus express the idea :- "Le djuad suivant sa race." ("The high-bred horse has no need of learning to run.")

The esteem of the Arab for his horse is conreyed in the following sentiment of the sage and saint, Ben-el-Abbas, which has been handed down from generation to generation:- "Love thy horses; take care of them; spare thyself no trouble: by them comes honour, and by them is obtained beauty. If horses are abandoned by others, I take them into my family; my children share with them their bread; my wives cover them with their veils, and wrap themselves in their housings; I daily take them to the field of adventure; and, carried away by their impetuous course, I can fight with the most valiant."

General Daumas thus describes a combat between two tribes, drawn from life, for he enjoyed many opportunities for witnessing such scenes:- "The horsemen of the two tribes are in front, the women in the rear, ready to excite the combatants by their crics and applause: they are protected by the infantry, who also form the reserve. The battle is commenced by little bands of ten or fifteen horsemen, who hover on the flanks and seek to turn the enemy. The chiefs, at the head of a compact body, form the centre

"Presently the scene becomes warm and animated-the young cavaliers, the bravest and best mounted, dash forward to the front, carried away by their ardour and thirst for blood. They uncover their heads, sing their war-songs, and excite to the fight by these cries, "Where are those who have mistresses? It is under their eyes that the warriors fight to-day. Where are those who by their chiefs always boast of their valour? Now let their tongues speak loud, and not in those babblings. Where are those who run after reputation? Forward! forward ! children of powder ! Behold these sons of Jewsour sabres shall drink their blood-their goods we will give to our wives!' These cries inflame the horsemen-they make their steeds bound, and unsling their guns-every face demands blood-they mingle in the fray, and sabre cuts are everywhere exchanged.

"However, one party has the worst of it, and begins to fall back on the camels which carry the women. Then are he on both sides the women-on the one animating the conquerors by their cries of joy-on the other, seeking to stimulate the failing courage of their husbands and brothers by their screams of anger and imprecation. Under these reproaches the ardour of the ranquished returns, and they make a vigorous effort. Supported by the fire of the infantry who are in reserve, they recover their ground, and throw back their enemy into the midst of the women, who in their turn curse those whom just before they had applauded. The battle returns to the ground 
which lies between the females of their tribes. At last the party who have suffered most in men and horses, who have sustained the greatest loss, and have seen their bravest chiefs fall, take flight, in spite of the exhortations and prayers of those bold men who, trying to rally them, fly right and left, and try to recover their victory. Some warriors still hold ground, but the general rout sweeps them off. They are soon followed by their women-then each seeing that all is lost, occupies bimself in saving that which is dearest; they gain as much ground as possible in their flight, turning from time to time to face the pursuing enemy. The conquerors might ruin them corupletely if the intoxication of their triumph did not build a bridge of gold for the vanquished, for the thirst of pillage disbsnds them. One despoils a foot-soldier-another a horseman. This one seizes a horse-that a negro. Thanks to this disurder the bravest of the tribe save their wives, and frequently their tents."

A touching incident is mentioned by Mungo Park as having occurred whilst he, friendless and forlorn, was pursuing his weary journeyings far in the interior of Africa. The simple narrative tells its own tale of accumulated misery:- "July 29th. Early in the morning my host, observing that I was sickly, hurried me away, sending a servant with me as a guide to Kea. But though I was little able to walk, my horse was still less able to carry me, and about six miles to the east of Modiboo, in crossing some rough clayey ground, he fell; and the united strength of the guide and myself could not place him acain upon his legs. I sat down for some time beside this worn-out associate of my adventures; but finding him still unable to rise, I took off the saddle and bridle, and placed a quantity of grass before him. I surveyed the poor animal as be las panting on the ground, with sympathetic emotion, for I could not suppress the sad apprehension that I should myself in a short time lie down and perish in the same manner of tatigue and hunger. With this foreboding I left my poor horse, and with great reluctance I followed my guide on foot along the bank of the river until about noon, when we reached Kea, which I found to be nothing more than a small fishing rillage."

Torn with doubt and perplexity, heavy of heart and weary in body, the unhappy traveller returned westward to Modiboo, after two days' journeying in company with a neg currying his horse accoutrements. "Thus conversing," says be, "we travelled in the most friendly manner, until unfortunately we perceived the footsteps of a lion quite fresh in the mud near the river side. Iy companion now proceeded with great circumspection, and at last, coming to some thick underwood, he insisted that I should walk before him. I endeavoured to excuse myself by alleging that I did not know the road, but he obstinately persisted; and after a few high words and menacing look, threw down the saddle, and went away. This very much disconcerted me, for as I nad given up all hopes of obtaining a horse, I could not th:nk of encumbering myself with a saddle; and taking off the stirrups and girths, I threw the saddle into the river. The Negro no sooner saw me throw the saddle into the water, than he came running from among the bushes where he had concealed himself, jumped into the nver, and by help of his spear brought out the saddle, and ran away with it. I contin:ed my course along the bank, but as the wood was remarkably thick, and I had reason to believe that a lion was at no great distance, I became much alarmed, and took a long circuit through the bushes to aroid him. About four in the afternoon I reached Modiboo, where I found my saddle; the guide, who had got there before me, being afraid that I should inform the king of his conduct, had brought the saddle with him in a canoe. While I was conversing with the dooty, and remonstrating with the guide for having left me in such a situation, I heard a horse neigh in one of the huts, and the dooty inquired with a smile if I knew who was speaking to me. He explained himself by telling me that my horse was still alive, and somewhat recovered from his fatigue." The happiness with which Park met his lost and faithful Barb mas be conceived, for in him he had one friend left in the world.

Another of our many victims to African travel thus touchingly laments a grievous misfortune which befel him. Returning from an excursion to Kouka, Major Denham writes:-“ I was not at all prepared for the news which was to reach me on returning toour enclosure. The horse that had carried me from Tripoli to Mourzuk and back again, and on which I had ridden the whole journey from Tripoli to Bornou, had died a very few hours after my departure for the lake. There are situations in a man's life in which losses of this nature are felt most keenly, and this was one of them. It was not grief, but it was something very nearly approaching to it; and though I felt ashamed of the degree of derangement which I suffered from it, yet it was several days before I could get over the loss. Let it, however, be remembered, that the poor animal had been my support and comfort-may I not say, companion? -through many a dreary day and night,-had endured both hunger and thirst in my service with the utmost patience,so docile, that he would stand still for hours in the desert while I slept between his legs, his body affording me the only shelter that could be obtained from the powerful influence of a noonday sun: he was the fleetest of the fleet, and ever fnremost in the race."

There are few who have not seen Stubbs's worlu-famed picture of the "Horse frightened by the Lion," which all sorts of describers-scorning even to reflect for a moment on the actual locale of the adventure-have spoken of as "an Arab ;" nay, his " crest" has been charged with exaggeration, and one of the great points of exactitude and truthfulness treated as extravagant. In an obituary notice of Stubbs, who died in 1808, I find the following:- "Having remained in Italy the time necessary for his improvement, Mr. Stubbs embarked for England; and during his passage he became acquainted with a gentleman, a native of Africa, whose taste and pursuits in life were similar to his own. This gentleman had been to Rome, and was returning to his family; he was liberally educated, and spoke the English language with accuracy. His information made him s delightfal companion to Stubbs, who often 
expressed how much it would add to his gratification if he could but behold the lion in its wild state, or any other wild beast. His friend, on one occasion, gave him an invitation to the paternal mansion he was about to visit. The offer was accepted with pleasure, and Stubbs landed with his friend at the fortress of Ceuta." They had not been on shore many days when a circumstazce occurred most favourable to the wishes of our pantel. The town where his friend resided was surrounded by a lufty wall and a moat. Nearly level with the wall a capacious platform extended, on which the inhabitants occasionally refreshed themselves with the breeze after sunset. One evening, while Stubbs and his friend were viewing the delightful scenery, and a thousand beautiful objects, from this elevation, which the brilliancy of the moon rendered more interesting, a lion was observed at some distance, directing his way, with a slow pace, towards a white Barbary horse, which was grazing not more than two hundred yards distant from the moat. Mr. Stubbs was reminded of the gratification he had so often wished for. The orb of night was perfectly clear, and the borizon serene. The lion did not make towards the horse by a regular approach, but performed many curvatures, still drawing nearer towards the devoted animal, till the lion, by the shelter of a rocky situation, came suddenly upon his prey. The affrighted Barb beheld his enemy, and, as if conscious of his fate, threw himself into an attitude highly interesting to the painter. The noble creature then appeared fascinated, and the lion, finding him within his power, sprang in a moment, like a cat, on the back of the defenceless horse, threw him down, and instantly tore out his bowels."

On his return to England, Mr. Stubbs becane exceedingly attentive to his profession, and met with great patronage, and to him we are indebted for the portraits of many of the most celebrated race-horses of his day. His anatomy of the horse was held in the highest estimation, both in this country and abroad; and his sporting pictures yet retain their places in the galleries of our nobility and gentry.

We may here note, incidentally, that the celebrated "White Arr.bian," the favourite charger of Napoleon Bonaparte, which was kept for many years in the Jardin des Plantes-of which many portraits are extant-betrayed all the chicf characteristics of the Barb. He came from Egypt, we know, wherever bred; but his broad open heels, round barrel, and low set-on of the dock, as extant in pictures by Isabey, the elder Vernet, and others, are against his Arabian origin.

Among the Maugrabins of the West, on the skirt of the Sahara Desert, is a renowned breed of Barbs, known as the Shrulzt-ur-reech, or "Drinkers of the wind." They are lean as greyhounds-a mere bag of bones-but their spirit and ondurance of fatigue are prodigious. On one occasion the chief of a tribe was robbed of a favourite fleet animal of this race, and the camp went out in pursuit eight hours after the

- A fortress on the coast of Africa, situated on a peninsula eastward of Tangier, and opposite to Gibraitar, belonging to Spain, who, in 1860, has extended her territories, efter a short war with the Moors, and at present holds Tetuan theft. At night, though the horse was not yet recovered, it was ascortained that the pursuers had headed his track, and would secure him before morning. The messenger whu returned with this intelligence had ridden sixty miles in the withering heat of the desert without drawing bit. These animals are stated by Mr. Davidson to be fed only once in three days, when they receive a large jar of camel's milk; this. with an occasional handful of dates, is their only food.

These animals, we are told by Jackson, are principally employed in hunting the antelope and the ostrich. This author says nothing about the dates, but informs us that be will eat nothing but barley or wheat; oats are unknown to the African horse. The account is yet further embellished by the statement that if he is taken from the Desert, and can no longer get a supply of his favourite camel's milk, he loses speed and wind, and perishes miserably. Credat Judous! Yet farther in Central Africa, we are told by Mr. Tully (History of Tripoli), is a grand breed, of noble stature, uniting the qualities of the Barb and the Arabian with superior height.

\section{1.-THB DONgOla, NUBIAN, AND ABYsSinlaN hORSB.}

Travellers in Dongola, Sennaar, Nubia, Abyssinia, Darfour, and the north-eastern countries of the African continent, agree in the existence of an indigenous horse of superior stature and coarser form than either the Barb or Arab. The degenerate Egyptian horse is probably a descendant of this race, which very possibly may have fiuced in the heavier chariots of the Pharoans. Bruce, in his Travels in Abyssinia, bears testimony to their stature and their distiuctuess from the horse of Tripoli, Tunis, Algeria, and Morocco. He says-" What figure the Nubian breed of horses would make in point of swiftness is very doubtful, their form being so entirely different from that of the Arabian; but if beautiful and symmetrical parts, great size and strength, the most agile, nervous, and elastic morements, great endurance of fatigue, docility of temper, and, beyond any other domestic animal, seemiug attachment to man, can promise anything for a stallion, the Nubian is, abore all comparison, the most eligible in the world. Few of them stand less than sixteen hands high."

Ludolph, who travelled in Abyssinia in the 17th century, bears the like testimony. He say's that "the horses of this country (Ethiopia) are powerful and active, spirited and mettlesome, and most of them of a black colour. They are used only in war and for hunting. They are not fatigued by travelling long journeys, for the labour of drawing loads and of carrying burdens devolves upon the mules." A native of Abyssinia, who accompanied Ludolph to Europe, was both astonished and pained when he saw, for the first time, a borse in a heavy cart, and loudly expressed his disgust at the cruelty of degrading so noble an animal to so base a drudgery He was surprised that the animals should submit to it, saying that in his country they would rebel against such cruel tyranny, and rend those who endeavoured so to ill-use them.

Bosman, another intelligent, and more modern traveller, expresses his admiration of the horse of these regions:- "The 
Dongola horses are the most perfect in the world, being beauiful, symmetrical in their parts, nervous in their movements, and docile and affectionate in their manners. One of these horses was sold in 1816, at Grand Cairo, for a sum equivalent to one thousand pounds." He further describes them as usually black, though there are a few bright bays and sorrels.

Some of these animals, which were at that time brought northwards by way of the Nile valley to Cairo, were seen by Europeans travelling in that country. They are agreed upon their noble appearance and fine lofty action, their elevated crest and high withers; but there is a deficiency of substance in the quarters, and an undue length below the hock -sure indications of a lack of stoutness and of sustained speed. Nevertheless, as modern intercommunication with these once mysterious countries is now comparatively facile, some attention to the horse of Dongola might repay the trouble. That he has many of the requisites of a grand horse for show or state purposes, and perhaps for a charger, seems probable. The reason why his endurance is not tried more severely in his native land is, perhaps, that they have not the art of shoeing. Ludolph says, when they come on stony ground they dismount and get upon mules, leading their horses, that so, having no burden to bear, they may tread the more lightly."

Mr. Salt, for many years English Consul in Egypt, and one of the most diligent collectors of antiquities in that ancient land, made a journey towards the sources of the Nile. He also describes these horses as of noble stature and action, their accoutrements as good, and the natives as first-rate horsemen.

\section{I11.-THE EGYPTIAN HORSE.}

We need not here repeat that Egypt was of old the source of the supply of horses to the countries immediately adjacent. Foremost in arts and arms, her chariots $\uparrow$ were renowned five centuries before Herodotus wrote of the royal haras of Babylon, and its 1,400 horses, which were undoubtedly derived from the northern breeds. The modern Egyptian horse, like the modern Egyptian himself, has wretchedly degenerated. The cruel tyranny of their oppressors and conquerors, Arab and Turkish, led the wretched tillers of the soil to avoid as a danger the possession of a handsome horse, suited for war purposes, inasmuch as the least evil that might befal him might be its seizure by the Mamelukes or by the Turkish ruler of the district. We are further told by travellers, that so strongly did this fear operate on the mind of the wretched fellah, that it became a custom to disfigure and mutilate the horses used by them, lest they should be robbed of them by the Pasha or his followers. The effect of this system in "the land of the horse," is borne testimony to by General Sir Robert Wilson, who tells us, in his relation of the expedition to Egypt under Sir Ralph Abercrombie, that the body-guard of the Pacha were so miserably mounted, that " although their horses

* Berenger' Horsemanship, vol i.

+ There is not more than a single representation of a mounted man in the Egyptian frescoes and relievi. There are warriors in chariots innumersble. seldom pass out of a walk into a gallop for more than a hundred yards or so, most of them are foundered; and none, if quickly trotted for ten miles, would be able from want of wind and stamina to go farther."

Since Sir Robert wrote, however, a new era has da whed in Egypt. Mehemet Ali, seeing the importance of a judicious liberality in encouraging the improvement of the horse, not only imported many Barbs and Toorkman horses, but in 1828 established a veterinary school at Abou-Zabel, of which an interesting account will be found in The Veterinarian, (vol rii, p. 549, 1834,) and subsequent numbers. A haras, or breeding establishment, was also founded, both under the care of French veterinary surgeons. An anecdote of an exploit of an Arab robber in Egypt, from "the Adventures of Gioranni Finati," shall close this brief account of the Egyptian horse.

"While some of the Mamelukes were encamped about Minieh, a thief set his mind on carrying off the horse and robe of one of their Beys. With this intent, at dead of night, he contrived to slip unperceived into the tent, where, as it was winter time, embers were burning, which showed him the rich clothes of the Bey lying close at hand. The thief, as he squatted down by the fire, drew them softly to him, and put them all on; and then, after filling a pipe and lighting it, went deliberately to the tent door and tapping a groom, who was sleeping near, with the pipe end, made a sign to him for the horse, which stood picketted in front. It was brought; he mounted and rode off. On the morrow, when the clothes of the Bey could no where be found, none could form a conjecture as to what could become of them, until the groom, on being questioned, maintained to his fellow servants that their master was not yet returned from his ride! and told them how he had suddenly called for his horse in the night, which at last seemed to give some clue to what really happened Upon this the Bey, anxious to recover his horse, as well as curious to ascertain the particulars, ordered it to be published abroad, that if the person who robbed him would, within two days, bring back what he had taken, he should not only be freely pardoned, but should receive also the full value of the animal and of the suit of clothes.

"Relying on the good faith of this promise, and possibly, too, not a little vain of his exploit, the Arab presented himself, and brought his booty ; and the Bey also, on his part, punctually kept his word; but since, besides the loss, there was something in the transaction that placed the Bey in rather a ludicrous light, it went hard with him to let the rogue depart so freely, and he seemed to be considering mbat he should do; so that, to gain time, he was continually asking over and over again fresh and more circumstantial accounts of the manner in which the stratagem had been conducted: the other was too crafty not to perceive that no good might be preparing for him, and began to feel anxious to get safe out of the scrape. He showed no impatience, however, but entered minutely into every detail, accompanying the whole with a great deal of corresponding action; at one time sitting down 
by the fire, and making believe as though he were slyly drawing on the different articles of dress, so as to throw the Bey himself, and all who saw and heard him, into fits of laughter. When he came at last to what concerned the horse, 'It was,' he said, 'brought to me, and I leaped upon his back;' and so in effect flinging himself again into the saddle, and spurring the flanks sharply with the stirrup-irons, he rode off with all the money that he had received for the animal in his pocket, and had got much too far, during the first moments of surprise, for any of the bullets to take effect that were fired at him in his flight, and nothing further was ever heard of him or the horse."

The country to the south of the great Sahara, we find a kindred race to the Barb among the Foulahs, Jaloffs, Dahomans, Ashantees, and inhabitants of Benin. As we approach the torrid zone, however, the horse much deteriorates; and although we are told by authorities that the single nation of Foulahs can muster sixteen thousand eavalry, the horses are undersized. Bosman, in his account of the Coast of Guinea, says, "they are ill-shaped, and that they hang the ear and head like the ass, that they are slow and obstinate, and so low that a tall man sitting on their backs can touch the ground with his feet." At Elmina, on the Slave-coast, he bought half a dozen of these, but they were of little use in his inland journey. In these wretched and savage regions, desolated by the ferocious passions engeudered by the slave-traffic, man and the useful animals are equally debased and degenerate. It is, however, certain that tropical heat and the lack of wholesome grasses are barriers to the due developement of the horse, and that in temperate climes alone does he combine grandeur of stature with beauty of form, courage, spirit, and endurance

$$
\text { 1V.-THE HORSE OF THE CAPE OF GOOD HOPE. }
$$

The original horse of South Africa would appear to have been a hardy, undersized, strong animal, presenting few qualities beyond endurance and slow strength.

Montgomery Martin, in that part of his history of the British colonies which treats of the Cape of Good Hope, has the following observation respecting its horses:- "The horse is not generally large, but it is extremely hardy. I have ridden one upwards of twenty miles without ever going out of a canter-the usual pace of the animal." A much fuller account of the Cape horse might have been given than this, and certainly something far more interesting.

In its breed, in its shape, in its colour, and in its temper, the horse of the Cape is very different from the English horse of any kind. A century ago, possibly, the difference was greater even than it now is; but, since the time when Lord Charles Somerset was governor of the colony, the old Arab blood has been more mixed with English than it was previously; and, now that the best of English blood is being yearly imported there, it may be expected that in time the peculiarities of the Cape horse will disappear, and, as has been the case with English horses, from an admixture of blood, something excellent in its kind will be at length obtained.
Mr. Surtees, a good authority, tells us, that at the time of the capture of the Cape, in 1806, the breed of horses there was probably a cross between the Barb of North Africa and the Persian or Arab: the latter must have been introduced by the Dutch East India Company, but as to the time of introduction of the former there is nowhere any record; still there can be no doubt that the Cape horse was in many respects Barb-bred. In many points he yet resembles the horse of Spain, which partakes of an African origin, and in no respect does he more approximate him than in his paces-the amble and the easy canter are in both alike. It was during the administration of Lord Charles Somerset as governor that the English horse was first imported to any extent; and, owing to the interest which that excellent sportsman took in the matter, much good has been the result, not only in the immediate improvement of blood, but also in the general interest that was then created on the subject, and has never since subsided. In May, 1844, Middleham, the winuer of the Liverpool St. Leger in 1840 , arrived at Cape Town; and where could be found better blood, or stouter, than that of Muley Moloch? He has been followed by a large number of blood and half-bred English horses.

The roan-or skimmel, as it is termed at the Cape-was a colour scarcely, if at all, known before the days of Lord Charles. It is now very common, and whether the blue or red, it is supposed to be the healthiest and hardiest colour for horses. The skimmel-or Lord Charles's colour, as it is also calledis usually attended with black legs, and the hue (if such a term is allowable) is generally extremely vivid; but as every why has its wherefore, and every beauty some drawback, so is this colour either sure to be accompanied with ragged hips or clumsy head, or in some way a want of symmetry Another singular colour to be met with at the Cape is the flea-bitten bay, or bay with white spots, which are in most cases on the quarters; but what is especially curious respecting this is, that all horses possessing it are natives of the same place. The flea-bitten bay is known as the bay of the Burg river. It is in shape and make, or, what are termed the good points of a horse, that the Cape horse is so far inferior to the English. Such a thing as good fore-legs are very rarely seen in the colony; yet this might easily be amended were more care taken of the horse when young. A most detestable practice is in vogue at that time of his life of tying one of his legs and his head nearly close together, to prevent escape from the large tracts of pasture in which he feeds: the consequence of this is that, when first taken up for use, he is crippled in his fore-legs, and to the end of his days will be a stumbler. To add to this defect before, the probability is, he has a heary, straight shoulder-nothing is more common amorgst all, even the best, Cape horses. The principal imperfection of those animals is, without doubt, their fore-legs: a good-thighed horse may often be met with, but a long arm, with a short, good leg, rarely. A flat, open foot, too, is a thing unfrequent; yet foot-lameness is not common unless from thrushes; and these are engendered by the shameful way in which the horse is neglected when young, and the marshy state of the pasture 
during the rainy seasons. In the distant parts of the settlement, and amongst the farmers, who are the principal breeders, such a thing as a horse-shoe is seldom used; but in the vicinity of Cape Town this is not the case-the horse is shod there as elsewhere, and, not unfrequently, he is shod all round.

Of the diseases and unsoundness which the Cape Horse is subject to, the writer of this lately gaincd much information from an officer of the 7th Dragoon Guards, who preceded his regiment to the Cape to purchase their regimental horses. No one could have been more indefatigable than this gentleman in his duties, and when the price to which he was limited (£26) is considered, no one could have been more successful. For some weeks he scoured the country for horses far and near; he had, therefore, many opportunities of picking up many useful hints, and improving them by his own observation. A species of glanders has been occasionally very prevalent; but, as an epidemic, it is nothing now to what it has been. A few years back, several thousand horses fell victims to its ravages; these have been partially stopped, but the disease has not been eradicated. Such a thing as a spavined horse he never once saw, but curbs often; and yet-will it be believed? - the removal of such things by the iron is unknown : and as to firing, if it bas been ever heard of by the farmer, it has assuredly never been attempted. Such a thing as a pied horse is not to be met with in the colony. But great is the want of veterinary knowledge, and most lamentable is the ignorance of everything connected with the modern treatment of the horse as practised in England.

The temper of the Cape horse is its great recommendation: it is rarely vicious, and this is best proved by the fact of geldings being unfrequently used, as compared with the number of entire horses. Now, as in the days of chivalry was the practice in Europe, mares are kept for the stud, and no oue thinks of riding a mare. As, too, in those good " auld days lang syne," the amble is a common pace; that and the canter are the best paces of the Cape steed-the latter is particularly easy, yat it is not so graceful to an English eye as the canter of the Englist horse; the step is shorter and the pace is more shuffling; bat, were the animal properly broken, his paces of course might be greatly improved.

Although the English groom would have much to teach the Hottentot, yet the former would be much surprised if he saw a team driven by the latter. When the word team is used a team of six and even eight in hand, as well as four, is intended. The ribbons are tolerably hand? of his whip that the Hottentot coachman is mainly a proficient: with a whip-handle of a long bamboo, sans the pliant top that in a good whip is so serviceable, will a Cape Jehu completely manage his foremost leaders, and, avoiding uneven ruts, drive over extremely bad roads with great adroitness.

Captain Brown, in his "Biographical Sketches of Horses," gives the following interesting account of a circumstance that occurred at the Cape of Good Hope. In one of the violent storms that often occur there, a vessel was forced on the rocks, and beaten to pieces. The greater part of the crew perished miserably, as no boat could venture to their assistance. Mean. while a planter came from his farm to see the wreck, and knowing the spirit of his horse and his excellence as a swimmer, he determined to make a desperate effort for their deliverance, and pushed into the thundering breakers. At first both disappeared, but were soon seen on the surface. Nearing the wreck, he caused two of the poor seamen to cling to his boots, and so brought them safe to shore. Seven times did he repeat this perilous feat, and saved fourteen lives; but alas! the eighth time, the horse being fatigued, and meeting with a formidable wave, the gallant fellow lost his balance, and was overwhelmed in a moment. He was seen no more, but the noble horse reached the land in safety.

The importation of English thorough-bred stallions at the Cape, and the institution of the Cape Town races have rapidly improved the breed of first-rate horses, which now furnishes many fine animals for Indian service. 


\section{CHAPTER I V.}

I.-THE AUSTRALIAN HORSE : 1I.-THE HORSR OF SOUTH A.MERICA : III.-THE HORSE OP XORT: AQTRRJGA

\section{THE AUSTRALIAN HORSE.}

The sporting spirit of the Anglo-Saxon race has not degeacrated at the antipodes; and the vast continent of Australasia, but yesterday boasting no quadrupeds more important than the dingo, the kangaroo, or the ornithorynchus, now shows what can be effected in the way of improving the ordinary imported breeds of the horse, under favourable circumstances of soil, climate, and treatment.

On the discovery of Tasmania, or New Holland, and afterwards of the larger continent, part of which was long designated New South Wales, there was no indigenous specimen of the larger quadrupeds. The first horses in Australia were procured from the Cape of Good Hope and a fow from India. These animals appear to have been got without selection, and to have been but sorry brutes. Atkinson, writing as recently as 1824, says:- "They are but nags in size, and bred without much care; by no means sightly in appearance, being narrow-chested and sharp-backed, as well as deficient in the quarters. They have an incurable habit of shying, and are by no means surefooted." The unfavourable description of Atkinson might, it seems, up to that period, be applied to Van Diemen's Land and all other parts of Australasia where the horse had been introduced. Adelaide, in South Australia, seems to have been about the earliest place in which regular races for public money were advertised in this land since so famous for its "diggings." Up to a comparatively recent period, says a local writer, the whole of the racing stock in the colony might be traced to three or four imported horses: an Arab-Abdallah-brought from Calcutta by Mr. Gleeson; the stallion Actæon, bred in France by Lord Henry Seymour; and Kiah-Khan-Kreuse and Forlorn Hope, both imported from England by Mr. Philcox in 1841. These, with one or two horses from Sydney, at a later period, complete the then list of South Australian stud horses. The Arab's stock has proved but moderately good, and showed to little advantage as young ones; being deficient in stride they were easily cut down by the produce of the English thorough-bred horse.* This was soon found to be the case here as well as at Calcutta, for a few "whalers," as the sporting men in Adelaide call horses from New South Wales, being sent there, took all the crack stakes from the Arabs.

Cattle, especially sheep, thriving so well, made the Australian farmer soon ashamed of his horse, and the sporting instinct carried him farther in the career of improvement. The ordinary saddle and gig horse, too, shared in the advance. "Bay Cameron, an English stallion standing near Sydney, netted for his owner, for the first season or two, more than six

- The Turf in Australia. By a Pigrim Sportmman. In The Sportsman for May 1857, p. 317. hundred pounds per annum, and good horsos rose tweuty pes cent. in value. Two hundred pounds were given in the capital for a horse of fine figure and power, and nothing good for saddle or harness could be got for less than fifty pounds." The colony of Wost Australia seems to be peculiarly adapted for the breeding of the horse, and secms likely to frove the nursery for the supply of our cavalry in India; an important stud formed by the now defunct East India Company has been removed from Van Diemen's Land to that colouy.

Mr. Poter Cunningham (Two Yeurs in Newo South Wales), says of the native bred horses that they are remarkably hardy, and can undergo considerable fatigue. "The greatest fault is a heaviness of the head, with a considerable degree of obstinacy and sulkiness-as much, however, the fault of education as of natural disposition."

Mr. Barton in his Excursions in New South Wales, adds, speaking of a heavier animal for draught, "the breed is rapidly improving, from the importation of some of the Cleveland breed from Fngland." The true dray-horse, however, was yet to be found, and could not be procured from any of the native horses, not even with the assistance of the Cleveland. The mixture of English blood had not lessened the endurance of the native breed; for at the hottest time of the year, with the thermometer at times as high as ninety-six degrees in the shade, the writer says he has ridden the same animal fifty miles a day for three successive days. "They will all go through a vast deal of work, but they would have more endurance if they were not broken in for the saddle and for harness so young. It is no unusual thing to ride them sixty miles in less than seven hours, and immediately turn them out to pick up what scanty herbage they can find."

Mr. Widowson (State of Van Diemen's Land, p. 194) tells us that there are some diseases to which the horse is subject in England, which are as yet unknown in New South Wales. Glanders has never made its appearance there. Greasy heels, the almost peculiar disease of Britain, have not been seen. Strangles, however, are prevalent, and, the author of the present work loarns from a communication to the Veterinarian, unusually severe.

In Van Diemen's Land the breed of horses, originally derived from India, is good. A valuable race of cart-horses is beginning to be formed. The riding-horses are small, but they are hardy. Horses of every kind are sixty per cent. dearer in Van Diemen's Land than in New South Wales. because the colony is smaller, and the number of horses that are bred is comparatively small. Their treatment is not sc good as in the larger colony. Many of them know not the taste of corn, and, when it is given to them, it is usually in the straw. 
It would appear from a few sentences in the series of papers contributed by Admiral Rous to Baily's Magazine, ${ }^{*}$ that the gallant Admiral is an advocate for a less tender and luxurious treatment of the horse, as tending to improve his hardihood and stamina, and to render him less susceptible of disease from slight ricissitudes of temperature and weather. The experience of Australia and of America would appear to support this opinion.

A writer in The Sportsman, already referred to, says, apropos of the racing stock in Australia, and the encouragement to breeders:-“ $£ 350$ was given in 1852 in Van Diemen's Land for a horse to run for the Adelaide Town Plate. This very horse, Swordsman, was, however, beaten easily by an Adelaide colt." South Australia, also seems to be well adapted for a feeder for our Indian empire in respect of this noble and useful animal, it being, with the exception of Swan River or the Sound, the nearest point for importations; while the poisonous grasses which exist in these two last named quarters must always be a bar to their being brought into any competition for this object.

The course at Adelaide is situated on the park lands to the south of the city; it is an oval in shape. It boasts of a commodious stand; always sure to be well-filled, as the inhabitants are "racing mad," and on the day of a meeting, business is almost suspeuded. "When the Queen's guineas were run for the first year, there was a great sensation, and a very laudable ambition to have thern. It was not with men alone, howerer, that this exhilaration was evident; for the winner, Minna, went to the post for the last heat as drunk as a lord, or rather as any young lady might hope to be, having taken at least two bottles of sherry to the health of Her Majesty."

By way of giving some notion as to the pace at which the imported Australian race-horse can travel, we give a tabular summary of a year's meeting.

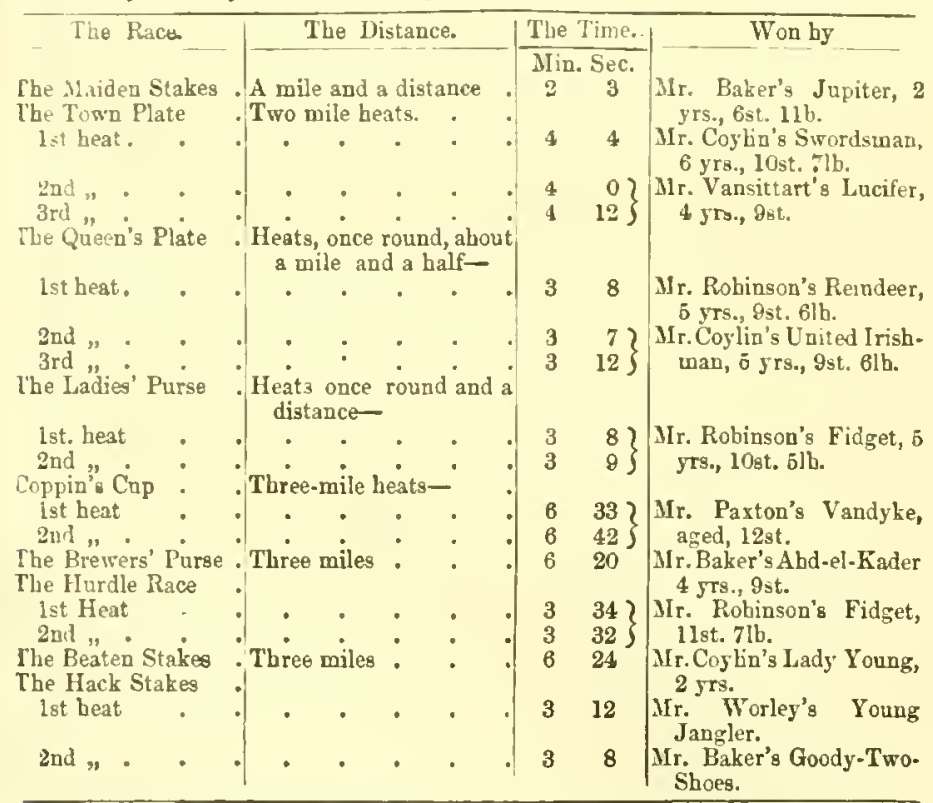

Jangler ran second to Mr. Penuy's Nimrod for the third heat of the Hack Stakes, ut the latter being disqualified, the stakes were given to Jangler.

* See Baily's Mragazine of Sports and Pastimes, for April, 1860.
The formation of race courses throughout Queensland, in the vicinity of Melbourne, Sydney, and all other considerable towns, indeed wherever the requisite support is offered, is yearly progressing. Steeplechasing, too, is extending in popularity. The importation of English thorough-breds is increasing, so that Australia is yearly making a turf history of her own. The great Australasian continent seems destined to become the breeding stud of our new Indian Empire.

\section{1.-THE HORSES OF SOUTH AMERICA.}

Altrojgh the vast American continent has been destitute, during the historic period, of the horse, fossil remains prove him to have been a denizen of those regions at some remote era-most probably one preceding the introduction of man upon the earth. Professor Owell, in his "British Fossil MIammals," remarks as follows on Fossil Equidæ:- "The species of Equus which existed during the Miocene periods of geology in both North and South America, appears to have been blotted out of the Fauna of those continents before the existence of man. The aborigines whom the Spanish conquistadores found in possession of Peru and Mexico had no tradition or hieroglyphic indicative of such a quadruped and the horses the invaders imported from Europe were. riewed with astouishment and alarm. The researches of Mr. Darwin and Dr. Lund have indisputably proved that the genus Equus was represented during the Pliocene period by a species (Equus curvidens), which is shown to be distinct from the European fossils, and also from the existing species. Fossil remains of the horse have been found aiso in North America. The geographical range of the genus Equus was therefore more extensive at the Pliocene period than that of the Rhinoceros, of which both the fossil and the existing species are confined to the Old World of the geographers. The horse, in its ancient distribution over both hemispheres of the globe, resembles the Mastodon, and appears to have become extinct in North America at the same time with the Mastodon giganteus, and in South America with the Mastodon of the Andes and the Megatherium. Well may Mr. Darwin say, ' it is a marvellous event in the history of animals, that a native kind should have disappeared, to be succeeded in after ages by the countless herds introduced with the Spanish conquerors." "

The New World is indebted for the myriads of wild horses which swarm upon the Pampas of the South and the Prairies of the North, to the Spanish stock carried by Cortez to Mexico, and to Peru by Pizarro. In genial climates it was natural that, with abundant herbage and few dangerous enemies, animals of such power and intelligence should increase and multiply with great rapidity. Dr. Rengger notes the first horses in Paraguay to have been imported from Spain and the Canaries in 1537, and Azara found, in the archives of Ascension, a document, proving that Irala, in 1551, bought a Spanish horse for the sum of fifteen thousand florins.

According to .Herrera, the Spanish historian, horses were objects of the greatest astonishment to the people of New Spain. At first they imagined the horse and his rider, 
like the Centaurs of the ancients, to be a horrible animal of a compound form, and supposing that their food was that of men, brought flesh-meat and bread to propitiate them. Even after they discovered their mistake they believed the horses devoured men in battle, and, when they neighed, thought they were demandiug lineir prey. A curious incident occurred when Pizarro was on one occasion in great straits, being hemmed in by a body of ten thousand men of resolute bearing, and eager to drive the invaders into the sea. As the Spaniards were making their way, hotly pressed, one of the cavaliers was thrown from his horse. This, which at first sight might seem an untoward event, was the salvation of the party, for the Indians were so astonished at this spontaneous separation of what they supposed to be one and the same being, that not knowing what would happen next, they instantly took to flight, and left the const clear for the Spaniards to reach their ships.

The inhabitants of the Isle of Peten listened attentively to the preaching of the Franciscan friars who accompanied the expedition of Cortez, and consented to the instant demolition of their idols and the erection of the Cross upon their ruins. How far these hurried conversions were founded on conviction is shown by the following anecdote. Cortez on his departure left among this friendly people one of his horses who had been disabled by an injury in the foot. The Indians felt a reverence for the animal as in some way connected with the mysterious power of the white men. When their visitors had gone, they offered flowers to the horse, and, as is said, prepared for him many savoury messes of poultry, such as they would have administered to their own sick. Under this extraordinary diet the poor animal pined away and died. The Indians raised his effigy in stone, and placing it in one of their temples, did homage to it as to a deity In 1618, when two Franciscan friars came to preach the Gospel in these regions, then scarcely better known to the Spaniards than before the time of Cortez, one of the most remarkable objects which they found was this statue of a horse, receiving the homage of the Indian worshippers as the Grod of thunder and lightning!

The admirable skill of the South Americans as horsemen is everywhere acknowledged, and has been described by many writers ; the following account, however, by Mr. Darwin, is so spirited that it conveys the best idea of their exploits. "One evening a 'domidor' (subduer of horses) came for the purpose of breaking in some colts. I will describe the preparatory steps, for I believe they have not been mentioned by other travellers. A troop of wild young horses is driven into the corral or large enclosures of stakes, and the door is shut. We will suppose that one man alone has to catch and mount a horse which as yet had never felt bridle or saddle. I conceive, except by a Guacho, such a feat would be utterly impracticable. The Guacho picks out a full grown colt; and, as the beast rushes round the circus, he throws his lasso so as to catch both the front legs. Instantly the horse rolls over with a heavy shock, and whilst struggling on the ground the Guacho, holding the lasso tight, makes a circle so as to catch one of the hind legs just beneath the fetlock, and draws it close to the two front. He then hitches the lasso so that the three legs are bound together, then sitting on the horse's neck, he i red \& strong bridle, without a bit, to the lower jaw. This he does by passing a narrow thong through the eycholes at the cnd of the reins, and several times round both jaw and tongue. The two front legs are now tied closely together with a strong leathern thong fastened by a slip knot; the lasso which bound the three together boing then loosed, the horse rises mitl difficulty. The Guacho, now holding fast the bridle fixed to the lower jaw, leads the horse outside the corral. If a second man is present (otherwise the trouble is much greater), he holds the animal's head, whilst the first puts on the horse cloths and saddle and girths the whole together. During this opcration, the horse, from dread and astonishment at being thus bound round the waist, throws himself over and over again ou the ground, and till beaten is unwilling to rise. At last, when the saddling is finished, the poor animal can bardly breathe from fear, and is white with foam and sweat. The man now prepares to mount by pressing heavily on the stirrup, so that the horse may not lose its balance; and at the moment he throws his leg over the animal's back he pulls the slip knot and the beast is free. The horse, wild with dread, gives a few most violent bounds, and then starts off at full gallop." When quite exhausted, the man by patience brings him back to the corral, where, recking hut and scarcely alive, the poor beast is let free. Those animals which will not gallop away, but obstinately throw themselves on the ground, are by far thif most troublesome.

All travellers, who have crossed the plains extending from the shores of La Plata to Patagonia, have spoken of the numerous droves of wild horses, the descendants of the Spanish horses of Cortez, Pizarro, and their successors. Some affirm that they have seen ten thousand in one troop. They appear to be under the command of a leader, the strongest and boldest of the herd, and whom they implicitly obey. A sccret instinct teaches them that their safety consists in their union and in a principle of subordination. The panther, the tiger, and the leopard are their principal enemies. At some signal, intelligible to them all, they either close into a dense mass and trample their enemy to death, or placing the mares and foals in the contre they form themselves into a circle and welcome him with their heels. In the attack their leader is first to face the danger, and, when prudence demands a retreat, they follow his rapid flight.

In the thinly inhabited parts of South America it is dan-

* The manufacture of the Guacho's boots is somewhat singular:- "The boots of the Guachos are formed of the ham and part of the leg-skin of a colt reeking from the mother, which is said to be sacrificed for the sole purpose, just at the time of bearing, when the hair has not begun to grow. At this stage the skin strips off easily, and is very white and beautiful in texture and and appearance. The ham forms the calf of the boot; the hock easily adapte itself to the heel; and the leg abore the fetlock constitutes the foot; the whole making a neat and elegant half boot, with an aperture sufficient for the great toe to project through." - Andrew's Journey in South Amerca, vol, i p. 26. 
gerous to fall in with any of these troops. The wild horses approach as near as they dare: they call to the loaded horse with the greatest eagerness, and, if the rider be not on the alert, and have not considerable strength of arm, and sharpness of spur, his beast will divest himself of his burden, take to his heels, and be gone for ever.

Sir F. B. Head gives the following account of a meeting with a troop of wild horses, where the country is more inhabited. Some poor captured animals are supposed to be forced along by their riders at their very utmost speed :- "As they are thus galloping along, urged by the spur, it is interesting to see the groups of wild horses one passes. The mares, which are nerer ridden in South America, seem not to understand what makes the poor horse carry his head so low, and look so weary."

"The little innocent colts come running to meet him, and then start away frightened: while old horses, whose white marks on the flanks and backs betray their acquaintance with the spur and saddle, walk slowly away for some distance, then, breaking into a trot as they seek their safety, snort and look behind them, first with one eye and then with the other, turning their noses from right to left, and carrying thcir long tails high in the air."

The same pleasing writer describes the system of horsemanagement among the rude inhabitants of the plains of South America. They have no stables, no fenced pastures. One horse is usually kept tied at the door of the hut, fed scantily at night on maize; or at other times several may be enclosed in the corral, which is a circular space surrounded by rough posts, driven firmly into the ground. The mares are never ridden, or attempted to be tamed, but wander with their foals wherever they please.

Miers, in his "Travels in Chili," thus describes the lasso, simple in its construction, but all-powerful in the hands of the Guacho.

"The lasso is a missile weapon used by every nature of the United Provinces and Chili. It is a very strong plaited thong of equal thickness, half an inch in diameter, and forty feet long, made of many strips of green hide, plaited like a whipthong, and rendered supple by grease. It has, at one end, an iron ring above an inch and a half in diameter, through which the thong is passed, and this forms a running noose. The Guacho, or native Peon, is generally mounted on horseback when he uses the lasso. One end of the thong is affixed to his saddle girth : the remainder he coils carefully in his left hand, leaving about twelve feet belonging to the noose-end, in a coil, half of which he holds in his right hand. He then swings this long noose horizontally round his head, the weight of the iron ring at the end of the noose assisting in giving it, by a continued centrifugal motion, of sufficient force to project it the whole length of the line.

"When the Guachos," says the same writer, "wish to have a

- An Englishman once attempted to ride a mare, but he was hooted and pelted by the natives, and thought himself fortunate to escape without serious injury. Sir John Carr, in his "Northern Summer," states that it is only in more modern timee that msires began to be ridden in Russia. grand breaking-in, they drive a whole herd of wild horses into the corral. The corral was quite full of horses, most of which were young ones, about two or three years old. The capitar (chief Guacho), mounted on a strong steady horse, rode into the corral and threw his lasso over the neck of a young horse, and dragged him to the gate. For some time he was very unwilling to leave his comrades; but the moment he was forced out of the corral his first idea was to gallop away: however, a timely jerk of the lasso checked him in the most effectual way. The peons now ran after him on foot, and threw a lasso over his fore-legs, just above the fetlock, and twitching it, they pulled his legs from under him so suddenly that I really thought the fall he got had killed him. In an instant a Guacho was seated on his head, and with his long knife, and in a few seconds, cut off the whole of the horse's mane, while another cut the hair from the end of his tail. This they told me was a mark that the horse had been once mounted. They then put a piece of hide into his mouth, to serve for a bit, and a strong hide halter on his head. The Guacho who was to mount arranged his spurs, which were unusually long and sharp, and while two men held the horse by his ears he put on the saddle, which he girthed extremely tight. He then caught hold of the horse's ear, and in an instant vaulted into the saddle; upon which the man who held the horse by the halter threw the end to the rider, and from that moment no one seemed to take any further notice of him.

"The horse instantly began to jump in a manner which made it very difficult for the rider to keep his seat, and quite different from the kick or plunge of an English horse: however, the Guacho's spurs soon set him going, and off he galloped, doing everything in his power to throw his rider.

"Another horse was immediately brought from the corral, and so quick was the operation, that twelve Guachos were mounted in a space which I think hardly excceded an hour. It was wonderful to see the different manner in which different horses behaved. Some would actually scream while the Guachos were girding the saddle upon their backs; some would instantly lie down and roll upon it; while some would stand without being held-their legs stiff, and in unnatural positions, their necks half bent towards their tails, and looking vicious and obstinate; and I could not help thinking that I would not have mounted one of those for any reward that could be offered me, for they were invariably the most difficult to subdue.

"It was curious to look around and see the Guachos on the horizon, in different directions, trying to bring their horses back to the corral, which is the most difficult part of their work; for the poor creatures had been so scared there that they were unwilling to return to the place. It was amusing to see the antics of the horses-they were jumping and dancing in different ways, while the right arm of the Guachos was seen flogging them. At last they brought the horses back, apparently subdued and broken in: the saddles and bridles were taken off, and the young horses trotted off towards the corral, neighing to one another." 
When the Guacho wishes to take a wild horse, he mounts one that has been used to the sport, and gallops over the plain. As soon as he comes sufficiently near his prey, "the lasso is thrown round the two hind legs, and as the Guacho rides a little on one side, the jerk pulls the entangled horse's feet laterally, so as to throw him on his side, without endangering his knees or his face. Before the horse can recover the shock, the rider dismounts, and snatching his poncho or cloak from his shoulders, wraps it round the prostrate animal's head. He then forces into his mouth one of the powerful bridles of the country, straps a saddle on his back, and bestriding him, removes the poncho; upon which the astonished horse springs on his legs, and endeavours by a thousand vain efforts to disencumber himself of his new master, who sits quite composedly on his back, and, by a discipline which never fails, reduces the horse to such complete obedience, that he is soon trained to lend his whole speed and strength to the capture of his companions."

These animals possess much of the form of the Spanish horse, from which they sprung; they are tamed, as has been seen, with far less difficulty than could be thought possible; and, although theirs is the obedience of fear, and enforced at first by the whip and spur, there are no horses who so soon and so perfectly exert their sagacity and their power in the service of man. They are possessed of no extraordinary speed, but they are capable of enduring immense fatigue. They are frequently ridden fifty or sixty miles without drawing bit, and have been urged on by the cruel spur of the Guacho, more than a hundred miles, and at the rate of twelve miles in the hour.

Like the Arab horses, they know no intermediate pace between the walk and the gallop. Although at the end or a day so hard their sides are horribly mangled, and they are counpletely exhausted, there is this consolation for them-they are immediately turned loose on the plains, and it will be their own fault if they are speedily caught again. The mare is occasionally killed for food, and especially on occasions of unusual festivity. General San Martin, during the war of independence, gave a feast to the Indian allies attached to his army, at which mares' flesh, and the blood mixed with gin, formed the whole of the entertainment.

On such dry and sultry plains the supply of water is often scanty; and then a species of madness seizes on the horses, and their generous and docile qualities are no longer recognized. They rush violently into every pond and lake, savagely mangling and trampling upon one another; and the carcases of many thousands of them, destroyed by their fellows, have occasionally been seen in and around a considerable pool. This is one of the means by which the too rapid increase of this quadruped is, by the ordinance of Nature, prevented.

In Chili a horse is not considered perfectly broken till he can be brought up standing in the midst of his full speed on any particular spot; for instance, on a cloak thrown on the ground; or again, will charge a wall, and, rearing, scrape the surface with his hoofs. I have seen," says Mr. Darwin, " an animal bounding with spirit, yet merely reined by a forefinger and thumb, taker at full gallop across a court-yard, and then made to wheel round the post of a verandah with great speed, but at so equal a distance that the rider, with outstretched arm, all the while kept one finger rubbing the post, then making a demi-rolte in the air with the other arm outstrctched in a like manner, he wheeled round with astonishing foree in the opposite direction. Such a horse is well broken; and although this at first may appear useless, it is far otherwise. It is only carrying that which is daily necessary into perfection. When a bullock is checked and caught by the lasso, it will sometimes gallop round and round in a circle, and the horse being alarmed at the great strain, if not well broken, will not readily tum like the pivot of a wheel. In consequence many men have been killed ; for if a lasso once takes a twist round a man's body, it will instantly, from the power of the two animals, almost cut him in twain. On the same principle the races are managed. The course is only two or three hundred yards long, the desideratum being, to have horses that can make a rapid dash. The racehorses are trained not only to stand with their hoofs touching a line, but to draw all four feet together, so as at the first spring to bring into play the full action of the hind quarters. In Chili I was told an anecdote, which I believe was true, and it offers a good illustration of the use of a well broken animal. A respectable man riding one day met two others, one of whom was mounted on a horse, which he knew to have becn stolen from himself. He challenged them; they answered by drawing their sabres and giving chase The man on his good and fleet beast kept just ahead; as he passed a thick bush he wheeled round it, and brought up his horse to a dead chcck. The pursuers were obliged to shoot on one side aud ahead. Then instantly dashing on right behind them, be turied his knife in the back of one, wounded the other, recovered his horse from the dying robber, and ride home! Animals are so abundant in these countries that humanity is scarcely known. MIr. Darwin was one day riding in the Pampas with a very respectable "Estanciero," when his horse being tired, lagrged behind. The man often shouted to him to spur him, when I remonstrated that it was a pity, for the horse was quite exhausted; he cried: "Why not?-never mind. Spur him-it is my horse!" When, after some diffculty, he was made to understand that it was for the horse's sake that the spurs were not used, he exclaimed with great surprise: "Ah! Don Carlos, oui cosa!" The idea had never before entered his head.

In England the powers of horses in swimming are but little tested, but in South America the case is different, as shown by an incident mentioned by Mr. Darwin. "I crussed the Lucia near its mouth, and was surprised to obscrve how easily our horses, although not used to swim, passed over a width of at least six hundred yards. On mentioning this at Monte Video, I was told that a ressel containing some moun. tebanks and their horses being wrecked in the Plata, one horse swam seven miles to the shore. In the course of the day I was amused by the dexterity with which a Guacho forced a 
restive horse to swim a river. He stripped off his clothes and jumping on his back, rode into the water till it was out of its depth; then slipping off over the crupper he caught hold of the tail, and as often as the horse turned round, the man frightened it back by splashing water in its face. As soon as the horse touched the bottom on the other side the man pulled himself on, and was firmly seated, bridle in hand. before the horse gained the bank. A naked man on a naked horse is a tine spectacle. I had no idea how well the two animals suited each other. The tail of a horse is a very useful appendage. I have passed a river in a boat with four people in it, which was ferried across in the same way as the Guacho. If a man and horse have to cross a broad river, the best plan is for the man to catch hold of the pommel or mane, and help himself with the other arm."

We have already said that the wild horses of South and North America retain the size and form of the well-bred horse, after three centuries. A collateral testimony against the theory of an entire change, such as we see in the extreme varieties of this animal, haring been the result of domestication on the one hand, or a relapse to a state of nature on the other.

The Frencn introduced the horse into the Falkland Islands in 1764, and since that period they have wonderfully muitiplied. The horses in these islands are always found on the eastern side of East Falkland, although there is no natural boundary, and that part of the island is by no means more fertile than the rest. The predominaut colours of these horses are roan and iron grey. Mr. Darwin says they are rather small-sized, but are generally in good condition.

In South America the horse was first landed at Buenos Ayres in 1537, and the colony being for a time deserted it ran wild. In 1580, forty-three years after, horses were found wild at the Straits of Magellan; horses, too, that showed plainly their Spanish origin.

Of the multitudes nor ranging the Pampas we may form some estimate by the fact that in 1850-1854 Monte Video and Buenos Ayres exported annually 90,000 lbs. of hides, and 9,500,000 lbs. of horsehair. The natives of Terra del Fuego are now well-stocked with horses, each man haring six or seven, and all the women and children each their own horse. The horse is now found over the whole continent of America. Sir John Richardson, in his Fauna Boreali-Americana, says it is numerous among the wandering Indians who hunt the buffalo in the Paskatchewan and on the Missouri.

\section{I11. THE HORSES OF NORTH AMERICA.}

Of the several varieties of the horses of North America, the most prominent are:- the Canadian, the Conestoga, and the English horse.

The Canadian is a hardy animal, and found, as its name denotes, in the northern states. It is an excellent sledge-horse, and well adapted for light-wheeled rehicles. One of them has been known to draw a light waggon over the ice a distance of ninety miles in twelve hours. He is small of stature but compact, and grows a furry coat in winter time, when his shoes are "roughed" by the insertion of two or three steel screws to give him foothold. The Canadian horse is most willing at collar, and altogether a serviceable and staunch animal. He is generally supposed to be of French origin, which is probable, as he shows no remarkable "points." He is much neglected, fares hardly, and is seldom groomed, in the English sense. With a cross of the English horse this breed has produced some of the celebrated trotters, with which the Yankees have challenged and beaten the world in that peculiar pace. But this we shall defer speaking of at length till we come to "The Paces of the Horse."

The Conestoga horse is a tall and somerhat leggy animal, light in the carcass, found principally in Pennsylvania, where he is bred for carriage-purposes. Some of these horses stand 17 hands high. We suspect them to be originally an English, Flemish, or Dutch importation. As some of our readers may remember IIr. Carter "the Lion King's" mammoth horse, "General Washington," standing nineteen hands, exhibited in London a few years since, we may observe that, to the writer's knowledge, the "General" was'bred in this country at Northampton. When of good form and close ribbed up. the Conestoga horse fetches a long price, and has been used in the hunting field.

The horses of the United States present every variety of the Old World; crosses of the English thorough-bred and of the Eastern horse being frequent. Much attention is paid in the States to the improrement of the breed. In the northern States horse races have been established and the usages of the British turi adopted. Indeed, our American cousins have improved their racehorses to a degree equal to our own, by sticking to the me blood. The renowned Shark is ancestor of many of the hest Virginian horses; Tallyho by Hightlyer figures in the pedigrees of the racers of New Jersey; while at a later period they had the discrimination to buy the best produce, as well as some of our very first stallions, such as Precipitate, Diomed, Priam, Trustee, Glencoe, \&c. They adhere too to the principles adopted by our earlier turf-men, of breeding only from stallions who could stay a distance; "and very naturally," says Admiral Rous, "seeing that all their great prizes and matches vary from two to four miles. We did the same until the commencement of the present century, when, the great stakes being made for shorter distances, it was soon ascertained that the sons of the stout old stallions could not win a 2,000 guineas stake against the blood of Rubens, Castrel and Selim. But if the Americans have bred for stoutness, we cannot blind ourselves to the fact, that though the American mare Prioress was the best four-mile marc in England in 1859, one half of the American racers brought to this country to do a good thing cannot last more than three quarters of a mile: such is the lottery of breeding race-horses. The comparative stoutness of the American and English racehorse has yet to be decided." An attempt was made by Mr. Ten Broeck to win the Derby with the American horse Umnire, but failed for lack of quality and uuskilful preparation. 
The breeds of the West Indies are from England or the mainland, those of Cuba from Spain.

Professor Low, incidentally speaking of the horses of North America, observes:-" North America seems as well adapted to the temperament of the horse as any similar countries in the old continent. The Mexican horses are derived from, but somewhat deteriorated by, a less careful management. Mcxican horses have likewise escaped into the woods and savannahs, and although they have not multiplied, as in the plains of the Plata, thenee they have descended northward to the Rocky Mountains, and the sourees of the Columbia. The Indians of the country bave learned to pursue and capture them, employing them in hunting, and transporting their families from place to place - the first great ehange that has taken place for ages in the condition of the Red Man of the North American woods. The highest ambition of the young Indian of these northern tribes, is to possess a good horse for the ehase of the buffalo. The Osages form large hunting parties for the chase of horses in the country of the Red Canadian River, using relays of fresh horses, until they have run down the wild herds To steal the horse of an adverse tribe, is considered as an exploit almost as heroic as the killing of an encmy, and the distances that they will travel and the privations they will undergo in these predatory excursions are scarcely to be believed."

Among the North American Indians the Camanchees held the first rank as equestrians; racing was with them a constant and almost incessant exercise, and a fruitful source of gambling. Among their feats of riding is one described by Mr. Catlin, as having astonished him more than anything in the way of horsemanship; and it is a stratagem of war familiar to every young man of the tribe. At the instant he is passing an enemy he will drop lis body on the opposite side of the horse, supporting himself with his heel on the horse's back. In this position, lying horizontally, he will hang, whilst his horse is at his fullest speed, carrying with him his shield, bow and arrows, and lance, fourteen feet loug, all or either of which he will wield with the utmost facility, rising and throwing his arrows over the horse's baek, or under his neck, throwing himself up to his proper position, or changing to the other side of the horse if necessary. The actual way in which this is is done is as follows:-A short hair halter is passed under the neck of the horse, and both ends tightly braided into the mane, leaving a loop to hang under the neck and against the breast. Into this loop the rider drops his elbow suddenly and fearlessly, leaving his hecl to hang over the back of the horse to steady him and enable him to regain the upright position.

The following very singular custom prevailed among the tribe of North American Indians known as the "Foxes." Of it Mr. Catlin was an eye-witness: "When," says he, "General Street and I arrived at Kee-0-kuk's village, we were just in time to see this amusing scene on the prairie, at the back of his village. The Foxes, who were making up a war-party to

- Doreetic Quadrupeds of the British Islands. Longman. F go against the Sioux, and had not suitable horses enough by twenty, had sent word to the 'Saes' the day before, according to ancient custom, that they were coming on that day, at a certain hour, to 'smoke' that number of horses, and they must not fail to have them ready. On that day, and at the hour, the twenty young men who were beggars for horses were on the spot, and seated themselves on the ground in a circle, where they went to smoking. The villagers flocked round them in a dense crowd, and soon after there appeared on the praririe, at half a mile distance, an equal number of young men of the Sac tribe, who had agreed each to give a horse, and who were then galloping them round at full speed, and gradually, as they went around in a circuit, coming nearer to centre, until they were at last elose around the ring of young fellows seated on the ground. Whilst dashing about thus, each one with a heavy whip in his hand, as he came within reach of the group on the ground, seleeted the one to whom he decided to present his horse, and as he passed gave him the most tremendous eut with his lash over the naked shoulders: and as he darted round again, he plied the whip as before, and again and again with a violent 'craek,' until the blood could be seen trickling down over his naked shoulders, unon which he instantly dismounted, and placed the bridle and whip in his hands, saying, "Here, you are a beggar; I present you a horse, but you will carry my mark on your back.' In this manner they were all, in a little while, 'whipped up,' and each had a good horse to ride home and into battle. His necessity was such that he could afford to take the stripes and the scars as the price of the horse, and the giver could afford to make the present for the satisfaction of putting his mark on the other, and of boasting of his liberality."

Mr. Catlin gives an interesting account of his faithful sorse "Charley," a noble animal of the Camanchee wild breed, which had formed as strong an attachment for his master as his master for him. The two halted generally on the bank of some little stream, and the first thing done was to undress Charley, and drive down the picket to which he was fastened, permitting him to graze over a circle limited by his lasso. On a certain evening, when he was grazing as usual, he managed to slip the lasso over his head, and took his supper at his pleasure as he was strolling round. When night approached, Mr. Catlin took the lasso in hand, and endeavoured to catch him, but he continually evaded the lasso until dark, when his master abandoned the pursuit, making up his mind that he should inevitably lose him, and be obliged to perform the rest of the journey on foot. Returning to kis bivouac, in no pleasant state of mind, he laid down on his bear-skin and went to sleep. In the middle of the night he awoke whilst lying on his back, and, half opening his eyes, was petrified at beholding, as he thought, the huge figure of an Indian standing over him, and in the very act of stooping to take his scalp! The chill of horror that paralysed him for the first moment held him still till he saw there was no need of moving; that his faithful horse had played shy till he had filled his belly, and had then moved up from feelings of pure affection, and taken his 
position with his fore feet at the edge of his master's bed, and his head hanging over him, in which attitude he stood fast asleep.

When sunrise came the traveller awoke and beheld his faithful servant at a considerable distance, picking up his breakfast among the cane brake at the edge of the creek. Mr. Catlin went busily to work to prepare his own, and having eaten it, had another half-hour of fruitless endeavours to catch Charley, who, in the most tantalizing manner, would turn round and round, just out of his master's reach. Mr. Catlin, recollecting the evidence of his attachment and dependence afforded by the previous night, determined on another course of proceeding, so packed up his traps, slung the saddle on his back, trailed his gun, and started unconcenedly on his route. After advancing about a quarter of a mile he looked back, and saw Master Charley standing with his head and tail very high, looking alternately at him and at the spot where he had been encamped, and had left a little fire burning. Thus he stood for some time, but at length walked with a hurried step to the spot, and seeing everything gone, began to neigh very violently, and, at last, started off at fullest speed and overtook his master, passing within a few paces of him, and wheeling about at a f w rods distance, trembling like an aspen leaf. Mr. Catlin called him by his familiar name, and walked up with the bridle on his hand, which was put over Charley's head as he held it down for it, and the saddle was placed on his back as he actually stooped to receire it. When all was arranged, and his master on his back, off started the noble animal, as happy and contented as possible.

Many of the American prairies swarm not only with buffaloes, but with numerous bands of wild horses, proud and playful animals, rejoicing in all the exuberance of freedom, and sweeping the earth with their flowing manes and tails. The usual mode of taking them by the North American Indians is by means of the lasso. When starting for the capture of a wild horse, the Indian mounts the fleetest steed he can get, and coiling the lasso under his arm, starts off at full speed till he can enter the band, when he soon throws the lasso over the neck of one of the number. He then instantly dismounts, leaving his own horse, and runs as fast as he can, letting the lasso pass out gradually and carefully through his hands, until the horse falls half suffocated, and lies helpless on the ground. The Indian now advances slowly towards the horse's head, keeping the lasso tight upon his neck until he has fastened a pair of hobbles upon his fore feet; he now loosens the lasso, and adroitly casts in a noose round the lower jaw, the animal, meanwhile, rearing and plunging. Advancing warily hand over hand, the man at length places his hand over the animal's eyes, and on its nose, and then breathes into its nostrils, on which the horse becomes so docile and thoroughly conquered, that his captor has little else to do but to remove the hobbles from his feet, and ride or lead it into camp.

\section{CHAPTER V.}

THE HORSES OF RUROPE.-TURREY, GREECE : SOUTHERN AND WESTERN RUSSLA: HUNGARY : POLAND, PRUSSIA : DENMARK AND HOLSTEIN : NORWAY, SWEDEN, FINLAND AND LAPLAND : AUSTRIA, BAVARIA: HOLLAND, BELGIUM : FRANCE: ITALY: SPAIN AND PORTUGal.

WE shall not dwell at great length on the horses of Europe, inasmuch as the original races of that quadruped are, except in some few isolated instances, almost without a history; and in more modern times, the continual intercourse among the more civilized countries of the continent has so blended and toned down the distinctive characteristics of race, as to make absolute and clear lines of demarcation impossible. Nevertheless, a fow brief paragraphs, arranged systematically, and travelling westward until, in our next chapter, we shall reach our own "tight little island," are necessary to our plan, and we begin with

\section{TURKEY IN EUROPE.}

Uur general notice of the Barb, Toorkman, and Arab, in "the Horses of Africa and Asia," dispenses with the necessity of much remark on the Turkish horse. The term "Turk" for two centuries was a general one, meaning any horse that came from the Sultan's or eren the Shah's dominions. The Byerley. Helmsley, Acaster, Belgrade, and other "Turks" thus came from Buda (in Hungary), Belgrade (Servia), Constantinople, Syria, Tunis, Tripoli and Morocco; a sufficiently wide range to have furnished us with horses bearing the same name, but of widely different parent stock.

The modern Turkish horse originally, would be the Greek horse of the countries once comprised in the Lower Empire. The irruption of the Turks into Europe in the thirteenth and fourteenth centuries brought with that nation of cavalry the Asian horse in myriads, while the African horse, in like way, made, under the fierce followers of Islam, a similar invasion of the Spanish peninsula. Though fine and stately horses are seen in various parts of Turkey, they are, from the neglect of the European Turk of the first principles of breeding, generally importations from Asia or Africa. The horses of the Northern provinces-Wallachia, Moldavia, and on the banks of the Pruth-partake more of the Cossack character, though of better size and roundness, owing to superior and more persistent natural pasturage. 


\section{GREECE.}

In ancient times the horses of Greece stood high in esteem; witness the numerous representations of horsemen on friezes of their temples: that of the temple of Mincrva, in the Acropolis of Athens, is the best known. We may observe, en passant, that while the sculptured representations of the men are perfect, if these horses are faithful, they were heavy animals, with poor quarters as compared with their forearms, preternaturally heavy forehand, the shortest of short necks, and a long barrel. They bear a resemblance in many points to the German horse of the middle ages. It is probable these were exaggerations of the bad points of the Thessalian horses, so much lauded in ancient writers. The modern Greek horse has not kept pace with his improvement in other countrics, and has merely the credit of being a surefooted animal with considerable strength.

\section{SOUTHERN AND WESTERN RUSSIA.}

Of late years the indigenous breeds of this portion of the empire have been greatly improved, especially in the characteristies of blood for the saddle, and size for the heavy cavalry of the "crack" regiments; this has been effected by the importation of stallions from England, Prussia, and Holsteinthe two latter furnishing the cross for the heavier animal, and England the blood, speed, and bottom.

The Emperor Nicholas of Russia established races in different parts of his vast empire for the improvement of the Cossack and other horses. On the 20th of September, 1836, the races at Ouralsk took place. The distance to be run was eighteen versts, or about four and a half French leaguesrather more than ten miles. Twenty-one horses of the military stud of the Cossacks of Oural started for the first heat, and which was won in twenty-five minutes and nineteen seconds by a horse belonging to the Cossack Bourtche-Tchurunief. The second race was disputed by twenty-three horses of the Kirghese Cossacks, and which was won in twenty-five minutes and five seconds by the horse of the Cossack Siboka-Isterlai. On the following day the winners of the two first heats strove for the point of honour. The course was now twelve verststhree French leagues, or about six miles and three quarters. It was won in fifteen minutes by the horse of the Cossack Bourtche-Tchurunief. The Russian noblemen who were present, admiring the speed and stoutness of the horse, were anxious to purchase him ; but the Cossack replied that "All the gold in the world should not separate him from his friend, his brother."*

In Southern and Western Russia, and in Russian Poland, the breeding of horses has lately occupied the attention of the land proprietors, and has constituted a very considerable part of their annual income. There is searcely now a seignorial residence to which there is not attached a vast court, in four large divisions, and surrounded by stables. In each of the angles of this court is a passage leading to beautiful and extensive pasture-grounds, divided into equal compartments, and all of them having convenient sheds, under which the horses may shelter themselves from the rain or the sun. From these studs a larger kind of horse than that of the Cossacks is principally supplied, and more fit for the regular cavalry troops, and also for pleasure and parade, than common use. The remounts of the principal corps in Germany are derived hence; and from the same source the great fairs in the different states of the German empire are occasionally supplied.

The stud of the Russian Countess Orloff Tshesmensky, in the province of Valonese, contains thirteen hundred and twenty horses, Arabs, English, natives, and others. The ground attached to it amounts to nearly eleven hundred acres; and the number of grooms, labourers, and others, is more than four thousand. The sum realised by the sale of horses is of considerable annual amount; and they are disposed of not only on the spot itself, but in the regular markets both of St. Petersburgh and Moseow.

Of the most recent improvers of the Russian horse, foremost stands Baron Ippolyte Petroffski, who with Mrr. Aveson as his stud-groom, and George Dockeray as his trainer and jockey, has given of late years an immense impetus to racing among the Russian nobility. A recent writer thus sketehes the Baron and his stud :-

Sixty-threc summers have done little to blanch his hair, dim his eye, or bend his light wiry frame erect, as becomes a captain of the Imperial Guard.

The English Stud Book is his Koran, and in his library may also be found every Racing Calendar and Sporting Magazine that has ever seen the light. He is himself an author, and has been at the pains of publishing, in the Russian language, a most complete synopsis of the celebrated stallions in England from 1811. It enters with the greatest accuracy into the number of years they were in the stud, the price at which they covered, and the dams of their most celebrated winners. Upwards of 135 paintings or engravings of racers and sporting subjects adorn his rooms; and if there was an alarm of fire, we are afraid that his gallery of old Dutch and Italian masters would be left to take their chance, till those well-loved forms of Derby and Leger renown were safe out of harm's way.

His views upon racing are best told in his own simple way; but we must premise that Elliot, Robinson, Dockeray, Ford, Yates, \&e., have wrought a wondrous change in training, and have no greater admirer than himself. "You like the horses of old stock," he says, in writing to a friend, "asd old form, which I also prefer to the new-fashioned, who win great prizes on a short distance. Our Russian men are quite ignorant in training. The English who come here are mostly grown-up boys, too heary for riding, and also inexpert They cannot understand yet the difference between our climate and the English. We have only two months to prepare horses for the races, that is May and June. The horses are led 500 versts," with all the road inconveniences. They change water 
and food, and suffer much before they come to the racing place. All that is not easy for a racing horse to endure. Our prizes are not worth carrying food and water, and the horse itself in equipage. It would be supportable yet, for once, to travel 500 versts, but they go again 200 versts and run, and then again 500 versts, and then 200 versts, and run again."

The Baron breeds his horses at one of his estates, and trains at another, where his string do their work in the winter, without shoes, on frozen snow, regularly harrowed for the purpose. The ground is, however, mostly flat, without any extent or variety of gallops. The breeding farm is bordered by a noble river of great width, and in summer, when the tlies teaze the young foals to distraction, they dash in and swim, while their dams watch them placidly from the bank, and occasionally join in the sport. If a ten-stone by five-feet-eight figure is seen standing by, in a blue tunic, and trowsers tucked inside his boots, it is even betting that it is the Baron himself, meditating on Moscow or Crenavoy Meetings to come. Many of them have excellent hind-leg action, and their owner invariably attributes it to their early swimming habits. The brood mares alone number about 160, some of which are still unbroken, and most of them never trained. The blood is, strictly speaking, a cross between the Russian and Asiatic mares, and the English horses imported by GovernmentMemnon, General Chassé, Van Tromp, Andover, \&c.; and the stock are generally browns, of great length and on short legs, having all the Arab deficiency of shoulder, but catching the Eastern character in their fine eye and small nostrils, and bearing the Sir Hercules crest.

The Baron also rather prides himself upon his breed of trotting horses, and he gave for Barklay, one of the best sires of that stamp, 11,000 roubles*. We believe that one of his best, once trotted eight versts under the sixteen minutes; and they are also used for racing in droskies on the ice, where the courses are marked out by bushes, and range from 15 to 25 versts.

A Surplice and an Irish Birdcatcher brood mare have gone out to the Baron's, along with Rifleman, who was purchased by his son for the Government. In 1859 his racing stud consisted of seventeen horses in training, fifty brood mares, twenty-five two-year olds, nearly as many yearlings and foals respectively, while Signal, Granite, and Bombardier are the principal sires. The Signals are his best racing stock. One of them out of Minerva is christened Maxfield after an English friend; but its half-brother, a four-year old grey, of singular beauty, out of Vesta by Barefoot, has never yet been trained.

The spring opens for training in April, and on June 7th the racing season begins at Moscow, where the Baron gives 500 silver roubles in prizes. The MIoscow Meeting then lasts for a month; they race for three days out of the seven, and have four or five races per day. The Jockey Club, of which Baron Petroffski is an active member, have a stand of their own, and the horses are entered the night before at their rooms. There

The rouble is 8d. $8 \mathrm{~d}$. is very little betting, and that has been principally introdaced by the English jockeys, who are too true to their old Tattersall's instincts. The Toola Meeting is on July 8th, and on August 18th the one at Crenavoy begins. Here the Baron has lately beat the Government on their own ground; but the advantage of home training is always so great, that the Emperor has generously refused to avail himself of the slightest advantage. Since 1863 these races have come off at Tsarskoe Selo, to give the private studs a better chance to compete. Lebedan, on September 12th, is the fourth and last meeting; and bere, in 1859, the Petroffski "boy in yellow" literally carried off every prize.

Russia may well rank George Dockeray as the worthy servant of a worthy master; 11,654 silver roubles were their spoils of 1859 ; and the future young "Riflemen" are not likely to lessen the score.

\section{HUNGARY.}

The immense plains watered by the Theiss and the tributaries of the Danube have always possessed a serviceable and valuable race of horses, light-spirited and active. We are told (credat Judoens) it was the practice of the Hungarian cavalry to slit their nostrils to prevent their neighing, which often proved troublesome in war.

In the early part of the present century, a wealthy nobleman named Count Hunyadi, of Urmeny, commenced breeding borses with great zeal; and having formed a stud of the very best the country could produce, he sedulously improved it by importations of the best foreign blood. He likewise established public races, and a Racing Calendar. At first these races had only the Count's own horses as competitors, but other neighbouring princes and noblemen soon saw the advantages which he had derived from his plan of breeding, and followed his example. Bright, who travelled through Hungary in 1814, saw the Hungarian Racing Calendar, and I shall give my readers a specimen of its first page, from Dr. Bright's work.

"This meeting took place May 22nd, 1814, between three mares.

\begin{tabular}{|c|c|c|c|c|c|c|c|}
\hline $\begin{array}{c}\text { Names of the } \\
\text { Mares. }\end{array}$ & $\begin{array}{l}\text { Coloor and } \\
\text { Marks. }\end{array}$ & Size. & Age. & Father. & Mother. & $\begin{array}{c}\text { Name of } \\
\text { Rider. }\end{array}$ & $\begin{array}{c}\text { With } \\
\text { what } \\
\text { Weight. }\end{array}$ \\
\hline Victoris & Light brown & ha. in & $\begin{array}{c}\text { yrs. } \\
3\end{array}$ & MIontedora & Roxalane & Johan & P. Fund. \\
\hline Capria & Chesnat & 14 & 3 & Yoscanello & Capria & Johan & $72 t$ \\
\hline Cocos & Iron-grey & $143 t$ & 3 & $\begin{array}{l}\text { Porla, from } \\
\text { Transyl- } \\
\text { vania }\end{array}$ & $\begin{array}{l}\text { Villam fm. } \\
\text { Transyl. } \\
\text { vania. }\end{array}$ & Kohan & $72 t$ \\
\hline
\end{tabular}

"In this case, Victoria and Capria ran the length of one English mile, or eight hundred and forty-nine Vienna klafters, in two minutes and eleven seconds; but Cocoa remained the length of six horses behind.

"That the above-described horses of this size and age, and carrying this weight, did really accomplish the distance in the time stated, we testify by our names."

(Here follows a long list of signatures of noblemen and others present at the race.) 
Graf Hunyadi persevered and even increased his exertions in pursuit of this important object. "In the spring of 1816 he ran thirteen three-year-old mares of his own breeding, before an assemblage of several thousand persons. In this case the whole were divided into three allotments, each forming a separate race. In the first, Justina ran the length of the course, which is one thousand and eighty-two Vienna klafters, in three minutes and fifty-eight seconds; then after resting for an hour, the three successful mares ran against each other, and Lodoiska went over the course in three minutes and three seconds."

The Croatian horses are very like the Hungarian. Buffon asserts that they retain the marks on their teeth much longer than those of any other country, Poland excepted.

Count Hunyadi had a noble successor in Count Batthyani, whose name on the English turf, and in the "first flight" at Melton, is familiar to English ears as a "household word." The Count sent to Hungary some first-rate English blood. Races are now run in our national fashion near Buda-Pesth, and in other parts of Hungary; and the imported blood has put Hungary in possession of a breed of first-class horses.

\section{POLAND, PRUSSIA.}

Prussia has by no means halted in the race of improvement of the horse; nay, she has rather in this respect taken a lead. During the war in which she conquered France, the superiority of the German cavalry was notable. Imperial Germany has established large national breeding studs, and has bought a number of the winners of our great races at large prices.

In the marshy lands about the mouth of the Vistula there is a heavy, large, and strong breed of horses, well suited for dranght and agricultural purposes.

Of late years some of our very best racers have gone to Prussia.

DENMARK AND HOLSTEIN.

The horses of Denmark, Holstein, and Mecklenburg are of the largest stature, especially the two latter. They are usually 16 , and often 17 to 18 , hands high. They are heavily made: the neck is too thick, the shoulders heary, the backs too long, and the croups are narrow compared with their fore parts: but their appearance is so noble and commanding, their action is so high and brilliant, and their strength and spirit are so evident in every motion, that their faults are pardoned and forgotten, and they are selected for every occasion of peculiar state and ceremony.

Before, however, we arrive at the native country of these magnificent horses, we must glance at the attempt of one noble individual to improve the general breed of horses. In the island of Alsen, separated from the duchy of Sleswick by a narrow channel, is the habitation of the Duke of Augustenburg. His stud is attached to it, and under the immediate management of the noble owner. It contains thirty mares of pure blood, and fifteen or sixteen stallions of the sane grade; and all of them selected with care from the best thorough-bred horses in England. Notwithstanding this selection of pure blood, or rather in its peculiar selection, it has been the olject of the duke to produce a horse that shall be useful for the purpose of pleasure, commerce, and agriculture. Some of the stallions are reserved for his own stud; but with regard to the others, such is the spirit with which this noble establishment is conducted, and his desire to improve the race of horses in Sleswick, that he allows more than six hundred mares every year, belonging to the peasantry of the isle of $A$ lisen, to be covered gratuitously. He keeps a register of them, and in the majority of cases he examines the mares himself, and chooses the horse which will best suit her form, her beauties, her defects, or the purpose for which the progeny is intended. It is not therefore surprising that there should be so many good horses in this part of Denmark, and that the improvement in Sleswick and in Holstein, and also in Mecklenburg, should be so rapid and so universally acknowledged.

Rae Wilson, in his Travels in Denmark, gives the following on the royal stables:- "The floors of the king's stables at Copenhagen are not laid with smooth pavement, but rough stones, on an inclined plane. This is said to prevent lameness, which often happens when the animals stand in their own litter. The mangers are high and semicircular. The cribs are of iron, and the name of each animal inscribed over his stall. The horses of the king are calculated at eleren hundred. The skin of a horse is suspended from the ceiling of the Museum, in the act of flying. These animals are

$$
\text { " Compact in frame, and strong in limb." " }
$$

There is another circumstance which should not be forgotten -it is that by which alone the preservation of a raluable breed can be secured-it is that to the neglect of which the deterioration of every breed must be partly, at least, and, in many cases, chiefly traced. The duke in his stud, and the peasants in the surrounding country, preserve the good breeding mares, and will not part with one that has not some evident or secret fault about her.

There is, however, nothing perfect under the sun. This determination to breed only from horses of pure blood, although care is taken that these horses shall be the stoutest of their kind, has lessened the size and somewhat altered the peculiar character of the horse in the immediate districts; and we must go somewhat more southward for the large and stately animal of which previous mention has been made. The practice of the country is likewise to a certain degree unfriendly to the full development of the Augustenburg horse. The pasturage is sufficiently good to develope the powers of the colt, and few things contribute more to his subsequent hardihood than his living on these pastures, and becoming accustomed to the vicissitudes of the seasons : yet this may be carried too far. The Sleswick colt is left out of doors all the year round, and, except

- Wo should say its effect would be just the contrart. 
when the snow renders it impossible for him to graze, he is, day and night, exposed to the cold, the wind, and the rain We are no advocates for a system of nursing laborious to the owner and injurious to the animal, but a full development of form and of power can never be acquired amidst neglect and privation.

NORWAY, SWEDEN, FINLAND, LAPLAND, ICELAND.

The horse of Norway is larger than the Swedish or Finland, but is equally hardy and manageable, attached to its owner, and its owner to it. The roads in Norway are the reverse of what they are in Sweden: they are rough and almost impassable for carriages, but the sure-footed Norwegian seldom stumbles upon them. Pontoppidan speaks of their occasional contests with bears and wolves, and chiefly the latter. These occurrences are now more matter of story than of actual fact, but they do sometimes occar at the present day. When the horse perceives any of these animals, and has a mare or foal with him, he puts them behind him, and then furiously attacks his enemy with his fore legs, which he uses so expertly, as generally to prove the conqueror; but if he turns round in order to strike with his hind legs, the bear closes upon him immediately and he is lost.

Of the horses of the islands of Faroe, which belonged to the Danish crown, Berenger speaks in terms of much praise. He says that "they are small of growth, but strong, swift, and sure of foot, going over the roughest places with such certainty that a man may more surely rely upon them than trust to his own feet In Suderoe, one of these islands, they have a lighter and swifter breed than in any of the rest. On their backs the inhabitants pursue the sheep, which are wild in this island; the pony carries the man over places that would be otherwise inaccessible to him-follows his rider over others-enters into the fuil spirit of the chase, and even knocks down and holds the prey under his feet until the rider can take possession of it."

The Sucdish horses in general, says Mr. Lloyd (Field Sports of the North of Europe), "are hardy and capable of considerable exertion; their manes and tails are usually left in a state of nature; they are seldom cleaned, and when in the stable, even in the most severe weather, are rarely littered down. This treatment of their horses arises as well from ignorance as neglect, on the part of the peasants. In saying this, hovever, I am willing to admit that many of them are almost as fond of these animals as if they were their own children. The average price of a good horse of the description I am now speaking of, may be taken at from five to eight pounds."

Sir Capel Brooke, in his Travels in Sueden, thus speaks of the courtry horse: "He is nimble and willing, almost entirely fed on bread composed of equal parts of rye and oatmeal. To this is added a considerable quantity of salt, and, if he is about to start on a long journey, a little brandy. While changing horses we were not a little entertained at the curious group formed by the peasants and their steeds breakfasting together; both cordially partaking of a large hard rye cake. The horses sometimes belong to three or even more proprietors: it is then highly amusing to observe the frequent altercations between them ; each endeavouring to spare his own horse. Thoir affection for their horses is so great that I have seen them shed tears when they have been driven beyond their strength. The expedition, however, with which these little animals proceed is surprising, when we consider the smallness of their size, which hardly exceeds that of a pony. The roads being universally good throughout Sweden, they frequently do not relax from a gallop, from one post-house to another."

The Finland horses are yet smaller than the Swedes; not more than twelve hands high. They are beautifully formed and very fleet. They, like the Swedes, are turned into the forests in the summer, and must be fetched thence when they are wanted by the traveller. Although apparently wild, they are under perfect coutrol, and can trot with ease at the rate of twelve miles in the hour.

Fish is much used, both in Finland and Lapland, for the winter food of horses and cattle.

Kerguelen tells us in his Voyage to the North, speaking of Iceland, that there are numerous troops of horses in this cold and inhospitable country, descended, according to Mr Anderson, from the Norwegian horse, but, according to Mr. Horrebow, being of Scottish origin. They are very small, strong, and swift. There are thousands of them in the mountains which never enter a stable; but instinct or habit has taught them to scrape away the snow, or break the ice, in search of their scanty food. A few are usually kept in the stable; but when the peasant wants more he catches as many as he needs, and shoes them himself, and that sometimes with a sheep's horn.

The Lapland horse, according to Berenger, is small, but itetive and willing-somewhat eager and impatient, but free from vice. He is used only in the winter season, when he is employed in drawing sledges over the snow, and transporting wood, forage, and other necessaries, which in the summer are all conveyed in boats. During the summer these horses are turned into the forests, where they form themselves into distinct troops, and select certain districts, from which they rarely wander. They return of their own accord when the season begins to change and the forests no longer supply them with food.

\section{AUSTRIA, BAVARIA.}

The remarks made on the horses of Poland and Hungary will apply in a great measure to those of Austria proper. Bavaria has, especially, a valuable, but rather sluggish description of horse, answering in some respects to the old German "destrier," whereon the armour-clad knights of the middle ages were mounted: this is suitable for heavy dragoons, but would be all the better for a little more "blood."

In 1790, a very superior Arab, called Turkmainath," was imported for the imperial stud, and his stock became cele. brated, not only in Hungary, but throughout most of the German provinces. In 1859, the Archduke Maximilian, brother to the emperor, purchased some valuable racers and

-We shrewdly suspect, from other reasons thsn the name, thet this was no Arab at all, but a Toorkman. 
nunters in England, and sent them to Austria. Some of them went to the imperial establishment of which mention is hereafter made, and the others contributed materially to the improvement of the horses wherever they were distributed. Races have been established in various parts of the Austrian dominions, and particularly at Buda, in Hungary. Of the good effect which this will have on the breed of horses there can be no dispute, provided the race does not degenerate into a mere contest of superiority of speed, as exhibited in an animal that, from his extreme youth, must inevitably be injured or ruined in the struggle.

In Austria proper there is the great breeding establishment at Mezöhogyes, near Carlsburg, of which we read in the works of the Duke of Ragusa:-This is the finest establishment in the Austrian Empire for the breeding and improvement of horses. It stands on forty thousand acres of the best quality ; and is surrounded in its whole extent, which is fifteon leagues, by a broad and deep ditch, and by a broad plantation sixty feet wide. It was formerly designed to supply horses to recruit the cavalry; at present its object is to obtain stallions of a good breed, which are sent to certain depôts for the supply of the provinces. To produce these, one thousand brood mares and forty-eight stallions are kept; two hundred additional mares and six hundred oxen are employed in cultivating the ground. The plain is divided into four equal parts, and each of these subdivided into portions resembling so many farms. At the age of four years the young horses are all collected in the centre of the establishment. A selection is first made of the best animals to supply the deficiencies in the establishment, in order always to keep it on the same footing. A second selection is then made for the use of the other: none of these, however, are sent away until they are five years old; but the horses that are not of sufficient value to be selected are sold by auction, or sent to the army to remount the caralry, as circumstances may require.

The whole number of horses at present here, including the stallions, brood-mares, colts, and fillies, is three thousand. The persons employed in the cultivation of the ground, the care of the animals, and the management of the establishment generally, are a major-director, twelve subaltern officers, and eleven hundred and seventy soldiers.

The imperial treasury advances to the establishment every year one hundred and eighteen thousand florins (the half rixdollar or florin is in value about 2s. 1d. English money), and is reimbursed by the sale of one hundred and fifty stallions, which are sent every year to the provinces at the price of one thousand florins each, and hy the value of the horses supplied to the cavalry. The other expenses of every description are paid for by the produce of the establishment, which is required to defray, and does defray all. This is, therefore, an immense estate-a farm on a colossal scale-with a stud in proportion, managed on account of the sovereign, and which produces a considerable revenue, independently of the principal object which is attained, the propagation and multiplication of the best breeds of horses. It can always supply the wants of the army at a price almost incredibly small. For a horse of the light cavalry he pays only one hundred and ten florins, for the dragoons one hundred and twenty, for the cuirassiers one hundred and forty, for the train one hundred and sixty, and for the artillery one hundred and eighty. It is a great element of power to possess at home such an immeuse resource against a time of war, at an expense so far below that which the powers of the west and south of Europe are compelled to incur.

The facility with which the large bodies of Austrian cavalry, their numerous and comparatively clumsy artillery, and enormous waggon-train were horsed and moved during the disastrous Italian campaign of 1859 , was due to this organised system of breeding for the army.

The German running horses were probably Ilungarian horses, with an Eastern cross.

\section{HOLLAND AND BELGIU1.}

Though these countries possess good horses for harness and saddle purposes, it is by their "long-tailed blacks," with their arched crests, profuse manes, and clumsy fetlocks, used in the funeral cortége, or, by their ponderous dray and waggon horses, that they are best known in England.

The fleshy, broad, and roomy "Flanders mare" has been proverbial for centuries. "Bluff King Harry's" unpolite exclamation in relation to his fiancée, Anne of Cleres, will be remembered. From some of the lighter of this stock we have had stately coach-horses; and the cream-coloured IIanoverians in the royal state-carriage owe their origin to a kindred race.

\section{FRANCE.}

"The horses of France are of all descriptions-out few or them handsome, and fewer still fast-goers," says a recent sporting traveller. This is easily accounted for. There is not and will not be, except in the very rare instances of immediate descent from imported blood, animals of that high class which result in England from a liberal and judicious expenditure in every part of the country on procuring the best stock to breed from. Baron Charles Dupin says "Comparant ensuite la France arec les contrées voisines pour la richesse en chevaux et en troupeaux, il s'arrête devant la deproportion qu'elle présente sous ce point de rue avec la GrandeBretagne." And it is probable this -will remain so as long as we have the law of primogeniture, and France is without it. The expenses of the turf will never be supported in France in the same way as in England on that very account. In a country like France, where property is so divided, and in a country like England, where money is in such masses-the turf being a luxury as well as pleasure-becomes the enjoyment of the nobility of the land; the law of primogeniture preventing the division of estates, secures at once the experience and the means of perpetuating the breed of horses of the first quality, from generation to generation. And to this may be added the long engrafted love of the horse among our yeomen, farmers, and all engaged in rural pursuits. In facm 
Frenchmen generally, though a few rare exceptions may be found to prove the rule, do not understand, and therefore do not admire thorough-bred horses. Beyond the army and the court, there are not many Frenchman but would be content with a moderate priced horse; and would rather avoid, we believe, the extra care and attention which a higher-bred animal might subject him to. The French, as far as our experience goes, are an economical people, not likely to encourage any expense which they possibly could do without; and therefore are in the main content with their present breed of horses. There are no hounds kept in the provinces, because there are no primogeniture estates of twenty thousand pounds a year to support them; there are no subscription packs for the same reason as there is no private one; property is so extensively divided, that if it secures comforts, they are satisfied, and are too wise to embark in any thing which they deem extravagant. There is no encouragement to stimulate the breed of hunters, and the breed of blood horses will, we suspect, still remain in the hands of the French Government, rather than be taken up by private breeders.

From the time of Napoleon I. the practice has prevailed in France for the government to send stud horses into the different provinces to assist the French farmer in the improvement of his horses, but with little advantage, as we shall note hereafter. This is absolutely necessary, for the French farmer employs so little capital that it would interfere too much with his economy to pay a price for a good stallion.

Louis Philippe, albeit no sportsman, at the earnest solicitation of his eldest son the Duke of Orleans, founded the great hippodrome, or race-course at the royal demesne of Neuilly. Though personally without taste for the pleasures of the turf, as a national recreation, he could not fail to see the importance of encouraging the breeding of horses upon a better principle than that of merely crossing the soft-boned and heavy Flanders mare with the hardy but clumsy Norman stallion. With an eye to war and to commerce, the astute "old Clysses" - whose cunning however overshot the mark, aud sent him wandering like the old Greek whose name was aptly applied to bim-saw that this branch of rural pursuits must be advantageous. Accordingly, the royal stud in Normandy was conducted on an immense scale. A writer in 1840 says, "The stud of stallions here is enormous; and when such horses are found in it as Lottery, Cadland, Pickpocket, Dangerous, Juggler, Teetotum, Mameluke, Young Emilius, Cleveland, and an endless et cetera of minor stars, it will be owned they have gone the right way to work. These horses during the season are sent all over the country." If they have gone "the right way to work" in procuring such stallions, they have gone "the wrong way to work" in the use of them, in thus travelling them like our cart-stallions. In this we are confirmed by an incidental remark of Admiral Rous, which we have this instant stumbled over in Baily's Magasine 0; Sports and Pastimes for April 1860. The gallant turfsman says:- "In France they order things differently: in addition to liberal prizes, the Government has purchased our best stallions, whose services are given to the public at a cheap rate. If in this country we pursued the latter policy, we should deteriorate our breed, because it would induce persons to breed from ordinary mares with a view to obtain a valuable marketable article by a crack stallion. The first-class horses would be overworked, and an inferior animal would be the natural production."

This then is one of the "things" they do not manage better in France. The Duke of Orleans-whose melancholy death, by being thrown from his phaeton, in 1842 , probably was the turning-point which led mainly to the expulsion of the Orleans dynasty, and thence to a republic, an empire, and a military despotism-was an ardent admirer of the race-horse. His visit to Goodwood, and his victory with Beggarman, for the Goodwood Cup, took place in 1840: a feat twice since performed by French horses-by Jouvence, in 1853, and by Count Lagrange's Monarque, in 1857. Since then a French horse, Gladiateur, won both Derby and Leger in 1865, and a French mare, Fille de l'Air, was victrix in the Oaks in 1864. The ex-emperor of the French, during his twenty years reign, gave an immense impetus to the breeding of a better class of horse. The most sedulous attention was given in all the imperial haras to procure the best crosses which money could obtain, with the view of propagating in France an animal of blood, hone, and symmetry, to rival our best chargers and hunters; while thorough-breas for the turf were not neglected, though, on the whole, treated as a subsidiary desideratum - substance being preferred to speed According to a recent survey, France possesses 2,750,000 horses, of every description; of which 1,440,000 w'ere mares: a great proportion of which were used in breeding mules. Besides these, there are annually 30,000 horses imported into France for sale, or with the express purpose of improving the breed. Host Frenchmen of fortune are ambitious to have first-rate English horses, and will give high prices for them.

Two-thirds of the French horses are devoted to purposes of light work, and possess a certain degree, and that gradually increasing, of Eastern blood. There is room, however, for a great deal more than the French horse usually possesses. One-third of the horses are employed in heary work; 70,000 in post work; and about the same number are registered as fit for military use, although not more than half of them are on actual service. The ascertained number of deaths is about one in twelve or thirteen, or leaving the average age of the horse at twelve. This speaks strongly in favour of the humanity of the French, or the hardihood of the horses, for it exceeds the average duration of the life of the horse in England by more than two years. Calculating the average value of the French horse at 400 francs, or $16 l .13 s .4 d$, there results a sum of about $160,000,000$ francs, or rather more than six millions and a half sterling, as the gross valua of this species of national property.

It must be supposed that so extensive a country as France possesses various breeds of horses. Aurergue and Poitou produre good ponies and galloways; but the best Frencb 
horses are bred in Limousin and Normandy. From the former district come excellent saddle-horses and bunters, and from the latter a stronger species for the road, the cavalry service, and the carriage.

M. Houel has published an interesting work on the varieties of the horse in France. He states that in the time of the Romans there were but two kinds of horses, - the warhorse, and the sumpter or pack-horsc. The carriage, or draught-horse, was comparatively or quite unknown; and even persons of the highest station suffered themselves to be indolently drawn by oxen. Great care was taken to preserve or to renew the strength and speed of the war-horse, and African or Arab blood was diligently sought. An animal, the type of the English Cleveland breed, the handsomest and strongest description of the coach-horse, was thus procured. By degrees, this horse was found too valuable for a hackney, and too high-trotting for a long journey, and a more smoothly moring animal was gradually intrnduced. Still the charger did not grow quite out of fashion, and in Normandy the rearing of this animal became an object of much attention to the farmer. At first they were bred too slow and ponderous, but by degrees a horse was obtained of somewhat lighter action and considerable speed, without much sacrifice of strength, and they now constitute a most valuable breed. "I have not elsewhere," says, M. Houel, "seen such horses at the collar, under the diligence, in the post-carriage, or the farm-cart. They are enduring and energetic beyond description. At the voice of the brutal driver, or at the dreaded sound of his never-ceasing whip, they put forth their strength; and thay keep their condition -when other horses would die of neglect and hard treatment." The little Norman cart-horse is, perhaps, the best for farm-work. The Norman horses - and the same observation applies to all the northern provinces of France-are very gentle and docile. A kicking or vicious one is almost unknown there; but they are, with few exceptions, treated with tyranny and cruelty from first to lası. The reign of terror may to a certain degree be necessary where there are many perfect horses; but the principle of cruelty should not extend, as it too often does, to the treatment of every kind of horse.

We, however, give our suffrage for the admirable system so widely propagated by Mr. Rarey, feeling convinced, by the case of Cruiser, King of Oude, and a dozen other entire horses, which have been subdued by that gentleman's system, that terror produced by suffering or violence is more likely to create or confirm vice, than really eradicate it. In regard to general treatment of the horse there is more humanity among the French than the English peasantry; but, on the other hand, there are horrible scenes of cruelty to the horse hourly taking place ir the streets of Paris, that would not be tolerated for a moment in the British metropolis.

The breeding of horses has more decidedly become a branch of agricultural attention and speculation than it used to be; what is taking place is attributable principally to this cause-it has been proved to the farmer that, with the proper kind of pasture, and within a fair distance of a proper market, instead of being one of the most uncertain and unprofitable modes of using the land, it yiclds more than an average return.

The establishment of races in almost every part of France has given a spur to the breeding and improvement of the horse which cannot fail of being exccedingly beneficial throughout the whole of the French territory. Nor has the Republic been slow, considering the terrible devastation of the recent war and the exhaustion occasioned by the ruinous indemnity to Germany, in re-establishing the public breeding establishments. The English thorough-bred horse has been preferred to the native Arabian. A great many of the best English stallions have been purchased for the Frencl studs, and have been beneficially employed in improving, and often creating, the hunter, the racer, and the better class of horses.

It has been stated that the most valuable native horses are those of Normandy; perhaps they have been improved by the English hunter, and occasionally by the English thoronghbred horse; and on the other hand, the English roadster, and the light draught horse, have derived considerable advantage from a mixture with the Norman; not only in early times, when William the Conqueror was so eager to improve the horses of his new subjects by means of those of Norman blood, but at many succeeding periods.

A certain number of Normandy horses used to be purchased every year by the French government for the use of the othel departments. This ied occasionally to considerable trickery and evil. None of the Norman horses were castrated unti! they were three, or sometimes four years old; and then it frequently happened that horses of superior appearance, but with no pure blood in them, were sold as belonging to the improved breed, and it was only in their offspring that the cheat could be discovered. The government now purchases the greater part of the Normandy horses in their first year, and brings them up in the public studs. They cost more money, it is true; but they are better bred, or become finer animals.

It is stated in the journals that the Norman horses, which were encouraged rather from political considerations, are to be proscribed from the national haras; many of them now find their way to 'Tattersall's establishment, and are bought by a number of the dealers and livery-stable keepera to be used as carriage and saddle horses. They are not of the very first class in either capacity.

The necessity of a stud-book, whenever horses are of sufficient value to deserve a record of their descent, is self-evident. The first work of this kind in France was drawn up as late a 1837. This fact alone warrants what to some persons may consider as savouring of insular prejudice in some of our pre cedent remarks. This book contains the names of 215 stallions, of pure English blood, imported into France, or foaled thert, 266 Barbs, Arabs, Turkish, or Persian horses; 274 mares, of pure English blood; and 41 Barbary or Turkish mares. Their stock is also registered. This work forms an epoch in the 
improvement of the horse in France. Of necessity, leading French turfites have extensively patronised English trainers and jockeys, as Frenchmen neither understand training nor riding racehorses.

\section{SPAIN AND PORTUOAL.}

In early times, the Iberian Peninsula was celebrated for a noble and high-couraged breed of horses, which owed their origin to African blood; and, in the days of Roman power, the district near Calpe, our modern Gibraltar, was renowned for a breed of horse superior to any other European variety, even that known as Arabian. The true Spanish horse is extremely handsome, well knit, clean-jointed, and easy in his paces. His disposition is playful, free from vice, and affectionate to his master. But, like his master, he has degenerated. Pliny's description of the "thieldones" or "tellers of their steps," applies accurately to the jennet of later times.

Cordova, in Catalonia, was once famous for its horses, but their glory is departed: indeed, the taste of the Spanish breeder is so depraved that he prizes a horse for those very points which would make an English sportsman reject him from the stud, viz. :-forelegs far back, almost under the belly; shoulders, consequently, heavy and forward; and tail set on so low that it appears squeezed close to the hams. The Spanish grooms do not suffer their horses to lie down, but keep them chained to a clean pavement by their feet. Within a few years, however, a healthy reaction has taken place, and some attempts have been made, by introducing in the various provinces Andalusian stallions, to check the degenerating progress so manifest in this mule-breeding land.

Solleysel, in his "Parfait Mareschal," has left us a florid description of the Spanish horse as he found him:- "I have seen many Spanish horses; they are extremely beautiful, and the most proper of all to be drawn by a curious pencil, or to be mounted by a king, when he intends to show himself in his majestic glory to the people. There will not be found any kind of horse more noble than they, and of their courage; I have seen their entrails hanging from them, through the number of wounds that they have received; yet they have carried off their rider safe and sound, with the same pride with which they brought him to the field, and after that they died, having loss life than courage."* It is delightful to read accounts like these, and we know not which to admire most, the noble horse or the writer who could so well appreciate his excellence.

Berenger, (Horsemanship, vol. i., p. 151,) whose judgment can be fully depended on, thus enumerates their excellences and defects:- "The neck is long and arched, perhaps somewhat thick, but clothed with a full and flowing mane; the head may be a little too coarse ; the ears long, but well placed; the eyes large, bold, and full of fire. Their carriage lofty, proud, and noble. The breast large; the shoulders sometimes thick; the belly frequently too full, and swelling; and the loin a little too low; but the ribs round, and the croup round and full, and

- Sollegsel, part i. p. 211. the legs well formed and clear of hair, and the sinews at a distance from the bone-active and ready in their paces-of quick apprehension; a memory singularly faithful; obedient to the utmost proof; docile and affectionate to man, yet full of spirit and courage."

The common breeds of Spanish horses have nothing extra. ordinary about them. The legs and feet are good, but the head is rather large, the forehand heavy, and yet the posterior part of the chest deficient, the crupper also having too mucb the appearance of a mule. The horses of Estremadura and Granada, and particularly of Andalusia, are most valued.

The modern Spanish horse is fed upon chopped straw and a little barley. When the French and English cavalry were there, during the Peninsular war, and were without preparation put upon this mode of living, so different from that to which they had been accustomed, they began to be much debilitated, and a considerable mortality broke out among them ; but, after a while, those who were left regained their strength and spirits, and the mortality entirely ceased.

There was a time when the Lusitanian or Portuguese horses were highly celebrated. The Roman historian Justin compares their swiftness to that of the winds, and adds, that many of them might be said to be born of the winds; while, on the other hand, Berenger, who lived at a time when the glory of the Spanish horse had not quite faded away, says, that "the Portugal horses are in no repute, and differ as much from their neighbours, the Spaniards, as crabs from apples, or sloes from grapes." (vol i., p. 308). He thus accounts for it. When Portugal was annexed to Spain, the latter country was preferred for the establishment of the studs of breeding, and the few districts in Portugal which were sufficiently supplied with herbage and water to fit them for a breeding country were devoted to the rearing of horned cattle for the shambles and the plough, and mules and asses for draught. Hence, the natives regarded the horse as connected more with pomp and pleasure than with utility, and drew the comparatively few horses that they wanted from Spain. The present government, however, seems disposed to effect a reform in this, and there are still a sufficient number of Andalusian horses in Portugal, and Barbs easily procurable from Africa, fully to accomplish the purpose.

ITALY.

There are some comparatively fast horses in Rome, the descendants of Spanish jennets, or small Barbs. They are kept for racing on the Corso. These races take place during the Carnival, and commence about dusk. So soon as they are announced, the coaches, cabriolets, and carriages of every kind are drawn up in lines on each side of the street, leaving a space in the middle for the racers to pass through. Five or six horses are specially trained for this diversion. They are drawn up abreast in the Piazza del Popolo, exactly where the Corso, or race-street, begins.

Balls with little sharp spikes are hung along their sides, which serve as spurs; pieces of tinfoil dangle against their 
buttocks, which make a hissing noise as they run, and terrify them to increased speed. A rope is stretched across the Corso to prevent them starting too soon, and the dropping of this is the signal to start. When all is ready a troop of dragoons gallop through the street to clear the course. A trumpet sounds-the rope is dropped-the grooms loose their hold, and away go the riderless horses. The harder the poor devils run, the more they are pricked. The unlucky animals, unable often to comprehend the cause of their torment, bite, kick, and plunge at each other, and a terrible fight is begun. The shouts and cries of the excited populace add to the uproar. Some horses from fear, cunning, or sulkiness stand stock-still, and are shoved and goaded on by brute force and cruelty. A strong canvas screen is passed along the bottom of the street. This is the goa!. It has the appearance of a wall; but some of the horses, in the excess of their agony and terror, dart full against it, tear through it, or carry it away.

The prize, after all, is mercly a piece of fine purple or scarlet cloth, or a flag, which is presented to the owner of the winning animal by the Governor of Rome, and is supposed to be a heirloom in the winner's family.

The decision of such a race, however, can have little to do with the speed or strength or value of the horses in any respect. The Italians, however, enter into the affair with all their characteristic eageruess of feeling, and are guilty of every kind of extravagance. During the first six days of the carnival, the horses are fairly classed according to the age, height, degree of breeding, \&c.; but on the two last days the horses are of all sorts and sizes, like a Welsh race at a country fair.

At Ancona, a gun is fired to start the horses, in order to warn those at the far end of the course to get out of their way and to be ready to receive them; when they have reached half-way another gun is fired, and a third on the victor passing the goal.

Macgill, in his amusing book of Travels, mentions a very curious and laughable circumstance in connection with these races, which took place at Ancona on an occasion of this nature. He says, "To guard the course, a great number of Roman soldiers, under arms, are generally ranged on each side of it. The morning after the first race, the wind blew from the north and was rather cold. I was sitting with his
Excellency the Governor, Signor Vidoni, when a messenger arrived from the General, with his compliments, requesting that the race might be deferred till another day, as he thouglit the weather too cold to put his troops under arms. 'The Governor replied to him, that, 'As the weather was not too cold for the ladies, he thought it was not too much so for Roman soldiers.' I have seen, on a day which only threatened rain, a guard of Roman soldiers turn out, every one of whom had an umbrella under his arm, the drummer only excepted."* Shades of Cresar and Brutus! could ye have witnessod this, what would have been your emotions? could ye have foreseen such effeminacy among the descendants of the "masters of the world," what would have been your dying pangs? This of course refers to the soldiers of the former papal states, now absorbcd in the kingdom of Italy.

The Corso bere is about 856 toises $†$ in length, and it has been satisfactorily observed by means of a stop-watch, that the horses, usually small Barbs, have run this distance \&n 141 seconds, or about the rate of 37 feet in a secoud; a rate of going by no means despicable, considering the small size and consequent short stretch of the racers, and which places them on a par with a second-rate English racer.

The length of the Italian course is, however, under an English mile, while the Beacon at Newmarket is four-a space too long for any horse to run at the same speed at which he started; and yet this has often been run at the average rate of 42 feet in the second. Childers ran a mile in a minute, which is at the rate of 87 feet in a second 1 so was Stirling said to do; and these were mounted, while the Italian racers have only to carry themselves.

Of the indigenous horse old Blundeville tells us, "The horsys that come out of Sardygnia and the isle of Corsica have shorte bodyes, and be very bolde and corageouse, and unquiet too in their pace, for they be of that fierce and hot cholericke complexion, and therewyth so much used to running in theyr countrie that theye will stand still on no gromnde. And therefore this kynde of borse requireth a discreete and patient ryder, who must not be over hastie in correcting him, for fear of marring him altogither." The original Welsh horse was of this stamp.

- Macgill's Travels in Italy, vol. i. p. 22. t A toise is $\operatorname{six}$ fort. 


\section{CHA PTER VI,}

I. THE IIORSES OF BRITAIN.-IISTORY AND VARIETILS.-II. GAllOWAYS AND PONIES: III. TIE DRAUGHT HORSE:

IV. THE CLEVELAND BAYS; THE COACH HOKE: V. THE HACKNEY.

1. -THE HORSE OF BRITAIN.

THE character of the indigenous horse of Britain, though not capable of definite description, can be fairly deduced from numerous incidental observations of ancient authorities and circumstantial evidence.

We have already noted $\dagger$ that at the earliest of our written historic period, when Julius Cæsar landed near Dover, that the Britons in their scythed chariots, drawn by "well-trained borses," struck terror into the veteran legionaries of the conquering Roman, who had subjugated Gaul without encountering any similar force. We are told further that he took on his return to Rome some of these war-horses to cross with his own breeds. Surely the most strenuous sticklers for a common original will not maintain that the "Foresters" of Exmoor or Dartmoor, the Cornish or Welsh pony, the Scotch Sheltie. or the Irish Hobby-supposing any intercourse at that early period had subsisted between what now forms the United Kingdom-could have amazed and awed the serried phalanx of the Roman army, or have tempted the world's conquerors to covet them as chargers? We may here incidentally notice that the Latin writers divide the horses of Imperial Rome into three classes, adapted for war, the circus, and the saddle. "For war," says Vegetius, "the Huns, Thuringian, Burgundian, and Frisian horses excel; next those of Epirus, Sarmatia and Dalmatia; for chariots, the Cappadocian. In the circus the Spanish horse excels all others, and also the Bicilian, although the African horses of Spanish blood are the swiftest of any. For the saddle above all the Persian horses, being the easiest in their carriage and most soft in their step; afterwards come the Armenian and Sappharenean; nor should the Epirotan and Sicilian horses be despised, though not equal to them in carriage, manner, and form." And this people-possessing all the norses of the Gauls and

- See Sporting Reviero, No. cclviii, June 1860. + Soe ante, page 8.
Belga-are said to have coveted a breed of horses that had no original qualities?

The horse figures upon the most ancient coins of the British Kings : the rude effigies of the monarch occupying the obverse and the clumsy figure of a war-horse the reverse. That the horse was then remarkably numerous in this island is shown by the fact that Cassibelaunus retained "four thousand warchariots to harass the Romans," after disbanding a large portion of his army. As the Roman horses were crossed with those of Spain and Greece, and those again with a strain of Barb or Arab blood, there can be little doubt, although subsequent neglect led to thiir degeneration, that the English heavy horse was improved during the long oceupation of Britain by the Romans.

That the ponies (or mannii) of Britain were a astinct race of animal, may also be assumed from the fact of notice being taken of their intelligence, docility, and small size, which specially fitted them for the performances of jugglers and strollers.

Passing from the Roman to the Saxon times, we find Athelstan celebrated for his attention to the "improvement of the horse," and, in order "that this advantage might be kept in this realm," he prohibited the exportation of English horses. Athelstan seems to have placed considerable value on some of his horses; for he bequeaths, in his will, the horses given him by Thurbrand, and the white horses presented to him by Lisbrand. These are apparently Saxon names, but the memory of them is now lost.

In the laws of Howell the Good, Prince of Wales, A.D. 890, there are some curious particulars of the value and sale of horses. A foal under fourteen days is to be sold for $4 d$; ; at one year and one day it is estimated at $48 d$. ; at three years at $60 d$. It was then to be tamed with the bridle, and brought up either as a palfry or a serving horse, when its value became one hundred and twenty pence. That of a wild or uabroken mare was sixty pence. 
Even in those early days, the frauds of dealers were too notorious, and the following singular regulations were established. The buyer was allowed time to ascertain whether the horse was free from three diseases. Ho had three nights to prove him for the staggers ; three months to prove the soundness of his lungs; and one year to ascertain whether he was infected with glanders. For every blemish discovered after the purchase, one-third of the money was to be returned, except it should be a blemish of the ears or tail, which it was supposed to be his own fault if the purchaser did not discover. The seller also warranted that the horse would not tire when on a journey with others, or refuse his food from hard work, and that he would carry a load or draw a carriage up or down hill, and not be resty.

The practice of letting horses for hire then existed; and then, as now, the services of the poor hack were brutally exacted. The benevolent Howell disdains not to legislate for the protection of this abused and valuable servant. "Whoaver shall borrow a horse, and rub the hair so as to gall the back, shall pay four pence; if the skin is forced into the flesh, eight pence; if the flesh be forced to the bone, sixteen pence." If a person lamed a horse, he was to forfeit the value of the animal; and if he was supposed to have killed a horse, he was to purge himself by the oaths of twenty-four oompurgators.

Then, as now, it would appear that some young men were - little fond of unwarrantable mischief, or perhaps there were thieves in the country, even so soon after Alfred's days, for cutting the hair from a horse's tail seems to have been of frequent occurence. However it shows the estimation in which this portion of the animal was held, and the manner in which the hair was suffered to grow ; for it was decreed that he who cut off the hair from a horse's tail was to maintain him until it was grown again, and in the mean time to furnish the owner with another horse. If the tail was cut off with the hair, the miscreant who inflicted the outrage was mulcted in the value of the animal, and the horse was deemed unfit for future service.

The Norman conquest brought important crosses to the British horse. To his superiority in cavalry the Conqueror was chiefly indebted for the victory of Hastings. The favourite charger of William was a Spaniard. His followers, both the barons and the common soldiers, principally came from a country in which agriculture had made more rapid progress than in England. A very considerable portion of the kingdom was divided among these men; and it cannot be doubted that, however unjust was the usurpation of the Norman, England benefited in its husbandry, and particularly in its horses, by the change of masters. The historians of those times, however-principally monks, and knowing nothing about horsesgive us very little information on the subject.

One circumstance deserves to be remarked, namely, that in none of the earliest historical records of the Anglo-Saxons or the Welsh is there any allusion to the use of the horse for the plough. Until a comparatively recent period, oxen alone were employed in England, as in other countries, for this purpose; but about this period-the latter part of the tenth centurysome innovation on this point was commencing, and a Welsh law forbade the farmer to plough with horses, mares, or cows, but with oxen alone. On one of the pieces of the Bayeux tapestry, woven in the time of William the Conqueror (A.D. 1066), there, however, is the figure of a man driving a horse attached to a harrow.

In William's reign the heavy horses of Burgundy, Picardy, and Flanders were imported largely. Roger de Bellesme, Earl of Shrewsbury, we are expressly told, brought over "Spanish stallions," and Giraldus Cambrensis, and Drayton (Polyolbion) speak in high terms of their fire, vigour, and fitness for the tilt and tourney. We have in another place noticed in the reign of Henry I. (A.D. 1121)-the importation of the first so-called Arabian, presented by Alexander, King Scotland, to the Church of St. Andrew. This solitary case, however, recorded as something extraordinary, may be passed over in considering the general stamp of horse in use at this time.

The Crusades, which followed this period, must have introduced many Eastern horses, though no particular esteem seems to have attended them or their progeny. The jennet of Spain is spoken of with approval, rather as an ambling palfrey than comparable with the heavy German horse. Improved agriculture and commercial labour caused the importation of heavy draught horses from the Low Countries, but the principles of breeding were little regarded and less understood.

The price of horses was singularly uncertain In 1185 , temp. Henry II., fifteen breeding mares sold for two pounds, twelve shillings, and sixpence. They were purchased by the monarch, and distributed among his tenants; and, in order to get something by the bargain, he charged them the great sum of four shillings each. Twenty years afterwards, ten capital horses brought no less than twenty pounds each; and, twelve years later, a pair of horses were imported from Lombardy, for which the extravagant price of thirty-eight pounds, thirteen shillings, and fourpence was given. The usual price of good handsome horses was ten pounds, and the hire of a car or cart, with two horses, tenpence a-day.

To King John, hateful as he was in other respects, we are much indebted for the attention which he paid to agriculture generally, and particularly to the improvement of the breed of horses. He imported one hundred chosen stallions of the Flanders breed, and thus mainly contributed to prepare our noble species of draught-horses, as unrivalled in their way as the horses of the turf.

John accumulated a very numerous and valuable stud. $\mathrm{He}$ was eager to possess himself of every horse of more than usual power; and at all times gladly received from the tenants of the crown, horses of a superior quality, instead of money for the renewal of grants, or the payment of forfeitures belonging to the crown. It was his pride to render his cavalry, and the horse for the tournament and for pleasure, as perfect as he could. It was not to be expected that so haughty and over- 
bearing a tyrant would concern himself much with the inferior kind; yet while the superior breeds were rapidly becoming more valuable, the others would, in an indirect manner, partake of the improvement.

One hundred years afterwards, (A.D. 1311) Edward II. purchased thirty Lombardy war-horses, and twelve heary draughthorses. Lombardy, Italy, and Spain were the countries whence the greater part of Europe was then supplied with the most valuable cavalry or parade horses. Those for agricultural purposes were chiefly procured from Flanders.

Edward III. (1328) bought fifty Spanish horses of such value, that he negociated with the kings of France and Spain to give them safe convoy. These were probably of a lighter and more active form; the prevailing taste for the heary war horse being on the decline among the courtiers: the ponderous armour of the cavalry, however, still kept the "destrier" in esteem for several succeeding reigns.

These horses were bought in order to enable the king successfully to prosecute a war against Scotland, and to prepare for a splendid tournament which he was about to hold.

Entire horses were alone used for this mimic contest, and generally so in the duties and dangers of the field. It was rarely the custom to castrate the colts; and the introduction of the female among so many perfect horses might occasionally be productive of confusion. The mare was at this period comparatively despised. It was deemed disgraceful for any one above the common rank to ride her, and she was employed only in the most servile offices. This feeling and practice was then prevalent in every part of the world. When, however, it began to be the custom to castrate the young horses, the worth and value of the mare was soon appreciated; and it is now acknowledged that, usually, she is not much, if at all, inferior to the perfect horse in many rospects, while she has far more strength, courage, and endurance than the castrated horse.

Edward also prohibited the exportation of horses jealously. It is, however, recorded that he allowed a German merchant to export some Low Country horses which he had brought here on a venture, but prohibited his taking them to Scotland. It was for several centuries a felony to export horses from England to Scotland.

In many points the English horse is already spoken of as superior to those of neighbouring countries, and his price was so enhanced, that the breeders and the dealers, then as now skilful in imposing on the inexperienced, obtained from many of the young grandees enormous prices for their animals. This evil increased to such an extent, that Richard II. (1386) interfered to regulate and determine the price. The proclamation which he issued is interesting, not only as proving the increased value of the horse, but showing what were, four hundred and fifty years ago, the chief breeding districts, as they still continue to be. It was ordered to be published in the counties of Lincoln and Cambridge, and the East and North Ridings of Yorkshire; and the price of the horses was restrictod to that which had been determined by former monarchs. A more enlightened policy has at length banished such absurd interferences.

In the same reign, in 1356, at the glorious victory of Poictiers, wherein the Black Prince took John, King of France, prisoner, we read in Bonnechose's History of France: "but the French kwightes could not contend against the great horses of the English, and the arrows of their archers."* And on the triumphal entry of the Black Prince into London, Stow tells us that the captive John was "mounted on a beautiful wyto steed, in royal robes, while the victorious Prince of Wales rode by his syde on a litel blacke palfre, like an attendante, not a conqueror."

The wars of York and Lancaster now devastated the land, and we can collect but little of the history of the horse until the reign of Henry VII., at the close of the fifteenth century. He continued to prohibit the exportation of stallions, but allowed that of mares, when more than two years old, and under the value of six shillings and eightpence. This regula. tion was, however, easily evaded; for if a mare could be found worth more than six shillings and eightpence, she might be freely exported on the payment of that sum.

The intention of this was to put an end to the exportation of perfect horses; for it is recited in the preamble "that not only a smaller number of good horses were left within the realm for the defence thereof, but also that great and good plenty of the same were in parts beyond the sea, which in times past were wont to be within this land, whereby the price of horses was greatly enhanced," \&c. The exception of the mare, and the small sum for which she might be exported, shows the unjust contempt in which she was held.

In the time of Henry VIII., we find from the writings of Sir Thomas Chaloner, who flourished at the beginning of Elizabeth's reign, horses were imported by that despotic monarch, who was "a great lover of the chase and sportynge," from "Turkey, Naples and Spain." The means adopted by Henry to enforce the breeding of full sized horses were arbitrary and characteristic in the extreme. He made a law, which remains in the statute book till this day, (32 Hen. VIII. cap. 13), by which it is enacted :- " That no person shall put in any forest, chase, moor, heath, common, or waste (where mares and fillies are used to be kept) any stoned horse above the age of two years, not being fifteen hands high, within the shires and territories of Norfolk, Suffolk, Cambridge, Buckingham, Huntingdon, Essex, Kent, South Hampshire, North Wilts, Oxford, Berks, Worcester, Gloucester, Somerset, North Wales, South Wales, Bedford, Warwick, Northampton, Yorkshire, Cheshire, Staffordshire, Lancashire, Salop, Leicester, Hereford, and Lincoln; nor under fourteen hands in any other county, on pain of forfeiting the same;" and it proceeds, "It is lawful for any person to seize any horse so under size, in manner following:- he shall go to the keeper of such forest, or (out of such forest) to the constable of the next town, and require him to go with him to bring such horse to the next 
pound. there to be measured by such officer, in the presence of three honest men, to be appointed by the officer; and if he shall be found contrary to what is above expressed, such person may take him for his own use."

Also, s. 6, "all such commons and other places shall within fifteen days after Michaelmas yearly, be driven by the owners and keepers, or constables, respectively, on pain of $40 \mathrm{~s}$, and they shall also drive the same at any other time they shall think meet; and if there shall be found, in any of the said drifts, any mare, filly, foal, or gelding, which shall not be thought able, nor like to grow to be able to bear foals of a reasonable stature, or to do profitable favours, by the diseretion of the drivers, or the greater number of them, they may kill and bury them."

Even infected horses are prohibited from being turned into such commons-(s. 9), "whereby it is enacted that no person shall have, or put to pasture, any horse, gelding, or mare, infected with the seab, or mange, in any common or common fields, on pain of 10s. and the offence shall be enquirable in the leet, as other common annoyances are, and the forfeitures shall be to the lord of the leet."

Carew, in his History of Cornwall, supposes this act of parliament to have been the occasion of losing almost entirely the small breed of horses which were peculiar to that country; and no doubt the same effect was produced in Wales. This loss, however, was well repaid by the race of large and powerful horses which took their place.

The following illustration of the horses of England in this reign is taken from the Regulations and Establishments of Algernm Percy, the fifth Earl of Northumberland, begun in 1512

"This is the ordre of the chequir roul of the nombre of all the horsys of my lordys, and my ladys, that are apoynted to be in the charge of the hous yerely, as to say, gentill horsys, palfieys, hobys, naggis, clothsek hors, male hors.

"First, gentill horsys, to stand in my lordis stable, six. Item, palfreys of my ladis, to wit, oone for my lady, and two for her gentillwomen, and oone for her chamberer. Four hobys and nags for my lordys oone saddill, viz.: oone for my lorde, and oone to stay at home for my lorde.

"Item, chariot hors, to stond in my lordis stable yerely. Seven gret trottynge horsys to draw in the chariott, and a nag for the chariott man to ride, eight. Again, hors for Lord Percy, his lordship's son and heir. A gret doble trottynge hors, called a curtal, for his lordship to ride on out of townes. Another trottynge gambaldynge hors for his lordship to ride on when he comes into townes. An amblynge hors for his lordship to journeye on dayly. A proper amblynge little nag for his lordship when he goeth on hunting and hawking. A gret amblynge gelding, or trottynge gelding, to carry his male."*

It is proper to explain that the gentill horse was one of superior cattle, and made the best chargers. Palfreys were an

- Fr. malle, a leather trunk, whence our English mail, the letters being monveyed on horseback in a malle. The French mail is called the malle-poste. elegant kind, mostly of a small size, and broken in to the use of ladies, and aged or infirm people of rank.

Hobys were strong active horses of a small sice, and are supposed to have come originally from Ireland. This breed being at one time in high repute, gave origin to the phrase, by which any favourite object is termed a man's hobby.

The clothsek, or "male horse," was one that carried the cloak-bag, or portmanteau.

Chariot horses, (derived from the French word charotte, from which again the English word cart), were waggon-horses.

A gret doble trottynge horse, was a heavy, powerful horse, whose pace was a trot, being either too unwieldy in itself, or carrying too great weights to gallop.

A curtal was a horse whose tail was cut or shortened.

A gamballynge horse was one of show and parade; from the Italian word gamba, (leg), gambado, (a curvet.)

An amblynge horse was one of much the same description, but whose more quiet ambling pace adapted him especially to the use of ladies.

In the reign of Edward VI., horse stealing was made a capital offence. By the 1st Edward VI., cap. 12, we find it enacted, "that no person convicted for felonious stealing of horses, geldings or mares, shall have the privilege of clergy." But this enactment being in the plural number, caused a doubt whether a person convicted of stealing one horse, mare, or gelding, was entitled to benefit of clergy, and two acts were subsequently passed in the same reign, to remedy this defect.

We have every reason to believe that the country derived much benefit to its breed of horses in the reign of Elizabeth; as it is more than probable that great numbers of Barbs, and Spanish horses descended from Barbs, were taken on board the numerous vessels captured by Lord Howard of Effingham, the British admiral, on the defeat and dispersion of the Spanish Armada. Elizabeth, though herself a great horsewoman, does not seem to have patronised racing, as we shall note when we come to the history of that pastime. We do not find it men. tioned as forming part of the amusements with which the Earl of Leicester entertained his royal mistress on her visit to Kenilworth; and Comnenius says, at this day, 1590, tilting or the quintain is used, when a ring is struck with a truncheon, instead of horse racing, which, he adds, is grown out of fashion. That this was not on account of any gambling or improper practices being attached to it, we may gather from the writings of John Northbrook, a puritan, who, though very severe against cards, dice, and plays, allows horse-racing, classing it with hunting and hawking.

It is remarkable that such was the large falling on in the number of cavalry-horses between the reign of Edward VI., in 1547, and the middle of Elizabeth, that in 1585, when England was threatened by the Spanish Armada, no more than 3,000 cavalry could be mustered in the whole kingdom, to suppress the invasion.

Towards the close of this reign coaches were introduced by Fitzallen, Earl of Arundel, their inventor, and such was the demand for horses thus occasioned, that a bill was actually 
introduced into the House of Lords, to restrain the excessive use of coaches. It was, however, lost on the second reading. Before this the Queen was, on state occasions, accustomed to ride behind her Master of the Horse. But for a considerable period after the introduction of eoaches, saddle horses continued in use at state ceremonies; for so late as the Restoration, King Charles II. made his entrance into London, May, 1660 , riding between his brothers the Dukes of York and Gloucester, with a splendid cavalcade.

We shall here pause in our general history of the English horse: the subsequent periods being so intimately mingled with the history of racing, as to class it more fitly under a History of the British Turf

\section{1.-Galloways AND PONiES.}

The name galloway, is said to be derived from a handsome, hardy, and much prized breed of horses, indigenous to the South of Scotland, on the shores of the Solway Firth; they have now, however, disappeared from the place of their origin, the agriculturists of the district having sought to breed an animal of larger stature, better fitted for draught purposes, sueh as the Clydesdale horse. There is a tradition, by no means warranted by physiology or probability, that the original galloway was descended from a cross with a horse escaped from the wreck of a ship of the Spanish Armada, cast away on the neighbouring coast. We have a record, indeed, of hardy horses supplied to the army of Edward I. from this district three centuries before.

The original galloway was between thirteen and fourteen hands in height, of a bright brown or bay, with a neat head, black legs, peculiarly deep and clean. It had a remarkable surefootedness and stoutness, with a fair amount of speed. Dr. Anderson thus describes the breed :-

"There was once a breed of small elegant horses in Scotland, similar to those of Iceland and Sweden, and which were known by the name of galloways; the best of which sometimes reached the height of fourteen hands and a half. One of this description I possessed, it having been bought for my use when a boy. In point of elegance of shape, it was a perfect picture; and its disposition was gentle and compliant; it moved almost with a wish, and never tired. I rode this little creature for twenty-five years; and twice in that time rode a hundred and fifty miles, without stopping, except to bait, and that not above an hour at a time. It came in at the last stage with as much ease and alacrity as it travelled the first I could have undertaken to have performed on this animal, when it was in its prime, sixty miles a day for a twelvemonth running, without any extraordinary exertion."

A galloway in point of size, whether of Scotch origin or not is uncertain, performed in the year 1814, a greater feat than Dr. Anderson's farourite. It started from London with the Exeter mail, and, notwithstanding its eighteen changes of horses, and the rapid driving of that vehicle, it arrived at Exeter (one hundred and seventy-two miles) fifteen minutes before the mail. The well-known Professor Youatt, who saw this animal about twelve months after his wonderful perform. ance, describes him as being wind-galled, spavined, ring-boned, and a lamentable picture of the ingratitude of some human brutes towards a willing and faithful servant. Other instances of endurance, equally remarkable, are recorded.

In 1754, Mr. Corker's galloway went one hundred miles a day for three successive days, over the Newmarket Course, and without the slightest distress.

A galloway belonging to Mr. Sinelair, of Kirby-Lonsdale, performed at Carlisle the extraordinary feat of one thousand miles in a thousand hours!

The galloway, or small stout horse known in England by that name, is often from Wales, or the New Forest.

The Welsh pony is a beautiful little animal. He has a small head, high withers, deep, yet round barrel, short joints, flat legs, and good round feet. The Welsh ponies are said to be indebted to the celebrated Merlin, for an improvement in their form and qualities. They will live on any fare, and can nerer be tired out.

This has arisen from a misconception. The Welsh pony was ealled "a Merlyn," as will be seen by an extract from the Cambrian Quarterly Iragazine, which follows :-

"Pony-hunting used to be one of the favourite amusements of the Welsh farmers and peasantry, a century and a half ago, and it has not, even now, fallen altogether into disuse. The following story of one of these expeditions is founded on fact :A farmer named Hugo Garonwy lived in the neighbourhood of Liweyn Georie. Although he handled the tilt plough, and other farming tools in their due season, yet the catching of the merlyn, the fox, and the hare, were more congenial pursuits; and the tumbles and thumps which he received, and from which no pony-hunter was exempt, served but to attach him to the sport. Rugged, however, as the Merionethshire coast and its environs were, and abounding with precipices and morasses, he sometimes experienced worse mishaps-and so it happened with Garonwy.

"He set out one morning with his lasso coiled round his waist, and attended by two hardy dependants and their greyhounds. The lasso was then familiar to the Welshman, and as adroitly managed by him as by any guacho on the plains of South America. As the hunters climbed the mountain's brow, the distant herd of ponies took alarm-sometimes galloping onwards, and then suddenly halting and wheeling round, snorting as if in defiance of the intruders, and furiously pawing the ground. Garonwy, with the assistance of his servants and the greyhounds, contrived to coop them up in a corner of the hills, where perpendieular rocks prevented their escape.

"Already had he captured three of the most beautiful little fellows in the world, which he expeeted to sell for $4 l$. or $5 l$. each at the next Bala fair-to him a considerable sum, and amounting to a fourth of the annual rent which he paid for his sheep-walk. There remained, however, one most untameable creature, whose crested mane, and flowing tail, and wild eye, and distended nostril, showed that he was a perfect Bucephalus of the bills; nor indeed was it safe to attack him 


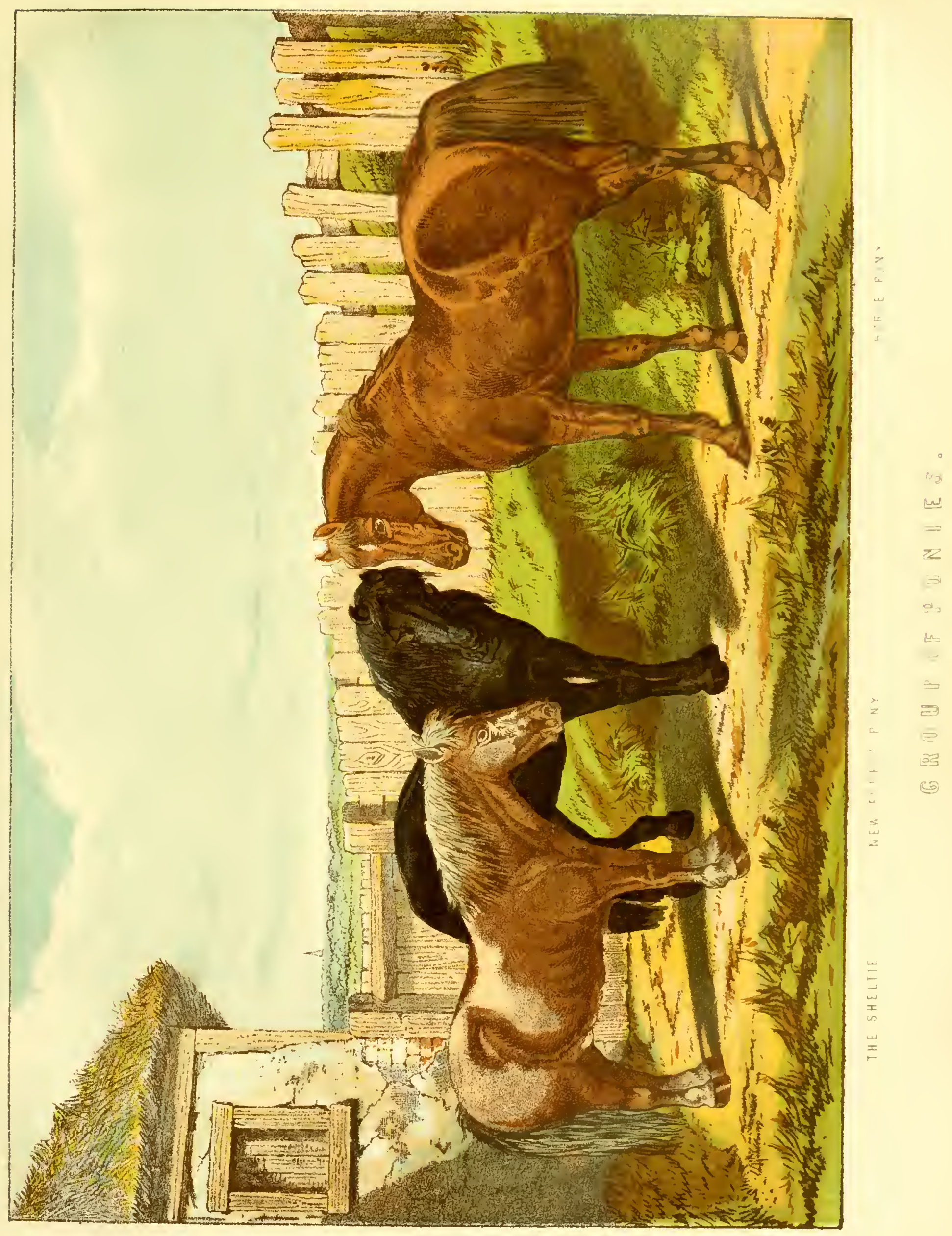



in the ordinary way. Many of the three-year-olds had been known to break the legs of their pursuers, and some had been dismounted and trampled to death.

"Garonwy was determined to give the noble fellow a chase over the hills, and so overcome him by fatigue before the lasso was flung. The dogs were unslipped, and off they went, swift as the winds, Garonwy following, and the two assistants posted on a neighbouring eminence. Vain was the effort to tire the merlyn. Hugo, naturally impatient, and without waiting to ascertain that the coils were all clear, flung the lasso over the head of the wild horse. The extremity of the cord was twisted round his own body, and tightening as the animal struggled, the compression became unsupportable, and, at length, in spite of every effort to disengage himself, Garonwy was dragged from his horse.

"The affrighted merlyn, finding himself manacled by the rope, darted off with all the speed of which he was capable, dragging poor Garonwy over the rocky ground and stunted brushwood. This occurred at some distance from the men. They called in their dogs that the speed of the merlyn might not be increased, but ere they could arrive at the spot at which the accident happened, the horse and the man had vanished. Whether the sufferings of the hunter were protracted, or he was dashed against some friendly rock at the commencement of this horrible race, was never known; but the wild animal, frenzied and blinded by terror, rushed over a beetling cliff, at a considerable distance, overhanging the sea-shore, and the hunter and the horse were found at the bottom, a mis-shapen semblance of what they had been when living."

Old Marsk, the sire of Eclipse, is reported to have given an improving cross to the Nero Foresters, ${ }^{*}$ nevertheless, these are generally ill-made, large-headed, short-necked, and raggedhipped, but hardy, safe, and useful; with much of their ancient spirit and speed, and all their old paces. The catching of these ponies is as great a trial of skill as the hunting of the wild horse on the Pampas of South America, and a greater one of patience.

A great many ponies, of little value, used to be reared in Lincolnshire, in the neighbourhood of Boston; but the breed has been neglected for some years, and the enclosure of the fens will render it extinct.

The Exmoor ponies, although generally ugly enough, are hardy and useful. A well-known sportsman says, that he

- Marsk was sold at the death of the Duke of Cumberland, in 1765, to a farner for a trifling sum, being considered a very indifferent stallion: in 1766 he covered country mares in Dorsetshire at 10s. $6 d$. He was afterwards bought by Mr. Wilkinson (first owner of Eclipse) for 20 guineas, the seller considering himself quit of a bad bargain. In 1767 be covered at Bistern, near Ringwood, Hants, at 3 guineas, seeming to be creeping into farour. In 1769, at Gibbons' Grove, Leatherhead, Surrey, at 5 guineas ; in 1770 at 10 guineas; then 30 guineas. Marsk soon became, by the unparalleled performances of the famed Eclipse, the first stallion in the kingdom; and was in consequence thereof purchased by the Earl of Abingdon for 1,000 guineas and sent to his Lordship's stud at Rycot, in Oxfordshire, where he covered, previous to his death, which happened in July 1779, at 100 guness and one guines the groom. rode one of them half a dozen miles, and never felt such powcr and action in so small a compass before. To show his accomplishments, he was turned over a gate at least eight inches higher than his back; and his owner, who rides fourteen stone, travelled on him from Bristol to South Molton, eighty-six miles, beating the coach which runs the same road.

There is on Dartmoor a race of ponies much in request in that vicinity, being sure-footed, and hardy, and admirably calculated to get over the rough roads and dreary wilds of that mountainous district. The Dartmoor pony is larger than the Exmoor, and, if possible, uglier. He exists there almost in a state of nature. The late Captain Colgrave, of Dartmoor prison, had a great desire to possess one of them of somewhat superior figure to its fellows, and having several men to assist him, they separated it from the herd. They drove it on some rocks by the side of a tor (an abrupt pointed hill); a man followed on horseback, while the Captain stood below watching the chase. The little animal, being driven into a corner, leaped completely over the man aud horse, and escaped.

The horses in the southern and western districts of Devonshire, called "pack-horses," from their former use, are merely a larger variety of the Exmoor or Dartmoor pony.

There is one description of pony, however, truly and unmistakably aboriginal in the northern parts of Britain-we mean the unmistakable little Sheltie, or Zetland pony; an animal which loses every characteristic if an attempt or accident should lead to an increase of their general size. The strength of these little animals almost surpasses belief. Seven, eight, nine, and at the outside ten hands high they are full of vigour, strength, and beauty of a peculiar stamp. There are some which an able man could lift up in his arms: yet will carry him eight or ten miles, and as many back. Summer or winter they never come into a house, but rus upon the mountains, in some places like flocks; and if at any time in winter . they are straitened for food, they will come from the hills when the ebb is in the sea, and eat the sea weed (as likewise do the sheep). Winter storms and scarcity of food brings them so low that they do not recover their strength till about the middle of June, when they are at their best. They will live to a considerable age, as twenty-six, twenty-eight, or thirty years. They last to be good for riding at twenty-four; especially if they are not put to work until they are four years old. Those of a black colour are judged the most durable. The pied often prove not so good. They have been more numerous than they are now. The best of them are to be had in Sanston and Easton; also, they are good in Waes and Yell. Those of the least size are in the northern isles of Yell and Uist. The coldness of the air, and the barrenness of the mountains on which they feed, and their hard usage, may tend to kcep them little; but if bigger horses are brought among them, their progeny degenerate.

Mr. Youatt says:- "A friend of mine was not long ago presented with one of these elegant little animals. He was several miles from home, and puzzled how to convey his newly-acquired property. The Shetlander was scarcely more 
than seven hands high, and as docile as he was beautiful. 'Can we not carry him in your chaise ?' said his friend. The strange experiment was tried. The Sheltie was placed in the bottom of the gig, and covered up as well as could be managed with the apron; a few bits of bread kept him quiet; and thus he was safely conveyed away, and exhibited the curious spectacle of a horse riding in a gig." 'The same writer adds: - "He is often exceedingly beautiful, with a small head, goodtempered countenance, a short ncck, fine towards the throttle, shoulders low and thick-in so little a creature far from being a blemish-back short, quarters expanded and powerful, legs that and fine, and pretty round feet. These ponies possess immonse strength for their s1ze; will fatten almost upon anything, and are perfectly docile. One of them, nine hands (or three feet) in height, carried a man of twelve stone forty miles in one day."

Her present Majesty has, on more than one occasion, purchased some interesting and perfect specimens of the Sheltie, for the use of the younger members of the Royal Family; and they lave always been very much prized for the use of children, alike from their smallness of size and docility.

The Highland Pony is far inferior to the galloway, and is not pleasant to ride, except in the canter. His habits make him hardy, for he is rarely housed summer or winter. The Rev. Mr. Hall says that when these animals come to a boggy piece of ground they first put their nose to it, and then pat on it in a peculiar way with one of their fore-feet, and from the sound and feel of the ground they know whether it will bear them. They do the same with ice, and determine in a minute whether they will proceed.

As to the English pony, almost every district has its breed, more or less, commingled; and the variety would appear to be most suitable to the circumstances of pasturage and soil. Owing, however, to the average large stature of the English horse, any thing under thirteen hands has, in horseman's phrase, come to be called "a pony." Many of our best trotters have passed under this name.

\section{III.-THE DRAUGHT HORSE.}

Up to within these few years our principal employers of draught horses in the metropolis aimed almost exclusively at the procuring of those grand, stately, and immense animals which judicious crossing with the Flemish and old Suffolk Punch so often produced. Of late, however, the immense demand for a horse of higher activity and handiness, for the service of the railway van, has given the waggon horse a stamp more approaching to the Cleveland, or the "machiner" -a smart trot, as well as a sheer-strength pull, being a desideratum When the old "sumpter," or carrier's horse, was used in England, for the conveyance of loads in packs or panniers, some of the Yorkshire sumpter horses have been known to carry 700lbs. weight sixty miles in the day, and to repeat this journey four times a week, while mill horses have carried
910 lbs. for shorter distances." This is the stamp of animas required by the Baxendales, Chaplins, and Pickfords; another sort is yet the pride of our great brewers, distillers, and London waggon owners. The remarks of a gentleman ".frae north o" Tweed" on these horses are so genuine and apposite that we transcribe them :- "A prevalent error of strangers is that these magnificent horses are merely meant as an advertisement of the firm to which they belong. The large and opulent brewer has less occasion for this kind of publicity than any other trader. His customers are compelled to come to him: a chance sale is a rara avis. He has these horses because extraordinary exertion is sometimes required, and he can command it wheu necessary : at the same time they are too valuable to be uselessly worn out, and pay better in the long run for the attention bestowed upon them. This has led many into the error of supposing these splendid animals cannot do the work of such as, from want of proper points to command the higher prices, get into the more laborious employments; and you will hear the owners of these inferior horses constantly remarking on one of these beautiful teams, as not only the pride of the drayman, who beckons them to him like old acquaintance, and which they answer with the sagacity of bipeds, but they are also the pride and admiration of all Englishmen, and the astonishment of most foreigners. A Scotchman is certainly not a foreigner, being but an Englishman of a distant portion of Great Britain; but I cannot help noticing, that, when visiting the Land of Cakes, I have always felt elated at the animated description of their feelings at first beholding these noble creatures. They were full of astonishment, and could not tell which made the greatest impression, their extreme beauty, vast size, sagacity, or dncility, amounting beyond parallel. One gentleman remarked, "I have been over most of the globe; I have seen many of its wonders; but the greatest I ever saw was in London. I saw a brewer's team lowering some butts of beer. The horse that performed this office, without any signal, raised the butts, and returned and lowered the rope: not a word or sign escaped the man at the top of the hole, who only waited to perform his part as methodically as his four-footed mate did his. Two others were sometimes playing at intervals in apparent converse. The cellaring finished, the horse took his place by the team : the other loose horse, that had been going wherever he pleased, also came, and was hooked on. The man adjusted his dress, then walked away; the team followed. Not one word has passed, not even a motion of the whip, or any other intimation of what was to be done next.' He added, he had never seen the same number of men work in such unison with the various changes: it was wonderful, and if it was not reason, he thought the greater portion of mankind had better give up some part of their reason to learn sagacity from a drayhorse. He continued: 'I followed some distance to see how it was that a man, who seemed as if he could be crushed at any moment by these monsters, had such control over them. I observed he never touched them : between carriages where there

- Youstt, p. 256. 
hardly seemed room enough to squeeze through, he went without touching, and this, too, by merely waving a bit of whipcord on the end of a long black rod." He finished with- 'I was quite astounded ; it was truly wonderful ; and I always recollect the sight with pleasure; and can hardly prevail upon myself that it was not some necromancer waving an enchanted rod." "

This digression dismissed, we will proceed to show that the observation that brewers' horses cannot do the more laborious kinds of work, particularly that of town carmen, is a mistake. There is not often an opportunity of proving the fact, the greater part of the brewers being too liberal to their old servants to part with them when worn out: most of them, therefore, have them destroyed when, from old age or accident, they are incapacitated from performing their work with moderate comfort. Some wealthy gentlemen, aye, and ladies too, may take a leaf in this respect, at least, out of the brewers' book, when many a favourite hunter, charger, ladies' pad, hack, and even racer, will be saved the torture of dragging streetcabs and costermongers' carts with aching limbs, crippled feet, galled shoulders and back, for the sake of putting into the pocket of the seller not perhaps one half what the old drayhorse would fetch.

There are a few exceptions of brewers selling their horses, and we feel confident all those who have bought them have found them work better than the ordinary horses at the same age: we have known many. One was sold out from being supposed to be lame: he turned out sound. Three tons and a half, including his cart, became his ordinary load, and with this he went all over London and the neighbourhood, and never had, or required, any assistance, not even over the bridges, or up hills. He certainly was a remarkably fine horse, and kept up his fat till he died, some years after leaving the brewhouse

The heary wlack horse, a favourite with the coal-merchants, is bred chiefly in the midland counties, from the fens of Lincolnshire to Staffordshire. Many are bought up by the Surrey and Berkshire farmers at two years old; and, being worked moderately until they are four, earning their keep all the while, they are then sent to the London market, and sold at a profit of ten or twelve per cent.

It would not answer the breeder's purpose to keep them until they are fit for town work. He has plenty of fillies and mares on his farm for every purpose that he can require; he, therefore, sells them to a person nearer to the metropolis, by whom they are gradually trained and prepared. The traveller has probably wondered to see four of these enormous animals in a line before a plough, on no very heavy soil, and where two lighter horses would have been quite sufficient. The farmer is training them for their future destiny; and he does right in not requiring the exertion of all their strength; for their bones are not yet perfectly formed, nor their joints knit, and were he to urge them too severely, he would probably injure and deform them. By the gentle and constant exercise of the plough, he is preparing them for that continued and equable pull at the collar which is afterwards so necessary.
The true Suffolk Punch, which did much for our best short-legged dray-horses, is not found now in its purity. It stood from fifteen to sixteen hands high, of a sorrel colour; was large-headed; low shouldered, and thick on the withers; deep and round chested; long backed; high in the croup; large and strong in the quarters; full in the flanks; round in the legs; and short in the pasterns. It was the very horse to throw his whole weight into the collar, with sufficient activity to do it effectually, and hardihood to stand a long day's work.

The present breed possesses many of the peculiarities and good qualities of its ancestors. It is more or less inclined to a sorrel colour; it is a taller horse; higher and finer in the shoulders; and is a cross with the Yorkshire half or threefourths bred.

The excellence, and a rare one, of the old Suffolk-the now breed has not quite lost it-consisted in nimbleness of action, and the honesty and continuance with which be would excrt himself at a dead pull. Many a good draught-horse knows well what he can effect; and, after he has attempted it and failed, no torture of the whip will induce him to strain his powers beyond their natural extent. The Suffolk, however, would tug at a dead pull until he dropped. It was beautiful to see a team of true Suffolks, at a signal from the driver, and without the whip, down on their knees in a moment, and drag everything before them. The immense power of the Suffolk is accounted for by the low position of the shoulder, which enables him to throw so much of his weight into the collar.

Although the Punch is not what he was, and the Suffolk and Norfolk farmer can no longer boast of ploughing more land in a day than any one else, this is undoubtedly a valuable breed.

The Duke of Richmond obtained many excellent carriage horses, with strength, activity, and figure, by crossing the Suffolk with one of his best hunters.

The Suffolk breed is in great request in the neighbouring counties of Norfolk and Essex. Mr. Wakefield, of Barnham, in Essex, had a stallion for which he was offered four hundred guineas.

The Clydesdale is a good kind of draught-horse, and particularly for farming business and in a hilly country. It derives its name from the district on the Clyde, in Scotland, where it is principally bred. The Clydesdale horse owes its origin to one of the Dukes of Hamitton, who crossed some of the best Lanark mares with stallions that he had brought from Flanders. The Clydesdale is larger than the Suffolk, and has a better head, a longer neck, a lighter carcase, and deeper legs; he is strong, hardy, pulling true, and rarely restive. The southern parts of Scotland are supplied from this district; and many Clydesdales, not only for agricultural purposes but for the coach and the saddle, find their way to the central and even southern counties of England. Dealers from almost every part of the United Kingdom attend the markets of Glasgow and Rutherglen.

Professor Low (in his Illustrations of British cradrupeds) says, that "the Clydesdale horse, as it is now bred, is usually 
sixteen hands high. The prevailing colour is black, but the brown or bay is common, and is continually gaining upon the other, and the grey is not unfrequently produced. They are longer in the body than the English black horse, and less weighty, compact, and muscular; but they step out more freely, and have a more useful action for ordinary labour. They draw steadily, and are usually free from vice. The long stride, characteristic of the breed, is partly the result of conformation, and partly of habit and training; but, however produced, it adds greatly to the usefulness of the horse, both on the road and in the fields. No such loads are known to be drawn, at the same pace, by any horses in the kingdom, as in the single-horse carts of carriers and others in the west of Scotland.

\section{IV.-THE CLEVELAND BAY; THE COACH HORSE.}

Though horses are bred in every county of England, Yorkshire has the credit of producing the greater number of good ones. It has, or rather had, in the old "Cleveland bays," a particular race, combining peculiarity of form, a certain cast of countenance, and high qualities of utility. This powerful and active breed have, by many writers, been considered as owing their valuable properties to early crosses with the race-horse of those times; it is probable that those qualities marked the indigenous Yorkshire horse. The large London carriage horses are of this stock, though the demand for a harness-horse of lofty size has much decreased; other qualities, which are to be had combined with more grace, lighter action, and less of the "farm" horse stamp, being now in request. A century ago, however, the carriage-horse had not even the form of the Cleveland-he was a round-barrelled, hollow-backed, clod-shouldered, thick-legged brute, with long tail, full mane, and hairy fetlocks, something between a hearse-horse and a dray-horse, full of flesh, pride and pawing, and capable of six miles an hour for three hours three times a week-not that he ever got half of it. The later coach-horse, though too large, was a great improvement on this Netherlandish animal. The points of a good coach-horse, are, depth in the body, good bone under the knee, moderately long pasterns, and sound tough feet, well open at the bars. Though differing respectfully from Professor Low, as to the origin of the Cleveland Bay, yet agreeing with him as to its more modern form. ve take the liberty of quoting his description :-

"It is the progressive mixture of the blood of horses of higher breeding with those of the common race, that has produced the variety of coach-horse usually termed the Cleveland Bay; so called from its colour, and the fertile district of that name in the North Riding of Yorkshire, on the banks of the Tees. About the middle of the last century this district became known for the breeding of a superior class of powerful horses, which, with the gradual disuse of the heavy old coach-horse, became in request for coaches, chariots, and similar carriages. The breed, however, is not confined to Cleveland, but is cultivated through all the great breeding district of this part of England. It has been formed by the progressive mixture of the blood of the race-horse with the original breeds of the country. To rear this class of horses, the same principles of breeding should be applied as to the rearing of the race-horse himself. A class of mares, as well as stallions, should also be used, having the properties sought for. The district of Cleveland owes its superiority in the production of this beautiful race of horses to the possession of a definite breed, formed not by accidental mixture but by continued cultivation.

"Although the Cleveland Bay appears to unite the blood of the finer with that of the larger horses of the country, to combine action with strength, yet many have sought a farther infusion of blood nearer to the race-horse. They are accordingly crossed by hunters or thorough-bred horses, and thus another variety of coach-horse is produced, of lighter form and higher breeding; and many of the superior Cleveland curricle and four-in-hand horses are now nearly thorough-bred. The bay colour is in the most general estimation, but the grey are not unfrequently used."

Such is unquestionably the "Cleveland" horse of our day; from a thorough-bred of moderate stature, and a Cleveland mare three-quarters blood, we obtain a horse fit for the small pair-horse brougham, the curricle-phaeton, or the four-in-hand.

A pleasant and most popular writer, who adopts the nom de plume of "Harry Hieover," thus agreeably contrasts the modern and antique carriage-horse:-

"The great alteration in the form and breeding of the carriage-horse has partly arisen from the alteration of the vehicle he draws, but still more from the improvement in the paving of the streets and the state of the roads round the metropolis. The heavy, old-fashioned machine that was built to suit the pavement over which the royal Hal and his fat friend were jolted to Eastcheap, became no longer necessary when, it a hole was found in a street, the paviours were set instantly to work; and when the two miles and a-half from St. Paul's to Hyde-park Corner, barring stoppages, became a work of fifteen minutes, instead of a long mortal hour, the heary old coachhorse found the pace so unpleasant-indeed, impossible to himthat it became necessary to infuse some quicker-flowing blood into his veins; yet perhaps this necessary change, though it improved speed, would have made the more high-bred animal refuse to fetch a heary load out of a slough or hole that let the vehicle in axle-deep. Each was fitted for a differont purpose, and each had its distinct merit.

"Doubtless the old coach-horse was little better bred than the light cart-horse; and I should think it more than probable that Lincolnshire and Suffolk mainly contributed to the early supply of coach-horses, for in those days the Yorkshire horse was the hunter, and would have been thought too light for harness-work. When roads got better, and gentlemen became charioteers, with their phactons-and-four, and when this was followed by the barouche, then Cleveland sent up its stock for carriage-horses, and they began to get those higher bred. George the Fourth, as Prince of Wales, aided by his friend Sir John Lade, was perhaps the first who showed the public the ne plus ultra of the carriage-horse, as regards size, breeding, 


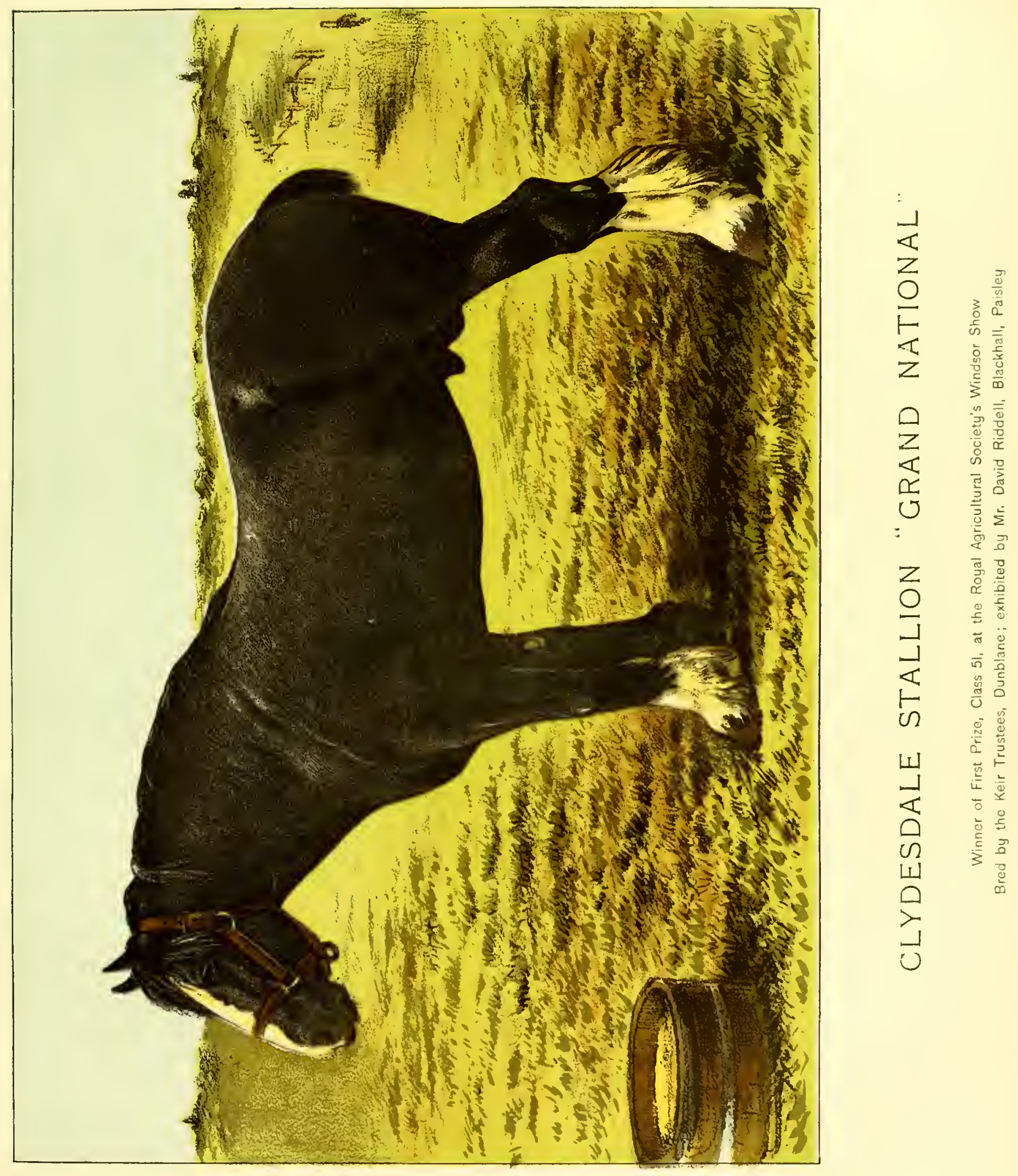



beauty, pace, and action all combined. They made me stare as a boy, and made many stare as men, to see them go down Constitution-hill. I have them as distinctly before my eyes now as I' had them then. These horses only wanted their 'switch' or 'barouche'-tails (as they were then called) cut off to a Leicestershire stump, their manes pulled to about an inch long, and they were very fair specimens of hunters, and were quite as highly bred as the generality of hunters then used.

"Partly, perhaps, to favour the kind of horse that had become in rogue, but much more in consequence of good roads, small carriages becarne in vogue also; all sorts of vehicles, with all sorts of names, shapes, sizes, and construction, were, and are, seen in the streots; and all the ingenuity of man was called forth to produce something new. But the ultimatum of all this ingenuity appears to have been to enable a family, constituting in itself a host, to arail themselves. of the convenience of one carriage and one horse. The large old-fashioned family-coach is no longer seen; this was a capacious, lumbering cooking vehicle, it must be allowed ; six inside, two footmen, and coachman, made nine in number. This was thought enough for two large coach-horscs."

Since the days of Harry Hicover a very great change has taken place in the size and structure of London carriages; for instead of being constructed to carry six, or even four, they are mostly built only to carry two inside; at least there are more broughams than larger carriages, excepting always open barouches, which carry four inside. But it is the roads rather than the carriages that favour horses. Bring back the roads as they were a century ago, and you must also get back the old coach and coach-horse; though, it is to be hoped, we have seen the last of both.

\section{V.-THE HACKNEY.}

A capital judge in equine matters has well said, that a perfect hack or roadster is the rarest phenomenon in horseflesh. To judge the just properties, we must have an accurate perception of the end for which the animal is designed, for according to the end the proportions vary. Thus, there is one set of proportions for the racer, another for the hunter, another for the hackney, another for the coach-horse, and another for the cart-horse ; and, as each of these merges into the other's qualities, so is it inforior for its special objects. Each too possesses its own style of beauty.

Why should that common-place animal, as he appears to the uninitiated, the roadster, be more difficult to be met with in perfection than even the hunter and racer?

There are many reasons for this. The price of the hack, or the horse of all work, is so low, that he who has a good one will not part with him; and it is by mere accident that he can be obtained. There are also several faults that can be overlooked in the hunter, but which the road horse must not have. The hunter may start, may be awkward in his walk, or even his trot; he may have thrushes or corns; but if he can go a good slapping pace, and has wind and bottom, we can put up with him, or prize him : but the hack, if he be worth having, must have good fore-legs, and good hinder ones too; he must be sound on his feet; even tempered; no starter; quiet in whatever situation he may be placed; not heary ix hand; and never disposed to tumble down.

The hack, like the hunter of the present day, is always a horse with some portion of racing blood, the whole English race, even to the cart-horse, being more or loss imbued, and equally improvod by it. Thus our road horses are half, threeparts, seven-eighths, or thorough bred. The two latter degrees are, in several respects, less fittad for the purpose of travelling the roads than the former : chiefly on account of the tenderness of their legs and feet, their longer stride, and straight-kneed action, not so well adapted to the English road pace, the trot Nevertheless, well-bred hackneys are elegant and fashionable, and, when good canterers, pleasant to ride; insomuch that, a certain colonel of the Guards of former days insisted, there was the same difference to be folt in riding a bred hack and one without blood, as between riding in a coach and in a cart. One good property in the thorough-bred road horse is, that he seldom shies, many of them never.

The road horse should have a considerably lofty yet light forehand or crest, a deep and extensive shoulder, well raised at the withers, straight back, with substantial loins and wide fillets, the croup not suddenly drooping, nor the tail set on low. The head should not be thick and fléshy, not joined abruptly to the neck, but in a gradual and tapering form; the eye full, clear, and transparent. The fore arms and thighs, with plenty of muscular substance, should be of reasonable length, but the legs should, at no rate, be long. Much solid flat bone bencath the knee, is a great perfection in a hackney; and the feet, standing straight, turning neither in nor outwards, should be of tough, dark, shining horn, the heels wide and open. The saddle-horse's fore-feet should closely approach each other, the wide chest being rather adapted to the collar. Nor need any apprehension be entertained from this near approximation of the fore feet, of the horse's cutting in the speed, or knocking his pastern joints, since those defects arise almost invariably from the irregular pointing of the toe, inwards or outwards, and for which, neither a wide chest, nor the most skilful farriery, has ever yet provided a sufficient remedy. A saddle horse of any description can scarcely go too close before, or too wide behind.

Perhaps the best pedigree for a road horse for general purposes is, that he should be bred from hackney stock on both sides, more particularly for a trotter.

In the hackney, says Blaine (Outlines of the Deterinary Arl) "we look with as much anxiety to his fore parts, as we do to the hinder parts of the racer or hunter: and as in them the fore parts are rather subordinate to the hinder, so in the hackney, on the contrary, the hind parts may be regarded as of less consequence than the fore; for, though speed is diminished, yet it is subordinate to safety. The head should be small, well placed, and well carried on a neck of due length; the withers high, the shoulders muscular but not heary; and above all 
they should be deep and oblique placed. The fore-legs must be perfect throughout, and stand straight and well forward under the horse; and what in the hunter or racer is of less consequence is here indispensable, that the elbows should be turned well from the body. The feet also, it is requisite, should be clean, open, and perfect, and the limbs, especially the fore ones, free from all stiffness. The height in the hackney is not so esential as in the racer and hunter; indeed the best hackneys are from 14-3 to 15-1. He should be equally set, without being in the least clumsy; and with such a form the more blood he shows, short of full-blood, the better."
The action of the hack shall be examined when we trcat of the paces of the horse, especially the Trot, and the choice of a horse for saddle.

A hackney is far more valuable for the pleasantness of his paces, and his safety, good temper, and endurance, than for his speed. We rarely want to go more than eight or ten miles in an hour; and, on a journey, not more than six or seven. The fast horses, and especially the fast trotters, are not often easy in their paces, and although they may perform very extraordinary feats, are disabled and worthless when the slower horse is in his prime.

\section{CH A P T E R VII.}

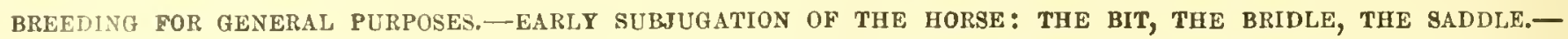
BREAKING FOR SADDLE AND HARNESB.

"Like produces like," and the progeny will inherit the qualities or the mingled qualities of the parents. It is proven that in respect of diseases there are few which affect sither of the parents constitutionally that the foal will not inherit, or, at least, a predisposition to them. Even the consequences of ill-usage or hard work will be entailed in the progeny. We have proof upon proof that blindness, roaring, thick wind, broken wind, spavins, curbs, ring-bones, and founder, have been bequeathed, both by the sire and the dam, to the offspring. It should likewise be recollected, that although these blemishes may not appear in the immediate progeny, they frequently will in the next generation. Hence the necessity of some knowledge of the parentage both of sire and dam.

Peculiarity of form and constitution will also be inherited. This is a most important consideration; for however desirable, or even perfect, may have been the conformation of the sire, every good point may be neutralized or lost by the defective form, or want of blood, of the mare. When breeders are careful that the essential points should be good in both parents, and that some minor defect in either shall be met, and got rid of, by excellence in that particular point in the other, the result is creditable to their judgment and highly profitable. The unskilled or carcless breeder will often so badly pair the animals, that the good points of each will be, in a manner, lost; the defects of both will be increased, and the produce will be far inferior to sire and dam.

In breeding the half or three-quarter bred horse, different men go on different principles. The generality put a half-bred mare to a thorough-bred sire, a mode that is mostly attended with the best success. Some use the thorough-bred mare and half-bred sire, while others breed from sire and dam half or three-quarters bred. In several instances we have known the experiment tried of putting a cart-mare tc a thorough-bred sire, and vice versa; but have never yet seen this answer.
The produce from such a connection does not, as might be expected, possess the strength of the cart-parent, lightened by the thorough-bred throughout his general formation, but is mostly a brute with light legs and body, with the head and shoulders of the cart-horse; or, at all events, in some parts or other of his form be will be this kind of nondescript; at least, all we have seen bred by such a cross have been so. The fact that the produce outwardly more resembles the sire than the dam, leads many people into the very great error of being careless in their choice of mares.

It may, perhaps, be justly affirmed, that there is more diffculty in selecting a good mare to breed from, than a good horse, because she should possess somewhat opposite qualities. Her carcase should be long, to give room for the growth of the foetus, and yet with this there should be compactness of form and shortness of leg.

The mare is capable of breeding at three or four years of age. There have been injudicious instances of their being made mothers at two years, which may be passed without comment. The mare comes into "season" about February, and continues "horsing" at intervals until the end of June or middle of July. The term of gestation of the mare is between eleven to twelve months; these periods forming its ordinary limits. According to MI. Tessier, who observed the result in 582 mares, who had copulated but once, the shortest period was 287 days, the longest 419 , making the extraordinary difference of 132 days, and of 89 day beyond the usual term of eleven months. It is a mere supposition that the mare carries her first foal longer than subsequent ones; neither does the term vary on account of the offspring being a filly or a calt. With racehorses, who take their age from the first of January, and who are brought to their post at two years old, early foaling is of the first importance. With other breeds, who do not figure in Weatherby'sregister, the beginning of May is the most desirable time for stinting them. The foal will then be dropped in the 
following April, when there is pleasant air, and natural food for dam and offspring, and they need not be so much in stable.

When nearly half the time of pregnancy has elapsed, the unare should be petted and varied in her food. This is about the period when they are accustomed to slink their foals, or when abortion occurs: at this time, therefore, the eye of the owner should be frequently upon them. Grood feeding and moderate exercise will be the best preventives against this. The mare that has ouce slinked her foal is ever liable to the same accident, and therefore should never be suffered to be with other mares atout the time that this usually occurs, which is between the fourth and fifth months; for such is the power of imagination or of sympathy in the mare, that if one of them suffers abortion, the greater number of those in the same pasture will share the same fate. The mare gives a day or so notice of the "event," by the appearance of adbesive matter about the teats. Even up to this time gentle work will not hurt her.

If a mare has been regularly exercised, and apparently in health while she was in foal, little danger will attend the act of parturition. If there be false presentation of the fœetus, or difficulty in producing it, it will be better to have recourse to a well-informed practitioner, rather than injure the mother by the violent and injudicious attempts which are often made to relieve the animal.

As soon as the mare has foaled, she should be turned into some well-sheltered pasture, with a hovel or shed to run into when she pleases: and as, supposing she has foaled in April, the grass is scanty, she should have a couple of feeds of corn daily. The breeder may depend upon it that nothing is gained by keeping the mother and foal on "short commons" at this time. It is the most important time in the life of the horse; and if, from false economy, his growth be arrested now, his puny form and want of endurance will ever afterwards testify the error that has been committed. The corn should be given in a trough on the ground, that the foal may partake of it with the mother. The mare will usually be found at heat at or before the expiration of a month from the time of foaling, when, if she be kept principally for breeding purposes, she may be put again to the horse.

One of the great things to be desired in a brood mare, after having properly selected her, is to render her perfectly familiar and quiet: she should be brought to be as tame as a pet sheep. Nearly all mares by kind and gentle treatment may be brought to this. The being perfectly free from alarm produces a general placidity of temper that is highly desirable in any breeding animal as to their well doing: fright, we all know, when in this state, has often most fatal effects both on mother and offspring: reasoning, therefore, on analogy, if absolute fright is often fatal, constant alarm or apprehension must be prejudicial Independent of this, mares galloping about to avoid being caught whenever they are approached is highly dangerous; and, after the foal is produced, he naturally follows the mother : if she is wild, the colt becomes so, and learns from her to avoid man as his enemy, whereas he should be taught to hail him as a friend. The mare should be taught $t$ come up to man the moment he enters her paddock or pasture, from always gaining caresses and indulgence when she does so A little corn from a sieve or a carrot from the hand will soor teach her this; and if, when laid hold of, she gets this and caresses, and is never suffered to be alarmed, she will come as readily and willingly as a favourite $d o g$. What, then, is the result of the tameness of the mother? The foal naturally follows her either to or from you, and, from constantly approaching man, he becomes familiar; and, as a matter of course, never being hurt or alarmed, he in a few weeks has no more fear of him than of his dam, and will suffer himself to be handled in any way you please. As soon as he is able to eat, he should get something from the hand, and will from this watcb for the approach of man, instead of (as most colts do) galloping away to avoid him. A flock of sheep follow the shepherd from habit, and finding him their friend. A herd of deer, from want of habitual intimacy with man, avoid him, but a tame deer is as tame as any other pet; and so will mare and colts be, if properly treated. Even supposing there was an inherent vicious propensity born with a colt, by beginning thus early with him it would in most cases be eradicated; if not, it would to a certainty be most materially softened.

To return, however, to the new-born foal :-It is not generally known thut the refusing to suck, which is the cause of the death of many foals, as well as the scouring, which about the third day kills many more, are both produced by irritation, and consequent inflammation of the bowels, from the retention of a few small hard fæecs in the rectum. These are generally more in quantity in proportion as the keep of the mare has been high.

The cure is simple; a few hours after the foal has been dropped, a tallow candle should invariably be passed into the rectum, and when the passage has been sufficiently softened, the fæces can easily be extracted by the finger.

In cases where scouring kills foals at a subsequent period, it is generally attributable to the foal heating itself by violent exercise; consequently the mare, for the first day or two that she is let out (supposing her to be housed,) ought only to be walked about with a halter, and the same practice pursued at the time of her first horsing.

Some mares will not allow their foals to suck. This arises from the tenderness of the teats; and in this case they should have their heads tied up, and if necessary, be otherwise prevented from kicking, while they are milked by hand; and the milk should be rubbed over the teats for some short time, after which they will allow the foal to suck.

Should the mare's milk be obstructed and fail, either from cold caught, or other cause, if out, she should immediately be taken up to the house, and enticed to lie down upon a large and deep littered bed of fresh straw, in a loose box, and every method taken to comfort her, and to encourage the secretion of milk. To promote this end, as much warm mild ale should be allowed, as she would drink; or should she refuse it, she may be drenched with a couple of quarts. to be repeated as may 
appear necessary; her food being the finest and most fragrant hay, sweet grains, with mashes of corn and pollard. In cases of chill and great weakness, the old well-known articie, cordial ball, may be given in warm ale.

Should, however, the case be inflammatory, from previous high condition and fulness of blood, cordial ball and all stimulants should be strictly aroided, and the regimen confined to warm water and gruel, in as copious quantities as can be administered. Should further measures of similar tendency be indicated, a mild solution of Glauber's or Epsom salts (ten or twelve ounces in a pail of warm water,) may be given, which she may be induced to drink by means of being kept short of water. A moderate quantity of blood may be drawn, should the symptoms demand it, not otherwise. Daily walking exercise abroad, the mare being clothed if necessary, should succeed, until she be sufficiently recovered to be returned to her pasture.

During the inability of the mare to give suck, the foal must be sustained on cow's milk. This alien milk will generally disorder and gripe the foal, for which the best remedy is two or three spoonsful of rhubarb in powder, with an equal quantity of magnesia, in warm gruel. This medicine should be given to the foals of working mares, which are often griped by sucking pent milk. The disorder arising from wet and cold, a table spoonful eacn, of the best 'Jrandy and syrup of white poppies, may be given several tirses.

Hares having dead foals, ought to lose a little blood, be fed moderately on cooling mashes with a little nitre, and on no account be allowed corn. Moderate walking exercise is very desirable for mares before foaling; and alternate mashes of plain and of scalded bran are much to be recommended.

It should be observed that geldings should not be admitted among the brood mares, as by leaping them, or harassing them about, abortion may be occasioned.

In five or six months, according to the growth of the foal, it may be weaned. It should then be housed for three weeks or a month. A rick-yard in good weather is a capital place for the foal, as affording, without trouble, both food and shelter. One or two urine balls, or a physic ball, will be useful, if the milk should be troublesome, or the mother should pine after her foal.

There is no principle of greater importance than the liberal feeding of the foal during the whole of his growth, and at this time in particular. Bruised oats and bran should form a considerable part of his daily provender. The money is well laid out which is expended on the liberal nourishment of the growing colt; while, however, he is well fed, he should not be rendered delicate by excess of care. A racing colt is stabled; but one that is destined to be a hunter, a hackney, or a general horse should merely have a square rick, under the lesward side of which he may shelter himself, or a hovel, into which be may run at night, or out of the rain.

EARLY SUBJUGATION OF THE HORSE.-THE BIT, THE BRIDLE, THE SADDLE, THE STIRRUP.

"The noblest conquest ever made by man was that of the horse," says Buffon: the earlier methods of rendering him submissive to the will of his rider have not descended to us The Jews fiercely denounced and despised the grandest and most useful of animals; and equally despised, adding persecution to their prejudice, the faithful dog. The heathen nations more liberal and enlightened, zealously patronised the horse.

The period at which the horse was first subjugated has been a matter of curious rather than useful inquiry.

Sir Gore Ouseley, from examinations of the scnlptures at Persepolis, inclines to the opinion that they were first used in chariots, and in this he is countenanced by many antiquaries. Homer describes all his heroes as fighting from chariots. Palæphatus says that men were first drawn in chariots. It would seem, however, more probable, that mounting the horse, with the skin of a wild beast for a saddle, would be the earliest method. Those interested in such enquiries, may consult Berenger's work "The History of the Horse."

It is in some of the Grecian sculptures that we first see the bit in the horse's mouth, but it is not always that we do see it; on the contrary, there is frequently neither bridle, saddle, or stirrup. It, however, was frequently necessary to make use of cords or thongs, in order to confine the horse to the place at which it suited the rider to leave him. These cords were fastened round the animal's neck, and may be seen in several of the ancient figures. According to some writers, the occasional struggles of the animal to escape from these trammels, and the strength which he exerted in order to accomplish his purpose, first suggested the idea of harnessing him to certain machines for the purpose of drawing them; and it is evident that soon after this it must have occurred to the horseman, that if this rope was put over the head and over the muzzle, or perhaps in the mouth of the animal, he would be more easily fastened or led from place to place, and more securely guided and managed, whether the man was off or on his back Hence arose the bridle. It probably was at first nothing more than the halter or cord by which the horse was usually confined. An improvement to this was a detached cord ar rope, with prolongations coming up on both sides of the mouth, and giving the rider much greater power over the animal ; and after that, for the sake of cleanliness and to prevent the wear and tear of the rope, and also giving yet more command over the animal, an iron bit was fitted to the mouth and rested on the tongue, and the bridle was attached to each end of it. This was the common snaffle bridle of the present day, the iron being jointed and flexible, or often composed of a chain. There were, however, no cross pieces to these bits at the mouth, but simple knobs or bulbs, to the inside of which the bit was attached.

Bits and bridles of this kind occur frequently in the Athenian sculptures of the time of Pericles, about four hundred and thirty years before the Christian era ; but the headgear of the bridle had not long been introduced, the bit being supported, in some figures, by the buckling or tying of the bridle about the nose, a little above the muzzle. These, however, soon disappear, and we have the present snaffle with very little alteration, except a straight leather or cord from the head tn 
the nose-band, and that not always found. The chain under the military art; and at this period the Greek word $\sigma \in \lambda \lambda{ }$ the chin is occasionally observed, probably for the sake of (sella) occurs. Vegetius, who wrote on the veterinary art, keeping the bit steady in the mouth.

In no period of Grecian history was the severe curb-bit knowl. This was an invention of after-times. The only instrument of punishment which was then attached to the bit was found in the knobs at the corners of the month : they had sharp or rough points on their inner surface, which by a turn or twist of the bridle might be brought to bear painfully on the cheeks and angles of the mouth. A bit so constructed was termed a lupatum, from the supposed resemblance of these sharp projections to the teeth of a woll. It would seem that this was, among the Romans, almost coeval with the introduction of the bit, for the poet attributes it to Neptune, the fabulous parent of the horse*.

We also find, even at this early period, that horses were moved in circles to supple them, and render them ready to turn any way they might be required. Lucan, in his "Pharsalia," praises the Massylians as being able to dispense with saddle and bit in the management of their war horses. He says-

"Et gens quæ nudo residens Massylia, dorso
Ora levi flectit frenorum nescia virga."
"Without a saddle the Massylians ride,
And with a bending switch their horses guide."

No mention is made of saddles, such as are used in modern times; by way of ornament, and partly of convenience too, the horses were often covered with beautiful cloths, or with the skins of wild beasts, secured by a girth or surcingle. Thus the horse of Parthenopæus $†$ was covered with the skin of a lynx, and that of Eneas $\ddagger$, according to Virgil, with a lion's skin. In their religious or triumphal processions the housings of the horses were particularly magnificent, being frequently adorned with gold and silver and diamonds. Rich collars were also hung round their necks, and bells adorned their crests. The trappings of the young knight in the days of chivalry did not exceed those of the Grecian warrior un days of ceremony.

"It is conjectured," says Nimrod, in the Sporting Magazine, No. cxxxviii., "that saddles having any resemblance to those now in use, were invented in the middle of the fourteenth century, and were generally covered with cloth; but previous to this period, in the fifth century, articles bearing something of this stamp were made so extravagantly, that a prohibition was issued by the Emperor Leo the First against any one ornamenting them with pearls or precious stones. In the sixth century the saddles of the cavalry had large coverings of fur, according to Mauritius, who wrote on

\footnotetext{
* "Neptunus equo, si certa priorum

Fama patet, primus teneris lesisse lupatis

Ora, et littoreo domuisse in pulvere fertur."

"Neptune, if we may credit give to fame,

First tanght with bits the generous horse to tame."

+ See Statius.

†Quem fulva lennis pellis obit.

I
} speaks of saddle-horses; and the saddle-tree is mentioned by Sidonius Apollinaris. It is considered probable that the invention of saddles belongs to Persia, not merely from the circumstance of Xenophon's mentioning the peorle of that country as being the first to render the seat on the horse more convenient and easy, by placing more covering on their backs than was common in other parts, but also because the horses of Persia were chosen for saddle-horses in preference to any others. The ignominious punishment of 'bearing the saddle,' had its origin in the middle ages, and was alone worthy of those times. That the word saddle is derived from the Latin word sedeo, to sit on, there can be no doubt. That the saddle, however, was unknown in this country until the reign of Henry the Seventh is, I believe, equally certain; and in Ireland also, it is conjectured, from the absence of any representation of it in the last three centuries. The first mention of side-saddles is in the time of Richard the Second, when his queen rode upon one." Witl all due deference to Nimrod's assertion, that the saddle was not used in England until the time of Henry the Seventh, we must cite the testimony of the venerable Bede, who informs us that the English began to saddle their horses about the year 630, during the Saxon struggle for the ascendancy.

Their harnessing the horse is certified by their use of chariots, even for war purposes, when first visited by the Roman invader.

The stirrup was likewise unknown. 'The adoption of that convenient assistance in mounting the horse was of singularly late date. The first mention of it occurs in the works of Eustathius, about the 1158 th year of the Christian era; but it was used in the time of William the Conqueror, nearly a century before that. Berenger gives the figure of a borse saddled, bridled, and with stirrups, copied from the Baseux tapestry, which was embroidered in the time of the Conqueror by his wife, and describes the circumstances preceding and attending his descent into England. The heroes of ancient times trusted chiefly to their own agility in leaping on therr horses' backs (corpora saltu subjiciunt in equos), and that whether standing on the right side or the left

They who fought on horseback with the spear or lance had a projection on the spear, or sometimes a loop of cord about two feet from the bottom of it, which served at once for a firmer grasp of the weapon, and a step on which the right or the left foot might he placed, according to the side on which the warrior intended to mount, and from which lie could easily vault on his courser's back. The hurse was sometimes taught to assist the rider in mounting by bending his neck or kneeling down, especially in Persia and Eastern countries. Casar's horse, who knelt for his master to mount, is facetiously alluded to in Hudibras (see quotation, ante, page 9). The magnates had their slaves by their horses' side to assist them in mounting and dismounting. Some made use of a short ladder; and it was the duty of the lucal 
magistracy, both in Rome and Greece, to see that convenient mounting-stones were placed at short distances along all the roads.

The boot for the defence of the leg from the dangers to which it was exposed was very early adopted, and the heel of it was, occasionally at least, armed with a spur.

\section{BREAKING THE HORSE FOR SADDLE AND IIARNESS.}

In every art there seem to be periods of enquiry, thoughtfulness, and awakening, with intervals of stagnation, routine, and slumber. This appears to have been the case with the art of horsebreaking. For generations, with some few exceptions of men with a genius for taming and instructing animals, and these so few and far between as not to affect the general principle, pretended secrets, coercion, cruelty, and fear was the rule; kindness, patience, and gentle firmness the exception. Drugs, whisperings, and other delusions, invented by knaves and believed in by simpletons, were pretended to effect what they never did or could do, and druggists sold oil of rhodium, oil of cumin, and other delusive nostrums, to the profit of the vendors and the disappointment of the credulous. About five years since, however, a rumour was wafted across the Atlantic that a wondrous discovery had been made in the art of taming vicious horses, and it was followed shortly by the arrival of the so-called "discoverer of the art." We would not rob Mr. J. S. Rarey of one iota of his well-deserved earnings, or of his credit as a skilful demonstratur of his system. If the pretensions by which it was heralded and supported will not bear cluse investigation, it is certain that he roused the public mind from long apathy, and by directing enquiry to the true principles of horsebreaking, served essentially the interests of humanity, and enhanced the value of the most valuable servant of man. There is no doubt that Mr. Telfer, of Northumberland, MIr. W. Cooke, of Astley's Amphitheatre, and others, had long practised portions of the plan promulgated by Mr. Rarey, but they kept their secret till Mr. Rarey disclosed his, and, pro tanto, were merely "dumb oracles, that opened not their lips." We do not claim for Mr. Rarey the "invention " or "discovery" of a system, but he is fully entitled to the credit of being its promulgator, demonstrator, expositor, and teacher, and this is enough to earn our grateful thanks. A horse of Lord Dorchester's, the noted stallion "Cruiser," a four-footed fiend, to our personal knowledge, was tamed by Mr. Rarey as a first sample of his skill, in two hours, so as to be ridden "as quiet as a sheep," as the groom expressed it, although no man had been able to mount him for three years previously. $\mathrm{He}$ was afterwards led on the high road from Murrell Green to London, behind a dog-cart.

Before entering on the practical portion of our subject, we shall digress for a few paragraphs to introduce a few words relating to celebrated horse-breakers, who certainly performed equally astonishing feats in this line, probably by similar methods; though they preferred, as more flattering to their conceit, practising on the ignorance which is prone to take omne ignotum pro magnifico, and this was possibly more profitable to the professors of the "mystery." Foremost among these stand the celebrated "horse-whisperer," James Sullivan, and a Yorkshireman called Jumper. We give them on the authority of Mr. James Castley.*

"When a very young man," says Mr. Castley, "I remember purchasing a horse at a fair in the north of England, that was offered very cheap, on account of his being unmanageable. It was said nobody could ride him. We found that the animal objected to have any thing placed upon his back, and that when made to move forward with even nothing more than a saddle on, he instantly threw himself down upon his side with great violence, and would then endeavour to roll upon his back. There was at that time in Yorkshire a famous colt-breaker, known by the name of 'Jumper,' who was almost as celebrated in that country for taming vicious horses into submission as the famed Whisperer in Ireland. We put this animal into Jumper's hands, who took him away, and in about ten days brought him home again, certainly not looking worse in condition, but perfectly subdued, and almost as obedient as a dog; for he would lie down at this man's bidding, and only rise again at his commandcarry double, or any thing. I took to riding him myself, and may say I never was better carried for six or eight months, during which time he never showed the least vice whatever. I then sold him to a Lincolnshire farmer, who said he would give him a summer's run at grass, and show him, a very fine horse, at the great Horncastle fair. Happening to meet this gentleman the following year, I naturally enough enquired after my old friend. 'Oh,' said he, 'that was a bad business; the horse turned out a sad rebel. The first time we attempted to mount him after getting him up from grass, he, in an instant, threw the man down with the greatest violence, pitching him several yards over his head: and after that he threw every one that attempted to get on his back. If he could not throw his rider,' continued my informant, 'he would throw himself down. We could do nothing with him; and I was obliged at last to sell him to go in a stage coach.' Jumper, like the celebrated Whisperer, Sullivan, was supposed to possess some charm, by which this wonderful effect was produced. There appears to have been a great similarity between these two men; and those who recollect Jumper, will easily recognize the similitude in the following account of the Whisperer, extracted from the Rev. Mr. Townsend's Statistical Survey of the County of Cork:-'James Sullivan, the Whisperer, was a horse-breaker at Cork; an ignorant awkward rustic of the lowest class. He gained this singular epithet by an extraordinary art of controlling in a secret manner, and taming into the most submissive and tractable

* Mr. James Castley, Veterinary Surgeon to the 17th Lancers, and the contributor of many valuable papers to the early volumes of the Veterinarian. The following anecdotes are from the Veterinarian. volume iii., pages $671-676$, whence they were copied bv Mu Youst. 
disposition, any horse or mare that was notoriously vicious and obstinate. He practised his skill in private, and without any apparent forcible means. In the short space of lialf an hour, his magical influence would bring into perfect submission and good temper even a colt that had never been handled; and the effect, though instantaneously produced, was generally durable. When employed to tame an outrageous animal, he directed the stable, in which the object of his experiment was placed, to be shut, with orders not to open the door until a signal given. After a tête-à-tête between him and the horse, during which little or no bustle was heard, the signal was made, and on opening the door the horse was found lying down, and the man by his side playing familiarly with him like a child with a puppy dog. From that time he was found perfectly willing to submit to any discipline, however repugnant to his nature before*.

"'I once,' says Mr. Townsend, 'saw his skill on a horse, which could never before be brought to stand for a smith to shoe him. The day after Sullivan's half-hour lecture, I went, not without some incredulity, to the smith's shop, with many other curious spectators, where we were eyewitnesses of the complete success of his art. This too had been a troop-horse, and it was supposed, not without reason, that, after regimental discipline had failed, no other would be found availing. I observed that the arimal seemed afraid whenever Sullivan either spoke or looked at him: how that extraordinary ascendancy could have been obtained it is difficult to conjecture; he seemed to possess an instinctive power of inspiring awe, the result perhaps of a natural intrepidity, in which I believe a great part of the art consisted; though the circumstance of the tête-à-tête shews that upon particular occasions something more must have been added to it. A faculty like this would, in other hands. have made a fortune; and great offers have been riade to him for the exercise of his art abroad, but hunting and attachment to his native soil were his ruling passions. He lived at home in a style most agreeable to his disposition, and nothing could induce him to leave Duhallow and the fox-hounds."

Mr. Castley remarks on this, very sensibly, "The days of miracles and of magic are gone by; and however necromantic this may look, it is nevertheless quite true. There are so many living witnesses of the extraordinary power this man possessed, and his mystical art was practised for such a length of time, and on such a variety of subjects, that there is no such thing as doubting the fact. It is a fact, be it recollected, of the nineteenth century. My friend, Mr. George Watts, of Dublin, who is a man not at all likely to be swayed by superstitious notions, has told me that he had more than one opportunity of witnessing the wonderful effect of Sullivan's art. 'And if I liad not seen it myself,' he always observes, 'I would not believe it.' One remark

* We are strongly inclined to believe that Sullivan practised the arey aystem or something closely akin to it. able instance in particular he relates, which, as it afford: another practical example illustrative of the point at which I wish to arrive, I shall take the liberty to repeat. This in. cident took place at the Curragh of Kildare, in the spring meeting of 1804. Mr. Whalley's King Pippin was brought there to run. He was a lorse of the most extraordinary savage and vicious disposition; his particular propensity was that of flying at and worrying any person who came within his reach; and if he had an opportunity, he would get his head round, seize his rider by the leg with lis teeth. and drag him down from his back. For this reason he was always ridden in what is called a sword, which is nothing more than a strong flat stick, having one end attached to the cheek of the bridle, and the other to the girth of the saddle; a contrivance to prevent a horse of this kind from getting at his rider. King Pippin had long been difficult to manage and dangerous to go near; but on the occasion in question he could not be got out to run at all-nobody could put the bridle upon his head It being Easter Monday, and consequently a great boliday, there was a large concourse of people assembled at the Curragh, consisting principally of the neighbouring peasantry; and one countryman, more fearless than the rest of the lookers-on, forgetting, or rather perhaps never dreaming, that the better part 0 : courage is prudence, volunteered his services to bridle the horse; but no sooner had he committed himself in this operation, than King Pippin seized him somewhere about the shoulders or chest, and, says MIr. Watts, "I know of nothing I can compare it to, so much as to a dog shaking a rat.' Fortunately for this poor fellow, his body was very thickly covered with clothes; for, on such occasions, observes my friend, an Irishman of this class is fond of displaying his wardrobe, and if he has three coats at all in the world, he is sure to put them all on. This circumstance, in all probability, saved the individual who had so gallantly volunteered the forlorn hope. His person was so deeply enveloped in extra tegument, that the horse never got fairly hold of his skin; and I understand he escaped with but little injury beyond a sadly rent and totally ruined state of all his holiday toggery. The 'Whisperer' was then sent for, who, having arrived, was shut up with the horse all night, and in the morning he exhibited this hitherto ferocious animal, following him about the course like a dog; lying down at his command; suffering his mouth to be opened, and any person's hand to be introduced into it; in short, as quiet almost as a sheep. He came ut the same meeting, and won a race, and his docility continued satisfactory for a long time; but at the end of about three years his vice returned, and then he is said to have killed a man, for whish he was destroyed.

"Sullivan used to say he got his secret from a soldier who chanced to be passing by his cottage in a state of exhaustion, and to whom lie offered some refreshment, and that he wus bound by an oath never to reveal it. Here then, indeed, was a secret well worth knowing. But whatever it was, it 
scems to have perished-to have descended to the grave with James Sullivan. His son pretended to some knowledge of it, but he certainly does not possess the right secret : of this I had myself an opportunity of being convinced by ocular demonstration, a few years since, when quartered at Cork."

One other paragraph from MIr. Castley's amusing paper and we have done. It relates to the failure of the younger Sullivan, whom his cunning parent had evidently left ignorant of his pretended "charm." "We have in the regiment a remarkably nice horse, called Lancer, that has always been very difficult to shoe; but seven or eight years ago, when we first got him, be was downright vicious in that respect; in which I believe consisted the secret of his having been sold at any thing like troop price. When the regiment was stationed at Cork, the farrier-major sought out the present Sullivan, the son of the celebrated Whisperer, and brought him up to the barracks in order to try his hand upon Lancer, and make him more peaceable to shoe; but I must say this person did not appear to possess any particular controlling power over the animal more than any other man. Lancer seemed to pay no attention whatever to his charm, and at last fairly beat him out of the forge; he was fain to make his escape from so unruly a customer. Time, however, and a long perseverance in kind and gentle treatment, together with the exercise of a little tact, have effected what force could not. The horse is now pretty reasonable to shoe.-Quâ Leonina pellis non perveniet, Vulpina est assumenda.

"The lion's skiu, too short you know,

(As Plutarch's morals finely shew,)

Was lengthened by the fox's tail,

Aud art supplies where strength may fail."

In a former part of this work (pp. 36-38) will be found, under The Horses of South America, some account of the horse-breaking of the Guachos; and under THE Horses of North America (pp. 41-42), a reference to Mr. Catlin's experience.

Those curious in the bibliography of the art of horsemanship may find how well-versed were our ancestors in most of the "systems" and "new methods," which are from time to time trumpeted forth as "discoveries" by charlatans, or men ignorant of what has been done before them*.

* We pass over Xenophon, the great historian and warrior, who wrote the earliest treatise upon the art, 300 years before Christ, and other ancient authors, some of whom will be found referred to in the earlier chapters (I. to VII.) of this volume, when treating of the History and VARIETIES OF THE Horse; merely noticing those writers who are accessible to the English rule, in good libraries or at the reading-room of the British Museum :-

"Horsemanshippe," By Frederick Gryson: Lond. 1571. This author was an Italian professor of horsemanship in Naples. He was considered the most famous in Italy.

"Horsemanshippe." By Clandio Corte : circa, 1560. Also an Italian profeseor of the art, who wrote upon the subject during the same century.
Among the books in our list occurs the name of Gryson, who performed, $a$ la Rarey, in public, about the year 1570 . In an address to the reader of his treatise, we find the following :-

"What his judgment was in the said art (of horse taming) may appear to all those who list to look upon the rules and

"The Art of Riding, \&c." By T. Bedingfield : 1584. An excellent and useful book.

"The Fower chiefest Offices of Horsemanship." By Master Thomase Blundevill. London, 1609, 4to. Black letter. A most elaborato treatise: the text of numerous subsequent writers. The "Fower Otfices" are the "office" of "breeder," and those of the "rider," the "keeper," and the "farrier."

"The Gentleman's Accomplished Jockey." By Gervase Markham, author of "The Masterpiece." Markham's books went through many editions hetween 1620 and 1700 .

"Horsemanship." By Nichs. Morgan, 1609. This again has fur. nished much of our later treatises with matter. This author, speaking of an English knight, hight Alexander, takes occasion thus to allude to Alexander of Macedon :-

"Great Alexander deerly lou'd his horse ;

The horse lou'd him, and suffered none to ride

Vppon his backe by flattery or by force,

But his dread lorde, that balfe the world did guide,

This knight did beare that Alexander's name,

Who brought the proudest coursers to his becke,

And with his hand, spurre, voice, and wand, did tame

The stately steedes that never brookt the checko.

Not only he in England was esteemed,

But eke in forraine countries for his art.

And yet to me (that honoured him) it seemed

His fame's report was less than his desart.

This knighte (the mirrour of all knights for riding;

Had mauy men of worth and great renowne

That were his schollers, by whose happy guiding

They in this art did put all others down."

William Cavendish, Duke of Newcastle. "Mothode et Invention Nouvelle de dresser les Chevaux," with a frontispiece and forty-two plates of the ménage, 1631. Originally written in French, and tranelated into Enghish. There were numerous French and German writere upon menage riding and horsebreaking about this period.

"The Compleat Horseman and Expert Farrier." By Thomas de Grey, Esq., 1650. A clever book, but full of conceits in its veterinary portion.

In 1686 appeared a cyclopœedic work in two divisions, called "The Gentleman's Recreation." By Robert Blome, Gent. The second division treats of horsemauship, hunting, hawking, \&c. It embodies much of the knowledge contained in more recent treatises.

Solleysel's "Parfait Marechale," translated by S: W?illiam Hope, and Michael Baret's " Hipponomie, or Vineyard of Hnrsemanship," abont 1750 .

"Military Equitation, or a Method of Breaking rIorses and teaching Soldiers to ride." By Henry Earl of Pembroke "to., with numerous plates. This book, with its motto, "Scientia ef Patientia," may well be consulted as to feeding and shoeing, as well as horsemanship. The Earl of Pembroke furnishes the text of the statements of half our modern professors.

"Berenger's History and Art of Horsemanship." A comprehensive work. In the writings of Clark, Morecroft, Osmer, John Lawrence, D. P. Blaine, Goodwin, Miles, and Darvill, wry be found much relating to the Eorse in general. 
precepts so perfectly set forth by him in writing. What his practice was in the said art openlie and dailie in the said citie, and what his praise was there, doth appear in that noble Caracciolo's writings, the Duke of Martina's brother, which he intituled Gloria de Cavalli, where he says of Gryson and another, 'These be the eyes of our toong.' For besides the true knowledge of this art, and the great practice they both had thereof, they with a most perfect judgment had this special grace given them, that every horse at the first riding seemed to obey unto them even at their becke, so as the standers-by were astonied thereat; whereupon all others studious of this exercise would unto these two persons as to the oracle of Apollo verie often resort, to be resolved in all their doubts."

Ancient writers upon the subject of horse-breaking one and all declare, that in training the horse, so as to make it obedient and useful to man, there must be a combination of and regard to three distinct principles-nature, art, and reason. In the absence of any or either of these, the efforts of the trainer will be unsatisfactory, if not useless.

The secret in the art of horse-breaking consists in a correct knowledge of the nature of the horse; and when that is understood, the trainer finds his whole efforts must be devoted to improvement of the natural intellects of the animal; no other method can ever succeed. It is impossible to give a horse either an artificial intellect or memory. A horse is naturally well-disposed to man, though fearful of and obedient to him. No human art can effect anything contrary to the nature of the horst, though the animal may be easily imposed on. Therefore, in training, there must be a reason for every artifice employed; and a practicable, natural, and beneficial result looked for, or capable of being produced through the means employed. If the trainer can give no substantial reason for any particular stratagem he employs, whatever the result produced, it can have no lasting or beneficial effect upon the horse. But if Nature be obeyed, and her order strictly kept, it follows as a certainty that the end desired will be attained. So that if art be employed with reason, it must be in accordance with the instinct of the animal; for nothing in the art of horsetaming is reasonable that is contrary to the nature of the horse. And these, the first principles of the art, should be kept constantly in mind; for nothing is easier than to impose on a horse, because the animal is naturally unconscious of imposition, and is. besides, fearful and obedient to man.

Neithoi force nor violence should be used in training colts ; they must be won by gentle treatment, for violence is opposed to the three fundamental principles of the art. Whatever a horse does by violent compulsion is of no avail in training, because the horse knows not what is required of him, or how to obey; therefore no useful impression is made upon the animal when the teaching is accompanied with violence. Correction should be administered without violence, and immediately after the fault. For instance, if a horse does wrong, and the trainer has to go and fetch a whip before administering the chastisement, it is unreasonable to suppose that the horse (which is not gifted with the power of reasoning) can know for what purpose the chastisement is administercd; thcrefore correction should never be resorted to at any other time than the instant the horse commits a fault. An impatient man is totally unfit for the art of training colts.

First advances to the Colt.-We have already said, when speaking of the thoroughbred colt intended for racing purposes, that it cannot be too early handled and made familiar with the presence of man. We will, however, for our present purpose suppose the colt to be wild and shy, and running loose with others in the field. In this case the first step is to get the whole of them into a small enclosure or a building, and patiently and without hurry separate the one you intend for immediate "schooling" from the rest by letting the others pass out of the gateway or door until your "pupil" and a quiet broken horse are the only ones remaining. As to getting him into stable for the first time we will quote "Rarey" as the most recent instructor. $\mathrm{He}$ says:- "One wrong move may frighten him, and make him think it necessary to escape at all hazards for the safety of his life-and thus make two hours' work of a ten minutes' job; and this would be all your own fault, and entirely unnecessary-for he will not run unless you run after him, and that would not be good policy unless you knew that you could outrun him, for you will have to let him stop of his own accord after all. But he will not try to break away unless you attempt to force him into measures. If he does not see the way at once, and is a little fretful about going in, do not undertake to drive him, but give him a little less room outside, by gently closing in around him. Do not raise your arms, but let them hang at your side, for you might as well raise a club: the horse has never studied anatomy, and does not know but that they will unhinge themselves and fly at him. If he attempts to turn back, walk before him, but do not run; and if he gets past you, encircle him again in the same quiet manner, and he will soon find that you are not going to hurt him; and then you can walk so close around him that he will go into the stable for more room, and to get farther from you. As soon as he is in, remove the quiet horse and shut the door. This will be his first notion of confinement-not knowing how he got into such a place, nor how to get out of it. That he may take it as quietly as possible, see that the shed is entirely free from dogs, chickens, or anything that would annoy him. Then give him a few ears of corn, and let him remain alone fifteen or twenty minutes, until he has examined his apartment, and has become reconciled to his confinement And now, while your horse is eating those few ears of corn, is the proper time to see that your halter is ready and all right, and to reflect on the best mode of operations; for in horsebreaking it is highly important that you should be governed by some system. And you should know, before 
gou attempt to do anything, just what you are going to do, and how you are going to do it. And, if you are experienced in the art of taming wild horses, fou ought to be able to tell, within a few minutes, the length of time it would take you to halter the colt, and teach him to lead."

In 1814, one Willis Powell published a book called "The Art of Taming Wild Horses," which contains some practical and clear instructions. At the risk of a short iteration, we will give them in the writer's own words, as containing the kernel of the preliminary steps in horsebreaking. Mr. Powell says: "Having your horse in a stable or room, which should be sufficiently large to move him about with the halter before you lead him out, see if he belongs to that class which appear only to fear man. If so, introduce gourself gently and silently into the stable or yard where you have left the horse awhile. He will instinctively run from you, and frequently turn his head from you; you must walk about very slowly and softly, so that he can see you whenever he turns his head towards you, which he never fails to do in a short time, say in a quarter or half an hour. I never knew one to be much longer without turning towards me.

"At the very moment he turns his head, hold out your left hand towards him, and stand perfectly still, kecping your eyes upon the horse, watching his motions, if he makes any. If the horse does not stir for ten or fifteen minutes, advance as slowly as possible, and without making the least noise always holding out your left hand, without any other ingredient in it than what nature put in it." * He says, "I have made use of certain ingredients before people, such as the sweat under my arm, \&c., to disguise the real secret, and many believed that the docility to which the horse arrived in so short a time was owing to these ingredients; but you see from this explanation that they were of no use whatever. The implicit faith placed in these ingredients, though innocent of themselves, becomes 'faith without works.' And thus men remained always in doubt concerning this secret. If the horse makes the least motion when you advance towards him, stop, and remain perfectly still until he is quiet. Remain a few moments in this condition, and then advance again in the same slow and almost imperceptible manner. Take notice-if the horse stirs, stop, without changing your position. It is very uncommon for the horse to stir more than once after you begin to advance, yet there are exceptions. He generally keeps his eyes fixed on you, until you get near enough to touch him on the forehead. When you are thus near to him, raise slowly, and by degrees, your hand, and let it come in contact with that part just above the nostrils, as lightly as possible. If the horse flinches (as many will), repeat with great rapidity these light strokes upon the

- Mr. Frederick Taylor, author of an interesting little tract on "Horsebreaking," recommends a piece of carrot, or biscuit soaked in aniseed. forehead, going a little farther up towards his ears by degrees, and descending with the same rapidity until he will let you handle his forehead all over. Now let the strokes be repeated with more force over all his forehead, descending by lighter strokes to each side of his head, until you can handle that part with equal facility. Then touch in the same light manner, making your hands and fingers play around the lower part of the horse's ears, coming down now and then to his forehead, which may be looked upon as the helm that governs all the rest.

"Having succeeded in handling his ears, adrance rowards the neck, with the same precautions and in the same manner; observing always to augment the force of the strokes whenever the horse will permit it. Perform the same on both sides of the neck, until he lets you take it in your arms without flinching.

"Proceed in the same gradual manner to the sides, and then to the back of the horse. Every time the horse shews any nervousness, return immediately to the forehead as the true standard, patting him with your hands, and thence rapidly to where you had already arrived, always gaining ground a considerable distance farther on every time this happens. The head, ears, neck, and body being thus gentled, proceed from the back to the root of the tail.

"This must be managed with dexterity, as a horse is never to be depended on that is skittish about the tail. Let your hand fall lightly and rapidly on that part next to the body a minute or two, and then you will begin to give it a slight pull upwards every quarter of a minute. At the same time you continue this handling of him, augment the force of the strokes as well as the raising of the tail, until you can raise it and handle it with the greatest ease, which commonly happens in a quarter of an hour in most horses, in others almost immediately, and in some much longer. It now remains to handle all his legs; from the tail come back again to the head, handle it well, as likewise the ears, breast, neck, \&c., speaking now and then to the colt. Begin by degrees to descend to the legs, always ascending and descending, gaining ground every time you descend, until you get to his feet.

"Talk to the horse in Latin, Greek, French, English, of Spanish, or any other language you please; but let him hear the sound of your voice, which at the beginning of the operation is not quite so necessary, but which I have always done in making him lift up his feet. 'Hold ur, your foot'-at the same time lift his foot with your hand He soon becomes familiar with the sounds, and will hold up his foot at command. Then proceed to the hind feet, and go on in the same manner; and in a short time the horse will let you lift them, and even take thern uo in your arms.

"All this operation is no magnetism, no galvanis $m$; it is merely taking away the fear a horse generally has of a man, and familiarising the animal with his master. As the horse doubtless expcriences a certain pleasure from this bandling, 
ho will soon become gentle under it, and shew a very marked attachment to his keeper."

The Halter, and Haltering the Colt.-A leather halter should be invariably used, and take care that it is so made that when he pulls on it it shall not draw tightly round his nose, but sit on his head easily with the noseband not too low. Never put a rope halter on an unbroken colt under any circumstances whatever. Rarcy says, and we believe him right, that they have caused more horses to hurt or kill themselves than would pay for twice the cost of all the leather halters that have ever been needed for the purpose of haltering colts. It is almost impossible to break a colt that is very wild with a rope halter, without having him pull, rear, and throw himself, and thus endanger his life; and I will tell you why. It is just as natural for a horse to try to get his head out of anything that hurts it, or feels unpleasant, is it would be for you to try to get your hand out of a fire. The cords of the rope are hard and cutting; this makes him raise his head and draw on it, and as soon as he pulls, the slip noose (the way rope halters are always made) tightens and pinches his nose, and then he will struggle for life, until, perchance, he throws himself; and who would have his horse throw himself, and run the risk of breaking his neck, rather than pay the price of a leather halter? But this is not the worst. A horse that has once pulled on his halter can never he as well broken as one that has never pulled at all.

You may now proceed to shew him the halter; allow him to approach it with his nose so as to feel and smell it, for reasons assigned under the next heading. We would recommend that the old horse should stand by all this time, which will give him more confidence than if he were alone; and, having convinced him that you mean him no harm, he will allow you to handle him about the head and ears. Before you attempt to place it on his head, let him again smell it and touch it, but above all things do not hurry the business, but by fondling with him, and using him to the feel of the hand and the halter, there will be no difficulty in placing it carefully on his head. The assistant wiil now lead on the old horse in the direction required to go, and taking hold of the halter shank, about a foot from the colt's head, lead him after, and close behind the old horse, now and then caressing him with the hand until the most perfect gordwill is established.

By a violent method of first haltering a colt, he is so terrified, that it will take weeks of kind treatment to convince him that it is not the intention of every man, who approaches him, to inflict pain or punishment.

At this stage of training, the colt cannot be too much handled, and accustomed to the sound of the human voice; commencing first very gently about his head, as before haltering, pass the hand along his neck, down his near shoulder, by the front and back of his near fore leg, along his withers and back, about his ribs and under his belly, over his loins, and his quarter to the hock joint, shank, and heel, finishing that side by again and again picking up his hind foot.
Then, returning to his head, pass the right hand all over his off-side in the same way. This treatment repeated a few times, will reconcile the colt, and establish more confidence between him and his trainer than a month's flogging him round a lounging circle with a whip.

Familiarising the Colt to surroundrey Objects and to Sounds.-By patience and allowing him to examine it, thereby giving confidence to the horse, he will allow with indifference any object, however frightful, to approach, come around or over him, provided it inflicts no pain. Fear in the horse appears to the hasty observer as a mere unreasoning paroxysm. A log or stump of a tree by the roadside does not alarm reasoning man, and the ignorant and unenquiring breaker too often endeavours to conquer what he assumes to be and calls "shying." In a state of nature the horse will examine this, or any such unaccustomed object, and having satisfied himself of its innocuousness, never after trouble himself at its appearance. The horse domesticated and under restraint is often prevented from this investiga. tion, and punished for his first startled movement. Take the colt up to the object of his fear, let him touch it with his nose, and he will care no more about it.

The same process will have the same effect with any other object, however frightful in appearance, from which he experiences no harm. Take a boy that has been frightened by a false face, or any other object that he could not comprehend at once; but let him have that face or object in his hands and examine it, and he will not care any. thing more about it. The same principle governs both cases. The horse is never so well satisfied when he is about anything that has frightened him, as when he is standing with his nose to it. In nine cases out of ten, you will see some of that same wild look about him again as he turns to walk from it. And you will, probably, see him looking back suspiciously as he walks away, as though he thought it might come after him yet. In all probability he will have to go back and make another examination before he is satisfied; but he will soon familiarise himself with it, and, in a few days, such an object as a bearskin, or coloured blanket, that frightened him so much at first. will be no more to him than a familiar stump.

"We might naturally suppose," says Mr. P.arey, "from the fact of the horse's applying his nose to everything new to him, that he always does so for the purpose of smelling these objects. But I believe that it is as much or more for the purpose of feeling, and that he makes use of his nose or muzzle as we would of our hands; because it is the only organ by which he can touch or feel anything with much susceptibility. I believe that he invariably makes use of the four senses, seeing, hearing, smelling, and feeling, in all of his examinations, of which the sense of feeling is, perhaps, the most important. I think that, in the experiment with the robe*, his gradual approach and final touch

- Practised by Mr. Rarey in his system of taming : sce his little treatiss. 
with his nose was as much for the purpose of feeling as anything else, his sense of smell being so keen that it would not be necessary for him to touch his nose against anything in order to get the proper scent; for it is said that a horse can smell a man at the distance of a mile. And if the scent of the robe was all that was necessary he could get that several rods off. But we know from experience, that if a horse sees and smells a robe a short distance from him he is very much frightened (unless he is used to it) until he touches or feels it with his nose; which is proof positive that feeling is the controlling sense in that case."

We need hardly add that the use of scented oils, recommended by old farriery books, is utterly exploded and rendered obsolete by modern research and experiment.

The Bit and Bitting.-Every horseman knows, and those who are not horsemen will soon learn (if they ride at all), that on the properly bitting the horse, the comfort, safety, and appearance, both of horse and rider, most materially depend. However good may be the natural carriage of the horse, if an unsuitable bit is put into his mouth, it will greatly counteract both the inclination and ability of the horse to carry himself handsomely.

It must be borne in mind that this proper bitting must not only relate to the mouth of the animal, but must be arranged with reference to the hands of the rider; for that bit which is the very one to suit a particular mouth, when given to a man with fine hands, would be quite an improper one to give to one whose hands are only fit to lug at the mouth of a donkey.

The mouths of some colts are naturally more sensible, or insensible, to the touch than others; and here the judgment, or the want of it, is shown in the colt-breaker, by the selection of the bit best adapted to the colt's mouth, and afterwards on the goodness of the breaker's hands and temper depends whether he turns out the colt with a good or bad mouth.

In a general way the colt's bit is the large heavy snaffle with a ring in the centre, from which hangs some loose tackling which hangs on the tongue, and by producing probably somewhat of a tickling sensation, induces the colt to keep his mouth more or less in motion. With the generality of colts their first bit cannot be too easy; but if the mouth be naturally callous, it must be rendered amenable to the bit by using a severe one, or by using the easy one with a severer touch.

Whether for the colt or mature horse, the snaffle is the simplest. It is true there are various forms of snafles, some of them so made as to become an engine (if the expression may be allowed) of great severity; the plain large sized one, with a ring instead of joint in the centre, is the easiest, inasmuch as the ring, allowing of, say an inch in width, in the centre, does not convert the bit into an acute angle when acted on by the reins, whereas, when the centre is a joint, without going into the mathematical demonstration of the angle being forty-five degrees or any other degree, it becomes a much more acute angle or kind of skeleton wedge in the animal's mouth, and pinches the bars laterally like a vice; in short, by passing the off-side rein through the near-side ring of the bit, and the near-side rein through the off ring, and pulling both reins, we make the bit actually a pair of pincers; and if the force employed was great, the jaw of the horse would be compressed by a mechanical force that would crush it like a nut in a pair of nutcrackers.

Do not forget to show the bridle and bit to the colt as you showed the halter, and hereafter submit the saddle to his examination. Never buckle up the bitting rein tight at first.

The Cavesson-Lounging.-The application of the crvesson is the first active restraint applied to saddle-horses. Before putting it on, it is prudent to boot racing colts, and indeed all others of value, to prevent them knocking their legs against each other while they are lounging. Darvill says"On their first being taken out, a steady lad should walk in the rear, in case any colt should hang back, to urge him quietly on by flourishing his whip or ash plant, but not to strike him. Colts with their cavessons and hoots on, and thus attended, may be led out to the downs or into a large paddock. At either place they may be accustomed to be led quietly about. As soon as they become tractable in this way, attempts may be made to lounge them, by first walking them in a small circle to the right or to the left, and when they know how to go steadily round at this pace, they may be quietly urged on into a trot, gradually in. creasing the size of the circle by giving them more length of rein. In three or four days, or when they go boldly and freely at full length of the rein each way in the lounge, for fifteen or twenty minutes, having by degrees been brought to this pace and time of lounging, the mouthing bits, rollers, and cruppers may be put on them.

Lounging is an exercise very frequently carried on 20 a most unconscionable extent. Introduced originally for the purpose of subduing animals that had beer neglected till they arrived at an age when their tempers became resolute, the custom of severe lounging has become one which many persons concerned in the management of young horses look upon as of paramount necessity, without any regard to the consequences which follow, or the motives which originally led to its adoption. One of these was evidently with a view of saving time. A resolute uncultivated creature four or five years old, that would neither lead nor drive until brought to subjection by fatigue, probably might appear to require such usage as the only alternative, unless an unreasonably lengthened period could be appropriated to render the animal tractable. "Lounge him till he is tired " is the usual exclamation and practice of the provincial coltbreaker, whenever he meets with a colt who is a little difficult to manage; but by such men more horses' $t$ empers have been spoiled than improved. Harassed and overcome, the poor brute submits sullenly to the coercion of the 
individual whose duty it should be to obtain by kind treatment and patient attention that which he vainly attempts by ruffianism. Thus a temper characterised by gloomy cowardice is formed instead of cheerfulness and courage. Such ought never to be the treatment of any stock, much less that which is thorough bred, or intended for the purpose of racing. Their young and delicate limbs will not sustain the rough exercise of severe lounging, neither is it at all necessary for any beneficial purpose. A little now and then is all very proper; it teaches them the use of their limbs, renders them supple and active, and as an exercise discreetly regulated is very desirable; but, judging from the effect it produces when practised upon horses of mature age and in hard condition, it is the most severe work a horse can be subjected to ; that is, when it is continued for any length of time, and the poor animal is made to go at a fast pace on heavy ground. We have seen old hunters put through this manœuvre, under the impression, that in consequence of there not being any weight on their backs their legs sustain no injury. But it is a most mistaken idea. Constantly working on a circle horses are extremely liable to hit their legs, and for this reason boots or bandages should be invariably used whenever horses are lounged.

The action of some horses is such, that they scarcely move in certain paces without striking their legs, yet there are unany who scarcely ever do so, and others who never touch their legs except by accident. With those of the first class there is but one alternative,--their legs must be protected or inflammation will speedily be established, and eventually lameness. The second class will be very likely to labour under the same infirmity unless means are adopted for their security; and the third class will scarcely require protection to their legs, unless some particular exercise, such as lounging, entails the probability of an accidental blow.

After these premises it may naturally be inquired what objection can be started to the use of boots? Simply this; that they are productive of some heat in the leg by the friction which they occasion. Much it is true depends upon the fittings, and the way in which they are put on; but however well they may be made, softly lined, and properly adjusted, they will to a certain extent produce heat in the legs. When very nicely put on, handages are preferable, but it is so seldom that they are so that we hesitate in recommending them. If they are bound on too tight of course much mischief and inconvenience arises; and if not sufficiently tight, they will of course come undone. When bandages are required for exercise, they are best made from old blanketing; it wears better than common serge, and affords better protection.

Always in lounging begin with setting off the colt to the right, so that in case of his breaking out of the trot he may lead off with the left leg, and although he must be lounged both ways, work him to the right first time and most frequentiy. The pace at which colts are lounged is usually too fast: they are often hurried by the whip into a canter, and thence into a gallop. A trot is the proper pace, and should not be excceded. It is a general practice to lounge colts on the most level surfaces: this is an error, especially with horses intended for hunters or hacks.

Such animals have much to learn when they leave the breaker. All horses calculated to make hunters or steeplechasers should be taught, while under the control of the breaking tackle, to leap small fences; there is no necessity for practising them over dangerous places, or where the ground is hard; but low hedges or stiles, open ditches, and narrow water courses, may always be selected for their tuition. It appears almost unnecessary to observe that the reins attached to the bit should be lengthened to an extent capable of affording the colt sufficient liberty.

The dumb jockey is an apparatus which finds favour in the opinion of most persons having the direction and management of young horses, and is no doubt a very useful agent, especially before the living rider is put up; but great caution must be used that the animal is not alarmed on the first introduction of what must appear to the astonished creature a wonderful production; and here the injunction as to halter and saddle must be observed. These inventions are usually made with soft pads at the lower branches to protect the back of the colt from injury; if, however, they are not so provided, a saddle becomes necessary; and that appendage must likewise be placed on the back in due course of time, whether it be intended as a seat for the dumb jockey or not; at any rate, the young animal should be perfectly accustomeil to it before any attempt is made to put a rider up.

The dumb jockey is provided with two adjustments on each side for the reins, designed for the purpose of regulating the position of the head : thus, if the horse carries his head too high, the lower reins are to be brought into action, and if the reverse, the upper ones; the carriage of the colt may be very materially altered by these means. When sufficiently accustomed to it, the dumb jockey may be left on two or three hours while the colt is by himself, either in a large loose box or in a small paddock. This will very materially improve his mouth, and as an auxiliary, a palate or slabbering bit may be introduced instead of the snaffle already mentioned. It is made with a straight mouth-piece, having three moveable ports or arches, all of which may be adjusted so as to hang down, or two may be allowed to hang in that position, and one placed upwards, in case the horse does not play upon them sufficiently without. This bit possesses one very great recommendation, that ut creating an even mouth, and is the best remcdy for correcting that defect sometimes occasioned by the common breaking snaffle. A crupper may be attached to the dumb jockey with good effect, and eventually some loose straps running through it, to fall over the loins and down the sides, especially with such horses as are intended for harness; in fact, they should be accustumed by degrees to all sorts of appendages. Pocket-handkerchiefs may be tied to the 
upper branches of the dumb jockey, a hat placed upon it, and other similar devices patiently and gently introduced: by these practices much future trouble and many accidents will be avoided. The greatest caution must, however, be observed not to alarm the animals, or the object will be defeated.

It would be unjust here not to break a self-prescribed rule; we mean, to omit all mention of the Gutta Percha Jockey. The various advantages of this well-made breaking and exercising apparatus will be found fully set forth in the advertisements and testimonials of the patentee, Mr. Blackwell. We can bear testimony to their valuable action in producing an easy mouth, and checking that tendency to resistance produced by the common leather rein and clumsy wooden apparatus. The yielding nature of the reins and checks is admirable. They are excellent, too, for preventing led horses from falling. They yield, too, if the colt should fall and roll over, avoiding thereby another great danger and inconvenience of the old wooden apparatus. They are also serviceable in frosty weather, in loose boxes, to teach easy and graceful carriage. The figure and construction of this useful contrivance will be seen from the subjoined illustration.

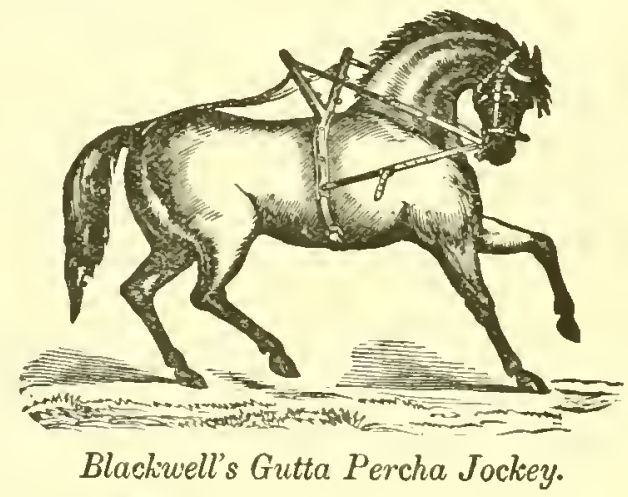

Saddling and Mounting the Colt.-We would recommend, unless the "casting" system of Rarey be adopted, that the saddle should be first introduced to the colt while he is lying down; and be drawn gradually over his withers, back, and hind-quarters, after he has had his feel at it. Turn the head of the colt to the right hand (when he lies on his near side), and he will partially rise, place his two fore feet flat on the ground, which he will permit you to do, and he has a good leverage for rising.

We shall here transcribe Mr. Rarey's directions for saddling, as the plainest and most succinct that have fallen under our notice:- "The first thing will be to tie each stirrupstrap into a loose knot to make them short, and prevent the stirrups from flying about and hitting him. Then double up the skirts and take the saddle under your right arm, so as not to frighten him with 1 t as you approach. When you get to him rub him gently a few times with your hand, and then raise the saddle very slowly, until he can see it, and smell and feel it with his nose. Then let the skirt loose, and rub it very gently against his neck the way the hair lies, letting him hear the rattle of the skirts as he feels them against him; each time getting a little farther backward, and finally slip it over his shoulders on his back. Shake it a little with your hand, and in less than five minutes you can rattle it about over his back as much as you please, and pull it off and throw it on again, without his paying much attention to it.

"As soon as you have accustomed him to the saddle, fasten the girth. Be careful how you do this. It often frightens the colt when he feels the girth binding him, and making the saddle fit tight on his back. You should bring up the girth very gently, and not draw it too tight at first, just enough to hold the saddle on. Move him a little, and then girth it as tight as you choose, and he will not mind it.

"See that the pad of your saddle is all right before you put it on, and that there is nothing to make it hurt him, or feel unpleasant to his back. It should not have any loose straps on the back part of it, to flap about and scare him. After you have saddled him in this way, take a switch in your right hand to tap him up with, and walk about in the stable a few times with your right arm over your saddle, taking hold of the reins on each side of his neck with your right and left hands, thus marching him about in the stable until you teach him the use of the bridle, and can turn him about in any direction, and stop him by a gentle pull of the rein. Continually caress him, and loose the reins a little every time you stop him.

"Always be alone, and have your colt in some light stable or shed, the first time you ride him; the loft should be high, so that you can sit on his back without endangering your head. You can teach him more in two hours' time in a stable of this kind, than you could do in two weeks in the common way of breaking colts, out in an open place. Take him a step at a time, until you get up a mutual confidence and trust between yourself and horse. First teach him to lead and stand hitched; next acquaint him with the saddle and the use of the bit; and then all that remains, is to get on him without scaring him, and you can ride him as well as any horse.

"Mounting the Colt.-First caress him on both sides, about the saddle, and all over, until he will stand still without holding, and is not afraid to see you anywhere about him. As soon as you have him thus familiar, get a small block, about one foot or eighteen inches in height, and set it down by the side of him, about where you want to stand to mount him; step up on this, raising yourself very gently: horses notice every change of position very closely, and, if you were to step up suddenly on the block, it would be very apt to scare him; but, by raising yourself gradually on it, he will see you, without being frightened, in a position very nearly the same as when you are on his back.

"When he will bear this without alarm, untie the stirrupstrap next to you, and put your left foot into the stirrup, and stand square over it, holding your knee against the horse, and your toe out, so as to touch him under the shoulder with the toe of your boot. Place your right hend 
on the front of the saddle, and on the opposite side of you, taking hold of a portion of the mane and the reins, as they hang loosely over his neck, with your left liand; then gradually bear your weight on the stirrup, and on your right hand, until the horse feels your whole weight on the saddle: repeat this several times, each time raising yourself a little higher from the block, until he will allow you to raise your leg over his croup and place yourself in the saddle.

"There are three great advantages in having a block to mount from. First, a sudden change of position is very apt to frighten a young horse who has never been handled: he will allow you to walk up to him, and stand by his side without scaring at you, because you have gentled him to that position; but if you get down on your hands and knees and crawl towards him, he will be very much frightened; and upon the same principle, he would be frightened at your new position if you had the power to hold yourself over his back without touching him. Then the first great advantage of the block is to gradually gentle him to that new position in which he will see you when you ride him. Secondly, by the process of leaning your weight in the stirrups, and on your liand, you can gradually accustom him to your weight, so as not to frighten him by having him feel it all at once. In the third place, the block elevates you so that you will not have to make a spring in order to get on the horse's back, but from it you can gradually raise yourself into the saddle."

The colt is now mounted; but before we proceed to perfect him in his paces, we shall advert for a moment to the method of "casting" a colt, which is the remarkable feature of horse-taming claimed by Telfer, Rarey, Mr. W. Cooke, of Astley's, Mr. Sanger, and others.

"Casting" a Horse or stubborn Colt, and Cure for Kicking.-Take up one fore foot and bend his knee till his hoof is bottom upwards and nearly touching his body; then slip a leather loop over his knee, and up until it comes above the pastern joint, to keep it bent, heing careful to draw the loop together between the loof and pastern joint with a second strap to prevent the loop from slipping down and coming off. This will leave the horse standing on three legs; you can now handle him as you wish, for it is utterly impossible for him to kick in this position. There is something in this operation of taking up one foot that conquers a horse more quickly than anything you can do to him. There is no process equal to it for breaking a kicking horse, for severat reasons. There is a principle of this kind in the nature of the horse, that by conquering one member you conquer to a great extent the whole horse.

There is a plan to make a bad horse stand to be shod, by fastening down one ear. Rarey says he tried it several times, and thought that it had a good effect. "I'he benefit arising from this process is, that by discomforting his ears we draw his attention to them, and he is not so apt to resist shoeing. By tying up one foot we operate on the same principle to a much better effect. When you first fasten up a horse's foot he will sometimes get very mad, and strike with his knee, and try every possible way to get it down; but he cannot do that, and will soon give in. This will conquer him without any danger of hurting himself or you : for you can tie up his foot and sit down and look at him until he gives up. When you find that he is conquered, go to him, let down his foot, rub his leg with your hand, caress him, and let him rest a little; then put it up again. Repeat this a few times, always putting up the same foot, and he will soon learn to travel on three legs. $\alpha 3$ soon as he gets a little used to this way of moving, put on your harness, and fasten him to a carriage. If he is the worst kicking horse that ever raised a foot you need not be fearful of his doing any damage while he has one foot up, for he cannot kick, neither can he run away to do any harm. If he is thewildest horse that ever had harness on, and has run away every time he has been hitched, you can nuw do with him as you please. If he wants to run, you can let him have the reins, and the whip too, with perfect safety, for he can go but a slow gait on three legs, and will soon be willing to stop; only hold him enough to guide him in the right direction, and he will soon be tired and willing to stop at the word. Thus you will effectually cure him at once of any further notion of running otf. K:cking horses have always been the dread of everybody; you always hear men say, when they speak about a bad horse, 'I don't care what he does, so he don't kick.' This new method* is an effectual cure for this worst of all habits. There are plenty of ways by which you can hitch a kicking horse, and force him to go, though he kicks all the time; but this doesn't have any good effect towards breaking him, for we know that horses kick because they are afraid of what is behind them, and when they kick against it and it hurts them they will only kick the harder; and this will hurt them still more, and make them remember the scrape much longer, and make it still more difficult to persuade them to have any confidence in anything dragging behind them ever after.

"But by this method you can hitch them to a rattling sulky, plough, waggon, or anything else in its worst shape. They may be frightened at first, but cannot kick or do anything to hurt themselves, and will soon find that you do not intend to hurt them, and then they will not care anything more about it. You can then let down the leg and drive along gently without any further trouble. By this process a bad kicking horse can be learned to go gentle in harness in a few hours' time."

Akin to this process is that of "casting ;" it of course adds another operation, that of making the horse lie down at the pleasure of his master. Bend bis left fore leg and slip a loop over it. so that he cannot get it down. Then put a surcingle around his body, so as to keep the strap in the right direction; take a short hold of it with your right hand; stand on the left side of the horse, grasp the bit in your

* It is claimed by many horse-tamers. 
left hand, pull steadily on the strap with your right; bear against his shoulder till you cause him to move. As soon as he lifts his weight, your pulling will raise the other foot, and he will have to come on his knees. Keep the strap tight in your hand, so that he cannot straighten his leg if he rises up. Hold him in this position, and turn his head towards you ; bear against his side with your shoulder, not hard, but with a steady, equal pressure, and in about ten minutes he will lie down. As soon as he lies down, he will be conquered, and you can handle him as you please. Take off the straps, and straighten out his legs; rub him lightly about the face and neck with your hand the way the hair lies; handle all his legs, and after he has lain ten or twenty minutes, let him get up again. After resting him a short time make him lie down as before. Repeat the operation three or four times, which will be sufficient for one lesson. Give him two lessons a day, and when you have given him four lessons, he will lie downby taking hold of one foot As soon as he is well broken to lie down in this way, tip him on the opposite leg with a stick when you take hold of his foot, and in a few days he will lie down upon the mere motion of the stick.

As these last described practices form the keystone of the "system" of breaking and taming, as practised by our transatlantic "gentler," as he delights to term himself, we have preferred to let him state the processes in his own words.

A few parting words, and we will proceed to treat of $T_{H E}$ Paces of the Horse. The rider is now on the road. He feels his horse's mouth done, is twice done). gently and encourages him by his voice and hand. Patting him frequently, and especially when he thinks of dismounting, the use of the rein in checking him, and of the pressure of the leg and the touch of the heel in quickening his pace, will soon be taught him. His education will now be nearly completed.

The Horse having thus far submitted himself to the breaker, pattings and rewards should be gradually diminished, and implicit obedience mildly but firmly enforced. Severity will not often be necessary; in the great majority of cases it will be altogether uncalled for: but should the animal, in a moment of waywardness, dispute the command of the breaker, he must at once be taught that he is the servant of man, and that we have the power, by other means than those of kindness, to bend him to our will. The education of the horse is that of the child. Pleasure is as mucb as possible associated with the early lessons; but firmness, or, if need be, coercion, must, if necessity arise, confirm the habit of obedience. Tyranny and cruelty will, more speedily in the horse than even in the child, provoke the wish to disobey, and, on every practicable occasion, the resistance to command. The restive and vicious horse is, in ninety-nine cases out of a hundred, made so by ill-usage, and not by nature. None but those who will take the trouble to try the experient are aware how absolute a command the due admixture of firmness and kindness will soon give us over any horse. The breaker should keep in his mind continually the proverb, "Quod factum est, bis factum est" (What is well 


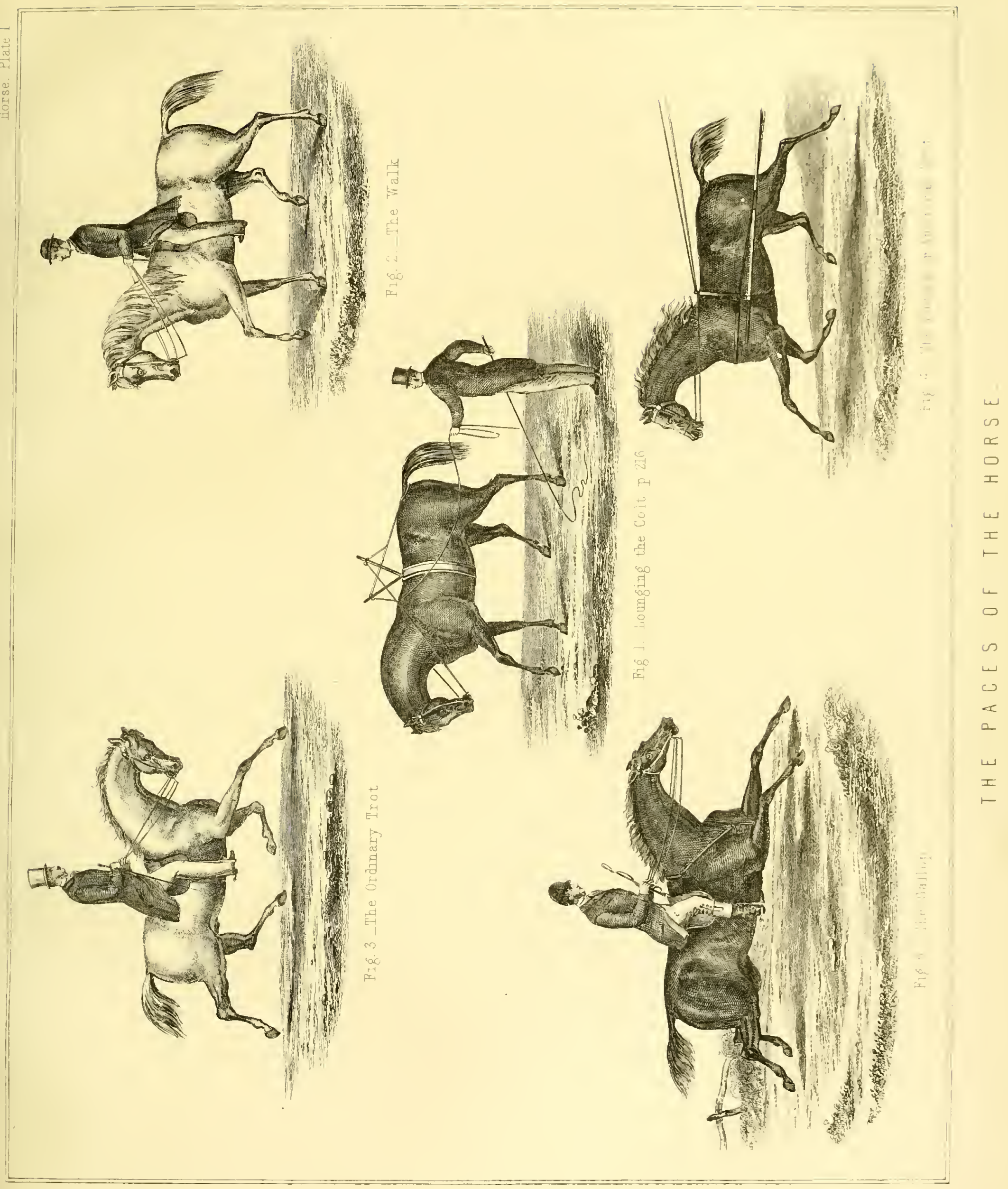





\section{CHA PTER VIII}

THE PACES OF THE HORSE, AND RIDING TO THEM.-THE WALK: THE TROT: THE RUNNINO TROT: THE CANTER: THE GALLOP

LEAPINO: THE STANDINO LEAP : THE FLYING LEAP : THE BLCK LEAP : TIMBER, WALL, AND WATER-JUMPINO.

ThE mode of progression of the horse comprises five distinct / immediately succeeded by the near hind; but the off hind modes of lifting the limbs: 1 , the walk; 2 , the trot, of leg seemed not to follow the fore leg at the same time as which there are two varieties; 3 , the canter; 4, the gallop; before (in the slower walk); but this was owing to nothing 5, leaping, which is akin to galloping, and exhibits several but the alteration in the poise of the body, when either the modifications, according to the obstacle to be surmounted.

The Walk.-The slow walk (Horse, Plate VII, fig. 2), is the simplest of the paces of the horse; but, if accelerated, breaks either into the amble, or an approach to the trot, whereby the succession of the movement of the limbs is varied. In the true walk, one foot only is lifted at a time, three remaining on the ground; increase the pace, and the two legs at opposite sides, that is, the near fore leg and off hind leg, or vice versa, are raised together. This, also, is the true trot, although the muscular movement in the walk is very different in degree and character. Borelli, the celebrated Italian mathematician, ${ }^{*}$ says that the walk is begun by lifting a hind foot first, and gives an imaginary reason, to the effect that if a fore foot were first lifted, it would disturb the true centre of gravity of the animal. We have observed that the walk is just as often begun with a fore-foot as a hind one ; the philosopher and professor may, therefore, be left undisturbed by any attempt to distrust their centre of gravity theory, inasmuch as the facts are against them. Old John Lawrence, in his "Structure and Economy of the Horse," thus describes the walk: "The walk consists of four motions, thus exemplified: the horse having advanced the near fore leg, and placed it again on the ground, the off hind leg is elevated and advanced under the body; but before it reaches the ground the off fore leg is raised and advanced, in order to make room for it, as is particularly the case when a horse oversteps the print of his fore foot with his hind foot. When the off hind leg has reached the ground, the horse stands upon three legs, forming a triangle. When the off fore leg alights on the ground, then the near hind leg commences its action, and is advanced in the same manner as before, and the horse is again supported upon three legs." A careful writer on horsemanship, Strickland Freeman, differs, however, from the author quoted ; but it is clear that the difference is more apparent than real. Lawrence's is the slow walk, Freeman's is accelerated. The latter says :"I found that, supposing the off fore leg to begin, it was one walk or the other took place. For when the off hind leg began, it was succeeded by the near fore leg being lifted up : and when the off hind leg was set down, the near hind leg was lifted up. But the off fore and the near hind leg seemed so connected together by the poise being on the same side, that it was the near hind leg which seemed to begin the action. The poise being altered by the will of the horse, the off fore seemed to begin, and not to be succeeded by the off hind foot being set down at the same time after it, as in the walk of the pace.* The near hind leg is in both cases taken up after the off hind foot is set down; and when the off fore foot is set down, the near fore foot is taken up, to make room for the near hind foot to be set down."

To walk well is a valuable property in any horse, but particularly so in the hackney. Such an one can compass his tive miles in an hour with ease. Where a horse walks well, the necessary harmony and accordance in the form of the limbs are such as to make it almost a rule that he is good in his other paces. The racehorse can stretch along in his walk, so as to get over much ground in a little time; but it is not often that he does it either pleasantly or safely; his stride is too great, and the elevation of his limbs is naturally curtailed by his training. It is a very great acquisition also to the hunter to walk well The walk as a pace should be performed harmoniously, whether it is quick or slow, each foot being dropped flat on the ground, and not, as is too often the case, the toe being placed first and then the heel. The breaking of the-horse will have much influence on his method of walking; the angles of his limbs will have much more; and not a little will depend on the hand of the rider. One horseman, by seat and hand, will force the horse to carry his head in the right place, and to elevate and extend his limbs the one in unison with the other; another rider, by his bad seat and worse hand, will bring the horse he rides to step short and irregular, and so to mix the trot with his walk as to do little more than 
shuffle over the ground. The maximum of speed in the true walk of the horse is under six miles per hour; there are but few can do thus much, but it has been done. Five miles pes hour is the common pace of a fast walker. Charles Westhall, the pedestrian, who can or could clear seven miles' walking in fifty-eight minutes, would dead beat the best walking horse, and break him into a trot before fifty yards were covered.

Of all the paces the walk is the easiest to the rider, provided he sits in the middle of his horse's back, as it consists of an alternate elevation and depression of the animal's fore and hinder quarters. The motion may be compared to the vibration of the beam of a pair of scales. It is difficult to confine young and high-mettled horses to a walk; good temper and a firm light hand are requisite to accomplish this. When such horses change to a trot, stop them for a minute or two; then walk them on again. If the horse carry his head well, ride him with a moderately loose rein, raising the hand when he tries to break into a trot.

The Trot.-The trot is also a mixed pace; it combines the true trot, and the running, pacing, or American trot. In what may be called the true trot (Plate VII., fig. 3), the legs are lifted diagonally, and brought down simultaneously. This motion is repeated more or less rapidly, the off hind foot and near fore foot being in the air together, and vice versa. Accelerate the trot to ten or twelve miles the hour, and a spring will have been imparted to the pace, by which the off fore and near hind leg, having struck the ground, the near fore and off hind leg not only are ready to elevate themselves, but have actually left the ground, and all four feet are in the air at the same time, as in the racing gallop, or flying leap. In a sprint race, you may easily see that a man at speed is completely off the ground; how this selfevident fact could have been so much discussed is proof of how much more ready to theorise than to observe for themselves. In the man's running, a spring is made from one leg; in a horse's extended trot, from two diagonally taken. The result is the same; a propulsion of the body forward, and a necessity of bringing up a leg in one instance, or two in the other, to save the fall of the body forward. Thus, a series of impulses is kept up, and, by a series of driving bounds, the weight of the body is rapidly driven forward. It is to be observed, that the quadruped is here much safer, from his diagonal line of gravity being distributed over the space from fore to hind foot, while in man the centre of gravity lies so forward, as to place him at the risk of a fall from the slightest mistake or mischance.

We have spoken of irregularities in the trot; Mr. John Lawrence thus speaks of the conformation which induces such irregularities: "When a horse, whose fore legs are much shorter than his hind legs, or whose shoulders are very upright, trots fast, he is obliged to go with his hind legs very wide, so that his hind feet may come on the outside of his fore feet. By this means he sinks his croup, and brings it more on \& level with his fore quarters, and at the same time he avoids striking his fore feet with his hind feet. Horses of this conformation sometimes go in the same form as dogs generally do, namely, with their fore and hind legs in two different lines of direction, by which one hind foot comes on the outside of the fore foot, and this is done with the same intention as in the former instance. They are, however, very unsafe to ride, for the hind foot is always more or less in danger of catching the fore foot, in which case, except the shoe is torn off, they must inevitably fall with great violence."

IIr. Lawrence gives a figure of what he calls " the elongated or darting trot ; "it is too near to that depicted in the pictures of Tom Thumb, Rattler, Ethan Allen, and other American trotters, to deserve distinction from what we call the running or pacing trot, of which we have more to say presently.

Training a horse to trot is not a difficult process; when lounging in the circle the horse instinctively falls into this pace.

Fast trotting, except in harness-for which work, by the way, it is the only pace that almost any horse can try either safely or pleasantly-is not so much practised by sportsmen or those who ride for mere pleasure; by this we should be understood to mean the maximum sixteen or seventeen-milean-hourproceeding. The race-horse may take two or three fine delicate steps in this pace just previously to his jockey sending him up the preparatory gallop; and hunters will thus jig-jog along to or through a cover; but with either of them it is never thought of when business begins. Ths man of fashion, so proud of and particular in the choice of his thorough-bred hacks, is content with a good walker and easy canterer, adopts high ports and long cheeks to his bridle, gets (if clever and lucky) a good mouth with a light hand, pulls his horse well back on the haunches, and sails along with an idea that the fast trot is a vulgarity confined to east end fanciers and butchers' boys, fast corn-dealers, jobbers, sporting publicans, with a turn for matches and bets, and the like Yet this is the true, best, and most serviceable pace of the saddle horse. Harry Hieover thus speaks of breeding the trotting hack:- "If a man wishes to breed hacks, there are two soris to breed-the blood-like galloping hack, and the trotting hack. By the first, I should say, a man must lose money, because there is seldom merit enough in them to command remunerating prices; for the really clever galloping hack seldom has high action, and most people (be it right or be it wrong) prefer those which have; consequently, the latter are safest to breed for market. Good action in a hack will always sell him; and we certanniy run a much greater chance of getting this if we breed from trotting stock, independent of sometimes getting something uncommon as to pace, when of course he will bring a very long figure, and is a trump card. We must also consider that if the trotting bred colt has good action, his pace is to be wonderfully improved by practice; and provided we do not deteriorate that action, the more we increase his speed the more valuable he becomes. This is not the case witb 
the galloping hack; if he goes smoothly, safely, and handsomely, we can make him no better; he is fast enough for a hack; and if by training we increased his speed, he would be worth no more, nineteen times in twenty not half 80 much; for we should spoil him as a hack, and as a hack only we want him To breed hacks I should select a low compact high-bred mare, a trotter herself, and put her to a regular trotting sire; not that we insure a trotter by this, but we put ourselves in the way of it, and then trust to our good luck; and I am quite clear that good luck and chance have much more to do with getting goers in any pace than is generally supposed. It is of course always wise to do that which is most likely to produce what we want, and to breed from going blood; but we all know how frequent is the disappointment when all this is done.

"I think trotting in a general way is more perpetuated in its breed than galloping; for in breeding from a certain strain on both sides we may pretty nearly insure a trotter more or less; and trotting being (at least I consider it so) a more artificial pace than galloping, if we get the action we can always increase the pace of the trotter in a greater degree than we can that of the race-horse. The speed of the latter is increased by training more in reference to speed as to a distance than for a few hundred yards. This is practice, and consequently wind and condition. It is not impossible that a two-year-old in fair state as to flesh might be able to go a quarter of a mile as fast before he went into training as he could afterwards, some perhaps faster; but even for that distance the speed of the trotter may to all but a certainty be very greatly increased ; in proof of which, all butchers' horses get faster than they were when they bought them, not only for a distance, but for two hundred yards. A very fast thoroughbred hunter in fine hunting condition will be made somewhat faster by training; that is, he will be able to go a greater distance when quite extended than he could before; he will also go two miles somewhat quicker than he could before; but training will not increase his speed in the same ratio as practice will that of the trotter. This induces me to call extraordinary speed in trotting more an artificial capability than that of speed in the gallop, where each have the natural gift of going in their different paces; for this reason, with under-sized horses, which the hacks should always be, aim at getting a trotter by breeding from trotters. Should they not ride quite as we wish, they are worth long prices for harness; if the galloping sort do not ride well, they are worth literally nothing."

With respect to trotting in saddle, this pace is but to attain a secure seat, combined with confidence and firmness. The rider has more control over the motions of his body in this pace than any other: in this the body is well brought down into the saddle by its own weight, and finds its true equilibrium. When the rider wishes to make his horse trot, let him ease his reins and press the calves of his legs gently; when his horse is at a trot, let him feel both his reins, raise his horse's forehand, and keep his haunches well under him.

\section{MATCH-TROTTINO.}

TIIE sport of match-trotting, 80 popular thirty or forty years since, has uttcrly degenerated, and fallen to a few outside sporting betting men and tradesmen, who "fancy" they have "something very fast," and post thrce, five, ten, or twenty pounds to "back their opinion." Across the water, however, in the United States, the troting-match substitutes for tens of thousands the race-course with its thorough-bred flyers. Though the Americans, however, may claim a superiority in speed in the trot, it must be borne in mind that their pace known by this name is more or less the running trot. Again, in estimating "time," which they record carefully in their great matches, the horses are driven up to the starting-point, and pass it at full swing, while in England the horse must walk to the start. Nevertheless, our go-a-head cousins, having paid attention to breeding and training for this special pace, have carried their peculiar animal, the "Morgan" horse, to a perfection with us unknown. Many of these horses can trot (English fashion) a mile in two minutes and a half; while "pacing trot," they can cover the same ground in 2 mins. 12 secs. On this side the water some remarkable instances of stoutness and speed are recorded Old John Lawrence has collected some early performances. He says, "I have met no account of trotting-matches in early writers, nor at what period the rising in the stirrups in riding came into vogue. Speed in the trot, as in the gallop, cannot be taught or acquired, although both may be much improved by training. As a man must be born a poet, so a horse must be born a trotter, or he certainly never will make one of any consequence in a racing view. The utmost speed of the trotter yet ascertained by stop-watch is a mile in a few seconds less than three minutes; and sixteen miles an hour, with a weight of twelve stone, seem the utmost that has been performed, unless the match in Lincolnshire in 1792 , with fifteen stone up, when 16 miles were done, is to be depended upon." These standards have been surpassed. Tom Thumb, (an American trotter), a galloway of 14 hands high, did 18 miles within the hour, and 100 miles in a few minutes over ten hours in harness, in a match against time; time allowed, 10 hours 30 mins. Driver, $13 \frac{1}{2}$ hands high, did 17 miles within the hour. Sir William, a half-bred horse, did is miles in the hour at Manchester. In the older volumes of the Sporting Mlagazine, there are some extraordinary accounts of trotting performances scattered up and down; of the performances of "The Norfolk Phenomenon," and numerous animals claiming blood relationship to that wonder, which must be received as doubtful, not from mala fides in the writers of the accounts, or the spectator's testimony, but from the imperfect method of timing, and the inferiority of the watches used. $\alpha$ grey mare, called "The Locksmith," in 1782, trotted, we are told, 72 miles in six hours. Phenomena, a brown mare, trotted in July, 1800,17 miles in 56 minutes on the road between Hun- 
tingdon and Cambridge, and afterwards the same distance in 53 minutes, when her owner, Mr. Robson, offered to back her to trot nineteen miles and a half within the hour, but the challenge was not accepted. A little before this there was a disprite in sporting circles "as to whether weight told upon the speed of a trotter," which John Lawrence set at rest by proving that it did! The American trotter's time we have already alluded to. Lady Hampton, Jerry, Confidence, Grey Eagle, Ethan Allen, and many others have supported the credit of the American trotter, and covered the mile in 2 mins. 12 or 13 secs.

Reverting to stoutness and the sustained exertion of the to trotter, we will give two matches on English ground: that of Tom Thumb's 100 miles, already alluded to, and the match between Rattler and Driver, concluding with an account of an American trotting-race as a picture of a national sport.

On Monday, Feb. 29, 1829, Tom Thumb performed the feat of trotting in harness 100 miles in 10 hours 7 minutes; time allowed, 10 hours 30 minutes; for the sum of $£ 200$ to $\mathfrak{£} 00$. The scene of action fixed on was a mile piece of road, commencing at the fifth mile-stone from Staines, into that town and back. "At four o'clock in the morning, the American groom, who seemed to regard his horse with the affection of a relative, was on the alert. He slept in the same stable, and roused him from his slumbers to give him a substantial feed At six, accompanied by Mr. Harry England and Mr. Frederick Smith, who rode as umpires for the horse, all set out for the five mile-stone, where the other parties had assembled. The distance from the Red Lion was about a mile and a half, and although not yet light, it was evident that the little horse was all life and spirit. $\mathrm{He}$ was driven by the groom, who weighs about ten stone. The match-cart, which was made in America, was one of the lightest we have ever seen, not more than one hundred and eight pounds, and decidedly the most compact, although not the most elegant, that has met our notice. The shafts ran level with the body of the horse; and the seat, which was lined with leather, was as near the axletree as possible, so as to give room for the driver to stretch his legs. The principle seemed to be, to place the weight close to the draught ; and, in fact the slightest exertion set the machine in motiun. The horse was unseemly in his aspect, rough in his coat, and, at first sight, sloucling in his gait ; in truth, anything but what an English eye would select for such a performance. He had four good legs, however, and a brightness in his eje, which led the connoisseurs to calculate there was something more than common in his qualities, and many began to guess that he would vindicate the fame of the Yankee breed of trotters, which are acknowledged to be the best in the world. Two watches having been regularly timed by the umpires, were now produced, and baving been stopped at the same moment, half-past six, were it a given signal started at the same instant, and with them the horse; and we must here pay a compliment to the excellent plans of Mr. England, who, having been appointed referee, rode the whole of the match before the American, in a gig, having been supplied with excellent relays of horses for the purpose. Mr. E. foresaw that, to perform so long a journey, the wisest plan would be to prevent overexertion at first; and, although he knew the speed of the horse was equal to fifteen miles an hour, he resolved to keep him to a steady pace of about ten miles an hour, thus husbanding his strength for the last, if it should be neces. sary; and, in order to effect this, he further resolved to drive before him himself, with his watch in his hand, so as to regulate his time. This plan had the additional advantage of encouraging the animal, and checking that desire to increase his speed, which, if the road had been clear before him, and horses were travelling on each side of him, he would have evinced, and which to check, would only have produced fretfulness. A stable was prepared for the reception of the American, close to the five mile-stone, into which be was taken at the end of every twenty miles. Gruel was his only food, but he occasionally took a snap of hay, and never once showed a disinclination to feed." "The distances were thus performed:-First twenty miles in one hour and fifty-nine minutes; taken out, and in stable eight minutes; second twenty miles in one hour and fifty-nine minutes; taken out, and in stable eight minutes; third twenty miles in one hour and fifty-eight minutes; taken out, and in stable eleven minutes; fourth twenty miles in one hour and forty-two minutes; taken out, and in stable eight minutes; last ten miles but one, fifty-two minutes; stopped to wash mouth with gruel, which he took with good appetite, two minutes : last ten miles, in one hour. The whole in ten hours, seven minutes." From this it will be seen that this game little horse won, and had twentythree minutes to spare of the allotted time, and that without being in the smallest degree distressed.

The celebrated American trotting-horse Rattler, when the property of Mr. Osbaldeston, was matched against Mr. Payne's famed American horse Rochester, Mr. O. backing

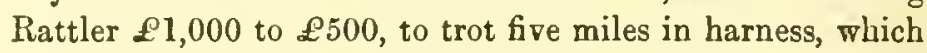
was performed in thirteen minutes, fifty-eight seconds. Mr. Osbaldeston came in first by the length of his carriage; but the match was however declared void, because $K, 0$. had neglected to pull up when his horse broke into a gallop.

The match between Rattler and Driver is thus recorded in the Old Sporting Magazine for August, 1832. The conditions were that Rattler was to carry eleven stone, and Driver nine stone; and should either horse break into a gallop, to turn round at the call of the umpire. Driver was formerly in the possession of the Duke of Gordon, and subsequently became the property of Macdonald, of whom Mr. Lawton purchased him. The day fixed by the articles was Friday, in the July meeting. Rattler, since his match with Rochester, remained in the neighbourhood of New. market; and Driver, after being in close training at Smitham Bottom, was conducted in the same dircetion in the early 
part of the week, as it had been mutually agreed that the match should come off in that direction. The horses started from the sixty mile-stone, out of Newmarket, to the fortythird mile-stone, through Chesterford, and back. Odds, previous to starting, six and seven to four, and two to one on Rattler. There was much betting on time; several persons backing the distance to be done in two hours. The weights having been adjusted, Mr. Osbaldeston mounted Rattler, and Macdonald Driver On the signal being given, the horses went off at a steady pace, the Squire rather in the rear, a position which it was understood he intended to preserve throughout till near home, when he purposed taking the lead, if in his power The road was alternately up and down hill, in some places the ascents and descents being rather precipitous, between chalk hills, which rendered it extremely warm and oppressive from a want of a free circulation of air. In going towards town, the horses were met by a gentle and refreshing breeze; but this being at their backs on their return, the disadvantage was obvious. As the horses proceeded Macdonald increased his speed, but Mr. Osbaldeston kept close to his quarters, and waited upon him with persevering industry. The first three miles were done in twelve minutes, and the first fourteen in fifty minutes. At the turn of the seventeen miles Driver was in front about a couple of lengths, and without pulling up they came on in the same relative position till within about a mile of home, near the Ditch Gate. Both horses were now greatly distressed; the pace, though not rapid, was fatiguing from the heat of the atmosphere. Macdonald tried his little nag towards the conclusion; but he always found Mr. Osbaldeston close upon his haunches. At last the Squire, finding the period for the push arrived, went forward, and in spite of all Macdonald could do, came in first by about fifty yards; performing the thirty-four miles in two hours, eighteen minutes, fifty-six seconds, or at the aggregate rate of a mile in four minutes throughout. In many parts of the road this pace was exceeded, as the trot for the last few miles did not seem to exceed twelve miles an hour. Mr. Osbaldeston was loudly cheered He immediately dismounted and weighed, apparently little fatigued. Rattler, however, was greatly distressed, and was led into the White Lion Stable, where every possible care was taken of him, but he was stated to be in a very precarious condition. Driver was also greatly distressed, but was conducted into the town and bled. Ae refused his food for some time, but gradually recovered his spirits, and was pronounced in a "fair way," though acknowledged to be "dead beat."

The death of Rattler, the winner, two days afterward, was stated to be a loss of $\mathfrak{E 4 , 0 0 0}$ to "the Squire;" owing to engagements for a renewed match with Rochester, and its forfeit. Driver, we may observe, was 13 hands 3, and had recently trotted 17 miles within the time at Smitham Bottom.

To return to the saddle, we may note two distinct methods of riding the trotting horse; 1 , that of rising in the stir- rup 8 -the civilian mode; 2 , the military style. The first saves an immense amount of fatigue to the horse and un. pleasantness to his rider. The second is a sacrifice to uniform appearance in a body of horsemen; as the effect of a number of men bobbing up and down synchronously with each horse's step would be something almost ludicrous : for it must be remembered that the man must here take his time from the horse, not the horse from the man Accordingly your dragoon bumps away upon his shecpskin as he best can. The civilian style is thus carried out: at the very moment when the near fore and off hind foot (or vice versa, according to the foot the horse starts with) have struck the ground in their effort to throw the horse forward in his stride, the body of the rider is propelled into the air, by hard and high trotters, to such an extent as fearfully to discompose an entire novice. Having reached the utmost height consequent upon this unpleasant propulsion, down comes the seat, reaching the saddle just in time to catch the next impact, and so on as long as the trot lasts. Now it is by performing each of these motions so as to rise and fall the instant before you are bumped that you ease yourseli and assist the animal. In this way the horse absolutely carries no weight at all during half his time, and the action and reaction are of such a nature that the trot is accelerated rather than retarded by the weight. No horse can fairly trot above 12 or 13 miles an hour without this rising, though he may run or pace in the American style; so that it is not only to save the rider, but also to ease the horse, that this practice has been introduced, and has held its ground in spite of the want of military sanction. It is here, as with the seat, utility is sacrificed to appearances: and whenever the long and weak seat of the barrack-yard supplants the firm seat of the civilian, the rising in the trot may be abandoned, but certainly not till then. The military length is not now what it was 30 years ago; and perhaps some time or other they may adopt the rise. In the trot, the foot should bear strongly on the stirrup, with the heel well down, and the ball of the foot pressing on the footprece of the stirrup; so that the elasticity of the ankle takes off the jar, and prevents the double rise, which in some rough horses is very apt to be produced. The knees should always be maintained exactly in the same place, without that shifting motion which is so common with bad riders, and the legs should be held perpendicularly from the knee downwards; the chest well forward, the waist in, and the loins nearly upright, but slightly forward, and as easily as can be effected without effort on the part of the rider, rather restraining than adding to the throw of the horse.

The military style, without rising, is effected by leaving the body as much as possible to find its own level. The knees should not cling to the saddle, the foot should not press forcibly upon the stirrup, and the hands should not bear upon the bridle. By attending to these negative directions, the rider has only to lean very slightly back from the 
perpendicular, and preserve his balance, when practice will do the rest.

We have already described the trot as performed by the fcet, $], 2,3,4$, diagonally; those who have pinned their faith on the fidelity of ancient sculptors-who certainly in most instances diligently studied nature-have been wofully misled in this matter, so far as the action of the horse in trotting is concerned. A visit to the British Museum, and a contemplation of the Elgin marbles, will show us two trotting horses with the legs of the same side raised at the same time, the other two being firmly planted on the ground-a mode of progression known to us only in the ungraceful trot of the bear. These are the only four horses, out of nearly two hundred, represented as trotting; the others are all cantering or galloping. The Romans, we may observe, condemned the trot. They called horses with this pace cruciatores or tortores (crucifiers or torturers); from which we may fairly infer that the art of riding this pace with ease was unknown to them, or at least not practised. Nimrod is severe on this useful pace: he says, "A very fast trot is a most ungentlemanlike pace, and only fit for a butcher; besides which it wears out a horse much sooner than a canter, from the weight being all thrown upon one fore leg at the same time, whereas in the canter it is equally divided between both." This opinion is controverted by experience and our best writers.

The Canter.-The canter, as we see it in the park hack and lady's horse, is an artificial pace. The exertion is less than the gallop, the pace slower, the spring less distant, and the feet come to ground in almost regular succession. In the gallop of speed the legs are simultaneous in their movement; in the canter, the reverse. In the slow gallop, too, there is a period when all the legs are in the air; in the canter this never occcurs. He has always a point of contact with the ground. The "canter" in our plate will show this. First, the horse puts his off hind leg a little in advance of the near leg; at the same time he lifts the fore hand and then drops the near fore leg on the ground, and throws the off leg forward and beyond it, following the near leg instantly, by bringing the former to the earth. Blaine thus describes the movements of the canter: "In the second movement the hind legs are thrown in, and, while elevated, the off fore leg becomes raised from the ground, but the near fore leg is not elevated until the hinder ones are replaced; and this, as remarked above, constitutes the grand difference between the canter and gallop. The sensation to the rider is as different as possible, and so is the action to the eye also. If this be established, it will call to mind that the whole weight of the body must at one time rest completely on the near fore leg: and that this does take place in the canter is evident from the effects observed; for it is a remarkable fact, though seldom observed by old writers, that in all cantering horses the near fore leg is more deteriorated, and exhibits more of the effects of work than the off. Judicious horsemen, sensible of this, do not therefore permit their horses always to lead on the same leg, but frequently change the centre, and gallop, canter, and trot, sometimes with the right and sometimes with the left shoulder forward. The right foot is usually employed in the lead, when a horse is 'breaking in' as a canterer; and it is proper so to commence the breaking-in. If the horse is awkward, or strikes off falsely, tighten the near rein, which, inclining his head to the left, naturally advances his right shoulder, and produces the disposition, when he is pressed forward by the hand, the whip, or the heels, to canter with the right shoulder forward But we evert to our caution, to avoid the continued use of one leading leg, which the reader may rest assured will suffer greatly, and become eventually contracted in the foot, gorged in the pastern, or lamed by splints. Some professed horsewomen use a screw crutch for their saddle, by which they can shift their seat; and to those who ride very much this is a very salutary custom, as the constant use of one posture has drawn the figure of the rider herself a little awry." Such are the remarks of that expericnced and eminent veterinarian Delabere Blaine; Nimrod, however, as we have noted while on the subject of the trot, does not con. sider this pace injurious to horses. "A canter," he observes, "is much more easy, as well as safer. tn the rider than a trot; the horse having his haunches more under him in the canter than when he trots, is therchy more likely to recover himself in case of making a mistake, which the best are sometimes subject to. Fast trotting also distresses a horse more than cantering, bccause in the one he is going uo to the top of his speed, and in the other much below it."

In riding the canter, the rider should have a light and firm feeling of both reins to raise his horse's forehand; at the same time, with a pressure of both calves, to bring the animal's quarters well under him, having a double feeling of the inward rein, and a strong pressure of the outward leg, to cause him to strike off in unison.

At all times the horse should be taught to lcad off with either fore leg; by doing so his legs will not be so mucb shaken, especially the off fore leg, which is the one he most generally leads off on. This must be the case when he is continually throwing the greater part of his weight upon the leading fore leg, as it comes to the ground, which causes lameness of the foot, and strains the back sinews of toe legs. Being thoroughly taught to change his legs, the horse is better able to perform long journeys with facility and comfort both to himself and his rider. Should the horse show a tendency to cross the canter, rouse his mouth with a slight reminder, and speak sharply to him; he will soon understand what is required, and behave accordingly.

The Gallop.-This is a natural pace, common to every description of horse in a state of nature, from the diminutive sheltie of the north to the onager (wild ass) of the African deserts, the ponderous Flanders cart-horse, and the flying thorough-bred of Eastern lineage, though their other paces may differ entirely.

All these move by a succession of leaps in which the hind 
quarters are the propellers. There are three distinct varities in the gallop: the hand or slow gallop; the thrcequarter gallop; and the full-gallop-the last capable of a yet further extension in the racing "finish." These are all modifications of the same mode of progression. We do not hold with those who class the canter as a gallop; for in the canter one foot is always on the ground, not so in the succession of leaps called galloping.

The Hand-gallop, with the right shoulder forward, is thus described by Blaine, than whom we can find no cleverer, better, or more practical writer on this topic: "At the instant the horse elevates his fore quarters by means of the muscles of the loins, he throws his fore legs also forwards, through the agency of the muscles distributed to the shoulders and arms: but it appears that he does not elevate his fore limbs equally; the right is raised a little more, and it is likewise carried a little further forward than the left, which makes the action a pace, not a leap. During this elevation, and in some instances preparatory to it, the right or off hind foot moves slightly forward, but only sufficient to gain a true centre, and to correspond with the increased forwardness of the right shoulder: the near hind leg, it must be remembered, yet remains fixed. The fore extremities now reach the ground, the near fore a little before its fellow, the off fore doubling over it, and placing itself a little beyond it; and the slower the gallop the more considerable will be the distance between the placing the fore legs. As soon as the near fore leg has met the ground, and before the off fore has yet taken its full bearing, the hinder legs are moved in the following manner, - the near hind elevates itself, and, as it reaches the ground, the off hind passes it and becomes placed also. It is now that the horse begins to be all in air in this pace; for, on the next spring that the hind quarters make, the fore quarters being already elevated from the last impulse, the animal is of necessity completely detached from the ground The next period when he is likewise so, is, when the fore quarters, meeting the ground, gain a new impulse by their rebound, the haunches are again thrown in to take their share in the support, and also to give their impelling power to the mass."

In the Three-quarter-gallop, though it is merely an accelexation of the hand-gallop, the horse, by describing a much less curve in each leap or bound, and lengthening his stride proportionately, changes much the stretch and increases the obliquity of his pasterns as the feet reach the ground; which fact is visible in faithful pictures of running horses by competent artists. The pace is the one gencrally seen in huntingscenes, and steeple-chasing, (not a "finish,") the racing-gallop being mostly incompatible with the nature of the ground.

The Full-gallop is the most simple of all the paces. "Sinple as it is," says Blaine, "it cannot, however, in any instance, be commenced without the intervention of the slower gallop, in which one of the hinder legs is first dvanced to establish a new centre; for it would require too great an effort to raise the fore parts at once frcm a state of rest by means of the loins, and to throw them forwards at the first action, to a considerable distance by means of the haunches and thighs. This fact is well known to jockeys and other sporting characters, and they often derive profit from the circumstance, by wagering with the unwary that no horse shall be found to gallop one hundred yards while a man runs fifty, provided each start together; in which case, so much time is lost in acquiring the due momentum that the man has often won: make but the race for one hundred and fifty yards and the horse would beat; for, now the impetus being acquired, he arrives at sufficient momenturn to overtake his antagonist. In the extended gallop the fore parts, when raised, are forced forward by ihe alternate flexions and extensions of the angles of the hinder parts; and as both of the fore and both of the hind legs, in the racing-gallop, become opposed to the ground in succession at the same moment, that is, as the two fore feet at once beat the ground together and then the two hind, so it is evident that the gallop of full speed is nothing more than a repeti. tion of leaps. Quickly as these leaps are repeated, yet the surface of ground passed over at each of them must necessarily be great, to accomplish the pace at which the good racer goes. Hambletonian, in his match against Diamond, is said to have covered eighty-three and a half feet of ground in a second; and by the calculations of IIonsieur St. Bel, Eclipse covered eighty-five feet of ground in the same time, when at the top of his speed. Every turf amateur must have remarked the horizontal position of the body in the racer at the momentous struggle. Every departure from a rectilinear form of the body would detract from the rapidity of its flight; and therefore even the head and neck are carried so as to fall within the line of the trunk. As a compensation, however, for the loss of the power sustained, the limbs are more extensively flexed, that the circles they form may be more extended."

The maximum of the speed of the race-horse appears admitted to be a mile in a minute ; but few, if any, horses can retain the full velocity of this rate for even that time. It has, however, been run at Newmarket, by a stop-watch, in one minute and four and a half seconds It is said, but was never proved, that Childers did run at Newmarket one mile in the minute : ccrtain it is that this celebrated horse, when carrying 9st. 2lbs., ran over the Round Course, which is 3 miles, 6 furlongs, 93 yards, in 6 mins. and 40 secs. Bay Malton ran 4 miles at York, in 1763, in 7 mins. 431 sccs. Eclipse also ran the same distance on the same course in 8 mins., with 12 st.

In 1848, Surplice won the Derby and Cymba the Oaks (both 3 year olds, 8 st. 7 lbs.), in the same time, 2 mins. 48 secs., $1 \frac{1}{2}$ mile; the fastest of those races up to that year, being at the rate of 14 secs. the furlong, 1 min. 52 secs. per mile.

- In 1861 and 1864 Kettledram and Stockwell covered the Derby coarse th 2 minnter 43 eeconds. 
Sir Tatton Sykes's Leger Race (3 years, 8st. 7lbs.) was faster ( 1 mile 6 furlongs and 132 yards), run in 3 mins. 16 secs., at a rati of nearly $13 \frac{1}{2}$ secs. a furlong, 1 min. 48 secs. per mile.

West Australian (4 yrs.), in 1854, ran over the Ascot Cup Course, $2 \frac{1}{2}$ miles, in 4 mins. 27 secs., or $13 \frac{1}{3}$ secs. per furlong, or a fraction less than 1 min. 47 secs. per mile. In this race Kingston ran West Australian to a head. From the above authenticated timing of the speediest racehorses on the British turf, the "mile-a-minute" tradition of the last century may be set down as too absurd a fiction to excite more than a smile at those whose credulity can cling to it. In some "time matches" in America, the best pace made was at New Orleans in 1855, when Lexington (4 years old), did 4 miles, with 7 st. 5lbs. up, in 7 mins. $19 \frac{3}{6}$ secs. And in the same year Brown Dick (3 jears old, 6st. 2lbs.), and Arrow (5 years, 7st. 12lbs.), ran 3 miles over the same course in 5 mins. 28 secs. (13 secs. per furlong). The heavier weight carried, and greater speed, of the modern English racer are here evident.

The gallop is ridden in two ways: the one seated in the saddle, the feet in the stirrup as far as the ball of the great toe, in the usual manner of riding throw paces, or with the stirrup home to the waist and instep of the boot-the ordinary hunting seat. With this the body is slightly bent backwards, in an easy posture; the knees press firmly against the saddle flaps; the hands low, with a gentle draw on the mouth ; the position of the hands, however, must be higher or lower, according to the horse's mode of carrying his head when galloping; that is, raised if he hangs downward, level if he does not bear on the bit, and absolute low if he "sniffs the wind with upturned nostril." The second way is the jockey's rising in the stirrups and standing. The weight is then on the irons, steadied by a moderate pressure of the knees. The seat is more backward than when down in the saddle, the loins and body leaning forward; the head not too low, and the knee slightly flexed to press the foot backward as well as downward. This seat is rarely used except in racing. It relieves the horse in bad ground, and over deep plough or fallow, and might be more frequently adopted with advantage. It, however, soon fatigues the muscles of the rider, if it saves those of the horse.

\section{LEAPINA.}

Leaping is a mode of surmounting obstacles common to most hunting quadrupeds, and to the horse tribe, though the style of jumping varies greatly in different animals. The kangaroo, which has no pace lut jumping, is the most abnormal, his jump being effecied by the base of his muscular tail and squatting hams. The trained horse alters his style of leap considerably, according to the nature of the obstacle to be surmounted, and hence, "fencing," as it is called in huntiug countries, presents several well-known varieties. The jump is effected by a sudden and vigorous extension of the hinder limbs after bringing them well under the animal by the action of the flexor tendons. The body is then, as it were, projected forwards in proportion to the force of the impulse. Hence the importance of the hunter possessing powerful loins, muscular thighs, wide and well let down hocks, and oblique shoulders for landing safely. Though weight-carrying hunters must be large framed, it does not follow that a large animal can leap a greater distance than smaller ones; the length or height of the leap being measured by the force in relation to the weight of the body projected thereby.

The varieties of leap proposed to be noticed are-1, the standing leap; 2, the flying leap; 3, the buck leap; 4, timber, wall, and water jumping.

The Standing Leap (Paces of the Horse, Plate VIrI., fig. 1) is, as the figure will suggest, only suitable for slight obstacles, such as a horse can easily surmount by rising at them with bent fore legs, and his head at liberty. In the standing leap the horse rises on his hind legs by bringing them well under him, his rise being more or less perpendicular according to the height of the obstacle. Some horses are remarkably clever at a standing leap, while others (often they have been spoiled by bad riders taking them too close up to the obstacle, and then not letting them have their heads) will scarcely rise unless allowed a run. The horse being thus in a rearing attitude, except that his fore legs are flexed to enable him to rise more easily, be springs, after a second or so of balancing, upward or forward, throwing out his fore legs and landing with a drawing action, and bringing the hinder feet well in under his quarters on landing, ready for another spring forward. It may be easily guessed that to keep your seat in a standing leap of good height requires some skill from the great change which the horse's position undergoes in regard to his rider. A judicious equilibrium and a good hold with the knees are quite as necessary in this style of leap, slow as it is voted by Meltonians, as in the more showy flying leap. Nimrod tells us of a splendid horse bought of the Earl of Stamford, which, after being a good flying leaper, changed his style, and could not be brought to jump any way but standing, except at water, when he would carry his seventeen stone master over any brook the width of which was at all practicable.

Mr. Waite, the riding-master, in a little concise treatise, entitled "Graceful Riding; a Pocket Manual for Equestrians," thus summarily directs the movements in the standing leap:- "Let the rider take up his horse at an animating pace, halt him with a tight hand upon his haunches; when rising at the leap, the rider should only just feel the reins, so as to prepare for slackening them, when he springs forward yielding them without reserve; as, at the time, the horse must be left quite at liberty. As the horse's hind feet come to the ground, the rider must again collect him, resume his usual position, and move on at the same pace. His body must be inclined forward as the horse rises, and backwards as he alights." 


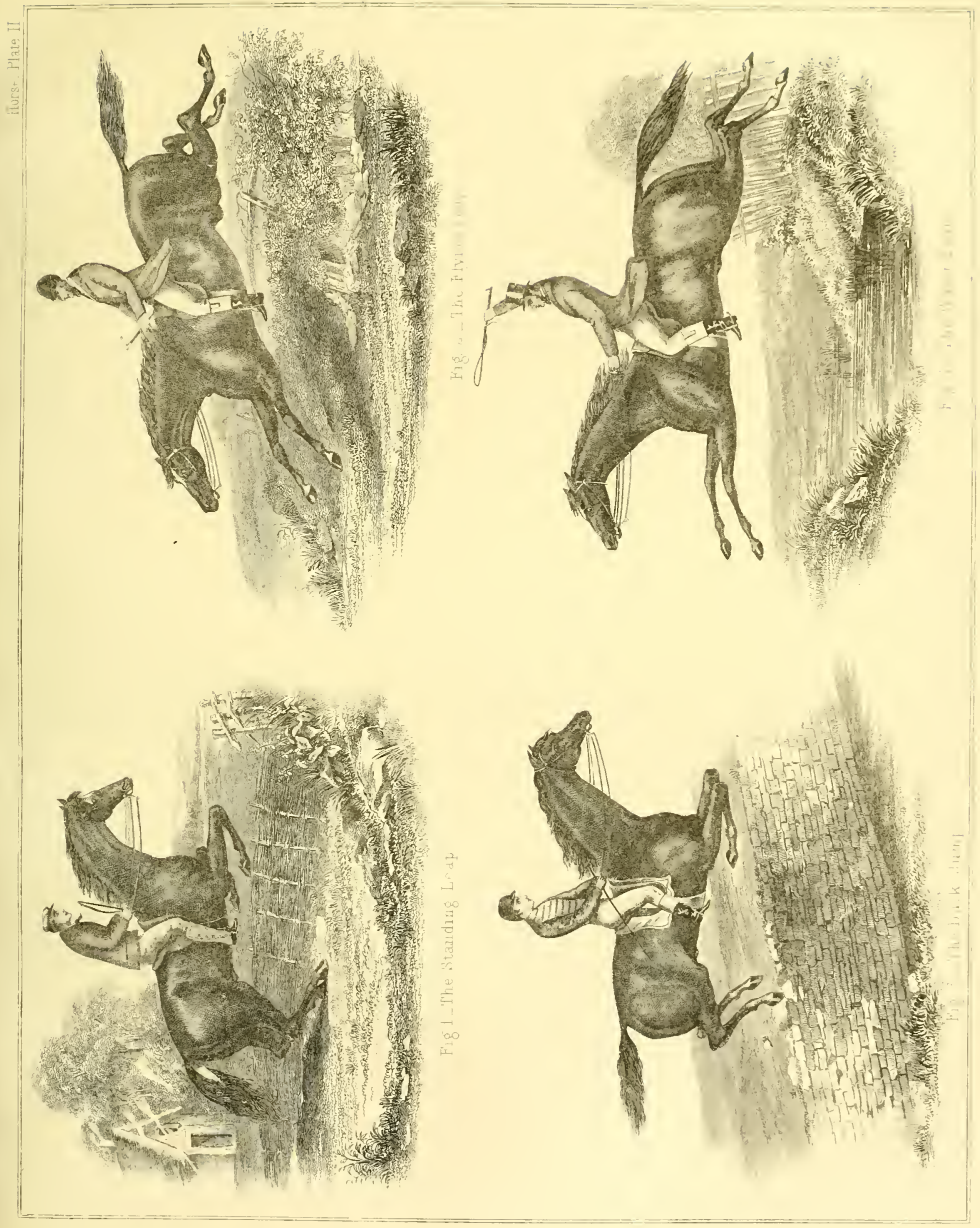



In many places where a stile or low gate, with a branch of a tree overhanging, has to be crossed, a perfect hunter will gather himself together and tilt himself over with a safety which a flying leap is far from insuring. Yet, as we have before said, the standing leap having been voted "slow hy modern "fast" men, we will pass to the next.

The Flying Leap.-This is of two classes: the rushing one, adopted from necessity in the jumping race known as the steeple-chase; the deliberate or hunting one, in which the horse is ridden steadily, and the fence, hedge, bank, or rail taken by a true leaping stride. The flying leap (Plate VIII., Fig. 2), is performed with all the limbs more or less extended, and the whole line of head, neck, and body nearly horizontal, more so in proportion to the width of the brook, ryke, or other space to be cleared. As in the flying leap the hinder limbs are the main instruments of propulsion, but the fore legs certainly take a greater part in the operation than is generally supposed, the last stride before the take-off of the leap the fore feet will be found to be violently thrown against the ground, to assist in lifting and propelling the animal, almost synchronously with the grand effort of the hinder limbs. The horse, having carried himself over the object, lowers his head, throws his fore legs yet more horizontally, and lands so as to offer the least resistance and jar; while his hinder limbs, which had been gathered up towards the belly to clear the leap, are brought under him, as in other cases, to again gallop on. Some hunters can rise well for a flying leap from the trot, but a steady handgallop is the best pace to rise from in the field; in that pace, or a canter, the horse is more under control, and can be more readily stopped. In the steeple-chase the jumps are all known, previously examined, and "eye-measured," both in "take-off" and "landing." In the field it is otherwise; and therefore rushing at fences is merely tempting mishap to horse and rider. At water a good pace is best, as it must usually be taken in stride; but a horse leaps better at a height from a steady pace, enough to secure a propulsive spring, than at extended speed. Double-posts and rails, and stone walls, require gathering together and "rousing ;" and never forget that the horse gathers courage from the confidence of his rider: a good horse, steady at his fences and straight at his work, may soon be spoilt by a nervous and irritable rider.

We again resort to Mr. S. C. Waite's manual. He directs the flying leap to be made thus:- "The horse must not be hurried, but taken up at a brisk pace, with a light and steady hand, keeping his head perfectly steady and straight to the bar or fence. This position is the same as in the standing leap; and the aids required are the same as for making a horse canter. If held too tight in the act of leaping, the horse is likely to overstrain himself, and fall. If hurried at a leap, it may cause him to miss his distance, and spring too soon or too late; therefore his pace must be regulated, so that he may take his spring distant enough, and proportionate to its height, so that he may clear it. When nearing the leap the rider must sit perfectly square, erect, pliant, and easy in the act of leaping; on arriving at the opposite side of the leap, throw the body well back, and again have the horse well in hand."

The Buck-jump, or double leap (Plate VIII., Fig. 3), is most remarkable in Irish horses, and among such of our own as are accustomed to banks and wall enclosures rather than water, hurdles, wattles, or quickset hedges. In the buck leap a second impetus is obtained by the horse striking the top of the wall or fence with his hind feet. Blaine has some sensible remarks, evidently based on close observation, on this peculiar repetition of the impulse in the act of leaping. He says, "Our experienced hunters, when facing a rasping leap, or when, after bounding over a ditch, and having reached the centre of a quick hedge, they get sight of a second ditch on the other side, will often be observed thus to double their leap, by applying the hind feet to the top of the hedge, and with such additional impetus, slight as it may appear, they carry themselves and riders over the whole. It must not, however, be supposed by this statement, that we consider the hedge itself to offer a fulcrum equal to the required propulsion. No; we consider that the horse himself makes a second extensile effort by the stimulus within, but instinctively put into action by this point dappui. This doubling of the hind legs is almost always seen in the greyhound when covering, not only a timber leap of the most trifling height, but also that of a low hedge in coursing, \&c., \&c., which we consider as bearing us out in our principle. It was by observation first made on greyhounds in our younger days, that we became apprised of this secondary effort in leaping, which led us, by attentive observation of every case of the kind that occurred, to detect the same in horses. Having also had much opportunity when in Ireland, of remarking the ease with which the common horses of the country, under Pat's 'cram and shout,' cleared the stone walls so numerous there (we beg pardon, we ought not to have said cleared them, for it was by always going over, and so seldom clearing the wall, but, on the contrary, invariably displacing a ridge stone or two), that we were led to a more minute inquiry into the matter, both practical and theoretical. The result of this inquiry satisfied us, that this doubling of a leap is instinctively implanted in all quadrupeds, whose form and arrangement of organs fits them for extensive saltation Having often, in the company of sportsmen, when we have noticed this capability, been met with doubt, and not unfrequently with a direct contradiction of the possibility of it, we cannot but be gratified when we meet with such an authority as $\mathrm{Mr}$. Apperley bearing us out in our statement of this secondary effort to extend the leap:- 'Yet after all,' says this talented writer, "the most extraordinary fact relating to the act of leaping in horses, is the power they have of extending themselves by a second spring as it were, when, on being suspended in the air, they perceive something on the further side of a fence, for which they were not prepared. That they occasionally do this under good horsemen. all good 
horsemen of experience can vouch for; but whence the fulcrum is derived, it would be difficult to determine." " (Encyclopoedia Britannica, vol. xi, p. 627.)

We need hardly say that the buck-leap is not made at the top of speed. The horse must not be at extended stride. The canter, trot, or short hand-gallop, are the most common preface, but we have seen it made under sudden alarm from a standing position. The buck-leap is made from the ground by the simultaneous action of all four legs at once; but the superior strength and more favourable angle of the hinder ones throw the horse forward, as well as up. When the wall or bank is topped, the horse, striking with his binder feet, the fore legs doubled, comes down by gathering his hind legs up and throwing out the front in such a way as to land them all together-a most dangerous and unpleasant concussion follows. Blaine says of a fatigued horse, under these circumstances:- "The horse in such case not being able to bear the jar of a secondary effort of the joints to relieve himself, the attempt often brings him down, and thus it is that buck-leapers are seldom safe ones. We would caution the nervous rider against the dangerous custom, which some have at every downward leap, of grasping the cantle of the saddle with the whip hand; for it not only displaces the body, and consequently unsteadies the seat, but it has likewise dislocated the shoulder. We have seen others elevate the whip hand at every flying leap; and the action appears to have become so natural to them as not at all to discompose their seat. In Ireland this is very common, and among the regular Pats it is zccompanied with a vociferous 'hough!' the rise of the hand and voice being synchronous; neither is it improbable that, from custom, both the action and sound are inspiriting to the rider-perhaps to the horse also."

In leaping much depends on the manner of bringing the borse up to the leap. He should be taken up straight and steady to the take-off, with the reins held in each hand; the bunds low, the curb-rein held loosely. The rider's body mist be erect, pliant, and easy in its movements. As the animal rises, the body must be well thrown back; and so at landing. The sitting a leap well is entirely dependent on the due poise of the body. The weight then accompanies the horse's movements, and the rider and his steed "keep time."

Timber, Wall, and Water-jumping.-Candour compels the admission that in these important points of cross-country riding the late Mr. Apperley has in various works; in his "Tours," "Riding to Hunds," "The Chase," \&c. ; well-nigh exhausted the subject, and to his pages, in the main, are we indebted for what we have here gathered.

Timber-leaping is of various kinds-posts and rails; a stile, with occasionally a font-bridge ; park-paling; doubleposts and rails, and swing gates, are the most common obstacles in this category. Sheep-hurdles and thorn-fences, with or without binders, are included in the timber-jump. As a preliminary caution we may note that many of the falls which occur in timber-leaping are attributable to the want of "catches" on the outer side of the shoes. These should be slight, and only on the outer side, as we shall note when we come to speak of the shoeing of the hunter. When the horse has not these as a foothold he is apt to slip his hinder quarters too far under in the attempt to stop the impetus of his gallop, and thus baulk his spring. Horses jump, however, as well as gallop, in all sorts of forms; and the judicious horseman will know that it is better to accommodate himself to his horse's habit, and cultivate his talent, than to interfere with his style; which is like an attempt to force a man to alter his settled opinions. The authority we have already referred to thus practically sets forth his opinion:-When you know your horse to be a safe fencer, be his fashion of performing his leaps what it may, do not try to force him to alter it; and whatever you do, by no means hurry such a horse, however prudent it may be to do so with others. Some horses, although sufficiently eager to get over, will always pull up at a timber-leap. particularly if it costs an extra exertion. In such a case, if you know your horse will clear his leap fairly, let him take it his own way; forcing such a horse will probably be very unsafe. Never, however, attempt such a leap merely to show off either yourself or your horse during the run; for several others of a similar kind inay be inevitable, and every such leap takes so much out of your horse that if he receives much shock on landing he will, perhaps, refuse a repetition. Never follow another rider when he is taking a timber-leap; for should he fall you may maim or kill hirn, or at any rate, lose your own credit. Do not force your horse at timber when he is distressed ; for should he then fall it may be with great force, and he will hardly rise, to say nothing of your own probable injury. Once more would we caution the aspirant in field riding against taking such leaps at the gallop : au contraire, it is good riding to pull up at some leaps, as we have already said, and to take them either from a walk, or at most from a canter. The late $\mathbf{M r}$. Assheton Smith-proclarum et venerabile nomen-never rode hard at any kind of leap whatever, with the excep. tion of brooks. We know "fast" men who would denounce much of this as savouring of "the slow."

The Stile-especially when it has a foot-bridge on one or both sides-is often a very ugly leap. If on the take-off side most horses will sooner face it and clear the whole; should this be impracticable or doubtfu', an experienced "fencer" will, if the bridge is strong enough, take it at twice, and do it cleverly. A slip, however, on the bridge is apt to hang the horse's stifle in the top rail, and keep him till the timber gives way; or, by getting a leg between the bars, the unlucky animal and his rider "come to grief." A good way-don't fear the vulgar imputation of "slow," -is to turn the horse over solus, if you have a friend to catch him for you.

The Gate, like the posts and rails, should be steadily ridden at: but rcmember that the foothold in these places is often 
very treacherous, owing to the ground being "poached" by the passage of neat-cattle and sheep at each side of the sbstruction.

Never ride at a gate that by probability is unfastened; to do so when it is actually on the swing would be madness; for as many good leapers measure heights and distance so accurately as almost always to brush the former, and exactly span the latter, so a gate on the swing, or even unfastened, would in all probability fly open, and the horse, instead of topping it, would first find himself swinging on it, and next rolling rider and all headlong from off it. In such case it would be uot unlikely also that the legs of the horse might, at the same time, become entangled in the gate rails; should this happen, first hold the head of the horse firmly down, and then let some one unhinge the gate, which is best done by putting the back against it. In these and other such like zases, wherein timber is concerned, we may remind the steady cider of the advantages which attended the heavy hunting whip of former times, with its hook and hammer mountings, as well as the sporting knife, with its cutting and sawing blades. Some good horsemen always ride briskly at a gate, which they say it is prudent to do ; first, because your horse will at once distinguish between your purpose of merely going up to open it, and your intention of going over it; next they observe, that by rushing at it, if the horse does not clear it, there is the greater chance of his breaking it by the impetus of the rush. The rider of a tired or blown horse, however, would do well to avoid timber when in his power, for such falls are usually serious ones to both parties: but when circumstances strongly urge the leap, let him push his horse at it with energy, lifting him by hand, and pressing him with the heel at the moment of the spring.

Park-paling is an ugly kind of timber to take, from the zig-zag forks at the head of the pales occasionally locking the hinder foot, where it is strong enough not to fly before the blow. Double posts and rails, where too yawning for a clearance, must be taken "in and out," or "on and off ;" at this, some Irish jumpers are very clever. Where there is a bank most English hunters lift themselves on to it, then, dwelling a moment, extricate their forelegs and drop into the next field, with just spring enough to clear a ditch if there be one. Double hurdles are an identical jump. Be careful to "give the horse his head," in rising, and in his second spring, feeling his mouth and lifting him when he touches ground.

Sheep-hurdles are generally too weak to occasion a fall, und may, therefore, he "rode at any how," as we have neard it expressed. They are a good means of teaching the colt, and impressing on "the young idea how to" jump. Three feet to three fect six is their usual height.

Water-jumping.-In going at a brook, take hold of your horse well, and ride him at a good striding pace straight at it ; choosing as good a "take off" and sound "landing" as possible. A horse to be good at brooks must be practised it smallish ones at first, which he must take in his stride at the three-quarter-gallop. Few horses take water-jumps kindly unless early instructed. A wide low-banked brook, if fordable, should be so taken. Straing and overreach art often the result of the other practice, to say nothing of \& rotten bank and a return by rolling over. It is superfluous to say that an overreach spoils your sport for the day; and that if you cram your horse at a water-jump he will not take, he may either stop dcad-in which case it is fortunate if you do not first taste the quality and sound the depth of the ditch, and so afford mirth to the field-or, if you havt him not well "felt by both reins," he will swerve to right or left, and carry you a circuitous bend homewards; to repeat the gyration as many times as you bring him up to the leap.

Stone-walls are noticed under the buck-leap.

The author of "The Horse and the Hound" tells you "how to fall from your horse;" and quaint as is the precept, it is well worth study, as "falls," like "offences, needs must come." In all falls, the horseman should roll away from his horse as soon as he possibly can, lest in his struggle to rise again he strike him with his legs or head It frequently happens that the horse himself rolls after he falls, and if in the direction in which his rider lies, is apt to crush and injure him. Indecd there is scarcely any hard rider who has not been thus served; but here, again, self-possession often stands his friend. When he sees the body of his horse approaching him, he frequently saves himself by meeting it with one of his fect, and, by obtaining a fulcrum, shoves his own body along the ground out of his reach. Coolness in this hour of peril likewise serves the sportsman in another way. Instead of losing hold of his reins, and abandoning his horse to his own will, as the mat who is flurried at this time invariably does, he keeps them in his hand, if not always, perhaps in nine falls out of ten. and thus secures his horse.

Of the wonderful leaping powers of the norse we have innumerable recorded instances.

Some years ago, a wager of 100 guineas was made between Lord Alvanley and Mr. Maher, that each did not leap over a brook of six yards width, without disturbing the water. Both riders leaped the brook handsomely; but, unfortunately for Lord Alvanley, his horse threw back a bit of dirt into the water after he had landed, which made him the loser.

Blaine witnessed a jump over the river Roding, in Essex, made by Sir William Rowley's huntsman, 24 feet in the clear.

The next is an example of sustained leaping powers and pace for a small animal. Sir Charles Turner's leaping match, made with the Earl of March, for 1,000 guineas, was performed on Fell, near Richmond, Yorkshire. "The conditions of the match were, that Sir Charles Turner should ride 10 miles within the hour, in which he was to take forty leaps; each leap to be 1 yard, 1 quarter, and 7 inches high" Sir Charles performed it on a galloway, with great ease, in 36 minutes. 
The Trial Leaps, as they are called, of the Irish horses, are however much more extraordinary. They are made over stone walls 6 feet high, and built firm throughout by coping and dashing: however, it is not expected that any other than a first-rate horse can tup such a fence; but several instances have occurred where this has been done, and that even by the common horses of the country. In the county of Limerick, one of these walls is shown which was ridden over by Colonel O'Grady. When Mr. Blaine, already quoted, was with his regiment in Ireland during the rebellion, he saw many such. "Over these walls it was a very common occurrence for their crack fieldsmen to ride; but it was owned that some of the stones were usually displaced in the leap. Indeed, it was this very circumstance that deprived the enterprise of half its danger. A good horse there, when hunting, seldom balks such a leap; for he is aware that either his knees or his breast will displace the first tier of loose stone; the next rider who follows does the same; and then each one who succeeds is in more and more peril from the loose stones, which very frequently give horse and rider an awful somersault. That high fencing horses are almost, as it were, indigenous to Ireland, we might conclude from the circumstance, that, at one of the great horse fairs held at Ballinasloe, the parish pound, which is 6 feet in height, forms the trial leap for the high priced horses bought there, each of which, we are told, is expected to leap it ere the bargain is concluded. It is also recorded of a discendant of Old Pot-8-os from an Irish half-bred mare, that she leaped a wall of 7 feet high, built for the purpose, in Phœnix Park, Dublin." The feat of leaping over the wall of Hyde Park is well known. It was to have been performed by an Irish mare, the property of $\mathrm{Mr}$. Bingham, but the trial was frustrated by her having passed into other hands: merely for the honour of Ireland, the leap was nevertheless attempted and achieved, on February 24,1792 , hy a bay horse in his possession, whose performance of it, it is said, was done merely to show the possibility of the thing. This was a standing leap; the height of the wall was $6 \frac{1}{2}$ feet on the inside and 8 on the outside, where a bed of long dung was laid to receive the horse in his descent. The willing animal, it must also be remarked, did it twice, merely displacing a few bricks at the last jump.

Well-authenticated brook and fence leaps of the steeplechasers of later years have far beaten these. Charity, winner of the Newport Pagnel Steeplechase in 1841, cleared 28 feet and a bank; while Peter Simple leaped the artificial water-cut, opposite the Grand Stand at the Liverpool Steeplechase, and left his measured foot prints 32 feet from bank to bank. Lottery cleared 29 feet with Jem Mason up; and The Chandler jumped 32 feet at Liverpool, across a watercourse, measured in presence of the writer.

We propose to speak of the accidental "PACES OF THB HorSE "-such as rearing, jibbing, shying, backing, cutting, lying-down, running-away, \&c.,- - when treating of the subjects of "Vices" and "Ridina." 
CHA P E K $1 \mathrm{X}$.

BUYiNG a GORSE: PREFATORY REMARES: TRICKS OF DEALERS: CHOICE OF A "OENERAL PURPOSE" HOR8E: "A OOOD SORT:

EXAMINATION FOR PURCHASE : EXAMINATION FOR DEFECT AND DISgASE: CONCLUSION.

No one who has mixed much in general society but has found, from peer to peasant, that one of the tenderest points of an Englishman's self-opinion is touched by the bare supposition that he "knows nothing about a horse ;" yet how few really have studied the subject, and how many less have possessed the opportunity of a technical acquaintance even with the leading points necessary to form an approximately just judgment of a horse's capabilities, powers, and suitableness for the purpose for which he is required. Next to choosing a wife, buying a horse to carry you "for better or for worse" is the affair in life that requires most deliberate circumspection. True, the former is proverbially "a lottery," but there is no reason that the latter need be. We will not be so ungallant as Lord Bacon, who likened wife-taking to a blindfold dip in a bagfull of snakes to draw forth the single eel; but however heaven may make matches, and "another place" dip them, the man who will study the subject need not, in suiting himself with a horse, buy one with such serious defects as may make him feel he is "sold again, and the money paid."

A dissertation on the various ways in which a horse may ve bought in London or in any otlee of our great commerciaj centres, such as Manchester, Liverpool, or Dublin, either at well-known auctions which are held periodically throughout the year, or from the livery-stable keepers and jobmasters who tourish wherever horses are bought and sold, or of a breeder, farmer, or "friend"- the last not the least dangerouswould waste too much of our space and of the reader's time. Much of this matter, more especially of the "stud" class, will be found pleasantly gossiped over in the small volume by "Harry Hieover" entitled "Precept and Practice," and similar works; our object here is to write for the "general " purchaser, who wants a "general" horse for "general "purposes, which is just the sort of person ninetenths of writers on this subject consider it would be beneath them, and a derogation from their character for sporting $\nu$ ov $\sigma$, to write for at all. They will insist upon showing you what a thoroughbred should be, according to the lighest standard; that, we opine, is not what an everyday buyer of a horse for his pleasure, comfort, business, or healthful exercise, wants. He may find it, in its right place, under the respective headings-the $\mathrm{R}_{\mathrm{ACE}}$ Honse, and the Hunter, and the article ON Breeding; also, and more to the point of our present topic, under THE Hackney, pp.
61,62 , ante. We have there described the best of that most useful class of horse as half or three quarter bred, and from $14 \cdot 1$ to $15 \cdot 1$ in stature, yet galloways and cobs under this height are often to be met with of undeniable utility, stoutness, and constitution. And here we would say to the "gentlemen in search of a horse," look rather for the good qualities, as you would in a friend or trusty servant, that mere beauty.

\footnotetext{
"Whoe'er expects a perfect 'horse' to see,

Expects what never was, or is, or e'er shall be;"
}

therefore, as all things have their defects in " this best of all possible worlds"-even you and I, gentle reader, includerlwe will just take a glance at a standard animal; the neares to which standard the horse you can buy approaches, the better for the fortunate man who becomes his owner.

An amusing, but, to our thinking, useless chapter or two might be given, studded with anecdotes of the various tricks of "copers," "chanters," "sharps," "flats," and "wideawakes;" with illustrations downward, from the aristocratic cavalry officer who "sells" the rich Cornet Greenhorn in the little matter of the 120 guinea charger, and the gentlemanly "friend" you met in the hunting-field-who has "the splendid fencer," and will part with, "to sou only, for $£ 250$, because he is just the thing to carry jou"through all the gradations, till you come to the hide-andseek-rascals who advertise a horse, "the property of a gentleman;" inquire of the groom, No.6, Backslum Mews, "ring the right-hand bell." Each of these has its horsedealing story, proving the axiomatic truth that "No man is honest in selling a horse." Our old friend Nimrod speaks to this. He says: "The moment a man has a horse to sell he becomes a suspicious character. Now, if the sale of one horse places a man in such an equivocal situation as to character, what must that man be who becomes a dealer in liorses? Why, by common consent, he is placed out of the pale of respectability; and if his conduct were to be in parallel with his character, he would be simply a systematic cheat." Again, "The horse seems a conductor to all sorts of villany; even friendship itself is no security in this matter, in which all the ordinary principles of honour and fair dealing, by common consent, are placed in abeyance, and a laugh is the rejoinder to the recital of acts which, if a horse were not in question, would expel a man from good 
society." There is quite as much fallacy in this as truth. The vendor is always the defendant in this moral court of inquiry; but in many-we had almost said most-instances the purchaser is a self-deluder, who querulously complains of the bargain he himself sought, and laments, in possession, the object he so earnestly coveted when another's. The better class of our London horse-dealers are quite as upright and fair in their dealings, as wine merchants, auctioneers, advertising jewellers, and a score of dealers in articles of a "fancy" description. This, many will say, is but poor praise; be it so. It is nearer truth than the senseless outcry about horse-dealers which fills the pages of lightreading periodicals, and points the pencil of the caricaturist. If to-morrow we wanted an animal, such as we shall presently describe, and distrusted our own experience and judgment, we should apply at once to an established dealer, on the same principle as we should to a respectable silversmith, and should not doubt to get fair value in one case as $n$ the other.

It is a gratifying fact, and we speak from observation and experience, that those tricks and dishonesties which used formerly so extensively and constantly to disgrace the repositories, are now of rare occurrence, if not quite gone down into desuetude; although, of course, caveat emptor cannot be flung to the winds when one is buying anything, but more especially in such an extremely delicate undertaking as purchasing a horse. The "knock-outs" are now confined to a few of the very needy and characterless cads. All the more respectable members of the trade repudiate the practice as beneath them. Improvement has also given the guinea-hunters the go-by; and here and there only, a crown or half-crown cad is tipped. Respectable agents, too, are not the rara avis they used to be. To return.

We will suppose you are not over-particular as to colour, and that the venerable saw, " a good horse is never of a bad colour," has its due weight with a sensible man. Grey, chesnut, roan, bay, brown, or black, there are good ones of all. Bay or brown, with black legs and hoofs, are usually most obtainable, and, all other points being equal, most desirable. Greys are handsome, but as they grow older and white, stain themselves so frequently by lying down that much more washing is necessary; add to which, their hoofs are often white, and softer and less dense than those of blackfooted horses.

To describe a "good sort" of horse is, perhaps, not a lifficult matter. A really good sort of horse cannot well be put quite out of his place; he is capable of all services that can be required of him, with the reservation of the two extremes-racing, or the waggon. Even for these, if he is well bred, he would make a tolerable good fight for the one, and his pluck and courage would, to the extent of his strength and weight, make him a most willing rival of "Gee woa," if the ingratitude and cupidity of man should destine him to such degradation and suffering: by no means an improbable ending of his career, and that often under circumstances at which the humane sportsman revolts.

There can be no doubt but that "a good sort" is a valuable acquisition to any man who wants a horse to perform well any purpose for which such sort is necessary or desirable; but he may not get what performs a particular kind of work in a superior manner notwithstanding; and we may sometimes, and under peculiar circumstances, show our tact and knowledge of horses, by purchasing one for a given purpose, which our judgment may tell us is really of a good sort, even for that purpose, or indeed any other.

A really good sort of horse is fit more or less for any purpose to which we may apply him, and will do that purpose moderately well; but it by no means follows he may be more than moderately good in any of them. A good sort of horse has so often been described by abler pens than ours, that we will not enter into the minutia of description here.

We are told, and with truth, that a tnin, clean, good head, and cheerful eye, are indicative of goodness, and (if we may use the terms in speaking of the horse) indicative also of an amiable and generous temperament and disposition; a head well put on, with a yielding and somewhat arched neck, denotes the head capable of being carried in the right place; and further, we may infer such a horse has a good mouth, it not having been hardened or spoiled by useless endeavours to bring the head in the place we wish it to be. Long oblique shoulders usually betoken freedom of action, so far as the fore parts are concerned. A deep girth and long back ribs show strength, as do good loins; wide hips, freedom of action; long good thighs and large clean hocks, with hind legs well put on, show strong propelling powers.

With these points (as we shall go more particularly into the subject in "Examination for Purchase"), we may say a horse has got what indicates goodness of temper, cheerfulness and courage, carrying himself handsomely and pleasantly to the rider or driver, goodness of action, strength, speed, and safety.

Yet, with all these good points, he may only be enabled to perform any of the purposes to which we may put him moderately well. In a general way such an animal cannot be a bad horse; but if we want perfection, or something like it, we must tie ourselves to special rules as to formation, and should show our tact in buying what our judgment must in a general way condemn, if we determine to have something uncommon in a particular way: such as a flyer for racing purposes, a jumper up to fifteen stone for steeple-chase or the hunting field, or an animal for the exclusive purposes of draught, all of which have their special conformations and characteristics

The most perfect mechanical forms are not ulways the most speedy or the most powerful: good conformation may give the power to perform extraordinary feats of endurance, activity, or strength; but it must never be forgotten that 
the vigour of motion depends not upon the form alone, but the will to exert its powers. This will, or energy in work, is proportionate to the excitability of that portion of the brain and nervous system which governs the muscles exerted in the desired action. Thus, oftentimes, a plain horse with a willing temper is far superior to a perfectly formed one who has not that virtue. "How can I tell," asks the reader, "anything about all this? I must trust to the seller." True, but not to the extent you suppose. A close and intelligent examination of the postures, countenance, eye, nostril, ear, movements, and carriage of the animal, will tell you more than you would believe until you try such a thoughtful inspection.

The energetic horse has generally a large eye, is attentive to what is going on about him, fine muzzle, large nostrils, small ears, thin skin, and clean limbs; he rarely carries much flesh ; and lastly, it has been frequently observed that many energetic horses have thin manes and tails.

The sluggard has usually a small sunken eye, in a large heavy head; the ears are large or sloping, and seldom move; the nostrils are almost always small, muzzle fleslyy, ribs flat, belly pendent, and the tail drooping and not unfrequently very full.

A small horse is capable of greater exertion than a largeone; the vital principle seems to act with increased activity in small animals; in one, it is diffused, and in the other concentrated : again, like us, some have better constitutions than others; in one, the texture of the organs may be compact, and in another weak and relaxed. Horses with thick skins are more predisposed to attacks of grease and canker. In proportion as the legs are hairy, the skin is thick and spongy, feeble in vital energy, and incapable of bearing changes of temperature.

With these preliminary remarks we will proceed to the

\section{EXAMINATION FOR PORCHASE.}

Unless proper precaution is used in the examination of horses for purchase, the law will not protect a man from the consequences of his own neglect; and it has been held that a warranty against apparent defects is bad in law, the purchaser being expected not only to possess ordinary skill, but to exhibit ordinary caution; we shall, however, have more to say on this subject when we come to "Warranty AND Unsoundness."

A defective horse is dear at any price; yet, though the buyer be ever so good a judge, and his inspection ever so minute, he must take some things on trust. A perfect knowledge can only be obtained on trial, which should always be taken, if possible, but which is not, under many circumstances, to be had. For instance, some horses, when turned six or seven years old, are subject to a dry chronic cough, which comes on at uncertain times, perhaps twice or thrice a day, sometimes after feeding or drinking; or changes of temperature may induce it, when he comes into or goes out of stable. Occasionally a dose of physic. and in some cases a little attention to his diet, will prevent recurrence of this cough for two or three days, or even weeks, when it will re-appear.

With a respectable dealer, after using your ejes and discretion, you had better depend on the warranty and the vendor's character, than by any unnecessary display of suspicion, offensively question hishonesty. Nevertheless, as the trade is taken up ly needy gentlemen of good standing in society, and broken down black-legs of respectable connexions, who are ever ready to give a warranty not worth a dump, or satisfaction if you are dissatisfied thereat, if you have reason to suspect the horse, or his master, the directions here laid down will be found useful. Always bear in mind that the observation of one symptom should induce the examiner to follow up the inquiry into those other symptoms which are characteristic of the suspccted disease, defect, or unsoundness. We would also recommend, when you have made up your mind that a horse is such as you would wish, to take with you, not as your dictator, but as your adviser and friend, a respectable qualified vet.; for, depend on't, he must be a wonder of incompetence and of the rarest dishonesty, if his judgment and disinterested advice are not superior to your unaided acumen, and perhaps prejudged decision. The fee is well saved in after satisfaction.

The best time to view a horse is early in the morning, in the stables; as if there is any stiffness in the joints, or tendency to swelled legs, it will then be most apparent.

The horse should always be examined from a state of rest. If there are any symptoms of his having been previously exercised, such as sweat about his withers, or his legs have been recently washed, it is advisable he should be left in his stall till cool. There is more than one species of lameness, which becomes less apparent after exercise, and where there is a tendency to swelled legs, a smart trot and grooming will fine his legs, and render them clean.

This precautionary measure is more especially to be taken when you suspect your man, for in horse-buying you must expect to deal with gentry who are adepts in the science of imposition. A stable examination is the best for observing indications of wind-sucking, crib-biting, chronic cough, the state of the respiration, and for discovering vice.

For this purpose, always have -a horse shown quietly. When there is much noise and bustle, there is generally something wrong; and when the animal is agitated, slight lameness will escape the eye. In going to look out for a horse in a dealer's stables, you will no doubt soon attract the notice of an attendant, who will endeavour to put the horses into a fidgety state by his presence, in all probability with a whip in his hand. Object, in limine, to this; your object is to see the animal in a state of repose, and as far from any exciting cause as possible It may be difficult to take a quiet survey; for the attendant is not always obedient to you, but often will persevere in exciting what you want to see in a quiescent state, and you ar 
driven to leave the stable in disgust. Old John Lawrence bas some sound cautions and remarks on this point, which we cite. He says:- "Suffer no person belonging to the seller to be with you in the stall (unless you know and are well satisfied with the dealer's character) during your inspection, that the horse may not be rendered unquiet, eitber designedly or at the mere presence of an habitual tormentor. A short time since I had occasion to examine a horse, for a friend, at the stable of a considerable dealer; it was a very beautiful and well-shaped nag, but, as is commonly the hard fate of such, he appeared to have done too much work. The attendant, from a superabundant share of regard to my safety, must needs hold the borse's head whilst I examined his legs, still assuring me he was perfectly quiet; nevertheless, every time I attempted to feel below his knees the horse started, and flew about the stall in a strange manner, to the no small risk of my toes and shins. Whilst I stood musing and wondering what beside the devil could possibly ail the animal, I discovered a short whip under the arm of the jockey, with which he had, no doubt, tickled the neck and chest of the horse whenever I stooped down with the intent of handling his legs. I wished this adept good morning.

"A good quiet stable survey is a material prelude, the horse being under none of that excitement which will probably have place in him when abroad upon the show. Unless, indeed, he should have been previously subject to that most barbarous stable discipline which I too often witnessed in days of yore, but which, I hope, does not in the present days, at least not in so great a degree or so usually disgrace the conduct of our dealers. I refer to the daily, too probably almost hourly, attendance of a fellow with a whip, who flogs and cuts the horses up and down in their stalls, causing them to jump and fly about as if mad, keeping them in such a constant state of miserable apprehension, that they dread the approach of any human being. The motive of this was to render them active, ready, and lively on a show, and to hide defects; and, as an exaggeration of this monstrous barbarity, the unfortunate cripples had even an additional share of this discipline, being whipped and beat most cruelly for putting out, in order to ease, a crippled limb."

The feet and legs.-The first thing to be observed is, that when standing evenly the weight is thrown equally on both feet. If there be any complaint in the fore feet one will probably be "pointed," that is, extended before the other, or be will frequently alter the position of them, taking one up and setting the other down; or the hind legs will be brought under the bo' . to relieve the fore feet of some portion of the weight. Any of these symptoms will direct your attention to the feet when you see him out.

Respiration.-To judge of his respiration it is necessary to be acquainted with the indications of healtb. Observe if the flank alternately rises and falls with regularity. In bealth the respiration of the horse is from four to eight per minute, average six in the day time; during sleep it is seldom more than four. If quicker than ordinary, it betokens present fever or defective lungs. Should it arise from present fever, otber symptoms will be developed, such as increased pulse, heat of mouth, and dulness, while the delicate pink appearance which the membrane covering the partition of the nostrils assumes in health will be increased in colour. But if none of these symptoms of ill health are present, and yet the horse heaves at the flank more than ordinary, if the weather be moderate, and the stable not oppressively hot, it is probable such a horse is thick winded.

When inspiration appears to be performed readily and quickly, as in health, by a single action, but expiration with difficulty hy an irregular and prolonged movement, or double action, the respiratory muscles appearing as if interrupted in the act of expelling the air, and then the flank drops suddenly, it is a symptom of broken wind. His cough should then be tried. The cough of a brokenwinded horse is a peculiar low hollow grunt, difficult to describe, but when once heard easily recognized.

Cough.-The cough can generally be elicited by pinching the larynx or trachea. This, however, is not an infallible test. We have met with sound as well as broken-winded horses that cannot be made to cough at all. In these cases, when there is any irregularity in the movement of the flank, which would lead to the suspicion of broken wind, and there is unusual hardness of the windpipe, which does not give way on pinching, it may be taken as a symptom of disorganization in addition to the probability of broken wind.

Mange.-Should the hair be rubbed off in some places, especially about the head, flanks, and tail, or he is observed rubbing himself against the sides of the stall, there is danger of his being mangy. In this case his coat will be found rough and staring.

Temper.-The absence of the vices of kicking and biting may be inferred from the manner of the groom when entering the stall, and by the quiet method with which he unclothes and dusts him over, and combs out his mane and tail. If he be a biter, his head will probably be tied short to the neck, or the groom will seize hold of him short hy the halter or bridle, sometimes giving him a shake, or looking sternly at him. Desire to see his hind and fore feet, and by the manner in which he permits the groom to lift them, a guess may be made as to his quietness to groom his heels, or in shoeing.

The Eyes.-While the horse is in the act of being led out of the stable to the light, closely observe his manner and action : if the ears move in quick changes of direction, as if alarmed at every noise, and he hangs hack on the halter, raising his feet higher than ordinary, and putting them down as if fearful aud uncertain of his step, it leads us to suspect his eyes, though sometimes these symptoms will be observed when the eyes are perfect, if the stable has been a dark one.

Standing, Grogginess.-When the horse is shown out, 
notice if he stand firm on his feet, with his weight thrown boldly on his back sinews and pasterns. If there is any appearance of shaking or tottering of the fore limbs indicative of grogginess, it will be endeavoured to be disguised by the groom continually pulling at the bit, to make him shift his legs and stand advantageously A lame horse is never permitted to stand still a moment, and the groom, though pretending to soothe, is in reality agitating him, while the shrewd and crafty seller will most probably endeavour to withdraw your scrutiny from the defective point, by calling your attention to his spirit or playfulness. If any of these mancuvres are apparent, be upon your guard. The groggy horse inclines a little forward at the knee, or it is readily bent by the least touch behind, he rests his weight on his toes, and when standing undisturbed brings his hind legs under him Some young horses, before they have been backed, have this deformity, from malformation of the knee; but if, in addition to this bending forward, there is any tremulous motion of the limbs, it is a decided proof of the existence of that most destructive affection, navicular disease; for an account of which the reader is referred to the Veterinary portion of this work.

To return, the horse being led out, he will most probably be placed upon rising ground, for the purpose of showing his fore quarters to advantage, which also affords the buyer an opportunity of another examination in a good light. The shoulder is by this position made to appear more sloping; and dealers, to give that appearance, try to make the near-leg to stand before the off-leg. Now is the time for perceiving whether his "understanding" is sound ; for though the dealer may declare that he is as sound as a bell, still we should disregard what he may say on that subject, and judge for ourselves.

Though the dealer is perfectly justified in these little manœuvres to show off his goods to the best advantage, more especially in so fancy an article as a horse-being no more than is done and allowed by every tradesman-the prudent purchaser will not please his eye at the expense of his judgment, but see the horse on level ground and with his feet placed evenly.

If one foot is more upright than the other, that foot is diseased ; the same weight is not thrown on it, and remember that the horse never shams a complaint. If the foot is of different temperature, active disease is going on; if an old standing complaint, the feet will be found of different size, and possibly the muscles of the arm and shoulder diminished in volume.

The purchase should take his position in front of the horse, and examine his fore legs-that they are in proper position; that there is no weakness in the pasterns, or enlargement of the fetlocks; and that the feet are of the same size, and stand square to the front. In brief, the fore legs should descend in a straight line from the bottom of the shoulder, i.e., in a lateral view; but when seen in front to incline gently inwards. If the elbow projects directly back- wards, and the toe points with precision forwards, we may rest satisfied that the horse is not twisted in his fore legs Turning the toe in or out, in standing, is apt to be accom panied with distortion or deformity of the limb; this circumstance, therefore, is seldom scen without materially lessening the value of a horse. Of the two faults, turning them out is the greater; for the pointing inward is seldom carried to extreme. A good arm is broad and thick; long when compared to the leg, and marked exteriorly by muscular prominences; the elbow cannot project too fal back, and the plumper the muscle immediately above it, the greater may we conclude to be the animal's powers.

General Health.-We may judge of the general state of the animal's health by his breathing condition, the brightness of his eye, the colour of the membrane lining the lid, and that of the membrane lining the nostril, which in health is of a pale pink. If it is a rosy red, there is excitement of the system; and if it is pale, approaching to white, it is a sign of debility.

Each nostril should be alternately closed by the hand, to ascertain that the air passages are not obstructed by polypus, or enlargement of the turbinated bones.

Nasal Discharge, Glanders.-Should there be any undue discharge from the nostrils you will probably be told it proceeds from slight cold; in that case an accelerated pulse and affection of the eyes are usually present. Nevertheless, as a precautionary measure, the branches of the under jaw should be felt for enlargement of the glands; if, although enlarged, they are moveable and tender, it is probably nothing more than a catarrhal affection. And here it may be necessary to observe, that in deciding upon the disease with which the horse is afflicted, it is requisite to bear it mind the age of the animal. In examining the head of a young horse, should the space between the branches be bot. tumid, and tender, the membrane of the nose intensely red, with profuse discharge from both nostrils, and cough and fever present itself, we may more than suspect strangles. Where, however, there is neither cough or fever, but one nostril, and that the left, affected, the discharge lighter in colour, and almost transparent, yet clammy and sticky, and the gland on that side adherent to the jawbone, glanders is indicated. In this case, should the lining membrane of the nostril be found pale, or cf a leaden colour, with small circular ulcers, having abrupt and prominent eajges, there can be no second opinion on the subject. We caution the inexperienced examiner not to mistake for an ulcer th $\epsilon$ orifice of the nasal duct, which is situated in the inner side, just within the nostril on the continuation of the commor, skin of the muzzle, and which conveys the tears from the eye into the nose. And yet more seriously would we warn him, in all suspicious cases, to be careful he has no chaps or sore places $\mathrm{cn}$ his hands or face. There is, unfortunately, no doubt that this dreadful disease is communicable to the human being. As few persons will buy a horse with any symptoms of actual disease, however slight, if they can helf 
it, the inquiry is better left to a professional man, in case any of these symptoms make their appearance after purchase.

The Crest, Condition, Age.-His crest should feel hard and full, and firmly and closely attached to his neck; if it be lax, he is out of condition. His skin should feel kind, and look glossy, and the muscles of the body feel hard and elastic to the touch. In the old horse, the head grows lean and fine, and the features more striking and blood-like, the aeck fine, withers short, and the back sinks; the lips exhibit a lean and shrivelled appearance, and the lower lip hangs considerably below the upper. In youth they are round and plump, and meet together, and the ridges of the roof of the mouth will be found prominent. In age, the nitdle of the nose will sometimes be found indented by the long-continued pressure of the nose-band of the head-stall.

The Teeth and Mouth. - In lifting his lip, if the incisor teeth shut close, even, and are perpendicular, he is young. As be grows older, they project forward in a horizontal direction, and the upper and under edges do not meet with evenness, the upper projecting over the under teeth. The longer his teeth are, the gums being dry and shrunk from them, the more advanced he is in age. This appearance of bis teeth cannot be altered by the arts of the dealer. In gouth, the teeth are flattened at front and rear, and long from side to side; at eight years old they are oval; as age advances, they become round, and in extreme old age triangular, yellow, and incrusted, and the tusks become blunt. If there are any marks of extraordinary wear in the central teeth, there is reason to suspect crib-biting, and in old cribbers the outer edge of the front teeth are worn away, and litle pieces are sometimes broken off by the attrition against the manger ; if such is the case, look to the neck for marks of the crib-biting strap. Dishonest dealers attempt to disguise age by reproducing the mark in the corner teeth by means of a hot iron or caustic; the fraud is easily detected by a judge, as it is usually overdone, and the marks do not correspond with the length, shape, and duration of the teeth, and the "bishoped" horse is usually loth to have his mouth meddled with.

In our chapter on the Age of the Horse as indicated by the Mouth, this subject is more fully treated.

\section{TRIAL AFTER EXAMINATION.}

Having attentively looked over the horse as he stands, and discovered nothing objectionable to the eye, it is prudent to see him through his paces before proceeding to ascertain, by careful examination, what defects, blemishes, \&c. which may have tendency to produce unsoundness, he is afflicted with; as the action of a horse, when closely observed, guides us to his defective points.

Action, Lameness.-He should be first walked, and then trotted, without any whip near him, slowly down the ride, allowing the animal to have the whole of the halter to him- self; his head will then be entirely unconstrained, and any irregularities in his action are easily detected.

The action should be scrutinized most attentivoly immediately he steps off, as defects are then most visible; for, not unfrequently, lameness disappears after few moments exercise.

Should one of the fore feet be much affected, it will be evident, by the up and down motion of the head, and the different degree of force with which he puts his feet to the ground. Horses that are lame before, drop their heads when stepping on the sound leg, and raise it when the weight is thrown on the lame leg; but when they are lame behind, the action (though not so perceptible) is reversed; they throw up their head a little when the sound leg comes to the ground, and depress it when the lame leg propels the body, and the motion of the lame leg is slow, while the sound one is jerked quickly forward to sustain the weight.

"Beaning" the Foot.-When both fore feet are equally tender (which is not uncommon in groggy horses) it is more difficult to judge of his action-it is not uneven, and the limp is not perceptible, but he steps short and tenderly with a general appearance of contraction. Dishonest dealers at fairs and auctions resort to a scheme by which groggy lameness in one leg is disguised by making the action even. This barbarous trick is known in various parts by the slang terms of " diamonding," " beaning," "balancing," or "wedging ;" and is performed by removing the shoe of the sound foot, and paring out the sole, until it yields to the pressure of the thumb. The shoe is then replaced, and a wedge of wood, a pebble, or bean, is driven in between the sole and shoe until sufficient pain is produced to make the horse equally lame on both legs. Although the lameness is less evident, yet a person accustomed to the action of horses will easily detect it; and if the animal is allowed to stand undisturbed, it will be shown something is wrong by his repeatedly shifting his legs.

Another trick of these rascals to conceal lameness, or to give an appearance of energy to the sluggard or worn-out horse, is the torture of the lash, termed "firing." The poor animal, previously to being shewn, is so barbarously flagellated, that, under the influence of terror of the further application of the whip, his attention is withdrawn from the disease, he feels not the lesser pain, but trots off heedless of his lameness, or at least showing it much less Whenever there is much punishment, or the threat of it, while showing a horse, be sure there is something to conceal.

The Trot.-If his trot is good, the foot is boldly delivered with an easy, light, and springs movement. Its course is straight forward and downward, not dishing to either side; the motion should be from the elbow as well as the knee; the hind legs gathered well under the body, following with regularity and precision; the toes fairly raised from the ground, and spread pretty accurately in the impress of the fore feet; if they pass beyond they are likely to overreach. In the trot he should go lightly with the fore feet; but 
strike the ground energetically with the hind, taking a long darting stride, and shooting, as it were, the body forward. The horse that throws his legs confusedly about should be rejected, for though most young and uneducated horses have an ungraceful and disorderly action, the sluggard is never precise and uniform in his trot.

In criticising action, attention must be paid to breed, but it should be sufficiently high in a hack to clear all ordinary irregularities on the ground; if it is very high, look out for trace of having worn a knee cap. Be careful to observe that he does not occasionally drop; a casual giving way on either leg, in the trot, is a sufficient hint to reject the animal, for such a horse is a constant danger to his rider's neck.

Though the best horse may stumble, yet, until after tripping, he springs out as if he feared the whip or spur if he does he is an old offender. Look again well to his knees and head. Observe that he goes clear in all his paces, and that one leg does not interfere with the other horses that go very near are more likely to cut when tired.

The Tail.-The "set-on" of the tail is not to be overlooked ; a horse that "carries two good ends," (of which the head forms one and the tail the other, always looks grand and showy. Above all others, the charger should possess this point in perfection, to coincide with the character of his display in the parade of a field-day. The tail, in most horses, should form when elevated a straight line, or nearly so, with the back ; a gentle declivity of the croup, however, from the summit of the rump, denotes the blood-like quarter, and adds much grace to this part in the thoroughbred horse. Should this line, however, decline very much the quarters lose much of their beauty as well as their natural power. Nothing is so ugly in a full-quartered horse as to see the tail set on low down, and issuing abruptly from the rump. The old-fashioned dealers figged all horses indiscriminately, which was injudicious, for those who naturally carried a good tail came under the same suspicion as those who were "gingered" for the dealer's purpose. Hackneys were often called "cock-tails" from this circumstance, in contradistinction to those of the thorough-bred, who never carry any but a drooping-tail. A cocked-tail would be incompatible with a blood-quarter, yet in a generation some of whom yet survive, the detestable practice of "nicking," and even "rat-tailing," hunters of good blood, though not stainless, prevailed, so potent is faslion over common-sense and humanity.

Discases and Unsoundness.--Satisfied with the tail in the strawed or tan-ride, he should next be mounted, and the trial be repeated on the pavement or road, for there ure many cases of defect which do not show on soft ground, at a walking pace, or when the horse is unburdened. If he step away boldly, the toe in a direct line with the body, the knee fairly bent, and his foot up and planted firmly down again on the ground, fearlessly and fat, without any dropping of bis head, you may conclude him sound in action. His hind legs, well lifted up and tucked well under him, should should follow his fore legs with regularity and if in running him up hill he goes without dragging his toe, you may infer the same behind. In the gallop, if he takes up his legs quick and dashes in his haunches, not bringing his hind legs after him, his action is gond. During this display of action, the examinant will have an opportunity of judging of the goodness of his wind; if he does not ride the animal hinself, he should stand close to the horse at the moment he comes into the gallop. The thick-winded horse breathes with difficulty, and is soon distressed. The flanks heave much and rapidly; there is some little roise; but the laborious heaving of the flank is the principal indication A horse unused to exercise, or if fat, or exercised on a full stomach, will show symptoms of thick wind; and it has been observed of great feeders who never breathe freely until they have gone a mile or two, or begin to sweat, that they are able to do more work than others that do not labour under the same difficulty.

"Wheezing" is a sound like an asthmatic person when y little hurried. Wheezing may frequently be heard while at rest in the stable.

"Whistling," or piping, is a shriller sound than wheezing, but it is only heard after exercise, and that of some continuance. A short gallop up hill is sometimes necessary to develop it, but the whistler is soon distressed. "Never buy a whistler, he cannot improve on your hand, and he is almost sure to get to worse," said Sir Henry Peyton to Nimrod; and the same advice may be given in respect of all these affections of the air passages.

"Roaring" is not heard when at rest. In the majority it is only developed by exertion, which quickens the breath. ing, and the noise is increased in proportion as the pace is accelerated; though in a few it is audible as soon as put into the trot. Knowing dealers, who wish to prevent the noise from reaching the ears of an inexperienced purchaser, when showing a "bull" of good action, start the horse a considerable distance before putting him to the gallop, and in returning, slacken the pace, so that the breathing becomes tranquil before the horse reaches the examiner; this is called "coming the long trot." Many of these lesions are consequences of inflamed lungs, or diseased alterations of the air passages, and most of them are modifications of the same disease. Sometimes they exist in so slight a degree as to be discoverable only by quick and long-continued exertion: but, when they are suspected, they should be tried by a brushing gallop, though this is not always allowed.

We next proceed to search for blemishes and those indications of unsoundness which are apparent to external examination, bearing in mind, any symptoms or suspicious appearances in his action, that may lead us to suspect particular parts, which should then be subiected to the severest scrutiny.

Any scars about the head should direct attention to the 
knees, or they may lead one to suspect there may have been an attack of stumbling or staggers.

The neck should be searched to ascertain that both jugular veins are perfect. This is discovered by pressing on the lower part of the neck, with sufficient force to stop the return of blood from the head; if the vein be perfect, it will fill and swell from that point upwards towards the head. The loss of one of them, if recent, predisposes the horse to staggers or apoplexy, and he cannot be turned out to grass or straw yard without risk. The withers should be examined for bruises from the saddle, as he will be unserviceable as long as the inflammation or swelling continues.

The slightest tendency to sore back makes a horse unserviceable for many months, and not unfrequently causes him to rear and plunge on mounting.

The shoulders should be examined for tumours. If there are any marks of setons or blisters about the points, it is probable he has been treated for shoulder lameness, and the attention of the examiner will be directed to the foot; which, ninety-nine cases out of a hundred, is the seat of lameness forward. If that is found narrow, upright, and strong, with the heels high, we may suspect navicular disease.

The chest and breast should also be searched for marks of rowels, setons, and blisters, for the remains of them render it probable that the horse has been under treatment for inflamed lungs or chest affections, and should, in prudence, direct the purchaser to ascertain by a smart gallop whether the mischief is of a permanent nature.

The knees should be examined with the utmost care, first that they correspond in shape, and secondly, to ascertain whether the skin has been broken by falls; but it does not follow that a mark or scar indicates a stumbler, and an accidental blemish should not induce us at once to condemn a well-formed animal.

A broken knee may happen from a variety of causes. The safest horse may fall by an unavoidable accident, such as a false step, from something giving way under the foot, as a round stone, from fatigue and over-exertion, or from a bad rider. But a broken knee is a suspicious circumstance; $i_{t}$ may be taken as an indication of existing or recent unsoundness, and the slightest mark calls for careful observation of every part of the horse, of his make and action, and suggests the narrowest scrutiny of the legs and feet. A tight shoe, a nail driven too close, or from bad shoeing; the toe being left too long, causes a horse to trip; tenderness in the feet, contraction, corns, and thrush : a scar on the head, above the eye; (for a forward fall of the horse leaves unmistakeable marks there) is a suspicious sign; when no trace of local disease can be found to account for them, the enquiry should be followed up into the horse's constitution, for the staggers or colic may have occasioned the accident.

When a scar on the knee is observed in connection with low withers, a thick and upright shoulder and pasterns, with the legs inclined under the bone, he is unwise who does not take the hint that the faulty formation has not produced its natural consequence. To discover the normal state of the knee is not so easy as some suppose, as occasionally the hair grows so well over the wound as to leave it hardly discernible; but on minute inspection, when there has been a scar, an interception of the gloss is apparent, as if the hair grew in an oblique direction; should this be observed on bending the joint, the secret will be exposed. The shank should be examined for splint, strained nr enlarged flexors, and the marks of firing or blisters.

In inspecting the leg, the eye alone should not be trusted, particularly in hairy-legged horses; but after minutely comparing the appearance of the two limbs, the hand should be deliberately passed down both shanks before and behind; any difference before or behind, points to a deviation from health.

In the sound flat-limb, the tendon is well defined, perfectly distinct, and has a hard tense feel that resembles the touch of a cord tightly strung. If the back sinews feel thick, the flexor tendons and their sheaths swelled and rounded, leaving no distinctive marks as it were between the one and the other, but all swelled into one mass with the bone, great mischief has at some time happened; either some of the ligaments have been ruptured, or there has been inflammation, effusion, and adhesion of the synovial sheaths of the flexor tendons; or such relaxation has taken place from strain and subsequent inflammation as will always keep him weak. When the injury is recent, it is accompanied with more or less swelling, heat, and lameness; by time and treatment the first are removed, but the swelling remains and the thickening of the tendons shows the mischief that has been done. Whenever there is manifest alteration of structure here, and yet the animal is apparently sound in action, the purchaser should bear in mind that the soundness is often the effect of rest; and should the animal be again put to work, he will become lame. Bear in mind, in such case, you cannot return him, for no man in his senses would give a special warranty against it.

Splints.-These, if large, are visible in the deviation of the outline of the leg; if small, the hand discovers them.

Every excrescence on the cannon bone, in horseman's language, is termed a splint. The true splint is in fact a conversion into bone of a part of the cartilage connecting the large and small metacarpal bones. The inflammation is set up by concussion or strain. Horses are lame from them while there is inflammation in the cartilage, and the tumour is growing and distending the membrane covering the bone and cartilage. But when the tumour is formed, the inflammation has subsided, and the periosteum has accommodated itself to the enlargement, the horse is no longer lame, nor more likely to become lame from that splint, than one without; the same causes that produced the first, may produce a second.

The splint, if so large as to interfere with action, rendering the horse liable to strike, is objectionable, or so near the 
knee or ligaments as to interfere with their freedom of action; otherwise it is of little consequence, beyond the blemish destroying the line of beauty. The worst splints are those discernible only by the lameness they produce.

Any marks of firing or blistering should make the purchaser cautious, and endeavour to ascertain the cause of the treatment : after blistering, the hair is sometimes a shade different in the colour, and stares a little, is shorter and bristly, and wants the natural gloss.

The fetlock joint, from being the principal seat of motion below the knee, and from its complicated structure, is particularly subject to injuries. The fetlocks should be subjected to the strictest examination for enlargements, which are best ascertained by carefully comparing them with each other, as any difference in size is indicative of strained or even ruptured ligaments, and consequently permanent weakness of that important part.

If the injury be recent, there probably will be heat and pain on pressure; and any signs of blistering or other treatment, though no enlargement or lameness is apparent, should indure the buyer to view the animal with increased suspicion.

Should there be any sores or callous places about the fetlocks or pasterns, he is a cutter, and possibly the marks of the foot may be visible. If there is no malformation to account for it, it may have been done when fatigued, or it may have arisen from improner shoeing; his feet should then be again examined.

If an old offender, he may probably have a peculiar shoe, rather thicker and narrower in the web on the inside than the outside, and nailed only on the ontside of the foot, and round the ioe; or the opposite shoe is found filed away or bevelled off, with the hoof projecting a little over the shoe. Where the feet, though well formed, are placed closer than desirable in narrow-chested horses, and therefore apt to cut, particularly when tired, we sometimes find a shoe which is thinner on the inside than the outside.

It other times various ingenious devices, calculated rather to increase than remedy the evil, have been resorted to; such as putting on shoes narrower on the inside of the foot, and the iron within the wall of the quarters reduced in thickness by the rasp. If none of these schemes have been resorted to, to obviate the defect, the horn of the opposite foot will sometimes be found polished by the attrition; for it is not the shoe that cuts once in a hundred times, but the hoof. In horses that interfere, we generally find the inside quarter lower than the outer, or the toes turned outwardsthe fault being in the leg that receives the mischief while sustaining the weight, not in the foot that gives the blow. The tired horse throws his legs about, and frequently cuts himself; and it is a fault of most young uneducated horses, especially if they have been backed inconsiderately, or worked too early

If there are any symptoms of "knucking over" or inclinatiun of the fetlocks forward, serious injury has happened.
The Fetlock joint.-The hair above and below the fetlock joint should be carefully searched for the scars loft by the operation of neurotomy. For the nature of this operation, see plate of "Horse's Foot" and article "Neurotomy" in Veterinary part. Pricking the fetlock, if you have reason to suspect it has been performed, will show whether sensation has been destroyed. About the fetlocks are frequently found little puffy tumours, absurdly denominated windgalls, from a supposition of farriers that they contain winid.

The Tendons.-Wherever parts move and press on each other, and between tendons, particularly about ihe extremities, there are placed vesicles, termed bursce mucosa, containing synovia, a lubricating fluid to prevent joint friction. When a horse has been compelled to undergo excessive exertion, an increased supply of synovia is secreted, which distends the sac; this sets up chronic inflammation of the synovial membrane-morbid secretion and visible enlargement follow. There are few horses that have done much work without these thickenings.

Though rest and pressure will diminish them, when once enlarged labour will reproduce them; they are of little consequence beyond the blemish, unless very large, and in most cases may be regarded as mere indications of hard work.

Ring-bone.-The pastern is the seat of a bony tumour termed ring-bone; it is the result of inflammation and partial conversion in to bone of that portion of the cartilages of the foot which rises above and nearly encircled the coronet. These cartilages, extending backward considerably beyond the coffin bone, form the elastic frame of the posterior parts of the foot; they here take the name of the "lateral cartilages." When ossific inflammation is set up in this part, from its tendency to spread round the pastern joint it has taken its name of ring-bone. When, however, the ossification appears only at the quarters, it is termed "ossification of the lateral cartilages." It is discovered by their prominence and rigidity when pressed between the finger and thumb. Upon the soundness of these parts depend the elasticity and consequent usefulness of the foot. However trifling the apparent alteration of structure, it is a serious detraction from the efficiency of a hack; though, on $\mathrm{s} \mathrm{ft}$ ground, at a slow pace, the draught horse will work upparently sound. If in feeling first one leg and then the other we discover any dirierence between them, disease more or less is present; he may not be lame, but he is not clean upon his legs. Splints, windgalls, and ring-bones, may be present without occasioning lameness; but they are all unnatural, are considered blemishes, and are to be regarded with a suspicious eye, as either denoting past hard work, or betokening future evils. On the same principle, a horse may have a spavin, and be only stiff from it at starting, or he may have a curb, or a thorough pin, and be perfectly sound; but these are still blemishes, and as such detract from the intrinsic value of the animal.

The Foot.-We now arrive at the Foor, the foundation of 
the horse; too much attention cannot be paid to it. The best way of judging whether there is malformation of the th feet, either natural or the result of disease, is to face the horse, and compare the two feet together.

The Hoof-C"No foot, no horse," is a trite but very true adage. First, we should look to the size of the hoof; a small foot is not only objectionable in itself, even though it be a natural formation, but is often a characteristic of disease. A small and upright hoof is a morbid structure. White hoofs are to be eyed with suspicion, for they are really weaker, and more liable to disease than black ones; and if a horse has one white, and the other dark colonred, and he is lame, in nine cases out of ten, it is the white hoof that is affected. Other considerations now engross our attention. Is it contracted? i. e., is its circular form destroyed by narrowness at the heels? A good hoof is circular in the tread, or nearly so, measuring as much from side to side, as from toe to heel; but we frequently find those that are morbid measuring as much from toe to heel as twice the lateral diameter. See plate of Horse's Foot, figs. 3 and 4. On the other hand, the wall of the hoof, which should, at all times, be perfectly smooth and free from ridges (the contrary indicating disease), may be very oblique, in which case, it is not only circular, but spreads out, even to an abnormal degree, in the tread. Its wall should be round, smooth, level, and of a shining dark colour; full in front, of a proper obliquity, free from ribs or seams, and perfectly cool. Its proper obliquity is an angle of forty-five degrees with the plane of the shoe. If the angle is materially less, the sole is flat, or perhaps convex; if the angle exceeds it, the foot is contracted.

Shape.-When the outward line of the hoof is irregular, it marks what is called a "shelly foot." This is decidedly bad. If there are any protuberances or rings round it, they indicate that the feet have suffered from inflammation to such a degree as to produce unequal growth of horn. This frequently leaves injurious consequences in the internal parts; such as a deposition of lymph between the horny and cartilaginous processes which connect the foot and hoof together. If there be any depression or cavity, it betrays separation of the foot from the hoof and shrinking of the cuffin bone; the sole will then be found bulging.

A superficial examination of the foot is not sufficient; the shape of the foot may be good, yet there are other things to be considered. It may be well formed, yet thin and weak; and those feet, externally the most perfect, are sometimes contracted internally, and liable to the insidious affection termed navicular disease. Contraction is a serious defect; it is apparent and general, or hidden and partial.

When apparent externally, which is common among highbred horses, with light heads and necks, bigh in the withers with sloping shoulders, and that go near the ground, the foot presents an oblong rather than a circular shape; the curved line towards the heels beconing straight, and the heels spproaching each other. The frog is hard, dry, and com- pressed; the foot small, and the heels upright; altogether the foot much resembles that of the mule.

Contraction.-But though a contracted foot is often an indicator of past disease, and there is a diminution of elasticity, it is not necessarily consequent that it is such unsoundness as incapacitates a horse from work. With care, such feet will work soundly to the end of life; for this change in shape has been effected by gradual and slow absorption and deposit; so that nature has had time to adapt the internal parts, and accommodate itself to the change, and elongation of the foot has taken fiace. When such feet feel hotter than ordinary, suspicion should be a wakened, more especially if there is a marked difference between the temperature of one and the other. If there is indisputable pointing, then the horse is unsound.

Occult or partial contraction is not obvious externally. but there is diminished cavity of the horny box, from increase of the sole in thickness. In this case we usually find the foot of a circular figure, more upright than natural, and displaying an unusual appearance of compactness and strength, the soles unsually hard and thick; and if you have a firm unyielding sole, in a circular foot, it is dangerous as the forerunner of navicular disease.*

Sand-crack.-The inner quarters of the hoof must be most minutely inspected for sand-crack; and it is not always easy, without minute scrutiny, to detect sand-crack, where an attempt has been made to conceal it. A month's run in marshy ground will close it up; and low dealers, particularly at fairs and markets, and others who gain a livelihood by dealing in "screws," have a knack of neatly covering the crack with pitch, and oiling the foot to conceal the crack. Any oily appearance about the hoof should excite suspicion, and any fissure at all resembling sand-crack should cause the horse to be peremptorily rejected. Cracks indicate a dry and brittle hoof. The heels should be examined for any cracks, or appearance of heat and tenderness, as they are exceedingly troublesome to cure.

The Frog. - Thrush.-The healthy frog is firm, yet pliable and elastic. Should there be a faint smell, or if on squeezing the frog matter exudes, there is thrush. By many people thrush is considered of little importance; but when it is remembered that where there is purulent matter there must have been inflammation, and that when a horse with a thrush steps on a stone he frequently drops with the pain, to the peril of his rider and the ruin of his knees, it must be admitted it is a serious objection in a saddle horse. If it can be ascertained that it is not of long standing, or that the horse has been placed in a situation to favour its approach-such as confinement on hot, moist litter-it is of no more consequence than so much diminution in his price as will cover the expense of keep and attendance while

- See "Navicular Disease," in Veterinary Divigion, coc. " Uisrase OF THE HORSE." 
healing; but when thrush accompanies a foot smaller than usual, the heels bend in, and the frog is soft, he will not long remain sound.

The Sole.-The sole should be subject to close examination; in its healthy and natural state it is inclined to be concave, but if, in connection with high heels an extraordinary concavity is present, it is a sign of internal contraction. If the sole is unusually thick, and does not give way during exertion, the elasticity of the foot must be diminished If the sole is less concave than natural, or approaching to flat, the foot is weak.

Undue Paring.-If the foot appears to have heen lately cut unusually deep at the angle where the shoe meets the inside heel, or if there is a peculiarity of shoeing at that part, the examiner may infer that all is not right, and that he has corns; send for the farrier to remove the shoe.

Firing, Blistering, \&c.-The stifle is very rarely diseased, but it should be examined for enlargement, or any marks of rowelling or blistering: and the groin should not be overlooked for rupture.

The Hock.-The hock is one of the most important joints in the animal machine, and should always undergo the most rigid examination previous to purchase, as from its complicated structure, and the work it has to perform, it is the seat of lameness behind in nine cases out of ten. When standing behind the horse, if one of the hocks is diseased, the observer will perceive the bone does not incline gradually, as in the sound limb, but there is an abrupt prominence. Though to the unpractised eye this is not always perceptible on comparing them, yet by passing the hand down the inside of both hocks, this abruptness will be felt. If there is any tenderness or heat on pressure, or the marks of recent cutting on the inside of the fetlock, or unequal wear of the shoes, especially at the toe, you may suspect spavin. Sometimes both hocks present an enlarged appearance, though there is neither heat, pain, or lameness (for hock lameness is frequently intermittent), such hocks should always be looked upon with suspicion. They are in fact unsound; for though the animal may, with natural malformation or morbid bone-growth, discharge his usual functions through life, in careful hands, without a return of lameness, yet the probability is he will fail, if called upon for unusual exertion, and one day's violent exertion may ruin him for evcr. In this case, the examiner must be guided by circumstances; if the horse has excellences which counterbalance the defect, the price is correspondingly low, and the work required but moderate, he may be serviceable for years, and worth his money.

Certain forms of hock are prone to disease. Those approaching each otleer are predisposed to spavin and curb; those in which the point of the hock inclines too much backward, are liable to spavin; and when the hock is too upright, narrow, and straight, it is subject to thoroughpin. Capped hock is a soft fluctuating tumour on the point of the hock, it is an enlargement of one of the mucous sacs which surround the tendons inserted into that part. It is produced by hlows, lying on rough stones, or kicking in the harness or stable. It is therefore frequently an indication of vice.

Curbs.-Curb is a longitudinal swelling at the back of the hind leg, three or four inches below the hock, seen best from the side; the enlargement is the result of a sudden strain of the ligaments, or inflammation of the sheaths of the tendon. It is attended with a good deal of lameness and swelling at first; but when that has subsided, and if time has elapsed without a recurrence of the lameness, it is of no more consequence than the unsightly blemish; but it should be remembered that curby hocks are liable to spavin.

Thoroughpin is situated above the hock joint, between the flexors of the hock and foot, projecting on each side; it is of the same nature as windgalls, being an enlarged mucous capsule, and is indicative of severe work or over-exertion.

Spavin.-Bog-spavin is a swelling situated in front of the hock, towards the inside of the joint; it is also an enlarged mucous capsule, but deeper seated, over which one of the subcutaneous veins passing, the hlood in it becomes obstructed in the return, and thus increases the size of the tumour.

The shanks should be scrutinized for any symptoms of weakness, and the fetlocks for marks of cutting and windgall.

The Hind Feet.-The front of the hind feet should be examined for fissure; it is a most serious defect, and generally produces lameness. N Jtice the way in which he is shod, as it leads to the discovery of lameness and defects in action; in dealers' stables, however, you will rarely see any peculiarity in shoeing.

If the tue of the hind foot is found to extend a little over the shoe, it is to prevent "hammer and click" from being audible. If the toes of the hind feet drag, or we find the shoe squared off or worn, we may suspect disease of the hocks; and if the inside of the shoe is bevelled off, he is probably a "cutter."

The Spine.-He should now be "backed," to ascertain if he has received any injury of the. spine; if he backs with difficulty, his hind quarters swaying from side to side, and when compelled to retrograde suddenly appears as if about to fall, he has received some injury. Some horses cannot be made to back, but when urged rear on their hind legs. His loins should be searched for marks of setons, or blisters. Among stable-men it is termed "chinked in the chine," or, ricked in the back.

A remarkable indication of diseased spine sometimes shows itself; the horse dropping when turned suddenly in the trot, the hinder quarters appearing paralyzed.

There are many blemishes and defects that render a hack unserviceable, which are of little or no consequence in harness. The greatest virtue in a gig horse is steadiness, which can only be ascertained by trial, and do not trust to the steadiness he evinces while the reins are in his owner's 
hands. The autlior of that capital work, "The Adventures of a Gentleman in search of a Horse," truly says, "whoever buys a stanhope horse without first driving him himself, is a fit subject for a commission of lunacy; it is not enough to put him in the break, he should be harnessed at once to the stanhope, and it is prudent to observe how he bears the ceremony of harnessing, and what kind of a start he makes. Much may be predicted of his qualifications for draught, or at all events his familiarity with the collar, by the degree of quiet with which he allows limself to be put to. If the ostler runs alongside of him at setting off, as is often the case, you may be sure the horse is distrusted; if you distrust it yourself, have notking to do with him."

The Eyes.-The examination thus far completed, the horse should be returned to the stable for the purpose of examining his eyes, the most favourable position for which is about half a foot within the stable door. There should be no back or side lights, or the rays falling hetween the eyes of the examiner and those of the animal will interfere with distinct observation. The liead should be so placed that a moderate liglit may fall on the eye of the horse, and the quantity of light can be easily regulated by bringing the horse's head more or less forws $d$ until placed in the most favourable angle of incidence.

Thougn any one may detect absolute blindness, yet the eye of the horse is susceptible of so many diseases, in which defective vision or partial blindness is present long before the sight is lost, that it requires more observation than most people imagine: indeed, a person unacquainted with the structure of the eye, and the different appearances it assumes, will not perceive it at all. There are certain forms of the eye, and structural peculiarities, that show a constitutional predisposition to disease. Small sleepy eyes, of a bluish gray colour, or wlich have a flat, retracted, and sunken appearance, or those of a longish oval figure, are predisposed to ophthalmia. When the eyes appear full, with a fleshy circle round them, these are symptoms of bad eyes, and often the forerunners of blindness, particularly in the heads of cuarse and fleshy horses, with lieavy countenances, who frequently go blind with cataract at seven years old. Slight thickenings of the lid, or puckering towards the inner corner of the eye, a difference in size, a cloudiness or dullness of the iris, are indications of disease.

In examining the eyes, both must have an equal degree of light; should any difference be apparent between them, one is diseased. The transparent cornea should be, as its name implies, perfectly clear.

- Specks are best detected by standing at the shoulder; if one is evident, and it can be clearly proved to be no more than the effect of accident, no importance need be attached to it. But it is impossible to ascertain this, and therefore the safest course is to assume that natural irritability and consequent inflammation of the eye is the cause.

Specks on the transparent cornea are generally the result of external injury; there is seldom more than one. When very small and near the circumference, they are of little consequence; but if large, or near the centre they interfere with distinctness of vision, and make the horse shy. If opaque or milky lines are traced on its surface, it indicates the remains of former inflammation.

But it is necessary to observe that horses, beiore they are six years old, have not that transparency in their eyes which they display afterwards, because while young and growing the vessels of the eye are full, therefore before that age it is not the brilliancy of the eye that denotes its goodness. If there is excess of tears, it denotes debility, and shonld occasion a more than ordinary scrutiny; in fact, all horses with weeping, dull, cloudy eyes, should be rejected.

It may be remarked, as a general rule, that diseases of the eye are incurable. Have nothing to do with a horse when the trace of disease of the eye is visible. It is impossible, in a brief examination, to distinguish between simple ophthalmia and inflammation of the conjunctiva-the cause of which may have been a blow, or the introduction of some irritating matter, which is curable by simple means-and the specific oplithalmia, a spontaneous affection, which ultimately culminates in cataract and blindness.

Viewed in front, the depths of the eye should be looked into; then sideways; which will assist in ascertaining the clearness and absence of specks on or within its surface.

Floating in the aqueous humour (which preserves the convexity of the cornea) is the iris, a muscular membrane the dilatation and contraction of which form an oval aperture termed the pupil, which varies in size according to the quantity of light which falls upon the eye. The iris varies very little in colour in the hurse, though it bears some analogy to the colour of the skin. It is rarely lighter than a hazel, or darker than a brown; except in milk white, cream coloured, or pied horses, when it is white, and they are termed wall-eyed. If it is of a pale variegated cinnamon colour, it is good. The pupil or aperture of the iris, is that horizontal oblong bluish opening, which admits the light to the posterior chambers of the eye. It is important that the oval shape of the pupil be perfect, for if any irregularity or unevenness is perceived, it is a symptom that the organ has received partial injury. In looking into the depths of the eye, through the pupil, in a strong light, it should exhibit a lively bluishness; in a moderate light it should be perfectly transparent; if milky or turbid, that is the remanet of former inflammation, which will probably recur.

In bringing the horse out of the stable to the light, if the pupil is large, it is a bad sign; by alternately shading and admitting light, if it enlarges and lessens under its stimulus, the eye is good. But if the retina is immoveable, the pupil large, and of an invariable size, whether shaded or exposed to intense light, - though no disorganisation is apparent, the eye appearing bright, of a peculiar glossy aspect, and of a greenish colour,-the animal is blind from the disease termed "glass eye," i.e., palsy of the optic nerve. A decided cataract, or opacity of the crystalline lens, is 
easily detected; but when very small it may escape observation. It appears as a cloudy or pearly white substance within the pupil, towards the bottom of the eye. If the pupil be round instead of a flat oval, it is an indication of cataract. When there is deep-seated cloudiness, the eye should be condemned; but if there is any white object before it, such as a white hat, neckcloth, waistcoat, or wall, the reflection on the cornea produces a mark having so much the appearance of a cataract as to have misled many an observer. Therefore, before deciding, hold the crown of a black hat against the eye, and observe at the same time if the unark disappears, which it will if it is only a reflection.

"Harry Hieover" says, upon the subject of defective sight, "I consider the eyes to be a part of the anatomy the most difficult for the non-professional to become competent judges of; and any disorder of those delicate organs in the horse is, generally speaking, of a more fatal nature to him than the same afliction is to the human being. This arises from several causes: among them are the following:-We can ask the horse no questions; consequently, if his eyes become diseased, we can only judge of the extent of the disease by the appearance of the organs themselves, and by the acts of the animal. If he runs his head against the stable-door instead of walking into it, we are made aware that he is blind, or very nearly so. If he bucks, or starts at things he sees on the road-for instance, a small pool of water, a stone, piece of white paper, \&c.-we may fairly judge his eyes are more or less affected (even should their appearance be healthy); for, it must be observed, there is a wide difference between a horse shying at carriages, or at common objects on the road, or by its side, and starting at things he suddenly comes on at his feet. Many horses, in the first case, shy or start from timidity, and this grows into a habit When they do this, it will be found, that long before they actually come upon the object, they will prick up their ears, slacken their pace, veer a little from the object, and, by various acts, show us they are getting alarmed. They may be more or less so as they approach the object, depending on its nature, and whether, on nearing it, they find it one of terror or the reverse The evincing fear when at a distance (from whatever cause it may arise) shows us, however, at once that they see it. Whether their alarm arises from confused sight or natural timidity on seeing any unusual object, we can only judge by the nature of the object creating alarm.

"The horse starting or bucking at objects when nearly under his feet is all but an infallible symptom of bad sight ; for it shows that till actually on the object he did not see it $x$ all: and if it should be a pool of water, or a stone, or some such trifle, it would further show that, when close to it, he was either a greater fool than horses usually are, or that he could not distinguish clearly enough to see whether it was an object of alarm or otherwise. It is only by attention to these acts on the part of the horse that we are enabled to judge of the correctness of his sight ; that is, before their apperarance demonstrates disease. The human being can complain, if he finds his vision defective; the horse cannot: and this accounts for the numbers of horses that are at this moment going with defective eyes, without their owners knowing or suspecting anything of the matter.

"Nearly all the diseases of the horse either arise from or are attended with inflammation to a very considerable extent. There are operations performed on the human eye with good effect, that, supposing they could be performed on the horse, would produce inflammation to a degree that would render the remedy, or rather the attempted remedy. an aggravation of the disease.

"Nothing is more deceptive to the casual observer than the first look at a horse's eyes. I have frequently been surprised at the very cursory glance dealers give them. It is true, that in a general way a fine healthy eye speaks for itself; such a looking eye does not, however, always speak the truth. A fine, very dark, clear pupil, and a fine darkishs brown or hazel iris is very handsome-in fact, a great beauty in a horse-and such looking eyes are, perhaps, mostly sound ones; but such appearances are by no means proofs. I have seen dealers walk up to such eyes, just look at them, and say "they're good enough ;" when the fact is, they might be quite bad enough: for though, on looking at eyes in this hasty way, an experienced judge would not, probably, buy a half-blind horse, still there are little defects that even the professional man will not he able to detect in the glare of open day.

"Slight temporary inflammation, if known to proceed from great excitement of the system, though it would quite warrant an examiner in rejecting a horse brought to him in such a state, need not cause the purchaser to decline him altogether, if, in a few days, the eyes became healthy; but I certainly would not make the purchase till they were so; and even then, only on ascertaining that the disease had not been one to which the animal had been subject before.

"Of course, in this disorder, as in many others, a great deal would depend on the value of the horse, and the purpose for which he is intended. If buying a horse as a wheeler to a coach, you might do so, though having suspicion of lis sight being good, or likely to last so; because, if he went stone blind, it would only deteriorate his value a few pounds, and, with a little attention on the part of the horse-keeper and coachmàn, his utility would be but little diminished. A horse of great beauty, and with very splendid action, would, of course, be much diminished in value to sell again if bought for a nobleman's carriage, and his eyes failed hin: still, he would be valuable for such a purpose : but, if a hunter got so afflicted, it would bring him down from two hundred to thirty or forty, indeed, to still less, unless he had harness action, which few hunters have : in fact, for the purpose of a hunter, he might as well break his neck as become in any way defective in his sight."

The reader who has carefully perused these minute directions, first, for the general examination, as buyer, of the 
ınimal he desires to possess,- and, secondly, for the more frequent causes of unsoundness, will thank us for the following summary recapitulation, by Professor Stewart, of the points to be attended to:-

"The head.-For the eyes; for cataract, glass-eyes, and specks. The nostrils; for glanders, tumours, and cold. The glands betreen the branches of the lower jaw ; for enlargement. The throat; for mark of crib-biting strap, and the tenderness which accompanies cold. The teeth; for the age, and marks of crib-biting. The veins of the neck; to see that both are entire.

"The fore-leg and shoulder.-The seat of the collar; for tumours. The point of the elbow; for tumours. The knee; for blemishes and stiffness of that joint. The shank; for speedy-cut, splint, and strain. The fetlock-joint; for enlargement, windgalls, neurotomy, stringhalt, and marks of cutting. The pastern; for ring-bone.

"The foot.-For side-bones; sanderack, contraction, thrush, corns, and fatsoles. The shoe; for signs of cutting.

"The trunk quarters.-Each side of the chest; for marks of blisters and rowels. The space between the fore-legs; for the same. The stifle; for enlargement. The groin; for rupture.

"The hock.-For capped hock, thorough-pin, bone-spavin, and bog sparin (not blood spavin). Then the horse should be mounted, and ridden a few hundred yards at a gallop, in order to quicken his breathing, and thereby display the presence or absence of roaring, thick-wind, or brokenwind."

This brief summary will assist the memory, bringing, as it does, the seat and causes of unsoundness into one point of view. It includes, however, some objectionables, which, properly speaking, do not constitute unsoundness; such as windgalls, thorough-pin, capped hock, and string-halt. The first two are objectionable, indicating that the horse has been severely exerted, and may be otherwise more seriously injured. The two last are eyesores, and to be avoided as such.

We will remark on a few of the points here specified, which relate to fraud and warranty. The eye is a point difficult to decide upon, and often a subject for fraud, particularly amongst the lower order of dealers, who used formerly to have very bright white walls, against which they showed their horses, when the reflection concealerl cataracts, which are in themselves white. But this important organ is difficult to judge of even in its healthy state, by reason of the varieties in its organisation; and still more so to detect the extent of disease which may have, at some time or another, attached to it. Even the best judges of horseflesh have purchased horses without having detected deeply-seated cataracts, which shows the necessity of caution; and the best security is the inspection of a professional man, who is alone equal to form a correct opinion on the subject, which sill be at once apparent on perusal of Mr. Percival's lecture, "On the Eye," Part III., p. 131.
The foot is now so generally understood, that it may be needless to say more than to remind the buyer of the proverb-" No foot, no horse." "The hock" is the most complicated, therefore most difficult, joint for the uninitiated to form a judgment upon. It is not in every person's power to detect the absolute presence of disease in this part, still more so to foretell the probability of it in future; but there is a certain conformation of this joint which almost ensures disease, and consequently it should be most minutely examined as to its shape, substance, \&c.

Broken wind is easily discoverable; and it is only amongst the most disreputable of the fraternity that it is ever attempted to be concealed, which can be done for a few hours, by administering a certain quantity of lead, which, by its pressure, checks the violent action of the abdominal muscles, or what is called heaving of the flanks. But "roaring," "wheezing," and "thick wind," are by no means always discoverable in a common trial of a horse, such as a dealer is disposed to give, on a good sound road. Nothing but a gallop over soft ground, or against a hill, can be depended upon in certain stages and degrees of either of these complaints.

Your examination having proved satisfactory, you decide on purchasing; but before you part with your money, pray learn something of the seller. For should your bargain not turn out as you expected, upon further acquaintance, trial, and second examination, you will be aware what chance of satisfaction or redress you have against the vendor.

The horse, if returned, must of course be in the same condition in which he was received, except so far as the disease for which he is returned may have progressed in the mean time.

It is advisable to inquire of the seller how he has been accustomed to diet and clothe the animal; whether his feet were stopped; and the same treatment should be pursued till his soundness is ascertained.

Note the temperature of the stable; if his new habitation should be hotter, you may probably induce an inflammatory attack of the lungs.

Beware of putting a saddle on a new horse that does not fit him. While the question of soundness is still doubtful, it is far better to use the saddle he has been accustomed to, for if his back becomes galled while trying him, which is not unusual, the dealer will object to take him back unless full compensation is made; and reasonably so, for he is unfitted for sale or for work till it is healed, which is not to be effected in a day. It is also a point for calculation, whether be may not chance to fall sick while standing in high condition in stable-in which case the dealer is subjected to loss.

As we intend to derote a chapter specially to UNSOUNDNEs8 and Warrantr, with the leading ancillary points in law and practice, we shall here break off, as we commenced. with a few general observations.

The horse trade, as now conducted in London, ws we may 
rather say in these days of facile and rapid railway communisation throughout England, is a business in which as much capital, skill, and activity are embarked, as in any other trade of this great commercial country. Agents from all the great London dealers' establishments are constantly travelling through the breeding districts, and competing with the country dealers for every good-looking horse reared, as soon as it has completed its fourth year. To breed a well-bred colt, break it, and maintain it until it is four years old, cannot cost less than 260 . Before the animal sold at a fair for that sum reaches the London dealer's stable it has to pass through the hands of one or two agents or intermediate dealers, who all require a profit on its sale; its travelling expenses and its keep must be paid for; losses from accident and sickness must be provided against; and the maintenance of the London dealer's establishment, and his fair profit, must be duly considered. It is not, therefore, easy to see how a colt bought at Horncastle or Rugeley for $\mathfrak{L} 60$ can be sold to a customer in London much under $\mathfrak{E} 100$. But if the colt be extraordinarily handsome, or if it possess remarkably good action, the breeder will be much more likely to require $\mathfrak{L} 100$ than $\mathfrak{L} 60$ for it; and the buyer, knowing his business well, will have no objection to pay that sum-being well aware that for extraordinary beauty and action almost any price demanded can be obtained in the London and foreign markets. For first-rate saddle-horses, able to carry high

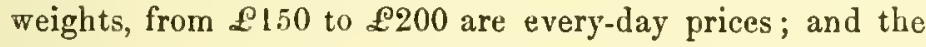
large bay and brown carriage horses used for first-class equipages are, when well-bred and well-actioned, more valuable still. Ladies' horses cost from $\mathfrak{L} 80$ to $£ 100$, according to the weight of the rider and the training the animal has received; brougham-horses, from $\mathfrak{L} 100$ to $\mathfrak{L} 120$; and light harness-horses for broughams and sociables, from

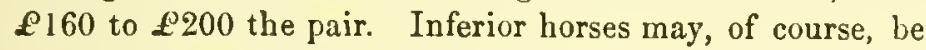
bought at inferior prices, but the first-rate dealer in first-rate animals will ask and get the sums we have named.

Lord William Lennox, a good practical writer, sets his figures on a much lower scale: and we can safely indorse them as nearer the mark than those in the last paragraph. His lordship says-

"In setting out to purchase a horse, it would be as well to resolve on a fixed price, from which you must resolve not to deviate easily. The following I should say would about fit.

"A hunter of the best description (counting the circumstance of its being in a dealer's possession), say,

"A hack, strong and likely (counting, \&c.),

"A genoral (when I say general, I mean a horse that would be fit to take the field or haruess when required),
Remember, too, to have clearly in your mind the sort of horse you want. And never forget that every horse is adapted to some particular purpose; for hurses not only differ in kind, but, like men, in courage, temper, intelligence, stamina, \&c.; and the selection of them, in regard to these particulars, constitutes the most arduous and nicest duties of the buyer. He should be able readily to acknowledge good or bad conformation; trace breeding in the outline, and discover what indicates good or bad in instinctive or in constitutional qualities.

It requires some experience, but more attentive observation, to be what is termed a "judge" in horse-phraseology. To know at once, almost by a cast of the eye, whether the nag is likely to suit. Is he cut out for a hackney, or is he calculated for harness? Does lie look like a hunter, or has he serviceable stoutness, a quiet eye, and look likely for the road? Does he show blood, or is he all over a "cross bred 'un?"

Some persons, though accustoned to horses all their lives and anxious to become judges, never can select from appearances; while those differently gifted can swear to a good one, to a considerable extent, the instant they behold him. And the questions that suggest themselves to a judge on purchasing the first description of horse, are,-if he can ride him? if he will not prove too much for him? if he will be sufficiently under his control with hounds? if his energetic disposition will suffer the trammels of harness?

There is an observation, common among horsemen, that it is all nonsense about the make and shape of horses; for, say they, "the best horse I ever possessed was the worst shaped;" but, on inquiry, you will and must find, that he possessed in a great degree the will and the power-they must accompany each other-the one is of little use without the other. What avails it if he is willing without the power, or if he has the power and is not willing? If it were possible to mould a horse in perfectly symmetrical form, in every way formed for speed,-still, without that great essential, that peculiar nervous excitability, he would at best prove but an indifferent animal. Remember, therefore, that, however important a good judgment of the outward indications of qualities may be, what he will prove in continuous exercise is more than the most skilful and experienced can fairly pronounce. Those who do are presumptuous or dishonest pretenders to a knowledge not attainable. Appearances are so deceitful, that those most skilful in the subject will find themselves occasionally mistaken, and, even after the best advice, much must be left to the operation of chance.

If you can answer the questions submitted in this chapter to your own satisfaction, buy a horse for yourself. If you cannot, and distrust your own opinion, get some more experienced horseman to look over the animal you desire to purchase, before you part with your cash.

In the next chapter we will, as connected with the subject in hand, take a look into The Horse's M! oure for indications of his age. 


\section{H A P TER X}

FBB AQE UF THE HORSE FROM HIS MOUTE.-PRELIMINARY REMARKS: TRICKS OF DEALERS: THE STRUCTURE OF THE TEETH

THE INDICATIONS OF $\triangle G E$ : THE TEETI AT BIRTH: AT SIX TO SEVEN MONTHS: FROM ONE YEAR TO TWENTY YEARS: IF EXTREME OLD AGE CONCLUSION.

THE knowledge that the teeth of the horse indicate the age of the animal seems to be a part of the transmitted "wisdom of our ancestors," and as an axiom is certainly not controverted by modern research. Common observation of the natural mouth tells us that the colt of two years and a half old, or thereabout, will be putting up his two permanent incisor teeth of the upper and lower jaw, indicating his becoming three years old; and between three and four the two adjoining teeth in each jaw ; and between four and five the two last, or corner teeth, in each jaw; and the tusks appear between four and five: but there are variations from this general rule, and we must not hastily conclude in this, any more than most other branches of human knowledge, that infallible and exceptionless rules can be laid down, and unerring accuracy attained. There is no magic spell, except in puerile romance, by which nature's mysteries can be commanded; "her ways are regular, but they are not uniform-her laws are fixed, but they cannot be lefined by rule and compass. The veterinary practitioner knows, from repeated trials and long experience, that the teeth of the horse are a worthy study; he feels that their indications, attentively read, will seldom mislead him; but he does not regard them with a reverence resembling that originating from an antiquated superstition, or look on them as the exemplification of a principal which admits of no exceptions." *

In the generality of common bred stock, foaled between jay the beginning of April and the end of June-that are living pretty much in a state of nature, on succulent food, to the end of three years old before they are handled-a considerable uniformity in the approach of their permanent teeth, and the age in general may be told without contradiction. But man, for his own ends and purposes, has used such artificial means in the rearing and treatment of the young horse, that he has in a manner subverted nature's laws in this particular; and it is not an uncommon occurrence to see a two, thrce, and four years old colt, showing a three, four, or five years old mouth; that is, the teeth indicating those particular ages will be up, and nearly matured, a full year before nature seems to ordain they

- Mayhew on the Horse's Mouth, p. 3. should be. This may be seen in three parts of the young horses brought into the market in the spring of the year, as four and five years old, which are in reality only three and four. This deception is accomplished by pulling out the sucking-teeth at an early period. The mouth thus altered is comparatively easier of detection than the one which has obtained this forward appearance in its natural development. The case is different in racing, or thorough-bred stock, inasmuch to some the object would appear of more advantage to make them, if possible, appear even younger than they really are. But "query," are not the peculiarities of nature so much altered in these young animals, by the early period in which they are foaled, the manner in which they are fed, and the early age at which they are broke and trained, as to occasion them to be more early matured in their general organization, and consequently their teeth to appear at a much earlier period (in many instances in colts) than if bred as common stock? Examples of this forward growth of the teeth have occurred, whereby the age might be doubted. We have also seen the reverse of this, though a rare occurrence, where the colt had arrived at the age of three, and not moved a tooth. These variations are commonly considered the result of early or late foaling, but as likely to occur from peculiarity of constitution.

The horse, as noted in natural history, ante, pp. y-11, has twelve incisors or nipping teeth in the upper and lower jaws, opposed $\frac{6}{6}$; four tushes or tearing teeth, placed $\frac{1}{1}, \frac{1}{1}$, on each side of the cutting teeth; and six molars or grinding teeth, in the branch of each jaw above and below. The mare not having the tushes or canine teeth has but thirtysix, while the full-mouthed horse has forty. A reference to the coloured maps, I. and II., entitled "The AGEs of the Horse" (Anatomy Plates III. and IV.) will, we trust, give a clear idea of the progress, perfection, and decay of the dental system of the horse, and thus furnish a chart for the guidance of the reader to a true decision on that oft-debated point, the age of the horse, should such question come before him in his own interest or as a referee.

In ordinary cases, the teeth will be found a sufficient criterion of the animal's age, if examined by one who can properly read their criteria. There is a prevalent notion about. that dealers can make horses appear of any age that 
is desired by torturing their mouths, and this idle belief is fostered by those who pretend to extraordinary acuteness in discovering and exposing the "tricks of horsedealing." We have several of these catch-pennies now before us, in the guise of "Confessions of a Coper," "The Mysteries of Horsechaunting," "A Guide to the Horsebuyer, with Exposures of the Tricks of Dealers," \&c., \&c., and such-like taking titles. They are, we need scarcely say, as rank impositions on the credulous purchaser as the swindles they pretend to expose.

Mr. Mayhew sensibly says, upon this point, and gives in an after part of his book full practical proof of "speaking as ore having authority," * that the credulity of the public in this matter of the teeth has no foundation. "A colt cannot be made by any barbarity to look like a horse, nor a horse be made to exhibit the mouth of a colt. That attempts are made to disguise the teeth, and that such attempts occasionally impose upon the buyer, is not denied; but all of such practices are sliallow in the extreme, and so easily detected, that the person deceived by them is not an object of pity. If people will presume to judge before they have learnt to recognize their temerity is more to be blamed than its consequence is to be commiserated. No one goes to buy a horse unwarned of the dangers that will surround him ; and if in his conceit he rather prefers to hazard these than to seek protection, what right has he to murmur at a result which it needed no conjuror to foretel? Is there any market in the world where ignorance is secure from imposition? The world is not yet so honest that the affairs of the horse-mart are a subject worthy of its special wonder; and it may be doubted if the principles which regulate the conduct of the horse-dealer, are not those which influence the transactions of the most honourable traders. There are men of the highest character living by the sale of horses; and it is creditable to humanity that, after all of a certain class have been unscrupulously stigmatized and openly reproached, there may still among its members be found beings preserving honour for the sake of itself alone. The liberal public, however, in its wisdom, has pronounced the character of the horse-dealex; it has rejected his attestations, and refused to listen to the testinony of those with whom he has communication. The age of a horse is not taken from the mouth of its owner, but looked for in that of the animal. This mode of procedure is convenient-the record is at hand, the evidence brief, and the decision to which it leads is that to which the purchaser by choice appeals. The dealer stands by and knows that his voice is to $b \in$ restrained. The teeth denote the age, and when the word of the owner is not to be accepted, there is no other evidence at hand.

* The reader who would go farther into the subject of the "Tricks of Dealers" is referred to pages 123 to 138 of Mr. Edward Mayhew's volume "The Horse's Mouth," published by Messrs. Fores. He will there see an exposure of the wretched trash of these pretended guardians of the public, againet frauds that exist chiefly in the scribblers' own practice.
Were additional proof to be required, in some instances it could not be procured, and in the majority its production would be attended with an expense perhaps equal to the price of the horse which it concerned. The expense, the seller of course could not be expected to bear, and the buyer equally would resist its infliction Nothing is more high priced than absolute proof of any kind; and there is always a further difficulty in the difference of oplinion which prevails, as to what constitutes absolute proof. A cursory glance at the matter is enough to convince us, that the custom of irspecting the teeth of the horse to ascertain the age of the animal, is one which has had its origin in necessity. Experience has taught that the mouth of the horse affords the must satisfactory evidence, and the author's investigations on this subject have convinced him that the public need require no better or more conclusive testimony."

With these preliminary remarks we shall proceed to a description of the teeth-their structure, growth, and changes, as auxiliary to the determining of the age of the animal by their inspection.

\section{THE STRUCTURE OF THE TEETH.}

Each tooth is divided into three parts for the purpose of description, the crown or table, which is its upper surface, the neck, which is the part surmounted by gum, and where it usually begins to diminish in size, and the fang, or root, which is the part out of sight in the alveolar cavity.

The teeth are contained in the upper and lower jawbones (or maxillaries), in small bony cups or holes, each tooth being contained in a separate cavity, called collectively alveolar cavities; and in the molars, where there are more than one fang, each root has its separate cup, with bony matter intervening between itself and other fangs.

The teeth are organised bodies; as is shown by the absorption of their substance, in case of the roots of the temporary teeth; their sensibility to pain upon application of extreme heat, cold, or strong acids; their growth and changes of form; and their resistance of decay, while possessed of vitality. They possess, for their supply and sustainment, arteries, veins, and nerves.

The teeth are built up of three distinct substances, distinguishable from each other by the naked eye, and differing materially in density, hardness, and composition. They are known as the ivory, the enamel, and the crusta petrosa (or stony crust).

The ivory (called bony or horny substance, by old writers), constitutes the larger portion of the bulk of each tooth, and has numerous small pores or cavities. Like the small canals in the substance of bones they seem to contain some colourless fiuid, which nourishes or maintains the part in which they are situated. The ivory is by no means so close and hard as the next noticed substance, the enamel In MaP II. the delineations of the tables of an upper and lower molar will give a clear idea of the arrangement of these two substances The dark parts there delineated show the ivory of which the 
body of the tooth is composed, the lighter convolnted lines, the enamel. In the "Cout's Incisor," back view, in the same plate, the enamel is shown, with the ivory sunk in the centre, in a carity called the infundibulum (funnel, or pit). It is lined with enamel, and presents ivory filling up to the table of the tooth.

The second substance, the enamel, is so close, hard, and homogeneons, as to seem without animal matter. It is thin, white, and somewhat transparent, and so hard that it will strike fire with steel, like flint.

The third substance is the crusta petrosa or stony coat. This forms the outer covering of the tooth, and having a dirty-yellowish or dark appearance, was mistaken by ignorant farriers for a deposit of tartar, or "fur." It contains a great proportion of animal substance, and, under the microscope, is full of small vessels or tubes. It is plentiful in the alveolar cavities, and is there yellowish-white; but when at the neck of the tooth, above the gum, it becomes exposed to the chemical action of the air, the animal jnices, and the food, it receives a dark stain, and looks like an accumulation of tartar. The crusta petrosa will be found filling up the pits (infundibula) of the grinding teeth of the upper jaw, and lining the top cavity of the incisors. It is full of vessels for nutriment and increase. Let ns now consider the nse of these three structures of the teeth, of various densities, cutting capabilities, and power to resist friction.

The onter coat, or crusta petrosa, which at first covers the tooth, is soon rubbed away from the greater part of the sides, so as to show the enamel. It is not reproduced there, but remains round the neck of the tooth, and appears to enact a part within the alveolar cavity, in which the fang or base of the tooth is situate. It is with the ivory and enamel, however, which build up the substance of the tooth, we have most to do.

Upon the ivory, and its wear in relation to the enamel, depends the great criterion, the presence, in a greater or less degree, or the absence of "the mark in the mouth." The ivory in the molars will be found generally nearly on a level with cutting ridges of enamel, in spite of the greater attrition which the substance forming the larger portion of the surface of the table must receive. There is, however, sufficient projection of the enamel ridges to enable you to feel that the latter material is the great resisting power, and saves the destruction of the ivory by the grinding wear, to which, but for such support, it would be inevitably exposed.

\section{THE MAPS OF THE MOUTH DESCRIBED.}

\section{MAP I., FROM BIRTH TO FIVE YEARS OLD.}

We will next proceed to give a description of the two coloured maps entitled "The Ages or the IIORSE."

At Birth-Many months, at least seven, before the foal is produced the germs of the teeth are visible in the cavities of the jaws of the fœtus, as small bags of jelly-like consistence. As these grow they harden and press towards the surface of the gum, forcing their way through it; so that. about the time of birth, three of the grinding teeth are discoverable in each jaw; and generally two front cutting teeth, in the colt called nippers, which are placed almost laterally (see figure), and are remarkably large in comparison with the size of the animal. In a less developed colt the nippers will present themselves as in our drawing, at the end of a week or nine days. In the next two months, two more cutting teeth in each jaw, above and below, will bring the number up to eight. And now the jaws having widened, as is seen more fully in our second figure (six to seven months), the two nippers, which filled all the forepart of the narrow jaw, will have taken their proper places in front of the mouth. They will now begin to wear a little, and the outer edge, which was raised and sharp, will be brought on a level with the inner edge. The month, too vill alter little now until it forms as in our second figure, when yet two more nippers begin to be felt, and then seen, making up six below, and a like number above-thus filling up the "colt's mouth," as shown in the third drawing, inside and outside being figured. The name of "nipper" is peculiarly applicable to the front teeth of a colt's mouth. Those of incisor or cutter, adopted by professionals and anatomists, do not so well convey the idea of their action. The twitch of the head in the act of browzing or grazing is rather the act of "nipping," and partly snatching, than merely cutting off.

It may be noted at the seventh or eighth month, that though the corner milk teeth are up, their edges do not meet, except at the front corners. This may be seen by our drawing, where the two outer teeth are remarkably low to the gum at the hinder part, towards the gape.

One Year old.-Here we see the four middle teeth level, and the two outer ones becoming so. The mark in the middle teeth is wider and fainter; in the two next it is somewhat darker, longer, and narrower. By this time two pairs of the permanent teeth, the fourth molars, have made their appearance. A yearling has, therefore, $t$ welve incisors and sixteen molars, or twenty-eight teeth in all. Of the molars we may here remark that they offer little guide as to the age of the animal. Indeed, it is not easy to get a fair look at them; yet a few particulars are good to be known. They are covered outside with enamel, but not at the top, though several pieces are incorporated, if we may so term it, in the substance of their ivory-not being infundibula or pits as in the incisors, but forming grinding edy 3 s of irregular form in the face of the table (see Molars, Map II.). The grinders in the lower jaw (see Plate) are much smaller in surface than those of the upper. The wisdom of this provision is evident. The upper molar is fixed, the lower is movable by the lateral grinding motion of the lower jaw. Hence it is passed over the larger surface in the act of triturating the food; the peculiar action of the horse's jaw in this opera tion is open to the most superficial observer. 


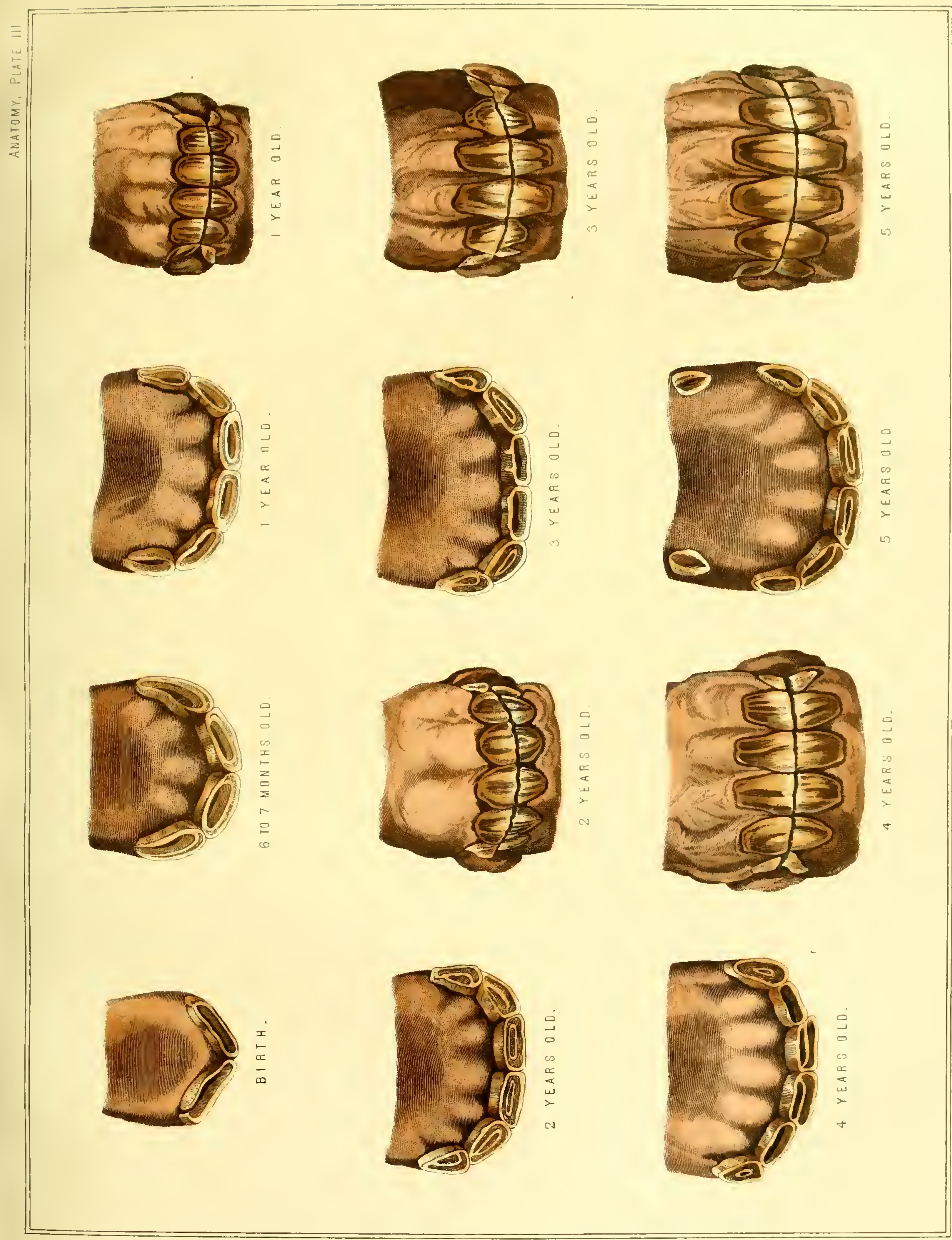



Two Years old-About two years old a fifth grinder is out. The incisors in forwa:d animals show considerable wear. Some care is required now, for the "milk-tecth" are very like the "horse-teeth" at five years old. The teeth only are now being spoken of ; for of course the colt is not "furnished" to the horseman's eye. And now an important process is about to begin.

The first teeth were adapted to the size and wants of the young animal ; and sufficiently large to occupy and to fill the colt's jaws; but when the jaws expand with the increasing growth of the animal, another and larger set is required. Evident provision is made for these, even before the colt is foaled. In cavities in the jaw, beneath the first and temporary teeth, are to be seen the rudiments of a second and permanent set. These gradually increase, some with greater rapidity than others, and, pressing upon the roots or fangs of the first teeth, the consequence of this pressure is, not that the first teeth are forced out, but the portion pressed upon gradually disappears ; it is absorbedtaken up, and carried away, by numerous little vessels, whose office it is to get rid of the worn-out or useless parts of the system This absorption continues to proceed as the second teeth grow and press upon their predecessors, until the whole of the fang is gone, and the crown of the tooth, or that part of it which was ahove the gum, having no longer firm hold, drops out, and the second teeth appear, larger and stronger, and permanent. In a few instances, however, the second teeth do not rise immediately under the temporary or milk teeth, but somewhat by their side; and then, instead of this gradual process of absorption and disappearance from the point of the root upwards, the root being compressed sideways, diminishes throughout its whole bulk; the crown of the tooth diminishes with the root; and the whole is pushed out of its place, to the forepart of the first grinder, and remains for a considerahle time, under the name of a wolf's tooth; causing swelling and soreness of the gums, and frequently wounding the cheeks. These would be gradually quite absorbed, but the process might be slow and the annoyance would be great; therefore it is proper to get rid of these diminutive teeth, either by punching thum out, or drawing them as soon as they are perceived.

Three Years old.-At three years old the two centre horse-teeth are so defined in their appearance, indeed so well-grown as to be unmistakeable. The superior length and squareness over the colt or milk teeth (see Two YEARS OLD) is manifest ; outside, too, they are darker in colour, the new coating of the stony covering (crusta petrosa) being only partially removed at the front edges. At "three off" the side milk teeth are shed, and horse-teeth take their places. In our drawing of a three year old mouth this has not yet occurred; but the inflammation of the gums, visible, though it does not appear painful to the nnimal, shows itself. The milk teeth are finally shed about the seventh month after the completion of the third year, those of the lower jaw coming out first. It is often asked, cannot this mouth be given to a forward two-year-old? We are told so; and here is the process, which we insert for what ir is worth. The central nippers are punched or dr.wn out, and the others appear three or four months earlier than they otherwise would (?). In the natural process, they could only rise by long pressing upon, and causing the absorption of the first set. The first set mecha. nically oppose their rising, and that opposition being $r$. moved, it is asserted their progress will be more rapid. Three or four months will be gained, and these three or four months may enable the breeder to term him a late colt of a preceding year. To the observer accustomed to horses (although it is long practice alone which could give this facility of judgment), the general form of the animal-the little development of the forehand-the continuance of the mark on the next pair of nippers, its more evident existence in the corner ones-some enlargement or irregularity about the gums from the violence used in forcing out the teeththe small growth of the first and fifth grinders, and the non-appearance of the sixth grinder, which, if it is not through the gum at three years old, is swelling under it, and preparing to get through-any or all of these circumstances, carefully attended to, will be a sufficient security against deception.

It is so unusual to look at the teeth in the upper jaw of a young horse, that the dealer who wishes to give a false appearance of age, frequently confines his operation to the lower jaw; and, in consequence of this, when the teeth of the lower jaw are thus made to push out, they are still below the gum in the upper jaw, although, in the natural process, they are cut a little sooner in the upper than in the lower jaw. It may, therefore, be good and cautious policy to examine both jaws.

A horse then at three years old ought to have the central permanent nippers growing-the other two pairs wastingsix grinders in each jaw, above and below-the first and fifth molars level with the others, and the sixth protruding. The sharp edge of the new incisors, although it could not be well expressed in our drawing, will be very evident when compared with the neighbouring teeth. As the permanent nippers grow, and press upon the teeth at their side, those teeth will begin gradually to diminish. Not only will the mark be wearing out, but the crowne of the teeth will be considerably smaller.

At Three Years and a Half, or betreow that and four, the next pair of nippers will be changed, and the mouth at that time cannot be mistaken. The central nippers will have attained nearly their full growth; a vacuity will be left where the second stood, or they will begin to peep above the gum, - and the corner ones will be diminished in breadth-worn down-and the mark becoming small and faint. At this period, likewise, the second pair of grinders will be shed, and, previous to this, will be the attempt of the dealer to give to his three-year-old an additional vear. 
but the fraud may be detected by an examination similar to that which we have already described.

Four Fears old.-Here the two lateral horse teeth are secn with the full "bean" in them, the two front incisors doing the principal work, as is shown by their surfaces and the inner-enamel edge We have here four pairs of horseteeth well up (in the two jaws), the two outside milk-teeth in each remaining. In the outside view the gum is swelling, and the corner milk nippers are about to go. The horse incisors will soon come in their place. The surface of the teeth is clearly delineated in our dental map. You here perceive the central nippers fully developed; the edge somewhat worn off; the mark shorter, and wider, and fainter: the next pair will be up, but they will be small, with the mark deep, and extending quite across them; the corner nippers, larger than the inside ones, yet smaller than they were, flat, and the mark nearly effaced. In the back part the sixth grinder will have risen to a level with the others, and the tushes will begin to appear.

Now, more than at any other time, will the dealer be anxious to put an additional year upon the animal, for the difference between a four-year-old colt, and a five-year-old horse, in strength, utility, and value, is very great; but the want of wear in the other nippers-the small size of the corner ones-the little or no growth of the tush-the smallness of the second grinder-the low fore-hand-the legginess of the cult, and the thickness and little depth of the mouth. will, with the man of experience, detect the cheat.

The tusnes (see Map II. Tush) are four in number, two in each jạ, situated between the nippers and the grinders, much nearer to the former than the latter, and nearer in the lower jaw than in the upper, but this distance increases in both jaws with the age of the animal. In shape they somewhat resemble a cone, protruding about an inch from the gum, and having their extremity sharp-pointed and curved. At the age of which we are now speaking, the tushes are almost peculiar to the horse, and castration does not appear to prevent or retard their development. All mares, how ever, have the beginnings of them in the chanbers of the jaw, and they appear externally in most old mares. Their use is not evident:-perhaps in the wild state of the animal they are weapons of offence; so that he can more firmly seize, and more deeply wound his enemy.

The breeder often attempts to hasten the appearance of the tush, and he cuts deeply through the gum to remove the opposition which that would afford. To a little extent he succeeds. He may possibly gain a few weeks, but cannot gain more; for the resistance of the gum is not like that of a solid and firmly fixed tooth, and is much more easily overcome by the regular process of nature. After all, there is much uncertainty as to the appearance of the tush, and it may vary from the fourth year to four years and six months. It belongs, in the upper jaw, both to the inferior and superior maxillary bones; for, while its fang is deeply imbedded in the inferior maxillary, the tooth penetrates tho process of the superior maxillary at the union of those bones.

At four years and a half, or between that and five, the last important change takes place in the mouth of the horse. The corner nippers are shed, and the permanent ones begin to appear; the central nippers are considerably worn, and the next pair are beginning to show marks of wear. The tush has now protruded, (see our drawing, Five Years OLd,) and is generally a full half inch in height; outside it is rounded, with a groove on each side (see drawing), and within it is hollowed. From the period of the rising of the corner nipper, the animal changes its name. The solt is called a horse, the filly a mare, thenceforward.

Five Years old.-At five years old the horse's moutn is all but perfect. The whole of the incisors are there; the edges of all the teeth meet fairly, and the whole apparatus looks more powerful and larger than in the fourth year. The tables of them all are, however, not yet formed, the two outermost displaying the bean perfect. The tush shows a mark of wear, the grooves, already spoken of, are disappearing. The outer edge is bulging, but the inside hollowed out and sharp. The sixth molar tooth is quite up, and the third grinder is wanting. This circumstance, with the general aspect of the horse-the wearing of the centre incisors-the growth and shape of the tushes-will prevent a late four year old from being substituted for a five. Though the incisore may be got up a few months before their time, and the tushes a few weeks, the grinder is with difficulty displaced. The three last grinders, as well as the tushes, are never shed, but come at once permanently. At "five years old off," the corner teeth are still but slightly worn, and the margins inside are rounding. Much of the original stony crust (crusta petrosa) is remaining, and the enamel, where bare, is transparent and pearly. The corver-nippers are so clean in their coat and mark as to procure them the name of "sbellteeth." The fifth year "off," ends our first map.

MAP I1., FROM SIX YEARS OLD TO EXTREME OLD AGE.

Six Years old.-At six years the corner teeth seem set more firmly, the enamel mark is irregular, and the edge uneven. The teeth, too, are getting more square on the external surface. All the cdges (as seer by the second drawing in Map II.) meet with accuracy. The semicircle which the teeth formed in the fifth year is widened out. The mark in the centre incisor is now growing indistinct. There will still be a difference of colour in the centre of the tooth. The cement filling the hole made by the dipping in of the enamel will present a browner hue than the other part of the tooth; it will be evidently surrounded by an edge of enamel, and there will even remain a little depression in the centre, and also a depression round this case of enamel; but the deep hole in the centre of the tooth, with the blackened surface which it presents, and the elevated 

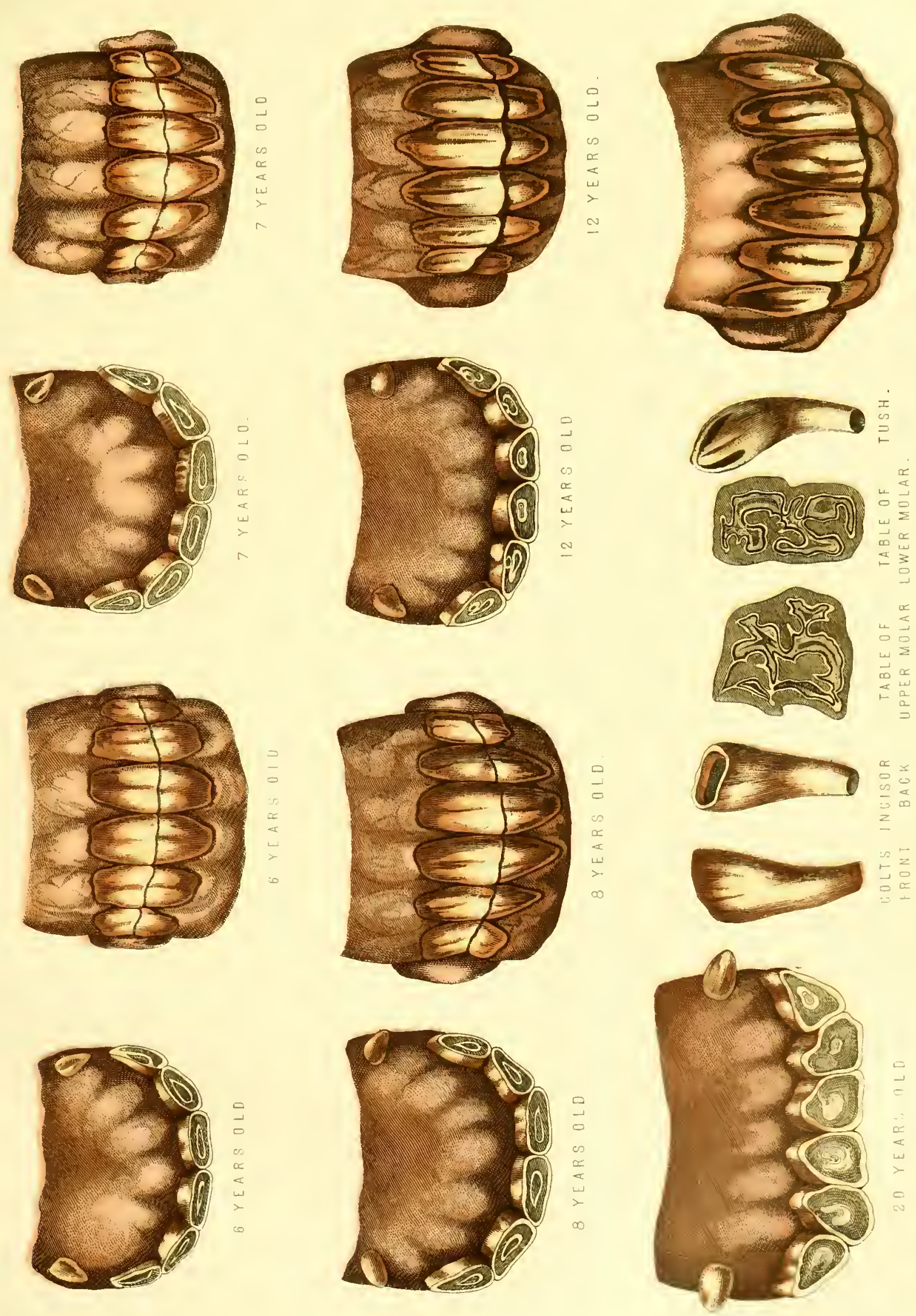

edge of enamel, will have disappeared. Persons not much accustomed to horses have been sadly puzzled here. They expected to find a plain surface of an uniform colour, and knew not what conclusion to draw when there were both discolouration and irregularity

In the next incisors the mark is shorter, broader, and fainter; and in the corner teeth the edges of the enamel are more regular, and the surface is evidently worn. The tush has attained his full growth, being nearly or quite an inch in length, convex outwards, concave within, tending to a point, and the extremity somewhat curved. The third grinder is fairly up, and all the grinders are level. Mr. Youatt says : "Now, or perhaps at a period of six months before, the horse may be said to have a perfect mouth. All the teeth are produced, fully grown, and have hitherto sustained no material injury. During these important changes of the teeth the animal has suffered less than could be supposed possible. With children, the period of teething is fraught with danger. Dogs are subject to convulsions, and hundreds of them die from the irritation caused by the cutting or shedding of their teeth; but the horse appears to feel little inconvenience. The gums and palate are occasionally somewhat hot and swollen, but the slightest scarification will remove this. The teeth of the horse are more necessary to him than those of the other animals are to them. The child may be fed, and the dog will bolt his victuals, but the food of the horse must be well ground down, or the nutriment cannot be extracted from it.

Seven Years old.-At seven years, although the corner teeth do not decidedly show age, they give further proof of wear. The teeth are yet whiter, the tushes are fully up, the mark is disappearing from the four central nippers, and is on the go in the corner teeth. The tusines, too, are changing shape, rounding at the point, at the edges, and inside; and the "eeth generally seem beginning to "crowd one another.'

Eight Years old.-At eight years the processes above noted are still in progress. The "beans" are gone from the bottom incisor's-in short, as the phrase goes, "the mark is out of the nouth."

And now steps in the most common and vulgar of frauds, that of "bishoping", as it is termed, from the name of the rascal who invented it, or was its most extensively known practitioner.

There are two modea by which this is effected. The eight or nine year old is thrown, and the teeth are simply touched with a red hot wire, which makes a black mark at its point of contact. This is a very clumsy and inartificial imitation. The more general one is to gently scoop the softer ivory in the cavities with an engraver's tool, and then to darken the spaces thus hollowed. Remember, however, that the shape of the table of the old tooth, with its inner edge of enamel, cannot be altered, nor can the line of enamel which surrounds and lines the infundibulum (or pit) be preserved. This coarse expedient cannot impose upon a veterinarian, or an experienced horseman. It will be as well to look at the upper nippers as there the very marks; which, without fraud, would be found strongest and best defined, will be found weakest. The diffusion of the "black" too at once strikes the practised eye as unnatural. Of the better class of dealer: Mr. Mayhew justly says, "they will not, knowingly, allow the character of their stables to be injured by the presence of a 'bishoped' animal. The dealers are not the rogues the enlightened public are fond of believing-many among them are as honourable as all men should be-some of the class. however, never let a horse escape out of their hands unmutilated. The teeth invariably receive the primary attention: if long, they are, by the application of a file, reduced to the length which the self-taught equine dentist supposes proper to youth. An acid is also applied to the enamelled surface, in order to render it white. No vast good is effected, but, if the means were not designed to impose, no great harm would perhaps be done. The acid is not allowed to corrode the tooth, and the diminution of the length may possibly in some degree benefit the animal The welfare of the creature, however, is not the object sought-the hope is to cheat; but no person who ought to be trusted, or even to trust himself to purchase a horse, should be so imposed upon. Whiteness is no sign of youth in the tooth of a horse, and the file cannot make the tables assume the juvenile figure. Horses that show such mouths, may be easily recognisedperhaps they are quiet while their legs are handled, but shy when the head is touched-they are not vicious, but timid, and the teeth tell the reason of their fear. It is well to pass them by, and dangerous to accept them at any price. If the teeth have been tampered with, what tricks may not have been practised to conceal other defects?" IOn the Horse's Mouth).

Twelve to Twenty Years old.-It is a generally recelved opinion that after the disappearance of the mark from the outer incisors, at the eighth year, all certainty with regard to the horse's age is over. As to the marks, this is true; as to other criteria, enlarged research has shown it to be only partially so. The teeth increase in obliquity, and apparently in length, and the "crowding" which renders them more and more misshapen is clearly perceptible by a reference to the drawings of eight, twelve, and twenty year old mouths in Map II. From birth to six years the study of the regular progress of the development of the mouth has almost the character of an exact science, and the age to a year can be pronounced. At the period we have now arrived at, mere generalities supply the place of particular marks; and further then the fact that the horse is old, growing rapidly old, prematurely old, or on the contrary sound and good, his years being taken into account, our chart-knowledge does not exactly guide us. We think, however, with M. Girard, that the characteristics of the mouth at twelve and say twenty years (see Map), are sufficiently distinctly marked to enable an approximate judgment, if not a confident and exact one. Some continental writers of eminence resort to 
the upper nippers as showing the "mark" from the ninth to the twelth year, but we must confess we have little faith in their guidance in this respect. We may, however, note incidently that the "bars," * (rough palate) of the mouth become less and less prominent as age draws on, first losing rugosity about the ninth or tenth year and becoming less prominent with advancing age. We may note that stabled horses kept on hard meat do not, as might be expected and has been asserted, show an earlier diminution of this rugosity of the palate than grass or softer-fed animals; this may be due to the active stimulation of a part well calculated to keep up its bulk and healthy renewal by its numerous bloodressels and its protected position.

As a pendant to these remarks, we will present the reader with a brief summary of the observations of some of the leading continental and English writers on this important and interesting branch of horse-knowledge; beginning with St. Bel, La Fosse, \&c., and pascing to Girard, Blaine, Percivall, Goodwin, and Mayhew

M. St. Bel, of whom a notice will be found under the article ECLIPSE, ante, taught a system averaging two years between each marked change in the horse's dentition; and he carried on his periods at which the "dental funnel," or mark, was obliterated from each pair of nippers at two years' intervals Ten years for the front (upper and lower); twelve years for the middle; fourteen years for the corner nipping teeth; were fixed for them to present plane surfaces. These prolonged criteria of M. St. Bel are now entirely repudiated. The successive changes wrought on the substance and general form of the lower or posterior nippers, after the central funnel is worn out, were early noted as characteristic of the age to a very prolonged period. La Fosse many years ago described indications of age to be gained by examining the figure of the nipping surface of the lower incisors, long after it has become plane. M. Pessina, professor and director of the Veterinary Institution at Vienna, carried out a similar examination to an extraordinary length, and his descriptions are given with much minuteness of detail. He explains the gradations of years, beyond the age of eight, uniformly, by the shapes that the incisors assume in consequence of their wear; which has led him to distinguish four successive periods, "the oval, the round, the triangular, and the biangular. After the disappearance of the central enamel, the table presents a coloured point, that appears before the wear of the funnel is completed, and takes different shapes; it is not even uncommon that, in very old teeth, this gives place to a small black cavity.

M. Girard-who published a capital treatise on the teeth, in French, which has been translated by Mr. Ganly, V.S., and published, with very poor copies of the plates, in New York and in London-generalises the criteria of age up to a late

\footnotetext{
* The term "bars" is applied to that firm and dense furrowed subotance which lines the roof of the mouth, and is known as the hard palate. Its ridges are called the "bars." See post, ANatomi (THE Palate), in Part II. Veterinary Surgery.
}

period. If we do not quite agree with the professor up to the last, his observations are worthy of respect and consideration, from his extended experience in the greatest veterinary school and haras in France. They may be thus summarised from eight years. At this age there is usually complete obliteration of the mark is the nippers, the dividers, and the corner teeth; in the lower jaw the central enamel becomes triangular, and nearer the posterior than the anterior edge of the tooth; the termination of the cavity next the root appears near the anterior edge in the form of a yellowish band, extending lengthwise from one side to the other. At nine years old the nippers appear rounded, the dividers oval, and the corner teeth have become narrow, the central diminish, and approach the posterior edge. At ten years old the dividers are become rounded; the central enamel is very near the posterior edge, and rounded. At eleven years old the dividers have become rounded; the central enamel is hardly any longer apparent in the teeth of the lower jaw At twelve years old the corner teeth are rounded; the central enamel has completely disappeared; the yellowish band is of more extent, and occupies the centre of the wearing surface; the central enamel, however, still remains in the teeth of the upper jaw. At thirteen years old all the lower incisor teeth are rounded; the sides of the nippers extend lengthwise; the central enamel is found to remain in the teeth of the upper jaw, but it is round, and approaches the posterior edge of the tooth. At fourteen years old the lower nippers assume a triangular form, the dividers become long at the sides; the central enamel of the upper teeth diminishes, but still remains visible. At fifteen years old the nippers are triangular, and the dividers likewise are begiuning to become so. At sixteen years of age the dividers are triangular, and the corner teeth begin to be the same; at the same time the central enamel of the tecth of the upper jaw also will, in many instances at this age, be found to have disappeared. At seventeen years old all the teeth of the lower jaw have become completely triangular; but, as we have before noticed, the sides of the triangles are all of a length. At eighteen years of age the lateral portions of the triangle lengthen in succession, first the nippers, then the dividers, and afterwards the corner teeth; so that, at nineteen, the lower nippers are flattened from one side to the other. At twenty, the dividers are of the same shape. Finally, at twenty-one years of age, this shape appears in the corner teeth also.

We think the reflective reader who peruses these lines with an eye to the 8,12 , and 20 figures of our second map, will see much worthy of remembrance in M. Girard's " History of Dental Changes." Thus far of the teeth; we will now pass to other criteria of age.

The indications of age connected with decay are not equivocal, but show themselves in the sunken eyepits and dimmed eyeballs. In such an one the lips will also be thin and pendulous, the under or hinder lip extremely 60; 
the anus, not wedged up by interstitial matter heretofore, and not sufficiently retracted by its weakened muscles, now projects considerably. The grey horse becomes white, and the darker colours become intermixed with grey, particularly about the head; the bony processes in every part of the body stare out, and give a rigidity of appearance which well accords with the actual state of the body. So much greater is the absorption of parts now than their increase, that even the diseased deposits of more youthful times, as windgalls and bony exostoses, are lessened or disappear altogether; the mouth likewise will present some appearances beyond those noted by the French writers. The incisors are sloped outwards and project, the upper corner one is often sawed in two parts by the action of the lower, which, in turn, loses its outer edge by the wear; the whole of the teeth become yellow and stand wide apart at the roots, which are gradually beilg thrust up out of the jaw by the filling up of the alveolar cavities with bony deposit.

It is an absurd piece of pedantry, as every horseman knows, to date the decay of a horse from his becoming "aged" in professional phrase. At seven and eight he is in his full bloom of his strength and fully matured powers, and, but for inordinate or premature hard work, is at a point of perfection which will last in full vigour for a period corresponding with the more extended manhood of the human being 1 short parallel will elucidate our meaning, and show the error of allowing the idea of eight years as fixing the period of decay in the horse. Blaine is here our authority: "A very considerable attention to the subject, over a wide field of observation, has impressed the writer with the propriety of drawing the following comparison between the ages of horses and men; that is, at these several periods of comparison, the constitution of horses and of men may be considered as in an equal degree of perfection and capability for exertion, or of debility and decay, according as youth or age preponderates. Thus, the first five years of a horse may be considered as equivalent to the first twenty years of a man; or thus, a horse of five years may be comparatively considered as old as a man of twenty; a horse of ten years, as a man of forty; a horse of fifteen, as a man of fifty; a horse of twenty, as a man of sixty; of twenty-five, as a man of seventy; of thirty, as a man of eighty ; and of thirty-five, as a man of ninety. So far from this comparison being too much in favour of the horse, we are disposed to think it too little so. Horses of thirty-five years of age are as common as men of ninety, provided it be taken into the account that there are at least fifty human subjects for every horse; and, unquestionably, a horse of forty-five is less rare than a man of a hundred and ten."

Coinciding entirely with this most experienced veter1aarian, we may be excused for pursuing the subject a little further. The eight years currently received as the incipient period of degeneration should be removed another seven years forward, as regards the powers of the animal in their natural state. We again quote Blaine:- "To those who are simply interested in horses on the score of their utility, and are not called on to certify the exact age for sale, purchase, or matching, the indications yielded by the tceth are in many cases less important than those offercd in the appearance of the wear and tear of the limbs. The practical judge, instead of refusing what is conventionally termed 'an aged horse,' provided he has limbs undeteriorated, on tha contrary, hails an opportunity of possessing himself of suct an one, conscious that the reputed age has produced only the best effects, by condensing the solid parts of the frame, and rendering them capable of continued exertior Such an age is also usually accompanied by a steadiness of tempes and disposition, that teaches him to employ his powers judiciously. Where is the foxhunter who fortunately has Inet with a nine, ten, or twelve-year old horse fresh on his limbs, that would exchange his hardihood, his judgment, steadiness, and method of husbanding his resources, for the impetuosity, and consequently more early tiring, of the young horse of five? What is eight years in the life of a horse that has been used as he ought to be? It is, on the contrary, not too much to affirm that all his 'points,' that is, all those external appearances or characters on which his most valued qualifications depend, do not show themselves until, according to the conventional notion of age, he is unfit to be looked at! Regard the well-marked head of the horse at ten or twelve, how angular! His fine eye, divested of much cellular matter, now stands out without a foil; his thin and thinly clad crest carries itself into withers which seem to rise to receive it. His circular carcass, trussed up by exercise, unites with hind quarters, square and muscular, supported on limbs equally well furnished. Would you refuse such an one because he had lost a mark from his teeth, when he had gained so cany superior marks all over?-marks which make him at once an interesting and most picturesque object. It is true, premature age is apt to overtake our horses, because we use them as though they could not wear out."

There is no rule laid down by man which nature will submit to be strictly bound by, either in the material or the moral world. She will have her wise irregularities, her apparently wilful exceptions, her "proofs" of the rules laid down by his limited judgment. Constitution in one horse is less robust and fails earlier, acute disease levels the strongest and handsomest, as it takes the best and bravest among men. Premature old age has come, and will come, upon the most promising colts ; and the cleverest actuary in calculating risks in life assurance would find as many disturbing influences calling for his "averages" among horses and their "chances of life." The excellence of our roads enables the horse not only to be put early to work, but to be called upon for "pace;" and thus it is that nature, stimulated inordinately, seeks with her vis medicatrix to strengthen the overtaxed organs. How she does this is the subject of veterinary inquiry Inflammation comes on, the cavities between the tendons and their sheaths are destroyed, 
and they become filled up by hurtful deposits; parts take on a bony structure whose original formation was cartilaginous; as the lateral cartilages of the feet, and the articular processes of the vertebra. A greater quantity of ossific material is deposited on the surface of some bones than is natural, by inordinate exertion. It is thus that splints, spavins, ringbones, \&c., are formed; and, to counteract the unnatural waste, other secretions are likewise preternaturally augmented producing, in the mucous capswles windgalls, and blood-spavins in the obstructed veins. But where horses are suffered to attain their full growth and the complete development of their organisation, if they are afterwards put to full exercise, not altogether inordinate, they become competent to the exertions expected of them, and reach old age sound and vigorous. Many good judges will not purchase a horse for hunting earlier than eight years old, and regard him only in his prime at ten or twelve. It is too little considered that the period of a horse's life, with moderate care and good usage, is protracted to twentyGive, thirty-five, and forty-five years; and an instance lately occurred of a horse dying at fifty. The accounts of their being vigorous and strong at thirty and thirty-five are rery numerous, and nearly as frequent as activity in men of eighty and ninety. Blaine speaks of an acquaintance of his it Dulwich, near London, who had three monuments of three horses, who severally died in his possession at the ages of tinirty-five, thirty-seven, and thirty-nine years. The oldest, is is to be remarked, was in a carriage the very day he died, strong and vigorous; but was carried off in a few hours by spasmodic colic, to which he was subject. At Chesham, in Buckinghamshire, there was a horse thirty-six vears old, which exhibited no symptoms of debility, nor any external signs of age, except being nearly covered with warts It was remarkable, with regard to this four-footed Nestor, that when an unusually hard day's work was required he was always chosen, as never failing in what was expected from him. A horse named Wonder, belonging to the riding school at Woolwich, may be quoted as living to forty years. Mr. Culley, in his "Observations on Live Stock," mentions one he knew which lived to forty-seven years, having during all that time a ball in his neck, received in the battle of Prestonpans, in the rebellion of 1715 , which was extracted at his death in 1758 : thus, judging him to be four years old at the time he received the wound (and it is probable he was more), he must, at his death, have been forty-seven. But even these venerables were mere babies to the bargehorse of the Mersey and Irwell Navigation, which was well known to have been in his sixty-second year when he died. It is true that these are not very common instances, but it is not the natural economy of the animal which inakes them uncommon; it is, on the contrary, the circumstance of horses being so early brought into hard work, and 80 unremittingly continued in active labour.

The subject of WARRANTY AND UNSOUNDNESs, will properly follow these chaptcrs of examining and buying the Horge, and the Criteria of his Ape 


\section{CHAPTER XI.}

HORSE-LAW : SALE: DELIVERY AND ACCEPTANCE : EARNEST: SIONED ROTE : WARRANTY : SALES BY ADGTION : LIRN : FRENCH LAY . CONCLUSION.

THE law, as it relates to the buying and selling of horses, either at the hammer, by private contract, or in market overt, seems to be totally overlooked in most works relating to the horse.

Lawsuits, it has been justly remarked, originate less th frequently in the positive dishonesty and bad faith of the unlucky litigants, than in their gross misconception of each other's rights and liabilities.

We therefore conceive that an occasional purchaser would often, by a very slight acquaintance with the first principles of the law of sales and warranties, be not only delivered from much anxiety in negotiating this delicate bargain, but also, in many instances, would escape the misery of being driven to contend for his rights in the dreaded arena of a court of justice. Our observatione on warranty shall be preceded by a cursory survey of the general contract of sale itself.

What is Sale-A sale is defined by Blackctone to be "a transmutation of property from one man to another, in consideration of some price or recompense in value."

To enable society to enforce the obligations resulting from such an engagement, some marks are obviously requisite of the mutual consent of the contracting parties having existed in a serious and deliberate form. By the Statute of Frauds it is enacted, "that no contract for the sale of any goods, wares, or merchandize, for the price of $\mathscr{E} 10$ or upwards, shall be allowed to be good, except the buyer shall accept part of the goods so sold, and actually receive the same, or give something in earnest to bind the bargain, or in part of payment; or that some note or memorandum, in writing, of the said bargain be made and signed by the parties to be charged by such contract, or their agents thereunto lawfully authorized."

Delivery and ACCeptance.-It is necessary to observe that a manual transfer, or " actual" delivery and acceptance, is not in every case essential ; for the law will often, from certain acts, "imply" a delivery to satisfy the statute. Thus, in a cise where the plaintiff, who kept a livery stable and dealt in horses, was in treaty with the defendant for the sale of two horses, and the defendant offered a less sum than was demanded, but at length sent word that "the horses were his, but that, as be had neither servant nor stable, the plaintiff must keep them at livery for him ;" the plaintiff, upon this, removed them out of his sale stable into another stable; and it was held that there was here a sufficient delivery to satisfy the statute. The key to this and similar cases seems to be, that the vendor, by the terme of the bargain, is converted into an "agent for the vendee," and thus occupies the double character of principal during the sale, and servant upon its completion. It is also sufficient evidence of a delivery, if a purchaser, with the privity and approbation of the vendor, exercises any act of ownership over the goods, though their local situation remains unchanged; as by selling (or even showing the animal out for sale) to a third person, or marking the animal in any manner. Delivery to a servant or agent is equivalent to a delivery to the employer himself.

EARNEST.-It would seem that giving a piece of money, however low its value (supposing it to be "altogether parted with"), is sufficient to bind the bargain.

Sianed Note on Memorandom.-It may be useful to observe that, although the names of both parties must appear upon the face of the memorandum, or, at least, in some writing capable of being connected therewith by sound legal inference, yet the signature of the party sought to be charged, or of his agent, is sufficient And this term "signature," be it observed, is not here used in the limited sense of subscription, so as to require the party to sign his name at the end of the instrument, but is equally applicable in whatever part the name is written. Whether sales by public auction are within the Statute of Frauds has long been a disputed point; the later opinion is in favour of their being so; and it, therefore, becomes necessary to mention here that the auctioneer is, in such sales, the "agent" of "both" parties.

Upon the regular completion of the sale, the property in the article is transferred to and absolutely vested in the vendee; and the purchaser thenceforward stands by all risks, and is the sole sufferer from any injury which may happen to the animal, otherwise than through the negligence of the vendor. As in the example given by Blackstone: If A sells a horse to $B$ for $\mathfrak{L} 10$, and B pays him earnest, or signs a note in writing of the bargain, and afterwards, before the delivery of the horse or money paid, the horse dies in the vendor's custody, still he is entitled to the money, because by the contract the property is in the vendee."

But although the right of property is thus absolutely transferred by the contract, yet, unless payment be expressly postponed to a future day, the buyer will not be entitled to "possession" without tendering the stipulated price. 
WARRANTY.-We now come to the important doctrice of WARRANTT, which is thus summed up by Coke: "By the civil law, every person is bound to warrant the thing that ae sells or conveys, although there is no express warranty; but the common law binds him not, unless there be a warranty, either in deed or in law, for caveat emptor: the meaning of which Latin expression is, that the buyer takes the article sold with all its defects, and must not look to the law for any redress if its intrinsic worth do not correspond with its outward appearance. It cautions the buyer, therefore, according to the Italian proverb, "that he has need of a hundred eyes, but the seller of only one.'”

By the law of England, warranties are divided into "express" or "implied:" the latter, however, differ in no respect from the former except in the circumstance of "proof." The intention to warrant is collected from the whole circumstances proved, and as a legitimate deduction from them, like the presumption of any otlier part not established by direct evidence; while the "express" warranty is proved by direct and express testimony to the fact itself. To give a single instance: In Jones v. Bowden, it was proved to be the uniform course and habit of dealing in a particular place, if the article were sea-damaged, to state that fact on the sale of it: a sale was made without any such statement, and it was therefore held that the article was warranted not sea-damaged This was an "implied" warranty.

A warranty can only exist as a term and condition of the contract of sale, into the very essence of which it so completely enters, that a breach of it entitles the buyer to 'reat, if be pleases, the whole contract as a nullity. It :onstitutes part of the inducement or consideration for the purchase. It follows that, for a warranty to be valid, it must exist or be made "at the time" of the sale; or, at least, that, being agreed to be made before, there should be an understood reference at the actual sale to that agreement. As, for instance, if previous to the time of sale, the vendor says he "will" warrant the goods, and having named his price, gives the vendee two or three days to consider of it, ind the vendee then agrees to purchase, the warranty, though only made hypothetically, is tacitly incorporated into the terms of the sale, and is a valid warranty.

But a warranty made "after" the completion of the sale is of no value whatever, being without any consideration.

From these premises also, coupled with the rule that where a contract is reduced to writing, the writing is the sole legitimate evidence to prove its terms, we may further deduce that an oral warranty made previously to a sale by written contract, but not inserted in the instrument, will not be valid Thus in Pickering v. Dowson, Gibbs, C. J., says, "I hold that if a man brings me $a$ horse and makes any representation whatever of his quality and soundness, and afterwards we agree in writing for the purchase of the horse, that shortens and corrects the representations; and whatever terms are not contained in the contract do not bind the seiler, and must be struck out of the case."
It is also a rule of law, that where a commission is given to execute any work, every power necessary to carry it on will be implied. A servant, therefore, employed to sell a horse, has an implied authority to warrant that it is sound; and in the case of a "general" agent-for example, the servant of a livery-stable keeper-this warranty will bind the master, though made contrary to his express directions; and, in every case, the warranty of a servant or agent, so entrusted to sell, will bind the principal, if he do not expressly prohibit it being made.

With respect to what declarations of the seller will amount to a warranty, the primary rule for the interpretation of contracts in general is applicable. It depends upon the "intention" of the parties.

Thus, a simple affirmation of the goodness of an article is a warranty, provided it "appear to have been so intended ;" whereas the sublimest epithets that seller ever employed to recommend his goods to a credulous buyer, will be regarded as the idle phraseology of the market, "unless an intention to warrant actually appear." For example, when the vendor declared at the time of sale, that he "could" warrant, it was beld to mean that he "would" and "did" warrant So when the seller affirms that the goods are his property, he is held to "warrant the title." And, on the other hand, when at the time of sale the seller showed the buyer a written pedigree, which he bad received from the person of whom he bought the horse, and said he sold him according to that pedigree, the mark being out of his mouth when he bought him, and the pedigree was proved to be false; it was held that this was no warranty. No general rule, therefore, can be laid down further than this-that it is from the "intention" of the parties, as collected from the whole transaction, and from the meaning they appear to attach to particular expressions, that the existence or non-existence of a warranty is to be inferred.

But the most important part of our investigation relates to the "extent" of the warranty. We must here observe, in the first place, that although a warranty may be made to extend to temper, freedom from blemish, age, aptitude for particular work, and many other similar qualities, as well as to soundness; yet, unless expressly so extended, it will be construed to apply to soundness alone. Thus, when an ambiguity arose from the insular position of the word "warranted" in the following notice :-" To be sold, a black gelding, five years old; has been constantly drivenwarranted," the warranty was held to apply to soundness alone.

"Unsoundness" is a term the exact limits of which are not very clearly defined. According to Lord Ellenborough, any infirmity which renders a horse less fit for present use or convenience, is an unsoundness. This doctrine was laid down by his lordship in a case which turned upon an alleged lameness, and wherein it was admitted by a witness for the defendant, that one of the fore legs had been bandaged, because it was weaker than the other: upcn this admission, 
the verdict in favour of the plaintiff seems to have been founded; and it was then observed by the court, "to constitute unsoundness, it is not essential that the infirmity should be of a permanent nature; it is sufficient if 'it render the animal for the time unfit for service:' as, for instance, a cough, which renders it for the time less useful, and may ultimately prove fatal." Now this decision appears to contradict a prior one, in which Eyre, C. J., held, that a slight lameness occasioned by the horse having taken up a nail at the farrier's was not an unsoundness. This learned judge, in his observations to the jury: remarks:-A horse labouring under a temporary injury or hurt, which is capable of being speedily cured or removed, is not for that an unsound horse within the meaning of the warranty. If these decisions are not to be regarded as conflicting, one deduction ought possibly to be, that such slight injuries as proceed from external causes, and are with moral certainty to be speedily and effectually cured, do not fall under the head of infirmities, which term properly comprehends such diseases only as may without much improbability hang by the animal through life, while they impair his present usefulness

"Crib-bitzny," in its incipient state, has been held to be "no unsoundness"; but when inveterate (and interfering with the health of the animal) it then falls within the meaning of the term.

It is commonly asserted that a warranty will not bind when it is obviously false. The instance given being that of a horse warranted sound, when it is apparent that he is blind; and for this doctrine, the venerable argument, which makes so conspicuous a figure in legal logic, is usually urged-for that it is his own folly. "For that it is the other's roguery," might, we think, be an argument of greater cogency the other way, unless knaves in this country are to be regarded with peculiar favour, like idiots in Turkey. We apprehend that this rule-if any such indeed exist-is one of presumption only, it being inferred that both parties meant to exclude the particular defect from the warranty. The case of Shillitoe v. Claridge, however, goes far towards disproving the existence of such a rule.

Let us now consider how the rights of the parties are affected by the horse being unsound at the time of warranty. The contract being thus broken on the part of the seller, it is at the buyer's option either to treat it as a nullity, and return the horse, or to retain him notwithstanding, and bring an action on the warranty. In the former case, the price paid is the measure of damages which he will be entitled to recover in an action; in the latter, the difference between that price and his real value. If he offer to rescind the contract, and return the horse, he may also recosar the expenses of his keep; but in order to this a

- See under beading VICrs, por. positive tender is said to be necessary. No notice of the unsoundness need be given to the vendor to entitle the vendee to maintain the action; nor is it necessary to bring the action immediately on discovering the unsoundness. As in a case where a mare was warranted to be sound, quiet, and free from vice and blemish, the buyer, soon after the sale, discovered that she was a roarer, had a thoroughpin, and also a swelled hock from kicking, yet kept her after this for three months, gave her physic, and used other means to cure her. At the end of that time he sold her, but she was soon returned to him as unsound. He subsequently sent her back to the seller as unsound, who refused to receive her, and in returning to the stables she died. $\mathrm{He}$ recovered the full price.

But although such notice be not essential, yet it is always advisable to be given, as the omitting to do so will furnish at the trial a strong presumption that the horse, at the time of sale, was free from the defect complained of, thus rendering the proof of a breach of warranty more difficult. Common justice and honesty, it has been remarked, require that the commodity should be returned at the earliest period, and before it has been so changed by lapse of time as to make it impossible to ascertain, by proper tests. what were its original qualities.

To entitle the buyer to the benefit of the warranty, he must, of course, strictly fulfil the conditions stipulated to be performed on his part. Thus, if, as is frequently the case, a condition be introduced into the warranty, that the horse, if objected to as unsound, shall be returned within a limited time, no action can be maintained for the unsoundness without the strict performance of this condition. So where the warranty was qualified by the vendor by an under. taking to take back the horse, if, on trial, he should be found to have any of the defects mentioned in the warranty, it was held, that the buyer must return the horse immediately upon the discovery of them. When the contract is rescinded by the buyer on account of the warranty being broken, the seller has a right to require that the horse shall be returned in as good condition as he was when the defect was discovered; and, therefore, "if the animal fall into a worse state subsequently to such discovery, the buyer cannot then return him, but must rely on his action to recover back a proportional part of the price."

There being no warranty, but the purchaser having been imposed upon, and entrapped into a losing bargain by the artifices or wilful misrepresentations of the seller, his remedy is an action "for the deceit;" to support which " he must prove a fraud" to have been committed by the seller, and also "that it was such as might well impose upon a person of ordinary circumspection:" or, in other words, that "he was deceived and misled by relying upon the integrity of the seller," in a point where he might reasonably have placed trust and confidence in hin

"Any wilful misrepresentations by the vendor 01 the qualities of the commodity to be sold, whercby the vender 
is induced to purchase, falls within the legal idea of fraud, and will vitiate the contract," as being a breach of that good faith which ought to reign throughout every commercial transaction. This is called "fraud in words." Thus, if A, knowing his horse to be broken-winded or lame, induce $B$ to purchase, by an assurance that he is sound in wind and limb; then, although A may have expressly refused to warrant, B will nevertheless be entitled to recover from A in an action for the deceit. It is obvious, however, that this action could not be here maintained upon mere proof of the abstract falseness of the representation made by the seller; but that evidence of the moral falsehood is requisite -the seller's "knowledge" of the falsity, which is called in technical language, the scienter. And herein it is, principally, that this action is distinguished from actions on breach of warranty; for the warranty extends to "all" faults, "known or unknown" to the seller.

The other kind of fraud may be termed "fraud in deed." An instance which may serve to exemplify the nature of those acts of the seller which would fall under this head. "I remember," says Gibbs, C. J., "the case of the sale of a house in South Audley Street, where the seller, being conscious of a defect in the main wall, plastered it up, and papered it over; and it was held that, as the vendor had expressly concealed it, the purchaser might recover." To extend this principle to our subject-matter :-it is conceived if the vendor were to deceive the purchaser, either as to colour, which may be easily done by chemical means; or as to age, by bishoping the animal; he would be liable for the deceit, although no verbal representations had been made.

Thus tar on the specially dry ground of the law; we cannot, however, quit this subject without a few illustrations, which may be of value as not being within the reach of a ready reference by those "perplexed in the extreme" as to their "rights" or their "liabilities" in the matter of sale or purchase of a horse. And first of

SALE BY Adction.-In selling your horses by auction you avoid not only a world of trouble, but obtain immunity from many prospective responsibilities. This security (although not absolute) against an action at law is something; since the judges, a quarter of a century back even, were getting stricter and stricter in their construction of general warranties of soundness, and qualified ones do not answer the purpose of sellers, as they necessarily diminish the prices obtained. "The owner of a good horse," observes Mr. Surtees, "has the same advantage of warranting him sound as he has on a sale by private contract, without incurring the risk of having him returned at the end of five or six weeks, or perhaps as many months (unless, indeed, it can be proved that the cause of the breach of warranty existed at the time of the sale), while the less fortunate owner of a bad horse puts him up for public competition, and though he may expatiate as largely as ever he likes on his good points, still (if he does not warrant him) he is not bound to mention any of his imperfections." Nor does either the owner, or the auctioneer for him, ever do such a silly thing. Undeserved praise does not lay grounds for an action. Simplex commendatio non obligat : the buyer ought not to be such a fool as to believe in laudations, and he consequently cannot in law procure the sale to be dissolved on any such pretext-in the absence, of course, of a warranty, either expressed or implied-for there are "constructive" warranties. All this goes to show the advantage which accrues to sellers by auction; to buyers the disadvantages are obvious. It is buying a pig in a poke. To dealers and such like, who are not a bit better judges than other people, it is quite a different thing; for they are the familiars of the yard-the depositories of the repositories, obtaining through the servants of the sellers and other channels the information that enables them generally to know all about every horse to be brought to the hammer. Then, as to a trial, of course that's quite out of the question: the animal is only run up and down a few yards-perhaps, all the while with a long whip at his quarters; and all that the most practised eye can possibly determine with absolute certainty, is the animal's style of going, with his visible symptoms of age, of soundness and unsoundness, of shape and make. But it must, nevertheless, be allowed that "the eye," as Tom Carlyle philosophically and justly remarks, "sees what it brings the power to see;" and, accordingly, a man who is an observer of horses will form a correct opinion of a horse's value and capabilities almost in a minute: supposing, though, all's right and aboveboard in the selling of the subject shown out and run down the auction-ride a dozen yards. But this presumption of honesty clearly implies too much.

The law (through Lord Kenyon) said, in a case of Mesnard v. Aldridge, where the plaintiff brought an action against the auctioneer because the latter refused to receive a horse as unsound after the lapse of a second day, that the action could not be supported. Mesnard was nonsuited. But no lapse of time bars redress, and an action against the "owner" is maintainable on good and sufficient grounds.

An action would lie against Tattersall, Aldridge, Dixon, Gower, or any other auctioneer, for the amount of the horses or other property confided to them for sale, if they let the lot or lots go out of their possession without first receiving the price of them from the purchaser. The law was laid down to this effect in the case of Brown v. Staton, as on many other occasions. An action is also maintainable where any deceit is practised, or misrepresentation is made respecting the ownership. To sell a horse as a hunter which has never been ridden with hounds, or to describe a horse as the property of a man to whom the animal does not belong-against both of these dishonesties an action will lie. In all clear cases, both of misdescription as regards the horse, and of misrepresentation as to ownership, the law has provided a remedy for the injured purchaser.

It was observed, some twenty years since, that "mang of 
the owners of horses sent to public auctions are persons whom fortune has placed in such a situation, that the difference of price obtained by selling their horses with warranties and without them is of no importance, and that many would prefer giving them away to running the risk of having them returned at a subsequent period as unsound." What is the case now? A horse put up at either Tattersall's, Aldridge's, or elsewhere, is seldom or ever warranted sound. What was imagined at that period to be a luxury, in which the rich alone could afford to indulge, is now discovered to be a profitable course for the million. Hence the universality of its adoption. Exemption from the plague of warranty is referrible to this plain cause: that all the parties concerned do better at the horse repositories without a warranty of soundness than they would do with it. Again, as to "the difficulty," if we may use the diplomatist's slang, doubtless a great number of desirable horses are not to be picked up at the repositories-or, for the matter of that, perhaps, anywhere else hardly. But the number of really nice animals, sound and fresh, bears a very small proportion to the number of brutes of screws, used up, stale things. Farther, you may go every sale-day for six months to every repository in London, and during the whole time of search after the right sort, see scarce a really good goer even; or if you do find one, the odds are high that he has done his work, and is not worth a straw to you. Success, however, it is not altogether impossible, may crown your search. Still, caveat emptor : it is not all gold that glitters, and every stable, as well as every garden, has some weeds. The latter are occasionally barrowed off-the former drafted to "the Corner;" care sometimes, perhaps, being taken that they are accompanied by other horses in the same stable much too good to be sold. Therefore, it happens sometimes, that when the stud of a nobleman is duly stabled and catalogued, the real thing, in point of fact, is that it is the weeds only, the refuse of the stable, and not the stud that is really to be parted with; the cracks are only colourable candidates for a new master, their old one causing thern to be bought in.

To return to another "bit of law." If a man is so "infirm of purpose" as to bid for a horse, and the moment after his bidding desires it to be considered as no bidding at all, the law will stand his friend. It will be to bim "faithful amongst the faithless;" for who would not be ashamed of being seen beside such a fellow, with his shabby backingout? The loophole of retreat, according to law, is open to the bidder, and "his bidding may be retracted at any time before the lot is actually knocked down;" supposing, of course, that the conditions of the sale do not provide against the contingency. The reason assignea is this: a contract to be binding must be agreed to by both parties, and the auctioneer not having signified his by knocking down the hammer, there is no contract.

Another "bit of law" will surprise not a few. It involves a very nice point with respect to the instructions given to auctioneers as to the price for which they are to sell a horse. An action does not lie against an auctioneer for sella horse at the highest price bid for him, "contrary to the owner's express directions" not to let him go under a larger sum named. But an action will lie if an auctioneer is told by the seller to put the horse up at a certain specified sum. This is the law; and to some persons, perhaps, it will be suggestive of a distinction without a difference. Bexwell v. Christie is one of the precedents cited as a case in point. Mr. Espinasse, in his "Treatise on the Law of Nisi Prius," says, "It was resolved in this case, that when a person sends an article to an auction which advertises to sell to the highest bidder, with orders not to have it sold under such a price, an action will not lie against the auctioneer if he sells it at a price less than that so mentioned, as 'such dealings are a fraud on buyers,' who suppose the lot to be knocked down to the best 'real bidder.' But it is otherwise, had he ordered it not to be set up under such a price."

Connected with the point of buying in, is that of "running up" the animal to be sold; and here we have legal protection for the purchaser beyond what is ordinarily supposed. Where a horse is bid up by a "puffer," and one condition of the auction is, that the highest bidder is to be the purchaser, the vendor cannot recover the price (Pilmore v. Hood, 5 N. C. 97). The law on this point was fully considered by the Court of Common Pleas in the following case : An action was brought by the plaintiff to recover the value of a horse sold by him to the defendant, at a public auction at Aldridge's Repository. It appeared that it was one of the conditions of sale, "that each horse should be sold to the highest bidder;" that the plaintiff's groom attended at the sale on the part of his master for the purpose of raising the price; that the last bonâ fide bidder had bid $£ 12$; after which, until the horse was knocked down to the defendant for $\mathscr{L} 29$, he and the groom were the only bidders; and that when the defendant discovered against whom he had been bidding he refused to take the horse.

Upon these facts Chief Justice Best said: "I am clearly of opinion that this action cannot be maintained. I have long been surprised that the objection has never been taken. A man goes to a sale, and is told that if he is the highest bidder he shall have the article. He bids a certain sum, and a person (employed by the seller) whom he does not know, attends and puffs against him, and in consequence of that he is compelled to pay a much larger price than he would otherwise have paid. Is not this a gross fraud? I am prepared to nonsuit the plaintiff." It was then proved for the plaintiff, by the evidence of the auctioneer, that the defendant was in the habit of attending sales of horses, and that he knew the plaintiff's groom was present; and it was stated that there was a case deciding that a seller has a right to have one person to bid for him at the sale, if he does not do it in order to impose. Chief Justice Best then said : "I agree that he has such a right, but then he must 
declare it by the conditions of sale. I am of opinion that a person acts in opposition to the conditions of sale where the highest bidder is to be the buyer, if he employs a person to bid for the purpose of enhancing the price. In this case the other person at the sale did not go near the ultimate sum. It is impossible under these circumstances to say that $£ 29$ was the highest price contemplated by the conditions; for the defendant, under them, was entitled to have the horse at the next highest bidding to that of the only fair bidder" (Crowder v. Austin, 2 C. \& P. 208). The Court of Common Pleas, on a motion for a rule, confirmed Chief Justice Best's ruling at nisi prius; and Justice Park said: "I entirely concur in the opinion expressed by Lord Mansfield ;" as to which Lord Kenyon, in Howard v. Castle (6 T. R. 634), said : "The whole of the reasoning of Lord Mansfield in Bexwell v. Christie is founded on the noblest principles of morality and justice,-principles that are calculated to preserve honesty between man and man. The circumstance of puffers bidding at auctions has been always complained of. If the first case of this kind had been tried before me, perhaps I should have hesitated a little before I determined it; but Lord Mansfield's comprehensive mind saw it in its true colours, and made a precedent which I am happy to follow." And this decision has been further confirmed by a recent case in the Court of Exclequer (reported in the Law Journal, vol. xv. N. S., Exch. 230), where it was held that in "a sale by auction without reserve, if a puffer be employed without notice of his being there to protect the interest of the seller, the sale is void."

It is necessary here to warn the horsedealer that there is one point in which the luminaries of the law have decided he must not act "like a gentleman" if he would not lose his horse or his money. Thus, in Fennells $\nabla$. Ridler (5 Barnewall and Cresswell, 406), the plaintiffs, horsedealers, sold defendant a horse on a Sunday, and Mr. Justice Bayley said, under the 27th of Charles II. c. 7, the plaintiffs could not maintain the action.* But if you are not a horsedealer the case is different. Sabbath-breaking is an indulgence extended exclusively to "gentlemen," in so far as horsemongering is concerned. In Drury v. De la Fontaine, it being shown that neither of the parties was "exercising his ardinary calling,"--and were merely cheating each other as "gentlemen," en amateur,-Chief Justice Mansfield declined to apply the statute of the pious Charles. There is another case in confirmation of this view, reported in the books as that of Bloxsome v. Williams. In this case, Justice Bayley said: "When neither of the parties is a horsedealer, a contract between them for sale of a horse is good, though made on a Sunday. But if a party take a warranty on a Sunday from a person he knows to be a horsedealer, he cannot sue

\footnotetext{
* The statute of that exemplary monarch is "An Act for the Better Observance of the Sabuath," and forbids any tradesman, artificer, \&c., to "pursue his ordinary calling on the Lord's Dav."
}

upon breach of that warranty." The cases upon this point may be found in Mr. Oliphant's book, and fully prove the Frenchman's satire, avec le ciel il a des accommodemenseven in the matter of keeping holy the Sabbath day.

From this digression we will return to warranty, un. soundness, and vice.

The most definite of legal dicta to be found on the general nature of unsoundness are contained in a couple of cases. The first was an action of assumpsit brought on a warranty ; and under the direction of Mr. Justice Erskine, at the trial, a verdict was found for the plaintiff. In refusing a rule for a new trial Mr. Baron Parke said, "The rule J laid down in Coates $\nabla$. Stephens is correctly reported; that is the rule I have always adopted and acted on in cases of unsoundness: although, in so doing, I differ from the contrary doctrine laid down my by brother Coleridge in Bolden v. Brogden. I think the word 'sound' means what it expresses, namely, that the animal is sound and free from disease at the time he is warranted sound. If, indeed, the disease were not of a nature to impede the natural usefulness of the animal for the purpose for which he is used, as for instance, if a horse had a slight pimple on his skin, it would not amount to an unsoundness; but even if such a thing as a pimple were on some part of the body where it might have that effect, as for instance, on a part which would prevent the putting a saddle or bridle on the animal, it would be different." * * * "An argument has, however, been adduced from the slightness of the disease and the facility of cure; but if we once let in considerations of that kind, where are we to draw the line? A horse may have a cold which may be cured in a day; or a fever, which may be cured in a week or a month; and it would be difficult to say where to stop. Of course, if the disease be slight the unsoundness is proportionably so, and so also ought to be the damages: and if they were very inconsiderable, the judge might still certify under the statute of Elizabeth, to deprive the plaintiff of costs." * * * But on the question of law, I think the direction of the judge in this case was perfectly correct, and that this verdict ought not to be disturbed. Were this matter presented to us now for the first time, we might deem it proper to grant a rule, but the matter has been, we think, settled by previous cases: and the opinion which we now express is the result of deliberate consideration."

Upon the same point Baron Alderson said, "I am of the same opinion. The word 'sound 'means 'sound,' and the only qualification of which it is susceptible arises from the purpose for which the warranty is given. If, for instance, a horse is purchased to be used in a given way, the word 'sound' means that the animal is useful for that purpose: and 'unsound' means that he, at the time, is affected with something which will have the effect of impeding that use. If the disease be one easily cured, that will only go in mitigation of damages. It is, however, right to make to the definition of unsoundness the addition my brother Parke 
bas made, namely, that the disqualification for work may arise either from disease or accident; and the doctrine laid down by him on this subject, both to-day and in the case of Coates v. Stephens, is not new law; it is to be found recognised by Lord Ellenborough and other judges in a series of cases."

The rule as to unsoundness applies to cases of disease and accident, which from their nature are only temporary, it not being necessary that the disorder should be permanent or incurable. This is laid down as law by Lord Ellenborough in Elton v. Brogden, and Elton v. Jordan; also by Mr. Baron Parke in Coates v. Stephens, and by the Court of Exchequer in Kiddell v. Burnard, although Mr. Justice Coleridge in Bolden v. Brogden was of a different opinion.

A vice is a bad habit, and a bad habit to constitute a vice must either be shown in the temper of the horse, so as to make him dangerous, or to diminish his natural usefulness; or it must be a habit decidedly injurious to his health.

The soundness or unsoundness of a horse is a question peculiarly fit for the consideration of a jury, and the Court will not set aside a verdict, on account of there being a preponderance of evidence the other way; and they sliould consider whether the effect said to proceed from the alleged unsoundness, is such an effect as in the eye of the law renders a horse unsound. It is also a question for them, whether a horse warranted sound was at the time of delivery rendered unfit for immediate use to an ordinary person, on account of some disease. And in case of vice they should consider, whetner the effect alleged to proceed from a certain habit is such an effect as the law holds to be a vice in a horse

Whether curbs, crib-biting (see ante, p. 259), or some other drawbacks, do or do not, according to law, constitute unsoundness, are vexed questions which conflicting verdicts have left sticking in the clay of litigation, the law all the while looking on, but doing little or nothing to settle points. To address ourselves to the ventilation of such debateable matters would take up too much time and space. All we can say on the subject is, that the law in relation to the buying and selling of horses is by no means in a satisfactory state. This glorious uncertainty is, perhaps, partly attributable to the profound ignorance of most of our judges of the actual status quo of the animal economy of horses, and of a thousand things besides, of and concerning horses, that cannot possibly be learned either in chambers, in banco, by an occasional ride in Rotten-row, or even by a run now and then with the beagles of old Sir Peter, or the harriers of young Paceleft. But whether or not our law judges are good judges of horses, knowing all about, or nothing at all about, the ills to which the animals are heirs and heiresses, it is certain that no person, learned or unlearned in the law, can a priori precisely say how the judge will direct the jury, and whether the verdict will be for the plaintiff or the defendant. As prevention is proverbially better than cure, it is prudent never to warrant a horse either by word of mouth (and mind, if your groom does, it is just the same as if you yourself did it; for the law says, Qui facit per alium facit per se), or by a written receipt.

'The mentioning a receipt recals one framed by Mr. Surtees," who observes, that if a buyer cannot induce a seller to be nailed in black and white, after the stringent fashion prescribed in his formula, he should get as much of it put in as the seller may be soft enough to insert! The form recommended by the learned "gentleman" is this :"Horncastle, Jan. 1, 1862.

"Received of A. B. the sum of pounds for a chesnut gelding, which I hereby warrant to be only six years old last grass (sic in orig.); and also that he is sound and free from vice, restiveness, and faults (particularly $\longrightarrow$ ); and that he is quiet to ride and drive, without blemish."

As we have mentioned Surtees' book, we will revert to the question as to how far the servant's warranty binds the master. In the case of Pickering v. Bush, Mr. Justice Bayley said-" If the servant of a horse-dealer, with express directions not to warrant, does warrant, the master is bound, because the servant, having a general authority to sell, is in a condition to warrant, and the master has not notified to the world that the general authoritv is circumscribed." Howevcr, in an analogous case of Fenn v. Harrison, where the above opinions were quoted, Lord Kenyon doubted the propriety of a master's being bound by his servant's warranty, and said lie thought the maxim of respondeat superior applied. In Helyear v. Hawke, Lord Ellenborough said"I think the master having intrusted the servant to sell, he is intrusted to do all that he can to effectuate the sale; and if he does exceed his authority in so doing, he binds his master." The circumstances of the case were these :-The lorse had been inserted in Tattersall's catalogue, but was not brought to the hammer, and Helyear afterwards, having the catalogue in his hand, inquired of Hawke's groom, who had the care of the horse, if the horse was but seven years old, and if free from vice; to which the latter replied "Yes, if you have him." And upon an objection to this evidence being received to bind the master, Lord Ellenborough said"If the servant is sent with the horse by his master, and the horse is offered for sale, I think he thereby becomes the accredited agent of his master, and what he has said at the time of sale, as part of the transaction of selling, respecting the horse, is evidence; but an acknowledgment to that effect made at another time is not so: it must be confined to the time of the actual sale, when he was acting for his master." It afterwards appeared that nothing had been said about the price; and his lordship was of opinion that it could not be deemed a complete contract for the sale of the horse, and would not support a warranty at all Who shall

* In a work On Warranty, now superseded, by lapse of time, by Oliphant's Law of Horses, of which there is an editiou brought down to reccnt times, in respect to the adjudired cases in the Courts. 
decide when judges disagree? The best way is to write down the instructions, if the master either cannot or does o ot choose to be referred to.

From all that is here set down the common sense deduction seems to be that warranty should be given only in very exceptional and rare cases, and that soundness is so indefinite and complex a thing that it is courting trouble to guarantee it. Indeed there seems no reason why a person buying a horse should not act as he would in any other transaction where there is risk. For instance, a man buying a house does not merely examine it himself, and then, because he likes it, buy it with a warranty; but he takes his surveyor with him, who points out all its defects, and then, the purchaser being aware of these, buys it or not, according to the opinion he forms of its value after they have been taken into consideration.*

In all cases where a risk is run and an insurance effected, there are regular rules laid down by which such transactions are governed Where too a person insures his life he submits

* In The Veterinarian, vol. vii., N. S., pp. 108-116, and pp. 162167 , is the translation of a lecture on Veterinary Jurisprudence, by Frofessor Renault, of the School at Alfort, from which a view of the law in France as to "warranty and unsouudness" may be obtained. Our neighbours d"outremanche are quite " as much to seek" as we are, though their written law looks plain. The Code Napoleon, arta 1641-1649, chapter ii., \& iii., of the Code Civil, attempted something; but the "anarchy of the law," \&s the Professor terms it, is complete in the practice of the Courts.

The laws of Sale and Warranty in France are as follow:-

"Art. 1. The vendor (providing he gives a warranty) is held responsible for all unapparent defects that may render the vended article infit for the required purposes, or so diminish that fitness that the purchaser, had he been aware of their existeuce, would not have bought it at all, or else not at so high a price.

"2. For self-apparent defects, such as the buyer could not fail to discover, the vendor is not responsible.

"3. But for such as are not perceptible, eveu though he was ignorant of their existence himself, still is he amenable, unless stipulated that he would not hold himself chargeable with any warranty.

"4. In a case of false warranty, it is at the option of the purchaser either to return the article and claim back the price of it, or to retain it and claim the restitution of such proportion of the original cost as shall by judicions arbitration be awarded.

" 5 . If the veudor possessed a knowledge of such defects, he is respousible not only for the return of the price of the article, but for any damage or inconvenience sustained by the purchaser in consequence thereof.

"6. But if the vendor was unconscious of them, he will be only liable to refund the price of the article, and reimburse the purchaser for any expenses attending the sale.

"7. If such defective article becomes lost in consequence of its defectiveness, the loss belongs to the vendor, who will have to return the price paid for it, as well as make good other expenses incurred by it: shonld the loss, however, be the result of accideut, it will remain chargeable to the account of the purchaser.

"8. Any action inteuded by the purchaser, in such cases as these, should be instituted with as little delay as the particular case demands, and as is consonant with the customs of the place.

"9. No such action will lie when the sale is one ordered by judicial quthority." to a regular medical investigation, and no company wouid act in so unbusiness-like a manner as merely to take a person's own "warranty" that he is sound in health and constitution, and so be put to the proof, in case of his death, that he was not so at the time he gave the warranty, for this would lead to endless disputes.

The best rule for a man therefore to follow, in selling a horse is, this: where the horse is of no great value, to refuse a warranty altogether, and such a horse is best sold by auction. Where the horse is of great value, if sound, but that appears doubtful, then to let the purchaser be satisfied by a veterinary examination, and so take the responsibility upon himself. Where, however, the seller is confident that the horse is perfectly sound, and that with a warranty he would fetch a much larger price than without one, he should have him examined and certified as sound, \&c., by one or two veterinary surgeons of respectability and experience, and then, knowing on what grounds he goes, he may take the risk of warranting him sound.

The vexation and difficulty experienced in horsedealing arise, in a great measure, from the loose manner in which such transactions are conducted, and from the thoughtless manner in which people give warranties; and we generally find that the smaller a man's knowledge may be with regard to horses, the more ready he is to warrant, little dreaming of the responsibility he is thus fixing upon himself.

Mr. Oliphant* thus remarks on

Veterinary Certificates. - When a horse 18 in the possession of his natural and constitutional health, and is also in such bodily perfection as is consistent with his natural formation, a veterinary surgeon will of course certify him to be sound. But as there is in most horses some slight alteration in structure, either from disease, accident, or work, a veterinary surgeon in giving his certificate had much better describe the actual state of the horse, and the probable consequences, without mentioning " soundness" or " unsoundness" at all, and so let the purchaser buy him or not as he inay be advised. Because in such a case a straight-forward statement would be made, and a man in the Veterinary profession would not be called upon in an off-hand manner to decide questions which are of the greatest nicety, being full of uncertainty, and upon which no conclusive decisiou can safely be arrived at. For we find the greater the difficulty, the more likely is a decision (if come to at all), to be the result of a slight preponderance of one over each of many conflicting opinions.

A man will sometimes warrant a horse in consequence of a veterinary opinion given in an off-hand manner, either without a sufficient examination of the horse having been made, or sometimes in the face of actual disease; for the giving a warranty seems to be considered quite a trifling matter. Thus, in the case of Hall v. Rogerson, tried at

* A Treatise on the Law concerning Horbes, Racing, Wagors, and Gaming. By G. H. Hewit Oliphant, Esq. 
che Newcastle Spring Assizes, 1847, it appeared that a witness, who was a veterinary surgeon, had taken off the horse's shoes, and examined his feet, when he found a slight convexity of sole. The owner then asked him if he would be "justified" in warranting the horse as it had been warranted to him; the witness then asked him if he was satisfied the horse "went sound ;" he replied, "Perfectly so ;" he then said he was justified. On cross examination, the witness said, "I pointed out a slight disease in the sole, but thought he would have been justified in warranting him; if I had taken the precaution to see him go, things might have been different." So that a veterinary surgeon finding that a horse has a disease in the sole, and without taking the precaution to sce him go, tells the owner he is "justified" in warranting. Now the use of the word "justified" shows that neither of the parties fully knew the amount of liability incurred by giving a warranty, and it seems as if they had considered it rather an affair of conscience or honour than of legal responsibility.

That the veterinary profession feel the greatest difficulty in dealing with the question of unsoundness when called upon for a certificate on that point, will appear from part of an article on "Soundness as opposed to Lameness," by Mr. Percival. He writes, "Reluctantly as we enter on this difficult and much debated question, we feel it our duty to make some observations on the subject, though these observations will be rather of a general than of a particular nature, and have especial reference to soundness, regarded as the converse of, or opposite state to, lameness. No person buys or sells a horse without feeling some concern as to the soundness of the animal ; the purchaser is apprebensive lest his new horse should from any cause turn out unserviceable or unequal to that for the performance of which he has bought him; the vendor is apprehensive, either lest the animal, in other hands, should not prove that sound and effective servant he conceived or represented him to be, or lest some unrepresented or concealed fault or defect he is aware the animal possesses, may now, in his new master's hands, be brought to light.

'Soundness, as opposed to actual or decided lameness (or as synonymous with good health), is a state too well understood to need any definition or description; when we come, however, to draw a line between soundness and lameness in their distinguished form-to mark the point at which one ends and the other begins-we meet a difficulty, and this difficulty increases when we find ourselves called on to include, under our denomination of unsoundness, that which is likely or has a tendency to bring forth lameness. It will be requisite, therefore, for us to say, not simply that every lame liorse is unsound, but to add these words, or who has that about him which is likely on work to render him lame. This will, it is true, open the door to difference of opinion and equivocation There may, as we have seen, spring up two opinions concerning the presence even of lameness. There will in more cases be two opinions concerning that which is accounted to be the precursor of lameness, or have a tendency at some period proximate or remote to produce it; all which differences are best got rid of by reference to the ablest veterinary advice. There will be less diversity of opinion among professional men than among others, and the more skilful and respectable the professional persons are, the greater will be the probability of a happy unison in their views of the case." (Veterinarian, vol. xviii. p. 366.) Mr. Goodwin, Veterinary Surgeon to the Queen, makes the following sensible remarks on the certificates given by veterinary surgeons to the vendors and purchasers of horses. He says, "it is to be regretted that the members of the Veterinary profession have not been taught to adopt some rules for rendering the certificates they are required to give upon examining horses as to soundness, at least somewhat similar in the construction and expression of their opinions so as to render them more intelligible to the persons who have to pay for them. I am quite aware of the impossibility of attempting to reduce professional opinions to one common standard; but I think that our leading practitioners might meet together, and agree upon some general principles for their guidance, that would make their certificates less liable to the censure and ridicule they both merit and incur. The occurrence is by no means uncommon for a buyer to send a horse to be examined by a veterinary surgeon, and, not feeling satisfied with the opinion he obtains, to send him to another; and then comparing the certificates of the two, and finding them diametrically opposite in their statements, he finally trusts himself to the warranty of the dealer, purchases the horse, and at the end of six months has had to congratulate himself upon the possession of a sound animal, and the escape he has had in avoiding two unsound certificates." (Veterinarian, vol xix. p. 88.)

Lien.-A look at "the law of lien"-as it is a kindred topic to the law of warranty-may not be amiss. A livery-stable keeper, then, has not a lien on horses standing with hirn; an innkeeper, on the contrary, has ; the latter being entitled by law to keep the horses in his stable until paid for their keep. The reason assigned by the lawyers for the difference in favour of the innkeeper is this:-The livery-stable keeper can refuse to receive the horses of any person; he is a free agent in the business; but the innkceper has no choice. Willing or unwilling it is obligatory by law upon him to take a horse in to stand at livery, even though neitlier the owner nor his servant lodge at the inn. Of course, horses, like all wther chattels, are liable to be seized at a livery-stable, under distraint for the landlord's rent; and the process of recovery is not seldom extremely unpleasant, although the result is pretty certain if people only go the right way about it Again, if a horse be stolen from the stables of an innkeeper, its proved value can be recovered from hin. in the case of Wallace v. Woodgate, Lord Wynford, Chief Justice of the Common Pleas, told the jury that a livery-stable keeper had not, by law, a lien for the keep of horses, unless by special agreement with the owner of them; and that if they were 
satisfied that there was an agreement to that effect, and that Wallace had removed the horses to defraud Woodgate of his lien, then their verdict must be for Woodgate, which they accordingly gave. It appeared that Woodgate was a dealer, and had sold Wallace three horses, and taken his bills of exchange in payment. As well as being a horse-dealer, Woodgate kept a livery-stable, into which (out of the sale stable) he removed the horses in question; but there was no evidence to show that there was any agreement made that they should remain there until their keep was paid for. Wallace was in the habit of using the horses whilst they were kept by Woodgate, and one day, under pretence of using them, took them entirely away to another stable. Woodgate, finding out where they had been removed to, in the absence of Wallace, repossessed himself of them, upon which Wallace brought his action; and the defence was that Woodgate had a right to retain the horses until the keep was paid for, he having a lien by agreement.

There is yet another phase of the law of warranty we had nearly overlooked. We give it in the subjoined paragraphs:-

"As to resale by a purchaser with a warranty, where a th purchaser, relying upon his warranty sells the horse to another, giving a similar warranty to tho one he received, and upon its failing an action is brought against him, and he gives notice of such failure and action to the original seller, who gives no direction for defending or abandoning the cause, the costs sustained thereby will be added to the amount of the original damage accrued by reason of the false warranty, and the second seller will be entitled to recover the sum from the original vendor. It must, however, be proved that the horse was unsound at the time of the first sale.

"Where a horse is delivered to a smith to shoe, and he injures him, an action can be brought. So if he delivers him to another smith, the owner may have his action against the latter. And it is said that an action lies for not shoeing according to promise, if the horse is injured from the want thereof.

"Formerly it was understood, if a veterinary surgeon undertook to cure a horse of any malady, and through negligence or unskilful treatment he died or was injured, that the owner could recover the value of the horse in an action against the surgeon, without proving any express agreement, on the ground that whoever undertakes a duty is bound to exercise proper and competent skill in his occupation. This doctrine, according to Professor Coleman, was reversed in an action wherein he was a witness, and bore testimony to gross mismanagement on the part of a veterinary surgeon; notwithstanding which the jury, under the direction of the judge, returned a verdict for the defendant."

As a good typical example of the perils of warranty we may relate the details of the case of Botterill $\nabla$. Batty, which lasted three days in the Court of Queen's Bench, before Chief Justice Cockburn and a special jury. The action was brought to recover $\mathfrak{1 2 5 0}$, the price of a four-year-old chesnut hunter, sold by the plaintiff to the defendant on the 26th of July, 1861. The defendant paid $£ 50$ into court, and, as to the residue, pleaded "never indebted."

The horse, whicn was the subject of dispute between $\mathrm{Mr}$ Richard Botterill, of Garton, in the East Riding, and Mr. John Batty, of Bishop Monkton, near Ripon, appeared to have been a remarkably fine animal. Mt. Botterill bought it in November, 1860 , for $\mathfrak{L 7 5}$. It was worked a little in a light chaise during the winter, and was broken in during the spring. On the 15th of July, 1861, there was a show at Leeds, and the horse carried off the second prize. On the 26 th of the same month there was a very large show at Driffield, and the horse carried off three prizes-as a fouryear-old, as a hunter, and as the best horse on the ground. In the interval between the two shows a little hair had been knocked off one of the hind legs, either in the railway truck or by some slight blow from shying at the station. But the material question did not turn upon the injury, which was noticed by the vendor and vendee at the time of the bargain at Driffield, but upon the question whether the horse was naturally sound or not. Mr. Botterill arranged

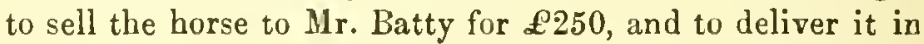
a day or two. Mr. Botterill sent it over to Malton on the 8th of August, and in a day or two it was taken thence to Bishop Monkton. Within a very few days Mr. Batty sold it for $\mathfrak{2} 260$ to Mr. Chinnock, near Reading, and Mr. Chinnock subsequently sold it for $£ 270$ to Mr. Collins, a dealer, in London. Mr. Collins, however, returned the horse, and so did Mr. Chinnock, and Mr. Batty desired to return it for unsoundness, or to reduce the price to $£ 50$, which he had paid into court, as its full value.

The case for the plaintiff was that the horse was perfectly sound on the 26 th of July, and that any defects now visible had arisen from subsequent causes, particularly from the effects of epileptic fits and a wound on the head. It was not denied that the horse was warranted sound to Mr. Batty, and Mr. Botterill relied upon the evidence of Professor Spooner, Mr. Bowman, Mr. Holmes, and other high authorities on horses who saw the animal at Driffield, and proved that at that time there were no indications of un. soundness. Mr. Holmes had a horse competing with the chesnut at Driffield for the prize, and if there had been any sympton of disease it would have been a disqualification. Mr. Holmes's horse took the second prize, and he said he should certainly have called attention to any defect in the chesnut had any been distinguishable on the day of the show, which was also the day of the sale.

The case for the defendant was that the horse was naturally unsound or affected with hereditary disease when Mr. Botterill sold it at Driffield, and Mr. Field, Mr. Mavor, Mr. South, Mr. Varrel, Mr. Cox, Mr. Greenway, Mr. Chin. nock, Mr. Brewster, and other witnesses declared most unequivocally their opinion that the chesnut was a "whistler," had splints inside each hind leg, showed enlargement of the hocks, commonly called spavin. on both hind legs, and also 
exhibited a curb on the off-hock. Great stress was laid on the enlargement of the hocks, and Mr. Field said the disease had probably existed for some months. No very great point was made of the curb, and that blemish was attributed to the accident before the horse arrived at Driffield. Mr. Collins, on discovering the "whistling," sent it at once to the Veterinary College, and it was there pronounced unsound, as a "whistler," and having enlargement of the hocks, of long standing, a little below the usual seat of spavin. Mr. Varrel, the assistant professor, admitted that the horse was not now a "whistler," and the enlargement of the bones of the hind legs was the unsoundness upon which reliance was placed.

Ur. Mavur (in reply to his Lordship) said that understanding that this horse had never done any hard work, he was of opinion the bony enlargement of the hocks was constitutional, and would therefore take more time to develop than if the animal had been hard-worked. He examined the horse on the 28th of October, and he thought the disease must have existed for at least three months.

Mr. Richard Barker, of Malton, to whom by defendant's directions the horse was delivered on the 8th of August, said that in his opinion the horse was not deliverable on account of unsoundness. The hair was off the leg and the hock looked large. Mr. Botterill bought the horse of him for $\mathfrak{2 7 5}$, and promised him if he was lucky with it to give him something more. When the horse took the prizes at Leeds and Driffield, witness thought that as a gentleman plaintiff should have given him $\mathfrak{E}$, but he had not found time to do so yet.

Mr. W. Rookes, of Exeter, and other witnesses, said that on the assumption that the horse was spavined it was not worth more than $\mathfrak{E} 40$. Plaintiff's witnesses said that in their opinion the horse was worth $\mathscr{E} 100$ in its present condition, or $\mathfrak{L} 80$ even if spavined, though they did not believe it. They admitted that the horse went lame to-day, when brought down to Palace-yard for the inspection of the jury, but they attributed it to the state of its feet. The jury, after three hours' deliberation, declared their inability to agree on a verdict, and were accordingly discharged. The Lord Chief Justice said that in this rase every effort should be made to arrange matters, because it was very likely it would be tried again with the same result.

This case aptly illustrates that "uncertainty" against which, "glorious" as it may possibly be, we must protest. The phases that a horse-case may exhibit, we are perfectly aware, are all pretty well known beforehand; but who can predict the result, we sbmuld like to learn? Who can aver with anything like certainty what the verdict will be ? unless, indeed, a dealer happens to be the defendant; then it is easy enough to give a shrewd guess that the poor devil will get his "gruel" from a jury of jewellers or drapers. For our part, we must think that this same "glorious uncertainty" is signally inglorious and unsatisfactory. We say, it is rather a serious fact that the hazy state of the law relating to the warranty of horses leaves a larger portion of the public, like so many foot-balls of fortune, to be kicked, and to be made the sport of chance and its thumbscrews. Every man in the kingdom who either buys or sells a horse may be robbed "accurding to law.' He may be plundered owing to the prejudices of a jury, pushed out of court by a crowd of stout swearers, and victimized by the contradictory dicta of veterinary surgeons-who often sell opinions not worth a straw. Sometimes, though rarely, the party is sacrificed to the caprice of counsel, together with the indifference of a napping judge, who sees plainly enough that the little "law" there is in the case is entirely smothered by the matter of "fact," and that portion exhibiting such a mass of agglomerated contradictions as not only to disgust him, but to defy all ordinary perception to distinguish truth from falsehood. Now, no system of law, it is clear, can entirely prevent the patent wrong against which public opinion is roused. What, then, is to be done in order to get rid of this incubus-of this morbid, most mischievous excrescence on the law of warranty relating to horses? This has now become a very serious question. Sporting men especially ask "How is such a thing to be remedied ?"

For purity of administration, there is no place in the world like an English court of law. But who will deny that the law itself-always impartially, and, on the whole, admirably administered-is susceptible of some simplifica tion in horse-warranty questions? Surely there is sagacity enough at bar and on bench to make it plainer to understand - to render it more uniform in its results, and less exposed to the scandal against which the public are in arms. The fraud and the folly, the clashing and the discord,-the exhibition of knaves making a harvest of fools, the conflicting opinions and contradictory statements that startle one's common sense almost every day, the chaotic and unseemly confusion revealed-this state of things, we think, supplies a valid argument for that reform in the law of warranty which the public urgently requires, and which has no practical effect but to favour the fictions, the anomalies, the ambiguities, and we may safely add the frauds, on which the low attorney fattens 


\section{CH AP'TER XII.}

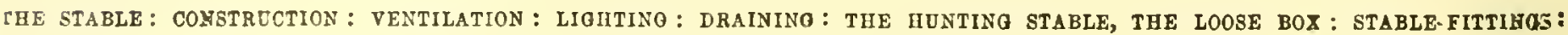
THE HARNESS ROOM.

MODERN research and enlightened experience bring us back from the artificial to the natural-nay, more, prevent us from confounding two things so essentially different. Our athers-those at least, who could afford such a luxury to their quadrupedal servants-baked and starved their "terrible high-bred cattle" in a compound of their own effluvia, consisting of hydrogen, ammonia, vaporized water, with even small doses of carburetted hydrogen and other agreeable airpoisons-and then pointed to their "blooming coats" as proof positive and irrefragable of their success in producing "high condition." How often they shortened life, how they destroyed the respiratory organs, how they filled their stables with inflammatory disease, let the old farriery books show; we have, however, less reliable statistics on this point than on the frightful loss of human life in the miasmatic dens of our great cities at the same period. We have scarcely yet, except in the stables of the wealthy and the enlightened, entirely overcome prejudice and tradition in this and other respects; but we hope yet to see thorough ventilation, light (without which there is no true cleanliness), effectual drainage, and moderate temperature, in the abodes of our most valuable of servants. At any rate these desiderata should form parts of the new "Health of Stables Bill;" of which we propose to place the rough draft before the reader, and which we hope, for the sake of the horseconstituency and their masters, will soon become the general "practice" if not the "law" of the land.

We are not about to treat, in this place, of the special racing stable, in which the first favourite for the "Derby" or "Sellinger" is brought into form and fettle at three years old-to fly over about one mile and a half that he may show his nose first to Judge Johnson, Judge Marshall, or old White of Nantwich*-but talk about the fit dwelling in which the serviceable saddle-horse, or park hack, the useful carriage horse-and, where worldly wealth blesses the owner, the stout hunter, with as much blood in him as there is any use for-may be brought out, each and all, "up to their work," and the last-named animal fit for a "long day."

* Bince writing this, "Old White, of Nantwich" has left his "chair" for ever
The regular hunting and training stables of large establishments are usually substantial and well-built edifices, and not a few, such as those at Goodwood (Duke of Richmond's). at Badminton (Duke of Beaufort's), at Billesdon Coplow, late (Mr. Lyne Stephens's), in Norfolk, and other places, exhibit great skill in design, and lavish outlay in construction. As a town stable, that of the Earl of Shelburne, in Bruton Street, though necessarily irregular in its form, from its adaptation to existent surrounding buildings, is a good example of plain and judicious arrangements, and comfort. able provision for horse and man. However, as it is prepos. terous to suppose that all stables can be brought to their standard of excellence, we will proceed to generalize on the desiderata of a horse's dwelling.

As stabling the horse is primarily a deviation from nature, it follows, as an inevitable sequence, that it often pares the way to disorders unknown, or varying in character from those of the animal in its aboriginal state. This tendency can best be obviated by judgment, care, and serlulous attention.

Space is an important element in stable arrangements. "Single-headed" stables, that is, those that have but one row of stalls, should never be less than twelve feet wide; while "double-headed" ones should be twenty-four feet, with sis feet six to seven feet each stall, by six feet wide. "Stable architects," says Mr. Stewart, in his clever work called "Stable Economy," " have not much to boast of. Their sole ideas are limited to shelter and confinement. If the weather be kept out, and the horse be kept in, their objects are attained. If light and air be demanded, the doorway will admit them. If the horse has room to stand, it matters little though he have none to lie; and if you can get him into the stable, what consideration is it, though his loins be strained, or his haunch bruised in getting out of it?" Narrow stalls are high)y prejudicial to horses; back-sprains are often produced by them in the attempt to turn the horse in his stall: whenever this is less than six feet wide, caution the groom always to back the animal out of it. Swinging bars or bails are highly objectionable, from the temptation to horses to play with each other, and to kick under or over them, according to height. They are also objectionable, inasmuch as horses vary as much as human beings in quickness of eating, and the tardy masticator gets robbed of his food bo the rapid swallower. 
Heat and cold should be graduated by the thermometer: the feeling of a groom or owner is a very fallacious guide. In summer $65^{\circ}$ to $68^{\circ}$ as a maximum, if possible, and in winter never below $50^{\circ}$ With horses, however, that must be kept up to the bright coat, we may spring a few degrees, and say $68^{\circ}$ as an average. As temperature is intimately mixed up with ventilation, and that with light, it is desirable to have the stables sufficiently airy without cold or draughts. It is taught in the old books that the horse, and the blood-horse especially, being originally the denizens of a torrid country, require not only warmth but heat in this northern latitude This notion was formerly carried to a most mischievous extent. Moderate warmth is doubtless congenial to all horses; but a high temperature is only permissible in a stable to produce and maintain the artificial state to which our summer-flyers of Oriental descent are brought for their few speedy strides over the turf, on the rare occasion of their carrying the silken jacket and its light-weight wearer. Such animals have their clothes on when led or ridden to paddock, or tan-gallop, close to the door of their country seat whereat they train and exercise. Nevertheless, even in this exceptional class, the excessive heat, especially in stables where there are several horses, is by no means necessary or beneficial even to the horse of stainless blood. Many of these have we scen-the more the pity!-who, worn by age, lameness, or accident, or perchance rejected for vice, engaged in the meanest and hardest service; exposed in all weathers, working in a Hansom cab! or that heavy town cart known to Cannon Street and Cheapside travellers as "the phee-a-ton," wherein your Manchester or Bread Street warehouseman packs his pattern-boxes, his samples, and his goods. Yet do such unfortunate outcasts from aristocratic horse-palaces adapt themselves to circumstances, and live to the average period of the fashionable racer; proof positive that the respiratory and secretory organs had kept their efficiency under all the variations of temperature of our variable climate. In confined stables, where the same air is breathed over and over again, and where the heat exhales unwholesome efluvia from every excrementitious matter, to clog the lungs and prevent the due oxygenation of the blood, where, too, the very food is deteriorated by these exhalations, we have a large percentage of the diseases which go to swell the treatises and lengthen the bills of our veterinary professors. The improvements in the ventilation of the stables of our cavalry horses have, of late years, wonderfully diminished inflamed lungs with its perpetual v. s. (vence sectio) in the veterinarian's diary. Grease, glanders, and farcy, too, have decreased in a like ratio. When any epizootic is raging, it is always found to be most severe and intractable in crowaed stables. Thus, when on board a transport during a storm, the standings of some cavalry horses were of necessity battened down, acute glanders immediately broke out among them, and carried almost all of them off; the princioal cause of the mortality arising from their own exhalations. With a full conviction, then, of the prime necessity of rendering stables moderately warm, but yet more of the importance of their thorough ventilation, especially where the standings are numerous, we pass to the general construction of a stable.

Although stables have not always choice of situation and aspect, these are often neglected where they are at com. mand. A south-eastern aspect for doors and windows is preferable: as dampness of the walls, too, is a fruitful cause of disorder, some of the methods adopted in dwelling-houses are worth consideration. Rising damp is a great generator of miasma, and may be checked by a course of stone laid in cement, a sheeting of zinc laid on thick plank, or in coal districts by a quantity of coal ashes or dust, the least expensive of all. This is for the footing of the outer wall. We need hardly dwell on the advantages of a dry stable when the evils of a damp one are so apparent; coughs, swelled legs, a rough staring coat, that defies the wisp and the hissing of the groom, are its constant concomitants. In some cases a stove-pipe passed through, or strewing the stables with sawdust or sand, may palliate the mischief.

Nimrod recommends that there should be no more than four stalls in a hunter's stable, and that these should have three horses, being on one side only; the centre partition of two being removable, so as to make a loose box 12 feet by 7 feet; the stable itself 16 feet wide. A pair of carriage-horses, in like manner, should have three stalls: the spare one will be found as useful as a spare bed in a house, in case of emergency; one of the partitions also shifting so as to form a loose box for an invalid. Coachhorses, however, are generally in a double row, which takes a general width of 20 feet from wall to wall. Each stall 6 feet 6 inches to 7 feet, by 6 feet wide. Isarge cart-horses will need yet more room.

The walls should be stone or brick, the latter the best, and 9 inches thick at the least-13 incles are better. They may be plastered or boarded, the latter the best, up to 3 feet from the manger, and plastered above: although a smooth-dressed wall is as good as either for utility. The stable should be lighted from above if possible, or if it is a single-headed one, from behind the horses' standings: this aroids glare. If the hayloft is above, lighting from the roof will of course diminish its capacity, but this is of minor importance. The ceiling must be plastered, firstly, to prevent the impure nitrogen and ammoniacal gases from ascending to the has and vitiating it; and, secondly, to prevent the hay-seed and dust from falling into the horses' eyes. White, the veterinarian, approves of an unplastered tiled roof (where there is no loft above); but Stewart, a much better authority, condemns this for any but the commonest of agricultural horsis. Where there is a loft above, 8 to 9 feet are a good height for the ceiling; which when too lofty is cold, when too low requires draughts and currents to too great an extent to be safe for the horses 
lungs and skin. Where there is no loft, the height should be greater, or the stable ceiled, otherwise the tiles and slates will make the stable an oven in summer, and snow on the roof convert it into an ice-house in winter.

The importance, then, of avoiding sudden and extreme alternations of heat and cold must be one of the points studied in the construction of a healthy stable. We have seen of late years, at the new Palace of Westminster, and in Jur Law Courts, how our scientific men have alternately chilled and baked the persons of our peers, the "collective wisdom " at St. Stephen's, and the frequenters of our Courts of Justice. Sometimes this has been effected by hyperborean blasts through pierced floorings, or ascending currents through cocoa mattings, and the like permeable contrivances. Then, by way of per contra to these draughts of "cold "rithout," up the trowser-legs of auditors and jurymen-not forgetting the inflation of the judges' robes-they have changed the tap, and turned on their "warm with," from ingeniously contrived furnace-flues, to such an extent, that it is only a few weeks since a learned judge in one of our Courts, finding that "science" had fastened up all the swindows of the reeking Court during the blowing of this jirocco, ordered an attendant to resort to a primitive mode of ventilation, by smashing the window-F anes. We fear the remedy was about as bad as the disease. There is a Spanish proverb-

$$
\begin{aligned}
& \text { "When the wind blows through a hole, } \\
& \text { Make your will, and take care of your soul;" }
\end{aligned}
$$

and if this is sound advice to the biped, it is no less so to the keeper of the quadruped. Change from one extreme to the other must be carefully guarded against. The late head of the Veterinary College, Professor Coleman, however, inculcated this error in his teaching, on purely "scientific principles;" which had only one drawback - that such "principle" was utterly erroneous. He says:- "In the formation of stables, let the rack be in the centre; two apertures, about 3 inches by 2 inches, or 3 inches by 4 inches, should be made on each side, as close to the horse's nostrils as possible; and two similar holes at the bottom." The Professor then assigns as a reason-that "the oxygen is in largest quantity in the lowest or heaviest stratum;" therefore, there will be no dranght inwards at the upper holes. We know differently. The theory reminds us of the old story of the Merry Monarch, who gravelled the savans of the Royal Society with the problem of the fish and bucket of water, which the royal mystifier suggested added not to the weight of the vessel and contents while it supported itself therein by the motion of its fins, but made so much the heavier, by its own specific gravity, when it lay at the bottom. The courtier-sages were seeking a solution for the royal problem, when one boldly said, "I deny the fact." "And so do I," said the king, laughing. The holes near the horse's nostrils are in the same category; the wind will blow where it listeth, in spite of the stratum theory of the Professor. It must, however, be admitted that the renewal of the air in a stable is indispensable to the well-being of the inmates; and the question is-how this can best be effected?

Whatever difference of purity may be attributed to the air of cities and of the country, the degree of agitation of the air has a marked influence on the extent to which the chest dilates itself. The slightest agitation of the air, when its state of dampness, dryness, and temperature are properly adjusted to the system, produces such a feeling of relief and of pleasure as to dilate the chest immediately, so as to drink in, as it were, a larger volume of the grateful and genial air.

The operation of heat upon the living animal is always stimulating; the operation of cold (or more accurately the absence of heat) is tonic or debilitating, according to its application. The animal frame, like inanimate matter, is liable to have its caloric extracted-abstracted externallyby the application of a colder medium; but its inherent powers of life quickly restore the equilibrium when the cold has been moderate and of short duration. Indeed, the evolution of heat generally exceeds the previous reduction of temperature, as is shown when the body is immersed in water. The pores in this case are strongly closed, and so are the extreme vessels on the surface of the body. The blood is impelled with increased momentum by the heart, and if the body be now emerged the reaction of the vital circulating fluid determines it to the surface, and a genial glow succeeds; but if the pores be too long closed-if nature be not thus relieved-and the cold is unduly prolonged, the effort to throw off the mischief assumes the character of general inflammation.

Pure air, then (and, as an accessory, cleanliness), being a prime necessity to the health of domesticated animals, those who desire a healthy steed will see to these most important points. As a simple mode of attaining a full supply of pure air, two sets of apertures are necessary: one set in the upper part of the stable, for the escape of the impure and heated air; another close to the floor, to admit the pure and unexhausted air. These latter openings must be so contrived that the air on entering shall not be directed in a current on any part of the horses, but diffuse itself gradually throughout the stable. The same rule must be observed in the upper ventilating apertures; and, as the air which has been expired ascends in a direction perpendicular to the horizon, these apertures should be placed upright. When this is not easy to effect, then they should be as near the ceiling and as far from the horse's nostrils as possible. They may be made oblique, which will give exit to the current of heated air, and protect the stable from rain and wind. But as, owing to the construction and confined situation of some stables, or from floors above, these openings cannot be made, then small tubes may be opened into the stable, in the ceiling, or as near its height as possible. These may be carried into a flue to the top of the building, or outwardly with perforations in the wail. 
A plan adopted by Mr. Brett, V. S. of the 12 th Lancers, at the barrack stables at Manchester, is described in "The Veterinarian" (vol. vii., p. 483), which may afford some hints in the case of stables unfavourably situated; we shall, therefore, transcribe it in the writer's own words:- "Suppose a stable to be blocked up by other buildings on all sides except at its two ends; in that case I propose to have a large wooden tunnel, two feet square, running the whole length of the stable under the mangers; and if it should he a double stable, one tunnel under each row of mangers. These conduits are to come through the end walls of the stable, and to be open at both ends on the outside, for the purpose of admitting a thorough draught or body of air through them This main stream of air is to be equally dispersed about the stable by means of perpendicular wooden shoots or chimneys, six inches square, emanating out from this main tunnel, one at the head of each stall partition. They should be seven or eight feet high, so as to avoid a draught on the horse's eyes, and open at their tops like chimney-pots, and should stand out two feet from the wall. The rarefied state of the air in the stable will cause a constant flow of cool air through this main tunnel and up these chimneys; and will equalize the temperature of the stable, and entirely obviate the drauglit of wind that blows in at the horizontal holes in the walls of our stables, as at present ventilated. These perpendicular chimneys may have one or two other apertures in them besides the one at their tops, at different heights, that may be opened or closed at pleasure, to admit air by means of a door with a hinge and button opening on that side next the wall, whereby a direct current of air on the horse will be averted. If these air passages should not be thought sufficient, other horizontal tunnels, branching from the main one, might run from it at right angles under each stall partition, and terminate in a perpendicular wooden chimney, six feet high at each heel post.

"But supposing the stable not to be blocked up on any side by other buildings, I would then dispense with the longitudinal main horizontal tunnel altogetler, and break a hole, two feet square, through the wall, under each manger, in each stall, and in a line with the stall partitions. These apertures should be fitted with square wooden tunnels, each two feet long, exclusive of the thickness of the wall, and closed at their ends which are inside the stable: out of each of these short horizontal tunnels a perpendicular shoot or climney, in heiglit six or seven feet, and open at the top, should ascend for the admission of fresh cool air. In the seiling, directly over each horse's head, a hole is to be broken through for the exit of the contaminated air, and a passage given to it through the roof by means of perpendicular wooden chimneys sheltered at the tops by curved tiles, to prevent the descent of rain on the horses: this could be effected notwithstanding that either a loft or a soldier's room were over the stable The whole being of wood,* the

- We should prefer the tunnels of a fire-proof materia! expense would be inconsiderable, and the henefit from s thoroughly and equally ventilated stable great. In a troop stable of sixteen horses the air admitted by the half-door or window is very unequally distributed: the coats of those horses next the doors are staring, while the centre horses can scarcely get a breath of fresh air to inhale. The mode of air by direct holes in the bottom of stables, though certainly better than none, is a rude contrivance. The air rushes in on the animal as he is ir his stall, which the groom perceiving, nevers fails to stop them up with bedding; and thus the mischiefs to eyes, lungs, and thence to the blood, go on increasing."

One of the best methods, where not precluded by some of the circumstances above noted, is as follows:-Revolving ventilators, as a general rule, we do not approve. A centre funnel, of large dimensions, should be let into the ceiling, its larger end downwards : at top of this should be an overhang. ing lantern, cap, or dome, having at its sides louvre boards moving on a centre horizontally. These may be regulated by two cords-one on each side of the lantern-so acting that the two opposite sides may be opened or closed to any degree required; and, if necessary, the windward one independently of the leeward, and vice versa. Air may then be admitted by the upper parts of the windows, as in hospitals, \&c., and will discharge itself upwards: the apertures to be regulated by season, circumstances, the health $\rightarrow$ d number of the horses, \&c. ; extra warmth being indispersable when horses are shedding their coats, or under pliysic.

We cannot quit the subject of ventilation without endeavouring to impress on the reader the importance, nay, the indispensable necessity of a clear comprehension of its influence on the animal economy. The respiration must not be considered, as is too often taught in elementary handbooks, as a mere chemical process-a simple combustion in the lungs, in which the oxygen of the inspired air unites with the carbon of the blood, to form carbonic acid, and then be expelled from the system. Respiration is a function much more complex : it consists of absorption and exhalation -the attributes of all living and breathing beings; and, farther, in the assimilation of tivo constituents of the air, oxygen and azote. The living principle is, then, par excellence, the breath, and through that the blood. The vital principle, then, is more readily acted on by the lungs receiving impure air, instead of its natural food, pure air, than by any other circumstance whatever. The lungs, let it never be forgotten, are a second stoinach, and the respiration but another form of digestion When food enters the stomach its nutrient parts are separated and converted into chyle; when air enters the lungs its vital properties are separated to repair the waste and purify the blood which builds up the animal system. If the stomac!. receive impure and unwholesome food disease is induced, if the lungs receive eflluvia from decayed animal or vegetable matter, instead of pure atmospheric air, then also the system becomes diseased. 
Glanders and farcy may be adduced as proving this fact. Both these diseases are originated by breathing aerial poisons, and the disease of the blood is the cause of the disease of the solids. When a horse is infected with the disease called the glanders, he will be found also farcied. The poison at first develops a local disease, which after a time travels through the system. In the case of direct inoculation with the virus, how is the poison conveyed to the other parts from the original sore but through the agency of the contaminated blood?

Quitting, however, a strict medical view of the evils of a want of judicious ventilation, we would ask any sensible man to enter one of these hot and pestilential stables at early morning-when the breath of its quadrupedal occupants has become an almost putrid exhalation, and the reeking atmosphere damps and saturates the walls-and ask tim whether such an atmosphere must not impair vitality, deprive the blood of red colour, and thereby render it unfit to stimulate the heart and feed the other organs through which it circulates. Reflect too on the deterioration of the stimulus to the energy of the brain, and thence its evil effects on the digestion, circulation, secretions, and eventually on the wind, endurance, souudness, and temper of the animal, and you will surely see to this important element in the construction of your stable. Mr. Karkeek, whuse researches on aerial poisons are worthy perusal by every one who loves and values his horse, says on this point:- "We have frequently observed a kind of balance between the respiration and the digestion; and he who is a careful observer of horses in a healthy as well as a diseased state, must have noticed that there is a certain balance between the quantity of vital air received into the lungs, and the quantity of food which can be digested in the stomach."

We have spoken of the expulsion of carbon from the system, and the results of some of the experiments of skilful investigators are too curious and instructive to be passed over.

An animal of the ordinary size, in a good state of health, gives off $27 \frac{1}{2}$ cubic inches of carbonic acid gas in every minute; in 24 hours 39,600 cubic inches (in round numbers $40,000)$. 100 cubic inches of this gas weigh $46 \frac{1}{3}$ grains, 40,000 then will weigh 18,532 grains. A volume of carbonic acid gas weighing 100 grains contains 28 grains of carbon; 18,532 grains will contain 5,190 grains of carbon or nearly 11 ounces, so that two-thirds of a pound weight of carbon is daily expelled from the blood and carried off by the process of healthy respiration.

Lavoisier, the eminent French chemist, gives a striking proof of the sensible deterioriation of air, where a number of animals are confined in small space. When the air out of doors contained 27 parts of oxygen and 73 of nitrogen $=100$, the air in the lowest ward of the Central Hospital in Paris contained 25 parts oxygen, 71 nitrogen, and 4 of fixed air $=$ 100. Before the play in the theatre of the Tuileries the air was 27 parts oxygen, 73 nitrogen; towards the close of the performance it was 21 parts oxygen, $76 \frac{1}{2}$ nitrogen, $2 \frac{1}{2}$ fixed air. Hence in the hospital the vital air had been diminished as 21 is to 27 , or nearly one-fourth. Thus, in all badly ventilated stables the air contains three fluids instead of two. the third most deleterious to life and health. The relative gravities of these gases may be seen in any good chemical work.

"As there are a number of bodies constantly abstracting oxygen from the air, it might be imagined that its relative quantity would decrease; but no such diminution takes place, except in instances, even from some local cause, where carbonic acid gas is evolved much faster than it can be removed. The fact is, that, if oxygen be absorbed from the air by one class of bodies, it is supplied by another. Plauts yield it in large quantities. Thus, by the respiration of animals, a portion of oxygen is withdrawn, and a corresponding portion of carbonic acid gas is substituted in its place. By the respiration of plants the carbonic acid is withdrawn, and an equivalent portion of oxygen substituted; so that, by the mutual action of the members of the animal and vegetable kingdoms, the balance of the constituent elements of the atmosphere is maintained.

"The blood requires pure air as its food; the first effect of the air is to remove the carbonic acid, which the venous blood takes up in the circulation, and when this is effected the properties of the blood become instantly changed. In the commencement of this process the air is the active agent, and removes the carbonic acid from the circulation; but when this is cffected, the blood then becomes the acting power, and attracts a portion of the atmosphere. The pure air, or at least it ought to be so, then occupies the place of the carbonic acid, which is just removed."

We shall conclude this subject of ventilation in the words of Mr. Karkeek, from whom we have quoted the above:

"Against the influence of noxious agents the living body is endowed with a power of resistance, which affords it security as long as its vital energies continue vigorous; but when these decline, the very causes which before made no impression upon it, now prove fatal. Hence, the weaker the body, the more susceptible it is of the influence of physical agents, and the less it is capable of resisting the influence of those that are noxious.

"Air, moisture, and heat are the principal agents which a living system has to contend with, and it is found capable of resisting them in proportion to the degree of vitality which it possesses. When the vital energies fail, putrefaction ensues, and it is soon resolved into the ultimate element of which it was first formed. By this process, the stately oak and the bramble, the creeping insect and proud and imperious man, pass back to their original and primeval elements. Thus, to put an animal into 'good condition,' is to increase the preserving powers, which, as it were, preside over its economy, repel the attack of injury, and guard it from the dangers with which it is incessantly surrounded."

Light.-Immediately connected with the subject of venti. 
Lation is the kindred topic-light, on which we now propose to say a few words.

Did the reader ever emerge suddenly from a dark cellar, or cave, or some place whence the sun's rays being excluded, the "palpable obscure," the "darkness visible," had dilated the eye to its utmost, in the endeavour to distinguish surrounding objects? Let him recal the painful giddiness of the distressing interval when the eye was suddenly called on to contract, and to accommodate itself to the bewildering glare. Now suppose, farther, at that instant a stranger, or even an old friend, had saluted you with a hearty clap on the shoulder, and an exclamation such as "Halloo, old fellow, you seem all abroad!" Should you consider yourself highly to be reprehended, nay, more, deserving of corporal punisliment, if, under such circumstances, you started with surprise, mingled with some alarm and bewilderment? Well, then, we have often seen this very thing done to an unfortunate horse. Confined for hours in a stable, with just so much light as will suffice to render the outlines of objects visible after the eye has fully adapted itself to the gloom; the principal aperture for the admission of lightthe door-is suddenly opened, the groom enters, and the coach-horse or hackney is led forth to be dressed. The horse is, for a few seconds, nearly blind, and painfully so. He strikes his haunch or stifle against the bar or the doorpost, and instantly is sworn at for his awkwardness; next moment he starts from nervousness, at the approach of some to-him-indistinct object, and he is pronounced a "starter," "uneasy to groom," \&c., \&c.; this character established, he is, upon such occasions, in the absence of the master's eye, treated to various little kicks and cuffs, and sly knocks, with a running accompaniment of objurgation. Can there be imagined a more efficient course of education to produce "starting," a threatening or vicious ittitude, or any of the other abominable habits to which imperfect vision and its attendant panic fear are calculated to give rise?

Then, again, the darkness of the stable is, we need hardly say, a cover for and a promoter of uncleanliness. A good large glazed window or two, in every middle-sized stable, would show the inattention or the neatness of the attendant. Darkness also greatly encourages the fermentation of the litter, and the evolution of the pungent ammonia so injurious to the eyes of the horse; leading often to inflammation, thence to blindness.

If, on the other hand, the stable have plenty of light, then the part of the wall which is opposite to the horse's face, and which from either side throws its refracted rays on the animal's eye, should not be of a glaring colour. The reflection of a whitewashed wall, where, from its aspect, the sun shines into a stable, is as injurious to the sight as the sudden alternations of which we have just now spoken. The stimulus is most mischievous, as the unfortunate animal is so situate as to be unable to relieve itself by a glance over a verdant landscape, or have the comforting sight of a brown or drab road, rock, or commron. Not many years ago, for instance, at a seminary connected with a certain religious institution, one of the inmates, a young woman, was, as a punishment for sundry real or imaginary breaches of discipline, sentenced to sit opposite a blank whitewashed wall for a certain number of hours per diem. The result was not exactly what was intended; the poor girl's eyes inflamed, the white wall became blood-red to her tortured vision, and she went incurably blind. This is an extreme case; but how many horses may owe their loss of sight to a want of care in this respect by their masters and their grooms? The fading light of day will usually bring the hour of rest. When, however, the hours of the horse's labour are at night, something approaching the dimness of twilight seems most grateful and natural to the animal, and to induce feeding and repose.

The Floor.-As to the slope to be given to the floor of each stall, many of the older stables have an undue declivity to the drain; although the rapid carrying off of the urine is certainly desirable, yet too rapid a slope strains the back sinews, and is not an unfrequent cause of occasional lameness. Mr. Isawrence illustrates this by a clear example, founded on a just observation of the horse's foot as campared with the human leg. "If the reader," he says, "will stand for a few minutes with his toes higher than his heels, the pain he will feel in the calves of his legs will soon convince him of the truth of this remark. Hence, when a horse is not eating, he always endeavours to find his level, either by standing acress his stall, or else as far back as his halter will permit, so that his hind-legs may meet the ascent on the other side of the channel." Blaine, too, judiciously remarks :-

"In the stables of dealers in carriage-horses, an ascent in the standings of nearly two inches in the yard is sometimes made, to give a greater appearance of lieight to the yet unfurnished four-year old horses, which are thus often passed upon the unwary as horses of five years old Is no strain put upon their legs? Our experience, which has been somewhat extensive in these matters, convinces us that the inequality in the standings of horses is a fertile source of contraction of the feet. What but the pain and inconvenience which follow an uneven position occasions horses, when not feeding, to be so frequently found standing across instead of lengthways in their stalls? How frequently also will the horse boxed in a stall be found with his croup turned towards the manger? To avert these evils, and yet to prevent the retention of the urine, the smallest possible slope should be allowed, which should proceed uniformly to the bottom of the stall. A central grating with a sess-pool is an imperfect remedy for the evil ; for there must still be a general inequality of surface to carry the urine to the centre. It is farther injurious by retaining the urine we wish to avoid, and moreover it promotes a draught of cold air from without, if it be so constructed as to carry the urine out of doors. It may also be remarked that a central cess-pool is utterly useless for mares. It is therefore the best plan to 
furnish each stall with a grating placed over a small trapped drain, at the foot of each stall, which will carry off both the urine and the washings into one general cess-pool out of doors, and from which, being stopped by the trap, nothing offensive can pass up through the gratings."

\section{GONTING-STABLES AND THE LOOSE-BOX.}

A short look into the hunting-stable will properly introduce the subject of the loose-box, and prevent repetition elsewhere. Of course, we do not mean here to enter upon the vexed question with which "Nimrod" so long agitated the equestrian world, as to "summering the hunter" on the "hard-meat," or on the "green-soiling" system, but to say a few words on the hunting-stable and its occupants. The humane sportsman desires and delights in the good treatment of the gallant animal that bears him in the chase, and the arrangements of the best stables in the kingdom-those of the Queen, the Billesdon Coplow, the Craven, Mr. Lyne Stephens, and the late Thomas Assheton Smith, Esq. (see "Diary of a Huntsman")-shall furnish the bases of our hints.

The Billesdon stables (See Ground Plan on Plate) were built by Lord Suffield to accommodate forty-one horses, and contain thirteen boxes, each nine feet by fourteen, with four feet space behind, and twelve feet high. There are twenty-four stalls, each six feet two inches wide, by eighteen feet deep, and twelve feet high. There are, besides the hunters' stalls, four stalls for lacks, a coach-house, hay and straw-rooms, a granary, a forge, a saddle-room, dressing-room, and a covered ride. The mangers are divided into two parts, one for corn, and the other for hay; that intended for corn does not reach the wall by more than half a foot-that which receives the hay, on the contrary, extends to the wall, or is bottomed with a grating, which lets the hay-seeds, dust, \&c., drop through. This is valuable to the owner of grazing land in the neighbourhood, who is thus benefited by a large saving of useful seed. The general width of the stable being eighteen feet, and the depth of the boxes fourteen, a passage of four feet is left around the inner area; but the doors of the boxes are so made that, in cases of sickness, or much ventilation being required, they can be made to continue the sides of the box up to the whole eighteen feet, an advantage in many instances. The benefits of a forge on the premises in large establishments are obvious, the horses are saved from colds, so often caught while waiting in the open forge of the blacksmith; it farther prevents that ill-treatment and teasing at the smithy, which oftens ruins the temper of many a valuable horse; and, lastly, the excuse of the servants for often absenting themselves on these gossiping, and often drinking or skulking expeditions, is taken away. This last advantage is more important than at first sight it may seem.

The Loose Box.-A loose box is an immense comfort to a horse after a day's hunting, or a hard journey in saddle; he can lie in any position that he may find gives the greatest ease to his wearied limbs; and if put into one the night before he is to go hunting, it ensures him a sound night's rest undisturbed by other horses, or persons passing through the place. It is true that this luxury of stretching their legs is not required constantly or generally by horses; for, though, after a hard day's hunting, a horse may, at times, be found lying on his side, with his legs stretched out at full length, he must be very tired or very ill to have recourse to such an unusual position. The reason for this is that the roundness of a horse's ribs is such that it is a most uncomfortable and unnatural position for him to lie on his side for any length of time. A horse in good health, under ordinary circumstances, will never be found on his side; he is either ill or has had an accident, when you find him so. Harry Hieover has some very sensible remarks upon the subject of boxes, which we shall take the liberty of condensing. Having said so much on the formation and structure of boxes, and having pointed out under what circumstances they are most needed, let us see how far they are applicable and useful in general stable practice.

We need not insist upon the fact that the habit and disposition of the horse are those of a very social animal; and although being quiet and alone may at times be good for him, as it is to a sick man, yet solitude, if long continued, is a severe and irksome punishment to him. Any one who has watched the "knuckering" of a horse when his companions return to him after an absence-his silence and uneasiness when left alone, and beyond earshot of some signs or sounds of their whereabouts, is remarkable; and equally so is the general disposition of the animal when at liberty to indulge in that rough sort of amusement which has obtained the proverbial appellation of "horse-play." Of his desire for mutual amusement you may soon have a proof, by placing him in a loose box, with the upper part of the door of iron rods, so that he can watch passing objects, or be on the look out for them. You will find him, when not in the act of feeding, with his nose close to the bars, and taking as good a peep as he can get of the outside world: and if you open the top-door entirely (don't do this if you don't know your horse intimately) he will be found for half the day with his head and neck thrust out of it, surveying so much of the moving scene, and of man's doings, as his horizon will take in. That he is amused and observant, if not reflective, any one who watches his action and eye can see.

Some one may remark that racehorses live constantly in boxes, and do excellently well; but a racehorse is an exceptional animal. $\mathrm{He}$ is bred, trained, and treated in a way peculiar to the high caste to which he belongs, and though we have had a Derby winnes in a street cab (teste Youatt), the racehorse, while he is a racehorse, is kept in a box. He is accustomed to such quarters from his colthood, and his instinctive social qualities are deteriorated thereby, whatever may be done for his speed. Instead of associating with his species, he has no real companions $\mathrm{He}$ does not 
miss his playfellows-he never had any. Instead of missing them or welcoming them, he is kept aloof from them; he is, says a clever writer, in a purposed Hibernicism, "a sort of domesticated wild beast, kept to run for money." Though he is not a "wild horse," he is a "solitary horse." He is brought up upon the "separate" if not the "silent" system of prison discipline; the desire for companionship is dead within him-he is a quadrupedal anchorite, and does not care for his kind. Horses, in general, do better in stalls than in boxes, unless in boxes with racks only between them and their next neighbours. Whatever rural sight or sound cheers the spirit of man, seems to cheer the horse also. Again, horses feed much better from hearing others eat ; and in many instances where a horse, especially after a hard run, would not touch his corn, if in solitary confinement, he will set to grinding when he hears others masticating their provender. There are strong advocates among many of our practical men for keeping valuable horses in boxes; they certainly permit the animal to stand or lie down at pleasure. There is no danger of their getting cast or getting loose; in which case, though horses are social animals, the intrusion into the stall of another horse, by the animal who has got loose, has often produced not only confusion, but the most serious accidents. The term "boxes" is not, however, quite applicable to the places we recommend, they are rather "compartments" for horses. These should be made seven feet high at the rack and manger, and for a yard from the wall, then five feet for the rest of the side, and merely of bars, so closely placed that a horse's nose could not be put through them. These should be of iron. A space for passing should be left behind these compartments-we should say of five feet. The railing at the end should be of wood or iron, so as to give a convenient view of the horse. It may seem superfluous to say that the door should open outwards, and be made so as to fall back, close on the other railings; this will save the horses from bruises in passing in or out. There are many elegant and useful designs for these "compartments" now in the market, and to those who have cash to spare, and room, the plan here laid down may be adopted. The stable with a proportion of two boxes to four stalls will be sufficient for the comfort and health of the horses.

In connexion with the loose box and its advantages in permitting the horse to lie down and rise easily without risk of injury, and the immense luxury to the wearied animal of having his head at liberty as conducive to his speedy restoration, we shall presently note an important though apparently trivial addendum to the fittings recently introduced.

The horse may be prevented from getting cast by a simple invention, which may be easily procured, while his getting loose is prevented by the safety "head collar," which any saddler will supply; and nothing but sheer carelessness can account for a horse getting loose. Double head-collar shanks, with reins, look more stylish than single ones, but the latter answer every purpose. Some horses are fond of rubbing their heads with the hind foot; the double shank or rein is more likely to entangle these gentlemen in this feat of scratching than the single, and risks are as well avoided.

\section{MODERN BTABLE-FITTING8.}

The furniture and fittings of the stable, keeping in view the comfort of the animal, which is no small aid towards "good digestion waiting on appetite, and health on both," comes next into consideration. The neatness, cleanliness, and convenience of the various articles and appliances which modern ingenuity and constructive skill have placed at the disposal of horse-owners, are not their least recommendations.

Many varieties of these may be seen by the visitor to the Crystal Palace, in the carriage, harness, and saddlery department of that monster glass-case ; at most of the agricultural gatherings; and at the establishments of their several manufacturers and patentees. The leading ones are figured on the accompanying Plate.

Although handsome, serviceable, and really good fittings are made throughout town and country of sound hard wood and hammered iron, yet there can be no disputing the superior patterns, the greater cleanliness, durability, healthiness, and convenience of the galvanized, enamelled, or componized iron mangers, water or gruel troughs, racks. \&c., now advertised in all parts of the kingdom.

We need hardly repeat that the old sloped hay-rack of the farmer's stable, filled from above, and from which the horse so wastefully dragged his provender, to the damage of his eyes and nostrils, is utterly condemned, and should be cast forth wherever it yet lingers, and its place supplied by an under-feeding square or corner rack. The obvious defects of the first-named vile contrivance are that the horse acquires the habit of pulling down the greater portion of his hay, with the view of culling, with his fine and sensitive upper lip and his delicate organ of smell, the sweetest and most succulent locks. Hunce, much of his provender is trampled under foot; and, though a hearty-feeding horse will afterwards pick up a great deat of what he has thrown down, a large quantity must be soiled and spoilt. We have seen a third of the whole amount thus lost by slovenly and capricious horses. These defects led to the abolition of the high rask in all well-contrived stables, and the substitution of manger-feeding, in which chaff, composed of equal quantities of clover or meadow hay, wheat, oat, or barley straw, were mingled with the corn or beans. The animal is thus compelled to masticate his food, and cannot, especially with such well-made contrivances as those under notice, waste his hay, while the sharp straw compels a more complete chewing of the oats. We shall answer our old friend Fenwick de Porquet, who so persistently asks us, under the feminine pseudonym of Mary Wedlake, "Do you bruise your oats yet?" in another place, when we come more particularly to the question of food. 
We have mentioned a "fitting" intended to prevent the horse from striking himself when rising; it is represented in our plate (fig. 3), under the name of the ventilating mangerguard, and includes the rack and water-trough. We have seen stables in which, with the same object in view, the rack has been boarded in. This is highly objectionable. It tends to foul the food, and worse, to make the rack-place dark; and we need scarcely repeat that darkness is the parent of dirt. The guard, it will be seen, consists of a light wrought iron rail, fastened at top to a bar following the curve of the rack-manger and trough, and at bottom to a bar which rounds off the angle of the stall. This ventilating manger-guard fulfils every purpose, ensuring the horse's safety from a blow against the edge of the fittings, while it keeps the fodder sweet and well-aired, and the corner in full view and accessible.

We have already remarked upon the danger of a mere swing bar between horses, recommending in all instances a boarded partition. The iron ramp-rail, grooved to admit $1 \frac{1}{2}$ inch planking, with the stable-stall-post, is a neat and most desirable division, whether boarded or open-railed; its appearance is shown in fig. 4. The hexagonal enamelled tiles are used in several of the drawings to line the walls. Thus much of stable-fittings; we will now step into the harness-room.

\section{THE HARNESS-ROOM.}

"Everything in its place and a place for everything" is a motto which should be inscribed over every place where horses are kept, or at any rate be ever-present to the groom or horse-keeper. It is amazing how much needless expenditure of labour, oaths, or ill-temper-how much confusion, how much loss of time may be avoided by regularity, method, and a use of those convenient appliances which modern mechanical skill and ingenuity have placed at the command of every one whose means allow them to fit up a stable properly; and surely no other should pretend to keep horses of a good class than such as can supply them with those conveniences which are necessary to keep them up to the highest point in cleanliness, food, warmth, clothing, and even ornamental appointments. How much of a horse's comfort depends on a well-made well-fitting saddle, a properly adjusted rein, bit, and bridle, and the true setting of his harness horses alone can tell ; and we doubt not, had they been gifted with speech, their "tailors in leather" would have heard of many a cruel misfit, whence "galls," "raws," "sitfasts," from saddles, abscesses on the tongue, and injuries of both upper and lower jaws by the barbarous tightness of the bearing-rein, aud the ill-made, ill-seated "post" of the bit." These and many minor ailments and discomforts damaging to the bealth, beauty, and temper of

* See Mr. Edward Mayhew's work, T/ue Illustrated Horse Doctor, page 61, \&ce, for the injuries to the mouth by ill-made and severe bits. the horse arise from barness badly made or carelessly adjusted and put on. The cleanliness of every part of a borse's clothing is only secondary to its goodness. A peep into a well-ordered harness-room is a pleasant sight; wellkept leather is always supple, soft, and pleasant to the feel, and how important is dryness and "elbow-grease" to preserving this useful material in that condition we need not say. If the harness and "fixins" of the horses are in prime order, we may almost safely trust that man with other details of management with confidence, as it shows he does not shirk labour or spare trouble. He must, however, be liberally supplied with the proper means of doing his work as it should be done. As a peep at a picture is no small aid in quickly conveying through the eye an impression of what a thing should be, we give a sketch (Plate "STABle,") of the fittings of a model harness-room for four saddle and four carriage horses: the fittings being left bare, that their form may be more readily understood (fig. 5).

Foremost of these articles we may note in the centre the stove, in conjunction with the airing and drying horse, an admirable appendage to the stable for drying and airing harness and saddles after use, and also for drying and airing horse clothing and the cloths in general use about the stable. An enlarged drawing of this apparatus is given as fig. 6 , It will be observed that this stove, besides warming the harness room, will supply hot water for the use of the stable. for cleansing the horses, for equine foot-baths, "bran mashes, gruel, and other purposes. Along the side walks of the apartment, on the right hand are two saddle-brackets and two harness-holders; the form of these, and especially the former, will be readily understood by inspecting the enlarged figures 9 to 13 in the plate.

It will be seen that a saddle placed upon this sort of bracket has no tendency to go out of form, but, on the contrary, is kept in shape, and will not be torn or chafed in its padding by removal. Harness also can be placed on the hooks without disturbing the saddle, and the longer jointed ones turned up out of the way when the shorter ones are in use. The ceiling and wall hooks, figs. 7 and 8 , do not require explanation; they are for the purpose of cleaning, and are made of iron covered with gutta-percha. On the left side of the room are harness, saddle, and bridle-holders; these are of iron either galvanised or japanned, and are vastly preferable to the common bracket, keeping the harness in its proper shape-an advantage too often overlooked. More mountings are damaged and broken by the want of such conveniences than would soon pay their first cost. The front flange, which prevents the article falling off, may be inscribed with the name of the horse to which the harness belongs, figs. $9,10,11$.

Two specimens of saddle brackets are given in the plate, the one boarded over (fig. 12), and the second of wrought

* See article "Laminitis" in Vhterinary Division, pos. 


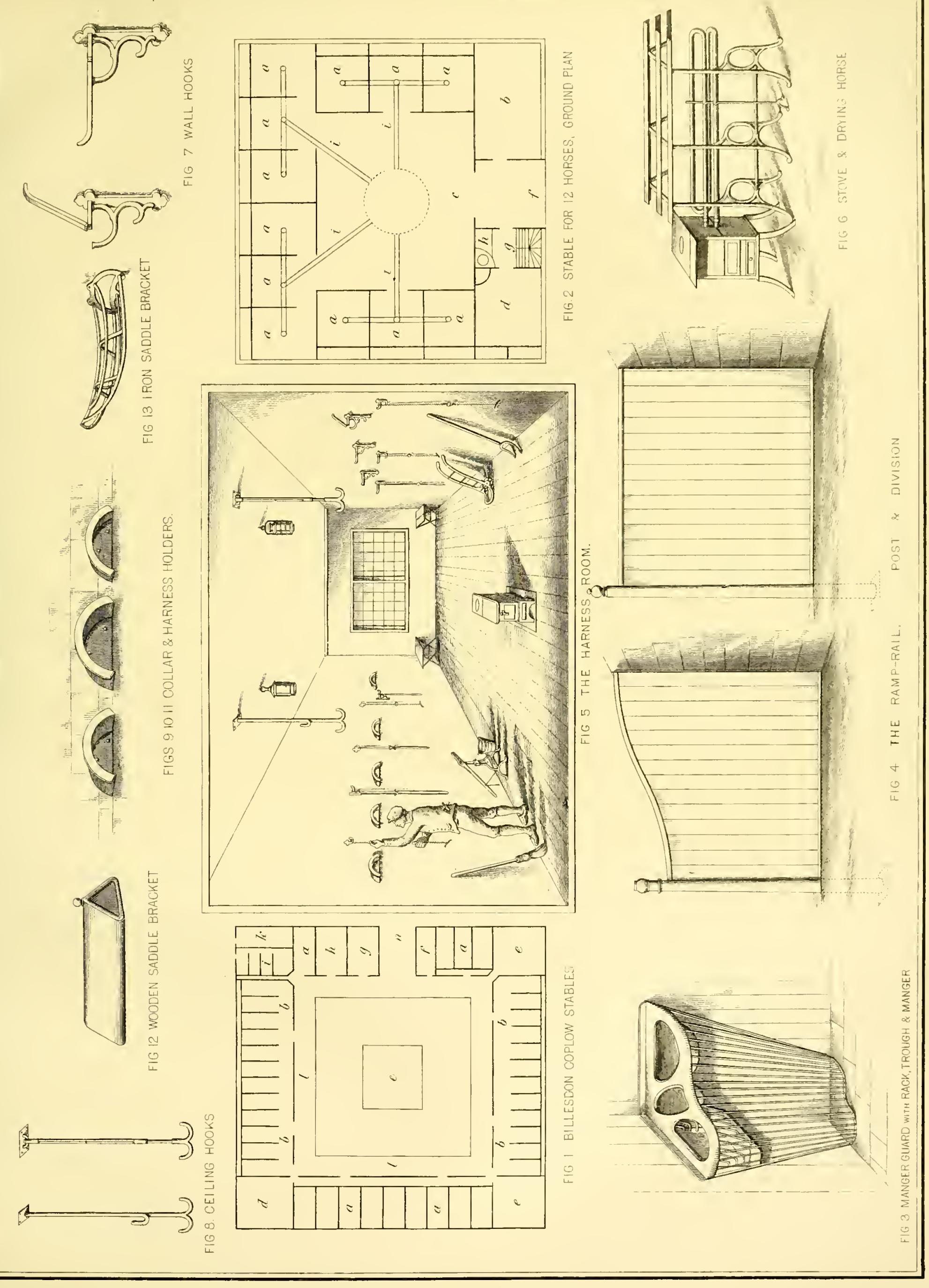



iroll, with the great advantage of ventilating and preserving the shape of the saddle, and allowing all moisture to escape. Some of this pattern (fig. 13), covered with gutta-percha, are tine neatest and best things for the purpose that can well be imagined.

The stable appendages always required, are buckets, whalebone-brooms or besoms, forks, body and dandy-brushes, curry-combs, mane-combs, bandages, leathers, rubbers, sponges, foot pickers, and scissors. If for harness horses and for cleaning carriages, there will be wanted also spokebrushes, mops, jacks, harness-brushes, and brushes for the lining.

The lodging room for the groom or coachman is generally over, or near, the stable; and it should, at all events, be so near as to allow of any unusual noise being heard by him, for sometimes, when a horse is cast, or has the colic, he dies for want of that assistance which could be readily given it his state were known.

The carriage setter, sack-truck, or barrow, pull, jerk, \&c., in our picture of the harness-room, are merely suggestive of those necessaries : they require no description. We should lay ourselves open to a charge of unduly favouring one or the other tradesman did we specially recommend from ous own experience, or that of others, any of the numerous blackings, pastes, compositions, \&c., used in the cleaning of harness; we shall, therefore, merely advise that the purchase of the required detergents or polishes be made of respectable oilmen, or better still of harness-makers : all are good, though some unquestionably better than others. That we may avoid a charge of puffery we specially mention none of them. The sncceeding chapters will deal with the subject of Stable Management, and its auxillaries. 


\section{C노 A PTEK XIII.}

gTABLE MANAGEMENT: THE GROOM: THE STRAPPER: STABLE-BOYS : RACKING AND DRESSING : CLIPPING AND BINGEING : FEEDING : EXERCISE : CONDITIONING.

WE shall not treat of the hierarchy of stable dignitaries in the crack establishments of our great public trainers, where strings of thoroughbreds go through an education to fit them for "competitive examination" for "public honours," at the post of a T. Y. C., but confine ourselves to the useful and practical treatment of the horses of the gentleman and sportsman.

The groom has several distinctive epithets indicative of the description of horse he attends, or of the class of duties expected to be fulfilled by him. The "pad groom" is employed in the hack stable and to follow his master, to whom he also in many cases officiates as valet. If his master sports blood nags, and particularly if he occasionally takes a turn with the hounds, the importance of his servant augments, and he borders on the next grade. The " hunting or stud groom " ought to be a very clever fellow; he should already know much, and be ready to learn as much more; for his is truly an important office, particularly if he have either a confiding or an idle master. It is necessary that he should have a full knowledge of training, with all its important bearings and dependences. He should be fond of the chase, and yet sufficiently manifest attachment to his horses and respect to his master, that he should be able to go to the field without making himself one of the company, or attempting, when in chase, to "ride to" hounds. We, however, to make our subject complete, must quit the field, and glance at these necessary and indeed important aids on the sod or turf. The regular "training groom" is a still more important personage than those already noticed: to him is entrusted the care and management of the racing stables; it is he that regulates the whole discipline of the racers; and he has likewise the direction of the subordinate grooms and stable-lads. The "trials" are conducted by him, and on his fidelity and judgment immense sums are dependent. The "training groom" is also a person of no mean consideration, for much of the future reputation of his employer's racing establishment depends upon him. He superintends the crossings and breedings, and on him devolves the care of rearing the young stock. Much likewise depends on his management whether they enter on their training in high form and vigour, or whether they are below par. Having said thus much, we will proceed with the duties of the groom generally, wherever good horses are kept and good grooming is required.
A good groom is as indispensable to the well-being of the inmates of a stable as a good whip is to their driving, good harness to their comfort, or good food to their health and condition. No gentleman can be well-carried, no family be well-appointed in their equipages, but, by care in the selection of the groom or horsekeeper. Nimrod sensibly says :- "The principal duties of a groom may be said to consist of cleaning - strapping, as it is called,-feeding, and travelling horses. A man should have a certain degree of substance to strap a horse properly; but we do not agree with those who think an herculean monster, whose blows would almost fell an ox, a necessary article. I have seen light lathy fellows full of muscle and sinew that would kill one of these plummy, lumpy gentry There is a wide difference between what John Warde used to describe as a man fit 'to strip a horse and starve him,' and a clean made light-limbed active fellow. Beyond grooming and feeding, I do not wish for much science in a servant-your pedantic, infallible-recipe fellows are no men for my money. Good strapping, and food proportionate to work, is the grand secret."

The "helper" is an adjunct in many stables. He is generally a hardworking man, or lad of eighteen, who is able to strap a horse well, and do all the mechanical work of the stable; but is wholly incapable of taking the management, or is so uncouth in his person as to forbid his employment in livery. The last is a very common reason for some helpers always remaining understrappers; they are excellent in that capacity, but so unwieldy in their movements that they would disgrace a neat livery, and would sit beside their master with all their native clownishness. If, however, they are honest, civil, and industrious, they are often very desirable acquisitions to a large stable, and frequently do all the hard work of these establishments. These men often do four horses well, and in livery yards or omnibus establishments more than double that number; though, in this latter case, the horses are of course not so well dressed as in private establishments.

"Stable-boys" must learn as boys somewhere or other, because it is a trade which is seldom learnt after this age. Nevertheless, no master who really looks to his own affairs will encourage their employment, knowing how frequently they play tricks with or neglect his horses. Under a steady and strict coachman they may be made useful, but they 
should seldom be trusted to do anything of importance out of his sight. When first put under him, he will, of course, show them everything they have to do by example; and, if naturally quick, they soon learn to carry out the ordinary stable operations in an efficient manner.

\section{RACKING AND DRESSING.}

The first morning duty of the groom is "rackıng and dressing." The first operation immediately follows the opening of the stable-door. The hay should be first shaken to clear it from dust, and then but a small portion given to leave the horse his full powers for the digestion of his corn; indeed, were it not from a fear that the eagerness of the early appetite might make the horse swallow his corn without sufficient mastication, we should prefer giving the oats first; and when two morning feeds are allowed, we strongly recommend to commence with the corn. When this is not the case, after racking, give the usual feed of corn, which should be first well sifted and looked over, to separate any extraneous matter. The morning allowance of water is usually reserved until after dressing, but we have known some horses who would not feed until they had drunk. We therefore advise that this time of watering be not obstinately adhered to; hut that it be made to suit the appetites of the horses themsclves. A careful groom will study the peculiarities of each horse, and then his own judgment will be his best guide.

You may now give his stable a slight "set fair :" that is, throw the dung off the litter, but do not disturb that just under him to raise the ammonia from his having staled thereon. Ne are supposing that you mean to give the horse a thorough "dressing" before he goes out. If, however, time does not serve, or there are other reasons for postponing this till his return to stable, you may " muck out" as hereafter described. We will now describe the important operation of "dressing," and would first impress upon the reader the fact, that it is not only to remove soils and make the coat glossy that we "dress" a horse, but that the process is most important, when diligently carried out, for ensuring the health of the animal, by the life-giving excitement of the whole exhalant surface of the body. Scales of scurf-dandriff-are constantly in process of generation over the whole surface of the animal's body; and the act of currying, brushing, and dressing clears off those scales, and stimulates those exhalant and inhalant pores by which excretory and noxious particles are thrown out, and air and moisture imbibed Itching, irritation - and consequent inflanmation-surfeit, and thirst, with a train of minor evils, are kept aloof from well-fed and warmly clothed horses by a diligent application of "elbow-grease;" for able physiologists have shown that the skin not only throws off impurities, but absorbs pure water and atmospheric air, at need, when kept in healthy condition. The observant horse-owner may easily satisfy himself of the fact that a well-groomed horse has more spirit, cheerfulness, and endurance than an undressed one, by a few days' experiment. With horses much in stable, too, periodical friction is exercise without fatigue. The curious reader may find in The Book of the Farm an account of the superior thriving of some pigs who were regularly curried. over those in a stye left to their own nasty ways. The writer, however, observes in defence of poor piggy, that he contracts many of those bad habits from confinement and domestication; and that the wild pig is as cleanly an animal as need be-currying himself daily by drawing himself through bushes, brambles, \&c., and industriously rubbing himself against trees. $O D$ the continent, too, stall-kept cattle are in many places regularly curried night and morning, to the great advantage of their working capabilities. There are two capital books on the subject of grooming, so little known to the general public, that we shall be thanked for an extract or two. The first is "Hipponomia, or the Vineyard of Horsemanship," by Michael Baret, 1720-a curious work, of which Mr. Bracy Clark says: "It contains more learning and reasoning (on horse-subjects) than any book of its time." The other is a little treatise by one Jeremiah Weal, calle? The Young Groom's Guide"-a practical book, by a practical man. The old writer, Michael Baret, shows that the approved method of "dressing" a horse has not varied, except in a few details of fashion and in improved implements, for the last two centuries. "Having tyed up your horse's head," says Baret, "take a currie-comb and currie him all over his body, to raise the dust, beginning first with his neck, holding the left cheek of his headstal in your left hand. Then currie him from the setting-on of his head to the length of his neck, where comes the setting-on of the shoulder. Thence go all over his side to his buttocks; and so down to his cambrel-hough. Then change your hands, and currie him before, on the breast; and laying your right arm over his back, place your right side against his left, and thus currie him all under his belly, near to his fore-bowels; and so all over very well, from the knees to the cambrelhoughs, upwards. After that go round to the far side, and do that in like manner. Then take a dead horse's tayl, or a dusting cloath of cotton, and strike that dust away which the currie-comb hath raised. Then take a round brush made of bristels, and dress him all over, both head, body, and legs, to his very fetlockes; always cleansing the brush from that dust it gathereth by rubbing it upon the currie-comb. Thus currying and brushing over, take a hair-cloth, with which rub him again all over very hard, to take away the loose hairs and help to lay his coat. Next wash your hands in fair water, and rub him all over with your wet hands, as well head as body, for that will fresh him, and take away any hair the hair-cloth hath left. Lastly, take one other clean cloth, and rub him all over till dry, when his coat will be smooth and clean. Lastly, take another hair-cloth (for note that you should have two, one for his body, the other for his legs), and rub his legs exceeding well, from the knees to the cambrel-houghs, downwards, to his very hoofs, picking, 
and dressing them very carefully about the fetlocks from gravel or dust, which will harbour in the bendings of his joints."

From this it will be seen that our great-great-grandfathers knew and practised a thing or two in dressing a horse. There is here, however, a remarkable omission. The wispthe great implement of the modern "strapper"-is not even mentioned. Ordinarily the wisp follows the curry-comb; but where the brush replaces the curry-comb, the wisp follows it. The best wisp is made from about two feet and a-half of a hay-band of fine twist. Loosely untwist and double it, moisten with a little water, and then slightly retwist it: the damping shapes it, and fits it for more effectually cleaning away the dust. As the time required thoroughly to dress a high-conditioned saddle-horse is about an hour, in very cold weather the horse should have a cloth on the loins while cleaning other parts. Stains from litter should be removed by the sponge, and from the tail by the water-brush. When the dust has quite settled, comes the "finishing-off", in the direction of the hair and the clothing. And here we will resort to the little book of Jeremiah Weal, above alluded to:- "Observe that whatever clothing you put on is put on in a workmanlike manner. Take the horse-cloths in both hands, with the outside of the cloths next you, and with your right hand to the off-side throw them over his back, not hang them over his tail. Place them no farther back than they will be straight and level, which you will find to be from a foot to eighteen inches from the tail. Put the roller round, and the pad-piece under it in the proper place, which is from three to eight inches from the fore-legs." So far Jeremiah. Now loosen the horse's head, and turn him about in the stall, and give his untied head a thorough rubbing and brushing in every part -ears, throat, and channel-with the dusting-cloth. Finish by manipulating his ears à la Rarey. This is called "pulling his ears;" however it should be nothing of the sort, but, what all horses so much enjoy, a passing through and through the hands of the animal's auricular appendagesaccompanying their passage by gentle intermittent pressures, and an occasional soothing, coaxing utterance. This over, comb out his mane and foretop, and pass over them a damp sponge; place your horse-napkin at the near side of the upper part of his mane, pulling it over to the off side, and pressing the mane smooth at the root of hair from belind his ears to his withers downwards. Turn him round once again to his manger, huckle on his stall-collar, comb his tail, and wipe his dock with a wet sponge. Don't use a cloth for this purpose, as a hanging-down end may make a ticklish horse kick, as we have seen. Pick out the foot, and wash if necessary, and once more rub the legs down with cloth and with hand. At the risk of repetition, we must once more impress on the mind of the groom, and therefore of the master, the paramount importance of leg-friction. Although Michael Baret, above quoted, has told us "to rub the lejs exceeding well," we cannot forbear from pressing on the minds of all who are concerned in horses, that friction to the legs is both a preventive and a cure of disease. The eminent veterinarian, Delabere Blaine, thus bears testimony on this point:- "Leg-rubbing prevents gorgings, which arc the forerunners of cracks and grease, and disperses such accumulations as are already made Few actions relieve the tired horse more than well rubbing his legs; and it is remarkable, that whatever else a horse resists, he very seldom resists this. Further, whenever a horse comes home in a dirty condition, it is prudent first to attend to his legs and feet, which should be well washed: but when the weather is frosty, it should be done in tepid water; it is essential to his health, and it also affords him much comfort and refreshment. We know how grateful it is to ourselves to put our feet into water after great fatigue; and we cannot but observe by their manner, also, that it is the same to them. The feet of horses require also daily examination; they should always be well picked out whenever they come in, to remove stones and dirt, which may have lodged between the shoe and the sole; and which, if suffered to remain but a few hours, might do irreparable injury. The state of the shoes should likewise be looked to every morning, not only as to their actual wear, but also to see that the clenches do not protrude to cut the legs, or that the shoe may not have gotten awry, or become loosened. Whenever a set of shoea has been on three weeks, particularly where the hoofs grow fast, even if such shoes be not worn out, they should be removed; for in every instance, as soon as the horn of the foot grows too high, it begins to contract; and there are more horses ruined by standing too long without paring down the hoof than by all the bad shoeing that is practised."

Watering should follow dressing, and then a second feed of corn, where four feeds per day are customary : but, if not going out to work, merely put hay in the rack. Jeremiah Weal shall again speak for us, as to "setting the stable fair," as he is in this matter certainly "the right man in the right place:"-" Shake the horse's bed three or four feet behind him, if the stable will admit of it; put some straw under the manger; lay the straw high near the sides of the stall, and rather high behind the stall-post; leave the straw somewhat hollow and thin in the middle, and behind the horse. Shake the sides well, and lay them level and smooth. The platted mat looks neat laid down in front of the beds, but it is more generally seen in dealers' stables than gentlemen's : it, however, looks neat in all."

A few words about "litter." We have already mentioned the pungent ammonia which arises so rapidly in a close and heated stable, to the detriment of the respiratory functions of the animal, and the damage of the hay in the loft above. As much of the litter as has been wetted and softened by the urine must be removed every morning, a little being left for the animal to stale on, as some animals object to and are uneasy at the splashing which takes place on the bricks or cobble-stone pavement. No heap of fermenting dung should 
ever be allowed in any corner of the stable; upon this point the master should be inflexible.

Whether horses should be allowed to stand upon litter at all during the day is a subject on which opposite opinions have been entertained by practical writers. When the litter is suffered to remain, it certainly encourages the horse to lie down, which is favourable to the recovery of strained or overworked limbs, and nrevents extreme pressure on tencler feet, if the stable should be bricked or paved. But, per contra, foul-feeding horses are very apt to eat their litter, and the other mischiefs from acrid exhalations, elsewhere spoken of, are multiplied. With some horses, too, the very disorder it would seem to alleviate is produced or aggravated by itnamely, swelled legs, which have been found to return to their proper size when the stimulus of warm litter was removed. Litter, when neglected and allowed to heat, is mischievous to the horny hoof, which is contracted by the increased temperature. We would recommend a little only of the litter to be left under the fore-feet during the day, and in the summer that the bricks should be lightly watered to keep them sweet and cool. Fresh green rushes, if they can be procured, make an excellent day litter. In many stables on the continent, and some of our racing establishments, the floor is of wood, cut across the grain; this, and hard "compo," are not bad for the purpose, with tan, a coat of sawdust, or a thin layer of straw, spread upon the floor of the stall.

\section{LIPPIDV AND SINGEING.}

Clipping, which for many years was the only method of relieving a horse of his winter's blanket, has now been almost entirely superseded by singeing. Dandyism, as much as utility, produced the general adoption of the former practice, and inflamed lungs, swollen legs, and a host of inflammatory diseases were the consequence. It was all very well to deprive a valuable hunter, who was never exposed to the cold air without his body clothes, except when hunting, of his coat, but it was dangerous in an extreme degree to such horses as were not so carefully attended to. Clipping has now had its reign, Singeing having dethroned it. The cutting of the hair, each of which is a hollow tube, gives the whole surface of the body an exposure to the cold air by millions of orifices. Singeing, on the contrary, seals up these as it proceeds, and is no more than a man taking off an upper coat. When clipping was the practice, it was lamentable to see carriage horses standing shivering with cold at the doors of great people, or when conveying some fashionable physician on his visiting round. Before an owner has his horse singed, let him consider what he is going to use him for, and whether he is likely to be kept standing still, exposed to the inclemency of the season; if not, let it be done. Singeing has this advantage over clipping, that to look well a horse must be clipped close. In singeing you may regulate this. The coat may be once gone over, and this will remove but a moderate portion; if more is desired a second singeing must be resorted to. After the hror:e is singed, he should be well washed over with soap and warm water, with an extra dose of soda in it: this will cleanse the coat and make the skin comfortable. Then, in a few days, if you want it shorter, repeat the process; and afterwards give the horse a gentle sweat, just as much as will enable you to give him a scrape. This, note well, is after the second singeing : with the coat left on after a first going over, it might be somewhat difficult to dry him, and risk giving him cold. The soap and soda, and the after-sweat and scrape, will immensely relieve the skin.

When clipping was in vogue, all the pretty bays, browns, and chestnuts. and many blacks, were made of an unsightly mouse or slate colour. Now we can singe a horse nearly as short as close-clipping without this unseemly effect There are some capital lamps made nowadays for this special purpose. The hair being charred as the operation proceeds prevents the light hue from prevailing. Grey, dun, or roan horses look as well, however, clipped as singed No sooner does the horse's coat begin to shoot in the autumn, than the groom will urge you to have your horses clipped or singed; and will, when he has your consent, get as much coat of them as he possibly can, for the sake of saving trouble, and, as he thinks, of improving their appearance. Let the master, then, consider what work his horses are likely to get during the winter. If he is a saddle-horse, merely to be used as a park and town hack, cantered or galloped the length of Rotten Row, or to carry his master from his country seat to his town house-or, if a harness-horse, to be kept standing at doors, while business or pleasure detains his owner within-leave his coat on, or moderately thick. If, on the other hand, he is to be used as a cover-hack, ridden possibly ten or a dozen miles to the meet, at a rattling pace, get him into hunting condition-and a short coat. In a word, the coat should be made lighter according to the fast work the animal is called upon to perform; and he will thus be in a better condition to go through his allotted task with comfort to himself and owner. If you are fastidious as to the appearance of your horses, get a man used to the business to singt them; the charge is small, and it will be more judiciously done than by a general groom.

\section{FEEDINO}

Feeding is a matter of observation, and requires study and attention. Most servants are so fond of stuffing themselves that they think horses must be equally so. Stuffing may do with a cart-horse, but will not answer with a hunter, or a horse required for quick strong work. A groom should study each horse's appetite and constitution. Some horses require farmore meat than others, but this truism never enters the head of most of the fellows calling themselves grooms Having ascertained the "maximum " quantity of corn master allows, they forthwith prepare for getting it down the horses' throats in equal proportion. A half-finished feed conveye no hint to them: they add a whole feed to it next feeding 
bour: then horses get cracked heels and swelled legs, and the fellows wonder how it happens. They perhaps have recourse to their antediluvian book, or some horse-leech in the neighbourhood, who cannot even write out a bill for the medicine he professes to give. Bleeding and physicking should be included in a groom's catalogue of qualifications; but never allow either to be done without an order.

Some grooms say they cannot keep horses in high condition without high feeding; but many masters would ride much more pleasantly if their horses were not in such high condition. What is the use of having a horse capable of double the exertion the rider is equal to? We are not all Osbaldestons, to ride two hundred miles in nine hours; and whether on the road or in the field, a horse above himself is a great nuisance.

Lord Pembroke truly observes, that "it is a matter of the greatest consequence, though few attend to it, to feed horses according to their work. When the work is hard," says he, "food should be plenty; when it is otherwise, the food should be diminished immediately, the hay particularly." That sentence should be placed in erery stable and saddleroom in the kingdom.

Hay.-The principal food of horses in the stable is hay and uats, and consequently it behoves every master of horses to be a good judge of their quality. The hay given to your horses should be old upland meadow hay, bright, greenish, fragrant, and not too dry and crisp : it ought indeed to be, in a trifling degree, tough, and not to crackle when twisted in the hand, thereby denoting that it has preserved its juices and nutritious qualities. Many people are in the habit of never giving any other than meadow hay to their horses, but this is not at all necessary Provided the quantity of hay you allow your horses in the day be not too great, they will be gratified by a slight change in their diet now and then; and you may with great propriety let them have an occasional handful of sainfoin hay, or of white clover and bents (rye-grass), though most grooms will assert that by so doing you will ruin your horse's wind. Those who say so, however, have never made the experiment themselves, or have made it improperly, by allowing their groom to stuff a horse with hay until he is surfeited, or by giving it in too new a state, when it will produce acidity and flatulence. The allowance of hay for each horse is, in most stables, two trusses per week; one-half this quantity is sufficient. Eight pounds of hay per diem is as much as any horse slould be allowed to eat, and those who give them more go the right way to breed listlessness, dulness, and disease. Of all animals the horse, in comparison to his size, has the smallest stomach, and consequently his food, when hard work is required of him, should contain as much nutriment as possible in the smallest compass ; for remember that the origin of impaired digestion, and consequently the cause of most diseases, is distension of the stomach and bowels, by which they become deblitated, and their secretions vitiated; the natural and inevitable result of which is general weakness of the whole system.
How can any horse possess vigour and sprightliness who is allowed to swallow as much hay at a time as he will eat, when a large quantity of this species of food does not contain sufficient nutriment of itself to keep a horse in condition? The food of horses, whatever it may consist of, should at all times be small in quantity, and of the very best quality; for as we require great exertions from them, so must we take the best means to provide them with the most nutritious sustenance without over-taxing their powers of digestion.

Hay that is at all mow-burnt is liable to produce gripes or flatulent colic; as likewise is that which has been recently made, and has not, as it is called, completely "sweated" in the stack. Indeed horses that are expecteo" to perform hard work should never be allowed to eat hay less than eight months old. Some people like it better when two years old ; it is then, however, little better than so much straw.

Oats.-Your oats should be at least a twelvemonth old, bright, clear, full, without smell of any kind, and weighing at least forty pounds per bushel. Many people prefer black oats to white; provided the weight of both be equal, and they be equally well kept, it matters little which of the two you use-horses will work as well when kept on the one as on the other. Nevertheless it is certainly a difficult matter to obtain black oats of as fine a quality as the white potato oat, inasmuch as they will generally be found to contain more "heads" and "tails" than the latter; and therefore those who are not simply satisfied with good oats, but will procure the very best, will be more likely to find the great desiderata of weight and plumpness in some species of the white than in the black oat. A horse of good constitution, and in regular and moderate work, should not have less than four quarterns of oats (weighing forty pounds per bushel) in the course of the day. Oats of the above weight may be thus given by measure, and they are by far better than a larger quantity of oats of less weight. It is the most absurd plan to feed a horse by measure without reference to the weight of his corn. It has frequently been found on examination, in the stables of gentlemen who never choose their own corn, but suffer a corn-chandler to send them what he pleases, that their horses have been feeding upon oats that to all appearance were little more than the light seeds blown aside by the winnowing machine, and only fit for poultry. No horse can of course be expected to thrive and stand his work upon such diet : therefore be particular, when you purchase oats, to see them weighed; and for this purpose turn out one-third of the oats in the sack, an weigh a bushel from the middle, for here you will often find them of an inferior quality, both as regards weight and cleanliness.

If you work your horsts hard they must be allowed eithes a larger quantity of oats than here specified, or you musi mix with them a few handfuls of old and sweet beans. This is good hearty food for a horse of strong constitution; but some horses of a foul habit of body will not endure 
being fed for any length of time on beans without exhibiting symptoms of heat of body somewhere-generally by greasy or cracked heels, or by scurf and surfeit. With a horse of this description you must every now and then-say three times a fortnight-adopt the plan of giving half a pailful of bran mash instead of a feed of corn, giving him at the same time half an ounce of nitre in his water; or you may add a double handful of dry bran to his oats every day, or whenever the state of his bowels requires it.

Peas.-Peas are a very good substitute for beans, and, according to the analysis which has been made of both, contain rather more nutritious matter than oats in a given quantity. They are not, however, in general use. A small quantity of barley added to oats is by many recommended as excellent food for horses; we can say nothing respecting it from personal experience.

Barley.-Barley is still a common food or the horse on the continent, and, until the introduction of the oat, seems to have constituted his ordinary stable food. It is more nutrilious than oats, containing nine hundred and twenty parts of nutritive matter in every thousand. There seems, however, to be something necessary besides a great proportion of nutritive matter, in order to render any substance wholesome and strengthening. Except where horses are very hardly worked, barley does not seem in our country to agree with them so well as oats: they are more subject to inflammatory complaints, and particularly to surfeit and mange. When barley is given, the quantity should not exceed a peck daily. It should be always bruised, and the chaff should consist of equal quantities of hay and barley straw, and not cut too short. If spotted barley is given, it will probably produce serious illness among them. For horses that are recovering from illness, barley, in the form of malt, is often serviceable, as tempting the appetite and recruiting the strength. It is best given in mashes; water, considerably below the boiling heat, being poured upon it, and the vessel or pail kept covered for half an hour.

Grains.-Grains fresh from the mash-tub, either alone, or mixed with oats or chaff, or both, may be occasionally given to horses slow at work ; they afford very insufficient nourishment for horses who are called on for smart exertion.

Wheat is in Great Britain rarely given to horses. It must always be bruised and given in chaff. Wheat contains a greater proportion of gluten than any other kind of grain; with the horse it is difficult of digestion, and apt to form obstructions in the bowels. This will often be the case if the horse is suffered to drink much soon after feeding. Wheaten flour, boiled in water to the thickness of starch, is given with good effect in over-purging, especially if combined with chalk and opium. There is no grain, however, that seems to agree so well with the constitution of the horse as the oat

Beans add materially to the vigour of the horse. There are many horses that will not stand hard work without beans being mingled with their food, and these not horses whose tendency to purge it may be necessary to restrain by the astringency of the bean. There is no horseman who is not aware of the difference in the spirit of lis horse if he allows or denies him beans on his journey. They afford not merely a temporary stimulus, but may be daily used witlout losing their influence, or producing exhaustion Beans are generally given whole. This is absurd; for the young horse, whose tecth are strong, seldom requires them; while the old horse, to whom they are in a manner necessary, is scarcely able to masticate them, swallows many of them whole, and drops much corn from his mouth in the ineffectual attempt to break them. Beans should not be merely split, but crushed; they will even then give sufficient employment to the grinders of the animal.

Tares.-Of the value of tares, as forming a portion of the late spring and summer food of the stabled, and especially the slow-worked agricultural horse, there can be no doubt. They are nutritive, and they act as a mild medicine. When surfeit lumps appear on the skin, and the slow-worked horse begins to rub himself against the divisions of the stall, and the legs are turgid, a few tares cut up with the chaff, or given instead of a portion of the hay, will often afford relief. Ten or twelve pounds may be given daily, and half that weight of hay subtracted. It is an erroneous notion, that, given in moderate quantities, they either roughen the coat or lessen the capability for work.

Lucern is by some agriculturists considered preferable to tares, and sainfoin superior to lucern. Although they contain but a small quantity of nutritive matter they are easily digested and perfectly assimilated; they speedily put both muscle and fat on the horse that is worn down by labour, and are almost specific for hide-bound. Some farmers have thought so highly of lucern as to substitute it for oats. This may do for the agricultural horse of slow work, but he from whom speedier action is required, and the horse of al] work, must have hard meat within him.

Carrots.-The virtues of this root are not too grestly esteemed. There is little food of which the horse is fonder.

Nutriment contained in the following vegetables-1,000 parts of wheat contain 955 parts of nutritive matter; barley, 920 ; oats, 743 ; peas, 574 ; beans, 570 ; potatoes, 230 ; red beet, 148 ; parsnips, 99 ; carrots, 98.

Of the grasses, 1,000 parts of the meadow cat's tail contain, at the time of seeding, 98 parts of nutritive matter narrowleaved meadow grass in seed, and sweet-scented soft grass in flower, 95 ; narrow-leaved and flat-stalked meadow grass in flower, fertile meadow grass in seed, and tall fescue in flower, 93 ; Swedish turnips, 64; common turnips, 42 ; sainfoin, and broad-leaved and long-rooted clover, 39 ; white clover, 32 ; and lucern, 23.

Thus much of the articles of the horse's food; we will now return to the subject of feeding him.

When horses are worked very hard, the practice of giving what is called manger-meat alone has been adopted, and with great success, according to the statement of those who 
have giren this plan most trial. Manger-meat is nothing more than a mixture of corn with hay cut into chaff instead of being put into the rack The advocates of this plan assert that a horse required to go through much work finishes his food quicker than with rack-meat before him, lies down sooner, and consequently has a longer period for rest than he would if treated in the usual way. This may be very true as regards some horses, but there are in fact very few who lie down directly after feeding; and a great proportion of horses, after having finished their manger-meat, will pick over their straw, and eat such parts of it as are not much soiled, in preference to lying down. The Americans, in addition to chopping up their horses' hay, grind their oats coarsely, and mix the whole together. For farm-horses while baiting such a plan may be a good one; but horses used for pleasure are generally allowed plenty of time for feeding, and there can therefore neither be any necessity for adopting this system. Horses again that have weak stomachs, and are slyy feeders, take a long time before they will eat a sufficient quantity of food to keep them in condition: and, if a large mess of hay and corn be placed before them, will take a few mouthfuls perhaps, and blow upon the rest, until they take a disgust to it, and refuse it altogether. There is many a hunter of this description not fit probably to take the field more than once a week, but who, when out, does his work in a stgle that makes him invaluable to a man that can afford to keep a large stud, and is therefore worth nursing. If you cram his manger with food, the animal will, in all probability, not touch one particle of it; you visit him hour after lour, and find his corn untouched, and himself dispirited from want of nourishment. What is to be done with such a horse? You bave over-taxed his powers-you have thought of nothing but keeping the lead; and when your horse has flagged under you you have roused him with bit and spur; and, despite the warning voices of heaving sides and shaking tail, of which some brother sportsman has perhaps given you notice, you have crammed along to the finish, and found that you had just killed in time, for your horse had already cried "Hold, enough!" You have your fears of "laving come it rather too strong" confirmed by finding your trusty steed refuse his corn and show other evident symptoms of distress. If you are enough of a veterinarian to be able to judge of the state of his pulse, and no symptoms of congestion of the lungs betray themselves, it may happen that a little warm ale and ginger may be advantageous to him; but as there is risk in giving stimulants after hard work, unless you have "good store of veterinary science" to guide you, after having seen him made pretty comfortable, give him (and this drink you should accustom him to take lest he refuse it when you wish him to take it) half a quartern or more of oatmeal made into porridge or gruel with a small quantity of boiling water-stirring in the oatmeal in small quantities, and keeping the whole simmering. diluted with linseed tea.
This last may be made by putting half a pint of linseed into a gallon of water, and placing it close to the fire for some hours, after which set it aside to get cold. On hunting days this should be prepared while you are out, and be ready for use on your return. The linseed tea on cooling gets very thick and glutinous, and contains as much nourishment as with the oatmeal is sufficient for a horse whose powers of digestion are for a time enfeebled. If your horse drink this mixture, you may put a lock of sweet hay in his rack, a few handfuls of oats in one corner of his manger, and as much beans in another, with perhaps a couple of chopped carrots, and it is ten to one, unless he be severely overmarked, that he will soon nibble sufficient of one or the other to sustain him until his appetite completely returns.

Water.-Soft water in all cases is better for horses than hard: home water from a brook or pond is preferable to that raised from a well by pump or bucket. Valuable horses, who are apt to be heated, should not, however, be allowed to slake their thirst at pond or brook, but liave water given them but little below the temperature of their stable, say $65^{\circ}$ to $70^{\circ}$, and this may be done by mixing a little hot water with the cold. Observe, extremely cold water will often produce staring of the coat, colic, and rheumatism. It is by no means an uncommon notion that if horses are to be got into condition for work, they should be allowed to drink but a very small quantity of water On what physiological basis this opinion is founded is a mystery. Nevertheless as many persons adopt this treatment, it is fitting to notice it. It is a bad plan to stint a horse in his water. Of course it is not asserted that when a horse comes in heated from exercise he should be suffered to drink, or should have a bellyful of water just prior to being ridden; but, if a horse be watered ad lib. in the morning, he will not require to drink again for some hours, and should never be allowed to do so then unless perfectly cool. Those horses that are only supplied with a limited quantity of water at a time, and are never permitted to slake their thirst fully, will be much more liable to be griped, if at any time they by chance should drink their fill, than those who are always suffered to take as much as Nature dictates to them; but, should a horse have been hardworked, and come into his stable very hot, after having seen him well dried, only at first give him a small quantity, for two reasons : first, because his eagerness for water may lead him to drink more at a time than is good for him; and secondly, because a large quantity of water will probably cause him to break out into a cold sweat, in which he may remain all night if not looked to. After having taken a third, or less, of a stable pailful of water, he should be kept without any for some time, and then be allowed to take what he pleases. When, however, you intend to stint your horse in this way, do not suffer your groom to offer him a pailful of water, and to take it from him when he has drunk a small portion of it. but let just the quantity you wish him to have, and no 
more, be given to him; he will then feel to a certain degree satisfied with what he gets: whereas, by taking from him what he expects to have, he becomes fretful and discon. tented. In the first instance he makes up his mind to slake his thirst with a short allowance of water; whereas in the second his just expectations are baulked in mid career, and his imagination cheated as it were in the height of his enjoyment: there is much more in this than may be generally supposed. Pliysiologists are well aware of the connexion existing between the stomach and brain; and those who have not inquired into this fact must either do so before they attompt to refute it, or take what is here stated as proven.

What is said with respect to giving a horse water while he is hot applies equally to his food. Never suffer a horse to feed until he is cool. After fatigue of body, the stomach of all other parts is perhaps the least capable of exertion; and although in some cases of severe exertion a slight degree of sustenance may be requisite to support the strength and stamina of every living animal, it should always be administered in moderation; and for this purpose there is nothing better than the gruel already recommended. I $t$ is a light species of diet when not given too abundantly, against which the stomach will seldom rebel, and it is always proper that this organ, like any other, should be in good tone before its work-that of digestion-be required of it; and as, when a horse is violently heated the blood is propelled by the beart in a much greater ratio than usual, the stomach, being consequently supplied with a greater quantity of blood within a given time than it would have received without undue excitement, is as unfitted to perform its task while under the influence of that stimulus, as the eye would be to bear a strong light after having been irritated by some heating application. Let your horse then remain quiet for some time after he has done his work, and he will not only feed the better for it, but will likewise digest what he eats.

There are not a few masters of horses, who, from a mistaken feeling of kindness, like always to see a good quantity of food before their animals, so that they may never be hungry; not stopping for a moment to consider the degree of injury they occasion by this perpetual cranming, but vainly imagining that every extra moutluful a horse swallows is so much added to his strength and condition. We cannot, of course, expect the brute creation to act as rational beings, or to be able to resist the temptation of eating more than is good for them; and therefore the first symptom of loathing food, which is the necessary consequence of perpetual repletion, is a proof that the powers of the stomach have been overtaxed, and that it requires the same rest-only for a much longer period-as does the body generally after severe exercise. Next to the quantity and quality of your horse's food, there is nothing that will tend so quickly to put him into condition as giving it at stated hours and at regular intervals. After a meal proportioned to his work-say from a quartern to a quartern and a balf of oats-four hours are the very least period that shonld be allowed to elapse before your horse is again fed; and during this time (unless he has been worked so hard tliat you wish him to lie down) his head should be fastened so that he may not be able to get at his straw, which very many horses will eat, no matter how soiled it may be. A horse in regular and fair excrcise should have but very little, if any, hay in the middle of the day; but a small quantity may be given in the early part of the morning, and a sufficient portion at night to make up his daily allowance of about eight pounds -not more. Although corn is certainly more nutritious than hay, yet if you increase your number of feeds of oats, and deprive your horses entirely of hay, it is surprising how quickly some of them will lose flesh.

Business of various kinds will sometimes compel you to alter your hours of feeding, but regularity should always be adhered to as strictly as possible ; for, after laving been for some time accustomed to be fed at a certain time, nature will crave food at the usual hour, even though the previous meal may have been more than commonly abundant. A horse that is generally taken out in the forenoon, if fed twice in the morning, should have the larger portion of his food at his first meal ; and if he be required to work on most days from about nine till one or two, the better plan is to divide his corn into three feeds instead of four. This is preferable to working him on a full stomach, than which few things in time are likely to prove more injurious.

\section{EXERCISE.}

Exercise, the prime necessity of animal health, is an instinct wonderfully active in the horse, when free to indulge his own will, and at leisure from the restraint and servitude of man. The benefits of exercise, as a preventive of disease and as a promoter of the working condition of the animal frame, are equally self-evident. If it be true then that in a state of nature horses instinctively play with each other, and that to such an extent as to produce perspiration and violent breathing, may we not infer that when we stable them, subject to restraint, and then neglect to exercise them, their health must be injured? In all great cities the evil of want of exercise sadly prevails among the better class of horses. We shall quote here a clever sporting writer, the late Mr. Bingley, "Harry Hicover," who says that he verily believes as many horses are ruined for want of work as from too much of it. It is true that the better sort of horses of the better sort of owners are ordered to be exercised, but how, where, and when they do not condescend to inform themselves, or to inform their servants. Well, the men hare too much to do, and gentlemen object to boys riding their valuable horses. So they rub the dirt off them; give them a brush over; make the stable clean, ventilate it by opening door and window, and are satisfied that they have done their duty. Or, perhaps the animals are ostensibly brought out and led-observe, not even ridden—up and down a covered 
ride perhaps fifty or sixty yards long, littered with strongsmelling, half-saturated straw, aided by the fine ammonia of the dung-pit itself, quite "convaynient" as our Irish friends would say. Ought an owner to feel astonished at "influenza," or any other disease which assumes an epizootic form, should rage in his stable? Of course he will hear from the "Vet.," according to bis enlightenment, an extensive amount of prate about " contagion, great prevalence of disease at this season," \&c., while he is positively brewing his own miasma, and cxposing his too-much-favoured animals to circumstances which must produce the visitation which exercise, involving change of air, would as assuredly prevent. Broken wind, incipient ophthalmia, sandcracks, grease, contracted heels, hide bound, and digestively-disturbed functions, staring coat, and general constitutional disturbance are among the mischiefs which physic and "horse-doctrine" will substitute for horse-exercise and horse-play: which is the more economical, which the more satisfactory, we leave the reader to judge. The spring and autumn shedding of the coat, too, is never properly gone through by horses who have not frequent and strong periodical exercise. So necessary is exercise to the health of the horse, that, unless prevented by sickness, lameness, hard frost, or a previous severe hard day's work, no day should be missed. The quantity, frequency, and pace, must, however, depend upon circumstances. Where horses work two or three days in the week, the resting days require no more than airing exercise ; for every horse should have, at least two days in the week, such wark or exercise that will give him a moderate sweating. This throws out through the pores of the skin, what might lodge in the system and create diseases; it likewise frees the horse of scurf adhering to the skin, and makes the coat fine. Those days, therefore, that the horse is not winted for work, he must be exercised for the fresh air, which is bracing and strengthening to his limbs, refreshes the body, and creates appetite. The early part of the day is preferable for this, but in wet weather embrace the best opportunity.

Exercise enlarges the muscles, by forcing more red blood into them: thus the arms of the blacksmith, the legs of the pedestrian, the sword-arm of the fencer, greatly increase by use; which is well fabled in the account that Milo, by every day carrying his calf, became insensible to its increasing weight, and bore it also when it had grown into a bull. The athletæ of Greece and Rome braced their limbs by constant exertion, and the gymnastics of the forum were the produce of much previous exercise. The boxer also is forced to submit to close training, which is principally composed of strong exercise. Our hounds take their training gallops preparatory to hunting; our hawks their training flights; and game-cocks were brought into wind and vigour by similar means. It is well observed by Nimrod, "That the ill effects of rest, and the good effects of work, on the powers and energies of a horse, are astonishing. In long-continued rest his flesh becomes soft and flabby, and the muscles lose their elasticity, and even their substance. This is parti- cularly exemplified in the human subject; for, let a man forego the use of one of his legs for twelve months, the muscles of that leg will fall away, though they will in some measure recover on his resuming the action of the limb. Horses lame in the fore-feet are generally seen to have the muscles of the chest fallen away, because such muscles are not called into their proper action, which a crippled horse has not the power of doing, although he may work every day." This gave rise to the vulgar, but now nearly exploded, opinion of chest-foundering in horses; whereas such a complaint does not exist; the evil lies in the feet, and the wasting of the muscles of the chest is the effect and not the cause. In strong work, when a horse is sound, every muscle, and indeed every fibre, of the body is braced, as it were, lintil the frame becomes a firm mass as a whole, but possessed of vast contractility in the separate portions.

Exercise greatly improves the wind, by promoting an absorption of the surrounding fat from the viscera of the chest, and thus allowing the lungs to expand uninterruptedly: it also enlarges the air cells of the lungs themselves; and hence, by the imbibing of more air, the animal can remain longer between his inspirations. The pearl-diver by practice, it is said, can remain under water between two and three minutes, while insensibility follows our own immersion after fifty seconds. And thus the colt in training is first able to take a gentle gallop, next a brushing one, and lastly he stretches over the ground at the top of his speed without distress.

The benefits of exercise as a preventive, and in many cases a curative, need not be further dwelt on, except to urge on owners that they should insist on its systematic and periodical observance.

The owner of a single horse should order his groom, as soon as the stable has been cleaned out in the morning, while the horse is eating his first feed, to hrush him over, and put on his exercising saddle and bridle; in cold weather, if only intended to be walked, keep the cloth or sheet on him under the saddle; in warm weather, though a horse's coat may be something the finer by being kept warm, yet he is certainly the more liable to take cold when he is necessarily deprived of it. We need hardly say that the most open and airy places should be taken for exercise, and this is the most favourable opportunity to improve a horse's walk, two hours of which he should get, and it is a great thing to endeavour always to make him step longer in his walk, and thus exercise the horse and improve him at the same time. If convenient, while out give him his water. If a horse is inclined to flesh, the like exercise may be taken in the afternoon, where persons have time and convenience. But every one cannot allow the time to be so taken up, for it would be nearly equal to training, and may not be thought necessary; it is more than the generality of horses require, and many inferior-bred horses, who look well to the eye, cannot for a continuance stand the ordinary work that a horse has in. training. If you inquire of training grooms, in charge of 
some terrible high-bred colt, why he is not "brought out," they will answer, "he would not stand his training." This is mere cant. He has been over-trained and galloped too fast, not judiciously and reasonably exercised.

Should the horse's work be so moderate as not to occasion a sweat, then, about $t$ wice a week, he should have exercise strong enough to sweat him; this may be done in the pace he is mostly ridden in, that he may be practised and improved in it; if he be admired for his trot, it would be wrong to gallop him, which might unsettle him in his esteemed pace; therefore, trot him out for the space of two miles, to bring him to a comfortable sweat, and walk him back; thus will his limbs be rendered supple, his muscles developed by red blood, and his ligaments and tendons strengthened. Inactivity debilitates, and over exertion may sprain and weaker, hut moderate exertion is good both for man and beast.

Sweatıng horses increases the labour of cleaning. Indolent grooms, and those who have several horses to look after, avoid this part of their business as much as possible : let no such grooms be trusted.

When a horse comes in from work or exercise, if perspiring, wet and dirty, he should not be left until completely dry, clean, and comfortable. Some horses, in good condition, will rub dry and clean in a short time, but others, with long coats, and some from constitution or ill condition, are a long time getting dry; hence clipping and singeing, which may be rendered unnecessary by diligent grooming. But these points will be remarked upon presently.

In some hunting establishments grooms only open the stables twice a-day instead of three times if the horses are not at work. Instead of sending the horses starving out the first dawn of the morning, they generally remain in the stables till the men have had their breakfasts, and are consequently not shut up till a little before mid-day. They then remain quiet for six hours. The late Lord Kintore's stable was conducted on this principle, and Nimrod, in describing it, said, "I must own that, although I never tried it, I see sound argument in favour of this stable management during the three dark and dreary months of winter, with horses that work hard, from a knowledge of the restorative powers of undisturbed rest both with horse and man; as also of its sedative effects in allaying excitement by whatever cause produced."

The hours of exercising might be advantageously left to the weather. Coid, damp, foggy mornings, the horses would doubtless be better in their stables; fine bright mornings should be taken advantage of, lest the day should change for the worse as it advances. There is no use in getting horses out in winter before day-break, unless indeed the men (which is not at all improbable) have fixed a particular hour for their own breakfasts That breakfast is one strong argument for exercising at a later period, the men having no interest in hurrying and shortening their work in order to get home to their morning meal.
When horses in returning from exercise show any heat or inflammation from saddle, girth, or harness, have ready a wash of Goulard water-that is, four draclims of sugar of lead diluted with water to a wine bottle full of fluid. Bathe the part with it, and you will give comfort to the animal and perhaps prevent further and more troublesome and pain. ful consequences. This cold lotion should always be at hand.

\section{CLEANING.}

REMoving THE MUD.-There are two ways of removing the mud. One may be termed the dry, and another the wet mode. The first is performed by means of the scraper and the curry-comb, or a kind of brush made of whalebone, which answers much better than the curry-comb. In the few coaching stables now surviving, the strappers are never allowed to apply water to a horse that has come off the road. The usual practice is to strip off the mud and loose water by the sweat knife; to walk the horse for about ten minutes, if he be warm or wet, and the weather fair, otherwise he stands a little in his stall, or in an open shed; then the man begins with the driest of those that have come in together. Mluch of the surface mud which the scraper has left about the legs is removed by a straw wisp, or a small birch broom, or the whalebone brush; the wisp likewise helps to dry the horse, The whalebone brush is a very useful article when the coat is long. That and the curry-comb, with the aid of a wisp, are almost the only implements coaching strappers require in the winter season. It clears away the mud, and separates the hairs, but it does not polish them. A gloss, such as the coat of these horses requires, is given by the wisp. The whalebone brush is sometimes too coarse, and many horses cannot hear it at any time, while others can suffer it only in winter. After the mud has been removed with this brush, the matted hair parted by the curry-comb, and the horse dusted all over with the wisp, his feet are washed, the soles picked, the shoes examined, the legs and heels well rubbed, partly by the hand, and partly by the wisp, and the mane and tail combed. In the best stables he is well dressed with the bristle brush before he goes to work. In other stables the usual mode of removing mud is by-

Washina. - When the horse is very dirty he is usually washed outside the stable; his belly is scraped, and the remainder of the mud is washed off at once by the application of water. Some clean the body before they wash the legs, but that is only when there is not much mud about the loorse. They do so that he may go into the stable quite clean. He soils his feet and legs by stamping the ground when his body has been cleaned It matters little whetler the dressing commence witl the body or with the legs; but when the legs are washed the last thing, they are generally left undried. In washing, a sponge and a water brush are employed. Some use a mop, and this is called a lazy method; it is truly the trick of a careless sloven; it wets the legs, but does not clean them. The brush goes to the roots of the hair; and removes the sand and mud, without 
doing which, it is worse than useless to apply water. The sponge is employed for drying the hair, for soaking up and wiping away the loose water. Afterwards, the legs, and all the parts that have been washed, are rendered completely dry by rubbing with a straw wisp, the rubber, and the hand. Among valuable horses this is always done; wherever the legs have little hair about them, and that little cannot be properly dried after washing, no washing should take place.

Fur ourselves we are advocates of the "dry" method; tor none but the best of stablemen, and they are of course rare, conscientiously rub them free from moisture. Hence imminent danger of cold and fever. Evaporation commences; after a time a process is set up for producing heat sufficient to carry on evaporation and to maintain the temperature of the skin. Before this process can be fully established the water has all evaporated; then the heat accumulates; inflammation succeeds, and often runs so far as to produce mortification. When the inflammation is slight and transient, the skin is soon completely restored to health, and no one knows that it had ever been inflamed. When the process runs higher, there is a slight oozing from the skin, which constitutes what is termed grease, or a spot of grease, for when this disease is spread over a large surface it is the result of repeated neglect. When the inflammation has been still more severe, mortification ensues; the horse is lame, the leg swollen, and in a day or two a crack is visible across the pastern, generally at that part where the motion is greatest. This crack is sometimes a mere rupture of the tumefied skin, but very often it is produced by a dead portion of the skin having fallen out ; what is called "a core" in the heel arises from the same cause; it differs from the crack only in being deeper and wider. The reason why cold produces such local injury of the skin covering the legs, and not of that covering any other part, is sufficiently plain. The legs, in proportion to their size, have a very extensive surface exposed to evaporation, and the cold becomes more intense than it can ever become on the body. To avoid these evils, the legs must either be dried after washing, or they must not be wet. With this train of evils "looming in the future," the owner must indeed be unworthy of being master of a horse if he neglects to assure himself that his animal's legs are properly rubbed dry. When you wash the legs with warm water to cool and refresh them, it will also at the same time relieve the feet, which of course must have undergone a considerable quantity of labour. The uses of the equine footbath are dwelt on in Mayhew's "Illustrated Horse Doctor," already referred to. Water is beneficial to the feet; we find the feet less injured by travelling on wet roads than on dry ones; and the hoof at grass, being continually wet with the dew and moist ground, is in a better state than when kept in the stable. The casual wet you meet with in exercise on the roads, or the moisture of the turf or grass you exercise on, contributes to preserve the foot from the injury which continually standing in a hot and dry stable occasions.

\section{CLOTHINA}

The advisability of clothing for the "general purpose" horse has been the subject of controversy in times by-past. With racers and high-bred hunters clothing is indispensable. The "old English gentleman's" cry of "sticking to nature" is mere nonsensical obstinacy and prejudice. We have adapted the animal to an artificial life, and artificial means are needed to keep him in the required condition. In winter, clothing warms the animal and improves his coat; in summer (lighter), it keeps the skin-temperature more equable, and prevents the irritation of flies. We do not recommend, however, the complete suit of the racer to the service of the hackney.

Where stables are dry and cross-draughts avoided, a horseclotl is, to our thinking, enough. Much of the heavier clothing may be dispensed with advantageously where the "dry-rubbing" so often insisted on in these pages is conscientiously carried ont. Good grooming is the surest prevention of sudden alternations from heat to cold; and we once again recommend that no stable should ever be without a registering thermometer, that its temperature may not be the subject of guess.

The clothing for private stables is composed of strong serge, made for the saddler's purpose, cut, and bound with galloon. Economy and smartness are best answered by having a suit of "best clothes," of finer and closer serge or kersey, for day wear, and a warm rug or even two for night. A roller with double straps is required to keep them in place. The best or day clothes will look much cleaner and smarter by this method. In warm dry weather a thin cloth is enough.

In the stable your horses should always have clothes enough to keep them warm, but not hot. Grooms are generally too fond of heaping rugs and blankets upon their horses, for the purpose of improving the appearance of the coat; but depend on it that too warm clothing not only renders a horse more susceptible of cold than he should be, but also diminishes the size and firmness of his muscles. Employ then the "just mean;" and however pretty may be the appearance of a smart and thick rug, covered by a gay body-cloth, and this again surmounted by a hood thrown over the quarters, with the ears neatly peeping up behind the rollers, do not sacrifice your horse's well-being to appearances, which may be all very well in the show-stables of a London dealer, but are uncalled for in those of a sportsman. If your horse be clipped or singed, he will of course require additional clothing, for a time at least.

The hunter's clothing in cold weather is a kersey-sheet and quarter-piece with roller, and usually a breast-piece also. To these, particularly where well-bred horses are employed, a hood is sometimes added; but, however proper it may be to exercise in a hood (which indeed should always be worn when walking only is allowed), we think is should not constitute a regular part of the stable dress 
Even breast-cloths have the effect of keeping a part in an undue state of heat, which, the moment the horse goes out to his regular work, is the most exposed to the wind and rain. The day clothing of the hunter is commonly exchanged for the rug and roller at night.

The clothing used for the better sort of hackneys is much the same with that worn by the hunter; even the hood and breast-piece are often employed; and, indeed, the general treatment is now much alike for both: but it must be allowed, that, however it may tend to improve the appearance of the hackney, or even increase his spirit, it must nevertheless subject him to cold on a change of stable.

The clothing in use for racers varies much, in quantity, quality, and fashion. The full set comprises the hood, sheet, quarter-piece, breast-cloth, pad-cloth, and fillet-cloth, with rollers to secure them; these form a complete suit of clothes. The suits vary in their manufacture; they are, however, usually made of kersey-check, like those of other horses, but of a lighter kind. There are likewise in racing stables heavy suits, particularly employed for the purpose of sweating. The first hood of the sweating clething should be made without ears, that additional hoods, when necessary, may go over it, the last only being furnished with ears. The body-sweater should be large enough to envelop the whole carcass, and to wrap round the neck likewise; and the breast-sweater, or breast-cloth, should be equally capacious. When the sweat is intended to be a profuse one, other large blanket pieces are usually added. In summer, racers usually wear suits of white serge for clothing. in Darvill's work some judicious improvements in the clotling are recommended; one of which is, that instead of the stiff leather used to attach the breast-cloth strap (and which, when hard-pulling horses are galloping, often chafes the knuckles of the riding boys seriously) softer leather should be substituted, as that of which the saddle-seats are made. He further proposes to substitute "loops on each side of the centre and back part of the quarter-piece and sheet, so that a portion of binding might be attached to those loops, in the way of a crupper, with such horses as would bear it."

\section{CONDITIONING}

The word condition is variously applied to the horse, chough widely different from what is here intended: thus, when we say a horse is in "condition for sale," we simply mean "dealer's condition," i.e., he is in flesh, his legs clean and fresh, his coat fine, his eye clear, and his movements lively. A horse may be all this, but not in condition for work. Another horse is said to be "in good working condition ;" such might be said of a cab-horse, bare of Alesh, with joints enlarged, and his legs puffed with windgalls, yet this horse may be capable of doing much work. His being worked more than was requisite to keep him in condition, has put him "out of condition."

Condition, therefore, without an expletive, implies that parfect state of body and limbs, in which the whole system is at its highest vigour, and capable of great exertion, whenever called on. This cannot be obtained or kept, without strictly adhering to three things, viz., proper food. proper grooming, and proper exercise; neither of these must be omitted, or injudiciously administered; for, like medicine properly administered, each does gocd, but is capable of doing much injury if misapplied. Wine, in moderation, cheers the spirits and invigorates the body of man, but taken to excess debilitates the constitution and prostrates the nervous energy.

"Nimrod," whose victorious controversy un Summering the Hunter," led to such oceans of "inkshed" some thirty years ago, is yet the first authority on preparing horses for the hunting field; and some of his directions are so generally applicable that we may adapt them easily to ordinary stable practice. He supposes, in this case, that you take your horse from grass on the Ist of August. "If you intend," says Mr. Apperley, "to physick him in the stable, give the purgatives hereafter mentioned: but if you prepare him at grass, give mild doses of not more than five drachms of aloes, and two and a half drachms of ginger, on the 24th of July, and repeat it on the 1st day of August, and again on the 8th day of August; take him into the stable on the 10th or 11th of August, but do not bleed; give a mash once or twice a day, as it is not right to put him on dry food too suddenly, at least for a week; let him have three or four hours' walking exercise every day for the first fortnight, then bring him by degrees to take regular stretching gallops. Let old oats and meadow hay be his food till he comes to severe work, then add a few old split beans, and give about a quart of sliced carrots or Swedish turnips clean washed, once or twice in twenty-four hours. The beetroot is excellent in colds or coughs. Do not clothe him too heavy, nor keep the temperature of your stable too warm Let all corn be bruised; give a small feed every morning before watering, and do not follow the plan of galloping afterwards; four times in twenty-four hours is often enough to feed, and do what is requisite in the stable; do not disturb lim oftener. A change of diet is good for all horses, particularly bad feeders. A small quantity of bruised wheat and malt with chopped clover is nourishing food, and boiled beans and some dry bran mixed with them and the water they are boiled in is an excellent mash. I have frequently given it after a hard day's work. Be careful not to give too much hay ; it is a good plan to shake up some fresh oat or wheat straw with it, they must masticate more thoroughly. Giving large quantities of corn at one time is improper, many eager horses will grasp such mouthfuls that it is impossible for them to grind it; they swallow it whole and dry, which swells in the stomach, causes obstructions, and the confined air originating from indigested food produces acute pain, convulsions, and frequently sudden death It is certainly an excellent plan to give chopped clover, saintfoin, and any seed hay with corn. When you go out in the 
morning leave orders for half a gallon of barley, well sifted clear of dust, to be put into a clean pail, to it pour two gallons of boiling water, let it be covered close over, it will be cool enough in six or eight hours, and give it altogether when your horse has been thoroughly dressed; he will eagerly take it.

"You can judge of a horse's condition by his coat, and firmness of flesh; his crest and his spirits or animation, in case of colds, being dull and feverish, use the following alterative powders :-

"Antimony, in powder, one pound; nitre, one pound; mixed together: give one ounce every night, either in their corn or made into a ball; it will greatly promote condition. It is a good plan when you buy a horse always to begin to get lim into condition with the above alteratives. It is a most excellent cooling medicine for horses hardworked in summer."

Leaving Nimrod, we will return to general treatment for conditioning.

We have already spoken of exercise, as ensuring the health of the stabled horse, or as preventing the accession of acute or chronic disorders by means of the lungs, the skin, and the hardening and strengthening of the muscles and lungs by promoting healthy excretion. We are not about to encourage quackery in grooms and horsekeepersfar from it-nor to give such advice as might interfere with the legitimate province of the veterinary surgeon. Yet, as a horse in precarious health, or whose exertions, exposure, or other causes of common occurrence may threaten to disable, must often be under the care of his stable attendant, it is as well that a few simple directions should be given in a sanitary sense. Now some grooms physic or bleed the horses entrusted to them at their own discretion. This should never be allowed by any judicious master. Proper feeding, due exercise, diligent grooming, will often preclude the necessity of physic. Sloth and neglect are the parents of disease in an animal so artificially treated as the stabled horse. Well fed, and not exercised, what can be expected but a train of evils, for which the drenching-horn, the balling-iron, and the fleam are to be the panacea! We have personally an intense aversion to unnecessary drugs and the use of the fleam or scalpel. A few plain directions, not to supersede but to obviate the dire necessity of the instrument case and the battery of the pharmacopoia, shall here be set down. We will first speak of the treatment of a horse who has been newly taken up from grass. Trass is cooling and aperient to the horse accustomed to hard meat; it will also fill him with $\mathrm{flesh}$; but observe, this is not flesh of a description fit for a horse to work upon: nay, if you tried him a hunting gallop you would find him faint and weak, and the fat accumulated on his cellular tissue would work out in a white lather This checked will probably produce inflammation of the lungs, and send, as it has sent, many a fine animal to the knacker's yard.

We will suppose your horse coming from grass or the straw yard* to the stable, with its systematic diet and con responding work; observe if he has irritation of the skin and heat. If so send for the veterinary surgeon, who will bleed him or reduce his fever, as he is a disciple of the "venesecting" theory or the "alterative." By the way, the first thing is to get the horse shod, as he is best with his shoes off when turned out, otherwise they become loose before being taken up. While he is full of grass he will not drink much water, but if you give him dry food he will become thirsty, and you need not stint him till he has had his physic. A good method is to give him a cold bran mash or two before the medicine. We will suppose then he has had his dose: tie him up and put on the muzzle, and in the morning gentle exercise will assist its operation. On returning to stable, give him a lock of the sweetest hay and a little chilled water, then a bran mash moderately warmed. More solid food may lessen the benefit to be derived from the aperient. After the sixth or seventh day a second dose of medicine is recommended by most practitioners, when the stable treatment before and after may be similar.

With respect to removing fat by purgatives, if you are not yourself a good judge of the operation of these medicines, you should first take the opinion of some good veterinary surgeon ere you attempt to meddle with them. A roundbarrelled, trussy horse of a hardy constitution will bear a dose of medicine which would be destruction to a slight and narrow-gutted one, and you should therefore be extremely cautious how you administer such quantities as you may occasionally see prescribed as "cathartic, \&c., ball," or "mixture," in veterinary works, without previously ascertaining as far as you can, the capabilities of your horse for sustaining their operation. For the purpose of taking of fat, and at the same time of improving your horse's stamina, active purgation is seldom required, and therefore you must never think of giving such doses as would be prescribed for the treatment of inflammation. Such a practice, so far from doing good, would render your horse weak and languid for several days, and prevent him only from taking any but the most moderate exercise. Generally speaking, from threo

* The Straw Yard affords another mode of restoring the legs of the overworked horse, and he is turued into it duriug the winter, with a shed to run into, and the soft manure or litter in the middle of the yard to run upon. Hay is given, but seldom more than enough tc keep the stomach in order, and barley-straw affords the chief sus. tenance in most cases; sometimes a little hay is given cut as chaff with straw, and in some cases also mixed with a feed or two of corn per day. When a suitable winter pasture cannot be obtained, the straw-yard is often efficacious for inflamed legs and feet; and, as its small extent precludes all galloping about, it is often even more suitable than any open pasture. Tips may be entirely dispensed with, and when the toes are pared down close, as in the "seedy toe," or when the horny foot has come off, as in intlammation or fever of the foot, the straw-yard affords the very best clance of a speedy growth, especially if the regular application of pitch, \&c., can be depended on.-Steroart's Stable 
to four drachms of aloes are quite sufficient for your purpose ; and they may be occasionally repeated as circumstances may require. Previous to giving physic, keep your horse for half a day at least on bran-mashes, which species of food, with a little hay, must be all that is allowed him until his dung becomes tolerably firm, or, in stable language, is "set." Without this precaution you will run the risk of inducing gripes. Water with the chill taken off should also be given during the operation of a purgative, and the horse be kept tolerably warm. Walking exercise will at first be all that he will comfortably endure after his ball has left off working him, and this must be increased by degrees.

Having by this means brought your horses into such a state as to enable them to stand hard work, it should be your care, by regular exercise and careful attention to their diet, grooming, and other matters connected with their welldoing, to see that they are not suffered to fall off in strength and condition.

The training of the hunter and the race-horse is conducted on the self-same principles, for which the reader is referred elsewhere under 'Training tine Racer, and TrainING TIIE IIUNTER. The grand arcana of training and condition are comprised in a knowledge of their constitutional treatment in the article of diet, and in giving them regularly as much exercise as their strength will endure with advantage to themselves. We speak not here of what their legs will bear in the way of work; for, if they are so faulty as to be an impediment to active exertion, the sooner they are put out of training the better.

We shall conclude this subject by the sound advice of one of the best and most practical of sporting writers. "Trainers in general are too fond of employing physic, of the operation of which in nine times out of ten they are grossly ignorant. To be convinced of this, you have only to listen to the jargon they will run over to you of the action of the simplest remedies-a liniment, for instance, which they frequently, nay almost invariably, use for a strain of any kind, and that immediately after it has occurred, when its application may be highly injurious. There is, however, in mankind in general a hankering after being thought skilled in medicine, and few people will be found who have not nostrums for most diseases, and of course recommend a similar mode of treatment for every case. We are quite as convinced that a horse once put into condition may be kept so by good feeding, good grooming, and good exercise, unless he fall ill, as that the less medicine a man in good health and of regular habits takes the better for him. A horse's habits and mode of life, while under the direction of man, must or ought to be more regular than those of a human being, and consequently the perpetual physickings that are prescribed in many first-class stables, cannot fail to be prejudicial.

"Let then your horse's work be proportioned to his powers of endurance ; pay strict attention to his diet, to cleanliness, \&c.; do not allow your groom to tamper with medicine, and to fancy himself an Esculapius, a Percival, a Blaine, or a Sewell: so shall the work you get out of your stud be proportionally increased, your veterinary surgeon's bill be diminished, and your purse the weightier by the price of some few horses, which by a different mode of treatment might have been either rendered useless, or have graced the kennel coppers."

The handling of the horse by rib and neck, to determine the state of his condition, is a very ancient practice. Xenophon and other old authors notice it; and we find one of these writers on the horse asserting, "that there are outward and inward manifestations of fat, some being outwardly fat and yet inwardly lean," which, although it seems to imply a contradiction, is yet in some cases true. Another denies the possibility of this, and a third thus discourses on the subject:-"Some horses feed outwardly, and carry a thick rib when they are inwardly thin, as may be; whereas others appear lean to the eye, when they are all grease within. In this case, the feeder of the horse has two helps to advantage his knowledge, the outward and the inward one. The first is the outward handling and feeling the horse's body all over his ribs, but particularly upon his short and hindermost ribs; and if his flesh generally handle soft and loose, and the fingers sink therein as into down, he is foul without all manner of question: but if he be hard and firm, and only soft upon the hindermost rib, he has grease and foul matter within him, which must be voided, whatever comes of it. And for the inward help, that is only sharp exercise and strong scouring; the first to dissolve, and the latter to bring it away" The same author, with much truth, gives the retraction of the testes to the body as an useful criterion of condition.

Our next chapter will treat of VICES IN THE IIORSE: firstly Stable Vices, then those of The Road and Harnegs. The Treatment of a Horse on a Journey, Care of the Feet, Shozino, a Chapter on Ridina and Drivina,--while an outline of what a Gentleman should know of the first steps and general outlines of horse-medicine, shall conclude this division of our work. Veterinary SCIence and Practice will follow. 


\section{CHAPTER XIV.}

THE VICES OF HORSES AND THEIR KEMEDIES.-STABLE VICES : RESTIVE WHILE CLEANING: KICKING: CRIB-BITING: WIND-8DORING:

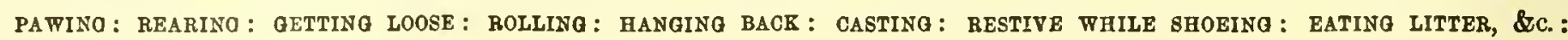

VICES ON THE ROAD.

The Vices of the Horse offer a tempting subject to the essay-writer; the idiosyncrasies of this valuable quadruped presenting almost as many leading features as those of erratic human nature herself; yet of the horse's "original sin " in the respect of "temper," we are somewhat sceptical, believing that, although horses of violent and even furious temper mas be found, the "vice" is far more frequently attributable to improper, harsh, or ignorant training, and to tricks taught him by the folly or mischievous propensities of his groom or keeper, than to temper.

The neglect of early kind treatment and association with mankind is the most prolific source of obduracy in the horse. Much of the disposition which characterises the animal at a mature age is established in his youth. The seeds of rebellion, obstinacy, and strife are readily sown by the hand of ignorance and indiscretion; like noxious weeds, they thrive more vigorously than those of obedience, docility, and cheerfulness. As that of the child, the education of the horse should commence at an early age, and both should be treated with kindness. Pleasure should be associated with early lessons, obedience inculcated by firmness, not by brutal severity; upon these points we refer the reader to our chapter on "Breakina and Training." Few there are who adopt the happy medium. In the horse, a dogged, sullen, spiritless submission may be enforced by the cruel brutality to which the breaker too frequently has recourse; but that prompt and eager response to the rider's will, that manifest alacrity to accord with every wish, which give to the horse so much of his value, can only be founded on habitual confidence and attachment.

Temper is a property, a virtue it may be aptly termed, when rightly directed, deserving the utmost attention, not only with reference to docility, but in a more extensive sense, in connection with the nervous energy of the system and corresponding physical power. This energy is affected by the amount of nervous excitability of the brain, in conjunction with the nervous system, influencing the muscles of locomotion. If that be in proportion with the physical power of the animal, he will be capable of manifesting great superiority, providing his physical powers are in a healthy state, and cultivated by proper work or training.

Extreme irritability or impatience of reasonable control, by overpowering the muscular system, will occasion prostra- tion of strength, and the animal will be found incapable of endurance. On the other hand, if the muscular powers are greatly in excess of the nervous energy, the horse is of little value except for purposes in which sluggishness is unimportant.

The ordinary means adopted by sportsmen and others connected witl horses, and which have been for ages more or less successfully the means of subjugating them, have been eclipsed by the performances of Mr. Rarey. Whatever scepticism may exist as to the permanency of his treatment with horses confirmed in vice, very great and important results are most unquestionably manifest in the facility with which he is enabled to reduce to quiet submission wild, unhandled, unbroken colts. Those who ride and drive for health and amusement, although their wealth may enable them to purchase horses perfectly tractable, cannot fail to enhance their pleasures by the confidence which a knowledge of this art must establish.

It is an unfortunate fact for creatures of instinct only, that their tuition is mostly entrusted to that class who have but a small share of the reasoning faculty themselves; and what they have, bad temper and worse feeling frequently prevent their exercising. There can be no doubt that the less reasoning faculty the pupil is endowed with, be it man or brute, the more enlightened should be the preceptor. If a master improperly chides or corrects a boy, the latter has reason to call to his aid, and sees the folly or injustice of the chastisement; thus, his progress in learning anything is not stopped or thrown back by the folly or ebullition of temper of the master; but the poor brute is confused by it; and no doubt that intemperate and misplaced correction often undoes far more in one quarter of an hour than can be rectified by a week's subsequent tuition. Parents would be figuratively "up in arms" if a boy was improperly or illadvisedly corrected; yet owners will look with perfect apathy or carelessness on the treatment their more-to-bepitied animals undergo at the hands of their teachers. More to be pitied, because the boy can complain; the poor brute cannot, whatever may be his sufferings.

The horse comes next to the dog in point of acuteness of instinct, the highest-gifted of those animals we have in a domestic state, or at least from the tuition we bestow on him, his instinct is the most developed. The ox, cow, sheep, and swine are left all but in a state of nature; the cow 
comes to be milked-the others to be fed; these are all the demands made on them; the labouring ox is a little more taught, but nothing more than the commonest instinct suffices to effect. The fact is, we want, in a general way, no more services of such animals than instinct enables them to perform. Even as regards the horse, highly as we prize him, but little pains are taken with his education, if the term may be used; he is mostly broke to carry or go in harness by very rude hands; bat no further pains are taken with him. He will sometimes show considerable cleverness in fencing; this is only the effect of instinct and practice. The dray-horse will quietly approach the trapdoor of the cellar, wait till his trace is fixed to the upcoming cask, lean sideways, as it may be called, against the collar, and on the cask reaching the pavement well knows that what was wanted of him is achieved, and if called on will willingly repeat the service. This is instinct, self-possession, and practice. Even with amphitheatrical horses "docility" is the one thing wanted. The "dancing" quadrilles, as it is called, is not by "ear," as is pretended, but by the hand and heel of the rider synchronously used with the cadences. The horse learns to obey a signal or a motion, and instinctive obedience does the rest. With these arguments for a gentle system we come to the subject of Vices, so-called.

\section{STABLE VICES.}

Restive while cLeaning.-We need hardly remark on the difference of "temper" displayed by different horses under the hand of the groom. Horses that are steady and quiet on the road and in the field cannot be dressed without hazard to the strapper or groom, as well as risk to themseives. This will often be found to be owing to a highly sensitive skin, in which case the remedy should be the adoption of other implements and a lighter method. For instance, to discard the ordinary curry comb, at least for a time, and substitute stout linen rubbers, horse hair gloves, and a flexible backed brush. Of the latter we can safely say that they are in all cases of fine-cuated animals preferable to the curry-comb, and searching enough if the horse is industriously groomed. In the majority of instances, however, this vice has arisen from teasing the animal; or a heavyhanded fellow with a broken-toothed comb, or a worn and uneven-surfaced brush, literally knocking the animal about. As to teasing, we have watched many strappers who took a delight in making the animal lash out at random, or show his teeth; can we wonder then that this "vice" is contirmed? A change of groom, perhaps, takes place, and what was previously done partly in play, by the stranger is treated as a manifestation of anger-or "vice." If the recalcitrant animal should inflict injury on the unsuspicious newcomer, of course "confirmed and dangerous vice" is the verdict, although the poor unreasoning brute was merely practising his rehearsed "horseplay." Gentle handling and encouraging words, with a firm and unhesitating approach, will soon render such a horse quiet and steady.
Kickina is too often caused by the teasing, tickling, or pinching above noticed. The habit becomes confirmed, and the illtaught animal is voted incurable.

An inveterate kicker is to be very carefully approached by all parties, and sometimes requires even more than ordinary caution, in which case a chain is run through a pulley in the stall-post, and from that to his head-stall, so that by pulling it his head may be drawn round towards the post, and by the same action his heels drawn from it, so as to allow the groom to go to his head, when he is safe from the heels. Most good grooms, however, are able to take care of themseives, and by constant practice they learn to keep the proper distance, either near enough to make the kick a mere push, or far enough to be out of reach.

KICKING THE STALL-POST is injurious both to the kicker and his next neighbour, who may come in, under a bail, for the knock intended for the post. We have known horses do this for hours together in mere idle play. Hard work cures it, and if that does not, or is not available, a branch or two of furze-bush nailed against the post will generally stop it. Mares are stated to be addicted to this bad habit far more than horses. A $\log$ of wood strapped to the leg most used in mischief has been advised. We think them very dangerous, and not heavy enough to be efficacious. A broad strap fastened round the pastern and the weight, about five pounds, attached, so as to avoid bruising the coronet, will be found an improvement.

Birına.-This dangerous and unpleasant habit which is often a mere indication of playfulness, is a decided vice in many horses. Watch carefully that your stable boys and grooms do not promote or encourage it, which they often do and then exclaim against it and punish the animal for what is caused by their own provocation and folly. Various inethods, some very cruel, have been proposed as cures for a biting horse, "Harry Hieover" has an amusing paper on the subject in his "Stable Talk," from which we shall here make an excerpt. The writer says :- "Supposing a horse to have that abominable vice of biting people, he gets well flogged for it: this may deter him in some measure from doing so: but if it does, it only prevents his doing it when we keep an eye on him; it does not cure his inclination to do it; nor would anything but finding he actually hurt himself by the act itself. A somewhat curious mode of curing this appeared in the public prints; namely, the giving such a horse a hot roast leg of mutton to seize. Absurd as this appears, it is really not so much so as many things that are done towards horses: in fact, if a horse was addicted to biting legs of mutton, it would be a rational and certain way of curing him of the propensity; but as legs of mutton do not often come in his way, and arms of men frequently do,-unless he was stupid enough not to be able to distinguish the one from the other, the mutton plan could not avail much. Now, if we could cover a man with a coat of mail, with invisible spikes standing from it, two or thres times seizing the man would, I doubt not, radically cure the 
horse-not of his disposition tu bite, but of attempting to do so. But as we cannot well do this, I believe a short stick, and keeping an eye on him, in approaching or quitting him, is the only thing to be trusted to. Flogging him after he has bitten will tend to increase his propensity to do it, for this reason : it is either dislike to man or fear of man that makes him bite: he seizes us to prevent our hurting him, or in revenge for having been hurt; consequently, punishing only confirms his fear and hate; so probably, if we do this, and he finds he dare not bite, he tries the efficacy of a kick.

"A friend of mine had a favourite mare that was exseedingly troublesome to dress, and bit terribly What inade it worse was, she would on no occasion bear to be rack-chained up; she would rush back and throw herself down. When she had the muzzle on, she would run at the manger, rack, and man, so that the blow was nearly as bad as the bite. It happened the groom had killed a hedgehog the day before: seeing this in the stable, it struck me I could turn him to some account; so I got him skinned, and fastened the skin to the bottom of the muzzle, of course on the inside. I put it on the mare, lengthening the head-strap so as to allow about three inches between the skin and the mare's lips, and offer her no inconvenience but of her own seeking. I begged the groom to strip and dress her. The moment be touclied the roller-strap to unbuckle it, she rushed at the rack-staves as usual, but not the usual result did she find. She ran back to the end of her collar-rein, snorting; he commenced dressing her: she went at him as usual: he was quick enough to meet her muzzle with his arm, giving it a hard blow against her nose: sle did not try that came again: she had a go at the manger; this was worse: after a few trials, she contented herself with squealing as usual, kicking and fiying about the stall : but slie kept her nose from coming in contact with the man or anything else. She found she punished herself, and had sense enough to leave off doing that which produced punishment by the act. The man punishing her never had, or never would have, produced the same effect. Could the groom have worn a hedgehog strapping-jacket or shirt, no doubt she would have been cured of attempting to bite him. The lesson, of course, only prevented her biting, or trying to bite, when the muzzle was on: when off, she would do as she always had done, for then she well knew a man's skin was not a hedgehog's. This we will call 'practical education,' and is in accordance with the system of education I advocate."

The following is confirmatory of the views taken by the writer just quoted:-An instance of a mare viciously addicted to biting being cured of the habit by an accident, occurred to us a short time since. Her former owner had foolishly taught her to do this by teazing her, and she had contracted the luabit to such an extent, that whenever any person went into her box, unless her head was tied up, she would assuredly run at him. Knowing that beating her, or adopting anv harsh measures, would have only a prejudicial effect, it was forbidden, and by putting the muzzle on when she was being dressed, any serious consequences were avoided. The way she cured herself was singular. She had been out to exercise, and the boy was washing her legs and feet, her head being racked up, and the muzzle taken off to allow her to eat a little hay. She turned her head suddenly, with the intention of seizing the boy, by which act she caught the stirrup-iron in her moutl, and, being racked-up, she was fixed as firmly as if she had been in the stocks. She plunged violently, and in doing so her hind-quarters slipped and she fell sideways, her head still held fast by the rackchain. By loosing the girths she was released from her perilous position, as she was almost strangled; but she never attempted to bite afterwards.

Crib-biting is one of the vilest habits a horse can acquire, and one of the most intractable. The horse seizes the manger with his teeth while he stretches his neck forward, and, after some spasmodic action of the throat, a slight grunting sound is uttered, which appears to be accompanied by a drawing in of air. The cause of this trick is not well understood; and whether it proceeds from a bad habit, or a defect in the formation of the soft palate and back part of the mouth, remains a question.

One serious effect of this trick is the wearing down of the teeth; and instances have occurred where they have been broken. It has likewise been found that crib-biters are more liable to colic than those without this vice. Whether this proceeds from the loss of saliva occasioned by the wearing down of the teeth is also an unsettled point.

It has been found that crib-biting is acquired by horses being in the stable with one which has the trick. Among the expedients which have been resorted to for the cure of crib-biting, the edge of the manger has been lined with iron; also with sheep-skin besmeared with aloes, tar, and other disagreeable substances, but all with little effect. The ordinary preventive is the use of a strap buckled round the neck, which lias the effect of slightly compressing the windpipe, and rendering it impossible to resort to it; but no sooner is the strap removed, than the horse recommences his old habit, so that it must be constantly worn to be of use. Unfortunately the continual use of it is apt to produce irritation in the trachea, and this will terminate in the affection termed roaring. A five or six months' run in a field has also been tried without proving a remedy. Cribbiters are generally in low condition.

A muzzle barred across the bottom will prevent cribbiting. This must be made only of sufficient width to allow full action to the lips, so that the animal may pull his hay from the rack and eat his corn, but so close as not to admit of him grasping the edge of the manger. Cribbiting is legally considered "unsoundness."

WIND-sUCRINa has such a strong family likeness to cribbiting that it may properly be considered a modification of it ; as it is accompanied by a want of condition, and the same bending of the neck, with the head drawn inward, is 
exhibited, and the horse alternately opens and closes his lips, and a sound is produced similar to sucking air. The horse presses his muzzle against the manger, quietly sucking in the air, without the noisy gulping which accompanies crib-biting. The remedies attempted have been, tying up the head of the horse, except when feeding; and the application of a muzzle with sharp spikes bending towards the neck, which will prick him when drawing in his head.

Pawing is a continual working away of the litter by the fore feet. A simple remedy is at hand in a pair of padded shackles with a connecting chain, 12 inches in length. These are placed round the smaller pastern bone, and must be taken off at night, or the horse will be afraid to lie down.

WeAvino is a restless habit of swaying the head from side to side, somewhat after the fashion of a polar bear in confinement. It is unsightly, and evinces a restless disposition. "Weavers" are generally poor feeders, and low in flesh. The remedy indicates itself; a short head-rein, and a little relaxation of the restraint while feeding.

Getring Loose is a very troublesome vice, and many horses are so cunning as almost to defy the efforts of the groom and saddler. If, however, a head-stall is made with a strong throat-lasl, and this tightly buckled, no horse can get it off, because the circumference of the head at the jaw is always greater than that of the neck from the back of the ears to the throat. If the horse bites his halter, a chain must be substituted; but as this makes a constant noise, it should be avoided if possible, as other horses are readily kept awake by it.

Hangina Back is an attempt to get free, by bursting the throat-lash or collar-rein, and in some cases great force is applied in this way, so much so that many horses have broken their hips from the sudden giving way of the halter letting them back, so that they fall over and irremediably injure themselves. The only cure is a strong chain, and a head-stall that no force will break; after trying to burst which a few times the horse will almost always desist. If the manger is not very firmly placed, another ring should be fixed in the wall, by piercing it, and screwing a nut on at the back. The groom should watch for the trick, and give him a smart lash from behind the moment he tries it on.

RoLlina.-Horses that roll in the stable are apt to be injured from want of sufficient room, and also to get entangled in the halter; and, strange as it may appear, although he may get severely hurt, and be nearly choked by the halter, he will repeat it night after night. The only thing which will prevent him from rolling, is to give him just enough of collar to enable him to lie down; but so short that his head will not touch the ground, because it is impossible he can roll over without resting his head upon the ground. If a horse is in a field, rolling is a harmless and even healthful amusement.

NoT LYINO Down.- Horses are sometimes prone to standing constantly; and some only lie down once in a fortnight, or even a longer period. When this is the case, clucy are generally liable to swellings in the limbs, and seldom able to go through much work. Such horses should, if possible be put into a stable by themselves and left at liberty; and a well-made bed will sometimes tempt them to lie down. No means can be adopted to force the animal to take rest by lying down. When it is not possible to place him in a stable alone, an empty box should be constructed so that he may be left for the night unhaltered in it. We had a remarkably fine harness-horse that never was known to lie down, and yet be kept in good condition, and was not troubled with swelling in the limbs: but this is a rare occurrence. He sometimes fell down on his knees while asleep, but the groom always found him on his legs before he could reach the stable. although his house was next door.

Castina. - This is the result of a sportive inclination in the horse to roll completely over in his stall, as though at liberty in the field. It is a trick fraught with danger, as the unwieldy animal in so confined a space gets completely over on his back against the wall or ramp, and there, unable to roll back again, struggles to his death by rupturing the colon, "ricking" his spine, or some other mortal injury. T'he prevention is difficult; but, if the horse is within hearing of the groom, a prompt attendance will usually prevent unpleasant consequences. We have known horses lie all night in such distressing positions that it was a miracle they lived till morning. By throwing a halter over both legs, or three or four straps buckled together, the cast horse may be readily drawn over on to his side, when he will gladly get on his feet, unless seriously injured. HaLter-castino is occasioned by the animal getting one of his fore-legs over the halter and throwing himself. Whether with rope or chain the animal is in danger of badly wounding himself. Horses addicted to pawing are most liable to accident, though we have seen it arise from a habit of scratching at the head with the hinder-foot-the drop weight of the halter or collar rein not acting so as to prevent it getting loose. A couple of collar reins should be used to prevent the paw. ing accident; for that with the hinder leg, a ring in the head wall, about seven feet from the ground, with a rack chain about three feet long, may prevent the calamity.

liying onder the Manger is obviated by the manger and rack-guard we have figured (3) in our Plate of Stable Fittings; it is described ante, p. 132.

Restive wille Shoeing will be included in uur general remarks on this vice. Where a horse, otherwise docile, exhibits a peculiar aversion to the smithy, and we have seen such, make an investigation as to his treatment there. It is only a month since we attended at a police investigation, where a shoeing-smith had struck wantonly a valuable saddle-horse on the stifle with his hammer, by way of preliminary to taking up the foot. The poor animal was irrecoverably injured; had he been less so, he might have been set down as "vicious to shoe." With a young borse great caution is necessary, and the gag or twitch should be 
only resorted to in extreme cases. It is the biped, not the quadruped, that is generally the aggressor in these instances. Mr. Youatt, whose humanity shines in all his writings, says on this point-c" It should be a rule in every forge that no smith should be permitted to strike a horse, much less to twitch or to gag him, without the master-farrier's order; and that a young horse should never be twitched or struck. There are few horses that may not be gradually rendered manageable for this purpose by mildness and firmness in the operator. They will soon understand that no harm is meant, and they will not depart from their usual habit of obedience; but if the remembrance of corporal punishment is connected with shoeing, they will always be fidgety, if not dangerous.

"This is a very serious vice, for it not only exposes the animal to occasional severe injury from his own struggles, but also from the correction of the irritated smith, whose limbs and even whose life being in jeopardy, may be forgiven if he is sometimes a little too hard-handed. Such a horse is very liable, and without any fault of the smith, to be pricked and lamed in shoeing; and if the habit should be confirmed, and should increase, and it at length becomes necessary to cast him, or to put him in the travis, the owner may be assured that many years will not pass ere some formidable and even fatal accident will take place. If, therefore, mild treatment will not correct the vice, the horse cannot be too soon got rid of." We have seen recently a very simple method tried to make a horse still while shoeing. It is merely fastening down one ear. The reader will find more on this point at page 370 , ante.

EATING LITTER.-The rack-rein and muzzle at once indicate the mechanical means of preventing this pernicious habit. For this purpose, we would recommend a rack-rein and muzzle, to be alternately used; when the one is taken off, the other to be put on. For instance, you put on the muzzle when you wish or expect the horse to lie down; consequently you put it on at leaving the stable at night. Some horses will eat the litter even when it is very foul: and when fresh litter is given, others will prefer it to hay; and though clean straw is not injurious to horses that are not required to gallop much, yet hunters and racers must not be permitted to eat it. The rack-rein is an iron chain fixed at the head of the stall, which passes through a ring sewed in front of the nose-band of the stall-collar; it is fastened in the same manner as a dog's chain to the ring in the collar, and, when dressing the horse, you can, after passing it through the collar, fasten him as short as you think proper; but, at other times, the chain must be long enough to permit the horse to feed out of his rack or manger, though not to let his head reach down to his litter.

Some horsekeepers place a piece of rock salt in the manger to wean the horse from his foul feeding, and satisfy his morbid appetite. It is worth a trial

\section{VICES ON THE KOAD.}

RESTIVE TO MOUNT.- In connection with this subject we bef to refer the reader to pages $66-76$, on Bredking, Traininis \&c., where the methods of " gentling " the animal are fully set forth; in this place our remarks shall be general. The term "restiveness" may be said to include plunging, rear. ing, kicking, bolting, and general impatience while being mounted. As we have already said, the suaviter in modo is indispensable here. Even if one resolute or strong person has brought the animal into subjugation, he is always dangerous to the next man who mounts him. When the difficulty of mounting arises, not from eagerness to start, but from unwillingness to be ridden, the sooner such a horse is disposed of the better, unless the owner is determined to try his hand at horsebreaking. When the restiveness, on the other hand, merely amounts to eagerness to start (very unpleasant, indeed, at any time, for many a rider has been thrown from his seat before he was fairly fixed in it), it may be remedied by an active and good horseman. "We have known many instances," says Youatt, "in which, while the elderly and inactive and fearful man has beeu making more than one ineffectual attempt to vault into the saddle, the horse has been dancing about to his annoyance and danger; but the animal had no sooner been transferred to the management of a younger and more agile rider, than he became perfectly subdued." Severity will here, more decidedly than in any other case, do harm. The rider should be fearless; he should carelessly and confidently approach the horse, mount at the first effort, and then restrain him for a while, patting him, and not suffering him to proceed until he becomes perfectly quiet. These horses should not be too highly fed, and should daily have sufficient exercise.

Shyina.-Whether this arises from fear, vice, or playfulness, it is equally important to check its earliest displays. Shying is one of the worst of habits, and more accidents have resulted from it than all other vices or defects. One cause of shying is defective vision, timidity stands next, and it often proceeds from a frolicsome disposition. Shying is less common among high-blooded horses than half-bred ones, although it is occasionally found among our first-class racers.

When shying proceeds from playfulness, it is difficult to judge what mode of cure is best to be adopted; because, if corrected for it, he will associate with any object that diverts his attention the infliction of punishment, which will tempt him to run away, under the dread of a flogging; and if caressed for the fault, it is liable to induce him to repeat it. But, of two evils, gentle correction must be adopted, and rather to pass by the object than to wake him up to it. He should also be spoken to sharply.

If shying proceeds from fear of new objects, the way to correct him of this, is not to force him up to them, but to pat him and soothe him: avoid beating, and take care to 
pass the objects of his fear again and again, always going nearer to them every time you pass. This will familiarise him to them. Seeing that these are harmless, he will soon learn to pass by unnoticed any novel object which he may meet with upon a road.

When an animal is given to shying from defective sight, the only method to effect a cure is to take him up to it, and in the act of doing so he must be coaxed to approach it, and on no account must he be beaten; and although it sometimes happens that the horse will manifest great reluctance to do so, he should be persevered with, and not allowed to proceed until he has seen closely and smelt at the object of his fear. After he has been a few times thus treated, he will soon learn to pass with indifference any object which he may meet. Many of Rarey's remarks, already referred to, may be remembered and applied with advantage. We will take here an illustration, from Blaine's book, of the principles laid down.

"We once purchased," says that experienced veterinarian, "a horse with an excellent character for steadiness, except that he was always much alarmed at a passing carriage, whether it was coming towards overtaking him. A tilted waggon or a stage-coach on the approach were such objects of dread as no power could get him to face. We knew it would be in vain to oppose human physical force to brute fears, and that it was only by introducing favourable recollections derived from those very objects, greater in degree than the fears hitherto entertained of them, that we could conquer this dangerous propensity. We began by leading the horse, previously exercised and fasted, towards a cart filled with clover hay the smell of the hay was irresistible, and soon dissipated all dread of the stationary cart; but when it was purposely moved gently onwards, he became rather discomposed: a little coaxing, however, induced him to follow it, and we had the pleasure, at this his first lesson, of seeing him proceed confidently with the cart round a farmyard, and finally into the road. To vary the effect, after he had steadily walked by the side of the carriage a certain time, we restrained him, so that it got ahead of him; when he again reached it, slight indications of fear appeared as he had to make his way up to the side of the cart, for we had a coverlet purposely drawn over the back, that he might not reach the hay from behind. We next passed the cart altogether, but it was a few paces only, and then turned him round to the other side of it; but his whole mind was so intent on the clover, that, with the most trifling symptoms only of alarm, he fell to again on the bay, which finished lesson the first. Our next attempt was made with a sieve full of corn, presented to him on an empty stomach, which he could only reach from the tail-board of a tilted wagonan awful object! After a few snortings and sniffings, here also hunger overcame bis fears, and he munched the oats with great relish; but when the waggon was put into motion, Lis dread for a little time got the better of his appetite, and the flapping of the covering of the tilt appeared to him most portentous : his fears even in this case, however, soon gave place to confidence, by the tact displayed by a groom to whom he was much attached. This man mounted the waggon, and, resting on the tail-board, offered the oats to the horse, at the same time calling and encouraging him. This worked wonders; nor shall we readily forget the knucker of acknowledgment with which the confiding brute followed the groom's call as the wagon moved on, occasionally dipping his nose into the sieve. After a few more lessons of a similar kind, one or two of which were varied by giving him hay from the window of a stage-coach, he lost all fear of carriages, and his former owner would willingly have taken him back at a very considerable increase of price. We introduce this merely as an instance of the truth of an opinion entertained by most observant sportsmen, but often acted against by grooms, that the punishment of blows will very seldom cure vicious halits originating in fear. All startings and fears of every description are only increased by them, for the horse in these cases associates the dread of two evils instead of one, that of the object itself, and that of the punishment which is to follow; the consequence of which is, that his resistance is doubled. How common is it with thoughtless persons, when a horse shies at an object, to force him up to it by blows; by which means we are confident that no horse was ever cured of shying, but, on the contrary, he has always been rendered doubly timid. It is, however, not amiss, when a horse shies principally at any one fixed object, as a tree, milestone, \&c., to cuax him towards it by every mark of encouragement. If he will not readily approach it, use no furce, but dismount, caress, and incline his head from the cause of his alarm, gradually drawing him nearer and nearer to the object itself, which laving approached, he will invariably closely examine him. self by smelling it. If this be practised with gentleness, it is more than probable that such horse will shortly be cured of shying at that particular object or its like."

That amusing instructor, "Harry Hieover," has a "wrinkle" of stuffing a horse's ears with cotton which may find a place here. He tells us, what wo all know, that "horses in any way nervous or high-tempered are much affected by sound: and noises, particularly when arising from any object or cir. cunstance they cannot see. I have had two remarkable in this particular, the one a mare. Whether in harness or uut, a horse or carriage behind her drove her almost mad; let either come alongside of her, she was quiet directly. When in harness, if she but heard a horse behind her, up went her head and tail, and she would bound something as we have seen a fallow deer do in passing us; and, though at other times possessing a fine mouth, on such occasions it was difficult to hold her. The other horse was a hunter, as placid and steady as horse could be when alongside hounds in chase; but, while they were finding, or, what was worse; running in cover, the cry of the pack would cause him to tremble with anxiety or some such feeling, and he would burst into a sweat ten times more profuse than any rur 
would call forth. Being both good horses and pleasant, except in these particulars, I was determined to try and palliate them. I had a pair of thick earcaps made for each of them. This I found produced a wonderful alteration for the better; but it struck me these earcaps must heat the horse. Why not try cotton? I did; stuffed their ears well with it when using them; and found no inconvenience from sounds afterwards."

A thousand pages of advice could not add to these practical experiences.

BACEING or JibBing.-It is by no means unfrequent for harness horses to back instead of drawing when first started, and others combine with this curious obstinacy the practice of other vices. When the backing is mere skittishness, which we have known it, an encouraging word and a smart smack of the whip have cured the inconvenience. Where the determination is more manifest take the thing coolly. Satisfy yourself by examination that the harness and its "fixins" are all right. Sometimes the withers are wrung, and the shoulders galled; and the pain, which may be moderate on level ground and with a fair draught, becomes insupportable when going up a steep acclivity. These things should be seen into, and, if possible, rectified; for, under such circunastances, severe punishment produces obstinacy and vice.

A horse, whose shoulders are raw, or have frequently been so, will not start with a cold collar. When the collar has acquired the warmth of the parts on which it presses, the animal will go without reluctance. Some determined jibbers have been reformed by constantly wearing a false collar, or strip of cloth round the shoulders, so that the coldness of the collar should never be felt; and others have been cured by keeping on the collar night and day, although the animal is not able to lie down so completely at his ease as without it, which a tired horse ought always to be able to do. When a horse jibs at his work, it has been sometimes useful to line his collar with cloth instead of leather ; the perspiration is more readily absorbed, the substance which presses on the shoulder is softer, and it is more readily eased off at a tender place.

With horses which have this habit at starting, one method io break them of it is to place a large heavy stone behind the wheel; and the horse, feeling he is unable to back, will generally proceed forward, finding it more easy to do so; and by carefully continuing this practice, the horse will gradually be broken of the bad habit. Another plan, nearly as good, is to start the horse, if it can possibly be managed, with the back of the machine placed towards a rising ground; and as it is more difficult at all times to force it backward than forward, besides the hill being against him, he will prefer going forward tc backward. Sometimes it will be necessary to lead the horse for a short distance, and when the groom has quitted the reins, a gentle touch with the whip will make him proceed. If, however, he is determinedly obstinate, there will be little chance of succeed- ing by forcible means; and if the driver is resolved to use compulsion, we would recommend that it should not be attempted unless there is a wide space, where by tight reining the driver may back him in the particular direction which he wishes, and it would be very desirable to do so uphill if the ground inclines in the neighbourhood. But still there is danger in the attempt.

Rarey is of opinion that the horse often jibs, or, as he calls it, "balks" at starting from hearing, or fancying they hear, something coming up behind them. He is speaking of such an occurrence in an American pair-horse trotting "waggon," but his remarks are as applicable to any pair of horses or to a single horse in harness. He says :-

"Almost any team, when first 'balked,' will start kindly if you let them stand five or ten minutes as though there was nothing wrong, and then speak to them with a steady voice, and turn them a little to the right or left, so as to get them both in motion before they feel the pinch of the load. But if you want to start a team that you are not driving yourself, that has been 'balked,' fooled and whipped for some time, go to them and hang the lines on their hames, or fasten them to the waggon, so that they will be perfectly loose; make the driver and spectators (if there are any) stand off some distance to one side, so as not to attract the attention of the horses; unloose their check-reins, so that they can get their heads down if they choose let them stand a few minutes in this condition until you can see that they are a little composed. While they are standing you should be about their heads, gentling them; it will make them a little more kind, and the spectators will think that you are doing something that they do not understand, and will not learn the secret. When you have them ready to start, stand before them, and as you seldom have but one balky horse in a team, get as near in front of him as you can, and if he is too fast for the other horse, let his nose come against your breast : this will keep him steady, for he will go slow rather than run on you; turn them gently to the right, without letting them pull on the traces as far as the tongue will let them go; stop them with a kind word, gentle them a little, and then turn them back to the left, by the same process. You will have them under your control by this time, and as you turn them again to the right, steady them in the collar, and you can take them where you please.

"There is a quicker process that will generally start a balky horse, but not so sure. Stand him a little ahead, so that his shoulders will be against the collar, and then take up one of his forefeet in your hand, and let the driver start them, and when the weight comes against his shoulders, he will try to step; then let him have his foot, and he will go right along. If you want to break a horse from balking that has long been in that habit, you ought to set apart a half-day for that purpose: Put him by the side of some steady horse; have check-lines on them; tie up all the traces and straps, so that there will be nothing to excite 
them; do not rein them up, but let them have their heads loose. Walk them about together for some time as slowly and lazily as possible; stop often, and go up to your balky horse and gentle him. Do not take any whip about him, or do anything to excite him, but keep him just as quiet as you can. He will soon learn to start off at the word, and stop whenever you tell him. All 'balked' horses can be started true and steady in a few minutes' time; they are all willing to pull as soon as they know how, and I never yet found a balked horse that I could not teach to start his load in fifteen, and often less than three, minutes' time."

Despite this last dictum of Mr. Rarcy, we believe many corses are such determined jibbers that they can nevir be cured. When this is the case they should be sold to the owners of a vehicle in which four-in-hand or unicorn are driven, and if placed as near wheeler they will be forced to do their work. Some have also been worked in a team by farmers; but nobody would think of keeping an animal which can only occasionally be rendered serviceable.

In connexion with this subject the reader is referred to another part of the work, where breaking and familiarising a colt with usual sights and sounds are treated of.

Kicking.-Elsewhere we have noted this as a Stable Vice; under saddle or in harness, however, it is far more dangerous to rider, driver, and the public. In saddle, get well hold of his head, lift it firmly and determinedly, then bring the whip smartly down the shoulder. Mind his head is well up when you deliver the blow, or he may get his nose down and lash out again. When the animal proves an inveterate kicker, a gag-snaffle will serve to keep his head up. The gag-snaffle is not, unless the horse wilfully hangs on it, more severe than a common snaffle, while, if he will have it so, it acts through the pulley-like attachment of the rein with augmented power, drawing the angle of the mouth above the usual seat of the bit. It is valuable, too, with "pullers" who "bore" in the hunting-field.

In harness, as we have said, a kicker may be yet more dangerous and mischievous. Horses that are fidgetty in the stable are most apt to do this on the road.

The slightest touch on such animals' quarters, even by the reins touching, will set them kicking; and in many instances the front of the carriage will be diven in, or a gig may be battered to pieces, the horse frequently coming off with a broken limb, or the driver may sustain serious injury. With kicking horses, the greatest care should be taken not to allow the harness to pass under the tail, as the moment they feel it the tail is pressed suddenly and tightly down, so much so, that it is difficult to extricate the reins, and the more the driver pulls the more the animal kicks and plunges. When the driver finds that the reins are so entangled, he should on no account attempt to extricate them by pulling, but quietly get down, and release them by lifting the tail gently.

Where persons cannot afford to part with such horses, as they must be sold at a great loss, a strong kicking-strap may be used, which circumscribes the use of the hind limbs, and prevents the horse from raising them for ar effective kick. Still, rely not too much on this; for, if the horse should once break the strap he is worse than ever. indeed incorrigible.

The uninitiated are not aware of the very slyght things which will cause a horse to kick on being first put into harness. The mere putting the crupper on, if done suddenly, in putting on the harness, will sometimes cause him to kick. Probably, with the liarness loose on his back, his kicking on first feeling the crupper sends it off him, or partly so. The horse gets seriously alarmed at this; a scene ensues; and then there is (to use the desgination of a farce) "the devil to pay."

Backing a horse into the shafts (which should never be done) is very likely to set him kicking. He comes suddenly in contact with the shaft in some part, and either he rushes forward in alarm, or sends his heels at it. This might be termed lesson the first in virtually teaching the animal to kick. If in double harness, the very turning a corner incautiously will cause many a horse to kick, from feeling the pole or trace suddenly come in contact with his thigh.

Even throwing the driving rein to be buckled over the young horse's back, instead of that of the break horse, which a stupid or careless fellow might do, will probably alarm a horse new to harness. He rushes forward, is checked by the traces, then backs himself suddenly, is then checked by the pole-piece and collar, feels himself hampered in every way, gets alarmed or angry. Here, probably, is "the devil to pay" again.

Mr. Bingley gives us, among others, the following incident of his horse-expcrience:- "An instance of an inveterate kicker in harness occurred under my notice. An elderly relative, with whom $I$ at that time resided, made a purchase of a remarkably good-looking horse, for the twofold purposes of working on the farm and running in harness. On the following morning he was attached to a plough on the gee-ho principle, and when required to 'move on' responded by kicking most violently. I was summoned to the scene of action, but for some tiine he would allow no person to approach him, and struck at those who attempted to go near his head with his fore feet, as viciously as he did with his hind ones; at length, by strapping uf his near fore-leg they succeeded in getting him released irom the plough. His gearing was taken off, and replaced by some strong harness, when he was placed between the shafts of a substantial roller, such as is commonly used for rolling the land. When properly secured at all points, a powerful and steady horse was put before him, and he was kept moving in a fallow field till night. He kicked the roller furiously and repeatedly, but in doing so he hurt his own legs, and, finding he got the worst of it, he left off. The next morning his hind legs were very sore, and he was again attached to the roller, but he did not evince much inclination to commence hostilities, and in the course of that day he was 
put to a gig. I drove him constantly, and he never repeated his vice. It was afterwards discovered that he bad been in the possession of a post-master, and that he had kicked the boot of a gentleman's carriage to pieces, for which he was sold as incorrigibly vicious."

It will be found that brute force or brutal violence rarely succeeds or produces the desired effect with horses, or, indeed, with any animal. Brute force subdued Van Amburg's lions, but it did not tame them. They were too much subdued to attack him while his eye was on them, he knew; but if he had turned his back or shown he had fear of them they would have pulled him down and torn him to pieces. Brute force may compel a horse to do a particular act at the time-it may even make him fear to commit one at variance with cur safety; but, and let opportunity occur, we shall soon find that fear alone will never eradicate a bad propensity.

Pudxang is akin to kicking, though very differently performed. The animal makes a bound or spring with his back bowed upward, with the apparent intent of unseating his rider. Sometimes he "tucks," i.e., springs with all four feet off the ground suddenly, an experiment very likely to answer his unpleasant intention. When a horse has this habit, hold his head closely, as for kicking, with which it is often complicated or alternated. A modern writer recom. mends that a horse-cloth rolled up, strapped to the front of the saddle like a soldier's cloak, will greatly add to the safety of the rider. The general treatment must be, as so often said before, the "soothing system," with firm but very moderate punishment.

REARING is a common trick with young horses, and is oftener playfulness and mere animal spirits than anything like "temper." It is, however, alarming, and may be very dangerous to the timid or unskilful rider, when it is a decided rise, involving also the unintentional danger to the animal itself of a roll over. Generally, however, it is in colthood a series of wanton gambolling skips, which sometimes go off like the freaks of a kitten; but lest they become a habit, and partake of an attempt to get rid of the rider, severity and hurry must be avoided. Use for a time, it may not be permanently needed, a martingale, with a running rein commencing at the breast strap of the martingale, and then, running through the ring of the snaffle, bring it back to the hand. This will give you a full power over the horse's head when its exercise is called for, and will not distress him while he behaves himself. When the horse rises, lean well forward and hold by the calf and inner thigh, loosening the bridle a little when he is in the air, and then bringing his head in as he descends. A rough remedy for rearing has been tried by some horse-breakers-we do not recommend it : the process is to provide yourself with a bottle of water, and when the horse rises break it between his ears by a smartish tap.

Shoolderina.-Some obstinate ponies and ill-taught horses have acquired this ugly trick. It consists in trying to squeeze the rider's leg against a post, paling, or wall, and to scrape him off the saddle. We once had a little Welshman who had a genius for this when he had a yourigster on his back; we cured him by mounting him ourselves, and when he tried this lateral movement (which is easily overcome by putting out the foot as he sidles towards the object), we found a sharp pull of the near rein (it seems almost universally tried on the off-side), coupled with a most unmistakeable simultaneous slash over the eff ear, brought him clear away. Three or four of these lessons, in an orchard well studdec with old trees, made him pass as clear of them as could be desired.

Hugarna the Pole. - "Harry Hieover" thus proposes to deal with an animal exhibiting this not uncommon propensity. "A horse having this vile habit I should strongly recommend others to sell, unless they were disposed to tiy a plan that I found effectually cure one of my own. I drove him at wheel on the off-side; but, whichever side he was put, he 'hugged the pole' the same. I had a piece of hoard, about ten inches in width, screwed to the off-side of the pole. On the off-side of this surface I nailed some strong green furze, clipping it till it did not project more than three inches on the side the horse went. I took care to give him a hole in the pole-piece, the same with the near side trace, and lengthened his coupling rein; so he had not eccasion to approach the pole thus armed. This being merely a lesson to the horse, I took care to manage the drive so as only to have occasion to turn the carriage to the off-side during the lesson: as usual, he began or attempted hugging the pole, but he started from it as if a tarantula bad stung him. I suppose in a few minutes the smarting went off, when he tried the same game with the same result. I conclude the second application of the furze, acting on the first, produced increased effect, for it was a longer period before he transgressed again, and before my drive was finished he took especial care not to approach the pole. Though this bid fair as to curing him of a bad habit, I in no way expected a lesson or two would cure him; but ten days' driving effectually did, and afterwards it was somewhat laughable to see, if he forgot himself, or attempted pole-hugging, with what alacrity he jumped back into his proper place."

Seizing the Cheek of the Bit.-When horses are so cunning as to get the cheek of the bit into the mouth, they have immense opportunity for displaying any impatience of control they may be inclined to : any moderately skilful saddler and harness-maker will show you how to prevent this being done a second time.

Ronning ATAY - vulgo, "Bolting."-This, in its commonest form, is merely a sign of a hard mouth, and self-will in maintaining the gallop. Its other phase is a most dangerous vice. When it is consequent on nervous excitement or fear, the usual expedients for "gentling" or calming irritability already recommended are to be adopted. All sorts of severe bits have been devised to prevent horses running away. Some excellent authorities recommend the "Bucephalus noseband." a contrivance which keeps the mouth of the 
horse closed, so that the "port" of the mouth-piece acts against the upper part of the mouth, in a manner it cannot do when the animal has the power of opening it to ease the pressure. This noseband will be found useful with hard pullers, and "borers" in the hunting-field.

This dangerous propensity generally shows itself in nervous young horses, who, at the least noise behind or beside them, become alarmed, break from a trot to a gallop, and, terrified by the impotent struggles of their riders to stop them, or the still pursuing sound of wheels behind them, become maddened and dash on in their perilous career. When a horse finds or thinks he has succeeded in these efforts to escape danger, on a recurrence of the noise or cause of fright he will pursue the same course, to the peril not only of rider or driver, but of himself, and whatever he may meet with in his impetuous flight. The vice becomes confirmed, and it is only by the utmost nerve, coolness, and command of temper, dashed with kindness, and the "rational " treatment of the mania (for panic-fear in horses is madness), that we can hope to check the disease. When a horse is known to have a tendency to running away, be extra particular that all portions of his "furniture" be sound and strong, particularly bridles, reins, and bits : get a firm, steady hold of him at starting, and speak to him soothingly and encouragingly. At the very first symptom of a bolt check him sharply and speak to him in a firm voice; never allow him to increase his pace of his own accord, or fear will augment it and he will break into a gallop. Keep the reins in driving evenly in hand, but do not by a constant pull deaden the mouth. Be ready to catch him well by the head quickly, and you may get him under command without frightening him.

In the saddle, on a determined brute, it is a good mancuvre to select a hill, and, giving lim his head, urge lim an up-hill burster ; this has "taken it out" of many a "bolter," by making him go his hardest for your pleasure, just as he was thinking of doing it of his own wilfulness and vice. In this the horse resembles not a few of our reasoning race, who will work hard for pleasure, but will do nothing in the shape of work, either for utility or to serve another. These customers we have found, when fresh, will try it on again; but a good rider, and none other should mount or drive them, will make them tired of their little game; and then such animals generally prove first-raters. As we have said, a dead pull is no use with such bolters; it is better to let them go when there is plenty of room, and then to try what a sharp and severe pull will do: not keeping it up too long if ineffectual, but loosing the mouth again for a time, and then tryin again. Sometimes, however, there is no room for this, and then the only plan is to try and bring the head round, cither with a view of galloping in a circle, or to run the head against a fence or even a wall or strong gatu. Sometime. anything is better than a straight course-as, for instance, in a crowded thoroughfare, where there would be an almost positive certainty of mischief: in such a case it is better to do anything than to persevere in the course which the runaway is taking.

A driver of good nerve may in this extremity pull or drive the horse straight for anything that is insurmountable and that must stop him - say a thick hedge, or even a wall, at all risks of damaging the animal. With judgment and coolness this is the best chance for rider or driver; indeed, a few bruises or loss of life may be the alternative. We will give an illustration. A friend of the writer's, a civic magnate, well known in connexion with the removal of the horse and cattle market from ancient Smithfield to its present site, was driving a high-couraged horse, a new purchase, in a dennet, down Parliament Street. He had a life-long experience in horseflesh as well as fat cattle, and was a match for any coper that ever chaunted a "screw" in the departed market for "blind 'uns and bolters" which for more than seven centuries was held " in the Smethfelde on the outer syde of Newgate." Our driver then, who had with him his wife, was no cockney with the ribbons, albeit his calling was exercised within the sound of Bow bells. At the corner of Charing Cross his horse took fright, and bolted along the somewhat crowded thoroughfare. Desiring his better half to hold fast in her seat until he should bid her jump, he got the animal well by the head, and guiding his frantic speed direct for one of the strong iron gas columns near the Horse Guards, the animal came flush with its forehead against it, fell instantly, as if shot, and rose no more. And how fared the worthy deputy and his better half? The one jumped out, at the word "Jump!" and got off with a graze and possibly a bruise; while the wealthy carcase butcher, as he told us cheerfully, was none the worse-except the repairing of the chaise, which was his own; and the dealer, who lent him the horse on trial, he added, "I have since learnt, knew he was a bolter, so he'll never get a farthing-though I don't think he'll have the face to ask me." With this example of how to deal with a bolter in the last extremity we pass on to Ridina and Drining, and Treatment or A HoRse ON A JOURNET 
CHA P TER X V

\begin{abstract}
RIDING.-GENERAL OBSERVATIONS: PROPER POSITION OF SADDLE, BRIDLE, \&C.: MOUNTING AND DISMOUNTING: MANAOEMENT OB
\end{abstract}
THE REINS, AND SEAT ON HORSEBACK : RIDING TO HOUNDS: LADIES' HORSEMANSHIP. DRIVING.-GENERAL OBSERVATIONB :

HARNESE : FOCR-IN-HAND : A PAIR: SINGLE HARNESS.

IN former chapters of this work the reader will have found numerous things necessary to be known and remembered as aiding the formation of an accomplished rider. A reference to these will enable the reader to refresh his memory upon these essentials. Historical and antiquarian lore, relating to the saddle, bridle, stirrup, \&c., will be found at pp. 64--66. Hints upon riding will be found scattered through the chapter on BrEAKING, pp. 69-76. But more especially, when treating of the Paces of TIIE Horse, will be found how to handle the animal in the Walk (p. 78); the Trot (79-81), civilian and military; the Canter (82), and the Gallop (84). The mode of keeping the seat, and of lifting the horse in leaping, will be found as follows:-The Standing Jump (84), the Flying Leap (85), the Buck Jump (86); while Timber Jumping, and Taking Gates and Stiles, will be found at pp. 86, 87. Lastly, not a few "wrinkles" for the horseman are contained in the chapter preceding this, which treats of VICES, their correction and cure. With these references, by which repetition may be avoided, we proceed to the-

\section{POSITION OF THE SADDLE, BRIDLE, AND STIRROPS.}

The Saddle, which ought to be wide and roomy, should be placed in the middle of the horse's back, a liand's breadth (four or five inches) from the point of the withers, but so as to give free play to the action of the muscles of the shoulders. Lay the girths evenly one over the other; draw them only so tight as to admit comfortably the fore-finger to be placed between the girth and the horse's belly. Fit the surcingle neatly over the girths, and do not buckle it tighter than they are drawn. The large ring of the breast plate or martingale, when worn, should be placed two inches above the breast-bone, and should allow of the hand being laid flat between it and the horse's shoulders.

The malposition of the saddle, particularly in horses with upright shoulders, is the cause of many horses falling, from its pressing too much on the shoulders, and by that means confining the action of the muscles, which thus become benumbed, and lose their elasticity. A partial deadening of the limbs having taken place, the horse, from want of vitality in the legs, stumbles. and is unable, through the torpidity of the muscles, to recover himself, and falls to the ground; in many cases be has been known to fall as if shot.

\section{THE STIRRUPS.}

The length of the stirrups should be so adjusted that the bottom edge of the bar hangs about three inches above the heel of the boot. This length will be found most convenient for the horse and his master in hack-riding The method of determining the best length for the stirrup is thus given by Mr. Waite in his little book called "Graceful Riding:" "Take up the stirrup-iron with the right hand, at the same time placing the bottom of the stirrup-iron under the left arm-pit; then extend the left arm until the fingers of that hand easily touch the stirrup buckles; this is a sure criterion with most people."

The Bridle is put on with the curb bit so placed that the mouthpiece in horses is no more than an inch above the tush of the lower jaw; in mares two inches above the corner teeth is the distance. The bridoon should just touch the angles of the mouth, so as to sit easy, with drawing them up. The headstall should be parallel to the projection of the cheek-bone, and not lie over or upon it. The noseband is better placed low, and should not be buckled tight. The curb, when properly fitted, should lie flat and smooth in the hollow of the lips, so as to allow the finger to be easily introduced between.

\section{MOUNTINO AND DISMOUNTJNO.}

Directions for mounting must always be taken with an allowance for the different relative heights of the horseman and the animal he is to ride. We shall therefore merely give such general instructions as apply to the medium size in both biped and quadruped, and the average activity and weight of gentlemen of the present day. When a horse is intended to be mounted he should always be approached quietly on the near (or left) side, and the reins gathered up in the hand steadily. The snaffle rein (or bridoon) first; then pass this rein along the palm of the left hand, between the forefinger and thumb. The curb rein must now be drawn over the little finger, and both reins being held of an 


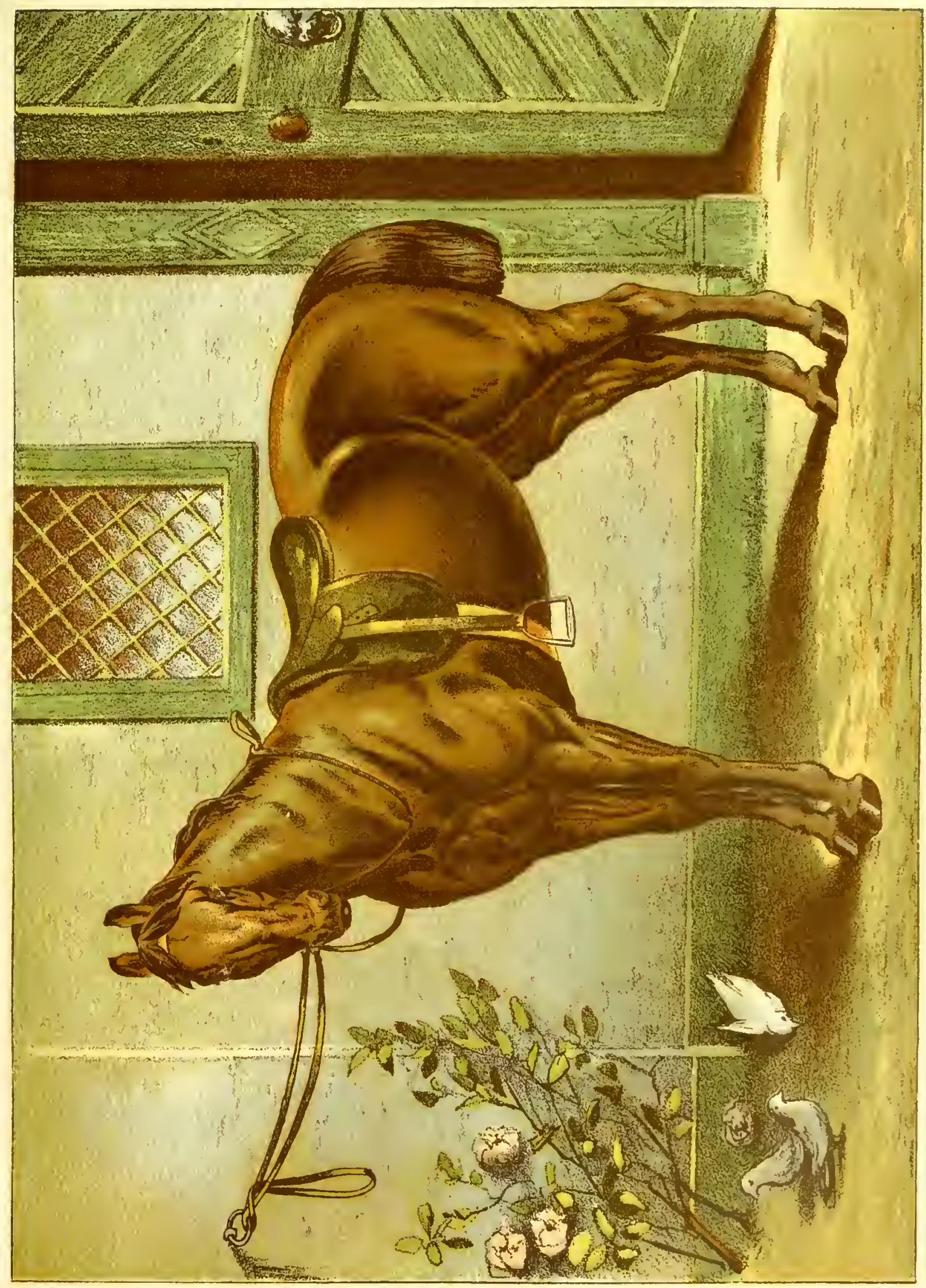



equal length, and having an even pressure on the horse's mouth, must be laid over each other, and held firmly in the hand; the thumb pressing upon them to prevent them slipping through the fingers. Be particular that the reins are not taken up too short, lest it should cause the horse to rear or run back; they must be held neither too tight nor too slack, but having an equal feeling of the horse's mouth. Next take up a handful of the mane with the right hand, bring it through the palm of the left hand, and twist it round the thumb. Take hold of the stirrup with the right hand, the thumb in front. Place the left foot in the stirrup as far as the ball of it, placing the right hand on the cantle (or back part of the saddle), and, by a spring of the right foot from the instep, the rider should raise himself up in the stirrup, then move the hand from the cantle to the pommel, to support the body while the right leg passes clearly over the horse's quarters; the rider's right knee closes on the saddle, and the body drops gently into it. The left hand now quits the mane, and the second stirrup must be taken without the help of eye or hand.

The left hand (the bridle hand) must be placed with the wrist rounded outwards, opposite the centre of the body, and about three inches from it, letting the right arm drop unconstrained by the side of the thigh.

Mounting without stirrups while the horse is standing still is effected as follows:-The rider stands opposite the saddle and takes hold of both the pommel and the cantle, keeping the reins in the left hand at the same time, and in the same manner as in ordinary mounting. Now spring strongly from the ground, and by means of the spring, aided by the arms, raise the body above the saddle; then twist the leg over, whilst the right hand is shifted to the right side of the pommel, and by means of both the hands the body is steadied into the saddle. Mounting without stirrups may, by very active men, be effected while the horse is going on, much in the same way as is seen constantly in the circus. The rider runs by the side of the horse, laying hold of the pommel of the saddle with both hands strongly, and allowing him to drag him along for two or three very long steps, he suddenly springs from the ground and is drawn into the saddle. This feat is seldom achieved by the ordinary equestrian; but it is easier than it looks, and in riding to hounds is sometimes of great service with a fidgety horse.

Dismounting is effected by first bringing the horse to a standstill; then shorten the left hand on the reins till it lies on the withers, with a steady feel of the mouth, twist a lock of the mane on the finger, and hold it with the reins; bearing also on the pommel with the heel of the hand. Next, throw the right foot out of the stirrup, and lift the body, steadied by the left hand, and borne by the left foot, until it is raised out of the saddle; throw gently the right leg over the cantle, and as it passes it grasp this part with the right hand; then lower the body gently to the ground by the aid of the two hands and the left foot; or if it is a very short person and a tall horse, by raising the body out of the stirrup on the hands, and dropping to the ground by their aid alone.

Dismounting without stirrups requires the horse to be brought to a standstill, then holding the reins in the left hand both are placed upon the pommel, and by their aid alone the body is raised out of the saddle; the right leg is now thrown over the cantle, and in doing so the right hand seizes it and with the left lowers the body to the grount.

\section{MANAGEMENT OF THE REINS, AND SEAT ON HORSEBACK.}

Our horseman at ease in his seat, and looking forward between the ears of his animal, adjusts the reins, which we will suppose to be bridoon, or snaffle and curb. The reins should hang untwisted from the bits. Mr. Waite gives the following minute practical directions, which we transcribe, for holding the reins with one or both hands.

"Holding the reins in one hand.-The rider must take up the bridoon reins with his right hand, and pass the second and third fingers of the bridle or left hand between them, draw up the reins with the right hand, until the horse's mouth can be felt, and then pass them between the forefinger and thumb. Next take up the curb reins (again with the right hand), and pass the little finger of the bridle hand between them, draw them up, as before directed, with the right hand, until the rider perceives there is an equal length and feeling with the bridoon reins; the latter having rather the strongest pressure on the animal's mouth. This done, lay them also over between the forefinger and thumb, and press down the thumb firmly upon them to keep them from slipping; the hand to be held with the wrist rounded outwards, opposite the centre of the body, and about four inches from it. The right arm should hang without restraint, and slightly bent, by the thigh; the whip being held about twelve inches from its head, with the point turned upwards.

"Riding on one rein.-Take up that particular rein with the right hand, and pass the second and third fingers of the bridle hand between them, then draw up the reins, but be careful, in doing so, not to hold the horse too tight in hand; the other rein should hang down, having the little finger passed between them, and the thumb also over them, so that they may be caught hold of, and drawn up quickly on any sudden emergency; the loose reins are to hang between those in use.

"Using both hands.-Take the bridoon reins between the second and third, and the curb reins between the third and fourtl, fingers of each hand, each rein having an equal bearing on the horse's mouth; the hands are to be held about six incles apart, with the wrists rounded outwards, and the thumbs pressing firmly upon the reins, the elbows well down, and held near to the sides, the whip held as directed above.

"A tight rein should always be avoided, because, if he carries his head low, it tends to deaden his mouth, and teaches him the bad habit of depending upon the bridle for support ; in which case, he always goes beavily in hand, and 
on his shoulders. The horse should at all times be taught to go on his haunches.

"If the horse naturally carries his head well, it is better to ride him with a light hand, only just feeling his mouth.

"Turning.-In the turn either to the right or left, the reins must be held quite evenly, so that the horse may be immediately made to feel the aid of the rider's hands; he (the rider) must then have a double feeling on the inward rein, also retaining a steady feeling on the outward; the horse being kept up to the hand by a pressure of both legs, the outward leg being the stronger.

"Reining Back.-The rider should frequently practise reining back, which is of the utmost service both to himself and his horse: by it, the rider's hand is rendered firm and materially strengthened; and the pliancy of wrist so essential to the complete management of the horse is achieved, likewise causing the body of the rider to be well thrown back and his chest expanded, thus forcing, and preserving, an erect position in the saddle. Also, the carriage of the horse becomes greatly improved; his head is maintained in its correct position, and he is compelled to work correctly on bis haunches.

"In 'reining back,' the horseman requires a light and steady feeling of both reins, a pressure of both legs, so as to raise lis horse's forehand and keep his haunches well under him, at the same time easing the reins, and feeling them again after every step.

"Stopping.-None are thoroughly taught until quite au fait in the stop It is of far greater importance than may be usually imagined. In the first place, it shows the horse to be well under command, especially when the rider is able to do so instantaneously: it saves, in the second place, many serious and inevitable accidents from carriages, horsemen, \&c., such as crossing before, suddenly pulling up, turning quickly round a corner, or coming unawares upon the rider.

"Care must be taken to make the stop steadily; not by a sudden jerk upon the bit; by doing so the horse, if "tender mouthed," will be made to rear and plunge. To make the horse stop properly, the bridle-hand must be kept low, and the knuckles turned down. The rider's body must be well thrown back; he must have a steady feeling of both reins, and, closing both legs for a moment, so keep his horse well up to hand. The rider's hands always must be eased as soon as halted."

As to Seat on Horseback, there have been small volumes written on it in sporting magazines, works on the manège, and books on "The Noble Science" of Foxhunting. With the haute école, as our neighbours call the teaching of horses to astonish the beholders by capricoles, demivoltes, lifting their feet in a manner to render them useless and unserviceable, and other tricks of the circus, we have nought here to do, confining ourselves to the modern English school of riding.

It is easy to discover the riders who have been taught in a good school, by their firm, graceful, and uniform position in the saddle, and by their ready and skilful application of the bridle, hands, and legs; such being indispensable to the skilful guidance and control of the horse.

It will not be necessary here to describe the marked characteristics exhibited by the jockey, the huntsman, the whipper-in, the groom, the postboy, the soldier, the dealer's lad, and the butcher. These have all different seats on horseback, each best adapted to their several occupations; for the inan who all his life is accustomed to one particular style of riding and to one particular kind of horse, will adopt a natural style, which marks the whole class of those adopting it.

In acquiring a good seat, there are four things necessary to be attended to-first, the position of the weight, so as to be sufficiently forward in the saddle; secondly, the fixing of the knees on the padded part of the flap; thirdly, the proper length and position of the stirrups; and fourthly, the carriage of the body.

The weight of the body should be well forwards, because the centre of motion is close to the middle of the saddle; and as the weight is chiefly thrown upon the breech, if the seat is far back it is not in that part, but near the cantle that it is placed. But by sitting well forwards the weight is distributed between the breech, thighs, and feet; and the horse is able to rise and fall in his gallop without disturbing his rider.

The knees must be well forward to effect this seat, and also well in front of the stirrup-leathers; for if they are placed behind them the body is thrown too far back, and the hold is insecure. The object of all young riders should be to get as far forward as possible, so that the knee is not off the saddle; and they can scarcely overdo this part of the lesson by any effort in their power. Riding well upon the fork, with the knees upon the padded part of the flap, will ensure a good position if the stirrups are not too short. These should be about the length which will touch the projecting ankle-bone, when the legs are placed as above directed, but out of the stirrups; and when they are placed in them, the heel should be about one inch and a half below the ball of the foot. This latter part receives the pressure of the stirrup in road-riding, but in hunting or any other kind of field-riding the foot is thrust "home" and the stirrup touches the instep, whilst the pressure is taken by the under part of the arch of the foot The reason of this is, that in leaping the pressure on the stirrup is almost lost; and if the toe only is placed within it the foot is constantly coming out. Besides this, in the gallop the attitude is of that nature that the spring of the instep is not wanted, the weight being too much thrown upon the foot, if standing in the stirrups; and if sitting down in the saddle the feet should scarcely press upon the stirrups at all, anc therefore the best place for them is where they will be most secure. The body should be carried easily, balancing backward and forward or sideways, as required, but not forcibly. Instinct is here the best guide, and the rider should follow 
its precepts rather than attempt to follow any preconceived rule. If the horse rears, he will feel called upon by nature to lean forward, and may even grasp the neck if needful, or anything but the bridle, which will only bring the horse back upon him. The body should not be held stiffly upright, but, short of this, it can scarcely be too still, the loins being slightly arched forwards. The legs also should be as motionless as possible, and nearly perpendicular from the knee downwards; but, if anything, a little forward, the heel being well depressed and the toes very slightly turned outwards. The shoulders should always be square-that is, at right angles to the road taken; and whether trotting or galloping neither of them should be advanced before the other.

If a man contemplates becoming a perfect horseman, he should consider in what way his riding will be chiefly required, and make himself master of that. If he only contemplates road riding, if he acquire a neat, easy, and firm seat, with good hands, he will do well enough; and having gained these, he may be satisfied. If he means to be a hunting man, he will find it will require a still firmer seat, stronger arms, and far stronger nerves, without which he will never become a "workman" across country; and, as to race riding, no man need hope to arrive at any perfection as a jockey, unless from a boy he has been more or less in the habit of riding race-horses.

There are two things all but indispensable to the man who wishes to become perfect as a horseman-good nerve and good temper: without the first, he will want confidence; and without the second, he will neither have patience to be taught himself or to teach his horse.

So far as seat is concerned, a great deal depends on the formation of the man. With very few exceptions, short chubby-made men never make neat horsemen; and without any exception, such persons can hardly possess an easy and graceful seat. Such men are usually very round in the thigh; a formation much against a firm seat, without which no man can be a good horseman.

Huntsmen usually sit more down in their seat than gentlemen do. This arises from their keeping a constant eye on their hounds, which they can have with that seat more than they conld standing in their stirrups as a jockey does. Huntsmen are apt to sit a little oblique on their horse. This is caused by their riding mucl with the rein in one hand, which hand is usually held rather more forward than other men hold it, so as to enable them to have more command over the horse; which is quite necessary for a man to have who has to get through thick covers at the risk of having his own and his horse's eyes cut or knocked out by brambles, thorns, or hanging boughs. The way in which both learn to avoid these is extraordinary: the more so when the man's whole attention is devoted to every turn his hounds make, and to every hound he hears throw a tongue. We will suppose a huntsman in the middle of a thick cover of perhaps a hundred acres; he hears a -iew halloo on which he can depend, and also hears his hounds making to the point from whence the halloo comes Get to them he must; and that over newly-cut stubs like harrows reversed, or through underwood where half his time he is forced keep his arm before his face to save it. All he can do is to trust to his horse; and the way in which those accustomed to it do gallop through and over such obstacles, no man but a huntsman, and no horse but a huntsman's can imitate. He gets to the cover's skirt; no matter how awkward the fence to get out, he has no time to pick a safer place. "Come up," and with a haul at his horse's mouth, and a whack with his whip on the shoulders, over they come somehow. He has then to rattle along over any ground, not merely at a chasing but a catching pace. He comes up with the crowd in a narrow lane, with half it hundred gentlemen trotting up the centre; these he cunnot command to get out of his way, though every good sportsman would voluntarily do so. "By your leave, gentlemen," is the utmost he dare say ; and with a "hark forward, hark!" or "hoick together, hoick!" and the occasional use of "by your leave," he rattles by them with a wagon-rut for his horse's path. He gets to the hounds, and with a half-blown horse has to face a country that others begin with one quite fresh. It is not to be wondered at, therefore, that halftired man and horse get on, in such a case, just as they can, but most huntsmen now-a-days are provided with a second horse, otherwise they could not get through their work.

Connected with the seat, is what is called in horse language "liands." When a man inquires what kind of bit he should use, he generally means what sort would suit his horse's mouth; it is of more importance to inquire what will suit his own "hands." This is to say that a man with "good hands" can ride with any bit; while it is most important, where the rider has "no hands at all," that the animal should not be punished and confined by a cruel piece of ironwork. The loridle with which, in the first case, he would go pleasantly and gracefully, would, in the latter, become neither more nor less than an instrument of torture, under the effects of which he could go neither pleasantly, gracefully, or even safely to himself or rider.

One would naturally suppose that any man in the habit of riding would be anxious to acquire so necessary a part of horsemanship as good hands. Daily observation, however, shows that it is not so; and this inattention or indifference arises from various causes. The first is, the man knows nothing about " hands," consequently does not know that he has bad ones; again, if he does know this, as he merely rides an animal for health and exercise, and having found one who has no more "mouth" than his master has "hands," the latter has probably found himself safely enough carried, and wants no more.

Bad "hands" are much more frequent causes of bad riding than even defects of seat. Indeed, the things act and re-act, and an unsteady seat will produce bad "hands." Should a friend, then, ask you candidly about bits and bridles, and so forth, be equally candid with him. Ask 
him, "Has your horse a good mouth?" that is, tender, and "Does he often throw up his head?"

Is his mouth, temper, and disposition such that a curb-bit can be dispensed with? If it is, ride your horse, by all means, in a plain snaffle and martingale (not a nose one). If he requires a curb, use an easy one, and only make use of it occasionally. We would recommend all men with bad hands to use martingales; not exactly to keep the horse's head down, but to counteract the effect of their hands getting up, which is nearly always the practice with bad riders. Martingales, too, are advisable, because with one it matters less where the hands are; they do not affect the horse's mouth as respects the elevating or lowering of the head. All they can do is to use such force in pulling the reins that the horse cannot advance. Probably the rider will take the hint, and moderate his pull at the reins.

"Hands" may be considered the refinement of horsemanship, without which no man has any pretensions to the character of a horseman; he may ride boldly, and sit fast. This does not make him a horseman. "The difference between riders," says "Harry Hieover," is_-" the one sits on the back of a horse, crossing a country in such form and style as the animal likes; the other causes the horse to do the same thing, but in a proper manner."

Good "hands" are to a man of fortune worth a diadem; in virtue of them, he is carried as no man wanting them can be. It may be said his money could purchase horses that want no hands to make them do their business handsomely. He might; but if they wanted no hands to make them go in such manner, still less do they want bad ones to thwart them when they do.

They are invaluable to the poorer man. They enable him to purchase horses hitherto thought little of from a bad style of carriage, and raise the price of the same horse, while in his possession, from, perhaps, eighty to a hundred and fifty.

Finally, "hands" are of the utmost importance to the horse himself, particularly in hunting; wanting them, beats many a good horse before his time. Permitting a horse, in technical phrase, to "make a spread eagle of himself," and go sprawling along over a deep fallow, "sows him up" at once. It is quite a fallacious idea to suppose that a horse knows the easiest way of going to himself. $\mathrm{He}$, perhaps, would do so in a state of nature ; but nature is not crossing a hundred. acre holding pasture, with twelve (or more) stone weight on his back.

\section{RIDING TO HOUNDS.}

We have, in various subsidiary branches of the subject of Ridina, forestalled so many points of the present subject, that we can almost deal with it by way of reference to the opening part of this Chapter.

To keep on terms with a modern pack when running hard, neither man or horse, whatever other faults they may have, must be troubled with "the slows." As an old-world enthusiast in the art of driving once told us, "the great secret of coaching, is to keep your time;" so in riding to hounds, the chief and indispensable accomplishment is to know how to gallop. This is not, as might at first sight be supposed, a mere matter of "horse ;" on the contrary, it has a good deal to do with the biped who bestrides him. One man will get across a field in half the time it takes his friend, though mounted on a faster animal, to accomplish the same distance; and this facility is a sort of knack, which it is impossible to teach and almost hopeless to explain. It is an accomplishment compounded of hand, eye, and seat, with a considerable allowance of nerve; for, strange as it may appear, men are far less shy of fences than they are of galloping; and many a bruising, daring rider, with good hands, undying pluck, and a first-rate eye to hounds, finds that, although in a hunting run he can generally go first and foremost, yet for want of this gift of galloping he is always beaten, he cannot tell how, in the first three fields of a really quick thing. The man cannot of cciurse "carry the horse," though young gentlemen often think they can "lift" him. We do not mean to say that the best hunter in England, if slow, will bear his owner satisfactorily through a burst, but that the quick man on the slow horse will go in a good place (supposing he wishes to show in the front rank) till his steed stops; whereas the slow man on the fast horse will be nowhere throughout, though doubtless of the two he will have the pleasanter ride home.

We will suppose, however, that man and horse are both of the "going sort"- the one devotedly fond of hounds and determined to be with them, the other sharing his master's attachment to the chase, and trained to that state of wind and condition which enables him to undergo the severest exertion, not only without inconvenience, but with positive enjoyment. This is but the foundation of the science : how much skill and judgment is required in its superstructure! The knowledge of hunting, necessary to place every turn of the hounds to account; the choice of ground, which makes all the difference between gliding smoothly down a furrow, or labouring uncasily athwart a ridge; the quickness of eye, which, on landing in a field, spies instantaneously the weak place at which to get out, and makes directly for that spot without deviation or delay; the accuracy of ear, that, when hounds are necessarily unseen, can be guided by their notes; the experience, which tells as it were intuitively the direction they are likely to take; and lastly, the dauntless nerve, that, among rasping fences, is determined to be forward, and prepared to run its chance of what there is beyond the obstacle.

"Eternal misery on this side, my Lord, and certain death on the other," said one of the best of our steeple-chase riders to a nobleman who was almost his rival; and in another instant he was in the air 'To put in practice the intellectual qualities essential to clever hunting, it is essential to possess likewise the physical advantage of fine horsemanship, of which more is required in crossing a country than the uninitiated are apt to suppose. Iforace 
says, "the horse's ear is in his mouth ; " and you need only deprive him of his bridle, to render the finest rider in England utterly helpless on his steed. "Harry Hieover" tells an anecdote illustrative of this quality, which we must preserve. "A gentleman in Northamptonshire was run away with some few years ago. His horse having got his feet through his reins in a scramble at a fence, and tore them completely from his head, away went the pair-the animal frightened out of its wits, as is the custom of the species when anything extraordinary happens; the biped cool and unmoved, as if he sat in an arm-chair. Fond, however, as he was of going fast, it was necessary on this occasion to stop; so, being a long-armed man, he leant well forward, and placing his hands over its eyes, completely blinded his horse, and brought him to a standstill, if we may be allowed the expression, in a twinkling. We are not all, however, gifted with such long limbs as this imperturbable equestrian, and must make up, if we can, for deficiency of arm by increased fineness of hand; and here we lay it down as an established rule, that no horse can go properly with hounds if he pulls. Let him lean upon his bit to that extent which enables us to draw him into a collected form; let him get his head up, or down, or sideways, or into any other position he pleases, with a proper feeling of resentment at undue interference with his mouth, and we freely forgive him; but for a boring, dead, stiffnecked puller, we confess to an insuperable aversion." Common riding, as Colonel Greenwood's book truly points out, is but common sense, and the whole object of bitting and bridling is, after all, to get the horse's hind legs into their proper place under his quarters, through the medium of his head. The animal is so formed, that when he bends his neck and tucks his nose in, he brings his hocks and hind feet well under his body, and vice versa hence it is that horses with well-made, powerful quarters, have for the most part light mouths. Should that sensitive organ, however, have been hardened by a bad education or bad usage, it must be our study to apply such an instrument as, by giving us additional power, or, in other words, inflicting a severer pressure, shall make up for this want of sensitiveness without giving pain, and thereby causing irritation at the time, and increased callousness afterwards. This is the whole art of bitting, and on this depends the skilful touch we term "hand." That such power is obtained over the horse by an almost innumerable diversity of bridles, we have only to look into any saddler's window to observe; and it is impossible to establish any of these as the best, inasmuch as the grey horse will only go pleasantly in one that would drive the chesnut mad, while that which brings the brown instantaneously on his haunches is a mere halter in the mouth of the bay. Different men, too, would ride the same animal in different bridles, so various are the methods in which people deem it safe and expedient to bandle their horses. The large plain double-bridle, with a thick bridoon, a lnw port, and a very long cheek, more particularly should the hit be made to slide up and down for an inch or so on the cheek aforesaid, will be found admirably adapted to three horse out of four; but then it may render the fourth totally unridable: so, as we have already said, it is impossible to lay down any rule on the subject. But that it is absolutely necessary to find out the bridle in which he goes most pleasantly, to get a horse quickly along over a country, it needs but little argument to demonstrate.

For mere galloping, we should be able to turn and trist him anywhere. The very fact of pulling up short to open a gate, and consequently keeping up the steam till within a few yards of that friendly egress, will give one man an immense advantage over another, who, although riding a second Eclipse, cannot quite command him, and, should he mean to stop at all, must begin hauling long ere he is half-way across a forty-acre field.

What, too, can be more provoking, when jammed into a lane amongst a hundred dear friends, than to spy a weak place in the fence, through which, if you could but hustle, you might be alone with the hounds; and to find that, pressed as you are by the galloping crowd around you, it is impossible to pull up or turn, till several hundred yards past the only practicable gap for miles? Though the hounds are running at right angles to you, it would take more time to turn round than to keep forward, and you are carried on by the tide till you find yourself in a turnpike road, from which, as we all know, there is no escape. All this is rectified by having horses what is called "handy:" and to make them so, should be the first object of any man who wishes to ride well to hounds, more particularly in the grass countries, where the crowd of his fellow-sportsmen is one of the greatest difficulties he has to encounter. A fast slug, if he has courage enough to face large fences, will generally slip away quicker than any other description of hunter; and it is extraordinary how many horses that have been ridden by good men become so quiet and temperate that we might almost call them slugs. When thus mounted, and in a good place with hounds, a really fine rider seems to glide over a country, almost like a bird upon the wing. It is beautiful to ride behind such, and watch his performance. How quietly he sits down in his saddle, giving and taking with every motion of his horse; how judiciously he selects the soundest ground, and at what a rattling pace he makes play when its inclination is at all in his favour. With what patience he waits at a slow canter, or pulls completely to a trot in the ploughs; what skill he shows in angling the ridge and furrow, or avoiding it altogether by making at once for the headland; how he seems to anticipate every turn of the hounds, and thereby gains a timely pull almost whenever he stands in need of a moment's breathing-space; and above all, with what determination he crosses the severe fences, which in every good run we may be pretty sure it will be his lot to encounter. 


\section{LADIES' HORSEMANSHIP.}

Albeit we do not expect lady-readers to con the pages of "The Book of Field Sports," yet do we esteem it a serious omission that the art of riding, as practised by lady-proficients, should be passed over without mention in such works; for surely a brother, father, friend, or, better still, a lover, may desire the knowledge which would enable them to speak, or, if need be, to instruct in these matters, "as one having understanding." We are not going to advocate the "first-flight" as an accomplishment; or torn veils and rent skirts, got in charging a "bullfinch," or rising, mermaid-like, bedraggled from the depths of a soft-banked brook, as a triumph becoming our British fair. We rate too highly their precious limbs and beauteous faces, to desire to see them exposed to the risk of iujury. Yet who can assert that painter or poet can have a more beautiful subject for pencil or pen than a fair Englishwoman on a Landsome horse, as she passes in the power of her charms, her eyes brightened, her colour heightened by the health and spiritgiving exercise, her hair floating, and her lithe figure swaying and bending in graceful pliancy to every movement of the glossy steed she manages with a woman's tact and a woman's pride? All this may be delightfully enjoyable in "the ride" in Hyde Park, or on the greensward of the avenue of the "old house at home ;" or the ten or twelve miles an hour may be enjoyed on the road, through bridlelanes, an occasional hand-gate and grass-field, as, with spirits gay, they repair to "the meet" they so radiantly adorn. But here, as we have said before, we pause, though perhaps some of our youtl-for human nature is ever the samemay yield to the modern Sauromatæ, of whom Herodotus tells the story so quaintly. This Scythian tribe of female warriors, says the old Greek, were called "manslayers ;" but this was in a more literal sense than we would apply in the present day How the Greeks fought with them in the field, intermarried with them, and were conquered at home, the reader may seek in the ancient historian referred to.*

* These antetypes of the "pretty horse-breakes" and heartbreakers of the 19th century, argued with their husbands in a style and with an effect that 4,000 years have not cast into oblivion. The husbands proposed a settling down to the calm duties of domestic life; to which the Amazons replied, "We never could live with the women of your country, because we have not the same customs with them. We shoot with the bow, throw the javelin, ride on horseback, and have never learnt the employments of women. But your women do none of the things we have mentioned, but are engaged in women's employments, remaining in their wagons, and do not go out to hunt, or anywhere else. If, then, you desire to have us for your wives, and to prove yourselves honest men, go to your parents, claim your share of their property, then return, and let us live by ourselves."

Need the result be wondered at? The story is repeated daily to this hour. A determined, though soft-spoken Amazon pleads, a young, or a fond old sportsman listens, and the cause is won. But the ancient Sauromatse went further : they proposed elopement to their busbands; and thus these wily syrens went about it.
There is, in our opinion, ample scope for what Tom Hood punningly called she-questrianship, without following the hounds.

Within the last quarter of a century, the maids, matrons, and widows of England have taken to the saddle in numbers unprecedented in former days, and far be it from us to wish it otherwise. A fine woman on a fine horse is a most graceful combination of beauty and power. Horse exercise is conducive to the health and spirits; and how it enhances the charms of the lovely Amazons, many a captivated youth can avouch with a loving sigh. It is, then, that he may understand the principles of graceful riding by the fairer sex, as well as for the lovely horsewomen themselves, that we pen a few practical lines on the subject.

Dress.-And here, upon the very threshold, we feel the danger and delicacy of our task. We have to advise the ladies on that subject most eminently within their province -dress. We shall not trespass on matters of fashion and taste, but hope they will agree with us that a habit cannot be too plain, if well made, well fitting, and well put on. Observe, we stipulate for light "ladies' cloth," strictly so called, which will tear easily. The skirt, too, shnuld be as short as is at all consistent with appearance. It need hardly be pointed out, what danger there is in the preposterously long skirt: we have seen it become entangled with the stirrup, a passing a rail, hedge, or even the horse's legs, and then the helplessness of the fair rider when unseated; for should the horse himself fall, the rider is involved with him in a peril from which she cannot be easily extricated without injury. A dangerous fashion, now happily on the wane, is that of wearing "habit-brooches," as the tradesmen who deal in these dangerous devices call them. This mode of confining the skirt of the habit is utterly superfluous to a graceful horsewoman. The position of a lady on horseback is much more constrained than that of a man. The "habit-brooch" deprives her of the chance of escape when an accident happens. A very slight fall may prove serious or fatal, where, with full liberty of the skirt, it would have been harmless or trivial. The arrangement of the skirt, without this impedimentum, is thus directed by Mr Waite He strongly advises a lady never, under any circumstances, to tuck her skirt tight over the crutch of

"Alarm and fear come upon us," said they, "when we consider that we must live in this country. In the first place, because we have deprived you of your parents, and, in the next, have committed great depredations in your territory. Since, therefore, you think us worthy to be your wives, do thus with us: come let us leave this country; and, having crossed the river Tanais, let us settle there!"

"So," observes Herodotus, "the youths consented tc do this also; and, having reached the country in which they are now settled, they took up their abode there. From that time, the wives of the Sauromatæ retain their ancient mode of living, both going out on horseback to hunt with their husbands and roithout their hassbands, and joining in war, and wearing the same dress as the men." The records of Sir Cresswell Cresswell's court show that the Ssuromatz have their descendants amoug modern wives. 
her saddle, but take pains to have them so easy as to be enabled on the instant to disengage both skirt and knee. A facility in this can only be acquired by constant practice; and it is of far greater importance to the lady equestrian to attain than may appear at the first glance. Had this apparently slight attainment been a matter of moderate consideration, many a parent need not have to deplore the more or less disfigurement or maiming of a beloved child.

When a lady has her habit drawn over the crutch of her saddle, and tucked tightly in under her leg (for the purpose of keeping the skirt in its proper position), she denies herself the full liberty of her knee, and, in case of accident, to be quickly off the horse. On the slightest warning, though unforeseen, whatever the danger, the tightness of the lady's dress will not allow her to get her leg out of its place in time to make any effectual effort to save herself; it is also probable that the habit may get entangled in the pommel, and she, frightened of course, will become unable to disengage her foot from the stirrup or shoe, in which case she inevitably experiences the most appalling of all accidentsfalling, and being dragged powerless by a terrified horse.

-Mounting.-Preparatory to a lady mounting her horse, let her steadily and without bustle approach his near shoulder. The quietest animal will occasionally start or even kick when suddenly approached from behind. It is also to the advantage of the animal, to see his rider as much as possible; though some would seem to think otherwise, by their coup de main mode of "getting hold" of the animal. On this point the reader may refer to our chapter on Breaking and Trainina, ante.

In assisting a lady to mount, two persons are necessary. The groom to keep the horse quiet, which he should do by standing in front of him, with one rein in each hand, holding the bridle-rein close to the bit. The other attendant-a proud privilege for the favoured cavalier, or a loving duty for the brother or friend-has to assist the fair one to mount. This he does by placing himself near to and almost in front of her. Having joined his hands by interlacing his fingers with each other, he stoops, and putting them near the ground receives the lady's left foot, which she should place lightly but firmly in them, taking care that no part of her skirt is under it. The left knee should be kept firmly straight, to give a safe purchase while she is being lifted perpendicularly and springily into her seat. Before this lift, however, the lady having regulated her habit, must stand perfectly erect, and taking the bridoonrein loosely over the thumb of her right hand (holding the whip between the thumb and forefinger), she lays gently hold of the upright horn of the saddle. Her right side being now close to it, the lift is easy of accomplishment; a spring from the instep, simultaneously placing her left hand on the assistant's right shoulder, will land the lady safe in her seat.

Being now in the saddle, the lady should lay hold of her habit with her right hand close to the knee, lifting it so as to allow the right knee to rise and fall well home into the crutch, and holding it there firmly. This will be much assisted by drawing the heel backwards, by which the muscles of the calf and the tendo Achillis come to the aid of the position. The left leg should hang easily, not resting the weight of the body on the stirrup; if this is done, the foot naturally turns outward, inclines the body to an insecure balance, and gives a wavering and ungainly appearance to the rider. To avoid this, keep the left knee pressed against the saddle, depress the heel, and turn the toes slightly inwards.

The position of the stirrup has much to do with the seat of the female equestrian. The stirrup must be correctly adapted to the length of the lady's foot when seated in a square and exact position in the saddle. The modus operandi is as follows:-Let the stirrup-foot hang down frecly from the hip-joint, the knee slightly flexed, the toes raised and turned towards the horse's side. Then, while the foot is immovable in the stirrup, let the strap-holes be taken up and permanently kept at the approved length. The pressure of the foot in the stirrup should come alone from the toes to the arch of the foot, which will give the desired elasticity of movement in the quicker paces of the horse. Should the lady be impelled to the endearour to retain her foot in the stirrup, her weight must preponderate on the left side. On the contrary, if the stirrup be too short, it necessarily gives a rolling motion to her body, destructive alike to grace, elegance, and security of seat, and will prevent her seating kôrself sufficiently back in her saddle. Thus much of seat and stirrupe The arms should be held freely and unconstrainedly, but near the sides. The motion of the bridle hand must be, like that of skilled pianoforte players, confined to the wrist. From that alone must its action be derived; and here Mr. Waite's little "Manual" shall again instruct us. "The motion of the lady's hand should be confined to the wrist, the action coming from it alone. By the management of the reins, in concert with the yielding or retraction of the wrists, the horse is guided in his paces. By this mode the sensibility and goodness of his mouth is preserved; the beauty of his action is developed; steadiness is combined with security in his paces; and the safety of his rider is secured. The degree of command which the animal can be placed under, entirely depends on the degree of proficiency acquired in this branch."

There are four motions requisite in guiding a horse.

"To go forward.--Lengthen the reins, and give the animal his liberty. For this purpose the lady's hand must be guided by the action of her wrist, and, at the same time, she must apply gently her whip. Here, it is proper to remark, the lady's bridle, or left, hand must never be left inactive, but, by practice, she must endeavour to understand the art of feeling the horse's mouth; should the bridle hand not be kept in constant use, this will never come easy to the rider, the hand will be unsteady, and the horse will become the same. 
"To go backward.-The reins must be shortened a little, the back of the hand turned down, the little finger next the body; the weight of the rider should be thrown back, with the little finger slightly wulled in towards the waist, then the horse will readily step back.

"To turn to the right.--The hand must be turned upwards, which will direct the little finger to the right. Throw the balance of the body into the turn, by inclining the bust to the right and applying the whip, which will canse the horse to move forward as he turns, obey the hand, and cross his legs one over the other correctly.

"To turn to the left.-Let the hand be turned down, so that the little finger may be directed to the left; the bust must also be turned to the left, and the hand up, with the left heel applied to his side, and the whip to his right shoulder."

Dismounting.- The remarks on mounting should be remembered here. Should hired servants only be at hand, there is some skill required to avoid the désagrémens or inelegance of a lady being lifted from the saddle in the arms of a groom.

Previous to dismounting, the attendant must stand by the horse's head, bolding the reins close to the bit, to keep him as steady as possible.

The lady, having removed her foot from the stirrup, and passed her hand down to free her skirt, \&c., from the chance of catching to the saddle or stirrup, should remove her knee from the saddle-crutch; at the same time taking the precaution to disengage the habit from that side. Then holding the crutch with her right hand (the rein hanging loosely on the thumb), and placing her left hand on her attendant's right arm, near the wrist; his arm being extended for the purpose, she must spring lightly and clear from the saddle, slightly inclining the bust towards the horse's shoulder.

By this method the lady will cleverly disengage herself, and descend gently to the ground.

The following are Mr. Waite's "Maxims:"- "Be particular to avoid nervousness and hurry, either in mounting or dismounting.

"Take time, and have everything correctly arranged before starting; serious accidents have occurred from haste in starting off.

"Arrange the habit and length of stirrup, and have the saddle-bands and buckles properly examined before the journey is begun, to prevent having to stop on the road.

"Be careful to keep the hand active, and watch the movements of the horse; by this means the rider will never be thrown off her guard, and will be prepared for every emergency.

"Keep the horse's mouth always in play, so as to keep up its fine feeling, indispensable to his correct guidance.

"Never allow the reins to hang loosely on the horse's neck, crutch, or pommel of the saddle. This oversight frequently causes serious and fatal accidents.

"Always use double reins. Should one become useless, there is still another to rely upon."
Mr. Waite winds up by justly observing that an elegant and accomplished equestrian becomes an equally graceful pedestrian, from the improved carriage acquired from proficiency in the former accomplishment.

To become an elegant pedestrian is no mean task, nor easy to accomplish. Yet it is of the utmost importance to a lady to achieve it. How often, in our experience through life, have we met with a lovely face and perfect figure,everything that could constitute the perfection of female beauty, while at rest: but once in motion, the illusion is dispelled by a bad carriage and shuffing gait, and the perfect form becomes common-place. These two detractions to beauty can be entirely eradicated by attention to the following directions, which apply equally to walking and riding.

Keep the bust and head erect; the shoulders well thrown back. The motive power to proceed from the hips alone.

Perseverance in these directions will soon give all that is required for a graceful and healthy carriage.

Finally.-At all times trust to your reins for security in cases of danger. Never grasp the pommel of the saddle; and never use a "habit-brooch."

Choosing a Lady's Horse.-The general ideas.in Burino A Horse are found under that heading; the special merits of a lady's horse are worth considering It should be remembered, and oftener than it is, that a "weed" should never be selected to carry our "fairest flower,"-that however sylph-like and fairy-formed our Venuses may appear, they are mostly ten stone, "horseman's weight," despite their affectation of slimness; and this, with habit, hat, gauntlets, whip, a spacious side-saddle and crutch, extra girths, shoe stirrup, \&c., adding twenty ponnds at the least, asks something more than a Queen Mab's grasshopper steed. We are not going to dilate on a horse for the hunting Amazon we have already spoken of, or we should say a fouryear-old hunter, with good mouth, great action, steady at fences, and up to thirteen stone, was wanted; just such a horse as is not to be had for the catching. Lord Maynard, a great man across country in the last generation, used to say, when he heard a horse mentioned as excellent to carry a lady, "I'll buy it: if he will carry a woman well, he'll carry me better."

As elegance must be studied in a park hack, a lady's horse should have a considerable show of blood, and should seldom exceed fifteen hands in height; the paces should not be rough; and an easy slow trot, the pace of health, is a valuable qualification. The canter is, however, of the chiefest consequence, and that it be formed naturally and handsomely, the neck gracefully curved, and the mouth having pleasant and good feeling. There are natural canterers, they will last at it, taking to it, and on the proper signal dropping into the trot or walk, without roughness, boggling, or changing of legs. But the first and grand consideration is going safely; for a horse deficient in that respect is, perhaps, always most liable to fall in his canter. The most graceful canterers may be observed to lead gene- 
rally with the off leg; but no doubt there is such an error a. a horse, both in his canter and gallop, going with the wrong leg first, to the considerable uneasiness of the rider; this is most felt upon worn and battered horses, which hange their legs to procure a momentary ease.

A naturally timid, nervous colt, however we may lessen the infirmity by proper treatment, will never be a perfect lady's horse. He should be naturally bold and fearless, and from being properly educated, should not know fright; for as ladies are naturally more easily alarmed than men, so in proportion should their horses be bolder, for if both get alarmed, the danger is imminent. Many ladies would fear to be put on a high-couraged horse. Fair ones, your fears are misapplied High courage, in man or horse, is your best safeguard, and will induce both to bend with cheerfulness to your slightest will; while the timid, actuated by fear, seeks his own safety, nor heeds the danger of his fair mistress.

Some masters teach their lady-scholars to ride on either side of the horse, and recommend to have the pommel of the saddle made very low, that the knee may not be thrown too high; and also that the pommel be made with a screw, to be taken off in case of a lady wishing to change sides on any particular account. Ladies' riding-shoes should be always straight soled, as, in case of accident, there is the risk of the foot hanging in the stirrup, when the sole, according to the old fashion, is hollow next the heel. A lady's horse should be particularly accustomed to walk off quietly; and with respect to his improvement in that pace, it is accomplished by touching him gently with the whip.

"Harry Hieover" has some pertinent though diffuse remarks in his "Hints on Educating Horses," from which we select some relating to the training of a lady's horse.

Although by no means advocating a riding-schoos eaucation for a hunting man or a hunting horse, yet it is the only place where a lady's horse can be properly made. There is a peculiar style of going that is only to be acquired "here"-a handiness that cannot be taught on the road; turning safely and easily cannot be learned elsewhere. Changing voluntarily the leading leg, so indispensable for this horse, must be practised by the figure of eight, to perfect him in it; and till he is perfect in this, he cannot carry a lady safely. She will find it necessary, if riding in crowds, to turn her horse often suddenly, to avoid coming in contact with different objects. Suppose a horse going a quick canter, leading with the right leg, something coming suddenly up may oblige his rider to turn quickly to the left. If the horse does not change his leg, it is an even chance whether he does or does not let his legs interfere, and come on his head Here he may be taught that quite necessary qualification in a lady's horse, to moderate his pace, stop by degrees, or stop short, in accordance with the voice that directs him; a lady's horse should be perfect in this with the reins resting on his neck. Why this is learned so much more readily in a school than elsewhere is, that the animal's attention is solely occupied by his rider's voice and move- ment, whereas out of doors it is more than divided by other objects. Independently of this, there is a confinement felt by a horse when encircled by four walls, that he of course does not feel in any open space, that makes him obedient.

In a school there are found guns, flags, drums, trumpets. umbellas, and every other monstrosity to which a lady's horse should be subjected: it therefore follows that in such a school a horse would be placed in a situation to see more strange sights in six weeks than in ordinary situations he would see in six years. For instance, a lady might ride her horse about Bath and not see the colour of a regiment once in seven years; in London it might happen she never rode at an hour when regiments were moving; consequently years might elapse, and the first time her horse saw such a sight he would start at it; and so on with any unusual thing that came across him; but in the school a day makes him conversant with everything of the sort. Let a man walk fifty yards distance from him round the school with a banner, he hardly notices it; get nearer to the man by degrees, and in an hour or two the horse will walk with the banner fluttering before his face (so with anything we wish to accustom him to see) without alarm. The great mistake people make, is in thinking that by doing too much at a time they accelerate what they wish, when, in fact, they retard it by such means.

If, for instance, we wish to teach a horse to stand fire-if we let off a gun, we should alarm him to such an extent that it would perhaps take a month to reassure him, if we even did it then. A more judicious man might let off a small pistol with a little powder in it. This is ten times too much. A flash in the pan is too much, except at a great distance. First burn a few grains of gunpowder so as to show no flash, while he is eating his corn in the stable; let him smell that; even this will arouse his attention, but, while it accustoms him to the smell, will not alarm him. Begin by clicking a pistol twenty yards from him; then put powder enough in not to make more ignition than the light of a rushlight; go on by imperceptible degrees, and in two days he will hear a musket go off without the least fear. Alarm him by the report of a gun at first, it will take years perhaps to reconcile him to it, if it is ever done; but by never creating alarm, he may in a week be brought to stand by a cannon without wincing. Absolutely hurting or absolutely alarming, produce nearly similar results in brutes as in the human race. A person that has been pursued by an infuriated ox has the same dread of an $o x$ as another who has been tossed on his horns-perhaps more, if the latter was not much hurt, the anticipations of the former being probably much more terrific than the tossing of the latter; as, in the ordinary circumstances of life, the dread of an event is often more horrible than the realization itsel' Many a man, who has worked himself into a fever and high state of nervous irritability during the night from the apprehension of an operation in the morning, has borne that operation firmly, and allowed that his fears had greatly exceeded the 
reality. Fear is a most powerful agent, and, where it is once awakened, a most difficult one to tranquillise. With horses, d minute awakens fear that years will not eradicate. We cannot reason with them, or explain away the cause of their alarm; so, if any irrational animal is once hurt by anything he sees or hears, or is seriously alarmed it, hearing or seeing the same thing without sustaining any injury from it a hundred times afterwards barely suffices to reassure his fears of it. Frighten a boy by the appearance of a ghost, and let that ghost strike at him, he is alarmed; throw off the sheet, and let lim see it was his sister dressed up, his alarm is gone; nay, he would probably think less of ghosts in future. We cannot do this with animals; so, in educating them, nothing but length of time can overcome terror; and till terror is assuaged, they have not even the instinct nature gave them.

Ladies may fancy that if a horse has a tender mouth, there can be no fear of his going off with them. He would not on any ordinary occasion or under any ordinary excitement; if, however, he gets frightened, mouth will avail nothing; he becomes totally insensible to pain. The more timid, therefore, he is, the more dangerous he is; and, vice $v e r s \hat{\alpha}$, the more courageous, the more safe. Why are veterans more to be depended on than raw troops? Mainly because the former, from habit, are more collected in moments of danger than the latter

Thus far of schooling. Any green field that is not too hard, forms an excellent practice-ground; and should it be varied by what is termed in the Midland counties "ridge and furrow," it will additionally improve the general activity of the pupil, his action, and the use he makes of his shoulders. Cantering him continually in small circles, and, as he is meant for a lady, chiefly to the right, will teach him to lead with his off leg, and will bring his head into the right place, and his weight upon his haunches better than any other discipline we can adopt. Observe that no horse can have a good mouth unless he has powerful and well-shaped quarters; also, that his lightness in hand is in most cases pretty exactly proportioned to his strength behind the saddle. The hardest puller of all is the brute that pulls from weakness; if you could stop him, he cannot stop himself; and having given you half his weight to carry in your arms all day, it is lucky if he does not finish by putting the whole of it on your neck and shoulders in one of those complicated somersaults that a bad one is so expert in making

\section{DRIVING.}

GENERAL OBSERVATIONS.-HARNESS HORSES :-PUTTING TO.PAIR HORSE.-SINGLE HARNESS.

Akin to the subject of Driving, and as a preface thereto, we would advise the perusal of pages $66-76$ ante, and THE Carriage Horse, pp. 60,61. The palmy days of charioteering passed away with Sir Henry Peyton, Sir John Ludd, Sir St. Vincent Cotton, Lord Molyneux, the youth of Lord Chester- field, the declension of the Four-in-hand Club, and the extinction of our fast four-horse coaches. Spasmodic efforts for its revival have merely led to a pleasant procession to a pic-nic, or a suburban "spread" on the banks of Father Thames, above or below the great city. We shall not, therefore, dwell on the glory of departed days, but address ourselves to the practice of the present. In our picture of pair-horse and single harness these will be found, and below such a description as will render them intelligible.

The harness horses here to be noticed are the gig, or singleharness horse, usually adopted for light or two-wheel work in dennet, tilbury, or dog-cart; the carriage, brougham, or cab-horse, for a heavier and slower vehicle; and ponies, whose uses are as various as their form and stature. The general gig-horse is too often merely the cast-off of the hunting stable, or even of the racing stud; the clumsy, unsteady, or slow being put into harness. A well-bred horse for the lancewood shafts is, however, too valuable an animal to be thus slightingly considered. Others are merely undersized carriage horses with the Cleveland or Clydesdale blood in them, and these, if got by well-bred or throughbred sires, are useful and handsome animals. Of the cab, brougham, or carriage horse there are several varieties. In olden times, before the idea of elegance was attached to lightness, we had a horse which truly deserved the name of the coach horse, rather than the more modern one of the carriage horse; for as we have already said, when treating of this variety, the old coach horse was merely the modern lighter cart horse, as we see him in the wheel-plough or in the unicorn railway wagons of London streets. A transition period brought another animal, which some writers of that middle age styled "the barouche horse," upon the scene; this was in the "Onslow Phaeton" age, which dovetailed with the "mail" age and the Oxford and Cambridge tandem. The drivers of the white "upper benjamin" bccame fast, and gentle and noble coachmanship at the zenith of its glory, drove very "leggy" animals, which the "short-legged machiners" "tied up" when the stage was ten miles. An agreeable writer thus chronicles the change. "When anything, say the philosophers, arrives at the summit of perfection, by the law of nature it retrogrades. Perhaps the perfection of the teams of 1820 worked their downfall. Such horses were then put into them, that, to outdo, or at all events vie with each other, men began putting their hunters into harness, and many that had breasted a bulfinch in Leicestershire, in spring breasted a collar in Hyde Park. Sadly infra dig. all this; but so it was

" "Fashion in everything bears sovereign sway, And 'nags 'and periwigs have both their day." "

This was perhaps the first ingovation on the different metiers of the horse; this the first blow at the root of the exclusiveness of the hunter and his inaster. Whether the hunter going in harness, or the master riding the harnesshorse with hounds, was the greater degradation, we do not say. There is something aristorratic in the sound of the 
bunter's stable and the coach-horse stable; but to see a collar in a box is something, in my idea, about as anomalous as it would be to see a maid of all work drawing a cork of champagne. The wine might be good, and the Hebe pretty, and each might be worthy attention from the most fastidious, but it is to the disadvantage of both to introduce them together.

Some one may ask what has become of the sort of horse specially bred for the fast coach. Like other articles for which a remunerative demand has died out, they are not now produced on a grand scale. The nearest horse to the stamp, is that used in our horse artillery, and a very good sort it is. These horses, bought when young, though they are thick and strengthy, learn such habits of activity, that no one who has watched their evolutions at Woolwich, Portsmouth, Chatham, or elsewhere, can help admitting that great strength and great activity are contained in them. But where there is want of "blood," sustained speed must not be looked for. Doubtless, where mere activity for short distances is wanted, the less highly bred horse may seem not to siffer from the comparison, but a speed kept up is not his forte. Heavy as a loaded omnibus looks, if you wanted it bowled along at great speed for a long distance, four thoroughbreds would beat four of these artillery horses; but for work on London stones or in a bad road, where stopping and starting would fret the high-bred cattle, specific gravity, strength, and short legs, carry the day. The wind and game of the thoroughbred carry him through his task better than any other horse, but it is only where these are called upon that he shines so pre-eminently.

There is, however, another perfection that the highly-bred horse has: he does any work with more willingness and cheerfulness than the coarse horse ; and this is why, for any purpose to which his strength is adequate, he will be found, on an average, so much pleasanter than the coarser animal. It is true, the inferior-bred horse is quite as free, and perhaps even more inclined to frisk about while quite fresh, than the thorough or higher-bred one; but this only lasts while work is play to him. At real labour, his energy leaves him; and once tired, the game is up. This has long since been found out; so, as our expectations as to distance and pace have more than gone hand in hand with the increased goodness of roads and improvement in vehicles, we have found improvement in breed absolutely indispensable-hence the change in the carriage-horse.

Our other harness horse is now the brougham or cabhorse. For a perfect cab-horse, be must now be kept to that vocation only. To be perfect, he requires many qualifications not easily met with; indeed, some of them are rare to get combined. In double-harness a horse may be a little awkward or lazy, inclined to bolt, or even to run away; may be somewhat restive, or a little unsafe in his action; still, with a good partner, a man anything of a coachman can make him do his business at least tolerably. Even in a gig-horsa there are many little imperfections that may be compensated for by other qualifications, for he is wanted to be fast and lasting. We may put up with many serious objections in such horses, for the sake of pace and style of going. Impatience would, to many persons, be a very serious fault in a horse for single harness. A clever driver of gig or dog-cart will not mind a hasty-tempered one for this purpose; but this would be intolerable in the cab-horse.

He must be, or should be, singularly handsome, of commanding size; must be fast, or at least, extremely quick in all his movements; be able and willing at one moment to go fourteen miles an hour, the next be as willing to walk, if wanted, at the rate of three. He must stand motionless while his aristocratic owner enjoys his colloquy at the coroneted carriage-window ; must not want the application of the toy-whip, or pull so as to stretch or twist the fingers of the white, lemon, or pink kids. To want hoiling at a door would render him useless, for who is to hold him? he must know by instinct that minute piece of humanity, yclept "the tiger," is before him, for s?eing him is out of the question to a horse in harness. In guing, the slightest indication on his mouth must suffice. He ought never, if a well-taught cab-horse, to voluntarily stop or attempt to stop at doors because he has often stopped at them before. This is the habit of butchers', bakers', and such plebeian horses; for though our scion of nobility or aristocracy may also at times stop at the same doors, it might be extremely inconvenient that his horse should indicate that his master did so.

Having stated some actions that the cab-horse must not perpetrate, we must look to the action he must have. This is precisely that which, some fifty years since, would have caused him to be rejected by any good judge as a "clamberer"-a style of going then considered as of the very worst sort; and so, in fact, it is for use, for such goers must tire. But the cab-horse is wanted for show; so the more parade he makes about what he does, the better he is thought of. One animal of this sort, not long since, was actually bought at seven hundred guineas, solely from his lofty action.

The learned and facetious author of "Adventures of a Gentleman in Search of a Horse," whose sportive pages contain more law, wit, and practical advice, than scores of more pretentious volumes, observes, "It is marvellous how few people keep fixedly in mind the nature of the work which they will require the horse to perform. Notone horse in fifty that is good under saddle is equally so in harness, and vice versâ. I once had a galloway that rarely stumbled in harness, though he could not have carried the best rider, of feather weight, half a dozen miles without a sorry fall. Yet he was perfectly sound, and continued sound for the five years he remained in my possession." Many horses do 
well in harness that are totally unsafe to carry weight: in fact, ferw of the most 'showy' and 'splendid' harness horses of the dealers' stables are so broken until they have proved their inability under saddle. For myself, I make it a rule not to put a horse in my stanhope that I have not taken a short trial of in saddle. When on his back, I am his master; when at his tail, he is mine; and I like to know something of his temper before I put myself in his power."

Harness-work is, of course, at the same pace, much less severe than weight-carrying, with a modern-built trap or carriage, and good roads. It follows, therefore, that many defects, unpardonable for saddle, are comparatively immaterial. Harness-work, too, is done usually on the trot; hence it is of less consequence that he should walk or gallop well. Still there is no doubt that in proportion as the animal is sound, and good in all his paces, his value is greater for whichever service he is designed.

Few people are very particular about driving a horse in a boot, or with a blemished knee, while the blinkers will hide any obvious defect in the eyes. Thus other serious obstacles that occur in the purchase of a saddle-horse are removed.

Subject to these preliminary observations, we would suggest that the form of a horse for single harness should be carefully considered; a full shoulder and a well filled-up loin, are of consequence; the action should be free, and rather high than otherwise; the body should be compact and close, the legs short, and rotundity the character of the whole.

Steadiness is a great virtue in a gig-horse; for his duty is in the streets, where every provocation is given to the contrary, and where the least swerving from the direct line may cause infinite mischief. It is quite impossible to decide whether a horse deserves this character till he has been tried; but a single drive down Oxford Street and Holborn Hill, will put him sufficiently to the proof. A man who buys a harness-horse, without first driving it himself, is a fit subject for a commission of lunacy It is not enough to put him in the break; he should be harnessed at once to the gig or dog-cart ; and it is prudent to observe closely how he bears the ceremony of being harnessed, and what kind of a start he makes. Much may be predicted of his qualifications for draught, or at all events of his familiarity with the collar, by the degree of quiet with which he allows himself to be put to. If the ostler runs alongside of him at setting off, as is often the case, you may be sure that the horse is distrusted : if you distrust him yourself, have nothing to do with him.

Sir George Stephen, in his little manual, already referred to, gives the following illustrative anecdotes.

"One of the best horses which I ever had in my life, as a gig-horse, was a little animal scarcely fourteen hands and an inch high, which I bought of a dealer named Thompson, an excellent judge of a horse for harness. His case was in some respects peculiar, and worth mentioning. I bought him for a relative, of very light weight, but a timid rider.
He was about half-bred, and inclining in form to a cob IIy relative rode him for about two or three months, during which time either he or the horse so contrived it as to fall every ten days; the last fall was a very serious one, and the knees were much blemished. He would not have produced ten pounds, though I had given nearly forty. I obtained permission to break him into harness, which I did myself, without any trouble or difficulty. His owner would not take him back again, but gave him to me. A year or two afterwards I refused sixty for him. It is a singular fact, that, for the first two years that I had him (he remained with me nearly five), he would allow nobody to drive him but myself. If other hands held the reins, he would swerve and shy, and at last perhaps fairly bolt; but in mine he never committed a fault. I used to drive him with a sharp curb, and very little whip ; but my command of him was so complete, that I have urged him to his full speed, thrown the reins on his back, and stopped him in an instant by my voice! The inference which I would draw is, that a purchaser should always try a new harness-horse for himself, and not trust to the steadiness evinced while the reins are in his owner's hands.

"I cannot dismiss my little horse without mentioning another incident connected with him, to me particularly interesting. Like most Cantabs, I acquired at college an un. lucky taste for tandem driving. I have driven my tandem for many thousand miles in safety, and used at times to exhibit at once my folly and my skill, by threading the narrowest or most crowded streets in London. It is scarcely necessary to add, that eventually I broke my head; though, in justice to my skill, I must declare that the fault was not mine, but my coachmaker's. The splinter-bar had been morticed into the shaft at the very point where the latter was rendered un. sound by a knot in the wood. One day, after a long journey into the country, and within a hundred yards of my own door, the shaft broke, and I was precipitated over the shafthorse, under the heels of my old favourite. There I lay, insensible. The awk ward hands who came to render assistance, wanted (as I was afterwards informed by my servant) to move the horse away from me, at the risk of putting his heels upon my face; but move he would not; nor would he allow a foot to be raised, till at last I was fairly lifted up froin under him, and then, though not till then, he readily changed his position, and moved wherever they pleased to lead him. I bave no inference to draw from this, except a caution even to the most experienced whips against tandems! I mention it as a tribute of gratitude to my poor horse, who showed at least as much sense as his master. Young gentlemen, however, who disregard my caution, as doubtless nineteen out of twenty will, may thank me for a hint of which 1 have experienced the advantage Tandems are rarely seen now; but those who still drive a leader, generally attach his traces to an eye in the traces of the shaft-horse: this looks better, but is not so safe as the old-fashioned way of hooking them to the end of the shaft. By the first plan, the 


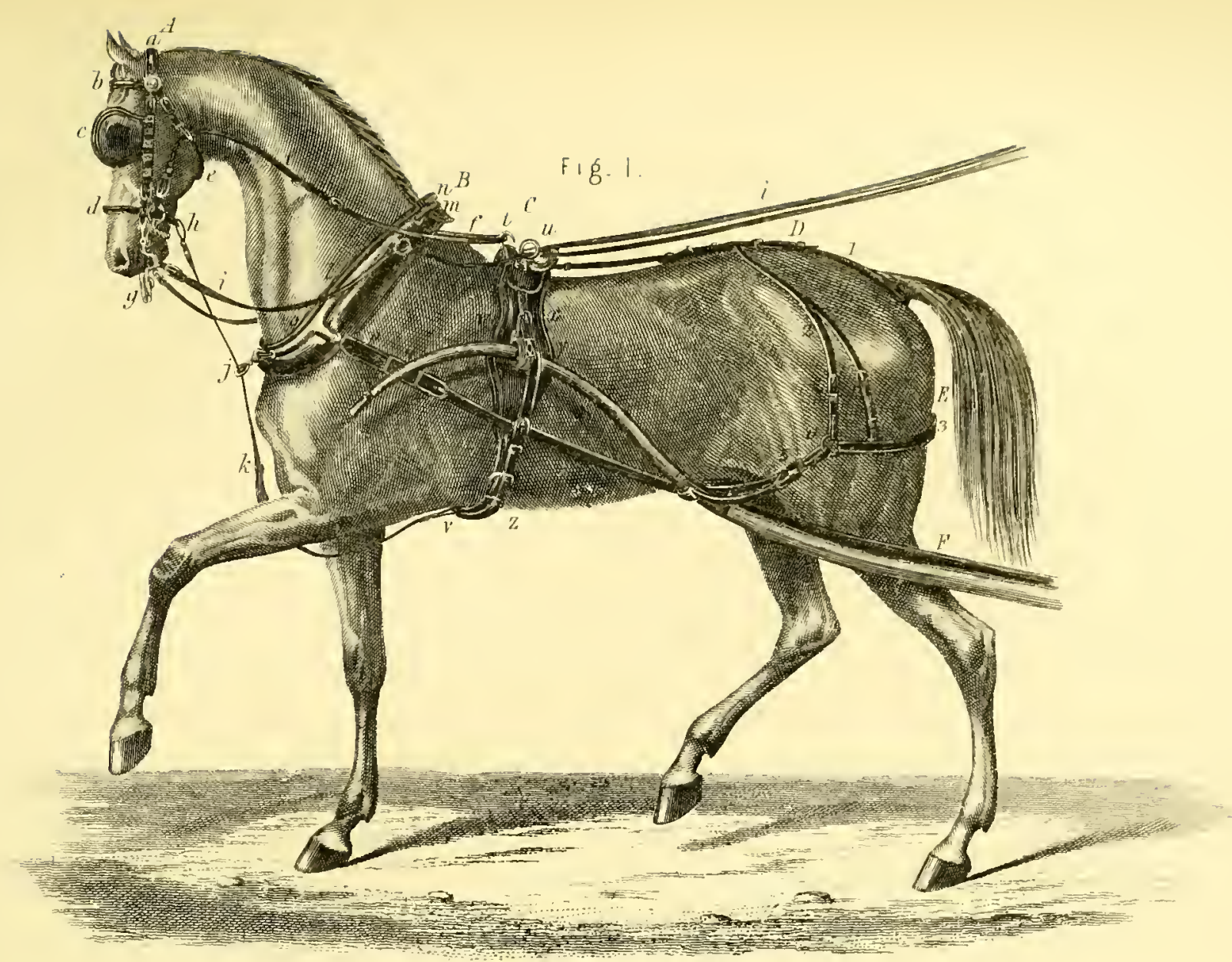

SINGLE HARNESS. see description.

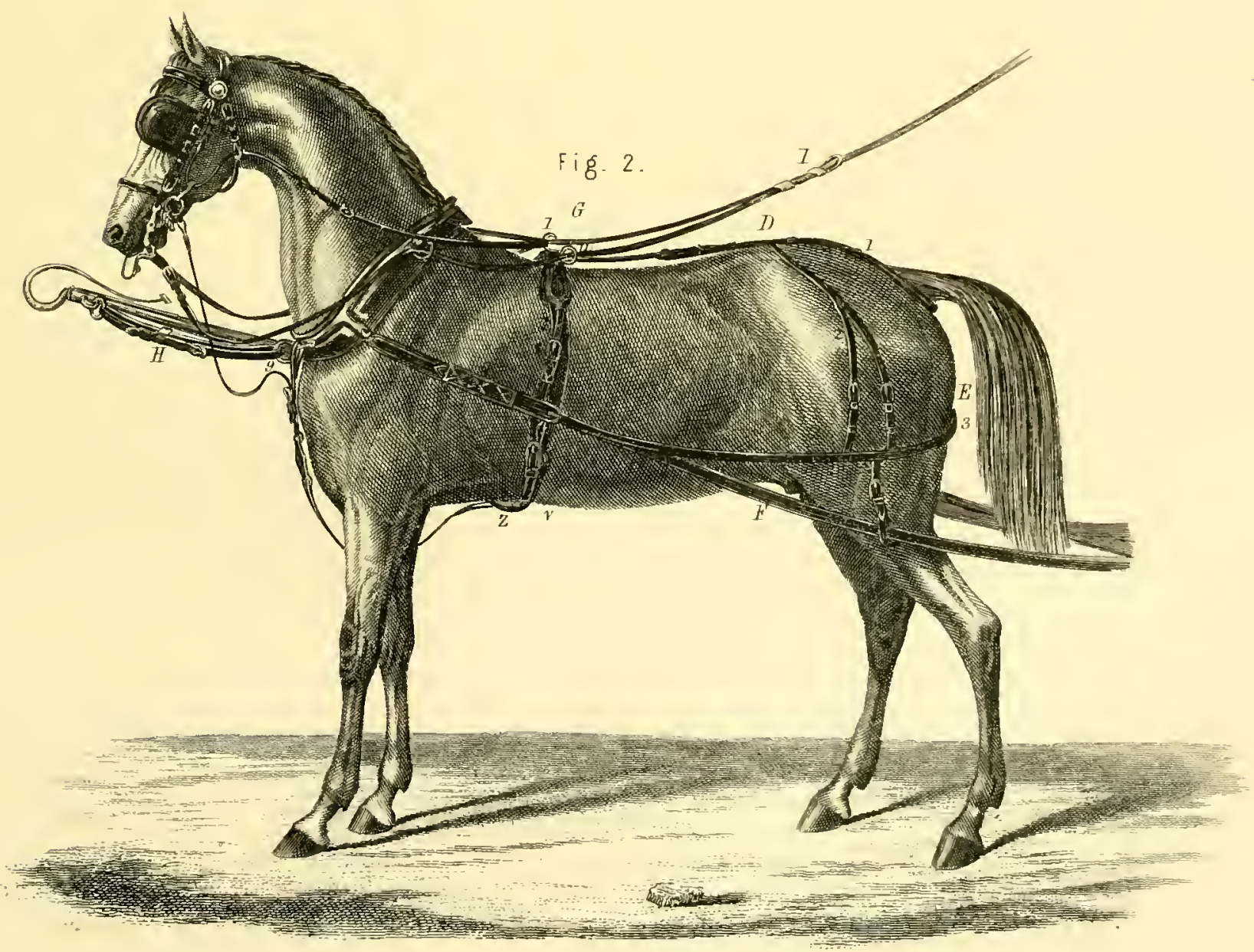

PAIR HORSE HARNESS 

stumbling of the shaft-horse is aggravated into a decided fall, for the animal is actually pulled down by the continued motion of the leader; by the old plan, the shaft-horse is allowed time to recover a casual trip, and is even assisted; the weight of the carriage being relieved by the shafts being retained by the leader's traces in a horizontal position. The greatest langer in tandem-driving arises from the stumbling of the shaft-horse; it therefore follows that if either of the team is distrusted in his feet or legs, he should be driven leader."

No man, if he can help it, should ever buy a mare for harness : no dependance whatever can be placed upon them : they may be temperate and steady for months, or even years, and yet when the season arrives, will kick your chaise to pieces. "I drove a little mare for nearly a year with the galloway that $I$ have just been mentioning; the following spring she kicked herself out of harness three times in the course of as many weeks. Purchasers are often tempted by their inferior price-a mare, cceteris paribus, being generally five or ten pounds less valuable than a gelding; but they forget that it is this very capriciousness of character that reduces their value, because it unfits them for the collar."

It can scarcely be necessary to remind a purchaser that any scar on the shoulders, or even under the tail, should lead to a suspicion of tenderness in those parts, not very consistent with length of service in harness; and in the same way that a blemished hock should excite a doubt whether the splinter bar is not equally damaged. If it can be managed, it would be prudent to see a horse driven in his master's trap, were it only to take the opportunity of observing whether the dashing iron or the floor retains marks of the shoe, or has been recently repaired in order to efface them.

Here is one more of the experiences of the author, of "Caveat emptor." "I once was trying a harness horse, in company with his owner, but not in his owner's chaise: I had no suspicions, for I was to receive a warranty of "sound and safe in harness,' but he appeared to me to show a great deal of work: and therefore, I wished to see the stanhope that he had been accustomed to draw. 'It was at the coachmaker's.' I offered to go there, and proposed that we should drive to the shop. 'It was a long way off, on the other side of the water.' I replied that my time was of no consequence; for whenever I perceive hesitation, I always feel distrust. 'It was taken to pieces to be fresh painted.' In short, I found that the chaise was not to be seen; and therefore, see it I would. When we returned to the stables, I took an opportunity of saying privately to the ostler, that I thought the horse had been over weighted, and I wished to compare his owner's stanhope with mine,-- 'When would it be at home again?' He could not tell, but at once referred me to the coachmaker's: this was all I wanted. I proceeded there without delay, and anticipated his customer by only ten minutes: this was enough, however, to apprise myself by ocular inspection, that the dashing iron had been

kicked away, only the week before, by the horse warranted 'safe in harness!' About a month after, not having yet found what I wanted, I read an advertisement in the paper of ' $a$ horse, stanhope, and harness, to be sold together; the stanhope almost new, and very recently from the coachmaker's shop; the horse possessing the grandest action imaginable, and making, altogether, the most elegant turn. out in London; bond fide the property of a gentleman that might be referred to.' I went to the place, and at once recognised my old acquaintance, whose action, à posteriori at least, had been as 'grand' as could reasonably be desired; and as for the stanhope, the most practised eye in Long Acre could scarcely have discovered the true cause of its having so recently quitted the coachmaker's loft! Another striking specimen of gentility in horse-dealing transactions!"

So much for the horses, now for the harness. Fig. ] of our Plate presents us a single suit of the most modert pattern, of which the several pieces bear the following names:-

\section{PALT' I) HARNESS (SEE PLATE).}

$$
\text { F10. 1.-Single Harness. }
$$

$a$, Head-piece.

$b$, Front, or Brow-piece.

$c$, Winker and Cheek of Bridle.

$d$, Nose-band.

e, Throat-band.

$f f$, Bradoon bearing Rein.

$g$, Curb Pit and Chain.

$h$, Bradoou Bit.

$i$ i, Driving Reins.

$k$, Nose-band Martingale.

$$
\text { B. collar. }
$$

$l$, Ring or Fore Wale.

$m$, Housing.

$n$, Cap.

o, Hame.

$p$, Tug.

q. Pipe.

$r$ Tug Buckle.

\section{SADDLE}

i, Bearing Hook.

$u$, Territ.

$v$, Surcingle.

* $w$, Skirt.

${ }^{*} x$, Back-band.

*y, Shaft Tug.

2, False Belly-band.

$$
\text { D. CRUPPER }
$$

1, Dock.

2, Hip Straps.$$
\text { Sint. }
$$$$
\text { 4, Tugs. }
$$$$
\text { *5, Shaft Strap. }
$$

*6, Preeching Ring.

$$
\text { F. TRACE. }
$$

*J. Martingale Ring.

Fla. 2.-Palr-horse Harness

Difference for Pair-horse Harness.

* G. PAIR-HORSE PAD.

*s, Short Tug.

*7, Point or Tug-strap.

*8, Trace-bearer.

*H. POLE-PIECE.

*9, Pole-ring.

* I. cotpling of rein.

The whole of the parts mentioned are used in each slass of harness, except those marked with a *; these take their respective places according to the nature of the harness, as arranged in the above scheme.

The harnessing and putting to come now to be considered. The borse is dressed, and turned round in his stall; when ready, the first thing to be put on is the collar. This is to be turned the large end upwards, an inversion rendered necessary by the fact that the top part of the head 
is the widest part, and hence requires the larger end of the collar; before the collar is seated in its place the hames are put on and buckled. This being done before the collar is reversed, their own weight prevents them separating, and helps the Jrawing of the hame-strap. They are now reversed together and the pad placed in its proper place before buckling the belly-band, the crupper being slipped over the tail by grasping up all the hair in the left hand, while the crupper is adjusted by the right. See that no hairs are left engaged in it, for this is oft-times a cause of kicking. Next draw the pad forward a little and take up the belly-band moderately tight; then put on the headstall and bridle, adjust the curb, slip the reins through the terrets, and buckle them on the outside only for double barness, on both sides for single.

The horse is "put to" for going in shafts in an entirely different manner than if to be driven with a pole. If single harness, the shafts are tilted up and held there by one man, while another backs the horse until he is under them, when they are dropped down, and the tugs slipped under or over the ends of the shafts, according to the formation of the tugs, some heing hooks, and others leather loops. Care must be taken that they do not slip beyond the pins on the shafts. The traces are now attached to the drawing-bar, the breeching or kicking-strap buckled, and the false belly-band buckled up pretty tightly, so as to keep the shafts steady. In four-wheeled carriages it should be left tolerably loose when a breeching is used, to allow it to have free play. The reins are untwisted from the terret, and the horse is put to. For double harness, the first thing is to bring the horse round by the side of the pole, and put the pole-piece through the sliding ring of the hames, the groom holding it, or else buckling it at the longest hole while the traces are being put to; as soon as this is done the pole-piece is buckled up to its proper length, each coupling-rein buckled to the opposite horse's bit, the drivingreins untwisted from the terret, and the two buckled together, and the horses are ready. The leaders of a tandem or four-in-hand are easily attached, and their reins are passed through the rings on the heads of the wheelers, and through the upper half of the pad terret.

Unharnessing is simply the reverse of the above, everything being undone in the same order in which it was done. The chief errors in either are-in double harness, in not attaching the pole-piece at once in putting-to, or in unbuckling it altogether too soon, by which the horse is at liberty to get back upon the bars, and often does considerable damage by kicking.

Driving a Pair has one grand leading principle, without which the others are all but nil. It is the "putting" the horses so well together that they may draw equally, and step in time with each other. This latter, however, can only be effectively done when the animals match in action and temper, and in height of step. We note temper as an important ingredient, because if one is a fast-goer and the other a slug, the amount of whipcord necessary for the slug will urge the free-goer to take all the work upon himself A partial remedy for this is giving more length to the coupling-rein of the slow one. In "VICES ON THE ROAD," pp. 300, 301, ante, will be found some remarks on polehugging, which may throw light on a remedy. In watching the working of the two horses, the pole-pieces should always be the guide; and if both are slack, with the end of the pole steady, and neither horse shouldering it, the driver may rest contented that his horses are each doing their share. If, however, the pole is shouldered by either, that horse is a rogne, and is making the other to do more than his share, keeping the pole straight by the pressure of his shoulder, instead of pulling at the traces. On the other hand, if either horse is pulling away from the pole, and straining at the pole-piece, he is doing more than his share, and his coupling-rein must be taken in accordingly. Sometimes both shoulder the pole, or spread from it, which are equally unsightly habits, and may generally be cured by an alteration of the coupling-reins of both horses, letting them out when they "shoulder," and taking them up for straggling.

In Driving a Single Horse, the near rein is passed over the forefinger of the left hand, and the off rein between the middle and fore fingers. The thumb presses the near rein fast against the forefinger; and if both reins, instead of being allowed to fall over, are passed between the little finger and the third or "ring-finger," it will much improve the grip, especially when the muscles are tired with long driving, and the attention is slack. We protest against the bearing-rein as a general piece of harness; it is merely a cover for careless driving. It can only be allowed where an old horse has been so accustomed to hang upon it, that he is unsafe and uncomfortable without his habitual tormentor. The cab-horses are as hard-worked as ever, yet they are now scarcely half as often down as when the bearing-rein was the rule and not the exception. With three legs and a swinger, while their head is free, they seldom make a mistake. Why, then, put on this useless restraint to a vigorous and spirited animal? Do not, however, fall into the error of holding too tight a rein yourself. It will gag your horse and lead him to unsure footing, while a loose rein is bad at the opposite extreme. "Feel the horse's mouth" so as to guide him on either hand, and assist him in a difficulty should he make a fault in going dorn-hill. 


\section{CHAPTER X VI.}

TREATMENT OF A HORSE ON A JOURNEY.-COTTING.-CARE OF THE LEGS AND FEET.-GENERAL MEDICAL HINTS.-CONCLUTINO OBSERVATIONS.

RAILROADS have not only consigned the "last four inside" to the lumber room of the past, but with them entombed the fast trotter of the natty bagman, and the stout surefooted roadster of the gentleman, the sportsman, and the gentleman farmer. Yet is a good hack called upon by those who love the saddle for a long ride home or out; and the wisdom and experience of our fathers is still worth treasuring in a matter so eminently practical as the treatment of a horse on a journey.

The maximum which a good hack (such a horse we have already described, ante, pp. 60, 61, and 78, 79), should perform, is fifty to sixty miles in the day or night; but if this is to be continued, thirty to forty is fair work, and should not be exceeded. But let no man ride his saddlehorse a long distance, unless sure that he is in full condition from the "hard-meat" system we have advised under Conditioning, ante, pp. 145-147. Should, however, any Mr. Verdant Green try a journey on a borse fresh from green fodder, with a burthen of grass flesh upon him, let him ride moderately, and see that he has good corm, or a month will not be too much to get lim into condition.

Many persons ride long stages, we have heard of thirty or forty miles, without baiting; but it is inconsiderate, and is injurious to the horse. Moderate feeds at the different stages, and an ample one at the last, are most beneficial; a quartern of oats, with a handful or two of beans, are sufficient quantities during the day; at night, half a peck of oats and a few handfuls of beans; so that a hack upon a journey of considerable length, may be allowed from a peck and a quarter to a peck and a half of oats. Hasty travellers will find an advantage in starting at a very moderate pace, and in finishing the last three miles of a stage, especially in hot weather, as leisurely as their haste will admit; since by such means they will save time, as their horses, on reaching the inn, will be the sooner dry and ready to feed. On the road, the horse may be indulged, every eight or ten miles, if he require it, with a few go-downs of water; and in hot weather, over hard roads, and with fast travelling, when the shoes acquire a burning heat, it is most refreshing to the horse, to ride him over his pasterns, momentarily, through any water that may be accessible. But a caution of much moment must have place here : be the weather not or cold, a horse in a state of perspiration should never be kept standing any length of time in water.

In fast travelling, every horseman of common sense, will ease his hack up the hills; in going down also, if he values his own neck and his horse's knees, he will dc the same.

When a hack of willing disposition and quiet temper does not start readily, or stops on the road, the rider may safely conclude that he is suffering from some bodily affection, or something galling, or misplaced in his furniture. Let him dismount instanter and examine him carefully. It may be colic, it may be strangury, and if so, urging him onward is as barbarous as it is useless. Should his nostrils become lilated, his ears sweat at the roots, and his flanks stare, with an attitude as though attempting to stale, the case is clear. Lead him about gently, and the strangury will probably cease, and urination will follow.

At the risk of a few repetitions, we will append the "treatment of a horse on a journey" as given by the author of the clever little volume entitled "How to Buy a Horse."

"As I have promised, I will add a few words respecting the treatment of a horse on a journey. The main points for consideration are, "What is the distance you have to go, and the time in which you are to accomplish it? Presuming that you are one of those who will rather 'take time by the forelock, than distress your horse by forcing him to make up by pace for the hours you have consumed in the enjoyment of creature-comforts, let him be fed full two hours before the time of starting, and that you begin your journey very leisurely, and proceed at an easy pace, well within your horse's powers, for the first ten miles; after which, as old Markham somewhat quaintly says, 'In God's name begin your journey.' If you have a strong, active, and hardy animal under you, step out moderately for another ten miles, ever taking advantage for this purpose of the level parts of the road, and easing your beast both up and down hill ; for a declivity occasions almost as great a strain on the forelegs as proportionally rising ground will upon the hind. Having ridden thus far, pull bridle, and walk your horse for a couple of miles or so, that he may recover himself in some measure, and get tolerably cool. Now put him into his stable, or a box if you can get one, and trust not to the tender mercies of an ostler to rub him perfectly dry. These gentry are too much accustomed to the rough treatment of farmers' nags and post-horses to pay any extraordinary degree of attention to a valuable hack without supervision. Moreover, if your horse be of full blood, it is ten to one but he will have the common trick of lashing out behind while being cleaned, which almost all these horses have, and which to me is 'right pleasant to behold. 
I love to see their little waywardness of temper disdainfully displayed in this manner; more especially as it very rarely arises from vice, for they constantly kick with the leg that is farthest from the person cleaning them, and seems to be only done as a vent for feelings which they cannot control. Your ostler, however, who seldom handles an animal of this stamp, sees broken ribs and legs in every kick; and, unless you stand by and assure him your horse, with gentle usage, will not kick him, either bullies him and knocks him about 'to make him quiet,' or leaves him to dry as he best may. Having, then, superintended the cleaning of your horse, water him moderately if perfectly cool, and give him about a quartern and a half of corn and beans, not more on any account, for that would only distend his stomach, and do him harm : then leave him to himself for a couple of hours ere you resume your journey. I confess I am one of those who never could admire the feats that are occasionally recorded, of riding and driving horses enormous distances in the course of the day, and that, tou, in a short space of time. A journey of forty or fifty miles per diem is as much as any humane man, fond of his horse, ought to perform. Let those who choose to go double the distance boast of their exploits in this way if they please; to my mind it is anything but creditable to them: and I can never forbear the thought that with respect to horse-flesh they are as ignorant as they are cruel.

"While a horse has any work to be done during the day, he should not be allowed any hay; and if fed four times, the extra half-quartern allowed him will make up for any deficiency in this article of diet. At night let his feet be stopped, and all the other rules which I have laid down for his comfort be attended to. It is a very bad plan so to divide your work as to complete the last stage at night. Always, if possible, let your horse be housed early, that he may have plenty of time to rest before his next day's work : and this also will give you an opportunity of looking to him oftener than you otherwise could, and of having cloths properly aired for him, if, as is frequently the case, you find the ostler prepared with a set that has been put on another horse because he was wet, and that are now destined for your horse because they are wet, and require to be dried. At almost all inn-stables a horse's back is the drying ground for damp cloths, but it will be your own fault if you suffer your hack to be used for this purpose. The main point is to endeavour to obtain for your horse as much care and as many comforts as he would experience in your own stables. If he be distressed, you may give him gruel ; but no hack in good condition ever ought to be too severely pushed. It is only in the chase that this may happen occasionally; for the man who has time enough, as he may have by starting early, to go a certain distance with a horse well prepared for work,-and no other should be used,-must ride him very unfairly or very injudicionsly if he require nursing instead of taking solid food."

In travelling the road, the vices and defects usually met with in saddle-horses are set forth in a preceding chapter (VICEs on the ROAD). The defect of Stumbling, here finds its place. Mr. Bingley says on this subject: "There is a mode of keeping our present roads in order which is called 'darn. ing.' It is effected by filling up a part somewhat lower than the general surface by broken pieces of granite, left to be crushed by the wheels of carriages, while the old smooth road forms the general surface. The substratum of ground is not picked up, but is left hard, and four or five-cornered pieces of stone are left to be trodden on by the first or any horse that is obliged to go over them. The hardness of the under surface prevents their sinking with any weight on them, so a horse might as well tread on an iron peg fixed and left an inch or two high. Let the rider, above all abominations as to ground, avoid a piece that has been thus 'darned ;' for unless the sole of his horse's foot is as hard as the granite itself, the chances are, if he is not exceedingly on the alert and quick on his legs, that he comes on his nose, though on all other occasions as safe as a cat on a carpet. Not to wince from the pain the pressure on such a surface occasions, is impossible; and if after doing so he keeps on his legs, all the credit he gets is being accused of having made a stumble; and perhaps a blow is the reward he gets for his activity in not, as a dull horse would have done, coming down headlong.

"One of these 'Carned' roads led, while I and a friend were out together, to a conversation on stumbling. On his horse making a false step, he gave him a stroke with his stick, and in a somewhat stentorian voice bid him 'hold up.' Whether my friend did this to show how resolute a horseman he had become, and his proficiency in stable terms, or thought that what he did would prevent his horse wincing when hurt, I know not; but it set him curvetting about in a way that would insure his not being struck while he continued doing so ; for my friend had occasion for all the hands he had for his bridle, and would have wanted a third if he wished to strike his horse.

"Let the rider call to his reflection the causes of stumbling," says our author, "he will then judge how far correction will remedy these. The usual causes are infirmity, peculiar formation, gait, indolence, and bad roads.

"If he blunders from weakness or infirmity, a blow with the stick will not render the infirmity less. Keeping such a horse a little on his mettle will in many cases make him go safely to a certain extent, - that is, it may, by preventing him dwelling long on either weak limb, also prevent it giving way under the weight imposed on it; but hitting him when it has so given way as to cause a stumble, cannot recall the stumble, but will very probably increase its effects.

"If blundering arises from malformation, no stick or spurs, apply them when you will, can alter that; and if from malformation the horse cannot put his foot fairly on the ground, blunder he will and must; he cannot help it,-so how can correction do anv good in this case? 
"When arising from gait, correction with the whip or stick, when he stumbles, will not alter gait; but the hands, with the whip and spurs as aids, may, if properly used when he is not stumbling. Correcting the cause may do a great deal of good; but correcting, or rather punishing, the animal, will not prevent or remedy the effect, which is stumbiling.

"Should he blunder from sheer indolence, correct the indolence as much as you please. If he will not be roused to energy, or, at all events, to quick motions by a switch, lay a tough ash plant about him; and if a touch of the spurs will not stimulate, give him a pair of good new rowels, and they will, by making so lazy a brute move more quickly, make him move more safely. We often find unsafe horses tolerably the reverse in their fast paces. Why is this? If we make a lazy horse trot three miles in twelve or fifteen minutes, he must move his legs quickly; this causes such horses going more safely in fast paces. If they would also step quickly in their slower paces, they would be safe in them. If a horse will walk cheerfully four miles and a half an hour, we generally find him as safe in a walk as a trot. The lazy horse has not energy enough to do this, nor are pains enough taken with him in his walk to make him do it; he must, when the whip and spurs force him into a fast trot. But no longer pipe, no longer dance; and as these cease so soon as he is allowed to walk, all his energy ceases also, and then he blunders again, - and so he will as long as he is a horse.

"There is yet another and very frequent cause for a horse tripping, blundering, or even falling-which is fatigue. In this case, striking him for doing what he cannot avoid, is absolute cruelty and injustice, and done, as on all other occasions, when he has tripped or blundered, is perfectly useless. No doubt the whip and spur, plied when he is not blundering, force the poor brute to increased action, and from that probably prevent his tripping as often as he might otherwise do ; but to ride a willing, good horse till he requires this, is so unjustifiable, that if I knew anything that would save such a rider a severe fall, I should glory in concealing it from him.

"Tripping is a habit or fault common to multitudes of horses who are nevertheless perfectly safe. It usually arises from striking the toe against some surface; and a horse well on his haunches may do this ad infinitum without once being in danger of coming down. He would, naturally enough, alarm a person not used to ride him, for he would not know how far it might go ; and even supposing a stranger to be riding such a horse in company with his master, though the latter might say, 'Don't pull him about,-he is quite safe,' a man must be an experienced horseman, a good judge of what is or is not unsafe, and must also have a good opinion of the owner's judgment, to feel confidence on such a horse.

"The rider may be quite sure that a horse of any spirit has as great an objection to falling as his rider has to his doing 80 ; and the quick way in which such horses catch themselves up, if they make a mistake or unavoidable stumble, shows that such is the case. Now a trip merely occasions a horse to bring the foot that he has not tripped with sooner to the ground than he would have done had he carried the tripping foot forward to its regular length of step, be that more or less;-something has stopped it in its progress, so instead of putting it forward, say fourteen inches, it is stopped at ten. This produces a somewhat unpleasant sensation to the rider, and an unequal step in the horse. This is a trip. If the horse is light and airy, he catches himself up; and, as the more spirited he is, the more quickly and energetically will he do so, this very often leads an inexperienced horseman into the belief that he has narrowly escaped a most serious fall, when, in fact, it is only the spirit and activity of the horse that have induced him to make a considerable effort to remedy a very inconsiderable mistake, and one that a more indolent horse, not noticing himself, would scarcely have been noticed by the rider. It will therefore be clear that, with a horse who has spirit enough to do of his own accord all that we could make or wish him to do if he does make a trip, any check on his mouth would only confuse him, and could do no possible good; and if a horse happens to be at all 'a loose-necked one, - that is, one inclined to throw up his head on any strong pull on his mouth,-we can do no good by checking such a horse, however bad a blunder he may make; but by doing so the rider would run great risk of bringing his horse's head in contact with his own.

"I have generally found (singular as the assertion may at first appear to the reader) that very light-hearted, cheerful horses are more apt to make trifling mistakes, or trips, than more steady and methodical steppers; and the reason they may do so I take to be this-such horses are constantly looking about them; the least thing attracts their attention ; and if that is fixed on different objects, it is called from looking at the road, or where they are going; so they come in contact with inequalities, stones, and so forth, on the ground, that the more staid, sober, and plodding goer carefully avoids."

The "SPEEDY-COT," or the horse cutting himself from faulty action, is a serious defect. It is sometimes occasioned by over-reaching the forelegs with the hinder toes, at others, by turning the toes much out, cutting the inside of the opposite foot. Indolence, or a long loose leg, produces this slovenly style of going, for which one remedy is to "get hold of his head," and make him trot briskly. We have seen this, mirabile dictu, alter a horse's style of "handling his legs."

It is sometimes difficult to decide with what part of the hoof or shoe the horse strikes the standing leg. A little careful observation will decide this. The method is "Harry Hieover's,"-palmam qui nieruit ferat. The original letter was in The Field newspaper, from which we have condensed its contents.

Take the horse into some clean place-a hard dry 
road is the best; smear his hoof and shoe with a little white paint if the legs are black, with black paint if of any other colour. Cause him to be walked for a quarter of an hour; if he has struck, or even brushed either leg, the paint will be disturbed or wiped off from the precise part he hits with, and it will further show (in cases where he does not actually cut) the spot he hits, for on it the paint rubbed off the other leg will be visible. If during his walk the paint remains undisturbed, we may fairly infer it is not in that pace he hits his legs. Trot him; if he hits, you will see where the offending leg has struck, and where the struck one is hit. As in his walk, if the paint remains as it was put on, we must infer it is in his canter or gallop that the collision takes place. Having ascertained this most indispensable fact, we must then endeavour to prevent it, or, at least, palliate its effects.

People attach a far greater degree of inevitable danger and likelihood to horses coming down from cutting than -objectionable as the failing is-is absolutely the case. When the horse cuts or hits his leg, the pain occasioned by it causes him to wince, falter, and, indeed, I have seen a horse go a step or two after the occurrence, absolutely on three legs; but the fear of falling is greater than the pain of the hit leg, and he mostly saves himself. This is when he cuts or hits his ankle only. But if he hits just below the inside of the knee, which he never does but in a quick pace, he will then sometimes come down as if shot. This is appropriately called "speedy cutting"-the worst and most dangerous failing among all cutting, and one that is incurable, for this reason: it proceeds from a particular direction of the offending leg when in action, which not once in a hundred cases can be altered. We have no resource but defending the part hit by a proper boot or legging for this express purpose, a most inconvenient and unsightly thing at best, and, moreover, all but certain to gall and chafe the leg to which it is applied. Put the horse to a description of work where the pace in which he is apt to cut is not required.

Cutting or hitting the hind legs is, of course, far less objectionable than the same failing as regards the fore ones, not alone from its not subjecting the rider to danger, but the hind parts being lighter than the fore ones, we can take greater liherties with the hind legs as regards shoeing, and can throw them by such means more out of their natural position than we can the fore ones, and still interfere but little with the horse's power, action, or safety.

Horses are decidedly more apt to cut behind than before when in harness, and vice versâ when under the saddle. Much may be done towards preventing cutting by judicious shoeing; but this is not always to be trusted to. We only prevent by this the sharp edge of the shoe coming in contact with the standing leg, which would otherwise be wounded by it. There are many horses that would still hit if they had no shoes on them. It is the position in wlich the standing leg is placed by nature, and the direction of the moving or passing leg, that produces the failing. We cannot. alter nature; we can only bring art to remedy, to a certain degree, the natural defect.

Smiths are very apt, on being told or seeing that a horse cuts, to shoe him, as it is termed, "thick-heeled" on the inside, or to make his shoe altogether thicker on the inside than the out. They tell you that by this mode they turn or twist the ankle further out of the way of the passing leg. They do; but they are not aware that if they do remove the ankle of the standing leg-say an inch further out of the way-they bring by this method the passing leg three inches nearer the standing one.

Our author proceeds to tell us of the success of an exactly opposite practice. He had a horse with this failing shod with a shoe thick on the outside. This did not remove the standing leg further out of the way, but gave the passing one a direction far away from the one it formerly struck. It succeeded, and three or four other horses that cut in the same way, were shod with similar beneficial results.

We doubt if this plan would have any efficiency in the case of cutting by the hinder foot.

To the above gossipping but sound remarks of "Harry Hieover" we may add that the remedy of making a shoe with a narrower web on the inside, so as to leave a portion of the sole overhanging, is merely temporary in its effects. When the cutting or "interference" is from a defect of structure, the cure is only apparent. When on wet roads, you will quickly find that the portion unprotected by the iron will be worn and spread, and that rawness will ensue.

If you suspect inflammation in the foot, a simple plan may detect its presence. Wet the hoofs thoroughly, and watch whether the suspected foot does not dry more rapidly than the others. If there is inflammation, the affected foot will always dry first, and resume its unnatural warmth in a few minutes; the sound foot will dry cool. Should a disposition to rest the heated foot be observed, let it be carefully looked to. Never neglect stopping the feet every night. Clay and cow-dung is the readiest and most generally available substance. We have already spoken of the expediency of giving gruel or bran mash to the tired horse; but occasionally, if the animal has been too severely taxed, cordials may be administered with advantage. Should your animal exhibit signs of being "done up" by exertion, do not hesitate to give him half a bottle of good sherry; but this certainly would be wrong after any of the inflammatory symptoms of a chill have shown themselves. In that case prompt and free bleeding only can save the horse, and any cordial is decidedly injurious. The state of the pulse will usually indicate the existence of inflammatory action $I_{t}$ is necessary to inform the inexperienced, that the only place where the pulse can be felt to advantage, so as to discriminate the sensation with accuracy, is under the jaw, where the submaxillary artery can be pressed against the bone. As the position of this artery is only known with certainty by the anatomist, it may guide the touch to direct the finger along 
the inside jaw, a little above the edge where it begins to decline downwards, gently pressing it against the jaw till the pulsation is felt. By doing this two or three times, any man will soon discover the exact spot where he should feel for the pulsation. In a healthy horse, the intervals should be about forty or fifty per minute. When it exceeds this by ten or twelve pulsations, the horse is not well; but the circulation may be momentarily accelerated even to that extent, by sudden alarm; it is, therefore, expedient to approach the horse quietly, and to caress him for a minute or two first, if he shrinks from approach. If the pulse exceeds sixty, prompt and skilled attention is required.

It often happens, however, that no veterinary aid is at hand, or only a groom who knows no more of his business than the horse itself. In such cases all that can be done is to observe some obvious principles, which, at all events, can do but little harm. If the horse betrays great pain, and especially a difficulty of breathing, copious bleeding should be resorted to without delay, and it is far better to bleed once very freely, than several times at intervals. Inflammatory action is often arrested by bleeding largely in the first instance; and when once arrested, all the distressing symptoms are speedily relieved; but so rapid is the secretion of the blood, especially in inflammatory disease, that four or five times the quantity abstracted, if taken away in several successive operations, will produce little or no effect compared with the loss of four or five quarts at one time. It may safely be assumed that wherever acute pain is indicated, inflammation obtains; and as the symptoms of pain are very unequivocal in a horse, an easy guide is thus given as to the necessity of bleeding.

If febrile symptoms appear, the same step may be taken, but not to the same extent. The symptoms of fever are not characteristic of paiu, though the breathing is often affected. In a febrile affection the horse is languid, his coat loses its even, glossy appearance, and becomes what the grooms call "staring;" the legs and feet are cold, and the appetite is gone; the bowels are usually confined, and the general look of the horse is what one would describe as miserable rather than restless and uneasy. In such cases we should recommend frequent, but not copious, bleeding, and the bowels should be opened by purgative medicine; two drachms of aloes is a sufficient dose, to be repeated every ten or twelve hours, and if they fail to operate, a clyster would probably prove of service; the stable should be cool, and the horse kept warm by extra clothing. His legs should be well rubbed, and bandaged with flannel rollers.

Whenever the severe symptoms, whether of inflammation or fever, are subdued, anxious attention should be given to the horse's diet. Gruel and bran mashes will keep the bowels slightly relaxed, and should be continued till he shows signs of returning appetite; but some time should be suffered to elapse before he is indulged with his usual food.

It is no uncommon thing for the owner to abandon the Z case as hopeless when he sees his horse spontaneously lying down. This is a great mistake; a horse in great pain will lie down and roll himself about; but, unless to relieve him. self, where the legs or feet are injured, a horse that is ill will continue standing as long as his strength will permit; it is considered a favourable sign if he lies down on the litter without being compelled by actual debility; and it follows, of course, that instead of relaxing exertion, all the remedies should be pursued more actively to save him.

In cases of recent local injury, fomentations, poultices. and local bleeding, are generally serviceable; this is parti. cularly the case in strains of the back sinews or accidents to the foot. It is very important in such cases to watch closely the operations of the country farrier. Fomentations, and even poultices, are troublesome, and therefore not con. tinued, even if first adopted. To a recent wound in shoeing or treading on a nail, Friar's balsam may be usefully applied; but where the wound is severe, this or any stimulant will increase the inflammation to a mischievous extent. The horn (if the wound is in the foot) should be pared away, and the place poulticed. Lameness occurring soon after shoeing should always excite a suspicion that the sensible sole has been pricked, and in such a case it is obviously impolitic to consult the smith by whom the horse was shod. In applying a poultice, it is a common practice to tie it tightly round the foot or leg with strings. This is injurious; a worsted stocking is a very convenient bag, and may easily be kept on by applying another stocking to the other foot, and passing a roller over the withers to connect the two. Any tight ligature round the leg is injudicious, if it can be avoided

Where any place is galled or swelled by the saddle or the harness, fomentation is the best of all remedies; should any abscess be formed, it should be opened and kept open by a seton, till the matter is entirely discharged. A kick or a bruise should receive the same treatment, if the contusion is considerable; and especially in the case of broken knees In this case a horse is often more blemished by the treatment than by the accident itself. If the joint is much injured, a cure is generally hopeless; it would be more humane, as well as more prudent, to destroy the animal at once. But if the wound does not affect the joint (and on this point the farrier alone can give certain information), it should be carefully and tenderiy washed out with a sponge and warm water, and then poulticed for two or three days; after this the inflammation will probably have subsided, and ointment should be applied-not gunpowder and greaseevery country blockhead recommends this, to promote the growth of the hair; it has no such effect, on the contrary it often irritates and retards the cure of the wound. Lard alone, or with a little mixture of alum, will be much better; care, however, should be taken to apply the ointment in the direction of the lair, otherwise, when the cure is effected, the hair will grow in an uneven or re. verted form, and will make the blemish more apparent.

In all cases of strains, local bleeding and rest are indis- 
pensable. Where the back sinews are affected, rest can only be secured by a high-heeled shoe : after all inflammation has disappeared, absolute rest, even for a considerable time, is requisite to a cure. If the part is enlarged, stimulating lotions, such as hartshorn and oil in equal proportions, and even blistering, may be beneficially applied. This, of course, is incompatible with continuing work. Indeed, some strains, accompanied as they often are by a fracture of some ligament, seldom admit of a permanent cure. In the early stages, an emollient poultice of linseed and bran should be applied to strains of the leg, whatever part of it may be injured, and the horse's diet should be changed. If by this treatment the horse apparently recovers the use of the limb without pain, the high-heeled shoe may be removed, but he should not be put to work for some weeks; he should be turned into a loose box, or straw yard, and indeed this should be done in every serious case of local injury or internal disease.

Let it borne in mind, that these general hints are not intended to supersede the calling in of a qualified veterinary surgeon, but in order that, in extreme cases, an intelligent promptitude in the horseman or rider may take the place of helpless inactivity.

We will now say a few words respecting the treatment of BROKEN lKNeEs, an accident which may occur at almost any moment, and which requires immediate attention. The first thing to be done is carefully to wash away with a soft sponge and warm water every particle of sand or gravel which may have insinuated itself into the wound, of which you will then be better enabled to ascertain the depth. It occasionally will happen in a very severe fall, that the capsule of the joint is lacerated, and in this case an effusion of a limpid and somewhat glutinous liquid, called "synovia" or "joint-oil," will take place. This may not be very perceptible at first, particularly if the opening into the joint be small; but so soon as your attention is directed to it, you skould lose no time in sending for the best veterinary surgeon within reach, as vou will scarcely be able to manage the case by yourself. Where the laceration of the capsule is extensive, the probability is that the subsequent inflammation will ultimately produce abscess, ulceration of the cartilages of the joint, and, if the horse live long enough, destruction of the bones which compose it. But should the opening into the joint be small, the object you must keep in view is to preserve it accurately closed until nature shall have had sufficient time to effect its union by granulations. For this purpose a heated iron, of proper dimensions, is usually employed, and the edges of the opening being cauterised, the eschar thus formed and the subsequent swelling contribute to close the opening for some days.

When the capsule of the joint is uninjured, and the flap of skin which covered the wounded part still remains, some veterinary surgeons have recommended that it be cut off, and the wound dressed with friar's balsam, which is a strong stimulant. This treatment can scarcely be vindicated by sound judgment. We should advise to lay the flap down as neatly as possible, and retain it in its proper position by a single point of suture at its least supported part, where the cut portion was large and but loosely attached, or by strips of adhesive plaster, together with a compress and bandage. These latter keep constantly wetted with goulard lotion.

Where the skin is entirely removed, the best application, after fomentations with hot water, is a soft and warm linseed-meal poultice, which should be removed every four hours until the inflammation subsides. You may also, in every case, give a gentle dose of physic, and no other food for the first few days than bran-mashes and hay.

When the inflammation has been subdued, and granulations appear, apply strips of adhesive plaster, neatly one over the other, so as to make some pressure on the wound, and bandage the leg very carefully with a linen bandage from above the knee to the coronet. Several stimulating applications may be requisite during different stages of the cure, among which Friars' balsam and nitrate of silver lotions, varying in strength according to the state of the parts, are perhaps as good as any.

Whether the wound have penetrated to the joint or not, and whether the skin be hanging to the wound or cut off, in every instance of broken knees, apply a splint of wood, of the whole length of the leg, to the back of the limb, and confine it by a bandage. This a precaution unattended to by many veterinary surgeons; but, as it prevents the injured part from being bent or moved, should never be omitted; for the quieter the state of the wounded limb, the less will be the consequent inflammation, and the speedier the cure. Where the injury is great, the splint should be kept on for at least six-and-thirty hours without removal.

Cold lotions and warm poultices have been mentioned as applicable to different degrees of broken knees. Poultices rather tend to hasten the process of suppuration, without a slight quantity of which, granulations will not be formed. They are therefore to be used where there is no flap of skin left. But if you wish to effect immediate union of the cut parts, which should always be attempted when practicable, suppuration is not to be promoted, and therefore cold lotions are preferable. It requires great care and nicety so to apply strips of plaster and bandages as to prevent the swelling so often consequent on a bad broken knee, and which blisters and stimulants nine times out of ten fail to reduce.

Farriers will tell you that the common adhesive plaster will not do for a horse, and would fain induce you to use slips of leather covered with pitch; but where your plaster perfectly encircles the wounded part, as the knee-joint, and is cut sufficiently long, one end overlaps the other, and consequently it adheres to itself. Where this is not the case the hair will prevent it from sticking.

INFLAMmation of THE Eye sometimes makes its appearance suddenly, either from irritating substances, as hay, seeds, \&c., making their way into it, or from blows with a brush while 
cleaning the head, or a rap with a stick from a brutal groom, who is in the habit of striking a horse over the head while riding him, and perhaps accidentally hits the eye by the sudden shifting of the horse's head when he expects a blow there. We have seen a very severe injury of the eye, where it presented the appearance of a mass of blood, from this very cause.

In this case you must bleed from the vein running just below the eye, and which is usually very easily distinguished, and give physic and bran-mashes. Cold lotions of goulard water are to be constantly applied to the eye, and the stable to be darkened while the inflammation is excessive. When this is reduced, and the membrane of the eye still remains clouded, you may inject night and morning with a syringe a weak solution of nitrate of silver, beginning with four grains to an ounce of distilled water, and gradually increasing its strength as the eye appears to improve under its application. A little speck will frequently remain on the membrane which cannot be removed. Indeed it is occasioned by the abrasion at the moment of injury of this most delicate part.

Greasy HeELs you will have few opportunities of treating if you follow the advice given under the head of Stable Management. They are most frequently occasioned by washing the logs with cold water while they are heated from exercise, and suffering them afterwards to dry ; the consequent reaction after the application of cold being excessive, and running into inflammation. Nature then seeks to relieve the gorged vessels by a discharge of ichorous matter from the inflamed part. Bringing a horse into a hot stable in the winter, when his legs are chilled with standing some time, perhaps in the snow, will produce a similar effect. These ills are easily to be avoided with a little careful supervision: by accustoming your groom to pay particular attention to rubbing the heels dry at all times, and keeping them perfectly clean.

When the disease has appeared, all causes inducing it must be avoided; and of these we may mention draughts of air blowing upon a horse from behind; and if the pain and heat of the part be great, warm and soft poultices must be applied in the first instance.

As soon as stimulating remedies are applicable, you can use nothing better or cleaner than a solution of nitrate of silver in distilled water, beginning with eight or ten grains to the ounce. Sometimes, however, the diseased parts will require a change of stimulants, and you may then apply a solution of blue-stone in a strong decoction of oak bark. A stick of nitrate of silver or lunar caustic may be lightly passed over the cracked part occasionally with great advantage But there is one circumstance which, although in every case neglected, you must not overlook. The motion of the diseased part must, as much as possible, be controlled. Every time the borse bends the fetlock-joint, he disturbs the process of nature in effecting a cure; and as it is necessary to prevent the crack in the heel from being disturbed, you will find that any moderately soft substance, as bees' wax or putty, placed over and close to the diseased part, will, by taking its form and accurately making pressure upon each portion of it, materially conduce to the cure. It must be applied directly after the lotions recommended, and must not only be kept on by a neatly-applied bandage, but the hollow in the back part of the fetlock-joint must also be previously filled up by a pad of tow, or some other soft substance, in order that the joint may thereby be rendered less capable of motion.

The heels being the farthest removed from the heart, the circulation of the blood in them is less active and vigorous than elsewhere, and consequently their restoration to a healthy state is achieved with more than usual difficulty. Some horses that have cracked heels are in too high condition, while others in a debilitated state are equally or perhaps more prone to the same disease. These different states of body of course require opposite constitutional treatment; the first demanding low diet with purgatives and liuretics; the second, generous food with tonics.

Of all the preventives of grease there is none-setting aside the avoidance of those causes already mentioned as conducing to the disease-so effective in its operation as bandaging the legs regularly with flannel rollers. We advocate their employment at most times in the stable, as they materially tend to fine the legs when properly applied, and also, when not put on too tightly, evidently keep up the circulation in the extremities, a point of much consequence. Those who are not shown the proper method of applying a bandage, generally do more harm than good with them. We do not in the least exaggerate when we say that we never yet knew a groom who could put on a bandage as it should be. They fail about the pasterns and fetlocks, and leave the bandage there loose and bagging, so that, when pressure is requisite, the circulation between the pasternjoint and the foot is impeded, and the latter will be found cold, and the part between the coronet and fetlock perhaps somewhat swollen.

Bandages, to be neatly applied, should not be so wide as grooms generally make them. You will hardly be able to put them on properly if of more than four inches in width. Begin by applying your roller just under the knee, pass it round in rather a slanting direction, keeping your finger on the extremity until you find it has taken firm hold of the limb; then let each turn of the bandage cover one half of that above it, taking care so to direct it that its under edge does not bag, but lies closely on the leg When you come to the hollow behind the pastern, the bandage must be half folded on itself, so that what was its upper border shall be undermost, and this must be repeated whenever it cannot be otherwise made to lie smoothly and closely to the leg.

By bandaging from above downwards, you in a great measure avoid leaving any marks of the roller on the hair. In the veterinary portion of the present work, will be found engravings of the various kinds of bandagings and their applications by the professional man. An eye-acquaintance 
with these will enable the proprietor of an animal to judge of the manual competence of farriers or grooms who may pretend in an emergency to understand the best modes of applying them.

We here close the treatment of some of those accidents and diseases which will occasionally call for our attention; repeating, what cannot be too strongly impressed upon the reader, that the intention here is merely to notice such cases as will every now and then occur in every stable, and which call for immediate remedy. Those who would go more deeply into the subject here touched on, may proceed with advantage to the studious perusal of the Second Division of the work, and make themselves masters of the principles on which the treatment of disease is founded. This will be found the best safeguard against being imposed upon by the inoorence of a country smith. or the officiousness of a would-be-learned groom, who deems nothing easier than the cure of all diseases of the horse; taking the old saying of "as strong as a horse" as his authority for essaying upon his unfortunate carcase every kind of dose of every sort of medicine which it pleases his conceit or his ignorance to assume that he must require.

It is a difficult thing to treat the simplest form of disease on really scientific principles, as experience is constantly demonstrating the errors of our previous practice; but it is by no means an arduous task to acquire that degree of knowledge which will enable us to strip ignorance of its cloak, and confound the empiric who is incapable of assigning a good reason for his plan of treatment.

We here close the general, the historic, and the preceptive division. What follows will be more strictly of a medica scientific, and practically surgical character. 


\title{
ANATOMICAL, SURGICAL,
}

\section{AND \\ V E T E R I A R Y P L A T E S,}

\author{
WITH LETTERPRESS REFERENCES.
}

\section{PLATE I.-THE BONES OF THE HORSE.}

BoNes of THE HEAD.-(1) The frontal (or forehead) bone. The parietal (or wall) bone (3) The occipital (or hinder skull) bone. (4) The temporal (or temple) bones. To these are attached the cartilages of the ears of the horse. (5) The nasal (or nose) bones. These contain the septum narium (division of the nostrils), a long cartilaginous plate (6) The lachrymal (tear) bones. (7) The zygomalic (yoke) bones. (8) The superior maxillary (jaw) bones. These, the largest bones of the face, hold all the grinders of the upper jaw. (9) Thie superior or anterior maxillaries. These receive the nipping teeth (incisors), and the cartilage of the nostrils. (10) The posterior or inferior maxillaries, or great jaw-bones. These receive the lower grinders, tushes, and nippers. (a) 24 molars, or grinding teeth. (b) 4 canines, or tushes. (c) 12 incisors, or nipping teeth. (d) The orbits of the eyes. The os hyoides (letter-Y-shaped bone) is situate inside the head, at the root of the tongue, to support and attach the muscles of that organ.

Bones of THE NeCK and Trunk. - (11) The geven cervical (neck) vertebræ. (12) The eighteen dorsal (back) vertebræ. The five most elevated of these form the withers. (13) The six lumbar (loin) vertebra. (14) The five sacral (haunch) vertebræ. (15) The coccygeal (cuckoobeaked) bones, or caudal (tail) vertebræ. These vary in number, generally thirteen or fourteen. There are eighteen ribs, thus divided:(16) Nine sternal (brea日t) or true ribs, articulated with the sternum, or breast-bone (18). (17) Nine false ribs, attached by cartilage. Sometimes eight are oternal and ten false. (18) The sternum (breast) bone. The haunch, comprising:-(19) The ileum (eileo, I turn), two in number. (20) The ischium (iskion, hip), two. (21) The pubis (share-bune), two. These and the two previously-named bones grow into one after birth. The hinder legs, consisting of:-(22) The femur (thigh-bone). (23) The patella (knee-pan), called by horsemen the stifle. (24) The tibia (leg-bone); $e$, the fibula (clasp or brace-bone). Bones of the tarsus (instep) or hock $(f)$ :- (and see an enlarged representation, Plate IX). (25) The os calcis (heel-bone), called point of the hock. (26) The astragalus (ankle-bone). (27) The cuboid and irregular bones of the tarsus. (28) and (28*) The metatarsal bones. The great metatarsal, cannon, or shank-bone, in front, and the amall metatarsal, or "splint" bone, behind. (29) The sesamoid (grain-shaped) or fetlock-bonee. (30) The os ouffraginie, upper or larger pastern-bones. (31) The os coronx, crown-bone, or lesser pastern. (32) The coffinbone (behind this, and articulating with it and the emaller pastern, is the os navicularis, boat-shaped or shuttle-bone. It is not here visible, but will be seen in a section of the horse's foot. $30,31,32$, are called by anatomists the first, second, and third phalanges. Bones of the forelimbs:-(33) The ecapula (blade), or shoulder-bone. (34) The humerus, or arm-bone. (35) The radiue or fore-arm; the ulna, elbow, or cubitus (g). (36) The seven carpal (wrist) bones, popularly called the "kneebones." (37) The metacarpus, cannon, or shank-bone, consisting of one large metacarpal bone and two smaller ones. (38) The two greater sesamoids. (39), (40), and (41) The larger and smaller pastern, and coffin-bone. The three phalange of the digital-region; the on naviculare is not visible. $3 \mathrm{z} *$

\section{PLATE II.-THE MUSCLES OF THE HORSE.}

Muscles of tue Head.-Motors of the Eyelids.-(a) The orbicularis (a sphincter which shuts the eyelid). (b) Levator palpebræ superioris (lifter of the upper eyelid). And see Plate VII. TuE EyE. Motors of the Nostrils. - (c) Dilatator naris latcralis. Draws the nostril upwards and sideways; rises from the external part of the iuter-maxillary bone. (d) Contractor naris. Motors of the Lips.-(e) Orbicularis orie. The labial muscle; a sphincter to close the lipe. (f) Levator labii superiorio. (g) Levator anguli orie. (h) Retractor labii (i) Zygomaticus. Runs from the zygomatic (ploughshare) process, and is the true retractor of the angle of the mouth. ( $j$ ) Retractor labii inferioris. Pulls back the underlip. MLtors of the Lower Jaw.-(k) 'The zygomatic-masillary, corered by the great masseter or chewing muscle of the lower law. (l) The temporal maxillary. Motors of the Ear.-(m) Attollens maximus. To bring forward the ears, and lift the triangular cartilage upward and forward. ( $(n)$ Attollens medius. (o) Attollens inferior.

Muscles of the Neck, Serving to Move the Head.- $(p)$ The dorso-occipital tendon. (q) Complexus major (atloido mastoideus). (r) Trachelo-mastoideus (here the tendon cervico-mastoideus is seen). $(s, t)$ The splenius, covered by fascia. (u) Levator humeri. (v) Sterno-maxillary (masseter externus). Muscles of the Ribs and Abdomen acting in Respiration. - ( $\left.a^{*}\right)$ Latissimus dorai (broad muscle of the back). ( $\left.b^{*}\right)$ Intercostal (between the ribs) muscles. ( $\left.c^{*}\right)$ Costo-abdominal muscles. $\left(d^{*}\right)$ Ilio-abdominal ditto. Motors of the Tail.-( $\left.e^{*}\right)$ Sacro-coccygis superior (raiser of the tail). ( $\left.f^{*}\right)$ Sacro-coccygis inferior (depressor of the tail). ( $\left.g^{*}\right)$ Ischia-coccygis. Motors of the Thigh and Leg.- $\left(h^{*}\right)$ Glutæus maximus. ( $\left.i^{*}\right)$ Glutæus externus. $\left(f^{*} o^{*} \delta^{*}\right)$ Triceps adductor femorie. ( $\left.k^{*}\right)$ Biceps rotator tibialis. ( $\left.l^{*}\right)$ The peronæus. $\left(m^{*}\right)$ Tensor vaginæ. ( $\left.n^{*}\right)$ Rotator femoris. ( $\left.0^{*}\right)$ See $\left(j^{*}\right)$. Motors of the Tarsus and Metatarsus. - $\left(q^{*}\right)$ Flexor metatarsi magnn. ( $\left.r^{*}\right)$ Exteusor pedis posterior. $\left(s^{*}\right)$ Flexor pedis accessorius et perforans. Motors of the Foot. - $\left(u^{*} u^{*}\right)$ Gastroenemius, and its lower insertion into point of hock. $\left(v^{*}\right)$ Flezor pedis perforans. $\left(x^{*}\right)$ Extensor pedis. ( $\left.y^{*}\right)$ Peroneus of fore pastern. $\left(z^{*}\right)$ Tareo-phalangian muscle, back of near leg and inside pastern. (8) The foot and coronet.

Muscles of the Fore Extremities.-Muscles moving the Shoulder. - $(a \dagger)$ Doreo et cervico acromion. (b†) Sub-scapular cervical. (c $\dagger$ ) Rotundus major (depressor of the shoulder). (d†) Pectoralis magnus. Motors of the Arm.- (u†) Levator humeri. (e†) Ante-spinatus. ( $f \dagger)$ Postea-spidatus. (g†) Teres externue. ( $h \dagger$ ) Caput magnus triceps exterior. (i†) Dorso-humeral (trapezius). MLotors of the Fore-arm.$(k \dagger)$ Caput medium triceps exterior. (l†) Musculus biceps. ( $m \dagger$ ) Longus extensor. (n†) Radius internus. (o†) Cubiteus internus. Muscles of the Carpus and Metacarpus.-( $p \dagger)$ Ulnarius accessorius. (q†) Flexor metacarpus internus. $(r \dagger)$ Flexor metacarpas medius. $(t \dagger)$ Extensor metacarpi. DLotors of the Foot.-(u†) The condylo-phalangian (profundus), or second bender of the pastern or coffin-joints. (v†) The cubito-phalangian tendon (sublimis), or first bender of the abore. ( $x+$ ) Extensor pedis. (y†) Flexor pedis externus. (†) Ligaments of pastern. $(8,8)$ Ligaments which cover the fore pastern. 
PLATES III. AND IV.-(THE MOUTH),

Are inserted, with their explanatory text, at pages 106 and 108 of this volume.

\section{PLATE V.THE HEAD OF THE HORSE.}

Fig. 1. Bones of the Head, and their Sutures.-(a) The occipital bone. (b,b) The parietal (wall) boues of the skull. (c, $c)$ The temporal (temple) bones. (d, d) The temporal fossæ. (e,e) The frontal (forehead) boues. ( $f, f)$ The zygomatic (yoke-shaped) arch. $(g, g)$ The supra-orbital foramina. The small bole beneath (some horses bave several) receives vessels which nourish the bone. $(h, h)$ The lachrymal (tear) boues. (i,i) The orbits, containing the eyes. $(k, k)$ The nasal bones. $(l, l)$ The malar (cheek) bones. $(m, m)$ The superior maxillary (upper jaw) bones. $(n, n)$ The infra-orbital foramina (holes below the orbits), through which pass branches of aerves and blood-vessels to supply the lower portion of the face. $(o, o)$ The openings into the nose, with the boues forming the roof of the palate. $(p, p)$ The inferior maxillary (the lower jaw boue), which is a separate boue in quadrupeds, containing the incisors or cutting teeth and the upper tuslses. $(q, q)$ The upper incisors, cuttiog teeth, or nippers; the one nest to these, on each side, are called the dividers, and the innermost ones on both sides are termed the corner incisors.

\section{Fig. 2. The Bones of the Head, from Nature.}

Fig. 3. Section of the Head, Showing its Internal Organs.(a) The crest, or ridge of the parietal bones. (b) The frontal bones; beneath are the frontal sinuses. (c) The nasal booes. $(d, d)$ The septum narium, or cartilaginous division between the nostrils. (e) The occipital bones. ( $f, g)$ The atlas, first bone, and dentata (toothed), second bones of the neck. (h) The cuneiform (wedge-shaped) base of the occipital bone. (i) The sphenoid (wedge-like) hone, and its cavities. (k) The ethmoid (sieve-like) bone, with its cells. (l) The tongue. ( $m$ ) The inferior maxillary. (n) The posterior maxillary. (o) The os hyoides, or bone of the tongue. ( $p$ ) The thyroid (helmet-shaped) cartilage. $(q)$ The epiglottis. (r) The arytænoid (funnel-shaped) cartilage. (s) The chorde vocales; ligaments concerned in forming the voice. ( $t$ ) Sacculæ largngis, ventricle of the windpipe. (u) The palate. (x) The soft palate, which prevents vomiting. $(y, z)$ The opening at back of the moutb, the fauces. (1) The cerebrum, or brain. (2) The cerebellum, or little brain. (3) The medulla oblongata, prolongation of spinal marrow. (4) The spinal cord. (5) The ligament of the aeck, or "packwax," which chiefly sustains the head. (A) The gullet. (B) The larynx. (C) The trachea. (D) The nostrils, and the dilator naris. (E) The under lip, aud the depressor labii inferioris.

Fig. 4. Tue Occipital Bone, and atlas Dentata or First Vertebra of the Necr.-(a) Point of the occiput. (b) Spine running down the centre of the bone, roughened surface, for the attachment of powerful muscles, which turn the bead in various directions. $(c, c)$ The places where these strong muscles are inserted. (d) A large hollow called the foramen magnum, or great aperture, through which the continuation of the brain, called the spinal cord, passes out of the skull. $(e, e)$ Two rounded protuberances, by which the head is connected with the atlas bone, and which fit into the condyloid, or cup-shaped processes of the occipital bone. ( $f, f)$ These two projections are an additional contrivance for the support of the great weight of the head. These are termed the ceracoid (beak-like) projections of the occipital bone.

Fig. 5. The Spinal Cord, its Decussated Nerves and Ganglia. -(a) The spinal cord divided, consisting of six distinct columns. (b) A column giving out fibres (aerves) of seusation. (c) A buadle of these nerves of sensation and motion, cut off after passing througb. (g) A ganglion (knot), or eulargement. These enlargements are called ganglia. $(f, f)$ The general eaveloping membrane, turued back.

\section{PLATE VI.-THE HEAD, EAR, BRAIN, AND PALATE.}

Fig. 1. The Internal Ear, Tympanum, Bone, etc.-(a) Meatus auditorius externus, outer passage of the ear. (b) Membrana tympani, tympanum (drum), or membrane stretched over the hollow drum of the ear. (c) The malleus, or hammer. (d) The ictus, or anvil. (e) The orbiculare, or round bone. $(f)$ The stapes, or stirrup. This bone rests on the membrane which covers the foramen ovale (oval opening), which leads into the labyrinth of the ear, called also fenestra ovalis (oval window). (h) The vestibula, porch, or entrance to the labyrinth. $(i, i, i)$ The semicircular cauals. These form parts of the labyrintr. , $(k, k)$ Openings into the canals. (l) The tympanum, or drum. $(m, m, m)$ The cochlea, or snail-shell-sbaped portion of the labyrinth of the ear. (n) Meatus auditorius internus (internal passage of hearing), through which the soft portion of the seventh pair of nerves enters, aud which is the auditory nerve, or uerve of hearing, and is spread over the cochlea and vestibula. The small curve below the lowermost letter $m$, is the Eustachian tube (so called from its discoverer), which communicates with the mouth.

Fig. 2. The Palate, Bars, Palatine Vein, Nerves, etc.- $(a, a)$ The incisors, or cutting teeth. (b) The palatine nerve. (c) The palate and its ridges. $(e, e)$ The bars. A strip has been removed, in a curved form, round $D$, to show the nerve, artery, and vein. $(f, f)$ The palatine artery. ( $g$ ) The palatine vein, on each side of this letter. $(h, h)$ The cheeks, divided, to show their longitudinal structure. $(i, i)$ The tushes, or canine teeth. ( $k, k)$ The gums. ( $l$ ) The upper lip (labium superius).

Fig. 3. The Brain, showing the Arteries, and its several Lobes.- $(a, a)$ The substance of the brain; bemispheres of the cerebrum. $(b, b)$ The anterior lobes of the same. $(c, c)$ The cerebellum, or little brain, in the posterior part of the skull. (See Section of Head, Plate V). ( $d, d)$ Inferior spinal, branches of, about to become single. (e) Basilar arteries. ( $f$ ) Post cerebel]ar. $(g, g)$ Basilar, with branches right and left. $(h, h)$ Pight and left commuaicating arteries, connecting the basilar with the circulus arteriosus. $(i, i)$ Internal carotids. $(k)$ Posterior transverse. $(l, l, m)$ Posterior cerebrals and branches, forming part of the circulus arteriosus of Willis. $(p, p)$ Ophthalmics, or eye arteries. ( $q$ ) Anterior cerebral, dividing into- $(r, r, s)$ Right and left anterior cerebral.

Fig. 4. Origin of The Nerves, etc.- $(a, a)$ The posterior substance of the base of the brain. $(b, b)$ The anterior ditto. $(c, c)$ The cerebellum, or little brain. (d, $d)$ The spinal cord. $(e, e)$ The olfactory nerves (1st pair). ( $f, f)$ The optic nerres (2nd pair). (g) The infundibulum, or funnel. On each side is seen the severed trunk of the carotid artery, where it divides into branches. $(h, h, i, i, i, k, k)$ Branches of the carotids, going into the substance of the brain. $(l, l)$ The fourth pair of nerves (deep-seated), called the pathetic. $(m, m, n, n)$ The fifth pair; the sixth pair. $(0,0)$ Origin of the fourth pair. $(p, p)$ The seventh and eighth pairs of uerves: the seventh pair being the auditory aerves; the eighth, the nervus vagus, or pneumogastric. $(q, q)$ Seat of the ninth or lingual pair; the branches of the tenth pair (sub-occipitals) arise from the begiuning of the spinal marrow.

Fig. 5. The Muscles and External Blood-vessels of the FACE AND NEck.-(1) Orbicularis (round) muscle, surrounding the eyo and closing the lids. (2) Nasalis labii superior (belonging to nose and upper lip). (3) Dilator magnus (the great dilator of the nostrils). (4) Dilator naris lateralis (side dilator of the nostrils). (5) Outer portion of dilator magnus, part of the lateralis being cut away above it at $S$, to show vessels. $(6,6)$ Orbicularis oris (muscle around the mouth). 7. Depressor labii inferioris (depressor of the lower lip). (8, 9) The buccinaton (trumpeter) muscle. (10). (11) The masseter (chewing), or chewing muscle, forming the cheek of the horse. (12) The sub-scapulo hyoides, from under the shoulder-blade to the root of the tongue, lies just bebind these figures. (13) The steruo-maxillary (belonging to the breast-bone and jaw) muscle. (14) The levator humeri (lifter of the shoulder), arising from the back of the head (occiput), and going to the shoulder. $(15,16,17,18)$ The complexus major (larger complicated) splenius (splintlike) tendons, supporting the head, with the upper ligament of the neck. (a) The jugular (neck) vein, the two branches having united. (b) The submaxillary artery here passes, with a brauch of the jugular and the parotid duct, under the angle of the lower jaw. The pulse is best felt bere. (c) The facial artery and branches. $(d, f)$ The nasal artery and veins. $(e, g, h, i)$ Tenporal artery ; branches of carotids. The branches of the fifth pair (verves of feeling of the face), and the main portion of the seventh pair (motor nerves of the face), are marked by a white baad: its ramifications are easily traceable. 


\section{PLATE VII,-THE EYE OF THE HORSE IN HEALTH ANT DISEASE}

Fia. 1. The Pupil, Retina, and Coats of the Eye.-(A) 'The horizontal line of vision, from which $\mathrm{B}$ and $\mathrm{C}$ are equidistant. (B, C) Object seen by the animal, of which an inverted picture is repeated in the retina between $\mathbf{E}$ and F. (D) The vitreous (glassy) bumour, flling the whole cavity behind the lens. (E, E) The ray passing through the cornea and lens, converging by the refracting power of the lens. (F, G) A similar ray from the upper part of the ohject, becoming the lower; between $\mathrm{E}, \mathrm{F}$, is the picture on the retina. (a) The crystalline (glassy) lens behind the pupil, and before the vitreous lumour. (b) The iris (rainbow-coloured circular membrane) on which the colour of the eye depends. The iris floats in the aqueous humour. (c) The aqueous (watery) humour, filling the space between the cornea and crystalline lens. (d) The choroid (covering) coat, covered with a black secretion called the pigmentum nigrum. (e) The cornea (horny), transparent part of the eye, covered by the conjunctiva, which covers the eye, uniting the different parts. ( $f, f)$ The retina (net-like) expansion of the optic nerve, spreading over the whole of the choroid except the lens. $(g)$ Muscles of the eye, and fatty cushion. $(h, i)$ The optic nerve, or nerve of eight.

Fig. 2. The Healthy Eye, showing the Pupil in a Moderate LigHT.- $(a, a)$ The pupil expanded, showing the black pendulous bodies attacked to its upper margin.

Fig. 3. The Healthy Eye, the Pupil contracted by the iNFLUENCE OF STroNo Light.

Fio. 4. Cataract.- $(b, b)$ The opaque apecks formed in the pupil, ar rather in the crystalline lens.

Fig. 5. Complete Cataract. - (b) The pupil and crystalline lene, wholly opaque, and out of shape, "Wall-blindness."

\section{PLATE VIII.-THE BONES, MUSCLES, AND ARTERIES OF THE FORE LEG.}

Fig. 1. Bones of the Pastern and Fore Foot.- $(b, b)$ The wings of the large pastern bone, with its cavities for the reception of the lower pulley-like head of the shank bone, and the sesamoid bones. $(c, c)$ Rough surfaces of the large pastern, for the attachment of ligaments. $(d, d)$ The small pastern (coronary boue). (e,e) Wings of the coffin bone. On their inner surface is a groove for an artery, which forms a semicircle within the substance of the bone. $(g, g)$ The coffin bone, light, spongy, and perforated with nnmerous holes for the passage of blood-vessels. The upper surface concave for the reception of the pastern. (d, $d)$ The lower, also concave, for the reception of the sensible sole. $(h, h)$ The foramina, or boles, for the passage of blood-vessels and nerves. (i) The toe and horny laminæ. The out, shuttle, or navicular bone, is situated behind the coffin bone, between its two wings, and not seen from the front.

Fig. 2. Bones of Pastern and Foot (Back view).--(b,b) Large pastern (as Fig. 1). (c, c) Projectione, \&c., as before. (d, d) Small pastern bone. (e,e) The navicular bone. Its upper surface is continuous with the articulated surface of the coffin bone; its lower rests on the perforans tendon. This is the seat of navicular disease. $(f, f)$ The wings of the coffin bone. $(g, g, h, h, i)$ Processes whereto the sensible sole and frog are attached.

Fig. 3. Muscles of the Fore Leg and Shoulder.-(a) Levator humeri, or raiser of the shoulder. It serves alsu to depress the head. This is in powerful action when the horee runs with his head projected forwards. In front is a portion of the sterno maxillaris connested with the lower jaw. $(b, b)$ The trapezius, or four-sided muscle. It occupies the withers, and lifts the shoulder blade. Part is here turned back to show the muscle beneath, which is the serratus major (great tooth-shaped muscle). ( $c, d)$ Lesser pectoral, or breast muscle; it lies below the greater pectoral, and is attached to both breast bone and shoulder blade. (e) The postea spinatus muscle, extends to the lower bone of the shoulder. (f) Ante-spinatus; above it is the swall pectoral muscle, connected with breast and shoulder bone. (g) Flexor brachii, fixed by strong tendons to the scapula, and by a flattened tendon below to the inner side of the radius. It throws the shoulder forward, and raises the fore arm. (h) A division of part of another muscle arising from the point of the scapula, and inserted by tendon in the elbow. (i) A deeper-seated purtion of tho 8ame. (k) The middle flexor, paseing down to the inner side of the knee. (l) The principal extensor, in front of the fore $\mathrm{arm}$. $(m, n)$ Al these points are seen the artery, nerve, and vein of the fore leg, and the downward course of the extensor pedis muscle. (o) The perforans (perforating) flexor. ( $p$ ) The perforatus (perforated) tlexor. It arises from the lower portion of the inner head of the lower hone of the shoulder, and is intimately intermixed with the perforans flexor muscle. As it descends the bone of the arm it becomes tendinous, and extending to the knee, it is bound down by ligamentary bands $(r, s)$, to prevent it from starting in eudden motions. (q) Descending arteries, vessels, and nerre日. $(r, 8)$ Ligamentous bands.

Fig. 4. Muscles, etc., of inside of Fore Leg.- $(a, b)$ Pectoralis transversus muscle, which crosses the breast. It binds the arm to the side of the horse, and keepe the lege straight before the horse in his gallop. Its point is the seat of capped hock. (c) Branches of the axillary artery, \&c. (e) The internal flexor of the arm. $(f, g, h)$ Branches of the extensor brachii, and blood-vessels. $(i, m)$ Descending radial artery and nerve. (l) The knee joint.

\section{Fig. 5. Situations of Diseases of Fore Leg.}

(a) Seat of sand-crack. (b) Ring bone; false quarter. (c) Point of breaking down, rupture of fetlock. (d) Seat of windgall. (e) The tendinous band in which the flexors work, with vein and verve descending to the pasterns-the last is divided in nearotomy. $(f)$ Sprain of back sinews. (g) Seat of splint. (h) Tied in below the knee. (i) Seat of mallenders. $(k)$.

\section{PLATE IX.-MUSCLES, ARTERIES, ETC, OF HINDEP. EXTREMITIES.}

Fig. 1. Muscles, etc., outside the Thigh.-(a) The gluteal muscle (glutæus maximus). (b) The outer gluteus (buttock) muscle (gluteus externus). (c) The triceps femoris (three-headed muscle of the thigh). It rises high up in the bones of the spine, and is inserted in the upper part of the lower bone of the thigh. Its office is to draw back the thigh, and 60 throw forward the trunk of the body. (d) This muscle descends from the sacrum, and runs behind the triceps femoris, forming the hinder part of the haunch. It is greatly developed in the thorough-bred horse, and is another important agent in propulsion. (e) The root of the tail with its muscles. $(f)$ The tensor vaginæ. $(g)$ The flexor metatarsi, which bends the hocks. (h) Extensor pedis, on the front of the thigh. It is attached above to the outer condyle of the thigh bone (femur), and below to the coronet of the fout, and to the upper end of the bone between the lateral cartilages. It extends the foot, fetlock, and pastern joints. (i) The poplitæus, or femoro-tibialis obliquus, a short thick muscle, seen again at $p$. It bends the stifle, and turns the limb inward. Just at this part the principal nerves appear before entering or underlying the muscle, they pass under $c$ to the spinal marrow. (k) This muscle extends the hock; it ends in a flat tendon below $l, p$. $(l)$ See preceding letter. $(m, n)$ The peroneus, another extensor. It arises from the fibula aud becomes teudinous before reaching the hock. It accomnanies the great extensor in the same sheath, half-down the shank-bone, and with it attaches itself to the coffin bone. It raises the foot and brings it under the body. (o) Flexor pedis. It originates in the tibia, and becomer a large round tendon in a groove at the back of the hock, and continues down the leg to the foot, assisting to bind the pastern and coffin joints. ( $p$ ) See above at $i . \quad(q)$ A layer of $d$, entering bock at $w . \quad(r, 8)$ Tendinous fascia binding muscles of the thigh.

Fig. 2. Muscies, etc., inside the Thigh.-(a) Muscle descending from the sacrum ( $d$, fig. 1). (b) Continuation of ditto. (c,e) Gracilis, or slender muscle. (d) Course of the principal arteries and veins. (f,g) Sartorius, or tailor's muscle. (h) Fasciæ. (i) The glutæus externus. (k) The peroneus, ascending to the coronet of the 08 pedis. (l) The poplitaus. $(m)$ The flexor metatarsi (tendon of the leg). (n) Extensor pedis. (See letter $h$, fig. 1.) (o) Inside view of the perforans muscle; $h$ is lifted up. $(p, p)$ Mark the course of the principal blood-ressels of the inside of the thigh. $(q, q, r, 8)$ Principal nerves and vessels of the hinder part of the thigh and hock. ( $t)$ The large cutaneous veis. $(u)$ Muscla below the vein, and a layer of fleshy fibre to the front of the hock. (v) The ligamentary bands which confine the hock. (w) Supplementary fibres, to 
brace the tendon and prevent its compression when the hock is bent. (y) See $y$ above in figure, whence, downward to (z) The nerves and vessels of the fore-part of the thigh are traced.

Fig. 3. Arteries and Nerves of the Hinder Leg.- $(a, a, a)$ The femoral (thigh) artery. (b) A branch of the same. (c) Continuation of the femoral trunk. (d) The anterior tibial artery. $(e, e)$ The femoral veio. $(f, f)$ The posterior tibial artery. $(g, g, g)$ The metatarsal artery. (i) $\mathrm{A}$ branch of the femoral vein. $(j, j, j)$ The femoral vein. $(k, k, k)$ Anterior tibial veins. (l) The metatarsal vein, ascending. $(m)$ The large metatarsal vein. $(n, n)$ The ioguinal (groin) artery.

Fig. 4. Bones of the Hock enlarged, to show their articuLATIONS.--(a) The astragalus, or knuckle bone. (b) The lower end or base of the tibia (thigh bone). (c) The os calcis, the hinder projecting part, called "the point of the hock." (d) The os cuneiforme magnum (great wedge-shaped bone) immediately under the astragalus. (e) The os cuboides (cube-shaped bone) on the outer side of the hock. $(f)$ The os cuneiforme, middle wedge-formed bone, immediately under the cuneiforme magnum. (g) The splint bone. (h) Upper head of shank bone. These are all connected with powerful ligaments, to prevent dislocation.

Fig. 5. The Hock and Hinder Extremity, and Situation of Diseases.- (a) Seat of thoroughpin; (b) Capped hock; $(c, d)$ Curb ; $(e, e)$ Seat of "rat-tails"; $(f)$ Splint; $(g)$ Windgalls; $(h, i)$ Grease, thrush, \&c.; (k) Tread; $(l)$ Seedy-toe. All which are noted under their several titles in the work.

\section{PLATE X.THE HORSE'S FOOT, AND NEUROTOMY.-PLATE I.}

Fig. 1. Section of the Foot, Pastern, and Shank.-(a) The shauk bone. (b) The large pastern bone. (c) The smaller pastern bone. (d) The coffin bone. (e) The navicnlar or shuttle bone. ( $f$ ) The sesamoid bone. (g) The small hard ligament tying down the sesamoid to the large pastern bone. ( $h$ ) The tendon of the perforatus, inserted into the coffin bone after passing orer the navicular bone. (i) A continuation of the suspensory ligament inserted into the small pastern bone. (k) Continuation of the suspensory ligament. (l) The extensor tendon inserted in both pasterns and coffin bone. (m) The sensible laminæ to which the crust, $p$, is attached; and position of the coronet. $(n)$ The inner or sensible frog. (o) The cleft of the horny frog. ( $p$ ) The toe and crust. $(g, r)$ The sensible sole and frog, in front the horny sole. $(s, t)$ A long ligament, reaching from the pastern bone to the knee.

Fig. 2. Bones AND Ligaments of Fore-Foot.-(a) Lower part of shank bone. (b) Sesamoid bone. (c) Upper pastern. (d) Lower pastern. (e) Suspensory ligament and shuttle (navicular) bone, dissected back. ( $f)$ Coffin bone, $(g, h, i)$ Branches of suspensory ligaments nniting with suspensor tendon.

Fig. 3. Ligaments of the Upper and Lower Pastern.

Fig. 4. The Blood-vessels of the Foot.-The greater and lesser metacarpal arteries, having joined, continue down the inside of the leg, under the nerve, and at the lower part of the cannon divide into the two plantar arteries; one of these passes on each side of the pastern bone. When they reech the foot they are at the back of it, and each sends a branch to the fatty frog. They are marked at $b, b, c, d$, and at $g, h$ some of these ramifications are seen. The main trunks pursue their course along the inner wings of the coffin bone, and are not seen here; they nnite with each other, and thus form an arterial circle inside the substance of the bone of the foot. From this circle are seut off various small branches, which penetrate the coftin bone, and, bending downwards, unite and form the eircumflex artery, which runs round the margin of the bony sole (Fig. 7), to which blood from the circumflex artery is transmitted. It is seen, in the figure just referred to, that numerous twigs are sent to nourish and supply every part near which the arteries run. The radial vein, which forms a venous circle just behind the knee, becomes, lower down, the internal metacarpal, and divides just above the fetlock into the two plantars, which are immediately concerned in bringing the blood from the fore feet. These ressels originate from the capillaries, and bring back the blood to the heart. $a, k, l, m, n, o$, mark their anastomoses, or openings into each other. $r$ The spongy bone of the foot, with the points or ends of blood-vessels.

Fig. 5. The Frog and Sole (horn removed). - In this and the two following figures, 6 and 7 , the letters indicate the same parts. $(a, a)$
The sensitive bars. $(b, b)$ The reflection of the coronet, forming the ba. . $(c, c)$ The cleft or fissure of the frog. $(d, d)$ The sensitive frog. $(e, e)$ The sensitive sole.

Plate XI.-THE HoRse'S FOOT, AND NEURotomy, Plate II.

Fig. 1. Foot of Foal a few Weeks after Birth.-The cylin. drical and upright form of the hoof, and largeness of the upper part at the coronet, are yet observable. The limbs are npright, the fetlocks little bent, and the toes dig in the ground.

Fig. 2. HalF-Grown Foot.-The ragged appearance of the inflections spreading over the sole is here very remarkable. In this and the two following figures (3 and 4), the letters denote the same parts. $(a, a)$ The sensitive bars. $(b, b)$ The heels. $(c, c)$ The fissure of the frog. $(d, d)$ The sensitive frog. (e) The sensible laminæ within the horny hoof.

Fig. 3. The Natural Foot.

Fig. 4. The Foot as changed in Form by Shoeing.

Fig. 5 Sensible Foot (Hoof removed).-(a) The sensible laminæ. (b) The sensible sole. (g) The secreting coronet.

Fig. 6. Neurotomy, the High and Low Operationg. - The High Operation.-(a) The metacarpal or pastern nerve, raised by the probe. (b) The vein. (c) The artery. $(d, f)$ The white cellular membrane divided and turned back. (e) The back sinews, or flexor tendons. (g) Flesh-hook, holding back the skin and tissues. The Lower Operation.-(a) The artery. (b) The nerve. (c) The tendon. (d) The vein. $(e, f)$ Cellular tissue, lining the skin.

\section{PLATE XII.-ANATOMY.-THE THORACIO VISCERA.}

Fig. 1. The Chest and its Contents.- (a) Ribs sawn off from sternum. (b) Rings of the trachea (wind-pipe). (c, c) Common carotid artery, dividing right and left, from (d) Its main trunk. (e) The heart. $(f, f)$ The lobes of the right lung. $(g, g)$ The lobes of the left lung. $(h, h)$ Posterior lobes of right and left lungs. (i) The midriff divided.

FIG. 2. THE HEART; shooing the right ventricle, tricuspid valve, dc. - (a) Orifice of the coronary vein. (b) The tricuspid valve, admitting the blood to the right ventricle, and preventing its return. (c) The carnex columnæ, and cortina tendinea, or fibres which fasten the ends of the valves to the substance of the heart. (d) The ventricle cut open lengthwise. (e) The septum or division. ( $f$ ) The opening of the pulmonary artery. (g) The opening of the aorta.

FIG. 3. THE HEART; the right ventricle, \&c.-(a) The sabstance of the muscular coat divided. (b) (c) The pulmonary artery. (d) The tricuspid valve. (e) The left auricle. ( $f$ ) The cortina tendinea.

Fig. 4. The Lungs.- ( $a$ ) The substance of the lungs. $(b, b, b, b)$ The lobes of the lungs. (d) The trachea (wind-pipe). (e,f) Bronchial tubes.

Fig. 5. The Pulmonary Artery and Venns, as ramified in the lungs. - (a) The pulmonary artery cut off close to the right ventricle of the heart. (b) The pulmonary vein cut off 'rom the left ventricle of the heart. ( $c, c, c, c)$ Branches accompanying the ramifications of the bronchiæ, spreading through the whole substance of the lungs. $(d, d, d)$ The capillary extremities of the blood-vessels.

\section{PLATE XIII.-THE ABDOMINAL VISCERA, KIDNEYS, \&c.-} THE CESTRUS EQUI (BOTS).

Fig. 1. The Intestines.-(a) The coecum. $(b, b, b)$ The colon. (c) The rectum. (d) The small intestines. (e) The onter integument (epidermis, cutis, and panniculus carnosus) divided.

Fig. 2. The Kidseys, Bladder, Etc.-(a) Part of a lobe of the liver. (b) Part of the intestines. (c) Part of the stomach and caul (omentum). (d) The kidneys. (e,e) Ovaries, with branches of spermatic arteries and veins. $(f)$ The descending aorta and vena cava. $(g)$ The 
emulgent veins leading to the vena cava, and emulgent arteries to the aorta. (h) Part of the rectum. (k) The bladder. (l) Spermatic cords. $(m)$ Gall-duct. $(n)$ The duodenum.

Figs. 3, 4, 5. The Larve and Ovum of the Cestrus Equi (GADFLY).-The deposit of the ovum, its maturing, and remedies for it expulsion, will be found at p. 450 . The figures are sufficiently explanatory to the eye.

\section{PLATE Xil. A.-Gestation, THE FETUS, AND FETAL CIRCULATION (and Bee pp. 218-219.)}

Fig. 1. The Fetus Enveloped in its Membranes.- $(a, a)$ The chorion. (b) A fold of membrane enveloping, (c) The hinder extremities of the fætus.

Fig. 2. The Foetus Denuded of its Membranes.-(a) The body of the foal, with the common eheath of the four umbilical vessels taken off, and the cord untwisted. (b) The umbilical vein. (d) The umbilical arterie日. (c) The common covering of the umbilical vessels laid open.

Fig. 3. The Fetus, with its Surrounding Membranes, in Section.-(a) The foetus in situ. (b) The fluid (liquor amnion) in which the foetus floate. (c) The amnion (from the Gr. amnios, a vessel or skin used to receive the blood at Bacrifices), or inner covering of the foetue. (d) The chorion (Gr. chorion, covering, protection), or outer membrane of the foetus. Between the amnion and chorion lies the allantoid (Gr. allas, a sausage, eidos like), containing the urine of the foetus, or sace in which the urachus terminates. These sacs are filled with the foetal urine, as the foetal bowels are with the yellow pultaceous mass called meconium (Gr. mecon, inspissated poppy-juice.) (e) The umbilicus or navel cord. $(f, f)$ Blood-vessels of the umbilicus dispersed on the amnion. Those of the urinary vessel, urachus, are epread on the chorion, which is the more vascular of the three membranes, and is intimately connected with the inner mucous lining of the uterus, by minute vascular projections, which fit into correspondent cavities on the thickened lining of the womb.

Fig. 4. The Fotus, with its Abdomen Laid Open.-(a) The umbilical vein. $(b, b)$ The umbilical arteries. (c, $c)$ The urachus, (urine-vessel), here divided for clearness. Its origin is the fundue of the bladder at $c$, passing out at the navel with the vein and arteries just described, and as soon as it has passed through the amnios it spreads into the cavity allantois. (d) The placenta. (e) The intestines.

FIG. 1. (a) (of Plate XIII.) - The Stomach, with its orifices.-(a) The cesophagus, its cardiac opening into the stomach. (b) (c) The portion of the stomach covered by cuticle or insensible ekin. (d) The entrance of the gullet into the stomach, the cardiac orifice. (e) The margin which eeparates the cuticular from the villous portion. ( $f, g)$ The communication between the etomach and first intestine. (h) The common orifice through which the bile and pancreas pass into the first intestine. (i) A smaller orifice through which a portion of the pancreatic secretion passes into the intestines. (k) Mucous, or villous portion of the stomach.

\section{PLATE XIV.-BANDAGING AND BRONCHOTOMY.}

For General Description, see p. 369. (Fig. 1.) Sore Throat. See p. 287. (Fig. 2.) Bandage for Criteral Abscess. See p. 332. (Fig. 3.) Bandage for Poll-evil. See pp. 334, 335. (Fig. 4.) Bandage for Strangles. See p. 290. (Fig. 5.) Bronchotomy. See p. 364.

\section{PLATE XV.-METHOD OF SLINGING THE HORSE, SHOWING ALSO THE HOBBLES PUT ON FOR CASTING.}

In Chapter XXVIII., pp. 358, 359, will be found remarks apon the best form of Hobbles; and on Plate XVII. our artist has given an excellent representation of so-called "Patent" Hobbles, which are the nearest to perfection of any we have seen in use. From the representation of the Horse elung, which faces this page, we presume, with a reference to the text, pp. 359, 360, the eye will sufficiently inetract the reader.
PLATE XVI.-VETERINARY INSTRUMENTS AND APPARATUS.

(A, a) Steaming apparatus for throat and head diseaser. (A) Tobaccosmoke enema. See Spasmodic Colic, p. 303, \&c. (B, B, B) Lancets and fleame. See Bleedrna, p. 360. (C) Bistouri cach6. See Hernia, p. 313. (D) Neurotomy knivcs. See pp. 365,366 . (E, F) Canterizing irons. See p. 367. (G) Clams used in castration. See p. 326, where the reference should be to Plate XVI. (H) Rowelling scissors and Rowell. (I) Seton needles, various. (K) Sutnre needle. (L) Forceps for Polypus. See p. 282.

\section{PLATE XVII.-FARRIERS' TOOLS AND INSTRUMENTS.}

(A) Patent Casting Hobbles. See remarks on Plate XV. (Fig. 1.) Buffer. See p. 372. (Figs, 2. and 3.) Drawing knives. See p. 372. (Fig. 4.) Searcher, for examining for foreign subetances. (Fig. 5.) Buttrees. See p. 372. (Fige. 6 and 7.) Pincers and Forge Tonge. (Fige. 8 and 9.) Sledge and Hand Hammers. See p. 374. (Fig. 10.) Shoeing Hammer. (Figs. 11 and 12.) Rasp, and Fuller: the latter makes the groove or channel in the shoe. See p. 374. (Fig. 13.) Stamp. (Fig. 14.) Pritchel. See p. 374, note.

\section{PLATE XVIII.-FARRIERY.-VARIETIES OF SHOES, Plate 1.}

Figs. 1, 2, and 3. Seated Shoes.-1 and 2, present the ground and foot surfaces of the best sort of shoe for general purposes. It gives as many points of bearing as possible. The web is of uniform thicknese thronghont, and the nail-heads, well sunk in the fullering, are soon level. The seating is on the foot side, and the bearing widens at the beels. It is usually made with nine nail-holes-five inside and four outside the foot. Fig. 3 is a shorter-heeled modification of the shoe, with all-ronnd nailing, and a broader web.

A. Frost Shoz.-This ehoe (condemned by Bracy Clark aв expensive and complex) was known as the American ice-shoe. Instead of mere calkine, by turning down the heele, screw clips of steel, corresponding with a female screw in the shoe, are inserted by means of the wrench. Made of Bessemer-tong steel, these will stand well.

B. Pointed Show.-This (with an expanding ateel tablet at the toe, and a dozen modificatione) ie, in the main, Bracy Clark's Expanding Shoe, which was to bring comfort to all horses and horsemen. Healthy feet go none the better for them, and they cost 10s. a set.

C. English Huntina Shoe.-The heele of the Hunting Shoe are Bomewhat ehorter than thoee for hacke. They are not so much bevelled off as the common-seated shoe; leaving only epace enough for a picker between the sole and ahve, lest clay should tamp in and tear off the shoe on heavy soils.

D. STEWART's SHoR.-This shoe has the inner circumference forged or filed away; and is advantageously adopted with borse日 who "strike" or over-reach in galloping. The edge, it will be seen, is ronuded or bevelled off.

E. BAR Shoz.-This shoe, applicable in tender heels, quarters, corno, \&c., is improved by the introduction of a sole of soaked leather between it and the suffering animal's foot. The nail hobe are here, foot-surface, four outside and three in; they should be far nearer to the onter edge than drawn.

F. Sandal Shoz.-A ureful resort in case of shoe-casting. It may be looked upon as a resubcitation and improvement of the earliest form of shoeing. The celebrated Percivall reintrodnced it, and warmly advocated its adoption as a temporary pedal protection in emergencies. Its form suggests its use.

\section{PLATE XIX.-FARRIERY.-VARIETIES OF SHOES, \&c.}

Fige. 1, 2, 3. Racing Plates.-The shoes of race-horses, called plates, are of two kinds, "full" and "three-quarter." The traininggroom is best judge of the plate required. Full plates are nsed where the crust is undeniably strong and healthy. Eight nail-holes are noual in the thin ring of deeply fullered iron, which is just wide enongh to defend the wall of the hoof. The "three-quarter plate" has six nails only, and is used for weaker feet. In the olden days racers' feet were sadly battered by long travel from place to place. Vanning and railroads 
bave changed all that. Darvill says:- "The plate must not be pot on nearer the end of the horse's heels than there is sound born for it to rest apon; and that the boof hold be sufficiently strong to give the two last nails a secure bearing, so that the plate may not spring at the heels when the horse is running." In the forging of either of these varieties of plating shoes, it is very necessary that reference be had to the size and powers of the horse that is to wear them. For one of a medium size and weight the breadth of the plate need not exceed three and a balf eightbs of an inch; but these dimensions may be somewhat increased for a tall and heavy horse. The fullering is in the middle of the plate. The hinder plate may be turned up a little in long-striding horses, especially if the race-course has sharp curves.

Fig. 4. Horse-SHOE NAILs. (a) French horse-nail. ( $b, c)$ Countersunk nails. (d) German horse-nail. (e) Fine-head nail for safety-shoe. (f) Rose-nail for frost.

F. Shoe to Prevent Cutring.-This is Moorcroft's shoe. The outer branch thickened and narrowed. White also says he has found it successful. The blow being struck inside the fetlock joint; the common method is to make the inner branch of the shoe narrower and thicker, increasing from toe to heel.

G. Froo-pressure Shoe (Coleman's). This old-school result of a whim of a clever theorist has still its adherents. There is nothing (but mischief) in its use which a common bar-shoe, judiciously modified in the leather attached, cannot effect.

H. Patren Shoe. The utility of this form of shoe in "Clap" or Strain of the Back Sinews, and Rupture of the Back Sinews, is noted at pp. 345 and 346.

I. Poultice Boot. The Poultice or Water Boot is made of leather, defended with iron plating. A linen drill-top is sufficient for poulticing; but if cold or warm water is to be constantly applied, felt, or two or three thicknesses of box-cloth, with a bottom of the same, are requisite, wetting the top of which, the moisture will descend to the bottom within the boot. With water, the boot must be removed every two days, and an unguent applied, or the water will "crumble" the hoof. If the borse paws much when the water-boot is off, put on a felt or rope boot as a defence.

K. The French Shoz. This highly-extolled system of shoeing, in which the toe and heel are curved upwards, and the nails driven low round the hoof-despite the elaborate praises of M. Jauze and a crowd of Continental writers, and of the clever Mr. Goodwin-proves a bad shoe for any but clumsy, coarse horses, and with them the curvature at the heel is bad. The only merit of the shoe is its not being nailed towards the beels, as our English shoes osed to be formerly.

\section{PLATES ILLUSTRATIVE OF "THE DISEASES OF CATTLE, SHEEP, AND PIGS."}

\section{PLATE. - THE AGE OF THE OX AS INDICATED BY HIS TEETH.}

Fig. A. Portion of upper jaw. $(1,1)$ Dental pad. (2) Stenonian ducts. Fig. B. Portion of lower jaw, taken from a heifer one year old. $(1,1)$ Eight temporary incisor teeth. Fig. c. Portion of lower jaw taken from an ox one year and eleven months old. $(1,1)$ The central permanent incisors, having replaced the deciduous teeth on each side of central incisors, the three temporary teeth appear. Fig. D. Portion of lower jaw taken from an ox two years and five months old. $(1,1)$ Central permanent incisors. (2,2) Second pair of permanent incisors, having replaced temporary teeth, on each side of which two deciduous teeth remain. Fig. E. Portion of jaw taken from a beifer two years and eleven months old. $(1,1)$ Central permanent incisors. $(2,2)$ Second pair of permanent incisors. $(3,3)$ Third pair of permanent incisors baving replaced the milk teeth, on each side, the remaining temporary tooth exists. Fig. F. Portion of lower jaw taken from an ox three years and four months old. $(1,1)$ Central incisors. $(2,2)$ Second pair of permanent incisors. $(3,3)$ Third pair of permanent incisors. $(4,4)$ Corner pair of permanent incisors, which have replaced their temporary precursors. Fig. G. Portion of lower jaw of full-mouthed ox. (1) First permanent molar. (2) Second permanent molar. (3) Third permanent molar. (4) Fourth permanent molar. (5) Fifth permasent molar. (6) Sixth permanent molar. (7) Permanent incisors.

Incison Dentition. The calf is usually torn with four temporary incisors, being the central and second pairs. At 10 to 14 days old the third pair of incisors appear. At 1 month corner incisors cut the gums. At 1 year and 9 to 11 montlus, the central permanent incisors replace deciduous teeth. At 2 years and 3 to 6 months, the second pair of permanent incisors replace milk teeth. At 2 years and 9 months to 3 years and a quarter, the third pair of permanent teeth occupy the places of the forerunning temporary incisors. At 3 years and a quarter to 4 years old the $0 x$ completes his incisor dentition, by the permanent teeth displacing the corner temporary incisors.

Molar Dentition. The calf is born without molars. At $\mathbf{l}$ month old, the first, second, and third have made their appearance, three on each side of either jaw, twelve altogether. At 6 to 9 months, the fourth permanent molar is in situ. At 15 to 18 months the fifth permanent molar appears At 2 years to 2 years and three months the molar dentition is completed, by the cutting of the sixth permanent molar. At 2 years and a half to 2 years and 8 months, the two anterior temporary molars are replaced by two permanent ones. At 2 years and 8 months to 3 years and 3 monthe, the third temporary molar falls ont, and its place is occupied by its permanent successor, when the molar dentition of the ox is completed.

\section{PLATE. - AGE OF SHEEP AS INDICATED BY THE TEETH.}

Fig. A. Portion of lower jaw of a sbeep eleven months old. $(1,1)$ Eight temporary incisors. Fig. B. Portion of lower jaw of a sheep one year and a month old. $(1,1)$ Central pair of permanent incisors having replaced deciduous ones, on each side, three temporary incisors exist. Fig. c. Portion of lower jaw of a sheep one year and eight months old. $(1,1)$ Central pair of permanent incisors. $(2,2)$ Second pair of permanent incisors in situ having removed temporary teeth on each side, of which two temporary teeth remain. Fig. D. Portion of lower jaw of a sheep two years and seven months old. $(1,1)$ Central permanent incisors. $(2,2)$ Second pair of permanent incisors. (3,3) Third pair of permanent incisors having replaced milk teeth, on each side of which the corner temporary incisors appear. Fig. E. Portion of lower jaw of a sheep three years and four months old. $(1,1)$ Central permanent incisors. $\quad(2,2)$ Second pair of permanent incisors. (3,3) Third pair of permanent incisors. $(4,4)$ Corner pair of permanent incisors. This change from temporary to permanent teeth completes the incisor dentition of the sheep. Fig. F. The nose of a sheep. Showing cleavage in upper lip. Fig. G. Portion of upper jaw of a sheep. $(1,1)$ Dental pad. $(2,2)$ Stenonian ducts. Fig. H. One side of the lower jaw of a full mouthed sheep. (1) First permanent molar. (2) Second permanent molar. (3) Third permanent molar. (4) Fourth permanent molar. (5) Fifth permanent molar. (6) Sixth permanent molar.

InCISOR Dentition.-The lamb is usually born without incisor teeth. At 1 week old the central and second pair of incisors are cut. At 10 days old the third pair appear. At 5 weeks, the fourth or corner pair cut the gums, and complete the temporary incisor dentition. At 1 year, and from 1 to 2 months, the central pair of temporary incisors are displaced by permanent teeth. At 1 year and a half to 8 months, the second pair of deciduous teeth are replaced by permanent ones, At 2 years and a quarter to 8 months, the third pair are similarly displaced. At 3 years and 3 to 9 months, the sheep completes its incisor dentition by the permanent teeth displacing the corner temporary incisors.

Molar Dentition.-At 1 month old the threo anterior remporary molars have made their appearance. At 3 months old the first permanent 
molar, fourth in position, escapes through the gum. At 9 to 10 months old the fifth permanent molar appears. At 18 to 19 months old the sixth permanent molar escapes from its socket. And from 2 years to 2 years and a half the three anterior temporary molars are replaced by permanent ones, and thus the molar dentition of the slieep is completed.

\section{PLATE.-THE AGE OF THE PIG AS INDICATED BY HIS TEETH.}

Fig. A.-The mouth of a pig one month and three days old. $(1,1)$, Fotal incisors; $(2,2)$, foetal tusks; $(3,3)$, middle temporary incisore; $(4,4)$, three temporary molars. Fig. B.-Anterior part of lower jaw of a pig three months old. $(1,1)$, Footal incisors; $(2,2)$, foetal tusks; $(3,3)$, middle temporary incisors; $(4,4)$, lateral temporary incisors. Fig. c.Lower jaw of a pig about six months old. $(1,1)$, Præmolars; $(2,2)$, fourth permanent molar. Fig. D.-Part of lower jaw of a pig ten months old. $(1,1)$, Permanent corner incisors have replaced temporary ones; $(2,2)$, permanent tusks have replaced temporary ones; $(3,3)$, præmolars. Fig. E. - Snout of a young boar. Fig. F.-Part of lower jaw of a pig about thirteen months old. $(1,1)$, Permanent middle incisors have replaced deciduous teeth. Fig. G.-Lower jaw of a pig nineteen months old. $(1,2,3)$, First, second, and third permanent molars bave replaced temporary ones; $(4,4)$, fifth permanent molar-this tooth replaced temporary one when the animal was about thirteen months old; $(5,5)$, sixth permanent molar, which has replaced temporary tooth; $(6,6)$, lateral permanent incisors, which have displaced the deciduous or milk teeth.

InCISOR Dentition.-The pig is born with eight teeth-four temporary incisors, and four temporary tusks. At 4 to 5 weeks old the deciduous middle incisors make their appearance. At 3 months old the lateral incisors escape through the gums. At 9 to 10 months old the corner incicors and temporary tueks are replaced by permanent teeth. At 1 year to 13 months old the central deciduous incisors are displaced by their permanent successors. At 18 months old the pig completes his incisor dentition, by the permanent lateral incisors replacing their deciduous forerunners.
Molar Dentition.-The pig is born without molars. At 4 to 5 weeks old twelve temporary molars, anterior in position, appear, namely, $1,2,3$ in each jaw. At 6 months old the præmolar (permanent tooth) is cut, holdiog a mid position between the corner incisors and tusks. At 9 months old the first permanent molar, fourth in position, makes ite appearance. At 1 year to 13 months old the second permanent molar, fifth in position, is in situ, and the deciduous molars are replaced by their permanent successors. At 18 months old the molar dentition of the pig is completed, by the appearance of the last permanent molar, being the sixth in position.

\section{PLATE.-SHEEP'S HEAD WITH SMALL-POX.}

This Plate was copied, by Professor Simond's kind permission, from a drawing in his work on Ovina Variola; the picture depicts the appear. ance the face of the sheep assumcs during the crustaceous and ulccrative stages of small-pox. The ulceration noticed has been largely produced by external injury inflicted on the parts, by the sheep rubbing the scabs off before the healing process had been effected; this injury always retards the progress to recovery.

\section{PLATE.-CALCULOUS CONCRETIONS FOUND IN THE INTERNAL ORGANS OF THE OX, SHEEP, AND PIG.}

Fig. A.-Carbonate of lime calculus taken from the bladder of the pig. Fig. B.-Section of the same calculus. Fig. C.-Calculas taken from the kidney of the ox. Figs. D and L.-Calculi, consisting of carbonate of lime mixed with carbonate of magnesia, taken from the bladder of the 0 . (D) represents calculi presenting a smooth exterior; (c), a tuberculated aspect. Fig. E.-Calculus, consisting of the oxalate of lime, taken from the ureter of a boar. Fig. F. - Section of a hair ball, consisting of the phosphate of ammonia and magnesia, takeu from the intestine of a cow. Fig. G.-Hair-ball calculus taken from a cow. Figs. $\mathbf{}$, I, $\mathbf{x} .-$-Three differeat forms of biliary calculi taken from the ox. 



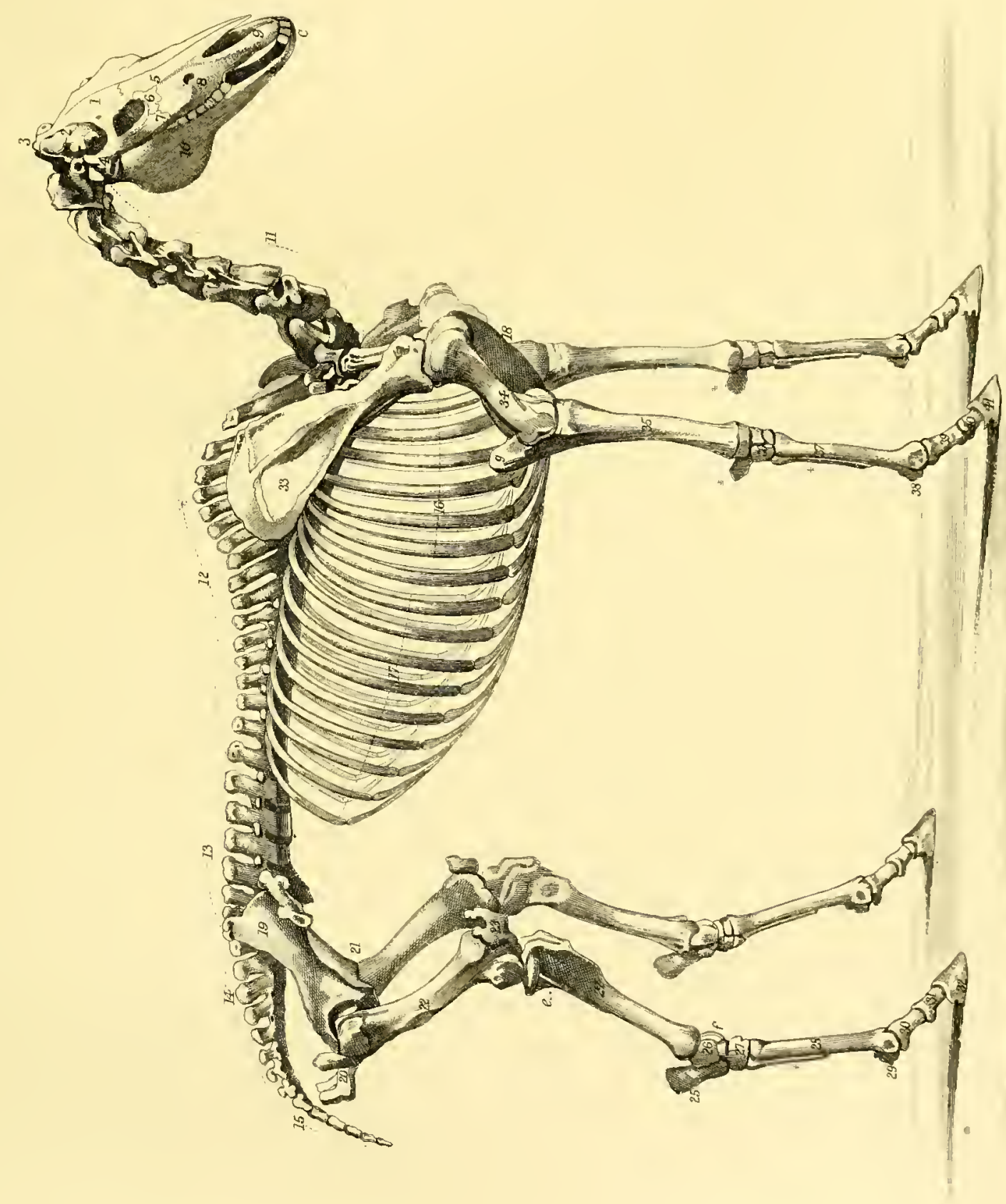





\title{
DIVISION II.
}

\section{A COMPENDIUM OF VETERINARY KNOWLEDGE.}

\section{THE STRUCTURE AND ANA'TOMY OF THE HORSE,}

\author{
CHAPTER XVI1.
}

THE BONY STRUCTURE.-COMPONENTS OF BONE.-GROWTH OF BONE.-THE SKELETON.-BONES OF THE HEAD.-THE SPINAI

VERTEBRE.-THE RIBS.-THE STERNUM.-BONES OF THE FORELEGS AND FEET:-THE 8CAPULA, HUMERU8, RADIUS, ULNA, CARPUS, METACARPUS, PAsTeRN, LOWER PASTERN, SESANOIDS, CORONARY AND COFFIN BONES, THE NATICULAR BONE.-BONEE

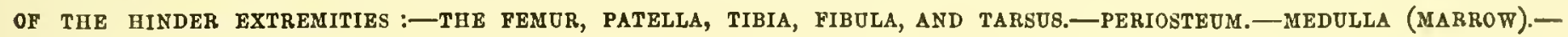
GYNOVIA.-CARTILAGES.-LIGAMENTS.

BONEs form the framework and support of the animal machine, give it dimension and figure, preserve the situation of the several viscera of the brain, chest, and stomach, afford fixed points for the attachment of ligaments, and act as levers in the various movements of the body and limbs. Bones are the hardest, and, in health, the most insensible substances of the body. Bone is chemically composed of phosphate of lime, fluate and carbonate of lime, soda, magnesia, and a small proportion of common salt, and in the fullgrown animal contains about 33 per cent. of cartilage (gelatine and membrane), with the earths above mentioned. The bones of the horse are much harder, and proportionately much stronger, than those of man. They are covered by a skin called the periosteum (bone-surrounder); it is highly sensible when diseased, white after death, red in the living animal. This membrane appears to be first formed in the fotus, and within it a gelatinous fluid, afterwards becoming cartilage, is deposited. This becomes vascular (containing vessels), and these pour out the earthy matters eliminated from the blood, until the bone is consolidated. This consolidating process is not entirely completed till full growth is attained, and those bones most indispensable to the functions of life are the earliest formed. The earthy matter of the bones is continually changing, being carried off by the absorbents, while the arteries deposit it. The stimulus of the circulatory system in the higher-bred horse thus leads to the deposit of a more solid and harder quality of bone than in the heavier and lower breeds. The cylindri- cal bones are hollow and contain medulla (marrow), and a sheathing membrane called the medullary membrane. These cavities lighten the bones without detracting from their strength, and are most remarkable in birds. The marrow was long thought to nourish the bones: this is an error; it is a mere store of superabundant fatty matter. Though furnished with bloodvessels for nutriment, and nerves, bones possess little sensibility in health; but in an inflamed state they are acutely tender. The bones are variously articulated (jointed) with each other: by cup and ball; by furrowed surfaces forming, as in the small bones, phalanges, which are hinged, bound firmly together by ligament and cartilage; or fixed closely into each other by notches, ridges, teeth, or spines, forming sutures (seams). An examination of the plates, The Skeleton (Plate I.), and The Head (Plate V.), will exhibit these jointings of bones. The following description of the bony, muscular, and interna] structure of the Horse, will be found calculated to assist and elucidate the figures and page references, printed to accompany each of the Anatomical Plates of the present work.

The bony structure we shall divide into nine sections.

\section{§I. BONES OF THE HEAD.}

The Seull (cranium), which contains and defends the brain, consists of twelve bones; four pairs (eight), and four single bones. These are, two frontal (forehead) bones; two pairs of temporal (temple) bones, distinguished as the squamous (scaly), and the petrous (hard-stony) temporals; 
and two parietal (wall) bones; the single bones are the occipital (hind part of the head) bone; the ethmoid (Gr. sieve-like) bone; the sphenoid (Gr. wedge-like); and the os triquetrum (Lat. triangular bone).

The frontal bones (two), form the arches of the orbits of the eyes. The arch is pierced by the supra-orbital foramen, and there is a hollow below for the lachrymal (tear) gland. The frontal bone in the horse also forms half of the lateral foramen of the nose, and enters into the framing of the top of the nose. Internally, one part of the face belongs to the nose, the other to the skull. The outer and inner plates of bone separate, and thus form the frontal sinuses. These are strengthened by little bony pillars between the plates of the forehead.

The orbits in the horse are merely bony rings, one on each side, not perfect cups as in man.

The squamous temporal bones (a pair) are in front of the petrous temporal. The projecting pieces on their outer sides are called the zygomatic (Gr. zygos, a yoke) processes. On the under edges are the cavities for articulating with the lower jaw.

The petrous temporal (a pair). These are the hardest bones in the whole body. A canal in these is the meatus auditorius, or opening to the internal ear, and along its bottom during life is stretched a fine membrane. The 08 hyoides of the tongue has its large horn attached to the internal side of this bone.

The two parietal (wall) bones are placed at the sides of the skull. They are smooth and convex on the outside, and are covered well by the temporal muscles. On the inside they are concave, and furrowed for receiving the arteries of the brain.

The occipital, the first of the single bones, is proportionately much smaller in the horse than in man, the greater bulk of the horse's head lying forward. At the back of the occiput is the large lole (foramen magnum) of the skull. On each side of the foramen magnum is a projecting smooth bony process called the condyles, which form a joint with the atlas.

The ethmoid, a single bone, is somewhat concealed in a view of the bones; it has on its wings holes called the optic and nasal foramina. Towards the nose two fine flat pieces of bone are pierced with numerous apertures, and arẹ called the cribriform (Lat., cribrum, a sieve) plates; these give passage to the nerves of sinell.

The sphenoid bone has been often compared to a bird,two wings, a body, and two legs, but the head is wanting. It has sinuses and holes for numerous nerves, the superior maxillary, the optic, the third pair, and the orbital, supraorbital, and maxillary arteries.

The os triquetrum, the last of the single bones, is angular; smooth on its outer surface, but indented inside for various nerves. It joins the occipital bone and lies before it. It has a projection which is called the tentorium, dividing the cerebrum, or larger brain, from the smaller, or cerebellum.
The lower, or hinder part of the head consists of a single bone, the lower jaw (inferior maxillary). The head is divided by anatomists into two parts, the skull and the face. The bones of the skull, as we have said, are joined together by indented seams, called sutures. This kind of junction is owing to the manner in which ossification takes place in these bones; for in the fotus the bones of the skull are perfectly distinct from each other, and thus calculated to allow the growth of the brain they enclose. The ossification begins in the middle of each bone, and proceeds gradually to the circumference. Hence this process, and of course the increase of the head, is carried on from a great number of points at the same time, until the growing edges of the bones meet, when the projecting fibres of one bone force themselves between those of the opposite bone, and constitute that indented line which we perceive on most skulls.

The skull of a horse is much smaller than that of a man, its capacity for containing brain being not one-fourth as great; but the bones which compose it are thicker and stronger than those of the human subject, and consequently better able to resist blows and other accidents.

The Bones of the Face.-The face consists of nine pairs of bones and two single ones. These are inter-maxillary (2), supra-maxillary (2), nasal (nose) bones (2), lachrymal (2), malar (2), palatine (2), pterygoid (2), inferior turbinated (2), superior turbinated $(2)=9$ pairs, or 18 bones The single bones are the vomer and the lower jaw, already mentioned, making 20 in all. Of these bones we may remark-that the two nasal are very unlike those of the human subject, being of a wedge-like figure, sharp below and broad above. They also differ from those of the human face; they are considerably larger, for increasing the capacity of the organ of smell, which is much more acute in the horse than in man.

The lachrymal bones are situated at the inner sides of the orbits, which they help to compose. Each of these bones has an opening through it for the passage of the tears.

The malar (cheek) bones are each connected in the orbit to the lachrymal bone just described, and to the superior maxillary; and its zygomatic (Gr., yoke-shaped) process bends over to join that of the temporal bone, and form the bony arch of the cheek.

The superior maxillary bones form, along with the malar bones, the ridge which is observable on the cheek of the living subject, and are connected with most of the other bones of the face.

The inferior maxillaries are connected, on the upper edge, in a curious manner to the superior maxillaries and nasal bones. They help to complete the bony palate, and afford sockets for some of the teeth. They are separate in the young animal, but completely joined in the adult.

The palatine bones are situated uppermost of the bony palate, and are connected to the superior maxillaries, vomer, sphenoid, and ethmoid bones.

The vomer (Lat., ploughshare), or share-bone, differs 

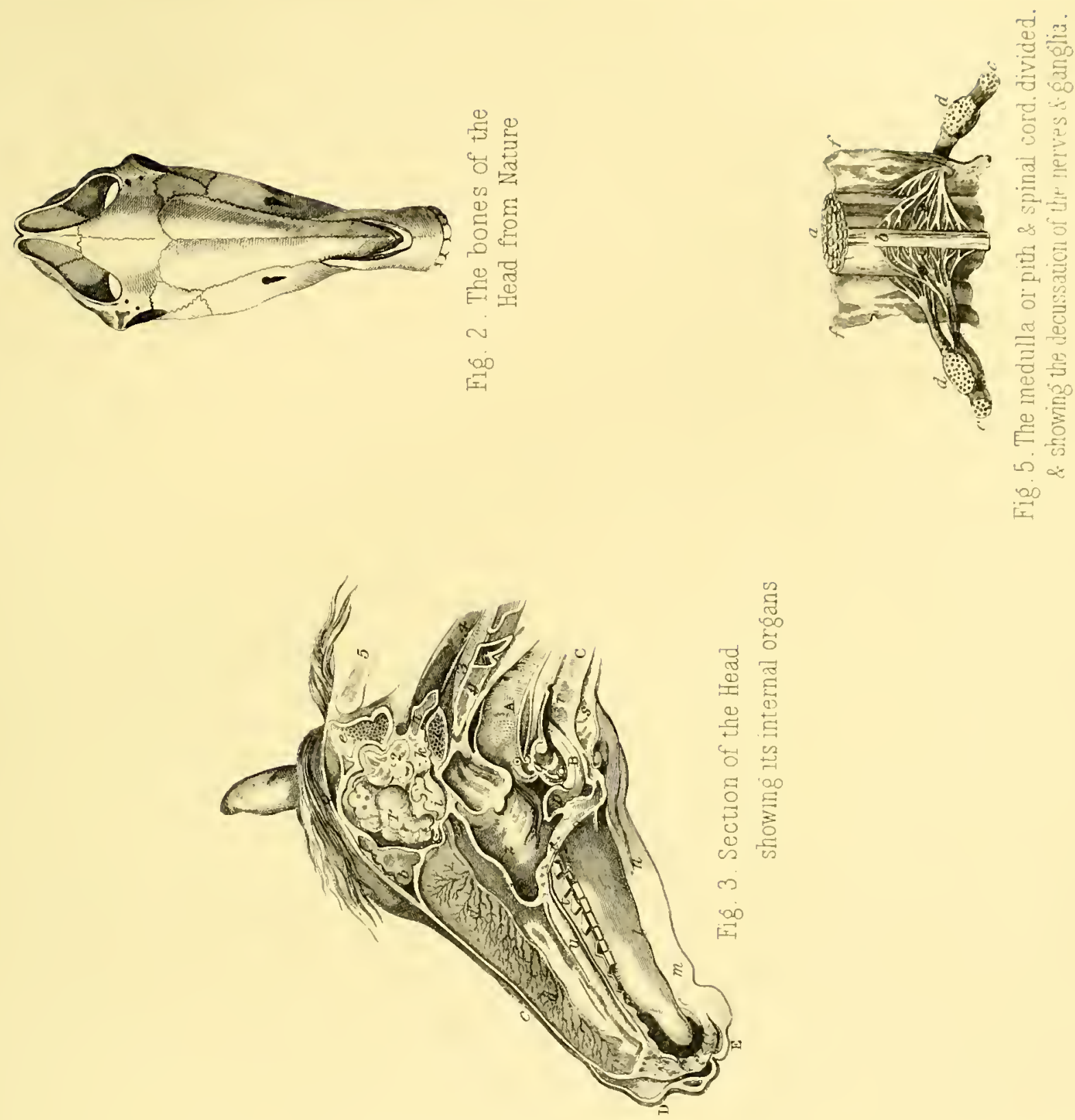

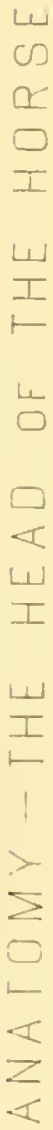
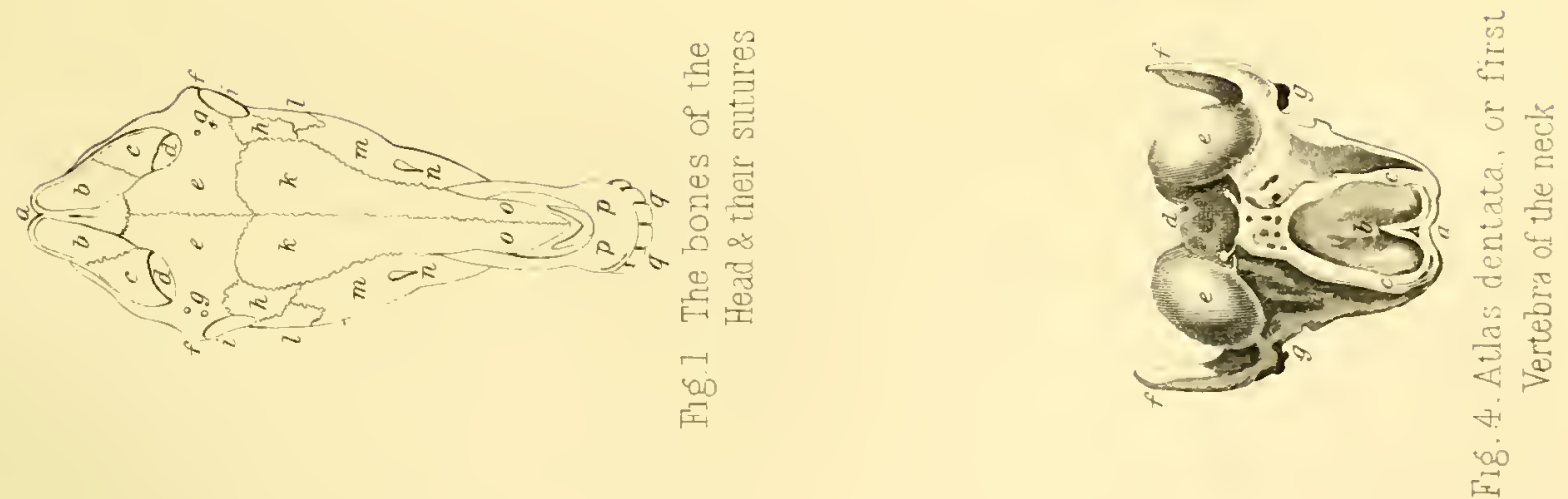
much from the human vomer, being much longer in the horse; it is concave anteriorly, for the insertion of the cartilage (septum) which divides the nose.

THE Lower $J_{A}$ differs from the upper in this, that the forme is movable, being articulated at each extremity with the temporal bone of that side.

In young animals it is divided between the fore teeth, so that the bones may be easily parted. This bone affords sockets for the lower teeth.

\section{§II. BONES OF TIIE NECR (CERVIX).}

The Neck consists of the atlas dentata and the seven cervical vertebræ. This number, seven, is the same in animals with the longest or the shortest necks. The number of bones which form other divisions of the back are not uniform. The tail, for instance, varies from thirteen to eighteen bones.

We may here note that the spine, which here begins, consists of 7 cervical (neck), 18 dorsal (back), 6 lumbar (loin), 5 sacral (rump), and ordinarily 13 caudal (tail) vertebræ, forming, in the whole, what is termed the spine.

The neck-bones are the largest of the spinal chain, but have not the upper projections; but on each side are considerable prominences, at the base of which is seen a hole (foramen) for the passage of the vertebral arteries and veins. The bones of the neck are strongly united by capsular ligaments, articular cartilages, and all the usual appendages of a joint. Each vertebra has a round head und a corresponding cavity below, to receive the next, so that dislocation of the horse's neck cannot easily take place; when it does, the animal dies from compression of the spinal marrow, and is said to have "broken his neck."

\section{§ III. THE BONES OF THE CHEST (THORAX).}

These include the sternum (breastbone); costoe (true ribs), and the five first vertebra of the back.

The breastbone is composed of several pieces of bone, embedded in cartilage. To it are attached the lowermost ends of the ribs. It is called the cariniform bone, from its resemblance to the keel of a ship. Its hinder part is spread out like the tail of a fish.

The ribs (costæ) are narrow half-rounded pieces of bone jointed above to the backbone, below to the breastbone They are not, however, bone throughout, the lower portions are formed of cartilage. The eight first ribs are called "true ribs," and are joined to the breastbone. The "false ribs" are merely connected with the breastbone by being joined to each other. The ribs are fastened to the breastbone by ligament only, except the first rib, which has a joint, to allow it more motion. All the ribs, however, are jointed into the spine with a regular synovial (joint-oiled) articulation, and have a backward and forward motion. The true ribs move forward, and the false ones outward at each respiration.

Of the five vertebroe included in this section, we niay observe the fifth has the longest spine of the back-bone. They slope downwards, from the sixth to the thirteenth vertebræ, which last is usually the most upright.

\section{§IV. THE BONES OF THE LOINS.}

The Loins (the lumbar region). The six spines of the loins are thicker than the others, they slope decidedly forward, and, the ribs having ceased, they have projecting transverse processes.

\section{§V. BONES OF THE SACRUM* (RUMP).}

The five spines of the Sacrum, which lean considerabiy backward, leaving a large open space between the top of the last lumbar (loin) spines and the first of the sacral (rump) spines, forming the great hinge of the rump and loins. The sacrum consists of five pieces, but is viewed as one bone.

\section{§ VI. CAUDAL (TAIL) BONES.}

The nine bones called the coccygeal bones; they are so named from the Greek $\operatorname{coccyx}$, a cuckoo; in man, the pointed bone which ends the spinal column is supposed to represent the beak of the cuckoo.

The tail-bones resemble vertebræ, but diminish down to short round pieces of bone with a little hollow. They have a remarkable formation ; instead of the cup and ball of the neck-bones they have each a rounded projection, giving the utmost play possible. Two small rounded surfaces moving on each other, so that, up and down, or in any conceivable direction, the tail can be switched by its flexors without chance of dislocation.

\section{§ VII. THE PELVIS.}

The pelvis (from the Latin, pelvis, a basin). This consists of the three ossa innominata (nameless bones) on each side. The iliumt; the pubis ; the ischium (loin-bone, ischion, Gr., the loin); these three bones form one cup to receive the head of the thigh-bone.

The pelvis is almost circular, open before and behind and at the top, where the sacrum fits on. Its forward part forms the projecting hip of the horse. A little lower, behind the joint of the spine, is the cup for the reception of the head of the femur (thigh-bone), called the "round-bone" by farriers. There are some important vital organs contained in the pelvis, second only to those in the skull :- the rectum; the urethra of the male and vagina of the female; the bladder; and, in the mare, the womb.

\section{§ VIII. THE BONES OF THE HINDER LEG.}

These are the thigh (the femur), the patella (Latin for a little dish), or stifle-bone, the tibia (pipe-bone), and fibula

* From sacer, Lat. holy. This part being specially offered in anims] sacrifices by the ancients.

f From the Greek, eileo, to turn about: a name given to the intestines from their convolutions. 
(clasp or brooch-bone); the bones of the hock-joint-the a bulging-out head containing a shallow cup to receive the astragalus (the ring or ankle-bone), the os calcis (Latin, head of the arm-bone. Its upper surface is covered with calcar, a spear), or heel-bone, forming in the horse the joint of strong ligamentous fibres, and its mode of attachment is the metatarsals (meta, beyond, tarsus, the hock): the cannon- beautifully contrived to give power without receiving conbones, or shank-bones; the splint-bones. The bones of the cussion.

pasterns-the sesamoids (sesamum, millet-seed, oidos, like), The humerus (or arm-bone) is strong and short; it forms the large pastern bone, the smaller pastern bone, the pedal an angle with the scapula from the joint of the shoulder and (foot), or coffin bones.

The femur (thigh-bone) is the largest and strongest bone in the skeleton. Yet it is shorter in the horse than in most other animals. It has projections and cavities for the insertion of most powerful muscles. Its upper part is called "the neck," and its rounded top "the head." In this there is a cavity, in which is a strong flat ligament holding it in the cavity at the end of the pelvis, and lower down is the capsular ligament. The lower end of the thigh-bone has two large round surfaces, called condyles (Gr. condylos, a knot). The stifle-bone ( patella) slides over the front of two projections, called trochlea (Gr. trochlea, a pulley). This bone is very loose in structure, and full of fibres; its outer surface is roughened for the insertion of several tendons and ligaments, which hold it on all sides.

The tibia (leg-bone) is a long triangular bone, connected on its outer side with the fibula, which, in the horse, is merely rudimentary. The top of the tibia has two hollows, divided by a ridge, upon which the two rounded cartilages of the stifle are supported. Its lower end has three prominences, between which two projecting parts of one of the hock bones neatly fits. (See Plate X., fig. 4.)

The tarsus, or hock, is a most important joint. The astragalus, or knuckle-bone, is seen well in the enlarged figure just referred to. When we come to the Musches, and to Veterinary Treatment of Injuhies, \&c., we shall have more to say of the hock-joint and of the foot. The bones of the last-named we defer to the next section.

\section{\$IX. THE BONES OF THE FORELEG.}

These are the scapula (blade), or shoulder-bone, with its shallow cup to receive the head of the humerus (or armbone); the radius (spoke-bone), and ulna (the cubit), or large bone of the fore-arm; the carpus (knee-joint), consisting of the trapezium (Gr., a little table), the table-bone which gives security to the great flexors of the leg; the cannon, or shank-bone; the splint-bones; the sesamoid, large pastern, small pastern, and pedal, or coffin-bones.

The bones of the fore extremities of the horse present but little resemblance to those of the human arm, especially in respect of the limb ending in a single solid hoof or toe.

The shoulder-blade is a broad triangular bone applied to the outside of the ribs, so that its point reaches downward between the first and second ribs, and its lower part as far back as the seventh; standing obliquely with its broadest part above and its narrow below. It is slightly hollowed and smooth on its inner side, and outwardly divided by a projecting ridge or keel. Its lower part ends in a neck, and

the elbow. It has a round head, with an indentation to receive a capsular ligament, like the thigh-bone. It terminates in two of the rounded bodies called condyles, which joint with cavities in the upper end of the radius.

The radius (spoke-bone) is the front bone of the arm, the hinder one the ulna. These are known in general as "the arm " and "the elbow." The radius is long and cylindrical, and flat at the upper end, with depressions to receive the projections of the arm-bone (humerus). It has some tuberosities in front for the attachment of tendons, and behind a place for the ulna. At its lower end it has eminences covered with cartilage, which are connected with the upper bones of the knee.

The knee-bones, called carpal bones-the fore knee of the horse corresponding to the wrist (carpus) in man. These bones are seven in number in the prepared skeletons; but an eighth bone, of diminutive size, of the shape of a pea, is always found just behind the trapezoid, to which it is attached. The names of the bones are the same as those in the human wrist. The carpal bones articulate with each other, and have but one investing capsular ligament; hence the smallest wound of the knee which penetrates this liga. ment opens the whole joint ; hence, also, the excessive escape of synovia (joint oil), and the unpleasant consequences of "a broken knee."

The metacarpus (Gr., meta, beyond, carpus, the wrist), cannon, or shank-bone, consists of one large boue and two small ones, called splint-bones. The cannon-bone is plain and cylindrical, enlarged at the two ends, the upper of which articulates with the second or lower row of the kneebones. Behind its head it has two indentations to receive the two splint-bones, one on each side. Below, it has two condyles (knots), by which it articulates with the great pastern and the sesamoid bones, in such a way as to give them remarkable freedom of action in a forward or backward direction, but almost prevents any lateral action at this joint. The splint-bones, as we have said, are placed one behind each side of the cannon-bone; they are each jointed to the lower carpal bones and have also a synovial jointing with the hinder part of the cannon. They taper downwards, and end two-thirds down the cannon-bone, in a button-shaped extremity, which is unattached. In age the ligamentary attachment of the splints hardens into bony substance. The purpose of this mixture of fibro-cartilage is to allow of motion, yet limit its extent. It gives that elasticity which is necessary to the animal's (and his rider's) safety. A strain from extra weight or effort is apt to produce inflammation in these ligaments, when they become 
vascular, hot. and painful, and are converted into bony formations, called, after the bones themselves, "splints." The inner splint-bone is more liable than the outer (see post, SPLINTS). At this point the comparative anatomist notes that the wide palm of the human subject and the paw of the toed animal is converted into a simple solid cylindrical bone and two small additamentary ones-the splints just described.

The bones of the pastern are four : the large pastern, the lesser pastern or coronet, and two sesamoids.

The large pastern bone is the first of the oblique group of bones that form the extremities of the horse. It is cylindri$\mathrm{cal}$, and on its length and its obliquity depend the elasticity and ease of the animal's motions. Nevertheless, as its length throws greater strain upon the tendons and ligaments to restore it to its position after each effort, very long pasterned horses are most liable to strain and break down, although more "springy" in movements within their powers.

The lesser pastern, or coronary bone, supports the lower end of the great pastern, and then expands to a large surface. At its upper end is a projection which fits into a hollow in the great pastern. It has two projections on its sides, to receive the perforans tendon. It rests upon and articulates into the coffin and navicular bones, which end the series.

The sesamoids are a couple of small wedge-shaped bones at the hinder and upper point of the fetlock, just behind the lower end of the cannon-bone, to which they are attached, and also to the upper end of the great pastern-bone, and thus support a portion of the stress and weight imposed on these upright and sloping bones. They are placed side by side with their smaller portions upwards, and by their thicker and lower ends they are firmly held to the pastern bones by stout tendons, in addition to the great suspensory ligament. The use of these small bones is obvious. They are most strongly attached to the pastern, but admit in action of a certain amount of downward motion when pressed by the cannon-bone; the flexor tendons keeping them from being too far displaced. In horses with very oblique pasterns the cannon-bone is always resting on the sesamoids, which tends to fatigue and weaken the springs. On the other hand, horses with very erect pasterns do not have these sesamoids duly depressed by the cannon-bone; hence a want of elasticity in motion and danger when their pace is accelerated.

The coffin-bone is peculiar to the horse and his congeners. In shape it corresponds with the shape of the hoof, which, with its appendages, it almost fills. (See Plate IX.) Its bony fibres are placed perpendicularly in rough lines, and its substance is very porous. In front is a projection to which the tendon of the extensor pedis is attached; its two lower and lateral processes are called the "wings" of the coffin-bone. On these wings is a groove to receive an artery which sends off branches, as explained in detail hereafter in the Anstomy of the Foot. The porous character of the A A coffin-bone serves a threefold purpose : it gives lightness with solidity to the foot; it affords protection to the nerves and vessels which ramify through its interior; and lastly, gives a strong hold to the laminæ and structures on its outer side, thus giving strength and durability to the whole machine.

The navicular-bone (Lat. navicula, a little boat), called also the shuttle-bone, the nut, and the quiltor, is situated behind and below the coffin-bone, and between its two wings. Its upper surface is continuous with its articulation with the coffin-bone; its lower rests on the perforans flexor tendon, that tendon on the insensible frog, that on the sensible frog, which has the tough and flexible horn of the external frog below it. The upper surface of the navicular-bone receives much of the weight of the animal, with synovia only to relieve the pressure, but below its elastic yielding is evident. It also forms a point of attachment for the perforans tendon. As Navicular Disease is one of the most ruinous scourges of horseflesh, we shall have more to say thereon in the proper place, where the hoof, also, will come to be considered.

The TeEтH we have considered of such general interest, apart from the general structure of the bones, as to bestow upon them, in a former part of this Work, a separate chapter. (See AGE of THE Horse, ante, pp. 104-112.) Their diseases and the operations upon them will come in the veterinary part hereafter.

There are also some internal bones, which shall be else where noticed. These are the os hyoides, or tongue-bone, so called from its resemblance to the Greek letter $v$ (upsilon); it is situated at the base of the tongue, several of the muscles are connected with it, to which, in its several movements, this bone serves as a fixed point: it also supports the muscles acting on the larynx and fauces.

The bones of the internal ear (figured in Plate V.) will be described in the proper place.

The Appendages of bone are periosteum (bone covering), medulla (marrow), synovia (joint-oil), cartilage, and ligament.

The Periosteum is a strong, fibrous membrane, covering the bones, and serving for the insertion of muscles and their tendons. It has few nerves, and is consequently scarcely sensible in a healthy state; but when diseased its sensibility becomes increased, and the most acute pain is produced. This is the case in splint and spavin; for, in these diseases, the bone beneath enlarging, presses forcibly against the periosteum covering it; and this membrane being inelastic, and consequently incapable of expanding, violent pain, attended with lameness, takes place.

This membrane, when covering the bones of the skull, is called pericranium; and when on cartilages, perichondrium: it is of a white colour in animals after death, but in the living subject it is red, and much more vascular than tendon.

Medulla (marrow), is found in certain hollow bones, and throughout the spinal column. It is enveloped in a mem. brane which lines the cavities of bones, and which is secreted 
from arteries which are seen entering the bone for that purpose. Formerly it was supposed the marrow possessed sensibility, but that idea is exploded, it being impossible to trace nerves into it. But though the marrow is itself perfectly insensible, this is not the case with the membrane containing it, which is supplied with nerves, and is consequently sensible.

The marrow was at one time thought to serve as nourishment to the bones, but this opinion is now also abandoned. It is supposed, with more reason, that it performs the same offices as the fat, in being absorbed when there is occasion for it to supply animal waste.

Synovia, popularly termed joint-oil, is not an oil, bat a fluid similar in appearance to white of egg, secreted by the membrane lining the interior of the joints. Its service in lubricating the joints is immense. Indeed, but for its interposition, the grinding at the extremities of bones would render movement intolerably painful : with this slippery addendum the joints are made to slide over each other pleasantly and smootlly. When an excess of secretion of synovia takes place, the joint swells and "dropsy" follows. When this happens on the hock of the horse, it is called "bog-spavin." In other joints it is recognised in what is called by farriers "wind-gall."

Cartilages are of four kinds: articular, inter-articular, non-articular, and temporary. They serve many useful purposes lyy their smooth and elastic properties. First, they form the extreme and prominent parts of the body; such as the nose, ears, \&c.; which, from being composed partly of cartilage instead of bone, are better enabled to resist injuries. The ribs, also, are cartilaginous in that part of them connected with the breast-bone, and which is most exposed to injury and violence. Secondly, in the foctus, cartilages supply the place of bones. Young animals, being very liable to falls and other accidents, have a material of an elastic and yielding nature in place of bone. Hence we seldom meet with fractures in the bones of the young, because they are still, in great part, cartilage. There are cartilages in the foot of the horse, which act as a spring, and, by their elasticity, serve to prevent concussion.

The third kind of cartilage is more universal than any of the rest, and is intended to prevent friction between the ends of bones, by being interposed where they form joints. In this case, the cartilage itself is covered by a firm mem. brane, called perichondrium, which performs the office of a gland in secreting a fiuid termed synovia. This fluid prevents friction in the joints. Continually covering the membrane by which it is secreted, it necessarily prevents the surface of that membrane from coming into contact with the opposite one. These cartilages are, as we have said, yielding and elastic; they carry no red blood, nor has any fluid been yet injected into them. They have, however, a small number of vessels, with a transparent fluid, and this is seen in the jaundice of the human subject, when the cartilages become yellow. They neither ulcerate nor exfoliate, nor do they ever granulate. They possess no sensibility; their nerves, if they have any, not being discovered; but the membrane covering them is both sensible and vascular. These properties are peculiar to this last kind of cartilage only; for the other classes are subject to disease, in consequence of which they become ossified. Cartilage is popularly called " gristle."

Ligaments are dense, white, fibrous substances which connect and tie the bones together. They are inelastic, and but little vascular; they, however, are covered by a membrane, which has several vessels, and which is similar nearly, in structure and use, to that of the cartilages of joints. The ligaments of a horse are not so liable to disease as those of the human subject are, but they frequently meet with injuries by the ends of the bones forming a joint pressing forcibly upon them when the animal makes a false step; in this case the lorse is said to be sprained.

The ligaments of the horse are liable to be wounded, which often proves dangerous, from the synovia of the joint escaping, and the air insinuating itself into the cavity. The object, then, should be to shut un the opening that has been made into the joint; for so long as it remains unclosed, the synovia will escape, friction will take place, and, the inflammation increasing, the pain will at length become so violent as to produce a, symptomatic fever, which frequently ends in death. 


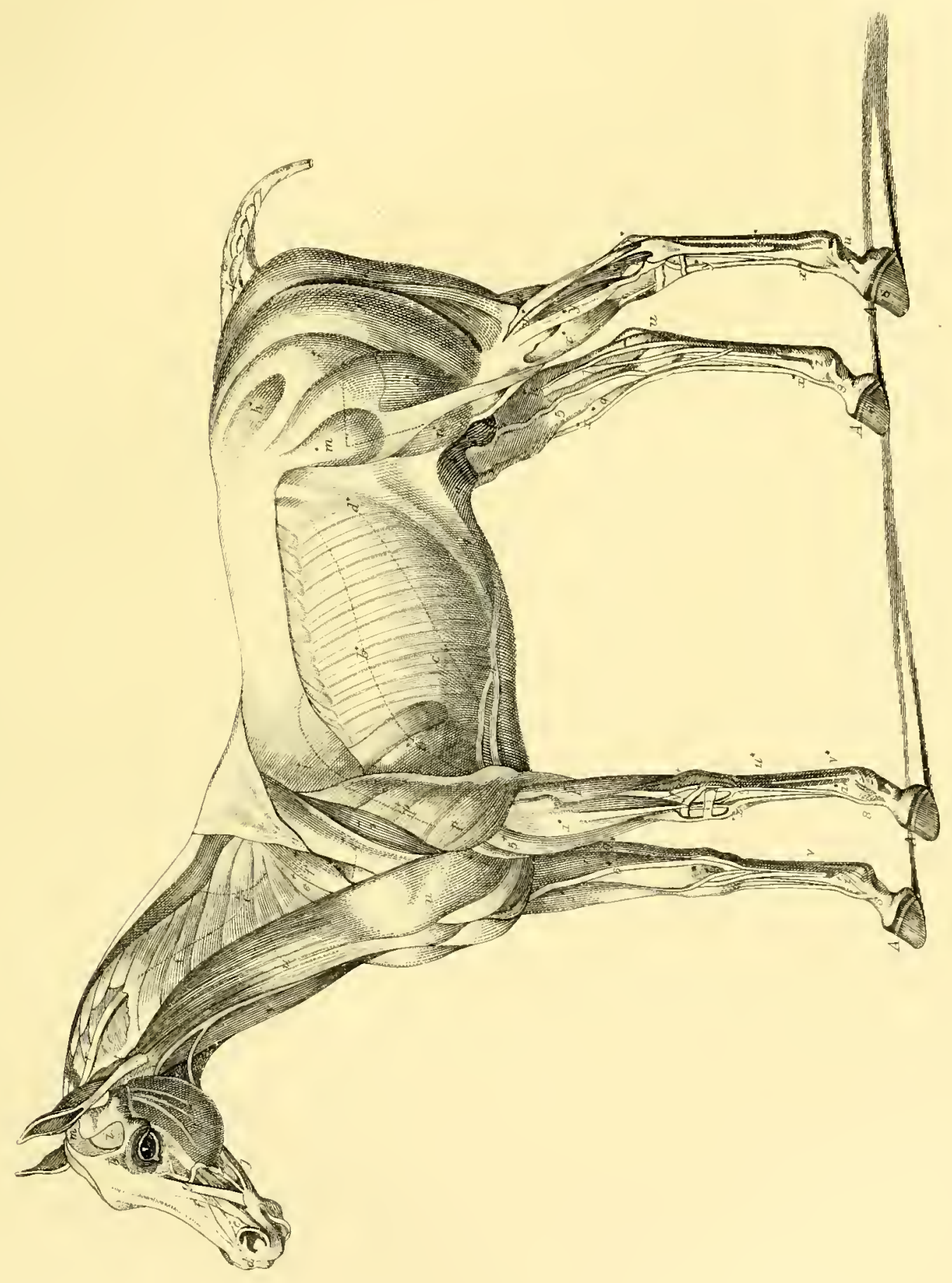

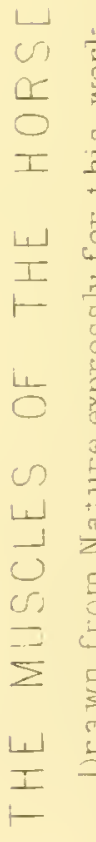





\section{CHAPTER XVIII.}

EXTEKNAL STRUCTORE OF THE HORSE, CONTINUED.-THE MUSCLES AND TENDONS.-MOSCULAR MOTION.- 1 , MUSCLES OF THB MEAD AND NECK.-2, OF THE TRUNK.-3, OF THE FORE-LIMBS.-4, OF THE HINDER-LIMBS.—5, OF THE ANOS AND TAIL.— 6, THE SKIN AND HAIR.

Moscle is the part of an animal popularly termed the flesh, or meat. It consists of collections of fleshy fibres, forming bundles, which are connected together by cellular membrane; and these bundles are again connected to others, till the whole muscle is produced. Each muscle is attached by its extremities to different bones. One of these extremities is called its origin; the other, its insertion. A muscle accomplishes motion by expanding its belly, or middle part, and contracting its ends towards the centre; when the parts to which those ends are attached must necessarily be made to approximate. Thus, when we wish to bend the hand at the wrist, the muscles engaged in this action, by expanding their middle part, contract their extremities, and consequently shorten their lengths; and having one set of ends fixed in the bones above the joint of the wrist and the other in the bones of the hand below it, the attached parts are pulled towards each other, and the flexure we desire is produced. In this manner are all the movements of the frame accomplished; and for this intent every animal designed for motion is supplied, more or less, with muscles, which constitute its flesh.

The muscles differ greatly in size and shape, being fitted both to the degree of force required of them, and the figure of the part they help to form. Thus some are long and round, as are most of those that move the limbs; while the muscles of the trunk of the body are generally broad and flat. Muscles often terminate in tendons for insertion. Tendons consist of a white, inelastic, insensible, and hard substance; and, as they require less room than muscles, they are well calculated to preserve the shape of the limbs and other parts.

It should be observed here, that the muscles of one side of the frame have corresponding ones on the opposite side ; and that they take their names generally in the horse, as in the human subject, either from the functions they perform, their figure and shape, or from the parts which they act upon. The most convenient way of considering these will be to divide them into-

1. The Muscles of the Head and Neck.

2. The Muscles of the Trunk of the Body.

3. The Muscles of the Fore-limbs, or Anterior Extremities.

4. The Muscles of the Hinder Limbs, or Posterior Extremities.

5. The Muscles of the Anus and Tail.

6. The Skin and Hair.
Of Muscolar Motion.-Numerous and complicated as are the motions of the horse, they are all reducible to two kinds-voluntary and involuntary. Each of these is effected by the contraction of the muscular fibre, which constitutes the fleshy portion of every vertebrated animal, and is the immediate agent of motion in them all. This contraction of muscular fibre is induced by the presence of a stimulus, which, acting on the irritability of the fibre, forces it to contract; and here we arrive at the immediate cause of animal motion.

Contractility, then, is that power in muscular bodies by which their actions are directly executed. These actions are called voluntary when effected by the contractility at the instigation of the will : involuntary, when accomplished by the same contractile power, but at the instance of some stimulus different from that of the will, and wholly independent of it. Thus, the blood, acting as a stimulus to the heart and arteries, causes these organs to contract, by which the circulation is sustained independently of volition. So also is it with the stomach, intestines, and indeed all other involuntary motionary organs; they are forced to contract by the presence of a stimulus different from that of volition, and consequently perform their functions likewise independent of the mind But the case is different with the voluntary organs. Here no single movement can take place but by the command of the will. Thus, for instance, do we wish a horse to walk, trot, or gallop; or that from any of these paces he should instantly discontinue and remain at rest; before the act we dcsire can be accomplished, it must first be known and determined upon in the mind of the animal. This subject, however, will be more fully explained when we come to speak of the brain and nerves.

Whether this contractile power of muscles, by which the motions of animals are executed, be derived from the nerves, or is a property wholly distinct from them, is a dispute amongst physiologists yet to be determined. All that is certain is, as we have seen, that whilst some muscles perform their functions wholly independently of the mind, and are therefore termed involuntary muscles; there are others called, in contradistinction, voluntary muscles, because they are unable to accomplish the smallest motion without the interference of the nervous influence. We will therefore avoid a subject yet veiled in uncertainty, with an observation on the close dependance of musculas motion on the atmospheric air. 
That certain properties, absorbed by the blood from the air taken into the lungs in breathing, are absolutely essential to the continuance of those movements called involuntary, and which directly support life, is demonstrated by numerous experiments. Thus, for instance, if an animal be confined to a certain quantity of air, it will continue without feeling change while it has a sufficiency of that fluid to respire; but the vital portion (oxygen) of the air being at length consumed, and no fresh supply admitted, the creature begins to gasp. His circulation becomes languid, convulsions follow, and all the vital movements gradually ceasing, death, to all appearance, shortly follows. And, in fact, if no means of recovery be promptly used, the creature absolutely must die. If, on the other hand, the apparently lifeless body be removed from the foul air in which it expired, and fresh oxygenated air be forced at proper intervals into its lungs, the heart will, probably, after a short time, be stimulated into its usual contractions, the circulation restored, and with it the life of the animal. Thus we see, that a constant supply of fresh atmospheric air is absolutely essential to life; and that, where it is denied, the muscular power must soon cease. Hence the necessity, which we have already urged, of preserving to horses in stable a sufficiency of pure unrespired air ; for if its total absence suspends, in a few minutes, life altogether, surely the partial corruption and diminution of this fluid must, in proportion, impair their strength, and expose them to disease.

Again, we observe the great dependance of muscular motion on the atmospheric air, in the increased quantity of this fluid which a horse, and indeed any other creature, respires when under violent exertion. This may be easily seen in the changes which a race-horse exhibits when running. Prior to commencing the race, his breathing is but little increased, and he respires not much more air than usual. As his exertions increase, his nostrils expand; he breathes quicker, and his blood is made to circulate much faster than before, owing to the additional stimulus it has received from the air in the lungs. He is now pushed by the rider, and his own generous and noble spirit urges him to surpass some rival. They rapidly approach the goalboth animals exert themselves to the utmost. At this moment all the appearances already described are at their height. The race being ended, and the horses allowed to walk gently, the increased breathing and circulation still continue, but not so violently as before. By degrees both subside to their ordinary degree of action, and the animal recovers the normal condition he exhibited prior to the race.

Now racing being a rapid movement of the animal, wholly performed by the voluntary muscles, and these muscles depending on the nervous energy to enable them to act, the increased motion which is necessary to the speedy gallop, requires additional energy from the nerves; hence, in fact, the increased velocity of the blood's circula- tion under violent exertion. The blood flowing, during the period of exertion, in greater abundance to the brain, excites that organ to impart a larger supply of that mysterious energy, without which the increased action of the muscles would flag and be so longer sustained. As the blood, then, is the medium which contains the properties which the brain separates for the purposes of exertion, and as these properties are greatly derived from the atmospheric air in the process of respiration, we find the breathing also accelerated, by which a more rapid oxygenation of the blood is also effected.

\section{MUSCLES OF THE HEAD AND NECK}

As there are a great number of motions peculiar to the parts belonging to the head and neck, they are supplied with numerous and some special muscles and ligaments. Some of these have their origins at a greater distance from their insertions, such as those which sustain the head, and give forward, backward, and sideway, or occasionally partially rotary motions to the parts. Of these two are common to the head and neck, and eight pairs pertain to the head only. The muscles, strictly so called, have some of their origins from the breastbone, and also from the vertebræ of the neck and chest. These are inserted, some into the occiput, others into the processes of the two temporal bones. Those of the neck which act in concert with the muscles of the head also take their origins from the breast-bone, the spines of the vertebræ of the chest and the lateral processes of the same; these are mostly, some higher or some lower, inserted into the trans. verse processes of the neck bones, and compose the bulk of flesh on those parts.

Muscular power alone would be insufficient to constantly sustain the head of the horse; nature has therefore supplied a provision as simple as it is efficient. At the back of the occipital bone, immediately below the crest, a round cord of ligamentous fibres, called the ligamentum colli (ligament of the neck), or "pack-wax," has its origin. This has some remarkable peculiarities. It passes over the first vertebra of the neck (the atlas) without any attachment, but is fixed firmly to the second vertebra, so that, while supporting the head at this point, it leaves the head free to turn on the first or second vertebral joints. The principal stress is on the dentata. It then sinks deeply, and is attached to all the other vertebræ of the neck; each of these attachments forms a separate point of support for all in front of it. Thus, when in a state of rest, the animal's head, without the fatigue of muscular tension, is supported by this great ligament.

But the head of the horse was not intended to be constantly carried high. In a state of nature the horse's food lies on the ground, or nearly so. This ligament varies, in one respect, from all others-it is elastic; that is, will yield when force is applied to it, and retract to its ordinary dimensions so soon as that force is withdrawn; thus, this ligament is some inches longer when the horse is grazing than when his 
head is elevated. The thickness of the occipital bone immediately below the crest is to adapt it to receive this ligament, which is carried down to the spines of the back, and there firmly secured.

The Eyelids have three pairs of muscles; one pair opens, and the other two pairs shut them. The pair that retracts is peculiar to the eyelid only, while the two others are inserted into both, to bring them together, and to shut the eye. All of them rise from the edge of the hole in the bottom of the orbit, through which the optic nerve passes to the eye.

The Eye of the Horse is moved in its different directions by six muscles, which take their rise from the bottom of the orbit, and are inserted into the sides of the eyeball, as in the human subject. There is, however, in the horse a seventh muscle, called the retractor oculi; it arises from the bottom of the orbit, and is inserted all round the ball of the eye. It is very strong, and is intended to draw the globe of the eye into the orbit from injury, at the same time that the haw is forced out for the better defence of the eye.

The Nose has four pairs of muscles, for widening and contracting the nostrils; they arise from the upper jaw and from under the eyes, and are inserted into the cartilages of the nostrils, and part of the upper lip. The action of these muscles is very perceptible in horses that are much heated by exercise, in broken-winded horses, and in cases of fever, when the nostrils open and contract in proportion as the animal is oppressed with disease.

The Lips have five pairs that are proper, and two common to the mouth and cheeks, some of which compose the fleshy part of the cheeks. The chief use of these muscles is to enable the horse to gather his food.

The Upper Jaw being of itself incapable of motion, all the muscles that serve to open and shut the mouth, belong properly to the lower jaw. The chief of these are the temporal muscles, which make up the fleshy part of the temples; also the muscles already mentioned as belonging to the chin and upper lip, and which have a considerable share in pulling down the jaw, so as to open the mouth; while the temporal muscles have the chief share in pulling it up, and shutting the mouth. There are other muscles for moving the jaw several ways in chewing, which are called the masseters; besides these, one pair thrust the jaw forwards and another pull it backwards.

The Tongue is itself a muscular substance, made up of fibres variously combined together, and in such a manner as may best suit and correspond with all its different movements. The tongue has five pairs of muscles proper to it alone, and two pairs that are common to it and the bone called os hyoides. Some of them arise from the lower jaw and os hyoides, and others that rise from this bone have their insertions into the apertures of the lower jaw-bone. One pair that pull the tongue backwards arise from the temporal bones, and are inserted into the sides of the tongue; and another pair from the lower jaw, near the furthermost grinding teeth, and are inserted into the liga- ment (or bridle) of the tongue; by which means they are suited to all its various motions. The muscles common to the tongue and os hyoides act chiefly in concert with the others, and give the tongue such motions as forward the aliment into the gullet, when it is sufficiently chewed and prepared to pass into the stomach.

The Larynx, or head of the wind-pipe, has six pairs of muscles for moving its different parts. The epiglottis, which serves as a valve for opening and shutting the wind-pipe, has its muscles very small, excepting in animals that chew the cud. These muscles are all more or less liable to be affected with colds; which is the cause of that soreness of throat observable in some horses, hindering them from drinking and swallowing their food.

The Pharynx, or head of the gullet, has also its muscles, which are often affected in colds: their office is chiefly to widen and contract the upper orifice of the gullet.

The Muscles of the Ears in horses are very distinct and perfect, and may be easily traced from their origins to their insertions. In man they are small, because in the human ear there is little capacity for motion; while brute creatures, being without hands, make use of their ears to drive away flies and other offensive things. The motion of the ears is also necessary to brute creatures for the reception of sounds, and to avoid danger. Therefore we may always perceive somewhat of the intentions of a horse by the motion of his ears. When a horse sees any remarkable object before him, he pricks up his ears, and points them forward, with an intention to hear, especially when the object is attended with any noise. When the noise or sound comes on one side, he turns his ears that way, to take the sound. When the noise is behind him, he lays his ears backwards; which is most observable in hot or timid horses.

The ear is properly distinguished into the outward and inward ear. The outward ear has four muscles; the first lifts the ear up, and points it forwards; the second pulls the ear backwards; the third draws the ear forward, and points it dowuward; and these act together, and move both ears, when a horse looks steadfastly to anything lying on the ground. The fourth assists the second, and pulls the ear backward and downward towards the neck. When a horse is wanting in a quick and sprightly motion of his ears, it is, in great measure, owing to the weakness of these muscles. For this defect is always more or less manifest in those that have their ears uncommonly large and thick, in which case the muscles are not fully adequate to the weight they are to move; and these horses are commonly the most dull and sluggish.

The internal ear has two muscles for moving the small bones it contains, which are employed in hearing; as will be explained when we come to treat of that organ.

From this mechanism of the muscles of the head and neck, and particularly by their remote origins of the breast and spine, it appears how well they are suited to the 
several articulations of the joints, so as to secure them from harm in all their various turnings. Otherwise, in parts abounding with articulations, though well connected and tied together by strong ligaments, the horse would easily be injured by quick motion or a trifling accident.

\section{THE MUSCLES OF THE TRUNK.}

The muscles of the trunk include all those employed in respiration and other important functions. They may be divided into those of the breast or chest, and those of the abdomen (belly), and the muscles of the back and loins, most of which are endued with great power.

But first it will be necessary to describe a muscle called panniculus carnosus (the fleshy pannicle), or subcutaneous muscle, which is peculiar to quadrupeds; at least it is not found in the human subject.

This muscle may be said to belong to the skin, its action being wholly on this part. It serves, by throwing the skin into folds, cr rugæ, to remove any offending matter, as insects, \&ce, that may lodge upon it ; and, for this purpose, it is closely connected with the skin covering the ribs, shoulders, and hinder parts of the body of the animal. It has also attachments with the muscles lying beneath it, and which serve as so many fixed points during its motions.

The Breast has four pairs of muscles for widening and dilating the chest, and two pairs that straiten and compress it. These make up that portion of flesh which covers the brisket and the breast from its upper part downwards to the pit of the stomach, expanding over most of the foremost ribs. Some of them have their derivations forwards, and from under the shoulder-blades and rack-bones of the neck and chest, and some backwards from the spines of the rackbones of the loins, and from the os sacrum; and are most of them so inserted into the ribs as to render their action of elevating and depressing the chest easy and complete. The intercostals are the external and internal small muscles which are situated between the ribs, and these also assist in widening and compressing the chest alternately in inspiration and expiration.

The Diaphragm, Midriff (or skirt, as some call it, in horse or bullock), is a muscular substance which divides the cavity of the chest from that of the abdomen, and is a principal agent in the act of respiration. Its fleshy fibres arise from the internal circumference of the chest, and, converging like rays to a centre, are all inserted into a tendinous flat substance at the middle. This muscle not only serves to divide the thorax from the abdomen, but also greatly contributes to the act of breathing. When its fibres contract, its convex side, which is turned towards the chest, becomes gradually fat, and, by increasing the cavity of the breast, affords room for a complete dilatation of the lungs, by means of the air which is then drawn into them by the act of inspiration. The fibres of the diaphragm then relax; and as it resumes its former state, the cavity of the chest becomes gradually diminished, and the air is driven out again from the lungs by a motion contrary to the former one, called expiration.

The Abdomen has five pairs of muscles, which arise from the ribs, haunch-bone, share-bone, breast, and wher contiguous parts, and are mostly inserted into the white line that divides the abdomen in the middle. One pair pass obliquely downwards; another pair obliquely upwards; a third have a straight direction from the breast to the sharebone; a fourth pair assist the straight muscles in pulling down the breast; the last are the transverse pair, which take their course from the loins and lowermost ribs on each side to the white line. This partition, or white line, of the abdomen, is formed by the tendinous junctions of the muscles of both sides, and is particularly well adapted to so large and roundish a surface; for had these muscles not been determined in the middle, but been stretched over the whole abdomen, it would have been impossitjle for them to have acted with such force and energy. The use of the abdominal muscles, besides completing the cavity of the abdomen, and supporting the bowels, is to assist the muscles of the chest in respiration, and also in expelling the foeces.

The Back and Loins have four pairs of muscles, common to both. The first are remarkable for their gres! length, extending from the haunch-bones and os sacrum, anc reaching to the two temporal bones. These being attached to the spines in their passage, are a great security to the back, and assist the other three pairs in all their motions. When all the muscles of the back and loins act together, the whole back is extended; but when the muscles of either side act solely, the body is inclined to that side only.

\section{MUSCLES OF THE FORE-LIMBS.}

The Shoulder-blade bones are carried through their different movements by four pairs of muscles; they arise frou the hind part of the head, from the transverse processes of the neck, and from the uppermost ribs, and are inserted into the blade-bones at different points. By these muscles the shoulder-blades are moved forwards, backwards, upwards, and downwards.

The Shoulder-i.e. that part which reaches from the point of the blade to the elbow-has nine muscles for performing its several motions. The first arises from the first rib, and, passing over part of the blade, is inserted into the shoulder-bone about its middle : this muscle helps to raise the shoulder upwards. The second rises from the spine or ridge of the shoulder-blade, and is inserted into the neck of the shoulder-bone: this also helps to raise the shoulder upwards. The two depressors pull the shoulder downwards. The first has its origin from the os sacrum, from the haunch-bone, and rack-bones of the back, and, with its fellow on the other side, spreads over a great part of the back, from whence it is called latissimus dorsi, or the broadest muscle of the back. The other rises from the lower side of the shoulder-blade, and is inserted into the upper and inner side of the shoulder-bone The two pairs 

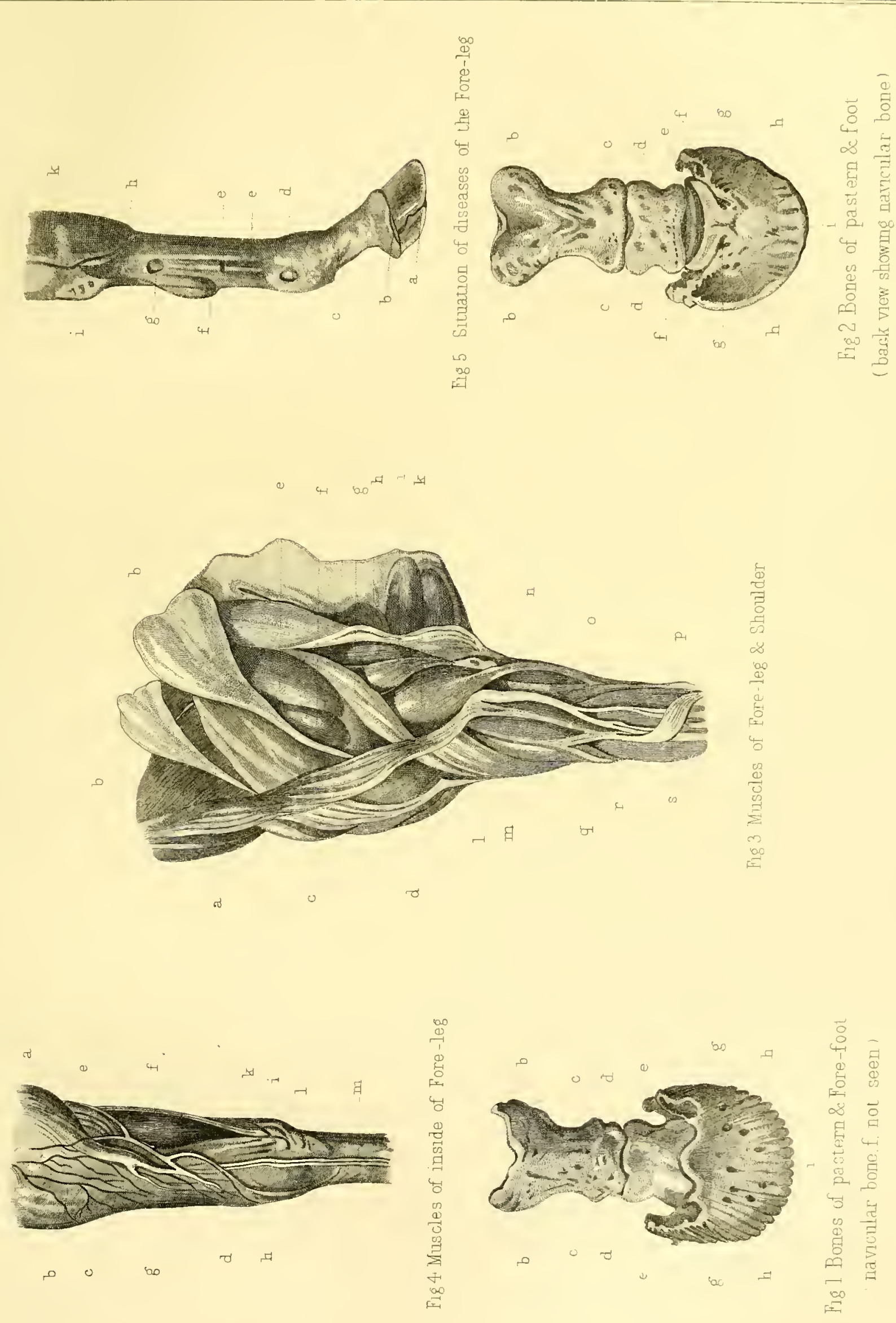



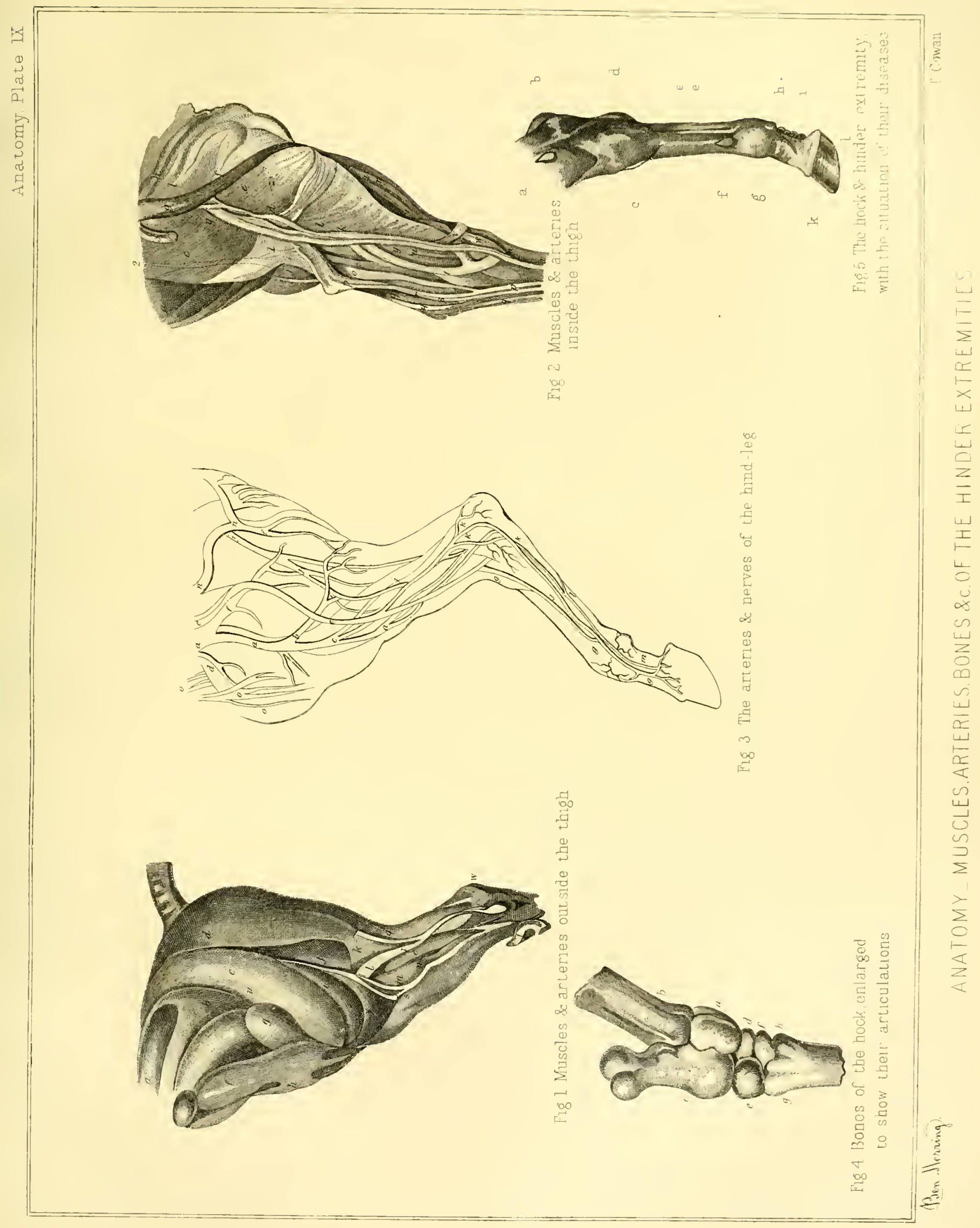





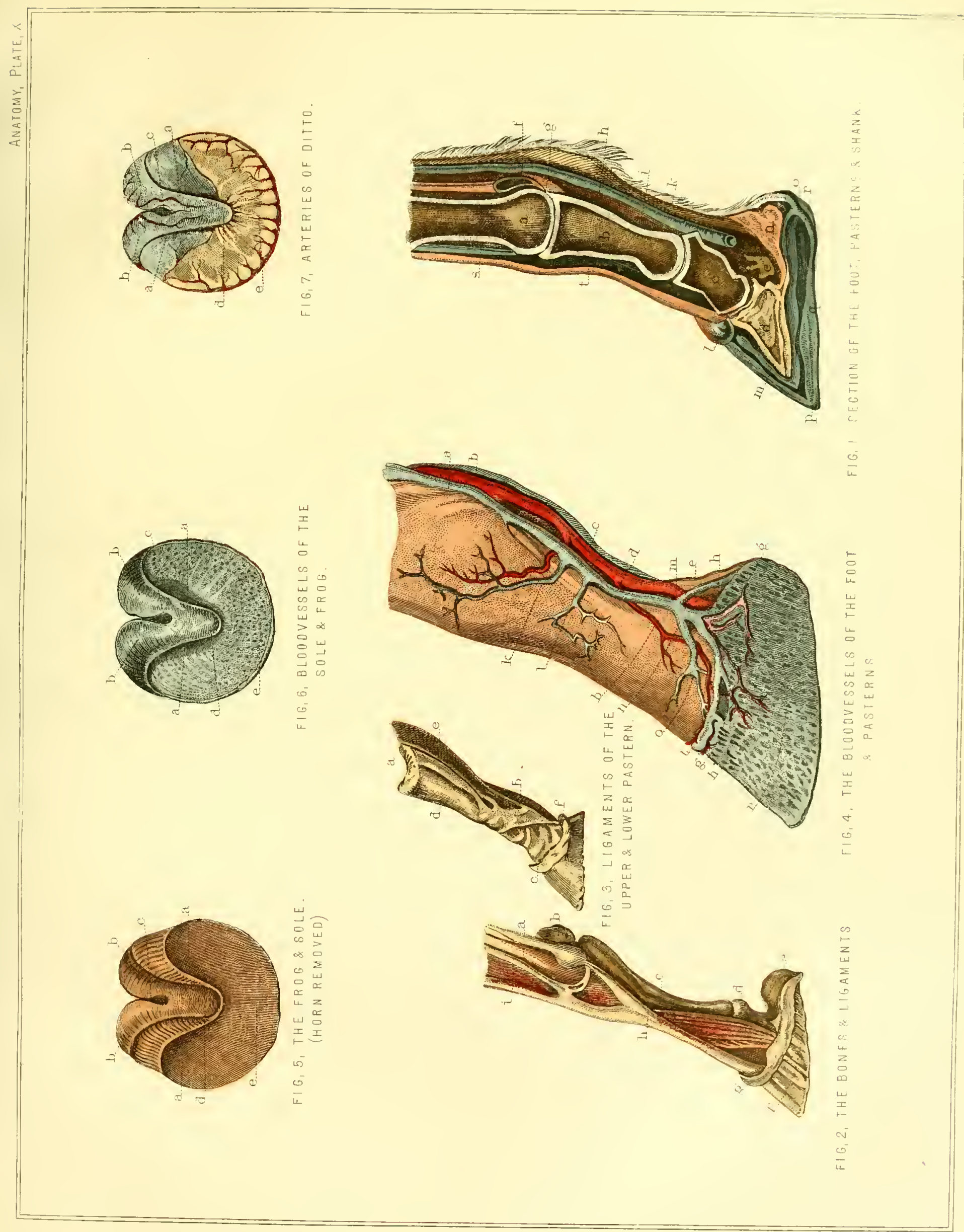




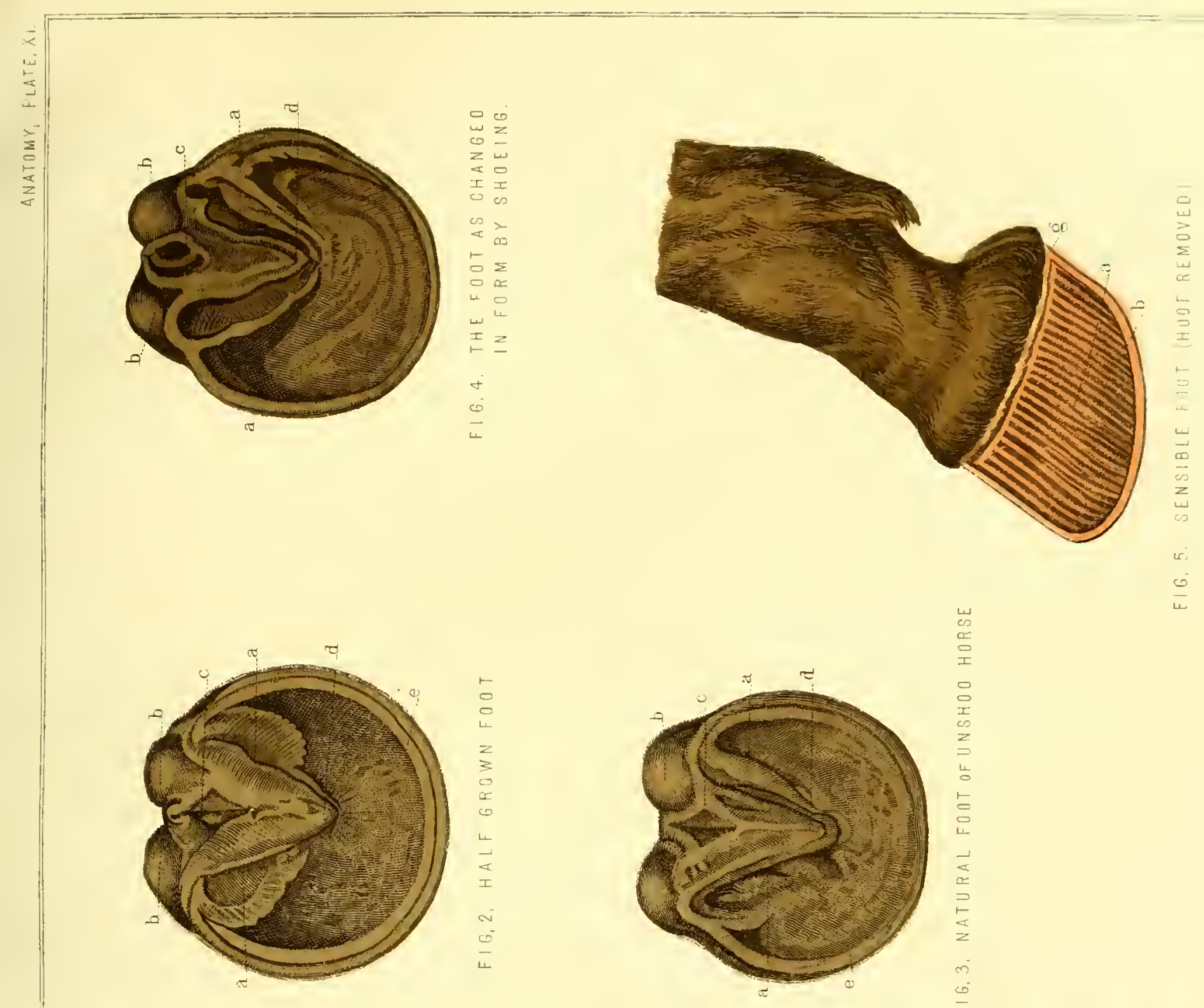


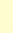


that bring the shoulder forward, are the pectoral muscles, and another which rises from the interior part of the bladebone, near its brim, and is inserted into the middle of the shoulder-bone. The pectural muscles are so called because they cover most of the breast, and are inserted into each shoulder-bone, a little beluw their round heads. The remaining three muscles move the shoulder backwards. The first has its origin from under the spine of the blade-bone, and is inserted into one of the ligaments of the shoulderbone; the second is placed tetween the shoulder-blade and ribs, and is inserted into anither ligament of the shoulderbone.

The motions of the shoulders of horses and most quadrupeds are more limited tlian in man, their chief action being forwards and backwards, wherein they have a capacity of being raised higher or lower, according to their several requirements.

The Fore-arm, extending from the elbow to the knee, is carried through its motions by powerful muscles, arising from the blade-bone; some of these muscles are inserted, by tendinous ends, into the olecsanon, or point of the elbow, and extend the fore-arm, while the arm itself is bent. Others are inserted into the bones of the fcre-arm for bending this part of the limb

The Shank, which reaches rom the knee to the pastern, has two muscles that bend tile knee, and two for extending it. The flexors arise from tl:e inner and upper part of the shoulder-bone, and, passing heyond the knee on the inside, are inserted into the hinder part of the top of the shank. The extensors derive their origins from the external and superior part of the shoulder.bone also; and their tendons, passing over the knee, are inserted into the fore-part of the head of the shank; and, together with the ligaments of this part, help to secure and strengthen the knee-joint.

The Fore-pastern and Foot have also their flexor and extensor muscles; which, from their arrangement and liability to injury, desirve particular notice. The extensor arises from the external and inferior end of the humerus, and also from the outward and lower extremity of the radius; and descending fleshy to within about two inches of the knee, it here becomes tendinous. From this point its tendon descends along the knee, under an annular ligament, and, continuing its course down the anterior surface of this cannon-bone, it passes over the fetlock, where it is also bound uown by anotlser änular ligament; still descending, it receives, about the middle of th: large pastern, two slips of ligament, from what is called the suspensory ligament, which shall be hereafter explained. And now the tendon of the extensor muscle expanding, is inserted partly into the anterior and lower end of the large pastern; in part, into the anterior surface of the small pastern; and, lastly, into the superior and anterior process of the coffin-bone. The use of this muscle being simpiy to extend the lower part of the limb, but principally the foot, and carry the leg forward after it has been raised from the ground by the flexors, it is neither so strong as these, nor so liable to injury.

The flexor muscles, from having to support a part of the animal's weight, are necessarily very strong and powerful; their tendons constitute what are vulgarly called the "backsinews;" and from the peculiar arrangement of these tendons, the muscles are themselves distinguished into the "perforating" and the "perforated."

The first arises by three distinct heads; viz., two from the lower end of the shoulder-bone, and one from the ulna; and descending fleshy, till approaching the knee, each portion here becomes tendinous; when the whole, uniting, form one strong broad tendon, which passes at the back of the knee, under a ligament, the inside of which secretes an oily liquid for keeping the surface of the tendon moist, and thereby preventing friction with the neighbouring parts. The tendon now descends along the posterior side of the cannon-bone, till having arrived within about two inches of the fetlock-joint, it perforates the tendon of the other flexor muscle, and runs within it as in a sheath, until both reach as low down as the lower end of the large pastern. The perforating tendon now passes over the navicular bone, and is inserted into the inferior and posterior concavity of the coffin-bone.

The second, or perforated flexor, arises from the posterior and inferior end of the humerus; and becoming tendinous as it approaches the knee, continues its course downwards to where it divides to form a sheath for the other tendon. After this it still descends, passing behind the pastern, and is inserted partly in the heels of the frog, but principally into the lower side of the large pastern, where it forms lateral ligaments to the pastern joint.

The suspensory ligament, of which we have already spoken, arises from the head of the large metacarpal bone, and dividing into two branches about two inches above the sesamoid bones, both branches are inserted in those bones, and serve materially in keeping them in their right place during violent motion of these parts.

\section{MUSCLES OF THE HINDER LIMBS.}

These are not only more numerous about the hips and loins than those about the shoulders, but they are of larger volume; a necessity imposed by the fact that they not only have to take their share of the animal's weight, but are also the organs of propulsion. For this purpose, therefore, the hinder part of the horse's skeleton is filled up to roundness with large and powerful muscles. Those giving motion to the thigh arise, some from the hinder part of the spine, others from the pelvis: these are inserted into the thigh-bone to effect its several movements. Some of these muscles form the fleshy part of the hip, whilst others pass over the whirl. bone, and form an additional security to the hip-joint.

The Leg, comprehending that part usually called the thigh, reaches, in the horse, from the stifle to the knee-pan, or hock. It is carried through its several motions by powerful 
muscles, some of which take their origin from the bones of the pelvis, others from the thigh-hone, and, descending, are inserted partly into the patella, or knee-pan, partly into the tibia or leg-bone. These muscles extend, bend, and move the leg a little to the side; and they, together with the muscles remaining to be described, compose the fleshy portion of the hinder limbs.

The Instep, including that part which reaches from the hock to the pastern-joint, and commonly termed the small of the leg, has its motions performed by means of a few powerful muscles. It is bent, or brought forward, by two muscles chiefly, which arise from the superior part of the leg-bone, and descending along its anterior surface, are inserted into the fore part of the cannon-bone, a little below the bend of the hock. But the muscle extending this part, being that which is principally concerned in effecting the progression of the animal, deserves a more particular description.

This muscle corresponds with that called gastrocnemius in the human subject, and which forms the calf of the leg; in the horse it is a single muscle, but arises by two heads from the posterior part of the thigh-bone. These heads, descending thick and fleshy, soon unite, and form a very strong and powerful (tendon called the tendon of Achilles), as in man; this tendon, continuing its course downwards, is inserted into the point of the hock, which, by its projection, enables the muscle to exert a greater force in sending the animal forward.

The remaining muscles of the posterior limb, which move the pastern and foot, being nearly similar in arrangement and action with the corresponding ones of the fore extremity, we shall refer to the description of them for a knowledge of the former ones.

\section{v. MUSCLES OF THE ANUS AND TAIL.}

These consist of four principal muscles :-

1. The sphincter (Gr., sphingo, to contract) ani, which encircles the opening of the anus, and enters it to the depth of four or five inches. It has, unlike other muscles, neither origin nor insertion. Its contraction, like the string at the mouth of a bag or purse, is powerful in health, and its relaxation in disease, or its loss of voluntary constriction, is a bad symptom.

2. The retractor ani inferior is fixed to the os innominata (see BoNes, ante), and inserted into the rectum, or straight gut. It mixes its fibres with the sphincter ani, and pulls back the gut after the animal has voided dung.

3 . The retractor ani superior is attached to the under side of the sacrum, and corresponds with the last-described muscle in mingling with the fibres of the spincter ani, but on the upper side. It co-operates with it in pulling the anus in and upwards.

4. The levator ani consists of two slips ot muscular fibres, which lift the anus, as their name implies.

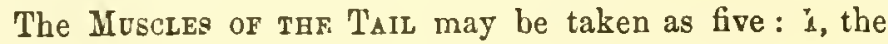

compressor coccygis, attached to the edge of the os innominata, to the first, and next three bones of the tail, on the under side; 2 , the levator, which lifts; 3 and 4 , the curvators, which bend the tail right and left; 5 , the depressor, which lowers the tail. These muscles are contained in a sheath as far as the last vertebra of the loin, and fastened to all the following bones down to the end of the tail.

Internal muscles will be noticed under the several viscera.

$$
\text { VI. THE SKIN AND HAIR. }
$$

Under the general name of Skin is comprised two exterior layers of the covering of the body, the cutis vera, or true skin, and the epidermis, or scarf skin. Connected with these are the fatty, cellular membrane and the muscle, already mentioned, the panniculus carnosus, which gives the motion to the skin, so remarkable in the horse.

The epidermis, cuticle, or scarf-skin, is the outer thir and tough, and somewhat transparent, integument.

The cuticle is composed of thin flexible scales, somewhat resembling the scales of a fish, and similar to them in arrangement. The cuticle is produced by the cutis vera (true skin), and is perforated by both its exhalant and absorbent pores. In almost all parts of the body the cuticle is thickly clothed with hair; but that of the nose, the lips, and the interior of the ear, the borders of the eyelids, and the inside of the superior portion of the thighs, is naked, and in all those places is thinner in substance than on the other parts which are invested with hair The colour of the cuticle is the same in all horses, whatever be their hue. But it is a known fact that the skin of the silver grey Arabian horse is of a bluish black; but whether this colour is in the cuticle or in the rete mucosum has not been decided.

The rete mucosum is merely the first secretion of the cuticle, which is deposited in minute oval bodies, containing a small quantity of colouring matter. This pigment disappears as the secreted skin is pushed outward; the ovoid particles being flattened till they become colourless hard scales, which fall off in the form of dandriff or scurf. When a blister is applied, it irritates the true skin, which exuder serum, and the cuticle, being impervious, is raised into bladders (vesications).

The cuticle is everywhere perforated by minute holes. corresponding in situation, size, and number to those of the cutis. First, there are the sebaceous glands, nourishing the hairs; secondly, the perspiratory, or exhalant pores; thirdly, the absorbent, or inhalant pores ; and lastly, largersized pores, through which unctuous secretions in various parts are emitted. The cuticle is destitute of both nerves and blood vessels, and consequently devoid of sensibility.

The cutis, or true skin, is that portion which is converted into leather. It lies immediately under the scarf-skin, and is attached to the under parts by the cellular and adipose (fatty) membranes, and in some places fits so tensely that it is incapable of motion of any kind. In 
other situations it is more loose, and can be pulled into folds. In the blood-horse it is thin and highly sensitive; while in the cart-horse it is much thicker and far less sensitle. The texture of the hair seems to depend in a great measure upon that of the cutis, for we find that of the thick-skinned black horse much coarser than in the racer and other high-bred varieties.

The cutis is beautifully adapted for giving strength as well as protection to the muscles; for we find in those parts that require to be firmly bound together, such as the bones of the knees, the pasterns, and tendons of the limbs, it adheres with such tenacity that it cannot be raised from those places, acting the part of a powerful ligature to the parts which are subjected to the greatest degree of stress; while, in those situations where its being tight would interfere with the action of the animal, it is loose.

The cutis is of a strong fibrous texture, very tough, yet supple, elastic, very vascular, and sensitive. Its fibres are curiously interwoven in almost every direction, and so interlaced as to give great strength to its texture, making it almost impenetrable by a knife in the living animal, and possessing extreme elasticity. It is this quality which adapts it so closely to the animal, whether he is plump and muscular, or reduced to skin and bone. In man and most other animals, where, from disease, a great reduction of the muscular fibre has taken place, the skin becomes loose and shrivelled. It owes this great elasticity to the inumerable larger and smaller glands which penetrate its entire substance, furnishing that unctuous matter, preserving the skin soft and pliable, maintaining that greasy moisture which its surface possesses, and giving a sleek appearance to the hair. When the animal gets out of condition, and the skin is diseased, the coat assumes a rough appearance, the hairs refuse to lie down, and it is said that the coat "stares."

The skin at the bend of the knee and hock is bountifully supplied with this excretion, to give them suppleness, and to preserve from friction those parts which are subjected to such constant and active movements. Sometimes this secretion exceeds the quantity necessary for due action, from want of attention and cleanliness becomes inspissated, and collects about those parts. If this hardness is permitted to remain, it will become a watery sore, which will terminate in lameness, stiffness, and pain in the joint when the animal bends it. When this is situated in the bend of the knee, it is termed mallenders; when it is seated in front of the hock-joint, it is called sallenders; diseases hereafter treated on
The skin of the heel has numerous glandular porcs, through which the unctuous secretion oozes. Sometimes these are unduly excited, the secretion becomes altered in its substance and odour, producing the disease called grease.

The cutis, when destroyed by any means, does not regenerate quickly. Great care should therefore be taken not to allow any portion of it to be broken. Many think that it is of little consequence for horses to have the skin of their back rubbed off by friction from a saddle. Such parts as have lost their cutis have it but slowly reproduced; and even when it has been restored, its vital power is much weaker than it was originally; for, although it appears at first to be very vascular, its vessels after a time either shrink in calibre, or some of them become altogether obliterated.

THE HaIr-Each hair of the horse is a minute tube, having a bulbous ${ }^{-}$end inserted in the cellular membrane which lies just beneath the cutis. From this little gland each hair penetrates the cuticle, or outer skin, and grows of various lengths and sizes. The hair covering the body and part of the legs is fine and soft, that which invests the ridge of the neck, crown of the head, and the tail, is of coarser texture and considerably lengthened. Each hair, as we have said before, is a tube; the outer covering is derived from the cuticle, within which a horny substance is enclosed; this horny portion being so disposed as to make each hair an elongated cone. The coat is of a uniform thickness all over the body, excepting upon the inner parts of the thighs, under the arms, \&c. It varies in quality, colour, and length in different breeds. The thoroughbred racer, the Arabian, Barb, and Turkish horses are remarkable for the shortness and sleekness of their coat; while the cart-horse, the Shetland pony, and horses of all northern climates, are distinguished by its length, roughness, and coarseness. The lighter the shade of colour, the finer the hair; and it has been found that in chestrut and light bay horses there are more hairs in a square inch than in black and other dark-coloured horses.

The coat is shed twice a year, in spring and autumn. In a state of nature this commences with great regularity as to time; but in a state of domestication this process is much influenced by the temperature and stable management. The hair of the mane and tail is never shed, except in specific diseases of a mangy character. The treatment of a horse when shedding his coat will be found in its proper place, under Stable-Management, Clipping, Singeing, Clothing, Conditioning, \&ce, in the First Division. 


\section{CHAPTER XIX.}

IHI BRAIN AND NERVES. - THE ORGANS OF SENSE :-I. THE EYE AND VISION.-II. THE NOSTRILS, THEIR MEMBRANES AND SINUSES: SMELL.-III. THE EAR, AND ITS CONSTRUCTION : HEARING.-IV. THE TONGUE AND ITS ORGANISATION : TASTE. -THE PALATE.

\section{THE BRAIN AND NERVES.}

ThE origin and seat of the nervous system is the soft white and reddish mass called the brain, contained within the cavity of the skull. Its membranes (or meninges) are three. or, more correctly, two. These, by lining the inside surface of the skull, prevent its inequalities from injuring that delicate organ. The first membrane is called dura mater, as in the human subject; it is of a strong tendinous nature, and serves to prevent concussions of the brain, by supporting its different divisions with the folds which this membrane sends in between the separated portions of that organ. The second (the pia mater), is strictly no more than soft cellular tissue. It differs from the first in being extremely soft and sensible. It lies next to the surface of the brain, dips into all its furrows and convolutions; and as this membrane is the medium through which the blood-vessels pass to the brain, for supplying its waste and recruiting the stock of mental energy, so it sometimes becomes the seat of disease. There is a very thin and delicate membrane lying between the two already described, but it does not enter the fissures of the brain, like the pia mater, or second membrane of that organ.

The third, the membrana arachnoidea (Gr., spider-weblike membrane), is a fine serous membrane, in connection with the inside of the dura mater. After investing every vein and artery, it is doubled back upon the surface of the brain itself. The arachnoid accompanies the spinal marrow out of the skull. It clings closely to the surface of the brain, and is said to facilitate the motion which is continually going on during life throughout the lobes of the medullary mass.

The brain of the horse, like that of most other animals, is partly of a roundish figure. It is of a pulpy consistence; and in colour is white internally, but greyish on the outside. As so soft a mass may be liable to concussion and injury from the violent blows and motions to which the head is frequently liable, the all-wise Creator has divided its substance for a considerable way from the surface in several places, and supported the divided parts by introducing folds of the dura mater between them, so as to sustain each portion of the brain in its proper place, and prevent it striking against, or being struck by, the adjacent portions of that organ.

In consequence of this partial division of the substance of the brain, it is commonly described as consisting of threo great portions, though in reality the separations cease long before we reach the centre of its base. The first great division, called cerebrum, is placed above in man, but below in the horse, owing to the position of the skull of the latter; and to the same cause is to be attributed the elevation of the second portion of the brain, termed cerebellum, above the first in this animal. The third portion of the brain of the horse also corresponds in name with that of the human subject. But in the former creature it occupies the hinder part of the skull, while in man it is situated below. It is a continuation, or union, of the white or medullary substance of the other two portions of the brain; and is partly on that account, and in part from its figure, called the medulla oblongata.

From this third portion arises what is generally termed the spinal marrow, but which in reality is a continuation of the brain. Its substance being, like that organ, partly of a white and partly of a greyish colour, and being covered and defended by similar membranes to those protecting the brain. This continuation of the brain passes out of the head by the great opening in the occipital, or hinder bone of the skull, and running along the canal formed by the bones of the spine, or back-bone, in which it is safely lodged, gives off several nerves to the body and limbs, as will be presently seen.

The NERves are white fibrous cords, which arise either from the brain or spinal marrow, and, passing off in pairs, are distributed to all parts of the body. Their texture is filamentous, and they are bound in a sheath of cellular tissue called neurilema. They receive blood, but do not become red. A nerve has no end; it passes round a part and goes into another sheath. Nerves have the power of reuniting. (See Neurotomy, post.) Some suppose nerves to be transparent, from the bottom of the horse's eye being discernible through that part of the optic nerve called the retina; but, notwithstanding this circumstance of the retina's transparency, both in the horse, dog, cat, and several other animals, yet that the other nerves of the frame are transparent is still unproved. The course of the nerves is in company with the arteries and veins, and, like these, they communicate, or their branches run into each other, and form what is termed a plexus. By this contrivance sensation is carried on, notwithstanding some principal branches should be obstructed or destroyed: 
which could not be the case but for this vicarious communication. That an accident or injury of this sort may be of the least possible evil to the creature, and the soundness of the parts be again restored, the th all-wise Creator has endowed the nerves, like other parts of the frame, with the power of regeneration. This is proved by dividing either branch of the eighth pair of nerves, called the par vagum, when it will be found that a coagulable lymph will be thrown forth, which, after changing in to a substance possessing all the qualities of nerves, will reunite the divided parts, and effect their regeneration as before. In this experiment also, it will be seen that while one branch of the nerve is totally divided, the other branch, by its communication, carries on sensation in the parts to which the divided branch is distributed, and which, but for this communication, must be rendered wholly without feeling by the division of the nerve. For if both branches of the same nerve (the par vagum) be divided, the communication with the brain is entirely cut off. If this happen to a horse he immediately dies, though a dog will survive some time.

Nine pairs of nerves are counted as arising from the brain within the skull; a tenth pair, with the spinal marrow, passes out of the great opening of the head. The remaining thirty-six pairs branch from the spinal marrow, after it has descended into the canal formed for its lodgment. Of those of the brain (cerebral nerves), the first pair are called the olfactory, because, passing through the ethmoid bone, they are spread in innumerable small branches all over the membrane lining the inside of the nose, for the purpose of producing the sense of sinelling.

The second pair are called the optic nerves. They pass through the sphenoidal bone of the skull, and, entering each orbit of the eye, form at its back part that nervous expansion called retina, a network to which the animal is indebted for vision. (See post, under EYE.)

The remaining seven pairs are distributed chiefly and almost exclusively to the different parts of the head and neck. The seventh are the auditory nerves. (See THE $\mathbf{E}_{\mathrm{AR}}$.) The eighth pair are peculiar, and called on this account par vagum, or pneumogastric nerves; they have branches running to almost all parts of the body.

The tenth pair, arising from the spinal marrow just as this substance leaves the brain, go principally to be distributed on the exterior of the head.

The Spinat Nerves, arising from the continuation of the brain contained within the canal of the spine, are, as we have said, thirty-six pairs. They pass out from the spinal marrow between the interstices of the vertebræ, and are distributed partly to the internal organs of the body, in part to the muscles covering the frame, and lastly to the limbs, in which they may be seen descending in branches.

There are 7 vertical, 18 dorsal, 6 lumbar, and 5 sacral pairs of nerves. Each spinal nerve has a double origin (see Plate V., Fig. 5, Spinal CoRd, \&c.), by filamentary bundles, one from the upper, the other from the under portion of the spinal cord. The filaments of the upper part only convey sensation to the brain. The lower ones merely effect motion (motory nerves), by carrying from the brain to the muscles the will (volition) of the animal. They form a ganglion (or knot) at a little distance, and thenceforward become of a mixed character, motor and sentient nerves being blended.

The brain and nerves of a horse, like those of other creatures, endow all the other parts of the animal with feeling or sensation. This is shown by tying or otherwise obstructing a nerve going to any part, so as to cut off the communication between this part and the brain, when a loss of feeling instantly takes place below the point of obstruction; this being removed, the parts recover their sensibility.

Nerves are also the cause of all voluntary motion. As may be seen by the loss of this motion taking place from the compression of the brain, either from an extravasation of blood or water, or from some other mechanical cause, when the whole body becomes paralysed, and the power of motion suspended. But on removing the compressing cause this paralysis will vanish, and the animal be restored to its capability of voluntary motion. If the spinal marrow be compressed, the same loss of feeling and motion will also take place, but only in the limbs and such parts of the body as receive their nerves from it; and the same return of both these powers will follow the removal of the compression. The obstruction of a nerve will, in like manner, cause a loss of motion in the muscles to which it is distributed, but which will also be removed with the obstructing cause.

Through what medium the brain and nerves cause the voluntary motions, is as unknown as is the mode in which these organs effect sensation and perception. We know that the will, having determined on an act, sends its commands along the nerves from the brain to the muscles to be engaged; these, irritated by the influx of the nervous energy, instantly contract (the mode in which muscles effect motion), when the act we desire is thus produced. This is the case in man, and also with the horse. Various and complicated as are the motions performed by this animal, independent of those termed involuntary-which are for the most part vital movements, carried on in the internal parts of the frame-yet are all the former ones the consequence of the will, nor can a single one of them be effected without this determination being first made. This appears evident from the obedience of a horse in performing such movements as we desire; and it is also illustrated in the resistance sometimes made by that animal to the accomplishing of our wishes. For both the execution of the act and its refusal are the result of that prior operation in the mind which we term volition.

Now where there is volition there must be perception, otherwise the former faculty could have no objects for its operation, and would be useless. This perception, for sake 
of clearness, we shall call the sense of the brain, as what we term sensation may be said to be that of the nerves. These possess the power of being impressed by various substances in nature, and of sending their impressions onward to the brain; which organ, having the power of being further affected by these impressions, perception or consciousness of the impressing object takes place in the mind. This may be ranked as the basis of all the other operations of the mind in animals, and is the medium through which they receive all the knowledge they possess of the objects existent in creation.

This perception again is divisible in the horse, as in man, into two kinds : 1, Direct perception, or such as is caused at the instant by the propagation to the brain of the impressions received by the external organs of sense-thus the eye, being impressed with the figure or colour of any object, communicates the impression by the optic nerve to the brain, where the perception or idea of the impressing figure or colour is immediately formed. 2, Perception by reflection, which is also the delineation in the mind of impressions, but such only as had been some time before conveyed to the brain from the organs of external sense, and consequently are now merely reproduced by that act of the mind called memory - or such as are created within the brain itself by the operation of the mind which we call thinking. And that the mind of a horse is capable both of recollection and thought, to a certain degree, is indisputable. The first is provable by a variety of familiar circumstances, known to every one conversant with the animal, therefore not requiring to be particularized; the second is shown by the increased exertions made by the animal in leaping and clearing a fence, wall, gate, \&c.; which unusual exertions must have been perceived and determined upon as necessary prior to his arriving at the place to be thus cleared.

But merely seeing and knowing things through the medium of sensation and perception, would not be sufficient to draw the animal from a state of inactivity. To effect this, the Creator has used the same means, but in a more humble degree, as in man; namely, he has interwoven pleasure and pain with the existence of the horse, and so contrived both, that they have the power, not only of leading him into action, but also of directing him to the choice of fit actions afterwards. This capability of pleasure and pain is evinced in so many actions of the horse as not to require demonstration.

We have now sketched the great outlines of the horse's mental constitution. We shall next consider the Organs of Sense by which the animal ranks so high in the scale of organized creation.

\section{THE ORGANS OF SENSE.}

The mind, as we have said in the general sketch, having charge of the frame, and being in constant correspondence with material objects around, organs are requisite to receive and transmit to the mind, for its information, the different impressions which these objects may make. Ac. cordingly, we find that the eye is impressed by light; the ear by sound; that the nose is adapted to smell; the mouth to taste ; and the skin (already treated of) to feeling.

\section{THE EYE, AND VISION.}

The horse has a very extensive field of vision. His eye is lodged for its security in the orbit, formed partly by the bones of the skull, and in part by those of the face, as in the human subject; but it differs from the eye of the latter in some particulars. The horse, for instance, is without eyebrows, and the upper eye-lid alone is furnished with eyelashes, excepting a few straggling hairs, which grow from the lower lid. There is also a seventh muscle for drawing the horse's eye inwards from injury, which is not to be found in man; while the more effectually to protect this tender organ in the animal, there is a cartilaginous substance, called by farriers the haw, by anatomists membrana nictitans (winking membrane), which, when forced out of the orbit where it is lodged, by the action of the retractor muscles drawing the eye farther into the socket, covers a great portion of the anterior part of the horse's eye. This provision against injury, which is unnecessary in man, who is furnished with hands, is very complete in birds : the haw in these creatures covering the whole fore part of the eye, and serving as an eye-lid during their sleep. In other respects the horse's eye does not differ materially from that of man, except that the transparent fore part of the former is considerably more extensive than in the latter, and consequently the horse possesses a greater range of vision.

At the back part of the eye there is a large quantity of fat, for protecting that delicate organ from the inequalities of the orbit, and also, by keeping it smooth and moist, to prevent friction in its different motions. Besides the protection it receives anteriorly from the eye-lids and haw, this part is washed by the fluid called tears, which is secreted from a small gland situated near the outer angle of the lids, and being spread by the action of the eye-lids over the whole anterior surface of the eye, not only keeps it moist and transparent, but also serves to remove dust and other injurious substances. The tears, having rendered these services to the eye, pass off by two openings at the inner angle of the eyelids, and are thence conveyed into the nose by a canal, the termination of which may be seen in each nostril. This canal, though not large, is capable of having fluids injected through it to the eye, or from the eye into the nose. But care should be taken that the fluids so injected are of a mild nature, otherwise the membrane lining the canal is in danger of becoming inflamed; in which case, the passage of the tears being obstructed, they will be forced to flow over the face.

Another fluid, of a mucous quality, is secreted from the surface of the membrane lining the eye-lids, for the defence of the eyes against the irritating saltness of the tears. This membrane, called conjunctiva, not only lines the inside $c$ f 

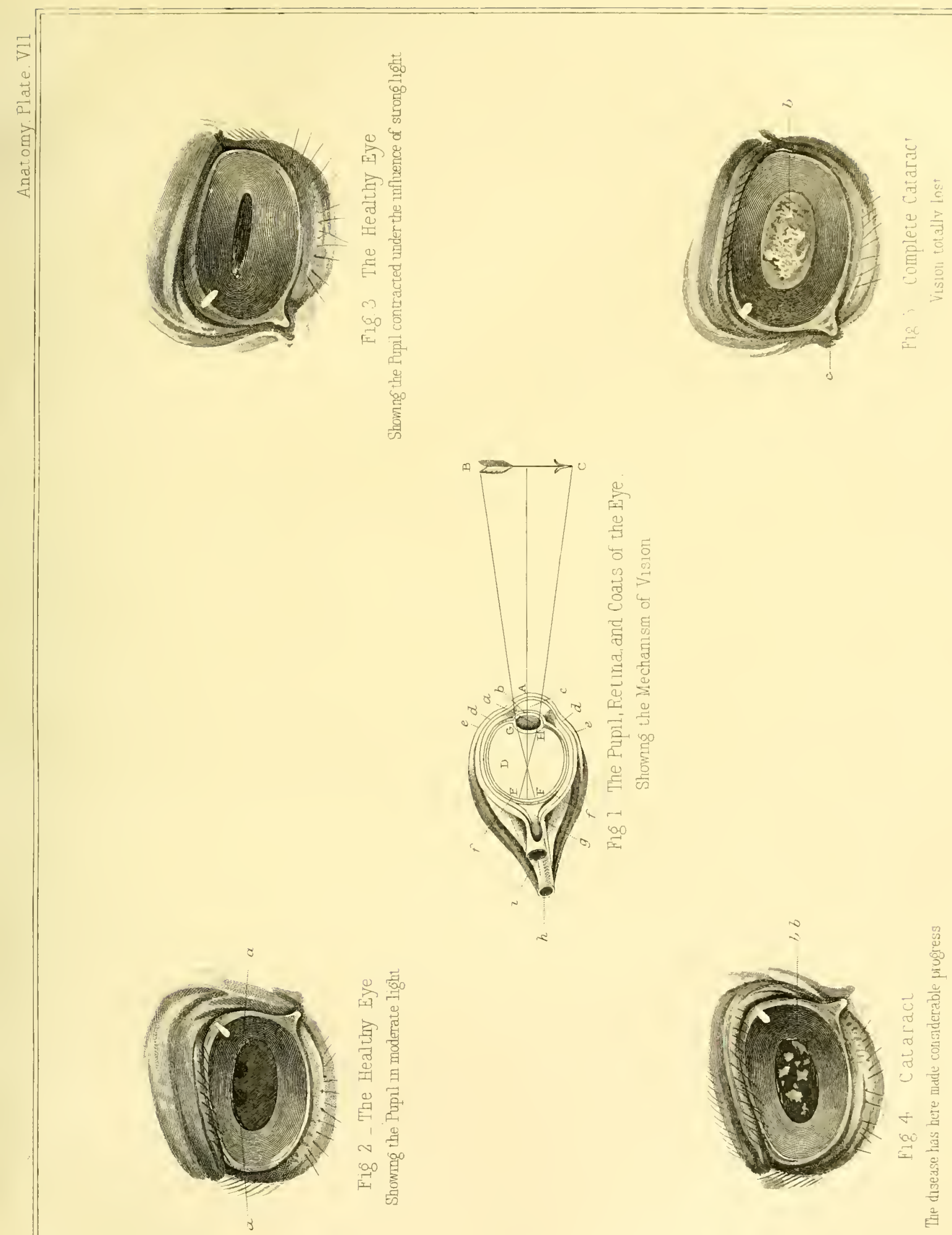

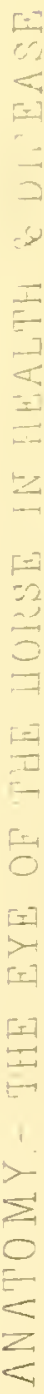



both eye-lids, but is reflected over the whole fore-part of the the eye, and consequently serves to keep the eye in its proper situation, and prevents all extraneous bodies from insinuating themselves behind it. It varies in its structure according to the nature of the parts it covers: the portion spread on the anterior part of the eye is transparent and but little vascular, while that lining the lids is full of vessels, as may be seen in inflammation of the eye. We shall now pass to the eye-ball, or that part of the eye which is directly engaged in vision.

The muscles of the globe of the eye are seven; four termed recti or straight, two others are the obliquus major and minor, and the seventh the retractor oculi. That they may act with promptitude, six nerves are directed to the eye or to particular muscles. The four straight inuscles which rise from the back of the orbit are inserted into the ball of the eye, immediately opposite, and at equal distances from each other. One of these rises to the upper part of the eye, immediately behind the transparent and visible portion of it, the office of which is to raise the eye. When it contracts, the eye must necessarily be drawn upwards. Another is inserted immediately opposite, at the bottom of the eye, for the purpose of depressing the eye, or enabling the horse to look downwards. A third is inserted at the outer corner, which turns the eye outward; and a fourth is inserted at the inner corner for turning the eye inwards. By means of these, the eye can be turned in any direction at the will of the animal. Should the animal wish to look upward and outward, then the outer and upper muscles are called into action, and can be modified in any manner at the will of the horse. These muscles perform another duty, namely, keeping the eye in its place, for while grazing the principal weight of the eye rests upon them; and to aid them in this, the seventh muscle, called the retractor, is added. This arises from the edge of the foramen through which the optic nerve enters the orbit. The use of this muscle is to support the eye generally, or when it is suddenly called into great action, and, aided by the straight muscles, it draws the eye back out of the reach of danger, and in the act of drawing it back it forces the haw to protrude as an additional defence.

These muscles perform another important office in altering the focus of the eye to accommodate itself to the examination of distant or near objects. The straight and retractor muscles draw back the eye, and force it upon the fatty substance, and thus in a slight degree flatten it, bring it nearer the retina or mirror, and adapt the eye to the observation of distant objects.

But as these muscles are chiefly employed in supporting the weight of the eye, they might not lave power to turn it so quickly and to such an extent as the animal might wish or require; therefore the eye is furnished with two other muscles, whose entire office is to turn it. These are the oblique muscles already mentioned. The upper one is curiously constructed. It emanates from the back part of the orbit, and follows a direction upwards, and towards the inner side, and there, immediately under the ridge of the orbit, it passes through a perfect mechanical pulley, called trochlea (Gr. a pulley), and, turning round, takes a direction across the eye, and is inserted a little beyond the middle of the eye, and towards the outer side. Thus the globe of the eye is directed inward and upward. This is not all that is accomplished by this remarkable mechanism. That the eye may be completely defended, it is sunk deep in the orbit; but it may be occasionally requisite to bring the eye forward, and enlarge the field of vision. Undor the influence of fear, the eye is positively protruded, and it is not only forced more forward, but the lids are opened more widely. It may be asked, how is it accomplished? The pulley-muscle, or trochlea, readily effects this, while as the straight muscles at the same time do not oppose it, or only regulate the direction of the eye, it is really brought forward. The lower oblique muscle has its insertion just within the lachrymal bone, and, proceeding across the eye, is fixed into part of the sclerotica opposite to the other oblique muscle; thus turning the eye in an opposite direction, and also assisting the upper oblique muscle in bringing the eye forward from its socket. The mechanism of the eye will be understood from an examination of the figures and reference to Plate VII., Fig. 1, Anatomy.

The globe of the eye is of a roundish shape, and may be divided, for sake of description, into two parts; the transparent and the opaque. The former constitutes the whole anterior portion, which is pellucid, for transmitting the rays of light, and is very extensive in the horse. The latter comprises what is termed the white of the ere; it commences at the circular edge, or termination of the transparent part, and, running backwards, covers the entire hinder portion of the eye-ball. The opaque part serves principally to enclose and defend the transparent and more delicate parts of the eye, and to limit the transmission of light. It is composed of the following parts; viz., the external, white, dense coat, covering the whole posterior part of the eye; this, from its hardness, is named the sclerotica: it is but little vascular, and is seldom diseased.

On the internal surface of the sclerotica is spread the second coat of the eye. It is a delicate, soft membrane, and is well adapted for the expansion upon it of the optic nerve. This coat, called choroid, is also opaque, and differs in appearance in various creatures, being black in some, white in others, and variegated in several animals. This difference of colour depends on the pigment lining the surface of the choroid coat; and to this is to be ascribed the peculiar colour of the pupil of the eye in different creatures. In animals with white furs, as white rabbits, \&c., the choroid coat being white, the eyes appear of a red colour. This, also, is the case even in the human subject, with persons having very white hair and eye-lashes; the pigment covering their choroid coat being generally fair, the pupils of their eyes also have a reddisb hue. But the 
pigment of the human eye being in general black, the pupil, in most persons, also appears black, or nearly so. The use of the black pigment, besides producing the various and beautiful shades, from the soft light blue to the deep sparkling black, which we see in the human eye, is to absorb and render useless the superfiuous and superabundant rays of light transmitted to the bottom of the eye; which, if not thus absorbed and rendered harmless, might irritate and injure the retina, or optic nerve, or otherwise confuse vision. Hence we may know the reason why dark-coloured eyes are generally stronger and better enabled to endure much light than are the liglit-coloured; for the black pigment on these being less in quantity than it is on the former, the light eyes have not an equal power of absorbing and moderating the rays of light as the dark-coloured ones, but, receiving them with comparatively little diminution, their force is too great for the retina to tolerate. Hence it becomes irritated, and the animal is forced to close, or nearly so, the lids, to exclude the stimulus of the light, either in whole or in part. In the horse this is partly compensated by the change of shape in the pupil. (See Plate VII., Figs. 2 and 3.)

The pigment on the choroid coat of the horse's eye is black at its lower part, but of a light green superiorly; and from the combined effect of these two colours arises the greyish appearance of his pupils. The choroid coat, after lining, as we have said, the whole posterior surface of the eye, extends towards the anterior part of this organ. Here its edges are thrown into folds for the purpose of occupying less space; and, inclining inwards to wards the crystalline lens, these folds, now called ciliary processes, attach themselves all round its circumference. These also are lined with black pigment, and serve to confine the passage of the rays of light to the lens. But what principally directs and limits the rays of light passing into the eye, is that circular curtain in the transparent part of this organ, which we see extending from the white part all round to the opening in the centre called the pupil: this is the passage throngh which the rays of light are transmitted to the nerve at the bottom of the eye This curtain is termed iris, and has a muscular power, as may be seen in the enlargement and diminntion of the pupil, or central opening of the eye, but which in reality is occasioned by the spreading towards the centre, or the receding from it, of the iris. The pupil being simply the opening formed at this part by the central edge of the iris. In a strong light, or when we want to view some very minute or near object, the iris contracts the pupil, by which the rays of light passing into the eye are greatly limited. On the other hand, the pupil is seen to be widely dilated when there is but a faint light, or when the object to be viewed is at a great distance. The iris, like the choroid coat, ores its colour to that of the pigment with which it is lined. Yn the horse it is generally of a cinnamon colour, which appears to be least liable to disease; but sometimes the iris is white, which is the cause of what are called wall-eyes in horses.
The pupil of the eye differs in shape in many creatures: in man it is circular; in the horse, horizontally oblong; and in cats, perpendicularly oblong. Hence the sphere of vision is different in the eye of each, owing to the capacity of its pupil. Thus the human eye, having a circular pupil, sees equally well at all sides, while that of the horse has a wider ranger of vision at each side, and the cat's from above downwards.

The optic nerve descending from the brain, passes through an opening in the bony orbit, and enters the back part of the globe of the eye in a trunk tolerably large; and having penetrated the sclerotic and choroid coats, already described, it then expands upon the latter into a delicate and partly transparent membrane, for receiving the rays of light transmitted to it by the transparent parts of the eye. It is now termed retina, and constitutes the third coat of the eye; on it are painted the various objects we behold, and it is the seat of the sensation of light.

We now come to the transparent parts of the eye, which constitute a most important portion of this organ. They consist of pellucid membranes and humours arranged in the following manner:-

First, the transparent cornea completes the globe of the eje at the fore-part, its circular edge running all round to be attached to the sclerotic opaque coat, just as the glass of a watch is joined to the case beneath. This membrane is of a hard texture, and serves to confine the fluids of the eye, and also, by its convexity, to refract the rays of light passing into the eye.

Immediately behind the cornea, lies the aqueous humour; it is a clear, thin, watery fluid, as may be seen on cutting the cornea, when this fluid will escape. This aqueous humour occupies the space between the cornea and the crystalline lens, and is partly divided into two portions by the iris, which floats like a circular curtain in this humour. The use of the aqueous fluid is, frst, to support the convexity of the lucid cornea; and, secondly, to assist the latter in effecting refraction.

The crystalline lens is the next humour to be described. It is partly of a globular form, transparent, and tolerably hard in consistence, particularly towards the centre. It lies immediately behind the aqueous fluid, and has the vitreous humour (to be presently described) between it, posteriorly, and the retina, or optic nerve.

The lens is retained in its situation partly by these humours, and, in part, by the ciliary processes; which, as before mentioned, attach themselves all round to its anterior surface, for the purpose of confining the passage of the rays of light to the lens. The function of the lens is similar to that of the other transparent parts: but, owing to its greater convexity and density, it accomplishes refraction in a much greater degree than they do.

Between the lens and the retina is situated the remaining humour of the eye. It is called the vitreous humour, from its resemblance to fused glass, and is a little hollow on its anto 
rior surface, for lodging the back-part of the lens. This humour consists of a fine pellucid fluid, contained in a clear cellular membrane, as may be seen by cutting the membrane, when the fluid will escape drop by drop. The use of the vitreous humour is to complete the refraction of the rays of light just before they fall on the retina behind it.

OF VIsion.-The eye effects vision through the means of light; for the rays passing from the objects we see to this organ, enter its transparent part, and are transmitted backwards to the retina, or expanded nerve, at the bottom of the eye. Here the rays impress the nerve producing the sensation of light, and also of the figure, colour, and motion of the objects viewed; and these sensations being propagated onwards by the nerve to the mind in the brain, there produce ideas or images of the visible properties of the things so creating impression; thus the operation and intention of vision are completed. The eye, then, is an apparatus for receiving the images of visible things, in the manner of a mirror, and for transmitting them to the mind for its information. The latter operation is effected, as we have said, by the nerve passing from the back part of the eye to the brain; and the former one is accomplished by the sensible or susceptible power of the retina, or expanded nerve at the bottom of the eye, which enables it to receive the images of objects as they are conveyed to the retina by the rays of light passing to it from these objects through the transparent parts of the eye. Now, as the retina, the seat of impression, and deiineation of objects, is extremely small-not being larger in man than the section of a hollow globe of an inch in diameter, and being not greatly increased in the horse, in comparison to the vast range of vision of which the eye is capable-it follows that there was a necessity of making a provision in the eye for reducing that great range into a miniature size, otherwise the whole of it could not be painted, as we perceive it is, on the limited retina. For this purpose, then, are the transparent parts of the eye principally given; their great use being to refract and converge the rays of light passing from any object, so that the image of the object may be conveyed to the seat of impression in such a diminished form as is fitted to the size of the part. This conveyance, and consequent diminution of the figures of objects, they effect by their convexity and density ; it being a law in optics, that these properties produce refraction in proportion to the degree in which these qualities exist. Thus, the rays of light coming from some object of magnitude, as a house or tree, at no great distance, strike first upon the transparent cornca; penetrating this membrane, they pass on, converged in proportion to the density and convexity of the membrane, to the aqueous humour; here, in their transmission, they become further converged; lastly, entering the crystalline lens and vitreous humour their convergence is completed, and the distinct figure of the object, in miniature, falls on the expanded nerve, and produces that impression we call vision. We shall suppose the animal looking at an arrow with the barb downwards, B c., Plate VII. Fig. 1. From every part of the arrow, rays of light will be sent forth in straight lines; and, in passing through the pupil, it is clear that those which flow from the under portion of the object, $c$, must flow upwards, while those from above, B, must pass down. wards; and pursuing this principle, all the intermediate rays, $d e f$, will intervene, consequently a reversed picture of the object will be formed upon the retina at $\mathbf{E} \mathbf{F}$.

Paley makes the following observation on this subject: he says, "In considering vision as achieved by means of an image formed at the bottom of the eye, we can never reflect without wonder on the smallness yet correctness of the picture, the subtlety of the touch, and the fineness of the lines. A landscape of five or six square leagues is brought into a space of half-an-inch in diameter; yet the magnitude of objects which it contains are all preserved, are all discriminated in their magnitudes, positions, figures, and colours. A coach passing at its ordinary speed for several minutes, passes in the eye only over one twelfth of an inch, yet is the change of place in the image distinctly perceived throughout its whole progress."

\section{TIIE NOSE, ITS MEMBRANES AND SINOSES.}

The sense of smell in animals is of the highest importance. It is with them one of the leading means of distin. guishing objects. In the horse, the nose and its apparatus are extensive and beautifully contrived. The nose extends from the forehead down to the lower extremities of the nostrils, where it has two large communications with the air; its breadth, too, is that of the whole face. Besides the nostrils, communicating with the outer air, there is an interior opening to the fauces (Lat., pl. of faux, a mouth). The openings of the nostrils end with the nasal and intermaxillary bones. Just over the arch of the palate, the nose communicates with the frontal sinuses by a sort of valve or Hlap, which, however, cannot to any great extent admit air into the sinuses. The nose is divided down the middle by the cartilage called the septum narium (Lat., septo, to separate), or division of the nostrils. The septum rests in a bone called the vomer (Latin for ploughshare), which is grooved to receive it.

The frontal sinuses are passages between the two tables of the frontal bones. There is also a bony partition which divides them into two equal portions. These sinuses communicate also with the nasal and the maxillary cavities. This conformation greatly increases the loudness and resonance of neighing. There are also important communications from the eye, called the puncta lachrymalia (Lat., tear-piercings); these open into the canal within the lachrymal bone, called the nasal duct (Lat., ductus ad nasum); this is continued between the turbinated bones, and ends by an opening inside the nostril, easily perceivabl. This duct, which carries off the superfluous saline fluid secreted by the lachrymal glands, is lined with the pituitary membrane, and therefore often clogged up in glanders. (See Glanders, post.) 
The pituitary membrane, which is the highly sensitive and delicate lining of the whole nasal passages throughout all their divisions, is the grand medium for the expansion of the olfactory or first pair of nerves, and with these forms the organ of smell. The pituitary membrane is part of the great mucous lining which begins at the eyes, nose, and mouth, pervades the stomach and intestines, and ends at the anus. It is furnished with a mucus, secreted over its whole surface, by which it is constantly kept moist, pliant, and susceptible. By this means insects are prevented from penetrating into the lungs. The design of this expansion of the olfactory nerves is to supply the place of touch, and what is acquired by experience by man. It is by this exquisite sense of smell that the horse selects such food as is best calculated for his nutriment, and is enabled to reject what is poisonous. By smell he judges of the quality of his food in a domestic state, and examines a stranger. The horse will recognise his master or favourite groom by the sense of smell, and frequently expresses such recognition by a neigh. These cavities are also the organs of voice; the sound reverberates through them, and increases in loudness as through the windings of a French horn. All the air which passes to and returns from the lungs must go through the nostrils, as he can breathe through the nose only. The nostrils ought therefore to be large and expanded. The skin also which covers them should be thin and elastic, that they may the more readily yield when the animal requires a greater supply of air while trotting hard or galloping. In the race-horse the nostrils are wide and flexible, while in the cart-horse they are confined, and surrounded by a quantity of cellular substance and thick skin.

The common skin covers the nose and upper lip, but without its usual accompaniment, the adipose (fatty) membrane. It has also some fine hair fringing the edges of the nostrils. The integument is turned in for a little distance up the nostril, being easily distinguished by its colour from the delicate mucous membrane. The wellknown pouch called the false nostril, outside each nasal opening, is made by a doubling-in of the integument. The purpose of these false nostrils is to allow the true nostrils to enlarge without distorting the face. The openings of the nostrils are guarded on each side by cartilages, and these are acted upon by the muscles of the nose and lips.

There are four distinct cartilages attached to the nostrils, which are exceedingly elastic, and bring them back to their ordinary dimensions whenever the muscles cease to act. The bones, also, of the nose are tapered off to a point, to give a wider range for the action of the muscles; while the cartilages are so constructed as not only to discharge the office above referred to but also to prevent this tapering point of bone from injury.

Blaine thus summarizes the physiology of the nasal organs:-"Comparative anatomy shows that the sense of smell is in most animals placed at the entrance of the respiratory organs; by which they are made subservient to both purposes of breathing and smelling; and by the same means are rendered as well voluntary as involuntary agents; for the action of respiration will carry all the effluvia from bodies, whether sought for or not, against the sensitive pituitary membrane. The herbivorous tribes smell vegetable matters, and have an abhorrence of all fleshy odours. In all the vertebrated animals, the parts connected with the organ of smell are, like the parts composing the other organs of sense, double. The cognizance taken of the volatile portions of bodies continually flying off from them, and impressed on the sensitive surface of the internal nostrils, is transmitted by the nervous expansion of the olfactory nerves to the brain; where it produces the sensation we understand by the name of smell."

\section{THE EAR AND ITS CONSTRUCTION.}

The ear consists of an inner and an outer part, called the external and internal ear The form of the outer ear, which shall be first considered, is admirably adapted to the habits of the animal; it consists of that part which is visible, from its root at the temporal bone to the point. It is formed by a flexible yet firm cartilage of an oval shape, hollow, and terminating in a point. It is varied in its motions; and as the horse is generally seen with the conch, or shell, of one ear directed forward and the other backward, there seems good reason to conclude that the sense of hearing is the only double sense that is equally true when one side only is brought into use.* The hair within the shell of the ear is long and fine, guarding it from the entrance of insects, dust, or foreign objects floating in the air. The clipping of this hair is a silly and dangerous practice. There is a peculiar gland inside each ear, which secretes a scaly whitish and greasy substance.

The cartilages of the ear are three. The concha, or shell, is the conical body which gives it form; it is covered by the skin, and clothed with muscles. This cartilage is attached to the skull-bone (cranium), through the second, the annular (ring-shaped) cartilage, a small movable body. The third is the angular cartilage placed upon the forehead, and which moves with the other cartilages by means of the muscles of the ear.

The muscles of the ear are twelve in number. They raise, depress, and partly rotate the ears. A specific description of the office of each would be tedious and useless, save in the dissecting theatre.

The meatus auditorius (Lat. meo, to flow, to run), is partly bony, partly cartilaginous. It is lined with fine

* Dr. Arnott, in his Elements of Physics, says :- "When horses or mules march in company at night, those in front direct their ears forwards; those in the rear direct them backward; and those in the centre turn them laterally or across. The whole troop seeming thus to be actuated by one feeling, which watches over the general safety." (vol. i. p. 478.) 


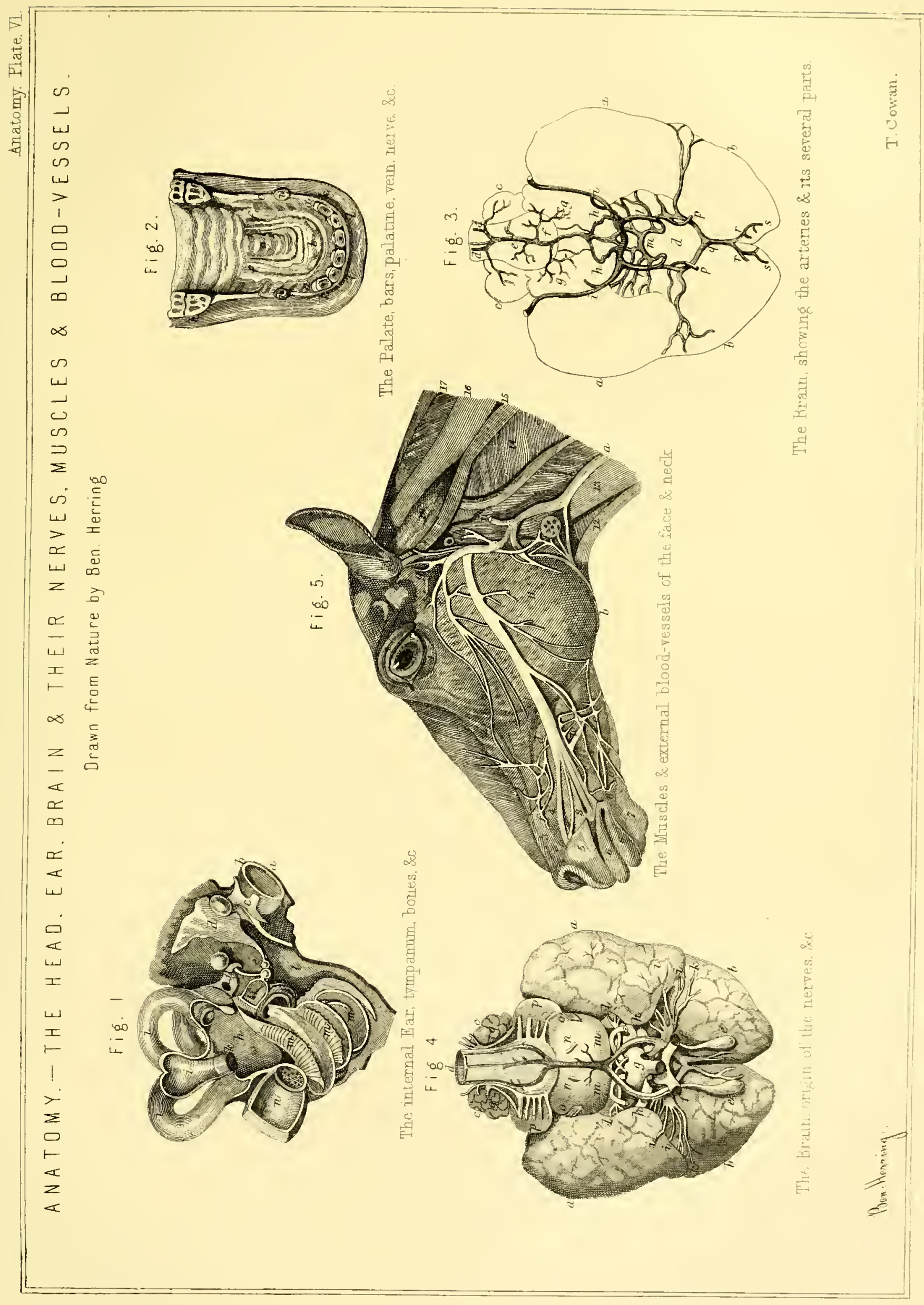



attenuated skin, which is stretched across its base, and has several follicles (Lat., folliculus, a little bag), to secrete the ear-wax.

The membrana tympani is a delicate membrane covering the cavity called the drum (Lat., tympanum) of the ear, over which it is expanded, and separates the outer from the inner ear. The tympanum, which is roundish in form, is therefore the first cavity of the internal ear.

The mechanism of the internal ear is so beautiful an example of creative design, that a brief description is demanded; the various parts here mentioned are figured and referred to in Plate VI., Fig. 1, and its accompanying description.

The cavity of the tympanum contains four small bones, united to the membrane and to each other. These are called malleus (the hammer), incus (the anvil), stapes (the stirrup), and orbicularis (globe-like), from supposed resemblances to those objects. All these bones are moved by muscles, which it is here superfluous to describe. The internal ear presents several openings. The mastoid cells are small cavities in the substance of the mastoid (Gr., mastos, the nipple, oidos, like-nipple-shaped), processes of the hard temple bone. They are lined by a fine membrane, communicate with each other, and have a common opening near to the entrance to the Eustachian canal.

The fenestra ovalis (Lat., oval window), is an opening between the tympanum and the vestibule (Lat., a porch), a cavity just beyond that of the tympanum. Below this is the fenestra rotunda (Lat., round window). The semicircular canals are three bony passages leading into the vestibule; and lastly, the cochlea (Lat., cochlea, a spoon), a spiral canal inside the opening of the vestibule into the tympanum.

The Eustachian tube (from Eustachius its discoverer), opens at the upper and front edge of the hollow of the tympanum by a small slit in the bony wall, and passes thence through the petrous part of the temporal bone, part of the sphenoid, when it becomes cartilaginous, and expands into the guttural pouch. The guttural pouches are large and empty bags in the horse, connected only by transparent cellular tissue, and each closed by a valvular opening which separates it from the nose. The nerves of the inner and outer ear are furnished by the soft portion of the seventh pair. The blood is supplied by the carotid arteries, and returned by the jugular veins.

The sense of hearing is thus excited :-The collision of bodies produces the phenomena called sounds, and these are a series of waves or tremblings communicated to the surrounding medium,-air, water, \&c.,-until they reach the external ear, which, in the horse, is remarkably adapted for catching these sonorous waves.

The sound collected by the concha, outer ear, passes through the lower or annular (ring-shaped) cartilage, and through irregularities, which, while they break and modify it, carry it on to another canal, partly cartilaginous and C C partly bony, conducting immediately to the internal mechanism of the ear. This canal (the external auditory passage) has at its base, stretching across it and closing it, the membrane called the drum, or tympanum. The vibrations now reach the four little bones already described. In Mr. Youatt's popular volume, "The Horse" (pp. 68-72), published by the Society for the Diffusion of Useful Knowledge, is an amusing and fanciful account, borrowed from human surgery, of the functions of these bones. These speculations are purely conjectural as regards the horse, and may, therefore, be passed over. What follows is more to our present purpose.

The impression, then, has been conveyed, by the medium of the bones, from the membrane of the drum to the membrane on which the stirrup rests, anu which closes the fenestra ovalis, opening into the labyrinth of the ear.

Passing the fenestra ovalis, we arrive at the seat of hear. ing. A very irregular cavity presents itself, filled with an aqueous fluid, while the substance or pulp of the soft portion of the seventh pair of nerves (the auditory nerve) expands on the membrane which lines the walls of this cavity. These interior chambers are filled witl water instead of air, because it is not one-hundredth part so expansible, and, moreover, its powers of conducting sound are so much greater, that while sound passes through air at the rate of 1,132 feet in a second, it passes through water 4,000 teet in the same time. Sound, too, is propagated more intensely through water than through air.

The fenestra ovalis opens into the labyrinth, which is divided into three compartments. First is the vestibule; on the upper side are several foramina, or holes, which conduct to the semicircular canals, also containing fluid. The hinder one is a perfectly semicircular canal, with two openings into the vestibule. The other two run into each other in a part of their course, and have one common opening, and one peculiar to each; so that these canals open into the vestibule by five apertures.

On the other side is another complex mechanism, of which the use is not known. It is the cochlea, a spiral lamina, which at the top approaches the Eustachian tube.

The cribriform plate extends beyond the base of the cochlea to the vestibule, and those portions of nerve there enter which spread over the vestibule and the semicircular canals; but the principal part of it seems to be given to the cochlea. What is the distinct and peculiar office of these parts, so curiously and yet so differently constructed, we know not. In the horse the cochlea is much larger, compared with the canals, than it is in the ox or sheep; but for what especial purpose we are unable to determint. Nor can we account for the large pouch-shaped opening of the Eustachian tube in the horse, nor for the sinall development of the mastoid cells in the horse, while they are exceedingly large in the ox. There are many parts of the frame, the precise use or function of which we cannot ascertain; but, as far as we do understand the mechanism of the tarious 
animals which pass under our notice, all is admirable in adaptation to its purpose.

\section{THE TONGUE AND ITS ORGANIZATION.-TASTE. -THE PALATE.}

The Tovare is the large fleshy body for the reception of which the cavity of the mouth seems to have been specially formed. It is composed of a bundle of small muscles, which unite to form its body, mixed with glandular substance and fatty matter. It is covered by the mucous membrane called the buccal (Lat., bucca, mouth), which also covers the gums and the palate. The top of the tongue has papillæ* of considerable size at the sides; towards the tip ther are smaller. The tongue is free from the lower part of the mouth for a short distance from its lower end ; thence it is fastened to the bottom of the mouth by a fold of the lining membrane called the frcenum (Lat. for bridle). At its base the tongue is fixed to the os hyoides (see ante, BoNES AND Muscles), and to this most of its muscles are attached.

The tongue is a double organ; that is, all its muscles are in pairs. The fibres too, if traced, will be found to cross each other net-fashion; that is, those of the right side end upon the left side of the tongue, and vice versâ. These muscles consist of five pairs and a small single one. $\dagger$

The nerves are the lingual, or mouth pair, which effect its motions; the gustatory (tasting), a branch of the fifth pair; and the glosso-pharyngeus (Gr., tongue-throat) nerve, of which the glossal branch only goes to the tongue, and is supposed also to confer a peculiar delicacy of sympathetic sensation to the organ.

The arteries of the tongue are derived from the branch of the carotids beneath the jaw-bone, and the blood returned into the jugular (throat) veins.

The protrusion of the tongue is an action somewhat difficult to explain clearly. If we give to the muscles of the tongue the single property ascribed to them by anatomists, that of contraction, we shall be at a loss to account for a body wholly of muscle being elongated and propelled out of the mouth, and, moreover, at the same time, moved in almost every direction according to the will. The glandular and the fatty matter interposed may account for some of this peculiar action, by their hardness, and partial resistance, acting in some measure like bone; but the question is too purely scientific to deserve space for its discussion in a work like the present.

The tongue is of great assistance to animals, in place of hands. It is not only engaged in the process of taking the

* From the Iat. papus (nipple of the breast). The papillw are terminations of nerves. These minute projecting filaments are said each, with much probability, to contain a separate branch of the nerves of touch.

$\dagger$ These are called Hyoglossus brevis (a pair), Hyoglossus longus (a pair), Accessories (two pairs), Genio hyoglossus (a pair), and the lingralis (single). These all attach in different ways to the os hyoides. food into their mouths, but in its preparation by mastication, by disposing it under the grinders, again collecting it, and conveying it to the back of the mouth to be swallowed. Its use in discriminating flavours we shall immediately notice.

The TASTE is originated or resides in the nervous papillæ of the tongue; and the importance of these organs to quadrupeds is evinced by their great number and length. By it, "what to eat, drink, and avoid," is a question of almost infallible solution; deleterious or poisonous food being immediately rejected, unless disguised so as to prove the rule by the exception. Taste would appear to be absent when the mouth and the food are completely dry: but in this case the saliva at once comes to the rescue. Liquids are therefore much more quickly and discriminately tasted than solids; the latter requiring mixture with the saliva, and mastication, for their due appreciation. The tongue in the horse, as in most vertebrated animals, is endued with high sensibility in this respect; but its discrimination is heightened by the co-operation of the sympathetic nerres of smelling. Who that has ever seen the loathing with which a horse turns from a greasy bucket, before he has even touched the water it contains, but must own the intimate connection of these senses?

Closely connected, too, with this organization, is the action of the salivary glands. These are three in number on each side. The first and largest pair are called the parotid glands. $\ddagger$ (See Plate VI.) These are situate on each side, in the hollow formed by the articulation of the head and neck, extending from the root of the ear to the angle of the lower jaw. It is formed of lobes (Gr., lobos, a rounded body), connected by cellular membrane. From each lobe issues a vast number of small ducts, which finally unite in a tube which empties the saliva into the mouth. This tube, called the parotid duct, on leaving the gland, passes along the inner side of the jawbone; then, in company with the submaxillary artery, crosses below the bone, and then enters the mouth near the third grinding tooth. These ducts will discharge a pint and a half to a quart of fluid per bour in the mastication of moderately dry food.

The next pair of salivary glands is called the submaxillary. They are much less in volume than the parotids, and are embedded in the channel between the sides of the lower jaw. They are also composed of a number of kernels, each having its proper duct, which unite in one trunk, and penetrate the buccal muscle, and open in and upon the froenum or bridle of the tongue, about a couple of inches from the front teeth. The terminations of these ducts are marked by small bulbs or projections, which, after the disease known as Stranales, by ignorant farriers are called VIVEs, and made the subject of barbarous treatment. BARBS or PAPS, in inflammation of the mouth, often sequent on catarrh, are also seated in these projections, and brutal torture is inflicted on the animal with knife and cautery by the farrier.

I Gr. from para, near, ous, otis, the ear. 
The sublingual glands are the third source of saliva. They are yet smaller than the submaxillary, but more numerous. They open by numerous little ducts, which may be seen on each side of the mouth. The openings resemble little folds of the skin of the mouth and underside of the tongue. When inflamed they have the appearance of small pimples, and receive a number of absurd names, as gigs, flaps, and bladders, and the farrier cuts them off or burns them down!

Besides these six great sources of supply, there are little glands scattered about the whole cavity of the mouth. These are the labial glands on the inner surface of the lips, the buccal glands on each side of the mouth, folliculose and mucous glands on the interior of the mouth, surface of the tongue, and soft palate. These all take part in or sympathise with the salivary secretion or its diseased retention.

The palate of the horse has two divisions, the hard and the soft.

The hard palate is full of vessels, and is formed of condensed cellular tissue. It lines the roof of the mouth, and is divided into ridges called bars. (See Anatomr, Plate V., Fig. 3, and Plate VI., fig. 2.) The use of these is the retaining of the food within the mouth in the act of mastication. For an account of the barbarity practised on this part, see Art. Lampas, post. Bleeding in the palatine vein for Staggers, \&c., will be noticed under the proper head.

The soft palate (velum or veil) falls down behind the tongue, where it divides the mouth from the fauces. It is an expanded uvula (diminution of Lat., uva, grape or berry) adhering to the arch of the palate bone, whese the hard palate terminates. Its lower loose edge rests upon the epiglottis (Gr., epi upon, glotta the tongue), at the opening of the larynz, called the glottis. Sloping in this direction, it is easily raised by any substance or fluid seeking to pass from the mouth, and is closed more firmly by anything coming in the opposite direction. Air itself has not body enough to raise the velum palati. The horse, except in coughing, therefore breathes through his nostrils. The soft palate has much glandular matter in its substance. It has one lifting muscle (levator palati) and two depressors. The lastnamed pair keep the soft palate in its place resting on the epiglottis. We shall have something more to say of this when we come to Swallowing (deglutition) and Respiration.

The fauces merely designate a part at which several structures join. Eight distinct parts open into the fauces, the two guttural pouches, two Eustachian tubes, the pharynx, the larynx, the nouth, and the nasal orifices, which have only one common opening - the nasal septum or division ending before reaching the fauces.

The gums are a compact, elastic substance, surrounding the neck of each tooth, and, adhering to its periosteum, support it firmly in all directions. The buccal membrane covers them and lines the mouth. The gums, in health, have little feeling; but when diseased they are intensely sensitive.

The lips of the horse are highly endowed with feeling. This may be seen by the combination of touch and smell when the horse is gathering his food. As he collects it, the delicate sensibility of the upper lip, aided by the olfactory nerves, enables the animal to reject all poisonous or unsavoury plants, and receive only the grateful and nutritive food. Grooms and farriers are well aware of this sensitiveness, and accordingly screw on the twitch here, to paralyse and dominate the animal.

The internal parts of the mouth are supplied with bluod by the inferior and superior maxillary arteries, after passing through the foramina in the upper and lower jaws. The facial artery and the lateral nasal also pour in blood. Motion is derived from the portiodura (facial) nerve, and the sense of touch from the supramaxillary branch of the fifth pair.

We here leave the cavity of the mouth. We shall consider the pharyno and osophagus with the stomach; the larynx and bronchioe with the lungs and respiration. 
CHAPTER XX.

THE ORGANS OF CIRCOLATION AND RESPIRATION.-VISCERA OF THE THORAX (CHEST), THEIR MUSCLES, MEMBRANE8, AND VISSELQ-

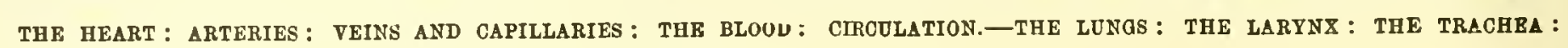

BRONCHIAL TUBES: RESPIRATION, CHEMICAL AND MEOHANIOAL.

THE ORGANS OF CIRCOLATION AND REBPIRATION.

THE second great cavity of the body, the thorax, or chest, contains the central organs of circulation and respiration. The first consists of the heart and the two great lobes of the lungs, with their appendages. When the chest is opened, a smooth bright membrane is perceived, lining its internal surface and covering its contents. Each side of the chest has its own pleura (Gr., pleura, the side), or lining membrane, and they double and join together in the middle of the chest into a strong septum (or division) called the mediastinum;* besides this rib-lining (called pleura costalis), and lunglining (called pleura pulmonaris), there is a third for the heart, of smaller size; they are all serous membranes, as such, secreting a fluid called serum, and preventing friction from the constant motion of the parts. The left pleura is smaller than the right, the right lung having an extra lobe, and therefore requiring a larger sac to hold it. The heart is farther continued in a bag called pericardium (Gr., peri, around, cardia, the heart), lined by the pleura just mentioned. This membrane usually contains about an ounce of pale yellow lubricating fluid. The use of the pericardium is to confine the heart in its situation, to sustain it in its reciprocal action with the lungs, to guard it from any undue collision, and to serve as a general protection to the heart. When the pericardium becomes inflamed, an undue secretion of this fuid is induced, sometimes to such an extent as to obstruct the action of the heart. (See Pericarditis, and Dropsy of THE HEART, post.)

The great muscles and membrane of respiration, the intercostals and the midriff or diaphragm (Gr., diaphragma, from diaphrasso, to separate by a partition), we shall speak of presently.

The Heart itself is a large hollow involuntary muscle of immense power : that is, its action is independent of the will of the animal, which is not the case with the organs of respiration, the action of which the animal can suspend for a short period, accelerate, or retard. There are four cavities in the heart (see ANatomy, Plate XII.), two below, called ventricles (diminutive of Lat., venter, a belly), and two

* Formed from the Latin, quasi in medio sicun, as standing in the middle. above, called auricles (little-ears, from Lat., auris, the ear). Each of these ventricles has two large openings, one into the auricle, or upper cavity, the other forming the mouth of a large artery. The cavities are separated by a muscular or fleshy partition called a septum. The right ventricle bas within it curious fleshy pillars, called by anatomists carnea columna, from which proceed tendinous cords (cortina tendinea), attached to three valves between the right auricle and ventricle, shutting them off from each other when closed. The left ventricle is longer than the right, but smaller in size, and has much thicker walls. The right auricle is irregularly round, and has two large openings for blood, each being the mouth of a vena cava. The left auricle is more muscular though smaller, and receives the pulmonary (lung) veins, five in number. It has also some fleshy and tendinous cords, or contractile braces. The valves, too, are strong membranous appendages, and there are also valves at the commencement of each artery, as well as between the auricles and ventricles. Those to the pulmonary artery are called the semilunar; that of the right auricle, the tricuspid (from having three flaps); that of the left, the mitral (from having two flaps). The use of these valves is to prevent the return of the blood ; for the aorta (Gr., aorta, coffer, ark) never being entirely empty when the ventricle dilates, the blood remaining in the artery would be sucked back but for this contrivance- the pressure closing the semilunar valves. The heart is furnished with blood for its own sustenance by the coronary arteries, it being returned by the coronary veins. Its nerves come from the eighth pair-the cardiac plexus, consisting principally of the par vagum and sympathetic nerves. (See Brain and Nerves, ante, p. 195.) Such is the main apparatus by which circulation is initiated and carried on, with the aid of arteries and veins.

The A RTERIEs † are elastic tubes originating from tue ventricles of the heart by two great trunks, the aorta and the pulmonic, the subdivisions of which supply the whole body with blood. They are mostly seated deep under muscle or bone, for their better security. Some arteries, however, as that of the lower jaw, run close to the surface; and it is from this circumstance, and the jawbone resisting the pressure

$\dagger$ Artery, from the Greek arteria, signifying an air-vessel. The ancients, ignorant of the circulation of the blood, finding the arteriea always empty after death, supposed they werc tubes containing air. 
of the finger, that the submaxillary artery is felt for the pulse of the horse. The outer coat is condensed cellular tissue, so elastic as to keep the artery cylindrical when empty. The middle coat is of a yellow elastic tissue, and the internal coat a serous tissue, like synovial membrane. By conveying the blood to the different parts of the body, the arteries keep up the vital principle, bearing nutriment and heat; and as the heart is the first propelling power, so the arteries, being distended by the column of blood, contract their muscular coats and drive the fluid continuously onward. The dilatation and contraction is called the pulse, and is perceptible in the larger branches, but not in the very small ones, except in cases of inflammation. It is noteworthy that the arteries of the horse have a much larger proportion of the elastic coat than those of man, and hence acute inflammations in the horse run their fatal course far more quickly.

The principal arteries of the horse are :-the aorta dividIng into posterior and anterior; the posterior aorta, which furnishes blood to all parts except the head and fore-limbs; the two iliac; the inguinal (groin); the renal (kidney); the mesenteric (intestinal); and the femoral (thigh) arteries.

The anterior aorta supplies the head and fore extremities. It is continued to the near third rib, when it divides into two branches called arteria innominatce (nameless arteries). The left branch supplies the dorsal to the back, and two vertebrals to the spine. The right branch of the aorta is much larger and longer than the left. After giving off several branches (see plate), it becomes the common carotid, which again divides into the right and left carotids, ${ }^{*}$ supplying the most important vital and sentient organs of the head and brain.

The axillary artery, as furnishing the fore extremities with blood, is next in importance. It gives branches to the humeral (shoulder), that again a branch to the brachial, and to the scapula and ribs; again behind the fore-leg to the seat of the "spur vein." A branch becomes the radial (spokebone, fore-arm) artery, which proceeds downwards, now reaching the flexor muscles; yet lower, it is the metacarpal (beyond the wrist) artery, and goes down under the nerve on the inner side of the leg; thence, at the lower part of the cannon-bone, it divides just above the fetlock into two plantar (Lat. for sole) arteries, on the sides of the pastern bone, and by the back of the foot, where each sends a branch into the fatty frog. The main trunks continue along the wings of the porous coffin-bone, bend downward, and, uniting, form the circumflex artery, which runs round the margin of the sole. The General Anatomy of the Foot will complete this subject. An examination of the anatomical plates will make the arteries and their courses more clear than any amount of verbal description.

* From the Greek carōo (to cause to sleep); because the ancients thought these vessels supplied the vayour or spirit which sent the brain to sleep.
We have said that the contraction and dilatation of arteries produces the pulse. The pulse of a middle-aged horse in health is from thirty-six to forty beats per minute; when slower it indicates debility, when accelerated, inflanmatory disorder. It is sixty in the colt at birth, but gradually de. creases till full growth. The smaller the horse, the more rapid the pulse, all other things being equal. The tho. rough-bred, from higher irritability, is quicker in the beat by five or six pulsations per minute than the heavy and coarse-bred animal. The pulse will receive due medical consideration when we come to treat of fever and inflam. mation. We may state that the arteries of the horse are seldom, if ever, found ossified, a circumstance of frequent occurrence in man.

The Veins and Capillaries. Veins are the general termination of arteries, their extremities commencing from them, after the manner of two trees joined by the extremities of their branches. They collect the remnants of the blood which the arteries had distributed over the body, and convey it back to the heart, to be prepared for taking a fresh round over the frame. The veins are furnished with valves on their internal surface, which are so constructed as to permit the blood to flow towards the heart, but to prevent its return. These valves are in great abundance, being found at the distance of only an inch, or even in less space, from each other; they are folds of the internal coat of the vein, and are generally to be met with three together, in the horse. Valves are not equally distributed throughout the veins of the horse. In some parts, where the blood has to travel upwards, against gravity, they are numerous; when it has to flow downwards, there are few or none. There are few in the viscera. In the jugular vein (Plate VI., Fig. 5) the valves are all placed opening towards the heart. Thus, when the horse is standing with his head elevated, the blood has only to fall through the vein, the valves being open, but when he has his head lowered, as in feeding, and the venous blood has to return uprards (or against gravity), the valves act and prevent its descending.

All the branches of the veins, returning from the different parts of the body, run into two great trunks, called cavas, which are inserted into the right auricle of the heart; the anterior cava conveys the blood returning from the head and anterior parts of the animal, whilst the posterior cava conveys that returning from all the hinder parts of the animal. Both empty their contents, as before observed, into the right auricle of the heart. Again, the blood distributed over the lungs, is also returned to the heart by eight pulmonary veins in the horse, but only by four in the human subject. These eight trunks are formed from the venous ramifications spread over the lungs, and empty themselves into the left auricle of the heart. The structure of the veins differs from that of the arteries, the former being much more thin in their sides, and having no pulsation; and hence the blood is 
forced through them principally by the impetus occasioned by the contraction of the heart and arteries, and which is communicated to it while passing through the veins. This, perhaps, is one reason why they are much more numerous in their branches than are the arteries, and also why they anastomose more frequently; for otherwise, the injuries these delicate vessels are liable to in their passage between the muscles must interrupt the circulation, and be productive of bad consequences. This provision for guarding the circulation of the blond against obstruction, by multiplying the venous communications, is particularly to be seen in the toot of the horse, where a most beautiful net-work is formed by innumerable branches of veins running into each other.

The Capillary Vessels (Lat., capilla, a hair) are so called from their minute fineness. Small as they are, they are indispensable to nutrition, calorification, secretion; indeed, every great function of the living body is performed mainly by these little channels. The great blood-vessels known as arteries pump the blood from the heart, and the veins return it exhausted. The arteries are arborescent, and increase in number and diminish in size as they become more distant from the circulatory centre; in like manner the veins branch out and anastomose. Now between these dwindling terminations of the arteries and the beginnings of the reins, comes the peculiar network of countless vessels called the Capillary System. Some of these are large enough to admit three or four red globules of blood, some only one, and most will pass nothing but the serum or fluid part. Minute research upon this subject would overload these pages; the functions and organization of the capillaries will be found in Schwann's Microscopical Observations of Animals, translated by $\mathrm{H}$. Smith, and Paget's Supplement to Huller's Physiology.

\section{OF THE BLOOL.}

Blood, in its primary or essential character, is alike in all animals. It is red in the higher orders, though its intensity of colour varies much under different circumstances. Venous blood is almost purple, and arterial of a bright red colour, for causes we shall note when we come to respiration. The temperature of the blood of the healthy horse is about $100^{\circ}\left(95.24^{\circ}\right.$ in Tiedemann's comparative tables), of man $98^{\circ}$, the ox $104^{\circ}$, the $\operatorname{dog} 101^{\circ}$, the cat and monkey $103^{\circ}$, pireon, hen, and duck $109^{\circ}$ to $111^{\circ}$. Arterial blood is one degree warmer than venous. In fever a rise of 3 to 7 degrees is not uncommon.

The specific gravity of blood varies, as well as its temperature. Water being taken as 1000 , blood may be estimated at 1050 specific gravity, and it has been found to bear the proportion of 1120 to 1000 . Venous blood is heavier than arterial

* Gr. ana (between), stoma (a mouth). The Latin worr. inosculata means the same thing, the opening of one vessel into anot'aer, as do the srteries, veins, and lymphatics (capillaries).
The quantity of blood in an animal, in proportion to its size, also varies. Very fat animals have less in proportion than lean ones; and it is said the domesticated horse has less than the wild animal of the Pampas. A middle-sized horse has had forty-four pounds taken from him.

The blood, while circulating in the body, is composed of two parts, a liquid and a solid. The one called by human anatomists blood-corpuscles, or globules. When blood is allowed to stand after being taken from the body, it separates into two distinct parts, one the solid portion, which contains the corpuscles and the fibrin or coagulable lymph, called the clot or crassamentum, the other the pale yellowish fluid called serum. The process of separation is termed coagulation. The proportion of red globules, fibrin, and serum, varies in different animals. The red particles seem connected with the strength and excitability of organs, as the parts sub. jected to the greatest exertions, - as muscles, - have most of them; colour being attended with development of flesh. Fibrin, however, appears the chief nutritive constituent of the vital fluid. If the serum and red globules are separated from it, a tough, white, fibrous mass remains. which in general character and chemical composition resembles muscular fibre deprived of its membranes and colouring matter. This forms the solids of the body, even to the callus of bones. It coagulates spontaneously, is dissolved in alkalies, but not in oils, spirits, or water. Spontaneous coagulation is much slower in the blood of the horse than in that of man; the human blood "sets" in seven or eight minutes in ordinary temperatures: that of the horse takes twenty-four hours to coagulate.

The fluid basis of the blood (8erum) serves to dilute it, and forms almost one-half of its bulk. It is slightly saline, and less putrefactive than the coagulum. It remains fluid in those degrees of heat between 30 and 160 degrees Fahren. heit: with a less heat it freezes; in a greater it partially coagulates. It appears chemically composed of albumen, gelatin, saline matter, and a considerable quantity of fluid, which drains from it, called the eerosity. Serum appears not only the fluid base of the blood, but it also dilutes all the secretions: when morbidly increased, it gives rise to dropsy. The blood, therefore, is viewed as a compounded fluid, made up of these several parts, and which, considered as an aggregate, is the most essential component of an animal. All parts of the body are formed of it; and all parts of the body can be resolved again into it, by means of the absorbents; hence we must conclude that there is a very intimate connection between the solids and the fluids.

The absorbents and excretories will come to be considered presently. The practice and indications of BLEEDINa will find their place under Inflammatory Disorders, and OperaTIONS.

Minute analyses of the blood of men and animals, and much curious information, may be found by those who would exhaust the subject, in Quain's A natomy (by Sharpey), 


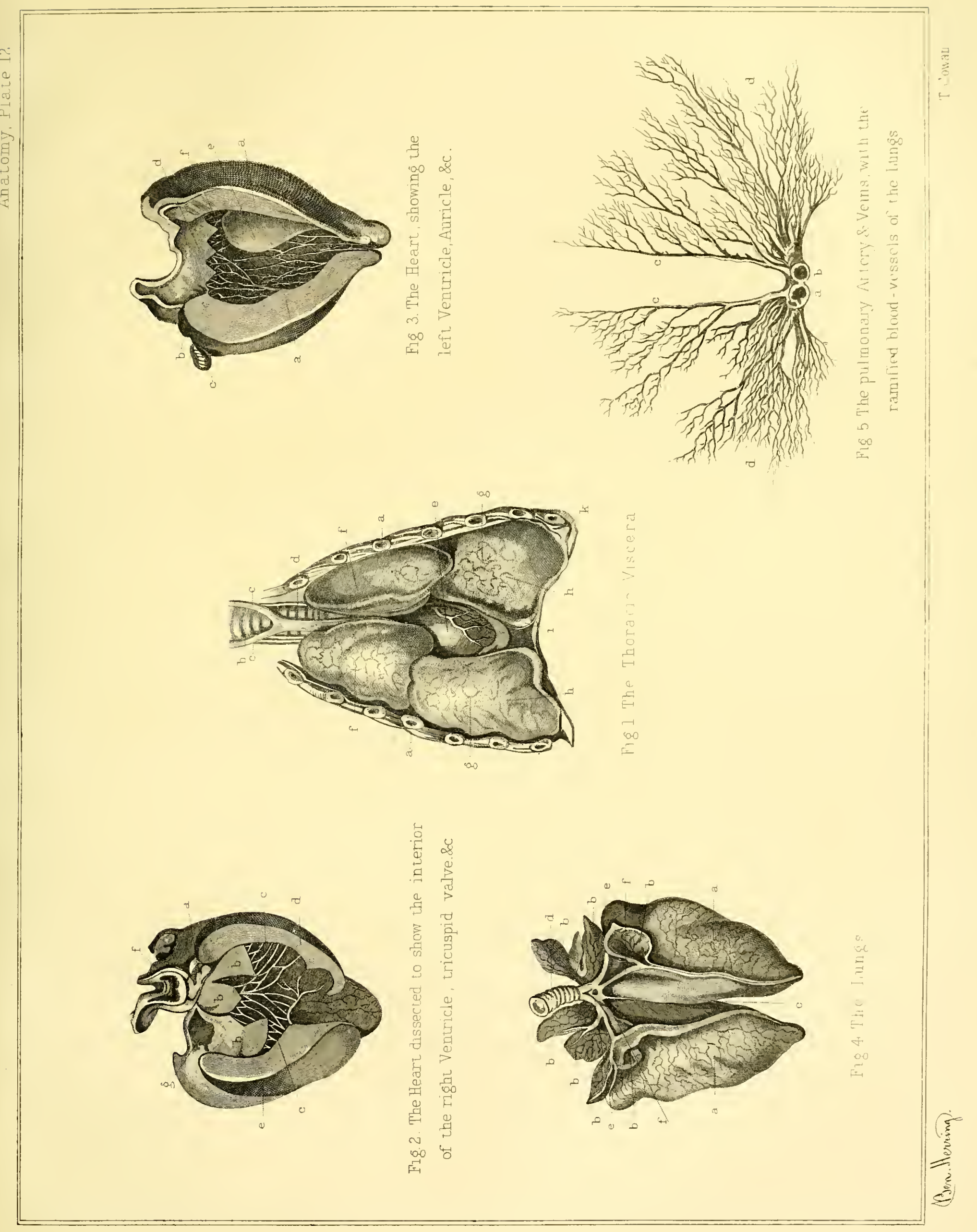


1 
Carpenter's Physiology, Liebig's Animal Chemistry, MilneEdwards's article "Blood," in the Cyclopoedia of A natomy and Physiology, \&c.

\section{THE CIRCULATION OF THE BLOOD.}

Such is the apparatus,-heart, arteries, veins, and capillaries.-by which the circulation is effected, and the composition of the fluid which is circulated. The manner in which the blood is sent to every part of the frame may be thus described. There are two circulations : one the general or greater, the second, the pulmonary (lung) circulation. We will take the first or greater circulation. The blood is now dilating the left auricle, which being stimulated contracts, and the left ventricle dilating, the blood is forced into the lower cavity on the left side. The left ventricle is filled, and, contracting, sends the vital stream into the aorta; that also contracts upon the pressure from within, driving it into the right and left aorta, and so on into all the ramifications of the blood-vessels and the capillaries. Having performed its office, it is returned from the capillaries by the veins; and, lastly, by the two great cavas (veins) into the right auricle of the heart. This double pump acts synchronously (Gr., syn, together, chronos, time), the right and left ventricle contracting and dilating at the same instant, and the auricles following suit. Thus, at the moment the left ventricle pumps its contents in to the aorta, the right ventricle empties itself into the pulmonary artery. Therefore, as the left auricle receives the pulmonary blood at the same time as the right auricle receives the venous blood from the two cava veins, the dilatation and contraction are simultaneous. Anatomists call these the systole (Gr., systole, contraction), and the diastole (Gr., diastole, dilatation). The systole sends the blood into the aorta and the pulmonary artery, and produces what we call the pulsation or beating of the heart.

The second is the pulmonic circulation. This is carried on as follows:-the two cava veins pour their stream into the right auricle, when that cavity dilates after its muscular squeeze. When it contracts again, it sends it into the right ventricle; thence it is urged into the pulmonary artery, being prevented from returning in each case by the valves already described. By the division of the pulmonary artery within the lungs (see Plate XIJ.,) the blood is exposed to the air-cells, and is changed in the capillaries from venous to arterial blood, in other words, is aërated, or oxygenated. The blood, thus restored in colour and stimulus, is brought back to the heart (the left auricle) by the pulmonary veins. This is termed the pulmonary circulation. It is noteworthy that this is the reverse of the greater circulation, inasmuch as here the arteries carry out venous blood and the veins return arterial blood. These two circulations, it will be seen, form but one direct round for the transmission of the blood through the whole system.
THE LUNAS, THE LARYNX, AND BRONGHIAL TUBE.

The cavity of the chest is filled by two soft and slightly elastic masses called the Lunos. They are divided into two large sections, one on each side the body, which again are subdivided into lobes; but the grand division is into the right and left lung; each lying within its respective side of the chest; and, as well as the internal surface of the ribs, being lined or "varnished" with the thin membrane (the pleura) already described. The right lung has four lobes, the left, three only, as we have before noticed. The colour of the lungs varies with age; in the colt they are pink, in the full-grown horse, darker red; in the old horse, bluishgrey and granulated.

The larynx (Plate V., Fig. 3, Plate XII., Fig. 5), which is the commencement of the windpipe (trachea), opens in the fauces (see ante), forming a cartilaginous box, which is the seat of the voicc. It has five pieces, connected with the os hyoides. (See Tongue, \&c.) The larynx has six cartilages; the thyroid (Gr., thyros, a shield, oidos, like), cricoid (Gr., cricos, a ring, and oidos), two arytenoid (Gr., arytaina, a funnel, and oidos), and the epiglottis (Gr., epi upon, glotta the tongue). The larynx is further coated with muscles within and without, giving it an immense range of movements. The lining membrane of the larynx is the most sensitive of the whole animal system. A grain of any substance, or even a drop of water, passing on to it, throws the animal into an involuntary and uncontrollable spasmodic coughing. It is thus the sentinel and guardian of the passage to the delicate apparatus of the lungs. Its folds are called the ventricles (bags) of the larynx, and it also covers the various ligaments extended across the tube, called the voice-cords (cordæ vocales).

The arteries of the larynx are the carotids, the veins empty themselves into the jugulars; the nerves, the recurrents and superior laryngeal, both from the eighth pair (par vagum).

The variations of sound emitted by the voice of quadrupeds appear to be governed principally by the number and form of the sacs of the larynx. There are usually three of these; one of them is seen under the vault formed by the anterior boundary of the thyroid cartilage, having its aperture near the root of the epiglottis. The other two are oblong sinuses contained between the lateral walls of the glottis and the thyroid cartilage. In the horse these sacs are very long and wide, and are not unlike the usual ventricles of the glottis. The aperture of the outer cavity is very large in the horse; in the ass, the opening into each of the three sacs is a small hole, and the anterior sac forms a bag-like cavity. In the mule these organs differ, but their anatomical formation is in general blended between those of the horse and ass.

Neighing appears to be produced by expirations, as are most of the vocal tones from the horse. The vibrations produred by the resonance of different sized cavities, assisted by 
morements of the cartilages of the nostrils, produce the compound sounds which are emitted.

Knuckering, as it is termed, is only a lesser neigh, with shorter, deeper, and less forcible tones, expressive of affection and joy. The horse has one acute sound, produced by the act of inspiration, which usually expresses either play or lust; but in most other instances sound is produced by the horse by expelling air. The tongue, teeth, and lips are not much concerned in the voice of the horse.

The trachea (or windpipe) is a large canal arising from the ring-like (cricoid) cartilage of the larynx, and reaching down the front of the neck into the chest. It is formed of more than fifty rings of cartilage, tapering from the front, having a strong muscular band their whole length, which unites them but does not fix them in position, thus leaving the trachea perfectly flexible. Outside of it is fastened a cellular substance; inside, it is lined by a mucous membrane, the secretion defending it against changes in atmospheric temperature. At the third dorsal vertebra it separates into two branches (the bronchial tubes), the principal divisions of which again branch off before they enter the lungs; and these again subdivide into numerous tubes, ending in small cavities known as the air-cells of the lungs.

We have said that the bronchial tubes are branchings off of the laryns They are composed of many pieces of cartilage, connected together by fine ligament (see Plate XII.); the cartilages becoming almost imperceptible as the tubes grow fine or approach the air-cells. The right and larger branch of the bronchiæ, given to the right lung, quickly divides into three trunks. The left, which is the longer, from the necessity it has to stretch itself under the posterior aorta, divides into two principal trunks. The bronchix are lined throughout by the same mucous membrane as the larynx and trachea, furnishing a moisture that loads the expired air or breath. The extreme ramifications of the bronchiæ, as has been previously stated, end in minute aircells; over whose surfaces are spread, in exquisite minuteness, the capillary ramifications of the pulmonary arteries, whose trunks accompany the bronchiæ to the lungs side by side. The pulmonic veins receive the blood from the surface of the cells, whence it is by these last vessels returned. The lungs are themselves nourished by their appropriate arteries, whose blood is returned by bronchial veins, as explained in the circulation of the blood. Their nerves are furnished from the sympathetic, and lymphatic vessels are distributed throughout them.

The Diaphragm (see also Muscles, p. 190) forms a fleshy and tendinous partition, dividing the cavity of the chest from that of the abdomen. It is of a broad circular form, flattened from before backwards ; its front surface is convex, and concave behind; divided or forked above, and having two elongations or appendices extending backwards, with pointed extremities. On that side next the chest it is invested by the membrane which covers the lungs, and towards the belly by that which covers the intestines. It adheres to the spine, the ribs, and the breast-bone by strong muscular fibres. Its structure is fleshy and tendinous. The fleshy parts are those which form the circumferent portions of the large muscle, and the principal part of the crura or appendices. The tendinous parts consist of a thin circular expansion, occupying the middle of the larger muscle, and uniting that with the lesser. Through the muscle are seen three remarkable openings, an upper one in the interspace between the crura, for the passage of the aorta; one a little lower, formed by the decussation of the crura, for the csophagus; and the third, or lower one, perforating the cordiform, or heart-shaped tendon, for the reception of the posterior vena-cava.

The diaphragm is the chief agent in respiration; it acts in opposition to the abdominal muscles, which are the chief expiratory powers. By the contraction of its radiated fibres, with the assistance of that of the crura, the cordiform tendon is transformed to a plane surface, and the dimensions of the chest from front to back thereby considerably augmented When this muscle acts, in consequence of the shortening of its fibres, it loses its convexity, as above stated, and the chest being thereby enlarged as well as the lungs, the air rushes in, and inspiration is performed. This muscle also assists in the natural constant motion of the bowels, lending its powerful aid in expelling the fæces and urine; and, in females, facilitates the birth of the young animal.

The membrane by which the diaphragm is covered is very liable to inflammatory attacks. In all cases of disease of the lungs and bowels, the diaphragm is almost certain to become inflamed and attended with considerable irritability ; and this is the cause of the breathing of the horse veing so much affected during inflammation of the chest and abdomen. It is likewise concerned in coughing, yawning, and sighing. Sometimes it is ruptured by violent over-exertion. We are, however, unable to give distinct indications of this condition; but no instance is known of the animal surviving this injury. In cases of small rupture some portion of the intestines insinuates itself into it, and there becomes entangled, so that an incurable obstruction is the consequence. In the event of a large aperture, the intestines protrude through it, and, by pressing upon the heart, totally suppress respiration. This organ performs such an important part in the act of breathing, that it may be easily imagined it is liable to be ruptured when the respiration is strong and hurried.

\section{RESPIRATION, CHEMICAL AND MECHANICAL.}

Respiration is that function of the animal by which the various tissues of the body are subjected to the chemical influences of the oxygen of the atmosphere, and the carbonic acid thus formed expelled from the body. This is attended with the evolution of heat. In the higher animals, as the horse, this process is constant, its suspension for a few minutes causing death. When an animal thus dies of deprivation of oxygen, he is said to be suffocated. The 
absorption of oxygen by the animal effects three great objects:-1. The preparation of the objects of food taken up by the glands and blood to the objects of nutrition. 2. The removal of certain constituents which have performed their th office. 3. The production of heat, which produces the accumulation in animals called "warm-blooded;" any of these objects unfulfilled, the higher animals die more or less quickly.

Mechanically, inspiration is the act of drawing in the air and expanding the cells of the lungs to their utmost. This distends the walls (parietes) of the chest, presses back the midriff upon the stomach, liver, \&c. ; the expulsion of the air is expiration, the two movements respiration.

The function of the lungs may be shortly stated. The blood, passing through the capillaries of the body, and contributing to the nourishment of the frame, and furnishing all the secretions, becomes, as we have described, changed. It is no longer able to support life : it is possessed of a poisonous principle, and that principle is a superabundance of a substance called carbon, which must be got rid of before the blood can again be usefully employed. That ingredient in atmospheric air called oxygen, has a strong attraction for this carbon, and will unite with it wherever it finds it. The chest enlarges by the action of the diaphragm and the intercostal and other muscles, as explained; and the lungs expanding with the chest, in order to fill up the vacuum which would otherwise exist between them and the sides of the chest, these cells enlarge, a kind of vacuum is formed in each of them, and the air rushes down and fills them: being thus divided from the venous and poisoned blood by these membranes alone, it is enabled to act upon the blood, and attracts from it this carbon which purifies, renders it arterial blood, and fits it for the purposes of life. This being accomplished, the chest contracts, the lungs D D are pressed into smaller compass, and a portion of the air impregnated with the carbon, and rendered poisonous in its turn, is squeezed out. Presently the chest expands again, the lungs expand with it, and fresh pure air is admitted, which is shortly pressed out again, empoisoned by the car. bon of the blood. These alternate expansions and contractions constitute the act of breathing.

When the animal powerfully exerts himself, a more ample supply of pure blood is required to sustain the energies of life, and the action of the muscles forces the blood more rapidly through the veins. Hence the quick and deep breathing of a horse at speed. Hence the necessity of a capacious chest, in order to yield an adequate supply, and the connection of this capacity of the chest with the speed and the endurance of the horse. Hence the wonderful relief which the mere loosening of the girths affords to a horse blown and distressed, enabling the chest to expand and to contract to a greater extent, in order to yield more purified blood. Hence also the relief afforded by even a short period of rest, during which this expenditure is not required, and the almost exhausted energies of these organs have time to recover. Hence, likewise, appears the necessity of an ample chest for the accumulation of much flesh and fat ; for, if a considerable portion of the blood be employed in the growth of the animal, and it be thus rapidly changed, there must be provision for its rapid purification, and that can only be effected by the increased bulk of the lungs, and a corresponding largeness of the chest to contain them.

As the diseases of these organs are among the most serious to which the horse is exposed, and interfere most with his usefulness, they will occupy due space in the part devoted to Veterinary Practice.

A few considerations on the aeration of the blood in the fotus will be found under Gestation and Foalina. 


\section{CHAPTER XXI.}

THB ORGANS OF DIGESTION, ASBIMILATION, AND EXCRETION.-THE ABDOMINAL VIBCERA: THE STOMACH : THE INTEBTINES.-

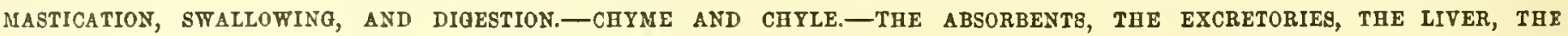
PANCREAS, THE SPLEEN.- VOMITINa.

THE ABDOMEN.

THE external parts of the abdomen are, the common integuments; the abdominal muscles (see ante, p. 190); the parts of generation in the horse, and the udder and mam$m æ$ in the mare.

The interior of the third great cavity, the abdominal, sontains:-the stomach, the intestines, large and small, the liver, and the urinary organs.

The whole of these are enveloped in a strong, dense, serous membrane, called the peritoneum (Gr., peri around, tonōo I extend), which forms not only a covering but a support to these organs, and facilitates their movements as they slide, press, or accommodate themselves and each other in the various actions of the living animal. It also secretes a moist vaporous fluid which prevents friction; and some physiologists have held, and with great probability, that the drying up of this vapour in the heat of inflammation is the cause of the intense pain produced in that case by any motion of its contents. (See Inflammation.) The peritoneum, by its various folds, forms the mesentery (Gr., mesos middle, enteros an intestine), omentum, \&c., by which these organs are attached to each other or to the walls of the abdominal cavity. In front the peritoneum is connected with the diaphragm, partially covering its hinder surface; it also covers all the contents of the abdomen, except portions of the uterus, bladder, and rectum. In males it covers the spermatic cords and testicles, and also lines the scrotum (Lat., scroteum, a leathern coat). Some of its folds form ligaments, as those of the liver and mesentery, and contain numerous small glands, through some of which the lacteals* (Lat., milk-bearers, from lac, milk) pass. The peritoneum is immensely strong as well as elastic, as may be seen in the distension, and "tucking-up" in flatulent and spasmodic colic.

The omentum, already mentioned as one of the folds of the peritoneum, is a curious and delicate fatty membrane, facilitating motion of the viscera. It has a very low sensibility, bearing cutting or tearing with little or no pain to the animal. It is this "caul," which is the seat of the deposit

- Their office is to take up the chyle and transmit it to the heart; pee pot, Diogstion and Nutrition. in man and fat animals, which occasions corpulency or protrusion of the belly. It is seldom so much loaded with fat in the horse as in man and in the ruminant animals.

The Stomach of the horse (see Plate XIV. Fig. 1), which is remarkably small, lies immediately behind the liver, its principal portion occupying the left hypochondrium (Gr., upo under, chondros a cartilage). The spaces in the abdomen under the false ribs are called "right" and "left." The right and left central is called the epigastric region (Gr., epi upon, gaster the belly), the middle the umbilical (Lat., umbilicus, the navel) region. The hypogastric region is behind an imaginary line drawn from the one side of the ilium to the opposite side, this is again divided into right and left iliac regions and the middle is called the pubic region. The central portion is divided by a white line called linea alba; a full explanation of these imaginary compartments is convenient in strict anatomical descriptions, but would be superfluous here. The forward (convex) part of the stomach lies upon the diaphragm and false ribs of the left side. Its hinder (concave) part is hidden by the intestines. Its lower surface is covered by the omentum $\dagger$ or fatty caul; attached to its left extremity is the spleen, and its right bend is in contact with the left and middle lobes of the liver.

The stomach may be compared to a sac or pouch, formed for the reception of the food as it passes from the mouth to the pharynx, and thence through the oesophagus, or gullet, by the cardiac orifice into its cavity. As we have said before, it is remarkably small; the stomach of a twelvestone man will contain more than three quarts, while the horse, eight times his weight, will scarcely hold three gallons; like other bollow muscles, however, it is capable of considerable distension. The pyloric opening is the outlet by which the contents are discharged into the duodenum: +

The stomach has three general investing coats: the first elastic, being a doubling of the peritoneum; the second of white muscular fibre in two separate layers; the last one, placed longwise, seems a continuation of the outer coat of

† From the Latin omen, so called because the Roman soothsayers prognosticated from the caul (omen-tum) in their sacrifices.

I Lat. duodeni, twelve; the ancients supposing that it was of the breadth of twelve fingers. 


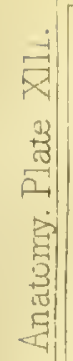
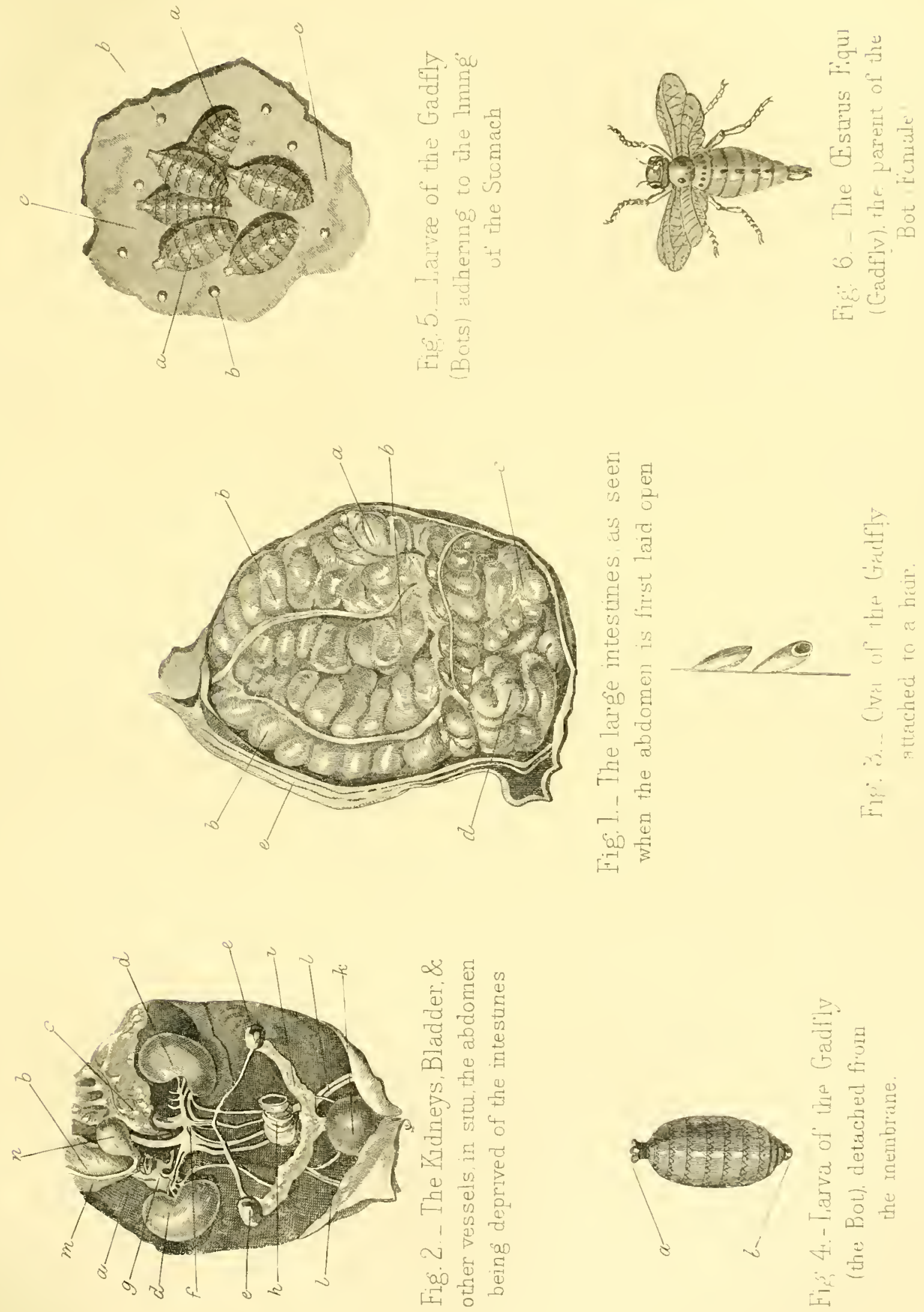

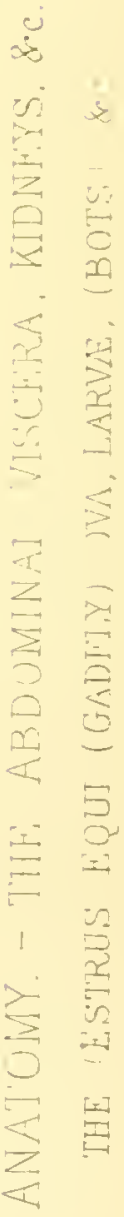


. 
the œsophagus, strengthened by additional fibres; these pass obliquely round the stomach, and then twist themselves into a whirl or vortex, and seem intended to prevent the return of the food.

The inner coat is mucous membrane, having a double character: one, hard, called cuticular (skin-like); the other, soft, covered with numerous beautiful projections, like the pile of velvet, is called the villous coat (Lat., villosus, shaggy). The cuticular coat is a continuation of the lining of the mouth, pharynx, and cosophagus, extending half-way down the stomach, where it ends abruptly and the villous coat begins. It is folded in the resophagus and perforated with excretory orifices, as we shall presently note. It is to the cuticular coat that we have generally found bots adherent, ihough they attack other parts.

The villous coat is soft, wavy, and covered with innumerable small bloodvessels; it is full of folds, which expand when the stomach is filled. This portion of the stomach secretes the gastric juice, and within it the chyme is formed. The blood of the stoniach is plentifully supplied from the gastric, splenic, and hepatic arteries, which are here very winding, to aroid distending the organ. The gastric veins, which return the blood by the venæ portæ, are peculiar in being without valves.

Passing through the pyloric (Gr., pyle an entrance, oreo I guard) opening we come to the INTESTINEs (Lat., intestinus, from intus inside). These are divided, in the horse, into large and small intestines, and extend from the pylorus to the anal outlet. The whole length of this irregular tube (see Plate XIII. Fig. 1) is from eighty to ninety feet, of which the large intestines form twenty to twenty-four feet, and the small intestines from sixty to sixty-six feet. It is not easy, as we have said when speaking of what anatomists call "regions," to describe in words the situation of the intestines; the "large," however, may be said to fill the forward and lower parts of the abdomen, the small to fill the space above and farther back, but occasionally shifting position on account of the peristaltic motion. They are prevented from going far out of place by the peritoneurn, which forms bands, as already described, and moors fast the intestines. The first (membranous) coat of the intestines is derived from the peritoneum ; the second is the muscular, presenting organic fibres-the lengthening and contracting of the longitudinal, and the constricting of the circular muscles, producing the peristaltic action. (See post, Diaestion.) The circular muscles are the most powerful, the intestines being found firmly contracted in cases of violent death. The inner surface of the intestines is both mucous and villous, extremely sensitive, and full of vessels.

Of the intestinal canal the first portion is the duodenum, hanging loosely on the right side and attached to the hollow side of the liver, from which it rises, and is fixed to the back bone, taking the name of jejunum.* The duodenum

- Lat. jejunus empty. It is generally foond empty in the dead body. of the horse is twenty inches, instead of twelve, so that the term is a misnomer.

The jejunum is attached to the mesentery, which follows its convolutions, and has two smooth surfaces. Numerous lacteal glands are situate on the folds of the mesentery and mesocolon, which are, as we have said, mere folds of the peritoneum.

The jejunum, when it passes into the iliac region, takes the name of the ilium (Gr., eileo, I turn about), but there is nothing but an imaginary division. It then passes into the coecum, protruding some distance into its cavity, to prevent the return of its contents.

The cæcum (from the Lat., blind-gut), is the first great intestine. It derives its name from the fact that it is open at one end only. The coecum rests on the belly (navel) portion of the linea alba, and is generally seen toward the right side upon opening the peritoneum. The head of the cocum, in which the ilium terminates and the colon begins, is generally near the diaphragm and liver. There are here several muscular bands which pucker up the intestines into little purses called cells, in which water or fluid is generally found, scarcely ever solids.

The colon (Gr., cholon, from chole, bile), originates in the cæcum, and is the largest of all the intestines. It reaches across the abdomen from left to right, and having reached it, bends back upon itself at the sigmoid (Gr., sigma, the letter $\mathrm{S}$, oidos, like) flexure. It is connected along this bend from the cæcum to the flexure or turn, but is loose on the other side, so that, when the belly is burst, the colon may trail upon the ground without breaking the other intestines. The continuation of the colon is the rectum or straight gut.

The rectum is thicker in substance than the other intestines, and has a longitudinal muscle on each side (for their action see ante, p.192, Moscles), the rectum is plaited with cell-like depressions, to prevent the too frequent expulsion of the dung. It is loosely-suspended from the spine and rump-bone by a band called mesocolon, part of the peritoneum. The anus is opened by the force of the peristaltic action, and shut by the sphincter ani. (See p. 19:2).

\section{MASTICATION, SWALlOWING; THE PHYSIOLOGY OF DIGESTIOP.}

At the close of Chapter III., and incidentally elsewhere, we have spoken of the salivary glands and their secretion, we shall here pass from mastication to the act of deglutition or swallowing. The organs engaged in this are, after the teeth and tongue, the pharynx and cesophagus, with their muscles.

The pharynx is a bag of a funnel shape, with its trumpet end forward, lying at the entrance of the gullet and back part of the fauces, and held fast to the upper end and back of the larynx, or windpipe, by three pairs of strong muscular bands. These all join in a tendon at the back or upper side of the pharynx. The dilator muscles of the pharynx and their action will be described in the physiologe of the act of swallowing. 
The asophagus opens from the smaller end of the funnellike pharynx, and leads thence to the stomach, which it enters by the cardiac opening. It tends a little to the left side in its course, and goes behind the trachea, passing through the chest and along the dorsal vertebræ, inside layers of the pleura, thence through the diaphragm into the stomach. It has three coats: a cellular and membranous one; a second muscular (longitudinal and circular): and an inner one, cuticular (skin-like), wrinkled into folds. It has a remarkable power of muscular contraction and expansion, for the purpose of propelling its contents. The physiology of swallowing is thus summarized by the late eminent veterinarian Delabere Blaine.

When a horse grazes, he first places with his lips a tuft between the teeth; when, elevating his chin, the sharp edges of the under cutting teeth become applied to the grass, and cut it through, while at the same time the upper incisors help to nip it off. Oxen and sheep, wanting upper nippers, wrap a tuft of grass round with their tongue, and then apply it to the under incisors, by which it is held fast, while a movement of the head tears the grass up; and thus we find that they are obliged always to carry the chin forward in collecting their grass. When a quantity of herbage is thus gained, it is carried by the tongue and muscles of the cheek to the upper part of the mouth, to eucounter the action of the grinders the matter being conveyed from side to side, to be placed in the most favourable direction for perfect mastication, by means of the tongue. During this process, it continues to be mixed with the salivary fluid, from the parotid, the submaxillary, and the sublingual glands (see ante), which pour out their secretions, excited by the pressure of the surrounding muscles.

The vegetable mass having been thus completely masticated, is placed at the back of the tongue; when, by the pressure of that organ towards the palate, it is squeezed against the velum palati. The soft palate readily yielding to force coming from the mouth. The morsel is at the same time driven against the covering of the throat (epiglottis), which, by its own elasticity released from the downward pressure of the velum palati, is raised, and covers the opening to the windpipe. The food is thus propelled into the fauces. Then the windpipe (trachea), protected by the epiglottis, rises and urges the mass into the funnelshaped pharynx; the contractors of which transmit it to the gullet (œsophagus); and its muscular coats, contracting as it descends, ultimately lodge it within the stomach. The mouth remains closed during the act of swallowing, that these muscles may find a fixed point. The deglutition of liquids is not very different. The muscles of the tongue draw it downward, whereby a tendency towards a vacuum is formed: to counteract this, the water is by atmospheric pressure forced into the mouth; when the entire agency which operated in the case of a solid is called into action, the raised velum palati closing the opening to the nostrils, and thus preventing the liquid from returning by that passage. We shall resort to the same authority for an explanation of the function of digestion, feeling that we cannot improve upon his horse-knowledge on this point

DiaEsTion may be characterized as that power whereby substances which are received into an animal body lose their own properties, and become endowed with those necessary to support the constitution of the creature that imbibes them. To restore the tone of parts, rest is required; and to repair waste, food becomes necessary; while hunger and thirst stimulate animals to take in solid and fluid aliments. That the stomach is influenced by the blind longings of inorganic life, is proved by the fact that the mere mechanical distention of a draught of water will, for a time, satisfy the sensation of hunger; but simple distention not satisfying an instinctive desire, instead of affording relief, it only adds to the general prostration. It is probably by its distending properties that food taken partly $\mathrm{n}$ vigorates long before perfect chylification has taken place. This fact is however better established by no man having absolute power to quicken or delay his desire for nourishment. The mere want of food does not dissipate immediately the strength; but the body can for some space support itself, and desire, though felt before, be actually forgotten ; thus the inanition of a hunter long employed in reaching a distant cover, is no bar to his after-exertions in the chase. The moment he hears the well-known sound, he receives a temporary supply of nervous energy; which, acting on his irritability, produces renewed muscular exertions : but the chase over, a double prostration is the consequence; for the nervous impulse being expended, it often happens that the stomach is sympathetic with the general frame, and the horse becomes " too tired to eat."

Thirst differs from hunger principally by its impelling us to receive liquids instead of solids. The instinct, which is independent of reason, and superior to the will, calls for fluids often not required for repair : it is true, perspiration will produce thirst, and that diuretics will do the same; but these are artificial, not natural causes. Drink is also instinctively sought, for no cause save that of fickle appetite, induced by long indulgence, which cannot be reckoned among life's necessities. Stimulated, therefore, by the sensations of hunger and thirst, animals seek for matters to which they are instinctively directed by their senses of smell and taste.

The mastication, insalivation, and swallowing of the food, have already been noticed. To the saliva, however, by no means is usually given its full merit as an important agent in the digestive process. When we consider the quantity secreted, the chemical nature of the fluid, its remarkable affinity for oxygen, and that a complete mastication invariably produces a direct change in the qualities of the food, it would be most unphilosophical to regard it as a mere diluent. The masticated aliments received into the stomach become subjected to the further action of the 
gastric fluid, the produce of the secreting surface of the villous division of the stomach. The true gastric juice is possessed of a solvent power, which is shown in a remarkable manner by the food being dissolved by its action.

The ordinary process is after this fashion with the horse. The masticated vegetable matter is first deposited in the cuticular cavity of the stomach; whence it is propelled forward by muscular contractions of the organ, from left to right, towards the pyloric opening; being, however, so turned and contorted in its passage that every portion of the insalivated mass becomes first macerated with the cuticular secretion, and then receives the solvent gastric juice. It is thus that a mass of matter undergoes the chymifying process within the stomach, after which it is hurried onward to be converted into chyle within the intestines.

Chyme (Gr. chymos, humour or juice) is the masticated bue undigested mass of food. It is a pulpy semi-fluid, with a slightly acid taste, creamy in appearance when the food is oily, like gruel when farinaceous. Part of this is absorbed by the stomach itself, and goes direct into the blood; the remainder goes into the duodenum, and is mixed with the bile and pancreatic juice, forming a milky fluid. This is called-

Chyle (Gr. cholos, juice), and passes into the jejunum and ilium and is there taken up by the chyliferous absorbents and passed into the large vein of the heart by the thoracic duct. The remainder of the worn-out food finally assumes th? form of fæces, and is expelled.

THE ABSORBENTS.

The Absorbents, although we cannot easily trace them, are distributed over every part of the body. Injections show them in some parts, but it is by their constant operations and effects they are best recognized. Thus the hardest parts of bone are removed by a natural process, 'or absorbed. Inorganized cartilage is likewise taken away, to allow the arteries and veins to enter, and bone to be deposited, when ossification ensues.

Absorbents are minute, thin-coated, transparent vessels, having numerous valves, like veins; they are spoken of as deep-seated and superficial; but as the difference of position is accompanied by no difference of structure, we shall here regard them as of one kind. Every absorbent conveys the materials it takes away from various parts into the blood; with which their contents mingle, and ultimately become blood; or they are emitted with the excretions. In starvation it is by means of the absorbents that the marrow is carried out of bones, and the fatty matter from other places in the body is emptied into the blood, which in this manner helps to support, or keep alive, the subject starved. It is thus accounted for why a fat animal is longer dying from starvation than one that is thin.

The absorbents, which take up the nutritive portion from the food within the intestines, are called lacteals, because the substance they extract is at first white, like milk; otherwise they are the same as common absorbents, all of which enter and pass through one or more of the little reddish bodies called absorbent glands.

The functional effects of this system are abundantly active in the constitution at large; we are certain that the various organs of the body are continually changing, wholly or partially. It appears to be the office of the arteries to build up new parts, and to repair the waste of others; bur the old ones must be first of all pulled down and removed by absorption, which is least active in youth, equal with the arteries in middle life, and predominates in age. By this wonderful power the roots of the temporary teeth are absorbed, that their crowns may give way; by this also the muscle which governs the testicles, having fulfilled its office, is absorbed, and the thymus gland (sweetbread) is likewise removed. It is thus cartilage is taken up, to make room for a bony deposit when the animal approaches maturity. By the absorbents the fluids as well as solids are continually changing, being taken up and carried back, but always in a fluid state, in to the mass of blood; it is by them that the dead parts are separated from the living in sloughing and ulceration By the superficial absorbents, even gases are received frum without. The water held in suspension by the atmosphere is thus taken in; hence grazing horses require little or no water, more especially if not exposed to the heat of the sun, whereby evaporation or exhalation is promoted. The functional office of the absorbents is most important also in the preservation of life under casualties. Long fasting is thus borne; their capability of displacing the animal oil or marrow from the bones, and the fat from the body generally, is here employed to make up the want. Hybernating animals live during their torpidity by a slow absorption of the adipose matter; thus it is found in the instance of the torpid bear, that, however fat he may enter his seclusion, ho returns lean and emaciated.

To our acquaintance with the power of the absorbents, the practice of medicine is greatly indebted; and although we own few means of lessening absorption, we fortunately have many of increasing it. Mechanical friction is the most active and universal agent in stimulating the absorbents, as the hand-rubbing of horses sufficiently proves. Pressure, also, increases their action: thus we bandage the swollen legs ; we girth the bodies of our horses, to promote absorption of the interstitial fluid. Exercise, by swelling the muscles, produces pressure; and thus exercise will remove swelled legs, and promote absorption generally. Rlisters likewise exercise an influence over absorption. A still stronger stimulant is iodine; which is especially useful in enlargement of the glands. Purgatives and diuretics, and whatever tends to lower the pulse, promotes internal absorption. For, by offering an impediment to the circulation, removing the contents of the intestinal canal, and increasing the urinary secretion, an absence is caused in the materials for building up, which the absorbents endeavour to re pair by removing other parts. 


\section{THE LIVER}

This ponderous secretory and excretory mass, the largest in the system, is placed nearly in the centre of the body. The circumference of the liver (Saxon, lifer) may be taken as two to two-and-a-half feet, thick towards the middle, and thinner at the edges. It lies between the stomach and the Jiaphragm, with its right lobe in contact with the duodenum and the right kidney. It is kept in its place by what are called the ligaments of the liver, but these are merely prolongations and thickenings of the peritoneal envelope already described. Besides the right and left ligaments, there is one in the centre, between the diaphragm and the middle lobe, called the suspensory ligament. Besides its lobes, the liver has several deep indentations, one of which separates the two large lobes, and is named the great fissure (Lat., fissus, a cleft); inside this, in mares, may be seen the remains of the umbilical vein which supplies the fotus, and in a smaller cleft about the middle of the concave surface, may be seen the opening for the vena portæ. Numerous lymphatic ressels run orer the surface of the liver, and the bloodvessels pass within a sheath called Glisson's capsule, a thin membrane, formed of white fibres, immediately beneath the peritoneum. The circulation of the liver, as 'we have noticed before, presents a remarkable peculiarity. The numerous veins of the intestines join into one common trunk which enters the liver as the vena portx. This trunk vein, having pierced the liver, branches off once again into innumerable divisions dispersed through the whole substance of the liver, performing the functions of an artery, its contents being distributed for secretion. The blood circulated through the whole body of the gland is poured from the terminations of the vena porta and the hepatic (Gr., hepar, the liver) artery, into the hepatic veins, which empty their contents at the hinder cava.

In the glandular capillaries a great change takes place in the blood, by which the fluid called bile is separated; the biliary pores end in small tubes, which, uniting, form the hepatic duct. As it leaves the liver, it accompanies the hepatic artery, and passing below the vena portæ, empties into the duodenum, five inches from the pyloric, or lower, opening of the stomach. Unlike the dog and man, the horse has no gall bladder. As the horse in a natural state is continually feeding in small quantities, and often emptying his small stomach, an uninterrupted flow of bile to assist digestion, rather than a store of that secretion for a heavy meal, seems to point to the reason of this peculiar organisation.

\section{THE PANCREAS.}

The Pancreas (Gr. pan, all, creas, flesh) is a flat gland that appears to have much in common with the salivary glands in its secretion. It is of irregular fgure, in three lobes, and extends across the spine between the stomach and left kidney. Its upper side touches the top of the abdomen. its under, the great bend of the stomach. We have said it greatly resembles the thymus gland in its fleshy structure. In the ox the butchers sell the thymus and the pancroas indiscriminately as "sweetbreads."

The bile and pancreatic fluid are both concerned in the preparation of the chyle, to which duties they are specially appointed; but over and above this it appears that the bile is useful in depurating the blood, and removing from it certain noxious elements, which, if retained, would become highly injurious. The pancreatic fluid is only secreted during digestion, but the bile is poured out at all times; and, if not secreted, from any torpid condition of the liver, the blood becomes overloaded with noxious particles, headache follows, and, finally, fever and even fatal injury. Bile is a kind of soap, and appears to act specially in converting sugar into albumen and the fatty compounds necessary for the support of life. The pancreatic fluid, on the other hand, seems to render the fat taken as food fit for absorption, which it is not in its raw state. But not only is the liver useful by supplying bile, but it also directly purifies the blood as it passes through it, in the return from the intestines to the heart; and besides this, it seems to exert a powerful influence in assimilating the new material to the condition which it must attain as a part of the blood Here also fibrine is largely formed from albumen, and fat from sugar.

\section{THE SPLEEN.}

The SpleEn (Gr., $\sigma \pi \lambda \eta \nu$ ) is a spongy livid body of soft structure, and having no excretory duct; its colour shades from red-brown to purple, and its size is various. It is triangular in shape, and so tender that its substance would be torn by the slightest violence, were it not for its membranous peritoneal covering. It is attached on its upper and thicker edge to the left side of the stomach, but the chief portion of it lies behind and rather above the stomach. Its front part comes in contact with the left lobe of the liver; its hinder is connected to the left kidney, and concealed by the convolutions of the colon. It is abundantly supplied with bloodvessels, absorbents, and nerves, especially the two first-named, yet the particular use of the spleen is still merely conjectural.

Great enlargement and also rupture of the spleen have been noticed after the death of horses; but we know little of the causes or the symptoms which indicate disease of this organ.

\section{voMITING.}

Vomitiva.-A structural peculiarity in the stomach of the horse remains to be noticed, by which, in all ordinary cases, the animal is denied the power of vomiting. The whole of the alimentary canal in that animal exhibits uniformity of intention, unfavourable to vomiting. The soft palate closes all return of the contents of the stomach by the mouth; and consequently, if vomiting were to occur, 
the rejected mass must come out by the nostrils. The next structural impediment may be observed in the œsophagus; which, by having a different arrangement of its muscular fibres to that of ruminants, evidently proves that regurgitation forms no part of the natural economy of the horse. The obliquity of its insertion, the number, strength, and direction of its fleshy layers, must form a sufficient bar to all ordinary tendency of the aliments to return. And the superior resistance offered by the greater volume of muscular fibre around the cardiac extremity, must, in all cases, effectually prevent it. The dog and cat, which romit rather freely, have the muscular fibre much the thickest at the pyloric orifice. Were the equine and the canine stomachs handed to a person perfectly ignorant of anatomy or physiological discussion, his sense of touch would be sufficient to decide the matter, so very marked and obvious is the difference. Added to the above reasons, though not of much force, is the circumstance of the horse's stomach being situated far from the abdominal muscles: this prevents these last from directly acting upon the digestive bag in that animal, but certainly cannot prevent their action being felt through the pressure of surrounding parts 
UHAPTER XXII.

THE URINARY ORGANS.-THE RENAL CAPSOLES: THE KIDNEYS : THE BLADDER: THE ORETHRA.-THE ORAANS OF REPRODOCTION:

OF THE MALE: OF THE FEMALE.-GESTATION : FOALING.

\section{THE URINARY ORGANS.}

The Renal Capsules are two irregularly-shaped bodies in front of the kidneys. They are large in the colt, but decrease in size as the animal grows. They consist of two substances, one yellow and vascular, the other paler and fatty: a fluid may be squeezed from these in the young colt. Their nerves come from the plexus called the renal plexus. Their functions and use are unknown.

The Kidnex8.-These are the most important glands engaged in the urinary circulation. They are supposed, small as they are, to carry, by the renal arteries, one-eighth of the whole blood of the body. The kidneys are situated in the upper part of the abdomen and dorsal region. The right kidney, against the liver, is more forward than the left, owing to the latter being pressed backward by the spleen. The bean-shape of the kidneys is too well known to need description; their central notch is the entrance for their arteries and vessels, and the outlet of their veins and ducts. They are kept in position by their coating membrane, often well lined with fat. The kidneys lie on the top of the peritoneum, and are outside the peritoneal sac. Lying behind "or above) the intestines, they are concealed by them in dissection, until shown by their removal. (See Plate XIII. Figs. 1 and 2.; When the kidneys are divided, two distinct structures are visible. The outer, called the cortical (Lat., cortex, bark), is of a dull dark red, and granular in structure : this is the web of emulgent capillaries, and the minute terminations of the urinary dacts. The second part is the medullary (pith or marrow-like), lighter in colour, and with a number of minute radiating tubes forming papillæ (Lat., papilla, a small nipple). The urine is secreted from the capillaries of the emulgent arteries, coiled round the small ends of the renal ducts, thence it passes through the tubular portion of the kidneys, flows towards the cup-shaped mucous membranes called the calices (Lat., calyx, a cup), and falls into the infundibula, which are canals or grooves enlarging into the ureters ( $\mathrm{Gr}$., ouron, urine), which last carry the urine into the bladder. Each ureter passes out of its kidney, and, connecting itself with the broad ligament (ligamentum latum), travels with it to the upper side of the bladder. Each ureter goes obliquely through the coats of the bladder, which thus perform the office of a valve.

The chief function of the kidneys is the secretion of the urine, and carrying off an ingredient which enters into its composition, called the urea, a substance which, if allowed to circulate with the fluids, would prove poisonous. The urine varies more in its quantity and quality in the horse than in any other animal with which we are acquainted, and hence the necessity of attending to its appearance and composition during disease; because attention to this enables the veterinarian to detect the disease, and also to judge the quantity of medicine which may prove beneficial to the animal. In the application of these, much good or much evil may be the result.

The Bladder is a muscular and membranous sac of a pear shape (pyriform), which, when distended, nearly fills the cavity formed by the great bones of the haunch, called the pelvis. (See ante, Bonks.) In this undistended condition it is wholly confined to the cavity of the pelvis; but, when full its fundus advances before the pubes into the abdomen, the advancement being in ratio with the degree of distention.

The bladder is provided with three coats. The outer one covers the greater portion of it, and is part of the peritoneum. The muscular coat consists of two layers of fibres; the external running longitudinally, and the inner circularly, which enables it to yield to the pressure of the urine as the cavity fills, and again contract to a small size when emptied. This contractile property also assists in expelling the urine from the bladder. The inner or mucous coat is white, soft in its texture, and highly organized. It possesses numerous follicles, or little glands, from whose excretory pores issues a plentiful mucous secretion, to defend it from the acrimony of the saline and other matters contained in the urine. This mucous matter being perpetually washed off from the surface of the inner coat by the urine, is kept constantly renewed, and it is sometimes voided in considerable quantities. When this is the case, it may be apprehended that the urine is unusually acrid, or that calculi or other irritable matter is within the bladder. About an inch before the cervix or neck of the bladder, in the sides of the bag, the orifices of the ureters are placed, which enter the bladder in an oblique direction, and prevent any reflux of the urine at the time the bag is contracting, which gives them the property of valves. The bladder terminates in a small neck of yellow elastic tissue, round which is a powerful muscle, which keeps the passage closed and retains the urine until the animal wishes to 


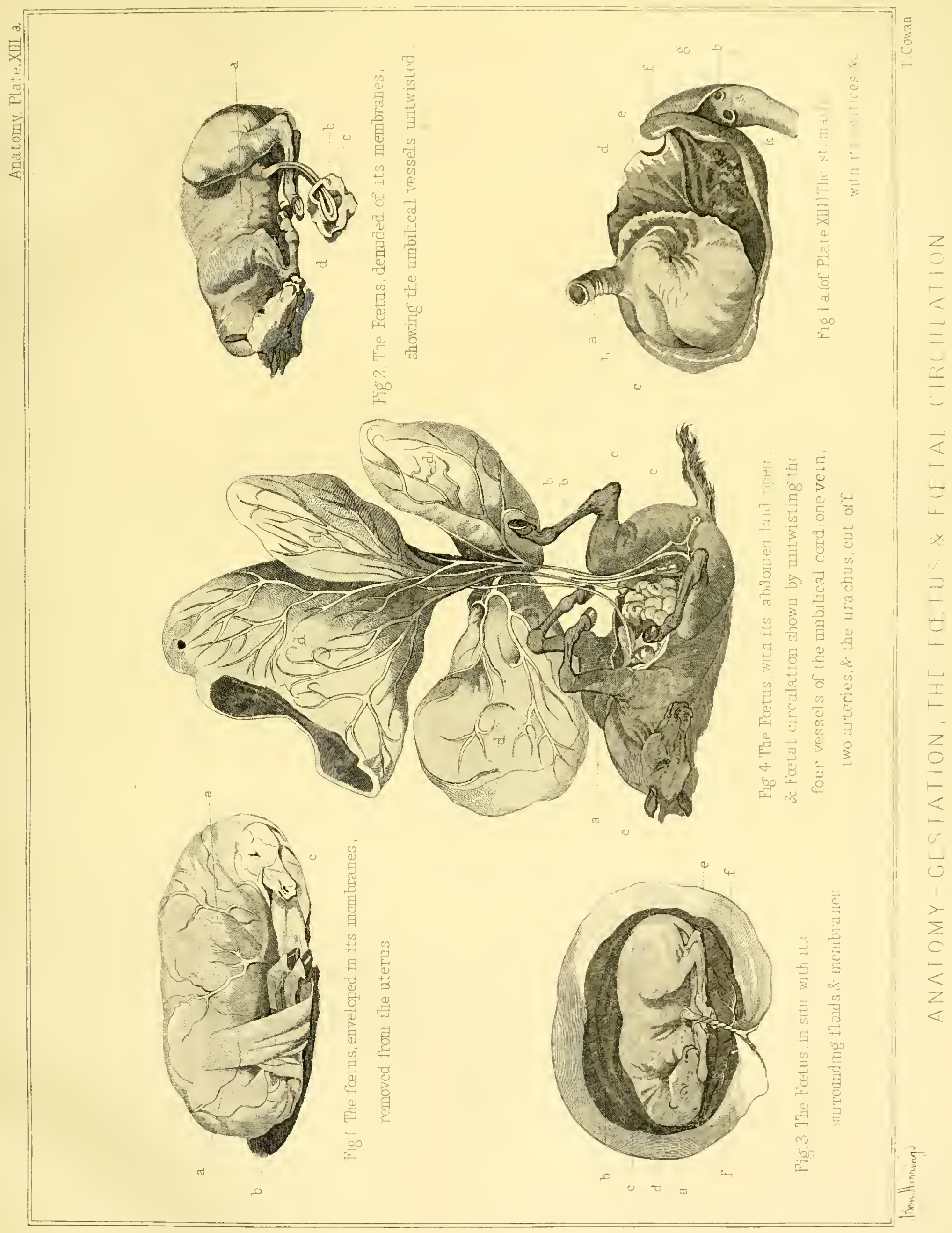



expel it; or when the bladder contains a certain quantity of fluid, the muscular coat contracts, and, the lungs being filled with air, the diaphragm is rendered convex towards the intestines, and they are by that means pressed upon the bladder, and by their united powers the fluid is forced through the sphincter* at the neck of the bladder, and escapes into the urethra (Gr., ouron, urine), whence it is voided on the ground. The urethra we shall notice in its more important functions in connection with the generative system.

\section{THE REPRODUCTIVE ORGANS.}

\section{THE MALE OROANS OF REPRODUCTION.}

Is the male animal the organs are mostly external; in the female, internal; in both, they are so connected with accessory organs as to answer a double purpose.

The scrotum (Lat., scroteum, a leather coat), the testes (Lat, testis, a witness, q. $d$., evidence of virility), the vasa deferens (Lat., vasa, vessel, deferens, carrying), the penis, theca (Gr., sheath), prepuce, and urethra.

The scrotum, or bag, is formed of the common integuments of the belly, and is outwardly smooth, thin, and scantily grown with hair. It has a peculiar muscular inner coat, called dartos (Gr., daro, to excoriate), by which the scrotum is corrugated and drawn up. It has also an internal septum or division, visible outwardly, which separates completely the two testicles.

The testicles, which fill the scrotum, are two glandular bodies, first formed within the abdomen. The coverings of the testicles are a white fibrous coat, continued up to the spermatic cord, and another from the cremaster (Gr., suspender). The cremaster muscles arise from the oblique abdominal muscle, and each support a testicle. The middle of the testes is divided by a mediastinum into separate portions like the segments of an orange. The third coat of the testes is a vascular tunic (called tunica vasculosum), being the nourishing covering of the gland, from which its ressels branch into all the divisions. These divisions are filled with the ends of the ducts called lobules (little lobes) in which the semen is secreted. The testicle is white, firm, and externally smooth.

The vasa deferens, as the excretory duct of the semen, joins the spermatic cord, and, passing through the abdominal rings, proceeds to the upper side of the bladder, terminating in the urethra in the opening of the seminal vesicles. These membranous sacs (vesiculce seminales) contain a special mucous secretion, and have large excretory passages ending in the urethra close to the vasa deferens.

The prostate glands are three or four in number. The lesser prostates (Cowper's glands) are two small bodies, the size and shape of a chestnut, near the greater prostates,

* From the Greek sphingo, to contract, or draw together, like the soouth of a bag or purse.

E E lying upon the spines of the ischium (haunch-bone). These also seem agents in elaborating the seminal fluid, but how has not been yet discovered.

The spermatic cord is covered by the peritoneum. It commences at the internal abdominal ring, passes through the groin, and comes out through the external abdominal ring.

The penis of the horse is a firm body, two feet in length, formed of an elastic and erectile tissue. One of these occupies the under portion beneath the urethra. The other is above the urethra, and is flaccid when not distended by venous blood, which, when the animal is under sexual excitement, it becomes to an immense degree, increasing in bulk and becoming very firm. At the extremity is a bulb called the corpus spongiosum, which, though appearing dis. tinct, is continuous with the lower portion of the erectile tissue.

The sheath, which encloses the penis from view, is formed of the general integuments continued loosely from the scrotum to the navel. The outer fold of the sheath owes its size to a ring of ligament which keeps its orifice firmly open, and from this the integuments are doubled back, be coming thinner and more full of vessels, again doubling back over the glans penis and forming the foreskin, or prepuce.

The urethra is the canal continued from the bladder through the body of the penis to its point. That part of the urethra encircled by the prostate glands is called the prostatic part, the otlier, the membranous part; and the part whereon the well-marked muscle, called the accelerator urince runs, is named the muscular part. From the lower surface of the points of the ischium come two muscles, inserted in the crura, called the erectores, whose function is expressed by their name. The urethra is highly sensitive and full of vessels; it secretes a mucus, by which it is protected from the action of the urine. Several mouths of ducts enter it, called lacunce (Lat., lacunoe, dots or pits). The nerves of the urethra rise from the loin (lumbar) and sacral flexures.

\section{ORGANS OF REPRODUCTION IN THE FEMALE.}

The genital orifice of the mare is surrounded by two roundish folds of loose, fatty, cellular tissue, covered with dark-coloured skin, called the labia majora (Lat., labia, lips, majora, greater). Two other folds lie within these, called vulvae, or labia minores, moist, fleshy, and full of vessels. The vulva has within its substance a sphincier muscle, called sphincter vagince (closer of the sheath).

At the bottom of the valve appears the clitoris, a body of erectile tissue, having a thinner extension of the same tissue on the vulva, and through the first or outer chamber of the vagina.

The vagina (Lat. for sheath), which lies between the bladder and the rectum, and extends from the labia minores to the neck of the womb, called cervix uteri (Lat., cervix, neck, uterus, cavity). 
The erectile tissue of the vagina is covered by a structure answering to the dartos of the male, and its mucous lining is thrown into numerous rugce (Lat., rugce, wrinkles), or irregular folds, varying in different animals, and remarkable for their want of uniformity. There is a contraction of the membrane lining the vagina near its middle, which divides it into two chambers. The hinder or outer of these is lined with erectile tissue, and is very full of vessels, the forward or inner portion is much less sensible and leads into the womb. A little way up the vagina, just within the vulva, on the lower side, is a small fold of membrane, easily felt by the finger. This is the opening into the urethra, or urine-passage, which is very short in the mare.

The uterus, or womb, is a rounded body, having at its fundus (Lat., bottom) two horns or wings. These are lined with mucous membrane, full of folds; outside this is a thick white lajer of muscular fibre, and outside this a thin cellular layer, and the common covering of the abdominal viscera, called peritoneum. Near the ends of the "horns" are two tubes, named after Fallopius, their discoverer, the Fallopian tubes. These are somewhat the shape of a cornucopia in the mare, small where they issue from the horns of the womb, and expanding at their extremities. They have been compared to a French horn, which they also resemble in being convoluted. They have a curious ragged fringe at the larger end, called, fancifully, morsus diaboli (Lat. for the devil's bite), attached to the ovaries (Lat., ovum, an egg) at one point. The loose pieces of this fringe are violently agitated during coition, and, seizing the ovum as it falls from the ovaries, convey it to the Fallopian tubes; these are also lined with mucous membrane, and their muscular coat is continuous with that of the uterus. The whole apparatus is supported by the peritoneal thickening known as the broad ligament of the uterus. The opening of the free end of the Fallopian tubes into the cavity of the abdomen, is a remarkable and solitary instance of a mucous membrane opening into a serous sac.

The ovaries, like the testes of the horse, have three coats: the outer, the peritoneum; the middle, white fibrous tissue; the internal, full of blood vessels. Old anatomists compared them to the testes, but the similarity ends with their form. They are cellular internally, and in the cells are the germs of eggs, which, as they come to the surface, are matured, and in copulation burst the coats and are carried down the Fallopian tubes. Whenever an ovum escapes, a corpus luteum is formed, of a yellow spongy mass, at the spot where the ovum has escaped from.

Before the period of conception, the Fallopian tubes become more full of blood, and have a writhing or peristaltic motion, like that already described as impelling the food along the intestinal canal. Certain prominences are also observed at this time on the surface of the ovaries, produced by the swelling of vesicles (called, after their discoverer Graaf, Graafian vesicles); these are the germs of the coming foal. The Tallopian tubes then become attached by their open fimbriated (Lat., fimbria, fringe) mouths over these prominences, and, receiving the vesicles as they burst through the peritoneal covering of the ovaries, convey them, by the peristaltic motion before mentioned, into the womb.

These germs are sometimes fecundated before they reach their destination, when what is called extra-uterine conception occurs. In these cases the germ never reaches the uterus at all, but remains in the intermediate canal, and attaches itself to its surface. In this position the fotus may grow, expanding the tube as it grows, till at length it gives way, and the foetus escapes into the general cavity of the abdomen.

The mammary glands in mares are placed a little in front of and between the hind legs. They are two in number, each composed of a bag and teat, with a muscular coating like the scrotum of the horse. The main substance of the gland is made up of bloodvessels and ducts for carrying off the secretion. The milk is secreted in minute glands, which empty into the ampullæ (Lat., ampulla, a bellied bottle) or dilatations, whence it is carried by other ducts which communicate with the milk-bearing tubes (tubuli lactiferi), which last end in the point of the teat. Thus much of the organs of reproduction. The physiology of conception, gestation, and parturition come next to be considered.

We may notice that although the male appetite is constant, it is by no means uniform. Cold weather, low feeding, and the absence of the effluvium of the mare, greatly moderating it. During the period when the mare is in "season," his desire is at its height. It is at periods when the stallion is "cold," that the avarice of breeders and dealers sometimes leads them to the ruinous folly of administering stimulants, to provoke him to an act of itself exhaustive, and, in excess, fatal. Farcy, glanders, and wasting we have seen consequent on this attempt to force nature.

\section{GESTATION AND FOALING.}

Conception follows the copulative act. Most mares require but one "leap" of the horse, to conceive; which having done the "heat" "cease, and the mare will refuse the male. As the "heats" recur at periods of nine days (as often eight), it will be as well, to make sure, to show the mare the stallion, and observe whether there is any sign of sympathetic orgasm. If so, she may be again covered.

We have already noticed that impregnation is effected by the action of the semen upon the ovum; whether by actual contact and inoculation or by sympathetic influence, is yet questioned, perhaps both. The evidence, we think, is in favour of an actual flow of the impregnating fluid through the tubes and oviducts to the ovarium; and this view is strengthened by the fact that in animals which produce several young at a birth, several of the fecundated ova never reach the uterus at all, but remain in its "horns," and there mature, till expelled as living animals complete in all their functions.

The ovum being lodged in the cavity of the uterus, $a$ 


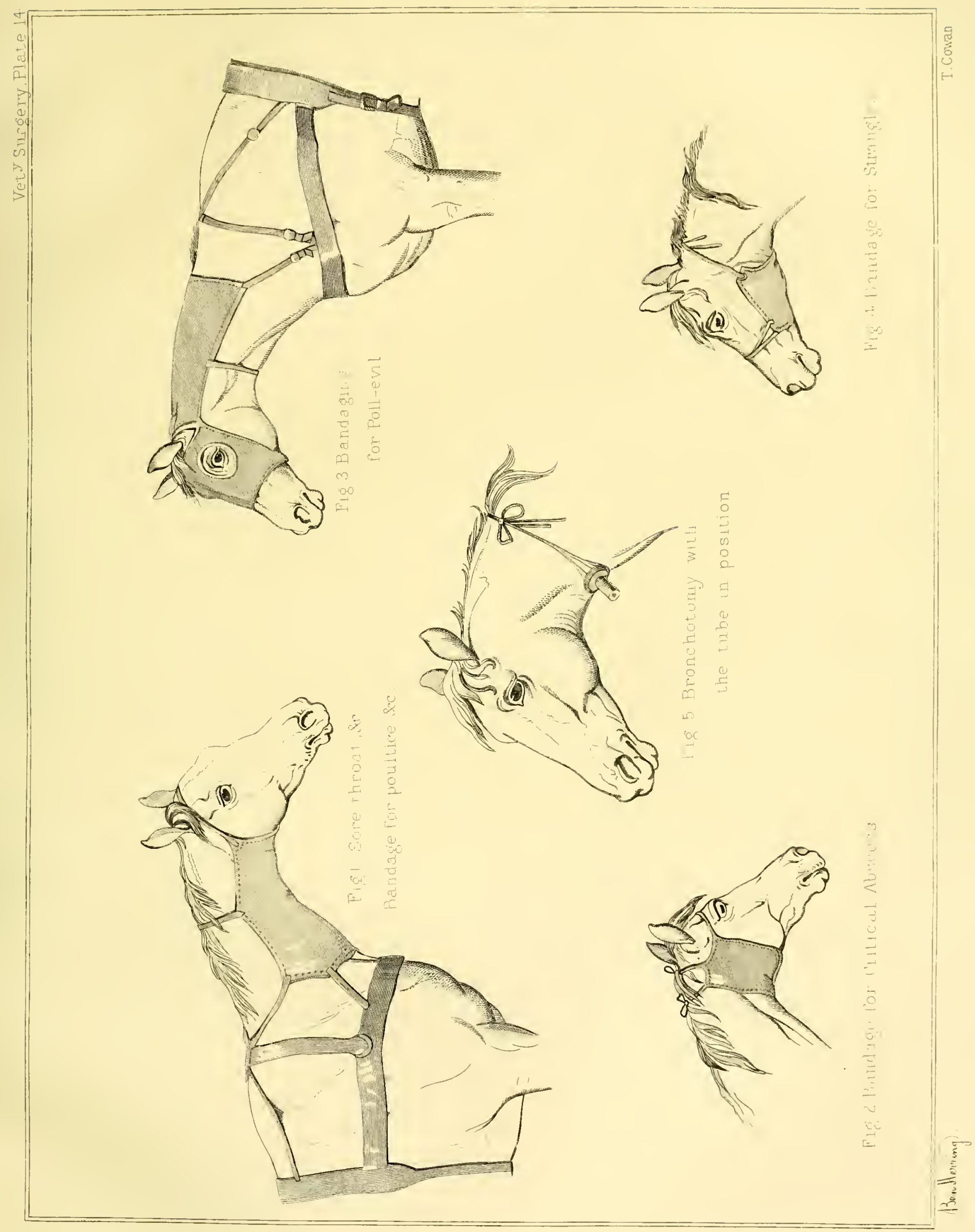



considerable change takes place in that organ. - It gradually enlarges so as to accommodate the contained foetus as it grows. A greater quantity of blood is now also determined into its ressels for affording the proper nourishment. When the ovum has become sufficiently large to enable us to distinguish the germ of the foctus, we find it consists of two membranes containing a fluid, in which swims the fœtus, still gelatinous and without shape. Gradually increasing in size, its parts are at length developed; and we see it attached to the whole internal surface of the uterus of the mare by a thick spongy mass. This is called the placenta, and is the organ through the medium of which the future animal receives its nutrition in the uterus of the mare.

The placenta consists principally of bloodvessels, which are collected at the centre of its membrane, so as to form a cord; this cord is continued to the navel of the fœtus, which it enters; and a vein runs from it onwards, to empty its blood into the venous canal, which further conveys this fluid to the vena cava, contiguous to the heart. Having entered the right auricle of the heart, the blood passes by an oval hole (which is peculiar to the fœtal state, being closed up after birth) into the left auricle, and a part finds its way by the right ventricle into the pulmonary artery. But as even this portion of the blood is not intended to enter the lungs of the fotus, it is conveyed by a canal (also peculiar to the foetus, being afterwards closed up), which communicates with the aorta. From the left auricle the blood passes into the ventricle of that side, and thence into the aorta, to be circulated through the fotal system, for conveying to it the principles of life and nutrition. Thus it will be seen that the blood does not circulate through the lungs of the fœtus; for, breathing being incompatible with the foctal condition, the lungs require no more of that fluid than is necessary to their growth. The blood, after having given out life and nutriment to the fœtus, is returned to the placenta by two arteries, which, arising from the aorta, a little after it has entered and divided into two branches in the pelvis, are called the umbilical arteries: these arteries pass out at the navel along the cord, and re-convey their contents into the placenta.

How the communication between the uterus and placenta is carried on, is still a mystery. The supposition, however, is, that the placenta performs an office, with respect to the foetus, analogous to that of respiration effected by the lungs after birth; and also, that it is the medium for supplying the blood with new materials for the growth of the foetus.

There is, it is true, an indirect communication between the mother and the embryo foal, in the attachment of the outer membrane of the placenta; but the foetal vessels in no way-communicate with those of the mother, and the finest injection fails to find its way from one to the other. The vessels, however, pass near to the uterine arteries of the mother, through the agency of two umbilical arteries and a rein, which occupy the membranous cord. This, when the foetus is fully grown, is an inch in diameter and three feet in length, and is called the umbilical cord, from passing into the navel (umbilicus) of the foal. (See Plate XIV.)

The membranes forming the placenta (or womb-cake) are at first two : the outer, called chorion (Gr., chorion, protection), the inner the amnion; * and at a later period of pregnancy a third membrane is developed, called the allantoid (Gr., alla, a sausage, and oidos, like). The allantoid communicates with the bladder of the canal called the urachus (Gr., urax, a mouse), which contains the urine of the fotus, and is always full of the contents of the foetal bladder. The amnion, which immediately encloses the fœtus, contains and secretes a fluid called liquor amnii, in which the embryo floats. The bowels of the fotus at birth are full of a yellow mass of pap-like consistency, called meconium (Gr., meconios, inspissated poppy-juice). The urachus, which reaches from the bottom of the bladder of the fotus, and the allantoid sac, break at birth, and that part which the foal keens dries up, and forms the long ligament of the liver.

The term un gestation in the mare is between eleven and twelve months. Blaine records, Cyclopoedia, p. 282, that of 582 mares, covered but once, and observed and registered, the shortest period from copulation to parturition was 287 days (78 short of twelve months), the longest 419 days (54 days beyond the year); thus making the extraordinary difference of 132 days, or four months and 12 days between the extreme periods of gestation.

Parturimion.-When the period for foaling approaches, the weight of the young animal rapidly increases, and the fluid of the amnion, which before was almost equal to its weight, decreases by absorption. The uterus, which was completely within the pelvis (Gr., basin) thrusts its fundus against the epigastrium and becomes painful from distension. The udder enlarges, and sometimes milk may be squeezed from the teats ; if milking does not alarm the mare, it will give her ease. In most cases an adhesive matter appears about the teats some hours before foaling. At last, the vulva (see ante), swell and protrude, and the tail is erected; some heaving of the flanks, acceleration of the pulse, and restlessness are generally observable, with deep drawings in of breath, constriction of the abdominal muscles, and a forcing of the uterine contents by aid of the diaphragm (itself pressed by the inflated lungs) backwards, to effect the expulsion. The mouth of the womb dilating, and the attachment of the chorion breaking, the hind legs are now set wide apart, and the membranes protrude like a bladder. This bursts, the liquor amnii escapes, and in favourable cases brings down the foal with it. In more protracted births, the head and forelegs are gradually forced into the ragina. Severe spasms follow till the foal is born; and the placenta (now called the after-birth) either comes

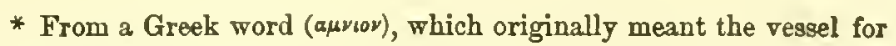
receiving the blood of the victims sacrificed, but was afterwarde applied to this membrane, with its contained fluid. 
away at the same time as the foal, or is long and dangerously retained, the fall to the ground rupturing the umbilical connection of the newly-born animal. In ordinary cases, the lungs of the foal immediately begin to act, and, directed by his newly-awakened organs of smell, he seeks the milk of his mother.

When the foal is weakly or torpid, it may be judicious to hold it up to the teat. The first milk, be it remembered, has a peculiar quality. It is purgative, and clears out the meconium from the alimentary canal of the young animal. Should the mother be dry, or die, cows' milk, boiled, or better, asses' milk, where procurable, will support the foal. Some celebrated racers have been hand-reared. The udder of the mare is not fully supplied with milk till the fourth day. When the nippers of the foal become fitted to bite the young grass, the mare weans it; or rather the udder dries up and returns to its ordinary form.

There is an interesting and remarkable point in the economy of the fotus, with regard to the descent of the testicles. The inner and outer abdominal rings have been already described, and, it must be remembered, the walls of the abdomen are chiefly formed by four pairs of powerful muscles, joined in the middle by the linea alba, where it is perforated by the navel (umbilicus). Now, in the fotus, the testicles are placed just behind the kidneys, and from that situation they eventually make their way into the scrotum. While in the belly, they are wrapped in the peritoneum, and attached to a ligament of almost triangular form : this ligament is called gubernaculum testis (ruler of the testicle), and is full-grown at birth. It then shrinks and draws down the testicle gradually to the abdominal ring, bringing with it the peritoneal covering, and thickening its substance. The gubernaculum absorbs when no longer useful, and an open communication is formed with the cavity of the scrotum, the matured testicles descend to the purse destined to hold them. This peculiar descent of the spermatic organs takes place soon after birth; and until the fourth, fifth, or sometimes sixth month, the testicles are found outside the outer abdominal ring. After this they are drawn back again, and remain in the canal of the groin (inguinal canal) till the tenth or eleventh month, when they again descend to occupy the scrotal sac for the remainder of the animal's existence, unless man should determine to render him more docile and useful as a gelding, which we shall come to consider under the head of Castration.

Puberty in both horse and mare arrives about the fifth year. The terms colt and filly are changed for horse and mare between the fourth and fifth years. 


\title{
THE PRACTICE OF VETERINARY MEDICINE.
}

\author{
CHAPTER XXIII.
}

INTRODHCTION.-HORSE MEDICINES AND REMEDIES, DOSES, FORNULA, AND PREPARATION.

h BSORBENTs. - At the head of these stands chalk. It has a tendency to correct acidity of the stomach, and in some cases to check diarrhœa. A carbonated alkali is useful. Cows, calves, and sheep, being more subject to acidity than the horse, are more benefited by chalk.

Acetated Liquor of Ammonia.-Pour Acetic Acid (which see), in the proportion of one ounce to seven of water, on carbonate of ammonia till effervescence ceases and a neutral solution is made. This is what is called in farriery books, Mindererus's Spirit. It is diaphoretic and mildly diuretic (q. v.). It is useful in the weak stage of fever after influenza. It is also advisable in the early stage of epizootic catarrh. Lose from five ounces upwards.

Acetate of Copper. See Copper.

Acids. See under their several heads as Sulphoric ACID, \&C.

Acetic Acid (Pyroligneous Acid). The Acetic Acid distilled from wood has properly superseded the ordinary fermented vinegar in medicine and the arts. Diluted with water, it forms an excellent lotion for various skin diseases, and in its strong state is a remedy for warts. Impure pyroligneous acid, as it first comes over, impregnated with tar, we have found a valuable application in chronic inflammation of the eyes and edges of the eye-lids, and in promoting the digestion of ulcers. It is also a good injection into sinuses to produce healthy discharge or adhesive inflammation. It is powerfully antiseptic; and decomposing meat plunged into it has at once its putrefaction checked. The empyreumatic oil it contains is the cause of rood-smoke acting in the preservation of tongues, hams, herrings, \&c

Erdao (Acetas Cupri). See Verdiaris, Copper.

Ether, SuLPhorrc.-An antispasmodic (q. v.) of the first order in veterinary practice. It is valuable as a diffusible stimulant and narcotic. It rapidly evaporates, producing cold and dryness, and is therefore, when applied externally, an active refrigerant. If, however, it be so confined as to prerent its evaporation, its action is directly the oppositestimulant, rubefacient, and on the human skin even blistering. Its drying qualities may be easily tested by rinsing a bottle with it, when drops of water obstinately adhere to the glass, and exposing it to a current of air; it will be completely dry in a ferr minutes. Sulphuric ether, mixed with ten times its quantity of water, is one of the safest of horse drinks. Nitrous Spirit of Ether (see NITRE), commonly called "Sweet Spirit of Nitre," is cheaper and more generally used as a febrifuge for the horse.

Athiops Mineral. See Mercury.

A LOES.-As this well-known resin is the sheet-anchor of farriers, a few words on its qualities and action may be indulged in. There are three kinds of Aloes: 1. The Socotrine (Aloë Spicata), or Cape Aloes; 2. Common or Barbadoes Aloes (Aloë Vulgaris); 3. Fetid or Horse Aloes (Aloë Caballina). Of these, Socotrine (or Cape) Aloes seem to be the purest, obtained by draining only; Barbadoes are less pure, and prepared by boiling or slight pressure; while Horse Aloes (to be utterly banished) are the dregs of the last-mentioned. Aloes are frequently adulterated with common resin. This may be detected by dissolving a portion in hot water or alcohol, when the common resin will separate from the aloetic. Every veterinary practitioner should buy his aloes in the gourd in which they are cooled, and reduce them to powder under his own supervision. Aloes are prepared by boiling the leaves and inspissating the juice, then pouring it into gourds to harden. Socotrine Aloes are of a brown colour, inclining to red, and brittle. Barbadoes black, with a shade of brown, of a greasy feel, and a dull fracture.

The Barbadoes Aloes are best, being, with the horse, more certain in action. The Socotrine or Cape, which are the finest, are most approved in human practice. The Caballine or Horse Aloes (which Blaine and others confound under the name of Cape Aloes) we would banish from the dispen sary. Aloes are a bitter stimulating purgative, emptying 
the large intestines, without making the stools so thin as many other medicines of the class. It is likewise a quickener of the circulation, warms the system, and slightly promotes uterine and hæmorrhoidal discharge. Hence in irritable states its use may be unadvisable. Its general action as a purgative will be found under Puraatives. As an alterative, aloes are sometimes given in doses of a drachm to two drachms daily. Barbadoes aloes powder best in frosty weather, when enough may be pounded and enclosed in stoppered boitles for a year's supply. A pound of the powder, warmed for a couple of hours, mixed with one ounce of powdered ginger and eight ounces of palm oil, and divided as wanted into proper doses, will be found a capital purgative for general use.

Aloes are boiled by some practitioners, to render them more mild. The great difficulty of keeping aloes in an equal state of consistence, as a purgative mass, induced Mr. Bracy Clark to adopt the following method, by which, he informs us, these inconveniences are obviated. He places one vessel within another, exactly as carpenters melt glue, having water in the outer vessel, and aloes, with onefiftl of their weight of treacle, in the inner one, which is carefully covered with a lid. The apparatus being put on the fire, is suffered to remain for an hour or more, or until perfectly melted, the aloes and treacle being now and then, but not too often, stirred to combine them. The inner ressel being now taken from the outer, the contents are expeditiously cast in paper moulds or tubes of the usual diameter of a horse-ball. When cold, Mr. Clark finds these balls flexible, yet solid, and they remain so. He gives an ounce to a saddle or carriage horse, and six drachms to a cart horse: but there is reason to fear that they do not prove so soluble in the stomach as when their particles are divided by oil, lard, or even syrup; but the last is a more objectionable ingredient than either of the others. No diuretic, such as soap or carbonate of soda, should be added to this mass; and it is a curious fact that nut-galls will neutralise effectually the purgative action of aloes. We may note here a recorded instance of the different action of the same drug on different animals. A horse will, under ordinary circumstances, be purged by an ounce of aloes; an ox by two or more; a dog will romit at the dose; for a man the dose is five to eleven grains. A large hog does not require so much; and lastly, according to the experiments of M. Gilbert, a sheep which took two ounces was not purged, although it died seventeen days afterwards. And see Art. Purgatives.

A WATERI SOLOTION OF ALOES should be kept by every veterinarian, which will be found, in many instances, a very convenient form, on account of its quicker action.

A SPIRITUOUS TINCTURE OF ALOES, made by digesting four ounces of the powder in a quart of proof spirit, forms a common stimulating application to recent wounds, \&c. Half an ounce of powdered myrrh is a good addition.

Alteratives. This is a class of medicines much mis- understood by the farrier. They are supposed to act upon the system in a slow and nearly imperceptible manner. They form the excuse for that vile propensity of grooms to dose the unlucky horse on all occasions, to the injury of his health and often of his constitution. These medicines are indicated in diseases of the skin, defective secretions, and debility of stomach. The alteratives in most repute among farriers, are nitre, antimony, sulphur, mercurial preparations, resins, and spices; to these many add everv drug and compound in the pharmacopoia. For ourselves, we would fain abolish the word alterative altogether, as a vague generality and mystifying term for any remedy for any disorder, and a cloak for ignorance; as, however, it is in constant use, we must retain it, confining it to medicines for the amendment of the state of the skin and general excretions. The leading formulæ for alteratives are :-

\section{(A) in disordered stateg of the sKin.}

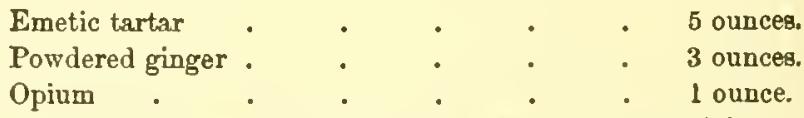

Syrup enough to form 16 balls : one to be given every night.

\section{(B) Simply cooling.}

Barbadoes aloes . . . . . 1 ounce.

Castile soap . $\quad . \quad$. $\quad . \quad$. $1 \frac{1}{2}$ ounce.

Ginger . . . . . . $\frac{1}{2}$ ounce.

Syrup enough to form 6 balls : one to be given every morning.

(C) in strangles.

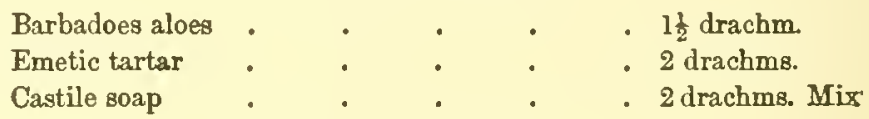

(D) ALTERATIVE BALL FOR GENERAL USE.

Black sulphuret of antimony . . . 2 to 4 drachms.

Sulphur . . . . . 2 drachms.

Nitre . . . . . . 2 drachms.

Linseed meal and water enough to form a ball.

(E) TOR GENERALLY DEFECTIVE SECRETIONS.

Flowers of sulphur . . . . 6 ounces.

Emetic tartar . . . . . 5 to 8 drachms.

Corrosive sublimate . . . . 10 grains.

Linseed meal mixed with hot water, enough to form 6 balls, one of which may be given two or three times a week.

\section{(F) IN DEBILITY OF STOMACH.}

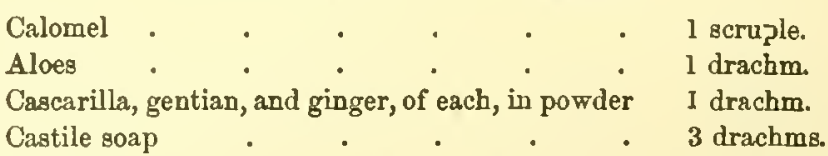

Syrup enough to make a ball, which may be given trvice a week, or every other night.

Alom (Alumen).-A well-known salt with a metallic base. It is in general use with veterinarians, internally and externally. It is used in cases of super-purgation in the form of alum-whey; two drachms of powdered alum in a pint of warm milk. In doses of one or two drachms, it is 
employed as an astringent in diarrhœa, diabetes, and other fluxes. If alum be mixed with a vegetable astringent, such as oak bark, instead of increased power, the action of both is diminished. As a wash for cracked heels, two drachms to a pint of water and a scruple of white vitriol is useful. It is also a serviceable wash in grease generally; and also tor those forms of swelled legs attended with exudation of moisture through the skin. Some add the Goulard lotion, forgetting the chemical decomposition that takes place; the result of which is, that the alumina, possessing little astringency, is detached, and two salts with no astringency at all, the sulplate of lead and the sulphate of potash, are formed. Externally it is by some used as a styptic to stop hæmorrhage, by sprinkling it on the bleed ing orifice, when its coagulating properties plug up the mouth of the vessel. It is also esteemed to be a useful escharotic to destroy fungus, and a detergent for foul ulcers.

Ammonia.-Crude Ammonia, or Muriate of Ammonia, is so called to distinguish it from the volatile or prepared ammonia which follows. It is, in general opinion, when diluted, one of our very best discutients; and, when in mixture with acetic acid or vinegar, to which camphor is added, it forms the favourite lotion of general practitioners in skin disorders. From it are prepared

Volatile Ammonia (Ammonia Subcarbonas). The gaseous ammonia, fixed into a solid form by combination with carbonic acid, forms the volatile ammoniacal salt of the druggists. It is a good stimulant in the latter stages of fever. United with acetic acid it forms the Spirit of Mindererus, an excellent preparation.

Ammonia Acetatis. See Acetated Liquor of Ammonia.

Carbonate of Ammonia is called salt of hartshorn; carbonated water of ammonia is the spirit of hartshorn of the shops. It is convenient in veterinary practice, from its peculiar property of uniting water and oil. Internally, it is an antispasmodic, in doses of six to eight drachms, administered in warm water. Externally, it is a rapid blistering agent.

Axmoniac.-A gum-resin; the inspissated juice of the dorema armeniacum, an oriental umbelliferous plant, common in Persia. This gum is sometimes given in obstinate coughs and in farcy. It is a useful expectorant, dissolved in the acetate of ammonia and rubbed with camphor, which is active in its effect on the horse.

ANISE SEED.-The powder of these seeds was formerly much used by farriers; and the druggists who make horse powders find it a profitable article; for it is adulterated to one-third only of the genuine powder. It may be very properly united with other warm aromatics when cordials are admissible. It is also thought to possess some pectoral properties ; but they are very trifing. The essential Oil is the most active preparation of it. See OrLs.

Anodrnes. - This class of medicine is given to soothe the general nervous system, or to relieve spasm, as in the case of tetanus. Opium may be said to be almost the only anodyne in routine veterinary practice, and may be safely administered to the horse in very large doses.

Its pervading use may be gathered from the following prescriptions; and a reference to OPIUM will show its general value and effects.

\section{Anodyne medicines, compounded.}

(A) in ordinary caseg

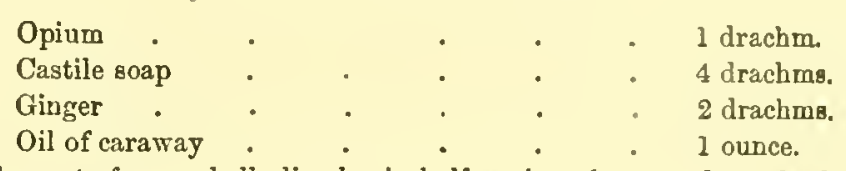

Syrup to form a ball, dissolve in half a pint of warm ale, and admi. nister as a drench.

(B) IN colic.

Powdered opium .

Camphor .

Castile soap

Ginger and give every hour during the agony.

\section{(C) IN DIARRHEA OR SUPER-PURGATION.}

Tincture of opium (laudanum) - . . 1 ounce.

Gum Arabic (dissolved in 1 pint of boiling water) 2 ounces. Add

Oil of peppermint

25 drops.

A drench. Give night and morning while indicated to be necessary

(D) IN CHRONIC DIARRHEEA.

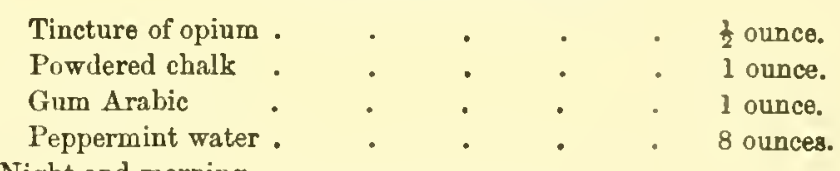

Night and morning.

\section{Antirelmintics. See Worm-Medicines.}

Antimony.-There are several medicinal preparations of this metal.

The Black Sulphuret of Antimony, a compound of sulphur and antimony, is a good alterative. It is given with sulphur and with nitre, in varying doses, according to the disease and the slow or rapid effect intended to be produced The maximum dose, and especially if it is to be continued, should not exceed four drachms. It should never be bought in powder, whatever trouble there may be in levigating it, for it is often grossly adulterated with lead, manganese forge-dust, and arsenic. The arsenic may be detected by placing a little of the powder on a red-hot iron plate. The pure sulphuret will evaporate without the slightest residue-so will the arsenic, but there will be an evident smell of garlic; a portion of the lead and the manganese will be left bohind.

Tartarized Antimony (Antimonium tartarizatum). The tartrate of potash and antimony, or a combination of super tartrate of potash and oxide of antimony, called Emetic 
Tartar, is a very useful nauseant, and has considerable effect on the skin. It is particularly valuable in inflammation of the lungs, and in every catarrlial affection. It is given in doses of one drachm, or one drachm and a half, and combined with nitre and digitalis. It is also beneficial in the expulsion of worms. Here it must be given in doses of two drachms, and with some mechanical vermifuge, as tinfilings, or ground-glass, and administered on an empty stomach for several successive days. Although it may sometimes fail to expel the worm, it materially improves the condition of the horse, and produces sleekness of the coat. To a slight degree the emetic tartar is decomposed by the action of light, and should be kept in a jar, or green bottle. It is sometimes adulterated with arsenic, which is detected by the garlic smell when it is placed on hot iron, and also by its not giving a beautiful gold-coloured precipitate when sulphuret of ammonia is added to it in solution.

Chloride of Antimony, formed by distilling corrosive sublimate with antimony, is called Butter of Antimony by farriers, on account of its butter-like (butyraceous) appearance. It, however, has a strong affinity for water, which it attracts from the atmosphere, and thus becomes fluid. The less water it is suffered to absorb, the more powerful its action, it should therefore be kept in close-stopped bottles. The test of its goodness is its density. It is the best liquid caustic we have; it is most manageable, and its effect can most readily be ascertained. As soon as it touches any muscular or living part, a change of colour is perceived on the part; and the effect of the caustic can be fairly judged of by the degree of change. For corns, canker, indisposition in the sole to secrete good horn, wounds in the foot not attended by healthy action, and for every case where the superficial application of a caustic is needed, the chloride of antimony is unrivalled.

Antimonial Powder-Powder of oxide of antimony, with phosphate of lime, is the factitious James's powder, and is used as a substitute for that medicine in many diseases of a febrile character. The dose is from one to two drachms. The late Mr. Bloxam used to trust to it alone in epidemic catarrh of the horse. It is decidedly inferior to the Emetic Tartar.

Antispasmodics. - This is not a large class of medicines in veterinary practice. We may refor to the chief anodyne -opium-as the chief. They, as their name imports, are intended to suppress or counteract the excessive muscular action called spasm, or cramp. These attacks are rather secondary to other irritating causes, and therefore remedies to attack the cause are more to be relied on than combating the effect. There are, however, two or three as palliatives, which may be administered with advantage. Camphor, hyoscyamus (henbane), beliadonna, oil of turpentine, and asafæetida have proved useful. Cold suddenly and continuously applied is a powerful antispasmodic, and bas succeeded in subduing tetanus.

\section{Antispasmodic Recipes.}

(A) FOR COLIC.

Spirits of turpentine . . . . 3 ounces.

Tincture of opium . . . . 1 ounce.

Mix with a pint of warm ale, and give as a drench.

(B) ANOTHER DRENCH FOR COLIC.

Spirits of turpentine

Tineture of opium

Barbadoes aloes.

Powder the aloes, and dissolve in warm water; then add the other ingredients, and give as a drench.

\section{(C) cLyster IN COLIC.}

Spirits cf turpentine . $\quad$. $\quad$. 6 ounces.

Aloes . . . . . . . 2 drachms.

Dissolve in 3 quarts of warm water, and stir the turpentine well into it.

(D) ANTISPASMODIC DRENCH.

Gin

Tincture of capsicum

- 2 drachms.

Torm $• c^{-} 3$ drachms.

Mix, and give as a drench, when there is no inflammation.

Aperients.-Aperients, laxatives, or purgatives, are degrees, quantities, or kinds of the same medicines. Laxatives may be classed as nilder purgatives, and as acting with less irritation in inflammatory affections. In chronic cases, too, they can be administered more frequently, which is very desirable. Calomel, with small doses of aloes, ranks high among these. The laxatives proper in fever are Epsom, Glauber, or Cheltenham salts, 8 to 12 ounces, dissolved in thin gruel, and repeated every six hours until they operate. In some cases, the bowels being inflamed, 6 or 8 ounces of castor or linseed oil, with a few ounces of the watery tincture of aloes, will prove excellent; it is improved by half a drachm of chloroform. The action of these is much assisted by bran mashes, gruel, and diluent drinks. It, must, however, be confessed that most of these aperients are doubtful and irregular in their action upon the horse. When this inefficacy is apparent, a mild copious clyster, or "backraking" (see post, in Veterinary Practice) should be resorted to.

Some Aperients act solely by exciting the muscular coat of the bowels to contract; others cause a copious watery discharge; whilst a third class combine the action of the two. The several purges also act upon different parts of the digestive canal; some stimulating the larger bowels, while others act upon the small intestines; and others, again, on the whole canal. There is yet another class, that combine with purging an influence on the liver, such as mercury and rhubarb; which is effected by absorption with the circulation. Drastic purges are the violent extreme of the scale, as laxatives are the mildest of aperients. As these medicines will receive full notice in the medical treatment of diseases, we shall spare space here by referring to the article specially bearing on the subject, where 
it will be found fully considered. Some of the most useful aperient formulæ are subjoined :-

\section{Aperient Recipes.}

(A) ORDINARY APERIENT, OR "PHYSIC" BALL.

Barbadoes aloes . . . . 3 to 8 drachms.

Hard soap . . . . . 4 drachms,

Ginger . . . . . 1 drachm.

Dissolve in as small a quantity of boiling water as will suffice; then slowly evaporate to the proper consistence, by which means griping is svoided.

(B) a WARMer aperient ball.

\begin{tabular}{|c|c|c|c|c|}
\hline Barbadoes aloes & & ". & & 3 to 8 drachms. \\
\hline Carbonate of soda & & $\cdot$ & & $\frac{1}{2}$ drachm. \\
\hline Aromatic powder & & • & $\theta^{\prime}$ & 1 drachm. \\
\hline Oil of caraway & & • & . & 12 drops. \\
\hline
\end{tabular}

\section{(C) Gently Lazative ball.}

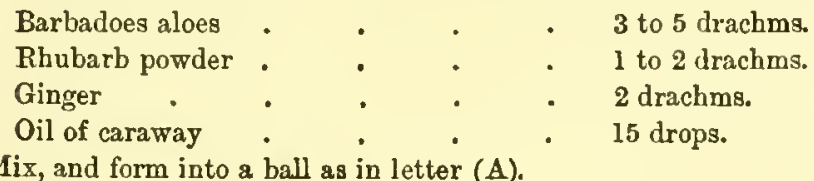

(D) PURGina baLl8, WITH CALOMEL.

\begin{tabular}{|c|c|c|c|c|c|c|}
\hline \multicolumn{2}{|c|}{ Barbadoes aloes } & • & & & & 3 to 6 drachms. \\
\hline Calomel & . & • & •• & . & • & $\frac{1}{2}$ to $1 \mathrm{drachm}$. \\
\hline Rhubarb & . & . & . & . & . & 1 to 2 drachms. \\
\hline Ginger & . & . & . & . & • & $\frac{1}{2}$ to $1 \mathrm{drachm}$. \\
\hline Castile so & & . & . & . & . & 2 drachms. \\
\hline
\end{tabular}

Mix. as in first prescription (A).

(E) StOMAChic LaXaTive BalL.

\begin{tabular}{|c|c|c|c|}
\hline \multirow{4}{*}{\multicolumn{2}{|c|}{$\begin{array}{l}\text { Barbadoes aloes } \\
\text { Rhubarb } \\
\text { Ginger, and Cascarilla powder } \\
\text { Oil of caraway }\end{array}$}} & \multirow{3}{*}{$\cdot \vec{\cdot} \cdot \dot{ }$} & \multirow{3}{*}{$\begin{array}{l}3 \text { drachms. } \\
2 \text { drachms. } \\
1 \text { drachm. }\end{array}$} \\
\hline & & & \\
\hline & & & \\
\hline & & . $\quad$. & 15 drops. \\
\hline Carbonate of soda & . $\quad$. & . & $1 \frac{1}{2}$ drachm. \\
\hline & & & \\
\hline & (F) LAXATI & DRENCH. & \\
\hline Barbadoes aloes & . & - & 3 to 4 drachms. \\
\hline Canella alba & . & . & 1 to 2 drachms. \\
\hline Salt of tartar & . & . & 1 drachm \\
\hline Mint water & . & . & 8 ounces. \\
\hline
\end{tabular}

Mix.

\section{(G) ANOTHER LAXATIVE DRENCH.}

Castor oil .

Barbadoes aloes . . . 3 to 5 drachms.

Carbonate of soda . . . . 2 drachms.

Mint water. . . . 8 ounces.

Mix, by dissolving the aloes in the mint water by the aid of heat, and then adding the other ingredients.

(H) A MILD OPENING DRENCH.

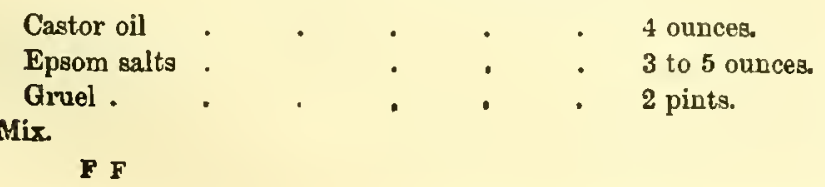

(I) A VERY MILD LAXATIVE.

$\begin{array}{lllll}\text { Castor oil, and Linseed oil } & \text { - } & \text { - of each } 4 \text { ounces. } \\ \text { Warm water, or Gruel } & \text { - } & \text { - } & \text { - } 1 \text { pint. }\end{array}$

(K) USED IN THE STAGOERS.

\begin{tabular}{|c|c|c|c|c|c|}
\hline Barbadoes aloes & • & 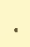 & - & & 6 drachms \\
\hline Common salt . & 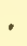 & - & & • & 6 ounces. \\
\hline Flour of mustard & & . & & & 1 ounce. \\
\hline Water . & . & . & - & - & 2 pints. \\
\hline
\end{tabular}
Mix.

(L) A GENTLY COOLING DRENCH IN SLIGHT ATTACES OF COLD

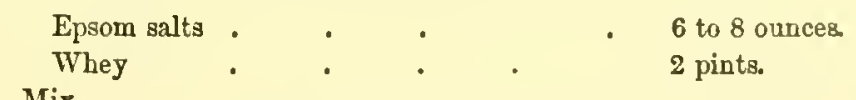

Mix.

\section{(M) PURGATIVE CLYSTER.}

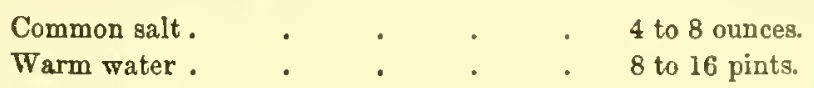

ARNica has for a time disappeared from our prescriptions and practice, to re-appear recently with good claim on our notice. It is the production of the Arnica montana, or Leopard's Bane, which grows plentifully on the Alps and other European high lands. In Germany all parts of the plant are used and esteemed,-leaves, stem, flowers, and root. It possesses through the whole plant an aromatic odour and a nauseous taste, arising from a volatile oil and an acrid resin. The roots contain a large amount of tannin; and "arnicine," as the chemists have called its extract, in small doses, accelerates the pulse, in large, irritates the alimentary canal, and causes faintness. It is diaphoretic and diuretic, and we have found the root in powder ( 20 grains 3 times a day), or the infusion ( 3 drachms of flowers and leaves and 1 pint of boiling water), given four ounces at a time, a good stimulant. In Germany they make a tincture and a vinegar of arnica, of which we would recommend trial to be made by the veterinarian. It is now applied by homœopathic doctors to wounds and bruises; with what effect it could be introduced in horse-practice we cannot at present with certainty say.

Arsenic.-Were it not that some practitioners continue to use it as a tonic, in doses of from ten to twenty grains daily, and others use it to core out old ulcers, we would not include it in our list, for we have little faith in it. There are better and safer tonics, and far better and safer caustics. The best form in which it can be administered is, the liquor arsenicalis, made by boiling its own weight of potash with arsenic and water (one ounce of water to every four grains of arsenic), in some glass vessel. It has some power in staying the progress of glanders; and is pretended to cure farcy when watched and continued. It also appears to have some vermifuge properties; Blaine believed it to retard the march of the rabies, though not ultimately successful.

Astringents. - These are supposed to act on the living fibres by producing increased contraction, in which point of 
view they form a very numerous and important class; but in a more limited sense, they are considered as substances that restrain immoderate fluxes, as of the intestines and kidneys. Those that act by constringing the divided ends of bloodvessels are called styptics. Opium, chalk, alum, starch, and catechu, act favourably in restraining intestinal fluxes. Catechu, alum, and acetate of lead, operate as astringents on the urinary passages.

\section{Astringent Recipes.}

\section{(A) FOR DIABETES.}

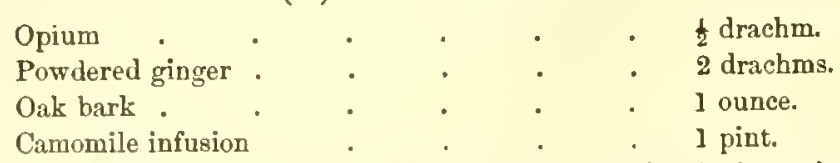

Mix for a drench; or, if powdered oak bark omitted, substitute alum, as much as the tea will dissolve.

\section{(B) FOR BLOODY URINE.}

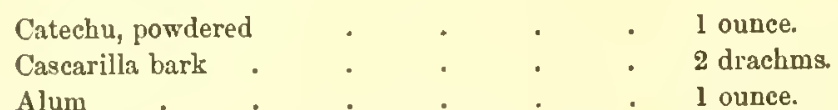

Liquorice powder and treacle to form a ball, administered twice a day.

\section{(C) EXTERNAL POWDER FOR ULOERs.}

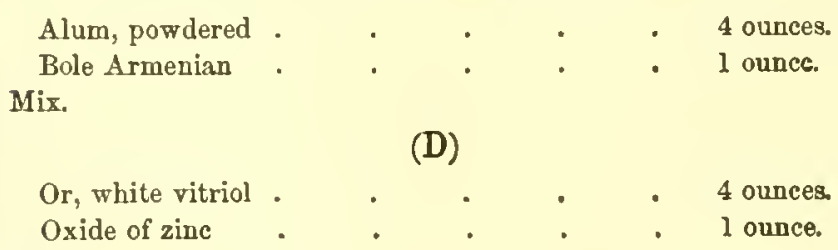
Mix.

(E) AN ASTRingent LOTION.

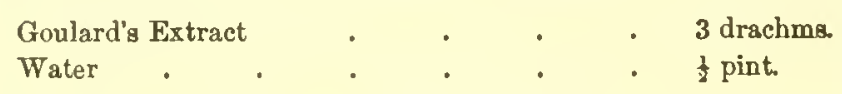

(F) astrinaent ointment.

$\begin{array}{llllll}\text { Super-acetate of lead } & \cdot & \cdot & \cdot & \cdot & 1 \text { drachm. } \\ \text { Lard } & \cdot & \cdot & \cdot & & \end{array}$
Mix.

(G) Or, for the same purpose :

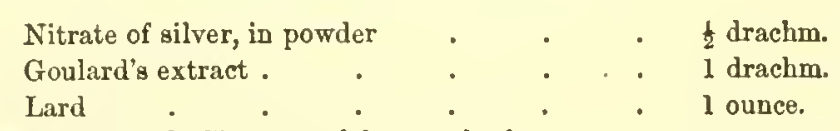

Mix. (F) and (G) are good for sore heels.

BALLS. - This is the favourite and most convenient mode of administering horse-medicines.

There are some circumstances, in the preparation of this form of medicines, not in general sufficiently attended to by veterinarians. Substances that are volatile do not keep well in balls, and therefore should only be made when used. The same caution is also requisite with such as liquify by the absorption of air. All bard substances entering into balls should be finely powdered, and the moist matter that is to form them into an adbesive mass should be of a nature that will not suon ferment or become mouldy. Hence, they are better compounded with oil than with honey or syrup.
A mass for balls should be pressed down in a jar, and covered with a bladder. Balls should not weigh more than an ounce and a half or two ounces, or they will pass down the gullet with difficulty; nor more than an inch in diameter, and three inches in length. The mode of "delivering a ball" is not difficult to acquire; and the balling iron, while it often wounds and permanently injures the bars, occasions the horse to struggle more than he otherwise would against the administration of the ball. The horse should be backed in the stall; the tongue should be drawn gently out with the left band on the off-side of the mouth, and there fixed, not by continuing to pull at it, but by pressing the fingers against the side of the lower jaw. The ball, being now taken between the tips of the fingers of the right hand, is passed rapidly up the mouth, as near to the palate as possible, until it reaches the root of the tongue; it is then delivered with a slight jerk, and the hand being immediately withdrawn and the tongue liberated, the ball is forced through the pharynx into the osophagus. Its passage should be watched down the left side of the throat; and if it is not seen going down, a slight tap or blow under the chin will generally cause the horse to swallow, or a few gulps of water will carry it down. If the gullet should be small, or strictured, and the ball should remain in some part of it, the tube used for "the bove" in cattle may be employed to remove it. If the case be urgent, tracheotomy must be resorted to. (See Tracheotomy, post.)

BALSAMS are a kind of resinous juice, united with some of the extractive matter of the various plants they are obtained from, in combination with an essential oil. All the balsams are occasionally in use in veterinary medicine, and were formerly in very high estimation, for their supposed salutary action in chronic diseases. They were also considered as a sovereign vulnerary for abraded urinary passages. It is the modern doctrine to think their efficacy overrated, which is probably in some respects true, particularly as regards their expectorant qualities; nevertheless they are far from being inert. They appear to act very favourably in some instances, as a warm terebinthinated stimulant. There are balsams of Canada ; of Copaiba ; of Gilead ; of Peru; and of Tolu. What is called balsam of sulphur is merely a compound preparation of sulphur in oil.

\section{Barbadoes Tar. See Tar.}

BARK.-Several of the barks enter into the veterinarian's list of medicaments, and all act by an astringent property on the animal fibre. Peruvian bark stands foremost in reputation; but as horses are little subject to intermittent fevers, we can therefore dispense with it. The elm and the oak barks, particularly the last, may be used in cases of debility, with advantage. Cascarilla bark proves also a valuable stomachic tonic.

Barytes (Murias Baryta) has been tried witb some benefit in glanders. "It is," says Blaine, "a very powerful medicament, but few glandered horses are able to bear the quantity requisite for the cure." 
Basiuicon, commonly called "Yellow basilicon" (Ceratum resina), is a useful digestive ointment.

BEANs, in a medical point of view, are sometimes used as a tonic, and the flour of them as an astringent.

Belzadonna (Nightshade).-An excellent sedative. Its specific action, however, appears to be expended upon the throat. It is largely used in affections of the lungs, in all diseases where sore throat is a prominent symptom. Its full effect is shown by loss of appetite. Its effect upon the eye in horses is not at all correspondible to that in man.

Buisters.-The modus operandi and the application of Blisters will be found under Operations, hereafter. The leading substance is the Cantharides or Spanish fly, though various substances are used for the purpose of vesication. As a simple blister, none equals in certainty and mildness the Spanish fly. In acute inflammatory disorders, however, its action is too slow, and caustic liquor of ammonia is resorted to, Euphorbium (q.v.) is also introduced as a substitute for cantharides. The tincture of croton is also used as an economical substitute for the flies.

\section{(A) BLISTER FOR GENERAL USE.}

Powdered cantharides

Lard

.8 pounds.

The liquid blister is made by substituting eight pints of oil for the eight pounds of lard, and allowing the flies to digest for a fortnight, or boiling them in a water bath. A pound of camphor is a good addition; it does not lessen the action of the blister, but diminishes its irritation.

\section{(B) A POWERFUL BLISTER.}

Spanish flies.

Lard .

Resin

Oil of turpentin

Melt the resin with the lard, after which add the turpentine. Wh beginning to cool, throw in the powdered flies.

(C) A MERCDRIAL BLISTER, WHICH MAY BE USED WHERE DEPENDENCE I8 PLACED ON THE ACTION OF MERCURIALS AND BLISTERS.

Of the former blister . . . . . . 4 ounces.

Corrosive sublimate, powdered finely . . . 1 scruple.

(D) OR THE FOLLOTING.

Strong mercurial ointment . . . . . 2 ounces. Oil of origanum . . . . . . 2 drachms. Corrosive sublimate . . . . . . 2 drachms. Cantharides, powdered . . . . 3 drachms.

Mix, and rub in with the hand.

(E) strona sweATiNa blister, FOR SPLENTS, RING-BONE, SPAVINS, ETC.

Of the liquid blister marked (F) . . 1 pint.

Biniodide of mercury . . . . 2 drachms.

To be well rubbed in the legs after cutting the hair short; and followed by the daily use of arnica, in the shape of a wash, as follows, which is to be painted on with a brush :-

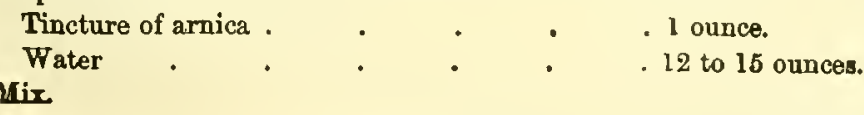

Major's British Remedy, which is supposed to be composed chiefly of sulphuric acid, but which sweats down bony matter very rapidly, though not without pain, and some. times followed by a blemish.

\section{(F) LIQUID BLISTER, WEAK; SOMETIMES CALLED SWEATING} BLISTER.

Spanish flies, in grose powder. $\quad . \quad$. $\frac{1}{2}$ pound.

Olive oil . . . . . . . 3 quarts. Steep the flies in the oil three weeks ; strain off, and bottle for use.

(G) LIQUID BLISTER, VERT MILD.

Of the above . . . . . . . . . . . . . . .

Olive oil . . . . . . . . . . .

The farrier's sweating blister is only a strong stimulant; it occasions heat and swelling, without excoriation or loss of hair; consequently it is a very convenient application, when it is an object to avoid a temporary blemish, and when the case is not of a very desperate description. But there are also instances in which it is to be preferred to an actual blister, as in strains, where some remains of heat and inflammation are present, but without activity: in such cases the sweating blister is very often efficacious. The mode of application is to rub it in of sufficient strength to irritate in a mild degree only; repeating it every day, until considerable swelling is occasioned, when the application should cease and the enlargement be allowed to subside.

Broe Vitriol. See Copper, Sulphate of.

Bole Armenian, vulgarly, "bole ammoniac," is an argillaceous earth combined with iron, and is supposed to possess some astringent property. The propriety of its being administered inwardly, is doubtful ; for it may remain in the intestinal canal, and become the nucleus of a stone. On account of its supposed astringency, it is occasionally employed to give consistency to ointments.

Borax. See SODA.

Bran. This valuable laxative is too well known to need description. As a poultice, it is objectionable, from becoming so soon dry. See Poultices.

Burgundy Pitch. See Resins.

Butter or Butyr of Antimony. See Antimony, Moriate oF.

Calamine, Prepared (Lapis Calaminaris). See Zinc.

Calonel. See Mercory, Sobmoriate of.

Canomile. The powder of the flower is a useful vegetable tonic, and the mildest in our list. It is given in doses of one or two drachms, and is exhibited in the early stage of convalescence, to ascertain whether the febrile stage of the disease is passed, and to prepare the way for a more powerful tonic-gentian. If no acceleration of pulse, or heat of mouth, or indication of return of fever, accompanies the cautious use of the camomile, the gentian, with carbonate of iron, may be safely ventured on; but if the gentian had been used first, and a little too soon, there might have been a considerable, and perhaps dangerous return of fever. Blaine 
does not think so highly of camomiles as Youatt. He says, as an aid to the other medicines prescribed for fever, or in the weak state of influenza, it is inferior to good sound stout.

CAMPHOR is extracted from the Laurus camphora and urrives here principally from India. It is in the form of a white brittle substance, greasy to the feel, but so tough as not to be easily pulverised, unless a few drops of spirit be added to it. Camphor burns brightly with much smoke, and melts at $288^{\circ}$. Water will not dissolve camphor, but an equal weight of spirit will; this must be remembered in compounding. If camphor is first worked up with a small quantity of oil, and then with a solution of gum arabic, it can be readily mixed with fluid medicines, and also with the resins. Its efforts are transient, and therefore small doses at short intervals are advisable where its use as a stimulant or sweating medicine (diaphoretic) is called for. Camphor is decidedly active as a horse-medicine. In large doses (say half an onuce) it has been known to produce convulsions. In modcrate doses (a drachm) it is antispasmodic $(q . v)$, and sedative $(q . v)$. Its use in flatulent colic is undoubted, opium being conjoined. It has been recommended by good practitioners in fever: and in the later stages of febrile disorders we have found it a gentle stimulant where the irritability has indicated such a remedy. It is, however, uncertain in its action; and its want of permanency makes it difficult to estimate its amount of efficacy. Externally, camphor has a mild action in dispersing indurations and in rheumatic affections. Camphor may be mixed with advantage in the ordinary blister where there is a purulent tendency in the animal.

CANada Balsam is the purest of turpentines. It is a transparent white juice, extracted from the Pinus balsamea, a common Canadian tree. It is wrongly called a bulsam, as it contains no benzoic acid. The old writers on medicine praised its virtues highly, as Balm of Gilead, Opobalsamum, Balm of Necca, Venice Turpentine, Cyprus Turpentine, \&c., \&c. See Turpentine for its veterinary uses.

Cantharides. (Cantharidis vesicatoria), the Spanish Fly, is that well-known beautiful winged beetle abundant in Southern Europe. They are collected in June and July from the leaves of the trees whereon they delight to dwell (especially the ash), destroyed by the fumes of strong vinegar, and dried in the sun: when touched, the insect, like many beetles, shams death, and when injured emits a peculiar pungent odour. It is of a bright green colour, fine specimens are three-quarters of an inch in length, with the legs, antennæ, \&c. of a bluish-black. As the leading ingredient in making blisters, we would recommend every veterinary practitioner to buy the beetles whole and powder them himself, to guard against adulteration. A muslin handkerchief should be placed over the face during the pounding, or an unpleasant vesication of nose and throat may follow. A little sweet oil will prevent the fine particles flying. Remember, the flies do not lose their virtue by being kept.
It is remarkable that these acrid insects are preyed upon by others feeding upon them; but as these only select the bright hard crust of the insect, the powdered residue is active as a vesicatory, although the contrary has been asserted. Of their use as blisters we have already spoken. They have been much relied on in glanders as an injection, and Percivall recommends 5 grains of cantharides in a ball with copaiba in nasal gleet. It is useful as an injection in sinuous sores.

CAPsicum. The capsicum pod or berry may be taken as a synonym for cayenne pepper, which is merely the admixture of the dried and ground pods of several sorts of capsicum, especially the bird pepper (capsicum baccatum). Observe, salt and red lead are often used to adulterate cayenne. For red lead, add to it some acetic acid, then dropping in a little sulphuret of ammonia, down will go the lead in a dark precipitate. Or boil a little of the suspected pepper in vinegar, filter the extract, add to it a little sulphate of soda (Glauber's salts), when a white precipitate will be thrown down, which, when dried, mixed with a little charcoal and exposed to heat, will give a metallic globule of lead. In horse practice, the capsicum is a good remedy in flatulent colic. It is also a worm expellent. It is a convenient external stimulant; and lastly is a better stomachic in judicious compounding than most of the general peppers used. The tincture is the most convenient form, but not economical. It mixes with water freely.

Caraways (Carum carui). These well-known seeds act as a capital cordial and antispasmodic with the horse, in conjunction with ginger and gentian. The cardamom seeds alone are retained in the human pharmacopeia.

Carbon. See Charcoal and Poultices.

Carbonate of Ammonia and Carbonated Water of Ammo. nia (Hartshorn). See Ammonia.

Carbonate of Iron. See Iron.

Carrors.-This root, as an article of horse medicine, is too much neglected. It is excellent in cough, fattens without heating the animal, is slightly laxative, therefore good for the coat. In incipient grease, farcy, \&c., we would substitute carrots for corn. In the "Pharmacologia" of Dr. Paris, carrots are recommended " as an antiseptic poultice, to allay the pain in cases of ulcerated cancer, and to correct the fotor of ill-conditioned ulcers." Surely, we much overlook what is at hand and cheapest, to seek remedies more difficult to procure? The addition of hemlock leaves, 2 ounces, and a trace of opium, to the mashed carrot, makes an unsurpassable cataplasm whenever a poultice is desirable.

CAssia is the fruit of a West Indian tree. The pods are about an inch in diameter, rough rinded, and contain a black pulp, easily dissolvable in water, but more readily in spirits. It is of a faint sickly smell, and is said to form the basis of the semi-fluid sold by some dishonest grocers as "essence of coffee." It must not be given except in compounded medicines.

Castor OIi (Oleum Ricini). The name comes from the 
seeds from which the oil is pressed resembling the insect called the tick, in Latin ricinus. It is by no means desirable as a purgative in horse practice. Youatt says, he names it "merely to warn the horse owner and practitioner against its use. If it must be used," he adds, "the expensive and enormous dose of a pound to a pound and a half must be administered." Its cathartic action on the horse is not only uncertain, but it often produces griping. Chloroform is said to have neutralised its evil effects; but why retain a doubtful and, to the idiosyncracy of the horse, an abhorrent purgative, when we have so many better and cheaper, without its drawbacks?

Cataplasms. See Poultices.

Cathartics. See Aperients and Purgatives.

CateCh v, commonly called Japan Earth (Terra Japonica) is an extract from the Indian Acacia Catechu, common on the hilly parts of Bengal and Coromandel. There are two sorts, a light and a chocolate-coloured, the latter has more of the astringent principle. It is nore active with the loorse than with man, and is a useful and safe astringent. It is given in super-purgation, in doses of one or two drachms, with one or one and a half drachm of opium, as a yet more powerful astringent; four drachms of chalk, to neutralize any acid in the stomach or bowels, and two drachms of powdered gum, being also added, to sheathe the over-irritated mucous coat of the intestines. It is not often adulterated in this country, but grossly so abroad-fine sand and aluminous earth being mixed with the extract. It should not be given with any alkali, yet the prescription just recommended contains chalk. But although the chalk, being a kali, weakens the astringency of the catechu, it probably neutralizes some acid in the stomach or bowels, which would have diminished the power of the catechu to a greater degree. It must not be given in conjunction with any metallic salt, for the tannin or gallic acid, on which its power chiefly or entirely depends, has an affinity for all metals, and will unite with them, and form a gallate of them, possessing little astringent energy. Writing ink is the union of this tannin principle with iron.

A tincture of catechu is sometimes made by macerating three ounces of the powder in a quart of spirit for a fortnight. It is very excellent for wounds; and, with the aloes, constitutes a remedy of a balsamic nature for the purpose of hastening the healing process of wounds.

Caustics. Called in medicine escharotics, are external remedies applied by cloth, brush, or sponge to the part where fungous excrescence is to be destroyed, or indolent ulceration stimulated to granulation. They are of two kinds- $-\nabla i z$. , first, the actual cautery, consisting in the application of the hot iron, and called firing, which will come under notice elsewhere; and, secondly, the potential cautery, by means of the powers of mineral caustics, such as potass, lunar caustic, \&c.

The Mincral Acids are active caustics. Sulphuric acid, or "oil of vitriol," is now seldom used. Nitrous acid (Aqua
Fortis) may be applied by means of a camel's-hair pencil to fungus on the foot.

The Chloride or Muriate of Antimony, commonly called the butter of antimony, is a caustic in very general use in veterinary practice. Applied to a raw surface it instantly changes it white, destroying a thin layer of substance; hence it is a very convenient application in cankered feet, as, by means of a small camel's-hair brush, it can be spread over as much or as little a portion of parts as is necessary. In sandcrack, when the sensitive substance protrudes, it may be applied in a similar way. In obstinate cases of grease, the buds are sometimes beneficially touched with it: but in quittor, poll-evil, and other sinuses, it is not so proper as some other escharotics.

Nitrate of Silver (Argenti Nitras), popularly called "Lunar caustic," is a preparation from silver, which renders it expensive: it is, however, essentially necessary to the veterinarian's dispensary, from its being so completely under command in its action; not extending its effects beyond the immediate part it is applied to. It proves the most convenient caustic for destroying the edges of a contaminated wound, when not too extensive, as the bite of a rabid animal. Dissolved in five, six, or eight times its own weight of water, it forms an excellent liquid caustic, peculiarly useful as a dressing for the foot-rot in sheep, and also to touch the protruded portions in sandcrack. Dissolved in twenty times its weight of water, it makes a ustful deter. gent wash for foul ulcers, and to keep down too luxuriant growths.

Lunar caustic consists of seventy parts of oxide of silver and thirty of nitric acid, when fused and cooled it is in small cylinders of a dark grey colour, and of a crystalline fracture when broken across. The sticks should be kept in a stoppered bottle covered with soft dry paper.

Caustic Potass, called Fluid Potass (Potassu Fusa), is powerful but difficult to manage, as it runs about where it is not wanted. Mixed with soap it has been injected in the pipes of quittor.

Blue Vitriol, the sulphate of copper, is a much milder caustic than several others, and is used in powder, to destroy fungus, especially in cases of broken knee. A solution of one drachm to sis ounces of water is a detergent wash for ulcers, grease, \&c.

White Vitriol (Sulphate of Zinc), is also a good escharotic in a saturated solution. See ZiNc.

Corrosive Sublimate (Oxymuriate of Mercury). See Mercory. In powder it acts most energetically upon warty growths, but should be used with great care and discretion. It may safely be applied to small surfaces, but not without a regular practitioner to large ones. It should be washed off after remaining on a few minutes.

The Nitrous Oxide of Mlercury, called "red precipitate," is also generally used for similar purposes.

Yellow Orpiment, not so strong as the corrosive sublimate, and may be used with more freedom. It will gene- 
rally remove warty growths by picking off their heads and rubbing it in.

\section{Caustic Preparations.}

(A) IN CANKER OF THE FOOT.

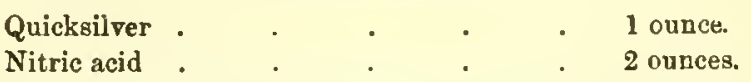

Mix in an earthen vessel, and when cold put into a wide glass bottle, and cork it. It may be mixed with lard, in the proportion of 1 to 3 .

(B) A SIMILAR APPLICATION, WHICH MAY BE USED ALTERNATELY WITH THE IAST.

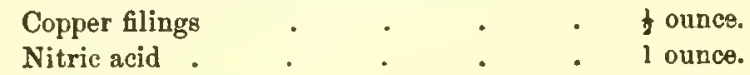

Mix and use in the same way.

Mild Solid Caustics. Verdigris, either in powder or mixed with lard as an ointment, in the proportion of 1 to 3 . Burnt alum, used dry. Powdered white sugar.

Mild Liquid Caustics. Solution of nitrate of silver, 5 to 15 grains to the ounce of distilled water. Solution of blue vitriol, of about double the above strength. Chloride of zinc, 3 grains to the ounce of water.

Quicklime sprinkled over ulcerated surfaces, is a convenient escharotic.

Cerates. Ointments of a drying, healing nature. Calamine ointment (Turner's Cerate). See Zinc.

Chalr (Creta). Carbonate of Lime. It is used as "prepared chalk," being levigated and purified by washing and drying. It is antacid and absorbent, and good in diarrhœa. With neat cattle it is more efficacious than the horse. It may be sprinkled over cracks and ulcers. The internal dose is half an ounce to two ounces in superpurgation.

Charcoal (Carbo tigni), when well-prepared, is black, inodorous, insipid, and brittle; having the quality of absorbing various gases, and of destroying the smell and taste of a number of vegetable and animal substances-especially mucilages, oils, and matters in which extracted and fermented principles abound. Hence its value. No fluid dissolves charcoal. Its antiseptic qualities are indisputable, and it is the real secret base of several "infallible" styptics. It is not duly appreciated (but it must be freshly prepared) for its excellent effects, when impalpably powdered, in correcting the discharge from ill-conditioned ulcers, or mingled in a poultice for general application in fotid discharges.

Charaes are thick adhesive plasters spread over parts that have been strained or weakened; they are applied warm, and left on while adherent. Charges are not much used by modern veterinarians. A more extensive acquainttance with the animal economy teaching us that there is but little activity in what are considered as external bracers. Nevertheless, there are some other points of view in which we may place this matter, to prove that "charges" may be of much service in some cases, if it is merely to act as 9. bandage, or to protect from cold. In this way a "charge" becomes a useful application to the loins in rheumatism; not only as it protects the affected part from cold, but also because of the resin proving a useful stimulant. Any strong adhesive, as resin, pitch, \&c., melted with wax or oil sufficient to keep it from being too brittle, may be formed into a "charge," and applied warm un the part ; and as it cools it should be covered with flocks of wool or short tow. Another favourite and effective "charge" in ligamentary lamenesses, consists of common salt with the white of egg.

The following mixture makes a good charge-

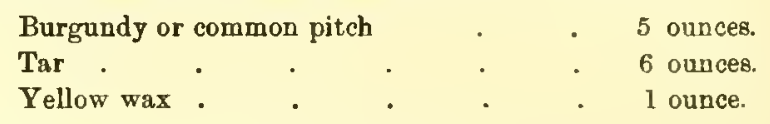

Melted together, and when they are becoming cool, half a drachm of powdered cantharides well stirred in. This must be partially melted afresh when applied, and put on the part with a large spatula, as hot as it can be without giving the animal too much pain. Flocks of tow should be scattered over it while it is warm, and thus a thick and adhesive covering will be formed, which cannot be separated from the skin for many months. This is applied for old sprains of the loins, and also strains of the back sinews.

A newly-introduced charge is called the Arnica charge. It is formed of two ounces of Canada Balsam, and half an ounce of Arnica leaves', melted and worked together 'with a little spirits of turpentine. This to be applied over the whole by thinly spreading, and then the first-named charge placed outside and over it.

\section{Chloride of Zinc. See Zinc.}

Chloroform is a peculiar compound limpid fluid, miscible with both alcohol and æther, and precipitated from them by water. It will dissolve iodine, phosphorus, and sulphur. The vapour of chloroform and of æther have wonderful narcotising powers over the lower animals as well as man. Chloroform has the advantage over æther that a far less quantity will produce insensibility to pain, and the expense is much less; 20 drops on a sponge will have the desired effect. Chloroform may be thus obtained :-To 4 pounds of chloride of lime in powder, add 12 ounces of rectified spirit, mixed with 12 pounds (pints) of water. Its applicability in cases of extensive and severe operations is proven. It is an excellent remedy in spasmodic colic, in doses of a drachm or two drachms in a pint of oil. It is also serviceable in guarding oil, intended as a laxative, from producing griping effects.

Cinchona. See Barks.

Clisters (Lat., clysterum, from Gr., clyso, to lave), -in many farming books glysters,--are useful aids in veterinary practice, being always safe and easy to administer. The principal art is to avoid alarming the horse. The syringe known as "Read's," with valves and a flexible tube, is the best apparatus; but failing this, a large hog's bladder, or, better, that of an ox, with a smooth wooden pipe an inch in diameter and sixteen inches long, may serve the occasion. The pipe must be well oiled, and the process conducted 
gently. We may notice here that BACK-RAKING (see post), is an operation often necessary before throwing up a clyster. The clyster must not be suddenly forced up, but gradually; and its heat $96^{\circ}$ Fahrenheit. Subjoined are several of the compounds ordinarily used as clysters, from which it will be seen that the clyster may be made, not only laxative, but nutritious and astringent. From the urgency with which relief of the bowels is required, and the length of time taken by purgatives given by the mouth, this class of remedy is invaluable.

\section{(A) A LAXATIVE CLYSTER.}

Thin gruel or broth

Epsom salts, $\frac{1}{2}$ lb. ; or common salt . $\quad 1 \frac{1}{2}$ pound.

(B) A CLYSTER FOR GRIPES.

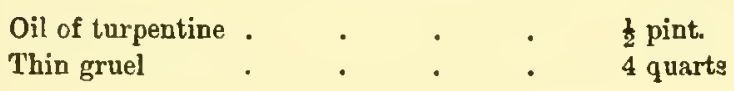

(C) ANODYNE CLYSTER IN DIARRHEA.

Starch, made as for household purposes . 1 quart.

Powdered opium . . . 2 drachms.

The opium to be boiled in water, and added to the starch.

\section{(D) A NOURISHING CLYSTER.}

\begin{tabular}{|c|c|c|c|c|c|}
\hline Thick gruel & & - & . & . & 3 quarts. \\
\hline $\begin{array}{l}\text { Strong ale . } \\
\text { Mix. Or, }\end{array}$ & - & . & - & - & 1 quart. \\
\hline Strong ale & . & . & - & . & 1 quart. \\
\hline Thick milk & • & . & . & . & 2 quarts \\
\hline
\end{tabular}

(E) ASTRINGENT CLYSTERS.

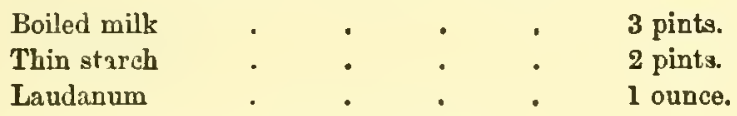

(F) ANOTHER.

Alum whey

Boiled starch

1 quart.

1 quart

CoLchicom (Colchicum autumnalis) the meadow saffron. This celebrated remedy for human gout and dropsy does not bear out its character for activity in horse complaints. Its flower is known as poisonous to cattle. It is diuretic with the horse, and is said to act upon the liver. In large doses, it is a dangerous purgative. The powder and tincture are the two preparations in use. It is said to be advantageous in ophthalmia.

CoLLYriugs are washes commonly in use for the eyes.See Lotions.

Conserve.-The conserve of red roses is a most convenient medium for forming balls, as it is adhesive, and, when properly made, keeps well.

CopaIBa (Capivi Balsam).-This fragant and peculiar liquid resin is improperly called a balsam. It contains no benzoic acid, but consists of resin and an essential oil. It forms a white soapy compound, soluble in water. Stimulant, diuretic, and laxative. It may be given in twice its weight of water and starch, and is active in its effects, though apt to disturb the digestion.

COPPER furnishes two combinations to veterinary practice. 1. Verdigris (Subacetate of Copper). 2. Blue Vitriol, or Sulphate.

Verdigris (Arugo), the common rust of copper; produced by vinegar, or anything sour, or even common salt. It is given internally by some practitioners, in doses of two or three drachms daily, as a tonic, and particularly for the cure of farcy. It is, however, an uncertain and dangerous medicine. The corrosive sublimate, with vegetable tonics, as recommended under Mercury, is preferable. Verdigris is, however, usefully applied externally as a mild caustic Either alone, in the form of fine powder, or mixed with an equal quantity of the sugar (superacetate) of lead, it eats down proud flesh, or stimulates old ulcers to healthy action. When boiled with honey and vinegar it constitutes the farriers' "Egyptiacum," certainly of benefit in cankered or ulcerated mouth, and no bad application for thrushes; but yielding, as regards both, to better remedies, which have been mentioned under the proper heads. Sume practitioners use alum and oil of vitriol in making their Egyptiacum, forgetting the decomposition which is produced.

Blue Vitrial (Cupri Sulphas), is the union of sulphuric acid and copper. It is a very favourite tonic with many, and has been vaunted as a specific for glanders; while others, and we think properly, have no very good opinion of it in either respect. As a cure for glanders its reputation has passed by; as a tonic, when the horse is slowly recorering from severe illness, it is dangerous, and its internal use should be confined to cases of long-continued discharge from the nose, when catarrh or fever have ceased. It may then be given with benefit in doses of from one to two drachms twice in the day, but it should be combined with gentian and ginger. It is principally valuable as an external application, dissolved in water in the proportion of two drachms to a pint, and acts as a gentle stimulant; but when an ounce is dissolved in the same quantity of water it becomes a mild caustic. In the former proportion, it rouses old ulcers to a healthy action, and disposes even recent wounds to heal more quickly than they otherwise would do; and in the latter it removes fungous granulations or proud flesh. The blue vitriol is sometimes reduced to powder and sprinkled upon the wound for this purpose, and is a good application for canker in the foot.

Copperas (Green Vitriol). See Iron, Sulphate op.

Cordials (and see Stimulants), are mixtures or simples that invigorate by their stimulating property, usually through the medium of the stomach. 'Cordials have been su long the very stronghold of the ignorant and presuming that the very term sounds ill in the ear of the well-informed veterinarian. A horse, unlike a gin-drinking groom, has an undebauched stomach, and does not require a cordias ball twice a week; nor on every evening after hunting; nor on every morning his coat stares with the altered 
temperature. To the animal, a cordial, as being unnatural, must be hurtful, unless required by some very extraordinary exertion; which, by calling forth too much of the constitutional powers, has expended the vital resources whence the stomach draws its tone. Thus, after a very bard run with hounds, this may happen; and then a gentle stimulant may excite the digestive sympathy artificially. Here a cordial may be proper and even necessary. A good one can, under such circumstances, be administered as follows:-

\section{(A) CORDIAL DRENCH.}

$\begin{array}{llllll}\text { Sulphuric ether } & \cdot & \cdot & \cdot & \cdot & 1 \text { ounce. } \\ \text { Laudanum } & \cdot & \cdot & \cdot & \cdot & \frac{1}{2} \text { ounce. } \\ \text { Cold water } & \cdot & \cdot & \cdot & \cdot & 1 \text { pint. }\end{array}$

Mir.

To recall the appetite of the horse slowly recovering from illness, a cordial may sometimes be allowed; or, to old horses that have been worked hard and used to these excitements when young; or, to draught horses that have exhibited slight symptoms of staggers, when their labour has been unusually protracted and their stomachs left too long empty; or, mixed with diuretic medicine, to fine the legs of the overworked and debilitated animal; otherwise they should never find a place in the stable, or be used at the discretion of the carter or the groom. The common cordial ball may be thus compounded :-

(B) CORDIAL BALL.

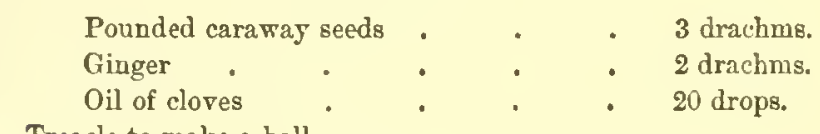

Treacle to make a ball.

\section{(C) ANOTHER CORDIAL BALL.}

Powdered aniseed.

6 drachns.

Caraways . . . . . 6 drachms.

Cassia . . . . 2 drachros.

Mix with treacle for a ball. Should catarrh be present, add powdered squills, 2 drachms, and use balsam of tolu with the treacle.

A quart of good sound ale, with some grated ginger, almost everywhere procurable, is often the best available drench in an emergency.

Coriander Seeds are a well-known stimulant, smelling, when fresh, like a bug; whence their Greek name corianon, from coris, a bug.

Corrosive Sublimate. See Mercury.

Cowhage, or Cow-ITCH, the hairs upon the pods of this climbing bean-like plant (dolichos pruriens) have been used (mixed with treacle, \&c.) to expel worms from the horse. We do not believe in their utility as a mechanical vermifuge. Many Indian plants of the mucuna tribe produce these irritating vegetable hairs, often employed in malicious practical jokes on newly-imported Europeans.

Cream of Tartar. See Potash.

Creosote, or Kreasote, is a fluid compound found in crude pyroligneous acid. It is nearly colourless and trans-

parent, with a powerful odour, resembling smoked meat. It is highly antiseptic, and therefore valuable in many diseases of the horse. Creosote coagulates albumen, even when much diluted, and also the serum or watery part of the blood. It is decomposed and rendered useless if mixed or applied with sulphuric or nitric acid. It is a valuable medicine externally, or a formidable poison introduced into the body. Dropped upon the tongue it occasions intense pain, and if swallowed coagulates the albumen of the fluids and membranes it comes in contact with. In skin disorders and bleedings its usefulness is undoubted. It is administered in external ulcers, and, applied strong, produces an artificial skin by coagulating the albumen. It will also act as a powerful styptic in cases of external hemorrhage. Its use as an ointment in grease, thrush, sallenders, \&c., is evident.

Croton OIL. The extract of the seeds of the Croton Tiglium, a tree of Ceylon, China, Malabar, \&c. The Croton Cascarilla furnishes the cascarilla bark. It is a violent purgative. All parts of the plant, leaves, root, \&c., are cathartic. In veterinary practice the meal, which possesses similar proporties, is often used; but, unfortunately, by the arts of the druggist, it is often so adulterated as to deceive the expectations of the practitioner. When it is pure, it may be given in doses from a scruple to half a drachm, with linseed meal, in the form of a ball, to shield its acrid nature. It is equally, indeed somewhat more, drastic than aloes, producing profuse liquid watery stools, often much griping, and it occasionally takes as much time to excite purgation. It is also somewhat uncertain in its action, but, under a favourable operation, it is quicker than aloes, although our first accounts of it denied this. It may, therefore, when immediate purgation is necessary, be very properly applied to; and also in tetanus its diminished bulk and great activity make it valuable. Dissolved in turpentine it forms a blister, only inferior to cantharides.

Cubebs, or Java Pepper.-The effects of the powdered cubeb are very similar to that of the Copaiba Balsam. With a mucilage of gum acacia it is good to promote urine and allay inflammation of the kidneys. Cooling purgatives must be used during the time of its administration.

Demulcents are medicines that act mechanically, by surrounding acrid matter, and sheathing it from hurting sensitive and irritable parts. For this purpose oily preparations are used, also honey, gums, mucilages, \&c. Diluents, as warm fluids, mashes, \&c., are also demulcents, because they dilute acrimonious matter and render it less active.

\section{(A) DEMULCENT DKENCH.}

$\begin{array}{lllllll}\text { Linseed } & \cdot & & \cdot & \cdot & \cdot & 4 \text { ounces. } \\ \text { Water } & \cdot & \cdot & \cdot & \cdot & & \end{array}$

\section{(B) ANOTHER.}

$\begin{array}{lll}\text { Gum arabic } & \text {. } & 1 \text { ounce. } \\ \text { Water } & 1 \text { qusst. }\end{array}$


(C) ANOTHER.

$\begin{array}{llllll}\text { Marshmallows } & \cdot & \cdot & \cdot & \cdot & 2 \text { handfuls. } \\ \text { Water } & \cdot & \cdot & \cdot & & 1 \text { quart. }\end{array}$

Simmer the first and third of these until a mucilaginous decoction is made, and administer when nearly cold.

DIAPHORETICS are medicines which increase the insensible perspiration, and open the exhalant pores of the skin. These remedies require smart exercise in clothing, to promote their action. The horse afterwards to be carefully wiped dry. Sudorifics $(q . v$. ) are intended to do it more actively, and to occasion actual sweating. Vinegar will often produce a violent perspiration, but it is not a salutary one; yet the same liquid, neutralized by ammoniacal salts into Mindererus's spirit, will often excite a favourable but mild diaphoretic effect. Antimonials in repeated doses, assisted by diluting liquors and warm clothing, will likewise commonly produce some diaphoresis. Camphor, in considerable doses, will also occasion a determination to the skin. Aloes, guaiacum, white hellebore, digitalis, \&c., are diaphoretics.

\section{(A) DIAPHORETIC BALL IN "HIDE-BOUND."}

\begin{tabular}{|c|c|c|c|c|c|c|}
\hline Emetic tar & $\operatorname{tar}$ & & - & - & & 2 drachms. \\
\hline Camphor & . & • & • & • & • & $\frac{1}{2} \mathrm{drachm}$. \\
\hline Hinger & . & . & - & . & & 2 drachms. \\
\hline Opium & . & - & . & 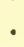 & . & 1 drachm. \\
\hline Oil of cara & ways & . & . & . & . & 20 drops. \\
\hline
\end{tabular}

Linseed meal and boiling water to form a ball.

\section{(B) ANOTHER.}

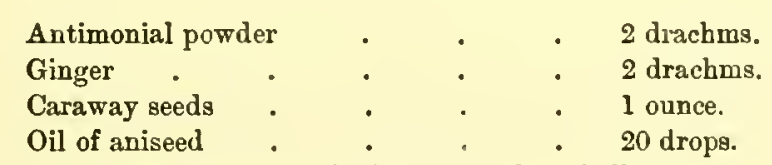

Mix with linseed meal and boiling water for a ball.

Diaestives, in veterinary practice, are stimulant applications, producing a tendency to suppuration. The gum resins are at the head of this class, and the turpentines. Myrrh, aloes, resin, tar, \&c., are digestives.

\section{(A) Common diaestive ointment.}

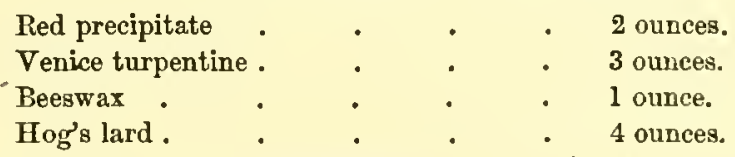

Melt the three last ingredients over a slow fire, and when nearly cold stir in the powder.

Drartalis. The leaves of the purple foxglove (Digitalis purpurea) are directly sedative, diaphoretic, and diuretic to the horse. When properly dried they have a slight narcotic odour, and powder a beautiful green. The leaves should be gathered just as the plant is coming into flower, and from plants exposed to the sun. They should not be hung up to dry, as is commonly done, but separately dried till crisp, and the powder preserved in opaque or very dark glass bottles in a dry place. Damp and light are fatal to its active properties. It acts upon the heart, and diminishes the frequency of the circulation and the general irritability of the system. The infusion is made by pouring a pint of boiling water on an ounce of the powder; the tincture by digesting three ounces in a quart of proof spirit. One drachm of the powder, one and a half drachm of emetic tartar, and three of nitre, every four hours, will be found to reduce the heart's action remarkably. This is not done regularly, by lengthening the intervals between the beats, but by a number of pauses very alarming to the uninitiated. This is the proof that the digitalis is combating the disease. The action of this medicine requires watching; but an overdose is not so dangerous to the horse as has been pretended. When the administration of digitalis is pushed too far, laudanum or ether may take the place of the emetic tartar and nitre, as a tonic. The infusion is a good application in inflammation of the eyes, alternately with any of the eye-waters. It has also been extolled in mange; but it is inferior to other remedies in that complaint.

Disinfectants have, of late years, come prominently into notice. The foremost of these are the Chloride of Lime and the Chloride of Zinc. They are most important in cases of glanders in stables. An ounce of the chloride of zinc in two gallons of water is a sufficient strength; and of the chloride of lime, one-tenth of powder to nine times its bulk of water is a fair solution.

DivRetics are medicines which increase the secretion of urine from the blood, thus depriving it of a large proportion of its watery particles, and enabling the absorbents to take up more water from the system. Some diuretics act directly upon the kidneys by sympathy with the stomach, while others are taken up by the blood-vessels, and in their climination from the blood cause an extra secretion of the urine. In either case their effect is to diminish the watery part of the blood, and thus promote the absorption of fluid effused into any of the cavities, or into the cellular membrane, in the various forms of dropsy. They are a much-abused class of medicines, from their indiscriminate administration by the groom and farrier. Turpentine and nitre, which see, are the leading diuretics in horse medicine.

\section{(A) stimulating diuRetic ball}

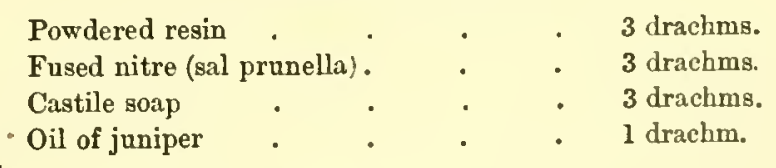
Mix.

(B) COMMON DIURETIC BALL

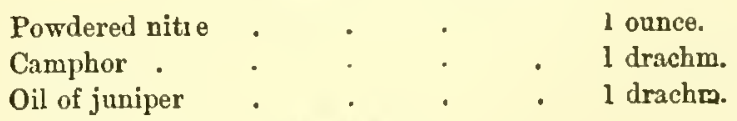

Linseed meal to form a mass.

(C) DIURETiC POWDER FOR a MAsh.

Fused nitre (sal prunella) . . to ounce. Mix. 
(D) ANOTHER MORE ACTIVE POWDER.

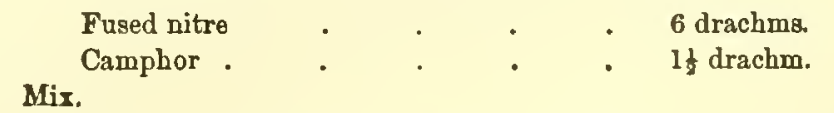

Drinks or Drenches.-Many practitioners and horse proprietors have a great objection to the administration of medicine in the form of drinks. A drink is not so portable as a ball, it is more troublesome to give, and a portion of it is usually wasted. If the drink contains any acrid substance, it is apt to excoriate the mouth or to irritate the throat already sore from disease, or the unpleasant taste of the drug may unnecessarily nauseate the horse. There are some medicines, however, which must be given in the form of drink, as in colic; and the time, perhaps, is not distant when purgatives will be thus administered, as more speedy and safer in their operation. In cases of much debility and entire loss of appetite, all medicine should be given in solution, for the stomach may not have sufficient power to dissolve the paper in which the ball is wrapped, or the substance of the ball.

An ox's horn, the larger end being cut slantingly, is the usual and best instrument for administering drinks. The common method is thus described by Blaine:-" The noose of a halter is introduced into the mouth, and then, by means of a stable fork, the head is elevated by an assistant considerably higher than for the delivery of a ball. The operator stands on a pail or stool on the off-side of the horse, and draws out the tongue with the left hand; he then with the right hand introduces the horn gently into the mouth, and over the tongue, and by a dexterous turn of the horn empties the whole of the drink into the back part of the mouth; the horn is now quickly withdrawn, and the tongue loosened, when the greater portion of the fluid must be swallowed. A portion of it, however, will often be obstinately beld in the mouth for a long time, and the head must be kept up until the whole is swallowed, which a quick, but not violent slap in the muzzle will generally compel the horse to do. The art of giving a drink consists in not putting too much into the horn at once; introducing the horn far enough into the mouth, and quickly turning and withdrawing it, without bruising or wounding the mouth, the tongue being loosened at the same moment. A bottle is a disgraceful and dangerous instrument to use."

ELDER.-Tho elder leaf, boiled in lard, forms an emollient ointment, usefully applied to inflamed and irritated parts.

Embrucitions.-External remedies applied by hand, friction, cloth, or brush. The following are the leading formulæ. We may as well note that the various oils are retained : there is none of them, however, which may not be dispensed with, if the turpentine and olive oil are retained and proportionally increased in quantity. The "oils" are mere traditions of a superstitious and ignorant period.

\section{Embrocations.}

\section{(A) stimolating embrocation.}

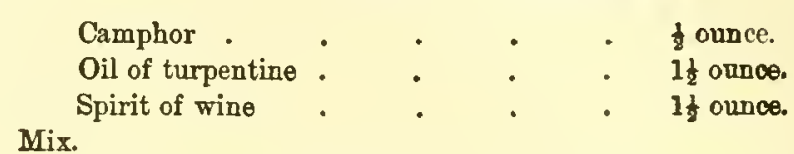

\section{(B) sweatiNg embrocation For WiNdGalds, eta.}

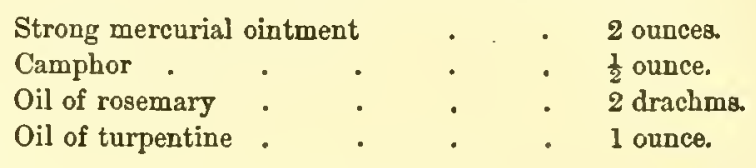
Mix.

(C) ANOTHER, STRONGER.

Strong mercurial ointment . . 2 ounces.

Oil of bay . . . . . 1 ounce.

Oil of origanum . . . $\frac{1}{2}$ ounce.

Mix.

Powdered cantharides . . . . $\frac{1}{8}$ ounce.

\section{(D) strona sweating embrocation.}

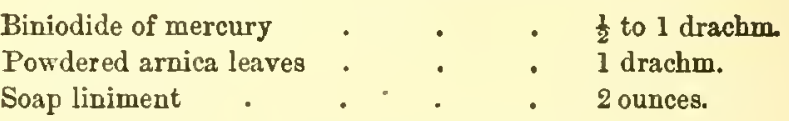
Mix.
(E) MUSTARD EMBROCATION.

Best flour of mustard . . . 6 ounces.

Liquor of ammeria . . . $1 \frac{1}{2}$ ounce.

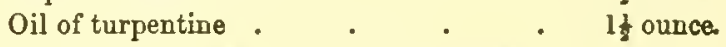

Mix with sufficient water to form a thin paste.

Emetic Tartar. See Antimony.

Eметісs are not used in horse medicine, for reasons explained in the anatomical part of this work.

Eudusions are serviceable in chronic cough. The following is a

\section{(A) SIMPLE EMULSION.}

\begin{tabular}{|c|c|c|}
\hline Honey . & . & 3 ounces. \\
\hline Linseed oil . & - & 3 ounces. \\
\hline Subcarbonate of potass & . & $1 \mathrm{drachm}$ \\
\hline Boiled water & . & l pint. \\
\hline
\end{tabular}

Melt the potass and honey in the water; then add the linseed oil gradually, working it well in till a smooth milky mixture is obtained. A fourth part thrice a day.

\section{(B) ANOTHER, MORE ACTIVE.}

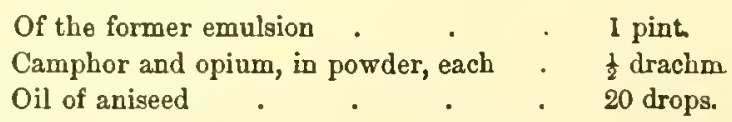

Mix the camphor and opium with some white sugar in a mortar, dropping in the oil, then add the emulsion gradually, beating up as before.

Epsoy Salts. See Magnesia, Sulphate of.

ERGot of Rye (Secale cornutum).--"Spurred rye," presents a long black diseased growth, possessing remarkable properties. It is a long blackish horn or spur, from an inch to two inches in length. When fresh it is tough and flexible, 
but soon becomes brittle and easily powdered. It will give its active principle to spirit or to water, but a little starch or treacle is the best thing to mix with it. Its power in strengthening and maintaining the uterine contractions in mares, is unquestionable. But it must never be administered except in desperate cases. Indeed, though parturition proceed ever so slowly, it should only be resorted to by the advice of a skilful practitioner. Nevertheless, as cases do arise where it may be serviceable, we have included it here. It may be given in solution by infusing one drachm in half a pint of boiling water for a quarter of an hour; or in substance, in doses of one scruple every fifteen minutes till its action is apparent.

\section{Escharotics. See Caustics.}

EUPноввIUM. This acrid gum-resin is used for blistering purposes by farriers, to save cantharides. A plaster of six ounces of pitch, and half a drachm of powdered euphorbium, with enough turpentine to soften it, has been recommended as a stimulant and counter-irritant in internal inflammation; we do not approve of it. When powdering euphorbium, the dispenser should wet the mass with vinegar, or it may rise and excoriate his face and nostrils. See BLISTERS

ExpeCTORAnts. These are medicines which assist the removal of irritating mucus, formed in the windpipe and bronchial tubes. Squills, with honey and vinegar, are the leading articles in this class. True, the horse does not expectorate, as we understand it, but the secretion can be increased by these medicines, and he will cough out the mucus; this is relief.

\section{(A) EXPECTORANT BALL.}

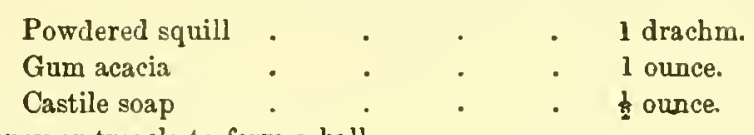

Honey or treacle to form a ball.

\section{(B) ANOTHER.}

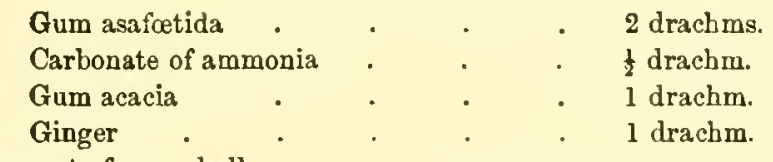

Honey to form a hall.

\section{(C) a powerful expectorant ball.}

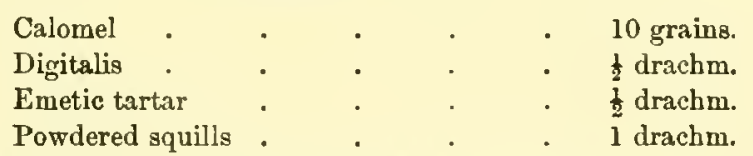

Linseed meal and treacle to form a ball. The result to be watched carefully before giving another dose.

\section{Extract of Lead. See Lead.}

FEbrifuges, fever medicines, act by increasing the secretion of urine and perspiration, and by moderating the action of the heart and the irritability of the circulatory system.
(A) FEVER BALI

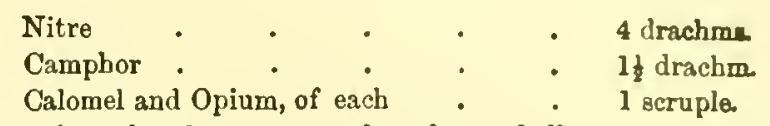

Linseed meal and water enough to form a ball.

\section{(B) ANOTIIER FEVER BALI}

Emetic tarta

Powdered acacia $\cdot{ }^{\circ}$

Linseed meal as above.

$1 \frac{1}{2}$ to 2 drachma.

2 drachms。

(C) COOLING DRENCH.

\begin{tabular}{|c|c|c|c|c|}
\hline Nitre & • & . & . & 1 ounce. \\
\hline Sweet spirits of nitre & $\theta^{\circ}$ & . & • & 2 ounces. \\
\hline Tincture of digitalis & & . & . & 2 drachms. \\
\hline Whey & . & . & . & 1 pint. \\
\hline
\end{tabular}

(D) Cooling Mash

Nitre . . . . . 1 ounce.

May be given in a bran mash.

Fomentations open the pores of the skin and promote perspiration in the part, and so abate the local swelling, and relieve pain and lessen inflammation. They are often used, and with more effect, when the inflammation is somewhat deeply seated, than when it is superficial. The effect depends on the warmth of the water, and not on any herb which may have been boiled in it. They are best applied by means of flannel frequently dipped in the hot water, or on which the water is poured, and the heat should be as great as the hand will bear. The benefit that might be derived from them is much impaired by the absurd method in which the fomentations are conducted. They are rarely continued long enough, and when they are removed the part is left exposed and wet, so that the cold of evaporation often does more harm than the warmth of the fomentation does good. Blaine says, and we think the hint valuable, he, in many cases, fomented first and then applied a poultice or liniment.

Gentian is, in our opinion, the best tonic bitter for the horse. It should be combined with ginger, and is then valuable as preventing the griping of aloes. See Stimorants.

Ginaer is the most grateful spice to the horse. It is the basis of the cordial ball and indispensable in the tonic ball. It may be occasionally given in doses of 2 or 3 drachms, and in flatulent colic, in doses of 4 to 6 drachms; it will also form a valuable assistant to saline and other cold remedies, given to tender stomachs and bowels. For horses, for cattle, and sheep, it is an excellent carminative, and should be always employed when a warm stimulant is want ing. It is, indeed, one of the most valuable cordials to invigorate the intestinal surfaces we know of. See CorDIALS.

Glauber's Salt (Sodae sulphas). See Soda, Solphats OF.

Glysters. See Clysters.

Godlard's Extract, Gojlard Water. See Lead. Grains of Paradise.-The seeds of the Amomum Grana 
Paradisi, a plant common on the coast of Guinea, near Sierra Leone. It is called Melligatta pepper in commerce. The properties are the same as cardamoms. They are a favourite nostrum with grooms, to produce a fine coat, and the animal is often injured in his digestive organs by their injudicious administration. As an addition to other stomachics they are useful in veterinary prescribing.

Gruel is an article of great importance in veterinary practice; care should, therefore, be paid to its preparation. It must be thick when intended as a cordial or for nourishment ; if as a diluent, it can hardly be too thin. Above all things let it be prepared in scrupulously clean vessels, and never smoked. A horse that lias had smoky gruel offered to him will with difficulty again be induced to taste it. Bran with boiling water poured upon it (bran tea), allowed to get cold and strained, is an excellent diluent.

Guaiacum, Gun, is the product of a West Indian tree, the stem of which produces that heavy, hard, black-green wood called lignum vitæ. The resin is a good stimulant, promoting secretions of the lungs and skin. It is combined with ammonia and other stimulants. See Stimulants. As it will not dissolve in water, and even a solution in spirit is precipitated by adding water, it is best in emulsions or pills. With potass water made hot, it forms a soap which may be worked into balls.

Gums and Gun-Resins :--

Gum Ammoniacum is soluble in water, spirit, and vinegar; water is its proper solvent. It is in the form of tears or fragments, yellow outside and white within. There is a cheaper sort of gum ammoniac in the market, called lapis ammoniaci, in lumps, adulterated largely with common resin, and therefore to be avoided. It is a stimulant, and sometimes diuretic, and, dissolved in nitric acid, is a good expectorant. See Ammoniac.

Gum Guaiacum. See Guaiacom.

Gum Myrrh. See MrrrH.

Gum Tragacanth. The inspissated juice of the Astragalus tragacanthus, a plant common in Greece and Persia. It is cordial, stomachic, and tonic, like most of its class.

Hartshorn. See Ammonia, Carbonate of.

Hellebore, White. The root of the Veratrum album is the part used. Its active principle can be extracted by water or alcohol. A new alkaline principle, called veratria, has been extracted by modern chemists from this acrid and poisonous plant. Those great veterinary authorities, Mr. Percivall, Mr. Blaine, and Mr. Youatt, hold white hellebore in high esteem, while Professor Sewell has little faith in its efficacy, and doubts its medicinal action. As the horse was not intended to vomit, nausea is difficult to excite. Blaine says, "the powdered root of the white hellebore is the most certain nauseant with which we are acquainted; but it is only safe under very watchful eyes and quick perceptions. It may be given to a certain point, and nothing but moderate nausea is observed: if pushed beyond this, the head droops in the manger, the mouth slavers, the pulse sinks, the horse reels to and fro, and purging comes on, which commonly proves a fatal symptom. It may be given in doses of a scruple every six hours, which may be increased to half a drachm; but the horse must be carefully looked to, and as soon as the pulse sinks and the mouth slavers, or any trembling appears, desist from its further exhibition, directly combating its debilitating and sedative effects by active stimulants." Hellebore lowers the system more speedily than digitalis, but digitalis more safely, when there is time for its operation; at least so we have found: it is for the observant veterinarian to select the proper cases for both. It ranks high also with some veterinarians when used with setons, by smearing them with the powder, but black hellebore is superior for this purpose. An ointment of powdered hellebore, muriate of ammonia, and lard, has been found a good application in mangy affections.

Hellebore, Black (Melampodium. Christmas Rose). The fibres of the root are the parts used: they are about the thickness of a straw, rough, of a deep dark colour, hence called "black," white or yellowish inside; taste bitter and burning. Choose the darkest, as the roots of the aconite (monkshood) are often substituted for them, though much lighter in colour. An ointment of black hellebore has been successfully used in fistulous withers and poll-evil. When the tumour has burst and been allowed to discharge two or three days-being dressed with an ordinary digestive, and the discharge being of the nature termed laudablethen take a few portions of the fibrous part of the root, sew in the seton passed into the sinuses, and allow them to remain a fortnight or more. Under this treatment Mr. Morton assures us he has observed its salutary action in several cases.

HemLocr (Conium maculatum). This handsome poisonous wild plant so much resembles several of its tribe which are destitute either of deadly or of medicinal qualities as to have led to very varied opinions of its activity in the treatment of disease. The efficacy of the plant, too, depends upon its place of growth, the season when collected, and the means taken to dry it or to make the extract; and lastly, on the temperature and dryness of the place in which it is kept, and the time since it has been gathered. The principle (conia) upon which its activity depends, is volatilised by time or lieat, and the residue becomes inert. The recent leaves are the most active part of the plant. As hellebore or digitalis are its equals in affections of the lungs, acute or clironic, it is not desirable in a veterinary dispensary. A drachm of the dried leaves, in powder, is a dose.

Infosions. These are watery solutions of vegetablo matters, obtained by macerating the substance either in hot or cold water, without boiling on the fire. Where volatile oil is the active principle, cold infusion is necessary; where mucilage, or astringent principle, warmth is requisite.

The active matter of some vegetable substances is partly or entirely extracted by water. Dried vegetables yield 
their properties more readily and perfectly than when in their green state. Boiling water is poured on the substance to be infused, which has been previously grossly pounded or powdered, the vessel is then covered and placed by a fire. In five or six hours the transparent part may be poured off, and is ready for use. In a few days, however, all infusions become thick and lose their virtue, from the decomposition of the vegetable matter.

The infusion of camomile is used instead of water in mild tonic drenches; the infusion of gentian is a fine stomachic; so is the infusion of catechu in astringent mixtures; the infusion of linseed for catarrh; and in some injections tobacco-water-the infusion of tobacco.

IODINE. This non-metallic elementary body is a remarkable constituent in sea-water, sea-weeds, and marine molluscs, and may be obtained from kelp, or sea-weed which has been burnt for the purpose of making potash. Iodine is soft, opaque, solid, and of a bluish-black colour and metallic lustre. When moderately heated it rises in a violet-coloured vapour, hence its name, from the Greek iōdos, violet-tinted. It has a strong odour and taste, and stains the skin brown, but not permanently. It readily dissolves in spirit, but with difficulty in water. Iodine, long before its separate discovery, was used empirically in "burnt sponge" and many mineral waters. It is a valuable remedy in glandular swellings, especially of the throat. It is reported, too, to be an antidote to poisoning with strychnine and veratria; but we do not know practically its claims in this respect. Its power over glandular enlargements in the horse is well proved. Its administration in doses of half a drachm to a drachm daily has overcome profuse discharges of urine in a marked manner. The iodide of potass is a valuable medicine, and acts on the absorbents when taken internally. The dose is from one to two drachms. The ointment called unguentum potassce iodidi is an excellent disperser of glandular enlargements, in cases where the use of the knife may be dangerous.

Iros.-The preparations of iron are tonic to the horse; and, of these, two are adopted by veterinarians. The rust (ferri carbonas) is a mild and useful tanic in dases from two to four drachms.

Iron, sulphate of, also called Green Vitriol, or Copperas, is more powerful, but should never be given in early stages of recovery, and always with caution. The dose should be the same as that of the carbonate. Youatt says:-The sulphate has been recommended for the cure of that deceitful stage or form of glanders, in which there is nothing to characterise the disease but a very slight discharge from the nostrils. It is to be dissolved in the common drink of the horse. It is worth a trial; but too sanguine expectations must not be encouraged of the power of any drug over this intractable malady. Iron should be given in combination with gentian and ginger; but never with any alkali, or nitre, or soap, or catechu, or astringent vegetable.

Forge water used to be a favourite tonic with farriers, and also a lotion for canker and ulcers in the mouth. It owes its power, if it have any, to the iron with whirh it is impregnated.

JALAP. This famous human purgative is utterly useless in horse medicine.

Japan Eartir (Terra Japonica). See Catecho.

Jesolt's Bark (Peruvian Bark). See Bark.

Joniper, Oil of. The essential oil of the berry is a stomachic and diuretic. It is a pleasant aromatic to the horse, and enters into the composition of the diuretic ball. Hollands owes its flavour and diuretic quality to this essential oil. English gin is flavoured with oil of turpentine. Kati. See Potass and Soda.

LARD. We prefer palm oil to lard as a basis for making up balls, simply because an animal substance is abhorrent to the horse as one of the graminivorx. Yet lard or palm oil is preferable to honey, treacle, or syrups, for making up balls, because the ball more readily dissolves in the stomach. It likewise renders a purgative less liable to grive. It is the principal basis of all ointments.

LAUDANOM, the tincture of OPIUM, which see.

Laxatives. See Aperients.

LEAD.-There are three products of lead adunitted to the veterinary materia medica.

1. The Acetate of Lead (Acetas Plumbi), is known popularly as Sugar of Lead, on account of its sweet taste. Dissolved in water, it makes a turbid solution, unless a little acetic acid is first added. Two drachms of the salt to a pint of water makes Goulard's Lotion. It is in doses of 1 gr., guarded by opium, a remedy for internal hemorrhage.

2. The Subacetate of Lead, called also Extract of Lead, or Goulard's Extract, and Solution of Subacetate of Lead. A drachm in a pint of water is a good eye-wash in early stages of inflammation. It is not so good, however, as opium or digitalis, and must not be used with them. It is useful in poultices in superficial inflammation, but is of no use in sprain or deep-seated injury. Alum has been added to increase its astringency, but the result is that it is rendered a totally inert sulphate of lead by the addition. Sulphate of magnesia (Epsom salts), and white vitriol also decompose it.

3. Carbonate of Lead, Ceruse, or White Lead. This may be used as a drier of ulcers by sprinkling it upon the sore, but the safety of the practice is questionable. Dry colic may be superinduced.

Lime. Lime Water (Liquor Calcis) is a solution of lime in cold water. It being a curious fact that lime dissolves more completely in cold than in hot water. Thus, one gallon of water at $212^{\circ}$ (boiling point) will take up little more than half the quantity of lime that a gallon of water at $32^{\circ}$ (freezing point) will hold in solution. Six pounds of lime infused in two gallons of water may, after standing three hours, be strained off, it must then be closely stoppered $u p_{\text {, }}$ otherwise the lime will take up carbonic acid from the air and become an insoluble carbonate. Lime water is a 
wholesome discutient wash. It is considered by many as a remedy for stone in the bladder, and it appears likely to be beneficial, as it may looseu the cohesion in the mass occasioned by lithic acid in the bladder. Lime water externally is applied for mange, and internally has valuable antacid qualities.

Chloride of Lime was known formerly as bleaching powder, and was merely used to deprive various substances of their colouring principle. Its value in veterinary medicine is now found not only as a valuable disinfectant (q. v.), but as an external application to putrid ulcers, though inferior to clloride of zinc. It is purchased in the form of a dry white powder, having an odour of chlorine. Blaine gives the following case, which bears immediately on its effects as an antiseptic. "In a retention of the placenta, called "not having cleansed,' in a cow, where the putridity had becoms so great as to produce larvæ or maggots and intolerable fotor, there was injected a wine-glassfull of chloride of lime, diluted with a pint of warm water, into the vagina; which itself brought away, in two hours' time, several quarts of putrid matter, by which the cow was greatly relieved; but some foetor returning, a second injection was passed the next day, which again sweetened the cleansing, and prevented further putrefaction. But as the placenta was not yet ejected, two ounces of the chloride of soda was now given in a pint of gruel every lour; the consequence of which was, that after the sixth dose the placenta came away, much decomposed, but without foetor; and the cow was evidently saved by these means, though apparently before in a dying condition."

LiNIMENTS are preparations of intermediate consistency between ointments and oils. They are intended either to soothe an inflamed surface, or, by gently stimulating the skin, to remove deeper-seated pain or inflammation. As an emollient liniment, one composed of half an ounce of extract of lead and four ounces of olive oil will be useful. For sprains, old swellings, or rleumatism, two ounces of hartshorn, the same quantity of camphorated spirit, an ounce of oil of turpentine, half an ounce of laudanum, and a drachm of oil of origanum, may be mixed together; or an ounce of camphor may be dissolved in four ounces of sweet oil, to which an ounce of oil of turpentine and a drachm of oil of origanum should be afterwards added. A little powdered cantharides, or tincture of cantharides, or mustard powder, will render either of these more powerful, or convert it into a liquid blister.

Soap Liniment, commonly known under the name of Opodeldoc, consists of hard soap, 1 ounce; camphor, 3 drachms; oil of rosemary, 20 drops; oil of origanum, 10 drops; solution of ammonia, 6 drachms. This is the renowned Steer's Opodeldoc. A cheaper and simpler liniment will do as well.

LinSEED. - The seeds of the common flax contain a large proportion of mucilage and one-sixth of their weight of fixed oil By infusion in boiling water, a clear, colourless, and nearly tasteless mucilage is obtained. Cold water will not extract mucilage from the unbruised seeds. A thin infusion is a good substitute for water in cold and sore throat; a pail being slung in the stable or loose box. We prefer, however, thin gruel of oatmeal. The meal of linseed is the best and smoothest of poultices.

Oil of linseed is a safe purgative, in doses of a pint to a pint and a balf; but is uncertain in its action

LIQUORICE (Glycyrrhiza Glabra).-The juice of the liquorice root, or Stick Liquorice, enters into the composition of many horse-medicines. It is a demulcent, soothing to the mucous membrane, thickens and gives cohesion to powders or balls, and covers the taste of some nauseous medicines better than any other substance.

Lotrons, which are synonymous with washes, are noticed under the several ingredients which go to their formation, as copper, zinc, lead, ammonia, acetic acid, \&c. The common lotions in use are:-

\section{(A) LOTION FOR EXTERNAL INFLAMMATION.}

\begin{tabular}{|c|c|c|c|c|}
\hline Goulard's extract . & & - & & 1 ounce. \\
\hline Acetic acid (Vinegar) & & • & & 2 ounces. \\
\hline Spirits of wine, or Gin & & . & & 4 ounces. \\
\hline Water & . & - & . & 1 quart. \\
\hline
\end{tabular}
Mix, and apply with a calico bandage.

(B) LOTION FOR INFLAMED LEGS, OR GALLED BACE.

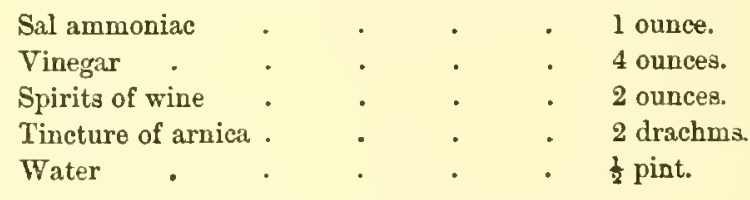
Mix.

(C) LOTION FOR FOUL ULCERS.

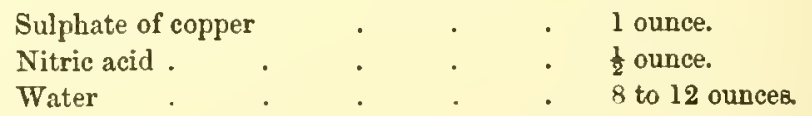
Mix.

Lunar Caustic. See Caustics.

Magnesia, Sulphate of (Magnesice Sulphas). Eprom Salts. A valuable medicine to the veterinarian. In early fever, in doses of six to eight ounces, it is preferable to aloes, unless disease of the lungs or primæ viæ are present. The dose often requires repeating before it operates. It is not, therefore, a certain laxative, but its operation should be assisted by bran mashes. It is also an adjunct to lasative clysters. The cathartic powers of Epsom salts are increased by dilution in abundance of fluid, and a little common salt (muriate of soda) quickens its action. There is no such good and ready test as the taste in cases of doubt between the crystals of Epsom salts and those of oxalic acid, which so closely resemble them. The bitterness of the one and the intense sourness of the other can leave no doubt.

MaLt. Blaine has a high opinion of malt, in which we coincide. He says: "It forms an excellent cordial in cases of debility, and, when continued, becomes a permanent 
tonic: it has also some pectoral qualities; but in active inflammation of the chest it is too stimulating for use. Malt is an excellent alterative: in farcy, in grease, and in mange nlso, when accompanied with emaciation, it has been used with efficacy; but, in such cases, it should be given in considerable quantities without other corn, and with as little hay as possible, so that almost all the nutriment received may be malt This practice is not generally known, but it has proved, in some cases, singularly efficacious: the best mode of giving malt is by mashes."

Marshmallow (Althea officinalis), is at the head of demulcents in horse-practice. Its leaves contain a bland mucilage and starch (amylum), which can be extracted by both hot and cold water. The root is carrot-shaped, white and fleshy, about as thick as the thumb, and a foot or more long. Its leaves are soft-stalked and heart-shaped, its stems two or three feet high, and covered with soft down, as are the leaves. The flowers are of the pale rose colour lately known as mauve, and appear in short clusters from the bosom of the leaves. The demulcent lozenges sold in the shops for colds and coughs, and called Pâte de Guimauve, are an inspissated syrup of marshmallow.

Mashes are a leading article in stable economy, and justly sc. A mash given occasioually to a horse that is otherwise fed on dry meat, prevents him from becoming dangerously costive. To the overworked and tired horse nothing is so refreshing as a warm mash with his usual allowance of corn in it. The art of getting a horse into apparent condition for sale, or giving him a round and plump appearance, consists principally in the frequent repetition of mashes; and from their easiness of digestion and the mild nutriment which they afford, as well as their laxative effect, they form the principal diet of the sick horse.

Mashes are made by pouring boiling water on bran, and stirring it well, and then covering it over until it is sufficiently cool for the horse to eat. If in the heat of summer a cold mash is preferred, it should, nevertheless, be made with hot water, and then suffered to remain until it is cold. This is not always sufficiently attended to by the groom, who is not aware that the efficacy of the mash depends principally on the change which is effected in the bran and the other ingredients by the boiling water rendering them more easy of digestion, as well as aperient. If the horse refuses the mash, a few oats may be sprinkled over it, in order to tempt him to eat it; but if it is previously designed that corn should be given in the mash, it should be scalded with the bran, to soften it and render it more digestible. Bran mashes are very useful preparatives for physic, and they are necessary during the operation of the physic. They very soon become sour, and the manger of the horse of whose diet they form a principal part, should be daily and carefully cleaned out.

When horses are weakly and much reduced, malt mashes will often be palatable to them, and very nutritive : but the water that is poured on a malt mash should be considerably below the boiling heat, or the malt will be set, or clogged together. If owners were aware of the value of a malt mash, there would be much physic saved. Speared corn mash, often talked of, is nothing more than a malt mash.

Mercury, or Quicksilver (Hydrargyrum). This peculiar metal, fluid at ordinary temperatures, solid, ductile, and malleable at $40^{\circ}$ below zero of Fahrenheit, furnishes some valuable items to the veterinary pharmacopœic. It boils at $656^{\circ}$, and throws off a volatile vapour, which, condensed by cold, is purified mercury. Mercury, in its metallic state, is not employed in veterinary medicine. It has, however, been employed in human practice to force a passage through the intestines by its specific gravity. Mercury is sadly adulterated by lead, bismuth, zinc, and tin: the methods of detecting these will be found in Dr. Paris's Pharmacologiu, article Hydrargyrom, but would take up too much space to detail here. Three forms of mercury will suffice for this compendium of Horse Medicines.

1. Calomel (Hydrargyri Submurias), the uildest preparation, is in truth proto-chloride of mercury. It may be given, combined with aloes, in mange, surfeit, or worms; yet better alteratives and more efficient vermifuges have been described. It is admissible in some cases of chronic cough, in farcy, and in jaundice, but it is not a medicine that seems to agree with the horse. Alone, it has little purgative effect, but it assists the action of other aperients. It is given in doses from a scruple to a drachm, but must not be too often or too long repeated. As soon as the gums or bars become red, or the horse is seen to "quid" or drop his hay, the calomel must be discontinued. The name calomel is compounded of two Greek words, kalos, good, fair, melas, black-i.e., say the old writers, because it is good for black (bile); but, as its colour changes from black to white in the process of preparing it, is there not a less fanciful derivation?

2. Corrosive Sublimate (Hyarargyri Oxymurias). This is the biclloride of mercury according to the latest chemists. Its form is a crystalline mass, easily pounded, and becoming opaque on its surface when exposed to the air. Light has no effect upon it. Its fumes when thrown on burning coals are highly dangerous to those who breathe them. It is one of the most acrid and actire of metallic preparations, yet numerous quack medicines are based on corrosive sublimate. As an alterative it mas be given to the horse in doses of from ten to twenty grains daily. In glanders and farcy the quantity may be increased as far as can be borne. As an external application, the perchloride of mercury has good effects. As a caustic, it has been noticed under that head. As a wash for mange, it has adherents; we are not of the number. It appears to be taken by neat cattle in large doses with impunity, while a small quantity sprinkled on a wound has killed the animal,

3. Red Precipitate (Hydrargyri Oxydum rubrum). An active mercurial, employed only as an external remedy. It is a good caustic, sprinkled on old sores. 
Mercurial Ointment (Hydrargyri Unguentum fortius). Blue ointment. The strength of this varies materially, from 30 grains of mercury in the drachm of ointment, down to 10 grains in the same quantity. Triturate the black oxide of mercury with lard (taking care there is no salt in it), in a cold place. It is employed with considerable advantage in preparing splents, spavins, or other bony or callous tumours for blistering or firing. One or two drachms, according to the nature and size of the swelling, may be daily well rubbed in ; but it should be watched, for it sometimes salivates the horse very speedily. The tumours more readily disperse, on the application of the stronger stimulant, when they have been thus prepared. Mercurial ointment in a more diluted form is sometimes necessary for the cure of mallenders and sallenders; and in very obstinate cases of mange, one-eighth part of mercurial ointment may be added to an ounce of flower of sulphur, half an ounce of turpentine, and an ounce of train oil, and well rubbed down together.

Ethiop's Mineral (Black Sulphuret of Mercury, Hydrargyri Sulphuretum nigrum) is a well-known black, tasteless, inodorous powder. It is an alterative. Blaine says, "it is less frequently given in horse practice than it deserves. There is too much fashion in our pharmacy, and too little experiment." In all skin affections we have found this a valuable alterative, and also vermifuge, in daily doses of two or three drachms.

MinT, as an infusion or decoction, is not worth retention in horse-medicines. See OrLs.

Muriate of Antimony. See Antimont.

Muriate of Barytes. See Barytes.

Muriate of Soda. See Salts.

MYRRH. This gum resin is used as a tonic in the form of tincture, combined with a warm bitter, as gentian. There are two tinctures of it; one simple, and one compounded with aloes; both of which are much used externally, as warm digestives, in wounds and sinuous sores, and the application is frequently attended with striking benefit: the aloetic tincture is by much the more stimulant. To cattle also it provcs a stimulating tonic and antiseptic in doses of from one to two ounces.

Naputha, Petroleum, Rock-Orl. See Tar.

Narcotics. See Antispasmodics and Anodynes.

Nitrate of Silver. See Cadstics.

Nitre (Potassce Nitras). See Potass.

Sweet Spirit of Nitre (Spivitus Etheris Nitrici), is a fragrant, colourless, volatile and inflammable fluid, which will mix with either water or spirit. It is cooling, yet cordial, and mildly diuretic. Four ounces twice a day, or divided into three doses, is a valuable medicine in the more advanced stages of fever. An ounce in the cold fit of coming fever is to be recommended.

Nitric Acid (Aquafortis). See Caustics.

Oar Barr. See Astringents.

OrLs. The following list contains the few which sur- vive of the multitude of useless "oils" in which the ignorant farrier and groom of the olden days placed their faith.

Oil of Almonds, of Amber, of Anise, of Bay, of Camomile, of Caraway, of Fennel-seed, of Juniper, of Lavender, of Peppermint, of Green Mint, of Origanum, of Pimento, of Savine, of Rosemary, of Rue, of Tar, of Turpentine, of Styrax, (benzoin), \&c., \&c. To these might be added a dozen of filthy animal oils, with names as ridiculous and extravagant as their imputed virtues.

Oils are fixed or volatile.

The fixed oils are so called because they are not liable to be vaporised under moderate temperature. They are mostly obtained by expression from seeds, or by melting from animal substances.

The volatile oils are procured by distillation, and evaporate by moderate heat.

The fixed oils used by the veterinarian are :-

Castor Oil (which see).

Oil of Olives. - The best olive oil may be substituted for castor oil, when the latter cannot be obtained. It is the principal medium in the composition of liniments, and enters into many ointments.

Oil of Linseed.-It is a pretty certain laxative, and is more to be depended on than olive oil ; and in many instances more than castor oil.

Oil of Palm.-This has the consistence of lard; with the addition of a fragrant smell. As it does not become rancids it is to be preferred : it is also less noxious to the stomach of the horse than the animal oils. It is the produce of the kernels of the fruit of the Cocos butyracea, Mackau-tree, or Brazilian palm.

The essential or volatile oils are :-

Oil of Amber.-An antispasmodic not much in use. It is said to have a peculiar property of hastening the action of aloes.

Oil of Anise Seeds.-This is an excellent warm aromatic, and may very properly be added to cordial balls.

Oil of Caraways may be used in the same way, and considered in a similar point of view.

Oil of Juniper.-This is often added to diuretic balls, to increase their effect : it acts, however, principally as a warm aromatic. It is now mingled with mange applications.

Oil of Tar is a cheap penetrating distillation from tar. It may be employed in a mixture with whale oil, as a suppling matter for the hoofs. See Creosote.

Oil of Turpentine.-See Turpentine.

Oil of Origanum.-This warm pene sating oil was formerly much used as an external stimulant; but it is inferior to the purest turpentine (Canada Balsam), and need not be retained.

Oil of Vitrior (Sulphuric Acid). See Acid, Sulphuric. OINTMENTS are greasy applications, consisting of a powerful drug mixed with lard, or some similar componnd, and thus 
applied to the sore; they are described under the several beads Astrinaents, Anopynes, \&c. Their number is much reduced in modern practice.

Oprum (the inspissated extract of the Papaver somniferum), is imported in solid flat pieces of compact texture, covered with the leaves of the poppy. It is oplaque, of a reddish-brown or fawn colour, with a peculiar heavy narcotic smell. It is dissolvable in water, spirit, wine, and vinegar. By boiling, its soporific powers are impaired, and if continued, they are destroyed. The tincture, which is Laudanum, is better made with spirit; the watery solution is much less efficacious, though spirit below proof is better as a solvent than that above. The narcotic principle of opium is an alkaloid called morphia, which is easily dissolved in olive oil

Opium is a valuable drug in veterinary practice, though there have not been wanting practitioners who have maintained it to be inert! True, it does not act as a narcotic, except in very large doses; yet it is powerfully antispasmodic, sedative, and astringent. As an antispasmodic it enters into the colic drink, and it is the sheet-anchor of the veterinarian in the treatment of tetanus or locked jaw. Youatt says:- "As a sedative, it relaxes that universal spasm of the muscular system which is the characteristic of tetanus; and perhaps it is only as a sedative that it has such admirable effect as an astringent; for when the irritation about the mouths of the vessels of the intestines and kidneys is allayed by the opium, undue purging and profuse staling are necessarily arrested. It should, however, be given with caution. It is its secondary effect which is sedative, and, if given in cases of fever, its primary effect in increasing the excitement of the system is marked and injurious. In the early and acute stage of fever, it would be bad practice to give it in the smallest quantity; but when the fever has passed, or is passing, there is nothing which so rapidly subdues the irritability that accompanies extreme weakness, and it becomes an excellent tonic, because it is a sedative.

If the blue or green vitriol, or cantharides, have been pushed too far, opium soonest allays the disorder they have occasioned. It is given in doses of one or two drachms, either the powdered opium being made into a ball, or the crude opium dissolved in hot water, and given with its sediment. Other medicines are usually combined with it, according to the circumstances of the case.

Externally, it is useful in ophthalmia. In the form of decoction of the poppy-head it may constitute the basis of an anodyne poultice; but it must not be given in union with any alkali-with the exception of chalk, in overpurging: nor with the superacetate of lead, by which its powers are materially impaired : nor with sulphate of zinc, or copper, or iron.

From its high price it is much adulterated, and it is rare to meet with it in a state of purity. The best tests are its smell, its taste, its toughness and pliancy, its fawn or brown H $\mathrm{H}$ colour, and its weight; for it is the heaviest of all the vegetable extracts, except gum arabic. Yet its weight is often fraudulently increased by bits of stone, and even lead. English opium is blacker and softer than Turkish, but not less efficacious in practice.

Oxymel, Simple. Is made by simmering two pounds of honey in a pint of vinegar. It is good in composition with nitre, digitalis, \&c., in pneumonia and catarrh; dose, from four to six ounces.

Palm Orl. See Orls.

Peppers.-Various kinds of peppers are sometimes used, particularly in colic. Mr. B. Clark has written a treatise expressly on the virtue of the pimento berry. As a general remedy, any of them may be properly given in dges of three drachms to six; except the cayenne, which, as being very strong, admits of only a drachm as a dose. Peppers are sometimes used as stomachics, or to warm other more permanent tonics, sucl as steel, bitters, \&c.

Prtch is used to give a consistence and adhesiveness to plasters and ointments, and is also the basis of charges. It has a strong medicinal quality, as its relationship with terebinthinated substances shows. Ordinary pitcl is as good as the more expensive Burgundy pitch; a pound melted with an ounce of yellow beeswax is a good plaster for sandcrack.

Physic. See Cordial, Aperient; and Didretic.

Porass (Potassa), is called the vegetable kali; to distinguish it from Soda, the mineral kali. In its pure state it is a powerful caustic, and enters as a base into the cumposition of salt. Two compounds of potass are used in horse practice.

Nitrate of Potass (Potassa Nitras) or Nitre, is a very common product, and is as useful as it is general. It is compounded of nitric acid and vegetable kali, whence its chemical name nitrate of potass. It is the most useful, powerful cooling medicine; greatly diminishes febrile action, and determines its depletory action more certainly to the kidneys than any of the saline articles. It is also antiseptic and diaphoretic, and therefore of great consequence in active fever, given two or three times a day, in doses of three or four drachms. As an alterative it is also well known; but it is not a good plan, as practised by some grooms, to infuse it into the water which horses are to drink; it is apt to disgust them with all liquids. Nitre, while dissolving, materially lowers the temperature of water, and furnishes a cold lotion for sprain of the back sinews, and local inflammations. The lotion should be used as soon as the salt is dissolved, for it quickly becomes as warm as the surrounding air. Fusech Nitre is sold solid under the name of Sal Prunella.

The Supertartrate of Potass (Potassce Supertartras), o' Cream of Tartar, is not a very active medicament in horse practice. It is, however, slightly febrifuge and mildly diuretic. It has some alterative powers, and unites with those medicines which are generally employed when horses are labour ing under cutaneous affections. 
Pooltrchs, or Cataplasms. - As bread would be expensive, bran is generally used in veterinary practice; which a little linseed meal improves in consistence. This is important, as otherwise the poultice runs through the cloth. Yet it must not be too thick, lest it dry too quickly; and its action is due greatly to its keeping moist. It should therefore be frequently wetted from without. In applying poultices to the legs, care should be taken not to tie them too tight, as is frequently done, and whereby the mischief is aggravated instead of relieved : a piece of broad list is, for this reason, very proper to fasten them on with. A poultice should never be applied too hot; very little good can be derived from it, and much pain may be occasioned. A hot poultice soon sinks to the heat of the part. Poultices are likewise, in many cases, applied cold. A convenient mode of applying a poultice to the extremities, is by means of an old stocking cut off at the ankle. The leg of it, being slipped over the hoof, is brought around the part, and secured below by means of broad list. The poultice is then put into the stocking by means of the hand, and afterwards secured above by another piece of broad list. In cases where it is found difficult to keep a poultice on any part of the extremities, from its inclination to slip down, still by no means tighten the supporting bandage; but, instead, pass a long tape from it over the withers, if in front, or back, if behind, and attach it to the other side of the bandage; it will then be effectually secured from slipping. If too tight, it will prevent the return of blood from the foot; if too hot, it will inflict unnecessary pain.

\section{(A) COMNON PODLTICE.}

Bran, any quantity; pour on it boiling water, to form a thick paste; add linseed meal sufficient to make it adhesive. After this, stir in one or two ounces of sweet oil.

\section{(B) Cooline Poultice.}

Bran, any quantity ; pour on it a sufficient quantity of cold water to for'm a poultice ; and, as it dries, moisten with more water.

(C) Cleansing poUltices in general USE FOR GREASE AND ULCEROUS WOUNDS.

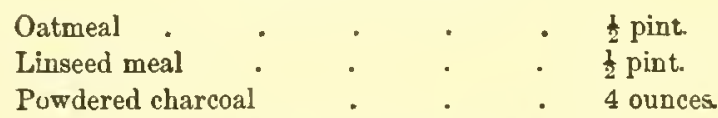

Stale beer and bran sufficient to make a poultice.

(D) $\mathrm{or}$,

Carrots, scraped, sufficient to make a poultice.

(E) $\mathrm{oR}$,

Turnips, toiled and mashed, sufficient to make a poultice.

To either of these last two, four ounces of charcoal may be added, if thought proper. Or,

Linseed meal, or oatmeal, any quantity ; mix with boiling water, and fermont with a table-spoonful of yeast: as it rises, apply to the part.
Powders.-Powdered medicines that have not much taste may be given in a mash. Emetic tartar and digitalis in fever; or calomel or the meal of the nut of croton tiglium as "physic." The horse, however, often refuses them, and then the mash is wasted. A careful and competent groom will prefer the more certain method of ball or drench.

QDASSIA.-The wood of the tree (Quassia excelsa) owes its properties to a peculiar bitter principle of wonderful durability. It is solid, and of a light yellow colnur. It is a useful tonic: dose from six to ten drachms.

Quinine.-This celebrated essential principle of the cinchona, or bark of the Cinchona lancifolia (Jesuit's bark), is too expensive for veterinary practice. It may be joined (as disulphate of Kina), in doses of a drachm, with camphor, where its cost is not regarded.

RAKINQ. - This method of emptying the bowels by hand will be noticed under Operations, \&c. Blaine thus directs its performance :-_" The right arm being stripped and oiled, with the left hand, the tail is drawn aside, when the right, being made as small as possible, should be gently introduced up the fundament, and any hardened excrement it may meet be removed carefully." From this it will be seen that back-raking must be useful in a vast variety of cases. It should always precede a clyster (see CLYsTERs), lest the fluid should be obstructed and thrown out again. It is useful in colic and costiveness.

Red Precipitate. See Mercury.

REPELLENTS.-Medicines whose action was supposed to consist in driving back humours from one part to another. They are exploded by modern science: tollic action alone can apply to the theory of repellents.

RESIN.- The several resins are noticed under their kinds. Yellow resin is that used in Charaes ( $q . v$.). It is a useful diuretic in doses of 5 or 6 drachms, made into a ball with soft soap.

Rowels. See Operations, post.

SALTS.-Common salt (muriate of soda) is useful in veterinary practice. See Soda.

Salt of Tartar. Sce Potass.

Salts, Epson. See Magnesia.

Sal Pronella. See Nitre.

Salt of Steel. See Iron.

SAvine.-The leaves of the juniperus sabina, or savine in veterinary practice, have had very opposite appreciation as an internal remedy. This has arisen from faulty preparation of the medicine, not that we consider it worth retaining, except as an outward application. It is almost impossible to so dry and pulverise savine leaves as not to lose the essential oil on which their activity depends. If, then, they are to be administered, an infusion of two ounces of the leaves in a pint of water, with a few drops of opium and some syrup, or a tincture in proof spirit, should be used. They are highly stimulant, hot, and acrimonious; they act on the nervous system, and especially on the uterus. The ignorant still believe that infus:on of savine leaves 
-ill procure abortion in women; in an overdose it will certainly kill the mother. The infusion is an excellent lotion for gangrenous sores, and the dried leaves are good for warts, soft ulcers, and caries. With lard or wax it is a good ointment to keep open rowels or setons; and the leaves in a poultice stimulate foul sores to granulation.

Sedatives.-This class of medicines is calculated to diminish the irritability of the system, to repress spasmodic action, and to deaden pain. Some sedatives act at first as stimulants, but this stage soon passes off. In some cases they act by enabling the system to resist irritation, in others they numb the nerves and lower the animal system by a narcotic or sleepy effect. In the horse we do not find these medicines act as positive narcotics, as in man: they merely lessen irritability and check spasmodic action. Digitalis, opium, hellebore, hemlock, opium, belladonna, camphor, and turpentine, act as sedatives with the horse: so also, in injuries and consequent fever, does the cold bath. Some irritative states are best met by tonics, as the mineral acids, \&c. The sedative medicines will be found under their several titles in this alphabetical list.

SILver gives us that excellent escharotic known as Lunar Caustic. See Caustics.

SoAp.-The soap used in prescriptions is the hard or Spanish soap, and soft soap, a compound of olive oil and potass. The latter is transparent, yellowish, with small seed-like lumps of tallow dispersed through it. Its application is noticed under the several heads. In large doses, soap is purgative; in small doses, it determines to the kidneys. The use of hard soap in forming diuretic and other balls is well known.

SoDA is the mineral kali, as potass is the vegetable Its base is the mineral called sodium. Soda is now generally procured by the decomposition of sea salt (chloride of sodium). The salt is first converted into sulphate of soda (Glauber's salts), then into crude carbonate of soda, and then by making it into a lye (lixiviating), and evaporating, becomes the crystallized carbonate commonly known as suda. Of its various salts we may note the carbonate, the sulphate, the tartrate, and the muriate (chloride).

Carbonate of Soda (Sodce Carbonas), is a white gritty powder, alkaline in taste. Its most familiar use is in the composition of soda-water powders, where half a draclim of the carbonate of soda is placed in a blue paper, and 25 grains of tartaric acid in a white one. Its medicinal uses are the same as the subcarbonate of potass, but it is milder and less nauseous. It is easily soluble in water at $60^{\circ}$, and in less than its own weight of boiling water.

Sulphate of Soda.-The well-known Glauber's salts. A most useful purgative. It is solublc in water, but totally insoluble in spirits. Muriate of ammonia and lime, nitrate of silver, and acetate of lead, all decompose the sulphate of soda. We would recommend it to be mixed in equal quantities with the sulphate of magnesia (Epsom salts) where one is prescribed. The compund is more active and more diffusible in water. Cheltenham salts consist of sulphate of soda, 120 grains; sulphate of magnesia, 66 grains; muriate of soda, 10 grains; sulphate of iron, $\frac{1}{8}$ grain.

Muriate of Soda (Chloride of Sodium), Common Salt. While in a state of solution, common salt is muriate of soda, when it is dried, it becomes chloride of sodium: "thus the same salt is chloride of sodium in the hand, and muriate of soda in the mouth!" The effect of salt upon the animal system is striking and important, and has furnished the most interesting inquiries to the physiologist, the chemist, the physician, and the agriculturist. These, however, rould lead us into digresssion here. Salt, in moderate quantities, promotes digestion in the horse; an excess destroys it. It is tonic, and corrects that disordered state of the bowels which produces worms. Its use is corrective of the load food which encourages the multiplication of bots. The value of salt to all herbivorous animals is fully indicated by their natural craving for it in cases of disorder of the system. The "salt licks" of North America and of the Pampas show the greed of the horse, elk, moose-deer, \&c., for this mineral. Salt does not act diuretically, but passes undecomposed into the kidneys. It is purgative in solution in tepid water, and forms the ordinary clyster. It is the natural stimulant of the digestive organs. The doses are a drink of eight ounces of salt in solution, for a tonic. One ounce of salt and one ounce of water is a healthy antiseptic embrocation for sore back. Sprinkled on the hay, or in a mash, it is palatable to the sick horse. Indeed, the value of salt in veterinary practice can hardly be over-rated.

Tartrate of Soda (Soda Tartarizata) is a triple salt, formed of an acid, soda, and potass. It does not differ in its effects from tartrate of potass, and need not be further described.

\section{Spanish Flies. See Cantharides.}

\section{Spurred Rye. See Ergot of Rye.}

Squills.-The bulb of the scilla maritima, or wilu onion, is expectorant, diuretic, and very slightly laxative. It is excellent in disorders of the bronchial tubes, in conjunction with demulcents. The bulb loses about four-fifths of its weight in drying, but this does not seem to lessen its powers unless heat has been applied. Its bitter principle (called Scillitin) is carried, by the circulation, to the secretory ressele of the kidneys, and thus stimulates them. The syrup, tincture, or dried root, is to be adapted to the form of the medicine, whether solid or fluid.

Starch (Amylum), is given internally, mixed with chalk and opium, and is used to guard acrid medicines. Starch clysters in diarrhœa are to be advised in preference to the ordinary gruel.

Stimolants (see Cordials). Medicines that exert an influence on the system by increasing the power and action of a part; hence they may be considered as very numerous, and the term as of very extensive signification. The following article from Blaine contains a summary of the classification of doses of these medicines. Local Stimuli are all 
such matters as either promote the vascular, the nervous, or the absorbing energies; as friction, rubefacients, blisters, \&c. General stimuli act on the sensorium at once, through the medium of the senses: the voice of the hounds stimulates the horse; the exertions of a rival racer will likewise stimulate; and the stallion's fire is drawn forth by the scent of the mare. Absorbing stimulants are heat, cold, friction, depletion, mercury, \&c.

Stomachic stimulants.-Such may be called cordials as are intended to have a temporary effect on the stomach; and those may be noted as stomachics whose action is more permanent. Both the one and the other appear to act by a sympathetic effect they excite between the stomach and the hrain. Warm spicy matters possess some efficacy; but, as might be supposed, such cordials (i.e. stomachics) appear to act best when they are received into the system at large, as generous food, malt, gruel, ale, \&c.

Gentian, powdered

Ginger, powdered . . . . 4 ounces.

Oil of anise seed . . . . $\frac{1}{2}$ ounce.

Make into a mass with lard, honey, treacle, or conserve of roses, and give one ounce for a dose.

(B)

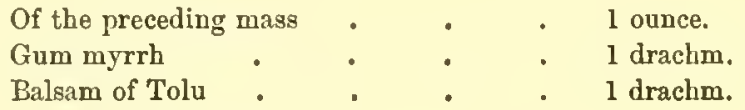

Of the first mass . . . . 1 ounce.

Camphor . . . . . 1 drachm.

Opium . . . . . $\quad .1$ drachm.

Either of these may be given as a drink also, by infusing the powders in a pint of ale.

As stimulant8, Mr. Vines, in his "Treatise on Glanders," enumerates the following articles:-Cantharides, Canella bark (Canelloe cortex), Capsicum berries (Capsici baccoe), $\mathrm{Cu}$ bebs, or Java pepper (Cubeba), Ginger root (Zingiberis radix). Grains of Paradise (Grana Paradisi), Pellitory of Spain ( $P y$ rethri radix); all the different sorts of Peppers, as the common black, Cayenne, Chili, long, and white; Pimento, or Allspice (Pimentee baccee), Sweet Flag-root (Calami aromat. radix), Winter's bark (Winterce cortex).

Nore permanent stomachic stimulants are such as act not only by determining a greater quantity of blood to the stomach, but also by strengthening the muscular tone of that organ, enabling it to act with more energy in its digestive movements. The following formulæ are inserted, and are proper in cases of convalescence, or recovery from debilitating diseases which have impaired the appetite :-

(D)

Powdered canella bark (cinnamon) $\quad$ - 4 drachms.
Ginger $\quad$ - 1 drachm.
Sulphate of copper (blue vitriol) . $\quad$ - 1 drachm.

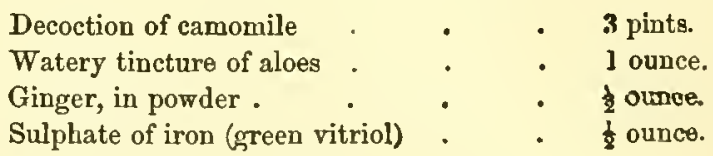

Mix and divide into four drinks.

\begin{tabular}{|c|c|c|c|c|c|}
\hline Gum myrrh & . & . & • & & 2 drachms \\
\hline Mustard flour & . & . & . & & $1 \mathrm{drachm}$. \\
\hline Cantharides & & . & & & 5 grains \\
\hline Gentian powder & . & . & . & . & 4 drachms. \\
\hline
\end{tabular}

Make into a ball with thin Venice turpentine.

Powdered gentian . . . . 3 drachms

Powdered quassia . . . . 3 drachms,

Powdered grains of Paradise . . 3 drachms.

Make into a ball with Venice turpentine.

Tonic stimulants are supposed to exert their influence on the muscular fibre, and to improve its tone: this they do, in some instances, through the medium of the stomach, and are then called stomachics; or they are received into the blood. Tonics are, therefore, stimulants of permanent action; from which we may learn that this class is numerous, and is, in fact, diffused through the whole materia medica. A complete knowledge of their number and effect can only be gained by an intimate acquaintance with the animal economy and the nature of the various agents employed in acting upon it. Either of the subjoined may be given daily :-

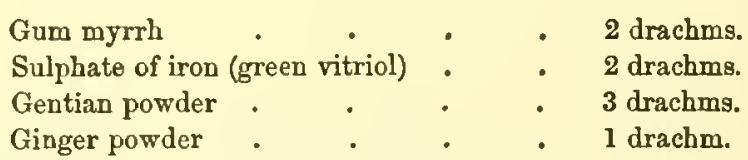

Mix into a ball with turpentine or palm oil ; or into a drink with pint of mild ale.

Arsenic . . . . . 4 grains.

Gentian, powdered . . . 3 drachms.

Cascarilla, powdered . . . 3 drachms.

Mix into a ball with conserve of roses; or, like the above, into 8 drink.

(K)

Gum myrrh $\quad . \quad$. 3 drachms.

Powdered gentian . $\quad . \quad$. 3 drachms.

Carbonate of iron . $\quad$. 2 drachms.

Make into a ball.

As Tonics, Mr. Vines also enumerates Angostura bark (Cusparioe cortex), Buckbean (Menyanthes trifoliata), Cascarilla bark (Cascarilloe cortex), Camomile flowers (Anthemidis flores), Gentian root (Gentiance radix), Quassia wood (Quassice lignum).

SToppinas are an important point in stable management. When a horse's work is irregular and he stands in stable too 
long, his feet are deprived of moisture, and the hoofs become hard and brittle, and have a tendency to corns, contraction, and founder. In cases of wounds or bruises on the sole, stoppings are yet more necessary. Clay is a bad stopping. It dries soon and adds to the evil it is intended to remedy; the addition of three parts of cow-dung to the clay will correct this. In wounds, a little tar is a good addition : but tar, as a general stopping, is too stimulant and drying. Oil of turpentine, one part; firm grease, two parts; and pledgets of tow dipped in it, bound on with withy strips and list, make an extemporaneous stopping. There are now, however, easily procurable, thick felt pads made for the purpose, which fit to the sole of the foot; these being passed within the shoe, and well wetted with water or cold lotion, swell, and thus are kept in their place by the shoe itself, and will retain their moisture throughout the night. Or, in case of prick of the foot, wet the pad liberally with chloride of zinc lotion to keep down inflammation. A good general stopping for keeping down fever of the feet, suppling the hoof, and rendering it tough, may be made of,-

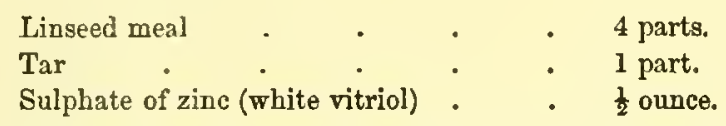

Strptics.--Such remedies as check bleeding internally or externally. Those used internally are-acetate of lead, sulphate of zinc, catechu (terra Japonica), alum ; externally, pressure, ligature, division of the blood-vessel, cold, the actual cautery, cobweb, felt, down, oak-galls, powdered alum, or any substance or fluid that has the property of rapidly coagulating the serum.

Dr. Paris ("Pharmacologia," p. 117) has some judicious observations on Styptics, especially as regards the horse and ass. He says: "The manner in which styptics act (on the human subject) is sufficiently shown by the pallor they at once produce on the lips, in consequence of the blood-vessels becoming diminished in diameter, and their coats increased in opacity. Great popular error, however, still exists, as regards these local agents, which has arisen from deductions drawn from their effects upon lower animals. Thus several substances have obtained the reputation of Styptics from the marked result which has followed their application to the wounded and bleeding vessels in the extremities of the horse and ass; whereas the fact is, that to these animals nature has supplied an inherent power of contraction which does not exist in man. Hence Styptics are of powerful action on the horse." Several Styptics have, at times, been held in high esteem, but galls, dissolved in spirit, or simple gallic acid, will be found as good as any. Filings of iron, tartar, and a little brandy, form the favourite Styptic of French and German practitioners, under the name of Helvetius's Styptic. Eaton's Styptic, well-known here, is merely sulphate of iron and brandy, and Ruspini's Styptic is gallic acid, brandy, and rose water. The application of a hot iron, not quite so hot as to utterly destroy the animal tissues, will be found, by coagulating the serous portions of the blood, and exciting the peculiar contractility of the blood-vessels of the horse, to check and eventually stop the loss of blood from severe wounds, and allow time for further remedial measures.

Sublimate, Corrosive. See Mercory.

Sudorifics. See Diaphoretics. A relaxation of the skin is produced in the horse by warmth, diluents, and diaphoretic medicines. A real sweat, however, is seldom excited without violent nauseants, and these are very uncertain in their action. Vinegar in half-pint doses will act as a sudorific, but is dangerous. A greater amount of clothing is preferable, but is very debilitating. Antimonials, as the acetated liquor of ammonia, will act as sudorifics in many cases.

Strrax, Storax.-Benzoin, commonly called Gum Benjamin. It is the product of a shrubby tree, the Styrax benzoin, common in Italy and the, Levant. Its name is from the Greek word styrax, signifying a reed, the gum styrax being preserved in reeds. It is a fragrant balsam, containing resin, and the peculiar principle called benzoic acid. It dissolves readily in spirits and ather, and is separated from them by the addition of water. It is good as a stimulant in lung disorders, and has been recommended in fevers. Its dose will be found in the compounds where used. It is an ingredient in fumigating pastilles.

Sulphates.-A salt formed by the union of sulphuric acid and a salifiable base.

Solphate of Copper. See Copper.

Sulphate of Soda. See Soda.

Solphate of Zinc. See Zinc.

Sulphate of Magnesia. See Magnesia.

Sulphur. Brimstone.-A well-known simple combustible substance found in the neighbourhood of volcanoes, in sublimed incrustations. It is extracted from pyrites, or firestones, by roasting them; these pyrites are in vast variety and are compounds of sulphur with various metals. When brimstone is melted at $228^{\circ}$ Fahrenheit, and cast in cylindrical moulds, it is called rough or roll sulphur; when this is purified by sublimation, it is sublimed sulphur, called flowers of sulphur, a bright yellow powder. When melted sulphur cools in the air, it is yellow and very brittle; when poured into water, white and tough.

Flowers of Sulphur (sulphur sublimatum) is a common remedy in veterinary practice. Internally, it is alterative, externally, a cure for eruptions of the skin. It is the basis of our applications in mange, and, combined with antimony and nitre, in surfeit, grease, hidebound, or want of condition. In doses of six or eight ounces, uncombined, it will open the bowels: but is not at all advisable as a purgative. When sulphur is internally administered, it exudes through the skin in the state of sulphureted hydrogen, and will blacken silver which is rubbed on the skin in a remarkable manner. Sulphur ointment is invaluable in mange. Observe, the black sulphur of the shops should never be used, as it often contains arsenic or mercury. Sulphur will not dissolve in 
water or spirit, but is soluble easily in linseed oil, which is an excellent solvent of all the sulphurous substances. Boiling oil of turpentine also dissolves sulphur. Sulphur, when kept in drawers or places where the air has access to it, becomes acidified and is supposed to produce a griping effect; we believe this to be a mere fancy. However, we are directed to wash the flowers of sulphur "to get rid of any sulphurous acid;" this the practitioner may adopt or not, as he pleases. Despite its disgusting smell, sulphur deserves yet more general use in horse-practice.

Sulphuret of Mercury (Ethiop's Mineral). See Mercury. Supertartrate of Potass (Cream of Tartar). See Potass.

$\mathrm{T}_{\mathrm{AR}}$ is an article in much use by the veterinarian. Melted with fish-oil, it makes a good external application, being brushed on the hoofs of the working horse when brittle or liable to exfoliate. Tar is also (see Stoppinas), mixed with an equal quantity of grease, a slightly stimulant dressing for bruised or wounded feet, preventing the access of air, dirt, or water to the wounded part. From its drying properties it is the chief ingredient in thrush ointments. Alone, or mixed with oil of turpentine to increase its activity, it is used with advantage in pricks and bruises of the sole. Tar is advantageously mixed, in doses of two and three drachms, with cough medicines. The Spirit of Tar If the farriers is the rectified oil; but oil of turpentine is best substituted for it. Barbadoes Tar, called also Green Naphtha, has been employed as an internal remedy for coughs.

TANAIN is the astringent principle of oak bark. It is prepared from oak-galls by powder and infusion. It is our most powerful astringent. The watery infusion possesses all the powers of the gall-nut. As an astringent in diarrhoa and a tonic in cases of fever, combined with aromatics and bitters, it is excellent. Also in washes. A gall ointment is specific in cases of protrusion of the rectum; when, also, a fomentation of infusion of gall-nuts with some opium is excellent. Those nuts which are bluish, small, and heavy, are the best; and they should be gathered before the larvæ have changed to flies, and have eaten their way out. Aleppo gallnuts are best and most astringent, but the cheaper must serve for horse medicines.

Tartarized Antinony. See Antimony.

Terra Japonica, See Catecho.

Tents are substances such as lint or tow, introduced into wounds to prevent their closing too early.

Tin is used to expel worms from horses. It has, however, proved utterly inefficacious in bots. It must be used as a mechanical remedy, in fine filings, and not levigated. Pewter filings are substituted, but their softness makes them useless. Dose, three ounces, in balls with honey or the like, daily It may be superseded by oil of turpentine.

Tincrures.-Many substances yield readily their medicinal properties to alcohol or spirit of wine. The tinctures, however, frequently require so much spirit to contain the dose necessary for the horse, as to make them impossible to be administered in this form, to say nothing of the great expense. The spirit necessary as a vehicle for the drug, has destroyed many a horse. Watery solutions, or infusions, or powder, are therefore more available. As lotions, tinctures. of cantharides, benzoin, myrrh, digitalis, aloes, and opium. are properly used. Tincture of catechu is an ingredient in astringent drinks.

A few of the tinctures kept ready compounded in the shops, or sold as patent medicines, may be mentioned here. Friar's Balsam-this is composed of gum benzoin, styrax, and tolu, with aloes. It is a moderately good internal remedy, diluted with water, to effect which it must be beaten up with starch or the yolk of an egg. As a styptic, or as a healing application to cuts and wounds, we consider it a mistaken remedy. It injures fresh wounds by its stimulant properties, and from the separation of the resins which follow the mixture of them with the blood. These combining form a solid mass between the lips of the wound, which mechanically prevents them coming together, and sc. setting up the healing process from the first intention. The Tincture of Gum Guaiac is a solution of that gum in aromatic spirit of ammonia. See Diaphoretics, StimuLANTS, \&c. Tincture of Myrrh, diluted, is a good lotion for spongy gums and sore palate, and a wash after reducing lampas by bleeding. Solomon's Balm of Gilead is a tincture compounded of cardamom seeds, brandy, and a trace of cantharides. A Tincture of Gentian and another of Ginger may be kept handy for the purposes of dilution, but the roots themselves and the infusion, as we have said before, are the cheaper and more potent remedies. Tincture of Muriate of Iron is a styptic, and an active preparation In warm water it is advisable in strangury, given every quarter of an hour in doses of twenty drops.

Toвacco is a remedy in costiveness and colic. It is most dangerous to the horse. "Two ounces," says Mr. White, "was given by a groom, and occasioned almost instant death." In the hands of the skilful it is a powerful remedy. We have seen it commended in farriery books as an ingredient in clysters. It would be as well to use a poleaxe or a pistol, on the score of humanity. The energetic action of tobacco, in solution, on the mucous membrane, the tremor, and the deadly action, through the nervous system, on the heart, will warn from a repetition of the practice on a second animal.

Tonics. See Stimulants and Cordials. They are valuable medicines when judiciously employed; but, like cordials, they have been fatally abused. Many a horse recovering from severe disease has been destroyed by their too early or too free use. The veterinary surgeon occasionally administers them injuriously, in his anxiety to gratify the impatience of his employer. The mild vegetable tonics, camomile, gentian, and ginger, and perhaps the carbonate of iron, may sometimes be given with benefit, and may hasten the perfect recovery of the patient; but there are few principles more truly founded on reason and experience 
of the horse, than that, disease once removed, the powers of nature are sufficient to re-establish health. Against the more powerful mineral tonics, except for the particular purposes that have been pointed out under the proper heads, the horse proprietor and the veterinarian should be on his guard.

\section{(A) TONIC BALL.}

\begin{tabular}{|c|c|c|}
\hline Powdered bark & & 1 ounce. \\
\hline Ginger & 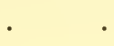 & 2 drachms. \\
\hline Carbonate of soda & . & $\frac{1}{2}$ drachm. \\
\hline
\end{tabular}

Form into a ball with linseed ineal and water.

\section{(B) ANOTHER}

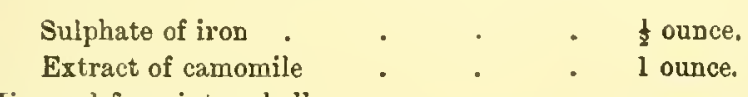

Mix, and form into a ball.

\section{(C) ANOTHER, MORE POWERFUL.}

Arsenic . . . . . 10 grains.

Ginger 1 drachm

Powdered aniseed . . . . . 1 ounce.

Compound powder of tragacanth . . 2 drachms.

Syrup euough to form a ball.

Tragacanth Gum. See Gums.

Turpentine forms a leading article in the veterinary materia medica. The Venice and common turpentine are those most in use. Almost every tree of the genus Pinus yields some sort of turpentine, the distinctions of which may be seen in botanical works and medical dispensatories. The best of turpentines is the Canada Balsam, produced by the Pina balsamea; the commoner, or Horse Turpentine, (Terebinthina vulgaris), is the juice of the Scotch fir (Pinus sylvestris). It contains more of the active oil, and is in our opinion preferable, at any rate for outward applications. Common turpentine is one of the best diuretics, in doses of half an ounce, and made into a ball with linseed meal and half a drachm of ginger. It is added to the calamine or any other mild ointment, to render it stimulating and digestive, and, from its adhesiveness and slight stimulating power, it is an ingredient in mange ointments.

The Oil of Turpentine is an excellent antispasmodic. For the removal of colic it stands unrivalled. Forming a tincture with cantharides, it is the basis of the "sweating blister," used for old strains and swellings. As a blister, it is far inferior to the savine ointment; as a stimulant frequently applied, it must be sufficiently lowered, or it may blemish. It also makes, in a diluted form, a gently stimulant liniment for nld sores and bruises.

Unauents. See Ointments.

Verdiaris. See Copper.

VERJUICE is merely apple vinegar. See Acetic Acid.

Vermifuges, or Worm Medicines. Tin or iron filings, not levigated, or powdered glass, are the mechanical remedies for worms in the horse. This class of remedy is called anthelmintic. The other remedies are-common salt, six to eight ounces; savine leaves, one ounce; cowhage, half a drachm; calomel, one scruple; arsenic, ten grains; aloes, till they purge; tartar emetic, a drachm for six successive mornings, and then a cathartic ball ; and, last and best, oil of turpentine, two or three ounces. All worm medicines should be given fasting. The best-known and most certain symptom of worms is a dry yellow matter under the tail; worms, however, are often present without this appearance presenting itself. A proper attention to a supply of salt in the manger or food, is the best preventive of these annoying parasites; and we need hardly repeat that prevention is better than cure. Clysters, with preliminary back-raking, will get rid of some sorts, such as ascarides (thread worms), taenia (tape worms), seldom found in the horse, and lumbrici (round worms), the special parasite of this animal The bots are not affected by our general vermifuges, and defy their action. The following clyster will often effect ar. ejectment of ascarides, tænia, or round worms: solution of aloes, 4 ounces; tepid water, 1 quart; common salt, 1 ounce. And give the horse at the same time 1 drachm of tartar emetic every morning in a ball, and after six of these doses of the tartar, a noderate dose of aloes, to expel the parasites, already enfeebled by the previous medicine.

A WORM BALL.

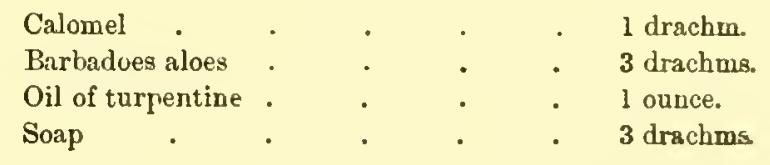

Mix.

WORM DRENCH.

Linseed oil . $\quad$. $\quad$. $\quad$. 1 pint.

Oil of turpentine . . . . 1 ounco.

Vesicatories. See Blisters.

Vitriol, White. See Zinc.

Vitriol, Blue. See Copper.

Vitriol, Gresn. See Iron.

Vithiol, Oil of. See Sulphuric Acid.

Vineqar. See ACETIC ACID.-The ordinary acetous acid is often used by the veterinary practitioner. Its purity is therefore of the first importance. It is, however, very liable to be adulterated with, or wholly made of, sulphuric acid, and then becomes very unfit for use as an internal remedy, being chänged into an active stimulant instead of a refrigerant. Vinegar, not neutralized by salt or sugar, is capable of proving very noxious to the horse. We have instances on recurd of a pint of strong vinegar destroying life; but, neutralized with carbonate of ammonia, it forms a most excellent febrifuge, under the old name of Mindererus's Spirit. Neutralized with sugar or honey, it forms a valuable expectorant, called oxymel. As an exterual application, the acetous acid is likewise valuable. In strains, bruises, and other local injuries, it is the base of the best remedies; either in combination with acetate of lead when active inflammation exists, or mixed with crude 
sal ammoniac, or bay salt, to counteract the effects of distension. Distilled vinegar is merely ordinary vinegar deprived of its fecula and water.

Wastes. See Lotions. - Of washes for the eye (Collyriums), Mr. Percivall observes: "A good deal of change of opinion has taken place among medical men concerning the strength and proportionate efficacy of topical applications to mucous membranes : at one time mere astriction or slight stimulation was considered to be all the effect that was requisite or safe to be produced; nowadays, however, stimulation in the highest degree, verging even on an escharotic effect, is found to be, in most cases, both warrantable and beneficial. Now, a surgeon will order a lotion for the eye, composed of five grains of lunar caustic to the ounce of water, and an ointment of double that strength, when, formerly, he would hardly have ventured to use such a potent preparation at all, or certainly not in above balf that strength. In veterinary treatment we shall find it to be good practice to produce a highly stimulant, even an escharotic, effect on the conjunctival membrane, with a view of relieving the internal ophthalmia by derivation or revulsion. The eye,even in a state of ophthalmia, will endure and derive advantage from applications of much more potent nature than are commonly ventured upon in practice My favourite collyrium is a scruple of nitrate of silver to che ounce of distilled water." Mr. Cherry, Principal Veterinary Surgeon to the Cavalry, uses bichloride of mercury as a collyrium in the potent form of solution in spirits of wine-one darchm to the ounce-and touches eyes with the sublimate itself; his note, in regard to their effects, is-"It is of importance to remark how soon the very considerable effect excited by the injection of corrosive sublimate in solution has subsided; even the application of it in substance to the surface of the eye producing a scarcely perceptible effect. We learn, both from practice and experiment, that our eyewashes, to do good, have been in general applied in too weak a form; we have not dared to do even what farriers before us did, and this is one reason why our practice, in many cases, has not turned out so successful as theirs."

Wax, White and Yellow. - The yellow is used to thicken ointments and stiffen plasters.

Worm Medicines. See Vermifuaes.

Zinc, the Spelter of commerce. This well-known bluishwhite granular metal furnishes three remedies to the horse.

1. Oxide of $\boldsymbol{Z}$ inc. This has been occasionally added to a ball as a tonic; but its great utility is as an astringent ointment, known as Calamine Ointment. Three parts of palm-oil and one of resin are melted together, and when these are cool, two parts of the oxide in powder are stirred in. Calamine powder is a good application, dusted on cracked heels and superficial sores. It is well-known, too, as the ointment called calamine cerate (formerly Turner's Cerate) as a human remedy for scalds and burns.

2. Chloride of $Z$ inc is valuable as a disinfectant, and also as promoting healing in suppurating or sloughing wounds. It has the peculiar property of suppressing luxuriant granulations. It acts admirably also in the closing of open joints: preventing fetor, coagulating the synovia, and at the same time promoting the healing beneath or the stopping of the orifice. It is beneficial in thrush and canker. It is used as a solution of various strengths, - a scruple to the pint, and a drachm to a pint and a half of water,-in grease, in thrushes or cracked heels with exudation.

3. Sulphate of $Z$ inc (White Vitriol). In the proportion of three grains to an ounce of water, this is an excellent application in ophthalmia, when the inflammatory stage is passing over. Quittor is successfully treated by a saturated solution of white vitriol injected into the sinuses. A solution of white vitriol of less strength forms a wash for grease that is occasionally useful, when the alum or blue vitriol does not appear to succeed. It is also used, in conjunction with opium, internally in diarrhœa and griping. It must always be dissolved in water, as spirit renders it insoluble.

\section{CONCLUSION.}

THE above list, though far less extensive than the druggist's bulky Dispensatory, will, it is believed be found to contain all the needful articles of a well-regulated veterinary surgeon's dispensary. We need hardly say how important order, cleanliness, and care are to the proper preservation and availability of the various drugs and chemicals; and how necessary it is that proper bottles, jars, and drawers adapted to each should be provided. Above all, let the practitioner test for himself, or prepare, a few of the leading articles he prescribes. We need hardly say that he should deal with a respectable druggist, and let him be aware that his customer knows what he is buying. The weights and measures throughout are Troy and Apothecaries' Weight and Measure.

\section{Weights and Measures}

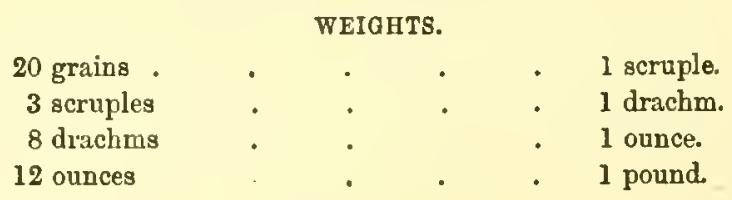

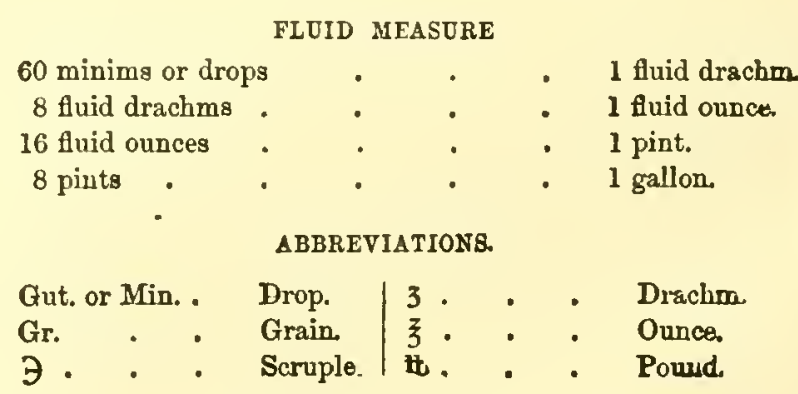




\section{CHAPTER XXIV.}

INTRODDCTORT. - SYSTEMS OF NOSOLOGY REJECTED.-ARRANGEMENT OF SUBJECTS.-REVIVAL OF THE VETERINARY AKT.-BPEOIPIO

DISORDERS : FEVER, INFLAMMATION, INFLUENZA, GLANDERS.

IN a treatise like the present, any attempt at the systematic classification of diseases, after the manner of many veterinary works, which themselves merely imitate the learned nosologies of Sauvages, Cullen, Darwin, Copland, and other human physicians, would, in our opinion, tend to perplex both the reader and the subject in a medical and practical view. A scientific classification of horse-diseases may well be abandoned when we see the failure of the greatest men in a science of which this is but a collateral branch of modern growthhuman pathology having claimed the exercise of the highest intellects in its study for 2,000 years. The arrangement, then, will be such as recommends itself for simplicity and convenience. We first say a few words on equine pathology; thence pass to a general consideration of the symptoms of the transition from a state of health to disease ; review the subjects of specific diseases-as fever, inflammation, and glanders; and proceed to a local system of referring the several diseases to the region or set of organs which are, or seem to be, most immediately affected by or involved in the disease. The appended table will afford an idea of this:-

\section{ARRANGEMENT OF DISEASES AND THEIR TREATMENT.}

\section{Chapter II.}

Introductory.-Systems of Nosology Rejected.-Arranaement of Subjects.-Revival of the Veterinary Art.Specific Diseases: Fever, Inflammation, Influenza, Glanders.

\section{Chapter III.}

Diseases and Injuries of the Brain, Skull, Eye, Teeth, Tongue, Palate, Pharynx.

Chapter IV.

Diseages of the Air Passages, Trachea, Bronohie, Lungs, Pletra, and Diaphragm.

Chapter V.

Digeases of the Heart, Pericardium, and Great Blood VESSELS.

Chapter VI.

Digeaseg of the OEgophagus, Stomach, Peritonedu, and INTESTINES.
Chapter VII.

Diseases of the Liver, Spleen, Glands, \&c.

Chapter ViII.

Diseases of the Urinary Organs.-Of the Organs of Generation in the Male and Female.

\section{Chapter IX.}

Diseases of the Sein.

Chapter $\mathrm{X}$.

Lamenesegs and Diseases of the Forelegs and Feet.

Chapter XI.

Lamenegses and Diseages of the Hock, Leas, and Hinder FeEt.

The several diseases form sections under these headings; thus presenting a convenient system, while the remain. ing chapters are devoted to Surgical Operations, Instro. Ments, Implements, and Shozing.

In the early history of the horse, in the former part of this volume, we have noted the ancient writers on the animal.

The ancient name Veterinarius, found in the classics of the Augustan age, degenerated in the dark ages into that of Farrier (ferrarius, ferrier) from the iron (ferrum) in which he worked. About the period of the revival of learning in the sixteenth century we find also the old veterinary learning following the awakening of the general human mind. After the fashion of the ancients, in the early periods of our own history, all published directions relative to the treatment of the horse were mixed up with agricultural matters in general. We see this instanced in "The Boke of Husbandry," by Sir A. Fitzherbert, a judge of the Common Pleas, which appeared in the reign of Henry VIII. In later times the sanative code became incorporated with the arts of the manège, and farriery was either practised and taught by the professor of equitation, or it descended to the forger of shoes. Of these additamentary arts we shall say little; nor will our limits allow us to do more than to specify the most popular of the works dedicated to the medical treatment of the horse particularly, and to his nor. 
medical treatment generally. One of the first and oldest works on farriery was printed in 4 to. by Wynkin de Worde about the year 1500, under the title of "The Propertys and Medycines for an Horse." The next was published in 1609, during the reign of Elizabeth, in small 4to. black letter, entitled, "The four chiefest offices of Horsemanship : that is to say, the office of the breeder, of the rider, of the keeper, and the farrier, by Master Blundevill." Leonard Pascal, Gervase Markham, and other writers, followed them.

Francis I. of France ordered the Collections of Cunstantine to be translated from the original Greek into Latin, whence it was soon after translated into Italian, German, and Frencl, and dispersed all over Europe. The works of Vegetius, too, were translated about the same period. In the seventeenth century, Italian writers open the period. Foremost among these are "Cæsar Fiarchi's Treatise on Horsemanship and Shoeing;" and the great work of Carlo Ruini, entitled, "Infirmita è suoi Remedi." In 1654 appeared the great French work, by Solleysel and others, "Le Parfait Mareschal." This was afterwards translated into English, temp. George I., by Sir Wm. Hope, and formed the basis of numerous books on horsemanship and farriery. Shortly after Solleysel's great work, appeared a folio, dedicated to Charles II., by Andrew Snape, jun., farrier to his Majesty, called, "The Anatomy of an Horse," with forty copper plates, copied from Ruini and Saunier.* The works of Michael Barret (Hippodomia), Gibson's "Farriers' Guide," Bartlett's " Farriery."

It was in France, however, in the eighteenth century, that the Veterinary Art made the most important advances. During this period, Bourgelat and La Fosse wrote well on horse diseases and shoeing. In 1761, France set the notable example of founding, under royal patronage, a public veterinary school at Lyons, having the celebrated Bourgelat as its professor. In 1766, a second was opened at Alfort, near Charenton, and others subsequently at Montpelier, Strasburg, \&c. Similar establishments have since been founded at Vienna, Berlin, St. Petersburg, Dresden, Leipsic, Munich, Hanover, Naples, and indeed throughout Europe. In Egypt, at Abou Zembal, in Australia, and the East Indies. Among English writers of the period were Osmer "On Lameness," followed by Morecroft, Clarke (of Edinburgh), Bracy Clark, White, Delabere Blaine, the Turners, Percivall, Castley, Youatt, Stewart, Spooner, and Mayhew, all of whom have written treatises, or systematic works, upon Veterinary Science and Practice.

Notwithstanding the labours of the earlier of the writers here enumerated, the veterinary art, as distinguished from

* The office of farrier is boasted of in the dedication of this curious book as being hereditary in the Snapes. "Being a son of that family that hath served the Crown of this kingdom in the quality of Farriers for these two hundred years, and myself honoured in that capacity." Wo may add that a really clever book by another Snape appeared solsequently. the lowest empiricism, is but of comparatively modern introduction into this country. Sixty years since, its practice was wholly in the hands of a set of men who, from their want of education, and the mechanical nature of their occupation, were unfitted for anything that required science or art, save the handicraft which they practised at the anvil, of making horseshoes and nailing them upon the feet. Like the barber-surgeons of old, from the circumstance of their operative services being required, and so frequently in one way, on the body, they were called (there being either a total want or great paucity of medical practitioners) to exercise an art of which they possessed no other knowledge than such traditionary lore as might have been handed down to them by their forefathers. In such hands as these, it was not to be expected that the art could thrive-that it ever could sufficiently develope its utility and importance, to assert those claims on society in general, to which every year in the present age is adding some fresh ones.

Such was the uncultivated state of the veterinary art when M. Vial St. Bel, a French gentleman from the veterinary school at Lyons, arrived in this country. He it was that prompted the first effort to redeem this art from the abyss of ignorance and superstition into which it had long and lowly fallen, and once more to set it on those pedestals of science and research upon which it had already rested during the ages of the Greeks and Romans. Such a strong hold, however, had the children of Vulcan got of the art (or rather, so unknown and undervalued were the advantages it held out in practice for skilful or qualified hands), that when St. Bel arrived in this country, in 1788, and made public proposals to teach an improved practice of it on the principles of science, his offers met with no encouragement, and he was compelled to retrace his steps to France Undaunted, however, by this one unsuccessful attempt, he made another visit to England two years afterwards; and this proved more fortunate; for, on this occasion, an agricultural society, "The Odiham," in proof of their good sense, and very much to their credit, gave ear to what Monsieur St. Bel had to propose; and finally resolved themselves into a body, called the Veterinary College of London, with a view to the erection of a public school, over which St. Bel was to preside. That St. Bel was a man who possessed some considerable store of medical knowledge, all who knew him agreed: at the same time, every one who stood beside him at the time he was at the College, and who themselves had any knowledge of veterinary matters, were of opinion that, so far as a veterinary professor was wanted, he was not, to the degree that might have been expected or desired, qualified to undertake such an office. However, he held it but a short time; for hardly was the erection of the college at St. Pancras (which was intended but as temporary, and preliminary to something better) completed, when St. Bel died, leaving the art in little better condition than that in which he had found it.

That St. Bel, however, had he lived, would have placed 
the art upon a scientific basis, may be augured from a passage in his oommendable work, entitled, "Observations on the Art of Veterinary Medicine." The passage runs as follows :"The object of this art is therefore not only congenial with that of human medicine, but the very same paths which lead to a knowledge of the diseases of man, lead equally to those of brutes. An accurate examination of the interior parts of their bodies; a studious survey of the arrangement, structure, form, connection, use, and relation of these parts, and of the laws by which they are intended to act; as also of the nature and property of the various foods, and other agents, which the earth so liberally provides for their support and cure: these form, in a great measure, the sound and sure foundation of all medical science, whatever living individual animal is the subject of our consideration." Whatever, therefore, may be said of the deficiencies of St. Bel in practical matters, his name must stand high in veterinary annals, not only from the fact of his having been the founder of the systematic teaching of the art in this country, but from having left behind him a series of observations (with a plan, grounded upon them, for the education of students), which at the present day are perused with admiration.

On the death of St. Bel, Mr. Coleman was appointed his successor in the Professorship During the many years Professor Coleman held this office, he greatly improved the position and teaclings of the veterinary art. In Edinburgh lectures on veterinary medicine were first given by Mr. Dick in 1819 , and at his death he bequeathed to that city the college which he liad founded along with his entire fortune to be devoted to the teaching of veterinary surgery. Since 1861 a veterinary school has also been conducted in Glasgow with great success. At all the colleges a preliminary examination is now recuired before a pupil can be enrolled.

It is not intended in this general work on the horse to supply a purely technical book for the special veterinary student; such volumes are properly confined to the school and college: the object in view is to furnish a treatise of ready reference, and of such a character as will render a gentleman, or man of average education, independent of the dictation of the groom or horsekeeper; and further, so qualify him that he may be able to judge of the competence and acquirements of the veterinary practitioner, and may himself understand the rationale and principles of the medical treatment of his most valuable servant, whose dumb sufferings should plead stronger than speech to his humanity and higher intelligence for their relief and cure.

As a groundwork for this knowledge, which we hope every lover of the horse will soon be ashamed not to possess, we have already sketched out the structure and anatomy of the animal; its physiology, organs, textures, fluids, and their functions-knowledge no more to be learned at the anvil of the forge than the practice of human surgery in the barber's shop, which for centuries was its theatre or university. The groundwork of the Veterinary Art is set in scientific study; and he who would understand it, must possess himself of that science. Much has been said and written on the importance of the respectability of the veterinary profession. Its utility should command a proper respect and position; and it deserves esteem as an art which involves the study of what have been styled the liberal sciences.

The respectability or social status of the practitioner will at all times and in all situations depend upon his qualifications and his character. When the connection of Veterinary Science with general medicine-with the pleasures, and habits, and pursuits of the superior classes of society-with the interests of agriculture, and even the well-being of our country - comes to be better understood than it is at present; when the Veterinary Art shall be taught and cultivated with advantages equivalent to those under which medicine has so rapidly progressed, and due encouragement shall be given to its improvement; then will those who practise it assert claims on society, and assume the position to which by intrinsic merit they are entitled.

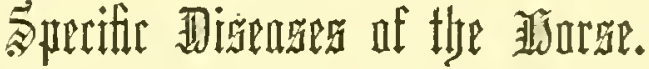

\section{\$ T. FEVER.}

Fever in the Horse was for long a subject of dispute by many in the veterinary profession; Professor Coleman and his disciples roundly denying its existence. Enlarged experience and observations have, however, disposed of the question, and the existence of simple or idiopathic fever is no longer controverted. Upon this point too much stress has been laid upon the discoveries and researches in human surgery. The signs and appearances of health or disease vary in many important points in every animal. Hence the knowledge and theories of Sydenham, Buerhaave, Cullen, Bell, Copland, and others, are of little applicability to horsepractice. The several stages of fever, so marked in the buman subject, do not appear in the horse, whose fever seems to be what Dr. Cullen calls synocha (Gr. synekō, t. continue), or persistent inflammatory fever

Fever in the horse assumes hardly ever any other than a mild, inoffensive form; and is no less insidious in its approach than (at least until it has made some advance) indeterminate its character. Now and then a cold and even a shivering fit is manifest: a sweating stage is rare, but not uninstanced. To assume that either one or both these paroxysms is requisite to constitute a fever, is not only to show ignorance of the pathological nature of horse-fever, but to argue in opposition to established practical evidence.

Inflammatory fever may be of two kinds; one idiopathic 
(Gr. idios, peculiar, pathos, affection), arising without any unanifest cause, or at least not dependant on any other disease; the other symptomatic, because it is the consequence of some manifest disease.

Whether fever, however, arise from any local and evident cause, or be self-creative, the phenomena observable seem in nowise to differ; from which we are led to the conclusion that in either case we may consider it the same disease.

The horse is at first observed to have become spiritless and heavy In the stall he stands with his head hanging down, and manifests unusual disinclination to turn or move : out of the stable, he has evidently lost much of his natural vivacity, and is found to sweat on comparatively trivial exercise. The extremities (the ears and legs) and the surface of the body grow cold; the coat becomes roughened ; actual shivering, or an approach to it, may or may not occur. He refuses the next feed put before him; or, should he pick at all, he prefers the hay, or even the new straw. By degrees the sense of coldness leaves the body : at length both the extremities and it grow warm-perceptibly warmer than usual. The mouth, likewise, which was livid and cold before, now becomes hot and dry; the pulse rises with the accession of heat: in all cases it becomes quick; in most, also full; in others, also hard. Respiration is visibly disturbed : the animal draws his breath, though perhaps still but slowly, with a sign of labour or weight evidently unusual. By this time, the early dejection is often succeeded by an unnatural watchfulness : the horse will have his head raiscd and his ears erect, as if he were in the act of listening, when he proves still, in reality, listless of all around him. He has now no appetite. His dung, if he should have lately voided any, is ligh-coloured, and in small rolls. He stales but little at a time, oftener than usual, and perhaps not without some groan, grunt, or extraordinary effort.

We find that debility is one of the first changes which takes place; and in all the varieties and changes of appearance, debility is always a leading feature.

CaUSES.-Debility, over-exertion, customary evacuations suddenly suppressed, cold applied to the body while hot. Horses that are kept in very warm stables, highly fed, and have very little exercise are peculiarly liable to febrile attacks.

Like most other disorders, however, and oftener, indeed, than most others, fever makes its appearance without any evident or determinate cause, unless we choose to ascribe it to those vicissitudes which are so common at the seasons when fever most prevails. Occasionally it assumes an epizootic (Gr. epi upon, zoon an animal) form, blended with catarrhal and suffocative (anginal) symptoms: under which type it has obtained various appellations, as "catarrhal, epidemic fever." CATARRH will be treated of under Diseases of the Air-passages.

The only disease liable to be confounded with fever, is pneumonia.

That disordered or deranged state which assumes the form of fever in the incipient stage, may continue and develope itself into a more perfect and decided form of fever; or it may prove only to have been the precursor of some other disease.

The disturbed breathing in fever never amounts to the hurried, laborious, and painful heaving of the flanks we find in inflammation of the lungs. It may be said the same symptoms are present in symptomatic fever, or fever arising from local injury, or where pus is forming. But then there are always some other concomitant symptoms to guide us, such as cold, clammy sweats, indicative of pain; or the pointing of a foot, if that be the seat of injury. Fever arising from external injury, or from local disease, is commonly more violent and active than any spontaneous febrile attack. It assumes more the form of painful or distressing irritation than mild and progressive disease; and is altogether such as the experienced observer refers directly to its proper source; ever keeping in view the previous history of the case.

The most unfavourable and frequent termination of fever is inflammation of the lungs.

Trearment.-In speaking of the treatment of fever, we confine ourselves to it in its simple form, every thoughtful practitioner being fully aware, that when it is the consequence of local inflammation, that is the primary abject to be attended to.

We must be guided in the use of the lancet by the state of the pulse; for, though blood-letting is indicated under all circumstances that have reference to inflammation, still here it must be done with circumspection. Older practitioners, in every case and indiscriminately, let the disease be what it might, bled and physicked.* In the milder forms of fever the less we do the better, and allow Nature to act for us; at least, our measures should be more palliative than active. In the more violent forms, bleeding, regulated by the state of the pulse; physicking in mild doses, so as to keep the bowels thoroughly open, without amounting to purging; acting upon the skin by the use of hellebore and digitalis; abstinence, green food, cool drinks, and cool air, appear to be the essential parts of the treatment.

When bleeding is resolved on, take at least three quarts, and give the horse a mash before any purgative, lest the

* Sufficient attention is not paid to the state of the pulse of the horse by the veterinariau; the quantity of knowledge to be ascertained by it being limited to the quickness or slowness of the pulsations, this being his chief guide in the use of the lancet; but the experienced practitioner well knows that the quality of the pulse will frequently inform him of the nature of the case, and be to him what the tongue of the human patient would be-his director.

We may elucidate this by referring to the state of the pulse in enteritis, where it has the quick wiry feel which it is impossible to mistake.

And again, the full hard pulse we always find when inflammation attacks rembranous parts, as in inflammation of the membrane of ths brain. 
colon be impacted with hardened fæces.

If not time for this, give a warm clyster of simple gruel. Then, when the bowels are moved, a fever ball (A, Febrifuges, p. 235), and all corn taken away; the water should have the chill taken off; warm clothing applied; the stable kept cool; and an abundance of litter given. In severe cold weather, the stable should kept about $55^{\circ} \mathrm{F}$. When the coat is staring, give-sweet nitre four ounces, acetate of ammonia eight ounces, watr $r$ one pint; repeat at a quarter of an hour's interval.

Diseases, no doubt, are often cured by obviating their remote causes; and in this way strict attention to the state of the stomach, from its close sympathy with the brain, is a matter of great importance, and to be attended to here. Though we may not be able so readily to apply this to veterinary practice, still we may do a great deal; and conjoining this with our practical knowledge of the pulse, it is here our medical knowledge will assist us.

Under every form of disease, simplicity of prescription is desirable, more particularly while our resources and powers are abridged by the limited pharmacopœia of the veterinarian.

In the incipient treatment, one precaution is to be especially attended to, and that is, that active purges must not be administered; for, in the early stage, it is quite impossible to say that the case may not be one of approaching pneumonia; and should this happen, and active purgation have been established, we shall but too certainly have cause to rue a practice which has induced so much irritation of the mucous surfaces of the bowels in combination with disorder in the lungs: the two, when present together, being found, invariably, highly prejudicial to the subject of their attack.

Symptomatic Fever being the result rather than the cause of inflammation, can scarcely be cousidered by itself. The simple fever often arises from exposure to cold, just as in the dog or in man; but this species generally arises from over-stimulation in some form, either by extra warmth or more food than usual, or by over-riding or driving. Whatever the precise cause, the effect is always to produce a congestion in some internal organ, generally followed by an inflammation, and accompanied by symptomatic fever. Thus, a horse is brought up from grass, and suddenly placed in a hot stable, with a liberal allowance of corn. In a short time his eyes become inflamed, his appetite fails, he has a violent cough, and he is what the trainers call "all to pieces." Now, this arises entirely from over-stimulation at all points, for not only is he kept in a state of increased heat, but the fire is fanned by feeding him with corn, and often by giving him an amount of work to which he is unaccustomed. The symptoms are quick and laborious breathing, stony coldness of the legs and ears, if inflammation of the lungs is present; yellowness of the eyes and mouth, if inflummation of the liver.

Treatment.-This, as before said, is merged in the treat- ment of its complication till that is got under, as will be found when treating of the lungs, liver, \&c. The debility which follows is now met by a boldly stimulant plan, a generous diet, and the administration of bark and ammonis in a manner that would have been thought by practitioners of twenty years ago mere horse-murder We now know better; hundreds of cures are effected by supporting the animal; by the early abandonment of the antiphlogistic measures borrowed from the Sangrado school of human practice, and preventing him from sinking into that state of exhaustion in which the poor animal dies of a disease closely allied to putrid or typhus fever.

Malignant Epidemic, Putrid, or Typhus Fever commences either as simple fever, or as common catarrhal fever; but this soon goes on to produce great prostration of strength, together with fetid breath, and discharge from the nostrils, and entire loss of appetite. Its course is much more rapid than in man. A congestive state of the vessels comes on, and they rapidly give way, by which life is soon destroyed. It is contagious, and few horses seized with it recover; indeed, its nature is such tlat most proprietors determine to destroy the infected animal, in order to prevent its spreading. See Glanders and Influenza.

Treatment.-This should be stimulating and strengthening. Either $(H)$ or $(K)$, p. 244, will be found serviceable. And if the bowels become relaxed, a little powdered oakgalls (see TANNIN, p. 246), chalk, or opium, may be added, with half a drachm of carbonate of ammonia, three times a day.

Fever in the Feet will be found under LaMinitis; and so of other local complaints to which the term is improperly applied.

\section{§II. INFLAMIIATION.}

Inflammation may be defined as a disorder of the capillary blood vessels, that being its most visible symptom; this, however, goes no further than enabling us to recognize its presence by the heat, distension, redness, and pain which are so called. The blood passing through the capillaries, gives forth an abnormal amount of caloric, hence the part is hot; the increased quantity of fluid distends them, hence the swelling; and from pressure on the nerves the tenderness; lastly, to the red globules of the blood, which, in health and its accompanying contractile power, are not admitted to the smaller vessels, but now enter them, the redness is ascribed. Although in the horse, his thick skin and hairy covering prevent the last sign from being so perceptible, it is nevertheless always present. The pain is the more acute in proportion as the part is supplied with nervous fibres: e.g. the brain, eye, internal ear, \&c.

Inflammation is divided into diffused and local, external and internal. The first class,-diffused inflammation,-we shall pass over. It is, in fact, general fever, indicated by an excessive irritability, carrying the constitutional disturbance of a severe local inflammation to the brain, and thence 
pervading the system. It therefore comes under consideration of diseases of the brain, nervous system, and heart, or sirculation. Nil est in corpore vivente planè sincerum: "Nothing in the living body," said Galen, "is ruled by invariable laws;" in other words, can be subjected to the same exact calculation as an inanimate machine; and this is particularly true of inflammation. In inflammation of the eye, function is impaired or suspended, and the sight affected; in the ear, deafness or preternatural and painful sensibility to sound; when of the liver, the faces are clay-coloured, indicating absence of bile; in the kidneys, inflammation impairs or stops the secretion of the urine; in the limbs, inflammation prevents motion or induces lameness.

Although inflammation appears simple in the symptoms, we have almost copied the quaint description of Celsus, two thousand years since, who gives us its concomitants rytlimically, as-

\section{“Rubor et tumor, cum calore et dolore."}

"Redness and swelling, with heat and pain." Yet these four points have furnished matter, for endless hypotheses and disputations: a summary of which may be found, with an especial view to veterinary science, in Mir. Percevall's " Hippopathology (Vol. I, section 2, pp. 53-63).

Causes and various Results of Inflanmation.-These subjects involve a vast proportion of the facts of veterinary and surgical knowledge, and deserve the deepest study and consideration.

Inflammation may arise from a variety of causes, some obvious, others veiled from our view, and only discoverable by reasoning, experience, and investigation. Their origin may be conveniently divided into-1. Accidental ; 2. Spontaneous; 3. Sympathetic.

1. Accidental. - In this case the exciting cause is generally evident enough, and usually a foreign body, which produces mechanical or chemical irritation.

Mechanical injuries comprise wounds and contusions and abrasions of all sorts; sprains, dislocations, and fractures; undue exertion of any part or organ, or the body altogether which, in hunter's plirase, is called being "overmarked.'

Chemicai excitants comprise all such substances as possess properties of an acrid, or corrosive, or poisonous nature; these are the mineral acids, the caustic alkalies, the metallic salts, and every caustic or irritant which we are in the habit of using in practice.

The state of the atmosphere, heat and cold, moisture and dryness, all in their turn become excitants of inflammation; their mischievous agency residing more in the vicissitudes from one state to its opposite, than in any obnoxiousness in our climate from their excess or continuance. Generally speaking, horses turned out from warm stables and exposed at once to the open air, even during the inclement seasons of the year, seldom "take cold," or experience any direct inflammation from the change; though the reverse of this vicissitude cannot be practised without such danger, and especially with young horses. Cold, without wet, even though alternated with heat, is not found to be nearly so prejudicial as when moisture is present too. Hence we are in the habit of viewing frosty weather as a season of health among horses; and hence it is that the spring and autumnal months are the most unhealthy, the weather then being moist and variable, and the wind generally in a cold quarter. Independently of these changes, there are conditions of the atmosphere not understood, which, when they prevail, are apt to produce an epizootic fever among horses, which has been called "influenza."

Animal Poisons, as well as natural ones, are fo snd to be occasionally suspended in the atmosphere, and through its medium produce their effects. The air of a hot and illventilated stable may prove an excitant of inflammation, not only from its high temperature, but also from the noxious eflluviæ with which it has become impregnated by the dung, urine, and breath of many horses stabled together. These poisons may also be conveyed through the medium of the secretions. Rabies and other diseases produced by the bites of venomous creatures, are transmitted through the saliva. Farcy and glanders may be transferred by inoculation with the matter of either disease; and mange is probably conveyed in some peculiar exudation from the skin.

2. Spontaneous Inflamiations are such as arise without any assignable cause. That there are many of that description, we have daily proofs. Were our knowledge of structure and function perfect, and had we a thorough comprehension of the relations subsisting between the body and the various agents and influences naturally or necessarily connected with it, we should probably be enabled, in every instance, to link disease with its cause, and thus frame a full and satisfactory system of nosology. But at present we are much in the dark concerning internal causes, and even lack knowledge about those that are external; and, in particular, in respect to atmospheric influence on the body.

3. Srmpathetic Inflamiations are such as owe their origin to disease or disorder already existing in the body. We know, in human patlology, how apt is one set of parts to take on disease through what we call "sympathy," at the time that another is suffering. In man, the digestive organs oftener than any other evince disorder; in the horse, the respiratory apparatus is the most common seat of disease: both which sets of organs, when disordered, may, in their turn, become the cause of disease in other parts of the body. The skin sympathizes readily botl with the digestive and pulmonary organs; and so do the urinary apparatus and the brain. Sympathy is also evinced in a remarkable manner between fellow organs on opposite sides of the body: one eye is no sooner affected with ophthalmia, than we begin to entertain apprehensions for the opposite one.

The Progress and Termination of Inflammation may bo 
rapid or may be slow, depending on its violence, its nature, the part it is affecting, its exciting cause, the condition of the animal, and other collateral circumstances. In the horse it generally assumes the violent form, and runs its course rapidly; or, in technical language, is of the acute character. At times, however, it appears in altogether a mild, or sluggish, or indolent form, taking then the epithet of chronic.

It too often happens in veterinary practice, that, in consequence of but trifling illness or lameness being manifested by the animal, his master does not imagine it worth while to call in medical aid: the consequence is, that mischief is present, and by the time the "vet" is consulted, is ont of the range and power of medicine altogether.

No sooner does inflammation become established, than we begin to look forward with more or less concern and apprehension to its consequences, effects, or terminations. John Hunter affixed the name of terminations, from the circumstance of the inflammatory action subsiding as soon as they had taken place. The terminations of inflammation are1, Resolution; 2, Suppuration; 3, Ulceration; 4, Deposition; and 5, Mortification.

Resolution is the term medical men employ to signify that inflammation has declined and disappeared in a part without occasioning any breach or material derangement in its organisation. A horse is brought to us with what is vulgarly called "a sprain of the back sinews:" we examine the leg, and find it puffed or swollen at one particular part, which at the same time manifests heat and tenderness on pressure. We apply a bandage wet with refrigerant lotion round the leg, and, perhaps, at the same time bleed and purge. The swelling, pain, and heat gradually subside: in other words, inflammation is arrested by the timely employment of remedies, before it has effected any change of structure. The leg recovers its natural size or fineness, and then goes sound again. This constitutes termination by resolution. But another horse, we will suppose, in reaching his hay out of a high rack directly over his lead, happens to have a hay-seed fall into his eye. Instantly the eye becomes closed, a flood of tears is discharged, and the animal twists his head about in every direction, to get rid of the annoyance and pain created by so irritative a body sticking in a part so highly sensitive. Some hours afterwards, the groom, not knowing what has accurred, or being unable to give relief, brings the horse to a veterinary surgeon, who, on raising and everting the upper eyelid, discovers the hay-seed sticking fast to the conjunctive membrane, which by this time has become as red as a piece of scarlet cloth from inflammation. However the hay-seed is removed, and by the following day the eye is seen to have recovered its natural colour and brightness. IIere is another instance of termination by resolution. There is, however, an evident difference between this and the case of the sprained leg, inasmuch as in the one instance resolution was accomplished within the space of twenty-four hours, while in the other it required a week-perhaps a month - to bring it about.
Metustasis (Gr. metastasis, translation, muviz irmin one place to another) implies the sudden shifting or translation of inflammation from one part of the body to another. This is very remarkably the case in pneumonia. When isflam mation in its acute form suddenly declines and quits the lungs, we may almost to a certainty predict that it will attack the feet-in the groom's phrase, "fall into the feet." In like manner, we find it often suddenly leaving one eye to invade the other. There are also instances of metastasis between the internal organs of the body-between the alimentary canal aud brain, the liver and lungs, the stomach, and kidneys, \&c.

Suppuration denotes the production of pus, or matter, in the inflamed part. It is the mode of termination we in general naturally look forward to when inflammation, resisting all we may do, runs higher, or even continues longer than the circumstances of the case permit us to calculate on resolution; or where there is breach of surface or any sort of wound: suppuration in this latter case becoming the natural and almost inevitable consequence. This is fully instanced in the case of a horse having that tumour under the jaw which we call strangles. We apply our remedies; but the swelling, instead of diminishing, increases in size, grows daily more prominent and tense, and tender on pressure, and then gradually clianges to a soft, impressible, fluctuating tumour. At this stage it contains pus; which, unless vent be given to it, will augment and accumulate in such quantity as to distend the tumour and burst it, leaving behind a vacuity or cavity in which the matter has been lodged. All unnaturally exposed parts-wounds and abrasions of all descriptions-readily run into suppuration: to them pus seems to form a sort of natural shield from injury, and, at the same time, a salve highly conducive to their healing operations. Mucous membranes-the linings of the air-passages and alimentary canal-promptly under disease assume the suppurative action. In common catarrh we see pus mingled with mucus ejected from the nostrils: and in inflammation of the bowels we may occasionally detect it coating the dung-balls.

In abscess, there needs, however, preparation, and seemingly a higher degree of elaboration, before suppuration becomes established; although it is apparently, from the very first, the end for which the local inflammation was set up. The cells of the cellular membrane in the beginning become filled and blocked up with solid matter, identical in appearance and nature with the coagulable lymph of the blood; in the very centre of which solid mass, or at the point where the inflammation runs highest, is deposited at first a drop of purulont matter. This drop gradually augments, the surrounding solid substance being as gradually absorbed, until, at length, a cavity containing a collection of pus is formed; in other words, an abscess makes its appearance.

Ulceration may be defined to be a loss of sulustance ap. parent externally, or a consumption of substance internally, occasioned by the removal of parts by the alssorbents. It 
is an effect of inflammation. External ulcerations are not common in horses, although we have instances of them. We see them upon the membrane of the nose in glanders; and upon the skin in farcy. One of the best examples we have of ulcerative inflammation is afforded by the skin of the heels; a part which, in consequence of its remoteness, from the source of circulation, and from the vicissitudes of heat and cold, moisture and dryness, to which, in the winter season in particular, it is exposed, becomes very subject to inflammation, and in that state very prone to run into ulceration: hence the origin of the foul troublesome ulcers we so often meet with in the heels in wet and cold weather. Some parts are more disposed to ulceration than others; a circumstance ascribable, apparently, to their relative degrees of vascularity. The skin seems to stand first on this list; the mucous membranes certainly rank next; then come ccllular membrane and bones; and, lastly, cartilaginous, ligamentous, and tendinous textures. Though comparatively but rare diseases, yet, when they do occur, poll-evil and fistula too often afford us dreadful examples of the ravages ulceration may make among bones and cartilages. Spavin likewise, and also disease of the navicular joint, furnish us with specimens of ulcerative action in the same structures.

Granulation is the process by which cavities occasioned by ulceration or by external injury are filled up again with fleshy matter, out of which parts similar to those lost are reproduced: it being commonly flesh that is wanted to fill the wound. As soon as the ulcerative process becomes arrested, and the parts remaining recover their healthy action, we perceive springing up from the innermost recesses of the chasm little red pointed eminences, which, from their grain-like shape, have received the name of granulations In the first instance, they consist purely of coagulable lymph; soon after, blood-vessels, and nerves, and absorbents shoot into them, and they then obtain the power of secreting purulent matter, which becomes very serviceable in defending them from external irritation of any sort. When they grow beyond the level of the skin, which they are very apt in their exuberance to do, they constitute what is called proud flesh, and require caustic applications to eat them away.

Cicatrization is the last stage of the healing process-the skinning over of the wound or nlcer. As soon as the work of flesh-making, or granulation is completed, and the chasm is become uniformly filled, the raw surface acquires a level, smoothness, and dryness-changes which, on close examination, we shall find to arise from a flmy covering of glutinous matter deposited upon the granulations, and the consequent cessation of the secretion of pus. Skin is one of those parts it is in the power of the constitution to reproduce. The surrounding old skin contracts over the sore, 80 as to leave as little as possible of the surface remaining to be covered with new skin, which contraction it is that occasions the puckered appearance we may observe the scar or cicatrix of all old sores to have: the middle of the scar, the part made up of the new skin, being commonly bare, or at least possessing but a few scattered hairs, and those mostly grey or white ones. Hair is speedily regenerated so long as the skin continues whole, and the bulbs that produce it (which are lodged within the substance of the skin) consequently remain uninjured. Indeed, so long as this is the case, hairs will be reproduced even though they be plucked out by the roots. Where new skin, however, exists,-or where the injury to the old is such as to destroy or disorganize the pilous bulbs, - no hair at all will grow over the place, or, at least, not for a considerable time; for I believe, in the course of years, even the bulbs themselves are regenerated, though, if we may reason from their produce, but in an imperfect manner. When we perceive weak, scattered grey hairs growing over the spot as soon as the part is healed up, we may conclude that the bulbs have not altogether been deprived of their organization. Attention to these circumstances will enable us to answer a question so frequently put to us in cases of broken knees:-"Will there be any scar left?"

4. Deposition includes adhesion, induration, scirrhus, bepatizatin $n$, ossification, softening, and changes of structure.

Adhesion is the mode of healing which the constitution, in case of wounds, adopts in preference to the tedious one we have just described. It is a direct union of the divided surfaces. Whenever a clean-cut wound is made through the skin (as in operations with the knife), and the sides of the wound are shortly afterwards brought together and maintained in apposition by plaister, suture, bandage, or other artificial means, the result, in ordinary circumstances, is what John Hunter called union by the first intention, in contradistinction to the process of granulation, which he designated union by the second intention. The blood answers an important purpose in the case of the fresh wound; for it keeps the divided parts glued together until such time as the blood-vessels ooze forth the real and permanent agglutinating medium, which is coagulable lymphthe same material as is thrown out in the form of granulations, and which forms the swelling in strangles and other tumours by being effused into the interstices of the cellular membrane. The process of union by adhesion is not completed until such time as this intermediate uniting substance is organized-is furnished with blood-vessels and nerves; an end which is brought atout by the vessels and nerves belonging to the parts divided shooting through the uniting material, and joining with one another. From the surface of a fresh wound, not more than four hours are required to produce the coagulable lymph; and, in a few hours after, it will be found to possess vessels capable of receiving injection.

The granulating process in horses is carried on witn a rapidity and healthiness hardly known in human surgery.

Induration, Scirrhus, Hepatization, Ossification. These surgical terms express changes in the structure and organi- 
zation of parts, one of which we may look for whenever inflammation is of long continuance, and so low in character as not to rise into suppuration. On some cccasions, inflammation of an acute kind will run to a certain height, and then, abating gradually, will leave the part swelled and hard, with diminished heat and sensibility; in which condition it may continue for some considerable time, and then, by a process of absorption, recover its natural state. Glands are especially subject, under long-continued or often recurring inflammation, to what is called scirrhus, which means consolidation, induration, and conversion of cellular and secreting textures. Hepatization denotes something of the same sort of change, only that the solidified and converted part has a liver-like aspect : oftenest found in pulmonary cases. In regard to bony formations, the horse is especially prone to them. He possesses hardly any structure but what, at one time or another, lias been found partially or entirely changed into bone; and where bone itself, or even cartilage, is concerned in the inflammation, we look for it as a sort of natural consequence: hence the production of splints, spavins, ringbones, ossified cartilages, stiff joints, \&c.

Softening denotes a change the reverse of induration, which has been occasionally observed to take place in certain parts that have laboured under inflammation. In the horses nervous or medullary substance, the glands and the liver, frequently exhibit softening, in which the finger may be pushed into the substance with the same ease that it would penetrate a rotten apple or pear. The farriers have caught at this similarity. Nothing is more common for them to find in the course of their post-mortem examinations, that the liver was as "rotten as a pear."

Mortification expresses the death of the inflamed part. It is comparatively rare in horses. The inflammation that gives rise to it is of the acutest kind; we meet witl it the oftenest in the lungs; though now and then mortification occurs in the bowels. Wounds, also, of a violent nature, in horses with bad constitutions, now and then turn to mortification. A part in which inflammation is running to this fatal issue, turns from red to purple, and from purple to black in hue, losing at the same time its heat, as well as its manifestation of sensibility and power of motion. We may know that circulation and vital action have ceased in it by its deathy coldness; its blackness; its soft and flabby feel; its crackling sensation under the finger, produced by the air extricated within it; and, finally, by its putrid odour. Should it be an internal organ that is affected, the signs of mortification having taken place in general observed are, a sudden and almost total cessation of the symptoms of pain, so that, to a common observer, the animal would appear at first to have experienced a change for the better.

We have spoken of the dangers of inflammation, yet, under certain circumstances, inflammation is not only to beendured, but even encouraged. Wereit not for inflammation and its concomitant effects, no wound could be healed, no boneunited, no breach repaired. A puncture into a joint, a lacerated intestine, K K is alike repaired by inflammation - tle same process by which the joint is anchylosed and the bowel mortified. Inflam. mation works good or harm, depending on the nature and circumstances of the case-on its degrec, its duration, the cause that gave rise to it, the part affected, its character and tendency, \&c., \&c. ; and the exercise of a sound discriminative judgment in these several particulars it is that constitutes a scientific and experienced practitioner. We often excite inflammation on the principle of counter-irritation, to remove inflammation from some internal and more important part: blisters, rowels, setons, and artificial irritations of all kinds are practised in cases of sickness with this view; and the practice is found not only lighly beneficial in relicving the patient, but also proves a safe one, inasmuch as the fresh inflammation, artificially excited, commonly exists in a harmless and manageable form, although we have no reason for believing that it at all differs in its nature from that which it is designed to counteract. We frequently, too, excite inflammation by similar means, with a view altogether different; namely, to produce absorption of some deposition, such as spavins, windgalls, curbs, \&c. Now and then we use means to stir up a fresh and more active inflammation in parts in which it already exists, but in too sluggish or unhealthy a form to accomplish the desired end. We act on this principle when we pour boiling dressings, or inject caustics, or introduce a red-hot iron into fistulas, poll-evil, quittor, or sinuses.

Treatment.-In the treatment of inflammation obtain the clearest insight possible into its seat, its kind, its causes, and its present and probable effects, both as regards the part inmediately affected and the constitution at large.

The degree and kind of inflammation must be taken into account in the treatment. The more active or acute the one, the more prompt and bold should be the other; though, where inflammation is of what is called a specific kind, experience teaches us that we do but little good in our treatment unless we can meet the case with specific remedies, such as are found peculiarly adapted for such anomalies. In specific ophthalmia, in mange, in farcy, and in glanders, we bleed and purge with but little comparative benefit. To be of real service to our patient, we must have recourse to something in the shape of a specific remedy.

The first thing to be done in the treatment of inflammation, is, to remove the cause, supposing it to be still operating. In some cases, such as that of a hay-seed in a horse's eyc, this is all that is required to be done. The cause being removed, the inflammation subsides, and ceases altogether. Should a horse pick up a nail in lis foot, and that be found penetrating the hoof, and simply wounding the quick, its speedy extraction, with a little subsequent attention to the cleanliness of the wound, will be all that is commonly necessary to effect a cure On the other hand, when, from the depth of the puncture, or from the irritability of the animal's constitution at the time, violent inflammation unay ensue, the case will call for every attention we can give it. 
When the eje is inflamed, the lids and the haw are drawn over its surface to slield it from the light; which, though under ordinary circumstances a natural and healthy stimulus, now that the sensibility of the organ is augmented, becomes an annoyance to it: this teaches us to take care in cases of ophthalmia to exclude the light.

It is important to put the diseased part, as far as lies in our power, into a state of repose. And in no way can we better accomplish this than by placing the animal in " $a$ loose box," with his head at liberty, in a pure and cool atmosphere, so as to lie down upon a comfortable bed whenever he feels disposed, and place himself in any posture that may afford him most ease.

Inflamed muscles, and tendons, and joints, should always be placed in a state of repose, if possible, and at the same time in that relaxed condition which leaves every fibre most at ease. We may commonly do much towards the attainment of this end in the limbs, by raising or lowering the heel or toe of the foot, as the case may require. Should the head or any part of the neck be the seat of inflammation, it may be found beneficial to keep the head elevated and confined: much mischief is done by suffering the animal to hang it down upon the ground. The principle by which we are to be guided in this respect is, to endeavour to maintain the part inflamed in that position which is most favourable to the return of blood from it back to the heart.

The next step in a general way, is attention to clothing. There are but few diseases in which it is not desirable to keep the surfacz of the body warm, for which purpose we employ woollen clothing. The quantity or thickness of the clothes must of course be regulated by the season of the year, by the previous labits of the animal, as well as by reference to the disease under which he may at the time be labouring. In hot weather, clothing is commonly required rather for the purpose of protecting the animal from the annoyance of flies than for warmth, and, consequently, linen clothing is mostly to be preferred. Where warmth becomes the object, rugs or blankets are preferable to cloths; when both are used, the former should be placed next the skin. In no case slould their quantity be such as to become burthensome.

The common food of a stabled horse consists of oats and hay. During the existence of inflammation or fever in the system, discontinue the oats, and substitute bran, in the form of mashes, which are laxative in their tendency, and good, as you cannot use purgatives. On this last account, green meat (whenever it can be procured) is to be preferred. Vetches, lucerre, green clover, and also the various esculent roots, -carrots, turnips, potatoes, \&c.,- - are all suited for the sick stable, because they are more grateful to the palate of the invalid than his ordinary stable diet. During the height of inflammatory disorder, however, food is not only not required, but would by its presence in the stomach be apt rather to irritate than benefit; and as the disorder declines, the appetite commonly returns.
It is of great importance, particularly in cases of inflam. mation of the lungs, that the air of the box of the sick horse be cool, free from impurities, and frequently renewed.

The medical treatment of inflammation consists in the employment of constitutional and local means. The constitutional are, bleeding and purging, with the assistance of sedatives and diuretics and alteratives. The local means are, bleeding, cold and warm applications, and counterirritation.

Bleeding.- When we consider the increased action maintained by the blood flowing with greater rapidity and in greater quantity through the vessels of the inflamed part, it seems that abstraction of blood must be one of the most direct means of subduing inflammation. In veterinary practice, in many cases, it is the only remedy we have it in our power to employ. In the acute stages of inflammation of the lungs, and even other organs of importance, neither internal nor external medicaments will take effect until we have succeeded in abating the inflammatory action by bleeding; and in cases where we cannot purge, we commonly effect nothing without the lancet. Although, as we draw the blood out of a part, we reduce the inflammation in it, yet we do not by this cure the disorder, for no sooner are the vessels emptied than they are filled again; in fact, time must be allowed for the inflammatory action to subside. Under the head BleEdina, will be found the modus operandi, instruments used, quantity, and effects of abstraction of blood.

Although the abstraction of blood rapidly from a large orifice is a check upon inflammation, it has some bad consequences, which in modern practice have been fully proven. The olden practitioner was so convinced in this respect, that, as Mr. Mayhew says, "he drew blood with the same complacency as he would draw beer from a barrel, and quite as often, even supposing him to be very fond of that exhilarating beverage. In the present day, however, either the character of disease has changed, or it is perceived the practice alluded to was founded upon a mistaken basis. Horses could not now bear the loss of half that quantity of vital fluid which is, on good authority, believed to have been formerly taken from them. Many an animal then, having influenza, has been bled into hydrothorax. Many an animal has been so reduced by repeated bleedings, that he has ultimately sunk, not from the disease, but in consequence of the measures pursued for its reduction. Bleeding has therefore lost its repute as the specific means of cure; for any disturbance of the circulation is easier and more safely equalized by the administration of a stimulant, than only apparently tranquillized by the abstraction of a fluid of which the animal rarely has a drop too much.

Purgatives, in the human subject, form the next active agents in combating arterial excitement; but there are some peculiarities in the structure and functions of the horse, which render these medicines less eligible than in man. To produce active purging in the horse, causes great constitur 
tional disturbance, and lowers the powers of the constitution in a remarkable manner, to say nothing of the time required for their action.

Sedatives and Nauseants are often valuable in inflammation; as it is a law in animal economy, that whatever excites the sense of sickness, lowers the pulse in force and frequency, and so diminishes the flow of blood to the inflamed parts. Of these, aloes is the first, both as a purgative, a sedative, and a nauseant. Dose, half a drachm to a drachm every four, eight, or twelve hours. Hellebore root is another nauseant (see list of horse-medicincs), especially when, as in diseases of the lungs, aloes are dangerous. In doses of a scruple to half a drachm every four or six hours, it lowers the pulse and inflammation; but is a poison in large doses, and therefore requires close watching. If saliva oozes from the mouth, and the animal hangs his head down, or turns outwards the upper lip, discontinue the hellebore immediately. It should be given only after bleeding has been tried. Of sedatives, digitalis is the favourite, in doses of half a drachm to a drachm twice a day. This also is a dangerous poison, producing stupor, cold extremities, clammy mouth, vertigo, convulsions, and death. It irritates the bowels less than hellebore. Percivall gives the following formula :-

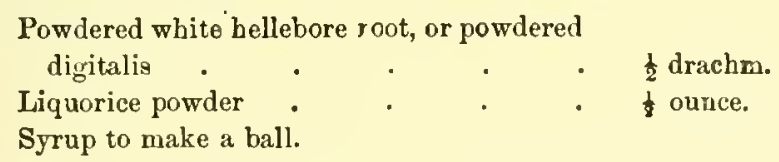

Diuretics (or "urine-balls," as the stablemen call them,) are more active in their operation on the kidneys of the horse than the same class of medicines are with man, who depends more on the excretions by the skin. The physician prescribes diaphoretics to smooth-skinned man; diuretics have the veterinarian's preference. Sweating a horse, except by exercise,-and that will not do in inflammation,-is next to impossible. Mow-burnt hay and fermented food act on the kidneys of the horse. Nitre is the leading diuretic; and for its combinations, and Sedatives, see those heads in List or HoRSE-MEDICINES, ante.

Alteratives, too, as antimony and mercury, are used in combating inflammation, as well as cold and warm applications. Cold water, or salt and water, or Goulard's lotion, are commonly used. Evaparating lotions have our preference. Vinegar and water, or spirits and water, answer the purpose well. In cases of much swelling, the following evaporating lotion can be recommended:-

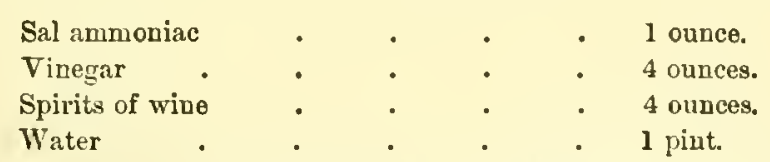

Mix the sal ammoniac and vinegar, then add the water and spirits.

Or,

Liquor of acetate of ammonis and spirits of

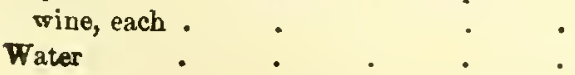

4 ounces.

1 pint.
Paradoxical as it may appear, warm applications are as serviceable in many cases of inflammation as cold ones. When heat, however, is applied, it must always be accorn. panied by moisture.

Blisters (see list of medicines), with rowels, and setons, and their appropriate instruments, will be found in their proper place under OPERATIONS.

\section{§III. INFLUENZA, EPIZOOTIC, OR CATARRHAL FEVER.}

This formidable disease has of late years extensively prevailed throughout every part of the kingdom. Malignant epizootics are on record which so strongly resemble its symptoms and course, though imperfectly recorded, that there is no reason to consider it a new disease. It is as well to be candid in acknowledging that we are ignorant of its immediate cause, though it is easy to talk learnedly of "atmospheric influences" of the real constituents or malefic action of which we know nothing; investigation having as yet shown no peculiar poison present in the air at the period or place of such visitations. Influenza spares neither young nor old, strong nor feeble, and neither regards scason of the year, nor situation, dry or moist, elevated or low. Sometimes it is mild in form and action, resembling much a common cold, at others accompanied with severe internal inflammation, and destroying like an angel of death passing through animal creation. The term influenza is that adopted by almost universal consent, and expresses its tendency to spread. In 1836, horses in all parts of the kingdom were scourged with this epizootic disorder. Again, in the autumn of 1840 , it made its appearance in various places. Olden farriers called infuenza by the unmeaning name of "distemper," which may well be discarded and thrown " to the dogs." MIr. W. C. Spooner, of Southampton, in a paper contributed to "The Veterinarian," has given a clear account of the disease, of which we shall here avail ourselves. He says, in a paper read before the Veterinary Medical Association of London :-

"The influenza made its appearance during the month of September, 1846, and has continued up to the present time. My first cases were few and isolated, but they gradually became more numerous and more cumulative. The symptoms were very similar to those of the epizootic of 1836, at any rate sufficiently so to justify me in denominating it the same disease.

"Symptoms. - The first symptom that awakened attention was the sudden failure of the appetite, which was either total or partial; the horse, perhaps, might have appeared perfectly well in the morning, and at noon refused his food. The mouth hot, the pulse quickened, varying, however, from 40 to 80 , being sometimes full and strong, but more frequently soft and weak. There was, generally, a sonewhat dull appearance of the animal at first, although nothing to what afterwards supervened; the coat was often staring, and, when so, the attack usually became more 
severe. This symptom, however, was far from being universal. The extremities were rarely cold. In the course of six or twelve hours, the symptoms became more aggravated, the pulse increased in frequency, and the appetite more diminished, and probably the legs and eyelids considerably swollen. In some cases the respiration became quickened, and in others there was cougly and sore throat; but in the majority of my patients, there was no bronchial affection whatever.

"In a few instances, the disease quickly reached its acme, but, generally, the symptoms increased in severity for two or three days, when, supposing judicious treatment had been employed, they gradually declined, and at length totally disappeared, the animal slowly regaining his former health and spirits.

"The bowels, generally speaking, were not apparently much deranged, but their mucous coat was particularly susceptible to the action of apcrient medicines; and the fæces were frequently enveloped in thin slimy mucus, and often softer than in a state of health.

"In some cases the affection of the eyes was so violent as to occasion temporary blindness; and in others pneumonia was present, but more frequently severe bronchitis. In many patients, the ædematous swelling of the legs was enormous, and continued obstinate when the other symptoms had abated; hut, commonly, in proportion as the legs and eyes were much affected, the internal viscera were free from disease, and vice versa. This rule, however, was by no means universal, for, in several patients, severe cephalic and thoracic symptoms were present in the same subject and at the same time

"Treatment.-When the pulse was full and strong, I abstracted blood, and with the best effect. The blood was slow in coagulating, and invarially presented a buffy coat. I took great care, however, not to abstract too large a quantity; and could produce the desired influence by half the quantity which, in ordinary inflammatory affections, it would be necessary to take away. The amount of blood withdrawn was always determined by its effect on the pulse, taking care, as soon as its character was materially altered-that is, softer and less perceptible-to pin up the orifice. This alteration was sometimes produced by the loss of only 4 lbs. of blood, oftener by $6 \mathrm{lbs}$, occasionally by $8 \mathrm{lbs}$, and in a few instances by $10 \mathrm{lbs}$. In two or three cases where there appeared to be severe internal inflammation, I repeated the blood-letting on the following day, and in one instance on the same day; but, as a general rule, even in cases where the pulse had on the following day regainel its strength and fulncss, I abstained from a second bleeding, trusting to medicine and the progress of the disease to soften the pulse, which I found to take place commonly on the second or third day.

"Local venesection was more frequently resorted to than general bleeding; indeed, whenever the eyes were much inflamed, or the lids swollen, Mr. Turner scarified the latter with a lancet, and opened the anglar veins with the best re- sults; the local inflammation generally subsiding in the course of twelve or twenty-four hours, whether the patient had been bled generally before or not.

"The treatment in the way of medicines consisted in administering the following :-

\begin{tabular}{|c|c|c|}
\hline Croton oil & • & 5 drops. \\
\hline Nitre . . & - & 4 to 6 drachms. \\
\hline Tartarised antimony & . & 1 drachm. \\
\hline Spirit of nitrons ether & . & 4 to 8 drachms. \\
\hline Spirit of Mindererus & . & 2 to 4 ounces \\
\hline
\end{tabular}

"Sometimes 4 drachms of bi-tartrate of potash were added to the above; and when the head appeared much affected, 1 drachm of camphor. This draught was administered generally once, but sometimes twice a day, the croton oil being omitted after the first dose. After the first day, in by far the greater number of cases, 2 drachms of gentian were added to the draught; and after the second or third day a ball was substituted for the draught, consisting of:-

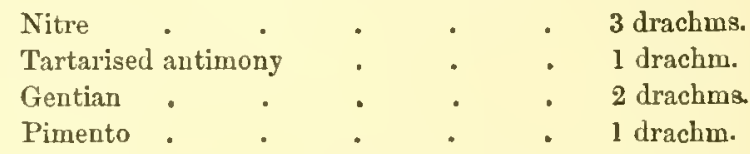

"In one case the above draught produced profuse perspiration inmediately after and each time it was administered. Although this effect may be principally ascribed to the idiosyncrasy of the animal, yet it proves the diaphoretic properties of the medicine, though this may not generally be distinctly perceptible.

"Counter irritation.-In by far the greater number of cases there was no inflammation of the air-passages; but whenever it was denoted, I blistered the throat, the course of the windpipe, and the breast; or inserted setons or rowels, as the particular case appeared to demand.

"Such is a brief account of the treatment found successful, not only in conquering the disease, but in restoring the health and strength in a short space of time. Although the majority of cases were not dangerous, yet many of them were so; and it is notoriously the fact, that a great number of horses have died from the disease in various places. Indeed, in the establishment to which I have referred, three horses died from it under the care of another person, not a member of the College; and in several instances where horses have been treated by the owners, although the case was not dangerous, they recovered but slowly, and with great loss of condition."

We have had occasional recurrences of this disease, though not to the same extent as before, and have found the best results attend the administration of calomel with tartarised antimony. Either a drachm each should be given once a day, or one-half this dose both morning and night, continuing for several days, adding occasionally Febrifuge and Diuretic medicines. (See List of Horse-medicines in Chap. XXIII. Mr. Spooner, found a greater disposition to æedematous swelling of the extremities and sheath in the later epizootics 
than in that of 1836 ; and so obstinate, occasionally, were these enlargements, that they were reduced with much difficulty, and only after the frequent and continued employment of diuretics, and the insertion of setons in the thighs. There likewise appeared to be throughout the attack a capability of taking large and repeated doses of diuretic agents without exciting the kidneys in any great degree. At least double the quantity could be given, and with no greater action than half the quantity in a state of health.

In an addendum to this paper, Mr. Spooner discusses the question of blood-letting and purgatives in influenza as follows. Of bleeding he says :- "I take it for granted that the chief art in treating the disease is to know when to bleed, and when to abstain; being guided in this matter chiefly by the state of the pulse. Where, however, I have not bled generally, I have witnessed the very best effects from local bleeding. It has, in a few lours, relieved the tumefaction of the eyelids, and the lieaviness of the head, to a great extent. One thing is most clear, -we can produce a very great effect on the system by very moderate bleeding."

To the question, Is aperient medicine judicious? he replies:- "This, too, is an old disputed point. I am in favour of a very moderate dose at the commencement, but against its repetition. I have most commonly administered five drops of croton oil, which has generally produced a sufficiently laxative effect. The addition of a few drops more I have known produce purgation. I am inclined to believe that a very moderate action on the intestines will hasten the recovery of the patient. Additional experience has so far modified this opinion, that in ordinary cases the gradual administration of a few drachms of the proto-chloride of mercury in small doses will have a sufficiently laxative effect on the system."

Cases of superpurgation, arising from the administration of full doses of physic in this disease by empirical practitioners, often occur.

We would recommend a drink compounded of sulphuric ether, landanum, and cold water, then wait an hour and watch symptoms. Repeat the drink at night; next day add to it a scruple of calomel sprinkled on the tongue, and wash it down with the drink. Persevere with this daily till the pulse is quicker and so soft as scarcely to be felt. Then leave off medicine and give a quart of the best stout night and morning, carrots chopped fine, fresh grass, and scalded oats. These will be found the best tonics when you have turned the corner upon the influenza.

\section{§IV. GLANDERS AND FARCY.}

Volumes upon this horrible and fatal malady have been written. Its bibliograplyy alone forms the subjectmatter of 28 pages of Mr. Percivall's third volume (pp. 252-280); whereto the studious and curious reader is referred.

Glanders consists in a discharge, from one or both uostrils, of matter which by transfer or inoculation will produce the disease in another animal (either of the equine or human species), and which discharge is, sooner or later, accompanied by injection of the vessels and chancrous ulceration of the Schneiderian membrane, by tumefaction of the submaxillary lymphatic glands, and by farcy. There is every reason to believe that glanders and farcy are merely modifications of the same disease; or rather that farcy, in rnany cases, supervenes on glanders. The seat of glanders is in the pituitary or Schneiderian membrane-that membrane with which the respired air comes in contact, and which lines the nose, the sinuses of the head, the windpipe, and its branches. Snape was the first who declared Glanders and Farcy to be the same disease affecting different parts. He ealls glanders, in his quaint way, "Farcy" in the head." The proofs of identity in nature between glanders and farcy rest upon-1st, their reciprocity of production through inoculation; 2 ndly, their traceableness to the same causes; 3rdly, their termination one in the other, which almost invariably takes place, when they are suffered to run their natural course previous to death; 4 thly, their frequent simultaneous appearance in the same subject, together with the similitude of the phenomena and course they exhibit. A clever paper written in 1859 , by M. Gerard, "Sur l'Identité de la Morve et du Farcin," in the "Journal de Medecine Veterinaire," seems to us to set the question beyond cavil as to the identity of these diseases of the lymphatics.

The diseases with which glanders is liable to be confounded, or for which it may be mistaken, are catarrh, nasal gleet, and strangles.

The signs of true glanders are with singular accuracy described by old Solleysell in his "Compleat Horseman" (1679). No better diagnosis has been made since, with all our science. He says:- "The signs by which the disease may be known, are when a horse, already too old to be troubled with strangles, without a cough, voids matter by the nose, and has a kernel sticking to the bone; and besides, in glanders, the matter usually flows from one nostril, whereas in a cold it runs almost always out of both."- "Some cast the matter that is voided by the nostrils into water, and if it swim on the top, they conclude the horse to be free of this distemper; but if it sink to the bottom, it is a sign of glanders: the principal use of this experiment being to distinguish the pus."- "But you must not depend on the certainty of this sign; for if the matter stick to the nostrils like glue, it is a bad sign, and you may conclude the disease to be the glanders, though the matter do swim on the top." - "When either the breatli or matter that comes out of the nostrils stinks, the disease is almost always incurable." - "I have seen horses troubled with this distemper without kernels, or, if there were any, they were little and movable; and the only sign by which we could discover it to be glanders was by the glueyness of the matter."-Hope's Translation.

Solleysell is well confirmed by a clever article by Mr. J. Turner on what he calls Insidious Glanders, in Vol III. of 
"The Veterinarian," page 694, in which he adduces instances where a horse, being glandered, propagated glanders without himself exhibiting anything more than a constant thin gleety discharge, without offensive smell; having no visible ulceration of the nasal membranes, no swelled legs, or even anything resembling farcy; yet the chronic discharge was glanderous, and capable of propagating the disease in all its virulence in otlier horses.

The forms of glanders, in modern books, are called acute, sub-acute, and chronic.

Acute glanders results from inoculation or contagion of the virus. This runs its deadly course, and includes what the French veterinarians have termed typhoid or putrid glanders. The course of acute glanders cannot be better illustrated than by the following note from the "Cases" of Mr. John Field.

"May 3rd.-An ass was inoculated in both upper eyelids, both sides of the loins, the off side of the withers, and on the inside of the ala of each nostril, with the discharge from the off nostril of a grey gelding (purchased by Sir P- Dthree years previous), which was affected with this same glanderous discharge at the time of purchase, and had so continued ever since.

" 7 th-All the wounds suppurating, except those on the nostrils, which appear to be healing.

" 9 th.-Absorbents inflamed from the ulcers on eyelids and back.

"14th-Absorbents much thickened, having diffused inflammation about them, and at different parts of their course circumscribed tumours suppurating; the inflammation from the ulcers of the loins proceeding to the groin, that from the off side of the withers to the breast, and, on the eyelids, producing small fluctuating tumours on the jugular vein, just below the ear: the alæ nasi were beginning to swell, and there was a snuffling in breathing, \&c.

"19th.-The alæ nasi much thickened, copious discharge from nostrile, and the swelling increasing.

" 2 2nd.-Kespiration greatly embarrassed. He died on the following day.

"Examination.- Inch frothy spume in trachea-general infiltration of lungs, which were inflamed-considerable consolidation of the anterior and inferior portion of right lobe-warty exulceration of Schneiderian membrane of both nostrils to a greater extent than I had ever witnessed before."

Mr. Ernes, of Bermondsey, relates a case in the "Veterinarian," for 1842, of typhoid glanders, of which the autopsy was as follows:- "The effusion into the swollen parts of the membrane was of a black colour, resembling oil paint, sticky, and of considerable consistence. The membrane of the nose was one mass of gangrene, and in many parts covered with the same black substance that was found in the swellings. The lungs were a complete mass of ulceration, and of the same black hue. The abdominal viscera were all of a dark colour. The mucuus membrane was healthy throughout, accounting for the absence of diarrhœa, which is a frequent complication of this disease." The French term this " morve charbonneuse."

In 1843 , acute glanders prevailed as an epizootic disease in and around Paris to a terrible extent.

Epidemic glanders is merely acute glanders in its spread. ing form.

Sub-acute glanders is the variety of most ordinary occurrence. "It commences with the usual signs-slight or otherwise-of indisposition; and the disease may, though the circumstance is a rare one, in the first instance assume the acute type. Instead, however, of continuing its rapid course, even after ulceration has displayed itself, both the inflammatory and ulcerative processes subside down to a state almost of total inactivity. The Schneiderian membrane grows pallid, acquires a leaden hue, and the ulcerations upon it lose their prominent red-streaked borders, and exchange their rugged bleeding bases for comparatively smooth and livid bottoms, throwing up a glass-like reflection from the lymphy matters covering them. It is evident, the moment the nose is inspected, that the disease exists in the sub-acute form; how long it may continue so is very uncertain It will not visibly impair the health, nor affect the appetite ur spirits, so long as it does so remain. The moment, however, anything occurs to derange the health, or even after a certain timeafter a month or two, or three-without any apparent superadded cause, we may expect the acute disease to supervene, and then the destruction of the patient's health commences, and is speedily consummated in death. Though there be an evident cessation of the external disease, we are by no means certain that the inward organs-the lungs in particular-are not all the while forming a fomes for its spreading. In most cases it is probable this does happen, inasmuch as, whenever death has followed from the supervention of the acute disease, we find those organs in a state of tuberculous disorganisation. It is this apparent cessation of the glanders outwardly, and the interval during which the disease continues in abeyance, that has afforded opportunities to experimentalists and hunters after a cure to make trial of their various nostrums. And it is the topical influence some of their remedies have had upon the secretion-and even upon the ulceration of the nasal membrane-that has led so many persons to delude themselves at various times, that they have discovered the true antidote. No sooner, however, has the fire which has been smouldering within the lungs or head broken out, and shown itself outwardly in the form of acute glanders and farcy, than the bubble of a cure has burst, and the boasted remedy shared the fate of those that have gone before it.

Chronic Glanders consists simply in a discharge from the nose, oftener from one nostril* than from both, accompanied

* Dupuy says, of eight cases of glanders, only one was affected in the right nostril. Percivall says, of 58 cases recorded from observation, 21 were in the left nasal cavity, 19 in the right, and 18 in both nostrils; which shows no decided majority, but nearly an average 
by enlargement of the correspondent submaxillary lymphatic gland or glands. Symptomatically, it differs from the acute and sub-acute diseases in the absence of nnything like inHlammation or vascular injection, or chancre, or in fact of any perceptible change whatever in the aspect of the Schneiderian membrane denoting morbid activity: all is as usual in the appearance of parts, and in the animal's health and spirits and appetite; nothing whatever seems amiss, save the flux from the nose and the submaxillary tumefaction And in this state, as we lave recently observed, the horse may continue for years. Pathologically, also, it differs from the acute and sub-acute disorders in having for its especial seat the membrane lining the sinuses of the head. It is possible a chronic discharge may proceed from the nasal membrane: however, it rarely does so for any length of time without some discoverable change in the aspect of that membrane. Although it is quite possible such a case might at first be supposed to be chronic glanders, a little time would suffice to show whether it really were so or not. If it be chronic glanders, having for its seat the nasal as well as the frontal membrane, or to the exclusion even of the latter, sooner or later we shall detect the miliary ulceration, the only ulceration present in this form of disease, and therefore truly characteristic.

Chronic glanders appears sometimes as the sequel of other disease in the air-passages and lungs. It mostly attacks its victim in a mild and masked form. The horse is thought to have caught cold; and no suspicion, perhaps, is aroused to the contrary until it comes to be discovered that this "cold" is lasting a great while longer than it ought to endure, and zhat it resists all means of cure. T'he horse's ordinary spirits and looks and appetite are not in the slightest degree impaired: he works as cheerfully as ever; but all the time he has a discharge from one nostril, with an enlargement of the submaxillary lymphatic gland or glands of the same side. And although the nasal issue may be of a nature of itself to excite suspicion, and the enlargement may be such as appears to confirm this suspicion, yet do cases incipient in their nature too often present themselves, in which it is impossible for any practitioner, from these appearances alone, to determine at once on the nature of the attack Give time, and the veterinary surgeon, by watching the progress of the case, will be enabled to solve the mystery, and at length to demonstrate beyond doubt the real nature of the animal's ailment.

No cough accompanies real glanders in any of its stages; and this, though a negative piece of information, should be taken as a criterion not to be neglected. A running may make its appearance at one nostril in glanders, and the glands may adhere to the jawbone, as they do in real glanders, but no cough accompanies these symptoms of glanders. When cough supervenes, the disease may be a catarrh, a consumption, asthma, or strangles, but these are not contagious, unless they last a long time, and adhesion of the glands takes place. In these last-mentioned disorders the discharge commonly proceeds from both nostrils alike: whereas, the running in incipient glanders is often confined to the one nostril, and the gland of one side only is then affected.

As the disorder proceeds, it affects both sides. Chancres appear all over the pituitary membrane, occasioned by the erosive nature of the discharge. This assumes a different appearance as the fluids of the individual may have been more or less vitiated. The appearance or quality of the discharge differs also, according to the manner in which the disease may have been engendered or caught by infection, as is already shown in distinguishing the acute and subacute varieties. If it come of the first-mentioned, through a depraved system, the glands are harder, often smaller, and always adhere more closely, than in those cases which are derived from infection, at a time when the animal is otherwise in comparatively good health. Again, with the infected horse, the matter comes off copiously; it is curdled, and may be rubbed to powder between the fingers when dried. It subsequently hardens, and becomes chalky when submitted to acids; whereas, the animal that engenders the disease without receiving infection, sends forth matter that is parti-coloured, less in quantity, blackish, watery, and mixed with bloody and white mucus. Finally, if the animal that receives the disorder by infection be previously in a bad state of health, those symptoms are complicated and more intense, the chancres are more numerous, the cartilages of the nose become rotten, and the bones likewise, in a shorter time. The creature seems to have combined the evils of its own system with that of the sufferer from whom he has received it. In both cases the swelled glands are simply hard tumours without any matter in them.

In addition to the preceding tokens for discovering at an early period glanders from other disorders, let the nostrils of the animal be examined, and the running nostril will be found of a deeper colour than usual, whilst the other, or dry nostril, is of a paler colour than ordinary, or almost white. At this period the discharge is a white glairy fluid, and the diseased state of the sub-maxillary gland of that side is but just perceptible to the touch : but these being symptoms that belong equally to a catarrh, it is best to be guided by the varied colour of the two nostrils, remembering that in catarrh, or cold, both nostrils run.

Well worthy of remark is the fact that when horses in a tolerable state of health first receive infection, they show mettle, and are full of freaks; as the disorder proceeds in its ravages this spirit goes off. Other acquired diseases have the same effects on animals-the venereal, for example, on man.

A great stench accompanies the discharge in lony-confirmed glanders, which increases during the latter stages of the disorder; and the stableman who has once scented it may presently ascertain whether glandered horses have been recently kept in any stable he may examine for the purpose of detection. 
In duration, hardly any disease can be more uncertain than chronic glanders. It may continue, simply as a discharge from one nostril, accompanied by submaxillary glandular enlargement, with very little or unimportant variation in either, for months-nay, for years: on the other hand, it may run into the acute in as many weeks. Any person, therefore, having a horse of this description in his possession can at no period say how long it may be before the disorder may show itself in an active, nay, rapidly destructive form. In some cases the nasal flux runs for a long period with but slight or unimportant alteration ; in others, in quality as well as quantity, it exhibits most remarkable fluctuations-at one time appearing so scanty and trifling as hardly to be worth notice; at another, pouring forth in all the abundance of the eruption of pent-up channels, solid as well as fluid, from the admixture of lymph with muco or sero-purulent flux; and all of the most fetid nature, in consequence of having been shut up for a period, and so undergone a putrefactive fermentation within the sinuses of the head. Its colour, too, is very variable, depending upon the time it has been retained within the sinus. It may be white, yellow, green, brown, black, according to circumstances; its colour being often a sort of guide to us in respect to its composition and probable duration in confinement.

A distinction must be made between chronic glanders and what we are in the habit of calling nasal gleet; an affection some horses are known to have either all their lives, or at certain periods of them. We must not set down every horse that comes to us, having for any length of time had, either constantly or only at times, a flux from one or from both nostrils. The membrane clothing the nasal chambers and sinuses of the head is, the same as other mucous membranes of the body, liable to derangements in its functions-to secrete too much or too little, or not of the proper quality. Therefore, like the membrane of the human urethra, it may become the source of gleet, and of gleet of so long duration that in time it becomes habitual to the secreting apparatus. This is the only way in which we can account for horses having, at times, discharges from the nose all their lifetime; yet they work, never showing glanders; indeed, to those acquainted with them, causing little alarm. The important question for us to consider is, how are cases of nasal gleet to be distinguished from those of chronic glanders? The discharge in gleet consists of an unusually white mucous or seromucous matter, and in several instances has been remarked to be lumpy. There is no enlargement under the jaw ; and this circumstance, as well as the white, mucous, and lumpy nature of the discharge, together with the history of its origin, which should be carefully inquired into, may be found pretty safe ground of distinction between nasal gleet and chronic glanders.

Beyond any information we can glean from the symptoms, and such as is to be derived from the history of the case, we have no means of testing its true nature save through an operation, or by inoculation of an ass (or another horse) with the discharged matter.

Mr. Percivall narrates the following:- "The good health horses having chronic glanders in general enjoy, together with the condition and apparent aptitude for work they nuaintain, it is that has given rise to a fraud often successfully practised in horse markets, in days when glandered horses were more common in the country than they are at the present time. Three knaves act in confederacy. The horse, who previously has been made by some sternutatory means to blow out any matter lodged in his nose, is by one of them led to the market for sale, where he is soon sold at a price much below his apparent value, the purchaser having been persuaded and urged on by a stander-by-a seeming stranger-who is the second confederate. Pleased with his bargaiu, the purchaser takes him away homeward; but has no sooner got clear of the market than he is met by another stranger-the third confederate-who happens to recognize the horse, and who at once expresses surprise and dismay that he should have bought an animal with such a foul and horrible disease upon him; adding that the horse ought to be, and must be, in obedience to Act of Parliament, shot without delay; and in order that the purchaser may not be at any further trouble or responsibility, offers at the same time for a small fee to take the horse of him 'at knackers' price.' In this way the subject of fraud finds his way back into the hands of his former possessors, and is offered again for sale; not perhaps in the same market, but in some other part of the country. The late Captain Harvey-a gentleman well known as one of the best rider: in the Old Surrey hunt-was cheated in this manner at Bromley Fair : in his case there was no third confederate. The Captain thought he had got an excellent hunter for very little money, with the trifling drawback of his having ' 2 slight cold in his head,' and brought him the following day to my father for his advice. The opinion souglit proved short and decisive; - the horse was "glandered." "

Cattle and sheep should on no account be trusted with a glandered horse; and the mangers and racks in the stable which have been: nsed by a glanlered horse, after being washed with soap and water, should be thoroughly cleansed with a solution of chloride of lime.

Strangles is another disorder with which glanders may be confounded, but not by an experienced practitioner.

Mr. James White, many years Veterinary Surgeon to the First Dragoons, whose excellent work has gone through nineteen editions, the last almost re-written by Mr. W. C. Spooner, paid the greatest attention to the subject of glanders, and certainly had the greatest opportunities for practical experience and observation. To that gentleman's instances of the causes of glanders, the Editor adds:-

"From the circumstance of horses having sometimes escaped the disorder, though they have been standing in the same stall or stable, or drinking out of the same bucket or 
trough, with a glandered horse, many have been led to doubt its being contagious; and the little care that some large proprietors have taken to prevent the spreading of the disorder, in consequence of such opinions having been held, has been the cause of very serious losses, many instances of which have come within my personal knowledge. That the glanders is contagious, has been clearly and indisputably proved by numerous experiments; and the manner in which it is propagated has likewise been satisfactorily demonstrated. At the same time, it is generally believed that the glanders takes place also independent of contagion; but from what causes or circumstances it is then produced, no author has attempted to state precisely.

"It has been said, in a general way, that close unwholesome stables, hard work, and bad provender, sudden changes from cold and wet weather to hot close stables, hard work, and insufficient keep, and, in short, anything that will weaken the animal considerably, is likely to produce glanders or farcy.

There will be no danger in admitting this opinion if, at the same time, we keep in view the contagious nature of the disorder, in whatever manner it may be produced. For if such cruel and foolish treatment of horses does not produce glanders and farcy, it produces other disorders which are often more speedily fatal than glanders; and if it does not actually produce a disorder, it weakens the constitution to such a degree that the animal is rendered more susceptible of the contagion of glanders, as well as of other diseases. It is from this cause that glanders spreads so rapidly amongst post and stage-coach horses, while among horses of a different description, its progress is generally slow.

"It has been said that glanders has often been prodectes in the cavalry by putting the horses, immediately after coming from camp, where they are constantly exposed to the weather, into warm stables, and giving them the full allowance of oats. This, it is true, has often brought on inflammatory disorders which were very destructive, and sometimes of the catarrhal kind, in which case they were accompanied with a discharge from the nostrils. The acrimony of the matter would sometimes even ulcerate the nostrils, and the disease would then be considered as a decided case of glanders.

"Later researches have fully proved that glanders may be produced, not only by contagion and the canses before enumerated, but also by catarrh, either in its common or epidemic forms, also by strangles, and by inflammation of the lungs. In such cases these diseases are said to degenerate into glanders. In the last three cases that came under my attention," says Mr. Spooner, "one was preceded by strangles, another by bronchitis, and the third by catarrh. That form of the disease called bastard strangles, in which the glandular swelling does not suppurate kindly, but becomes hard and scirrhous, is very apt to degenerate into glanders."

It is a remarkable circumstance that glanders cannot be L L communicated by applying the matter which is discharged from the nose of a glandered horse to the nostrils of a sound horse, unless there be an open wound or sore, even though a piece of lint soaked in the matter be put up the nostrils, and kept in contact with the pituitary membrane for a short time; or even if the matter be thrown up the nostrils with a syringe. But, if the smallest quantity of matter be applied in the way of inoculation, either to the membrane of the nostrils, or to any part of the body, a glanderous ulcer will be produced, from which farcy buds and corded lymphatics will proceed. After a few weeks, the poison will get into the circulation, and the horse will be completely glandered. The circumstance of glanders not being communicated by applying matter to the nostril, enables us to account for a horse escaping the disorder, as he sometimes does, after being put into a glandered stable, or standing by the side of a glandered horse. Glanders, however, is frequently communicated by (accidental) inoculation; and there is only one other way in which it can be communicated, that is, by swallowing the matter which flows from the nose of a glandered horse. M. St. Bel, the first Professor of the Veterinary College, mixed some glanderous matter with flour, and formed it into balls. These balls were given daily to three horses for one week. The youngest of the horses became glandered in about a month; the others were not affected till some time after. Glanderous matter has been rubbed on a sore place, or ulcer, that had a healthy appearance in a sound horse. It altered the appearance of the sore for a time; but, after a few days, the healing process went on again, and the sore soon got well. From this it appears that, to communicate the glanders, the matter must be applied to a scratch or wound fresh made, and not to a sore on which matter has formed. A sound horse has been inoculated with glanderous matter that had been mixed with ten times its weight of water. This produced some degree of inflammation, and a small ulcer of a suspicious appearance; but after two or three days it got quite well. This shows that glanderous matter may be so far weakened by dilution with water, saliva, or the watery secretion from the lower part of a glandered horse's nostrils, when he has the disease in a very slight degree only, as to render it incapable of communicating the disease. On the other hand, when a large opening is made in the skin of a sound horse, and a piece of tow or lint, soaked in glanderous matter, put into it, in the manner that rowels are inserted, the disorder is communicated in so violent a degree that the animal is generally destroyed by it in a few days. The same effect is produced when glanderous matter, mixed with a little warm water, is injected into the jugular vein of a sound horse.

A horse affected with glanders may inoculate himself, and thereby produce the farcy. This has happened to horses while at grass. The horse has an itching in the hind leg, which leads him to rub and bite the part, and, at the same time, rub on it the glanderous matter which flows from his 
nostril. The possibility of this circumstance taking place may be easily proved by inoculating a glandered horse, in any part of his body, with some of his own matter. There are many ways in which a sound horse may be accidentally inoculated with the matter of glanders, for the slightest scratch in any part of the body is sufficient. Horses that are cleaned with a curry-comb are very liable to be scratched in those parts where the bones are prominent, such as the inside of the hock and knee, the shank bones, and the head. To such scratches glanderous matter may be applied by the hands of the groom after he has been examining the nose of a glandered horse, or wiping off the matter from his nostrils; or by the horse bimself transferring glanderous matter from the nose of a diseased horse, or from the manger, or other part where any matter has been deposited; for horses are very fond of rubbing their noses against the manger or stall, and a glandered horse will generally try to rub off the matter from his nose against the manger, the rack, the stall, or against another horse. If a sound horse happens to stand by one that is glandered, they will often be seen nabbing or gently biting each other, or rubbing noses. In short, having proved that glanders is thus communicated, we can conceive a variety of ways in which a horse may be accidentally inoculated. When a horse has been twitched, be generally rubs his nose and lips with considerable force against the manger, and may thus easily inoculate himself with a glandered splinter. The parts where local farcy first appears are those most likely to be accidentally inoculated; that is, the inside of the hocks and knees, the shanks, the lips, the under jaw-where grooms are often trimming off the long hair with sharp-pointed scissors, or singeing them with a candle, and often causing an itcling, which makes the horse rub the part against the manger. In this way the heels also are often wounded. Horses that are too highly fed and little worked are liable to prurient humours, which make them nab or bite their skin, and scratch the hind leg with the opposite foot; and we may often see them bite, rub with the nose, and scratch with the hind foot, alternately, the other leg.

It is possible that in some cases where inoculation nas failed, the virus was not sufficiently matured or was in too small a quantity to effect glanderous inoculation; it having been found that by introducing a considerable quantity of matter, the horse is speedily destroyed. The same rule will probably be found to hold good, in a certain degree, when glanderous matter is swallowed; as the horse's stomach possesses a wonderful power of resisting the impression of poisonous matter. A fact proved by the large doses of arsenic, corrosive sublimate, sugar of lead, \&c., that have at different times been given, by way of experiment, to glandered horses. A horse, therefore, may possibly swallow one large dose of glanderous matter without being injured by it, while a repetition of smaller doses will produce the disorder. M. St. Bel gave the virus internally daily for a week; and the same method has been pursued in other experiments.
The disorder, too, would probably be more readily caught by eating the glanderous matter mixed with oats or hay, than by drinking it with water, as in the former case it is so intimately mixed with the food by mastication.

Having treated of the several ways in which glanders may be propagated ; the modes of prevention almost suggest themselves. The glanderous matter exposed to the gas arising from a mixture of common salt, magnesia, and oil of vitriol has been so disinfected, that it has become inert, even when a young ass has been inoculated with it. This gas as a fumigation may be used when the stable is to be purified after glandered horses. Some persons advise the stables to be pulled down; this is altogether unnecessary. Let every portion of the stable to which the animals could have had access be thoroughly washed with chloride of lime, the following day scrubbed with warm water and soap, and when thoroughly dry washed over with sulphate of zinc. Three days after, they may be occupied without danger.

From these observations we gather that the precautions against the generation and spread of glanders and farcy, are, 1st, Ventilation of Stables; 2dly, Cleanliness, in which is included the draining of them; 3dly, The immediate and complete Separation of the Sick from the Healthy. To enter here, further than has already been done, into the subject of ventilation is unnecessary, after the full treatment it has received in the chapters on Stables and Stable-ManageMENT in the former part of this volume. It seems right, however, to remark, in regard to the segregation of a horse having or suspected of having glanders or farcy, that his separation can neither be too early nor too complete. To satisfy every doubt respecting contagion, he should be placed at such a distance from his associates in health, and in such a situation, that no direct atmospheric communication can exist between their habitations; and his pail, halter, bridle: even harness and saddle, perhaps, ought to be restricted to the patient's use, or not used among other horses until such time as they have undergone the necessary purification. Moreover the groom looking after the glandered subject should be careful not to allow himself or his clothes to become the medium of contamination between the diseased and the healthy animals. In large establishments, where many valuable horses are stabled together, we can hardly exercise too much nicety and fastidiousness on the occasion of any contagious disease, and especially of such a one as glanders or farcy, breaking out amongst them

Communication of Glanders to the Human Subject.Though for a long time disputed, the melancholy fact that glanders is communicable by the horse to man has received ample evidence of late years. It is as well proved as inoculation in syphilis, the absorption of the vaccine virus, or the contagion of itch or mange multiplying the acarides which produce those irritating skin diseases. Of the nature of the virus of glanders we know no more than we do of those of syphilis, rabies, smallpox, \&c.; we can only speak from observation of their effects. When glanders is commu- 
nicated to man, the consequences are indeed horrible. The whole secretory and excretory systems are affected, the glands of the armpits, the groin, and cspecially the salivary glands, swell painfully and burst, and the sufferer dies pitiably. Mr. Mayhew says :- "Three cases have come to the author's knowledge. Two respectable gentlemen, moving in good society, were contaminated, and both perished miserably of the terrible disease. Mr. Gowing of Camden Town, informed the writer of a boy who went out of a shop to hold a customer's pony. While the boy was so placed, the pony cleared its nostrils, and a portion of the ejected matter flew into the lad's eye. The handkerchief removed the soil, and the accident was forgotten. The poor youth was glandered, and died in the University Hospital."

The treatment of glanders in the human subject is not within the scope of this work. Suffice it to say, that, from some cases in the Lancet, it appears to be in human practice also an opprobrium medicorum.

Treatment of Glanders.-The general opinion of English and French veterinarians has settled down into a belief that glanders is incurable, and that farcy is curable. This is not, however, a reason why investigation should be relaxed or abandoned, although the long-sought-for and oftenproclaimed specific, or the successful plan of treatment, yet remains to be discovered; we shall, therefore, run over the practice and remedies adopted with the most plausible appearances of success, and which from time to time have been asserted to have cured this fell disorder.

Lafosse's method was trumpeted to the world as a wonderful discovery, and pictures of horses' heads "with holes cut in them," and syringes injecting "proper and convenient remedies into the nose," were engraved in his work, in that of his disciple Bartlett, and in the Cyclopædias of the last century and the beginning of the present. Lafosse's work * was translated all over Europe ; and, if the results did not answer expectation, he contributed a good many facts to the knowledge of the disease. A very few years of experience shewed even Lafosse the inefficacy of his "trephine," and in an after work, we find him covering his defeat by confessing "there is no answering for the cure" owing to "the stubbornness of the disease;" and making, as a bridge to retreat over, another "discovery," that besides "confirmed glanders" there are "six other kinds of discharges, jour of which are incurable." Truly this is admirable and solemn fooling. We may therefore dismiss the trephine and local scouring of the nasal passages. Learned societies and colleges have been as credulous as the general public in their faith in cures, and have rewarded the supposed discoverers. The Royal Academy of Sciences rewarded Lafosse for his "discovery of the nature, seat, and cure of glanders;" the Royal Society of

- "A Treatise upon the True Seat of Glanders in Horses, togetner with the Method of Cure," \&c., with cuts. By M. de Lafosse, Master Earrier of Paris, and Farrier to the King's Majesty's Stables. 1751.
Agriculture in France gave a medal to Professor Collaine of Milan who cured(?) glanders with sulphur; and Professor Sewell, of our own Veterinary College has been rewarded for his specific-sulphate of copper. Later still, common salt (chloride of sodium) has been highly favoured by the Royal Agricultural Society. That sulphate of copper, administered in a state of solution, in gum mucilage, two drachms in a quart of water, twice a day, has a peculiar effect in healing abrasions and diminishing nasal gleet, is undeniable.

The sulphate of iron was Mr. Turner's favourite remedy ; dissolved in the water the horse drinks, in his bucket "suspended in his box, and that he may drink whenever he pleases."

Cantharides is the sheet anchor of Mr. Vines.

"This medicine I have found of the greatest service," writes this author, in his chapter on the "Treatment of Glanders and Farcy," section, "Remedies to be employed." "whether alone or in combination. Cantharides appear to me, when given internally, to act on the system in two ways:-first, by stimulating the vascular surface of the inner coat of the stomach and intestines, thus promoting the greater formation as well of gastric juice as of the other fluids; and also increasing the appetite and digestion, and consequently forming a greater quantity of chyle, or new white blood. Secondly, by absorption, their active properties being taken into the circulation, and producing in a very short time a material change in the mucous membrane, followed by ulcers of the nose as well as ulcers of the skin." Mr. Robertson, a surgeon, has published an excellent work on the efficacy of cantharides for gleets or affections of the urethral membrane, and for unhealthy sores in the skin; he (Mr. R), twenty years ago, recommended its use at the Veterinary College, where it failed, Mr. Vines says, "from its having been given in too large doses (two drachms)." The principal precautions to be attended to in using cantharides internally in the horse are, not to administer them either at the commencement or early stages of inflammatory diseases, or in too large quan. tities for a dose, or too frequently to repeat them. For they are only proper to be used when the symptoms of disease are of a chronic, or slow form and nature; that is, when the system is either in a state of debility, or approaching to it." The doses are-" for a middle-sized saddle-horse, four grains; for a large carriage or dray horse, six grains, in fine powder," made into a ball with ginger, gentian, \&c. "A ball may be given every day, or every other day, either in the even. ing or morning." Should the horse's appetite amend, and he appear to be going on well, after a week, ten days, or a fortnight, the dose may be augmented a couple of grains; but after another like interval the medicine had better be suspended for a few days or a week, when the first doses may be resumed, and after a week increased to ten and twelve grains.

Iodine has been administered, and also the iodide of 
potassium by Professor Dick, with no appreciable effect. We will notice diniodide of copper under FARCY.

Iodine and copper mixed (iodide of potass and sulphate of copper), made up into powders, one grain daily, with green food ad libitum, were administered by Mr. Lord, V.S., of Parsonstown, Ireland, to a farcied horse on the 12th of August, and on the 4th of September. The treatment being persevered in, the ulcers of the nostril "had then dried up and the discharge and farcy-buds disappeared."

Barytes was once insisted on by Mr. Percivall as having effected cures, but he afterwards admitted, on extended experience, that "its success must be regarded incidental or circumstantial."

From an idea of its similarity to gonorrhœe or syphilis, copaiba balsam, cubebs, and especially mercury, have been resorted to. "Recoveries" under the use of barytes, copaiba, cubebs, and cayenne pepper are confidently recorded. Internally, mercurials may be said to have utterly failed with the horse, though some Italian surgeons have declared they have found blue ointment (ung. hydrarg.), one ounce, rubbed on to the inside of the thigh daily, cure farcy.

Mr. Storry relates several instances of glandered horses cured by him by fumigating the nostrils with carbonic acid gas, assisted by tonic medicine.

Creosote has been used with success in glanders of the human subject as a topical application to the ulcers; and it has in a few instances been tried on the horse with good effect. In a case of glanders it has stopped the nasal discharge, and healed the ulcers by its use.

The combination of iodine and sulphate of copper, which readily unite by adding a little proof spirit, has been recommended by Mr. Norton, and administered with excellent effect in doses of two drachms daily. It is preferable to the "powders" mentioned above.

To sum up the system of treatment to be adopted in this disease, it should first be repeated that there are but few cases in which the symptoms are sufficiently mild and the horse of sufficient value to justify the expense incurred in keeping and treating the animal, except by way of experiment; we must therefore closely examine the horse previous to our attempts. If the pulse is increased, though only eight or ten beats in a minute, the lungs are probably affected, and it is better to destroy the animal. So likewise if the animal has been affected for several years, although the symptoms may still be mild. Should, however, the case be comparatively recent, and the appearances favourable, we would then administer daily the tonic recommended by Mr. Sewell, or that advised by Mr. Vines ; or what, perhaps, is still better, give the one for several days, and then try the other, or the iodide of copper in doses of one or two drachms daily. If there are any ulcerations within sight, a solution of creosote should be syringed up the nostrils daily; and if there are none visible, it may be well to try the effect of fumigating the nostrils with carbonic acid gas; if creosote could be applied in this manner it would be still better.

An ointment of hydriodate of potash should be rubbed on the enlarged glands; and if the symptoms should disappear with the exception of the indurated gland, it would be advisable to excise it, as it generally contains glanderous matter, which may inoculate the system anew.

All these are given merely as indications of the treatment to be pursued: were any one of them generally, or even frequently efficacious, we should not still be driven to the stern necessity of passing sentence of death upon the glandered horse.

\section{FARCY.}

We have already said that farcy and glanders are modifications of the same disease. Farcy was for a long time supposed to be a disease of the veins; a natural error, seeing the lymphatic vessels along which the virus travels were ther considered as a sort of vein, if not veins themselves. Later writers regard the farcy-bud as the degeneration and coagulation of the lymph. Farcy may be said to have its seat in the skin; that of glanders being accounted to be the pituitary membrane. Glanders and farcy together constitute one and the same disease of the lymphatic vessels and their glands. The disease originates in these vessels, and for a time confines itself to them; in the course of its progress; however, it extends into the contiguous tissues, affecting in one case the true skin, in the other the mucous lining of the air-passages, and it is in these parts respectively that the phenomena of farcy and glanders are exhibited. No wonder, therefore, that the appearances in farcy (the local symptoms) should differ so much from those of glanders; and that the buds and ulcerations of the one should be found, in the course of treatment, so much more manageable or more "curable" than those of the other form of disease; or that one disease should be so much more dangerous to the animal affected, as well as to horses (in health) around him, than the other. Inflammation in the cutis is a different disease from inflammation in a mucous membrane-productive of different phenomena, and requiring a different treatment : hence the apparently wide differences between two diseases essentially or in nature alike.

In general, in dissecting farcied limbs or other parts, as soon as we have cut through the thickened and indurated skin, we appear to have bottomed the disease-to have reached its depth or profoundest seat; the subcutancous tissue everywhere around is infiltrated, apparently in a state of local dropsy, but of the farcinous disease the skin has manifestly borne the brunt. In cases, however, of inveterate or malignant farcy, in which the deep-seated as well as the superficial order of lymphatics have taken on disease, we meet with farcy-buds and pustules, and occasionally with abscesses of large and irregular dimensions, situated among the muscles. 
Dupuy informs us he has met with "tubercles" (or farcybuds) and farcy-pustules upon the mucous lining of the alimentary canal; and Leblanc, so far as having witnessed one case of the kind, confirms this account. On the same authorities also we may state that the liver, the spleen, and the testicles have all been known to exhibit farcy.

Whatever tends or operates to the production of glanders, the same has the power of causing farcy. Contagion becomes no exception to this admitted truth, supposing its agency to be through the medium of the constitution. Contaminated blood is quite as likely to emit its virus in the form of farcy as in that of glanders. Professor Coleman, however, appears to have viewed the operation of contagion in glanders as being local, upon the Schneiderian membrane; and that, to take effect, it must have a local operation also in the production of farcy; since in his lectures, he informs us, that, "of all three affections,"-viz., acute and chronic glanders and farcy,- " farcy affords the most conclusive evidence of the production of the disease in the absence of contagion." Undoubtedly, it is out of the range of probability-out, almost, of that of possibility-for the inside of the thigh of one horse to come into contact with the nose of another horse, or, in fact, with any contagious virus, through chance or accident; supposing, however, that the contagion enters the system before the local disease be produced, there is in that case quite as much likelihood of farcy following as that of glanders. We know that, by inoculation, farcy has been produced by the matter of glanders, and glanders by the matter of farcy, and that, consequently, there is every reason to infer a similarity, or rather an identity in the viruses of the two diseases. In further proof of this, as was said before, one disease, or form of disease, almost invariably terminates in the other prior to dissolution. There can be no question but that the same contaminated or miasmatic atmosphere of the stable or elsewhere which produces glanders may occasion farcy ; and vice versá. Mr. Percivall (" Hippopathology," vol. ii, p. 230), disposes, to our thinking, of this question.

M. Rodet, Professor at the Veterinary School of Toulouse, in his work on glanders (1830) gives the best description of farcy-buds we have met with. Detach a moderate-sized farcybud of recent formation, and before the softening process has commenced in it, and cut into this firm, indolent, rounded, everywhere-isolated, completely-formed bud, and its interior will be found composed of a hard, fibrous, condensed, milkwhite tissue, and though exhibiting thoughout, in certain cases, a homogeneous texture, is nevertheless, in other instances found grooved and traversed by some sanguineous capillaries. At a rather later period than this, at the time when it commences growing soft in its centre, and is about to become adherent to the skin, and sometimes before it has adhered, we may observe (providing the recent internal process of liquefaction be not completed) that its circumferent parts still retain the white fibrous indurated texture which formerly constituted the entire bud, and that within its interior is inclosed a pultaceous matter of a yellow or dirty-white colour, or else slightly reddened. At length, when the process of softening is completed, and before it is converted into abscess, we find within the bud several little morbid productions, united by lamina one to another -arranged in concentric layers, and resembling serous membranes slightly infiltrated, the raw interior of which gives the appearance of ulceration to its inner surfaceforming the walls of the abscess, inclosing a white, thick, homogeneous matter, of a consistence at one time caseous, at another puriform, at another analogous to thick jelly.

The peculiar well-known spheroid shape of the farcy-bud, as well as that of the pustule which succeeds it, is proved to be owing to the existence of the valves within the lympha. tic ressel; these preserving their integrity while the coats of the lymplatics are vanishing through absorption. In very bad cases the valves, as well as the tunics, inflame and ulcerate or become absorbed. In consequence, the farcy pustules run one into each other, and by such communication lose. their characteristic shape, lengthening into fistulous abscesses, well known to farriers under the denomination of "farcy pipes," or spreading into abscesses of large and irregular shape, burrowing deep in the connecting cellular tissue.

The skin itself undergoes changes, resembling thickening and induration of the farcy-bud. In time the "bud" becomes enormously augmented in substance, remarkably white, and unusually tough and hard, cutting like so much white leather rather than skin, especially in the immediate vicinity of the buds; several of the more superficial of which, that have become pustules, will be found embedded in its thickened substance. We, however, no sooner cut through the indurated cartilaginous-like cutis than we expose chains of farcy-buds and pustules, immediately underneath it, invested by cellular tissue full of infiltration of a jelly-like citron-coloured fluid, beyond which bed of effusion we appear suddenly to lose all vestiges of disease. In inveterate farcy, however, the infiltration will sometimes be observed extending deep between the muscles, and every now and then abscesses, deposits of matter of considerable volume, will be discovered buried among the fleshy structures. Nor do the bones, any more than the muscles, escape the ravages of farcy and glanders. The turbinated, ethmoid, nasal, and maxillary bones have suffered in malignant cases of the former disease: and we are assured by Dupuy and others, that many of the bones of the limbs and body have proved extensively diseased in horses that have for a length of time been afflicted with farcy.

Treatment of Farcy.-The system must be supported by a generous and agreeable, but not too stimulating, diet, to which carrots and green food form useful additions. The horse must be exercised daily. If we determine on emptying the bowels, mix firstly a purgative and diuretic mass together (see MEDicines), into a ball of moderate strength. Next administer tonics. Of these sulphate of copper, sul- 
phate of iron (see Glanders), in his drink; chloride of barium, (muriate of barytes), in half-ounce doses at first, increased to one ounce daily, in a ball with meal and molasses, have each their advocates. For ourselves, we advise the tonic to be varied, upon experience of its efficacy or the reverse. Blaine tells us that nearly all the mineral acids bave been found useful, and some of the regetable ones. All the different forms of mercury have been tried with some success, but corrosive sublimate appears to have answered best; and, when determined on, should be given to the full extent the stomach and bowels will bear without salivation or symptoms of inflammation being brought on. Ten or fifteen grains may be commenced with, ground very finely with sugar, and given night and morning in gruel as a drench. If this occasion no distress, it may be increased to a scruple, and from this to half a drachm, if it be borne with ease; but the utmost care and watchfulness should be exerted when the dose is considerable. When the weakness and irritability of the horse are too great for the exhibition of the corrosive sublimate, give half a drachm of calomel twice a day; or the blue pill, or the sulphuret of mercury may be substituted, still carefully watching the salivating process. Should the stomach suffer much under the use of these active agents, either join with them bitter tonics, or alternate them with each other. We would also recommend that they be in these cases given in solution, and further sheathed by some ingredient of a mucilaginous nature.

After the trial of mercurials, arsenic ought next to claim the attention, as that has also proved efficacious in farcy, and it may be given in the form of liquor arsenicalis, or Fowler's tasteless solution. Verdigris was for some time a favourite remedy at the Veterinary College, in doses of a scruple three times a day, increased to a drachm. We have witnessed also good effects from this preparation; but we have found it most efficacious when given in a ball in conjunction with the blue vitriol, half a drachm at a dose. Some practitioners choose to employ several articles in conjunction, and they assert the cure is speedier from the combination than from any one article separately. In this case, give the following:-

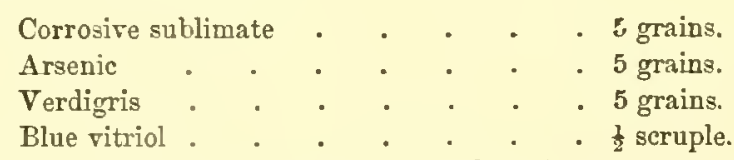

Mix into a ball with palm oil and linseed meal ; give every moruing.

In addition to the several acids, benefit may be derived from the following drinks, in conjunction with the ball last mentioned.

\begin{tabular}{|c|c|c|c|c|}
\hline Sulphuric ether & - & . & . & 1 ounce. \\
\hline Laudanum. & . & . & & 1 ounce. \\
\hline Tincture of quassia & . & . & . & 1 ounce. \\
\hline Oak bark & . & . & - & 1 ounce. \\
\hline Capsicums . & . & . & - & 2 drachms. \\
\hline Water & . & . & . & 1 pint. \\
\hline
\end{tabular}

Sea bathing and daily doses of sea water have been tound bencficial in cases of farcy with enlarged limbs and œdematous swellings.

Local treatment in farcy is of as much consequence as constitutional means. In glanders we are, in respect to the extent and nature of the disease, working in the dark; we know neither the precise condition nor the exact situation of the ulcerations; in farcy the local disease is under our eye, and we can apply topical remedies suited to the inflamed, tumefied, ulcerated, scirrhous, or other condition of the limb.

In their inflamed condition, the best application to the cords of farcy-buds is a refrigerant or evaporating lotion; with this they ought to be sponged often enough to keep the hair wet, the object being to repel or disperse the swellings.

As soon as heat and tenderness have subsided in the buds-supposing that, instead of softening and suppurating, they evince a disposition to diminish and grow harder-we must alter our treatment. We must use lotions of a discutient character, or, in fact, any applications, liniments or ointments having the effect of causing absorption of the swellings. Of this description are, mercurial ointment and camphor, iodine ointment, blistering liniment or ointment, \&c. Indeed, when there appear signs of hardening and approaching insensibility in the buds, a blister is by far the best application. Mr. Percivall advises the acetum cantharidis; dipping a painter's brush in the blistering essence, and applying it, after the manner a painter does his paint, upon the tumefactions; tying the horse up afterwards, or putting a cradle on him; and after an interval of twentyfour hours sponging the blistered parts with warm water; an operation that should be repeated daily so long as any moisture or issue appears upon the surface. "Sweating blisters," like this need not interfere with the patient's regular exercise; and as soon as one has "worked off" another may be applied; the repetition being regulated as well by the condition of the skin as by the demands of the case.

The practice of Mr. Percivall seems to us so intelligible and practical, that we shall not hesitate, with slight modifications, to adopt it entire.

In the majority of cases of farcy, it happens that, instead of diminishing in size and growing harder in consistence, the buds plump up and become soft, and at length turn into pustules; and once a pustule formed, it will ripen and burst, and turn into an ulcer. As soon, therefore, as we perceive that it is out of our power to prevent the suppurative stage, it becomes our duty to contribute all we can to its promotion For this purpose fomentations may be used to the parts, poultices likewise, if we can manage to apply them. The patient's diet, also, must be improved in this stage; he should no longer feed on mashes, but have scalded oats, carrots, turnips, linseed, \&c. When the pustules are ripe, some practitioners make a point of opcning them; others suffer them to burst and discharge their cuntents sponta- 
neously. The old or farriers' mode of opening ripe farcy-buds is with the actual cautery - the heated budding-iron; and it is a practice still in vogue with many very respectable veterinary surgeons. In this manner the contents of the pustule are, as it were, fried by the red-hot iron, while its base and interior are altogether destroyed, and the result is a slough, followed commonly by a superficial ulcer of larger dimensions than the original pustule, and presenting a healthy granulating surface; this ulcer is in the end, under judicious management, very often got to heal. Should we suffer the pustule to burst of itself, we may still cauterize its base with the budding-iron; or, if we prefer it, we may rub it with a pencil of lunar caustic. At all events some caustic or strong escharotic dressing will be demanded; without it we shall never obtain what we so much desirea healthy granulative action. The bottom of the ulcer once cleaned out, dressings of various kinds, depending upon its aspect (healing or spreading, sloughy, stationary, \&c.) will be required by it afterwards. Commonly, mild escharotic applications answer best, though, at times, stimulant or astringent ones appear preferable ; in short, the selection of a dressing must be left entirely to the judgment of the practitioner.

Water or spirituous dressings are better than greasy ones, and we have ordinarily observed the best effects from such as these:-Solutions of lunar caustic, of the sulphates of copper and zinc, and of alum; the tinctures of benzoin, and of myrrh with aloes. The nitric acid lotion is an excellent dressing for sloughy sores; and the solution of chloride of lime an admirable one for such as secrete fetid matters. The ulcers should always be cleaned, and have any hairs shooting over their edges trimmed off, preparatory to their being dressed of a morning; and it tends to the preservation of them in cleanliness, and promotes their healing tendencies as well, to besprinkle their surfaces, immediately after dressing them, with some powder that will imbibe the discharges, correct acrimony, and have some effect in restraining their production; none answers these ends better than common (baker's) flour. It should be made as dry as possible before being used, and may, when required to be additionally astringent, have some powdered alum mixed with it; which it will sometimes have already. As a change, on occasions, we may employ for the same purpose powdered bark or calamine. Mr. Turner recommends a strong solution of sulphate of iron plentifully applied over the ulcerations, and well rubbed into the sound parts likewise. Mr. Blaine, as we have already noted, found sea water and saturated solutions of common salt good dressings; he speaks, too, in favourable terms of sea bathing for farcinous limbs, aided oy "daily doses of sea water."

The internal remedies and exercise are not to be omitted on ascount of the ulcerated condition of the swollen parts.

The Tumefied Lymphatic Glands, in farcy as well as in glanders, will require treatment. By some French veterinarians their extirpation has been recommended with much assurance of success in farcy, notwithstanding the notorious failure of a like operation in glanders. For the disease in the hind limbs, M. Maurice, veterinary surgeon in the First French Artillery, directs us to cut out the inguinal glands. For farcy of the back, loins, or flanks, the glands in the flank; and for farcy in the fore limbs, neck, and shoulders, the axillary glands. M. Maurice makes mention of three hundred cases of farcy cured by such operations. And Renault informs us that the practice has proved successful at the Veterinary School at Alfor:

On this Mr. Percivall remarks : "I no more doubt that horses with farcy have recovered after such operations than I do that others have returned to health after taking copper, or iron, or barytes; between the post hoc and the propter hoc, however, there is all the difference in the world. It is absurd to think or extinguishing a disease proved to be constitutional by the extirpation or destruction of tumefied lymphatic glands and farcy-buds."

The treatment proper for the enlarged glands is the same in the various stages of disease, as has been recommended for the farcy-buds. Endeavour, in the first instance, by refrigerant and evaporating lotions, to abate inflammation in them, and so to effect their dispersion; secondarily, when

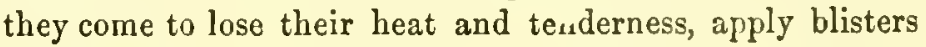
over them. It is in vain to try to "bring them forward" to a state of suppuration, like the ripening farcy-bud; they are hardly ever known to take on the suppurative action.

By pursuing such a course of treatment we not very unfrequently succeed in patching up the ulcerations and getting rid of the corded swellings in which they originate, and at the same time so far reduce the size of the limb as to render the patient (his general health and condition being good) capable of undertaking work. Indeed, it is advisable that he should do so, since under the operation of slow or moderate work it often turns out that his limb experiences, by degrees, further reduction, and that his health and condition, by generous feeding, improve. All, in fact, is likely to go on well so long as the animal experiences no return of his disease or fresh attack of it. Should he do so, in the same limb or part even, it will much lessen the chances of his second restoration; and, if it recur in some other limb or remote part of his body, above all in the head, wearing the aspect of approaching glanders, we may bid adieu to all hope of recovery. The destruction of the animal is now the most merciful course. We have known, however, kind-hearted masters object to this fatal sentence being carried out. Should, then, the season of the year be favourable, pasture may offer a resource, certainly pleasant to the animal, and one that the medical attendant will, with satisfaction to himself, if not with benefit to his patient, recommend. A change of diet, from dried to green and relaxing food, living in the open air, and the constant exposure of the farcinous limb to a lower temperature than that of the stable, together with the walking exercise the animal is from time to time taking upon it, all bave a 
tendency to do good, and have sometimes proved of eminent / is desirable to soil the patient in his box; vetches or rye, or, in service. In particular, salt marshes have been regarded as the winter season, carrots or Swedish turnips, become a desirbeneficial, and apparently not without reason. Whenever and able change of diet. There arrives a period, in this protracted wherever the patient may be turned out to grass, he ought to and indolent stage of farcy, when the resources of medicine have no companions save such as night happen to have on seem to be exhausted; and when the discase is judiciously them the same disease as himself. It would be full of danger "left to nature," to take, uninterfered with by art, her sponto suffer him to run with healthy horses. In sitnations where, taneons course. Mr. Vines recommends cantharides in comor seasons - hus, pasture cannot be procured or resorted to, it $\mid$ bination with vegetable bitters as a cure for farcy and glanders.

CHAP'LE XXV.

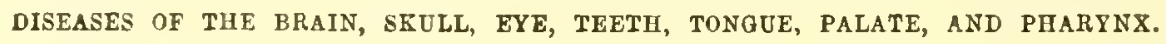

\section{DISEASES OF THE BRAIN AND NERVES.}

INJURIES OF THE BRAIN.-CONCUSSION.-FRACTURE OF THE SKULL.-PHRENITIS.-STAGGERS.-ABSCESS OF THE BRAIN. VERTIGO. - MEGRINS.- HYDROCEPHALUS.-PARALYSIS. - TETANUS.-RABIES.-STRINGHALT.-SPASMS.

WHeN we observe the smallness of the brain of the horse, we find physical causes for the animal's limited intellectual development. In treating of the Structure and Anatomy OF THE Horse (ante, p. 358), we gave a general anatomical view of the brain, its membranes and nerves. Insanity, in the sense of human medicine, does not exist in the horse, whose sensorium is not affected by causes of a social or moral nature; though his brain may be affected, as the centre of the nervous system, by wounds and irritating disorders, through what we now know as "reflex nervous action." Its sympathy and connection with the stomach is also clear. The brain is disordered by severe indigestion; and a violent blow upon the stomach, or that organ seriously overloaded, may give rise to what is called "stomach staggers"-a decided cerebral attack. Tetanus, or locked-jaw, from wounds, is also another example of reflex nervous irritation. 'A horse pricks his foot with a nail, and tetanus is sometimes the result. The spinal marrow, which is a continuation of the substance of the brain, exhibits clearly the same nervous mechanism. Division or injury of the marrow produces loss of sensation and voluntary motion in those parts only which derive their nerves from it beyond (or below) the part injured or divided. A perusal of the works of Sir Charles Bell, and of Dr. Marshall Hall, "On the Excito-Motory Nerves," will give a large insight into these interesting points of vital economy.

Notwithstanding the brain is the source of all sensation, it is, in itself, destitute of feeling. In operations on living animals it has been pricked, lacerated, cut, even burnt, without any manifestation of pain. We remember having heard the late John Abernethy mention a case where a man lost two ounces of brain by an accident, and lived many years, at the head of a mercantile establishment, with apparentlv unimpaired faculties.

Pressure and Concussion, however, have serious effects. A portion of bone depressed from above, prostrates the animal and destroys life; not so laterally, or from the side: and pressure on the spinal cord produces paralysis behind the part so interfered with.

Injuries of the Brain are not frequent in the horse, though backward falls and blows are not uncommon, owing to the immense strength of the parietes or walls of the skull.

Concussion, so fatal to man, with his higher organization, produces nothing more than fright or giddiness; a bleeding a cooling dranght, and a warm fomentation to the occiput, will generally dispose of this apparently dangerous accident

Fracture of the Skull, for the same reasons, is rarely seen unless at the base, or basilary process. There is in most cases more danger of bloodvessels giving way than bone, even in these heavy concussions; unless abscess of the brain, of which we shall speak presently, ensue, external injury seems but temporary in its effects.

Bloodvessels are liable to give way in any part of the brain; those, numerous and large, about the base, contiguous to the seat of the blow, are most likely to become ruptured. The symptoms will of course vary in their nature and intensity with the kind and degree of the mis. chief done; the faculties of motion and sensation will be more or less impaired, should not death itself immediately result; the senses also, one or more, will probably be lost or disturbed. By the parts affected, and by the pxtent to 
which they are affected, must we form our opinion of the nature of the case, as well as our prognosis. Commonly, the animal is found down, unable eitker to rise or stand without assistance. Should lie still retain feeling, and be in possession of his senses, and there be means nigh or at hand of treating him, remedies may be tried upon him; but when he has to be removed upon some drag or carriage to any distance, he will in general do himself so much mischief by struggling before he has arrived at his place of destination, that his case will probably be rendered yet more hopeless than it was in the first instance. Fresh hæmorrage will be likely to ensue, and may prove fatal, even when, before the struggling, hopes of recovery had been entertained. In this account, it is of importance, when the case holds out prospects for treatment, to house the animal somewhere close to the place where the accident has occurred. In general, bloodletting will be proper; though the symptoms from loss of blood or nervous depression may be such as not only positively to forbid this evacuation, but even to demand the exhibition of stimulants.

Vinegar, muriate of ammonia, and spirit of wine, with warm water, should be applied to the head. A mild purgative, if the animal can stand, may be administered. Where paralysis is marked, death usually soon supervenes.

PHRENITIS (INTLAMMATION OF THE BRAIN), STAGGERS.

The farriers divide inflammation of the brain into three disorders, called, in their peculiar phraseology, sleepy staggers, mad staggers, and stomach staggers.

Sleepy staggers (or coma) is usually no more than the first stage of mad staggers. The horse is drowsy and dull, and falls into a lethargic state. His appetite is rather interrupted than lost. The horse is found with his head hanging between his forelegs, or resting in the nianger and forced against the wall of the stable; or, if at grass, against a tree or wall. The eyelids droop, and when forced open, show the pupil unnaturally dilated ; the lining membrane of the nostrils is of a dull leaden colour (we have found them, as well as the conjunctiva, just the reverse, increased in redness). Costiveness is present; and the stupor extending to the absence of all nervous irritability. It is only in this stage of the disorder that remedial measures prove efficacious.

Treatment.-Copious blood-letting is urgently indicated. Open both jugulars and let the blood flow till the eye awakens or the animal sinks. Give purgatives (see List) every three hours till the bowels are fully relieved : and sedative infusions. Half a drachm of aconite, or a drachm of digitalis, with a pint of hot water poured upon it. Cool, and give this quantity every half hour till weakness, not stupor, supervenes. He will then (if down) breathe more gently, open his eyes and look at and perhaps recognize things or objects. When this treatment fails, and the mere congestion or surcharging of the vessels of the weakened brain ensues, then inflammation comes on, and we have the serond stage, or,
Mad Staggers, Phrenitis. - This fatal termination is ushered in by the animal waking out of his sleepy state, and staring about him with a fearful wildness and vacancy, his breathing becoming quicker and laborious, and the pulse rising with the respiration. Suddenly, he makes a frightful throe, dashing himself against rack, manger, or wall, or throwing himself down, and then lying breathing stertorously, his eyes looking as if starting out of their orbits; no light at the time affecting the dilated pupils, and the animal totally heedless of anything that may be done or said to him. On other occasions the frantic animal will rear both his fore legs into the manger, and in this posture stand, with his head erected, for several minutes, no person daring to approach, lest he should unexpectedly spring up, or reel and fall upon the intruder. In a word, our patient is now "mad;" furiously so, in the worst sense of the word as applied to staggers; and how, or where, or upon whom he may in his delirious plunges precipitate his body, is so uncertain, that any approach without extreme caution, or in a way in which ready escape is at hand, is fraught with imminent peril As the disease increases, instead of lying quiet as before, in a state of apparent insensibility after a throe, convulsions will follow so quickly upon one another that the patient will be kept in a continual struggle; panting and perspiring, and perhaps foaming at the mouth; leading his attendants to believe he is not only phrenitic but actually rabid. This is a circumstance engendering so much apprehension and alarm, that not only is a prompt and decisive opinion demanded of the veterinarian, but, at the same time, such a line of conduct on his part as will at once convince his employers that he is right in his decision.

Mad Staggers must not be confounded with rabres-there being no dog, or mad dog at least, visibly connected with the case, is primâ facie evidence. Further, the symptoms of the two cases are different : there being, according to Mr. Blaine, in rabid phrenitis, "not merely a frantic, but a decidedly mischievous disposition:" the animal purposely attacking everything, living and dead, all around him: rack, and manger, and stall-are all laid prostrate.

In the true Staggers, nothing of this kind appears; the horse is wild and beats himself about, and endangers everything about him, but not with premeditated design. On the contrary, he merely labours under spasmodic contractions of the muscles, which force him to these violent efforts: he rears, plunges, falls, and injures himself in the frenzy of pain." Veterinary authorities recommend the opening of both temporal arteries in mad staggers. Recovery is, however, scarcely to be hoped for, as a return of the disorder is to be feared, or an entire loss of energy, withoul which the animal is almost valueless.

Mr. Percivall's experience furnished him with several cases of recovery from phrenitis. He says, after speaking of bleeding from the temples, "I have had several cases which were despaired of, until, as a last resource, while the 
unimals were desperately struggling and throwing themselves about, I have contrived to plunge the lancet into their temples, and allowed them to bleed ad libitum, regardless of the quantity lost, paying attention, in fact, only to effects. In several instances, to the surprise of all around, the frantic patient, from kicking about in a pool of blood, jumped suddenly and unexpectedly upon his legs, and, after shaking himself once or twice, appeared, as it were, by magic, almost all at once restored to his senses. Mr. Rickwood, veterinary surgeon at Bedford, has likewise related a case in 'The Veterinarian' for 1839, which tells eminently in favour of preferring blood-letting from the temples. Mr. R. was sent for to attend a mare, who had just come in with the Leeds coach, and was seized with staggers. She was wandering about, with dilated pupils and laborious respiration, and symptoms of palsy of the hind extremities. She was bled to twelve pounds from the jugular vein, and had administered an aloetic drink and frequent clysters. The symptoms increasing, both temporal arteries were opened, from which she was bleeding rapidly when Mr. R. was compelled to leave her. The bleeding continued until she became so exhausted as to begin to make a noise in breathing 'as a roarer would make in his gallop.' At length she fell; after which the symptoms began to subside, and in a few days she was sent home."

A black mare, who was attacked with phrenitis after concussion of the brain, had been bled copiously twice or thrice from the jugulars, without any very apparent benefit. When Mr. Percivall visited her she was lying upon her side, flinging herself about in a state of frenzy, surrounded by spectators, who were betting any odds she could never rise again. He promptly plunged his lancet obliquely into one of her temporal arteries, from which instantly issued such a stream of blood-spouting up like a jet d'eau-that it seemed quite unnecessary to endeavour to turn her to puncture the other temple. She lay, rapidly and profusely bleeding, for some minutes, when, to the astonishment of all beholders and despairers, she suddenly sprang upon her feet, gave herself a rustling shake or two, and immediately commenced eating some hay which happened to be in her manger. In fine, from that hour she was a recovered mare.

Purgation for this disease has ever stood in such high " repute with farriers, that a common saying among them is-" purge a horse with staggers, and you cure him ;" and this, like many other veterinary adages, appears to have been founded in sound observation. In fact, it is a practice pursued by every surgeon in brain affections, with the twofold view of removing any source of irritation or cause for the head-affection that may exist within the bowels, and of indirectly abstracting blood by derivation and discharge. No surer or more effectual cathartic is known than aloes, which is aided by the addition of calomel. It may be administered in ball or drench, as most practicable.

$\begin{array}{llllll}\text { Decoction of aloes } & - & & - & - & 1 \text { punt. } \\ \text { Calomel } & - & - & - & - & \frac{1}{2} \text { drachm. }\end{array}$

Warm the decoction, and stir in the calomel.

Or of

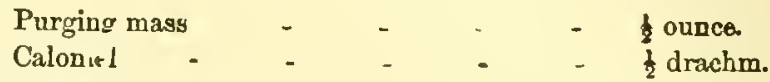

Mix into a ball. A drachm of the farina of croton seeds may be used instead.

Mr. Percivall concludes: "It would be futile to give further directions, where so much must depend on the circumstances of each individual case, and so much rest on the nerve and discretion of the practitioner." The French veterinary writers recognise a disease to which they attach the name of arachnoiditis, or inflammation of the arachnoid membrane. It is merely staggers in its inflammatory stage.

Abscess in the Brain may be looked upon as beyond the reach of veterinary skill. Abscess in its general sense will be noticed under a separate head, and in the parts in which it occurs. Abscess in the brain is the result of external injury. It is usually the result of fracture of some of the skull bones. A small wound is sometimes seen after a runaway horse has dashed a vehicle to pieces. It heals, and there is no discharge. The mischief is within. Abscess is forming In the picturesque description of Mayhew"The horse becomes dull, as in sleepy staggers. It refuses its food, lies down, and after a time beats its head upon the pavement. Death ends its misery, and a small abscess, containing about half a drachm of healthy pus, is discovered in the superficial substance of the brain." Neither operation nor physic avail here. The only means of relief would be to afford an exit to the matter, but this is "past all surgery" of a remedial character.

\section{VERTIGO (MEGRIMS).}

As apoplexy, in the sense of human practice, can scarcely be said to be a horse disease, though scientific veterinarians have recognised a distinction between it and sleepy staggers, which seems sufficiently marked, we shall consider vertigo or megrims as its equivalent; and megrims as minor apoplexy, or rather epilepsy, in horse nosology. Megrims, is known also to stablemen by the names of "sturdy" and "turnsick."

It frequently attacks horses during their work, particularly in harness: it is, however, now and then seen in hot weather, in the stable or at grass. When it seizes a horse in exercise, he stops short, shakes his head, looks irresolute and wandering; in this state he remains for a fer minutes, and then proceeds as before. In more violent cases he falls at once to the ground; or first runs round, and then sinks senseless; or the limbs may continue to move after consciousness is lost, when the animal thus affected becomes very dangerous. In either case, the whole system appears agitated by strong convulsions. The horse may dung and 
stale insensibly; he sometimes is violent, at others more passive, but is equally unconscious to everything around. After remaining so a longer or shorter period, his faculties return, and he rises. It is frequently brought on by mechanical causes, which produce a momentary congestion of the brain; as tiglit reining up, or the pressure of the collar in ascending a hill, which obstructs the return of blood from the head. It may also be occasioned by a morbid pressure produced by constitutional causes. Such are found in the plethoric, over-fed horse; particularly when subjected to long confinement.

The Treatment must be regulated by the cause. If it be mechanical, remove it, or the affection may become habitual. If plethora be apparent, purge; or give a course of mercurial alteratives, followed by relaxing medicines. It is said that covering the skull with a wet cloth will prevent megrims, where the horse is subject to their recurrence. Of course a horse liable to megrims is most dangerous to drive or ride; the frontispiece of Mr. Mayhew's "Illustrated Horse Doctor" is an alarming example of the results of this disorder.

Hydrocephalus, or water on the brain, is so rare a disease in the adult horse, that, though recognised by the French writers, it is not wortl wasting space upon. Should it exist congenitally, serous effusion in the ventricles of the brain may bring on mad staggers or megrims, or produce paralysis. It is useless to try to make a horse so afflicted serviceable to his master.

\section{PARALYSIS.}

Palsy of the whole muscular frame is very unusual in the horse, except from actual pressure or irritation of the sensorium by blows on the skull, by portions of bone forced in, or by abscess in the brain: sometimes it is constitutionally brought on by unknown agencies. Paralysis of one side is of very rare occurrence. Paralysis of half the body, most frequently of the hinder parts, is sufficiently common, and is either primitive or secondary.

The causes are often involved in nuch obscurity; in some cases they are sufficiently obvious. Mechanical injuries are of this kind, as casting in the stable, turning round in a confined stall, blows on the spine, sudden falls or slips may, any of them, luxate, or more likely fracture, the vertebræ, and, by occasioning pressure upon the spinal cord, produce paralysis. Ulcerations of the bones, or exostoses, abscesses, or tumours within them, may be the cause of the affection. It may be altogether secondary, as being derived from accidental lesions of other organs, or from inflammations in them: it may and does occur from a diseased state of the stomach, bowels, liver, and more particularly from those of the kidneys, badder, and womb. The symptoms are total or partial loss of either the mobility or the sensibility, or both, of some part of the body, usually of the hinder quarters and limbs. The secretions are sometimes lessened or almost stopped, or the urine flows involuntarily; convulsive twitchings affect the skin, partial sweats present themselves, and the anima: remains utterly helpless, although he may fatigue himself with fruitless efforts to rise. These are, however, extreme cases.

The treatment of paralysis must, in a great degree, follow the cause. If mechanical injury have occasioned fracture in any part of the spinal column, the case is hopeless. If the injury be less severe, it is possible that extravasated blood only, or serous deposit, or coagulable lymph, are effused into the spinal canal, and disturb the functions of the part; in which case, topical applications are requisite, to encourage an absorption of the obstructing deposit. When the paralysis can be traced to some visceral affection, or to disease of the stomach, kidneys, or bladder, the result is not necessarily unfavourable, although our hopes of a recovery are lessened. We should, in these cases, primarily attend to the exciting cause, if it can be discovered. But when there is loss of sensation without loss of motion, the limbs being cold and the horse insensible that he is in possession of such parts, and moving them only when absolutely forced-or otherwise, when they are entirely paralytic, and yet sensitive, it is probable that the nervous irritation originates within the spinal canal. Here, though we may with propriety use external stimulants, there will be but small prospect of success. Of internal remedies, strychnia has been found sometimes useful, in one grain, gradually increased to three grain doses; and it may be united with other tonics, as gentian, or aromatics. This, with purgatives as required, blisters, sheepskins, or a charge over the loins, has occasionally effected a cure, when the paralysis has been confined to the hinder limbs only.

TETAXUS.-LOCKED JAW.

The spasmodic rigidity, hardness, and apparent tension of the muscles in this formidable disorder, are indicated in its Greek name tetanos, stretching, from teino, to stretch. When the spasm exclusively affects the muscles of the jaw it is called trismus, from trismos, gnashing [of the teeth]. Tetanus differs from other spasms in its permanency, its rigid contraction being rarely alternated with periods of relaxation. Locked jaw, so called from the persistent closure of the mouth, is the result of a morbid irritation of the whole nervous system, acting on the brain, and thence by the excitor nerves reflected on the motory nerves. ${ }^{*}$ As this irritation is capable of pursuing "a retrograde course along the spinal marrow," a wound in the hind-foot or hock is almost as likely to induce a locked jaw as one in the forefoot.

Tetanus is divided into symptomatic and idiopathic. The first, also called traumatic (from the Greek trauma, a wound),

* The reader will do well, if he desires to pursue this subject, to peruse Dr. Marshall Hall's works on the Diseases and Derangementso the Nervoics System. 
is produced by external injury : the second developes itself from various obscure or conjectural causes acting on the spinal cord and brain. Cold, caused by evaporation; standing still after a severe burst in the hunting-field; the dripping of water from an unsound roof, or the eaves of a hayrick or shed when the animal bas been at grass, have been known to produce it. Worms, scvere visceral affections, and even bots (when producing solution of continuity in the lining membrane of the stomach), are assigned as causes of the tetanic spasm.

In traumatic tetanus, upon pushing our inquiries, we may gain clearer information. There has, perhaps, been some slight injury; a nail has been driven too close; or a piece of glass bas cut the foot; or a blow has been lodged just above the eye; or the knees have been recently broken; or the stable fork bas been used to strike the horse about the legs, and the point of it has only gone a little way into the back sinews. Sometimes an operation has been recently performed; let not the proprietor blame the surgeon, if such should lave been the case. Any puncture, however small, may produce tetanus; but it may not follow the most severe and the largest wounds. No means we know of can originate it, no care or skill can prevent its appearance. We may learn, however, that the tail has been docked or nicked; the wound has very nearly healed, and it may look as well as could be desired; or it may all at once have assumed an unhealthy appearance; a thin ichorous fluid may be discharged from it, and there may be a spongy appearance around it. IIost commonly the wound nearly heals, when this alarming affection bursts forth. Castration, when performed under unfavourable circumstances, has sometimes produced tetanus.

The fibril of some nerve has been injured ; irritation ensues, It rapidly spreads along the varions branches of that nerve, and, through the spinal marrow, affects the whole body.

SYMptoms. - One of the first observable is a certain stiffness about the head, and a peculiar mode of standing. Upon raising the head, the haws of both eyes are pushed out, giving to the countenance of the animal a strange expression; but sooner or later it extends all over the body By the tetanic action, the haw is drawn partly over the globe, at the same time that the tension of other muscles gives the eyes a vivid appearance which ill accords with the more placid effect of a protruded haw. The jaws are not invariably fixed, thongh from their being generally closed springs the popular name of the disorder. As the disease extends over the voluntary muscles of the trunk and extremities the appearances are distressing in the extreme. The head is raised, the ears pointed forwards, the nostrils dilated, and the nose is protruded; the legs straddle wide; the tail is cocked, and quivers; and the abdominal muscles are drawn tig'st over the belly, giving to the horse an appearanee of having just completed some extraordinary exertion. The complaint presents a few moments of imperfect relaxation, sometimes, from the extreme contractions of over-strained muscles; while profuse sweats mark the dis- tress of continued convulsion. The circulation is, in most instances, at first not much affected; but as the disease increases, the pulse quickens and becomes tremulous and irregular. The respiration, also, gradually becomes hurried and intermittent; costiveness is usually present, and the urine is sparingly voided. In this state of suffering the animal may remain from six to ten days, when, worn bv inanition and irritation, he dies in convulsions. At others, either from remedies or spontaneously, the contractions give way slightly; feeble attempts are made to eat, the limbs become gradually under the action of the voluntary muscles, and a slow recovery takes place. Post-mortem examination shows no change from the healthy state, except some inflammatory appearances in the lungs or intestines, one or both.

TREATMENT.-There are many cases narrated in veterinary books in which some modes of treatment of very opposite kinds, have been practised with success. Some bleed largely, that they may gain the full advantage of this sedative influence. This depletion is followed by strong purgatives, and then the disorder is attacked locally by a blister, from the poll down to the rump, the sides, and, in some cases, all over the belly. By this system of counter-irritation, they tell us they have overcome the original affection of the spinal cord. Setons, too, have been inserted along the whole course of the spine; but they have not proved efficacious. Sheepskins, applied warm, from the poll to the tail, have been found to give more relief, and are certainly more humane. Docking and nicking being barbarities fortunately out of date, we may forget the treatment given in the oldex veterinary books, so often called for by tetanic attacks from those cruel operations. For ourselves, we do not advocate the severe treatment as necessary. The pulse is not usually accelerated in tetanus; bleeding, therefore, is not in every case indicated. The bowels are not invariably constipated; and purgatives are not required. The benefit of violent connter-irritation is not demonstrated; its employment, therefore, is not justified. The best practitioners doubt the efficacy of the active tortures of the old school, and think that perfect quiet is of more use than violent medicine. If the horse be costive, administer a purgative, and a bold one; because an ordinary purge will have no effect during the existence of tetanus. Sedatives are now indicated. Two drachms of opium, with one drachm of camphor, as a first dose ; and one drachm of opium and half a drachm of camphor (with the same drugs as a clyster), have been found serviceable. The subjoined will be found a powerful compound :-

\begin{tabular}{|c|c|c|c|c|}
\hline Powdered opiun & - & - & - & $\frac{1}{2}$ ounce. \\
\hline Sulphuric ether & - & - & - & 1 ounce. \\
\hline Camphor - & . & - & - & 2 drachms. \\
\hline Tincture of aconite & - & - & - & 20 drops. \\
\hline Spirit of Turpentine & - & & - & 2 ounces. \\
\hline Strong ale & - & - & & 1 pint. \\
\hline
\end{tabular}

Mix the turpentine with the yolks of two eggs, then the other ingredients, and give in two doses, at the interval of two hours; and repeat if the symptoms do not mitigate. 
Then place the animal where it cannot be disturbed, and take care to visit it as seldom as possible. The door being locked, the horse left alone, and every precaution taken to prevent the slightest noise. The absolute quietude thus obtained, has been found to be of more service than anything else; and the horse which has thus been shut up in silence has more frequently recovered than the one which has been continually annoyed under the pretence of assisting its restoration

As for food-the horse is not able to take any solid nourishment; but he may have a mash more than usually wet in his manger, and a bucket of gruel may be slung in some part of the box; from either or both of which he may, perhaps, contrive to extract a little nourishment. The appetite of the tetanic horse rarely fails him; though he may be unable to eat, he will, under the influence of hunger, manage to imbibe enough for his support. Even if he makes no attempt to touch that which is placed before him, he should be left some days before any effort is made to drench him; and if he takes only a little nourishment, a further period should elapse before he is annoyed hy forcing food upon him. Should he, however, appear to be losing strength, and to be sinking, he must then at every hazard be supported. Should it be possible to insert a small horn or the neck of a small bottle between his tushes and his grinders, almost any quantity of gruel may be given him; and, when he is in a manner starved, it is interesting to see how eagerly the poor animal will take the nourishment which is attempted to be given to him in this way. The dreadful cramp of the muscles of his neck should not, however, be forgotten; and the gruel should be given to him as gently as possible, and without elevating his head more than is absolutely necessary. Frequent injections of arrow-root or gruel may also be thrown up. The ordinary horse catheter, with Read's pump attached to it, will enable any amount of gruel to be thrown into the stomach; not only quickly, but without the necessity of elevating the head. The catheter is simply passed up the nose, along the floor of the nasal chamber, and, being pushed onward, it will enter the gullet. When the tube is inserted its full length, the fluid may be injected. This plan answers admirably ; subjects the horse to little annoyance, and causes but small disturbance. There is a good engraving of this method in "Mayhew's Illustrated Horse Doctor," already referred to. Some animals, however, are so irritable that any interference throws them into convulsions; and, in such cases, perhaps the injection of nutritive liquids into the rectum is all which the symptoms will permit to be done.

In a disease of this nature, the humanity and patience of the attendant must be exerted. These virtues will aid him more in the end than all his science, however learned he may be. The disease may terminate quickly. We have known a horse to die of it in less than thirty hours. So speedy a close, however, is rather unusual. The animal with idiopathic tetanus often lingers. It occasionally hap- pens that the horse does not begin to amend until ten or twelve days have elapsed; and in one case a month passed without more than an occasional remission of the symptoms. The treatment was, nevertheless, persevered in, and the animal perfectly recovered.

When the horse does begin to get better, not a particle of medicine should be administered. By giving tonic medicines much dangerous excitation may be produced. The best tonir, is nourishing food, and even that should be supplied with caution. Green meat will in these cases be useful. If the weather, however, will admit of it, a run for twu or three hours every day will be of essential benefit.

\section{RABIES, OR HYDROPHOBIA.}

The ymptoms of rabies in the horse are the only important points in the present state of veterinary knowledge, Curative means are unknown. It is never spontaneously developed in the horse, but induced by the bite of a rabid dog. Mr. Iouatt says, "The earliest and most decisive symptom of the near approach of rabies in the horse, is a peculiar spasmodic movement of the upper lips, and particularly of the angles of those lips." Close following this is a depressed and anxious countenance, and an inquiring gaze, suddenly lighting up, and becoming fierce and menacing at a slight noise, or the approach of a stranger. Then cumes an irrepressible desire to attack and bite at any person or animal within reach of the teeth. Then comes an almost systematic demolition of rack, manger, and stable fittings; and the poor wretch lies snorting and foaming amidst the ruins, paralysis of the hinder extremities incapacitating him from further mischief by kicking and plunging. The disease proves fatal in from three to six days. When the bite of the rabid $\operatorname{dog}$ is early known of, and can be found, of course thorough cutting out, and the actual cautery, will save the animal. Mr. Spooner relates several cases of this. When, however, rabies has developed itself, treatment is useless, and liumanity dictates that the animal should be destroyed without delay.

\section{STRINGHALT}

This spasmodic contraction of some one or more of the flexors of the hinder leg, is, like most nervous disorders, of obscure origin. It is seldom seen in the fore-leg, though an instance is now under our own observation. It is not a lameness, as the other leg does not sink, and the rider cannot feel it as he does the "dropping" in hock disease. The animal is useless as a racer, as he cannot control the voluntary nerves for a start, till he has gone through his preliminary jerks and whippings-up of his leg. It is not usually developed except in the adult horse. Professor Spooner attributes it to a pressure or defect of the great sciatic nerve which supplies the muscles of the hinder extremities. It is correspondent to chorea, or St. Vitus's dance, in man. There is no treatment available. Stringhalt has been decided not to be unsoundness: and we often see instances where this 
singular spasm is merely momentary at going off, disappears, and the horse has a more than ordinary amount of strength and courage.

\section{SPASMS.}

What we have said generally upon tetanus, staggers, \&c., renders further remarks upon spasms here superfluous. Under Diaphragr, Urethra, Biadder, Intestines, the spasms of those several organs will be treated of.

\section{§II. DISEASES OF THE EYE.}

GUTTA SERENA (GLASS EYE).-SIMPLE OPHTHALMIA-SPECIFiC OPIITHALMIA (MOON BLINDNESS).-CATARACT.-FUNGOID GROWTHS.-OBSTRUCTED LACHRYMAL DUCT.

The eye of the horse is exceedingly liable to disease. Its th structure will be found described ante pp., 196-199; and figured in health and disease, Anatomy, Plate VII.

The "haw" (membrana nictitans), at the inner corner of the eye, is, in health, a thin slippery membrane, thicker or more cartilaginous towards its base, where it is embedded in fat; its action is to remove dust, insects, \&c., which may have fallen on the cornea. It is no unusual thing for a thickening of this part to take place, and it will then protrude itself on the fore part of the eyeball. In this disease the retractor muscle pulls back the eye to protect it from the irritating effect of the light, and this thickening of the haw pusling it forward, and the adjacent parts being also thickened, no retraction can take place.

The olden practice of cutting out this, is absurd, and ought never to be resorted to. Ignorant farriers have, in this state, taken the enlarged haw for an extraneous excrescence, and cut it out; the eye, consequently, being left unguarded. Bleeding, gentle physic, and cooling applications, will effect a cure.

\section{GUTTA SERENA (AMAUROSIS).}

This disorder, called by farriers glass eye, from the peculiar greenish glassy appearance it assumes, is dependent on a paralysis of the optic nerve in its expansion on the retina. This, however, is disputed by some, who consider it to arise from inflammation, by which coagulable lymph is effused over the optic nerve, rendering the retina insensible to the stimulus of light. Both may be right in different cases. It is certain, however, that irritation of the brain produces amaurosis, and it often follows staggers. In this disorder the horse shows blindness in his actions rather than in his eyes. He lifts his feet high, moves his ears quickly, and shows himself anxious to supply want of sight by the exercise of other senses. A simple test is waving the hand pretty close to the suspected eye, when of course there will be no winking: we have, however, seen a cunning horsedealer who could make a blind horse wink by the peculiar manner in which he drove the air upon the eyeball and lid while bringing down his hand. We have also seen amaurosis supervene temporarily while the mare has been with foai. which would seem to point clearly to a nervous origin.

In gutta serena, local applications are of little service Bleeding from the jugular veins, calomel and opium, or in some cases strychnia, may be tried.

\section{SIMPLE OPHTHALMIA.}

This is common or accidental inflammation, and has generally its origin in a mechanical cause; as blows, injury of the conjunctiva from a whip-lash, hayseeds, or other matters within the eye-lids, not being removed by the nictitating membrane, and the like. It is occasionally the consequence of a common attack of cold.

Simple inflammation of the eye looks outwardly an affection of the conjunctiva only, whereas specific ophthalmia involves the internal parts of the eyeball. Another distinction is, that in specific ophthalmia there is symptomatic fever, loss of appetite, staring skin, and constitutional disturbance. Both disorders, however, are alike in impatience of light, in distension of the vessels of the haw, and sometimes in its extreme protrusion. The cornea, too, is often opaque. From that sympathy which is found to exist between double organs, even when the affection has been entirely brought on by violence done to one eye, the other will by sympathy become affected also, but in a minor degree. Such liability should be borne in mind, as a mistake in this particular might lead the practitioner into important error.

Treatment.-First turn up the eyelid carefully, if the cause is not apparent, and remove anything which may have intruded itself. Wash the eye with tincture of opium and a pint of cold water, laying a wetted cloth also over the eye. If the inflammation is considerable, lance the eyebranch of the angular vein, and give the horse some food of which he is fond upon the ground; this will eucourage the bleeding. If blood does not come freely, bleed also from the neck, and give a dose of physic. If the case is obstinate, and a film appears upon the cornea, take two grains of lunar caustic (nitrate of silver), mix in two ounces of water, and touch the eye over with a camel-hair brush. The next article will contain the treatment of the disorder in its constitutional form.

\section{SPECIFIC OR PERIODICAL OPHTHALMIA.}

This destructive disease of the eyes, by which a valuable animal is often reduced in price from a hundred guineas to a tenth of the amount, is, as already remarked, distinguished from the simple disorder by the constitutional disturbance which acconpanies it, and its attacking the internal structure of the eye, the outer covering being merely involved by sympathy. Among farriers this disease used to be termed moon-blindness, from a superstition that the periodical attacks were influenced in their monthly return by the moon. The period of a monthly recurrence is, however, merely imaginary. 
Sxмттомs-These generally appear suddenly; in the evening, perhaps, there may have been nothing amiss, but on the following morning sometimes both eyes, but usually one eye only, is found nearly closed and suffused with tears, there is great impatience of light. Indeed it is somewhat difficult to induce the animal to open the lids sufficiently for examination, and when he does so, the pupil is found exceedingly small, so as to keep out the light as much as possible. The cornea is not so opaque as when the inflammation is brought on by an external injury; but on looking into the interior of the eye we observe that it has lost its brightness. The attendants of the horse usually report that some hay seeds must have got into the eye, or that he must have injured it in some way: but a proper examination will detect the difference, and this will be greatly assisted if we can ascertain that the horse has had a previous attack.

The eye is remarkably retracted, and this retraction forces the haw over a portion of its "globe, where it is seen swelled and preternaturally red, from its participation in the disease. The inner lining membrane of the lids will be found highly vascular and hot, pouring forth, in most instances, a flood of tears, which continually trickle down the face; and the whole conjunctiva will present a network of turgid red vessels over its opaque white surface. If the cornea be not too opaque or too much inflamed, we shall discover the aqueous humour thick and muddy also; the iris and choroid will likewise be found altered from their natural colour. From this state it follows sometimes, that a central yellow patch is discovered at the bottom of the eye; in which case matter has formed, from the usual suppurative inflammation, but it most commonly becomes absorbed again, and sometimes very speedily. In very acute cases, however, there is a large deposit of fluid, which disorganizes the eye. The rapidity of the changes in the state of the eye is a very marked feature of specific ophthalmia ; and the transition from an almost opaque to almost a clear state of the cornea, and from a simple dimness in the appearance to a perfect opacity, sometimes occurs in a remarkably short space of time. We have seen an eye opaque within and without, which was merely dim the night before; and perhaps within twelve hours it would again have almost become transparent, without any apparent medical agency.

Specific ophthalmia commonly attacks only one eye in the horse, leaving the other totally unaffected, or at most only sympathetically involved. Worthy of remark is the complete and sudden change which often takes place in this disease. From being in a very aggravated state of inflammation in one eye, it will suddenly shift its seat to the other, leaving the original much amended or nearly well; and it will not only thus change about from eye to eye, but may likewise either spring from, or be transferred to, other organs

The eye or eyes, however, thus far recovered, seldom remain very long sound; but often are again subject to the diseased action, and the complaint recurs with all its pristine violence. As these attacks are repeated, they leave the eye less and less transparent. The remaining opacity forms a nucleus for future and rapid accretion: sometimes, however, it will remain stationary for a long time, and now and then it never enlarges. But, usually, repeated inflammatory attacks succeed each other; and the whole crystalline lens at last becomes opaque, when the disease takes the name of cataract, in which almost all these inflammations terminate.

CAUSES.-Plethora acting upon a weakness of the parts, often hereditary, seems a cause of periodic ophthalmia, to which the horse is more liable than any other domestic animal. The fumes of ammonia in close, dark stables, stimulating food, or severe work and bad food, may equally induce the disorder, which seldom appears before the fourth year, or, for the first time, after the seventh. Harness horses are more often attacked than saddle horses; and it has been observed to be more frequent when many horses are kept together than in gentlemen's studs, which may be due chiefly to better ventilation.

Treatment.-Though the immediate attack may be removed without great difficulty, its recurrence is not easily guarded against; resembling, in this, scrofula in the human subject. General bleeding, warm fomentations (one dozen poppyheads in two quarts of water) at first, and then the cold lotion. (See Lotions, Zinc, \&c., in List.) Stimulants, as tincture of opium, or the nitrate of silver wash, may also be applied with advantage.

The food should all be boiled, and of the most supporting kind-roots of all kinds, malt, oats, ground beans, clover hay, linseed, \&c., \&c. This will probably sufficiently open the bowels; but should it not, avoid giving more than one drachm of aloes night and morning; and even continue this quantity no further than is imperative to render the bowels soft, yet by no means to induce watery stools.

With regard to physic, anything administered must be of a soothing and supporting description; therefore give, night and morning, during the violence of the attack, the following drink :-

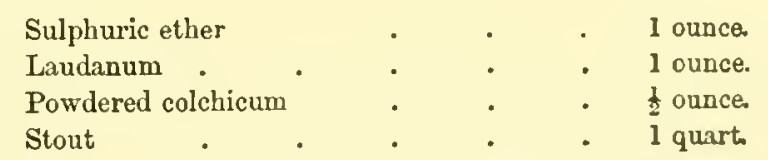

Should the inflammation run very high, the superior branch of the angular or facial vein, called the eye-vein, may be opened as before directed.

On recovery, remove the horse to a high, clean, cool, stable, where there are no irritant exhalations from excrement. Listen to no quacks who pretend to infallible remedies for the remaining defects visible in the eye, should any remain. You may now and then strengthen the eye by a little cold lotion of crude sal ammoniac and red rose leaves, or laudanum and rose-water, if sou must 
be doing something; but don't let farriers put their ruinous messes into the sore and sensitive eye.

\section{CATARACT.}

Cataract is often the result of specific ophthalmia. Cataract is total, partial, or consists of specks on the capsule of the crystalline lens. In the first the lens is quite white.

In other cases that have stopped short in their career, spots only of an uncertain size are visible on the lens or upon its capsule; a white opaque spot on either is called a cataract. Cataracts, however, can and do exist in eyes that have never been subjected to ophthalmia; and as they make their appearance without any apparent cause, so they occasionally will depart without any treatment. Blows sometimes produce them; and when caused in this manner, they are for the most part stationary. However, in cataract following ophthalmia, there is generally much derangement of the other internal parts of the eye ; particularly of the iris, which sometimes adheres to the lens, at others to the cornea; and in some cases its pupillary opening is so reduced by contraction as to render the cataract hardly perceptible. This internal derangement greatly prevents any benefit being derived from the operation of couching; added to which, a horse so operated upon, to have perfect vision, would require to wear spectacles. It has, however, heen suggested that, even without glasses, so much benefit might be gained from it as to prevent accidents, like running against posts, falling into pits, \&c. This, nevertheless, would be greatly overbalanced by the imperfect vision, which would render the horse so operated on very dangerous from his liability to shy.

Treatment.-Cataracts of all sizes and shapes are best let alone. Should they cause the horse to shy, blind the eye or eyes in which they may exist. The measures generally pursued, with very doubtful success indeed, are the blowing of mercurial preparations into the eye, the application of caustics, either in powerful solutions or in substance, to the organ ; and, in short, all kinds of cruelties, more likely to favour the formation than to cause the dispersion of cataract.

\section{FUNGUID GROWTHS OF THE EYE.}

Small polypous excrescences occasionally form on the globe of the eye; fungus-like projections are also met with on the transparent cornea, sometimes from injuries, at others apparently of spontaneous growth. When these are evidently of a polypous, or merely fleshy nature, the knife and a styptic takes them off and stops the hæmorrhage. If fungoid and bleeding, wash with chloride of zinc in solution; and red precipitate ointment, thinned with Florence oil, may be painted over it daily with a camel-hair pencil. Observe, if the growth is within the ball of the eye (when a bright yellow substance will be visible on its interior base), extirpation of the eye is the only remedy. It has been often performed, is not difficult, but so barbarous, and withal useless in an animal of which such services are demanded, that a speedy death is the more humane and advisable alternative. In lacerations of the eyelid, from a blow against a nail, hook, or other projection, obtain union of the parts by a suture of thread, and it will generally heal from the first intention. Remember, in cases of laceration, simple cold water is better than Goulard's or evaporative lotions.

In cases where the injury reaches the eye-ball itself, and there is active inflammation, the activity of treatment must correspond. Bleed from the head; give a strong purgative and cooling drench, apply anodyne fomentation (boiled poppy heads) to the eye with soft sloths or sponge. When the physic has operated, separate the eyelids and examine the extent of the injury. If the iris should protrude, touch it with lunar caustic or butter of antimony, to destroy the projecting portion, which causes agonizing pain, and to deaden the morbid sensibility of the parts. Apply the caustic till the protrusion is got level with the cornea, and use an astringent wash or unguent-(E) (F) (G), AstrinaENTs, p. 370-to repress the discharge of pus and cleanse the sore. White vitriol, one ounce, twenty drops of laudanum, and water at discretion, is a good eye-wash in sucb a case.

\section{OBSTRUCTION OF THE LACHRYMAL DUCT.}

This disease, called "watery eye" by the farriers, is occa. sioned by the stoppage of the small canal leading from the eye to the nostril, at the inner corner of the upper and lowel eyelids, and ending in the dark skin of the nostril on the inner side. This minute sinus obstructed, the tears flow out upon the face of the animal, excoriate the flesh, and make bald places and sores. A bougie, or, better, a thin elastic probe of catgut a foot long, may be passed through the channel, an assistant holding open the eyelids, a mechanical cure is effected. (See, for detailed cases and cure, Percivall's " Hippopathology," Vol. III., pp. 154-157.)

\section{WARTS.}

The eyelids are sometimes affected with warts, which are very irritating to the animal, in consequence of his rubbing them on some prominent object: this causes them to bleed, and increases their number.

They should be cut off with a pair of sharp scissors, and the roots touched with nitrate of silver (lunar caustic), or blue vitriol.

\section{§ III. DISEASES AND INJURIES OF THE TEETH, PALATE, TONGUE, NOSTRILS, AND PHARYNX.}

The "dentistry" of the horse will not occupy much space. Teeth disorders are the results of domestication, artificial diet, irregularities in feeding, and injury from the iron bit.

The teeth are often troublesome to the domesticated horse. Sharp edges on the outer side of the upper molars and the inside of the lower-one wounding the check, the other the 
tongue, and causing the horse to swallow his food unmasticated, or producing "quidding" (i.e., throwing out his food in balls from the mouth)-are a serious though apparently a trivial defect. The tooth-rasp, which requires no description, is the remedy; and the same when one of the grinders stands higher than the others. Sharp ragged teeth have been often overlooked, and the poor animal physicked and doctored for all sorts of internal complaints, even ulcerations in the mouth and lampas, when a scrutiny of the teeth and a rasp were all that was required for the restoration of the services of a valuable animal.

Carious Teeth.-Mr. Cherry, Veterinary Surgeon to the Life Guards, and Mr. Percivall, relate cases where this complaint has occasioned a discharge mistaken for glanders. The smell of the discharge being horridly fetid. The key, and extraction of the tooth, is the remedy. The "key" will be found figured in our plate of InStruments.

\section{PARROT MOUTH.}

By this appellation horse-people understand what dogfanciers call "overhung ;" i.e., a mouth so formed-or rather so malformed-that the upper jaw projects considerably beyond the lower; so much that the inferior incisor teeth, instead of meeting the upper, come in contact, when the mouth is shut, with the bars of the palate, while the teeth of the superior jaw have no opposing surface whatever, unless the lower lip can be so regarded. This deformity is not of very common occurrence. The horse has less power of gathering up his hay and corn with his lips, and of the retention of the food while being transferred to the grinders; as is seen by the animal, while feeding, wasting part of his corn, ana slobbering. In grazing, the parrot mouth is yet more disadvantageous, much difficulty being experienced in nipping off the grass; this seems the chief objection to the purchase of such a horse. There is, of course, no remedy for such a malformation.

\section{INJURIES TO THE MOUTH AND TEETH.}

Colts while breaking are often hurt in the mouth by pressure of the bit ; and the lower jaw of many horses is injured by the snaffle between the teeth and first grinder. When severe damage is done, the bone exfoliates, or abscess is formed in the jaw. In this case mashes should be given, and, to prevent the formation of sinuses, the bone cut down upon, and chloride of zinc, one drachm, water one quart, and a little essence of aniseed, syringed into the opening several times a day. Don't let the wound heal, but keep open with the knife, so that the exfoliated bone may come away freely when grasped by the forceps.

Injuries under the tongue, and on the roof of the mouth, are sometimes occasioned by the "port" of the bit. If there is much inflammation and tumidness, bleed locally, use depletory measures, and a weak lotion of alum and laudanum.

Excoriated Angles of the Mouth.-These arise from bad driving or riding, "jagging," or "sawing" the animal's mouth. The treatment is obvious. A lotion of chloride of zinc, and water, one quart, applied with a soft cloth, and dress with a little alum, honey, and water. We chietly mention this because vile and disgusting animal fats as ointments are often applied, to the horror and nausea of the cleanly and delicate animal.

\section{INJURIES TO THE TONGUE.}

In the clumsy administration of a ball, the under part of the tongue is sometimes lacerated, which renders feeding painful, and makes the horse slaver and froth at the mouth. This may be cured by a solution of alum, thrown in with a syringe.

The practice of tying a horse's tongue to prevent him from running away, may not be frequent, but it is done, and the loss of the tongue may be the consequence. Mr. White, in his "Farriery," says :- "Three cases of this kind I have met with; one I was told of by the person who did it, and who cut off the swollen part of the tongue to relieve the animal from his intolerable sufferings, the ligature being buried in the enormous swelling that had taken place. Two others I have heard of, in which the tongue was liverally drawn out by the roots. The most common manner in which the tongue is wounded is, by the horse hanging back when he is tied up with a coil of the halter in his mouth and over the tongue; or, as it is vulgarly termed, with a "charv" in his mouth. On this, Mr. Spooner remarks in a note: "The editor has met with many cases in which the tongue has been divided in this manner, and a good portion of it cut off; but though the horses for some time were unable to take their accustomed food, yet the remaining portion of the tongue gradually accommodated itself to the mouth, becoming flatter and flexible, and at length capable of gathering up the food apparently as well as before." When the tongue is partially divided, sutures must not be used. Metallic sutures wound the mouth or cheeks, silk or thread soon sloughs out. The tongue must be left alone after cleansing with a styptic lotion (zinc is best), and the horse fed solely on gruel.

Fistula of the parotid duct, and glandular abscesses, will find their place under Abscess, Fistula, and Tunours, in Cuapter IX.

\section{LAMPAS.}

We have here an opprobrium of farriery, not but that the older practitioners of human medicine have their barbarities and blunders on record. Lampas is a swelling of the root or bars of the mouth or palate, near the front teeth. Blaine, forty years ago, raised his voice against the barbarous practice of burning the horse's mouth with a red-hot iron for this "imaginary disorder," as he properly called it ; Percivall, years afterwards, says in despair, that "in the army you can hardly prevent the shoeing smith burning for lampas." Mr. Nayhew in his book (pp. 58-60) has given a drawing 
of a poor horse under the torture of the actual cautery, and eloquently declaimed against the barbarity.

Lampas occurs from an early age, throughout colthood up to five years, when the horse's mouth is perfect. It arises from fever, the mastication of dry food, and, of course, with a sore mouth, the poor creature is "off his feed." The groom looks into the mouth of the animal, when, perceiving the bars to be almost on a level with the incisor teeth, he pronounces his charge to have the lampas, and takes the poor creature to be burnt within its mouth accordingly. It is true the animal has recovered its appetite by the time the effects of the burn have passed away, but so it would have done had no hot iron been cruelly employed. The fact is, the young animal is then cutting a molar tooth, and a day or two having elapsed, all the fever and pain occasioned by the process would have been over. "No man," says Delabere Blaine, "should allow his horse to be burnt for the lampas. It is a torturing and a wanton operation, and tencls ratlier to do harm than good. In most cases a few mashes and gentle alteratives will relieve the animal, and a few slight incisions with a lancet across the bars will relieve inflammation, and never do harm.

\section{NASAL POLYPUS.}

A pear-shaped body, filled with blood-vessels, which pass through its stalk or peduncle, is often found on mucous tissues; it is called polypus, from an erroneous supposition that it has many feet, or roots. Polypi should never be sliced off in the old way of farriers, but extirpated by a single cut, or by ligature or torsion. Torsion is a good method, and not so painful as might be supposed, for the polypus has little sensibility under the knife or scissors. A pair of scissors, with sharp curved claws, are sold by surgical instrument makers for this purpose. The polypus is grasped by these claws, wlich are then drawn down to get a firm hold, and twisted round several times; this twists the stalk, or peduncle, and ruptures it, when it comes away. The twisting should be done quickly, and the bows of the scissors secured together by a piece of soft wire as soon as a good grip of the tumour is got by the claws. Ligature is more tedious; but there is no bleeding. It is, however, doubtful whether it is less painful than torsion. The ligature is a piece of fine zinc wire, a yard and a half long, doubled, and the two free ends passed down a small tube, leaving a loop at the doubled end large enough to put over the polypus; then draw the loop tight on the neck or stalk of the polypus, and secure it to a cross piece of wood at the bottom of the tube. The horse is to be carefully reined up, and next day the tumour will feel cold; if not, give the cross piece another turn, and tighten the wire. Watch the tumour, and, when it appears quite dead, twist the pedicle gently, and it will give way.

\section{NASAL GLEET.}

This distressing afliction must not be confounded with glanders. Horses taken up from grass, are found with the bones of the face swollen and soft. A blow on the facial bones is sometimes the cause. Pus gathers in the cavities of the turbinated bone, and there corrupts. In extreme cases, these carities may be cleansed by the use of the trophine, by which a circular piece of bone is cut out; an elastic probe, armed with a tape, inserted and brought out at the nostril, thus establishes a seton, or gives a passage to syringe out the pus. To describe such a purely professional operation in a compendium like this, would be out of place. La Fosse's work, and Bartlett's "Farriery," contain engravings of the operation and instruments, as a supposed cure for glanders, where the inquirer may consult them. When nasal gleet, however, will not yield to medicine, diluto injections of warm water and chloride of zinc, or of creosote, the animal is valueless, and should be destroyed.

The ball recommended in this disease, is, copaiba balsam, 3 drachms ; cubebs, half an ounce; powdered cantharides, 3 grains. Mix. A solution of sulphate of copper, blue vitriol, or the muriate of barytes, once supposed to be a specific for glanders, introduced in small quantities into the water the horse drinks-two drachms of the salt to a quart of water-may be put in the pail or bucket. The steam vaporiser, for steaming the nostrils, is also to be recommended. It is described under CATARRH, post.

\section{DISORDERS OF THE PHARYNX.}

Choking, and the methods of relieving it, will be noticed in Chapter VI., under CEsophagus. The organs of swallowing may be injured by the practice of giving balls, especially when they are large or hard. A morbid state of the pharynx is thereby induced, which renders deglutition difficult, and sometimes impossible; the lower part of the pharynx acquiring a morbid irritability, which causes it to contract upon the approach of the food, and return it into the nostrils, or into the mouth, where it is often re-masticated, and at length thrown out into the manger like a quid of tobacco.* Such horses have been named "quidders" by dealers, and are considered of little or no value: such cases are often incurable, and sometimes so because not understood. Were the horse, in the early stage of the disease, kept a few weeks on gruel and bran-mashes, and then turned to grass, the muscles of deglutition would sometimes gradually recover their lost power.

Mr. White states that he met with a case, in a mare, where both swallowing and breathing were much impeded by ulceration of the pharynx, or upper part of the cesophagus or gullet, produced probably by her having swal-

* Sometimes there is a partial palsy of the muscles employed in deglutition, by which the animal has been gradually starved. 
lowed hastily some hard or sharp substance, such as a stub of wood, or the unchewed stalk of a dock, thistle, fern, or bramble. "The pain and irritation which swallowing occasioned caused coughing, and some of the food to be thrown into the nostrils, and some into the larynx, where it produced a great deal of pain and difficulty in breathing, so much so that they were about to destroy the animal. Relief was afforded by making an opening in the windpipe, and passing a surgeon's probang into the opening, and up through the larynx, and then quickly withdrawing it. I then passed it up again, and withdrew it a second time, in order to remove completely, or as far as could be, whatever might be lodged in the larynx. I put two stitches in the skin over the opening in the windpipe, and did nothing more. The mare was greatly relieved, and brought up a colt she had. When the colt was fit for weaning, the mare, being of little value, was destroyed; and then the ulceration in the pharynx was discovered. I saw the animal just before she was killed, and found her breathing freely and looking tolerably well (considering she had been kept at grass, and on a common), and with a good udder of milk. But the owner informed me that she appeared sometimes much distressed, and coughed a great deal, probably by some food still getting into the larynx"

\section{CHAPTER XXVI.}

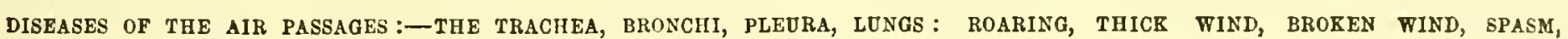
AND RUPTURE OF THE DIAPHRAGM.

Is considering the important class of disorders which attack the organs of breathing in the lorse, we shall divide the inflammatory affections of the air-passages into three sections; a division justified by recent discoveries and the improvements of modern practice, thus :-

1. Bronchitis; inflammation of the mucous lining of the bronchial tubes and trachea.

2. Pleuritis (pleurisy); inflammation of the membrane (the pleura) covering the lungs and lining the chest.

3. Pneumonic; inflammation of the substance of the lungs (Gr. pneumon).

\section{BRONCHITIS.}

Bronchitis may be acute, chronic, or epizootic. The causes of bronchitis may be set down as the same which induce common catarrh or cold. Most frequently the extension of inflammation is from the throat downwards. It is often a very insidious disease; though sometimes slight, and free from danger. In many cases it creeps on so gradually that it fails to attract attention until too late. It is not uncommon for a cough and a slight diminution of the appetite to be the only symptoms noticed for several days; although, if the animal were examined at this stage, he would be found to have a quickened and a disturbed pulse with slightly laborious breathing, with a slight discharge irom the nostrils. The disease, after creeping on in this manner for several days, sometimes exhibits on a sudden the most dangerous symptoms; the pulse being exceedingly uquick and weak; the respiration greatly accelerated; the membrane of the nostrils and eyelids of a red colour, and the discharge from the nostrils diminished or suspended. When bronchitis presents itself in this form, it is frequently fatal-the membrane of the nostrils becomes of a purple hue, and death too frequently closes the scene in the course of a week or ten days.

The disease fortunately does not always exhrbit itself in this severe form. We often find the first symptoms are a loss of appetite, dulness, discharge from the nostrils, and cough ; it can only be distinguished from a common catarrh by the quickness of the pulse (advancing from 50 to 70) and the disturbance of the breathing. From common inflammation of the lungs it may be distinguished by the warmth of the surface and the extremities which usually prevails, and by the more moderate acceleration of the pulse and respiration. It should, however, be observed, that it is by no means uncommon for this disease to be complicated with inflammation of the lungs; and when such is the case it is the more dangerous. It is sometimes attended with costiveness; the dung being often offensive, and coated with mucus; and yet the membrane lining the bowels is so irritable as to be violently acted on if physic is administered. On applying the ear to the chest, instead of the healthy murmur, we generally hear a wheezing or sucking sound; sometimes one resembling brickbats being rolled down from a considerable height is audible, owing to the air struggling with the mucus; but this, of course, will depend very much on the quantity of secretion which is effused. The breath is warm, and the mouth usually hot and dry. 
Treatment.-One of the sequelæ of chronic bronchitis is thickening and change of structure in the air passages from which decreased capacity follows, with "thick wind" and wheezing. There may be a seeming necessity for bleeding, yet, violent as the symptoms may appear, the patient will not often bear loss of blood; here, therefore, more than in any other disease, will appear the propriety of the caution elsewhere recommended when treating of the operation of bleeding. No fixed quantity should be abstracted. The operation should never be left to the assistant, but should take place under the practitioner's own eye, in order that the bleeding may be stopped on the very first indication that the system is affected. There is no rule which admits of so few exceptions as this; that a disease of the mucous surfaces (and this is one) requires prompt and decisive treatment, but at the same time very cautious remedies, from the rapid debility which is connected with all these affections.

Perhaps, after all, it is better bleeding should altogether be alsstained from. Such a bloodletting as we dare liazard in bronchitis is not likely materially to affect the disease; while the smallest abstraction of the vital fluid is sure to tell with dangerous (perhaps fatal) certainty during the subsequent debility.

Although it will be desirable to relax the bowels, aloes will be dangerous, except in the quantity of one or two drachms, and not repeated; but it will be better to substitute a pint, or nearly so, of linseed oil, guarded by a drachm of chloroform, and to assist its action by clysters if there is costiveness.

Sedative medicine, such as the fever-ball, should be given twice a-day; digitalis, calomel, and tartarised antimony, each half a drachm, with three drachms of nitre, is a good formula. Mr. Percivall prefers white hellebore to the digitalis; it is more active, but requires greater vigilance in the attendant.

Counter-irritation by means of setons or rowels in the brisket, or the liquid blister rubbed on the tliroat down the course of the windpipe, when the first acute symptoms have abated, are often attended with good effects. Mashes, gruel, and green-meat should form the food of the horse, but even these in stinted quantities.

\section{PLEURITIS (PLEURISY).}

It was formerly the practice to mix up this disorder with pneumonia or inflammation of the lung: but, although in complicated cases the two are co-existent, yet in most pleuritis is marked and distinct, and examination after death shows that the substance of the lung itself is not involved. The pain of the inflammation of the fine smooth glistening membrane which invests the lungs is intense, every breath drawn or expired by the poor animal causing the irritated surfaces to crepitate in moving upon each other.

Symptons. - The suffering of the animal is indicated by a constant pawing of the fore-foot and a looking round, slightly showing his teeth. The nostrils are dilated, as in pneumonia, to assist the difficult respiration, but their membranes are not much discoloured. Pain, on pressure of the sides, is intense; but the pulse is hard, full, and but slightly accelerated, until suffering has weakened the system. If the symptoms do not become aggravated by the fifth day, a recovery may be expected. If, on the contrary, a thin, wiry, and rapid pulse, with sweats and restlessness come on, hydrothorax (or death) is at hand. Mr. Field thus enumerates the distinctive symptoms of pleurisy from pneumonia. "In the former the pulse is hard and febrile, in the latter, oppressed; the peculiar saw-like respiration in the one, the difficult and convulsive breathing in the other; the absence of intense redness of eyelids and nostrils in pleurisy, and its presence in pneumonia ; the extreme pain of pressure in the former, and the comparative insensibility in the other; the coldness of the extremities in pneumonia, the variable temperature of those parts in the other. The frequent lying down and getting up in pleurisy, and the obstinate standing up in pneumonia." The food should be mashes, and no corn.

Treatnent.-Mr. Field recommends the immediate abstraction of ten to twenty pounds of blood. A small dose of aloes (linseed oil is preferable), sedatives as prescribed in the last article, seton or rowel in brisket, and blisters on chest and sides. Mild diuretics when hydrothorax is feared.

\section{PNEUMONIA (INFLAMMATION OF THE LUNGS)}

When we consider how totally we have removed the horse from a life of nature to one of art, in which the lungs, more vascular than any other organs, are subjected in an extraordinary degree to the extremes of exertion and temperature, we cannot be surprised that they should in a great measure become the seat of acute inflammation.

The causes may be looked for in constitutional plethora, occasioned by high feeding, hot clothing, stabling with high temperatures, and accelerated exercise; all which render the lungs more susceptible to congestion, and less able to resist the effects of it. Among the various causes, alternations between heat and cold are probably the most common; and we have the more reason to believe that it is the alternations themselves which provoke the disorder, as we find that horses bear the extremes of both heat and cold, in different countries, with seeming impunity. Heat suddenly applied may be supposed to heighten the circulation generally, and produce congestion immediately within the lungs. Cold suddenly applied may act instantly also by driving the blood from the skin to the deeper-seated organs. A very fertile source of it is inordinate exercise, as regards quickness of progression, which wears out the vital activity of the lungs; thus pneumonia frequently follows severe runs in hunting. Cold, moist spring seasons are often marked with pneumonic attacks, which rage in an epidemic form.

Symptoms.-This disease sometimes attacks the horse suddenly, and be exhibits, with one or two shivering fits, 
the excited breathing which is symptomatic of the complaint ; at others, it steals on, almost unobserved for two or three days ; but whether the approach be sudden or retarded, the general functions are disturbed. One that first shows itself is the unequal distribution of heat; the legs and ears being much colder than the other parts of the body. The coat stares; the horse loses his appetite; is evidently uneasy, and occasionally looks gently round towards his ribs. In the early stages, the nasal linings look paler than usual; but as it advances they become of a leaden hue; and although the general surface of the trunk may vary in its temperature, the extremities, as the legs, ears, and tail, and sometimes the muzzle, are found uniformly cold. Cough is by no means a pathognomonic symptom; many cases are without it; but when it does exist, it is at first short, dry, and frequent, and becomes eventually heavy, thick, and painful; occasionally some mucus with bloody striæ is thrown up in coughing, particularly when the bronchi, articipate in the affection. The respiration becomes disturbed as soon as the disease is formed; the first febrile attack will hurry it, but, the severity of that over, it becomes simply laboured. The local inflammation having pervaded the substance of the lungs, thickened the lining membrane of the tubes, and lessened the calibre of the air cells, respiration now becomes permanently quickened The flanks are found to heave, and the breathing is carried on with labour and irregularity; the inspirations being delayed to retard the pain produced by the distention of the chest, while the expirations are more hurried to relieve it from distress. The cavity is, however, no sooner emptied, than a new source of distress, in the stagnant condition of the heart, forces the horse to renew the breathing. The state of the pulse is variable in this disease, according as the lungs or the pleura bear the greatest share in the complaint. It is, however, almost always quickeued, sometimes to 100 even, from the irritated state of the arterial system; it is also in most well-marked cases small and oppressed, the pulmonary congestion preventing the free passage of blood through the lungs. We have occasionally found it moderately full and bounding, dependent probably on the membrane being more diseased than the substance of the lungs. The horse is now seen to look more anxiously round to his sides; the whole body also seems stiff and sore. Partially elevating the head occasions great pain, and he is altogether disinclined to move; on the contrary, he stands fixed with his head extended forwards, his nostrils outstretched, his fore legs somewhat apart but forward, and he seldom if ever lies down, or if he does he rises again quickly. The chest, if tapped with the hand, emits a dead sound; while the ear, applied to the side of the chest, will detect a dull but more urgent murmuring. As the complaint increases, the pulse becomes still more oppressed and irregular, so as to present, at the region of the heart, nothing but the faintest flutter; the legs, ears, and muzzle feel still more intensely cold, although partial sweats may visit the carcass. The nostrils change to a still more livid bue, and the air they expire is chill. The mouth now becomes cold and pale; convulsive twitchings affect the breast, neck, and face; the teeth grate; and death ensues earlier or later, as the disease has been more or less rapid ; occurring sometimes as early as the second or third day, but more often between the third and seventh, being also sometimes prolonged to the fourteenth or fifteenth.

The terminations of pneumonia are more varied than in most other complaints. Resolution is that most to be desired; in which the symptoms gradually subside, either spontaneously, or aided by the curative treatment. Congestion is the termination to be dreaded; which sometimes suffocates the patient on the fourth or fifth day, by filling up the air cells with thickened blood. In the epidemic pneumonia, where a considerable degree of malignance is occasionally present, instead of hlood, the air cells often become choked with serum.

Gangrene is not a frequent termination of true pneumonia. The irritation or the congestion usually destroys the animal before the tissues are completely broken up. Suppuration sometimes follows pneumonia; in which case there is a deceitful remission of the symptoms, but not so great as in hydrothorax. It is further marked by an irritating cough, a purulent discharge from the nose, with a hard, hurried, and an irregular pulse. In these cases a speedy termination follows by suffocation, or a more protracted one, in which the animal dies emaciated. Hepatization (Gr. hepar, the liver), or degeneration into a liverlike substance, is also not an uncommon termination; in which the substance of the lungs becomes so blocked up and solidified as to make them, contrary to the usual state, sink in water. When the condensation is only partial, the affections called thick wind and broken wind are the consequence; or an increased irritability of the lungs themselves, or of the mucous membranes of the bronchii and trachea, may be left, which subjects the horse to a longcontinued or permanent cough. It is also the parent of tubercles, which end in phthisis or glanders.

On the subject of symptoms, it remains to guard aganst mistaking pneumonia or inflammation of the lungs for such other affections as it may be confounded with; as with influenza, bronchitis, or other diseases of the mucous membranes. In influenza, the extremities do not continue invariably cold; the distress of countenance is not so great; sore throat is commonly present; the breathing, thongh quickened is less laborious, and the pulse seldom oppressed. The cough in influenza is generally deep, sonorous, and very painful : a weakness, not corresponding with the violence of the symptoms, is very early seen in influenza; and though the lining of the nostrils may be inflamed in influenza, it is seldom so much so as to present a purple hue. The principal necessity which exists for making a careful distinction between the two diseases, arises from its not being found 
prudent to push the treatment so far in influenza as in pneumonia; for if the two slould be confounded, and the milder be treated as the severer case ought to be, then it is a thousand to one but disease of the chest supervenes, hydrothorax sets in, and brings the mistaken disorder to a termination. Inflammation of the lungs has also been mistaken for CoLIc, from the horse sometimes expressing considerable uneasiness, and often looking round to his sides; but in colic the horse evinces acute pain, by kicking at his belly with his hinder legs. By turns, he lies down and rolls, and then suddenly rises, appearing quite well for a certain space, during which he will fall to eating; while, on the contrary, in pneumonia, he never lies down, but stands stupidly quiet; except now and then, when he may look at his ribs, but without any of the impatient indications of pain, or intervals of perfect ease. It may also be added, that in inflammation of the lungs the pulse announces danger from the beginning, while in colic it is, at the commencement, of a healthy character.

The Treatment must be prompt. The old practice was to extract blood immediately upon entering the stable. The first blood-letting was to the amount of two gallons at least, the second of one gallon, and two, or even more, subsequent withdrawals of half or three-quarters of a gallon each; thus, at all events, four gallons of blood, or more, were taken away. A full-sized horse has but eight gallons of blood in his body, and one moderately fat has not that amount. Here, however, the veterinary surgeon withdraws half the blood from the poor horse's body, under the impression that the animal's disease announced it had too much of that fluid, to regulate the quantity of which is the care of the whole system. After this, he used to look upon the subsequent signs of excessive debility as natural results.

The antiquated notion about a horse having too much blood, is now exploded; many excellent practitioners do not bleed at all; but if you resolve to take any, watch the animal ; never mind the pulse at this time; and at the first sign of change, though it be ever so slight, pin up the vein, and on no account repeat the experiment.

Blaine's practice in pneumonia cannot, we think, be bettered; we therefore extract it in his own words:- "The next point to be considered is counter-irritation, and most practitioners blister both the sides largely, choosing for their agent cantharides, which is uncertain and slow in its action. One of the signs of improvement in inflammation of the lungs, is the animal lying down, which during health it always does upon its sides. The rendering of these parts sore seems to be opposing an obstacle to the animal resuming the recumbent attitude. The better plan would be to reject cantharides, and spare the sides. A more active vesicatory, and a safer place for its action, can be found. We proceed to bave the hair clipped from off the entire length of the back; then we take liquor ammonia, diluted with four times its amount of cold water, and with this we thoroughly saturate the place from which the hair has been cut. We next cover the part with cloths sereral times folded, to prevent the ammonia from evaporating. This needs to be watched, but will often raise a blister in ten minutes, whereas, cantharides rarely has any effect before the next day. The ammonia is likewise more certain than the Spanish fly, and is altogether to he preferred, as in inflammation of the lungs in the horse there is no time to be lost before remedial measures are adopted. While this is doing, we procure four men if possible, and place one at each leg, to rub the part with their hands as hard and as long as they can. Four thick woollen bandages are then produced, and one wound gently, not tightly, round each leg. A hood is then put upon the animal's head, but the whole of the body left uncovered.

"The next thing is to procure a cool loose box, not a cold one, but a cool loose box, and to have the horse gently led into it; and then to look about and observe that no draughts blow directly upon his body; this being ascertained, provided the weather be favourable, the door and windows may be left open throughout the day.

"All this accomplished, order the following drink to be prepared and administered :-

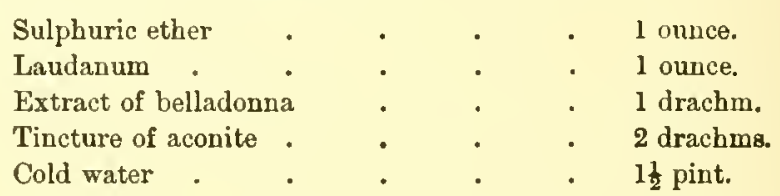

"Rub down the belladonna in a little of the water. Then mix with the other ingredients. The aconite (wolfsbane) should be of the strength of a drachm to an ounce. If stronger or weaker, make the due allowance, so as to have but the virtue of the fourth of a drachm in the drink.

"Should the foregoing bo rejected, either of the following may be employed :-

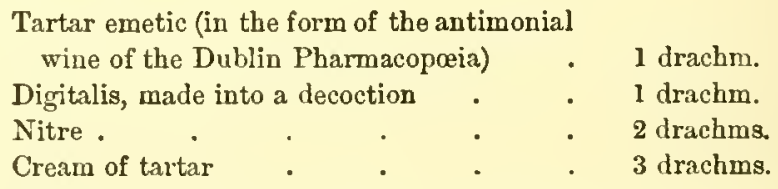

"Mingle with a pint of warm water and give; or the annexed may be tried :-

Powdered white hellebore . . . 10 grains.

Powdered ipecacuanha . . . $\frac{1}{2}$ drachm.

"Make the last prescription into a drink, with half a pint of thick gruel. Either of the above drinks is to be given four times daily at the commencement, and to be gradually lessened as the disease abates.

"Great caution is required, in giving a horse with inflammation of the lungs anything in the shape of a drink. Time and patience accomplish wonders. Lower the horse's head the moment it begins to cough. This last direction is most important, and should not be neglected, or the horse may fall dead from the fluid having fallen upon the lungs, which the examination after death is certain to 
disclose. The best plan is to proceed with firmness and yet gentleness, dividing the drink into four portions if necessary, and allowing the animal to take its time over each.

"All food should be removed. No trouble should be expressed because the horse does not eat. The animal, with inflammation of the lungs, generally has no disposition to feed, or if the inclination remain it should not be gratified. Starvation is one of the most active means of cure, and one of the surest agents in cutting short the complaint. The horse will lose more flesh in one day from the wasting effects of the disorder, than he can in seven days from actual abstinence. Warm mashes, not hot, however, may be placed in the manger, because in inflammation of the lungs it is dangerous to give any physic, lest the bowels sympathize, and the animal perish. Two ounces of Epsom salts may be dissolved in every pail of water, which should be repeatedly changed, and placed continually before the horse. Enemas of simple soap and water, in conjunction with backraking, may also be tried, in order to excite the bowels into action.

"If debility should appear, tartar emetic should be withheld. If, in spite of this, the weakness increase, the horse may have linseed tea made thick placed before it, with two quarts of stout per day. The aconite, likewise, should be withdrawn, and attention paid to the legs, rubbing them whenever they are cold. In extreme cases, brandy and ammonia are admissible.

"When the disease abates, which it generally does in forty-eight hours, the care must not lossen; for the attack is likely to recur, or remain in a chronic stage as thick or broken wind, or even to degenerate into glanders. It is apt to involve other structures in its progress, as the pleurx, when the symptoms will be somewhat confused, being between pleurisy and pneumonia. In such a case, the terminations may be either those of inflammation of the lungs, or of the pleura.

"It is a bad sign when the flanks heave, and the horse's head is put out of the window; and a much worse one when the head is withdrawn and the eye becomes amaurotic. When the animal keeps walking round and round his box; and breaking into partial swea $\mathrm{s}$, sometimes raises its head and neighs, proving he is delirious, and in imagination answering the call of his species. In this last case be certain that deatl is not far off"

\section{hYDROTHORAX (WATER IN THE CHEST).}

T'nis is a result of pleurisy-or pleuro-pneumonia as the double disease of both pleura and lungs is called-it is generally fatal. The only chance is by the operation called "tapping," which is effected by introducing a trocar (a cutting instrument with a canula four inches in length and a quarter of an inch in diameter), when the fluid contained in the cavity punctured escapes. Percivall* recommends

* See Hippopathology, vol. ii., pp. 112, 122, where operations and zuccessful cases are detailed. aloes, calomel, digitalis, and tartarised antimony to be per sisted in; and after the tapping the following :-

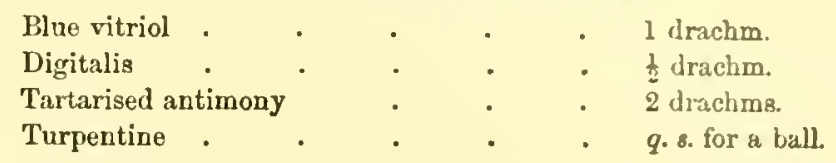

Mayhew, who gives drawings of the trocar and its stylet, with the operation of drawing off the fluid, advises, after the process, carcfully boiled oats and beans, and the following night and morning.

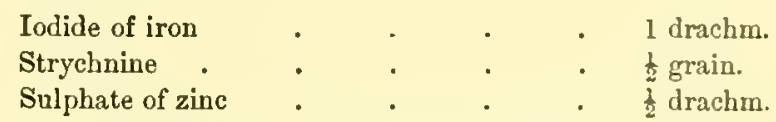

Extract of gentian and quassia (powdered) sufficient to mix the ball.

\section{CATARRH, COUGH, COMNON COLD, SORE-THROAT.}

Common cold is an inflammation of the mucous membrane lining the nostrils and throat. It may attack the neigh. bouring parts, or be confined to one only; it may be so slight as to ask no treatment, or become so severe as to threaten suffocation. We have already noticed influenza or catarrhal fever. In the simple attack on the Schneiderian mombrane, which shows itself by a thin watery secretion from the nose, or perhaps the eyes, wc have the first symptoms of common cold. In a few days the lymphatic glands become inflamed, swelled, and tender, and symptomatic fever is present, and the tendency of mucous membrane to form pus without ulceration begins to shew itself. Some cough is not unusually present. The discharge thickens, then ceases, and the horse is over the attack.

The Treatment is very simple. Extra clothing, \&c., warmer dwelling, with a mild purgative ball, bran mashes with nitre (six drachms); a drink of linseed meal or tea, with an ounce of ipecacuanha wine mixed in, should the cough be annoying, will suffice. If there be much fever (A) or (C) Febrifuges, $p$ 235. When the discharge is considerable, infuse bran or hay in boiling water, and steam the horse's nostrils with a suspended nosebag. Read's patent Vapour Inhaler is a most convenient and effective apparatus where a vailable.

Professor Spooner recommends sulphate of iron, two drachms; ginger, one drachm; and gentian, two drachms ; in treacle, as a tonic ball, once a day, when the discharge from the nose in catarrh seems obstinate.

In Sore-throat, where the region of the gullet and fauces is hot, and the salivary glands swollen and tender, a good addition to the practice is a blister or mustard poultice to the throat, with a fever ball, containing half a drachm of tartar emetic and a drachm of nitre, night and morning. Purgatives to be omitted, the food scalded, and the water chilled. 
CHRONIC DISEASES OF THE AIR PASSAGES :-ROARING, CHRONIC COOGH, THICK WIND, BROKEN WIND.

The artificial life of the domesticated horse occasions numerous diseases and changes of structure in his respiratory organs. Not only do the great lobes of the lungs suffer, but the passages to them are altered in dimension, and more or less obstructed, so that the sound produced by the passage of air is modulated, and "wheezing," "whistling," "roaring," \&c., become familiar terms among horsemen. Thus, a horse "wheezes" when any obstruction exists in the nostrils; "whistles" when the obstruction is situated farther back, and near the opening to the larynx; and "roars" when the larynx is malformed, or the hindrance to the passage of air lies within the windpipe.

ROARING.-The causes of roaring are of two classes, acute and chronic. The acute are from obstructions accidentally formed, as cicatrices from wounds or injury, foreign substances lodged in the windpipe, extravasation of fluid or coagulable lymph, which, once organised, forms a permanent obstruction: when this extends up to the glottis, it produces whistling. Whoever has handled the throats of many old horses must have observed a hardened state of the larynx, which almost resisted all attempts to what is termed "cough them." This ossification is not an uncommon cause; and a similar state in the cartilages of the trachea is productive of it also. A cause, also, of roaring is a band of lymph stretched across the tracheal tube; at others, an internal ring of the same matter simply diminishes its diameter. The obstruction is sometimes so considerable as to excite the sound upon the slightest exertion; in general cases, however, roaring is only exerted when forcible inspirations and expirations are made. Mechanical obstructions to free respiration may eventually be productive of roaring: the custom of tightly reining in our carriagehorses, especially such as run in pairs or double harness, there is reason to think, produces it ; the practice of using tight throat-lashes or neck-straps may likewise induce it. In furtherance of which last opinion it may be recollected that horsemen have a very general supposition that cribbiting ends in roaring, in thick wind, or in broken wind. May not the tight collar, strapped around the throat, here tend to the former of these affections? The custom of "coughing" horses, and so frequently as it is practised in fairs, may be readily supposed as a cause. A horse passes from fair to fair, having his unfortunate throat brutally pinched thirty or forty times each day. Is it to be wondered at if inflammation takes place, and adhesive deposit follow?

Treatnent. This must be regulated by circumstances. When it is acute, and depends upon the diseased state of neighbouring parts, the inflammation of those parts must be relieved. When it can be discovered to be the consequence of recent inflammation of the laryngeal or tracheal cartilages, a physic ball may be given, and the seat of the disease blistered, while, from day to day, some sedative medicine is administered. In every case of roaring, however, excepting the acute, the cure depends quite as much upon chance as upon skill.

Chronic Codgh.-Coughing is a spasmodic effort of the diaphragm, intercostal, and abdominal muscles, produiing a forcible expulsion of the air from the chest with such violence as is calculated to remove any extraneous body that may intercept the free passage of the air. Whenever it accompanies a general affection of the constitution, it is regarded as simply "symptomatic," and the original disease is attended to for its removal. Thus catarrh is accompanied by a cough, but we attend principally to the general affection, as the best means of subduing it. A "chronic cough" is often symptomatic of some affection of the airpassages; it is also an attendant upon the state called broken wind. It likewise accompanies glanders; and appears when worms are in the stomach and bowels. But besides these cases, there exist at times, without any attendant difficulty of breathing (the horse at the same time eating well and thriving), a permanent cough, usually more considerakle in the morning and evening, after meals, particularly after drinking, or on first going out to exercise; and it will remain in this state, without otherwise affecting the horse, for years; sometimes it will even be continued with no obvious injury for his whole life.

The Treatment of "chronic cough" must depend on our view of its causes and consequences. When it appears to arise from a want of mucous secretion, give expectorants which excite such secretion (A) or (C) ExpEctorants, p. $23 \overline{5}$. When a redundancy of the mucous secretion is apparent, tonics are required. See Tonics and Stmolants in List. When the secretion is acrid, try a Demolcent, p. 232. The cough, which is the effect of an irritable state of the parts, is sometimes relieved by stimulating the throat externally, and by giving internally opium with bitter tonics.

When worms in any large numbers are present in the stomach, or intestines, a continued cough generally exists, with irregular appetite and unthrifty coat, stools fetid and slimy, at one time loose and at another hard and dry; for whicl turn to the head under which those parasites are specially treated of. In all chronic coughs the best effects sometimes follow from feeding with carrots. Turnips, parsneps, beet, and potatoes, may be beneficially used where carrots cannot be got; and a mash with bran and linseed, or malt, may be occasionally given. Try the following every morning, made into a ball with honey :-

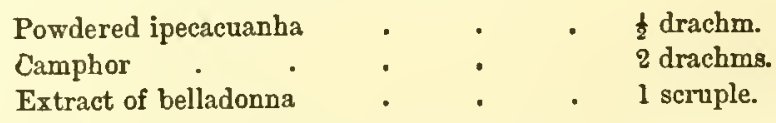

Thicr WIND.-This is also a consequence of either acute or chronic pulmonary inflammation. In some instances, it is the immediate consequence of violent or long-continued exercise, and particularly if the exercise be taken upon a distended stomach and bowels, or after full drinking; or it 
may be brought on by the application of cold. It is often connected with a plethoric state, and is therefore very common among pampered animals and gross feeders; and more particularly in low-bred and thick-set horses. The postmortem examinations of such cases exhibit, in some instances, a slight hepatization of lung, the consequence of repeated congestions; in others, the minute bronchial cells are filled with adhesive matter, or the general substance may be pervaded with minute granulations of a bluish colour.

The Srmptous of thick wind are sufficiently known to any one at all conversant with horses. The capacity of the aircells being diminished, renders it necessary for the air to be more frequently taken in, because, being acted on by a less surface, the blood is not thoroughly oxygenated; and a sufficient number of air-cells not being expanded, the animal makes hasty inspirations to remedy the default. The force with which these are effected occasions the sound so well known as the distinguishing mark of thick wind. In this affection, the obstruction to both being equal, the inspirations and expirations are alike, which serves to distinguish it from broken wind. Thick is however very apt to degenerate into broken wind.

The Treatment of thick wind can seldom be more than palliative, for, once established, it remains permanent. The remedial means are more in the hands of the proprietor than of the surgeon. The food must be moderate in quantity, and of such a kind as will occupy the least possible space. No hay should be allowed; and as thick-winded horses are gross feeders, the muzzle ought to be put on as soon as the manger has been emptied.

BROKen WIND.-This peculiar affection has long excited the attention of veterinarians. The older writers indulged in the most extravagant notions respecting it. On the Continent it has occupied, in later times, the research of many eminent veterinarians, but with little satisfactory issue. It has been attributed to external and internal causes; to a defect, and to a superabundance, of vital energy ; to altered structure of the heart, of the lungs, of the diaphragm, the stomach, the liver, \&c. It is injury with some, nervousness with others, and simple distension with a third. Among our own writers the discrepancy is equally great: Gibson attributed it to an enlargement of the pulmonary mass generally; Dr. Lower to a rupture of the phrenic nerve; but in later times it has been mostly attributed to struc-aral change.

The cause of broken wind is hereditary or constitutiunal predisposition. A certain form of body is unquestionably favourable to its production, and it is from this circumstance that it proves hereditary. The narrow confined chest, and the pendent belly, which mark low-bred horses and gross feeders, predispose towards the affection. It may be the subjecting horses to a long-continued unhealthy course of feeding on dry food, as chaff, bran, barley meal, \&c. \&c. that brings it on; as also working in mills, where much dust is necessarily inhaled. It is seldom o o the immediate consequence of pneumonia; but frequently it results from those states of disordered respiration which succeed to it, as thick wind, chronic cough, \&c. We are much in the dark about its origin: we see that it gradually steals on a horse, occupying months, and even years, with a slight occasional cough, which, ripening into a state of impeded respiration, at last ends in broken wind. We see it also follow one hard gallop; and we may leave a horse well one day and find him broken-winded the next.

It is not by any means uncommon to meet with brokenwinded horses whose lungs after death are neither emphy. sematous or otherwise structurally deranged; and which, with the exception of their lighter colour, and greater bulk than natural, cannot well be distinguished from the sound lung, although they crepitate or crackle when pressed by the hand. It appears likely that rupture of the air-cells is the cause of broken wind, because it is not always sudden, but gives some years of a warning cough, or of thick-winded wheeze.

There is another view of the cause of this disease, namely, that it depends upon derangement of the digestive canal; and if the irritability of the larynx favours the opinion advanced with respect to the lungs, the constant passing of wind supports the other conjecture. Horses with broken wind will eat almost anything, which again is opposed to the conclusion that the lungs are the sole seat of the disorder. The belly is enlarged, the stomach distendec, and its coats much thinned, which last-named facts would seem to decide the question. But the truth is, broken wind appears to be a universal derangement, and it is not one structure that suffers, but the entire body undergoes more or less alteration.

Sympтомs.-These are well marked: the cough anu the manner of respiration may be considered as conclusive. The sound emitted by the cough is peculiar, and is often forced out with a kind of grunt, in a short but vibrating feeble tone compared with the usual cough of sound-winded horses. The respiration is conducted with a remarkable difference between the inspirations and expirations. Inspiration is effected quickly; and the lengthened laborious strain of expiration, is performed by two distinct efforts, in one of which the usual muscles operate, in the other the abdominal muscles come into violent action, to complete the expulsion; after which the flanks fall with peculiar force, and the air is again inspired as by a spasm. An auxiliary symptom is the peculiar flatulence of every broken-winded horse; this is strikingly characteristic of the disordered state of digestion common in these cases, and of the constant thirst which is invariably present.

The Treatunent of broken wind can seldom be more than palliative. Whatever increases the distension of the stomach and bowels aggravates the complaint, by increasing the diffculty of expanding the lungs. Therefore, avoid stimulants, and promote regular evacuations; abstain from over-distension of the lungs by too violent and too sudden exer. 
discharge from the nostrils, of a yellowish colour, and unaccompanied by disagreeable odour: it is also in most cases slightly purulent. There is, besides, a discharge of slimy stringy fluid from the mouth. The membrane which lines the nose is red. It will be found that considerable swelling has taken place under the jaws, accompanied by fever; which is distinguished by want of appetite, a quick pulse, a hot mouth, and a general wcakness of the whole frame, producing a dejected appearance. There is likewise a quick motion of the flanks, and coldness in the ears and limbs. The swelling is in the form of a tumour between the jaws, increasing with various degrees of rapidity, occupying nearly the entire space, and giving pain to the horse when eating; who also manifests a great disinclination to feed. This is accompanied by thirst, but the swelling prevents him from indulging in water; and having swallowed a moutliful or two, he desists. After which, and even after eating, he is frequently seized with a spasmodic cough, with suffocating symptoms. The swelling is one uniform body, and consequently differs from the enlargement of the glands in catarrh and glanders.

Treatment.-As the visible complaint consists in the swelling between the jaws, the first thing to be attended to is, to bring the tumour to suppuration. A sharp blister is the first thing to be applied. This, administered in time, will facilitate the discharge a week or two earlier than it would have taken place if allowed to come to a period naturally It will also have a tendency to draw out the inflammacion from the mucous membrane of the throat, and consequently ameliorate the cough. The following stimulating ointment may be applied with advantage after the removal of the blister :-

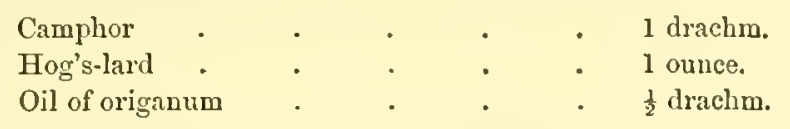

Shortly after having been anointed with the above, a large hot poultice may be applied, and both repeated twice a-day until the tumour is full of matter and is quite soft. It frequently breaks of its own accord; but it is better that it should be laid open with a lancet, from the bottom upwards. The matter must be well squeezed out, and the lips of the ilcisiun izept open with a piece of lint for several days, until the matter is completely discharged; otherwise, a second tumour may be formed, which frequently proves difficult of cure. After the matter is dislodged, a small quantity of Eriar's balsam should be injected into the cavity of the tumour daily. It will be found rnat where tumours break spontaneously, the lips of the wound, from having uneven edges, will be more difficult to cure.

Should the neighbouring glands show signs of induration, sub them with an ointment of hydriodate of potass daily.
At this stage of the complaint, if there is no unusual degree of fever, a gentle laxative and a tonic to follow may be administered. Cooling medicines will be beneficial should there be fever. If there is no fever, the animal will soon manifest a desire to eat. His food shouid principally be oatmeal gruel and bran mashes, with a supply of grcen meat, consisting of cut grass, or tares. Should these not keep the bowels sufficiently open-which is of great im. portance in diseases of this kind-then a laxative must be given. This will have the effect of preventing eruptions, which sometimes follow the strangles; and nothing more will be required, if it operates freely.

If, however, the complaint is followed by wealiness, it will be necessary to have recourse to tonic medicine, which should be repeated daily until the borse recovers strength.

In bad cases of strangles the parotid gland will swell to a great size, and even become ulcerated; and in other instances an accumulation of fluid will take place, and burst into the cavity of the mouth, being discharged through the nostrils. The Eustachian tubes, tuo, have been found full of pus. In some cases the tumefaction has been so great as to call for Broxcuorom (see Operatioxs), which is explained elsewhere, and delineated in Plate XIV., Fig. 5.

Strangles seems incidental to almost every horse; and as it is a complaint which is often of long continuance, foreign veterinary surgeons conceived the idea of inoculating to produce a milder degree of the disease. This they performed either with part of the discharge from the nostrils, or with matter from the tumour. In many cases this has had a beneficial result, the disease being both shorter in its duration and milder in its effects.

\section{DISEASES OF THE DIAPIIRAGM.}

The s reat muscle which divides the chest from the abdo. men, or the organs of respiration and heart from those of digestion and secretion, is liable to two lesions, spasm and rupture.

Spasm of the Diaphragm is marked by a loud thumping noise, audible some yards from the sufferer. The pulse felt at the chest is feeble and rapid, and but scarcely perceivable at the jaws. The lreathing is quick and laborious, and the animal shivers distressingly. Over exertion on a full stomach is often the cause. Bleeding, aperient medicines, and then a sedative, are the active treatment called for.

Rupture of the Diaphragm, induced by the same causes as spasm, is, it extensive, fatal. If slightly ruptured, the horse has been known to live with symptoms of broken wind. Extra exertion will be at once fatal, as the viscera would come through the fissure and become strangulated. There is no treatment for ruptured diaphragm. 


\section{CHAPTER XXVII.}

DISEASES OF THE HEART, PERICARDIUM, AND BLOOD-VESSEL8.

\section{GENERAL OBSERVATICNS.}

AIR, food, and exercise in good quality, and proper quantity we the first requirements for good blood; with these, the production of the fluid which builds up every structure of the body-bone, sinew, and muscle-would remain in due proporcion and quality, and disease (if nature did not scorn to be bound by our limited logic) would be unknown. The cunstituents of the blood are given already at Page 350, to which the reader is referred. The organic functions of the other viscera may be summed up in two words, AssiMiLATION, and sEcretion. That of the blood, the product of assimilation, is to build up and renovate. Every part of the living animal is constantly running into decay from use, and requiring renovation; a process which begins with birth and ends with death. The air and food, then, as we said in the first instance, form the blood, the residue of unassimilated matter being expelled as fœces. The blood thus supplied would soon over-nourish the system, and occasion what is called plethora, but this again has its escape in the excretories which throw off its useless or redundant portions.

The blood is the medium through which all this is accomplished; but we shall here merely look upon it in connection with the organs which mechanically distribute it, its vitiation embracing the whole range of diseases.

Until the application of the stethescope, and the general practice of auscultation, disonse of the heart was, as a rule, unrecognised by the veterinarian, and consequentl! treatment adopted for other and often non-existent disorders. So far as the heart itself was concerned, this was, perhaps, of the less importance, as heart-disease in the horse may be considered an organic and incurable defect. To form a correct judgment, however, of the true seat of a disease, is of the very highest consequence; and a study and practice of auscultation is of the greatest use to this end. In the horse, the practised ear will readily discriminate between the natural beat of the heart and that accompanying diseasc. A reference to Circulation and Respiration, Chapter IV., in Structure and AxAтомr, pp. $204-2 n 8$, will show the mechanical action of the heart and pulsation. These movements in a state of health must first be well understood, especially as to the strength of the shock or beat, and to the time (or ryth $m$ ) of its recurrence. We must also examine the animal when he is in a state of quietude and has not bee exciting limself, and fake care that he is not alarmed at ou presence or proceedings, all of which any observer can quickly judge of.

Of course, we must expect a fat or a thick-made horse to give less sound than a lean one, with thin walls or parietes to his chest. In lean and narrow-chested horses, too, the heart may be listened to on the right as well as the left side, while in round fat ones it will be only well audible on the left and over a smaller extent just opposite the heart. Violent exercise, or fear, will often cause palpitation, or such violent beats as may be heard, not only in the region of the chest, but in the abdomen and other parts of the body. By hypertrophy, or enlargement of the substance of the heart, the impulse to the touch is increased, but the sound diminished; by simple dilatation, or increase of the size without thickening of its walls, weakness and diminution of impulse is produced; and lastly, when increase of its substance and dilatation of its cavities takes place, the violence of the dead abrupt blows strongly repels the hand.

The diseases of the heart divide themselves into three classes, - those affecting the substance of the heart; those of the surrounding membrane (pericardium); those of the lining membrane, and of the valves and coats of the great blood-vessels.

\section{INFLANMAIION OF THE HEART (CARDITIS).}

French writers treat upon this disorder in the routine style, describing its symptoms, causes, and treatment; but as it is clearly pe icarditis they describe, further reference need not be made to them The signs of heart-disease should, however, be known, as the animal so afflicted is a very risky investmeıt. "He may appear pleasing and even skittish," says Maghew, "yet his existence shall at any movement be cut short." Auscultation is the surest means of detection. The visible signs, however, are sometimes sufficiently emphatic to admit of no doubt. The eye is expressive of anguish; the countenance is haggard; the pulse irregular; the throbs of the heart visible; and occasionally as visible on the right side as on the left. The carotid artery can be seen to pulsate in the neck. The regurgitation within the jugular vein is nearly always excessive-it often reaches almost to the jaw. It takes place by jerks, which ascend higher and higher, each becoming smaller and weaker as it mounts upward. The apnetite is sometimes ravenous, but 
more often it is fastidious. The breathing is not accelerated in any marked degree, which distinguishes heart disease from many other disorders. The animal suddenly stops, trembles, and appears about to fall; but, often as suddenly recovers and proceeds upon the journey. Sometimes the horse will refuse to move, and is always very unwilling to turn in the stall. Occasionally he will open his mouth as if yawning, and then heave a long-drawn sigh. No peculiar symptom, however, can be specified as heralding the final attack. Death is always at hand, and comes without any special warning. Worse than all, it is most imminent when the horse is going at speed.

\section{INFLAMMATION OF THE PERICARDIUM (PERICARDITIS).}

This is the disorder usually known as inflammation of the heart. The membranous envelope of the heart is by no means unfrequently the seat of inflammation. In opening horses that die of pleuritic disease, nothing is more common than to find effusions of lymph and water within the pericardiac cavity, as though the one membrane had morbidly sympathised with the other.

Mr. Pritchard, veterinary surgeon, of Wolverhampton, has communicated to "The Veterinarian" some interesting cases of heart-disease, whence we may gather much information. The effused lymph is mostly disposed in layers upon the internal surface of the sac, and upon the exterior of the heart, giving additional substance to the one, and often a complete coating to the other, and, in some instances, forming adhesions between the two. In this manner, the pericardium may be increased in thickness to an enormous extent. The lymph assumes the same albuminous character as it does in the chest, and on being cut into, while recent, displays a honey-comb sort of texture, having its interstices loaded with a yellow serous fluid; in fact, putting on the same appearance, only that it is more concrete, as it does within the chest, and undergoing-should it remain - the same changes towards organization. In process of time, and when it exists as an additional lining to the pericardium, it grows close and firm, and attenuated in substance, and turns of a white colour. It has been found converted into a substance of the nature of cartilage, an eighth of an inch in thickness.

Pericarditis may assume either the acute or chronic type. It may exist as an idiopathic affection; but in most cases it will be found to be secondary-consecutive on inflammation of the pleura. That it may, at least in a chronic form, commence by itself and run its course alone, is in some measure proved by the cases of heart dropsy which every now and then present themselves unaccompanied by disease of other parts.

DROPSY OF THE HEART, (HYDROPS PERICARDII),

Is that stage of pericarditis where effusion has taken place, and the membranous sac is supposed to contain both lymph and water.
"The symptoms of this affection, apart from pleurisy and pneumonia," Mr. Pritchard informs us, "are well marked. They are, palpitation of the heart; the carotid arteries beat forcibly, and are readily recognized on applying the finger to their course in the neck. There is a good flow of blood through the jugulars, a copious return of blood through the neck, when the statc of the pulse is considered, the surface of the body and extremities is warm; and these latter symptoms continue until within one or two hours of the horse's death." "In addition to the above symptoms, there is such an expression of alarm and anxiety in the countenance of the animal as no other malady produces." "The respiration is but little disturbed."

The fluid collected in most cases resembles the serum of the blood. Sometimes it is red, from being tinged with exuded blood-at others, it is turbid from lymph floating in it-often it is sero-purulent in character, and looks like so much whey. Now and then we find pus in flakes mirgled with it. In quantity it varies considerably-from a pint to a gallon or more. The horse generally sinks from other disease, or from constitutional irritation, before the cavity is filled. Mr. P. mentions the case of a cart-horse which occurred while he was a pupil at the Veterinary College, whose deatll, without any previous ilness, took place most suddenly and unexpectedly, in whom the pericardiac sac was found distended to that degree with water, that it was inundated and choked in its action.

\section{RUPTURE OF THE HEART.}

This is more frequent than is supposed. Where it takes place, even from violent exertion, it is the result of previous enlargement, dilatation, or aneurism of the aorta. Mr. Percivall says ("Hipopathology," Vol. ii. p. 167), "During one of the racing meetings that used to be held annually at Woolwich, one of the horses, who had vehemently contested, and lost only by half a neck, a heat, suddenly fell and died just after he had passed the winning-post; I afterwards examined the body, and therein found the heart burst: I think it was the right auricle that had given waythe animal had literally died of 'a broken heart.' In my regimental predecessor's time, one of the troop-horses, intended to mount king's guard, from the same cause, dropped down dead on the parade." There are several cases of rupture of the heart in the "Veterinarian," and other works. As there is no TREATMENT to be prescribed for such fatal lesions, we will not waste space upon them. Where disease of this important organ is suspected, attention to the gencral health, and regular, moderate, and slower work than the animal has been accustomed to, may prolong life, and preserve the utility of the animal in a humbler capacity than the saddle, the ast trap, or the carriage. 


\section{ANEORISM OF THE AORTA.}

The horse is by no means so subject to this fatal disorganization as man. It is, however, met with generally as a consequence of ulceration. A number of cases are given in the French veterinary books. The horse with this "weak point" in his main blood-vessel, (or in the iliac artery, which also occurs,) is past all treatment, and may be looked on as "a dead 'un" for any serviceable purpose.

\section{infLAMED VEIN (PhLebitis).}

Inflanmation of the vein is an affection now and then met with in practice, and ordinarily a discreditable result of careless or clumsy bleeding, and the effusion of blood in the divided integuments and membranes. A dirty or rusty fleame has been known to produce it.

The natural process by which the parts wounded in letting blood are repaired, may be thus described:-As soon as the aperture in the skin is pinned up, the blood extravasated between it and the opening in the vein, into the cellular tissue, becomes coagulated, by which the latter is so completely plugged that all further escape of blood is effectually prexented. Soon afterwards, the lips of the wound in the vein take on inflammation, and adhesive matter is effused, which so perfectly restores their union, that, in the course of but a few days, it will be found to have assumed the appearance and texture of the parietes of the vein itself. In the interim, the coagulum between the skin and the vein is becoming every day less and less, until, by a process of alsorption, it is totally removed. Lastly, the new-formed membrane-that which but lately was adhesive matter-occupying the site of the puncture, in time acquires such perfect identity, as to be with difficulty distinguishable from the coats of the vein themselves.

Shoula anything occasion a fresh separation of the lips of the wound, and thereby destroy this natural adhesive process, suppuration will probably ensuc, the parts will fester, but the hair will generally become matted over the external orifice, so that, until we come to disturb it, no matter makes its appearance. At the same time the parts become tumid and hot, and tender on pressure. In fine, everything indicates the approach, or rather the presence, of internal inflammation.

Inflamed vein has also been observed to occur when the lancet has been employed by operators not long used to that instrument, which has occasioned the integumental and renous opening to be not exactly opposed to each other. Whenever, therefore, an early extravasation of blood follows bleeding, first having removed the pin, carefully press cut the effused blood with the fingers; and, if there appear no likelihood of more hæmorrhage, do not again insert the pin, but tie the horse's head up day and night. Should the swelling not be observed immediately, or when it happens that inflammation has already taken place within the cellular membrane, first treat by rest, and frequent bathing with a cold solution of muriate of ammonia and vinegar ; or apply a mild blister. If the tumour suppurate, as soon as fluctuation is felt, make a depending opening, or introduce a seton through it. We will now consider something further than the mere integumental inflammation, and come at once to the point we set out atthe inflammation of the substance of the vein itself, which is either communicated from the integuments, or originates within the vessel from the puncture, which is supposed to occasion a peculiar inflammation of the inner coat of a wounded vein.

The Srmptoms of the injury appear about the third or fourth day usually, when the lips of the cut begin to gape, and a little lymph is thrown out; the next day the edges are more cast back, as well as more red and expanded. A sanious discharge issues, or perhaps hæmorrhage occurs. The tumefied vein now feels corded, hot, and tender; and if the progress of the inflammation be not stopped, the tumefaction extends along the course of the vein. If in the jugular, it proceeds towards the head; and if it occur in any of the other veins of the body, as the saphena and piate vein, it extends towards the heart, hardening the vissel into a cord-like substance. This appears to be the consequence of the inflammatory action, by forming the contained blood of the venous trunk into a firm coagulum, and thisefore all attempts to save it afterwards fail. Suppuration of the tumour now often appears; though sometimes the punctured part itself will present little more than a spongy mass, from which a grumous liquid distils, while abscesses form in various situations around the course of the ressel. As the morbid action extends upwards, it frequently involves the whole neck, and often affects the side of the head, from which results hindrance to motion: and often some difficulty is experienced in eating and arinking. There is commonly constitutional disturbance. In some cases the symptomatic fever runs very high. The pulse has been above ninety; and the excess of irritability brought on has destroyed life.

Treatnent. - The course to be pursued will depend on the state of the disease. It is of importance to keep the horse as quiet as possible, and to restrain the neck from movement; which latter is best effected by tying up the liead, and giving liim gruel for food $T_{t}$ is a!so recommended to apply a mild blister in the course of tne tumefied vein, which seems to assist by lessening the general inflammation: this, in fact, is an indication never to ve lost sight of.

When, however, we have no hopes of saving the vein from obliteration, but, on the contrary, a disposition manifests itself to form abscesses in various situations we must proceed to more active measures The abscesses must be opened freely with a knife, or, if one appears to communicate with another, setons may be passed through the sinuses by which they are joined. The head must be tied 
ıp, and blister follow blister; another being re-applied before the action of the first has ceased. In this fashion the life will be saved, although the vein will be lost; the horse subsequently may become equal to the severest service, though immediately after the loss of a jugular he may require some care. He must not be fed from the ground, or ridden hard, for twelve months succeding his recovery. His manger ought to be elevated, and his water even lifted up, so as to prevent him from stooping his head. At first, his food ought to be such as requires little mastication, but in three months he may return gradually to hay and oats. At the termination of a year, he may feed off the ground.

A marked morbid consequence of bloodletting arises from bleeding in the plate or in the thigh vein; in which the fleame often passes through the vein into the fascia that lies between the vessel and the muscles. In these cases the fascia inflames, and a formation of pus tak ss place within it, which, as it cannot escape, insinuates itself to some depending situation : an opening should, therefore, be made to evacuate the matter, or a seton may be inserted for this purpose, and the part be repeatedly blistered; the animal being taken good care of, and not put to hard work too soon afterwards.

MIr. Percivall recommends the actual cautery. The "budding iron" "when hæmorrhage takes place, should be introduced at a red heat, to sear the interior; our oljject being twofold - to seal up the vein, and afterwards to slough the wound."

\section{PLETHORA AND AN EMIA.}

Plethora, or richness of blood, is a condition premonitory of disease; poverty of blood, also, may give rise to its production. We are now about to learn that the system may become vitiated or corrupted, and disease in that manner be engendered in it. There are various ways in which noxious matters may obtain introduction into the system, some of which are palpable and open to demonstration; while others elude our observation so far as to become apparent only through their effects. The channels through which they gain admission are, the alinentary canal, the air-passages, and the skin.

An animal may eat that which is unwholesome, mingled with his food, or he may drink water that is insalubrious; or he may, under some casual or incidental circumstance, lick in and swallow, mixed with his saliva, matter of a contaminating or morbific nature; in either of which ways he may lay the foundation of disease in his system. We know that within the alimentary canal is elaborated the chyle; that the chyle feeds the blood; and that the blood nourishes and repairs every part of the body: consequently it is natural to suppose that any hurtful or morbific matters existing within that canal, will contaminate the chyle; the chyle, the blood; and the blood, the system In this manner medicines, given internally, affect tne constitution: there are many whose presence, independently of their effects, can, a very short time after their administration, be satisfactorily attested in the blood. Madder has been mixed with the food of hogs; and some weeks afterwards, on their being killed, has been found tincturing with its scarlet dye even the inmost parts of the animal's bones. As pastures are known to liave their degrees of nutritiveness, so do they possess their salubrious and insalubrious properties, arising not only from baneful plants that may be growing among the herbage, but even from the quality of the grass itself.

Blood may exist in the animal body to a greater amount than is required for its economy, or is compatible with its lhealth; in like manner the same fluid may, under parti. cular circumstances, exist in a less aggregate quantity than is natural or salutary: these conditions are vulgarly called its richness and poorness. In fact, in the one the blood is redundant, in the other, deficient in nutritive properties. In a general way, most domesticated animals consume more food than is required, or is converted into nutriment; a circumstance that, considered in connection with the customary mode in which horses at the present day are treated, renders a case of anæmia proceeding from lack of aliment of somewhat rare occurrence. Such a condition, however, may and does occasionally proceed from torpid or defective action in the digestive, or absorbent, or assimilating powers of the system.

Anæmia may give rise to disease, either from the insuffciency of the quantity of the blood for the purposes of the animal economy, or from the thinness or poorness of its quality. It is too prevailing a practice in the regimen of the stable, to keep horses "short of water," under the impression that much fluid is injurious; a notion that probably originated in the very proper custom of giving water very sparingly at the time the animal is required to exert himself. Hunters and racers are not allowed any, or but very little indeed, on the morning of the day they are to go to work. This, however, furnishes no good reason why the animal is to be debarred from quenching his thirst after his work is performed.

The water the animal drinks may prove the vehicle for the introduction of disease. It may contain some noxious impregnation, mineral, saline, or of other nature; or, it may, from being long stagnant, have becume putrescent. Water forms an excellent vehicle for the exhibition of such medicinal substances as are almost or quite tasteless and inodorous. Mr. Percivall recommends the administering of arsenic and mercury in this mannes. It is in the recollection of all, that race-horses at Newmarket were poisoned by the treacherous introduction of arsenic into their water-troughs.

Morbid or contagious matter may likewise gain introduction into the system through the alimentary canal, though we have not much apparent reason to believe such is often the case; nor are we by any means well advised in 
regard to its probable consequences when such does, or is supposed to occur. A horse running at the nose from glanders, will drop the discharge into the unanger, and smear it upon the rack and other parts of the stable within reach of his head, from which situations the matter, become probably dry and encrusted, may subsequently be licked off by some other horse occupying the same stable. All this may, and no doubt does, occasionally happen ; considering, however, how much alive horse-owners now-a-days are to the danger of glanders, together with other circumstances of improvement, it is by no means, a common or even very likely occurrence.

Through the air-passages it is that disease finds the most ready inroad into the blood of the horse. Considering how accessible, and at the same time how susceptible these parts are, and how much they in particular suffer by the change from a state of nature to one of domestication, it becomes no matter of surprise to us that they should prove so frail a medium. The air an animal breathes is a more common vehicle of the seeds of disease than the food he consumes. Miasins, influenza, animal and malignant effluvia, all by turns pervade the atmosphere, and exert their influences on the delicate and sensitive membrane lining the air-passages; through it tainting the system, either by absorption or by direct effect on the blood itself in its course through the lungs. The natural stimulus of this membrane is pure airat least air free from any irritating property; whereas, the atmosphere of the stable is rarely free from animal exhalations, and but too often imbued with animal poison. The subject of atmospheric influences, in-doors as well as out of doors, is one on which we greatly lack information; and he will be eminently serving the cause of veterinary science who successfully embarks in its investigation.

Through the skin, densely clothed as almost every part is with hair, disease finds a difficult entry into the system. We know, however, from experience that many inedicaments rubbed into parts whose skin is thin and almost hairless, - the insides of the thighs, sheath, muzzle, \&c.,will take effect on the constitution. We therefore cannot doubt the possibility of disease being introduced in a similar manner, though we believe instances of it to be rare where there lias been no abrasion of uriace. For, so long as the cuticle remains entire, there is an evident indisposition in the absorbent pores of the skin to imbibe any morbific or noxious matters : destroy, however, the cuticular covering, and the disinclination ceases to exist. Even upon the bare membrane of the nose, glanderous matter may be applied without ill consequences; although its effect has proved certain in any part of the body by inoculation. Such is the case, likewise, with the virus of rabies. So long as the integrity of the skin remains unbroken, there is little reason to apprehend any ill consequences, even though the saliva may have been resting upon its surface.

\section{SANGUINEOUS AND SEROUS CONGESTION.}

In those parts of the body in which the serum-bearing vessels terminate,-many of them in exhalants,-through these terminations exhales a sero-albuminous fluid for the purposes of moisture and lubrication. Now it frequently happens that accumulations of this serous fluid take place, imperceptibly to us, as well as unconsciously, at least without producing any inconvenience, to the animal himself, and without any previous or existent signs of inflammation, such are called serous congestions. These cases can hardly be called inflammatory, seeing that they occur without the combination of signs mentioned before: viz. heat, redness, swelling, and pain, which all consider to mark the existence of inflammation. Indeed, often the only one among them that we can recognize is swelling, and that manifestly owing to the presence of the collected fluid. It is by no means uncommon to meet with a circumscribed tumour in some part of the body where the skin is loose; which, on being opened, proves to be a collection of serous fluid in the cellular tissue, and which has come on without any antecedent inflammatory action whatever.

In the internal cavities of the body, likewise, we occasionally find accumulations of serous fluid, without any accompanying traces of inflammation. In the cavity of the pericardium; in the ventricles of the brain; and, also, within the thorax and abdomen. In this respect there appears to be remarkable sympathy evinced between these several parts. Should a horse die from water in the chest (hydrothorax), we find water collected in his belly, and like. wise within his brain; in which two last-mentioned cavities the effusion may be regarded as the result of serous congestion.

Sanguineous and serous congestion may exist in combination. When a horse's legs fill from standing in the stable (which they do from serous infiltration into the cells of the cellular membrane), the tuinour is not the result of inflammation, but of sanguineous and serous congestion, in consequence of standing long without exercise. Blood accumulates in these parts remote from the heart; the seriferous vessels especially suffer from distension, and the easiest mode in which they can relieve themselves is to suffer the fluid to exude through their exhalant terminations. A similar disposition of parts may pervade the whole limb, as well as any cavity, organ, or part of the body, and thus give rise to that condition which goes by the general name of dropsy.

Windgalls of all denominations may be regarded rather as the effect of congestion than of any inflammatory disorder. They are formed, generally speaking, without heat, and withou causing lameness. They are, in fact, enlarged (hypertroplic, bursæ mucosæ, originating in congestion and augmented secretion, induced by the frequent or undue exertion of part. and are simply indications of over-work. 


\section{CHAPTER XXVIII.}

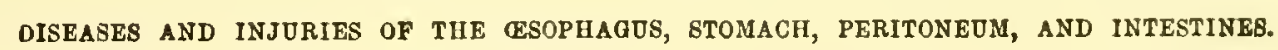

\section{\$ I. DISEASES AND INJURIES OF THE ESOPHAGUS.}

STRICTURE OF THE GSOPHAGUS.-CHOKING.-ESOPHAGOTOMY.

By stricture, in surgery, is meant the contraction of some tube or passage of the system. The three most common are those of the cesophagus, of the intestines, of the neck of the bladder, and (in the human subject only) of the urethra and vagina. There are two sorts of stricture-the spasmodic or sympathetic, and the organic or meclianical. In the first, the contractile or nervo-motory action is at fault. In the second, the lining membrane is thickened, and there is often an alteration in structure, almost or quite obstructing the passage. Sympathetic stricture is owing to other than local causes, and is noted elsewhere under Stranales, \&c., the organic or mechanical stricture will be here spoken of.

The gullet or œsophagus of the horse is a most delicate organ, yet barbarous violence is often practised on it by grooms, carters, and farriers. Its lining mucous membrane is thrown into small folds or wrinkles, marking the amount of distension intended by nature. Its outside is enveloped by a large mass of cellular tissue, to ensure its independence of motion; unembarrassed by the surrounding parts. Its channel is small, but large and strong enough for an animal which masticates a long time before it attempts to swallow, and to which nature has forbidden the power to vomit. Yet, when some foreign substance, ignorantly or accidentally administered, becomes impacted in this delicately-organised structure, the butt end of a carter's whip is employed to drive the obstructing substance onward. In the words of Mayhew', "Should the obstruction be situated low down the gullet, the whip handle is neither small enough nor pliable enough to reach the offending object. Should it be high up, the mass is thrust partially onward, beyond reach of the human hand, and ultimate relief rendered difficult indeed. As the passage grows narrower, greater violence is resorted to, and the thrust is persevered in till the whip moves onward, and the stablemen congratulate each other that all is right at last."

"When the whip seemed to yield," continues Mr. Mayhew, "something more than the obstruction gave way; the membranous wall of the tube was ruptured, and an almost inevitable death awaits the unfortunate animal. He makes every effort in his power to complete his, imperfect swallow, and gulp down the cause of his distress. Should he not succeed his throat and neck become, through his ineffectual exertions, spasmodically drawn up ; and probably he gives every now and then a loud shriek, expressive of anguish. Should he attempt to swallow water, the fluid, together with the saliva abounding in his mouth, returns through his nostrils. The refusal of food, with symptoms of apparent sore throat, connected with circumstances of a suspicious nature, should induce us to examine the pharynx and œsophagus well with our fingers, to detect any prominence; also, to give the animal water, with a view of ascertaining whether there be obstruction of any sort or not. If the fluid is ejected through the nose, we should be warranted in introducing a probang, than which, in case the obstructing body lie below the neck, we possess no other means so sure of discovering its seat, or so readily removing it. A probang, however, is an instrument in the possession of professional persons only, and one which often happens to be at home when they want it abroad, and therefore they are frequently forced to seek a substitute. A stout cane might answer the purpose. In all cases no time is to be lost: water-often a great assistant-and the probang, are to be immediately had recourse to."

A word about the probang for the horse. It should be like that used for the human subject, consisting of a slip of fine whalebone, having a sponge at one end. When required, saturate the sponge with water or sweet oil, and sponge it dry before driving it down the csophagus. The material will adapt itself to the diameter of the gullet without injury, and will not be difficult to draw back, even should it enter the cardiac orifice.

Mr. Percivall suggests a perforated or tubular probang, through which, when the obstruction had been sent forward, fluids might be injected without the irritation or loss of time of a fresh introduction. The patent stomach syringe is more effective, and, following the probang first described, will be found preferable.

Mr. King, veterinary surgeon, Stanmore, has furnished some cases to the "Veterinarian," which illustrate the subject by examples.

The following shows how a practitioner may be led astray by false accounts:-Mr. $\mathbf{K}$. was called to a horse belonging to a coach proprietor. The owner said his horse "had a bad sore throat, and could not swallow." Mr. K $\mathbf{P} \mathbf{P}$ 
examined the throat and gullet, but, finding nothing, suspected nothing. The horse was blistered and drenched; but the liquids all returned, without any effort being made to swallow them. The animal died; and, on examination, was found, within the thoracic portion of the cesophagus, a ball composed of the ashes of tobacco, enveloped in double paper. At first, all knowledge concerning this discovery was stoutly denied; but afterwards a confession came, that the ball had been administered for worms. Had not such delusion been practised, the probang would have been used, and, Mr. K. thinks, have proved effectual.

Mr. King observes, there is a notion among grooms that a new-laid egg will improve the condition of horses. Its administration has, in some instances, been the means of choking the animal.

Mr. King says he was once called to a horse with a reported "sore throat." The groom "swore" he knew no cause for it. Mr. K., however, had reasons for entertaining doubts of the man's veracity, and therefore proceeded at once to pass a probang. On the return of the instrument, the bulb was found covered with fragments of egg shell. The horse speedily recovered. Two similar cases fell under his notice in cattle practice.

The following fatal case of the same description occurred to Mr. T. Cooper, veterinary surgeon, Coleshill, Warwick.

Mr. C. was called to Dunton Hall, to a bay horse that was taken suddenly unwell. He found the animal "coughing violently, and stamping with his fore feet; with saliva running from his mouth, which he occasionally attempted to swallow, but the greater part returned through his nostrils." There was evidently obstruction. He was told the horse had been eating Swedish turnips. Mr. C. passed a whalebone probang down the cesophagus, "and a rounded substance could be distinctly seen driven before it. The horse after this appeared to be relieved: he ate some hay and drank some water, and was left for the night." "Next day lie is much worse. He does not cough, but heaves very much at the flank; refuses all food and drink; is dejected ; saliva with mucus runs from his nose, and much of it he swallows." He was bled; took an aperient with digitalis; and his throat was blistered, from a notion that "the substance might have injured his throat." Third day: much the same. "Takes gruel from a bottle, but will not eat." Mr. C. from the first had no hope of saving him, and early next morning he died. On dissection, a large-sized hen's egg, entirely whole, was found firmly impacted in the cesophagus, within a few inches of its cardiac termination; the parietes of the tube around the egg being "much dilated, and ulcerated nearly through." The groom confessed he had given the egg a few hours before Mr. C. was sent for, with a view of improving the horse's condition. The balls which had been given must have passed the egg in a liquid state, probably along with the gruel.

The following case shows a successful removal of a soft obstruction without resorting to cesophagotomy.
Mr. King was summoned to a horse that had had a ball administered to him by the groom, wrapped up in writing paper; since which he had ejected everything he had eaten or drunk. A prominence appeared in the neck, a little above its middle, but all means to force the obstructing body onwards were without avail. At length he determined on cutting down upon the œsophagus; having done whichwithout opening the tube-he found the obstruction arose from the lodgment of the ball the groom had given. Feeling the tumour soft and compressible, he squeezed and kneaded it with his fingers and thumb for some time : after which he left it in statu quo. Shortly afterwards the ball. was by natural efforts carried down into the stomach, and liquids were taken and easily passed. It was not for some time, however, that the animal became enabled to take solids into his stomach. They were rejected through the mouth and nose the moment they had descended as low as the place where the ball had stopped. Mr. King thought that this must have been owing to the presence of a stricture-an opinion he conceived warrantable from the circumstances of the ball being in itself but a small one and of soft composition, yet incapable of being stirred by the pro. bang.

\section{ASOPHAGOTOMY.}

When the means detailed under the head of Chorisa prove ineffectual for the removal of the foreign body obstructing the canal of the csophagus, the operation of cutting into the tube, " œsophagotomy," is our resource ; unless it happen that the obstruction is below the neck, when no knife can reach it. The same operation may likewise be practised with a view of overcoming stricture, or for the purpose of injecting medicinal or alimentary matters into the stomach, when there is no possibility of introducing them through the mouth. In the hands of a competent veterinary surgeon there is nothing to dread in the performance of cesophagotomy; although, from the œsophagus lying behind the windpipe, and much deeper, and there being the jugular veins and carotid arteries, the par vagum, and sympathetic and recurrent nerves by the sides of the trachea, the scalpel requires to be handled with caution as well as skill. Recollecting that the csophagus, after proceeding down one-third of the neck, inclines to the loft of the trachea, and before it reaches the chest gets quite round to the left of that tube, we should select the left side of the neck, and below the upper third of it, for the operation. Supposing we take the middle of the neck, our first incision should be three inches in length, and directed along the inferior border of the jugular vein; which ressel had better be kept distended the while by pressure from the hand of an assistan the lips of the wound being kept apart by the assistant, the operator carefully prosecutes his dissection through the cellular tissue with which this hollow abounds, keeping his knife from wounding the jugular on his right, and guarding against the carotid artery and nerves which lie enveloped in the cellular 
substance contiguous to the windpipe, whose situation he will best ascertain by feeling for the pulsations of the artery. His object now is to get behind the carotid, and there feel for the windpipe; and this being found, will guide him to a firm, cordiform, shining, red substance, in close apposition with it; this is the esophagus. In case any injection into it be required, the esophagus must be drawn forward with a blunt hook, and opened by a longitudinal incision, and an appropriate tube introduced. But where the extraction of a foreign body is our object-a circumstance that will render the operation much more facile, the tumour being our guide for incision-nothing remains to be done after this but to liberate the enclosed substance, and close the wound in the œsophagus with a common suture of silk thread, and unite the lips of the external wound with pins and tow twisted round them, in the same manner as the wound after bleeding is closed. Lastly, a compress upon the wound, confined by a roller around the neck, will give support, and, perhaps, be found serviceable. During the healing of the wound the animal's diet must be liquid, or ncarly so: gruel, thick and nutritive, and boiled roots, and mashes of semi-fluid consistence. Chopped green meat of any soft and succulent kind, and short-cut grass, are also admissible.

\section{§II. DISEASES AND INJURIES OF THE STOMACH.}

BTOMACH STAGGERS-GASTRITIS.-INDIGESTION.-DIARRHGA.COSTIVENESS. - SPASMODIC COLIC.-TYMPANY, OR WINDY COLIC. -RUPTURED STOMACH.-PUNCTURED BELLY. - SWELLED BELLY,

(DROPST).-WORMS.-BOTS.-CRIB-BITING AND WIND-SUCKING.

Stomach Staggers. The disorder known by this name may be referred to phrenitis or mad staggers, of which it is the first or premonitory stage. See ante $\mathrm{p} 417$. In this case, however, the mischief, if observed in time, must be relieved by the unbinding of the stomach, whose oppression has involved the brain by recurrent sympathy. Medicine is often powerless from the gorged state of the intestines, and bleeding is accelerating death, although the books recommend it. The first thing is to back-rake, administer a clyster of salt and water, and drench him with warm water, in which a couple of teaspoonfuls of the compound spirit of ammonia is mixed with double that quantity of carbonate soda, to soften the contents of the stomach. If bleeding is ventured on, it should be in the sleepy stage, taken from the jugular veins. The drenching and clystering must be assiduously followed up till their good effect is visible. Some ease will be given to the animal in the sleepy stage by giving him a cask with a straw pad on it, to rest his heary head upon. If a purgative is advisable after the above-mentioned treatment, give the following drench :-

\begin{tabular}{|c|c|c|c|c|c|}
\hline Barbadoes aloes & • & - & - & - & 1 ounce. \\
\hline Calomel . & - & - & • & - & 1 drachm. \\
\hline Oil of peppermint & . & . & • & . & 20 drops. \\
\hline Warm water & $=$ & - & ' & - & 1 pint. \\
\hline
\end{tabular}

Instead of the common drenching horn, the fluids may be injected into the stomach with Read's syringe. White recommends croton oil, 20 to 40 drops, instead of the aloes, on account of its smaller bulk and more rapid action.

\section{GASTRITIS.}

Inflammation of the Stomach (Gr., gaster), is unknown in the horse, except as the result of poisons, acrid substances, or some powerful stimulant introduced into the stomach. However, it is sufficiently common from the above causes, and every case is attended with great danger, though unmarked by any characteristic symptom. It cannot be easily distinguished in its severe stage from $t w i s t$ of the intestines, stone in the bowels, \&c.

The mode of treating it has already been detailed under Stomach Stagaers. The symptoms from poison are extreme distress and restlessness, a loathing of food ; for if anything be given by the mouth it creates increased pain a long time afterwards. The animal breaks out into cold sweats; lies down and quickly rises again, as in inflammation of the bowels; becomes early and greatly prostrated in strength; and has a pulse usually quick and much oppressed. There may be purging, and generally is, though the opposite state may also exist. The signs are also materially shaped by the nature of the substance swallowed. The treatment will depend on timely detection of the true cause. All tests, however, are of more use to find out the reason of deatb, than to save life. The general treatment consists in a rejection of bloodletting, the administration of plenty of gruel, starch water, chalk and water, and abundance of opium. White gives a number of cases of death under this heading, from "a pint of vinegar," an "infusion of two ounces of tobacco in a quari of beer," "two ounces of ether," \&c. They cannot be properly considered as "gastritis" in the sense of a disease, but as cases of chemical irritants inducing inflammation of the stomach traceable after death. In cases where there is reason to suspect that the cause is an overdose of mineral acids, or an ignorant administration of an excessive quantity of a purgative drug-chloroform, ether, or opium, by producing insensibility to pain, may give time for the recovery of the system from the nervous shock. The following is advised, where the symptoms are doubtful, and what has been done to the animal cannot be ascertained.-

\begin{tabular}{|c|c|c|c|c|}
\hline Sulphuric ether & & - & - & 3 ounces. \\
\hline Tincture of opium . & . & • & & 3 ounces. \\
\hline Carbonate of soda or ma & nesia & . & • & 4 ounces. \\
\hline Carbonate of ammonia & . & • & . & $1 \mathrm{drachm}$. \\
\hline Cold gruel & . & - & . & 1 guart. \\
\hline
\end{tabular}

CHRONIO GASTRITIS.

This affection is, in our opinion, more common than is suspected. It is set down as merely "indigestion," and a consequence of a dyspeptic state of the gastric juice. This is plausible, but not all the truth. The disorder is said to be produced by rearing the animal on soft or somn land. 
Jayhew, whose account is the best, thus describes it:Gastritis, in its chronic form, "is frequently first displayed at the period when the services of the animal are esteemed most valuable, or between the fifth and sixth years, long after the mode of rearing has ceased to operate. The symptoms are various, and hardly ever alike. The stomach may affect the nervous system; then, its complications become difficult to disentangle. The affection is mostly declared by an irregularity of bowels and a capriciousness of appetite The animal starts off violently purging. The looseness stops as suddenly as it commenced. Obstinate costiveness then sets in, and each state can be traced to no abvious reason. The straw or litter may be eaten ravenously, but all wholesome provender obstinately refused. The dung shows the condition of the appropriating functions; it crumbles upon the slightest force being imposed; it appears to consist of fibres not agglutinated together. Sometimes it is coated with mucus, and always smells abhorrently. A dry cough may be present; the visible membranes are pallid; the mouth feels cool; the breath is tainted; the eyes are sunken; the respiration is catching; the belly is pendulous; the anus is lax and prominent; the coat dry and ragged; while the body quickly becomes emaciated.

"The slightest exertion produces a thick and copions sweat. The symptom, however, which is most remarkable, when the cleanly habits natural to the animal are considered, is the peculiarity of the appetite. The rack and manger are generally neglected; but every unnatural or offensive substance within reach of the extended jaws, is devoured with avidity. Woodwork has largely disappeared. Soil and stones have been removed from the stomachs of creatures destroyed for incurable disease. Either of the substances last named, however, are usually spared, so long as a morsel of plaster, a portion of mortar or of brick, is within reach. Animals, when in the field, will leave the grass and enter any ditch to gnaw at bricks and mortar. When confined, they will, under the morbid influence of this affection, employ themselves for hours searching for a morsel of either amongst the straw."

The old custom of purging and bleeding for a case of this kind is positively injurious. It is better to administer bitters, alkalies, and sedatives; - the first, to amend the appetite; the second, to correct the acidity of the morbid secretion; the third, to destroy the uneasy sensation which provokes too many of the symptoms.

\begin{tabular}{|c|c|c|c|}
\hline Strychnia & . & . & $\frac{1}{2}$ grain. \\
\hline Bicarbonate of ammonia & . & . & 1 drachm. \\
\hline Extract of belladonna & . & . & $\frac{1}{2}$ drachm. \\
\hline Sulphate of zinc & & . & $\frac{1}{2}$ drachm. \\
\hline \multicolumn{4}{|c|}{$\begin{array}{l}\text { Extract of gentian and powdered quassia, of each a sufticiency. } \\
\text { Or, }\end{array}$} \\
\hline Powdered nux vomica & . & . $\quad$. & . 1 scruple. \\
\hline Carbonate of potash & . & . & 1 drachm. \\
\hline Extract of belladonna & - & . & $\frac{1}{2}$ drachm. \\
\hline
\end{tabular}

Strychnia

Sulphate of zinc

Or,

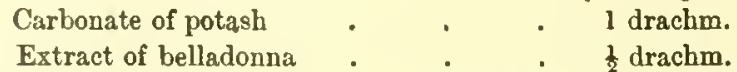

Extract of gentian and powdered quassia, of each a sufficiency.
ive. morning and night.
One of the above balls may be given daily. When their benefits seem exhausted, give, instead of a ball, half an ounce each of liquor arsenicalis, the same of tincture of ipecacuanha, with one ounce of muriated tincture of iron and of laudanum, in a pint of water. Also, damp the food and sprinkle magnesia freely upon it. Then, as the strength improves, introduce sulphuric ether, one ounce; water, one pint, daily ; and ultimately change this last for a quart of good ale or ștout.

\section{INDIGESTION.}

Indigestion, in a medical sense, is a phrase of much comprehensiveness. In man, whose digestive organs are in some respects differently constructed from those of horses, there is much reason for regarding the stomach as the grand agent of digestion; but in the horse, who is a graminivorous animal, one that is almost always feeding, and whose food is for the most part of a nature that occupies a large volume, notwithstanding his stomach is in itself but small, that organ appears to do less towards the completion of the process, leaving much to be done after the alimentary matters have passed into the intestines. To say, therefore, that indigestion is owing to some fault in the stomach alone, is taking too confined a view. Equally in error should we stand, were we to hold the stomach altogether without fault.

The comparatively short time the aliment continues within the stomach, and what remains to be performed to complete its digestion in the intestines, accounts for the latter being oftener the seat of indigestion than the former; though the stomach, as we have already seen, may, by being over-crammed with food or over-distended with air, become the seat of what may be regarded as the most dangerous kind of indigestion.

The Srmptoms of indigestion are:-the horse does not thrive as other horses in the same stable, nor is he capable of the same work; though his appetite, so far from being impaired, may be even voracious. Often it is fastidious-good at one time, indifferent at another. Sometimes it is depraved. He will gnaw and even eat almost anything within his reachdirt or stones,-a brick wall, and particularly the plaster or mortar from it,-his crib or rack, \&c. His coat has an unhealthy aspect ; it is what is called "pen-feathered" and arid, and, perhaps, scurfy; nor is it shed at the usual season. $\mathrm{He}$ is hide-bound. His dung has not the appearance it ought to have; it is either darker or lighter than is natural, has an offensive odour, and, when broken, crumbles to pieces, and appears to consist of lumps of loosely-compacted chopped hay, mingled with many entire or imperfectly changed oats. In the stable, the horse is mostly inclined to be costive; but when taken to exercise is soon excited to purge.

The Ordinary Seat of Indigestion would appear to be within the villous membrane of the stomach, or else that which lines the intestinal canal; both these membranes 
furnishing secretions indispensably necessary for the due conversion of the food into alimentary and fæculent matters. Independently, however, of any derangement in these membranes, various other causes might be mentioned, sufficient of themselves to account for the incomplete performance of the digestive process. Mastication may not have been duly performed; the salivary secretion may be bad or defective; the liver may not have done its duty; the bile may be faulty in quality or quantity, or the pancreatic juice; or there may exist some derangement in the peristaltic action, and consequent irregularity in the progress of the alimentary matters. Other causes may exist, although irritation, or inflammation, or disorder in some form or other of the membranous lining of the stomach and bowels appears to be the ordinary one, and that to which our observations in this place are confined.

Treatment.-The ordinary mode of dealing with these cases is to administer two or three doses of physic, at intervals of a week or so. A preferable procedure to this, is the old one of dividing the ball into two doses, and giving them at intervals of three or four days. The bowels being, in many of these cases, in such a state of morbid susceptibility that a full dose of purging mass is very apt to bring on diarrhœe. "Besides, keeping up a very moderate discharge from the bowels is, in the end, productive of more benefit than giving full doses of physic. When scouring is actually present, without any medicine having been given, or in a case where ever so little aloes induces it, much good may be effected by administering hydrarg. cum creta in doses of a quarter ounce once or twice a-day, made into a ball with common treacle. Cases in which, on the contrary, costiveness is a prominent symptom-there appearing to be a deficiency of bile-are benefited by the exhibition of a scruple of calomel once a day, either in combination with a drachm or a drachm and a half of purging mass, or else followed up by a dose of physic.

Change of diet will often much assist in the restoration of healthy digestive functions. When green meat can be procured, soiling in the stable will be advisable; though in mild weather, and when flies are not troublesome, a run at grass is to be preferred. Breathing the open air all day long, with the moderate exercise the animal takes of his own accord, being both very conducive to his health. In the winter season, carrots are given with advantage. Swedish turnips are also commendable; and bruised or scalded oats may be tried. When simply the mastication is found faulty, mingling the oats with chaff often proves a preventive. Linseed and malt may be given in mashes, or the latter may be made into tea; or hay-tea may be offered; though the horse is not likely to drink either of them voluntarily, unless he has been kept short of water. Drink should be given ad libitum, the pail being so placed that he can belp himself.

\section{DIARRHEA.}

The leading symptom of diarrhoea is the voiding of the fæces in a liquid state. In other words, an increased peristaltic action with a greater secretion of watery fluid in the intestines, or a deficiency of the absorbent power as regards the fluid contents; or, lastly, an irritability or slight inflammation of the mucous lining of the stomach.

It is distinguished from dysentery by the purging being incomplete from the very first; by its being less copious, having all the fæces in solution without any glairy mucous matter; and, also, by being seldom accompanied with fever, or any great affection of the general health. Some horses are very liable to purging on exertion, and such are termed, by grooms, "washy;" having usually narrow chests and lank bellies, in which the intestines have not sufficient room for their natural processes; but are pressed on, and thus forced to a hasty expulsion of the unassimilated contents.

Causes.-Diarrhœa may arise from mechanical pressure resulting from the last cause; thus, a light belly is often found with occasional diarrhœa; or it may arise from a debility in the intestines themselves. A weakened state of the bowels, inclining to this affection, is often brought on by drastic purges. It may likewise spring from the intestines containing some offensive matter, which nature is striving to cast out, little dung being emitted at a time.

It may also be occasioned by the sudden application of cold, whereby, the exhalant vessels of the skin becoming checked, more fluid is necessarily thrown on the intestines; which operates not only by increasing their quantity, but likewise by the addition of something foreign, hence irritating to them. In those cases which are marked with thirst and increased pulse, the restoration of the healthy action of the skin is necessary to a cure; diaphoretics, as antimony, warm clothing, \&c., are advisable; and the use of outward astringents.

The Treatment.-In general cases, when the motion is copious, little need be done. Nature is then relieving herself, and requires little more than warmth and a change of diet. If constitutional, we must palliate by a mild but constant check on the existing causes. A light-bellied horse should not be worked severely several days together; avoid too much water, or too early labour directly after meals. Let the freces be examined: if the food passes away undigested, the stomach requires tonics; but if it be a recent attack, examine well for the probable cause. Has it followed any undue exposure, any violent exertion, any change of food, any great difference in the warmth of the stable? Is the water good in quality? Are the oats, or is the hay, new? If none of these causes operate, we must first make ourselves aware that it is the fæcal discharge which passes, for such appearances have concealed an obstinate constipation. Being convinced of the diarrhœa, commence the cure by mill astringents. 
In general cases of diarrhœa, give the following drink once or twice a day, according to the violence of the complaint :-
Prepared opium .

Prepared chalk

Sulphate of iron (green vitriol) .

Mix in thickish gruel.
Powdered catechu.
$\frac{1}{2}$ ounce.
1 drachm.
1 ounce.
条 $\mathrm{drachm}$.

Should the horse be weak, boiled starch, or arrow-root, or boiled bean-meal, may be passed down the throat frequently. Give no cold water to drink, but, instead, give thin gruel or rice-water, tepid. Clothe warmly, encourage a high temperature also, and carefully avoid exposure to sudden currents of cold air. The subject will again occur under DYSENTERY.

\section{COSTIVENESS.}

Some horses are habitually costive, which arises either from a defective secretion of the fluid of the bowels, or that the absorbents act too strongly, and take up too much of the liquid contents, by which the fæcal mass becomes dry, hard, and difficult to pass ; or it arises from a defect in the formation of the bile, either as to quantity or quality. This we know from what occurs in jaundice, in which, from a loss of the bile by extravasation, there is always present a strong disposition to a costive habit. Some food is prone to occasion constipation, as whatever is stimulating or heating. Corn of all kinds, therefore, has this tendency, but beans more than all. Habitual costiveness should not be counteracted by purgatives, as they generally increase the evil; but attention should be paid to the habit itself, and the peculiar tendencies of that should be counteracted. Dry food should be remedied by occasional bran mashes. Green meat is particularly useful in these cases in summer, and carrots in winter. A costive state of bowels may sometimes be remedied by placing a lump of rock salt within the manger. When costiveness arises from defective bile, treat as directed under jaundice.

Occasional or accidental costiveness must be treated differently. First, back-rake, next throw up a large laxative clyster; and then proceed to give a mild purgative by the mouth.

\section{SPASMODIO COLIC.}

Colic, "the Fret," "Stomach Cramp," or "Gripes" of farriers, is divided by medical authorities into several varieties, of which only two seem worth notice in a general compendium of horse diseases; these are spasmodic, and flatulent or windy colic. We liave preferred treating of it here, though the section on the Intestines, or Bowels, has fully as much claim to it.

The pain of Spasmodic Colic is due (unlike enteritis, or inflammation of the bowels, ) to a contraction of some portion or portions of the intestinal tube. The tube, by virtue of its muscular coat, possesses a power of contracting its canal, which contractile property it is that enables it to press the alimentary matters onward from the stomach, until they arrive at their ultimate outlet. This muscular tunic, in common with other muscles, is liable to be affected with spasm or cramp; when this takes place the intestinal canal is locally contracted to that degree that the aliment is arrested in its course, and the pain, while the cramp or gripe continues, becomes poignant in the extreme.

The best description of the Symptoms is that of Percivall. "The symptoms of colic are the same as, with two or three notable exceptions, denote painful bowel-affections in general. The attack is sudden. The horse appears to be all in a moment seized with acute pain in his belly. He com. mences violently pawing and stamping, and striking his belly with his feet. After a few times bending his knees and crouching his body, and advancing his hind feet under him in attempts to lie down, he at last drops rather than lies down, issuing a sort of grunt from the fall, and immediately commences rolling upon his back, endeavouring every time he turns to balance timself in the supine position; though often he is unable to accomplish this until his legs, in rolling, happen to come against the side of the stall or box. When once he has got upon his back, he will, witb his feet drawn downward upon his belly, and his head and neck, perhaps, curved to one side, remain quiet for a minute or two together, this posture appearing to afford him temporary relief. On other occasions, after several ineffectual endeavours to roll upon his back, he will suddenly rise again, and, having given himself a shake, as it were to get rid of the straws or dust about him, stand so quiet for a time that he appears by his rolling and struggling to have got rid of his pain. Soon again, however, he arerts his head and regards his flank, with his ears down and an expression in his eye as much as to say, 'There lies my pain, and now I feel it coming on again.' Each successive fit or paroxysm turns out commonly to be longer and more violent than the one preceding. Early in the disorder, the remissions from pain, or intervals of ease, are evident enough; but as the case proceeds, the paroxysms growing longer, the remissions become shorter, and after a time altogether unobservable. He heaves at the flanks, and breaks out into profuse perspiration: drops of sweat stand upon his brows and eyelashes, and every hair in his coat becomes wet through. The next change, should his torture continue unmitigated, is one bordering on delirium. He grows heedless of all around him; his eyes turn wild and frantic; his violent motions render all approach to him perilous; cold sweats beder his body; tremors succeed; he falls down, maddened and exhausted with pain, and in convulsions expires. The pulse at the onset of the disease, and during the remissions frem pain, is but little altered; but while the paroxysm endures it grows frequent, and becomes contracted to a thread, and indeed, at times, is so indistinct as hardly to be felt at all Under the extremity of suffering, its quickness, and with that its strength and perceptibility, become augmented. The belly is tense, sometimes percep. 
tibly swollen, and commonly very tender to pressure. The bowels are constipated, though oftentimes dung will be to passed on the eve of the attack; and in the height of his pain the animal will void his urine."

On this Mr. Percivall remarks :- "To these symptoms, as enabling us to distinguish colic from enteritis, great importance, by the generality of practitioners, has been attached, on the score of the remedies prescribed for spasm being of all others the most improper ones for inflammation; but I find, as I grow in experience, that my practice is becoming of a kind suitable to both cases, and consequently the distinction is losing much of its interest. I first made the experiment of combining my antispasmodic with a cathartic, and became so satisfied at the result, that I have, from that time to the present, continued the practice, and with the happiest effects."

The cause of colic, ordinarily, is a draught of cold water, especially while the horse's body is lieated. Water from certain mineral springs has been-apparently from its impregnations-notorious for having this effect. Sudden chill of the skin is said to have produced gripes. A common dose of physic will now and then occasion it. Violent spasms have been produced from linseed or castor oil. Vetches and other green-meats will at times gripe; so will new straw, and particularly that of wheat; and likewise peas: in fact, any irritating or acidulous matters in the bowels may have this effect. Now and then, spasm is brought on by costiveness, and by hardened dung, or stony concretions.

Unless some deciaed check, if not a satisfactory stop, be put to the progress of the disorder within the first half-adozen hours, we may begin to harbour apprehensions. Ordinary cases are relieved by a single dose of medicine; many without any medicine at all. Cases that run on unrelieved to death, seldom exceed twenty-four hours in duration.

In entire horses, particularly in such as have raced or been in training, or have been kept as covering stallions, an attack of colic or enteritic symptoms is on all occasions to be viewed as, possibly or probably, connected with hernia. The scrotum should be examined without delay, and all inquiries made relative to the existence of rupture. See Hernia, post.

Treatment.-Every farrier and groom, horse-dealer and horse-keeper, fancies himself quite as competent to treat colic as the most skilful veterinarian; and, in point of fact, providing the complaint be purely spasmodic, his remedy is likely to prove in the first instance quite as effectual. It being notorious that almost every sort of spirits and aromatics possess antispasmodic properties. The groom, being well convinced of their efficacy from experience upon his own person, as naturally runs for gin and pepper, or peppermint water, for his horse wnen "griped," as he does for some agreeable spirituous compound for himself. Given at the instant, it seldom does fail; for it imports less what we give than when the remedy is administered. That which is given at the outset appearing to have a decided advantage over anything exhibited later in the attack.

Opium holds the first place among antispasmodics. A very effectual antispasmodic ball, combining the three properties, narcotic, stimulant, and terebinthinate, is composed of one drachm of opium, of two drachms of Cayenne pepper or half an ounce of ginger, and of a sufficiency of Venice turpentine and meal to make a moderate-sized ball Combine with the antispasmodic a full dose of purgative medicine. Mr. Percivall advises, in a pressing case, to give, without loss of time, the following drench:-

$\begin{array}{lllll}\text { Decoction of aloes* } & \cdot & \cdot & \cdot & \cdot 12 \mathrm{oz} . \\ \text { Tincture of opium } & \cdot & \cdot & \cdot & \cdot 2 \mathrm{oz} . \\ \text { Spirits of nitric ether } & \cdot & \cdot & . & \cdot 2 \mathrm{oz} . \\ \text { Water, boiling } & \cdot & \cdot & \cdot & \cdot\end{array}$

Mix.

Should the decoction of aloes-that admirable formulanot be at hand, we must content ourselves with a simple solution of aloes in hot water; bearing in mind that the dose is meant to be either ten drachms of Barbadoes aloes or twelve of Cape.

Spirits of turpentine, in four-ounce doses, was Professor Coleman's remedy, and is still in favour at the Veterinary College. It is dangerous without olive or linseed oil, as producing sore throat. Hartshorn, with tincture of myrrh, is open to the same objection Mr. White's formula is un. objectionable :-

\begin{tabular}{|c|c|c|}
\hline Turkey opium & . & . \\
\hline Cloves, bruised & & - \\
\hline Ginger, ditto. . & • & • \\
\hline Brandy, Rum, or Gin & . & . \\
\hline
\end{tabular}

Exercise is often productive of a great deal of benefit after the antispasmodic remedy; it increases the peristaltic motion, causes often the expulsion of air and dung; and, should he sweat, it tends rather to relieve than to augment the spasm; however, he must go willingly, and not be urged.

A clyster composed of two ounces of Cape aloes dissolved in six quarts of soap-water or gruel, may be administered with a view of emptying the rectum; or one in which a pint of oil of turpentine is substituted for the aloes may be given with a view of relieving the spasm. But what, in a case of any danger, is better than either, is the clyster of tobacco-smoke; and the best apparatus for conducting this operation is Read's enema syringe, furnished with a metallic box for containing the tobacco, with a pierced plate across the inside for transmitting the fumes. An

\begin{tabular}{|c|c|c|c|}
\hline * Barbadoes aloes, por & & & 202 \\
\hline Carbonate of potasl & • & & . $1 \mathrm{oz}$ \\
\hline Acacia, powdered & . & & $1 \frac{1}{2} 02$. \\
\hline Boiling water & & & 1 pint. \\
\hline
\end{tabular}

Should the decoction be required to keep, two ounces of some spirit must be added. 
apparatus for this purpose is figured in our plate of Apparatus and Instroments.

A warm bath would certainly prove a most desirable situation for our patient, could one be procured. A sackful of hay, dipped in water nearly boiling, and bound upon the belly, may likewise relieve him.

\section{FLATULENT COLIC.}

Tympany, or windy colic, is produced by the distension of the intestines by gas. It is most frequent in summer, when horses are fed with green meat, but may be produced by indigestion of any description of horse fodder. A draught of cold hard water, having sulphate of lime in suspension, will often cause flatulent colic. It somewhat resembles in symptoms the inflated panch of ruminating animals called "hove," "hoven," or "blown," which is induced by overloading the stomach with succulent herbage, especially clover, by the fermentation of which gas is generated in such volumes as to distend the animal almost to bursting. The horse, however, unlike the cow, has no rumen (paunch), and cannot be, strictly speaking, "hoven ;" though it is by no means unfrequent for him to be affected by tympany, or windy colic. Windy colic is frequently an affection of the aged horse. The notion that tympany is produced by crib-biting or "wind-sucking," though entertained by such authorities as Blaine and Percivall, is now obsolete. It is not the entrance of atmospheric air (which does not pass down the osophagus in any case, though a small quantity of air is found in the intestines), but the generation of carbonic acid gas, or sulphuretted hydrogen gas, the products of decomposition. Either of these gases will destroy life by asphyzia if drawn into the lungs.

Symptoms,-Mr. Mayhew, in his lively and picturesque style, has sketched the symptoms of flatulent colic so accurately that we make no scruple of substituting them for any description we could indite. He says :- "The horse which is to be oppressed by flatulent colic, exhibits uneasiness after feeding; it hangs the head; breathes laboriously; fidgets ; rocks the body, and rests first on one leg, then on the other. These symptoms are exhibited before any enlargement of the abdomen is to be detected. With the swelling of the belly pawing commences; that action is, however, far too leisurely displayed to be for an instant confounded with the same energetic movement which characterises spasmodic colic.

"The horse will stand in one spot throughout the day; even the movement of the foot, before noticed, appears to be an exertion. The eye is sleepy, the pulse heavy, wind frequently passes from the body; and in such a condition the animal remains, slowly becoming worse. Almost in the same place the horse may stand three or four days; then the abdomen is much increased in size; the animal is restless; the pulse is extremely feeble; the breathing is very fast; the pupil of the eye is dilated, and the sight is lost. A walk, as in a mill, is commenced; obstacles are run into or upset; delirium begins; weak neighs are uttered, in reply to visionary challenges; the coat is ragged; copious and partial perspirations break forth; the beat of the artery is lost at the jaw ; an intermittent flutter is indistinctly felt at the heart. At last the limbs fail; the body falls; and a death struggle ensues, the creature dying in consequence of the distended abdomen compressing the lungs and prevent. ing the breath being inhaled."

Mr. Mayhew recommends in extreme cases, puncture of the belly with a trocar, sheathed with a canula. The operation is thus performed:-Draw the skin up tightly over the place selected for puncture, and nick the integument with a sharp scalpel. Insert the trocar, push in the stylet, withdraw it, and the gas will rush out, having a probang ready to clear the canula lest it become-choked. The trocar should not be larger than that used in hydrothorax. When the trocar is withdrawn, the skin, having been drawn aside in the manner above directed, at once closes the orifice by returning to its place. For ourselves, we think, so far as the stomach is concerned, that this operation is not advisable, though in inflation of the small intestines it may be ventured on. It should be remembered, that when gases are generated the intestines change their position, and, owing to the pressure, communication from one convolution to another is obstructed; thus, the trocar empties only one cell, and one convolution holds so little that its evacuation does not give the relief sought for. It is otherwise with the "hoven" ruminant. We need hardly say that no food should be given during the attack of windy colic, and that the groom should sponge out the eyes, mouth, and nostrils. Mayhew recommends the administration of tobacco-smoke per anum by the apparatus already described. It is worth a trial. Should the animal recover, give gruel and bruised oats, and a ball compounded of extract of gentian, powdered quassia, and sulphate of copper.

\section{RUPTURED ITOMACH.}

This is sometimes the result of tympany or gorged stomach. Percivall gives several cases ("Hippopathology," vol. ii., p. 201), and others will be found in the pages of "The Veterinarian." Copious draughts of water on a full stomach have occasioned rupture. Another class of injuries -blows, falls, or strains-have lacerated this organ. As the lesion is past remedy, we shall not devote further space, except to observe that the extravasated matters have been known to be forced into the sheath, so that a hasty examination might cause rupture to be mistaken for inguinal hernia. See RUPTURE, post.

\section{PUNCTURED BELLY.}

A stab by a pair of scissors, a pitchfork, or some sharp instrument, in the lower, middle part, or side of the abdomen, though a disgraceful, is by means an uncommon occurrence. It is oftentimes the result of carelessness or bad temper in the person engaged in trimming or bedding down 
the animal. In the section specially devoted to wounds, lacerated, punctured, or contused, the treatment will be found.

SWELLED BELLY, DROPSY, ASCITES, ANASARCA.

External dropsy, either in the form of swelled belly, sheath, and breast, or in that of swelled legs, is a frequent consequence and an occasional accompaniment of constitutional disease. Hydrothorax (water on the chest) is denoted by dropsy of the breast, extending often to the belly, and by swelled legs. Ascites is strongly indicated, in combination with certain other signs, by dropsy of the belly and sheath, such proves of an obstinate or permanent nature, or else speedily returns, after having been by remedy entirely dissipated. The swellings in these cases being the attendants or consequences of other disease, the treatment of them must form a part of that adopted for the original disorder, whatever it may happen to be. Occasionally, however, anasarca presents itself as a constitutional chronic disorder. The cellular membrane underneath the skin becomes filled with a watery fluid, the result of which is one or more diffused puffy swellings, having no defined limits, but most full in those parts of the body that hang lowest, from the circumstance of the fluid gravitating through the cells of the subcutaneous tissue into them. These swellings have a soft, doughy, or flabby feel, and pit on pressure.

The symptoms of a general attack of dropsy are, swelling of the belly, the sheath, the loose skin in the space between the arms, the breast, the sides of the face and nostrils, the arms, thighs, and legs. These are the ordinary situations for dropsical swellings; though it does not always happen that all these parts are affected. In general, the legs are only secondarily affected; the tumour in the first instance appearing in the body and arms and thighs, and from them gravitating into the legs. At times the tumefaction is, when once it has commenced, very rapid in its progress, and spreads to such an extent in the course of a few hours after its first appearance, as to render the animal almost incapable of locomotion. Although the animal, when first attacked, evinces no apparent pain or uneasiness, and seems totally unconscious and indifferent concerning what is going on, feeding and looking as lively as ever, yet, after a time, the pulse rises, the respiration becomes accelerated, the mouth hot, the eyes and nostrils reddened. A common accompaniment of the irritation now necessarily excited in the skin, is a sympathetic inflammation of the air passages. The animal coughs up, on occasions, a slimy straw-coloured sort of fluid, looking like a mixture of saliva and mucus and sero-albuminous effusion; it the same time there is, probably, a bloody froth issuing from the nostrils. Where anasarca takes this turn, unless an immediate and effectual check be put to the disorder, it is likely to end in farcy and glanders. The urine is scanty, and now and then it will happen that the serous as well as the mucous membranes will partake of this dropsical disposition; and the animal consequently be Q Q in danger of losing his life from water in the chest or belly, or even head.

Causes.-Horses that are turned out to the strawyard in the winter season, are the frequent subjects of dropsy. They leave a warm atmosphere for a cold and humid one; a generous diet for one that comparatively starves them; and they drink ad libitum of water which may be, but most probably is not, of the most wholesome description. The skin will certainly receive a check in regard to its perspiratory functions; the air-passages, also, will feel the effects of cold and moisture; while the digestive organs will experience more or less alteration in their economy in consequence of the change of aliment.

The Treatment of ascites promises little; because it is rather a symptom of visceral disorganization than of simple irritation. We are warranted, however, in attempting the removal of the fluid by exciting the absorbents, as observed in Hydrothorax, and by strengthening the system generally by tonics. We must, however, use no depletion. It may also be observed, that purgatives are not admissible here: on the contrary, they may be expected to occasion much constitutional disturbance. Mild blisters, \&c., external friction, frequent and long-continued, are best; with gentle, repeated exercise, aided by warm clothing.

Mr. Mayhew sensibly recommends that the food should be small in bulk, but nutritious in quality; no work should be imposed; he prescribes

$$
\begin{array}{ll}
\begin{array}{l}
\text { Strychnia } \\
\text { Iodide of iron }
\end{array} & \begin{array}{c}
\text { A quarter of a grain, worked } \\
\text { gradually up to one grain. } \\
\text { Half-a-drachm, worked gra- } \\
\text { dually up to one drachm- } \\
\text { and-a-half. }
\end{array} \\
\begin{array}{l}
\text { Extract of belladonna } \\
\text { Extract of gentian }
\end{array} & \text { - Ane scruple. } \\
\text { Powdered quassia } & \text { A suffiency. A suffiency. } \\
\text { Make into a ball ; give one at night and at morning. }
\end{array}
$$

Half-a-drachm, worked gra-
dually up to one drachm-
and-a-half.

Should the fluctuation and tumidity not yield, we must proceed to the operation of tapping, which offers the most reasonable chance in the complaint, when performed early.

Tapping (paracentesis abdominis) is a simple operation The spot chosen for the opening should be upon the linea alba, midway between the umbilicus and the sheath : in the mare, between the umbilicus and pubes. This point should be chosen for the puncture, which ought to be made directly upwards; and both this and the former operation for wind must be conducted and treated upon similar principles, with the exception that in ascites the whole of the fluid may be evacuated at once, and allowed further to drain off by the simple application of a linen bandage. Should benefit be derived, endeavour to prevent a recurrence, by strengthening the general habit.

Water farcy, general œdema, dropsy of the skin, and collections of fluid within the cellular membrane, are disorders which, in their treatment, ask for no separate directions beyond those here given. 
Swelled legs shall receive separate cousideration, for obvious reasons.

\section{WORMS, B015, AND PARASITIC ANIMALS.}

Worms, most frequent in the stomach and bowels of the horse, have been found in every part of his system. In abscesses, in the mesenteric glands and artery, in the substance of the abdominal muscles, in the liver, in the windpipe, in the salivary ducts, and even in the pancreas.

The worms most generally found in the stomach of the adult horse are Bots. The parasite most inimical to colts is the trenia, or tape-worm. Lumbrici teres, or roundworms, most frequently found in the small intestines; Ascarides, a small worm infesting the large intestines; and Stronguli, found occasionally not only in the bowels but in the kidneys and cœliac artery of both man and horse.

The groom always pronounces the symptoms of chronic indigestion to be what he calls "a wormy condition." The consequence is, that the most potent "worm-powders," most of them so strong as to peril the life of the animal, are at once administered; with what result, in hundreds of instances, we need not say. Ignorance, "with the best intentions," is the most charitable verdict.

Bots. Our knowledge of the origin and habits of the cestrus equi or stomach bot, before the investigations of Bracy Clark, was nil; we shall, therefore, with this acknowledgment, condense from that author's "Essay on Bots in Horses," his account of this troublesome parasite.

"When the female has been impregnated, and the eggs sufficiently matured, she seeks among the horses a subject for her purpose, and approaching him on the wing, she carries her body nearly upright in the air, and her tail, which is lengthened for the purpose, curved inwards and upwards: in this way she approaches the part where she designs to deposit the egg; and suspending herself for a few seconds before it, suddenly darts upon it, and leaves the egg adhering to the hair: she hardly appears to settle, but merely touches the hair with the egg held out on the projected point of the abdomen. The egg is made to adhere by means of a glutinous liquor secreted with it. She then leaves the horse at a small distance, and prepares a second egg, and, poising herself before the part, deposits it in the same way. The liquor dries, and the egg becomes firmly glued to the hair : this is repeated by these flies till four or five hundred eggs are sometimes placed on one horse.

"The skin of the horse is usually thrown into a tremulous motion on the touch of this insect, which merely arises from the very great irritability of the skin and cutaneous muscles at this season of the year, occasioned by the heat and continual teasing of the flies, till at length these muscles appear to act involuntarily on the slightest touch of any body whatever.

"The insido of the knee is the part on which these flies are most fond of depositing their eggs, and, next to this, on the side and back part of the shoulder, and less frequently on the extreme ends of the hairs of the mane. But it is a fact worthy of attention, that the fly does not place thein promiscuously about the body, but constantly on those parts which are most liable to be licked with the tongue; and the ova, therefore, are always scrupulously placed within its reach.

"The eggs thus deposited, I at first supposed were loosened from the hairs by the moisture of the tongue, aided by its roughness, and were conveyed to the stomach, where they were hatched. But on more minute search I do not find this to be the case, or at least only by accident; for when they have remained on the hairs four or five days, they become ripe, after which time the slightest application of warmth and moisture is sufficient to bring forth in an instant the latent larva. At this time, if the tongue of the horse touches the egg, its operculum is thrown open, and a small active worm is produced, which readily adheres to the moist surface of the tongue, and is from thence conveyed with the food to the stomach.

"At its first hatching it is, as we have observed, a small active worm, long in proportion to its thickness, but as its growth advances, it becomes proportionably thicker and broader, and beset with bristles.

"They are very frequent in horses that have been at grass; and are in general found adhering to the white insensible tissue or coat of the stomach.

"They usually hang in dense clusters to this white cuticular lining of the stomach, and maintain their hold by means of two dark brown hooks, between which a longitudinal slit or fissure is seen, which is the mouth of the larva. When remowed from the stomach by the fingers by a sudden jerk, so as not to injure them, they will, if fresh and healthy, attach themselves to auy loose membrane, and even to the skin of the hand. For this purpose they sheath or draw back the hooks almost eutirely within the skin, till the two points come close to each other; they then present them to the membrane, and keeping them parallel till it is pierced through, they expand them in a lateral direction, and afterwards, by bringing the points downwards towards themselves, they include a sufficient piece of the membrane to remain firmly fixed for any length of time as at anchor, without requiring any further exertion.

"These bots, as is also the case with two or three other species, pass the autumn. winter, and spring months in the stomach, and arrive about the commencement or middle of the summer at their full growth, requising a twelvemonth fully to complete their structure.

"The Estrus Hamorrhoidalis, or Fundament Bot.-The part chosen by this insect for the purpose is the lips of the horse; which is very distressing to the animal, from the excessive titillation it occasions; for he immediately after rubs his mouth against the ground, his fore-legs, or sometimes against a tree, with great emotion; till the animal at length, finding this mode of defence insufficient, quits the spot enraged, and endeavours to avoid it by galloping 
away to a distant part of the field ; and if the fly still continues to follow and tease him, his last resource is in the water, where the æestrus is never observed to pursue him. These flies appear sometimes to hide themselves in the grass; and as the horse stoops to graze, they dart on the mouth or lips, and are always observed to poise themselves during a few seconds in the air, while the egg is preparing on the extended point of the abdomen.

"When several of these flies are confined in a close place, they have a particularly strong, musty smell; and I have observed both sheep and horses, when teased by them, to look into the grass and smell to it very anxiously; and if they by these means discover the fly, they immediately turn aside and hasten to a distant part of the field.

"I once saw in a meadow or field upon the cliffs at Margate, a fly of this sort teasing a horse that was confined to a small space by a spike stuck in the ground, to which a cord was tied. He could not get away from its attack, and became quite furious, for in kicking at the fly with his forefoot, which he did vehemently, he often struck the bone of the lower jaw, creating excessive pain ; for in that direction, while grazing, the fly comes to the beard of the lower lip.

"The eggs of this species are difficult to be seen upon the horse's skin or beard, owing to the agitation of the beast, and from the colour of the egg being dark like that of the skin of the horse The animal has been generally too impatient, while undergoing this operation, to let me examine them very well. I ascertained, however, its form by pressing one of these eggs from the abdomen.

"The larva or grub of this species inhabits the stomach as the former, generally adhering to the white lining, and is disposed promiscuously in dense clusters, after the same manner; they may, however, be distinguished from them by being in general smaller, and longer in proportion to their bulk.

"The larva of this species may be obtained from almost any horse that has been much at grass the preceding year, and exposed to these flies, and will be found during the summer montls sticking more or less within the verge or opening of the anus, adhering to its soft lining, and producing considerable irritation and uneasiness. Indeed, I once well remember being on a tour of pleasure in the Isle of Wight, and experiencing much annoyance from these larvæ. The little horse I had hired for the journey became so lazy and unwilling to go on, and moved so awkwardly, that I could not keep pace with my company, and I was at a loss how to proceed; on taking up the tail, I discovered three or four of these insects hanging to the rectum, and their removal instantly proved a cure."-Bracy Clark.

The tania, or tape-worm, is classed by naturalists among the entozoa (Gr. entos, within, zōon, an animal) ; modern entomologists call this family of worms cestoidea (from Gr. cestus, a band, eidos, like).

The tomia infesting the horse is a long, flat, jointed worm, every joint of which, when broken, will from a new animal. It has been found from 20 to 50 feet in length and an inch in breadth. The colour is dirty white. Its head, which is tuberculous, is placed at the slenderest end of its body, and is said to be always directed towards, and sometimes to be actually within, the pyloric opening of the stomach. Percivall says he never met with the tapcworm in the horse, often in the dog; in the human subject it is common.

The lumbricus is a round worm, found oftener in the small intestines than in the stomach. Cuvier classes them among the Annelidx, on account of their blood being red, as in the leech and earthworm, and their bodies formed of a number of rings (annella, a little ring, and eidos, like). White and other veterinarians speak of a "fluke-worm," which is merely a lumbricus which occasionally penetrates living tissues, and differs nothing in its suctorial apparatus, which, under certain circumstances, seems to be used in a sort of mechanical boring through soft and permeable tissues. The "fluke-worm" is classed by naturalists as of the order Trematoda (Gr. trema, foramen, a little opening The lumbricus is often found in the dung of horses, nearly as thick as the little finger, and from three to fifteen inches in lengtll. Gibson says, "I have seen them eighteen inches long, and larger than a man's finger." The worm is largest round its middle part, from which it tapers off to each end, where it is pointed. They are more generally white than red. A French veterinarian, Chabert, says he found fourteen pounds of them in a horse's small intestines; and balls of them are often found in aged horses' small guts, complicated with bots (if the animal has been at grass) clinging to the vascular part of the stomach itself. They are always sheathed in mucus.

Ascarides, of these, the most frequent of entozoa, eighty species have been described, one, the small needle-like lively parasite which we find so commonly tormenting the rectum of the horse, is the only variety we are concerned with. It is thin as a stocking needle, inhabits the large guts, and is often found in the blind pouch of the cœcum. It is sharp at one end and blunt at the other, seldom more than half an inch in length, and of a dull white. It frisks or coils eel-fashion when immersed in fluid, and is often detected escaping from the anus.

The strongylus, (Gr. strongulus, round), is an allied worm to the ascaris, but is distinguished by the power of eating through or perforating important structures. It is slender, from two or four inches in length, consisting of two distinct portions:- a body, constituting not quite one-half of its entire length, rather smaller than a crowquill; to which is appended a contracted thread-like part or tail, making up the remainder of its length When first voided, the body appears black; the tail transparent. No sooner, however, are they taken out of the dung than they vomit up their black contents, which have the appearance of writing ink; and then their bodies, like their tails, become transparent. This ejectment seems to be their last 
act of life, for they never move afterwards, but gradually shrink and dry up to almost nothing. Numbers of strongyli were voided by a young horse, under the operation of physic, who had given no reason to believe he hasboured worms of any sort.

Symptoms.-The best-known symptom of worms in the rectum or cocum, is a dry yellow matter under the tail; but it is not invariably present even when worms are known to exist. When worms are irritating, there is unequal appetite and an irregular state of bowels; at one time costive, and at another loose, with glair or mucus around the dungballs. When ascarides prevail, the horse is much disposed to rub the tail, to ease the itching of the fundament. The presence of bots is seldom detected by any distinct signs, except in the spring, when one or more may be detected half protruded through the anus; the reason of its appearance being, that the time has arrived for it to quit the state of a grub for that of a fly. The lumbricus, or round worm, is probably the most generally found; but it is only when it exists in great numbers, or itself becomes morbidly irritated to seek a change of situation, that it seems to trouble the animal. This symptom also applies to ascarides, in which cases both may interfere with digestion and the regular bowel discharges. The provender of the horse, although he eats heartily, does not digest healthily. The skin, also, sympathising with the stomach and intestines, occasions a staring coat and harsh feel of the hair. There are frequent attacks of slight gripes; the horse stands with his legs wide apart, and his belly hangs low. The breath is often hot and fœtid, and it is not unusual for a short dry cough to be present. Worms, however, exist without any of these symptoms. Whoever will take the trouble to visit a knacker's, and to turn over the dunghill in his yard, will find it to be composed quite as much of worms as of excrement. This dung is taken from the aged borses sent to be slaughtered, and is sufficient proof that worms are much more common than is generally supposed.

Treatment of worms. - Nature has endowed these animals with such tenacity of life, that no matters known to us will effect their destruction, though a few may answer the purpose of their expulsion. Bots are so hardy as apparently to survive immersion in oil, in alcohol, spirits of turpentine, and even powerful solutions of mineral acids. The continued use of salt mixed with the food appears, however, obnoxious to them; for sometimes under its use their hold gives way, and they are ejected. Bitters, purgatives, and the mechanical irritation of pointed bodies, as pewter, tin filings, \&c., have no effect whatever upon bots; but with regard to the other parasites, rather more success may be expected from medical aid, in the form of vermifuges. It has been attempted to effect the removal of worms mechanically, by dissolving the mucus they are supposed to be imbedded in, for which purpose lime-water, oil, solutions of aloes, \&c. have been injected by clyster up the rectum, and which practice is most to be depended on for the ejection of asca- rides when in the rectum. This practice of washing away the mucus of the intestine, and thus depriving the intestine of the secretion given for its protection, is not to be recommended, though oil for this end would be harmless. Strong purges are given with the same intent, which may remove them also from the whole alimentary canal $R e$ medies have likewise been exhibited to destroy them within the body, by the mechanical irritation of their spicula; under which view tin, brass, iron, pewter, are thought remedial The Indian caustic barley, and Indian piuk, are reputed vermifuges against the teres and ascaris. The oil of turpentine has also been strongly recommended as an excellent general vermifuge; but, except for the destruction of the tænia, or tape-worm, it does not appear to deserve that character.

The mode most in favour with modern practitioners, is to give the horse having worms a drachm or two drachms of tartar emetic, for six mornings running. The tartar emetic is to be administered in the form of a ball, and to a fasting stomach. On the seventh, administer a sharp dose of aloes, to drive out the parasites, enfeebled by the previous medicines. Mr. Spooner recommends the following :-

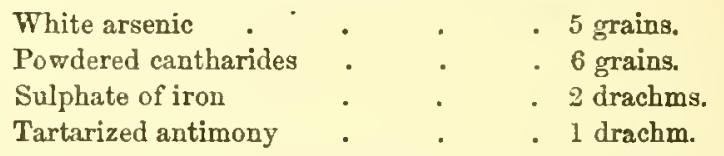

Mix with a handful of bran, and give in a feed of corn every evening for a fortnight. Administer a dose of "physic" after two-thirds of the medicine has been given, and, as soon as it "sets," the remainder.

Under Vermifuaes, page 247, ante, will be found some formulæ and remarks. Mayhew gives a scale of doses of turpentine adapted for the different ages of the horse :-e.g. for a three months' foal, half an ounce; for a six months' foal, an ounce; one year old, an ounce and a half; two years', two ounces; three years', three ounces; four years', and upwards, four ounces. Take one pound of quassia chips, pour on them three quarts of water, strain, beat up the turpentine with yolks of eggs to make it blend with the infusion, add one scruple of powdered camphor, and give fasting in a drink before any food, in the morning. If the tænia are expelled, a tonic (see ToNics in List) till the coat is smooth.

The tobacco smoke enema (see Apparatus in Plate or Instronents, \&c.,) is also used to advantage in the expulsion of ascarides.

\section{CRIB-BITING AND WIND-SUCKING.}

This curious and dangerous practice, which rapidly grows into a confirmed habit, and is taught to, or initiated by, animals who have the misfortune to be stabled with those confirmed in the vice, has been the subject of much extravagant speculation and wild theory. Ignorance has invested it with mysterious significance, and a symptom of existing acidity of the stomach, or of its distension by gases, has been made, by a post hoc propter hoc sort of reasoning, into the cause of fiatulent colic and other intestinal disturbances. 
The premonitory symptom of a resort to crib-biting is that of heartburn. The animal begins by licking the manger; and if there should be iron anywhere, which imparts a sense of coolness, that is particularly grateful. The licking of cold substances is a sign of disordered stomach The act of crib-biting is thus performed:-The incisor teeth are firmly pressed against any solid substance, say the edge of the manger, he violently extends his neck, and then, after a convulsive action of the csophagus, a portion of gas is belched up with a grunting noise. This heated air expelled, the animal draws in his breath with a sucking sound, and the horse finds relief in the process. As the animal will leave the most tempting food to go through this peculiar performance, we cannot look upon it in the light of a mere habit, but as an instinctive mode of seeking relief, sometimes practised when the first motive has ceased, and hence becoming an inveterate propensity. We find, then, that crib-biting is most prevalent among horses that pass long weary intervals in the stable, consuming a diet of "oats and hay, varied," as Dr. Kitchener facetiously says, "by hay and oats, for a change." Such an animal, in a close and impure atmosphere, and without the slightest excitement for eye, ear, or brain, may well have a disordered stomach, and fall into a solitary and, to him, agreeable pastime. Crib-biting has been cured in an early stage by a common stimulant, and this would point to a confirmation of our opinion. A lump of rock salt placed in the manger has stopped it, to which we would add another of chalk, or damp the food and sprinkle on it carbonate of soda.

The name, "crib-biting," is a blunder. The horse does not "bite" his "crib;" the manger is simply used as a point of pressure for the upper teeth, and thus the animal is enabled by pulling back to act on the muscles of the gullet, and to force a portion of the offending acid gas up a passage, which is so constructed as to prevent vomiting. The human being in a state of dyspepsia, is relieved, in like manner, by an eructation, but through a more open channel.

For the cure of crib-biting a turn out at grass is recommended. This arises from a misapprehension of the case. The crib-biter will at once make for a gate-post or rail, as soon as the fit comes on. Lining the edge of the manger with iron is evidently inefficacious, as it forms nearly as good a fixed point as before. Sheepskins rubbed with aloes or spread with tar will not keep the inveterate crib-biter from his game. A muzzle with bars across the bottom, sufficiently open to enable the horse to pick his hay, but not to fix his foreteeth on the edge of the manger, has been tried, and the horse, after some time, has been supposed to have abandoned his "habit." Let his stomach become disordered and it will be seen immediately that he is at his old trick to relieve it.

We would advise in every case the treatment of cribbiting as a case of windy colic, chronic gastritis, or of indigestion, according to the methods already laid down; and where it is evident that the practice has, which we doubt, become a mere wanton pastime, to try the muzzle, not neglecting to persevere with the medicinal remedies. Blaine says a strap which constricts the cosophagus has prevented cribbiting, which we can perfectly understand, though no cure.

Although crib-biting has been declared to be unsoundness, we have known many horses work well and freely, and their usefulness, where their work has not been fast not perceptibly deteriorated.

The injury to the teeth by crib-biting, though dwelt upon by Youatt and other writers, is merely imaginary.

Wind-sucking we take to be an imaginary variety of cribbiting-a distinction without a difference.

\section{CONCRETIONS AND POLYPUS IN THE STOMACH.}

Concretions, and especially calculi in the stomach, are not so common as in the bladder, intestines, and kidneys; and to the lesions of those organs we refer the reader. We are under obligation to Mr. Percivall for the following cases:-

"It is no uncommon circumstance for hard substances to be found within the stomachs of horses. I have seen several specimens. They were chiefly calcareous. The largest I ever saw was taken from a horse of my father's, that died of old age after having worked in a clay-mill for a number of years. I think this was nearly as large as an ostrich's egg, and not very dissimilar in appearance; it was of an argillaceous nature, and was, doubtless, formed of the fine dust of the clay which the horse was continually imbibing with his food. Its nucleus was the large end (about half) of an old nail. I believe they are always found to contain a nucleus." Thus much, on the subject before us, writes a correspondent, who signs himself J. F., of "The IIippiatrist" for 1830.

In "The Veterinarian," vol. vii., is to be found the case of an Andalusian horse-reported by M. Blavette, veterinary surgeon-who was, in addition to being a notorious crib-biter, a depraved feeder. "Neither manger nor rack, nor the fragments of the bars, escaped him : he gnawed his halter, and licked the walls, ate up all the earth he could get at, and was a confirmed roarer." For many years he had been subject to violent colics, which became latterly more and more frequent. In one of these paroxysms, at last, he died. There was found in his stomach, after death, four pounds and a half of earth and sand. He had, as was learned afterwards, escaped from his groom on the morning of the day he died, and galloped to the riding-school, where he was found eating the earth and sand composing the floor. A brass wire, about the size of a knitting needle, and eight or nine inches long, was found sticking in the intestines, through whose walls it had penetrated aud had run into the lumbar muscles.

Polypus in the Stomach. Mrr. Brown, veterinary surgeon of Melton Mowbray, has a preparation of a polypus which was taken out of a horse's stomach.

The subject-an old brown horse, named Sheffeld-was found, early in the morning of the Ist of May, "labouring 
under an attack of the bowels." The animal experienced great pain, cold sweats, quick pulse, \&c. No veterinarian attended. Oily purges and frequent clysters were exhibited without giving relief. The lorse died on the fifth day from the first attack. About fifteen inches in extent of "the first small gut were mortified."- "The stomach was full, but its contents were liquid, and at the lower extremity there was a pendulous substance, which was plugged into the gut, totally obstructing the passage. I am informed that the animal was a remarkably healthy one, and apparently suffered 10 inconvenience from the polypus, until it formed a mechanical obstruction to the pylorus. The pedicle is rather tortuous, with an artery and two veins in the centre, having an expanded origin, which becomes converged into a firm cord, one inch in diameter and three long, terminating obliquely in the body of the polypus, which is a firm flat substance, weighing seven ounces and a quarter.

\section{§ III. DISEASES AND INJURIES OF THE PERI- TONEUM AND INTESTINES.}

PERITONITIS. - ENTERITIS. - DYSENTERY.-TYMPANY.-INTUS-SUSCEPTION.-STRANGULATION.- HERNIA : STRANGULATED, INGUINAL, SCROTAL. - HERNIA OF CASTRATION, AND VENTRAL. RUPTURE OF THE INTESTINES. - CALCOLI ETC. IN THE INTESTINES.

\section{PERITONITIS.}

The three varieties of inflammation of the bowels are called-Peritonitis, inflammation of the investing membrane (peritoneum); Enteritıs, inflammation of the muscular coat (Gr. enteron, a bowel ); and Dysentery, inflammation of the mucous or internal coat (dys, bad, entera, the bowels), understood in the horse as a flux, and synonymous in veterinary practice with luman diarrhcea.

Peritonitis is so little different either in its symptoms or treatment from ENTERITIS that we may defer directions to that head.

Acute peritonitis is seldom met with except as the result of injury, such as accidents in castration, puncture of the belly, an overstrain in leaping, or over-exertion. Hence the peritoneum is found inflamed in liunters who die "overmarked." Accidents, too, in operations for stone in the bladder, hernia, \&c., bring it on. After wounds, an access of cold will cause gangrene to supervene: see Enteritis. The tendency of chronic peritonitis is to dropsy of the belly (ascites) or of the chest (hydrothorax), which see.

\section{ENTERITIS.}

The intestines are composed of three layers of substance, called coats, any one of which may become the seat of inflammation, to the exclusion-altbough all three are intimately connected-of the other two; or, at least, so far to their exclusion, that the others appear to be but secondarily and comparatively mildly affected. Enteritis consists in an in. flammation of the middle or muscular coat-that which forms the principal substance of the gut We have evidence of this when we slit open an enteritic intestine : although the exterior looks as red as scarlet, the interior is found to be hardly flushed; even the aspect of the exterior is likewise deceptive; for, if we strip off the external or peritoneal coat we shall discover that the redness is underneath, the raised membrane being in itself translucent, with a red bloodressel to be seen only here and there, instead of such crowds of them as appear in the muscular tunic.

Enteritis is the "red colic" of farriers, under which name they also include dysentery. There are, however, sufficient grounds for a division of the inflammations of the bowels in to enteritis-or that which principally affects their middle coat, and is generally accompanied by costiveness-and that which primarily attacks their viliuus surface, and is productive of diarrlicea or dysentery Between these states there is a sufficient mark; but between inflammation and spasmodic colic the distinctive lines are familiar only to the experienced observer. When the gripes, or fret, as spasnodic colic is called among farriers, attacks a horse, it is usual and useful to give him powerful stimulants, active motion, and strong friction, all which would be extremely baneful in the red colic. A careful distinction should therefore be made between the two diseases, which may be readily done by attending to the characteristic marks of each, as particularly detailed in spasmodic colic.

Enteritis sometimes commences by a shivering fit, to which succeed heat of skin, restlessness, loss of appetite; the mouth being particularly hot and dry ; the inner membranes of the eyelids, and the linings of the nostrils, being rather redder than natural. As the inflammation advances the pain increases, so as to force the horse to lie down and get up again frequently; yet, unless the pain be very acute, he seldom rolls on his back or remains stationary there; but as he will occasionally do so in particular cases, this should not be considered as a criterion between this disorder and gripes. He will kick at his belly, stamp with his feet, scrape his litter or stall with his hoofs, and look wistfully round towards his sides. The pulse in most cases is frequent, as 90 or 100, and invariably very hard, small, and wiry. The breathing is accelerated : the belly is sometimes painful to the touch, which never occurs in colic; it is also hot to the feel, and the pain, instead of remitting as in colic, is constant; the extremities being cold, while the surface of the body is often warm. The bowels are usually constipated, and if any dung be evacuated, it is small, hard, and in dry masses. The anus, if examined, will be found very hot; and if the hand be intruded up, it will be felt sometimes even internally inflamed; it also, in many cases, quivers with the intensity of the general affection. Frequently, towards the later stage, there is some tympanitis or distension of the belly, which much aggravates the general tenderness evinced on examination. The urine is 
painfully evacuated in small quantities, and very highly coloured; sometimes it has much mucus suspended in it. In the progress of the disease these symptoms increase in intensity : the distress of the horse is expressed by his groans, his violent efforts to change his position, as if to fly from his malady; while perspiration, partial or general, breaks out, and is then succeeded by a chilly state, with muscular twitchings; the pulse becomes more and more hurried, intermittent, and at last nearly imperceptible; the respiration is as quick and irregular as the pulse, and occasionally interrupted by a convulsive sigh. The vital powers are now fast ebbing, and the animal sinks after a few feeble struggles, or he parts with life with more violent convulsive movements.

Treatuent.-The clearest and most judicious treatment we have met with is that contained in an editorial addition by Mr. Spooner in the last edition of White's "Veterinary Art ;" and as it has the further merit of brevity we here transcribe it:- "Having properly examined the case, we should immediately have recourse to bleeding, and that as extensively as possible; for this purpose, a large opening should be made in the jugular vein, or one on each side, and from six to eight quarts taken as quickly as possible, continuing the bleeding till the pulse becomes almost imperceptible. The bowels being costive, the dung should be removed by back-raking, and a copious injection thrown up. A pint and a half of linseed oil and one drachm of powdered opium may next be given, and a half pint of the oil, with half a drachm of opium, may be repeated every six hours, till the bowels are relaxed; the injections being also frequently repeated.

"The abdomen should be fomented with very hot water. which should be continued for some time; and it will afterwards be very useful to apply hot sheep-skins, just removed from the dead animal, to the abdomen, the woolly side outermost. If these cannot be procured, the fomentations should be repeated, or the abdomen may be stimulated by a blistering application.* The legs must be kept warm by flannel bandages, assisted, if necessary, by rubbing in a stimulating liniment, composed of oil and spirits of turpentine. During the continuance of pain the horse will, of course, take no food, nor is any desirable. He will most probably be disposed to drink, of which circumstance advantage should be taken, by offering him oatmeal gruel, or linseed tea, as often as he will take it.

"If relief be not obtained in the course of six hours, our prognosis will be unfavourable, particularly if, on again resorting to bleeding, we find the blood very dark and thick, and with difficulty obtained.

- "Mr. Mavor has introduced some apparatus, whereby the steam from hot water may be applied to the abdomen for an hour together; this is likely to prove of great service in cases of enteritis, as well as in tnflammation of the chest."- "Veterinarian," vol. xii., p. 198 ; "Veterivary Medical Association."
"A second, and even a third, bleeding should be tried, though in less quantity than at first. If the pain ceases, or greatly diminishes, the pulse becoming more distinct or moderate, we may then augur a favourable result, which opinion will be greatly strengthened by the bowels becoming gradually relaxed. If a favourable result should attend, great caution is necessary for some little time as to the diet; and soft food should be given for several days.

"When death occurs, we find, on examination, the muscular coat, particularly of the large intestines, quite black from inflammation, and the other coats likewise involved in a secondary degree."

\section{DYSENTERY (MOLTEN GREASE).}

This disorder is an inflammation of the internal surface of the bowels. It is caused by obstructed perspiration; the continued use of certain kinds of food; but more frequently by the injudicious administering of improper purgatives, either as to quantity or quality, by which such irritation is brought on as ends in inflammation. Dysentery is com. monly accompanied with purging, whereas enteritis is almost always associated with costiveness; neither is the pain so acute in dysentery, consequently the horse seldom expresses his uneasiness by rolling or stamping; the pulse is also quick and small, but is seldom very hard, even from the beginning. However urgent may be the symptoms, and whatever the pulse may denote, no blood must be withdrawn in this disorder; for ut is inflammation of the mucous membrane, and after all we can do to support the horse, be will bardly have strength to get through the attack. Stimulants should, however, be applied to the bowels, as in inflammation of the intestines, properly so called. The stable and the clothing also should be warm, and means should be taken to keep up the circulation in the extremities by hand-rubbing and bandaging. The following drink may be given every two hours :-

\begin{tabular}{|c|c|c|c|}
\hline Prepared chalk & • & . & . 1 ounce. \\
\hline Laudanum . & . & . & 2 ounces. \\
\hline Liquor potassæ & . & . & I ouuce. \\
\hline Tincture of catechu. & . & . & . $\frac{1}{2}$ ounce. \\
\hline Tincture of ginger . & - & . & . 1 ounce. \\
\hline Tincture of capsicums & • & . & 2 drachms. \\
\hline Water . & . & . & . 1 pint. \\
\hline
\end{tabular}

Ir. Spooner's prescription is more simple.

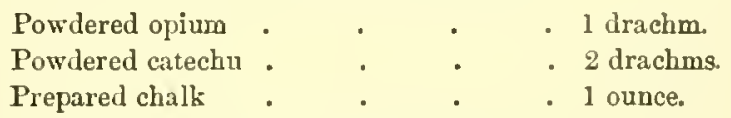

In thick gruel made from wheaten flour, or in boiled starch.

Throw up frequent injections of rice-water, and have a pail of thin cold gruel in the manger, which, however, should be repeatedly changed, though most likely the poor animal will drain it almost as fast as it can be prepared.

The reader is referred to the preceding section under the heads Diarriega and Costivenes. 
TYMPANY. - A reference to our observations on windy colis, D. 448 , will save repetition.

\section{INTUS-SUSCEPTION OF THE BOWELS.}

Strangulation, intervagination, volvulus, or intus-susception-for by these names a twisting, knotting, or unnatural torsion of the bowels is called-is more frequent than has been supposed. Fatal cases of this disorder having been often treated as colic, and post-mortem examination neglected.

INTCS OR INTRO-SUSCEPTION means the slipping of one portion of intestine into another-commonly into the one behind it. In the human subject, especially in children, this appears to be an accident by no means uncommon, and one that happens and rights itself again without any knowledge on the part of the person in whom it occurs. The two most frequent descriptions of strangulation will be best understrod by a drawing. We give them from Percivall :-

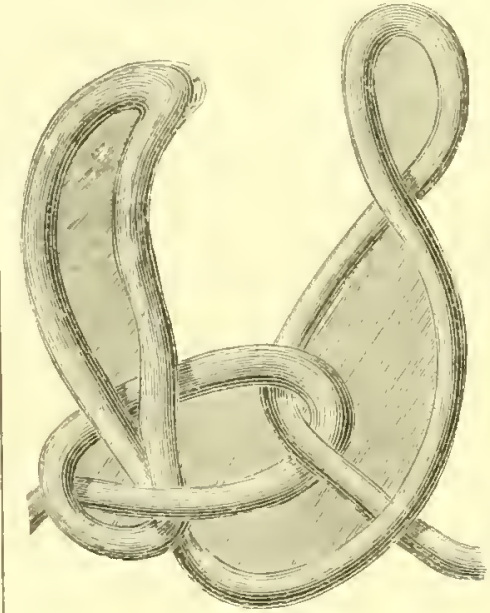

Fig 1.

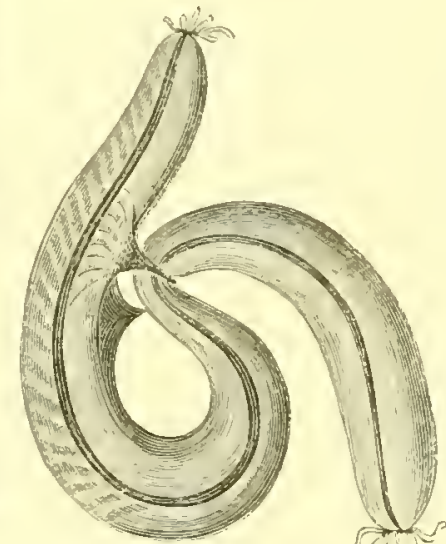

Fig. 2.
The first represents a strangulation of the small intestines, the second, a strangulation of the rectum. The spasmodic action of the ileum long continued, may be succeeded by an inverted action from the cœcum towards the stomach, more poweriul than the natural action; and the contracted portion of the intestine is thus forced into a portion above it that retains its natural calibre; and the irritation caused by this increases the action, until more is forced in, and an obstruction is formed which no power can overcome. Even the natural motion of the bowels will be sufficient to produce intus-susception, when the contraction in the ileum is very great. There are no symptoms to indicate the preseuce of this, except continued and increasing pain; or if there were, all our means of relief would here fail.

There is another singular consequence of colic. Althorgh the ileum is enveloped in the mesentery, and its motion to a considerable degree confined, yet under the spasm of colic, and dnring the violence with which the animal rolls and throws himself about, portions of the ileum become so entangled as to be twisted into nooses ind knots, drawn together with a tightness scarcely credibie. Nothing but the extreme and lengthened torture of the animal can lead us to suspect that this has taken place, and, could we ascertain its existence, there would be no cure.

The Srmptoms.-Internal stricture and strangulation of intestine are, in general, violent to a degree, though the same in kind as result from colic, or, rather, enteritis. The poor sufferer paws, and lies down, and rolls, and looks at his flank, and pants, in horrible agony; his belly becomes tympanitic, tense, and enlarged; and his pulse is quick and small, 70 or 80 , but not thready. For the first three or four hours, all that we do appears of no avail. Afterwards a calm takes place, and we are apt to think our remedies have worked it; if, however, we again examine the pulse, we shall find our patient evidently sinking; perhaps, at the time, all over in a tremor and cold sweat. This deceitful calm is nothing but the too certain precursor of mortification. The animal commonly dies in convulsions.

\section{HERNIA (RUPTURE).}

The signification of the Greek word, 'ernos, a branch, is too narrow to express properly what we understand by rupture in its varieties. We shall here confine ourselves to a displacement of the intestines from the abdominal cavity, either through some of the natural openings, or through artificial ones, as the effect of accident.

The places where these protrusions commonly take place in the horse, are, the groin, the navel, the sides of the belly, and the diaphragm. It is these differences in situation that constitute the different sorts of hernia:- that protruding at the groin, called inguinal ; the same extending through the canal and descending into the scrotum, called scrotal ; that at the navel, umbilical; that apparent upon any part of the belly (the navel excepted), ventral; the one passing through the diaphragm, diaphragmatic.

The parts protruded in hernia are commonly either the intestines or the omentum, or both. Every viscus, however, even the thoracic and cerebral, is liable to hernia.

Hernia is again divided into reducible, irreducible, and strangulated. When the contents of the tumour admit of being returned into the abdomen, the hernia is said to be a "reducible" one; when, either in consequelsce of their bulkiness, or their adhesion to the sac containing them, or to each other, that is found impracticable, the hernia becomes an "irreducible" one. Should there be constriction at the mouth or contracted part of the sac, which in inguinal hernia is at the internal abdominal ring, to that degree that the circulation is either impeded or altogether arrested, the hernia is said to be "strangulated."

The hernia most frequent, as well as most important. is inguinal. To which, on both these accounts, it will be necessary that we should give our fullest consideration. Many of the following observations become equally applicable to the other kinds of hernia, a circumstance that wils tend still further to abridge our description of the rest. The reader who would pursue the subject is referred to th. 
translation of M. Girard's treatise, by Mr. W. Percivall, and to a paper on hernia, by Mr. Simonds, in the "Veterinarian," vol. $x i$.

Inguinal hernia, as we have just said, is the most common, of which the scrotal (when the bowel descends into the scrotum) is most frequently observed in the stallion. Bubonocele, or that of the groin, is a very rare form of disease, but is occasionally witnessed in geldings. In the former, the intestine accompanies the spermatic cord by the inguinal canal through the abdominal rings into the scrotum : in the latter the bowel alone lodges in the groin. The ruptures we have named may be considered as the only ones common to the horse. Hernia is more frequently on the right than on the left side; and scarcely ever appears in mares. However, ventral hernia or rupture of the muscles of the abdominal sides, and protrusion beneath the skin of a portion of intestine, is sometimes found in either sex, and perhaps occurs more frequently in the female.

The causes which produce hernia are various, but all arise from violence of exertion, or the effects consequent upon external injuries. With us the efforts used in racing, and the leaps taken in hunting, are causes, as we may readily suppose; when we consider that the dilatation of the abdomen, restrained as it is by weight and tight girthings, must press backwards the intestinal mass. Rearing and kicking also, and being cast for operations, particularly the rising up after castration, have all brought it on. Blows with a thick stick, or from the horn of a cow, may likewise induce it.

The Symptoms of strangulated hernia are in this respect very similar to acute enteritis; there is the same uneasiness, shifting of position, getting up and lying down again. The borse rolls in the same manner, and in turning on his back sometimes seems to get a momentary respite from pain; yet it is but momentary, for the suffering is not one of remission; it is constant. This serves as one distinguishing mark between it and spasmodic colic, with which it has been confounded. In stallions, the testicle on the ruptured side is drawn up to the abdomen, and is retained there, with only momentary fits of relaxation, the scrotum often drops with sweat. Towards the last, the pulse is quick and wiry; the horse paws, looks at his flanks, but seldom kicks at his belly. We assure ourselves of hernia by an oblong tumour in the groin, of larger or smaller bulk; hard or soft, as it may contain either fæces or gas, in which latter case it will also be elastic. When the tumour is raised by the hand, or pressed, a gurgling sound is emitted; or if the horse be coughed, it will be sensibly increased in dimensions. The Schneiderian membrane is often injected, and the horse gazes at his groin or scrotum.

Treatment.-Supposing the animal to be a stallion, we first examine the hernial sac. In this both hands are employed; one is introduced into the rectum, the other into the sheath. The one within the rectum must seek the internal ring; while the other, pursuing the course of the B R cord on the side affected, is to be pushed up to the external ring; and thus, in the natural state, the opposed fingers may be made nearly to meet, and so estimate the size of the opening. However small the protruded portion of gut, the practitioner will be able to detect, and even to reduce it. This exploration may be made in the standing posture; but it will be conducted with more facility and certainty if the animal be cast, which is the preferable mode of proceeding.

Bleed and partially paralyse the parts by administration of chloroform; lessen the volume of distension by dashing the parts with cold water; or, if the horse be already cast, by spreading ice over the belly.

Next, endeavour to return the displaced gut. The horse is thrown upon the opposite side to that disordered; and after one hind leg has been drawn and fixed forward, as for castration, he is to be turned upon his back, and in that position maintained by bundles of straw, while other bundles are placed under him to raise the croup. With both arms well oiled, the operator will now commence his exploration, taking the precaution of emptying the rectum as he proceeds. As soon as he shall have ascertained that it is a case of hernia,-having assured himself the gut protruded through the ring is undergoing neither stricture nor strangulation,-he may endeavour to disengage the hernial part, by softly drawing it inward within the cavity, at the same time pushing it in the like direction with the hand within the sheath. Should he experience much difficulty in these attempts, he is to desist; violence being too often the forerunner of strangulation and gangrene. He must bear in mind that, although the reduction is effected, unless it be followed by immediate castration, it does not always prove a cure. The protrusion recurs after a time, and occasionally even the moment the animal has risen. If the hernia should be reduced by taxis," and it is not intended to castrate the horse, apply a well-wadded pledget, or folded cloth to the part; this may be retained with a bandage crossed between the legs from side to side, and fastened by one part under the belly to a girth; and also, passing between the legs, it may be again made fast to the back portion of the same girth. The intention of this is, to prevent the protrusion of the gut by the exertion of rising; and consequently it should be removed as soon as that danger is over.

Mr. Rogers (after M. Girard) recommends a bistourie caché as an operating instrument, and from his paper on "Hernia" we extract a description of the operation for scrotal hernia.

We will suppose the horse thrown as described in the last paragraph, and the examination made. The operator takes the testicle of the affected side in both hands, and, manipu-

* Taxis (from the Greek taxis, order,) means merely the putting back of the intestine in its place in the cavity of the belly: this is called "reduction by taxis." 
lating it so as carefully to bring it in close contact with the scrotum, leaves it in the left hand. Tightening the skin, and guided by the raphe, he makes a free incision through the integuments, and then through the tunic, which latter he dilates to the extent of three or four inches by means of the scissors or scalpel, first introducing one of his fingers as a guide. If the operator has a knowledge of the parts, he need not be afraid of opening the scrotum by free incisions, made with caution. On opening the scrotum, a quantity of serum, depending on the length of time the strangulation has existed, will escape.

If the operator takes the testicle firm in his hand, there will be little danger of wounding the gut.

After having opened the scrotum, by putting aside the testicle, he may generally obtain a view of the intestine.

$\mathrm{He}$ next attempts to introduce the index finger of his left hand into the stricture; but this is sometimes difficult, as the spermatic cord becomes occasionally enormously enlarged, the stricture preventing the return of blood by the veins, but allowing it to proceed to the testicle by the arteries. In such a case it is an advantage first to castrate, and so get this distension out of the way.

Having carefully passed the finger into the stricture, he then introduces the bistoury, and, having taken great care to avoid the intestine, very carefully dilates the stricture; but this is to be done with the greatest caution, so as just to enable him to return the gut and no more, for if he much enlarges the opening he will, in all probability, have a return of the hernia, and lose his patient. Having reduced the hernia and removed the testicle, he dresses the scrotum with turpentine liniment, and allows the horse to rise.

Treatment of strangulated hernia in geldings.-Inguinal hernia taking the same course, is susceptible of the same terminations, and reouires the same treatment, as in stallions. The operator (the horse lying upon his back) extends the hernial sheath with one hand, while he manipulates with the other; or, should this fail, by instructing his assistant to hold up the hernial mass from the belly, so as to take its pressure off the ring, and thus give him an opportunity to renew his efforts with more effect. In some cases, the introduction of one hand into the rectum becomes necessary. The reduction of the hernia should be followed up immediately by the application of the clams, if we unite with the reduction an attempt at permanent cure of the hernia; taking care, at the time, to draw out the part of the scrotum to which the vaginal sheath is adherent, and to push up the clams as close as possible to the belly; they are then to be closed, as for castration.

Of congenital hernia, our limits allow of little more than the mention; nor need more be detailed, as its consequences are seldom injurious. It appears that inguinal hernia commonly exists in the foetus in utero. Chronic or permanent hernia, our observations being limited to geldings, we see little of. Castration, however, with the armed clams, is the evident remedy.

\section{RUPTURE OF THE INTESTINES.}

There are a number of cases in veterinary books, of rupture of the intestines, especially of the colon. A rent of the ileum nine inches in length, at the part where the mesentery is attached, is recorded by Mr. Spooner. The mesentery was also split. It has been said that rupture of the stomach or intestines is an effect of colic; we suspect that the rupture having taken place by some accident, or disorganization of the parts, the symptoms of colic supervene: and hence the cause is mistaken for an effect.

\section{CALCULI TN THE INTESTINES.}

Stones in the intestines of the horse are not unfrequent. They are occasionally of enormous size. Mr. Spooner has one, round as a cricket ball, and weighing six pounds, found in the colon of a miller's horse. They often occasion dangerous colics, by accidentally altering their situations. Whenever, therefore, colics occur frequently without any apparent cause, they often prove, after death, to be referable to irritation from these displacements.

It is evident that this is an evil we have little power to combat; if a horse, by passing a stone with his fæces, indicates a constitutional disposition to separate chalky matter from his food, and afterwards to concrete it by the mucus of his bowels, the removal of a stone actually formed is hopeless. The abdominal calculus generally has a nucleus, or centre, consisting of a nail or stone. It is composed of the triple phosphates, is generally round, and is easily recognized by its external surface bearing a polish so bright as to seem the creation of art. Otbers are composed of the fine hairs which cover the substance of the oat, and some, called dung-balls, are formed by the fæces becoming impacted. The first is usually found within the small intestines, the two last invariably in the hinder bowels. 


\section{CHAPTER XXIX.}

DISEASES AND INJORIES OF THE LIVER, SPLEEN, AND GLANDS.

\section{\&. DISEASES OF THE LIVER.}

HEPATITIS (INFLAMMATION OF THE LIVER).-JAONDIOE.-ENLARGEMENT OF THE LIVER.-ROPTORE OF THE LIVER.BILIARY CALCOLI.-WORMS AND HYDATIDS.

THE liver of the horse is less frequently diseased in early and middle life than in man and many other animals. Oxen and sheep, having a gall bladder and cystic duct, which the horse has not, are more liable to biliary obstructions. Cows are specially the subject of liver disorder, called by herdsmen and cow-doctors by the characteristic name of "the yellows."

The liver of the horse, then, is seldom primarily affected with inflammation; but hepatitis is induced when this immense gland participates in other abdominal inflammations or injuries. When the liver is involved, there is the additional symptom of the yellow or biliary tinge in the schneiderian, the buccal, and the conjunctival membranes of nose, mouth, and eye respectively. Blaine thus describes the disorder:-

The chronic or torpid state of the disease, which is very common among high-fed and slightly-worked carriage and brewers' horses, may be unsuspected till the animal is suddenly seized with gripes, or otherwise shows signs of being seriously ill. These symptoms are caused by the rupture of the fibrous case of the liver, called Glisson's capsule, and the escape of blood into the peritoneum or serous covering of the huge gland. It is then almost too late to try calomel. A few days' quiet, and a dose to open the bowels, will be all that can be ventured; and the horse is returned to its owner, with a caution to work him gently and feed him sparingly for the future. Such cautions, however, are rarely long attended to. Nevertheless, the peritoneum stretches, and at the same time thickens in substance, containing, and at the same time restraining, the fluid that is poured into it. Another rupture in time takes place, and the same measures are repeated; however, the peritoneum at last gives way. If the rent should be large, the animal may suddenly fall dead. If small, he is apparently labouring under a severe fit of colic, but the dilated pupil, the inability to bear the head lifted up, and the yellow tinge of all the visible membranes, declare the seat of the disorder; and the examination after death shows the cavity of the abdomen full of thin black fluid. It is a curious fact, and one upon which we shall comment hereafter, that in livercomplaint, the horse is often lame of the right foreleg, as if (which is the case in man) the pain extended to the shoulder. What does the inquiring reader think of the following case given by Percivall?

"The horse belonged to the Artillery, at Wonlwich, and was lame in the off foreleg, through which ultimately he became so disabled, that he with difficulty projected the limb even in walking. No cause whatever being discover. able, and the lameness continuing in defiance of all that had been done by way of remedy, it was deemed advisable to destroy the animal. The limb was dissected; but every part appeared healthy. His body was then opened, and, strange to say, a thorn of considerable length was found sticking in the substance of the liver." Hunters kept in stable are subject to hepatitis; which may arise from liberal feeding, injuries to the right side, gall-stones, and mischief in the immediate neighbourhood of the liver in which this gland sympathises. The brain is always disturbed when the liver is congested.

Treatment.-In the first instance, four to six quarts of blood should be abstracted; and this immediately followed by ten drachms of purging mass in a ball, or twelve drachms in solution; the operation of which may be accelerated by the occasional administration of a clyster. Calomel, and indeed every other preparation of mercury, being a stimulant to the liver, is to be scrupulously avoided. As soon as we perceive the physic to be setting, should there be occasion for it, we may take away another gallon of blood; and at the same time, after having had the hair shorn off, apply a blister to the right side, extending it from the borders of the ribs as far forwards as the place of girthing. The first dose of medicine once "set," we may resume our operation on the bowels by giving daily the following ball, omitting it only at such times as purgation shall have recommenced :-

$$
\begin{aligned}
& \text { Take of Purging mass . . . } 2 \frac{1}{2} \mathrm{drachms} \\
& \text { Powder of digitalis . . } 1 \text { drachm. } \\
& \text { Powdered nitre . . . } 3 \frac{1}{2} \text { drachms } \\
& \text { Soft soap, sufficient for a ball }
\end{aligned}
$$

Should the blister not have taken proper effect, twelve hours after its application, it may be repeated. In case the disease appear to be merging into the chronic form, the 
insertion of two or three setons through the skin of the right side is a commendable practice.

Mr. Cupiss, to whom we are indebted for a very clever essay ("Veterinarian," vol. xii.,) on liver diseases in the horse, describes three other affections under the names of unnatural enlargement, decayed structure, and unhealthy secretion. The second may be included as one of the sequelæ of hepatitis, the third as general biliary fever, or a form of jaundice.

\section{JAONDICE.}

The remarkable yellowness of the skin, eyes, and mouth in this disease have obtained for it the name of "Yellows."

The Srmptoms of jaundice are the same as those of hepatitis. It has been said that vetches and green food produce jaundice; we do not believe it. Its treatment is, like enteritis, by alteratives. Try the following:-

\begin{tabular}{|c|c|c|c|}
\hline Calomel & . & - & - \\
\hline Aloes & & & . \\
\hline Powdered gentian & & & . \\
\hline Castile soap & • & . & . \\
\hline
\end{tabular}

Form into a ball, and give night and morning until the bowels are actively purged; then continue only so much of the same, for a week or ten days, as will keep the bowels lax, not in a purging state. If the symptoms be such as bespeak chronic inflammation or incipient consolidation, blister the right side. In cases where costiveness is not present, but, on the contrary, a relaxed state of the bowels appears, give the following:-

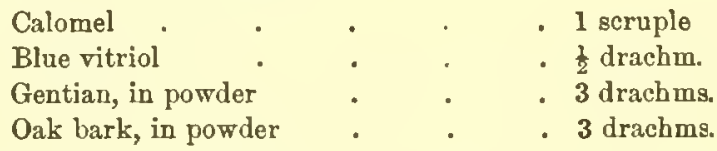

Make into a ball, and give night and morning, unless the calomel should affect the mouth, in which case give only once a day. Should the looseness increase on this plan, add powdered opium, a drachm to each ball. In all cases of yellows, a change of food is proper, and generally necessary. In winter, spear the corn, or give carrots; in summer, soil, or give green grasses; but, in such case, avoid exposure to the night air, making use of moderate clothing so long as the calomel is continued.

\section{ENLARGEMENT OF THE LIVER.}

Mr. Cupiss says of enlargement of this gland:-

"Unnatural enlargement of the liver sometimes takes place. It is swollen to two or three times its natural size. It presents an appearance of general congestion; it becomes gradually filled with a black bloody fluid. The progress of this variety of liver disease is uncertain, generally slow, and almost invariably fatal.

"The symptoms are, an enlarged and tense abdomen; the bowels sometimes constipated, at other times relaxed; there is sometimes considerable thirst; the pulse is accele- rated to 100 or more, loud and thumping, and easily mistaken for a primary affection of the heart.

"The most effectual treatment will consist in a cautious administration of laxatives, accompanied by diuretics and counter-irritants. To this tonics may succeed. In my opinion, the ioduret of iron, in doses of half a drachm, two or three times every day, would be preferable to any other medicine.

"One post-mortem examination presented the liver abont three times its natural size, and consisting of a mass of coagulated blood."

\section{RUPTORE OF THE LIVER.}

As there is no curative treatment for this lesion, we shall dwell on it briefly. The age and habits and condition of horses disposed to this accident are such as conduce to and indicate some morbid condition of the liver. Enlargement and degeneration of substance alike conduce to rupture. Since the stall-fed ox is so prone to disease of the liver, is it not reasonable to suppose the stall-fed horse should be subject to some similar disorder? Chronic hepatitis is a disease so obscure and insidious in its course, that horses in general have it without any knowlege on our part of its existence. In fact, we know nothing about it until the subject of it comes to dic, perhaps from ruptured liver, and we find the gland clay-coloured, softened, and so rotten in texture that it will hardly bear handling without falling to pieces.

The rupture in most cases happens all at once; but the hæmorrhage from it would appear as if it became partlynay, in some cases perhaps completely-stanched, and then relapsed. In a case that occurred to $\mathbf{M r}$. Siddall, the horse had been ill, and subject to frequent faintings for upwards of three weeks before he died; which appeared afterwards to have been caused by small ruptures of the peritoneal covering of the liver in different places, of all which he rallied, not sinking until the grand rupture had happened.

A grey coach-horse, belonging to his late Royal Highness Prince Albert had been unwell the day before-heaving at the flanks, and off his feed-when Mr. Siddall was sent for to attend. His respiration was now short and accompanied with sobbings, and particularly when moved, though comparatively tranquil while standing alone undisturbed, except now and then, when a sort of paroxysm came on. Extremities cold; pulse frequent and small, and easily compressed. Sclerotic coat and buccal membrane blanched; tongue covered with frothy saliva; breath stercoraceous; fres scanty and dry. Medicine and gruel were prescribed. The next morning the groom found he had eaten his mash, and thought he appeared more cheerful. Soon afterwards, however, while doing something upstairs, over the stable, the groom heard him fall, and in a very few minutes after he breathed his last.

In the above case, the horse survived forty-eight hours after the rupture.

The immediate cause of the rupture appears to be either 
excessive distension, or some effort of respiration or bodily a case recorded by Mr. Blaine, that both patients died on exertion, or some injury. In a case of enlargement fol- the fourth day.

lowed by rupture, the liver had acquired the weight of sixtytwo pounds; was intensely black; and from a rent in its lower border three gallons of blood had escaped.

\section{BILIARY CALCULI, WORMS, AND HYDATIDS.}

Biliary calculi, from the structure of the liver in the horse, and his want of a gall-bladder, are not so frequent as in the ox or cow. Urinary calculi will be noticed under the BLADDER AND KIDNEY.

Worms are said to have been found in the liver of the horse; we never met with any. In the sheep they are not uncommon.

Hydatids are sometimes hid in the horse's liver. In sheep they are so common that rot was at one time attributed to them by the cow-doctors.

\section{$\$$ II. THE SPLEEN AND GLANDS.}

\section{SPLENITIS.-CANCER OF THE SPLEEN.-ENLARGEMENT AND} RUPTURE OF THE SPLEEN.

Splenitis (or inflammation of the spleen), we know only in post mortem examinations. In this compendium we have merely to record the fact that no veterinarian doubts that the spleen is the occasional seat of inflammation; but in what its symptoms differ from ordinary colic, we know not. Mr. Cartwright, in the "Veterinarian" for 1836, describes a case which he confesses he treated "as obstruction of the bowels," in which the spleen-the only viscus diseasedproved "double its usual size, gorged with blood, and black as jet. Its natural tough texture was quite broken down, and it was soft, and in a manner approaching to gangrene." There appears the singular coincidence between this and

The French veterinarians elaborately describe splenitis and its symptoms, but, as we said before, they do not differ from those of colic.

Cancer of the SpLEen has several cases recorded under the name of carcinoma melanosis-black cancer. In one of the cases in the "Veterinarian" for 1837, Contraband, a dark brown stallion, eight years old, was treated for disease of the kidneys, and died. The spleen weighed, with the cancerous tumours on the gastric side of it, 102 pounds, and was sixty-eight inches circumference: the portions of spleen re. maining were of all colours. Mr. Huntley, veterinary surgeon, relates a case where "the spleen weighed fifty pounds, and was a mass of scirrhus; and the pancreas in a similar condition, weighing more than thirty pounds. Emaciation was the only actual symptom of this frightful state till the animal, a mare, died suddenly.

\section{RUPTORE AND ENLARGEMENT OF THE SPLEEN.}

This formidable lesion is occasioned by enlargement, spasm, or accident; often the presence of the first render: an accident fatal that would not otherwise be so. Interesting cases are related in Percivall's "Hippopathology," vol. ii., p. 331, and in various volumes of the "Veterinarian," to quote which would overload our pages. One case, in which Mr. Cunningham, veterinary surgeon, found a ruptured spleen weighing ninety-two pounds, is recorded in the "Veterinarian" for 1855 , p. 72.

Disorders of the glands, naturally, range themselves under several diseases. specific and general, as glanders, farcy, indigestion, enlargements of structure. inflammation of tissues. \&c 


\section{CHAPTER XXX.}

DIBEASES OF THE DRINART ORGaN8, AND OF THE ORGaNs OF GENERATION, IN THE HORSE AND MaRE.

\section{§ I. THE URINARY ORGANS.}

NEPFRTTIS (INFLAMMATION OF THE KIDNEYS).-ABSCESS, SOFTENING, INDORATION (SCIRRHUS), AND ENLARGEMENT.-DIABETES.-ALBUMINOUS URINE.-BLOODY URINE (HAMATURIA). -CYSTITIS (INFLAMMATION OF THE BLADDER).-SPASM OF THE URETHRA.—DRINARY CALCOLI.—TAPPING THE BLADDER.

THE kidneys and bladder are the chief parts of the urinary apparatus. The ureters and urethra being merely channels for the fluid, which is elaborated by the furmer organs, and received and retained by the latter until such time as becomes convenient for its ejection. The exemption of horses from venereal affections, and their less liability than men to generate stone, contracts the list of their diseases of these organs. Indeed, were it not for injury-inwardly as well as outwardly inflicted-we should probably hear but little of them. Over-exertion, particularly under heavy burthens, is one grand cause of kidney disease ; medicine and food possessing diuretic properties constitute another; bearing which in mind, it will at all times become a leading desideratum in the treatment, to take care to remove or avoid the repetition of such influences. The kidney of the horse is a peculiarly susceptible organ. It is easily acted on; and manyindeed most-medicines that we are in the habit of using take some effect or other upon it. Mr. Percivall says, this is one reason why so very few medicines will purge horses; the majority of them being so readily carried out of the system through the kidneys. A fact strongly corroborative of this opinion, is that of a copious flow of urine of a dark colour being frequently observable in horses who have been but slightly affected by doses of pliysic they have taken, and who, notwithstanding the little or no purgative effect they have experienced, have shown afterwards quite as much temporary weakness and loss in condition as if the physic had worked their bowels. This the same authority sets down as a reason why mercury produces salivation with such comparative tardiness and uncertainty in horses. This susceptibility of the kidney, in veterinary medicine and dietetics must never be lo:t sight of. It is of vast importance in practice, and renders our treatment in many cases different from what surgeons would pursue under similar circumstances, we being able to effect so much more through the agency of these organs in the system of the horse than is to be accomplished in that of the human being. The veterinary surgeon, in fact, must often effect that through the medium of the kidneys, which the human surgeon does through the agency of the skin and bowels.

Nephritis (Gr. nephroi, the kidneys), or inflammation of the kidneys, as a primary disease, is not very common with the horse; but by its fatal tendency, it becomes important. Small as these organs are, they are most essential to life, and the quantity of blood passing through them is very great; therefore, we cannot wonder at their aptitude to inflame, nor the great derangement that inflammation occasions the machine.

Inflammation of the kidneys is not now so common, because horse owners are not so much the slaves of the groom's and their own ignorance. In the words of Mayhew : "Urine balls are no longer kept in every loft. Nitre-one ounce of sweet-nitre (that is, an overdose of harsh saltpetre), may be yet permitted by some horse-owners, who regard it as a charm for every ill. It is true that such a dose of a powerful diuretic is four times the strength which science would prescribe; yet certain people, we hope only in remote parts, yet are happy in the conviction that 'an ounce of sweet nitre can do no harm.' It is fortunate the urinary organs of the horse are so little disposed to take on disease, or half the horses in England would be disabled by inflammation of the kidneys."

The causes are, exposure to cold, standing in the rain, water dropping on the loins we have known bring it on; a beavy awkwardrider by his motions, or even the action of the psoæ muscles in great exertion, may bruise the kidneys; and occasionally it may be caused by a sympathetic inflammation. How-burnt hay, musty or even kiln-dried oats, in common with other diuretic substances, which under the name of staling or urine balls, are such favourites with every groom, may produce it. It may terminate in resolution, suppuration, or gangrene.

Symptoms.-Dull appearance; pain, expressed by looking at the flanks; urine made frequently and in small quantities, with much effort or groaning; often red or bloody, and as the inflammation increases almost wholly suppressed; still attempts are made by the bladder to evacuate, and the mucous secretion from the organ and urethra only are pressed out with much pain. Pulse at first rather hard. 
frequent, and somewhat full ; but, as the disease advances, it becomes smaller, oppressed, and intensely quick. The animal stands with his legs wide apart, as though going to stale, and shrinks when the loins are pressed. If it be an entire horse, the spermatic glands are alternately drawn close to the belly, and pendulous or relaxed. To distinguish it from inflammation of the body of the bladder, or from spasm of the neck of that organ, the horse should be examined by passing the hand up the rectum; when, if the inflammation exists in the kidneys, the bladder, whether it contain anything or not, will not be hotter than the surrounding parts, or more tender : but should the affection be confined to the body of the bladder, it will be surely found einpty, but very hot and painful to the touch; if, again, spasm of the neck of the bladder, as sometimes happens, should be the seat the disease, no heat or tenderness will be felt, but the bladder will be found distended with urine. The horse shows much disinclination to move, straddles wide behind, and his back is "roached."

Treatment.-This must be directed to the equalization of the arterial action. Back-rake, and examine carefully by inserting the hand up the rectum, and feeling for heat and tumefaction of the diseased organ. Throw up frequent clysters, consisting of cold water, in every gallon of which one ounce of sulphuric ether, and one ounce of crude opium, are dissolved, both with a view to promote a soluble state of bowels, and to act as a fomentation to the inflamed organs; and if any costiveness be present, give a purgative without any diuretic substance intermixed. It should, because aloes contain resin, consist of linseed oil, a pint and a half, in which a drachm of chloroform is mingled; and one half of this may be repeated in six hours, if the animal display no improvement. It will be prudent also to endeavour at exciting an external inflammation on the loins. The administration of cantharides is here questionable, from a disposition in them to stimulate the kidneys. Turpentine, for the same reason, should not be applied; but no such fear prevents the use of liquor ammoniæ, in the manner before directed, when treating of enteritis; neither can any objection be formed to the application of a simple mustard poultice, which may be renewed every two hours; and if a newly-stripped sheepskin be laid upon the place the liquor ammoniæ or mustard poultice has occupied, the activity of each will be increased. In acute pain, give belladonna extract, half a drachm, and crude opium, two drachms, thrice a day, in linseed meal and honey. Without giving violent sudorifics, which would increase the action of the heart and arteries, we should attempt to moderately determine the blood to the skin and the limbs by clothing, friction, and bandaging up the extremities; as well also by nauseating the stomach with white hellebore. Injections of warm linseed tea may be thrown up every two hours, and a pail of the same placed before the horse; he will want no other provision during the attack. Diluting liquors are among the best means of lessening inflammation, for which reason a pail of tepid gruel should be kept constantly in the manger. These cases, however, generally last some time, during the whole of which the efforts should be continued, and exertion only relax as death, from known and well-marked signs, appears certain.

Percivall says: "should the inflammation not abate, keep the bowels soluble and the skin supple by the following:-

$$
\begin{aligned}
& \text { Purging mass . . . . } 1 \text { drachm. } \\
& \text { Tartarised antimony . . . } 1 \text { drachm. } \\
& \text { Carbonate of soda . . . } 3 \text { dracnms. }
\end{aligned}
$$

Mucilage to make a ball. If this produces purging, reduce the purg. ing mass to half a druchm, or discontinue.

ABSCESS, SOFTENING, INDURATION, AND ENLARGEMENT OF THE EIDNEYS

Most of these are preceded by acute nephritis. The first, abscess, is sometimes the result of accident. The French veterinarian Hurtrel d'Arboval, relates the case of a mare who fell into a hole, and was got out with difficulty, it being supposed she had received a spinal injury. Her urine was turbid, with streaks of blood. After a time a tumour appeared in the right flank, which was opened, and discharged an immense quantity of pus : the wound did not heal, but a fistula formed. The horse sunk After death the right kidney was found to be four times its natural size; the pelvis, greatly distended, contained three pints of pus streaked with blood. The left kidney was also enlarged, and its pelvis filled with a quart of limpid urine. The bladder was thickened and inflamed, and contained merely a sediment of urine.

Mr. Cartwright, veterinary surgeon, records a case where the kidneys were light blue, in a complete state of putrefaction, and "the finger would pass through their substance like so much mud."

Induration, or scirrhus, also follow on injuries or inflammation.

The symptoms of kidney disease are fotid, bloody, or filamentous urine; a small irregular pulse; recurrence of sweats, especially in the flanks; these ceasing, the patient falls, and convulsions close the scene. The gait of the horse, and his wide mode of standing, are characteristics of these disorders. The animal, too, can bear no pressure on the loins. In some cases he will resist in evident agony any attempt to press his back, at others he will sit down on his hinder parts like a dog, and there is obstinate retention of both urine and fæces.

The treatment is included in that of nephritis.

\section{DIABETES.}

Disbetes, polyuria, or profuse staling, has been divided into a number of distinct disorders according as the composition of the urine exhibited different constituents or proportions. Thus we have diabetes insipidus (watery diabetes,) diabetes mellitus (sugary diabetes), \&c. We shall here merely speak of excess of urine, as inflammation is alread $J$ mentioned as the cause of deficiency. 
Simple augmentation of the urinary discharges, without any material change in the composition of the urine, is the effect of a multitude of causes, some alimentary, others medicinal, others again of a nervous nature. Every horsekeeper knows how certain kinds of hay and corn cause horses to stale more than they ought to do, and that drinking a large quantity even of plain water will produce the same result. Medicines called "urine balls," or diuretics, are given for the especial purpose of increasing the urine. But nervousness will likewise do it, fright, or anxiety of any kind almost, will make a horse stale inordinately. How frequently do we see hunters at the covert side, when the hounds are about finding, staling or continually stretching themselves out to do so; and a horse having wounds will commence staling the moment the twitch is put on, from the remembrance that some painful cutting or dressing had followed this, to him, unpleasant operation

Profuse staling can only be regarded in the light of disease when it amounts to much more in quantity than is natural, and continues for that length of time that the wellbeing of the animal is evidently affected by it.

The cause for this must in general be sought for in the food or the water. Dark-coloured, highly fermented, or mow-burnt hay; kiln-dried oats, or such as have speared or become musty from lying long in heaps; barley that has malted, and water having some mineral impregnation, are each and all injurious agents, notwithstanding they are consumed in many cases with impunity.

The kidneys, too, may be subject to this excess of secretion from the tampering of the groom with diuretics. Mayhew advises the following test, in his amusing but practical style. "Take into the stable two slips of blotting paper. Dip the ends of one of them into the interspaces of the brick floor where some of the urine is retained. Smell the piece: if it smells like violets, that is proof positive that turpentine has been given to the animal. Dry the other piece after dipping; should that, when dry, and a light is applied, prove to be touch-paper, the evidence is conclusive: sweet nitre has been given to the animal. Should both these tests fail, the groom is innocent; other diuretics are unknown in the stable."

The symptoms, in ordinary cases, attendant upon this immoderate flux of urine are-insatiable thirst, with, unless this be satisfied, a refusal to feed as usual ; unhealthy appearance of the coat, dispiritedness, inability to bear fatigue, loss of flesh, and debility.

The quantity of urine voided in some of these cases is so great as to be quite incredible. The stall is deluged with the fiow. In an account of the disorder as it occurred at one time in France, M. Lassange informs us, "the horses attacked voided five or six pints of perfectly clear urine every hour.

The urine is thin, aqueous, and perfectly transparent. Carbonate of lime, sulphate of soda, muriate of soda, benzoate of soda, and phosphate of lime, amounting altogether to one-eighth of the fluid, and seven-eighths of water, maks up the healthy urine of a horse; but in simple diabetes the water forms more than ninety-five per cent. of the fluid.

Treatment.-Should the animal be attacked during the spring or summer season, a desirable change would be from the stable to the grass-field; or, when this cannot conveniently be done, soiling may be practised with advantage. Should the water appear to be the cause, and there be no means, or very great difficulty of obtaining any other kind, we may put a piece of chalk into the pail with a view of neutralizing the obnoxious impregnation.

The medicines most serviceable in this disorder are astringents and tonics. Mr. Percivall's prescription is composed of sesqui-carbonate of iron and prepared chalk, of each half an ounce, made up with syrup, and given once a day. Mr. Castley gave powdered galls, alum, and bole armeniac, each one ounce, ginger one drachm, in a quart of beer: half at night and half in the morning. Mr. Stewart speaks in laudable terms of opium. He recommends daily a ball consisting of three drachms of opium, and of catechu, gentian, and ginger, two drachms of each, made up with a little tar.

Slıould fever exist, such medicines, of course, become inadmissible. In their place moderate blood-letting and purging must be practised. In case the urinary disorder outlive the febrile one, which it will not often be found to do, recurrence may be had to the opiate and astringent medicines.

A pail of linseed tea, made by pouring boiling water on whole linseed, and letting it stand till lukewarm, should stand within reach. Attend to the skin, and employ friction if the horse takes it kindly. A ball daily of one drachm of iodide of iron, with linseed meal and honey; or a drink of phosphoric acid, one ounce to a pint of water, is extolled, and rightly, by Mr. Mayhew. The iodide of iron acts as a tonic, and reduces thirst.

\section{ALBUMINOUS URINE-BLOODY URINE.-HEMATURIA.}

Albuminous or serous urine is a symptom of kidney disease, which it is well to be acquainted with. The water becomes of a deep straw colour, and thick as a solution of gum water. With a test of bichloride of mercury it will precipitate a copious milky flocculence, resembling white of egg, which may be coagulated by heat or a little vinegar and prussiate of potass. The symptoms, as in other kidney disorders, are straddling behind and "roaching" the back. Though sometimes the straddle is made backward and the spine curved in, with an expression of intense pain. Stimulants, mustard plasters, sponged off before destroying the hair, are first employed, then abstinence from exercise, and, finally, opium in repeated doses, are our only dependance.

Hcematuria, or Bloody Urine, is a complaint often met with, and our first suspicion is that a strain, blow, or other injury should be looked for. The blood may come in clote 
or mixed with the urine, or show itself in its pure form only upon coagulation.

The Treatment is guided by the circumstances of the origin of the attack. Examine the kidneys by the rectum, and sweat the loins and pelvis; then let the animal rest without any disturbance or irritation, and administer gently two drachms of acetas plumbi in half a pint of cold water; then, in a quarter of an hour, give the like dose of the acetate of lead, with one ounce of tincture of opium. Repeat these till four doses are given, when, if the patient is not benefited, take four drachms of the ergot of rye, and infuse in a half pint of boiling water, when cool add one ounce of laudanum, and four of dilute acetic acid. Throw pails of cold water from a height upon the loins, and inject cold water per anum. Should the hæmorrhage cease, and the kidneys not be enlarged or hardened (scirrhous) give the following:-

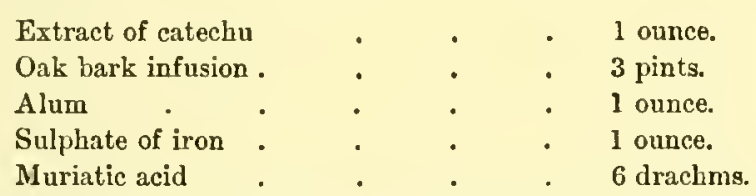

This quantity to last the day, administered at four. tive, or oix periods, as most convenient.

\section{URINARY CALCULI-STONE IN THE BLADDER.}

We believe these to be much more talked of than seen. Renal calculi are unfrequent, but vesical or cystic calculi (stone in the bladder) are more common. A reference to Percivall ("Hippopathology," vol. ii., pp. 356-373) will put the inquiring reader in possession of what English and French veterinarians have done in investigating the varieties of calculi, and the diseases produced by them, or of which they are the products. Mr. Morton, late Professor of Chemistry, at the Royal Veterinary College, has published a volume on "Calcular Concretions," which exlausts the subject.

The symptoms of renal calculus are not certain. The urine may or may not become purulent, opaque, gritty, or bloody. The first of these symptoms occurring when we have convinced ourselves there is no stone in the bladder, may lead us to suspect renal calculus, especially if the animal shrinks from slight pressure on the loins. Our only treatment is hydrochloric acid in the water, in hopes to arrest the increase of the deposit.

The chemical composition of calculi in horses is nearly uniform, consisting of carbonate of lime (common chalk, and carbonate of magnesia in varying proportions, mixed up with albumen and mucous secretion. There is in the Museum of the Veterinary College a stone found in the bladder of a horse as large as a man's head; the animal for many years had been accustomed to stale every ten minutes, and was known by the peasantry through the country he lived in as " the Pissing Horse."

Stone in the bladder is denoted like other kinds of stone s s by altered conditions of the urine and difficulty and irregularity in its discharge. The water, when flowing freely, will sometimes be stopped suddenly, and great pain come on, small emissions being effected by violent straining. The back is oftener hollowed than "roached," and in some cases the point of the penis is constantly exposed. The horse often stops short, especially in going down hill, from a sudden spasm, or in hopes to relicve the bladder.

In order to make certain of the presence of stone in the bladder, an examination by the rectum is necessary. A firm substance will be felt near the neck of the bladder, which generally contracts pretty firmly upon it. The size, form, and outline of the stone can be ascertained by the experienced surgeon.

Lithotomy or lithotrity is the remedy for this disease, as well as urethral calculus-the one being the cutting down on the stone (Gr., lithos, a stone, and temno, to cut), the other breaking or comminating the stone (Gr. lithos, and tero, to break). Of the first we have a large number of recorded cases from the time of Lafosse downwards. A single case, as related by Percivall, will convey a clear idea of the operation, for further details of which the technical elass-books of veterinary surgery must be consulted.

"On the 26th Feb. the animal appeared to be in a favourable state for the operation of lithotomy, which was performed by securing him upon his back, with the hind legs drawn forwards to the shoulders. The penis being drawn out, a three foot whalebone staff was introduced as far as the perinæum, and the urethra opened by an incision about three inches in length; a grooved sound was then passed straight into the bladder, and the stone was most distinctly felt, and heard on being struck. It was attempted to be extricated without cutting open the pelvic portion of the urethra and the neck of the bladder, being readily grasped with the forceps, assisted by pressure made upon the calculus by the left hand introduced into the rectum; but being too large, these parts were laid open by a lateral incision made with a strong, curved, and probe-pointed bistoury. It was then, by the same means, but with considerable force, brought gradually forward to the perineum, when it was forcibly contracted upon, and a further extension of the external incision was necessarily made to effect its removal. The hæmorrhage was not very great or alarming, but it was thought best to secure a perineal vessel with a ligature.

'The calculus is of the mulberry kind, very rough, of a depressed oval form, weighing nearly three ounces; it has no distinct nucleus. Dr. Prout, having obligingly undertaken to analyse it, found it composed principally of the carbonate of lime, some phosphate of lime, and a little phosphate of magnesia.

"The horse, immediately after the operation, became tranquil and cheerful, and the pulse fell by evening to the healthy standard, of 32 per minute, and so continued until noon the following day, when, being rather agitated by 
numerous visitors, it rose to 38 , and by night to 45 . Four quarts of blood were taken from the jugular rein, a mild purgative giren, and frequent clysters.

"Feb. 28.-Pulse 40; in the evening, 44. Bowels relaxed.

"Narch 1.-Pulse 4t. Purgative and clysters repeated.

"March 2.-Pulse 42 ; and so continued until the Sth, when it declined to $3 \varsigma$, and subsequently to 32 , at which it continued this day (the $1 \mathrm{Sth}$ ), three weeks since the operation. The bowels haring been kept open by aperient doses of aloes and by clysters. The urine was evacuated partly by the orifice until this time; but the wound is now healed, and it flows through the whole length of the urethra without the least impediment. The horse is exercised daily, and is fit to be discharged."

In cases of urethral calculus, that is, of a stone passing from the bladder and becoming fixed in the urethra by its muscular contraction, it has been found possible to extract it without an operation, by the dilatation of the passage by mechanical means, aided by relaxing lubricatory injections and fermentations; in all these cases hydrochloric acid should be administered. Mr. Spooner observes: in the case of urethral calculus, "lithotomy consists merely in laying open the canal along its median line and from behind forwards: it is to be performed with a bistoury directed by one of the fingers of the left hand. In this manner, M. Dufils, veterinary surgeon at Bourdeaux, in 1821, extracted a stone from a mare, which was lodged in part in the meatus urinarius; whereby she, who was before the subject of frequent colics, became at once restored to ease, and spcedily afterwards to health. In the centre of the stone was found an almond, forming its nucleus. At the time it was shown to us, MI. Dufils assured us that it had lost much of its weight and rolume, proving thereby that these calculi contain a large proportion of fluid, the evaporation of which evidently brings on this diminution." *

\section{CYSTITIS (INFLAMMATION OF THE BLADDER).}

Inflammation of the bladder is said, but not proved, to be more common among mares than horses; but of all the causes of this affection none can compare with the powerful diuretics in general use with erery stable-man or groom. The symptoms are frequent-nay, continual-emissions of small quantities of urine, roided with much straining, during which the dung commonly is passed. The bladder will be felt by the greased hand passed gently up the

* A case has recently come under the attention of the writer, in which a stone was removed from the urethra by craration with success. This case was complicated with perineal abscess and striature of the arethra, and was followed, as well as attended, by a remarkable disposition of the horse to earthy depositions in the urine. This latter disposition was treated with hydrochloric acid, in doses of 2 drachms, given in solntion, with much advantage. The stricture was removed by caustic, carefully applied to the part. When the calculus in the bladder is ton large for removal, it may be softened or dissorved by acid injections. rectum, hot, tender, and contracted into a firm substance of about the size of a cricket-ball.

The treatment is the same as for nephritis, and equally as urgent; erery precaution pointed out when treating of inflammation of the kidneys, should be rigidly adopted; in addition to which, warm water, in every gallon of which a quarter of a pound of gum arabic and an ounce of crude opium have been dissolved, may be injected into the bladder by Read's syringe with an elastic catheter attached

\section{SPASM OF THE NECK OF THE BLADDER.}

We have preferred the old name of this attack, though it is not so correct as spasm of the urethra, inasmuch as it is not the neck of the bladder, but the urethra which acts in this case in the retention of urine. It is distinguishable from inflammation of the kidness by the large secretion of urine held in the bladder, and the consequent endeavours of the horse to empty it. The true nature of the disorder is discovered by passing the hand up the rectum; the bladder will be found distended; the distension may indeed be felt in the front of the pubes. The retension of urine, however, is the principal symptom, although in spasm of the neck of the bladder there mas be a small quantity of urine evacuated at different times; for after the bladder is distended, there will be, by the force of the accumulation, a few drops now and then squeezed out. But in this disease frequent or copious staling will not take place, whereas in the previous disease it will be continual.

As to the Causes of this complaint we know little; but it may be reasonably supposed that the spasm of the part is occasioned by morbid irritation, and our opinion of the probable termination must depend on our being able to empty the distended bladder, and restore the lost tone of the orvan. Every effort must be made to accomplish this, or the animal may perish under irritation; he may sink through gangrene of the distended bladder supervening, or he may, as he uswally does, die of rupture of the bladder, in consequence of the kidneys continuing to secrete urine but the spasm offering an obstacle to its emission. Attempt therefore to accomplish the ejection by introducing the hand up the rectum, and gently pressing the fundus of the bladder forwards, which may force the passage. If this fail, the urethra must be opened by a catheter. In a mare, the catheter may be easily passed up, and the water drawn off; but in the horse, to effect this, a flexible catheter must be introduced, and gently guided forward. When a horse is affected with spasm, the penis is generally much retracted, but with a little patience, aided by a handkerchief wrapped round the hand, inserted up the sheath, this may be overcome. The part is then given to an assistant to hold firmly, while the practitioner inserts the point of $t s$ : catheter, which he pushes forward with his right hand, while he places his left beneath the anus, in order to turn the tube by manipulation when it shall have reached the perinæum. The rest is straightforward work; only be careful to make 
steady, continued, rather than sudden or violent pressure. After the urine has been evacuated, inject a gallon of cold spring water, with which an ounce of tincture of gall-nuts has been mixed ; and if this last is at the time, or shortly afterwards, ejected, no fears need be entertained about the lost tone. If it is not cast forth, draw it off, and inject another gallon, and continue till the bladder freely contracts. At the same time you may give a clyster, composed of two quarts of cold water, with two ounces of sulphuric ether, and the same quantity of laudanum, which may be repeated for three times. Mild food and good water, both procured from a new source, are all that is required to perfect the cure, excepting it may be thought proper to give a dose of physic upon recovery.

Strangury, Stricture, \&c., may be passed with the remark that, to draw off a horse's urine, it was formerly thought that, in the male, you had no resource but to cut through the perinæum into the urethra. We now know that a flexible catheter can be passed by a skilful veterinarian. Should the cutting be thought necessary, it is performed by a full-sized whalebone staff, flattened and ground at the end, passed through the penis till its extremity is felt by the other hand protruding in the perinæum. In this situation it is cut down upon sufficiently to admit the straight (or female) metallic catheter into the bladder, when the distended bladder is emptied, and the desired relief given.

\section{§II. DISEASES, \&c., OF THE REPRODUCTIVE ORGANS.}

GYPHILIS NON-EXISTENT IN THE HORSE.-URETHRITIS.-PHYMOSIS AND PARAPHYMOSIS.-VAGINITIS AND LEUCORRHQBA (WHITES). - SCIRRHOUS TUMOURS.-OBSTETRICS. - EMBRYOTOMY.-CASTRATION.

Extensive and important as the variety and modes of treatment of the diseases of the sexual organs are in human surgery, the absence of those vices in the lower instinctive animals to which proud reasoning man is prone, fortunately renders this branch of veterinary science comparatively meagre. The practice of castration, too, makes disorders of the testicles nearly a blank, except to veterinarians practising in breeding or racing establishments, where entire horses are more frequent. Even here disease is rare. Older writers, and especially Continental veterinarians, in love with systematising, have set down diseases akin to syphilis, and described cases to bolster up their theory. We may safely dismiss them, and that too with the authority of one of their own greatest writers and practitioners. Hurtrel d'Arboval, in his veterinary dictionary-"Dictionnaire de Médecine, de Chirurgie, et de Hygiène Vétérinaire," Paris, 1838,--repudiates with disgust the imputation that the horse is the subject of syphilis, and expresses his surprise that the authorities at the College of Alfort should have admitted it into their pathology. He slows that lues venerea is a disease peculiar to man, and can have but one specific origin. If an animal could contract the disorder, it must be from a crime of man of too revolting a description to be more than alluded to. D'Arboval continues, "I have not passed through a long course of practice without meeting with cases which biassed minds might lave taken for syphilis. I have had occasion particularly to observe and to treat irritations, inflammations, paraphymoses, discharges, ulcerations, \&c. I have even remarked an obstinacy in some of these genital affections, with sympathetic swelling of the inguinal glands, and of one or both testicles, without, for all that, entertaining any notion of the disease being syphilitic. So far from it, I have always been contented with simple antiphlogistic treatment, modificd as circumstances required, and I never had cause to repent of not having introduced mercurials." To this we need only add, that although cases of urethritis (inflammation of the urethra) have occurred, with a flow, or gonorrhoea (Gr. gone, seed, reo, to flow), yet it has been what Cullen calls in his "Nosology," gonorrheea pura vel benigna. D'Arboval declares its causes to be, foreign substances within the urethral canal, too frequent acts of copulation, diuretics or balls of cantharides often given by injudicious grooms to excite the stallion, ascarides within the rectum, and inflammation of tbe bladder, causing retention of urine.

The treatment in all these cases is simply antiphlogistic,tepid, bland, and mucilaginous drinks, with nitre, green meat, and, if that is scarce, mixed with sound straw, together with fomentations and clysters; and, if the pain be intense, both fomentations and drenches may be rendered narcotic In entire horses, leeches may be applied to the testicles, or local bleeding practised. If there be any foulness, dilute acetate of lead or dissolved alum may be used as an astringent and discutient.

Phymosis (Gr. phimos, a bridle) is a contraction of the orifice of the sheath, which prevents "drawing," or protrusion of the penis. Paraphymosis (Gr. para, beyond, phimos, a bridle) is, on the contrary, a contraction of the sheath when the penis is protruded and swollen, preventing its being drawn back again, and thus bridling or strangulating the glans penis. Both of these occur from blows, kicks, contusions, or wounds. In the first, a troublesome disease ensues, from the animal urinating within the sheath. In the second, which has been seen after accidents in attempts at copulation, a kick from a vicious mare-or worse a blow from some human brute with stick or whip upon the yard while in a state of erection,-the treatment is similar. Cold lotions to abate inflammation; local scarifications, produciug free evacuation of blood If there are concealed ulcerations, or purulent collections in phymosis, we must cut through the prepuce, and slit it far enough back to insure its retraction, then treat the disorder as in cases of abscess or ulcerations elsewhere described. In paraphymosis, remember, all cuts must be made lengthwise, and along the upper part and sides of the penis, to avoid the urethra, and that they cannot well be too long, as they shrink up on the part 
recovering from its distension, and retiring within the sheath.

Amputation of the Penis by ligature and the knife will be found described, with cited cases, in Perrivall's "Hippopathology," vol. ii, pp. 385-388.

VAGINITIS AND LEdCORRHEa. - These, to use the words of Percivall, is no more than catarrh of the vagina, an inflammation of the same sort as may attack the nose, the bladder, or any other mucous canal. Mares who are not allowed the horse, invariably have derangements of this kind during the spring season, when "horsy." At times it is white like whey, at others yellow and almost purulent in character. The discliarge collects, and comes away, when the lips of the vulva are opened, with a gush. A cooling drink, or a ball, as follows, may be given :-

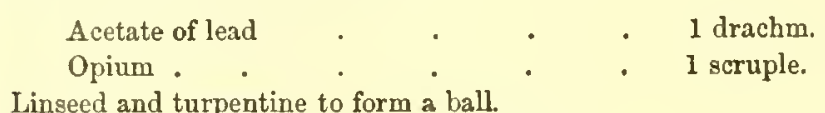

An astringent injection five or six times a day :-

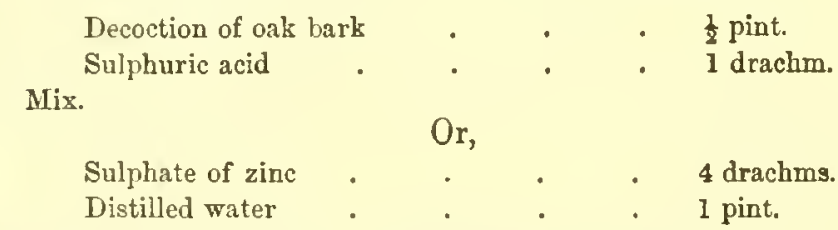

Sprinkle wheaten flour on the external organ and the inside of the thighs after the injection.

Scirrhus of the Vulva is recorded in the books, but we have never met with it. The treatment would be excision of the tubercles, and rubbing the parts with ointment of iodine. If it spreads to the udder, the animal should be put out of its suffering.

Diseases of the Ovaries are too obscure, and hitherto too little investigated by the veterinarian, to deserve more in a compendium like the present than a record of their occasional existence.

\section{OBSTETRICS.}

Parturition with the mare is generally a natural and unassisted act. Cases of protracted and difficult parturition do, however, occur; and in these instances the veterinary practitioner should be au fait to the position of affairs, and the intelligent horse-master should not be under the tutelage of the farrier or the often pretentious groom. We shall here quote the simple and practical observations of Blaine in his "Outlines of Veterinary Art," edit. 1854, p. 365. "The principal cases that occur arise either from weakness in the mare, or from a disproportion between the fotus and the mother. False presentations are also to be witnessed, but chiefly of the back and croup : that of the back requires much labour, but the foal is to be delivered, the hind legs being presented, without turning in the womb being necessary. When, either from debility of the mare, or disproportion in the size of the foal, a natural birth is despaired of, the practitioner, having introduced his arm, and having ascertained that the presentation is a natural one, should draw the feet gently forward, and then endeavour to place the head between them. If the head only is met with, seize it by the muzzle and draw it gently onward, searching for the feet, and drawing them one after the other in the line of the head; which manipulations are, of course, only to be attempted during the throes of the mother. So soon as the head and legs are got near the external orifice, enclose each foot within the loop of a rope, then, holding both ends so attached, endeavour to liberate the foal by steady not violent pulling, timing your pull with each throe or labourpain, unless by debility or protraction they have ceased. When this is the case, try to revive them by the administration of stimulants, especially infusion of the ergot of rye, in two-drachm doses every twenty minutes. Should this not effect the object within the hour, proceed to extract the foal, longer delay may lose both mother and offspring. The blunt hook is sometimes used on these occasions where the hand cannot be introduced : it is a powerful aid with those who can direct it skilfully."

When the obstruction arises from an unnatural presentation of parts - that is, of other parts than the head and forefeet, as of the loins, the croup, and one leg, the other being doubled backward-it is evident we should endeavour to change the position to the natural one (of the head) if practicable. If not, we must bring the hinder feet forwards, and endeavour to make the extraction by this method. Lastly, if all these means fail, we must proceed to lessen the fœtal mass by cutting out the embryo.

EмвRуотомY.-When, from weakness, a very narrow pelvic opening on the part of the mother, or monstrosity on the part of the foal, no efforts can bring the foetal mass away entire, it must be dismembered. A knife made for the purpose, having the blade concealed, with the haft lying within the hollow of the hand, is to be taken up into the vagina. We are told that, occasionally, hydrocephalus in the colt prevents the head from passing Such a case will detect itself by the volume that will be felt on examination, and which will be easily lessened by plunging the point of the knife in the forehead, and evacuating the contents by pressing the skull in; when, laying hold of the muzzle, the head may be brought through the pelvic opening. But it is usually the natural size of the head which forms the obstruc. tion; in which case the head itself must be removed. When the head has been dissected off and brought away, it will be necessary probably to contract the volume of the chest, which will not be difficult, by cutting the cartilaginous portions of the ribs, detaching the thoracic viscera, and then crushing or kneading the empty chest together; after which, the rest of the body will offer little obstruction. When the head cannot be got at, the limbs must be de- 
tached; after which the body, and at last the head. may be drawn out entire, or reduced for that purpose.

\section{Castration.}

In England, the practice of castration may be said to be almost universal; the exceptions being a small number of horses kept for racing purposes and covering, and a few cntire horses used in draught and for "black jobs," where the stallion crest is considered to add to the majestic appearance of the animal. Length in the arms and wider-spread angles of the limbs are asserted to be obtained by early castration; certainly the docility and steadiness of the animal are vastly improved. Hernia, founder, and some skin disorders are less frequent with geldings than entire horses.

The best period for castration depends much upon the breed of the horse and the class of work for which he is intended. If there is no object in obtaining a heavy and arched neck and a prominent crest, then the earlier the animal is castrated, the safer and simpler is the operation. From the fifteenth day to the fourth month is the most eligible period, and "foals castrated early grow larger then those cut later," says Mr. Brettargh a veterinarian of extensive experience. He adds:- "Colts are foaled with their testicles within the scrotum, which remain there, in ordinary cases, until the fifth or sixth month, when they are taken up between the internal and external abdominal rings, and there they remain until the eleventh, twelfth, or thirteenth month, all depending upon the degree of keep, as in some that are particularly well fed the testicles can at all times be found within the scrotum."

Colts, therefore, can be castrated any time between the first and fourth month; and this period is preferred by some persons, from the little disturbance it occasions to the constitution. Some breeders of horses castrate at twelve months; others object to this period, because they think the animal has not sufficiently recovered the check experienced from weaning, before this new shock to the system occurs. In the more common sort of horses, used for agricultural purposes, it is probably indifferent at what time the operation is performed; this consideration being kept in view, that the earlier it is done the lighter will the horse be in his fore-hand; and the longer it is protracted, the heavier will be his crest, and the greater his weight before, which in heavy draught work is desirable. For carriage horses it would be less so, and the period of two years is not a bad one for their castration. The better sort of saddle horses should be well examined every three or four months; particularly at the ages of twelve, eighteen, and twenty-four months; at either of which times, according to circumstances or to fancy, provided the fore-hand be sufficiently developed, it may be proceeded with. Waiting longer may make the horse heavy : but if his neck appear too long and thin, and his shoulders spare, he will assuredly be improved by being allowed to remain entire for six or eight months later. Many of the Yorkshire brecders never cut till two years, and think their horses stronger and handsomer for it. Some wait even longer, but the fear in this case is, that the stallion form will be too predominant, and a heavy crest and weighty fore-hand be the consequence; perhaps also the temper may suffer.

In regard to season and weather, the operator shouldwhere he can-object to castrate either during very cold or very sultry weather, or while the horse is shedding his coat, or in the season when, or situation where, flies prevail. These precautions will especially demand attention when our subject is an aged horse, or one that has been highly groomed or fed. The time to be preferred is late in the spring, after the horse has shed his coat, and before the flies have made their appearance.

The colt should be prepared for castration by being kept on short diet for a few days and his system slightly lowered, but by no means to a state of debility.

There are several methods of castration, the commonest with us is that of castration by cauterization. On the Continent, the general practice is by the "caustic clam," by two methods, the "covered " and "uncovered." Castration by torsion bas also its advocates and practitioners, we shall therefore add it to our list.

A preliminary observation should be made previously to casting, to see that the horse is not suffering from a rupture : such cases have happened; and as in our method we open a direct communication with the abdomen, when the horse rises it is not improbable that his bowels protrude until they trail on the ground. Hernia as a consequence of castration may easily occur by the uncovered operation, as it makes the scrotal sac and abdominal cavity one continuous opening. It is not to be wondered at, therefore, if the violent struggles of the animal should force a quantity of intestine through the rings into the scrotal bag. Should we be called on to operate on a horse which already had hernia, it is evident we ought not to proceed with it unless the owner be apprised of the risk, and willing to abide by it.

As unbroken young horses are the most usual subjects of this operation, and as such often have not yet been bridled, if a colt cannot be enticed with oats, \&c., he must be driven into a corner between two stendy horses; where, if a halter cannot be put on, at least a running hempen noose can be got round his neck; but whichever is used, it should be flat, or the struggles, which are often long and violent, mas bruise the neck, and produce abscess or injury. When his exertions have tired him, he may be led to the operating spot. Here his attention should be kept engaged while the hobbles (see Plate $\mathrm{XX}$ ) are put on, if possible; if not, a long and strong cart-rope, laving its middle portion formed into a noose sufficiently large to take in the head and neck, is to be slipped on, with the knotted part applied to the counter or breast; the long pendent ends are passed backwards between the fore-legs, then carried round the hind fetlocks; brought forward again on the outside, run under the collar. 
rope; a second time carried backward on the outer side of all, and extended to the full length in a direct line behind the animal. Thus fettered, says Mr. Percivall, his hind feet may be drawn under him towards the elbows. It has been, however, often found that, at the moment the rope touches the legs, the colt either kicks and displaces the rope, or altogether displaces himself; but his attention can generally be engaged by one fore-leg being held up, Rarey fashion, or by having his ear or muzzle rubbed, or even by the twitch. The rope may now be carried cautiously round each fetlock, which then acts like a hobble; and the rope may be gradually tightened. This last, lowever, is a very questionable method, and the others, therefore, ought to be tried before it is resorted to. In either way, as soon as the rope is fixed, with a man to each end of it behind the colt, let them, by a sudden and forcible effort in concert, approximate his hindlegs to his fore, and thus throw him. Before the colt is cast, however, it should be endeavoured to ascertain that he is free from strangles and hernia.

Being satisfied that no hernia exists on either side, proceed to cast the colt, turning him, not directly on the left side, but principally inclining that way; and if possible let the croup be very slightly elevated. It is usual to place him directly flat on the left side, but the above is more convenient. Next secure the near hind-leg with a piece of hempen tackle, having a running noose; or, in default of this not being at hand, make use of the flat part of a hempen halter, which should for safety be put on before the hobble of that leg is removed; as may he readily done if the hobbles having shifting or screw D.s are made use of. Every requisite being at hand, the operator, having his scalpel ready, should place himself belind the horse, as the most convenient way to perform his manipulations. Firmly grasping the left testicle with his left hand, and drawing it out so as to render the scrotum tense, he should make an incision lengthways, from the anterior to the posterior part of the bag. The resistance of the cremaster muscle has to be overcome before the testicle can be forced to the bottom of the scrotum; and this is the more readily accomplished if the animal's attention be engaged. The incision may be carried at once through the integuments, the thin dartos expansion, and the vaginal coat of the testicles, with a sweep of the scalpel. But with one less dexterous at the operation, it will be more prudent to make the first incision through the scrotum and dartos only, to the required extent; and then to do the same by the vaginal coat, thus avoiding wounding the testicle, which would produce violent resistance, and give unnecessary pain. Cases have occurred, when the tunica vaginalis was divided, that no testicle followed; firm adhesions between this coat and the tunica albuginea having retained it fast. In such cases the scalpel must be employed to free the testicle, by dissecting it away from the vaginal sac. When no such obstruction occurs, the testicle, if the opening be sufficiently large, will slip out; but the operator must be prepared at the moment of so doing to expect some violent struggles, more particularly if he attempt to restrain the contractions of the cremaster, and by main force to draw out the testicle. Preparatory to this, therefore, the twitch should be tightened; the attendants, especially the man at the head, must be on the alert; and the testicle itself, at the time of this violent retraction of the cremaster, should be merely held but not dragged in oppesition to the contraction. If the clams (see Plate XXI.) have been put on over the whole, according to Mr. Percivall's method, they will assist in retaining the retracting parts; but they must not be used with too much pressure. The resistance having subsided, the clams must now be removed; or, if they have not been previously in use, they must now be taken in hand, and having been prepared by some tow being wound round them, should be placed easily on the cord, while time is found to free from the grip of the pincers the spermatic tube, which is seen continued from the epididymis. The Russians, Mr. Goodwin informs us, cut it through when they operate. Humanity is much concerned in its removal from pressure, because of the excess of pain felt when it is included. It is necessary, before the final fixing of the clams, to determine on the part where the division of the cord is to take place. Mr. Percivall says, "If it be left too long, it is apt to hang out of the wound afterwards, and retard the process of union ;" on the other hand, if it be cut very short, and the arteries happen to bleed afresh after it has been released from the clams, the operator will find it no easy task to recover it. The natural length of the cord, which will mainly depend on the degree of the descent of the gland, will be our best guide in this particular The place of section determined on and marked, close the clams sufficiently tight to retain firm hold of the cord, and to effectually stop the circulation within it. There are now two modes of making the division: the one is to sever it with a scalpel, and then to sufficiently sear the end of it so as to prevent a flow of blood. The other, and in some respects the preferable method, is to employ a blunt-edged iron, which is to divide by little crucial sawings, so that, when the cord is separated, it sliall not present a uniform surface, but ragged edges, which will perfectly close the mouths of the vessels. This done, loosen the clams sufficiently to observe whether there be any flow of blood; gently wipe the end of the cord also with the finger, as sometimes an accidental small plug gets within the vessel; this had better be removed at the time. Retain a hold on the clains a few minutes longer; and while loosening them gradually, observing to have an iron in readiness, again to touch the end of the cord, if any blood makes it appearance; satisfied on this point, sponge the parts with cold water. No sort of external application is necessary, still less any resin seared on the end of the cord, which can only irritate, and will never adhere. On the after-treatment much difference of opinion has existed, and even yet exists. The powerful evidence of accumulated facts has now convinced us of the necessity and propriety of some motion for the newly cas- 
trated horse, as a preventive of local congestion; such practice is common in most countries, and seems salutary in all. Hurtrel d'Arboval, thus impressed, recommends the horse, immediately after the operation, to be led out to walk for an hour; and it is a general plan in France to walk such horses in hand an hour night and morning. Mr. Goodwin, in proof of its not being hurtful, informs us that whole studs of horses brought to St. Petersburg to be uperated on, are immediately travelled back a certain portion of the distance, night and morning, until they arrive at home. We have, therefore, no hesitation in recommending a moderate degree of motion in preference to absolute rest.

The French method of castration is advocated by Mr. Goodwin, who quotes its description from Hurtrel d'Arboval. "Castration by means of the clams is the method in general use, if not the only one now employed; it is the most ancient, since it was recommended by Hierocles among the Greek. It is performed in two ways, the testicle being covered ur uncovered. In the former, the exterior of the scrotum, formed by the skin and dartos muscle, is cut through, and the testicle is brought out by dissecting away the laminated tissue, the gland being covered by the tunica vaginalis; the clam is then placed above the epididymis, outside the external peritoneal covering of the cord. In the uncovered operation, the incision is made through the serous capsule of the testicle; the tunica vaginalis being divided, the testicle presents itself, and the clam is placed well above the epididymis, on the cord. The operation, performed in either way, requires us to provide ourselves with a scalpel, a pair of clams, a pair of long pincers, made purposely to bring the ends of the clams together, and some waxed string. The clams may be formed of different kinds of wood; but the elder is considered the best, and generally made use of. To make a clam, we procure a branch of old and dry elder, whose diameter should be about an inch, and whose length should be from five to six inches: of course, the dimensions must at all times be proportioned to the size of the cord we have to operate on. At the distance of half an inch from each end, a small notch, sufficiently deep to hold the string, must be made, and then the wood should be sawed through the middle lengthways. Each divided surface should be planed, so as to facilitate the opening of the clams, either when about to place them on or to take them off. The pith of the wood is then to be taken out, and the hollow should be filled with corrosive sublimate and flour, mixed with sufficient water to form it into a paste. Some persons are not in the habit of using any caustic whatever; then, of course, scooping out of the inside of the clam is not necessary: notwithstanding, the caustic, inasmuch as it produces a speedier dissolution of the parts, must be useful, and ought not to be neglected." The addition of the caustic, however, Mr. Goodwin objects to with great reason, remarking, that unless it be a very strong one, and therefore dangerous to employ, it cannot be of any use to parts compressed and deprived of circulation and life. He further informs us that he has operated in six cases in succession with the same effect, without any caustic matter whatever. An experimental case of $\mathbf{M r}$. Percivall's terminated fatally: by the use of caustic, the cord was greatly inflamed, as high as the ring, which unquestionably produced the unfortunate result. "The covered operation," continues Mr. Gondwin, "is the one that I am about to advocate, and which differs only inasmuch as, that the scrotum and dartos muscle must be cautiously cut through, without dividing the tunica vaginalis. It was Monsieur Berger who was accidentally at my house when I was about to castrate a horse, and who, on my saying that I should probably do it with the cautery, expressed his surprise that I should perform the operation in any other way than on the plan generally approved of in France. Being a stranger to it, lhe kindly consented to preside at the operation: and, after seeing him perform on the near testicle, I did the same on the right, but of course not with the same facility. After opening the scrotum, and dissecting through the dartos-which is very readily done by passing the knife lightly over its fibres-the testicle, and its covering, the tunica vaginalis, must be taken in the right hand, while the left should be employed in pushing back the scrotum from its attachments; and, having your assistant ready, as before, with the clam, it must be placed well above the epididymis, and greater presure is, of course, necessary, as the raginal covering is included in the clam."

Mr. Goodwin further observes, that in Russia he has seen hundreds of horses operated on, even after the human fashion, with safety; and he remarks it certainly produces less pain, the animal loses less flesh and condition, and is sooner recovered than when operated on by the actual cautery.

Castration by torsion is advocated, among others, by Messrs. Daws, Simonds, and Wardle, and is thus described by Mr. Daws :- "The operation of castration by torsion is performed as follows:-An incision through the scrotum on one side is first made with the scalpel, sufficiently large to admit the free escape of the testicle; the vasa deferens is then divided with the same instrument about an inch above the epididymis. By pursuing this plan, the resistance of the cremaster muscle will be defeated; and the testicle, with its vessels, will lie in a quiet state until the conclusion of the operation.

"A longitudinal incision is now to be made through the tunica vaginalis reflexa, and a portion of the spermatic artery laid bare, and freed from its adjacent attachments. The torsion forceps is then to be applied to the artery, which should be divided in that portion immediately below the grasp of the instrument, the thumb and index finger of the left hand pressing back the blood in the vessel. The artery is then to be trristed by the forceps, held in the right hand. until the elasticity is destroyed, and it will no longer recoil: but remain curled up in a knor. The torsion forceps may then be removed with safety, and the remaining portion "s 
the cord should be divided, and returned within the scrotum. Should the hæmorrhage from the artery of the cord prove at all troublesome, it may be arrested in a similar manner. The number of twists will depend upon the size of the artery, from four to six revolutions being sufficient for small, and eight or ten for larger vessels. The effect which torsion produces on the vessel, independent of destroying its elasticity, is a laceration of its internal tunic, the edges of which become speedily agglutinated by means of plastic lymph: a clot of blood plugs up the end, so that the obliteration is rendered doubly secure." This description is followed by numerous cases, in which this method of operating has been practised by the three practitioners before mentioned with success.

Castration by ligature is a painful, barbarous, and very dangerous practice; and consists in enclosing the testicles and scrotum within ligatures until mortification occurs and they drop off. It is practised by some breeders on their young colts, but it is always hazardous, and disgracefully cruel. The substance of the testicle in some countries is also broken down either by rubbing, or otherwise by pressure between two hard bodies: this is practised in Algiers instead of excision, and tetanus is a frequent consequence of it. In Portugal they twist round the testicle, and thus stop the circulation of the gland. Division of the vasa deferens has been performed, it is said, with success on many animals; and is proposed as a safe and less painful process than the emasculation of the horse. It consists in a longitudinal section through the scrotum, dartos, and vagina] sheath, so as to expose the cord, from which the vasa deferens is to be separated, and severed from the vein.

\section{CHAPTER XXXI.}

DIBEASES AND INJURIES OF THE SKIN.

MANGE, ITCH, PRURIGO.-RINGWORM.-SURFEIT.-HIDEBOUND.LICE.-LARVE IN THE SKIN.—MALLENDERS AND SALLENDERS. -MELANOSIS. — WARBLES. — SITFASTS. — GALLS. — WARTS.WATER FARCY. - ABSCESS (PURULENT AND SEROUS).-ULCERS.

UNDER this head we propose to consider the diseases and injuries of the integument and the cellular membrane.

The structure of the three coats of the skin and of the hair have been described, ante, pp. 192-193.

\section{MANGE.-ITCH.-PRURIGO.}

Mange, the form in which, in hairy animals, the itch makes its appearance, is the most contagious of a loathsome class of diseases.

The irritation has been shown by microscopic observation to depend upon the presence of minute insects called acari. The mange insect of the horse is of a different species to that of the human itch-insect, yet it is abundantly proved that itch may be caught by man from a mangy horse, dog, or other hair-coated animal. Though mange is, in the vast majority of instances, the result of contagion, yet poor living, neglect of cleanliness, and a lowering of the vital system generally, will produce it spontaneously, and it will then spread ruinously, even to better-conditioned animals.

The most remarkable characters of mange are, the annoy- ing itch it creates, and the bare scabby places it occasions on the skin. A mangy horse will rub himself against any part of the stable or yard where he may happen to be. He will even rub himself against his companions, should he be at grass or strawyard with others; and by frequent and violent rubbing, will irritate and excoriate the diseased places, and thus considerably aggravate the malady. Though no part of the skin can be said to be exempt from mange, the places it commonly occupies are the neck, shoulders, withers, sides, thighs, and head. On removing with a brush the incrustations, or rather the kind of scaly dust produced by the dried pustules, and examining it attentively in the sun or any warm place, a person may distinguish, even with the naked eye, little organised, transparent, shining bodies moving about; these are acariinsects belonging to the same family as the sarcoptre of human itch. There is almost always to be discovered, in places within the substance of the skin, more or less larva of these animalcules. In the horse, the insect is large enough to be seen without the aid of a lens, in its travels over different parts of the mangy animal's body.

Syмpтомs.-The symptoms of mange are seldom noticed till the disease is established. They are very simple: the animal is observed to rub himself uneasily, and then, on examination, the hair is found loose and coming off; and 
the multitude of minute pimples leave no doubt of the nature of the case. Mange being suspected, its existence may also be readily ascertained by inserting the fingers among the roots of the hairs of the mane, and slightly scratching the parts. The horse will extend his neck and head, and continue motionless so long as the hand remains upon its crest.

Treatment.-Though mange is principally treated by local remedies, yet constitutional ones,-cleanliness, warmth, malt-mashes, carrots, beet-root, speared corn, \&c.,-will materially assist and expedite the cure. As in human itch, sulphur is most relied on. When ointment, liniment, or wash is to be applied, should the weather be fine, place the animal in the sunshine for an hour; if not, put it in a warm stable, clean the coat sedulously till the scurf is removed, and allow nothing to be used for other horses that has touched the animal-brushes, combs, cloths, or even halter or harness. Then rub in, with the hand or a piece of flannel, either of the following, missing no part from the nose to the end of the tail.

\section{MANGE OINTMENT.}

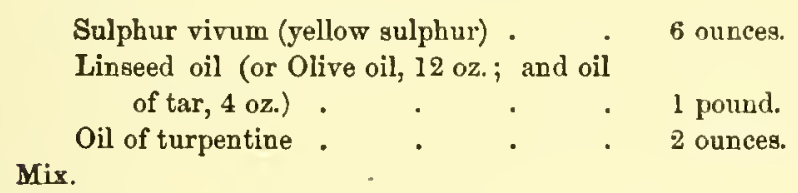

If the colour of the horse is desired to be preserved, add some soot for a black or brown animal, or bole armenian where the colour is bay or chestnut. Yellow sulphur and antimony, in a dose of six drachms the two, may be mixed with the food.

\section{ANOTHER OINTMENT.}

Strong mercurial ointment $\quad \cdot \quad \quad \cdot \quad 4$ onnces.
Soft soap $\quad \cdot \quad \cdot \quad \cdot \quad 2$ pounds.

LINIMENT FOR MANGE.

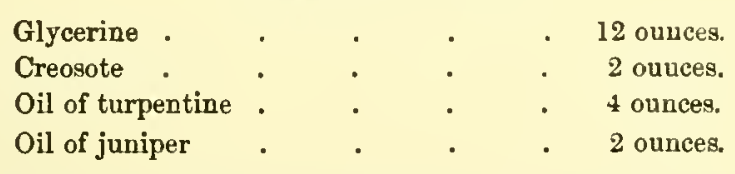

Soak the coat thoroughly, and the third day after wash thoroughly off and dry the animal, letting him stand an hour in the sun, if possible. Rub down, and apply the liniment once again, washing off as before. Or a lotion may be used as follows :-

\section{LOTION FOR MANGE.}

Corrosive sublimate . . . 1 drachm.

Spirits of wine . . . . 1 ouuce.

Tobacco-water, 1 quart, made from 2 ounces of tobacco.

Though mercurial preparations cure mange, they are not so certain in operation as sulphur. Percivall says, Barbadoes tar and linseed oil, simmered a few minutes in an old T T kettle, surpasses all more compound remedies. Some pow. dered hellebore root, say half the quantity of the yellor. sulphur, mixed with that mineral, is an improvement on our first recipe.

A common prurigo or itchiness sometimes occurs in spring, which makes the horse rub himself violently and remove patches of his coat. It is merely heat of skin, and may be relieved by a wash of glycerine and rose water, or a liniment of creosote and oil, with a cooling drench of

$$
\begin{aligned}
& \text { Liquor arsenicalis . . . } 1 \text { ounce. } \\
& \text { Tiucture of muriate of iron . . } 2 \text { ounces. } \\
& \text { Water . . . . } 1 \text { quart. }
\end{aligned}
$$

In four doses.

\section{RINGWORM.}

Ringworm, though not common among horses, does occa sionally present itsclf.

Although we have little or nothing to apprehend from "tetter," it often turns out a very intractable disorder when we try to cure it; and especially when it has become inveterate through negligence or long standing. It is ascribed to a variety of causes, constitutional as well as local. It is very apt to make its appearance, in the spring and autumnal seasons, among horses that have suffered from exposure and bad keep, and will attack many at the same time.

Treatment.-Unacquainted with the specific organic disturbance to which tetter owes its existence, our "remedies," as they are called, are empirical. We must attend to the general health and condition of the animal, and take care that his diseased skin is well washed with soap and water, as often as required; without which the dressings cannot take proper effect. Should the bare places exhibit inflammatory action, we must foment, and (if practicable) poultice them, and bleed and purge the animal. Sulphur ointment, empyreumatic oils, corrosive sublimate in weak aqueous solution, \&c., are recommended. At the Alfort Veterinary School, good effects have been derived from the use of the liquor plumbi in combination with nitric acid.

Creosote and simple cerate, and an ointment of the nitrate of lead, with the liquor arsenicalis as a drink, may be tried. A solution of copperas applied with a sponge are known to have perfect success.

\section{SURFEIT.}

The appearance of surfeit is a quantity of round, blunt, heat spots on the skin, which occasionally proceed to exudation and form small scabs. The horse has generally an unlealthy coat, or hidebound, or is in a plethoric state. It is a consequence of excessive feeding. Prurigo may be looked upon as the simplest form of surfeit.

The Treatment must be such as tends to relieve plethora, and to remove any inflammatory disposition that may exist in the system; at the same time the eruption itself should be as much as possible encouraged. In cases of simple 
evanescent eruption, nothing more is required, in general, than the substitution of a mash for a corn diet-green-meat, if it can be procured, for hay-chilled water, warm clothing and bandages, and additional walking exercise. Should the eruption evince a permanent character, or should it shew a disposition to relapse, it may become requisite to bleed and purge moderately ; and these evacuations may be followed up by cooling febrifuges-antimony and nitremingled in powder with the animal's mashes. The following is good:

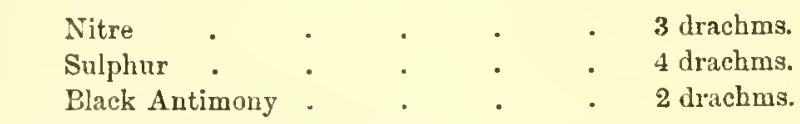

Mix with bran and give in the corn.

D'Arboval truly remarks, however, when the lumps on the skin are bursting and discharging, the time for evacuating remedies seems to have gone by. We may then content ourselves with a cooling regimen, and the exhibition of alteratives; and sponge the surface with warm water. Though, "should the skin require excitement," the same author recommends "frictions with camphorated spirits."

\section{HIDEBOUND.}

When a horse's hide or skin sticks to his ribs, as it were, and cannot be drawn out or moved, as in the healthy state, he is said to be hidebound. It indicates great weakness and poverty, and sometimes a diseased state of the mesenteric vessels, and consumption. It is generally occasioned by ill-usage, and bad or insufficient food, and cannot be removed without proper feeding and good treatment. One of the great causes is turning the animal out in a straw yard.

The following powder may be given daily in the food, 'he effect of which will be, by stimulating the stomach and bowels, not only to assist digestion, but also to affect the skin by sympathy :-

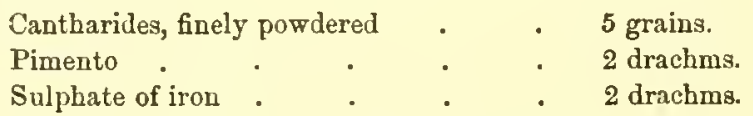

If the horse refuse this powder in his food, it may be made into a ball with treacle, and given for a week or a fortniglat. Or a tonic alterative drink may be given. See Tonics in List.

\section{LICE.}

The vicinity of a henroost is often the cause of this annoyance. These parasites cannot be destroyed by the same means as those of the horse, which die when anointed with oil or grease, and washed off. When lice occur with hidebound, they generally disappear with the disease.

\section{LARVE IN THE SKIN.}

Mr. Mayhew has given not only a verbal description but Srawings of this pest of horseflesh; and from him we condense the following :-
These annoyances are another result of turning an animal out to grass, the fly whence the trouble is derived never entering the stable. The insect rejoices in the freedom of the field; and man, by turning out his horse, finds the creature a fitting spot for the deposit of its eggs. The warmth of the animal hatches the larvæ; no sooner is it endowed with life, than, with the instinct of jts kind, it burrows into the skin. The integument of the horse, however thick it may appear, is soon pierced by the active little maggot, which, thus snugly housed, retains its lodging until the following spring. During the winter, a small lump denotes its abiding place; but as the second summer progresses, a tolerably large abscess is instituted. The interior of the abscess, of course, contains pus. Upon that secretion the insect lives and thrives.

Such swellings are acutely painful, and prove the sources of much annoyance. They mostly occur upon the back. The saddle cannot be laid on one of these tumours; and, as the spine supports much of the harness, the proprietor has the vexation of beholding his horse rendered useless; for suffering, should service be exacted, occasions the creature to excite displeasure; besides, the pranks thus provoked by torture often continue after the cause has been removed.

Upon the summit of the abscess appears a black spot. It is at this spot the larva receives the air needed to support a dormant existence. This fact being known to certain people, the knowledge is employed to destroy the parasite. The swelling is first slightly greased, and then a drop of melted tallow is let fall upon the breathing place. By such means, the insect is effectually suffocated, and assuredly dies. Others employ a darning needle as the instrument of execution. The needle is thrust through the central spot into the swelling, for three-eighths of an inch. The larva thereby is pierced, and the life certainly is sacrificed.

Neither methods occasion at the time the slightest pain to the horse. In either case the maggot dies ; but the business, unfortunately, is only rendered worse by killing the source of evil. The dead body putrefies. A foreign and corrupting substance, beneath the skin, may enlarge the abscess to many times its original dimensions. After all, the system has to cast forth the irritating matter; and for that purpose inflammation, with its attendant fever, must be perfected. Much suffering is thus occasioned, and the proprietor is, for several weeks, forced to forego the employment of a valuable servant.

The safest, the surest, and the quickest manner of tradicating these parasites is, with the point of a lancet, slightly to enlarge the central opening; and then, with the finger and thumb applied on either side of the swelling, to squeeze out the intruder. The abscess rapidly disappears; and it only requires a few dabbings with the solution of chloride of zinc, one grain to the ounce, to close the wound. However, the best manner to avoid such annoyances is, not to turn the horse out, and treat a domesticated as an untamed quadruped. 


\section{MALLENDERS AND SALLENDERS.}

When a scurfy or scabby eruption at the posterior part of the bending of the knee appears, it is termed mallenders: and when a similar one appears at the bend of the hock, it is called sallenders. Neither of them lame or do much harm; but sometimes, when neglected, they degenerate into a foul ichorous discharge, a little more troublesome, and always unsightly. Both of them are easily removed by washing with soap and water, and by applying the following :-

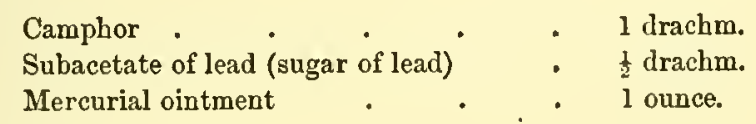
Mix.

Mercurial ointment . . . l ounce.

Tonic and alterative drinks should be given. This is Mayhew's ointment for the disorder :-

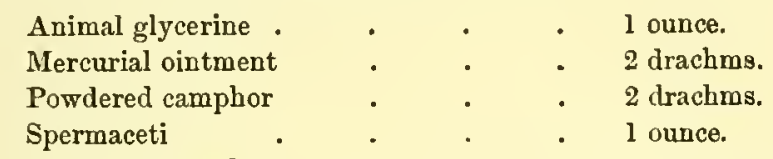

Mix and rub in gently.

Crown Scab, and Rat Tails.-These are of the same nature as mallenders, and may be cured by the same means. They generally, however, leave a blemish, consisting in a loss of hair, and a thickening of the cuticle. Crown scab occurs on the coronet, and rat tails in lines on the back part of the leg, extending from the fetlock upwards.

\section{MELANOSIS.}

This curious disorder, which seems exclusively to attack horses that have once been grey, consists of a black deposit in the cellular tissue, and occasionally in other parts of the body. In India it has been called "taildisease," from the remarkable fact of a tumour or excrescence being almost always present at the root of the tail. Mr. W. C. Spooner gives a case in White's Farriery, p. 258, of a white Arabian who was destroyed with melanosis. Melanosis is defined by Laennec as "a pathological production deposited upon the surface, or in the substance of an organ, of a darkish or blackisls colour, having no analogy with the healthy tissues of the body." The disease, which was described by Brugnini in 1781, as being hereditarily transmitted among the horses of Chevasso, and which he termed hemorrhoids, was evidently melanosis; it was usually developed around the root of the tail and the anus.

Some years later, in 1784, the same disease was observed at Bresse Gollety. Latournelle transmitted an account of it in 1809. He says, "there supervened in a young stailion on the second year of his covering, black 'boutons,' or buds, around the anus. They soon extended to the scrotum and sheath. They were placed between the skin and muscles at first as large as a small nut, and they increased until they attained the size of a pullet's egg; they did not sup- purate, and were insensible to the touch. In a short time all the cellular tissue was similarly affected, and the animal died. When cut into, a matter like the grease of a cart wheel flowed out. All the progeny of this stallion which had the same colour was similarly affected; those whick were black, bay, roan, or iron grey escaped."

The opinions of most writers as to the composition of the melanotic substance, agree that its black colour is owing to the presence of a large quantity of carbon. Many persons are of opinion that the black principle is an aberration of the pigment destined by nature to be deposited elsewhere, as the rete mucosum, the choroid, or the hair. It is said that persons with light hair, and elderly persons whose hair is white, as well as light grey or white horses, are most commonly the subjects of this disease. As horses thus affected are usually slaughtered, we may dismiss the subject by saying that a glycerine wash to cleanse the skin, and the administration of iodine to promote absorption, seem the most likely palliatives, where the animal is desired to be preserved.

\section{GREASE AND CHAPPED HEELS.}

These important disorders we shall postpone from this chapter to that where we treat of the diseases of the hinder foot.

\section{WARBLES, SITFASTS, AND GALLS.}

Warbles are enlarged bursæ inflamed by the pressure of the saddle. Open them with a sharp-pointed knife, thrust in, and cut outwards. Then, to prevent inflammation, take a piece of lunar caustic, and apply it freely till the sac is burned out. Wash and sponge with chloride of zinc and water, and kcep a rag wet with the lotion over the wound.

Sitfasts are very annoying. They are a patch of horn, somewhat like a corn on the human foot. They are not simple corns, however, as they have an ulcerated margin. They are tedious and sometimes obstinate. The knife and lotion, as above, offer the best chance: it is more humane, too, than the slow process of rubbing in blistering ointment. Bran-mashes and a tonic drink (Liquor arsenicalis-see List), may be given.

Harness Galls.-Poultice till the swelling has subsided or suppuration cume on. If the matter has not sufficient vent, open the channel of discharge. Dress with digestive ointment, and finish with an astringent application (C. or E in List.)

\section{TARTS}

Are best removed by tying a ligature round them; or, with scarcely any pain, by applying every day, with a camel's hair pencil, a small portion of strong acetic acid; or they may be cut off with a knife or scissors, and the root touched with any caustic body. There is sometimes seen a sprouting luxurious species, whose roots are larger than their heads, so that a ligature is not easily passed around 
them; these are best removed by touching their surface daily with the following paste. The following application will seldom fail to remove such as cannot be conveniently got at by the knife or ligature, dressing with it once a day :-

\section{$\left.\begin{array}{ll}\text { Sulphuric acid } & \cdot \\ \text { Powdered sulphur } & \cdot\end{array}\right\}$ a sufficiency of each.}

Make into a paste, and apply a little to the wart. Blaine recommends :-

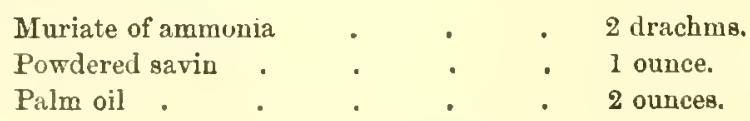

WATER FARCY, EDEMA, ANASARCA.

Water farcy is quite another disease from farcy (already considered, p. 412, Specific Diseases), in causes, symptoms, or effects. Gibson thus describes it:-

"Water farcy is of two kinds; one the product of a feverish disposition; the other is dropsical, and of that kind which in man resembles the anasarca, where the water is not confined to the belly and limbs, but shews itself in several parts of the body, with soft swellings which yield to the pressure of the fingers, as is usual in all dropsical habits. This last kind usually proceeds from foul feeding, or from the latter-grass and fog, that often comes up in great plenty with long-continued rains, and breeds a sluggish viscid blood."

Treatment.-However much practitioners may differ on the questions of the origin, specific nature, and organic seat of this disease, there exists little variation of opinion concerning the most efficient mode of treatment. Gorged with blood, distended-to bursting even-by internal effusion, hot, tense, and tender as the limb evidently is when first attacked, nobody can hesitate for a moment to draw blood: and this ought to be done to an amount that will sensibly impress the system. Abstract two gallons from a horse in condition; one even from a subject not so; and follow the bleeding up by the immediate administration of the following ball :-

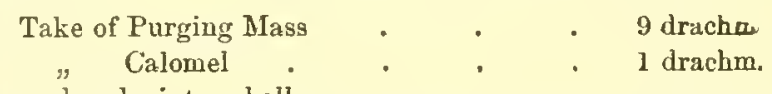

Mix and make into a ball.

Anasarca is noticed under SwELled Belly, \&c., p. 449, ante. Edema will fall naturally under SwELLED LEGS.

\section{ABSCESS}

As connected with the skin, we luere consider abscess generally : its particular treatment will be found under POLL Evil, Strangles, and other diseases wherein it occurs.

By abscess, in its most extensive sense, we mean any collection of fluid which interposes between parts in a kind of sac. In its limited sense, the word represents a collection of pus formed by a quick process of suppuration, and contained within a closed sac. When a purulent abscess forms, the following process takes place. An injury, generally a bruise, is received : part of the vital body is crushed or dies, and nature is desirous to repair the loss, and to cast off the dead substance. The minute vessels of the part are stimulated to effuse coagulable lymph within the cellular tissue; the consequence of which is distension or swelling; that here, as elsewhere, produces tenderness and heat, and, when the hair allows us to detect it, a reddened blush. The effusion around the immediate part which is dead, thickens, grows vascular, and ultimately forms a closed sac. Arrived at this state, the tumour may take on various changes by peculiar processes within it. The suppurative one is supposed to ensue all over the internal sides of the sac, where, by a change in the action of the inflamed vessels, pus begins to be secreted. It then presses against the adjacent muscles, causing these structures to be absorbed : and it is fortunate that, by an apparent conservative law of animal life, such absorption is most active towards the surface of the body, thus aiding the evacuation of its contents, which can be effected without prejudice to the constitution.

The treatment of abscess.-In the early stages of such tumours, endeavour to forward them, through the application of warmth and moisture, both of which are gained by a poultice. A blister may likewise be applied to the surface, and a poultice over that, when it is very important to draw the abscess forward. Horse poultices, on account of their magnitude, are generally formed of bran, upon which boiling water is poured, and the whole well stirred together; or a very good poultice may be formed of hay, soaked in hot water, any excess of moisture being squeezed out afterwards. About a gallon of substance is sufficient for one application. Being assured that maturation is completed, the thickness of the integuments, and the fear of the extension of the suppurative process inwards, make it always prudent to form an artificial opening in the more dependent as well as prominent part of the tumour. This may be done by direct section. Incision is effected by the abscess knife : but in every case the opening should be sufficient to give a ready exit to the matter which has formed, and that which may subsequently be secreted. In some situations, as where the natural outlet has appeared on a place we do not desire it should point in, or where the abscess does not point upon the precise spot we could have wished, it may be prudent to make an incision in the natural prominence, and insert a seton through the place we could desire the fulness should have occupied. It is, however, necessary to be careful in making the incision when it dips downwards, that it is made in the course of the muscular fibres, and not in the direction of considerable branches of nerves or bloodvessels.

Notling further need be done for the eradication of an abscess than the establishment of a free depending orifice Putting the finger into the opening and stirring it round, is unnecessary, to say the least of it. All injections are ob- 
jectionable, to speak of them in the mildest terms. Should, however, the sac of an abscess display an indisposition to contract after its contents have been evacuated, apply a blister over it, and when the effects have somewhat abated, support the pendent parts by means of bandages.

SERous ABSCESS.-As a termination of inflammation, and, in the form of Strangles and Poll-evil, purulent abscess is considered. There is a second kind, called serous abscess.

The ordinary situations for these swellings are upon the outer side of the quarter or thigh, in front of the stifle, and upon the breast, the shoulder, and the arm. They are occasionally of considerable volume. They are usually eggshaped, flattened upon the surface, and liave a soft, elastic, fluctuating feel. When punctured, they emit, with considerable force, a limpid, straw-coloured, aqueous fluid, like the serum of the blood.

Treatment.-Percivall's practice is clear and decisive. He says it is time lost to set about attempts at dispersing or resolving these tumours. The most summary mode of getting rid of the swelling, is to plunge a lancet into it and evacuate it. Were we, however, to do nothing beyond this, we should find in a day or two that the tumour had become as large as ever. Evacuate it a second time, and the fluid still will speedily re-collect. To make a cure, we must either follow up the evacuation by throwing into the cavity with a syringe one of the following injections, or else pass a seton through the sides of it.$$
\text { Mix. }
$$$$
\text { Take of White vitriol . . }
$$

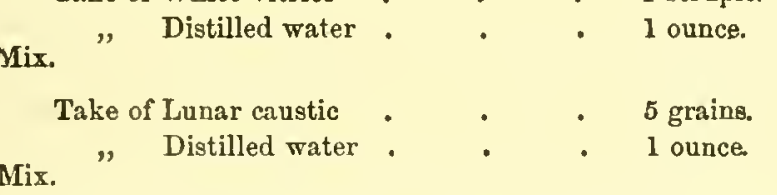

After the injection, or even after the withdrawal of the seton, which should only be retained until a laudable pus is produced-a compress and roller (should they be applicable) will be found much to assist the granulation and cohesion of the sides of the cavity.

\section{ULCERATION.}

An ulcer is a sore arising from imperfect granulation, secreting an unhealthy, impure, thin, irritating (sanious) pus; these imperfect granulations cannot fulfil the purpose of building up muscle (flesh) or tissue, while absorption goes on and a loss of substance ensues. Granulation ceases to build up regularly; absorption removes irregularly, and hence comes an uneven surface, more or less a hole, with hard irregular edges, called an ulcer. In most cases, ulcers are attended with great irritability of system, which must be attacked by opium or generous digestible food. The general treatment of ulcers is to cleanse by means of a poultice, then stimulate, and keep up the system by a nutritious diet.

Ulcers are often found of a greater extent internally than externally, when the fluid which is secreted by them absorbs in different directions, forming narrow pipes, the sides of which are scirrhous, from which issues a glairy discharge. These pipes are called sinuses by the surgeon. In general cases, the longer an ulcer has lasted, the more diffculty there will be to bring it back to a healthy state. The external means employed for this purpose are usually stimulating injections, or incision. Ulcers are apt to be treated by farriers erroneously, by plugging up the sinuses. When the caustic penetrates farther than was intended, sloughing a way the diseased and the healthy parts, the true remedy is equally simple and effective, namely, to slit them up, and then to lay within the divided pipe a piece of tow, saturated with some caustic solution. By this means the scirrhous lining will be cast forth, and that which was a sinus will be converted into a simple wound.

\section{FISTUL赵.}

There are three fistulous disorders in the horse, which more particularly demand notice, and to these we shall confine our attention. 1, Fistula of the Parotid Duct. 2, Poll-evil. 3, Fistula of the Withers.

\section{FISTULA OF THE PAROTID DUCT,}

The outward sign of this disease is an unnatural outlet for the saliva in some part of its passage. A recent wound of the duct itself shows little more than an opening wet with moisture, except when feeding, at which time the saliva will pour or spirt from the aperture like blood from an artery. The edge of the opening becomes ulcerous and soon changes to a true fistulous ulcer, the pipe itself, in old cases, becoming as hard as cartilage. The digestion, too, becomes deranged, from the loss of that valuable secretion the saliva, which is squirted out through the fistula instead of being conveyed, as when the duct is whole, into the mouth to be mixed with the food and conveyed from thence to the stomach. The position and function of the parotid gland have been already described. The fluid expelled is semitransparent, afterwards tinged with pus from the ulceration, and occasionally coloured with thin blood.

The causes of fistula of the parotid duct are generally accidental injury, or abscesses resulting from strangles; hay seeds, and particles of hard food entering the opening of the duct during mastication, have produced it. These afterwards swelling, obstruct the egress of the saliva, which accumulates; the confined secretion produces agony, inflammation, and abscess, which nature relieves by bursting; the pent-up secretion pours forth, and fistula is established.

Treatuent.-In olden times the horrid torture of the "budding iron" was resorted to. The late Professor Coleman and his disciples proposed to apply the iron "at a dull heat over and over again, to create an eschar" which should "plug up the orifice;" and the "heat starting up reparative inflammation beneath it," the opening "would be effectually closed," by the time the roasted living flesh would 
be sloughed off! We pass from these useless barbarities to the modern practice. This we greatly owe to Mr. Gowing, veterinary surgeon of Camden Town, whore name we feel proud to record in connection with this painful disease and its cure. Mr. Gowing's treatment may be thus described:A firm, agglutinating liquid is formed by dissolving gun cotton in sulphuric ether, which is called collodion. Upon applying this liquid to the surface of the body, the vital warmth occasions the ether rapidly to evaporate, leaving the cotton in an altered form, sticking firmly to the part.

Mr. Gowing first applied some mild caustic to the wound, th till the orifice presented the reddened appearance he desired it should assume. He then places above the opening a bulky pledget, sufficiently large to thoroughly close the wound, and sufficiently solid to resist the solvent powers of the saliva. A piece of cork, cut to the required shape, answers the purpose admirably. Over this, to bind it to the part he wished it should close, he passed some cotton thread, the ends of which he fixed to the hair of either side by a liberal allowance of the liquid we before alluded to. This he repeated several times, till the plug was held firmly to the place by the cross bands of cotton. He repaired this dressing from day to day as it was necessary, having the horse's head tied up, and supporting the animal entirely by fluids. After a few days had elapsed, the horse was allowed to lie down; and a short time subsequently the bandage was removed, when the orifice was effectually stopped. This is a far better, and a far more effectual plan than any of the old measures once fashionable, but now we trust, on account of their barbarity, discarded. Treated after the above method, should the first trial not succeed, a second can be made; and this plan may be repeated an indefinite number of times, without inflicting suffering amounting to positive torture.

Should it be more convenient, a solution of gum mastic in spirit of wine, or a solution of India-rubber in sulphuric ether, will answer the same purpose as the collodion.

We may add that the horse should be allowed no food that requires mastication, and his head should be fixed by pillarreins during the process of cure; and make hio bed of tan, not straw, lest he should eat it.

\section{POLL-EVIL.}

This loathsome and troublesome disease consists in a deep abscess, with sinuses or pipes, working outwardly to an ulcerous sore, preceded by swelling and inflammation in the poll or nape of the neck, just between the ears, towards the mane.

The causes of poll-evil mark it as discreditable to the stable where it occurs. Mechanical injury from blows, bruises, \&cc., are the ordinary origin. Farm horses and cart horses are most frequently the subjects of poll-evil. Their coarse, ill-made, stiff and hard head-collars or bridles chafe their polls, and cause them to be continually rubbing the part. The halter or bridle, from constant friction, begets a mangy affection of the skin about the nape of the neck, from the itchy annoyance of which the animal en. deavours to relieve himself, by rubbing his poll aqainst the manger, occasioning that part to inflame, swell, become excoriated, and generate among the roots of the hair foul ulcerations Or, it may happen that the roof or beams of the stable, or the threshold of the door, may be so low, that the horses are daily hitting their heads against it. Or, worst of all, the brute who drives the team may be fond of exercising the butt end of his cart-whip in preference to the lash. Hanging back in the halter (to which stalls with a great slope from the manger to the drain much dispose the animal), by impeding the circulation, produces numbness and itching. The horse rubs his head violently against the travis or division of the stall, a bruise of the fleshy substances, between the hard woodwork and the bones at the base of the skull ensues, and a deep-seated abscess results. The first cause, therefore, of poll-evil is wilful, neglectful, or purely accidental external injury.

Tenderness on pressure on the poll or nape of the neck, and the peculiar stiff and crouching manner in which the animal carries his head, indicate poll-evil. The symptoms of course depend upon the extent of the disease and the stage the inflammation and abscess have reached. You may find a solid tumour, or a matured abscess, or it may have advanced to the ulcerative stage, exposing cavities and sinuses horrible to belold.

Treatment.-The knife and caustic tents of chloride of lime are our great resources in poll-evil. In the early stage of abscess, whether deep or superficial, open the parts freely, and then we may hope to induce the healing process in due time. Should the abscess not be fully formed, we should use our best endeavours to ripen it; which will be best attained by a mild blister rubbed in as often as required, till the fluctuation is felt either on one side or the other. The next object is to procure a speedy evacuation of the contents, and a depending orifice for its future passage, that no sinuses may form. This may be done by the introduction of a seton, first inserting the needle in the middle of the tumour, and passing it out at the most depending part. In case the tumour is a central one, and its limits extend equally over the neck, do exactly the same by the other side. But when, from improper management, matter has not only formed, but has been suffered to remain, or has only evacuated itself by a superficial opening, either natural or artificial, and not from one in a depending situation, in such cases the healthy secretion of pus always ceases, and, instead of it, a thin ichorous discharge succeeds. The ulceration also extends further; sinuses form in every direction, and even the bones of the cervix (nape of the neck) become absorbed. The ravages which this disease makes are truly dreadful. It has been known to disease the occipital and parietal bones, burrowing around the ear, and has insinuated pus into the parotid gland, as well as into the spinal canal, or the brain itself. Under any 
appearance, a very strict examination must be made, which is best done when the horse is cast, having his head elevated by a bundle of straw, and turned towards the light. Enlarge the lateral opening so as to admit of a free examination, by means of the finger, of every part liable to be injured. Carious bones must be laid bare, scraped, and then exposed to the caustic effect of a strong solution of chloride of zinc. Hardened callous edges must be removed, and the smaller sinuses laid open, so as to form one continuous cavity: If all this be not thoroughly done, it will happen, that, when the whole seems on the point of healing, a new tumour will suddenly appear, and frustrate all our hopes. In this way the expert operator, well acquainted with the anatomy of the parts, will combat the worst cases.

We have mentioned caustic tents; these are recommended by White and other practical men, and denounced by Mayhew, who relies solely on the knife. We have many wellauthenticated cures by means of caustic pledgets of chloride of lime; the sinuses being examined carefully from time to time with a probe, carious bone freely scraped, and, if there be exostosis, the piece removed. The horrors of boiling injections, of forcing hot irons up the sinuses, and plugging them with arsenic-for thess are among the tortures of country farriers" "remedies"-we hope never again to see or hear of.

In the fifth volume of the "Veterinarian," Mr. A. Gray relates a case of successful treatment of poll-evil, in which pressure by means of splints greatly aided the cure. He thus describes their application and the result :"When the mare was sent to me, I proceeded to examine the extent of the disease. I found two deep sinuses, one on each side of the neck, the bones of which could be distinctly felt with the probe. After cleaning away the matter, I took a scalpel, and laid both orifices open in an oblique direction downwards; then, having fomented the parts with warm water, I dressed the wounds with tincture of myrrh and aloes; and, in order to apply pressure to the parts (for in this I founded all my hope of success), I had two pieces of wood prepared, about twelve inches long and three broad, thicker in the middle than at the edges, which were rounded off, and also a long flannel bandage, four inches broad. I then placed two pledgets of tow next the wounds, putting on the pieces of rood one on each side, and then applied the bandage vver all, and as tightly as I could, without impeding deglutition. It is necessary, while putting on the bandage, to keep the nose extended, in order to adapt the bandage more perfectly to the part. and apply it more closely. I removed the bandage night and morning, and had the parts well fomented and dressed with the tincture. In the course of four weeks the mare was well."

\section{FISTCLA OF THE WITHERE.}

Continuous and undue pressure of the saddle, either by its misfit or the improper management of a careless groom or incautious rider, and this evil repeated day by day and at frequent intervals, establishes an inflammatory tumour. This generally originates in one of the bursa in connection with the tall dorsal spines (see Skezeton, Plate I.). This should be immediately laid open, and subsequently treated after the manner explained under the head of WARBLES. When this is not done, the whole hardens, suppuration generally takes place within the part, and the strong fascia on the back prevents the pus escaping. The pus becomes virulent, being confined: it absorbs, thus creating numerous pipes, and a case of fistulous withers is established. Should the attention be called to a case that has proceeded to a fistulous state, treat exactly in the same manker as with poll-evil Instances have occurred where the matter has penetrated under the scapula, and made its way to the point of the elbow or the front of the breast. In these cases a depending orifice should be made, and a seton introduced through the whole extent of the sinus; for which purpose setonneedles of sufficient length, with their points guarded, to prevent them injuring important vessels, are manufactured (see Plate of Instruments). Occasionally the disease extends and involves the dorsal spines. The stench will offer disagreeable proof when the bones are affected. When the bones are diseased, slit up the fistula, and scrape them, until a healthy surface is exposed; after which, the milder lotion of chloride of zinc and water may be used. But when the cartilage that tops the spines is affected, without delay saw it off, leaving a healthy surface of bone. When the sinuses, likewise, are slit open, to cut from within outwards produces less pain, which in surgery is a consideration. After the incision has been made, lay into the opened sinus some tow, saturated in the strong solution of chloride of zinc, which, after twenty-four hours, may be removed, and the wound subsequently dressed with the milder lotion.

Mr Mayhew recommends, when the sinuses burrow from the withers towards the chest or elbow, and cannot be opened up by the knife, that an elastic probe, having been passed down the sinus, should be dipped in a small quantity of powdered bichloride of mercury, and repeatedly pusher down it, until you have used up the whole of the salt 


\title{
CHAPTER XXXII
}

\author{
LAMENESEE, DISEASES, AND INJURIES OF THE FORELEOS AND FEET.
}

THE SHOULDER-THE ARM AND ELBOW.-THE KNEE.
LEG.-THE PASTERNS.-THE FETLOCKS.-THE FEET.

BEFORE entering on the diseases and injuries of the foreleg, the reader may refer with advantage to the description of the bones (ante, pp. 184, 185), and of the muscles (pp. 190, 191); and ANATomy, Plates VIII., X., and XI., with their letterpress descriptions.

The causes of lameness in the horse are so various, and often so obscure, that we may almost say that a hasty and confident opinion on the nature and origin of lameness is a sign that the man consulted has little judgment or knowledge of the difficulty of the question before him. Rashness, self-conceit, and a desire to obtain an undue reputation for acumen, may be almost invariably assumed as regards these positive gentlemen, who deliver oracular opinions on matters which demand sound knowledge, careful investigation, and deliberate reflection, even from the most experienced. Above all things we would warn the horse-owner against people who have "secrets" for curing lamenesses. They are generally ignorant and dishonest barbarians, with neither humanity nor principle, and we always look with extreme suspicion on those who recommend their advice or services to be called for. Shoeing, as a cause of lameness, is now hardly known, however convenient a stalking-horse the farrier's shortcomings may be to a drunken or careless groom. Where the smith is really in fault, the mischief is obvious enough; where the causes lie deeper, the skilful veterinarian or the well-read anatomist alone can trace them.

In the present chapter we propose to arrange the several disorders and injuries as follows:-The Shoulder: The Arm and Elbow: The Knee: The Leg: The Pasterns: The Fetlocks : The Feet.

THE SHOULDER. - SPRAIN OF THE SHOULDER. - BLOTS. SHOULDER LANENESS.-RHEUNATISM.

Sprain or Strain of the Shoulder.-When the farrier finds himself at a loss to point out the exact seat of lameness, he generally takes refuge in the convenient generality of "sprain of the shoulder." The occurrence is rare, but when it does occur is easily detected. The tenderness of the muscle itself, inside the shoulder, and its inflammation, together with the peculiar action of dragging the toe along the ground, then dropping the knee suddenly, are indications of sprain of the shoulder. Its causes are a side fall, or a wrench, by which the forelegs are suddenly stretched apart so widely as to sprain either the muscles or ligaments, probably both. In this case the animal cannot move down the slightest declivity without intense pain, from the weight being thrown upon the shoulders; and, in the attempt, swings round the leg in a peculiar manner, endeavouring so to accomplish the movement as never to call upon the shoulder muscles to elevate the scapula. If the foot be laid hold of, raised, and brought into a straight line, the seat of pain will be indicated by the suffering animal. Again, pressure on the serratus muscle* will cause the horse to shrink. Of course, if lameness has its seat in the arm or foot, neither of these tests are even noticed by the patient. A decep. tive appearance of shoulder sprain occurs when, riewing a lame horse from the front, we find the muscle of one shoulder wasted, imparting an appearance of swelling to the sound limb; this resulting from the lame limb having been saved from exertion by the suffering animal, and therefore diminished in volume. In this case the sound limb is condemned as the seat of lameness, and treated, or illtreated, accordingly. Never, therefore, omit both the tests above mentioned.

White says: "There is one kind of shoulder lameness which is consequent on an injury of the great synovial cavity, or bursa mucosa, through which that great tendon passes which arises from a protuberance on the lower part of the shoulder-blade and slides over the large grooved process at the head of the shoulder bone. This large grooved process is covered with a slippery cartilage, as in other

* The shoulder-blade is united to the chest by muscle alone. Here is a large muscle, with remarkable tendinous fibres, and of immense strength (the serratus major, greater saw-shaped muscle), attached to the chest and to the extensive smooth internal surface of the shoulder-blade, and by which, assisted, or rather strengthened, by the muscles of the breast, the weight of the body is supported, and the shock of the widest leap or the most rapid motion is sustained. Had there been a bony union between the shoulder and the body, the vital parts contained in the ehest could not have endured the shock which they would occasionally have experienced; nor could any bone have long remained whole if exposed to such violence. The muscles within the shoulderblade act as powerful and safe springs. They yield, as far as necessary, to the force impressed upon them: by their gradual yielding they destroy the violence of the shock, and then, by their elastic power, im. mediately regain their former situation.-Yonatt. 
synovial cavities, to prevent any friction while the limb is in motion. I have scen shoulder lameness that appeared to depend upon a rheumatic affection of this part. The manner of the horse's going, when this part is the seat of lamencss, is very remarkable. In endeavouring to trot, and sometimes even in walking, the fore leg suddenly gives way or bends, and it is only by a considerable effort that the horse can save himself from falling. I had a filly under my care for this lameness, which fell down several times in walking. The remedies I employed were, passing a seton over the point of the shoulder, and blistering all round it pretty freely. This, and confining her some weeks in a box, effected a cure."

The general Treatment of shoulder sprain slould be to bleed freely from the plate vein (see BleEvina, post), just opposite the elbow joint. Three to five quarts is not too great a quantity. Bathe frequently and copiously with a lotion consisting of half-a-pint of tincture of arnica in a gallon of water. Should the case be recent, and the symptoms not violent, bathe with cold water only; and in either case, when the inflammation subsides, change the cold water for hot.

In this manner, keep the shoulder wet for a week or longer, when, every sign of active disease having departed, a blister may be applied. With regard to the manner of applying the blisters in these cases, the late Mr. Blaine speaks very confidently; he says:- "I would recommend the following practice, which $I$ have long pursued in these cases with invariable success. As soor as the more active inflammatory symptoms are abated, I proceed to raise an artificial inflammation by the free use of stimulants, generally of the liquid blister, in the following manner:-Mix six ounces of common oil with two or three ounces of liquid blister, and with this rub the whole affected part twice a day until the swelling and inflammation it will bring on prevent the use of more. In two or three days these will subside, when it should be repeated, until the same effects again prevent the application. In this way kecp up a mild inflammation for a week or ten days, according to the original violence of the affection: in general cases, the subsiding of the second swelling will leave the horse sound. This will be found a much more efficacious mode of practice than the common blister; but it must be more particularly remembered, that I know of no affection so liable to return as this; consequently, although the horse may appear sound, it will be very dangerous to put him to immediate work."

There are awful barbarities in old books, professing to relieve this or the next-mentioned affection-rheumatism; among them, "swimming the horse," as it was called. Imagine a horse plunged in river, pond, or sea, with a sprained shoulder, and called on to "swim" with a ruffian on his back Hinds, in his "Veterinary Surgery" (Whittaker, 1829), tells a story of one Dennis Lawler, a Dublin farrier, who was great in this line of "cure." He tells us, $\mathrm{U}$ U
"His method was to ride his horse to a convenient depth of water in the bay, and then, jumping forward suddenly on the animal's neck, thus souse it head-foremost to the bottom. The feat caused great marvel at the time; but not so the total disappearance, upon one occasion, of the performer. Poor Dennis is supposed to have received a kick to the bottom, and that his body drifted out to sea. At any rate his Howth friends saw no more of him." Without quite wishing the fate of poor Dennis to every horse-swimmer in shoulder-sprain, we trust never again, as we have done, to witness this cruelty.

\section{SHOULDER LAMENESS.-RHEUMATISM.}

To this head we have preferred to refer Rheumatism, a disease which many writers have denied as existent in the horse. Its presence, however, in the muscles of the shoulder, and occasionally of the loins, is too often recognisable not to place its existence beyond doubt, if not beyond controversy.

Of acute rheumatism, well-marked cases are occasionally encountered, which are traceable to the effects of cold or moisture. The leading characters are alike in all; the attack being ushered in by universal stiffness, but more particularly of the fore extremities. Sometimes the case is attended with considerable tumefaction in front of the breast.

Rheumatism is remarkable for "flying about" (metastasis, as it is termed by the surgeon). Sometimes it attacks one or two joints, then another member, shifting from the shoulder to the knees and hocks, and back to the shoulder. These being its favourite points of attack in the loorse.

The Treatment consists in first decreasing the food to so much only as will support life and diminish fat. Then give the following ball night and morning, until the bowels are freely opened, when it is to be withheld till purging has ceased, and then recommenced:

\begin{tabular}{|c|c|c|c|c|c|}
\hline \multicolumn{2}{|c|}{ Powdered colchicum } & - & - & . & 2 drachms. \\
\hline Calomel & . $\quad$. & . & - & ${ }^{\circ}$ & 1 scruple. \\
\hline Opium & . & . & . & . & 1 drachm. \\
\hline Aloes & . & . & - & & 1 drachm. \\
\hline Powderes & capsicums & . & • & . & drachm. \\
\hline
\end{tabular}

In the mean time the swollen parts may be freely fomented with very hot water, and afterwards well rubbed with soap liniment, to every pint of which a quarter of a pint of liquor ammoniæ has been added.

Should the above ball not succeed, try the following drink, which, in some cases, is even more effective :-

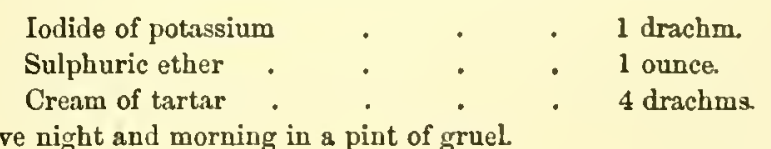

Give night and morning in a pint of gruel.

Chronic Rheumatism may be the sequel of the acute; in some cases it appears as the immediate consequence of exposure to rutting winds, humid atmosphere, \&c.; and is 
indicated by stiffness and tenderness of the parts it attacks. When the extremities suffer, it is not unusual to observe some tumefaction, but always great disinclination to move. It occasionally visits the loins, but is most common in the fore quarters. Sometimes one extremity and occasionally both are affected, when sudden metastasis will often remove it to the other parts; these cases were well characterised by the old term of "flying lamenesses."

The Treatment of chronic rheumatism does not materially differ from that recommended to be followed in cases of the acute description, excepting that strychnia, in doses of a grain, gradually increased to three grains, has occasionally been attended with benefit.

\section{THE ARM AND ELBOW.}

FRACTURES.-PUNCTURES.-CAPPED ELBOW.

The arm extends from the elbow to the knee, and consists of two bones; the front long bone, the radius; and the short hinder bone, the ulna.

The elbow joint is sometimes punctured, either accidentally, or through the brutality of the groom or carter. The swelling is often rapid and extensive, and fatal inflammation may ensue. Rest, and the closing of the wound, are the most important considerations.

The elbow is sometimes fractured. If the animal be placed in the hands of a skilful veterinarian, although the chances of cure are certainly against the horse, yet the owner need not despair. Absolute and long-continued rest, and that produced by means of slinging (see Plate XXI.), will be indispensable.

Capped Elbow, or capulet, is in its treatment similar to cupped hock. These enlargements about the elbow are either the cunsequence of a violent blow, or from the calkins of the shoes injuring this part when the horse sleeps with his legs doubled under him. If a seton be passed through the tumour, it will sometimes rapidly diminish, and even disappear; but if it be of considerable magnitude, the skin should be slit open along the middle of the swelling, and the tumour dissected out.

\section{THE KNEE.}

\section{BROKEN KNEES.-OPEN JOINTS.}

This important and complicated joint is the seat of the most frequent and the most deteriorating of accidents to which this powerful animal is liable; in most instances from the incautiousness, the severity, or the incompetency of the driver or rider, or the requirements of ostentation and fashion in severe bearing reins, monstrous blinkers, and the like, rendering the horse comparatively helpless and blind, and punishing him for every false step, hesitation, and blunder.

We will suppose the horse has fallen, no matter hor. the question is the treatment of the injury.

Treatment.-If called in while the wound is recent, the first thing is to sponge the knee clean from any grit, dirt, or extraneous substance; and even in this simple operation there is much difference in the right and wrong way of using the sponge. Slopping, smearing, and wiping should be eschewed; the immediate wound not touched in ordinary cases, but the sponge saturated with warm water squeezed dry above the laceration. The sponge will thus not become charged with dirt, and do the very mischief it is intended to relieve, nor will the water in the pail be fouled with grit (most important trifles are these), but the foreign matters clean washed away, the animal saved much pain, and the parts cleared for surgical examination. Let the horse get easy and calm after the washing, take him to his stall, give him a feed of corn, and water him.

Place the palm of the hand over the joint, and ascertain if there be much heat or swelling. Should no synovia appear upon the surface, it is prudent to avoid probing; it can "merely gratify curiosity," says Blaine, "and a surgeon has no business with any such meddling impulse; the welfare of his patient should be his single thought, and experience should tell him that the dimensions, depth, and magnitude of the wound are not at first to be ascertained. Such knowledge is not to be acquired till the slough has taken place." In this we agree; we have often seen the probe recklessly used; we believe to the aggravation and extension of the injury. When the joint is ascertained to be open, the injury must no longer be treated as a common wound. Our prognosis in such case will depend on the exteut of the wound, particularly that in the capsular ligament, and on the circumstance as to whether inflammation has been set up in the cavity of the joint.

Our object must now be to close the joint as quickly as possible, and thus prevent the escape of synovia, or joint oil; unless we succeed in doing this, the inflammation of the knee will greatly increase, and the discharge of synovia become augmented in quantity, partly coagulating as it escapes from the knee, and hanging in large flakes from the wound; the animal, from the pain experienced, keeps the knee in a bent position, or paws with the foot continually. A vast deal of fever is excited in the system, which in some cases wears out the animal, and produces death. In other cases, bony substance is thrown out round the joint, which at length closes the wound, but destroys the motion of the joint and renders the animal useless.

It is, of course, important that the animal should be kept perfectly quiet, and the leg as straight as possible. If the horse can be slung conveniently, it will vastly facilitate the cure; for he must not lie down, lest he opens the wound. Mr. Turner's method is excellent in severe cases of open joint The wound being cleansed, he prepares a paste of wheaten flour and table beer, mixed with a little bole armenian, which he spreads thickly above and below and round the knee. A pledget of tow is then wound round the joint and covered with some stout brown paper, and over all a cotton stocking. Outside the stocking is another layer of the paste, 
and a calico roller bandage, six yards long, is passed outside, all wound round with a gentle and continuous pressure; then another bandage of the same length the contrary way. The horse having been dressed is then bled, and a laxative is administered; the dressing is not removed until the joint is closed. It is understood that the horse is slung. If the leg swells from pressure of the bandages, he makes small cuts in each layer on each side the knee, but never in front. In six or seven days, should there be a great accumulation of fluid within the bandages, an incision will afford it a way out, and another dressing of the paste, with a similar bandage, applied. The horse is to be kept suspended a week after the joint is closed, when the paste is removed, the knee washed, and the usual wound dressing applied. If there is still swelling above the knee, bathe with cooling evaporating lotion, but don't allow it to wet the dressings. A very superior splint or knee-cap may be now made by moulding gutta-percha, softened in hot water, to the shape of the knee.

With respect to coneealing the after blemish, no power of earth can make the hair grow on a scar. It is not skin, and it cannot be covered with the appendage only to be seen upon true skin. But the cicatrix will with time become less. Often the wound, which on first liealing appears rather large, in the course of three months will be all but imperceptible. siny application of blisters, be they mild or strong, can but increase the blemish it is their intention to remove. Let the scar alone. If you have thrown down a horse, no veterinary surgeon can be sure he shall afterwards stand upon perfect limbs. You must, therefore, take the consequences without complaint, and be grateful that you have, in the effects of time, some hope left when science has abandoned you.

Broken Knees without opening of the Synovial Cavity.Occasionally broken knees prove to be mere skin injury, with slight contusion. Undue and too early exercise may force these into permanent thickening of the part, with injury to the free motion of the joint, whereas an extra rest and fomentation would complete a cure. When, therefore, a cut has taken place without injury to the cavity of the joint, the wound having been washed, bring the edges of the integument as closely together as possible by strips of adhesive plaster, as already directed; or, if the wound be extensive, it would be well to sling the horse. A cure by the first intention, or adhesive process, can only be hoped for in this way. If heat and tumefaction come on, use the lotion composed of arnica and water, two ounces of the tincture to a quart; and, after applying the arnica and water night and day for forty-eight hours, if the skin be broken, exchange the lotion for one composed of chloride of zinc and water, in this way a cure may often be established, without injury to motion or blemish to the animal

\section{STRAIN OF THE RNEE-JOINT.}

The knee-joint is seldom strained, so well is it secured by ligaments. It, however, occurs to young horses and colts in training, the seat of injury being the side of the knee, by slipping outward on the turf. Bleeding from the arm, warm fomentations followed by cold lotions, and a little iodine ointment when the inflammation has gone, are advisable.

\section{THE LEG.}

SPLINTS.-IN.TIRIES.-SPRAIN OF THE FLEXOR TENDON.-WIND. GALLS.

This we consider as the part between the knee and the fetlock, consisting of the cannon-bone in front, and the two splint-bones behind, and is the seat of that common calamity of the horse-

Splints. - These are exostoses or bony tumours, formed by inflammation of the periosteum, and are found in three positions: on the inner side of the leg, close under the kneejoint; half way down on the inside; and sometimes on the front of the cannon-bone, in which last position they would more properly be called "nodes." Splints are formed by the animal being worked too soon or too severely. Inflammation follows, and a bony instead of a ligamentous deposit takes place. A bony union, too, is set up between the two smaller bones and the cannon-bone, and hence the ease of motion is impaired. In the young and vigorous horse, however, other elastic principles are called into action, and the of action is not strikingly deteriorated; though at some distant period the mischief will crop out in stiff joint or splints in an aggravated form. The disposition to bony deposit, moreover, seems a spreading complaint, and is not confined to the space between the larger and smaller bones of the leg. A tumour, at first callous, afterwards bony, is formed with a part of its base resting on the line between these bones. This is a simple splint, and is invariably found outside the small bone and inside the fore-leg, and outside the hinder one.

When a splint is not situated immediately under a tendon, or contiguous to ligamentary matter, it occasions no lameness. The veterinary practitioner should, therefore, in his consideration of the consequences in these cases, be guided in a great measure by the situation of the splint. If placed in front, it is productive of much less injury than when placed behind; for, as already pointed out, in this latter case, the swellings may press on the ligaments, or interfere with the flexor tendons. For the same reason also, a splint placed at the lower end of the cannon is still more prejudicial than when situated higher up the leg. It is not uncommon to attribute that lameness to a splint which is dependent on other causes. A fully developed splint never lames, unless it interferes with a tendon or ligament. A splint, in the course of formation, however, may produce the most acute lameness, and often does so in young horses 
A splint, also, by its situation, may excite imflammation in the ligaments and tendons themselves. As a splint is neither more nor less than a conversion of fibro-cartilage into bone, once formed, it can never be entirely removed; nevertheless, from the absorption common in later periods of life, the splints nften diminish in bulk, or, as farriers call it, "wear away."

Treatment.-As we lave just said, "a splint once is a splint always." Periosteotomy, or division of the skin which covers the bone, is the modern treatment for splints. It may be thus described. The horse is cast, and the leg straightened and properly secured. A small opening is then made just below the splint, sufficient to introduce a long, narrow, convex, probe-pointed knife (see Plate XXIII., INSTROMENTs), the edge of which is on the convex side. This knife is passed under the skin, and by drawing it backwards and forwards the periosteum is completely divided. A small opening is then made through the skin above the splint, and a narrow seton passed from one orifice to the other, after which a bandage is placed on the leg and the horse released. The seton is moved daily and dressed with digestive ointment, and at the end of a week removed and the wound allowed to heal. Our own dictum on splints which do not involve lameness, is to let them alone; or, if the horse goes slightly stiff, to apply a little tincture of cantharides, which may be repeated if benefit is derived from it.

In the olden time, dreadful measures were adopted with splints, most of which left matters worse than before; of these we may speak when we come to spavin and ring-bone. Among these were "thumping with a hammer, rubbing the swelling with a stick, piercing it with a gimlet or hot iron, and pressure by means of sheet lead, blistering, 'sweating' with acrid 'oils," "* \&c., \&uc.

We have mentioned nodes in conjunction with spiints; of these Mr. Spooner says:- "Bony tumours form on various parts of the cannon bone; but, though sometimes large and offensive to the eye, they rarely produce lameness. They are more frequent with hunters than other horses, from blows in leaping. Iodine ointment is the best treatment. They also occur by the side of the sesamoid bones. When near the suspensory ligament they often cause severe lameness. Should they arise from strains of the ligaments they are more obstinate, and blistering or even firing becomes necessary. In the latter case, persevere with the iodine ointment.

STRAIN OF TUE FLEXOR TENDONS, OR "CLAP" OF THE BACK SINEWS.

This serious injury is of frequent occurrence, owing to the violent exertions to which the horse is too often urged. The structure and relation of the parts implicated in the injury will be understood by a reference to page 191 ante,

* Blaine, Outlines of Veterinary Art, edit. 1854, p. 411. where the muscles of the foreleg are described, and to Plates II. and VIII., Anatomy, where they are delineated.

There are, of course, degrees of this injury, and the terms a strain of the flexor tendon, a sprain of the back sinews, a "clap" of the back sinews, a bad break-down, may be taken as mere progressive expressions of the degree of mischief inflicted by one and the same kind of accident. In the case of "break-down," however, it is a rupture of the suspensory ligament, as will be noted hereafter.

When the strain is slight, we may not discover tne injury for some hours, when the animal, without being positively lame, will go in an unusual manner, as if slightly cramped or stiff. Pass the liand gently down the affected limb, and a small swelling will be felt, and tenderness on pressure be shown. Do not listen to any fellow who tells you " $\mathrm{Oh}$ ! he will work sound." As Mayhew shrewdly says, "The many horses seen in the London cab-ranks with fore-legs permanently contracted, bear witness to the result of such very knowing treatment." To which we may add the thousands of cases where complicated and permanent disease destroys the wretched animal from first neglect. Where there is strain, bind a linen roller round the leg tightly, and wet it diligently with cold water day and night; examine the limb every morning; give four drachms of aloes and a very small suggestion of nitre, to cool the system Pressure may be gently and conveniently applied by a broad vulcanized India-rubber band, and a wetted piece of spongiopiline. Of old, the farrier was ready with his firing-iron even in cases of sprain : the veterinary surgeon has in the interest of humanity driven him out.

When the sprain is more severe, bleed copiously from the arm; put the loorse where he may be quiet, and have a high-heeled shoe placed on the foot of the affected leg; a good form of this is figured letter $\mathrm{H}$, Plate XIX. Cold applications, in the very early stages, particularly when the swelling is considerable, will tend to unload the ressels; and the same indications will be followed by immersing the whole limb in spring water. In two or three days, change this plan for formentations or embrocations. Any treatment more stimulating than this in the early stages tends to increase the deposit of lymph, and to organize it into a permanent tumour. But when the active stage of the inflammation has subsided, then mildly stimulating applications are proper; and they should be accompanied here with due friction and bandaging. The recovery from a severe case is usually very slow; the parts being ligamentous, do not readily reinstate themselves; the after-treatment must, therefore, fully accord with this view, which is that of giving sufficient time; and in most cases it ought to be some weeks after the horse may seem sound before he is put to full work. It is better, in the most favourable cases, to give a few weeks' rest, using, as already recommended, a vulcanized India-rubber bandage and spongio-piline, saturated with water. A lotion of muriate of ammonia, 1 oz., pyroligneous acid and spirits of wine, 2 ozs. each, camphorated spirit, 
2 drachms, and cold water, 1 quart, may be applied. Where the induration remains obstinate, repeated blisters, applied as recommended by Mr. Blaine in shoulder lameness, are the best means of reducing the tumours.

\section{SPEEDY-CUT.-OVERREACH.}

The inside of the leg, immediately below the knee, and up to the head of the inner splint bone, is liable to the injury called "speedy-cut." A horse lifting his legs high in a fast trot, strikes this part with the hoof or edge of the sloee. Occasionelly, bony enlargement is the result, preceded by great heat and tenderness; and sometimes the pain from the blow is so great that the horse drops as suddenly as if shot. Care is necessary that with such horses no part of the shoe projects beyond the foot. In our plate of Shoes will be found a special shoe to prevent speedy-cut, and under Shozing the subject will again occur. The term overreach is also applied to a blow inflicted on some part of the fore leg by the hind foot; frequently it strikes the flexor tendon, and produces inflammation and tumour. We shall have something more to say of this when we come to the pasterns, to which we shall also defer the subject of "breakdown."

\section{THE PASTERNS AND FETLOCKS.}

BREAKING-DOWN (RUPTURE OF SUSPENSORY LIGAMENT).-OUTTING.-RINGBONE.-GROGGINESS.-SPRAIN OF THE COFFIN-JOINT.

\section{BREARING-DOWN.}

This accident, as already observed, is not strain of the back-sinews, though that is bad enough as a disablement. The distinction should be made, for the sake of the accurate local application of remedial measures, and the correct observation of the progress of amendment. "Break-down," then, is a rupture of the suspensory ligament of the leg, or of those passing from the sesamoid bones to the pasterns. The treatment is the patten-shoe, as already mentioned under sprains-or, more commonly, a pistol-shot. With valuable racehorses, where work is not demanded, breaksdown have been followed by a stud-life, and nature has partly repaired the rupture, the intervening space of the severed ligament filling up with granulations.

Sprain of the fetlock-joint arising from injury to the ligamentous and tendinous connexion of these parts, has sometimes been mistaken for a common swelling, and the horse exercised to "take down the enlargement." Hence incurable deposits of coagulable lymph, forming stiff joint. The treatment should be the same as in other cases of sprain.

\section{Cutrina.}

Wo have already mentioned "speedy-cut" as a blow inflicted on the inside and lower part of the knee joint, when the animal is urged to a very fast pace. Some carriagehorses (the bearing rein must with these be dispensed with) strike the fetlock of the fore foot, and produce lameness, often without external wound : when fatigued or weak, the lameness is increased. Mr. Morecroft advises the raising of the outer side of the shoe so as to make it much higher than the inside. He says :- "When a horse is at rest, he supports his weight equally on both feet; but having the inner heel and quarter raised when one foot is elevated, he must be supported obliquely on the other, and hence have a tendency to fall outwards; to prevent which, he brings the moving foot nearer to the supporting one, by whicb he strikes it; but by raising the outer instead of the inner branch of the shoe, we necessarily give it a disposition to lean inwards, which will induce the horse to throw or incline the moving foot fartler from the supporting foot."

Mr. Goodwin describes an improvement of the common boot, as it is termed, for defending the fetlock joint, when cutting cannot otherwise be prevented, which may be had at Mr. Long's, veterinary instrument maker, Holborn, London.

Mr. Spooner adds on this point: "The best boot for cutting the leg, is made with leather fitted to the leg and laced, the leather being double at the part struck by the other foot.

"In some instances it is found that a boot buckled round the loof that cuts, and softly stuffed, prevents injury from the blow, when other methods fail.

"For cutting the fetlock, a piece of cloth tied round above the joint and doubled down over it, answers the purpose."

\section{RINOBONE, OSSIFICATION OF CARTILAGES.}

This is a formation of bone (or exostosis) surrounding the whole or a part of the circle of the coronet, and involving the joinings of the large and small pastern bones. The situation of ringbone is marked on Plate VIII. From the great mobility of the pastern joints and the shocks to which, despite their admirable contrivance, the ligaments are exposed when man overtasks the animal machinery, inflamnation is induced, followed by the deposition of bony matter. Sometimes ringbone begins as high up as the superior articulation of the larger pastern bone; oftener about the joint formed by the two pastern bones; and sometimes it involves only the lower pastern bone. The lateral or side ligaments are those that are oftenest or soonest affected; ringbone is then discovered, in its earliest state, by a rounded hard projection on each side, immediately above the coronet. The hind legs are not so subject to ringbone as the fore legs.

Ringbone is always accompanied by lameness at the commencement: but the extent of the after lameness depends on the degree in which bony tumour interferes with the action of the joint. In some cases it goes off altogether, particularly in the lind feet, where the concussion is not so sreat and the inflammation is not generally so intense. In the fore feet, which support more of the weight of the 
body, and are liable to severer injury, the bony deposit is usually greater, and commonly involves one or both of the pastern joints. Lameness, and of an incurable nature, is the result if side bones also exist, or the ring should extend under the cartilages; and it not unfrequently happens that the coffin joint, being surrounded by unyielding bone, is entirely lost.

Theatment.-Local bleeding (from the toe), and evaporating lotions, should be first employed; the inflammation being removed, setons should be inserted, or the part should be stimulated. All, however, will often fail ; for the incessant action of the parts, and the pressure on them, render it very difficult to arrest the progress of the inflammation. In a confirmed case of ringbone, especially when the joint is lost, it would be the height of cruelty to subject the poor animal to the useless torture of the iron; and when sidebones and ringbones exist together, neurotomy (see post, "Operations") is the only means to afford relief.

Professor Sewell recommends periosteotomy in case of ringbone, as well as splints; which refer to for method of effecting.

Ossification of the lateral cartilages is known as "false ringbone. It is produced by concussion, and is most frequent among heavy horses driven on London pavement. When unattended with lameness, leave alone; when it appears in lighter horses, blistering, iodine ointment, a cessation from active work, and sometimes firing, may be necessary.

\section{GROGGINESS. - KNUCRLING, ETC.}

This is a frequent tremulous motion of the fore leg, with a bowing of the knee, and some degree of knuckling of the fetlock; while upon the slightest tap behind the knee the joint yields. There is an evident loss of power and energy in the limb; and though in some measure a natural defect, it is often a proof that the horse has been hardly worked, and it is probable that he can endure little more exertion.

The various structures which compose the limb have been overtaxed; they have become weak; their debility preventing the animal from giving to the leg that fixed position which the member otherwise would assume. There is little remedy for it but stimulation, or the constant application of cool lotion with comparative rest, while the horse enjoys the salutary and bracing, and not sufficiently appreciated, influence of cold on weakness of the legs and feet.

\section{SPRAIN OF THE COFFIN-JOINT.}

The lameness is sudden, and the heat and tenderness just about the coronet. Bleed at the toe, physic, and foment; blister if obstinate. This accident is often confounded with shoulder-lameness, and consequently wrongly treated. It is then the precursor and cause of ringbone.

\section{THE FEET.}

LAMINITIS.-FEVER IN THE FEET.-ACUTE FOONDER-CHRONIC FOUNDER.-PUMICED FEET.-SAND-CRACK, SEEDY-TOE, FALSE QUARTER. - QUITTOR. - CONTRACTION. - TREAD.- PUNCTURED SOLE.-CORNS.-THRUSH.-CANKER.

The sensible laminx, or fleshy plates on the front and sides of the coffin-bone, are full of blood-vessels, and therefore, like other highly vascular parts, liable to inflammatory action.

When it is recollected what the laminæ, which are inter posed between the hoof and the coffin-bone, have chiefly to sustain, the violent concussion to which the feet are exposed when in rapid action, it will not appear surprising that intense inflammation of these parts sometimes ensues. Besides this, there is no structure in the body of the horse so exposed to other causes of inflammation as the foot. After the animal has been ridden far and fast, while he is reeking hot, he is occasionally plunged up to his belly in pond or river. Almost every groom immediately washes the feet of his horse; while very few of them take the pains carefully to dry the dripping members. What is so likely to follow as inflammation? A horse may have been travelling many a mile up to his coronets in snow; and when he arrives at his journey's end, instead of having the warmth gradually restored to his feet by half-an-hour's good handrubbing, he is put up to his knees in straw, or his legs are immersed in warm water. Is it not reasonable to expect that fever in the feet will follow this sudden change of temperature? In other cases, there may be a metastasis, or change, of the place of inflammation : the animal is recovering from inflammation of the lungs, and suddenly the feet are attacked; and that without any fault of the surgeon or the groom.

Inflammation of the laminæ can scarcely be mistaken. The horse is continually shifting his posture; yet without violent action. The feet are constantly moving; but they are moved as gently as possible. When the hand is passed down to them, the heat of the feet is evident enough. Generally, however, the horse, tired of shifting his place, and yet retaining the pain, lies down, and can with difficulty be induced to rise again. All the characteristics of general inflammation are exhibited. The pulse is hard and fastthe breathing sharp and quick - the skin harsh-the mouth hot-and the ears cold. But there are also signs which indicate the seat of the disease; for, besides the hoofs being unnaturally hot, the arteries of the legs throb; while the horse often points to his feet as the seat of pain, by looking at them, and resting his muzzle upon them.

The treatment of inflammation of the feet must be prompt.

Other inflammations may possibly, to a certain degree, brook delay; but here not a moment is to be lost. The in- 
flammation must, if possible, be made to terminate in "resolution;" for, if the next process, and in some inflammations, a salutary one, commences-if pus is thrown out within the foot-the hoof will inevitably come off.

Without a moment's delay the horse must be bled, taking blood from the toe; but it is not always safe to wound a part during the existence of acute inflarmmation within it. The jugular may in that case be opened, and the stream allowed to flow till the pulse falters. If in five or six hours the pulse regains its inflammatory character, the coronet may be punctured in several places. A third bleeding, but of a local character, may be justifiable; yet it should be remembered that such excessive depletion retards the th recovery, although it may check the primary disease.

A full dose of physic should be administered; and injections should be thrown up to quicken its action. Sedatives and febrifuges combined should also be freely given; not only to allay the general fever, but also to subdue the vascular excitement as well as to deaden the pain. The following ball should be repeated every second hour until the pulse intermits :-

\begin{tabular}{|c|c|c|c|c|}
\hline Digitalis & . & - & . & 1 drachro. \\
\hline Opium & . & . & 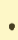 & 2 drachms. \\
\hline Calomel & - & - & . & $\frac{1}{2}$ drachm. \\
\hline Colchicum, & in powder & . & . & 1 drachm. \\
\hline Nitre & . $\quad$. & • & . & 3 drachms. \\
\hline Emetic tar & $\operatorname{tar}$ & . & • & $\frac{1}{2}$ drachm. \\
\hline
\end{tabular}

Make in a ball with treacle.

We would desire to do something to the feet, but often the horse obstinately stands and will not suffer them to be raised or touched. If the shoes can be removed, they ought to be taken off; and the soles, should it be possible, be pared. The feet then should be put into poultices; or constantly fomented. If, however, the horse resists, these things had better not be attempted. Moisture is necessary to soften the horn of the hoof, so as to allow the inflamed parts to expand; and the low temperature is required to reduce the inflammation. Ice is of great service, if it can be constantly applied; but if only for an hour or two, with an intermission during the night, it does more harm than good. It should only be applied when the inflammation is high; but when that is the case, and the foot is very hot, a lump or two of ice constantly kept in the poultice will be of great service. Wet cloths can be placed upon the legs; and these can be kept constantly moist with the coldest water. The straw should be removed; and its place supplied with damp tan, or even sawdust, which may be moistened, and will be less heating to the animal's feet. The body should be clothed-a sheep's skin placed upon the loins; even if the horse will eat, only a few spare bran-mashes should be allowed; but water ought to be constantly before him.

When the first symptoms abate, the coronets and legs may be blistered; but this ought not to be done until the acute stage has passe? A seton, however, may at the commencement be plsced in the chest; and often, when thrust througl the diseased frog, seems to be attended with benefit.

The practitioner will carefully look out for the worst symptoms, as well as those of amendment. When separation begins to take place at the coronet, between the hoof and the hair, it indicates that the process of suppuration is established by exudation; and, that process once thoroughly set up, it will go on, in defiance of all that can be done to stay it. It will be useless further to punish the horse ; but some relief may be obtained by surrounding the feet with poultices. Another hoof will in process of time be produced; but it will be smaller and weaker than the first, and liable to inflammation.

It is seldom that intense inflammation of any kind terminates without effecting some change of structure. Disunion to a very considerable extent between the horny and fleshy laminæ is a frequent consequence; and the result of that is, that the coffin-bone is no longer retained in its place; but sinks backwards and downwards. A malformation which no surgery can remove is the result. The sharp edge of the coffin-bone rests upon the sole, and often pierces through it. This is an incurable state of the foot. The attempt at forcing up again the coffin-bone betrays ignorance of anatomy, and of the progress of disease. When the coffin-bone begins to recede from the crust, the loof follows it to a certain degree; but its structure limits this, and another process commences in order to fill up the vacuum: an unnatural quantity of plastic matter is secreted by the sensitive laminæ; the crust thickens, and inclines inward as the coffin-bone retires: it has sometimes been observed more than two inches in thickness. Nature is, as it were, attempting still to maintain the union between the parts.

What power applied to the sole can force back the coffinbone, pressed upon and kept down by this thickness of horn? or what power can be applied to the external sole without bruising the internal and sensitive one? Lameness, which no art can relieve, ensues; it is lasting and incurable. The horse should be destroyed; but many animals in this state are forced to do slow work; and, by the whip, compelled to move in agony.

\section{CIRONIC FOUNDER.}

Lameness often appears in a chronic form, but is alrrays distinguished, no matter in what state it may exist, by the peculiar manner of going which it induces. The horse with inflamed laminæ endeavours to cast all his weight upon the heels; in order to spare, as much as possible, the wall with which the diseased part is connected. The gait is peculiar, and the toes pointing upwards denote the condition of the animal.

Chronic laminitis may be the consequence of the acute disorder ; more frequently it comes on gradually; and is at all times difficult to remove. Setons through the frogs, with repeated purgatives, and a course of alterative medi. 
cine, have answered best, although too often this form of the disease resists every treatment.

Laminitis may appear in one or all of the legs.

Most frequently the two fore feet are attacked, and the animal then brings his hind legs under him, as much as possible, with the intention of taking the weight from the affected members. When only one foot is attacked, the other is always ultimately the seat of poignant lameness, and what once was the healthy limb becomes the most diseased; because the animal, to spare the lame leg, continually casts his whole weight upon the sound one. The horse with laminitis in one leg, should be destroyed. With all four limbs attacked he may recover, but when laminitis appears in one only, he has no chance of being relieved, and it is mercy to shorten his sufferings.

\section{PONICED FEET.}

When, trom inflammation, the sensible horny little plates which were separated by the heat and swelling do not unite again, their elasticity is lost, and the coffin-bone, no longer supported, comes down and renders the foot convex, or rounded outwards : this is a "pumiced foot." The crust of the hoof also falls in at the front, leaving a hollow of a remarkable character in the middle and front of the fore foot.

The treatment of this disorder can only be palliative, and no skill is competent to effect a re-union between the separated fleshy and horny leaves, or to restore to them the strength and elasticity of which they have been deprived, or to take up that hard herny substance which very speedily fills the space betwecn the crust and the receding coffinbone. Some efforts have been made to palliate the disease, but they have been only to a very slight extent successful. If horses, on the first appearance of "flat foot", were turned out in a dry place, or put into a box for two or three months, sufficient stress would not be thrown on the leaves to increase the evil, and time might be given for the growth of horn enough in the sole to support the coffin-bone; yet we much doubt whether these horses would ever be useful even for ordinary purposes. The slowest work required of them would drive the coffin-bone on the sole, and gradually the projection would reappear, for no power and no length of time can again unite the separated leaves of the coffinbone and the hoof. All that can be done in the way of palliation is by shoeing. Nothing must press on the projecting and pumiced part. If the projection be not great, a thick bar shoe is the best thing that can be applied, but should the sole have much descended, a shoe with a very wide web, bevelled off so as not to press on the part, may be used. These means of relief, however, are only temporary, the disease will proceed; and, at no great distance of time, the horse will be useless.

\section{SAND-CRACR.—SEEDY-TOE.-FALSE QUARTER.}

Sand-crack is a well-named disorder. It is a solution of continuity of the horny fibres of the hoof in the direction of their growth, that is from above downwards. It is consequent upon a dry, brittle state of the hoof, and attacked the horses of the British cavalry and artillery when in Egypt to a great extent. These fissures are much more frequent upon the fore than the hind feet; but they are sometimes seen on cart-horses in front of the hinder foot, from the violent strain put upon this part in drawing heavy loads. They are mostly on the inner side of the fore foot, where the weakness of the quarters, when accompanied by brittleness, renders it liable to separation. As a sand-crack generally extends to the sensitive parts, it requires that the horse should be taken from work for a time. If the sandcrack shows no signs of active suppuration, although it have completely penetrated the horn, and a little blood or serous moisture shows itself at the edges, but only under the effects of motion, proceed to pare away the horn around it; and next, by means of a camel's-hair pencil, introduce within the edges a small quantity of the solution of chloride of zinc, as recommended for thrush. Bandage the hoof up moderately tight for two days, then again examine the fissure; when, if the ouzing be altugether stopped, and no inflammation appear, proceed to draw lines of a moderate depth with a sharp firing-iron; one very little above the upper limit of the crack, another just beyond the lower limit also, and afterwards bandage as directed below. If preferred, these lines of separation may be made with a rasp, or fine drawing-knife; but the iron is best, as the seared line of distinction is stronger or more perfect, while the melted horn binds the edges together. But in case no moisture at all has appeared at the crack, then the iusertion of any caustic matter is unnecessary, and the treatment for this kind of fissure is very simple. The measures necessary for such an injury will be as follows. The horse being shod with a bar shoe, and the hoof either pared away in a line with the crack; or otherwise the shoe chambered, so that the horn immediately under the fissure may not be pressed on: proceed to bandage up the foot, so as to fulfil the following intentions. Bring the divided edges of the fissure togetlier, and completely retain them there, in such a manner as totally to exclude moisture from entering the opening. Whatever mode will answer these purposes best may be adopted : some shoemaker's wax, melted and applied all over the hoof, may be bound round, while yet soft, with some three yards of tape, fastened with a hard knot, the knot again covered with wax. Then smoothe off to an even surface, and rub over with lard or grease. In all cases of simple "crack," pare away the divided edges so as to cut out the crack, and then with a hot iron draw a line above and below the place where the division has been.

SeEdy-ToE.-We are indebted to Mr. Mayhew for the most lucid and practical notice of this variety of sand-crack 
It consists in a separation of the two layers of horn which compose the crust of the hoof. These layers have a separate origin. The outer, which is harder, darker, and thinner than the inner, is secreted from the coronet. The inner, which is softer, lighter in colour, and thicker, is built up by the sensible laminæ, elsewhere described. When the foot is sound and the animal healthy, these two are one substance, and together make the "hoof" to which the shoe is nailed. When overwork, interrupted or disordered secretion, or unobserved injury affects the functions of the parts, the mischief begins, and the two kinds of horn begin to separate, as the human nail does from the "quick" as it is popularly termed. This beginning is always at the front, hence the term "seedy-toe." On gently tapping a foot with this affection, a peculiar hollow sound is perceived if the mischief is extensive; and upon removing the shoe a cavity between the two layers of horn is visible, up which a piece of soft wood may be passed, to ascertain the depth of the lesion.

Treatuent.-Put the horse in a loose airy box, and feed him with sound, dry, food, and give a mild dose of cooling medicine. Then gradually cut away so much of the outer wall of the hoof, beginning at the toe, as is clearly detached from the inner. Examine from time to time, and cut away the crust as far as the detachment, should it not have been already completely removed. The new solid hoof will be found to be growing downwards from the coronet, and in a month or two rapidly forming and hardening. Rest and good feeding accelerate the secretion; the cure is in most cases complete.

\section{FALSE QUARTER}

is the absence of a portion of the outer crust of the hoof, and the sensible laminæ are consequently exposed at the point where this deficiency occurs; the spongy inner wall, spoken of in the last article, alone covering them-an insufficient protection, and liable to painful injury and rupture, when bleeding and fungous growths follow; the latter being squeezed painfully between the edges of the remaining hoof, and laming the sufferer. The treatment of sandcrack is to be followed; but as the hoof will not grow again in false quarter, owing to a portion of the secreting coronary band being absent entirely, there is no remedy but a palliative. This is found in the bar-shoe (Plate XVIII. E), with a clip at the toe, the bearing of the foot being eased off at the place where the want of hoof is visible. Then place a piece of softened gutta percha of the required thickness to fill up the hollow between the foot and the upper face of the shoe, and mould it up the side of the injured part. This will keep on for several days, when it may be renewed. The part being thus relieved from pressure, the horse-at moderate bohour, on fair ground-has long preserved his usefulness.

\section{QUITTOR}

is the serious consequence of a severe wound of the coronet The injury, whether from an accidental tread, a side slip in frosty weather, or a blow upon the inside quarter, should be carefully and immediately attended to; because if sand or gravel get into the wound, it is likely to produce those deepseated ulcerations and sinuses which constitute the disease called "quittor."

Quittor may also proceed from any wound of the foot; and there is much difficulty in the matter proceeding from ulceration finding its way from under the hoof, which covers the foot with its various complicated parts. The consequence is, it accumulates under the hoof until it has increased to such an extent that it forces itself out in all directions, separating the little fleshy plates from their connection with the horny ones of the crust; or disuniting the fleshy sole from the horny one; and in extreme cases eats its way deeply into the internal parts of the foot, forming pipes or sinuses which run in all directions.

Treatment. - White's practice is as follows:-The extent and direction of the sinuses must be ascertained with a probe. Then spread sume powdered corrosive sublimate on pieces of paper smeared with lard; cut them into narrow slips, and twist them up to a point, insert them into the sinuses and push them to the bottom with the probe. It often becomes necessary to remove the greater portion of the horny sole, and thereafter restore the healthy state of the tender surface beneath. When this has been effected, the horn will ! quickly be reproduced. But in cases where mucb of the sole has been removed, it will take at least six months to restore fully the deficient part, so that the horse may again be subjected to labour.

If it is found, when the probe is inserted into the fistulous openings on the coronet, that the direction of the sinuses is backward, it is probable a cure may be effected; but if the direction of the fistula be forward, and more especially if the probe touches bone, the case is of great difficulty and doubt.

Mr. Spooner objects to White's "severe treatment" with caustics; and says there is danger of destroying the lateral cartilage and producing false quarter, in which we agree. Mr. Newport, in the "Veterinarian," reports cures by injecting a saturated solution of sulphate of zinc every twentyfour hours, poulticing also the foot. This is much less painful, and we believe quite as efficacious. In severe cases, setons from the lower parts of the sinuses and brought out at the heels, or between the bars and frog, are often serviceable.

\section{CONTRACTION.}

This disorder or defect, to which such prominence and space has been given in many veterinary works, especiall! Cuntinental, may be conveniently referred to two articles that on "ShoersG," and in its chronic torm, to NaricularsJoINT DLsEdsE. Contraction is produced by bad shoeing. 


\section{NAVICULAR-JOINT DISEASE.- "GROGGY" LAMENESS.}

In stable-phrase, the horse afficted with what some modern veterinarians have called "navicularthritis," is not inaptly described by the grotesque term "groggy." The learned compound term "navicularthritis" pedantic nonsense, and expresses what the disease is not.

The perforans tendon is inserted in the hinder part of the coffin-bone, and to reach that part it passes under the navicular-bone, which rests upon it, with the interposition of a small synovial sac, for facilitating the motion of the little bone upon the tendon. It is on the upper side only of this sac that the appearances of navicular disease are found after deatl.. The sac above the navicular-bone, and between it and the lower bone of the pastern, is never found partaking in the disease.

The cause of the disorder, which is direct injury, is obrious. The immense weight of the animal has been placed with an impetus on some liard substance, which has taken the foot at a disadvantage, and bruised the navicularbone-the first solid substance receiving the extreme concussion. True, that the fleshy frog and the body of the dense perforans tendon lie between the face receiving the blow and the injured bone; but the fleshy frog is, by nature, highly organised, and adapted by its secretory powers to recover its tone; while the tendon, less organised, is wonderfully elastic and yielding in the living subject. The bone, then, the first unyielding substance, receives permanent injury from the concussion, forced downward as it is from above by the coronary-bone. When the injury is recent, the horse is found simply lame. The foot is examined, but it is generally quite cool, There is no apparent reason to be assigned for the lameness; indeed, it often goes off, and the circumstance is forgotten. After a period of three to six months, during which unseen mischief has been going on, the lameness reappears. It is relieved, comes back again, and the horse is lame for life. As one foot is painful, greater stress is thrown upon the sound member, which is often injured in consequence, and hence both feet are found, in so many instances, with disease of the navicular-joint.

We may observe that a sure sequel,-we might rather say a symptom, - of navicular disease, is contraction. The foot is thrown out of use, or "saved by the animal," indeed he will be found "pointing" it in the stable; hence the quarters draw inwards, the heels narrow, the frog hardens and diminishes in size and plumpness, the sole thickens, the hoof itself grows higher, and is marked by ridges. In short, "contraction" marks navicular disease.

Navicular disease is of an ulcerative tendency, and most seriously affects the adult and the aged animal. Hayhew remarks, - which is confirmatory of the view we have already taken,- " the foot in the first instance exhibits no heat, and

* Inflammation of the navicular joint. Navicula (Lat., navicula, a little boat) arthron (Greek, a joint), and itis. the affix for inflammation. in the after stages becomes no more than warm. Moreover, the consequences of this disease are absorption, which it takes years to effect; not deposition, which is accomplished in a few days. All internal structures of the foot lessen, till the hoof becomes visibly small and contracted; for it is a law in nature that, in the living creature, the contents should govern the covering. Thus, the brain controls the skull; the lungs regulate the chest, \&c., \&c.' With these views the treatment of Mr. Mayhew corresponds, and has our fullest assent.

Feed liberally on crushed oats and old beans. Soak the foot in hot water for one hour every night for fourteen days; put tips on the hoofs, which part smear over with animal glycerine. Put the feet in a sponge-hoot (see Plate XIX. L), and wrap the shank in flannel. Remember Professor Coleman's "remedy"-a frog-pressure shoe-is the provocative of the disease, if not often the cause of its incurable aggravation. A leather sole, applied when the horse is shod, is of the utmost importance to his more permanent utility. Never use clay as a stopping, as the cold is apt to yet further enfeeble parts already deficient in blood-stimulus. Neurotomy, in extreme cases, is resorted to. It affords in these cases the only chance of the horse being serviceable for a time. Of course it does not cure the disorder, but it destroys sensibility. Hence, the animal often ruptures the tendon, or fractures the bone by a violent contact of the insensible foot with the ground. The animal must then be destroyed.

\section{TREAD.}

This, which often results in quittor, will be noted under disease of the hinder feet, in which it is more frequent; and see Speedy Cut and Overreach.

\section{PUNCTURED SOLE, OR WOUNDED CRUST.}

The sole is obviously very liable to wounds by nails, flints, pieces of glass, and the like. Frequently too, but not so often as in former times, the laminæ are wounded by the nail in shoeing; or if the nail does not penetrate through the internal surface of the crust, it is driven so close to it that it presses upon the fleshy parts beneath, and causes irritation and inflammation, and at length ulceration. When a horse becomes suddenly lame, after the legs have been carefully examined and no cause of lameness appears in them, the shoe should be taken off. In many cases the offending substance will be immediately detected, or the additional heat felt in some part of the foot will point out the seat of injury; or, if the crust be rapped with the hammer all round, the flinching of the horse will discover it ; or pressure with the pincers will render it evident,

When the shoe is removed for this examination the smith should never be permitted to wrench it off, but each nail should be drawn separately, and examined as it is drawn, when some moisture appearing upon one of them will not unfrequently reveal the spot at which matter has been thrown 
out. In the fore-foot the injury will generally be found on the inner quarter, and on the hind-feet near the toe, these being the thinnest parts of the fore and lind-feet.

Sudden lameness occurring within two or three days after the horse has been shod, will lead us to suspect that the smith has been in fault; yet no one who considers the thinness of the crust, and the difficulty of shoeing many feet, will blame him for sometimes pricking the horse. His fault will consist in concealing or denying that of which he will almost always be aware at the time of shoeing, from the flinching of the horse, or the dead sound, or the peculiar resistance that may be noticed in the driving of the nail.

When the seat of mischief is ascertained, the sole should be thinned round it; and, especially at the nail-hole or the puncture, it should be pared to the quick. The escape of some matter will now probably tell the nature of the injury, and remove its consequences. If it be puncture of the sole by some nail, or any similar body picked up on the road, all that will be necessary is a little to enlarge the opening, and then to place on it a pledget of tow dipped in Friar's balsam, and over that a little common stopping. If there be much heat and lameness, a poultice should be applied.

The part of the sole wounded and the depth of the wound must be taken into consideration. A deep puncture towards the back part of the sole, penetrating even into the sensible frog, may not be productive of serious consequence. There is no great motion in the part, and there are no tendons or bones in danger. A puncture near the toe may not be followed by much injury. There is little motion in that part of the foot, and the internal sole covering the coffinbone will soon heal; but a puncture about the centre of the sole may wound the flexor tendon where it is inserted into the coffin-bone; or may even penetrate the joint which unites the navicular-bone with the coffin-bone; or pierce through the tendon into the joint which it forms with the navicularbone; and a degree of inflammation may ensue, which, if neglected, may be fatal. Many horses have been lost by the smallest puncture of the sole in these dangerous points. All the anatomical skill of the veterinarian should be called into requisition, when he is examining the most trifling wound of the foot.

If the foot has been wounded by the wrong direction of a nail in shoeing, and the sole be well pared out over the part on the first appearance of lameness, little more will be necessary to be done. The opening must be somewhat enlarged, the Friar's balsam applied, and the shoe tacked on, with or without a poultice, according to the degree of lameness or heat, and on the following day all will often be well. It may, however, be prudent to keep the foot stopped for a few days. If the accident has been neglected, and matter oegins to be formed, and to be pent up and to press on the neighbouring parts, the horse evidently suffers extreme pain, is sometimes scarcely able to put his foot to the ground, and much matter is poured out when the opening is enlarged, further precautions must be adopted. The fact must be recollected, that the living and dead horn will never unite, and every portion of the horny sole that has separated from the fleshy sole above must be removed; and, as directed in SeEdr-ToE, \&c., the separation must be followed as far as it reaches. Much of the success of the treatment depends on this. No small strip or edge of separated horn must be suffered to press upon any part of the wound. The exposed fleshy sole must then be touched, but not too severely, with chloride (butyr) of antimony, some soft and dry tow placed over the part, the foot stopped, and a poultice placed over all if the inflammation seems to require it. On the following day a thin pellicle of horn will frequently be found over a part or the whole of the wound. This should be, yet very lightly, touched again with the caustic; but if there be an appearance of fungus sprouting from the exposed surface, the application of the butyr must be more severe, and the tow again placed over it, so as to afford considerable yet uniform pressure. Hany days do not often elapse before the new horn covers the whole of the wound. In these extensive openings the Friar's balsam will not often be successful, but the cure must be effected by the judicious and never too severe use of the caustic. Bleeding at the toe, and physic, will be resorted to as useful auxiliaries when much inflammation arises.

In searching the foot to ascertain the existence of prick, there is often something very censurable in the carelessness with which the horn is cut away between the bottom of the crust and the sole, so as to leave little or no hold for the nails, while some months must elapse before the horn will grow down sufficiently far for the shoe to be securely fastened. Youatt adds:- "When a free opening has been made below, and matter has not broken out at the coronet, it will rarely be necessary to remove any portion of the horn at the quarters, although we may be able to ascertain by the use of the probe that the separation of the crust extends for a considerable space above the sole."

\section{CORNS.}

A corn in the human subject is a very different thing from that of the horse, although both arise from pressure. In the horse they are ordinarily seated in that part of the horny sole which is situated between the inner quarter and the bars. When violent pressure is applied, even for a short time, it produces inflammation and extravasation from the secreting sole, the vessels of which becoming ruptured, a "sappy" or "bleeding" corn, called a "new corn," makes its appearance, presenting a blood-marked spot. The suppurating corn we will notice presently. The sensible sole thus injured, unless immediately relieved and not again subjected to pressure until perfectly reinstated, takes on a permanently diseased state. Ever after, instead of perfect horn, a morbid secretion is deposited, and in some cases a semi-purulent matter, or pure pus, fills up the place, the inflamed vessels retaining an exquisite sensibility. 
Corns are usually found upon the inside of the foot, because the inner wall and heel are weaker, and also bear a greater portion of weight than the outer. The coffin bone not reaching to the heels, is the reason why these structures are the seats of corn, for the coffin bone is the active agent in its production. This bone is moved upwards and downwards at either end, as the weight rests upon one extremity or the other of its articular surface. It is the wings of the coffin-bone which cause corns. The descent of these wings squeezes the sensitive sole between them and the shoe in open feet, the shoe in this case being the passive agent; but in the contracted foot, the high, thick, hard, and unyielding sole becomes the passive agent, and between that and the wing of the coffin bone the sensitive sole is bruised. Too little horn subjects the feet to corns, because a slight pressure will indent weak feet. The best shoe, suffered to remain on a foot too long, will produce a corn or corns. Neglecting to prepare the foot for the shoe is also a fruitful source of corns; for in preparing a foot, this angular portion should be so pared as to remove it from contact with the iron, without weakening the horny covering of the sensible sole. Anotler common cause is the neglect of removing or renewing the shoes at proper intervals. When a shoe has been long worn, the growth of the hoof carries it forwards, by which the parts originally opposed to the heels are carried beyond them, and now press on the sole, often becoming indented within the line of the crust, and producing a most injurious pressure. Sometimes, also, either from the original form of the shoes, or by long wear, they become loose or "springy" at the heels, as smiths call it; in which case gravel is apt to make its way between the shoe and foot, which, by the pressure of the heels during action, is indented into the substance of the horn; other gravel is received in the same manner, which presses still onward, until at last it harms the sensitive part of the sole. Extravasation of pure blood ensues, and forms a corn, or it may proceed to suppuration

Corns, when new, are deeply seated, and of a bright crimson colour, requiring much digging with the drawing knife to be found. When old they are black and near to the lower surface of the sole, which has then only to be scraped clean to perceive them. A corn, however, should be followed with the paring knife to its source in the sensitive part; for horses with old corns only go well when fresh shod and newly pared; and as soon as the portion of sole between the bars grows to a level with the surrounding horn, the sensible sole receives a fresh bruise, and lameness again appears.

Treatment. - When a corn of moderate extent first appears, it is not difficult by proper means to remove it completely : but when it has existed some time, the injured part becomes weakened, and the diseased action established. As soon, therefore, as it is discovered, the cure should be immediately attempted; first, by removing the shoc, then with a fine drawing-knife cutting away every portion of horn around; avoiding, however, wounding the sensitive sole underneath. If any contraction of the heels be present, the sole should be thinned till it yields to pressure of the thumb, and the blood appears like dew upon the surface. A unilateral shoe should be then applied, chambered opposite the weak part. Every third week remove the shoes, and pare the horn away from the seat of corn. In this way corns may be cured at their outset. But having become habitual and permanent, a palliative treatment only can be pursued. In the first place, the pressure of the horn must be guarded against by a regular and frequent paring out of the sole; and if the hoof be very strong, and at all disposed to contract, the quarters also should be attended to, and not allowed to become too thick. We have also in very strong feet found the short shoe or tips sometimes of the greatest possible service. To a weak foot, a chambered shoe is preferable. When the weakness is very considerable, or the corn a very bad one, a bar shoe is the most proper support; more particularly remembering, in these very aggravated cases, to remove occasionally all the surrounding horn likely to press on the injured part. Animals that could not wear tips or bear a bar shoe upon the foot, have gone well when shod with leather, and with a shoe shortened at the quarter, which is the seat of corn. By regularly attending to this, horses, before useless, have been able to perform work with comfort to themselves and satisfaction to their owner. In slight cases of corn, the shoe proper to be used is one of rather more substance than common, with the web a little wider than usual, and its width equal throughout, that is, as wide at the heels as the toe; it should also extend rather farther back than it generally does, and present a perfectly level surface to the sole. This affords ease and protection: future pressure must be avoided by keeping the seat of corns clear from offending horn.

Turusi. See Diseases of the Hinder Feet, post.-When tlirush occurs in the fore-feet it may be considered indicative of navicular disease : by inserting a piece of tow in the suspected frog, the characteristic odour will be at once discovered.

\section{CANKER.}

Canker is distinguished by the growth of a fungoid substance, instead of healthy horn, over the surface of the soft parts of the sensitive frog and sole, exuding a thin and offensive discharge, which has the property of decomposing horn.

In mild cases every portion of diseased horn must be removed; otherwise the confinement of the fungus will not only exceedingly torture the horse, but, by the irritation which it produces, will prolong the disposition to throw out the unhealthy substance. The owner must not be terrified at the extent to which the foot is laid bare: not the slightest good can be effected while there is any portion of fungus confined.

Having laid the unhealthy part perfectly open, the 
practitioner will consider what kind of surface it presents. If there is much fungus, he will probably resort to the knife. The fungus must be destroyed, and it cannot be done too soon, or with too unsparing a hand. A level surface being thus produced, the muriate of antimony may be lightly applied over the whole of it.

There is no disease for the relief of which there are more numerous remedies, all strongly recommended, than for canker. All and each of these will sometimes be successful; but on other occasions every one will fail. Solutions of the various caustics; the different acids, either diluted or of the full strength; powders in which the sulphates or chlorides are mingled with chalk, bark, or charcoal, and compounds of all kinds of things have their advocates. Nitric acid and tar is in great favour with some parties. Others employ verdigris, mixed with tar and treacle, or honey, to which is often added a portion of sugar of lead. In fact, the recipes are too numerous to be repeated; but they all have one and the same intention, namely, to act as a caustic and astringent; reducing the fungus, and stimulating the part to take on a healthy secretion. No recipe can strictly be given in a case of this kind. The strength of the agent should be suited to the state of the disease, and in this particular no two cases will be alike. Let, therefore, the judgment be exercised; and at the same time let it be remembered that it is better to change the application than to continue its use when it appears to produce no marked or beneficial effect. A rapid succession of different agents employed in different forms will often do that which a pertinacious adherence to a favourite nostrum will too frequently fail to accomplish. When not judiciously employed, the more potent remedies for canker not only destroy the surface to which they are applied, but deeply and injuriously eat into the foot. The whole cankered surface being exposed, sprinkle it with the following powder :-

\begin{tabular}{|c|c|c|c|c|c|}
\hline Chloride of zinc & & - & • & . & l drachm. \\
\hline Resin & . & . & . & . & 4 ounces. \\
\hline Chloride of lime & . & . & . & . & 1 ournce \\
\hline Alum and resin & . & . & . & . & 2 ounces. \\
\hline
\end{tabular}

Obser ve, neither of these powders will keep dry, and, therefore, must be made îresh for use.

A layer of lint and dry soft tow must be spread over the whole of the exposed surface, and made firmly and equally to press upon it by thin strips of spring-steel slid under the shoe, the horse must be put into a thoroughly dry box, from which the urine will immediately run off, and where no kind of moisture can reach the diseased part. A cankered foot, however, must not be dressed too frequently. The two or three first dressings may be given on succeeding days; but, when the fungus las been in some degree subdued, the bandages should only be removed every fourth day, or even once a week. Every time that the foot is exposed it should be carefully examined, in order to see that there is no portion of unhealthy horn; for if there is, it must be immediately removed. The appearance of the exposed surface must also be inspected with great attention. Fresh fungus will require a fresh application of the powder, or possibly of the knife. Every little pellicle of skinny matter or soft and porous horn must also be pared away: the healthy horn which has been secreted must be lightly run over with the knife; and then the butyr of antimony applied to the whole of the surface; the quantity used on the different portions of it varying with the progress towards a cure. After this the foot must be bound up as before.

A few days having passed-if the sprouting of the fungus has been quite checked, but yet the horn does not grow so healthily as could be wished,-a pledget of tow may be dipped in the solution of the chloride of zinc, and spread over that portion of the foot, with more dry tow placed upon that. A sudden change will thus often be efected; but, should not this take place to the desired extent, try muriate of antimony, laid on with a brush.

The secret of the treatment of canker consists in the use of superficial caustics or stimulants; pressure as firmly and as equably as it can be made; and the careful aroidance of greasy applications or of moisture, either applied immediately to the foot, or suffered to penetrate to it through the dressing. The solution of chloride of zinc is an exception to this last rule, for it corrects the exudation from the foot and stimulates the sensitive parts to the secretion of healthy horn, while the small quantity that need be used will be far from supplying constant moisture.

If wet can certainly be avoided, a horse with a cankered foot will, immediately after the first apparent growth of good horn, do much better at work than standing idle in the stable.

As canker, however, is a constitutional disease, local applications must not be singly denended upon. It is often connected with grease (see GrEAsE), and with grossness of body. The condition of the horse must be considered, and measures adopted to improre the system. 


\title{
CHAPTER XXXIII.
}

\author{
LAMENESSES, AND DISEASES AND INJURIES OF THE HOCK, LEGS, AND HINDER FEET.
}

THE HAUNCH.-THE STIFLE.-STRAIN OF THE "ROUND-BONE." DISLOCATION AND FRACTURE OF THE PATELLA.-ANCHYLOSIS.

TнE bones of the haunch and hinder leg are described, ante, pp. 183, 184, and the muscles, pp. 190, 191. The Plates (X. and XI.) of The Foot and Neurotony, and Plate IX., representing the hinder extremities and their diseases, should be referred to.

The haunch consists of three bones: the ilium, which is joined to the spine, and, when projecting at its wings, produces the appearance called "ragged-hip;" the ischium, or hip-bone, behind and below the ilium, and which projects on each side under the tail; and the pubis, which unites the two last-named.

Fracture of the projecting part of the ilium or haunchbone occasionally occurs. When it is of a simple kind, adhesive inflammation is set up, and the parts re-unite; owing, however, to the action of the muscular fibres inserted in the loosened portion, the piece is sometimes drawn aside, and no surgical application can keep it in its proper position. In these cases the horse is what is called "let down in the hip."

Although the "stifle," in comparative anatomy, corresponds with the "knee" of the human subject, yet the different proportions of the bones of the horse cause the parts below it to be called the "thigh," instead of the "leg."

As in old books of farriery "chest-founder" was the cloak for almost every obscure lameness in the fore-limbs, so to a "strain of the round-bone" or of the "stifle," the lamenesses of the hinder-limbs were conveniently referred. Violence, doubtless, occasionally injures the ligaments, especially of the inside of the thigh. The deep situation of the part presents difficulty. Cold applications, where tumefaction and heat are present, followed by stimulant fomentations, a mild blister frequently repeated, and local bleeding may be tried with good effect. What is called "lameness in the hip" proves, however, in most cases, on careful examination, to have the "hock" for its true seat.

Strain or Injury of the Ligaments of the Stifle, or Patella, is shown by the difficulty the horse feels in putting forward the hind leg; also by swelling and tenderness of the part.

The Treatment should consist of bleeding, either generally or from the thigh; warm fomentations to the part, followed by cold lotions; and, if the lameness continue, the joint should be blistered, or setons inserted over it.

Dislocation, or Fracture, of the Patella.-This injury, also included under "lameness in the stifle," is often mistaken for "cramp," as farriers term it. The signs of a dislocated patella (knee-pan or whirl-bone) are the rigid thrust of the hind-leg backwards, where it remains fixed; the head is erected, and the muscles quiver, while the pastern of the injured leg is bent upwards. An unusual swelling will be perceived at the outer and lower part of the buttock. By grasping the condyles (knobs) of the thigh-bone, the displacement of the patella can be felt, and the absence of the protuberant patella from its proper position, and its shift to the outer cdge of the thigh, are visible, though not so to the unskilful observer in coarse, fleshy horses.

The bone, is always dislocated outwards; the form of the lower end of the femur, the strength of the ligaments, and the power of the muscles on the outward side, all prevent the bone from being dislocated inwards. It sometimes happens from weakness, when mere motion will be sufficient to reduce it. Nevertheless, in other instances, surgical aid is needed. In such cases proceed as follows. In the first place, have the leg drawn forward, if necessary, by means of a rope passed over a beam or rafter, and around the fetlock; then pust violently against the dislocated bone, the position of which will be accurately told by the swelling it produces. It will generally fly back, with some noise; and having got it in its proper situation, partially release the drawn-up lcg, and have an assistant to hold the bone justly, by pushing against it for several hours; afterwards blister the part, to render the animal averse to using it.

Fracture of the Patella is occasioned by a violent kick or blow. When the action of the tendons inserted into its surfaces disunites the fractured portions beyond the power of veterinary surgery to bring them together, the limb is useless, having lost the antagonism to undue flexion. It will be, therefore, of no avail to attempt a course of treatment.

In human surgery, the treatment of dislocations and fractures forms a most important branch of practice. In the horse, though these separations sometimes occur, the immensity of the muscular resistance is such, and our surgical machinery at present is so little calculated to make resistance to the power thus exerted, that the subject may be briefly dismissed in such a treatise as the present. 


\section{ANCHYLOSIS (STIFF AND BENT JOINT).}

When bony matter is deposited within or upon the cartilaginous extremities of bones, or upon the capsular and investing ligaments, so as totally to destroy the motion of a joint, it is called anchylosis, from the Greek word ankyloo, to bend. This tendency is remarkably shown in the horse. Few of the joints of the animal escape anchylosis, as none of his bones are out of the ordinary reach of bony deposit. The joints of the spinal column, particularly of the dorsal and lumbar vertebræ, are frequently the seat of this affection, which seems to be occasioned by heavy weights. It is anchylosis which renders old horses stiff, and in some instances unwilling to lie down, or when down averse to rising up again. When anchylosis of the knee or hock occurs, it usually follows injuries extending into the cavities of those important joints. The treatment is of course merely palliative, promoting absorption where possible by iodine and stimulants, and soothing pain, where present, by wet bandages, warm and cold.

\section{THE HOCK.}

GTRAIN OF THE LIGAMENTS.- CURB. - ENLARGEMENT OF THE HOCK. - CAPPED HOCK.- BOG-SPAVIN, BLOOD-SPAVIN, BONESPAVIN.-THOROUGH-PIN.-WINDGALLS.

Strain of the Ligaments of this important joint is by no means unfrequent, and, as we have said before, the injury is supposed to be higher up. If taken early, the horse rested, and the case treated on the principles before laid down, we shall generally succeed in effecting a cure. When inflammation can be detected at the hock, bleeding, from the thigh or saphena vein, will effect great relief.

By violent and long-continued exertion of the hock joint, so great is the consumption of synovia, in consequence of its peculiarly extensive motion, that the synovial membrane becomes at length incapable of supplying any more, and in this exhausted state is itself the subject of friction. The joint then becomes inflamed and ulcerated, and the lameness is "past all surgery."

\section{CURB.}

This, which is, in fact, extension of the ligaments of the hock, is usually brought on by some violence offered to the sheath of the perforans tendon, passing downwards at the back of the hock. It is often the effect of leaping, rearing, kicking, \&c., and as such is usually sudden in its appearance. A kind of predisposition to curbs from conformation is apparent in horses with "sickle hocks." For the confirmation of this fact the public are indebted to the dissections and observations of Mr. W. Percivall, a writer whose diligence and research cannot be too highly commended. The lameness arising from curbs is not, in general, severe: occasionally, however, it may and does prove considerable. We have already noticed under Ligaments the ring-like bands which, in the horse, tie down the tendons at the joints; these, by sudden extension, are injured, and hence a curb. An enlargement at the back of the hock, three or four inches from the point (see Plate IX., Fig. 5), is visible. Horses are found to "throw out" curbs after a severe race, an extraordinary leap, a fast gallop over heavy ground, or a sudden pull-up. Youatt thus describes the usual treatment of curbs:-

"The first object in attempting the cure is to abate inflammation, and this will be most readily accomplished by cold evaporating lotions, frequently applied to the part. Equal portions of spirit of wine, water, and vinegar, will afford an excellent application. It will be almost impossible to keep a bandage on. If the heat and lameness are considerable, it will be prudent to pliysic the horse, and to bleed from the subcutaneous vein. Whether the injury be of the annular ligament, or the sheath of the tendon, more active means will be necessary to perfect the cure. Either a liquid blister should be rubbed on the part, consisting of a vinous or turpentine tincture of cantharides, and this daily applied until some considerable swelling takes place, which should be allowed to subside, and then the liniment again resorted to; or, which is the preferable plan, the hair slould be cut off, and the part blistered as soon as the heat has been subdued. The blister should be repeated until the horse goes sound, and the swelling has disappeared. In severe cases it may be necessary to fire, but we cannot recommend the indiscriminate recourse to the hot iron in every case of curb, and we would uniformly give a fair trial to milder measures. If the iron be used, the strokes should be in straight lines.

"There are few complaints in whiclı absolute and longcontinued rest is more requisite than in curb. An injury so serious leaves the parts very materially weakened, and, if the horse be soon put to work again, the lameness will frequently return. No horse that has had curbs should be put even to ordinary work in less than a month after the apparent cure, and even then he should rery gradually resume his former habits.

"A horse with a curb is manifestly unsound. A horse with the vestige of curb we should regard with much suspicion, or generally condemn as unsound; for although the neighbouring parts may have accommodated themselves to the slight enlargement that remains, they are not in their natural situation, and have lost a portion of their natural strength. Some latent disposition to relapse may continue, which extraurdinary exertion may rouse to action; and, besides this, it should be remembered, that curb is an hereditary complaint, and that there may be sume constitutional weakness of these parts."

\section{ENLARGEMENT OF THE HOCK-JOINT.--CAPPED HOCR}

The point of the hock is sometimes swelled, and a suft fluctuating tumour appears. This is an enlargement of one of the mucous bags (bursæ mucosæ), which assist the 
motions of the os calcis, and surround the insertion of the tendons in the point of the hock. It is very unsightly, and sometimes becomes of a great size, particularly when it is occasioned by the practice of kicking; in which case not only is there an immense increase of the secretion, but the integuments also thicken, and accumulations take place about the capsule, which become of semi-cartilaginous consistency. It has been punctured occasionally with partial success, and the contents have been drawn off by setons, but the inflammation raised has endangered life. It has also been opened, and its contents, which in the enlarged state are partly fluid and partly semi-solid, evacuated, but after-irritation has endangered life; and no great advantage has been gained, for the incision made has united, and the sac has filled again. Hand-rubbing, almost continuously applied, has done more good with regard to diminishing the size, than all the puncturing, blistering, and firing put together. The hand is also assisted by an India rubber bandage made to fit the part, and worn at such times as the friction is stayed. When, however, opening the sac is insisted upon, it is best to dissect away the lining membrane, or to destroy it by the application of caustic.

It is exceedingly difficult to apply a bandage; and puncturing the tumour, or passing a seton through it, would be a most injudicious and dangerous practice. Blisters, repeated as long as may be necessary, are the usual means employed. Sometimes the tumour will disappear of itself, but at others it will attain a very large size, or will assume a callous structure that will bid defiance to all curative appliances.

BOG-SPAVIN.-BLOOD-SPAVIN.-BONE-SPAVIN.

Bog-spavin is the commonest form among young horses, chiefly at the time of breaking.

Bog-spavin may be termed "wind-gall" of the hock. From over exertion, the bursæ mucosæ, which lubricate this complicated joint (see Plate IX. Fig. 4), become inflamed and enlarged; hence the subcutaneous vein, which passes over these bags on the inside of the hock, is compressed, and the blood interrupted in its flow; blood-spavin is thus produced, but bog-spavin may exist without it. Bloodspavin is a mere fanciful distinction, which may be dismissed without further comment.

Spavin and splint in their most advanced stage are the conversion of ligament into bone; yet when spavin is found, though it may be small, no one can tell where it may stop. It is alarming to find them in young horses; but in old animals they are often perfected, and will not only grow no bigger, but often decrease, and become partially absorbed. The bones locked together by exostosis never become loosed, though the swelling may disappear. As a general rule, we would say, when spavin does not produce lameness, let it alone. However unsightly, do not risk setting up a new action where the disease is quiescent.
The Treatment of bog-spavin may be briefly given in the words of Youatt, to which we will append the shrewd and lively observations of Mr. Mayhew :- "Uniform pressure will sometimes cause the absorption of the fluid contained in cysts or bags like these, but in a joint of such extensive motion as the hock, it is difficult, or almost impossible, to confine the pressure on the precise spot where it is required; and could it be made to bear on the enlarged bag, it would likewise press on the vein, and to a great degree hinder the passage of the blood, and increase the dilatation below the obstruction. The old and absurd method of passing a ligature above and below the enlarged portion of the rein, and then dissecting out the tumour, is not, in the advanced stage of veterinary science, practised by any surgeon who has a regard to his reputation. The only method of relief which holds out any promise even of a temporary success, is by exciting a great deal of inflammation on the skin, and thus rousing the deeper-seated absorbents to carry away the fluid effused in the enlarged bag. Repeated blisters then will afford the fairest prospect of removing the tumour, or firing may be tried; but in the majority of cases, the disease will bid defiance to all our means, or will return, and baffle our hopes when we had seemed to have been accomplishing our object."

Mayhew's advice is worth the space we here give, as a contrast of the "difference of doctors." He says:- "The regular treatment is to purge, give diuretics, bleed, blister, rowel, seton, periosteotomy, neurotomy, fire, and punch. The bleeding may be great or small, local or general; the blister, mild or severe, applied over balf the joint at a time, or rubbed in after the limb has been scored by the iron. Rowels and setons may also be simple, or they may be smeared with irritants, which are made of different strengths. Periosteotomy may be single or may be made compound by the addition of a seton and a blister. Neurotomy is very unsatisfactory, and very often a most tedious affair when employed to cure spavin. The fire may be down to the true skin; it may be through the skin and on to the tumour; or it may be inflicted by means of a bluntpointed instrument, which, when heated, burns its way into the bone itself. The punch also admits of variety; it may be with or without a blister; it may be holes made in a living body, which holes are filled with a corroding paste. Or the operation may consist of the exposure of the bone, and cutting off the offending portion with a saw, or knocking away part of a breathing frame with a chisel and a mallet :

"All these tortures have for centuries been inflicted; they have been practised upon thousands of animals, only for men at this day to doubt whether the cruelty has been attended with the slightest service. Flesh, as capable of feeling as our own, has been cut, irritated, burnt, and punched for hundreds of years, and now, at the twelfth hour, such operations are not discarded, but their efficacy is mildly questioned. 
"Reader, if you have a horse which is lame from spavin, and your calculations tell you it will not pay to nurse the cripple, have it slaughtered. Do not consent to have it tortured for a chanca; do not sell it to the certainty of a terrible old age and of immediate torment.

"The cure for spavin is good food and rest,-perfect rest. Such rest or stagnation as a lealthy horse submits to in the stable. This enjoined for months, with the occasional application of a mild blister, with the best of food to enable nature to rectify man's abuse will do more good, cost no more money, and occupy no more time than the devilries usually adopted, and very often almost without success. As an additional motive on the side of humanity, it may be stated that the horse suffers much more when disease is located in the hind, than when it is exhibited upon the forelegs. The ravages which in the first case would endanger the life, in the last would be borne with comparative tranquillity. The posterior parts of the animal seem to be endowed with exquisite sensibility; yet, in spite of this, the so-called cure for spavin and the boasted treatment of ages only consists in torturing the hocks of the animal.

"While inflammation exists, apply poultices, and well rub the part with a mixture of belladonna and of opium; one ounce of each drug rubbed down with one ounce of water. Or place opium and camphor on the poultices; or rub the enlargement with equal parts of chloroform and camphorated oil. The pain having subsided and the heat being banished, apply with friction some of the following ointment. It may reduce the disease by promoting absorption, at all events it will check further growth by rendering further deposit almost an impossibility :-

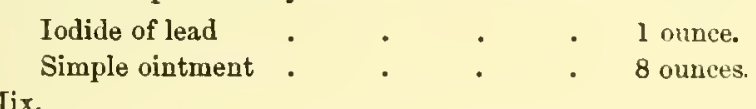
Mix.

Bone-spavin is an exostosis, or deposit of bone on the inner side of the hock, which, when low, is called by the horsedealer a "jack;" it corresponds to splint in the foreleg, and originates at the head of the splint bone. The "highspavin" is the most mischievous, as it locks the joint, or renders the motion of the hock excruciatingly painful, the tendons having to move over the rough bony deposit. 'The mode of lifting the hind leg in the trot will show spavin; the foot, instead of being freely raised from the ground and slightly rotated outwards, drags, with the toe pointed stiffly forward, describing a much less curve in its passage through the air. The toe being thus brought forward, is worn blunt with the shoe. Look then at the horse's shoes (if worn), and see the horse when first brought out of the stable; when warm, the stiffness, in less severe cases, will disappear. Horses with "sickle" or "cow-hocks," i.e., with the great joints of the hinder-limbs approaching each other like the knees of a knock-kneed man, are most liable to spavin, thorough-pin, and splint. On Plate IX, Fig. 5, will be seen represented the locality of spavin and other diseases of the hinder extremity.

\section{THOROUGH-PIN.}

This is of the nature of bog-spavin, and allicd to the "wind-galls" of the farrier. We have more than once mentioned the bursæ mucosæ as the seat of discase; there are two situations in which thorough-pin appears, one rather above the point of the hock, the other below it. Thorough-pin derives its name from the circumstance of its appearing as a round swelling on both sides of the hock, between the flexor of the tendons of the foot and the extensor of the hock, and is a sign of heavy work, though often not accompanied by decided lameness. Thorough-pin, when not interfering with work, is not unsoundness, though a serious diminution in market value.

Thorough-pin and bog-spavin often exist together, and then the fluid can be pressed from one to the other, though not readily. These thorough-pins are generally produced by the sudden violent straightening of the limb, whilst bogspavin is probably caused by its sudden bending.

Mr. W. Spooner says:-"I have, however, known a troublesome and obstinate lameness produced from the upper thorough-pin, or perhaps rather from some strain of the tendon which attended it. It gave way, however, at length, to a seton placed over the part, - not through it. I have also succeeded in removing a very large thoroughpin in the lower situation, in a high-class race-horse, by the long-continued application of equal parts of iodine and mercurial ointment, previously, however, stimulating the part with a mild liquid blister. The subject was a racehorse of great value, and the thorough-pin entirely disappeared in about ten weeks. In some cases the synovial fluid in the thorough-pin coagulates, and becomes organised and firm."

\section{THE HIND-LEGS, PASTERNS, AND FETLOCK-JOINT}
MALLENDERS AND SALLENDERS.-SWELLED LEGS.- GREASE.- WEED.-SPRAIN OF TIIE FETLOCK-JOINT.- HALTER-CAST. - TREAD.-RINGBONE.-WINDGALLS.

Mallenders and Sallenders.-On the inside and front of the hock, or a little below it, is often found a scurfy eruption called Sallenders; and a similar one on the back part of the knee bears the fantastic name of Mallenders; words of which the derivation is unknown. Their treatment is identical, and will be found, ante, p. 331, under DiseaseE of THE SKIN.

\section{SWELLED OR “FILLED" LEOS.}

This common grievance of the stable is commonest among coarse and heavy horses; though the exactions of the animal's hard taskmaster, man, render the best-bred ones su'ject to the visitation. The hinder-limbs, below the hock, are the most affected, though the fore-legs, below the knet, come in the same way to grief from undue exertion. Debility is also the constitutional cause of swelled legs. Some 
horses are liable to swellings in the limbs in the spring and fall of the year. This can be accounted for by the principal activity of the circulation being employed in preparing a fresh covering of hair at those periods, so that the vital influcnce in the extremities is somewhat diminished; and the same cause produces swellings in the legs.

Frequently, when a horse seems to be affected with no other disease, the hind-legs will suddenly swell to a very great extent from the hock to the fetlock, in some instances even from the stifle downwards. This is accompanied by heat and tenderness of the skin, inducing lameness of a peculiar character. A quickened and hard pulse are usual concomitants of this seizure, with a considerable degree of fever. This complaint is acute inflammation of the cellular substance of the limbs, sudden in its attack and violent in its degree, consequently attended with the secretion of fluid in the cellular tissue. Young horses, and those which are over-fed, with little exercise, are most liable to be thus attacked, and without having had previous inflammation.

Swelling of the legs is common to loorses which are used for hunting and pleasure only. This, it will be seen, arises from irregularity in their habits; one day having a more than sufficient exercise, and probably standing for days or weeks in a stable, and only walked out or trotted for a short distance. In such cases the limbs should be well hand-rubbed, to stimulate the vessels. Bandaging judiciously is advisable : but do not allow the groom to administer diuretics, as he says, to "cool the animal ;" the remedy is ruinous to the constitution, and aggravates the tendency to "filling."

The most troublesome, as well as the most frequent swelling in the limbs, is that caused by inactivity, from high feeding, and want of due exercise. One kind is accompanied by local or comparative debility, or loss of power in the part affected. Those horses which are over-fed, without exercise, are liable to swellings in the limbs from the capillary vessels having sent forth an over-supply of fluid to the extremities; and in consequence of the want of muscular exertion and the perspiration naturally connected with it, the fluids accumulate in the extremities, the vessels not having sufficient power to return them. The heart is thus acting upon an additional quantity of fluid; while, by the want of exercise, the limbs are deprived of that power by which the fluids are returned. Here "physic" a little soft food, exercise, and a mild diuretic are indicated, with active hand-rubbing.

Horses taken in from grass are often seized with swelling in the legs. This is occasioned by the difference of food, owing to its containing a greater proportion of nutriment, which increases the quantity of the blood, and the want of muscular and respiratory exertion necessary to carry it off by the skin. Exercise and a little opening medicine will effect a cure.

Treatment. - This, of course, must vary as the cause of the complaint varies. If from fatness of condition, bleed moderately; you will find the upper surface of the blood at first colourless, and a thick coat of buff afterwards. If the cause is debility, and the horse has had too much moisture in his food, bleeding is improper, and if a diuretic is given, follow it by a tonic. White recommends, if the swelling extend much above the hock, that we make some punctures with a lancet, which will produce great relief, particularly if the leg be afterwards fomented with warm water. Care, however, must be taken to rub the leg dry afterwards.

Place the animal in a good roomy box; give no hay. Sprinkle a handful of ground oak bark on-each feed of oats, which should be damped to prevent the powder being lost. Walking exercise should be given twice or three times a day. It will be necessary to repeat the diuretic medicine every alternate day; and if the animal is debilitated, give in addition the following tonic:-

$$
\begin{aligned}
& \text { Powdered ginger . . . . } 2 \text { drachms. } \\
& \text { Sulphate of iron . } \quad \text {. } \quad \text {. } 3 \text { drachms. }
\end{aligned}
$$

Either as a powder or in a ball.

If in the course of two days the leg is not so materially reduced in size as to lead us to infer its speedy restoration to a normal state, we may insert a rowel or seton in the thigh. If abscesses should form in the thigh or leg, we must take care to distinguish the case from farcy, to which it then bears some resemblance; but in the latter disease the abscesses are usually smaller, and lie in the course of the absorbents, which are enlarged, whilst in odema the abscesses are larger and more independent in their position. These abscesses being opened, usually heal with little difficulty; but if the skin should slough, as it sometimes does, the cure is much more tedious. There is, however, a difference in this respect between the human and the equine subject; for whilst, in the former, the cure of ulcers is tedious and protracted, in the horse it is generally speedily accomplished.

\section{GREASE.}

This offensive disease is consequent on a morbid alteration of the quantity and quality of the fatty matter secreted by the sebaceous glands of the heels. Its sign is a white discharge from the skin of the heels, sometimes extending as high as nearly to the hock or knee. There is usually dropsical enlargement of the legs, the skin is red, and the hair staring, with pain and stiffness of the part. Horses with much hair on the leg are most subject to grease. Dr. Jenner supposed grease to be a specific disease, communicable by inoculation; but the idea has not been confirmed by experience.

In the simple form of grease, the stiffness and pain of the limb go off after a while; but if the disease is neglected, the discharge increases in quantity, the skin becomes thickened, and large excrescences,-called from their shape "grapes,"cover the heels and back of the legs, while ulcerations form about the heels, and slough large portions away Nayhew says, with proper indignation, "Grease is a filthy disorder, and a disgrace to every person concerned with the stable in which it prevails; it proves neglect in the proprietor, want 
of fitness or positive idleness in the groom, and culpable ignorance or the absence of the slightest moral courage in all people entering the doors of the stable. It is one of those disorders which it is easier to prevent than to cure. By an ordinary regard to cleanliness, and by an average attention to the necessities of the animal, this taint may be avoided; wherever it is witnessed, it not only argues the human being to whom the building belongs to be in the lowest stage of degradation, but it also testifies to the sufferings endured by the poor creatures which are compelled to drag out life in such custody."

There is so much honest and just indignation here, that we forgive a little exaggeration. Grease is not always produced by mere neglect, though hand-rubbing, free ventilation, and cleanliness have almost banished it from our cavalry horses and well-regulated stables. Swelled legs, cracks, and grease are so much more common in winter, that grease has even been called a winter disease, and the "chilblain" of horses. Moisture is likewise favourable to the complaint, for it first produces a determination to the parts, and then, as a parent of cold, it weakens the already distended vessels Grease sometimes follows injuries; as halter-casting. 'I'he disease may become serious when it occurs under other circumstances favourable to its production, as in moist, cold, and particularly frosty or snowy weather; or when, from previous illness, a horse has been thrown out of condition; and, more than all, when such a case has been maltreated by the idleness or ignorance of those around, who, finding a swelled heel, immediately fly to urine balls, or purging balls, whereas a little local attention will cure the surfaces at once. Colour, likewise, as it marks debility, so it influences grease; thus, it has been remarked that white-legged and light-coloured horses generally are more liable to cracks, to grease, and to diseases of the feet, than others which are darker, or whose legs are black. After all, however, the grand origin of grease isbad stable management. No matter of what breed, or how old the horse may be, the groom is to blame if the animal becomes greasy. In all well-regulated stables, the appear. ance of this loathsome disorder should be a signal for a change of attendants therein; for as the affection is now banisled from the army, what earthly reason can be urged why it slould be found in private stables?

Treatment.-In the older veterinary books, pages are devoted to this opprobrium of the stable. Our directions shall be simple. Clip off the hair; it can only heat the skin and retain the discharge. Wash the leg with warm water and curd soap. Then take a soft cloth saturated with the following lotion :-animal glycerine, eight ounces; chloride of zinc, one ounce; water, one gallon; and lay it on the hot skin. As soon as it is warm, change it for another left ready in the lotion, and persevere in this till the temperature is lowered Two men should be employed, and four cloths, eact as removed being thrown over a line to expose as large a surface as possible to the cooling action of the air. The chloride of zinc deodorizes the discharge. When the cracks are ulcerated, a stronger lotion is to be used, of the perman. ganate of potash, one pint to a gallon of water, or:creosote, four ounces; chloride of zinc, two ounces; and a gallon of decoction of oak-bark, cooled. A good powder to sprinkle grease is made thus:-chloride of lime, one ounce chalk, four ounces, powdered gall nuts, two ounces.

A drink of tincture of muriate of iron, one ounce; liquor arsenicalis, one ounce; and one quart of sound beer, may be administered. Blaine recommends sound ale, one quart; carbonate of ammonia, half a drachm; extract of gentian, one ounce; tincture of capsicum, half a drachm; but we prefer the first, with the addition of the gentian if the animal is low and lymphatic.

It is, moreover, essentially necessary to the cure, that all sprouting luxurious granulations should be reduced to the level of the surrounding integuments. Caustics only render the "grapes," as they are termed, of greater size. The mode best adapted for their removal is the knife. Cast the animal, having a flat piece of heated iron ready to pass over the surfaces, in case the hæmorrhage is profuse; as the horse having grease can but ill afford the loss of blood. Employ the strongest lotion into which chloride of zinc enters, and sprinkle the legs with either of the powders before mentioned, only rendering each weaker as the symptoms abate. In this manner a cure may be accomplished. Moderate exercise is of the utmost importance; indeed, the pain of grease goes off greatly during gentle motion of the parts. The disease, however, is apt to return. Should it display this disposition, discharge the groom, and procure one that is less sparing of his labour.

WEED.

This name is applied in the north country to a disease simulating œdema, or swelled legs; yet is quite distinct in its nature, and should be looked for. It consists in a swelling of the thigh vein, extending sometimes from the hock up to the groin, very hot and tender. It is not mentioned by Percivall, Blaine, Mayliew, or in ordinary books; but is important, as its otler symptoms are similar to ordinary swelled leg. When this affliction of the vein is found, bleedings, fomentations, and mild purgatives, to lower the system, should be adopted.

\section{SPRAIN OF THE FETLOCE-JOINT.}

This we have noticed, ante, p. 341. When occurring in the hinder feet, it may be mistaken by a superficial observer for œdema. Put the limb in a bucket of lot water, bleed from the leg, then apply a cloth wetted with muriate of ammonia, one ounce; pyroligneous acid, two ounces; camphorated spirit, half-an-ounce; water, one quart; and if much lamed, apply a patten shoe, and give absolute restwhich is the reverse of the treatment for œdema

An Overshot Fetlock-joint sometimes renders a horse useless; he is only just able in this case to bring the toe to the 
ground. There is but one remedy-division of the flexor tendon. The divided ends recede, and the intervening space is filled with granulations. The operation will be described hereafter.

\section{HALTER-CAST.}

The horse often injures himself by entangling his hind-leg in the halter, and injuring his fetlock or his heel. Wrap the part in a large linseed poultice, and then apply an astringent paste; pipe-clay mixed with water in which a piece of alum has been dissolved, is a cheap and useful application. When this is taken off, soften the cicatrix with a little Elorence or palm oil.

\section{WINDGALLS.}

The similarity of windgalls to bog-sparin and thoroughpin,- the two latter, however, being looked upon as hock diseases, and the former as affecting the fetlock joint and the sheath of the flexor tendons,-renders detail almost unnecessary. They are almost always on the hind legs. There are two situations in which they most usually appear; one on each side, and at an equal distance from the front and back of the fetlock joint; the other on each side of the flexor tendons. The former communicates with the fetlock joint itself; the latter, which are larger and more frequent than the others, with the sheath of the flexor tendons. Thus connected, there must be considerable danger in opening them. Windgalls are, therefore, neither more nor less than a distension of the synovial bags with synovia, and sometimes an extension of these bags by a rupture of their connections. Blaine says:- "In the treatment of windgalls we must attend to three particulars; the removal of any diseased alteration they may have occasioned in the neighbouring parts; the removal of their own distension; and the prevention of its recurrence. Stimulating applications are the most likely to produce a removal of any coagulating deposit; these are likewise still more proper, as they will tend to effect a removal of the contents of the windgall itself. The "liquid blister" will be very proper for this purpose. But simply to promote absorption of the contents of the windgall, continued pressure will be found the most convenient and efficacious remedy. A calico or a flannel roller may be prepared, of two, three, or four yards long, according to the part affected: four inches is a proper width, and, from its superior elasticity, flannel is preferable to calico or linen. In addition to this, be furnished with one or two pads, stuffed with horse-hair or other elastic matter. Begin to apply the roller, and after having made a turn or two below the swelling, place the pad exactly upon the windgall; if in the pasterns, one should of course be placed over each side : continue the roller firmly and evenly over all, and fasten off. It however must not be forgotten, that but little benefit can be expected unless this be continued as a constant application for a considerable time, during day and night, when not in exercise; also, it must be remembered, that upon a repetition of the original cause (hard work), they are apt to return; the dilated capsule seldom regaining, with its original size, its original strength. It may be necessary liere to warn the practitioner never to puncture a windgall. Most of those of great bulk and long continuance actually communicate with the cavity of the joints they surround; and the others of themselves excite similar effects with open joints, when they are laid open; and even if no mischief followed, no good could result; the cyst would be only momentarily emptied; for its capacity would commonly remain the same, and it would almost immediately fill up again. Such an operation is, therefore, not only useless, but usually produces such inflammation as destroys the horse, or ends in stiffness and anchylosis of the joint." Touatt recommends iodine and mercurial ointments.

RUPTURE OF THE BACK-SINEW.

This, which in racing parlance is called "breaking-down," is a tearing asunder of the suspensory ligament, causing the fetlock to come to the ground. A patten shoe, rest, and a good constitution have got over this frightful lesion in valuable animals. The treatment will be found, ante, pp. 339-341, under Fore-Leg and Pasterns.

RINGBONE (ossification of cartilages) is described and treated of ante, p. 341 . Splints, Sprain of Tendons, \&c. under FORE-LEG, p. 339, \&c.

\section{THE HIND-FEET.}

CHAPPED OR CRACKED HEELS.-TREAD.-INJORIES IN SHOEING.

Chapped or Cracked Heels are, like grease, penalties suffered by the poor horse for man's mismanagement or neglect. They are most prevalent in winter, and with horses that are entirely denuded of nature's hairy covering, (the "fet-lock"), by fantastical or oftener lazy grooms, who fancy because thorough-breds have clean (not naked) legs, they must trim up their roadsters or harness horses equally fine. The skin does not get dirty under this small mat of hair; and if masters would see that the servant rubs the horse's fetlocks dry, instead of drenching the poor brute's heels with water and leaving them to chap in the wet and cold, prescriptions for chapped heels would be out of date. The milder remedies for GREASE are resorted to in this disorder. Forbear exercise, give bran mashes; and, should ulceration come on, the advice given under the head just referred to will need to be carried out.

If in lower-bred horses, - or in better animals, from laziness or unpardonable neglect, - an ulcerative process should have been set up, creosote or permanganate of potash must supersede the chloride of zinc for a time; this must be mixed in proportions of half an ounce of creosote, or permanganate of potash, with two ounces of animal glycerine to a quarter of a pint of water, and the state of the general health attended to; the system however, must not be reduced, or depletory measures resorted to. A drink composed of the liquor 
arsenicalis, half an ounce; tincture of muriate of iron, an ounce; and water, half a pint ; should be given once a day. But never forget that leaving nature's covering on the heels, merely-if the master is so fantastical as to require ittrimming off the ends of the fetlock, and diligent cleaning, first with cold water, then drying them thoroughly with more than two cloths, and lastly, diligent hand-rubbing, will prevent, in animals thus stripped and exposed, a return of chapped heels. Where there is a marked predisposition, from light colour and tender skin, to this and similar disorders, after the drying and rubbing already directed, smear the heels with glycerine, and stop the feet now and then, in cold weather, with corroborative stopping of tar and linseed meal, wetted with chloride of zinc. We liave found one of the convenient felt pads, slipped into the shoe, smeared with thin tar, after the washing with the white vitriol, a good preventivt.

Mayhew pleads so eloquently against the practice of denuding the fetlocks of their ornament, that we are sure the reader will be pleased with his earnest appeal. $\mathrm{He}$ says:- "The liability to disorder, induced by removal of the natural covering, exemplifies the folly of those practices, which have lately become so very fashionable as, at the present time, to be almost universal. But there has always appeared to exist in the human mind a restless desire to improve the beauty of the horse. Now, the tail has been docked; then the ears have been cut. A short space prior to these amendments, the skin was tampered with, to produce a star, as a white spot upon the forehead was termed. At the passing hour, almost every man who owns a horse must have the body clipped or singed. The length of hair is given in this climate as a necessary provision. Nature never forms anything without its use; though man, in his ignorance, may not always be able to comprehend her intention.

horses allowed to retain that adornment which Nature gave, and were the parts not shorn of their shaggy beauty,-were men not inclined to confound the different breeds of horses, and, because the thorough-bred has clean legs, to imagine the cart-horse can be artificially made to display members equally fine-were masters more resolute in resisting the selfish suggestions of lazy grooms, who love to have the bushy heels clipped-were the stable-keeper not afraid of doing his duty, but would go down upon his knees and rub the fetlocks dry, instead of drenching them with water, and then leaving them to chap in moisture and in cold-were these things attended to, there is no reason why cracked heels should not speedily become a thing which has been, but no longer is.

"However, if animals are exposed throughout the wintry season, under the pretence of being placed in a straw-yard, the proprietor must expect to taike the creatures up with some defect. The worst case of cracked heels the author ever looked upon, was produced after the last-mentioned method; the skin was much thickened and deeply marked by fissures. In places it had sloughed, and, where the integument was absent, fearfully deep ulceration was established. Fortunately, the absorbing process had reached none of those important structures which are situated about the heel of the horse; and the animal, after lengthened treatment, was cured."

TREAD.

This is a wound inflicted on the coronet of the hinder foot by the act of crossing the feet when the animal is fatigued. In some cart-horses it happens in coming down bill, the calkin of the one foot striking its fellow in front, and tearing away a portion of the coronet. In light fast horses a very similar injury is produced by the inner part of the hind foot striking the outer part of the fore coronet, when it is called "overreach." Quittor or false-quarter results from this tearing away of the part which nourishes the hoof. Cut away the separated pieces of flesh, and wash with chloride of zinc, and give the animal generous diet. If a slough takes place, dress as for ulceration, but do not poultice. In slight cases a pledget of tow moistened with Friar's balsam, inserted in the wound, after washing carefully with warm water, will suffice to effect a cure.

In the first instance, all cases of "tread" are to be considered as simple wounds, or rather as bruises, which if extensive have produced death in the surface and adjacent parts of the hurt; in which some inflammation must occur and be followed by slough of the edges thus injured. Sometimes the injury is so great as to cause slougling of the extensor pedis tendon and opening of the coffin joint. In no instance, therefore, should an early application of irritating or caustic matters be made, by which more extensive inflammation and an increase of sloughing are produced. On the contrary, wash with water to remove dirt, \&c., and if the wound be considerable, wrap up the foot in a poultice; if not, apply ovcr it simply the mild lotion of chloride of zinc. Shonld the injury be slight, it may heal at once; but if not, sloughing and suppuration will occur. Under some circnmstances, however, more extensive mischief will follow, as "quittor," or "open joint ;" the treatment of which, will be found under the proper heads.

\section{INJURIES IN SHOEING.}

These, arising from carelessness in nailing the shoe to the foot, or "pricking" him in the operation, from ill-shaped shoes, and the like, will come to be considered in the Chapter on Shoeing. 
CHAPTER XXXIV.

OPERATION8, INSTRUMENTS, ETC.

CASTING THE HORSE.-HOBBLES.-THE TRAVIS.-SIDE-LINE.SLINGINO THE HORSE. - THE TWITCH.-CHLOROFORM.-BLEEDINA.-ROWELS. - SETONS.-TRACHEOTOMY.—ESOPHAGOTONY.LITHOTOMY. - PERIOSTEOTOMY. - NEUROTOMY. - DIVISION OF THE FLEXOR TENDON.-FIRING.-NICKINO AND DOCKING.BLIsTering, POUlticing, AND BANDAGINa.

CASTING THE HORSE.-THE HOBBLES.

As a preliminary to the more serious operations of veterinary surgery, the mode of casting the horse has far more importance than is generally attached to it. To avoid awakening resistance from fear or suspicion of injury, is most important in so powerful an animal. Yet to see the violence and force with which a horse is too often brought down, what is emphatically termed, "a burster," by a set of hard-handed clumsy clowns, is a sorry sight. Terror, exciting to stubbornness and resistance, possesses the illused horse, aggravates the pain, and half maddens the firmlybound sufferer, who, with his four legs drawn into a cluster, and with a heavy-sterned stable-helper sitting on his head, and another with his knee and fists upon his cheeks and jaws, is held down amid exclamations, confusion, tugs, threats, sly punches, and oaths. Let us, after a brief mechanical description of the improved hobbles, devote a few paragraphs to a more rational and humane method of securing a horse, especially for the less severe operations.

The HobBLES, as represented on Plate XV., are of the simplest construction. Four straps of strong leather, a yard long, are doubled to eighteen inches, one end liaving sewn strongly into it a stout iron buckle. Five inches from this buckle is a strong iron $\mathrm{D}$, consisting of a half circle of iron and a flat iron pin on the inner-side of the straps. Through these passes the rope or chain with which the horse's feet are to be drawn together. The rope in our picture is first fastened to the hobble on the fetlock of the foreleg, thence threaded through $D$ of the near forefoot, so running to the near hind foot, the off hind foot, and thence the loose end comes out at the $\mathrm{D}$ on the off forefoot. Pulling at this, the near forefoot is first brought home, followed by the hind-feet in the same order, and these, being brought up to the forefeet, the whole are together, and the animal gently but quickly pushed down on his near or left side, on a number of trusses of straw, neatly arranged. The side for throwing the horse is easily reversed by placing the hobble with the fixed end of the rope on the opposite foot, and pulling in the contrary direction.

Mr. Gloag has introduced some improved hobbles which possess all the advantages of the ordinary apparatus, and are far more convenient. Each of his hobbles he advises to be furnished with a buckle, as well as with a $\mathrm{D}$ at each end, of unequal sizes, so that one $\mathrm{D}$ can be passed through the other. Thus, by means of the buckle, the size of the hobble can be varied so as to suit different legs, as well as to unloose any one leg that may be required during an operation; the D.s will enable each separate leg to be free the instant the screw is withdrawn.

The safety of the horse and of the operator requires the use of the improved hobbles, by which any leg may be released from confinement, and returned to it at pleasure; and, when the operation is ended, the whole of the legs may be set at liberty at once without danger. Putting the legs as closely together as possible before the pull, - the necessity of the assistants all pulling together,-and the power which one man standing at the head and firmly holding the snaffle bridle, and another at the haunch pushing the horse when he is beginning to fall, have in bringing him on the proper side, and on the very spot on which he is intended to lieare evidently needful to a proper and safe position of the thrown animal. After all, however, this is a method of securing the horse to which we should not resort except necessity compelled, for reasons which we will briefly state, and on account of an improved practice laving been inaugurated. If the horse is to be thrown with the hobbles, he should have his eyes covered before they are put on, and in some instances the "twitch" may be necessary, but should be removed befure he is thrown. The men who pull the rope should not be more than two yards from the horse, as the power of lifting the legs from the ground is doubled by being at this short distance; and observe, above all, they must be silent. The man who has charge of his head should stand directly in front of him, holding the halter, steadily and without bustle throwing himself on the neck, and must lift the halter so as to raise the horse's nose the moment he is over on his side.

M. Girard, in his Traite du Pied, proposes an improvement in throwing horses, which is very simple. If the horse is to be thrown on the right side, a long piece of web 


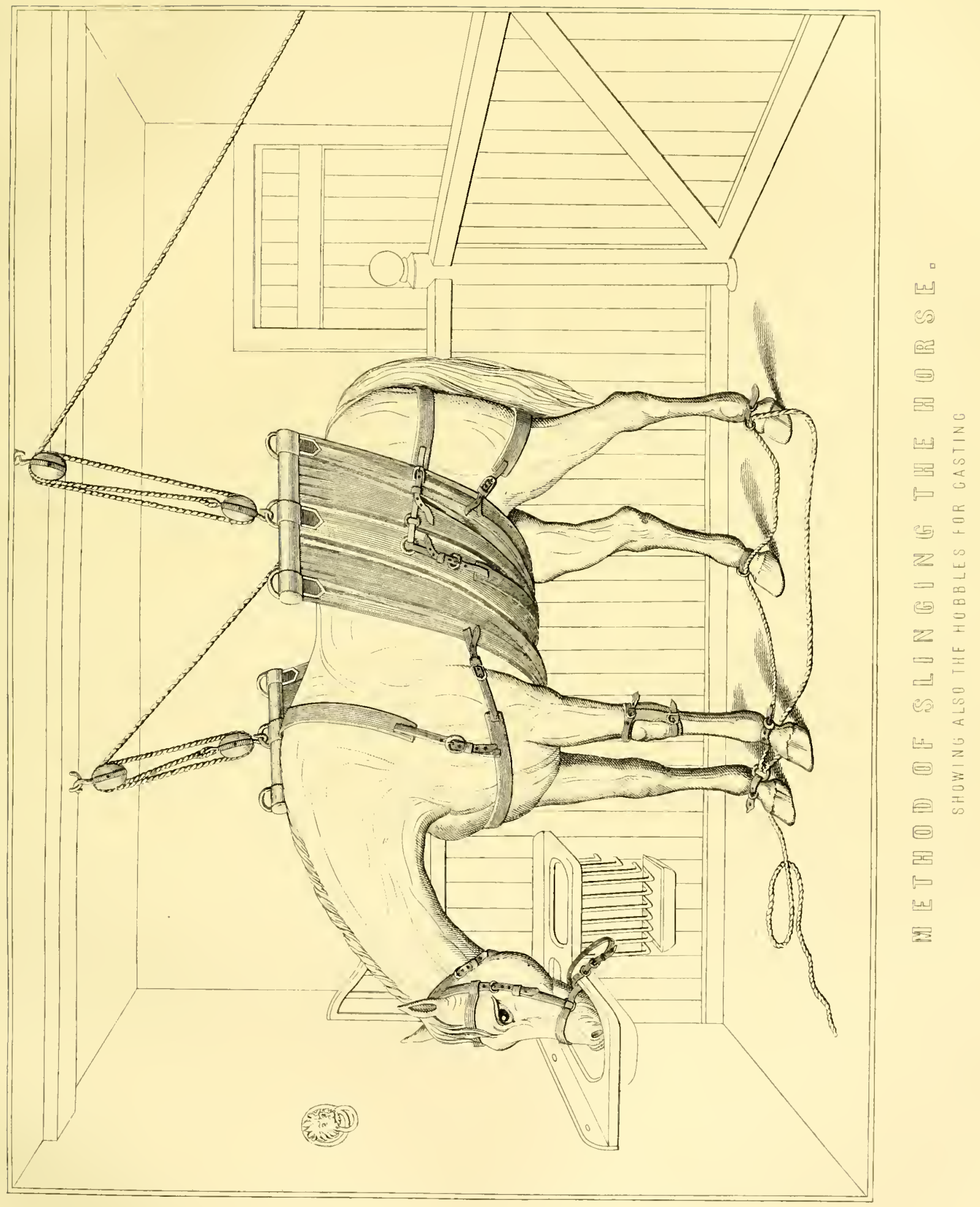



or a rope is to be fastened round the right fore arm, close up to the elbow. The other end is then to be passed over the withers, and held at a little distance by one or two men. The force which is applied in this way will cause the horse to fall more readily, and with more certainty, and exactly in the situation where he is required to be tlirown. This contrivance, therefore, is extremely useful in confined places, where there is just room enough to throw a horse, and no more Rarey's method of securing the fore legs, presently noticed, is yet superior to this. The lorse being thrown down, and his legs closely drawn together, the end of the hobble rope is to be passed under the hobble rings, between the fore and hind legs, and secured with a hitch, as it is termed, so that he cannot separate them again until the hobbles are unbuckled, and then they all may be taken away at once, and the horse suffered to get up.

A suspicious affectation of mystery, the outward and visible sign of quackery, attended the introduction, in 1858, of the system adopted and partly invented by Rarey, and consequently its immense merits and advantages have been decried by prejudice and rejected by conceit and ignorance. The "grand secret," for which the original subscribers paid their ten guineas, and which the general public were admitted to see practically illustrated for a shilling, has suffered from the "showmanship" with which a really important process was accompanied. Resolution, firmness, gentleness, and apparent kindness, with a simple securing of the animal, enabled the American horse-trainer to produce by the simplest means almost miraculous results. The horse thrown by Mr. Rarey's method (which will be found fully described under "Breaking," ante, page 75), instead of being in the usual state of fear, will be found entirely quiescent. Indeed, for minor operations, the strap which doubles the fore-foot up to the elbow will be found sufficient security. The extent of influence which this simple process has over the hind-legs of the most vicious horse, might have been known before, but was never so convincingly illustrated as by Mr. Rarey. The "gentling" of which he makes so much, and at which brutal conceit is so tempted to scoff, will be found by no means over-rated, when applied with nerve and coolness, and directed by an enlightened feeling of humanity.

It was thought, before tne system was divulged, that some drug, the smell of which was pleasing to the horse, was employed to produce that disposition to follow the operator about, which almost every horse exhibits on being submitted to the process; and even now there are obstinate persons who insist upon some such influence being used to induce the horse to follow the operator. We have found no such trick necessary for this purpose.

The Travis* is a frame of heavy bars of wood, into which, on the Continent, the quietest horses are placed to be

* The French term traves, merely means the space between two beams or pillara. shod; even when padded, it is a most dangerous apparatus, and horses have been known to kill themselves in their struggles, when confined in it. A picture of this clumsy contrivance, formerly used here for cropping, docking, nicking, and other blacksmith barbarities, may be seen in Bourgelat's “Essai sur les Appareils propres aux Quadru. pedes." The term travis is now applied to the separation between the stalls of a stable.

The Single and Double Side Lines are also used to limit the capability of resistance. The single side-line is thus applied. A soft collar is put over the horse's head, and a lobble is fastened to the foot it is desired to have elevated. From the collar is dependent a metal loop, ring, or other contrivance. By the side of this a strong rope is attached. The cord is then passed through the D of the hobble; afterwards, it is brought back and run through the side ring or loop. A man then takes hold of the end of the rope, and, by gradual traction, causes the leg to be advanced. It is neither wise nor humane to drag the foot off the ground. The side line is most useful when the hocks or hinder parts are examined. Many unbroken horses, though quiet in other respects, will not allow these portions of the body to be touched. By causing one leg to be advanced, the other is deprived of all power as a weapon of offence. The horse would obviously fall, if he were to project the only free hind member.

The Double Side Line consists of a rope fixed to a loop on either side. The loop or ring is attached to a soft collar. The rope is afterwards threaded through a hobble on each pastern. Both legs are then gently pulled forward, and the animal, having its posterior supports drawn from under it, comes to earth. The ropes are held tight, while the horse is turned upon its back. The instant it is in that position, a man seats himself upon the head, while the body of the animal is propped up by numerous trusses of straw.

For every minor operation, and even for many that are of more importance, this mode of restraint is sufficient; especially if the operator has active and determined assistants: and we confess that we are no friends to the ordinary casting of horses if it can possibly be prevented. When both legs are included in the hobble or rope (as in another way of using the side line), the horse may appear to be more secure, but there is greater danger of his falling in his violent struggles during the operation.

Sunging is clearly represented in Plate $X V$.; it is a restraint which horses submit to with great impatience, and not without much inconvenience, from the violent ex. coriations occasioned by the friction and pressure of the bandaging around his body. Graver evils are also brought about by the abdominal pressure. Some horses stale and dung with difficulty when suspended, and inflammation of the bowels has not unfrequently come on during slinging. The slings are, however, forced on us in some cases, as in fractured bones, the treatment of open joints (the horse slung in our picture is thus injured), and some other wounds 
where motion would be most unfavourable to the curative treatment. Suspension may be partial or complete. Suspension of any kind will require the application of pulleys and ropes affixed to the beams, that the whole body of the horse may be supported. A sling may be formed of a piece of strong sacking, which is to pass under the belly, the two ends being fastened firmly to pieces of wood; each of about three feet long, and which are to reach a little higher than the horse's back. To the pieces of wood, cords and pulleys are to be firmly attached, by which means the sacking can be lowered or raised at pleasure. To the sacking, also, are to be sewn strong straps, both betore and behind, to prevent the horse sliding in either direction, without carrying the sacking with him. Upon this so formed-cradle he is to recline. If horses when they are fresh should be placed in this machine, most of them would either injure themselves, or break through all restraint. However, by tying up their heads for three or four nights, their spirit is destroyed. The slings may then be applied without the fear of resistance. It is best not to pull the canvas firm up, but to leare about an inch between the horse's belly and the cloth, so that the animal may stand free, or throw his weight into the slings when he pleases. In this fashion a horse may remain for months in the slings, and at the end of the time display none of the wear and tear described by old authors.

Among the older "Vets," several other restraints are common, among them The Twiтcн. When too frequently used, it has the evil effect of making many horses violent in resisting its application. The TWITCH consists of a noose of cord passed through a hole in the end of a stout stick of wood; in this noose the muzzle is held and pressed in the most cruel manner; and as every turn of the stick following a struggle aggravates the pain, he ordinarily becomes quiescent, though we have seen cases where the madness of agony produced frantic resistance. The barnacles is a name given to the handles of the smith's pincers placed over and compressing the muzzle or upper lip, and torturing the animal, like the twitch, into submission.

In many instances blindfolding will do more than the " twitch; and some horses may be quieted, when the pain is not excessive, by holding the ear in one hand, and rubbing the point of the nose with the other. A soothing manner will often engage the attention and prevent violence; but it is seldom that either threats or punishment render an unruly horse more calm. Inexperienced persons guard themselves only against the hind legs; but they should be aware that some horses strike terribly with their fore feet. It is prudent, therefore, in all operations, to blindfold the animal, as by this he becomes particularly intimidated, and if he strikes he cannot aim. When one of the fore extremities requires a very minute examination, it is prudent to have the opposite leg held up, or even strapped; and when oue of the hinder feet is the object of attention, the fore one of the same side should be held up, as by this means the animal is prevented from striking.

\section{CHLOROFORM.}

This important agent has been recently experimented upon with the horse with marked advantage in severe operations. The inhalation of the vapour of sulphuric ether or of chloroform is easily effected. A sponge wetted with chloroform being applied to the nostrils of a horse, the first effect is a certain degree of excitement; this is followed by insensibility, and the comatose state is found to continue during the severest applications of the knife and cautery. The stupor remains for some time after the operation is over. The utmost care must be taken that the vapour does not escape externally, and at the same time that the animal is not wholly deprived of atmospheric air. Castration and the extirpation of tumours have been effected under its influence. The horse, unlike man, being little subject to heart-disease while in ordinary service, is a safer subject for the action of chloroform.

\section{BLEEDING.}

The modern instruments used in taking blood from the horse, are figured and described in Plate XVI. B 1, B 2, B 3, B 4, and the accompanying letterpress. The olden instruments, the common fleam and blood-stick (a piece of hard wood loaded at the end, to drive the fleam into the vein by a blow on the back) should be dismissed to the limbo of obsolete contrivances, and superseded in skilful hands by a large and strong lancet (B 1); or better still, with so strong-veined and thick-skinned an animal, the abscess-lancet (B 2); or, best of all, either of the two patent fleams ( $B 3$ and 4), with their regulating machinery and powerful and steady depth of incision. The two latter may now he procured, by order, of any surgical-instrument maker.

Bleeding is of two kinds, from a vein, called phlebotomy (Gr.phleps, a vein, tomos, section), or from an artery (arteriotomy). Some bleedings (as at the toe-point, division of the vessels of the eye, \&c.,) combine both these operations. Bloodletting is further divided into "general," and "local," or "topical"; the first being intended to act on the constitution, the second, very near to the affected part, is intended to act more rapidly and directly than general blceding, and to produce more effect with less abstraction of blood. Local bleeding is usually practised on the lesser branches of arteries or veins, as the temporal artery, the "plate" vein, the thigh (saphena) vein. In inflammation of the eye, bleeding is effected by scarifying the inner surface of the eyelid and opening a small vein which is seen passing from the inner corner of the eye towards the nose. Cupping and leeches may be left to human surgery, though the latter may be useful in affections of the eye. We shall first notice "general " bleeding.

Bleeding from the Jugular Vein.-The near side in ordinary cases will be found most convenient for the fleam, the off-side for the lancet. Elevate the head so as to stretch the vein, which should then be pressed with the fingers of 
the left hand, to stop the blood. It is advisable to blindfold the horse, or to turn away his head from that side from which blood is to be taken. The hair is smoothed along the course of the vein with the finger, which has been previously moistened; then with the third and little fingers of the left hand, in which the fleam must be held, sufficient pressure is applied to the vein to bring it completely into view, taking care, however, not to distend it too much, as the too rounded surface is apt to roll or slip when the incision is about to be made. Never forget that immaculate cleanliness in lancet or fleam is a duty to neglect which is an atrocious crime. The particular part from which the blood is taken lies three to four inches below the union of the two branches of the jugular vein at the angle of the jaw. Farriers sometimes tie a cord round the neck, to "raise the vein;" it is unnecessary and dangerous. The fleam or lancet must be placed in a direct line with the course of the vein, and over the precise centre of the vein, with its point as close as possible to the skin, without touching the vein. A large-bladed fleam should always be preferred, which will make a greater opening, and thus facilitate the operation; besides, what is of greater importance, blood drawn speedily has far more effect on the system than double the quantity taken slowly; and the wound, although larger, will heal as fast as a smaller one. A slight pressure on the neck with the pail, or other vessel used while blood is taken, will be enough to cause the blood to flow sufficiently fast. Some persons introduce the finger into the mouth between the tushes and the grinders, when, by gently moving it about, motion in the jaws is induced, and the stream of blood flows more rapidly from the action of the muscles surrounding the vein; but by keeping the fingers of the left hand firmly pressed on the vein, so as to obstruct the reflux of the blood, the stream will flow freely.

The blood should be received into a vessel the dimensions of which are exactly known, so that the operator may be able to judge from time to time of the quantity that has been taken. A graduated tin can, holding six or eight quarts, is most convenient; pints being marked on the inside of the ressel. The blood should flow in a regular stream into the centre of the vessel; for if allowed to trickle down the edges, it will not, when cold, exhibit those changes necessary for ascertaining the degree of inflammation. When it has been necessary to repeat the bleeding, if more than three or four hours have intervened, it will be better to make a fresh incision lower down than to open the old wound. The blood coagulates soon after it is drawn. That portion of it which is coagulable is composed of two substances-that which gives colour to the blood, and the thinner part in which the red particles float.* By degrees these separate, and the red particles sink to the bottom. If coagulation takes place slowly, the red particles have more time

* The composition and properties of the blood are treated of ante, pp. 350,351 .

$\mathrm{Z} \mathrm{Z}$ to sink through the fluid portion, and there appears on the top a thick, adhesive, pale, yellowish-orange substance, called the buffy coat. In proportion to the slowness of coagulation and the thickness of this coat, the degree of inflammation is determined. In the healthy condition, coagulation is more rapid, and consequently the red particles have not time to sink, and the buffy coat is thin. When the horse is much exhausted, and there is a general decay of his constitution, coagulation will not take place at all, but the blood will exhibit a uniform blackish colour, with a thin and loose consistence. When blood is drawn from a large orifice, coagulation is slower, and from a small wound it is more rapid ; so that the difference must be carefully considered, and the changed condition of the pulse attentively marked.

Some persons consider it unnecessaly to yin up the orifice after bleeding. These bleedings may not renew, but we would advise the edges of the wound to be brought close together and kept in their place by a small pin being passed through the contiguous skin, with a little tow wrapped round the extremities of the pin, figure of 8 fashion, so as to cover the entire wound. The pin should not be large, and care should be taken that no hairs are between the lips of the cut. In bringing the edges of the wound together, care should be taken not to draw the skin too much from the neck, otherwise blood will insinuate itself between the skin and the muscles, and cause a swelling which sometimes proves troublesome. The edges of the wound will heal in twenty-four hours, after which the pin may be withdrawn.

For affections of the head, as well as extended inflammatory action and fever, the jugular vein is decidedly the best. Blaine has some cautions and cases which should be present to the practitioner's mind; for common as the operation is, and qualified as every one thinks himself to perform it, very serious accidents occasionally arise. "It has occurred that the carotid artery lias bccome penetrated. When the puncture has been made through the vein, the accident is known immediately by the forcible and pulsatory gush of florid arterial, and dark venous blood together. In one instance of this kind, which occurred to a French practitioner, he immediately thrust his finger into the opening, through the vein, and thus plugged up the artery, intending to wait for assistance. In this state be remained, we believe, an loour or more; when, removing his finger, to his surprise, he found the hæmorrhage had ceased, and did not again return. In another case, where an English practitioner accidentally opened the carotid, he placed a compress on the orifice, and had relays of men to hold it there for eight-andforty hours, when it was found the bleeding had stopped. The admission of air is also another serious accident that now and then attends bleeding It sometimes happens from the sudden removal of the fingers or blood-can, or whatever was used to distend the vessel by obstructing the return of the blood. This being suddenly taken away, allows the escape 
of the blood towards the heart, and occasions a momentary vacuum, the air being heard to rush with a gurgling noise into the vein through the orifice; it then mixes with the blood, and occasions, in some instances, almost immediate death. The animal begins to tremble; he next staggers, and finally falls in a state of convulsion. If the quantity of nir taken in has been considerable, deatl ensues. The remedy must, therefore, be instantaneous, and consists in again opening the orifice, or making a new one, to gain an immediate renewed flow of blood, which will, in most cases, renovate the horse, who has been found afterwards to be tormented with an intolerable itching.

Local, or Topical Bleeding.-The leading operation in local bleeding is the puncture and division of the temporal artery in inflammation of the brain. These vessels do not supply the brain, it is true; but by opening them an artificial drain is made, through which much of the blood escapes that would otherwise have gone to the brain ; besides which, a large quantity of blood is abstracted in a short time, when, perhaps, it would have been difficult to have bled from the neck at all, owing to the violence of the animal. The lancet is here vastly safer than the common fleam. The spot for its puncture or division is where the vessel leaves the parotid gland, to curve upwards and forwards round the jaw, a little below its condyle. It affords much blood, and when the desired quantity is taken, divide the vessel, then the parts will recede, lessening by their own contractility, and the bleeding will stop.

Bleeding from the Palate.-This is a favourite spot with ignorant farriers, who recommend it in spasmodic colic and stomach staggers, or megrims. Fatal hæmorrhage has often resulted from the incomplete severance of the palatine artery. This artery and its vein run near each other on each side the roof of the month, so as to divide the inner surface of the hard palate into three nearly equal parts. The vein only should be divided by plunging a lancet across the ridges, one inch inside the moutl, between the middle and second nippers. If the artery should be wounded, it must be completely severed so that its retraction may check the flow of blood. Bleeding from the palate, except under extraordinary circumstances, had better be avoided.

Bleeding from the Plate Vein.-This is resorted to in affections of the shoulder, fore-leg, and foot, and sprain of the back sinews. The principal trunk of the superficial brachial vein ascends along the inner side of the radius or armbone. If, when taking blood from these veins, a difficulty is found in making it flow, lift up the other foreleg, which will call the muscles of the punctured one into action, and force the blood in greater quantity. The external thoracic (plate vein) is best opened just as it emerges from behind the fore-arm, as it is here easily got at and readily pil.ned np.

Bleeding prom the Thigh Vein.-The saphena is a prominent vein, continued from the inner part of the hock, The opposite leg to that to be operated on having been raised, the practitioner places himself in front of the thigh; grasping the hock with his left hand and pressing the vein with the side of the right, he punctures the vessel with his adjusted fleam. It is a troublesome vein to pin up.

Bleeding by the Toe.-This is practised in acute founder, or laminitis, in our opinion most mischievously We have here, however, only to do with the mode of effecting it, should it be deemed necessary. A searcher, or drawingknife is driven down between the crust and sole at their line of union, then, by puncturing the part with a lancet, an immense flow of blood will follow.

If the blood should not flow with snfficient freedom, place the foot in warm water: the bleeding finished, cover the puncture with some tow and a little tar, and lightly tack on the shoe. There are, however, other methods of bleeding from the toe. Mr. Mavor uses a drawing-knife with a long curve, so that one sweep of the blade may cut a piece out of the foot. This seems dangerous, as it leaves a space to be filled, instead of a mere cut to heal. Others take away none of the horn, but merely make a slit through the outer covering on to the vascular portion of the foot. The flap of horn they hold up so long as they desire blood, by the insertion of a piece of wood; and when they have obtained blood enough, they take out the wood, so as to let the horny flap down. The last method appears to us the easiest and best.

Sometimes the plantar vein is opened as a substitute. Scarifications are also occasionally practised, which, of course, divide both venous and arterial branches.

As it was the practice of our fathers to bleed themselves, their wives, and horses "for everything and for nothing," of course the horse-doctor followed the fashion, and the poor patient, temperate servant of man, without his vices and their consequences, was murdered or debilitated, secundum artem, his life-blood drained, and even the "constitution of a horse" ruined, by what doctors called "antiphlogistic remedies." We must not, however, err on the other side and reject bleeding, when a judicious diagnosis indicates its necessity. In order to reap the advantages of general bleeding, we must continue to draw blood, when once a vessel is opened, until such time as some visible impression is made on the system. Some horses will bear to lose a much larger quantity than others, without our being well able to explain the reason of the difference. In a general way, the quantity an animal can afford to lose will depend on his condition at the time; his age; and on the nature of his disease, should there happen to be any present. Horses that work hard and live well, will bear bleeding best : fat, bloated subjects, worst. Under acute inflammatory disease, especially of the brain, an animal will support the loss of a much larger quantity than if he were in health. Under ordinary circumstances, a gallon is reckoned a moderate bleeding: under pressing disease, take three gallons: four have been taken. By way of a rough estimate, a gallon of blood may be reckoned equal to the loss of about a pint in man. Though under conditions of health and forms of disease of no great consequence, we are in the habit of prescribing st 


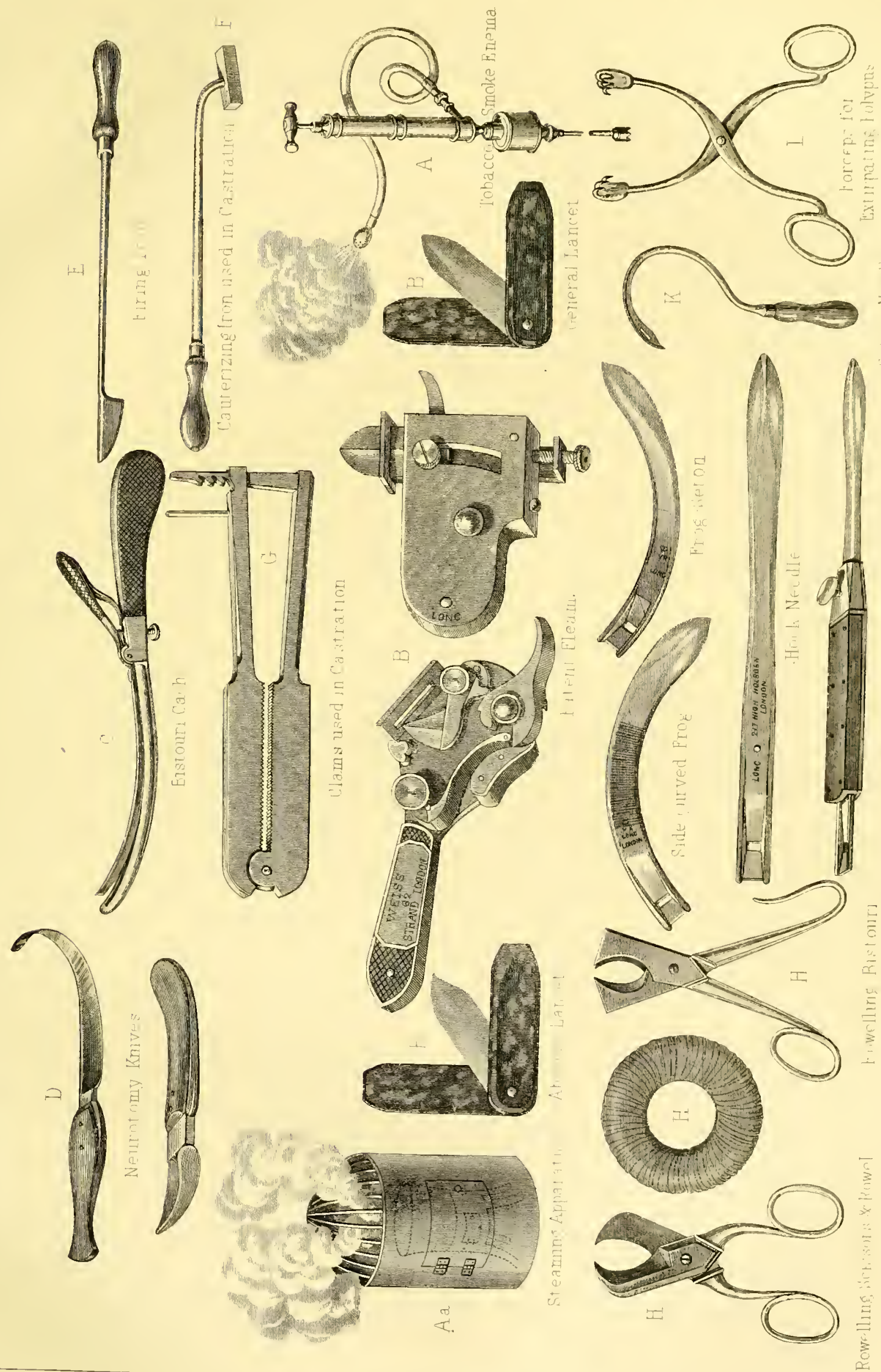



many pounds or quarts of blood to be drawn, yet, when it becomes necessary to make a sensible impression on the systcm, our only safe and true guide, as to quantity, is a steady observance of the effects produced on the animal as the blond flows from its vessels

The effects of bleeding will depend on two circumstances. The fuller and more rapid the stream, the greater will be the effect created by any given quantity; when we are desirous, therefore, of producing what is called "an impression on the system," and to do this at the least possible expenditure, we make a large opening into a large bloodvessel, and draw away the blood as quickly as we can. In order to know when this impression is made, we keep our fingers, during the time the blood is flowing, steadily upon the pulse, with pressure just sufficient to feel its beats distinctly; the declining force and perceptibility of which, with their subsequent total failure and simultaneous shrinking of the artery from beneath the fingers, indicate to us that the required effect is accomplished: this we call "the sinking of the pulse." Absut the time that the pulse sinks or fails, the animal himself commonly evinces signs of uneasiness: he becomes restless and fidgety; jerks his head up and down; and moves step by step backward, feeling, as it were, for support, until he has backed himself against the side or corner of the stable, where, finding a rest for his hind quarters, he becomes once more tolerably tranquil again for a time. Should the bleeding be continued beyond this (which, by the bye, it ought not to be), the respiration becomes disturbed; the animal heaves at the flanks and puffs at the nostrils, sighing, as it were, deeply for want of breath. His strength also now begins to fail him; his body rocks from side to side; if he lifts a foot, he quite staggers in putting it down again: in fine, things are now arrived at that pitch that there is danger every moment of his falling headlong upon the persons about him. These symptoms of distress are quickly followed up, if not accompanied, by a profuse sweat all over the body; and this is often succeeded by a sort of rigor or shivering fit. In some instances, these symptoms make their appearance some little time after the operation of bleeding is all over, and even in cases in which we hardly expected their supervention. After the animal has been tied up for a time, on returning to him, we find him heaving and puffing, and wet with sweat. When we perceive exhaustion approaching, we may often succeed in arresting its further progress by turning the animal's head towards or (if possible) into the open air, and suffering him to drink three or four go-downs of cold water; and with the same water afterwards sponging out his nostrils and his eyes; all which will so refresh bim as probably to arrest the fainting fit altogether.

In bleeding horses that live idle and pampered lives, it not unfrequently happens that this puffing and blowing comes on even as early as during the flowing of the second or third quart of blood. When this happens, take away the blood-can, and suffer the blood in the vein to circulate for two or three minutes, by which time the animal will com. monly have recovered himself. The operation may then be resumed, and the required quantity generally be obtained.

\section{ROWELS AND SETONS.}

These are merely different modes of applying the principle of counter-irritation; thus drawing away the inflammation from the point attacked in the form of purulent issue. In this point of view, blisters, rowels, and setons are merely three methods to attain the same object, and their applicability is merely governed by circumstances; the blister being the most expeditious in acute cases, the rowel and seton more certain and permanent in chronic affections.

A RoweL can only be formed where the skin is loose, as in the chest. The instruments for rowelling, and the rowel itself, are figured on Plate XVI., H, H, H. Having prepared a round piece of leather, with a hole in the centre, and about the size of a crown picce, wrapped with a skein of fine tow (see $\mathrm{H} 3$ ), smeared with digestive ointment; we cut the skin with the rowelling scissors, and with the forefinger, or the "cornet" (a piece of crooked horn made for the purpose), or the handle of the improved scissors figured in our Plate ( $\mathrm{H} 2)$, separate the skin from the underlying tissue for the space of an inch. The circular leather is then introduced, the opening plugged up with tow, and in four or five days suppuration is established. The rowel should now be turned every twelve hours, the matter allowed to flow out, and the rowel be kept scrupulously cleansed every twenty-four hours. We do not think the digestive ointment, or any sther application beyond the tow, at all necessary.

SETons are tapes, threads, or lamp-cottons passed under the skin by needles made for the purpose. (See Plate XVI., I $1,2,3,4$.) Setons may be introduced in almost every part of the body : the side or front of the face, the poll, the throat, the neck, the back, the loins, the arms, and feet are all available for this counter-irritant, which can be made longer or shorter, deeper or shallower, as skill may dictate.

The skin should first be punctured with a lancet, which will much facilitate the subsequent insertion of the needle, whether the sharp or the blunt one be used. The latter will be found preferable in every situation where it is possible to make way with it through the subcutaneous tissue: in fact, the sharp-pointed needles are but seldom used. It would be idle to pretend to give any specific directions for using these needles : the operation can be learnt only from actual observation. The best material for setons is the coarse brown or beggars' tape, as it is calied; which will admit of being medicated (if thought necessary) in any manner the operator may fancy. The practitioner must not tie the ends of the seton, making a bow of it From its liability to hitch against anything and be torn out with risk of laceration of the skin, this becomes objectionable. and even dangerous. The ends had better be made into knots, and left hanging out of the extremities of the wound. 
When a seton is placed in a sinuous track for the purpose of inflaming, it is moved twice a day frequently, and moistened each time with some stimulant, as oil of turpentine, tincture of aloes and of benzoin. All setons require daily cleaning and moving. When they are required to act more quickly, the tape is infused in turpentine, with powdered cantharides; or small pieces of black hellebore are sewn within it. An old material composed of woollen, flax, or cotton and hair, is also used instead of tape.

The frog-seton recommended in navicular disease (see I 4), is to be inserted through the heel. The animal being secured by the twitch, an assistant holds up the foot. The needle is then plunged into the heel, and by a second push brought out at the cleft of the frog (previously thinned off for the purpose). Then draw the tape through and knot the ends. If the horse is down, insert the seton-needle from below upwards.

$$
\text { OESOPHAGOTOMY.-BRONCHOTONY.-TRACHEOTOMY. }
$$

A wound or division of the esophagus or gullet, was long supposed to be a fatal injury; this is now known to be a fallacy. The operation is described under Choring, p. 298, and need not here be repeated.

Bronchotomy.-Tracheotomy.-Cases occur when this operation is the only hope of saving life. It consists in making an opening into either the larynx or the windpipe, through which the animal is enabled to breathe with ease; and is an operation practised in some cases to the saving of the animal's life, in others to the affording him instantaneous and effectual relief, at a time when he has difficulty in drawing his breath through his nose. The animal's head being kept elevated by an assistant, the windpipe may be plainly felt projecting underneath the skin, as it proceeds in its course along the anterior and inferior part of the neck. About one-third of the length of the neck from the head will be found a convenient place for operating. Make a longitudinal incision, three or four inches in extent, through the ski $i_{x}$, and carry the point of the knife at once down to the windpipe, which must be laid bare nearly to the same extent by lateral dissection. The surface of the pipe being freely exposed, the point of a double-edged scalpel is to be thrust through its substance in a direction to make a crosssection of two of its rings; the object being, to excise either a square or circular portion of the substance of the tube, of about an inch in diameter. This done (in order to prevent the skin from closing over the opening, as well as the aperture itself from becoming plugged by lymph, or obstructed by secretion) it will be necessary to introduce a canula, or tube, into the windpipe, and confine it there by carrying tapes or strings from it around the animal's neck. A piece of elder, about three inches in length, with a notch cut around its middle, will answer the purpose; though an ivory or bone tube with shoulders to it, and holes through the shoulders, will be found still better adapted. After the performance of the operation, and the introduction of the tube, the animal will appear as in Plate XIV., Fig. 5.
The tube will require to be taken out from time to time, and cleansed. A weak solution of sulphate of zinc is best. The animal ought to be continually watched; and as he will be unable to swallow any solid food, he should be abundantly supplied with well-made gruel and malt-mashes, which (providing he be kept without water) he will, after a time, drink with avidity. Should the case take a favourable turn, the breathing tube is to be removed as soon as the natural passages become sufficiently cleared to carry on free respiration. Mr. Gowing's tracheotomy tube, with its trochar, figured in Mr. Mayhew's work, is a most efficient and ingenious contrivance.

\section{LITHOTONY.}

Cutting for the stone in the bladder of the horse is rather a curiosity of veterinary surgery than a part of customary practice. In Hurtrel d'Arboval's Dictionary, art., "Lithotomie," and by other Continental writers, minute accounts of this operation may be consulted. At p. 321, ante, under the head URINary CaLCoLI, will be found a general description of these abnormal deposits, with a case relieved by lithotomy.

\section{PERIOSTEOTONY.}

This term is applied to an operation which hus grown into much favour with modern practitioners for the reduction of splints and ringbone. It is, as its name implies, a cutting of the periosteum, or membrane surrounding the bone, and is effected with a curved knife, having a blunt probe point, and sharpened on the inner or scythe edge. The late Professor Sewell, of the Veterinary College, has strongly advocated periosteotomy for the removal of bony tumour, and it proved highly successful in the cases he thus treated.

The horse is thrown upon his side, and the leg to be operated upon relensed from the hobble, and extended on a bag of straw. A piece of webbing is passed round the hoof and given to a man to hold, who pulls the foot steadily forward. The operator kneels and examines the splint or node; then, with a pair of rowelling scissors (Plate XVI., H 1) he snips the skin just below the exostosis. He then forces a blunt seton-needle,-fixed in the shifting handle (Plate XVI., I 1), and armed with a tape-through the cellular tissue, under the skin covering the tumour. $\mathrm{He}$ then makes another cut with the rowelling scissors above the splint, pushes the needle through it, and then draws it back. The probe-pointed knife is then introduced, and turned with its cutting edge downwards, and the periosteum cut through and through; the tumour being sliced in pieces, when not too solid, as it sometimes is in older animals. This cutting down over, the seton-needle, armed with a tape with a knot at the end, is passed through the opening, knotted at the other end, and treated as an established seton, being moved daily. A blister is sometimes applied over all, which is considered more likely to defeat than to assist the 
object in view. When periosteotomy is successful, it is generally so at the first start; if not, the seton may be abandoned, to avoid a certain blemish for an uncertain benefit.

\section{NEUPOTOMY.}

This important operation has been the subject of the fiercest polemic among veterinary writers and practitioners Like most discoveries, velıement partisans have obscured its real merits by their indiscriminate and unmeasured praises of its value, without allowing a qualification or drawback. It has restored innumerable useless animals to usefulness, and has occasioned destructive injury to others; but it is probable, as these were diseased subjects, it merely somewhat hastened the inevitable end. No neurotomized horse goes with the same freedom and safety; and from the loss of sensation he has battered the feet to pieces, or fractured his legs. On the other hand, hunters and hacks have gone "as well as ever" in horseman's phrase, after division of the nerve. Improvement in the constitution of the animal has also marked the relief from pain which neurotomy confers. Blaine tells us, that "an aged and crippled stallion, from constant and painful irritation, became so emaciated as to be unable to fecundate; but being relieved from a constant state of suffering by neurotomy, he improved in health and condition, and was again used to cover. It happened, also, that a mare similarly circumstanced ceased to feel " œstrum:" but after neurotomy it returned, and she resumed her character of a brood mare. It appears to act with most certainty when a piece of the irritated nerve is cut out. One case has actually occurred where tetanus, occasioned by a wound in the foot, was arrested and removed by neurotomy. It also promises much in the painful state of severe cankers, where the irritation has rendered the application of dressings almost impossible. Here, by depriving the foot of sensibility, we deprive the horse of that which is injurious to him. The sore itself is often amended by it; but in every instance the dressings can be effectively applied, and the healthy processes cannot be at all suspended.

When, however, the sole of the foot is convex (pumiced foot), neurotomy is mere destruction. The sole of the foot, scarcely able to bear the pressure of the coffin-bone, which has fallen below its natural situation, having now no feeling, will be battered against hard substances, worn through, and destroyed; and this will be aggravated should any tendency to ulceration exist among the ligaments or cartilages. Nevertheless, neurotomy, dependent as it is on the judgment and experience of the surgeon, is the most important and valuable discovery in veterinary practice of the present century. It would, therefore, be unjust to omit the name of Mr. Sewell, then Assistant Professor of the London Veterinary College, who first communicated the modus operandi and its results in a paper contributed to the Royal Sociecy. It has been asserted that Mr. Moorcroft and others had previously performed neurotomy: if so, they never published their success or non-success, or recommended it to their professional brethren. To Professor Sewell, then, belongs the credit of this invaluable discovery, of which MIr. Spooner truly and candidly says in his work "On the Foot:"- "Although it is vilified by a few veterinary surgeons, and often condemned by the ignorant as a cruel and barbarous operation inflicted on a dumb creature, yet, for my own part, having fairly tested its merits, I regard it as one of the most merciful and humane operations that surgical science has ever invented for the relief of suffering quadrupeds."

"Nerving," "unnerving," or "neurotomy" signifies the cutting out of a piece of the metacarpal (or pastern) nerves on each side, to the extent of an inch or more. From Plates X. and XI. (ANatomy), the reader may form a clear idea, not only of the structure of the parts, but in the latter (Fig. 6), a clear representation of both the upper and lower operations is given, with letterpress references. For ourselves we would recommend the lower one, for the reason that in this case the coronet and front of the foot will still retain a certain degree of sensibility, which (if those parts are not involved in the disease), will greatly improve the style of going and safety of the animal.

Mode of performing the Nerve Operation.-The horse being thrown as directed (ante, p. 358), and having decided as to whether the upper or lower incision would be advisable, examine the part to be operated upon Remember, the hair should be clipped from the part. A piece of tape tied tightly round the leg just below the knee or hock will be found to deaden sensation. The instruments being in readiness, ${ }^{*}$ the operator kneels over his subject. An accurate acquaintance with the course of the nerve is indispensable. It descends in two main branches from the knee, one on each side of the leg. It proceeds in company with and behind the artery and vein on the inner side of the fore leg, while on the outer side it has no blood-vessel near it. About the middle of the leg the two nerves join by a branch, which goes over the perforans tendon, and connects the fibres of nerve on each side. The "high" incision is better, therefore, "below" this. At the pastern the nerve divides; the hinder branch runs to the frog, the front travels in front of the artery a little way, then divides into several branches, in which reside the sensibility of the foot. We will suppose you are operating on the inside. Ascertain the exact course of the artery by its pulsation; then make a cut close to the edge of the flexor tendon. Let the in. cision be near to but rather behind the artery; if below the fetlock joint, an inch in length. The cellular substance being cleared away will bring the vessels into view, and the nerve will be readily distinguished from them by its whiteness. In horses of very clean legs there is little cellular membrane to remove. Having clearly distinguished the nerve.and artery, elevating it from the vessels and its mem-

* See Plate XVI, where the nerving knife, D 1, for making tne incision, and the curved knife for dividing the nerve. I 2. are deliveated. 
branous attachments by means of a tenaculum, or crooked needle, armed with some small twine, pass the needle under the nerve, withdrawing it, leaving the twine behind, and tie its ends firmly together. Inserting your finger in the loop, raise the nerve, and insert the curved nerving knife (Plate XVI., D 2), turn it, and the nerve is instantaneously severed by a drawing stroke, as near to the upper angle of the section as possible. The violent spasm the division of the nerve produces may be somewhat lessened by pressing the nerve between the finger and the thumb, when the opportunity may be taken of dividing it; then, taking hold of the lowermost portion between a pair of forceps, clip out about three-fourths of an inch of its trunk. Having finished, if both feet are affected, proceed to operate upon the contrary side of the other leg; after which turn the horse, and repeat the operations on the like parts of each leg as they come in succession.

The reason of dividing the nerve at the upper part of the incision, is, that from the moment of severance all below the cut is deprived of communication with the sensorium, and the after-dissection and cutting is upon a substance deprived of feeling. The nerve should be always dissected out to the length of the incision, about an inch, or it will probably reunite and restore sensation. The skin may be closed with a single stitch ; no bandaging is required, but a compress or linen roller may be applied, as looking more surgical and neat. For the first three days, sponge the leg with lukewarm water; and, if there is any heat, change this for cold water, with cloths frequently changed. No dressing is required, and the wounds should be healed in three or four weeks.

White says, in his excellent practical "Farriery," the horse may be "turned to grass after three weeks." To this we positively object. The animal, relieved from pain, gallops wildly about the field, and is apt to injure the tendon opposite the navicular bone, if not to produce a mechanical rupture of the parts. Of the success of neurotomy under his own eye, Mr. Spooner says:- "We have collected no less than sixty-three cases of the successful performance of neurotomy, nearly all being on horses that stood sound a considerable time afterwards; some of them having been hunted, and others severely worked. Of these cases we find twenty-seven in which it is not mentioned whether the operation was performed above or below the fetlock; and there are eight cases of the low operation on one leg, and two in wlich it was thus practised on both legs. We have thirteen cases of the high operation, nine out of which are on one fore-leg, two on both fore-legs, one on one side of the leg only, and one on both legs, but one side of each. Besides which we have six cases in which it was performed on one or both hind legs. There are many other cases mentioned, though not related; and there are two instances in which the operution failed."

\section{DIVIBION OF THE FLEXOR TENDON.}

"Clap of the back-sinews," already treated of, and sprains of tendon, are the cause of that "knucking over" seen in many horses that have been overworked to so disfiguring and disabling an extent. Some look ready to fall forward on their knees, while others can only put the toe of the hind foot to the ground. In these cases, division of the tendon is both humane and serviceable. The operation consists in making a longitudinal incision of about three inches in length along the inner lateral edge of the tendon; dissecting each portion from its cellular attachment, so as to expose the nerve, artery, and tendons. A stout curved knife, with a probe point and a blunt back, cutting at the inner edge, is used, when the above-cut has been made. The leg is then bent. This opening will allow the perforans to be freed from the perforatus, when a division should be made by a scalpel applied to its surface. It is evident that this should take place below any thickening or adhesions which may have permanently connected the tendon with the neighbouring parts. Any lesser attachments will be broken through by forcing back the foot to the just position. By Mr. Dick this was done "by placing his knee against the front or projecting part of the pastern, at the same time laying hold of the foot with one hand and the upper part of the leg with the other, and using considerable force; and this appears to be necessary, in order to break any adhesions that may have formed." To return: We will suppose the leg bent; the knife is inserted behind the nerve and artery, and under the tendou; the back is towards the former, when by a simple turn of the wrist the operator brings the cutting edge to the tendons, and an attendant forcing the leg straight, the perforans is brought against the knife, while the suspensory ligament and bloodvessels are safe behind it. If the tendon resist the edge, the curved knife is brought out with a drawing cut. Sometimes, on the division of the flexor tendon, the extensor pedis muscle, relieved of its antagonism, brings the fetlock joint straight. The wound is then closed with a pin and twisted tow, and treated in the usual way. A shoe with a long piece projecting at the toe should be worn for a few weeks, till the leg is well.

\section{FIRINO.}

"There is not in the records of blacksmith brutalitythough for that matter our older professors of the veterinary art were fully their equals, if not their masters, - a more humiliating record than that of the application of red-hot iron to the uncomplaining and tortured horse. They seared his palate for lampas; the end of his tail after docking; the under vertebrx of the same appendage in nicking; his legs (with more reason) in the special operation of "firing ;" and frizzled and fried his skin for wounds, cuts, ulcers, and farcy buds; in short, for anything-when the red-hot iron was handy. Professor Coleman, an eloquent and plausible teacher in his day, was a very apostle of the actual cautery. 
He viewed a scorching or sudden roasting of the skin as a permanent bandage, and of the flesh, as the readiest of styptics. It was declared excellent to promote absorption of the callus; it was inconsistently asserted to promote granulation in broken knees, and to check granulations when too luxuriant. In glanders, they slit the nostril, scraped the hone, and then fired the swelled gland with a hot iron; and or.e writer says, by the use of the searing iron "ulcers, and abscesses generally, may be reduced to common scalds." (See "Ilinds' Veterinary Surgery," 1829). Finally, it is related by Lafosse, the eminent French veterinarian, that in 1801, several regiments in Alsace and Lorraine employed the actual cautery as a cure for glandered horses. Some "applied fire to the jugular gland in three lines; others cauterised the bones of the forehead and nose;" but the most ridiculous affair of all was, to see "forty horses together which had fire applied round the eyelids to cure the running," common to all glandular affections in the head: In short, there was no cruelty or folly which hot iron was not guilty of, through the ignorance of its manipulators. Firing may now be confined to its legitimate use; that of constricting those parts of the leg which consist of tendon and ligament, enclosed with a skin and lined with the hardest bone; and its application to farcy-buds (ante, pp. $270,271)$; though in both it may often be advantageously substituted by caustics, blistering, fomenting, and detersive lotions.

The iron ior firing is represented in Plate XVI. (E.), and there are various modes of its application. Old books contain sorne grim drawings of attempts at fancy patterns scored with red-hot iron on the integuments of the prostrate beast, bearing a remote resemblance to the tattooing of South Sea savages. The Veterinary College, erewhile the head-quarters of the firing iron, recommends that the legs should always be scored in perpendicular lines. White recommends the "feather" pattern; others, horizontal, vertical, and oblique lines. Some veterinarians cast the horse, others fire him standing. We prefer the former. Sorne recommend the firing to be very light and superficial, others declare that there is no virtue in hot iron unless you go deep. Messrs. Turners, good and intelligent surgeons, say they find firing quite through the skin most effectual; and, if the iron is resolved on, we agree with them. The theory of the benefit of firing is, by creating a superficial inflammation, to draw, by counter irritation, the inflammation from a deeper-seated part ; also, by the thickening and constriction of the skin, to create a permanent bandage, or compress, on parts inclined to "fill." Firing leaves a blemish ; which should also be a reason for avoiding its application, unless deemed indispensable.

The horse being thrown, and the legs secured in the manner already directed, the hair is cut off close from the part to be operated upon. The firing iron should lave a smooth round edge, the thickness of a worn shilling. For ourselves, we would never penetrate the skin while running the vertical lines. This direction, in the upright line of the leg, produces the most efficient contraction, while the cross way, or horizontal, leaves less blemish. A combination may be adopted by which the horizontal lines are combined with lighter lateral scorings in a sort of herring-bone pattern: these should not be close. Mr. Spooner proposes, where deep cauterization is thought advisable, that small punctures with a pointed iron may be made in various places, when a glutinous exudation will be seen after the operation. These punctures must not be too close, or there is danger of the skin sloughing between them and making an extensive blemish. We have said thus much of firing, once so prevalent. The absence of the hot iron from the hands of the veterinary surgeon, - though we would not squeamishly reject a remedy of the "heroic" sort-is a proof of his judgment and skill, as well as of his humanity.

NICKING AND DOCKING.

These once prevalent, dangerous, and barbarous disfigurements having passed away-except in sorne dark parts of the sister island, where animals thus mutilated and deformed are still to be seen-we shall merely record our satisfaction that they are obsolete. The first-named consisted of tying the hair at the point of the tail in a bunch, and attaching to it thereafter a heavy weight passed over a pulley, to keep it drawn up. The tail being lifted, the torturer sought for the middle of one of the vertebre (not its point of articulation), and fiercely slashed through the depressor muscles from one side to the other with a curved sweep of a sharp knife. With a thoroughbred, we are told, one "nick" was sufficient, with a lunter, two; while a hackney had three gashes under his tail, as lie was thought to look handsomer for an extra cock-up of the caudal appendage. With a pair of scissors the "fibres," if any appear across the incisions, must be cut off, and pledgets of tow inserted deeply in the wounds. We are also cautioned to see that "the muscles are divided equally on each side the tail ;" for, risum teneatis, "you would not like to see him carry his tail sideways" It is confessed that intense inflammation, swelling, and death, frequently followed these painful barbarities, when the weight dragging up the tail was too heavy, or long continued. Yet " the tail must be kept back for some weeks, until after the wounds are healed; for, if allowed to hang down, the edges of the cuts would unite, and the object be defeated!" Credit is taken for a double line carried to a pulley on each side of the stall, by which the suffering wretch's caudal appendage can be regulated "when growing awry." Lastly, we are told, if "severe inflammation come on, take the weight off the tail-ropes and foment the part with warm water; but if locked-jaw comes on, take off the tail at the first joint above the highest nick:" And we read this, and more, in "The Complete Modern Farrier," by Thomas Brown, published by a highly respectable firm in 1861 ; from which work also, as we shall never consent to be a party to such mutilation, we extract this curious rather than usefui account of docking. 
Dockina.- "It has been a long-established custom to dock the tails of horses. Convenience justifies it, and fashion guides it (?) The length of the stump varies with the taste of the times, or the fancy of the owner. A medium length is undoubtedly the best, and a very short one is not only unseemly, but also a very great injury to the animal, as he is thus deprived of that which nature intended as a switch, and as a substitute for hands to drive off insects.

"The operation of docking is performed at different ages of the animal; some consider it best to do it at two years, while others think the earlier the better. From what we have ourselves noticed, we coincide with the latter opinion. At a fortnight it may be done with perfect safety, and even sooner; and it unquestionably affects the foal less at this period than at the age of two years.

"The manner of performing the operation is, to fix upon a part of the tail, and having determined on that, take the one next joint to it; let the hair be turned up and fastened with tape for an inch or two above the joint, while that which grows upon the vertebra itself must be cut off. The horse is then restrained by the side line, and the surgeon now applies his docking machine, and cuts it through at the division between the vertebræ, at one stroke. It is not uncommon for farmers and other breeders to perform the operation with a sharp knife, resting the tail on a board, and striking the back of the knife with a mallet or hammer. Although considerable bleeding is caused by this operation, there is no danger to be apprehended from it. To stop this, the speediest manner is, to sere the stump with a red-hot iron, with a hole in its centre to prevent it from touching the bone, which would cause exfoliation; or, if severely injured, it would fall off at the joint above, and thus shorten the desired length of the tail. The bleeding vessels are all on the outside of the bone. The iron must not be too hot, nor much pressure applied to it, neither should it be long continued. No kind of dressing is required after this operation. In some cases slight bleeding occurs after the use of the cautery; but when this occurs, it is better to allow it to stop of its own accord, as a repetition of the burning might cause locked-jaw, or constitutional irritation."*

\section{BLISTERING.}

The preparation and ingredients of Blisters will be found in List of Medicines, ante, p. 227. When a "vesicatory" becomes absorbed through the pores of the skin, it inflames the sensible cutis underneath; the consequence of which is an effusion of serum through the part, which, in man, elevates the cuticle into a bladder of the same extent as the surface inflamed; but in the horse, from the greater tenacity of the cellular connections, it becomes separated in the form of small distinct vesicles only. If the irritating cause be quickly

* The Complete Modern Farrier, by Thomas Brown, M.P.S., London : Virtue, \& Co, 1861, pp. 328, 329. removed, the serum may be re-absorbed, and the surface restored by a slight effort of adhesive inflammation. If the irritant act in a still minor degree, it simply stimulates the vessels of the skin to an infiltration of fluid through the sensible pores, but produces no destruction of cuticle: such has been called a sweating blister. But when by continued irritation the cutis is exposed, suppuration succeeds, and the part is fully blistered. The salutary action of blisters is exerted in several ways; in promoting absorption; in combating deep-seated inflammations, and in aiding others. As a stimulus to the absorbents, they act beneficially in the removal of injurious deposits; as the coagula remaining after inflammatory lesions. Blisters are very important aids in inflammatory affections, as counter-irritants, derived from a law in the animal economy, that two inflammations seldom exist in the vicinity of each other. Therefore, when such an affection has taken place in any part, and we wish to remove it, we attempt to raise an artificial inflammation in the neighbourhood by means of blisters; which, if persevered in, destroy, or at least lessen, the original one. Occasionally, also, we blister the immediate inflamed part, with an intention to hasten the suppurative process by increasing the activity of the vessels-as in deep-seated abscesses, and also in those which attack glandular parts. We, therefore, employ blisters to hasten the maturation of the tumours in strangles.

In applying a blister, cut the hair as close as possible from the part; then hand-rub in the hlistering compound from ten minutes to a quarter of an hour. In blistering the legs, take care the hinder part of the heel, under the fetlock joint, is rubbed with lard or melted suet, to prevent the action of any of the blister that may run down the leg; this will often prevent some troublesome sores forming, from the blistering ointment falling on these sensitive parts. While a blister is acting, the litter should be removed from uuder the feet, or it will tickle the legs, and irritate; the head ought to be carefully secured for two days and nights, to oppose lying down, more especially to prevent the horse biting the blistered part. On the third evening he may be permitted to repose; but a prevention should even then be continued, by means of what is called a cradle. (This apparatus may be bought at every turnery shop; or may be made of eight or ten pieces of round wood, an inch and a half in diameter, and two feet long: these are strung at each end on a rope, and fastened around the neck.) When it is intended to blister repeatedly, the effects of the first blister should have subsided before the second is applied; the scurf and scabs also be cleared away, and the part well washed with soap and water. In all cases, the third or fourth day after the application, the part should be thoroughly painted over by means of a long-haired brush (such as are in use with pastry-cooks to glaze their crusts) with lead liniment, which should be repeated every day; and when it is proposed to turn a horse out, it should never be done until the whole blistered surface is quite healed; otherwise 
dirt, flies, \&c., may prove hurtful. Some practitioners blister mildly one day, and on the next wash off the blistering matter, thereby saving loss of hair. But there is more of apparent than real good in this plan. If a bliste? be necessary, it requires all its activity.

Ammoniacal Blister.-Mr. Mayhew strongly recommends this in spasmodic colic and enteritis. Spanish flies are only efficacious when the animal can afford to wait their action, which is rather slow. In most of the acute diseases, the horse would perish before the blister began to rise, wherefore resort has been had to boiling water and red-hot iron. The action of these last coarse and brutal measures was alone controlled by the violence of the internal inflammation. We have in the liquor ammonia an agent quite as formidable as boiling water or heated iron, but it is rather longer in displaying its force; wherefore it allows time for watching its action, and for checking it the instant it has sufficiently blistered the skin. It is true the liquor ammonia upon the skin cannot be removed, neither need it be counteracted. The ordinary soap liniment, if covered over, would, because of the ammonia it contains, produce a lasting blemish; but every veterinary surgeon knows how very harmless a preparation that is when simply rubbed upon the surface. So, when we desire the active effects of liquor ammonia, we double a blanket or rug four or five times, and hold it over the liquid. It takes from ten to twenty minutes to raise a blister, and it consequently can from time to time be observed; and when its action has reached the wished-for point, all we have to do effectually to stop it is, to take away the rug or blanket. That removed, the free surface and the heat of the body occasion the ammoniacal vaponr to be dispersed, and the animal is safe.

\section{POULTICING AND BANDAGING.}

There is much comfort and relief to the animal in the neat-handed application of poultices and bandages. With this object we have devoted Plate XVI. to delineating some of the more generally useful bandages. Fig. 1, is adapted for poulticing for sore throat, \&c. The sloth to be employed should be of stout but supple linen; Russia duck, or fine sailcloth, or if you have it at hand, a piece of sheepskin or a chamois leather will do. You need not steep the cloth in any solution to make it water-tight.

When spread out, the cloth will be of an irregular octagon shape, at each corner whereof is to be strongly sewed on a piece of broad tape for the purpose of fastening to the girth, or round the neck, and to a breasting of broad web, which is supported by another piece, that passes over the withers, and which two should be previously fastened together by stitcling the cross-piece ends upon the breasting. The two extremes of the bandage will be the fillet across the forehead and the fastening at the girth; therefore, measure should be previously taken of the whole length proper for the individual patient, lest the tie, which would otherwise be necessary at the ears, might discommode the animal and occasion uneasiness; on the other hand, the application would not be kept in its place properly. A glance, however, at the figure will instruct a tolerably expert workman (or workwoman) how to manufacture such a bandage as would answer every purpose.

In Bandaging for Strangles (the steaming apparatus is shown Plate XVI., A, a), another form of cloth and straps is required. The explanation above, and the drawing on Plate XVI., Fig. 4, are sufficiently explanatory.

The Bandage for Poll-evil is represented on Fig. \& The poultice (see PoLL-EviL) should be of sufficient quantity to cuver the whole swelling two inches thick at least, having a small quantity of sweet oil, hog's lard, or oil of turpentine mixed therewith. Fix it on by means of a contrivance sufficiently explained by the figure, in which it will be seen that the girth is to have a web breasting, to which the lateral corners of the cloth are to be attached by broad tapes, as was explained above. The bandage in the drawing is longer than requisite for poll-evil, so that it may not be liable to shift, and be serviceable for other diseases lower down the neck.

Fig. 2, Plate XVI.,-the bandage for "critical abscess" is equally intelligible from the representation. 


\section{CHAPTEK XXXV.}

ON SHOEJNG.-PREPARING THE FOOT.-MARING THE SHOE.-FORM OF THE SHOE.-NAILING.-CLIPS AND OALRINQ.

ThE history of horse-shoes may be read in Beckmann's "History of Inventions," Bracy Clark's works, and other compilations. We may presume that the cavalry in ancient Greece were not shod, as Alexander the Great and Mithridates were stopped in military expeditions by their horses requiring time to restore the horn of their hoofs. There is little doubt that at an early period the Tartars of central Asia, and probably the Chinese,-though the latter are no horsemen, except in imitation of their conquerors,- shod their horses. Numerous barrows and tumuli about Tomsk, on the Amoor, the Yenissai, and the Sener, have of late years been opened, where, with the bones of ancient Tartar and Mongolic warriors, have been found rude carved idols and the remains of horses with their shoes on, of a circular form, and (alas for modern invention) nailed on the outer side only, as in the "unilateral" shoe. In the western world, Cardanus, Beckmann, and Mr. Bracy Clark refer the introduction of horse-shoes to a period even later than the age of Augnstus; the latter in their comments endeavouring to prove that golden, silver, and even iron shoes were not what we understand by them, but mere plates, more or less thin, according to the metal, fastened to leather, and this secured by ligamenta (straps or shackles) to the hoof or fetlock.

Suetonius, in his "Life of the Emperor Vespasian," tells an anecdote in which the fact of the Emperor's mules being shod, is incidentally mentioned; though the manner of shoeing is by no means indicated. The historian says, that the Emperor was wont to travel eighty miles to his Castilian villa. On an occasion of this kind, a petitioner (litigator) having bribed the driver of the imperial carriage to contrive to loosen a shoe of one of the mules, that worthy found himself under the necessity of alighting to fasten it; thus giving the petitioner the opportunity of access to the Emperor at a leisure moment. Vespasian, we are told, suspecting the trick, facetiously put off the supplicant by addressing his driver, and inquiring how much was to be his reward for this well-timed shoeing; intimating that he, the Emperor, "meant to go shares with him." * Our inference from

* The words of Suetonius immediately relating to the shoeing, are: Mulionem in itinere quodam suspicatus ad calciandus mulus desilisse, ut adeunte litigatori spatium moramque præberet: interrogavit, quanti calciasset : pactusque est lucri partem.--Suetonizs, Vit. Tmp. Vespasian. de Facetis p. 120. this, would be in favour of metal shoes with ligamentahorse sandals, in fact-rather than nailed shoes; though Schœeffer, in his learned work "De Re Vehiculari," jumps the conclusion, that the muleteer got down to nail on a loose shoe, "soleam ferreum pede unius ex mulis." A proof of this mode of fastening, extending ligh up the shank of the leg, will be found in a drawing from a Roman tablet of terra cotta, in the British Museum, $\uparrow$ wherein the bands of these boot-like defences of the feet are shown on the legs of four chariot-horses engaged in a race. These boots, being intended only for a special occasion and a brief exertion, may have been no more than leather : indeed, in cases of tender hoofs, Columella, writing in the time of Augustus, speaks of solea spartea (shoes made of the spartum or broom twigs); Vegetius and Clusius also mention shoes made from this tough material. $\ddagger$ Leather, with iron "acorn-shaped" (glantes ferrei), is advised for healthy feet, to be exchanged for the spartum (broom shoe) detritis pedibus; and here, perhaps, lies the whole question.

It is, however, obvious, where once iron or other plates were applied, the form of the shoe was necessarily adapted to the animal's foot; and the internal surface was of very secondary interest, the whole difficulty in question being in the mode of fastening them on. In some cases this was clearly by nails driven, as now, through the corneous substance, as is evident from poetical notices, such as that of Catullus :-

"Ferream ut soleam tenaci in voragine mula derelinquit."

We know that Nero had his horses shod with silver; and Poppea, his wife, had her mules similarly pratected with gold. The exact form of these shoes, it is sufficiently probable, was the same, or nearly the same, as the modern shoe of France and Italy; for on the battle-piece discovered at Pompeii, the horse standing before the chariot wheels of Darius, about to be mounted by a Persian satrap, is shod as here stated. This remarkable work of art cannot be of later date than 79 of the Christian era, when Pompeii was destroyed; and, it being to all appearance the copy of some

+ It forms the frontispiece of Bracy Clark's Essay on the Knowledge of the Ancients respecting Shoeing the Horse, dic.

† They were probably no more than boots for inflamed feet. At any rate they could not have been used on modern roads, if they even were on the flat stone causeways of the Romans. 

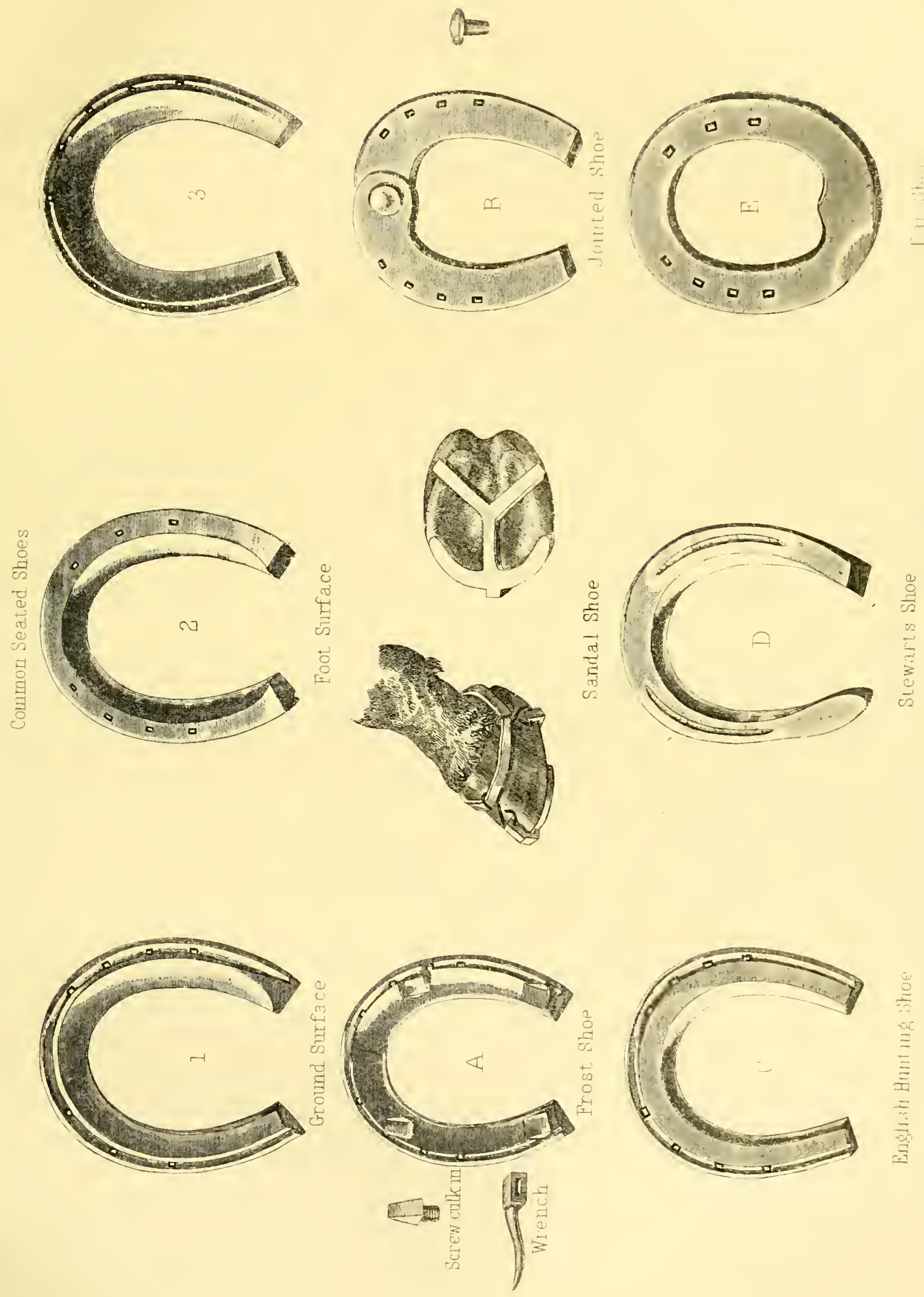

celebrated picture of the Greek school, the original may be older than the Roman supremacy among the Hellenic nations. If, therefore, the mosaic really represents horse-shoes on the feet of the Persian steeds, the antiquity of the invention is carried up to a date coeval with, and most likely to one anterior to, the Christian era by more than a century. Upon the whole, there is no real objection to the existence of horse-shoes-not during the wars of Alexander, for we have already noticed his cavalry being detained in consequence of their worn hoofs-but a century at least before the Augustan era. The date affords time for the appearance of them in the mosaic, and the use of them at Rome for the use of the imperial family, and for horse-shoes in the tombs of Tartar chiefs. This also makes the tradition not impossible, that the iron work about the banner of Hossein, at Ardebil, is made from a horse-shoe belonging to Abbas, uncle of Mahomet, by order of his daughter Fatima. It was brought from Arabia by Sheik Bedreddeen, son of the holy Sheik Sefi, who was son of another holy villager, after the manner of the Moslem.

It is most likely that the story of the horse-shoe is true; but that it was one of a horse belonging to the Beni Coreish -a camel-riding tribe, without horses till the Prophet had begun his successful military career-may be doubted. Horse-shoes, from the foregoing observations, are sufficiently proved to be of more ancient date than Beckmann will admit; he referring them to the ninth century, notwithstanding his thorough acquaintance with the passages in Roman authors on the subject. The fact is one more in illustration of the inconceivable tenacity there is in man to defend an opinion once adopted. Whether the iron shoe is fixed by means of three nails clamped round a hoof, or by eight or ten driven in, as now, through a plate more or less different in form, or alleged to be used for mules, are one and all so many amusing quibbles to escape from a selfevident fact.

Although the practice was long opposed, and ages passed before shoeing was general, yet when it was once understood, the presumed difficulty vanished, and Tartars and Cossacks at this day very generally understand the shoeing of their own horses. In England it is pretended that it was William the Norman who introduced it ; but the assumption is like that which, some years ago, maintained that there were no stone churches in England before the Conquest, and none in Ireland before Henry II.-they are mere instances of the audacity of ignorance. Saxon England contained a number of Northmen adventurers, Danes and others, who had served, and who continued to serve after the Conquest, among the Varangi-life-guards of Greek emperors; it had monks that went regularly for education abroad, and travelled to Rome. England was infatuated with female saintship, then most fashionably exemplified by a pilgrimage to the Papal throne, and that in such numbers that the 11,000 virgins of Cologne, martyrs, \&c., were held to be, in general, Englishwomen; besides more authentic records describe the crowds passing up and down the Rhine on their route, with rather equivocal characters. It is impossible, therefore, that horse-shoes should not have been known and used; though, as the Anglo Saxon is not shown to have been essentially a horseman, it is likely that the practice was confined to the nobility, as indeed it was till a late period in parts of France.

Horse-shoes have varied little in Europe, retaining now very nearly the form even of that figured in the wall-pictures before-mentioned. But the most ancient Circassian horseshoe appears to have been round; and if the figure of it remaining in a brand be correct, it had only three nails or clamps secured on the outside of the hoof. Another round horse-shoe is in use among the modern Egyptians, and partly the Syrians; it is a round plate with a hole in the middle; the common shoe, also used, has the heels turned against the heel. In other parts of Turkey, the plate is square behind, and rounded at the toe. On the continent of Europe, the ends, particularly in winter, are always turned up; and when there is ice on the ground, both are frequently pointed. The forms of modern shoes, many of them adapted to special purposes, will be found engraved in Plates XVIII. and XIX., and described hereafter.

Considering the apparent simplicity of the process to an ordinary observer, the method of fastening a piece of iron to the horse's foot has been the occasion of more dissertations, essays, guides, manuals, "practical" instructions, theories, disputes, and-we sorrow to write it-hard words and abuse, than any subject we are acquainted with. It will be our aim here rather to simplify the matter than to overload it; and instead of wearying the reader with the investigations of something like a hundred (many of them ingenious) writers on the mode of defending the horse's foot, endeavour to combine the proven facts of all with the results of our own experience in a plain and succinct compendium. A reference to Plate XI., Figs 2, 3, 4, where the sole, frog, \&c., are delineated in its natural and its contracted states, will help to elucidate the subject.

Shoeing, then, is a necessary evil. Among the evils inseparable from every kind of metal shoe, is the severe bat. tering upon hard roads, rendered yet more severe by the interposition of an unyielding substance, such as iron. Every step the horse now takes, is made upon iron; and the wonder should be, not that a foot occasionally gives way, but that any part of a living frame should be able to withstand such treatment. Then, not only are the roads hard, and the pace at which the horse is driven along killing, but we have also to weigh properly the treatment the horse receives within the stable. Here he stands often for days together, cramped in a stall where he can only stand, frequently he cannot turn round, and very seldom can he lie upon his side, and stretch out his limbs. He stands here generally for twenty hours out of the four-and-twenty, with iron upon his feet, resting upon wet stones or damp bricks. No wonder if the feet should become cold; and those who 
are accustomed to bleed horses from the foot can tell how cold the first drop or two of blood flows from the part, owing to muscular action being suspended, which is necessary to circulatior and to vital warmth.

With regard to shoeing itself, and the share of the farrier in producing lameness, Mr. Youatt says, sensibly, "We must protest against the opinion that contraction is the necessary consequence of shoeing. There can be no doubt that an inflexible iron ring being nailed to the foot, prevents, to a very considerable degree, the descent of the sole and the expansion of the heel before; and it is likewise possible, that when the expansion of the heels is prevented, they will often begin to contract. But here again, nature, cut off from one resource, finds others. If the coffin-bone has not so much descent downward, it probably acquires one backward, and the functions of the foot are usefully if not perfectly performed. The plain proof of this is, that although there are many horses that are injured or ruined by bad shoeing, there are others, and they are a numerous class, who suffer not at all from good shoeing, and scarcely even from bad. Except it be from accident, how seldom is the farmer's horse lame? and it might even be further asked, how seldom is his foot much contracted? Some gentlemen who are careful of their horses, have driven them twenty years, and principally over the rough pavement of towns, without a day's lameness. Shoeing may be a necessary evil, but it is not the evil which some speculative persons have supposed it to be: and the undoubted fact is, that when the horse is put to real hard work, and when the injury produced by shoeing in destroying the expansibility of the foot would most of all shew itself, the foot lasts a great deal longer than the leg; nay, horsemen will tell us that one pair of good feet is worth two pairs of legs."

As we address ourselves specially to those who love the horse, it will not be too much to ask the horse-owner to spare an hour a month to see his horse or horses shod. Mary a valuable horse may thus be saved some suffering, if not injury. Do not have your horses shod at an ill-lighted place, but one with side-lights as well as skylights. Cast your ejes about for signs of drinking, and see that there is no screaming or bawling at the horses, rough tossing of the hammers and tools, and a prevalence of cant and self-sufficiency-all these we have seen, but never in conjunction with good shoeing and trustworthiness. See, too, that in tying up, the halter or rope does not annoy the horse's ears or fore top, rub his eje, or constrict his throat, as a "vicious" resistance, as it is called, is often thus established.

With these preliminary remarks we shall proceed to the Practice of Shoeing.

Preparation of the Foot.-The horse is standing in the forge with his old shoes on, and these have to be taken off. We have gathered much of the character of the smith, by watching the way he has gone about this seemingly trivial preliminary See that he handles his "buffer" in raising each clench separately. The clenches of the nails should be raised, which few do; but, after turning one or two of them, he seizes first one heel and then the other, and wrenches them loose, then, seizing the toe with his pincers, tears off the iron. By this the hold of the new shoe is weakened, the nail-holes enlarged, and sometimes a portion of the hoof splintered or torn off. The horse often shows that he suffers, by a sudden shrinki.jg or trembling, when the pincers are thus used. Stubs, too, are sometimes left in the crust of the foot by this off-handed violence, and prove the seeds of future lameness or exfoliation, to say nothing of the animal being rendered timid and difficult to shoe.

The general principle of healthy shoeing is, to support the foot off the ground by means of the "wall," and by this only; so that the frog shall not come in contact with the hard plain road, whilst it may be allowed to receive pressure upon going over soft ground. The first prevents injuries and resists wear and tear, the latter promotes the secretion of healthy horn, by a proper degree of pressure-that is to prevent this being received by the heel, frog, and bars. Whatever is here said, the fore foot is still kept in view, unless the hinder foot is particularly mentioned; and occasion will present itself for the distinction, as there is great difference in the wall and other external shape between the two, especially as regards heavy draught cattle. The shoe removed, the crust is to be rasped down at the edges; and although a little roughness may be exercised in this, yet there is little danger of injury to the hoof, only that too much must not be removed, so as to render it too thin. The hoof requires considerable labour to pare, and this is of great importance to the comfort of the animal, as well as his safety on the road. It is a part of the operation of shoeing which is too often done in a hurried and slovenly manner. We would advise the owner of the animal, when he emplnys a new or strange farrier, to see that paring is thorouglily performed; because, if the sole is not well pared, its elasticity will be destroyed, and the internal portion be prevented from descending. This will impair the functions of the foot, and induce many of the maladies to which it is liablenavicular disease, contraction, corns, inflammation, and the diseases of which we have already treated. Nothing is of more consequence than to prevent an accumulation of the horny substance of the sole, which, it is easy to see, must increase, because, being protected by the shoe, it cannot get worn down as it would in a natural condition. Sufficient thickness should be left, so as to protect the internal parts of the foot from injury, and enough taken away to allow the external sole to descend. This can easily be determined by the pressure of the thumb on the sole, which should yield slightly in all its breadth. This operation is performed by the drawing-knife, figured in Plate XVII.

It will happen that the horn of the sole becomes so hard

* The buffel is a square, short iron knife. See Plate XVII. 


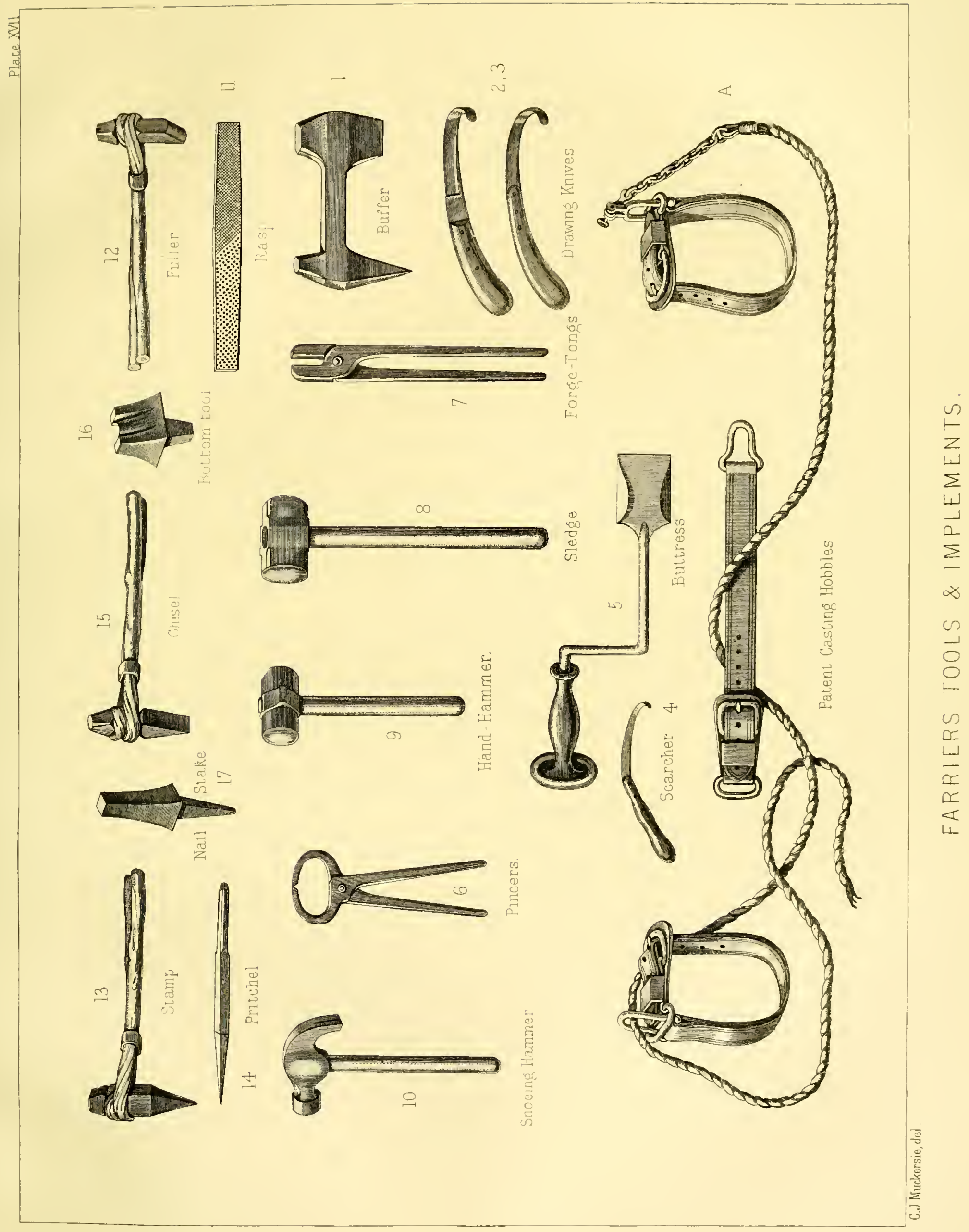



that it is removed with very great difficulty, in which case it becomes necessary to soften it by heat. 'This is effected by means of a flat lieated iron, drawn over the sole, and even kept close to it for a little time. If the sole is thick, no injury will be sustained from it, and, on the contrary, it will render the paring more easy and less disagreeable to the horse; but if the sole has been regularly pared out during shoeing, this must not be permitted. The quantity of paring necessarily varies much, according to the formation and condition of the foot. The foot which is pumiced should only have the ragged parts cut away; when the foot is flat, little paring is needed; from that which is concave, the crust must be pared until it yields slightly to strong pressure from the thumb; if the foot is strong, a great deal of paring is requisite. Care must always be taken that the crust is not reduced to a level with the sole, as this would permit the sole to press upon the edge of the seating, and thereby be bruised and injured. The entire circumference of the crust should be perfectly level, but projecting a little beyond the sole.

We must now direct attention to the heels. More stress is thrown on the inner heel than on the outer, and, from natural weakness of the quarter there, it generally wears quicker than the outer one. This being the case, less horn must be pared from it than from the outer, as taking the same quantity of horn from it would leave it lower than the other, whereas they should be perfectly on a level. Almost all smiths have a fancy for opening the heels, from the idea that it does good by rendering the foot neater, which is a fallacy, as they ought seldom or never to be touched; nothing should be removed but the ragged portions.

It is intended that the heel of the shoe should rest partly on the heel of the foot; consequently the bars should be allowed to remain nearly in their natural condition from the first inward bend, and down the side of the frog. When the frog becomes level with the crust, however, paring of the frog becomes necessary. The quantity to be taken from the frog depends on its greater or less prominence, and the shape of the foot. It should project so much as to be just within and above the inner surface of the shoe, that is, upon a level with the hoof when no shoe is on the foot. This will give it room to descend with the sole. If it is much higher, the bars will contract; if lower, it will be bruised on hard roads.

Blaine, one of the best of veterinary writers, places "neglect and insufficiency of paring" at the head of the causes of misshapen feet. The hoof is continually growing, the crust is lengthening, and the sole is thickening. This is a provision for the wear and tear of the foot in an unshod state; but when the foot is protected by a shoe, and none of the horn can be worn away by coming in contact with the ground, the growth of horn continues; the hoof gets high, and the sole gets thick; and in consequence of this, the descent of the sole and the expansion of the heels are prevented, and contraction is the result. The smith might lessen, if not prevent the evil, by carefully thinning the sole and lowering the heels at each shoeing; but the first of these is a matter of considerable labour, and the second could not be done effectually without being accompanied by the first, and therefore they are both neglected. The prejudice of many owners of horses assists in increasing the evil. They imagine that a great deal of mischief is done by "cutting away the foot." Mischief may be the result of injudicious cutting, when the bars are destroyed, and the frog is elevated from the ground; but more evil results from the unyielding thickness of horn impairing the elastic and expansive principle of the foot. if gentlemen would stand by, and see that the sole is properly thinned and the heels lowered-and occasionally, perhaps, give the workman a trifling gratuity for his increased labour-they would be repaid in the comfort and usefulness of the horse.

When the foot is fitted to receive the shoe, the bottom somewhat resembles the hollow rim of an oval dish. Being placed on a plane surface, the frog and heels should bear equally, leaving the thickness of the shoe, as above explained, to save the frog. At the heels, for an inch of its length, the rim of the shoe is to project a trifle outside the hoof, lest the growing horn should cause the shoe to imbed itself at this part, where the substance is soft and the wear little.

Having completed our directions for the preparation of the foot, we will here interpose a few paragraphs on the forming of the shoe, and its material, as a more fitting opportunity will not present itself.

Making the ShoE.-The forge of the modern smith, in addition to bars of iron of various thicknesses, from which to select such as may come nearest to the size and weight of shoe required, is supplied with a large assortment of shoes ready made, hanging on the walls or disposed on bars. 'These being placed horizontally, with the shoes ranged on them, are much more handy to select from than when piled one upon another, as is common, with a perpendicular bar of iron to keep them from slipping down. The modern malleable cast-iron shoes are very durable and economical. In working up old shoes, one and the half of another will be found an average quantity for a new oule. This half should be laid on one side of the old shoe, then the half of the entire one lapped over it; thus, when welded into a mass, the middle of the quarter of the old shoe will form the toe of the new one. The hind shoes are thus made of old shoes, the work not being in general so regular and neat as that of the fore shoes.

In forging the shoe from the bar, a piece is to be cut off somewhat shorter than the intended shoe, to allow for extension under the hammer, and that there may be as little waste as possible by cuttings from the heels when the shoe is finished. Two or three of these pieces may be placed in the fire at one time, to save fuei. With saddle-horses, however, it is an expeditious, as well as more correct method, to divide or cut the bar into pieces or lengths forming 
pairs, according to the sizes required. The iron for these shoes not being very stout, there is no difficulty in turning it in the tongs over "the bick" with the hand-hammer;" but with ene heavier cart-horse shoes, it is usual not to cut it from the bar till a circular figure is given it, for which the bar itself serves as a powerful and convenient handle. Some, lowever, prefer cutting the cart-horse iron into equal lengths first, as we have just described, and then bending these pieces, by placing one end upon the anvil, and resting the other against the head of the sledge-hammer, bending it by a few blows of the hand-hammer, which thus gives to all the shoes an equal weight and size. The iron, having received the requisite curve, is then cut off, and is termed " a monld."

It is usual for the workman to finish the outer limb of the shoe first, which being roughly formed, and the web thinned and hollowed out, is commonly reversed by the smith, that is, the hammered side is brought to the anvil; that which was before next the anvil being more smooth and uniform in its surface, and of better appearance.

The shoe, or rather the outer limb of it, is then fullered; that is, a deep groove or channel is driven round it, at a small distance from the outer edge, indenting it more than laalf through the thickness of the iron. The tool for "fullering " is a sort of chisel, about four inches long and two wide, flat and almost concave on one side and very convex and rouuded on the other, and circular below on its cutting edge. It is generally used in a rod of hazel, the flat side to the interior of the shoe, and the convex side to the exterior: it is liastily driven along the limb, deeply indenting it, and forming a channel at a suitable distance from its exterior edge. (See Plate of Implements.) The fullering is useful on several accounts; as, preparing it for the nails, as the pritchel $\dagger$ can then pass through the iron without much difficulty: it also renders the shoe somewhat wider without adding to its weight, and gives it a much more agreeable and lighter appearance. The hind shoes, even for saddle-horses, are often not fullered; at least only on the sides and for a short distance: nor are the cart-horse shoes, either fore or hind.

In France and Spain they do not fuller any of their shoes, even for nag-horses, but a stout square stamp is driven deep into the web of the shoe, and the perforation is then completed by the finer point of the pritchel. The fullering has this advantage also; that the holes for the nails can be made nearer to the outer rim of the shoe, rendering the work finer, - to use a phrase of art opposed to coarse, as they say of a shoe whose perforations are far within the rim. The French shoes, therefore, are stamped very coarse by necessity, as there would be danger of bursting the iron out with their coarse tool, if applied near to the outer margin of

\footnotetext{
- The tools of the shoeing smith, given in Plate XVII., will explain these implements withont repetition of references where mentioned.

$†$ The "pritchel" is a shaft of iron, steeled at the end, and drawn ont to a fine square point. To "pritch" the ohoe, in farrier's langagge, is to perforate it.
}

the shoe. The fullering gives the "doorman" more latitude in inserting or pitching, as also in driving his nails; and with us in England they are brought out higher up the hoof than in France and Spain, where they drive their nails more obliquely and suddenly outward.

The outer limb being finished, the inner limb is next formed, somewhat narrower and finer than the other,-that is, straighter, and less projecting in the middle exteriorly; the nail-holes, also, are more carefully brought nearer to the exterior edge, and are made smaller, especially the last, and not so far back, or near to the inflexures, as in the outer limb; and generally with four holes only instead of five, the number usually given to the onter limb. The inside quarter of the horse's hoof is very often bent and curved inwards about its middle height; whereas the outer is quite straight, or frequently somewhat bulging exteriorly at this part, and requiring less care in driving the nails, and distinguishing easily the feet, whether off or near.

In forming the nail-holes, attention must be paid to the direction or sloping of the hoof, as those nearest the toe or front of the shoe should be made strongly sloping hackwards, agreeably to the figure of the hoof at this part, whilst those on the sides or quarters of the hoof should be more upright, otherwise it must be obvious the nail cannot be inserted in the hoof without bending in the hole to accommodate this difference of direction.

In the next place, the "pritchel bumps" and "burs" $\ddagger$ in the iron about the holes are to be knocked down: these arise from the distension of the metal by the entrance of the pritchel, and are seen upon the outside of the rim of the shoe, and also on its upper surface. This is done upon the anvil-bick by chasing the shoe round with the hammer. The burs, also, should be forced down, as they endanger coming in contact with the sole, or "vein" as the smiths call it, which is running round it. Lameness may result from this cause, when, on the removal of these roughnesses, the horses have gone well again.

Form of the Shoe.-The surfaces, also, of the web of the shoe will admit of great variety of form; which do not at all constitute a change of principle, as has been vulgarly apprehended. It is the mode only of figuring the ring that is changed, the principle remaining the same. On the whole, those made concave next the foot or opposite the sole, and flat below, to the ground, are with good reason preferred by the soundest and most experienced writers on this subject. However, a shoe such as is commonly made, with the web and whole npper surface with a gentle inclination inwards, is as good and useful a shoe as any, and has this great recommendation belonging to it, that it is the most readily made. The former, or seated shoe, can be made rather lighter perhaps; but its flat level upper surface, where it receives the hoof, is not so good, we believe, as a very gentle inclination or slope of this part, as by its flatness

$\ddagger$ "Burs" are eplinters about the edges of the boles. 


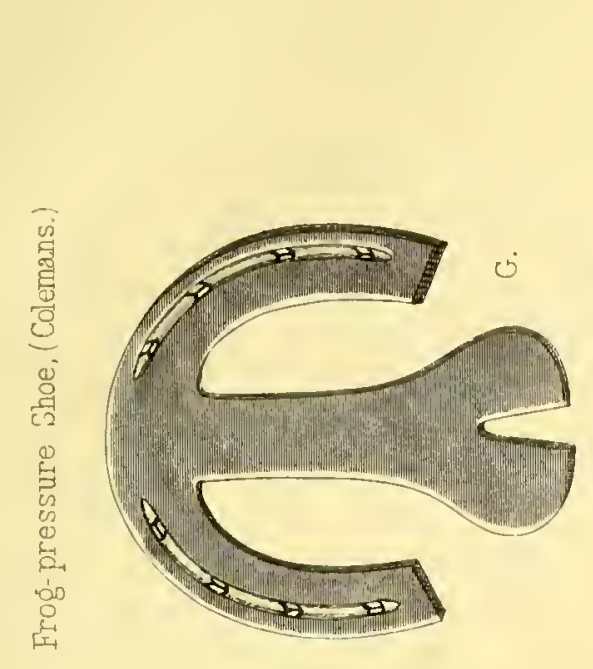

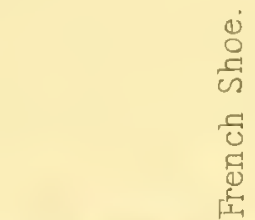
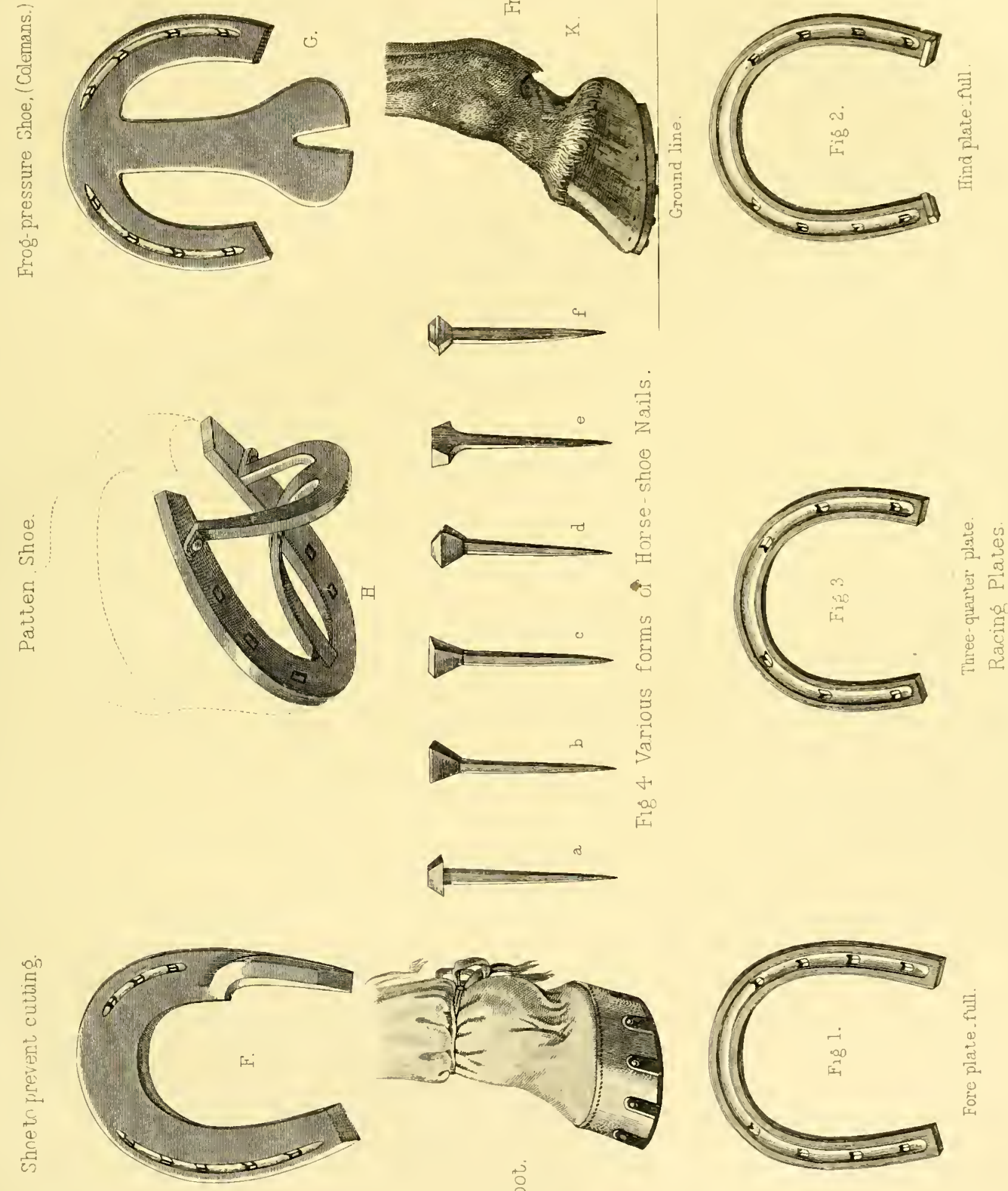

3
0
0
0
0
0
7
3
0
0
$0-1$ 

it is more liable to split the hoof, and to carry oppressive bearing towards the vein and sole. The concavity is useful in admitting the play of the sole, and in permitting the free use of the picker, and letting out again all dirt or stones that may get in. The Varieties of Shoes for special purposes, defects, or disorders, delineated on Plates XVIII. and XIX., will be explained in the letterpress accompanying those engravings.

Putting on the Shoe.-The first thing in ordinary shoeing is the selection of the shoe; and in this, experience and a judicious eye is worth all the learuing of a college. The judgment of a shoeing smith is shown in the adaptation in quantity and quality of the iron to the horse. The thick-walled foot will require a good bearing; the thin hoof cannot carry a heavy shoe, though it stands most in need of defence. The hoof, too, should guide the farrier in the number of nails. The shoe is the work of the "fireman," as he is called in the forge ; the preparation, of the "doorman," who also nails on and clenches the shoe made by the "fircman." The "doorman" takes the task of preparing the foot, as already described, to receive the shoe, by removing the superfluous horn of the sole.

For hunting, the shoe must be narrower than for the road, and an additional nail may be placed on the inside; no evil will result from this, because in the field the pressure on the crust is, in a great degree, relieved by the sole and frog. There must be space for a picker to pass between the foot and inner rim of the shoe, hut no more, as the foot can then be withdrawn from heavy soil with less difficulty than when the usual space is permitted. To avoid overreaching, the heels of the fore shoes should scarcely project beyond the heels of the crust, and they should be rounded off, instead of being left square, as is usually the case. The hind shoes should also, where there is any disposition to overreach, be square at the toe, set a little within the crust; and the inner rim at the toe should have a piece cut out, so that, instead of a sharp edge, there should be a rounded surface, which, of course, is not so likely to catch the heels of the fore feet.

"Nailing." a very important operation, requires much previous study of the formation and functions of the internal sensible parts of the foot, many injuries being inflicted by penetrating those parts to the quick. A good aphorism has it thus-" If it were possible to keep the shoe in position without nailing, we should then have arrived at perfection in the art of shoeing; it follows that the least number of nails that are driven, consistent with safety, is the most commendable practice." Mr. Bracy Clark, among his many inventions, once proposed to fasten on the shoe by enveloping the whole hoof in an "iron defence," and fastening it by outside screws; but the scheme failed for obvious reasons.

The nails for shoeing horses, are received from the hands of the manufacturer soft, without point, variously bent, and unfit for use till they have passed through a process, requiring some dexterity, called "pointing the nail ;" they receive for this purpose a smart hammering from the hand of the "donrman," on an upright steel-headed shaft, termed "the stake," beginning at the head of the nail and continuing it along the shank on both sides and edges to its extremity, which is then drawn out to a clear point. By this means, the nail is rendered hard and stiff, and its surface smooth and polished. But of as much or more consequence than this, is the figure which the point of the nail is made to receive; for after it has been drawn to a clear good point, the workman gives it a final stoke, obliquely directed over or upon the very extremity of the nail, so as to impart to it the figure of an inclined plane on one side, leaving it perfectly flat on the other. This bevelling of the point of the nail is of the greatest use in driving it, giving it always a tendency to pass out of the hoof, from the bevel being placed next the interior of the hoof, which facilitates the process of shoeing very much, and greatly diminishes the risk of pricking the horse; for the, foot being softer within than it is externally, would naturally draw the nail in that direction.

The nail mostly used at present has a lurs conical square head, with a view of fixing it tight in the shoe; and the pritchel point is directed to be made of the same figure, that it may be the more firmly fixed.

This conical nail, when made too long in the hear, or neck, is apt to enter the hoof and distend it unduly, rending or splitting the horn; a short shoulder or neck is therefore to be preferred.

The first nail usually driven is one near the toe, on the side of the foot next the right hand of the workman, as more convenient to the hammer. This may draw the shoe out of its place, which is again adjusted by a blow or two of the hammer on the projecting side, bending the nail or forcing the hoof, or both; the second nail is then passed through the hoof on the opposite side, which renders it in a degree fixed; the rest are then driven indiscriminately, smaller nails are however used near the heels or inflexions, on account of the horn being thinner. The presentation or planting the point of the nail first in the hoof, in order to give it a proper direction for driving, is called by the smiths "pitching the nail;" this is done with the finger and thumb, and on its being judiciously chosen, the success of driving the nail, it is obvious, will much depend. In giving the first strokes of the hammer, they strike, not on the flat part of the head of the nail, but on its exterior edge; and wher safe in the hoof, or nearly home, upon the flat head. The smith is led to judge by the sound, as also by the resistance the nail makes to the hammer, whether it be in its right course or not, and he aims to bring out the nails as nearly at equal distances round the loof as may be, and at equal heights up the hoof, the accuracy of which exhibits the skill of the workman. On the first entering of the nail, he proceeds with caution; but when the point is felt by the finger, or makes its actual appearance, he strikes more boldly till the head is driven home to the shoe. The nail having passed through the hoof, the shank or extremity of it is turned down and bent against the side of the horf, so that 
the horse, in struggling or suddenly withdrawing his foot, should not tear the clothes or wound the thigh of the workman.

In England, ir is usual to see the doorman perform the nailing on of the shoe by himself, unless with very heavy draft horses, when he gets assistance. In France, two men are generally employed, one to hold the foot, the other, however, standing behind the foot. In France and Holland, also, the travis, described in the last cliapter, is used, and a hind foot lashed to a post.

The nails being driven and turned down, the smith next proceeds to give them all round a smart hammering upon the head, to fix thein more firmly; and, by holding the pincers to the shank of the nail, he draws the sloe tighter against the hoof. This done, he wrings off the shank or point of the nail, and files the clenches with a rasp to a uniform length, filing away, also, a little of the hoof, that they may lie the more closely. He should not use too much force, as that may draw the sole too strongly against the coffin-bone, and distress, stun, and benumb the sensitive sole. Now, by reversing the situation of his pincers and hammer, and holding the former against the head of the nail, which prevents its return, he heats down the clenches with his hammer, and forces them into the hoof. The clench is in part imbedded in the hoof; but if any part projects, or if there should be any irregularities, they are removed with the rasp, and the process is completed.

The various forms of nails are shown on Plate XVII., and described in its accompanying letter-press.

Of the manner of attaching the shoe to the foot, the owner can scarcely be a competent judge; he can only take care that the shoe itself shall not be heavier than the work requires-that for work a little hard the shoe shall still be light, with a bit of steel welded into the toe-that the nails shall be as small, and as few, and as far from the heels, as may be consistent with the security of the shoe; and that, for light work at least, the shoe shall not be driven on so closely and firmly as is often done, nor the points of the nails be brought out so high up as is generally practised.

The Hinder Shoe.-As the hinder limbs are the chief instruments of progression in the animal, except while walking, the whole stress of the frame rests upon them. In consequence of this, the shoes of the hind feet are always made broader than those of the fore feet, and the toe is widened still more by rasping. When there is the slightest tendency to over-reaching, the toes of the hind feet should be shortened by sloping in the surface, and rendering the shoe somewhat less projecting than the toe. The hinder differs a little from the fore foot, in being straighter in the quarters. The nails in the hinder shoe should be situated nearer to the heel than in the fore shoe.
Calkins. - It is scarcely possible that a shoe thinner at the heel than at the toe, can ever be serviceable; on the contrary, it will generally occasion lameness, by throwing undue stress on the flexor tendon. It will be a fruitful source of sprain of the back sinews, also of navicular disease. On the other hand, a shoe a little elevated at the heel may favour a leg weak in the back sinews. In the hinder foot, and particularly in draught horses, custom has sanctioned the use of a shoe raised at the heel by calkins. This certainly gives the horse a better purchase; enables him to descend a hill more securely, as well as to draw a heavier load. A draught-horse always digs his toe into the ground when he has a heavy weight to move; and he can do this more effectually when the heel is raised. But this practice is carried to an absurd and ruinous length. In many horses of heavy draught, the only bearing points - the only parts of the shoe which to'ach the groundare the tip of the toe, and the end of the calkin. There must be inequality of pressure here; and by it the ossification of the cartilages; enlargement of the pasterns; and other diseases with which the draught-horse is often afflicted, are too well accounted for by shoes too high in the heel.

Clips are portions of the upper edge of the shoe, hammered out and turned up in such a way as to lap over the outer surface of the crust, which is also pared away a little, to bed the clip. Their use is to give greater security in attaching the shoe to the foot, and lessening the stress upon the nails, which might prove injurious. In horses subjected to heavy draught, clips are indispensable, and are useful to all employed in draught of any kind. They will be found a useful preventive in securing the shoes from being torn off, when the strain is great on the feet while drawing. Clips are also beneficial when horses are given to stamping and pawing, as either of these tricks are likely to loosen the simple shoe. But clips should only be used in such horses as we have named, because they press upon the crust as it grows down, and are therefore unsuited to animals emplnyed in light draught or hackneys.

We trust we have given a simple and clear account of the practice of an art obscured by much mystery and pretence, but without a difficulty in the mastering of its main principles and practical details which need deter, or can perplex an inquiring and a well-instructed mind. It would have been easy to extend even the present chapter by compiled accounts of the merits and demerits of a large number of varieties of shoes, but we have preferred appealing to the eye, aided by a brief description of their differences in the letter-press accompanying the Plate engravings. 


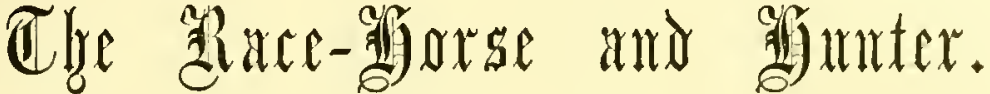

\section{BRERDING, BREARING, AND TRAINING THE RACEHORSE-TRAINING GROUNDS.-EXERCISE.-BWEATS.-THE TURKISH \\ BATH. - TRIALS.}

THR two great objects in breeding domestic animals may be summarily stated. The first, purely profitable, or commercial, aims at multiplying their numbers; the second, of a higher order, has the ohject of improving their forms and raising their qualities. To the latter, the sportsman and the breeder of the superior class of animals directs his judgment and his attention.

So much has been written on the subject of breeding for the turf, that it would be absurd in a work intended for general perusal to overlay its pages with scientific questions of physiology or psychology; such as what share each parent takes in impressing the sex, the temper, the form and qualities of the future progeny, and the like." It will suffice if we speak generally of the main admitted facts in breeding as they relate to the race-horse, the hunter, and the saddle-horse.

\section{BREEDING THE RACE-HORSE.}

The requisites necessary to render breeding the race-horse profitable as a "business," are, judgment in selecting, and plenty of money at command to secure mares and stallions of the first blood; paddocks and necessary buildings on a suitable soil; and intelligent and trustworthy grooms to look after the establishment. With these essentials in proper order, breeding, distinct from racing, cannot fail to pay, on the average, whether the foals are sold off at weaning time, or as yearlings.

The present race of stud-grooms and trainers are a very different class of men from their predecessors, whom they far cxcel in point of respectability and intelligence, the result of education and the general diffusion of knowledge. Books written by those who have taken practical experience and nature for their guides, have been published for the service of breeders and trainers, who have both read and reflected on their contents. The breeder, taught by practical knowledge the bad effects of a humid atmosphere, and rank and succulent food, now provides warm sheds, small paddocks on a dry upland soil, and, as we shall presently show, plenty of corn for his young racing stock.

Having fixed on a dry, healthy situation, such as, for instance, the neighbourhood of Downs, and provided every convenience and accommodation for the mares and young

- The reader desirous of becoming thoroughly au fait in the minuties of training, may consult the Philosophical Transactions, vol. Ixxix. p. 173, (paper by Sir Eyerard Home), Phil. Trans, for 1809, p. 357, (paper by Mr. Knight). The Veterinarian, vols. for 1832 to 1840, articles by Mr. Castley, and Mr. Karkeek, of Truro. Percivall's Lectures, part iii. p. 112. Breeding for the Turf, by Mr. N. H. Smith. Blaine's Cyclo., art. Breeding, p. 277. Professor Morton's Works. Darrill on the Race-horse. The Stud Earm; by Cecil, \&c., \&o.

$$
3 \mathrm{~B} \text { * }
$$

stock, together with loose boxes, and a small exercise ground, well secured with a high and impervious fence for the stallions, the breeder's next care is to purchase brood mares and entire horses, particularly the latter, as experience has long confirmed the truth of the supposition, that in breeding a racer in his highest form and excellence, the stallion is of more importance than the mare. On consulting the racing calendar for the last seventy years, it will be seen that the produce of the highest bred and most successful mares by inferior stallions, has turned out comparatively worthless, while all our most celebrated winners have been got by the best entire horses. The judicious breeder from this sees that it is the worst possible economy to purchase cheap stallions, and never grudges paying the difference between the price of a first-rate and an inferior one. Above all things, it is essential that both mares and stallions should be free from "constitutional infirmity ;" by which term is understood a tendency to defects in the wind, and of their legs and feet to give way in training.

The most eminent authorities on human pathology have agreed as to hereditary transmission of certain diseases and defects, such as scrofula, gout, insanity, \&c., and guided by their discoverios, able veterinarians, both foreign and British, have shown that the horse is subject to the same law of nature. This opinion, which is founded on reason, common sense, and experience, existed in the days of the Cæsars, and is beautifully expressed by Horace in the following lines:-

\section{Fortes creantur fortibus et bonis. Est in juvencis est in equis patrum Virtus; neque imbellem feroces Progencrant aquilæe columbam.}

Inattention to this important law of nature has occasioned many an owner of race-horses large sacrifices of money, by breeding from favourite stallions and mares a weedy progeny incapable of standing the severity of training, or which "goes amiss," before making the slightest return. On the other hand, the knowledge of this defect has frequently prevented breeders sending mares to stallions of otherwise good repute; instances of which it would be invidious to quote.

To the defects above mentioned, we must add badnesss of temper, which is a great drawback to a full and safe exercise of the powers of the racer, and which is often found to be hereditary.

In the choice of the brood mare, after the soundness of her constitution, and freedom from the above disqualifications have been ascertained, the breeder should direct his attention to shape and substance, selecting an animal with a good 
coomy frame; what is termed a "fashionable" pedigree is also requisite, in case her produce is to be brought to market previous to performing in public.

The racing capabilities of both mare and stallion form an important consideration with the breeder in matching them; his object being to combine the good qualities of both sire and dam in the produce; as, for example, should the forte of the mare lay in speed, then a stallion remarkable for the stoutness of his running should be selected.

The system of breeding in-and-in with race-horses, has occasioned much difference of opinion, and given rise to much discussion among those most interested and best capable of forming a judgment on the subject. The adrocates in its favour certainly appear to have the best of the argument, as they adduce many instances of its success, against the theory of its opponents. Among these instances are Flying Childers, and very many of our best racers from his time up to the present; the case also of George IV.'s favourite mare, Maria, has been particularly dwelt on, her produce by Rubens and Soothsayer being worthless, while that by Waterloo and Rainbow, both closely allied to her, proved winners.

In a former part of this volume, under "Turf Celebrities," many confirmations of this will be found. Mr. Hankey Smith, who resided a considerable period among the Arabs, remarks in his "Observations on Breeding for the Turf," that " colts bred in-and-in, show more blood in their heads, are of better form, are fit to start with fewer sweats than others; but when the breed is continued incestuous for three or four crosses, the animal degenerates."

It must be understood, however, that by breeding in-and-in, this writer does not mean breeding from brother and sister, or from a mare with her own sire, but "after the first cross, to return to original blood."

Contrary to the practice pursued with other sorts, blood mares are put to the horse very early in the year, the object being that their produce may be dropped as soon as possible in the commencement of a new year; colts dating their age from the first of January. This is a great point, as the modern racer is called upon to show his quality before he is two years old.

The careful stud-groom will make it a point to pay the utmost personal attention to the comfort and safety of the sires and dams under his charge, learing no important duty to the mercy of underlings.

According to the conditions of the most important racingstakes now annually the subject of competition, thorough-bred stock must be considered in training from the moment they first see the light. ioo much care cannot be taken in sheltering the foals from the rain and weather, in warm sheds, constructed with rollers on the side of the entrances, so as to prevent injury to the timid little animals as they rush in and out by the sides of their dams. These entrances, as well as the walls or hedges of the paddocks, should be free from any projection against which they might hurt themselves in their quick and giddy movements.
As they are required to display at the "starting-post" at two years old, in a form and with power as nearly as possible approaching to maturity, their constitution must be forced with the most generous nourishment; consequently, we find that corn, in large quantities, is given to the young animal, in addition to the mille of the highly fed dam; and, as occasion may require, physic is administered under the direction of the careful stud-groom.

\section{BREAKING AND TRAINING THE RACER.}

Young blood stock cannot be handled too soon, too carefully, or too gently; as their tempers, good or bad, in after life are almost invariably the result of their treatment at this period. We are, however, happy to say that the present system of breaking colts is conducted with less severity, and therefore with less danger to the animal than formerly.

To command obedience and insure confidence are the first points aimed at; and, as such, the importance of the early handling we have recommended must be evident, as greatly simplifying this part of the process. Colts are now taken "in hand" much earlier than formerly; racing colts at a twelvemonth, and saddle colts of promise are now bitted and suppled at two. They are finally and fully broken and trained, some at three, and few later than four years old. When a colt has had early "handling," and at two years old is subjected to some initiatory discipline, his full breaking being protracted to his fourth or even fifth year, much may be expected from him, for the usual wear and tear will hardly make an impression on a constitution that has had all its powers developed.

The breaking of racing colts and fillies commences at twelve months old. Nor would this be so injurious as is supposed, were the exercising less severe. On the other hand, what is done is perhaps actually necessary to bring about that early extension and suppling of their limbs and joints, so essential to the future speed of the animal; at least, it certainly is so, to bring such young horses out for two-year-old stakes. Rope dancers, stage dancers, posture masters, \&c., never acquire celebrity unless their initiatory exercises are begun at an early period of life; and to insure high form in the racer, and firstrate speed, mild training, but mild training only, cannot be commenced too soon. To such an extent, however, is this early engagement of the race-horse now carried in large racing establishments, that it is not uncommon to warke severe trials of the speed and bottom of colts and fillies at very early periods, that time and keep may not be thrown away on such as give no promise of future excellence; but that, if necessary, they may be at once disposed of for inferior purposes. By three years old, the breaking of the young racers of the present day is completed; about which time the breaking of the better sort of saddle-horses of all descriptions commences; unless an early initiatory handling, lounging, and partial backing at two years old have preceded, which is a very prudent practice.

The details of the application and use of the cavesson, and of saddling, bitting, and backing the colt, hare already been treated of under "Breaking the HoRse For GeNERAL 
Purposes," we shall, therefore, pass them over bere. The same remark will apply to food and physic.

We have already observed that training-stables should be in the vicinity of open downs, as well for the benefit of the air as for suitable exercise. Their extent also presents greater variety, and avoids the necessity of constantly using the same track or course, a practice which much injures the surface for galloping. When, however, this cannot be avoided, rolling at a proper time may be resorted to with advantage.

Mr. Darvill is of opinion, that it is not so much the hardness of the ground as the uneven surface that occasions horses to break down; and that small molehills and cart-ruts are the principal causes of this injury. This is reasonable enough; but, at the same time, the bad effects of galloping horses over the hard soil which the principal training-grounds of the south of England present in summer and a dry autumn, are too well known to require further explanation. A remedy, however, has been found which, to a great extent, if not completely, remedies this evil, and it has the advantage of being both cheaply and easily obtained. The material is common tan, which may be obtained from the tanner's yard, sometimes for the trouble of carting, but always for a few shillings a load; this, having been exposed to the sun and air, should be spread over the turf, which should be afterwards rolled.

Training Grounds.-At Newmarket, as may be supposed, there is great variety of ground to gallop over, and in spring and autumn it is generally in good order-that is, if a moderate portion of rain should fall, without which it is mostly very hard; it is, therefore, not good for summer work; but, as that is a season when there is not so much going on at that place, it does not operate so importantly, except with horses which are in preparation for country meetings. In order to obviate this evil, Marson had a ploughed gallop contignous to where lie usually exercised. This lias been much resorted to; it presents a yielding surface at all seasons, and a similar practice has been adopted at other places where there are many lorses in training.

The very fact of a number of horses being constantly exercised over certain places, must in time have the effect of rendering the land very solid; and it is astonishing how some ground appears to have a tendency to shaking horses-that is, of making them gallop sore and short.

Although a considerable portion of the downs in the vicinity of Newmarket has been inclosed for many years, enough remains to afford both racecourses and training-ground of great extent and variety. The horses standing at the west end of the town, are generally galloped and sweated on that part of the Heath where the courses are situated; for which there is ample space along the Flat by the side of the Ditch, and home up Cambridge Hill, or over the Flat coming home round the Turn of the Lands on the lower side of the Beacon Course, without touching the running ground. The principal training-ground for the horses that stand at the east end of the town is the Warren Hill, on the road leading to Bury.

The Downs of Epsom and of Ascot are the principal training- grounds of the south. In the neighbourhood of Epsom various places are resorted to on the approach of those races; and there are several training-stables in the vicinty, where horses are kept at work throughout the year. The first that may be noticed is the exercise on Epsom Downs, which has not much to recommend it: in dry weather it is sufficiently hard, and the natural solidity of the surface is enhanced by the numerous race meetings which have been held, and which have attracted such multitudes of persons, who, with their carriages and horses, have trampled more or less over every inch of it; in wet weather it is slippery. The surface is a light chalky clay, with a substratum of chalk and flint, upon which tan has an admirable effect.

Leatherhead Downs demand a preference over all others in this locality, especially so far as the nature of the soil is concerned; the only objection to them is, that they are not quite so extensive as might be wished, therefore it is necessary to make several turns in order to get a gallop of sufficient distance.

Mickleham Downs, which are only on the other side of the hill, are very good, and it is almost impossible to conceive a more picturesque or interesting spot; the upper part, parallel to which the termination of the gallop extends, is protected by a narrow belt or plantation, and the Downs are studded over with hawthorn and juniper bushes, which, though wildly arranged, produce a very pretty contrast, as the hawthorn is, at the season of the year, in full blossom. Its appearance is that of a gentleman's domain, rather than the uncultivated rudeness of a common. The gallops pass between the clumps of hawthorn and juniper, which serve to define the track.

Many horses are trained for the Midland Counties' Meetings at Hednesford, between Carnock and Rugeley, in Staffordshire.

A portion of Delamere Forest, in Cheshire, is used for training racers. It is a light sandy soil, which never becomes hard but in dry weather. It is liable to work into holes, the land not being good enough to carry a sound turf.

There is a training-ground arranged at Aintree, near Liverpool, comnected with the racecourse, comprising a circle, or rather an oval, within that upon which the races are held. The intention is giving gallops to those horses which are sent to run there, although it has been occasionally used for regular training at other seasons. The nature of the soil is good, but it wants that importaut auxiliary to the establishment of condition, a hill-without which horses cannot be brought to the highest state of perfcction.

Cleeve Hill, near Prestbury, Wilts, is the site on which Cheltenham races are held. The nature of the land, taken altogether, is good; there is, however, one disadvantage-the horses have a long hill to ascend in going to their work, and, of course, the same to descend afterwards. The situation-two miles from Cheltenham-is central for many country meetings worthy of notice.

The ground over which John Scott trained at Malton is highly spoken of ; indeed, nothing could more truly demonstrate the fact of its being well calculated for the purpose than the excellent 
condition in which his horses always appeared when brought to the post, especially the remarkable freshness which they invariably exhibited in their legs. He had stables at Newmarket, as also at Pigburn, near Doncaster, at which place most of his horses underwent the latter part of their preparation for the Great Northern Meeting.

Yorkshire contains the four best training-grounds in the north of England. Of these, the most extensive is Black Hamilton, on the high road leading from Thirsk to Helmsley. Notwithstanding that the soil is a strong stiff clay, this ground gallops well-the turf being very much intermixed with moss, which prevents it from becoming hard, and preserves it elastic even in the driest weather.

Langton Wolds, the next ground, is extensive, contains every variety of surface, and is principally covered with a short heather, intermixed with moss, affording a fine springy turf for galloping. These wolds, or downs, are divided into the training-ground and the racecourse, by the high road leading from the town to Malton, the latter lying on the right of it; and the only drawback on them is their difficulty of access from the training-stables.

The Middleham Mloors, divided into the upper and lower moor, is the third training-ground, and is open to the same objection as the Whiteclift Moors, on the score of not containing sufficient space; the upper moor contains the best galloping ground. The Whiteclift Moors, about two miles from the town of Richmond, are likewise divided into higher and lower moor. The latter is the racecourse, and is within a mile from the town.

Perhaps the best training-ground in Britain is that of the Curragh of Kildare in Ireland. It is a fine open heath of nearly five thousand acres of elastic turf.

In Scotland, Gullane Links, to the east of Edinburgh, and close to the sea, is the most celebrated training-ground. It is a large tract of sandy soil, never hard, but apt to work into holes.

Whether training-ground be public or private some attention is requisite to keep it in order; and if it be a very poor, weak, hungry soil, occasional dressings of manure will be found the greatest auxiliary possible. The description of manure must depend upon the nature of the land; on some, stable manure will have an admirable effect, but upon almost all tan will be found to be the best.

Rolling during wet weather is, in many instances, indispensable to press in the tracks and holes which have been made by the horses' feet; but the less this practice is resorted to the better, as it must tend to render the land more solid; therefore, the lighter the roller which is used for the purpose, the more advantageous, so that it is sufficiently ponderous to press in the turf which has been misplaced. If, previously to rolling in the spring, some seeds of the finer grasses, which are natural to the land and productive of a firm, tough, and elastic sward, be sown, it will add greatly to the verdure and improve the closeness of the turf. In order to avoid the use of the roller as much as may be, the boys should be sent on to turn down the footmarks and tread them in their proper places whenever the surface is so soft as to be cut up. This should be done when they have not got their lorses to attend to. The employment keeps them out of mischief and does good in another way.

Exercise.-The exercise necessary to get a racer into proper condition varies of course with constitution, the forward or backward state of the colt, and other incidental circumstances; and in no one thing is the talent of the trainer more evinced than in regulating the work according to the time for preparation, the "sluggish" or "free" disposition of the animal, and the nature of his coming engagements. Exercise is of three degrees-walking, galloping, and sweating. After getting the horses into form by walking exercise every morning and evening, for from half an hour to two hours, as may appear requisite, the training-groom commences giving them short gallops, increasing their length gradually, as his horses' condition and wind improve; taking care, however, to observe from day to day the manner in which they stand the work, and relaxing or adding to it accordingly. These gallops not only have the effect of preventing a horse from getting on too much Alesh and of improving his wind, but at the same time they teach him to stride and to be active on his legs.

At exercise the horses are divided into classes, the arranging of which depends principally on their age, but sometimes on their qualities-such as stoutness or speed; each class having a horse to lead the gallops or sweats. When the pace is slow, a common hack is good enough for this sort of work; but should it be severe, or should the trainer wish to form some idea of the rate of going of any of his untried horses, then a horse of superior powers, and of known public running, is generally selected.

The length of gallops for different horses varies from half a mile to a mile and a half; but distances of three quarters of a mile and a mile and a quarter are most frequent.

The horses being at length in proper condition to undergo sweating, this severe exercise is to be given them from tine to time. While some horses are so extremely delicate, and have to run such short lengths, that they may be brought to the post without sweating, others require this severe sort of exercise as often as three times a fortnight.

In addition to the important task of regulating the quantity of work according to age, constitution, \&c., the trainer must observe the length of ground necessary to make them sweat well; and bear in mind that in the commencement of their training, his principal object is to get the flesh off them. But as they are getting forward in their work, and approach the day of public trial on the racecourse, it will become necessary to increase the rate of going sufficiently to bring them stout to pace.

The trainer, or in his absence a groom he can trust, having mounted a hack, accompanies the horses about to be sweated. The horses are clothed in their sweaters, and, on the way, the trainer gives such directions and advice to the boys who have to ride as they may require, more especially to the head lad, 
who has to lead the gallop and regulate the pace. While the horses are taking their gallop the trainer is oceupied in watching their action and rate of going, making the lads increase or diminish the latter as may be necessary, and taking care to be where the horses are pulled up, so as to perceive the effect of the sweat on each horse.

The ground selected for this purpose should be at least two miles, and, if possible, considerably more in circumference; and a place having in some parts one or more gradual ascents and descents is preferable to a perfect level. According to Darvill, the proper length for a yearling to go a sweat is two miles; for a two-year-old, two miles and a half; a threeyear-old, three miles or three miles and a half; a four-yearold, four miles or four and a half; while a five or six-year-old may, at times, sweat five miles. But, as we have before observed, these lengths are frequently altered from circumstances as the trainer may deem requisite. We consider these prescribed distances purely empirical.

After the horses are pulled up, they should be allowed to stand a minute or two to recover their wind a little, and as it is phrased in stable vernacular "blow their noses." They should then be ridden gently to the rubbing-house, or should there not be one on the training-ground, to the stable, where the lads having turned them about in their stalls, dismount and proceed to loosen their horses' girths and unbuckle their boots. The next proceeding is to heap on the horses a quantity of additional clothing, which has the effect of immediately and considerably increasing their perspiration, and cansing them to break out into a violent sweat. This operation occupies from five minutes to a quarter of an hour, during which time the horses may be refreshed by having their heads wiped and their legs rubbed.

When they are considered to have perspired sufficiently the cloths are removed, and the boys proceed immediately to scrape the sweat off them with a wooden scraper and well rub them down; after which they should be refreshed with a few mouthfuls of lukewarm water, be warmly and drily chothed, and then again walked out until sufficiently cool to be dressed. During their absence from the stable, the stabledoors and windows may be thrown open, the beds set fair, \&c. The length of sweating gallops, and weight of clothing, are matters of much variance in modern and former training.

The Turkish Bath, or more properly speaking, the Roman bath-for the world's masters bequeathed the hot-air bath to the Greeks of the Lower Empire, and from them it was inherited by the Turks, Moors, and Saracens-is by no means a novelty in horse-training. Professor Gamgee, of the New Veterinary College in Edinburgh, speaks of having been consulted by Sir Hedworth Williamson on the substitution of the hot-air bath for the ordinary process of sweating horses then in vogue. This took place at Florence, where Lord Normanby, with some English noblemen and gentlemen, had established races.

We must confess that from a study of the physiology of the horse, and of the phenomena of absorption and excretion in the animal economy, we cannot view this with the fervour of its advocates, by whom it is elevated, as we thiuk with indiscreet zeal, into a panacea for all the ills which horse"flesh is heir to." We shall, however, place before the reader points of Admiral Rous' essay, appending thereto such observations as may tend to elucidate, confirm, or controvert its theories and propositions.

After some laudatory remarks on that very eccentric individual, Mr. David Urquhart, as the introducer of the said Turkish or Roman bath, Admiral Rous proceeds to say:- "There was always a difficult problem to be solved. How is a trainer to prepare a horse to race? alias to get his inside clean and his muscles in full vigour, without the assistance of strong purgatives, and galloping distances under a weight of heavy woollen clothing. I do not deny the necessity of giving horses the strongest exercise, wisely adapted to their age and condition. It is proved that you can lighten a horse's frame as well by the operation of a hot-ail bath as by a four-mile sweat; and the question arises, which is the best practice to get them into condition? My belief is that a smal't two-mile or a three-mile gallop with the horse stripped, carrying a light weight, and a hot-air bath afterwards, is more beneficial to a horse's lungs, and, no doubt, to his legs and sinews, than a four-mile gallop under heavy clothes. Try it on a jockey; let him take his usual walk of nine miles under sweaters; and the next time walk half the distance, and then take a hot-air bath; I fancy he will find himself a lighter, a stronger, and a wiser man after the second process. Owing to the exhaustion of a four or fire mile sweat, a horse is only fit to walk the following day, and many horses are annually disabled by this severity; but after a hot-air bath a horse is fit and ready for any task. I therefore pronounce the hot-air bath a most powerful and valuable auxiliary: with this assistance you may bring an infirm horse to the post which would break down in two orthodox four-mile sweats. With respect to the sound horses, why should not we try to keep them sound?-is not prevention better than cure?

"The Roman bath invigorates a horse's frame, gives increased action to his liver, improves his appetite, cleanses the pores of suppressed perspiration, and fortifies the slin from extreme heat and cold; the joints become more supple, the sinews more elastic, and the heart, lungs, and kidneys being freed from fat, lorses are able to take the strongest exercise without suffering from internal fever. Rheumatism, sore shins, and cutaneous eruptions are speedily subdued by hot air. Under this system no lorse ought to be exercised in heavy clotbes; in my opinion it is always objectionable to give a horse a sharp or a very long gallop when he is clothed; and looking to hot air as an agent, we may keep our horses sound for thrice the estimated period of their present efficacy; the retcrinary surgeon and the saddler will send in diminished bills: this will balance the expenses of the bath, and will save large sums of money to the proprietors of racehorses."

The next important physiological question noticed, is the 
use of the bath for absorbing the fat and superfluous flesh of the yearling colt. A healthy well-managed colt, which has been allowed space for voluntary exercise, will not, at the age of eighteen or nineteen months, have accumulated deposits of fat that require other means to diminish than the necessary breaking and training proces As to the superfluous flesh spoken of, we had always believed that trainers, in conformity with physiological laws, tried to increase flesh, it being the very element of power and speed; any process, including starvation, that causes the flesh to be absorbed, would prove as destructive to the racehorse as to any other animal. "Whilst I am no adherent to old errors," observes Professor Gamgee, "I consider it equally important that we should not run from one extreme to another. The old errors were of slow growth and have had their sharp errors taken off. New projects, plansible in themselves and warmly advocated, may mislead; and if so, the retracing of our steps may be very difficult and very costly. If the tender yearling could, by being submitted to the hot-air bath, be prepared for trial as to speed and power, what will not art be able to accomplish? Such doctrine contemplates a reversal of some of Nature's fundamental laws; physical power in all animals, as well as mental power in man, increases by exercise."

We omit the Admiral's remarks on the allowance of water to horses in training, as irrelevant to the questions under consideration. The writer proceeds:-

"Thus the raw material, in the shape of a healthy, wellgrown colt, eighteen or nineteen months old, is introduced to the care and tender mercies of the groom. After the usual process of leading him about, lunging him, backing him, his proud spirit bends to the yoke; from gentle exercises he is abruptly called upon to mend his paces, and within fourteen weeks he is tried with older horses, from six hundred yards to half a mile. A trainer may justly complain and object to these early preparations. He generally quietly acquiesces, owing to a natural curiosity to find out a trump, or to be able to select the wheat from the chaff. As far as these early trials are concerned, the experiment can now be made at half the risk of destroying the colt, or, in other words, laying the seed for future unsoundness, by using the hot-air bath for absorbing lis internal fat and superfluous flesh, without having recourse to strong medicine or long preparatory gallops.

"At two years old the trainer considers it necessary to clothe the unfortunate colt more warmly, on the principle that he becomes more tender as he advances in age (a novel doctrine), and he is not satisfied until he makes the horse uncomfortable by a flannel or a woollen hood when he goes out to exercise. A showman thinks it right to dress up his dancing dogs or his monkey at a fair; that is quite admissible: but a hood makes a horse susceptible of cold; it is laying a trap for a sore throat. A hood is excusable in a railway van: for all other purposes it is only good for trade. Ask a trainer why he uses it, you will receive an unmeaning answer.

"If their predecessors quarrelled with fresh air, and stopped up the holes for the pure love of ammonia, which propagated the disease of roaring, and made a great many horses blind, there was one redeeming point, they took out their horses twice a day to exercise for eight montlus in the year, which gave two opportunities for reventilating a putrid stable. This practice was in vogue for many years after I went to Newmarket and highly approved; it is now changed because it disturbs the domestic felicity of the trainer.

"You would imagine that during the height of summer the horses would be out at daybreak, when the dew makes the grass pleasant to their feet, and that the work would be over and the stables made up and the horses fed by seven o'clock. Not at all. Instead of exercising their horses in the cool of the morning, and taking them out a second time at 6.30 p.m. to walk them for an hour when the stables might be thoroughly cooled, the trainers consider it a more judicious plan to coinmence work at seven in the morning, and to keep the horses out till ten o'clock, frequently the hottest time in the day, before the breeze springs up. By this policy they evade the trouble of saddling their horses a second time.

"When oxygen is a scarce article in the stable, and ammonia gets the ascendency, horses suffer from lassitude, loss of appetite, and a dull coat significant of disease. This is expected as a matter of course, and parried with calomel and aloes.

"When a horse's coat breaks in October, and racehorses are deeply engaged, a cough is heard, and coughing runs like. wildfire through the stable. What is this owing to? The stable temperature charged with ammonia, the warm clothes, flannel bandages, hoods, and deleterious physic have won the battle; every horse's skin impregnated with suppressed perspiration was susceptible of disease, and they have caught what the trainers have so studiously engendered. I have known more horses coughing in a stable at Newmarket than in all the cabs from Hyde Park Corner to Somerset Honse, simply because the cab-horses stand for fourteen hours in the open air, and racehorses are shut up for twenty-one hours in a hot stable. The laws of Nature cannot be defied with impunity.

"The trainer now has a lucid interval. He turns the horses into open boxes from a temperature of $65^{\circ}$ to $40^{\circ}$; the cold air invigorates them, the fever is checked, the cough ceases, and the horse gets well in a week. Woe to the invalids if they are still confined to the warm stable. They may be on the sick list for months. But the racing season is over, and the money is lost. Again the trainers fall back to the ancient system, and all experience is lost upon them."

Four-fifths of Admiral Rous' essay are devoted to an eulogy of pure oxygen, and a fierce denunciation of ammonia and au exhausted atmosphere. Ou these points no one will join issue; but their merits seem to be confused inextricably with those of low or high temperature: and "pure air" is almost converted into a synonym for "cold."

Of clothing the Admiral says :-

"My training theory is that no racehorse should be clothed beyond a linen or a cotton sheet, either in the stable or at 
exercise, excepting during a cold winter, when a simple rug may be allowed both indoors and when his work is confined to a straw bed during a frost. It is an outrage on common sense to say that an old horse is more tender than a sucking foal The hot-air bath, by cleansing and opening the pores of the skin, restores its tone and reinstates the animal in his original purity to despise the changes of the weather, the trainer having exerted all his ingenuity to make him tender, helpless, and susceptible. As the lot air stimulates the action of the liver, physic will seldom be required, and then in very small doses. When a yearling comes into the stable fat and fleshy, instead of giving him extra slow work and keeping him out four hours, it saves a great deal of trouble to physic him well. Extra physic is less troublesome than extra work, and it is supposed to be all the same thing in the end.

"From the 15th of March to the end of the racing season the horses should be exercised twice a day, and be kept out altogether four hours, instead of the present system, from two hours and a half to three hours at one interval. They should always have access to water, or, according to the American system, it should be offered to them in small quantity six or seven times in the course of the day. Most horses you cannot feed too lighly when they are in strong work; and my belief is that no three horses require exactly the same food and the same exercise.

"A stable should be built on brick arches, unless the foundation is chalk or limestone. Rooms about seventeen feet in height, witl large windows, ventilated near the ceiling by hollow or perforated bricks; no mangers to the stalls or boxes; large white wooden basins hooked on to staples in the wall for corn-the said basins to be taken away and washed when the horses have fed; and in every stall a fixture for a water-pail. 'There are three appendages necessary to a perfect establishment: a dormitory for the lads, who should not be allowed to sleep in the stable, because, when the night air is cool, they will shut the windows; a Roman bath; thirdly, a weighingmachine, to register every horse's weight after each operation of the lıot air, and after every public race or trial. A wooden grating over the floors of the stalls, fitted with iron hinges to trice up to the sides, in order to be washed and purified, would be a great improvement, and there would be no necessity for straw litter."

Dr. F. Page, an eminent plyysiologist, thus gives his decision on the "last new adjunct" to training:- "I fear the plausible reasoning upon this subject may have a mischievous influence on the minds of persons to whom it is more particularly addressed, and thus propagate the humbug. Everybody who understands the structure and functions of an animal must be quite aware that it is not only having the machine in a favourable condition-that is, sound, with the muscles fully developed, and the system free from superfluous flesh, \&c.-but that the force or power by which the machine is propelled, and by which the animal undergoes its great exertion, shall be at its maximum; without this the machine, however perfect, is useless. I maintain that the nerve force or vital power in an animal subjected to this parboiling system will be so depressed or exliausted, so enervated, that he will be good for nothing for racing purposes; and therefore the idea of training racelorses by such a system is perfectly absurd.

"What authority has any person for saying that the fat of the animal is the only tissue removed by sweating under a ligh temperature? Why may not the muscular, the tendinous, and the nerve fibre be reduced, and thus rob the animal at once of his meclianical powers, instead of increasing them? Is the Turk famous for his great muscular development? lis great powers of endurance? Or is he not emasculated both in body and mind by the use of this great depressing agent? Let an advocate for the Turkish bath subject himself to one every day for a week, and see what he will be fit for. He will prefer his quiet cigar on the sofa to a gallop round the Bury Hill, I imagine. The feeling of the racehorse will be the same, for all animals are governed by the same plyysical laws.

"This bath may be of use in some cases of disease, and, under judicious advice, highly beneficial; but as to its application to animals in health for training purposes, it is a 'delusion, a mockery, and a sluam."

Having thus placed the leading pros and cons of this moot point before our readers, we leave the subject to the criterion of "Time," which "tries all things;" coupled with the opinion that the hot-air batl will be found in practice ratler a remedial application for abnormal states of the horse's condition, or a direct agent for the removal of disease, than a systematic adjunct to ordinary training processes.

TRIALS.

Among the divisions of practical training which especially require the attention of the trainer, the trials of racehorses require particular notice; for unless the greatest care be taken in selecting a horse of known public running, and in proper condition at the time, the nicest skill in regulating the weights, according to age, fixing the distance, \&c., and putting up the best jockeys, will not prevent the trainer and his employer from being misled by the result.

The necessity of ascertaining a horse's powers before lie is brought cut to run in public, must be obvious to every one, and it is a subject of no mean importance; by the opinion which is formed of him in his trials, the propriety of paying forfeit, or starting him for such stakes as he may be engaged in will depend; and, furthermore, the propriety of backing him for a still greater sum must be determined.

It is a very common thing to find that old horses, as they improve in stontness, diminish in speed; thus, single-handed, they are not honest tests of the merits of young ones. To have a trial which is really to be depended on, it is requisite to start two or three young ones, with a horse four years old or upwards, who has not lost his speed, to make the runuing; at the same time, also, it is necessary that the latter has recently been running in public-they are found to vary so much at different times of the year. Before it is possible to form an 
accurate estimate of the powers of a horse, three or four trials must be obtained, and the important fact established whether his speed or stoutness be his specialty. The weights at which the horse is tried must depend upon the goodness of the trial horse and the time of year, which latter circumstance may easily be determined by reference to the Calendar. The nature of the course, whether hilly or flat, on which a horse can run to the greatest advantage should be ascertained; some little judgment of this may be formed in the common course of exercise; but it may be taken as an established fact that, previously to running, no true opinion can be formed of any horse, except after two or three well directed and unbiassed trials; favour and affection to any animal, pedigree, or owner, being completely set aside in the deductions made from the experiment.

If trials are to be looked upon as affording real information, each horse must be prepared with as much scrupulous attention as if he were going to run in public; unequivocal proof should be sought for, and wothing deemed satisfactory until it is established. In order to ascertain a horse's power, it is obvious that he must be beaten; because, however often he may be tried, either in private or in public, it is impossible, so long as he be a winner, to say how much farther he could have won had there been a horse superior to his second to have urged greater efforts of the victor. The rock upon which so many persons founder in trials is having a slow old horse in the capacity of schoolmaster-one whose speed is so much reduced that, at the distance which young ones are tried, he cannot go fast enough to get them out; in consequence of which they win their trials, and are immediately supposed to be flyers. The best horse to try young ones with is a speedy animal who can run but a mile; if his rider have orders to make the pace as good as he can, he will stretch the tyros, and give some measure that may be relied upon.

It frequently happens that a boy is put up to ride the trial horse, and jockeys are employed to ride the juveniles. This is just reversing the order of propriety, because the boy is required to perform the most difficult and important duty, that of making the running, and the experienced jockeys being upon the young ones, their performances are made to appear more Alattering than they really ought to be.

There are many persons who place but little faith in private trials. That they should not be held cheap in many instances is neither to be wondered at or condemned; independently of the mistakes which are made, the misrepresentations of the results are frequently so great that little reliance can be placed on them.

There is no contrivance by which more money can be thrown away, than in so-called trials. The trial horse is often stale with hardly a leg to stand on, at high weights, and perhaps on a course which does not suit him; and thus is brought out against a young one in the highest possible train, iresh, and ready to fly out of his skin, and a light weight on his back. The old one, whether it be his forte or not, must inake the play; and, as naturally may be expected, the young one runs up to the old like a shot, as the trainers say. He is accordingly backed heavily, and on the day gets a comfortable beating, to the great surprise of those who are not in the secret. The solemn secrecy which, on many occasions, is employed to keep the result of a trial from the knowledge of a vulgar public is oftentimes exceedingly unnecessary, as well as marvellously troublesome to those who are concerned. Indeed, if a trainer knows his business, he need not care who witnesses the trial; because, if properly managed, no man can be wiser from what he sees-indeed, he is certain to be misled. Here, however, to avoid inculcating a principle of deception, we must explain the difference between misinforming a friend, and using those precautions which the peculiarity of the transaction requires for the purpose of maintaining secrecy into that which the intruding eye of a bystander has no right to penetrate.

Any man who would be guilty of misinforming an acquaintance, and thereby inducing him to back a bad horse, does so for the purpose, directly or indirectly, of robbing him. It matters little whether he actually win from the person so deceived, by directing an agent to bet with that individual. His friend is caused to lose his money; others follow his example in backing the horse; and the treacherous knave wins his stake from some one. Such deception cannot be too severely condemned, or too conspicuously exposed to public contempt. But against other persons, who will not scruple to resort to any measures to gain information for their own pecuniary profit, to the exclusion of all who are first entitled to that profit, on a subject which they have clearly no right to be permitted to discover-all stratagems are warrantable for defeating their object.

Every man who acquires fair and honest information has an undoubted right to turn it to his own advantage. A merchant learning from certain sources that a rise or fall in the markets is likely to take place, buys or sells any commodity in which he deals: so has any one who bets a right to avail himself of the knowledge of a horse's powers, an equal right to back him or to lay against him; but the owner of the horse is clearly justified in keeping that secret to himself, or submitting it only to his intimate friends.

In order, therefore, to defeat the ends of those who may be desirous of watching trials, one ruse is readily managed-for the horses to gallop on some distance beyond the place where the trial actually terminated, and, in so doing, to change places; when it is very easy to have the horse which won the trial last at the point where a spectator imagines it is finished Another thing-the weights never ought to be suffered to transpire. Thus, by having saddles and saddle-cloths, the weight of which none of the boys or other persons about the establishment have any knowledge of, the secret cannot transpire through their agency.

That the reader may have a thorough understanding as to the regulations concerning trials, he should become acquainted with the laws of the Jockey Club; we would also recommend to the trainer the careful perusal of that part of Mr. Darvill's 


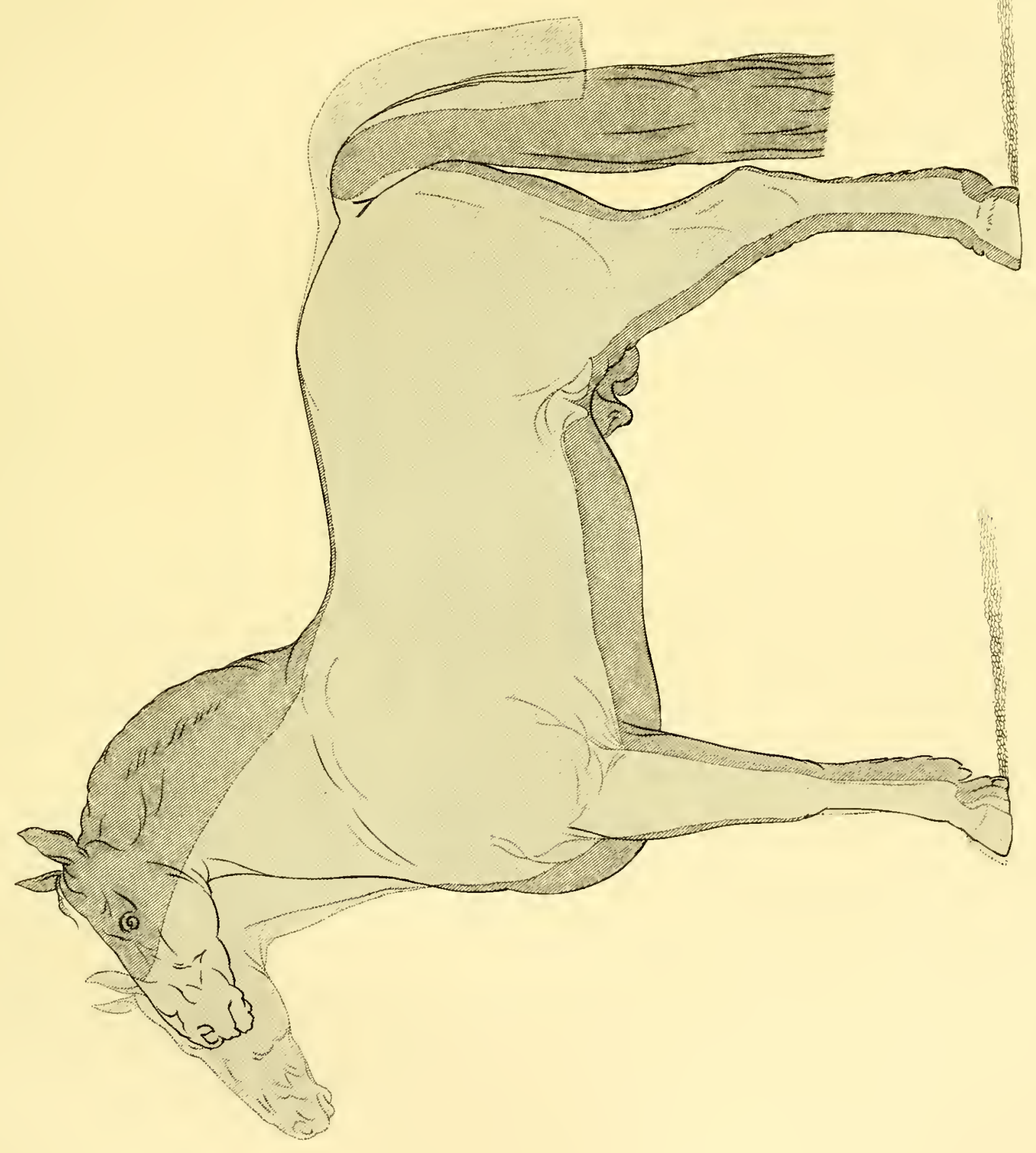



excellent work on racing which treats on this subject, and in which he will find proper directions for trying horses of every age, and of every description of temper and constitution.

In no calling of life are shrewdness and caution more required than in the trainer; in fact, without these qualifications a man might as well attempt to scale the moon as to do any good on the turf. In addition to these indispensables, he should be of the strictest integrity; which, sooner or later, amply repays its possessor, by obtaining for him the confidence of his employer and the public. He must also be sober, that he may always have a clear head to study and attend to the various tempers and constitutions of the horses placed under his management, so as to do the best with them in training, and afterwards run them to the best advantage. Finally, he must be close to all the world, except his employer, concerning the secrets of the stable.

As the trainer is expected to know everything relating to a racehorse and to the turf, his apprenticeship to his calling cannot begin too early in life. The knowledge we speak of may be briefly defined under the following heads, which are not unworthy the attention of those noblemen and gentlemen on the turf, who may not be ashamed of learning.

In the first place, the trainer should acquire a competent knowledge of the Stud-book, so as to be able to advise and guide his master in the purchase of brood mares, the selection of stallions, or even the purchase of young horses to run. This has reference to their selection with regard to pedigree, or what is commonly called fashionable or running blood.

From actual observation, in preference to theory, he should endeavour to make himself a good judge of the formation and action of a racehorso The very nature of his calling, of course, gives him abundant opportunity of doing this.

The Racing Calendar should be his constant study and companion; the laws, rules, and regulations of racing, he should have at his fingers' ends, and he should know with accuracy the running of all the horses of the day, the length of the courses they run over, the weights they carried, and the opponents they defeated.

In addition to mere works of reference on racing, and the best works on the training and management of racehorses, the trainer should furnish himself with the works of our best veterinarians, and make himself thoroughly conversant with the different symptoms, modes of treatment, remedies, \&c., which they explain and recommend. A catalogue of such works can be readily obtained at booksellers who deal in sporting works. A visit involving a short stay at a veterinary college will be of immense service in his practice.

In conclusion we must mention, as not the least important of a trainer's duties, that, in a moral point of view, he is bound to make the lads under his control as happy as circumstances will permit, to instruct them in knowledge fitted for their station, and to keep them from the temptations of bad examples which so much surround them. John and Isaac Day, and several of our most eminent trainers, were and are remarkable in these creditable particulars.

\section{CLOTHING THE RACER.}

In the article on the Turkish Bath, we have given inoidentally the opinions of Admiral Rous on clothing, which we look upon as rather heterodox. Upon this point, and the routine of stable physic, we shall here say a few words.

Clothing forms an important article in the economy of the training stable, and is of the greatest utility to the urainer, as by its use in sweating his horses, he is enabled to reduce them to the necessary lightness of body, without running the risk of injuring their legs by extra strong gallops, or their constitutions by physic; these latter, and the hot-air bath, being the means of effecting his object.

The clothing in general use in the racing stable is made of a sort of kersey check, of much finer and lighter quality than that which is used for hunters or other horses. It may be of whatever colour the owner may fancy; and the initials of his name are commonly embroidered on it.

The clothing may be divided into the following parts, viz.:-the sheet, breast-cloth, quarter-cloth, pad-cloth and hood; the latter piece being generally used to throw over the horse's loins after he has been dressed, instead of what was formerly called the fillet cloth.

These different pieces are secured with proper rollers and strings; but as these and other details are perfectly understood by saddlers, it is not necessary to proceed with furthes particulars; a fow general explanations and remarks are, therefore, all we propose to offer.

The clothes commonly called sweaters are made of swan's skin, a sort of woollen stuff. They consist of nearly the same pieces as those mentioned, and care should be taken that the sheet is of sufficient size to cover the whole body, shoulders and quarters of the horse, and to lap well over beneath his belly; for which purpose Mr. Darvill observes, that the centre part of it should be nearly two yards and a half long. According to the same authority, the breast-cloth or sweater should be made full three yards in length, and three quarters of a yard in breadth.

Judging from the prints of horses sweating, dated the middle of the last century, the hood was not then in use; nor are we aware when this article of clothing was introduced. Of those used in sweating, when only one hood is required, it should have ears to it; but in the case of more than one being required, the last only should have them, to enable the groom to put them on with greater facility. When the trainer deems it necessary to put additional clothing over the abore, he should use old cloths for the purpose, having, of course, first seen that they are in proper repair, and that any necessary alterations have been made. Admiral Rous's condemnation of the hood, we have already noticed.

In the hottest part of summer, lighter clothing, made of serge, linen, or calico, may be used both in the stable and at exercise.

A proper supply of rollers, straps, boots, knee-caps, fetters, \&c., should always be kept in the stable, in such order and 
place as to be serviceable at a moment's notice. A list of these, and of all the other articles of saddlery used in the racing-stable, can be at all times obtained from the principal saddlers at Newmarket, York, Doncaster, Epsom, \&c. The trainer should make it his business to inquire, from time to time, at these places, as to any inventions and improvements in these matter's which may have been made, so as to avail bimself of them if really serviceable.

It is not our purpose, in offering these details and remarks to the reader, to have it for a moment supposed that we are laying down a complete system of training racehorses. We are perfectly aware that it wonld require a rcasonably-sized volume to do this fully and efficiently. Feeling, however, that a work of this nature might be considered incomplete were we to pass this subject entirely, we flatter ourselves that, to the general reader at least, these remarks may not be found altogether barren of interest, as yielding him some little insight into the training and management of the horse in bis highest form. Should fuller information be desirable, we wonld recommend the works of Messrs. Nicholas Hankey Smith, and Darvill, and a series of papers by "Cotherstone," in the Sporting Review; these gentlemen having written after much practical acquaintance and stndy of their subject.

Physic.-The next point to which we would direct the attention of our reader, is the use of physic in the trainingstable; not as administered to horses labouring under serious diseases, and which require the services of the veterinary surgeon, but in those cases which come directly within the province of the trainer.

The occasions we refer to are, when at the end of the autumn, and in the spring, the animal has to undergo a regular course of physic, or, when in training, the state of his legs or any minor ailment may require the use of medicine. On the conclusion of the racing season, after being kept for some months on diry and highly nourishing and stimulating food, and constantly in work on the hard soils of the different race-courses and exercising-grounds, three or four doses of physic, administered with an interval of about ten days or a fortnight between each dose, will be found necessary to get rid of that worn and feverish state commonly known under the name of staleness, and will at the same time bring the horse's legs, which will almost always then be found swollen and inflamed, to their proper size.

In the spring, too, before the animal is again put in training, a repetition of the same treatment is desirable, in order to carry off the grossness of humour he contracts when "soiled." At these periods, it is not necessary that the physic should be of the same strength as that given in training; the preparation for it, however, is the same, that is to say, mashes of bran and oats for two or three days. The precautions and gcneral treatment in use with horses of other descriptions when in physic, should be of course adopted with the racer, and are too well known to require mention in this place.

Horses in training are very liable to suffer from injuries in the legs, from blows while exercising, and other causes, and these cases require the utmost attention and skill on the part of the trainer. He must necessarily stop the horse from his work, as rest is indispensable to his cure. But this remedy is sometimes productive of, if possible, worse evils; for should the accident occur not long before the horse has to race, he may put up more flesh while idle than can be trained off again in sufficient time to bring him in proper condition to the post. It is now that the trainer calls in the aid of physic, and by its judicions use, keeps his horse from getting fat in his inside until his leg shall be sufficiently recovered to stand work. This of course should be gradual; in fact, too much caution cannot be exercised in this respect, and to prevent any risk from the thoughtlessness or trickiness of boys, the trainer should himself watch his first gallops and sweats, taking care to put one of his best and most steady riders on the horse.

Every training stable should be provided with a medicine chest, in which the following drugs, \&c., should be kept; and to prevent accidents, as some of them are deadly poisons, the key should never be out of the possession of the trainer.

$\begin{array}{ll}\text { Aloes, Barbadoes, } & \text { riesun, } \\ \text { Alum, } & \text { Sal anmoniac, } \\ \text { Arrow-root, } & \text { Spanish flies (Cantharides), } \\ \text { Basilicon, yellow, } & \text { Sweet spirits of nitre, } \\ \text { Camphor, } & \text { Spirit of turpentine, } \\ \text { Castile soap, } & \text { Spirit of wine, } \\ \text { Ginger, in powder, } & \text { Salt, common, } \\ \text { Goulard's extract, } & \text { Soft soap, } \\ \text { Honey, } & \text { Tar, Barbadoes, } \\ \text { Hog's lard, } & \text { Tartar emetic, } \\ \text { Laudanum, } & \text { Tincture of myrrh, } \\ \text { Linseed meal, } & \text { Treacle, } \\ \text { Nitre, } & \text { Vcnice turpentine, } \\ \text { Oil of carraway, } & \text { Vinegar, } \\ \text { Oil, castor, } & \text { Vitriol, blue, } \\ \text { Oil of cloves, } & \text { Vitriol, white, } \\ \text { Oil of olives, } & \text { Verdigris, } \\ \text { Oil of origanum, } & \text { Wax, } \\ \text { Prepared ammonia, } & \text { White lead; }\end{array}$

also apothecary's weights, a measure for fluids, an apparatus for compounding medicines, \&c. In addition to these, the following instruments and articles should be kept, viz.:-fleam and blood-stick; tooth-rasp, with a guard; seaton and curved needles; abscess lancet; firing, searing, and budding irons, casting hobbles, improved balling-iron; drenching horn, flannel for fomentations and poultices, woollen and linen bandager tow, \&c. 


\title{
THE H UN T ER.
}

\begin{abstract}
THE HUNTER OF THE OLD AND THE NEW SCHOOL-GLENGARRY-FORI AND CHOICE OF A HUNTER-PURCIIASING AND HIRING-TREATMENT IN THE FIELD-OVER-MARKING.
\end{abstract}

The modern hunter, to "live the pace," must be a blood-horse, or one of those very best of stout cocktails, who, with fourfifths of "blood" in them, pass dealer's muster as thoroughbreds. His height should be not under fifteen nor over sixteen hands; over the latter he will scarcely be handy through dirt and at his jumps, under the former standard he cannot so well measure the height of the object before him. True, some exceptional and wonderful, if not quite credible, cases are in tradition of the jumping of cobs and galloways, but these are so very exceptional that they do not invalidate the general rule, that under fifteen hands is too small, and over sixteen is too big for a hunter. In a former chapter, pages 81 to 86 , will be found some general remarks on the conformation of the racehorse, many of whick will apply, with little modification, to the modern hunter. In a work like the present, which aims at giving the best thoughts of the best thinkers, and the experiences of the most practised upon the raried and numerous subjects of which it treats, it would be unpardonable to omit the neatest sketch of what a modern hunter is or should be, as depicted by that facile princeps of hunting writers, "Nimrod," in his celebrated Quarterly Review article, "The Chase."

"The half-bred horse of the last century was, when highly broken to his work, a delightful animal to ride; in many respects more accomplished, as a hunter, than the generality of those of the present day. When in his best form, he was a truly-shaped and powerful animal, possessing prodigious strength, with a fine commanding frame, considerable length of neck, a slight curve in his crest, which was always high and firm, and the head beautifully put on. Possessing these advantages, in addition to the rery great pains taken with his mouth in the bitting, and an excellent education in the school or at the bar, he was what is termed a complete snaffle-bridle horse, and a standing as well as a flying leaper. Held well in hand-his rider standing up in the stirrups, holding him fast by the head, making the best of, and being able, from the comparatively slow rate at which hounds then travelled, to pick or choose his ground-such a horse would continue a chace of some hours' duration at the pace he was called upon to go, taking his fences well and safely to the last; and he would frequently command the then large sum of one hundred guineas. But all these accomplishments would never have enabled a horse of this description to carry the modern sportsman, who rides well up to hounds, on a good scenting day, over one of our best hunting countries. His strength would be exhausted before he bad gone ten minutes, by the increased pace at which he would now be called upon to travel, but to which his breeding would be quite unequal; and his true symmetry, his perfect fencing, his fine mouth, and all his other points, would prove of very little avail. If ridden close to the hounds, he would be powerless and dangerous before he had gone across half-a-dozen Leicestershire enclosures.

"The increased pace of hounds, and that of the ? orses that follow them, have an intimate connection with each other, if not with the march of intellect. Were not the hounds of our day to go so fast as they do, they would not be able to keep clear of the crowd of riders who are now mounted on horses nearly equal to the racing pace. On the other hand, as the speed of hounds has so much increased, unless their followers ride speedy, and, for the most part, thorough-bred horses, they cannot see out a run of any continuance if the scent lies well. True it is that, at the present time, every Leicestershire hunter is not thorough-bred; but what is termed the cosktail, or half-bred horse of this day, is a very different animal from that of a hundred years back. In those days, a cross between the thorough-bred, or perhaps not quite thorough-bred, horse, and the common draught-mare, was considered good enough to produce hunters equal to the speed of the hounds then used. There was not such an abundance of what may be termed the intermediate variety of the horse in the country - 'pretty well bred on each side of the head'-which has of late years been in demand for the fast coaches of England, in which low-bred horses have no chance to live.* Mares of this variety, put to thorough-bred stallions, and their produce crossed with pure blood, create the sort of animal that comes now under the denomination of the half-bred English hunter, or cocktail. These are also the horses which contend for our several valuable stakes, made for horses not thorough-bred, though, when brought to the post, they are sometimes so much like race-horses in their appearance and their pace, that it would be difficult to detect the blot in their pedigree. A prejudice long existed against thorough-bred horses for the field, particularly such as had once been trained to the course; and in some quarters it still lingers. It is argued by their opponents that the thinness of their skins make them afraid

* The reader must bear in mind that though this was written before the locomotive had thrown the "fast coaches" off the road, the fact of the improved racing blood of the modern hunter is yet more general. The park hack of the present day would have been a cocktail racer, if not a so-called "blood-horse," of the last geueration. The popular prejudice against the thorongh-bred is now extinct. 
of rough black-thorn fences, and that they lose their speed in soft, or what, in sporting language, is termed deep ground; also, that having been accustomed from their infancy to the jockey's hand, they lean upon their bits, as when in a race, and are therefore unpleasant to ride. Such of them as have been long in training may undoubtedly be subject to these objections, and never become good and pleasant hunters; but when purchased young, and possessing strength and bone, they must have many counterbalancing advantages over the inferior-bred horse. So far from not making good leapers, the firmness of bone and muscle peculiar to this variety of the breed is prodigiously in favour of that desirable qualification. [ndeed, it bas been truly said of them, that they can often leap large fences when lower bred horses cannot leap smaller ones, - the result of their superior wind when put to a quick pace.

"Whoever wishes to see two distinct species of the horse in the most perfect state, should go to Newmarket and MeltonMowbray-to the former for the race-horse, to the latter for the bunter. In no place upon the earth is condition attended to with so much care, or managed with such skill, as in this renowned metropolis of the fox hunting world. Indeed, we conceive it would be useless to expect horses to live with hounds in such a country as Leicestershire, unless they were in condition to enable them to contend for a plate."

Colo tel Cook, in his Observations on Hunting, fully indorses this $\mathbf{v}$ tew. "Many fox hunters," he says, "prefer thoroughbred horses, others cocktails; I always gave the preference to the former, if it was possible to get them. It is the general opinion that thorough-bred horses cannot leap so well as cocktails: I think otherwise; and if you will try the experiment, by taking ten young horses of the former, and ten of the latter sort, I am convinced you will find the thorough-bred ones to have the advantage, and naturally to clear their fences with more ease to themselves. Horses that have been in training for years cannot be expected to make hunters; but, nevertheless, what superiority has a thorough-bred one in every respect -above all, in speed, bottom, and wind? It often happens, when a cocktail is at the height of his speed, a thorough-bred horse is only at three-quarters, and the latter will always go through dirt (as the term is) best." This absolute opinion requires some qualifications. A cocktail, with a well-placed head, a good bridle neck, high withers, deep and oblique shoulders, broad and low-placed knee, muscular arms, deep girthing-place, good loins, muscular and blood-like haunch and tbigh, and low-placed deep hocks, such as Harry Hall has drawn in the opposite plate of GlengarRY," should bave our

- The following note from the artiat accompanied the portrait of ALENGAREY :- " He i a dark-bay horse, with black points, clear of white, standing 15 hands $3 \frac{1}{2}$ inches, rather long on the legs, with magnificent ahaped ahoulders -neck rather thin and atraight; is very deep in the girth, round in the barrel, and well ribbed home; has great power in his thighs, Lina, and hindquarters. He hes been in the posaession of his present owner, Mr. Sadleir Bruere, for eight year, and has been hunted now for nine years, and is a most extraordinary animal for endurance and bottom. Mr. Bruere has regularly vote for a welter weight: all but his head, which we cannot admire-but " handsome is that bandsome does."

In the selection of a hunter a primary consideration is the nature of the country to be hunted over. In stony and thickly enclosed countries, the beavier and lower-bred borse may get along creditably; but in the best countries where "racing" is required, such an animal is "out of the bunt" in no time. Where a heavy deep soil predominates, presenting also a large portion of ploughed ground, intersected by wide and strong fences, like those of Essex and some of the midland counties, such localities will require a horse of sufficient height with much substance; while one with lighter build, and in height not exceeding fifteen hands and a half, is best adapted to a hilly country, as the Surrey Hills, the Sussex and Wiltshire Downs, the Cheviots, \&c., \&c.

The sportsman who rides a welter weight should always be "over-horsed." It is imperative on him that he be mounted on one presenting a combination of power, activity, and durability. These are essential requisites to him, and when such a form is united with high-breeding, the rider, spite of his weight, may hope to be in the right place. Some Irish horses are well adapted for the purpose of carrying heary weights; and if they do not always go at a racing pace, their admirable fencing will tend to make up the defioiency. Neither are the Irish bunters at the present time defective in their breeding, as their local races and steeple-chases testify.

As to the choice of a hunter a condensed enumeration of his "points" will serve to form an ideal of his best form.

The first property of a good hunter is, that he should be light in hand. His head must be moderately small, the neck thin beneath, the crest firm, the jaws wide; it will then form that angle with the neck which gives a light and pleasant mouth.

The forehand should be loftier than that of the racer. A turf borse may be forgiven if his hind quarters rise an inch or even two above his fore ones. His principal power is wanted from behind, and the very lowness of the foreband may throw more weight in front, and cause the whole machine to be more easily and speedily moved. A lofty foreband, however, is indispensable in the bunter; a shoulder as

hunted him through every aeason for the last eight yeara with the Bedale hounds; and the horae has done the work of eny two snimals throughout each aeson-sometimes going twenty-five miles to cover on the morning of hunting, distinguishing himself afterwards in a aevere run of an hour or so, and having perhaps twenty or thirty miles to get home on bad roads. Glengarry has never been known 'off his feed' after such exertions; and could come again in three or four daya as freah as ever. Need I add, he is one of the soundest horaen possible in every way-is very speedy, and a most extraor. dinary careful fencer, and has never been down in his life at any jump; and, at his present age, thirtcen yeara, he can still keep his own with the very best of horaes, and would be bard to beat. To prove his good qualities, his owner ran him for the Hunters' Stakes at Calleuch this apring (vide the Calendar, 1860); and, carrying the heary wcight of 12 st. 7lb., he beat the field of thirteen horses (all of a superior clasa), with the exception of a 5-yr. old mare, and lost his race of two miles by a head only, with the difference of 1st. $21 \mathrm{~b}$. in the mare's farour. He is considered one of the best, if not the very beat, horse that has been known in the county for these twenty-five years at least." 


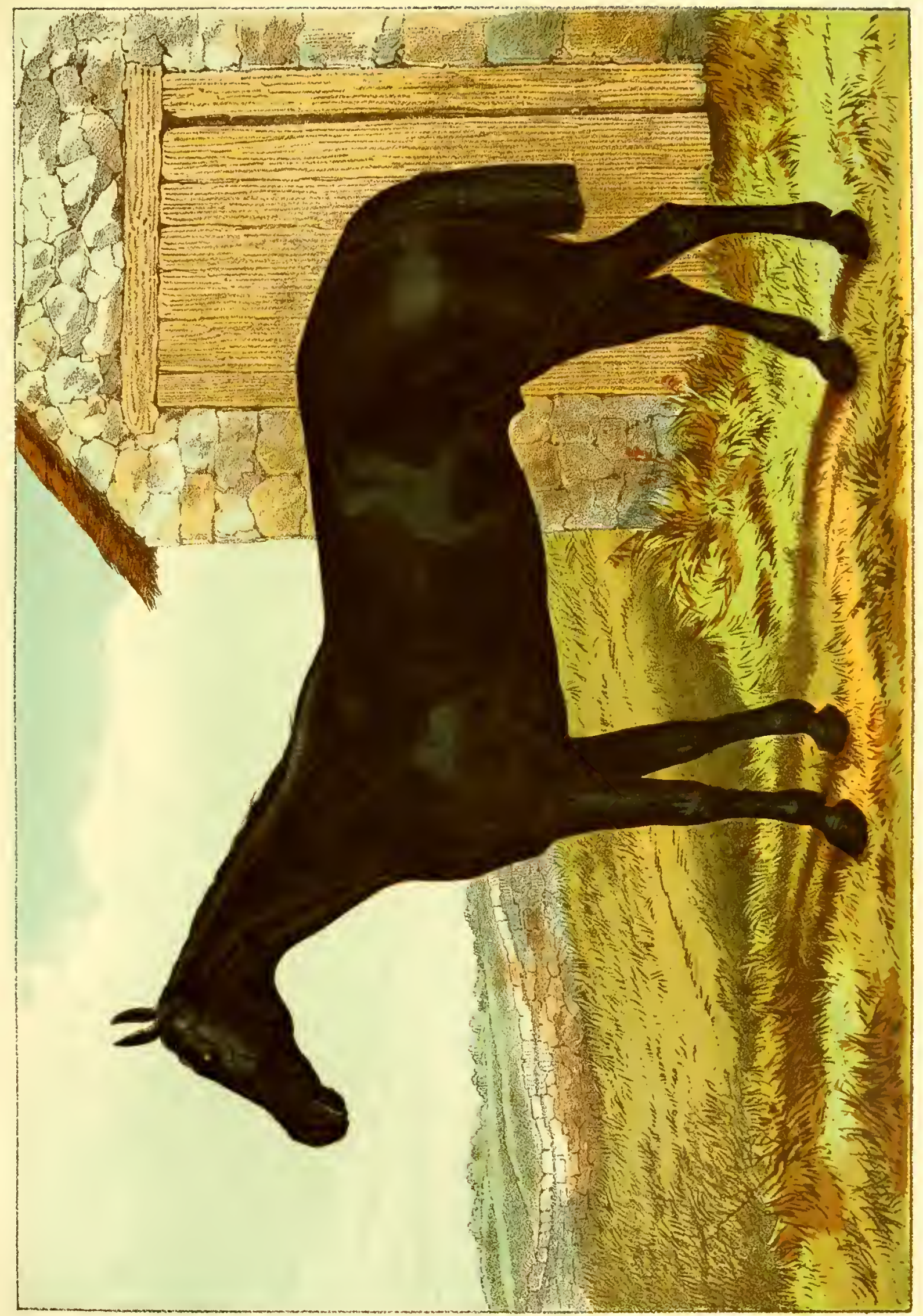



extensive as in the racer and as oblique, and somewhat thicker. The saddle will then be in its proper place, and will continue so, however long may be the run.

The barrel should be rounder, in order to give greater room for the heart and lungs to play, and to send more and purer blood to the larger frame of this horse, especially when the run continues unchecked for a time that begins to be distressing. A broad chest is always an excellence in a hunter. In the violent and long-continued exertion of the chase the respiration is much quickened, and hence more blood is hurried through the lungs in a given time than when the animal is at rest. There must be sufficient room for this, or he will not only be distressed, but possibly destroyed. The majority of the horses that perish in the field are narrow-chested.

The arm should be as muscular as that of the racer, or even more so, for both strength and endurance are wanted.

The leg should be deeper than that of the race-horsobroader as we stand at the side of the horse-and especially beneath the knee. In proportion to the distance of the tendon from the cannon or the shank-bone, and more particularly a little below the knee, is the mechanical advantage with which it acts.

The leg should be shorter. Higher action is required than in the racer, in order that the legs may be clearly and safely lifted over many an obstacle, and, particularly, that they may be well doubled up in the leap.

The pastern should be shorter, and less slanting, yet retaining considerable obliquity. The long pastern is useful, by the yielding resistance which its elasticity affords to break the concussion with which the race-horse from his immense stride and speed must come on the ground : and the oblique direction of the different bones beautifully contributes to effect the same purpose. With this elasticity, howerer, a considerable degree of weakness is connected, and the race-horse occasionally breaks down in the middle of his course. The hunter, from his different action, takes not this length of stride, and therefore wants not all this elastic mechanism. He more needs strength to support his own heavier carcass, and the greater weight of his rider, and to undergo the fatigue of a long day.

The foot of the hunter is a most material point. The narrow and contracted foot is the plague-spot of most of our racing blood. The work of the racer is, however, all done on the turf: but the hoof of the hunter is battered over the hard road and the stony field, and if not particularly good must soon be ruined.

The position of the feet in the hunter requires some attention. They should if possible stand straight. If they turn a little outward there is no serious objection; but if they turn inward his action cannot be safe, particularly when he is fatigued or over-weighted.

The body should be short and compact, compared with that of the race-horse, that he may not in his gallop take too extended a stride. This would be a serious disadvantage in a long day and with a heavy rider, from the stress on the pasterns; and more serious when going over clayey poached ground during the winter months. The compact short-strided horse will almost skim the surface, while the feet of the long-reached animal will sink deep, and he will wear himself out by efforts to disengage himself.

Every sporting man knows how much more enduring is a short-bodied horse in elimbing hills, although perhaps not quite so much in descending them. This is the secret of suiting the race-horse to his course; and unfolds the apparent mystery of a horse decidedly superior on a flat and straight course, being often beaten by a little horse with far shorter stride, on uneven ground and with several turnings.

The loins should be broad; the quarters long; the thighs muscular; the hocks well-bent, and well under the horse.

The reader needs not to be told how essential temper and courage are. $\mathbf{A}$ bot irritable brute is a perfect nuisance, and the coward that will scarcely face the slightest fence exposes his owner to ridicule.

The methods of procuring hunters are of course various. Many are passed from one gentleman to another in the different bunts, while more are purchased from the London and country horsedealers. The inexperienced hand will most readily suit him. self at once in purchasing from among those horses he may see performing in any celebrated hunt. There is a pleasure in horse-dealing, that makes almost every horse comeatable; and it is better for a novice to give a good price at once for a known good horse, than to be taken in two or three times with cheaper but indifferent ones. The enormous prices now given for hunters of character would almost call the grandfathers of some of the buyers out of the grave to stop the bargain. 500 guineas have been frequently paid, and in some instances even a larger sum has been given for a hunter; 200 and 300 guineas are every day prices.

The London horsedealers of respectability furnish their stables with hunters of some pretensions, and occasionally of no small ones either; such, if young, are usually horses bred by sporting farmers, which, having been a little fielded, are then warranted as steady hunters, and many of them turn out so. The west end dealers have high-bred and seasoned hunters of known repute on sale; and, at all times, we believe, they have well-bred young horses, that a little good fielding, under a judicious rider, will make good hunters.

Colonel Cook is favourable to purchasing at Tattersall's, and says, "If you wish to give a large price for what is called a well known made hunter, from one cause or other, there are, every spring, some such valuable horses to be purchased at Tattersall's. It is a lounge three times a week, where you are sure to meet your friends, and can listen with pleasure to their reports of the achievements of the different packs of hounds the season past, and the arrangements for the future. Suppose you purchase half-a-dozen young horses, at a hundred guineas each, to carry fourteen stone; if two ont of the six turn out well, you ought to be satisfied, as there is every probability of your selling the remaining four for 50 each, barring accidents." We are acquainted with several sporting characters, some of them owners of hounds, who make a point, tow ards the autumn, 
of buying such blood-like nags as are likely to suit their purpose from among those parted with by the Londoners and others, to avoid the expense and trouble of keeping through the winter. These are taken to the country, and, having been tried, the buyers select perhaps three out of five that will suit either themselves or others. The remainder they sell, probably by the same hammer, at $£ 5$ or $£ 10$ loss, still leaving the others decided bargains; and, if so inclined, "obliging a friend" with one of the remaining three, at a "good figure," serves to pay for the whole lot.

Masters of hounds, who have sufficient and extensive range both of paddock and stable, have many better opportunities of obtaining horses than by breeding them. Horse breeding, except on fancy occasions, or when it is done from some particular strain, where all the progeny turn up trumps, is a losing speculation to most gentlemen. If such an one should be a thorough judge of colts- $\mathrm{a}$ judgment by the bye that requires half a life and close attention into the bargain to gain-we repeat, if he be possessed of this judgment, he can use it to great advantage in sclecting from the colts of the neighbouring breeders such as promise well. These being picked up as occasion offers, at three or four years old, having been already early handled, bitted, and backed, but not worked, are now to be trained, and gradually conditioned, and worked in turn by the under-attendants in the field, which soon enables the eye of the master to judge what will suit and what will not. The 10 or 50 guinea horse thus soon grows into a 200 guinea hunter; and others, rejected from the hunting-stable, fetch 80,90 , or 100 , for the saddle, cabriolet, brougham, \&c.

IIany country horse-dealers, who reside in the breeding districts, have opportunities of furnishing their customers with horses of high hunting qualities: but the best of these are generally collected and brought to the great metropolitan or provincial emporiums.

The hiring of hunters is a modern custom, and much favoured by the facilities for human and equine locomotion afforded by the development of railroads." The hiring may be by week, month, or season - and in some cases includes groom and appointments of every description. To foreigners, who come to this country for a few months; to mercantile and professional men, who can spare only a few weeks in the hunting season; this mode is most convenient, and, we think, economical also. Speaking of Leamington-and it is the same in many other parts of the country-Lord William Lennox says :- "If a gentleman distrust his own judgment, or does not like the trouble and expense of getting such a stud together, he has nothing to do but to hire them in the county (Warwick). In the town and neighbourhood of Leamington he will find plenty of sporting liverymen, farmers, and horsedealers, who, for a fair consideration, and with the chance of

- The reader will find this point dilated upon amusingly in a couple of light papers by Lord William Lennox, called "Chaunting for the Million," aul " Dporting Life from London," in the collection published by his lord. whip entitled Merrie Ingland: London, Newby, 1859. selling, will furnish him with horses that can go the pace, and do the trick."

Of the love of the chase inherent in the old hunter so many anecdotes are told, that a small volume might be filled with them. In the chase, in the days of his activity and strength, he shares the enthusiasm of his rider. No one who has seen an old hunter turned into a park for life, but must have marked his animating when the distant cry of the hounds or the horn of the huntsman meets his car. If power and chance is left him, he will join the chase, and come in at the death. It is recorded by an unimpeachable authority, that a hunter, who had shortly previous been fired in both hind legs, and placed in a loose box, with a hatch-door four feet high, and an aperture of three feet square above it, hearing the cheering of the huntsmen and the cry of the dogs, sprang through the opening, and joined the hunt. The horse was nearly sixteen hands, and master of fifteen stone.

It is, then, easily credible that, entering as fully as his master into the sport of the day, the horse disdains to yield to fatigue, and voluntarily presses on, until nature is exhausted, and he falls and dies; but, much oftener, the poor animal intelligibly enough speaks his distress-unwilling to give in, yet painfully and falteringly holding on. The true sportsman, though unwilling to relinquish the chase-he who "is merciful to his beast"- -soon recognises the symptoms of ixcessive and dangerous distress. To the drooping pace and staggering gait, and heaving flank, and heary bearing on hand, will be added a very peculiar noise. The inexperienced may fancy it to be the beating of the heart; but that has almost ceased to beat, and the lungs are becoming gorged with blood. It is the convulsive motion of the muscles of the belly, called into violent action to assist in the now laborious office of breathing.

Over-working the hunter is a too frequent occurrence, and often requires very judicious and prompt treatment to save life. It unfortunately also happens, that when death does not immediately ensue, from the congestion which has taken place in the lungs, either broken wind or founder follows, and thus the horse is equally ruined for active service. We will, however, premise, that there appear to be two dangers to be apprehended from inordinate exertion; one from a cessation of the powers of life, the other from the tendency which such inordinate excitement has to produce congestion of the lungs, or active inflammation of some of the vital organs: sometimes spasm of the midriff occurs, and rupture of it has taken place.

When the vital powers have been brought almost to a stand. still, the horse with great difficulty reaches home, and often scours, and stales bloody urine on his journey there. $\mathrm{He}$ breathes with irregularity and difficulty; becomes hot and cold by turns: or a clammy sweat breaks out, at first partially, but if he cannot rally, it becomes universal. His skin has a peculiar feel and loses its elasticity; the haw* is drawn forward; the nose, at first fiery, now becomes pale; the ureath-

\footnotetext{
- See in Glossar $\mathbf{Y}$, post.
} 
ing is hurried, and the pulse is found to be tremulous, and almost invariably intermitting. Some cases are marked with a settled determination in the horse not to lie down; while others not only lie down, but are with difficulty made to rise again. Bleeding as a remedy is commonly resorted to; but Blaine advises, if no active symptoms of inflammation are present, not to do so. Place the hand on the chest; does the heart vibrate quickly rather than beat lustily, by no means bleed. Press any one of the larger veins, and, unless it swells up at once, let bleeding alone, at least until the medical adviser arrives. Should it, however, happen that no veterinary surgeon is near, if the breathing becomcs hurried, the nostrils dilated, and the horse reaches out his neck as though reaching for more rein liberty, if the linings of the nose, although at first pale, now begin to look flushed and red, and the mouth becomes hot, proceed to bleed. If the vein rises well, make a large orifice, so that it may discharge the blood quickly, watching the effects of the flow. If it rushes out, and the horse does not falter, take three quarts, or even more, away. Let his head be turned to the door, and rub and bandage his legs up. As soon as the first symptoms go off, or his legs and ears become cold, briskly hand-rub them, clothe the body also, and throw up a gruel clyster; and, unless the weather be very cold, allow a free current of air, but clothe the body and give the following:- Sweet spirit of nitre, half an ounce; mix with a pint and a half of gruel. Should retive symptoms of weakness come on, horn down equal parts of gruel and sound ale; and, should the debility increase, horn these down every half hour, with occasional full doses of opium also, to allay irritability in the system, and to arrest the looseness that is usually present.

When active inflammation follows the over-exertions of a hard day, the over-marking does not immediately show itself. The horse probably appears at first only moderately fatigued, but he soon gets a strong shivering fit, accompanied with an oppressed pulse. The lining of the nose becomes highly injected, and the breathing much disturbed. The symptoms which follow vary according to the organ which is the principal object of attack, and the treatment also must vary witl that. While proper medical assistance is procuring, the groom, under these symptoms, with propriety may bleed, back-rake, and bandage up the legs if cold; but he should avoid giving any heating, i.e. stimulating, drinks, under the name of cordials; indeed, he should not give anything supposed to be medicinal until the horse has been seen by a veterinary surgeon.

In the article "Fox-Hunting," in our companion volume, "British Field Sports," will be found some Remarks on "Riding to Hounds." When treating of "Breaking and Training the Horse," we shall aroid useless repetition by noticing the several peculiarities of "Education" required by horses, according to the purpose for which the animal under consideration is intended. The article on "The Paces of the Horse," will slso furnish numerous incidental suggestions.

\section{TRAINING THE IIUNTER.}

Training the hunter is a simple process, all that is required being to bring him into good wind, without, at the same time, reducing him too low in flesh or injuring his sinews; since, on a long chase, more especially over a heavy country, a liorse needs the aid of lis full bodily strength and of his unimpaired tendinous and muscular powers. It is extremely dangerous to ride a horse over the country which is weak in its joints, or has the common hurt on the back sinews; but the danger is tenfold in taking a flying leap upon such a horse where the opposite descent is considerable, and the stress upon his lower limbs in his landing, with a heavy weight upon his back, must be excessive. Training must commence with two or three doses of physic, should the horse be gross and not have been previously trained. A young horse in his first training will require most work; but it is an error of the surest side rather to underdo this business than exceed, because, if a horse come into the field rather under-worked, being full of good meat and heart, the easy remedy is to favour and ride him carefully the first week or two; but should your traininggroom set you upon a horse harassed and weakened by too much exercise, he will get worse as the season advances, and perhaps be totally ruined by the end-exclusive of the probable disgrace of failing you in a long and important day. Old hunters from spring grass can scarcely be trained too lightly; the true test is, that their wind in its course be free and unembarrassed; to that point, however, their exercise must at any rate extend. The lighter the horse's clothing the better, in view of the heats and colds he must necessarily undergo in the chase. An early morning's gallop at a good steady stride, but not speedy, of a mile or two, with a canter after water in the afternoon, is sufficient for the hunter, and two months ought to bring him into good condition. A young horse may have once a week a tolerably sharp rally for one or two miles, a method which should never be practised with a seasoned hunter; with which, indeed, walking exercise may be substituted for the gallop.

Some years since a wordy warfare broke out with respect to "summering the hunter," in which the disputants bespattered each other with much animosity. Fiery zealots arose on either side: the one maintaining the "old" or "natural" system-to wit, the turning out the hunter after his winter's work to a summer holiday in the grass. The other party, at the head of whom was the celebrated writer "Nimrod" (Mr. Charles Apperley), contended that if we wished really to befriend and preserve the animal that has carried us gallantly through many a long day, we nust keep him near us, sonfine him within doors, and feed him upou "hard meat." Mr. William Selby Loundes, M.F.H., turns all his horses out during the summer montls, and insists on its being most conducive to the strength, health, and endurance of his hunters during the liunting season, - a system, of course, like every other about which there is a difference of opinion, to be tested by experience; but for ourselves, while con- 
sidering "turning out" as both humane and advisable in cases of blistering, ill-health, fever, firing, \&c., we must give our vote, from an extensive observation of cavalry and hunting stables, in favour of the in-door system.

Count Veltheim's opinion is strongly in favour of stablesummering the hunter: and he assures us that the cavalry of all continental countries, except 'Turkey, are no longer' turned out in the summer. "I hope," he says, "I may be permitted to adduce something from my own experience, having for nearly thirty years constantly had at my country seat from seventy to eighty horses-partly saddle, partly coach, draught, and breeding horses and colts; and that, from predilection to horses, I have always bestowed particular attention upon them. For a long time it has not been customary on well-managed estates in this part of the country, to turn horses to grass in summer, or to give them green food in the stable, with the exception of brood mares and their foals."

Mr. Apperley's method of summering the hunter is thus stated:- "The first step I should take, would be to put the horse into a loose box, if convenient, and by degrees diminish his corn, giving him an hour's walking exercise as usual. I snoaid then give him two doses of physic, which would not only cool his habit of body so as to prevent the danger of inflammatory attacks, but world have that effect on his legs as would enable me to see what injury had been done to them in his work-whether there were any ligamentary enlargements-any injury to the joints or sinews-any callous substances produced by blows-or, in short, any thing going wrong. The clear state of his legs which this treatment will produce, would prevent the possibility of working in the dark, as they will become finer, to use the language of grooms, in three weeks than they would at the expiration of a three months' run at grass in the summer." (Letters on Condition, p. 104.) We must not, however, do this ingenious writer the injustice to suppose, that he is so wedded to this system as never to relax from it when occasion requires; on the contrary, we find him observing, "so far from beng averse to it (i.e. to turning out), I would strongly recommend it under favourable circumstances. In case of having recourse to blistering it is most serviceable; and, after firing, almost necessary; but then they (the hunters) should be turned out only at night, and into a place where there is but little grass, and have two, if not three feeds of corn a day, but nothing else to eat till they go out, unless it be a few vetches, for four or five days at a time, when they are young and tender, in the months of May or June; but these should not be repeated more than three or four times, as they tend to make horses very fonl, and when in pod are most injurious to them." 


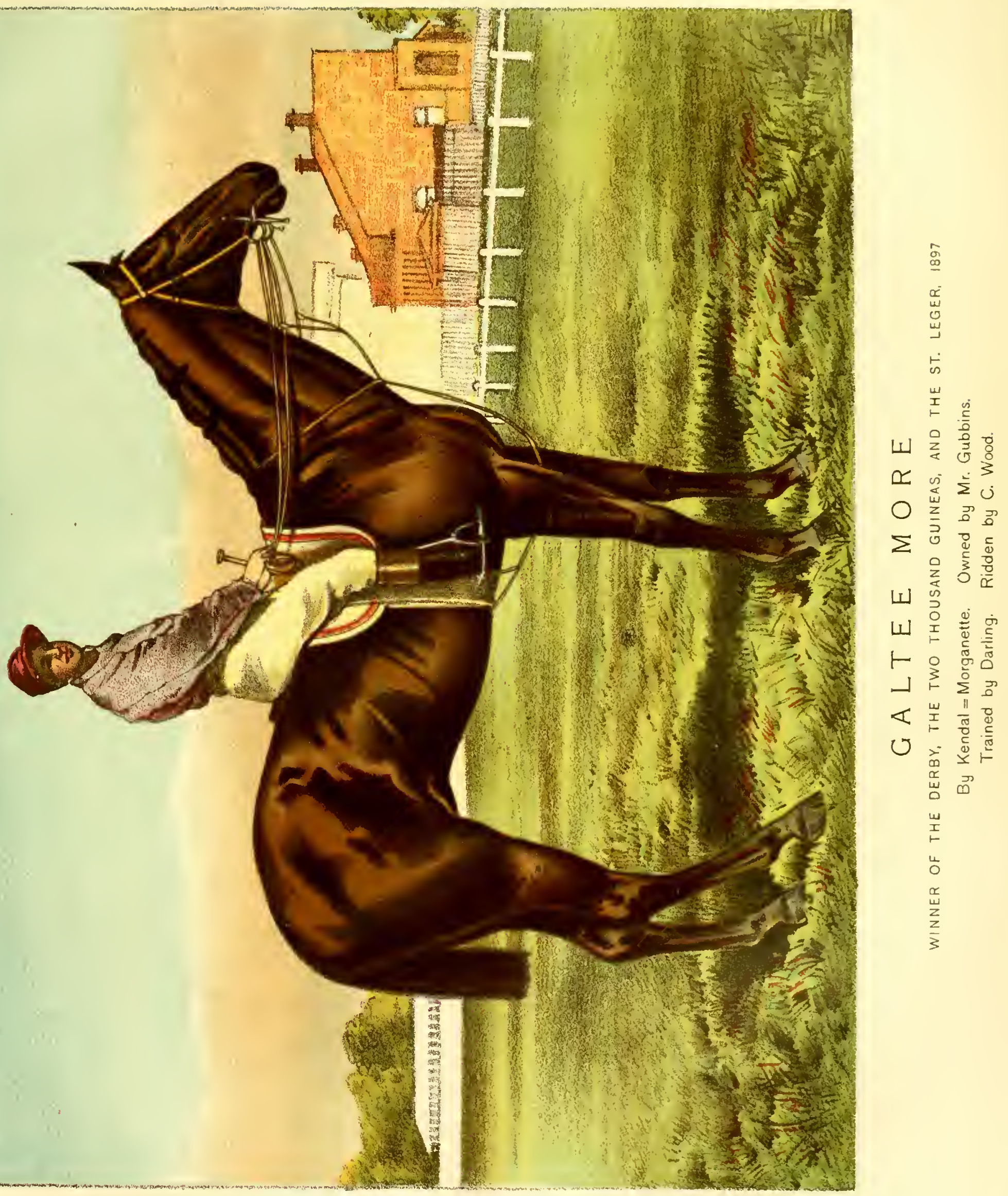





\section{WINNERS OF THE GREAT RACES.}

THE DERBY,-(Epsom, May or June.)-1 mile 4 furlongs.

\begin{tabular}{|c|c|c|c|c|c|c|}
\hline Year. & Owner. & & Winner. & & Stra. & Jockey. \\
\hline 1780 & Sir C. Bunbury . & & Diomed, by Florizel . & & 9 & S. Aisull. \\
\hline 1781 & Mr. O'kelly & & Y. Eclipse, by liclipse & . & 15 & Ilindley. \\
\hline 1782 & Lord Egremunt . & - & Assassin, by Sweetbriar . & . & 13 & S. Alnull. \\
\hline 1783 & Mir. Parker. & . & Sultram, by Eclipse. . & . & 16 & IIindley. \\
\hline 1784 & Mr. O'Kelly & & Serjeant, hy Eclipse . & - & 11 & J. A rrull. \\
\hline 1785 & Lond Claremnat. & & Almwell, by Marc Antony & . & 10 & II indley. \\
\hline $17 \mathrm{SB}$ & Mr. Panton. & & Noble, by llightlyer. & . & 15 & J Wlite. \\
\hline 1787 & 1.ord Derlyy : & & Sir P.'Teazle, by llightlyer & . & 17 & s. Ainull. \\
\hline 1788 & Prince of Wales. & & sir Thomas, by loatac. & . & 11 & w. South. \\
\hline 1789 & Duke of Bedford & & Skyaciaper, by II igliffyer & & 11 & Chifaey, sen. \\
\hline I790 & l.ord Grosvenor. & & Kliadamanthus, by Justice & & 10 & J. Araull. \\
\hline 1791 & Duke ot Bedford & & Eager, by Florizel . & . & 9 & Stephenson. \\
\hline 1702 & Lord Grosvenor. & & John Bull, by Fortitude. & . & $i$ & Buckle \\
\hline 1793 & Sir F. Poole & . & Waxy, by Potsos . & & 13 & Clift. \\
\hline 1794 & Lord Grosvenor. & & Drodalus, by Justice : & . & 1 & Buckle. \\
\hline 1795 & Sil F. Standisl . & & Spread Lagle, by Volunteer & & 11 & Wheatley. \\
\hline 1796 & -ir F". Standislı. & - & Widelot, by Trumpeter & & 11 & J. Amuli. \\
\hline 1797 & Duke of Bedford. & . & c. s. to Pharamond, by Fidge & $t$. & 7 & J. Singleton. \\
\hline 1798 & Mr. Conkson & & Sir Harry, by Sir l'eter & & 10 & S. Arsull \\
\hline 1789 & Sir F. Standish & & Arcluduke, by Sir Peter & . & 11 & J. Araull \\
\hline 1500 & Mr. Wilson. & & bChampion, by Pot8os & & 13 & Clift. \\
\hline $1 \mathrm{~S} 0 \mathrm{I}$ & Sir C. Hunbury . & & c Elennor, by Whiskey & . & 1 & Saunders. \\
\hline 1502 & Duke of Grafton & & Tyrant, by Potsos . & & 9 & Buckle. \\
\hline $1 \Omega 03$ & Sir ll. Willinmson & - & Ditto, by Sir Peter & : & 6 & Clift. \\
\hline 1804 & Lord Egremont. & . & llannibal, by Driver. & . & 8 & W. Arrall \\
\hline 1805 & Lord Eigremolit & & Card. Beanfort, liy Gohanna & : & 15 & Fitzpatrick. \\
\hline 1806 & Lord Foley. & . & Paris, by Sir p'eter. & . & 12 & Shepherd. \\
\hline 1807 & Lord Egreniont . & . & Election, by Gohanaa & - & 13 & J. Arsull. \\
\hline 1808 & Sir Il. Williamson & & Fan, by St. George. & . & 10 & Colliason. \\
\hline 1809 & Duke of Grafton. & & Pope, by Waxy & . & 10 & Goodison. \\
\hline 1510 & Duke of Gralton. & & II'halebone, by Waxy & . & 11 & Clift. \\
\hline 1811 & Sir J. Shelley & & Phantom, hy walton & $\dot{.}$ & 16 & Buckle \\
\hline 1812 & M1. Lad broke : & & Octavius, by Orville. & . & 14 & W. Araull. \\
\hline 1813 & Sir C. Bunbury . & & asinolensko, by Sorcerer & & 12 & Goodison. \\
\hline 1811 & Lord Stawell & & Blucher, by IVnxy . & & 14 & W. Arnull. \\
\hline 1815 & Duke of Grafton & & Whisker, hy Waxy : & : & 13 & Goodison. \\
\hline 1816 & Duke of York. & & Prince Leopold, by lledley & . & 11 & W beatley. \\
\hline 1817 & Mr. Payne. & & Azor, by Selim. & : & 13 & Robinson. \\
\hline 1818 & Mr. Thoruhill: & . & Sam, by Scud : & : & 16 & S. Chifney. \\
\hline 1819 & Duke of Portland & & Tiresias, by Sootlisayer & . & 16 & Clift. \\
\hline 1820 & Mr. Thorshill. & & Sailor, by Scud. & . & 15 & S. Chifneg. \\
\hline 1821 & II II Inter & : & Gustavas, by Election : & : & 13 & S. Day. \\
\hline 1522 & Dilke of Yotk & : & Voses, by Seym. or Wh'lebı & : & 12 & fioodison. \\
\hline 1823 & Mr. Uduy . & & Emilius, by Orvillo . & . & 11 & Buckle. \\
\hline 1824 & Sir J. shelley & • & Cedric, by Phantom . & : & 17 & Kobinson. \\
\hline 1825 & Lord Jersey & & Middleton, by Pliantom. & : & is & Robinson. \\
\hline 1526 & Lord Egrernont. & & Lapdog, by Whalebono & . & 19 & Dockeray. \\
\hline 1827 & Lord Jersey & & Mameluke, by Partisan & - & 23 & Robinson. \\
\hline 1828 & Duke of Rutland & & aCadland, by Andrew. & . & 15 & Kobinson. \\
\hline 18.9 & Mr. Gratwicke. & & Frederick, by Liltle Jobn & . & 17 & Forth. \\
\hline 1830 & Mr. Cliffney & & Priam, by Emilins . & - & 23 & S. Day. \\
\hline 1831 & Lord Lowtlier & & Spariel, by whalebore & . & 23 & Wheatloy. \\
\hline $1 \times 32$ & Mr. Lidsdale & . & St. Giles, by Tramp. & & 22 & Scolt. \\
\hline 1833 & Mr Saller. & & l'angerous, by Tramp & : & 25 & Chapple. \\
\hline 1534 & Mr. Batson . & & Plenipotentiary, by Ernilins & . & 23 & Conolly. \\
\hline 1835 & Mr. Bowes . & & Mundig, by Catton . & & 14 & $\operatorname{sen} t$ \\
\hline 1836 & Lord Jersey & 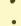 & abry Middleton, by Sultan & : & $2 \mathrm{I}$ & kobinson. \\
\hline 1837 & 1.ord Berners & & Phosphorus, by lamplighter & . & 17 & G. Edwards. \\
\hline 1838 & Sir G. Heatheote & & Amato, by Velocipede. & . & 23 & Chapple. \\
\hline 1839 & Mr. W. Rilsdnle & . & Rloomshury, by Mlulatto. & : & 21 & T'enpleman. \\
\hline 1840 & Mr. lobertson. & & Little Wonder, by Maley. & . & 17 & M acdonald. \\
\hline 1841 & Mr. Rawlinson & ? & Coronation, by Sir llercules & . & 29 & Conolly. \\
\hline 1842 & Colonel Anson & • & Attila, by Colwick . & . & 24 & Scott. \\
\hline 1843 & Mr. Bowes. & . & aColherstone, by Touchstone & 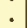 & 23 & Scott. \\
\hline 1844 & Colonel l'esil & & Orlando, by Touchstone & . & 29 & Flatman. \\
\hline 1845 & Mr. Gratwicke & & Mlerry Monarch, by Slane. & : & 31 & F. Bell. \\
\hline 1546 & MI., Gully. & & Pyrrhas the First, by Epirus & & 27 & S. liay. \\
\hline 1847 & Mr. Pedley: & : & Cossack, by II. Platoff & : & 32 & Templeman. \\
\hline $18+8$ & Lord Clifilen & & c Surplice, by Touchstone . & : & 17 & Templeman. \\
\hline 1849 & Lord Eglinton & & $c \mathrm{~F}$. Dutchman, by Middleton & & 26 & Marlow. \\
\hline 1850 & Lord Zetland & . & $c$ Voltigeur, by Voltaire. & : & 24 & J. Narson. \\
\hline $1 \mathrm{~S} 5 \overline{1}$ & Sir J. Hawley & & 'Tedilington, by orlando . & . & 33 & J. Marson. \\
\hline 1852 & Mr. Bowes . & - & D. O'Rourke, by Birdcatcher & . & 27 & F. Butler. \\
\hline 1853 & Mr. Bowes . & . & arAustralian, hy Melbonrme & . & 28 & F. Butler. \\
\hline 1854 & Mr. Gully . & & Andover, by Bay SLiddleton & : & 27 & A. Day. \\
\hline 1.855 & Mr. Pophan . & • & IIild Dayrell, by Ion & . & 12 & Sherwood. \\
\hline 1856 & Admiral Harcoute & & Ellington, by $\mathrm{k}$. Dutchman & 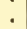 & $2 i$ & Alderoft. \\
\hline 1857 & MIr. W. I'A Ansod & & b Blink Bonny, by Melbonrne & . & 30) & Chariton. \\
\hline 1858 & Sir J. llawley. & & lieadsman, by weatherbit & • & 23 & Welis. \\
\hline 1559 & Sir J. 11awley & & Musjid, by Newtninster . & . & 30 & Wella. \\
\hline 1850 & MI. Meriy & & Thormaniby, by MIelbourne & & 30 & Custance. \\
\hline 1861 & Colonel 'l'owneley & & Kettledrum, by Kataplaa. & . & 18 & Bullock. \\
\hline 1562 & Mr. Snewiar & & Caractacus, by Kingston . & & 34 & J. Parsons. \\
\hline 1863 & Mr. R. C. Nrylor & & aJIacaroni, by Sweetmeat. & & $3 i$ & Challoner. \\
\hline $1 \times 64$ & Mr. W. I'Ansnn. & & c Blair Athol, by Stockwell & & 30 & J. Snowdea. \\
\hline 1865 & Ct. F. de Lagrang & & cGladiaten', by Monarque. & & 29 & Grimsliaw. \\
\hline 1866 & Mr. Sutton. & & acl.ord Lyon, by Stockwell & . & 26 & Custance. \\
\hline 1867 & Mr. Chaplin & & Jlermit, by Newminster. & & 30 & Daley. \\
\hline 1868 & Sir J. Ilawley & & Blue (iокn, by Beadsman & & 18 & Wells. \\
\hline 1869 & MIr. J. Johastome & & a Pretender, by Adventurer & . & 22 & J. Osborne. \\
\hline 1570 & Lord Falmouth . & & Kingeraft, by King Tom . & . & 15 & T. French. \\
\hline
\end{tabular}

THE DERBY-Continued

\begin{tabular}{|c|c|c|c|c|c|}
\hline Year. & Owuer. & Wlaner. & & 8tre. & Jockey. \\
\hline $187 \mathrm{I}$ & Baron Iiothschild & Fатолius, hy P'armenn & - & 17 & T. rencb. \\
\hline 1872 & Mr. H. Savilo. & Cremorne, by Parmesan & & 23 & Iaidment. \\
\hline 1873 & Mr. Merry . & Doncaster, by Stockwell & & 12 & Webh. \\
\hline 1874 & Mr. Cartwright . & G. Frederick, by Mlarsyas & & 20 & Cinstance. \\
\hline 1875 & l'rince Battligany & Galopin, by Vedette. & . & 18 & Morria. \\
\hline 1876 & Mr. A. Baltazzi . & Kisber, by linccaneer & . & 15 & M siủment. \\
\hline 1877 & Lord lialnouth . & c Silvio, by Hlair a thol & . & 17 & F. Arclier. \\
\hline 1878 & Mr. Crawfurd & Sefton, by Speculum . & . & 22 & Constahle. \\
\hline 1879 & I. Ac:on & Sir Beryy, by Favonius & & 23 & Fordhare. \\
\hline 1880 & Duke of Westminster & Bend Or, hy Doncaster & . & 19 & F. Aicher. \\
\hline 1881 & MI: Lorillard : & c I oqaois, by Leamington. & & 15 & F. Arclier. \\
\hline 1882 & Duke of Westminster & ashoover, by llermit & - & 14 & T. Cannon. \\
\hline 1883 & Sir F. Johnstone & St Binise, by llermit & • & 11 & C. Wood. \\
\hline 1884 & $\left\{\begin{array}{l}\text { Mr. J, Jammond } \\
\text { Sir J. Willongliby }\end{array}\right.$ & $\left.\begin{array}{c}\text { St Gatien, } \\
\text { cHarrester, dead heat }\end{array}\right\}$ & . & 15 & \\
\hline 1885 & Lord Hastings. & Melton, by Master kildare & & 12 & $\begin{array}{l}\text { S. Lonte日. } \\
\text { F. Arcizer. }\end{array}$ \\
\hline 1886 & Duke of Westminster & ac Ornonde, by Bend Or & & 9 & E. Archer. \\
\hline 1887 & Mr. Abington : . & Merry llamptna, by Han & mpton & 11 & Wates. \\
\hline 1889 & Duke of Portland & aA yrshire, by Hampton & & 9 & $\because$ larrett. \\
\hline 1889 & Duke of Portiand & c Donovan, by (ialopin & & 13 & T Loates. \\
\hline 1890 & Sir J. MIiller . & Sainfoin, by Springfield & . & 8 & J. Watts. \\
\hline 1891 & Sir k. Jolunstone & accommon, hy Isonomy & & 11 & G. Barrett. \\
\hline 1892 & Lord Bradford. & Sir llugo, by Wisdom & & 13 & F Allsopp. \\
\hline 1693 & Mr. II. M'Calmont & acl singlass, by 1 sonomy & & 11 & T. Ioates. \\
\hline 1894 & Lord Rosebery & aLadins, by Hampton . & & 7 & M. Carmon. \\
\hline 1895 & Lord Rosebery . & esir Viato, by Barealdine & & 15 & S Loatea. \\
\hline 1896 & Prince of Whilea & cPersimmon . . & & 11 & J. Watts. \\
\hline 1897 & Mr.J.Gabbias. & acGalteo More & . & 11 & c. Wood. \\
\hline 1898 & Mr. Laraacb . & Jeddah & & 18 & o. Madden. \\
\hline
\end{tabular}

Thoge horses marked (a) also won the Two Thousand, (b) the Oaks, and (c) the St. Leger.

THE OAKS.-(Epsom, May or June.)-1 mile 4 furlongs.

\begin{tabular}{|c|c|c|c|c|c|c|c|}
\hline Year. & Owner. & & Wintier. & & & Strs. & Jockey. \\
\hline 1779 & Ld. Derby . & . & Bridget, by lIerod & & • & 12 & Goodison. \\
\hline 1780 & Mr. Douglas & . & Teetotum, by Matcb 'em & & . & 11 & - \\
\hline 1781 & Ld. Grosvenor & . & Faitl, by llerod & & . & 6 & - \\
\hline 1782 & Ld. firosvenur & & Ceres, by Sweet Willism & & . & 12 & Chifney, sen. \\
\hline 1783 & Ld. Grosvenor & . & Mr. of the Oaks, by llerod & & . & 10 & Chifney, sen. \\
\hline 1781 & Mr. Burton & . & Stella, by Plusder & & . & 10 & C. Hindley. \\
\hline 1785 & Ld. Clermont . & . & Trifle, by Justice & . & . & 8 & J. Bird. \\
\hline 1786 & Sir F. Standish . & . & Perdita filly, by Tandem & : & . & 13 & J. Edwards. \\
\hline 1787 & Mr. Vernon . & . & Annette, by Eclipse. & . & . & 8 & Fitzpatrick. \\
\hline 1789 & Ld. Egremont & & Nightshade, by Potsos, & . & . & 7 & Fitzpatrick. \\
\hline 1759 & Lul. Egremont & . & Tag, by Trentham. - & - & . & $i$ & Chifney, sen. \\
\hline 1790 & D. of liedford & & IIyppolita, by Nercary & . & . & 12 & Chifney, sen. \\
\hline 1791 & D. of Bedford & . & Portia, by Volunteer. & & . & 9 & J singleton. \\
\hline 1792 & Ld. Clermont & . & Violante, by llighfyer & . & . & 11 & c. Hindley. \\
\hline 1793 & D. of Bedford & . & Colia, by volunteer. & . & . & I0 & J. Sirgleton. \\
\hline 1794 & Ld. Derby . & & Hermione, by Sir Peter & & . & 8 & S. A rmill. \\
\hline $179 \overline{5}$ & Ld. Egremont . & & Platina, by Wlercury. & - & & 11 & Fitzpatlick. \\
\hline 1796 & Sir E Standish. & . & Parasote, by Sir Peter & . & . & 13 & J. Arnill. \\
\hline 1797 & Lal. Grosvenor. & & Nike, by Alexasder. & & . & 5 & Buckle. \\
\hline 1793 & Mr. Durand & . & Pellissima, by 1 henomeno & & . & 7 & Buckle. \\
\hline 1793 & Ld. Grosvenor & & Belliaa, br Rockinghara. & & & 4 & Buckle. \\
\hline 1800 & Ld. Egremont . & & Ephemera, by Woodpecke & & . & 8 & Fitzpartick. \\
\hline 1801 & Sic C. Banbuly. & & c Eileanor, br Whiskey & . & : & 6 & Saunders. \\
\hline 1502 & MIr. Wastell . & 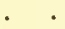 & Scotia, by Delpini & . & 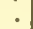 & 6 & Buckle. \\
\hline 1803 & Sir T. Gascoigne & & "Theophania, by Delpiai & & & 7 & Euckle. \\
\hline 1804 & D. of Grafton & . & Pelisse, by Whiskey & : & & 8 & Clift. \\
\hline 1805 & Ld. Grosrenor & . & Meteora, by Meteor. & & . & 8 & Buckle. \\
\hline 1806 & Hi. Crares & & Bronze, by linzzaró & & & 12 & Edwards. \\
\hline 1807 & Gen. Grosvenor. & & Binseis, by Beningbrough & & . & 13 & S. Cbifoey. \\
\hline 1808 & D. of Grafton & . & Morel, by sorcerer. & & : & 10 & Clift. \\
\hline 1809 & Gen. Gower & & Md. of Ot leans by Sorcere & & & 11 & J. Moss. \\
\hline 1510 & Sir W Gerard & & Orıлna, by leningbrough. & & . & 11 & W. Peirse. \\
\hline 1811 & D. of Rutland & . & Sorcery, by sorcerer. & & . & 12 & Chifrey. \\
\hline 1812 & No. llewett & & Manuella, by Dick Andrem & & & 12 & W. Peirse. \\
\hline is 13 & D. of Grafton & & Mnsic, by Waxy. & & . & 9 & Goodison. \\
\hline 1811 & D. of liutland & & Medora, by Seliru & . & . & 9 & Barnard. \\
\hline 1815 & D. of Grafton & : & Jlinuet, by Waxy . & : & : & 11 & T. Gnodison. \\
\hline 1816 & Gen. Gower & & Landscape, by Riubens & . & & 11 & S. Chifaey. \\
\hline 1817 & Mlr. Watson & & bNeva, by Cervates. & . & . & 11 & Buckle. \\
\hline 1818 & Mr. Undy & : & bCorinne, by Wryy & . & . & 10 & Buck Ie. \\
\hline 1819 & Mr. Thorahill & . & Shoveller, by Scud . & . & & 10 & S. Chifney. \\
\hline 1820 & Ld. Egremont & & Caroline, by Whatebone & & & 13 & II. Edwards. \\
\hline $1 \mathrm{~S} 21$ & Ld. lxeter. & . & Augusta, by Woful. & . & & 7 & J. liobinson. \\
\hline 1822 & D. of Gisfton & : & aPastille, by Rubens: & : & . & 10 & 11. Edwards. \\
\hline 1823 & D. of Grafton & . & bZinc, by Woful . & - & & 10 & Backle. \\
\hline 1821 & Ld. Jersey . & - & bcobweb, hy Phatom & • & . & 15 & J. Robiuson. \\
\hline 1825 & Gen. Grosvenor. & & Wings, by The Flyer & . & & 10 & S. Chifney. \\
\hline 1826 & Mr. Forth & & islias, by Interpreter & . & . & 15 & Lye. \\
\hline 1827 & D. of Richmoud . & & Gultare, by Smolensko & . & & 19 & F. Hoyce. \\
\hline
\end{tabular}


THE OAKS-Continued

\begin{tabular}{|c|c|c|c|c|c|}
\hline Year. & Owner. & & Winner. & Btrs. & Jockey. \\
\hline 1828 & D. of Graftod & & Turqnoise, by Selim. & 14 & J. B. Day. \\
\hline 1899 & Ld. Exeter. & . & Green Mautle, by Sultan. & 14 & Dockeray, \\
\hline $1<30$ & Mr. Stanehewer. & . & Variation, by Bustard . & 18 & G. kdwards. \\
\hline 1831 & D. of Grafton & . & Oxygen, by Emilius. & 21 & I. B. Day. \\
\hline 1832 & Ld. Fxeter. & & bGalata, by Sultan . & 19 & Conolly. \\
\hline 1833 & Sir M. Wood & . & Vespa, by Muley & 19 & Chapple. \\
\hline 1834 & Mr. Cosby. & & Pussy, by Pollio & 15 & J. B. Day. \\
\hline 1895 & Mr. Mostyn & : & Q. of Trumps, by Velocipede & 10 & Lye. \\
\hline 1836 & Mr. Schot. & & Cyprian, by Partisan . & 12 & Scott. \\
\hline 1537 & I. Powlett. & . & Miss Letty, by l'riam & 13 & J. Holmes. \\
\hline 1838 & Ld. Chesterfield. & . & Industry, by Priam. & 16 & Scott \\
\hline 1839 & Mr. F. Craven. & . & Deception, by Uefence & 13 & J. B. Day. \\
\hline 1840 & Ld. G. Bentinck. & & alcrucifix, by ['riam . & 15 & J. B. Day. \\
\hline 1811 & Ld Westminster & & Gluaznee, by Puntaloon & 22 & Scott. \\
\hline 1542 & Mr. G Dawson. & . & Our Nell, by Bran . . & 16 & Lye. \\
\hline 1843 & Mr. Ford . & - & Poison, by Pleaipoteotiary & 23 & F. Hutler. \\
\hline 1844 & Col. Anson . & & The Princess, by Slane & 25 & F. Butler. \\
\hline 1845 & D. of lichmond . & . & Refraction, by Glaucus. & 21 & II. Bell. \\
\hline 1516 & Mr. Gully. & - & b.Meadicant, by Tonchstone & 21 & $\$$ 1)ay. \\
\hline 1817 & Sir J, II awley & . & Miamj, by Yenison. & 23 & Templeman. \\
\hline 1815 & Mr. H. IHill & & Cymba, by Jielbourue. & 26 & Templemaa. \\
\hline 1819 & Ld. Chesterfield & . & 1.ady Evelyn, by Don Jolon & 15 & F. Butler. \\
\hline 1850 & Mr. Hobson . & . & Rhedycina, by Wintonian & 15 & F. lututler. \\
\hline 1851 & Ld. stauley & & Iris, by I thuriel & 15 & F. Butler. \\
\hline 1852 & Mr.J.Scott & & Sougstress, by Birdeateber & 14 & F. Butler. \\
\hline 1853 & IIr. Wanchope . & : & Cath. llayes, by Lamerenst & 17 & Marlow. \\
\hline 1854 & Mr. W. Cnoksoa & & Mincemeat, by swertmeat & 15 & Chariton. \\
\hline 1855 & Mr. R. Read . & & Marchioness, by Melbourne & 11 & Templeman. \\
\hline 1856 & Mir. II. llili . & . & Mrincepie, by Swentmea: . & 10 & A. Day. \\
\hline 1857 & Mr. W. l'Auson. & & $c$ Blink Eonny, wy Melbourno & 13 & Charlton. \\
\hline 1858 & 111. Gratwicke. & & bGoverness, by Ćbatham. & 13 & Ashmall. \\
\hline 1659 & Ld Londeshoro'. & & Summerside, by W. Australia & 15 & G. Fordbam. \\
\hline 1860 & Mrr. Eastwood. & . & Butterfy, by Turnus. & 13 & J. Suowden. \\
\hline 1561 & Mr.J. Saxon & . & B. Duchess, by F. Dutchman & 17 & L. Snowden. \\
\hline 1862 & Mir. Naylor. & & Feu de Joie, by Longbow. & 19 & T. Chalover. \\
\hline 1863 & Ld. Falmouth & . & Queen Bertha, by liogston & 20 & Aldcroft. \\
\hline 1864 & Ct. Lagrange . & . & Fille de l'Air, hy $\mathbf{F}$. a Ballagh & 19 & A. Edwardo. \\
\hline 1865 & Mr. WV. Grabam. & & Regalia, by Stockwell & 18 & Norms. \\
\hline 1566 & Mi: Dunbar & & Tormeotor, by King Tom. & 17 & J. Inaa. \\
\hline 1867 & Baron Rothschild & . & Hippia, by King Tom . & 8 & J. Daley. \\
\hline 1868 & Mr. W. Graham . & & bFormosa, by Buccaneer. & 9 & Fordham. \\
\hline 1869 & Sir F. Jolinstone & & Brigantine, by Buccaneer. & 15 & T. Cannoa. \\
\hline ISTo & Mr. W. Graham. & & Gamos, by Saunterer & 7 & Fordham. \\
\hline 1571 & Raron Rothschild & & $b d$ Hanoah, by King Tom & 9 & Maidmeut. \\
\hline 1872 & Mr, l,efevre & & bReine, by Jionarque . & 17 & Forduatu. \\
\hline 1873 & M1. Merry. & & bdMaria Stuart, by S. Chief & 18 & T. Cannon. \\
\hline 1874 & Mr. Latunde & & bdA pology, by Adventurer. & 11 & J. Oshorne. \\
\hline 1875 & Ld. Falmouth & & bSpinaway, by Macaroni & 7 & F. Archer \\
\hline 1876 & M. Lnpin . & & Enguerrande, by Vermont & 14 & Hudson. \\
\hline 1877 & Mr. Pulteney & . & Placida, by Lord Lyon . & 9 & H. Jeffrey. \\
\hline 1878 & Ld. Falmouth & . & dJannette, by Lord Clifden & 8 & F. Archer. \\
\hline 1879 & Ld. Falmouth & & Wl. of Fort., by Adventurer & 8 & F. Archer. \\
\hline 1880 & Mr. Perkin . & & Jenny Howlet, by The Paluer & 13 & J. Snowden. \\
\hline 1881 & Mr. Crawfurd & & $b$ Thebais, by Hermit . & 12 & Fordham. \\
\hline 1882 & Ld. Stamford & & Geheimuiss, by Rosicrucian & 5 & T. Cannon. \\
\hline 1883 & 1,d. Rosebery & & Bouny Jean, by Macaroui. & 14 & Watts. \\
\hline 1584 & Mr. A bington & & Busybody, by Petrarch . & 9 & T. Cannon. \\
\hline 1885 & Ld. Cadogan & & Lonely, liy Hermit . & 10 & F. A rcher. \\
\hline $18 \$ 6$ & D. of Ilamilton & & byiss Jummy, by Petrarch & 12 & Watts. \\
\hline 1587 & D. of Beaufort & & UReve dor by liampton. & 9 & C. Wood. \\
\hline $18 \subseteq \mathrm{s}$ & Ld. Calthorpe & & dSeabreeze, by I sonony & 6 & Robiuson. \\
\hline 1889 & Ld. R. Churehill & - & L'Abbesse de Jounre & 12 & J. Woodburn. \\
\hline 1630 & D. of Polttand & & dslemoir, by St. Simon & 7 & J. Watte. \\
\hline 1891 & Sir T. Sykes . & & Mimi, bs Barcaldine . & 6 & Rickaby. \\
\hline 1892 & Baron de Hirsch & & $b d \mathrm{~L} a$ Fleche, by st Simon & 7 & G. Barrett. \\
\hline 1893 & Duke of Portland, & & Mrs. Butterwick, by St. Simo & 17 & J. Watts. \\
\hline is94 & Duke of Portland & & bAmiahle, by St. Simon, & $1 i$ & W. Bradford. \\
\hline 189.5 & Sir J. Miller . & & La Sagesse, by Wisdom & 15 & 8. Loatea. \\
\hline 1896 & Lord Derby & & Canterbury Pilgrim & 11 & Rickaby. \\
\hline 1897 & Lord llindlip . & & Limasol . & 8 & W. Bradford. \\
\hline $1 \leqslant 98$ & MI. W. T. Jones & & Aira and Graces & 13 & Brad ford. \\
\hline
\end{tabular}

(a) also won the Two Thousaud, (b) One Thousand, (c) Derby, (d) St. Leger.

THE ST. LEGER-(Doncaster, September.) 1 mile 6 furlongs 132 yards.

\begin{tabular}{|c|c|c|c|c|c|}
\hline rear. & Owner. & & Whner. & Stro & Jockey. \\
\hline 1776 & Ld. Rockingham & & Allabaculia, by Sampson. & & Singleton. \\
\hline 1777 & Mr. Sotheron. & & Bourbon by Le Sang & 10 & J. Cade. \\
\hline 1778 & Sir T. Gascoigne & & Hollandaise, by Match'em & 8 & G. llearon. \\
\hline 1779 & Mr. Stapleton. & . & Tommy by Wildair & 10 & G. Lowry. \\
\hline 1750 & Mr. Bethell. & & Ruler, by Young Marske. & 7 & Mangle. \\
\hline 1781 & Col. Radcliffe & & Seriua, by Goldender. & 9 & Forsier. \\
\hline 1782 & Mr. Pratt. & & Imperatrix, by Alfred & 5 & Searle. \\
\hline $17 \mathrm{S3}$ & sir J. L. Kaye & & Phenomenn. by llerod & 4 & llall. \\
\hline 1784 & Mr. Coates. & & Omphale, by llighfiyer & 7 & Kirkton. \\
\hline 1785 & Mr. Hill : & & Cowslip, by Ilighflyer & 4 & Searle. \\
\hline 1786 & Lord A. Hamilton & & Paragnn. by Paymaster & 8 & Mangle. \\
\hline 1787 & Lord A. II amilton & & Epadille, by Highflyer: & 6 & Mangle. \\
\hline 1788 & Lord A. Hamilton & & loung Elora, by Ilighflyer & 5 & Mangle. \\
\hline 1789 & Lnrd Fitzwilliam & & Pewet, by 'T andem & 6 & Mangle. \\
\hline 1790 & Mr. Dealiry & & Ambidexter, by Phenomenon & 8 & Searle. \\
\hline 1791 & Mr. Ilutchinson. & & Ig. Traveller, by 15 . Fergus & 8 & Jackson. \\
\hline 1792 & Lord A. Itamilton & & Tartar, by Florizel . & $1 \mathrm{t}$ & Mangle. \\
\hline 1793 & Mr: Clifton . & & Ninety-tliree, by Flnrizel. & 8 & Peirse. \\
\hline 1794 & Mr. llutclinson. & & Ileningbroug, by $\mathbf{K}$. Fergue & 8 & Jackson. \\
\hline 1795 & sirC.Tu:ner . & & Il ambletonian, by K. Fergus & 5 & Boyes. \\
\hline 1796 & Mr. Cookron & & A mbrosio, by Sir Peter. & & Jackson. \\
\hline
\end{tabular}

THE ST. LEGER-Continued

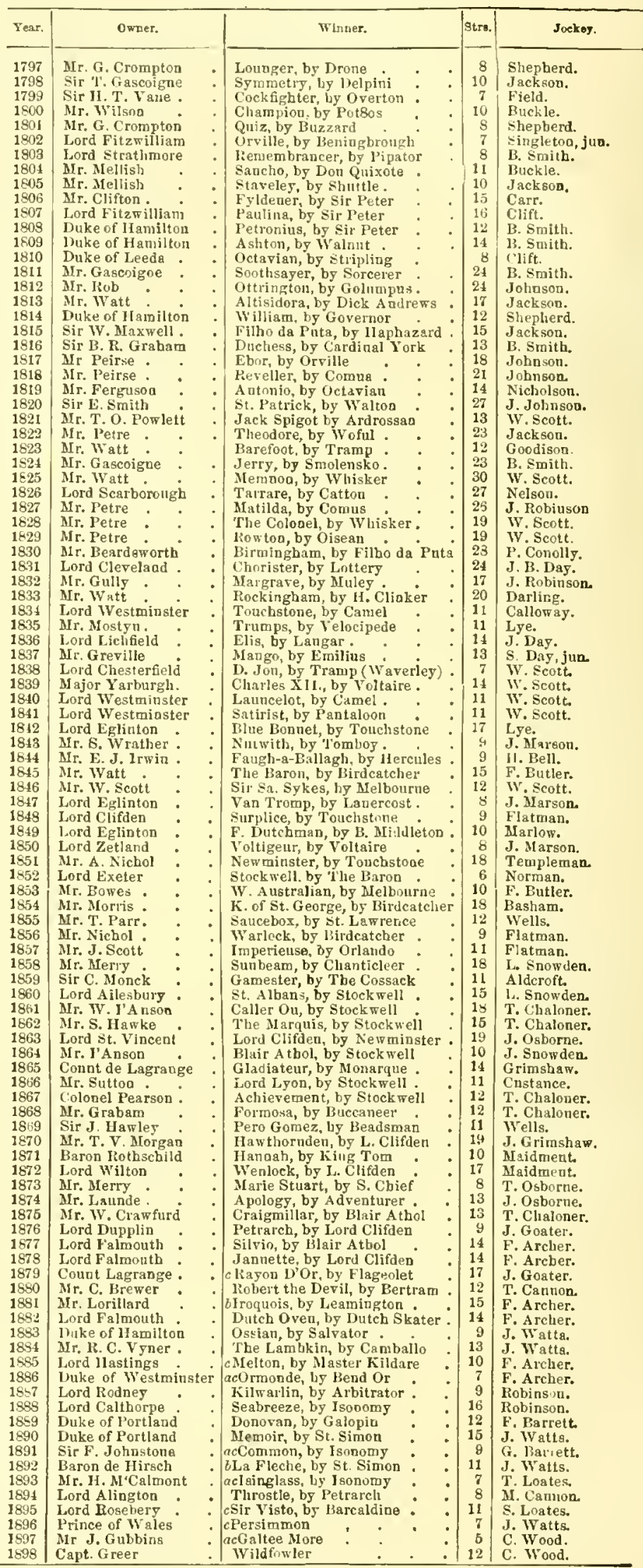

(a) also won the Two Thousand, (b) One Tbousand, (c) Derby. 


\begin{tabular}{|c|c|c|c|c|c|c|c|c|c|c|c|}
\hline \multicolumn{6}{|c|}{$\begin{array}{l}\text { ASCOT GOLD CUP-(June.) } \\
2 \text { miles } 4 \text { furlongs. }\end{array}$} & \multicolumn{6}{|c|}{$\begin{array}{l}\text { DONCASTER CHAMPAGNE STAKES-(Sept.) } \\
2 \text { ycar old-5 furlongs } 152 \text { yards. }\end{array}$} \\
\hline Year. & Winner. & & Age. & Welglat. & Jockey. & Year. & Wtnner. & & & Btrs. & Jockey. \\
\hline 1507 & Master Jack & & $\begin{array}{c}\mathrm{yr}_{3} \\
3\end{array}$ & $\begin{array}{rl}\text { st. } & \text { lb } \\
6 & 12\end{array}$ & - & & & & & & \\
\hline 1808 & abrighton & ? & 4 & 82 & -. & 1933 & Swiss & & . & $\theta$ & W. $S \cot t$. \\
\hline 1809 & Anderia & . & 4 & 713 & - & $18: 4$ & + Vemnon & $\dot{ }$ & : & 4 & W. seott. \\
\hline 1810 & Loiterer & . & 4 & 82 & - & $1 \% 25$ & King Catton & & & 8 & J. Jackaon. \\
\hline 1811 & bJannetto & - & 4 & 713 & - & 1826 & M oonulune & $\because$ & & 7 & G. Ldwarda. \\
\hline 1812 & Flash. & . & 3 & 610 & - & 1527 & \$The Colonel & . & . & 3 & iv. Scott. \\
\hline 1813 & Lutzen. & - & & 82 & - & $15: 8$ & Cant & . & & 9 & T. Lye. \\
\hline 1814 & Pranke. & - & 5 & 89 & - & $18: 9$ & Bud & . & & 10 & Owner. \\
\hline 1815 & Alnidio. & . & $\dot{5}$ & 812 & - & 1830 & Frederica & & . & 7 & S. Darling \\
\hline 1516 & Anticipation & i. & 4 & 82 & - & 1831 & Francesea & & $\vdots$ & 10 & W. scott. \\
\hline 1817 & Sir Richard & . & 4 & $\& 2$ & - & 1832 & Muler Moloct & & & 8 & T. Lye. \\
\hline $18: 8$ & Beiville. & . & a & 43 & - & 1833 & Cotilion. & . & : & 11 & W. Scolt. \\
\hline 1919 & Auticipalion & . & n & $\ddot{9} 3$ & - & 1834 & Coriolemina & $\therefore$ & $:$ & 12 & P. Conolly. \\
\hline 1820 & Champignon & & 4 & 82 & - & 1835 & Beeswing & . & & 7 & Cartwright. \\
\hline 1821 & Banker & & 5 & 812 & - & 1836 & Jereed & - & & 6 & W. Seot. \\
\hline 1822 & Sir llildeura & and & 4 & 82 & - & 1837 & ఫD н Joho & . & . & 6 & W. seott. \\
\hline 1823 & c Marcellıs & . & 4 & $8 \overline{2}$ & Wheatley. & 1838 & Elizil & : & . & 8 & T. Lye. \\
\hline 1824 & Bizarte. & . & 4 & 82 & W. Arnull. & 1839 & †Launcelot & . & & 8 & W. scott. \\
\hline $18 \%$ & Bizarre. & . & 5 & 812 & W. Arnull. & $18 \cdot 10$ & Kedga. & . & & 7 & J. Holmer. \\
\hline 1826 & Margaux & - & 4 & 82 & G. Dockeray. & 1811 & *Attila. & . & & 6 & W. Scott. \\
\hline 1827 & Ilemnon & . & 5 & 812 & S. Chifney. & 1812 & British Yeom & $\operatorname{man}$ & : & 5 & s. Templeman. \\
\hline 1528 & Bobndilla & . & 3 & 67 & T. Lye. & 1813 & The Cure & & & 10 & Heaseltine. \\
\hline 1849 & Zinganee & : & 4 & 82 & Clifney. & 1814 & Lanes. Witcl & & & 12 & Flatmas. \\
\hline 1830 & Lucetta. & . & 4 & 713 & Rolinson. & 1845 & Prineess Alic & & : & 13 & W. Abdalo \\
\hline 1831 & Cetns: & : & 4 & 82 & Robiusol. & 1816 & ‡Van Tinmp & . & & 7 & J. Marbon. \\
\hline 1832 & dCamarine & . & $i$ & 713 & Robinson. & 1847 & Assault. & & & 8 & Edwarde. \\
\hline 1833 & Galata. & . & 4 & 713 & Arnull. & 1819 & "IF, Dilehma & & & 5 & Marlow \\
\hline 1834 & Glaucus & : & 4 & 82 & Scott. & 1849 & The dtalian & . & & 3 & Templeman. \\
\hline 1435 & Gleneso & : & 4 & 82 & Rohinsos. & 1550 & ZA pbrodite & . & . & 8 & J. Marson. \\
\hline 1836 & Touchstone & : & 5 & 812 & J. Day. & 1851 & Aurur. & . & & 9 & J. Marson. \\
\hline 1837 & Touchstone & : & 6 & 93 & Scott. & 1652 & Vindex : & $\vdots$ & $\dot{0}$ & 4 & J. Mlargon. \\
\hline 1838 & Groy Homus & & 3 & 610 & W. Day. & 1853 & Champagne & & . & $\overline{5}$ & S. Rogera. \\
\hline 1839 & Caravan & . & $\Sigma$ & 90 & liobinson. & 1851 & Bondie Morn & & & 5 & J. MI arson. \\
\hline 1840 & St. Vrancia & . & j́ & 90 & Chifuey. & 1855 & *Ellington & . & & 7 & Alderoft. \\
\hline 1841 & Lanercost & : & 6 & 93 & Nohle. & 1856 & Tasmania & : & . & 8 & ilolmes. \\
\hline 1842 & Beeswing & & A & 9 & Cartwright. & 1557 & Gildermire & & & 7 & A lderoft. \\
\hline 1813 & Ralph? & : & 5 & 90 & Robinson. & 1858 & Prelude. & & & 10 & J. Osborse. \\
\hline 1814 & eThe Emperor & & 3 & 63 & Wh hitehouso. & 1859 & King of Dian & mond & & 8 & Fordham. \\
\hline & & & & & & 1860 & Walloon & & - & 10 & A. Edwatds. \\
\hline & [ТнЕ & EмP & EROF & Q'S Plat & TE.] & 1861 & tThe Marquia & & & 7 & Fordham \\
\hline 1845 & The Empero & & & & Whitehousg. & $\begin{array}{l}1862 \\
1863\end{array}$ & †Lord Clifdes & & & 10 & $\begin{array}{l}\text { Fordham. } \\
\text { Alderoft. }\end{array}$ \\
\hline 1846 & Alorm? & . & 4 & $\stackrel{\circ}{8} 5$ & Flatman. & $\begin{array}{l}1863 \\
1864\end{array}$ & $\begin{array}{l}\text { Ely } \\
\text { Zamheij: }\end{array}$ & $\dot{:}$ & : & $\begin{array}{c}4 \\
10\end{array}$ & $\begin{array}{l}\text { Aldert. } \\
\text { 11. Covey. }\end{array}$ \\
\hline 1847 & The IIero & : & 4 & 85 & A. Dry. & 1865 & $h$ Redan . & & & 13 & J. Grimshaw. \\
\hline 1818 & The Ilero & : & 5 & 90 & A. Day. & 1866 & Achierement & & & 5 & Custanee. \\
\hline 1849 & Vas Tromp & $\therefore \quad:$ & 5 & 90 & Mnrlow. & 1857 & Virtue. & . & . & 12 & J. Snowden. \\
\hline 1850 & Flying Dutcl & chman & 4 & 85 & Marlow. & 1868 & Morna: & . & & 4 & J.Adams. \\
\hline $18 \overline{1} 1$ & Woolwich & . & 5 & 90 & J. Mlarson. & 1869 & Sunshing & & : & 6 & Fordhan \\
\hline 1852 & Joe Miller & . & 8 & 610 & G. Mann. & 1570 & $\mathrm{~K}$. of the For & rest & : & 5 & J. Snowdea. \\
\hline 1853 & Teddington & . & 5 & 90 & J. Maraon. & 1871 & Cremorna & & . & 3 & Maidnent. \\
\hline & & & & & & 1872 & •Kaiser . & & & 6 & Maidnent. \\
\hline & {$[\mathrm{AscoT}$} & GOLD & $\mathrm{Cur}$ & $P-R E N$ & EWED.] & 1873 & Napoleon IIl & & & 12 & F. Webb. \\
\hline 18.54 & West Alustra & aling. & & & A. Dav. & 1574 & Canba!lo & & & 7 & J. Osborne. \\
\hline $\begin{array}{l}180.7 \\
185\end{array}$ & West Allstra & $\operatorname{arinn} \cdot$ & & 610 & A. slupail & 1875 & Farnese & & - & 6 & F. Archer. \\
\hline & Frudango & & & & Asminat. & 1576 & 1.ady Golight & atly & & 6 & F. A rcher. \\
\hline & Winkfiell & . & 5 & 90 & Bartholomew. & 1577 & Clementine & . & - & 6 & Goater. \\
\hline & Skirmisher & . & 3 & 610 & Charlton. & 1573 & Charibert & . & & 5 & F. Areher. \\
\hline 1853 & Fisherman & . & 5 & 90 & Wells. & 1879 & Evasion. & . & & 12 & Snowden. \\
\hline 1859 & Fisherman & . & 6 & 9 & Cresswell. & 1890 & Bal Gal: & : & & 8 & F. A rcber. \\
\hline 1860 & Rupes. & . & 3 & 6 & H. Grimshaw. & 1551 & Kermesse & : & : & 6 & Canon. \\
\hline 1861 & Thormanby & & 4 & 87 & Custance. & 1552 & llatelis & . & & $\mathbf{5}$ & Fordham. \\
\hline 1862 & Asteroid & . & $i$ & 87 & Wells. & 1893 & Superba. & : & & 4 & F. A reher. \\
\hline 1863 & fiuckstone & : & 4 & 87 & A. Edwarda. & 1681 & Langweli & : & & $\begin{array}{l}4 \\
8\end{array}$ & IF. Archer. \\
\hline 1861 & Scottish Chit & ief & 3 & 75 & 11. Covay. & 1885 & Mlinting. & & & & F. Arcber. \\
\hline $18 \% 5$ & $g$ Ely & . & 4 & 810 & Cuatance. & & Panzerchiff & $f(j) \mathrm{de}$ & ead & & Watta. \\
\hline 1866 & Glodia teur & . & 4 & 810 & H. Grinshaw, & 1886 & $\{$ Grandison & s lie & ent & 4 & G. Barrett. \\
\hline 1867 & Lecturer & . & 4 & 810 & Fordham. & 1887 & $\begin{array}{l}\text { A prshine } \\
\text { A }\end{array}$ & ? & . & 7 & U. Wood. \\
\hline 1563 & Blue Gown & . & 3 & 75 & Cameron. & 1858 & Chitabob & . & & 7 & Fagan. \\
\hline 1869 & Brigantine & - & 3 & 72 & D. Butler. & $\begin{array}{l}1859 \\
1899\end{array}$ & Riviera. & & & 4 & T. Lonter. \\
\hline 1870 & Sahinus. & - & 3 & 72 & Rowell. & 1890 & Haute Sa one & & & 3 & F. Barrett. \\
\hline 1871 & Mortimer & : & 6 & 95 & Fordham. & 1891 & La Flecha & : & & 6 & G. Barreti. \\
\hline 1872 & Henry. & . & 4 & 810 & Fordham. & 1892 & Prize & . & & 7 & J. Watte. \\
\hline 1873 & Cremorne & - & 4 & 810 & Maidment. & 1893 & Ladas & : & & 2 & A. White. \\
\hline 1874 & Boiard. & . & 4 & $811)$ & Carver. & 1894 & Solaro: & : & & 5 & M. Cannoul. \\
\hline 1875 & Doncaster & . & $\overline{5}$ & 93 & Fordham. & 1895 & Omladina & : & & 7 & Mi. Camnon. \\
\hline 1876 & A pology & : & 5 & 90 & J. Osbarne. & 1596 & Velnsquez & . & & 2 & $J_{\text {i Watts. }}$ \\
\hline 1877 & Petrateh & - & 4 & 810 & Cannon. & 1597 & A gah. & & : & 8 & T. Lates. \\
\hline 1878 & Verneuil & . & 4 & 810 & Goater. & 1998 & MIark For'ard & & & 5 & i. Cannon. \\
\hline 1879 & lsonomy & - & 4 & 810 & Cannon. & & & & & & \\
\hline
\end{tabular}

GRAND NATIONAL STEEPLECHASE-

(Liverpool, March.)_ 4 mes 856 yards.

\begin{tabular}{|c|c|c|c|c|c|}
\hline Year. & Winder. & & Ago. & Wolght. & Btartera \\
\hline 1870 & Colonel & - & $\begin{array}{l}\text { yrm. } \\
\mathrm{gg} .\end{array}$ & it 1160 & 23 \\
\hline 1871 & Lamb & . & as. & & 25 \\
\hline 187? & Caqne Tete & . & as. & 100 & 25 \\
\hline 1873 & Disturbance & . & 6 & 1111 & $=9$ \\
\hline 1874 & Reirgny. & . & $B$ & 1012 & 22 \\
\hline 1875 & Pathfinder & . & ab. & 1011 & 19 \\
\hline $1 \$ 76$ & leegal . & . & 5 & 113 & 19 \\
\hline 1877 & Austerlitz & . & 5 & 108 & 16 \\
\hline 1878 & Shifnal. & . & Ag. & 1012 & 12 \\
\hline 1879 & Liberator & . & $\theta \mathrm{g}$. & 114 & 18 \\
\hline 1880 & Empress & - & 5 & 107 & 14 \\
\hline 1881 & Woodbrook & . & ag. & 113 & 13 \\
\hline 1882 & Seaman. & - & 6 & 116 & 12 \\
\hline 1883 & Zoedone & . & 6 & ii 0 & 10 \\
\hline 1884 & Voluptuary & . & 6 & io 5 & 15 \\
\hline $1885^{\circ}$ & Roquefort & . & 6 & 110 & 19 \\
\hline 1886 & Old Joo & . & ag. & 109 & 23 \\
\hline 1887 & Gamecock & . & eg. & II 0 & 16 \\
\hline 1888 & Play' fair & : & ag. & 107 & 20 \\
\hline 1689 & Frigate & . & ag. & 114 & 20 \\
\hline 1890 & 1]ex . & . & 6 & 105 & 16 \\
\hline 1891 & Come Away & $:$ & 日g. & 1112 & 21 \\
\hline 1892 & Father $O^{\prime}$ Fly & ynn & $\mathrm{ag}$. & 105 & 25 \\
\hline 1893 & Cloigter & . & $8 g$. & 127 & 15 \\
\hline 1894 & Why Not & & ag. & 1113 & 14 \\
\hline 1995 & Wild alan, fr. & r. Borneo & ag. & $10 \mathrm{il}$ & 19 \\
\hline 1896 & Sosrer &.$\quad \cdot$ & ag. & 913 & 28 \\
\hline 1897 & Manilesto & . & Dg. & 113 & 28 \\
\hline 1898 & Drogheda & . & 6 & 1012 & 25 \\
\hline
\end{tabular}

NORTHUMBERLAND PLATE(Now castle, June)-2 miles.

\begin{tabular}{|c|c|c|c|c|c|c|}
\hline Year. & Whoner. & & & Age. & Welght & Joekey. \\
\hline 1833 & Tomboy. & . & - & 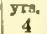 & $\begin{array}{ll}\text { st. } & \text { lb. } \\
8 & 2\end{array}$ & li. Johnson. \\
\hline 1834 & Fanny: & : & : & 4 & 72 & Wintringham. \\
\hline 1835 & Satan. & . & . & 5 & & T. Lye. \\
\hline 1836 & Cyprian & . & : & 3 & 60 & J. Gras. \\
\hline 1837 & Wedge. & : & : & 4 & & T. Lye. \\
\hline 1838 & S:. Bennet & . & . & 4 & 70 & T. Lye. \\
\hline 1839 & St. Benset & & . & 5 & 88 & T. Lye. \\
\hline 1810 & IIetman PIat & toff & : & 4 & & Flatman. \\
\hline 1811 & Calypso. & 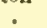 & : & 4 & 80 & Tampleman. \\
\hline 18.12 & Heslingtos & & . & 4 & 74 & J. Joy. \\
\hline 1843 & Mnsa Trooper & & . & 4 & & Francis. \\
\hline 184 & The Era & . & . & 4 & 71 & T. Lye. \\
\hline 1845 & laheritreas & : & : & 6 & 710 & T. Lye. \\
\hline 1846 & Dolo & . & . & 3 & & J. Prince. \\
\hline 1847 & bryx : & : & : & 3 & & J. Prince. \\
\hline 1848 & Chantieleer & : & : & 5 & & Bumby. \\
\hline 1819 & John Cosser & : & $\therefore$ & 4 & 70 & Chariton. \\
\hline 1850 & Eltliron & . & : & 4 & 77 & Cart wright. \\
\hline 1851 & Neasham & : & : & 3 & & 11 axby. \\
\hline 1852 & Stilton. & . & . & 3 & 610 & Alderoft. \\
\hline 1853 & Kingston & : & : & 4 & 87 & Basham. \\
\hline 1854 & Grapeshot & . & . & 4 & 612 & Ashmali. \\
\hline $185 \bar{a}$ & Whitelock & . & : & 4 & & J. Walters. \\
\hline 1856 & Zeta & : & : & 3 & & T. Chrloner. \\
\hline 1857 & Underhand & : & . & 3 & 61 & Plumb. \\
\hline 1858 & Underhand & : & . & 4 & 80 & Basham. \\
\hline 1859 & Underband & : & : & 5 & 812 & Alderoft. \\
\hline 1860 & First Lord & $:$ & . & 3 & 58 & Page. \\
\hline 1861 & Joey Jone, & : & : & 3 & 57 & J. Dovle. \\
\hline 1862 & Montebell. & : & : & 3 & 57 & $J$ Grimshaw. \\
\hline 1863 & Callet o. & : & : & $\tilde{\text { o }}$ & 88 & T. Clialoner. \\
\hline $186 !$ & Caller U & & . & 6 & 812 & T. Clialoner. \\
\hline 1865 & Brown l'jead & & ${ }^{\circ}$ & 3 & & Carrol. \\
\hline 1866 & Pocoeo & 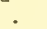 & & 3 & 63 & Cameron. \\
\hline 1867 & Fervacques & : & : & 3 & 513 & D. Butlar. \\
\hline 1868 & Fortua 0 & : & . & 4 & & J. Snowden. \\
\hline 1869 & Tha Spy & & & 4 & & Morris. \\
\hline 1870 & Kennington & & & 3 & 70 & II uot. \\
\hline 1871 & Tarabas. & & . & a & 70 & Grad well. \\
\hline 1872 & Spenaithorne & & & 4 & 612 & w. Gray. \\
\hline 1873 & Falkland & & & 6 & 79 & T. Osborne. \\
\hline 1874 & $\begin{array}{l}\text { l.ily Agnes } \\
\text { A }\end{array}$ & & : & 3 & $6: 1$ & iv. Chalonar. \\
\hline 1975 & 11 arriet Lavs & & . & 3 & 57 & H. Morgan. \\
\hline 1876 & Snail & & & 6 & & II orbey. \\
\hline 1877 & Hampton & 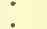 & . & 5 & 812 & F. Webb. \\
\hline 1578 & Glastinbury & $\therefore$ & ${ }^{\circ}$ & 5 & 78 & Carlile. \\
\hline 1879 & Clearhead & & 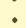 & 5 & & Luke. \\
\hline $1 乞 80$ & Mycenis & & , & 4 & 713 & IIorgan. \\
\hline 1831 & Bonne Doon & & & 4 & 73 & Kellet. \\
\hline 1582 & Vietor Emad & ouel & : & 5 & 80 & iv. Platt. \\
\hline $1 \mathrm{SS3}$ & Barcaldine & . & & $\bar{o}$ & 910 & F. A reher. \\
\hline 1854 & l.awminster & & • & 6 & 713 & J. Fagan. \\
\hline 1885 & Blua Grass & . & - & 5 & 713 & A. Giles. \\
\hline $1 \mathrm{s86}$ & Stone Cliok & . & . & 4 & 78 & Goodway. \\
\hline 1587 & Exmoor. & & & 4 & 812 & Watts. \\
\hline 1568 & Matin Ball & : & & 4 & 610 & Chandiey. \\
\hline 1589 & Drizzlo. & & & 5 & 610 & Blake. \\
\hline 1890 & Houndsditch & & & 4 & 711 & Morgan. \\
\hline 1891 & Queen's BIrt| & liday & & 4 & 90 & J. Watis. \\
\hline $\begin{array}{l}1092 \\
1892\end{array}$ & Newemrt & & & 4 & 73 & ifullen. \\
\hline 1893 & Senton Delav & $\mathrm{v} \& \mathrm{l}$, & & 4 & 75 & Finlay. \\
\hline 1894 & Newcourt & . & & 6 & 86 & Colling. \\
\hline 1895 & Docker. & & & 4 & & Finlay. \\
\hline 1896 & Dare Devil. & . & & ag. & 87 & Fagan. \\
\hline 1897 & Brad wardine & & ${ }^{\circ}$ & 4 & 85 & Wood. \\
\hline 1898 & King Crow & . & & 4 & 87 & F. B. Black. \\
\hline
\end{tabular}


WINNERS OF THE GREAT RACES.

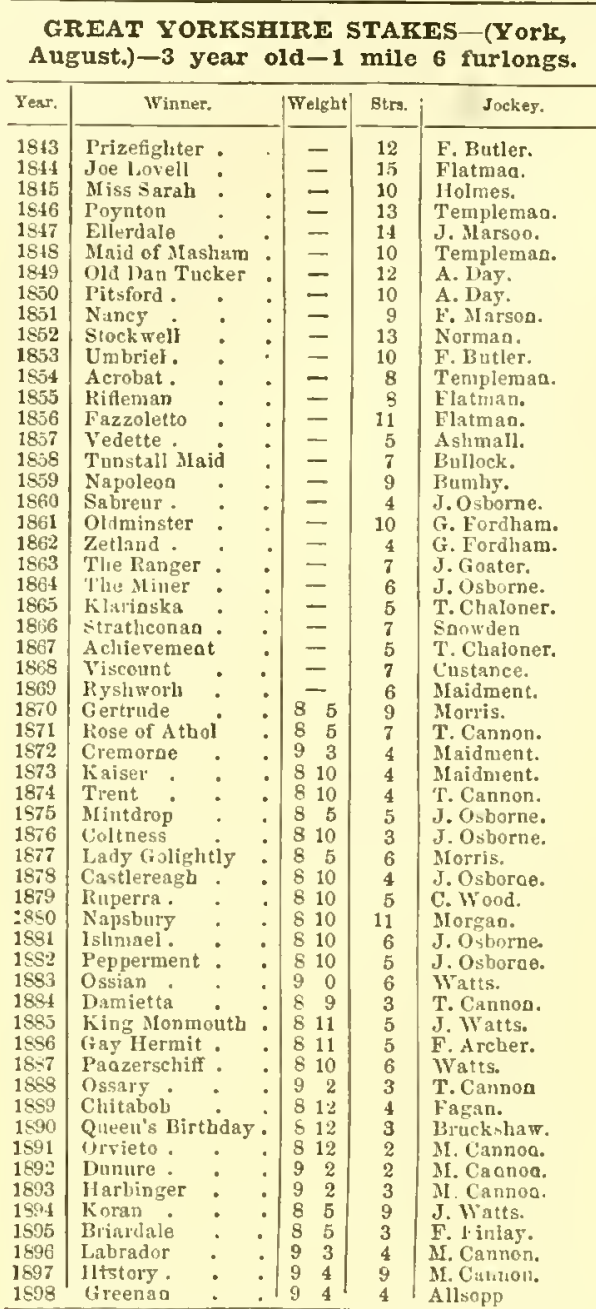

LIVERPOOL AUTUMN CUP-(November) 1 mile 3 furlongs.

\begin{tabular}{|c|c|c|c|c|}
\hline Year. & Wiuner. & Age. & Weight. & Jockey. \\
\hline & Md. of Derwent & 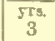 & & \\
\hline & Special Licence & 3 & 58 & $\begin{array}{l}\text { J. Snowdea. } \\
\text { Pritchard. }\end{array}$ \\
\hline & Specinl Liceace & 4 & 710 & $\begin{array}{l}\text { Pritchard } \\
\text { Plumb. }\end{array}$ \\
\hline & $\begin{array}{l}\text { Meg Merrilees } \\
\text { The Brewrer }\end{array}$ & 3 & 410 & Buck. \\
\hline & & ag. & & \\
\hline 862 & Gardener: & $\begin{array}{l}0 \\
4\end{array}$ & & Midgley. \\
\hline & Blith field & $\frac{4}{3}$ & & G. Noble. \\
\hline & Tastar. & 3 & $\begin{array}{ll}6 & 13 \\
6 & 4\end{array}$ & $\begin{array}{l}\text { Frencly. } \\
\text { Frem }\end{array}$ \\
\hline & Elland : & 3 & $\begin{array}{ll}6 & 4 \\
6\end{array}$ & $\begin{array}{l}\text { J. Grimshaw } \\
\text { G. Supp. }\end{array}$ \\
\hline & Beeswing & 3 & $\begin{array}{ll}6 & 7\end{array}$ & $\begin{array}{l}\text { G.Sopp. } \\
\text { kenyon. }\end{array}$ \\
\hline & Mandrake . & 3 & 610 & J. Hudson. \\
\hline & The P'almer. & 4 & $\begin{array}{cc}8 & 2 \\
7 & 0\end{array}$ & Morris. \\
\hline $\begin{array}{l}1870 \\
1870\end{array}$ & $\begin{array}{l}\text { Luter } \\
\text { Exciseman }\end{array}$ & $\begin{array}{l}4 \\
3\end{array}$ & & $\begin{array}{l}\text { D. Butler. } \\
\text { DV Grar }\end{array}$ \\
\hline 1871 & Whinyard : & 5 & $\begin{array}{ll}0 \\
6 & 0\end{array}$ & $\begin{array}{l}\text { W. Gray. } \\
\text { T. Ostorne. }\end{array}$ \\
\hline 872 & Yanulerdecken & 3 & & 1.. Jeffery. \\
\hline & Sterling & 5 & 94 & Custance. \\
\hline 1874 & Lonise Victoria & 5 & & Const:able. \\
\hline 876 & $\begin{array}{l}\text { Activity } \\
\text { f'ootstep }\end{array}$ & $\begin{array}{l}3 \\
3\end{array}$ & 52 & F. Archer: \\
\hline 1577 & Arbitritor : & 3 & r $\quad \begin{array}{rl}5 & 13 \\
8 & 0\end{array}$ & $\begin{array}{l}\text { Mlopkins. } \\
\text { Giluver: }\end{array}$ \\
\hline 1878 & Belphucble & 4 & 81 & 11. Jeffery. \\
\hline 1879 & Master Kiildare & 4 & 813 & F. Archer. \\
\hline & $\begin{array}{l}\text { Prestonpins } \\
\text { Piralys }\end{array}$ & 8 & 82 & Fordlam. \\
\hline 1,82 & $\begin{array}{l}\text { Piratis. } \\
\text { Gogrtes }\end{array}$ & ${ }_{4}^{4}$ & $\begin{array}{ll}6 & 7 \\
7 & 11\end{array}$ & Woodburn. \\
\hline 1883 & $\begin{array}{l}\text { Ponswell. } \\
\text { yons }\end{array}$ & 5 & $\begin{array}{l}711 \\
83\end{array}$ & $\begin{array}{l}\text { Huxtanile. } \\
\text { c. Wood. }\end{array}$ \\
\hline & Thebais. & 6 & & F. Arclier. \\
\hline & Kilcreene & 3 & $\begin{array}{ll}6 & 1 \\
0 & 0\end{array}$ & J. Wall. \\
\hline $\begin{array}{l}1857 \\
1857\end{array}$ & St. Mirin : & 4 & $\begin{array}{ll}9 & 3 \\
8 & 1.2\end{array}$ & Watts. \\
\hline & Lady laosebery & 3 & 512 & W. Wood. \\
\hline & Philomm:1 : & & & J. Wondburn \\
\hline & $\begin{array}{l}\text { Lady Roselery } \\
\text { Myadiame d'sllanan: }\end{array}$ & 5 & 78 & S. Loates. \\
\hline $\begin{array}{l}1592 \\
1592\end{array}$ & Windgall & ${ }_{3}^{4}$ & $\begin{array}{ll}0 & 0 \\
8 & 2\end{array}$ & Q. Birrett. \\
\hline $\begin{array}{l}1091 \\
1091\end{array}$ & $\begin{array}{l}\text { La fleche } \\
\text { soa of a } \mathrm{Gun} \text {. }\end{array}$ & 4 & $\begin{array}{ll}9 & 6 \\
8 & 4\end{array}$ & $\begin{array}{l}\text { J. Watts. } \\
\text { AI. Carnou. }\end{array}$ \\
\hline 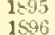 & ${ }_{\text {Columt Schombero }}^{\text {Rush }}$ & 3 & 613 & Grimshaw. \\
\hline 1897 & $\begin{array}{l}\text { Cont Schomberg. } \\
\text { Clisel liampten }\end{array}$ & ${ }_{4}^{4}$ & 811 & $\begin{array}{l}\text { S. Loates. } \\
\text { s. Lortes. }\end{array}$ \\
\hline & Alt SLart $\ldots$ & & & 8 loan. \\
\hline
\end{tabular}

LIVERPOOL SUMMER CUP-(July.) 1 mile 3 furlongs.

\begin{tabular}{|c|c|c|c|c|c|}
\hline Year. & Winzer. & & Age. & weight. & Startera \\
\hline 1853 & Goorkah . & & $\frac{5 r s}{3}$ & $\begin{array}{l}\text { Et. } 16 . \\
5 \\
5\end{array}$ & \\
\hline $\begin{array}{l}1853 \\
1854\end{array}$ & A mmonia: & & 5 & & \\
\hline 1855 & Seducer & & 4 & 75 & 8 \\
\hline & Pretty Boy： & & 3 & 510 & 8 \\
\hline 1857 & Baslif Bazonk • & & 3 & 64 & 14 \\
\hline 1858 & Roman Candle • & & 4 & $\begin{array}{l}6 \quad 9 \\
0\end{array}$ & 13 \\
\hline & Ancient Briton - & & 4 & $\begin{array}{l}65 \\
7\end{array}$ & 8 \\
\hline 1861 & $\begin{array}{l}\text { Mloorcock } \\
\text { Doefoot }\end{array}$ & & 3 & $61 z$ & $\frac{9}{7}$ \\
\hline 1862 & Frirwater： & & 4 & & ii \\
\hline 1863 & The linare : & & 4 & & 11 \\
\hline 1564 & Black Deer . & • & 4 & & 3 \\
\hline $\begin{array}{l}1865 \\
1566\end{array}$ & 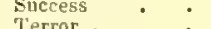 & & 3 & 611 & 7 \\
\hline $\begin{array}{l}1567 \\
1567\end{array}$ & Challenge : & & $\begin{array}{l}3 \\
4\end{array}$ & $\begin{array}{l}510 \\
65\end{array}$ & 8 \\
\hline 1568 & Deaa : & . & 3 & 612 & 6 \\
\hline 1569 & spy $\cdot \cdot \cdot$ & & 4 & 83 & 5 \\
\hline 1570 & Fidelia & & 5 & $\begin{array}{r}80 \\
8 \\
8\end{array}$ & 3 \\
\hline $\begin{array}{l}1871 \\
1572\end{array}$ & $\begin{array}{l}\text { Pretty John } \\
\text { Indian Ocean }\end{array}$ & & $\begin{array}{l}6 \\
5\end{array}$ & $\begin{array}{l}87 \\
76\end{array}$ & $\begin{array}{l}5 \\
7\end{array}$ \\
\hline 1873 & Jarnac. & & 6 & 79 & 8 \\
\hline 1874 & Elantyre : & & 3 & 71 & 13 \\
\hline 1875 & Tam o' Shanter . & & 4 & 612 & 8 \\
\hline 1876 & Controversy - & & 5 & 812 & 1 \\
\hline 1877 & Snait $\cdot{ }_{\text {Stit }} \cdot$ & & aged & 712 & 27 \\
\hline $\begin{array}{l}1878 \\
1879\end{array}$ & $\begin{array}{l}\text { Straxtimare } \\
\text { Maximilias: }\end{array}$ & & $\begin{array}{l}4 \\
4\end{array}$ & $\begin{array}{l}72 \\
7 \\
7\end{array}$ & ${ }_{11}^{9}$ \\
\hline 1880 & Blackthora : & & 4 & & 6 \\
\hline 1881 & Dunsinic . & & 4 & 70 & 9 \\
\hline 1582 & $\begin{array}{l}\text { Ishmael } \\
\text { • }\end{array}$ & & 4 & & 4 \\
\hline $\begin{array}{l}1843 \\
18 \div 4\end{array}$ & The Jilt & & 4 & $\begin{array}{l}64 \\
6\end{array}$ & 10 \\
\hline 1885 & Sandiway : & & 4 & 710 & $\begin{array}{l}5 \\
5\end{array}$ \\
\hline 1886 & $\{$ Middlethorpe & & 6 & 88 & 14 \\
\hline 1897 & Castor. & & 4 & 78 & 7 \\
\hline & Satiety & & 8 & & \\
\hline 1889 & Veracity & & 5 & 80 & 14 \\
\hline 1890 & Fatber Confessor & & 5 & & 8 \\
\hline 1871 & $\begin{array}{l}\text { Ratbleal, } \\
\text { Nunthorpe : }\end{array}$ & & $\frac{4}{6}$ & $\begin{array}{ll}8 & 1 \\
8 & 11\end{array}$ & 8 \\
\hline 1692 & $\begin{array}{l}\text { Nunthiorpe } \\
\text { Simonian }\end{array}$ & & 6 & & 8 \\
\hline 1893 & Son of a Gun & & 4 & $\div 3$ & 0 \\
\hline 1595 & Bushey l'ark & & 6 & 613 & 8 \\
\hline 1596 & Canteibury Pilgrim & & 3 & 75 & 8 \\
\hline 1897 & Braylead . & & 3 & 66 & 6 \\
\hline 1593 & Viuna Forget & & 6 & 87 & 6 \\
\hline
\end{tabular}

CITY AND SUBURBAN HANDICAP(Epsom, April.) -1 mile 2 furlongs.

\begin{tabular}{|c|c|c|c|c|}
\hline Year. & Winner. & Age. & Weight & Sockey. \\
\hline $\begin{array}{l}1851 \\
1852\end{array}$ & $\begin{array}{l}\text { EIthiron } \\
\text { Butterfly } \\
\text { Etherlbert }\end{array}$ & $\begin{array}{c}. \\
0 \\
5 \\
3 \\
3 \\
3\end{array}$ & 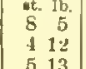 & $\begin{array}{l}\text { Marlow. } \\
\text { Sisendali. }\end{array}$ \\
\hline
\end{tabular}

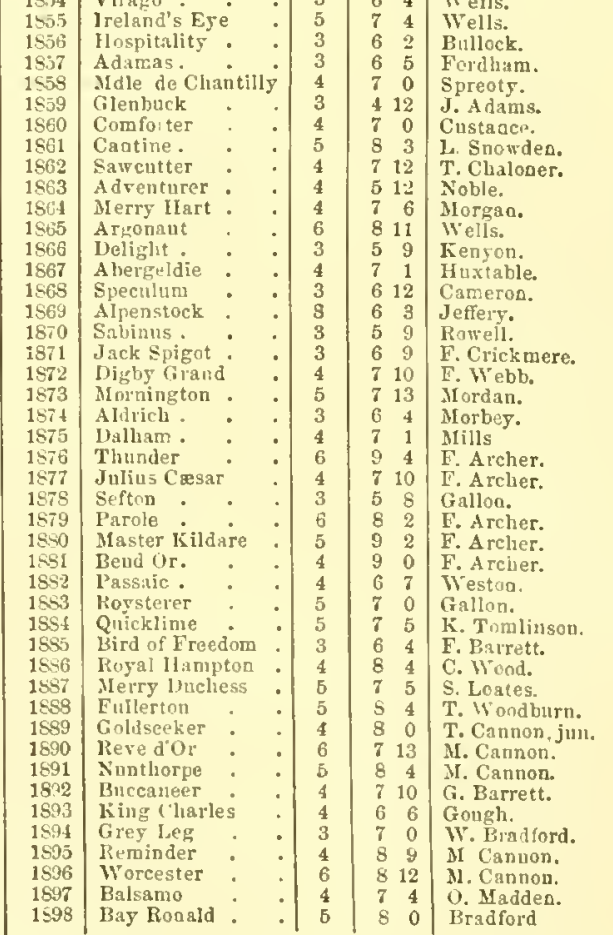

ASCOT STARES-(June). 2 miles.

\begin{tabular}{|c|c|c|c|c|}
\hline Year. & Winner. & Age. & | weight. & Jockes. \\
\hline & & srs. & st lo. & \\
\hline 1840 & Darkness & 3 & 54 & $\begin{array}{l}\text { Percy. } \\
\text { Per. }\end{array}$ \\
\hline & $\begin{array}{l}\text { Welfare } \\
\text { wWe }\end{array}$ & 4 & 711 & Flatman. \\
\hline $\begin{array}{l}154: 2 \\
154\end{array}$ & Vibration & 3 & 513 & 11. Bell. \\
\hline 1543 & Teetotaller & 4 & 66 & Riley. \\
\hline 1844 & Johaoy & ag. & & Flatman. \\
\hline 1545 & $\left\{\begin{array}{l}\text { (1st ci.) Lotluatio } \\
\text { (2nd cl.) Q. Jab. }\end{array}\right.$ & $\begin{array}{l}5 \\
6\end{array}$ & $\begin{array}{ll}8 & 1 \\
8 & 7\end{array}$ & $\begin{array}{l}\text { Flatman. } \\
\text { Flatman. }\end{array}$ \\
\hline 1546 & $\{$ (1st cl.) Akbar & 5 & $\begin{array}{lll}8 & 2 \\
8 & 2 & 1\end{array}$ & Chapple. \\
\hline 1547 & (20d cL) Petitioger & $\begin{array}{l}3 \\
5\end{array}$ & $\begin{array}{ccc}5 & 7 \\
7 & 13\end{array}$ & $\begin{array}{l}\text { W. Mlarson. } \\
\text { S. NIang. }\end{array}$ \\
\hline 1818 & Vamprie. & 4 & & Kitcheoer. \\
\hline & & 5 & & Flatman. \\
\hline 1850 & Wanota & 6 & & J. Marson. \\
\hline 1851 & Yaticas & & & Fiatman. \\
\hline & Lucio & 3 & $5 i$ & $\begin{array}{l}\text { W'ells. } \\
\text { W. }\end{array}$ \\
\hline 1853 & Buckthorn : & 4 & 85 & A. Day. \\
\hline 1854 & Little II arry & 5 & 87 & Wells. \\
\hline $18 \overline{5} 5$ & Mortiner & 5 & $\begin{array}{ll}7 & 1\end{array}$ & Cleneat. \\
\hline $\begin{array}{l}1856 \\
1557\end{array}$ & liedemption & 4 & $\begin{array}{lll}5 & 12 \\
5\end{array}$ & $\begin{array}{l}\text { Prior. } \\
\text { Parr }\end{array}$ \\
\hline $\begin{array}{l}1857 \\
1558\end{array}$ & Claude Lorraine & 3 & $\begin{array}{cc}6 & 3 \\
5 & 7\end{array}$ & Parry. \\
\hline $\begin{array}{l}1588 \\
1559\end{array}$ & Rouble! & $\begin{array}{l}3 \\
3\end{array}$ & $\begin{array}{ll}5 & 8 \\
5 & 0\end{array}$ & Pritchare \\
\hline 1560 & Mouravieff & 4 & & $\begin{array}{l}\text { D. Adame } \\
\text { A.deroft. }\end{array}$ \\
\hline & Uptinist & 4 & & Fordham. \\
\hline 1862 & Rapparee & 4 & & isborne. \\
\hline & Stantoa. & & & Midgler. \\
\hline 1564 & Hippolyta & 3 & 66 & Grimsliaw \\
\hline & Tomato. & 4 & 84 & Daley. \\
\hline 1866 & War. & 3 & $\begin{array}{lll}6 & 10\end{array}$ & Cameron. \\
\hline & Zenobia . & 5 & 74 & Hibberd. \\
\hline 1868 & Fmigration • & 5 & $\begin{array}{ll}6 & 7 \\
5 & 8\end{array}$ & lienyon. \\
\hline $\begin{array}{l}1569 \\
1 \times 0\end{array}$ & Bute Soir & 3 & $\begin{array}{lll}5 & 8 \\
& 12 & 0\end{array}$ & Gradwell. \\
\hline 1871 & Hosictucian: & 6 & & $\begin{array}{l}\text { Chaner. } \\
\text { Viells. }\end{array}$ \\
\hline $18 \pi 2$ & Molly Cobroy & 4 & & Grav. \\
\hline 1873 & Uhlan. & 4 & 12 & Yajdment \\
\hline $15 \pi 4$ & Coventry & 3 & & Clay. \\
\hline 1875 & Organist & 4 & & Grifiths. \\
\hline & Whitebait & 5 & & Newlonse \\
\hline 1877 & Cbypre. & 5 & & Wood. \\
\hline 1878 & Chestertoa & 4 & & Wood. \\
\hline & Ridot to & 4 & & Constable. \\
\hline 1890 & Teviotonale & 3 & & Kellet. \\
\hline $1=2$ & $\begin{array}{l}1 \text { eriotuate } \\
\text { Retreat. }\end{array}$ & $\frac{4}{5}$ & & Osborne. \\
\hline 1683 & Ishmael. & 5 & & Fordham. \\
\hline 1854 & Greenbank & 4 & & Вонтал: \\
\hline & Althorp. & 3 & & 1. Burrett. \\
\hline $1: 6$ & Belinda. & 5 & & J. Woodbura. \\
\hline 1507 & Eurasinn & 5 & & F. Barrett. \\
\hline 1548 & 1) an Incer & $z$ & & Allsopp. \\
\hline 53 & Lord Lorne & 3 & & Chandley. \\
\hline & Iatd loome & 4 & & Fagan. \\
\hline & lloundsditch & 5 & & Fagan. \\
\hline 103 & Bunow & 4 & & A. Wats \\
\hline & Enorigine & 年 & & 1.. Dates, \\
\hline 95 & . & 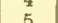 & & if (1) \\
\hline & Arlequin & & & \\
\hline & & & & \\
\hline 1898 & IIerminnts & 4 & & c. Wood. \\
\hline
\end{tabular}

PRINCE OF WALES STAKES-(Ascot, June.) - 1 mile 5 forlongs.

\begin{tabular}{|c|c|c|c|c|}
\hline Year. & winner. & Strs & Weight. & Jockey. \\
\hline 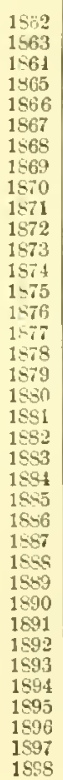 & 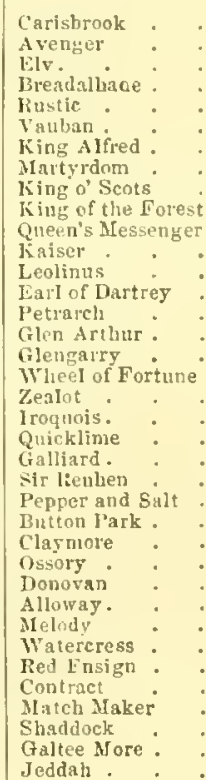 & $\begin{array}{r}= \\
= \\
= \\
= \\
=- \\
= \\
= \\
= \\
6 \\
12 \\
6 \\
8 \\
7 \\
11 \\
12 \\
7 \\
19 \\
7 \\
4 \\
8 \\
9 \\
5 \\
9 \\
8 \\
5 \\
8 \\
12 \\
6 \\
4 \\
8 \\
3 \\
4 \\
8\end{array}$ & 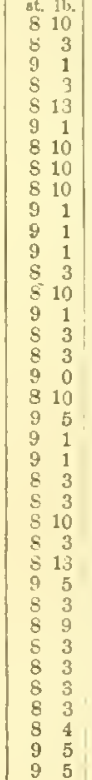 & 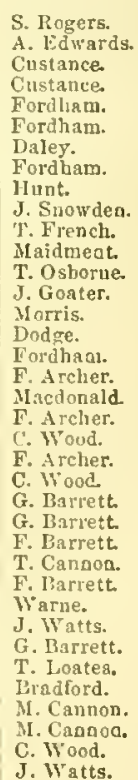 \\
\hline
\end{tabular}


WINNERS OF 'THE GREAT RACES.

CESAREWITCH STAKES-(Newmarket, oetober) - 2 miles 2 furlongs 35 yards.

\begin{tabular}{|c|c|c|c|c|c|}
\hline Year. & Whoer. & & Agd. & Wolght. & Jockey. \\
\hline 18.99 & Cruiskeen & - & $\begin{array}{c}\mathrm{gra}_{5} \\
5\end{array}$ & $\begin{array}{l}\text { st. } \\
6 \mathrm{~b} . \\
6\end{array}$ & Stagg. \\
\hline 1810 & Clarion. & . & 4 & & Kobinaon. \\
\hline 1841 & Hiona . & . & 4 & 6 i1 & R. West. \\
\hline 1842 & A reanus & . & 3 & 54 & 'T. 1) ny. \\
\hline 1843 & Coranua & & 4 & $7 \mathrm{il}$ & W. $1305 \mathrm{ce}$. \\
\hline 1814 & Faugh-a-Thall & lagh . & 3 & 80 & Il. Bell. \\
\hline 1445 & The Buron & . . & 3 & & Flatman. \\
\hline 1846 & Wit's-end & & 3 & 62 & Doualdson. \\
\hline 1817 & Conuroucls (h- & b) & 4 & 70 & G. Abdale. \\
\hline 1818 & The Cur & & 6 & & legers. \\
\hline 1849 & 1.egerilemain & . & 3 & & IIiett. \\
\hline 1850 & Glanca. & & 4 & 77 & Cliapple. \\
\hline 1851 & Mra. 'I'aft (h- & & 6 & 60 & S. Steggles. \\
\hline 1852 & Weathergage & & 9 & 611 & Welis. \\
\hline 1853 & Haco & & 3 & 512 & Palmer. \\
\hline 1854 & Muscovite & . & 5 & & Fintiman. \\
\hline 1855 & Mr. S) kes (li & $-b)$ & 5 & 68 & F. Bites. \\
\hline$i 856$ & Vengernce & . & 4 & 77 & Alderoft. \\
\hline 1857 & Prioresa & . & 4 & 69 & G. Fordlasm. \\
\hline 1858 & Rocket. & - & 3 & & Custance. \\
\hline 1859 & Artless. & . & 3 & 53 & Diewe. \\
\hline 1860 & Dulcibella & . & 3 & 611 & A. Sadler. \\
\hline 1861 & Audrey. & . & 5 & & Custance. \\
\hline 1862 & Ilartington & . & 3 & 510 & J. Grimshaw. \\
\hline 1863 & Lioness . & . & 4 & 68 & 11. Covey. \\
\hline 1864 & Thalestria & . & 4 & 62 & J. Grimshaw. \\
\hline 18,5 & Salpinctes & - & 3 & 63 & Scorey. \\
\hline 1866 & Lecturer & . & $s$ & 73 & llibberd. \\
\hline 1867 & Julius & - & 3 & 80 & 'T. Chaloner. \\
\hline 1868 & Cecil. & . & 3 & 513 & Wyatt. \\
\hline 1869 & Chélie & & 3 & 57 & F. Webb. \\
\hline 1870 & Cardinal Yor & & 4 & & Parry. \\
\hline 1871 & Corisaude & . & 3 & 712 & Maidnent. \\
\hline 1872 & Salyanos & . & 3 & 57 & F. Archer. \\
\hline 1873 & King Lnul & & 4 & 75 & 13171ckshitw. \\
\hline 1874 & Adventurière & & 3 & 612 & Glaver. \\
\hline 1875 & Duke of P'arr & ma & 3 & 60 & leossiter. \\
\hline 1876 & liosebery & . & 4 & 75 & F. Archer. \\
\hline $187 \%$ & llilations & . & 3 & 65 & J. M'Donald. \\
\hline 1878 & Jester & . & 5 & 610 & L, like. \\
\hline 1879 & Chippendale & & 3 & 75 & W. M'nonald. \\
\hline 1880 & linbert the $D$ & evil & 3 & 86 & T. Cannon. \\
\hline 1851 & Fexhall. & . & 3 & 712 & W. M'Donald. \\
\hline 1882 & Corrie lioy & . & 4 & 87 & C. Wood. \\
\hline 1863 & Don Jian & . & 3 & 510 & 1. Murtin. \\
\hline 1884 & St. Gntien & . & 3 & 810 & C. Wood. \\
\hline 1885 & Plaisanterie & . & 3 & 78 & Hartley. \\
\hline 1856 & Stone Clink & - & 4 & 77 & W. Glover. \\
\hline 1887 & linmewood & - & 3 & 76 & Robinson. \\
\hline 1885 & Tenebreuse & & 4 & 812 & T. Canuon. \\
\hline $1 \leqslant 89$ & Primrose Da & & 4 & 61 & W. Wood. \\
\hline 1890 & Sheen & . & 5 & 92 & F. Wels. \\
\hline 1891 & Raginunde & . & 3 & 610 & I. Clialoper. \\
\hline 1592 & l3arnaby & & 5 & 611 & J. Dryle. \\
\hline 1893 & \{ Red liyes & dead & 4 & 710 & T. Loates. \\
\hline & \{ypria $\}$ & lent. & 3 & 66 & W. l'ratt. \\
\hline $\begin{array}{l}1594 \\
1805\end{array}$ & lieldwick & . & 4 & 79 & Bradford \\
\hline 1805 & Rockdove & * & 4 & $6 \mathrm{J0}$ & U. Ward. \\
\hline 1896 & St. Bris . & . & 3 & 66 & К. Cвnnon, \\
\hline 1897 & Mierman & - & 5 & 75 & J. Sharplea. \\
\hline 1898 & Cbsleureux & & 4 & 75 & o. Madden. \\
\hline
\end{tabular}

MIDDLE PARK PLATE-(Newmarket, October) -2 year old-6 furlongs.

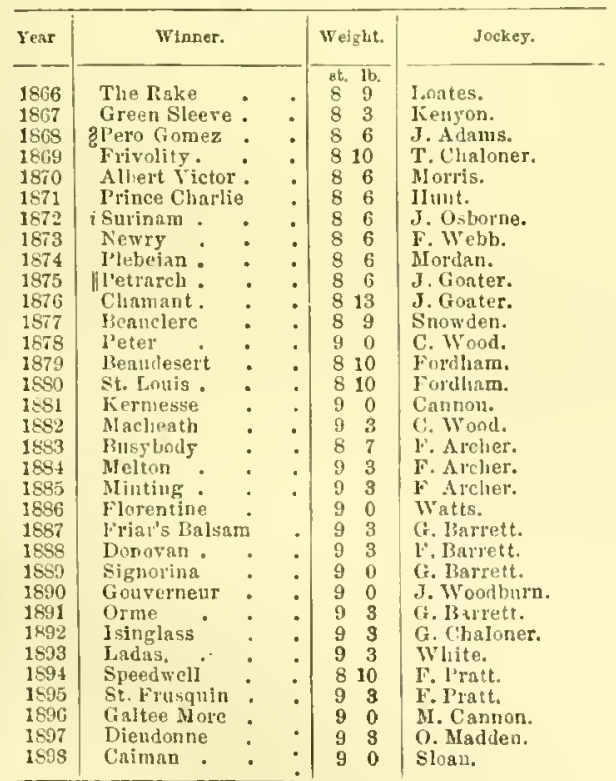

THE GREAT METROPOLITAN STAKES(Epsom, April.)-2 miles 2 furlongs.

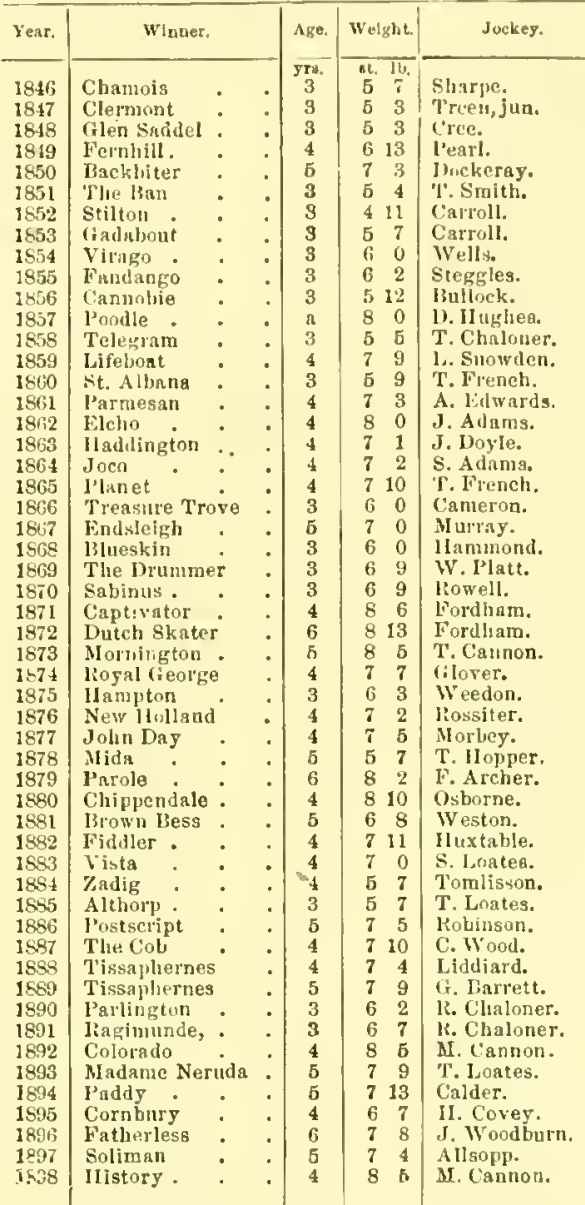

ROYAL HUNT CUP-(Aseot, June).-1 mile,

\begin{tabular}{|c|c|c|c|c|}
\hline Yeass. & Winner. & Age. & Weight. & Jockey. \\
\hline 1856 & Forbidden Fruit & ${ }_{3}^{5 T 3}$ & $\begin{array}{ll}\text { st. } \\
6 & 0\end{array}$ & Creswel!. \\
\hline 1857 & Ibosa dienhentu" & 3 & 5 io & C. Rayner. \\
\hline $1 / 58$ & 1lesperithuчR & 3 & & T. Clinloner. \\
\hline 1859 & King at Arms & 3 & 72 & Britton. \\
\hline 1560 & Crater. & 3 & 613 & W. Bottom. \\
\hline $1\llcorner 61$ & Ijuccaneer & 4 & & J. Goater. \\
\hline 1662 & Canary. & 4 & 60 & Deacon. \\
\hline 1863 & Victor & 4 & 512 & Morris. \\
\hline 1864 & Gem of the Sea & 4 & 710 & 11. Grimslaw. \\
\hline 1865 & Grstitude & 5 & 78 & II. Covey. \\
\hline 1866 & Attaché. & 4 & 712 & Parry: \\
\hline 1867 & Jasper . & 3 & & Il. Jeffery. \\
\hline 1568 & Satys. & 4 & 81 & J. Adaras. \\
\hline 1869 & See Saw & 4 & 87 & Fordlian. \\
\hline 1970 & Judge . & 4 & 65 & Newhunse. \\
\hline 1571 & Valuer. & 6 & $6 \quad 6$ & G. J arvis. \\
\hline 1872 & Kipponden & 4 & 72 & 11. Covey. \\
\hline 1573 & Winslow & $i$ & 89 & Fordham. \\
\hline 1874 & Lowlauder & 4 & 77 & Constable. \\
\hline 1875 & T'buringian Prince & 4 & 74 & C. Wood. \\
\hline 1876 & Hopuloom . & 3 & 60 & Jlopkins. \\
\hline 18.7 & Cradle. & 4 & 64 & IJopkins. \\
\hline 1578 & Julius Cresar & $\overline{5}$ & 86 & I. Archer. \\
\hline 1879 & The Mandariu & ag. & 84 & C. Wood. \\
\hline 1880 & Stratlers & 4 & 65 & Brockwell. \\
\hline 1851 & Peter. & 5 & 83 & F. Archer. \\
\hline 1882 & Sweetbread & 3 & 64 & Wondburn. \\
\hline 1893 & Elzevir. & 3 & & (c. Wood. \\
\hline 1544 & Acrostic & 4 & 65 & IF. Barrett. \\
\hline $18 \$ 5$ & Eastern Emperor & 4 & 62 & Tomlisson. \\
\hline $18 \propto 6$ & Despair. & ag. & 7 13 & C. Loates. \\
\hline 1587 & Gay Ilermit. & 4 & 713 & C. Wont. \\
\hline 1685 & Shillela;h . & 3 & $6 \quad 3$ & (i. C'laloner. \\
\hline $15 \$ 9$ & Whitelegs & 4 & 66 & W. linke. \\
\hline 1890 & Morion . • & 3 & 79 & G. Barrett. \\
\hline 1891 & Laurente II. . & 5 & 712 & M. Connon. \\
\hline $1 \subseteq 92$ & Suspender. & 3 & 710 & G. Chaloner. \\
\hline 1593 & Amandier. & 5 & 73 & T. Luates. \\
\hline 1894 & Victur Wild . & 4 & 77 & $J$ IHarrison. \\
\hline 1595 & Clorane. & 4 & 811 & M. C'annon. \\
\hline 1596 & Quarel & 5 & 711 & Fingan. \\
\hline 1897 & Kuight of the Thist & 4 & 75 & Allsopp. \\
\hline 18.8 & Jaquemart . & 4 & 56 & T. Loates. \\
\hline
\end{tabular}

CAMBRIDGESIIRI HOUGHTON STAKES

(Newmarket, Oetober).-1 mile 240 yards.
STEWARDS' CUP-(Goodwood, July) 6 furlongs.

\begin{tabular}{|c|c|c|c|c|c|}
\hline Year. & Winper. & & Age. & We:sht. & Etartera. \\
\hline 1870 & Typhous & & $\begin{array}{c}523.3 . \\
5\end{array}$ & $\begin{array}{l}\text { 8t. } 14 . \\
\text { s } 10\end{array}$ & 23 \\
\hline 1871 & Anton. & & 3 & & 34 \\
\hline 1872 & Oxonian & & c & S 12 & 28 \\
\hline 1973 & Sister IIelen. & & 5 & & 31 \\
\hline 1874 & Modena. & & 5 & 71 & 25 \\
\hline 1875 & Trappist & & 3 & $\div 10$ & 22 \\
\hline $15: 6$ & Ionaco. & & 4 & 67 & 27 \\
\hline $157 \pi$ & Herald. & & 5 & $=0$ & 23 \\
\hline $18: 8$ & Midlothian & & 4 & 72 & 20 \\
\hline $167 ?$ & I'eter. & & 3 & 50 & 30 \\
\hline j\$50 & Elf king & & 4 & 79 & 28 \\
\hline $1-51$ & Mazulkr & & 3 & 610 & 29 \\
\hline $18+2$ & Lowland Chief & & 4 & $s \mathrm{~s}$ & 19 \\
\hline 1 ins3 & Jormpipe. & & 6 & 59 & 18 \\
\hline 154 & Swectbread & & 5 & 93 & 23 \\
\hline $1 \leqslant 85$ & Dalmeny & & 5 & (f) 13 & 18 \\
\hline $1 S \in 6$ & Cratton. & & 4 & $\div 11$ & $2 i$ \\
\hline $1 \leqslant 87$ & Epset. & & 4 & 63 & 23 \\
\hline 1885 & Tî́b . • & & 5 & 37 & 21 \\
\hline 18s? & Doy lacuse & & 6 & 612 & 16 \\
\hline 1590 & Marvel. & & 3 & 76 & 22 \\
\hline 1841 & Unicorn. & & 3 & 62 & 21 \\
\hline $1<92$ & Marvel, & & 5 & $s 8$ & 28 \\
\hline 1893 & Iledira. & & 8 & 612 & 19 \\
\hline 1594 & Ganiway. & & 4 & $\& \bar{T}$ & 21 \\
\hline 19900 & Wise Virgin . & & 3 & 66 & 22 \\
\hline 1596 & Chasseur & & 4 & S 5 & 24 \\
\hline $15: 7$ & Ampliors & & 4 & $\& \&$ & 23 \\
\hline 1598 & Altesse . & & 4 & 84 & 15 \\
\hline
\end{tabular}


GREAT EBOR HANDICAP-CYork, August). -1 mile 4 furlongs.

\begin{tabular}{|c|c|c|c|c|c|}
\hline Year. & Winner. & & Age. & Weight. & Jockey. \\
\hline 1843 & Pagan - . & & $\begin{array}{c}9 \pi{ }^{2} \\
5\end{array}$ & $\begin{array}{cc}\text { st. } \\
71 \mathrm{lb} \\
13\end{array}$ & Templemar. \\
\hline 1541 & Godfrey. & & 3 & & Berwick. \\
\hline 1815 & Coheiress & - & 4 & & W. Abdale. \\
\hline 1816 & Arthur . & . & 4 & 63 & J. Shalpp. \\
\hline 1817 & Mathematician & . & 3 & & Donaldson. \\
\hline 1848 & Mleaux , . & . & 4 & & Flatman. \\
\hline 1849 & The Hero & . & 6 & & A. D.F. \\
\hline 1550 & Mark Tapley & . & 3 & 59 & A rnoli. \\
\hline 1551 & Nancy & . & 3 & 613 & Charlton. \\
\hline 1552 & Adine: & & 3 & & Rickards. \\
\hline 1853 & Pantomime : & - & 3 & 58 & T. Olliver. \\
\hline 1854 & Grand Inquiaitor & & 3 & & Fordhans. \\
\hline 1555 & Yandnl & & 3 & & Cresswell. \\
\hline 1856 & Warlock & . & 3 & 58 & Withingtod. \\
\hline 1857 & El llakim & . & 3 & & Little. \\
\hline 1858 & Vedette. & . & 4 & & J. Osborne. \\
\hline 1859 & Underluand & : & 5 & 91 & Alderoft. \\
\hline 1860 & Pax & - & 4 & 611 & A. I.dw srds. \\
\hline 1561 & Risiog Sun & : & 4 & 79 & Fordham. \\
\hline 1862 & Makeshift . & . & 5 & 68 & Ilardenstle. \\
\hline 1863 & Golden Pledge & . & 3 & 60 & J. Loates. \\
\hline 1954 & Raglan. & . & 4 & & Morris \\
\hline 1865 & Verdaut. & . & 3 & 67 & Heartfield. \\
\hline 1836 & Westwick & & 3 & & 11. Cor. 5. \\
\hline 1867 & Mandrake & & 3 & & Cameron. \\
\hline 1868 & Fairwind & 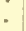 & 4 & $\begin{array}{ll}6 & 6\end{array}$ & W. Platt. \\
\hline 1869 & Fortunio & . & 5 & 812 & Chaloner. \\
\hline 1870 & laganiai & . & 5 & & J. snow dea. \\
\hline $1 \mathrm{sin}$ & Not Uut. & . & 4 & 70 & D. Butler. \\
\hline $18 \pi 2$ & Albert Victor & 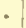 & 4 & 812 & Custance. \\
\hline 1873 & Louise Victoria & 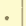 & 4 & 613 & Constable. \\
\hline 1974 & Chivalrous & 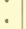 & 4 & $\begin{array}{lll}7 & 0\end{array}$ & Griffiths. \\
\hline 1875 & Lily A gues & 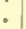 & 4 & 88 & W. Wood. \\
\hline 1870 & Litian • • & & a & 711 & F. Arclier. \\
\hline 1577 & 11 Gladiatore & & 3 & & Morrell. \\
\hline 1879 & Cesrau. & . & 3 & 69 & Lemaire. \\
\hline 1879 & Isonomy & . & 4 & 98 & Canoon. \\
\hline 1830 & Norice . & . & 3 & & Bell. \\
\hline 1581 & Sother Sbipton & 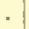 & 3 & 511 & Percival. \\
\hline 1582 & Victor Emanuel & 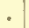 & 5 & $\begin{array}{lll}9 & 0\end{array}$ & J. Osborne. \\
\hline 1883 & Corrie Roy . & . & 5 & 912 & C. Wood. \\
\hline 1884 & Ben Alder & 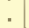 & 4 & 78 & J. Fagan. \\
\hline $188 \overline{3}$ & Nate : & 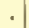 & 6 & 812 & F. Archer. \\
\hline 1586 & Le Caissier & - & 3 & 67 & Allsopp. \\
\hline 1887 & silence. & & 5 & 69 & Calder. \\
\hline 1888 & Nappa . . & & 4 & 810 & T. Snowden. \\
\hline 1589 & King 3100 mo ith & 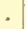 & ag. & 812 & J. Watts. \\
\hline 1890 & Silver spur . & . & 4 & 71 & T. Loates. \\
\hline 1891 & Buccaneer & & 3 & 75 & J. Woodbura. \\
\hline 1692 & Alice & . & 5 & 90 & S. Chandley. \\
\hline 1593 & Senrputty & 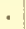 & 3 & 73 & Bradford. \\
\hline 1594 & Quilon. & & 4 & & S. Loates. \\
\hline 1895 & Llanthony & & 6 & 7 & Finlay. \\
\hline $18: 6$ & Dingle Bry . & . & 4 & 7 & T. Loates. \\
\hline 1897 & Harrest Iirney & . & 4 & 77 & MIaddeu. \\
\hline 1998 & Invincible Il. & & 3 & 75 & Mauden. \\
\hline
\end{tabular}

NORTHAMPTONSHIRE STAKES-

(March or April). -1 mile 6 furlongs.

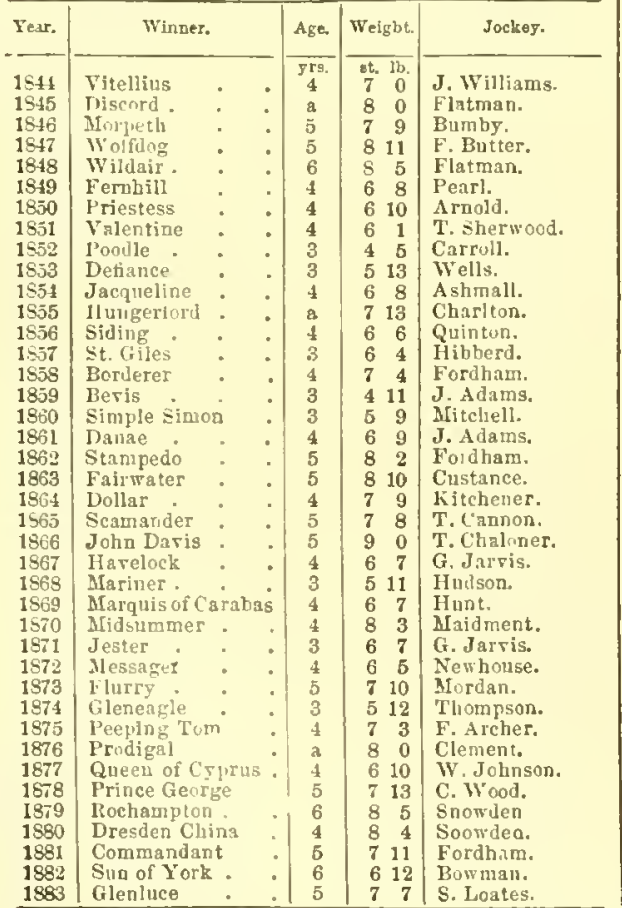

Northamptonshire Stakes.-Continued.

\begin{tabular}{|c|c|c|c|c|c|}
\hline Year & Winner. & & Age. & Weigbt. & Jockey. \\
\hline $188 t$ & Lnch Ranze . & & $\underset{3}{\mathrm{yrs}}$ & $\begin{array}{ll}\text { st. } & \text { lb. } \\
7 & 5\end{array}$ & Isuke. \\
\hline 1885 & Marmorn & : & 3 & 511 & Kickaby. \\
\hline 1886 & Sir Kenneth. & . & 4 & $8 c$ & C. Wood. \\
\hline $158 \overline{1}$ & Middlethorpe & 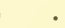 & ag. & 812 & F. Bariett. \\
\hline 1868 & Oliver 'Twiat. & & 5 & 811 & Webb. \\
\hline 1889 & Claymore & . & 5 & 85 & Allsopp. \\
\hline 1890 & Padua . & & 4 & 73 & J. Woodbura. \\
\hline 1591 & Lusignan & - & 4 & 612 & Harper. \\
\hline $1=92$ & Colorado & - & 4 & 610 & Brad ford. \\
\hline 1893 & Paddy. & • & 4 & 83 & Calder \\
\hline 1894 & Rodomont & . & 3 & 67 & W. Pratt. \\
\hline 1895 & Barbary. & . & 4 & $7 \quad 7$ & S. Lnatea. \\
\hline 1596 & Paris $11 \mathrm{I}$. & - & ag. & 86 & M. Canoon. \\
\hline $189 \overline{\mathbf{i}}$ & Telescope & . & 5 & 87 & M. Cannon. \\
\hline 1849 & Barford & 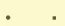 & 5 & 611 & H. Jones. \\
\hline
\end{tabular}

GOODWOOD STAKES-(July). 2 miles 4 furlongs.

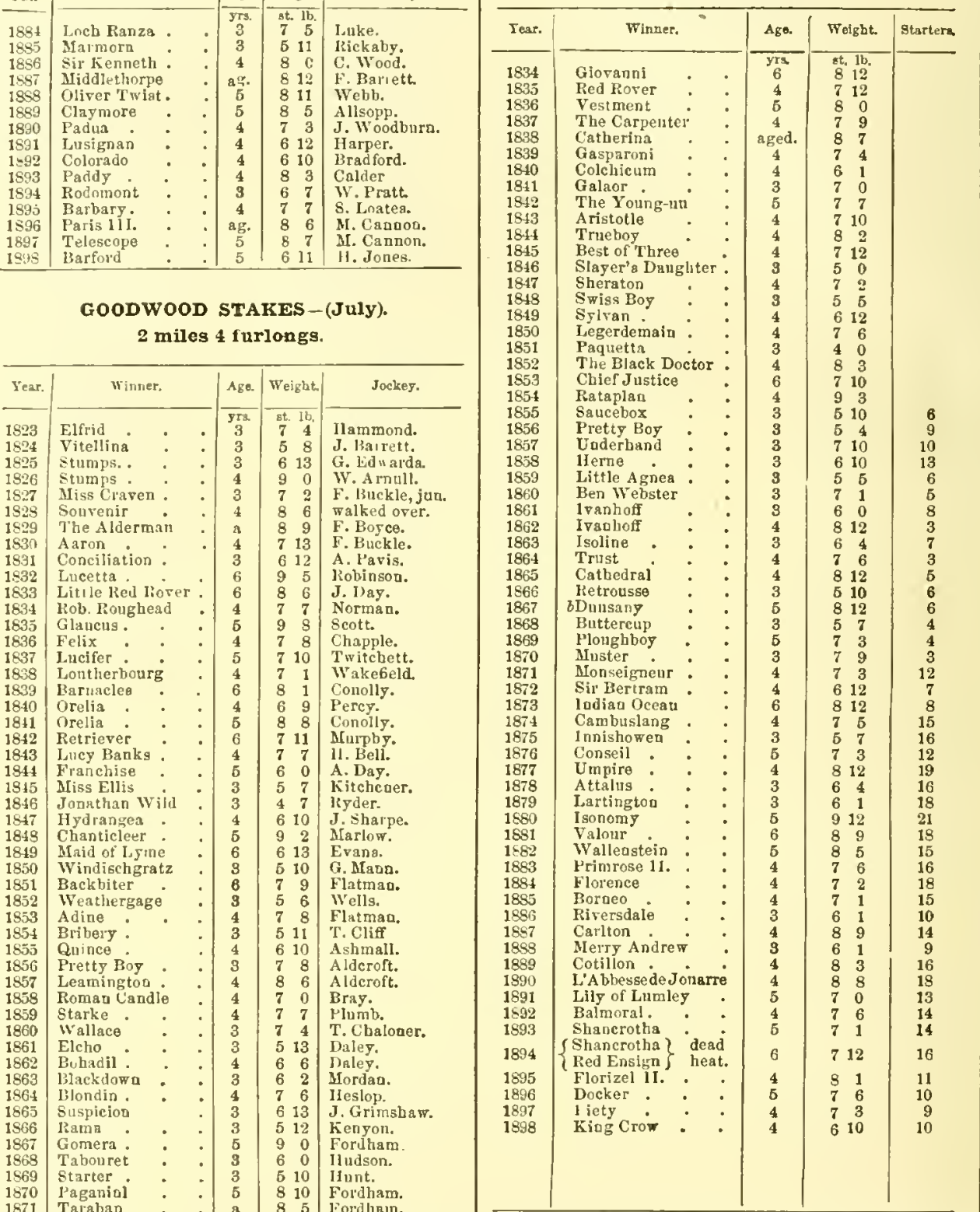

1872 Spennithorae: 4

\begin{tabular}{ll|lll} 
& 4 & 8 & 8 & Mridment
\end{tabular}

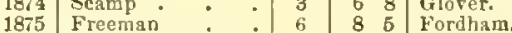

1876 Hampton : : 4 . 7 10 10 Mordan.

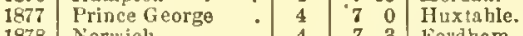

1878 Norwich : : $\begin{array}{llll}4 & 7 & 3 & \text { Fordham } \\ 1879 & 6 & 8 & \text { Gallon }\end{array}$

1580 Reveller * * $\quad \begin{gathered}\mathbf{4} \\ \mathbf{7}\end{gathered}$

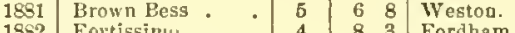

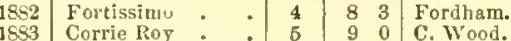

1883 Corrie Roy * - 50990 C. Wood.

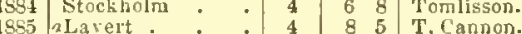

1886 Winter Cherry: $33^{5} 7$ Cleminson.

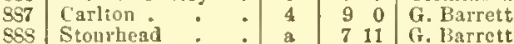

1589 Ingrant

1589 Ingrani

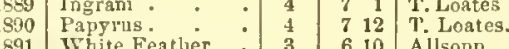

1891 Raluh Feather - 350610 Allsopp.

1693 Re Eyes : $\quad \begin{aligned} & 7 \\ & 4\end{aligned}$

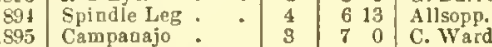

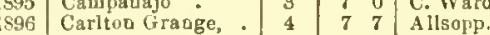

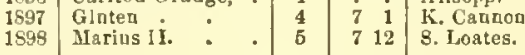

a. The Goodwood Stakes became roid in consequence of are there not being 10 acce

ECLIPSE STAKES-(Sandown, 2nd Summer). 1 mile 2 furlongs.

\begin{tabular}{|c|c|c|c|c|c|}
\hline Year. & Whinger. & & $\Delta$ ge. & Welght. & starters. \\
\hline $\begin{array}{l}1886 \\
1687 \\
1858 \\
1889 \\
1890 \\
1891 \\
1892 \\
1893 \\
1894 \\
1895 \\
1896 \\
1897 \\
1898\end{array}$ & $\begin{array}{l}\text { Readigo } \\
\text { No race. } \\
\text { Orbit } \\
\text { Ayrshire } \\
\text { No race. } \\
\text { Surefoot } \\
\text { Orme } \\
\text { Orme : } \\
\text { Isinglass } \\
\text { Le Justicier } \\
\text { St Frusquin } \\
\text { Persimnou } \\
\text { Velasquez }\end{array}$ & 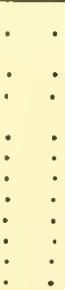 & $\begin{array}{c}\begin{array}{c}9 r 3 \\
6\end{array} \\
3 \\
4 \\
4 \\
4 \\
3 \\
4 \\
4 \\
8 \\
3 \\
4 \\
4\end{array}$ & $\begin{array}{rr}\text { st. } & \mathrm{lb}, \\
9 & 7 \\
8 & 12 \\
10 & 2 \\
& \\
10 & 2 \\
9 & 1 \\
10 & 2 \\
10 & 2 \\
9 & 1 \\
9 & 4 \\
10 & 2 \\
10 & 2\end{array}$ & $\begin{array}{r}12 \\
13 \\
6 \\
9 \\
9 \\
7 \\
6 \\
7 \\
8 \\
4 \\
5 \\
9\end{array}$ \\
\hline
\end{tabular}

MANCHESTER CUP-(June).

1 milo 6 furlongs.

8 Divided, after a dead heat with Deceit, 3 yro. 6 st 
WINNERS OF THE GREAT' RACES.

GT. YORKS. HANDICAP-(Doneaster,

September.) - 1 mile 6 furlongs 132 yards.

\begin{tabular}{|c|c|c|c|c|c|}
\hline Year. & Winzer. & & Age. & Weight. & Jockey. \\
\hline 1842 & Galanthua & & $\begin{array}{c}\mathrm{yrs} \\
3\end{array}$ & $\begin{array}{l}\text { Bt. } 1 b_{2} \\
512\end{array}$ & G. Abdale. \\
\hline 1843 & Ponpey. & & 3 & 67 & G. Noble. \\
\hline 1844 & l'otnpey. & & 4 & 78 & J. Ilowlett. \\
\hline 1545 & My Mlurg & - & 3 & & Kitchener. \\
\hline 1846 & Cranebrook . & & 3 & & i. Abdale. \\
\hline 1817 & Yardley . & & a & 75 & II'hitebouse. \\
\hline 1848 & Mlag Sarah & & 6 & 88 & F. Butler. \\
\hline 1549 & Snowstorm & & 3 & 512 & J. A ruold. \\
\hline 1850 & Mat'k Tapley. & & 3 & & J. Arnold. \\
\hline 1851 & The Confessor & & 3 & 64 & Charlton. \\
\hline 1852 & Hungerford. & - & 4 & & Hiett. \\
\hline 1853 & Ilungerford . & & 5 & & Charlton. \\
\hline $1 \times 51$ & Grapeshot : & & 4 & 78 & A shmall. \\
\hline 1835 & Wild II untsman & & 4 & 70 & Rates. \\
\hline 1856 & Турев • . & & 6 & 812 & Flatman. \\
\hline $1 \subseteq 57$ & Warlock & & 4 & 82 & Flatman. \\
\hline 1853 & Prioresa. & & 5 & 73 & Fordham. \\
\hline 1859 & Paul . & & 3 & 510 & 1. Sadler. \\
\hline 1860 & Moorhen & & 3 & 62 & H. Grimshaw \\
\hline 1561 & Wallace & & 4 & 87 & L. Snowden. \\
\hline 1862 & Cowleg. & & 4 & 78 & Drewe. \\
\hline 1863 & Dulcibella . & & 6 & 78 & A. Edwards. \\
\hline 1864 & Magnum Bonum & 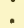 & 5 & 85 & Nolman. \\
\hline 1865 & Jolin lavia. & & 4 & 82 & Fordham. \\
\hline 1866 & Caithness . & & 3 & 62 & Thomson. \\
\hline 1867 & Seville. & & 3 & 510 & 1). Butler. \\
\hline 1868 & lomping Giri & . & 4 & 76 & Kenyon. \\
\hline 1869 & Gt. des isatailles & . & 4 & 710 & II udson. \\
\hline 1870 & Border knight & . & \pm & 810 & Custance. \\
\hline 1871 & The Dwarf & . & 3 & 711 & Hunt. \\
\hline 1872 & Dalnscardoch & $\dot{0}$ & 4 & 812 & T. Chaloner. \\
\hline 1873 & Pirate. & & 3 & 62 & Newhollse. \\
\hline 1874 & Louise : . & . & 5 & 77 & Constable. \\
\hline 1875 & Saint Leger : & : & 3 & 62 & 'Thouson. \\
\hline 1876 & Bersaglier : & & 3 & 68 & J. M'Donald. \\
\hline 1877 & Albert Edward & - & 3 & 68 & Ilopkina. \\
\hline 1873 & Flotsare. & . & 3 & 69 & W. I'Donald. \\
\hline 1879 & Dresden China & . & 3 & 60 & Coates. \\
\hline 1880 & Reveller & . & 4 & 712 & Kellet. \\
\hline 1881 & Petronel & & 4 & 812 & I. Archer. \\
\hline 1882 & Baliol. & & 3 & 67 & J. Woodburn. \\
\hline 1883 & Vista & & 4 & 611 & S. Loates. \\
\hline 1884 & Lawminster . & - & 6 & 86 & J. Osborze. \\
\hline 1885 & King Monmouth & . & 3 & 713 & J. Snowden. \\
\hline 1856 & Selby & & 4 & 71 & F. Barrett. \\
\hline 1887 & Merry Duchess & & 5 & 82 & G. Barrett. \\
\hline 1888 & Biutton Park. & & 5 & 78 & G. Barrett. \\
\hline 1889 & Iloundsditch. & & 3 & 611 & Blake. \\
\hline 1890 & Silver Spur. & & 4 & 85 & 'T. Loates. \\
\hline 1891 & Alloway, & & 4 & 811 & II. Caanon. \\
\hline 1892 & Springtime & & 4 & 711 & Pratt \\
\hline 1893 & Cherterfield: & & 5 & 90 & G. Barrett. \\
\hline 1894 & Bushey Park & & 5 & 812 & 1I. Cannon. \\
\hline 1895 & Bayd of A von & & 4 & 78 & S. Loates. \\
\hline 1896 & Drip & • & 3 & 70 & N. Robinson. \\
\hline 1897 & Carlton $\mathbf{G r a n g e}$ & . & 5 & 712 & 8. Loater \\
\hline 1898 & Locarno. . & & 3 & 65 & A. W. Pratt. \\
\hline
\end{tabular}

LINCOLNSHIRE HANDICAP-(Lineeln, Mareh.) - I mile.

\begin{tabular}{|c|c|c|c|c|}
\hline Year. & Winner. & $\Delta_{\text {E e. }}$ & Weight. & Starters. \\
\hline 1870 & Royal Rake. & $\underset{4}{y_{1}^{13}}$ & $\begin{array}{l}\text { st. } 1 \mathrm{~b} \text {. } \\
7\end{array}$ & 10 \\
\hline 1871 & "Vulcan : & aged. & 68 & 24 \\
\hline 1872 & Guy Dayrell . & 5 & 713 & 27 \\
\hline 1873 & Vestminster . & aged. & 81 & 21 \\
\hline 1874 & Tomahawls : : & 3 & 64 & 35 \\
\hline 1875 & Gumner . . & 4 & & 32 \\
\hline 1876 & Controversy . & 5 & 77 & 30 \\
\hline 1877 & Footstep . & 4 & 72 & 32 \\
\hline 1878 & Kaleidoscope & 5 & 712 & 27 \\
\hline 1879 & Toncliet & 5 & 84 & 27 \\
\hline 1880 & liosy Urosa . & 6 & 713 & 25 \\
\hline 1881 & Buchaan & 4 & 610 & $36^{\circ}$ \\
\hline 188: & Punlet $\cdot$. & 5 & 87 & 25 \\
\hline 1883 & Knight of Burghley & aged. & 78 & 17 \\
\hline 1884 & Ton:ıns . - : & 6 & 84 & 29 \\
\hline 1885 & Bendigo. & 5 & 85 & 21 \\
\hline 1886 & Fulmen. & 6 & 713 & 23 \\
\hline 1587 & Oberon . & 4 & 78 & 20 \\
\hline 1888 & Verncity & 4 & 610 & 25 \\
\hline 1889 & Wise Man & 4 & 78 & 26 \\
\hline 1890 & Rejected : & 6 & 811 & 19 \\
\hline 1891 & Lord George . & 5 & & 21 \\
\hline 18923 & Clarence & 3 & 68 & 25 \\
\hline 1593 & Wolf a Crag . & 3 & 67 & 20 \\
\hline 1894 & Le Nicham . & 4 & 87 & 19 \\
\hline 1875 & Euclid • & 6 & 712 & 15 \\
\hline & Clorane $\cdot$ & 5 & 94 & 18 \\
\hline I897 & Winkfield's Pride & 4 & 89 & 18 \\
\hline 1898 & Prioce Barcaldine & 5 & 75 & 14 \\
\hline
\end{tabular}

- Walked over, after a dead heat with Verauda, 3 years
THE ONE THOUSAND GUINEAS

STAKES-(Newmarket, April or May). I mile 11 yards.

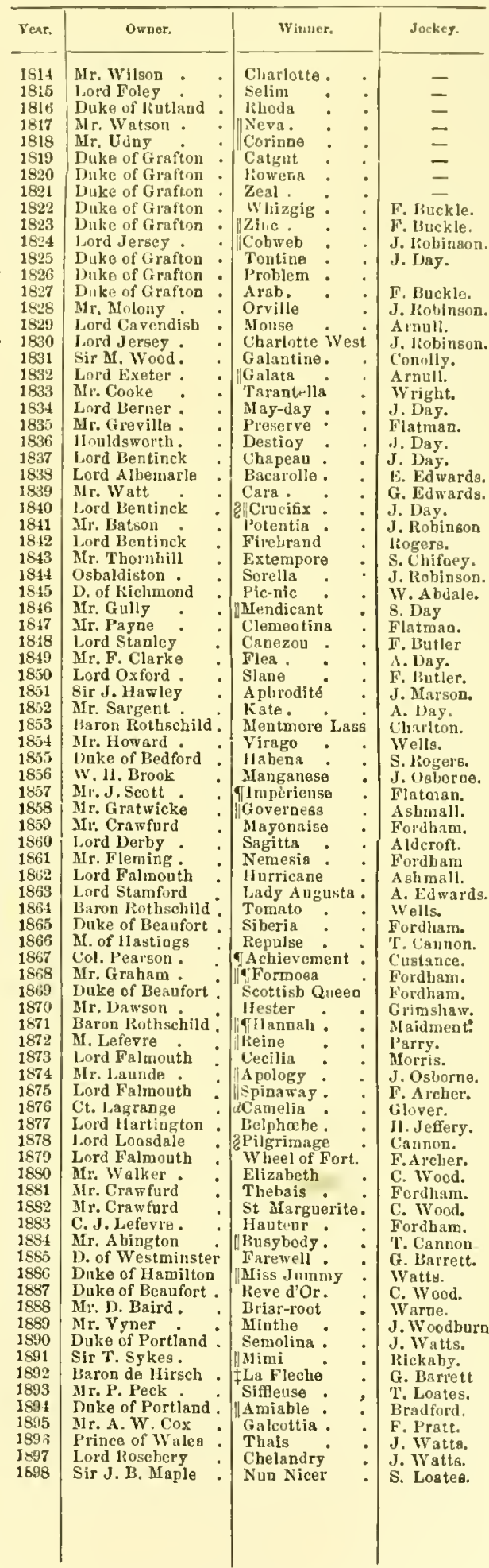

THE TWO THOUSAND GUINEAS

STAKES-(Newmarket, April or May). 3 year old-I mile 11 yards.

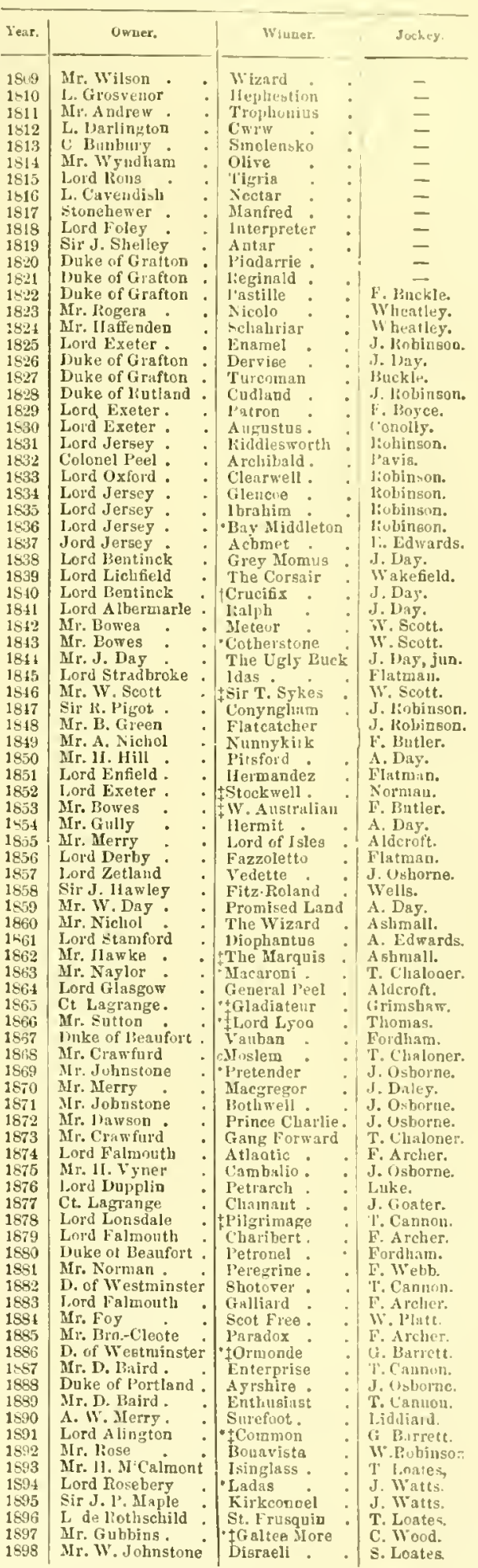

c After a dead beat with Mr. W. Graham'a Formosa (Fordham), who afterwards divided the stakes

$d$ Ran a dead leat with Enguerrande for the Oaks.

Those marked (8) also won the Two Thousand, (I) the Oaks, (I) the St. Leger.

Horses marked ( $\left(^{*}\right)$ also won the Derby, ( $\left.\uparrow\right)$ the OakB, and ( $\ddagger$ ) the St. Leger. 


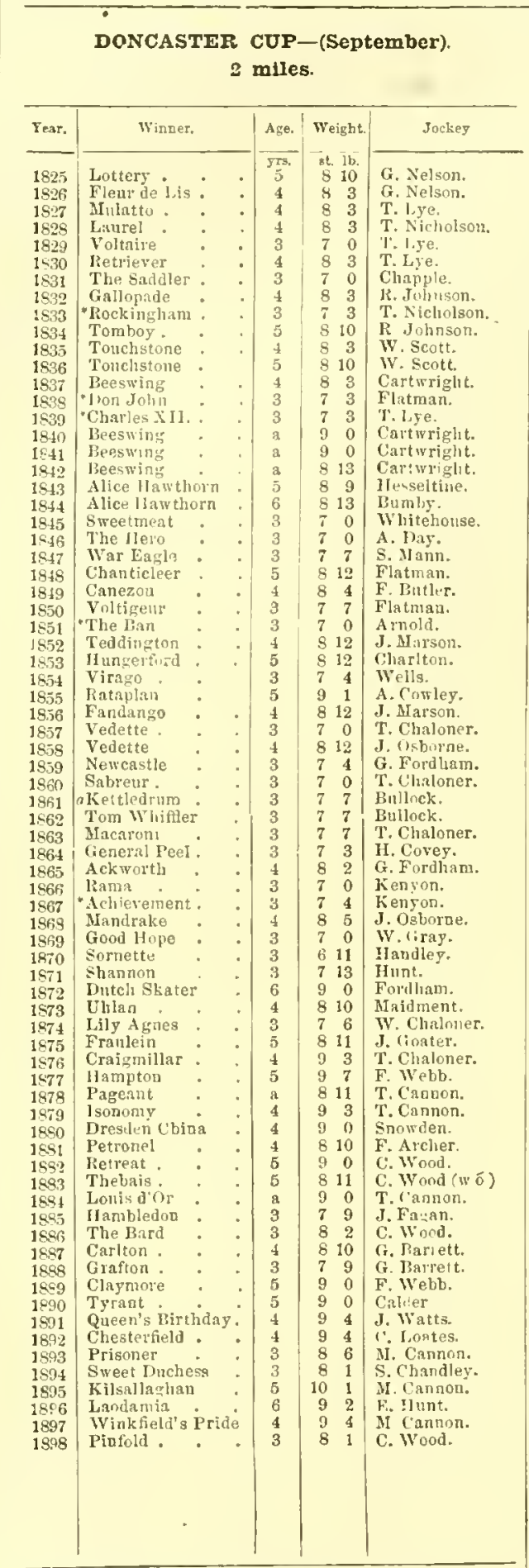

Horses marked (*) won the St. Leger the same year. a W Walked over and divided after a dead hent witb 11 .
Saxon's Brown Ducluss (MIidgley).
GOODWOOD CUP-(July).

2 miles 4 furlongs.

\begin{tabular}{|c|c|c|c|c|}
\hline Year. & wimer. & $A_{g} \theta_{0}$ & Weight. & Juckey, \\
\hline $\begin{array}{l}1825 \\
1826 \\
1827 \\
1824 \\
1529 \\
1830\end{array}$ & $\begin{array}{l}\text { Cricketer } \\
\text { Stumps. } \\
\text { Linkboy } \\
\text { Miss Craven } \\
\text { Fleur de Lis: } \\
\text { Fleur de Lis: }\end{array}$ & $: \begin{array}{c}\mathrm{yra} \\
3 \\
4 \\
4 \\
4 \\
4 \\
\mathrm{a} \\
\mathrm{a}\end{array}$ & $\begin{array}{cc}\text { 8t } & \mathrm{Ib}^{7} \\
7 & 0 \\
8 & 11 \\
8 & 4 \\
8 & 1 \\
9 & 3 \\
9 & 9\end{array}$ & $\begin{array}{l}\text { G. Edwards, } \\
\text { salked over. } \\
\text { F. Royce. } \\
\text { F. Boyce. } \\
\text { liobinson. } \\
\text { G. Nelson. }\end{array}$ \\
\hline
\end{tabular}

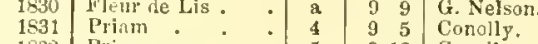

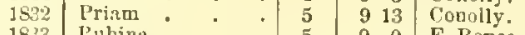

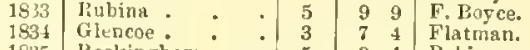

\begin{tabular}{ll|l|ll|l}
1835 & $\begin{array}{l}\text { Rockirgham : : } \\
\text { Hornsea }\end{array}$ & $\mathbf{5}$ & 9 & $\mathbf{4}$ & Robinson. \\
\hline
\end{tabular}

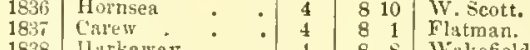

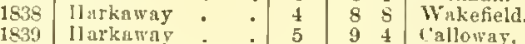

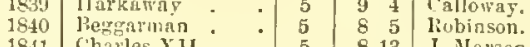

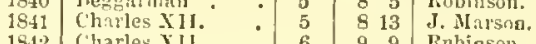

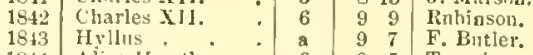

1844 Alice 11aw thorn : $6 \begin{gathered}9 \\ 0\end{gathered}$

1815 Miss Flis : : 3 : 7 O W. Ahdale.

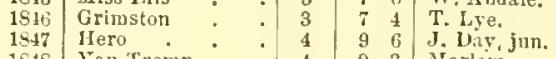

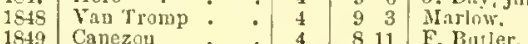

\begin{tabular}{l|lll|llll}
1849 & Canezou & $:$ & $:$ & 4 & 8 & 11 & F. Burler. \\
1850 & Canezou & $:$ & 5 & 9 & 7 & $F$ & Butler.
\end{tabular}

\begin{tabular}{lll|l|llll}
1851 & Naney \\
1852 & Kingston : : & 3 & 7 & 0 & Charlion. \\
Klatman.
\end{tabular}

1853 couvence : $: \begin{aligned} & 3 \\ & 3\end{aligned}$

18.4 Virago.

1855 cBaroneino

1857 c.Ionarque

5 S 9 Ashmall.

1859 Promised Land: 40.

1860 Sweetsauce

861 dStarke $\quad:$\begin{tabular}{ccc|c}
3 & 7 & 7 & Charit on. \\
6 & 8 & 10 & Fordhar.
\end{tabular}

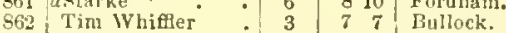

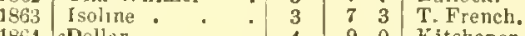

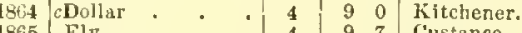

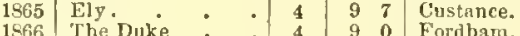

1967 Vauban.

1868 speculıa?

1669 Kestitution

\begin{tabular}{l|l}
1870 & Siderolite \\
18.1 & Shannon
\end{tabular}

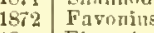

1873
1874 Flagreolet
Duncister

1574 Dencister

1876 New Ilolland

1878 HKincsem

\begin{tabular}{l|l}
$18 i 9$ & Ísonomy \\
1580 & Dresden Cbin \\
\hline
\end{tabular}

1880 Dresden China

1852 Friday

1583 Borler Ninstrel

1 sts St simon

1856 The Bard

1887 Sarille

1859 Trayles

1590 Philomel

1831 Gonsalve,

\begin{tabular}{lll}
1892 & Martagon \\
1893 & Barmecide \\
\hline
\end{tabular}

1893 Barmecide

1894 Kilsallaghan
1895
Florizel 11.

1896 Count Schomi er

1598 King slessenge
ChESTER CUP-(May).

About 2 miles 2 furlongs.

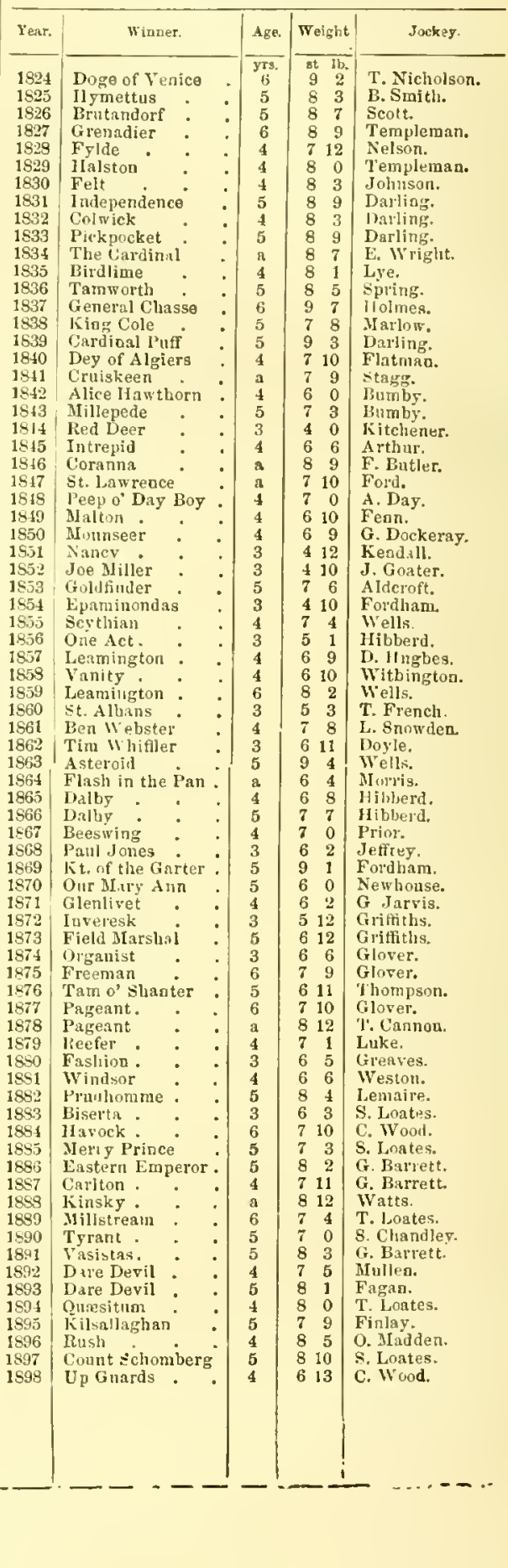




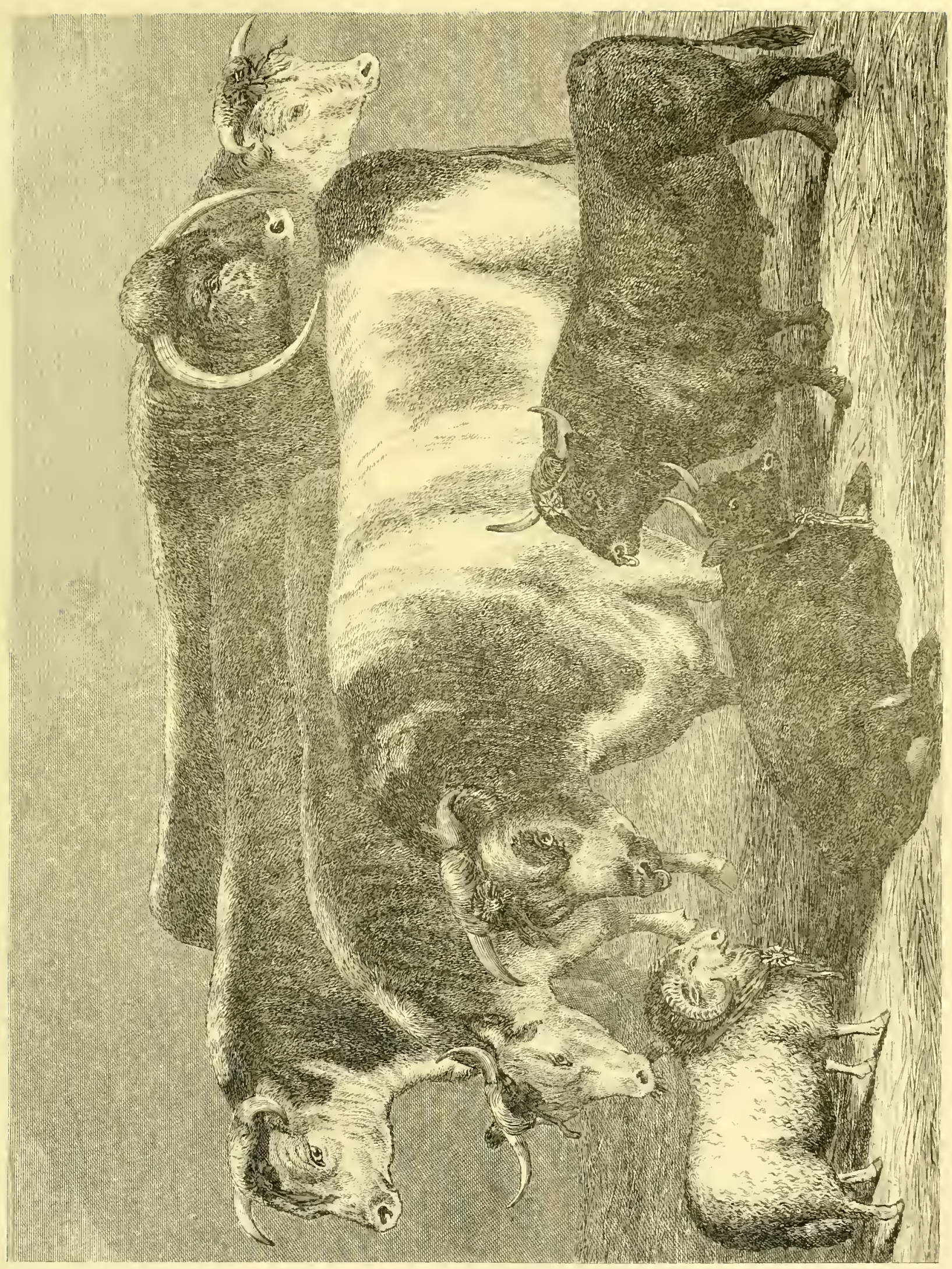




$$
\text { . }
$$

- 


\title{
DIVISION III.
}

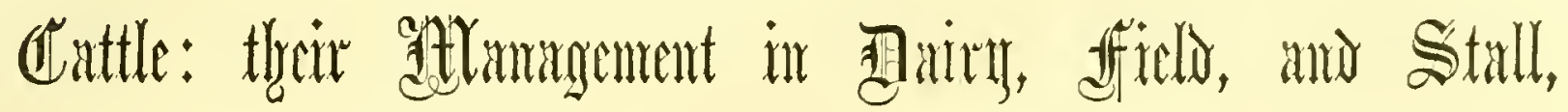

\author{
BY JOHN WALKER, \\ AUTIIOR OF "FARMING TO PROFIT," \&O
}

\section{BREEDS OF CATTLE AND THEIR MERITS.}

There is in Great Britain and Ireland a variety of breeds of animals, far too numerous to comment upon here. The quaint, semi-wild Scotch kine, and others, on their native soil-

" Hard, ragged, and rough as their heathery haunts,

As the hills where they love to dwell,"

are only occasionally brought farther south, to be fattened for the butcher on luxuriant pasture, under a more genial sky. Just over the Borders the productive little breed of Ayrshire thrives.

The North and South Welsh cattle are reared for the most part in mountainous districts, where only scanty herbage prevails for them in summer and still harder fare in winter. Between the ages of eighteen months and three years they are disposed of annually to the English graziers in large herds. Having fared hardly, and arrived at nearly full growth, they make rapid improvement on the rich English pasture-land.

Ireland can boast of the far-famed Kerry cattle, and some other kinds, most of them being, however, of a nondescript breed; but here and there the blood of good English Shorthorns has made marked improvement in the herds. Then there are, among a variety of others, the Shorthorn, the Hereford, the Long-horned, and the Suffolk Dun. These latter kinds are indigenous to our country, and can be found on no other portion of the globe, bred, reared, and fattened to such perfection. Lastly, the Channcl Island breeds, which will presently be fully discussed.

The Scotch breeds do not, as a rule, yield large quantities of mulk, although such as they do give is of excellent quality, and when more generously fed on English land the cream is peculiarly rich in butter-forming constituents. In some districts it is a practice to introduce one or two Highland or Kyloe cows into the English dairies, in order to increase the richness of the milk of other cows, the produce of which may be remarkable rather for quantity than quality. The Ayrshire is essentially a dairy breed, and possesses such admirable qualities for the latter purpose as to be held in high esteem in districts other than those of Scotland. The Angus cattle are more valuable as meat makers than milk givers. They have been so honourably spoken of on both sides of the Border as to need little comment here. Indeed, no showyard is complete without them.

The colour of the Ayrshires is for the most part red and white, in distinct patches; occasionally they are all of a red colour, more or less deep. We have sometimes seen the patches approach a fawn colour, and we have also seen prize Ayrshire bulls of a grayish colour Red and white spotted may, however, be considered the standard marking of an Ayrshire. The horns are short, spreading a little at their junction with the head, and then turning upwards. 'l'heir other prominent points are a fine, tapering head, with pleasing countenance; thin neck; narrow chine, back, and hocks; flat ribs, large belly, thin buttocks, fine bone, thin hair, and soft hide; udder of a hemispherical shape, well formed, having loose, soft skiu behind. The milk produced is rich in butter-making properties. A feature of the Ayrshire cow is the length of time over which its milk-producing powers extend. The following results of a milking competition at Ayr show the milking capabilities of this breed:--

\begin{tabular}{|c|c|c|c|c|c|c|c|c|}
\hline Cow beloaging to & 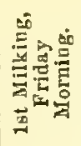 & 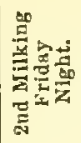 & 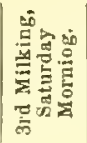 & 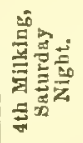 & 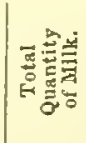 & 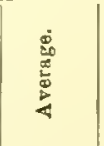 & 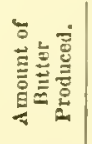 & 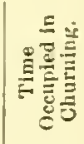 \\
\hline \multirow{7}{*}{$\begin{array}{l}\text { 1. A. Wilsua, Car- } \\
\text { rick St., Ayr. } \\
\text { 2. James Headrie, } \\
\text { Balston, Ayr. } \\
\text { 3. W. Reid, Claae, } \\
\text { St. Quivox. } \\
\text { 4. W. Reid, Cluae, } \\
\text { St. Quivox. } \\
\text { 5. R. Wallace, Kirk- } \\
\text { landholm, do. } \\
\text { 6. R. Wallace, hirk- } \\
\text { laadholm, do. }\end{array}$} & Ibs. oz. & lbs. oz. & Ibs. oz. & Ibs, oz. & Ibs.oz. & Ibs. oz. & lbs, $0 z^{2}$ & hs. mo \\
\hline & 2214 & $21 \quad 14$ & $27 \quad 12$ & 246 & 9614 & 243.5 & 34 & 025 \\
\hline & 225 & 2411 & 260 & 244 & $97 \quad 4$ & 245 & $214 \frac{1}{2}$ & 050 \\
\hline & 230 & $25 \quad 7$ & 113 & 229 & 823 & 20875 & 29 & 045 \\
\hline & 3015 & 250 & $24 \quad 12$ & 2715 & 1096 & 275.5 & $3 \quad 6 \frac{1}{2}$ & 145 \\
\hline & 2811 & 286 & $28 \quad 14$ & 283 & $114 \quad 2$ & 288.5 & $19 \frac{1}{2}$ & 25 \\
\hline & 25 & $23 \quad 13$ & $\begin{array}{ll}23 & 9\end{array}$ & 220 & 9411 & $23 \quad 10.2$ & 115 & 145 \\
\hline
\end{tabular}
$3 \mathrm{~F} \%$ 
The North and South Welsh are a hardy breed, supplying to our markets some of the best beef on offer. The cows are good, fair milkers, and when crossed with the shorthorns are hard to rival. They will not, however, answer for the English breeder and rearer to utilize, as their progeny would not be as valuable as something more closely approaching the shorthorn. A cross between the shorthorn and the Welsh must not, however, be depreciated. Steers of this mixture have ere now proved good enough to compete successfully in the showyard; indeed, as a rule, they are splendidly fleshed animals, hardy in constitution, and apt at fattening. Howbeit, the writer luas reared them side by side with well-bred, or rather nearly pure, shorthorns, and the latter have ever proved the most valuable animals in the end. For the first eighteen months the Welsh will hold their own, but during the next year or two a marked difference is observed. Again, there is still another drawback-viz. after the first cross the progeny are not so much to be depended upon. This experienced men find to be the case in crossing pretty well all animals. The first movement is a success, but later on all kinds of nondescript creatures turn up.

The Kerry Cow is a large yielder of milk, and a remarkably useful little animal, as light-hearted as its countrymen. It is to be regretted that up to the last few years it has been much neglected; but in these days of pastoral farming it is again sought out and found to be remunerative. This cow is hardy in constitution and active in habits. The head is small, fine, and furnished with bright intelligent eyes; the horns are short, and turn upwards. The carcase is round and rather long; the legs are short. The hind-quarters are light, but high-boned, and wide over the hips. The colour is of a varied description, sometimes black, sometimes brindled, sometimes of a grayish mixture, and occasionally mingled with all these shades.

\section{ENGLISH BREEDS.}

The Shorthorn or Durham stands out far in advance of any other kind. It is the breed par excellence of Great Britain, although now distributed over many parts of the globe. It is distinguished by its own excellences, the facility with which it communicates these to the animals of other breeds, and by its remarkable adaptability to the various circumstances of soil and locality. It has been said regarding this excellent breed of animals that the shorthorns have such an aptitude to lay on flesh that they will get fat while many other breeds are thinking of it. Indeed, the writer himself has many times marvelled at the short interval it takes for cows or heifers of this description to get fat upon some really rich pasture-land. They usually arrive at a ripe state before the steer and bullock; but in Lincolnshire, and one or two other favoured spots in England, the first lot of large oxen can be got off from pasture in June, and the next lot before the entry of winter.

One drawback, however, attends these otherwise faultless animals, and that is, they are not, as a rule, good milkers.
Many lovers of the shorthorn try to disbelieve this, but years of experience have taught the writer that just as a shorthorn will go round a lower breed in fattening, so will many a three-cornered cross-bred animal, rejoicing in perhaps many mixtures of blood, put the Durham out of sight in milk and butter production. The milk of the latter is only of moderate quantity, and the quality varies very much, while it is seldom that they hold up the supply for an extended period. We have had an abundant supply of milk for three months, and suddenly the quantity has been reduced to half, and shortly from half to none. Others supply for a more extended period, but few longer than seven or eight months. Nevertheless it is found, as a rule, that where these animals are not too highly fed, and forced out of their natural healthy state, they are more capable of imparting very fair dairy qualities to their progeny. Our judges in the cattle showyards are now doing wisely by encouraging, in all ways possible, more natural and healthily fed animals to compete for prizes. Another point in these animals' favour -and it is an important one-is the readiness with which they may be fattened for the butcher, after being used for the dairy. The colour of the true-bred shorthorn is either dark red or white, mixed red and white, or roan; any admixture of black is fatal to its pretensions-roan, however, may be said to be the favourite colour. As regards the points of merit of a shorthorn cow, the following are the ideas of the writer, and will doubtless compare favourably with the prominent features of many of our prize-takers in the showyard:-

\begin{tabular}{|c|c|c|c|c|c|c|c|c|}
\hline & & & & & & & $\begin{array}{l}\text { Number of } \\
\text { Points. }\end{array}$ & What constitutes Goodness. \\
\hline Head, . & & • & & & - & - & 4 & $\begin{array}{l}\text { Moderate length, wide, and rather } \\
\text { disked, with yellowish horns and } \\
\text { flesh-coloured nose-not black. }\end{array}$ \\
\hline Neck, . & • & • & & - & - & - & 1 & $\begin{array}{l}\text { Being well sprung from shoulders and } \\
\text { slightly arched. }\end{array}$ \\
\hline Neck-vein, & & - & & • & - & - & 2 & Prominent and full. \\
\hline Shoulder an & & & & & - & - & 6 & $\begin{array}{l}\text { Former being well thrown back and } \\
\text { wide at top, points well covered, and } \\
\text { not prominent, crops being very fnll. }\end{array}$ \\
\hline Breast, & & & & - & • & • & 2 & Coming well forward, wide and full. \\
\hline Back, . & • & - & • & • & - & - & 2 & Breadth and levelness. \\
\hline Loin, · & • & • & • & - & - & - & 3 & $\begin{array}{l}\text { Breadth, and being well covered, not } \\
\text { low. }\end{array}$ \\
\hline Hocks, . & • & • & & • & - & - & 2 & $\begin{array}{l}\text { Breadth, and being at right angles } \\
\text { with hackhone. }\end{array}$ \\
\hline Rnmps, & • & • & • & • & - & • & 2 & Not being drooped. \\
\hline Quarter, & • & • & & • & - & - & 2 & $\begin{array}{l}\text { Length, levelness, and being well filled } \\
\text { np. }\end{array}$ \\
\hline Thigh,. & . & • & • & & - & - & 2 & $\begin{array}{l}\text { Length and fineness, and being well } \\
\text { beefed inwards. }\end{array}$ \\
\hline Twists, & & & & & • & • & 3 & Coming well down. \\
\hline Hock, . . & • & - & • & • & - & • & 1 & Being well bent, and not tnrned in. \\
\hline Flank, . & & . & • & • & - & ${ }^{\circ}$ & 3 & Foll, and coming well forward. \\
\hline Back-ribs, & & - & • & • & - & $\bullet$ & 3 & Well sprnog from hack and ronnd. \\
\hline Fore-ribs,. & & & & - & . & . & 3 & Round, and coming well down. \\
\hline Quality and & & & & & & - & 4 & $\begin{array}{l}\text { Skin not being too thin, bnt soft and } \\
\text { mellow, bair long and silky. }\end{array}$ \\
\hline $\begin{array}{l}\text { Colour, } \\
\text { Udder and }\end{array}$ & & & & & & $\dot{\bullet}$ & $\begin{array}{l}1 \\
3\end{array}$ & $\begin{array}{l}\text { Roans and reds. } \\
\text { Well-formed teats and ndders, largo } \\
\text { mills-veins. }\end{array}$ \\
\hline
\end{tabular}

The Hereford breed is a noble class, surpassed in value as feeders by the Durham only. Much of the richest pastureland in England is yearly stocked with pure Herefords, and they hold their own with any other large breed in our 
metropolitan markets. They grow to great size, and are usually given a year or two extra time over the shorthorns in which to develop. Indeed up till recently, and even now in a few isolated instances, they were used for drawing the plough, and were not sold off for fattening until six or seven years old. Oxen of such an age are now few and far between; they are much sought after by wealthy graziers in the rich Midland counties, and being got up for Christmas markets, are pictures worthy of observation.

Like the shorthorns, the Hereford cows have a failing, and it is in their milk-production. They are in this respect even less remunerative than the former, and are much used in their native county for calf-rearing. Hence it will be seen that the Hereford calf, being thus reared by the mother, has a really good start in the world, a great matter with all young animals on the farm.

Like the shorthorn, and some other breeds, the Hereford of to-day is a much nobler animal than it was a ferw decades ago; and the native county breeders may well be proud of their favourite. Foreign breeders are not so partial to it as to the Durham-perhaps from its inadaptability to various climates.

The colours of Herefords are a rich red on the body, and a clear white on the face, throat, belly, the lower part of the legs, and the tip of the tail. The forehead is broad, the hide thick but mellow, the hair soft and sometimes curly. The oxen are very heavy, and much larger in proportion than the cows. The flesh is excellent, and the animals are easily fattened. Although, as before observed, they are not a dairy breed, we have seen cows which were heavy milkers, and doubtless the attention which has been paid to the development of the grazing properties of the breed has destroyed whatever qualifications it may have possessed at one time for the dairy. George Culley says, on the authority of MIr. Ellman, referring to the Hereford cattle"The calves run with the cows till they are eleven or twelve weeks old, when they are weaned and turned to grass. A good cow, after the calf is taken from her, if well kept, will produce from 6 to $8 \mathrm{lbs}$. of butter a week for three or four months after taking off the calf, and double that quantity of skimmedmilk cheese. They do not give so large a quantity of milk as the Suffolk cattle, but it is much richer in quality." The above quantity of butter is liberal for any cow to make after rearing a calf, and it may be taken for granted that such a yield seldom occurs from the Hereford. Perhaps a cow may sometimes be slightly crossed with a good milk-producing kind; or one that is fed beyond the common might milk freely; but it must not be expected, and will scarcely occur in a breeder's herd in a lifetime. So it will be seen that though the Hereford reaches within measurable distance of the top of the bovine standard in meat-producing qualities, it is by no means a remunerative milker.

The Longhorns are coming again to the front, and are readily discernible from all other breeds by the disproportionate length and sometimes encumbering forms of their horns. old Craven breed the horns projected almost liorizontally, but in the offspring and improved varieties they sometimes grew perpendicularly down, so as to render grazing difficult, or made such curvatures as to threaten to meer before the muzzle, or swept so round as to threaten to lock the under jaw, or turned their points so inward upon the nose or other parts of the face as to seem to be about to pierce them. Host of the present English longhorns liave long, spreading, and sometimes drooping horns; a dark red and brindled

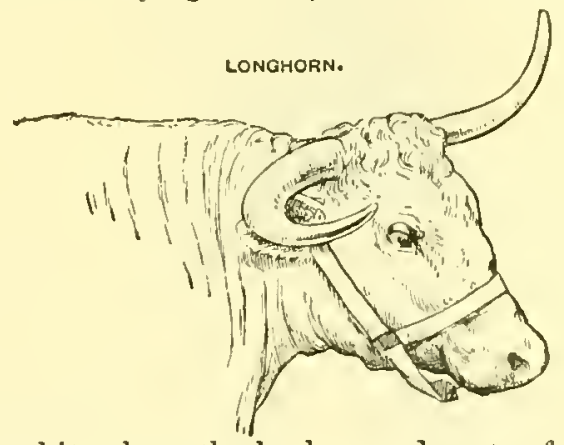

colour, with white along the back; good coats of hair; rather coarse bones; fair symmetry; a good adjustment of beef along the back; a capacity of attaining great weight; and a habit of both sound and somerwat rapid feeding. But even the Craven group, like the whole of the Irish longhorns, though with no such wide difference of value, is divisible into two great and very distinct sections. The smaller Cravens inhabit the moorlands and hills, are hardy and easily kept, yield a large produce of excellent milk, have a capacity of rapid fattening when removed to good pastures, and are much and justly prized by cotters and small farmers. The larger Cravens inhabit the low and level districts, and yield less milk, in proportion to their size and food, than the smaller Cravens, but possess an extraordinary tendency to fatten rapidly, and to acquire a great bulk and weight. "As either of these found their way to other districts," remarks Mr. Youatt, "they mingled to a greater or less degree with the native cattle, or they felt the influence of change of climate and soil, and gradually adapted themselves to their new situation, and each assumed a peculiarity of form which characterized it as belonging to a certain district, and rendered it valuable and almost perfect there. 'The Cheshire, the Derbyshire, the Nottinghamshire, the Staffordshire, the Oxfordshire, and the Wiltshire cattle were all essentially longhorns, but each had its distinguishing feature, which seemed best to fit it for its situation and the purposes for which it was bred. Having assumed a decided character, varying only with peculiar local circumstances, the old longhorns, like the Devons, the Herefords, and the Scotch, continued nearly the same." The longhorns were cherished in preference to all other breeds, and maintained to be the best by the celebrated improver, Mr. Bakewell; but they are generally admitted now to be decidedly inferior in aggregate worth to the shorthorns, and not equal for the shambles to any one of several of the Scotch breeds.

The writer saw some bullocks and heifers being got up 
for a Christmas market, crossed from the longhorns and Herefords, that showed good size, excellent quality, and extraordinary aptitude for fattening. The longloorns searcely, however, as a pure breed, meet with the requirements of the present day in many districts.

The Suffolk Dun, or the Suffolk cow, is the last species we can find space to treat upon here. It is a good all-round milker, being proved by the dairymaid alike for making good

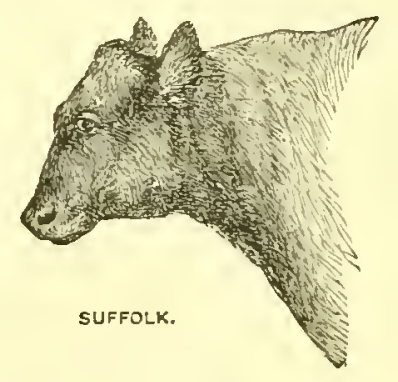

cheese, high quality of butter, and giving rich milk. It is the only true hornless breed in England, and is supposed to have originated from the polled or hornless breeds of Scotland. The colours generally met with are a light dun or yellowish cream, red or red and white. The carcase generally is rather narrow and flat, legs short and thin, ribs well arched, belly heavy, chine thin and hollow, loin narrow. The head is fine, throat clean, dewlap not large. The udder is large and square, the milk veins large. The skin is fine, the hair silky. The general appearance of the Suffolk is bony or angular, not presenting the fine rounded outlines of the slorthorn, the Devon, or the Hereford. It is an animal, when dried off, capable of being quickly fattened up for the butcher when generously fed, and might, we think, taking it all in all, be more widely utilized in our dairies, either as a distinct breed or for crossing purposes.

\section{THE CHANNEL ISLAND BREEDS.}

It may not be at first quite apparent to my readers why certain cows are more suited to hold different positions; further on, however, it will be shown that while the Channel Island cows are most at home in the nobleman's paddock or park, a

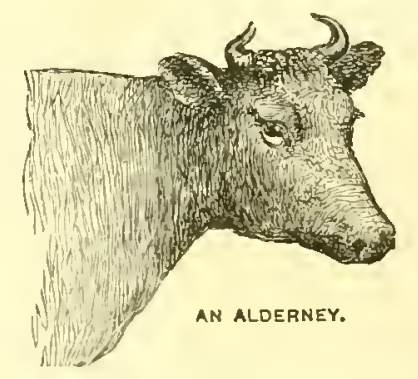

different class is called for on the tenant-farmer's holdings. Again, between the rearer, or what we will in future term the breeder, and the seller of milk, other varieties still are needed.

The gentleman's cow is required to find milk, cream, and butter for the owner's household; cheese-making is seldom touched upon here. It is essential that the milk, cream, and butter should be of irreproachable quality, quantity not being taken so much into consideration. A warm cowshed and generous treatment are usually provided, therefore animals live in happiness that would waste into "screws" in more exposed quarters.

Again, rich men's dwellings are seldom situated in unfertile quarters, therefore nutrition and luxuriant lierbage can be obtained in summer time, this being highly advantageous to a cow required to produce milk of the best quality.

Of all the breeds in the world none is more suitable for this position than the Channel Islanders. Small, lean, and ill-favoured as they are, they nevertheless produce a higher class of milk than any other of the bovine species.

The beautiful yellow imparted to the butter cannot be obtained from any other source, while the cream is almost too thick to be termed a fluid. Even the breeder who desires to rear high-class animals is often induced by the dairy-wife to keep just one Alderney in his herd to give a better colour to the butter. Under the most generous treatment this cow carries comparatively little flesh, and is about as bad an animal to prepare for the butcher as can be found. Coming from a warmer climate than most parts of Britain, it requires careful attention in winter; but with such favour amply repays its opulent owner. It is of a gentle disposition, and when not abused by an unkind herdsman seldom displays any vicious habits. One disadvantage is, that it is more liable to suffer from parturient apoplexy (dropping after calving) than any other sort. This may also be said of the other two breeds, viz. the Guernsey and Jersey.

II. Le Cornu, writing in the Journal of the Royal Agricultural Society some time since, considered the following points of merit to be regarded in a high-class Alderney:(1) Pedigree on the male side; (2) pedigree on the female side; (3) head small, fine, and tapering; (4) cheek small; (5) throat clean; (6) muzzle fine and encircled with a light colour; (7) nostrils high and open; (8) horns smooth, crumpled, not too thick at the base, and tapering, tipped with black; (9) ears small and thin; (10) ears of a deep orange colour within; (11) eye full and placid; (12) neck straight, fine, and lightly placed on the shoulders; (13) chest broad and deep; (14) barrel-hooped, broad and deep; (15) well-ribbed home, having but little space between the last rib and the hip; (16) back straight from the withers to the top of the hip; (17) back straight from the top of the hips to the setting on of the tail, and the tail at right angles with the back; (18) tail fine; (19) tail hanging down to hocks; (20) hide thin and movable, but not too loose; (21) hide covered with fine soft hair; (22) hide of a good colour; (23) fore-legs short, straight, and fine; (24) fore-arm swelling and full above the knee, and fine below it; (25) hind-quarters, from the hock to the point of the rump, long and well filled up; (26) hind-legs squarely placed, not too close together when viewed from behind; $(27)$ hind-legs not to cross when walking; (28) hoofs small; (29) udder full in form-i.e. well 


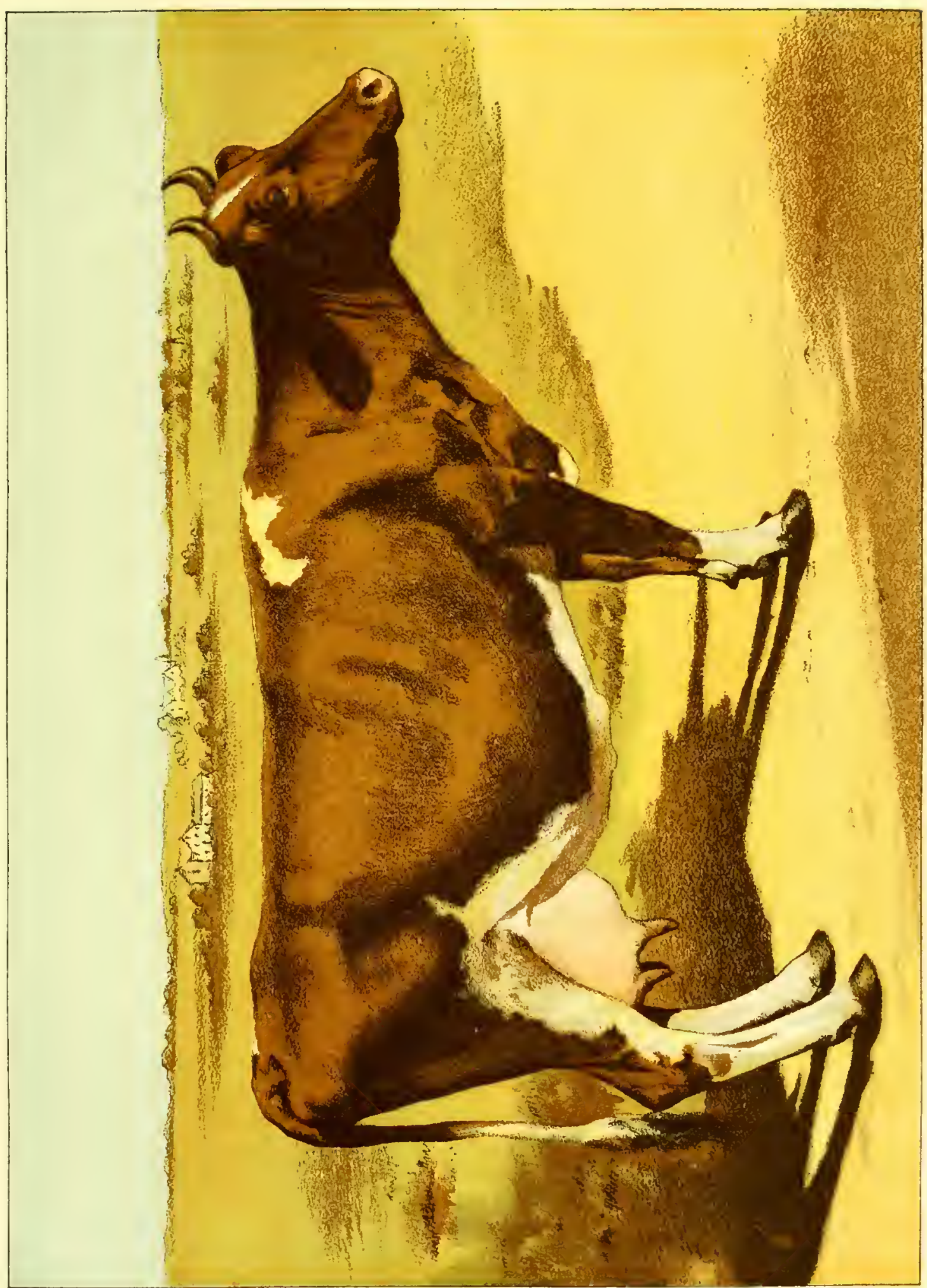

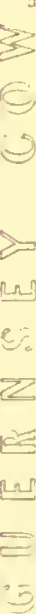



in line with the belly; $(30)$ udder well up behind; (31) teats longish and squarely placed, being wide apart; (32) milk veins very prominent; (33) growth; (34) general appcarance; (35) condition.

The above would be the beau ideal of an Alderney, and some of the points would be difficult to find. Within the last few years this breed has come very much more into favour, and in some instances has been crossed with other kinds to advantage. The dairy cow proper may be looked for in a cross between a shorthorn and Guernsey; indeed for a small farmer a mixture between the latter and an Ayrshire is valued. Too abrupt crosses, however, have not favour with the writer as a rule, for nondescript progeny may result. A step has been taken in the right direction in the issue of a pure herd-book, entitled the "English Guernsey Cattle Society's Herd-Book," and this will be likely to lead to an improvement in the breed.

The colour of the Alderney varies, but is usually of a faint yellow shade, mixed sometimes with white, and sometimes white and dun. The hair is short, and the warm winter garment provided for most other cows is not vouchsafed to this breed. Thus it is necessary to provide the animal with comfortable winter quarters.

In addition to large imports from the Channel Islands, and occasional shipments from Normandy and the adjacent ports of France, great numbers are now annually bred in the more genial districts in England.

There are, and always will be, certain classes, not stockowners by occupation, who feel pleasure in keeping one or two cows. For instance, the clergyman with his glebe, the opulent county gentleman, and the wealthy retired tradesman, have almost without exception a pet milk-supplier.

To those then who are blessed with plenteousness, and who reside in any but the most exposed localities in Britain, I can advise Channel Island cows as being most suited to their purpose. For it has been shown that their milk is most highly esteemed, the cream is of such consistency as to bear the proverbial mouse, and the butter is second to none.

It should be understood that the Channel Islands can boast of three distinct breeds of cows-viz. the Alderney, Jersey, and Guernsey; the latter are the best fleshed animals.

\section{SELECTION OF COWS FOR BREEDING PURPOSES.}

In choosing a herd of cows to breed and rear from, the young stock-master needs to use great care and foresight. It is not so much required that every animal should have reached a high state of perfection at the outset, as that cows should be bought that will in future improve into a valuable herd. The ordinary grazier cannot afford to go in for pure blood. It would be too expensive; besides, the attention, accommodation, and general requisites for a pure-bred herd are not to be found upon an ordinary farm; and unless every appliance and means are at hand, it is unwise to start a pure-bred herd with a view of making profit. Indeed even those who have everything at their disposal often find the balance-sheet on the wrong side at their banker's. Therefore it will be clearly scen that the common stock-master had better refrain from spending money on too high-class and fancy stock; but at the same time he must bear in mind that inferior auimals should not find their place on the breeder's establishment. It is well for stock-keepers generally that certain people should keep good pure breeds. They are the greatest boon to those who desire mixtures of blood, for in making crosses a pure strain can be procured either through sire or dam. What the breeder really requires to commence with are some nice breedy-looking heifers, such as would be perhaps three-fourths bred shorthoms. A good age to buy them at is two years old, and in choosing the

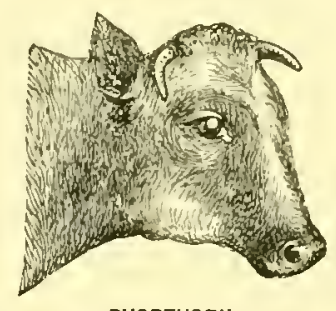

SHORTHORN.

sort, clear judgment is required-such judgment as the stockkeeper can only get by years of experience. Another time to lay in a stock is at three years old, this being the proper time for them to bring their first calves. Some farmers believe in breeding from heifers at an earlier date, either from two years or two years and a half old; but while the milking qualities of an animal are improved by this early breeding, the general size, symmetry, and constitution are deteriorated. It was for some time doubted if early breeding did really give a greater capacity for free milking, but practical and experienced men have now decided that such is the case. It is, however, the object of the breeder to produce a good herd of beasts, that he may breed and rear from them animals that will meet a ready sale at any age. He may keep or sell the males, and use the heifers for the dairy, or he may keep both steers and heifers to go oft when at maturity.

The object must be to breed steers that possess an aptitude for fattening, and heifers with a compact frame, gay carriage, and approved colours, so well appreciated by judges of highclass cattle. There is far more character in the head of a dairy cow than the inexperienced farmer might think. It should be carried with a jaunty air, and should be rather small than otherwise; not too short, but by no means long and thin, and not too far from the eye to the nostrils. The latter should expand, the forehead slould be tolerably wide, while the eye should be large, full, soft, and expressive. There is something peculiarly interesting in the expression of a well-bred cow that will always be found wanting in one descending from questionable parents. The liorns should have that stout, mellow appearance that denotes a strong constitution and perfect health. In buying in a herd, colours will of course vary; but they should only 
be divided between deep reds, roans, and clear reds and whites, with flesh-coloured nostrils. White animals will turn up in a course of breeding, for it is a colour natural to the Durham breed, but not one to be encouraged.

The Bag or Udder is particularly to be examined. A fortnight before calving it will have become so developed that a good judge should make no mistake. The teats should hang square; should be rather long and slender than thick and short. Slender teats denote good milking qualities in the cow, while thick short ones point to the reverse Moreover, when they are short, it is a most tedious process to milk the animals until they have had several calves. The result often is that such cows go dry first, this state being frequently brought about by the milkers neglecting to clean out the bag, being desirous of dispensing with an animal that gives them so much trouble. The bag needs not to be too big; it should, however, extend well up to the twist. The udder is formed by the assemblage of the glands which secrete the milk, by the cellular tissue, fatty matter, ganglion, and by the outer skin or bag which envelops the whole. The milky glands are four in number, two on each side, and the whole constitute what are called the "quarters," so that each gland in a well-proportioned udder is about the fourth part of it. And here it is necessary to add that it is of great importance to see that all the quarters are perfect. It is a vulgar error to suppose that the udder is like a single bag or vessel, the contents of which may be withdrawn by any une of the teats. The very opposite is the fact: each quarter is separate from its neighbour, distinct by itself; so that if any one of the quarters is deficient-as is sometimes the case in practice-it simply amounts to a loss of so much of the milking qualities of the cow. In the majority of cows the supply of milk is in proportion to the size of the mammelles or milky glands. The following signs are indicative of a good constitution of glands:-(1) Large development of the hind-quarter; (2) lumbar region wide and strong; (3) rump extended; (4) large space to contain the udder, gained by width apart of lind legs and haunches; (5) mammelles well developed, giving considerable size to the udder. It is necessary, however, to pay close attention to the structure of the udder, for it may be large, and yet the yield of milk may be small. The bulk of it should be made up of the milky glands, so that when the cow has been milked these shrink in dimensions, and the udder, from a state of tension, becomes shrivelled up in creases or folds, soft and Alabby. A fat or greasy udder, which does not yield much milk, remains almost of the same size after milking as before; it resists applied pressure, so that squeezing scarcely lessens it, its texture being uniform and firm. An udder of this sort is called fleshy. While, therefore, the udder should be large, it should not be fleshy, or rather greasy. Dealers, to prove to their customers that the udder is not greasy, draw back its outer covering or skin, and if it stretches much it is considered to be a good skin. It is easy to understand that skin which has been habitually distended and relaxed by great quantities of milk and its withdrawal, is sure to be more capable of being stretched than that which has not been subjected to such influences. Dealers have another object in view while thus extending the skin of the udder, namely, to prove that the cows have a fine, pliable, and soft skin. But inasmuch as the skin of the udder of all cows has these properties to some extent, it is necessary to go elsewhere-to the skin of the barrel or ribs -to prove the touch of the animal. The form of the udder is considered by some to be of great importance; some deem the udder best shaped when it is extended well forward, and the glands clearing in close contact to the belly. We have seldom found very good cows in which the udder has been shaped like a bottle hanging well downwards. Contrary to popular notions, the number of teats attached to the uddes is six; four only are large and well developed, the othe1 two being very small and placed behind, and seldom giving milk. The four large ones only are those to which attention is necessary. Their size depends upon the length of time which the cows have been milked or suckled by the calf; cows, therefore, which give much milk have large teats, because they are milked frequently and for a lengthened period. In this way only their size indicates the yield of milk. Usually more milk is obtained from the two back or hinder than from the two forward or front teats, and this because the hind-quarters of the udder are larger than the fore-quarters. The teats should be soft and flexible, not obstructed in their passage; and smootl, not indurated or shrivelled, on their surface. Warts are often present; but although they do not affect the milking capabilities of the cow, still they are better absent, inasmuch as they may be painful when touched, and thus cause the cow to be restless when being milked. Frequently they wear away from the friction of the hand after the cow has been milked for a short period. The position of the teats indicates the size of the glands. If they are huddled closely together, as each teat is connected with its own quarter, it follows that the quarters must bc also closely together, and that the milky glands cannot be extensive. The teats, therefore, should be placed, as before observed, well apart from each other. But the form, nevertheless, of the udder exercises an iufluence on the position of the teats. Cows which have been long unmilked have the udder much extended, hard, and painful. Dealers, to convey the notion that bad cows are good milkers, endeavour to bring about this full appearance of the udder, and to effect it do not hesitate to carry out cruel plans. If the ndder is hard, and much distended in proportion to its real size; if the teats are hard, wide apart, painful when tourhed; or if milk is seen to exude from them, even when untonched, it may at once be decided that the poor cow has been long unmilked.

Milk Veins.-The best signs indicative of a good milk cow are those afforded by the bloodvessels. If those surrounding the udder are large, bend in their course, and are varicose-that is, are not of uniform diameter throughout 
their length-they indicate that the glands receive much blood, are in full activity, and therefore that the milk will be abundant. The veins on the stomach, or what arc called the milk veins par excellence, are very easily observed, and are acknowledged by nearly all authorities to afford one of the best indications of the milking qualities of the cow. The milk veins issue from the udder in front and at the exterior angle, and in good cows form at this point a varicose swelling or dilation. Proceeding towards the fore-quarters, they form angles more or less marked, frequently dividing towards their hinder extremity, and finally disappear into the body by several openings. By compressing the milk veins at the points where they disappear into the body, we can make them dilate, and their size then can be well ascertained. The openings through which the milk veins disappear into the body are termed the milk ways (portes du lait) or fountains; but improperly so, for the blood contained in the veins which traverse them, instead of going to is returning from the glands, so that it is that portion which has not been utilized in the formation of milk, and may be termed the residue of the secretion. When the cow is not giving milk, the milk veins, from being little swollen, are not in proportion to or in accordance with (en rapport) its milking qualities. Hence it is necessary to give an artificial swelling to the milk vein by compressing it at its anterior extremity. The best way is to thrust the end of the finger into the opening through which the milk vein disappears into the body, and we can then determine the size of the vein, for the opening contracts more slowly than the vein.

Most of these indications and signs of good milking qualities in cows are more fully developed after the animals have had several calves, although even with heifers the clever stockman will form some true conclusions. With an eye to beef-making qualities, some desirable features in the udder and milk veins have frequently to be overlooked; yet the purchaser will do wisely to secure as many favourable marks as may be, with other outward signs of a well-made beast. The rumps should lay wide, as also the hips, and the back display the flatness of a table, while the skin should give the soft feeling to the hand which we will now explain in extenso.

The Touch.-It is only men well educated in the art of buying cattle that are good judges of touch, and to such men the feeling of the skin and hair of the cow is as important a guide as the rudder to the ship. The touch may be good or bad, fine or harsh, or, as it is often termed, hard or mellow. A thick, firm skin, which is generally covered with a thickset, hard, short hair, always touches hard, and indicates a bad feeder. A thin, meagre, papery skin, covered with thin, silky hair, being the opposite of the one just described, does not, however, afford a good touch. Such a skin is indicative of weakness of constitution, though of good feeding properties. A perfect touch will be found with a thick, loose skin, floating as it were on a layer of soft fat, yielding to the pressure, and springing back towards the fingers, like a piece of soft, thick chamois leather, and covered with thick, glossy, soft hair. Such a collection of hair looks rich and beautiful, and seems warm and comfortable to the animal. It is not unlike a bed of fine soft moss; and hence such a skin is frequently termed 'mossy.' The sensation derived from feeling a fine touch is pleasurable, and even delightful. You cannot leelp liking the animal that possesses a fine touch, with which is generally associated a fine, symmetrical form. A knowledge of touch can only be acquired by long practice; but, after having acquired it, it is of itself a snfficient means of judging of the feeding quality of the ox; because, when present, the properties of symmetrical form, fine bone, sweet disposition, and purity of blood are the general accompaniments.

Unfortunately it is too frequently found that good milking qualities are not met in conjunction with the signs indicative of good form. The best milkers are often indeed badly shaped, lean, raw-boned, and in no way distinguished as beautiful. Hence, then, the danger there is in choosing from a herd of cows the most beautiful as the best milkers. On the contrary, we not unusually find that in a good milk cow the hind-quarters are defective in form, being largely developed; flesh too little in proportion to the bone, so that the bones and haunches protrude; the pelvis is wide, and the hind legs are wide apart to afford space for the udder; the muscles are slender, and the buttocks and thighs small and narrow. The breeder must sacrifice milk rather than introduce such a cow into his herd, or the steers reared from this kind of stock will be ill-adapted to fill the stalls, and to be made up at three years old for the good ripe Christmas beef for which England has justly gained renown. Still by good judgment and perseverance in tracing out the qualities for milk-producing and beef-making, both may be very fairly combined. Such animals, on the majority of breeding farms, are the best class to keep. There are other breeds which are eminently adapted for certain localities, but year by year the well-bred shorthorns take the position of even our other cherished breeds; and ere the present century has passed away we anticipate that the Durham cattle will occupy the major part of our pasture-land.

Seeing, then, that such herds of beasts as we have described are the most profitable kind for the breeder and rearer to keep, he will further improve them at little extra expense by continually using a really good pure-bred Durham sire. Thus in years to come a herd of beasts will be formed very nearly pure bred-a herd that any man may well be proud of, and one sure to prove remunerative to the owner under judicious treatment.

\section{THE DAIRYMAN'S COW.}

The animals specially adapted for the dairy-farm are those that will give an abundance of milk. Quality is not so much the object as quantity; and although it is desirable that an animal should be bought that looks like holding its money together, yet size, uniform appearance, and colour must give way to power of milk production. These free milkers 
are not found among the better class of shorthorns, and the Herefords must be totally discarded for this purpose. The Channel Island cow's milk is rich, but not plentiful enough for the milkseller. The hardier Welsh excels more in the richness of its milk than its plenteousness, while the small Ayrshire is a nearer approach to what is required, being a

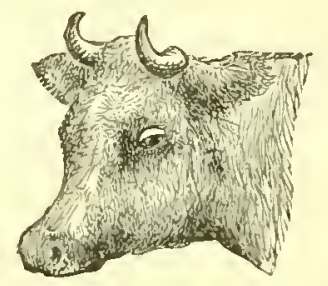

AN AYRSHIRE.

wonderful milker as far as it goes, but unfortunately, being of such diminutive size, does not go far enough. No cow, however, in the British Isles gives more milk according to its weight than the Ayrshire.

Where, then, are we to look for the beau ideal of a cow that shall give such a plenteous supply of milk as to make the selling of it profitable to the cowkeeper? Probably amongst all the above, or rather from a general mixture of blood. Some of the best milkers we have ever bad have been strongly dashed with Ayrshire blood, the other parts being shorthorns and Alderneys. The first cross between the two latter kinds is hard to beat, providing a good strain on either or on both sides is chosen. Here the Alderney male should be used to mate the shorthorn cow. Probably either Jersey or Guernsey would answer as well as Alderney for crossing purposes. There is an extraordinary breed of cows for milk of the race Flamande or Flemish; these, however, are not British animals. The best and purest specimens are found in France, and are to be met with on the rich pasture-land in the districts of Hazebrouck, De Bergue of Bailleul, and Cassel. It is the favourite animal of the north to north-east of France, and especially of the celebrated districts of East and West Flanders. It owes its origin probably to the same source as the cattle of

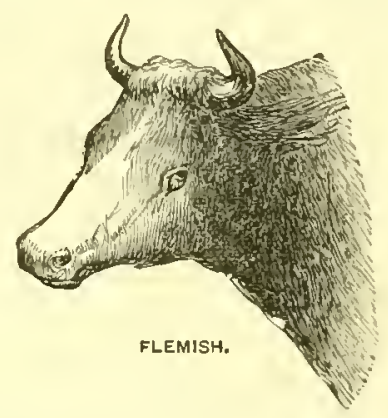

Holland. Generally speaking, in their native country, the Flemish cows are kept permanently in the cowhouses, being allowed a run in the stubble fields when the crops have been cleared off in early autumn. Here they are either tethered or attended by the lads or lasses of the district, for hedges or fences are few and far between. In some districts, however, these animals are depastured in the field during the day and sheltered at night; and at Bergue, near Dunkirk, they are pastured out night and day for the summer months. This fine herd of milking cows is now being improved by crossing with our shorthorns and the Normandy breed--the combination having for its aim to impart to the animals the facility of being rapidly fattened which distinguishes the English shorthorn, the fineness of the tissues, and the milk-giving faculties of the Flamande, and to retain the milk-giving properties of the Normandy breed, while toning down its coarseness. The Flemish blood might be used to mix with our home breeds, but would sadly reduce the value of the carcase, while it improved the aptitude for milking. This is a consideration; for, although a plentiful supply of milk should be the prior object, yet some sort of regard should be paid to what the animal will bring when sold out dry to the farmer or grazier for breeding from again, or for fattening purposes.

'The London milkman requires not only free milkers, but such animals as will hold their flesh, and go off direct to the butcher when they no longer answer for milking. Therefore

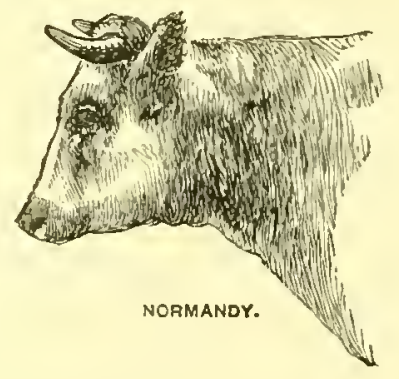

these milksellers buy all the best cows in the autumn time that can be procured. The aninals must be fat, or they will not pass for the London market, and large-framed animals with promising udders are much preferred. They are required to give two gallons of milk at a meal, and this they often do for some months, for the food-supply consists of everything that will produce milk, without regard to expense. The object is to force the milk-supply and keep the cows fat at the same time, and no sooner does the milk diminish than they are sent off to the butcher, and the stalls are filled with a new importation from the rich pastoral farms of Warwickshire, Nortbamptonshire, and Leicestershire. Grazing cows for the London milk market has been one of the most remunerative occupations associated with farming for the last two decades. Warwickshire particularly is favourably suited for grazing these cows, as, in addition to its rich pastures, warm strawyards are provided for the wiuter season. This shelter is needed, as the beasts have to by bought in during early winter, served by the bull, and be sold out done calving, or with calf at foot, between the 1st September and Christmas. In most other towns, aside from London, a lower class of animals is used, which are milked out and sold, much reduced in flesh, to the farmers to fatten or breed from again. 
The purchaser of these milking cows is not particular to a year or two in the age. Usually animals showing a few wrinkles in the horns give a more plenteous supply of milk than heifers with their first calves; and as the traders in milk only keep the animals, as a rule, during one year, they do not deteriorate much on hand if they have passed their best. Still even here anything approaching a worn-out cow must not be invested in, for however great nay be the show of milk, the worn-out constitution, weakened by age, will assuredly prevent the animal from proving remunerative.

We do not, then, counsel milksellers to adhere to any fixed breed or cross-breed, but rather prefer several mixtures of blood in animals that show light flesh and many of the good qualifications for giving milk which we described in the last section It may be looked upon as an established fact that richness of milk will be best procured through the Alderney blood; hardness of constitution, through the Welsh; large frame and aptitude to feed, from the shorthorn; and quantity of milk, through the Ayrshire.

The Constitution.-This is the next matter for consideration, and though it applies to all animals, three-fourths of the cow-buyers fail to investigate sufficiently closely into it. A large milk return will not be given long unless the cow is in perfect health. The drain on the system is only drawing upon nature's laws, and it may be kept up in a healthy animal if she is supplied with generous diet; but if the constitution becomes weakened by age or any other infirmity, or the feed is dealt out too sparingly, or of an unwholesome character, the milk fonts will decline their office, and shortly cease to produce at all.

A good milk cow should, in addition to the signs indicative of active development of the mammary glands, possess good digestive organs, large lungs, and a prominent chest. The appetite should be good for solid and wholesome food-not, as is sometimes the case, depraved, so that the animal is desirous of devouring all kinds of innutritious substances. The inclination for fluid should be strong, as such a desire is promoted by an abundant flow of milk. When these signs are present the cow makes good blood, so that activity is given to the whole nervous system; the organs are rendered animated, and the gland amply provided with the material necessary for a copious secretion. Possessed of all these characteristics, cows give much milk for a lengthened period, and sometimes possess the additional advantage of fattening rapidly after they become dry. It liappens frequently, however, that activity in the mammary glands is united with bodily characteristics the opposite of those now named, so that we find cows abundant milkers which have the ribs closely set, the brisket narrow, the digestive organs delicate, the appetite only moderate, but the thirst frequently great; with such signs the milk may be large in quantity, but it is poor in quality, and the animals are liable to suffer from lung disease. Animals of this kind are very often shy breeders, although they display the usual natural restlessness at intervals. They are also ill thrivers, even when in apparently good hcalth, and when not yielding much milk. Still, good milking cows sometimes turn up in all kinds of three-cornered shapes.

As a good milk-producer, without regard to anything further, Mr. Mayne gives the following description:-"As regards the general appearance of the cow, preference in all cases should be given to those whose form is furthest removed from that of the male. They should possess, then, (1) a small bony development; (2) fine and slender legs; (3) the head should be small and somewhat long, and get narrow as it approaches the region of the horns; (4) the horns should be of a clear colour and transparent, should taper gradually to the extremities; (5) the skin should be soft, and covered with fine soft and shining clear hair; (6) the natural passages should be provided with a soft silky down; (7) the neck should be small; (8) the shoulders slender, especially near the head; (9) eyelids not much shrivelled; (10) the eyes prominent and bright, but with a mild, feminine expression."

The following will, however, perhaps be more generally received by English cowkeepers as the truer specimen of a dairy cow:-She should have a long thin head(?), with a brisk but placid eye, be thin and hollow in the neck, narrow in the breast and point of the shoulder, and altogether light in the fore-quarter, but wide in the loins, with little dewlap, and neither too full-fleshed along the chine, nor showing in any part an indication to put on much fat. The udder should be especially large, round, and full, with the milk veins protruding, yet thin-skinned, but not hanging loose. The teats should also stand square, all pointing out at equal distances, and of the same size; and although neither very large nor thick towards the udder, yet long and tapering to a point. A cow with a large head, a high backbone, a small udder and teats, and drawn up in the belly, will, beyond all doubt, be found a bad milker. It is important that the temperament of a milk cow should be considered, for it is a bad sign when the animal is habitually restive or uneasy, especially when the milking process is going on. On the contrary, she should have all the appearance of being lappy, and the greatest kindness on the part of the attendant is essential; it is singular how instinctively a cow discriminates between one who is careful with her or otherwise. She loves to be fondled, and in return yields extra profit.

The kind milking cow will be observed to chew the cud while the milking process is going on almost invariably when not feeding. Some cows that are in the habit of suspending their milk will give it down quite freely when fed with some tempting morsel when the milking is going on. Care in all these things is essential; and if regard is not paid to them, good cows may be spoiled.

The master should ever be present during rnuzing-time, and nothing that goes on amiss should escape his vigilant eye. Conducted under such management, milk-selling is a good business, providing the market or station is near; but otherwise expenses eat up all profit. It is not, in our opinion, 
generally known how nutritious a fluid milk is, or it would be more largely used. It is wholesome for all persons either in health or illness, and the more children live on it the better. Even skim milk has valuable nutritious qualities, and should in some way or other be more freely conveyed to the centres of rast cities. Millions of gallons of skim milk are annually given to pigs, which often do not answer to pork; while if it were conveyed to large towns, it would be a perfect boon to mothers who have families to provide for. No food could be more wholesome, neither could any other be obtained at so cheap a rate. Expense of conveyance is the one great burden now, and railway companies would do well to reduce their cliarges for such commodities, and then the occupation of cowkeeping for milkselling would be rapidly sought after, more milk would be submitted to the public, and the community at large be benefited by it.

\section{THE COTTER'S COW.}

The cows that are needed by cotters or labourers with allotments are such as will subsist upon hard fare at times, and feed in the paddock or orchard, with little other change perhaps than an occasional run along the roadside to graze the sparse herbage which is there to be found. In some instances they get a wider range, it is true, on lean grass fields, or on the over-stocked common, where only cows of a hardy kind could find support. Still, thousands of animals are kept under such circumstances in England, Wales, Scotland, and Ireland, and very much help the wellto-do peasant to live in a more comfortable manner, while the poorer neighbours are benefited from the spare milk. In many cases the owner is the thrifty servant who has saved sufficient from his hard-earned gains to purchase a cow, and from one the number may be increased under favourable circumstances to two or three. It is, however, to be regretted that at times impartial disease seizes the much-cherished animal, and does not relinquish its grasp until death has claimed the victim for its own. Such cases are sad indeed, for all the hard-gotten gains of the peasant are wrested from him at once.

We have found, from careful observation, that cows kept upon limited spaces of ground are much more liable to diseases than when they are allowed to roam over wider pastures. These animals need change of food, and one plant counteracts any evil results that may arise from another, providing the range of ground is sufficiently wide to supply the antidote. The ranunculus or buttercup has been greatly condemned by some stockowners, and veterinary surgeons too, as being the cause of red water and other malignant diseases. It may tend to such complaints if eaten by an animal of depraved appetite, but a creature in health only takes just sufficient to help to digest other food. How a practical man can retain the doctrine that this plant is poisonous we are at a loss to explain-considering that all the richest pastures in England abound with it. Such lands as a rule are reputed as being particularly wholesome and nutritious for horned cattle. Again, if this species oi herbage is so poisonous, wherefore is it that no injury arises from animals taking hay containing great quantities? If mankind would reason and commune with nature a little more, and leave her laws to take their course, a much more correct conclusion would be arrived at. The fact is, that when the young free-growing grasses of spring first prevail, they contain much watery sap, and if taken largely by the bovine species which have been wintered on dry food, the sudden change is likely to cause colic, or hoven, or blown, and inflammation might follow. Howbeit in many pastures the buttercup or ranunculus at this season carpets the whole face of the earth like a cloth of gold. Animals will scarcely take the plant in by choice, but it is impossible for them to feed without occasional flowers mingling with the grasses. The buttercup is of a hot and most acrid nature, and mixing with the cold grasses, stimulates the stomach into action, and thus assists digestion-indeed it acts upon a cow much as a glass of spirits would do upon a human being. Towards midsummer, when the grasses become more wholesome, the buttercups depart, leaving only a few hard stems which cattle refuse to takeneither does their stomach then need any stimulant to aid the digestion of the fast-maturing grasses. As the cotter's cow is more liable to disorder than such as roam at large, and considering that he can less afford to lose his animal, as probably with it would go his all, it would be well if the more opulent classes would assist him to insure against such disasters.

The poor man's choice of a cow is between three breedsviz., the Ayrshire, the Welsh, and the Kerry. The Channe Islanders have been tried many times, but found wanting in constitution, being unable to rough it, as the peasant's animal ever has to do. The Ayrshire will doubtless thrive on a less span of land than any other breed; we have, however, already commented upon its many advantages.

Welsh cows are most hardy, and may be roughly divided into the North and South "Walers." Those of North Wales are of a hardier breed, having mucl more hair to protect them against the cutting winds than their southern neighbours, which are mnch more highly prized for dairy purposes.

Those termed Pembrokes, from being bred in Pembrokeshire, are the pick of the country for milk produce, buttermaking, and for fattening for the butcher when milked out. The flesh is well mixed, and held in repute for its good quality; but Welsh cattle do not appear to be improved much of late, or rather, there is a deterioration, arising in no small degree from the circumstance that the breeders in Wales have for some time been selling their best heifers for fattening purposes, instead of retaining them to breed from. Such a system is enough to spoil any breed. By careful selection of the heifers, and a due attention to the character of the bulls which are used, much improvement might be effected in the cattle of the mountainous districts of Wales; and with this there might well be an infusion of other blood derived from mountain breeds-the best for 
the purpose being the Argyleshire and West Highland. The true colour of Welsh cattle is black, and the horns are fine, turned upwards at the points, and tipped with black.

They have hardy constitutions, and will live on land where others would starve; some of them have also the advantage of retaining their supply of milk longer than almost any other beasts. It is not uncommon to milk them quite round-i.e. until they calve again. This, however, is ever a reprehensible practice, and will, if repeated, spoil any cow. These animals only need housing during the coldest nights in winter, and even in the dead of that season are better depastured by day.

Of the Kerry we can but speak favourably; and it is no doubt well suited for the cowkeeper who has a limited space to graze. While these animals are not so hardy as the Welsh, and therefore not so fitted for exposure and northern localities, still they will endure more hardships than our English breeds.

The Kerry cow is as small as a cow of the Scottish skibos, and somewhat similar to her in points and shape. Slie is, compared to her size, a very copious milker; and she possesses the same kind of reputation throughout a large portion of Ireland which belongs to the Ayrshire cow in the western districts of the Scottish lowlands. Kerry heifers are in constant demand at comparatively high prices, and they may be met in droves, in many parts of the low country, ready to be sold in pairs or singly to the small farmers of the rural districts, and the cowkeepers and milksellers in towns. Xerry cattle, when unmolested or very gently treated, are perfectly quiet; but when disturbed or even slightly irritated, they break all bounds and overleap every ordinary fence. A writer observes:- "The Keny is an Irish breed of great value, both for dairy purposes and the value of the beef when fattened. It has, lowever, been sadly neglected. Kerry cattle are small, many of the cows not exceeding, and being sometimes under, forty incles in height at the shoulder. Their milk is rich, and when fattened the beef is fine-grained and well mixed. Black is the general colour, but black and white and brown or brindled are also common colours. The cows are gentle (?), and while suited for poor mountain pastures, they are also an appropriate kind for the villa farm."

Leaving, then, the small cowkeeper to make his choice between the above breeds, which he will from locality and other prevailing circumstances be best able to do, we will now close this part of the subject for other matters also demanding attention.

\section{INDICATIONS OF AGE.}

It is of the first importance that the purchasers of cows should be conversant with the signs of age. The roughand-ready scowl-of-brow conclusions that certain men use are not sufficient in many instances, and other more truthful indications must be sought for. It is requisite to be able to mark the signs of youth as well as of old age, for the young animals may be spoiled by being bred from too soon, or by being exposed to hardship, while the old should be disposed of at a certain period, before they have far advanced on the downward path of life.

The mammary glands of cows, like all other organs, develop themselves in proportion to the exercise of their functions: hence it happens that a cow does not give so much milk after its first or second calf as after the third or fourth, although the milk is never richer than in the younger animal. It may be taken as a fact, then, that the cow yields its maximun of milk after several calvings, if she has been treated on a good system of management. It is not a good plan to buy five or six year old cows at fairs or markets, for it rarely happens that they are sold at reasonable prices at this age, if free from faults; and, further, they will shortly begin to go downhill.

It is obvious, therefore, that in judging the value of a milk cow, it is particularly important to be able to determine its age, for after it has reached a certain period of life its milking capabilities are decreased. A cow when she has had her fourth calf, or is in her sixth year, may be said to have reached her best point; after which the milking qualities will get jearly less valuable. The flow of milk may be pretty well kept up, but the quality will become much deteriorated, and the animal more quickly goes dry after calving when advanced in years.

The horns and the teeth afford ready and sufficiently accurate means to determine the age of a cow. The horns vary much in length and in general appearance. Their annual growth is indicated by a ring more or less visible. The sign of the first year of the calf's existence is a circular depression between the skin and the bulging horn; that of the second year, a second bulge, with a depression below it; that of the third year, a third bulge, with a depression below it. These marks, or annular bulges and depressions, are, however, by no means easily observed; and it is not till the third year that the mark is distinct. Culley, in his celebrated treatise on "Live Stock," says that the first wrinkle upon the horn does not take place until the animal is three years old, after which there comes another circle or wrinkle every year as long as the horn stands on, though not always equally discernible in all horned cattle; and stockowners generally believe in Culley's doctrine. We are sorry to say that it is too common for jobbers and cow-dealers to scrape, rasp, or file down these wrinkles in old cattle to prevent the age being known, and by that means to deceive and impose upon the unwary, the ignorant, and the unsuspicious; and this process is called among the fraternity "bishoping." In reckoning the age of a cow, then, by the circles on the horn, they should be counted from that nearest to the tip and point, and as the last well-developed circle will be the third (being the first which is plainly observable), two more will have to be added to the number. Thus, if there are five well-developed circles, the last furthest from the tip of the horn will be the third year's circle; so that, reckoning the two first years, the age of the animal will be shown to be seven. If there are four 
well-developed circles, the age will be six; if six circles, the age will be eight; two being added in all cases to the number of well-developed circles will give the age of the cow.

But from what we have stated above it will be noticed that the indications afforded by the circles of the horns cannot always be relied upon, as they are frequently subjected to the tampering of dishonest dealers; and although the same may be said regarding their practices with the teeth in some cases, still these are generally taken and relied upon as affording pretty correct indications of age. It seems a somewhat strange thing to say, but it is nevertheless true enougl, that the indications afforded by the teeth of the age of cows and oxen are less to be depended upon since the improvements made in breeding and feeding than when the animals were raised in a more natural condition, and this arises from the circumstance that these improvements naturally induce a "precocity of development" and exercise "a modifying influence upon the teeth in common with other parts, and even more particularly upon them as parts of the digestive system." Another cause is much hard food, such as cakc, which is now extensively given, and tends to break and wear out the teeth.

Professor Simonds, in his paper on "The Teeth of the Ox, Sheep, and Pig, as indicative of the Age of the Animal," in vol. xv. of the Journal of the Agricultural Society, has thoroughly exhausted the subject, and shown the errors which have crept into our agricultural treatises through insufficient knowledge of the subject. Thus a very general opinion amongst breeders, which has found a place in several treatises, is, that the ox cannot be said to be "full-mouthed" -that is, possessed of all his teeth-" until he is six years old." Professor Simonds, as the result of a most extended and carefully made series of observations and investigations, finds, on the contrary, that, "as a rule, even under unfavourable circumstances, the dentition of the ox is completed before the fourth year of his age." The following table of the dentition of the ox is given by this excellent authority:-

\begin{tabular}{|c|c|c|c|c|c|}
\hline \multicolumn{3}{|c|}{$\begin{array}{l}\text { Table of Early A verage (the breed and } \\
\text { other causes favouring development). }\end{array}$} & \multicolumn{3}{|c|}{$\begin{array}{l}\text { Table of Late Aversge (the breed and } \\
\text { other causes retarding development). }\end{array}$} \\
\hline Years. & Montbs. & & Years. & Montbs. & \\
\hline 1 & 9 & Two permanent incisors. & 2 & 3 & Two permanent incisors. \\
\hline 2 & 3 & Four do. & 2 & 9 & Four do. \\
\hline 2 & 9 & Six & 3 & 3 & do. \\
\hline 3 & 3 & Eight & 3 & 9 & Eight do. \\
\hline
\end{tabular}

The following remarks and table are quoted from Professor Brown's paper on the same subject in the Bath and West of England Agricultural Society's Journal some time ago:In all animals whose ages are matters of inquiry, we gain most evidence from the incisors, or front teeth, from the ease with which the appearances may be ascertained; but in any doubtful cases the molars, or back teetb, will be referred to with advantage for the purpose of correcting the opinion. The farmer can, however, hardly be expected to know sufficient of the anatomy of these parts to consult them success- fully, although to the professional examiner they are more definite than the incisors, besides being less subject to exceptions, and undergoing very marked changes at a time when the incisors are almost useless as tests. It is satisfactory to be able to add that no authenticated case lias occurred in which both incisors and molars have shown exceptional appearances; on the contrary, a peculiarity in the one has been invariably corrected by the absence of it in the other. To enable the stock exhibitor to examine his animals and form an opinion of the condition of their mouths at intervals, the following tabular view of dentition will, it is hoped, suffice. As no average can be taken in many cases, it will be advisable in such to take two or three periods, such as early, late, and ordinary times, for the changes that will be mentioned. Even a fourth period might be permitted to include instances of extreme precocity; but these are so few that no practical benefit could follow their classification, although they may often affect the opinion of the examiner who is familiar with them. To economize space as far as may be, we shall use the letter $\mathrm{T}$ for temporary or milk teeth, and $\mathrm{P}$ for permanent or adult teeth. The ages in any cases are only pursued as far as the restrictions extend.

Dentition of the $O x$.

8 incisors (T) in lower jaw only. 6 molars (T) in both jaws. 8 " (P) " 12 " (P) "

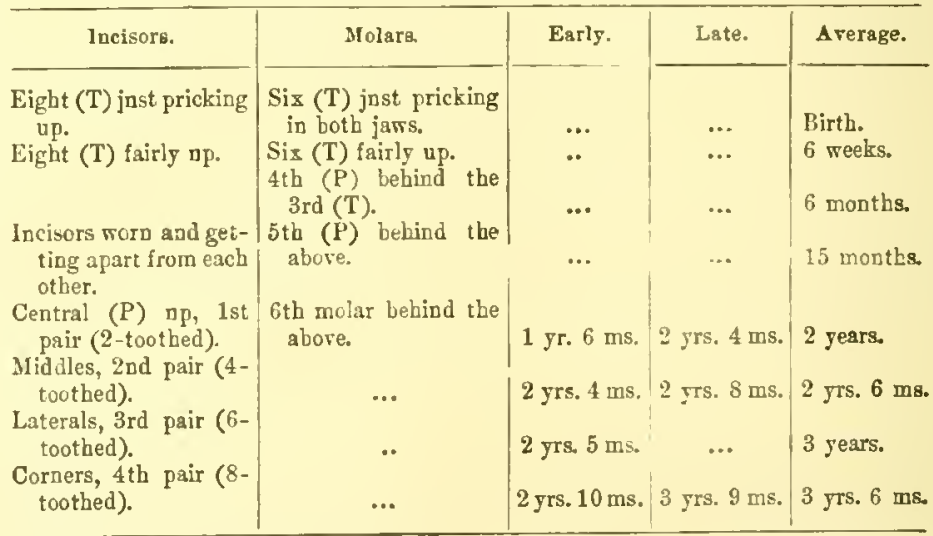

Between the second and third years the three anterior molars are changed for permanent, and their examination is indispensable for the formation of an opinion; during this time the incisors, as will be seen by the table, being subject to extraordinary variations. The remark "early" and "late" refers only to the incisors.

Those cattle-buyers who do not wish their purchased cows to have more calves, nor to retain them long in their possession, sometimes find it advantageous to buy rather older animals, taking care that they are in good condition and have good teeth. In such instances the condition should not be lost. There is a chance of these animals answering certain purposes; they give a large yield of milk, and when dried off and well fattened they fetch a pretty good price from the butcher-not, however, so much per pound as younger animals. There are such other indications of age as loss of teeth, or teeth worn short and 


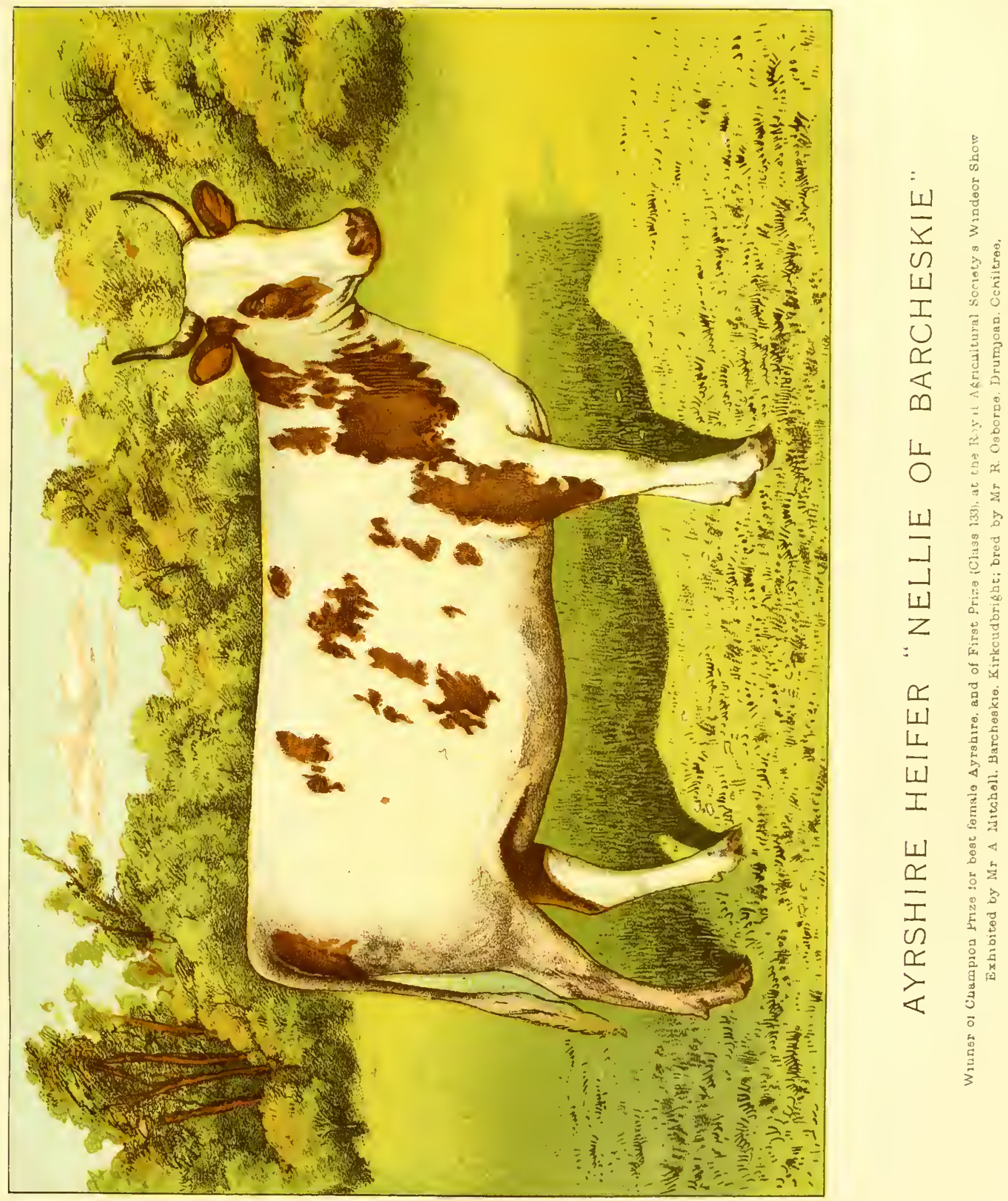



standing a distance apart, an overgrown carcase, long bag, and general ancient appearance that at once reminds the experienced cattle-buyer that old age is coming on, and that the milkmaid has sung too many songs under the cow to render such a purchase likely to prove remunerative.

\section{PURCHASING.}

In laying the foundation of a herd of cows the breeder needs to use his whole stock of knowledge, for as he commences so may he expect to follow on. It is not so easy to correct defects in animals by way of mating them with approved sires as people are apt to imagine-far more easy to engender more faults. It is a common error made in breeding to try and improve a fault that the dam may have, by using a sire that is particularly good about such a point, while possibly at the same time overlooking some other defects of his. This proceeding is clearly wrong, for it should be the object to lose nothing, while any improvement that can be made should be taken advantage of. As an instance, if a cow has a little slackness of the loin, it would be well to choose a sire extra good in this part, but it would be just an open question if the offspring would prove as correctly made in the same part, while any disapproved make in the sire might, and likely enough would, be imparted to the calf. A sire should be perfectly made, and it is better at all times to sacrifice size rather than make.

In choosing heifers for a permanent herd, therefore, the buyer should not be too extravagant in his idea of size, or defects in make are almost sure to be overlooked, and these will descend to the offspring pretty much as they are present in the parent. They may not be imparted to the first calf, perliaps not to the first generation, but glaring faults are sure to display themselves sooner or later in the offspring, although they may lie dormant for such a prolonged period that the stock-master has congratulated limself that he is well rid of them. Thus it is that true make must be the first motto, and then as much size as may be. Another rock on which the purchaser is often cast is in buying animals that are too fat, for flesh covers a multitude of defects, and high condition not unfrequently deceives good judges. Rather poor healthy animals that liave been subsisting on hard fare improve from the day they are bought, and receiving more generous treatment, please the owner more each visit he makes to them. The sleek, high-conditioned animal has, ten to one, been living on all imaginable good food, and languishes under ordinary treatment. In buying poor, improving cows, touch, of which we spoke at length in a previous section, must be the grazier's beacon and guide. It is not un nommon for the inexperienced to pick up a poor animal which is a confirmed "screw," but in such a case the good qualities of the skin and hair will be ever absent. No sooner does the young beginner enter the market than he is besieged by all the dealers that have "screwy" animals to dispose of, and he is lucky if he escapes them all. 'These chafferers do not "try it on " with experienced hands, know- ing full well that their nefarious tricks will not work there; so their victims are the amateurs. The "screw" will be found to lave a dry hard coat, the skin fixed on to the flesh as if glued there, and such signs as dry nostrils, sunken eyes, tucked-up belly, wasted twist, barcness of flesli, and an unnatural gait in walking. It often proves that the lungs are the seat of the disorder, and a dry liusk or cough will betray the secret. This cough will be brought on by stiring the animal suddenly along. Practical men look upon this sudden movement as a test, and whether it is practised in the fair or field it will generally bring on a fit of coughing. Diarrhoea or looseness must be looked upon with suspicion when present in a poor animal, while rumination is a favourable symptom, and seldom practised by a cow far gone in decline. The tail, too, often shows a weak, thin appearance, the bottom part being void of muscular power; hence the ignorant attribute the whole decay of the animal's health to what they are pleased to term tail-worm. So the tail is cut with a penkuife at the extreme end, the small muscular cords- which the operator terms the worm-removed, and the cow is expected at once to return to a state of convalescence. Wre need scarcely say all this is utter nonsense, for no such thing as tail-worm exists, and the stupid stockowner might as well expect to cure his animal by cutting a nick in the nearest gate-post.

There are a few more common defects to be guarded against in buying beasts, such as partial or total blindness, displaced hips, ill-shaped bags, defective teats, \&c. The last peculiarity, however, will not be detected in the maiden heifer. In purchasing a cow that has already calved, the first step will be to take a gencral view of the animal, and if sle appears suitable, to study more minute particulars. The age should first be ascertained, for on no account should any one be induced to buy an old animal, no matter how tempting the price may be, for they decline on hand, and always turn out too dear. Few people would credit the extra food that old animals take. "The "touch" of the cow should next be proved satisfactory, and then the udder carefully examined. Each teat must not only give milk, but the same free stream should flow from all. If the milk runs of itself from the teats, suspicions may be had that the cow sheds her milk. This is objectionable; in such instances dealers take care to keep the udder pretty empty. Small tumours often form in the passage of the teats, which are liable, later on, to cause the loss of the quarters where they are located. These tumours can be detected, even when very small, by carefully passing the finger and thumb over the milk passage. By standing in front of the animal, a good idea will be formed of the fore part, consisting of the head, neck, and brisket, or chest. It is, however, behind where the judge loves to take a general surrey, for from such a situation the rumps, hips, loin, ribs, and chine will at once come under view. If there is one thing more essential than another-in not only a cow, but in all other animals-it is a good set of ribs. They should not be flat, but placed 
evenly well back into the loin, in barrel shape, or well curved. In the cow the back rib is of vast importance. It is considered a great point with the butcher, and is about the first nart that his hand is put upon. Other particulars of

the proper shape of the cow will be found elsewhere. The question of colour is of importance to the breeder, who intends rearing his stock, while to those who do not intend rearing calves, but selling off fat, colour is not of paramount

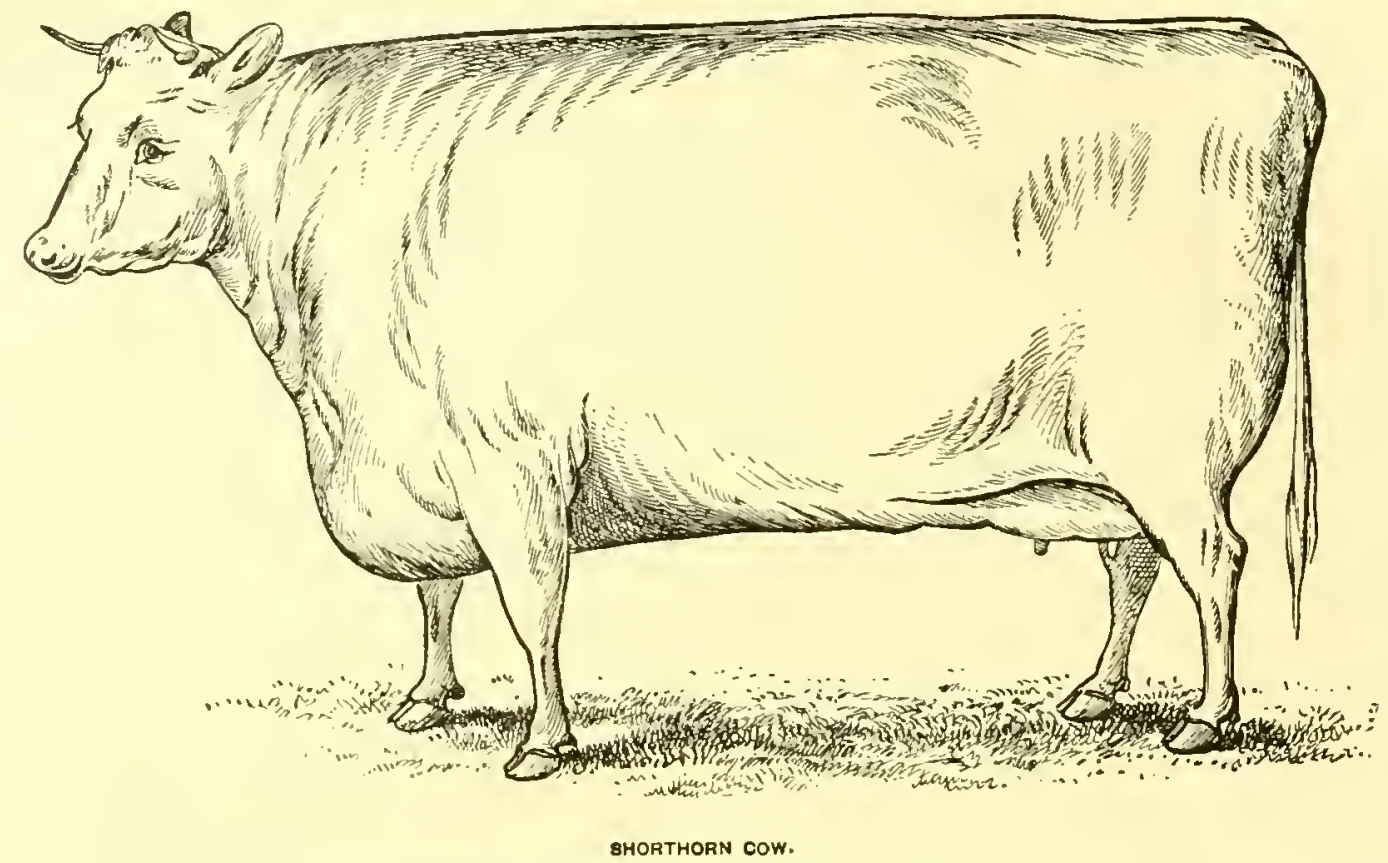

importance. The breeder, however, chooses such colours as deep reds, reds and whites, light roans, strawberry roans, and avoids dark nostrils. Thus the offspring will prove of good colour also A neat head, gay colour, with jaunty gait, adds much to the appearance of the beast, and such qualities so attract the eyes of customers that a higher price is paid, the purchaser knowing full well that they are never pronounced in the mongrel-bred cow.

It is preferable to buy stock on the farm where they are bred, if possible, as not only are animals often injured through the abuse of drovers at fairs and markets, but a risk of taking or creating disease is run, and in pregnant animals abortion is often brought about. The manner in which cattle are abused in our fairs and markets is a crying disgrace to the enlightened age in which we live, and it is high time the police authorities bestirred themselves in the matter, for they are empowered to do so; indeed; it is their duty. Blows are applied as if the poor creatures had no feeling, and overdriving without food or water is commonly practised.

If purchasing could be done on the home farms, besides the above evils being avoided, all middle-men-for whom there is no spare profit in these depressed days of farmingwould be shut out, animals would be more healthy, and many coutagious and other diseases would be avoided. The general closing of fairs owing to the prevalence of "foot-andmouth disease" proved this, for not only was this disease arrested in its progress, but other contagious ones also disappeared from our herds and flocks. Every experienced grazier knows how often cows are bought that have been driven from fair to fair until they are so footsore and jaded that they are half a summer before they commence to thrive and lay on flesh. Therefore the grass season passes away, while they are not nearly made up for the butcher-the only resource left being expensive stall-feeding, or selling out at little, if any, over cost price. Buying and selling stock at home, then, is to be commended in every way The advantages to the seller are that they never look so well in any ather position, and therefore he gets the best price without paying any outpocket expenses whatever, while the advantages to the buyer chiefly are that the animals are healthy, rested, and in a good state to go on immediately they are removed to fresh quarters.

\section{TREATMENT DURING GESTATION.}

Approved animals having been bought in, we will now consider their further treatment-assuming that a herd of maiden heifers have been purchased in the spring-time, at the age of two years, just as the grass fields begin to display a verdant face. After the animals have passed a month and become settled to their pastures, it will be time to mate them with an approved sire. We are now advising for the breeder's herd. A young sire is essential here, say from twelve to eighteen months old; and to ensure the fruitfulness of all the animals, he should lie with the herd, or within measurable distance. Otherwise the shepherd, upon whom attention to these matters generally falls, may fail to interest himself to take the heifers to a distance, and thus a portion of the herd prove unfruitful from neglect. When in a healthy state, cows usually come in use every fortnight or three weeks until impregnated, and their period of gestation is forty-one 


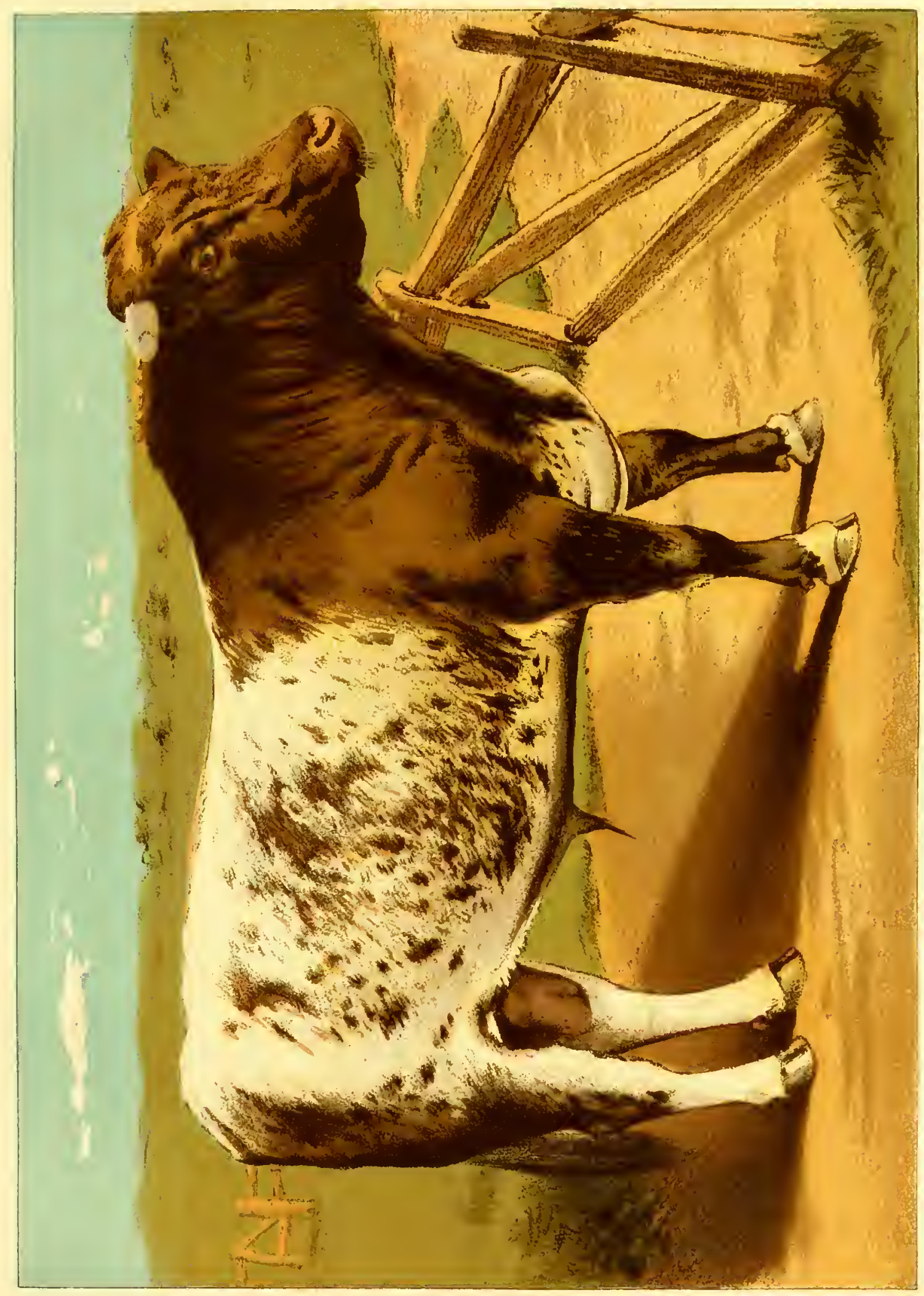

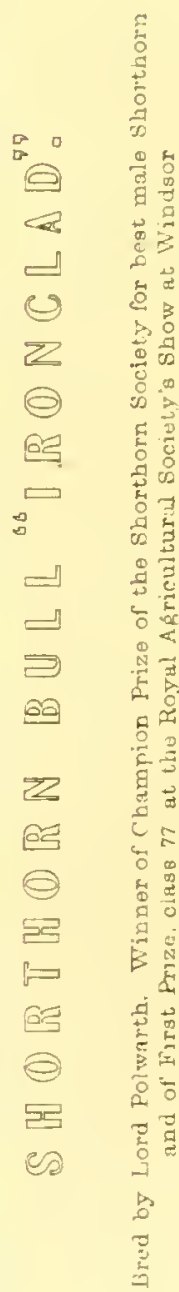



weeks-a few days more or less. 'The heifers would calf down from two years and nine months old to three years. For the breeder, under all circumstances, this is quite early enough, although for the dairyman or milkseller six months younger would be considered a good age for heifers to have the first calf. No doubt breeding from animals too young stops their growth, bad times at calving are liable to result, while the first calf is often but an undersized creature, totally unfit to bring in to the herd It should, however, be understond that heifers that have been well cared for the whole of their lives are as forward at eighteen months old as others that have subsisted on less generous diet, or that have been neglected, are at two years, so that the graziers may best judge when to conmence breeding from the animals under their care.

The sire slionld be of pure shorthorned blood, and an aninal as near perfect shape as possible. Extra size may be passed over-a mass of fat is not needed; but stainless blood, good make, and colour are sine qua non to the improvement of the herd. If a pretty numerous one, the owner will best serve his own interest by keeping a bull on the farm; but in cases where only several cows are kept this will scarcely answer, and the services of the neighbour's must be utilized.

During gestation the quiet field is the best place until winter sets in, but it is above all things requisite that the aninals should not be subject to fright. No dog should be allowed to disturb the quiet of the herd, for nothing would be more likely to bring on cases of untimely birth. The water supply should be pure and wholesome; and it is the exception rather than the rule to find such the case in the common pasture-fields. Too often stagnant pools, offensive to the smell, are the only drinking-places that cattle have to quench their thirst at. The bottom of the pond pro-

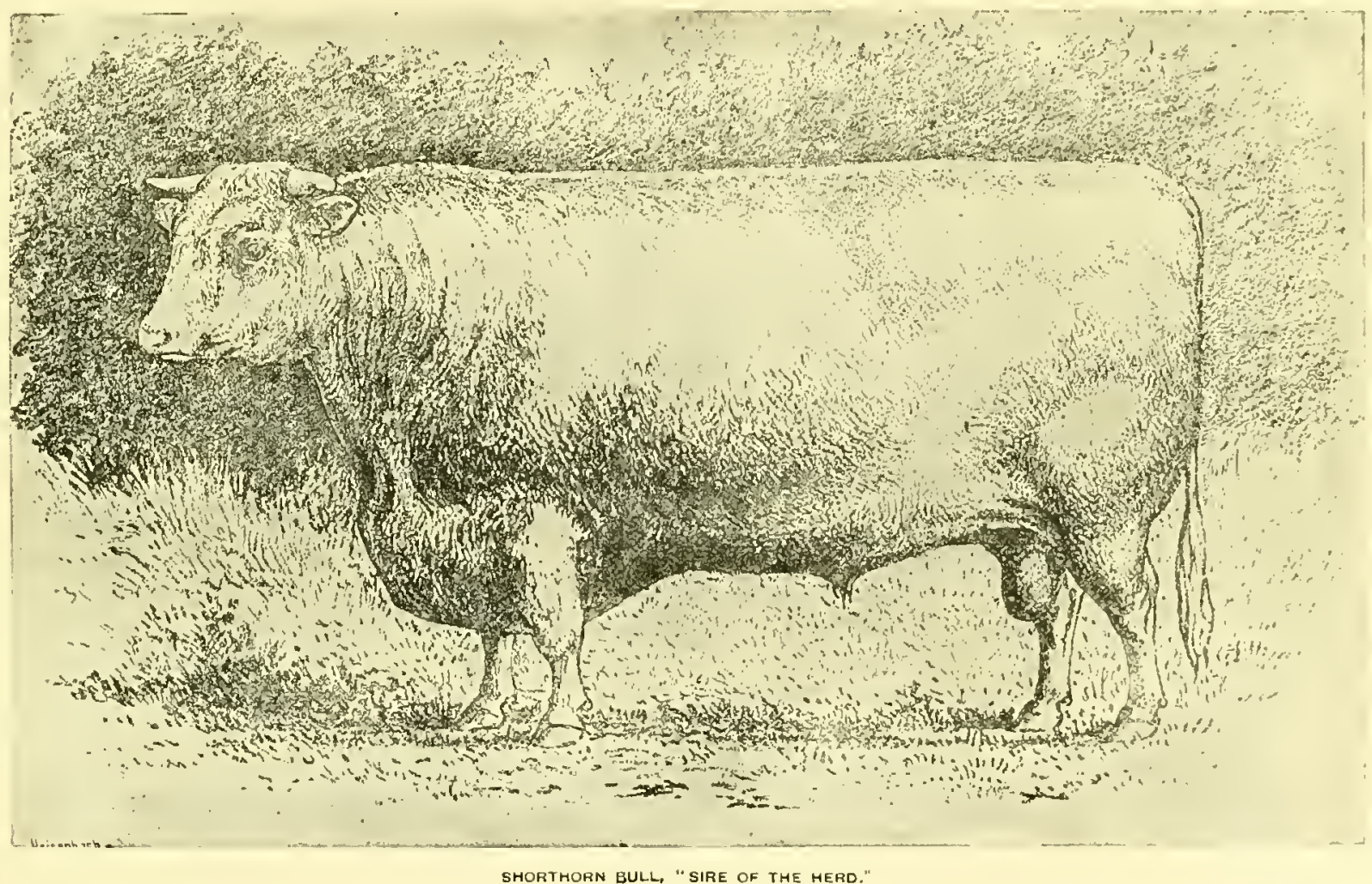

bably contains the relics of fallen and decayed branches and leaves of many years' aecumulation from trees above or around. 'The excretion and urine of many herds of beasts may have been added to the filthy fluid for many a sum.ner owing to the botfly (CFstrus bovis) or the heat having driven the excited and panting herd into the water; while many a pond is made a general sepulchre for all animals that diz in its immediate vicinity. Is it a wonder, then, that disease prevail in our land? No ; but it is marvellous that more dire maladies do not rage than is now the case. The nearest way to produee an unhealthy system is foul water, and the most fruitful method of causing abortion amongst any pregnar.t animals is ill-health.

While animals are upon a summer pasture their food con- sists wholly of grass, and if the plants are healthy nothing is more wholesome for the breeding cow. But there is a disease now common to our grasses, known as ergot, which in wet seasons prodnces more cases of abortion than any other one cause; and this fact is far too little known and understood by the ordinary stock-keeper. Ergot is a parasitic fungus that fixes itself on the grasses in the shape of a minute balloonlike germ. This germ lodges on the bloom of the grasses, taking possession of the small cavity prorided for the grass-seed. Here the germ grows into a dark-brown or black spur, varying from a quarter to three-quarters of an inch in length, and in thickness between that of a fine needle and a wheat-grain. It is characteristic of the plant that it invariably grows in the shape of a cock's spur; henee the French 
give it the name of ergot. Eaten in sufficient quantities, it canses inflammation of the uterus or womb of any pregnant animal, when abortion is liable to result. Breeding cows should be removed from pastures which are so diseased. Spurs are not often present before the end of July or the beginning of August, so that before this time the poisonous parasite need not be feared, and it is never found to any extent upon aftermath in meadows in the year they have been mown. Therefore the farmer can generally remove his cows from the "ergoted" uplands and ensure wholesome herbage on the mown pastures. The hay should be examined in winter time, as the spurs sometimes prevail amongst it.

In the winter season the pregnant cow needs more attention. First, the food must all be of a light, wholesome, nutritious character. It is essential that animals should come dowu calving in good condition, or there will be small hopes of a profitable dairy cow. The hay must be neither overgrown nor weather-beaten in the field, nor mouldy or overheated in the rick. The best hay is - such as holds the fragrance of that newly made in summer time-so much the better if the colour is not clianged. Roots are quite wholesome diet given in moderation, and in a matured state; indeed they are requisite where the animals cannot get a run to pasture for a few hours during the day. Mangel-wurzel are unfit to use before Christmas-better to be withheld until past Lady-dav Some veterinary surgeons deem them poisonous before Christmas. Carrots are a most wholesome root at all times, and should be more widely cultivated by the farmer. Ground oats or three or four pounds of mixed linseed and cotton-cake are wholesome food, and beans, pease, and rice meal may be given in judicious quantities. It is better to nnderfeed than to overfeed, and the man who breeds from animals that he intends keeping on need not force them into such high condition as if they had to be sold to dealers. Indeed, really prime hay and roots are sufficient in themselves, but if straw is mixed with the hay in the chopping process a little meal or cake may be required. The roots should always be pulped and mixed with some chaff until they begin to ferment; thus the food is served up in a slightly warm state, when it is much more wholesome for the cow's stomach than when taken in cold.

Secondly, the water must be pure; but we do not approve of it taken from the cold spring. If it is too hard and cold, it should stand in some warmer temperature for twelve hours before it is given. Cold spring water served out to a thirsty cow living upon dry food is positively unwholesome, and still more so if the animal has just been feeding on cold roots. It is better to take the water from a clear stagnant pool; but the best water of all is pure rain-water; and cows like it better than any other. Many a washing-woman has applied the broom freely to the poor dairy cow that has made too free at the soft-water butt. Nature's laws are always displayed by animals, if their owners would but study them. It would be better if buildings were so arranged that all rain-water could be saved for cattle; the extra outlay would thus be repaid over and over again in a few years.

Thirdly, exercise is requisite for cows during gestation, and a few hours' run in the pasture-field during the day all winter is desirable. In such cases they get a little grass and seek their own drinking-places. The shed or yards should be cool and well ventilated, or the animals will feel too severely the chill in the pastures. Cool yards promote the growth of a warm garment in the shape of hair, and when this is assumed cows seldom take cold. It is foliy to tie animals by the neck during gestation, even during the night. A comfortable roomy bed on a high and dry spot should always be provided, and if under an open shed so much the better. It is most important that heifers should not lie too crowded, for they are far more spiteful than older cows or steers; and any more than usually quarrelsome one should be removed to other quarters. It is a good practice to tie them up while they are taking their extra food, such as cake, roots, and any other diet that they are likely to fight over.

Fourthly, no frights or disturbance should be allowed, and no bad smells should prevail. The attendant should be a steady, trustworthy, good-tempered man, one who feeds his animals punctually, and is fond of and takes delight in his work. These men are now difficult to procure, and any one getting hold of such should pay them well, for many a herdsman who has a quantity of stock to attend to wastes more than his week's wages come to. When cows have passed half their time of gestation their food should be of a more generous kind, or they will be found to decline in flesh, having the living fotus then to support.

\section{TREATMENT DURING PARTURITION.}

In cases of heifers bringing their first calves, little if any change of treatment is required until they calve. In winter they should lie in a roomy yard, be frequently watched, and in summer the precaution should be taken that those whose time is accomplished do not lie in a field where treacherous watering-places exist, such as brooks, rivers, and ponds. If these watery graves could render up an account of their dead, they would amount to myriads. Often the thirsty mother goes to drink when the calf can scarcely stagger along, and the latter upon blundering over the river bank has little power to save itself. Ponds may be easily so mounded that no fear need arise from such a loss, but how seldom are these important matters considered on the farm! Young lambs and foals also at times share the same ill fate of drowning.

When the heifer shows signs of calving, "the labia pudendr -or external shape-increases in size, and discharges a thick viscid mucus; the mammary gland becomes swelled, hot, and full of colostrum, or the first milk; and, what is always regarded by the breeder as an immediate forerunner of delivery, the ligaments of the pelvis give way, or, ts use the farmer's language, the cow is down in her bones." Delivery being at hand, the animal displays great pain and restlessness, lies down suddenly, only, however, to rise as quickly; labour 


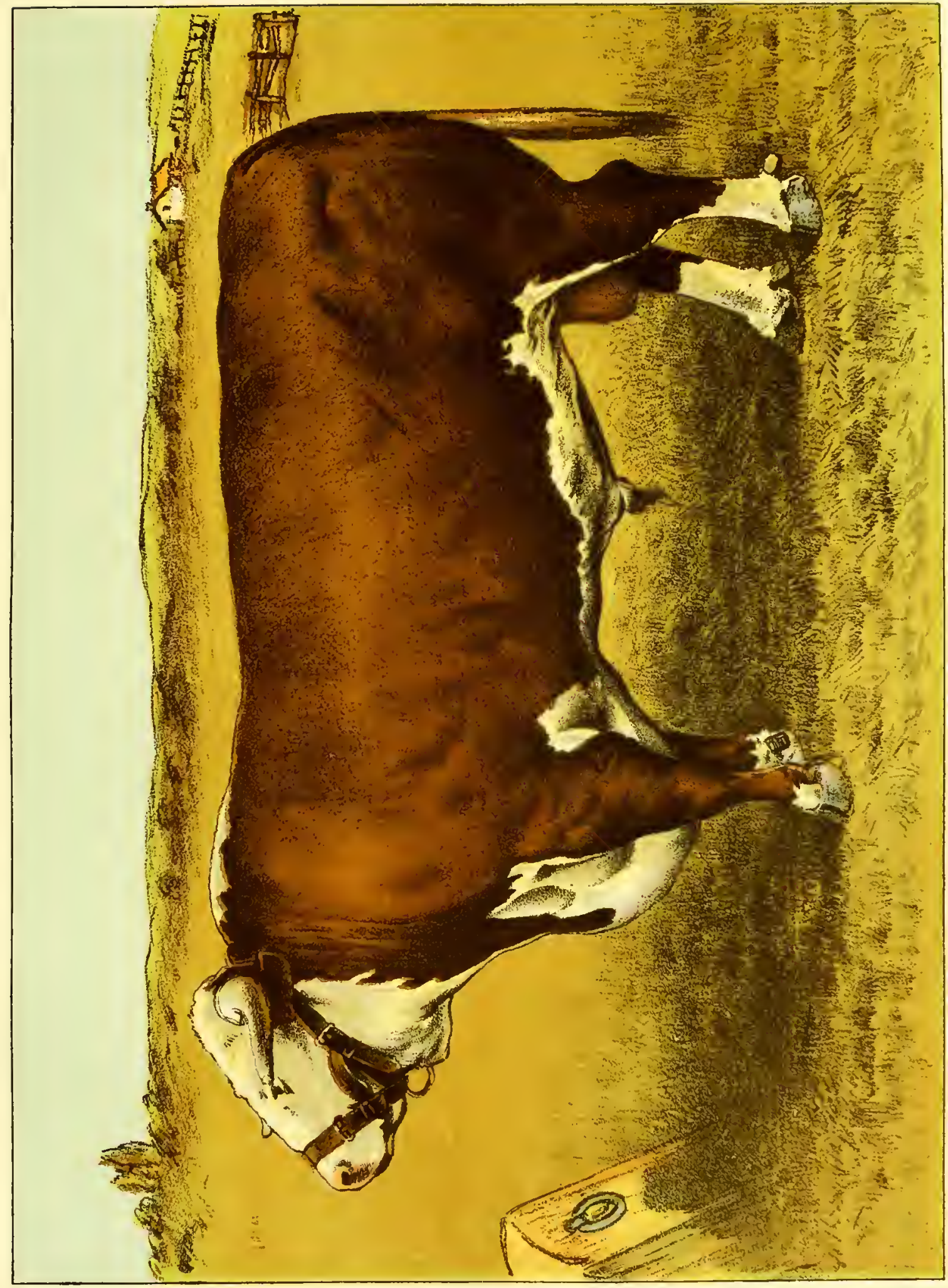

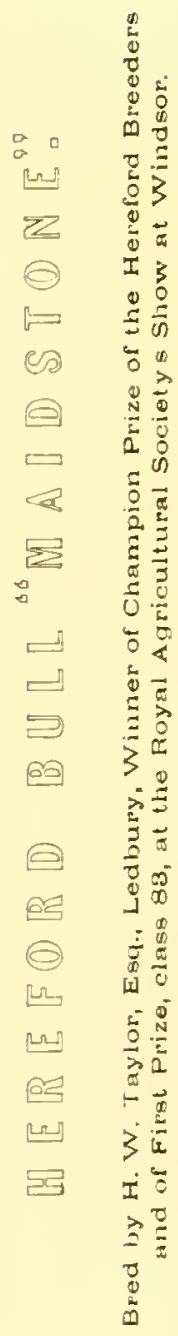



pains come on at first in a slight degree, but later on grow in intensity even until delivery is complete. Although it is desirable to render some assistance, more particularly to heifers, yet too much haste must not be used, for the heifer needs much more time than the cow that has had several calves. The amion, or, as it is commonly called, the water-bladder, is first presented, and this should be ruptured by the attendant, when, if natural delivery is taking place, the fore-feet and nose of the calf shortly are prescnted. The fore-legs being just protruded, the head will be observed resting upon them about the knees. Assistance should now be rendered, and the birth will be at once accomplished. Should any unnatural position of the calf be observed, the veterinary surgeon should be called in. In too many instances both master and servant are in too great haste and fear evil consequences, when if only a little more patience was exercised all would be well; and this more often occurs with heifers, which frequently require three or four hours to bring forth.

When the mother has been safely delivered, if in the genial days of summer, she may be brought into a cool shed at night and have given to her a bran-mash a little chilled, or rain-water, and the bag must be eased if painfully full. It must now be ascertained if the calf has sucked: if so, it will look after itself for the future; but if it has not, it must be assisted to the udder. There is, however, seldom much difficulty with the young calf, for it is by no means a delicate or tender creature-very different in such respects to a foal. We do not approve of milking the bag quite out for the first two or three days after calving; such is contrary to nature's course, and might lead to parturient apoplexy. Still more is the practice to be condemned of milking before the birth has taken place. The first milk taken after calving, called colostrum, is too rich for forming a cream and making butter, therefore is kent apart from the other milk for the first three days; this richness is seen more in the heifer's' than in older cows' milk. The umbilical cord or navel-string of the calf is generally - we may say almost always-ruptured or broken in the act of giving birth; and should such not be the case, it will be sure to break when the cow gets on her legs or the calf is moved. This natural breaking of the navel-string is far preferable to the herdman or attendant severing it. The placenta or after-birth is withheld a few hours, and should be removed from the presence of the cow immediately it falls away, but must not be forced away from the animal. In severe weather in winter a large airy loose-box, with plenty of clean litter, is the best place for both cow and calf for the first week, after which time the calf is generally weaned. Chilled water, bran-mashes, pulped roots, with a little sweet hay, form proper food for the newly-calved cow in the winter season, when green herbage is not procurable. The more aged cow requires a little different treatment, particularly when parturient apoplexy is suspected. Then the food-supply for a week or a fortnight before calving should be of a sparse kind, and several doses of mild purging medicine may be given. When one dose has worked off another may be administered.
After calving the same precaution should be taken for the first week, when danger from this malady will be past. Heifers seldom if ever suffer from this fearful malady, and upon certain land older cows are seldom known to be attacked. Therefore we do not advise purging and such artificial means to be used unless an attack is suspected. Frec milkers full of flesh, and more particularly the Channel lsland breeds, after the second calf, are the most liable to "fall." We counsel that the calf should remain with the cow as well as the heifer for a week after birth. Thus the youngster has the advantage of sucking at frequent intervals and getting the colostrum, so needful to its tender stomach. An exception to this rule may be made with the milkseller's cow, where the milk is more valuable tlan the calf. The calf should lie loose with its mother, when it will suck at frequent intervals-a much more commendable plan than its being fasted twelve hours, and then perhaps supplied with inferior milk. In the summer season it is not desirable, as a rule, to separate the heifer or cow from the herd until signs of delivery are observahle; and even then it is better for the birth to takc place in the open field, for suddenly removing the animal does not tend to hasten labour. When cows calve that are intended for sale, they are just as well left in the paddock night and day, the only thing being needed is that their bags should be eased when showing signs of being too much extended with milk. In instances where the calf is fattened, after the first week the youngster gets milk twice a day, is kept up in a small pen, and either takes its milk direct from the cow, or the milk is milked into a vessel and then given. The former plan is the better one.

\section{FOOD FOR DAIRY COWS.}

Whether our readers are the owners of single cows, to which they look for a supply of good wholesome milk for their families-whether they are dairymen supplying towns, or dairy farmers in remoter country districts, we would desire to impress each of them with the importance of treating their cows liberally with regard to food; reminding them, that whatever tends to render the yield of cows less than it should be, recoils on the owners, no matter what particular breed of cattle they may prefer, and that in all cases "the cream comes by the mouth."

In the feeding of dairy cows four main points must be kept in view-(1) to aid the increase of milk; (2) to improve the quality of the milk; (3) to maintain the condition of the cow; (4) to produce manure of high quality. Too often the careless dairyman only looks as far as his milk-pail is concerned, and fails to notice that his cow is rasting flesh day by day, until at last the milk falls off, and the beast has to be dried much sooner than she need have been under more judicious treatment. Sweet, well-harvested hay that is got in the latter end of June or first week in July is the very best quality, providing it is not gathered in too quickly to heat in the stack. Grass cut at the above season contains the maximum of sap. Most of the plants are in full bloom, 
and therefore the crop is in its proper state for cutting. Grass is not the most nutritious when the seed is ripe. Many of the seeds are dislodged in haynaking, and the remainder of the plant is woody, indigestible, and innutritious, thus such fodder is unwholesome for the dairy cow. Clover hay, when well got, is supposed to be a better milkprovider than meadow hay; but, in the writer's opinion, this would much depend upon the sort of land the hay was cut from. However, it is sufficient for us to observe, that eitler meadow or clover liay is wholesome for the cows when well harvested, and must, when the grass season is over, form the principal food. Bran stands very high in the list of good milk-producers. It increases the flow of milk, improves its quality, and holds up the condition of the cow, while no unpleasant flavour is imparted to the butter: it is also a cheap diet. This food should be given warm in mash shape, and two gallons per day will be a good allowance with other food. Oats are very similar in favourable results to wheaten bran, and from one to one and a half gallons, with other food, per day may be given. In most instances it is needful to liave them crushed, or they are liable to pass whole, when of course no nutriment is obtained from them, besides the pain and inconvenience felt by the cows in passing undigested food. Bean and pea meals tend more to improve the carcase of the animal than to increase the milk-supply, while if given too freely an unpleasant flavour is imparted to the butter. Therefore we only advise these meals to be used very sparingly, amongst other mixtures. Linseed-cake is rich in both milk and flesh producing qualities, and gives no bad taste to the butter, unless used in too large quantities. Cotton-cake is still more strongly advised; it is cheaper than linseed, produces nearly as much milk, and does not make the butter strong. Both these cakes render milk of high quality. Rice-meal, when got pure, is strongly advised for cows. It needs, however, to be purchased at wholesale price from large firms, for such as is obtained in odd sacks is often much adulterated. This meal tends to sweeten all other food, in addition to its own nutritious qualities, and is best mixed with pulped roots and chaff. Roots need using with caution. Swedes, when well matured, may be given pretty liberally where the milk is to be sold, but must be used with callion where butter is made, or the flavour will be spoiled. They should be well matured before being used for dairy cows, and this is best done by storing them early; in this situlation they soon attain a ripe state. Mangel-wurzels are a much-overrated root; during March, April, May, and June they are the most nutritious. Given earlier, they are unipe, cause scour, and produce milk of poor quality, although they increase the quantity later on. They are, however, at no time rich milk-producers, being more profitable to the seller of milk than to those who keep a butter dairy. The condition of the animal is almost invariably lost when these roots form a considerable portion of the food. Cow cabbages stand high in our list of foods, and not only produce excellent milk, but keep the cow in good order. The only thing against growing cabbages to a great extent, is that they come in before the grass is consumed, and therefore when keep is pretty plentiful. The carrot, however, is the root. It is equalled by no other, and should be grown much more largely. Sutton's long red cattle carrots, or such as are sold by other large firms, are the most profitable roots the stockowner can grow. If an animal is sick, nothing is more wholesome or more thankfully received. If the cow has a fastidious appetite, carrots prove a nutritious and tempting diet. This root is also a rich milk-producer, and gives even in winter that rich yellow colour to butter that is so much admired, and which is only otherwise obtained when cows are in the summer pasture. Carrots also keep the animal in first-class condition, and may be used nearly all the year round. The stockowner's owl discretion must be used in dealing out these foods, and he should bear in mind that a mixture and change of diet is most essential. Let all possible food in winter be given in a slightly warm state-which can be arranged with the assistance of the bran mash, and by leaving the pulp and chaff eighteen lours to ferment. Apropos of the bran mash, water should be put on at a slightly lower temperature than boiling heat, or some valuable properties are destroyed; but so long as boiling heat is not reached, these are retained.

In the ordinary pastures, during summer, one cow usually requires one and a half acres to graze. No sheep or horses should be allowed in the field at that season, although they will do good by nipping off rough grass in winter, when the cows are in the yard. Three or four pounds of cotton-cake per head per day is not badly given even during the grass season. Ensilage is coming fast to the front, and as far as our experience goes, is especially good for dairy cows, given with liay, when no grass is forthcoming. However, the ensilage should be made of grasses or clover of good quality. It is nonsense to imagine that all weeds and innutritious herbage will make first-class ensilage.

The value of manure produced by varieties of food employed is well described by Mr. Lawes, Rothamsted, as follows :-
Description of Food.

1. Decorticated cotton-seed cake,

2. Rape cake,

3. Linseed cake,

4. Blalt dust,

5. Lentils,

6. Linseed,

7. Tares,

8. Beans,

9. Pease,

10. Locust beans,

11. Oats,

12. Wheat,

13. Indian corn,

14. Malt,

15. Barley,

16. Clover bay,

17. Mleadow hay,

18. Oat straw,

19. Wheat straw,

20. Barley straw,

21. Potatoes,

22. Mangolds,

23. Swedish turnips,

24. Common turnips,

25. Carrots,

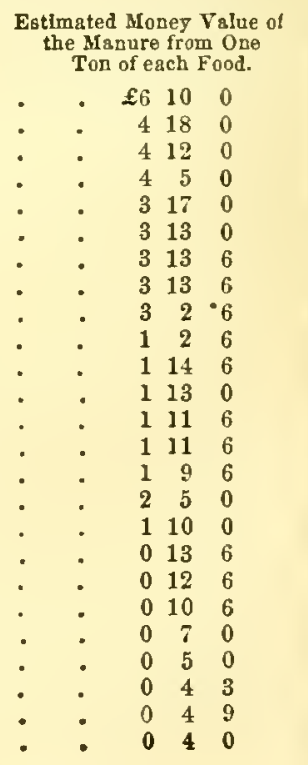


The dairy cow should be fed at intervals, and should always clear up one scrving before the next meal is given; from six until nine in the morning, lay, meal, and roots, with water, will be required; from nine until the middle of the day the animal should take rest and chew the cud. At midday an hour or two's feeding will again be needed. Most of the food up till now consists of long or chopped hay and pulped roots. Towards four or five in the evening feeding must again commence, and at eight o'clock a final meal of long hay should be given, with what water the animal will take. A knob of rock salt shonld be always in the manger.

\section{MILKING.}

A good milkman is of paramount importance, and there is perhaps no requisite so often overlooked by the modern cowkeepers. The small holder who milks his own animals has an advantage, and it is seen by his profits how much the masters' interests are neglected who have to depend upon hired men. Women are the best milkers, and to women cows will give down their milk when they would not do so to a man. The woman is gentler and kinder in all her dealings with the cow, and this animal appreciates such treatment to a high degree. The rough-handed coarse milkman, with his threatening attitude, is quite sufficient to induce the cow to withhold her supply; what, then, must be the result when the nilk-stool, the besom, or ash-plant is applied freely? The result often is that cows frequently either go dry, prove kickers, or lose flesh, notwithstanding a liberal allowance of food; again, they abort their calves or prove fruitless, and then the stockowner finds that he is losing. money by his occupation. The cow by nature only gives milk to her calf, for which she has great affection. How far, then, is nature lost sight of when the coarse, ill-tempered man substitutes the loved offspring!

It would be much to the benefit of the farmer if he would study more decply the habits and nature of his animals, instead of, as is usually the case, treating them as mere machines rather than creatures possessing instinct and feeling in a high degree. Whether it be the horse, cow, sheep, or pig, each animal has great affection for, and fraternizes with, those who show it kindness.

Assuming that a lad or maid is being instructed in milking, the first thing to advise is that the animal be driven slowly from the pasture, and as quietly as possible tied up, without any ill-usage or even a harsh word. When the cow walks to the shed chewing the cud, and continues doing so during milking time, the owner may know all is going well; but if, on the other hand, rumination does not go on, it is most likely that the animal is not well, or is in fear of the milkman. Some are of a far less nerrous disposition than others, and here the attendant needs to use discretion. We always approve of a little dainty food being served to the cow during milking time, for it gives her confidence, leads her to look upon the operation with pleasure, and induces all milk to be given down readily. The milker should not force the stream out more freely than the passage can take it. From too much force being used many a cow has turned out a confirmed kicker. Neitlier should the teats be pressed too freely until the animal opens them first, as it were, or gives the milk down; but as soon as that time comes the work should be finished with despatcl. 'The last dregs should be taken out of the udder, as they supply the richest milk by far-the first half pint being little better than skim milk. When the animal has been milked and fed, she slould be gently driven back to the pasture in summer or yard in winter. Punctuality is a most important matter; cows should be milked to the minute at a corresponding time, night and morning. So much should this be observed, that each should be taken in its turn. When the gadfly abounds in summer, the milking-cow should be kept under a shed during the heat of the day. In milking young heifers with their first calf, much paticnce is needed. Often the udder is inflamed and painful, and the mother is much concerned about her offspring; generally, however, in the course of a week the bag will become all right. The mother will allow the calf to take the milk, although the pain would not be endured if caused by the milkman. We do not, as a rule, approve of lads for milking, for they are not to be depended on, and should only be employed under the eye of a good man. The master should examine the udders of the cows after they are milked, to ascertain if all the milk is taken; indeed, it is a good plan to measure each cow's produce at every milking-time. Thus bad milking, inferior food, or any ailment that has attacked the cow, is at once discovered. Buckets with marks of measurement by inches can easily be obtained, thus saving the stockowner much daily trouble measuring. Nothing proves more clearly that something is amiss with a cow than a sudden decrease in the milk.

'The cow should be dried off two months at least before next calving; the milking should be stopped gradually. Once a day for a fortnight, twice a week for the next fortnight, will leave the bag so that it only occasionally needs drawing out. When an animal is a good milk-producer, the supply will not go unless the diet is given less generously, and an occasional dose of physic may be needed. It is important that this drying-off process should be conducted with care, or a quarter of the udder may be lost at the future calving from the passage in the teats being closed.

In a lecture upon milk, delivered before the Royal Agricultural Society by Professor Voelcker, there is much matter that is interesting and instructive. On the constituent elements of milk, the Professor stated that "it was essentially an emulsion of fatty particles in solution of caseine and milksugar. The fatty matter was not contained in it in a free condition, but was inclosed in little globules which, when the milk got sour, were precipitated. In other words, the buttcr and fatty portions were encased in curd or caseine. Those cells were of different sizes in different animals, and varied from $\frac{1}{200}$ to roo of an inch in diameter, some 
of them being round and others egg-shaped. In addition to the substances just mentioned, milk invariably contained a certain proportion of mineral matter, which consisted of the same material as the incombustible part of bone, the ash of which was rich in phosphate of lime and phosphate of magnesia. Thus bone, earth, butter, curd, milk-sugar, and mineral substances were the normal constituents of milk. In diseased milk there were a number of accidental substances which could not be identified by chemical tests, but only by the microscope. Pus generally manifested itself under the microscope in diseased milk, but even the microscope was not sufficient in all cases to prove whether milk was wholesome or not. Many things which possessed a medicinal power were speedily absorbed into milk, that often became as medicinal as the original remedies; and in the same way colouring matter, such as the red of madder, the blue of indigo, or the common weeds, Mercurialis and Polygonum, passed into the milk and tinged it. The flavour of milk was sometimes materially affected by the food of the cows.

"Milk was white on account of the suspended opaque globules, and, generally speaking, the bluer it was the less cream there was in it, because the globules separated and rose to the surface; consequently, in testing milk by the eye the more opaque it was the more curd and butter it contained, and the richer it was. From September to November, generally speaking, the quality of milk became better, but it decreased in quantity; and if animals were stinted in food, not only would they yield very little, but what little they did yield would be very poor." The Prolessor further observed: "He had analyzed the milk of the cow, the ass, the goat, ewes, and also the milk of a carnivorous animal, the dog, and it was a most singular fact that in all the various constituents of milk, and more especially in curd and butter, the milk of the dog was by far the richest. No kind of food could at all compare with it, and solid butcher-meat contained less nutritive qualities by far than did this description of milk. This would explain the diffculty of bringing up puppy dogs by hand; and indeed, if any one wished to preserve a rare and valuable puppy that had lost its mother, the only food that could be given at all approaching in nutrition the natural food of the puppy was a very strong and concentrated effusion of beef-tea. It was also singular that naturally there was no sugar in the milk of a bitch; but after it liad been domesticated and fed upon bread and starchy food it made its appearance. That slowed the intimate connection between food and the composition of milk."

\section{DISPOSING OF THE DAIRY COW.}

In most instances when the cow gets past her prime she should be fattened off, and sold to the milk-dealer; or if she fails to be in calf, to the grazier. It is of little consequence which course is adopted; but one thing is quite certain, and that is, that the man who breeds his own stock shonld never have any old animals about his ground. His object should be to rear and keep the cows until they reach maturity, and then dispose of them either in high condition, coming down calving, or fattened up for the butcher. In either case, if due precaution has been taken to select good calves, and to rear them well, large prices will be made.

In setting about making up a cow for the butcher in summer time, little more will be needed than a good rich pasture. No other animal lays on flesh with the rapidity of a well-bred shorthorned cow that has arrived at maturity. Some of the other breeds are by no means so easily fattened, and for that reason the dairyman often prefers to sell them for what they will make as stores, thus leaving the fattening to be done by the grazier.

Stall-feeding will be the only plan in winter time, and a couple or three months will generally be sufficient to produce a ripe animal. The agents needed are good hay, swedes, cake, and meals. The animal must be lightly fed at first, and gradually brought on to its full diet. Too often the farmer hurries on his animals, giving them most injudicious quantities of food, and that of such a kind as their stomachs are unaccustomed to. Thus the cow becomes sick, refuses its food, and sometimes more serious disorders follow. Immediately the feeding cow refuses her food from being so overforced, a pint and a half of linseed oil should be given, and after an interval of two days the dose may be repeated; in the meantime, all richer food should be withleld until the patient is again in a fit state to take it. Again, a cow hurried ou into condition so fast does not touch firmly, or come out well in fat when killed; this the butcher speedily detects, and buys at a low price accordingly. Stall-feeding is often found unprofitable: in many instances this loss is greatly increased by using improper diet, and by thus making the animal averse to all food.

\section{TREATMENT OF THE CALF.}

It should be impressed on the mind of the breeder that to rear a profitable and creditable animal he must begin at birth, and generous but discreet treatment must be continued until the animal is matured. Few animals find their way into a showyard that have not been treated well from their earliest days, fewer still carry off honours. A large percentage of the animals bred are neglected in the first fortnight of their existence, not a few die from bad management, and not one in twenty is so reared as to maintain its calf's flesh. If ever this flesh is lost it is never regained, and twelve months are lost in the process of fattening the animal. No sooner does poverty display itself in the young animal than disease, finding the gates open for its attack, steps in. If a true return could be given of calves that never survive the first year, it would astonish every breeder.

We observed above that a year was lost when the calf's flesh was allowed to fall off; and we aver that a young beast that has not lost its early flesh will come out worth as much at two and a half years old as the neglected one will at three 
and a half. Nothing ensures this generous rearing so much as letting the offspring run with the cow, and this is a common practice with Hereford breeders, and has doubtless much to do with the excellent white-faced bullocks we see got up for our Christmas markets.

But it is too expensive for the ordinary breeder of good bred beasts to allow the calf to take all the milk, and therefore more economical means must be used. Many a time the writer has reared a couple of calves upon a Welsh cow or some animal not too valuable; and one cow will rear two calves better than they can be reared with the bucket if the cream is taken off the milk. When this method is followed, however, it should be on the summer pasture, and calves reared in this manner may afterwards be identified by a stranger among any number brought up in the ordinary way, being so much better developed.

A few remarks upon calves' foods is essential. The leading dealers (Messrs. Bibby \& Son, and others) give some excellent substitutes for milk; few breeders of cattle fail to find the use of some kind in cases of emergency most useful and even necessary; but often the feeds are but substitutes, and do not prove as nutritious as the mother's milk. Still where the latter runs short, we advise free use of such feeds, for liberal treatment the young animals must have. The calf-feeds do not frequently receive proper care from the farmer and his servants, thus the seller scarcely gets his dues; and so it comes to pass that while one man's herd of calves looks excellent upon some bought diet, his neighbour's have

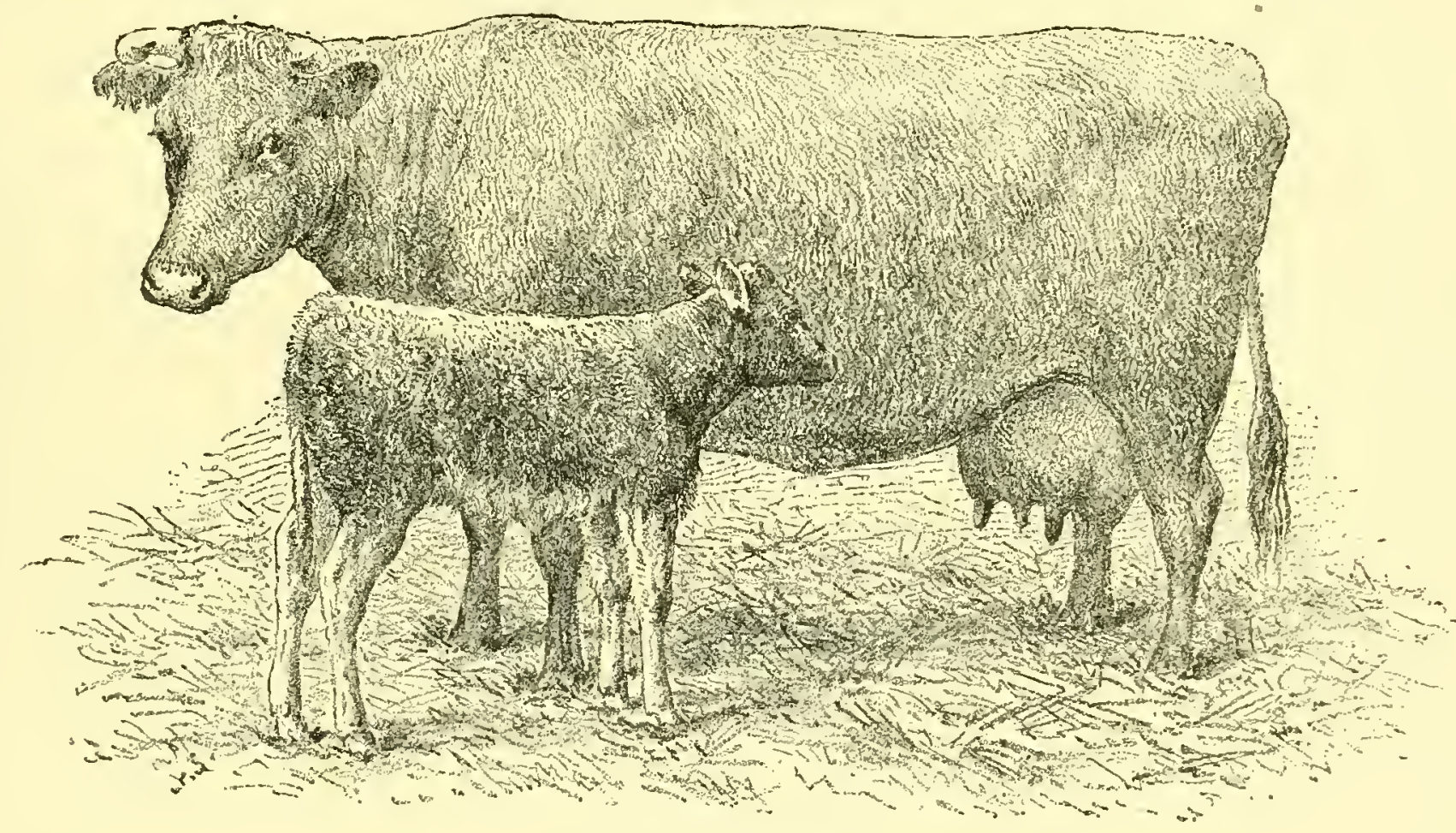

PRIZE COW AND CALF.

a very indifferent appearance. In many instances, doubtless, $/$ milk. The herdsman will form a good opinion about this such a state may be traced to carelessness on the part of the servant in preparing the food. Indeed, the same fault is observable in supplying the mother's milk. Food given to calves a little too warm or a little too cold may bring on scour or other disorders that may be either of trivial consequence or may lead to death; and seeing how difficult it is at the present day to get reliable servants for ordinary domestic work, it may be considered tenfold more so to find agents for the most responsible of all offices-viz. that of calf-rearing and general attendance upon young animals. The fact is, that the master's eye and the master's hand bne will guarantee the necessary attention.

We will now commence with the treatment of the calf at birth. Assuming that the mother has a comfortable bed, the calf can be left for a few hours after birth, and upon next visiting the shed it must be ascertained if it has taken any by examining the udder of the cow. If the young animal has helped itself, well; but if not, it must be assisted to do so. When it has once sucked, no further fear need be felt on this head. It should be allowed to enjoy the mother's milk and company for a week ; the practice of removing the youngster immediately after birth should be discouraged, if its future welfare is to be studied. Aside from the mother s bag being reduced considernbly and more neturally by th: calf, the rich milk or colostrum that the mother gives the first few days acts as a slight purge upon the bowels and clears offensive matter from the intestines, leaving them in healthy working order. When the calf is removed from the cow at birth it has not the advantage of the beastling, or colostrum, or first milk, and in consequence becomes in not a few cases costive, and this costiveness generally, later on, leads to the opposite evil, diarrhcea; this is hard to cure, and 
even when remedied the young creature looks au abject thing indced. The uneducatcd cattle-breeder "gangs his ain gait." He removes the calf at birth, and as a substitute for its mother's milk gives some new milk perhaps from a cow that has been milked some time, and which contains scarcely an atom of the colostrum so needful to prevent constipation, which is frequently followed by acid secretions on the lining membranes of the intestines. 'T'hese acid secretions coagulate the milk and separate it into component parts; the curd or cheesy part remains as a foreign or irritating agent in the intestines, and the fluid or whey part comes away in the form of semi-fluid freces. This disease is above all things to be avoided in calves, and goes by the name of gastroenteritis or white scour. To prevent such a complaint the ignorant breeder gives the young calf doses of some purging medicine such as castor-oil; this is perhaps the best thing he could give under the circumstances, but avails little while milk of inferior quality is still supplied to so tender a stomach; others give medicine to cause costiveness, and this is much to be condemned. The fact is, nature's laws are being abruptly broken, and in animals so young results are sure to be unsatisfactory. Therefore we do not advise that the calf should be weaned from the cow until a week old, when its intestines will be in a state to receive food of a less delicate character. The calf, when removed, should be placed out of hearing of the cow in a dry, warm, but wellventilated shed, and a good bed of straw is of the utmost importance.

We now put the calf upon three meals per day, each meal to consist of three pints of milk-not such as has been robbed of the cream, neither necessarily very rich new milk, but just such as is of fair quality. This treatment may continue until the animal is one month old. At this age calves are too often supposed to only require milk of the thinnest character, such as has been skimmed "sky blue." This has not the needful nutritious qualities in it. In some instances, questionable messes are added to the milk, boiled linseed is frequently used, but not being well cooked gives but an unsatisfactory result. Here some well-prepared advertized calf food had far better be used. However, those who cannot spare milk of good quality should not attempt to rear, and breeders must at times be content to put up with less butter in the calf-rearing establishment.

From one to thrce months old give the calf three quarts of milk each end of the day, and the cream may be taken from it once. The animal will now begin to pick a little swect hay, and for economy's sake a small coarse net should be placed filled with the fodder near the head. Hay is little given unchopped at this time, although later on the small trough may be introduced, and a little linseed-cake dust and some pulped carrots or swedes supplied with chopped hay. It is most essential that the hay and all other food given at this time should be of the best quality, for the digestive powers of the young animals are by no means strong, and are unaccustomed to the work required of them. The hay that is got without exposure to rain, in June, is the best for calves, providing it has not been allowed to heat in the rick. We like to see it come out the same colour as it goes in, and to contain the same sweet aroma. Hay got later on is too woody in the stems, and indigestible for calves, and is often the cause of several common ills to which calves are subject.

From three to six months old the quantity of milk may be increased and the quality reduced. The hay and roots should be increased, but up till twelve months old, cotton cake must be carefully withheld. The latter is too indigestible for calves-portions passing through them whole, thus causing purging and irritation of the stomach and bowels. Carrots may be looked upon as the most wholesome root, and mangelwurzel as the least wholesome. Cow cabbages are very good when they can be obtained, and swedes are advised when the young animals get strong enough to digest them. A little linseed cake, rice meal, pea or bran meal, or wheaten meal, are each wholesome when given prudently.

In rearing calves with the bucket, it is very essential that the animals should be all tied separately before they are fed, and if left tied for a quarter of an hour afterwards they will not acquire the much-detested habit of sucking each other. Moreover, when tied, each animal gets its share of milk, without being subjected to the blows frequently administered by the unfeeling attendant in order to keep one calf from interfering with its companion's food.

After six months old, milk can be entirely withheld; indeed it should be rendered of very poor quality during the last month, then it is not so much missed. Until twelve months old, light and wholesome food is the proper diet, and the judicious stockmaster will judge what kind is suitable, according to the condition of his stock. Chopped hiay, and sweet straw mixed with pulped roots, and laid by to ferment, will form the standing diet for yearlings. The young animals will then be easily treated by any ordinary herdsman, and may be considered safely reared. With regard to water, that termed soft, or rain water, is preferable.

Our above advice has chiefly pointed to the winter season, but even in summer calves should not be turned to grass too young. It may be taken as sound counsel not to allow them to be depastured while they are taking milk, for grass and milk do not go well together. There is no objection to a little green vegetables mixed with chopjed hay, but they should not be offered otherwise.

Nichaelmas is a good time to bring calves in for rearing, and then they go to pasture in May straight from milk. Nany rearers will not allow their youngsters to go to grass before twelve months old, and such rcarers can often show the best herds of cattle.

Only full-sized and healthy-looking calves should be chosen for rearing. Any not reaching the standard should be fattened for the butcher. They are fattened best by being kept confined, and the mother being allowed to visit them twice a-day, or by being given a full supply of new milk of the best quality. 


\section{THE D I R Y}

WITIIN the last decade there have been so many improvements in dairy utensils and contrivances as to cause a complete revolution in that important branch of the farmer's industry. To enumerate a tithe of the inventions lately introduced would take up far more space than I have at command; therefore, while enlarging on a few of the most important contrivances, I must invite my readers who may require further information to pay a visit to the Dairy Supply Company's works in Mnsem Street, London, where every new and useful invention is on view.

The first thing to consider is the situation of the dairy. It is of paramount importance that the building should have a northern aspect, to get as little of the sun as possible; if shaded, so much the better. It is essential that everything connected with a dairy-room, utensils, and attendants-be kept perfectly clean. Milk and butter are most susceptible to taints from any impurities in utensils or the air; for which last reason the dairy should be far removed from piggeries or anything emitting offensive effluvia. The dairy should be well ventilated, and so built that a cool temperature in summer and a warm one in winter can be ensured. Shady trees and low-growing shrubs are advised in the vicinity, but not so near as to droop upon the building.

On the requisites to be attended to in the construction of dailies, the following résumé of points are worthy of consideration:-Air to circulate freely round the dairy; shelter to be had from the south and west; trees excluded from close contact with it, none nearer than thirty feet, and all neighbouring shrubs to be close standards; the soil, if possible, a gravel subsoil; ample ventilation to be secured within the building, both at top and sides; windows to be double, to secure warmth in winter and cold in summer; water to be plentifully supplied; means for rapidly flushing the drains; no cesspools allowed near the building; walls to be hollow; floors and walls to be paved and covered with glazed tiles; tables and shelves of marble or slate; roof such that no vicissitudes of weather can affect the milk; a thatched roof, tiled over for neatness, will give the most uniform temperature, summer and winter. The milkpans are best sluallow, say six inches deep, as milk, thinly set, keeps better than when in deeper vessels; although it may be preserved longer in winter than in summer, I would not even then recommend deep pans being used. Before being milked, cows must on no account be hurried so as to overheat them; hence during summer the shorter the distance they have to travel home the better; and in the pastures where they lie there should be some trees or other shelter from the sun, as overheated milk will not keep well. It is a good plan to tie ap cows in some adjoining sheds in the sultry hours of the day, when the bot-fly is troublesome. At such times cows are harassed by this pest to such an extent that their milk becomes so overheated as to be rendered nearly useless. When brought into the dairy the milk should be allowed to cool a little before it is poured through a fine strainer into pans, in which it is set for cream. The latter should be taken off only once in twenty-four hours, instcad of, as is commonly done in small dairies, every twelve hours; the reason being that the oftener the milk is skimmed the more is taken up with the cream, thus giving it a tendency to become soon sour, as cream keeps longer fresh than milk. 'l'o ensure really good butter, cream should not be kept in summer more than four days, or in cold weather longer than a week. Care must be taken that neither cream nor churn be above $60^{\circ}$ Falrr. Where circular churns are used, they should be turned slowly at first, gradually increasing the pace till butter is formed, which ought to be in about an hour. The churn requires turning much faster in winter than during summer. When the butter has come, wash and salt it in the churn, then scoop out and place it on the "butter worker," which will effectually remove all water; thus handling the butter is avoided. When new milk is sent to market a great deal of trouble is saved in the dairy-the cows only requiring to be milked regularly, and the milk cooled before being despatched. To expedite the latter when time is limited a refrigerator is used, by which the milk is soon rendered in a fit state for transit.

As to the new inventions, previously alluded to, readers can judge which are most suited to their dairies. Old customs are apt to be adhered to in all branches of business, but nowhere more than on the farm. I am strongly opposed to the practice, so common, of men rushing in undue haste to invest in every new invention that offers, but when such inventions have been duly tested and proved beyond doubt to be useful and decided improvements, it is great folly to disregard them. The British dairyman has much trouble in the present day in competing witls the vast quantity of foreign butter, \&c., which gluts our markets. It will be impossible for him to withstand articles sent over the sea unless he avails himself of many new and useful contrivances which are offered. Irish dairy folk have stepped in advance of their English neighbours of late years by making use of improvements in dairy utensils. Canon Bagot has done much good by his lectures on that side of the Channel, and all enterprising dairy farmers on this side ought to avail themselves of the good example set by the sons and daughters of Erin.

In carrying on any important business or industry at the present day, it is a sine gua non that labour be economized. This cannot be done unless useful machinery be brought to the front. Further, it is now much more difficult to get skilled labour than in the days of our forefathers, or rather, I should say, that servants are more careless than in olden days. Wherever machinery works well it surpasses hand-work, but too complicated inventions are to be avoided. I will 
illustrate some of the mechanical contrivances in the dairy that I deem most useful, at the same time give brief details as to the advantages of such.

I have pointed out that it is important to cool milk intended for transit with despatch. The following refrigerator is most

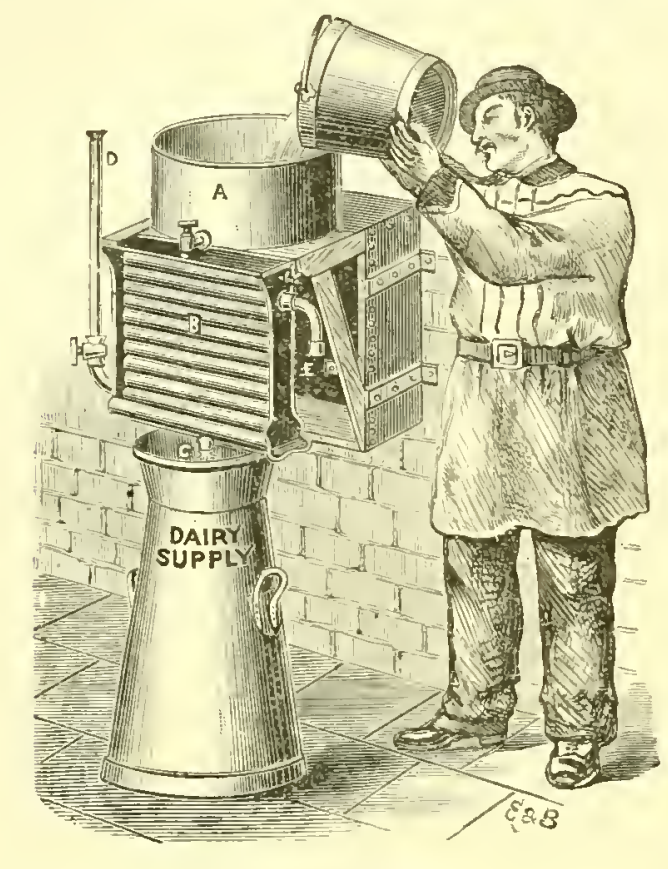

REFRIGERATOR.

useful for the purpose. Through it an immense trade has lately been carried on in milk-selling with large towns.

Railways and all other means for rapid transit are useless, without some means of rapidly reducing the temperature of milk after it is drawn from the cow. But if milk is well cooled immediately after milking, it will keep for a sufficient length of time to enable it to travel for practically any distance. The first successful apparatus introduced for cooling or refrigerating was an invention of $\mathrm{Mr}$. Lawrence, and the original idea and various improvements on it having been patented, it has retained its prominent position, and although having many rivals, none surpass it for rapidly and thoroughly reducing the temperature. It is universally acknowledged that the souring of milk is caused by the action of certain germs in the fluid, and under certain limits the higher the temperature the more rapid its decomposition; whereas rapidly cooling the milk renders these germs powerless and inert so long as the lowness of temperature is maintained. The apparatus referred to is illustrated above, in which $\mathrm{A}$ is the recelver for warm milk, whence it runs over both sides of the refrigerator $B$, and leaves the latter at $\mathrm{C}$, falling into the vessel ready for despatch by rail. The water from a spring or well-the colder the better-enters through the pipe $\mathrm{D}$, and working upwards the inside of refrigerator leaves from pipe $\mathbf{E}$.

Seeing the vast amount of milk that is conveyed from the country by train and other ways to our thickly populated cities and towns, the usefulness of a refrigerator is at once apparent. A machine for 80 gallons of milk costs about $\mathfrak{f 4}$, while one of a larger kind, to cool 250 gallons, can be bought for about $£ 910 s$.

The next contrivance in the dairy that $I$ have to deal with is "the separator," and taking all things iuto consideration, I have seen none to surpass Laval's Baby Hand Separator. The extra profit resulting from the use of this mechanical cream separator is universally acknowledged by modern dairy people, but there are those of the old school who are still somewhat ignorant on the subject. I will now make the advantages of this contrivance plain to all, when doubtless many will avail themselves of it. As soon as a farmer has become acquainted with the use of the separator, and learnt its advantages, he often commences a better system of feeding

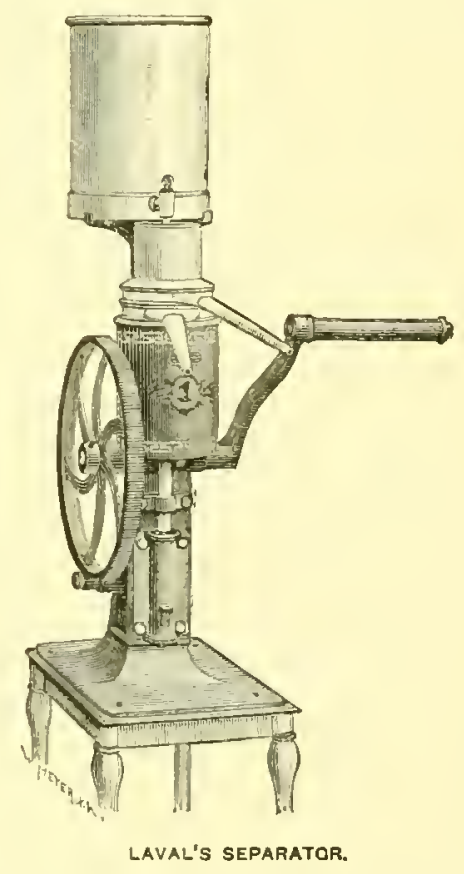

lis stock, and procures better cattle in order to obtain a richer quality of milk. In fact, such an introduction imparts new energy in the dairy, seeing that greater profits are made. The illustrated machine, which gained the champion cup offered by the Lord Mayor and Corporation at The Dairy Show, will separate 15 gallons of milk per hour.

In a dairy supplied by ten or twelve cows the Baby will be found sufficient; and if the farm has only five or six cows the saving in one year will, it is claimed, pay the whole cost of the machine. For larger dairies the separators are made in various sizes. The one known as the Windsor, separating by hand-power 35 gallons per hour, is as easily worked as the smaller machine. It is stated that the amount of butter resulting from a daily yield of 14 gallons of milk will, by the use of a good separator, be increased by about $1 \frac{1}{4}$ pounds per day, or 456 pounds in a year. On this basis it can be calculated that on any farm where the quantity of milk set for butter-making is over 650 gallons a year, it will pay the farmer to purchase one.

Speaking at the show of the Merionethshire Agricultural 
Society, Lord Harlech mentioned the case of Mr. Vaughan, one of his tenants, who worked a hand separator. The milk from the dairy being divided, and half passed through the separator, the other half was skimmed in the ordinary way. 'The result of nineteen days' working was that the separator produced 173 pounds of butter against 132 pounds from the set milk, or a gain of 41 pounds in favour of the separator. The above statement, which, however, no one has a right to dispute, seems somewhat startling. Besides giving an increased butter yield, the separator permits of the use of fresh skim milk, either for calf-rearing or for sale. I will give details on the advantages of such milk presently, when writing upon the Cooley Creamer.

The following description, with illustrations, will give a clear idea to my readers of the simplicity of an invention known as the Cooley Creamer. Fig. 1 shows a portable vessel containing four tins: it can be made to hold more. It is filled with water and the tins are submerged, while, to keep them under water, will be noticed four strips of wood fixed across the creamer. Fig. 2 exlibits a magnified tin taken from the water; A is the lid, B is a glass fixed in the tin, which shows the cream as it rises; $C$ is a second glass, which is very requisite to show when the milk is run off and only cream remains; $\mathrm{D}$ is the tap that draws off the milk; and $\mathrm{E}$ shows the distance that the handle of the tap should be turned to

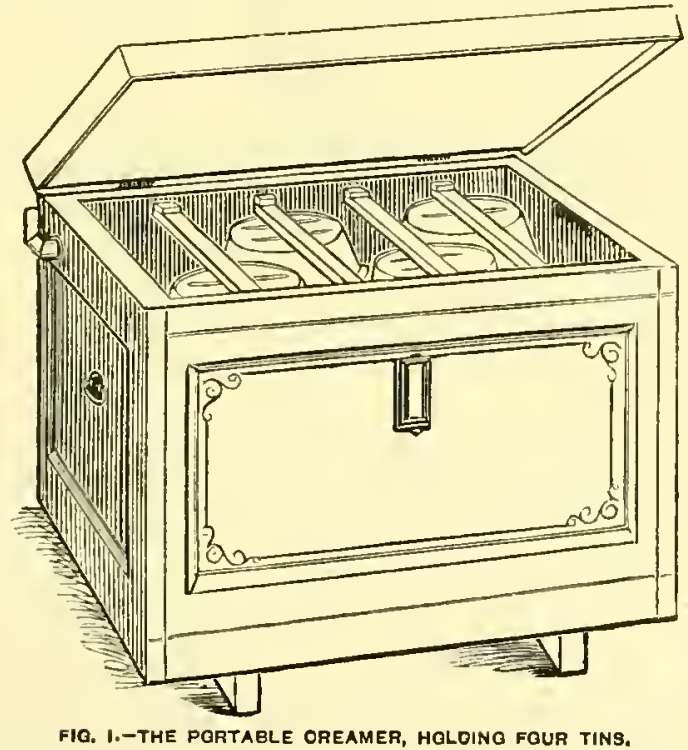

prevent the cream running off with the milk. Fig. 3 represents a tin submerged in water; the position of water, air, cream, and milk is here clearly defined.

The advantages of the creamer are as follows:-First, the new milk being placed in water at from $45^{\circ}$ to $52^{\circ} \mathrm{Fahr}$., the whole of the cream rises in twelve hours. If the water stands at a lower temperature the cream rises in a correspondingly shorter timt. The advantage of securing the cream so quickly in the lueat of summer is great. It is in sultry weather, when thunder is in the air, that milk goes sour before half the cream can be taken under the old system. Then milk which should be fresh and wholesome for calves, or such like, is sour and unfit for use. If given to young animals it often causes scour. Where the creamer is used no loss is sustained by the foregoing cause, while much more butter is made and the skim milk is as wholcsome as in rinter. Second, much

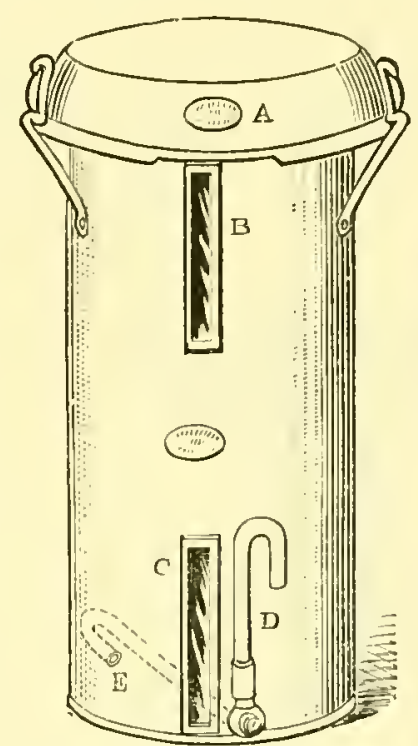

FIQ. 2.-ONE OF THE TINS MAGNIFIED

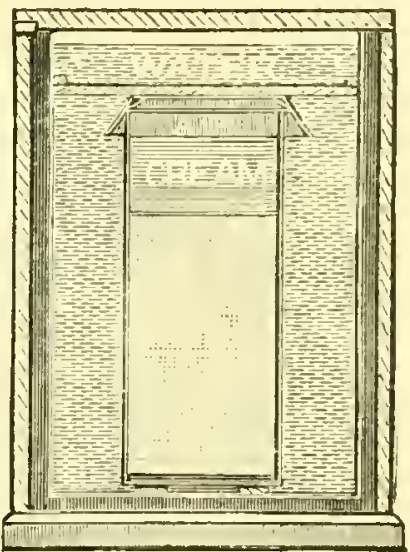

FIO. 8.-A TIN SUBMERGED IN WATER. less dairy room is needed. No long rows of shelves for milk vessels are required. The apparatus may be placed in the garden, orchard, or any out-building where the water supply is laid on. It is better that it be under cover, particularly in winter, for then it would be unpleasant work taking the milk and cream away and setting the new milk, although the operation would only last a few minuces. Third, the saving of labour is a feature not to be overlooked. A tol able milkman can, with a little care, do in a few minutes all that is required. Only the tins need to be cleaned, and as they are continually in use, and hold four gallonis each, not many of these are required. They can be madô to hold more or less, but four gallons is the usual size. When the evening mcal comes in, the morning one is removed, and the same tins used. The same process is gone through in the evening meal. Fourth, more butter is made from a certain quantity of cream, by about half-a-pound to the ordinary cow per week in the summer months. There is no advantage gained by allowing the milk to stand in the Cooley Creamer above twelve hours, providing the water is at the low temperature I have previously advised. The inventor claims that the creamer tends to produce better butter, as the milk does not become contaminated by impurities of the atmosphere, and that the taints of turnips and artificial foods in the milk are effectually disposed of. Fifth, it is much cheaper than working milk in the ordinary manner, no other vessel being needed except a cream tin and churn, thus great expense in utensils is avoided. Sixtl, we estimate that all calves reared from this system of managing milk, average, when twelve months old, a pound more per head in value than where the old process of setting milk is carried out. Where calves are reared in 
the hot summer months farmers are put well-nigh to their wits' end to arrange provision for them. The milk is at certain times all sour, and if some substitute were not at hand the youngsters would fare badly. Finally, a good supply of water is necessary for working the Cooley Creamer to advantage.

Another useful contrivance in the dairy is a mechanical butter-worker. Its advantages over kneaded butter by hand are universally acknowledged. However cool or clean dairymaids' hands may be, butter must be purer if through its entire process of manufacture it is untouched by hand. A

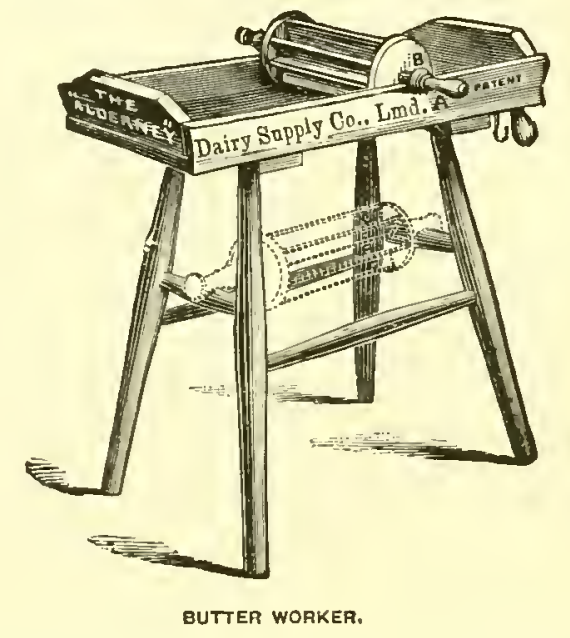

small worker suitable for farm dairies is the Alderney, shown in illustration. It is made either with stand or to place on an ordinary table. To work the butter the loose handle, A, is held to revolve the fluted roller, and the fast liandle, B, is held to give the roller a sliding motion to collect the butter into a lump for re-rolling. When not in use as a butterworker, the fluted roller can be placed underneath the tray out of the way, as shown in the drawing, and the tray used for making up butter, \&c.

The Sandringham Dairy Herd Recorder is also useful. To obtain a good milking herd it is necessary to breed only from those cows which give a full supply of milk. The only reliable nieans of ascertaining this is to carefully measure or weigh the milk occasionally. The appliance named above, and shown in sketcl, is a patent of the Dairy Supply Co. It is specially designed to readily measure milk when warm from the cow. Not only is the quantity shown by the gauge marks in pail, but the dial points to both weight and measure, the weight in pounds and ounces, and measurement in pints and gallons. The pail is allowed for on the balance, so that no reduction or calculating is necessary. The recorder can be set in any desirable place, or if preferred it may be hung to any beam most convenient to milkers. To simplify the necessary accounts as far as may be, the patentees of the

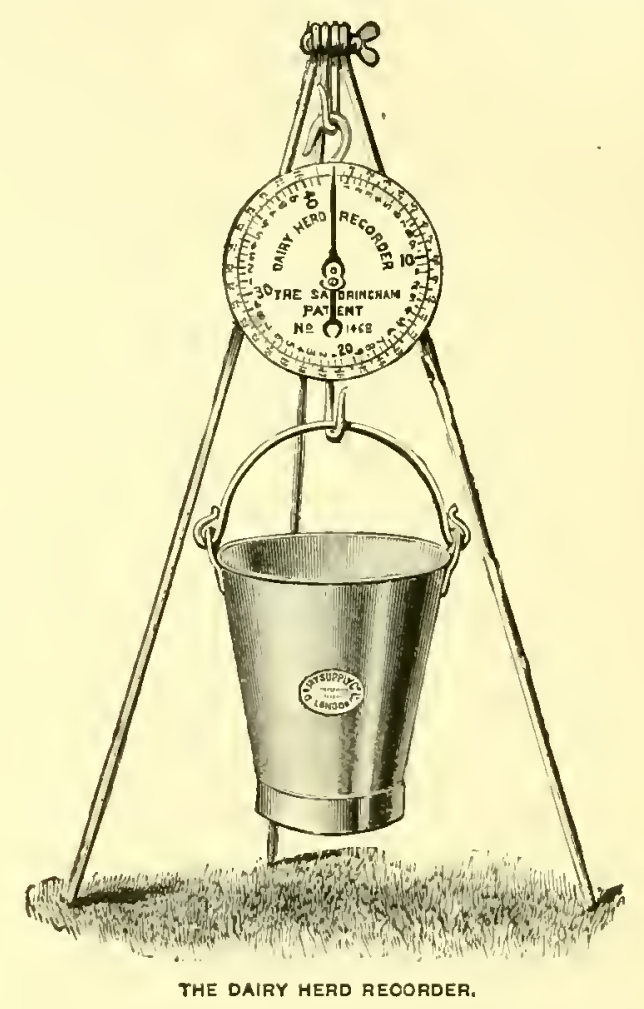

contrivance have also compiled some "Record Sheets" and simple account-books to be used in conjunction with it if desired. There is no better criterion of a cow's health than a uniform flow of milk. If this falls off suddenly the animal is amiss, and should be carefully watched to see that whatever ailment she is suffering from does not reach dangerous limits. Again, when milk gradually falls off it is often owing to one of three causes-either (1) the food is unsuitable; (2) the milkman does not do his work in a proper manner; or (3) the cow is getting into an advanced stage of pregnancy. The above invention plainly indicates such a state of things. 


\section{A T T L E R A I S I N G.}

I HAVE previously treated upon calf-rearing, and now purpose to devote some space to the raising of cattle after they have passed the age of calfhood, and are what is termed in farming parlance "reared." Until twelve months old the young animals need much more care than afterwards, and until that age they are usually termed calves. Simple work as it appears to raise cattle when they begin to shift for themselves-that is, to take ordinary diet-there are not 5 per cent. on an average in the United Kingdom brought up in an approved manner. This is a bold assertion, I am aware, but one which I will presently make plain to every reader of this work. Animals for fattening purposes should never be allowed to lose flesh from their earliest days until disposed of to the butcher. Every experienced hand knows that when the calf's flesh is lost it is never regained; yet how seldom is it retained. Let anyone look throngh the store herds throughout the country in the spring, and he will find many little better than frames. Then comes a season of plenteousness, and the animals improve in flesh until the following winter. Such as are too young to be made off to the butcher are either put in the straw yard, or so sparsely fed upon a lean pasture throughout the ungenial winter months, that in the following spring the same miserably poor state is again seen that I have previously spoken of. So it transpires that a game of see-saw is practised. The summer's gain is lost in winter, and the only advantage left to the raiser is that his cattle grow and become older. As soon as they are considered of sufficient age to finisl off for the fat market, they are made up on generous food in field or stall, but prove not so heavy by scores of pounds per quarter as they would have been if proper treatment had been given from the beginning. Even growth is retarded, and disease is courted, while a general ill-thriftincss is set up. An enormous amount of extra food is required to make the animals in a fit state for the butcher when they have been neglected. It is a fact beyond dispute, that an animal in good condition does not cost so much to keep in that state as such as are brought up on the see-saw principle. Neither will a poor animal, whose constitution has been impaired, eat coarse food with such relish as one that has been kept in robust health. Further, it is found that well-reared animals stand hardships far better than such as have been neglected. The former produce a warm garment that will withstand the most severe winter weather, providing a little shelter be given. The poor cow will be seen quaking under some hedge when the searching east winds in spring prevail, while the robust animal will be browsing or ruminating in exposed parts of the field. A lean ill-thrifty animal's blood is so reduced in quality that the whole system is liable to be upset by a trivial hardship, which would be endured withont inconvenience by the cow whose high condition and rich blood protected her. I have found indigestion the first trouble that often besets the ill-cared-for animal. This may, and often does, lead to nearly all the ailments to which the bovine race is subject. Even if nutritious food be given when the digestive organs are impaired, the result is often unsatisfactory. Particles of the diet pass through the stomach and bowels undigested, so that not only is there no support gained from it, but scour, colic, and such like complaints often cause much pain, which the animal is little able to bear. So it will be seen that the true method of bringing up cattle may be summed up in a few words, viz.- to keep them in a flourishing state from youth to age. But how to carry this out will need considerable space.

\section{TREATMENT IN THE SECOND YEAR.}

When cattle enter upon the second year, supposing spring to have commenced, the farmer will contemplate getting them into the grass fields. All is not plain sailing even here. The old saying is, that "May, early and late, makes the old cow quake." As a matter of fact, the season is a trying one. If the spring is a backward one there is but a sparse bite of grass, and if the season proves forward, as was the case last spring, herbage is too plentiful. The grass in early spring contains overmuch water and sap, and being new food, causes several malignant ailments in young cattle as well as old. On the other hand, a common error is made by stock-raisers to depasture their cattle before a necessary quantity of grass is found. Bitterly cold winds at intervals are typical of April and May in our variable climate. It is the sudden changes that cause so much mischief. A continuance of cold weather would be better endured. Hedges prove but a poor shelter to animals that have been wintered in a comfortable yard. The long winter coat is just being cast for a fine summer garment, hence animals in robust health have enough to endure, while halfstarved ones often succumb to the hardships which they cannot bear.

The farmer may take three useful precautions:-(1) He should introduce the animals gradually to their new food and exposed quarters. This is done by at first only giving the herd a few hours' run in the field during the middle of the day, and by extending their liberty until they will not only become accustomed to their food, but inured to exposure. (2) Give a liberal quantity of dry food. It must be of better quality than bas been served before the dainty bite of grass was offered, otherwise it would be rejected. The dry diet will not only counteract any ill effects from young grass, but guard against over-gorging on the herbage, which is a common practice of hungry animals. (3) There are, on most farms, some pastures much more sheltered than others. A thick fence, although it may not be in full foliage, affords useful shelter. Sound ground to lie on gives comfort and prevents chills, while hill and vale often lend natural protection. 
Then a sound bank under a copse, wood, or spinney will give welcome shelter. Before leaving this important part of the subject I wish to point out how essential it is that winter quarters be not made too warm. Airy sheds and open yards ensure needful comfort and establish good constitutions. So it proves that with care the herd may be introduced to their new homes in the pasture-field without any rude shock to the system, and a gentle improving condition be sustained without a check.

There is little further car. needed after the animals have settled down in their pasture until winter approaches. They should be visited twice a day by the shepherd, and frequent visits from the master will ensure all necessary attention. In the second year, where early maturity is not the order of the day, only an ordinary pasture is needed. Sheep and horses may be grazed with cattle so long as there be sufficient herbage for all. There are pasture-fields, often found above blue limestone rocks, that are not suited to cattle, although the herbage may be most wholesome for sheep and horses. Here scour is often set up. A continuation of such a relaxed state should be a signal that the fields are not fit for bovine animals. It is a common error to overstock fields. This is a most reprehensible practice. Better by far let a little grass run away. The rank spots may be mown as broken grass if the season prove more than usually fruitful, or hungry animals will take off the rejected patches in winter time, when all green vegetable food is eaten with avidity. A dressing of salt or lime will induce animals to eat coarse grass with relish, and also encourage sweeter herbage.

When leaves have fallen from tree and fence, and fieldfares begin to chatter above head, it is time to prepare yards and sheds for wintering the herds. Still I have found that there is not such immediate hurry to house the animals at latter end as many stock-raisers suppose. A warm winter coat has taken the place of the fine summer one, and the colder temperature, as a rule, comes by degrees. Where one case of illness takes place in late autumn or early winter from exposure in the field, ten will be found in the spring. As to the time for yarding beasts, I am often guided by the amount of grass on the fields. Just as the herd is introduced gradually to its pastural food in spring, so ought a similar precaution be taken not to withhold the grass diet all at once. It is true roots prove a good substitute for grass, but on the approach of winter swedes are scarcely ready, and mangelwurzel are unwholesome. Thus it will be seen that I advise tardiness in depasturing in spring, and the same as regards bringing beasts into yards upon the approach of winter. Exposure at latter end encourages the growth of a long warm coat, and this is of infinite comfort to animals in an inclement winter, when severe frosts, deep snows, and boisterous winds have to be endured.

The diet of young cattle in the second winter need not be expensive, but should be wholesome and sufficiently nutritious to ensure a gentle thriving state. Where roots are available the chaff-cutter and pulper should be brought into active use. Chaff should be cut, mixed with pulp, and lie for twenty-four or thircy-six hours until a gentle fermentation is set up. One part hay to three of sweet oats, barley, pea, or even wheat-straw, will make a good mixture, and with a liberal allowance of swedes will carry the herd through the winter at little expense. A little inferior hay might well be given at night, or a portion of unchopped straw. It is not prudent to feed animals altogether upon chopped diet, as rumination is not then enjoyed in a normal manner. Where there is sound pasture-land with rough grass upon it near the farm-yard, I prefer that store-cattle run out a few hours each day. They get exercise, a little grass diet, and are invigorated by the change. Moreover, while the grass-fields are being trimmed up by the cattle, the latter take such wholesome herbage that saves more expensive dry food in the yard. If there is convenience it is better that the animals be tied up, especially while the pulp and chaff is given, for then each has its fair share of food.

Water should be provided ad libitum. Pure rain-water is the best. Landlords ought to arrange the drainage of farm buildings so that rain could be secured for the herd. Few stock-keepers are aware how much is lost by neglecting-to give proper fluid. In many a farm-yard the whole of the cattle drink at ponds in which possibly the very essence drains from their own excreta. Moreover, other foul matter finds its way into the home pond, and to allow animals to drink thereat is folly in the extreme. If pouds could be kept pure they would be much more wholesome than water that is drawn from a cold spring, for the tempered would correspond in a great measure with rain-water. Still where one wholesome draught of fluid is taken from a pond only filthy stuff is imbibed in innumerable cases. It is much better that animals be allowed to drink at will, rather than only visit drinking places occasionally, for too copious draughts sometimes cause colic, particularly when roots compose a considerable portion of their food. Swedes contain over ninety per cent. of water, therefore animals feeding freely upon these would not take nearly so much fluid as when fed on all dry diet. It is only when long abstinence has been endured that over-copious and injurious draughts are taken. When the herd runs to water at will there is no danger of harm arising.

The cost of carrying store animals through the second winter, when they get a run out into fields, and all provender is grown on the farm, will be from $1 s$. $6 d$. to $2 s$. $6 d$. per head per week. This will, under proper treatment, keep the animals not only growing, but gradually improving in flesh. Considering the value of the manure made even this low sum might be made less. Upon the face of this, why are so many half-starved animals seen in the majority of straw-yards in the country? They cost quite as much kept in a miserable state as in a more approved and creditable manner. I have carefully reckoned the cost, and watched the result of the different processes of raising, and speak from actual experience extending over many years. 


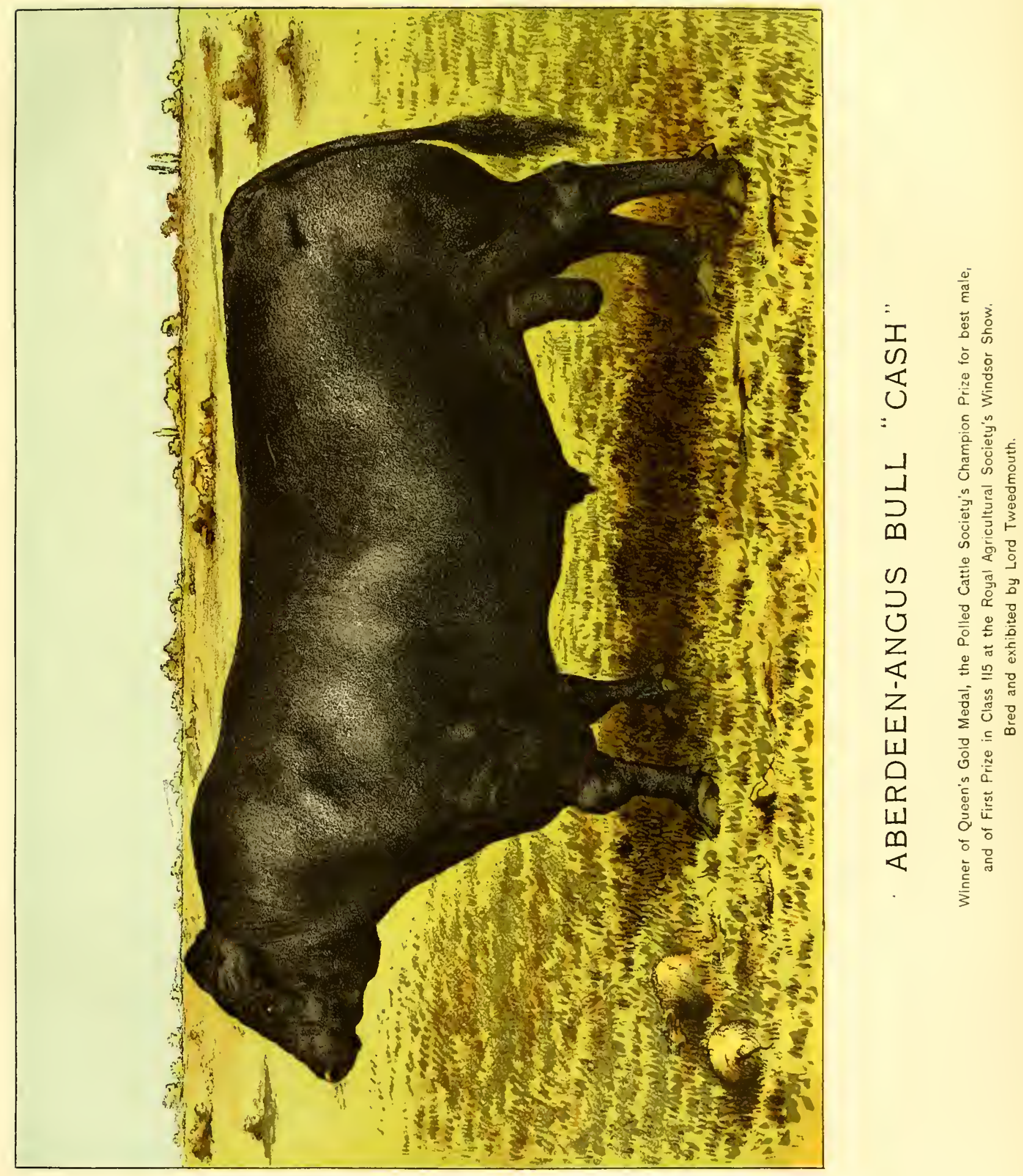





\section{FATTENING IN THE FIELD.}

Making becf in the present day is conducted with much more despatch than in the days of our forefathers. Even three decades back the majority of farmers did not sell their fat oxen until they were hard upon four years old. Few animals are kept until that age now-a-days. So it comes to pass that thousands of heifers are sold straight from the pastures when about two and a half years old, some younger; while oxen are finished off in the stall on or before their third birthday. Still, to make such progress the grazier needs to set systematically about his work. Heavy weights may be made of animals brought to moderately early maturity, and plenty of profit left behind, providing my advice in raising is carried out. Indeed by raising animals in the orthodox manner they will weigh as much at three years as neglected ones would a year older. If the extra year's food and labour be saved, it leaves a good profit to the raiser. 'Too often the farmer errs in leaving all the fattening to be done in the last summer and back-end. This is unwise: the thriving state should commence at the birtl of the calf-then the finishing off is but a trifling business.

In the spring of the last year, however, such extra food must be given as is necessary, until the pasture grasses are not only sufficiently luxuriant to give a full bite, but the herbage so far matured as to provide the necessary nutriment to put on fat. There is not a day then to lose, and a few extra pounds of cake or meal per head per day is often well spent. In the far-famed Leicestershire pastures many of the shrewdest graziers give cake all summer. This they supply to their oldest and best beasts, and on the richest land. With what result? (1) They get their cattle ready for market early in the season when beef is in demand-hence a penny per pound is made more than would be obtained when markets become over-done towards Michaelmas; (2) the land being cleared of fattening animals, stores can be bought in early for making off the following year; (3) the land is improved by cake being consumed thereon.

In some instances home-grown corn can be used instead of cake. Bean-meal at the rate of 2 gallons per day is an excellent food for fattening animals at grass, while pea-meal is equally useful. If meals are used instead of cake, lome industry is encouraged. The great complaint about giving meals is that they are not so convenient for feeding as cake. Even where the greatest care is exercised there is waste in meals. Troughs are frequently turned over, the meals spilled out of the feeding hods, or chaff which is fed with the meal becomes separated from the more tempting diet. Hence cake is the favourite article for hastening on fattening cattle in the field all over the kingdom.

It will now be well to define what really constitutes fattening land There are many farms, even of considerable magnitude, that will not feed either oxen or heifers. Oxen require a much better class of land to fatten upon than lieifers or cows. It is a common error to attempt to make beef where the land does not produce such herbage as will ripen off cattle without much assistance from extra food. Such middling ground will do well for rumning stores upon, prove all that is required for sheep, and keep horses in good condition; but it is pulling against wind and tide to endeavour to fatten either heifers, cows, or oxen thereon.

Assuming, then, that well-chosen land is at our command, beasts should be depastured as soon in the spring as a fair and wholesome bite of herbage. offers. The very best land, such as is found in Leicestershire, Northamptonshire, Lincolnshire, and some parts of Warwickshire, will fatten a beast to the acre. Still, as a rule, on ordinary rich land, eight beasts to twelve acres are all that can be profitably made up. Where fields are utilized for fattening beasts, sheep must be run very thinly, or kept entirely therefrom. One sheep to the acre is all that ought to be grazed amongst the cattle. Horses are not suitable to be depastured with the latter. They take the sweet grasses, such as horned cattle wonld not only eat with relish, but which would prove most wholesome to mix with the coarser herbage.

Towards the latter part of July a few of the most forward heifers can generally be found fit for market. This is the time when beef usually sells dearer than at any other season. It is wise to make a draw early, for oftentimes as much money is made as if the animals were kept to get heavier, when they would probably only mect with a slack sale. There is another object in getting them off betimes-viz. such as are left behind get a more generous diet. It is generally found that grass on old pasture-fields begins to go off after midsummer, so that if no stock were marketed in July the land would be over-stocked-a state of things to be steadfastly guarded against.

About the beginning of August some good aftermath should be ready for fattening animals to be drawn on. These fields must not be stocked after mowing until the cattle are depastured thereon in August. If this grass is a foot or so long it will be all the better. Cattle, to fatten fast, should not be expected to graze about for hours to satisfy their hunger. The more abundant the herbage the sooner appetites are satisfied, and longer time is thus given for repose, rumination, and sleep. Upon the first sigus of frost coming on, some sweet hay, cake, and meal should be given; just as much hay as is well cleaned up, and for ordinary sized beasts four or five pounds of mixed cake and meal. 'The extra food may be increased weekly until eight pounds per head is reached.

The grazier will continue drawing from the herd for market, but in doing this will sell the closest grown animals, such as do not indicate much improvement. The largest, best fleshed ones will be put aside for the Christmas market. Steers, oxen, and maiden heifers are usually chosen for this purpose. Butchers need heavy weights at Christmas, and at the same time top quality. The best are found among shorthorns, Herefords, and Angus, or amongst crosses from these. It will generally be found that some of the above-named are found at the head of the fat classes at the large Christmas 
shows. There is a great deal more judgment needed in selecting proper animals to bestow expensive food upon than is generally supposed. The ordinary grazier can point out a good fat animal when he sees one, but it requires a good and experienced judge to see in advance what an animal will come to It is better to choose a growing animal to keep on tor extra beef, but it must at the same time give indications of good points all round, and making prime quality of beef.

Assuming, then, that judicious selections liave been made, it answers to keep these approved animals up till Christmas, for nine years out of ten a penny per pound more money is made than during the two or three prior months. Of course, in some instances, it is profitable to keep animals on until February, or even until the following spring. Farmers are often gnided in this plan by their large or small store of roots, hay, and meal.

Thus far I have not spoken upon the grazing of Welsh and the hardier kinds of Scotch beasts. They are usually wintered in the pasture fields, only getting a little extra food when frost and snow prevail. Brought up as they are in exposed districts of Wales and Scotland, they pass through the most inclement seasons in England without any inconvenience. These animals will fatten on more inferior land than many English cattle, and are generally made off to market before expensive diet in the late autumn is needed. They do not pay so much per head, as a rule, as larger beasts, but they are profitable, as they subsist on rougher diet. Indeed, after plenteous seasons of grass, there always is a great deal of old sour herbage left on the fields against winter. Welsh and Highland herds are not over-fastidious in their food, so they make clean work in the pastures, before the advent of young grass in spring.

It is important that every grass-field be grazed bare some time in the year, and that time, for choice, should be in March or April. It will always be found that this dressing off the land must be done with hungry store stock, for it is not practicable to keep a field grazed evenly with fattening cattle. The latter soon begin to reject coarse grasses for sweeter herbage. When coarse plants are allowed to grow up in fruitful seasons and rot down unconsumed, they encourage superabundance of cocksfoot, timothy, and other sour plants, which, although useful in every field, should not be allowed to accumulate to the crowding out of finer and more enticing grasses. Further, careless management encourages weeds, pests in the soil, and invites fungoid and other diseases in plants. 'The malignant ergot parasite may be named as being almost ever present on the parts of fields where sour grass is allowed to mature.

\section{THE STALL.}

Stall fattening has engaged the attention of farmers in all ages, and while under favourable conditions it proves a profitable business, in other cases it results in disappointment. In periods when grain and other produce of the farm make high prices, the stockowner needs to be careful how he en- gages in fattening in the stall, particularly when meat is not making a good price. All kinds of home-grown stuffs have been very low of late, much too low for the tiller of arable land; meat has, however, generally sold well Therefore it is in such times that stall-feeding often proves remunerative. Still there are many other things to consider than the foregoing:-(1) Roots are essential diet to use in the stall, for their cheapness, nutritious qualities, and their wholesomeness; (2) good hay is indispensable; (3) the manure from beasts in sheds should be looked upon as a considerable part of the profit. On stiff clay land, or on purely pastural farms, roots, if used, have to be purchased, and probably drawn a considerable distance, which renders them expensive. A good supply of hay is likely to be at hand on a grass farm, but the manure made from the sheds is not so valuable as on mixed holding. Thus I offer a word of caution to farmers occupying certain farms, lest they rush into stall-feeding, and find, as a result, the balance on the wrong side of the sheet.

On mixed farms, where a fair proportion of hay is grownwhere animals will get three-parts fat on summer pastureswhere roots are grown, and every load of manure is valuable, fattening in the sheds is an occupation which, if skilfully conducted, will not fail to give satisfactory returns. On rootgrowing farms, turnip crops are the making of the land, providing they are consumed in a proper manner. If two-thirds are eaten on the land by sheep, and the other third drawn off for stall-fattening cattle, it makes such use of the roots that gives a rich manuring for the farm. So it transpires that the farmer gets two returns-one in his well-fattened animals, the other in his manure heap. It is not found profitable to tie up lean animals, and many a farmer has found out this to his cost. Where they are-as before observed-got forward in the pasture, it often answers well to finish them off in the stall, and that for the following reasons:-By the latter end of October beef is usually a drug in the market, especially such as is not ripe, therefore it is then only practicable to sell at a great disadvantage. If cattle are finished in the stall, the flat markets are in the interval tided over, and the animals are ready by Christmas. They improve in weight and quality, too, so that often $1 \frac{1}{2} d$. per pound more money is made than could have been realized at Michaelmas. Roots are among such beasts profitably consumed, and are indispensable diet. They are not so valuable as fat-producers as many men suppose, containing as they do 92 or 93 per cent. of water, yet they prove a good substitute for grass, and are very useful to feed with chaff, meals, and other food. It is seldom that cattle get out of sorts when a prudent amount of roots are given, and this point should not be overlooked, for when a fattening animal goes amiss it often sinks at a rapid rate, when much expensive diet is literally thrown away. Nanure from prudently fed beasts is of ligh quality, and tells its tale wherever it is applied.

It is important that the different kinds of food given should fulfil two ends. They should fatten rapidly, and prove rich in manurial value, after passing through the stomachs of the 
eaters thereof. On page 420 of this work a tabulated list is given of the manurial value from different kinds of feeding stuff. Decorticated cake is very rich in manurial value, being estinated at $£ 610$ s. per ton, nearly or quite its original cost. Linseed cake, which costs much more money, is estimated as only productive of $\mathfrak{E} 412 \mathrm{~s}$. per ton as manurial value. All roots give but a very low return to the dunghill, about $4 s$. or 5s. per ton. However, too much in the way of fat and flesh making must not be sacrificed for the sake of the dung-heap; still, he who pays regard to all these things will be able to make good ripe Christmas beef at shillings per head per week less cost than others who do not study the best methods of feeding. Before leaving this part of the subject I should point out that no animals, excepting horses and pigs, give better manurial return for their food than full-grown stall-fed cattle. Dairy cows make inferior manures, as do also young animals that have bone as well as meat to provide for.

\section{THE SHEDS.}

Cowsheds now demand attention. The majority are far from what they ought to be. Dark, badly drained, ill-ventilated, draughty, they certainly are not suitable quarters for animals that have breathed the fresh air of pasture fields for the previous half-dozen months to which they are introduced to the stalls. It is the exception, rather than the rule, to find sheds sufficiently cold. Thus newly tied-up beasts perspire a great deal the first week or so. This state is liable to lcad to ailments that prove tedions and weakening. IIore-

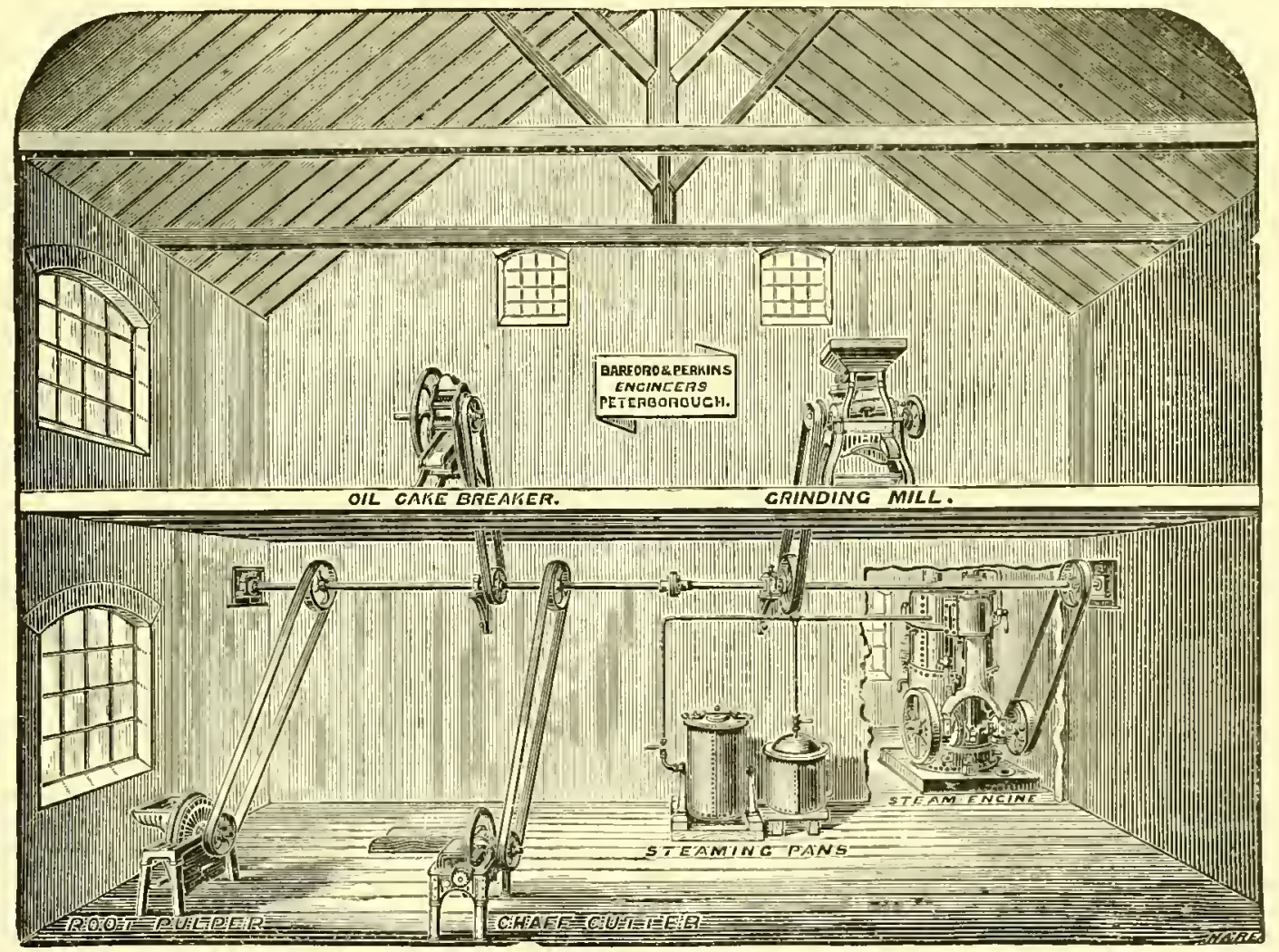

FOOD PREPARING MACHINERY BY MESSRS. BARFORO AND PERKINS.

sver, valuable time and expensive food are thus lost. Oversrowding is a common and reprehensible practice; few stalls are made sufficiently large. Seeing the confined scale on which cowsheds are often built, one would imagine the land on which the building stands to be as valuable as it is in large cities. As to draining, there is frequently literally none. Every cowshed should be drained with piped drains and trapped gullies. These should be flushed often, say twice a week, and have good fall. The fluids ought to be discharged into a tank. Thus, in addition to the sheds being made dry and clean, the urine is saved, and proves a valuable fertilizer. If the latter is not saved there is at once a sum lost which ought to be added to the right side of the balance sheet. Ventilation is seldom given on an approved plan, even in modern buildings. Usually apertures are made comparatively low in the walls, causing draught. All sheds should be ventilated from the top. If there be no loft, ventilators can be easily fixed in the roof; if there is a loft, a zinc pipe can be carried through the ceiling and outer walls. One ventilator to two beasts would suffice. Thus the air is purified in all parts of the shed, and a suitable temperature is ensured. Water-troughs should be placed conveniently for catsle, and so that they can be filled or emptied at will.

Light is a necessary adjunct to the cowshed, yet not 1 per cent. get sufficient. It is better that animals liave ordinary light in the day. The attendant cannot feed his animals properly in the dark. It is not possible to see when each animal has made a clean manger unless light is admitted. 
Darkness is a cloak for filth and waste. Finally, cattle thrive better in good light. It is of primary importance that there be sufficient space in front of all the animals, to allow the herdsman to feed and water them without risk of being interrupted by them. There are no neater and more approved sheds than such as have skylights. The latter prove threefold useful: they give light, ventilation, and fresh air. Of course the windows in the roof should be made to open and shut conveniently. This is easily arranged by hinges to the skylights, pulleys, and cords.

I am not in favour of lofts unless side ventilation is given to the sheds in the way I suggested previously when foul air is allowed to pass through the ceiling of the shed. Otherwise the hay and other diet in the loft is rendered in a measure unwholesome and unpalatable. Gases will ascend, and through the smallest crevices. Thus it is seen how essential it is to deal with foul air in an effectual manner, and with the greatest possible despatch. There should be adjacent to the cowshed a well-arranged room for pulping, grinding, cake-breaking, chaff-cutting, and steaming. In the illustration on preceding page my views of a properly arranged food department are shown.

\section{THE FOOD.}

The kind of food that proves most profitable depends upon what the farmer has at hand. The more home-grown produce is served the more satisfactory will be the result, for not only is it usually cheaper, but its wholesomeness is ensured. I disapprove of grain being sent from the farm to the mill for grinding. All the necessary machinery for this work can be arranged in the food-preparing room, and here the grinding can be done at leisure when the steam is ready for other work. Grain sent away to be ground might be changed, adulterated, or even tolled, and if this occurred it would go sadly against the profits of feeding in the sheds.

Fodder and grain vary much in their composition according to the land they are grown upon, the atmosphere and temperature they are ripened in, and the weather they are harvested in. Even Dr. Voëlcker pointed out how the public might be led astray by certain would-be scientific ones. He observes:- "In speaking of the nutritive value of any article of food, too precise a language is out of place; and it is simply absurd to draw general conclusions from small differences which the analysis of different feeding materials may have yielded. Unless the differences are strongly marked and constantly observed in a great number of cases, it is unsafe and irrational to attach a precise nutritive value to different articles of food, especially if the opinion is founded solely upon analytical data, and not corroborated by actual experimental trials; for, after all, the chemical composition alone of an article of food is insufficient to determine its practical value." The following would, however, be the average nutritious value of home-grown cattle food:-Beans, 570 parts of nutritive matter out of 1000 parts; pease, 574 ; barley, 920 ; wheat, 955 .
As for giving an analysis of either grass or hay, why, it could lead to no reliable end unless every ton were tested. Some grass, like hay, from rich land will fatten animals of itself, while other qualities give but little aid to the extra food supplied. Seeing this, it is obvious that the farmer who stall-feeds upon inferior hay is hereby handicapped, as this provender should form the staple food. There are many kinds of cake in the market, and as many qualities. Good sound mixed cakes are essential auxiliaries to other food in the stall; therefore such reliable firms should be dealt with as supply the genuine article.

In returning to hay, it is most in perfection when about twelve months old. When of this age it retains, or should retain, somewhat of its green colour, its agreeable smell, and its pleasant taste. It has undergone the slow process of fermentation, by which the sugar it contains is developed, and its nutritive quality is fully exercised. After grass is cut and the hay stacked, a greater or less degree of fermentation takes place. Some fermentation is necessary for the development of the saccharine principle. Occasionally the heating goes too far, and the hay becomes morvburnt, when it is unwholesome. The herdsman generally prefers overheated hay, on account of its rich smell, but cattle soon sicken on such diet, and not uncommonly go amiss from being compelled to feed upon it. I have said that hay is preferable when twelve months old. It is, however, difficult to use it at this age in the stall, as the animals are mostly fed in the winter. Therefore a stump of old hay to commence on is useful, then the new hay can follow on. In choosing the latter it is better that it should not have heated much; such as has gone through many degrees of heating needs extra time in the stacks, and therefore should be left until the following winter. It is not in the farmer's power to get his hay in any uniform state, as the weather may, in a few hours possibly, change the condition; but it is in his power to cut his grasses while in bloom, and so avoid the over-ripe seeding state which leaves the material woody and innutritious.

\section{FEEDING.}

It is better that cattle for the stall be brought at once, rather than gradually, to the shed. It would be well to bring the animals by degrees to their new quarters, were it not that they would lose flesh through restlessness. Roots can be used as a substitute for grass, so that there really is no necessity for pastural herbage. Animals that are to be got off to the Christmas markets should be lioused by the latter end of October. This will give scarcely two months in the shed, which is only just sufficient time to finish them off as prime Christmas beef. There are frequently prolonged intervals of warm muggy weather in late autumn; when this atmospheric state prevails, cattle should be supplied with all the fresh air possible in their new quarters. It is oftentimes necessary to leave open both doors and windows during the day, for too high a temperature proves injurious.

The feeding hours should be from 6 to 8 a.m., from 12 
to 1 (midday), and from 5 to 7 p.m. Of course, during the foregoing hours opportunity will be taken of completing all the necessary cleaning out of the stalls and bedding of the cattle. So long as animals are judiciously fed, the more hours given for rumination and repose the better. It is a too common practice to disturb them unnecessarily during the day, thus fattening is retarded. Beasts in the stall ought to be kept as quiet as possible, and only the herdsman allowed to attend on them.

The first food in the morning should consist of a little unchopped sweet hay. Water vessels must then be replenished; if from a fresh rain-water tank so much the better. Three servings may then be given as fast as the mangers are cleared-the servings consisting of chopped hay, pulped roots, cake and meals. Another serving of long hay will complete the morning repast. At the midday meal a serving of short food (similar to the above-named), a fresh supply of water, and a little unchopped hay will suffice. The evening meal to be similar to the morning, with the exception that no unchopped hay need be served at commencement; but an extra quantity of the latter should be supplied to finish up with, so as to last the animals during the night.

Salt should be always kept in the manger of the cow in the lump state (i.e. rock salt), for it is essential to ensure the healthy state of the animal ; and the importance of this substance in the animal economy may be learned from the fact that when the blood and other nourishing liquids in the animal system are burned, the ash which is left consists of one half its weight of common salt. Indeed, instinct appears to guide animals in their search for common salt. Thus in North America there are inland districts into which the water flows during the rainy season, and which become dry at other times, and the surface of the ground is left covered with a deposit of salt. To these districts the cattle come in herds ain gait." from great distances to lick up the salt, and hence the valleys are called "Buffalo licks." Similar districts in South America to which cattle resort are named "Salinas."

It is not practicable to give hard and fast rules as to quantity of food, as animals vary much in size, and not a little in their natural requirements. It is essential that rich diet be supplied in moderate quantities at first, and gradually increased as the animals become accustomed to it. The first signs of food being rejected should be a signal to lessen the food for several days. In feeding ordinary full-sized oxen, I have found the following a good ratio of diet to commence with in the stall, assuming that they have received extra diet in the field: -3 lbs. linseed cake; 3 lbs. cotton cake; 1 gallon bean or pea meal; $\frac{1}{2}$ gallon barley meal; and $\frac{1}{2}$ gallon of wheat, with long hay ad libitum. Rice meal, too, is useful. This allowance may be increased by a fourth or so, as time goes on. Swedes may be given liberally so long as they do not act too freely on the bowels.

The preparation of the food is an important work. Swedes should be pulped and mixed with chaff until the heap begins to ferment. Meals, \&c., should be added fresh before serving. Thus the diet is given in a warm state, which is desirable, as cold food does not give nutriment until it becomes of the same temperature as the animals' stomachs; further, the diet is rendered in this manner more appetizing and digestible. The heap will be from twenty-four to forty-eight hours getting of a proper temperature, according to the quantity of swedes used. As to steaming, there is no doubt some advantage in thus cooking the food, but practical men differ upon the system. One thing is quite clear: no extra nutritive qualities are added to articles of food by cooking-there is rather a detraction therefrom; therefore in this matter I will leave each of my readers to "gang his 


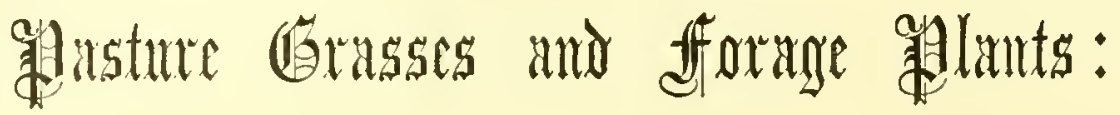

\author{
THEIR SEEDS, WEEDS, AND PARASITES,
}

\author{
BY SAMUEL P. PRESTON.
}

\section{INTRODUCTORY.}

There have latterly been much discussion and divergence of opinion regarding the comparative merits of the different cultivated grasses, some authorities praising beyond measure certain varieties and depreciating others, while other anthorities as strenuously advocate the opposite. Others, again, advocate the use of forage plants and grasses hitherto nnknown to our agriculture; and so far has all this gone that a large section of the agricultural public is puzzled what guide to follow. Again, it may be noted-if one may draw inferences from the queries addressed to the agricultural press, and from the results of many conversations held by the writer with farmers, and with people who sell seeds in different parts of the United Kingdom - that there is a surprising lack of information on the subject of the parasites that injure or destroy the forage plants, and the weeds that rob or stifle them.

Under these circumstances it appears to the writer that there is room for a work, the plain and practical object of which is to bring within handy reach the essence of the opinions of the best British, Continental, and American authorities, many of whom are of world-wide celebrity and acceptance, and all of whom have devoted the best part of their lives to the study of this and kindred subjects.

In the part devoted to the grasses the writer has set himself the task of sifting out those passages which most directly illustrate the points that have practical importance to those connected with agriculture, summarizing and arranging same ? by the aid, on the one hand, of an experience derived from a long connection with the home and foreign seed trade, and on the other hand, of an enthusiasm developed by long application to a particular line of study.

The aim also has been to avoid elaborate statements of matters with which most intelligent farmers are already acquainted; and to abstain from cumbering the work with botanical descriptions, or with historical accounts of the derivation of species and varieties-matters which, whatever interest they may have for the curious student of botany, are of small importance to the farmers and seedsmen for whose nse this treatise is intended.

The contents comprise the following:-

1. The opinions, in brief, of the best authorities up to date on the comparative merits and values of the principal pasture and forage plants used in the agriculture of Europe and North America, with notes on suitable soils and situations

2. Analyses of the leading natural and artificial grasses, notes on their comparative values as regards produce and nutritive matter, deduced from the celebrated Woburn experiments.

3. Notes on the weeds and parasitic plants that infest our pastures and forage crops (a large proportion of which objectionable vegetation finds its way there through the medium of the sced).

4. Revised standards of purity and germinating faculty of agricultural seeds as recognized or used in the home and foreign seed trade.

5. Remarks on the impurities and adulterations of seeds, with extracts from the Act of Parliament known as, but miscalled, "The Adulteration of Seeds Act."

6. Detailed instructions as to how the quality (purity, genuineness, \&c.) of a parcel of seed may be judged; accompanied by illustrations giving enlarged sketches of those seeds that are somewhat difficult of recognition.

7. Notes on the manures that snit, or are unsuitable to, the various pasture and forage plants.

The information contained in this treatise has been collected from works that are in many cases bulky, rare, and expensive, insomuch that but few men could spare the time for, or care to go to the trouble of, collecting them, and plodding through their contents. On these grounds the compiler ventures to hope that his labours, in collecting and arranging, will be appreciated by a large number to whom the information will be useful.

Of original investigation into the subject ot pasture and forage plants there has been a surprising dearth in the United. Kingdom; which is all the more to be wondered at when 
one remembers that in such a humid and uncertain climate as ours there is no tribe of plants so important as the natural and artificial grasses.

Since the time of Sinclair little or nothing has been done n the same line in the British Islands. The only break in he clouds is that afforded by the investigations of Sir John B. Lawes, but these, while highly valuable, are only directed to one branch of the subject-viz. to the question of the effects and value of manures in different combinations on the growth and character of the grasses, \&c.

On the Continent of Europe and in North America, on the the other hand, there has been a great activity of inquiry into those subjects. Dr. Stebler, of the Swiss Governmental Seedcontrol Station, in his wonderfully complete work on "The Best Forage Plants," makes reference to an astounding number of works, published in Germany alone, on the subject of the grasses; and Dr. Vasey, of the United States Department of Agriculture, quotes a long list of works on the grasses of the United States, some of which are treatises on the grasses of a single State. The reports issued by the United States Department of Agriculture afford evidence of much valuable leading and assistance given to the cause of agriculture (in particular to the subject of the grasses) in the great Republic of the West; and in Denmark the agricultural schools and the Copenhagen Seed-testing Station (subsidized by the Government) are centres of activity and investigation. The various German states pay special attention to agriculture and forestry; some of their seed-testing stations have been in operation for almost half a century. The Swiss Seed-testing Station and its superintendent, Dr. Stebler, are of more than European reputation; and Dr. Stebler's book on "The Best Forage Plants," in the publication of which he was assisted by his Government, is a monument as well of scientific arrangement and accuracy as of profundity and completeness of information.

As the great bulk of our seed supply is drawn from the continents of Europe and North America, and as particular attention has been paid to the seeds of the agricultural grasses in Dr. Stebler's book, I have given his opinions a special prominence.

There are signs that this subject is about to receive more attention than it has hitherto received in these kingdoms. Our situation and our climate point to the fact that the cultivation of grass and other forage plants is one of those things our country is best suited for, and now that the introduction of the silo promises to make us, so far as these plants are concerned, to a considerable extent independent of the weather, it cannot be doubted that the careful selection and growth of the pasture grasses and forage plants suitable to locality, soil, rotation of cropping, and other circumstances, will form a very prominent feature in the farming of the future.

The following is a list of the authorities whose works have been consulted and quoted from :-

Dr. Stebler, Superntendent and Director of the Swiss Seed-testing Station (Station Fédérale de Contrôle des Semences).
Dr. Parnell, author of the "Grasses of Scotland," a standard work. Dr. Vasey, of the United States Agricultural Department.

Chas. Johnson, author of the "Grasses of Great Britain."

Sinclair, author of the celebrated "Hortus Gramineus Woburnensis," and director of the renowned Woburn experiments.

Mr. M. J. Sutton, author of "Temporary and Permanent Pastures," and member of the well-known firm of Sutton \& Sons of Reading.

Mr. Hunter, of Chester (to whose kindness the compiler is under obligations for loan of the major portion of the illustrations).

Lawson's "Agrostographia," which still remains second to none as a standard of careful arrangement and accuracy.

Mr. Carruthers, Botanist to the Royal Agricultural Society of England.

Sir John B. Lawes, Bart., whose Rothamsted experiments are known and appreciated in every quarter of the globe where improved agriculture has obtained a footing, and whose name is a household word at the fireside of every intelligent farmer in the United Kingdom.

Mr. Faunce De Lauue, of Sharstead Court, Kent, whose spirited exposure of the erroneous processes by which land has beeu laid down to grass has had wonderful effects in bringing about desirable improvements in the said processes.

Curtis and Stillingfleet, early and honourable pioneers in this field of investigation.

J. C. Morton's "Encyclopædia," a surprising monument of industry, careful research, and intelligent classification.

And other authorities too numerous to particularize.

\section{PRELIMINARY REMARKS ON THE GRASSES.}

It has been remarked of the grasses that they are the true plebeians of the vegetable kingdom, constituting as they do the broad understratum of its vast society of flowering plants. They form a group of great extent and of universal distribution, occupying every range of temperature, from the most extreme of polar lands to those under the equator, and from the low ocean shores of the tropics to the alpine limits $O_{3}$ perpetual frost.

The grasses have found a name in every tongue and time, from the earliest periods of human record or tradition; and the application of the seeds of many of them to the support of mankind is of such remote origin as to be not only beyond the earliest annals of the human race, but even to figure as a myth in the traditions which preceded them, and to occasion the practice of agriculture amongst all nations of antiquity to be deduced from the teachings of a god. We can understand how the attention of people would be attracted to certain of the larger fruits as articles of food; but it seems extraordinary that the various races of mankind should have adopted grass-seeds as their principal support, and pursued the cultivation of the same till it has become a science involving the subsistence of millions, and engrossing the paramount consideration of kings and governments. Equally singular, in connection with some of the cereal grasses, is the fact that neither change of climate nor treatment under cultivation during thousands of years has brought any important alteration in general character, so that the cereal grasses grown under the rainless and burning skies of Egypt and those of the same species grown in Northern Europe differ no more than varieties which may be reared on the same field.

Every grass has its stem cylindrical and jointed at intervals throughout-the erect or ascending portion (the culm or straw) 
being almost universally hollow between the joints; and this $\mid$ used for pasture or forage purposes. It is with this very applies irrespective of stature-equally in the little Poa annua, important section we deal in detail in the following pages. which finds a living, and even thrives, in the chinks between the paring-stones of an unfrequented street, and in, for instance, the Panicum arborescens, which contends for elevation with the loftiest trees of the forests of Hindustan, through the branches of which its slender stems, scarcely thicker than a goose-quill, penetrate till they reach the upper air.

We may make a rough division of the grasses in the following way:-

1. Those which are cultivated for the purpose of using their seeds in the manufacture of food for mankind. This would include the cereal grasses (wheat, barley, rye, oat, maize, \&c.), and of these two prominent facts are worthy of notice: (1) they are annuals; and (2) they are never found in a wild state, unless where met with as solitary and temporary productions from seeds of chance distribution. Also, it would include rice, millet, and other grasses which have acquired local or occasional value in cultivation. Such, for instance, are some species of Panicum, also Setaria, Zizania aquatica, Stipa pennata, Poa fuitans, \&c.

2. Those grasses that are cultivated for their foliage, and

3. Grasses such as those of the Saccharum or sugar-cane family, from the expressed juice of which sugar is manufactured.

4. Those grasses considered by the agriculturist as weeds, but which, while of little or no value as producers of food for man or beast, are yet extremely useful in the economy of nature as colonizers and pioneers to vegetation of a higher grade. The grasses which come under this section fulfil most useful functions-some as land-formers, slowly changing marsh or morass into land that will bear ameliorative processes, or contributing largely towards fixing and rendering solid the mud-flats that accumulate about the mouths of rivers on low coasts. Others act as land-protectors-sand-bindersspreading a dense and rapidly-formed network over the surface of the loose material, as well as fixing it below by an interlaced root-system.

We may be sure that in nature there is a place and a use for everything, if we only knew, and would confine it to its right place and purpose; and in no tribe of plants is this better exemplified than in the grasses.

\section{W E E D}

Ruskin defines a weed to be a plant out of place; and fur- three-pronged fork, for instance, would be found detrimental to thermore, a plant that has an invincible tendency to get out their existence.

of its place. J. C. Morton defines a weed as any plant, different from the crop, found growing with the crop to its hindrance. This will hold as a general definition, but still there are certain wild plants which are more specifically known as weeds. Weeds may be roughly classified as follows:-

1. Flat or Prostrate Weeds (such as ribgrass and some of the thistle tribe).-In addition to their other objectionable characteristics, these weeds are obnoxious, inasmuch as they cover the ground and shade it, taking up considerable space.

2. Creeping Weeds, such as crowfoot (buttercup) and certain of the inferior grasses.-These do not attract much attention at first; but as each plant-by sending out side-shoots, which root and form distinct plants-is able to create a large colony of weed tufts, they would, if allowed, soon take entire possession of the field.

3. Rusning Weeds (such as coltsfoot, stinging nettle, brake fern, couch-grass, \&c.) - These not only increase by seeds, but almost every joint or division of the creeping root (rhizome) is capable of producing a separate plant. They are amongst the most troublesome in the whole list, and they are very exhaustive to the soil. Again, the ordinary processes of agriculture only result in propagating them by subdivision-the patches get broken up only to be spread over a large area. Removing the underground stems is the only effectual way of dealing with this class of weed-a special attack with a

4. Deep-rooted Weeds (such as the dock, burdock, marsh mallow, ragwort, and wild carrot).-They are for the most part biennial, and seed the second year. Some of them can be easily pulled up by hand when the ground is soft after rain, or they can be mastered by hoeing if cut below the crown. The foregoing operations should be performed before the seeds of the weeds are perfected, otherwise the ground may be stocked with fresh seed, and the weeding process have to be repeated all over again on a future occasion. After having pulled or cut the weeds they should be burned, as their fleshy taproots possess great vitality, and they have the capacity of perfecting their seed even after being pulled up.

Jost of the common species of weeds will be found to complete their growth and ripen their seeds in a single year. The best known specimens of this class (the annual weeds) are the common groundsel, chickweed, wild mustard (cliarlock), cleavers, \&c.

Nothing is more surprising than the length of time the seeds of some of the above will remain dormant in the soil, until, in the course of events, they are turned up and exposed to the influence of light and air, when they start into growth and produce a luxuriant vegetation, to the astonishment of the farmer. The latter in his perplexity to understand how such a crop of weeds came there, usually takes a short cut out of the difficulty by trying to connect the seedsman with it in some way or other. Almost every seedsman can furnish 
from his experience instances of this nature-some of the instances being of an extraordinary and almost unaccountable sharacter.

Professor Buckman, in his prize essay "On the Extirpation of Weeds," mentions how charlock will often make its appearance in great quantities after the breaking up of pasture or old sainfoin lea; how quantities of wild plants will spring up quickly and abundantly in woods after trees and underwood have been removed; and how newly-formed earthworks frequently caused the sudden growth of wild plants which had never before been observed in the district.

Sir Jobn Sinclair has given us some observations to the effect that though it is impracticable to extirpate annual weeds altogether, yet the number of them may be so much lessened as to prevent them from materially injuring corn crops. Two measures, he says, are necessary for that purpose-first, to bring the seeds within the limit of vegetation; and, secondly, to destroy every weed that vegetates-thus regularly lessening the original stock. By the operations of ploughing, harrowing, and rolling-first to cause the weed-seeds to start into growth, and afterwards to kill the young weeds-many farms which formerly were nests of weeds have been brought into such order that the weeds are kept under subjection, and are easily managed.

Certain weeds in meadows betray a want of drainagesuch, for instance, are the sedge grasses, hassock-grass or bull-snouts (Aira cospitosa), water dock, wild forget-me-not, \&c. Others show poverty in the soil, such as ox-eyed daisy, sorrel, ribgrass, cowslip, and common daisy when in quantity.

Plants coming under the head of weeds, whether growing in poor or rich soil, not only take up space we should rather have occupied by the crop, but appropriate the most valuable part of its food; they impede the due growth of the crop by cramping and confining it; they clog the ground mechanically; they keep air and light from the young seed; and they delay the processes of harvesting and stacking, and make the work more expensive.

It will, in some measure, illustrate the loss caused by weeds to quote the results of an experiment which demonstrated that the difference in produce of an acre of wheat that had been weeded over that of an acre of wheat that had not been weeded was $4 \frac{1}{2}$ bushels; and that the same process applied to oats showed a gain of 10 bushels on the weeded acre, and applied to barley showed a gain of 15 bushels.

Bearing in mind the immense loss caused to the country at large by the prevalence of weeds, it is not going too far to say that their suppression is a matter of national importance. Relentless and continuous war should be waged against weeds, and there should be official direction and supervision to ensure that systematic efforts shall be made towards the destruction of these impoverishing pests of the plant world. There can be no greater nuisance, and none calling more londly for the interference of the anthorities, than a field or dyke or common covered with weeds which are allowed to seed and spread themselves all round; and those who attempt to estimate the national loss caused by weeds will yearn for a revival of that statute of King Alexander II. of Scotland, which denounced that man to be a traitor "who poisons the king's lands with weeds, and introduccs into thicm a host of enemies."

Professor Buckman remarks that one of the most fertile sources of the continuation of weeds is that of constantly allowing them to seed on the land.

In addition to the weed-seeds produced on the land, there are other agcncies at work to increase the weed colony. The seeds of weeds are brought on land, for instance, by (1) the wind, (2) by floods in the case of low-lying lands, (3) in farmyard dung that has not been sufficiently decomposed, (4) in the excrement of fowl, and (5) through the medium of impure seeds.

\section{THE SALE OF IMPURE SEEDS.}

However difficult it might be to prevent the introduction of weeds by the first four of the processes alluded to above, there should be no important difficulty in preventing the sale of impure seeds.

If we include bad grasses as weeds, which we are certainly bound to do, those of us whose connection with the seed trade supplies a means of knowing can easily understand how largely the weed family may be, and is, recruited from this source. Yorkshire fog, hassock-grass, useless brome grasses, couch or scutch, \&c., find their way in immense quantities into land where they should not be through the medium of dirty or badly-cleaned seeds. It is not alone the bad grasses that are thus introduced, but many other weeds more or less injurious. In the proper place the reader can note how, for instance, we may-through the medium of badly-cleaned ryegrasses-get ox-eyed daisy, buttercup, trefoil, large dock, sorrel dock, ribgrass, dragon-grass, \&c. Through impure samples of the clovers we get sorrel dock and ribgrass in large quantities, corn camomile, haresfoot trefoil, and sometimes that worst pest of all, the clover dodder. Along with the natural grasses we may get large dock, sorrel dock, brome grasses, hassockgrass, self-heal, and sometimes ergot. So if we begin with perfectly clean land, and if there were no other source from which weeds could be introduced, we could soon accumulate a good stock by the use of unclean seed alone.

Writing on this subject, Mr. Carruthers, botanist to the Royal Agricultural Society of England, says:- "It would be difficult to calculate the injury done to a meadow by the introduction of Yorkshire fog, and of the two Airas (hassockgrass, \&c.), which form so large a portion of some of the mixtures" (that liad been sent in to him for examination). In mixtures for laying down land examined by him, he found samples showing as much as 25, 26, and even 41 per cent. of Yorkshire fog, which-in some cases, at any ratemust have been added as a substitnte for meadow foxtail. In other mixtures $\mathbf{M}$ [r. Carruthers found 27 per cent. of Aira flexuosa added as a substitute for jellow oat-grass. He has had samples of a seed sold as meadow fescue that contained 
scarcely a single grain of the seed of that grass, while samples of it containing 20 and 10 per cent. of ryegrass were quite commonly met with. He has seen samples of dogstail containing up to 50 per cent. of blue melick grass (a grass found on all moors in Great Britain and Ireland, but possessing no agricultural value).

This is not the place to multiply instances of natural impurities or of substitutions, which will be found detailed under the proper head further on, but one observation made by MIr. Carruthers may be quoted, viz.:- "I have no reason for supposing it (substitution or adulteration) is done by any one connected with the trade in Britain, and I have little doubt that the worthless seeds are introduced before the goods reach England. It is greatly to be desired, then, that the buyers employed by the trade should be able to detect the presence of adulteration in samples offered to them."

Many people think that there should be a law putting a penalty on the sale of seeds that contain a conspicuous quantity of the seeds of weeds or inferior plants. It certainly does seem strange that a grocer may be fined for selling as coffee a harmless compound of coffee and chicory; while the same grocer may with impunity scll, as ryegrass seed, a most hurtful compound, in which it is quite possible there may be as much as (let us say) 50 per cent. of the seeds of bad grasses and other weeds. Those who buy the adulterated coffee suffer only to a most insignificant extent in comparison with those who buy and sow the adulterated or impure seed. In the latter case, not only is the purchase money wasted, but the crop is deteriorated, the land poisoned, and much expense incurred in getting rid of the weeds thus introduced.

Many who have heard of the "Seeds Adulteration Act," but who have not read it, may think that it deals fully with the adulteration of seeds, as its name implies; but the fact is that it is a "Seeds Adulteration Act" in name only, and would be more properly entitled "The Dyeing and Killing of Seeds Act," as it deals only with the killing and colouring of seeds $\rightarrow$ a practice never very general, and, in any case, one not a tenth part so damaging to the farmer, or so hurtful to the commonwealth, as the practice of selling weed-seeds, be they present as natural impurities or introduced as adulterants. (A copy of the "Seeds Adulteration Act" will be found on page 439).

In view of the evil consequences resulting from the sale of impure seeds, there are many who think that, in addition to imposing penalties on the sale of such by Act of Parliament, the sale of seeds-as of drugs-should only be entrusted to the hands of those holding a certificate of qualification. That certain steps, on some such lines as these, will be taken sooner or later, there can be no doubt; but it is very necessary to remark here, that measures of such a character would be incomplete and barren of good result unless accompanied by a regulation placing a liability to prosecution on such landowners or farmers as allow weeds to grow and seed on their land. It is obvious that there is not much use in one's going to the trouble of cleaning his land, or taking pains to procure seeds of high purity, if there is a weed nursery on a neighbouring farm, or on some contiguous railway embankment or piece of common.

Those remarks apply with much force to the sister kingdom of Ireland, of which it has been said with perfect truth that, as far as weeds are concerned, she is the richest country in the world.

Dr. Macaulay, in his "Tour of Observation in Ireland in 1872," says:- " The amount of weeds is a national disgrace. It is not uncommon to see a ton of weeds in a dozen tons of hay. Many a field has more weeds than a whole parish in England. Fields and roadsides are alike neglected, and weeds help to keep Ireland green but poor. I never saw such a country for weeds. I am sure it is no exaggeration to say that the direct loss to Ireland from weeds is above a million and a half sterling per annum, and $I$ have heard the loss estimated at nearly double that amount." From observations made during a recent and extensive tour in Ireland, the writer can indorse every word of the above; indeed, it is a question whether matters are not now in a worse condition, as unchecked reproduction would naturally increase and extend the evil. The fertility of the soil, combined with the humidity of the climate, produces thistles, nettles, ragworts, \&c., as large as bushes, and as profusely as if they had been sown for a crop. Whatever little is done, and it is only a little, to remove weeds from the fields, there is no attempt made, apparently, to remove them from the waste corners, the roadsides, the wide fences (known as "double ditches"), the railway embankments, and such like; and in the latter end of the autumn the gigantic nettles, luxuriant ragworts, and great flaunting thistles sending their down forth into the breeze, are conspicuous objects of the laudscape. RegistrarGeneral Donnelly, in his Irish Agricultural Abstract of 1874, stated his opinion that "until legislation affords some remedy to those who keep their land free from weeds against such parties as allow weeds to grow and seed, the practice of clean agriculture in Ireland cannot be hoped for."

The enormons increase which may result from allowing weeds to seed may be conceived from a study of the following list, which shows the number of seeds each of the weeds named is capable of producing in a single season :-

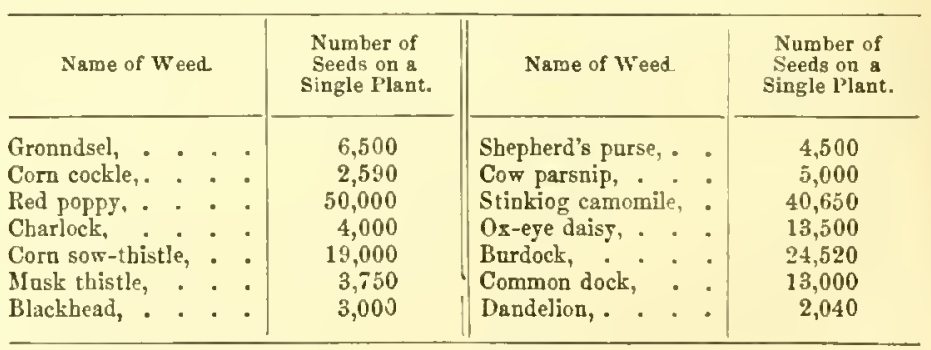

From the above may be gathered the significant fact, that after allowing a wide margin for the casualties to which seeds are constantly liable, yet plenty would be left, even where seeding is allowed but for a single year, to give trouble for many years after. 
Most people have noticed the beautiful parachute-like apparatus attached to the seeds of the thistle, dandelion, and other weeds, by which they are capable of being wafted miles away from where the parent plant grew. Again, the seeds of Yorkshire fog and those of the Aira family (hassock-grass or bull-snouts) are so light that they can be blown by the wind to a considerable distance. Bearing these things in mind, one can realize to some extent what damage can be done by even one foul field in a district, or by neglected waste spots, railway or canal embankments, on which weeds are allowed to grow.

It is apparent to all who have studied the matter, that if farming in Great Britain and Ireland is to continue to afford a living to those connected with land, it can only be done by allowing none of the resources of the soil to go to waste, or to be diverted from the use and benefit of mankind. We must consider weeds as the persistent and implacable enemy of the farmer, and through him of all mankind. If we are to flourish they must go to the wall, and vice versa. Whatever way the problem of weed extirpation is solved, it must be faced; and, impelled by a sense of responsibility, but with great diffidence, the writer ventures to put forward a few suggestions, which, if put in practice, would, he considers, go a long way in coping with this evil.

1. Steps must be taken to prevent by law the sale of impure seeds; and to effect-

2. The establishment of governmental seed-testing institutions in each of the three kingdoms.

3. Grand juries should be obliged to compel those who contract for the care and repair of roads to remove and destroy all weeds found on, or growing on, the roadsides.

4. The police or other local authority should be empowered to prosecute owners of fields or railway embankments, and overseers of commons, on which weeds are allowed to seed to the detriment and injury of the neighbourhood.

[It will not do to throw the onus on the aggrieved neighbour (as the law does in some countries) of prosecuting the offending party. People will suffer a great deal of this kind of loss and annoyance sooner than go to law with their neighbours and arouse bad feeling.]

\section{SEEDS ADULTERATION.}

(32\& 33 VICT., Cu. 112.)

An Act to Prevent the Adulteration of Seeds.

Whereas the practice of adulterating seeds, in fraud of Her Majesty's subjects, and to the great detriment of agriculture, requires to be repressed by more effectual laws than those which are now in force for that purpose :

Be it therefore enacted by the Queen's most Excellent Majesty, hy and with the advice and consent of the Lords Spiritual and Temporal, and Commons, in this Parliament assembled, and by the authority of the same, as follows:-

1. This Act may be cited as "The Adulteration of Seeds Act, 1869."

2. In this Act-

The term "to kill seeds" means to destroy by artificial means the vitality or germinating power of such seeds:

The term "to dye seeds" means to give to seeds by any process of colouring, dyeing, sulphur-smoking, or other artificial means, the appearance of seeds of another kind.

3. Every person who, with intent to defraud or to enable another person to defraud, does any of the following things; that is to say,

(1) Kills or causes to be killed any seeds; or,

(2) Dyes or causes to be dyed any seeds; or,

(3) Sells or causes to be sold any killed or dyed seeds, shall be punished as follows; that is to say,

(1) For the first offence he shall be liable to a penalty not exceeding five pounds.

(2) For the second and any subsequent offence he shall be liable to pay a penalty not exceeding fifty younds:

Mloreover, in every case of a second or subsequent offence against this Act, it shall be lawful for the Court, besides inflicting upon the person guilty of such offence the punishment directed by this Act, to order the offender's name, occupation, place of abode, and place of business, and particulars of his punishment under this Act, to be published, at the expense of such offenders, in such newspaper or newspapers, or in such other manner as the Court may think fit to prescribe.

(The other sections of the Act deal with summary proceediugs for offences; recovery of penalties; intent to defraud particular person need not be alleged; appeal from summary conviction; limiting time for proceedings; court unay order prosecutor to pay costs of unreasonable prosecution; and so on.)

In 1878 the above Act was amended by a short Act of two sections-the second section of which is the only important one, and alters section two of the first Act as follows:-

Section 2 of the Adulteration of Seeds Act 1869 shall be read as if instead of the words, "The term 'to dye seeds' means to give to seeds by any process of colouring, dyeing, sulphur-smoking, or other artificial means the appearance of seeds of another kind," there were therein inserted the words, "The term 'to dye seeds' means to apply to seeds any process of colouring, dyeing, or sulphur-smoking."

\section{ERGOT AND ERGOTISM.}

Ergot has been described as a monstrous condition of the grain, in which the enlarged and diseased ovary protrudes from the floret in a curved form resembling a cock's spur (hence the name ergot-from the French-meaning a spur). This spur is of a blackish-brown shade outside, while internally it is whitish, and contains much oil. In this condition it is taken by animals in grass and hay; causing, when taken in sufficient quantities, abortion in the case of in-calf cows that have arrived at a certain stage of pregnancy, and disease of a more or less acute character in other animals.
Ergot spurs ripen with the grasses in the autumn, and falling to the ground, remain there during winter and spring -unchanged and unaffected by frost or rain. About the beginning of May the ergot commences to develop minute fungi, which ripen in June and discharge spores in every direction. Such of the spores as alight on the grasses when in flower attach themselves to the seed-case, cast the embryo seed from its position, and commence at once to grow as parasites. When the ergot reaches its full growth in August, it has a second stage of reproductiveness, giving off spores 
from its tip or snout in greater numbers than those which were developed from the fungi. Misty, foggy weather and light rains assist the propagation of the spores, but heavy rains are apt to wash them away. Dry, hilly pastures-with-
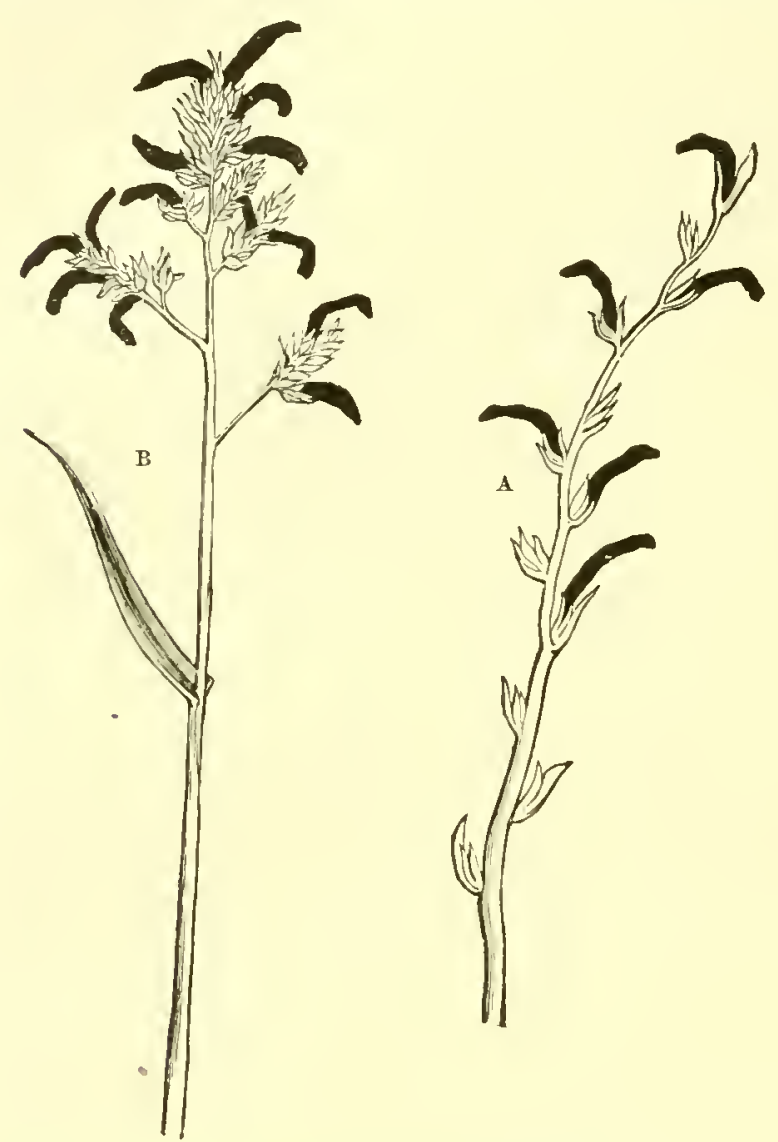

A, a spike of ryegrass (Lolium perenne) showing ergot spurs.

B, a head of cocksfoot grass (Dactylis glomerata) thickly studded with ergot spurs.

out trees or hedges to prevent free currents of air-are not favourable to the growth of this parasite. In medicine, ergot is employed in modern practice to stimulate the motor nervecentres which are connected with the uterus, in order to cause active contraction when that organ has lost its muscular force. In large doses ergot is an acrid poison-causing dullness, vertigo, dilated pupils, intoxication, muscular tremblings, and tetanic spasm, especially of the hind extremities, which afterwards become paralyzed. Dry gangrene is a final result of the action of the poison; and by degrees the extremities, and even portions of the trunk, are rotted and fall off.

"The action of the ergot," says Mr. J. Walker, "taken in such quantities as it is found in our grasses, acts as an excitant upon the womb of the pregnant cow, whereby the parts contract, and give the animal a desire to abort the calf. Its malignant influences are little dreamt of by the majority of graziers. Thousands of cows annually abort during wet seasons from eating the ergot grains amongst the grass and fodder. It is no imaginary evil, but has been proved by direct experiments instituted by men of undoubted veracity. It has been given to the mare, the cow, the ewe, and the cat, and has never failed to cause untimely birth when given in proper quantities and when the animal had arrived at a certain stage in pregnancy."

In many cases it has been noticed that when a cow aborts in a herd many others follow suit. This is commonly ascribed to some infection or sympathy, but it is quite clear that many cases assigned to sympathy are really caused by the poisonous ergot. A case is mentioned in the Field where ergotism appeared amongst eighteen cows in a dairy. The animals' legs began to swell as high as the hock joint, and in about a week the hoofs began to slough off. Some cases assumed a more severe form-the appetite failed, scab formed from the top of the hoof to above the fetlocks, and the parts below the line of the scab rotted off.

This subject is worthy of the most serious attention, for losses, one year with another, from abortion and other animal ailments incurred by ergot in Britain may be estimated at as much as is caused by foot-and-mouth disease.

Treatment of ergotism, as a matter of course, includes the removal of the animals from the place where ergot is found; or, in the case of ergotized fodder liaving been supplied, a change of food at once. Medical treatment, including the use of antiseptics and restoratives, will prove in some instances beneficial; but it is obvious that in this disease prevention is far more important than cure, and what is wanted is a determined effort to stamp out the pest. Meadow grasses should be cut before the period when the ergot spurs develop on the flower-head. Special attention should be paid to the corners of fields, to places under the shade of trees, and to the banks of streams and ditches. It is in such situations, where coarse grasses grow, that ergot is most likely to be found, and care should be taken to cut down such grasses in good time to prevent the pest being propagated.

Farmers might offer a small reward per dozen for flowerheads of grasses snowing ergot spurs, thus stimulating the boys and unemployed persons of the locality to search for same. A few shillings spent in that way might save many pounds; and if a sufficient quantity of the spurs could be collected, there might be a market for them in the drug trade. Tall meadow fescue grass seems to be particularly liable to attack of ergot, and on that account should not be allowed to go to seed.

As in the majority of cases it would not be worth while collecting the ergots, the next best course to pursue is to cut and collect the ergoted grasses and burn them-taking care that they are shaken and tossed about as little as possible, as the grains of ergot have only a slight hold on the seed stalk, therefore are easily detached, and if allowed to drop off and remain on land each grain will serve as a centre for the propagation of the pest at a future time.

A writer in a recent number of the Agricultural Gazetle suggests that experiments should be made with ergot on in-calf cows, with the view of getting answers to the following questions-viz. How much ergot is required to produce abortion? Is the effect of ergot greater or less as the time of 
pregnancy advances? Does ergot affect a cow when given on a full stomach? Does it act immediately on the cow, or must she consume it for a length of time to make her abort? This is a subject on which further investigation is very urgently required.

\section{CLOVER DODDER (Cuscuta trifolii).}

This is a genus of leafless annual plants allied to the bindweeds, and like them strangling the plants they lay hold of.

A dodder plant maintains its existence by twining round other plants, into whose stems it inserts its suckers and destroys the plants by appropriating to itself the sap. The

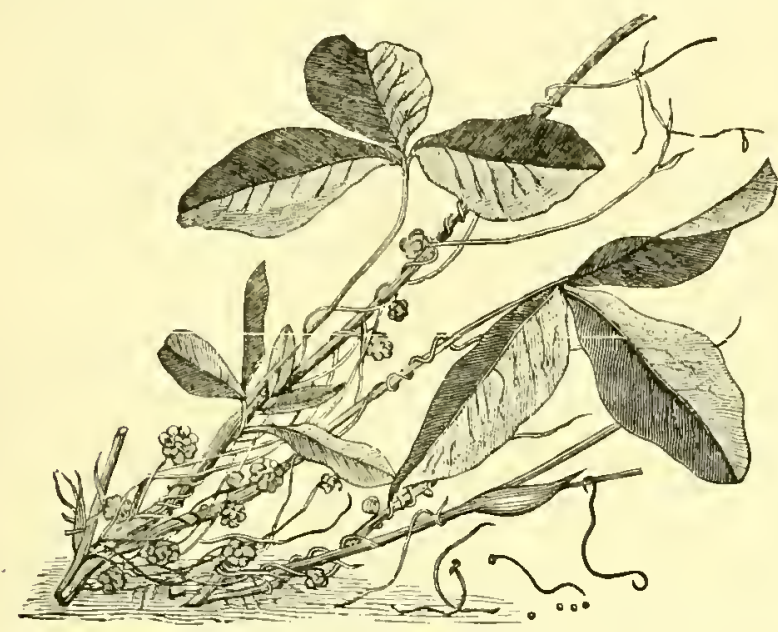

A Clover Plant attacked by Dodder.

seed of the dodder on being sown with the crop comes up at first an independent plant, but when it seizes a plant and sends its suckers into the stem thereof, it lets go its hold of the ground and lives thenccforth as a parasite. In appearance it resembles a number of fleshy threads twisted round a branch. One writer describes it as appearing like a large mass of yellow horse-hair shooting up through the clover and twining itself round every stalk of it It commences in small patches all over the field, and gradually extends itself-destroying in its progress all vegetation, and leaving the whole area as black as if a fire had existed on the spot. The seed of clover dodder is of a pale gray colour, and looks so like fragments of grayish clay that it takes a keen sight and a close inspection to detect $j$ t amongst the seed. As it is not much more than half the size of any clover Seeds of the Clover Dodder seed it is easy to get rid of it by (enlarged and natural size). sifting. When dodder appears the only remedy is to dig up the crop on, and for a considerable distance around, the spots where the dodder appeared, and then to burn all the plants along with the pared soil. If the dodder is allowed to mature and shed its seeds those may lie dormant in the soil for many years.

\section{LESSER AND GREATER BROOM-RAPE}

(Orobanche minor and 0 . elatior).

These also attack clover, attaching themselves to the roots of the seedling clover, and drawing nourislument therefrom. The tall broom-rape sometimes has a stem as much as an inch and a lialf thick and a foot and a half high, and looks as much out of place growing on the clover stump as does the young cuckoo in the hedge-sparrow's nest. The qualities of this parasitic plant are powerfully astringent. When it has once established itself it can only be removed by hand-picking. 


\section{THE GRAS SES.}

MEADOW FOXTAIL (Alopecurus pratensis).

Seed of ordinary quality weigbs from 5 lbs. to $9 \mathrm{lbs}$. per bastel; best quality, $12 \mathrm{lbs}$. Standard of germinating power of H.M.'s Office of Works, 60 per cent.

Dr. Parnell (author of the "Grasses of Scotland") says that this is one of the most valuable grasses to the farmer -one of the earliest and best for permanent pastures, and

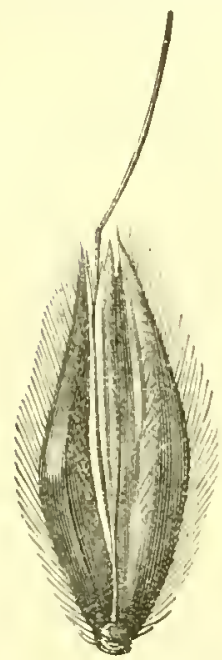
most grateful of all grasses to every kind of cattle. Its produce is nearly three-fourths greater on a clayey loam than on a sandy soil, and the quantity of nutritive matter is also greater in the proportion of three to two.

Martyn says it possesses the three great requisites-quality, quantity, and earliness, in a degree superior to any other.

Charles Johnson (author of the "Grasses of Great Britain") reports that its strong fibrous roots take a firm hold of the soil, but the plants have little or no tendency to extend themselves laterally. It has been affirmed Seed of the Meadow Fortail. to yield more bulk and weight of hay than any other grass hitherto subjected to experiment. The first crop may be cut abont the middle of May, and the aftermath is unusually prodnctive.

Sinclair (director of the celebrated Woburn experiments, and author of "Hortus Gramineus Woburnensis") holds the opinion that it should never form a less proportion than one-eighth of any mixture prepared for permanent pasture.

Dr. J. A. Vœlcker says that in meadow foxtail, perennial ryegrass, and timothy, the amounts of nitrogen and true albuminoids are considerably higher than in the other grasses. Meadow foxtail, indeed, shows a marked superiority in almost every respect; for, besides being so rich in nitrogen, it has also the highest amount of digestible matters.

IIr. J. S. Gould (of New York) says that pastures well covered with this grass will afford a full bite at least one week earlier than those which do not have it. No grass bears a hot sun better, and it is not injured by frequent mowingson which account, as well as for its early verdure, it is valuable for lawns.

Dr. Stebler (of the Swiss Governmental Seed-control Station) counts this and sweet vernal as the earliest of the good grasses of our meadows. It puts forth its long succulent leaves at the commencement of April, and its flower-spikes begin to appear about the middle of the same month. It reproduces itself by means of short stolons from the stump, and consequently does not grow in thick tufts. It does not acquire its full development till the third year.

Ir. Hunter (of Chester) says that it thrives best on a rich, moderately stiff, moist soil, and does well under irrigation, but it is of little value on poor dry soils.

Mr. Martin J. Sutton (author of "Temporary and Permanent Pastures") thinks it is only suitable for alternate husbandry when the ley is to remain at least three or four years. There is scarcely a forage plant known which endures cold so well as this, and spring frosts do it little harm. Also, it is one of the few grasses that thrive well under trees. By the third week of May it is in full flower, and should be cut if there is sufficient of it in the meadow to warrant early mowing. This necessity for early cutting should influence the proportion of foxtail in a permanent prescription. The aftermath frequently exceeds the early growth in bulk.

Manuring.-Experiments at Rothamsted proved that both nitrate of soda and ammonia salts did equally well with the foxtail plant.

The Seed.-True seed of foxtail, as Mr. Sutton says, is always expensive, and so light and delicate as to require exceedingly well prepared land to ensure vegetation. It has been pointed out by Dr. Stebler that in the ordinary seed of commerce the germinating power stands at a low figure, which is due to the fact that the seed is often gathered while unripe. They used to consider it fair seed that grew 30 per cent., and called it excellent when it grew over 40 per cent. From seventy-nine trials he found an average of only 19 per cent. of germinating faculty. Since the above was written, however, the quality of this seed has been improving year by year. The collectors, more particularly in the North of Europe, are beconing more awake to the necessity of allowing it to ripen properly. The sorting and cleaning of the seed is also receiving much more attention, so that at the present time seed may be obtained with a guaranteed germinating power as high as 70 per cent. This notable improvement has been brought about in a great measure by the investigations and reports of the botanist to the Royal Agricultural Society of England. Also some credit for this change for the better is due to Mr. Faunce de Laune in calling public attention to the low germinating power of the foxtail seed at that time usually supplied. According to Mr. de Laune one could formerly meet with samples of foxtail seed, of which not a single grain would germinate, and in other cases the germinating power wonld run to such figures as 5 per cent., 8 per cent., and so on.

It would not be a difficult thing to collect the seed of the meadow foxtail. The best plan is to cut the flower-sprkes witl a portion of the stem attached, bind them in little bundles, and let the seed come to perfect maturity. By this plan seed of a much higher germinating faculty will be obtained than by the plan of stripping the seed from the standing stem.

A few years ago it was not an uncommon thing to meet 
with a good many samples of foxtail containing a considerable proportion of Yorkshire fog, and, it may be presumed, samples of that class are not yet quite extinct. Such

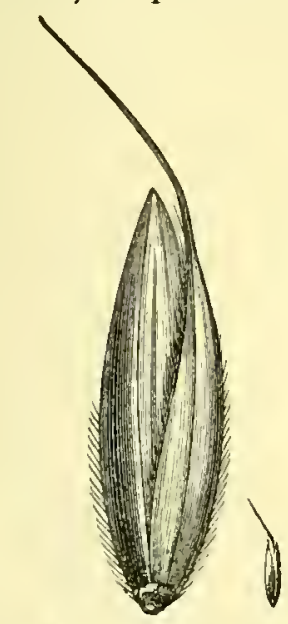

Seed of the Black Grass. impurities, however, can be easily recognized, as the seed of the Yorkshire fog is usually whiter in colour, and not so hairy as that of the foxtail. Furthermore, the kernel of the latter is of a yellow hue, while the kernel of the Yorkshire fog is of a silvery white colour.

We have it on the authority of Mr. Hunter that the seeds of Alopecurus agrestis (black grass) were also much used to adulterate meadow foxtail; and the same authority adds that "this black grass is one of the most execrable of weeds, and not a seed of it should be permitted to enter into the composition of any permanent pasture, yet tons of this seed are annually used to adulterate the true Alopecurus pratensis."

\section{SWEET VERNAL}

(Anthoxanthum odoratum).

The best seed weigbs from 10 to $12 \mathrm{lbs}$. per bushel. Standard of germination of H.MI.'s Office of Works, 60 per cent.

W. Carruthers, F.R.S. (botanist to the Royal Agricultural Society of England), thinks that this is a perennial grass deserving of a place, though not an important one, in permanent pastures. It is one of the earliest grasses, showing flowering heads even at the end of April. The foliage is at the best but scanty, and it is never a favourite food with stock.

Mr. Sutton says it is one of the earliest grasses, coming into full flower at the beginning of May, and therefore no surprise will be felt that it yields only a small hay crop. It is a true perennial, and continues growing until late in autumn, this fact clearly indicating that it is even better for grazing than for cutting. It grows luxuriantly on deep, rich, moist soils; and in wet peaty land it becomes so large and reed-like as to deceive any but the most experienced botanist. Strange to say, it is equally at home on thin moors and exposed sandy dunes, and will live in soil which will not feed any other grass.

Dr. Stebler's opinion is that, as it starts to grow so early in spring, it has the advantage of the moisture remaining in the soil from the winter, and thus is enabled to thrive even on the driest soils. After being sown it starts growing more quickly than any of the other grasses, and gives, even in the first year, a fair return. In warm situations it comes so rapidly forward that it has ripened and shed a portion of its seeds before the hay-cutting season, by which means the quantity of it in the land is increased (perhaps out of proportion to its value.-Ed.) At the time of hay-making the flowering stems and heads are almost as hard as straw, and not much more nutritious. It is on account of its fine aroma that the culture of it has been so strongly recommended, but it is not by any means certain that the odours which are pleasant to mankind are equally agreeable or in any way of advantage to the beasts of the field. The latter will judge their food by the tongue and palate; and as sweet vernal grass, notwithstanding its name and smell, has a bitter taste, it is probalule, and more than probable, that, instead of being liked by cattle, it is avoided by them, and only eaten when they are almost famished.

Mr. Hunter says its yield is somewhat scanty, and its early produce not nutritive. The latter-growth is more nutritious; and as the peculiar aroma of this grass gives a relish to and improves the flavour of other grasses, the addition of a moderate quantity of seed to mixtures for permanent pasture is recommended.

Dr. Parnell found that it constituted a part of the herbage of pastures on almost every kind of soil, though it only attains to perfection in those that are deep and moist. It is said that the flavour of mutton is greatly improved when sheep are fed on pastures where this grass abounds.

The seed as imported contains a good deal of sorrel and other weed seeds that are collected with it. It is also very necessary to bear in mind that the seeds of a worthless annual variety (Anthoxanthum Puelli) are in a great many cases substituted for the true sweet vernal. It requires a very close examination to distinguish the seeds of the one from the other. In the true kind the apex of the palea is evenly rounded, and the edge uniformly and finely serrate. The hairs are scattered irregularly over the surface. In the false kind the apex of the palea is roughly serrated, and the hairs are arranged along the midrib and veins and along the edges. These distinguishing characteristics are not, however, always to be depended on, and would not by themselves be a safe guide. The smell of the seed furnishes some help towards arriving at a correct opinion, but the most reliable test is an examination of the kernel. Rub some of the seed between the palms and blow away the chaff. The kernels of the false kind will be found pale coloured and short, while those of the true kind are dark brown (or almost black) and are more elongated than those of the Puelli. The seed of the true sweet vernal (A.odoratum) is, and must always be, costly. It is gathered by hand from plants growing wild in the woods and clearings of Central Germany, and only a very small quantity is sent to this country.

\section{TALL, OAT-GRASS \\ (Avena elatior, Linn.; Arrhenathemen avenacenm, \&c., \&c.; Holcus avenaceus). \\ Standard of germination, per Dr. Stebler, 70 per cent.}

This grass is known under a variety of botanical names; in France it is called Fromental, and in other parts of the Continent it is known as French Ryegrass.

Dr. Parnell says this grass produces a plentiful and early supply of foliage, and is valuable either for hay or pasture. On the Continent it is highly prized. All kinds of cattle eat 
it with avidity, although it is said to be unpalatable to horses.

Dr. Stebler's opinion is that it is certainly one of our best fornge grasses. In mixture with other grasses it is an excellent plant, which should not be omitted from any mixture, provided it is not sown on too moist a soil. It is most valuable as a grass for meadowing purposes. On account of its deep-rooting propensities it succeeds well on dry soils that have depth and are not too compact, but if the soil is too poor the plant becomes sickly, and gives but a mediocre produce. It is a quick-growing grass, flowers at the beginning of June, and gives considerable produce the first year, but the second year's cutting is the most important. Having a bitter taste, it should not be given by itself to cattle in a green state. For hay it is especially suited, as it is easy to save and keeps well. In dry warm situations it might be used in mixtures to the extent of 20 per cent. If only for one year's cutting Italian ryegrass is of more value, but if for two or three years' meadowing the tall oat-grass should get the preference.

Sinclair's remarks upon it are rather contradictory, but certainly very little in favour of its agricultural value. After mentioning the properties it possesses, which would entitle it to a high rank among the grasses adapted for alternate busbandry, he adds that it contains tro large a proportion of bitter extractive and saline matters to warrant its cultivation without a considerable admixture of other kinds.

Charles Johnson says:- So long as it has to struggle for existence with other self-established tenants of the soil, it is harmless, and probably beneficial to the animals feeding upon the mingled herbage among which it is an admitted but never a prominent associate.

Mr. Sutton says that its roots penetrate so deeply as to enable the plant to withstand the effects of both cold and drought. It is almost indifferent to soil, and may be grown pretty nearly everywhere. It cannot be called strictly perennial, but is twice as long-lived as Italian ryegrass, and grows as much herbage in its first year, while in its second and subsequent years it is far superior to its better known rival. When sown in autumn a much larger produce is obtained in the following year than from a spring sowing. For a three years' ley one-fifth of entire sowing would not be an unreasonable quantity on good deep soil.

Dr. Tasey (of the Agricultural Department of the United States of America) says:-The cultivated grass best adapted for winter pasture in the South is the tall meadow oat-grass, which will thrive on a more sandy soil than most of the cultivated grasses (though it prefers a rich upland), and will yield more green food in winter than any other grass. It and cocksfoot are thought to endure the heat and drought better than auy other cultivated grasses.

Protessor Plares (of Mississippi) says:-It may be sown in March or April and mown the same season, but for a heavier yield it is better to sow in September or October. Not less than two bushels per acre should be sown.

The Seed.-According to Professor Phares it is a little difficult to save the seed. In about ten days after blooming the seeds begin to ripen and fall off, the upper ones first; therefore, as soon as the top seeds are sufficiently ripe, the panicle or flower-head should be cut off and dried, when the seed will all thresh out readily. For an acre of arable land 20 lbs. of seed is sufficient; but as it is seldom desirable to cultivate it except along with other sorts, from one-fourth to one-half of that quantity will be found sufficient.

There is a variety of this grass (Arrhenatherum bulbosum) of which the base of the stem forms small bulbs. This is rightly looked upon as a weed-or, as one writer puts it, "the cultivation of it under any circumstances would not fail to create suspicions of lunacy against the owner." As there is no way of distinguishing the seed of the one variety from that of the other, it would perhaps be as well not to sow either of them unless there is the clearest proof that what is about to be sown is beyond question free from any admixture of the bulbous-rooted kind. It is owing to the latter being so commonly mistaken for the true variety that tall oat-grass is so little used in these kingdoms. One is no better than a couch or squitch grass, while the other-used with judgment-is capable of filling a very useful place in our agriculture.

\section{GOLDEN OR YELLOW OAT-GRASS.}

(Avena flavescens; Trisetum flavescens.)

The best seed weighs np to $10 \mathrm{lbs}$. per bushel. Standard of germination of H.M.'s Office of Works, 60 per cent. Flowers at the end of Jaly.

Mr. Carruthers reports that it is found in dry meadows and pastures, and may be grown in any kind of soil or situation. It produces a considerable quantity of foliage, is a favourite food of sheep, and is important as a late grass in pastures.

Dr. Stebler quotes Langethal's remark to the effect that this grass is always an indication of the superior quality of the fields in which it is found; and observies further that it thrives in almost all soils except those that are extremely strong or extremely light. Its produce is sure as well in wet seasons as in dry, though excess of either moisture or drought will hinder its development. It is entirely unsuited to meadows that are liable to be flooded but are not provided with suitable drainage, is very advantageous in meadows and pastures, gives a grass of good quality which beasts eat greedily, and should never be omitted from mixtures unless they are destined for places quite unsuited to it.

Curtis (an early pioneer in the field of investigation) says that in excellence it comes near to meadow foxtail, for which it may prove no bad substitute.

Dr. Parnell says it grows naturally in almost every kind of soil, from the limestone rock to the irrigated meadow, and is always present in the richest natural pastures. It thrives best in dry calcareous soil, and does well only when combined with other grasses. It is to be noted that sheep prefer it to most grasses.

The Seed.-The supply of the seed of this grass is exceedingly small, as it is very difficult to collect. In fact, so 
scarce is the real article that a totally different thing, viz. Aira flexuosa, has been quite openly offered and sold for it (see below).

There is a very strong resemblance-i.e. to the naked eye-

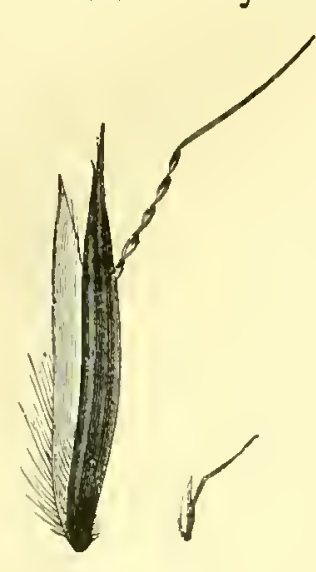

Yellow Oat-Grass. between the seeds of the two grasses, so buyers should be on their guard in this matter. Indeed, when we consider the scarcity and dearness of the seed of yellow oat-grass, and the danger of getting instead the seed of a perfectly useless grass such as Aira flexuosa, it is a question whether it would not be better to omit yellow oat-grass altogether from prescriptions for laying down land. At the same time, true seed of it, with good germinating faculty, can be had if one goes to the right source and pays the price. The enlarged illustrations given herein will enable the reader to notice the distinguishing features of the seeds of the two grasses.

\section{HASSOCK GRASS OR TUFTED HAIR-GRASS}

(Aira caspitosa).

Dr. Parnell says this grass has a most unsightly appearance in meadows, pastures, and parks. It forms large tufts (termed by farmers hassocks) very hard to get rid of. The

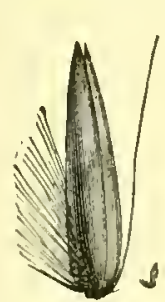

Hassock Grass. leaves are extremely rough and coarse, therefore cattle seldom touch it; and as it possesses little nutritive properties it does not merit the attention of agriculturists.

J. C. Morton says it forms unsightly rigid tufts, which should invariably be eradicated by grubbing them ont with a mattock or strong hoe, at the same time dropping amongst the loose soil a few seeds of cocksfoot, timothy, or some other strong and rapid-growing grasses.

The seeds of this grass are found as impurities or adulterants among the seed of the Poas (rough-stalked and smooth-stalked

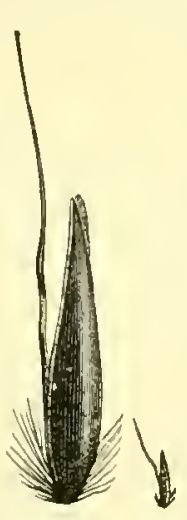

Aira flexuosa. meadow grasses), and among the seeds of others of the natural grasses. Wherever met with it is most objectionable.

\section{WAVY MOUNTAIN HAIR-GRASS}

\section{(Aira flexıos $\alpha$ ).}

W. Carruthers, F.R.S., reports that it is common on sandy heaths, moors, and hilly pastures, and is no doubt of value as an ingredient in such exposed native pastures, but is otherwise a wortlless weed.

not recommended for cultivation.

\section{THE BROME GRASSES.}

J. C. Morton says that among modern agriculturists there are not wanting some who question the propricty of so rigidly excluding the brome grasses from field culture, sceing that they yield a weighty produce in stems and seed, and do this, especially in the case of Bromus mollis (soft bromc-grass or goose-grass) on very poor dry soils.

\section{MEADOW BROME GRASS}

(Bromus arvensis).

That grown at Woburn on a sandy loam gave of green food per acre-

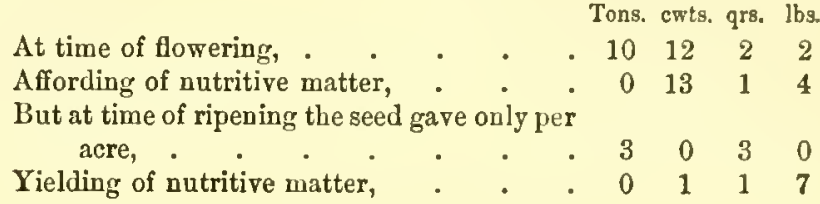

\section{BRONUS ERECTUS.}

(Sometimes called Bromus pratensis and montana, also Festuca erecta and montana).

Dr. Stebler reports that this grass has been for a long time in cultivation in the south of France, is fibrous rooted, and grows in compact tufts forming a level turf. It can be sown in autumn or spring, is not usually sown by itself, but generally with a mixture of sainfoin or lucern. It is not remunerative on good land, but is a useful and lasting grass on dry warm chalky soils, and suits dry hillsides that are exposed to the sun. In favourable situations it begins to grow early in spring, flowers at end of May or early in June, and should be cut before the flowering stage. After cutting it grows more leaf foliage, which is eaten with relish by cattle.

\section{BROMUS INERMIS.}

Dr. Stebler reports this as a perennial stoloniferous grass, useful for binding the soil of embankments of railways or
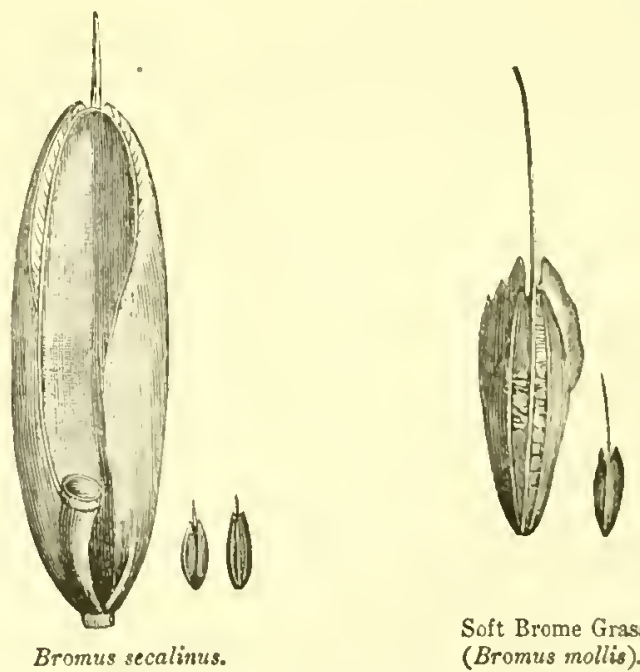

Soft Brome Grass (Bromus mollis).

canals because of its property of pushing out a large number of long twisted underground stolons. It is capable of resisting 
a drought that would kill any other grass, and is equally insensible to cold. It has only a small nutritive value.

The seeds of the brome grasses are found in very large quantities as natural impurities in badly cleaned ryegrass. Bromus secalinus will be found in large proportion in some samples of perennial ryegrass, and as it is rolled together in such a manner as to be of about the same thickness as the seed of the perennial ryegrass, it is impossible to separate the one from the other. The great flat white seeds of Bromus mollis, and occasionally the slender, long-awned seeds of Bromus sterilis and Bromus asper, may be easily recognized in impure samples of home and foreign Italian. Agriculturists should carefully avoid sowing seeds that contain admixture of the seeds of any of those brome grasses. In any land except the very worst they are out of place, and come under the head of weeds.

\section{SCHREDER'S BROME GRASS.}

Mr. Sutton says that this grass lias not been sufficiently cultivated in England, and strongly urges its inclusion in mixtures for two or three years' ley which are mainly to be fed off. There is a prejudice against it because of the harshness of its foliage, yet it is a valuable forage plant. It is one of the earliest grasses to start in a temporary pasture, grows so strong as to crowd out weeds, feeds on the surface, and will thrive on the thinnest soil. In warm moist seasons especially its usefulness will be manifested. Mr. Sutton once saw a field of this grass keeping an extraordinary flock of sheep, which were penned on it during a hot summer. The crop was ready at one end of the field as soon as the sheep had finished at the other.

Professor Phares says it varies in the time of starting growth, but when once started its growth after the successive cuttings or grazings is very rapid. It is tender, very sweet, and stock eat it greedily. It makes also a good hay, and produces an immense quantity of leaves.

\section{CRESTED DOGSTAIL (Cynosurus cristatus).}

Extra good seed will sometimes weigh np to $36 \mathrm{lbs}$. per bushel. Standard of germination of H.M.'s Office of Works, 90 per cent. Some seedsmen guarantee 95 per cent.

Charles Jolnson reports that this grass frequently forms the principal part of the sward in situations natural to it-viz. high and dry pastures or sheep downs. In such situations no species is more valuable. Owing to the depth to which its roots penetrate, it remains green long after most other species have withered. It is not at all, however, adapted for general cultivation-the stems being too harsh and wiry, and the herbage unproductive where a crop of hay is required.

Curtis (who bases his qualifications to pronounce Crested

Dogstail. opinions regarding the grasses on "twenty years' culture and observation of them") says that, finding this grass produces but little foliage; that its stems are wiry and constantly refused by cattle; that, on account of its roots being fibrous and penetrating to no great depth, it becomes in dry summers little better than an annualhe is induced to think less favourably of its intrinsic merits.

Dr. Stebler considers it one of the best grasses-valuable not so much in respect of its produce as in regard of its high nutritive qualities. It prospers best in a humid climate, and forms an essential part of the best pastures in England, Holland, Schleswig-Holstein, and Switzerland. It begins to throw up foliage early, and flowers from the middle to the end of June.

Dr. Parnell pronounces it to be a most valuable grass for permanent pasture, but not recommended for hay. It thrives better in tenacious elevated soils than in those of a drier or sandy nature, and in irrigated meadows attains an unusual size.

Mr. Hunter says it should be included in all mixtures for permanent pasture, but the quantity of seed should be very moderate, as when once established it will iucrease from year to year by self-sowing. The leaves are fine and form a dense turf.

J. C. Morton says of the crested dogstail, that from a more intimate knowledge of its actual merits, it is not now generally considered worthy of field cultivation. Few grasses, however, are better adapted for bleaching-greens and scythekept lawns.

Manuring.-At Rothamsted it appeared to thrive equally well on unmanured plots and on plots that had been dressed with mineral manures only. It showed a dislike for ammonia salts and a preference for nitrate of soda.

The seed varies in quality very much, owing to carelessness in collection and in handling by those who save it. A difference in price of as much as $100 \mathrm{~s}$. per cwt. between a superfine and a poor sample is not an unusual occurrence. Through bad handling (during the process of drying the seed) many samples get heated and become discoloured. Many inferior samples will be found to contain various weedseeds-sometimes ergot in addition; and again, the shelled seeds of Yorkshire fog are prominent in many samples.

Considering the price of good pure dogstail seed, and the adverse opinions of the grass expressed by some of the authorities we have quoted, it is a question for the farmerespecially in districts where it abounds naturally-whether it would not be as well to exclude it entirely from the mixtures for laying down his land. Certainly, as a general rule, considering how copiously it resows itself, it is well to diminish the quantity of this seed in specifications to the lowest point.

It is stated that crested dogstail is frequently adulterated with the seed of the blue melick grass (Molinia corulea)-a grass of no agricultural value which grows ou heathy and moory land. The seeds of Miolinia may be distinguished by their larger size and darker colour, and can be recognized by the naked eye on a close scrutiny. 


\section{FIORIN OR CREEPING BENT}

(Agrostis alba, var. stolonifera).

As there are a number of varieties of Agrostis, all of which are next to useless except this one, and as the seeds of the other varieties are usually sent out instead of the true fiorin, it is as well to give here a short botanical deseription of the plant:- This is a variety with the branehes of the panicle (flower-head) densely tufted; sheatlıs rouglish; stems long, smooth, and procumbent, putting out roots from the nodes or joints. It differs from Agrostis vulgaris in having broad leaves; a much eloser and larger paniele, with green or pale flowers; the large glume minutely toothed all along its back; the ligule long, narrow, and sharp.

Dr. Stebler's view of it is that, if it has been grown on a suitable soil, it will produce herbage of a suceulent nature which cattle eat with pleasure; but if grown on poor or dry ground it will be avoided, as it becomes hard and without flavour. It suits best on a light moist soil, and on peaty soils that have not been drained; also on wet clayey soils; but does not suceed on dry soils, especially if composed of compact clay, into which its fine roots cannot penetrate.

Professor Baldwin (Ireland) writes as follows:-_" Fiorin grass is extensively grown in Donegal. On reclaimed moor and other deep land there it makes most valuable permanent meadow. I speak of the true Agrostis stolonifera, with which worthless and even noxious plants are confounded."

Charles Johnson says that the value of all the varieties of Agrostis alba depends upon the creeping stems, which afford a heavy crop of hay late in the year, and also supply leaves for early feeding. The fiorin of nature's own planting flourishes in a rich well-watered soil, and produces an almost miraculous quantity of fodder; but it is unreasonable to suppose that, in the absence of such conditions, any parallel success can attend its cultivation. The creeping bent may be a useless weed-wiry, nearly leafless, and unpalatable to cattle-or it may be succulent, abundant in foliage, and as grateful to them as it is productive, aceording to the soil and situation in which it finds itself. The creeping runners, stems, or stolons of this and other grasses of similar habit are lighlly nutritive.

Mr. Sutton says it affords very early feed in spring, but its power of yielding late keep in autumn is its most remarkable feature. It has been pastured as late as the middle of December, and the herbage, if allowed to remain till the following spring, not deteriorated. In wet seasons it overpowers other grasses, and its ereeping roots become almost as objectionable as couch. It is also very exhausting to the soil.

Mr. Hunter says this grass is suitable for affording a supply of herbage during winter and early spring months when other grasses are dormant. The liabit of growth resembles the strawberry-long trailing shoots or stolons being produced during the autumn and winter months. It thrives on all good soils, particularly those that are wet; also does well on peaty soils, but is not suited to dry pastures.
As the fiorin grass eame at first prominently into notice through the writings of Dr. Richardson, who had experience of it in the north-east of Ireland, we give the following report from a gentleman in Donegal, who farms some reclaimed bog there on which a plantation of fiorin had been made by sowing pieces of the creeping stems and covering liglitly with soil :"I believe it is an excellent grass for our soil; in fact, we could not raise anything like the same quantity of any other kind of grass. My experience is that newly-broken bog is the most suitable land for it. I believe we have had as much as ten tons of hay per aere (Irish), but this I consider an extra good crop, and you will not lave that quantity except for one or two years on good land well manured." The following report on this grass is from anotler Irish correspondent of experience:- "Fiorin grass-the kind with the creeping stem-should be cultivated by itself on moist ground for hay, of which it gives several cuttings in the year of enormous produce and excellent quality. Cattle are extravagantly fond of it, and the farmer by its use may convert almost unprofitable swamps into the most valuable land on his holding."

The Seed.-As has been pointed out by Johnson, the fiorin, as is the ease with plants generally which propagate themselves by lateral extension, produces very little seed. Hence those who are desirous of eultivating it will succeed best by planting euttings of the creeping stems in drills an inch deep and slightly covering them with soil. The seed of commerce is almost invariably not that of the true fiorin, but is the seed of some of the other worthless varieties-such as Agrostis dispar, Agrostis vulgaris, Agrostis canina, \&c. Some of the leading seedsmen having discovered this, and having ascertained by experiment the impossibility of getting seed of the true fiorin, have struck it out of their lists altogether-which is a much better plan than to send out seeds of grasses that are no better than noxious weeds. Even when the seed of the bona fide fiorin grass has been procured it is very diffcult to get it to grow. Our Donegal correspondent writes:"I have no faith in the seed of fiorin, as I have seen it sown and it never eame to anything, but we plant the stems and cover them lightly with earth." Another correspondent writes: "I have tried to raise it from seed, but have entirely failed to do so."

According to the Woburn experiments, the fiorin grass grown on an aetive peat soil produced-
A. At time of flowering, per acre, .
Tone. cwts. qurs. lbs

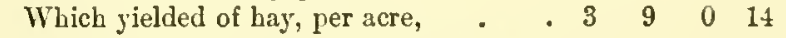
B. Yield at time of ripening its seed, per acre, $\begin{array}{lllll}8 & 10 & 0 & 17\end{array}$
C. Further produce of green aftermath, per
D. Portion left uncut till December produced at rate of, per acre, . . . . 92016

So as to give the reader an idea of the merits of the other varieties of Agrostis, which are so commonly sold as the true fiorin, the following is appended:- 


\section{HERD'S GRASS, OR REDTOP OF ANERICA}

\section{(Agrostis dispar).}

J. C. Morton says that, however suitable it may be in comparatively warm climates for dry soils, yet to the British grower it can only, like Agrostis vulgaris, be recommended for the most barren and worthless land.

\section{FINE BENT GRASS}

(Agrostis vulgaris).

Dr. Parnell says it grows on dry heaths and pastures, is said to be disliked by cattle generally, and is not of sufficient importance to merit the attention of agriculturists.

COCKSFOOT

(Dactylis glomerata).

Seed weigbs 18 lbs. per bushel. Standard of germination of H. MI.'s Office of Works, 90 per. cent.

Dr. Parnell says it succeeds best when the subsoil is porous and not stagnant, so that the fibrous roots can penetrate deep. It is less impoverishing to the soil than ryegrass; and though

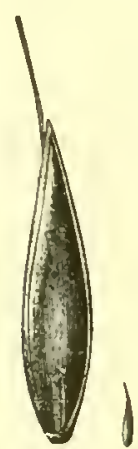

Cocksfoot. it is as a pasture grass that it possesses most value, yet even for hay it is superior to ryegrass and many other grasses. In pastures it should not be allowed to grow coarse, but should be kept closely cropped either by cattle or by the scythe.

Charles Johnson says for an alternate crop it is by far the best grass that can be employed alone. Rooting deeply, it is less liable to snffer from excess of drought than most others on dry sandy soils. ds moist retentive land is more favourable to its luxuriance, and indnces an overgrowth destructive of those of weaker habit but equally productive, it may be advisable, as a general rule, in laying down land to grass to exclude cocksfoot where other species of a fine quality are found to flourish. This grass, Johnson thinks, is more valuable for pasture than for hay.

Mr. Hunter says, for permanent pasture, for alternate husbandry, or for hay, there is not a more valuable grass. It is one of the earliest, most productive, nutritious, and valuable of the cultivated grasses, and no grass comes sooner to perfection. If kept closely cropped its produce is enormous, and it is relished and greedily eaten by all kinds of stock.

Dr. Stebler's opinion is that it is an excellent grass, growing quickly and ripening early. It constitutes in his country (Switzerland) the principal part of the best pastures. It should be cut before the flowering stage, as at and after that period it contracts a toughness. After each cutting it produces less stems and a large proportion of root leaves, which give excellent forage whether in a green state or as hay. Of all grasses this one furnishes the most substantial aftermath. It reaches full development the second year after sowing. It is not advisable to sow it alone, or in too large proportion for forage purposes, as it forms large clumps with bare spaces between. It is best to use it in mixture with clover, ryegrass, foxtail, and timothy-the proportion of cocksfoot not to exceed (unless in exceptional cases) 15 per cent. A good rolling in the spring serves cocksfoot, the operation reducing the projecting clumps to the level of the sward. In irrigated meadows it does very well, attaining in such situations a very large size.

Sinclair recommends a mixture of three parts cocksfoot with one part each of hard fescue, rough-stalked meadow grass, tall oat-grass, timothy, perennial rye-grass, and white cloverto secure the most productive and nutritive pastures in alternation with grain crops on soils of the best quality; and even on soils of an inferior nature, under the circumstances of unfavourable seasons, this mixture will afford nutritive herbage when the land would have been comparatively devoid of it if one species of grass only had been employed. It is further stated, on the authority of Sinclair, that when cocksfoot is suffered to grow rank or old for want of sufficient stocking, it contains nearly one-lialf less nourishment than that which is of recent growth.

Professor Phares says it may be mowed from two to four times a year, according to latitude, season, and treatment. It will grow well on any soil containing sufficient clay and not holding too much water. Cocksfoot grass is easily cured and handled; also it is readily seeded, and catches with certainty. I know but one objection to it-i.e., like tall oat-grass it is disposed to grow in clumps and leave much of the ground uncovered. This may be remedied by thick seeding, using $2 \frac{1}{2}$, or better, 3 bushels of seed per acre. In common with others I prefer red clover with cocksfoot-it fills the gaps and matures at the same time. One peck of red clover seed and six pecks of cocksfoot is a good proportion per acre. Sheep leave all other grasses if they can find this, and, acre for acre, it will sustain twice as many sheep or other stock as timothy Cut at the proper stage it makes a much better hay than timothy, and is greatly preferred by animals, being easier to masticate, digest, and assimilate, in fact more like green grass in flavour, tenderness, and solubility.

Mr. Sutton says that its proper place is on good, strong, damp soils in low-lying districts, where it produces an enormous quantity of leafy herbage. It is entirely out of place in upland meadows. Its valuable qualities are better realized in a three or four years' ley than in a permanent pasture. With ryegrass and clover it forms a superior feeding ley. Its quality is always higher before flowering.

Mr. Eilliott (of the Border Union Agricultural Association) gives a contrary opinion to that of Mr. Sutton with reference to suitability of cocksfoot for inferior lands. He says he saw it growing luxuriantly at Sharstead Court (Mr. De Laune's place) on poor land at the head of a steep bank. Also he has grown it himself successfully on poor and high land.

Mr. Gould says it affords a good bite earlier in spring than any other grass except the meadow foxtail. It gives a very large amount of aftermath, and continues to send out reotleaves until very late in the autumn.

Manures.-We have it stated that when not liberally fed cocksfoot almost disappears. Ammonia salts and mineral 
manures are conducive to its growth, but it does not take kindly to nitrate of soda.

The Seed.-We draw our supplies of cocksfoot seed from a wide area-viz., from North America, from New Zealand, from France, and Germany. The New Zealand seed would be almost perfect if it were free from the seeds of Yorkshire fog, which is present in large proportion in many samples. American seed, on the other hand, is free from fog, but sometimes contains seeds of dock, \&c. French seed is worst of any in the matter of impurities, containing, it might almost be said, a little of all sorts.

At Woburn cocksfoot produced green food per acre-

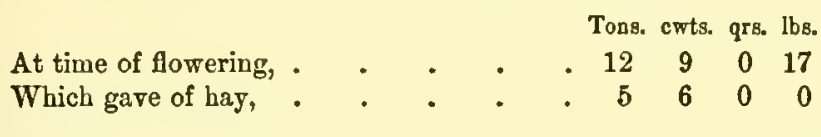

\section{THE SHEEP'S FESCUES.}

Some Continental authorities comprise under the heading of sheep's fescues all those sub-species and varieties that grow in compact tufts, and increase by lateral intra-vaginal shoots. Of those sub-species and varieties as many as eight are specified; while of the creeping-rooted fescues (such as $F$. rubra and its sub-species and varieties) six are specified.

Of the sheep's fescues there are only two that have importance from an agricultural point of view-viz., $F$. ovina, var. vulgaris, and $F$. ovina, var. duriuscula. In commerce, with the exception of fine-leaved sheep's fescue, we cannot tell by ordinary examination of the seed which sub-species or variety that particular sample of seed belongs to. It may belong to one of the sheep's fescues, or it may be seed of red fescue or of $F$. fallax, or $F$. heterophylla. The latter seed is the longest and largest of the lot, but the size of the seed is no certain guide. Seeds as well as plants vary in size according to soil and situation, and for that matter each plant of each variety will have some seeds larger or smaller than the normal size, and so a process of sifting will easily equalize the sizes all round.

How unsatisfactory this is from the farmer's point of view will appear when we discover that each of the various kinds which are liable to be sold as sheep's fescue requires a special soil and situation in order to attain its maximum development.

Some of the kinds, for instance, are only suited for dry soils, while others are served by irrigation. Some creep at the root and exhaust the surface soil, while others are fibrousrooted and go deep. Some do best under shade, while others prefer the open. It would clearly, therefore, be of great advantage to get the kind that suits the circumstances of our land; but the seed is little or no guide, and the farmer has no remedy except to deal with seedsmen of skill, experience, and integrity.

\section{HARD FESCUE}

(Festuca duriuscula).

Seed weighs 20 ths. per bushel. Standard of germination of H.Mf.s Otice of Works, 75 per cent. Some seedsmen gaarantes from 10 to 15 por cent. higher than this.

Dr. Stebler's opinion is, that the variety known as hard fescue is only distinguishable from the other sheep's fescues by its somewhat more robust growth. For good land, or even for poor land that can be irrigated, grasses of more value can be found; and it is only on dry and thin soils, where the better grasses will not do well, that the sheep's fescues become of much importance to agriculture. On good soils it is useful as a bottom-grass in mixture with other grasses, and may be mixed with the clovers for soiling; but by itself, or in large proportion, it can only be used to advantage on land that is dry, poor, and thin, of a sandy or silicious nature. On such it is truly a godsend, as it supports extreme drought, and is absolutely insensible to temperature and to climatic influences. It should never be sown alone even in the worst land, as it grows in thick close tufts and does not cover the ground. To fill up the blank spaces it is necessary to mix it with other grasses or forage plants-with Anthyllis vulneraria, for instance, on soils of the poorer class; and with white clover, smooth meadow grass, or perhaps timothy, on soils of a somewhat better kind. The year it is sown it develops slowly and gives but a poor yield. It is the second or third year that it reaches its maximum, after which it begins to decline. Cattle will not eat it except under pressure of extreme hunger. Sheep like it well enough, but not so well as they like some other grasses.

Sinclair remarks that it withstands the effects of severe dry weather better than many other grasses, and recommends its use to a small extent in laying down new pastures. . He adds that it attains greatest perfection when combined with meadow fescue and rough-stalked meadow grass.

Dr. Vasey says it is indigenous in the mountainous parts of New England, in the Rocky Mountains, and in various northern localities. It is without doubt the very best of the grasses growing on sandy soils. It is only as a pasture grass on such soils that it is valuable, and in these when highly manured it is driven out by the more succulent species. It roots deeply, and forms a dense, short turf, which adapts it admirably for lawns and pleasure-grounds where the soil is sandy.

Mr. Sutton says it is the most robust of all the small fescues. The herbage is tender, succulent, and much liked by all kinds of cattle. On moist and rich soils it affords an immense amount of herbage. It is of importance in forming a close bottom to the turf amongst stronger-growing varieties, and in this respect is of especial service for upland pastures. It may properly be considered one of the least expensive and most desirable of bases or bottom-herbage grass of a permanent mixture for all soils that are not very wet.

Charles Johnson says that it is generally regarded as one of our most valuable grasses, being very productive consider- 
ing the slender character of its foliage, and thriving in most soils and situations. Few grasses retain their verdure during the severest winter to an extent so remarkable. The spring produce, however, is but trifling, the foliage not attaining much length until the approach of the flowering season. Meadows in which it abounds should be mown when it is in flower, as both bulk of produce and proportion of nutritive matter are greater at that time.

The Seed.-The great bulk of what is offered in commerce is collected (we may presume for the most part in a hasty and careless fashion) from plants growing wild in the woods and clearings, consequently it contains a great many seeds of weeds in its natural state. The most noticeable of weeds to be found in it are sorrel, tufted hair-grass, and soft brome grass.

The writer remembers meeting with a sample of hard fescue a few years ago. It was offered by a Continental house, and looked so bad that he analysed it, with the following result:-A hundred grains contained 58 of hard

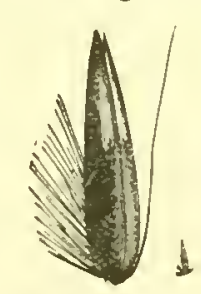

Tufted Hairgrass. or red fescue, 27 of tufted hair-grass, 4 of meadow grasses, 4 of sorrel, 1 of chickweed, 2 doubtful seeds, and 4 bits of quartz. This, of course, was a very bad case, and there are not many like it (let us hope), but still a sufficient number of impure parcels of the smaller fescues may be met with to warrant the statement that almost all the seed of this species that is imported would be the better of a special cleaning and recleaning before being sown. There are wholesale and retail seedsmen who devote themselves to the cleaning of the natural grasses, and the buyer can purchase perfectly pure seed if he will go to the trouble to look for it.

Stimulating manures do little or nothing for hard fescue; they only encourage other grasses at its expense.

At Woburn, hard fescue, grown on a hard clayey loam, gave of grass per acre-

At time of flowering, Tons. cwts. qrs. lbs.

Which yielded of hay per acre, .

$\begin{array}{lrll}8 & 4 & 0 & 0\end{array}$

At the seed-ripening period it increases its weight of grass, but loses nutritive matter.

\section{FINE-LEAVED SHEEP'S FESCUE}

(Festuca ovina tenuifolia).

Extrs good seed weighs 24 lbs. per bushel Some seedsmen guarantee a germination of 80 per cent.

Curtis says that it appeared to him applicable only to the purpose of making a fine-leaved grass-plot that shall require little or no mowing.

Dr. Stebler describes it as a dwarf variety, with the leaves very fine and almost hair-like. The seeds are not awned. It has no agricultural value, but is useful in lawns and ornamental grounds, particularly in sliady places.
Charles Johnson says also that in the practice of agriculture it is almost nseless, being entirely unproductive as hay; while for grazing purposes, on temporary pasture, grasses of larger growth are proportionately far more profitable. Nature in her distribution of it on poor, rocky, sandy soils, where other species would dwindle and die, points out the only situation to which it is properly adapted. He shares the opinion of the other authorities as to its suitability for lawns, bowling-greens, and pleasure-grounds.

The seed is of a tawny orange colour, sometling less than half the also from the other sheep's fescues in being awnless.

It is stated on good authority that only a small quantity of the true seed comes into the United Kingdom, and that a small-seeded sample of hard fescue is usually sold for it. However, there is no difficulty whatever in procuring the true $F$. ovina tenuifolia if people will go to the price of it, which is usually about three times the price of hard fescue. It is also stated that it is sometimes adulterated with the seeds of the blue melic grass, which is a most objectionable adulteration in this instance, as it is a most obnoxious grass to introduce into lawns in the formation of which fine-leaved fescue is much used.

At Woburn, grown on a light sandy soil, (Molinia corulea). it gave of grass per acre--

\section{At time of flowering,}

Tons. cwits. qrs. lbs.

. $\begin{array}{llll}2 & 8 & 2 & 13\end{array}$
At time of seed ripening did not increase in weight, but nutritive matter had decreased very much.

\section{VARIOUS-LEAVED FESCUE}

\section{(Festuca heterophylla).}

Dr. Stebler's opinion of it is, that it is a first-rate grass, and that he has obtained very satisfactory results from it. It succeeds better in the shade than in the open. It requires strong rich land and a warm situation, as it belongs naturally to the south of Europe. Most of the seed sold as F. heterophylla and $F$. rubra is really the seed of $F$. fallax.

Mr. Sutton says it is a most valuable fescue grass, and indeed one of the best of the finer grasses. The earliness of its growth makes it exceedingly useful in a pasture. For hay it is comparatively unimportant, and the aftermath is small. It will not make a continuous turf alone, but in company with red fescue and smooth meadow grass will fully occupy the soil.

J. C. Morton says it is suited for a strong class of dry soils, and for permanent pasture on such it is recommended to sow 1 or 2 lbs. of it per acre.

The Seed.-See remarks on the seeds of the small fescues under the head of Sheep's Fescue. Considering the uncertainty whether one gets the true seed, it is little use going 
to any pains to particularize this fescue or $F$. rubra in our specifications.

At Woburn, grown on a sandy soil with manure, it gave of grass per acre-

At time of flowering, . Tons. cwts. qrs. lbs.

Yielding hay,

$\begin{array}{llll}6 & 1 & 2 & 4\end{array}$

$\begin{array}{llll}1 & 16 & 1 & 23\end{array}$

At the time of seed ripening the yield of grass was about one-fourth less, but the yield of hay did not suffer much diminution.

\section{RED OR CREEPING-ROOTED FESCUE}

(Festuca rubra).

Dr. Stebler's opinion is, that the ouly essential difference between this and the sheep's fescues is to be found in the roots, the root-systems of the latter being fibrous and deep, while that of the red fescue is creeping, having underground stolons with extra-vaginal shoots or scions. It succeeds best on soils of a porous or somewhat peaty character, as in such it can freely develop its stolons. It can be cultivated with success even on shallow soils if same are fairly good and not too dry. In the mountains of Switzerland, where it has but a thin layer of earth, it forms the principal part of the vegetation. It flourishes on the dry sandy banks of rivers, and will exist even on the sandy dunes by the sea. As its roots extend themselves principally through the upper spit of the soil, it is that section that is exhausted by it. In point of nutrition it is not up to meadow hay of average quality.

Mr. Sutton says this grass derives its name from the reddishbrown colour of the lower leaves. He is quite of opinion that hard fescue is infinitely superior, except for poor, dry, harsh soils, and on uplands where red fescue may fairly be considered essential, especially for its great power of withstanding drought. This quality fits it for use on railway slopes, and for all burning soils and hot climates. It must be regarded as exclusively a pasture grass. All cattle like it, but for hay it is of small utility, and the lattermath is inconsiderable.

J. C. Morton says that it and its varieties, like all creepingrooted grasses, exhaust the fertility of the soil and extirpate the more valuable fibrous-rooted sorts; hence they should never be sown on ground suited for the growth of hard fescue and its varieties.

At Woburn, grown on a light sandy soil, it gave of grass per acre-

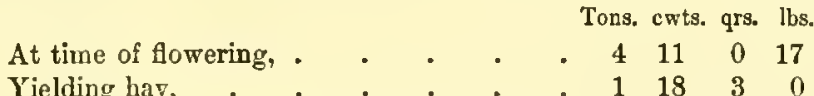

At time of seed ripening the quantities of grass and hay had increased to a small extent.

\section{THE MEADOW FESCUES.}

The German botanist Hæckel, whose ruling in the matter also adopted by Dr. Stebler, places Festuca pratensis and arundinacea as sub-species of $F$. elatior, and divides those again into varieties and sub-varieties. He states further that F. loliacea (darnel or slender fescue grass) is a liybrid betwcen F. pratensis and perennial ryegrass, and adds that there are also in existence liybrids between meadow fescue, Italian ryegrass, and $F$. gigantea (giant wood brome, or fcscue grass). Dr. Parnell also thinks it is very probable that $F$. pratensis is only a variety of $F$. elatior.

\section{TALL MEADOW FESCUE}

(Festuca elatior).

Seed weighing 20 lbs. per bashel. Standard of germination, per H.M.'s Office of Works, 75 per cent.

Mauke, a German botanist, so far back as 1818 wrote that this was one of the best and most useful of grasses.

Dr. Parnell describes it as growing from three to five feet high, the root being perennial, fibrous, somewhat creeping, and forming large tufts. It is a nutritive and very productive grass, grows naturally in rich, moist soils of a clayey nature, and notwithstanding its coarse appearance cattle appear fond of it, especially cows.

Professor Fnares says it grows well in nearly all situntions, wet or dry, on hill or bottomland, even though subject to overflow, and matures an extraordinary quantity of seed. The seeds germinate readily, and it is easy to set a piece of land with this grass. On account of remaining green throughout the winter, it is sometimes called "evergreen grass." Mowed and dried it makes good hay, much refished by stock.

Dr. Stebler reports that it flowers at the end of May or beginning of June, some days later than tall oat-grass and cocksfoot, and ripens its seed about end of July. It gives abundant produce of good quality, and, being a true perennial, should never be omitted on land that is suitable to it-viz. good loam or clay soils where a sufficiency of moisture can be had. It will also do fairly well on a cool sandy soil that can be irrigated; in fact, there is scarcely any grass that profits so much by irrigation as this one. It takes rather longer to develop than some of the grasses, and it is only in the second or third year that it reaches its complete development. When established it conmences to vegetate early in spring, and grows quickly, so that on good ground one can get three good cuttings in a favourable season. In point of earliness it comes immediately after meadow foxtail.

Although tall fescue is usually represented as doing well only on damp soils-moist clay, and so forth-it is reported by Mr. De Laune that plants of it during the exceptionally dry summer of 1884 retained their fresh green colour, and continued to grow, when all other grasses in the same pasture were suffering from the excessive and long-continued drought. From this it would appear that it might be used with advantage on light soils as well as on those that are heavy and wet.

Mr. Sutton would exclude this grass entirely from prescriptions for meadows which are generally cut for hay, not only because of the tendency of the grass to become ergoted, but because of the extreme coarseness of the hay produced. This 
authority adds, further, that the plant when indigenous to this country is practically sterile, yet on the Continent of Europe, where it is known as Festuca arundinacea, it is fertile, and seed of it is saved and exported to England annually. The plant, whether produced from the divided roots of the indigenous variety or from seed of the Continental $F$. arundinacea, equally maintains the characteristic creeping habit of the root, which is a distinctive feature as compared with $F$. pratensis.

The seed of the true tall fescue is larger, flatter, and more pointed than that of the common meadow fescue. Formerly it used to be difficult to get seed of tall fescue free from admixture of perennial ryegrass, and in some cases even yet such samples may be met with. Mr. Hunter says that "absolutely pure seed of $F$. elatior cannot be obtained, the purest samples usually containing from two to five per cent. of ryegrass, about the same proportion of cocksfoot, and some meadow fescue."

In addition to a natural sterility, a good deal of the seed of the tall fescue grass is rendered useless by the attacks of an insect which penetrates the ovary and destroys the germ. Therefore, from one cause or another, as much of the tall fescue seed of commerce is of low germinating power, it follows that if a proportion of perennial ryegrass (which germinates well) be present in it, either as a natural impurity or as an adulterant, the produce may perhaps show little else but ryegrass plants, leading the experimenter to suppose that there was a larger proportion of ryegrass seed in the sample than in reality was present.

At Woburn, grown on a black rich loam, it gave of grass per acre-

At time of flowering,

Yielding dried hay,

$\begin{array}{cccc}\text { Tons. } & \text { cwts. } & \text { qrs. } & \text { lbs. } \\ 22 & 15 & 3 & 3 \\ 7 & 19 & 2 & 2\end{array}$

MEADOW FESCUE (Festuca pratensis).

Seed weighs 26 lbs. per bnshel. Standard of germination, per H.MI't Otfice of Works, 90 per cent.

Dr. Stebler's opinion of the meadow fescues generally will be found under the head of Tall Fescue.

Sinclair states that it constitutes a very considerable portion of the herbage of all rich natural pastures and irrigated meadows, and makes excellent hay. The leaves are succulent and tender, and they never form rank tufts. It is of greater value at time of flowering than at the time the seeds are ripe, in the proportion of three to one.

J. C. Morton says that it possesses high merits both as a spring and autumn pasture grass, and is surpassed by few as a hay grass when cut at the time of flowering.

The "Agrostngraphia" of Lawson pronounces it to be an excellent grass, either for alternate husbandry or permanent pasture (particularly the latter), combining as it does most of the properties without the defects of common ryegrass.

Mr. Hunter reminds us that this is one of the six grasses recommended by Curtis for laying down moist or moderately dry soils to permanent pasture, and adds that no grass has a stronger claim to that position, and that it should be a large constituent of all mixtures of seeds fo permanent pastures. Although it loses muclı of its nutritive value if not cut at the time of flowering, yet, as the seed is not ripe till about the 1st of August, the sowing of this valuable grass along with ryegrass, cocksfoot, \&c., for hay crops or alternate husbandry need not be restricted, as the seeds of these grasses ripen two or three weeks earlier than those of the meadow fescue, so that such crops would be ready for mowing at the time the meadow fescue was in flower and in its most nutritious state.

Wr. Sutton's opinion is that meadow fescue may properly be regarded as one of the most valuable, perhaps the most valuable, grass that can be sown. Its presence is a pretty certain indication of good land. It flourishes in strong deep land, especially in low-lying meadows and valleys where a moist atmosphere prevails. Scarcely any grass equals this for land under irrigation, though entirely unsuited to a waterlogged soil. As it requires three years to attain maturity, Mr. Sutton looks upon it as a landlord's grass, to be used principally for permanent pasture. With cattle the plant is ever a favourite, and, if possible, is even more relished than foxtail. The early growth of meadow fescue is not large by comparison, but before the end of June it leaves foxtail far behind.

The Seed.-A few years ago complaints of the difficulty of getting genuine seed of meadow fescue were numerous and emphatic. The adulteration of it by means of perennial ryegrass must have been carried on to a very large extent-vide the reports of the botanist to the Royal Agricultural Society of England. Taking the report for 1883 , for instance, we find that of the samples of meadow fescue examined by lim only 29 per cent. were free from ryegrass. Of the balance 12 per cent. contained ryegrass to the extent of one-half! 22 per cent. contained ryegrass to the extent of over one-fourth, but under one-half; and 37 per cent. contained ryegrass to the extent of less than one-fourth. The great difficulty of dis- Fescue (magnitinguishing by the naked eye

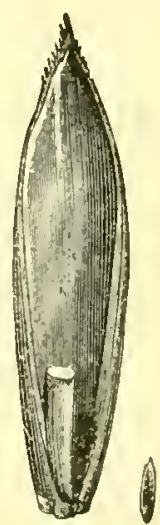

Seed of Meadow size).

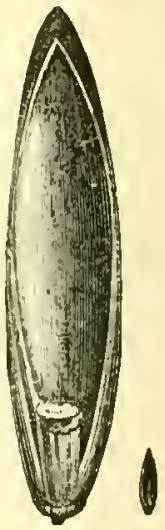

Seed of Perennial Ryegrass (magnified and natnral size). (and sometimes even by the magnifying glass) the seed of the one species from the other smoothed the way for such malpractices. Of late years, however, there is no difficulty in getting the seed perfectly pure. From America especially we get some splendid seed of this grass, and most seedsmen are now prepared to supply seed which they can guarantee perfectly pure, allowing a small margin for seeds of ryegrass that may get into it during the collection. It should never 
be bought unless specified as "recleaned," as in the rough state it contains often a considerable proportion of seeds of bad grasses and weeds-notably seeds of the brome grasses. The illustrations appended (see also p. 447) will give an idea of the characteristics of the different seeds as they appear under a magnifying glass. It is easy enough to distinguish the seeds of the brome grasses by the naked eye, but not so easy to find distinguishing marks between the seeds of meadow fescue and perennial ryegrass without the aid of a good magnifier.

At Woburn meadow fescue gave of grass per acre-

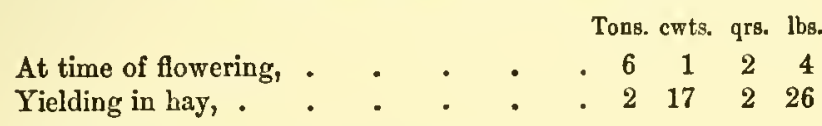

At the time of seed-ripening the weight of crop per acre had increased considerably, but the quantity of nutritive matter had fallen off to less than one-half.

\section{SQUIRREL-TAILED FESCUE GRASS}

(Festuca bromoides, Linn. ; Festuca sciuroides, Koch).

The seed is known in the trade as hairgrass, being long and slender, with a long hair-like awn. The plant is of no agricultural value, being rigid, dry, and innutritious. It is mentioned here in detail only because its seed is so often found as an impurity in Italian and perenuial ryegrass.

\section{BPIKED FESCUE GRASS}

(Festuca lotiacea).

Mr. Carruthers says it is hybrid between meadow fescue and ryegrass, is occasionally met with, but nowhere has been able to keep its place as a permanent variety. Like other hybrids, it does not perfect its seeds, the flowers being generally abortive. It has no special merits.

The seed generally offered for it is Glyceria fuitans, or manna grass.

Professor Buckman (author of "Natural History of British Meadow and Pasture Grasses ") holds it is a variety of meadow fescue, and says - "It is not only found, but is constant, and a most valuable grass for hay or pasture, in meadows by the side of rivers, especially where subject to floods."

Mr. Baker (of the Royal Herbarium, Kew) reports that $F$. loliacea is a mere variety of $F$. pratensis. A friend of his experimented with it on garden soil, and it simply grew into pratensis.

Mr. Sutton says that he does not recommend the sowing of $F$. loliacea, and does not consider the high cost of its seed a necessary outlay, although the plant is admirable on those soils where it will remain constant.

\section{YORKSHIRE FOG, OR MEADOW SUFT GRASS}

(Holcus lanatus).

The average germination, according to Dr. Stebler, is 50 per cent.

There seems to be a wonderful divergence of opinion about this grass. Some authorities dismiss it as a noxious weed, or denounce it in most vigorous language, while others seem to take a more appreciative view of it. The reading of the contradictory opinions given below will cause onc some bewilderment.

Dr. Parnell says the only advantages this grass possesses are its being productive and easy of cultivation. It has no merits either for pasture or hay, as cattle of every kind, especially horses, seem to dislike it. It attains its greatest degree of luxuriance on light moist soils of a peaty nature.

E. F. Hansen (Plön) says it is a sweet and succulent grass, much sought after when in a green state by cows and sheep. If cut and saved before the opening out of the flower-stalk, it gives a hay which cannot be excelled in quality, and which is much liked, especially by horses.

Curtis thinks that, if not disliked by cattle on account of its woolliness, it may rank with some of the best grasses.

Sinclair states that in consequence of the soft down which covers the surface of this grass, it is not willingly eaten either by horses or liorned beasts.

Dr. Stebler, though his written opinion of it is not very flattering, yet gives it a place in his book on "The Best Forage Plants." He describes it as an early perennial grass, but of little value in agriculture. He alleges that the most competent contemporary writers are unanimous in recognizing in it a plant not deserving of a place on land capable of growing the better grasses; but on peaty ground, or on poor sandy places where other grasses will not succeed, it has a certain value. In humid climates or situations it shows less of the woolliness which is so objectionable to cattle. To neutralize this woolliness it is recommended to sprinkle salt on it, which renders the small hairs moist and soft. It should always be cut up and mixed with other food.

Professor Phares quotes the case of the Hon. Mr. Lewis of Louisiana, who has cultivated this grass many years with great satisfaction, and adds-"It is by no means the best of our grasses; but best for some lands, and on such lands more profitable than other grasses."

Sir Humphrey Davy, in accounting for the dislike of cattle to this grass, puts it that its nutritive matter consists entirely of mucilage and sugar, whilst the nutritive matter of the grasses most liked by cattle have either a sub-acid or saline taste.

An Irish agriculturist, who is one of the largest stockbreeders and butter-producers of the county of Limerick, writes-"We like ryegrass and Yorkshire fog in our pastures, and stock here appear to relish them."

\section{ITALIAN RYEGRASS}

(Lolium italicum).

Seed weighs op to $22 \mathrm{lbs}$. per bushel. Standard of germination, 80 per cent

Charles Johnson says the great value of this grass consists in its being of more rapid growth from seed than any of the other kinds, and in the quantity of fine close herbage it produces under favourable circumstances. The water-meadow 
seems to afford the widest scope for its capabilities, as being the nearest apprcach to its natural habitat, and most accordant with the circumstances under which it originated.

Lawson's "Agrostographia" says that it is an invaluable grass for alternate husbandry, yielding as it does an early, bulky, and quickly succeeding herbage. General experience, since the first introduction by Messrs. Lawson of this grass to Britain, has demonstrated that two seasons of Italian ryegrass are all that can be depended upon with certainty; and in very wet, cold, spongy soils, it will often exhibit a thin stock the second season. nstances have, however, occurred in which as many as five or six successive years' produce have been reaped from the same field, yielding annually, on an average, about $7 \frac{1}{2}$ tons of dry hay per acre; but this has arisen more from the ground laving been resown in the course of reaping the seed, than from the actual duration of the original plants.

Ir. Hunter says that no agricultural plant of greater value has been brought into notice during the present century. It is indispensable for alternate husbandry, but as it does not last for more than two years it is of no use in permanent pastures. It is indeed a mistake to include it in mixtures for permanent pasture, as the spaces left bare at the end of the first or second year will most likely be occupied by worthless grasses, such as Yorkshire fog, brome grass, annual meadow grass, \&c. The produce of one year's growth of Italian ryegrass compared with one year's growth of perennial is as 23 to 14. The nutritive value of Italian compared with perennial is as 35 to 28 .

Dr. Stebler's opinion is, that as a grass for cutting or soiling purposes the Italian ryegrass is that which occupies the first rank. On light warm soils it suits well to sow it in August in association with crimson clover (Trifolium incarnatum), which will give an abundant cutting in the month of May following. It is with clovers other than the above that it is usually associated, but in sowing it in mixture with ordinary clover there is this drawback, that the Italian grows more rapidly, and is already over-ripe and past its best when the clover is only commencing to develop. This is why that latterly the custom is becoming more general to decrease the proportion of Italian ryegrass and substitute an equivalent of other grasses (such as timothy, tall oat-grass, and cocksfoot) when sowing down land for alternate cropping.* No other grass shows such a return for manure as this does, especially when treated with the liquid manure of the farm. By the use of liquid manure as many as eight or nine cnttings have been got from it in certain years. It succeeds best on warm, moist soils, particularly on loams rich in regetable matter, and also does well on clay soils of which the subsoil is permeable. In warm situations and on light land it is much benefited by irrigation. Its quality of rapid, vigorous, and luxuriant growth bas caused it to be occasionally used for the extirpation of weeds which are difficult to get rid of in the ordinary

- Dr. Stehler's remarks have reference to the Continent, and more especially to his own part of it, viz. Switzerland. way, and the same qualities make it suitable for filling up the blanks in meadows of clover, lucerns, or sainfoin. [For this purpose the soil is stirred with a harrow, the Italian sown, and the ground then rolled.]

Mr. Sutton says, given the desire of obtaining from an acre of liberally fed land the largest possible produce within twelve months, and Italian ryegrass has no equal. The most profitable way of growing it is alone, because the crop can then be cut before any of the stalks become hard and lose their nutritious qualities. Many farmers make it a rule to sow in October, and crops have sometimes been cut on warm, moist soils at Christmas, and again in the following April. Valuable as it is for alternate husbandry in company of other grasses, such as cocksfoot, perennial ryegrass, and timothy, yet in a permanent pasture it is distinctly harmful, and should never be included in a prescription for that purpose. It is so gross a feeder as actually to choke and smother the Poas (meadow grasses) and finer fescues, and when its own ephemeral course is run it leaves the land destitute both of plants and nourishment. It is objected that twitch is produced by Italian ryegrass. With pure seed this is impossible, but plenty of Italian ryegrass with twitch in it is freely bought and sold every season.

The Seed.-That portion of the seed which is imported from the Continent yields a very heavy crop, but is so infested with pernicious weeds as to need most careful cleaning before it is fit to sow. The writer lately took an ordinary sample of average French Italian, weighing $3 \frac{1}{4}$ ounces, and out of it picked 253 seeds of ox-eyed daisy alone. That is equivalent to 1157 seeds of the weed to each pound weight of ryegrass, or over 250,000 to each bale of 2 cwts. Besides the abovenamed weed it also contains trefoil (in the husk), wild forgetme-not (dragon-grass), buttercup, bromus, \&c.; and as there can be no doubt that the great bulk of the imported seed is sold without being cleaned, the consequences of sowing such a quantity of weed seeds may be guessed at. The impurities found in home-grown Italian are generally the same as those mentioned in connection with perennial ryegrass. It may be interesting to note that the seed of this grass when first introduced in 1831 was sold at $42 s$. per bushel.

\section{PERENNIAL RYEGRASS \\ (Lolium perenne). \\ Seed weighs up to 30 lbs. per bushel.}

Seed weighing $22 \mathrm{lbs}$. per bushel will germinate as well as, or even better than, the very heavy weights; and the 22lb. or 24-lb. seed, if equally pure, is the best value for the money. Dr. Stebler's trials gave an average germinating faculty of 70 per cent.; but his standard for good seed is 75 per cent. Some seedsmen guarantee 80 per cent.

There has been more controversy over this grass than over any other in the list-that is to say, over its qualities, its duration, its feeding value, and so forth. We must only let the various authorities speak, and draw our own conclusions. 
Lawson's "Agrostographia" says it possesses several good qualities to recommend it to the attention of cultivators, the principal of which are-

1. Its suitableness to a great variety of soils.

2. The facility with which it is propagated by reason of its seed being produced in abundance, and their uniformity in ripening.

3. The fibrous structure of its roots, which fits it in an eminent degree for alternate husbandry.

In respect to duration the most permanent varieties of it have no claim to any title beyond that of subperennial.

Stillingfleet, writing more than a century ago, says that many are tempted by the facility of procuring the seeds of this grass to lay down grounds near their houses (where they want a fine turt) with it, for which purpose, unless the soil is very rich, a worse grass cannot be sown, as it will certainly die off entirely in a very few years.

Curtis, alluding to the many varieties of this grass he had met with, reports that he had seen a double-flowered variety; also one with awns (Curtis's work was published thirty-five years before Lolium italicum was introduced by the Lawsons). Again, he had seen a variety with viviparous florets, and another with branching panicle.

Charles Johnson says it is exclusively in the successional system of cultivation, and in a few isolated instances apart from it, and dependent upon peculiarity of soil and situation, that the importance of this grass is chiefly manifested. As an uncultured pasture grass, it holds perhaps a very subordinate rank, but admitting this to be the case is not denying its utility in other respects. It readily vegetates on almost every kind of soil, and produces a plentiful supply of early herbage before the young plants come into flower. In the spring it is highly valuable-being greatly relished by cattle, by which, however, the rigid flowering stems are left untouched; and, unless the latter are removed by timely mowing, the after-crop is nearly worthless. No grass so rapidly impoverishes the soil-or, rather, takes from it that which is necessary to its own support to an extent equally prejudicial to its future growtb As a pasture grass it is of much lower rank than several other very common species; but, considered in its proper place, or merely as an artificial grass adapted only to peculiar circumstances, its worth cannot be reasonably disputed. Other species of grass may be more extensively applicable, but this is one that-of small account in its original state-culture has modified, has indeed forced into umatural productiveness. Ought we to be surprised that a plant so conditioned should fail when the stimnlus that first wrought the change is exhausted or withheld?

Sinclair comments upon the differences of opinion respecting the merits and comparative value of ryegrass. He notes that it produces an abundance of seed, readily vegetates on most kinds of soil, soon arrives at perfection, produces in its first years of growth a good supply of early lierbage, which is much liked by cattle. On the other hand, the after-crop is very inconsiderable, and the plant impoverishes the soil in a high degrce if the culms, which are invariably lcft untouched by cattlc, are not cut before the seed advances towards perfection. When this is neglected the field, after inidsummer, exhibits only a brown surface of withered straws.

Dr. Parnell endorses the statement that tor jermanent pasture, the produce and nutritive powers of the ryegrass compared with those of the cocksfoot grass are infcrior nearly in the proportion of 5 to 18 , and inferior to meadow foxtail in the proportion of 5 to 12 , and inferior to meadow fescue in the proportion of 5 to 17 .

Mr. Faunce de Laune, in vol. xviii. of the Journal of the Royal Agricultural Society of England, says that this is a short-lived grass; and that, owing to the shortness of its roots, it exhausts the surface of the soil, so that, when it dies ont, the bare space is so impoverished that though grasses may germinate upon it they will fail to live unless highly manured by accident or on purpose. Besides, the feeding qualities as determined by chemical analysis do not encourage its cultivation. In his own experience it las proved at some seasons injurious to stock. The grasses most pernicious to newly formed pastures are, first and principally, ryegrass in all its varieties, and Yorkshire fog. Both these grasses are rapid in growth and make a great show; they produce an abundance of seed and are very cheap, hence their popularity with superficial observers.

Mr. Sutton says that, while other grasses are dependent on season and weather, ryegrass is able to hold its own under all circumstances, enduring winter frost and summer heat. Another great advantage is that it is so little injured by being allowed to grow old before it is cut. It deserves to be widely known that ryegrass straw cut into chaft is a very substantial food for cattle. Everi on land where it is certain to die out, excellent service will be rendered while it lasts; and, by yielding up its place when other kinds are sufficiently established to occupy the land, weeds are kept in check, and crops of valuable herbage are secured meanwhile. On all those grounds Mr. Sutton advocates the use of peremial ryegrass in prescriptions for permanent pastures; and adds that for alternate husbandry it may be regarded as indispensable for all soils. Even on land where it certainly nould not be permanent, it should be liberally sown for a short term of years.

A burning sand or thin gravel is least suited to it, but it answers on a gravelly clay, is at home on all loams, and positively revels on tenacious land. The poorer and drier the soil the shorter will be its duration. The roots are very shallow; and as a poor soil speedily becomes exhausted by the rapid growth, of necessity the plant dies. Pastures which are stimulated by the droppings of cattle, or are dressed at proper intervals with farmyard manure, continue to grow ryegrass year after year withcut the sowing of seed.

The objections which have been urged against the use of perennial ryegrass for pastures are largely owing to the improper employment of annual ryegrass in its place. The latter is only adapted for one year's ley, and its use in a permanent prescription is no better than a fraud. 
Dr. Stebler's views on perennial ryegrass read to the effect that while sometimes bighly praised and at other times denounced, still it is, in spite of all, one of the best of our forage plants, and should never be omitted when laying down good land. It will not suit moory or dry light land, but for hea-y clay soils its place conld not be filled by any other grass. It furnishes a rapid and dense growth, is not injured by trampling, and has other high merits as a pasture grass. For mowing purposes, however, it is notably inferior to other grasses, and chemical analyses of ryegrass hay shows that its nutritive valne is a little inferior to that of meadow hay of average quality. On light soils, and with a dry atmosphere, it will be scarcely more than biennial; while on good heavy land, with a humid atmosphere, it should last seven years or more.

Professor Wallace (of Edinburgh University) holds the opinion that it cannot be said to be a permanent grass unless when grown on rich old pastures where there is an abundance of humus or decaying vegetable matter. He adheres to what may be termed a modified view of Mr. De Laune's opinion of ryegrass-viz. that it is not necessary to exclude it altogether, provided we do not allow of or encourage the adulteration of other seeds by its admixture.*

Ryegrass is vigorous and has some very good qualities, especially when grown on good soil. Its disadvantages are-

1. A tendency to run to seed and take ergot when in that condition;

2. The small amount of aftermath; and

3. Its liability to disappear in a few years.

The better the after-treatment, the better will be the results got from ryegrass.

Mr. Hunter says that the use of a large proportion of ryegrass cannot be justified now that it is possible to obtain most of the true permanent grasses equal in germinating power to perennial ryegrass, and in some cases surpassing it. It is a grass that quickly exhausts the soil, and becomes year by year less productive. Although the plants are short-lived they do not disappear from the pasture, but are reproduced from the seeds which are freely ripened and shed, the flowerstems being invariably left untouched by cattle. Again, as regards cheapness, when the number of seeds in a pound of each of the leading kinds is ascertained, it will be seen that ryegrass seed is really dearer than the seed of some of the permanent grasses.

The Seed.-Perennial ryegrass seed of less weight per bushel than 24 lbs. cannot be thoroughly cleaned, so that lighter samples should always be avoided. On the other hand, there is no advantage, except perhaps on the score of extra purity, in the use of seed of very heavy weight, as it has been proved that seed of $22 \mathrm{lbs}$. or $24 \mathrm{lbs}$. per bushel will yield a greater bulk of produce than seed of $28 \mathrm{lbs}$. per bushel.

- This allusion is to tha adalteration of meadow fescne seed by admixture of perennial ryegrass seed, a practice on which some comments will be found ander ths haad of Meadow Fescue.
The weed seeds usually met with in ryegrass (both perennial and Italian) are those of the buttercup (called "crawtae" or crowtoe in Scotland), ribgrass, large dock, sorrel dock, hairgrass (Festuca sciuroides), wild forget-me-not (sometimes called scorpion grass), goose grass (Bromus mollis and secalinus), and "last but not least," Yorkshire fog

The grass-seed merchants of Scotland and the North of Ireland take great pains to remove all weed seeds from the ryegrass; and, by the aid of expensive and elaborate machinery, succeed in producing samples of a very high degree of purity. The total quantity of weed seeds thus removed annually in the cleaning process would astonish most people. The labours of the merchants to produce pure seed are, however, in many cases rendered useless by the foolish and shortsighted practice of many farmers, who throw into this pure seed a mixture of some cheap rubbish, perhaps hayloft sweepings or rougl uncleaned seed got from a neighbour, and thus restore a considerable proportion of the bad grasses and weed seeds which the grass-seed cleaners have been at such pains to remove.

The presence of annual ryegrass seed amongst perennial must likewise be looked upon as an impurity. As has been pointed out by MIr. Sutton, the selling of the annual for the perennial variety is "no better than a fraud." The seed of annual ryegrass is large, flat, and can be easily distinguished from the seed of perennial or Italian varieties. It is almost as broad as the goose grass, but is more chaffy, and has no awn. It is impossible to remove the seeds of Bromus secalinus from perennial, as they are rolled up tight, and will slip through any mesh that will let ryegrass through. A sharp scrutiny is required to detect the presence of this impurity, but it may be recognized by its rolled-up appearance, and by the short awn that is attached.

Weight per Bushel.-On this point Dr. Stebler gives a table, showing results of an examination of four qualities of ryegrass seed, and demonstrates that, while No. 4 quality was only one-third the price of No. 1, yet by making a calculation, founded on the purity and germinating power of each, the No. 4, or worst quality, was actually eight times dearer than the No. 1, or best. Something similar could be demonstrated of the seeds of almost all species of plants used in agriculture.

At Woburn, Pacey's perennial, grown on a brown rich loam, gave of grass per acre-

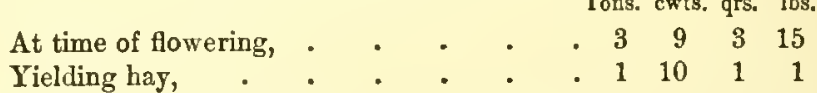

A variety called Russell's perennial, gave of grass per acre-

Under same conditions,

Tons. cwts, qrs. Ibs.

BLUE MELIC GRASS

(Melica carulea or Molinia carulea).

As mention has been made of the seed of this grass being found as an impurity or adulterant in the seeds of other 
species, it becomes necessary to briefly allude to its leading characteristics.

It is a perennial grass, is frequent on moors and wet heaths, and has a conspicuous purple flower, somewhat

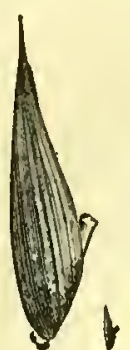

Blue Melic Grass. resembling a sprig of lavender. The roots are extraordinarily long and numerous.

Johnson says that it is eaten by sheep, but that cattle generally refuse it, or crop it only when compelled by hunger, or early in the spring before the flower-stems shoot up. Its slender rigid stems have considerable elasticity, and in places where this grass is abundant they are employed to make brooms, mats, baskets, and even ropes.

Sinclair remarks upon the presence of this grass as indicating those deep peat soils which are adapted for the production of ash, alder, and willow.

\section{TIMOTHY GRASS (Phleum pratense).}

Seed weighs 50 Jbs. per bnshel. Standard of germination-Bome seedsmen guarantee 95 per cent. Flowers third week in Jone, and ripens its seed at end of Jnly.

Sinclair says it is a most valuable grass for hay, but as the aftermath is inconsiderable, it should be combined with other species, whose produce consists chiefly of lattermath. It is remarkable for its weighty produce of culms, which are more nutritive than those of any other grass. It should always form a part of mixtures for permanent pasture or alternate husbandry.

Dr. Parnell says it is a hard, coarse grass, not much liked either by horses, cows, goats, or sheep. It has been highly recommended for hay, as the stems-during the time the seeds are ripe-contain more nutritive matter than the stems of most other grasses.

Curtis says it affects wet soils, and is very productive, but coarse and late. It has no excellence, that he could see, which meadow foxtail does not possess in an equal degree.

Charles Jolinson says that where quantity rather than quality is an object in making hay, the timothy is fully equal, if not indeed superior, in yield to meadow foxtail, but the hay is harsh and wiry. All of its better qualities are dependent on the depth and retentive character of the soil. On a moderately rich and tenacious soil it is a durable and nutritious grass, though too coarse to be generally liked by cattle, unless in the spring, when the early and abundant foliage is often remarkable in those pastures in which it is plentifully distributed amongst the scanty verdure of the later grasser Unless in very dry soils, it has a tendency to creep at the root and interfere with the growth of other grasses.

Mr. Hunter says that notwithstanding its coarse appearance, it is a grass of the highest nutritive value, and for productiveness stands in the very first rank. It produces an abundance of early herbage, which may be cropped till a late period of the spring without injury to the hay crop. It attains greatest perfection on deep, moist, retentive soils; on dry soils it is of less value.
Dr. Stebler reports that in Schleswig-Holstein, Mecklenburg, and over large districts of the Northern States of America, it constitutes the chief part of the pastures, and from year to year its cultivation is becoming more general in Northern and Central Europe. It takes a high place for nutritive qualities, but to secure these in largest proportion it should be cut just as the flowers begin to make their appearance (about the end of June), as later on it develops woody fibre, and gives a coarse hard hay. Being deficient in albumen, it is advisable to use it in conjunction with other grasses in which that substance is prominent. It associates best with red clover and alsike. When grown by itself, or in large proportion with clover, it is better to use it for soiling than to save it for hay, as it becomes hard in the saving. For permanent pasture mixtures the quantity used should never exceed 10 per cent., as it is not a lasting grass, and its herbage thins out after the third or fourth year. It resists the rigours of winter better than most other grasses, and it is said that it suffocates and destroys moss. Another advantage about it is that its seed is easily saved, and is very cheap. Taking it all round it is an excellent grass.

Dr. Vasey in his report on grasses of the United States of America says, "As a hay grass timothy has no superior; for a pasture grass it gives out too early in Julv."

Mr. Sutton says that a substantial advantage abuut it is that it reaches the height of its produce the first year after being sown, but unless properly fed there is a tendency to weakness the third or fourtl year. No other grass will bear extremes of heat and cold better than timothy. All cattle eat it greedily, and horses manifest especial fondness for it. It produces a heavy hay crop, is exceedingly nutritious when young, and becomes still more so when old and the seed is formed. Still, its hard wiry stems when dried can scarcely be called hay; they may be very nutritious, but they will have to be cut into chaff before being given to the cattle. The crop is really mown to greatest advantage before the ears are out of their sheaths, having regard to the fineness of the hay and the aftermath.

Timothy should form a principal constituent for heavy soils, but mischief may be done by using it in excess. 'The herbage is coarse; the stocks soon become hard, and their increased feeding value in that state is of no avail if cattle refuse to graze them (as they undoubtedly do), or if the presence of this grass in abundance lowers the price of the hay. When seed is freely shed there is a danger that the plant will take almost exclusive possession of the land, especially on those formations that favour its growth; and once sown it is a very difficult grass to eradicate Timothy is not so suitable for sowing with clovers for alternate husbandry as other grasses, on account of its late flowering; but with cowgrass, which flowers considerably later than broadleaved red, this difficulty does not arise, and perhaps it would be impossible to find two plants which could more suitably be sown together.

Manures.-Those of a nitrogenous nature appear to have 
a very marked effect in promoting the growth of this grass.

The seed being cheap, there is little temptation to adulterate it. Besides, it is easy to detect adulteration or impurity, as there is no other seed which resembles it to any extent. Samples from which the silvery husk or covering las been separated should not be discarded or undervalued on that account, as it does not affect the germination. Some samples of Continental seed may be occasionally met with containing a very large proportion of weed seeds.

It is impossible not to notice these weed seeds, they are so different from the timothy seed; so that people who buy such seed must do so either through most culpable carelessness, or actuated by a desire for a little extra gain in the retailing of it, as such samples, being discarded at once by the better class of merchants, can only find buyers by being offered at a price that will induce some people to take them up.

At Woburn, timothy grass, grown on a clay loam, gave of grass-

Cut when flowering, . Tons. cwits. qrs. lbs.

Which yielded hay, $\begin{array}{llll}18 & 4 & 2 & 13\end{array}$ $\begin{array}{llll}7 & 14 & 3 & 24\end{array}$

Further experiments showed that, in the grass cut when the seed was ripe, the loss in drying was smaller, and the nutritive matter was more than doubled; but this was fully counterbalanced by the deficiency of the aftermath.

\section{THE MEADOIV GRASSES.}

\section{ROUGH-STALKED MEADOW GRASS}

\section{(Poa trivialis).}

Extra good seed weighs ap to 26 lbs. per bnshel. Standard of germination, of H.M.'s Office of Works, 75 per cent. Flowers tbird week in June, and ripens seed in the middle of Jaly.

The roots are fibrous, not stoloniferous; flowers acute, and connected by a web. Lower palea five-veined-the middle vein only having silky hairs, the marginal veins smooth.

Sinclair states that the superiority of this grass over others of its species-its high nutritive qualities, and the marked partiality which oxen, horses, and sheep have for it-distinguish it as one of the most valuable of those grasses which affect moist rich soils and sheltered situations. He further adds, that it is unprofitable for any purpose on dry, exposed situations, and advises its use exclusively for permanent pastures on rich soils and in sheltered positions. When combined with other grasses it gives almost double the produce that it would give if grown on the same soil by itself, which shows how beneficial shelter is to it.

Charles Johnson says it is certain that not any among our indigenous species are more generally liked by sheep and by cattle of all kinds. Its merits, however, have their limits, and a moist rich soil is essential to its development. On such soils no grass is better adapted for constituting a leading portion of both permanent and alternate pasture.

Stillingfleet makes mention of a meadow at Orcheston, near
Salisbury, which produced enormous crops. Curtis got pieces of its turf sent to him (cut from five different parts of the field) and planted same in his garden, when he found they contained the following grasses:-Rough-stalked meadow grass in all five, twitch grass in four, meadow foxtail in two, Agrostis palustris (Fiorin?) in two, and Avena elatior in one.

Dr. Stebler reports that a humid climate and a strong rich soil suit it best, and that it is not absent from any good grass land of Central and Northern Europe. The first year it makes only lateral growth, pushing out stolons which lie along the ground, strike root, and branching off in all directions form a thick interlaced growth, which gives, however, only a spare yield. In the second year it makes a dense upright growth, so close and compact that the scythe has difficulty in cutting its way through it. Notwithstanding this vigorous growth, it gives, however, but a feeble second cutting. It is a very suitable grass for irrigation meadows. Being a shallow-rooting grass, it takes its principal supply of nutriment from the soil nearest the surface. It should be cut before the flowering season.

Mr. Hunter says that rough-stalked meadow grass, compared with the smooth-stalked (Poa pratensis), is 25 per cent. more nutritious.

Lawson's "Agrostographia" says it is a valuable grass in a mixture for pasture land, particularly on damp soils, and where partly shaded by trees. It is well suited for irrigated meadows. Its creeping shoots begin to grow pretty early in spring, and, by lying prostrate on the ground, form a beautiful verdant sward. As the season becomes more advanced, however, these shoots are apt to get dried up by the effects of the sun, but they shoot out again towards the end of the season, and continue green during the greater part of winter.

Mr. Sutton says that, valuable as this grass is for rich soils in very moist and sheltered situations, he does not consider that, for any other land, it is worth while to incur the cost of the seed, which, if true, is always extremely expensive. On strong moist soils it is now generally considered to be superior to Poa pratensis, but the favourable comparison does not extend to light land liable to burn. It is liable to injury by spring and autumn frosts, and by severe winters.

Manures.-It takes from the soil, according to $\mathrm{D}_{2}$. Stebler, a large proportion of phosphoric acid and potash, and a heavy manuring in the autumn promotes the development of this grass. The Rothamsted experiments established that nitrate of soda, combined with mineral manures, has a marked effect on the development of this grass, while, on the contrary, ammonia salts diminished its growth. In this respect it differs altogetlier from smooth-stalked meadow grass.

The Seed.-The pure seed of this grass is very scarce in commerce, because it is seldom or never grown by itself fo: seed. Thus the bulk of what is offered and sold as rough meadow grass is in reality the seed of some of the other species of the Poa tribe, with, in the worst cases, a fair sprinkling of the seeds of bad grasses and weeds (Aira coes- 
pitosa, for instance). It takes a very close examination with a magnifying glass in most cases to distinguish the roughstalked meadow grass from the seeds of the other Poas, some of the distinguishing features being obliterated in the process of cleaning. This is a serious difficulty in the path of the seedsman and farmer, for we can easily comprehend that to substitute one seed for another is to defeat the ends of the agriculturist, and to impose on him not only loss of time and of money, but the greater loss of that increase and return which the use of plants rightly suited to his soil and to the circumstances of his land would have brought him.

The following descriptions afford a few indications by which the seeds of the different meadow grasses may be distinguished from each other:-

The seeds of rough meadow grass incline to a bluish colonr, are more deeply grooved in the interior than any of the others, are but slightly woolly at the base, and have hairs on the keel only. "It has a neat, slender, and tapering appearance" (Hunter).

Smooth Meadow Grass.-The seeds of this are a little thicker than those of the other, are more of a brown colour, much more woolly, and have hairs not only on the keel, but on the marginal ribs also.

Annual Meadow Grass. - The seeds of this are a little longer, more pointed, thinner, and of a lighter colour.

\section{WOOD MEADOW GRASS}

(Poa nemoralis).

Extra good seed weighs up to $23 \mathrm{lbs}$. per busbel. Standard of germination, of H.M.'s Office of Works, 75 per cent.

The root is fibrous, and not stoloniferous; florets are more or less webbed at the base. Lower palea five-veined; the central and marginal veins silky; the web sometimes wanting.

Dr. Parnell says it ranks amongst the superior permanent pasture grasses, producing a considerable deal of fine succulent and nutritious herbage, which horses, cows, and sheep are remarkably fond of. It will grow freely in exposed situations, but in its natural state is found only in shady places, or in woods on rich soil.

Charles Johnson says that this is a grass of variable habit, and that for agricultural purposes its valne seems doubtful. In mountainous districts he never saw it eaten down by sheep, and deer generally leave it untouched in parks. Hares and rabbits devour the herbage, and game birds are fond of the seeds; hence it may be worth introduction in preserves where it does not grow spontaneously.

Mr. Hunter says that its pleasant green colour and fine herbage adapt it for sowing in mixture with other fine-leaved grasses for lawns and pleasure-grounds; and when these are much shaded by trees, no other grass is so well suited to the purpose.

The seed is often adulterated with the seeds of hassock grass (Aira coespitosa), a small shiny seed (see p. 447).
SMOOTH-STALKED MFADOW GRASS

(Poa pratensis).

According to Dr. Stebler, good seed shonld have 95 per cent. of pore seeds, and 50 per cent. of those should germinate.

The root is creeping; flowers acnte, and more or less copiously webbed; the lower palea five-veined; the intermediate veins, and sometimes the marginal oncs, are liable to hc obscure and inconspicuous; the middle and marginal veins are hairy.

Curtis says it has a root which creeps like the couch grass, and is almost as difficnlt to extirpate. It ought therefore to be cautiously introduced where the pasturage is not intended to be permanent. As it only throws up flower-stems once in a season (in May), it should be suitable for lawns and grass plots.

Dr. Parnell says that, although it is called smooth-stalked meadow grass, this characteristic cannot always be depended on, as in some varieties of Poa pratensis the sheaths are occasionally roughish, while in Poa trivialis they are sometimes nearly smooth. It is an early grass, producing a large quantity of herbage which is liked by all cattle; but its creeping root is said to impoverish the soil, and it is therefore not recommended for cultivation.

Sinclair says it cannot justify its claim to a place in the composition of the best natural pastures, and on this account it should be carefully avoided as an unprofitable plant.

Charles Johnson says it prodnces abundant foliage, and at an earlier season than most of our other common meadow and pasture grasses, and being a favourite food with cattle generally might be considered one of the most valuable did not its creeping habit interfere with the growth of others equally luxuriant and better adapted for the promiscuous crop of the lay field. Its habit of early flowering has this disadvantage - that its seeds are ripening while the other grasses are only in blossom; and if it is not cut before the seeds are ripe, a loss of more than one-fourth of its produce is snstained.

Lawson's "Agrostographia" says it is liable to be injured by the disease called "rust," and from its growing in large patches all the other grasses within its reach are destroyed.

Dr. Stebler says it does not succeed on heavy stiff soils or on those that are very light and poor in vegetable matter, gives but a small produce the first year, and only reaches its full development in the second or third season. It does not agree well with clover in a mixture; is extensively cultivated in North America, notably in the State of Kentucky; and as it succeeds best in soils that are friable, mellow, and rich iu hnmus, its presence is taken as an indication of good agricnltural land. It will succeed fairly well on bog or fen land that has been well drained. Possessing a dense and spreading root, and having its underground stolons protected by the soil, it is able to withstand a considerable degree of heat or cold. It is an early grass, and flowers from end of May to niddle of Jnne, according to situation of the ground. The produce of the aftermath is small. The plant may be distinguished from Poa trivialis by its deeper colour, and by its 
sending out underground stolons; while those of the $P o a$ trivialis creep along and root on the soil.

Dr. Vasey says that it forms, in all the middle portions of the United States, the principal constituent of pastures, though its excellence is said to be rather depreciated in the Eastern States. Is illustrating the different estimates formed about this grass, Dr. Vasey mentions that it is very much in favour in southern Olio, whilst in the north and north-eastern portions of that State it is considered a very unwelcome guest in the grass-lands. He adds that this difference of estimate is probably due to varieties, or to difference of soil and to treatment.

\section{WATER MEADOW GRASS}

(Poa aquatica, Linn. ; Glyceria aquatica, Smith and others).

This grows from 3 to 6 feet high. Root perennial, creeping; leaves long, broad, and flat; florets not webbed. From its large size and broad leaves cannot be mistaken for any of the other Poas.

Curtis says that in flat countries which do not admit of being sufficiently drained, it is almost the only grass for hay and pasture.

Dr. Parnell says that, grown in suitable places, it affords abundant crops of valuable winter fodder which cows and horses are fond of. Its nutritive matter is greatest at time of flowering. It flowers second week of July and ripens its seed about middle of August.

Lawson's "Agrostographia" describes it as growing naturally by the side of muddy pools, fresh-water lakes, and sluggish rivers; also on rich alluvial soils where occasionally flooded. It is apt, by its rapid growth and creeping roots, to choke up ditches and small streams. It is one of the tallest and at same time most productive in herbage of all the British grasses.

Charles Johnson also refers to its tendency to choke up streams (and even slow rivers) by its roots, and thus to coustitute a formidable obstacle to the improvement of the land by drainage.

Mr. Sutton says it is nutritious, and generally liked by cattle. In the fen districts it forms a large part of the herbage, and yields abundant crops of hay. It may be included in permanent mixtures for undrained clay.

J. C. Morton says that this is the most productive in herbage of any of the British grasses, and it is astonishing that its cultivation should hitherto have been so little practised, seeing that it might be used advantageously both for the summer and winter feed of cattle. On the banks and small islands of the Thames, as well as in the fens of Cambridge, Lincolnshire, \&c., it is generally mown twice in the year and dried in sheaves for hay (which improves by undergoing a slight heat in the rick). On lands intended for irrigation it may be sown at the rate of 4 to $6 \mathrm{lbs}$. per acre either in antumn or in spring.

At Woburn, grown on a strong tenacious clay, it gave at time of flowering-

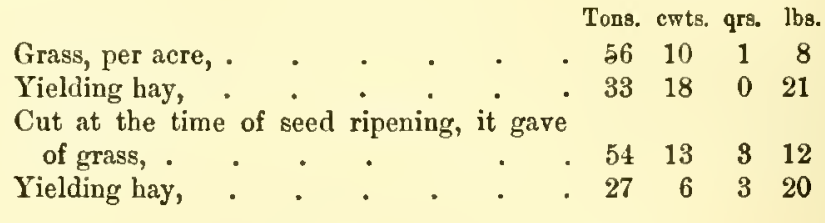

FLAT-STEMMED MEADOW GRASS

(Poa compressa).

Creeping-rooted; florets obtuse, the lower ones webbed. Lower palea with three hairy or silky veins.

Charles Johnson is inclined to believe that this is only a variety of Poa pratensis. Indeed, he believes the latter to be not only the type but the origin of all the stoloniferous forms of the genus. He adds that it is said to be liked by cattle, and produces its foliage early in spring; but the yield is too scanty to prove of much service.

Dr. Parnell says that, were it not for the small quantity of foliage this grass produces, it would rank as one of the most valuable, as it shoots its leaves early in spring, and possesses a large share of nutritive properties.

Dr. Vasey says that this grass has been sometimes confounded with Poa pratensis, from which it differs in its flattened, decumbent, wiry stems, its shorter leaves, and shorter, narrower, and more scanty panicle. Very contradictory accounts have been given as to its agricnltural valuesome denouncing it as worthless, and others entertaining a good opinion of it. It thrives well on clay, or hard-trodden and poor soils. One report says:-It is certain that cows fed upon it both in pasture and in hay give more milk and keep in better condition than when fed on any other grass. Horses fed on this hay will do as well as when fed on timothy hay and oats combined.

These discrepant opinions may be due in part to having mistaken the Poa pratensis for this grass. It is probably a nutritious grass, but from its spare yield can hardly attain much favour for a hay crop.

\section{ANNUAL MEADOW GRASS}

(Poa annua).

Dr. Parnell says it is one of the commonest of all our grasses-flowering throughout the whole summer, and growing on any kind of soil and in every situation. It produces an early herbage, which cattle are foud of, especially cows; but being an annual, and often destroyed by a continuance of dry weather, it is unprofitable to the farmer for cultivation.

The seeds do not possess wool at base of the floret, and are never to be found suspended from the calyx, as may be observed with some of the other meadow grasses.

\section{WOOD-REED MEADOW GRASS}

(Poa sylvatica, or Festuca calamaria).

The root is perennial, creeping, tufted; the leaves are broad, flat, and of a light green colour-roughish on both surfaces. It grows in damp shady woods of rich soil.

Dr. Parnell says that its broad, tender leaves, which are 
produced in great abundance, and are muclı sought after by cows and horses, render this grass worthy of agricultural attention.

\section{REFLEXED MEADOW GRASS}

(Poa distans, or Glyceria distans).

This is only mentioned here because its seeds are sometimes used to adulterate the other meadow grasses. As a grass it is said to rank amongst the most inferior of the British grasses for agricultural purposes.

\section{MILLET}

(Panicum miliaceum).

This is the brown and yellow millet of Southern Europe, and the Cheena of the Hindus.

Dr. Vasey says it has been cultivated in the United States to a limited extent for forage, and will thrive and ripen in the Northern as well as in the Southern States.

Charles L. Flint (another American authority) says that millet is one of the best crops we have for cutting and feeding green for soiling purposes, since its yield is large, its luxuriant leaves juicy and tender, and much relished by milch cows and other stock. For feeding to cattle it should be cut in the blossom, as, if allowed to ripen its seed, the stalk is no more nutritious than, probably, oat straw.

\section{REED CANARY GRASS}

(Phalaris arundinacea).

Flowers second week of July, and ripens its seed about middle of August. Flower-stems vary in height from 2 to 5 feet.

Charles Johnson reports that it creeps widely at the root, but, unlike many grasses of similar habit, tends to form dense tufts, which contribute greatly to the consolidation and support of the banks on which it grows. It is one of nature's pioneers; and though exceedingly valuable in habitats of its own selection, is of small economical importance elsewhere. The herbage is too coarse and rigid to be liked by cattle generally.

Dr. Parnell says it produces a large and early crop, and will bear cutting three times during the summer. From the coarseness of the foliage cattle are said not to be fond of it. It is best suited for tenacious clay soils, and grows naturally by the sides of rivers and standing pools.

Dr. Stebler's opinion is that it is not at all suitable for pastures, but on wet soils it has considerable agricultural value, considering that in such situations it gives a large yield of vegetation which, if cut before the flowering period, is freely eaten by cattle, and is especially useful as forage for horses. It is not affected by extremes of temperature, nor by inundations; and though growing to a considerable height, does not lodge. It receives no injury from the overshadowing of trees, \&c., and when once establislied it never dies out. Its chemical composition is somewhat similar to that of maize. When young it has a sweetish taste, due to the sugar in its composition; but if not cut till after the flowering period its produce is only fit for litter. Owing to its extensive rootsystem, and numerous and vigorous underground stems, it is useful for consolidating the borders of rivers and lakes, and for rendering marshes and mosses more firm and accessible. It is sometimes used in mixture with fiorin for moist land.

Curtis says that where great quantity of produce is the object, he would recommend planting this and tall fescue in marshy ground.

Sinclair says that the superior nutritive matter which the striped reed canary grass possesses recommends it to the notice of occupiers of tenacious clayey soils. The foliage cannot be considered coarse when compared with other grasses which afford a produce equal in quantity. Dry straw is a much coarser food than the hay made from this.

J. C. Morton mentions the case of a Mr. Black, who cultivated it on the home farm of the Duke of Buccleuch at Dalkeith, and who had a high opinion of its merits, having invariably cut it earlier than clover or ryegrass in the spring, for feeding horses as well as shorthorns and Ayrshire dairy stock.

The Seed.-From 20 to 25 lbs. of its seed will be sufficient for an acre, but even lalf that quantity may be made to do, as the rapidly-spreading roots of the young plants will soon fill up all the interstices.

At Woburn, the variegated variety, grown on a strong tenacious clay, gave of grass per acre-

$$
\begin{aligned}
& \text { Cut at the flowering period, . } \quad \begin{array}{cccc}
\text { Tons. crts } & \text { qrs. lbs } \\
\hline & 15 & 3 & 11
\end{array}
\end{aligned}
$$

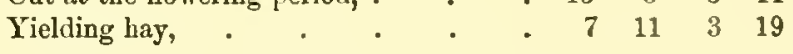

GREEN BRISTLE GRASS

(Setaria viridis, or Panicum viride).

This is an annual, flowering in July and until end of autumn.

Charles Johnson says it would be a valuable grass to sow in game-preserves and warrens, hares and rabbits feeding upon it with engerness. It will flourish in the poorest and driest of light soils-indeed, in almost any medium (water and shifting sand excepted) 


\section{THE CLOVER S.}

\section{RED CLOVER.}

Seed weighs $64 \mathrm{lbs}$. per bushel. Standard of germination, 90 per cent. (Some sepdsmen guarantee 95 per cent.)

Dr. Stebler says very justly that this plant has had a considerable influence on, and is of general interest in connection with, European civilization. By greatly augmenting the supply of meat necessary for the support of human life, it indirectly has been a source of energy by which science, industry, and comnerce have received an immense development. For forage and house-feeding during the summer it is of more importance than any other forage plant-although it does not succeed everywhere, and requires more attention and more skill than the majority of other forage plants. It can be depended on to prosper only in well-prepared fertile soils, on which clover has not been grown for several years.

Of red clover there are two principal varieties--viz. (1) Trifolium pratense (Linn.), var. perenne (otherwise, and perhaps more correctly, Trifolium pratense, var. pratorum); this variety is sometimes erroneously confounded with one known commonly in Great Britain and Ireland under the name of cowgrass. (2) Trifolium pratense (Linn.), var, sativum.

Though of the two varieties the latter is capable of the greatest development, yet the former is most durable, and being endowed in a larger degree with capacity to adapt itself to variations of climate and of soil, a crop from it can be depended upon under conditions where the success of the latter would be doubtful. Nevertheless it is not always easy to distinguish one of those varieties from the other; and if the two varieties are cultivated together in the same field for some years, they do not in the end present any points of difference, and become of equal value.

The values of red clovers derived from different countries vary a good deal.

American red, which is largely imported of late years, gives a yield about equal to that of the average of European reds, but is less robust than they, and consequently offers less resistance to the variations of temperature and of humidity. Some interesting observations made at Copenhagen showed that the severe winter of 1878-79 killed three plants of the American clover for one of European parentage. In milder winters the American clover does not appear to suffer in any greater degree than the others.

English and Swiss red excel all others in regard to durability, size, and robustness of plant.

Styrian and Silesian red rank next after English and Swiss in respect to the qualities mentioned.

French red has neither the size nor robustness of the preceding, and is more delicate every way.

Italian red is very early, and germinates well, but exhausts itself quickly, and stands frost so badly that it often disappears the first winter.
Red clover in a green state, and while in full flower, contains 80 per cent. of water, which is 10 per cent. more than what the grasses contain; and when the clover plant is made into hay the proportion of water is 16 per cent. During the process of haymaking (by the ordinary process of saving) clover loses a quantity of its leaves. Now the leaves constitute at least a fifth of the total produce; and as they are at the same time the richest in nutritive matter of any part of the plant, it follows that the loss in question is very serious, amounting as it sometimes does to one-third of the feeding value.

The experience of all agriculturists goes to show that, in feeding with a view to the production of milk, clover in a green state has a decided advantage over an equivalent quantity of clover hay.

Common Red or Broad Clover.-Writing of this plant, Mr. Sutton says that it is quite unsuited for permanent pastures, but should form a large proportion of an alternate mixture. The prejudice against foreign seed, especially that imported from America and France, is well founded.

Soils.-The red clover plant succeeds best in rich loamy soil, also on good clays, and on soils of an alluvial nature. Bog or marsh land does not suit it any more than soils of a dry, sandy, or arid, chalky class. Peaty soil is also unsuitable, unless it has been dressed with marl or lime. It especially delights in a well-mixed soil, rich in vegetable matter, and containing a moderate proportion of marl or chalk.

Trifolium pratense perenne.-Under this head Mr. Hunter says :--It is the variety of red clover usually found in old pastures, is more durable than the common broad-leaved red, and suits medium and heavy soils better than light ones. It is of greater value for permanent pastures than the true cowgrass (except on light soils), being more productive and nutritious.

Mr. Sutton states his belief that perennial red clover originated in a cross between common red and the zigzag clover. The root of perennial red clover reaches down into the subsoil, thus enabling it to obtain moisture and nourishment in the hottest weather, when common red gives up from drought. This penetrating habit also affords a means of sustenance to the plant on land which is too poor to grow the common or broad red, and makes it desirable to increase the proportion of this seed for pastures on thin uplands. It does not begin to flower until at least ten days later than broad clover, and its more robust and solid stems remain succulent and eatable by stock long after broad clover has become pithy and withered. It fills up the gap between the first and second cuttings of broad clover, coming into use at a time when there is no other available green food for the horses of the farm; but it rarely gives a second crop of any consequence. It produces comparatively little seed from its single cr $\cap p$ (it is 
sometimes called "single-cut cowgrass"), and the seed of it is consequently high in price, and is rarely abtainable except from those who make its culture a study. It is an invaluable plant for permanent pasture. Its presence in a pasture at midsummer, when alsike is giving up, is of greatest service, and although it does not produce a good crop for the scythe, it yields a quantity of excelient feed.

Cowgrass, in Berks, Oxon, Hants, and a few other counties, means a perennial variety giving only one cutting per annum, coming into bloom fourteen or twenty-one days after other red, and having a solid stem (though this peculiarity is not invariable). Grown for seed it gives on an average $3 \mathrm{cwts}$. per acre.

Single-cut Cowgrass.-One grower says it produces very large crops on good land. He has had it so luxurious as to measure 5 feet long, but in such cases it exhausts itselt in one season.

Dr. Masters, F.R.S., thinks English red and single-cut cowgrass are the same species - i.e. both might have been developed from the same stock; but as to Trifolium medium, he does not believe it could have sprung from the same stock. (See "Improvements of the Plants of the Farm," Journal of Royal Agricultural Society of England, vol. xx.)

I.I. Hunter thinks single-cut cowgrass only a variety of red clover, which flowers about three weeks later than the common species, and would be more correctly named late-flowering red clover

\section{TRIFOLIUM MEDIUM}

(Marl-Clover or Cowgrass, sometimes called Zigzag Clover).

This is the true cowgrass of botany, but does not exist in the trade. It is not cultivated, and is only found in a wild state and in botanical collections. It has zigzag stems, and the flower-heads are usually two inches distant from the uppermost set of leaves. As pointed out above, Dr. Masters thinks it could not have been developed from the same stock as red clover.

Mr. Carruthers says it is not in commerce. Its roots are creeping, and the stem takes a fresh turn at every leaf, which gives it a zigzag appearance. Its produce is said to be less than that of red clover; and though it may not be of equal value in alternate husbandry, yet it is perhaps a more importaut ingredient in permanent pasture than common red.

For the production of seed it is best to cultivate clover in a light and dry soil than in one that is moist or strong. In the latter the plant is liable to shed its seed, and carries besides a larger number of barren flowers. The seed is asually taken from the second crop, as the luxuriance of the first crop renders it more likely to shed its seed. Also, a number of objectionable plants usually grow up with the first crop, and their seeds get mixed with the clover seed.

The weed seeds most commonly found in red clover seeds are those of the ribgrass, but this is quite easily distinguished. Sometimes dock seeds are found, also those of the clover dodder. The latter is a most destructive parasitical plant, the seeds of which are very difficult to detect, being so small and of an earthy brown colour, resembling minute pieces of soil. In season 1877-78 the seed-testing station in Switzerland found that 46 per cent. of the samples of red clover submitted to them had more or less of dodcter. Year by year, however, the percentage of samples containing dodder is growing smaller; still it must be remembered that it is only the better class of seeds that finds its way to the seed-testing station. Those who have inferior samples to vend take care to keep them out of the reach of testing stations. The clover dodder (Cuscuta trifolii) is the most terrible enemy of the clover plant. It is sown with the seed, and develops simultaneously; it winds its liair-like stems round the clover plant (as explained already), and fixes itself on to it by means of suckers, which extract the sap from the clover plant. The roots which the dodder possesses in the early stages of its growth wither after a while, and then the parasite is altogether dependent on the sap it draws from the clover plant, in consequence of which the latter wastes and perishes.

Clover Sickness. - The phenomenon called clover sickness arises, according to Liebig, from the deficiency of mineral matter in the subsoil, which opinion is sustained by Kutzleb, whose experiments have demonstrated that it is brought about by the want of a sufficient proportion of potash in a soluble state in the subsoil. On soils which, by their composition, are not suitable to the culture of this plant, it should not be planted at shorter intervals than from nine to twelve years, if a satisfactory crop is to be expected. Experience has also proved that red clover is more likely to fail when it succeeds a plant of the same family, such as the pea, bean, vetch, Trifolium incarnatum, \&c.

Manuring.-At Rothamsted ammouia salts had the effect of eliminating this plant from the various plots to which they were applied, whether in conjunction with mineral manures or alone. Nitrate of soda also diminished the growth.

\section{ALSIKE CLOVER (Trifolium hybridum).}

Weight per bushel, 65 lbs. Standard of germination, 95 per cent.

Mr. Sutton says of this clover that it flourishes on the same deep moist soil as timothy, and makes an excellent companion to that grass; but it is equally suitable with tall oatgrass, Italian ryegrass, and cocksfoot. For meadows it is far superior to white clover, as it produces a crop tall enough for the scythe, and materially adds to the total weight of hay. It also produces more keep, and is better relished than white clover.

Mr. IIunter sums it up as follows:- It grows as tall as red, and produces abundant crops. Nutritive value almost equal to red, and grows on some soils where red will not succeed.

Dr. Stebler's opinion is that alsike lasts longer than red clover. Its average duration is three years, but it has been known to give a fair return for five years, and in meadows where sown with other grasses endures even longer. It ean 
be cultivated on soils where other clovers do not succeed, and gives an abundant produce of such chemical composition as shows it to be a forage plant of first-class quality. The fact of its having been for a long time cultivated in the north of Europe shows that it is capable of resisting cold well. It suffers little from late frosts; and humidity, instead of being injurious, is advantageous to it. It is the only species of clover that succeeds under irrigation, and it will grow on clover-sick land if well manured and in good condition. On the other hand, it is not well qualified to resist long drought, as its roots do not go deep It is more leafy than red clover, and as it contains a little more water in its composition it is more difficult to make into hay. It is at the flowering season that it presents the largest proportion of nutritive elements, and that period is therefore the most suitable for cropping it.

On account of the slightly bitter taste of alsike, it is not eaten so readily as white clover is; but its feeding value, according to chemical analysis, is fully equal to that of white. Its yield is larger and of better quality when sown in mixture with other plants than when used alone, as the other grasses support the clover plant and prevent it shedding its leaves. The best grasses for mixing with alsike, named in the order of their merit, are timothy, cocksfoot, English ryegrass, tall oatgrass, and Italian ryegrass. Those who have been in the habit of sowing red clover by itself should try instead a mixture of 50 per cent. red, 25 per cent. alsike, and 25 per cent. timothy.

Soils.-Alsike can be cultivated on the strongest clay soils -even where the subsoil is impermeable - as well as on peaty soil, and on ground so moist that other clovers will not grow there, provided always that such soils do not retain too much water.

The Seed.---In the alsike seed of commerce many samples contain a number of weed seeds of different varieties, and sometimes an admixture of trefoil seed. Of the weed seeds, the worst are clover dodder and ribgrass.

Alsike clover seed is sometimes uncertain as regards germination. The appearance of the seed is very little guide towards enabling us to guess what faculty of germination resides in it. It may have a beautiful fresh colour, yet be under-rine; or be of a dark glossy green, and yet be over-ripe and hard. In both cases the germinating power would be feeble. It follows from this that retail seed-merchants should make a point of ascertaining the percentage of growth of samples of alsike submitted to them.

There is a species of clover, very similar to alsike, called Trifolium elegans, which, according to Dr. Stebler, sometimes grows among alsike, and has been known to produce a peculiar disorder in horses that have eaten of it. Whether it produces the same or any injurious effect on horned cattle has not been as yet ascertained.

WHITE OR DUTCH CLOVER (Trifglium repens).

Weight per bashel, $65 \mathrm{lbs}$. Standard of germination, 95 per cent.

Dr. Stebler gives it as his opinion that this species is indispensable for low-lying pastures. Compared with red clover its produce is not so large, but it is richer in nutritive matter. It will succeed in land of inferior value, is not injured by grazing, and is less sensitive to atmospheric influences. It is regarded as a valuable bottom plant in pastures, but in certain soils it becomes excessively luxuriant and smothers the other plants with its creeping stems and thick foliage; in such cases it is so hurtful as to almost deserve to be characterized as a weed. Although its fibrous roots extend but little below the surface, yet it is enabled to stand drought well by the aid of the principal root of the parent stem, which penetrates deeply and keeps up the supply of sap in times of drought.

Wet seasons favour the development of this plant; and, in general, a climate that is warm and humid is best suited to its nature. It succeeds well even on drained bog or marsh land.

Mr. Sutton says it does better in poor land than red clover; all cattle eat it with relish, but it is less useful for the production of milk than of Hlesh, and is of special service in fattening sheep. In early spring it produces very little food, and the plant is so dwarf that it is practically useless for cutting, so that alsike should take its place for a crop of hay.

Manuring.-In the list of mineral matter which white clover extracts from the soil, potash and lime are the most prominent. The application of ammonia salts alone reduces the plant to insignificant proportions, and nitrate of soda is little better in its effects. Both these result in a smaller growth of white clover than when the land is left unmanured. Mineral manures-potash especially, with a small quantity of nitrate-considerably angment its growth; so also do dressings of marl or vegetable ash.

It has often been observed that when land has been suitably top-dressed, a vigorous growth of wlite clover has made its appearance where none had been previously perceived. In such cases its roots and creeping stems have lain almost dormant in the soil, and escaped notice until re-invigorated by the manurial stimulus.

The application of liquid manure is especially effective in increasing the growth of white clover. Not only does it yield to the plants already in existence such nourishing properties as are exactly suitable, but it also conveys to the land a considerable number of white clover seeds which have passed uninjured through the digestive organs of the cattle. An examination of the dry residue taken from the bottom of a liquid-manure tank showed that about $2 \mathrm{lbs}$. of such residue contained no fewer than 11,816 seeds (or about one-fourth of an ounce) of white clover, of which 62 per cent. were capable of germinating.

The Seed.-There is a great deal of inferior white clover seed in the market. Buyers do not appear generally to take so much interest in the appearance and quality of white clover as they do with reds, consequently the quantity of old, brown, withered seed that finds a market somewhere is far larger than one would wish who had the interests of agriculture at heart. Very few samples are entirely free from sorrel, while 
a good proportion of samples contains the seeds of that weed in strong proportion. Sorrel in the husk is of a brown, earthy colour; and shelled it is a small triangular seed that glistens: in either state it is easily recognized, and samples containing it should be promptly rejected. Another weed-seed that appears prominently in many samples of white clover is ribgrass. This is not quite so objectionable. Yet one does not want to pay the price of white clover for ribgrass seed-the latter being worth commercially only about one-tenth the price of white clover. The seeds of corn csmomile are also found in many samples of white clover; but it is stated that a little of this plant may be of advantage in a pasture or meadow on account of its aromatic properties. Among the other impurities, which are objectionable in a minor degree only, may be enumerated the seeds of suekling clover, haresfoot clover, and trefoil or yellow elover.

\section{COMMON YELLOW CLOVER OR TREFOIL}

(Afedicago Lupulina).

Weight per hnshel, 64 lbs. Standard of germination, 95 per cent.

The "Agrostographia" of Lawson says that this is a fibrous-rooted biennial or sub-perennial, and that it grows in dry pastures. Although its produce is bulky, cattle are not generally fond of it either in a green or dry state.

Mr. Sutton says trefoil starts so early in spring as to give a bite before any other clover, and it flowers ten or fifteen days in advance of the red variety. Chemical analysis shows the herbage to be nutritious. It grows eompactly and helps to make a good bottom to a pasture, but its procumbent habit of growth prevents it from having much value for the scythe, and there is no aftermath worth speaking of.

Trefoil is seldom sown alone, but frequently in company with white clover. The following combine well with trefoil in affording early and valuable herbage-viz. foxtail, sweetvernal, and Poa pratensis.

Dr. Stebler's opinion is that trefoil should never be sown by itself, and only in mixture intended for a period not longer than two years. Whilst it is not very produetive nor very durable, it is nevertheless very useful for certain soils in which red clover would not succeed. It should, lowever, be confined to sucl soils, even though it is true that in resard to nutritive matter it takes a higher place than red clover. It is more adapted for grazing purposes than red clover is, but is not so well suited for meadowing, as its stems lie close to the ground and escape the scythe. Its roots do not go deep, but confine themselves to the top spit of the soil, therefore the nature of the subsoil is not of much importance where this plant is concerned. Altlough possessing a slightly bitter taste, it seems to be eaten with relish by cattle, and it is said that it imparts a nutty flavour and a rich yellow colour to the butter. Nevertheless the balance of evidence is against employing it in pastures on good land, particularly as-owing to its overshadowing and partly creeping habit-it stifles better plants than itself.

Manures. - A dressing of fresh manure does not serve trefoil, but an application of certain artificial fertilizers, particularly those with a large proportion of potash or of phosphoric acid, causes a surprising development, even in cases where the plant was previously struggling for existence.

The seed comes to hand generally more free from impurities than that of any other sort. This can be accounted for partly on the ground that the trefoil plant smothers all other vegetation, and its seeds can therefore be gathered pure, and partly because it is so cheap that it is not worth while adulterating it. Trefoil seed possesses great vitality, and will grow a fair percentage even though several years old.

\section{OTHER FORAGE PLANTS.}

LUCERN (Medicago sativa).

Weight per bushel, 64 lbs. Standard of germination-average, 98 per cent. of pure seeds, of which 90 per cent. shonld be capable of germinating.

Its height is about 3 feet, and it flowers in June or July. Root perennial, thick, branching, and penetrates very deep in to the subsoil-sometimes 10 or 12 feet.

A writer in a recent number of the Agricultural Gazette says that lucern will grow almost anywhere if there is a system is adopted. This writer says that between May and depth of soil; but it requires a fine tilth and a very gentle November he mowed over the entire breadth four times at covering. Once successful, it may be maintained for years least, and found no subsequent treatment required beyond with fair manuring and with very little labour in boeing. It hoeing or pecking between the rows to keep under the grass is one of the most advantageous grasses that we have. It and weeds. Roots 13 feet long bave been measured by the yielded an immense crop at the beginning of the summer, side of a sand-pit.

and might bave been cut a second time three weeks ago American authorities say that in California (especially in (letter dated 30th July), when it was fully ready and almost the southern part of the State) lucern-under the name of 3 feet high, but is being given to cattle, thus maintaining alfalfa-is cultivated largely for hay, and large crops are their milk and their condition at the same time. $3 \mathrm{~N} *$
J. C. Morton says that nothing is so fatal to lucern as to allow sheep to graze it, as they mutilate the crowns of the plant to such extent as to render the plantation useless. Ten pounds of seed is enough when sown in drills with the rows, as they ought to be, at least 12 inclies apart. The quantity must differ essentially according to the distance of the drills, and it must be the highest where the broadcast made by irrigation. It succeeds well in Montana. In some 
parts of Utah scarcely anything else in the way of forage plant is cultivated. The same may be said of New Mexico. It is also cultivated largely in Texas, and does very well.

Dr. Stebler's opinion is, that when green, and cut before the flowering stage, lucern gives a forage of the best qualityin fact, more nutritious than red clover of average quality. It is first-rate for milch cows; and is so rich in albumen or Hesh-forming materials that it answers well for mixing with fodder which is poorer in that substance-for instance, with chopped straw, \&c. It does well only on a free, deep, mellow soil which has been cleared of weeds, and suits to follow after a potato or root crop. It is sown at end of April or early in May, when no further fear of damage from late frosts. Some people mix red clover with the lucern, but Dr. Stebler does not approve of that, as the clover hinders the development of the lucern, and after two or three yearswhen the clover disappears-a large number of blank spaces are left in the field. In good land it comes to its full development in the second year. It commences to make growth at end of April, and gives good cuttings before, during, and after the red clover. At the end of from five to seven years the yield begins to diminish, and it then becomes advisable to break up the plantation at any time from thenceforwardalthough in some favourable situations it may be found growing on same soil from ten to twenty years, and even longer. As its roots go very deep, it can stand drought better than any other of the leguminous plants, but it is not suitable for climates of excessive humidity. Owing to its deep-rooting habit, it is the nature of the subsoil that has the most importance for this plant. It wants a subsoil that its roots can permeate. Those of a calcareous or marly nature suit it best, but clay land, with a compact subsoil, does not suit it at all; neither does land that contains an excess of moisture. The deeper the subsoil the better does lucern succeed.

Manuring.-It is not recommended to dress the land with farm-yard manure just before sowing lucern, as this favours the growth of weeds, which become very injurious to the young plants. If the latter are slow in developing, it will be found advantageous to apply a dressing of nitrate of soda. The ash of lucern contains large proportions of potash, lime, and magnesia.

The seed of commerce is found sometimes to contain grains of dodder. In view of the great injury this vile parasite causes the crops of lucern (and of clover), it is of the utmost importance that buyers should always look for a guarantee that the seed they buy is free from dodder. It is also stated that the seeds of trefoil (common yellow clover), as well as the seeds of two or three other more or less useless annual varieties of the Medicago family, are used for adulterating M. sativa.

According to M. Vilke, lucern takes between 250 and $350 \mathrm{lbs}$. of nitrogen per acre from the air, which would be a sufficient supply for four times as large an area under wheat.

Sir John B. Lawes (whose Rothamsted experiments are known and appreciated wherever improved agriculture has obtained a footing), however, in commenting on this point, is not sure that this nitrogen is not derived from the subsoil. There is (July, 1886) a field of lucern at Rothamsted which is seven years old, and yields from $250 \mathrm{lbs}$. to $350 \mathrm{lbs}$. of nitrogen per annum; but the roots of the lucern have been followed into the chalk, some 8 or 9 feet below the surface. [The land had received mineral manure, but none of nitrogenous for thirty years.]

GOAT'S RUE (Galega officinalis).

This is a leguminous plant, growing to from 2 to 5 feet high, well furnished with foliage.

Messrs. Carter \& Co., who took an interest in recommending the culture of this as a forage plant, say of it, that its perennial habit and robust growth are points worth attention, as seeming to imply abundance of forage with little labour. It is also useful for green-manuring, as it contains much nitrogen. It stands drought remarkably well, and has been successfully used as a forage plant in the south of France, where its only drawback-viz. a certain peculiarity of flavour - has been overcome by perseverance in the tuition of the stock.

From April till June is the time to sow, at the rate of 24 to 30 lbs. per acre broadcast.

Another authority says it is an excellent forage plant for warm sheltered situations, and succeeds in such places on dry and even poor soil, provided it has depth, and that the subsoil is free from moisture. Its long root enables it to resist dronght well, and as it draws its support mostly from the subsoil, it can be grown on the warmest soil. It possesses a similar temperament to that of the lucern, but does not require the same manurial dressings, and on that account is found on the Continent a very useful and durable plant in sheltered places amongst mountains, to which manure could not be carried. It is most generally used as a green forage, as it is difficult to dry and save. It gives two cuttings even in the first year, if sown in the spring. [A sowing made the 4 th of May was in flower the 21st of July.] The second cutting is almost as large as the first, and it makes its second growth quicker than sainfoin, but not so quickly as lucern. It should be cut when the leading branches are beginning to flower, as up to the flowering period the plant remains soft and succulent, but afterwards becomes hard, and is not voluntarily eaten by cattle.

It should be sown in spring without a crop, and without mixture with any other seed. The best way to plant it is in lines, so that the ground around the plants can be kept clear of weeds.

Analysis shows that the Galega furnishes a very nutritious forage. It is rich in albumen, showing 3 per cent. more of it than either sainfoin or red clover.

PRICKLY COMFREY (Symphytum asperrimum).

Caucasian prickly comfrey is a distinct plant from the common comfrey (S. officinale). Sutton's Farmer's Year- 
Book says :-This forage plant is rapidly increasing in favour, and although we do not agree with all that has been said in its praise, yet we believe the plant to be valuable for giving a supply of green food in hot and dry seasons. The long roots, which penetrate a great distance into the ground, enable it to obtain moisture which lies beyond the reach of ordinary plants. Prickly comfrey will succeed in almost any soil, but is especially valuable on soils of a dry or sandy naturc. It is very hardy, gives an early cutting, supplies a constant succession of green food, and is permanent. The plant is cultivated by dividing the roots, and spring and autumn are the best seasons for the operation. Instead of 24 or 30 inches each way, we recommend from 16 to 18 inches only as the most profitable distance. The roots should be covered with about $1 \frac{1}{2}$ or 2 inches of soil. It is very important to keep the ground clean and free from weeds. The cutting should commence early, and be frequently repeated, that the plant may not run very much. It must certainly be done before the bloom appears, for the leaves are most relished when in a young state. As many as five heavy cuttings, each 20 tons per acre, or 100 tons per acre, in one season have been obtained by good management. We recommend prickly comfrey especially for small occupations, as few crops can be more easily grown, or prove so useful to those whose live stock consists of a horse, cow, and a few pigs.

Mr. Phillips, a recognized authority on comfrey, says :It may be planted all the year round, excepting when the ground is frost-bound. The sets planted early in autumn almost save a season, as they become somewhat established before winter, and form crowns for the next season; those planted in spring and summer rush into inmediate productiveness. All kinds of land suit comfrey, but it thrives best in rich moist loam, with plenty of manure, especially liquid manure; it loves warmth and moisture. Dig or plough the land to a fair depth (if double-dug or subsoiled all the better), working in a heavy dressing of manure. If you give comfrey a double dressing of manure you will have a double crop, and only one rent to pay; on poor land, where manure is scarce, you will get a greater crop of comfrey than of anything else you can grow; and when once planted it is there for ever, only requiring a heavy dressing of manure to be dug in every season. As one or two confrey-growers seem to have had a little difficulty in getting their stock to eat it, it may be well to state that, in feeding it to stock for the first time, only a little should be given, and not that till it has been allowed to stand for a few hours after cutting, so as to allow the prickles on the under surface of the leaves and along the stalks to wither slightly; or the young leaves only may be given at first.

Sets can be obtained for $10 s$. per thousand. About 5000 sets will plant an acre if planted a yard apart each way.

Mr Rochford, of Nenagh, Ireland, says:-It has now been planted in about twenty places in the Nenagh district, and there is sufficient evidence to prove beyond a shadow of doubt its great value as food for dairy cows and stores for horses, sheep, and pigs. It can be used early in May, thus saving other expensive food, and the last crop of the season comes in during Scptember, and is available up to the middle of October. 'There is no difficulty in preventing it from spreading beyond the area on which it is planted if proper means are taken, but it is very difficult to get it out of land in which it has becn planted.

The two English varicties of comfrey may be distinguished from the Caucasian by the colour of the blossoms. The English varieties have flowers of a yellowish-white tinged witl green, and occasionally pale purple flowers will be found on the same stalk with the greenish ones. The Caucasian flowers, on the other hand, are all purple.

\section{SERRA DELLA}

(Ornithorpus sativa).

This is an annual plant frequently cultivated in Northern Germany. It is there considered one of the most important plants for good light soils. Its nutritive value is considered equal to that of red clover, while its produce is larger. It gives good results, except on land that is too heavy or too poor. On very light land it is considered best to sow it with hard fescue. Cattle like its produce either as hay or green fodder. It is usually sown in spring-from middle of MIarch to middle of April-sometimes alone and sometimes in a corn crop (oats or rye), and furnishes after the removal of the corn crop a good cutting or pasturage. The quantity of seed required is about equivalent to $30 \mathrm{lbs}$. per English acre.

\section{ANTHYLLIS VULNERARIA.}

This is a forage plant much nsed in Northern Germany for soils too light for red clover. It is cultivated both for mowing and grazing-does not stand more than one year's mowing, but in a pasture will continue for three or four seasons. In summer it fills the gap in the fodder-supply between the first and second cutting of red clover. As a resister of drought it will compare even with sheep's fescue, but on arid soils its leaves become somewhat woolly. It is a very hardy plant, resisting the heat of summer as well as the cold of winter. As it is almost insensible to atmospheric influences, it is of very rare occurrence for it to fail, and then it gives a sure, though not a large, return. It is not recommended for land that will grow clover, but is very useful for soils on which clover does not succeed, and where serradella or yellow lupins give but a feeble and uncertain return. Horses do not care for it; but sheep, goats, and horned cattle eat it greedily. If one wishes to have two cuttings in the season, it is necessary to take the first before the flowering stage; but if only one cutting is wanted, and the second crop to be fed off, it is best to cut it when in full flower, so that the second growth may consist of leaves without flower-stems. The proportion of nutritive matter in cured anthyllis is larger than in clover hay of average quality. 
GORSE, WHIN, OR FURZE (Ulex Europreus).

Standard of germination, 70 per cent.

J. C. Morton says it is a nuisance or weed in our hilly pastures when allowed to attain the size of a bush; but considered most valuable forage, and extensively collected or cultivated as such, in Brittany and other provinces of the West of France, and well wortlyy of attention in our own western counties.

From dry sandy soils, where turnip husbandry is unadviseble, a large quantity of useful fodder may be procured by the cultivation of this plant; but, excepting where climate, or the steepness of the land, or the expense of any attempt to improve the soil, forbids the adoption of the alternate husbanclry, its cultivation does not offer any advantages sufficient to warrant its adoption. In North Wales and in many parts of Ireland the horses of the farm are maintained upon it almost wholly during the winter months, receiving about 40 lbs. daily each of the crushed two-year-old shoots. It has also been found useful for dairy cows, along with hay, during the winter and spring months; and as for sheep, the experience of many a northern flockmaster can testify to the merits of gorse as food.

It may be sown from February to Mlay, in drills one foot apart, with or without a light corn crop. Sow $20 \mathrm{lbs}$. of seed per acre for cover, or $25 \mathrm{lbs}$. for forage. It is better to sow in drills than broadcast, as the weeds can be got at more easily under the drill husbandry. In the second autumn after the sowing-having beels cleaned at intervals during both summers-the crop will have attained a growth rendering it worth cutting.

\section{MUSTARD (Sinapis)}

This is one of those coarse, quick-growing plants with widespreading leaves which obtain a very considerable portion of their nourishment from the atmosphere; hence it may be considered an ameliorating crop, giving back to the soil more than it takes from it. Ordinarily it is of trifling value as forage; but the failure of other plants may make it valuable for this purpose, and at anyrate it assists in the preparation for grain crops. It may be sown with some advantage for autumn feed, or it may be taken as a second crop after vetches, early pease, \&c., when, from the season being too far advanced, it is impossible to grow anything of greater value.

The white mustard (Sinapis alba) is the variety grown for the purpose of forage or green-manuring. If sown or drilled at rate of one to two pecks per acre in last week of July or in August in a tolerably favourable season, it will be fit for ploughing-in or folding-off in two months from time of sowing. Sheep are generally healthy when feeding upon it, but make little progress if kept to it alone. The experience of heavyland farmers in Suffolk is in favour of sowing about a peck of white mustard on the long fallows in August or early in September, and ploughing-in the herbage about six or eight weeks from time of sowing. The effect upon the barley crop is considered by practical farmers as equal to half a coat of farm-yard dung. (J. C. Morton, abridged.)

\section{CRIMSON CLOVER (Trifolium incarnatum)}

This extremely useful forage plant is pretty extensively grown in England, particularly in the southern counties, where it is sown on stubbles immediately after removal of the corn crop. It is also sometimes sown on bare patches of spring-sown clover, and may be sown up to the middle of September, or might even do well up to October; but that would in a great measure depend on the kind of winter following the sowing.

Treatment.-According to J. C. Morton, the only requisite preparation of the land is a course of harrowing, just sufficient to stir the surface soil so as merely to facilitate the covering of the seed. On very stiff soils shallow ploughing is sometimes resorted to, but as a general rule the young plants stand the winter and thrive best when the soil is left in an unloosened state. When so treated the crimson clover forms excellent feeding for horses and cattle in the early part of the following season; or it may be finally cut in June for hay, in time for late turnip-sowing, or for fallowing the land preparatory to wheat or other crop.

Soils.-It does well on a variety of soils, but a moderately stiff deep soil suits it admirably, and if at all disposed to be loamy all the better.

Seed required.-If sown broadcast and alone, an acre will require from 18 to $24 \mathrm{lbs}$. of seed; sown in mixture with Italian ryegrass, the allowance is $16 \mathrm{lbs}$. clover to one bushel Italian. If sown in drills, at from eight inches to a foot apart, about $12 \mathrm{lbs}$. seed will be required.

\section{COMMON VETCH OR TARE (Vicia sativa).}

This is a well-known forage plant of the leguminous family, and is universally cultivated over Europe and a great part of Asia. There are several varieties known, the most important of which are the winter vetch and the spring vetch, differing more in their physical constitution adapting them to these different seasons, than by any tangible external characters. They are supposed to have acquired their different habits of growth and ripening simply by having been sown respectively in spring and autumn.

Tares form a most valuable green crop, and will grow in almost any soil; but the best soils for their growth (according to Morton) are clayey loams. On poor clays it is customary to sow considerable breadths, either feeding them off with sheep or mowing for summer-soiling in foldyards-this course being an admirable preparation of the land for wheat. Green tares, according to chemical analysis, are about equal in nutritive value to the better sorts of clover. As live stock of all sorts are very fond of this green food, there is a danger of colic being produced from overloaded stomachs; consequently, when tares have grown too succulent or are overcharged with moisture, they should be mown some hours before being given 
to the animals, or mixed with straw and hay, or passed with these dry foods through the chaff-cutter.

When intended for hay, tares should be left standing until the flowers have for the most part given way to the pods, and some of the seeds become well formed. The crop is then ready for the scythe. When well saved it forms excellent fodder, surpassing meadow hay in nutritive power; but if saturated with rain it becomes injured more than other grasses. The produce may yield about three tons of hay per acre, but is commonly coarse in quality.

The time of sowing, for winter tares, is from the beginning of October to the middle of November; for summer tares, from the beginning of March to the end of June, according to the purposes for which they are intended. For spring sowing use three bushels of tares and one bushel of oats, and for winter sowing three bushels of tares and one bushel of rye.

\section{COMMON RYE (Secale cereale).}

J. C. Morton says that rye is extensively and increasingly cultivated as a forage crop for early spring feeding. Cultivated as a grain crop it is an exhauster of the soil, but when fed off green the crop improves and ameliorates. As a green crop it follows wheat, and is itself succeeded by a late crop of turnips. For a green crop, the rule is to sow as thickly as possible-namely, from three to four bushelssometimes drilled, but more generally broadcast.

The chief use of rye as a forage crop is to supply food for sheep and lambs in the spring, in the interval that elapses after the turnips are consumed. This rye is sown on the root-fallow, and is followed by white turnips. Rye is peculiarly snited for animals giving milk, as ewes and milch cows; to the latter it may be given with the addition of straw chaff. As a soiling crop its chief advantage is its earliness. When in a forward state it is mown for horses; but the best method of applying it is by being cut into chaff with a mixture of straw and hay, increasing the proportion of green to dry fodder as the season advances. Green rye, from its laxative nature, requires this addition; and this application is useful as supplying a gradual change from the dry food of winter to the green food of summer.

From the toughness and pithy nature of rye straw it is little liked by cattle, and is of slight use as fodder. It is probably, however, the most nutritious of any, as containing a less proportion of silica and more organic matter. Cut into chaff, steamed, and given with a proportion of linseed, it would perhaps become more palatable to stock.

\section{COMMON SAINFOIN (Onobrychis sativa).}

The standard of purity, according to Dr. Stebler, should be 98 per cent., and of germinating faculty 80 per cent.

The root is perennial, somewhat woody, and penetrates to a considerable depth. The stems are nearly upright, and the height two to three feet; it flowers from June to August. This is considered the most important leguminous herbage and forage plant in the calcareous districts of France and England, and particularly on the poor, dry, thin chalky hills and downs in the South of England. The usual period of duration of sainfoin in a profitable state is from eight to ten years in chalky soils, and seven or eight in those of a sandy or gravelly nature. The duration of the crop may, however, be increased by judicious top-dressing. A very judicious method of raising this plant, which is practised in some parts, is to sow it with about half the quantity of barley or other grain used for a full crop, which gives it the advantage of being shaded and kept moist during the first summer without weakening the sainfoin plant.

Mr. Sutton strongly urges that, instead of sowing sainfoin alone, it should be used as a predominant constituent in a mixture of grasses and clovers for three or four years' ley. The sowing of sainfoin alone, he says, is an expensive and more or less a precarious proceeding. It is by no means certain to produce a plant, but combined with strong-growing grasses there is less risk. Again, the grasses keep down weeds and prevent the growth of couch and other pests which almost invariably overrun a pure sainfoin ley after the first two years. In Norfolk and some other of the Eastern counties, sainfoin takes the place of red clover, and is rarely allowed to remain down more than two years-generally only one. Against this practice nothing can be urged; but the method adopted in Berks, Wilts, Hants, and Oxford of putting down sainfoin alone for four or five years has grave disadvantages.

Dr. Stebler reports that this plant has proved a great boon to certain districts in Switzerland, and that, although best suited to warm climates, it does fairly well even in those cantons that possess a comparatively cold and harsh temperature. By this plant, he says, it becomes possible to turn ground to use which otherwise would be without value. It stands excessive drought, succeeds even without manure, and is of long duration. If sown too often in the same land, or at short intervals, the land gets "sainfoin sick," and refuses to grow it. As its roots descend to twice or thrice the deptlu that those of lucern do, the nature of the subsoil is of much importance to it. However unfavourable the surface soil may be, sainfoin will prosper if the subsoil is favourable, always provided that the surface soil is, at all events, sufficiently fertile to nourish the plants the first year so as to allow them time to push their roots into the snbsoil.

It prospers best in fertile land of a calcareous or marly nature, with a sunny aspect; and requires a subsoil which, without being humid, is sufficiently mellow to allow the roots to penetrate it. Compared with other plants the growth of sainfoin is slow. The yield is poor the first year and pretty good the second, but it is in the third year that the plant comes to its full development, after that the roots have established themselves in the subsoil. People make the first cutting when the plant is in full flower, as it loses its value soon after that period. When well established it is not so liable to injury from winter frosts as from the evil effects of wet cold 
summers. It lends itself better to the haymaking process than red clover does, loses less of its leaves in that ordeal, and as regards value as forage is superior to red clover. Sainfoin hay is not only nourishing, but is also health-giving or tonic in its effects, from which peculiarity it derives its name. It is especially beneficial to horses. The best crops to precede sainfoin are those which clear the soil of weeds and leave it in a. mellow condition. The best time to sow is in the spring-abont the end of March or early in April. It can be sown with a cereal, but this is not usually done, and is somewhat risky, unless the cereal is to be cut green. It is for the most part sown alone, and seldom in association with other grasses, as in such circumstances it is liable to perish.

The seed is very seldom adulterated, but in its natural state it contains many impurities, of which the most prominent are the seeds of the common salad burnet (Poterium sanguisorba)-the pimprenelle of the French-and seeds of the brome grasses. These are both easily removed, and the seed usually offered in Great Britain and Ireland is clean and merchantable.

\section{GUINEA GRASS}

(Panicum jumentorum).

We see this, and the two grasses which follow, sometimes referred to as strong growing grasses, giving a heavy produce which might be suitable for ensilage. The guinea grass is described by Dr. Vasey as a large vigorous perennial grass, attaining in good soil a height of from 6 to 10 feet. The leaves are 1 or 2 feet long, and frequently an inch or more wide-rough on the edges, and with a few scattered hairs on the surface. It is a native of Africa, but has been introduced into many tropical countries, and in the West Indies is extensively cultivated for pasturage. It has been introduced into Florida, but is not yet much known in the Southern States. It seldom matures seed in the United States, but can be propagated by dividing the roots, or by obtaining the seeds from foreign countries. If the roots are planted in March or April, it is said they will be ready for the first mowing by the end of May, and that mowing may be repeated every six weeks till frost occurs. It is too tender, Dr. Vasey says, to be cultivated except in the warmest portions of the States. He adds, further, that an analysis made by the chemist of the Agricultural Department showed this grass to be very rich in nutritive materials.

\section{SUGAR CORN OR SUGAR GRASS \\ (Sorghum vulgare; Sorghum halapense, \&c.)}

Dr. Vasey reports that Sorghum vulgare (known in North America as Johnson Grass) is frequently sown thickly for a forage crop in certain of the States, and in good seasons, with proper cultivation, furnishes a very heavy yield. Sorghum halapense was imported from Turkey to South Carolina in 1835 , and is highly valued by agriculturists in the Southern States. It is said to have been introduced into California from Australia, and is there known as evergreen millet. A Kansas farmer reports that he has tried it on very dry soil on an upland farm with very good results. It is reported to be perfectly hardy, rapid in growth, affording three cuttings in one season, and producing a heavy growth of aftermath for fall-grazing. Horses and cattle are fond of it, both in its dry and green condition. Probably no grass gives better promise for the dry and arid lands of the West. In Utah it has been cultivated under the name of Arabian millet grass.

\section{INDIAN CORN OR MAIZE}

(Zea mays).

The maize is a stout, erect annual, growing to a height of from 3 or 4 feet to 8 or 10 feet, according to the variety; the leaves are from 1 to 2 feet long and 2 to 3 inches broad. Grown for its grain, according to J. C. Morton, it has constantly failed in England as an object of permanent cultivation.

The common large maize is, however, sometimes grown for mowing, with great advantage in climates where the grain will not ripen. Its abundant produce and excellent quality as green fodder, especially for horned cattle, would make it worth a trial for the same purpose in this country.

\section{A P P E N I X.}

TO JUDGE SEEDS.

The quality of a parcel of seed is to be judged according to the following points-colour, weight, size of grain, purity, genuineness, and germinating faculty, and of these the three latter are the most important.

Purity is understood to mean freedom from seeds of any other species or variety, as well as from weed seeds, broken seeds, or dirt.

Genuineness means trueness to name.

Germinating faeulty means the proportion per cent. of true and pure grains that possess the faculty of growth. This is tested by taking a hundred grains from the bulk as they come, picking out and discarding the foreign matter-i.e. seeds of other plants or broken seeds, bits of dirt, \&c. (by counting these you get the percentage of impurity). Put the remainder--i.e. the true and sound seed-througl the process of germination, and ascertain how many seeds grow.

Colour.-New, well-saved seed has a fresh, bright, plump appearance. According as seed gets old it becomes faded, brown, and wrinkled, loses the plump appearance, and of course takes lower rank as regards germinating power.

Weight.-An important consideration in estimating the 
value of grass seeds is the weight per bushel of the sample, as there may be a very wide difference in different samples of a particular species-chaffy, unripe seeds weighing perhaps only one-third of what a prime, well-cleaned sample of the same species would show.

For instance, Italian ryegrass seed can be had as light as $8 \mathrm{lbs}$. to the bushel, and as high as $22 \mathrm{lbs}$. (in some rare cases even higher). Foxtail, according to Mr. Hunter, may vary from 5 to 12 lbs. per bushel, cocksfoot from 6 to 20 lbs., and meadow fescue from 10 to 28 lbs.

Grass seeds should therefore never be bought by measure, which is quite misleading. As a matter of course, light, chaffy seed will germinate badly, as the light weight implies the absence of kernel. As a farmer wants seed, and not empty husks, it follows that a knowledge of the weight per bushel is the next best thing to a knowledge of the germinating faculty.

In practice it is not easy for a seedsman to give guaranteed germinations in the hurry of a season, especially when, as in the case of seedsmen in country towns, they have to make up many small orders; but there is no difficulty whatever about ascertaining the weight per bushel, and grass seeds that approximate in weight to the standards given in this work should germinate well if pure and sound.

\section{CHEMICAL ANALYSES OF THE GRASSES.}

Undernoted will be found a table extracted from an extremely interesting and useful report on the grasses of the United States compiled by the United States Department of Agriculture. A study of the tables given in the abovenamed report shows clearly that the composition of the plant varies according to difference of soil, situation, climate, time when cut, and general environmeut, so that the publication of chemical analyses is of little use unless accompanied by descriptions setting forth all the above particulars. The conclusion the compiler of the report arrives at is, to use his own words:-" Species are not in themselves at all fixed in their composition, there being as large variations among specimens of the same as between specimens of different species." For instance, in the case of timothy grass, procured from different localities, the undernoted will sliow a wide margin of difference in some of the most important constituents of the plant:-

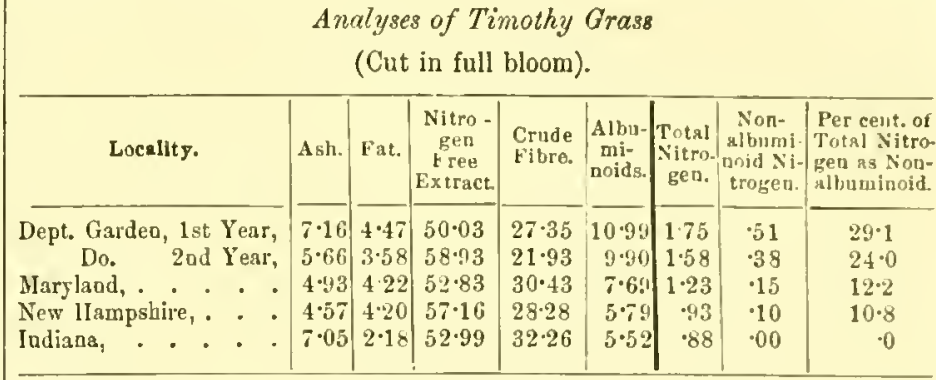

Even a superficial glance at the foregoing will show that in the grass grown in the Department Garden in the first year there is twice as much fat and albuminoids as in that grown in Indiana; and again, one cannot fail to be struck with the difference in the analysis of the timothy grown in the Department Garden in the second year as compared witl that of the first. A similar table is given showing the variations in composition of cocksfoot grown in different localities; also tables showing composition of the grasses cut at different periods of growth, which are lighly instructive, but too long for reproduction here. We have, however, compiled from these a table which will be interesting as showing the average and comparative compositions of some of the most important of the grasses:-

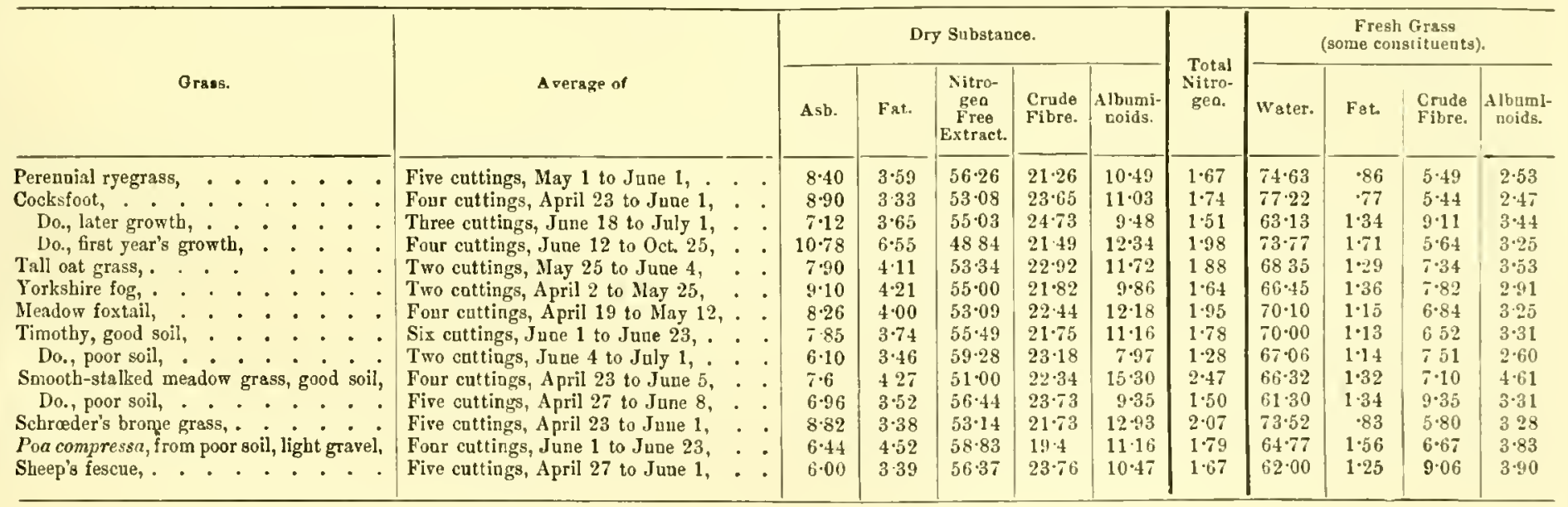

The detailed tables furnish data from which is derived the general conclusion that as a grass grows older its contents of water decrease, and so also does its ash, fat, and albuminoids, while there is an increase in the carbohydrates (sugar, starch, and gum) and in the crude fibre.

There is almost no exception to the fact that the water decreases in the maturer specimens; that is to say, the plant gradually dries up and becomes less succulent. The ash is very dependent on locality and surroundings, and as the analysis here given includes wlatever soil may be mechanically adherent to the blade or stock as collected, it sometimes shows irregularities. The albuminoids decrease in amount 
with great regularity. The fibre sometimes decreases (as, for instance, in Bromus erectus), but the change in that direction is never large. The non-albuminoid constituents (of the exact value of which to the animal our knowledge is rather uncertain) are often quite the reverse of constant in their manner of appearance and disappearance, and show themselves to be more affected by environment than any other constituent is. The averages show that the best grasses contain the least non-albuminoids. The usual changes in the non-albuminoids seem to point to the possibility that they increase at the time of the formation of the seed, in the act of transferring to the seeds, as amides, the nitrogen of the plant.

\section{SOME POINTS IN HAYMAKING.}

Hay is not simply the dried stems and leaves of grasses and clovers; in other words, there is more than mere drying required in making hay.

The first point is to cut the grasses and clovers which are to form the hay, at the proper time, so as to have the largest quantity of food. This time is immediately after flowering, wheu the pollen has been shed, and before the seed has begun to ripen. When a plant has shed its pollen and ceased to flower it has reached its full growth, and it then contains the maximum amount of feeding in it. No further sustenance is derived from the soil to any appreciable extent, but the fertilized ovules begin to swell and mature into ripe seeds. The material which forms the seed is derived from other parts of the plant, where it previously existed as starch, sugar, \&c., by a process of transition, so that the stems and leaves lose all their succulent nutritious parts, and only the woody fibre is left; thus hay ripened for seed is not so good for feeding as it would be if "green cut." As different grasses ripen at different times, however, it is not possible to catch all those in a misture of "seeds," or in meadow hay, at the proper stage, so that an average must be hit on. In practice, of course, the state of the weather, and the forwardness of other work on the farm generally, have more to do with the time of beginning to cut than anything else, but strenuous endeavours should be made not to let the crop get ripe, but rather cut green; the aftermath will be all the better.

The turning, cocking, and piking are all preparatory to getting the hay safe in the stack; and as these depend on the nature of the stuff and the state of the weather, it is impossible to lay down rules. Everything is done for the purpose of drying the fodder to prevent heating; but the writer has seen more stuff spoiled from being too dry, or from getting too much weather, than from over-heating. If it has been dried too much from actual sunshine it becomes hard, brown, and wiry, and there is not enough of moisture left in to start the "haying fermentation" (of which more anon); if it has been exposed to too much wet weather the juices (containing sugar, soluble albumen, \&c.) get washed out, especially if the crop is tossed about much; while, if it is lying in a heap and wet, alcoholic fermentation is set up at the expense of the sugar. The fragrance of grass and good hay is due to the presence of a volatile organic principle known as coumarine $\left(\mathrm{C}_{9} \mathrm{H}_{6} \mathrm{O}_{2}\right)$, and this is dissolved out by the alcohol in the presence of warm rain water. The green colouring matter (chlorophyll) is also separated by alcohol, and becomes yellow by oxidation when the swathe lies too long. Thus the valuable food elements, the fragrance, and the colour of the hay are all lost by weathering.

It is pretty much a matter of opinion as to whether a little heating ("sweating") improves the quality of hay or not. Circumstances differ; horses and cattle generally relish it better if the process has been properly done, while in some markets-notably in London-the hay which has the appearance and odour of tobacco finds the readiest sale. Overheating, however, will produce the same effect as weathering, while it is deleterious to the animals that eat the stuff. When a field of grass is cut the plants are, in a sense, immediately killed; but though a stalk of grass, as a whole, ceases to live, yet the individual cells of which it is formed still retain their vitality so long as the moisture and temperature are suitable. When the plant's connection with the root is severed, a process called by Mr. Fry "intercellular oxidation," or, in otler words, "haying fermentation," takes place. This oxidation is the canse of heating in stacks, and if not overdone is a desirable state of matters. Its action is to change starch into sugar, and this actually takes place in the stems of the grasses. To this change is due the fragrance of hay when half dried, and the avidity with which cattle eat it at this stage.

When the stuff is completely dried, however, the cells are killed by desiccation, and the action ceases. For this reason over well-dried hay is a mistake, as the process of converting the starch into sugar ought to go on in the rick, producing a gentle heat if not overdone, and improving the flavour and digestibility of the product. The point to be attended to, therefore, is to put up the lay not too much dried, so that the cells may be living and able to form sugar, but yet dry enough to prevent oxidation or heating from going past the sugar stage, and thus spoiling the stalk: keep it green, fragrant, and with the maximum of sugar. The way to do this can only be learnt by experience. 


\section{(Ensilage: Silos and Staclis.}

Ensilage (Fr. silo, a pit) is a process of storing the various grasses and other crops while green, and preserving them in this condition for consumption by cattle during the winter months. The system is said to be not so much a new idea as one of the lost arts which has been improved and adapted to the requirements of modern civilization-the process being seemingly as old as the hills, though as a practice of modern farming one of quite recent adoption. Green food, grass, and even leaves, such as those of the mulberry, have been stored, salted, and preserved in many countries, notably in Hungary and in the Steppes of Russia, for all the years of this century; and it is believed that Virgil refers to the process. It is, however, only within the past few years that ensilage has been tried on a large scale, and it was at the Château Burtin, in the department Loir-et-Cher, France, that M. Goffart, in 1874, pitted Indian corn in a cheap and satisfactory manner. From time to time French agriculturists paid their visits of inspection, and some few followed the example, but the practice did not become general; and it was reserved for Americans to take up the "new fashion" with enthusiasm, to build immense silos, and announce to the world that ensilage was the best winter food for stock, and especially for milch cows.

Ensilage may be defined, in a few words, as simply the placing of green herbage in a pit, which is termed a silo, and in such position and circumstances as will first get rid of and afterwards permanently exclude the destroying oxygen of the atmosphere. The silo is made either above or below the ground, or partly in and partly out of the ground. It ought to be as far as possible air and water tight, and must be so constructed as to admit of great superincumbent pressure on the contents of the silo, this pressure being absolutely necessary to get rid of the inclosed air. The silo is intended for the storage and preservation of green forage, which may be either wet or dry, and if properly constructed it allows of the least possible change in substance of that which is packed in it. The object of its construction is to supply the stockfeeder and dairy farmer with nutritious food for his stock, which can be secured independently of the state of the weather, and be convenient of access at all seasons.

It has been found, however, that a pit or building is not absolutely necessary, and that good ensilage may be made in a stack above ground, provided some efficient means exists of applying sufficient mechanical pressure to secure the expulsion of the ir. Several methods of supplying this pressure by mechanical means have been invented, some of the simplest of which are here described. The best guide to the amount of pressure required is the temperature of the material, which is lowered in proportion as the pressure is increased. Mr. H. Kains-Jackson recommends that it should be kept between $120^{\circ}$ and $130^{\circ} \mathrm{Fahr}$. The following table of temperatures and their corresponding products will, he considers, be a pretty reliable guide in ordinary practice:-

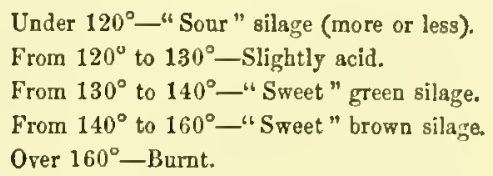

The direct application of weights to compress ensilage is most applicable to silos which are more or less sunk below the ground level. The silo being filled and the material well trodden down, it is covered with boards, and the weights, whether stones, earth, or any other material, placed upon

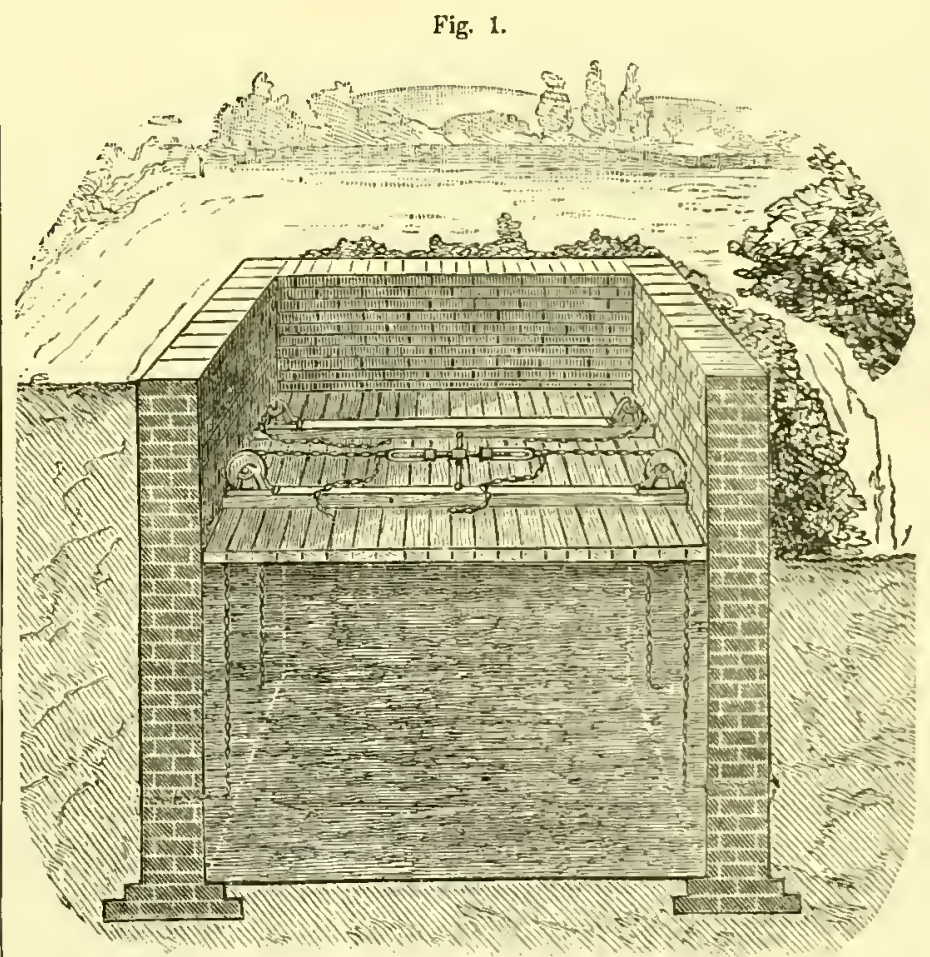

these until the required compression is obtained. It has been found advantageous to cover the ensilage with a layer of bran immediately beneath the boards.

The chain-and-screw system of compression is applicable either to silos or stacks. In fig. 1 we give an illustration of this system as applied to a brick-lined silo sunk below the $30 *$ 
ground level, by the patentees, Messrs. F. W. Reynolds It is stated that a surface pressure of 200 pounds upon each \& Co., Engineers, Blackfriars Road, London. One of the square foot of upper surface of the silage is found to be the

Fig. 2.

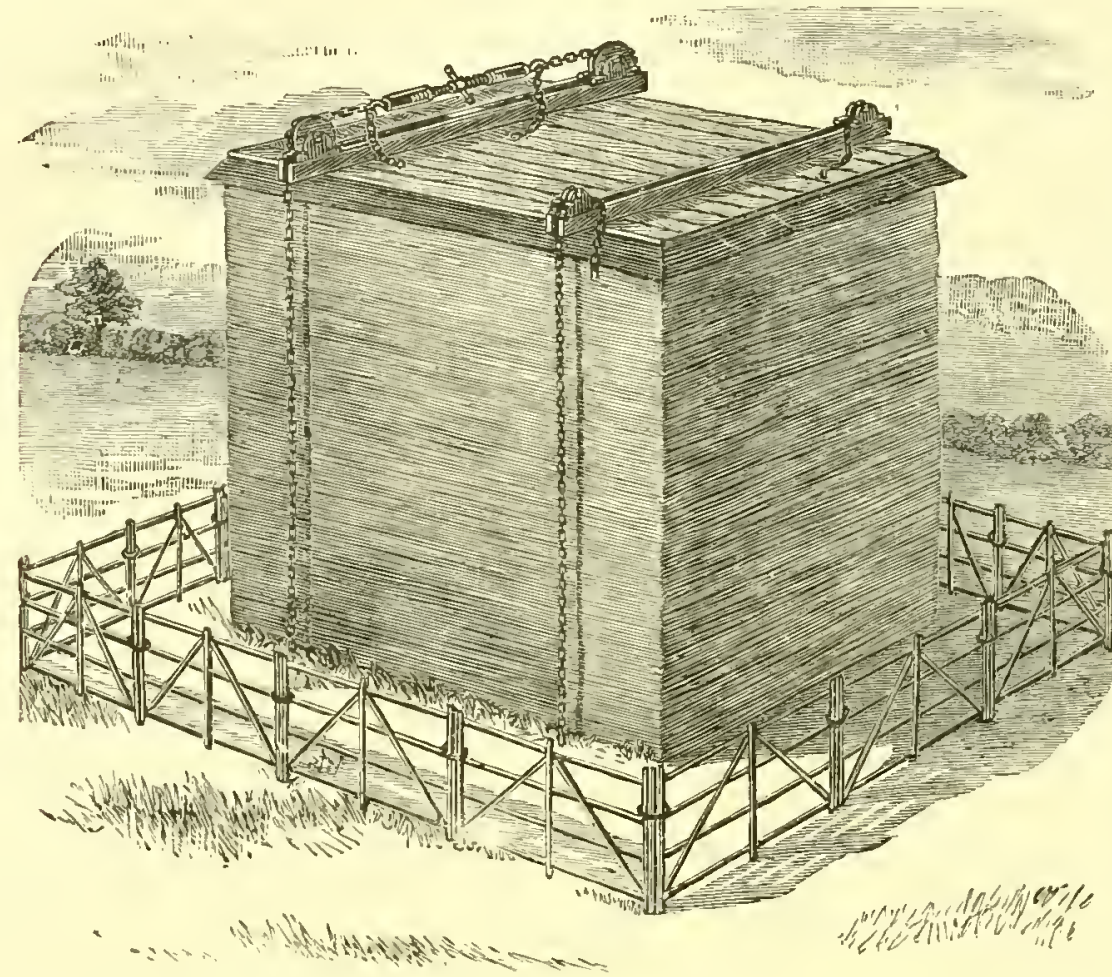

best for preserving it. 'To produce this pressure each beam sloould command 90 square feet of surface of the silo, an extra beam being used for each additional 90 square feet or portion of 90 square feet. If it should be desired to arrange the apparatus to give a greater or less surface pressure than 200 pounds per square foot, it is only necessary to place the beams nearer together or further apart, so that they command a smaller or greater area. In fig. 2 the same system of compression is shown as applied to a silage stack. This is, of course, less costly than a silo, requiring no permanent buildings, but there is a loss of material where the air has access to it at the outsides of the stack. It is, however, claimed by some experimenters that this loss can be prevented by dressing the outsides of the stack with salt to the depth of eight or ten inches. The stacks are built in the ordinary way, the chains being securely anchored in the ground, attached to sleepurs or rough pieces of timber When the stack is finished the covering-boards and crossbeams are placed on the top, and pressure applied with the scrow-tightener in the way previously described. The illustration shows the

walls is removed to show the position of the chains, tha lower ends of which are secured to metal plates sunk in the ground or in concrete, or else attached to beams at the foot of the walls Thence they are led up close to the inside of the walls in pairs, and when the silo has been filled are brought over movable pulleys on the ends of wooden pressure-beams, which rest across a quantity of stout boards with which the silage is covered, as shown in the figure. These beams are generally made of two deals, 9 inches deep by 3 inches thick, with distance-pieces nailed between them, so as to give strength combined with lightness. For covering-boards for the silage, $7 \times 2$ inch battens are sufficient, and they should not be so close that the air cannot easily escape. A coupling screw, or chain-tightener, is now applied to any suitable link of each of the two opposite chains, and on turning the screw pressure is applied, causing the chain and covering-boards to sink, and so compress the material below them. When the chain-tightener has been screwed up as far as it will go, a pin is inserted above the pressure-beam at each end, passing through a link of each chain, so that on releasing the screwtightener the pressure is retained on the beam. The tightener can now be run out again, and made to take a fresh hold on the chains for further compression, or it may be removed, along with the two pulleys, to another beam. The one tightener and two movable pulleys are sufficient to tighten up any number of chains. A man of average strength is capable of putting a strain of 4 tons on the chain, which, by means of the pulleys, becomes 8 tons of pressure on the beam. projecting edges of a waterproof cover or of strips of felt

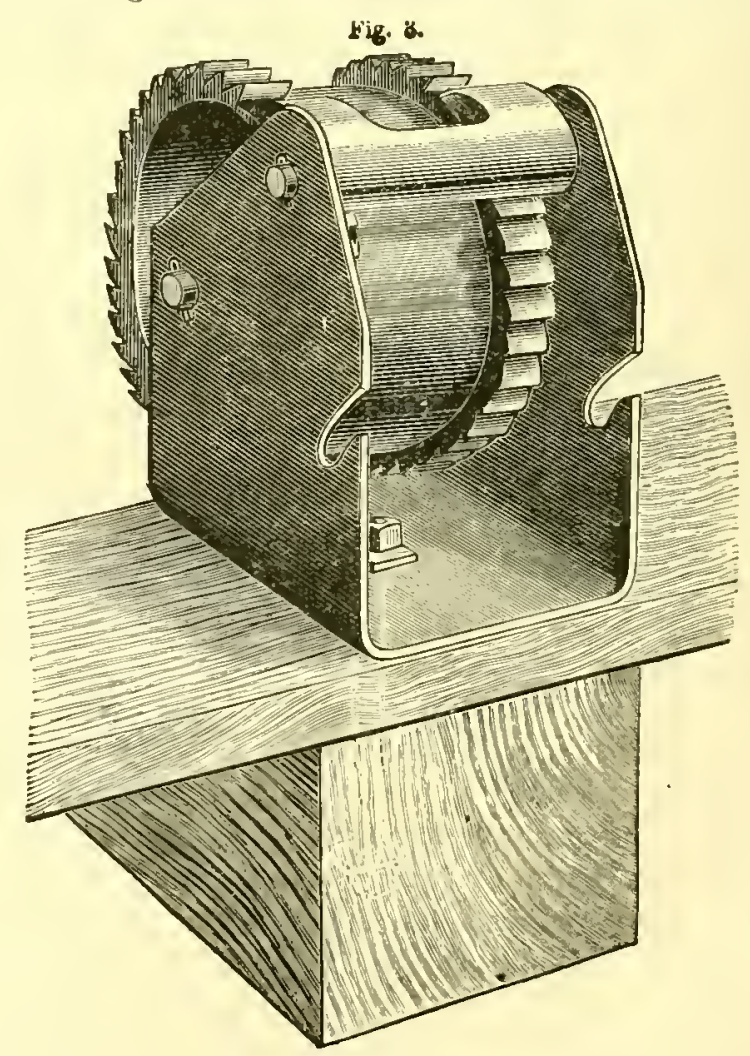

laid under the covering boards to keep off the rain. Stacks with sloped or rounded tops may also be pressed by a modi- 
fication in the form of the pressure-bcams, so as to admit of the stack being roofed or thatclied.

Somewhat similar in principle is the "Johnson" system of pressure, with wire-ropes wound on ratchet-drums, for which the agents in Great Britain and Ireland are the Aylesbury Dairy Co., 31 St. Petersburg Place, Bayswater, London. This system is applied to ensilage stacks, and its chief feature is the ratchet-drum, of which we give a representation in fig. 3. The apparatus consists of two or more pairs of such drums placed exactly opposite each other on either side of the stack, and of wire-ropes attached to both of each pair of drums, and passing over the top of the stack. The ropes are tightened by means of a lever fitted with two pawls for engaging with the rack-teeth of the drums, as shown in fig. 4. Each set of teeth on the drums is also provided

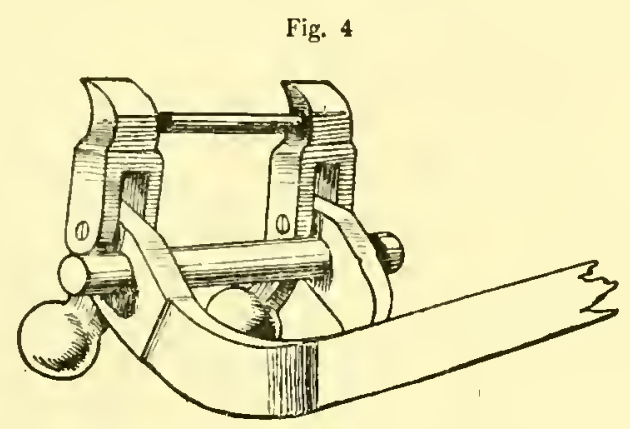

with a pawl, so that the drum is held in the position it has reached until the next stroke of the lever brings it round to another tooth. The framing or foundation of the stack consists of as many timbers as there are pairs of drums. These are let into the ground so that the upper sides are level with the surface, and are placed 3 feet apart from centre to centre. They must be long enough to project 2 feet beyond each side of the stack, and should be 8 inches deep and not less than 6 inches wide, and the top surface should be flat, so as to receive an 11-inch by 3 -inch plank laid flat across the ends the full length of the stack for the drums to rest upon, as shown in section in fig. 5 . A few pieces of rough wood, such as usually form part of a stack bottom, may be placed across this frame length wise, and close inside the 11 by 3 -inch plank, to prevent the timbers from being forced up into the stack. The spaces between those rough pieces should be well filled with earth, so as to make a perfectly level bottom. The ratchetdrums are secured to the wooden framework by bolts, which pass clean through the 3-inch plank and the 8-inch timbers, as shown in fig. 5 . Suitable lengths of galvanized steel wire-rope are supplied with each pair of drums. These ropes, which pass over the stack, as shown in fig. 5, are fastened to the drums by passing about 4 inches of the ends through the holes in the drum-faces. When in use the ropes should not be allowed to lap on themselves or the drums.
The length of the lever is so adjusted that a man pressing with a weight of 8 stones upon it puts a pressure of 3 tons on each ratchet-drum. As these drums are placed with a space of 3 feet between each pair, a stack 17 feet in width has a Fig. 5.

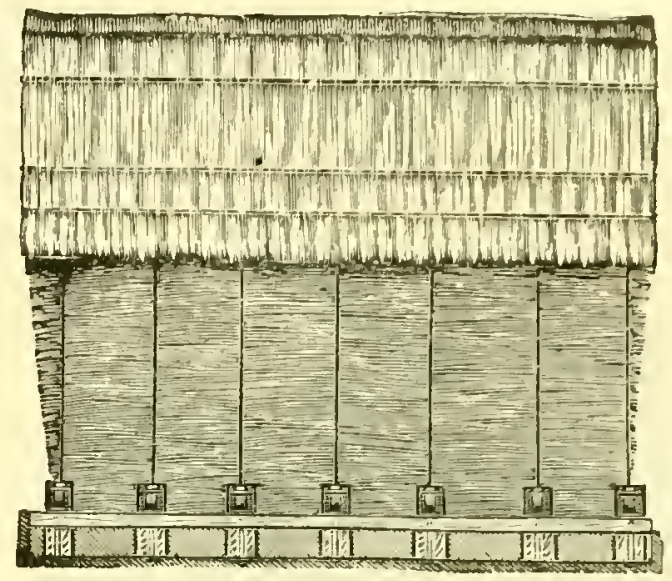

pressure of about $250 \mathrm{lbs}$. per square foot After the crop is stacked the wire-ropes should be attended to every day for the first few days, and should always be kept as tight as a man can make them.

The lever system of pressure differs from those above described in making use of weights; but these, in place of being deposited on the top of the silage, are attached to levers, by means of which the pressure exerted is greatly increased, and the weight required correspondingly diminished. Fig. 6 represents an ensilage stack with Blunt's Screw and Lever Ensilage Press, as manufactured by the Ensilage Press Co. of Leicester. The fulcrum beams A A are sunk in the ground, so as to be level with it. A number of strong boards are

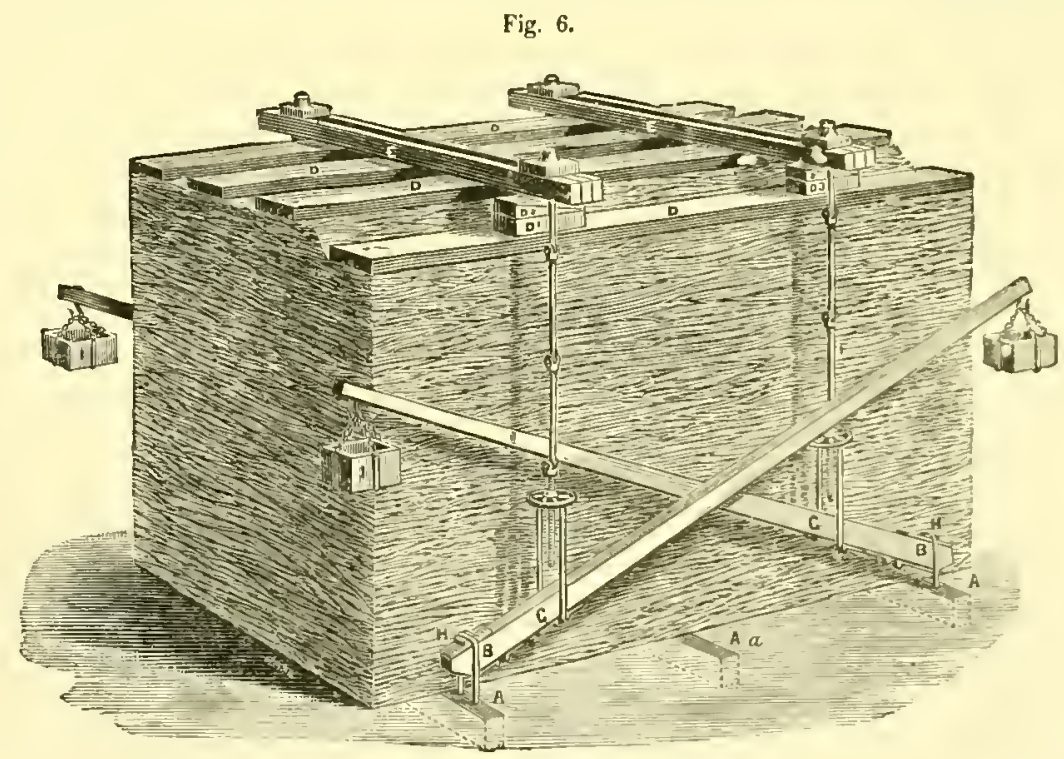


the stack as possible at one end, and 6 inclies further from the sides at the other end, so as to allow the levers to cross each other. To keep the pressure on when the ensilage is being used, a third fulcrum beam $\mathrm{A} a$ is placed about the middle of the stack, so that the staples may be removed, and the crossbeam worked from the centre when found necessary.

Before putting the press on, it should be seen that the sides of the stack are level all round, and fairly solid, and

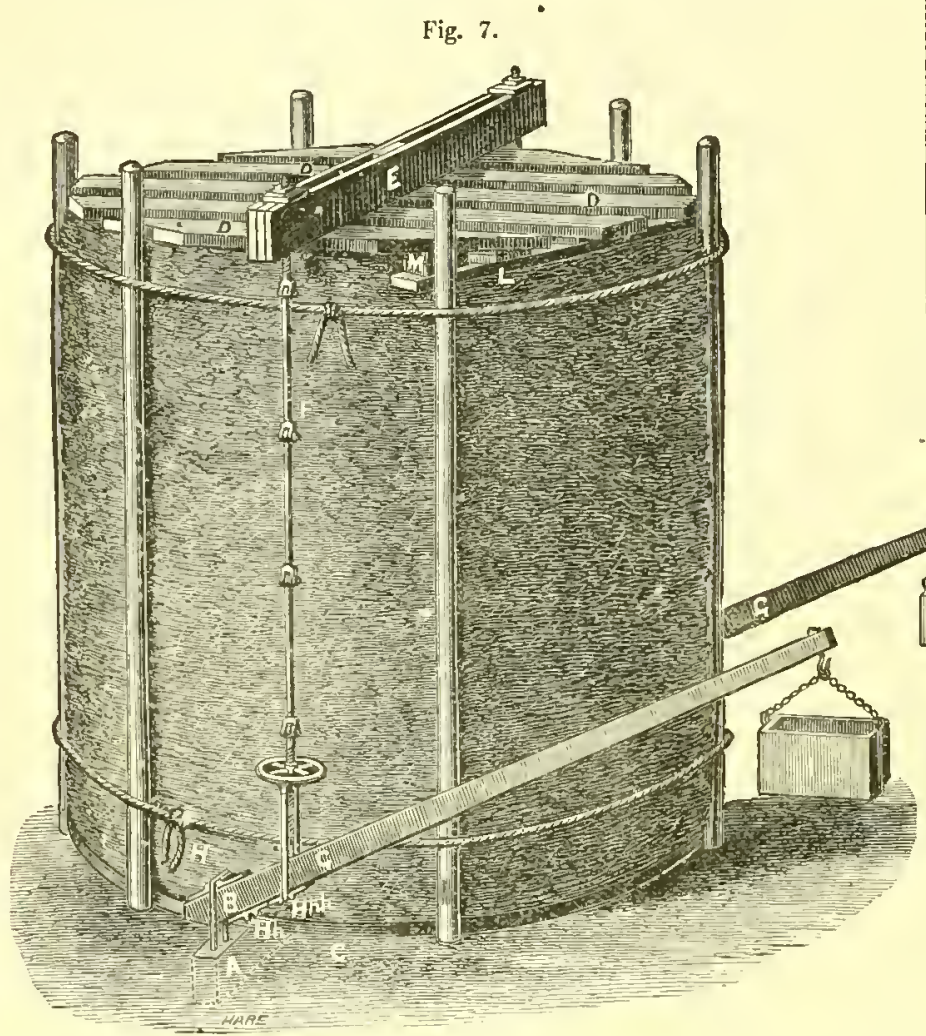

rather higher than the middle. The beams D D D are then placed on the ensilage 20 to 30 inches apart, and the crossbeams $\mathrm{E} E$ (which may be made of two beams with distance pieces between them) placed as shown in the figure. Each crossbeam is placed in such a position that the iron stirrup when hanging down shall be one foot from the corresponding fulcrum staple. The iron rod $\mathbf{F}$ with block attached is passed through the crossbeam, the wooden lever $G$ is placed in the stirrmp at the end of the rod, and the short end of the lever is caught under the fulcrum staple $B$. The levers are then screwed up into position by means of the wheel and screw, and weighted by attaching the boxes I I to the longer ends, which boxes may be filled with stones or other weights. If the sides sink more rapidly than the middle, the crossbeam will bend and may break. In such a case blocks $D^{1} D^{2}$ should be placed between the crossbeam $\mathbf{E}$ and the beam $\mathrm{D}$, at the edge of the stack. To remove silage from the stack for consumption, the levers are lowered by the screw until the pressure is taken off. The beams $D$ are then driven back from the end of the stack as far as necessary, and the silage is cut from top to bottom. The pressure can then be again applied. This can be repeated until all is consumed up to the cross- beam, which, with the staples, must then be removed to the centre fulcrum beam $\mathrm{A} a$, and the cutting can be continued as before. The mode of applying this system to a round stack is shown in fig. 7 , in which the reference letters denote the same parts as in fig. 6 .

The anxiety, expense, and risk which haymaking involves in our uncertain climate, especially in the case of late meadow hay, are all (it is claimed by the advocates of this system), swept away by a process which renders the farmer perfectly independent of the weather, and also provides a forage which cattle prefer to hay, and on which they thrive better. At a dairy conference in 1886, Sir John Lawes said-" It is probable that when both (hay and ensilage) are of the very best quality that can be made, if part of the grass is cut and placed in a silo, and another part secured in the stack without rain, one might prove as good food as the other. But it must be borne in mind that while the production of good hay is a matter of uncertainty-from the elements of success being beyond the control of the farmer-good silage, by taking proper precautions, can be made with certainty." It is, however, claimed by the chief advocates of ensilage, that it more nearly approaches the qualities of fresh grass than any other preserved fodder, and in support of this view may be quoted the following analysis of grass and of ensilage made from it, by Dr. J. A. Voelcker on behalf of the Royal Agricultural Society :-
Water,

Soluble albumiuoids,

Insoluble albuminoids,

Digestible fibre,

Woody fibre,

Soluble carbo-hydrates, chlorophyl, \&c., .

Soluble mineral matter

Insoluble mineral matter.

Volatile acids,

Non-rolatile acids, .

Total nitrogen,

Albuminoid nitrogen,

Non-albuminoid nitrogen,

$$
\begin{array}{r}
\text { Grass. } \\
. \quad 73.67 \\
. \quad 21 \\
. \quad 1.94 \\
8.64 \\
. \quad 7.36 \\
\hline \quad 6.38 \\
1.19 \\
. \quad-61 \\
\hline \quad- \\
\hline 10000 \\
\hline .42 \\
\hline .34 \\
\hline .08
\end{array}
$$

M. Goffart, to whom we have already referred, was the first to publish a work on the subject, and an English translation of it was brought out in America in 1879. The system was at once widely adopted in the State of New York, and in 1882 an ensilage conference was held, at which samples of stored forage were exhibited, chiefly maize, clover, rye, and various grasses. Some of those present suggested the propriety of ensilaging nitrogenous fodder, such as rye and clover together, in order that cattle might be fed on the product without grain. Others recommended that pease, oats, maize, and vetches might also be ensilaged together. So important was the process considered in its bearings on British agriculture, that in 1885 a select Commission was appointed by the British Government to take evidence and collect reliable information on the subject. They issued an intcrim report in August, 1885, and a final report in March, 1886, both of which we give here. 
PRELIMINARY REPORT OF THE ENSILAGE COMMISSION.

The Commissioners have, up to the present time, held eleven sittings and examined thirty-eight witnesses, comprising among their number owners and occupiers of landed estates and their agents, tenant farmers, desiguers and inventors of different forms of silos, or of different systems of applying the necessary weights to stacked or ensiled green fodder, chemists, and anthors of pamphlets on the general sulject. They liave also had the advantage of hearing the views of Sir John Bennett Lawes, whose eminent knowledge of all matters relating to the chemistry of agriculture, combined with the fact that his published opinions on the process of ensilage have been regarded as unfavourable to the system, has rendered his evidence of great value and interest.

The Commissioners have by no means desired to exclude unfavourable evidence; on the contrary, they have endeavoured to induce some of those who were believed to be opposed to the system to give them the benefit of their opinions, but they have so far heard no expression of any decidedly unfavourable views. The evidence tendered has been entirely voluntary, all witnesses attending at their own expense.

The evidence of all those who have practically tested the various methods of converting green fodder crops into preserved food for animals without putting them through any process of drying, such as is necessary in the making of hay, has, without exception, established their claims to a considerable amount of success; and although, in some cases, the results have been evidently more satisfactory than in others, the advantages which the different operators, one and all, have claimed for their systems seem to show that a nourishing and useful food for animals can be preserved, independently of any drying process, within wide lines of divergence in the details of the methods adopted.

It has been conclusively shown that, by different degrees of weighting and of expulsion and exclusion of atmospheric air from the material stacked or ensiled, different degrees of heat, and of consequent chemical cliange, are produced.

The degree to which such chemical changes increase or diminish the feeding value of the silage itself or its relative value in comparison to the green crop, is, in the present state of knowledge, in great measure a matter of opinion, and careful feeding experiments conducted with a view to test the exact effect of these changes will be highly important to a solution of this question.

Silage which has been covered in immediately after cutting, and not again uncovered, has been shown to retain its colour and freshness, although developing small quantities of certain acids indicative of a process of fermentation, without any con- siderable accession of heat. Other silage which has been put in at intervals, and from which the air has not been immediately or entirely excluded, has undoubtedly developed considerable lieat, and in this case the colouring matter of the leaves has been less well preserved. Yet in both cases a useful feeding material has been rendered available which, in unfavourable weather, would have been practically lost if any attempt had been made to convert it into hay.

Bearing in mind the importance of economy, the Commissioners have inquired into the efficiency of various systems of stacking unchaffed green fodder crops without drying, by which it has been contended that, with a proper system of pressure, the necessity for a silo can be done away with.

The Commissioners are not at present prepared to express any opinion upon the economy of any such system, or to compare its advantages with those which are claimed by the advocates of chaffed and close-stored silage; but it seems to be established that a temperature sufficiently high to involve danger of fire can be controlled by a proper and efficient system of applying weight to the stack of green fodder.

The different systems of applying weight have greatly occupied the attention of the Commissioners, but as the quality of the silage does not appear to be materially affected by this question, it becomes simply one of economy, and may safely, for the present, be left to each operator to decide for himself according to the special circumstances affecting the particular locality in which his farm is situated.

Some of the best samples of chaffed silage have been produced with pressure not exceeding $70 \mathrm{lbs}$. per superficial foot, but the degree to which weighting is necessary or desirable remains to be decided upon the greatest amount of evidence that may become available to us. Good results are claimed to have been obtained by means of weights varying from 7 to $300 \mathrm{lbs}$. per superficial foot on the top of the silage.

The experience of dairy farmers does not appear to justify the assertion which has been more or less circulated, that dairy produce is in any way injurionsly affected by silage as food; on the contrary, much valuable evidence has been received to show that the feeding of cows with well-made silage distinctly improves the yield of milk and cream, and the quality of butter.

Where complaints have arisen of milk becoming tainted, the cause has been, in our opinion, traceable to its having been in proximity with strong-smelling silage, or with per- 
sons who have handled it, rather than to the use of such material as food.

The Commissioners have already heard sufficient evidence to justify them in encouraging the development of the system of storing undried green fodder crops as a valuable auxiliary to farm practice. In addition to other advantages, the losses occurring through weather unfavourable to laymaking may be avoided, and some crops not hitherto grown in this country on account of the impossibility of ripening their seed (such as certain varieties of maize), may probably be successfully cultivated in certain districts, to the increase of our present means of feeding various kinds of live stock on arable or partly arable farnis.

IVALSINGHAM (Chairman).

H. A. Brassey.

A. M. Caruwell.

DROGHEDA.

N. Eckersley.

Egerton of TatTon.

J. S. Gathorne-Hardy.

WM. J. Harris.

Mitchell Henry.

JAMES HOWARD.
H. KAINS-JACKSON.

Nigel Kingascote.

C. de L. Faunce de Laune.

J. C. Lawrance.

Peter M'Lagan.

Fredk. Marshall.

Henry Robinson.

Stanhope Tollemache.

JACOB WiLson.

\section{FINAL REPORT OF THE ENSILAGE COMMISSION.}

1. The Commissioners in their Preliminary Report have already expressed the opinion that the system of storing undried green fodder crops is a valuable auxiliary to farm practice. The questions, for what reasons and to what extent it is so, are simply and entirely questions of economy. A number of different considerations affect the answers to these questions.

2. The primary object to be aimed at in the storage of crops is the preservation to the greatest possible degree of the nutritive properties which they contain. It will be obvious that, however perfectly this may be done, the value of the results attained should be estimated only in connection with the expense incurred in securing those results. If the cost of preserving the largest possible proportion of nutriment per acre be found to amonnt to a serious deduction from the final value to the farmer of the crop which he grows, it becomes a question how far he may be justified in incurring loss by waste or by deterioration in order to reduce the expense of the process. The value to a farmer of silage, as of other food, must depend, in the first place, upon what consumable or marketable commodities it enables him to produce; and, secondly, upon the actual expense incurred in securing the requisite degree of perfection in the food itself.

3. The products to be considered may be briefly classed under three heads-meat, milk, and manure. The quantity and quality of these products must depend directly upon the chemical constituents of the food given to animals, as well as upon the degree in which such food is palatable and easy of assimilation; and, therefore, indirectly upon the mechanical means employed to render that food available, in so far as mechanical means affect the changes to which it is liable.

4. The scientific chemist claims to estimate by analysis the value of the different constituents of the dead matter of various food plants. He can evaporate the water and critically examine the residue, clearly determining what proportion of socalled fat-forming, bone-forming, and flesh-forming matter it contains. The practical farmer, on the other hand, estimates by observation the general effect of such food-plants, in dif- ferent conditions of preservation, upon the growth and development of the animals to which he gives them.

5. It has been made plain to us throughout this inquiry that there is a general consensus of opinion among practical farmers who have adopted the system of ensilage, that the results are of much economic value, and in this respect their experience must be admitted to be somewhat more favourable to ensilage than the not very sanguine estimates formed, in the first instance, by scientific authorities. It is admitted that all known methods of chemical analysis involve a destruction of the perfect natural distribution of water throughout the cellular tissue of plant-life, and that this distribution cannot be re-established by the subsequent addition of a similar quantity of water to the dry residue. We think it possible that this fact has not been sufficiently regarded in estimating the feeding value of different kinds of forage.

6. It has not been proved to our satisfaction that any chemical change occurring in the process of ensilage increases the value for feeding purposes of the plant preserved; except in so far as it may render it more palatable or more easy of assimilation. We think that the object to be striven for is to retain the crop, whatever it may be, up to the time of feeding with it, as nearly as possible in its natural condition as at the time of cutting.

7. No feeding experiments at present carried out have gone so far as to prove that the beneficial effect to farm stock of preserved forage is equal to that of the same forage in a condition of life and growth, although in the case of many kinds of silage they undoubtedly consume it more readily.

8. The question thus arises, what is the method by which forage may be preserved subject to the least possible change?

9. Chemical change, as affecting vegetable matter, requires the presence of moisture and air. The degree in which such change becomes destructive is dependent upon the influence of these elements, in so far as they promote oxidation and fermentation.

10. A certain amount of moisture is practically unavoidable, and is, moreover, inseparable from the chief advantages of the 
system of ensilage. Excessive heat in a silo or stack can only arise by excess of oxidation, and must therefore be controlled by the exclusion, as far as possible, of air. The varions means whereby this can be most completely effected form the first and most important part of the subject.

11. Among the plans of silos which have been submitted to us, those which consist of external walls, either above or below ground, whether of concrete, or of stone, brick, or clay lump, cemented within, appear to be the most efficient; but in all cases the absence of air depends upon two conditions: first, upon its expulsion from the mass of forage ensiled, and secondly, upon its exclusion when this is covered. Whatever may be put into a silo, it should be thoroughly well trodden in, and rammed down at the edges into a compact mass; with this object the advantage of rounding off the corners lias been impressed upon us by some witnesses. Compression is greatly facilitated by first passing the material through a chaff-cutter, as the longer stalks of unchaffed herbage occupy a greater space and oppose more resistance to the expulsion of air. To secure the cxclusion of the outer air, it has been found useful to cover the mass with close-fitting boarded lids or shutters, in one or more divisions, with a layer of bran, sawdust, or earth above them; air-tight roofs or covers liave also been used Bran, being itself a useful feeding substance for subsequent admixture with the forage, may be recommended as cleanly and unobjectionable. Weights, being required above this layer to keep the mass compact, may be applied either in the form of any convenient dead weight, such as bricks, boxes or baskets of stones, \&c., or of mechanical pressure exercised by means of various systems of chains, screws, or levers. Instances are known of silos being successfully weighted without the use of boards, by simply covering the ensiled material with rushes, ferns, or other waste sulsstances, and above these with dry earth or sand to the depth of nine inches or a foot. Where a silo can be filled at one time, and where there is no intention of reopening it for additions, dead weights appear to be the most economical. But where the coverings have to be removed to compensate by addition for waste of space through shrinkage, the value of mechanical appliances becomes apparent. To avoid the necessity of refilling, a super-silo, or false silo, removable at will, consisting of a screw-bolted, boarded structure, fitted above the coping of the silo proper, has in some cases been usefully employed. By filling to the top of this, sufficient space is allowed so that the silo itself may still be full after shrinkage, which should not amount to more than one-fourth of the bulk, if the material be chaffed and well trodden when first put in.

12. The system above described can be followed out by means of newly-constructed buildings above or partly above ground, which should cost not more than $15 \mathrm{~s}$. to $30 \mathrm{~s}$. for every ton of their contents; but this estimate must neccssarily vary according to their size, and according to the cost of labour and materials in different localities.

13. If old buildings, such as barns, sheds, ice-houses, \&c., be converted for the purpose, the cost of conversion will pro- bably vary from $8 s$. to $12 s$. per ton contained, according to the work required.

14. Where old chalk pits are available, a long trench cut back into the soil, with a sliding roof, enabling it to be filled from the surface, while emptied from the level of the bottom of the pit, should not cost more than from $8 s$. to $14 \mathrm{~s}$. per ton contained, according to what lining of brick or cement it may require, in all cases exclusive of the cost of any system of weighting. 'These figures are necessary to enable us to contrast the advantages of such a system with those of other and cheaper methods.

15. Expense can be saved on three items connected with the preservation of grcen forage-viz. (1) on chaffing, should this be regarded as unnecessary; (2) on treading and ramming where it is not desired thoroughly to expel the air ; (3) by dispensing with the structure of the silo itself, the cost of which is a serious objection to many tenant farmers, and storing the forage in stacks under heavy pressure.

16. The saving on the first of these items may be taken roughly at 18 . per ton, and in the case of meadow grass as good results are claimed to be obtained by the storing of unchaffed crops as by the alternative method. Owing, however, to the greater amount of air left in the silo, it will be found that most unchaffed materials have a greater tendency to heat, and therefore to undergo chemical change, more perceptibly varying their condition from that of the growing crop. Whatever advantage is to be derived from the facility with which chaffed silage can be mixed with dry straw, liay-chaff, or other food when given to animals, is sacrificed by storing it in an unchaffed condition, unless it be subsequently passed throngh the chaff-cutter when taken out for use, which cannot usually be done with equal facility.

17. If any saving be effected on the item for treading and ramming, the operator must be prepared to expect far greater chemical change in the material ensiled, unless greater expense be incurred in administering external pressure to the mass, whether by hydraulic or other mechanical means.

18. In the system of stacking there will usually be found to be not only such increased chemical change as must arise from the development of a considerable degree of heat in the mass, but also a very appreciable waste on the outside of the stack, where decomposition, through the mavoidable ingress of air, must to some extent occur. This will be found to constitute a loss, seldom less, and frequently much more, than 5 per cent. of the mass of the material, even in large stacks. The stack which gained the prize offered by the Royal Agricultural Society must at present be regarded as a remarkable instance of the minimum of external loss.

19. Another consideration affects the question of stacking. but the available data are not at present sufticient to form' an estimate of the degree of importance which it assumes. Whereas in close-built silos, if the amount of moisture contained in the forage when carried be not greater than can be evenly distributed and retained throughout the mass by capillary attraction, no occasion need arise for drainage, and 
thus the loss of valuable constituents of the food arising from this cause, whatever such loss may amount to, can be avoided. In a stack there is no means of preventing drainage, and with it the loss of whatever value may attach to the expressed juices of the forage under the influence of the weight applied.

20. In order to contrast the most perfect system by which green fodder crops can be preserved as nearly as possible in their natural condition, as when cut, with other systems which less perfectly effect that object, and with a view to determine, at least approximately, the money loss which different degrees of imperfection represent, it is first necessary to establish what are the precise advantages gained by the process of ensilage in its highest degree of efficiency.

21. The advantages which are claimed for the process may be classed under three heads :-

1. In rendering the farmer independent of weather in saving his crops.

2. In inc easing the productive capabilities of farms:

(a) In greater weight of forage saved.

(b) In greater available variety and rotation of crops.

(c) In increased facility for storage.

\section{In connection with feeding:}

(a) Dairy stock.

(b) Breeding stock.

(c) Store stock.

(d) Fattening stock.

(e) Farm horses.

\section{Independence of weather in saving Crops.}

22. In this respect it has been abuudantly proved to us that ensilage is of great economic value.

In Scotland, in Ireland, and in the north and west of England, few seasons occur in which more or less difficulty is not experienced in reducing green fodder crops to a sufficiently dry condition for stacking in the ordinary way. This is especially the case with second crops of clover and aftermath. The loss occurring through ineffectual attempts to dry such crops, or through their inferior condition when carried, is often very considerable, and it is obvious that any system which enables a farmer to store these in good condition for future use must be a great saving of expense and anxiety. It has been objected that the cost of carting green forage, when fresh cut, must necessarily be heavier, owing to its greater weight, than the cost of carting the same when dried in the field. 'The evidence received tends to show that this disadvantage is amply counterbalanced, in the majority of seasons, by the saving of expense in the turning and making of hay, and in the certainty which the system affords that the men engaged will be required only for such time as is necessary to carry the crop as it is cut.

\section{Advantages in increasing the Productive Capabilities of Farms.}

\section{(a) In greater weight of Forage saved.}

23. It is obvious that unless the forage in a weighty condition be of more feeding value per acre than when saved in a less weighty form, there can be no gain to the farmer. It has been contended that the loss of weight in the process of drying is simply loss of water by evaporation, and that by avoiding this nothing is saved. If such were truly the case, dry forage should give the same feeding results per acre as green forage. No practical farmer would contend that it does so, and the difference is especially noticeable in the case of dairy stock. So far as we have been able to ascertain the opinion of competent men on this subject, we estimate the value of green forage well preserved in a silo at somewhat more than one-third, weight for weight, of the value of the same material made into hay under favourable conditions. The very wide difference of value between good and bad silage cannot be too strongly insisted upon. It is found that grass well preserved in a silo, after deduction for loss, will yield approximately five times the weight of the same grass made into hay. We have, therefore, say, five tons of silage, which, taken at one-third the value of hay per ton, yields a profit of over 60 per cent. as compared with one ton of hay. If we take it at one-fourth it still leaves a profit of 25 per cent.

24. Any waste that may occur to reduce the weight of nutritious forage, whether by evaporation or by excess of chemical change, must necessarily affect this calculation, which is based upon the highest degree of perfect preservation so far known to be attainable.

\section{(b) In greater available variety and rotation of Crops.}

25. By the process of ensilage many crops can be preserved which would not otherwise be found profitable if used in the form of green forage. Rye, oats, millet, maize, barley, and even wheat, if cut about the time of attaining their full development, but before the seed begins to harden, have been successfully used as food for cattle through the medium of the silo. Such of these crops as are found to reach the required condition before the middle of June, if cut before that time, will leave the land free for a second sowing, and thus increase its capabilities of annual production, while maintaining the fertility of the soil. Where land is well treated, maize, buckwheat, or in some parts of England also turnips, can be sown after green rye or oats are cut and carried, and thus a second crop may be secured for preservation in the silo, or for consumption by sheep on the land.

\section{(c) In increased facility for Storage.}

26. This advantage has been forcibly impressed upon us. It enables farmers to guard themselves against emergencies, such as frequently arise in our climate through prolonged cold in February, March, and April, causing great scarcity of food for cattle and sheep where the supply of roots is inadequate. 


\section{Advantages connected with Feeding.}

(a) Dairy Stock.

27. We have received the strongest evidence of the undoubted advantage of the system for the feeding of dairy stock. The effect of dry winter food given to such stock has always been to reduce in quantity and to deteriorate in quality milk, cream, and butter, as compared with the same products resulting from green summer food. Although the degree of perfection attainable in summer has not been reached, it has been at least much more nearly approached by ensilage than by the use of hay and other dry foods, while at the same time the objections inseparable from the employment of roots for this purpose have been overcome. A sensible improvement in the colour of butter has been especially noticed. Where the process has been properly carried out without destructive fermentation, no trace of disagreeable flavour has been detected in dairy products except such as has been traceable to external proximity or contact of these products with the food supplied. Since there is reason to believe that the somewhat pungent smell of forage thus preserved, varying in degree according to its nature and quality, does communicate some taint to dairy products when brought under its influence, care should be taken to. keep these separate, and that the vessels used for the dairy should not be left where the food is stored or handled.

\section{(b) Breeding Stock.}

28. Green fodder preserved by ensilage has been successfully employed in feeding sheep and cattle, at the time of breeding, and as it has been shown to increase the flow of milk, it will undoubtedly be found useful for this purpose, although the proportion of its admixture with other kinds of food must always require care and judgment.

\section{(c) Store Stock.}

29. It forms a complete and wholesome food for store stock.

\section{(d) Fattening Stock.}

30. The value of this process for the purpose of forming flesh and fat has not yet perhaps been so widely demonstrated as in the case of dairy produce. At the same time the results attained show that it compares favourably with the use of roots, and, if given in proper proportions with other food, it affords a cheap substitute for the same bulk, which would otherwise be required in some different form. The advantage of its use is most apparent in. the degree to which it enables a farmer profitably to consume straw chaff, rough hay cheff, and other dry materials, which, without admixture with some $3 \mathrm{P}^{*}$ kind of moist food, would not be palatable or advantageous to the growth of stock.

\section{(e) Farm Horses.}

31. Strong as the evidence has been of the advantage of ensilage for keeping all stock in healthy condition, farm horses have by no means been excepted. We have received highly satisfactory accounts from several quarters of the health of working teams when given a limited proportion of silage mixed with other food.

32. As in the case of all important inmovations, it is not surprising that the introduction of the system of ensilage into this country has been met by a considerable amount of prcjudice and incredulity. During the progress of our inquiry we have endeavoured amply to discount all exaggerated estimates of its merits. After summing up the mass of evidence which has reached us, we can without hesitation affirm that it has been abundantly and conclusively proved to our satisfaction that this system of preserving green เodder crops promises great advantages to the practical farmer, and if carried out with a reasonable amount of care and efficiency, should not only provide him with the means of insuring himself to a great extent against unfavourable seasons, and of materially improving the quantity and quality of his dairy produce, but should also enable him to increase appreciably the number of live stock that can be profitably kept upon any given acreage. whether of pasture or arable land; and proportionately the amount of manure available to fertilize it.

33. We would conclude by expressing our thanks to the numerous witnesses and correspondents who have gratuitously supplied us with valuable information, and by commending to the grateful consideration of the agricultural public the name of one of our members, Mr. H. Kains-Jackson, at whose initiative, and through whose exertions, this inquiry was instituted, and has been conducted to its present conclusion. We are also indebted to the Agricultural Department of the Office of Her Majesty's Privy Council for the special facilities they have afforded us in our labours.

Walsingham (Chairman).
H. A. Brassey.

A. M. Cardwell.

DrogIIEDA.

N. ECKERSLEY.

EGERTON OF TATTON.

J. S. Gathorne-Hardy.

WM. J. IlarRIS.

Mitchell Henry.

JAMES HOWARD.
H. KAINS-JACKSON.

Nigel Kingscote.

C. De L. Faunce de Laune.

J. C. Lawrance.

Peter i'tlagan.

Fredk. Marshall.

Henry Robinson.

Stanhope Tollemache

JACOB WILSON 


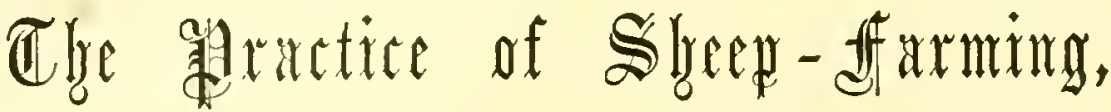

\author{
BY CHARLES SCOTT,
}

AUTHOR OP BLACKFACED SHEEP, ETC

\section{INTRODUCTORY.}

Frow the earliest times the value of the sheep has been appreciated by the human race. It is supposed to have been the first animal domesticated for the use of man, and we read in almost the first pages of the oldest records that a man's possessions or wealth were computed by the number of his flocks and herds It does not appear, however, that in those times sheep were valued much as an article of food. They were principally regarded on account of their wool; and doubtless they held much the same position with the ancients as they now do in some parts of the world where the species is still unimproved, or where they are yet reared solely on account of their wool.

With regard to the earliest existence of sheep in Britain we have no authentic record. They were not much known until after the invasion of the Romans, and it may be presumed that previous to that time sheep either did not exist at all in this country, or only occupied a very insignificant position. Julius Cæsar never alludes in the most distant manner to the sheep, or the employment of its wool, when he describes the habits and employments of the inlabitants of Britain. But the conquerors soon turned their attention to the improvement of the country, and established a woollen manufactory at Winchester, which produced cloths that equalled any other in the Roman Empire. In later years, as the feudal system declined, the quantity of the sylvan game decreased, and better laws were made for the protection of property, the attention of the flockmaster was directed more to the improvement of the carcase than the fleece. It was not, however, until the middle of the last century that any real progress in sheep husbandry was effected. Previous to that time farming had been exceedingly primitive, and more especially in the breeding of stock. But as more peaceful times began to dawn, so did agricultural pursuits begin to receive greater attention. Sheep, which formerly were reared in an almost wild condition, were now more thoroughly domesticated, and counted upon as a source of industry and wealth by the farmer They became more and more an article of food, and have now for fully a century been bred and reared more on account of their mutton than for their wool. The day has long passed when wool-growing of itself could be made profitable. We cannot compete with the colonies and foreign lands, where limitless grazings afford a cheaper and more congenial opportunity for the production of this staple.

The sheep being adapted for every locality in the British Isles, it received much attention from the farmer, because it could be raised with greater ease, and in situations where other animals could not exist; making a better return than other animals, as supplying to the nation a staple article of food, and giving employment to thousands of artisans by converting its wool into manufactured goods. Where Nature is left to herself she always produces animals suitable to her vegetation, from the smallest sheep in the highest mountains to the largest sort on the richest pastures. But good husbandry admits of our increasing the value of the one in promertion to that of the other; and as improvement in the production of the soil has progressed, so have improved breeds of sheep come into existence. The flesh and wool of the sheep are but the products of the soil, and contain only what has existed in the plants which the sheep have consumed. Thus it comes that we have so many different sizes and breeds of sheep. Soil and climate exert an allpowerful influence on the character of the animals which inhabit any particular locality; and by great care and observance of these facts, man has been successful in propagating and distributing various breeds over the face of a variously constituted soil, until it may now be said that every description of soil and climate has its own variety of sheep.

Sheep-keeping is, after all, but a means to an end, that end being the conversion of the green crops of the farm into marketable produce. It subserves, at the same time, the double purpose of maintaining and increasing the fertility of the soil. But before stock can be kept, there must be some crops grown to feed them. In too many cases, however, it is found easier to grow cattle crops than to dispose of them with profit. Simple as farming seems to be, it presents a peculiar difficulty in the secondary manufacture which is involved in the feeding of stock. This is the most important, as well as the most difficult, branch of farming. Crops that can only be disposed of by selling them to the live stock of the farm, have no determinable value until realized in the meat, wool, and manure which are in turn produced. This secondary manufacture, moreover, with all its uncertainty, is not carried on without much additional outlay of both time and capital, which must needs be reckoned in taking account of the raw crops. It is one of the reasons why meat manu- 
facture on pasture land with a smaller head of stock, is oftentimes more profitable than sheep-feeding on arable land.

The ways and means by which sheep husbandry can be made profitable require years of practical study, just as any other business must be learned before the man engaging in it can reasonably expect to master it. It is supposed by many that sheep are more easily managed than most other farm stock. They fancy that sheep can very well take care of themselves, and any further attention is simply waste of time and labour. Those, however, who entertain such ideas are very greatly mistaken. Indeed there are no other animals on the farm more difficult to manage than sheep, and there are none which will so quickly respond to the treatment they receive, be it good, bad, or indifferent. Single animals, such as the horse or cow, for example, are much more easily taken care of than any large number of the same. Where animals are kept separate their food can be duly apportioned, each receiving its proper share; and should anything be amiss in the health of the animal, it can at once be detected, and the remedy applied. With a large flock of sheep the same facilities for providing all with an equal share of food do not exist, and according as there may be any scarcity of food, or insufficient accommodation for the whole flock, a like proportion of the sheep will be unprofitable. Now no flock, be it large or small, can afford to retain these unprofitable members. For every sheep kept a certain return ought to be made; but when the average results are reduced by a large number of thriftless culls, the profits from the whole are consumed. In sheep-farming, therefore, one of the most important points is in having every sheep a source of profit. This, however, can only be done by great care in everything pertaining to the supply of food; and yet, where a large flock is maintained, it is equally essential to study economy so as to avoid waste. Next to a sufficiency of food it is necessary that it be fed in the best possible manner, securing to the timid as well as the more forward of the flock their due share; and the skill of the shepherd is best shown in the methods he adopts in carrying forward his flock from one season to another. At certain periods of the year there is abundance of keep, and at others it may be scarce; but the experienced feeder looks ahead, and calculates how to provide a regular fare throughout the year, so as to prevent either an over or under supply, and thus maintain his sheep at all times in an even and thrifty condition. Sheep cannot be profitably kept in any other way, and the more knowledge put in force in aiming at such results, the greater will be the chances of success. If well managed, they are fully more certain to yield a profit than any other description of stock. In the course of a year they give two returns-the lamb and the fleece; and things are sadly out of joint indeed, if they do not leave something over the cost of their keep. But, on the other hand, with injudicious treatment, they may prove a means through which the money of their owner may be squandered.

\section{BREEDS OF SHEEP.}

The origin and history of the various breeds of sheep would no doubt be exceedingly interesting, but for the present we can only briefly enumerate and classify the principal varieties, as typical of the different regions they occupy. As to the extent of territory occupied, or the numbers of each breed, we can form no definite idea. From the agricultural returns we only ascertain that the total number of sheep in the country amounts to fully $30,000,000$ head, and that may be reckoned about the general average maintained. The numbers occasionally vary a few millions, from different causes which nobody knows very much about. When sheep are dear they are apt to be pretty freely marketed, and in this way the total numbers may be considerably reduced; whereas, on the other hand, when they are cheap, farmers do not sell more than they can lielp, and thus an increase takes place. The numbers are also affected by disease and unfavourable seasons, but we can give no account of the actual losses from such causes, which is much to be regretted. Farmers do not care to give a statement of their losses, and seem to consider such a question a reproach on their management. If they do not choose to tell their losses, it would at least do no harm to give a description of the breeds of stock kept, and that information, in addition to the numbers given in the returns, would be greatly welcomed by all breeders of live stock.

The different breeds may be classed as follows:-

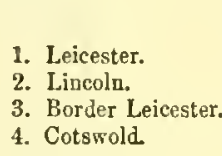

9. Southdown.

10. Shropshire.

11. Hampshire Down.

14. Dorsets.

15. Exinoors.

17. Cheviot.

18. Blackfaced.

\section{LOWLAND BREEDS.}

5. Kents or Romney Marsh

6. Devon Long-rools.

7 . Wensleydales.

8. Roscommon.

DOWN BIEEDS.

$$
\begin{aligned}
& \text { 12. Osford Down. } \\
& \text { 13. Snffolk. }
\end{aligned}
$$

UPLAND BREEDS.

$$
\text { 16. Half-breds. }
$$

MOUNTAIN BREEDS.

$$
\begin{aligned}
& \text { 19. Herdwick. } \\
& \text { 20. Welsh. }
\end{aligned}
$$

The Lowland breeds are typical of a great variety of soils. The Down breeds represent the driest and warmest soils. Then the Upland breeds occupy a ligher region, while the Mountain breeds are typical of the very highest grazings. There are still some other breeds not mentioned, but the above include all the better known varieties. Within the last few years there has been considerable shifting in the relative importance of the breeds, which is still in progress, some gaining in favour, others losing, and we need never be surprised to see entirely new breeds contesting for honour and recognition. At the present time the Cotswold-Hampshire cross in England, and the Leicester-Cheviot or Halfbred in Scotland, are attracting much attention, and there is no doubt but that both of these crosses will yet come to be 
widely known. The latter has received partial recognition from the Highland and Agricultural Society, as we notice they have lately been honoured with a place in the prizelist. New breeds of sheep, or any other variety of stock, ought to be recognized and encouraged by every agricultural society, instead of, as is usual, debarring them until they can no longer be kept out. Nearly every one of the most valuable breeds has had to fight against public opinion for years before our national societies would entertain their claims to a place in the prize-lists; and when we look back and observe the benefits which have been derived from these sheep which were so strenuously opposed, it seems absurd to find certain individuals ever ready to discourage new varieties, that may probably liave greater merits than any breed now in existence. It should be the object of every society to encourage new breeds, and unless that be their line of march they become a hindrance instead of a help to those ther pretend to benefit.

The Lowland breeds are chiefly remarkable for their great size of carcase and length of wool. None of them are considered as producers of the finest quality of mutton, there being too large a proportion of fat in their meat. They have the merit, however, of growing an enormous quantity of both meat and wool, which in a measure counterbalances the deficiency in quality. Their wool is long and coarse, and usually brings a low price in the market. Each breed is adapted for a different region, and one breed is found to thrive where others do not succeed at all, but as a rule they are best suited for rich and heavy soils.

Of the Down breeds, the Southdown, a model of symmetry, is the type and originns. lt has been extensively used in crossing and improving other breeds, and is especially well suited to the dry soil and climate of the eastern and southern counties, though it answers well on the lighter class of soils over the greater part of England; but on the heavier soils, and in the humid climate of the north, and in very cold and exposed situations, some other breeds are found to do better. For quality of mutton the Southdown is equalled by very few other breeds, and is surpassed by none. 'They mature early, are apt fatteners, and thrive on the barest keep, though some growers complain that they are large consumers in proportion to the increase of mutton made by them. Their small size is perhaps their only fault, and is certainly much against them in any comparison with some of the heavier breeds.

The other Downs are all of them larger but coarser sheep than the Southdown, but still noted for producing excellent mutton, and for health and endurance under hard stocking and occasional bare keep. Wherever the land is not quite good enough for the heavier breeds, then one or other of the
Downs will be found the most profitable. They are also better for folding on roots and green crops than any of the long-woolled races.

The Hampshire Down, though a larger sheep than the Southdown, does not mature so early, and is not such a kindly fattener. It is also a large consumer, but is extremely hardy and strong in constitution, and adapted to a wide geographical range. The ewes are not very prolific, but they are in great request for raising early lambs. The improved Hampshire owes all its good qualities to Southdown blood. When fully matured they make heavy weights, but their fleece is generally rather light.

The Shropshire is of similar size to the Hampshire, and is a more handsome sheep, whilst it is equally hardy. It is a lighter consumer, makes better mutton, with less offal in proportion to meat, and clips about a pound more wool.

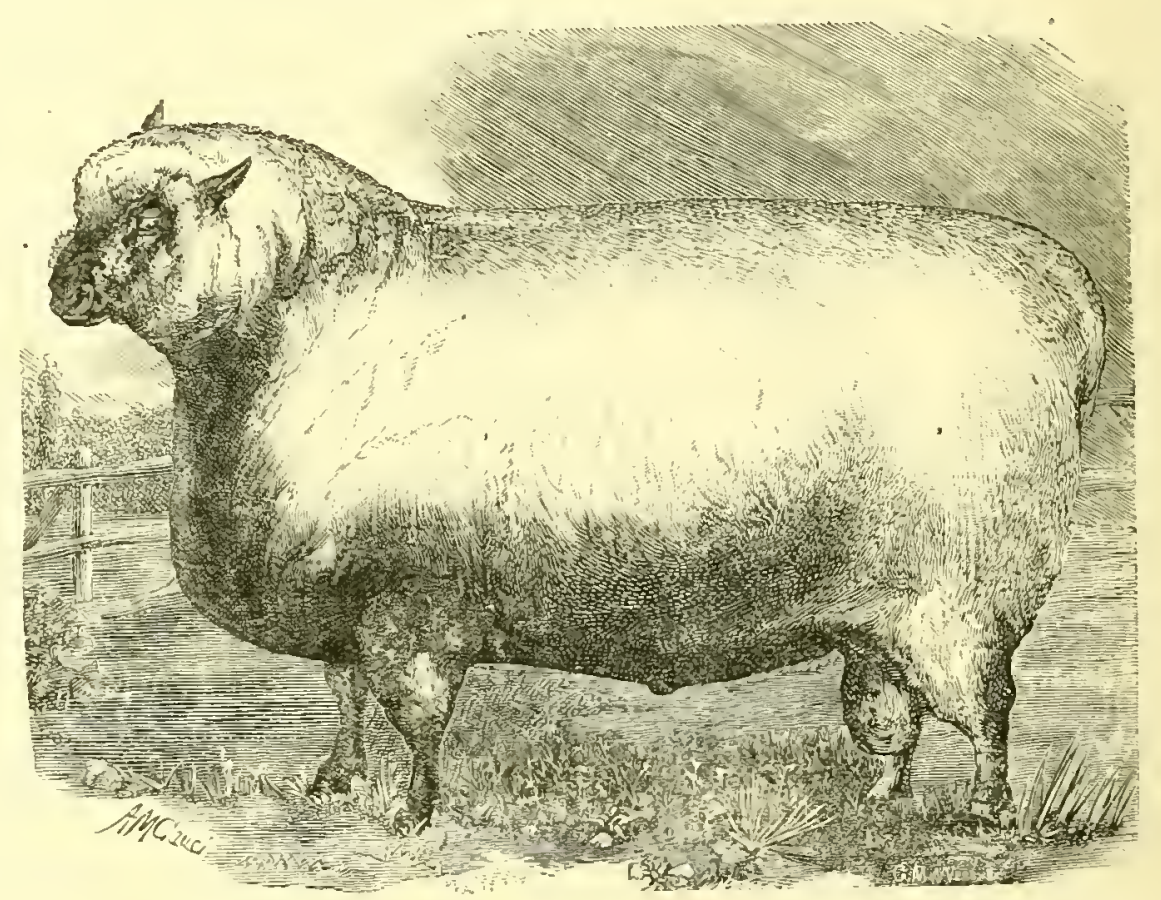

SHROPSHIRE SHEARLING RAM.

The ewes are very prolific, and capital nurses. For quality of mutton, the Shropshire, by universal opinion, comes next to the Southdown. It is the most popular sheep of the day, and has of late years proved itself well adapted to thrive under great varieties of soil and climate.

The Oxford Down is still larger than the Shropshire, whilst it is an equally apt fattener, comes as early to maturity, and carries a heavier fleece. Both the wool and mutton are, however, coarser than that of the Shropshire.

The Suffolk is a similar sheep to the Shropsure, and the formation of a Suffolk sheep society is likeiy to bring this breed into greater prominence. Like the other Downs they possess the peculiarity of having black legs and faces, which the butchers take much pleasure in exhibiting to their customers. The wool of the Down breeds brings the highest 


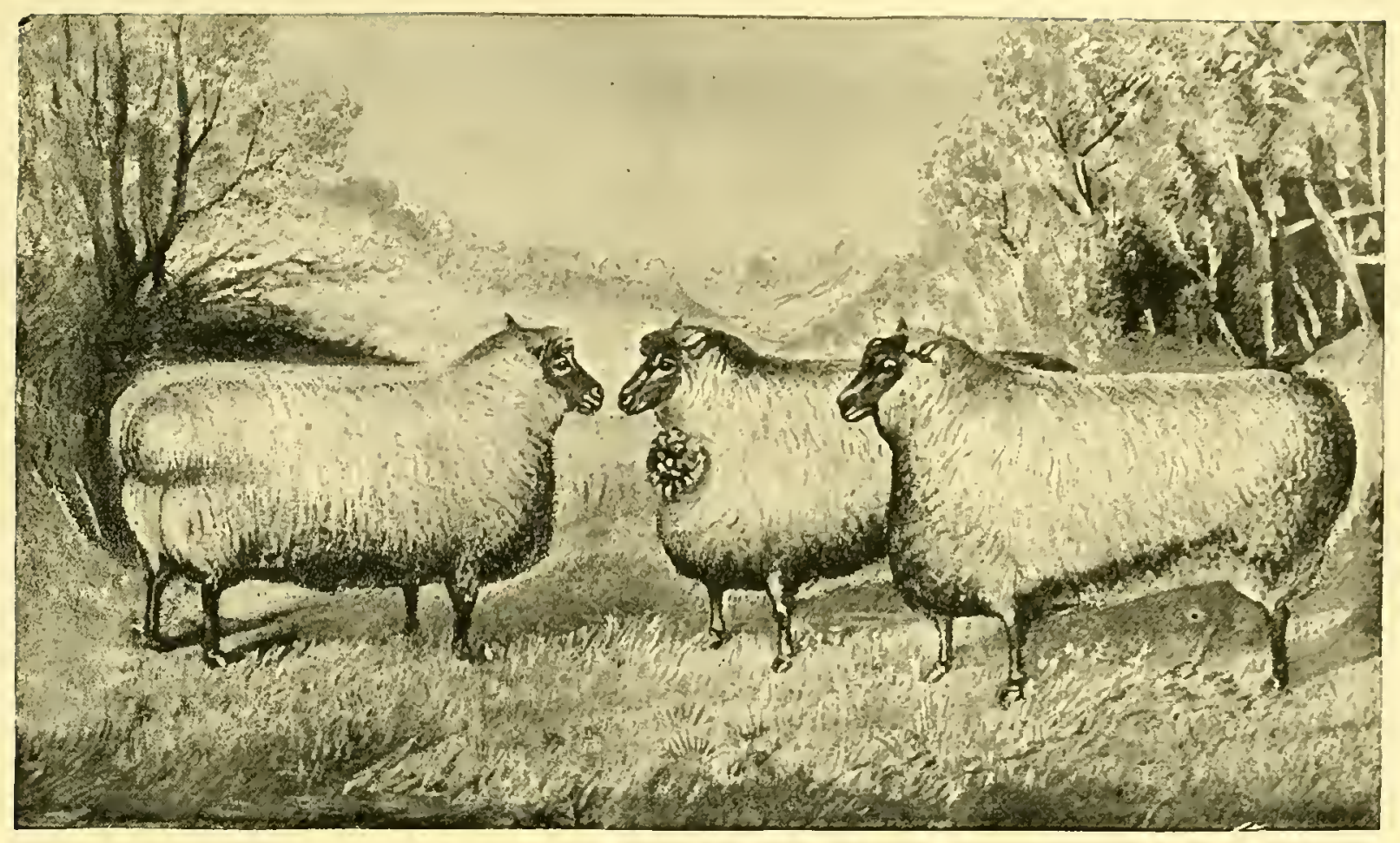

OXFORDSHIRE DOWNS.

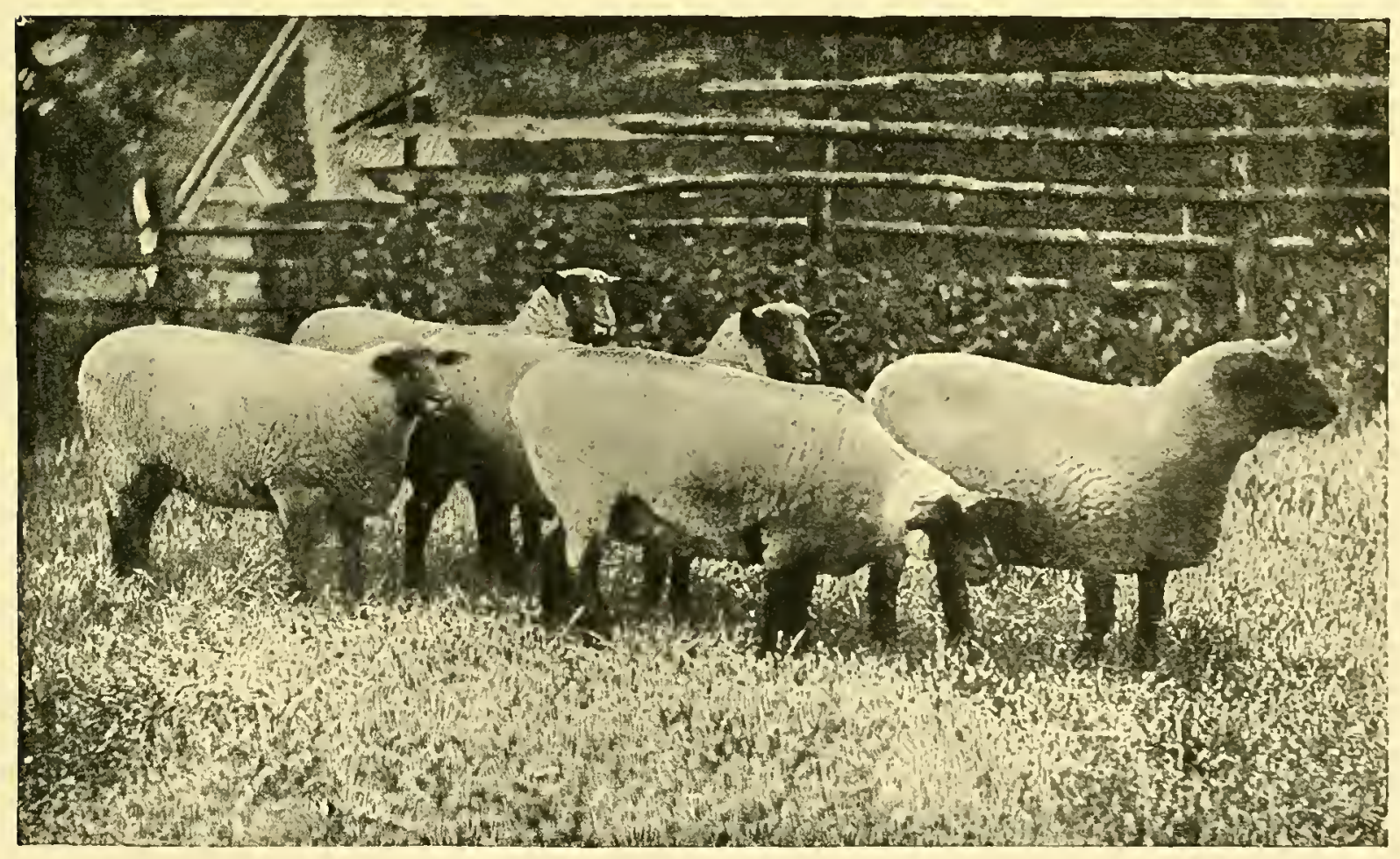



price in the market, on account of its being of a generally fine quality.

Among the Upland breeds the Dorset horns are famous for rearing early fat lambs. No other breed can excel them for this purpose, and they are also the only breed which will bring two crops of lambs the same year. The Upland breeds are all of them hardy, and well adapted for high-lying arable farms. Their mutton and wool are of medium quality and weight, and altogether they form a sort of go-between sheep, dividing the Lowlands from the Highlands.

The Mountain breeds excel all the others in hardiness, which makes them adapted for situations where other races could not exist. The Cheviot occupies the lower and grassy hills on the borders, and is found more or less throughout Scotland. The Blackfaces are the typical Scotch heath breed, and possess a wonderful stamina for enduring severe weather, whilst at the same time subsisting on meagre fare. The Herdwicks are confined to the mountains in the north of England, and although they are a small sheep they hold their position on these hills against all other breeds. The Welsh sheep are also indigenous to their own country, and no imported breeds can oust then from their position. The Mountain sheep are also celebrated for the Havour of their mutton, which invariably brings a high price.

\section{DENTITION.}

In sheep the teeth are not only of extreme importance, but may be said to overlie the whole question and econnmy of

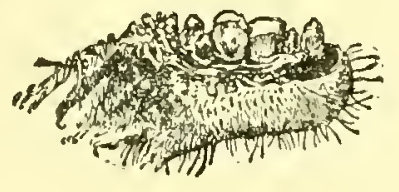

Incisors of Lamb at birth.

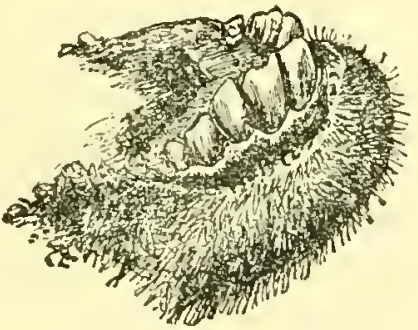

Incisors of Sheep at two ycars and three months,

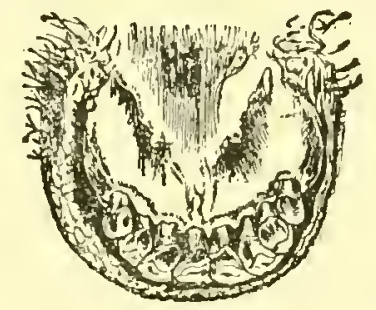

Incisors of Sbeep at one rear.

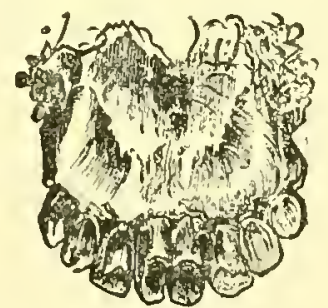

Incisors of Sheep at four years. food and feeding. Their function is to bite and masticate the solid parts of the food, and in proportion to the ease and perfectness with which this is performed the animal thrives, and profits by the consumption of a given quantity of food. When this function becomes impeded or suspended, either through accident, wear, or natural decay of the teeth, the animal will often pine with hunger, because it can no longer bite or masticate, and fails to appropriate the aliment contained in what it eats; so that except under altered conditions it can no longer be fed and nourished without a direct loss and waste of food. In a state of nature the teeth of the animals which man has domesticated to his own use would probably continue fitter for mastication until a much later period of life than they do, now that their natural moist and soft food has been changed for that which is hard and dry. The coarser and harder the food, the earlier the teeth become worn down, and so much more complete the loss of function. In the case of sheep fed on turnips, cake, and corn, the ewes of the flock have to be drafted when a year or two younger than is necessary where they are only grass fed. The practical effect of this is, that, with the ewe so artificially fed, the teeth begin to loosen and fall out, or get broken, almost before the animal is full-mouthed; and, as a rule, it does not pay to keep ewes until they begin to fail in condition from this cause, as they are no longer fit to rear a lamb without extra nursing, and would soon be very difficult to fatten.

'The accompanying diagrams by Professor Brown, in the Journal of the Royal Agricultural Society of England, show

very clearly the position of the teeth of the sheep at the diffcrent stages of development.

There are two sets of teeth in all the domestic animals a first, deciduous, or milk dentition; and a second, permanent, or adult dentition. Each set when complete consists of incisor, canine, and molar teeth. The incisor or front cutting teeth are easily distinguished by their sharp chisel-like edges,

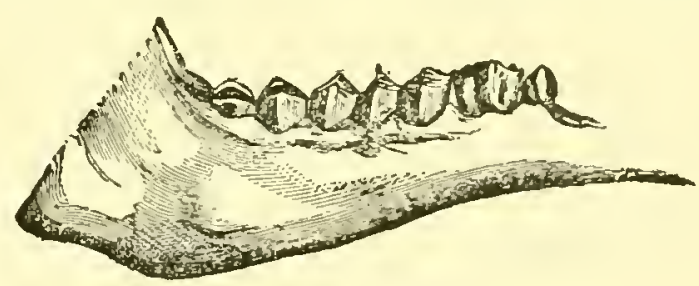

Miolars of Lamb at three months

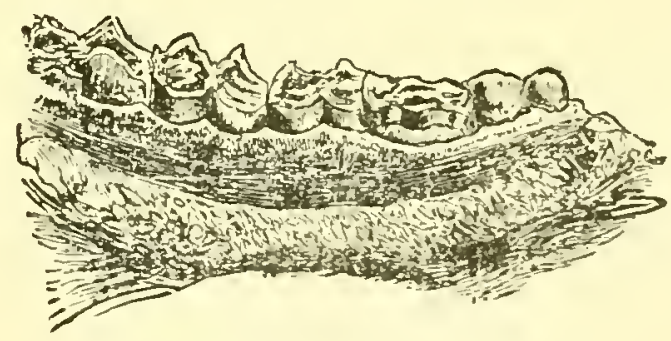

Molars of Sbeep at one year and ten months.

and to their condition chiefly depends the facilities for feeding. The canine or eye teeth come next. They are never more than four in number, and are stronger and more deeply fixed in the jaw than the incisors, but both the canine and incisor teeth have only one fang. The other teeth are molars or grinders. They have two or three fangs each, and their crowns are broader than any of the other teeth. The molar 
teeth are well adapted for masticating and reducing the food to a pulp, when it is afterwards returned to the month in the process of chewing the cud. Sheep never suffer from decay or injury to the grinders. At whatever age they may be examined the molars will always be found sound and perfect.

The age of the sheep can be determined by the incisor or front teeth. At a month old a lamb will have eight incisors or milk teeth, which are temporary. At from ten to twelve months old the centre pair of incisors will be replaced by two larger teeth, which are permanent. At from fifteen to twenty months the second pair will have appeared; the third pair at two years and three months; and the fourth and last pair at three years or shortly after. The age at which the teeth are shed greatly depends upon the nature of the food which the sheep receive. If fed on grass or soft food only, the period of development will be much later than when they are fed upon roots or other food which exert a loosening effect on the teeth. Since early maturity and precocity have been cultivated and encouraged by breeders, the dentition in sheep is developed at a much earlier age. As a rule, a sheep when well fed from birth onwards will acquire its permanent teeth several months sooner than one that is maintained in a poorer conditiou. There are, however, instances of irregular development of the teeth, as has sometimes been discovered in show-yards; so that, while a generally correct opinion can be formed of the animal's age, it cannot be called definite in every instance, yet it is sufficiently accurate to be depended upon for ordinary purposes.

\section{NAMES OF SHEEP.}

In different locaitities the names or terms used to express the age and description of sheep are somewhat ambiguous. A North-countryman scarcely can understand the definitions given by those of the sonth, and the Southerns, no doubt, experience a like difficulty in the north. Generally speaking, the age of a sheep is reckoned from the time it is first shorn, althongh the first year may include two or three months over that period. The following are the usual terms:-

\begin{tabular}{|c|c|c|}
\hline AOE. & M $\triangle \Delta L E$. & FEM \\
\hline Lambs till weaned. & $\left\{\begin{array}{l}\text { Tup or wether lamb. } \\
\text { A heeder. } \\
\text { A pur lamb. }\end{array}\right.$ & $\begin{array}{l}\text { Ewe lamb. } \\
\text { A chilver. }\end{array}$ \\
\hline From weaning till shearing. & $\left\{\begin{array}{l}\text { Wether teg, tnp or wether } \\
\text { bogg. }\end{array}\right.$ & $\begin{array}{l}\text { Ewe teg. } \\
\text { Ewe hogg. }\end{array}$ \\
\hline From first to second shearing. & $\left\{\begin{array}{l}\text { Dinmont ram or wether. } \\
\text { Shear-hogg. } \\
\text { Shearling. }\end{array}\right.$ & $\begin{array}{l}\text { Gimmer. } \\
\text { Theave. } \\
\text { - Shearling ewe. }\end{array}$ \\
\hline Second to third shearing. & $\left\{\begin{array}{l}\text { Two-shear ram or wether. } \\
\text { Two-year-olds. }\end{array}\right.$ & $\begin{array}{l}\text { Two-shear ewe. } \\
\text { Twinter. } \\
\text { Maiden ewe. }\end{array}$ \\
\hline
\end{tabular}

After the third shearing, three-shear or four-shear, three or four year olds, are the definitions employed, until the sheep are drafted, when they again assume different names. Ewes drafted at the regnlar age and uncrossed are simply termed draft ewes. When they have been crossed with rams of a different breed, they are called crones, crocks, or milled ewes. In buying draft ewes, by whatever term they are named, it is also essential to know whether they are good or bad in the mouths. The cordition of their mouths is usually given by the seller, but it is well to malse certain on this point before buying at auction marts, as mistakes sometimes occur merely from neglect to mention the fact, even when no intention to deceive is at all intended. Barren sheep are termed eild, yeld, or yell ewes, and these may imply any age. When a lot of sheep are drafted, they are assorted according to quality before being sent to the market. The best lot are called "tops," the next "seconds," and the next thirds, shots, or culls. Deformed and crippled specimens in Scotland are termed "pallie lambs." The descriptive names of sheep are thus not a little confusing, and strangers freqnenting districts where different terms are used with which they are nnacquainted, require to be careful in ascertaining the real meaning of the definitions given.

\section{SELECTION OF BREEDING STOCK.}

To maintain a flock of sheep in an improved and profitable condition, it is necessary, once or twice a year, to weed out every animal that fails to come up to the required standard of excellence. However much attention may be devoted to securing good rams or a few choice ewes, their influence will entirely fail to effect an improvement unless the whole flock be subjected to a thorough and careful selection. The large hole through which the profits of the farm are constantly dropping, is the poor utterly profitless members of the flock. The influences that are destructive of profits are often beyond our control, but it is recklessness of which any man ought to be ashamed to keep a leak of this kind dropping from year to year. It is a necessary duty of every flockmaster to examine his flock carefully, and rid it of any unprofitable sheep it may contain. No sheep should be kept that will not pay for what it consumes. Turn it off as quickly as possible, and better give it away than retain such stock on the farm. It is such an easy matter to cull a flock and keep it up to the highest standard, that this element of weakness in sheep husbandry which poor sheep represent should never be permitted to exist. It ought to be realized that only good stock is really profitable. When drafting is being done, it is a very common practice to select by numbers instead of for profit. The usual plan of maintaining a certain number, entirely regardless of the quality, is a decided mistake. It may be very important to keep up the flock to a certain number, bat retaining every kind of sheep for this purpose is a wrong principle to go by. Drafting should be done according to merit in the first place, and if the number be afterwards deficient never attempt to make it up from the culls. For fattening stock we want the best, and surely for breeding purposes the very ntmost care should be taken to select only those likely to yield a profit.

The selection of breeding stock is a matter of the utmost importance to the flockmaster. It is not only important to 
pay great attention to the race, but individual merit nust be looked after to ensure success. As to the best breed, this is a point that each individual breeder must decide for himself, taking into consideration location, object in view, available food, and preference. A man is not likely to succeed with any breed of sheep that he has no particular fancy for. He soon loses all interest in his flock, and neglect means failure sooner or later.

When the intention of the breeder is to grow sheep for slow or stock purposes, animals must be selected that combine the highest individual merit with the most fashionable or favourite pedigrees. If he is not posted upon these points, the breeder should have some reliable veteran in the business to make selections for him. There are certain families in all breeds of sheep that produce a greater number of first-class animals than others; and certain crosses will invariably show up the most important characteristics of a breed in the highest degree of perfection. When the sole object is to breed for slaughter, a certain amount of laxity may be permissible in the females of a flock, but even then a high-class male is of prime importance. One of the first and most important principles in the breeding of our domestic animals is the wellknown fact that the sire and dam, or their ancestors, transmit to their progeny the characteristics peculiar to themselves. In starting a flock we should select only those animals for breeders whose ancestors possess, in a marked degree, the excellences we desire in the progeny. In other words, if we would have strong constitutional vigour, a good tendency to fatten, and whatever other desirable quality we want in the lamb, they must be possessed by its sire, dam, and their ancestors.

In selecting a ram observe carefully the important points of constitution, feeding quality, and good breeding. These your sheep must have, and as much of finish, style, and symmetry as you can afford to buy. It is in the male we look for quality. He should show in a marked degree all the attributes of the improved type he represents, carrying, with a masculine appearance, a head far removed from coarseness, and whose fine muzzle and mild eye betoken aptitude to fatten. He need not necessarily be upon an extra large scale. In fact we would prefer a medium-sized, close-made, levcl-backed animal, fine in bone, but not weak, with wool of the right length, thickness, and quality. In selecting rams, notice closely whether they show a tendency to weakness in the hind legs. Some rams stand up as squarely on their feet as a horse, while others are extremely faulty. The model ram of any kind should have clean bones, pretty straight hocks, and free motion sufficient to carry him over any ground.

While the ram is fitly termed the head of the flock, it by no means follows that little or no attention must be paid to the selection of the ewes. Breadth and depth of frame are of paramount importance in the ewes, and, as a rule, the short close-made ewe is not as good a suckler, or as prolific a breeder, as those more rangy and of greater length. But in selecting an animal of great length, be careful to observe that she is strongly coupled. A ewe should invariably lave a strong constitution. The full girth around the lieart tells of lung powcr, strength of kidneys are told by broad strong loins, and the round well-developed barrel tells of strong digestion and ample room for food and foetus.

The breeders thus selected, we would develop gradually, attempting to remedy every defect in the next generation, by pairing the faulty individual with one of the other sex which is free from the blemish in question. This is the whole secret of breeding animals to perfection. While, howcver, this is the line on which improvement must procced, it may be laid down as a main principle in breeding, that the male and female cannot show too close an assimilation in general characteristics, if we would keep up the standard we have with reasonable success. Cross-breeding with a view to improvement, although a valuable means to that end when judiciously pursued, is often totally misapplied. If we have the best-shaped breed, we can obtain no advantage on that point at least, but may very probably lose ground by crossing. There is much prejudice in many quarters against breeding in-and-in-that is, inter-breeding too closely between members of the same family; but if we set off right, feed well, and carefully select the fittest, we may breed from the same stock, with increasing success, to the end of the chapter. The reason why many have failed here-why their animals suffered in size, in fertility, in constitutionis simply because they have ignored atteution to details anc principles, or never understood them.

While greater care may at times be necessary in selecting rams for special breeding purposes, there need be no difficulty in securing those suitable for ordinary use. When the flock is maintained by the home-bred ewe lambs, it is advisable to secure at least a proportion of better class rams than where the flock is maintained by purchasing the necessary number. And yet, although many breeders do not hesitate to pay ligh prices for several of their rams, it is surprising how little care many of them bestow in selecting ewes for these rams. Instead of selecting the choicest of the ewes for the rams specially purchased to improve their flock, they deliberately turn good and bad rams all together amongst the ewes. Now this kind of breeding is simply an absurdity. The man who pays a high price for a ram, and does not take the tronble to select his ewes, spends his money needlessly. There is only one method in breeding that can bring success, and that is selection of both ewes and ram. It takes a little extra work to keep each ram and his ewes in separate lots, but where good results are required no other system will be effective

The ways and means by which sheep husbandry can be made profitable require years of practical work, just as auy other business must be learned before the man engaging in it can reasonably expect to find it profitable. If the following experiences of one who has served his apprenticeship be of any value to those less fortunate, the writer's object will have been accomplished. 


\section{SHEEP LANDS.}

Sheep are known to prosper and thrive under nearly every condition of soil and climate found in Great Britain. It would be difficult to state in what part of the island sheep arrive at their fullest perfection. Perhaps snch a locality does not exist. In every district where the same geological formation predominates, a similar influence is effected upon the herbage produced, and the breeds of sheep which have, as it were, been grown from such materials, are alike well snited for the lands they occupy. Animals differ essentially under the variations of soil and climate; but they are always found of the fairest statnre and finest flesh in localities abounding with herbage and moderately warmed by the heat of the sun.

Better land enables us to keep a better class of stock, and vice versâ. There are, however, some breeders who would have us believe in the comparative merits of the different kinds of sheep, regardless of either the quality of soil or food; but it is only those who have no experience of sheep lands that can be gulled by such doctrine. There is no breed of sheep withont some particular merit which fits them for certain localities and circumstances, and for which they are peculiarly adapted; but while one breed may lay claim to one or two points of superiority, it is perfectly clear to the unbiassed mind that the merits of any breed entirely depend upon the conditions under which they exist. It is possible in some localities to improve botb land and sheep to a higher degree of excellence than they can elsewhere be maintained, and it is for this reason that sheep well adapted for one locality may be very unfit for another.

Hills, downs, and high lands produce small or middle-sized, and lively breeds of sheep, having small and hard bones, firm, finely-grained flesll, inclining to the wild or venison flavour. These small breeds are obviously proper for situations where the keep or pasturage is not very abundant; they will also thrive on good keep to a pitch of fatness they never attain upon their native downs, and they are susceptible of great improvement in bone and size, but probably with the loss of a considerable share of the original flavour of the flesh, unless that can be retained by the cultivation and use of the mountain grasses. Low country pastures and marshes, affording a full bite of rich and rank grass, produce large, bony, and fleshy animals; but stock on these lands are apt to overtop the mark in point of size, their flesh to become close-grained and insipid, and to lose in flavour and nutritive power as it gains in weight. Such animals will not thrive when transported to poor land and short pastures. Farmers with indifferent grass land must take care to proportion the size of their sheep to suit the quality of their pastures; the animals had much better be too small than too large. Any attempt to increase their size without improving their food, by which their size is regulated, is a fruitless effort to counteract the laws of nature. To increase their size under such conditions is to make them worse in form, less hardy, and more liable to disease. The only satisfactory and judicious mode of en- larging the size of any breed of sheep is by maintaining better the original stock on the farm, more especially during their youth. In every case where the enlargement of the carcase is brought about by cross-breeding, the cross bred must be better fed than the native parent.

Profit from sheep, or any other stock, depends greatly on laving the proper number for a given quantity of food. Whether the animals be pastured or hand-fed, they require a certain amount of food on which to produce a given amount of meat and wool. If the food be insufficient, the sheep will suffer and cannot possibly grow to the same value they would otherwise do on a full diet. On the other hand, when there is more food than can be profitably consumed, there will be waste, and consequently loss. In hand-feeding the rations can be served out in exact proportions, and the maximum of results obtained with certainty; but it is different when the animals are to be grazed. An idea may be formed from the quality of the soil and pasture of how many sheep per acre the grazing will maintain, yet there are many influences at work which may considerably alter the value of a pasture. The weather, for instance, has a very great deal to do in determining results. A continued drought may affect the growt th sufficient to cause almost starvation; or a very wet season will affect the quality of the pasture, and this, together with the injury done to the animals, may materially alter the most experienced calculations. As we cannot form any definite opinion as to what the season will be, we must hark back and form conclnsions from past expericnces But every prudent grazier will stock his land rather under its resources. Should an unfavourable season occur, there will then be a surplus which the sheep will fall back upon, and which may be the means of carrying them through a trying period without much damage being done; and should a more than ordinary season occur, it will give the sheep a greater abundance of choice food, which will always pay in proportion to the condition of the sheep. In sheep-farming, then, one of the chief points in determining the profits or the excellence of a flock depends on laving the maximum number of head for the given quality of food.

The stocking of land with the most suitable description of stock is, indeed, one of the nicest points in the science of farming. When sheep are the stock preferred, the next problem is, What particular breed will in the long run return the most profit? and this question must be viewed in strict relation to the management that can be adopted on the particular farm. It is not merely, which breed will make the most meat and wool? but, which will make it in the shortest time and on the least food? which can stand bad weather, or hard keep, or a particular mode of management the best? From want of first taking all the points into consideration, fatal mistakes have sometimes been made in estimating the value of sheep lands.

Sheep pastures ought, as a rule, to be pretty well stocked, as the younger the grass is the better they thrive on it. This should be more particularly attended to on rotation grasses, 
where ryegrass forms very often a large proportion of the herbage; for unless ryegrass is kept well fed down it runs to seed, and as the ears of this grass are particularly liable to ergot, it then becomes dangerous not only to sheep, but to milk cows and other cattle.

In grazing the great object is, no matter what the stock, to carry the animals forward as fast as is desired, without the herbage being wasted. To do this, both the land and the stock must be carefully inspected every day; and fattening animals especially are liable to suffer if this is neglected, as it sometimes happens that, in order to keep them progressing, they require an immediate change of pasture, even where in addition they are liberally fed with oilcake and other kinds of food.

\section{SYSTEMS OF S'TOCKING.}

\section{ON ARABLE FARMS.}

On arable sheep-farms the rotation of cropping is generally controlled by the stock, but in many cases where sheep are not so much the object the rotation of cropping regulates the system of stocking. In other words, the stock is either master of, or subject to, the crop. The location of a farm, and the nature of the crops produced, also materially determine the number and description of the stock. Owing to the variety of circumstances which affects the nature of management, and the vast number of systems practised both in cropping and stocking, the profits from any of the methods cannot be shown from fictitious examples. In comparing the results of two or more systems, it is necessary that the whole working expenses of the farm be included; and as these are subject to infinite variation, it is impossible to arrive at any definite conclusions. What might appear, on paper, to be the most profitable method to adopt, may in practice prove the reverse; consequently we will merely show the systems possiblc to pursue, leaving each one to decide for himself which is likely to be the most profitable.

A regular ewe stock is maintained by keeping a proportionate number of the top ewe lambs, and is necessarily a pure-bred flock. On arable farms the ewes are generally sold at four years old, after having brought three crops of lambs. Thus a regular ewe stock consists of four different ages. In a flock of 500 sheep under this system, the following numbers and ages should produce the quantity of sale stock shown:-

Keeping Stock.
132 ewe boggs.
125 two-shear ewes.
120 three-shear ewes.
115 fonr-shear ewes.
8 rams.
500

$$
\begin{aligned}
& \text { Sale Stock. } \\
& 275 \text { wedder lambs. } \\
& 143 \text { second ewe lambs } \\
& 115 \text { draft ewes. } \\
& 2 \text { rams. } \\
& 132 \text { top ewe lambs. } \\
& 500 \text { fleeces }
\end{aligned}
$$

The 132 top ewe lambs are retained to keep up the stock, and there will only be two rams to purchase annually. The sale stock are disposed of according to the system of cropping pursued; but of course, whatever method may be adopted in disposing of these, it will be understood that the numbers of the keeping stock are subject to alteration, unless the quantity of food provided is sufficient to fatten all the produce without encroaching on that which belongs to the keeping stock.

$$
3 \mathrm{Q} *
$$

With a regular ewe stock, either of the following systems may be carried out:-

(a) Selling the lamba at weaning time, and also the draft ewea, lean.

(b) Selling the draft ewes fat, together with their lambs, before weaning time; the balance of the lambs aold as before.

(c) Fattening of the lamba as hoggs, and also fattening the draft ewes, or parta of the same.

(d) Rearing young rams for aale at six or twelve months; selling the remainder of the lambs and draft ewea fat or lean.

By a running ewe stock is understood the practice of buying-in ewe lambs to maintain the flock, and selling all the produce. This system is followed where half-bred ewes are kept. The expenses are much the same as with a regular flock, but with this difference, that having to buy the ewe lambs to maintain the flock, we should probably have to pay a proportionately higher price for them than we could sell the home-bred lambs at. The keeping stock would be the same in number and ages as in the previous system, but there would be 132 more lambs to sell; and the methods of disposing of the sale stock would be as follows :-

(a) Selling all the lambs fat before weaning time, and also the draft ewes.

(b) Selling all the lambs and draft ewes in store condition.

(c) Fattening off all the lambs as hoggs, and also fattening the draft ewes, or parta of the same.

With a running stock some prefer to buy in gimmers instead of ewe lambs, which is probably an improvement, as more ewes can be kept when there are no hoggs to keep. The only difficulty about this system of buying gimmers, is in not being able to secure so suitable a description of stock; in the lamb market a much better choice can be had.

A flying ewe stock is one where the ewes are bought in annually, and sold out again after bringing a lamb. Where a stock of this kind is kept, the best system is to fat both ewes and lambs; sometimes, however, they are both sold lean; at other times the ewes are fattened, and the lambs sold to go to keep; and in other cases the lambs are kept on and fattened as hoggets.

Where the stock is subject to the crop, store sheep or lambs are bought in, and either grazed for six months and then fattened, or put to fatten right away; in other cases they may be bought in and wintered or grazed, then sold out again in store condition.

In some situations the farmer who grows root and green crops may find it pay better to have them fed on the land by somebody else's flock, than to keep one of his own for that purpose. By doing so he can net a definite sum for the crop he has already been at the trouble and expense to grow, without incurring the additional risks and outlay which are necessarily involved in the conversion of vegetable into animal produce. Under ordinary circumstances, lowever, this plan is not advisable, where the farm is suitable for the maintenance of a regular flock, and the farmer understands the business of stock-keeping and stock-feeding. But the latter is confessedly the most difficult branch of farming; and where the farm is not well adapted to it, it may be better to leave the risks of this secondary manufacture to another.

On arable farms where root crops are grown and no flock is kept, it is the practice to let the roots to be fed on the land, 
sometimes at a stipulated price per acre, though more generally at a fixed charge per sheep. The charges vary a good deal, according to the season and the crop; but usually the price of turnip feeding ranges from $4 d$. to $7 d$. per week for hoggss, and from $6 d$. to $10 d$. per week for ewes and old sheep. These prices are occasionally exceeded when turmips are scarce, and as much as $1 s$. a week is sometimes paid in the spring for turniping old sheep; but when it comes to an extreme price like that, feeders quickly fall back on other descriptions of food. On dairy or cattle farms the winter grass is usually let to slieep graziers in the same way, from $5 s$. to $10 s$. per head being charged for young sheep, according to the quality of wintering; extra food in the shape of hay or turnips, which is sometimes necessary in the time of a storm, being charged also at a fixed rate. This system is practised largely by the Kentish sheep graziers of Romney Marsh.

\section{ON HILL FARMS.}

The stocking of hill farms is a much simpler affair, as it does not admit of so much variation. A hill ewe flock is always regular or self-maintaining, the top ewe lambs being retained for this purpose. Hill ewes are never turnip fed, and keep good in the mouths longer than arable land flocks. For this reason they are not drafted at so young an age. Formerly the practice on hill farms was to keep six ages, taking five crops of lambs; but latterly keeping only five ages, and drafting a year earlier, has become more general. On most liill farms the ewes have their first lambs as gimmers, or at two years of age; but on some of the highest-lying breeding farms no lamb is taken from the gimmers, which makes them stronger ewes, and they afterwards do better. In a good season the top wedder lambs, and a few of the eild sheep from some of the best farms, are occasionally sold fat from the hill, but otherwise all the stock are sold in store condition. There is no other system but selling lambs and ewes at the usual time on hill farms, except keeping a few of the best tup lambs and selling them as young rams. A breeding flock of about 1000 sheep is made up of the following numbers and ages, and sliould produce the stated quantity of sale stock:-

Keeping Stock.
215 ewe hoggs.
210 two-shear ewes.
205 three-shear ewes
200 four-shear ewes.
195 five-shear ewes.
20 rams.
1045

Sule Stock.

360 wedder lambs.

145 second ewe lambs.

195 draft ewes.

4 rams.

215 stock ewe lambs.

1045 Hleeces.

$$
1045
$$

The 215 top ewe lambs are kept to maintain the flock, and five rams are purchased annually. If ram breeding is pursued then there may be these extra to sell, but there would then be fewer lambs to dispose of.

Wedder flocks are generally kept on the highest hirsel of the farm, and are maintained from the wedder lambs of the lower hirsels. Where wedders are kept the land will usually graze one-fifth more of these than ewes. Wedders are drafted at two or three years of age, and generally they bring good prices for feeding purposes.
In high districts the hill farmers are dependent on lowland farms for winter keep for hoggs. The hoggs are sent to the low grounds from October to April, and are wintered at a fixed sum, being about $6 s$. to $8 s$. a head. The ewe hoggs are wintered on grass, and only get hay iu the event of a storm. The wedder linggs are generally allowed a run on turnips for a couple of months in spring, which makes them stronger in the bone. All the lambs or their skins have to be returned, and in some years they come back mostly in skins. It has often been a wonder to me how it pays at all to send them.

\section{FOOD AND FEEDING.}

In the Appendix a table is given showing the approximate composition and the albuminoid ratio of the principal foods. A careful study of that table is the first and most important step in the science of feeding, and every stock-man may profitably devote a leisure hour to its perusal. Until the stockfeeder acquires a thorough acquaintance with the composition of the substances used as food he must continue to grope in the dark. In every operation of nature simple elements combine in direct mathematical ratio. One volume of oxygen to two volumes of hydrogen are required to produce waterneither more nor less of either, or there will be waste, but with just the right proportion of each there is no waste. The same principle is true when we consider the production of animal organisms. Every kind of food requires an equivalent of something with which to unite in forming a part of the organism. The food that nourishes the animal must contain not only the right elements, but in the right proportion. If there is a lack, the animal may have stored up the means of supplying the deficiency for a season; but sooner or later the supply will be used up, when the organism will collapse for want of the missing element. This shows the necessity of a knowledge of the composition of foods, and the value of having a correct proportion of the different elements properly balanced in the ration. The feeder should not forget, however, that the tables of analyses are only approximations to real facts. Very much depends upon the quality of the food-the stage at which it was cut, and the condition in which it was secured. The tables may be accurate so far as the samples from which they were made were concerned, but still the question arises, How nearly does the quality of our food correspond with those on which the tables were based? An analysis of somebody else's fodder does not determine the quality of ours; and until every feeder is able to analyze foods for himself, he can only examine the feed tables, however correct they may be, and guess at the quality of his own fodders. But still the tables are not without use. They enable us to tell what foods are rich in nitrogen and what are rich in carbon, and about the proportions of each ingredient. 'Then we can combine the foods with a much greater degree of intelligence, and approximate much more nearly the proper balance. With such information, we would not readily commit the blunder of feeding all carbonaceous 
food, or all nitrogenous food, nor of combining two foods of the same gencral character.

Feeding substances may be classed under three distinct heads :-

(1) Non-nitrogenous compounds, which fulfil the office of supporting respiration and animal heat, and the production of fat.

(2) Nitrogenous compounds, which repair waste of body and build up new tissues.

(3) Mineral matter, which forms bone, \&c., and the saline matter of blood.

The non-nitrogenous compounds consist of legume or woody fibre, starch, sugar, gum, oil or fatty matter. 'These form the greater part of the dry substance of vegetable productions used for food, and when received into the animal system, become the fuel necessary for sustaining the animal heat in the process of respiration. 'The breath of animals affects the combination between combustible materials in the blood and the oxygen of the atmosphere, and as in this process a certain amount of heat is liberated, the animal heat requisite for the animal's functions is kept up. These combustibles may be called animal fuel. When a larger quantity of this kind of food is taken by an animal than is required to sustain the proper heat of its body, the excess is stored up in the shape of fat. Thus an animal confined in a small space, and not exposed to a chilling atmosphere, lays up fat from the formation of this material from the food that would otherwise be consumed by exertion or the influence of the weather. Therefore the members of this group of organic compounds, when used as food, act either by supplying the animal system with warmth, or by furnishing material for the formation of fat.

The nitrogenous compounds constitute the smaller and clioicer portion of the vegetable substances used for food. They differ from the preceding ones in having a less simple composition. They contain, in addition to carbon, hydrogen, and oxygen, nitrogen; as also smaller quantities of the rarer mineral substances, sulphur and phosphorus. They all closely resemble in character the animal substance called albumen, or white of an egg-hence they are called albuminoids; and from the fact of their being the more valuable principles of food, or that portion of it which supplies animals with the nuaterials of which their blood, flesh, and structures are made, derive their more common name of flesh-forming principles. The names of these compounds are albumen, vegetable casein, gluten or vegetable fibrin, and legumin. Since it is from these nitrogenous materials that the bodies of animals are built up and strengthened, it follows that the nutritive value of food, as far as its power of forming flesl 1 is concerned, depends on the amount of those substances it contains, provided, of course, they exist in a condition that will admit of appropriation by the digestive organs of the animal that receives them. The greater the amount of exposure the animal undergoes, the larger must be the quantity of these substances that must be given in order to sustain its condition. In young growing animals the proportion of these materials in the food must be still larger. With young animals we have not only to provide for building up new muscle, \&c., but at the same time the food must contain sufficient non-nitrogenous substances to support respiration and keep up animal heat, and also a supply of soluble phosphates for the formation of bone. When we want to fatten an animal these different compounds must be given in excess. The young lamb is nourished by milk. Now milk is a natural and most perfect food. It contains a proper mixture of the flesh-forming elements, along with those of respiration and fat. It contains (1) casein or curd, which is precisely the same as the fibrin or lean part of flesh; (2) fat, in the shape of butter or oil ; (3) sugar, which is required in the process of respiration; and (4) certain mineral substances which are connected with the eartlyy part of the bones and the saline matter of the blood. The next food a lamb has after birth is probably grass, and here again we have all these materials-heat and fat producing, fleshforming, and mineral matter present, only in different proportions; and the same may be said of swedes, oats, hay, \&c., each of which again is seen to vary, not in the elements of composition, but in the form of that composition.

Next to providing a sufficient quantity of nutritıve matter in the food, its bulk is to be considered, and this is important. The function of digestion requires that the food shall properly fill the stomach; and however large the supply of nutritive matters may be, the effect is imperfectly brought out if the food be too small in bulk. On the other hand, if a food be too bulky, the sense of repletion causes an animal to cease eating long before it las obtained a sufficient supply of nutritive matter. It is most needful, then, to study the bulk of the food, and to consider how to mix different substances in such a manner as to adjust the proportions of nutritive matter to their bulk. Thus it is that in practice we generally find a very bulky food is combined with another of opposite properties-turnips or laay, for example, being fed along with oil-cake or bean-meal.

Sheep and other ruminants in collecting their food, such as grass, form it into a bolus with little or no mastication, and with the expenditure of saliva they pass it down the gullet into the paunch, which, when it has become distended with a sufficient quantity, causes the animal to seek for rest and quiet, when it generally lies down. The paunch begins now to exert its extraordinary powers of separating a portion of the contained mass, and to return it into the montly, where it undergoes a complete mastication; being retained from falling out of the mouth again by the numerous papillæ or rouglnesses of the tongue, which are pointed backwards, and also by the ridges of the palate. When sufficiently masticated and mixed with the saliva it is again passed down the throat; but instead of again entering the first stomach, the muscular gutter forms itself into a tube, and carries it at oncc into the third stomach, where, having to undergo a further change, it is pressed into the red bag (fourth stomach), to undergo a further solution by means of the gastric fluid, preparatory to its being converted into nutriment under the name of chyle. 


\section{DIFFERENT KINDS OF FOODS.}

Grass. - Grass as pasture is the cheapest of all foods that can be given to sheep, and it must ever form the staple food supply in sheep husbandry. Wherever grass is found to flourish, there sheep also are found to prosper. In all countries and in all climates grass is found to flourish for so many months in the year, but it is only in a few where it remains green and growing for more than half of that period. It is for this reason that the British Isles, New Zealand, and other temperate zones, stand pre-eminent in sheep husbandry. The grass, of course, can be supplemented, but where sheep have to be fed on auxiliary foods for six months in the year, we may rest assured that sheep farming will never become a leading industry under such circumstances. Pasture, then, is the chief source of food supply for sheep; and where it is found in greatest abundance, in moist, temperate climates, is where sheep of the best descriptions are most numerous.

The nutritive qualities of grasses depend, to a large extent, on the nature of the soil. Where the soil is naturally poor, or deficient in material essential for plant growth, the pasture is of a like quality, and equally deficient in feeding substances; whereas, on a rich soil, full of manure, and in a favourable climate, the herbage has a higher nutritive value. Nearly all kinds of grasses are relished by sheep, but neither the very richest nor the poorest are best suited for sheep pasture. Where the grass is most abundant, the reason of its not being best adapted for sheep, is because the number of sheep it is capable of maintaining is greater than the space provides for preventing the food from becoming soiled; and on a poor pasture, the nourishment provided is generally insufficient to maintain sheep in a profitable condition. Pasture that will carry from two to three sheep per acre, will give better results than that which carries either a greater or a smaller number. The thinner sheep are pastured the healthier they are, and the better they will thrive, provided they receive a certain amount of nutriment. A sheep pasture need not be of the richest kind, so long as it consists of a variety of grasses in sufficient quantity; and if the soil and climate be favourable, there is no fear but that the sheep will thrive. No animal, but especially a sheep, cares to eat foul or tainted food; and it is generally sound policy to be rather under than over stocked, more particularly when it is desired to rear the best quality of sheep or lambs of which any certain land may be capable. Young grasses are better adapted for feeding sheep than old pasture, and will carry a considerable number more per acre. The closer a pasture is eaten to the ground, the greater value will be the food. It is sweeter, and sheep prefer the fresh growth to matured blades; but there is a danger in eating pasture too close, and it is hardly possible to eat any young or rich pasture very near to the ground without injury to the stock. Any pasture that will carry more than four ewes with lambs per acre is too rich for sheep, and unless it will pay to graze that number, it had better be stocked with cattle.
On very rich pastures, or those specially manured for the purpose, hurdle-grazing has been tried on several occasions, but it never seems to become generally adopted. There is no doubt but that a larger number of sheep per acre can be kept, but the expense of working, it appears, is greater than the advantage to be gained. Still, on a small scale, the system appears feasible. With the aid of manure and irrigation, an extraordinary weight or quantity of grass can be grown on a single acre of choice land, but the difficulty lies in supplying it to the sheep cheaply and without waste. Grass is altogether different from turnips or cabbages, which can be folded withont being trampled under foot; but with the former this is why it often does not pay to fold sheep on pasture, or all such crops where there is no vacant space for the sheep to move in. By using revolving hurdles, through which the sheep can eat, the difficulty is partly overcome. But it is evident that even this method is impracticable on anything like a large scale. The distance a sheep can eat through a bar or a fence is so very limited, that a constant attendance is necessary. Unless for small flocks, on the very best quality of land, hurdle-grazing can never become general.

This method of grazmg has been practised with irrigation at Stoke Park, near Windsor; at Newbattle, on the property of the Marquis of Lothian; by the Duke of Sutherland, at Dunrobin; and by Mr. Brown, at Colinton, near Edinburgh. But at each of these places the system has been abandoned, not from any fault in the system, it is said, but solely owing to the want of facilities for carrying out the experiment on a large scale, and also owing to the fact that proper land had not always been selected suitable for the purpose in view. Mr. Brown, Edinburgh, who patented a revolving hurdle for this kind of grazing, and carried out a trial of the system on a small scale, without irrigation, drew up a report of his experiment, which he read before a large meeting of Lothian farmers in Edinburgh, October 1881, from which the following interesting facts liave been extracted:- "The land under the system at Colinton may be described as a strong boulder loam of medium good quality, 500 feet above sea level. Its condition after a potato crop succeeded by two white crops, was in the spring of this year reduced to the lowest state of fertility, or, in other words, exhausted. It was cultivated in the usual way. No farm-yard dung was applied, but suitable manures for the growth of grass and clover, without any soluble constituents, were ploughed into a depth of nine inches, and a portion was also harrowed in upon the surface. - . The weights of the ten sheep as weighed by Mr. Penman of Bonaly on the 28th of July, when put upon the grass, gave a total of $1175 \frac{1}{4} \mathrm{lbs}$, and varied between the heaviest, $126 \mathrm{lbs}$., and $100 \frac{1}{2} \mathrm{lbs}$, the lightest. When taken off and weighed again by Mr. Penman, the total weight was ascertained to be $1463 \mathrm{lbs}$; the heaviest sheep weighing 155 lbs. and the lightest $127 \mathrm{lbs}$. The total gain is $288 \mathrm{lbs}$. for the ten sheep, or a little over $3 \frac{1}{3}$ lbs. for each sheep per week for the eight weeks." In addition to the grass the sheep 
were fed with $1 \frac{1}{2}$ lbs. of cake and grain daily; but during that time, owing to the grass being too early stocked, the sheep were removed to another poor pasture for the space of three weeks, which, it was stated, did not improve them, and consequently the gain was virtually made during five weeks. The ordinary number of sheep on such land varies from three to five; but Mr. Brown estimated that, under his system, with artificial rain showers, thirty-five sheep might be reared on that space, and without irrigation at least twenty. As previously stated, however, this experiment did not meet witl much favour, and like the others was discontinued.

Hay.-Hay is the principal winter fodder for sheep. Clover hay, or, what is better, a mixture of grasses preserved in good condition, is a perfect food for sheep. It is, however, not so extensively used as one would suppose; a good many farmers do not use it at all, even where a supply is to be had. Its price is doubtless the reason why many do not find it a profitable food, yet there are none who do not admit that it is a most suitable winter food for sheep. Hay can be fed more profitably by itself than any other single food we could name-that is, when its price is in proportion to that of other foods. Alone it will sustain sheep in good store or breeding condition, but its greatest value is found when fed in conjunction with roots or grain. It is also a healthier diet for sheep in winter than cold watery turnips, and especially so for breeding ewes. Abortion in cows has in many cases been traced to ergotized hay, but we have never seen it similarly to affect ewes, although admitting that feeding ewes on such food would certainly favour the disorder. On hill farms, where hay is generally the only winter food provided, abortions are uncommonly rare, and when they do occur, are not always attributable to the hay. Bad hay, no doubt, is to be avoided in any case, and is neither good for sheep nor any other animal; but, singularly enough, we seldom hear of or see much harm being done by feeding hay of any kind. On the contrary, many farmers feed nothing else but hay in winter, and their ewes never do better than when maintained chiefly on this food. The cost of the hay crop in some districts is its greatest fault; still, where it can be clueaply grown, no better food can be had. Average-sized sheep fed on hay alone will consume about three pounds each daily, but where they can get a bite of grass, or a few roots or grain in addition, they will thrive excellently on one pound or even less per day. But sheep that are being fattened on roots or grain only, should not have less than one pound of hay daily. If the cost of hay does not exceed that of roots or grain, calculating the value of one pound of hay equal to one pound of grain or eight pounds of roots, hay will invariably give the best results, and especially when the sheep are to be grazed, not fattened, the following summer.

Strcw.-Straw can also be profitably used in feeding sheep. Indeed the value of straw is not sufficiently known, otherwise its use might become more general. One ton of good oat straw, cut before it was over-ripe, contains of fat- formers 952 lbs.; flesh-formers, 90 lbs. $=1042$ lbs. A ton of good linseed cake contains of fat-formers 1508 lbs.; of Alesh-formers, 582 lbs.=2090 lbs. This comparison shows well in favour of the straw when the difference in the price of the two articles is considered. Sheep on roots will eat a large quantity of straw supplied to them in racks the same as hay, but the best mode of preparing straw for feeding to sheep, is to put a large quantity through the chaff-cutter, and mix it with treacle or pulped roots, which must be evenly distributed so as to permeate the whole mass, and then fed in boxes the same as cake or grain. Its feeding value is not of course very high, but it supplies the required amount of dry bulk, which is so essential in the feeding economy of roots, and as a health agent is nearly equal to the best hay. For ewes on roots a supply of good fresh straw uncut is invaluable in preventing abortion, which is often caused by a too watery diet. It is not at all recommended as a food upon which sheep can be fattened or even maintained, but as a cheap and healthy material for supplying bulk and dry substance lacking in grain and roots.

Silage.-Ensilage must now rank as one of our principal foods. It has been proved that all green forage crops can be preserved by means of the silo or stack process, and that any loss in saving these crops in bad weather can be entirely prevented.* No further proof of the practicability of ensilage is necessary than to say, that wherever it has been tried great satisfaction has been the result in almost every instance. On arable farms, where roots involve a great deal of labour for their successful cultivation and storage, ensilage can take their place, and a great saving in labour will be gained. On clay land root-culture is always attended with very serious difficulties, but now green forage crops can be grown in summer, and preserved until the season when no other succulent food is available. And while ensilage is of immense value to lowland farmers, it is even more so to those on upland or hill farms, where, from wet weather, haymaking is so often an uncertainty. Ensilage will probably become the chief winter food on all sheep farms. It has been found a most suitable food for bringing ewes forward to lambing in good condition, and it causes an abuncant flow of milk afterwards, which makes it invaluable in rearing early or late lambs. It will also be of great value to the wool-grower. It has been found that the change from pasturage to dry winter feed often injures the wool at that period, causing a break or a weak part which destroys its value for some purposes. The use of ensilage overcomes many difficulties in sheep management, and when its cost is compared with that of other foods, it again shows a handsome balance in its favour.

Roots.-Roots form the principal winter food supply in all cultivated districts, the most valuable of which are turnips and mangold. Sheep will fatten on either of these crops without the addition of any other food. It is, however, bad 
economy to use them alone, as experinents have proved that a much greater increase of meat will result when they are judiciously augmented with dry food, such as hay or grain. Turnips contain, according to variety, from 86 to 96 per cent. of water; still they are admirably suited for the food of slieep. Yellow turnips have to a great extent taken the place of swedes on sheep farms, and the growers of them find that they are little, if anything, inferior in their feeding qualities. They also keep well, and have bulky tops. A heavier crop of white turuips can generally be grown than of other varieties, but they are not suitable for keeping purposes, and require to be eaten early, or before the advent of frost. They are most valuable in the autumn when the pastures are beginning to fail, and supply an enormons amount of fairly substantial feeding to sheep when first commenced to fatten, but further than this it is useless to go with them, and yellows or swedes must be resorted to.

The nutritive value of turnips varies with the variety, the climate, the soil, and also the manures used in their cultivation. They become less nutritious after being stored for some time than they are when newly taken up, and also lose a proportion of the water which they naturally contain, although storing for a certain period greatly assists in perfecting their maturity, which is most essential to the health of the animals to which they may be fed. Turnip-tops contain a considerable amount of nutritive matter, but they are only of value for feeding store or lean sheep. When turnips are allowed to stand in the field until they put forth a second growth, a deterioration in their quality is the result, owing to certain of their elements becoming changed into indigestible woody fibre. Of all varieties of turnip the swede is probably the best. It yields a larger proportion of nutritious food than any of them; it is the liardiest, and best withstands the severities of winter weather; and if properly stored up in dry weather, will retain its nutritive juices long after all other turnips have become withered and valueless.

Next in importance to the turnip for feeding purposes during spring is the mangold; and, where soil and climate are suited to, its growth, even more dependence is placed on it, as it has fewer diseases, and yields a heavier crop of greater feeding value. It is needless to attempt its growth if the soil and climate are not suitable-for which reason in Scotland it is seldom grown. In England and Ireland, again, it is extensively grown, and is highly valued for its productiveness and excellent feeding qualities. At the time of lifting the crop, however, in October and November, mangolds are not good food, as they are too full of sap at that time, which is of an acrid nature, and acts injuriously on the health of sheep fed on them: But in spring, when turnips lose much of their nutritive properties, mangolds are excellent in condition, having, from keeping, lost much of their watery nature, and gained in saccharine richness.

Potatoes are also well adapted to the fattening of sheep, if used in combination with other food. When given raw, which is the preferable way to ruminating animals, they are served in the same manner as turnips; but care must be taken to begin with them gradually, as they are apt to scour and injure the animal at first. Like other roots, they are most economically given along with cut dry food. Three or four pounds of potatoes and half a busliel of chaff will be a fair allowance for a breeding ewe, and their palatability and nutritiveness will be beneficially raised by adding a little cake or grain to the mixture. So long as potatoes are not fetching more than $50 \mathrm{~s}$. a ton, it pays to use them for sheep and convert them into meat, rather than sell them in their natural state. Potatoes contain about 75 per cent. of water, and from 2 to 3 per cent. of flesh-forming ingredients, consequently dry food rich in these elements should be used in combination with them.

Two-year-old sheep folded on roots will require about ten weeks to fatten them for the butcher. In that time 100 wethers will consume 80 tons, which is equal to 5 acres of an average crop of 16 tons. The same number of ewes will consume rather mure, and will also require a month longer to fatten, so that they will not eat less than 8 acres of a similar crop in that time. Younger sheep or lambs will eat proportionally less, but these figures make no allowance for waste or destruction from bad weather. Sheep on an average will consume about $28 \mathrm{lbs}$. of roots daily. It is generally believed that frosted turnips are not so good or so fattening as when they are fresh or unfrosted, but experiments have somewhat contradicted this belief. Mr. John Caverhill, Greenburn, Berwickshire, read a paper before the agricultural association of that county, on the results of experiments he conducted to ascertain the relative value of frosted and unfrosted turnips in the feeding of sheep. He selected two lots of ten slieep, which each weighed 1256 lbs. The first were fed on stored turnips, and weighed at the end of three weeks $1305 \mathrm{lbs}$; and the second, which were fed on frosted turnips, weighed $1292 \mathrm{lbs}$. At the end of six weeks the first lot weighed 1431 lbs., and the second 1390 lbs. The total gain of the first lot, fed on stored and unfrosted turnips, was $175 \mathrm{lbs}$; and the second lot, fed on frosted turnips, was 134 lbs. When the two lots were killed, they each yielded an equal amount of dead meat-viz. 707 lbs. The quantity of frosted turnips consumed by the second lot was one-sixth more than that of the stored and unfrosted turnips eaten by the first lot. Dr. Aitken, chemist to the Highland and Agricultural Society, analyzed the frosted and unfrosted turnips. The first contained $90 \cdot 7$ per cent. of water and 9.3 per cent. of solid matter, while the latter contained 91.5 per cent. of water and 8.5 per cent. of solid matter. He was of opinion that the frosted turnips were the better feeding material.

'The root crop of Great Britain is an extensive as well as a very valuable one, and it follows that the extent to which it is used in feeding sheep must also be very great. Roots are fed in every possible way, cut and uncut, with other foods and without, and by all of these methods good results have been given; but, on the other hand, their too free use 
has often been fraught with disastrous events, both from an economical as well as a health point of view. We will not here discuss their cost, but any one who investigates the point will find they are a most expensive food. It has long been supposed that without roots it was impossible to keep up the fertility of a farm, but recent scientific researches have shown their value in this respect to have been overestimated. As to their being a healthy food we do not deny, yet it is well known some of the severest losses amongst breeding ewes have been traceable to their over or injudicious supply. Swedes have been oftener blamed for causing abortion than yellow turnips, owing to their being deficient in saccharine matter and the nitrogenous element abundant, causing irritation of the bowels and foetal derangement; but let the same conditions or unripeness be present in any kind of roots, and their effects will be much the same. There are many flockmasters who practise flushing their ewes at tupping-time, and it is very customary with them to fold their ewes on green or unripened turnips. Now at that time, which is early in the season, there is scarcely an acre of turnips in the country fully matured, and as a cousequence we continually hear of abortions among ewes. That is a long time previous, some may say, and no doubt it is, but our best veterinary authorities tell us that abortion in its very worst forms can easily be traced to the period of conception. At any time there is a danger in feeding ewes solely on turnips, but when they are well ripened there is never so much harm done if they are fed clean and free from an undue amount of dirt. Again, in winter they are liable to get frosted, and to feed them largely in that condition is not unfrequently the cause of ewes aborting. There are other fatal disorders attributable to feeding too many roots, and it is evident that a certain amount of caution is required, taking care always to augment them with an addition of dry food. Still there are some who feed them in almost every conceivable way, regardless of all experiences, and have met with no mishaps. But these are more lucky than prudent, as they may yet find to their cost.

There are two methods of consuming roots with sheep. The first is turning the sheep on to them where they grow; the second is pulling and carting them into heaps, where they are sliced and fed in boxes. Which system is best to pursue will depend on the kind of sheep being fed, the nature of the soil, and the system of rotation followed. Full-mouthed sheep can very well be allowed to eat them whole, but for old sheep, or those not good in their mouths, and lambs or hoggs that are also not strong toothed, the better plan is to cut the roots and feed from boxes If the soil be light and subsoil porous, no injury will be done by folding on the land; but if wet or of a clayey nature, then the roots are better carted off and fed on dry ground. By either method of feeding, when the roots are consumed on the ground, the manurial value of the crop will be equal, but if necessary the turnips can be carted to where the soil is most in need of enriching. The labour involved by the first mode of consumption is comparatively trifling, much less than by the improved modern way of pulling and cutting; and the whole operation we may briefly describe.

After fixing on a certain breadth or portion of the turnips, called a "break," the extent of which is regulated by the number of sheep to be put on, pull two or thrce drills of turnips around the intended space, which facilitates the setting up of the ncts, and likewise leaves no temptation for the sheep to put their heads through the meshes of the net to nibble the tops of the fresh turnips or the shoots of the thorn hedge, should there happen to be one along the end or side of the break. A clear space being made round, a cart is brought up with the requisite quantity of "stakes and nets," which on going round lays out a net at intervals of fifty yards, or whatever may be the length of the net, and the stakes are laid out in bundles of about as many as a man can carry on his shoulder. The man then, provided with a "gavclock" or "piercer" $\rightarrow$ a strong iron bar rounded and sharpened at the heavy end-makes holes at intervals of eight or ten feet for the reception of the stakes all round the break. Having completed this, he next shoulders a bundle of the stakes, and walking smartly on, deposits one in each of the holes previously made, all the way round; this finished, he gets his wooden "mall," and with a stroke or two fastens the stakes in their holes; next he fastens on the nets, and the break is ready for the flock.

Having the work carried on as described, an active man, and one who knows how, will set a great length of nets in an incredibly short space of time. After three or four days the shells or bottoms of the turnips will want picking up, and after another day or two the sheep will want a fresh break: which can be provided as already described, though more nets will be required, as those set round the first break must be allowed to stand until a third break is wanted, to enable the sheep to fall back and pick up all clean, which they will do to a nicety if the weather be dry, leaving nothing but the smallest top roots. By the above mode of consumption an active man will, with the assistance of a boy or woman at picking shells, manage 600 full-mouthed sheep.

The process of cutting and feeding in troughs requires more labour, and consequently entails a much heavier expenditure. In carrying out this system, the first operation is to pull the turnips, cut off tops and roots, and cart into heaps of one, two, or more loads all over the field; and this ought to be done when the weather is dry and without frost, so that the roots may be stored in good condition, to keep them sound during the winter. Some prefer to pull only as wanted for feeding. The turnips being pulled and stored, the nets set as before, and immediately adjacent to a row of heaps, the turnips are then sliced and put into the troughs, and the nets removed as the heaps are finished. By this system of feeding the sheep have always the advantage of a clean bite, but the extra outlay is considerable. A moderately active man can tend from 200 to 300 sheep, but he should have assistance on Sundays. 
Green Crops.-On good land cabbages make excellent sheep food, and also stand the winter well. An acre of these, if a fair crop, will equal nearly two acres of turnips, and they are also a more healthy food. In the autumn, when the pastures are failing, a few cabbages carted out to the flock will keep them going on cheaply and well. On many accounts they are a superior crop to turnips. They are not subject to so many diseases, or liable to so many failures; they grow above ground, and less dirt is eaten with them. They are easier taken up if necessary, and they never need to be cut for the sheep, which is a great saving of labour. On wet soils they must not, however, be eaten where they grow, but cut and carted out to a dry pasture. Sheep will fatten on cabbages alone, but the addition of a little dry food, such as hay or grain, will give a better return for food consumed. A sheep will consume from 20 to $30 \mathrm{lbs}$, , or three or four good cabbages, daily. Thirty to forty tons per acre is not an unusual crop. They are also preferable to turnips for ewes at lambing time, and are very "milky." Those who make a practice of growing field cabbages find they cannot get on without a supply all the year round, and accordingly plant out in spring and at midsummer, as well as in autumn, for successional crops.

For early spring feed and summer fattening, green crups of rye, trifolium, trefoil, rape, vetches, sainfoin, mustard, and lucern will be found invaluable. There are other crops, such as pease, beans, and maize, which are also used in a green state for feeding sheep. As to the relative merits of these crops we do not profess to decide, but they all have their advocates, which no doubt depends a good deal on the nature of soil and climate of the district in which they are grown. All of them have been found to succeed, and each one must decide for himself which will be most suitable. A variety is best, however, and those who go in for summer green crops can have no difficulty in securing it here. There is at least little doubt that any of them wonld be better than a summer fallow, and in many cases they may be made to leave a greater profit than almost any other kind of crop that could be grown. Il ost of all green crops may be folded with sheep, but some of them are better adapted for the soiling system. They are all, also, capable of being converted into silage, and the time is not far distant when by this process they will supersede the present methods of growing turnips and haymaking. In a good climate, with good land, a regular succession of green crops may be grown, and a cuntinuous draft of fat sheep taken from the farm every week in the year.

The quantity of green forage required to maintain a sheep varies according to the purpose in view, and it necessarily varies among different breeds. It will be sufficiently correct, however, to reckon on an average-sized sheep consuming twenty-eight pounds of green food daily. At this rate nearly five tons will be required for its yearly maintenance. This quantity will not be required when an allowance of dry food is substituted.

Cake and Grain.-Of concentrated food in the shape of cakes there are an almost unlimited variety and supply, nearly all of which are suitable for sheep. Cake is, more strictly speaking, however, better adapted as food for cattle than sheep, as we have observed that more beef than mutton can be made from a given quantity, and more especially when only one kind of cake is used. Of all the cakes manufactured we would prefer linseed for sheep. Linseed cake, or oil-meal as it is sometimes termed, is always relished by a sheep, as it is soothing in its effects, and exceedingly nutritious beyond the percentage of oil in it. Nearly all the other cakes are too heating, and if largely ted will bring the wool off the sheep. Linseed will not do this. It will, instead, increase the growth of the wool and add to its lustre, as well as nourish the body. The yolk in wool is nothing else than a certain kind of oil which perspires from the body through the fine tubes called staple of wool, and upon which the growth of the wool depends. Now all sheep-men know that unless the wool on the sheep's back is moist and strong in the staple, the sheep is not thriving. When the wool becomes dry and weak, and hangs down by the sides of the sheep, it is a sure sign that the animal is being insufficiently nourished. It is thus that linseed, from the oil it contains, proves so valuable a food. But while linseed may be the best single cake we could use, it is not recommended to use it alone. A far better sheep, and a heavier growth of both mutton and wool, can be obtained by feeding a mixture. A change of diet always works well, and more especially in high feeding. This point is not so fully appreciated by farmers as it ought to be, as many suppose that one kind of food is all that is necessary.

Nearly all the grains raised are healthy for sheep unground, with the exception of millet, which is probably neither bealthy nor economical when fed unground; because of its hard husk and small size it is not masticated nor digested, but mostly passes through the animal whole. And while all other grains can be given profitably, oats and pease are probably most relished by the sheep. But, like the cake, only one kind of grain should not be fed. Sheep are fond of a mixture, and feed faster when allowed a variety. They never do well when fed wholly upon dry food; and besides a combina. tion of cake and grain, require a certain amount of succulent and bulky material, such as roots, grass, or green forage. When the green food is scarce linseed is a good substitute, as it is laxative and nutritious, and prevents feverishness, so apt to accompany heavy feeding on dry food. The quantity of cake or grain fed to a sheep should never, in any case, exceed two pounds per day, and generally from one to oneand-a-half pound is sufficient. The most economical and appropriate combination of foods will in measure depend upon the cost. The cereal grains contain on an average rather more than six parts of total non-nitrogenous to one of nitrogenous compounds, and the leguminous seeds often not much more than two parts to one. Oil cakes and foreign corn contain rather more than six-sevenths, and home-grown corn rather less than six-sevenths, of their weight of dry substance. 


\section{FEEDING EXPERIMENTS.}

The whole art of feeding sheep lies in a judicious combination of foods; and by laving these intelligently supplied, in suitable proportions and at the proper time, success is virtually assured. On a farm all kinds of food and several kinds of sheep may be found. The problem then is, how to consume the food so as to give the largest increase of weight in the sheep. If the sheep cannot be made to increase a certain amount in weight and value for every pound of food consumed, the operation had better be left alone, and the sheep and food disposed of in some other way. A profit, of course, cannot always be reckoned upon, for as long as farmers will persist in buying and selling their live stock by guess instead of by weight, no definite calculation can be made of what the real value of the fattened beast will be. It entirely depends on the cost of the lean animal to begin with for making a profit out of the feeding. If the cost of the lean beasts per pound be in proportion to what they will fetch when fat, the fattening process is then a certain operation; but when, as it often happens, lean sheep are bought at $9 d$. per pound live weight, and sold when fat at $6 d$. a pound, no man on earth, be he ever so good a feeder, can make it pay. However, no one need have any doubt about the profit and loss of converting farm produce into mutton, as by having a full knowledge of the food analysis, a very nearly correct estimate can be made of how much meat may be produced from a given quantity of food.

According to Sir J. B. Lawes, "fatting sheep, fed liberally upon good food, composed of a moderate proportion of cake or corn, some hay or straw chaff, with roots or other succulent food, and well managed, will on the average consume about $15 \mathrm{lbs}$. per week, and should yield over a considerable period of the time one part of increase in live weight for about nine parts of the dry substance of their food. If the food be of good quality, sheep may give a maximum amount of increase for a given amount of total dry substance of food, even provided the latter contains as much as five parts of total nonnitrogenous to one of nitrogenous compounds."

Feeding experiments showing the amount of increase from different compounds of food are among the most important that can be made, and it is rather unfortunate that farmers do not, as a rule, make this a greater study. They are apt to study only the best they can do with what food they have at command, without considering whether it would be advantageous to purchase the elements necessary to give the highest percentage of increase from food consumed. Tests of this kind, made by Professor Brown at the Ontario Experimental Farm in 1883, are most interesting, the results of which are as follows:-

\section{OATS AND HAY IN SHEEP FEEDING.}

Results per head per day, with four head for fifteen weeks beginning 10th November:-The sheep in this test, and all the others hereto noted, are Oxford Downs and Shrops grade $3 \mathrm{R} *$ wether lambs, dropped on an average in March, and, with the exception of the high and low feeding, were altcrnated to the different foods in pens, as described.

The average wether lamb receiving $1 \frac{8}{4} \mathrm{lb}$. oats, $2 \frac{2}{3} \mathrm{lbs}$. of clover hay, and $1 \frac{1}{3} \mathrm{lb}$. turnips, gave a daily increase of fully $\frac{1}{3} \mathrm{lb}$., at a cost of 9 cents per $\mathrm{lb}$. to the added wcight of the animal.

\section{PEASE AND HAY IN SHEEP FEEDING.}

Results per head per day with four head for fifteen wceks:In this experiment the average wether lamb consumed fully $1 \frac{1}{2} \mathrm{lb}$. of pease, nearly $2 \frac{1}{2} \mathrm{lbs}$ of hay, $2 \frac{1}{2} \mathrm{lbs}$. turnips per day, and increased in live weight at the rate of $\frac{1}{4} \mathrm{lb}$. per day; cost, 12 cents per $1 b$. added weight.

\section{BEANS AND HAY IN SHEEP FEEDING.}

Results per head per day with four head for fifteen weeks:The daily consumption by this ratio was $1 \frac{1}{8} \mathrm{lb}$. beans, $2 \frac{7}{10} \mathrm{lbs}$. lay, and $1 \frac{1}{4} \mathrm{lb}$. turnips, and the increase to live weight scarcely $1 \mathrm{lb}$. per week, which makes a cost of 19 cents to produce every pound added to the live weight of the average wether lamb.

\section{LOW FEEDING OF SHEEP.}

Results per head per day with four head for fifteen weeks:Upon a daily ration of $2 \frac{1}{2} \mathrm{lbs}$. of clover hay, $1 \mathrm{lb}$. pea straw, and $4 \mathrm{lbs}$. of turnips, the average wether lamb increased in weight at the rate of nearly $\frac{2}{3} \mathrm{lb}$. per week, and the cost of producing $1 \mathrm{lb}$. to live weight amounted to 22 cents.

\section{IIGH FEEDING OF SHEEP.}

Results per head per day with four head for fifteen weeks:-

\begin{tabular}{|c|c|c|c|c|c|c|c|c|c|c|}
\hline \multicolumn{8}{|c|}{ Food consumed. } & \multirow{2}{*}{ 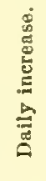 } & \multirow{2}{*}{ 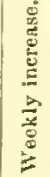 } & \multirow{2}{*}{ 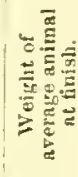 } \\
\hline Osts. & Pease. & Besus. & Brso. & Hsy. & Roots. & Oilcske. & Tborley. & & & \\
\hline $\begin{array}{l}\text { lbs. } \\
.507\end{array}$ & $\begin{array}{l}\text { lbs. } \\
.354\end{array}$ & $\begin{array}{l}\text { Ibs. } \\
-10 \mathrm{I}\end{array}$ & $\begin{array}{l}\text { lbs. } \\
601\end{array}$ & $\begin{array}{c}\text { lbs. } \\
\text { I } \cdot 992\end{array}$ & $\begin{array}{c}\text { lbs. } \\
\text { r } 269\end{array}$ & $\begin{array}{l}\text { Ibs. } \\
\cdot 27\end{array}$ & $\begin{array}{r}\text { Ibs. } \\
2\end{array}$ & $\begin{array}{c}\text { Ibs. } \\
.2\end{array}$ & $\begin{array}{l}\text { lbs. } \\
1 \cdot 4\end{array}$ & lbs. \\
\hline & & & & & & & & & & \\
\hline
\end{tabular}

The food above enumerated is the daily ration as consumed by the average wether lamb, upon which it increased in weight at the rate of $\frac{1}{5} \mathrm{lb}$. per day; cost of production, $12 \frac{1}{2}$ cents per $l b$.

COMPARATIVE RESULTS IN SHEEP FEEDING.-WETHER LAMBS.

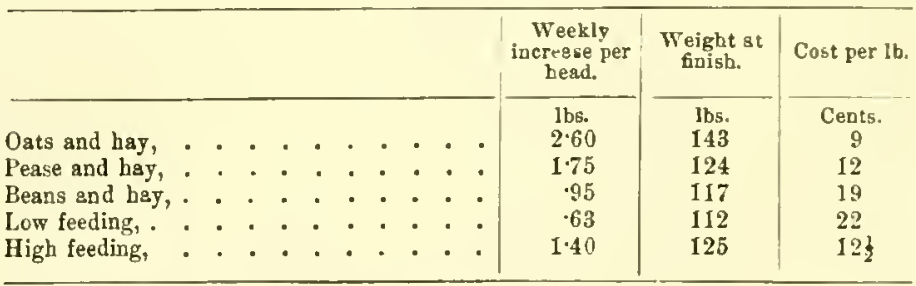

ANALYSIS.

The rapid and cheap production of mutton in winter has been attained best by the use of oats and hay; and, second, 
by pease and hay; this places six wether lambs as equivalent to one two-year-old steer. The average of these two only distinct ordinary forms of feeding sheep in this test equals $\frac{1}{8} \mathrm{lb}$. per head per day, and $10 \frac{1}{2}$ cents for the added pound in weight.

Beans do not seem to act as profitable grain for sheep, as the rate of growth of the average wether is little over half, aud the cost of production is double, that of pease.

That poor feeding is expensive feeding is well illustrated here; not one-third the ordinary rate of progress, and twice the cost of production, must be very much the position of those who practise what they consider economy.

The case of what is callcd "high feeding," although apparently good in results, is yet not equal to moderate management of lambs, which can evidently be expensively fed for their age, and even kept back by a high-pressure process.

Another report of the Ontario Experimental Farm gives details of some experiments in feeding grade shearling wethers of the various breeds, embracing Cotswolds, Leicesters, Oxford Downs, and Southdowns. The lambs were got by purebred sires of the above-mentioned breeds, and out of common mixed-bred Canada ewes. They were dropped about the middle of March, and weaned 1st July. The exact date when the weights and measurements were made is not given, but it is not especially material, as these were all taken at one time, and simply for the purpose of comparing the various breeds with each other. The measurements were as follows :-

Cotswolds,
Leicesters,
Oxford Dorrus

Oxford Downs

$\begin{array}{cc}\text { Heart Girth. } \\ \text { Ft. } & \text { in. } \\ 4 & 3 \\ 4 & 1 \\ 4 & 0 \frac{1}{2} \\ 3 & 11 \frac{1}{2}\end{array}$

$\begin{array}{cc}\text { Flank Girth. } \\ \text { Ft. } & \text { in. } \\ 4 & 0 \frac{1}{2} \\ 4 & 1 \\ 3 & 11 \\ 3 & 11 \frac{1}{4}\end{array}$

\begin{tabular}{lr}
\multicolumn{3}{l}{ Length. } \\
Ft. & in. \\
4 & 2 \\
4 & 0 \\
4 & 0 \\
3 & 10
\end{tabular}

The Cotswolds averaged 199 lbs.; Leicesters, 198; Oxford Downs, 177; and the Southdowns, 157. In commenting on the above result, the report states:-

Practically the two long-wools are equal in weight as shearlings, and even to ourselves this result has been somewhat surprising, because we have been accustomed to look upon the Cotswold as a slower and more irregular fattener. That they are so in the latter respect we have already seen; and while they do not want in weight, they certainly do not give it proportionally to size of bone, of length and height of frame. The two Downs are, relatively to height, very much greater in girth than either of the long-wools.

Counting the cost of all food, attendance, keep of dams, casualties, \&c., the report estimates the cost as follows:Cotswolds, 9.30 dols.; Leicesters, 8.10 dols.; Oxfords, 7.40 dols.; and Southdowns, 6 dols. The value of the wool is given, in the order above-named, as 2.52 dols., 2.24 dols., $2 \cdot 80$ dols., and $2 \cdot 40$ dols.; and of the mutton, naming them in the same order, 9.50 dols., 9.90 dols., 10.62 dols., and 10.20 dols. - which leares the balance-sheet showing a profit on the Cotswolds grade shearlings of $3 \cdot 17$ dols.; Leicesters, 4.04 dols.; Oxford Downs, 6.02 dols.; and Southdowns, $6 \cdot 60$ dols.
The report sums up by stating that:-Most of our farmers are well aware of the important fact, that under the best management there is always most money in getting rid of fat sheep as shearlings, instead of holding them on for another year. It pays best-(1) in earlier returns, (2) in greater weight proportionally to time, (3) in quality of flesh, and (4) in quality of wool. On an average of kinds, the increased weight during the second year is only at the rate of one-fifth pound per head per day-that is, the average shearling of $183 \mathrm{lbs}$. would not exceed $250 \mathrm{lbs}$. twelve months afterwards.

\section{EARLY MATURITY.}

The early-maturity craze has of late years been eminently manifest among sheep breeders. The old theory that prime mutton conld only be had from three and four-year-old wethers has exploded. Ripe three-year-old wethers are now rarely seen in the market. Indeed the proportion of twoyear-olds is also on the decline. One-year-olds seem to be growing more numerous every year, and are becoming the staple mutton of the country, notwithstanding it was once thought that sheep could not be put in first-class order at that age. At present everybody goes in for early maturity, and probably it is only by doing so that meat-making can be made to pay; excepting, of course, in the case of old ewes, which make up a considerable proportion of the fat sheep killed every year, and which may, under certain conditions, leave a good profit for fattening. Mountain wethers are also excepted, which are sold for fattening at two and three years of age. When the grazier finds it profitable to keep his sheep till three or six years of age, the fattening of these comes under quite a different account. It is only to sheep that are bought or bred for the sole purpose of being fattened that early maturity applies.

Nothing is more certain than that the age at which sheep can be fattened is being constantly lessened. During recent years the Smithfield and other fat stock clubs have been compelled entirely to recast their prize lists and the arrangement of classes, so as to put themselves more en rapport with the requirements of the times, and be of greater service to feeders of stock. Classes for lambs have been instituted, and since their introduction they have been the leading feature among the sheep classes, besides carrying off the champion honours for the best sheep in the show. These illustrations of early maturity are too strong logic for the old-style feeders, who hold the opinion that an animal must have completed growth of frame before it can be profitably fattened. Alternate fattening and starving will no longer pay in the process of making a certain weight of meat from a certain quantity of food; and the system of carrying on animals to a certain age on merely sustenance diet, before commencing to fatten them, is also proved to be unprofitable feeding. These methods may be pursued in the case of coarse ill-bred sheep that are slow to fatten, but they will not suit improved breeds that lay on flesh early, and with food so 


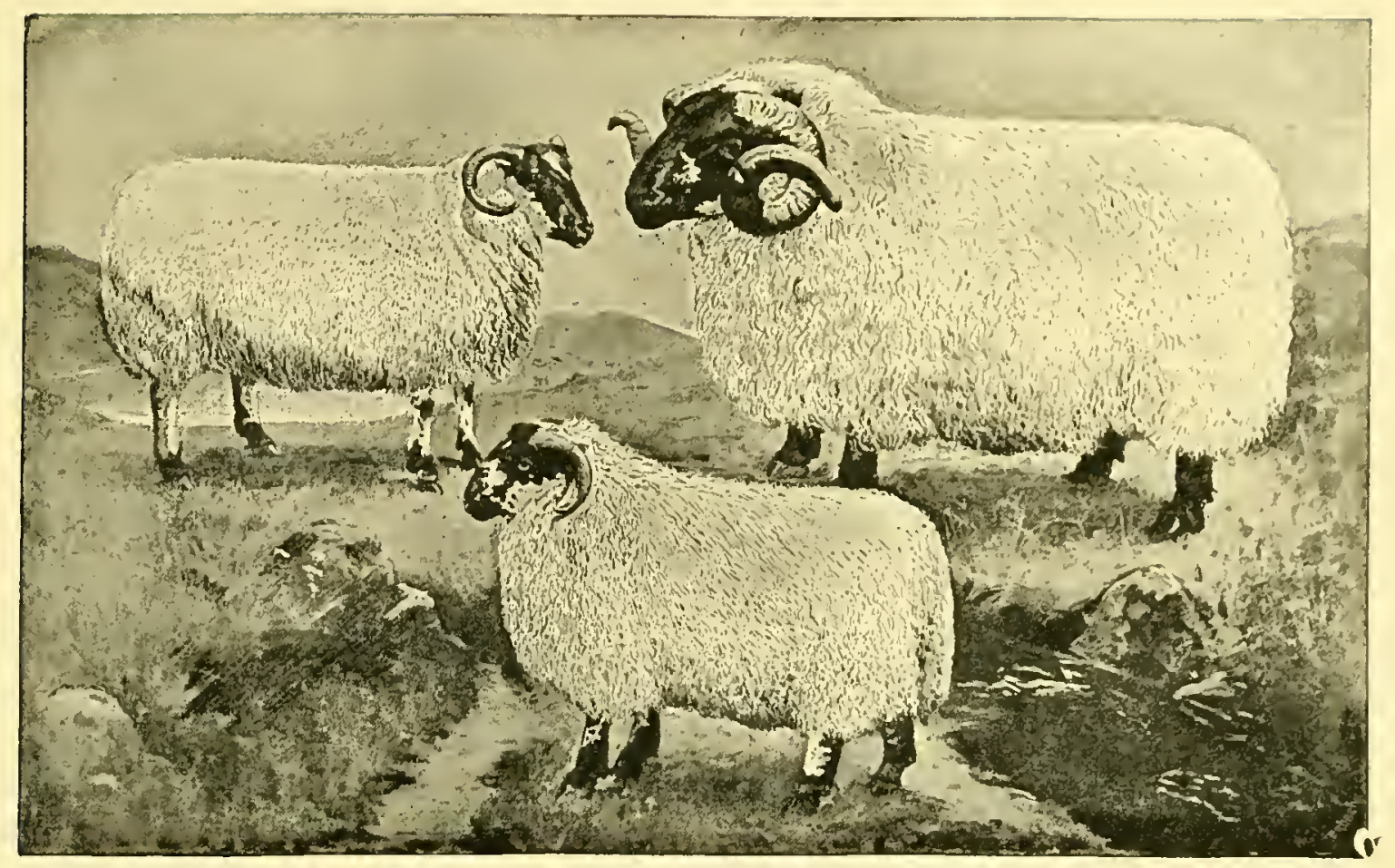

BLACKFACED SHEEP.

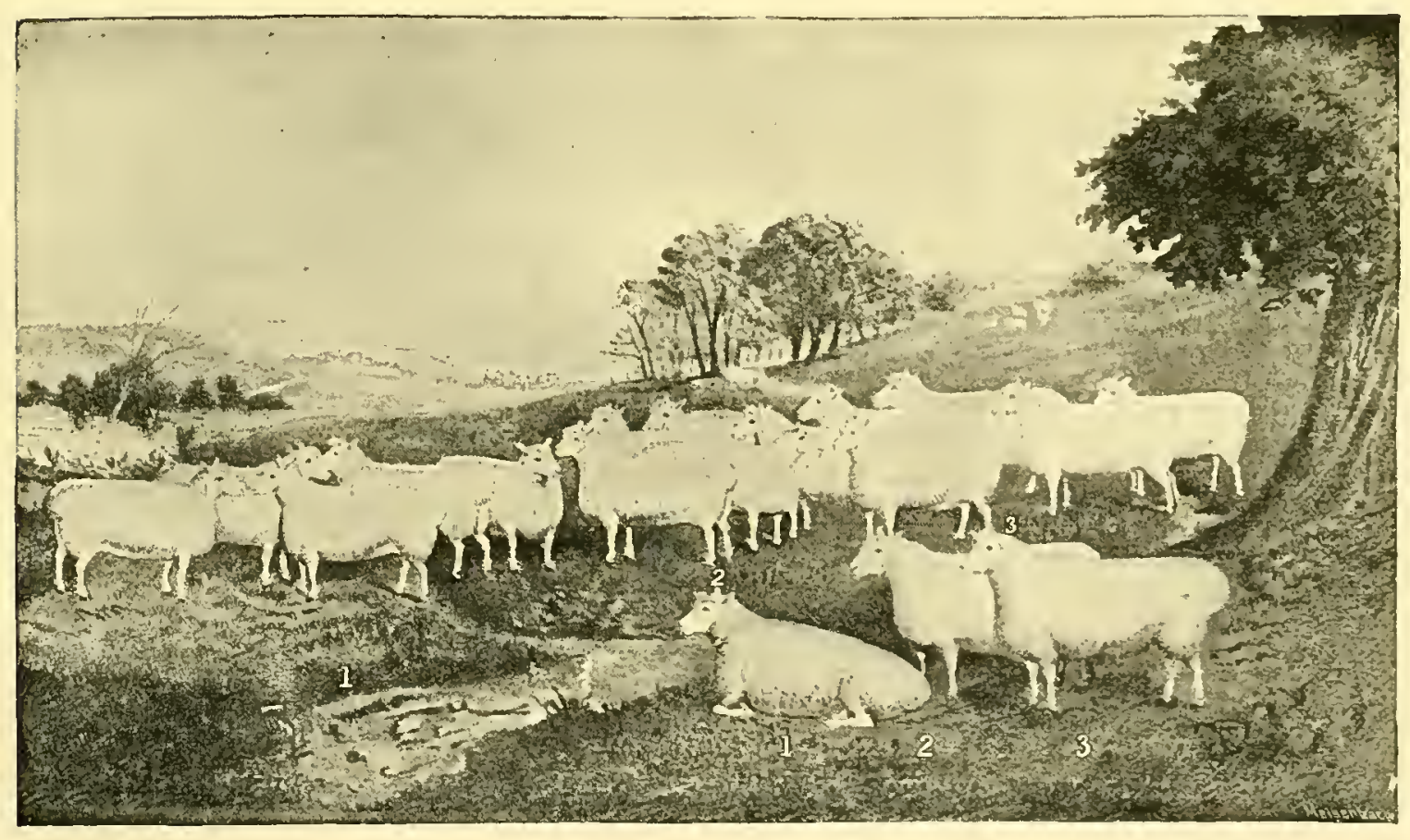

GROUP OF COTSWOLDS.

1, FIRST PRIZE: 2, SECOND PBIZE; 3, THIRD PRIZE-EWES AND RAMS 

adjusted to meet the wants of nature that there shall be no check in growth from birth to maturity.

It has been alleged that a sheep aged two years yields a greater or heavier quantity of flesh than a sheep one year old. But this is a fallacy. It is now ascertained that a sheep from its birth till it is one year old makes as much flesh as one double the age, provided the young sheep be fed carefully, plentifully, and methodically; that is to say, there shall be no starvation or short eommons stoppages in the rations. Now it is a law of physiological growth, that the time lost by insuffieient feeding or the absence of sanitary care in the development of animals, can never be recovered. In the first year of its growth, the assimilation of food and the formation of the tissues of the sheep proceed the most actively. No food is thus lost in the system; all is applied to build up; nothing is demanded for repairs. At one year old the period of development in a measure terminates, and henceforward the animal has not only to feed to keep up life, but to repair the daily waste of the tissues. Thus more food is necessary to produce a pound of flesh when, after one year old, the tissues have to be restored, than before and up to that period, when all vitality is not repairing waste but developing growth.

It has been demonstrated that the quantity of meat produced by sheep delivered to the butcher at the precoeious ages of from nine to fifteen months, costs exactly one-half less expense to those retained double the time. Sheep sold off at one year old implies a double profit in point of meat realized for the market, the return of the capital invested in half less time, the allowing of double the number of sheep to be kept without any augmented demand on the food. By bringing the animals early to the bloek, we reduce risks and labour and time to the minimum. The liability to disease is averted for one whole year, and when the average annual mortality of sheep stoek cannot be calculated at less than five per eent., it is evident that the praetice of early maturity has many favourable aspects.

The great fight among the mutton breeds of sheep hereafter, must hinge on the matter of early maturity more than on anything else. Contest after contest has demonstrated that there is but little differenee in the quantity or quality of the mutton they yield. Indeed so elose has been the fight, that there has never been a fat stock show held in whieh there was not some division of honours among the different breeds. Under such circumstanees as these it is no easy matter for either breed long to hold any special honour gained, a fact which heightens the struggle for development of precocity in mutton points.

\section{IMPLEMENTS USED IN SHEEP FEEDING.}

The implements required for practical use in feeding sheep are comparatively few, and need not be expensive. When hay is fed it should be put into racks, and not scattered on the ground, which will keep the food dry and prevent waste. Hay-racks are best made with a light roof and frame set on low stout legs. If mounted on wheels, the racks can be drawn by a horse from one part of the field to another; but they are equally handy without wheels, as several of them can then be easily loaded on to a cart or waggon and moved from place to place. The ordinary sheep hay-rack is made to stand above the shcep, so that they eat from under it, but unless a railing is put around the sides to prevent the sheep from trampling what hay they pull out, a good deal of waste will oceur. A rack 9 feet long will accommodate twenty sheep. Sheep racks can either be purchased from implement makers or made by any eountry joiner, and cost from $15 s$. to 25s. each. If well taken care of they will last many years. Whenever the racks are taken out to the fields for use, they should be tied to two stakes driven into the ground at alternate corners, and this will prevent them from being blown over and dashed to pieees by the wind. When not in use they should be earted to some place of safety, under cover if possible, where they will take least harm from weather or other destroying influences. Nlany farmers consider hayracks too costly, and use instead bags made of cord or wire; but these methods are really the most expensive in the end, from damaged hay and less satisfaction to the sheep. Hill farmers, who use hay only oceasionally, and for indefinite periods, seldom use racks. They either scatter the hay on the top of the snow, or put up a double line of wire netting on stakes, from which the sheep ean eat their hay. This plan is eertainly better than nothing, as it at least prevents the hay from being trampled upon or blown away by the wind. A different kind of a rack is necessary for feeding ensilage. The hay-rack is slatted so elosely that the sheep cannot put their heads through the bars, but this kind of a rack is not adapted for ensilage, and especially if the silage be made from rougher crops than grass. An ensilage-lack does not require to be on legs at all, nor is it absolutely necessary that it should be roofed. It should be made to stand low, and so as the sheep ean put their heads through the bars while eating. The sides of the manger should be at least 3 feet ligh-if lower the sheep will get into them; the width from 24 to 30 inehes. Nake the slats 3 or 4 inches wide, with rounded edges. For grown sheep, wail the slats on 14 inches apart; for lambs, 9 inches apart. This will give the animals plenty of standing room, one slat being between each two sheep. Such racks, without a roof, can be made by any handy shepherd out of common fenee rails.

In feeding grain, eut roots, or ehaff, boxes or troughs of different sizes are required. It is best to have different boxes for the different kinds of food. When the same boxes are used for both eorn and roots, there is generally much of the grain wasted from the troughs not being clean. Corn boxes do not need to be so large as the root troughs, but they had better be large than too small. The small $V$-shaped boxes made by nailing two narrow boards together at right angles, although very common in use, are not the most suitable. They are very light and easily moved, but they are only serviceable for feeding on pasture land. When they are used 
on turnip land, the sheep from having so much mud on their feet and getting into the troughs, are certain to dirty a good deal of their food, which they will not afterwards eat. Fron their being so very small, the food is also apt to be dropped from the sheep's mouths on to the ground, and trodden under foot. Corn boxes are best made of three boards-having two sides and a bottom, with a top-rail or cross section. A trough of this kind, 9 feet long, 6 inches deep, and 5 inches wide on the inside, will be found the most suitable, and can be used on either pasture or turnip land. Turnip or root troughs should be made on the same principle, only largeralways with a cross section, about 10 inches deep and 6 inches wide on the bottom. Boxes of these dimensions will cost about $5 s$. and $7 s .6 d$. respectively. A trough 9 feet long will feed from fifteen to twenty shcep, according to size. Ewes in lamb should never be allowed to crowd each other, but have plenty of box-room provided when feeding.

A large corn-bin or barrel is requisite for storing a supply of feeding-stuffs near the feeding ground. If the fold be adjacent to the farm granary, from whence the food can be carried out as needed, then a bin will not be required. A bin that will hold from four to six sacks of feed, placed by the sheep, will give the shepherd better facilities for regular feeding than when the food has to be carted from the barn once or twice daily, which is an everlasting trouble and apt to be done irregularly. The corn-bin should be made thoroughly waterproof by having a zinc covering to the lid, and furnished with lock and key. It may also be better to have it made in two divisions for keeping different kinds of food, but all the food should be mixed in the proportions intended for feeding before leaving the barn, and not after being taken to the field.

The implements required in sheep-folding are hurdles, nets, and stakes. Hurdles can be made of either iron or wood. The former are the most durable, but they are more expensive; still they are highly recommended by those who have used them. Hurdles of any kind we do not favour, and would never on any account use them for folding sheep. They are expensive to begin with, unwieldy to handle, and do not make any better fence than can be made by nets and stakes, which are much lighter and cheaper. Hurdles are, moreover, not so safe a fence as the nets. No matter how securely they may be set, should it happen to storm over night, they are sure to be all down in the morning, and the sheep all over the field. There is nothing provokes a shepherd more than this, and it is very hurtful to the sheep, as it unsettles them, and for ever keeps them on the alert for a break-out. Nets of either cord or wire are stronger and less liable to be blown down by the wind The wire is more expensive than the cord, the cost pe: yard varying according to strength and size of mesh. Wire is also thought to be more durable than cord, but under certain conditions such is not the case. When frequent shiftings are required, the rolling out and in of the wire is apt to break it, whereas with cord the shifting does not injure it. If the fence is not moved too much wire will many times outlast the cord, but not when daily shifting has to be done. In some parts it is difficult to procure stakes. If young larch trees, from 4 to 6 inches in circumference and about 5 feet long, can be had, they are the most durable; but suitable ones can be sawn out of timber, 2 inches square, and these will do quite as well as the natural grown stakes. It must not be thought, however, that nets and stakes are an impregnable fence. They are quite the reverse; and if sheep once learn the habit of getting over or through them, they will serve a very bad purpose, in fact will not keep the sheep at all. In setting nets care should be taken to pull or clear away the row of turnips immediately behind where the fence is to stand. This prevents the sheep from trying to reach food through the meshes, which is generally the cause of their making holes, or getting hung by tlie neck in the nets. Where there are many liares, holes will be eaten in the nets, which the shepherd must patch up before the sheep make them any larger, from trying to get through them. But if the annoyance from hares is anything serious, wire nets only should be used-they can't eat holes in them. When the nets are well attended to and kept in good repair, they will keep the sheep quite securely; whereas, if they are carelessly set, and allowed to become tattered from want of mending, they become an everlasting source of trouble.

A heavy wooden mallet and an iron "gavelock" or "piercer" are used in setting up light fencing of this kind. Where the ground is hard, the holes for the stakes are made with the pointed piercer, which saves the points of the stakes. Having the holes well pierced, and the mallet lightly used, the stakes will last a long time; whereas, if they are driven home trom the top, they will soon be all in splinters. The stakes are set about eight or nine feet apart. With a handy turnip hoe or picker, for picking up the shells of the roots, these, together with a good turnip cutter, are about all the tools requisite for feeding shesp.

\section{SHEEP AS FERTILIZERS.}

The dung of the sheep is more valuable than that of horses, cattle, or pigs. From its coldness it does not ferment, and consequently retains its value much longer than the manure from either horse or ox. All grazing animals extract a certain amount of mineral matter from the soil, but sheep take the least in proportion to live weight. The experiments of Lawes and Gilbert show that 1000 lbs. live weight of sheep or lambs carry off about twenty-six pounds or less of phosphate of lime from the soil. The quantity of phosphate is less in a given live weight of fat than of lean animals. In regard to each description of animal, it may be asserted that a given live weight will contain less of every constituent of mineral matter the more it is matured or fattened. Growing sheep will cause a greater loss to the land, or will make a poorer quality of manure from augmented food, than those which have arrived at maturity. The loss of mineral matter to the farm by mere increase of fat is almost insignificant; 
and the estimate is made, that the increase of sheep during the final four or six months of the fattening period will not contain more than about $1 \frac{1}{2}$ per cent. of such constituents. It is also coneluded that an acre of land would lose more phosphoric acid in milk, and four or five times as much in wheat or barley, or in hay, as in the fattening of sheep. Of lime the land would sustain a loss of about twice as much in the animal increase as in hay; and of potash said acre would yield only a fraction of a pound in animal increase, six or eight times as much in milk, perhaps twenty times as much in wheat or barley, and more than one hundred times as much in hay. The loss to land by annual increase is chiefly in phosphate of lime, in amount varying from five to ten pounds per acre.

The mineral matter taken from the soil by a five-pound fleece of wool is only 1.6 ounce in a year and 5 ounces of nitrogen. In order to show what part of the food is stored np in the body of the sheep, and what is passed in solid and liquid excrement, we will quote from the German tables of experiments. It was found that when sheep consumed 100 lbs. of nitrogen in their food (being barley meal), $16.7 \mathrm{lbs}$. were voided in the solid excrement, $79 \mathrm{lbs}$. in the liquid excrement, and $4: 3$ were stored up as increase of the body. Thus $95 \cdot 7$ per cent. of the nitrogen of the food was voided in the excrement, leaving as a loss to the soil (stored up in the body) only 4.3 per cent. Of the mineral or ash constituents of the food, it was found that sheep roided in the excrement 96.2 per cent., and used in the body only 3.8 per cent. When sheep were fed upon good clover and meadow hay, the solid excrement contained of ash 3.5 per cent., and of nitrogen 0.7 per cent. ; while the urine contained of ash 5.6 per cent., and of nitrogen 1.4 per cent.

By far the largest proportion of the fertilizing substances contained in the turnip crop, probably about seven-eighths, is returned to the land if the crop is consumed by the sheep on the field, and only about one-eighth of the materials useful as manure is earried away by the sheep in the form of bone and the nitrogenous matters which enter into the composition of the animal organism. The bulk of the animal is produced from the sugar, pectin, vegetable fibre, and other non-nitrogenous constituents of turnips, and these constituents have no value as manuring agents. The land is left in a better agricultural condition after the turnip crop has been consumed on the ground by sheep, and the latter has been sold off, than it was before the turnip crop; for there is but little fertilizing matter carried away by the sheep, and the manuring elements in the turnip crop are deposited in the shape of sheep-dung and urine over the surfaee of the soil, and. in a perfectly prepared and readily available state. In general the land is more produetive after a turnip erop has been consumed on the ground by the sheep than before; but this is a point which some doubt.

The Italians have a proverb that "A sheep is the best dung-cart," and modern science tells us on what the truth of that proverb is founded. It is because thirty-six pounds of sheep manure are equal, as a fertilizer, to one liundred pounds of ordinary farm-yard minnre. Richer in nitrogenous substances than the manure of the loorse or cow, it is scattered upon the field, the sides and tops of the hills, in the most desirable form to be easily trodden into the earth and mixed with the soil. We are yearly paying enormous sums for foreign fertilizers to secure the means wherewith our sterile fields may be enriched, while we sometimes overlook the best of all agencies with which nature enables us to accomplish that object. Pastures which are stocked to their full capacity with eattle or horses, will still give acceptable sustenance to a few sheep. Sheep will eat weeds and grasses the dainty cow passes by; and fron what would corrupt the pastures, they glean an abundant living, and return to us a right royal benefaction for the little they ask at our hands. Sheep by nature are constituted to gather up the very fragments of the vegetable kingdom, and work them up into materials of the highest use and importance to man.

\section{SHEEP ON ARABLE LAND.}

\section{AUTUMN MANAGEMENT OF EWES.}

After the lambs are weaned the ewes may be kept for ten days or a fortnight on rather bare pasture till the milk goes off them. There is then less danger of garget; and to make sure that none of the ewes are ruined at this stage, the shepherd ought to look out for any that seem to suffer from inflamed udders, and take the trouble to draw a little milk from them every other day. In obstinate cases an occasional rubbing with camphorated oil may be advisable, and in severe cases a dressing of cold tar will be beneficial. When the milk has left them, the draft ewes should be taken out and put on rape or other improving feed, whether they are to be sold lean or fattened for the butcher.

Draft ewes that have been well fed while nursing their lambs should have the feed continued, and gradually increased, after the lambs are weaned. This is the best way to prepare ewes for the butcher, and is much more profitable than to allow them to get very poor from nursing on insufficient food. When ewes are in thin flesh, their feeding should be begun very moderately. They cannot be brought up in condition very rapidly without a great deal of good food, which is expensive. It is better to start them slowly, and after they fairly get used to the food it may be further increased, when they will fatten rapidly, and with profit. The quantity of grain or cake that may be given, should be from half a pound at starting, and inereased to two pounds per ewe daily towards the finish. When the grain ration exceeds one pound daily, it will do more good to the sheep if they receive it twice-morning and evening. Roots or other green food should also be given liberally; and if the ewes are done in their mouths, they will require to be cut. Sheep will feed faster netted on the turnip land than when the turnips are laid on grass land. All sheep feeders are agreed on this point. When folded, it is a great point not to give too large a break at once, but shift the nets or hurdles at least twice a 
week, or every day if possible. With careful attention and a well-appointed diet old ewes may be fattened in from six to nine weeks, but when they are very low in condition to start with a month longer will be required.

As soon as the flow of milk has been checked, the keeping ewes may have a few days' run on the newly cleared stubble. They will pick up any heads of grain left, and eat off all the grass by the sides of fences; and while this lasts the pastures are freshened up a bit. It is well known to practical sheepfarmers that this is a most important period of the year in the management of breeding ewes. Yet not a few tlockmasters are in the habit of treating their ewes rather carelessly during the last four months of the year. They try to keep them as cheaply as possible, which is commendable; where they err, is in not keeping them straight on through autumn into winter in the same even condition.

As the tupping season approaches it is well to have the ewes in good thriving condition before then. It should not, however, be accomplished by a process of hurried and temporary stimulation. The improvement should be gradual, and not above what it is intended to sustain. The practice of supplying the ewes with turnips, cake, or corn two or three weeks previous to putting out the rams is open to grave question. It certainly goes against nature to feed the ewes extra well one month at this stage, and then put them on mere sustenance diet for the next three months. It is from mismanagement at the period of conception, and subsequently, that we can trace, months hence, the causes of abortion, or weak and dead lambs, and other disastrous results. Nor is this the only evil of "flushing" the ewes when they are put to the rams. Hrom actual test we are convinced that ewes which have been flushed one year are never so prolific the next. Most shepherds will have observed this fact. And indeed the extra number of lambs raised in any one year by this system is, on the average, not very great. 'Twenty lambs per 100 ewes is about the most we could expect to increase the yield of lambs by a month's extra keep, costing $£ 12$ for that number of ewes. This is a heavy tax on the twenty lambs; and if on the other side we throw in a little extra for the better quality of more single lambs, and a better average condition of the whole flock, there remains little, if anything, to be credited to the practice of "Aushing" ewes, even when no injury follows from subsequently letting them down in condition. We are not to be understood as advocating a poor diet at tupping time; by no means, give them as good a diet as can be sustained through the autumn and winter.

The period of gestation in the ewe is twenty-one weeks. Where early fat lambs are reared, the rams are admitted to the ewes accordingly. The usual tupping time for ordinary lambing is some time in October, as best suits the locality. The lambs should generally be made to arrive with the grass in spring; if sooner, they are more expensively raised, and seldom so good. The number of ewes allowed to a ram depends on his age and the nature of the ground. A good strong lamb ram will serve as many as twenty-five ewes without hurt, a shearling may be allowed from fifty to sisty, and forty to fifty for an aged tup. If the ram be confined and not allowed to run with the ewes, he will serve a hundred ewes quite well; bnt it is a deal of trouble bringing up the ewes in this way, and is only advisable with some very special stock-ram, whose progeny is valuable. The older ewes should be served first, reserving the shearlings to the last, as these make but indifferent nurses, and it is therefore desirable that there be plenty of fresh grass before they begin to lamb.

'The breast of the ram should be rubbed with ochre; and the ewes that are served marked at the end of every week, on the shoulder or rib, with a dot of oil paint, so that the shepherd who makes a note of the different dots he puts on weekly, may have a key, as it were, to the order in which the ewes will lamb.

\section{WINTER MANAGEMENT OF EWES.}

To say how much or how little condition should be maintained on breeding ewes in the winter season, is a point on which depends the system of summer management. But, as a rule, the surest guide is the condition in which the summer grazing will sustain them. Every farm, and indeed every field, has a certain feeding quality of its own, which makes the sheep just as good, or bad, and this of a remarkably distinct character. To give the best possible return for food consumed, a sheep must be kept near a certain level of condition; neither higher than what is likely to be maintained throughout the year, nor lower than the standard we have just indicated. This, then, is the object in view; and, although food may be extremely short, every farmer should make his best endeavour to come as near to this mark as possible.

It is the usual practice at this time of the year to keep the ewes as cheaply as possible; but at the same time it should not be forgotten, that while it may seem a favourable opportunity to practise economy, it is nevertheless a very important period with the ewes. Up to this time they have maintained their summer condition, but now, from a less nourishing diet and colder weather, they begin to lose flesh. Of this fact a man may be aware; yet he is apt to consider the consequences too trifling, and is sometimes tempted, from short supplies, to withhold the food he would otherwise deal out liberally. A slight reduction in condition is not at this period hurtful to ewes, most shepherds will admit. For some reason or other, breeding ewes that are kept too well all through winter, and never allowed to fall off in condition, seldom acquit themselves at lambing time, or bring as strong healthy lambs as those that have been slackened a little in winter. This is a nice point in sheep management, and requires much skill to bring to a successful issue But, generally, more harm is done in the opposite direction, by allowing too much condition to be lost. When this is the case the final result is never so satisfactory as might be, and will require heavier feeding in spring, or else the ewes will be deficient in milk, and make poor lambs. 
When the grass begins to get scant, and there is any fear of the ewes falling away in condition, they should get something extra, and it could not possibly be begun at a better time. Commence gradually, and do not go beyond what will be kept up, or nearly so. In fact we could not advise a lowering at all, and would rather choose a smaller but steady supply all the time. As long as the pastures are available they will be of great service while the weather remains open Keep the ewes spread over the fields as thinly as possible, and in each division may be placed a rack, and half a pound of hay allowed to each ewe. With a small bite of grass this will keep them going along nicely, but with a bare pasture, or in the event of a storm, in addition to the hay, half a pound of cake or grain might be given with advantage. A month on this keep will save a lot of turnips, and the cost need not be great. As the season advances and the ewes require a fuller diet, they can then be given an allowance of turnips. These can either be carted out to the pastures, or the ewes folded on the turnip break for an hour or two daily, or all night if the turnips are plentiful. Ewes will be quite as healthy netted on to the turnip land all the time, even if they be only getting a small share of roots; and besides preventing them from picking up dirt on bare fields, it will leave the manure where it is wanted, and the pastures will be earlier in spring from not being eaten too close in winter. The hay and grain ration will be subject to the quantity of turnips given, and their portions may be adjusted accordingly

It is not uncommon to see ewes put on turnips entirelyfull turnips, as it is termed-for a month or two previous to lambing time, and although we do not question the resultsome do-it is undoubtedly expensive feeding. But full turnips are even more expensive in spring, when the tops are withered and the bulbs are often dry and tasteless. A few turnips should be given all the time, but there is no necessity for using them to so great an extent as some do, and the relative cost of feeding between turnips and a mixed ration of grain, hay, and turnips, is decidedly in favour of the latter. A bad turnip year has also proved to us that the worst results in the lambing fold are not then obtained; in fact, it is often remarked that when turnips are plentiful so is the death-rate in the flock. There is no better winter food for sheep than good sound fresh hay, and in ordinary years we question if there is any cheaper. In Canada and the Northern States of America large numbers of sheep are kept, and in most cases they get nothing but hay the whole winter, or nearly six months, and they thrive excellently every year. Those who have gone in for ensilage may bring their ewes equally well through the winter, and cheaper on silage alone, without either roots or hay.

Bring the ewes forward to the lambing healthy and hearty. They shonld not be fat, as there is then some danger in lambing, and if they are in higher condition than their pasture is likely to sustain them, they will fall away and not nurse so well. Experience has taught us that althongh the ewes were put to grass in the best condition, even fat, they did not make the lambs so good as we expected. The reason is plain: the ewes were not receiving the same amount of nourishment from the grass as they had from hand feeding in winter. If ligh feeding be practised at all, it must be continued. Still the ewes must be kept in good Alesh, for if they are lean even worse results will be obtained, and there is a possibility of overstepping the mark on either side.

\section{THE LAMBING FOLD}

No other event during the year can in any way compare with "the lambing" for creating enthusiasm and interest. Not only is this so with the farmer himself, but with every workman on the farm; and as to the feelings of the slepherd, his ideas of the affair are at least sincere, if not oftentimcs sacred. It is well this is so, for when all take an interest in anything, the effect must appear in some way or other. We do not mean that this man or the other should be allowed to interfere with the ewes; but every shepherd knows the advantage it is to have a man who will, when (say) carting turnips to the lambing field, instead of getting his load off all in a heap the handiest way possible, use his best judgment in selecting the most sheltered and cleanest part he can find, and distribute the food carefully and evenly.

Those who have carefully watched and tended their flocks, and who, at all times, have been careful to provide a sufficiency. of good wholesome food, will every day have proof of reward for their untiring zeal and liberality; whereas those who have been inattentive, and have grudgingly provided for them, will probably find the results correspondingly disappointing. It is not always where we find the most lambs per hundred ewes that we find the most successful lambing. It is essential to have numbers, but they must also be good.

The lambing of the ewes on an arable farm is of the very greatest importance, and every needful preparation should be made beforehand. The fold should be on dry ground, and the site which combines that condition with the best natural shelter should be chosen. A field sheltered from the nortl and east offers the most desirable exposure. It need not be level; in fact an incline is an advantage, the ground keeps cleaner and sweeter, and on bright days, when the ewes are apt to roll, there is less danger of their "awalding" than there would be on the level.

Having selected the site, next consider what shelter has to be provided. The number of the flock must determine this; but whatever the number may be, there should be sufficient covered pens to accommodate singly as many ewes as can possibly lamb on any one day. Temporary erections, which can be removed as soon as done with for the season, and be pitched on fresh ground every year, are found to be in every respect preferable. Some flockmasters have sustained serious losses through permanent buildings of this kind, and it is well to diminish the risk as far as possible by fresh ground and a new construction every year. Still, since becoming aware of a remedy for the most fatal of all diseasez 
in the lambing fold, we would not hesitate, under certain conditions, to erect a permanent building.

Admirable lambing folds can be constructed very readily by the shepherds, with no other materials than wattled hurdles and straw. A fold inclosing sufficient space to hold all the ewes comfortably is first erected. This is done by setting a double row of hurdles, which are stuffed between with old straw or litter so bad that the sheep will not eat it. This will form a complete barricade against the wind, and a fold with this provision alone would afford a vast amount of shelter to the sheep. But with a little more labour covered huts or pens may be formed, at suitable parts, against these lines of stuffed hurdles. Single hurdles are set up transversely within, and on their tops, together with those of the side hurdles, more wattled hurdles are laid down flat, and straw laid overhead to form a roof, which declining from within to without, allows no rainfall to drip therefrom inside the fold. Thatch is then laid on, and if the work be well executed, such a place will give every comfort to the young lambs.

The floors of the pens will be much improved by having them covered to about 6 inches deep with burnt clay or gravel, and if the yard inclosed be raised in the same way the whole will keep drier and healthier. The yard should also be made large enough to allow a straw stack to be built in the centre. This will give a great deal of warmth to the premises. Everything needs to be kept clean and tidy, and all the pens and yard well bedded with litter from the stack.

A root store, a small hay shed, a corn-bin, and a comfortable hut for the shepherd, are all requisites of the lambing fold, and these can also be erected so as to give additional shelter. A number of small feed boxes, suitable for feeding the ewes in the pens, are also required. A few covered pens in different corners of the adjacent pastures are also necessary, for sheltering weak or hungry lambs on stormy days. Only a single night's shelter in these side pens is often the means of fairly setting young lambs on their legs.

The ewes will have been marked at tupping time for each week's lambing, and the first lot should be brought into the lambing field a day or two previous. At the end of the first week the second lot of lambers may be brought in; and at the end of the second week all that are left may be brought in, as all but a few are due to lamb in the third week. They should have the run of the field during the day, and be put into the fold during the night, and where the shepherd can see them as often as necessary, having a lantern for the purpose. In case of stormy and wet weather the fold will be a protection by day or night.

'I'wo shepherds are necessary-one for night, and the other for the day. When the flock does not exceed 300 ewes, however, one shepherd has generally to suffice. Two men can take care of 600 ewes, but in stormy weather they will need the assistance of an active boy to attend to the hungry lambs needing care out in the fields. A few lambs saved pays for extra help, and the shepherds, who are already overworked, are sometimes unable to give sufficient attention to everything.
The flockmaster ought to make it a matter of pride that no lamb which once sees daylight shall be lost through any fault or failure on his part. Every lamb ought to count one. After the ewe has passed her whole period of gestation, it is arrant folly to allow the lamb to be lost through neglect of some little service which could be rendered in five minutes.

The duties of the shepherd in the lambing fold are unceasing, and demand great skill and attention, both in giving assistance to the ewes and care in reviving weak lambs. Whenever a ewe requires assistance in delivery, he must be there to give it. The experienced man, however, never acts hurriedly. He gives the ewe ample time for nature to operate, and only when he suspects that all is not well he makes an examination. If his fears be groundless, he will allow the ewe to take her own time; but when he discovers that the preseutation is awkward, he must exercise his skill in putting the head or limb of the lamb into proper position. There is often difficulty in such cases, and they are also so various, and often intricate, that long experience only can teach a man how to act. When a ewe is exhausted from severe parturition, she is in a very critical condition, and requires careful nursing for the next few days She should be placed in a dry comfortable pen, and have absolute rest. The lamb, if alive, is put beside her, but if her lamb be dead, as it not unfrequently happens, the ewe should not be troubled with another until she is completely recovered in health. The hospital pens should never be used for newly lambed ewes. They should be kept solely for this special purpose, and always thoroughly clean. Foul pens are generally the originators of inflammation, and when once it begins, the premises should be daily disinfected with a weak solution of carbolic acid and water, which will usually arrest further spread of the infection.

Reviving weak lambs is likewise a delicate task. Those naturally puny need to be kept in good shelter for some days, and if their dams have plenty of milk they will soon get strong. The usual trouble with young lambs is cold and liunger. A lamb so chilled that the thumb and finger held on opposite sides of the chest can scarcely detect the heartbeats, can be restored by an immediate plunge into bloodwarm water. But this should be resorted to only in desperate cases, for the water is likely to obliterate the scent, by which alone the ewe recognizes her offspring. For the same reason it is equally dangerous to wrap the lamb in malodorous cloths, and allow it to lie before a fire. It will probably be a long time in recovering, and the chances are that the natural scent will be lost; then there will be trouble in establishing relations again between it and the mother. Then, too, the lamb will most likely have to be fed on cow's milk, which is the greatest evil that could happen. If at all possible the lamb should never be removed from its mother. Carry out soft woollen wraps, well warmed, and wrap it up, letting the head remain out where the ewe can smell and lick it when disposed; she will thus keep up her acquaintance with it. The sooner some warm milk is given it the better. 
The creature may be so chilled that it cannot suck, yet it may not be advisable to carry it to the fire. Catch the ewe gently with the crook; lay her on her left side, yourself being squatted at her back; lay the lamb on its right side; with the thumb and finger of the left hand hold the jaws apart, and milk a few drops into the mouth. Still holding the jaws apart, rub the throat with a downward stroke, and it will swallow. If it cannot swallow, it will probably have to be carried to the kitchen. But try every expedient before carrying the lamb away from the sight and touch of its mother. Never give a young lamb more than a tablespoonful of milk at a time; and a teaspoonful every ten minutes will be more effective still, when life is but a spark.

The number of lambs reared varies considerably. In untoward seasons, or with bad management, the lambs often do not exceed 100 per cent. of the ewes. There are instances in some years where the percentage of lambs exceeded 160 per cent. on arable sheep farms, while on the same farms in other seasons only 60 per cent. of lambs were reared, the deficiency being caused as much by abortions as by barrenness of ewes. Some breeds are, of course, more prolific than others; but twins, or couples, in the proportion of one-third to one-half of the ewes, may be expected where the keep is good and the management judicious. The following statistics of several different flocks may be accepted as affording evidence of fairly average results. In a flock of half-bred ewes the percentage of lambs is 140 ; in a small flock of Southdown ewes the number of lambs is 130 ; in a larger flock of Oxford Down ewes it is 129; in another large flock of Shropshire ewes it is 145 ; in a flock of 500 cross-bred Hampshire ewes it is 110 ; and in a flock of 600 Southdown ewes the percentage of lambs reared is 109

It is well to give the shepherd a bonus of sixpence or a shilling for every lamb above the number of ewes at weaning time. This encourages him to do his best to bring the lambs safely through the most risky period of their lives. The Lincolnshire Agricultural Society gives prizes to the shepherds who have reared the largest percentage of lambs from ewes put to the tup. The prizes are distributed in three classes:-A, for shepherds whose flock exceeds 300 ewes, at least one-fourth of which must be shearlings; B, for those whose flock has between 150 and 300 ewes; C, those whose charge is below 150, but above 40 head. By far the best percentages are those from flocks of the middle size; showing that, if a shepherd be overtaxed, or have so small a charge as to lead to his having to follow other employments, the returns are less than where a man has enough to occupy his whole time fairly, but no more.

The feeding of the ewes while in the lambing fold is not the least important matter in leading to success. If they are short of milk, it is better to feed the ewes on a little grain than have endless trouble with starving lambs. Yellow turnips are better for milk than swedes, but they should not be fed alone. Fewer roots, with a lianáful of oats and a little hay, can be fed more economically. The common plan is to give daily three moderate cartloads of turnips to about 80 ewes. But we have found one cartload of turnips, with two bushels of oats and $40 \mathrm{lbs}$. of liay, give equally good results, and at a less cost. Charging turnips at say 5s. per load of $10 \mathrm{cwts}$, oats at $2 s .6 \mathrm{~d}$. per busliel, and hay at $18.6 \mathrm{~d}$. per $40 \mathrm{lbs}$., the mixed ration costs $3 s .6 d$. per day less than the full turnip ration, and this on 80 ewcs is a saving of nearly $3 \frac{1}{2} d$. per ewe per week.

When the lambing is over, and the ewes dispersed into different fields, the hand feeding must be kept up until they have a full bite of grass.

Let us now add that nothing is more conducive to a successful lambing than a good shepherd. And we can say this of those of our acquaintance, that, compared with other agricultural labourers, they stand a head and shoulders above their fellows for intelligence and faithfulness of trust.

\section{MANAGEMENT OF EWES AND LAMBS.}

The management of ewes and lambs differs very much according to the time of the lambing and the climate and food supply of the district. On the hills in the north, for example, the ewes and lambs never get a change of pasture, and rarely or never any extra feeding. On the arable lands in the same districts the management is still very simple, owing as a rule to the small variety in the crops to be fed. The lambs begin to arrive while there are a few turnips still on hand, and when the last of these are consumed there is seldom any choice of sheep keep, except perhaps between first year's grass seeds and second or third year's grass. The seeds in the north consist largely of rye-grass, and the younger they are the earlier the spring growth, and the more esteemed they are for ewes and lambs. As the first year's seeds are not enough for the entire flock, it is customary to put the "couples" into them, and the ewes with the single lambs go upon the older grasses. Headow grass, thougl quite as early as first year's seeds, is usually too scarce in such districts, where the flocks are large, to count for much. When the spring is late and the grass backward, the only resource open to the northern farmer under these circumstances is to give corn or cake to the ewes and lambs on the pastures.

Very different is the practice of the southern farmer. $\mathrm{He}$ would think he was badly placed indeed if he had only the choice of turnips or grass to produce early and fat lambs upon. Although the lambing time is earlier with him than it is in the north, he takes care to provide a nice piece of winter rye or barley for the ewes to turn upon, long before the turnips are finished, and long before there is a bite of young grass even. The rye is soon followed by trifolium, vetches, cabbage, \&c., and by the cultivation of the two latter only, no sheep farmer in any part of Britain need ever be in want of good keep for his flock at any season of the year.

When the spring is a forward one, turnips are worth little for ewes and lambs after the middle of April, before which time the rye or other green food should be available. In 
open seasons the rye will indeed often afford a good bite early in February, in which case the blade should be eaten down, and a second growth will be ready to feed in April. Toward the end of April or beginning of May the winter vetclies or tares will be fit for feeding, and by the time the tares are eaten off the trifolium, clover, sainfoin, \&c., will be ready to receive the flock.

In a late spring it may happen that the turnips are all consumed, and also the first bite of rye, before there is any feed of vetches or clover. Under such circumstances the grass on the water-meadows or marshes, if the farm be fortunate enough to possess any, will be of the most signal value, and will indeed often afford a good bite to a sheep at the beginning of April. Where there are no watermeadows on the farm, it is a prudent measure, against a backward spring, to have in reserve a winter-hained old pasture, which the ewes and lambs can fall back on. Sometimes a forward piece of wheat may be fed down with advantage, and will help to lengthen out a supply of green food uritil the vetches or a second bite of rye is ready. Then by shifting from one to another of these, the lambs may be carried forward in good condition in the most backward of seasons. It is management of this sort that shows the good farmer. A resort to corn and cake in such circumstances is no doubt possible, but that means a heavy expense, which a better manager would try to avoid, while yet keeping his sheep well.

When folded on turnips the lambs should be allowed a pen ahead of the ewes, so that they may liave the first nibble at the fresh tops. This is easily accomplished by bringing into use one or more "creeps." It is indispensable to the prosperity of a breeding flock that the ewes, during the time of suckling, should be kept in a healthy and thriving state. For this purpose they should be thinly stocked on the sweetest and best suckling pastures the farm will afford; but by no means selecting the most fattening pastures, as in such case they will accumulate fat, and decrease in their milking properties. The lambs will, if thus thinly stocked, have room to roam about in search of such varieties of food, or of such natural grasses, as instinct appears to direct them to, for their better sustenance; at all events we know that the more pasture-room lambs have to roam over, the better they thrive.

The ewes should be shorn before the middle of June. This will cause both ewe and lamb for a short time to improve fast in condition. The ewe, having no fleece to support, will yield more and richer milk, and will also add to her own fattening considerably. As this proceeds her milk will slightly decrease, and it will soon become desirable, and may be sufficiently evident, that the time for weaning has arrived. The lamb, which will now be larger and require more milk, will be constantly teasing the ewe, and abstracting every drop of milk from her udder. This constant application, and consequent drawing of the udder, will begin to show detrimentally on the ewe; and it then becomes requisite, and in accordance with good management, to wean the lamb immediately, for which contingency every good breeder will have made provision.

We have previously referred to the variable percentage of lambs reared, but a high percentage in mere numbers is not everything. A fair crop of good lambs is better than a larger number of inferior ones. The latter are not only worth less relatively to begin with, but are more subject to misfortunes and diseases of every kind, and all the care and trouble which it is possible to bestow upon them will never succeed in making them good lambs. They are a loss in every way, as a rule, from first to last, and the sooner they are off the land generally the better.

In taking note of the percentage of lambs, let it be remembered, however, that many discrepant returns might be reconciled were a uniform system of reckoning to be adopted. Thus while some flockmasters count all the lambs dropped, others reckon only the number of lambs castrated and tailed, while others again do not take stock of their lambs at all till they come to be weaned. Now it is unquestionable that a very large percentage of lambs die before the time of weaning arrives, and that even in the best managed flocks and under the most faroured circumstances. What must this loss, then, amount to under adverse circumstances and bad management? Speaking generally, and for all classes of farmers, we do not suppose it can be put at less than 10 per cent. This loss, be it recollected, occurs within a period of three or four months, and is not on the whole year. The death-rate amongst young lambs is greater than among sheep of any other age, and it is greater amongst hoggets than amongst old sheep. In the absence of statistics the actual loss cannot of course be arrived at. If, however, we are nearly right in assuming the average loss of lambs before weaning to be 10 per cent., which is well within the mark, then the average loss of tegs or hoggets between weaning and first shearing will be about 7 per cent.; of one-shear sheep, 6 per cent.; of two-shear sheep, 5 per cent.; and of three and four-shear sheep, 4 per cent. Occasionally the loss of old sheep does not exceed 1 or 2 per cent. but that is rare, and generally greatly below the average.

The difficulty with lambs in most cases begins with overstocking. Any one who has tried it knows that a good lamb cannot be raised where this is practised. Not only is there a greater "tail" among the lambs, but the death-rate is higher. "Over-sheeped" land has become too common in some parts of late years, and has shown itself in nothing more clearly than in its effects upon lambs.

There is also much wet-bottomed land in various parts of the country, which is ill suited for rearing lambs. On these lands the lambs, whether store or fattening, are sure to go wrong unless they are skilfully managed The only safety, and the only chance of rearing good lambs in such cases, lies in thin stocking, and giving a liberal supply of dry nourishing food. Even store ewes and lambs will require half a pound of corn or cake per head daily to keep them right on such lands. 


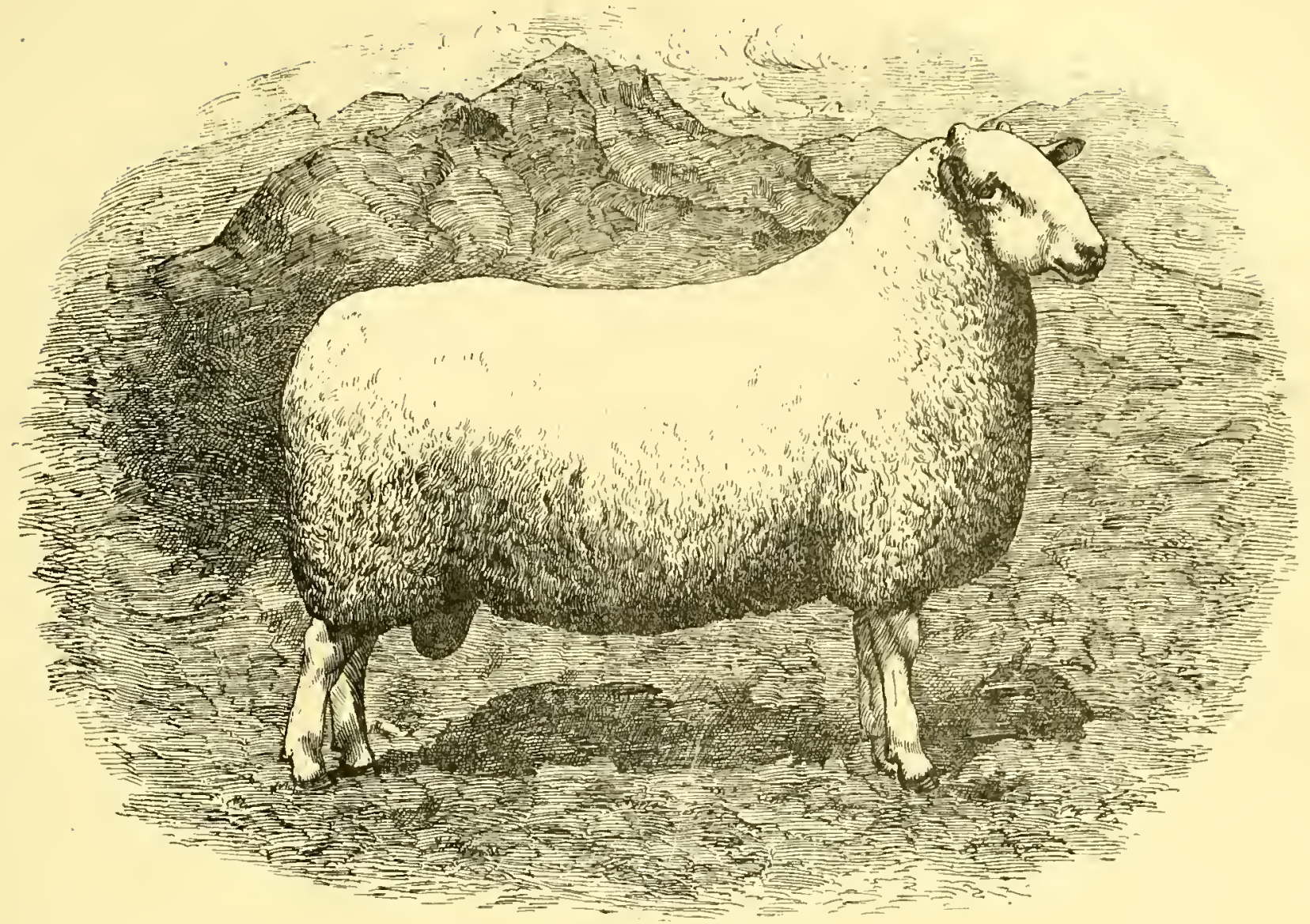

PRIZE CHEVIOT RAM.

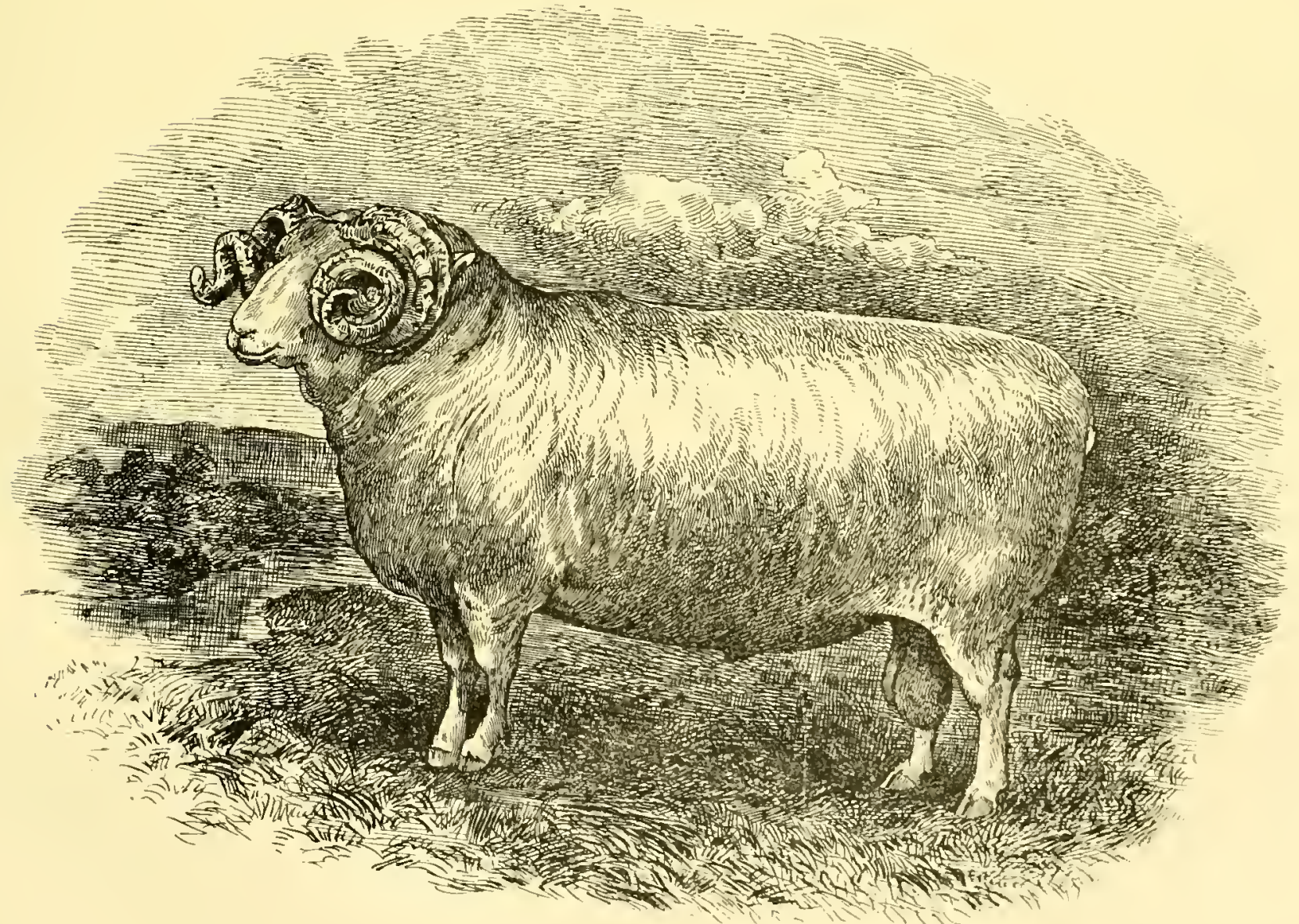



To the flockmaster no cartlly scene can bring more joy, or tune his thoughts to sweeter satisfaction, than to see his lambs at play. Neither is it altogether this show of sportiveness in the young flock that brings him all the pleasure. It is the fact of knowing that the food he has provided for them is being put to good use; that his labour and expense have not been in vain; that their well-doing means his prosperity.

A prettier sight one cannot see
Than lambs at play round rock or tree;
Their gambols tell of buoyant health,
Of thrift, of growth, and future wealth.

There is, however, another side to the picture, where we see "lambs at work," aye, and hard at work, with not a moment to spare, busy all day nibbling at the scant and withered blade, trying their very best to keep life and limb together.

\section{Their lambkin life is doomed to toil, By some hard master of the soil, Who neither feeds his land nor stock, Nor tends with care the bleating flock.}

A thrifty lamb means money, a poor starved thing money thrown away. Who can take pleasure in pallie scrubs or even peuny murts? Years ago a certain individual conceived the bright idea of teaching his horse to live on a straw a-day; but alas! the animal died before completing its education. This is not the age of chance or happy-go-lucky golden sheep days; these times are gone, but they have left us in possession of the knowledge that he who would keep sheep must keep them if he would have them keep him.

Thus lambs that play the reut will pay,

And fatter grow from day to day;

But he that grudgeth lambs their keep,

Will lose his all, and curse the sheep.

\section{REARING EARLY FAT LAMBS.}

In certain districts rearing early lamb is extensively practised. In the south and west of England, and on arable farms in the neighbourhood of larger towns, the date of the lambing is a mere question of management-where the climate is favourable for winter cropping and the production of early spring food, and where provision can otherwise be made for tiding the flock safely through the early spring months. In Devon and Wilts there are numerous sunny glades and warm sheltered vales where, assisted by the hot vapours of the Gulf Stream wafted across the Atlantic by south-western breezes, the grass is ever green. This is probably the leading reason why it is considered in this part of the kingdom, that lambing and the new year should commence concurrently, or at least fall tolerably close together. Many, however, do not wait for the balmy breezes, and have their lambing, or yeaning, take place at a much earlier period. In Dorset and the Isle of Wight lambs are looked for in September, and are fit for the butchers by Cliristmas.

All breeds are not equally fitted for rearing early lambs. The Dorset Horns have long been pre-eminent for this purpose, but latterly the Hampshire Downs have come into repute. Nor can all the art of the flockmaster avail in imparting this valuable characteristic to any other brced; neither are there any other cwes capable of forcing their progeny so quickly into the market for slaughtcring; nor are these propensities the consequence of any local circumstances, influenced, as may be supposed, by rich, stimulating food. In all situations these two varicties will be found to drop their lambs three months before any other breed, produce a great number of twins, and yield a more abundant supply of milk; and it is no uncommon occurrence for a flock of Dorsct ewes to produce two crops of lambs in one yearbut the practice is not to be recommended, as nature becomes the sooner exhausted, and the value of the ewe consequently deteriorated.

Formerly there was no choice between "house lamb" and "grass lamb," but now the earliest fat lambs go to market long before the grass comes, and yet the old house lamb system is pretty much abandoned. With artificial food at command, and with a greater variety of root and green crops available for cultivation, the possibilities in the direction of open-air feeding have correspondingly increased. It is not implied that on the whole the most artificial system pays best. Grass-fed lambs usually make capital prices: as much as 57s. 6d., and even 60s. each sometimes, when they have had some artificial food on the grass. Each lamb commonly sells at from $9 d$. to $10 d$. per lb. live weight, while Christmas lamb not unfrequently makes $1 s$. or more per $1 \mathrm{~b}$. These prices are all the very highest that can be obtained, but whether they leave a satisfactory margin to the feeder entirely depends on the cost of production. There can be no doubt, however, but that lambs of these ages make a large quantity of meat in the shortest time possible; and if the ewes can be cheaply maintained during the remainder of the year, there ought to be at least a fair profit from the transaction. Fattening the ewes along with the lambs would seem to be the surest mode of receiving a full return for food consumed, but we still think a good deal might be made from a "ewe dairy" after the lambs are weaned. This point is noticed under ewe milking.

To be successful in rearing fat lambs for Easter or earlier, it is obvious that a proportional quantity of winter cabbage, rape, carrot, rye, \&c., in addition to the usual mangolds, must be provided. It is of no use to have young lambs so early in the season unless abundance of succulent food of some kind can be depended on, otherwise their dams would give little milk, and the lambkins themselves, when big enough to eat a little solid food, would famish, there being none to partake of. The water-meadows of the south-western chalk country are in many parts the source of food supply upon which large finely matured lambs are reared, the small streams which trickle through the valleys being utilized for this purpose. Most of the large farms have a few acres of such land, the advantage of which enables them to depend on a crop of fresh succulent grass, even in the depth of winter, at a very small cost. On dry land, however, quite as good succulent feeding 
can be obtained by cultivating thousand-headed kale. The value of this plant is only slightly known to sheep farmers as yet, but one extensive breeder of Hampshire rams in Kent finds that by growing it largely he can afford to bring his ewes to yean as early as those who have water-meadows to fall back upon. In feeding kale it should never be allowed to grow sticky and hard before being consumed. When it is fed down close to the ground ere becoming too much advanced, the plants will sprout again, which prevents any waste and trouble in carting such from the ground. Vetches and trifolium may come in between the rye and the grass for ewes and lambs after Easter.

To fatten lambs rapidly, the utmost care must be given to their feeding. When folded on green crops they should feed in advance of the cwes, by having "creeps" provided, with space between the rounds to allow the lambs to pass through freely, without being sufficiently wide to admit the ewes. Feeding should commence as soon as the shepherd can see in the morning, giving hay first to both lambs and ewes; after which the troughs may be filled with cut roots, taking care to have them cut finest for the lambs, which is done by passing them twice through the cutter, a plan which reduces the food into a state which the lambs can readily consume, and induces them to eat at the earliest period, without loss of time and without waste. After the roots have been fed, a supply of oil-cake and pease should be given, the erves getting nearly one pound each, and the lambs just as much as they will eat up clean. The troughs should in all cases be made with a cross section, to prevent the lambs from getting into them with their feet, or dropping the food on to the ground, and the cake sliould be broken a suitable size, not too big, for them to chew easily. Feeding should be done three times a day, and great regularity observed in the attendance. The ewe lambs may be kept separate from the rams, and the couples favoured with a better dietary if possible. At a month old the ram lambs should be castrated.

\section{WEANING.}

To keep the lambs improving after taking them from the ewes is the problem of weaning. The ewes in their natural and free state would continue to suckle the lambs for about nine months in the year. Experience has shown, however, that the amount of nourishment so given is not equal to what can be supplied in a cheaper form, and that the cost, or drain on the condition of the ewes, is greater than the benefit derived from the lambs. Whether the lambs be intended for immediate sale or further keep makes little difference as regards the economy of nursing; keeping up the condition of the ewes is an important consideration in either case. The state of the market, as well as the supply of food, are also important factors in determining the date of weaning. There are buyers for all lambs in their season, and weaning, as a rale, goes on during several months.

When the lambs are strong and healthy at weaning time, it is a sign they have been well nursed, and will require keep in proportion. Poor, ill-nursed lambs will not require so much food, nor as rich, to keep them progressing. Inferior lambs have been reared on inferior food, so that what would be sufficient to improve them after weaning may be altogether inadequate to maintain condition in better lambs. This shows us that, whatever may have been the condition of the keep previously, we must improve on it after weaning if the lambs are to be successfully managed. It does not pay to let lambs fall off in condition after weaning. Every sheepman will grant this, yet it is surprising how little it is guarded against in actual practice. Neither lambs nor any other young stock can be profitably kept at only sustenance pointthey must be kept gaining in flesh and weight, or they will not leave a profit for the food consumed.

When lambs are weaned, they should be put on a clean pasture, where no other stock has been very recently, and where they can get a full clean bite. They must have clean pasture, and plenty of it; yet it must not be too rich, for fear of bringing on scour. Young shoots of grasses and clovers, on land that has been previously folded and allowed to freshen up, are particularly to be avoided. This second growth of grass, from the droppings of previous stock on the same land, often harbours the germs of various diseases, and particularly those of filaria and tapeworm. A change of pasture every three or four days will do much to keep the lambs healthy; and nice clean old pasture is preferable to betterlooking young seeds, if they have been previously heavily stocked. When grain or cake is fed to lambs there is less danger of disease, and they can with greater safety be put on succulent food. Plenty of good clean water, easy of access, is also very essential for lambs newly weaned.

\section{WINTERING AND FATTENING HOGGETS.}

Lambs intended for fattening purposes should be good to commence with after weaning, and they should be carried right along by box-feeding. A quarter of a pound of grain or cake and bran per head daily will take the place of the ewe's milk, and will easily repay the expense by the continued growth in the lambs. Frequent changes of green fodder and a daily supply of dry food are the right materials for making fat hoggets. Keep them improving all the time, and never give them more than will do them good.

When tegs or hoggets come to be put on roots it should be before the grass gets too bare, beginning with white turnip, to be followed by yellow turnip, swedes, or mangold, as the case may be. Roots should never be fed before they are matured, but where it cannot possibly be avoided, their insipidity can be remedied by pulling them a few days in advance of the sheep. In teaching them to eat turnips, a break, in size suitable to the number of sheep, should be netted or hurdled off, and the hoggets put on the turnips for several hours daily, and in a few days all will have learned to eat; but until they get accustomed to them they are better not to get full turnips for the first fourteen days; after that they may be netted on where the turnips grow, and hove as many 
as they can eat. They should also have hay in racks. The size of the breaks should be calculated to serve a week or ten days at longest; but in the event of a hard frost, they should only have what they can eat daily, shifting the nets or hurdles every morning, the shepherd picking up the shells in the afternoon. In this way there is no waste, and the hoggets do better in such weather than on a larger break.

These remarks apply to store loggets, and to fattening hoggets as well, during the first fourteen days; but for the litter, after that time, the turnips should be cut and put in boxes, being stored previously and protected from frost.

Assuming they have since weaning been fed on cake or corn, this feeding must still be continued, and the quantity increased-say, from $\frac{1}{2} \mathrm{lb}$. linseed cake daily when put on turnips, they should now have added to that $\frac{1}{4} \mathrm{lb}$. of Indian corn, oats, or, what is better, pease, and the mixture increased gradually, until at the finish they are getting from 1 to $1 \frac{1}{2}$ lb. daily, along with as much hay as they can eat. If this system is properly carried out, the loggets will be prime fat by Cliristmas, or they may be carried on to the end of March if thought desirable, and shorn before being sold.

As regards store hoggets, after being folded on turnips as above described, they begin to lose their teeth about February, when they too should have their turnips cut and put in boxes, taking care this is done before they suffer from the loss of teeth. Store hoggets should always have a part of hay along with their roots, but it may not be advisable to allow them any grain until the spring, when half a pound of oats and linseed cake will be a decided advantage in keeping them healthy and growtlyy at a time when there is comparatively little nourishment in the roots. When a full bite of grass can be had, the corn may be gradually discontinued.

\section{FEEDING IN YARDS.}

Shed or yard feeding is now much practised in winter, and with considerable advantage when extra feeding is to be given; but the system requires a great deal of attention. It will, however, in all probability become quite general on clay-land farms, when green forage crops converted into ensilage take the place of roots. On such farms the difficulty in keeping sheep is on account of poaching the land, by feeding them over the roots or other crops grown; but now since ensilage has given such satisfactory results, it is with every reason of feasibility that growing green crops and shed feeding may be practised. In exposed situations, too, there is little doubt but that shed feeding might be carried out beneficially. In the course of a year a tremendous waste occurs from the sheep being exposed to the severity of the weather, and the economy of feeding must be greatly improved by sheltering such sheep as are intended for the butcher. Exposure to a single storm will consume enough feed for fuel to add several pounds' weight, and with sheep, as well as all other animals, one step backward is harder to recover than to take a dozen steps forward. A fattening sheep in the open field will gain several pounds weekly in dry weather, while in bad weather it will not gain at all, however well it may be fed. The loss which may thus occur in a single week in a large flock, is far more than is required to provide artificial shelter for the whole of the sheep.

The following is the theory of this subject, and in the whole compass of the art there could not be a more satisfactory instance of scientific explanation:- "One bundred sheep in the turnip field during the four winter months from November to February will inhale about 1,400,000 cubic feet of air at an average temperature of perhaps $38^{\circ}$, weighing therefore $100,000 \mathrm{lbs}$, which will burn within them about $6000 \mathrm{lbs}$. of carbon, corresponding to $100,000 \mathrm{lbs}$. of turnips, or 40 per cent. of their whole consumption, and thus maintain the heat of their bodies. Now if this heat were maintained artificially, or, to speak within bounds, if the waste of it by excessive external cold were diminished by shelter against wintry winds, the necessity for this enormous loss by combustion within the lungs of these animals would also be diminished, and a great saving of food would follow. And not only the necessity, but the possibility also, of so great a consumption would be avoided; for as shelter and confinement produce warmth, they will rarefy the air breathed; and even supposing the animals to inhale an equal bulk of it, this will no longer represent an equal weight, or a quantity of equal ability to burn up the food they consume."

It is, at the same time, perfectly possible to injure sheep by too much shelter. There is no animal stands crowding in sheds worse than sheep. In fact they had ten times rather be exposed to the very worst storms than be huddled up in a close thed, where they have neither room to breathe freely, to erascise, nor to lie down comfortably. If they are closely confined in an ill-ventilated shed over night, with no room to move about in during the day, they will make slow progress in fattening. All the shelter that a sheep requires is protection from rain and cold winds, and a partial shelter is to be preferred to one where the sheep would be crowded. For fatting sheep it is best to have their shelters portable, so that they may be shifted when required, although in some situations permanent erections may be constructed. There are now so many light roofing materials-such as the Willesden roofing paper, galvanized iron sheeting, \&c.-that a comparatively light framework is needed. The sides may either be weather boarded, or covered with iron sheeting. Where other materials are wanting, nothing is more suitable for sheep than thatched hurdles. All that is needed is to make a close fence of the liurdles, behind which the sheep and lambs can find shelter. A lean-to-hurdle against a side wall or fence will sometimes be the best plan; and another plan is to set up two or more rows of vertical hurdles, the rows four or five feet apart, and lay others horizontally on the top of them to form a roof. If a more permanent erection is required, it may still be covered with straw. A straw covered roof, however, requires a sharp pitch to prevent leaking But thatching is understood by most farm labourers, and the principles upon which good work depends are so simple, that any handy 
man will make a light roof after a little experience. There are several methods of using straw to form the sides or walls of the sheds. A convenient way, when the shelter is not intended to be portable, is to set upright poles about eight inches apart, and draw wisps of straw round each, so that both ends of the wisp shall be outside. It is best to lay these in horizontal courses, and beat down each course as it is laid, keeping it uniform and tight. As the filling-in with straw progresses, there may be a split pole woven in, once in three feet or so, to hold the uprights in place. The straw has finally to be raked down on the outside, so as to shed rain well. The inner side is quite even, and it may be sprinkled with mud if there is danger of the animals pulling out the straw to eat.

For the accummodation of a hundred sheep, a shed sixty feet long and eight feet wide, with a yard at least four times that size, must be provided. The yard and sheds should be divided, by a railing four feet high, into five compartments, so as to separate the sheep into lots of twenty. Troughs for ensilage or roots should be placed in the yards, and boxes and racks for corn, cake, or hay should be fitted up around the outside walls, and the floors of the sheds should be kept well bedded with plenty of dry straw. Keep the shelters clean. Of all farm animals sheep are, perhaps, the most quickly and seriously injured by filth, which cannot be in a situation worse for sheep than in their shelters. If manure is allowed to accumulate therein, it will get into the cleft of the foot and produce scald; and while scald may not progress into foot-rot, it at least favours it. Clean out the manure every morning, and bed liberally. It is no economy to be sparing of bedding in the shelters.

A flock of one hundred sheep in the yard will nearly occupy a lad's whole tine, as if turnips are fed they must all be cut, and carried to the troughs. In feeding, the sheep should only get as much food as they will eat up clean, and no more. As soon as they have done feeding, the troughs should be swept out and kept fresh for the next feeding time. The food should always be given at stated hours. Feed at a certain hour, and then stick to that time; for where feeding is done regularly.you can go among them, and the sheep will not pay any attention to you until the feeding hour. The allowance of cake or grain may vary from three quarters of a pound to a pound and a half per head per day; half the quantity to be given in the morning, and while they are eating it the keeper should be filling the troughs with what green food they are getting, and during the time the sheep are feeding he should clean out the sheds. The fresh hay should be put in the racks, and their water attended to. To feed successfully, sheep should have water accessible at all times. The fold should then be closed, and the animals left in quietness till the next feeding time, which should be about noon. The second allowance of cake or corn should now be given, and turnips to follow - adopting the same process as in the morning. They should again be fed late in the afternoon with fresh hay, and their boxes left full for the night. Quiet and rest are the two grand requisites in yard feeding, with regularity and cleanliness.

Sheep versus cattle have not unfrequently been tried in yards during such times as when the lung plague was prevalent, and many found sheep quite as profitable as cattle, kept in the very same yards. Six lambs will tread down as much straw, and make it into as good manure, as a full-sized two-year-old bullock. One acre of roots, an average crop, will fatten twenty-five lambs; old sheep would consume more, and twenty per acre would be a fair estimate-that is, when the roots are cut and fed in boxes, and the sheep receiving in addition an allowance of cake or grain.

\section{HILL FARMING.}

Hill grazings are of a most variable character; still they can generally be classed under two heads-soft land and hard land. The former produces the heaviest and most valuable sheep, and carries a greater number of them, the soil in most cases being composed of deep clay, moss or peat, and bog land; the latter consists generally of a more variable soil, patches of light, rocky, and heathery land alternating with a limited quantity of peat and bog. Provided this land be not overstocked, it makes equally as well-conditioned sheep as the former, though not so heavy. Good deep soils are the best and most healthy. There is a great deal of hill-land which has only a few inches of soil overlying a subsoil of a different nature; that sort of land. with a hard wet bottom; always makes an inferior sheep.

Not two grazings are alike. 'they may be found of the same size, the same altitude, and the same rent; but two farms with the same mixture of soils and grasses, the same exposure, and the same situation, are not in existence. Again, there are many farms that can produce sheep of equal quality with similar management, although some of them would appear vastly superior to the other. It is on these points that many are deluded, especially those who are not thoroughly acquainted, from experience, with all the different situations, soils, and grasses most suitable for sheep, in offering rents for such farms. Sheep of all kinds do best with a mixed pasture ; but the health, the size, the quality, and the number of sheep the land is capable of carrying, all depend upon the nature of the soil.

The time of entry to hill farms is at the Whitsunday term. In most cases the ingoing tenant takes the stock on the farm at valuation, otherwise it is sold by auction. Hill stocks should always be fixtures on the farm. The sheep having been bred and reared upon the ground for many generations, are perfectly acclimatized and domiciled, so that they know their heaf, and will not wander therefrom. Bringing strange sheep on to new ground is surrounded with many dangers. They may not have been accustomed with the same kind of soil and pasture, and when such is the case are very liable to disease and death. It is very seldom sheep can be moved from one hill farm to another with success. They do not know the ground. and there being usually few or no fences 
to confine them, they are liable to wander; and from being unsettled in their feeding, it is not to be expected that they will thrive so well as those acquainted with their heaf. The transference of hill stocks by valnation has very many favourable aspects. It enables the outgoing tenant to get a cheap and quick sale of all his stock, and the ingoing tenant has an equal advantage in getting a full stock of all the appropriate ages, and is thus saved much trouble in securing others from a distance, which in most cases he would fail to accomplish, at least satisfactorily.

It is questioned whether Whitsunday term is the most favourable time to enter a hill farm. At that term the incomer takes possession when the largest amount of capital is required. He is obliged to take not only the stock ewes, but the whole cast of the farm for that year, which he had no hand in producing, and has to pay for what he may probably never realize. The farm may happen to be under-stocked or over-stocked, and the period of most sickness and death in the flock immediately follows. But the greatest objection to a Whitsunday entry and valuation, lies in the impossibility of correctly judging what the price of sheep and wool will be the following summer. At that time there are no public sales for that description of stock, and the arbiters have to take a retrospective as well as a prospective view to guide them in their decisions. These methods of arriving at a conclusion have in so many cases proved unsatisfactory, that a change from Whitsunday to Martinmas entry is being strongly advocated by many hill farmers.

The Whitsunday term is not the time of year when a correct valuation of the stock can be made. It is the middle of the year, so to speak, when the work of the farm has advanced to the stage that it cannot be altered, and must be carried out whether it be right or wrong. A Martinmas entry, on the other hand, gives a better opportunity for arriving at the true value of the flock. The autumn sales have just then been held, and a fairer valuation could not possibly be made than according to current prices. There would be no young lambs to take, the ingoing tenant could breed as he thought fit, and he would also be able to winter his stock as he pleased. Another great advantage of a Martinmas entry lies in from one-half to a third less capital being required to begin with. Martinmas, properly speaking, is the beginning of the year on a hill farm. The stock is then reduced to their minimum number, and the ingoing tenant pays for nothing but what is really necessary, and the chances are he wonld not be called upon to pay above market price, or the proper value of the sheep. By a Martinmas entry, of course, several other changes would also be necessary. The away-going tenant would have to be bound to leave a certain amount of winter provender on the farm, to be taken at valuation by the ingoing one, and some other arrangements, such as engaging shepherds; but these are obstacles which would soon conform to the requirements of the other, although at the first a difficnlty is possible. How such a change could be effected is the knotty point. Tenants who entered at Whitsunday term are entitled to quit at that term; and as it gives them a larger sale than a Martinmas outgoing, they will not forcgo that advantage unless by special arrangement. It then comes to be more a landlord's question than a tenant's. In fact the whole thing is in the owner's power, and unless he sees it to be an advantage to pay the difference betwcen the two valuations, or arrange to carry on the farm for the summer six months, it will be some time before any such change need be looked for. It is at least evident that the farm offering a Martinmas entry would stand a much bettcr chance of letting than the same would do at Whitsunday, and it may safely be assumed that the farm showing the best induccments to entry would also bring the best rent.

The method of calculating the rent of a hill farm is based upon the number and quality of sleep the liolding is supposed to keep. Having ascertained the number, and estimated the value of what stock there would be to sell, the expenses of working and management, with every probable outlay and interest on capital invested, are deducted, and what remains will be the amount chargeable as rent, which if divided by the total number of stock will give the rate at so much per sheep. Blackfaced sheep farms run from 1s. to $6 d$. a shcep less rent; but both are subject to great fluctuation, according to the quality of the grazing and the price of sheep.

When the stock on a hill farm is taken at valuation, the out and in-going tenants each appoint an arbiter to fix the value of the stock. These arbiters mutually choose a third party to settle any disagreement. A certain day is fixed for the valuation to take place, which is devoted by the neighbouring farmers and shepherds to giving a farewell to the party leaving, and a welcome to the new tenant, by assisting in collecting the stock for the inspection of the valuators. A number of the farmers present are deputed to make a count of all the stock as soon as passed upon by the arbiters. When this has been completed, the company adjourn to the house, where a lunch is provided; and while the valuators are discussing the price to put upon the stock, the others amuse themselves by speechifying and drinking toddy. The price is not always agrecd upon that day; the valuators sometimes considering it advisable to wait for a time before dcciding.

The routine of management of hill flocks is simple and unvarying. Of course, on any kind of farm there is always something that can be done; still, no class have more time in which to do their work than hill farmers. They have short spells of busy periods, sucl as lambing and hay-time, but for other work they take it at their leisure. The chief operations will be described iu detail, but the sortings, \&c., are performed in the same manner as with arable flocks, and, therefore, we will here only give them as they occur.

Let us suppose it is the month of November. I'he first work to be done is to have all the lambs, or hoggs as they are now called, ear-marked with the stock and age "bit;" then the whole flock should be dipped and afterwards "keeled." Every farm has its own particular stock and keel mark. On high-lying farms the hoggs are usually sent to wintering about 
this time. The rams are put out with the ewes about November 22nd; and taken in at the end of the year. Sixty ewes are allowed to each ram. Lambing time thus commences about the 17th of April, and finishes at Whitsunday. It is an anxious time with the shepherds, and much depends on the condition of the sheep and the state of the weather for a successful lambing. Castration and docking of the lambs take place when they are from a month to six weeks old. Washing and clipping begin about the last week in June and the first week in July respectively. Hill farmers assist each other with this work, so as there may be only one gathering of a birsel. A good hand can clip four score of hill sheep in a day. After the sheep are clipped the hay season ensues, and requires the active attention of the farmer, so that no opportunity may be lost in securing as much as possible for the sustenance of the flock during the winter montbs. In wet seasons hill farmers will, we lope, not forget that they can provide winter provender equally as well and cheap by making ensilage, although hay is probably to be preferred when it can be got. There is no other food that can be given to hill sheep in the time of a storm equal to hay or ensilage. In the montl of August the lamb sales commence; as many of the best ewe lambs as are required to keep up the stock are retained, and all the wether and the second ewe lambs are sent to the market. The wedder lambs go to make up wedder flocks, and at two or three years old are sold from the hill, and afterwards finished off on turnips in the lowlands. The second ewe lambs find a ready purchaser in breeders who cross the Cheviot ewe with the Leicester ram. On this account the mid ewe lambs are as valuable as the top wedder lambs, or worth about $3 s$. a head more than the wedder side of their own class. The ewe lambs for keeping are herded apart from their dams for ten or twelve days, when they are put back to where they were bred. A new system of not weaning the keeping ewe lambs at all has lately been practised on some hill farms, and those who have tried it speak very favourably of the result in helping to check sickness or braxy, which in many districts is most fatal to the lambs in autumn. In the month of September the ram sales take place, and what breeding tups require to be sold or bought are attended to at this time. The draft ewes are next sold in the month of October; and this finishes the sales of stock for the year, with the exception of a few eild ewes and old rams, which are sent to the butcher. The wool is sold at any time during the year, but it is generally best to dispose of it at the wool fairs held in July.

Thus proceeds the work of hill sheep-farming from year to year, the farmer, as a rule, when prices are good, leading a comparatively happy and enjoyable life. A great deal depends on the shepherd for bringing out the sheep in good condition; and it is but right to say, that in most cases the shepherd is fully as anxious as his master that his flock should do well.

LAMBING ON THE HILL.

A successful hill lambing depends very much upon two things-the state of the weather during the lambing season, and the condition of the ewes at that period. Hill ewes are never in too high condition; the danger is all the other way. If the winter has been a mild one the flock may come to the lambing in fair condition without having been hand-fed, but in severe winters extraneous feeding must be the chief dependence; and it is a question for consideration whether, in mild winters, it would not pay to hand-feed with hay or ensilage, at least more than is commonly done.

On hill farms the regular lambing season begins about the third week in April. It is held better to be late than early in this matter in high districts, so that there may be a full bite of grass on the hills when the lambs begin to arrive. When such is not the case, the ewes have no milk for the lambs, and then troubles and difticulties begin. Hill ewes when in good condition are kind mothers, but when they are very lean they not unfrequently drop their lambs, and never own them, which becomes a serious matter for the shepherd. When a ewe refuses to attend to her lamb, the only way of restoring her affection is to take her along with the lamb and pen them up together. This of course is no small job if the ewe happens to be away miles out on the hills, and far from any stell or keb-house, when at the same time there may be several such cases demanding similar attention, and equally far apart.

Hill sheep are allowed the full range of their pasturage during lambing time, as at other seasons; but it is a great convenience to have one or two fields inclosed on the earliest ground of each lirsel. A few weeks before lambing time the weakliest of the ewes should be drafted into these inclosures, and later on ewes with twins, and any others which seem to need assistance with single lambs, and there sheltered and hand-fed until they are strong enough to go back to the hill. Couples are in very small proportion amongst hill sheep, and, when they do come, are generally broken up to fill the places of dead lambs. A lamb for every ewe on a hill farm is very extra luck, and yet in some seasons it has been exceeded, but more generally the crop of lambs on a hill farm does not average more than from 85 to 90 per cent. of the ewes. Five per cent. is the very least that will run eild, and the loss of young lambs no fewer in any year; while in a bad season the number of lambs reared may be reduced by storms or bleak weather to a percentage almost shocking to mention, but in many instances to as low as twenty-five for every hundred ewes.

At various parts of the hill, or where there may be a stell, small sheds should be erected for sheltering or penning up any lamb or ewe that requires it. Such a shed, in shepherd's parlance, is termed a keb-house-a "keb" being a ewe that has lost her lamb, and the house the place where she may be confined while being made to adopt another. There should also be a large keb-house in one or both of the fields, so that any weakly ewes and lambs can be put under shelter when necessary in wet or stormy weather. In these sheds several small pens are set apart for confining any ewe whose lamb 
has died until another can be put to her. A twin lamb is taken from some ewe that is least able to keep a pair, the skin of the dead lamb put upon it, and the little stranger placed in the pen with the ewe, when the foster mother, as a rule, soon takes it. If there are no couples, and a good ewe requires a lamb, it may be advisable to lift a small gimmer's lamb and put it to her.

The shepherd requires to go over his hill three times a day during the lambing season. His first round should be at early dawn, and his duties for the day end only with daylight. He gets the assistance of a boy at lambing time, and that is generally all the help allowed. But where there are two or more "hirsels" on a farm, a lambing-man is employed, and he takes a share of the ground from each shepherd. About twenty scores of hill ewes are sufficient for a man to attend to. In going his round the shepherd carries a bottle of new milk in his pocket, to help a newly-dropped lamb when needful. After pouring a little of the milk down its throat, it may be left with safety until he has seen the rest of his flock, knowing that it will not die of hunger at any rate before he can more fully attend to it.

Lord Kames in his "Sketches on the History of Man," says-" I have it upon good authority, that ewes pasturing in a hilly country pitch early on some snug spot where they may drop their young with safety. Hence the risk of removing a flock to a new field immediately before delivery. Many lambs perish by their being dropped in improper places." This statement is not wholly correct. There have been instances known of mountain ewes selecting a particularly favourable spot to lamb on, and very curiously the same spot for consecutive years; but, as a rule, hill ewes seldom lamb at or near the same place, even when they have the opportunity to do so. Ewes, on either hill or low land, when about to lamb, if undisturbed, will often become partial to certain parts of their ground, and will be seen to keep near to that place for a day or so before delivery, but generally they will pitch on their favourite spot without consideration. They all choose a spot from which they will not move until they lamb; but, as Lord Kames says, many lambs perish from being dropped in improper places, which is quite true, as while some ewes will select remarkably secure and wellsheltered places, others again consider the brink of a precipice, or the bank of a stream, an equally safe retreat, even although they have wandered beside these dangers for many years. We have seen remarkable instances of wisdom and care shown by some ewes in leading their young from danger; but sheep, as a rule, are only gifted with ordinary intellect, while some of them are profoundly stupid, and will heedlessly go astray.

The mountain breeds of sheep being active and hardy, the young lambs, if all right, are soon upon their feet. Were they to lie as long as the softer breeds of the lowlands before getting to their feet, they would soon be frozen to death. For a chilled lamb that has lain all night in the cold, it is generally recommended to give a little "gin toddy," and most $3 \mathrm{~T} *$ shepherds are averse to taking the lamb to the house or atvay from the ewe if it can at all be avoided. After a cold and rainy night in the lambing season, instead of having the kitchens filled all day with drooping lambs, it may sometimes be an advantage to dip them one by one for five minutes into a tub of lot water, at the temperature of an ordinary warm bath, when they will sooner be restored to life and activity. But great care will afterwards be required with the lambs, and they will have to be kept warm for some time, and gradually put out again into the cold.

When a young lamb first endeavours to suck-which it will do as soon as it is on its legs-if the ewe repels it, the shepherd must take hold of her and examine her udder. If it be all right, and she is found to have plenty of milk, it may be necessary to confine her for a day or two in a small pen, to which the lamb has free access, until she becomes reconciled to the nursing of it. It will sometimes be found, however, that the ewe's unkindness in refusing to let the lamb suck is owing to sore teats. This is nsually indicated by an inflamed appearance. The remedy in such cases will be to draw the milk from the teat by hand, until it begins to flow freely, then allowing the lamb to suck. A little care in this way is better than applying saives to the udder, as they generally only prevent the lamb from taking loold of the teats. If the ewe must necessarily be confined for some days in the pen, she needs to be liberally fed on a cooling dict. There are two distinct cases of deficiency of milk in the ewe, from which the lamb may suffer equally. 'The first is, where there is only a small appearance of milk, in which case the lamb must be helped on with cow's milk for a day or two, until by more liberal and succulent food the milk is brought upon the ewe. The second case is that known as "false udder," when there is a good appearance of milk, but in reality none. Here also good feeding and constant sucking generally soon put matters right.

\section{HILL HERDING.}

Hill lambings terminate about the 26th of May. After that the shepherds have a comparatively easy time, which is chiefly devoted to herding the sheep. Castration and docking of the lambs take place as soon as possible after the finish of the lambing, and a full count made of all the lambs. Between that time and the latter part of June, or beginning of July, when the sheep are shorn, the shepherd requires to be amongst his sheep early and late, so as to prevent any of them from dying "awald," or rolled on their back and unable to rise. There is a continual anxiety from this cause, and even with the most vigilant care a few sheep may be lost. Careful dipping is about the only preventative for sheep rolling, so that when that work is being performed it is well to have it done thoronghly, as it may be the means of saving the lives of several sheep at this period.

Hill herding may seem a very simple employment, but it is an occupation where mucl, scientific skill can be displayed. The shepherd who imagines his duties are merely the performance of a few mechanical rules widely mistakes his 
calling. It is not going round his hill once or twice a day, to see the sheep move in from the heights in the morning, and out again in the afternoon, and to pick up what dead ones he may find, which constitutes the work of the shepherd. That is not what he is there for at all. The natural instinct of the sheep will lead them to accomplish that by themselves, and the dead ones could be lifted periodically much cheaper than by having a man constantly employed for the purpose. The duties of the shepherd are "to lead his sheep, to herd them by the green places, where they will get good-not evil-all the days of their lives." On a wide expanse of any mountain land there are a certain amount of herbage and a certain number of sheep, supposed to be sufficient to consume or profitably subsist upon what food the said land is capable of producing. This, then, is the shepherd's work-to herd his sheep in such a manner so that they will consume a given quantity and quality of food to the greatest benefit. Let the sheep have their own free will of their pasture, and what will they make of it? They will seek out the sweetest places, and leave uneaten other parts, which wonld consequently bring disease and ruin to the whole flock.

The successful herding of hill sheep consists in distributing them equally over their pasture, giving each and all of them a variety of the existing grasses, and having them feed such food as is most abundant at certain seasons of the year, reserving other portions until the time when their use becomes more valuable. Every flockmaster and shepherd should be familiar with every grass and every herb that grows upon his hill, its nature and feeding quality, its season of growth, and the best time for pasturing. An acquaintance with geological formations, and the influence of soil on pasture and on the growth of wool and the health of the flock, are equally necessary. Each farm has its own peculiarities, so that no rule will apply to all; but a study of the botany and geology of a sheep-walk is one of the first steps to successful herding. When a farmer or shepherd has advanced that step, he will be able to divide the hill into "hirsels," and the hirsel again into "cuts," so that each division will contain a share of all the different grasses sufficient to provide a suitable variety of food for the sheep all the year round. On an occupation of this kind, with which we are well acquainted, there were three shepherds. When one of these shepherds went to that farm he got the worst hirsel of sheep; but he was not there many year's until his sheep were the best on the farm. For some reason or another he was then shifted to one of the other hirsels, which had become the worst, and before long the hirsel under his care again became the best. He did this merely by good herding. The breeding of the flocks was under the farmer's own personal charge, so there was no partiality or different judgment used in that respect. He had no advantage in the way of food for his flock that the other shepherds had not, only he knew how to manage his sheep so that they were always supplied with the best grasses the hill provided at the proper seasons.
It is evident that the man who can most skilfully distribute or "herd" his flock, so that they find the most nourishment at all seasons, will, by long odds, produce the best sheep. That there is a great difference in the results obtained by different shepherds is a fact, and we believe that better results might be obtained generally if the science of hillherding was better studied. How far fences will enable us to pasture wide and variable sheep ranges, so as to obtain from them their full value, is a problem deserving of consideration.

\section{WINTERING HILI SHEEP.}

The winter management of hill sheep is attended with much that is both interesting and difficult, and is not altogether, as some may suppose, monotonous repetition winter after winter. It is the season when the natural food of the sheep is brown and bare, with comparatively little nourishment left in the withered grass, and besides the food being scant, the sheep have to contend against the full fury of the winter's blast, in wind, in wet and snow. This is how mountain sheep are so much dependent upon a mild or open winter for their welfare; and, owing to the uncertainty of the weather, and the pliases which it is wont to assume, the wintering of hill sheep is ever a subject of vital importance to the pastoral farmer. It is one, moreover, which has connected with it a great varlety of problematic theories, many of which have been put into practice, and the results obtained have been so conflicting, that the question of whether hill sheep should or should not be fed every winter, is still among flockmasters an unsettled point. With some it is the practice to feed every winter, mild or severe; more, however, believe in feeding only in times of a storm; while a few act on the other extreme, and never think of providing food of any kind, allowing the sheep to subsist as best they can.

It is questioned whether our winters are as severe now as formerly, and the belief is gaining ground that we have not the same depth of snow and fearful drifts as used to bring terror and ruin to many a mountain cabin. "Storms," says Hogg, "constitute the various eras of the pastoral life. They are the red lines in the shepherd's calendar-the remembrancers of years and ages that are past, the tablets of memory by which the ages of his children, the times of his ancestors, and the rise and downfall of families, are invariably ascertained. Even the progress in Scots farming can be traced traditionally from these, and the rent of a farm or estate given with precision, before and after such and such a storm. Though the narrator is uncertain in what century the said notable storm happened, 'Mar's year,' and the year of the 'Highlanders' raide,' are but secondary mementoes of the year nine and the year forty-these stand in bloody capitals in the annals of the pastoral life, as well as many more that could be mentioned." "But of all the storms," he continues, "that Scotland ever witnessed, or, I hope, ever will again behold, there are none of them that can once be compared with the memorable 24th January, 1794, which fell with such peculiar violence on that division of the south 
of Scotland that lies between Crawford Muir and the Border. In that bounds there were seventeen shepherds perished, and npwards of thirty carried home insensible. But the number of sheep that perished far outwent any possibility of calculation One farmer alone lost seventy-two scores, and many others from thirty to forty scores each. Eskdale suffered severely in that storm." Hogg says he witnessed "one particular instance on the farm of Thickside, where twelve scores of excellent ewes were missing all the time the snow lay, which was only a week, and no traces of them could be found When the snow went away they were discovered all lying dead, with their heads one way, as if a flock of sheep had all dropped dead coming from the washing. Many hundreds were driven into waters, burns, and lakes, by the violence of the storm, where they were buried or frozen up, and these the flood carried away, so that they were never seen or found by the owners at all. The greater part of the rivers on which the storm was most deadly run into the Solway Firth, on which there is a place called the 'Beds of Esk,' where the tide throws out and leaves whatsoever is carried into it by the rivers. When the flood after this storm subsided, there were found at that place, and the shores adjacent, eighteen hundred and forty sheep, nine black cattle, three horses, two men, one woman, forty-five dogs, and a hundred and eighty hares, besides a number of meaner animals." "The mere mention," said the bard, "of these traditionary stories and pictures of desolation to an old shepherd on a stormy night, never failed to impress his mind with a sort of religious awe, and often set him on his knees before that Being who alone can avert such another calamity." We have good and bad winters yet, but they do not make such gaps as Hogg tells us about. It was nothing uncommon then for whole farms to be entirely divested of their sheep stock, in which condition they sometimes remained for many years. So low an opinion was held of the high-lying grazings, that a lease could be had for the rent of a gray coat and a pair of hose, for the same farms as are now let at $£ 600$ per annum. The seventeenth, eighteenth, and beginning of the nineteenth century bear record of these dismal events; since then no such losses have occurred. Now and again we hear of a shepherd being lost, and a score or two of sheep being "smoored" in the snow, with occasional serious reduction in the condition of hill sheep, which in spring are carried off, or are unable to bring their lambs, but the wholesale destruction of entire flocks is fortunately a thing of the past. Napier, in his "Store Farming," estimated the winter losses of hill stock during the last century at 25 per cent.; whereas it will not now exceed 10 per cent., and in many years is much less, even without any particular care, which would indicate a more temperate climate or better management, the latter being the most likely.

Winter feeding hill sheep was introduced early in the century, and as the practice gradually became known, so did severe winter losses gradually pass away. Before that time cattle were kept on hill farms in great numbers, and the grassy spots on the hills were cut and made into lay for their use only, and not for the sheep Enclosed mearlows were doubtless first constructed about the time when it became important to have a supply of hay for both slicep and cattle. But even then it was found impossible to obtain a sufficiency, and the sheep being the more remunerative of the two, the remainder of the cattle, which at one time pastured the most of the hills in Scotland, were displenished in favour of the sheep. Improvements were looked upon as innovations in those days, and so slow were any new methods of management adopted, that it might be said the old men dicd before the rising generation could put advanced ideas into practice. Progress, however, eventually prevailed. Hay was provided for winter feeding in the time of storms, and "stells" were erected at various parts of the hills for slieltcring the sheep, and these have proved a lasting benefit in the preservation of our flocks. Then on farms where little or no hay can be had, artificial feeding has been used in assisting the sheep through trying times, and the use of turnips for wedder flocks has become quite general. The latest advance in wintering hill sheep has been made in ensiling the grass on the hills, when in wet and moist seasons it is impossible to procure hay. This system is as yet a new one, and comparatively untried, but it presents many favourable aspects for the solution of this important question of wintering hill sheep. Removing the flocks in winter to low country grazings is another of the methods extensively practised on the highest lying farms, and by adopting one or other of these methods no farmer need now dread the consequences of the weather. Expense in providing for emergencies will of courze be necessary, but on that every prudent man will calculate before undertaking the management of hill sheep. Those who trust to chance or negligence in bringing their sheep through severe weather, will even now-a-days, with milder winters, find themselves in no better plight than those the Ettrick Shepherd so woefully describes in the last century, and have graven on their memories reflections of the disastrous day which came at last.

It is universally admitted that hill flocks ought to receire more attention in the way of winter feeding than they usually do; but it is a very unsettled point how far this can be done with benefit. Most necessary it is, however, where hand feeding must be adopted, that it should be begun in time, and not put off until the sheep have lost condition; and it is equally necessary, when the season is advanced, that hand feeding, if once begun, should be continued until there is grass, or, at all events, as long as the sheep look for it. Cheviot sheep do not work in a storm with the same energy as blackfaced sheep do, hence tliey require to be sooner handfed; and, again, some farms storm far easier than do others.

Natural hay, or ensilage, made on the farm, is the best provender for hill sheep, and it should always be largely provided, otherwise great losses are sure to occur in severe seasons. A hay park, or meadow, should be set apart on all hill farms and hained for this purpose, and all the better if 
there is a field or two of this kind for each hirsel. In moist summers, however, if the land is at all grassy, large supplies of hay can be cut from the bogs and marshy spots on the hills; but in dry summers it is seldom to the farmers' interest to cut a great quantity of bog hay. Some flockmasters make a rule of having always two years' supply of hay on hand, and the practice is to be commended for several reasons; for when a winter of more than ordinary severity or devastation occurs, the hay is not so liable to run short, and, on the other hand, in a droughty summer cutting may be dispensed with altogether for that year, and the sheep allowed the full benefit of the pasturage. A sheep is known to eat an equivalent of grass and dry hay; and as grass losses three-fourths of its weight by evaporation, it follows that a sheep that eats $10 \mathrm{lbs}$. of grass will consume $2 \frac{1}{2} \mathrm{lbs}$. of hay. This multiplied by the number of days in which hay feeding may be necessary, affords a ready rule for calculating the quantity of hay which should be provided.

The usual mode of feeding hay to bill sheep, is to scatter it in handfnis on the top of the snow, and the sheep will pick it up quite cleanly; but in windy weather this method of feeding is wasteful. The most economical plan is to put up a double line of wire netting, about 2 feet apart, on stakes driven into the ground. The sheep will eat the hay nicely through the meshes of the wire, which also prevents the hay from being trampled upon, or blown away by the wind. When feeding either fully or partially, it is well not to have too large a number of sheep together at one place, not more than two hundred if it can be managed. The greater the number of sheep in a cut, there is just the less room for them to feed on what bare ground there may be available.

When recourse must be had to more artificial measures for feeding hill flocks, supplies of cake and corn are best suited for this purpose. If it be intended to use box food, the sheep require to be trained to eat from the boxes when hoggs, and for this purpose they are bronght into the field for a time. They generally soon all learn to eat, if they are brought in early in the winter, while they are in good heart and condition. They only require to be accustomed to hand feeding, and then put back to the hill. In this way all the sheep may be brought to know box-feeding, and they will not soon forget it. But if circumstances should compel boxfeeding when the sheep are reduced in condition, and they have not been taught beforehand, it will be found of littlc benefit, and they will die of hunger rather than take the corn or cake offered them. Box-feeding hill sheep is, however, a practice that should only be attempted when no other means are available, and care should be taken not to feed too highly -not more than from $\frac{1}{2} \mathrm{lb}$. to $1 \mathrm{lb}$. per sheep daily. There are several who have fed cake or corn, and who put great faith in the system, but from what we know of it we would never practise it on a whole flock. In the early months of the year a good plan is to be always on the lookout for any ewe that begins to show signs of poverty, and have all such brought in from the hill, and hand-fed with hay and corn if absolutely necessary. But all those sheep that have been so treated should be drafted the first opportunity, and not wintered again. That is how to take care of the leanest of the flock, and for bulk we would provide a supply of hay or ensilage to feed only when the ground was stormed.

There should be more systematic management of the feeding business than is generally the case. How far any method can be carried on with profit, depends on the conveniences the farm is provided with-in meadows for hay, in fences to confine the sheep where wanted, and some of these things. If the farm cannot supply sufficient hay or ensilage, then some other course will have to be pursued. But lacking a supply of hay, removing to low ground for a time is about the next best and cheapest course to take. The various phases which storms assume, and what can be best done under the circumstances, requires a good deal of experience, both in understanding when and where not to feed, and how to handle the sheep while the storm remains.

\section{SHEEP SORTINGS.}

\section{WASHING.}

Sheep-washing is generally considered an indispensable operation in this country, although in some others it is not much practised. The advocates for not washing say, that to immerse sheep in cold water for several minutes is unnatural and dangerous to their health, and that the handling and tossing about the animals get is injurious. With regard to the inferior value of unwashed wool, we have heard it said the extra weight (in dirt) compensates for the lower price at which it is sold. We have our doubts on this point, however; but even if the wool could be sold so satisfactorily from the farmer's point of view, we still hold with the time-honoured custom of sheep-washing. It is hardly necessary to state to a practical man, that a washed fleece is easier to shear, and easier to do up, than an unwashed one. "Shearing in the dirt" is hard work, and the fleece falls to pieces in a vexatious fashion on the table, especially if the sheep has been fed for the shambles, or is naturally very yolky. "It is essential," says a manufacturer, "to the ready and accurate sorting of a fleece into the half-dozen or more grades to which it is ultimately assigned, that it should be kept well together, and washing is a great aid thereto. It should also be borne in mind, that wool is never so well washed, and never washed with so little injury to the fibre, as when it is washed on the sheep's back. 'The increased severity required to get dirty wool clean in the process of manufacture is injurious, and consequently reduces its value." It is not worth while to go the length of some non-advocates of washing, who assert that the buyer cannot classify wool so correctly when unwashed as when it is washed. A genuine expert, though he may declare that he likes the "feel" of washed wool better, can pronounce upon the actual merits of a clip as well in one condition as another; if not, he has mistaken his calling.

Nor do we believe in the injury to the sheep. Granted 
that they will not plunge into the water like a duck of their own accord, still we believe the bath is not displeasing to them on a hot summer's day. As to the handling, we have seen thousands of sheep washed, and do not remember ever seeing a sheep hurt therefrom. There is a right way and a wrong in getting them into the water, and those who are sccustomed to handle sheep will not hurt them. Instead of washing being hurtful to sheep, we have noticed quite the opposite effects, and consider it highly beneficial. It will invariably be noticed that the lambs thrive and grow better after the ewes have been washed, than they do during any other month in the year.

The chief object is to improve the wool in quality, and make it bright and clean. Wool buyers pay for lustre, and they tell us that, however carefully we may breed our sheep, and however superior the wool may be which they grow, our returns will be disappointing unless the greatest attention is bestowed upon the washing of our clip. The only chance of obtaining full value for the wool is to have it well washed. Still, on many farms, even where the facilities for sheepwashing are convenient, it is omitted.

There are various methods of washing sheep. With large flocks, all the sheep, before being shorn, are washed by being made to swim two or three tumes across a running stream or pool, as described so graphically by Thomson in the "Seasons":-

\section{"Or rushing thence in one diffusive band, They drive the troubled flocks, by many a dog Compelled, to where the mazy-running brook Forms a deep pool; this bank abrupt and high, And that fair spreading in a pebbled shore. Urged to the giddy brink, much is the toil, \\ The clamour much, of men, and boys, and dogs, Ere the soft fearful people to the flood \\ Commit their woolly sides. And oft the swain, On some impatient seizing, hurls them in. Embolden'd then, nor besitating more, Fast, fast they plunge amid the flashing waves, And, panting, labour to the farthest shore."}

Pool-washing is most general, and, all things considered, is perhaps the best. Sheep do not wash clean in a running stream. A stagnant pool is much better, as the yolk of the wool, which consists of fatty acids combined chiefly with potash, being left in the water, acts like soap, or better than any soap, in scouring and giving a bright lustre to the wool. The pool should be twenty-five yards long, five yards wide, and at least six feet deep at the jump, gradually ebbing to the point where the sheep can walk out on a well-gravelled beach. In a pool of this description the sheep can be washed very clean, if they get a good high "jump," and are put across two or three times. The jumping-stage should be three feet higher than the water. The ewes soon learn to jump into the water of their own accord, and are much less liable to get injured than when each one has to be pushed in. Sometimes the washing-pool is formed directly facing the sheepfold, where the lambs are shut up for the time being, and having the ewes looking straight in that direction they then jump freely, and swim the pool to get to their lambs. The old saying, "If a'e sheep loup the dyke, a' the rest will follow," is very true, and many ill mtrations of it are to be seen at the washing-pool.

Tub-washing is sometimes morc convenient for small flocks, and is certainly preferable to driving the washed sheep over lusty roads from some neighbour's washing-pool, if there is not one on the farm, as by the time they get back they are often as dirty as before. "Tubs" can be made in almost any form, the situation being the architect in that respect Many of them are somewhat novel, but a little ingenuity will generally contrive a handy sort of bath. Here is how an Irish farmer describes the course he has adopted, with marked success in result and price of wool:- "I wash by a clear running river about four feet deep. There is a causcray at one side; here is set up my sheep-dipping trongh, which is kept full of hot water and soft soap. Each sheep is taken by the legs and is soused on its back four times in the water and soap, then placed on the rack to drip back into the tub; then the sheep is slipped into the river. As soon as it rights itself a ring is put over its neck, attached to the end of a pole. It is then guided swimming twenty yards against the stream, and then let walk out. The result is all that can be wished. One great benefit is that no man need wet a foot, and no drink is required. We usually wash 500 sheep in three or four hours; then the pens are struck, and all hands go to a hearty dinner. We never have an accident. My wool sells for $\frac{1}{2} d$. or $1 d$. per lb. more than inferior washed wool."

Sheep-washing usually takes place about the beginning of Jnne, a little earlier or later, according to locality and condition of the sheep. As soon as the new wool begins to rise the sheep may be washed; and in six or eight days after washing they may be shorn. If the weather should become wet so as to prevent clipping at the time intended, it may be advisable in some cases to repeat the operation of washing.

Foreign wools are noted for their cleanness and quality, which is in a great measure due to the care taken in the washing of the sheep. It may not be amiss to give some idea of the pains taken by the Germans and Australians in some of the best districts to wash the wool before shearing.

The process of washing sheep at Alcarth, in Hnngary, says a Patent Office Report, is done under the roof, and accordingly no sudden showers or rainy weather can interfere with it. Before the shower bath is administered to the shecp, their dirt and pitch have to be dissolved and loosened. For this pnrpose a soaking vat has to be put up, which is covered and tightly put together of strong planks or boards. It is filled with hot water, equal to $84^{\circ} \mathrm{Fahr}$; the sheep are then placed in two lines, and constantly handled until the yolk and dirt are dissolved, which ordinarily takes from fifteen to twenty minutes. The solvent effect of the water is increased by adding a few pounds of potash, and also by the lye arising from the natural oily matter of the wool. The sheep, after being well soaked, are placed under shelter, where they have to wait their turn of the shower bath, in order that the animal, 
now too much heated, may not pass immediately from the hot soaking-vat into the shower-bath, this being from $61^{\circ}$ to $63^{\circ} \mathrm{Fahr}$. The water is let upon the sheep through a hose with a strainer at the end. It falls with considerable velocity, and is brought to bear upon all parts of the sheep until the wool is of a snowy whiteness. The sheep are then driven to a warm dry shed, and shom as soon as the wool is dry, generally about the sixth day. On an average forty sheep are thus washed in an hour.

In Australia sheep farmers do not stick at $£ 1000$ or $£ 2000$ for steam engine and washing gear. The sheep wash at Mount Fyans is an excellent construction, and has attracted the attention of many sheep farmers. The plan adopted is to pass the sheep through a cold water tank over night, which washes a good deal of the loose dirt off the bellies and legs, and thoroughly saturates the fleece. They are then packed pretty closely in a sweating house, with numerous subdivisions in it to prevent the sheep from being smothered. By this means the points of the wool are softened, and the work of cleansing the fleece is rendered very much easier than it would be if the sheep were taken into the wash without this preparation. The hot-water tank into which the sheep are put next morning has three divisions, in each of which they are well crutched. At the end of this tank there is a movable floor, which is raised by a lever, so that the sheep leave the tank without having to struggle up a steep incline. The water is heated to about $108^{\circ}$ or $116^{\circ} \mathrm{Fahr}$, and bar soap is used to soften it, and render the process of cleansing the wool more easy. After draining for a short time, they are passed down shoots to the men at the spouts, where, on Sharp's patent sheep rollers, they are well spouted; and when the hot water has been fairly driven out of the wool, they go on to the landing stage, where they drain for a time, and are then allowed to walk on the grass by a long battened stage. The water for the wash is drawn from a large dam, which is kept constantly full by a stream from the spring in front of the house. Centrifugal pumps are used to throw up the water to a height of twelve feet, and one spout will wash about five hundred sheep a day.

Iany of the foreign wool-growers wash their wool after it is shorn. At the Wool Exhibition held at the Crystal Palace, London, some years ago, Messrs. J. \& W. M'Naught, of St. George's Foundry, Rochdale, Lancashire, exhibited an apparatus for this purpose, which appeared to do admirable work. The wool was placed on a self-feeding table. It then passed into a trough twelve feet in length, containing soap of an alkaline character and water. In this trough the wool is stirred with forks, worked by a most ingenious crank, and carried forward to the far end. Here it is carried up an inclined plane of glass, on which the greater portion of the alkaline fluid drains and falls back into the trough. The mechanical contrivance for carrying the wool from the trough consists in a double set of rakes, which act alternately similarly to the action of the shakers of a threshing machine, but of course the teeth of the wool-raker are at the bottom. On reaching the top of this inclined plane it is received by two heavy pressed rollers, where it is well pressed, when it is passed into another trough of the same iength, and again agitated in another quantity of liquid. Having buen agitated by the same form of machinery in this second troughi, it is conducted at another inclined plane by the same form of machinery, when it is again passed between rollers. On leaving this second pair of rollers it is met by a drum, which threshes it-so to express the opinion-into fine loose locks, when it is ready for the drying machine which is attached. This drying machine is simply a trough or box with a wirenet covering, in which are revolving the blast screws that circulate air rapidly. This air may be heated, or of a natural temperature, acrording as the wool is required to be dried rapidly or not

\section{SHEEP SHEARING.}

Eight or ten days usually elapse between washing and shearing; not that it requires so many days for the wool to dry, but it takes about that time to recover "yolk," without which the wool lacks lustre. The time it takes to recover this depends much on the condition of the sheep and the temperature of the atmosphere. Fat sheep can be shorn earlier than lean sheep, and the hotter the weather the sooner will the yolk rise after washing.

In sheep farming districts it is commonly the practice for eight or ten farms to unite their clippers, and shear their flocks alternately. In this way only one gathering of the sheep on each farm is necessary, and much time is saved in other respects. The hands arrange to meet at a certain farm one day, and when that flock is shorn they go to another farm, generally taking about two weeks to get over them all. The farmers provide the shearers with food and drink of the hest, but clipping festivals are not the affairs they were half a century, or even a quarter of a century ago. .In those days the farmer who supplied the best food and the most whisky was accounted the best stockman, and the "herd" who could perform the greatest feats in jumping and wrestling was reckoned the best shepherd. Clipping-time came orly once a year, and the pastoral worthies made the very most of it. Nowadays there is less merry-making at these annual meet-

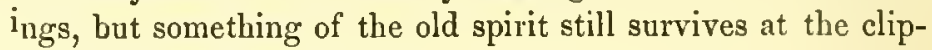
pings on the hill farms.

On lowland farms the clippings pass off more quickly. Most of the work is done by hired hands, who are paid by the day, or according to the number of sheep they shear. When the latter is the case, the price varies from $3 s$. to $5 s$. per score, according to the kind of sheep and their condition. A good hand can shear eighty hill sheep, and from forty to sixty lowland sheep in a day. Sheep intended for the fat market or for the showyard are done up in extra style and cost a little more. The men in such cases are employed by the day, or the shepherd does it himself.

The flock about to be shorn should be gathered by early dawn, as the sheep are less liable to injury than when brought into the pens with paunches full. When penned the lambs 
should be separated from the ewes, then both lambs and ewes counted, and the numbers entered in the stock book. Clipping may then begin, each shearer going to the catching-pen for his first sheep, after which the catcher or "gripper" supplies the shearers with a fresh sheep as soon as he is finished with the former. One man can "grip" for about ten or twelve clippers. Lowland sleep are mostly shorn round the rib, but in many places it is customary to shear lengthways, and when well done it looks as well as the other, and is quicker. The shearer gets a longer cut the long way, and does not have so many turnings. Heavy sheep should not have their legs tied "all-fours," and should be shorn on the ground and not on stools. Hill sheep are best shorn on the stools, as they are easier to lift and turn, and not so liable to injury.

The "buist" or brand mark is put upon every newly shorn sheep, before the clipper lets it go. This consists in marking the initials of the owner npon eacl sheep immediately the fleece is off The stamp or buist is made of iron, and is dipped in boiling tar or pitch before applying it to the sheep. On the clipped tegs, or shearlings, the mark is put on the shoulder, to distinguish them from the older sheep, the latter being buisted on the loin or rib. The draft ewes, which are known by their ear mark, are also looked out at this time, but instead of being buisted they only receive a "pop" or dot of the same tar from a round stick on the shoulder, so that they can be readily taken out from the flock at any time they are required, and before being sold receive a fresh buist, which looks better than when it is put on at clipping time.

As soon as the fleece is off the sheep, it should be rolled up. A boy or girl is usually employed to pick up the fleeces as they are ready, and carry them to the wool-winders. Women make the best winders, and it requires two to do it well and expeditiously. This should be done on a sparred table, so that all dust or dirt in the fleece may fall through between the boards in the process of handling. The fleece is spread lengthwise on the table, outside up. One of the wuters has a pair of shears, which are used to clip off any dirty wool from the tail of the fleece; the other in the meantime twists a rope out of the neck wool. Then the sides are folded in till they meet, after which the whole fleece is rolled firmly up, beginning at the tail end, and tied with the neck band. After the fleeces are rolled, they are either packed in sheets on the spot, or carter to the barn or wool store and piled up. The ewe and hogg wools are kept separate, so as to distinguish them and afford the wool buyers better facilities for examining them. Wool should only be stored in good barns or houses. Vermin, dust, and damp very soon render it an inferior articie. If a good store room is not available, it is best to pack it into sheets as soon as clipped, when it will keep cleaner and brighter, besides taking up less room.

The practice of shearing lambs is far from common in this country, but it is on the increase. Shearing in the case of lambs does not, or need not, take place until midsummer or later, when they do not miss the wool. Those who have tried this practice say that, while it rather tends to dimin sh the next clip, any loss in this way is counterbalanced by the greater progress made by the sheep in the interval. And how many hoggets are fattened off during tlie winter and early spring, and never come to the shearing of the following summer! In all snch cases the shearing of lambs may be taken with advantage. If the flecces are small, the fine short lamb's wool is the most valuable of its kind. Lamb-shearing has long been an established practice in East Cornwall and other parts. We find it repeatedly mentioned in the reports of the Royal Agricultural Society's prize farms, and, from the lambs picking up much less mud in the wet season of winter and spring, great benefit is found to be derived from the practice. At the end of June, or early in July, Cotswold lambs are shorn on some farms, and yield about $2 \frac{1}{2} \mathrm{lbs}$. of fine wool.

In shearing it is essential to observe a few rules in the execution of the work. "Running" or "ringing," in shearing phraseology, is a practice to be discouraged. It is well that the shearing be done rapidly, but it shonld not be rushed in a careless manner, at the expense of cutting the sheep or destroying the fleece. The master nceds to insist on good clean shearing, and have it accomplished at a reasonable speed. A man that cannot do his part in a workmanlike style, and at a proper rate, without injuring the sheep, should not be employed, or else made to work at a slower pace, on a lower wage. All cuts or wounds should be dressed with tar before letting the sheep go, and any man noticed to turn a sheep away without tarring the cuts, should be made to bring back the sheep. Make every shearer notify the shepherd, or master, of anything he sees wrong with a sheep - such as a bad udder on a ewe, when she should be marked the same as the draft ewes, or a hoof or horn growing the wrong way, when it can at once be pared or sawn off, which prevents further trouble. Do not overcrowd the sheep in the pens, and especially after being shorn, as they are then liable to crush each other. Avoid dogging the sheep as much as possible, and let their time in the yard be limited after they are shorn.

Large as some of our flocks are they fall far short of the immense herds in the colonies, and we have only a faint idea of the magnitude of the work which has to be got through at slearing time. We do not imagine that any sheepowner in the United Kingdom shears more than 10,000 sheep in a season; what will then be thought of the shearing of upwards of 250,000? Yet some of the Australias ranchmen shear as many as 250,000 sheep in a ssason. Shearing takes place there in November and December. For such a flock 100 shearers, 50 "rouseabouts," and some 20 musterers are required. Shearers are paid a sovereign for every 100 sheep, rouseabouts about an equal sum per week, and musterers six shillings a day; the total expense of the shearing, so far as labour is conccrned, may be calculated at $£ 2000$ The yield of wool averages nearly five pounds weight to each sheep, lambs included. The gross weight of the clip from a single ranch is $1,250,000$ pounds, made up into 2500 bales, and valned

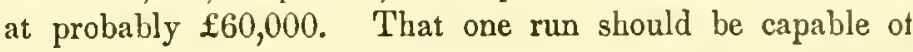


producing some 500 tons of wool is indeed marvellous, and the fact that 150 waggons are employed in conveying the clip to the railway is enough of itself to show the great amount of work entailed by the ownership of upwards of 250,000 sheep.

Shearing aheep by machinery has also been invented in that country. A steam sheep-shearing machine has been successfully used in Melbourne. It consists of a cutting wheel geared to the shaft of a small turbine, about three inches in diameter, and which is operated by a current of steam conveyed from the boiler by an india-rubber tube. In front of the cutter is a comb which serves as a guard against cutting the skin of the sheep. The apparatus is made of brass, something in the shape of a small trowel. It is used in the same fashion as the shears, but cuts much more rapidly and cleaner, without the least danger of injuring the fleece or the sheep.

\section{DIPPING.}

In all climates and on all soils, and under all kinds of management, sheep are liable to become infested with parasites, the most troublesome of which are the ked, the louse, the acarus or scab insect, and the maggot. To destroy and prevent the attacks of these insects it is necessary to "dip" the sheep once or twice every year. On this point all flockmasters are agreed, but they are not all so decided in their opinions as to what is the best preparation that will most effectnally kill all vermin, and do least injury to or promote the growth of the wool. The old-time practice of "salving" or "smearing" with tar and butter is now laid aside, and not likely ever again to come into use. Smearing was superseded by "pouring" with poisonous liquids, but that method has also been abandoned in favour of dipping. It might be supposed that oil would be an excellent material for waterproofing the fleece, but such is not the case. Greased wool is of less value than white; and it is the opinion of many practical men that sheep heavily greased do not dry so soon after rain, nor thrive so well as those with their wool free and unfettered. The grease makes the wool clog, and shed or open in the very worst places-viz. along the back and about the neck; thns the rain penetrates to the skin, and the outside of the fleece is so clogged that the water will not run off, and the sheep cannot shake it out. As, however, the addition of grease or oil is quite distinct from the killing of the vermin, those who think it does good may still continue to use it, from the idea that it waterproofs the fleece. This is best performed by the natural yolk of the wool, and that can be best promoted by good feeding and keeping the skin of the sheep free from vermin.

Of patent manufactured sheep dips there are great abundance, and as to their efficacy when used according to directions, they generally give good satisfaction. The greatest fault farmers have to find with these patent dips is their very high price. It may be possible that the manufacturers sell at the lowest prices possible, but it is nevertheless a fact that any farmer can procure the substances of a like material, and mix for themselves, at a considerably less cost. The patent compounds cost from $6 s$. to $12 s$. per 100 sheep; whereas a home-made dip, which is equally efficacious, does not cost more than $2 s$. or $3 s$. We have not tested all of the "dips" in the market, but have used both Bigg's and $\mathrm{II}^{\prime}$ Dougall's with very good results. For those who wish to try a homemade article, we give several receipts, all of which have been recommended by practical farmers:-

$$
\begin{aligned}
& \text { No. 1.-1 gall. Carbolic acid. } \\
& 2 \text { lbs. Arsenic } \\
& 4 \text { lbs. Soda } \\
& \text { No. 2.-2 lbs. Arsenic. } \\
& 1 \text { gall. Pitch oil. } \\
& \text { No. 3.-1 gall. Pitch oil. } \\
& 4 \text { lbs. Soft soap. } \\
& 3 \text { lbs. Soda }
\end{aligned}
$$

$$
\begin{aligned}
& \text { No. 4.-1 gall. Carbolic acid. } \\
& 2 \frac{1}{2} \text { lbs. Arsenic. } \\
& \frac{1}{2} \text { gall. Spirits of tar. } \\
& \text { No. 5.-1 gall. Carbolic acid. } \\
& 2 \text { lbs. Arsenic. } \\
& 3 \text { lbs. Soda. } \\
& 3 \text { lbs. Soft soap. }
\end{aligned}
$$

The dips will all be best prepared by dissolving in boiling water, and then added to about 80 gallons of water; which will be sufficient for 100 sheep.

The use of more than 2 lbs. or $2 \frac{1}{2} \mathrm{lbs}$. of arsenic per 100 sheep is not free from danger, especially with young sheep. An instance of arsenical dip having been too strong once came under our notice. It was in the lambing-fold, and all, or nearly all, of the gimmers lost one or both teats. It was a very serious affair; the teats were so destroyed and sealed up that the young ewes could give no milk, although the udders were quite full, and the lambs had to be removed. Investigation led us to the conclusion that the teats had been burned off by an overstrong dip which they had received when lambs. It was also remembered that the lambs had not thriven well after that dipping.

If a dip kills the vermin and keeps the sheep's skin clean and healthy, it is all that is to be expected from it. There is no such thing as a dip promoting the growth of wool; but the man who can invent a dip that will in a measure waterproof the fleece, without injuring the sheep or wool, will confer a benefit on the flocks. I'Dongall's winter dip comes the nearest to this of any we have tried. But dipping with almost any of the dips in use very much improves the fleece, and gives to a lot of sheep, especially lambs, a nice buff coloui and a uniformity which is very desirable. In the sale ring let a lot of lambs which have not been dipped follow a lot which have, and although they may be of equal quality, the latter will make one or two shillings a head more, simply because they have a fresher and thriftier appearance.

The time to dip must be regulated by the kind of flock kept, the conditions of climate, and other circumstances. Host flockmasters make a practice of dipping all their sheep at least once a year, but this is not sufficient where there is a regular stock to deal with, even assuming it to be in a perfectly healthy state. Two dippings at least are necessary if the sheep are not to be the prey of vermin at one season or another; the first of these should take place soon after shearing, and the second after the stock has been made up for the winter, and the saleable lambs and draft ewes have been disposed of. It costs less to dip the sheep when they have been newly shorn, and the dipping is more effective; 
besides, summer dipping goes a long way in preventing the attack of maggots and flies generally. Some dip the lambs only, maintaining that all the ticks fly to them as soon as the old sheep are shorn. This is correct so far, but it never suffices to thoroughly cleanse a flock from vermill. Dry weather is very essential, both immediately before and after dipping. If the weather be wet, the fleece is already full of moisture, and absorbs less of the dip than it would do when dry; while a heavy rain after dipping washes most of the solution out of the wool before it lias exercised its full effect.

The description of dipping trougl most suitable for the operation will be subject to the size of the flock. For small flocks an expensive apparatus will hardly pay, and therefore, in such cases, a small tub with a sinple dripper will be all that is necessary. For large flocks a more expensive construction will be required. A trough made to accommodate one sheep at a time will be big enough for a flock of 500 sheep; and if the size be calculated at the same ratio for every 500 sheep, the work can be orertaken in a single day. But taking 1000 sheep as an average flock, the size of the apparatus may be something like the following dimensions-length, 15 feet; depth, 4 feet 6 inches; width, 1 foot 8 incher The bottom of the bath is sloped at both ends, so that the sheep can walk both in and out with ease. Thus the total length embraces a 4 -feet entrance slope, 5 -feet swim, and 5 feet of a slope for the sheep to walk out. It is very essential that the bath be made with an entrance slope, although a good many dipping apparatuses are made so that the sheep are all to be hand-lifted into the bath. It is, however, not good for the sheep to be dragged from a pen and forcibly hoisted over the end of a tub, by sometimes not too gentle hands. It costs no more to make a grade for the sheep to descend than the one at the opposite side for ascending; and it will besides save a considerable amount of hard work, especially when the sheep are newly shorn, and little but the skin for the "gripper" to hold by. Another advantage of a sloping entrance is found in the case of ewes heavy in lamb, as they can then be dipped without the least injury. The material best adapted for making the tub of a dipping machine is concrete. It can be made of wood, too, but the rays of the summer sun and the winter frost very soon make it leaky, which both wastes the dip and makes it very uncomfortable for the men who have to stand low down by the side of the trough. For a permanent construction concrete is much to be preferred, and on a sheep farm the dipping-trough should be always the landlord's property, and a fixture. The dripper of a bath consists of a couple of pens capable of holding from thirty to forty sheep, set upon a water-tight floor. A small gate at the exit of the bath directs the sheep into either pen desired, and while one pen is filling, the sheep in the other will be dripped sufficiently, so as not to drop any material quantity of dip on to the ground after being let out. The floor of the dripper is pitched so that the water which runs from the sheep will all flow back into the tub. With a con- venient catching or entrance pen, the operation of dipping is rendered simple and easy for both sheep and men.

The selection of the site for to set up a dipping machine requires due thought. In the first place it must be placed near to a plentiful supply of water, which can either be supplied by hose or carried by hand. In the latter case it takes a deal of work if the distance is anything great. Next, the machine should be built on dry ground, and if it be on the slope of a bank so much the better, as the whole surroundings can then be kept cleaner and more comfortable. It is also an advantage to have it convenient to the regular "sorting folds," in fact it should be part and parcel of the same if possible. The whole apparatus, complete, will cost from $£ 5$ to $£ 10$, more or less according to size.

\section{CASTRATING AND DOCKING.}

Castration is usually performed when the lambs are from two to four weeks old. The younger the lambs the less risk. But it is still more important that the lamb be in a lealthy condition at the time it is operated on, and that the weather be mild. It should only be done when there is a prospect of a fine evening; and the shepherd should be frequently amongst the lambs for a day or two afterwards, gently stirring them up, as they are better for moving about at intervals until all fear of inflammation is past. With these precautions, it is seldom that any casualty results. The operation is usally performed by the shepherd. It should be done as gently as possible. One person holds the lamb with its back pressed against his left shoulder, and a hind and fore foot grasped firmly in each hand. Then the sheplerd with a sharp knife cuts off the lower part of the scrotum, and starts the testicles by pressing both hands against the belly of the lamb, afterwards drawing them away with his teeth. The operator then pulls the lamb's tail sharply two or three times, to replace the cords and ressels which have been so violently disarranged. Where the lambs are older and stronger, the testicles should not be entirely drawn, but cut away with the knife when the spermatic cord is reached. Searing is not recommended for young lambs.

Before the lambs which have been castrated are let go, they should be docked or have their tails cut. Docking is necessary to the health and comfort of the sheep that have to be folded, and therefore it requires to be performed on ewe lambs as well as others. The operation is, however, often rendered needlessly severe, by shortening the tail too much, and causing excessive bleeding. The different breeds have their own style or length of tail, which seems to be pretty generally adopted. The Down breeds, for instance, have their tails entirely cut off; then some other breeds have about a couple of inches left on; while in the case of mountain sheep, the tail is not shortened above the hock, merely cntting away the fleshy part of the tail below the last joint of the vertebræ.

SHEEP MARKING-EAR MARKS.

The fock mark, the age mark, and the pedigree mark, are 
all put on the ears of the stock lambs at weaning time. The markings are sometimes tattooed, but the more general plan is to mark by clipping a small snip or bit out of the ear by means of the ear-nippers. The marks made are of different kinds and shapes, as well as differently put on. The main thing is to have the marking as simple and distinguishable as possible, and not to disfigure the lamb. A "cropped" or a split ear looks extremely bad. A small hole in one of the ears answers very well for a private flock mark, and every sheep, of all ages, belonging to the same owner, should have this mark on the same ear. The barbarous practice of branding on the cheek with a hot iron is now abandoned by all except a very few old flockmasters, who are opposed to every change in the system they were taught when young. The age mark is of course different every year. If the flock is drafted at five years old, then there must be five different age marks to use in turn. For example :-

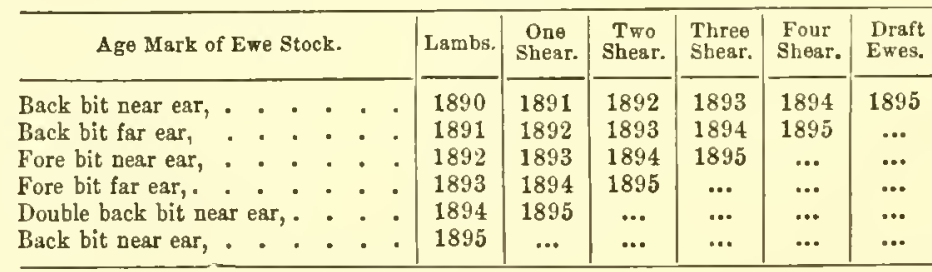

Thus in the year 1895 the ewe lambs would take the same mark as the draft ewes. Some prefer to have their lambs marked the same as the oldest age of keeping ewes, considering the difference between the hogg or teg and the old ewe sufficiently distinguishable without the aid of a separate mark. This plan does away with one of the stock marks, and for the ahove number of ages kept four instead of five marks will only be required. But the former method is the more satisfactory of the two, because at drafting-time, if the flock happens to be all in one lot, the shearlings have an altogether different mark from the draft ewes, and the latter can be drawn out more readily without trouble or mistake. If the shepherd is allowed a "pack," then of course the "pack sheep" have marks totally different from the flock.

The pedigree is indicated by some other mark that can be easily registered in the pedigree book of the flock. With a large flock there is some difficulty in having the marks simple enough so as to avoid multilating the ear, and yet perfectly plain in recognition. One very good plan is to have all the ewes in a flock belonging to a particular tribe tattooed with the letter $B$ on the near ear, then the individual ewes of this tribe must be numbered $1,2,3,4$, \&c., so that their names would stand thus, B1, B2, B3, \&c.

For example :-

\begin{tabular}{cccc}
\multicolumn{4}{c}{ Ewes-Gaity's Tribe. } \\
"Fore bit far ear." \\
Year of Birth. & Name. & Sire. & Dam. \\
\hline & B3. & Guido & N6
\end{tabular}

The rams have the same tattoo marks as their dams.

A Canadian plan of recording pedigree without having to tattoo-which, by the way, is expensive and difficult-by simple punch marks only, can be readily seen from the accompanving figures :-

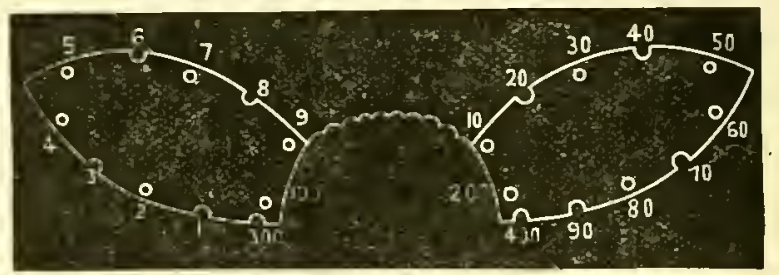

The above diagram denotes what a mark in a certain part of the ear signifies. Thus:-'To number a sheep 333, make two semicircular nips in the under side of the left ear, and a hole through near the top part of the right ear, as shown below :-

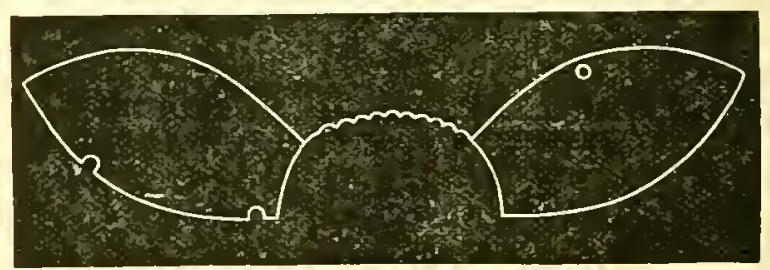

The snip and hole are used alternately, to designate with more certainty the exact part of the ear intended to be marked. This system does not require more than three marks till 500 is reached, after which by adding another mark the numbering can be carried on into thousands.

Buisting.-The ear-marking, it should be observed, only applies to the ewe lambs kept for stock; but at weaning time, likewise, all the lambs are marked on the wool with a stamp or buist, which sometimes combines the initial letters of the owner of the farm, the iron being dipped in boiling tar or pitch before being applied. This work should be done on a dry day, particularly with the lambs for sale, as if the wool is wet the tar spreads in it and disfigures the lamb. Indeed much care and judgment are needed to buist lambs properly. If the letters used are too large, the buist detracts in appearance from the size of the lamb; and if not judiciously put on, it has an equally bad effect The wether lambs are buisted on the off-side, and the ewe lambs on the near-side. The older sheep on the farm are buisted at shearing time.

Keel-Mark.-On a hill farm, some days after dipping, and when the stock has been made up for the year, the whole flock are usually "keeled" or ruddled. As with the stockmark, every farm has its own keel-mark. The keel-mark being more distinguishable at a distance than the buist even, is of much use to the shepherd. The keel is put on various parts of the sheep, farmers in the same district studying to have them all different, such as a mark round the left hip, down the off-rib, or across the shoulder. Each farm having its own keel, strayed sheep can be readily detected from a distance and brought back; whereas without such a mark there would be difficulty in finding sheep that have wandered amongst others. In some parts of the country the marks on the sheep of each farm are registered, and an annual meeting advertised at some appointed place, to which all found sheep 
are taken, and those who have any missing attend to claim what they have lost. In the north of England there is a record of stock-marks, compiled and published by Mr. Gate of Keswick The register displays the ear-marks, the buist, and the keel-mark on illustrated diagrams, together with the names and addresses of the owners of the sheep bearing the respective marks. By this means any strayed slieep can at once be identified by referring to the guide. "Keel" is a paint composed of red ochre mixed in oil, which prevents it from washing out. A nice keel considerably improves the appearance of a flock. At weaning time the sale ewe lambs in hill flocks are also keeled on the neck to distinguish them from the wether lambs.

\section{SCORING NUMERALS.}

"Probably few are aware," says Professor Wrightson in the Agricultural Gazette, "that there are such things as 'sheep-scoring numerals.' They exist, however, and the subject certainly struck me as novel when I first met with it in that delightful work of Mr. Joseph Lucas, 'Studies in Nidderdale.'

"Dale shepherds, it seems, have a way ot their own of counting their fleecy charges, but this way savours of high antiquity. I went to my own shepherd at once, but was disappointed to find that, saving for a slight difference in pronunciation, he counted his sheep much as most of us would count them.

"In Nidderdale and Swaledale, in Yorkshire, Wasdale, Borrowdale, Man, Cornwall, and other places where the Celt long lingered, an old form of scoring, it appears, exists, closely related to what is found in Sanskrit and Hindustani, Old Welsh, Modern Welsh, and Gipsy (Romany). This is a most important philological fact, and must be of interest to all who add a taste for antiquities to their love of agriculture. The fact strikes me as strange, and as highly creditable to the person who unearthed it.

"Perhaps some of the Agricultural Gazette readers may be able not only to confirm what is known of these sheepnumerals, but also to add other forms as modifications of the same. As an example I will first take Nidderdale numbering. 'Yain' evidently stands for one; but what are we to think of the remaining numerals up to twenty, which run on as follows?-

$\begin{array}{llll}\text { Yain. } & \text { Tayter. } & \text { Yain-dix. } & \text { Yain-o-bumfitt. } \\ \text { Tain. } & \text { Later. } & \text { Tain-dix. } & \text { Tain-o-bunfitt. } \\ \text { Eddero. } & \text { Overro. } & \text { Eddero-dix. } & \text { Eddero-o-bumfit. } \\ \text { Peddero. } & \text { Corerro. } & \text { Peddero-dix. } & \text { Pedero-o-bumfitt. } \\ \text { Pitto. } & \text { Dis. } & \text { Bumfitt. } & \text { Jiggit, or Giggit. } \\ \text { "The Eskdale numerals are thus given :- } \\ \text { Yaena. } & \text { Hofa. } & \text { Yaen-a-dec. } & \text { Yaen-a-bumfitt. } \\ \text { Taena. } & \text { Lofa. } & \text { Taen-a-dec. } & \text { Taen-a-bumfitt. } \\ \text { Teddera. } & \text { Seckera. } & \text { Teddera-a-dec. } & \text { Tedder-a-bumfit. } \\ \text { Meddera. } & \text { Lekera } & \text { Medder-a-dec. } & \text { Medder-a-bumfitt. } \\ \text { Pimp. } & \text { Dec. } & \text { Bumfitt. } & \text { Giggot. }\end{array}$

"At Knaresborough, Yorkshire, the corresponding numerals are :-

$\begin{array}{llll}\text { Yah. } & \text { Teezar. } & \text { Yah-dick. } & \text { Yah-de-bumper. } \\ \text { Tiah. } & \text { Seezar. } & \text { Tiah-dick. } & \text { Tiah-de-bumper. } \\ \text { Tethera } & \text { Catterah. } & \text { Tether-a-dick. } & \text { Tether-de-bumper. } \\ \text { Methera } & \text { Horua. } & \text { Metber-a-dick. } & \text { Mether-de-bumper. } \\ \text { Pip. } & \text { Dick. } & \text { Bumper. } & \text { Jigger. }\end{array}$

"At Middleton, in Teesdale, the score is thus told:$\begin{array}{llll}\text { Yau. } & \text { Sezar. } & \text { Yan-a-dik. } & \text { Yan-a-bum. } \\ \text { Teau. } & \text { Azar. } & \text { Tcan-a-dik, } & \text { Tean-a-bum. } \\ \text { Tether. } & \text { Catrah. } & \text { Tether-a-dik. } & \text { Tether-a-bum. } \\ \text { Mether. } & \text { Horna. } & \text { Mether-a-dik. } & \text { Ifether-a-bum. } \\ \text { Pip. } & \text { Dik. } & \text { Bnmfit. } & \text { Jiggit. }\end{array}$

"In order to show the Celtic origin of these expressions, the old Welsh numcrals are also given :-

$\begin{array}{llll}\text { Un. } & \text { Chwech. } & \text { Un-ar-dec. } & \text { Uu-ar-pymthec } \\ \text { Dau. } & \text { Saith. } & \text { Deu-dec. } & \text { Deu-ar-pymthec. } \\ \text { Tri. } & \text { Wyth. } & \text { Triar-dec. } & \text { Tri-ar-pymthec. } \\ \text { Pedwar. } & \text { Naw. } & \text { Petuarar-dec. } & \text { Petuar-ar-pyinthec. } \\ \text { Pump. } & \text { Deg-or-dec. } & \text { Pymthec. } & \text { Ucent. }\end{array}$

"A study of the Sanskrit, Hindustani, and Breton forms of numerations, shows clearly that these curious old methods of counting are the actual remains of an ancient language once spoken over ancient Britain, then confined to the remoter portions, and finally only discernible in such fast-dying relics as the above."

\section{RAM BREEDING.}

For a century or thereabouts ram breeding has been an important branch of sheep farming, and now exceeds in magnitude the traffic in all male stock of every other breed of animals put together. The name of Mr. Bakewell is associated with the earliest efforts in the trade. Marshall, in his "Rural Economy of the Midlands," states the hire of tups, prior to 1780 , to have been from one guinea to ten for the season; at which latter price Bakewell, in that year, let several. His stock from that period rose rapidly in value, from 10 to 100 guineas, and in the year 1786 he let two. thirds of one ram to two breeders at 100 guineas each; thus valuing the entire service of the animal at 300 guineas. From thence to 1789 the priccs still kept rising, until the sum of 400 guineas was repeatedly given for a single ram. In that year Bakewell received 1200 guineas for three, and for his whole stock of rams, 3000 guineas; and several other breeders made from 500 to 1000 guineas each. The spirit of enterprise kept increasing so fast that 500 guineas were occasionally paid for the hire of a single tup; and in three seasons one ram produced to its owner the enormous sum of 1300 guineas. That Bakewell succeeded in producing a marked advance in the sheep world, was evident by the appreciation and wonderful prices he was able ultimately to command for his stock. Within a period of thirty years he raised the value of his rams from 15 s. to as high as 500 guineas a-piece. His success was remarkable, and is yet unequalled in live stock history. He raised, we might say, at a jump an animal from the lowest grade to a perfection, which, after the lapse of a hundred years, has hardly been improved upon, and which still stands unrivalled amongst our breeds of sheep. The monopoly he held was no doubt the secret of the high prices he obtained, still he must have been a rare shepherd, and well deserved the honours he lived to enjoy. To him is due, also, the example of improving all our other breeds of stock. Collings and Bates copied from his laws in developing the shorthorn, and all other improvers who followed only turned the ball which Bakewell set 
a-rolling. Shepherds are often accredited with more than ordinary intelligence, but we have here an example of it, which has proved a blessing to the world.

The business of breeding pure-blooded rams for sale has certainly been somewhat overdone of late; still it will have a beneficial effect in weeding out a good many of the inferior sheep. It is a frequent complaint, too, that these sale rams are injured, and in many cases rendered useless, by overfeeding. But we see less of this year by year. Breeders are beginning to understand that it is to their interest to have their sheep prove well. Getting them up for the sale-ring is all very good, but they must be got up to stay. The way to secure buyers is to give them sheep with sound constitutions, that will thrive on good plain keep. Besides, an overfed sheep never shows to the best advantage in the ring; at least never so well as when it moves freely and easily.

The increasing number of ram lambs now offered at these sales is a very recent departure in the ram trade. And one of the most remarkable points in the lamb trade is shown by the number of these now sold amongst the blackfaced breedthe breed which is noted above all others for its hardiness and slow maturity But buyers say they find the lambs quite as serviceable as shearlings, while the former are far less liable to be spoiled from over-feeding. There is a great diversity of opinion whether it is wise to use ram lambs, some claiming that it will ultimately lead to the ruin of the flock; while, on the other hand, it is stated that by using ram lambs many breeds have been immensely improved, rendering them more susceptible to early maturity. Since the use of ram lambs has been attended with good results in the case of some breeds, there is good reason to think that other breeders, who have not yet tried the system, would do well to follow the example.

In establishing a flock for ram breeding, those contemplating the business should make mature calculations beforehand. It is asserted that the thoroughbred horse, the shorthorn, and some other animals can be reared with equal success, and to the same perfection, regardless of soil and elevation, other things bsing equal. This we doubt very much with horses or cattle, at least it is not the case with sheep. Most of our breeds of sheep are indigenous to locality; and a location which is well adapted for one breed would be altogether unsuited for another. Therefore, in commencing a flock which it is intended to bring to the very highest state of excellence, it is well to make sure the breed is adapted for the situation. Never attempt to raise a Down sheep where a Cotswold would be better, or a Leicester where the Cheviot would succeed. The soil and climate are the two influences which determine the size, the quality, and the constitution of the sheep. The Down breeds are known to thrive best on light dry soils, in not too cold a climate; and the long-wooled breeds have the reputation of being most suitable for heavy soils. Then as we ascend to higher situations, the mountain breeds only can be profitably kept. Having made certain that the situation is every way adapted for the breed, the next point is the selection of the ewes to breed from. There are wonderfully few specimens in a flock that are fit to fill this bill, and even after securing the best, they will not be faultless. However, do the best possible, but never think that success will be achieved by careless selection. The ewes should have the characteristics of the breed clearly defined in every point. They should be equal in size, have lieads alike, wool alike, and all symmetrical, with plenty of style and quality. Type is a great thing in a flock of sheep; but, unfortunately, we cannot describe what is the true type of any one of the breeds. There is no standard guide, or scale of points, drawn up for our direction. What would seem to be a favourite type in one district, is different in another; and, in fact, this local fancy has drifted so far as to result in the creation of new breeds-for instance, the Leicester and Border Leicester. These two breeds were of the same origin, and are now the Scotch and English types which each country consider the correct one to cultivate. This proves the necessity there is for a recognized type in all our breeds. No one who has attended a ram sale where several different breeders were represented by the same breed of sleep, but must have been struck by the diversity of character displayed by each of the lots. But since there happens to be no standard basis to guide us in selecting a certain type, each one must depend upon his own judgment, and the nearer that coincides with public opinion the greater will be the success. Have a model in view, and strive for it at every move. It takes years of patient breeding to form a character which the sheep will maintain, and great perseverance is required to gain even a very small point.

The ram to use is the next consideration. No ram, however valuable or good-looking he may appear, should be put to ewes without first having been proved. In his first season a few ewes should be selected likely to suit him, and then a careful examination of the progeny will reveal his true worth better than any outward signs can indicate. The strictest care must be taken on that point, or a valuable flock may be ruined by the indiscriminate use of a single ram. In choosing a ram, pick only from well-known healthy flocks. Let him be masculine and healthy in appearance, having a frame as nearly perfect to your ideal as is possible, and specially good on the points where the ewes are most defective. He should have plenty of bone, with a straight back, strong loins, wide ribs, deep chest, heavy quarters, and good on his legs. The latter point is highly essential in a ram. Then in wool he should possess the exact texture and quality of the breed, covering his body evenly and on all parts where the wool ought to grow. A ram that is imperfectly wooled on the under parts of the body should be avoided, and any superfluous growth generally indicates a coarse bred sheep. For every stud ram in the flock select the ewes weak in the points he is strong, and keep each lot separate during the breeding season. Jlark the rams and ewes with colouring of different shades, and make a correct entry of these in the breeding-book, so that when lambing 
takes place the sire of every lamb can be given. It may also be necessary to mark the lambs by the different rams with a small snip in the ear, as a pedigree mark, as soon as they are dropped. An extra good ram should not be allowed to run with the ewes. If he be confined in a yard and well fed, and the ewes brought unto him morning and evening, he will serve about double the number he would otherwise do if allowed to remain with the ewes all day.

As to the price which may be given for a good ram there is no rule. A $£ 50$ ram may get better lambs than one costing four times that money, yet it as often happens that the highest priced sheep are the cheapest in the end. When a ram can be found that appears to be what is wanted, and has proved himself suitable, he is cheap at any price, as his progeny should sell at a similar rate if they are properly brought ont. It would, however, be a mistake to suppose that because $£ 200$ had been given for a sire, his progeny are worth a corresponding value. That entirely depends whether the ewes to which he is bred are equally valuable and the flock has a public reputation of being pure and of the very choicest blood.

Ram breeding need only be attempted under the most favourable circumstances, on good land, and where high feeding can be carried on profitably. Much as buyers decry overfed rams, it generally happens that the fattest sell best, so that the breeder cannot very well help himself. If he brings out his sheep lean they sell in proportion, consequently a certain amount of feeding is indispensable for success. High prices are only made by sheep of known character, and such as are endowed with special qualities which they have the power of transmitting to their progeny. For gaining a reputation, it is now essential that the flock should have an authenticated pedigree.

The average price at which it will pay to breed young rams for sale, will of course be found to vary greatly in the case of different breeds-such as the Down breeds, for instance, as compared with the Cheviot or Blackfaced. Any breeder can settle that to his own satisfaction, as it largely depends on the expense of rearing. The cardinal point, as already observed, is not to lower the average by retaining too large a lot of ram lambs. Select them carefully, and start with the best only, and the result is sure to be satisfactory, if the same watchfulness is displayed thronghout.

\section{PREPARING SHEEP FOR SHOW.}

The sheep department of the showyard never fails to attract a large share of interest. In some districts, indeed, the sheep are more closely inspected and admired than any of the other classes of stock. There are comparatively few farmers who have not got some interest in sleep, and whether they are judges of them or not, all enjoy the pleasure of examining them at the shows. Amongst exhibitors of sheep, as well as their attendants, keen rivalry always prevails. Let the show be great or small, there is aure to be something lively and instructive going on amongst the sheep-men. cannot be denied that the sheep stocks of this country have been greatly benefited by showyard competition; and, taking them all in all, our flocks are probably in a more improved state than either our horses or cattle.

There may not be more direct profit in showing sheep than other descriptions of stock, but there is at any rate more room to clear expenses. Extra care and feed ought to give an increase in wool, and the lambs will also be better than those of the ordinary flock; so that these helps, together with the opportunity of selling the show sheep fat, or for breeding purposes, gives the sheep exhibitor an advantage that others do not have. We do not mean to say that, as a rule, sheep can be shown with profit, but when an exhibitor can lay hold of the premiums he should do more than clear expenses. Great time and labour are required to fit them up, and they take the best of the food from the other sheep. Still, those who can bring their flocks into notice can well afford to show. for the better prices they can obtain for rams or ewes that they may sell to other breeders; and besides the pecuniary benefit, there is always an honour attached to it, which is worth a good deal.

The worst feature some think in showing sheep, is its effect upon the remainder of the flock. The best being taken, it reduces the average quality; and when a cast lot comes to be sold, the want of the top is severely felt. However, if the show sheep clip more wool, rear better lambs, and sell for more money, they may more than counterbalance this discrepancy, even without the premiums. So long as the show sheep pay their own way they do very well, without making up any shortcoming of the bulk. The fact of the top being awanting does not alter the value of those that remain. They are only worth so much whether they be sheltered at the side of a good one or not; and if the value of the one is raised with the help of the other, we must also remember the value of the best is correspondingly lowered.

Every famous flock has had to prove its merits in the showyard, and but for its success in the riug it would probably never have acquired its celebrity. Moreover, many breeders, who in the first place were at great expense and trouble in bringing out their sheep for the shows, are now resting on their oars, and reaping ten times over any preliminary outlay they incurred in the showyard. Nor have any a better right to rest on their laurels than those who have won fame by actual test. We like to lear the old euthusiast recount his battles won, and although the open game may be left to others, the same shrewd care in breeding is pretty certain to go on at home. Each year never fails to bring back former buyers, and many new ones, all confident that the once successful exhibitor will still preserve his flock in their former purity. This is where the profit comes in. But those who have earned such reputation know full well it was not gained without an effort. Every point was made a study: and success was only achieved after many attempts to win. But for every one that maintains his reputation after leaving the showyards, there are a hundred never more heard of; 
so that when the showyard is chosen as a field to gain a name in, it is not every one who can keep that name. At any rate those who count on after success must make sure they deserve it.

In breeding sheep for show, besides the attention required in mating, we must not forget that the soil and climate exert a powerful influence on the character of the stock, and over which we have little or no control. The adaptability of the sheep to the soil is, however, sufficiently powerful, either to advance or retard all other efforts. When any special breed is favourite, and wished to be reared, we have to consider the conditions under which their best properties have been acquired, if the fullest success is to be attained, or even an ordinary profit assured. Take any of the breeds we please, and examine the description of soil on which they are found in greatest perfection, and it will become plain that in breeding sheep of the most perfect type, we will have to regard very closely the nature of the soil on which they are reared before we can succeed. It makes no difference what experience or skill a man may have, he cannot alter the character of the sheep further than the quality of the soil will allow; so that in breeding or showing, it is in the first place necessary to have a farm with a soil and climate well adapted for the purpose and breed of sheep.

If a few breeders have failed in improving their flocks even after having taken prominent places in the lists, it is no reason why the showing of sheep should be deprecated. If they have not done well, it was not from the fact of their having exhibited, it may rather have been caused through injudicious feeding and breeding. Many a time we have seen breeding sheep fed to their ruin, and as often have we seen wrong selections in mating, all through trying to raise something for the show. Success might attend the effort as far as show sheep were concerned, but then the system pursued, and the result with the regular flock which had been similarly bred, turned out to be a vast failure, merely because the sheep were bred for one single purpose-the showyard. They had been bred without an eye to general utility, and thus the whole were ruined. Instances of this kind have been common amongst Cheviot breeders, who raised fine show sheep, but which were hardly fit to roam the hills; and thus the show was blamed for the evil. No doubt it was, so far, but then the real error was a want of forethought, and failing to see the ultimate result. Let the lessons of the past be a future guide, and where no misguided notions are pursued good results are sure to follow.

\section{SELECTING SHOW SHEEP.}

It is scarcely possible to expect to buy show sheep, or even advisable to do so. A good ram can sometimes be purchased, but it is very seldom any other sheep of a suitable age are to be found for this purpose. At any rate there are more honour and satisfaction in showing those of our own breeding. The exhibitor will have to breed and rear them on his own account. Having selected the best ewes in the flock, and mated them with the best ram, their progeny may be ex. pected to be good, and most likely they will be the best obtainable. It is to be regretted that the sheep-men of Great Britain do not draw up a scale of points for their respective breeds. The Shropshire breeders are in advance of the others in this matter. It would be well if there was a standard to guide the inexperienced regarding the points of all the various breeds. It is very annoying when a long price has been paid for a sheep, to find that when transferred to another quarter it is not the fashion of that district, merely because of some very trivial point. In the absence of a recognized type or fixed standard, every one is free to indulge his own fancy about the points of any particular breed.

Selecting lambs for show is not always an easy matter. It may be simple enough to tell which are the best lambs, but it is more difficult to say positively which will be the best sheep. There are many things to consider besides present merit in the lamb. The owner will know how his lambs have been bred, and a lamb that is well "comed" may eventually be worth more and prove better than one that is not so well bred, although the latter beats the other at the start. Then there are lambs with some remarkably good points, but having say a bad head, or some other prominent fault. Such are not desirable, and neither are those that do not appear to be growthy. The best and most likely lambs to come out well are those with a head rather long and wide, a strong neck, thick lengthy body, heavy quarters, and strong bone. These qualities, along with fine symmetry and carriage, a good coat of the right kind of wool, and a pleasing head and ear, are indicative of lambs likely to make show sheep. When a number are required for a pen, get them as much alike in size and character as possible. "Like as pease" goes a long way towards making a good pen, even although the lambs have some faults. Having them all exactly alike in shape and quality of wool, is also very essential when prize-taking is the object. Single lambs will generally be stronger and more suitable than twin lambs, although the latter may in the course of a year make good their deficiency at the start. There are very few ewes able to nurse twins to the same weight that they can a single lamb, and for this reason the single lambs are the best. The same rules apply in selecting older sheep.

\section{FEEDING SHOW SHEEP.}

Show lambs need attention from the day of their birth. Milk is the first and most important agent in rearing lambs. No matter how well a lamb may be bred, unless it is well nursed it will never do for the showyard. To produce the milk, the ewe must be liberally fed; and it is better to feed the ewe, than to try and cram the lamb at this early stage with grain or other concentrated foods, and especially if the lambs are to be carried on for a future showing or breeding purpose. The ewes will require, besides good pasture, about one pound of artificial food from and after lambing. 'The lambs themselves will begin to eat at the boxes at about a 
month old, and it will then be necessary to gradually increase the allowance of cake or corn to the ewes. If the ewes and lambs are folded, lamb creeps can be brought into use, and the lambs allowed to run over the ground ahead of the ewes; they can then also have a trough for cake or corn to themselves on the opposite side of the hurdles. From about the third month half a pound more grain or cake may be given, and finally, when the pasture begins to fail, the daily ration of box food for ewe and lamb may amount to from 2 to $3 \mathrm{lbs}$, and this will be sufficient to make them both fat. If a change from grass pasture to rape, cabbages, or turnips can be given them, that quantity will scarcely be required.

With fat lambs or wedders for Christmas show, that are to be then slaughtered, no respect need be paid to the ultimate results of feeding, making good lambs at any cost being the sole object. The lambs may then be encouraged to eat as soon as possible by giving them plenty of trough room. Supposing both ewes and lambs are intended for fat stock shows, too much care and art cannot be devised for heaping on fat. They will need fiom two to three pounds of grain per ewe daily, and should be fed this at trice, morning and evening. Plenty of change and variety of food, with regular feeding, is the way to make them grow; and they should also be confined to moderately close quarters, not having to go in search of their food.

It is not necessary to wean fat lambs at all. They may be allowed to run with their dams up to Christmas, or as long as may be found suitable.

Feeding cannot be commenced too early, no matter whether the show be two months or twelve distant. It takes every day in the year to fit sheep for show, but generally from six to eight months will be sufficient if the sheep are in average condition to start with. When they are well kept all the time very little extra condition is required, which can easily be put on in the last three months. The way to make real good shearlings, is to commence early with the lambs, and keep them growing, never having them fat, though next door to it all through winter. Steady progress is far cheaper and much better for the constitution of the animal than attempting to rush the feeding a month or two before the show. No sheep can be fully developed by irregular feeding. They must be gradually grown, not standing still one week and making up the next. It is easy enough to fatten sheep in three months, but having them fat is about the last object any breeder should aim at. Their whole frame needs building up, and three months extra keep will fail to develop all their points. It can only be done by regular feeding, and that never at any time too heavy. A mistake often made in feeding young sheep is getting them ready too soon. It is not always easy to find suitable food all the year round, and at certain stages they would seem to make but little progress. This is sometimes on account of the feeder not knowing the real strength of the food supplied. The food should be arranged so that every change is for the better. It is not at all times easy to keep up improvement in the quality of the food, but it is well, at any rate, not to consume the best first.

If the lambs intended to be brought out the following summer or antumn are weaned about the bcginning of August, they will do very well during that month and September if they have the run of a good aftermath or foggage. If they have been accustomed to grain along with their dams they will still require it, but if they have never previously had grain they need not just yet receive any. As long as the aftermath lasts the lambs should keep growing for the next two months, but as soon as there is any sign of the pasture failing they should be allowed some grain. Begin them with a quarter pound each, and as soon as they get accustomed to the troughs, and have also acquired a taste for turnips or cabbages, the grain ration should be advanced to half a pound per head. With this and plenty of cut turnips or other green food and a little hay, they ought to go on well until the New Year.

January and February are generally cold, and less growth will be made during these months. It is not advisable, however, to angment the grain ration. If the lambs are fed much grain in the winter they will not develop so well in summer. Rather, if possible, provide better slielter, and give a fuller supply of roots and hay three times a day. About March the roots and hay become rather stale. food, still, if nothing better be at hand, they will do well enough. When the wool assumes a dry appearance in the spring months, about March the grain may again be increased, and the best food at that time is linseed cake or oil meal. The lambs should not previous to this time of the year receive linseed, and its use then has a wonderful effect in keeping their wool from becoming loose and open. To the half pound of grain already given add a quarter of a pound of linseed cake. This then brings the artificial food up to three-quarters of a pound per head daily at the beginning of March, and will be sufficient for the next three months if a fair supply of roots or other green food is available. The grass will by that time be forward, and will be an acceptable change. The box food may then be increased to one pound per head. The better the pasture is, the better it will be for the sheep; and when an extra push is required, the next resource is summer green crops of rape, lucern, \&c. Should the pasture or summer grazing be only medium quality, from one to one and a half pounds of cake may be allowed to each sheep. On such fare they may be brought to shearlings in good healthy condition, not by any means overfed, and their breeding powers uninjured, while at the same time they will be in first-rate show condition.

With older sheep for fat stock shows, the feeding may be of much the same description, only in larger quantities. About double the quantities named may be given full-grown sheep, but we warn those who feed much heavier than recommended that they cannot do so with impunity. It is the practice with some to feed just as much as the sheep will eat. This may be allowable with fat sheep, but it is waste- 
ful, and in any other case it would be a mistake to ruin valuable sheep for the sake of a prize when rational measures may be employed to secure the object.

A great many show sheep are fed almost exclusively in sheds, and there is little doubt that, with a few sheep and nice roomy slieds, greater progress can be made in fattening; or in other words, sheep can be fattened to greater weights in sheds than they can in the open field. 'This, however, only holds good under certain conditions. If the sheep are not well attended to, regularly fed, and kept thoroughly clean, they will do better outside. Sheep that are in preparation for a Christmas show may be housed, but breeding stock are better not confined; and in any case the sheep should not be kept in sheds all the year round. If they are kept in good order at all times, three or four months is about as long as they will require to be housed. They need not be hindered to get out into a yard, and the exercise will do them good. Let them always have access to plenty of pure water, and a supply of salt within their reach. Give them cabbages all the time if they can be had, turnips and mangolds in their season, and as much clover and green pea straw as they will eat up clean. Well made hay will be a good change, and the dry food may consist of a variety of grains, such as bran, oats, maize, pease, linseed cake.

\section{SHEARING AND TRIMMING.}

This may be termed the shepherd's fine art. The sheep should be clipped as early as possible, but not before they can be shorn on the new wool. Blocking them out on the old wool is often done, but it should be remembered that any old wool left may disqualify a winner.

Begin by making a sheep stand in a perfectly natural position, letting it be held the while by an assistant. Then proceed to cut into the wool at the tail head, level with the back. Clip along the centre of the back, making it as level as possible, and not too bare. Then the point of the shears may be turned down the sides, commencing at the head, and working from head to tail gradually down to the belly, which last it is best to shear first, turning up the sheep for the purpose. The shearer must thoroughly understand the shape a perfect model of the breed he is dealing with should be; and ever keeping his hand and eye in concert, will make good or bad work according to his skill in the art.

Trimming is the modelling or clipping from time to time of the already rongh shorn sheep. They may be trimmed once a fortnight up to the last, when they may get an extra or final trim a month or a day, according to the breed, before the show. Before they are trimmed they should be washed; but too many washings are not advisable, as it takes the lustre out of the wool. Two washings are as much as are necessary, and for some breeds one is sufficient. Choose a bright forenoon for washing, and then there is no fear of giving the sheep a chill. Soft soap and water slightly tepid may be freely used, rinsing off with clean water. Three or four days should elapse between washing and trimming, so as to give the wool time to set. If trimmed too soon there is a danger of cutting holes in the fleece, which can never be taken out again without much hurt. The first trimming should only be to mark or cut out the block in rough shape; as the wool grows, opportunity is afforded to give the final mould and polish.

To be able to trim well it is necessary to be a good judge of sheep, but the quickest and surest way of becoming a good judge is to practise trimming; and unless a man can trim, and understands trimming, he is not by any means fit to be a judge. There are some very dexterous hands with the shears, and the art they can display is very fine.

Colouring is the art of painting the wool on the sheep's back, so as to give the animals a better or a more characteristic appearance. The sheep should not be too highly coloured -just sufficient to make them all alike. If this is done we see no objection to colouring; for, as is well known, the colour of the soil gives a certain hue to the fleece, and sheep from different parts of the same farm even will sometimes show a great want of uniformity in colour when they are brought together. The colour, if any be used, is best put on with a fine syringe, and rubbed in witl a brush. The substances used for colouring are usually red or jellow ochre and burnt amber dissolved in water.

Light cotton sheets are useful for covering the sheep while in transit to the shows, so as to keep the wool from being soiled; and if they are waterproof they are sometimes of further service in keeping the sheep dry on wet show days.

\section{JUDGING SHOW SHEEP.}

There can be no fixed rule for judging all breeds, but a few general points may apply in judging sheep as well as other animals of the same kind.

First take note of the character or type of the sheep. No matter how good they may otherwise be, they must show plainly the characteristics of the breed in size, shape, colour, and staple of wool. Every breed has its own peculiar features, and unless these be prominent and clearly defined, the specimen should be passed over.

Then their mutton qualities may be examined. This is done by handling. The hand will at once reveal the amount of mutton the sheep carries, or is capable of carrying. In male sheep the neck should be strong and thick, not flat and long. The shoulders should be broad, and scarcely perceptible to the touch, from being nicely rounded and well filled. The ribs should spring evenly, wide from shoulder to loin; and the hind-quarters should come out lengthy and well rounded, not pointing behind. The back should be level and evenly covered with meat, the bone nowhere projecting; the breast wide and dcep; the underline straight; and the thighs full, and well shaped.

In breeding sheep, frame and bone should count for more than fat. Then the wool, which in some breeds is paramount, requires careful scrutiny. Whatever the breed, the wool should be particularly noticed as to length, fineness, evenness, 
and strength of staple. But not only is it important to have the right staple, it must be growing in the right place. Some sheep may show a good coat on back and sides, and yet be very inferiorly clad below or in other parts. 'They should be well covered from head to lock with an even compact fleece.

Then the head, ears, legs, and general symmetry have to be observed. Constitution and quality are strong points in favour of animals possessing them, as well as beauty and carriage.

\section{PREPARING SHEEP FOR MARIET.}

In preparing sheep for market, the object should be to have them look to the very best advantage, and any extra work incurred in this not only pays, but affords an opportunity for displaying skill and taste in sheep management. The more equal in size, quality, type, colour, and age a lot of sheep are, the better they will sell. Of course, the sheep cannot be remade-the aim is to make the most of them. In the case of fat sheep, the best of the lot are frequently picked out week by week, and sold as they are ready. But take the case of a large lot that have to be cleared out at once.

Having brought the sheep together into a large pen or yard, commence by catching out the worst ones, and while drafting is being done, if the lot be ewes, do not hesitate about sending off all that are considered bad specimens of the breed, no matter what their age may be. Sell every sheep, in fact, that has any unhealthy signs present, either from accident or natural causes, and only keep those that are likely to thrive and rear a good lamb. Rather keep a good over-age ewe than a bad young one. After the worst have been drawn, it can then be seen if what remains are fit to go as one lot. If they still appear unequal, it is often better to divide them again, making a top lot, a second, and a third. There are buyers for all the classes, so that each lot will sell for what it is worth; and the average obtained in this way will generally be better than if the whole had been sold in one lot.

After the lots are arranged, any superfluous wool on the head or legs is pulled or cut off, to give the sheep a more uniform character. Formerly ewes and wedders were sent to the market with wool in its natural state of growth, but now almost all of them are trimmed or dressed with the shears, the same as show sheep. The wool on their backs is cut level, and their sides are nicely rounded off, so as to give them a trim appearance. This does not, of course, benefit sheep that are to be kept on for further feeding or for breeding purposes. Clipping the ends of the wool on the back, making it stand erect, is not what nature intended, for naturally the long ends of the wool hang over and carry the rain off the sheep's back; whereas, by clipping the back wool short the rain goes straight to the skin. Whatever pecuniary advantage it may bring to the seller is certainly at the buyer's expense, except when the sheep are sold for slaughtering, and even in the latter case there is a damaged fleece.

A lot of sheep can be improved in appearance by colouring. $3 x^{*}$
This may be done by dipping, or by showering any colourcd liquid over the sheep's back with a syringe or otherwise.

The different lots are next marked, each of the three lots bearing the same mark, but on different parts of the body. The top lot may be marked on the near side, the secona on the far side, and so on. Ewes and ewe lambs are marked diffcrently from the wethers. The former are generally marked red across the loins, wethers on the shoulders, or in many cases the latter are only buisted. In different markets the marks for distinguishing ewes from wedders are very variable.

Sheep and lambs for the fat market are generally marked with colour in red or blue. The less of this, however, the better, especially for lambs. A great blot of red or blue on a lamb's neck makes the animal look smaller than it is, and other marks of the same kind are all more or less open to the same objection when applied to lean sheep or lambs. On fat sheep and lambs a little colour, if neatly applied, improves their look. A thin streak along the back is perhaps the best style of putting it. This shows out the length of a fat sheep, and does not diminish its appearance otherwise. But it is only very large sheep that look well with a strip of colour drawn the whole length, from the crown to the rump. Smaller sheep and lambs show better when the line is drawn from the shoulder top as far back only as the hinder rib, or at most not more than from the shoulder to the rump.

\section{EWE MILKING.}

Ewe milking, at one time general on all sheep farms, hus during the present century gradually fallen out of practice. From time immemorial the milking at the ewe-buclits was considered a kind of annual holiday or festival. It came when the mornings and evenings were balmy and inspiriting, and the pleasures of the season have been handed down in old songs in almost all languages. The poet has enumerated among sylvan pletsures "the lilting at the ewe milking," and the lover's pride in singing "I've nine milk ewes, my Marion," which he would present to her on her bridal day. Hogg alludes to the milking when he says-

"When o'er the hill, the eastern star, Tells buchtin' time is near, my jo!"

Burns also mentions it in many of his songs, and there is little doubt but that it was quite common in bis time. Besides the two quotations of his above, he sings-

"The salt sea we'll harry, and bring to our Charlie,

The cream from the bothy, and curd from the pen."

Again,

$$
\begin{aligned}
& \text { "Hark the mavis' eveniu' sang } \\
& \text { Soundin' Cluden's woods amang, } \\
& \text { Then a-faulding let us gang, } \\
& \text { My bonnie dearie O!" }
\end{aligned}
$$

Ewe milking is one of the old institutions now exploded, where systematic thrift was a main essential to success. Our ancestors had many ways of gathering small things, which 
we now-i-days do not consider worth stooping for ; and ewe milking was one of these pickings. Time is no doubt money, but it is often not in taking sufficient time about a thing that fails to pay.

About the beginning of this century farmers began to milk the ewes less, not considering it judicious management, and as a general principle they were perfectly right. It was not to be expected that ewes after rearing a lamb to full size, could afterwards give sufficient milk to pay for milking. In former days a man's time was of comparatively little value, and it then probably did pay to milk even for small returns. But doubtless ewe milking was kept up for many years after it was understood to be no pecuniary advantage; it was one of those inherited practices, handed down from generation to generation, and persisted in by sheer force of habit or custom. It was believed to be essential and humane, until some farseeing genius discovered that it was about the same thing to let the lambs suck a little longer. There is now about two months' difference in the time of weaning since ewe milking was abandoned. We have not the least intention of advising a return to the old practice, but wish to point out a system by which ewe milking might be very profitably pursued. At the present value of mutton and lamb, it is not to be imagined that ewes can be spared for any other purpose than nursing their lambs; but where the system of rearing early fat lambs is practised, ewe milking seems to suggest a way of overcoming the greatest obstacle to that system-viz. very long keep of the ewes for very short service. When the lambs are sold fat early in the season, just at a time when there is abundance of succulent food forthcoming, it is difficult not to believe that the ewes might be milked a few months without injury, when, as we will presently show, the practice can be turned to good account.

Ewe cheese is richer than cow-milk cheese, and used to be counted a great dainty; but the home-made article is not now obtainable except at an extravagant price. In France, however, the industry is carried on on a large scale. In the district of Roquefort there is a factory where the milk of some 250,000 sheep is made into cheese of that name, and the amount turned out averages from 3000 to 3500 tons annually. It is also said that many of the choicest Continental cheeses owe their fine flavour to the presence of a proportion of ewe-milk. Considering the new energy that is now being infused into dairying, it may be worth suggesting that the ewe is capable of contributing very materially to the making of fine cheese.

We do not, however, recommend ewe milking for the purpose of assisting in the production of a fine-flavoured article of diet only. We recommend it as a business complete in itself, the same as an ordinary cow dairy - with this exception, that every ewe would have to nurse her lamb for a short time. As already mentioned, the only disadvantage that attends the rearing of early fat lambs, where the ewes are not fattened and sold off fat also, is the heavy expense of bringing the ewes into condition for rearing fat lambs, when they have to run barren for the remainder of the year. It stands to reason that the ewes most suitable for making fat lambs would naturally have good milking capacities, and would therefore be the best for dairy purposes. We hope, some day before long, to see early lamb and ewe cheese being turned out from the same farm, and those who keep sheep near to large towns may find this scheme more remunerative than any other they can adopt.

We are not in possession of any test giving the comparative yield of milk by different breeds, yet there is evidence enough to prove that some of the breeds of sheep milk very heavily, and would easily, by selection, give sufficient to satisfy even the most sceptical. In Iceland they milk the ewes for six weeks after the lambs are weaned, and from a hundred well-kept sheep easily realize from 12 to $15 \mathrm{lbs}$. of butter daily. If this can be done with the small Iceland sheep, what ought we not to expect from some of better developed breeds? At Roquefort each ewe is estimated to produce 24 lbs. of cheese in the year, besides suckling her lamb for two months. Now taking three months as the average milking period of the ewes after rearing an early fat lamb, and allowing 1 gallon of milk to $1 \mathrm{lb}$. of cheese, reckoning on the same total as abore, the daily yield of milk would be something like two and two-third quarts per ewe. The milk made into cheese might be expected to command $1 s$. per 1b. or even more. How far the Roquefort estimate could be exceeded we will not predict, but we have little doubt that there are milk ewes in this country that are capable of averaging three quarts of milk daily.

\section{WOOL GROWING.}

Wool is not only a source of wealth to the farmer but to the nation. It is a provision of nature to supply heat and wealth to its producers, and to be afterwaids used as clothing for man. Its mode of growth on the sheep's back is exceedingly simple. Beneath the skin are a series of sinall cells, from one of which each fibre of wool emanates, so closely packed together that the whole surface is completely covered with a dense growth, which varies according to the climate and breed of the sheep. Like every other organic structure, it needs suitable nutriment upon which it may feed, and from which it may extract the materials required in building up its framework. This nutriment is secured by the small cells by which the wool is rooted beneath the skin, which absorb all that the wool requires from the blood circulating beneath them. If the blood does not contain the materials required for the wool, it is simply impossible for any growth to be secured. The cells cannot absorb the necessary supplies if not presented to them in the blood. It therefore becomes evident, that unless the animal's food is of such a character as to supply the nutriment required, its growth must cease. On the other hand, a liberal supply of proper matter promotes a rapid growth, and gives it a strength of texture considerably greater than is obtained from inferior food, whilst its softness is fully preserved. 
The food required for promoting the growtl of wool differs but little from that usually given under any liberal system of feeding. The special requirement is a supply of sulphur, which it usually secures from such grcen crops as clover, vetches, pease, \&c. The influence which these have on wool has been frequently observed, and we have in this fact an explanation of much of the softness of texture which is thus produced. Wool appears to require other materials for growth, but only such as are necessary for the production of the other parts of the body. In addition to the ordinary supplies of food, if we give the animal some variety of the leguminous crops named, or feed more directly a quantity of sulphur, there is no doubt but that the growth and quality of the wool can be greatly promoted. In this country the practice of feeding the sheep a mixture of salt and sulpliur is little practised, whereas in America no sheep farmer ever thinks of allowing his sheep to be without a constant supply. The condition of the skin has a most important influence upon the character of the wool. It acts as a sort of gauge, regulating the size of the fibre. Any circumstances which enlarge this gauge produce an opening for the growth of coarser wool, and the opposite result is secured by any agency which decreases the size of these apertures, thereby producing a finer fibre. It is essential to the character of a good wool, that there should be an evenness of staple. Irregularities in the size of the fibre are always undesirable, causing weaker portions, which do not withstand equal tension, and consequently decrease the general strength of the wool for manufacturing purposes. This arises from the inAluence of the skin in contracting or expanding the pores, and usually originates in a change of food or temperature. Excessive heat naturally opens the pores, and favours the production of coarse wool; any great severity of cold contracts the pores, and makes the wool small in the fibre; and the same effects are caused by abundant or short supplies of food. It is generally noticed that when the growth of wool is rapid and of a healthy character, there is not only an abundance of yolk in the wool, giving it a soft greasy feel, but the skin has much the same condition. This is never found upon sheep which are badly fed and in poor condition. Under such circumstances the blood is naturally free from any oily matter, and consequently the roots of the wool cannot get their supply, neither can the skin maintain its soft and greasy condition. A liberal supply of good food, and shelter from extremes of heat and cold, are therefore essential for the production of the best quality of wool. The influence of food does not end here, for a regularity in the supply is almost as important as the quality. Any period of short supplies, or of inferior food, leaves a clear record in the fibre of the wool, producing a harsher and weaker structure, which is readily distinguished from the growth produced when the animal is well fed. These portions are of necessity less able to stand the strain of manufacturing processes, and the value of the wool is decreased. Large quantities of wool are thus injured by irregular supplies of food, which would have been materially increased if some additional food had been given at the time when the ordinary supplies were insufficient. These cases unfortunately occur more frequently at a time of the year when the severity of the cold increases the damage; but, on every principle of economy, they should be very carefully guarded against. A climate that is cold, yet not too cold-that does not know a temperature ranging from excessive to extreme frigidity-that knows neither a torrid sun, nor severe storms of frost and snow-is certainly the most favourable for the production of the best wools.

The soil also exerts a great influence on the growtl wool. The best wool of the United Kingdom comes from sheep fed on open downs or marshy lands, both of which are much colder than many of the inclosed counties where the wool is not of so much value. This leads us to think that it is the soil and the grasses that affect the quality of the wool, rather than the warmth of the climate. We have leard it said that a flock of sheep brought from Norfolk into the rich warm inclosures of Essex or Herefordshire do not retain the quality of their wool for one year, and that the longer they are kept there the more is the difference observable. At all events, the counties which produce the finest wool do not always afford the finest pastures. The downs about Hertford, in Norfolk, Salisbury, and Marlborough, and the pastures of Cotswold and Leominster have nothing peculiar to them that is not to be found in other parts of the kingdom, and yet the wool of these places is superior to that grown in most other parts of the country. Sometimes we find that richness of pastures and excellence of wool go together, as in Lincolnshire and Romney Marsl, where the sheep are fed on rich deep grass, and yield fleeces of a fine quality, for length of staple especially. But this is not generally the case, for in Buckinghamshire, where the pasture is equally rich, the wool grown is of a much coarser quality. This proves that the soil, or the mineral matter contained in the herbage it produces, is an important factor in determining the quality of wool grown. The softest wools are grown on an argillaceous or a silicious soil; whilst a calcareous soil, whether limestone or chalk, produces wool remarkable for its harshness in touch. Not only is the quality of wool in regard to its softness affected by the soil, but even its colour mindergoes a change from the same cause. In Gloucestershire, for instance, it acquires a deep yellow. In Hertfordshire, Warwickshire, and other counties possessing a similar soil, the wool partakes of the same hue, inclining to brown. In Lincolnshire and Cambridgeshire, the fenlands communicate a dark brownish tint. On a chalky soil the wool is distinguished by its whiteness; on heath and peat lands the colour is more blue; and thus, in every district, the colour of the fleece evinces the action of the soil, either by insinuating its particles into the fleece and its fibres, or chemically uniting with its surface; and it is remarkable that the colour thus obtained is indelibly fixed in the wool, so that no washing or other method can remove it, nor can its whiteness be quite restored by any artificial process bitherto discovered. 
It is interesting to note the differences in the quality of wool as exhibited in the different breeds of sheep. Whether all the present diversities of the sheep race are descended from one original pair or not, we may take it for granted that in progress of time a variety of circumstances was sufficient to have created a variety of races. The original sheep in most countries where improved species are now found were invariably fine-wooled, and by cultivation and crossing of the different tribes the wool has in many instances become both longer and coarser, having altered to a greater extent than even the form of the sheep themselves. However, the property for which wool is most valuable is not so much in variety of breed as in the trueness of breeding. In a true-bred sheep the staple of the wool is of an equal length and texture on all parts of the body. It will not be fine on one part of the body and coarse and shaggy on another, and the more even it is the more valuable it becomes. In ill-bred sheep the variety of wool found renders the article unsuited for the manufacture of fine cloths, and, consequently, its value is diminished. Hairy wool, or what is better known as "kempy" or dead hairs, is another kind deprecated by manufacturers. These "kemps" vary in length and coarseness according to the breed of sheep. They appear to be fibres of wool, which have been killed by some cause or other, so far as power to grow beyond a certain length is concerned. But they still continue to grow in thickness and hardness, till they become glazed and hairy looking; and, owing to their horny qualities, they resist the substances of the dye. They never alter in the process of carding, combing, or spinning, nor do they unite with the rest of the wool to form the thread, but lie on the surface, only held down by other fibres of wool which may be wrapped round over them. It should be the object of every breeder of sheep to diminish, if possible, these very kempy varieties of wool.

To grow wool without fault or flaw in its fibre, it is necessary that the sheep be kept in uniformly good and thrifty condition every day in the year, and not exposed to extreme degrees of heat or cold, and most especially to wet in cold weather. The sheep must not be overfed or underfed at any time, so as to fever the system or to allow it to become debililated, as eitlier condition is likely to weaken the fibre or make it brittle. If the sheep are allowed to get out of condition, or to lose flesh, the wool deteriorates in direct proportion, and there will be a weak place in the fibre, no matter if their condition is afterwards improved. It is a fact beyond dispute, that the flockmaster has the making of the quality of the fleece almost entirely in his own hands, and if his clip of wool is not first-class he has only himself to blame.

The quantity of wool which each breed of sheep will produce cannot be given with any degree of accuracy. Individual specimens have been known to shear as much as 30 to $40 \mathrm{lbs}$. of unwashed wool, but the average fleeces of such beeds under ordinary treatment may not weigh more than $8 \mathrm{lbs}$. It entirely depends on how the sheep are fed, and whether the soil is adapted to the particular breed. The following table gives the actual clip of wool from thirteen different breeds on the Cirencester College Experimental Farm:-

\begin{tabular}{|c|c|c|c|c|c|c|}
\hline Breed of Ewes. & & \multicolumn{2}{|c|}{$\begin{array}{l}\text { Weight of } \\
\text { Fleece. }\end{array}$} & \multicolumn{2}{|c|}{$\begin{array}{l}\text { Price of } \\
\text { Wool } \\
\text { per lb. }\end{array}$} & Remarks. \\
\hline Lincoln. & & & $\begin{array}{c}\text { oz. } \\
2\end{array}$ & & $\begin{array}{l}\text { d. } \\
0\end{array}$ & Long in staple, bright and ailky. \\
\hline Cheviot, . & & 8 & 6 & & 0 & A wool of medinm length, soft and rich. \\
\hline Shropshire, · & & 7 & 5 & 1 & 1 & $\begin{array}{l}\text { Looger in staple and more lostre than } \\
\text { other Dows wools. }\end{array}$ \\
\hline Border Leicester, & & & 13 & 1 & 0 & Not so soft and silky in staple as Lincoln. \\
\hline Osford Dowa, . & & & 10 & & $0 \frac{1}{2}$ & Equal to Shropshire in quality. \\
\hline Leicester,. . & & 6 & 6 & & 0 & Similar to Border Leicester. \\
\hline Blackfaced, . & & 4 & 8 & 0 & 9 & Coarse and long. \\
\hline Dorset, . . & & 5 & 6 & 1 & 0 & $\begin{array}{l}\text { Longer in ataple and not so fine as the } \\
\text { Downs. }\end{array}$ \\
\hline Hampshire, . & & 5 & 2 & 1 & 0 & $\begin{array}{l}\text { Short wool very aimilar to South Down, } \\
\text { bot longer in ataple and not ao fine. }\end{array}$ \\
\hline Herdwick, . & & 5 & 0 & & 9 & Coarse and long. \\
\hline South Down, & & 4 & 5 & & $0 \frac{1}{2}$ & A short, small-haired wool. \\
\hline Exmoor, . & & 5 & 0 & & 11 & A long stapled wool or medinm quality. \\
\hline Cotswold, . & & 8 & 0 & 1 & 0 & Long, and rather coarse lustre. \\
\hline
\end{tabular}

The above figures represent the average of three ewes of each breed. The sheep of each lot were all fairly equal, and the treatment of all the lots during the previous winter and spring had been exactly alike. All the ewes, also, had reared one or more lambs during the summer. It is more than likely, however, had the trial been made in another district, with a soil and climate different from that of Gloucestershire, there would have been more or less variation in the results. According to the best calculations, the average. weight of fleece is in England and Wales $5 \frac{3}{4} \mathrm{lbs}$, in Scotland $4 \frac{3}{4} \mathrm{lbs}$. , and in Ireland $6 \mathrm{lbs}$; but the average may vary as much as from a quarter to half a pound per fleece, according to the season.

British breeds of sheep are chiefly cultivated on account of their mutton qualities, their wool-bearing properties not being considered of sufficient importance to warrant special attention. For this reason 90 per cent. of all our British fleeces belong to the class technically described as "long-haired" or "lustre" wool, and consequently, foreign wool, where mutton is considered of no account, being grown for a single purpose, is of a much finer quality. The finest of all wools - the only wool, in fact, that can be used for the finest broadcloths-comes from the Merino sheep; and an inspection of these animals will show at the first glance how distinctively a wool-producing breed they are. Compare these species with the British breeds, and it will not need the lecture of a naturalist to define the marked distinctions between the wool-producing and the fleshproducing species. Wool and mutton productions in sheep are exactly similar to milk and beef propensities in cattle, from no one breed can the highest quality or value of either product be obtained. And as the British farmer finds the mutton producer the most profitable, the supply of fine wools is left to other countries.

While speaking of fine wools, it reminds us of a very good story we have somewhere read of a distinguished agriculturist, whose enthusiasm for rural pursuits had always been more than a match for any skill he possessed in them, who was once betraved into a mistake of a ludicrous nature. It was 


\section{BREEDS 올 BMEEP.}

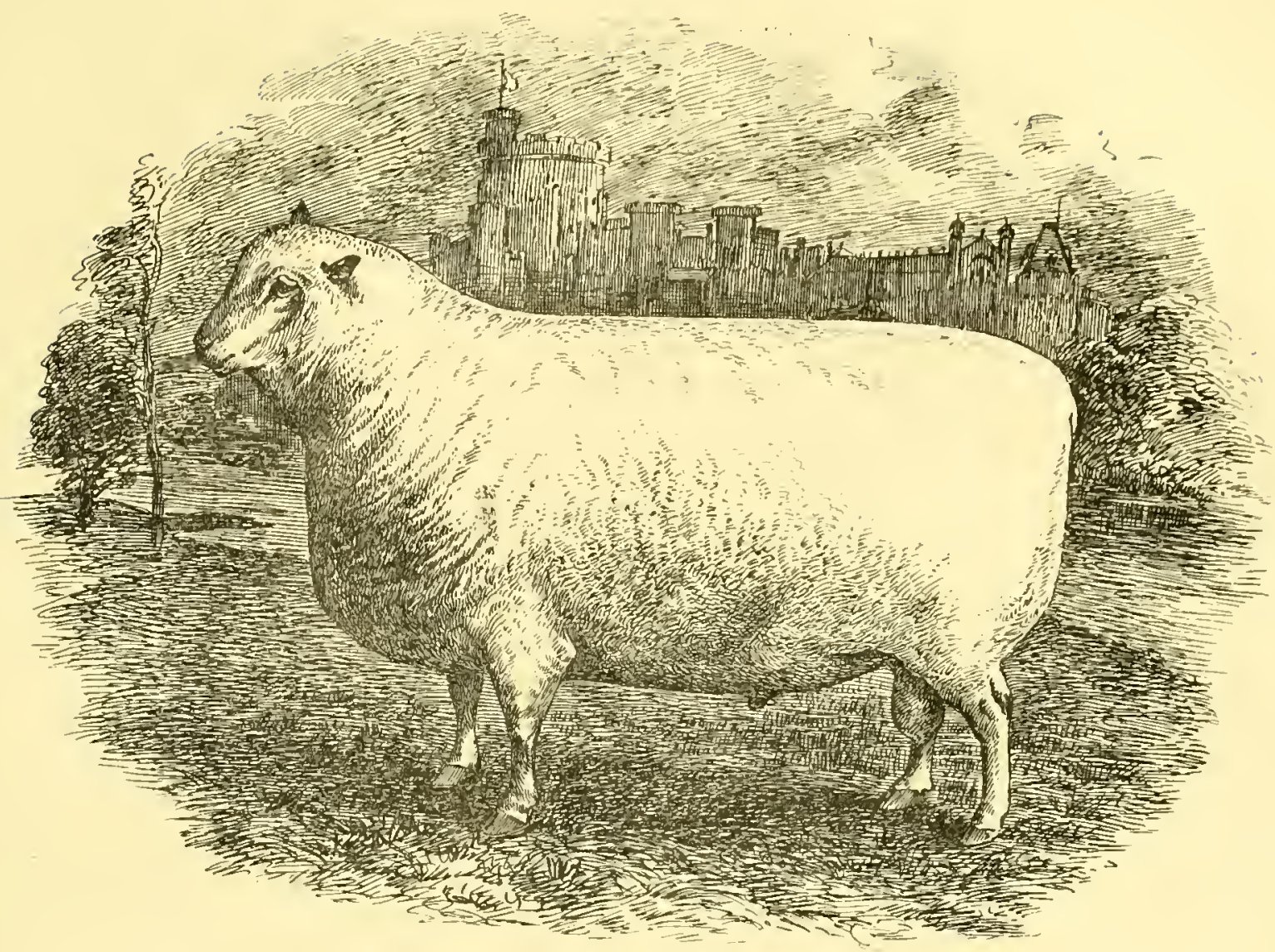

SOUTHDOWN SHEARLING RAM.

Winner of Champion Cup at the Windsor Show of the RAS.F

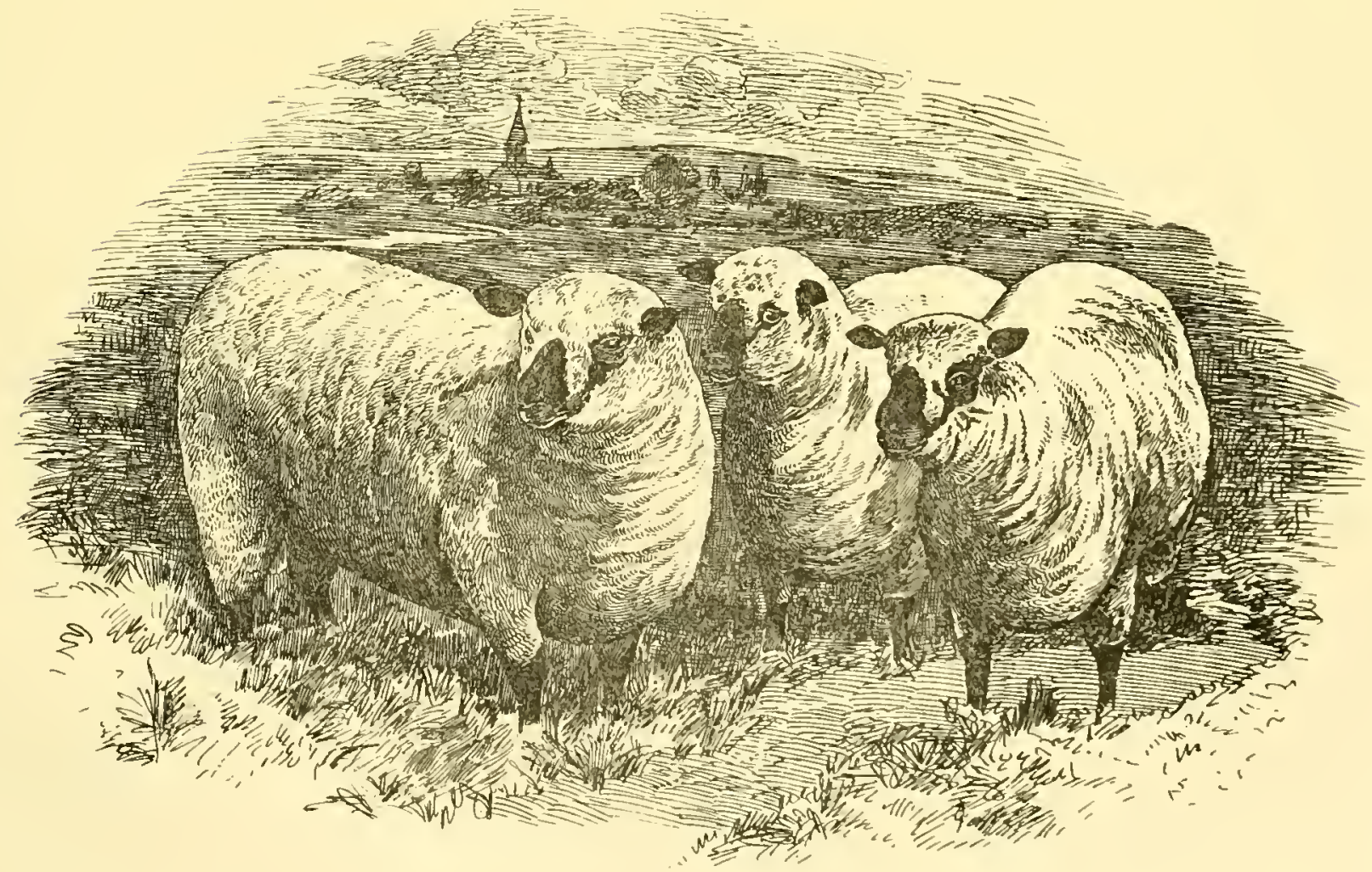

PRIZE GROUP OF SHROPSHIRE SHEARLING EWES. 
at the time when the merits of the Merino breed of sheep it, and be convinced. Was there ever so fine a wool divided the suffrages of the wool-growers of England. The seen?"

gentleman alluded to, who was an advocate for the supcriority The sample bcing lianded round, the sly purloiner begged of the Spanish fleece, brought in his pocket to a mceting of to put in a word for the Soutlidowns.

fleece amateurs a sample of Merino wool grown under an "He was," he said, "no speechifier, but a plain matter-ofEnglish sun, with the intention of making an eloquent fact man; the Merino wool might be all that they were told, speech in praise of the foreign brecd, and then, by way of but he had a handful of wool in his pocket, which he had proof, exhibiting the sample, to the utter confusion of the shorn that morning from the back of a Southdown wether, partisans of the Blackfaces and Southdowns. A friend of the which he thought quite as fine, and he would appeal to the Southdowns got a hint of the gentleman's design, and being judgment of the company if it was not."

as much of a wag as a wool-grower, he hit upon a very amnsing expedient of putting the real knowledge of the Merino advocate to the test.

Previous to the meeting he contrived to abstract from the hin sample of wool in the gentleman's pocket a good handful, which he silently transferred into his own. When the party were all assembled the gentleman made his speech in favour of the Merino fabric - a very confident and a very warm oneand concluded with drawing it forth, saying:-

"But, gentlemen, I don't want you to take my word on the subject; here is a specimen of the wool itself. Only look at

On this he exhibited the stolen handful of Merino as genuine Southdown. Most of the company were of opinion that it was every whit as good as the Merino; but the Merino grower himself, seizing it, eagerly exclaimed-

"That he could not sufficiently express his surprise, that gentlemen with their eyes open should talk so; the difference between the two wools was as obvious as the difference between black and white." He went on in the same strain till the witty hoaxer stopped him by letting out the secret, to the great amusement of the company and the inexpressible confusion of this nice discriminator of rare products.

\section{THE COLLIE.}

The name of the collie has at different times assumed various forms. Chaucer writes of "Colle-our-dogge;" Ramsay spells it "Colly;" Fergusson, "Colley;" and Burns, "Collie." The latter term, which is of comparatively recent date, is now the form usually written. The meaning and origin of the word collie has also been a subject of controversy, and it is still doubtful whether the proper derivation of the name has yet been discovered. One writer asserts that the shepherd's $\mathrm{dog}$ is called collie, because it has a fox-face; and a fox being a false, cunning, deceitful beast, it was in some places called a coll, or a false animal. Another suggests that the name is derived from cole, meaning marked with black, wlich is said to have been the prevailing colour in the early days. The author of a dictionary avers the term describes the dog as it was the custom to treat it. The tail apparently had been thought an incumbrance, and was commonly docked; hence collie means, according to this authority, neither a fox-faced, nor a black and white, but a bob-tailed dog-cole being the Scotch equivalent for cutting off an apendage. These definitions are, however, contradicted by one who says, "Collie has nothing to do with either the colour of a dog or with its tail. I lived some years in the Highlands; I heard there all young dogs called collie, until they had some individual name given them; collie, then, is equivalent to whelp." A more probable definition than either of these is given by one who says, "The word collie is the Sassenach corruption of the Gaelic words, $C u$, luth-the th silent-hence $C u-l u$, collie. $C u$ in Gaelic means dog; and luth, active enduring power." Collie, therefore, means a smart active dog of enduring strength and power. In considering the origin of the dog, it is still an open question among zoologists whether the numerous breeds that are scattered over the world arose from one common stock, or

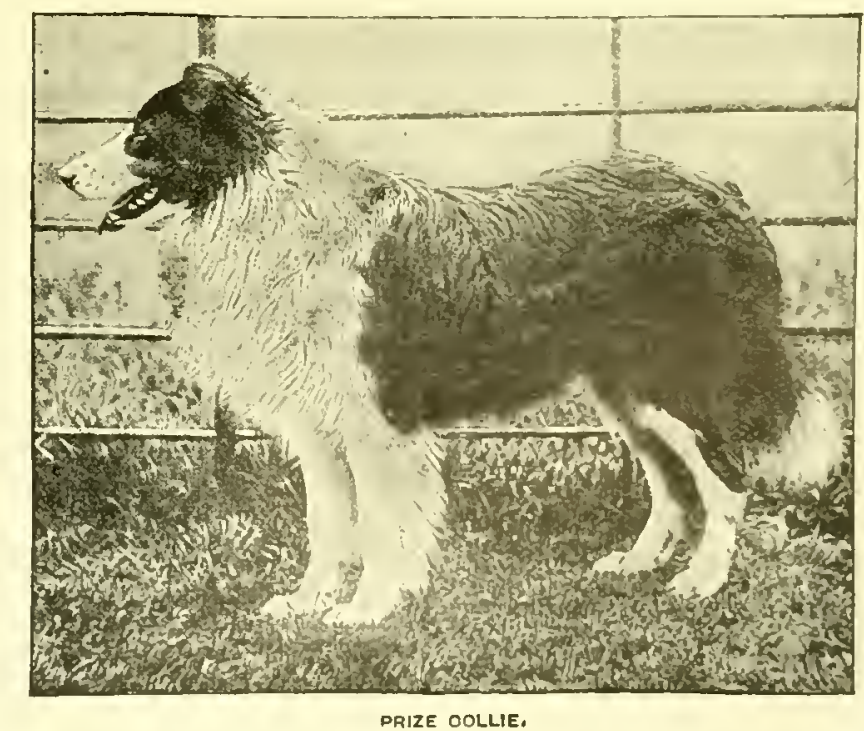

were derived from the admixture of a species of the wild dogs and wolves of the prehistoric times; but the latter opinion appears to meet with most support. The subject is, however, so veiled in mystery, as to defy the greatest scientists of the 
day. That it is so can scarcely be wondered at, when the first illustration of a domestic dog appeared 3700 B.C.

It appears that the early Britons cultivated three varieties of dogs, one called a mastiff, a dog used for hunting, and as unlike the animal bearing that appellation in the present day as it is possible to conceive; another, termed a boarhound; and another, a large-sized rough greyhound, generally known as a wolfhound. These three varieties were kept to guard the flocks from wolves and other predatory beasts of prey, and also for the chase. We are also told that these three types had erect and semi-erect ears; dogs with pendulous ears not being seen till near the decline of the Roman Empire, at which time they were classed by the Romans under three heads-house dogs, shepherds' dogs, and sporting dogs.

In all truly wild dogs the ears are erect and the tail pendent or drooping. The former characteristic is accounted for by the animal being ever on the alert to secure its safety, and the latter by the want of exercise of the tail, which in the domesticated dog, from frequent expressions of pleasure, becomes strengthened and encurved. These characteristics are typical of the sheep $\operatorname{dog}$ (to which breed the naturalist, Buffon, has given the priority of race), as, when in the act of listening, it stands with ears nearly erect and tail drooping. In the wild dog, the low carriage of tail is more to be attributed to its stealthy nature, than to its inability to carry it curled; as with animals in the domesticated state, when fear or distrust is betrayed, the tail is always lowered. In those countries where the canine race has not been so thoroughly reclaimed from the savage state as in Europe, the domestic dogs have a striking resemblance to the wolf, the jackal, or wild dogs which inhabit these regions. Darwin's opinion was, that the domestic dog is descended from one or other of these species, and there is every reason to credit his belief.

From whatever source the collie may have been descended, the present types or specimens of the race are extremely diversified in form and colour, which would suggest a vast commingling of strange blood at one period or another. The different kinds of dogs-we cannot call them breeds-now employed by shepherds in tending their flocks, entirely baffle description. They are of every size and colour, rough and smooth coated, soft and hard haired, mostly representing, faintly or strongly, a dash of nearly every known breed of the canine species. This great diversity of type may be accounted to the common influences of carelessness in breeding and crossing with other breeds. In nearly all the varieties, however, there are to be found sheep-dogs of superior intelligence; and to this fact, perhaps, may be ascribed the cause of so much indifference amongst shepherds in cultivating any particular sort. Still, it cannot be denied, that while an occasional good dog is found among the cross-bred species, the great majority of the best and most useful collies are bred from recognized pure strains.

In days gone by the collie was considered as a representative of all that is mean and servile; but within the last ten or twelve years he has been raised above the plebeian level, and adopted as a fit companion for lords and ladies of high degree, and has become an essential member of the fashionable establishment, more so as an ornament than for any special services he is expected to render. This rage among fanciers has given rise to special attention being devoted to cultivating pure strains; and now at agricultural shows, as well as at special exhibitions of dogs only, the collie is usually Le chien du jour, the dog of the day.

To describe what is at present considered the true type of collie, the following scale of points, drawn up by the Collie Club in July, 1885, will best fulfil the purpose :-

The skull of the collie should be quite tlat and rather broad, with fine tapering muzzle of fair length, and mouth the least bit overshot, the eyes widely apart, almond shaped, and obliquely set in the head; the skin of the head tightly drawn, with no folds at the corners of the mouth; the ears as small as possible, semi-erect when surprised or listening, at other times thrown back and buried in the "ruff."

The neck should be long, arched, and muscular, the shoulders also long, sloping, and fine at the withers; the cliest to be deep and narrow in front, but of fair breadth behind the shoulders.

The back to be short and level, with the loin rather long, somewhat arched, and powerful. Brush long, "wi' upward swirl " at the end, and normally carried low.

The fore-legs should be perfectly straight, with a fair amount of flat bone; the pasterns rather long, springy, and slightly lighter of bone than the rest of the leg; the foot with toes well arched and compact, soles very thick.

The hind-quarters, drooping slightly, should be very long from the hip-bones to the hocks, which slould be neither turned inwards nor outwards, with stifles well bent. The hip-bones should be wide and rather ragged.

The coat, except on legs and head, should be as abundant as possible; the outer coat straight, hard, and rather stiff; the under coat furry, and so dense that it would be difficult to find the skin. The "ruff" and "frill," especially, should be very full. There should be but little "feather" on the fore legs, and more below the hocks on the hind legs.

Colour, immaterial.

Symmetry.-The dog should be a fair length in the leg: and his movements wiry and graceful; he should not be too small; height of dogs from 22 to 24 inches, of bitches from 20 to 22 inches.

\section{SCALE OF POINTS.}

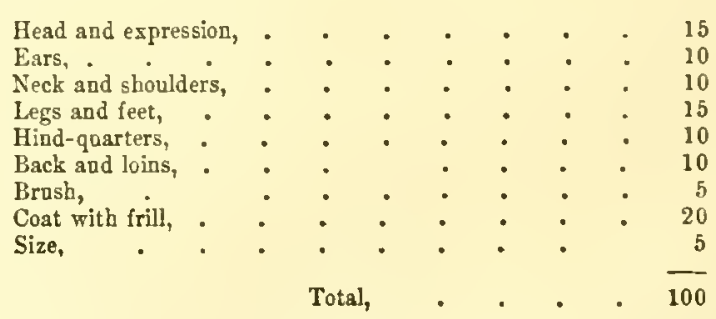

The greyhound type is very objectionable, as there is no 
brain room in the skull, and with this there is to be found a fatuous expression and a long powerful jaw.

The setter type is also to be avoided, with its pendulous ear, full soft eye, heavy feathered legs, and straight short flag.

The smooth collie only differs from the rough in its coat, which should be liard, dense, and quite smooth.

In the north of England great interest is taken in the breeding and training of the collie. Several years ago the leading landowners in the distriet, acting upon the initiative of the Countess of Bective, formed the Northern Counties Association for the Improvement of Sheep-dogs. Under the auspices of this society, working trials are held alternately in Cumberland, Westmoreland, Lancashire, and Yorkshire, at which handsome money prizes and silver eups are awarded. At these trials it has been demonstrated that the pure bred collie, from its vast intelligence, is better adapted for work than the ordinary cross-bred strains. The shepherds have been partially convinced of this fact, and are now bestowing greater eare in selecting their dogs than they formerly were wont to exercise. Sheep-dog trials ought to be a branch of every agricultural society in sheep-farming districts. They would not only be interesting to many, but would materially assist in perfecting the best type of dog for this special purpose. One half of the sheep-dogs in actual work are very unfit for their position; and, besides, are often a source of much annoyance to the farmer, from the abuse they not unfrequently inflict upon his sheep. It is well known that there are certain strains of the collie which take to work much more readily than others, are easily trained, and more careful of the flock. Now, were a little more attention given by farmers and shepherds to securing only those naturally possessing these traits, instead of retaining mongrels and curs of every sort, there is no doubt that both would be well repaid for their trouble.

Dogs are best studied at work; and a day spent among the hills with the shepherd and his dog is fraught both with interest and instruction to an intelligent observer. Sitting on a hillside, looking across a wide glen, the sheep of an adjoining proprietor are observed erossing the boundary line in search of richer pasture. The shepherd addresses a few words to his dog, which darts off like a greyhound. We watch him spanking across the glen, now elearing a wide ditch at a bound, then fording the stream, half wading, half swimming. He waits but a moment to shake the water from his coat. His master calls to him. He raises his head and ears to listen to the order which is repeated, and nimbly he threads his way up the distant acelivity. He now comes in sight of the sheep, and in getting ahead of them takes a wide, circular course. The sheep have taken the alarm and commence to run, but "Tyne" is too swift for them, and presently he appears clear in front. The shepherd, by a sharp whistle on his fingers, stops his dog, which, at the moment, happens to be on a patch of thick heather; and were it not for the splashes of white about his neck and breast, his whereabouts would not be easily made out. The sheep are slow to retreat; but upon receiving another command, "Tyne" moves smartly up behind them, and in a few minutes the poaching flock are sent seampering back to their own proper walk. 'The dog is seen leisurely retracing his steps. He quenches his thirst as he re-fords the stream, and, returning to his master's side, sits down composedly, turning his keen eyes towards the opposite lill as if to make sure he has fully completed his task.

Such is a simple performance of the collie; yet it serves to show how quickly and well he accomplishcs a piece of work which, without him, would lave oceupied the shepherd many hours. The sheep may be seattered miles apart over a wide range of hills, and he will collect them in shorter time than could a score of men. Alone he will drive the flock to any part of the hill, or bring to the shepherd any sheep lie may want. Distance is no object to a well-trained collie; and although he may be a mile away, a motion of the liand is sufficient to command him when oral directions cannot be heard.

Working at hand, he is equally expert, and will feteh, take, or keep the sheep whcrever wanted, in the gentlest manner possible. The shepherd goes to a field where the flock he wisles to collect are grazing, and giving a quiet word or look his dog darts off around the field, following the fence to make sure that not a single sheep will be left. After getting fairly around the sheep he retraces his steps, and thus he runs backwards and forwards, every time reducing the circle, until he gathers the flock to the point from which lie started. During this time the dog has been running fast, but he keeps a wide distance from the sheep, which have all the while been moving no faster than a walk. When the sheep are collected, by the aid of his dog the shepherd can separate out any he may want; and should the flock be divided into two or three different lots, the active collie will keep them thus apart withont allowing one to mix. In pemning the dog works elosely to the sheep; and when much foreing is required, if his near presence is ineffective in driving them forward, he barks lustily at their heels. In such cases some dogs are often tempted to bite; but the well-trained animal will not do this, although we have occasionally seen a dog which could "heel" them quite harmlessly in his endeavours to urge on the sheep. To drive a lot of newly weaned lambs is sometimes a rather difficult task, and severely tries the skill of the dog. Indeed it not unfrequently happens, when the lambs are determined to break, that they will completely get away from the tery best collie. When the lambs burst off in every direction, a single dog has no elance to restrain them, as by the time he stops one point he is wanted at another; and so fast does the running become, that the willing dog, although he puts forth his utmost speed and efforts, is sometimes fairly overpowered. When a sensible collie gets beaten in this fashion, it is truly ludicrous to see how ashamed of limself he looks. There are not many dogs, however, that can govern lambs; and unless they have the art of turning quick, and know the exact point to attack, the runaways will have it all their own way. At 
this work a small dog has less command over the sheep than a large one, which comes round with a heavy swack, working close to the sheep. A collie should always wheel with his face close to the sheep, as one which turns the opposite way takes double the time, and has far less power in kecping them together.

The well-trained collie is able to perform not merely one or two such points as we have mentioned, but to do and act in a thousand different ways known only to those whom he serves. He is ever on the alert, and always ready promptly to fulfil the commands of his master. His whole mind is devoted to his work; and when fully experienced, his sagacity tells him what work is required, and he anxiously awaits permission to be allowed to perform it. But it must not be supposed that every collie is thus endowed with a sense of his duty. On the contrary, there are many with equal opportunities that never acquire a great liking for work among sheep. They are fonder of, and have a desire for, other pleasures-some preferring cattle, others various employments, such as following a cart. But these fancies are generally influenced by the surroundings of their puppyliood; and whichever circumstance predominates, that they will invariably follow. As previously remarked, there are certain strains which take more readily to work than others; but at the same time, even those naturally so inclined, before they can become skilled performers must undergo a thorough training for the business. Shepherd dogs are not picked up bere and there of any age, and put to work in a single day. They are best bred on the farm, and the instruction begins with the pup. A full course of training occupies, at the very least, two years, sometimes longer, according to the smartncss of the animal. To educate a dog properly, one should commence before his powers are fully developed, and carry his education along with the development of said powers, so that when age advances he is a satisfactory performer and a credit to his owner.

The pup should have one master and one only; all the other members of the family should be strictly forbidden to give him orders or cultivate his affections. This applies especially to the children; they will eventually make a fool of any dog. At six months old the young dog may be allowed to accompany the shepherd in his daily rounds. If left about the house at this age he is apt to fall into bad habits, especially if in the company of other idle dogs. The first step in the training of the pup is to gain his affection, and at the same time teach him obedience-to come to heel-and on no account must he be allowed to hunt. A dog that will break away from his work in pursuit of a hare or rabbit is of no account, as he may be absent at a time when his services are urgently needed. The pup should be allowed to work as soon as he has acquired strength and speed of foot to run easily around or past the sheep. If he lacks speed in racing a sheep, he is certain to acquire the bad habit of running straight when he ought to take a wide circuit in getting to the front. Some dogs begin to run very early, at six or nine months, and others again do not commence until they are a year old or more. But the age at which they commence to run has nothing to do with what the dog will eventually become; it. often happens that those which show the least intelligence to begin with, turn out the best dogs in the end.

In his first attempt at working the young dog generally tries to imitate an older one, and, reasonably enough, will make some sad mistakes; but for these he should not be punished. Rather encourage him to run, even although he may go wrong, and very soon he will acquire such a liking for the work that it is difficult to prevent him. After becoming fond of running, cliastisement will not discourage the dog, and there will be times when severe punishment must be given. The master should always give his orders in an even, calm voice, devoid of passion, so that the dog cannot tell from his tone whether he is to be scutched or not. The best of dogs are greatly tempted to run away when they know from the angry bellowing of their master that they are to be chastised. But some dogs are of such a sullen or nervous disposition that they camnot stand a whipping, and the trainer must study the temper of the animal he is dealing with. There are dogs which require, and wilı submit, to a sound flogging every day; but, on the other hand, there are some that must not be whipped at all.

A collie cannot be properly trained where only a few sheep are kept. He must be constantly employed every day, and have nothing to divert his attention from duty. Plenty of hard work is the best way of bringing him to understand his business; and if that cannot be given, the training must necessarily be more tedious, and probably it will also be less satisfactory. When the young dog has fairly begun to work he should occasionally be well tired out, and he will then show whether lie is likely to be of any good. His training afterwards only needs careful attention, to see that he performs his work in an expert and steady manner.

A well-trained and experienced collie excels in sagacity all others of the $\operatorname{dog}$ family. His is not the intelligence of the trick dog; one look into those "grey wise" eyes, will tell you that for antics or pranks like those of the showman's troops of canine artistes, your collie has the supremest contempt. A dog's life is to him quite too serious to be wasted in such frivolities; his mission is hard work; he has duties to perform, as had generations before him. His one particular task is to care for flocks of sheep; and because he does this, and does it well, he may take rank as the most useful of all dogs. "Without him," writes Hogg, the Ettrick Shepherd, "the mountainous land in England and Scotland would not be worth sixpence. It would require more hands to manage a flock of sheep, gather them from the hills, force them into houses and folds, and drive them to market, than the profits of the whole are capable of maintaining."

Anecdotes, telling of his deeds of darnig and faithfulness to mankind, are known around the world. For herding and driving cattle and many other kinds of animals, including goats and ostriches, the collie has been found of signal value, 

Certain writers have also lately been extolling his great merits countenanced by all shepherds. A sheep-dog with a strong setter and retriever. Such work for the collie, however, is is invariably is useless, and one that inclines to retrieving

\section{A P PENDIX.}

I. Composition of Foods.

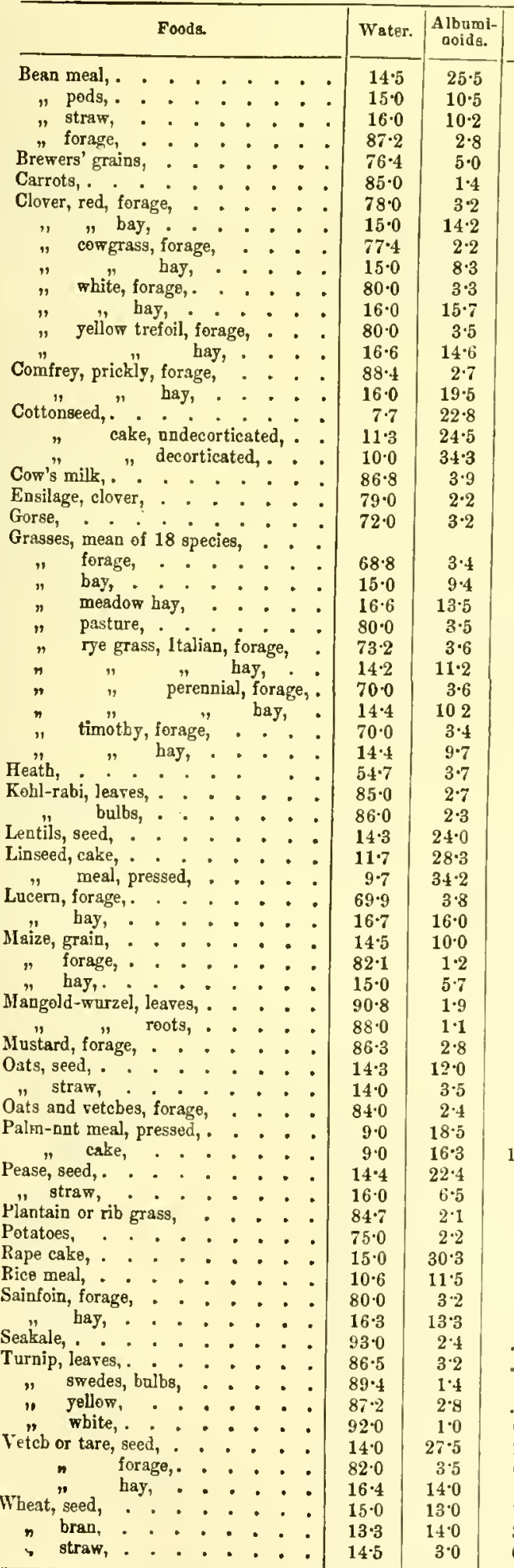

\begin{tabular}{|c|c|c|}
\hline Fats. & Carbo- & $\Delta \theta h$. \\
\hline $\begin{array}{l}1 \cdot 4 \\
1.9\end{array}$ & $44 \cdot 0$ & 80 \\
\hline
\end{tabular}

\begin{tabular}{l|l|l|l}
1.2 & 34.6 & $5 \cdot 5$ \\
0.5 & 35.2 & $4 \cdot 5$
\end{tabular}

\begin{tabular}{r|r|r|}
0.5 & $85 \cdot 2$ & $4 \cdot 5$ \\
$0 \cdot 2$ & $5 \cdot 2$ & $1 \cdot 0$
\end{tabular}

\begin{tabular}{l|l|l}
0.2 & $5 \cdot 2$ & $1 \cdot 0$ \\
0.4 & $9 \cdot 4$ & $1 \cdot 2$
\end{tabular}

$0 \cdot 2 \quad 11 \cdot 0$

\begin{tabular}{r|r|r}
0.8 & 9.5 & 1.7
\end{tabular}

\begin{tabular}{l|l|l}
$3 \cdot 1$ & $37 \cdot 2$ & $5 \cdot 7$
\end{tabular}

\begin{tabular}{l|l}
0.9 & 10.0
\end{tabular}

\begin{tabular}{l|l|l}
$3 \cdot 3$ & $37 \cdot 6$ & $10 \cdot 1$
\end{tabular}

0.8
3.6

\begin{tabular}{r|r}
$3 \cdot 6$ & $36 \cdot 7$ \\
$0 \cdot 5$ & $8 \cdot 5$
\end{tabular}

$2 \cdot 0 \quad 36.2$

27.

5.5

$1 \cdot 1$

$0 \cdot 9$

$2 \cdot 6$

$1 \cdot 2$

0.

1.4

0.3

0.8

0.5

$1 \cdot 4$

$1 \cdot 0$

$0 \cdot 4$
$0 \cdot 2$

$2 \cdot 2$

$3 \cdot 9$
$0 \cdot 8$

\section{Albuminoid Ratio.}

Ratio between the nitrogenous and the non-nitrogenous constituents in the digestible part of the principal foods for sheep :-

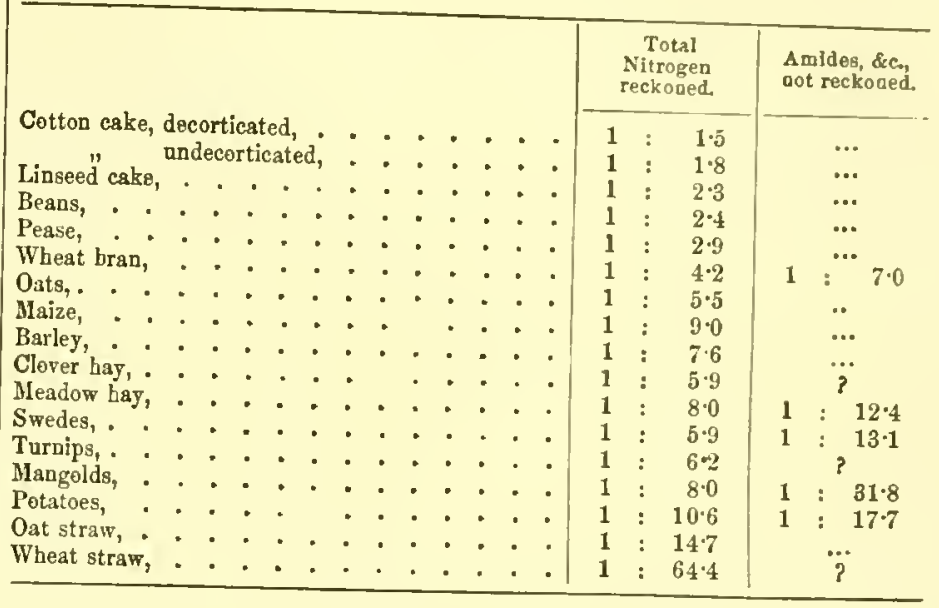

\section{III.}

The following tables are compiled to show the different proportions of the same ingredients which are digested by sheep or cattle :-

\begin{tabular}{|c|c|c|c|c|c|c|c|c|}
\hline \multirow{2}{*}{\multicolumn{2}{|c|}{ Food. }} & & \multicolumn{5}{|c|}{ Digested for 100 of each Conetituent enpplied. } & \multirow{2}{*}{$\begin{array}{l}\text { Albamicold } \\
\text { Ratio of } \\
\text { Foods } \\
\text { actaally } \\
\text { used. }\end{array}$} \\
\hline & & & $\begin{array}{c}\text { Total } \\
\text { Organic } \\
\text { Matter. }\end{array}$ & $\begin{array}{l}\text { Albumin- } \\
\text { oids. }\end{array}$ & Fat. & $\begin{array}{c}\text { Soluble } \\
\text { Carbo- } \\
\text { bydrates. }\end{array}$ & Fibre. & \\
\hline Linseed caks, & - & - & 80 & 84 & 90 & 78 & $?$ & $1: 17$ \\
\hline Beans, . . & . & . & 90 & 88 & 93 & 93 & $?$ & $1: 2 \cdot 1$ \\
\hline Oats, . & - & & $\pi 1$ & 79 & 84 & 76 & 24 & $1: 6.5$ \\
\hline Barley, . & - & . & 81 & 77 & 100 & 87 & $?$ & $1: 8 \cdot 2$ \\
\hline Maize, . & . & - & 88 & 79 & 85 & 91 & $?$ & 1 : \\
\hline Wheat bran, & - & - & 67 & 75 & 50 & 70 & 37 & $1: 4 \cdot 5$ \\
\hline Meadow hay, & - & - & 59 & 56 & 47 & 62 & 57 & $1: \quad 9 \cdot 2$ \\
\hline Clover bay, . & . & - & 59 & 55 & 56 & 69 & 44 & $1: 6 \cdot 2$ \\
\hline Lncern hay, & . & - & 59 & 76 & 38 & 67 & 40 & $1: 2 \cdot 8$ \\
\hline Oat straw, & - & - & 51 & 38 & 30 & 43 & 61 & $1: 14 \cdot \overline{7}$ \\
\hline Wbeat straw, & & - & 46 & 20 & 36 & 39 & 56 & $1: 44 \cdot 1$ \\
\hline Bean straw, & - & - & 50 & 51 & 55 & 60 & 36 & $1: 6.2$ \\
\hline
\end{tabular}

DIGESTIVE POWERS OF SHEEP.

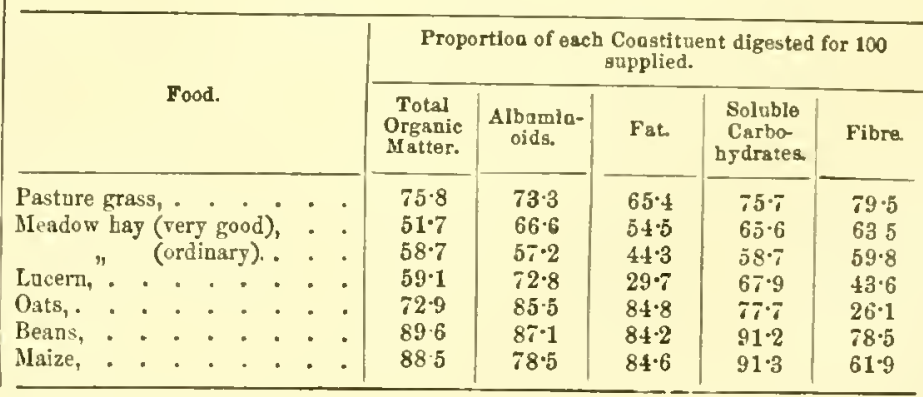


IV. Food Equivalexts of 10 LBs. of Hay.

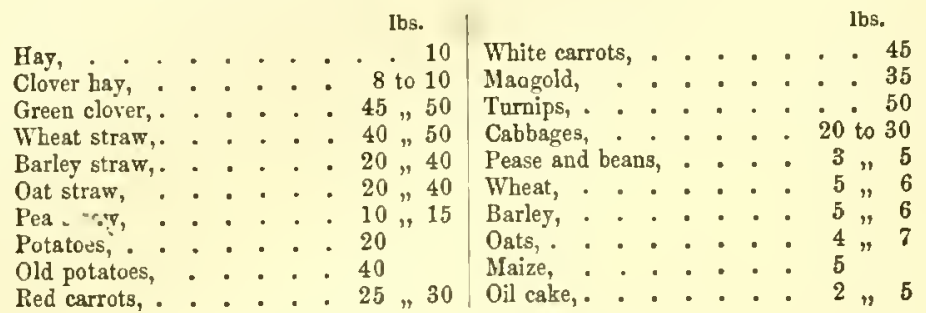

\section{Weight of Fat Sheep.}

The offals of sheep weigh, in ordinary cases, as follows:-
Skin, without fleece, from . . 6 to $10 \mathrm{lbs}$. Tallow,. $\quad: \quad \cdot \quad \cdot \quad \cdot \quad 5 \% 14$, Head, - • . • • • • . 4,6 ,

Feet

Pluck, .

Lood,

Fleece,

Horns
The following table will lead to a tolerably close approximation to the truth in a majority of cases to which it may be applied:-

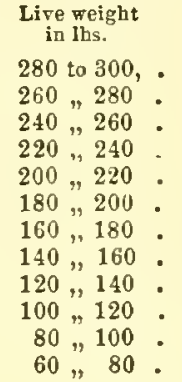

Per cent of Mintton In wool. Newly shorn.

71 to 72 to 75

$69,70 \quad 73,74$

$67,68 \quad 71,73$

$65,66 \quad 69 \quad 70$

63

61,62

60

58,59

$55 " 56$

53,54

67,78

, 66

$62 " 63$

60,61

$58 " 59$

, 57

Another rule is-weigh the sheep alive, to ascertain weight in stones (14 lbs.); double the number of stones which the sheep weighs will give pounds weight per quarter if the sheep is fairly fat. Thus a sheep weighs alive 9 stones; 9 multiplied by $2=18$, or 18 lbs. per quarter. 


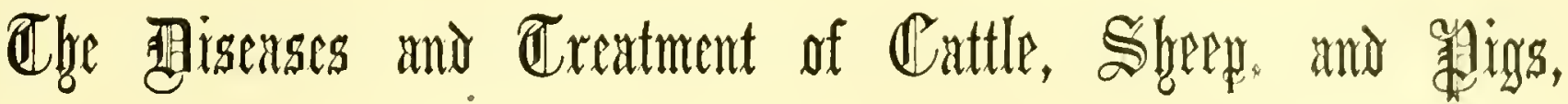

\author{
By JAMES IRVINE LUPTON,
}

TELLOW OI THE ROYAL OOLLRGE OY VETRRINARY GURGEGNG

DURING the earliest days of the world's history, flocks and herds constituted the chief wealth of individuals; for payments and presents were made in kine, and afterwards the prosperity of nations was indicated by their large possession of stock. With the fall of man came "death and all our woe;" one of which was disease, both that appertaining to man and the lower animals. But to man was given dominion over every "beast of the field and fowl of the air," or, in other words, superiority of intelligence, rendering him capable of ascertaining how, first, to provide for the wants and necessities of the inferior animals in health; and, secondly, to protect them against the attacks of disease; and, thirdly, how to tend them during its progress. Owing to this providential gift, we learn that, from the days of the Egyptian magicians to the present time, the prevention and cure of disease has been a topic upon which wise men have thought and written. Among those who have handed down their works to posterity on this subject, we meet with philosophers, historians, and poets-ever-living names, ranking highly among the immortal dead. The pens of many of these men were called in requisition by the existence, at the time, of diseases which devastated the stock of their respective countries, and in some instances nearly produced national ruin; so injurious pecuniarily as to have caused legislators, in attempting the conservation of their countries, to seek advice, and in so doing to have brought to light the works of Hippocrates, Virgil, and all such persons who by their wisdom have prevented and cured disease.

Many authors, in treating the subject before us, wrote jointly upon the cultivation of the soil and care of stock. 'The poet Virgil evidently considered the two subjects inseparable, for in the Georgics he has devoted equal consideration to both; as the first two books treat of crops and trees, the last two upon the management and diseases of cattle and bees, the last-named creatures being at the time Virgil wrote an important item in Italian agriculture. What circumstances led to the foundation of the first veterinary school in Europe? Why, the inseparability of agriculture and veterinary science; and at the same time proved the importance of that art by the results which it developed ; for Bourgelat, a French barrister, observing that certain maladies were devastating the French herds, forsook the bar and devoted his time and energies in seeking out a remedy for the then pest, which resulted in his founding a veterinary college at Lyons in 1760 , from which establishment he despatched students, with weapons in their hands all-necessary for combating disease by science with practice; and in a short time from this period the plague was stayed and the health of stock restored, through the assistance rendered to agriculture by veterinary science and art.

\section{INFLAMMATION.}

As the medicines to be mentioned hereafter are alone of benefit to animals when in a diseased state, it is my intention to briefly enumerate those maladies to which the ox is liable, the most important of which certainly is inflammation, for with it some diseases commence and others terminate; and, moreover, this pathological state has not until very recently been properly understood, and consequently has been improperly treated.

John Hunter wrote on diseases of the fluids, and drew particular attention to blood diseases, but never accounted for the causes of the blood's coagulation. This was left for Dr. Richardson, who asserted that blood remained fluid both inside and outside the body, so long as it was in association with the volatile alkali ammonia, and that immediately on its escape the blood coagulated. 'This theory, it was contended by Professor Sir Joseph Lister, did not fully account for the cause of the blood's coagulation, but that blood remained fluid so long as it was in contact with living tissue, and coagulated immediately that tissue became devitalized, or died.

In order that I may clearly explain my views as to the causes which bring about inflammation, it will be necessary for me to explain why inflammation cannot take place unless the nerves be first involved in diseased action, and the experiments which led to the elncidation of the true nature of inflammation.

Professor Sir Joseph Lister, whose lectures on pathological anatomy and practical surgery I had the good fortune to attend, performed the following experiments:- He applied, previous to slaughter, two bandages firmly around and above the knee joints of a sheep. The animal having been killed, both legs were amputated just above the bandages, when the skin was carefully dissected up from the leg, taken off the right side, viz. A, in order to expose the metacarpal or leg vein. This being done, the external coat of the vein was 
painted with liquor ammoniæ, and the skin was again replaced, and this leg, together with $B$ (the one taken from the left side), was laid aside until the following day. After a lapse of twenty-four hours the legs were reproduced, and в was now placed on the table, and the leg rein was exposed, which, be it remembered, had undergone no treatment with ammonia, or otherwise. The vein was now opened, and from it the blood in a perfect state of fluidity was poured into a plate. The coats of the bloodvessel whence this fluid was obtained had not been killed or devitalized by the application of caustics, blisters, or any other compound, calculated to destroy the integrity of or paralyse tissue; but with the $\operatorname{leg} \mathrm{A}$ the case was different. This had been dressed with ammonia. By it the coats of the bloodvessel had been paralysed, and therefore the blood within had coagulated, because it was in contact with devitalized tissue. A was opened, and from it a thin threar of coagulated blood was obtained.

A small piece of mustard applied to the web of a frog's foot causes the coagulation of blood, not only underneath, but around the mustard. A burn, intense cold, the persistent application of pressure to parts, as caused by the pressure of a hat against the forehead, causes coagulation of blood, because they temporarily destroy the vitality of the part by removing nervous influence from it. Further experiments and microscopical investigation have proved how the nerves, primarily affected, involve surrounding tissue in pathological results; how by irritating the spinal chord of a frog temporary congestion will take place over the body generally, markedly so in the web, which is easily noticed by the aid of the microscope. From this and other experiments, too complicated to be amusing to any save those engaged in physiological research, we learn how beautifully nature works both to protect animals from disease, and to set up curative processes when it exists.

The blood-the vital Huid-is from the moment of birth to the day of death continually and rapidly passing through the bloodvessels, and by this means supplying the various organs of the body with nutrition. Let the blood for a moment carry in its current deleterious or poisonous compounds, and immediately an impression is made upon the nervous system, which sometimes involves the brain also in diseases. Inject pus (bad matter) into the blood, and abscesses will ultimately make their appearance in various parts of the body. Administer to an ox through the medium of his mouth, or inject into his veins, white hellebore, and the symptoms of vomiting will be produced. To a person unacquainted with physiological inquiry the above may appear strange, but not so when we consider the beautiful provision nature has made to purify the blood. First, by supplying a chamber (the lungs) in which to receive a purifying gas wherein chemical decomposition of a very important nature may be carried on; these important functions being that a certain or fixed amount of oxygen shall be conveyed during each inspiration to the lungs, in order to keep up animal heat, decarbonize the blood, and thercby sustain life, and that carbonic acid during expira- tion shall be expelled from the lungs It will now be readily understood that if oxygen deficient in amount be inspired, an unnatural state of things will be produced; and further, that if carbonic acid gas sufficient in amount be not expired; a certain amount of poisonous gas must be thrown back on the system, and as a consequence the blood will become too strongly impregnated with carbon, and the nervous system will suffer. But should disease occur to the lungs-should certain tubes become blocked up, or should the bloodvessels therein be implicated in disease-the due amount of oxygen, owing in the latter case to mechanical obstruction, cannot be inspired; and therefore oxygen is not present in the lungs in sufficient quantity to unite with the carbon existing in the blood to form carbonic acid, and the consequence is, the circulating arterial blood contains carbon in excess, and the brain becomes affected, owing to the fact that a too highly carbonized blood is determined to that organ. In the next place, it will be my humble endeavour to explain how nerves, being paralysed or involved in diseased action, produce a baneful effect on parts :-

Firstly, mechanical injury produces local inflammation; scarcely an individual lives who has not noticed around the edges of a wound, caused by the cut of a penknife, an inflammatory blush. This state is brought about by mechanical injury to the nerves of the part, when by direct impression their integrity is lost, their action impaired, and so they cease to exert their all-necessary influence upon the coats of adjacent bloodvessels, and the consequence is that local inflammation is manifested.

Secondly, the mechanical application of pressure causes congestion. The long-continued and repeated pressure of the saddle or collar impairs nervous power, and creates inflammation, noticed in the sore neck and galled back of colts during the period of breaking. In these cases nature often effects a cure by hardening or thickening the cuticle or outer skin. By long-continued exertion on hard roads inflammation of the feet is brought about, noticed in Laminitis.

Thirdly, mechanical impressions cause inflammation. The persistent application of a piece of ice to a part interferes with nervous action, and intense congestion supervenes, observed in men suffering from frost-bitten feet. Great heat, blisters, caustics, \&c., all bring about local inflammation-i.e., cause coagulation of blood in the parts over which they have been applied.

Fourthly, external influences calculated to devitalize living tissue produce inflammation by involving the nerves in pathological states. How many horsemen during a run with hounds have been compelled to pull up, in order, as they call it, to save their horse from suffocation. When the rider alights he observes the following symptoms:-The forelegs out, the nostrils dilated, and he hears a deep, stertorous, and laboured breathing. 'The animal at this time is suffering with congestion of the lungs, caused by his being galloped at a racing pace, during which period the lungs have been conpelled to dilate and collapse with unusual rapidity; and thus 
by long-continued and excessive physical exertion the nerves become devitalized, the lung tissue weakened by the withdrawal of nervous force, and the blood, being in contact with injured tissue, begins to coagulate, and congestion of the lungs results. The application in medical practice and surgery of the law suggested in the above remarks on the theory as to the cause of inflammation in the treatment of diseases, and particularly so in cases of fever; the adoption of the rules which this teaching necessarily involves-has rendered medicine rational, and has been very conducive to successful treatment, by causing practitioners to discard the depletive system of purging and blood-letting, and in its place to adopt that of supporting with stimulants animals affected with maladies once considered to be the result of too exalted general or local systemic force, but now proven to be of a depletive nature: and for this reason an article has been devoted to the consideration of the theory of inflammation.

\section{AN ÆMIA AND PLETHORA.}

That cattle, and especially those exhibited at shows, are over-fattened, has for years past been recogmized as a fact by physiologists, who have equally described fat men and fat oxen to be subjects of discase. That such is the case I will attempt to prove. As anæmia, or the bloodless state, is caused by imperfect assimilation, or by an insufficient supply of blood to the various organs of the animal body, so, on the other hand, plethora or redundancy of blood is produced by an excess or an undue appropriation of that fluid. In the latter case, the bloodvessels become distended, and the heart labours heavily under inordinate pressure. But although such is the case, yet the plethoric subject considers himself, and is said to be, in robust health: for he eats and drinks well and sleeps soundly, proving that the functions of digestion and assimilation are actively performed. But unfortunately this very excess of health is constantly, although insidiously, working onwards to his destruction; for as the blood-forming process is always in advance of the assimilative, does it not naturally follow that if too much blood is supplied to the organism, that such excess must sooner or later mechanically break through its barriers by rupturing some important organ?

Plethora nearly always places the subject of it in dangerous case; in which state he remains until bleeding at the nose or some unimportant hæmorrhage relieves the system from the high pressure imposed on it, or some ailment, such as gout or bilious attack, \&c., when the remedial measures demanded necessitate the giving up of indulgences, and insist on a course of living calculated to reduce the system generally, and primarily the supply of blood. But often no warning as above detailed is given; for apoplexy, structural disease of the heart, or rupture of some organ, as the liver or important bloodvessel, cause death; instances illustrative of which have lately occurred among fattening cattle in a malady known as splenic apoplexy, where oxen, after six or eight weeks' stall-feeding, have become the snbjects of plethora, and as a result, of ruptured spleen. Usually, the plethoric state is followed by that of obesity (the end the stock feeder has in view); but sometimes, as with the disease in question, the system refuses to deposit the superfluous material, fat, yet cannot prevent the redundancy of blood, and consequently rupture of the spleen results, and death supervenes. The cause of this affection has been investigated by Dr. Crisp and several eminent veterinarians, who consider that splenic apoplexy is the result of plethora brought on by overfeeding, "whether it be in the stalls or from too luxuriant pastures;" and in answer to the question, "Is splenic apoplexy of malarious origin?" we read, "It has been observed in malarious districts, but then only among plethoric cattle, whereas lean ones have escaped." This last sentence is significant; for in what position, or under the operation of whatever baneful influences oxen may be placed, it has been proved beyond doubt that the plethoric have contracted the disease, whereas the "lean ones have escaped."

Nature, ever economical in her means and wise in her ends, is always attempting to avert fatal affections, and in acting for the safety of the plethoric, brings about, as before stated, minor diseases, which necessitate self-discipline, or selfremedying hæmorrhages, or sometimes causes fat to be stored up in the system, as a means by which the excess of blood may be diverted from the over-distended vital organs to the nourishment of this superfluous material. Lucky it is; for Dives by that indigestion is occasionally warned to seek medical advice, to swallow his antibilious mixture and dinner pill: but the dumb ox cannot inform his owner of these minor ailments, although doubtless they often occur, until devastating inroads have been made upon the system, until disease occurs easily recognizable by a ploughboy; consequently the plethoric man, to a certain extent, owing to his gift of communication by speech, has at hand the means by which to avert fatal results, which are denied to over-fed cattle. Obesity in man reqnires, in many instances, years for its production, but in the lower animals it is obtained rapidly; and why? Because the former takes exercise and occasionally medicine, which tends to check, for a time at any rate, the progress from plethora to fatness; whereas the latter is fed upon aliment highly charged with those constituents calculated to produce fat, and, moreover, is placed in a yard or tied up in a stall, where no exercise is allowed from the time he enters until the day on which he is removed to the slaughter-house, and even then is constantly conveyed to the shed in a van. But whether the formation of fat be rapidly or slowly developed, the same evil occurs to both. The man groans, complains, and if he attend to medical advice is relieved; and, on the other hand, the ox endures his position without a murmur, and, as his owner wills it, goes on from bad to worse, until the pole-axe terminates his sufferings.

From the foregoing, therefore, it will be readily understood that if we have the means at our disposal for the prodnction of fat, we, on the other hand, must necessarily know how to prevent its accumulation, by denying ourselves that food 
which is capable of forming it. The first remedy usually presenting itself is partial starvation; but such a system, although it may effect the desired end, will, as experience proves, in nine cases out of ten injuriously affect the wellbeing of those adopting it, and consequently must not be resorted to, especially by those who have previously lived generously. But in the further investigation of this matter, it has been discovered, and practically proved, that certain foods are fertile in fat-generating products, whereas in others they only sparingly exist; therefore common sense suggests the propriety of discarding the former from our bill of fare, and in their place substituting the latter. To prove this assertion that certain foods are fertile in fat-generating products, it will be necessary to consider, first, of what compounds fat consists; and afterwards, the composition of those foods which cause its development.

Fat is a chemical mixture in variable proportions of three componnds-viz., stearine, oleine, and margarine, in association with a sweet principle named glycerine-and when resolved into its ultimate elements contains in 100 parts, according to Cherreul-

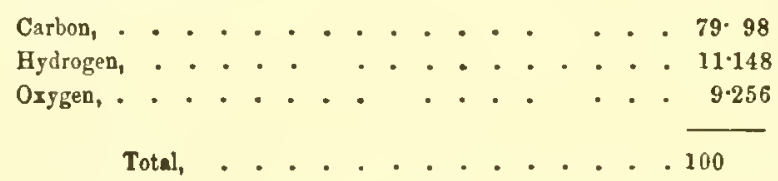

It therefore will be observed that fat persons are themselves in part hydrocarbons; when it follows, as a matter of course, that if such people deny their systems hydrocarbonaceous foods, that obesity will vanish: in the same manner as when fuel is added to the fire it burns, but when the supply is stopped it goes out; so if fat-producing materials be given to the body it accumulates therein, but if such diet be discontinued, then no more collection of fat can possibly take place.

The food that contains hydrocarbonaceous fat-producing th compounds in large quantities, are those usually drank and eaten by us daily - viz., potatoes, bread, pastry, butter, sugar, alcoholic fluids, such as beer, wines, and spirits. Now all these are made up with starch, sugar, oil, or alcohol, or both, and are consequently fat-generators: for instance, starch and sugar enter into the composition of potatoes, bread, and pastry; and in butter glycerine and oil are found; and in beer, wine, and spirits sugar and alcohol, one or the other, are always present. Starch and sugar consist of the same chemical elements, and nearly the same equivalent numbers: for instance, the formula of starch is carbon 12, hydrogen 10, oxygen 10 ; that of sugar, carbon 12 , hydrogen 11, oxygen 11 ; from which it appears that the addition of one atom of hydrogen and oxygen to starch changes it into sugar, and during fermentation (the process of distillation) starch becomes dextrine, dextrine sugar, and lastly, sugar is converted into alcohol; and if this process be carried still further, alcohol degenerates into acetic acid (vinegar); but in the obtainment of alcohol this last operation is of course avoided.
Similarly, as fermentation can be conducted without, so it can within, the living organism under the guidance of certain vital functions; but this internal distillation, if it may be so called, during its operation is hidden from the eyes of men, and is involved somewhat in mystery, and therefore the varied changes effected and how they are brought about are left for physiologists to discover by experiment; but although such is the case, still it is a well established fact that starch, when within the system, during the functions of digestion, \&c., becomes sugar, and is finally deposited throughout the tissues of the body in the form of fat. That sugar existed naturally in the liver, and was more abundant during digestion, was long since proved by Magendie; but it remained for Bernard and Hensen to discover the existence of a sugar-producing substance in that organ, which, under the influence of saliva, blood, \&c., possessed the power of converting starch and similar compounds into sugar; and from the experiments of Bernard and Lelımann on dietary, we learn that this sugarproducing material is obtained from nitrogenous food, such as meat, eggs, \&c., but is greatly increased in amount by a non-nitrogenous diet, such as potatoes, beer, bread, \&c.; which amount of increase Dr. Parry estimated at nearly doubleviz., with the former, 6.97 per cent., with the latter, 14.5 . Bernard, moreover, considers this transformation of starch into sugar the result of fermentation; and, consequently, views this sugar-generating material as a disease.

\section{FELLON, EPIZOOTIC COLD, OR INFLUENZA.}

The observations most worthy of notice in all diseases relate to their causes. Cold generally proceeds from the sudden change of the atmosphere-from a warm to a cold, but more commonly from a cold to a warm medium. Long prevailing north or north-easterly winds at the spring time often produce dangerous and sometimes fatal symptoms, by injuriously affecting the whole animal frame, by shutting up the pores of the skin, and in a great measure putting a stop to perspiration. In cases of this kind the hide becomes thickened, the hair becomes pen-feathered, and stands the wrong way on the animal's back. Heifers in calf, and cows, are more subject to this malady than other stock, owing to their being more tenderly managed, by being housed during the winter.

Influenza will often in a few days reduce such animals from the greatest state of perfection to mere skeletons. In such cases the secretions generally are deranged, associated with constipation, and sometimes foetid diarrhœe. Local congestions may also set in and involve the stomach, intestines, kidneys, bladder, and very frequently, symptomatically, the brain. Hence arise diseases of different descriptions, which will be discussed under their proper heads in different parts of this treatise. The first symptoms that are produced by taking cold are heaviness of the head, tardiness in motion, suspension of milky secretion, weak pulse, with weeping eyes, and if the hand be pressed in the region of the spine, the animal will immediately crouch on the application of sach 
pressure. This state of disease was called in Clater's time "Chine fellon," and was understood by that name in the country. At other times, when the joints became more particularly affected, the disease was denominated "Joint-fellon." Cows are most subject to this latter complaint, especially a short time before calving. It is attended with considerable pain and weakness; if the animal lie down she is seldom able to rise without some assistance, until after calving. In other respects they appear well, and eat their food as usual. In order to cure colds, the first attempt must be to attack the cause, by giving the patient a warm cordial drink, which, acting as a stimulant on the stomach and intestines, will give fresh motion to these parts, and will thus enable nature to resume her former functions. The following drinks may be given with benefit-assafoetida and carbonate of ammonia, of each one drachm, and half an ounce of nitrate of potash. Give this in a pint of warm ale. In the course of two or three hours, afte- administering the above drink, let the animal liav' a good mash, made of scalded bran or ground malt In cases of cold during the summer the above drink may be given to cattle while they pasture; and where it can be made convenient let them fast two hours afterwards, and then graze as usual. It is also necessary to examine the sick animals every day, to watch while they both dung and stale, and see whether the body be of a healthy heat, and the nose or muzzle of a natural breeze. If these be regular there is not much danger. If, however, feverish symptoms should appear, and the animals should become costive, give the following aperient drink:-Epsom salts, half a pound; Ginger in powder, one ounce. Put the ingredients into a pitcher, and pour upon them two pints of thin and hot oatmeal gruel; when new-milk warm, give the whole for one dose. If either of these drinks fails in operation, after twenty-four hours let one-half of the above be repeated. By the above simple means a fever may be prevented, and the patient speedily restored. After the effects of the aperient draught have passed away, the cordial drink may be repeated daily, until the unfavourable symptoms have disappeared. In all cases of the above, and if occurring in the winter, the patient should always be placed in a warm shed, where good ventilation is secured. This, together with a warm cloth thrown over the loins, and plenty of clean litter, will greatly assist nature in her attempts to cure.

\section{PNEUMONIA, OR INFLAMMATION OF THE LUNGS.}

Pneumonic diseases are produced by a variety of causes:First, by the powerful effects of the elements upon the animal frame-by dry, harsh, and north-easterly winds, which, in shutting up the pores of the skin, check the transpiration of it, the due performance of which is so essential to the life and health of the animal. Secondly, it has been brought on, in the ox, after drinking cold water when overheated; or it may result from too severe labour at plough or elsewhere. In such cases the system becomes overtaxed, when the nervous system refuses to send its all-important influence to the lungs, and inflammation of the lungs results. Thirdly, at other times it has attacked those which have been turned out into fresh pastures, when their stomach has been overcharged with herbage. Here, again, the digestive organs have been overworked-liave been asked to assimilate food beyond their power-which has resulted in the withdrawal of nervous force from the stomachs and lungs, thus causing inflammation of them, which is manifested by difficulty of breathing, attended with a troublesome cough and hoosing. These symptoms indicate the lungs to be considerably affected. While the discharge from the nose and mouth continues, the disease does not make such rapid progress as when it is dry. Symptoms of an inflammatory character taking place are discovered by the body becoming alternately hot and cold; the extremities for the most part cold, especially the ears and horns. Clater states-" If the beast be in low condition, weak, and much debilitated, bleeding is seldom necessary; but if, on the contrary, the animal be in high condition, the fever begins to increase, and the body feels of a hot, dry, and parching heat, and the breath the samefurther, if the white of the eyes appears to be much inflamed and tinged with a yellow hue, bleeding will become highly necessary in this stage of the disease. From two to four quarts of blood may be taken away, and a small guantity may be taken every day, or every other day, according to the violence of the symptoms." In prescribing the treatment of blood-letting, Clater has evidently considered that in the disease under notice exalted action has to be counteracted. Now, it will be readily seen, from the symptoms above detailed, that the opposite-namely, the devitalized or depressed state-demands our remedial measures; and if so, certainly the depletive treatment must be banished in toto a mensa et toro, and in its place we must attempt to rebuild the injured fabric, and this must be accomplished with the exhibition of stimulants, an perhaps afterwards by giving tonics.

Sometimes thrs disease puts on a flattering appearauce, the fever and heat appear small and scarcely perceptible; at other times it seems rapid in its progress. The cause of this disease appears in a great measure to proceed from a deficiency in the animal's nature of performing its regular course in carrying on a due circulation through all the vessels. The redundant state of the blood in the lungs becomes surcharged, the liver ceases to secrete bile, which is not poured into the intestines, but finds its way into other tissues, and into the blood. Hence is produced jaundice, which is recognized by yellowness of the eyes and on different parts of the body.

It is well known that in 1812 and subsequently the system of blood-letting was resorted to in almost every case of disease; even those of debility were compelled to lose quarts of blood, and that, too, repeated at intervals of three or four days. Since such times physicians, both human and veterinary, in most cases of disease have discarded the use of the lancet, and in its place have substituted more rational-treatment. In cases of congestion of the lungs, if the breathing be 
laborious and the pulse high, it is good practice to immediately administer, in a quart of warm ale--

Carbonate of Ammonia, . . . . . . . 2 drachms.

Etber, . . . . . . . . . . . 1 drachm.

And this must be administered every two hours, until the symptoms have somewhat abated in intensity. The sides of the chest should also be clipped, and over it a mustard plaster can be applied, confined to this region by a blanket. As the bad symptoms subside, it will then be advisable to administer half an ounce of nitre in solution, to be followed about three hours afterwards with three drachms of powdered aloes in a pint of water. This latter dose acts very beneficially after the stimulating, in correcting and in rousing to action the animal secretions. The above treatment I have found generally successful, and very often good nursing, without more medicine, effects cure. Sometimes, however, the patient evinces signs of weakness and loss of appetite, when daily drachm doses of the disulphate of quinine usually succeed in restoring the animal to health.

\section{THE YELLOWS, OR JAUNDICE.}

This malady is frequently a sequent to the former, in which the secretions of the body are vitiated, and in this case are diverted from performing their particular functions. This is so with the bile. In jaundice this fluid is diffused throughont the whole body, and is favoured by everything that obstructs its passage into the first intestine or duodenum. This disease is first observable in the white of the eyes, which appears of a yellow hue, and as it increases the whole skin becomes impregnated with the same yellow tint; the ears, tail, eyes, and mouth are the parts where it is most conspicuous to the sight. In every stage of the disease the animals are attended with weakness and great lack of nervous force, a listlessness to move, and want of appetite. When in the pasture, they wander about by themselves by the side of hedges or fences in a dejected manner. These appearances sufficiently indicate the malady. Milch cows are most subject to it in the spring and fall of the year, although they are liable to it during other seasons. The most dangerous state is when a scirrhous liver is the cause; little hope can then be entertained of a permanent cure. The fluctuating state of the weather has a powerful effect upon the animal frame in retarding or promoting the cure; care should also be taken to house them during unfavourable weather. As soon as this disease makes its appearance administer-

$$
\begin{aligned}
& \text { Barbadoes aloes, in powder, } \quad \text {. . } 6 \text { dracbms, } \\
& \text { Castor oil, . . . . . . . . } 2 \text { ounces; }
\end{aligned}
$$

and six hours afterwards give, in a pint of warm beer, two drachms of carbonate of ammonia; let this latter drink be given thrice daily. Should, however, the aloes, as above prescribed, fail to relieve the secretions, administer in a pint of gruel-

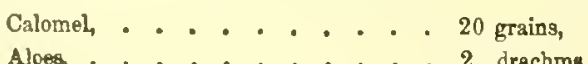

and repeat this dose every other day, not omitting, at the same time, to continue the draught containing the two drachms of carbonate of ammonia thrice daily. During this treatment the patient should be kept in a loose box; and, if possible, a Turkish bath, allowed twice weekly, would act as an adjuvant in securing recovery; as also food easy of digestion, such as bran mashes, boiled carrots, and cut fresh grass, or, if in winter, hay previously soaked in warm water. The patient should also have easy access to water impregnated with nitre, about two drachms of the latter to a bucketful of the former.

\section{PLEURO-PNEUMONIA.}

Pleuro-pneumonia (commonly called lung disease) is a malady, as its name suggests, involving in inflammation and its results the lungs and their tissue, and the membrane investing them. But although such is the case, yet the disease in question is a specific per se common to the bovine tribe, and differs (if we may so express ourselves) from pleuro-pneumonia, indicating merely inflammation of the pleura and lungs, by its assuming chronic and typhoid characters, and its tendency to exudation from, and to the ultimate consolidation of, the lung tissue. This affection for centuries has raged in Europe, but never made its appearance in Great Britain until 1841, where it has prevailed more or less ever since.

That it is of a highly contagious nature no one can deny, if he considers, first, that it never was known in this country until after foreign stock were imported; secondly, its being satisfactorily and clearly traced to cattle imported from the Continent; thirdly, its prevalence amongst stock replenished from open markets, where cattle, both foreign and British, healthy and diseased, congregate; and fourthly, its comparative absence from those farms and localities which are isolated, and upon which stock are bred and sold, but rarely, if ever, are bought in. These reasons, if circumstantial evidence avails anything, prove that pleuro-pneumonia spreads through the medium of contagion, and such being the case, we may conclude that a remedy is within our grasp for its suppression and its ultimate eradication. But more of this hereafter.

Symptoms.-The disease progresses rapidly, and makes, generally, very injurious ravages long before the herdsman notices "that anything is amiss;" and if a milch cow, his attention is first drawn to the fact that the secretion of milk is diminished, and on examination he discovers that the udder is tender and flaccid. These indications of disease are sufficient to cause him to investigate matters still further, when he discovers that the function of rumination is irregular or suspended, that the extremities are sometimes hot and sometimes cold, that the breathing is laboured, and the pulse beats rapidly. A veterinary surgeon is called in, who immediately diagnoses in his patient the disease under notice; and on examination he discovers the right lung, rarely the left, to be involved in disease, which auscultation makes manifest by a crackling sound called a crepitus, 
which becomes louder as the disease progresses, and ultimately, when the lung consolidates, becomes inaudible. At this period the breathing is laboured; the animal constantly grunts and coughs; sometimes the month is dry, sometimes a copious discharge is emitted from it (the latter being usually the case in the London dairy sheds); the body wastes away; constipation, and sometimes the opposite, viz., diarrhoean sets in, and death terminates the secne.

Treatmest.-Separation from the healthy must be immediately obtained by placing the patient in a well-ventilated and perfectly-drained loose box or clean shed, either having been well littered down with clean straw, over which chloride of lime should be carefully sprinkled. Having by this means a necessitated cleanly lodging, and an atmosphere productive of health, our treatment, as follows, can be commenced under somewhat favourable circumstances:-During the early stage of this malady it has been our practice to administer a mild saline purgative, combined with nitre, carbonate of ammonia, in order to cleanse the system and set up, if possible, healthy action. The murmur heard in the lung (usually only one lung is involved in disease) is a clear metallic noise, called a crepitus, which, to a practised ear, indicates to how great an extent the lung tissue and bronchial tubes are affected; when it is good treatment to clip the hair closely off the sides of the chest, and apply blistering ointment, made up with biniodide of mercury and turpentine; this application must be repeated thrice during the week, both in mild and severe cases, and after the effects of the purgatives have passed off, administer, twice daily, draclım-doses of the valerianate of iron, which we have given with great success. Arofessor Lessona, of Turin, advises the exhibition of daily draclım-doses of the disulphate of quinine in a quart decoction of anchona. 'The decoction is made with threc ounces of bark to a quart of water. Mr. Finlay Dunn recommends from twenty-five to thirty drops of the tincture of aconite three or four timcs daily; and all the various treatments advised both by British and foreign veterinarians differ merely in the selection of drugs, but not in the principle of treatment, which consists in the exhibition of stimulants and tonics, viz., carbonate of ammonia, liquor ammoniæ acetatis, sulphuric, nitric, and hydrochloric acids, sulphate and todine of iron, \&c.; and many other compounds could be aamed, differing only very slightly fiom one another in the effect produced upon the system. It therefore follows that thcse medicinal agents should be placed under the control, and in the hands of qualified veterinarians; and we are sure that the agriculturist and stock-owner will always consult their interests best by employing, not the farrier with his specific, but the-veterinary physician. Another very important curative adjunct, and which has been highly extolled by eminent writers, is the careful use of the Turkish bath, which produces a very beneficial effect upon the grand emunctory, the skin, by causing profuse perspiration; through the medium of which much of the poison existing in the blood is carried off. We have seen several good effects result upon the use of the batl, but have not ourselves been able to test it as a remedial measure in treating pleuro-pneumonia; still we fcel sure that its action is calculated to be of great benefit. During the progress of the disease and the period of treatment we have often alternately severe constipation, and diarrhoea, and loss of appetite, to contend with, and sometimes by attempting to remedy one evil, we, by so doing, produce the other; therefore, great care must be exercised in avoiding this Scylla and Charybdis. Never give hard or dry food to pneumonic cattle, but moist mashes, and all provender easy of digestion, and of that only a little, because the power of secretion and assimilation is very feeble; and if your patients eat too freely dangerous indigestion is nearly certain to supervene.

The premonitory sign of returning health is the appetite, together with the function of rumination, being restored, but even now do not feed too lavishly; still give mash food, to which add a little treacle and oil-cake, and also attempt to remove the products of inflammation by administering three or four ounces of nitre and common salt, and one drachm carbonate of ammonia; the two former act upon excretory organs, and the latter stimulates the organs to increased action. By this treatment, together with early separation of the diseased to a well-ventilated and healthy place at some distance, even on a farm, the ravages of pleuro-pneumonia can be stayed, health can be restored, and, in many instances, the disease be cured.

Post Mortem Appearances. - On remoring the lungs from the thorax it will be seen that one or both, as the case may be, have been involved in severe inflammation and its results, which the physical fact of the lungs being heavy, and, if placed in water, of their sinking to the bottom instead of floating on the top, as is the case with healthy ones, clearly manifests. On making an incision the lung tissue presents a marbled and consolidated appearance. intersected with patches of hepatisation, sometimes associated with ulceration and abscess, and extensive adhesions between the pleura appertaining to the sides of the chest, and that proper to the lungs themselves, together with copions effusion, is the constant result of this affection

Preventive Measures.-Dr. Williams, of Hasselt, in 1850, proposed the inoculation of the virus of pleuro-pneumonia, in order to produce a mild form of the disease, and by this means prevent its occurring naturally with all its virulence.

The operation is performed as follows:-A portion of a diseased pneumonic lung is selected, into which the point of a lancet or large needle is plunged in such a manner as to remove with it the lung-consolidating material, and this is immediately plunged into the end of the tail; when the animal operated upon is said to be inoculated. The operation should always be performed with lymph that is recently obtained, and that is not putrid: if the latter be the case, extensive inflammation of the tail and dock supervenes, which often involves the dock, rectnm, and abdomen in induration and suppuration, terminating nearly always in the loss of 
the tail, and oftentimes in death. But sometimes, even with all care, the same results occur as when putrid matter is used. When the question occurs, "Is inoculation useful as a preventive of pleuro-pneumonia? we most distinctly aver that it is useless; and why? because, in the first place, a milder form of the disease is not produced; secondly, no external symptoms nor internal sign follows, which would lead us to believe that a disease in the slightest degree similar to the one in question was produced-and consequently the only benefit that can (which we deny) possibly result from inoculation is of a derivative nature, or, in other words, an injury to the tail might have the power of detracting from the lungs a specific disease of them. The bulk of scientific evidence, and of our practical experience, leads us to the conclusion that the operation of inoculation is ntterly useless and very cruel. What were the results? Sheds full of cows with only two inches of tails, and in answer to an inquiry relative to the stumps, the owner tells you he has inoculated them, and the tails "lave come off." To what suffering must these poor creatures have been subjected, and most uselessly! for pleuro-pneumonia is a malady affecting the lungs, but inoculation only involves intense inflammation of the tail and abdomen, and does not, in the slightest degree, produce lnng disease, not even a mild form of it: consequently, if a milder form be not produced, but only inflammation of a distinct and distant organ, how is it possible, therefore, that this operation can insure an immunity from pleuro-pneumonia? We agree fully with Finlay Dunn, who writes, "Inoculation, where fairly tried, is found quite ineffectual." We shall recur to the matter on a future occasion, but shall leave it for the present by repeating that in inoculating for pleuro-pneumonia, a milder form of the disease is not produced, and, moreover, that the pneumonic virus possesses no protective power against this malady.

.ome years ago, "Old Scratch," in a letter to the "Field," insisted upon the necessity of bi-weekl ${ }_{j}$ inspection of stock at which each animal was to be carefully anscultated, when he averred that any deviation from health would be discovered; and particularly so in the case of pleuro-pneumonia, which eren in apparently healthy cattle conld be detected by the indicative murmur or crepitus occurring to the lungs in this malady even at its commencement; which, if taken early, was amenable to treatment, but which, if allowed to progress, proved usually fatal to the subject of it. This system has been adopted in many instances, and has met with success; and even allowing that its preventive influence cannot always be relied upon, yet the frequent inspection of stock by experienced persons must lead to beneficial results, by their being able to detect disease not perceived by the mninitiated, and by adopting treatment and suggesting plans which, if carried into operation, are calculated in some instances to cure, and in others to prevent disease. The same remarks made about the propagation and extension of epizootic aphtha, relative to the travelling of cattle in railway trucks, and their association at fairs, is equally applicable to lung disease. One pneumonic ox once visiting a fair or travelling in a car, becomes in these positions a centre for the spread of contagion; consequently great care should be taken, or power given, to qualified veterinarians to prevent diseased animals from entering trucks, fairs, and markets.

We feel assured that as years pass on the services of the veterinarian will be sought to prevent, more often than to cure, cattle maladies, and then upon a large scale in prescribing hygienic measures for large flocks and herds, when the farmer will hail the veterinarian as his friend in having suggested plans which, he having carried into effect, have warded off disease; and he will then own that the agricultural and veterinary sciences are inseparable. If the inspective system sends from the fair, or elsewhere, the cattle of $\mathbf{A}$, it, on the other hand, removes contagion and consequently disease from B's stock: therefore in legislating for this important subject, the immediate benefit of individuals must not be taken into consideration; but the ultimate service to be rendered to the nation, and to the agriculturists and stock-owners at large, must be the grand principle upon, and from which, veterinary cattle inspectors must take the initiative.

The Turkish bath, not only as a medicinal agent, but also as a preventive of disease, deserves consideration; and we cannot help thinking the hot-air chamber is almost as necessary an adjunct to the extensive stock-keeper as to the veterinary surgeon, and for the simple reason that in it we have an agent which exerts a more powerful influence than any derivative, ox-purge, or blister, without lowering vital power; for it carries off, or at any rate diminishes, the amount of any virus that may circulate in the blood, and by this means cleanses the system, and renders it better able to throw off disease, and to resist the attack of it

\section{FOOT AND MOUTH DISEASE,}

named by Professor Simonds Eczema epizootica, and by Professor Gamgee, Aphtha epizootica, is an affection of a highly contagious nature, and consists of a vesicular eruption on the tongue, moutl, teats, and between the digits of the feet, which if neglected runs on to suppuration and ulceration that, if occurring on the feet, causes sloughing of the horn. It is, moreover, communicable from one animal to another of a different species, as numerous experiments have proved. For instance, it has been communicated to the pig through the medium of food previously insalivated in the trough of an aphthous ox. Calves and pigs have died after drinking milk drawn from affected cows. Hertwig, Villain, and Maun, for the sake of experiment, drank the warm milk from an aphthous cow, and produced upon themselves an eruption similar to that of epizootic aphtha. This fact earnestly demands our consideration, as, at the present moment, hundreds of persons probably are daily consuming milk taken from aphthous cattle, which is calculated, as above 
shown, to produce disease, and, under certain circumstances, capable of operating fatally. Fortunately, from the knowledge we possess of this disease, relative to its coutagion, we have the means within our grasp of cutting short its further progress. For instance, the disease must be communicated from one ox to another until it has involved so many in disease as to become epizootic. Animals, if placed in sheds in which aphthous cattle have been previously located, are nearly sure to become affected; and for this reason we find many animals conveying disease from the railway trucks in which infected ones have been placed; or it may occur from the intermixture of healthy with diseased stock in trucks during one and the same journey, and often afterwards contact at fairs or on farms leads to its still further propagation. This disease, which runs its course in about nine or ten days, usually easily yields to treatment, which consists in washing the mouth twice daily with a weak solution of sulphuric acid an $\$ water, and the affected feet with carbolic acid and water. The lotion which we are in the habit of prescribing for the diseased teats is composed of nitre and water. Sometimes the vesicles are broken down during the operation of milking, and sores are created, in which case it is good treatment to keep the sores clean, and to dress, after every milking, with glycerine. Mild aperients and diuretics should be given every other day during the progress of this malady. During the last few years this disease has existed throughout Great Britain, and in some instances has caused considerable loss to stock-owners. 1 have above asserted that young pigs have died after drinking warm milk obtained from aphthous cows. Such unfortunately has occurred; though during a recent outbreak Professor B- gave warm milk taken from cows, the subjects of foot and mouth disease, to young pigs, and failed to produce in them any symptom of this malady; but at the same time such has happened, and therefore may happen again. Pigs have undoubtedly been affected with the complaint, and death has resulted. It is consequently wise " to be ou the safe side," which warns us to make away with milk taken from cows when suffering with epizootic aplitha.

\section{RED-WATER AND BLACK-WATER.}

This disease is common among neat cattle of every description, but more particularly attacks milch cows than any other kind. Red water and black seldom occur separately. The former, doubtless, is the original disease, and the latter is occasioned by the retention of part of the blood about the orifice of the leaky vessel, which coagulates, and in a short time the beast stales, and constitutes what is termed blackwater. The origin of this disease is ascribed by different authors to different causes: for instance, the taking of cold when turned into low pasture-grounds at the spring of the year. Others attribute it to change of pasture or scarcity of water in a long dry summer, and some to the changeable atate of the atmosphere. In some animals it appears to be more hereditary than in others. "Clater" has known some animals to have been attacked with this complaint once or twice for two or three successive years, and at last literally bled to death, defying all the powers of medicine and change of diet. It will be difficult to point out the exact seat of this disease, but the following observations will in some measure enable the pracutioncr to form his judgment in this respect:If red water proceed from external injury-such as a violent strain across the loins, in consequence of other beasts jumping on them, or from a severe blow on the part-our treatment will be of a local nature; but when this disease proceeds from other causes, as already mentioned, it produces a different effect. An inflammation takes place about the neck of the bladder, and produces the two different kinds above mentioned. When the change takes place from red to black water, the animal generally stales free from either for several timcs. In slight cases, where the blood is passed away with the urine, the beast does not appear to be much affected by it; if a cow, she holds less quantity of milk, and seems no worse. But when the blood passed away is considerable, and continues for a length of time, it reduces the quantity of milk, and likewise the animal, to a very low state. The chief symptom, therefore, of this affection is the admixture and consequent evacuation of certain constituents of the blood with the nrine. The cause of this blood disense is attributable to the defective state of the assimilative system, which indirectly exerts an injurious influence on the blood-forming process, produced by bad feeding, or more properly by feeding upon substances in which the elements of nutrition do no: sufficiently abound-such as coarse grass, watery turnips, and all roots that have grown upon cold, damp, and badly-drained lands; and, on the other hand, it is scarcely known upor farms where the lands are well drained, and where the stock are allowed to partake only sparingly of turnips. The symptoms usually evinced are loss of appetite, cessation of or irregular rumination, diarrhcea, followed by constipation, when bloody urine is evacuated. Treatment:-By all means avoid blood-letting, for in this malady support must be given to the patient, by administering, three or four times daily, carbonate of ammonia, one drachm; warm ale, one pint. If constipation be persistent, use warm-water clysters, and give a pint of linseed oil. Allow plenty of water, and let the patient have access to common salt. If diarrhœea sets in, and the urine be very abundant and black in colour, half a drachm of powdered opinm may be given daily. Ronts must be withheld, and gruel, mashes, and good hay given.

There is a totally different disease, known by the name of black-water, which is very clearly described by Professor John Gamgee, and which we transcribe-"It has been believed dne to the wild anemone by some, by others it has been ascribed to the poisonous influence of Lolium temulentum; but my experience proves that it constantly occurs on pastures in the immediate vicinity of woods, and where cows can partake of the astringent shoots of young trees, especially of the oak. The symptoms are very similar to simple red- 
water, but we sometimes find a discharge of blood by the bowels. There is constipation at first, but diarrhœe towards the latter stage-generally colicky pains and evident indication of intestinal irritation. There is great tenderness over the loins, the urine is deeply tinged with blood, the general disturbance is very considerable, particularly when diarrhœa, with hæmorrhage from the bowels, sets in. The secretion of milk emits a bad odour, and is scanty in quantity. Occasionally convulsions occur, and the animal dies, in three or four days to a fortnight, in a state of great prostration. Treatment:-Very similar to red-water, with more active recourse to purgatives. Camphor may be used as a stimulant when the prostration is great."

\section{¿NFLAMMATION OF THE BRAIN-PHRENITIS.}

This disease is one of the most distressing to which eattle are subject, and is most prevalent during the hot months in the summer season. It is sometimes idiopathic, or a primary disease, and at other times it is symptomatic. Phrenitis sometimes results as the sequent of other affections, particularly those of the stomachs. This malady is usually ushered in with a shivering fit, bounding pulse, laborious breatling, and listlessness. These symptoms are rapidly followed with a kind of madness; the animal appears in a very fierce state; the eyes are much inflamed and ready to start from their orbits; the beasts often fall suddenly down to rise again as rapidly, until nature becomes exhansted, when constant trembling of the muscles, with a dry harsh skin, a suppression of urine, and grinding of the teeth, give evidence of a fatal result. Phrenitis is sometimes occasioned by wounds or contusions on the head, that are attended with intense inflammation of the local ressels, which, if not speedily relieved, may terminate in mortification. The administration of a brisk cathartic, consisting of-

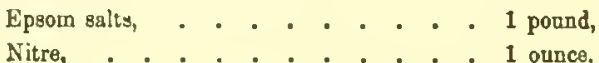

cold applications of ice to the head, and bleeding from the jugular vein, will in most cases reduce the intensity of the symptoms.

Sometimes, after the recovery of the patient from phrenitis, swellings take place upon the jaws and different parts of the head. In cases of this kind there is a difficulty in swallowing; as the inflammation increases the jaws become gradually closed. This state of disease is termed locked-jaw, the treatment of which will be discussed under that heading. Professor John Gamgee, in his book on "Dairy Stock," mentions a case of phrenitis in a cow, which resulted from the presence within the auditory meatus of a concrete mass of wax, which induced inflammation of the ear, communicating with the brain, and killing the animal with that affection.

\section{BLACK-LEG, QUARTER EVIL, OR BLACK-QUARTER.}

This disease is called by a great number of other names, but as they indicate the same disorder, it would be no advan- tage here to repeat them. Quarter evil does not appear to be either infectious or epizootic in its nature, and is almost wholly confined to young cattle from one to two years old, and chiefly affects such as are in the best condition; milch cows and lean cattle of all descriptions are seldom the subjects of this malady, and during the winter it is unknown. This disease, like many others, has received in some localities the name of murrain. Quarter evil is a blood disease common to young stock; it prevails both at the rise and fall of the seasons from over-feeding. At the former because the young cattle, who generally have been ill fed during the winter, are unable to resist the effects produced upon the powers of digestion and assimilation by the too luxuriant pasture that then springs up; and in the autumn because, when removed from scanty pastures to stall food, consisting of turnips and oilcake, \&c., plethora is produced, blood is formed too rapidly, the tissues instead of gaining strength lose power, the coats of the bloodvessels are rendered incapable of supporting the circulating blood within them, which in depending positions, at the legs and joints, exudes, swellings result, and paralysis and stupor supervene. So rapidly does this affection run its course to a fatal termination that many of a herd in blooming health at night may be found dead on the following morning. The symptoms manifested are usually dulness, failing strength, stupor, a quick and weak pulse, associated with extensive swellings of one or more parts of the body. These external signs are, of course, modified according to the extent of disease to which the patient is subjected.

It has been stated that too luxuriant food, whether it be obtained by the animal itself from a rich pasture, or exhibited to it when stall fed, is the fruitful source of this malady, by its producing plethora; but although such is the case, yet we must take into consideration the quality of the soil and food taken from it, and upon which the subject of quarter ill has been fed. It occurs, for instance, more frequently upon farms "where the land is undrained, the herbage coarse, rough, and innutritive, and has entirely disappeared from others where drainage, top dressing, and better cultivation has improved the quality of the pasture." These circumstances, therefore, which at first sight appear contradictory, remain to be accounted for; but in attempting to explain this seeming incompatibility, luckily physiology comes to our assistance by asserting that undue labour never can with impunity be inposed upon the digestive apparatus; for by so doing the function of digestion is but inadequately performed, the assimilative power is impaired, and, as a consequence, the blood-forming processes do not thoroughly pass under the operation of nature's laboratory; or the system as a result becomes devitalized. "Est modus in rebus;" nature cannot be compelled to overtask the animal organism; she can proceed thus far, but no farther, without necessitating the occurrence of baneful results. If the stomach is persistently overloaded with an excess of highly nutritive food, even then the functions become overtasked and some part of the organism gives way; but if animals are supplied 
with an innutritive and coarse grass, and allowed to feed at pleasure, then to the evil of overfecding is added that of overstuffing: for be it remembered, we may overfeed with a highly nutritious food, produce plethora, and afterwards black-quarter; and so we can by overstuffing our cattle with innutritious food, in which case such animals eat twice as much of the latter before they can obtain the elements of nutrition in abundance so great as to produce the plethoric state, the dominant cause of this malady. Moreover, in attaining this end, consider how much extra work has been imposed upon the digestive and assimilative powers; so great, indeed, as to devitalize the whole system, and with it the coats of the bloodvessels, to such an extent as to permit the escape of blood through them, forming externally soft diffused swellings, which crackle with the gas eliminated from the decomposing blood within them. It is, therefore, readily seen that this affection is attributable to a faulty dietary system, which overfeeds, and in so doing upsets the due balance between waste and supply, causing an excess or deficiency of those albuminous constituents and saline compounds all-necessary to the formation and elaboration of that healthy blood demanded to resupply waste and to develope corporeal size; but if these items be obtained with alimentary substances, as above considered, then, for a certainty, disease must occur. Such are the causes of this fatal blood disease. Therefore, to prevent it, we must abstain from placing our stock under the operation of circumstances which experience has taught us to be productive of it. For example, when taking animals up from grass to stall food, it is never wise to commence feeding largely at first upon roots, meal, \&c., but little by little to increase the amount from day to day, until the necessary maximum is obtained. It will be good treatment, also, to administer a dose of Epsom salts. A similar system can be brought into operation with stock that have been turned out to grass in the spring, by placing them for the first two or three weeks on pasture where the herbage is scanty, before putting them upon a fuller and richer one. The adoption of this plan alone will often prevent the occurrence of black-quarter.

Treatment.-In the early stage, before the swellings have appeared, and whilst the pulse is full, the abstraction of a little blood is advisable; at the same time administer half a pound of Epsom salts, and one ounce of nitre; feed upon a sloppy food, and by no means give any that is not easy of digestion. In the more advanced stages treatment is almost useless; the exhibition of a mild purgative and diuretic draught, to be followed with two-drachm doses of carbonate of al monia, twice daily, may act beneficially. Local relief can be afforded by lancing the swellings, and by this means evacuating the decomposing blood. But in these and all other similar diseases the cause should be treated, and not the effect, as the former prevents, whereas the latter constantly destroys. To a herd, among which some have been attacked with this malady, give nitre and rock salt in the food, and at all times allow pure and fresh water, and plenty of it; in short, adopt hygicnic measures, and consult common sense, for by so doing you will prevent disease, save your cattle, and perhaps fill your coffers.

\section{DIARRHEEA.}

This disease shows itself with frequent and copious stools, which, according to the appearances they present, often leads us to detect the cause. Its cause may arise from various circumstances - from the eating of young and luxuriant spring grass; by the presence in the intestines of acrid and indigestible food; by perverted secretions and imperfect quality of the gastric juice; by blood poisons, and from irritation of intestinal mucous membranes. The diarrhœea, when of long-standing, is always attended with danger; the frequent motion of the intestines to eject their contents quickly reduccs the animal to a very weak and debilitated state, attended with loss of appetite; in consequence of which the foundation of an incurable disease will be laid unless timely removed. It is supposed by some authors to be occasioned by severe effects of the north and north-easterly winds at the springtime. The time when cattle are most liable to be seized witl diarrhœa is in the months of A pril and May, especially if the season be wet and cold, grass plentiful, and of a sappy nature. The relaxed powers of the animal nature are not able to perform the office of digestion, as they are too apt to overload the stomach. Thus a large quantity of acid is formed in the stomach, and is conveyed from thence through the intestines, which produces slimy stools. Here nature, by her own effort, endeavours to check its progress by an effusion of bile, which function is to correct acidity and assist digestion. But in many cases it fails. Cows, after calving, are liable to take cold when exposed in wet situations in severe weather, which frequently causes this malady. The following are the unfavourable symptoms:-The animal loses her appetite; the dewlap hangs down and has a flabby appearance; her dung runs off with a putrid and offensive smell, and as it falls on the ground, rises in bubbles; the coat is staring. Cattle thus affected should be taken from grass and placed in a large cow-house or open yard, where they can be sheltered from the weather, and be kept on dry meat-such as hay, ground oats, and beans. A proper quantity of the above should be given three or four times daily; but if they are much reduced, and their appetite is quite gone, a stiff gruel made of the same should be horned into them three or four times daily. A strict attention to this method of diet will convey a sufficient quantity of nutriment to the animal, so as to enable it to undergo the operation of medicine. The cure of this affection must first be attempted by evacuating the stomach and intestines of those juices and unhealthy secretions which irritate, and in some instances destroy, the mucous membranes of these parts. This method may appear inconsistent to the judgment of some; but its good effect will soon be perceived if we consider that, unless the offending irritant be removed, the same effort to remove 
it-viz., diarrhœa-will remain. Administer in a pint of warm gruel-

Aloes, - . . . . . . . . - 4 drachma,
Castor oil, - . . . . . . . . . 4 onces,
Ginger, in powder, . . . . . . . balf an ounce.

About twelve hours after the administration of the above, the following may be given twice daily in a pint of gruel, made up with oatmeal-

Opium, in porder, . . . . . . . 3 drachms,
Ginger, in porder, . . . . . . . half an ounce,
Alum, in powder, . . . . . . . half an ounce,
Bicarbonate of potash, . . . . . 4 drachms.

Should the above treatment, after some days' continnance, prove successful, tonics-such as daily drachm doses of the lisulphate of quinine in strong ale-will tend greatly to produce strength, and with it good condition.

\section{INFLAMMATION OF THE LIVER}

This malady frequently takes place. It does not seem to be confined to any particular part of the liver. This organ is a glandular substance, and the largest to be met with in the animal body; its chief use is to secrete bile. Inflanmation of the liver may proceed from various causes; sometimes from external, at other times from internal, but mostly the latter. F'at beasts, or such as are in good condition, are most liable to be attacked with this disease, particularly in hot weather, when over-heated with driving, or from running about the pastures on very hot days; drinking cold water, or being exposed to sudden chill after the body has been so lieated. Inflammations occasioned by external causes chiefly occur as the result of cattle goring one another with their horns, or from violent blows or bruises inflicted by foreign objects. The symptoms of this malady, especially when the result of full condition, consist in violent pain and swelling abont the short ribs on the right side, attended with difficulty in breathing, loathing of food, great thirst, with jaundice. If the inflammation run high, induration and purulent deposits are likely to occur; and, moreover, it is a fact worthy of notice that cattle, apparently in perfect health, after slaughter have been discovered to be the subjects of the above hepatic depositions. During the year 1869 I saw a case in Richmond Park of a buck which died suddenly, previously to which Mr. Sawyer, the head keeper, had never noticed anything amiss. On opening the animal the liver was discovered to be three times its natural size, and indurated; on its right side an abscess occurred. This malady in hot climates often rages as an epizootic. Lessona, of Turin, points to the fact that in 1827 it assumed this type in Italy.

Treatment.-Apply mustard poultices over the region of the liver, and use clysters; and administer daily in a quart of warm water-

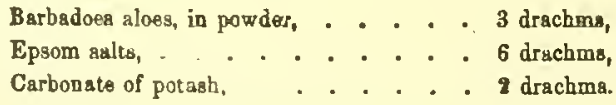

Feed on bran mashes and roots, with a very limited supply of hay.

\section{INFLAMMATION OF THE KIDNEY8}

is of frequent occurrence among cattle, and is often attended with very fatal consequences. Small as the kidneys are, they are all-important organs; if their functions are interfered with the life of the animal so attacked is in jeopardy. The quantity of blood which passes through them is very great; and whatsoever may obstruct the renal circulation, or impede the workings of the renal organism in transmitting the urine into the bladder, and to its after destination, or whatever cause may come into operation to affect the constituents of the urine or the structure of the kidneys, will invariably bring on disease.

Inflammation of the kidneys may proceed from violent blows inflicted across the loins, or a sprain to the part (in which cases the treatment of the cause will usually cure the effect); or from violent action, or from any circumstance which will too forcibly drive the blood into the kidneys. The first symptom the subject of this malady manifests is straining to void urine, which only escapes in small quantities; the loins are hot, and on the application of digital pressure to the part the patient flinches. As the disease progresses the difficulty to urinate increases; the animal becomes dull, and refuses food; the urine now assumes a high colour-sometimes nearly red, and often mixed with bloed; shivering of the whole body, cold, clammy sweats, and the extremities grow cold.

The sudden cessation of nephritic pains, and urine dribbling away in small quantities, of a black and foetid character, and weakuess, if not paralysis, of the hind quarters, are signs of an unfavourable termination. The symptoms which indicate a favourable result in this disease are the urine assuming a high and coffee colour, is secreted in much larger quantities than stated before, and at last is copieus, thick, and mixed with mucus. Our treatment must be so applied as to reduce inflammation, and giving medicine which will allay renal irritation; which is best effected by applying alternately hot fomentations to the loins, by means of hot flannels, thickly doubled, and kept continually moist with hot water, and by the application of ice to the same part. This end is best attained by forming a kind of cup, made with the assistance of a flour-sack, in which the ice over the lumbar region can be placed; warm water clysters will evacuate the rectum and will also tend to lessen the intensity of the local inflammation. Bad food, such as musty hay, and the administration of diuretics, such as turpentine and nitre, often, doubtless, bring on renal complications. Give linseed tea in large quantities, and administer in a pint of it twice daily-

$$
\begin{aligned}
& \text { Barbadoes aloes, in powder, } \\
& \text { Tincture of opinm, . . . . . } 2 \text { drachms, } \\
& \text {. . . . half an onnce. }
\end{aligned}
$$

This medicine, if the symptoms subside, can be followed by the administration of half a pint of linseed oil. Warm bran mashes and food easy of digestion must alone be given. 
Diuretics and all stimulating medicines must be strictly prohibited.

\section{SPLENIC FEVER OR ANTHRAX.}

Splenic fever or anthrax has for its most obvious result an enlargement and consequent rupture of the spleen. The animals affected often bleed at the nose and mouth, and death speedily supervenes. Although this malady was not recognized until comparatively recently as a specific disease, yet veterinarians and others have had their attention, during the course of their practice, directed to maladies of this type; for instance, M. Fochentin, of Baden, writes-"The sheep are said to die in a few hours, and sometimes suddenly; the liver to be partially decomposed, and the spleen enlarged and filled with tubercles and ulcers."

Again, under the head Inflammatory Fever, "The spleen is large and disorganized, the liver gorged, and the viscera congested. Overdriving and luxuriant pasturage are supposed to have been the causes."

In the "Transactions of the Veterinary Association, 1843," Mr. Mleggins, Sussex, brought before the Veterinary Society several cases of death in oxen and colts, evidently from this disease. "The spleens were all enlarged, and their cells filled with blood." And from other reports it is evident that some years previous to 1859 , splenic fever, although not recognized under this term, existed in many parts of Europe, and at the present time it is not unfrequent among cattle. In this country it consists, according to Dr. Crisp, of two kinds-viz. of a mild and a malignant form-the first being sometimes amenable to treatment, and the latter generally causing death in a few hours. In the malignant form, the animal is dull, off its feed, the head is down, the back more or less arched, the gait unsteady, the pulse quick and feeble, and towards the termination of the attack the breathing becomes difficult, and convulsive twitchings affect the muscles; the urine and excrements are sometimes bloody, and occasionally bloody froth appears about the mouth and nostrils; the animal frequently falls dead when standing, in from four to eight hours from the commencement of the attack. In the mild form, the disease manifests less dangerous symptoms, although sometimes the subject of it, especially sheep, die previous to the malady being detected-that is, before symptoms of the disease have shown themselves. The morbid appearances seem to arise from a disintegrated state of the blood, so that without any rupture of a ressel the blood exudes throngh the attenuated coats of them, causing the exudation, \&c., above mentioned. "In most instances," writes the doctor, "in oxen, sheep, horses, deer, and antelopes, I have found the spleen large, soft, pulpy, with extravasation of disintegrated blood from its proper vessels. Sometimes the blood is extravasated under the capsule of the spleen as well as to the interior, and the skin and cellular and muscular tissues frequently present a livid or violet-coloured appearance, from extravasation of blood, which is generally fluid and of a violet colour."

Mr. Thomas Crisp informs his brother that a Mr. A. lost, from disease of the spleen, an ox which had been fed on marshy ground. 'This spleen was two feet long and one in width, was much ulcerated, bloody, and pulpy, and readily fell to pieces; and he indirectly blames the marshy soil.

Again, splenic disease occurred one April in a very healthy district. The animals affected were all stall-fed upon oil, cake, chaff, and beetroot. Eight heifers and four bulls died, and only one (a bull) recovered; and the man who fed this fortunate animal said he had only eaten two bushels of cut beetroot for his breakfast, instead of two bushels and a half, his usual allowance. The root had bcen taken from land that had been manured with ooze from the Saer Water, together with five hundredweights of salt to the acre; and as all the animals fed upon the root taken from this soil manifested the disease, it was considered that this food had caused splenic apoplexy. It is a fact worthy of record, that in the outbreak which took place in Northumberland during 1859 , most of the animals that died had fed upon swedes grown on a particular field.

Let us further consider the effects produced upon living creatures by eating, or on man by handling, the diseased parts taken from an animal the subject of splenic apoplexy. The spleen, when removed from the body of Mr. A.'s ox, was handled by the butcher, whose arm soon afterwards became affected to such an extent as to prevent him using it for some time. Cats died after eating it, and a sow that eat the paunch and part of the spleen also died. In another instance, a man cut his finger whilst taking a diseased spleen, weighing eighteen or twenty pounds, from the body of an $0 x$, in which case the wound did not heal for several weeks. In addition to these, other similar cases could be cited; but we trust sufficient has been said to prove how important it is for all persons to be careful in removing diseased flesh from animals; and, moreover, to show that all such refuse should be burnt or otherwise destroyed, as matter utterly unfit for the hog-tub, or for food of carnivorous animals.

Its cause was for many years a matter of conjecture, bnt it is now generally agreed that it is dne to the growth of a minute organism or bacillus in the blood, which is called the Bacillus anthracis. It is by far the largest of the known pathogenic bacteria, and one of the most deadly. They grow in enormous numbers, and are found after death filling all the capillaries of the body. These bacilli, when growing exposed to air, produce oval spores, which are extremely tenacious of life, and are not destroyed by the action of most disinfectants.

Those minute organisms called bacteria stand in a causal connection with various diseases, such as splenic fever, septicæmia in mice, chicken cholera, septicæmia in rabbits, malignant œdema in guinea-pigs, and tuberculosis in the lower animals. This they do in two ways, either by producing changes in the fluids in which they grow, leading to the formation of poisonous products; or by growing in the blood or tissues of animals, and thereby leading to disease and death. That the products of the gro th of bacteria in albuminous fluids are of themselves poisonous was long ago made ont by 
Panum, who found that putrid fluids, boiled and filtered so as to get rid of all bacteria, still caused fever, and, if injected in large quantities, the death of the animal. Bergmann was able to separate a substance from these fluids which was soluble in water, and produced when injected into animals the same symptoms as the original putrid fluid. Of late Koch has found that if a large quantity of putrid material was introduced into animals they died very quickly, as described by Panum, but if the quantity was small the majority remained unaffected, while a small proportion died after a day or two. The minutest portion of blood from an animal which had died inoculated into another animal of the same species infallibly caused its death in twenty-four to thirty-six hours. The blood of these animals, when dried on a piece of glass and stained with certain aniline dyes, showed the presence of numerous bacteria, all apparently of the same kind. Koch was able to cultivate these bacteria on gelatinized meat infusion or solidified blood serum, where they grew in large colonies, and could be transferred from one flask to another without undergoing any change in form or characters. The minutest quantity of these bacteria, cultivated in this way and inoculated into an animal, produced the original disease in its full virulence. Such experiments prove that the bacteria growing in the blood were the real cause of the disease.

Splenic fever when once it has seized on an animal, seems to be incurable. Therefore every precaution should be directed against the spread of the infection. It is believed to be communicated by pasture on which infected animals have grazed, or by food which has been in any way in contact with such animals or their droppings

Attempts have been made by various experimenters to discover a material which would, by inoculation, render animals proof against this scourge. Toussaint first discovered a method of inoculation for splenic fever which protected the animal from a virulent attack. He heated the infected blood to $126^{\circ} \mathrm{Fahr}$. for from five to ten minutes, and found that after injection of this blood the animals were protected. Various degrees of strength in the attenuated virus could be obtained by varying the length of time that the blood was heated, but as the results obtained were rather uncertain, Pasteur, after his success in the attempt to protect fowls by inoculation from chicken-cholera, took up the investigation.

He found that by artificially cultivating the Bacillus anthracis with exposure during their growth to oxygen at a somewhat elevated temperature, an attenuated virus was at last obtained. Great hopes were at first entertained that by the inoculation of animals with this, the disease might be wholly eradicated, but such hopes have not been realized. It was found that only sheep, and possibly cattle, are protected, but that horses and other animals are not. It was also found that to completely protect sheep a virus of considerable strength must be used, and that a certain number (about 10 per cent.) of them die after the inoculation. As, however, a much smaller percentage die in this country from the natural disease, the general use of inoculation wonld not offer any advantages. But in certain localities splenic fever tends to occur, and in these districts a much larger proportion than 10 per cent. die. In this case the protective inoculation of the animals, though accompanied with a certain amount of loss, would, on the whole, be a material gain to the farmer.

\section{FOG SICKNESS; HOVE, OR BLOWN.}

This disease, more properly known by the name of Tympanitis, usually proceeds from a voracious and greedy disposition incident to neat cattle, when permitted to satiate their appetites with food of which they are most fond, such as red clover, vetches, rich fog, or different kind of grasses; likewise turnips, potatoes, corn, and sometimes chaff. The latter are more likely to choke the beasts, and the former to blow them. In fact, any food which remains in the rumen or first stomach for any great length of time, without undergoing the process of rumination, is liable to decompose, and in so doing to ferment, when gaseous eliminations occur, which distend the stomach in question, and produce tympanitis, associated with symptoms of suffocation; or pieces of food may be retarded in their passage down the gullet (œsophagus), and may when there choke the animal, in which cases the rumen becomes distended, and the disease "hove" is established.

Treatment.-When there is little food in the stomach the introduction of the probang will remove the gas, and with it also any impediment in the gullet can be readily removed. If the above fail to remove the distension, but it rather increases, and the animal's life is in danger, the canula and trochar must be introduced into the paunch on the left side, mid-way between the prominence of the haunch and the last rib, and about eight inclies below the transverse processes of the lumbar vertebræ; the trochar, having here been plunged into the stomach, must immediately be withdrawn, but the canula, or tube, must be retained within the wound made until the gas has escaped and the swelling subsided. In these cases, always send for a qualified veterinarian, who can alone successfully perform the above operations. On the first appearance of tympanitis, administer

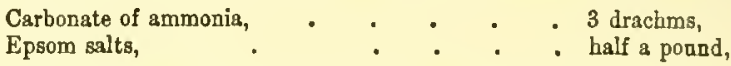

and use warm clysters. If the unfavourable symptoms do not yield to the above, the after treatment should consist of two drachm doses of carbonate of ammonia in a pint of water, followed by giving a brisk purgative.

\section{STAGGERS, VERTIGO, FARDEL BOUND.}

"Clater" evidently considered that this complaint arose from "a large quantity of phlegmatic humours pressing upon the brain and optic nerves, which caused the animal to have a wavering and staggering motion of body." To those unacquainted with pathology this may seem to be the case; but in truth, the implication of the brain is the effect, the stomach being the cause. The symptoms are attended with heaviness and dulness, a constant disposition to sleep, which is manifested by the beast attempting to rest its head upon any place 
convenient for that purpose; as the disease progresses the patient becomes wild, trembles, foams at the mouth, and runs at imaginary objects; persistent constipation is also a prominent symptom.

The above signs of the affection under notice may be produced by overfeeding upon too luxuriant herbage, from which the animals eat voraciously, or from partaking of indigestible or innutritious food; it is therefore more frequent in summer and autumn, when there is abundance of rough grass and when the lesves begin to fall. Rye-grass in seed, and ripe vetches, and insufficiency of water in a dry season-in fact, any food calculated to produce impaction of the stomachs, particularly the third-may be accounted sources of fardel bound; poisons also, and particularly lead, have been known to produce constipation and vertigo. Attention has been drawn to the evils which were likely to accrue by dressing land with the manure taken from large towns, where pieces of lead, floor cloth, and broken paint-pots, found their way to the pastures in the form of dressings. On such pastures animals are allowed to graze, and in so doing to often lick the sweet carbonate of lead from the above-mentioned substances, besmeared or impregnated with it. The symptoms produced by lead-poisoning are very similar to the above, only, perhaps, the suffering animal exhibits greater signs of delirium. In this malady we nearly always find the third stomach, or "omasum " impacted with indigestible food. Our readers will remember that the two first stomachs, viz., the rumen and reticulum, are principally engaged in the function of rumination; and that the food, after having undergone this process, is sent into the third stomach, there to be triturated, in order that no nutritive matter may be lost. If indigestible food or poison finds its way amongst the folds of the omasum, then through the medium of the nerves the system soon becomes deranged, the omasum refuses to send on deleterious compounds to the fourth or digestive stomach, the third is, as it were, locked up, constipation or a very scanty discharge of liquid dung supervenes, and, as a result, the brain becomes affected, vertigo is set up, and often the subject of it dies in a state of delirium.

The treatment consists in removing the constipation with purgatives; these must be very powerful, as in this disease no time can be lost, and experience proves that repeated small doses are of little service. Administer, therefore, a mechanical mixture which has proved very successful-

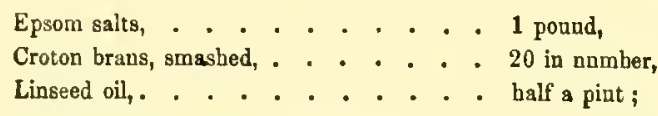

and afterwards use warm-water clysters, and give three times daily two-drachm doses of carbonate of ammonia; this will assist the action of the purge; allow large quantities of water to drink, and prohibit food until the symptoms abate.

In cases of lead-poisoning, in addition to the above treatment, antidotes must be sought. Sulphuric acid may be given often in water or linseed tea, and two to four ounces of the sulphate of soda exhibited; every two or three days use clysters. "Opium is recommended to allay pain, if the latter be intense; sulphuretted hydrogen is a chemical antidote, forming with the lead an insoluble black sulphuret;" alum, also, has proved useful. "MI. Melsers has found the iodide of potassium the most effective antidote to poisoning by lead compounds, the soluble iodide being formed, and eliminated from the system by the kidneys. - "Veterinarians' Vade Mecum," page 172.

\section{COLIC, OR GRIPES.}

Oxen and cows of every age are liable to this disease; it seems to arise from a spasmodic contraction of some part of the intestines. Almost all pains of the belly go under the denomination of colic, or gripes. It therefore will be necessary to consider them under different heads. Flatulent colic is, for the most part, occasioned by an animal's eating hard and indigestible food; also, from drinking too large a quantity of cold water when in a state of perspiration, or from stoppage caused by impaction of ingesta or calculi of various kinds in some part of the intestines, when, unless speedy relief be afforded, flatulence results, and the diseise (windy colic) is set up. Colic is not so frequent nor so fatal among cattle as with horses. The symptoms evinced in cases of this kind are:-The animals frequently lie down to rise up suddenly; and sometimes strike their horns and hind feet against their belly. The pulse is not usually much affected at first; but if the disease continue for any length of time it becomes much quicker and harder than usual; this generally indicates the commencement of inflammation, and is accompanied with considerable abdominal tension. Spasmodic colic, for the most part, proceeds from the former, which, if continuing for any length of time, must terminate in inflammation of some part of the intestines. Colic, as the foregoing remarks indicate, is always attended with persistent constipation, and may be, by the unscientific, mistaken for "fardel bound." In fardel bound persistent constipation is not always present, as frequently a very scanty discharge of very liquid dung is a symptom of it. Considerable danger attends cattle in this situation, as these deceitful appearances are often mistaken for purging. When these symptoms of costiveness occur, no tine should be lost in administering a purgative; that dung is passed in a liquid state in some cases of fardel bound is well known to veterinarians, but generally obstinate constipation prevails as in cases of colic. In fardel bound an animal may live for ten days or a fortuight, whereas, in colic, unless decided relief be given within forty-eight hours, the patient usually dies. The treatment of colic consists in the frequent use of clysters, and in administering-

$$
\begin{aligned}
& \text { Epsom salts, . . . . . . . . . . } 1 \text { pound } \\
& \text { Linseed oil, . . . }
\end{aligned}
$$

to be followed by giving twice daily two-drachm doses of the carbonate of ammonia in a pint of water 


\section{PUERPERAL OR MILK FEVER.}

This is a disease peculiar to cows in high condition at the time of calving; both young and old are liable to be attacked by it. This malady is better known now by the name of "parturient apoplexy," and, among dairymen, as " dropping after calving." It causes great loss to owners, owing to its carrying off the flower of the herd, and especially the best milkers. It generally occurs two or three days after parturition. When the object of it ceases to ruminate constipation sets in, the lacteal secretion is suspended, congestion of the brain and spinal marrow occurs, the serum of the blood is thrown out, which causes nervous and cerebral pressure, the breathing becomes laborious, stupor supervenes, and death closes the scene. This affection is the result of overfeeding before the period of parturition, which, in many instances, is considered necessary in order to insure a large supply of milk afterwards. So it may; but it must be remembered that during the months of utero-gestation the blood is determined in large quantities to the foetus, which, after birth, is rethrown, if we may so say, upon the system; but as yet is not directed towards its new channels for the production of milk. This I believe to be the most usual and potent canse of dropping after calving. Other causes consist in the absorption of pus from the uterus, and milk into the blood. Mr. Finlay Dunn writes:- "One kind common to most animals consists in inflammation of the membranes of the womb and intestines, and is produced by exposure to cold, by overdriving, or injury inflicted during parturition;" but all operate detrimentally in a similar manner by devitalizing the system, paralyzing the action of the nervous centres, and, in so acting, by arresting the due performance of the hodily functions.

Treatment.-Administer a purgative drink in a pint of warm ale, viz., Epsom salts, one pound; carbonate of ammonia, two drachms; assafœetida, one drachm; nitre, half an ounce. A similar amount of carbonate of ammonia should be given in a pint of warm ale, thrice daily. Use clysters, and apply ice persistently to the spine. As a preventive of this aftliction, some ten days or a fortnight before calving, give aperient medicine, under the advice of a qualified veterinarian, and in some instances blood-letting can be advantageously resorted to.

\section{ABORTION, OR SLINKING.}

A bortion, or cows slipping their calves in the early period of utero-gestation, is a great misfortune to the owner; it appears that cows in the best condition are most liable to it. It sometimes happens as the result of injury by cattle launching each other; at another it assumes an epizootic type, several having slipped their calves in the course of a few days: in these cases it results from debility or relaxation of the generative organs. This malady may occur any time between conception and parturition, but usually takes place about the fourth or fifth month of pregnancy. Cows are most liable to slink their calves towards the latter end of the year, whilst feeding on fog or autumnal grasses, or on low, marshy, fenny grounds; at other times it has proceeded from the smell of putrid flesh, which may have been exposed on the pasture, or too slightly covered with earth. The sense of smell with cattle is remarkably acute; "Clater" has noticed them on a warm day, when in an open pasture, collect in great numbers to a particular spot, where dead carcasses had been buried for years, and with their horns and feet tear up the ground in a surprising manner, at the same time making a most horrid noise. Other authors also have considered the smell of carrion to be productive of abortion; but doubtless the chief cause exists in the food or water, in which some deleterious agent exists, which injuriously affects the uterus. In proof of this, and as most authors have drawn attention to the fact that the disease under notice usually occurs during the late summer or autumnal months, the space cannot be better employed than by reproducing a portion of an article from the pen of Protessor Tanner, which appeared in the Edinburgh Veterinary Review.

"I shall not go into any notice of the generai subject of abortion, but rather restrict my remarks to the cause which is much overlooked, and yet probably is more influential than all other causes combined. I refer to the growth of ergotised seeds in our pastures. The action of the ergot of rye (Secale cornutum) upon the womb is well known as an excitant to powerful action, which usually terminates in expulsion of the fœtus. We have a similar disease appearing on the seeds of our grasses, but especially on the rye-grass, and thus we have an ergot of the seed of rye-grass produced, possessing similar exciting powers upon the womb to those produced by this ergot of rye. Two conditions are necessary for the production of this ergot upon the seed of rye-grass. The first, the grass must be allowed to run to seed; and the second is, that the climate must be favourable for encouraging the development of the ergot. In practice we find that on land which has been fed on during the summer, unless it has been grazed upon with unusual care, much of the grass throws up seed stalks and produces seed. In districts where the climate is humid and rain abundant, as well as in very wet seasons, these seeds become liable to the growtl of this ergot. Cattle appear to eat it with a relish, and the result is, that abortion spreads rapidly through the herd. Heifers and cows which, up to the appearance of the ergot, have held in calf, are excited by consuming it in their food to cast their calves. The abortion having once commenced, we know that the peculiarly sensitive condition of the breeding animal will cause its extension, even while the original cause may not be in operation; but their combined action renders the loss far more serious. If we add to this the tendency which the animal receives from her first abortion to repeat it when next in calf, we see how seriously the mischief becomes multiplied."

The cause of abortion baving been discovered, 2.8 indicated 
by Professor Tanner, the remedy is readily seen: it consists in removing cows and heifers in calf to pastures devoid of these seeds. These seeds are seldom met with until after the end of July, or early in August: consequently, lands may be deemed free from the ergot up to this time; the mowing of grass, also about the end of June, or early in $\mathrm{July}$, is a guarantee against the formation of the seed, and consequently the development of the ergot; if, however, mowing be commenced early, and a rapid growth of grass afterwards occurs, the seeds may grow, and upon them the ergot may appear, when cattle in calf feeding from such pastures are liable to abort.

Treatment.-Remove cattle from the cause, such as bad smells, \&c., and if one cow abort take her from the herd, having previously buried the calf in some place at a distance from all pregnant stock. If an animal manifest symptoms of premature labour and is in high condition, she should be immediately placed in a loose box, and two quarts of blood may be taken from her with advantage. Purgatives and any irritating medicine should be avoided. Administer in a pint of water, twice in the day, tincture of opium one ounce. Chloroform also may be given under medical advice, but is dangerous in the hands of any save persons possessing extensive chemical knowledge. Feed also upon food easy of digestion, and under all circumstances keep the remainder of the herd from all exciting causes.

\section{HOW TO EXTRACT A CALF WHEN IT PRESENTS IISELF}

\section{IN A WRONG POSITION.}

Persons who keep cattle ought to be well acquainted with che manner in which a calf should present itself when in a natural or proper position. All those positions are called unnatural in which the calf presents itself otherwise than with its head and fore-feet first, and its back towards the cow's back. It is well known to all those who have the management of cows, or those who practise in medicine among them, that calves are very commonly presented in a variety of different postures, for which no just reason can be assigned; and whenever they lie in a wrong position, both cow and calf are in danger, and the more or less so according to the ability of the person employed to afford the necessary assistance. In the first place, then, after the waters are evacuated, and the head and only one foot present themselves, yon must hold the calf's head and await an interval, during which the throes are off; then gently push it back, and bring forward the other foot. By this means a natural presentation is obtained, and the calf may now be extracted without danger. Secondly, if the head only presents itself, and both feet are drawn back, the head must be pushed back with a gentle hand, the utmost care at the same time being exercised, in order to avoid wounding or tearing the uterus. The head having been returned within the uterus, the feet, one by one, must be drawn forward, and be thus placed as in a natural presentation. Thirdly, if all four feet be turned where the back ought to be-towards the top of the uterus-in this situation it will be impossible to extract the foetus until it be put in a proper position. In operations of this kind much depends upon the management and activity of the person employed in placing the beast in a favourable position. The fore parts of the cow should be slightly raised with straw, or otherwise filled with that or anything else that is soft and easy to lie upon, and properly placed under her. It is seldom, however, in this case that manipulation, without the assistance of instruments, succeeds in extracting the foetus. Therefore, if repeated manual efforts fail to remove the calf, it will be necessary to secure the head with a rope, by passing it underneath the lower jaw, and afterwards by fastening a rope around both fore-legs, and by bringing both the ropes that secure the legs out on one side of the calf's neck. This done, the hand of the operator must be introduced, and be pressed firmly against the calf's withers, which he must endeavour to turn upwards towards the cow's back, and at the same time an assistant, with the ropes in hand, must be directed when, how, and in what direction to draw them. If little or no impediment exists, the foetus will gradually turn on itself, and a natural presentation will thus be obtained; when the calf can be steadily removed. Fourthly, it sometimes happens that the hind legs make their appearance. In this case it will be found better to extract in that position than attempt to turn them. Fifthly, frequent instances have occurred where the shoulder has presented itself at the mouth of the uterus, and requires the hand to be introduced in search of the fore legs; or, if thought more proper, the hind legs may be brought forward. This must be left to the judgment of the person employed. Sixthly, instances occur of calves being dropsical in the head. This may be discovered by its size, in which case the other parts are generally small and wasted. Under these circumstances, if the calf cannot be extracted in the common way, nor with instruments, the head must be reduced, or it must be cut away; and this can only be effected with instruments proper for that purpose, and used by a qualified and practical veterinarian. A description of the operation would not be understood by the public generally; therefore it will not be advisable to detail the processes adopted in extracting a calf suffering under the above complications. Seventhly, it sometimes happens, in cases where a calf is dead, that instruments of necessity must be used. In a few cases the dead fœetus, if properly presented, can be removed by inserting the hooked extremity of a long iron rod-an instrument made for this purpose-into some part of the calf's head, as the orbits, sockets of the eyes, mouth, or any other part that may appear at the time most convenient to the operator. Sometimes, however, the fotus is so enlarged, and the womb so contracted, as not to admit of extraction by this means. It will then be necessary to take it away by pieces-i.e., limb by limb-and in so doing the abdumen of the calf is often obliged to be evacuated in order to lesser its bulk, and thus facilitate its exit.

Several cases of difficult labour, in addition to the abovo- 
mentioned, occur; but they are cases requiring great surgical - skill and proper appliances, which are seldom met with excepting in the veterinarian's surgery; and, moreover, although these cases of unnatural parturition bear wellknown names, indicative of their nature, they often assume varied forms of complication, which cannot be controlled without anatomical knowledge and great practical skill. Therefore, to write a description of the above would little serve the stockowner, for the interest of whom this essay is intended; and to the scientific veterinarian it would be repeating second-hand stories.

\section{RETENTION OF THE PLACENTA, OR AFTER-BIRTH.}

Some authors have stated that the placenta should be removed immediately after the act of parturition is accomplished. To do so, however, shows great want of knowledge, and in nine cases out of ten would injure the animal operated upon. If, however, the animal does not cleanse at the proper time, it is good treatment to administer thrice daily-

$$
\begin{aligned}
& \text { Carbonate of potasb, . . . . . half an onnce, } \\
& \text { Infusion of savin, . . . . . . I pond-Hering; }
\end{aligned}
$$

and if the above does not assist nature-which sometimes happens, owing to debility of the animal's system, or its not possessing sufficient vital force to contract the uterus, and thus to throw off the after-birth, or persistent contraction of the os uteri may prevent its escape; in either of the above cases, and particularly if decomposition of the placenta has occurred, it will be necessary for the veterinarian to introduce his hand and dilate the os uteri, and extract the placenta carefully, separating it from the cotyledons, one after the other. Afterwards, if the foetor be great, the uterus may be well syringed out with a weak solution of Burnett's disinfecting fluid. The following may be afterwards given in a pint of warm ale-

$$
\begin{aligned}
& \text { Epsom salts, . . . . . . . . . half a pound } \\
& \text { Powdered ginger, . . . . . . . } 1 \text { ounce, } \\
& \text { Carbonate of ammonia, }
\end{aligned}
$$

Ergot of rye sometimes acts beneficially in assisting nature to remove the placenta; but it should be given always under professional advice.

\section{PROLAPSUS UTERI,}

or, more properly termed, inversion of the uterus, is a very frequent complaint among cows, particularly old ones, after calving, and often proceeds from violent motions that attend the extraction of the calf, and likewise from relaxation of the uterine ligaments. Some cows are more subject to this complaint than others, which in great measure is due to the shape and make of the generative organs. Clater thinks cows most liable to this complaint are those that rise considerably on the small of the back in the form of a curve, and begin to lower towards the tail; the hips, rump, and sirloin being for the most part straight.

J. R. Dobson, in his book on "The Ox: his diseases and their treatment," writes- " A proximate cause of inversion of the uterus is debility in the animal, proceeding from badly got and innutritious provender. As a proof of this in the spring of 1861, following the wet hay harvest of 1860 , inversion of the uterus was exceedingly common." Cows that have been previously known to have been subjects of this affection should be kept in a cow-house a short time before the period of calving, the floor or pavement of which must be level; and better still, an advantage will be gained by compelling the cow to stand on an inclined plane, extending from the hind extremities to the fore. By this means the hind quarters will be raised higher than the fore, and when down, the animal will be able to rise with more ease and with less danger of straining herself. If inversion be suspected, the cow ought to be carefully watched at the time of calving, and immediately after it has taken place, Gowing's patent truss should be applied; which consists of a collar which surrounds the animal's neck, and from which two straps proceed on either side of the neck, to be buckled to a pad on the top of a bellyband. To this pad a saddle or backband is attached, ending in a crupper which surrounds the root of the tail; from each side of the commencement of the crupper two pieces of leather form as it were a second or outside crupper, from which point a thick pad to press upon the vagina is obtained, and is secured firmly to this part through the medium of two straps which are passed up on the inside of each hind leg, and on each side of the udder, to be fastened to buckles on the backband, about a foot behind the pad or saddle above mentioned. This apparatus is very useful in cases of inversion of the uterus, and ought to be in the possession of all large dairy keepers. If', however, as is sometimes the case, the inversion foils our endeavours, a clean sheet should be placed under the uterus, which must be carefully cleansed with water at a blood heat temperature from all particles of dirt or dung. The operator now, with the aid of two assistants holding the uterus upon the sheet, should use gentle pressure on the neck of the uterus, and pass in as much as possible; and afterwards the lower and remaining part can with increased force be returned to its natural position. Many ways of operating in this injury have been recommended, but it is always wise to leave it entirely in the hands of those skilled in such matters. In severe cases, when all attempts to return the uterus prove unavailing, very likely mortification of it will set in, when it will be found necessary to remove it; a ligature should be first tied around the neck of the uterus, when the nterus below the ligature can be detached with a sharp knife. The only medicine calculated to be of any use in this affection, is to give, twice daily in thin gruel, half an ounce of tincture of opium.

\section{INFLAMMATION OF THE UDDER,}

or mammitis, known to stock-owners by the name of garget, long slough, \&c., consists in an inflammatory state of the 
ndder. Young cows in high condition are its frequent subjects, and especially just after the time of calving. The more aged ones are most liable to it during hot and sultry weather, particularly those wlich are fattening for the shambles; when this is the case the loss is considerable, as a summer's keep is generally thrown away, to the loss and disappointment of the owner. Cows of gross habit, when overheated or when they have taken cold, or received any injury by blows, \&c., or when allowed to remain unmilked for twenty-four or more hours in order, as it is termed, "to stock the bag" for purposes of sale, when it is to the interest of the would-be seller to prove that his cow has a very abundant secretion of milk, are causes most fruitful in the production of mammitis. In this lastnamed case the udder appears distended, the teats jut out, and from them large drops of milk may be seen dripping on the ground, and sometimes quite a small pool of milk is there collected. It can be readily understood that immediately after parturition, and especially with such animals as are of plethoric habit, that redundancy of blood is sent to the udder, and that milk also in large quantities is determined to that organ for the support of the calf; at first the calf is not able to take milk largely, and consequently the udder becomes overstocked, inflammation sets in; in other words, mammitis occurs. The symptoms indicative of the disease are increased heat of udder, attended with swelling, hardness, and with evidence of much pain on the application of pressure, and sometimes lameness of one hind leg, will be premonitory symptoms of it. The above signs are alwaya associated with much constitutional disturbanceviz., shivering fits, dulness, quickened pulse, laborious breathing, and in severe cases suspension of the function of rumination, and refusal to eat. If the teats be drawn (a process which is always advisable to attempt), a serous fluid will make its escape; and if any milk, it will come away in a curdy form; and if the disease has continued for a length of time, thick matter mingled with blood may make its escape. At a late stage of the disease the ndder becomes nodulated, manifesting the formation of matter, and sometimes a large tumour filled with pus will form; but more commonly mortification sets in, in which case death usually terminates the scene.

Treatment.-During the early stage it is good practice to administer

$$
\text { Epsom ealts, . . . . . . . . . } 1 \text { pound, }
$$$$
\text { Nitre, . . . . . . . . . } 1 \text { ounce, }
$$

and to strip the teats as clean as possible. Some practitioners advise the abstraction of blood from the abdominal or milk vein, hot and frequent fomentations to the udder; and if the udder be very large, it must be supported by means of a towel fastened by cords over the loins, when a linseed meal poultice, mixed with bran and about two drachms of belladonna in it, will in many cases greatly relieve the sufferings of the patient. Should the above fail, and induration of the udder supervene, or an abscess form, active means must be resorted to. In the first case, stimulating embrocations must be applied daily to the part, viz.,

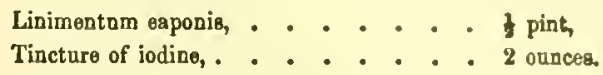

In the second, if the abscess points it must be carefully opened, and afterwards be well fomented with hot water; gentle pressure, in so doing, must be used in ordcr to evacuate the pus.

If mortification occurs, powerful stimulants must be administered twice daily-

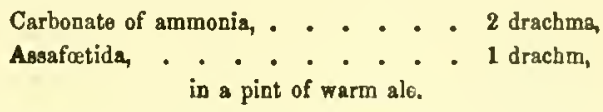

The last phase this malady assumes is induration of the udder, generally on one side; the only treatment for which is to cause the diseased part to be repeatedly hand-rubbed, and also to apply an ointment consisting of

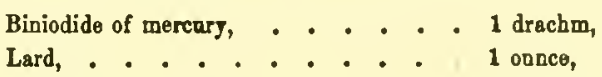

or the udder may be rubbed daily with linimentum saponis. The administration of drachm doses daily of the iodide of potassium in a pint of ale is recommended by some practitioners. Feed sparingly at first, and upon easily digestible provender; when abscess or mortification occurs, the patient must be well supported with food.

\section{RHEUMATISM, OR JOINT FELLON.}

The word felon is of frequent occurrence in the country, and is chiefly applied to diseases proceeding from cold, and is variously called as follows:-Cold fellon, joint fellon, and chine fellon. This complaint chiefly affects milk cows and young cattle at the spring of the year. It may proceed from animals being kept in a state of poverty during the winter, and being suddenly exposed in the early spring to the inclemency of the north or nortl-easterly winds, in low situations: sudden at mospheric change is also a fruitful source of it.

Symptoms.-The animals for the first two or three days appear stiff in their joints; afterwards they tumify or swell, the inflammation being confined to the ligaments, tendons, and synovial membranes of the joints. Rumination is suspended, pulse accelerated, breathing disturbed, and suspension of the lacteal secretion and constipation mark the extent at which the disease has arrived. The sudden shifting of the pain from one joint to other, and its coucentration in the white fibrous tissues, are very distinctive symptoms of rheumatisn. Sometimes the inflammation runs so high that disorganization of a joint may occur, when bony depositions will grow on it to so great an an extent as to impede permanently its action.

Treatment.-As soon as the disease makes its appearance, the patient must be placed in a warm cow-house or stable in which ventilation and drainage is properly secured; and the joints or parts affected should be placed in flannel bandages 
and rugs must surround the body, which can be previously well rubbed with a liniment consisting of turpentine and olive oil, of each equal parts, and administer in a pint of warm ale, twice daily.

$$
\begin{aligned}
& \text { Carbonate of ammonia . . . . } 2 \text { drachms, } \\
& \text { Aloes, . . . . . . . } 1 \text { drachm, } \\
& \text { Camphor, . . . . . . . } 1 \text { drachm. }
\end{aligned}
$$

Feed on barley flour and roots, and good hay.

\section{SORE TEATS.}

Injuries and obstructions in the teats are of frequent occurrence, and particularly during very cold weather, among cows that have recently calved. Sometimes they are only inflamed, owing to not being dried after milking, and exposed immediately afterwards to the inclemency of the weather; this inflammation often is associated with the existence of cracks, which are very painful, and cause the animal to be very fidgety during milking time. Small tumours and lacteal calculi (stones), and strictures, occur in the teat and often stop the fall of the milk, and impede its passage through the duct. Warts are often a cause of great discomfort to the cow ; but they are generally of such a shape as to enable us to remove them by placing a ligature around the base of each wart, and keeping it there until it sloughs off. If the base be very wide, excision with the knife must be resorted to.

Treatment.-Administer in a pint of warm gruel-

$$
\text { Epsom salte, . . . . . . half a pound, }
$$$$
\text { Nitre, . . . . . . . . half an onnce. }
$$

Well foment the udder and teats with warm water; afterwards well dry them, and if cracked, apply glycerine : if inflamed only, apply a lotion, after every milking, consisting of-

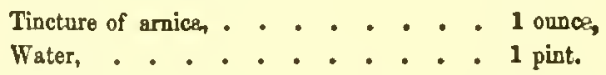

In cases of lacteal obstructions their removal must be attempted with a probe, when they must be extracted either bodily or in pieces. Strictures must be dispersed by passing up the duct a probe at first of small size, and gradually increasing the size of them until a probe sufficiently large in diameter has removed the constriction.

\section{TO DRY A COW OF HER MILK.}

Old authors placed much reliance upon certain useless medicines which they prescribed " to dry cows of their milk." Every stock-owner of experience knows well that if a cow is "to be let off her milk," she requires that it be done gradually, by half milking at first, missing one milking, two, and so on. A dose of Epsom salts and nitre may tend also to drain the system; and if the feeding of milch cows be attended to at this time-namely, if only small quantities of food be administered-the milk will cease to be secreted, without any fear of mammitis occurring. It has been proved that the administration of iron compounds tends powerfully to arrest the secretion of milk, and on one or two occasions I bave given daily drachm doses of the iodide of iron to cows, for this purpose, and have succeeded in producing the required result within a week.

\section{THE COW-POX.}

This disease was never noticed by any author before Jenner attempted to convince the world of its utility in protecting the human race from that baneful disease-small-pox. Vaccination, since this time, has been introduced throughout Europe, the East and West Indies, besides many other parts of the civilized world. Some persons conjecture, (and Jenner was of their opinion) that grease in the heels of horses is of the same nature as cow-pox; but this is evidently a mistake, as facts contrary to this belief have proved. Variola of the cow consists in an inflammatory condition of the udder and skin, and more particularly such parts of it as are denuded of hair, associated with slight constitutional disturbance. The disease, which is highly contagious, commences with slight inflammation of the skin, indicated by the appearance of small red patches on the udder or hairless parts about the dock. Upon these papillæ arise in four or five days; small bladders or vesicles appear containing a transparent fluid, the true vaccine lymph: at the expiration of three days more the vesicles secrete a thick yellow matter, and are then called pustules. In the course of a few days a scab forms upon them, which, if not rubbed away, peels off, leaving the skin underneath sound; should the scab be removed in the act of milking, ulcers will supervene. A very mild solution of alum water, however, will often put matters right. In this affection the most simple treatment is demanded, chiefly consisting of warmth and good nursing : all lotions and medicinal applications for the skin should be avoided, as the disease will run its course. A mild aperient may be administered at the onset; afterwards good soft food, such as bran, boiled carrots, oatmeal made into a mash, can be given.

\section{ANGLE-BERRIES}

are cutaneous warty excrescences growing out above the surface of the skin, and are of different sizes, and constitute great eye-sores. Young cattle are most subject to them, and sometimes when animals are well fed, and as age advances, they fall off without any interference. Warts make their appearance on different parts of the body, and on the udder they are not only disagreeable to see, but cause the cow to be very troublesome during milking time. These excrescences, if narrow at the neck, are called angle-berries, and may be removed by tying tightly round the neck a piece of tar string. when in a few days they will drop off, as the result of strangulation. A wart with a wide base can be extirpated with the knife, and the bleeding surface afterwards touched with a heated firing iron; or warts, if dressed with the following ointment, thrice weekly, in two or three weeks slough off: by this means bundreds may be removed:- 
Arsenions scid, . . . . . . . . . 1 part
Lerd. . . . . . . . . . 4 parts

or they may be dressed with a paste made up with sulphur and snlphuric acid; this must be most cautiously used, and should not be applied excepting by a professional man.

\section{WARBLES}

consist of small tumours existing in different parts of the skin, and owe their presence to the existence within them of small grubs or larvæ. The eggs producing the larvæ are deposited there about the latter end of the summer by a flythe CEstrus bovis, ox-fly-where they remain until the spring, when the larvæ having been matured, make their escape, and are converted by metamorphosis into the gadfly. Warbles are removed by pressing them between the finger and thumb, or by puncturing with a red-hot needle. They seldom affect the health of animals infested with them.

\section{THE MANGE.}

This affection is well known to most graziers; it is seated in the skin, and poverty of condition seems to favour its extension. Symptoms:- The skin all over the body appears thrifty, and every time the beast rubs himself, which he is constantly doing, a thick, white scurf, of a scabby nature, is to be seen on the spot where he has rubbed himself. Scabies bovis is occasioned by the existence in the skin of an insect-the Acarus bovis-which burrows beneath it, and in so doing raises up raw-looking pimples. The mode of cure is to destroy the parasites, which is easily effected by dressing the skin all over, twice weekly, with a lotion-

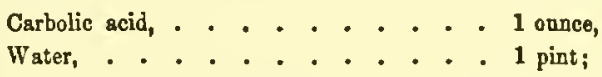

or an ointment may be rubbed into the affected part, consisting of-

Iodide of eulphur, . . . . . . . 1 drachm,
Lard, . . . . . . . . . 1 ounce.

Remove affected cattle from their companions, as this disease spreads rapidly by contagion.

\section{LICE IN CATTLE}

require no description, as this filth is always visible to the eye. The irritation caused by these creatures is so excessive as to prevent animals infested by them putting on flesh. Wash the affected parts with-

$$
\begin{aligned}
& \text { Corbolio scid, . . . . . . } 1 \text { onnce } \\
& \text { Water, . . . . . . . . } 1 \text { piok }
\end{aligned}
$$

and feed well, as low condition, like mange, seems to favour the increase of these parasites. The author has known lice leave the skins of animals, without any medicinal application, in a few weeks after having been well fed, and after they had improved in condition.

\section{BULL-BURNT.}

Gonorrhœa is not common to the horse and dog, but ferquently occurs amongst cattle; it is a local disease affecting the mucous membranes of the urino-genital organs of the bull and cow. It is supposed to follow the act of copulation in an animal of plethoric habit, and especially in hot weather. The animal, the subject of it, evinces slight febrile symptoms. associated with uneasiness, and the urine is emitted very scantily, with evident pain.

The mucous membranes of the part expel a muco-purulent discharge from small pustules, which ultimately devclope into ulcers and fungoid growths. Treatment:-Administer, thrice weekly, half doses of Epsom salts, and, with a cow, well cleanse the parts with warm water, and afterwards bathe the parts with a lotion-

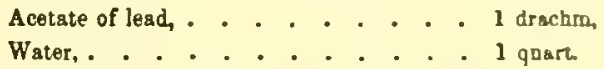

On this disease happening to a bull, unless the case be very simple, it will be necessary to cast him, in order to examine the sheath and penis, and to apply the requisite remedies, which consist of mild astringent lotions, such as-

$$
\text { Snlphate of zina . . . . . . tounce, }
$$$$
\text { Water, . . . . . . . . } 1 \text { pton, }
$$

which must be injected up the urethra and over the parts affected. If the disease extend to the development of warts, or extensive ulcers, then such must be dressed twice weekly with a rod nitrate of silver; and in iong-standing cases fungoid growths must be excised with the knife. In all cases great cleanliness must be observed, which is an all-important adjuvant in producing cures.

\section{WOUNDS,}

although not so common to cattle as horses, yet do sometimes occur from injuries sustained in consequence of their breaking through fences, or from blows inflicted with their horns whilst fighting. Wounds, for the sake of description, may be divided into four kinds, viz., contused, incised, lacerated, and punctured. A contusion is simply a bruise; but, at the same time, it may be of so extensive and complicated a nature as to involve in injury adjacent parts, especially when occurring near the region of the lungs, liver, \&c.; and sometimes such wound causes internal hæmorrhage, which is always accompanied with a greater or less amount of danger. In treating bruises warm fomentation should be resorted to, and the following lotion, by means of a bandage kept continually moist with it, must be applied :-

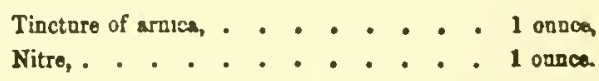

An incised wound consists of a clean cut, more or less deep, inflicted with a sharp instrument, through the skin and muscles. In cases of this kind it is always advisable to 
send at once for a skilled veterinary practitioner, whose attention will be immediately directed to the copious bleeding which usually attends such accidents. This hæmorrhage it will be his duty to arrest, which, if only small vessels are cut, may be stopped by sluicing the part with cold water: if, however, large vessels, or an important artery be divided, then the bleeding end, or ends, must be secured with a ligature. Having arrested the hæmorrhage, the only step remaining is to draw the edges of the wound together, which is effected by bringing the lips of the wound in close contact, and securing them in this position by means of sutures. This is accomplished with a curved needle, made for this purpose, and threaded with strong silk cord, or wire, silver being the best; each suture must be separate from the other, and, of course, must necessarily be tied, or in the case of wire, be twisted, the one independently of the other. Cold water applications, by means of a wet bandage, will also afford the best dressing for the injured surface; sometimes, however, to arrest the formation of pus, syringe tlie wound carefully with a weak solution of nitre and water. Lacerated wounds are the most severe the veterinarian has to deal with, as they are usually inflicted with a blunt instrument, and are sometimes associated with fractured bones; and if not, they usually consist of large rents of the skin and muscles, and sometimes with loss of substance (as a piece of skin and muscle is not uncommonly removed), or is so much injured as to necessitate extirpation. The edges of these wounds having been well examined and bathed with warm water, must be brought in apposition with sutures, and sometimes one or more quill sutures must be provided, which consist of the quill end of turkey or flexible feathers, which are secured to the lips of the wound with looped sutures. Should mortification ensue, a lotion consisting of-

Carbolic acid, . . . . . . . . . . 1 onnce,
Water, . . . . . . . . . . 2 pints,

can be syringed into the wound daily, and stimulants consisting of two-draclim doses of ammonia in warm ale can be given twice daily. Punctured wounds occur very often among cattle, as such injuries are inflicted with the horns. Somctimes the accident in these cases appears trifling; but experience proves that sometimes they are attended with disastrous, if not fatal consequences. A punctured wound should always, even if the aperture is very small, be probed in order to ascertain its depth, which must be kept open for some time in order to prevent the occurrence of deep-sented abscess, which, if allowed to form, will involve a simple wound in other complications, such as fistula, \&c. In this case it is good practice to open with a knife the external wound, and syringe into the more deep-seatct disease a solution of nitric acid and water; half an ounce of the former to a quart of the latter will cause a slough, which will destroy the pus-generating membrane, and leave behind a healthy granulating surface. When the bones are broken the detached pieces should be removed; but if not easily operated upon, they nust be left to exfoliate of themselves. During this process the animal is to be fed well, and in some cases sup. ported with strong ale and tonics, such as-

Disalphate of quinine, . . . . . 1 drachm,

Warm ale, . . . . . . . . 1 pint.

It is advisable in all cases of the above to allow a skilful veterinarian to attend, who will be able to diagnose coming mischief, which those unacquainted with physiological research would fail to recognize, and will therefore often preserve life, which otherwise would be sacrificed for lack of skill.

\section{WOUNDS OF THE JOINTS}

are constantly associated with fractures, which are described as simple, comminuted, and compound: simple, when a bone is broken into two pieces; comminuted, when broken into several pieces, or is crushed; and compound, when any portion or portions of the broken ends protrude through the muscles and skin. In cattle, simple fractures alone are capable of being set, and this may be effected by placing the patient in slings, and placing the injured parts in splints and starched bandages. In cases of injury to the joints, where the synovial membranes are opened, it is good practice to well wash the wound, and afterwards sprinkle over it a powder, consisting of-

$$
\left.\begin{array}{l}
\text { Powdered myrrh,. . . . . . } \\
\text { " anlphate of iron,. . . } \\
\text { " alum, . . . . . . }
\end{array}\right\} \text { of each equal parts, }
$$

and place over the wood a pledget of wool, and confine the joint, and the whole of the leg below it, in a linen bandage: a pressure only sufficient to keep the bandage in its place, and not so great as to impede circulation, must be insured. Feed upon a nutritious diet, and allow plenty of it.

Strains of the joints, where evident pain and swelling occur, are best treated by the application of light linen bandages, kept constantly saturated with one of the following lotions :-

(1.) Tinctare of araica, . . . . . . 1 ounce.

Water, . . . . . . . 1 pint.

(2.) Gowland's extract, . . . . . . . 1 ounce Water, . . . . . . . . 1 pint.

(3.) Tincture of opium, . . . . . . $\frac{1}{3}$ onnce. Tincture of arnice, . . . . . 直 ounce. Nitre, . . . . . . . . . . 1 onnce.

No. 3 should be applied when great pain is evidenced. A mild dose of physic, also, can be given, viz.:-Epsom salts, half a pound in a quart of water.

LOCKED JAW.

Tetanus, commonly called locked jaw, is an affection of the nervous system, which causes contraction and spasm of the muscles of voluntary motion, attended with tenderness and rigidity of the parts affected. T'etanus arising from injury-such as wounds-is called traumatic; and when from a variety of causes, is denominated idiopathic. This malady has received various names, indicative of the parts affected:-

1. Trismus, when the rigidity is confined to the flexor muscles of the lower jaw or throat. 
2. Eprosthotonos, when the flexor muscles are affected and the spine is arched, presenting a concave line to the ground.

3. Opisthotonos, when the extensors are involved and the spine is curved downwards, presenting a convex line to the ground.

4. Pleurosthotonos, when the body is drawn to one side.

Each of these states is very difficult of cure, and if arising from injury (traumatic tetanus) rarely yields to treatment. Locked jaw is most commonly noticed in veterinary practice, and is readily recognized, by the subject of it stretching out its neck and nose. On placing the fingers in the mouth, it will be immediately ascertained that the jaws are fixed almost to immobility. Great nervous excitement prevails; the bowels are constipated, and the excretions are constantly locked up. The treatment for tetanus consists in first opening the bowels with purgatives, which, in the case of trismus, will be administered with difficulty; and placing the patient in a loose box, removed from all noise, and from the ingress and egress of strangers: half-grain doses of strychnine given daily have in some instances acted beneficially. I have seen good results follow the inhalation of chloroform; but the influence of this anæsthetic must be repeated. Perfect rest and quietude is the great essential in the treatment of all kinds of tetanus. Oils to rub into affected parts, and medicines, have been prescribed. The Pharmacopœia itself has been ransacked, but to no purpose; no specific for this malady has yet been discovered. I once heard Professor Spooner tell his pupils, that the best treatment for tetanus was the "stable-key." "Secure your patient in a loose box; keep the key in your pocket; insist upon perfect quietude." This advice was sound, and without comment is repeated to my readers.

\section{THE FOUL IN THE FOOT}

proceeds from full habit of body, or from any external cause, by foreign agents insinuating themselves between the digits. These should be at once extracted; when the removal of the cause usually cures the effect. Sometimes, however, it makes its appearance in the form of a deep crack, either between or around the claws, which is attended with considerable inflammation, and in a short time will discharge an offensive matter, similar to that noticed in horses the subjects of grease.

Nany have been the theories about "foul in the foot." Youatt, in his book on "Cattle and their Diseases," clearly sums up all evidence in the matter-"It is generally believed that there is a constitutional tendency to diseases of the feet in cattle, resembling the rot in sheep, but this has never been satisfactorily proved; and the simplest explanation of the matter is, that inflammation was produced by some external cause; that it ran its usual course; that suppuration followed, and matter was formed; that it burrowed in various parts of the foot, and broke out on the coronet; that sinuses remained, and that the ulcer took on an unhealthy character; fungus shooted up-in short, there was a quittor similar as in the horse, but on a smaller scale, and more manageable."
This malady is most prevalent in low marshy grounds, when the hoof, from the continual presence of moisture, becomes softened, and by this means is rendered more susceptible to disease, and less able to resist injury. When an animal is noticed to be lame, it should be immediatcly placed in a loose box or cow-shed, and the foot should be carefully examined. Sometimes to effect this object it is necessary to secure the animal with hobbles, when the horn should be cut down at the seat of injury; and if a stub or grit be present, it must be removed, and afterwards a linseed-meal poultice applied. If the operator fail to discover the seat of mischief, then a poultice, as directed, can be applied for two or three days, and sometimes a projecting red spot will arise, which he must open; and if any sinuses occur, they should be well syringed out daily with a solution of hydrochloric acid and water-a wine glassful of the former to a pint of the latter. If fungoid growths occur, remove them with a knife, and afterwards reduce them still further with a rod of nitrate of silver; and also use caustic to any ulcer or proud flesh which may appear, which is often the case in this disease. Dress feet, from which a foetid discharge flows, with Burnett's disinfecting fluid. If the diseased parts above alluded to assume a healthy appearance, they may be dressed daily with tincture of myrrh, and an aperient given, viz.:-

Barbadoes aloes, in powder, . . . 4 drachms,

Lizesed oil, . . . . . . . 1 pint.

\section{ON THE DISEASES INCIDENTAL TO}

\section{IOUNG CALVES.}

THE METHOD OF TREATING THE NAVEL-STRING AFTER EXTRACTION.

As soon as the calf has been properly cleaned by the mother licking it, the navel-string should be examined, and if it bleeds, a ligature can be passed round it, about two or three inches from the belly. Secure it fast, and then clip it off with a pair of scissors a little below the tied part. Sometimes, four or five days after birth, swelling, attended with inflammation of the navel, takes place; when hot fomentations must be frequently applied, and if the tumour points, it may be opened with a lancet; and an ounce of castor oil in a wine-glassful of port wine will assist treatment. Sometimes bleeding occurs from the navel itself, caused by the removal of the entire length of the cord, by the cow biting it off, or as the result of accident. In this case the lips of the wound can be brought together with a large pin; or sometimes a pledget of wool inserted in wounds and confined there by means of a bandage, will arrest the hrmorrhage. Hæmorrhages of this kind often cause great prostration, and the subject of them will derive benefit from the daily administration of the following:-

Disolpbate of quinine, . . . . 5 grains,

Port wine, ......... . mine-glassfol 


\section{HOOSE IN CALVES.}

This disease most commonly attacks calves during the first year, and generally seizes them while at grass in the zummer. In some dry summers it has carried off large numbers. The symptoms are a dry, distressing cough, caused by the presence in the trachea (wind-pipe) of numerous small worms (the Filaria bronchialis), sometimes collected together in a bunch, surrounded with mucus, or dispersed in the smaller branches of the bronchial tubes. This malady causes the subject of it to breathe laboriously and rapidly waste in condition, and if prompt remedies be not applied, death supervenes in a few days.

Treatment.-Administer an ounce thrice daily of the following:-

Linseed oil, . . . . . . . 6 ounces,

Torpentine, . . . . . . . 4 onnces.

I have found marked benefit derived from inlalation of chlorine gas; it must be administered cautiously. All animals affected should be placed in a loose box, in which all windows and apertures must be closed; and in such building several plates, each containing chloride of lime, should be distributed. The lime must be well saturated with water, when a small quantity of sulpluric acid can be poured over it, and the chlorine gas will be eliminated, when the patients will breathe this atmosphere impregnated with the gas, which, in passing to the lungs, will come in contact with the parasites, and cause their death and ultimate expulsion. Repeat the inhalations every other day. Should the above treatment succeed, and the animals be left emaciated, of course nutritious food will do much in obtaining good condition; but it can be judiciously supplemented by administering daily ten grain doses of the disulphate of quinine in half a pint of warm ale. Clater writes-" In many instances where this complaint has baffled the power of other medicines, the disease has instantly given way on their taking one tablespoonful of spirits of turpentine, without mixing it with anything. It may be repeated every third day for three times."

\section{DIARRHEA, OR DYSENTERY.}

This is a disease to which young calves are very subject, at the age of from two to six weeks, and is chiefly brought on by change of diet, or by scarcely allowing these young creatures that subsistence which nature requires at so early an age, and for want of which great numbers die. The milk of the mother may not agree with the calf; it may be too poor, when acidity in it is likely to occur, and to irritate the mucous membranes, particularly of the fourtli stomach; or it may be too rich, and act in too stimulating a manner, and thus derange the digestive functions. The time of changing the diet demands much caution; and if the calf is to be fed by hand for the first fortnight, it should be fed on the milk direct from the cow, and afterwards it may be mixed with older milk; but in no case must it be in the least degree acid, and a little porridge may be introduced. The symptoms are great weakness, loathing of food, a continual purging; everything it takes seems to turn acid, and coagulates on the stomach. Towards the last stage of the disease the stools become bloody and foetid, and large portions of the defensive mucus of the intestines is mixed with them; after which mortification sets in, which terminates in death.

Treatment.-Administer with a wine-glassful of port wineCastor oil, . . . . . . . . . . l ouuce,
Tincture of opium, . . . . . . . halr̃ a drachm.

In cases of long standing there is always a continual motion to dung, called tenesmus. The pain in this case appears to be limited to the rectum, and may be removed by the administration of warm water clysters. Administer also daily a teaspoonful of tincture of opium and half a drachm of carbonate of soda in the same quantity of port wine as above directed. The calf also should be drenched with starch and thick gruel.

\section{COSTIVENESS IN CALVES.}

The costive habit of some calves may take place at the age of three or four days, and this occurs generally from the mother's first milk, commonly called "beestings," having been denied the calf by previous milking. The prompt administration of the following nsually relaxes the bowels-

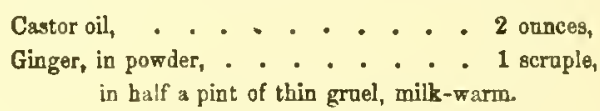

Sometimes this disease occurs from over-feeding; the calf having been allowed to lie by the side of its mother in a stall and take milk at its pleasure. This practice is good if the calf be allowed to follow its mother about the pasture, for then exercise is necessitated, which assists digestion; and in this case the young can be allowed with impunity to take milk when it pleases, as it is only obeying a natural law. But in the former instance no exercise can be taken; the calf sucks, gets too full, and lies down. This is repeated time after time, nntil the digestive powers are overtaxed, and the fourth stomach becomes filled with hardened curd, and a stoppage to the passage of the ingesta is present. At other times, again, change of milk, especially that of a foster-mother, will derange the secretions, and then similar constipation supervenes.

Treatment.-Administer daily-

$$
\begin{aligned}
& \text { Epsorn salts, - . . . . . } 2 \text { ounces, } \\
& \text { Liquor ammoniz, . . . . . . . } 4 \text { drops, }
\end{aligned}
$$

in a pint of warm water.

Calves are subject to this malady when first introduced to dry feeding-viz., upon hay, \&c., say, at about eight or ten weeks old. 'This food becomes impacted, not in the fourth, as above noticed, but in the third stomach, before this organ has derived sufficient power to grind down the hard and fibrous portions of food. This disease is indicated by cessation 
of rumination, enlargement of the abdomen, and persistent constipation.

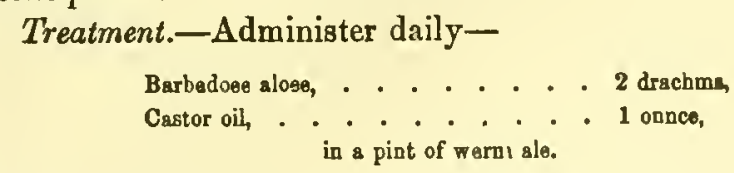

After recovery, feed upon oatmeal and bran mashes, and allow plenty of good water.

\section{PCIsONs.}

Poisons may be considered under two heads-external and internal. A poison is defined to be "any substance which, when applied externally or internally to the animal system, is capable of destroying life." Poisons have differents effects upon the system, according to the parts they are brought in contact with. For instance, if injected into the veins, they rapidly destroy life; and if absorbed into the stomach or intestines, or exhibited to the serous and mucous membranes in a fluid or gaseous form, they are sure to produce death. Their action, however, is not so rapid when applied to the skin, as the power of cutaneous absorption is not so great as that of the mucous membranes. There are also poisons, as that of the viper, which, if applied to a wounded surface, prove fatal, but are quite innocuous when taken into the mouth, the stomach, or intestines.

"The action of poisons may be considered as local and remote. The local effects are of three kinds, viz., corrosion, or chemical decomposition, as is seen in the effects of strong mineral acids and alkalies; irritation, or inflammation, varying from simple redness in its mildest to ulceration and gangrene in its most severe degree; and a sympathetic effect produced on the sentient extremities of the nerves, as is felt on the local application of prussic acid, \&c.

"The remote effects are those affecting an organ remote from the part to which the poison has been applied. Various narcotic poisons produce but little local change, though their remote effects are very remarkable. Many substances have both a local and remote action, as is well seen in the influence of cantharides upon the part to which they are applied, and their remote effect upon the urinary organs.

"Medium by which the remote effects are conveyed:-This is by one of two modes, or, as some contend, by both; by absorption, i.e., by the passage of poisonous particles into the blood, or by sympathy, i.e., by an impression transmitted through the nerves."-_Memoranda on Poisons." T. H. Tanner, M.D.

Much evidence could be adduced proving absorption to be the most potent agent in transmitting poison through the system, i.e., in conveying its influence to remote parts; for instance, prussic acid has been discovered in the blood of an animal which died in thirty-five seconds after administration, and prussiate of potash was evacuated in the urine within one minute of its being swallowed on an empty stomach. As absorption, therefore, is so rapid, it is somewhat difficult to explain how poisons do act by sympathy; the only argument in its favour that has ever been adduced being the rapidity with which death ensues after the administration of some poisons. It has been shown above how rapidly absorption takes place, so rapid, indeed, as to render it almost impossible to determine whether an animal has been destroyed by the action of poison, througl the medium of absorption or sympathy; ferrocyanide of potassium was injected into the jugular vcin of a horse, and was discovered in the vein on the other side of the neck in nineteen seconds. And other experiments showing the rapidity with which poisons are absorbed could be cited, showing how quickly poisonous agents destroy life.

Poisons which injuriously affect the well-being of anmmal life may be divided into two classes, viz., vegetable and mineral. The former more commonly find their way into the stomachs of the ox tribe; the latter also, as in the case of lead-poisoning, mentioned under "Colic," and when exhibited for malicious purposes, produce death among cattle. In all cases of poisoning it is good practice to effect the discharge of the offending agent from the system, which is obtained by the stomach pump or purgatives, or both, and by emetics. The last-named agents will not answer our purpose in cattle practice, although useful in the treatment of carnivorous animals. In a case of suspected poisoning, antidotes, if the nature of the poison be somewhat accurately ascertained, can be administered in order to counteract the action of the supposed poison. In cases of corrosive and irritant poisoning, linseed meal, mingled with wheat-flour, as a thin gruel, can be given to sheath the mucous membranes of the alimentary canal, and immediately afterwards administer the following dose :-

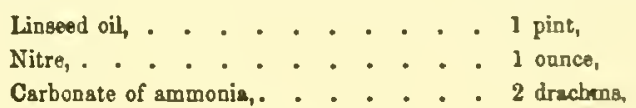

in a pint of strong ale.

To describe the action of various poisons, and the antidotes capable of counteracting their effects, would fill a volume, and would, when detailed, be little understood by "every" stockowner. In cases of poisoning it is always wise to send for a scientific vcterinarian, who can detect symptoms, and with the aid of a toxicologist, i.e., if not one himself, can suggest remedies, or prescribe antidotes.

The Bite of Venomous Reptiles.-In this country we have but few poisonous reptiles compared with those found in warmer climates, where they often prove fatal to man and beast.

The viper and adder are most common in this country, and the bite of these reptiles is often attended with dangerous consequences. Neat cattle are more liable to be stung by these reptiles than any other of the domestic animals. Some instances have been known where the tongue of the beast has been stung while grazing. Adders seldom attack cattle, except the latter disturb them when grazing; this is the chief reason why so many of them are bitten about the head, and 
sometimes about the feet. The stings of the hornet, wasp, or bee, are attended also with considerable pain and inflammation, and require similar treatment to the former. The following liniment Clater, informs us, he has found to be a powerful remedy in checking the progress of the poison, and in expelling it from the part effected, viz.:-T'Take olive oil, half a pint; strong spirits of hartshorn, four ounces; opodeldoc, six ounces; spirits of turpentine and tincture of opinm, of each four ounces. Put them altogether in a bottle, and shake them well every time they are used.

The above prescription is given in extenso, as it contains medicinal compounds (viz., opium and olive oil) which we have applied since we were children to "stings," but more especially because Clater prescribes spirits of hartshorn, or liquor ammonia, which is said lately to have counteracted the effects of snake-poison. An Australian plyysician informs us that, on two or three occasions, he has injected into the wound caused by a snake-bite three or four drops of liquor ammoniæ, and that it has acted as an antidote to the poison; others also bear testimony to the truth of this assertion. If future applications prove its efficacy, of course a very valuable antidote to the poisonous effects of venomous bites inflicted by reptiles has been discovered. Hot and frequent fomentations to the affected part will also assist the above treatment.

\section{the cattle plague,}

or Rinderpest, is a malady that has defied almost every treatment, and during its visit to our shores in 1865-66, the pole-axe alone prevented its ravages. The rinderpest is seldom absent from the steppes of Russia, and is said to spontaneously originate there-a statement which demands more investigation, until this assertion can be received as a fact. When once this disease makes its appearance in a district, experience has proved that few cattle escape its infection, or are able to resist its fatal termination; consequently, this malady acts heavily as a pecuniary subtracting influence to the wealth of stock-owners. The opinions of many eminent physicians and veterinarians will be detailed in the following article, particularly because, during the outbreak in this country in 1865-66, it became law, that when the disease appeared, immediate slaughter was to take place.

'The materies morbi, like other allied maladies, lies dormant in the system for several days-about nine; and during this period the animal does not manifest symptoms of ill-health. The disease is first recognized by a slight cold, ushered in with shivering fits and with spasmodic twitchings of the muscles, especially of the shoulders; the coat stares, the back is arched, the appetite fails, and the patient ceases to ruminate; as the disease progresses the extremities grow cold, and pulse rises to ninety The above symptoms, by themselves, would not give sufficient evidence of rinderpest were they not followed with others, viz., a discharge from both nostrils, consisting of mucus mixed with flocculi of lymph, soreness of throat associrted with a distressing and busky cough; the countenance also gives evidence of pain; the vessels of the eye-balls become red and swollen, and discharge, mixed with blood and pus (matter), escapes from their inner angles; the bowels are at first constipated, but afterwards violent diarrhoea sets in ; the stools at the same time being very offensive are mixed with a jelly-looking substance, composed of mucus, flocculi of lymph, and blood, and, in some instances, of small detached pieces of the inner lining of the intestines; the animal's strength now rapidly fails, the twitchings of the muscles subside, and within the areolar tissue of the same, emphysema occurs, caused by the gas eliminated from the decomposing blood, and death terminates all suffering.

It will, perhaps, be remembered that in December, 1865, Dr. Murchison wrote a letter to the Lancet, in which he asserted that the cattle plague and small-pox were similar diseases; to this statement many subscribed. Soon after Dr. Murchison's letter came to my notice experiments were immediately instituted, in 1866. Dr. Murchison argued, if small-pox and cattle plague are identical diseases, then the vaccination of heal thy stock will prevent in them the occurrence of rinderpest. Dr. Murchison, in his examination of cattle the subjects of cattle plague, discovered in some instances "circumscribed circular flattened vesicles, some as large as a threepenny piece, on the udders of cows that had died of the plague, resembling in every respect the vesicles of cow-pox." This state of the malady was, of course, sometimes presented, but was in my experience a very unususal pathological state; that is to say, during the examination of some two thousand subjects of rinderpest, I only found three cases with vesicles on any part of their bodies; but as Dr. Murchison's is one of the valuable contributions to medical literature, it is reproduced in extenso.

"On the points of resemblance between Cattle Plague and Small-pox, by C. Murchison, M.D., F.R.C.P.

"The main anatomical characters of the disease are catarrhal or croupal inflammation of the lining membranes of the digestive canal and of the respiratory passages, and, in fact, of all the mucous membranes; an unusually dark colour of the blood; ecchymoses or hæmorrhages in various parts-such as beneath the skin and into its substance, beneath the mucous and serous membranes of the third and fourth stomachs and bowels, and beneath the endocardium; an aphthous condition of the mouth, nostrils, and vulva; the exhalation of a peculiar offensive odour from the whole body, but especially from the abdomen; and an unusual proneness to decomposition.

"In my former communication, it was show $\mathrm{n}$ that the dogmatic assertion that rinderpest was the precise pathological equivalent of human typhoid or enteric fever, was devoid of foundation. So far as I know, this opinion has been confirmed by every subsequent observer who has dissected the diseased cattle for himself, and published the results of his investigations. All agree in stating that the essential lesions of human typhoid fever are abent. A grave pathological error has thus been corrected.

"Typhoid fever, however, is not the only human malady to which cattle plague bas been thought to be intimately related. 
By different writers rinderpest has been compared to contagious typhus, scarlet fever, erysipelas, influenza, and dysentery. A careful study of the subject has satisfied me, that all these affections are entirely distinct. It is not my present object to enter in detail into the points of distinction between rinderpest and the several diseases now mentioned. This I have done in a report which I have been requested to prepare for the royal commission 'On the Relation of the Cattle Plague to Human Diseases.' In the meantime, I desire to impress more particularly on the profession, that there is one human disease which, as regards its relations to rinderpest, cannot be dismissed so lightly. If this disease be proved to be the same as rinderpest, not only will the benefits to pathological science be enormous, but a certain means of preventing the cattle plague will be placed within our power. The disease $I$ allude to is small-pox.

"The resemblance of rinderpest to small-pox is no new discovery, although latterly it has been lost sight of. Upwards of 150 years ago, Ramazzini, in his admirable accrunt of the cattle plague which pervaded Italy in 1711, enumerated among the symptoms 'pustulæ quinta vel sexta die per totum corpus erumpentes, ac tubercula variolarum speciem referentia."* Lancisi likewise, in his description of the same outbreak, observed, 'Semper autem phlogoses, pustulæ, et ulcera linguam e: fauces summo cum ardore obsidebant.' $\dagger$

"The physicians who described the outbreak of cattle plague in Britain in the middle of last century, constantly refer to the pustular eruption. Dr. Mortimer describes "scabby eruptions in the groins and axillæ which itch much; for a cow will stand still, hold out her leg, and show signs of great pleasure when a man scratches these pustules or scabs for her." $\ddagger$ Dr. Brocklesby remarks: "Frequently we may observe pustules break out on the fifth or sixth day, all over the neck and fore parts. $\S$ And lastly, in 1758 , Dr. Layard writes thus: "Whoever will compare the appearances, progress, and fatality of the smallpox with what is remarked by authors of authority, as Ramazzini, Lancisi, and other observers, relative to the contagious distemper among horned cattle, will not be at a loss one moment to determine whether this disease be an eruptive fever like unto the small-pox, or not." $\|$ The outbreak of cattle plague here referred to commenced in England in 1745, and is generally said to have died out at the end of twelve years, or about 1757 , and not to have reappeared until the summer of 1865 . But in 1769 the disease was again so prevalent and fatal that it was referred to by his Majesty George III., in his speech at the opening of Parliament in January, 1770, as a great national calamity. It is a most remarkable fact, that this last outbreak has been alluded to by most subsequent writers as an undoubted epizootic of variola, and that Layard, who described both this outbreak and the preceding one in the Philosophical Transactions, regarded them as identi-

- Opers Omnia, Genevæ, 1716, p. 787.

† De Bovilla Peste, Romæ, 1715, p. 155.

t Philosophical Transactions, 1745, vol. xliii. p. 564.

S Essay on the Mortality among the Horned Cattle, London, 1746, p. 88.

Philosophical Transactions, 1758, vol. l. p. 531. cal, recommended and practised inoculation in both, and in support of his opinion quoted the following passage from a letter addessed to him by Vicq d'Azyr, a great French authority on Epizootics: 'Il me parait comme à vous que c'est toujours la même maladie qui a regné depuis 1711 ; et qu'elle a des grands rapports avec l'eruption varioleuse."* It is generally believed that it was the remains of this violent epizootic that Dr. Jenner found in Gloucestershire, which, being communicated to the milkers, rendered them insusceptible of small-pox. With these and many like observatione on record, it is surprising that the cutaneous eruption should have been so long overlooked in the present epizootic.

"Early in the month of September I was struck with the occasional presence of circumscribed circular flattened vesicles, some of them as large as a threepenny piece, on the udders of cows that had died of the plague, resembling in every respect the vesicles of cow-pox. In one specimen which Professor Gamgee had the kindness to show me, this resemblance was most striking. Further observation has satisfied me that these large well-developed vesicles are only present in a few cases, but that in almost every case, and probably in all where death has not occurred within the first three days of the disease, there is a papular or pustular eruption on the skin, closely resembling the eruption of small-pox. This eruption is not confined to any particular part of the integuments, but is most abundant on the back of the neck and shoulders, in the neighbourhood of the mouth, on the udder and scrotum, and on the skin surrounding the anus and the entrance to the vagina. A minute description of this eruption is contained in my official report. At present it will suffice to state that it appears to consist, in the first instance, of minute pimples or elevations, which become softened at their summits into pustules. These speedily dry up, and form a scab, on detaching which the subjacent cutis appears raw or superficially ulcerated. Petechiæ are not unfrequently interspersed through the eruption. This eruption accounts for the spots and stains observed in the tanned hides of cattle that have died of the plague.

"But the cutaneous eruption is not the only character in which rinderpest resembles small-pox. Its close resemblance, if not still more intimate relation to human variola, is borne out by the following considerations:-

"1. Small-pox is the only acute contagious exanthem in man that assumes a pustular form. The eruption in rinderpest is also pustular. Any difference between the two eruptions may readily be accounted for by differences in the skin of men and cattle. In both cases, the eruption extends from the skin to the interior of the mouth and nostrils; and in both the pustules are often interspersed with petechiæ. Moreover, in certain cases of rinderpest, the eruption on the udder assumes the form of large flattened resicles, indistinguishable from thcse of ordinary cow-pox.

"2. The other prominent symptoms of rinderpest are also those of small-pox-viz., pyrexia, lumbar pain, running trom

- Philosophical Tranesctiona 1780, rol. loc., p. 648. 
the nostrils, alvine flux, albuminuria and hæmaturia, and the ' typhoid state.'

" 3 . The anatomical lesions of the two diseases are identical -viz., inflammation of the mucous membranes of the airpassages and digestive canal, dark-coloured blood, ecchymoses, and a pustular eruption with petechiæ on the skin. This will be apparent on comparing the post-mortem appearances of human variola as detailed by Dr. Copland,* with those of rinderpest described by me in The Lancet of August 26.

"4. In both diseases a peculiar offensive odour is exhaled from the body, both before and after death.

" 5 . In both the duration of the pyrexial stage is about seven or eight days.

" 6 . The two diseases resemble one another in their extreme contagiousness, and in the facility with which the poison is transmitted by fomites.

"7. Both diseases can be propagated by inoculation. This can be said with certainty of no other human malady than small-pox.

"8. In both diseases there is a period of incubation, which is shorter when the poison has been introduced by inoculation, than when it has been received by infection.

"9. Vaccinated persons are constantly exposed to small-pox poison with impunity; and with regard to rinderpest, there are numerous instances in which individual cattle, or entire herds, appear to have led charmed lives in the midst of surrounding pestilence. This last fact has never been explained; but the immunity of the cattle in question would be readily accounted for on the supposition that they had previously suffered from ordinary cow-pox.

"10. It is a mistake to imagine that variolæ vaccinæ is of necessity a mild disease. Under ordinary circumstances it undoubtedly is so. But there are many epizootics of cow-pox on record $\dagger$ where the disease was of a malignant character, and destroyed the cattle almost as extensively as small-pox did the human race.

"11. It has been repeatedly stated of late years that ordinary cow-pox had become so rare, that it was difficult to obtain lymph direct from the cow for the purpose of human vaccination. As a natural consequence, the majority of the cattle in these kingdoms are unprotected from the invasion of the disease in a more severe form.

"12. Although it may be objected to the view that rinderpest is simply small-pox in the ox, that there is no proof that the diseased animals have communicated small-pox to the human subject, and that in fact human small-poz is far less prevalent in Britain than it was a few years ago when there was no rinderpest, yet it is well known that there is often a difficulty in transmitting small-pox from one species of animal to another, and that when transmitted the disease is modified, although essentially the same. The rinderpest

- Copland'e Dictionary of Practical Medicine, rol. iii. p. 821.

+ See, for eramples, "Report of the Section of the Provincial Medical and Surgical Asscciation appointed to inquire into the present etate of Vaccination," read at Liverpool, Jaly 25, 1839 itself, notwithstanding the assertions to the contrary made when it first appeared among us, is transmissible to sheep, goats, and deer; yet there is more difficulty in communicating it to these animals than from cow to cow. The difficulty ought to be still greater in communicating it to the human species, than to animals so closely allied to cattle as sheep, \&c. Evidence, however, of the transmission of rinderpest to the human subject is not altogether wanting. Through the kindness of Dr. Quain, I had recently an opportunity of seeing a man who had accidentally inoculated the back of his hand abont ten days before, with matter from the hide of a cow which had died of rinderpest. The result was a large vesicle surrounded by a red areola, indistinguishable from a vaccine pock on the ninth day. A surgeon in the country, who had seen the man and sent him up to town, had no hesitation in pronouncing the disease to be cow-pox; and J understand that this opinion has since been confirmed by no less an authority than Mr. Ceely of Aylesbury. Moreover, the general, as well as the local symptoms in this man, were those of cow-pox. For a few days he suffered from a considerable fever, headache, and pain in the back. He had previously been vaccinated, but the protective power of the former vaccination had probably become exhausted. Although this is the only instance of the sort that has fallen under my notice, I have reason to believe that it is not a solitary one. It is to be borne in mind, however, that most of the inhabitants of this country are protected from small-pox by vaccination during infancy, and thus possibly may also be protected from rinderpest.

"These considerations may not be sufficient to establish absolutely the pathological identity of rinderpest and variola, but they unquestionably point to a very close analogy between them. The object of this communication, however, is not to insist that the two diseases are pathological equivalents, but to enlist the assistance of the medical profession in clearing up the matter. The mode of procedure is obvious and sufficiently simple. It is to produce cow-pox in cattle by inoculating them, on the one hand, with vaccine lymph, and on the other with the matter of human variola; and afterwards to ascertain if they be proof against the prevalent plague, or if the course of the rinderpest be thereby modified. If the results of these experiments turn out as I think there is reason to anticipate, the vexed question of the pathological nature of rinderpest will be finally settled, and mankind will be furnished with a certain remedy for arresting its ravages."

The Post Mortem Appearances.-The mucous membranes from the mouth to the anus, of which sometimes prolapsus exists, exhibit signs of intense inflammation, as also do the respiratory passages. Ecchymoses and hæmorrhages also occur beneath the serous and mucous membranes of the third and fourth stomachs, and ulceration of the fourth stomach and intestines is usually a post mortem manifestation. In the third stomach also the food is dry and hard; and the folds of this stomach soon after death can be rubbed into powder botween the finger and thnmb. 
It is difficult to prescribe treatment. The pharmacopoia has been ransacked for drugs, and almost every treatment has been adopted, both the depletive, with the lancet, and purgative; and the opposite, with its stimulant, its tonic, and gruel. One system, viz., that of giving small doses of sulphuric acid and water, seems to have answered better than any other; and reports from continental authorities, especially the Dutch, state they have always placed the greatest reliance on mineral tonics, and have found them more beneficial than anything, cases being cured at the rate of 45 per cent. To m knowledge, certain cases that were treated with mineral acids recovered; but whether the recovery resulted from the use of the above medicine, or from the "vis medicatrix naturæ," I shall not venture to affirm; but the author of the "Principles of Organic Life," with whom I have often talked the matter over, is very sanguine that the system advocated by him, in his article on the remedies used for rinderpest, would cure, not 45 , but 90 per cent.; and for this reason his article is here transcribed:-

"I will now speak of inflammation, in which I include all cases of inflammatory actions, whatever character they may assume, but which produce in the system more or less a febrile tendency; also, all cases where sudden damages are to be repaired, or reconstruction carried on.

"Inflammatory actions never exist without destroying the balance of the inorganic and organic fluid elements in the system. In fact, as heat and thirst prevail there must evidently be a drought; this drought therefore shows that the natural inorganic fluids of the body are below par. The organic elements may remain in the same proportion, but the inorganic are considerably lessened. The very first natural acts shown in these states are conservative, in order to get these elements again. Thus, perspiration ceases, urinary secretions are lessened, and constipation of the colon ensues. No amount of foreign fluid taken into the system can possibly supply what it now requires. Therefore, the conclusion must necessarily arise that nature herself is unable to make up the quantity for the due labrication of her machinery, or to support the chemico-vital principles of life. It is evident that the three great conservative actions mentioned above are known to all medical authorities, including also the veterinary. Because, directly they occur, they all exclaim, 'Get a secretion on the skin! Get the kidneys and bowels to act!' The more these unnatural acts are pursued by equally unnatural means, the farther off is the wished-for result. To say that these make matters worse, is the mildest expression that can be used. From the disappointment often experienced in trying to effect these objects, the great wonder has appeared to me that the physiology of nature has not been more deeply studied.

"There have existed in every generation of men practising medicine keen observers, who have said, 'Do not give aperients in fevers;' yet they will give medicines which, in ordinary circumstances, when inflammation does not exisr, will produce renal actions and perspirations, but fail to do so when inflammation is present. In our own day, men who have got some credit for their works on fever have said, 'We seldom see any benefit arising from cathartics in fever; nay, we have often seen great evils arise; better then leave a little constipation to some natural law-it seldom does an injury to the system.' Again, 'Pneumonia is none the worse for having allowed some conservancy of the bowels.' But inasmuch as these are only opinions, backed up and supported by no law; other writers, equally esteemed, advocate aperients, and will show cause for doing so by a number of cases where absolute benefit is proved to have resulted by the proceeding, while in a few they are candid enough to admit the reverse.

"This touches on my last section; for it may so happen that the fevers thus treated have been congestive, and could stand this treatment to a certain extent; while, on the other hand, the authors who decry aperients may have had more purely inflammatory ones. But inasmuch as neither party knew the difference between the two, the dogmas of both sects are seen to be only their opinions, totally unconnected with any physiological law whatever. If, as physiologists have said, the body depended upon the blood for all its moisture, why does it not supply this now, in its utmost need, when its organic elements remain the same, and even totally unimpaired? Simply because the inorganic fluids are made from totally different sources. Nature not being able to supply fluid diluents to the organic reconstructing elements, she retains in the system all those which she wants for these purposes, but which the faculty try all they can to carry away. This, forsooth, is called physiology, and the scientific practice of medicine, when it is neither the one nor the other.

"Nothing shows the truth of these remarks more than the dreadful pestilence called the rinderpest, which has lately, with its 'scientific stamping out,' carried off millions of cattle, and caused millions of money to be lost. I am in possession of the Government report on this disease; and a wonderful production it is. It is a great lock, with the key lost, and nobody seems able to pick it. Therefore, the rinderpest must remain a mystery, and the Blue Book which records it simply an oracle, which will answer no question or give any sign. Now, I believe that the rinderpest is as capable of being cured as the measles, if the oracle is only questioned in the true spirit of physiology. We have all we want to enable us to solve what is now a mystery; but it must be done by the greatest sacrifice, and that is nothing more nor less than to throw overboard all our prejudices, all our dogmas, all our false physiological theories. Can this be done? We have the disease now amongst our herds, and foreign herds breed it still. Is it to remain in England as its habitat? Is the pole-axe still to be the only safe modus medendi? Are we still to lose our cattle and their money value; and is every householder to be mulct in twopence a pound for all his meat, because science is so helpless in this second half of the nineteenth century? These are serions questions for the community to have put to them; and more serious, as well as disgraceful to science, to be told it is powerless. All the 
beautifully coloured pathological drawings of the Parliamentary Report leave nothing to be desired. The description of the disease is perfect. What does it lack, then? Only two things-its true physiology and treatment. At present there is nothing but what is either false in the one, or most pernicious in the other; yet they are capable of being resolved into the most marvellous simplicity.

"The physiology fully demonstrates the want of the inorganic elements in the system; and the treatment, the best means of supplying these, and to assist nature to do so as well.

"The letter concluding this work ended with the year 1865 . In February, 1866, I received a letter from a surgeon in Shropshire to the following effect:-

\section{"February 25th, 1866.}

" Dear Sir,-I muclı regret that you have discontinued your most interesting and most valuable letters on physiology. From the views which you have maintained on certain points, it struck me, as soon as I saw the great outbreak of the cattle plague, that you might break through the mystery which surrounds it.

" All have tried their skill without any good results. Acting upon your general physiology, designed only for human ailments, I assisted a neighbour of mine six weeks ago in the treatment of his cattle, which consisted in giving the sulphates. The result has been most successful. My mode was to give dilute sulphuric acid, two ounces; sulphate of iron, three quarters of an ounce; sulphate of zinc, half a drachm.' (He does not mention in what proportion of water, or how often the dose was given.) 'Then excessive purging came on, sulphate of copper twelve grains, in a quart of water twice a day: Barley, linseed, oatmeal, or rice gruel, to be the chief article of diet. I have saved one in five; whereas others' treatment here has scarcely exceeded one in ten, or even more. I wish to ask you whether you can suggest any better treatment, that, according to your views, would be more beneficial, as I have the disease a few yards from my house, and have also two cows of my own at present free from the disease. I may here remark, that from six post-mortems I have seen, the contents of the first and third stomachs (rumen and omasum) were as dry as dust. I may add, that brandy, whisky, laudanum, chalk, \&c., in any quantities, in my experience are injurious, and that simply cold water is best."

"At the beginning of August, 1867, a friend of mine who has often derived personal benefit from my principles in the practice of medicine, as well as his horses and stock, was in Bedfordshire. While there, he accidentally fell in with a dairy farmer near Hutton. Speaking to him of his large stock and the rinderpest, the farmer said he had no fear of the cattle plague, for when it was most severe he bought cows at his own price, and everybody thought he would be ruined; but he had heard of a good thing for them, and he never allowed them anything but acidulated drinks At first they did not seem to like them, bnt afterwards preferred them; and the quantity of sulphuric acid he used was enormous ; for it was cheap enough.
Directly he saw them lop their ears and their gums were red, and they refused their food, be gave them drencheie of it; also opium and chlorodyne, and so stopped all scouring and purging immediately; and in a few days they were all right, and he never lost an animal. My friend asked him how he found out all this? 'Oh l' he said, 'he heard it from somebody, and wondered why others did not do the same.' Here, then, is a proof of the singular benefit of the physiological treatment I have laid down; but whether this farmer got his knowledge directly or indirectly from my betters on physiology, or from other sources, I cannot say: I hope the latter, because others may be engaged on these principles of treatment as well as myself. "I may here add that I wrote a very long letter to my Shropshire correspondent and several letters afterwards; but I never again heard from him, and can therefore give no further account of his proceedings. To return to his postmortem cases. There is no way of accounting for the contents of the first and third stomachs becoming as dry as dust, except from the absence of naturally formed moisture; and I must here say, that no amount of extraneous fluid would or could have moistened them, for any time sufficient for natural uses. The absence of power in the animals themselves to make their own inorganic fluid elements, by the natural generation of hydrogen from their own secretions and freces, in order to combine with the oxygen of the air taken in such large quantities with their food and drink, was one most exciting cause of this dry state of their aliment after certain processes of digestion. The second, that no gases can exhale without the presence of moisture; and as the natural resisting gases could not be formed in their bodies, the oxygen, as a sequitur, finding no elements of combination, dried up the contents of their stomachs. Attrition and friction, producing their dne amount of inflammatory actions, was the consequence -We have only to see this fully and graphically described in the Government report. What, then, does this bugbear the rinderpest amount to? Simply this, that the self-supporting action of the system is out of gear; that the natural resistance of the oxygen is taken away, or rather hydrogen in sufficient quantities is not generated; therefore the animal, being unable to make the proper amount of inorganic fluids necessary to life, a general and universal destruction of all tissues and parts ensues. If an adult liuman being makes these inorganic lubricating fluids to the extent of thirty pints in every twentyfour hours, entirely independent of the blood and any fluid he may drink, and uses them-how much more must animals make? Perhaps little short of one hundred! I refer to the fat obtained entirely in this way by inspissation of these fluids; which, when deposited in its proper places, becomes not only the natural oil can of their bodies, but the storehouse of aqueous matter to be used-not by combustion, as our present physiology teaches us, but simply by dissolution and absorption. In the face of all the symptoms in this disease so characteristic of rapid destruction, owing almost entirely to the loss of inorganic elements, I shall quote from the Government third report, which I shall now merely refer to, what 
were the principal remedies administered for the disease:Vaccination; inoculation from the humours of the diseased animals; bleeding; injection of antiseptics into the veins; injection by rectum of carbolic and cresylic acids; sulphate and bisulphate of soda; inhaling the vapour of warm water and vinegar The animals had given them, by the mouth, brandy and opium in full doses; strong ale; hyposulphate, sulphate, and disulphate of soda; common salt; water impregnated with iron; Worms' mixture of onions, garlic, ginger powder, and assafoetida, to which cayenne pepper was often added; oil of turpentine; carbonate of ammonia; solution of acetate of ammonia and chloric ether; half-pound doses of charcoal; bichloride and chlorate of potash; bark, tinctures, and all kinds of diaphoretics; linseed oil, in constipation; sulphate of magnesia, sulphur, and all their aperients, sucl as saline laxatives, with diffusible stimulants. Certain hygienic means and diet followed all these different treatments. Only now and then do I find by the merest accident, and that evidently for the sake of experiment, that the mineral acids were given. Again, although it was constantly observed that diarrhœa, evidently from mucomenbranous inflammation and irritation, always lowered the animals, yet laxatives and aperients were nevertheless given. I need scarcely add, what the Report is fully justified in saying, that not only no good arose from any form of allopathic treatment; that little benefit was derived from the use of drugs, but rather the greatest evil from them, every symptom being aggravated; and it could not well be otherwise.

"To show that all treatment was founded only on supposition and conjecture, a trial was set on foot between the three great sects: the allopaths, the homøopaths, and nature. One hundred beasts were allotted to each. As a matter of course, the natural sequence ensued between the two first, as to what was, or what was not rinderpest. The animal quarrelled over was then set aside for nature to determine; and so something was done to put an end to 'such unseemly disputes.' The homøopaths' treatment consisted of aconite; ammonium causticum and arsenicum; belladona and phospliorus; nuxromica; phosphorus and sulphur; arsenicum and rhus; pulsatilla; arsenite of iron; mercurius corrosivus. These medicines were sometimes given separately, and sometimes combined one with the other, according to the fancy of the giver. Porter entered into all their dietary. The treatment by this sect was not more satisfactory than the other. Now for the Dutch system of treatment. They have always placed the greatest reliance on the mineral tonics, and 'have found them more beneficial than anything.' Muriatic acid in linseed tea; sulphuric acid, with quinine, gentian, ginger, ginger and tormentilla, and other astringents and tonics, as natural remedies; washing the eyes, mouth, nostrils, vagina, rectum, \&c., with solution of carbolic (phenic) acid, as well as giving it internally as a prophylactic remedy. Preparations of chlorine, for fumigating purposes, were found injurious, and often affecting the lungs. Distillers' wash and stimulants were found nnsuccessful, and often hurtful. By this Dutch method, we are informed, success at the rate of 45 per cent. ensued. But nothing more than empiricism was manifested in this treatment. They found it the 'most beneficial,' and that is all they have to say on the subject. Neitler philosophy nor physiology of the disease, nor cause nor effect, ever transpire. No reasons are given bcyond the old, old ones, of being found beneficial. I will now state wliat is done in eastern Europe:-

"Odessa.-Vapour baths, nitre, linseed gruel, and gentian; injections of tobacco water; bleeding; warm milk mixed with garlic as drenches, which always failed, while repeated doses of vinegar and cold water were of great service, when every other remedy had failed. 'Hashha' (or poppy-heads) and 'huibia' (or chicory) stopped flux and allayed pain In other cases, setons and mustard plasters are applied to the chest; the seton steeped every day in fresh turpentine. ' Burn all swellings with red-hot iron immediately they appear.' Four or five pounds of blood to be taken from sanguine animals. A pint of infusion of linseed and olive oil, as a drench, three times a day. When the disease augments, add enough sulphuric acid to extract of nux vomica to the drinking water, to give a bitter taste. Half a drachm of spirits of ammonia in half a pint of water, three times a day as a drench. Three ounces of glue dissolved in a pint of tepid water will stop diarrhœa. This latter treatment in Southern Russia and Bessarabia has been found perfectly efficacions, and caused the disease to disappear. At Jassy they depend on acetate of ammonia, alternately with gentian, quinine, and peppermint, every two hours during the day. Black hellebore steeped in wine is given to the animal, which is made to take active exercise immediately afterwards, in order to cause sweating.

"At Ragusa. - Sulphur, mercury, and antimony are given, and hypophosphate of soda. In all this treatment nothing but usage appears to guide the administration of medicine, like every other medical treatment, human or animal, throughout the world; supposition and conjecture on the best authorities, founded on hope, but neither physiology nor philosophy entering into the question. Now, without these the hope expressed in the report has small chance of fulfilment, "that the labours and views of so many minds brought to bear upon the subject will go far beyond the cattle plague itself, and point to the benefit of the human race for the prevention of and cure of zymotic diseases.'

"This is just the point where fresh thought ought to come in; but it never will, while speculation is the sole act even of the greatest experience. Disease, as a simple effect, is a myth ; and instead of being treated specifically, as it has been, on what is called the best authority-which is nothing more than the opinion of certain men who in every age lead the whole community-the causes which produce it unust be better understood. So, when once philosophy and plivsiology go hand in hand, those unseemly disputes so constant among ourselves, as well as our theories and medical speculations on all 
medical subjects, will disappear, or will be resolved into the one question of the best way of carrying out sound principles.

"Let ns find a germ in the rinderpest, which is only an aggravated form of the rapid and sudden loss of inorganic elements, leaving the organic as they were, and as they exist when the inorganic are in their full integrity. Any impartial reader will see if he has followed me from the commencement, that the corrections by all the alkaline remedies are the best when the inorganic elements are in excess, and the body in a superfluous, or over-exuberant, or acid state; that when given they cause the highest state of combustion, and either lessen or destroy them; that caloric is produced, and rapid conversion of the products formed from such treatment are again acted upon by other elements; and these again on freshly developed secretions, until the whole system is relievedrelieved because the organic elements are not interfered with or lessened, but are ready in the body to come to the rescue, and keep up the strength of all its general structures. It will be found true that we can be almost heroic in our remedial and prophylactic treatment of the inorganic elements, which constitute 95 per cent. of the whole mass; but that we must be cautious in what way we attack organic elements. We must not tamper with these; for they are only 5 per cent., and we cannot replace them as we can their opposites. The lamp of life may be represented by the oil and the wick, the former by the inorganic, the latter by the organic elements; so that there may be plenty of oil and no wick, or plenty of wick but no oil-in either case the lamp goes out. Now the rinderpest, and all inflammatory fevers, choleras, and most of the zymotic diseases, represent the lamp with plenty of wick, but no oil. What will every one find, when the alkalies are given in any form in all these inflammatory diseases? That things are made worse: for the few remaining inorganic elements, which are the acid ones, are removed by them. What when purgatives and cathartics are given? That the hydrogens, the great resisters of the oxygen of the atmosphere, are carried away, leaving this latter gas to work destruction, because it has no opposing element, and the system is unable to form its own lubricating fluid. What when bleeding is resorted to? That organic elements are being robbed from the system; so that if a beneficial change actually took place, naturally or artificially, the bases of reconstruction are cut away. What when counter-irritants are applied? Only putting animal life to greater misery ; because eruptions are nature's legitimate counter-irritants in supervital states and seldom or never come, certainly never in any form to diminish natural powers, in inflammatory actions; therefore, as nature does not point to their use, they should not be applied artificially. What when the mercurials are used? Why, nothing but a transfer of some inflammation from one part to another, causing only a temporary relief of the one for which it has been given. What when alcoholic stimulants, such as brandy, tinctures, and turpentine, are given? That they increase irritation on all present inflammatory surfaces, and excite other parts which may yet be free from them to take on these states. What when spices, peppers, and all similar heating condiments, are administered? That they cause greater irritations, and aggravate all the symptoms. What when onions, garlic, and all these analogous bulbs, are used? That they relax the mucons surfaces, and often promote diarrhoea, as well as cause thirst and absorb inorganic fluids. What when diaphoretics and diuretics are given? That they carry away the watery elements of the fat stores, wherever these are deposited, when the object should be to retain them. What when vaccination is performed? That doing this, on the supposition that something exists which does not; that the disease is from some specific blood poison, when it is not, and cannot be. What when inoculation is performed? That the diseased elements, both inorganic and organic, will produce in the bodies of sound animals a similar inflammatory state, which is most culpable; because, if any animal so having the disease induced cannot be cured with any certainty-as has been proved by the treatment of those who had it naturally -it is only placing that animal in danger of its life, without the slightest benefit likely to accrue. The administration of charcoal cannot be of any service, because the animals are already robbed of all elements which poison the system, which are the inorganic in excess; and therefore there is nothing to be counteracted by this remedy. So much for the allopathic remedies of the faculty and veterinary fraternity in rinderpest.

"The homæopathic remedies are more or less visionary in their actions, and if administered homoopathically could not possibly do either good or harm; yet if given dishonestly by them, that is, in similar doses which the allopaths would use, some of them would be most injurious; while those that were beneficial carried no logical deductions with their administration. It would be certain that ammonium causticum, and arsenicum and mercurius corrosivus, would go more quickly to destroy life by aggravating the disease, and so to save the use of the pole-axe, the knife, or the bullet. Taking all these things into consideration, it will be clearly seen that all the foregoing remedies and measures went far to aggravate the disease. On the other hand, what is actually wanted is nothing more nor less than the restoration of a balance of power of the inorganic elements; and this object is only to be attained by the opiates in their crude or aqueous, not in their alcoholic form, to arrest all secretions, and the administration of the acids, which, in their conversion into gaseous elements, help to make such resisting ones, which the system always requires to oppose the action of the oxygen. The Dutch and some others, as I have shown, have fully established the empiricism of this treatment; but science requires more than this: it wants to know upon what principles it does good, both physiologically and philosophically.

"I have proved for years, that in all fevers and inflammatory conditions of the mucous and serous membranes, opiates are given for the express purpose of locking up the bowels, which 
is done by detaining the natural secretions; and that the acids generate such gases as mix with and oppose the oxygen, and furnish most rapidly the self-generated fluids, whose duties are to assist the organic elements to repair and reconstruct destroyed tissues. Having watched this in the human family for many years, I cannot deny myself the pleasure I felt in reading the following in 'The Report of the Rinderpest,' p. 93, and which I can fully verify :-

" 'Rapidity of Repair in Diseased Tissues.-It is very curious, considering the tendency there is to the formation of sloughs, how rapidly parts heal, even during the progress of the disease towards a fatal issue. In the abomasum, shallow depressions have been seen in the mucous membrane, which are manifestly the cicatrized or cicatrizing excavations whence sloughs have recently separated. Again, we find the edges of perforations of the folds of the omasum cicatrized or healed, whilst sloughing is still in progress in other parts of the folds. It is remarkable, too, how rapidly, on the supervention of convalescence, the mouth and other organs regain their original healthy condition.'

"All this is perfectly correct, as I can verify in thousands of instances, and is constantly occurring in the colon of the human being; but this organ has been completely ignored by the profession, except to purge it constantly of its natural manure, or only to examine the fres coming from it; and men think by doing so more assidu- ously than others, that they ought to know its physiology, while, nevertheless, all its true and noble duties are yet to be discovered. The liver and many other organic centres have had too much notice and importance, while the colon and its uses, have been entirely overlooked. I therefore conclude this section on the rinderpest, which has only been incidental to greater conclusions, but is analogous to many affections to which the human frame is subject, and which have been treated in precisely the same way, and will be to the end of time, unless a physiology that will serve ns steps in to supersede one that does not. The conclusion, then, is obvious, that opiates, and mineral acids, and tonics in such doses-mild at first when the disease first shows itself, and bold when it advances-in either man or animals, are the only true prophylactic remedies, as they restore the balance of power and the principles of life. And I here repeat, that as there are very many diseases, such as fevers, \&c., showing similar symptoms, it will not do to treat them all in the same way, simply because their causes may be distinctively different: one set, where the inorganic elements are in excess, requiring the alkalies; and another, where they are deficient, requiring the acids and opiates. They are easily distinguished, and when once known their treatment becomes exceedingly simple, as well as effcacious and scientific.-" Principles of Organic Tife." R. Hardwicke, 192 Piccadillv.

\section{DISEASES INCIDENT TO SHEEP.}

\section{THE LAMBING SEASON.}

ONE hundred and fifty-two days after intercourse with the ram tne ewes commence lambing, which generally is so arranged that they shall bring forth their young towards the latter end of February or beginning of March. About a month or six weeks previously to this period such ewes as are in bad condition should be supplied with plenty of food, in order that nature may provide for her offspring at the appointed time; but it is always better to feed ewes during their pregnancy on moderately good pastures. Ewes, if half starved at the time of parturition, are often sick, but many, on the other hand, die of inflammation, as the result of being overfed with too stimulating food; and often lambs have been destroyed from sucking overrich milk. A medium course, therefore, should be adopted, in feeding moderately during the period of pregnancy. Previously to the lambing season a fold-yard suitable for the purpose should be provided, arranged in such a manner as to afford protection from the north-easterly wind, with a suitable shed, close by a shepherd's house, in which all the necessary conveniences for assisting the parturient ewes should exist. Thus the shepherd will be better able to attend them during the night, to give assistance if required, and to take proper care of them. By the adoption of these simple precautions many lives, both among the ewes and lambs, will be saved. After the birth of the first lamb the attention of the shepherd must be directed to the remainder of the flock; each ewe should be carefully observed. Interference with those in labour is fraught with evil, unless the ewe has remained in such a state for twenty or more hours, and her strength is beginning to fail; then the necessity of immediate aid is indicated. This last case usually is brought about by a false presentation, of what kind must be left for the attendant to discover, who must use the same means as directed for cows at page 17 ; but of course, ewes are timid and much smaller animals, consequently require very tender usage, and will not bear the introduction of 
instruments similarly as the cow. In cases of dead lambs the foetus must be extracted with the hand, if possible-if not, with an instrument made for this purpose. Medicine is little required for ewes after lambing, although the placenta (cleansing) may not become detached for a day or two; sometimes, however, to check febrile symptoms, the following may be administered in their gruel:-

$$
\begin{aligned}
& \text { Epsom salts, . } \\
& \text { Ginger in powder, }
\end{aligned}
$$

ON THE DISEASES OF YOUNG LAMBS.

Young lambs are liable to a variety of different diseases, either from insufficient support, or from a redundancy of milk on the part of the ewe. If they proceed from the former support must be given them, either by allowing them to suck other ewes, or by giving them cow's milk: when the ewe has too much milk it is apt to coagulate in the stomach of the lambs, and causes constipation, by which the best of them are frequently carried off.* At other times the acid produced from the coagulated milk in the stomach brings on diarrhoea, which, if not put a stop to in a short time, will cause the death of many lambs.

Treatment.-Administer in a pint of warm gruel-

$$
\begin{aligned}
& \text { jastor oil, . . . . . . . . . . . } 1 \text { tabls-spoonfol, } \\
& \text { Ginger in powder, . . . . . . . . } 1 \text { drachm, } \\
& \text { Coarse sugar, . . . . . . . . . } 1 \text { table-spoonful. }
\end{aligned}
$$

This drink may be repeated once a day for two or three times, until a proper passage is obtained. The quantity of castor oil may be increased or diminished, according to the size and strength of the lamb. A strong lamb, six weeks or two months old, will require one table-spoonful and a half; but if only two or three days old, half a table-spoonful will suffice. If the disease be permitted to continue for some time, and no means to give relief be attempted, the diarrhoea increases, and the stools are attended with a copious dejection of mucus from the intestines, and the young animal pines away. After the bowels have been properly evacuated with the above purgative drink, if the diarrhoa still continues, twenty drops daily of tincture of opium in starch and oatmeal can be given, which often succeeds in effecting a cure.

\section{RED WATER.}

This disease is of an inflammatory nature, and prevails chietly at the end of the year or during the winter, among sheep feeding upon turnips or succulent grasses. Clater writes:- "In the neighbourhood of Retford, 1812, this disease has been common for several years past; it seldom misses a season; it makes its appearance amongst some of the numerous flocks that feed on regetables of those kinds, and for the most part attacks those sheep which are in best condition; and if no relief can be obtained they generally die in the space of twenty-four hours, or less." Sometimes

- Admizister every six boars, until reliof be afforded, half ounce doses of Epsom salts, and afterwards turn the ewes and lambs into a succulent pasture. a change of pasture, from a dry to a moist and cold one, will produce this malady, and prove as injurious as an immediate change of food. This disease manifests itself sometimes without giving any premonitory symptoms of its coming : for iustance, at night the flock may appear in good health; on the following morning several dead bodies may be discovered lying in a natural position, with the exception of protrusion of the head. At other times premonitory symptoms occur; the diseased sheep separate from the flock, stand with protruded head, breathe with difficulty, and evidence considerable dropsical enlargement of the abdomen, with frequent watery stools, mixed with blood and mucus, giving evidence of the true nature of the disease, "red water;" more often, however, constipation is present. On opening such sheep the disorder on examination has been found to proceed from inflammation, either of the stomach, the intestines, kidneys, or neck of the bladder, associated with dropsy of the abdomen; and Clater says the intestines sometimes become loaded with sand or gravel while feeding on turnips, by which the inflammation is considerably increased. The last post-mortem appearance I have never observed, and think Clater must have mistaken this state for some systemic disorganization. This malady is usually, in its last stages, associated with peritoneal and hepatic inflammation, and indicates a general break up of the organism.

Treatment consists in the removal of the flock to a dry and warm ground, where turnips and succulent food must be denied, and in its place oats and hay should be given. The following medicine Clater has had an opportunity of trying on a large scale, sometimes on five or six hundred sheep, belonging to one man, in the course of the day:-

$$
\begin{aligned}
& \text { Epsom salta, . . . . . . . } 6 \text { ounces, } \\
& \text { Nitre, . . . . . . . . . . } 4 \text { ounces, } \\
& \text { Boiling water, . . . . . . . . . } 8 \text { pints. }
\end{aligned}
$$

Pour the water hot upon the salts, and when milk-warm add-

$$
\begin{aligned}
& \text { Spirits of turpentins, . . . . . . . . . } 4 \text { onnces, } \\
& \text { Bole-armeric in powder, . . . . . . . } \frac{1}{2} \text { ounce. }
\end{aligned}
$$

Mix and shake them well together. The dose is from three to four table-spoonfuls.

When this medicine is intended to be given to a number of sheep, they must be taken from the turnips, or whatever they are feeding on, and put into a pen or fold-yard for two hours before it is given; then a small horn should be provided that will just hold the proper quantity for each sheep. This method of giving drinks to sheep will be found very advantageous when many require it at one time. They must be kept from food two hours after the medicine is given, either in a foldyard, or pen. The medicine should be repeated every other day. The treatment the writer has prescribed on several occasions, consists in the daily administration of-

$$
\begin{aligned}
& \text { Epsom salts, . . . . . . . . . . . } \frac{1}{2} \text { ounco, } \\
& \text { Disulphate of quinine, . . . . . . . . . } 3 \text { grains, } \\
& \text { Ginger in powder, . . . . . . . . . } \frac{1}{8} \text { drachm, }
\end{aligned}
$$

in thin gruel, with a little starch added. 
Sometimes the dropsy must be evacuated through the medium of the trochar, which operation can only safely be entrusted to a veterinarian. Usually recurrent dropsy intervenes, and consequently tapping fails in its purpose. The system, however, if it has gained sufficient vital force, may cause the absorption of the effused fluid, and thus effect a permanent cure. 4 very valuable medicine during this stage consists in the daily administration of a table-spoonful of the syrup of the iodide of iron, which acts as a tonic and absorbent, consequently is a medicine indicated in this affection

\section{THE ROT.}

This disorder has been more fatal to sheep than any other; and having at different times carried off great numbers, it has occupied the attention of the learned, who have favoured the public with a variety of opinions. Dr. Harrison was the first person to scientifically investigate this malady, and to draw attention to the true cause of its existence, and as his views upon the subject are very carefully detailed, and the post mortem appearances correctly described, his paper on rot is here given :-

"When in warm, sultry, and rainy weather, sheep that are grazing on low moist lands feed rapidly and some of them die suddenly, there is reason to fear they have contracted the Rot. This suspicion will be further increased if, a few weeks afterwards, the sheep begin to shrink and become flaccid in their loins. By pressure about the hips at this time a crackling is perceptible. Now, or soon afterwards, the countenance looks pale; upon parting the fleece the skin is found to have exchanged its vermilion tint for a pale red, and the wool is easily separated from the pelt. As the disorder advances, the skin becomes dappled with yellow and black spots. About this time the eyes lose their lustre, and become whitey and pearly, for the red vessels of the tunica adnata, conjunctiva, and eyelids become contracted, or entirely obliterated. To this succeeds debility and emaciation, which increase continually until the sheep die, or else ascites, and perhaps general dropsy supervenes, before the fatal termination. These symptoms are rendered more severe by an obstinate purging, which comes on at an uncertain period of the disorder. In the progress of the complaint, sheep become what graziers call cliockered, i.e., affected with a swelling under the chin, which proceeds from a fluid contained in the cellular membrane under the throat. In five or six days after contracting the rot, the thin edge of the small lobe of the liver becomes of a transparent, white, or bluish colour, and this spreads upon the lower and upper sides according to the severity of the complaint. Sometimes it does not extend more than an inch from the margin. In severe cases, the whole of the peritoneum investing the liver, is diseased, and then it commonly assumes an opaque colour, interspersed with dark lines or patches. The upper part of the liver is sometimes speckled likc the body of a toad, to which it is said to bear a striking resemblance. Round the ductus communis choledochus and hepatic vessels jelly-like matter is deposited, which varies according to the severity of the attack, from a tablc-spoonful or less, to five or six times that quantity upon boiling. The liver looses its firmness and separates into small pieces in the water, or remains soft and flaccid. Some graziers and butchers with whom I have conversed at different times, having observed that sheep arc much disposed to feed during the first three or four wecks after being tainted, omit no opportunity of producing it to incrense their profits. When this stage is over, flukes begin to appear in the pori biliarii, ductus communis choledochus, and the gall bladder. At first the quantity of these creatures is small, but, as the disease advances, they increase, and before death are often very numerous. In the first part of the complaint, they are sometimes found in the stomach, as well as in the intestines and liver. This, like the visceral disorders of the human body, may terminate in resolution, effusion, suppuration, or scirrhus. First, the complaint is said to terminate in resolution, when inflammatory action goes off, without destroying the state and texture of the parts. However, I am strongly inclined to believe, that every considerable inflammation in the human body and in other animals, although it ends in resolution, leaves behind it some remains which may be discovered by an experienced anatomist. When the vessels are thrown into inflammatory action for a few days only, effusion commonly takes place, the coats become thicker, and assume a buffy colour. These changes in the sanguinary system often continue through life, and lay the foundation of many chronic and incurable diseases. Sheep that recover from the rot, exhibit very different appearances after death, according to the severity of the attack; but the taint is seldom or never entirely removed. I was desired within these few days to look at the liver of an old ewe that died fat, and contained fourteen pounds of suet in her body. The back part of the small lobe was dappled with whitish spots, the coats of the ductus communis choledochus and pori biliarii were considerably thickened and more solid than usual. In colour they resembled the human aorta of old people, and were full of flukes; in other respects the liver appeared to be sound and natural. The butcher asserted that this was occasioned by a slight taint of long standing, which had not been considerable enough to disorder the economy, or impair the health of the animal sufficiently to prevent its feeding. Secondly, when sheep die suddenly in the first stage of the disorder, an effusion of serum, or of wheyish-coloured fluid, may commonly be discovered in the cavity of the abdomen, and then the peritoneum surrounding the liver is generally covered with a membrane or coat of coagulable lymph. This form of the rot has been frequently confounded with the resp, or red water, though it differs from the latter disorder in the colour of the effused liquid, in being much less disposed to putrefaction, and in several other particulars. Thirdly, abscesses in the liver exhibit another termination of the malady. They are seldom considerable enough to kill immediately, but in consequence of the absorption of purulent matter from them, the sheep frequently waste away, and die hectical or dropsical. When the collections are 
small, sheep will recover sufficiently to bear lambs for three or four seasons, and afterwards become tolerable mutton. Fourthly, the most common termination is in scirrhi, or what shepherds call knots of the liver. I have seen the whole substance of this important viscus so full of small roundish lumps or scirrhous bodies, that it would be difficult to find any sound part in it. The first attack is unfortunately so very iusidious, that the disorder is scarcely observable before the animal begins to waste and lose flesh. In this advanced state it is said to labour under rot, or pourriture, from overlooking the commencement of the disorder." The fluke-the Fasciola of Linnæus, the Distomum hepaticum of Rodolphi, the Planaria of Gosse-is met with in livers of many animals; but the exact method by which it finds its way there, demands further discovery to elucidate the fact. Küchenmeister thinks that in all probability man and animals infect themselves with free encysted young Distomata, either by devouring snails which adhere to the grass on pastures, especially in moist ones, or by drinking from impure stagnant pools, marsh or pond water. Exactly the same thing would take place in man by means of snails adhering to salad, fruit, or such other edible. Nay, such small snails might be introduced with dry fodder into the stomachs of our domestic animals during the winter, by their eating the small species passing their winter sleep in closed sacks, in their closed shells, or the shell-less slugs adhering to roots, protected from the frost in warm cavities or cellars.

"Youatt considers the fluke is not often the cause of rot, but that the tissues having become weakened by previous derangement, the liver then is reduced to such a condition as to favour the propagation of Alukes; or, in other words, if a sheep in robust health becomes infected with the Distomata, the chances are they would not find comfortable quarters in such a body, and would die or leave it, owing to its being no habitat for them. It is also well known that in wet seasons this malady is very prevalent, whereas in dry ones it is not; this fact all veterinary writers and men of experience acknowledge; and Küchenmeister accounts for it very clearly; as slug life is favoured by a continuance of wet weather. Of course, grass supersaturated with moisture is not the best food for sheep; but such keep may tend first to devitalize the ovine system, and weaken those tissues into which the fluke, as above indicated, finds its way. But whether the Distomum hepaticum be the cause or effect of rot, when once it is established in a flock the grazier well knows that some loss is inevitable, and his first thought is how to prevent its occurrence in the remainder of his flock. If wet ground favours the development of the rot, the removal of the flock to high and dry lands appears to be indicated, and is generally advised; or they may be brought near home, and placed in a straw yard, and be fed on dry food, such as oats and hay, and the following drink in a pint of warm griel, can be given to each patient:-

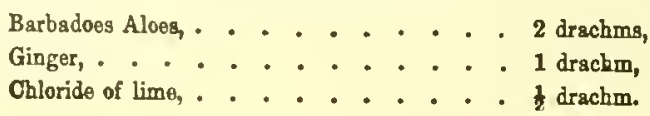

Clater recommends the following, and states that he has effected numerous cures with it, and several farmers at this day extol it as a valuable medicine in Sheep Rot:-

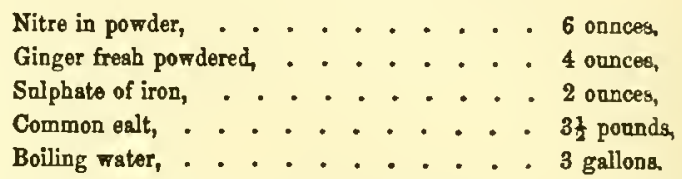

Pour the water hot upon the ingredients. Stir them, and when new-milk warm, add to every quart of the mixture three onnces of spirits of turpentine, and bottle it for use.

Directions for $\mathrm{Use}$ :-Keep the infected sheep from food all night, and on the following morning give each sheep two ounces or four table-spoonfuls of the above mixture. To those which are weak or reduced by the disease, onehalf, or three parts out of four, may be sufficient for a dose. Keep them from food three hours after giving the medicine, and turn out into a dry pasture. It will be necessary to repeat the medicine every fourth day for three times, observing the above rules. But where only half the quantity has been administered, it will be proper to repeat it every second or third day for six times. Every shepherd should be provided with a small horn, containing just the proper quantity ; this will save considerable time and trouble, when it is necessary to give the above drink to a number at the same time.

THE SCAB

is a cutaneous affection very common to sheep, and is of a very contagious nature, as one infected sheep will communicate the disorder to a whole flock in which it is placed; much caution, therefore, is needed by the grazier in introducing sheep purchased from other districts among his own flocks, lest any of them should be infected with the disease. It is first discovered by the animals rubbing themselves against every post, gate, bank, or any other convenient place suitable for this purpose, and they are frequently seen to pull off the wool with their mouths. Clater writes:- "This disease appears to be of a cutaneous nature, and only affects the skin with a scabby eruption; but if permitted to remain without attempting to cure, it will enter the system, and unless great care be taken, the sheep will sink under its pressure." The scabby eruption noticed by Clater has since been clearly traced to the existence of a parasite (Acarus ovis) which infects and burrows under the skin, where it sets up great irritation and inflammation. If an acarus be placed on the wool of a sheep, it will soon bury itself in the skin, scarcely leaving a trace of its entrance; in three or four days a red spot appears; in five or six days more a little swelling occurs, which soon developes into a pustule which breaks, from which the parent acarus escapes with a young brood attached to her feet; the little ones immediately enter the skin of the sheep, grow and propagate, and thus the disease is kept up; i.e., if the acari be not at once destroyed, the sheep will speedily die. The following sheep-dipping mixtures will be found very useful in treating scab, as they seldom fail in effecting cures :- 
(1) Arsenions scid, . . . . . . . 2 pounds, Carbonate of potash, . . . . . . 2 pounds, Boiling water, . . . . . . 60 gallons.

Boil for half an hour:-

(2) Powdered Arsenions acid, . . . . . 2 pounds, Sulphate of iron, . . . . . . 200 ponnds. Water, . . . . . . . 60 gallons.

Boil until the fluid is reduced to a third, and then add as wuch water as has been lost by evaporation.

(3) Carbolic acid, . . . . . 1 part to 20 parta of water.

In using dips 1 and 2, or any dipping mixtures containing poison, it is always necessary, in fact it is imperative, that sheep on being removed from the dipping tub be placed in some inclosed spot or yard, in which no food of any kind can be obtained; for this reason, that if sheep are allowed to go from the dipping trough to the pasture, the drops of the solution fall on the ground, and thus saturate the grass with poison, which if taken with the grass into the stomach is sure to cause death. The idea that sheep dips containing arsenious acid can be absorbed by the skin, is erroneous, as the experiments instituted by Dr. Stevenson Macadam, Professor Gamgee, and Mr. Finlay Dun, clearly prove, and the anthor had the good luck to see carried out. These experiments were instituted previously to the trial, Black versus Elliot; in which Mr. Black, a farmer, sued Mr. Elliot, a chemist and druggist, for loss sustained by him of 850 sheep, out of a flock of 869 , after dipping the said animals in a dipping mixture composed of-

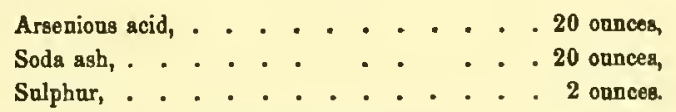

Directions:- "Pour upon each packet three or four gallons of boiling water, and stir well together for ten minutes; add about forty-five gallons of cold water, and dissolve in the mixture four pounds of soft soap. The preparation will then be completed, and the quantity sufficient to dip fifty hogs." Mr. Black, after dipping his flock, allowed them to pass from the trough to the pastures, and the consequence was that the above mixture dropped from the wool on to the pastures, and thus saturated the grass, upon which the sheep fed, with poison. Packages sent by Mr. Black, containing the above ingredients, were chemically examined, and arsenious acid was detected; and in the stomachs of several sheep that had died distinct traces of arsenious acid were discovered. Mr. Elliot also sent sods taken from the pasture above alluded to, to Edinburgh, to be chemically analysed, and they also were found to be impregnated with this poison. The question, therefore, arose by what means the poison had entered the system of the sheep; it was contended on one side, Mr. Black's, that it got there through the medinm of absorption, and, on the other, that the close-biting sheep had obtained it from the pasture, and that proper care had not been used by the plaintiff in sufficiently wringing the wool out, or in preventing the sheep in a dripping state, after having been dipped, to roam over the pasture. The truth was these sheep partook of the grass impregnated with the poison; it found its way into their stomachs, and death, as a consequence, resulted. The absorption theory cannot be entertained for a moment; if it had taken place the poison would have been discovered in the blood, and not in the stomachs; and, again, why had this dip, which had been previously so extensively used, not caused death before? Simply because due precaution had been taken, as above indicated. The following evidence given at the trial (1860), detailing the experiments instituted, is reproduced on account of its importance :-

"Finlay Dunn.-I am not connected with practical chemistry at present, but was so up to 1856 . I am the author of a work entitled, 'Veterinary Medicines,' \&c. 1 have made, for the purpose of this inquiry, certain experiments on sheep with various sheep-dipping solutions. I wrote down the results. On Saturday, 19th February, 1 made a mixture exactly like Mr. Elliot's. I had twentythree sheep brought up, and the whole I dipped in this solution. The sheep were turned into a yard, into which hay, loose straw, \&c., had been removed. No mischief arose to the animals. Besides that I made another experiment, taking the same proportions of soda ash and sulphur, but half the quantity of water. I immersed four sheep in this solution, and again without injury. I made a third experiment, taking $10 \mathrm{ozs}$. of arsenic, 10 ozs. of soda ash, $1 \mathrm{oz}$. of sulphur, and $2 \mathrm{lbs}$. of soft soap. I dissolved that in six gallons of water. In that I dipped four sheep. I also got one of the sheep that had been previously dipped, and kept it in sixty-five seconds. I consider Mr. Elliot's powder perfectly safe."

"John Gamgee, Member of the Royal College of Veterinary Surgeons, London, and Lecturer on Veterinary Medicine, deposed: I have made some experiments on sheep. On the 10th of January, this year, I made experiment No. 1. I nsed $1 \frac{1}{4}$ lbs. arsenic, $1 \frac{1}{4}$ lbs. soda, and 2 ozs. sulphur. In this solution I immersed two sheep. They were in no way injured by that experiment. They are well now. I watched them up to last Wednesday. Experiment No. 2 was made on the 15th. I used one of the packets that I received from Mr. Elliot's shopman. I used from thirty-seven to thirtyeight gallons of water. I dipped in that solution four sheep. I used three healthy sheep. The fourth was badly affected with scab. The three sound sheep were immersed five minutes each. The other was in half an hour. No harm came to those sheep; on the contrary the unsound one was cured. On the 25th of January I made a third experiment, using $3 \mathrm{lbs}$. of arsenic, ? lbs. of soda ash, 4 ozs. of sulphnr, and 4 lbs. of soft soap. About thirty-seven or thirty-eight gallons were used in this solution. I put into the solution six black-faced sheep. They were not altogether sound. One was affected with scab, and another with foot rot, in which the vascular tissue is exposed. The healthy ones remained in five minutes each, and the other two half an 
hour. No injurious results followed; on the contrary, the scabby one was cured, the other one considerably improved. In experiment No. 2 I used $\frac{1}{2} \mathrm{lb}$. of arsenic, $\frac{1}{2} \mathrm{lb}$. soda ash, without sulphur or soap. Four sheep were immersed in this -two for five minutes, and two for half an hour each. The result in this case was also uninjurious. Experiment No. 5 I made with Dr. Macadam on the 21st of February, using $1 \frac{1}{2}$ lbs. of arsenic, 8 ozs. of soda ash, 2 ozs. of sulphur, and 4 lbs. of soft soap. I am the author of the 'Veterinarian's Vade Mecum, published in 1858. I have recommended baths for sheep as strong as Mr. Elliot's, as safe and proper baths. I made an experiment to ascertain whether sheep would eat matter saturated in arsenic. A dipping mixture was prepared according to Mr. Elliot's prescription, in which I aided in dipping two sheep-the head shepherd holding the head, and I pressing the liquid out of the wool. The two sheep were placed in covered shed, separated from other two that had not been dipped. One oat sheaf and four quarts of oats were saturated in that solution. The oat sheaf was placed in a tent containing the two dipped sheep. The sheep were left there all night. I have seen these sheep this morning, and they present symptoms of the introduction of arsenic into the system."

"Henry Wilkinson, veterinary surgeon in Newcastle, deposed-On the 27th instant I made some experiments for the purpose of ascertaining whether sheep would eat food impregnated with Mr. Elliot's powder. I spread the solution over part of a field. I chose a piece of ground 24 yards by 23 yards, nearly square, and a piece of ground 23 yards by 3 yards. Over these I carefully sprinkled one quart of the solution. There were four sheep left. They had their option of other pasture, and they ate indiscriminately of either. Of the four sheep, two had been dipped, and two had not. I consider that they are suffering from the effects of having taken arsenic, and one of them is very likely to die."

The evidence given for the plaintiff was not backed up with experiment; it was asserted, that if the mixture was not horned down the sheeps' throats, it must have found its way to the stomachs and livers by absorption, and moreover that they would not eat grass "seasoned with poison;" they were delicate animals both in taste and smell. This statement was proved not to be correct, as the sheep experimented upon ate grass, \&c., "seasoned with poison," and a similar composition to that complained of, and for the supplying of which the action was brought.

Every sheepowner using poisonous mixtures should be careful, after dipping, to see the wool be well wrung out, and the sheep confined to a circumscribed area for six or seven hours, and in no case to allow the drippings to fall on the pasture or feeding ground. The dip prescribed, the author has been in the habit of recommending as a very useful one, and if the above precautions are strictly attended to, there is not the slightest fear of fatality occurring.

$$
\text { SHEEP LICE AND TICKS. }
$$

Sheep of every description are liable to this kind of filth, but especially such as are not in a thriving state. The sheep louse (Hippobosca ovina), is small, active, and of brownish colour, and often swarms in thousands on young sheep. The tick (Acarus reduvius) is nearly of the same colour as the louse, but is much larger; they are furnished with a proboscis and suckers, which dig into the skin of the sheep. They are of great detriment to sheep, prevent them from thriving, and cause them to scratch and tear off their wool by rubbing themselves against fences, and sometimes they will tear it off with their mouths, to the great injury of the pelt and fleece. In order to destroy these noxious vermin, a number of different applications have been employed; but the author has found none so effectual as-

$$
\begin{aligned}
& \text { Commercial carbolic acid, . . . . . . . . } 1 \text { pint, } \\
& \text { Water, . . . . . . . . . } 1 \text { gallon. }
\end{aligned}
$$

Apply as a dip; use it once weekly, for three consecutive weeks. In the application of all dipping mixtures care should be taken, that the animals' heads be kept sufficiently above the water after dipping; the sheep must then be placed in a second tab, and the liquor pressed from the wool with the hands; this done, the pressed out liquid must be returned to the former trough. By this method a considerable number can be dipped in a short time. Many veterinary authors recommend the application of mercurial ointment, common turpentine, and linseed oil, as agents calculated to destroy ticks and lice. "Ointment," writes Clater, "possesses a great superiority over all washes; the former promotes the health of the animal, as well as the growth of the wool, while the latter produces the contrary effect." This statement is contrary to my experience; and I think sheep farmers will agree with me, that washes are to be preferred to ointments for woolly sheep infested with ticks or lice.

\section{TO PREVENT THE FLY, SORE HEAD, AND MAGGOTS.}

Sheep during the summer, and especially about the month of May, are constantly teased with flies, particularly those kept in lanes or in woody districts. They give the animal so much trouble at times, as to cause them to run into hedges and the bottoms of ditches or dikes, to the detriment of their fleeces and pelt, and otherwise by preventing them from feeding at a time they ought to make the greatest progress. Certain flies during the spring, being in quest of a convenient situation to deposit their eggs, select various parts of the sheep and wool for this purpose; sometimes they choose a sore place or the parts around the tail, especially if the dung collected there be putrefied: The eggs having been here deposited, soon hatch, and are called maggots, and immediately begin to burrow in the skin, when they cause by the severity of their bites continual annoyance to the sheep. If the head be the part selected, the sheep, in order to ward off their attacks, is constantly seen striking its head with its hind legs until a sore is created, which spreads as the result of continual injury. The removal of the cause will usually cure the effect; to accomplish which, clip the wool off the diseased 
part, and apply an ointment, once weekly for two or three consecutive weeks, consisting of -

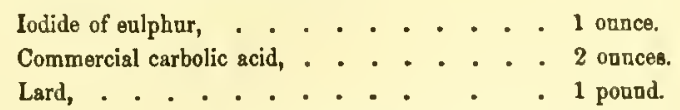

Hogg asserts that the strongest kind of fish oil always prevents the attack of the fly; doubtless it will, and so will any ointment containing strong smelling medicinal ingredients, such as carbolic acid, \&c. Youatt recommends for sore head a compound which, in its action, is similar to carbolic acid, and consists of the following plaster :-

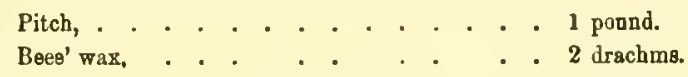

Melt together, and spread, whilst warm, on soft leather or linen, and apply to the head.

\section{INFLAMMATION IN THE UDDER OF EWES.}

This is a common complaint among ewes at the time of yeaning or lambing. Those which have been well kept for some time before they bring forth are most liable to this disorder, as it is apt to cause a flush of milk at that time; and from the glutinous state of the first milk, and also from being long retained in the udder, it blocks up the passages, and soon brings on inflammation of that part. If ewes are noticed to refuse their lambs to suck, they sloould be immediately examined, and often it is then discovered that the udder is tender and inflamed, and that milk will not flow from one or both teats. In this case it is necessary at once to apply to it repeated hot fomentations, and to administer two ounces of epsom salts, and the ewe and lamb should be confined in a pen by themselves, in order to see that the lamb does suck its mother; if, after two or three days, the young is not permitted to suck, it is better to remove it to some ewe, if possible, that has just lost her lamb. Fomentations must be still applied to the udder, and the following ointments can be rubbed in twice daily-

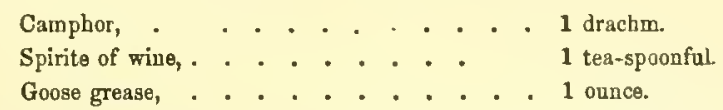

Should the udder continue to enlarge, and kernels make their appearance of greater or less size, and should they afterward soften and contain pus, the matter must be evacuated by plunging a sharp knife into the swellings at that point, and by squeezing them well out, and reapplying hot fomentations. If an ulcer occur at the point of operation, syringe it with a weak solution of Burnett's disinfecting fluid. Resolutions occur similar to those mentioned under Mammitis in the cow, and as those demand like treatment, the details need not be repeated in this chapter.

\section{THE FOOT HALT OR FOOT ROT.}

These diseases in the feet of sheep appear to proceed from one and the same cause; yet if any person wishes to make a distinction, it may easily be done by considering the first stage of the disease as the foot halt, and the last as the foot rot. For rot is first observed by the subject of it being lame; if caught, and the foot be examined, it will be found to be hot and tender, the horn softer than usual, and at the part between hair and hoof enlargements associated with slight separation of hoof coronal bands from the horn will be discovered; sometimes, also, ulcers occur and excrete a thin fetid discharge, and if allowed to increase often develop into fungous granulations, which grow to such an extent as to cause the entire separation of the hoof horn from the subjacent tissues. In accounting for the occurrence of this affection, it will be necessary to consider, first, the situations which sheep in a natural state select to live upon; and secondly, to detail the reasons why the artificial life in this particular respect, and in the production of foot rot, interferes with the health and well-being of flocks. In a state of nature, the sheep, like the goat, was evidently intended for mountainous and rocky districts, and was supplied with a foot structure thoroughly adapted to travel over hard roads and rocky precipices, and consequently such being the case, it will be easily seen that in such an animal the hoof horn growth would be rapid, in order to withstand its continual exposure to the friction such localities would necessitate. The next question which arises is, Do o"r flocks, as a rule, inhabit localities similar to the above? Certainly not; they live for the most part upon soft pastures, and seldom, if ever, travel over a hard road. In such positions their feet being denied necessary friction grow to an inordinate length; they become sodden with the wet ground; the tissues of the foot grow weaker and weaker, until the connection of the tissue is so far interfered with as to render it incapable of withstanding external injury; for the different parts of the hoof being deprived of their wear, grow out of all proportion, and thus throw the foot out of its natural bearing, when pieces of hoof break off or are irregularly torn away; or by "overshooting the sole," cannot prevent the introduction to the hoof of sand and grit, and these, reaching the sensitive parts, set up inflammation and its results, which, if not cured, ultimately cause sloughing of the hoof horn. To bear out the truth of the statement of a soft pasture being the chief cause of foot rot, we have the fact, that sheep brought from the-uplands to marshy districts frequently contract this malady; and this is easily accounted for. On uplands, the growth of grass is commonly not very luxuriant, and consequently the animals are subjected to greater exercise in gathering their food than they would be on lower grounds, where the herbage is generally more plentiful. The hardness of the ground, again, would cause the hoof horn to wear away as quickly as it grew, and by this means any inordinate growth of the foot would be prevented. It is well known to flockmasters that sheep, like goats, will select the highest grounds in a field to lie upon, and in mountainols countries always prefer the hills to the valley; in such countries the scarcity of food on the hill tops, the hardness of the soil, and the exercise necessarily imposed upon the animal in gathering sufficient food to keep it in good case, an:t 
markedly in preventing the occurrence of foot rot. The feet of flocks feeding on low marshy lands should be examined from time to time, and if any superabundance of horn exists, it must be immediately pared down with a sharp knife, as this simple precaution proves the truth of the saying, "Prevention is better than cure."

Treatment.-Let sheep infected with disease be fetched from their pasture, and put in a dry fold yard; and let the foot of each animal be carefully examined, when those feet which are diseased can be well washed clean with a water brush, every particle of grit and sand being at the same time removed. Should an inordinate growth of hoof horn, large excrescences, or proud flesh be present, cut them down with a sharp knife, and afterwards use the following lotion, which in some cases minst be applied with a pledget of tow, and confined in its situation with a piece of tape.

\begin{tabular}{l} 
Hydrochloric acid, . . . . . . . . . . 1 ounce. \\
Water, . . . . . \\
\hline
\end{tabular}

If the growth of proud flesh recurs, touch the part as often as required with a rod of nitrate of silver. The ulcers on the sensitive structure of the feet usually dry up after two or three dressings with common commercial carbolic acid. The secret in treating this malady is never to allow the hoof horn to grow too long, for such growth takes away the natural bearing of the foot, and moreover devitalizes the tissues of the foot, and causes the irregular tearing away of the hoof horn, and injury to the subjacent structure, which terminates in foot rot.

\section{THE SCOUR, OR DIARRHCEA.}

This disease occasionally attacks full-grown sheep, but is not so prevalent among them as with lambs; it generally proceeds from bad and scanty keep during the winter season, and makes its appearance in the spring, as soon as the young grasses begin to put forth their succulent qualities. The sheep are not able to stand against so luxurious a change; the fresh grass acts as a too stimulating food, and diarrhoa sets in. This discharge must not be checked too suddenly, for in five cases out of six, in the course of twenty-four hours, without any treatment on man's part, the dung regains its normal consistency; but should the diarrhnea continue for a longer period than the above, then it will be necessary to move the affected flock to dryer pasture, and one on which the herbage is scanty, and also allow a little hay once a day, for a short time. This treatment is usually sufficient to check the scour in sheep. Generally this disease lasts only a few days; but if the symptoms should continue to increase, the following powders must be given twice daily to each sheep :-

$$
\begin{aligned}
& \text { Disslphate of quinine, . . . . . . . . } 10 \text { grains. } \\
& \text { Powdered ginger, . . . . . . . . . . } 1 \text { drachm. } \\
& \text { Prepared chalk, . . . . . . . . . . . } 1 \text { drachnı. } \\
& \text { Bracdy, . . . . . . . . . . . . } 1 \text { table-spoonful. }
\end{aligned}
$$

In some cases where the disease assumes a very severe type, half a tablespoonful of tincture of opium can be added to the above dose.

\section{STURDY IN SHEEP}

This disease luxuriates in many names, in turnsick, giddy, goggles, \&c. ; its existence is due to the presence on the brain of a bladder worm hydatid, the coenurus cerebralis, which varies in size from a hazel nut to a pigeon's egg, and in this situation interferes most injuriously with the cerebral functions. The subject of sturdy turns round, cannot walk straight, and partial, and often total, blindness ensues; the bones of the skull grow soft, and become pierced by absorption; and if the parasite be not removed the animal so affected dies in convulsions. Sturdy was long ago thought to be a nervous affection produced by the worry and fear inflicted on sheep by the continual presence of the sheep dog when acting as guardian over them; but it has since been discovered by Von Siebold, the German helminthologist, that the disease existed owing to the presence on the brain of the hydatid above named; and further that the $\operatorname{dog}$ was to a certain extent answerable for the damage. Von Siebold instituted several experiments, and the results led him to the conclusion that the conurus cerebralis was not a complete individual, or, in other words, that this hydatid would not develop into a complete being until it had passed into the intestines or elsewhere of some other animal, and experiments proved the truth of the suspicion. Von Siebold gave the brain containing the coenurus cerebralis to a dog, and some time afterwards destroyed the animal, and found he was infested with numerous tapeworms - the tænia serrata. A few rings of this tapeworm were given in milk to lambs, and within six weeks they exhibited symptoms of giddiness, and on opening the crania hydatids were discovered on their brains. This experiment was repeated, and has been again and again carried out by helminthologists, and has led to the establishment of the fact, that the conurus cerebralis on the brain of the sheep if given to the dog or man will produce in either of them tapeworm; and again, if the tapeworm be given to the sheep, it will breed in them the cœenurus cerebralis. It has therefore been most satisfactorily proved, that the conurus cerebralis which infested the brain of the sheep lived in another form in the intestines of the dog. In the latter habitat thousands of germs are developed, which, strewn on the pastures and pools, are taken into the stomachs of sheep, and from the stomach find their way through the medium of the bloodvessels to the brain.

The tapeworm common to man is called the tenia solium, and that met with in the dog the tænia serrata; but although different names are given to them they are, according to Von Siebold, identical worms, and have corresponding hydatids existing in animals of another species. Every bladder worm, therefore, on passing from the body of one animal enters that of another to become a complete individual or tapeworm, when it is supplied with organs of propagation for the multiplication of its kind. Thus the hydatid on passing from the brain of the sheep would die unless a proper habitat were found for it, in which, by metamorphosis, it could develop into a tænia.

Kückenmeister writes:- "Were I to bring forward all 


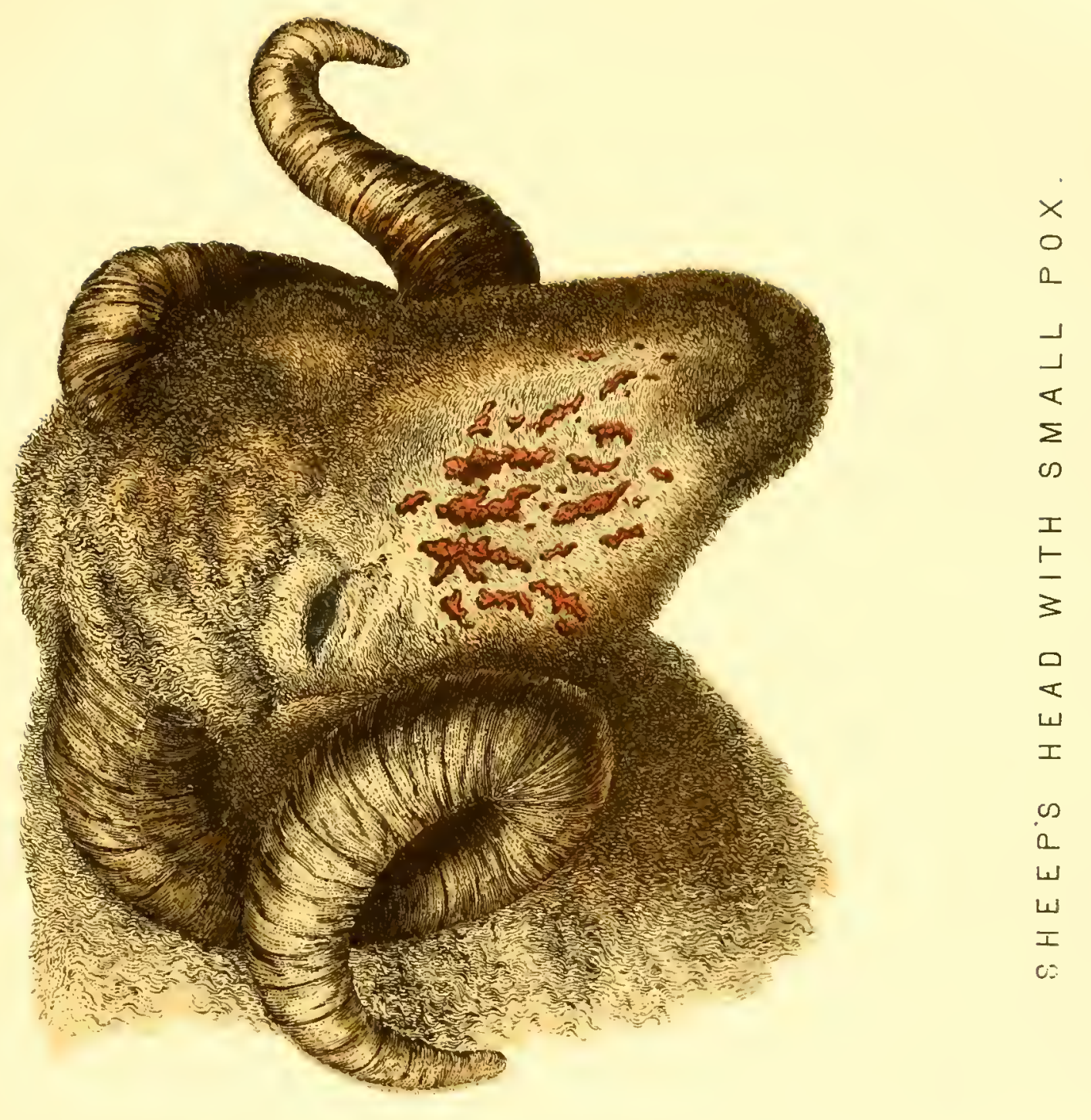



the various causes to which the origin of the coenurus has been referred, I should far exceed the limits of these pages. That the doctrine of equivocal generation played a conspicuous part therein will surprise no one, since there yet exist veterinarians who adhere to that doctrine on all points." The only mode of insuring the destruction and removal of the worm, and hence the only effectual cure for the disease of sturdy, is trepanning. The operation is, of course, only admissible when the conurus cerebralis is imbedded in the anterior and upper portion of the ruminant's brain, whilst if, on the other hand, it be deeply seated in the base of the brain, or in the spinal marrow, it cannot be reached by trepanning. For this reason, therefore, we find cases reported in which the hydatid has been successfully removed; but these must have been those in which the conurus was superficially situated; whereas, on the other hand, veterinarians have lost credit for not having extracted from the brain the hydatid when deeply seated, i.e., when so much imbedded in the brain structure as to prevent even the possibility of a successful operation. Many persons reading the above may think that flocks can be preserved from the attacks of tapeworm by not allowing the sheep dog to accompany them. Perhaps fewer dogs might be kept; but then even stray dogs might also be the cause of mischief. The excrements of man and carnivora should not be thrown on fields where sheep are fed, because the tænia solium of man, similarly as the tænia serrata of the dog, produce the sheep hydatid; the flesh of animals known to be affected with parasites should not be eaten; and lastly, meat containing worms must not be given to dogs raw; if well cooked, however, the germs of such creatures are destroyed, and consequently food so treated can be given to carnivorous animals with impunity. In trepanning great care must be used in finding, first, the spot, which often is soft, where the hydatid lies; and secondly, in removing the bone above it; and thirdly, in crtracting the cyst bodily in which the worm lives. 'I'his operation, as before indicated, is rarely successful, and sturdy consequently is a very fatal malady. The preventive measures, however, suggested will, if thoroughly carried out, gradually reduce the number of sturdy cases; and it is trusted that, in a few years, it will be struck out of the list of diseases to which sheep are liable.

THE DISEASES OF THE EYE, COMMONLY CALLED BLINDNESS.

Ophthalmia attacks sheep as an epizootic at certain seasons. In 1850 it was prevalent among cattle and sheep. Cattle about a year old suffer most; and during 1568 many sattle in Richmond Park were subjected to the author's treatment. In sheep the symptoms are closed eyelids, congested eyeballs and conjunctival membranes, opacity of the cornea, and great defluxion of tears, and sight almost lost, and sometimes the formation of pus in the eyeball itself. The treatment for sheep consists in placing them in a dark place, and bathing the eyes with the following lotion:-

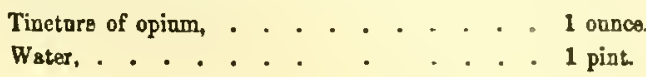

and giving in gruel-

Nitre, . . . . . . . . t onnce

Epsom sslts, . . . . . . . 8 odocer

If the disease increase in intensity use an eye lotion-

Goulard's extract, . . . . . . . 1 onoce.

Diatillad water, . . . . . . . 1 pioc

and apply it twice daily; sometimes a solntion of caustic can be employed; it must be painted on the eye with a camel's. hair brush-

Nitrate of silver,. . . . . . . 6 graids.

Distilled water, . . . . . . 1 ounce.

and much benefit is derived by daubing the orbits with a plaster of the extract of belladonna. In some cases, also, the eyeball has to be punctured in order to evacuate the pus therein formed. The above treatment was prescribed and adopted by me in treating cattle in Richmond Park; and even including three animals the eyeballs of which were punctured, did not fail in a single case to effect a curc. The exclusion of light, by placing a linen bandage over the eyes, kept continually wet, and the exhibition of mild and laxative food, will act as very important adjuvants in restoring the eyes to health.

\section{OVINA VARIOLA, SMALL-POX AMONG SHEEP,}

may be defined to be an eruptive fever, in which there art several stages through which it passes before the discase can be fully developed. First, the stage of incubation; that is, a period during which the seeds of the malady are latent in the animal system, when the subject so infected gives little or no evidence of suffering, and consequently is placed beyond the limit of our observation. The incubative stage rarely extends over more than fourteen days, and in some cases only ten. The stage of incubation being passed, it will be noticed that a general failure of health manifests itself, by the subjects of the malady separating from the flock, by hurried breathing, and by a feverish state of the whole system. On catching, and closely inspecting these animals, on their bodies will be observed several red spots, more particularly developed on the parts devoid of wool, such as the inside of the thighs, arms, face, and lips.

In the second or papular stage of this malady small turnours arise on the red spots above mentioned, which sometimes are distinct one from the other; at other times they are thickly clustered together, this latter pathological state being recognized as confluent small-pox. It is during the papular stage that the greatest amount of mortality occurs, and particularly so when it attacks the face, and assumes the confluent form After three or four days, or at most six, the papular stage passes off, which is indicated by the papula parting with thein previous redness, and becoming white, and by the appearance of the vesicles or blisters on the papulæ; and for this reason the last-mentioned period has been designated the vesicular stage. These vesicles contain lymph, and from them veterinarians have been recommended to take material (lymph) for 
purposes of inoculation, or, in plain words, to obtain lymph by which they may be enabled to communicate small-pox from one animal to another; this stage lasts about three days, during which few animals die.

The vesicular is sometimes, although not always, succeeded by the pustular stage, by the matter within the vesicles degenerating into pus, at which period the face usually swells to such an extent as to close the eyelids; and this pathological state terminates similarly to the vesicular, in the formation of scabs. In the progress of maturation the contents of the vesicles undergo similar changes to those that are produced by ordinary causes; at first they are distended with a clear Aluid, which becomes milky in colour, then turbid and strawcolonred, and ultimately by drying hardens into a crust, which is cast off with the epidermis or scarf-skin. As before said, the vesicles sometimes degenerate into pustules; but this is by no means a common phase of the disorder, and both Professor Simonds and Mr. Ceely, who carefully watched the progress of sheep-pox in 1848, have satisfied themselves "that it was not essentially a pustular, but a vesicular disease." In 1862, during the ontbreak of ovina variola in Wiltshire and Berkshire, the author examined several hundred sheep, the subjects of this complaint, and noticed that many affected sheep passed through an attack of small-pox without the development of the vesicle into the pustule; but doubtless the formation of pustules indicates a more complicated form of disease, as this stage often leads to the ulcerative, which extends more or less into the skin proper, or dermis, and not unfrequently the subjacent tissues. This state of course prolongs the existence of disease, and as it often terminates fatally, is the most dangerous form of the affection we have to contend with.

In a case of sheep-pox which has reached the vesicular stuge, our desire should be for the vesicle to dry up and form a scab, which in six cases out of eight takes place. But as before mentioned, sometimes the lymph within the vesicle degenerates into pus, but if, even with formation of pus, our case progresses favourably, both these pathological states terminate in the formation of scabs; the pustules remain as such for about three days, and then terminate in the formation of scabs; these changes being known as the processes of desiccation and desquamation, which are always protracted when suppuration takes place. The crusts forming the scabs are of a brownish-black colour, and are thicker when cast from a pustule than from a vesicle. The crustaceous stage is, if matters progress favourably, accompanied by a subsidence of the eruptive and feverish symptoms, and soon after the skin regains its natural appearance. The above description details the favourable termination of ovina variola; but unfortunately the vesicular and pustular stages do not always run on to the crustaceous state, as both the vesicles and pustules sometimes degenerate into ulcers (the ulcerative stage), which usually attack the head, when we have a very dangerous form of the malady to contend with, and especially so if the disease has assumed the confluent type. Professor Simonds gives the following summary of the gradations through which small-pox in sheep passes :-The first 10 or 11 days are those of incubation; 12, 13, of invasion; 14-16, of papulation; $17-19$, of vesication; $20-22$, of desiccation and separation of the crusts.

An attempt has been made above to describe the local manifestations of ovina variola, which of course are under the control, as it were, of the constitution, and I will now detail its symptoms. While, as before suggested, the disease is incubating in the system, the patient gives not the least evidence of of ill health, no indication of failing appetite, hurried breathing, or any febrile state of the system-nothing, in fact, to lead one to suppose that it was not in perfect health; but it must be remembered if a man were exposed to the infection of the variola hominis, which is in many particulars closely allied to that of sheep, he might, during the period the disease was lying dormant in his system, complain of being a little out of sorts; he might have pain in the head, his appetite might not be good as usual : but such slight symptoms as these are not readily recognized in sheep, although no doubt they have existed.

The incubative having passed, we notice that tne infected sheep separate from the remainder of the herd, and lie down in remote corners and secluded spots of the feeding ground. They exhibit the following symptoms-dejected head with pendulous ears, laboured breathing, swollen eyelids, associated with a copious defluxion of tears; the conjunctiva assumes a deep-red colour, and a discharge of mucus, sometimes associated with blood, flows from the nostrils; the pulse beats ninety in the minute, and as the disease progresses, becomes weak and tremulous; the patient refuses to feed, and the function of rumination is suspended. The fæces are little changed at first, but occasionally constipation sets in, to be quickly followed by diarrhœa, which usually effects a fatal termination; the temperature of the body varies, the extremities being generally cold, but elsewhere the skin is hot. These symptoms continue unabated until the papular stage is succeeded by the vesicular, when the patient manifests by its manner that relief has been obtained. Of course, when the disease assumes the confluent type, our prognosis is rendered unfavourable, as this phase is always associated with greater systemic disturbance, which retards to a considerable extent the wished for termination of the disease. The same remarks also can be made when the fever continues high, for then the patient's sufferings are immensely increased; the breathing now grows more laboured, the animal continually groans, frothy saliva is now discharged from the mouth, the wool separates from the skin, ulcers form on the conjunctiva, and sometimes the eyeball itself becomes involved in disorganization, and the pulse grows weaker and weaker, until it ceases to beat, and death terminates all suffering.

Captain J. Carr thus describes the symptoms, when ovina variola takes on a malignant type:-_"The pulse becomes increasingly rapid, the mouth dry and hot, the breath fotid, and the eyelids, and even the head, so much swollen, that the creature can scarcely be recognized. The pustules being very 
numerous become confluent, and form a mass of matter which, especially in warm weather, is apt to assume a putrid character, degenerating into malignant ulcers, by which the poor animal is rendered blind, lame, or loses part of the lips, and is at last carried off by violent diarrhoea."

Professor Simonds asserts that in the majority of fatal cases of sheep-pox, "death occurs during the first week of the eruption," but under ordinary circumstances the chief danger has passed; i.e., when the fever has not run very high, and when the vessels of the skin have expelled the variolous poison from the system; but both Professor Simonds and the continental authorities speak unfavourably of a recurrence of fever during the period of suppuration.

Sacco states, that "this period is the most dangerous, and that during it the patients abstain altogether from food, and utter tones expressive of great pain; they heave quickly at the flanks, the eyelids and lips are tumefied, a viscid and foetid mucus flows from the nostrils, and an augmented quantity of saliva from the mouth; they never move from the fold; the prostration of strength is great, and they lie principally on their sides. The tenderness of the body is so extreme, that a simple touch will produce convulsions; the alvine evacuations are copious and offensive, and the deranged condition of the alimentary canal speedily carries them off."

Regarding the post mortem appearances of small-pox, no person has investigated the matter more fully than Professor Simonds, consequently his report will be transcribed as follows:- "In most instances the mucous membranes, especially of the respiratory system, are the principal parts affected, the serous membranes, however, do not escape; but for the sake of perspicuity we describe seriatim the lesions of the different organs:-

"The condition of the common integument (skin) will depend altogether on the time that the animal survives. If death takes place in the early stages, papular elevations, a few of them covered with vesicles, are abundantly spread over the surface of the body; in the latter stages ulcers of various size and depth are met with. The skin also varies in colour, being in some parts of a red, in others of a blueish-black hue, and everywhere the slightest force will separate the wool from its follicles. The subcutaneous areolar tissue is more or less engorged with blood, and purulent formations often exist beneath the confluent papulæ. Infiltration of albuminous serum into the cellular tissue of the face and extremities is occasionally present. The conjunctiva and transparent corneæ in many instances are free from disease, but now and then give signs of approaching ulceration. The pituitary membrane (Schneiderian, the membrane which lines the cavities of the nose), always exhibits an abnormal condition, but in various animals presents various degrees of sanguineous congestion, and is frequently so much inflamed that disorganization ensues. In many cases it is studded here and there with mucous vari of a light copper colour; these vari are doubtless internal papulæ modified by the structure on which they are developed; these lesions are not simply confined to the uasal portions of the respiratory system, but extend into the laryıx, trachea, and bronchi. Occasionally small ulcers are situated on the epiglottis and other parts of the larynz, and along the course of the mucous membrane; rarcly, however, do they extend as far as the bronchi. The smaller bronchial tubes and air-cells of the lungs are mostly filled with dark-coloured mucus, and are in general less engorged with blood than other portions of the air-passages. The serous membranes of the thorax (chest) are comparatively free from discase We have seen them, however, very much inflamed, and in one instance the greater part of the surface of both lungs was adherent to both sides of the chest by a thick layer of colourless fibrin. The lobes of these organs were, in like manner, glued together; the outer portion of the pericardium was coated with lymph, the heart was inflamed, and partially united to its sac by bands of fibrin; an effusion of serous fluid also existed in the pericardial and thoracic cavities. Such appearances are unfrequent, and in general the lungs are congested, and liver-coloured spots, irregular both in size and form, are seen immediately below the pleural covering. The digestive system shows fewer traces of morbid action; the buccal membrane and velum palati are sometimes inflamed; but we have not observed any lesions on the lining membrane of the csophagus (gullet), rumen, reticulum, or omasum (i.e., the first, second, or third stomachs); the villous coat of the abomasum (fourth stomach) is in some cases infiltrated with blood, and ecchymosed. The cavity of the abdomen occasionally contains an effusion of serum. The peritoneal tunic is even more rarely inflamed than the other serous membranes, and the intestines are free from disease, except when the patient sinks from diarrhoa, in which case they participate in the general morbid changes, and contain fluid and fœtid ingesta. The kidneys are sometimes softened, and now and then similar spots to those seen on the lungs exist beneath their capsules; for the most marked case of which we are indebted to Mr. Ceely, who kindly forwarded the morbid parts for the inspection of Mr. Marson and ourselves. The bladder, and other urinary organs, are unaffected. The generative system does not participate in the disease, and, according to the French authorities, when an impregnated ewe is carried off by the malady the foetus gives no indication of it.

The spleen is often enlarged, and the liver soft in structure, sometimes pale, but more frequently of a dark colour. The condition, however, of this organ in sheep cannot be said to afford correct evidence of the existence of small-pox in sheep, for it undergoes a variety of structural changes from a multiplicity of causes, some of which are the very reverse of each other. The brain and spinal marrow are affected in some animals, and free from disease in others. Simple congestion, either of the "meningis or substance of the encephalon, is the morbid product usually observed."

\section{ORIGIN OF OVINA VARIOLA.}

As before stated, ovina variola is in many points similar to 
small-pox of man, although it does not produce the same local effects in the former as it does in the latter. This, however, is more due to the special arrangement and structure of the skin, than to any actual difference in the nature of the affection, since both are governed by the same laws, i.e., both spread through the medium of contagion and infection. Moreover, the adoption of the same preventive measures equally protects man and the sheep from the extensive ravages of small-pox.

Small-pos is considered by some medical investigators to be of spontaneous origin. Of course, all disease must have had a beginning; but the origin of small-pox is of very remote date. Homer, Livy, Ovid, and Virgil, all have described a disease, if not identical, at any rate not very dissimilar to small-pox; all attribute its origin to a vitiated air, and Virgil also draws attention to the great extent to which the disease involved whole flocks in its ravages. He wrote, "Pecus languescit et omnis," and this proves that even in his day its contagious and infectious nature was fully recognized. Consequently, when small-pox has once made its appearance, its extension is certain, unless in a district where measures proved by experience to be preventives are resorted to. From the above, therefore, it will be observed that there is no need in the present article to argue about the for and against theories of spontaneons origin; suffice it to say, that whatever combination of causes may lead to the production of small-pox, when once it is established it immediately spreads rapidly through the medium of contagion and infection, and for all practical purposes our remarks need only be directed to its existence, without asking how that existence originated; as our arguments would begin and end in hypotheses, neitler history nor experience affording an axiom in this department of medical research.

Simonds writes, "Whatever the combination of causes may be which produces these maladies, certain it is that very many of them assume an infections nature: otherwise we cannot account for animals separated and kept apart from those which are diseased, frequently and sometimes altogether escaping, while those are sure to become early victims that are allowed to pasture and live with the affected. Moreover, we can often succeed in producing the malady by inoculating healthy cattle, thus showing how closely the spread of the disorder depends upon contagion and infection. The fact, however, of animals, when in health, if placed with affected ones, contracting a disease of the same kind as that which the latter are suffering from, is the best proof of the infections and contagious nature of a complaint. An animal escaping an attack, when such affections are raging in the locality in which it is placed, may arise from a variety of causes, as non-susceptibility, and also a possibility of the exciting agents never having been brought within its sphere of inhalation. For although each victim to a destructive epidemic may be considered as adding new seeds or fresh energy to the malady by the exhalations arising from its body, we must not lose sight of the circumstance that very many infectious diseases assume an endemic type, whilst others, which are spread over a vast extent of country, are often observed to take a particular direction. There are, however, diseases of this kind that appear to be guided by no determined laws, breaking out again and again in the same neighbourhood. But even here we may suppose that the deleterious atmosphere floats, as it were, in nebulis, and is driven hither and thither by currents, sacrificing fresh subjects placed in the course of its passage."

Judging from our present experience and observation, and the history of the past, we can arrive at no other conclusion than that small-pox spreads both by contagion and infection.

The introduction of ovina variola to England has generally originated from foreign importations, although in the outbreak during 1862-63 its occurrence could not be satisfactorily accounted for. The origin of the previous attack, however, during 1847, was distinctly traced to Spanish sheep purchased at Smithfield market by Mr. Statham, of Datchett, who a few days after purchase noticed two or three of his Spanish sheep affected with a cutaneous eruption, which he considered to be the result of stings, and therefore the subjects of the disease were not removed from the remainder of the flock, and in consequence the disease was allowed to spread with fatal result.

Mr. Statham, noticing the spread and fatality of the abovementioned skin disease, sought the advice of Professor Simonds, who on his arrival at Datchett found the affected sheep divided into three lots, which were placed in fields situated at prescribed distances from each other. The first lot comprised sheep supposed to be healthy; the second, those recovering; and the third, those recently attacked. Professor Simonds thus reports upon the cases:- "Those in the first stage of the affection were extremely low in condition; a mucous discharge from the nostrils was present, the breathing was quick and catching, the visible mucons membranes were inflamed, particularly the conjunctiva, from which tears flowed in large quantities; all food was refused, rumination had ceased, the ears were lopped, the head held low, and a disinclination was evinced by the patients to associate with one another; some standing and having a dejected appearance, and others lying down. The pulse was considerably accelerated, and scarcely perceptible at the maxillary artery, but at the heart it gave to the hand a jerking sensation; the skin was hot, red, and elevated in patches in the form of nodules or papulæ, approximated to each other. The chief seat of the eruption was on the inside of the arms and thighs, on the sides of the face, the labia of the female and the praeputium of the male, parts which are either nude or covered only with hair; but on separating the wool the whole skin was seen to be similarly affected, although less intensely. In the second stage greater emaciation and debility existed; the discharge from the Schneiderian membrane was increased, viscid, and adherent to the alæ of the nostrils, impeding the respiration; the capillaries of the nostrils were in a highly congested state; the pulse was indistinct, even at the heart; the ears and feet were cold, and the wool came off easily, showing the skin underneath 
it inflamed, the redness existing chiefly between the elevations, although no distinct areola was present. The summits of the nodules were blanched, arising from effusion of a very small quantity of serous fluid beneath the cuticle, which scarcely gave to it the character of a true vesicle. All the papulæ, however, had not taken on this change.

"In the third stage the vital powers were prostrate; the fever had become of a typhoid character, the discharge from the nostrils fetid, and the other general symptoms much aggravated. The cuticle covering the majority of the nodules had assumed a brown colour, and pus here and there was formed on the margins of some of them, showing the ulcerative state to have cominenced; in others simple desquamation of the cuticle had begun to take place. In some extreme cases the ulceration had extended to the subcutaneous structure, and large unhealthy sores existed on the sides of the face, the inferior parts of the abdomen, the prepuce, and the inside of the thighs." On noticing these pathological states, Professor Simonds was at once struck with the identity of small-pox in man with this disease, and at once communicated with several medical friends, among whom was Erasmus Wilson, who similarly with Professor Simonds pronounced the disease to be small-pox in sheep. From 1817 to the present time much experience has been gained relative to the existence and spread of small-pox in sheep, and particularly so in the outbreak in this country during the years 1862-63. It was then stated by many farmers in Wiltshire, that as the disease broke out in Mr. Parry's flock, one bred from home stock, and where sheep were never bought in, it was impossible for small-pox to have occurred otherwise than spontaneously. It must be remembered that there is no record of small-pox in sheep in this country until after the repeal of the law prohibiting the importation of foreign animals. The first outbreak, as above mentioned, in 1847, was directly traced to the Continent. The attack in 1862 was said to be involved in mystery; certainly it never was determined that foreign sheep brought over the infection, but at the same time the port of London, previously to this outbreak, had seen imported cases of contagions disease, including even small-pox in sheep; and it was then surprising to me, that more disease among cattle, the seeds of which were imported from the Continent, did not devastate British herds. It was said, relative to Mr. Parry's flock, that having been entirely bred upon the farm, it was impossible for it to have come in contact with diseased stock, as no fresh animals, either healthy or diseased, ever entered the farm at Allington. In writing of the outbreak in 1562, I find that Professor Gangee, in a speech delivered at Devizes, drew attention to the possibility of Mr. Parry's flock having been infected by foreign importation :- "I first noticed that the contagious diseases of this country did not receive that amount of attention from veterinary surgeons that they deserved. I have consequently devoted myself specially to inquiries as to the geographical distribution of these disorders, the sources of their origin, and their means of spread. the course of my travels it has been my lot to investigate even the subject of small-pox in sheep, and I now propose to state briefly my opinion as to the origin of this disease in the county of Wilts, and afford you whatever information I can on the subject of its prevention. In the first place, I wish you to understand that it is impossible small-pox should have appeared amongst us spontaneously. What some people call the contagion theory, I call a contagion fact. And this disease has litherto bcen at all times one of foreign importation into Great Britain and Ireland. It is one of those disorders which we have unfortunately introduced into this country since that memorable date the 9 th July, 1842. Five years elapsed before we were affected by it. It remained amongst us for a short time; and here we have it bursting out among us in the most unexpected manner. Before reaching Devizes I understood that the origin of the disorder was involved in mystery. The only plausible statements afloat referred to the malady having been communicated through the canal, or from the flying of starlings from one flock to another. But such far-fetched theories are not needed. I find that on the Downs of Wiltshire there is a constant traffic in animals, healthy or diseased, driven along the Wansdyke to avoid the payment of tolls. At every step I have received confirmation of the passage of animals along these Downs, and into the very heart of Mr. Parry's farm. I do not mean to say that the undoubted existence of this traffic demonstrates that the disease was thus imported, but I wish to show that Mr. Parry's flock has not been so privileged from any communication with other animals as to drive us to imagine that the malady must have been of spontaneous origin. The great cause of the mystery attending this ontbreak has been, the want of direction in accumulating all the facts necessary to come to a conclusion. I may illustrate my meaning in a very simple manner. If a thief entered this inn to-night, and stole some plate, the fact of the robbery would not be doubted, notwithstanding that the man might evade the vigilance of the police. But with regard to disease, we often find effects result where causes have operated in a most mysterious manner. That is no proof that the causes have not been in operation. When in the county Cork a few days ago, I had a good illustration of the way in which contagious diseases are communicated, notwithstanding the greatest care on the part of the farmer to avoid contamination of his flock. An extensive short-horn breeder, who avoided the public markets, and purchased with the greatest care, so as to prevent an outbreak of pleuro-pneumonia, observed one fine morning that a case had occurred among some cows that he had nursing some of his high-bred calves. He was extremely puzzled to know how the disease had enterea his domain, but, determined to get at the truth, he instituted a searching inquiry; and he found that whilst he was comfortably asleep in bed a drover had taken the opportunity of turning some cattle to feed upon his land, and had removed before he (the farmer) was about in the morning. That act of trespass was the cause of a loss amounting to several hundred pounds." 
8MALL-POX IN SHEEP-THE HISTORY OF ITS EXTENSION DURING 1862.

THE introduction of ovina variola to England during 1862 was never clearly traced to foreign importation, although it is not unlikely that the suspicions suggested in Professor Gamgee's speech go a long way in explaining this difficulty; but certain it is that small-pox spreads by contagion and infection, and when once established involves with fearful rapidity whole flocks in its ravages: such was the case during 1862. Mr. Parry's Anck was the first to be attacked; and as this gentleman's farm was situated in the midst of an extensive sheep district, extending over at least 70,000 acres, there need be no surprise that the neighbouring flocks soon became affected with variolous disease. When small-pox appeared, Mr. Parry being then in ignorance of its nature, placed his sheep in a field adjoining certain pasture lands tenanted by Mr. Harding, of Etchillampton, and in which this latternamed gentleman's flock was feeding. Soon after this smallpox broke out among Mr. Harding's sheep, and Professor Simond's aid was solicited.

In order to make matters clear, it will be necessary to inform my readers that, on a certain morning in the month of May, 1862, Mr. Joseph Parry, of Allington, noticed several of his sheep to be sick, upon which he sought the assistance of a local farrier, who stated that the flock generally was labouring under the baneful influence of a "chill" (a term used to designate many diseases occurring in Wiltshire), but that a draught or two would soon put them right again. The prescribed treatment was consequently adopted, and persisted in for some time, but unfortunately without benefit, for the animals continued to die daily.

At this crisis, in July, Mr. Parry became alarmed, and went to London to consult Professor Simonds as to the cause of this ovine devastation; the result of which visit was, that the professor came to Allington on the 2 nd of August, pronounced the disease to be ovina variola, advised inoculation, and consequently operated upon 800 sheep (lambs and ewes). Ur. Parry's flock, prior to the date of the outbreak, consisted of 1720 sheep, out of which number 920 were attacked in a natural way, and of them fifty per cent. had died; of the 800 inoculated cases only thirty-six terminated fatally.

The question which naturally arises, and has been proposed over aud over again, is-How did the disease first occur? How could it have arisen as the result of contagion, since Mr. Parry's flock were bred upon the farm, and when fresh stock had not been imported for years? Doubtless there is great difficulty in answering this question. Nobody has been able to throw any light upon the subject, and as yet all suggestions offered amount only to so many vague ideas; still it will not be unavailing to inform my readers that the "spontaneous origin" theory met with many supporters amongst flock-masters, and for this reason, that being unable to find a cause to account for this sudden outbreak, they embraced the "spontaneous origin" theory, as they had no other to choose from. Besides, they argued small-pox must have had a beginning: Abraham and Lot might have possessed animals the subjects of small-pox, and the disease with them must have been spontaneous. It is admitted that it occurs spontaneously in Africa. Why not, then, in England? Why should not a number of afflicting causes operate in such a manner upon our flocks as to produce small-pox? We know that certain devitalizing atmospheric influences produce skin diseases, and facilitate the appearance of pustular irruptions; and in the case of Mr. Parry's flock, singularly enough, such influences have had their sway: for it so happens that his sheep were washed when they were overheated, that shortly afterwards they were sheared, and on the night following they were exposed to the baneful effects of a cold wind, accompanied by a heavy fall of rain. Soon after this the "chill," as it was termed, attacked, or more properly, small-pox commenced its ravages amongst them. But, be this as it may, whether small-pox be of spontaneous origin, or whether it arises as the result of contagion or infection, it is certain that, having once established itself, it has a great tendency to spread as an epizootic, and to cause a greater amount of mortality than any form of disease affecting other sheep.

Not only did small-pox spread as an epizootic from Allington to Etchilhampton, but also to Mr. Neate's flock at Allcannings, a farm adjoining the first-named village, the disease being discovered in the following manner:- It happened that Mr. Neate, then not entertaining even an idea that his flocks were in any way diseased, seut 250 lambs to Marlborough fair, which he sold to a Mr. Lowsley, a large sheep-dealer residing at West Hayburn, Berkshire. On the Saturday after the fair his shepherd, out of the flocks that remained at home, noticed a ram to be sick. Mr. Neate, being fully conscious of the spread of small-pox, asked Mr. Parry (who necessarily had a good practical knowledge of the malady) to examine his flocks for him-in which proposal that gentleman readily acquiesced, and, after an inspection, announced that several sheep were diseased similarly to his. Upon which Mr. Neate, in a very praisewortly spirit, started for West Hayburn in quest of the lambs he had sold to Mr. Lowsley, with the determination to repay and retake possession of them, which he succeeded in doing two days after the fair. On the Sunday following, thinking most likely that the lambs were affected with the malady, Mr. Neate sent a telegram to Professor Simonds, with intent of securing his presence and advice. The professor came to Allcannings, and an inspection demonstrated fourteen cases of small-pox. Inoculation was advised and performed during Tuesday and Wednesday on 1000 sheep, out of which number sixty-four died.

As may be naturally supposed, the farmers in and adjacent to the districts where small-pox was raging, became alarmed. In particular Mr. Hitchcock, a gentleman who had 300 sheep located in the midst of the three diseased flocks before men. 
tioned, owing to this fact, and to a belief that the disease would spread to his flock as the result of contagion or infection, ard knowing of no treatment but inoculation, sent for Professor Dimonds, who performed it and produced by artificial means small-pox amongst the 300 previously healthy sheep, out of which number forty-six deaths occurred.

Soon after this, and during the period the disease was gaining ground, Professor Gamgee arrived in Devizes, and, in conjunction with Mr. Hussey, the local government inspector, visited several flocks, and amongst them one the property of Mr. Giddings, of Horton, a flock 400 strong, said to have been affected chese sheep were inspected one after the other, and only une was found to be diseased, which was separated. Three days later the flock was again examined; no sheep, however, presented symptoms of small-pox. Three days later four cases were discovered, and were inmediately separated; one of the four unfortunately died.

The next flock that became diseased was Mr. Simpkins' of Stanton, two out of 500 being attacked, as Mr. Simpkins thought, with swollen lips; he sent for his veterinary surgeon, Mr. Coleman, who pronounced the above cases to be variolous. Ir. Simpkins, lowever, adhered to his own opinion, but fortunately took the precaution to destroy and bury the two sheep, the subjects of swollen lips. The followiug day, or soon after, Professor Simonds, in his capacity of government veterinary inspector, having been informed that small-pox had broken out at Stanton, examined Mr. Simpkins' flock (be it remembered the sheep examined by Mr. Coleman were dead and buried), and pronounced them sound, and gave him a "clean bill," bearing testimony to their healthy condition, and thus enabling him to send to and sell at market. Accordingly, on a following Thursday, part of the flock to which these two diseased sheep had belonged, and which Mr. Coleman had pronounced to be affected with small-pox, were sent to Wilton fair, there to be exposed for sale, amongst perhaps 70,000 others. In this matter, therefore, Professor Simonds' opinion was seemingly directly opposed to Mr. Coleman's, and the latter gentleman thought at that time that his professional knowledge was called in question. As might be expected, it aroused his indignation; for in a conversation with Professor Gamgee he reiterated his former opinion, and desired him to accompany him to Mr. Simpkins, in order there to inspect the above (as he stated) variolous cases, and to clear up the matter. In this Mr. Simpkins was unwilling to acquiesce. The propriety, then, of digging them up; was suggested and refused. To investigate this matter they were determined; and it happened that on the following night these two sheep were dug up without permission, and proved to be the subjects of small-pox. One head, covered with pocks, the author saw at Devizes, preserved in spirits, to satisfy those most unwilling to believe. Professor Gamgee, having satisfied himself as to the correctness of Mr. Coleman's opinion, and having learnt that a part of IIr. Simpkins' flock had left for Wiltor fair, telegraphed at once to the mayor of that place and to Professor Simonds, to acquaint them with the above circumstance, "early on Friday morning," the day of the fair. "Unfortunately the message did not reach them until the evening, after the sheep were sold and driven away." They were traced, however, to Woodford, and were returned to Mr. Simpkins.

'The next, although slight sufferer, was Mr. Dark, of Avebury Down. Here, again, the system of separation and destruction was resorted to, and by this means the malady was limited to only two cases.

My readers will remember that MIr. Neate's infected lambs stopped (after they were sold at Marlborough to Mr. Lowsley') at Mr. Church's farm, Aldbourne, on August 22, and doubtless during their short visit communicated the virus of smallpox to Mr. Cliurch's previously healthy flock, as, soon after, thirty cases occurred, upon which the separation system, without destruction, had been adopted; and this early removal of the diseased subjects from the healthy stopped the progress of the malady; only seven deaths occurred amongst the thirty above alluded to, and no fresh cases in a flock of nearly 400 ewes and lambs occurred. Prior, however, to the outbreak of ovina variola at Aldbourne, Mr. Church sold 200 lambs on August 26 to Mr. Hulbert, of Langley F'arm, Newbury, Berks; four days after purchase the disease manifested itself in this little flock by eighty cases immediately breaking out; the larger number in a flock of 300 , with which the 200 previously mentioned had been located. The whole of this flock was inoculated by Professor Simonds. Mr. Drew, the local veterinary surgeon of Ilsley, informed me in 1862 , that there had been a large percentage of death amongst the inoculated cases, and that he should hesitate on a future occasion to inoculate with a view to produce a benign form of small-pox.

It is not difficult to understand by what meas small-pox spread to the Aldbourne flock, when we remember that MIr. Neate (then in ignorance of the fact) sent to Marlborough fair 250 lambs infected, if not affected, with the malady, and that these, after sale to Mr Lowsley, stopped for a night at Aldbourne, on their journey to West Hayburn, and thus by contact communicated small-pox to MIr. Church's flock. It is fair to state that Mr Neate, on discovering his mistake, did all that man could do to repair the mischief, by repaying Mr. Lowsley and retaking his lambs to Allcannings; but unfortunately Mr. Church, not knowing that his lambs were infected, sent 100 to Henley fair, which were sold to $\mathrm{Mr}$. Hulbert, who, four days after purchase, noticed a lamb ill, after which the disease spread through his other flocks. Inoculation was practised, and great mortality occurred; but fortunately, at this period, small-pox was confined to the comnties before alluded to, riz., Wiltshire and Berkshire.

Ovina variola was nnknown in Great Britain until after the repeal of the law prohibiting the importation of foreign animals; and moreover, its first appearance in this countryviz., in 1847-was directly traced to a flock of variolous sheep imported from the Continent. These sheep were sold in Smithfield to several buyers, by which means small-pos 
was distributed over the country, and soon manifested itself in a flock near London, in the autumn of 1847. During the three following years it spread through several counties, and thus became the source of serious loss to British flockmasters. In 1853 it again broke out in Essex, Norfolk, and Suffolk, and its origin was again traced to the Continent.

But, unfortunately, the outbreak of this malady in 1862 is somewhat involved in mystery, when we consider that Mr. Parry's flock was not increased from without: it had no fresh animals, male or female, introduced into it.

Profesor Simonds, in attempting to account for this outbreak, writes, "We have regarded small-pox as spreading by contagion; now we must ask whether it can have a spontaneous origin?"

From the above question it seems that the Professor arrived at no satisfactory explanation, asserting, as he did, that Mr. Parry's flock could not have taken the disease from animals passing along the "drifts," it being fully established that the said flock was located at least two miles from these "by-paths" at the time they were first exposed to the infection. In support of this theory all that can be advanced in its favour is, that all disease must have had a beginning; the same aftlicting influences which effected the manifestation of the first variolous case, might have similarly operated in this our day to produce disease, as they perliaps did in the time of Adam Another suggestion, which somewhat strengthens this idea, is attributable to the fact that in Mr. Harding's flock at Etchilhampton, 400 ewes evinced symptoms of infection, when being folded a mile and a half from Mr. Parry's diseased sheep. The same remark, however, would similarly apply to the Allcannings' flock; to which point, as before stated, the recent outbreaks were readily tracedravages attributable to contagion.

Having pointed out to my readers the reasons the supporters of the spontaneous origin theory assign, it will be my endeavour also, on the other side, to state clearly the ideas advanced and the arguments opposed to it. It is distinctly stated by Professor Gamgee, and it is well known to the Wiltshire farmers, that their downs are traversed by driftways over which flocks from the Continent can travel on their journey to the different parts of the country, and it is not improbable that diseased flocks from abroad might have fed off the downs in question, and (as the result of infection) have communicated small-pox to healthy flocks.

Having previously drawn attention to facts referring to the direction in which small-pox spread amongst the flocks of Wiltshire and Berkshire, it is my intention at present to consider how and in what manuer the extension of this malady was facilitated.

It will be remembered that the disease first broke out as early as June, 1862, in Mr. Parry's flock (although it was not then eliagnosed by him to be small-pox); that soon afterwards about fifty per cent. of the natural cases died, and the remaining 800 were inoculated; therefore it is plain that at one and the same time an enormous amount of disease existed at Allington, in a centre from which it was likely to spread as an epizootic to the neighbouring flocks. But the question which first arises is, By what means was small-pox imported to Allington? Professors Simonds and Gamgee were both opposed to the spontaneous origin theory, both stating positively that it arose in Wiltshire as the result of actual contact. To support this statement, it is well known that there was no mention ever made in this country of the existence of small-pox until after the repeal of the law prohibiting the importation of foreign animals, and that the first outbreak in 1847 was directly traced to the Continent. The outbreak referred to was certainly involved in mystery, as Mr. Parry's sheep were all bred on his farm.

Previously to 1862 cattle often affected with disease were to my knowledge, allowed to pass from our ports into the country to be sold, and this owing to the ignorance of the inspectors, in many instances not veterinary surgeons, and therefore, in every sense of the word, incapable of recognizing, and consequently detecting, disease. But, for the sake of argument, allowing that sheep affected with small-pox did leave our ports for the country, let us consider how they could.have arrived in Wiltshire and infected the flock of MIr. Parry, at Allington.

It is a system with the Wiltshire farmers to feed their flocks during the day on the downs from April to November, a shepherd being with them during that time, and at night to place them in a fold; it must also be understood that the down appertaining to each farm is not divided from the one adjoining it by a fence of any kind, but merely a landmark indicating the extent of range allowed on the one side to $A$, and to $B$ on the other. "Each farm has, therefore, a certain amount of arable land in the vale, and a strip of down on the hill." Such being the situation and position of the downs in Wiltshire, and being so defenceless against inroads from without-so lax, also, was the inspection of foreign stock at our ports-it is not altogether difficult to account for the introduction of small. pox amongst the Wiltshire flocks, when we consider that this district is traversed in all directions by driftways, so that drovers can pasture their sheep on the downs for days, and go from Bristol to London without the payment of a single toll, or from Southampton to Ilsley, \&c., in the same way. An extensive dealer has assured us that many a hundred sheep, driven for several days along the Wiltshire downs, cost, for travelling expenses, $4 s$. a day. No money is needed for food, shelter, or tolls.

From the above, therefore, it seems neither impossible nor improbable that diseased flocks brought from Bristol might have fed off the very downs during the night upon which Mr. Parry's flock was to browse the following morning, and by this means infection or contagion might have operated to produce small-pox amongst his flock.

This notion Mr. Parry disagreed with, because his flock, previous to their being affected, fed upon a pasture close beside the banks of a canal, and had not been on the downs; and be it observed also that this canal led to a superphosphate of lime manufactory, by the banks of which pasture the barge 
containing bones and sometimes skins had to pass on their voyage to the above establishment. Is it not possible, therefore, that these bones or skins might have belonged to bodies the subjects of small-pox, and that by this means the infection passed to the Allington flock?

From the above remarks, it seems not unlikely that smallpox in sheep might have been produced by infection or contagion from either of the above-assumed causes.

But diseased animals, having passed inspection-that is, having been pronounced healthy by an examiner-are driven to and perhaps across the Wiltshire downs; during the daytime no doubt the drovers keep them moving gently along the roads, but at night they are allowed to range over the downs appertaining to the several farms; perhaps a flock affected with small-pox did range over Mr. Parry's, Mr. Neate's, and others, and by this means infected the flock. This, however, is speculative; but still such introduction might have brought, and perhaps did bring, small-pox into Wiltshire.

Secondly, as regards the bones and skins noticed on the barges whilst passing near the banks of the canal close by the spot where Mr. Parry's flock browsed: it is very difficult to trace the disease to them, and therefore I shall not attempt to say more upon it. It is merely a suggestion thrown out, which may at some future period be a means of casting some light on this mysterious subject.

\section{HISTORY OF THE TREATMENT OF SMALL-POX IN SHEEP.}

The first course to be adopted in the treatment of small-pox in sheep is that of separation; the next to be described is the indication of the different medicinal agents prescribed. In 1863 H. C. Miles, F.S.S., assistant surgeon to the Royal Artillery, in a paper on an Indian remedy for small-pox read before the Epidemiological Society of London, advised the use of the Sarracenia purpurea, vulgarly called Indian cup, or pitcher plant, as a medicine calculated to be of benefit in the cure of small-pox Professor Cleveland, U.S., makes the following remarks on effects produced by it:-

"My experiments are confirmatory of the utility of the plant in cases where there is a sluggish or torpid condition of stomach, intestine, liver, kidneys, uterus, or various functional derangements, and it must be evident that this plant possesses valuable properties. It is even possible that a new salt, similar in importance to morphia and quinia, may be extracted from it, and thus a new and valuable remedy may be added to our Materia Medica."

This remedy seems first to have been discovered by the North American Indians, who, when small-pox broke out and devastated their tribes, used a decoction of the root of the Sarracenia purpurea, believing that it acted with prophylactic effect.

An Ind1an authority on this matter asserts that the root of this plant alone is beneficial in the treatment of small-pox, but that preparations made from the leaves are useless in that malady. The directions for the preparation and use of this decoction are as follows:-That the root, when fresh gathered and divested of its thin fibres, should be slowly dried; that two oz. of the dried root should be cut into pieces and placed in an earthen pot, upon which a quart of cold water should be poured, and afterwards be permitted to simmer gently over a steady fire for two or three hours, "so as to lose one-fourth of its weight."

Observations.-1. In the case of an individual suspected to be under the influence of small-pox, but with no distiact eruption upon him, a large wineglass of the infusion of the root of the plaut Sarracenia purpurea, or pitcher plaat, is to be taken. The effect of this dose is to bring out the eruption. After a second or third dose, given at intervals of from four to six hours, the pustules sabside, apparently losing their vitality. The paticat feels better at the end of each dose, and in the graphic expression of the "\$licmac," "knows there is a great change within him at once."

2. In a subject already covered with the eruption of small-pox in the early stage, a dose or two will dissipate the pustules and subdue the febrile symptoms. The urine, from being scanty and high-coloured, becomes pale and abuadant, whilst from the first dose the feelings of the patient assures him that "the medicine is killing the disease." Under the influence of the remedy, in three or four days the prominent symptorns of the constitutional disturbance subside, although, as a precautionary measure, the sick person is kept in camp until the ainth day. No marks of the eruption (as regards pitting, \&cc.) have been left ia cases exarnined, if treated by the remedy.

3. With regard to the medicine acting (as is believed by the Indians) in the way of a preventive, in those exposed to infection, it is curious to noto that in the campo where the remedy has been used the people keep a weak infusion of the root prepared, and take a dose occasionally during the doy. so as to "keep the antidote in the blood."

These observations by the Indian have been fully corroborated by Europeans, who have noticcd that, consequent upon the administration of the root Sarracenia purpurea to persons covered with variolous eruptions, the following results have manifested themselves-

1. Rapid diuretic action with immediate lessening of the febrile symptoms; and, more tardily, it acts as an evacuant on the large intestines.

2. On a repetition of a dose of the decoction (which perhaps should bo given after three or four hours, instead of at longer intervals), the mitigation and obvious improvement, should any symptoms of cerehral disturbance be present.

3. Its extraerdinary effect (within a brief period) in altering the character of the cutaneous eruption. It seems to arrest the morbid process, and induce a healthy instead of a diseased action. The pustales appear simply to be deprived of their vitality; they desiccate and fall away.

4. The preveation of pitting, consequent, it may be supposed, on the whole nature of the pustule being changed in the manner just noted.

The dried root of the Sarracenia purpurea can be obtained of Messrs. Savory and Moore, London.

The fact of the prevalence of ovina variola in England during 1862-63 elicited a Ictter from Dr. Rennie, of the 31st Regiment serving in China. Dr. Rennie's theory is, that small-pox is generated, like typhus-fever, owing to the neglect of sanitary and lyggienic measures, which neglect permits the generation and elimination of fetid compounds; and they, entering the aninal economy, deleteriously affect it by contaminating the blood with this supposed malarious poison. This foreign and injurious substance, when pervading the system, devitalizes it, and consequently an effort on the part of nature is called into operation, which attempts, by throw- 
ing out a pustular eruption, to eradicate the virus from the system.

The treatment prescribed in cases of cutaneous eruptions is the external application of a liniment consisting of tartar emetic and croton oil, the effect of which, the doctor states, is the production of a strong "galvanic or electric" action, which causes the eruption to assume a "healthy and mild form." The doctor considers that a further investigation of small-pox will lead us to the direct use of electricity. The report forwarded contains several cases successfully treated in the human subject by the above means.

During the outbreak of ovina variola in 1862 and 1863, it was asserted by some that the disease among sheep was not small-pox, but a severe cutaneous eruption. And what is ovina variola but a skin disease-an eruptive pustular malady, having received the name of small-pox in sheep because of its similarity, in external manifestation and in constitutional effect, to the same disease known as small-pox in man? Small-pox in sheep passes through similar stages to the disease in man-namely, the incubative, when the malady is latent in the system; secondly, the vesicular, when spots or vesicles appear; thirdly, the papulated, when the papulæ often run into one another, i.e., coalesce and assume the state known as confluent small-pox. Again, the malady will run its course in sheep as in man; and any attempt to arrest its development is attended with most dangerous results. Now, in the treatment of small-pox in man, the physician has the means of cure under his control to a greater extent than the veterinarian when attending the same disease in sheepthat is, the physician can keep his patient in a bed, can have the room well aired and heated if the day or night be cold, and his patient has the sense to take medicine willingly; and therefore, by a strict observance of these means he can facilitate the development of the pocks, and avoid everything calculated to frustrate the operation of nature in producing them cor the veterinarian quite an opposite state of things exists: he often lias to treat his patients when they are located in ill-drained and badly ventilated stalls, in which fetid effluvia, caused by the presence of impure gases, exert their baneful influences on the inmates; and sometimes in the open fields, when atmospheric changes, heat and cold, act injuriously upon animals labouring under disease. Perhaps no malady to which the ovine race is subject demands greater care and protection from the operation of bad weather, than small-pox. For the sake of argument let us imagine a flock to be infected with it; that is, in the state of disease which may be designated "incubative." The owner of the flock fails to observe that any animal is sick, and they are allowed to range, and are treated as formerly. Now, even during this stage, a cold, wet night would not fail to injuriously affect infected animals, by throwing (as the shepherds would say) the lisease inwards, or more properly, by retarding the development of the pock, and consequently keeping the supposed virus of variola in the system for a longer period than is usually ordained bs nature; by which means the system, owing to the presence of this poison, becomes devitalized, and the operation of vital powers necessary to the production of the pock is interfered with. These remarks can with equal force be applied to patients when passing through the other stages of variola; and especially so during the papulated stage, when inclement weather often causes the development of the form of small-pox known as confluent. Both Messrs. Parry and Neate informed me that their sheep, when in the latter stage of the malady, seemed sicker after wet weather and extreme heat, and died in greater numbers; whereas during dry weather and a medium temperature, they seemed less affected, and progressed more favourably. In some of the cases in which post-mortem examinations were made (the time when I carried out these examinations, being after three consecutive days' rain), I found that the lambs died as the result of congestion and hepatization of the lungs; in these instances cold had doubtless impinged upon the system, previously devitalized by disease, and by attacking the most vital organs, viz., the lungs, produced congestion of them and consequent death.

Looking at the above facts, the question suggests itself-lf in treating small-pox in the human subject such care is required to insure warmth, cleanliness, \&c., both during the continuance of the malady, and for some weeks afterwards, why should not the same be demanded for the variolous sheep? It is well known, however, that sheep are gregarious animals, and dislike being housed; and often, if shut up in confined places for ever so short a time, die, even though not previously diseased. But although this is the case, why could we not locate variolous sheep in places similar to those in use at lambing time, with a shed around the yard? This might be adopted with benefit, because, as before indicated, it would protect them against the injurious effects of bad weather, and the too severe heat of the sun. During the outbreak in Wiltshire little or no protection was afforded to these miserable sufferers, and, in my opinion, many died in consequence of the inclemency of the weather. Therefore if disease at some, and, I hope, far distant period, should occur, let me advise flockmasters to place their affected flocks in habitations protected from the weather, in a similar way to the folds used in lambing time.

This place or infirmary would be the spot to which the variolous sheep could be sent when separated from their healthy companions; and segregation should be resorted to on the immediate appearance of disease. In bad cases, viz., those manifesting symptoms likely to be fatal, the animals should be destroyed and burnt, and the ashes buried. Near the infirmary, and with benefit, a Turkish bath might be constructed, as an adjusst to the treatment of small-pox in sheep, but so built as also so accommodate larger animals upon the farm. Scientific men, who have borne testimony to the effects produced on the animal system by the use of the bath as a curative influence, inform us that "at a temperature over 160 degrees infection is destroyed and fever is conquered." Now if this be true, we have in the Turkish bath a very 
valuable agent in stopping the progress of this disease by destroying infection, and it might be tried by my readers at any future outbreak of small-pox. It should seem that in treating skin affections the first course to be adopted should be that of shearing, in order to obtain a surface capable of being rapidly operated upon, and quickly dried afterwards; and more particularly would I recommend shearing previous to the application of hot-air baths for small-pox in sheep.

It must be remembered that sheep are very timid animals, and consequently great care must be exercised in administering medicine. A sheep, if caught and drenched three times weekly for a fortnight, will often die, either as the result of fright or of some derangement caused by the handling necessary to be called into operation during such process. It will therefore be wise, in treating small-pox medicinally, to give nitre in the water-troughs, and to feed the animals on an easily-digested and at the same time nutritious diet, such as oil-cake, carrots, \&c. ; and after the disease has runs its course, to administer tonics, and occasionally stımulants. This treatment during the outbreak in 1862 was attended with success.

\section{INOCULATION OR OVINATION.}

The inoculation of sheep with the view of producing a mild or "benign" form of small-pox, has for years past been practised on the Continent, and at various periods since 1847, in Great Britain. Professor Simonds, during the outbreak among sheep in 1862, operated upon several flocks with varied success, and from his book on Ovina Variola we learn that he, together with many English authorities, recommends inoculation as an artificial means, calculated to modify the type of disease, and to lessen the mortality which usually happens when-small pox occurs naturally. This being the case, I will endeavour to explain the mode of operating, and the period at which lymph should be collected from the smallpox vesicle. It is of no consequence whether the lymph be obtained from the vesicle which has occurred de naturâ, or has appeared as the result of inoculation; in each case it must be regulated by the duration of its incubative stage. The lymph required for the operation must be obtained from the vesicle when fully pregnant with the fluid, but on no account when the smallest amount of pus has formed, i.e., when the vesicle is assuming the pustular type. Professor Simonds considers that the vesicles very seldom are sufficiently matured to yield lymph before the twelfth or thirteenth day after inoculation. Continental authorities state that lymph may be obtained from inoculated sheep on the eighth or ninth day; but this statement is contrary to the experience of British authorities, and especially of Mr. Ceely, who informs us that he has seldom been able to obtain lymph before the twelfth day. He writes as follows:- "On the fourth day succeeding the inoculation of the animal which yielded the ichor, there were febrile symptoms, and roseola and stigmata near the inoculated parts, which were hard, elevated, and of a brick-red colour. The general and local symptoms increased, and on the sixth and seventh day of inoculation, large papulæ appeared, chiefly in the vicinity of the punctures. Subsequently papulæ showed themselves near the mouth, and eventually the absorbents of the groin, near to the inoculated places, became indurated; yet it was not until the eleventh day of the eruption, and sixteenth of inoculation, that any lymph could be procured from either the eruptive or inoculated vesicles."

\section{MODE OF OPERATING.}

Having selected a sheep with the vcsicles upon it, as above indicated, and procured the necessary lymph, it will be wise to confine the flock about to be inoculated, in a circumscribed area, and to catch every animal one by one, until each has been operated upon.

The places usually selected for the insertion of the ovine virus, are the inside of the ears and thighs, the under surface of the tail, or any other part devoid of wool or hair. Captain Carr gives the following instructions for the performance of inoculation:--" The places best suited are the inner side of the flap of the ear, or the under part of the tail, close to the root. The instrument employed is a kind of needle made for the purpose, with a fine and somewhat flattened point, which having been dipped in the virus is carefully inserted between the upper and second skin, carefully avoiding piercing so deeply as to draw blood, which is found to render the success of inoculation less certain. Of course, in the absence of such a needle, a lancet will answer the purpose."

The lymph may be obtained from the small-pox vesicle by plunging a needle or lancet into it, as abore mentioned, and immediately inserting the charged point into the skin of the sheep on the inside of the flap of the ear, inside of the leg, or under the tail ; or, in other words, those parts devoid of wool and hair. The number of punctures ought not to exceed three or four, and should be about two inches apart, so as to prevent the extension of inflammation from one to the other. Professor Simonds writes-" It is better to have one incision on either side of the abdomen, and a third on the inner part of the thigh. The greatest care is required in making the punctures, for, if deep, they are certain to be succeeded by ulceration and sloughing of the surrounding integument, often to the extent of two or three inches. They cannot be too superficial. Indeed, with primary lymph, i.e., lymph procured from the vesicles of natural ovine-pox, we have found that the slightest incision, even if it did not penetrate the dermis, has been followed by an ulcer, varying in size from that of a shilling to half a crown."

The experience of Mr. Ceely agrees with that of Professor Simonds, for he writes-"I find superficial scratches better than punctures, and I place the lymph upon them by means of a portion of moist cuticle recently removed from a vesicle, and secure it with a piece of adhesive plaster: large punctures are sure to be followed by extensive or deep and dangerous sloughing." Professor Simonds, for the sake of comparison between the effects produced by scratching and by puncture, had recourse to the following experiment:November 29.-Three-year-old sheep, Irish breed, ovinated 
by scratching the epidermis inside each thigh, and making a slight puncture on the brisket. Dry lymph used to the separate places.

November 30.-Swelling is present, associated with diffused redness of the abraded integument. No change in the incision.

December 1.-Small pustules are found on the scratches. The red colour is declining.

December 2.-The pustules have discharged their coutents, the swelling has nearly subsided, and the cuticle is desquamating. The puncture is marked by a deep red dye of variolous inflammation.

December 4.-The absorbents surrounding the incision are corded. The inflamed spot is larger; but the animal's health is scarcely affected.

December 6.-A few papulæ have appeared. These subsequently passed through the regular stages, and on the 18th the patient was convalescent.

The animals selected to be operated upon with the variolous poison, should always be such as are in good health and not less than six months old, as young lambs seldom recover the effects of inoculation. We must also be guided by the weather in our determination of the period when to operate. The extremes of hot, cold, and wet weather must be avoided, but a dry and mild season can be wisely chosen; and after a flock has been inoculated it will be good practice to place it in a protected situation or shed, similar to those used during the lambing season. Some persons advise, under any circumstances, the gradual preparation of the flock selected for inoculation by dieting, so as to produce a healthy state of their systems; and in certain cases, the exhibition of medicinal agents, to be given under the advice of a qualified veterinarian.

It has been stited by Hurtrel D'Arboval, that the exudations from inoculated vesicles are not so efficacious in producing small-pox as those of the eruptive ones. In opposition to this opinion, both Professor Simonds and Mr. Ceely have succeeded in inoculating successfully with the contents of both vesicles, and consequently have not noticed the difference referred to.

The lymph used for inoculation is said by some, during its transmission from sheep to sheep, to undergo degeneration and ultimately to become effete; by others it is asserted, after several transits a lymph equally protective, but far less virulent, is obtained.

Hurtrel D'Arboval writes:- "After the same matter has passed through twelve or fifteen lots of sheep, it loses its efficacy, and requires to be renewed from sheep having the natural pock." To this opinion Mr. Ceely is opposed, and thus writes:- "If this be true when great pains are taken to repeat inoculations with lymph in a proper state, viz., clear and limpid, it is a very remarkable and highly interesting fact, and well worthy the attention of the medical and veterinary professions. We know that care and selection in the transmission of the vaccine are necessary to prevent degeneration, which has often taken place to the injury of patients and the damage of the reputation of the vaccine; but we do not see, when proper care is taken to select good lymph and fitting subjects, that such degeneration ensues, or we should be in a sad state for want of fresh supplies. I should like to be able to ascertain the truth of the statement made by French inoculators or clavelizators; and whether it be a contingent or an unavoidable degeneration."

Again, it is said that the virus is not so good from the inoculated as from the eruptive vesicle; that is a point of interest. It is very probable that the eruptive vesicles have the lymph less blended with the adventitious products of inflammation excited by the scratch or puncture of inoculation, which will often in man, after vaccination, spoil one or more vesicles. After all, I cannot but suspect that these difficulties have been overstated, and might be met with where large numbers have been clavelized. Where one or two only are inoculated, as with vaccine in man, the supply may be lost, or degeneration ensue."

THE SELECTION AND PRESERVATION OF VARIOLOUd LYMPH.

Lymph should never be selected from very large vesicles, as these are often filled with little else than serous exudation; small ones, when distinct, are therefore to be preferred.

The author has had no experience in the preservation of lymph, the reason for which will be sufficiently shown liereafter, when the benefit to be derived from, and the propriety of inoculating, will be discussed; consequently, for the use of those readers who believe in its prophylactic effects, the following passages are selected from Simonds' work on Ovina Variola:-_"Various expedients have been adopted to preserve the lymph, so that it might be depended on for future ovinations; all these, however, have failed more or less. The method of collecting it in capillary tubes, and afterwards hermetically sealing them at the end, is probably the best. Mr. Ceely has long been accustomed to preserve the vaccine lymph in this manner, and speaks highly of it. Next to this plan, that of charging ivory points, and allowing it to dry, is to be recommended. How long lymph will retain its specific properties cannot be determined with accuracy; probably it will be useless after being kept a few months. The fresher the lymph the more it is to be depended upon for ovination, as undoubtedly it is deteriorated by age, and ultimately becomes inert."

Lymph, taken from a vesicle arising de naturâ, primary lymph, and used for the inoculation of sheep, is said to produce intense inflammation, and to cause sloughing; and consequently lymph of the first remove cannot be safely used. Mr. Serres writes - "If the ichor is trausmitted through the systems of several sheep, we obtain by the tenth remove a fluid which merely produces a general eruption, so that the malady induced by inoculation is very mild, and unattended with danger." But, of course, when small-pox occurs naturally amongst two or three in a flock of sheep, and the owner determines to inoculate the re- 
mainder, he has no choice left him; if he inoculates, he must do so with primary lymph. To remedy this, which by inoculators is considered an evil, many attempts years ago were made to purify the lymph by first ovinating other animals, as the ox, and then bringing it back to the sheep. The opinions of experimentalists on this subject, however, are at such variance, that it is impossible to place any reliance on their statements. Suffice it to say, that, when possible, it is safer to use lympl of the ninth or tenth remove; for when sheep are inoculatcd with primary lymph very dangerous symptoms occur, which constantly terminate in deatl. The above remarks on the ovination of sheep have been written in order to inform my readers of the modus operandi of the preventive influence said by many authorities to follow such operation. Having closely watched the progress of ovine small-pox during 1862 and 1863, I must state that my opinion is quite adverse to the authorities alluded to in the foregoing cliapters: but that I do so with all respect to such, and particularly to Professor Simonds, who has investigated this subject of veterinary pathology more perhaps than any person living, and whose opinion is at all times much respected by the author. It will not, therefore, be out of place to introduce certain remarks made by Professor Simonds during 1862, in advocating inoculation as a treatment for ovine small-pox :-

"He believed that there was nothing which they could use so effectually, no means at their disposal so good, as that of artificially inducing the disease by inoculation. Supposing, for example, that they had to deal with one hundred sheep, five or six of which had given early evidence of the affection Let them bear in mind that they had only two things at their disposal to arrest the progress of the disease, and lessen its fatality; one, the early separation of the diseased animals from the healthy, or apparently healthy; the other, the artificial production of the disease. The disease, artificially produced, was exceedingly benign compared with the natural form, and consequently this plan afforded the means of saving a great number of sheep. He had no desire to give utterance to a single expression which would militate against the plan of isolation; but he knew that it was frequently altogether impracticable. If they had merely to deal with tens, twenties, or even hundreds of sheep, there would be little difficulty. The sheep might be caught every day, turned, and carefully inspected; but it must be remembered that at the identical moment when it made its first appearance on the skin the disease was infectious, so that if the sheep were allowed to remain together ever so short a time after the eruption made its appearance, it was impossible to say how many would receive the infection. Early removal, therefore, necessitated a daily examination. With sixty or one hundred sheep such an examination was not difficult; but with flocks of thousands it was impossible that it could be practically or advantageously carried out. This being the case, they were thrown back completely upon inoculation. With regard to inoculation, certain rules had been laid down, which it was absolutely imperative should be well carried out so as to secure success. A great deal had been said and written within the last few wecks about inoculation; and persons who were well known in the agricultural world had thought fit to publish letters in the Times condemning inoculation. Those individuals, however, had drawn their deductions trom incorrect data. He liked to be honest in these things, and he would say with regard to the letter of Sir John Tyrrell, with reference to the disease in Mr. Bramston's flock, that a greater mistake was never wade. Sir Joln Tyrrell said truly that Mr. Bramston had his flock inoculated, and that he lost a great number of animals. But the fact was, that the greater number lost were natural cases. He did not lose any great number that were inoculated. Although they were not inoculated by himself, they were inoculated by an individual to whom he (Professor Simonds) supplied the lymph; indeed, the inoculation was carried out under his own superintendence. He had letters in his possession which would show, that Mr. Bramston did not lose one-third as many of his inoculated animals as he did of those suffering from natural causes. He (Professor Simonds) was therefore justified in saying, that Sir J. Tyrrell had drawn his deductions from wrong data. It should be borne in mind that one essential to success in inoculation, was that the operation should be performed in temperate weather. $\mathrm{He}$ stated this here because he had to mention that Mlr. Bramston's sheep were inoculated at Christmas, a period when, as they knew, so much protection could not be given to sheep as at other times. The temperature was generally ill-adapted to preserve the health of the animal, and consequently operated against the success of inoculation. If, therefore, there was a little greater fatality in Mr. Bramston's flock than in other cases, it was partly, if not wholly, due to the period of the year when the operation was performed Another rule to be laid down was, that animals which were not pregnant were the best to be inoculated. At the same time, if small-pox should make its appearance amongst our ewes in lamb, they must be inoculated, and the owner must take the consequences. There was undoubtedly a greater likelilsood of fatal results in such cases; and he might mention that, in Mr. Bramston's case, the ewes were heavy in lamb at the time of their inoculation. There was, therefore, a second cause brought into operation to iucrease the fatality. But there was still another point, and an important one, that militated against inoculation in the case to which he had referred. With fluid lymph he never thought of inoculating in more than one place. One puncture was sufficient for the purpose, and could not be too snperficially made. If he should be called upon to inoculate a flock of sheep to-morrow, he should have the sheep from which he proposed to take the lymph at one end of the table, and the sheep to be inoculated at the other. He should dip the end of the inoculating needle in the virus of each vesicle, and then insert it very snperficially in the other animal; just one puncture. But then he must have a natural case to choose from, and he must have an 
animal in a particular stage of the disease. Without such a case the only plan would be to collect lymph upon an ivory point, and use it in the same way as it was used upon a child. The lymph dried on the point, and of course lost some of its potency. So in the case of sheep. If they kept the lymph for several weeks it became exceedingly weak, and therefore it was important to make, not merely one puncture, but two, three, and occasionally even four. Assuming, then, that they made four punctures, and that all of them proved effectual, it was not difficult to see that if there was danger of one producing the death of the animal, there was more danger of four producing it. The consequence was that dry lymph was less successful in inoculation than fluid lymph, merely becanse the operator had to produce more punctures."

From the above it will be learned that Professo simonds advises, first, inoculation as a modifier of ovina variola; secondly, how and in what manner he performs the operation; and thirdly, his reasons for advocating it as a valuable treatment for small-pox in sheep. In doing so, he remarks, you have two courses at your disposal-one, the separation of diseased animals from healthy ones, and the other, the artificial production of the disease by inoculation.

One of the chief reasons given by the professor in advising inoculation, was because a greater amount of time was necessarily expended in examining a flock, the diseased sheep from which were to be segregated, and afterwards to be isolated. I must confess that it seems to me quite as easy to examine 1000 sheep as to inoculate the same number; and moreover, more time would be consumed in inoculating 1000 animals than in examining them simply with a view to the separation and isolation of those diseased. Admitting that early removal demands daily inspection, which, when dealing with hundreds we are told is easy enough, but with thousands is impracticable, it therefore appears, that the only reason assigned against the separation system is an assumed, by no means great, difficulty. Did it not take Professor Simonds more time to inoculate 800 sheep in one place and 1000 in anotleer, than it would have taken to have inspected each sheep, and to have separated the diseased from the healthy? Again, it is asserted that by inoculation a "benign" form of small-pox is produced. In very few instances indeed during 1862 did benign cases, following inoculation, come under my notice. In a flock, the property of Mr. Hitchcock-which I carefully examined whilst suffering with small-pox, the result of orination-I met with the most virulent form of small-pox; there were animals with swollen faces standing outside the fold, and about to die as the subjects of diseased lungs, the result of inoculation, which we are told produces small-pox in an "exceedingly benign" form; but it could not have been more virulent, so my experience teaches me. The inspection and separation system can be easily carried out, provided a sufficient number of persons qualified are engaged to inspect flocks, and to separate the diseased from the healthy. This system Professor Simonds distinctly advocates-" he had no desire to give utterance to a single expression which would militate against the plan of isolation"-but prefers inoculation, because it takes less time, and consequently gives less trouble to the attending veterinarian.

No one will deny that inoculation propagates the disease, consequently it increases the amount of danger to be dreaded, and facilitates, by rendering more animals diseased, the actual spread of the malady; for who can predict that, out of a flock of 400 inoculated sheep, one would have taken the disease naturally, or how many would have died if they had? or if, in cases of small-pox in man, inoculation is prohibited because productive of such serious consequences, why should not the same rule similarly apply to our domestic animals? Again, inoculated sheep suffer almost as severely as those that take the disease naturally, and therefore every animal so situated is reduced to half its previous amount in money value; i.e., if a flock is worth $£ 1000$ before inoculation has been practised, it is only worth $£ 500$ afterwards; and besides, there is always a certain amount of mortality; whereas separation, immediate destruction, and burial in lime, or still better, bnrning, diminishes the disease by, so to speak, actually destroying it. In Norfolk, where small-pox raged among the sheep during 1847 and 1848, a Mr. Bramston inoculated a flock of 600 , which resulted in his losing ten daily. On the other hand, Sir J. Tyrrell possessed 500 sheep; he separated the diseased ones from the healthy, and he informed a friend of mine that $£ 20$ covered all his losses. Certainly, therefore, when it is proved by reasoning from analogy and from fact, that the effects produced upon animals by inoculation are to be dreaded nearly as much as the disease itself when occurring de naturâ, such a treatment in my humble opinion is to be deprecated; from personal observation, I am positive that it is better to destroy and so to suffer a slight loss at first, than to extend by inoculation an area containing the disease, as inoculated sheep will infect healthy ones as rapidly as those which have taken the disease from natural cases.

The adoption of the system of segregation, i.e., the separation of diseased from healthy sheep, of course, is the first and most reasonable plan which is suggested to the mind of those even the most ignorant of the management of sheep. This system was during 1862 in many instances carefully carried out, and where isolation was early insured, several sheep escaped and less mortality occurred, than among inoculated flocks. The wholesale inoculation of flocks throughout a district, because, perhaps, two flocks within it are suffering from a contagious malady, can only have the effect of involving the whole in such disease, and of infecting the surrounding neighbourhood, whereas, early separation must confine the disease within certain limits, or at any rate we are not in so doing attempting to spread it by artificial means. One affected animal in a district is less likely to cause the extension of the malady than twenty; now, the system of isolation does all that is practicable to prevent No. 2 catching small-pox, whereas, by inoculation, we spread the disease from flock to flock, and by this means increase the 
centres of contagious disease from one to an indefinite number, each centre becoming a nucleus, from which the malady is assisted in spreading to neighbouring flocks. Early separation and isolation is therefore liere prescribed. This system worked well during 1862, and if it be carefully and strictly carried out, will similarly answer during any future ontbreak, should it unfortunately ever again occur in Great Britain. A letter from Mr. Rose is reproduced here, as it clearly gives the opinions of a practical Hockmaster:-

\section{To the Editor of the Times.}

Sin,-I learn through your paper that small-pox has broken out among the sheep at Allington, and has already committed lamentable ravages. I was situated in the very focus of the epidemic when it occurred in West Norfolk in 1848, and I paid some attention to the subject.

The following is the statistical result of my experience at that invasion of the pestilence, having a knowledge of what occurred in various flocks comprising 19,526 sheep :-

Of the sheep that took the disease naturally nearly onethird died.

Of 9720 that were inoculated 345 died.

Of 4800 sheep among which the disease broke out naturally, and where the flocks were very carefully watchedviz., examined, and the diseased immediately separated from the unaffected (as far as conld be judged of -only twentytwo were affected, and of those eight died.

From the above results $I$ came to the conclusion that separation would be the best plan of management on the occurrence of a similar epidemic, for inoculation must intensify and diffuse the poison, as every inoculated flock would be a fresl focus of contagion, and vaccination, as practised during the early period of the epidemic in Norfolk, was worse than useless.

I therefore advocate neither vaccination nor inoculation, but separation, provided the watchfulness of the shepherd can be depended on.-I am, Sir, your obedient servant,

Great Yarmouth, Ang. 14, 1862.

C. B. ROSE.

VACCINATION A PREVENTIVE OF SMALL-POX IN SHEEP.

Any sudden outbreak of disease amongst cattle, and the consequent loss incurred by it, necessarily causes the proprietors to consider what means can best be adopted to prevent disease or lessen its intensity. As men directly protect themselves against corporal aggression, so do they indirectly against mercantile loss; and this same spirit leads them to act on the defensive, and sometimes on the offensive, if circumstances demand it.

Now in the case betore my readers, ovina variola, it will be remembered that the malady was not diagnosed in Wiltshire until after Professor Simonds had inspected, pronounced judgment, and prescribed treatment. Soon afterwards other veterinarians appeared amongst the diseased flocks; but, while agreeing with Professor Simonds' opinion, that the extant disease was small-pox, they deprecated the system of inoculation, as calculated to extend rather than circumscribe the area in which the malady existed. I, for one, advocated a system of separating the diseased from the healthy shcep, and destroying those in whom the lope of recovery was small; and this plan undoubtedly answered. For there were two farms, on each of which two variolous sheep in the early stage of the malady nere removed from their companions, and in neither of these flocks did any fresh case occur; whereas the inoculated flock at Langlcy suffered severely.

'The first idea which is naturally suggested to farmers and others when disease is devastating their herds, is, "W'hat treatment shall I apply to eradicate disease? or, better still, what means can I adopt to prevent it?" The treatment has been alluded to above. When in Wiltshire, and bearing in mind that "prevention was better than cure," I suggested to MIr. George Brown, of Avebury, that although Professor Simonds disbelieved in the utility of vaccination, it would be worth trying a few experiments. In this Mr. Brown acquiesced; at the same time adding that several medical men liad previously proposed vaccination as a preventive. Soon after this conversation a meeting was convened in Devizes by the Wiltshire Mutual Association for the Prevention of the Spread of Small-pox in Sheep, at which my presence was requested. At this gathering several matters were considered relative to the wording of certain rules to be printed for the guidance of the association; and afterwards the subjects of inoculation and vaccination were freely discussed. I there stated that it was our duty to obtain proof, and not to take statements for granted without investigating for ourselves. For this reason I advocated the propriety of testing the effect of vaccination as a preventive, on several sheep; and, in the event of the pock taking, to place such sheep in the midst of the previously diseased flocks. If the vaccinated sheep failed to contract the disease after a due time had been allowed for its production, then these sheep might be considered exempt from smallpox, and, consequently, vaccination might be looked upon as a preventive agent.

During 1863, experiments on a somewhat extended scale were carried on by the Royal Agricultural Society of England, under the supervision of Professor Simonds; and six ewes were also vaccinated by Mr. Parker, surgeon, Shrivenham. Four of these ewes, after the effects of vaccination had passed off, were allowed to remain eleren days with $\mathrm{Mr}$. Hulbert's flock; the other two were placed during twenty days in the midst of variolous sheep at Aldbourne, but wer afterwards removed to Mr. Hulbert's flock, where they stopped four days, without manifesting the slightest signs whatever of small-pox, "although during the whole of that time sinallpox was raging in both flocks to a fearful and virulent extent.' On Monday, Nov. 3, the six ewes were inspected at Langle by Mr. George Brown and Mr. Parker; they were found to be perfectly healthy, and the only sheep amongst the flock 
free from small-pox: "the vaccinated ewes showed no symptoms of small-pox, and were, indeed, the only healthy ones in the flock."

MIr. Hulbert's sheep were then examined, and one, considered to have passed through the various stages of small-pox and to have recovered, was caught, and inspection revealed the fact that the inside of its thighs was covered with pustules in a confluent form. From this sheep Mr. Parker obtained lymph, and inoculated the six previously vaccinated ewes, and left them still with Mr. Hulbert's flock. On the 13th of November Mr. Parker wrote to Mr. Brown, informing him that he had inspected the ewes and found them affected by the inoculation, but not to the same extent as those which had not been vaccinated.

The question is often asked "What is the difference between inoculation and vaccination?" Inoculation is conveying a disease from one animal to another of the same species; whereas raccination is taking a disease from one animal to another of a different species.

It seems that Mr. Webb, of Wick, in Gloucestershire, was the first person who gave to the world a knowledge of the protective power possessed by cow-pox in preventing small-pox in the human subject; but be this as it may, it was left to Dr. Jenner to prove beyond doubt that lymph taken from the cow while labouring under variola, if injected into the human arm, would produce a mild form of disease and act as a preventive to small-pox-or at least would modify the eruption. It is proved that milkmaids and people engaged in dairies have the power of resisting variolous poison, and this must be attributed to their continued contact with the udder of the cow, where the pocks occasionally occur (oftener than is supposed) in a very mild form, and by this means with these people an antidote to small-pox is continually exerting its influence. As the subjoined points out clearly the manner in which the operation for vaccination is performed, it is reproduced.

It is most puzzling to know why moculation has been preferred, when vaccine lymph is so readily come-at-able. Vaccinia, or cow-pox, is a most common disease, and enough matter can be obtained from one vesicle to vaccinate many scores of sheep. A hard colourless eminence is found upon a cow's teat, upon the centre of which, when about three days old, a concave vesicle appears, gradually increasing in size, when, on the sixth or seventh day, it presents a tense, prominent head-the surrounding surface of a deep red colour. Matter, taken from the eruption at this latter period of its growth, should alone be used for vaccination; and it is a spurious vesicle unless marked by the peculiarities above-named.

Taccination, although a simple operation, requires some little caution in its performance. Make a perpendicular parting of the wool at the outside of the arm of the sheep; take hold of the limb, including the wool round the inner side, drawing the skin tightly; and, with the other hand, introduce the point of a lancet, charged with vaccine lymph, into the skin, in an oblique direction, and allow to remain in the same position for a moment or two, and then withdraw: the puncture should be compressed for a few seconds, in order to prevent it from bleeding, and the operation is finished. Report of the Wiltshire Mutual Association for the Prevention of Small-pox in Sheep; result of Vaccination as a preventive.-Mr. Norris narrated as follows the result of his experiments by vaccination instituted by the Association :-

Your committee would, however, but imperfectly have discharged their duty, had their intention been limited merely to the extinction of the disease where it was found to exist. They therefore put themselves into communication, through their secretary, with several gentlemen in Norfolk who had had considerable experience of the small-pox of sheep, when that disease was imported into England some ten years ago, and, among others, with Mr. Allan Ramsay, who was said to have tried with success the preventive effects of vaccination in several large flocks in that county.

The communications received from these gentlemen were of a very encouraging nature, and your committee proceeded forthwith to put the matter to a practical test. With this object in view your chairman (Mr. George Brown) procured six healthy sheep from Mr. Pritchard, of Loncot, near Swindon, and had them vaccinated by Mr. Parker, a medical gentleman of Shrivenham. Having taken the vaccine satisfactorily, two of these sheep were, on the 9th of October, forwarded to Mr. Church, at Aldbourne, where they were placed with two very bad cases of small-pox-so bad that the animals afterwards died in a most loathsome state of disease; the vaccinated sheep, however, appeared in no way affected, and on the 29th they were removed to Mr. Hulbert's flock, at Langley, where small-pox was raging in its most virulent form, and where, it should be stated, the four other vaccinated sheep had been previously sent on the 23rd of October. Here the six vaccinated sheep remained until the $3 \mathrm{rd}$ of November, mingling with a mass of diseased sheep, resisting all contagion, and continuing all of them in a perfectly healthy state.

But Mr. Brown determined to put the experiment to the most extreme test; and on Nov. 3 he accompanied Mr. Parker to MIr. Hulbert's, and there had the six sheep inoculated. That there might be no question about the matter, each sheep was inoculated in two places, and on the following week there was strong evidence of their having all taken the disease; indeed, the fact was soon placed beyond doubt, for on the 13th one of them died in a very bad state, followed by the death of another on the 19th, two more being at the same time exceedingly ill, with pustules fully out; but the remaining two appeared little affected, and, with the other two, have since quite recovered.

It will be observed, therefore, that up to tne time of inocnlation-during the twenty-five days that a portion of the vaccinated sheep were exposed to the small-pox in its most virulent form-the resisting effect of the vaccine was complete. How far the six sheep might have continued to escape contagion it is impossible to say; and your committee canuot but regret that the severe experiment of inoculation was not 
limited to three of the sheep only, leaving the other three to test the permanent effect of vaccination. 'The experiment has, however, exemplified one result, that inoculation is not always certain to produce the disease in a mild form, two of the sheep thus artificially impregnated with the virus having died in a shocking state; and in Mr. Hulbert's flock the losses were greater, by about 14 per cent., among the inoculated cases than among the natural ones.

Another good result has also, in the opinion of your committee, been satisfactorily established, viz., that separation, and not inoculation, is the proper mode of dealing with affected cases; for in every instance that has come within the knowledge of your committee, and there were many, where separation was practised at the outbreak of the disease, its effects were confined to those animals only first affected in each flock, and these having been removed from the others, in no single case did the disease extend further; whereas, in all cases, where inoculation was practised, the disease has been extended, and its virulence and fatality have been as great, and in some instances greater, than where it was allowed to wear itself out naturally.

The inoculation or ovination of sheep was proposed by Chalette in 1762, by Bourgelat in 1765, by Coste in 1797, and by Simonds during 1847 and 1862. Hogg gives a very clear description of ovine small-pox which devastated French flocks on several occasions during the last century, and in a very excellent articlc details treatment, and informs us that both the proposers of inoculation and vaccination had their supporters.

The vaccination experiments which were carried out during 1863, were, as far as they went, satisfactory; but so small a number as six sheep was not sufficient to raise a theory into a fact. Hogg informs us, that on the Continent vaccination gave immunity to four-fifths of the sheep which were subjected to it. The article, which is here reproduced, gives a distinct description of small-pox in sheep, which received, it will be seen, the name La Clavelée, and was thought by many continental authorities to be a disease possessing certain characters which distinguished it from ovina variola. The following will settle the question better than a theoretical argument :-

"The sheep in France, and on the greater part of the Continent, used to be subject to a dreadful pustular disease, principally propagated by contagion, yet thought by some to rage at times as an epizootic. Scarcely a sheep escaped its attack in some period of its life. It never reached Great Britain, although it has thinned the sheep-flocks in every district of France opposite to the English coast. It was termed La Clavelee, and the virus by means of which it was propagated was called Le Claveau.

"It was a peculiar eruption chiefly, and always at first appearing on parts that are most denuded of wool, as the inside of the arms, and the thighs under the belly and tail, on the teats and scrotum, and around the eyes and nose, "and not unfrequently spreading at last over the whole surface of the body. These pustules contained a purulent fluid, highly infectious, and when that is secreted they become dry, and fall off. La Clavelee appears at all seasons of the year, and attacks without distinction the strong and the weak, selecting however, the lambs in preference to the adult sheep. The animal in which the disease has once been fully developed, is ever afterwards free from its attacks; but a full half, and frequently two-thirds of the flock, are destroyed by it. The contagion was communicated in a variety of ways, or in almost every possible way; the slightest contact was suffcient to accomplish the purpose. A portion of the virus seems to be detached from the sick animal by everything which it tonched, and there it remained for an indefinite period, detaining all its dangerous properties. Direct individual communication did not seem necessary. If it broke out in a flock, it was almost sure to be communicated, sooner or later, to all that were within a few hundred yards of it. It might be unknowingly conveyed, and probably was, by the butcher, the shepherd, the dog, the sheep-merchant, and the medical attendant. It spread by means of the transport of the wool and the skins. If a sound flock was turned into that in which a diseased one had been pastured two or three months before, or if it was driven along the same road over which an infected flock had lately travelled, the malady was sure to be developed. It was for many a century the sudrge and the destruction of sheep. In the regular Clavelee there were four distinct periods: first, the symptoms which preceded the eruption, as dullness; loss of appetite and strength, and debility marked by a peculiar staggering gait, the suspension of animation, and slight symptoms of fever. This continued during about four days, when commenced the second period, or that of eruption. Little spots of violet colour appeared in various parts, and from their centre there sprung pustules, accompanied by more or less inflammation, isolated or confluented, and with a white head. Their base was well marked and distinct; they were surrounded by a red areola, and their centre was flattened; they were larger than an ordinary lenti ${ }^{7}$ in some animals they were confined to few spots, in others $t_{t}$ ey spread over the whole body. They were scattered here and there, or disposed in form of beads, or congregated together in a mass. When the disease was not of an acute eharacter, and the eruption was not considerable, and the febrile symptoms were mitigated as soon as the pustule was deve'oped, there was not much to fear. The eruption ran through its several stages, and no serious disorganization remained; but in too many cases the whole of the integument became reddened and inflamed, the flanks heaved, the pulse, whether strong or obscure, increased in frequency, the mouth was hot, the conjunctiva red, the breath foetid, the head swellcd, the eyelids almost closed, rumination had ceased, the muscular power was exhausted, the pustules died away with little apparent fluid secretion, fœid diarrhœe ensued, and death speedily took place. The progress of the eruptive stage of the disease was frequently, lowever, a very unsatisfactory one. When the pustule had risen, and the suppuration had 
commenced, a new state of febrile excitement ensued, accompanied by more than usual debility. It lasted from three to four days, and during its continuance the pustules became whiter at their summit, and the fluid which they contained was of a serous character, yellow or red, transparent or viscid, and by degrees it thickened and became opaque, and then puriform; and at this period, when danger was to be apprehended, a defluxion from the nose ensued, and swellings abont the head, as already described. 'This was the contagions stage of the disease, and when it was too easily and fatally transmissible by accidental contact or by inoculation. Then came the last stage, that of desiccation; and about the twelfth day irom the commencement of the disease, the pustules subsided or the integument gave way, and the fluid which they contained cscaped, and a scale was formed of greater or less size and density, yellow or black, and which detached itself bodily or crumbled away in minute particles or powder. The contagion was now at an end, and the animal recovered his appetite, and spirits, and strength. This stage of desquamation frequently lasted three weeks or a month.

"A secondary eruption occasionally followed, of an erysipelatous character. There were no distinct suppurating pustules; but there was a mole serous or watery secretion, which soon died. This was the regular and the fortunate course of the disease; but too frequently there was a fatal irregularity about it. Almost at the commencement there was an excessive fever, and prostration of strength and fotid breath, and detachment of large patches of the wool, and more rapid and bounding or inappreciable pulse, and strange swellings about the throat and head, and difficult deglutition. There was also a discharge of adhesive spumy fluid from the month, and of ichorous, or thick and yellow, or bloody and fotid, discharge from the nostrils, often completely occupying and obstructing them. The respiration became not only laborious, bnt every act of it could be heard at a considerable distance; there was a distressing cough; the lips, the nostrils and the eyelids, the head and every limb, became swelled; the pustules ran together, and formed large masses over the face and the articulations; diarlicea, that bade defiance to every medicine, ensued; and the end was not far off. Medical men were much struck with the resemblance between this disease and the small-pox of the human being, and they believed them to be identical; and every shepherd, of course, adopted this opinion, and the Clavelee of the sheep was supposed to be the small-pox of the human being, modified by certain differences of structure and function. This, however, was very erroneous. There was an evident difference in the pustule; that of small-pox was developed in the texture of the skin, and surrounded by a rose-coloured areola; that of the Clavelee was evidently more deeply seated; it reached to the subcutaneous cellular tissue, and it was surrounded by an areola of a far deeper colour. The virus of small-pox was usually contained in a simple capsule, which elevated the scarf-skin. The virus of the sheep-pox seemed to be more diffused through the cutaneous and subcutaneous tissue, and there was abundantly more swelling and inflammation. 'The matter of small-pox was first limpid, it then became turbid, puriform, and at length assumed the form of white or yellow or thick pus, which became concrete; and scab was formed, which became at first yellow, and then brown, and then black, and when it fell off it left an impression or depression, more or less distinct, on the surface of the skin. The pustules of the sheep-pos, before there was any appearance of pus, degenerated into scabs, or formed a hard or thick crust under which the pus accumulated; and when that scab fell off there was a sore left behind, or sometimes a deep ulcer. There were other particulars of disagreement, but these would be sufficient to prove that they were not identical diseases.

"The treatment of this disease was necessarily very simple; it consisted, first, in separating the sound sheep from the diseased, and in being careful that having been thus separated they were not subjected to the influence of cold or wet, or insufficient food. The diseased sheep were supplied with wholesome food; during the febrile stage aperients of Epsom salts were administered. The state of fever having passed, mild tonics, as gentian and ginger, were administered; the Epsom salts being still retained, but in smaller doses Common salt was a favourite and a very useful medicine, on account of its antiseptic and tonic properties. About the end of the seventeenth century it was discovered that the virulence of the small-pox could be modified and controlled by artificial means, and by those which would appear at first sight to have a kind of daring about them. The child was inoculated with the virus taken from an otherwise healthy subject, and a disease of a milder character, milder to a degree that was scarcely credible, was produced. Half a century and more passed before the experiment was tried on the sheep; but about the year 1760 it was attempted with the most perfect success; a disease with every character of the sheep-pox was produced, but much more mild, which rapidly ran its course, and left no bad consequences behind. This was not immediately acknowledged; the operation was ridicnled and abused at first; but experience has proved that it is an invaluable one. It is now adopted by almost every continental sheepmaster. When the sheep-pox used to break out in a flock, the owner lost a third, and sometimes half, and sometimes three-fourths of his stock. He now inoculates, and he does not lose more than one in a hundred. The professors at the veterinary school at Alfort say, that not more than one sheep in four hundred is lost. When it is seemingly followed by disastrous consequences it is because it is delayed until the Clavelee actually breaks out in the flock, and then the loss of those that die of the natural disease is unfairly attributed to the inoculation. Whenever the natural disease appears in his neighbourhood, it is now acknowledged to be the duty of the sheepmaster to subject the whole of his flock to inoculation, and the greater part of the owners of sheep do inoculate the whole of the lambs. The immunity lasts during the life of the animal. The spring and the autumn are the most favourable periods for inoculation, and the sooner after the 


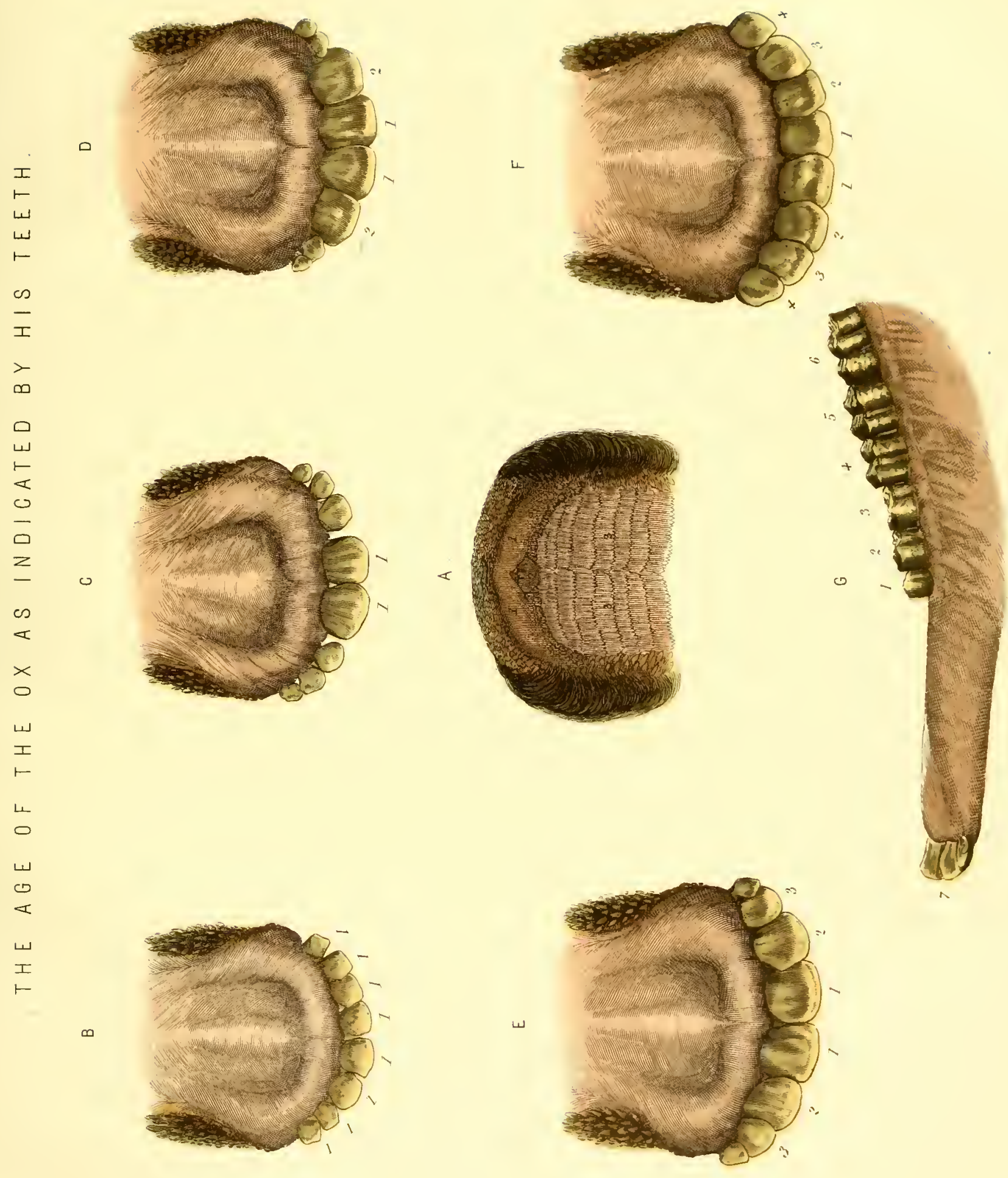



weaning of the animal the better. The ear or the inside of the forearm, or the thigh, are the parts usually selected for the inoculation. In process of time inoculation with the vaccine matter was introduced into Great Britain as a preservative against the small-pox, and the French veterinarians very naturally put the power of the vaccine matter to the test as a prescrvative against the sheep-pox. It had power, and to a very considerable degree. An experiment was made on a very large scale; 1523 sheep were vaccinated, and the disease passed through its different stages; they were all afterwards inoculated with the matter of sheep-pox, and in 308 of them the disease was produced in the usual mitigated form after this operation Other experiments were made on a smaller scale, and with a similar result; and therefore the vaccine inoculation is now abandoned on the Continent, although it gives immunity to four-fifths of those that have been subjected to it, for inoculation with the claveau, or the virus of the sheep-pox, will give immunity to all. There is one disadvantage attending the use of the claveau, that it retains its power not more than a few days, whatever care may be taken of it. The vaccine matter retains all its properties a much longer period."

\section{THE AGE OF THE OX AS INDICATED BY HIS TEETH.}

\section{PREHENSION OF FOOD.}

Previously to explaining the dentition of the domestic animals under notice, it will be necessary to consider briefly the mode by which different animals, and particularly the ox, sheep, and pig, select and collect their food. Everybody knows that the act of prehension varies. Man, fo instance, employs his hands and mouth, and is assisted in so doing by artificial means; the elephant by a prolongation of the nose, "trunk," accomplishes this act; the horse selects food with his lips, the ox gathers it with his tongue, the sheep collects the herbage from the pasture between his teeth, (incisors) and dental pad, and is assisted in so doing by his tongue. Consequently it is readily seen that several distinct organs, comprising what is commonly called the mouth, act either by themselves or in association with each other in the prehension of food. One animal first grasps his food with his teeth, which is immediately moved within his mouth by his tongue; another first collects food with his tongue, which organ conveys it to the teeth, and among other animals the lips constitute the prehensile organs; but in every case each organ assists in placing food in the mouth, to be afterwards conveyed between the molar teeth for the purpose of mastication and deglutition.

\section{THE MOUTH}

is bounded in front by the lips, on eacl side by the cheeks, below by the tongue, above by the palate, and terminates behind in the formation of the fauces. The moutl is lined throughout with mucous membrane. Immediately within the lips and cheeks the dental arches occur, consisting of gums and teeth, \&c.; the gums are composed of fibrous tissue, are closely conuected with the periosteum common to the alveolar processes, and are in adult life surmounted by teeth.

THE DENTAL PAD.

The incisor teeth, although placed in the front part of the mouth, are variously arranged in different animals: for instance, the pig possesses, like the horse, twelve incisors, six in the upper, and six in the lower jaw; the wearing surfaces of which immediately oppose each other in the act of collecting food. In the ox and sheep, lowever, a different arrangement is presented to our notice, as in them only eight incisors occur, all of which arc placed in the lower jaw, and consequently cannot oppose their grinding surfaces to teeth in the upper jaw, as none exist. To make up for this lack of teeth, nature lias provided for these ruminants a dense cushion, the dental pad, in the upper, to abut against the incisors situated in the lower jaw. The dental pad is formed by the bars of the mouth, which thicken, as they reach its anterior part, until they concentrate in the development of the pad. "The pad, however, is of a more fibrous, elastic, nature than the bars, and of course in this position answers the purpose of teeth; in fact, teeth in these ruminants could not be retained in the mouth, as the incisors in the lower jaw possess small fangs, and are otherwise very loosely implanted in their sockets. Moreover, the sliape of the teeth does not cause them to be capable of withstanding the effects produced by dental attrition; the $o x$ and sheep in gathering their food can and do employ only that force which is sufficient, and can be easily withstood by the teeth when meeting the yielding substance of the dental pad. The Stenonian ducts, two in number, pass from the mouth to the nostrils, and open on the dental pad, and are placed there as a means whereby the odour of plants inay be appreciated by the smell, to enable the creature possessing them to select good food from bad or poisonous substances. The ducts of Steno have not been discovered in the pig, but communications between the mouth and nostrils equally direct exist, as in the pig there is a large plexus of nerves running down each side of the nose and ramifying over the nostril, in which resides the peculiar power which enables the hog to detect (or, more correctly, smell out) food buried many inches below the surface of the ground. The olfactory nerve, too, is large; and although it is smaller than that of the $\mathrm{dog}$, it is much larger than the same nerve common to the $\mathrm{ox}$ and sheep; in short, the omnivorous animal the pig holds, in this particular, an intermediate position between the herbivorous and carnivorous classes.

\section{CLEAVAGE IN THE UPPER LIP OF THE SHEEP.}

The prehensile organs of the sheep are his teeth and dental pad, assisted by his lips in a very marked and peculiar manner. Every sheepowner knows that a sheep will get fat where 
an ox or horse would starve, i.e., the horse and ox would waste in condition on a down, where a sheep would grow plethoric; and this is owing to the cleft in the npper lip, which by being pressed out from within outwards allows the sheep to bring its teeth or dental pad much nearer to the roots of plants than any other animal. The ox, perhaps, with a similar division in the lip, might bite the herbage nearly as close; but then the thickness of the nose as compared with that of the sheep, and the naked structure of it, i.e, its being denuded of hair, would prevent that close approximation to the ground which would be necessary in the collection of food. Nature, however, has given to the upper lip of the sheep a defence, in the shape of a dense coat of hair covering the whole of the lip with the exception of the direct fissure. By this beautiful arrangement it is almost impossible for any foreign substance, whether it be dirt, any thick or glutinous material, insect, or water, to penetrate to the skin. The portion of the lip denuded of hair is small in the sheep, as compared with the $o x$; it consists of the nostrils above, and terminates in a narrow channel which enters into the formation of the cleft in the upper lip, and is usually bedewed with moisture; this, again, also materially assists in protecting the lips, \&c., against the invasion of foreign objects.

\section{THE TEETH.}

Generally in mammals two sets of teeth appear during the lifetime of the animal; the first which are put up constituting the temporary or milk teeth, whilst those which replace them or spring up afterwards, are named the permanent. Teeth, although divided into several classes, present certain characters in common; for instance, each tooth exhibits a crown, or that part of the tooth which projects above the gums, and immediately above and just within the gums, a constricted portion of tooth occurs, which has been named the cervix or neck, and below the cervix the tooth structure is lodged in the socket or alveolus, and in this position has been denominated the fang.

The tooth fangs are accurately adapted to the alveoli; so firmly are they fixed in their sockets, that a nail could not be driven into a garden wall more firmly, and for this reason the mode of union has received the name of gomphosis, from the Greek ropфos, a nail. The alveolus and the fang are both lined with a membrane which invests the external surface of tones, and is called periosteum. This membrane extends as high up as the neck of the tooth, and owing to its dental arrangement, by some anatomists has been called the periodontal membrane. Although for the sake of description a tooth has been divided into its crown, neck, and fang, we find in investigating the mouths of the horse, ox, and sheep, that more than half the body of the tooth is imbedded in the alveolus, and some of the molar teeth and tusks are in fact destitute of fangs and necks. This fact is to be observed in the incisors, \&c., of the horse and pig.

\section{THE TOOTH STRUCTURE.}

Ur making a section of a tooth, we discover that three constituents, varying in density, and partaking somewhat of tne character of bone, combine in forming the dental structure; these are named-enamel, dentine, and crusta petrosa. Enamel is the hardest; it is met with on the crown of the simple tooth, and invests the body and sides of the compound one. In the centre of a tooth a cavity occurs, which is called the pulp cavity, which during life is filled with a highly vascular and sensitive organism, the dental pulp, supplied with bloodvessels and nerves which enter the tooth by means of a small orifice at the point of the fang. The size of the pulp cavity depends upon its age, being always large in young animals, but decreases in size as age advances: this cavity is lined by dentine. "On inspecting an incisor of an ox, we observe that a white incrustation, having in the young subject more or less of a pearly white appearance, covers the crown of the tooth; this is enamel. If the tooth should have been recently put up, this substance forms also its cutting edge. It is thicker on the front surface of the crown than on the back, an arrangement which tends to keep up a sharp edge to the tooth; it extends, also, downwards to the neck, where it ceases. The enamel not only covers the exposed surface of a tooth, but in some teeth it enters deeply into their interior. It matters not what may be the size or shape of a tooth, or how numerous its projections, the whole of these are originally covered with a layer of enamel. Microscopically enamel has been discovered to be composed of several rods lying side by side, named enamel prisms or fibres, which always rest their ends upon the dentine to which they are immediately attached. Minute canals, also, have been detected in the enamel recently formed, the use of which is explained by Professor Simonds:-_"In looking to the situation of enamel in compound teeth, it is stated that this structure dips inwards, forming cups of greater or less depth in different teeth, and which are always filled with crusta petrosa. On the slightest reflection we perceive, that the crusta here placed can only receive the fluid necessary for its support through the layer of enamel which is interposed between it and dentinal tubes; and there seems no reason to doubt that the tubes, from the boundary of the dentine, may extend to the canals between the prisms, and thus supply the materials of nutrition to the crusta petrosa within the cup. Mr. Tomes, many years since, drew attention to the fact that dentinal tubes passed in great numbers into the enamel of the Kangaroo and other animals of this class. From my own examinations I can also say that the dentinal tubes penetrate the enamel in the Herbivora; and it is more than probable that in consolidated enamel the passages referred to are united with these dentinal tubes, and thus become consolidated with them."

Todd \& Bowman, in their work on Physiological Anatomy, support this view, that the enamel prisms " are arranged in the most suitable manner for the percolation of the fluids derived from the dentinal tubuli. These tubuli, indeed, may be seen to communicate directly with the interstitial passage of the enamel." Enamel, when subjected to the action of dilute acids yields scarcely any trace of animal matter, but contains cartilage, and not more than two-tenths of organic matter (apparently 
membraneous tissue), in the enamel of the human tooth. Berzelius found-

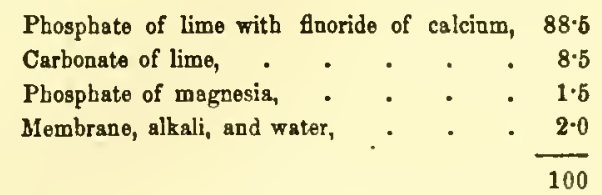

Nearly similar results have been obtained by Von Bibra and Frèmy. The former chemist found as much as four-tenths of fluoride of calcium in enamel.

Second in density to enamel is the ivory tooth substance, or dentine, which principally forms the mass, and gives the general configuration of the tooth structure. Dentine differs little from bone in appearance, but is not identical with it in structure ; for although it appears to the unassisted vision to possess a compact subsistence, by the assistance of the microscope it is found to be composed of numerously arranged fine tubes (the dental tubuli), which terminate at their inner ends by minute orifices opening into the pulp cavity. These tubes describe a wavy course, which split into branches; first into two, and by further separation numerous ones are formed, which ultimately terminate in very fine inosculating branches. "Towards the terminal portion of the fang the dentinal tubes in some animals, of which the sheep is an example, are collected into little bundles, having between them a comparatively large space, which is occupied by the intertubular substance."*

The intertubular substance is translucent and finely granular. Henle describes the animal basis which remains after the suhatance has been treated by an acid, "as separable into bundles of pale, flattened, granular fibres, running in a direction parallel with the tubes;" and Nasmyth "that it consists of brick-shaped cells, built up as it were around the tubules." Dr. Sharpey disputes both these assertions, which are in opposition to observations that have been made in reference to the cachalot and sperm whale, in which the animal substance can readily be torn into fine lamellæ, "disposed parallelly with the internal surface of the pulp cavity, and therefore across the direction of the tubules." Moreover, the laminated structure of the dentine has bcen noticed by Salter and Czermak in the human tooth.

The chcmical composition of dentine is very similar to that of bone; the quantitative ratio between the organic and inorganic constituents approximating very closely to that occurring in the denser bones, and averaging 28.72. From 3 to 8 tenths of carbonate of lime has been found, with from 65 to 67 tenths of the phosphate of lime, together with a little of the fluoride of calcium and phosphate of magnesia.

The third substance entering into the tooth formation is crusta petrosa, which closely resembles bone, both in its physical and chemical character, although it is slightly modified in structure. Crusta invests the entire fang of the tooth, and those parts of the dentine which are devoid of enamel. The quantity of crusta present depends more upon the character than the size of the tooth, owing to which we find crusta

- Simonds on the Formation of the Teeth. more largely developed on a compound than on a simple tooth, for the reason that this substance covers only the fangs in simple teeth, whereas it not only invests the fangs, but also covers with enamel the interior organization of compound ones.

As age advances the crusta grows thicker, especially at the apex of the fang, and sometimes is developed then to such an extent as to block up the orifice through which the nerves and bloodvessels pass to the pulp, for the support of the dental structure.

Under the microscope crusta is found to resemble bone, as it possesses cells, "lacunæ," from which minute canals emerge, called canaliculi, which anastomose with the terminal tubules of the dentine. Where the crusta is thick, numerons vascnlar canals occur, similar to the Haversian canals of bone.

On the fangs of teeth recently cut, little crusta is discovered when compared with that existing on old teeth. It may nevertheless be asked how the increased quantity upon old teeth is accounted for? Professor Simonds accounts for this diffculty as follows:- "I premise the explanation of this matter by stating, that anatomists are generally agreed that, after a given time, the pulp ceases to produce any more dentine, and becomes converted by ossification into a substance which Professor Owen designated osteo-dentine. This substance, therefore, would now fill the pulp cavity of the tootls. However true this statement may be of man or many species of animals, it does not appear to be positively correct when applied to our domesticated Herbivora. In the horse, as an example, obliteration of the cavity is gradually effected by the pulp continuing to form dentine. This, as its normal action, goes on, and is not supplanted by an abnormal or diseased one, as it would be were the pulp to become ossified. As the producing organ of dentine, the pulp simply gives way to its own product, which is ultimately made to occupy its place in the cavity. In proportion as the pulp diminishes, so is the supply of nutriment to the tooth lessened, and at length entirely cut off from the interior. To provide for the vitality of the tooth under these circumstances, the crusta increases in quantity on the fang, at the expense of the perfectly formed dentine which is lying in immediate contact with its inner surface. Through the medium of the canals of the crusta, which open on its border, the tooth now draws its nourishment from the bloodvessels of the socket, and thus it contiuues, long after the obliteration of its pulp cavity, to serve all its purposes as a part of the living organism."

Crusta petrosa chemically seems to be almost identical with bone. The researches of Lassaigne and Von Bibra, on the teeth of different animals, could detect no definite difference between the teeth of herbivorons and carnivorous animals.

\section{THE DEVELOPMENT OF TEETH.}

In considering the mode by which the teeth are formed, it is necessary to commence with a description of their creation in fœtal life; for we find that, even so early as this period, indications not ouly of the temporary or deciduous teath, but also 
of the permanent ones, or those which succeed them, exist. This process in the human foetus, Professor Goodsir asserts, begins about the sixth week.

For the sake of description, we must first explain the origin and growth of teeth, and afterwards the mode by which their eruption in two sets, namely, the temporary and permanent sets, takes place. The process of dental formation lias been divided into four separate stages, namely-1st, the papillary; 2nd, follicular; 3rd, saccular; and 4th, eruptive; and from the researches of eminent physiologists it is certain, that teeth are developed from the mucous membrane covering the bones in opposition to them. Professors Goodsir and Arnold discovered, independently of each other, that the first stage of development consisted of certain changes in the mucous membrane, and that about the sixth week in the life of the human foetus a depression or groove, having "the form of a horse shoe," was noticeable "in the mucous membrane of the gum," named by Professor Goodsir the "primitive dental groove." This groove is lined by the membrane of the mouth, which consists of two layers almost identical with the epidermis and dermis of the cutis, or skin proper. From the floor of the dental groove papillæ spring up, which constitute the early formations of the dental pulps about to belong to the milk or temporary tceth ; in the ox, for instance, eight papillæ in the lower jaw, and twelve in the upper and lower jaws, indicate the situations of the eight incisor teeth in the former, and the twelve temporary molars in the latter. Concurrently with the growth of the papillæ bony partitions spring up, which form a "series of four-sided cells," and by subsequent growth these cavities, called loculi, become established, when they are named alveoli. This formation of the papillæ constitutes the papillary stage. The papillary stage is succeeded by the follicular, which consists in the thickening and prominence of the dental groove, and the prolongation of the mucous membrane, which forms for each papilla a distinct cavity called a follicle, and, as time advances, grows so deep as to hide the papilla which corresponds to the shape of the future teeth; and now the edges of the dental groove begin to approach each other, and ultimately join, and thus close up the entrance to the cavity; and in so doing form a closed sac, at which time the saccular stage is said to be completed.

The fourth or eruptive stage, as it occurs in the human gums, is, as follows, very distinctly explained in Dr. Quain's "Auatomy," edited by Doctors Sharpey and Ellis:-

"The dental sacs formed by the closure of the follicles continue to enlarge, as well as their contained papillæ. The walls of the sacs, which soon begin to thicken, consist of an outer fibro-alveolar membrane, and an internal highly vascular layer, lined by epithelium; thin bloodvessels are derived partly from the dental arteries, and partly from those of the gums. The papillæ, now the dental pulps, adhere by a wide base to the bottom of the sacs, but are unattached elsewhere; and having acquired a perfect resemblance to the crowns of the future teeth, the formation of the hard substance commences in them. This process begins very early, and by the end of the fourth month of foetal life thin shells or caps of dentine are formed on all the pulps of the milk teeth, and a little later on that of the first permanent molar. The mode in which it proceeds, taking a canine tooth as an example, may be stated as follows:-A thin osseous shell or cap of dentine appears on the point of the pulp; this increases in extent by a growth around its edges, and in thickness by a similar formation in its interior, the latter taking place at the expense of the substance of the pulp itself, which accordingly decreases in proportion. This growth of the tooth continues until the crown is completed of its proper width, and then the pulp undergoes a constriction at its base to form the cervix of the tooth. From that time the pulp elongates, and continues to become narrower, so as to construct the fang. During the whole period another process has been going on, by which the outer surface of the crown is covered with enamel. This substance is formed from a peculiarly organized body lying on the pulp, and accurately adapted to its surface and to its cap of dentine, and which was called by Hunter the outer pulp. Sooner or later after the completion of the crown this part of the tooth appears through the gum, whilst the growth of the dentine to complete the fang is continued at the surface of the elongating pulp, which gradually becomes encroached upon by successive formations of hard substance until only a small cavity is left in the centre of the tooth, containing nothing but the reduced pulp, supplied by a slender thread of vessels and nerves which enter by a little aperture left at the point of the fang after the dentine is completed. In the case of teeth having complex crowns, and more than a single fang, the process is somewhat modified. On the surface of the dental pulp of such a tootl, as many separate little shells of dental substance are formed as there are eminences or points; these soon coalesce, and the formation of the tooth proceeds as before as far as the cervix. The pulp then becomes divided into two or more portions, corresponding with the future fangs, and the ossification advances in each as it does in a single fang. A horizontal projection or bridge of dentine shoots across the base of the pulp, between the commencing fangs; so that, if the tooth be removed at this stage, and examined on its under surface, its shell presents as many apertures as there are separate fangs. In all teeth the pulp originally adheres by its entire base to the bottom of the sac; but when more than one fang is developed the pulp is, as it were, separated from the sac in certain parts, so that it comes to adhere at two or three insulated points only, whilst the dentine continues to be formed along the intermediate and surrounding free surface of the pulp." From this description it will be readily understood, that immediately after the crown of the tooth has penetrated the sac and gum, the eruptive stage has been established.

\section{THE FORMATION OF THE HARD TISSUES OF TEETH.}

The mode by which dentine is developed has been explained differently by various investigators; but the opiniou of the ancients, and which since their time has been re-intro- 
duced by Sehwanm, asserts that dentine is in reality the ossified pulp; but the exact manner in which this change is effected has not as yet been clearly exposed. It is well known, howerer, that bloodvessels exist at the points of commencing ossification, and that the exterior of tle pulp is surrounded by superimposed layers of rounded cells; in addition to which, also, the pulp is lined by a thin membrane called the preformative or basement membrane. Simonds states that the dentine is first produced upon the apex of the papilla, and that from this point it extends downwards upon its sides, and thus incloses it as with a cap. "This may be better understood by supposing one's finger to be covered with a thumb-stall, and looking to the finger as the papilla, and the thumb-stall as the dentine. The papilla thus capped with dentine is now called the tooth-pnlp."

During the process of ossification, as determined by Schwann, the preformative membrane and cells before mentioned gradually become impregnated with calcareous matter necessary to the formation of dentine; but in what manner the tubuli and intertubular substance are developed, remains for future investigators to discover. Suffice it to say, that when the dentine first appears it is very thin; but it hourly increases in thickness at the expense of the pulp, which decreases in extent, as does also the pulp cavity. The gradnal diminishing of the pulp cavity can be seen in the transverse section of an incisor taken from the mouth of a calf. Simonds writes-"To the unassisted eye a preparation of this description shows concentric lines, one within the other, making fresh deposits of dentine. The varying size of these rings, and sudden curvature of the dentinal tubes in these places, would seem to indicate an irregularity in the rate of the formation of the structure. In the lower animals a similar disposition regarding the fangs of complex teeth, commonly called double, is noticed; for instance, a horizontal projection of dentine (as in the human subject) shoots across the base of the pulp, in order to cause the separation of the fangs, and then there individual development, which is accomplished in the same manner as noticed in the human tooth, and which has been explained above. On the surfaces of componnd teeth several projections occur, which are caused by a similar formation existing on the papilla previously to their being incoated with dentine. At the same time several indentations occur in the dentine, in which we find enamel. By this arrangement of two cusps, between which enamel exists, we find that the papilla divides and forms the points for the future development of the two cusps, when each becomes coated, first with dentine, and afterwards by enamel; between the cusps, therefore, it will be seen that a depression or hollow occurs. Simultaneously with the formation of dentine from the pulp, and immediately after the lips of the cavity have united to establish the sac, its membraneons wall grows thickened, and develops a soft pulpy mass which is adapted, in the first place, to the dental pulp, and afterwards to the dentine This structure is named the enamel membrane, and by many authors is considered to be a distinet orgauiza- tion for the formation of enamel; but Professor IItuxley disputes this view. The enancl membrane "he conceives to be altered epithelium of the basement membrane of the pulp and sac; and that, although for a long time considered to be the enamel organ, it takes no part directly in the formation of the enamel, but is merely a continuation of the preformative membrane, previously described. Whatever may be the nature of this substance, it is generally admitted that the enamel is formed from a pulpy mass generated within tlie sac, which was called the outer pulp by Hunter. Enamel covers only the crown of a simple tootl, reaching as far down only as its neck, and is consequently never met with on the fang; the enamel membrane, however, always dips down into the hollows formed between the cusps of compound ones, and is not cut asunder, but merely s.dapts itself to the shape of the subjacent dental structure.

Professor Simonds evidently agrees with Professor Iluxley that the enamel and preformative membranes are identical; " in fact, there are not two membranes, but only one. The general opinion seems to be that the onter pulp produces the enamel, and the inner surface of the sac; that is, the tooth capsule, the crusta which lies both upon the fangs of the tooth, and also upon the surface of the enamel, where it covers the dentine. This opinion is negatived, however, by the fact, that "the capsule is not reflected into the enamel cups of compound teeth, although these are always filled with crusta; and therefore it is evident that this crusta has some other source, and this I am inclined to think is the outer pnlp If this pulp produces the crusta in one part, it necessarily would do so in another; if within the enamel cups, then on the outer surface of the enamel, and also on the fangs of the teeth."

From the above, therefore, it will be observed that the enamel membrane becomes altered in condition as the tooth grows, and that when the slightest layer of enamel is formed a membrane can be detected around that part of the tooth from which the fang takes its origin; i.e., just below where the enamel commences. This pulp, Professor Simonds considers, is the "formative organ of the crusta," in which opinion he is supported by other investigators; others, however, assert that the enamel membrane pours out a material which subsequently becomes ossified. When the structures, dentine enamel and crusta petrosa, are fully developed, then the capsule becomes the lining membrane of the tooth and socket, and thus establishes a firm bond of union in the gnm; and owing to their respective positions, they have received the names of the periodontal and periosteal membranes.

The dental constituents, therefore, in combining to form a tooth, grow, 1st, the dentine, beneath the membrane of the papilla ; 2nd, this membrane produces the enamel, and according to Professors Huxley and Simonds, is identical with the preformative and enamel membranes, "these two being one and the same ;" 3rd, trom the pulpy mass the crusta petrosa is formed; and lastly, the capsule is converted into the periodontal and periosteal substances.

\footnotetext{
- Simonds on the Formation of the Teoth.
} 


\section{THE ERUPTION OF TEMPORARY TEETH.}

Previously to the appearance of temporary teeth in the mouth, the gums become sharp; as the tooth increases in size they grow rounded and swollen, and present a congested appearance, and when the tooth is sufficiently developed a white speck marks the point at which it is about to protrude through the gum. Concurrently with these changes, the fang adapts itself to an alveolus, or bone socket, which is at the same time formed for its reception. On the mucous membrane of the gums Serres discovered numerous small pearllike bodies, which he considered to be glands, and consequently named them "dental gland ." Their use has not been dis covered. Meckel described them as abscesses resulting from inflammatory action.

\section{PERMANENT TEETH.}

The development of the permanent teeth is more complex than that of the temporary ones, and consequently must be separately described; and to understand the matter fully, the reader must carry his thonghts back to the follicular stage of the temporary dental formation, when it will be noticed that behind each follicle a small indentation occurs, from which the sac and pulp, previously to birth, commences to develope. Ihese being attached to the temporary sacs were thought to spring from them, until Professor Goodwin proved that they originated from the dental groove, and consequently existed quite indepeudently of the milk sacs. These cavities, named by him cavities of reserve, elongate and enter the substance of the gum behind the follicles, when the papillæa appear; and lips, similarly as those noticed in the temporary sacs, meet and close the cavities, and in so doing divide them into two parts, the upper or narrow portions of which become obliterated, and the lower, containing the papillæ, form the sac and pulp of the future permanent teeth. As the dental structures attain certain growth, the permanent sac is separated from the milk tooth by a bony partition, and therefore the permanent cootl, in attempting its escape through the gum, must necessarly press against this bony partition, and also against the fang of the superimposed temporary tooth. Nature therefore, in order to assist in the development of the teeth, causes the absorption of the dental structures of the decidnous teeth, and in so doing deprives them of their fangs, which, together with the pressure from below (already explained), causes the expulsion of the temporary crowns. The absorption of the dental substance commences at the fangs, and proceeds upwards until nothing but the crown remains. The cement is first attacked, the enamel last; but the process is similar in each tissue." The permanent molars, which do not succeed temporary ones, spring up from successive extensions of the dental groove placed behind the temporary teeth, and called the "posterior cavities of reserve."

THE AGE OF THE OX AS INDICATED BY HIS TEETH.

In the foregoing chapters we have endeavoured to explain briefly the microscopical character of the teeth, and the mode by which they are developed, these remarks respecting them being equally applicable to all mammals. The teeth of the mammals under notice give evidence of their ages up to certain dates, in the changes to which their teeth are subjected by the fall of the deciduous, in making room for the permanent teeth, and in the gradual development of the latter to maturity. Certain causes, such as the rapid growth of the teeth, the enlargement of the jaws, the diversion of the nutriment to the permanent sacs, the absorption of the fangs and consequent partial loss of the dental structure, and the pressure of the youthful teeth upwards, all combine in forcing the deciduous teeth from their respective positions, and in their places establishing their permanent followers. Many persons experienced in the habits and management of the ox tribe often assert that the horn manifests certain signs by which the age of this animal can be determined. In some cases, and up to a certain period, the horns may furnish such indications, but they are never so distinctly marked that a correct conclusion as to age can be established. The age is told from the horn, as follows:- "Shortly after birth the development of the frontal processes on each side of the head indicates the position of the future horn, which appears through the skin within the first month. At the age of four or five months the little horn is firm, and protected by a scaly cuticular covering, which exfoliates when an animal is about one year old. At this period the base of the horn becomes knotty, and a circular depression between the skin and the bulging horn is the sign that the animal has fully attained its first year; a second bulge forms, and a depression below it, by the second year; a third by the third, and so on as long as the animal lives. But in calculating the age of a cow at five or six, an error may be incurred by supposing that the first marks can be readily perceived. It is only the third year's circle which is very distinct, consequently we should count from the ring nearest the point; and if we found six, one of which represents the third year, the animal would be eight years." *

The above representations relative to the age of the ox, as evidenced by the markings on the horn, are considered by many stockowners to be unerring guides; but, as before said, there are others, and with them the anthor, who believe them to be worthless. For instance, sometimes one or two bulges become entirely obliterated, or so fused one into the other, that it is impossible to draw a true line of demarcation between them. Again, the castrated animal nsually possesses very long horns, upon which the marks are situated at longer distances than noticed in the cow, and are often very faintly discernible. Add to this the accidents which are likely to occur to the horns, such as their entire or partial removal, and we are obliged to conclude that little dependence can be placed upon the horn-markings, as indications of age. Consequently, the only sure guide, and that only up to a certain age, is to be found in the teeth, the explanation of which we will continue.

- Gamgee on Dairy Stocit 
The absorption of the temporary fang is facilitated by the pressure from below upwards of the permanent crown, and in the horse and pig the pressure into the original socket is more direct than that obtained in the ox and sheep; and for this reason we notice that sometimes the permanent incisors spring through the gums in an irregular manner; i.e., the permanent teeth arrive in the mouth previously to the removal of their predecessors, the deciduous incisors. This state lappens more readily in the ox and sheep than in the horse, owing to the smallness of the fangs noticed in the teeth of the former animals, and to the ease with which the bone of the jaw seems to recede; and for these reasons it often happens that the permanent crown passes into the gum at the side of the temporary socket, and by this means the said alveolus to a ccrtain extent escapes that amount of pressure of the coming tooth which is necessary in obtaining its removal previous to the appearance of the permanent tooth, which was destined to fill its place. Moreover, as the temporary teeth only serve their purpose in collecting and masticating food for a limited period, their formation is not so perfect as their followers, the permanent; for the former are constantly hollow from above, and to such an extent as to permit of slow decay, often leading to disease of the gums, which prevents the animal, the subject of such disease, from gathering his food. Above we have spoken of the tardy removal of the deciduous teeth; sometimes, however, these teeth are prematurely removed by disease or accident. This constantly happens to lambs when feeding on heath plants, or those wherein the wood is hard, and of which sheep delight to partake; and this premature removal has been said by many to hasten the development of the permanent incisors, and consequently to throw investigators out of their reckoning in determining the age of animals so injured. But the examination from time to time of such mouths leads to the conclusion, that the early removal of temporary teeth does not hasten the development of their permanent successors.

The presentation of teeth in the mouth varies; sometimes two, and sometimes even six, are in situ at birth, said to depend by some on the period of utero-gestation having been exceeded or prematurely ended. This is the opinion of Youatt, but Professor Simonds does not think this sufficient to account for " all the variations we observe;" for instance, a cow often carries a bull calf longer than a cow calf, and yet, in examining their mouths, it happens that often the development of teeth is as forward in the one as the other, and sometimes more teeth appear in the mouth of the female than in that of the male; consequently little reliance can be placed on the "ntero-gestation" theory, and particularly so as it was advanced by Youatt, who in his work on Cattle Diseases certainly could not have written from personal knowledge, but from information received from cattle-owners, who must have ventured opinions never the result of careful investigation or actual observation. Nevertheless, in Youatt's day, cattle, owing to lack of forcing, might have come to maturity later than in ours, and when the teeth might have participated in the general tardy growth; but even allowing such to have been the case, it is impossible to imagine how the full development of the ox's moutl could have been retarded until the age of five years. Such is Youatt's statement, and moreover, he illustrates his book witlı drawings, which are as incorrect and contrity to fact as are lis assertions. Until 1854 Youatt was an aceepted authority in the matter of the age of cattle, when Professor Simonds, after years of careful research, gave publicity to his ideas on this subject in a pamphlet printed at the request of the Royal Agricultural Society, in which he entirely upset the teachings of Youatt and others, and demonstrated most clearly how easily, up to a certain date, the age of the ox could be determined by his teeth. Of course, difference in breed operates largely in causing the early or later eruption of teeth, and perhaps also climate may exert its influence in early producing or retarding development. Professor Gamgce informs us, "we must not imagine that the periods of eruption and change set forth in his (Professor Simonds') tables are applicable all over the world. Thus, in examining the herds of Brittany cows recently sold in Edinburgh, I found that the whole indicated a more tardy development of teeth than is observed in the finest breeds of this country, and the tables framed by Girard and others are substantially correct, according to my observations on these animals." Professor Bonley, in commenting on Girard's work on teeth, writes, "In rendering animals more precocious, in order to hasten the day of their death, and to furnish more rapidly their flesh for the growing exigencies of human consumption, agricultural enterprise has succeeded in accelerating the development of all the organs; and the tceth, which by periodic appearances, as by modifieations in form which they undergo, enable us to measure the duration of life, participate also in the rapidity of growtlı. Thus, that which was perfectly true in the days of Girard is not so for those animals which art las improved."

Tro periods occur in the dentition of the ox, the first consisting in the eruption of the temporary teeth, and the second in their fall, in making room for their permanent successors, and in the after development of the molars. The calf at birth is usually possessed of four incisors, and in about a fortnight afterwards two more, the third pair, make their appearance, and within ten days from the latter period the two corner incisors are cut-making in all eight teeth. At the same time that the dentition of the incisor tecth is being cffected, that of the temporary molars is progressing to completion, which is obtained also within one month after birth It is therefore evident that within four weeks from birth the temporary dentition both of incisors and molars is completed; but although such is the case, yet the molars at birth are never met with in the gum, their eruption, like the incisors, following no special order, but usually the first in position; i.e. the anterior molar tooth is cut last, or, abont three weeks after birth. The first and second temporary molars in the upper jaw are larger than those situated in the lower, but in shape differ very slightly from their permanent successors. This however, cannot be said of the third temporary molar situated 
in the lower jaw, as it is dissimilar to the other molars, and also differs materially from the tooth which afterwards fills its place permanently. Professor Simonds writes, "It is the last of all temporary molars which, as a rule, is renewed, and consequently throughout it furnishes much assistance in determining a question of age. It occupies a space in the jaw equal to, or even greater than, both the other molars together which stand before it, in consequence of its increased width from front to back, which however, woula be mere correctly called its long diameter. It is composed of three main parts or lobes of a semi-cylindrical form, having in the hollows between them, on the outer side, two smaller portions, which also rise into asperities or cusps. The latter, when the tooth is somewhat worn down, add to the strength of the body, as well as to the irregularity of its grinding surface. Each of the three principal lobes likewise rises into cusps, an inner and an outer, of which the inner are always the higher. This tooth, for brevity's salse, might be called a tricuspid tooth; but this, critically speaking, is far from correct, for originally, as we have seen, it has six principal with two minor projections or cusps.'

After the trist month of the animal's life, i.e., when the temporary dentition has become perfected, we have no change occurring in the teeth, with the exception of slight wear; consequently, until the calf is six months old, the general appearance of the creature must be alone considered in determining its age. Many persons have asserted that the first permanent molar, viz., the fourth in position, escapes through the gum when its possessor is one year old. Youatt says, "the fourth appears about the expiration of the eighth month;" but my examinations prove that these teeth are in situ at the end of the sixth month, and sometimes before. Professor Simonds' investigations relative to the fourth permanent molar corroborate my statement, that sometimes this tooth is put up "before the expiration of the sixtl month after birth." $\mathrm{He}$ writes, "I have found as a rule, that this molar in the lower jaw is usually a little more forward than its fellow in the upper, and that now and then it appears even before the sixth month." This molar is wider than the third if measured from side to side, but in length-i.e., from before backwards-is much shorter. At nine months old these four permanent molars, i.e., two in the upper and two in the lower jaw, have grown to the same level with the temporary teeth placed just anteriorly to them. At fifteen months old the fifth molar in position, or second permanent, escapes through the gum; it does not differ much in shape from the fourth molar placed anteriorly to it, and like its neighbour assumes the same level with the otlier molars at the expiration of eighteen montls from birth When the ox has reached two years of life the sixth permanent molar is cut, and attains its general configuration within three months; that is, when the animal is two years and three months old. This tooth is dissimilar to the two teeth just before it, but resembles in some particulars the third molar, in that it possesses three cusps, in fact, is tricuspid; the prominences, however, aro not so well delineated, and the one situated farthest back in the jaw is often concealed by the gum. This tooth is somewhat triangular in shape, presenting its base towards the mouth, and its apex to the fauces; that is, it gradually decreases in width from before backwards. Immediately after the temporary incisors are well delineated, it will be readily understood that, as time progresses, their surfaces during the process of feeding wear down from attrition, and consequently become blunted; and not only is such the case, but the mouth expands, and with it the jaw, when the necks of the teeth present a separating appearance, and sometimes are detained in the jaw by very slight adhesions. This last fact is particularly manifest in the central pair of incisors when the animal is about eighteen months old, at which period these teeth usually possess little or no fangs, and are about to vacate the gum in order to make room for their permanent successors, which are just coming into position. Sometimes even they are present before the deciduous teeth have been shed, and give to the mouth, when such is the case, a very irregular appearance; but as a rule, the centre temporary incisors are not replaced by permanent ones until the animal is one year and nine months old, and this occurs only amongst cattle that have been "forced," and more properly amongst those breeds which years of careful breeding and high feeding have forced to early maturity. Examples of such are met with at our prize cattle shows in the short horn and Devon and Hereford breeds, and all animals similarly treated as above indicated; but among cattle which from youth are allowed to enjoy a less artificial life we find that the process of dentition is more tardily developed, and that in the mouth of an animal of this nature we notice, that the central pair of deciduous teetl are not replaced by permanent ones until the expiration of the second year. This proves that it is impossible to state the precise period (i.e., within two months) at which the teeth fall and rise; consequently we must always take the average, when repeated and careful examinations of the teeth will enable us to form a very correct opinion of age.

The permanent incisors (central pair) soon after their appearance in the gums often overlap each other; but as they grow firmly within their sockets, and the jaw expands, and dental growth is obtained, they separate from each other. The gums recede from the bases of the crowns which they at first surround, and become concentrated around their necks. Of course the size and growth of these teeth, and the position of the gum around the crown or neck (if around the crown base, the animal is younger than if it be developed below, that is, around the neck), must be carefully considered in determining the age of the ox. The overlapping of the permanent incisors is noticeable in all of them when first put up, as is also the fact, that when fully developed they assume an upright and separate appearance. This is markedly the case in the next pair of permanent incisors, which usually cut the gums when the animal is one year and three months. Professor Simonds has observed very few cases in which the second pair of permanent incisors have been cut, and he has always found them 
in those animals certified at cattle shows to be two years and two months. He writes, "My note-book furnishes so many cases of the second pair of incisors being cut at two years and a quarter, especially in short-horn and Hereford bulls, that $I$ have taken this date in the preparation of the table on early dentition as the time of cutting these teeth. In our Devon cattle there are fewer instances of this; but both they and our other breeds furnish some cases of the same kind. I have only met with about half a dozen cases where a second pair of incisors was cut before two years and three months, and these were in animals certified to be two years and two months old. At an agricultural meeting a heifer was exhibited (in the class for bulls and heifers under two years old) to which objection was taken. The examination showed that there were four incisors well up. Satisfactory proof of the correctness of the certificate was called for, which having failed to be given, the animal was disqualified." This animal, according to the table of early average, was three years old; but doubtless its age only amounted to two years and a quarter. This occurrence in the age of cattle proves beyond doubt that two tables of dental development are demanded in classifying the age of cattle; for, as a rule, especially in the advanced classes, an animal with four permanent incisors well up in the mouth would represent the possessor to be two years and a half old, whereas, in the coarser-bred creatures, the second pair of teeth do not even appear in the mouth until the expiration of this period.

At two years and nine months old, the third pair of incisors are replaced by permanent ones. This is noticed in the forced classes, and consequently finds a place in the early dentition table. These teeth, however, among slowly developed animals, do not escape through the gums until the age of three years and so many months, and consequently are classified in the late average table, at which very time in the higher-bred animals, which I have termed "forced classes," the fourth or corner temporary incisors fall out, to make room for their permanent followers; whereas, in lower-bred cattle, their appearance in the mouth does not occur until six months later. Thus we observe, as regards the incisor dentition, that among high-bred animals, namely, those prepared for cattle shows, the temporary incisors are replaced by permanent ones as follows:-The centre incisors at one year and nine months old; the second pair, at two years and three months; the third, at two years and nine months, and the last or corner pair, at three years and three months. Among coarser-bred cattle, those animals which have been compelled to rough it, and to lead a less artificial life from their youth, develop their teeth more tardily: i.e., at two years and three months the centre pair of teeth are replaced by permanent ones; at two years and nine months the second pair appear; at three years and three months the third permanent pair are cut; and lastly, at three years and nine months the incisor dentition is completed by the escape from the gums of the fourth or corner milk teeth, and by the development in their place of permanent ones.
In referring to the fourth pair, or comer incisors, Professor Simonds writes:- "By far the greater number of oxen wili not put up the corner pair of permanent incisors until after three years and a quarter, and I have repeatedly examinec animals whose ages ranged from three and tlree-quarters to four years, and found these teeth to be in the act of cutting. On the other hand, I have occasionally seen them in short-hor: bulls fairly through the gum at three years and one month. These things should guide the opinion of the examiner. If an animal is certified to be threc years old or wanting that time by a week or two, and all the incisors are permanent, it most certainly is a proper case for investigation, so few are the exceptions to these teeth being cnt before three years and a quarter. In these early cases of dentition the judgment wil: often be assisted by the examiner noticing the amount of the overlapping of the incisors, and which is best seen on their upper surface. Thus the outer edges of the middle teeth are partially covered by the inner edges of the second, the seconci by the third, and the third by the fourth, or corner incisors. This overlapping of the edges of these teeth arises from ine broad and flat crowns being at their height of developmen: when they penetrate the gums, and from the rapidity with which one pair has been succeeded by another, the jaw not having fully adapted itself to their larger size. In judging $\mathrm{cl}$ age, also, the fulness and redness of the gums, combined with, the extent of protrusion of the incisors last cut, is to be corsidered. In about two months from the appearance of the first, second, or third pair, these teeth will have acquired their full development, the second pair becoming nearly level with the first, or the third with the second, as the case may be. 'The corner incisors, however, although they more quickly acquire their full size after being put np, rarely gain the proportionate level of the others."

We must now return to the consideration of the molar teeth, when it will be remembered that we left them laving six molars in position on each side of both jaws; the three anterior ones being temporary, and the three posterior, permanent teeth. Now the changes which the three anterior molars undergo in vacating their places for their permanent successors, give us certain indications of the ox's age, even if the incisors should present any irregularities in their development; and for this reason, a careful study of these phases is necessary. After the animal is two years and a half to eight months old, we find that the two anterior temporary teeth have been shed, and the permanent ones are filling their places. These teeth follow no precise order in their removal; sometimes the first in position gives way for its permanent follower before the second; and sometimes the second, which is usually the case, has the start of the first in developing its succeeding molar; and sometimes these teeth are replaced at one and the same time. This, however, is the exception, the rule being, that the second in position is a very short time before the first in developing its permanent successor. During the second half of the third year, i.e., when the $o x$ is past two years and a half old, the third temporary molar is shed and 
exchanged for a permanent one; and when this is effected, on dentition, must have trusted to information, instead of the dentition of the molar or double teeth is completed. It relying on actual knowledge based on practical investigation has been before explained how, in many important respects, and diligent research-a process always demanded in examinthe third temporary molar differed from all the other double teeth, and the same may be said of its successor, as it resembles it in every particular, with the sole exception of its being much larger; in fact, of its being merely an enlarged edition of its forerunner, as it is longer than the two anterior teeth put together and is much wider than either. It moreover possesses three divisions or lobes on its outer side, and between the hollows formed by the three lobes two asperities, called cusps, arise; from the upper surface also of the lobes three large cusps spring. This tooth, therefore, is readily distinguished from its.partners on either side, the fourth and fifth, if it is remembered that the latter possess only two lobes, and are much shorter, and not so wide. The molar dentition may be thus again explained: at six months old the fourth molar in position is cut; at one year and three months, the fifth; and at two years, the sixth. At two years and a lalf the two anterior molars are replaced by permanent ones, and at three years old the third tooth in position makes room for its permanent successor. When dentition is completed, that is, when all the permanent teeth are in position, our judgment relative to the age of the ox must be guided more by general appearances, than from any indications the teeth themselves can afford; but, at the same time, these organs will manifest certain signs. At four years old the four centre incisors will present worn edges; and at five years old the hollows will increase, and will show to what an extent attrition has enlarged and blunted the wearing surfaces; at this age also, the edges of the incisors will have ceased to overlap one another. As age increases, the wearing surfaces grow broader, an ' the teeth consequently become shorter, and the dental constituents manifest discoloration. These appearances in the teeth, together with the general external configuration of the animal after the expiration of the fifth year, will afford us certain data, upon which we are enabled to found a moderately accurate guess relative to the age of the full-mouthed ox.

Youat, in his book on the management and diseases of cattle - a work that for years was received as an authority in this matter, and on the age of the ox as indicated by his teeth, in particular-considered that an ox was not full-mouthed until he was six years old. He wrote, "At the commencement of the fifth year the eight permanent incisors will be up, but the corner ones will be small, so that the beast cannot be said to be full-mouthed, i.e., all incisors up, until it is six years old." This assertion does not, as will be seen by the foregoing, coincide with recent investigations; it does not even apply to animals of common breed, as such animals are, with very few exceptions, full-mouthed at four years old. That oxen in Youatt's time might have exhibited later development of teeth, or in other words, that the progress of dentition might have been slower, is possible; but that so late an average uccurred sonld not have been the fact. Youatt, in framing his chapter ing intricate subjects. The development of teeth is doubtless sometimes retarded beyond the natural period; this usually occurs owing to the persistency with which the temporary teeth cleave to the gums, and thus become obstacles to the permanent in their progress upwards; and as they constantly will make an exit through the gums, we frequently find both the temporary teeth and their succeeding permanent ones side by side in the mouth at one and the same time, thus causing great inconvenience to the animal during the act of collecting herbage. This irregularity, Professor Simonds sajs, applies more commonly to the third and fourth pairs, than to the first or second ;" but the existence of this abnormal appearance ought not to mislead a practical examiner; and even should it throw him somewhat out of his reckoning, the molars will come to his rescue, and cause him tn form a correct opinion of age.

\section{THE AGE OF THE SHEEP AS INDICATED BX HIS TEETH.}

In the preceding chapter attention was drawn to the incorrect statements made by Youatt on the age of the ox. The same remarks may with equal truth be applied to his assertions relative to the teeth of sheep; and as this is the case, portions selected from his book on the management of sheep will be reproduced, in order that this subject may be more fully ventilated, and to show how injuriously to the exhibitors of stock his inaccuracies must have operated. He writes: - "The mouth of the lamb newly dropped is either without incisor teeth, or it has two. They rapidly succeed to each other, and before the animal is two years old he has the whole of the eight. They continue to grow with his growth until he is fourteen or sixteen months old, when the two central incisors are shed; and attain their full growth when the sheep is two years old. Between two and three years old the next two incisors are shed, and when the sheep is actually three years old the four central teeth are fully grown; at four years old he has six teeth fully grown, and at five years old all the teeth are perfectly developed. This is one year before the horse or ox can be said to be full-mouthed.

"In examining a flock of sheep, however, there will often be very considerable difference in the teeth of hogs, or one shears, in some measure to be accounted for by the difference in the time of lambing, and likewise by the general health and vigour of the animal. There will be a material difference in different flocks, attributable to the good or bad keep which they have had. Those fed on good land, or otherwise well kept, will take the start of others that have been half starved, and renew their teeth some months sooner than these. There are, however, exceptions to this. Mr. Price says that a Romney Marsh teg was exhibited at the show at Ashford, weighing fifteen stones, and the largest ever shown there of that breed; and that it had not one of its permanent broad teeth. There are also irregularities in the times of renewing teeth, 

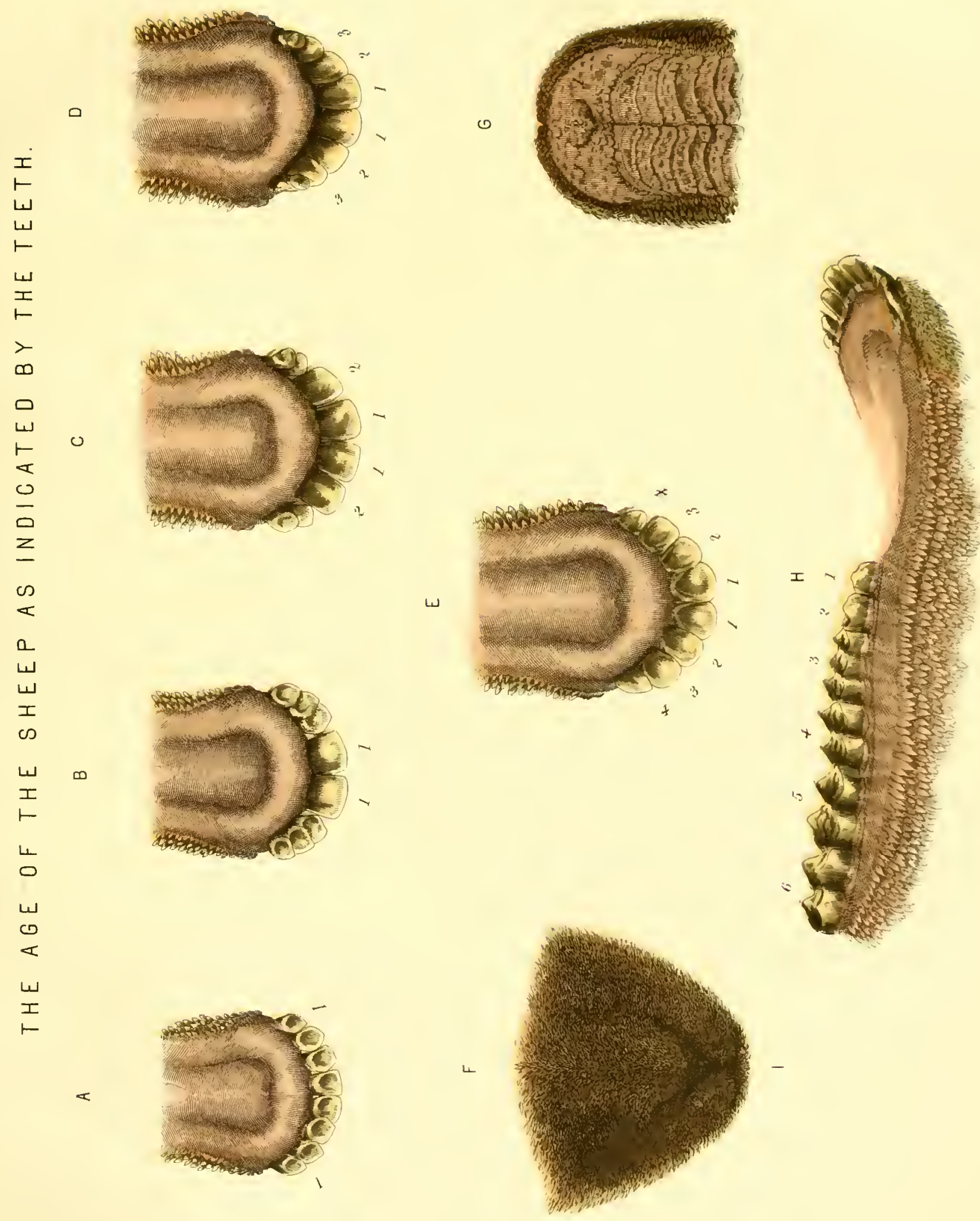

not to be accounted for by either of these circumstances relating to the breed and keep of slieep. The same author remarks that he has known tups have four broad and permanent teeth when, according to their age, they should have had but two. Mr. Culley, in his excellent work on Live Stock, says, "A friend of mine, and an eminent breeder, Mr. Charge of Cleasby, a few years ago showed a shearin-tup at Richmond, in Yorkshire, for a premium given by the Agricultural Society there, which had six broad teeth, in consequence of which the judges rejected his tup, although confessedly the best sheep, because they believed him to be more than a shearing; however, Mr. Charge afterwards proved to their satisfaction that the tup was no more than a shearing. JIr. Price, on the other hand, states that he once saw a yearling wether which became quite fat with only one tooth, that had worked a cavity in the upper jaw, the corresponding central tooth having been accidentally lost."

Such are the opinions of Youat, and others, which will be referred to presently. From him it will be observed that the sheep is said not to be full-mouthed until the expiration of the fifth year; such late development not being the result of dental irregularity or disease, but occurring as a natural consequence. Mr. Youatt, in all his assertions relative to the escape through the gums, progressive growth, and replacement of ovine teeth, is incorrect, excepting in the detail given of the lamb's mouth at birth, and within a month afterwards.

The sheep is usually born with no teeth: in some instances, however, two incisors are observed just cutting the gums; but within a week after birth four teeth, namely, the two central pairs, make their appearance, and three or four days afterwards the third pair escape intc the mouth, and before the animal is a month old all the temporary incisors are cut. In this, and this alone, Youatt's opinion is in consonance with that of recent investigators; namely, that the eight temporary incisors are developed when the lamb is one month old. The incisors differ in size one from the other. The central pair are longer and broader than the second pair; and from the second to the fourth pair the teeth similarly and gradually decrease in size. This fact is more marked in the mouth of the sheep than that of the ox, perhaps owing to the former animal possessing more semicircular gums than those noticed in the ox; hence the more gradual slope from the centre tooth to the corner one, and the decrease in size noticed from the former to the latter tooth, and when these teeth are replaced by permanent ones, their successors although much larger always observe the same physical exterior and slope as noticed in the deciduous teeth. The sheep, like the ox, possesses when full-mouthed thirty-two teetheight incisors and twenty-four molars-twenty of which first occur as deciduous teeth and are afterwards replaced by permaneut ones; viz., eight incisors and twelve molars. The temporary molars are always situated in front, viz., three anteriorly on either side of each jaw. These teeth also, like the incisors, are developed before the lamb is one month old, the two anterior ones usually making their appearance before the third or posterior molar. The permanent teeth that rcplace them possess the same external features, and only are presented as a larger type of the same edition. The third molas is composed of three divisions or lobes, and does not differ materially from the same tooth noticed in the ox, and describec above as being longer, broader, lobular, \&c. An interval o! two months occurs between the development of the decidu. ous teeth, and the appearance of the first permanent molar namely, the fourth in position; i.e., when the lamb is three montlis old this tooth cannot be confounded with the third temporary molar, as it possesses only two lobcs, and is not so long nor broad as its companion anteriorly situated. Between the cutting of the fourth and fifth permanent molar, a period of six months intervenes; i.e., the fifth molar does not escape through the gum until the animal is nine montlis old, consequently we have at this time of life very marked signs to rely upon, in determining the age of the lamb at this date. The fifth permanent molar very closely resembles the fourth in its physical characteristics. Both the fourth and fifth molar teeth consist of two main parts or lobes, which are blended together. Each tooth, therefore, when first cut has four cusps of enamel, of which the inner are always higher in the lower teeth, and the outer in the upper. It is, however, to be remembered that the points of these cusps are soon worn away, and that consequently each of them is thus made to form two ridges of enamel, and thereby to give to the tooth eight elevations of this substance of varying height. instead of four.

At eighteen months old the sixth permanent molar is cut, when the six molars on each side of either jaw are in position, the three anterior ones being temporary, and the three posteriorly situated representing three permanent tecth. Whell the sheep has reached the age of two years, the sixth molar has attained the same level as those teeth placed before it, viz., the fifth, fourth, \&c. Soon after the appearance of the sixth molar, the first and second temporary molars are replaced by permanent ones, when sometimes the first is displanted before the second, and sometimes the reverse occurs. In fact, this exchange of teeth follows no direct rule; all that can be said is, that the first and second molars, when the sheep is about one year and seren months old, are shed to make room for permanent ones, and that they are replaced at almost one and the same time, and often simultaneously. The same indeed might be related con cerning the third temporary molar, if it were not for the almost invariable rule that this tooth never leaves the gum until its anterior companions have been shed, although they all three escape from their sockets, and are replaced by permanent teeth in very immediate succession; i.e., between the age of one year and six months, and one year and seven months, the sheep is provided with its three anterior and permanent double teeth, and this change is effected within the short space of one month, when the molar dentition is completed.

We must now recur to the incisors, which were left 
when the lamb had completed its fourth week, from which period, until the time the animal has lived eleven months, no replacement takes place. The teeth, however, attain their full size, and give evidence of the effects of attrition by their edges becoming somewhat blunted. The jaw expands, the fangs grow out of the gums and are consequently exposed, and between them hollow spaces occur. At about this time the central teeth possess only a slight hold within the sockets, and give signs that they have served their purpose, and that the permanent crowns are forcing them out of their positions; and such in reality is the case, for when the sheep is twelve or thirteen months old the central pair of deciduous teeth are shed, and are replaced by their permanent successors. This change takes place, thus soon, only in such breeds as have arrived early at maturity-those that have been well fed and tended from infancy upwards; whereas in coarser-bred sheep-those that had to rough it, and have been scantily provided with provender or herbage-the development of the central teeth does not take place until four or five months later. It has been asserted by many, that some breeds of sheep arrive at maturity earlier than others, and consequently the latter cut their teeth later than the former, and that the ram lamb exhibits his two first permanent incisors before the ewe of the same age. Professor Simonds in considering this subject writes, "It is a matter of great practical import for us to decide, if possible, whether any of the established breeds of sheep are likely to cut the first or central pair of teeth earlier than others, and what other causes besides breed may hasten the process. With reference to the former part of this inquiry, it may be affirmed that Cotswold sheep as a rule, have their first permanent teeth before either Southdowns, Shropshire, or Hampshire downs. Leicesters tread so closely on the heels of the Cotswolds, that it is only by comparing numbers that any decision can be come to with regard to this question; but when it is done, Cotswolds are found to be earliest in their dentition. How much of this may depend upon a naturally large frame, and general increase of the size of this variety of breed over others, and low much upon the efforts that have been successfully made to bring such animals to early maturity, are matters requiring an extended series of experiments of feeding, \&c., to decide. An opinion prevails pretty generally among sheepbreeders, that the ram lambs cut their first pair of permanent molars before ewe lambs. In our examinations this should be borne in mind, and allowance always made in cases where a point to be decided is a nice one, as it frequently happens to be at this particular period of the animal's life. It must be observed, however, that sex has not so great an influence as is commonly supposed. I find in comparing Southdown ewes with ram hoggets which have been bred and reared on the same farm, that there is but very slight difference in favour of young rams."

At about one year and nine months, the second pair of temporary incisors are replaced by permanent ones; although cases do occur in which these teeth are developed within one year and six months from birth. In fact, this is the period Professor Simonds gives as his early average; but although such is the case, on the other hand instances of later dentition with these particular teeth sometimes come to our knowledge, in which the second pair of deciduous teeth have been in the mouth of an animal two years old. But we never have met with them in the gums of sheep between two and three years of age-the period assigned by Youatt for their fall, and six months more for their full development, namely, when the sheep has reached his third year. Simonds asserts, and such is our experience, that one year and three quarters is the average time when sheep will cut their second pair of permanent incisors. The third pair of incisors are replaced by their successors when the sheep is two years and a half old; but instances are of common occurrence in which, especially among advanced breeds, these teeth are shed when the animal has lived only two years and three months. This of course is the early average, whereas the late average represents sheep as not cutting the third pair of permanent incisors until sis months later, i.e., when the sheep is two years and nine months old. The same latitude, or a period of six months, must also be allowed in considering the time when the fourth pair of milk teeth make room for their succeeding ones; the mean average being when the sheep is three years and three months old. Sometimes however, these teeth appear three months earlier (the early average); at other times three months later than the mean average, i.e., when the animal's life extendz to three years and six months. At the time the above teeth are cut, the central and second pair of permanent incisors will give indication of considerable wear, and not uncommonly rise in their sockets to compensate for their decreased height, which has been effected by attrition. These central teeth, also, are frequently broken whilst the sheep is biting the wood of hard plants, which are constantly met with on heath lands, \&c. This gives to the mouth an old appearance, and sheep with such injured teeth are often said to be very old, and for this reason have been named "crones" (old women), from the Greek word xpóvos, "time." In this consideration however, we are likely to be much mistaken, as this accident may occur, and sometimes does, before the sheep is three years old. Such animals often lose condition, and consequently require more care than those having these teeth intact. "The Norfolk heath-land farmer has to look well to his flock, and to draft such sheep. When removed into other districts where they can live on good grass land and have manger food, these animals, however, are profitable for breeding purposes until they are ten, twelve, or fifteen years old, as we see in Leicestershire and other counties. There is this important difference, however, between the old sheep of Leicestershire and the crones of Norfolk; namely, that in one instance the incisors have been gradually woru down, while in the other they have been prematurely forced out or broken off. A broken incisor often leads to the displacement of other teeth. It will also occasionally lacerate the dental pad, and not unfrequently works its way through the 
substance of the pad to the bone itself." From the foregoing it will be understood, that when the sheep is three years and six months old, the permanent dentition of this animal is completed, although sometimes the process terminates three mouths before, and at times three months, or more, later. After this period therefore, our judgment in determining the age of the sheep must be guided, first, by the wear and tear of the teeth, and secondly, by the general appearance of the animal. Although as a rule, the sheep is full-mouthed when three years and six months old, yet a few instances are not wanting in which the corner temporary incisors are in the mouth at four years; but this is an exception to the rule, which seldom varies, in that the sheep, before the expiration of the fourth year of life, possesses all its permanent incisors and molars, and consequently is full-mouthed.

\section{THE AGE OF THE PIG AS INDICATED BY THE TEETH.}

Correct information relative to the age of the pig as indicated by the teeth, was never given to the public by Girard or Youatt, although these writers were received as authorities on this important matter for years previously to the appearance of Professor Simonds' work "On the Age of the Pig." Youat doubtless translated from Girard, and in so doing repeated his errors, which a slight examination of the dentition of this animal would have prevented. In fact, he copied without investigating the subject for himself, and consequently we find Girard and Youatt writing in the self-same strain; the latter repeating all the mistakes of the former. "The hog," writes Youatt, "has fourteen molar teeth in each jaw, six incisors and two canines; these latter are curved upwards, and commonly denominated tushes. The molar teeth are all slightly different in structure, and increase in size from first to last; they bear no slight resemblance to those of the human being. The incisors are so fantastic in form as to baffle description, and their destined functions are by no means clear. Those in the lower jaw are long, round, and nearly straight; of those in the upper jaw, four closely resemble the corresponding teeth in the horse, while the two sorner incisors bear something of the fleur de lis shape of those of the dog. These latter are placed so near to the tushes as often to obstruct their growth, and it is sometimes necessary to draw them in order to relieve the animal and enable him to feed.

"The calculation of the age of the hog by means of reterence to the mouth has not yet been carried beyond three yearsno writer seems to have gone much beyond the protrusion of the adult middle teeth of the lower jaw. The hog is born with two molars on each side of the jaw; by the time he is three or four months old he is provided with his incisive milk teeth and two tushes. The supernumerary molars protrude between the fifth and seventh months, as does the first back molar; the second back molar is cut at the age of about ten months, and the third generally not until the animal is three years old. The upper corner teeth are shed at about six or eight months, and the lower ones at about seven, nine, or ten months old, and replaced by permanent ones. The milk tushes also are shed and replaced between six and ten months old. The age of twenty months and from that to two years, is denoted by the shedding and replacement of the middle incisors or pincers in both jaws, and the formation of a black circle at the base of each of the tushes. At about two years and a half or three years of age the adult middle teeth in both jaws protrude, and the pincers are becoming black and rounded at the ends. After three years the age may be cornputed by the growth of the tushes: at about four years, or rather before, the upper tushes begin to raise the lip; at five they protrude through the lips; at six years of agc the tushes of the lower jaw begin to show themselves out of the mouth and assume a spiral form. These acquire a prodigious growth in old animals, and particularly in uncastrated boars. As they increase in size they become curved backwards and outwards, and at length are so crooked as to interfere with the motion of the jaws to such a degree that it is necessary to cut off these projecting teeth, which is done with a file or with nippers."

The above contains the views of Youatt respecting the development of the pig's teeth; these views were considered correct until Professor Simonds found that little reliance could be placed on Youatt's assertions, and therefore determined to study the teething of the pig "from the period of its birtl onwards until the permanent set of teeth should be completed, and to mark the changes these organs might undergo, depending on wear or increasing age."

The incisors of the pig differ in their external outline from those of any other domesticated animals. Their formatior. and arrangement in the upper jaw differs from that noticed is the lower; for instance, the fangs of the teeth fixed in the sockets of the former take a curved course backwards and inwards, and their crowns pass down into the mouth almost vertically, i.e., at right angles to the lower jaw, from which the incisor teeth common to it run out almost in the same straight line with the jaw. Their fangs, also, slightly curve backwards and upwards, but are much longer than the fangs of the corresponding teeth in the upper jaw. The fangs, however, common to the upper teeth gradually decrease in length from the middle to the corner ones, whereas the fangs of the middle pair of the lower incisors are not quite so long nor thick throughout their entire length as the lateral teeth situated next to them. These last-named teeth possess fangs more than double the lengtl of the corner incisors, which are in every respect much smaller teeth, both as regards their fangs and cromns. The pig is boru with four teeth in each jaw, in all eight; and by taking one side of the lower jaw for examination, we find one tooth in the place of the corner incisor, and another in that of the tush. Simonds has named these teeth, respectively, the foetal incisor and fotal tush, owing to the place they occupy in the mouth during foetal life. The situation of these at the sides of the month leares a space between them in the middle of the month, and consequently the nipple of the sow can be brought into the young pig's mouth through the space created between the eight teeth 
above mentioned. Moreover, the nipple of the sow is yet further protected from injury by the tongue of the sucking pig, which in this act may always be seen surrounding and firmly adhering to its mother's teat. This grasping power of the tongue is greatly facilitated by the existence of a fringed border which surrounds it when "in the act of sucking; the tongue is doubled along its middle, so that these fringes are brought into such a position that they can partially overlap the nipple, and thus produce the grasping porrer alluded to." At one month old, four incisors being then situated in front of the month, viz., the middle temporary teeth, two in the upper and two in the lower jaw, appear in the gums, as also do the two temporary molars, being the second and third in position. The first or anterior deciduous molar sometimes is cut at the expiration of the first month, but as a rule this tooth does not make its appearance until five or six days later. The third molar in the lower jaw presents a very similar configuration to that noticed in the ox and sheep, described under their respective headings as being composed of lobes and cusps, and as occupying a much greater space both in diameter and length than its two anterior companions. When the young pig has reached the age of three months, four more temporary incisors, the lateral teeth, issue from their sockets, and in so doing complete the temporary dentition of the pig, both that of the incisors and that of the molars; consequently, before the pig is three months and a half old its mouth exhibits (taking one side of a lower jaw for description) a foetal tush, a foetal incisor escupying the situation of the corner incisor of other animals, and two middle incisors and two lateral ones; these last-named pairs occupying the front part of the mouth. In addition to the above, three temporary molars are situated anteriorily to the three permanent molars, which enter the jaw at a later period, afterwards to be considered. From three months and a half to six months, no new teeth escape into the mouth, neither does any replacement of teeth occur. On the wearing surfaces of the temporary teeth, however, signs of attrition indicate that the pig is nearing the age of six months, soon after which period, on each side of both jaws, just in front of the molars and behind the foetal tush in the lower, and directly in front of the molars in the upper, two teeth are added to the previously described set. These have been named by Professor Simonds "Premolars," which appellation he has borrowed from Professor Owen, but has mistaken the latter's reason for naming certain teeth premolars. Simonds writes, "Professor Owen has applied the term premolars to the teeth which succeed the temporary or deciduous set of molars. He limits the ordinary word molar to those teeth which are not preceded by similar ones. The term premolar therefore, is intended to signify the pre-existence of other teeth in the situation of these molars." Such is Professor Simonds' explanation of the peculiarities of premolars; now the description given of these teeth by Professor Owen leads me to believe that by premolars he meant to signify that such teeth existed in the jaw anteriorly to the permanent molars, and snch would be tne true meaning of the Latin preposition (pra, before), ind not on account of such teeth being preceded by deciduous ones. For instance, Professor Owen calls the tooth now under notice (the premolar of Simonds), the first premolar, and the three molars situated posteriorly to it, respectively premolars No. 2, No. 3, No. 4 . Now, in furtler confirmation of my view, it is known that the premolar of Simonds and the first premolar of Owen is not a deciduous tooth; it is never shed to make room for a successor; consequently Owen would not have called this tooth the first premolar, if he had intended to convey the idea, that by premolar he meant to signify the pre-existence of another tooth in the situation of this molar. The word premolar is a very well applied and distinctive term in describing the dentition of the pig, especially so, as the terms temporary molars and permanent molars in the present chapter have been used; and therefore the first premolar of Owen can be called the premolar, as no other tooth of this name has been mentioned in our above nomenclature. In other animals, similar teeth to the premolar of the pig exist. For instance, in the sheep and ox these teeth are called supernumerary molars; in the horse they are named wolf's teeth. These teeth are permanent ones, and conscquently if removed by accident or as the result of a surgical operation, are not renewed. At six months, or soon after, the first permanent molar, viz., the fourth in position, breaks through the gum. At from nine to ten months the fœtal incisor and the foetal tush are replaced by permanent teeth; these, it will be remembered, were existing in the mouth at the period of birth, on each side of the jaws. Just previously to the fall of these teeth, a slight inspection of the mouth will demonstrate to how great an extent, during the past nine months of life, they have been exposed to the effects of attrition, as they will appear nearly ground down to a level with the gums. The tusk of the hog is the same tooth as the canine of other animals, and holds in the mouth a similar position. Professor Owen usually calls them canines, and in describing their development in the wild boar, writes:"The upper canines in the wild boar curve forward, outward, and upward, their sockets inclining in the same direction, and being strengthened above by a ridge of bone which is extraordinarily developed in the masked boar of Africa. The enamel covering the convex inferior side of this tusk is longitudinally ribbed, but is not limited to that part; a narrow strip of the same hard substance is laid upon the anterior part, and another upon the posterior concave angle forming the point of the tusk, which is worn obliquely upward from before, and backwards from that point. In the sow the canines are much smaller than in the boar. Castration arrests the development of the tusks in the male."

The lower tusks are mnch longer than the upper ones, and take a direction upwards and backwards; their fangs assume a downward and backward course, but as age advances, they become vertically disposed. From ten months we pass on to twelve or thirteen months, at which period the middle temporary incisors are shed, and replaced by their permanent 


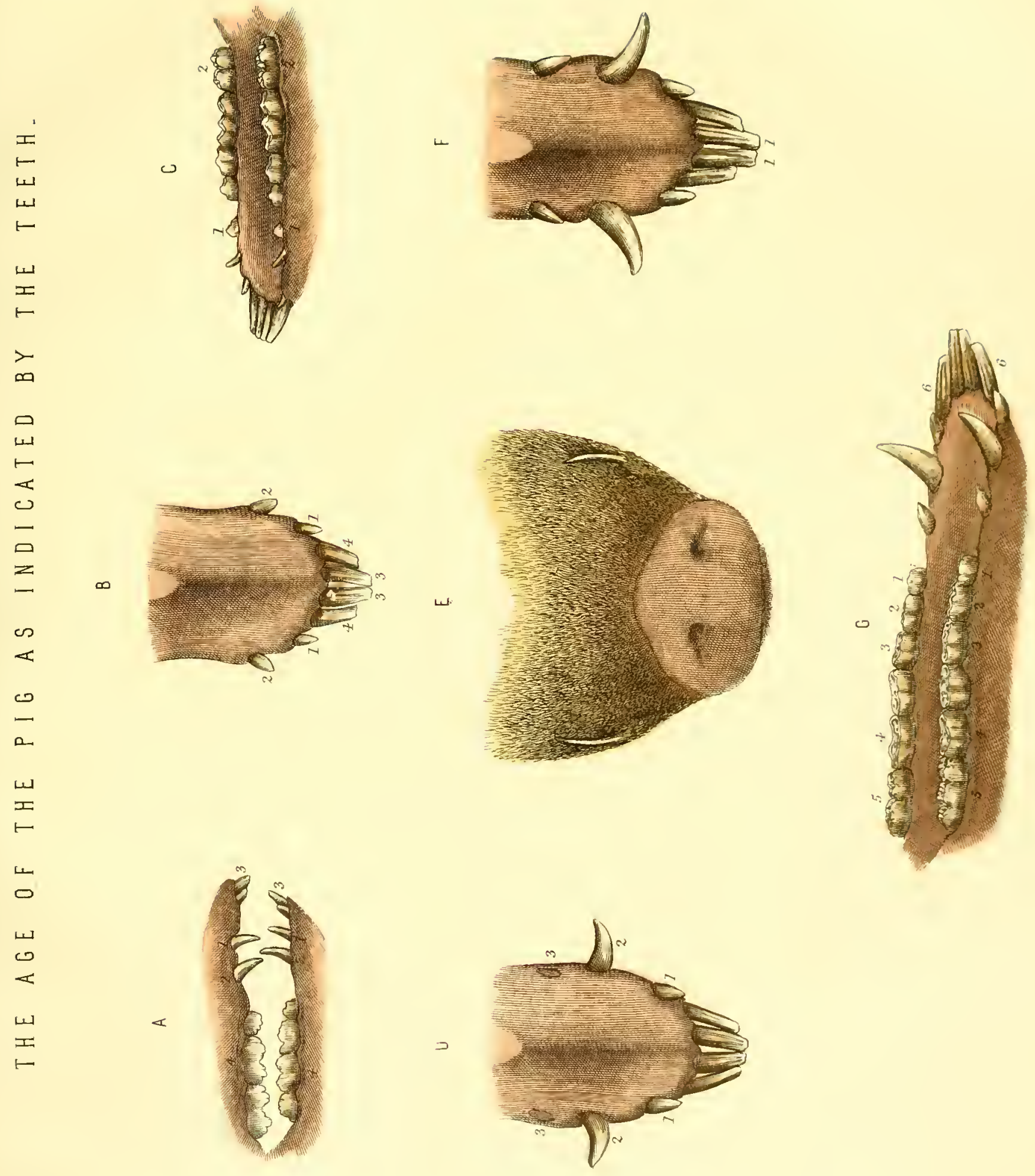



snccessors. The middle permanent incisors differ little from their temporary forerunners. They are broader and flatter, but their chief difference consists " in the existence on their upper and inner surface, of a well-marked ridge running parallel with their long axis, and bounded on either side by a deepish hollow. In the recently cut incisor, these hollows unite.at the apex of the tooth, giving a pointed extremity to the ridge just described." The same remarks apply equally to the middle permanent incisors, both of the upper and lower jaws. At this period also it will be observed that the corner incisors and tusks have considerably grown, the lower tusks to nearly an inch long. Soon after the appearance of the permanent middle incisors, the three anterior temporary molars escape from the gums and are replaced by permanent teetli; the two anterior teeth generaliy fall before the third, and consequently their places are filled with permanent molars. A sliort time before, a similar exchange is noticed in the third molar, and that situated posteriorly to the second (now) permanent double tooth. Before the pig has attained the age of sixteen months, the permanent molars will be nearly on the same level, the middle incisor will have become almost fully developed, and the tusks also commence assuming a circular course upwards and backwards. The only temporary teeth now remaining in the mouth, it will be recognized, are the lateral incisors; these, however, before the animal is one year and seven months old, are replaced by permanent teeth; at the same period the last or sixth permanent molar makes its appearance, and before two months have elapsed it will be on a level with the other double teeth. The dentition of the pig is, as a rule, therefore completed by the time the creature has lived one year and seven months, and after this time its age must be guessed at by its general appearance. In the boar, however, the greater or lesser development of the tusks will afford some guide in determining its age up to three or four years. Professor Owen, in describing the molar dentition of the hog, writes:- "The teeth of the molar series progressively increase in size from first to last. The first premolar (the premolar of Simonds), has a simple, compressed, conical crown, thickest behind, and has two fangs. The second premolar (the first molar of Simonds), has a broader crown, with a hind lobe having a depression on its inner surface, and each fang begins to be subdivided. The third premolar (second molar of Simonds), has a similar but broader crown implanted by four fangs. The fourth premolar (third molar of Simonds), has two principal tubercles and some irregular vertical pits on the inner half of the crown. The first true molar (fourth of Simonds), when the permanent dentition is completed, exhibits the effects of early development in a more marked degree than in most other mammals, and in the wild boar has its tubercles worn down, and a smooth field of dentine exposed by the time the last molar has come into place. It originally bears four primary cones with smaller subdivisions formed by the wrinkled enamel, and an anterior and posternor ridge. The four cones produced by the crucial impression, of which the transverse part is the deepest, are repeated on the second true molar (fifth of Simonds), with more complex shallow divisions, and a larger tuberculate posterior ridge. 'The greater extent of the last molar (third of Owen, sixth and last of Simonds), is cliefly produced by the development of the back ridge into a cluster of tubercles; the four primary cones being distinguishable on the antcrior main body of the tooth. The crowns of the lower molars are very similar to those above, but are rather narrower, and the inner and outer basal tubercles are much smaller, or are wanting:" 'The sixth molar is, as stated by Owen, much larger tlian its tellows, and consequently cannot be mistaken. It resembles somewhat the form of the third molar of the lower jaw, in that it possesses three divisions, 2.e., is trilobate; and that from eacl lobe two cusps arise, which are intersected by small subdivisions. 'Ihis development is readily noticed on the newly cut tooth, but in a short time daily attrition causes its obliteration.

\section{THE P I G.}

\section{THE CONSTRUCTION OF PIGGERILD.}

Nothing to those keeping or about to keep pigs can be more important, if the well-being of these creatures is considered, than the selection of suitable ground whereon to build proper habitations-" Principio sedes" porcis. Jany persons, in past years and even at the present time, think any hovel is good enough for the pig's home, and that he delights to wallow in his own mire. This is a most unfortunate mistake; one that has retarded both the growth and fattening tendency of such animals, and sometimes produced disease, and consequently caused great loss to owners. The land suitable for building piggeries on is not very different to that which is required for other animals, viz., rising grouna from which the drainage can flow naturally. The back of the sties, also, should be so constructed as to afford shelter from the north and east winds; and if this arrangement be carsied out, it is obvious that the open parts and yards in front must face the south or south-west; it is also very important to insure perfect ventilation. The above items mentioned as being necessary to the health of pigs, can with rery little forethought and expense be thoroughly and efficiently obtained. Having chosen a plot of rising ground, the extent of which must of course be defined according to the size and number of sties required, it will be our next endearour '? build the dormitories and yard walls. It matters little of what material these are composed, so long as they are impervious to wind and weather (this remark particularly applies to the sleeping compartments); but perhaps brick or stone, when these can be readily and cheaply procured, recommend themselves more particularly to our notice, as being likely to form the most durable fabric. In order to explain the mode of constructing piggeries and of keeping them clean, and of insuring easy drainage and perfect vintilation within them, it will be con- 
venient for the sake of plainness to describe the construction and the system of hygiene to be adapted to one. Given then a plot of ground, as above described, sufficient to build one sty upon. The walls composing the sleeping shed should be built of brick or stone; but if these materials are not of easy access, then rough wood covered outside by mud walls will form a perfect protection against wind and bad weather. The walls at the back of the sty should be at least five feet high, and those at the side should gradually slope downwards to the yard, to about three feet and a half. The roof always productive of the greatest comfort to the inmates is found in good straw thatch; for this substance tends not only to keep the apartment warm in winter, but also forms the best protection against the sun's rays during the excessive summer heat. The floor of the sleeping compartment should consist of boards resting on planks raised at least six inches from the ground, when the sleeping chamber can be shut in two-thirds of the way across, by boards, bricks, or any other building material that is ready to hand. The sties in which breeding sows are kept will be beneficially supplied with a ledge running round the chamber, and raised about six inches from tive floor and extending over it about one foot. This arrangement prevents the sow lying close against the wall, an operation which she constantly performs when about to suckle her pigs, and in so doing often crushes one or more of them. The barrier above mentioned keeps the sow from close proximity with the wall; and forms a bridge under which the young pigs can shelter themselves against the crushing effect likely to be produced by the heavy fall of their mother's body, during the act of lying down.

\section{THE TARD IN FRONT OF THE SLEEPING CHAMBER.}

The extent of the yard, like the sty, must be large or small, depending upon the number of pigs kept, but in either case the floor should consist of some hard substance; large flagstones about three or four feet square (like those noticed in Oxfordshire) are best. These stones being large, do not admit of so many apertures as those noticed in brick and pitched floorings, which allow the moisture to pass between them and thus undernine the structure. This, of course, is constantly noticed where the drainage is imperfectly obtained. To insure the rapid escape of all liquid from the sty yard, it is necessary that the floor should be so arranged as to gradually incline towards a middle, side, or centre drain, which should be continued at some distance from the yard to a main (liquid manure) tank outside. The drain in the bestconstructed yards generally runs up half the middle of the yard, and is partially open at the top. Of course, when the drain is arranged the floorings slope down towards it, as they should do to the side when the drain is there situated, but to the centre when central drainage is intended. The yard must be inclosed by a wall about four feet and a half high, and can be built of brick or stone, when a wooden gate either at the right or left hand corner will secure the safe keeping of the inmates.

\section{TROUGHS.}

Pigmasters do not all agree as to the best position for the feeding troughs. In our opinion troughs are better kept outside the dormitory-in the first place, because the pigs during the process of eating and drinking always throw over some food and a large quantity of liquid, and by this means saturate their beds with moisture; secondly, wash not disposed of during a meal may ferment, when certain gases are likely to be generated, which constantly prove deleterious to porcine health; the only good to be derived from placing pig troughs under the roof of the piggery, is that the rain cannot find its way within them, and for this reason alone many owners have thus placed them inside the sty. The best position for the feeding trough is found in the front wall not far from the door, where it must be a fixture, and should (if the wall be brick or stone) be placed on the ground in the middle of the wall, which raised about two feet above it forms a covering and an opening for the reception of the trough, and for the application of a door, or more properly, a falling lid, which can be opened and shut as occasion requires. At feeding time the lid can be raised, and the wash food can be readily emptied into the trough. The lids, or as I may call them trough doors, are sometimes (in fact, nearly always so now) arranged that they can be closed either on the inside or outside of the wall; i.e., when the pigs are to be fed the wash can be poured into the trough whilst the lid is closed on the inside. This prevents the usual porcine rush at the wash bucket, which often wastes much of the spoil. When the trough has been filled, the lid can be drawn forward until it reaches the rim of the trough on the outside, where it can be fastened until the meal has been completed. By placing the trough in the wall it is sheltered from the rain, and the escape of food or liquid from it will cause little or no harm. By these means the evil mentioned by the advocates for inside troughs is removed, and the existence of a dry and clean bed is insured.

\section{EXTRA YARD.}

Pigs, as before stated, are naturally clean animals, and when in a domesticated state they are otherwise, the fault must be owing to the carelessness of the owner. How constantly do we see the sty yard with filthy litter in it up to the pigs' knees, in which during hot weather the inmates are compelled to lie; for in the period of intense heat it will be noticed, if pigs are allowed to roam over a pasture through which a rivulet runs, that they will seek such stream and wallow in the mud at its banks; and this they do with a view to cool their bodies by the application of the cold water. When confined within a piggery, a similar tendency to cool themselves is noticeable in placing their over-heated bodies on the dung and litter that has been previously saturated with urine, which often proves a fertile source of disease, and consequently we onght to use all means at our disposal for its prevention. This end can be attained by a very simple 
and inexpensive arrangement, in the construction of an extra yard. As I have never heard that the arrangement about to be proposed was ever advocated previously, it will not be out of place to narrate the reasons which operated in suggesting the advantages likely to be derived from its adoption. Some years ago I possessed four pigs, each about six months old, that were placed in a piggery, the sty doors of which opened one into the otlier. As the sty next to it was without occupants, the door communicating from the one to the other was removed, and the pigs were allowed the range of both sties; and the result was that the animals used the sty $\mathrm{A}$ to sleep and feed in, and the far end of sty B, namely, the one from which the door had been removed, to dung and urinate in. The result was that sty $\mathrm{A}$ was always clean and dry, whereas sty $\mathrm{B}$ was used as a urinal, \&c., and was seldon: entered except for the purposes of nature just indicated. Such being the case, at the side of each yard, and separated from it, a second yard smaller in dimensions than the preceding, might run at a parallel to it, an inlet into which could be made sufficient to allow two pigs to pass through at the same time. This yard should also possess a gate through which the dung could be removed; in fact, there need be no other doorway through which to enter than this. The doorway of each sty ought to be so hnng that it will open outwards or inwards, so as to give the animals free ingress and egress; and to do this it should be hung across from side to side, and the pig should be able to push it in to effect its entry and out for its exit: for if it were hung in the usual way, it would derange the litter every time it opened inwards and be very liable to catch. The construction of the extra yard has some advantages: namely, 1st. Its presence causes pigs to perform the offices of nature therein. 2nd. For this reason, it necessarily follows that the feeding yard will always remain dry and clean. 3rd. The animal will be able to feed at a distance from the dung yard, and, better still, in one quite clean and consequently free from polluting gases. 4th. The sleeping compartment and feeding yard will not so freçently require fresh straw nor cleansing; moreover, in an extra yard all the droppings and dirty litter will be located in one spot, and can therefore be readily removed, after which the floors of both yards can with advantage be washed. It is a good practice to sprinkle coal or wood ashes over the floor of the extra yard, to act as a disinfectant, and purify the whole building, as well as to help the dung heap.

'The following diagrams will explain how the extra yard can be arranged either for a single or double piggery :-

\section{1.-SINGLE PIGGERY.}

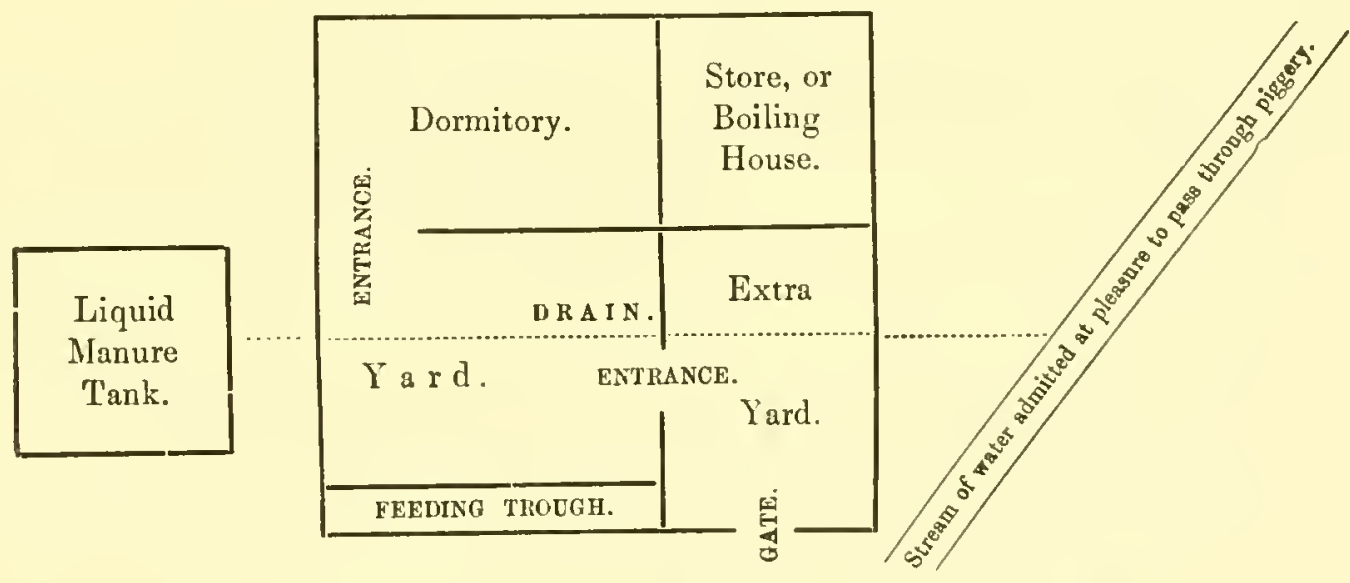

2.-D O U B L P G G E R Y.

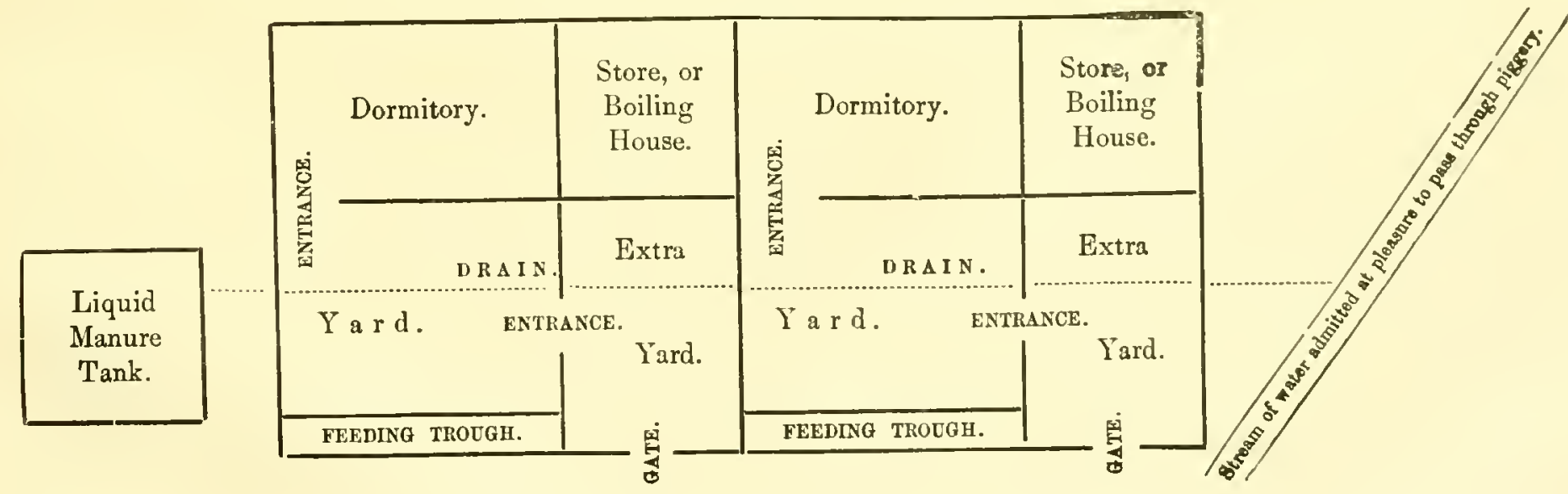


Where ttato is unlimited space, as in large farm yards, it is always wise to allow store pigs an extensive range, to be met with in straw yards protected from the northeast wind by sheds. In such locations the more elaborate construction of a piggery is not required for swine until the period when fattening is to commence arrives, when, of course, the piggery comes into requisition. Some persons, however, prefer, from the very first, keeping their pigs within bounds, even if a large quantity are housed, when the piggeries have to be constructed on a large scale, but should always be built on the hygienic principles above directed. The drain running through the piggery yards should be washed out daily, and for this purpose a stream can with advantage be admitted from without. This can be effected either by causing the water from a brook to be diverted from its course, when required, into the drain; or it may be obtained from a tank, through the medium of an india rubber tube being directed into the drain at its highest elevation. Of course, if these means are not easily procurable, then buckets of water thrown through the drain will sufficiently well answer the purpose of cleansing. As before stated, the drain should run into the liquid manure tank, which must always, where convenient, be situated at least five or six yards, if not farther, from the piggery. It is always well to build piggeries near that part of the establishment from which the supply of food can be readily collected. Wash, grain, and roots, can be stored under the dormitory roof of the extra yard; in large establishments in one of these a copper can be fixed in which to boil the various foods intended for the pigs.-See Diagram.

\section{FOOD FOR PIGS.}

\section{DAIRY REFUSE.}

Sour milk, butter-milk, and dairy washings constitute, with the addition of barley, oat, or pea meal, a very nutritious food for fattening purposes. "Farmers are of opinion that this mode of employing their sour milk is more profitable than making cheese." But it must be remembered that, when pigs have for any length of time been fed upon milk, they will fall off in condition if it be afterwards denied them. In the year 1846, Earl Radnor exhibited some very handsome pigs, aged about six months, which had been fattened on forty-eight bushels of barley meal and six bushels of potatoes, with an adequate quantity of whey; these pigs were in prime condition, and no pig could have presented better quality or quantity for the age. Dairy-fed porknamely, that produced from dairy refuse-is without doubt more delicate and wholesome than that reared and fattened on otber aliments.

\section{THE REFUSE OF BREWERIES AND DISTILLERIES.}

Brewers and distillers, who brew extensively, often keep a Large herd of pigs for the purpose of having the wash and grains consumed by them. This is constantly the case in the country; but in large towns, and especially in the suburbs around London, there are classes who make a good living by keeping pigs upon the wash purchased from the brewers and distillers. Wash and grains by themselves do not constitute wholesome food for pigs, as they are said to be too heating, and consequently can with advantage be mixed with a little water or kitchen wash, combined with pollard or barley meal. Thäer "advises that the refuse of brandy distilleries should always be diluted with water first, otherwise the animals will reject it, or, if they take it, become giddy and unable to keep their feet; afterwards the quantity of this food may be increased until they are completely accustomed to it." Neuenbahn says "that the refuse of the brandy distillery cannot be given to pigs too warm, or too soon after removal from the still, and that it never heats their blood; but that, if it be allowed to get cold and stale, it is rather injurious than beneficial to them. On the other hand, many experienced distillers, who fatten large numbers of hogs, assure us that it requires great attention, and the employment of a man on whose care we can rely, to prevent this residue from being given to animals while too warm, for it is then that it injures and materially retards their growth. It should be sometimes thick, sometimes diluted with water, and at others mixed with meal or pollard, in order, by thus varying the food, to keep up the appetite of the animals."

\section{REFUSE FROM STARCH MANUFACTORIEs.}

Thäer, in his "Principles of Agriculture," very clearly explains the advantages to be derived from employing the residue from starch manufactories as food for pigs. He writes:"The residue of the manufacture of starch, the products of the various washings which this precaution involves, and the refuse of wheat, are far superior to brewers or distillers' grains. Hogs fed upon these articles fatten more quickly, produce firmer flesh, more substantial bacon, and a greater quantity of lard. At first the animals will often eat these matters with great avidity, and even to excess: and when this is the case, they invariably become disgusted, and refuse them after a time. The quantity, therefore, must be carefully regulated, and the troughs kept very clean. If this kind of food be used alternately with one of a different nature, the fattening will be effected with greater certainty. The quantity of this refuse collected at once, is often greater than can be consumed at the time; and it is difficult therefore to store it, because it so soon putrefies. The only mode of preservation is to dry it, make it into cakes, and bake it." Starch, the first cousin to sugar, contains within itself the fat-producing material, and the residue from the starch manufactories, also, is largely pregnant with fat-giving elements; consequently, it may be readily seen that if the hydrocarbon starch be given as food to an animal, it will within it cause the formation of the hydrocarbon fat. All the artificial foods for fattening pigs contain such substances as starch and sugar, combined with aromatics, materials which incite the animals 
to eat greedily. Starch and sugar stand prominently forward as fat-producers; and as the residue of the starch manufacture contains both, it is very plain that this refuse constitutes, when mixed with meal, an excellent food for pigs during the process of fattening.

\section{ROOTS AND VEGETABLES.}

Nearly every root and vegetable grown has been pressed into the service for feeding pigs, and experience has proved that cabbage and lettuce-leaves and turnip tops are of little value as fat-producers. They form, however, a very good food for store pigs, and for this purpose are largely used. Roots, on the other hand, contain the fatty elements, as starch and sugar largely enter into their composition. This is particularly the case with the starch-yielding potato, and among the sugar-givers, such as the beet-root, carrot, and parsnip. These roots, even in the raw state, are exceedingly nutritive, but by cooking they are rendered more digestible, and their nutritive and fattening properties are increased. This fact has been attested by numerous experiments carried out during more than a century. On the Continent, parsnips and carrots are extensively used in fattening pigs, but these roots by themselves are not sufficient to give tenacity to muscle. They always require to be given in conjunction with barley or some other meal; yet such substances, and especially carrots, when treated as above directed, are said to impart a very delicate flavour to pork. For store pigs potatoes may form a staple food, and in Ireland, upon this root alone, without the addition of any other feeding material, hogs are constantly fattened; but in animals so tended, the flesh when boiled is liable to shrink instead of plumping, which should occur, and always does, when the creature has been fed upon corn in addition to the potato.

Previously to giving potatoes as a food to pigs, they should be boiled or steamed; the latter, perhaps, is the better course to adopt with some kinds of potatoes, whereas others require the former treatment, as steaming will never sufficiently cook them. But whether steamed or boiled, when thoroughly done the water in which they have been boiled should be immediately strained off and thrown away, when the potatoes can be well mashed up, mixed with meal or pollard in sour milk or whey, and if these are not procurable, then in kitchen wash, until the whole mass assumes a pulpy form. "This root," writes Youatt, "should only be given for a short time, as it is by no means a rapid fattener, and does not make good firm fat, and never alone if it can be avoided." This assertion, that the potato is by no means a rapid fattener, is contrary to $\mathrm{my}$ experience. Both chemical science and practical observation prove, first, that the potato contains a large quantity of starch, a potent fat-producing substance; and secondly, that this root, when given to pigs, not only acts powerfully in developing fat, but in prodncing it rapidly. I have fattened many pigs on potatoes and barley meal for five consecutive months, and have always been satisfied with the result; and consequently have proved, that pigs always fatten better on potatoes than any otlier known root, when they are judiciously combined with some kind of meal.

\section{GRAIN.}

Without grain pigs cannot be kept at a profit, as it affords both the means of bringing them to carly maturity, developing size, and when the period arrives of preparing them for the butcher, of producing fat. Store pigs, if they are to be done well, should be fed on wash, either that derived from the dairy or the kitchen, mixed sparingly with pollard or finely ground oats; and where little wash can be obtained and no pollard or meal is allowed, and especially when the range of a paddock is permitted, turnip tops, cabbage leaves, \&c., will prove useful in filling the pigs' stomachs. Such food, however, alone will not keep the animal even in good case without some additional supply, and this should be selected from the grain series. Beans and peas, especially the former, constitute the best food for animals daily devouring green stuff, as it tends, as pigowners say, to bind the lot together; therefore, half a pint of beans given daily to each pig will assist markedly in developing its form, and in facilitating its growth. In rearing pigs, it has always been my habit, at about ten months old, to wean them and keep them for about a month in a large shed, and feed them upon dairy refuse and oatmeal twice daily, and during the daytime to turn them into a paddock or some place where they could take as much exercise as was pleasurable to them; at the expiration of the month, to diminish the quantity of oatmeal, and in its place to give each pig daily half a pint of old beans or peas. I cannot too strongly advocate the necessity of allowing growing pigs plenty of exercise. Common sense tells us that they cannot breathe such pure air within the sty as outside; and particularly in a grass field not only is pure air obtained, but amusement is afforded and exercise necessitated during the frolics which the creatures are compelled to take whilst collecting the herbage, \&c. Horeover, the sty in which they are located during the night is all the better for its daily airing; and besides, as the bulk of the urine and dung is not deposited therein, the piggery is sweetened by the adoption of the course recommended. Some people are unable, owing to restricted space, to allow their pigs sufficient range for exercise, when, of course, confinement to the sty is compelled. Under these circumstances the sties should always be kept scrupulously clean, and to effect this end daily cleansing is necessary. Feeding similar to the above may be resorted to, but the beans or peas, if given, should not be thrown on the floorings, but must be placed in the troughs. after these have been well cleaned out Mr. Fermore exhibited a contrivance he had for feeding his swine with beans, which was like the hopper of a mill placed orer the sty, "into which a certain quantity of beans having been put sufficient to fatten so many hogs, these continually descend about half way down the sty in a large square pipe, which there divides itself into six smaller ones, which terminate, each of them, in a small trough just large enough to admit the nose of the hog, and come all of them with their ends so 
near the bottom that there is never more than a handful of beans in the trough at one time, which being taken away by the hog, there follows another, and so on; and he having drawn a rivulet of water through the sty, the daily trouble of waiting on the hog is saved, the animals are constantly kept supplied, and are unable to waste or dirt their food."

In preparing grain for pigs' food, there are some who consider it is better macerated; by which, they say, its fattening properties are increased, and especially so if it be afterwards allowed to lie and ferment, when it can be dried and malted, and then placed in water until it turns sour. This process does not answer, as pigs sornetimes will not eat such food, and moreover, it is not so digestible as meal.

The best mode of giving grain to pigs is in the form of meal moistened with milk, or wash of any kind, which has been previously mixed with potatoes or boiled roots of some sort. The mass never should be given too warm, as, when in this state, sometimes a recently boiled potato, and even hot meal, will scald the internal coats of the stomach, and may thus act as a proximate cause of death. The fluid medium, whatever it may be, is better administered cold, or at any rate lukewarm, as boiling liquid when poured on meal often causes the conglomeration of it into lumps, which never become intimately blended with the mass, and consequently, if eaten in this form, are likely to create indigestion followed by obstinate constipation. Arthur Young, in his book on fattening cattle and swine, writes as follows:- "The most profitable method of converting corn of any kind into food for hogs, is to grind it into meal and mix it with water in cisterns, in the proportion of five bushels of meal to 100 gallons of water; stir it well several times in a day, for three weeks in cold weather, or for a fortnight in a warmer season, by which it will have fermented well and become acid, till which time it is not ready to give. It should be stirred immediately before feeding. Two or three cisterns should be kept fermenting in succession, that no necessity may occur of giving it not duly prepared. The difference in profit in feeding in this manner and giving the grain whole, is very great; so great, that, whoever tries it once will not be apt to change it for the common method."

There are many people who speak lightly of Indian corn as a food for pigs; it certainly produces fat, but is not to be depended upon equally with barley, beans, or peas, as maize does not cause flesh or fat to be laid on so surely or rapidly as the three species of grain mentioned. I have watched pigs during the period they have been fed on rice, and from experience cannot recommend it as a fattener; but at the same time some practical pig-keepers speak in its praise. One in particular writes, "We fattened our pigs on rice, and such pork I never saw before or since; the fat was as firm and solid as :he lean, and the flavour of the meat was superior. The way the rice was prepared was as follows:- My copper held forty gallons; in the afternoon it was filled, or nearly so, with water. As soon as the water boiled the fire was raked out, two pails of rice were immersed in the water, and the whole covered closely down and left to stand until the morning. On the following day the copper was emptied of its contents, which consisted of a thick jelly, so firm as only to be taken out with a shovel; and on these coutents the pigs were fed. The effect was perfect. As to the economy of the plan, that of course must be a matter depending on crrcumstances; we found it more profitable than almost any other kind of food we could have given, from the price at which we were able to purchase the rice, and its goodness. From some slight experiences, I am induced to think that equal parts of rice jelly and mashed potatoes would constitute an excellent food."

"Another person who tried rice as a food for pigs, put up two weighing five stone each, and fed them entirely on equal parts of boiled rice and steamed potatoes. At first they progressed but slowly, but eventually attained the weigd $t$ of fifteen stones each. Their flesh was fine and delicate, the fat white and firm, and the flavour of both excellent." It will be observed from the above that, although rice was used to increase the weight of pigs from five to fiftcen stone, yet the writer "from some slight experiments" is led to the conclusion, that the addition to it of mashed potatoes would answer better; and we cannot find sufficient reason for this adrocacy, excepting it be found in the fact, that in the experiments alluded to, the potatoes played an important part in producing better fattened animals than those that were fed exclusively upon "rice jelly." Of course, rice in combination with meal or potatoes will fatten pigs to a great size; but unless rice can be bought at a very moderate rate, its place can be more advantageously filled by other species of grain, which fatten both well and rapidly. Moreover, rice has a tendency to cause constipation, and nearly always does, unless some laxative diet consisting of vegetables be supplied; for this reason, and for others which experiments have proved, we cannot recommend boiled rice as a staple food for fattening swine.

\section{- FeEdiNg and fatteniNg.}

In feeding pigs, either store to be fattened, regularity should be the order for every day. Once, I remember, an extensive fattener of oxen told me, that if cattle were not fed until some time after their usual hour, they would fret and become irritated, and he had known them lose condition as the result of the herdsman's repeated neglect to attend to them at the prescribed hours. The same remark applies with equal force to pigs. Swine from habit learn to expect their meals at certain times, at which the stomach is usually empty and ready to be re-supplied with food; consequently, if this demand of nature is not attended to for hours perhaps after the appointed period, it can be readily understood that the animals grow irritated, and the healthy working of their digestive powers is interfered with, which prevents the due performance of that functional activity necessary in causing perfect digestion. Consequently, as evils are likely to occur from irregularity in feeding, I cannot too strongly impress upon my readers the importance of supplying pigs with food at regularly appointed hours. When pigs are first put up to fatten, they will eat more than they do after the 
process has been continued, when they become plump. At first, therefore, three meals a day can be given, provided they always clean their troughs out previously to the second time of feeding; but afterwards smaller meals, and those more frequently supplied, can be allowed with advantage, as swine if over plentifully fed are apt to gorge themselves, and thus to impair the digestive functions and retard their progress to obesity. It will be found that pigs, when advanced in fat, eat very little. At such times, therefore, it is necessary to give them a highly nutritious food, one that shall contain the elements of nutrition in a concentrated form; and sometimes, as their appetites are capricious, to tempt them to eat with delicate food, varied from time to time: that is, in the place of barley-meal use pea-meal, \&c., and instead of potatoes employ carrots or beet-root, or any other vegetables the animals may show a disposition to devour; for when swine are far advanced in fat, not only will such change tempt them to eat, but, will be actually demanded, as one kind of food will not supply all the nutriment required to develop the fat, and increase the size looked for in the fattened hog.

\section{THE PERIOD AT WHICH TO FATTEN SWINE.}

The best time to commence fattening pigs is about the month of August, but, of course, this must be regulated by the period in which these animals are intended for the butcher. Pork has in recent times been killed "all the year round ;" to supply this demand it necessarily follows that certain pigs must be fattened during every month in the year. But the usual course adopted is to "shut" pigs up during July or August, in order to make them into delicate pork by October or November. Let it be remembered we are now considering pigs calculated to grow into small porkers, not those animals which appear as juvenile monsters at our cattle shows. These latter are fed sumptuonsly from their youth to the day of their slaughter; they require similar feeding and treatment to other pigs, with this exception that they do not demand the fattening process to be carried to so great an extent. Porkers should not be fattened exactly in the same way as bacon pigs, neither should they be allowed to accumulate too much fat; and this rule should be strictly carried out with those animals reared and intended for domestic consunption. The pig-keeper who fattens for profit will tell you, that fat represents weight, and weight yields profit; and as long as such is the case he intends to make his porkers as fat as possible. This course no doubt keeps a "good balance at the banker's," but it does not produce that delicate pork which the epicure pronounces to be toothsome. A porker, to be properly prepared for the butcher, should not be made fat to the extent of plethoric; he should possess a plump form, showing that plenty of firm flesh and sufficient fat exist, but should not manifest that condition of body which scarcely allows him to see, breathe, or move. The porkers intended for domestic consumption should be placed in the fattening sty about the end of August, as the weather at that time is neither too hot nor too cold, and moreover, the slaughtering period arrives at that time when it can be carried out with the greatest advantage, and the flesh can be kept longer both during the process of curing and for purposes of disposal. In the summer, on the other hand, meat must be salted and pickled without delay, or be sold immediately, as in hot weather it soon goes into a state of decomposition. Various opinions are entertained, by practical pig-feeders, as to the best mode of preparing porkers for the table. Some advocate shutting them up and allowing no exercise excepting that obtainable in the sty yard, supporting this treatment by asserting that if pigs are allowed to run about they will "run off" their condition; and as condition is the prime object in view they consider it their duty to remove any obstacle calculated to defeat it: whilst others prefer allowing their pigs to graze or run in woods during the day, saying that excrcise causes growth, and that the roots and earth they sometimes eat correct any acidity that may occur in their systems. Pigs thus given their liberty should be fed twice daily, namely, in the morning before being turned out, and in the evening on their immediate return. By the turning-out system, doubtless, pigs are kept at less expense than by that of housing, for by this plan one meal during the day is dispensed with; and moreover, swine, as above stated, grow more rapidly with than without exercise, and the medicinal substances found in the ground are known to act beneficially on the health of such animals. But whichever plan be adopted, artificial food must be given to those housed three or four times, and to those grazed, twice daily; when the question arises what substances constitute the best kind of food for fattening porkers. This cannot be better answered than by recounting the result of my own experience and that of practical owners with whom I have conversed on that subject. Having selected out of a litter five or six pigs, about three or four months old, place them in a sty and supply them with a bed of clean straw. Having thus obtained a suitable habitation for the youngsters, it should be our endeavour, in the next place, to provide them with that food best calculated to cause growth and produce a certain amount of fat. As grain contains the elements of nutrition and the fatty principles in abundance, it should always constitute the staple upon which we feed; but while this is the case, it is at the same time better to gradually introduce the pigs to their new mode of life necessitated by different feeding. This can be done by feeding the animals, for the first month or sis weeks, upon milk mixed with pollard and mashed potatoes, and by giving eacls pig twice daily half a pint of peas, and by allowing then in the daytime a run in the field. By the adoption of this plan it will be from day to day noticed, not only that the animals grow, but that they both fatten and thrive, better than those subjected to permanent confinement; and as they increase in bulk they cease to run about and frolic so frequently as when first put up, consequently the accumulation of fat is little interfered with. This system, however, though desirable at first, is by no means so after the expiration of five or six weeks; for then the animal likes to lie down more, 
and will not, if turned out, hunt for roots, \&c., so eagerly as formerly. Therefore, at such time it is wise to close the door of the sty against them, and feed more frequently than twice a day upon a more highly nutritious diet; which consists in giving in the place of bran, and instead of the peas scattered in the trough or on the ground, a mixture of barley and pea meal, with carrots or potatoes mashed in whey, sour milk, or wash. Pea meal and carrots both give a very delicate flavour to pork, and the change in the diet from that given during the past five or six weeks causes the animals to eat with a greater relish, and thus tends to facilitate the fattening process. If after a time the latter-mentioned is not devoured with avidity, the meal may be changed for some other, such as oatmeal; and the potatoes and carrots can be supplanted by beet root or parsnips. In fact, any change of food beneficially acts, both in creating an appetite, and in giving a fresh impulse to the system to assimilate food, and to appropriate it for the purpose of producing coudition. Pigs when shut up shonld always have fresh water before them, both to drink and cleanse their snouts in; and a piggery is always better arranged that has a stream of water passing through it, whether it it be obtained from a stream or by artificial means. Pigs treated as above directed will be found about the middle of November to be very plethoric, and only a few touches of the feeder are required to make them fat. At this time they will eat very little; consequently food must be given repeatedly and in very small quantities until near Christmas time, when, unless "anything has gone amiss," they will "be fit" for the butcher, to whom they can be sold or killed for home consumption.

Pigs which are designed for bacon require a longer period for the process of fattening; and if large meat be desired, they are better put up between their first and second year. These require no liberty, but in other respects should be treated similarly to those intended for pork. Patent foods for cattle, carefully prepared by this or that Company, the cattle-feeding public largely use. These foods contain, as a rule, stimulating compounds, aromatics, and sometimes tonics combined with various kinds of meal. Such compounds, nine times out of ten, are not needed; as a change of food, as above presented, would provoke the appetite and give that fresh vigour to the stomach, which the patented foods profess to effect. When medicine is required, give it under proper advice; but to administer it to an animal in health is most foolish, and very injurious in its effect. By feeding on "Aliquis's" food for cattle, you are always giving to the animal some compound calculated to stimulate the stomach; in short, you every day administer medicine. Such a course we have never adopted, and yet have been able to produce as good, if not better pigs, than those fed on the various patented foods We have seldom used medicine, but have usually added a little salt to each meal. Cleanliness, both as regards the sty and its appointments is a sine quâ non, and if this necessity be not strictly observed, pigs will not thrive. Moreover, the skins of these creatures should always be kept free from dirt or dust of any sort, as sach filth blocks up the pores, and prevents the performance of their transpiratory function. To keep the skin clean and the pores of it open, it will be necessary from time to time to groom your pigs, and sometimes to wash them. This ablution can be better performed by the pigs themselves in a tank, about one foot deep, situated on a level with the floor of the yard; in this, especially during warm weather, they will lie and bask for hours, and will afterwards dry their bodies on the clean straw placed in the dormitory or elsewhere for that purpose. Indeed, if a tank be arranged in the sty, the grooming can be dispensed with, as the washing cleanses, and the rolling in the straw answers the purposes of the wisp. Some people may consider the remarks relative to cleanliness are out of place, as regards pigs. No more mistaken notion exists than to suppose that swine like filth, and thrive better in dirt. A Norfolk farmer instituted the following experiment:- "He put up six pigs of almost equal weight, and in equal health, to fatten; treated them with one exception all exactly the same; and fed them on similar food, given in equal quantities to each for seven weeks. Three of these pigs were left to shift for themselves, so far as cleanliness went, and the other three were carefully curried, brushed, and washed. These latter consumed less food by five bushels than the other three, and yet, when killed, weighed more by two stone four pounds on the average." From this experiment it is evident that cleanliness of body insures health, and produces weight, which represents profit.

During the period of fattening, even when a system of hygiene has been fully carried out in the construction of the piggery, and the greatest care has been bestowed on its inmates, we find they are occasionally troubled with slight ailments, the most prominent of which are indigestion, often caused by acidity on the stomach, and overgorging. The former of these is usually corrected by the administration of a small dose of finely powdered charcoal and sulphur, mixed together in a pellet of butter, when it can be thrown into the trough, and in this form the pig will quickly devour it; a little lime added to the meal will also act beneficially. "On the duke of Montrose's estate the pigs have ashes and cinders given them occasionally to correct the acidity of the stomach, and they are frequently turned out on a piece of ground sprinkled with lime, which they root in and eat, or else if this is not possible on account of the weather, a little magnesia is now and then mingled in the milk. These simple precautions are always more or less necessary to animals tlat are highly fed and have little or no exercise, and we should recommend them to the attention of all owners of pigs." The above rules for fattening pigs will, if strictly attended to, produce fat animals, but at the same time overfattening is neither profitable to the seller nor buyer, neither is overfat meat so useful for the table as that which is less so. Moreorer, animals in such a state are in reality diseased, suffering and sometimes dying from the result of obesity; consequently, our readers are recommended in this particular to take a medium 
course, by preparing their pigs fairly fattened for the butcher, remembering the motto, "Est modus in rebus."

In conclusion, observe the following:-

1. Feed at regular intervals, avoid foul feeding, and do not overfced.

2. Change the bill of fare when occasion requires.

3. Keep your sties clean and dry, and do not neglect afterwards to sprinkle over the floors ashes or dry earth.

4. Cleanse the troughs previously to each feeding.

5. Do not forget to keep your pigs clean, dry, and warm, either by allowing them a bath in the piggery, or by washing and afterwards brushing.

\section{BREEDING.}

Before proceeding to consider the rules which should be observed in obtaining parents likely to produce good pigs, our investigation in this matter will be greatly assisted by describing the laws generally which regulate the selection of males and females, with a view to develop the strongest, and in the case of our domesticated animals, the most profitable offspring.

\section{LAWS REgULATING THE RESEMBLANCE OF PROGENY TO}

\section{PARENTS.}

Walker, in his book on intermarriage, states that the laws which regulate the mode in which the organization of parents affects that of offspring are the most curious and interesting, but somehow appear to have escaped the notice of philosophic observers, although it requires very little analytical power to detect them; that in the propagation of organs from parents to offspring organization is nearly indestructible, and that each parent communicates a distinct series of organs; or, in other words, a portion of each parent may be said to live again in its offspring.

I will now endeavour to explain the laws as laid down by Walker. In the first place, "where both parents are of the same variety," he assumes that either parent may communicate either system of organs. In this case, one parent communicates the anterior part of the head, the osseous or bony part of the face, the forms of the organs of sense (the external ear, under lip, lower part of the nose), and the whole of the internal and nutritive system (the contents of the trunk, or the thoracic and abdominal viscera).

The resemblance to that parent is consequently found in the forehead and the bony parts of the face, as the orbits, cheek-bones, jaws, chin, and teeth, as well as in the shape of the organs of sense and the tone of the voice.

The other parent communicates the posterior part of the head, the cerebellum or little brain, situated within the skull, just at its junction with the cervical vertebræ, and the whole of the locomotive system-the bones, ligamcnts, and muscles.

The resemblance to this parent is consequently found in the backhead, and the few more movable parts of the faceas the external ear, under lip, lower part of the nose, eye- brows - and the external forms of the body, in so far as they depend on muscles, as well as the form of the limbs, even to the fingers, toes, nails, \&c. "Sevcral circumstances indicate that with this series of organs go the skin and its appendages. They evidently have much affinity with the osseous systcm." Mr. Walker thinks that on an average the male and female influence over their progeny is equal, but that sometimes the male, and sometimes the female, predominatcs. Mr. Knight, on the contrary, gives it as his opinion, that the influcnce of the male and female is always very nicely balanced when both parents are of the same species, size, and variety. In confirmation of this theory, "that either parent may" communicate either series of organs," Walker gives many illustrations existing in man-that is, between parents and their children-which it is needless here to detail.

Many authors, however, previous to Walker, have given it as their opinion that the influence of the male predominated over the exterior life, while that of the female predominated over the interior life, of their offspring. Vicq-d'Azyr stated, with regard to mules, that the exterior and extremities were communicated by the father, and the viscera (internal organs) by the mother. In this opinion he is also supported by Buffon.

This theory does not coincide with that of Walker, in which he states that either series of organs may be given by either parent; but in cross-breeding-that is, breeding from a male and female of a different family, though of the same variety-he states, greater vigour is given to the offspring than when the parents are nearly related; and in crossing, when each parent is of a different breed, then the male corw. manicates the backhead and locomotive organs, while the female communicates the face and the nutritive organs. As an example, he gives the cross between the male European and female negro. The male here communicates the backliead and general figure. Neither the bones of the thighs nor legs are bent as with the negro, the heels long, nor the calres high; while the under lip and nose are less, and quite European in character. The negro mother communicates the narrow retreating forehead, ligh cheek-bones, the large eyes, the long upper lip, and the remaining parts of the face.

Thus, in human crosses, Walker considers the male gives the locomotive system, and the female the nutritive one. Of the power of the horse to communicate his locomotive system generally, Knight gives the following examples. He obtained offspring from Norwegian pony mares and cart stallions, of which the legs were very short, the shoulders and body unusually deep. In attempting this experiment Knight was very careful, fearing he might subject the female to a painful death, owing, as he then thought, to the too great size of the foetus; but such did not happen: from which we learn, that the size of the foetus is governed by the size of the female. Thus, in this equine cross, the male gave the locomotive system, while the female gave the vital one.

As to mules, Knight says the fact, in mule quadrupeds, that the influence of the male predominates over the female 
in giving form to the offspring is beyond all doubt; as also the disposition and the mind of the beast.

Mr. Orton very nicely exposes this fact. The mule, says Orton, the produce of the male ass and mare, is essentially a modified ass. The ears are those of the ass, somewhat shortened; the mane is that of the ass, erect; the tail is that of the ass; the skin and colour are those of the ass, somewhat modified; the legs are slender, and the hoofs high, narrow, and contracted, like those of an ass. In fact, in all these respects it is a somewhat modified ass. The body and barrel of the mule are round and full, in which it differs from the ass and resembles the mare.

The hinney, on the other hand, the produce of the stallion and she-ass, is essentially a modified horse. The ears are those of a horse, somewhat lengthened; the mane flowing; the tail bushy, like that of the horse; the skin fine, the legs stronger, the hoofs broad and expanded, like those of the horse. In fact, in all respects it is a modified horse. The barrel and body of the hinney are flat and narrow, in which it differs from the horse, and resembles its mother, the ass.

It is clearly evident that these two hybrid animals have followed the male parent in all external characteristics. In two respects, however, there is a striking departure from him. First, in size, they both follow the female parent, the mule being in all respects a larger and a finer animal than his sire, the ass; while the hinney is the reverse, being smaller and less spirited than his sire, the horse. The mule also brays, like its sire the ass; whilst the hinney, on the other hand, neighs, like its sire the horse. This is easily accounted for, as the bone of the tongue (os hyoides) and the laryngeal muscles cause the voice-parts given by Walker under the locomotive system, and stated by him, in cross-breeding, always to be communicated by the male parent.

Mr. Cline, speaking of crosses, says:- "The characters of both parents may be observed in their offspring, but that of the male more frequently predominates. This may be illustrated in the breeding between a hornless ram and a horned ewe, when the lambs will be hornless, and partake more of the characters of the male than the female parent. $\mathrm{Also}$, if a horuless bull be put to a horned cow, the offspring geverally has no horns, and resembles its male more than its female parent.

An offspring without horns may be obtained from the Devonshire cattle, by crossing with hornless bulls of the Galloway breed. Mr. Charless Colling put a short-horned bull to a hornless Galloway cow. The cross was successful, and exists at present in the most improved short-horned cattle. It is difficult to distinguish this cross from the pure shorthorned breed. MIr. Vansittart used a well-bred short-horned bull to well-bred Hereford cows. The produce had all the appearance of the short-horned cattle.

Thus in crosses of cattle, as well as of horses, the male (except when feebler, or of an inferior voluntary and locomotive power) gives the locomotive system; the female the vital one.
As to dogs, the breeder states that, in a cross between the bulldog and terrier, if the bulldog be the father, the progeny have the shape of the bulldog-that is, his locomotive system; if the terrier is the father, they have the shape of the terrier. Mr. Helps states that, when a dog and bitch are both equally vigorous, such is the case; but if the $d \circ g$ is old and enfeebled, and the bitch, on the contrary, young and vigorous, the reverse is the case. The same rule applies to all crosses of dogs.

Thus, in crosses of dogs, the male gives the locomotive system, the female the vital one.

Respecting birds, the breeders state that, in the cross between the male goldfinch and female canary, the shape and the skeleton of the mule produced is always that of the male.

Mr. Nash states that in crosses, as in that between the cock goldfinch and hen canary, the male not only gives the beak and skull to the mule, but the longer neck, the wider chesi, the longer sternum, and the longer legs. Walker makes the following remark on this circumstance:- "The cause of this evidently is, that in a mule all growth contributes only to individnal life; and as to the sternum, we know that it is always shortest in the female, to facilitate the producing and laying of eggs; and it is evidently longer in mules, because they are incapable of the due performance of any reproductive process.

Thus, in crosses of birds, the male gives the locomotive system, the female the vital.

As to fish, Sir A. Carlisle's statement shows that in the mule between the female salmon and male trout, the skeleton is given by the male, as appears from the following letter addressed to Walker :-

"Mlore than thirty years since the breeding of trout was tried by impregnating their ova in confined water cages, made to protect the young against their natural enemies. As I had some share in those experiments, I undertook to breed those mule fishes known to be a produce between male trouts and salmon-roe, or the reverse. I accordingly procured a quart jug full of ripe salmon-roe from the freshest fish just arrived at Billingsgate, in the month of January; and I proceeded with them directly to Carshalton, where they were carefully deposited by a man who waded the stream, and raked the ova among the gravel in the trout-spawning gravel heaps.

"In the month of April a new sort of fish appeared for the first time in that river, which proved to be the mules called skeggers in the Thames, smelts in the north of England rivers, and gravel last springs in many of the western and southern counties. They were, in this case, very abundant, and apparently their numbers corresponded with the salmon-spawn deposited in the trout gravel hills.

"These mules never appear but where the salmon invade the breeding gravel hills of trout; and in my experiment the impregnators were necessarily male trouts, because salmon never pass the mills upon the Wandle The influence of the male trout in this instance was, therefore, unquestionable.

"These mules partook of the character of trout more than 
salmon. They had bright red spots on their sides, but the black colour was shaded downwards, in bars, like those of the perch. The tails were not forked like those of salmon, as I have seen them in the Thames skeggers, from which $\mathrm{I}$ infer the male salmon in that case to have been the impregnators. They grew to the length of the male parent, and to the weight of a quarter of a pound. They disappeared before autumn.-Yours, \&c.,

\section{"A. Carlisle."}

Mr. Knight says: "The natural history of the mule between the male trout and the salmon is, I suspect, very little known, after the first nine months of that animal's life. Instead of going off to the sea with the first spring floods, they remain till autumn, when they go off; and nothing more is, I believe, known respecting them. They are almost wholly males."

From all these cases it is evident that the locomotive system in crosses is given by the male, and from the general law it follows that the vital and nutritive system is given by the female.

REMARKS ON BREEDING FROM ANIMALS THE OFFSPRING OF CROSSES.

Mr. Knignt says: "If I were to breed from a female and male, both crosses between the Hereford bull and the Alderney cow, the offspring would be extremely dissimilar to each other. Some would appear nearly pure Herefords, and some nearly pure Alderneys; and if such a stock were to become the stock of a farm, some apparently perfect Herefords, and some perfect Alderneys, however begotten, would be produced during a long succeeding period."

Sir John Sebright also says: "Although I believe the occasional intermixture of different families to be necessary, I do not by any means approve of mixing two distinct breeds with the view of uniting the valuable properties of both. This experiment has been tried frequently by others, as well as myself, but has, I believe, never succeeded. The first cross freqnently produces a tolerable animal; but it is a breed which cannot be continued. If it were possible, by a cross between the new Leicestershire and Merino breeds of sheep, to produce an animal uniting the excellencies of both, that is, the carcase of the one with the fleece of the other, even such an animal, so produced, would be of little value to the breeder; a race of the same could not be perpetuated, and no dependence could be placed on such animals. 'They would be mongrels; some like the new Leicester, some like the Merino, and most of them with the faults of both."

Now, according to Walker, the cross between the Alderuey and Hereford is a reasonable one; that between the Leicester and Merino is not so, because the carcase and wool go together with the locomotive system, and whichever animal gives one, would, in reality, give both. Walker explains these difficulties thus :-

"A and B, who are more or less perfectly crossed, may have very different vital and locomotive systems. Of their immediate progeny, C may have the vital system of A, and the locomotive system of $\mathrm{B}$; and $\mathrm{D}$ may, on the contrary, have the locomotive system of $\mathrm{A}$ and the vital system of $\mathrm{B}$ (for in feeble and imperfect crosses such variations may occur). And of the progeny of these last, $\mathrm{E}$ may have from $\mathrm{C}$ the vital system of $A$, and from $D$ the locomotive system of $A$; and $\mathrm{F}$ may have from $\mathrm{C}$ the locomotive system of $B$, and from $D$ the vital system of $B$. Thus $A$ and $B$ may be re-formed in the third generation."

In order to explain fully the principles of the physiology of breeding, it will be necessary, in the first place, to briefly explain the natural system of anatomy, by describing the particular structure of organs, and dividing the body of the vertebrate animal (after Bichat), into three classes of organs possessing different functions:-

1. The locomotive organs and functions, consisting of bones and ligaments which connect them together-that is, "one piece of bone to another," thus forming joints, and which, as a whole, support the body and its parts-and finally of muscles, which, together with other parts, form an apparatus of levers which enable the animal to perform its rarious necessary movements.

2. The vital or nutritive organs and functions, consisting of fine tubular vessels (lacteals), which absorb nutritious matter from the food taken into the intestines, and carry it towards the heart to be converted into blood; bloodvessels, which circulate the blood thus formed; and various glands, which secrete or deposit not only the various substances composing the different organs, but the fat, milk, hair or wool, and other animal products.

3. The nervous or mental organs and functions, consisting of the organs of sense, the eye, the ear, \&c., which receive impressions from external bodies; the cerebrum, or brain, which perceives, compares, \&c.; and the cerebellum, or little brain, situated at the back part of the cerebrum, which wills, and consequently throws the muscles into those actions which fulfil its purposes. Although these three systems thus exist, they do not, like three distinct families, reside in separate parts or stories of the body, but co-exist in one point, and by their combination form a whole; yet it is evident that each of them has its peculiar station, when it more especially unfolds itself and acts; and if one of these systems was injured, the two others would suffer with it; if one were removed, the other two would perish-or in other words, death would follow. The three systems, therefore, co-exist so as to form one grand whole-a living animal.

The more perfect animals, as well as man, are not boru with the faculty of immediate reproduction of their like. The organs which at a future period perform that important function remain entirely torpid long after birth, and the appetites connected with them do not exist. The longer the infancy, the longer the period of puberty is delayed. Puberty, as a rule, is earlier developed in the female than the male. Some animals arrive at puberty before others-for example, the sow arrives at puberty before the mare; and in animals of the same species the same thing occurs. 
The temperature of the climate tends greatly to hasten the period of puberty. Heat increases the vital energies in all organized bodies, and renders their growth more rapid; it must, therefore, necessarily hasten the period of puberty. It prof is notorious that warm climates increase the development of the generative organs, and excite erotic desires in both sexes.

The quantity and the quality of aliment is a second cause of hurrying on puberty. Very nutritious and stimulating tood, for instance, greatly accelerates it; and horses having a great development of nervous energy, namely, those of an excitable temperament, arrive at puberty before those of a more sluggish disposition. On the other hand, the period of puberty may be retarded, its retardation being, of course, attended with most disastrous results-more particularly noticed in man. Retardation of puberty in man retards often the intellectual powers, \&c. Insufficiency of food, especially during winter, tends to retard its development in animals. The too early development of the reproductive functions is equally disadvantageous; it diminishes stature, and canses the body to fade and perish early. Citius pubescunt, citius senescunt.

The follow ag changes take place in the body, but more especially in the reproductive organs of both sexes.

In the male, great development of the bones, and especially the joints, takes place, which gives the animal a somewhat awkward appearance. While growth is thus proceeding in all directions, the weaker parts appear not always to receive sufficient supplies, while the strong parts acquure an excess of energy, which accounts for some portions of the animal at this period being out of proportion: for example, a three-year-old stallion will exhibit perhaps a big head with long ears, big hocks and knees, \&c. The same will apply to other domestic animals, and to man.

At this period, also, the motive organs connected with the voice are affected. The formation of the bone of the tongue (the os hyoides) is completed, and the muscles of the glottis increase in growth, which renders the voice of the man deeper than that of the youth, and the neigh of the stallion deeper and more sonorous than that of the colt, and enables the songbird to put forth his melodious note, indicating that the period of puberty has arrived. In the female the same, as regards the development of bones, takes place, but not to so great an extent. The formation of the os hyoides is accomplished, but the difference of the voice is not so well marked as in the male; there is great difference between the bleat of a lamb and that of a ewe.

At the time of puberty the circulation is increased, the vessels which enter into the secretory organs redouble their action. The glands often swell, and become painful; this tendency necessarily extends to the glandular parts of the generative organs. That the blood is specially directed to the parts subservien' to reproduction at this period is common to both sexes.

In the male the flow of blood towards the reproductive organs, accompanied by sensibility, turgescence, and heat, causes the secretion of the reproductive fluid. While this is going on internally, the external generative organs are further developed, by the production of horn and of certain callous protuberances.

In some animals the reproductive fluid communicates to all the other liquids a strong odour, which causes both the species and the sex to be easily distinguished. The effurium is a natural stimulant between the sexes.

In the female the ovaries, bodies in the uterus, secrete a particular liquid, which concurs in furnishing elements for the embryo. This is contained in vesicles, which are denominated eggs (ova), as they occur in the ovaries. An excess of vitality seems to pass to the parts which are sympathetically connected with the ovaries. The organs neighbouring the genitals swell, as also the labia, \&c., and become sensitive. The bones of the pelvis increase in strength and width.

Let me briefly describe how impregnation takes place: the female at the time of puberty has, as before stated, ova existing in the uterus; these ova become ripe, and leave the ovaries, and only require, in order to form the rudiment of a. foetus, contact with the male reproductive fluid, "semen," which the copulatory act accomplishes.

\section{BREEDING AND REARING.}

From the foregoing chapter it is evident that a slight knowledge of physiology is needed by those who breed animals, either for purposes of slow-exhibiting or for profit; consequently, in breeding pigs, care and judgment must be devoted to the selection of suitable parents. Sometimes even a good sow and good boar, if brought together, will not produce perfect progeny; and, on the other hand, if an indifferent sow be put to a good boar, the latter will often supply, in the produce, the points lacking in the female, and vice versa. Much practical experience, therefore, in this matter is needed for those seeking to be successful breeders of stock. Many mistakes are made in the purchasing of pigs by persons ignorant of the properties of live stock. For instance, the vicar of a country parish, possessing a large garden, thinks he must keep a pig or two to eat the refuse, and thus turn it to account; he sends his man John to market, to purchase the required commodity. John, perhaps, who has never had any experience in such matters, goes to market and returns with two animals, bony and poor, and of no particular breed. These, with a smile of knowingness, are presented to the owner, whose knowledge of such creatures does not appertain to them in a live state, although perhaps in the flesh his opinion might be taken for a correct one. John informs the vicar they "wuss very cheap," and he likes "'em poor, 'cause they'll be sure to eat all the garden refuse, and get fat on't." This view coincides with that previously entertained by the mastar, and consequently both he and his servant are mutually satisfied with the "day's deal." Three or four days after the establishment of a piggery at the vicarage, Farmer Dobs, who lives about a mile off, pays the vicar a visit, who wishes at once for the opininn of Mr. Dobs, 
who has bred pigs " all his life." Dobs inspects the animals, declares them "not to be his sort," and states his reasons why. They are too large of bone; too long in the leg; of a large sort, that will not come early to maturity; their coats are too long, no well-bred animal could possess such long bristles; and, moreover, two hogs, he should think, would have answered the vicar's purpose better than two sows. Oh! the vicar strictly enjoined John to buy sows for the purpose of breeding. Dobs retreats, saying, "Well, sir, then you will have a rum lot of young pigs, for the best boar in England could not bring anything good from such sows. Give a little more money, and ask some one who understands the thing to buy for you. What does John know about pigs? Why, he has been all his life, before he came to you, in Farmer Jump's nag-stable, and don't know a good pig from a bad one. How should he?" The vicar, however, having laid out his money once, does not care to do so a second time; and as he thinks his pigs will eat the garden refuse with greater avidity than purer bred ones, determines both to keep his present stock and breed from them; for whatever Dobs may say, he feels convinced that the black and white sow is decidedly handsome; his wife thought so the moment she saw it. The above short story is founded on fact, and other instances could be cited, bearing testimony to the evils likely to result from selecting coarse and ill-bred animals to breed from. Like begets like; therefore, if you seek the possession of liandsome pigs, buy, in the first place, and keep only ever afterwards, parents of quality and of "good family," as the offspring from such will most likely inherit their excellent properties, and perhaps in a superlative degree.

\section{CHOICE OF PARENTS.}

In commencing a stock from which to breed swine, it is important not to be led a stray by a mere name, which denotes a particular breed supposed to be held in high estimation, for often a pig is said to be a pure Berkshire, when it possesses neither the blood nor points of such animal; and during late years fresh breeds have sprung up, differing from former ones more in name than reality; consequently npon good form we must chiefly rely in judging and selecting parents from which to breed our future stock. Of course the history of particular breeds should be taken into account; that is, whether animals coming to early maturity are required, whether small or large breeds are desired, \&c. ; but in whatever direction our wish may preponderate, it is essential to procure animals with good points. In this particular, different judges have their $2 w n$ opinions as to what external configuration of body constitutes good points; and for this reason it will not be out of place to enumerate the different ideas entertained on this subject by others. "Good one-year bacon hogs being much in request, we must do all we can to obtain a breed well adapted for producing them. Swine of such a breed may be known by their long bodies, low bellies, and short legs. Long pendulous ears are usually coupled with these qualities, and attract purchasers."-Youatt. "Sufficient depth of rarcese, and such an elongation of body as will insure a sufficient lateral expansion. Let the loin and breast be broad. The bone should be small and the joints fine: notling is more indicative of high breeding than this; and the legs should be no longer than, when fully fat, would just prevent the animal's belly from trailing the ground. The leg is the least profitable portion of the hog, and we therefore require no more of it than is absolutely necessary for the support of the rest. See that the feet are firm and sound, that the toes lie wel! together, and press straightly upon the ground, as also that the claws are even, upright, and healthy. MIany say that the form of the head is of little or no consequence, and that a good pig may have an ugly head, it being no affair to any one but the animal himself, who has to carry it; but I regard the head of all animals as one of the very principal points in which pure or impure breeding will be most obviously indicated. A highbred animal will invariably be found to arrive at maturity, to make flesh earlier and with greater facility, and altogether to turn out more profitably than one of a questionable or impure stock; and such being the case, I consider the head of the hog is by no means a point to be overlooked by the intending purchaser. The description of head most likely to promise, or rather to be concomitant of high breeding, is one not carrying heavy bone, not too flat on the forehead, or possessing a too elongated snout; indeed the snout, on the other hand, should be short, and the forehead rather convex, recurving upwards, and the ear should be white, pendulous, inclining somewhat forwards, and at the same time light and thin. Nor would I have a buyer pass over the carriage of a pig. If this be dull, heavy, and dejected, I would be disposed to reject him on suspicion of ill health, if not of some concealed disorder actually existing, or just about to break fortl ; and there cannot be a more unfavourable symptom than a hung-down, slouching head, carried as it were about to be employed as a fifth leg. Nor is colour altogether to be lost sight of. In the case of pigs I would, in reference to any description of live stock, prefer those colours which are characteristic of the most esteemed breeds. If the hair be scant I would look for black, as denoting connection with the delicate Neopolitan; but if too bare of laiir I would be disposed to apprehend too intimate an alliance with that variety, and a consequent want of hardihood that, however unimportant if pork be the object, renders such animals hazardous speculations as store pigs, from their extreme susceptibility to cold, and consequent liability to disease. If white and too small, I would like them as exhibiting connection with the Chinese. If light or sandy, or red with black marks, I would recognize our favourite Berkshire, and so on to every possible variety of hue."-Richardson on the Pig.

Our choice in the selection of a breeding sow must be guided by the class of animal we seek, and by the purposes for which it is intended. She must consequently be selected from a breed well suited to the requirements; for instance, if pork be our object, a cross between the Berkshire and Chinese constitutes a sow likely to produce animals that come easily 
to maturity, and at the same time grow into very delicate pork, and therefore demand the attention of small owners who rear pigs for domestic use. If, however, larger (and, as it is generally considered, large meat represents larger profit than small), then perhaps the pnre Berkshire is the animal to procure, as it grows into excellent pork, grows to a large size, and arrives early at maturity. Whatever kind of sow we select, it is essential that she be free from blemishes and hereditary defects and bad habits, such as eating her pigs, bringing forth dead ones, difficult and protracted labour, \&c. It is also important that a sow possess at least fourteen teats, as a sow with only twelve nipples could not bring up a larger number of pigs, as each pig has a teat to himself, and keeps to it, so that one pig born beyond the number of teats on the mother would starve, and usually does so (when such occurs), as numerous examples have proved. The habit of lying upon young pigs, which some sows are prone to do, cannot be reckoned under the title of bad habits, but is due more to the lack of care than of a bad disposition. This evil can in a great measure be obviated by placing around the wall, and above the floor of the dormitory, a large boarding, as mentioned in the chapter on the construction of piggeries. (See page 74.$)$

The selection of a good boar is quite as important as the possession of a good sow, and in my opinion more so, as the male, if vigorous, gives the stronger impress to the progeny. A boar, to be good, should present a long cylindrical form, small bones, broad back, shoulders, and neck, wide chest, thick head between the ears, but short and small at the snout, loose skin, slight quantity of lıair, few bristles, and small, short legs, with a belly rather pendulous than otherwise. The ears, also, should be small and erect, not drooping (a point which Richardson, as quoted above, admires in sows). In my opinion neither in the sow nor boar is a long pendulous ear a sign of superiority in any particular. Years ago, when pigs were not tended as now, and when coarse breeds existed and had not been toned down by judicious crossing, then doubtless instances occurred in which animals with these elongated appendages proved themsclves to be good breeders, and producers of good pork and bacon. Such animals, in their day, were considered best, because their owners, not knowing any better-i.e., seldom being able to find pigs with fine, short, and erect ears-rested satisfied with what they possesscd; and if a particular sow with a long ear proved to be $a^{\circ}$ good breeder, \&c., then the conclusion was arrived at that a pig having a long, pendulous ear possessed one point indicative of superiority. I have seen, especially in the west of England, pigs with long, drooping ears, but such animals have usually shown bad form, and generally been coarse and illbred. Sometimes, of course, a good animal may possess a pendulous ear, but it is the exception, and not the rule.

\section{BREEDING.}

In bringing the males and females together it is always important to determine that the one be adapted to the other; in other words, that any over or under development in the former does not exist in the latter, else most likely the progeny from such animals would manifest such defect to a greater degree than either parent. It is, moreover, well to select animals from a good stock, known to produce large litters. The system of in and in breeding is much to be deprecated, and particularly so with swine, as no other domesticated animal degenerates so rapidly under the operation of this injurious custom. Where this course is persisted in, it is found that the litter's gradually decrease in size and number, until the sows become almost barren. Should, however, degeneracy occur, even under careful management, and where in and in breeding is not resorted to, then the breed should be crossed from time to time. "The Chinese and Siamese pigs will generally be found the best that can be used for this purpose, as a single, and sometimes even two crosses with one of these animals, will seldom do harm, but often effect considerable improvement. Selection, with judicious and careful admixture, is the true secret of forming and improving a breed. Repeated and indiscriminate crosses are as injurious as an obstinate adherence to one particular breed, and as much to be avoided."Youatt.

In crossing, great care and knowledge of each particular breed is requisite, in order to insure success. This being known, I trust that the chapter on the physiology of breeding will afford sufficient information to enable the breeder to pair his animals in such a manner, so as to obtain a "good cross." By judicious crossing our present excellent breed of pigs has been obtained, instances of which are met with in the Berkshire, Improved Essex, Suffolk, and Bedfordshire breeds. Our improved swine in Englind owe their great merits, not to a long line of ancestors of the same breed, but to judicious crossing, carried into effect under the advice of persons possessing scientific and practical knowledge on the important subject-the physiology of breeding.

A sow is capable of conceiving at a very early age; but to allow her intercourse with the boar at six or seven months old is most unwise, as this course tends to retard growth, and to spoil ever afterwards the breeding properties of such sow. Thäer writes- "Sows are almost always in heat until they lave received the boar. This state commences even as early as at four or five months, but they are usually a year old before they are allowed to be put to the boar. About ten months or a year old is quite early enough for a sow to be allowed intercourse with the boar; and even at a later period, say two years old, she is more likely then to produce a strong, numerous litter than she would be if bred from a few months sooner. There is only one reason which should operate in making breeders put their sows to the boar when very young, and that is when a sow shows an unusual tendency to accumulate fat. This plethoric state of body is never a good omen of a mumerous litter, nor of easy delivery, and consequently for young sows is not a desirable exhibition. To prevent this state, as above indicated, it is a good plan to put a sow about eight months old to the boar, and within two 
or three days of the birth of her litter to introduce her to the male, and so continue this course until it is deemed wise to fatten her, when it will be found that she will with unusual rapidity, and with comparatively little food, become prepared for the butcher.

The period of utero-gestation continues sixteen weeks, and very few instances have come under my notice where this period has been curtailed or exceeded, although some authorities give rather an extended margin. Youatt tells us that "the period of gestation averages from seventeen to twenty weeks, according to age, constitution, \&c., of the mother. Young or weakly sows farrow earlier than those of more mature age or stronger constitutions. It is commonly asserted that three months, three weeks, and three days is the period of gestation." From MI. Tissier's observations on twenty-five sows, it would appear that the period varies from 109 to 123 days. Be this as it may, experience tells me that sows carry their young in utero not longer than sixteen weeks, certainly never more than three days before or beyond this time- of course, barring accident and disease.

A good breeding sow can produce with impunity two litters in the course of the year; but for how many years she could coritinue to breed at this rate can hardly be determined, as few sows are allowed to have litters after they are three years old. Cases, however, are on record where sows have for a number of years been most prolific. White, in his "Natural History of Selborne," cites a case in which a sow continued to produce large litters until she was seventeen years old. "For about ten years this prolific mother produced two litters in the year, of about ten at a time, and once above twenty at a litter; but as these were double the number of pigs to that of teats, many died." Although sows will continue to breed successfully until they are seven or eight years old, it is generally considered more profitable to obtain from them only five or six litters, and immediately after the birth of the last pigs to shut them up to fatten. The plan I adopted for some years always was attended with success, or, more properly, by it strong and unusually large litters were obtained, and the mothers, after they ceased to breed, always grew into fine animals and fattened well. The sows bred from were put to the boar when about ten months old, and it was so arranged that the young pigs should be born during the month of March. Immediately after the birth of the March litter-i.e., as soon as the sow was in heat-she was allowed to have intercourse with the boar. By this means two litters were farrowed during the year. For the third time the same sow was bred from during the next year, but was then only allowed to have one litter, which was usually born about the month of MIay. After suckling her pigs for about two months, the sow was allowed to roam about a yard and paddock until August, when she was put up for fattening. The pigs born in March were kept as stores; the hogs sometimes were fattened for early pork, but more frequently were kept until they were sixteen months old, when they were "made into bacon." The second litter, immediately after leaving the mother, was fattened, and usually obtained a good price as delicate pork. My reason for always fattening the pigs born during the latter lalf of the year was, because, 1st, animals born just upon the approach of cold weather never grow into such good animals as those born in the spring; and, 2ndly, they nevcr thrive so well as those early bred, unless they are fed upon a highly nutritious food, which would be too expensive for stores; and, lastly, these young creatures, during the process of fattening, receive nutritious food, which amply remunerates the owner when they are sold to the butcher. The pigs born in MIay were fattencd for pork or kept as stores for a time, and afterwards put up for bacon; of course the sows, in either of the spring litters, if promising, were retained for breeding purposes. The mother of the three litter's was, about the month of August, placed in a sty, with a view of preparing her for the knife; and such animal was usually made into large bacon, and was fully developed in flesh and fat about the end of February of the following year, when she was sold. From the above it will be observed that the sow, when killed, was about three years old, at which age she was fully grown, and was at a good age to make into bacon; in fact, sows treated as above described have, in many instances, weighed at killing time over twenty-five score, and even a greater weight than this has been recorded.

Instances do occur where it is advisable to keep sows for a number of years, but only when they prove unusually prolific, and at the same time produce good pigs. Some of our prizewinners are the offspring of old sows, which it would be bad policy to kill, so long as they are able to stamp their excellence on their progeny. The treatment adrocated for sows will, however, for the general owner, be found profitable. The advice is based on the observations of practical men, and an experience of many years.

\section{PARTURITION.}

During the period of pregnancy a sow requires good food, gradually increased in quality until a fortnight before parturition, when the diet should be somewhat limited in quantity. She should never be left to suffer from thirst, and should always be allowed daily exercise, which can easily be done by turning her into a paddock or field during the daytime, where she can roam about at pleasure. Pregnant sows should be kept by themselves. About one month before farrowing time they must be kept in separate pens, as at this period they are heavy, and are consequently unable to withstrnd the effects of blows, \&c., which they are in the habit of inflicting on one another. The injury arising from such rough usage is by no means an uncommon cause of miscarriage, and hence the necessity of this precaution to prevent its occurrence. The sow gives indication of her near approach of farrowing time by the swelling of the vagina, depression of the back, increased size of the belly, and distension of the teats; and for a few hours previously to the birth of the soung pigs, the mother will be seen carrying about straw and hay, or some substance, wherewith to form her bed. When this is noticer she must be 
immediately placed in a sty, the dormitory in which should be very sparingly supplied with litter, as young pigs constantly burrow under the straw, and when unobserved in this position, the mother is very apt to crush them with the weight of her body during the act of lying down. The, sow also should be watched, and as the farrowing progresses each pig, as soon as born, should be placed in a warm situation. When the afterbirth has been removed the sucklings can be placed upon the teats, the weaker ones upon those which contain the most milk. If two or three be born beyond the number of nipples possessed by the mother, the weaker ones in excess should be destroyed, or given to the care of a foster-motlier, to suckle them. Parturition, unfortunately, is not always effected without danger to the sow or offspring. Sometimes before the expiration of the period of utero-gestation, the pregnant sow will manifest symptoms similar to those indicating approaching parturition, only more intense. There is generally restlessness, irritation, and shiverings, and the cries of the animal testify the presence of severe labour-pains. Sometimes the rectum, vagina, or uterus becomes relaxed, and one or the otlier protrudes, and often becomes inverted at the moment of the expulsion of the foetus, preceded by the placenta, which presents itself foremost. This is not so common to sows as to other domesticated animals, and is usually in swine the result of injury from blows, shocks, or other accident, whicl either directly or indirectly acts upon the nervous system, and ultimately upon the womb, and thus disturbs the connection between the uterus and fotus. Youatt says, "there are varions causes which will tend to produce it-insufficiency of food, eating too much succulent vegetable food, or unwholesome, unsubstantial diet. Blows and falls will also induce it; and one very prevalent cause arises from this animal's habit of rubbing itself against hard bodies, in order to allay the irritation produced by vermin, or cutaneous eruptions, to which some swine are subject."

Abortion is, in nine cases out of ten, the result of nervous derangement. It may arise, as Youatt says, from improper diet, but this acts directly upon the nervous system, ultimately impairs the nervous influence of the uterus, and consequently interferes with the health of the fotal life. The same might be said regarding the irritation caused by the existence of cutaneous disease and vermin. In cases of abortion the foetal pigs are usually dead, and it is therefore necessary to give some assistance to the sow in her efforts to remove them. This done, the parts should be cleansed and the mother treated in the same manner as after parturition. If a putrid and unpleasant smell arises after a thorougl washing with warm water, a mild solution of disinfecting fluid (Burnett's) can be used as an injection with benefit. Aroid administering purgatives, and on no account bleed, which would only be adding fuel to fire. It abortion occurs from lack of nervous force, we must endeavour to restore the due balance, which depletive measures would reduce. A teaspoonful of sulphuric acid in half a bucket of oatmeal wash will usually, in a short time, allay all irritation, both uterine and systemic. A sow, however, that has once aborted, is better placed in the fattening than in the breeding pen, unless the cause can be traced to some accident or direct injury, for a sow that has aborted with her first litter is likely to do so with her second; it is therefore better for the owner to insure himself against a recurrence of this mishap by preparing her for the butcher. Accidents also occur to pregnant sows, at the end of the period of gestation, in the form of false presentations, monstrosities, diseased uterus, and debility, which render the expulsion of the foctus difficult and often dangerous. Perhaps the most troublesome disease the veterinarian has to contend with in parturient swine is prolapsed or inverted uterus, both caused by the violent efforts made by the sow in attempting the expulsion of the fœtus. The uterus, when protruded, should be washed with tepid water, freed from all grit and dirt, and then gradually, with the greatest care and with only slight pressure, returned and kept in its proper position, through the medium of an instrument similar to that used for cows, as mentioned in my article on cattle. Youatt considers that " the easiest, and perhaps best way, is not to return the protruded parts at all, but merely to tie a ligature around them and leave them to slough off, which they will do in the course of a few days, without the effusion of blood or further injury to the animal." Many persons, even now, immediately uterine protrusion occurs, resort to the operation recommended by Youatt, but it is much to be deprecated in cases of recent prolapsus. In these cases we should use all means at our disposal to reduce it. If the bandages and instruments applied fail in this, then, and then only, as a last resource, shonld the above operation be performed. The pessary, an instrument for particular kinds of rupture, may be used with success for preventing prolapsus of the uterus and vagina in the sow; but it cannot be applied except by a qualified veterinarian, who understands the anatomy of the parts involved in the malady. The judicious application of this instrument will, however, as experience has proved. reduce uterine rupture when all other means have failed.

THE TREATMENT OF SOWS AND THEIR SUCKLINGS.

The way a sow is fed when suckling her young is more important than many would imagine. Sometimes immediately after farrowing a sow shows symptoms of fever; at other times, and more frequently, she suffers from debility. In the former case a scanty diet, consisting of a small quantity of oatmeal and boiled cabbages, should be given for a few days, and fresh water, with a little nitrate of potash in it, should be placed in the sty, that the animal may sip of it from time to time. In a case of debility our treatment must be conservative. We must give a highly nutritive food in small quantities, sis or seven times daily, gradually increasing the quantity as strength is gained. A sow should always be fed well, but not to excess. "The more carefully she is fed the more abundant and nutritious will her milk be, the better will the sucking pigs thrive, and the less will she be pulled down by suckling them." Regularity in meals should also be strictly insisted 
on, and these should be given five or six times a day, in rather small quantities, yet at the same time sufficient. Oft-repeated meals are, in small quantities, to be preferred, as large ones, given twice daily, injuriously affect the function of digestion, and thus cause a vitiated secretion of milk, which, on finding its way to the stomach and intestines of the young pigs, is likely to produce diarrhœea and other concomitant diseases. Where possible, sows should be turned out daily to exercise, either in a paddock or field; but for the first fortnight the young pigs must not accompany her, as at this early age they are unable to follow her during her perambulations. About weaning time, when the sucklings are about two months old, the sow must be fed less plentifully, and the young should get peas and other food in greater abundance. Sometimes, after weaning, a dose of physic may with advantage be given to the sow; but, as a rule, if care be exercised in weaning, and the supply of food be gradually diminished, little anxiety need be experienced on this score. Young pigs, during the first two or three weeks, can obtain all the sustenance they require from the sow, but after this they require some food in addition to her milk. At first warm cow's milk can be given, and afterwards dairy refuse, thickened with oatmeal and bran, will constitute a very substantial diet. It is never advisable to allow the sucklings to feed out of the same trough as the mother, for in nine cases out of ten she will scarcely allow them a mouthful, and will often injure them in the act of pushing them from the trough with her snout. Lastly, the food proper for the sow is of too stimulating a nature for her family In establishments in which several breeding sows are kept, apertures, just sufficiently large to admit one young pig at a time, are made in the wall of the breeding sty, communicating with the one next to it. By this arrangement the sucklings can be fed in the yard nest to the breeding sty, and thus escape maternal molestation, and be dieted in whatever manner the owner pleases.

Young pigs should not be taken from their mother until they are about ten weeks old, and some two or three weeks previously to this they should be gradually weaned in the following way:-The sow must not be fed too abundantly, and should be removed from the pigs for two or three hours daily. As time goes on this period of absence must be increased, until the young are able to obtain sufficient food from the trough, and seem to thrive with only a small quantity of the maternal milk. Sucklings, after they are two weeks old, should be allowed to follow their mother; and when she is removed from them, during the process of weaning, they can be turned into a paddock by themselves. By this means exercise, so essential to their health and growth, is necessitated.

\section{DISEASES INCIDENT TO PIGS.}

Space will not permit onr entering minutely into the subject of the diseases incident to swine, but we shall endeavour to give an account of the ailments most common to pigs, considering chiefly those which retard the progress of fattening, or render the flesh unwholesome for human consumption :-

\section{A POPLEXY.}

This is a malady common to swine, which, in nine cases out of ten, owes its origin to over-fattening. At the cattle show at Islington, in 1870, two pigs died of this disease; and that it should frequently occur can surprise no one. As high feeding and lack of exercise produces plethora, the bloodvessels become congested, particularly those of the brain, when, owing to their distended state, they press injuriously upon the cerebral substance, and thus produce torpor, leading to immobility, which, if not quickly relieved, terminates fatally. Sometimes, again, the bloodvessels of the brain become ruptured, and death immediately results; in fact, of apoplexy we are seldom able to prognosticate favourably. Youatt informs us that sometimes it will run like an epizootic through a whole piggery. If so, it is evident that some potent cause (most likely to be found in the feeding) operates in producing it. The prominent symptoms of this affection are general dullness, drooping head, staggering gait if locomotion be attempted, congested eyeballs, associated with partial or entire loss of sight, and insensibility to pain. When these symptoms are observed, our treatment must be directed to relieving the distended bloodvessels, which may be accomplished indirectly by bleeding at the ear, or any part the owner may determine, and emptying the stomach and intestines of their contents by administering an emetic (potassio-tartrate of antimony) to induce vomiting, and afterwards by evacuating the intestines through the medium of a brisk purgative, consisting of two to three ounces of Epsom salts. The application, also, of cold water, or still better, ice, to the head, in the region of the brain, will be attended with benefit. If the patient recovers, great attention must be paid to the diet; no stimulating food must be given, and from time to time small quantities of nitrate of potash and sulphur may be mixed in the wash with advantage. If this affection assumes an epizootic type, the pigs within the piggery must be judiciously dieted. Stimulating food must be withheld, and doses of Epsom salts, about two ounces to each pig, must be given occasionally until health is restored.

\section{MEASLES}

This is a disease which injurionsly affects pigs during life; and, after slaughter, renders the flesh unfit for human food. Many authors have described the symptoms and post mortern appearances of this malady, but few have "told the whole truth" regarding it, simply because the knowledge they possessed of it was very limited. One, for instance, writes"The symptoms are redness of the eyes, foulness of the skin, depression of spirits, decline or total departure of appetite, small pustules about the throat, and red and purple ermptions on the skin. These are more plainly visible after death, when they impart a peculiar appearance to the grain of the meat, with fading of its colour and distension of fibre, so as to give an appearance similar to that which might be produced by puncturing the flesh." M. Dupuy records a case of para- 
lysis of the hind extremities, noticed in a pig the subject of measles, which was produced by the existence in the muscles (psoce) of " numerous cysts, inclosing hydatids; these being in close contact with the lumbar vertebræ, had caused softening of the spinal marrow in that region, and consequent paralysis." Youatt tells us that measles has been regarded by many as a mild form of leprosy, and he considers this opinion as not erroneous. But whatever may be in this, measles, it is evident, are a subcutaneous disease, produced by inattention to hygienic laws, and so injuriously interfering with the sale of pigs, that in several parts of Germany a law has for many years existed, which compels the vendor to give a "warranty of four weeks against measles, and other cutaneous eruptions, in swine." Youatt, although he was by no means confident in his opinion, had an idea that perhaps this malady was of a parasitic nature, as appears from what follows:- "It yet remains to be discovered whether measles in swine is an epidemic like that disorder in the human being, or whether it is hereditary, or whether, as many suppose, it arises from the development and presence of a variety of the cysticercus." It has of late years been ascertained, and proved beyond doubt, by the researches and experiments of Küchenmeister and Von Siebold, that measles in the pig is produced by the presence of a vesicular worm, which invades the muscular tissue. This hydatid, the Cysticercus cellulosa, is (like the Cænurus cerebralis of the sheep, oefore described) an incomplete individual; i.e., the Cysticercus cellulosa, if eaten by the dog, would develop in his intestines into a tape-worm, or complete individual; and again, if segments of this tape-worm were devoured by the pig, they would cause the existence, in his muscular tissue (the proper habitat), of numerous Cysticerci cellulosæ; in fact, would create measles. From this, therefore, it will be observed that, if no tape-worms existed, no Cysticerci cellulosæ could be created. The hydatid is, by metamorphosis, converted into a tænia, which breeds the cysticercus, or primary generation, which in the intestines of another animal developes into a tape-worm. The ordinary habitation of the cysticercus is the flesh of the pig; and we find the Tænia solium is almost entirely unknown where the use of the flesh is avoided-as, for example, amongst those whose religion forbids them to eat pork, the flesh, as they consider, of an unclean animal. "The reason why we find Tænia solium so plentifully in butchers and their families is, that the butchers contaminate their own hands in sausagemaking, and also the blades of their knives in cutting up and selling beef. When they now wipe their mouths with the hands thus contaminated, or place the knife bedaubed with cysticerci in their mouths, or, lastly, transfer these cysticerci from the knife to the bread or sausages which they cut up for themselves, their families, or servants, the insignificant and scarcely perceptible cysticerci are introduced into the month and swallowed." These cysticerci, as before explained, in the intestines of man produce the tape-worm known as the Tænia solium, provided the meat infested with them be raw or partially cooked; for it appears from numerous experiments, that during the process of roasting or boiling meat the cysticercus is destroyed, and consequently rendered incapable of developing into the 'T'mia solium.

\section{EXPERIMENTS OF FEEDING WITH TAPE-WORM.}

Küchenmeister administered to three sucking pigs the segments of tape-worms on the $7 \mathrm{th}, 24 \mathrm{th}$, and 26th of June, and 2nd July. One of these pigs was killed on the 26th of July, and "exhibited young cysticerci, corresponding with the day's administration, of which the largest individuals formed vesicles of the size of a hemp-seed, with a certain turbidity; i.e., the commencement of a head. The second pig was killed on the 9th of August, when thousands of cysticerci were found in all parts of the body. The largest individuals were as large as peas, and exhibited a distinct head, whilst the smallest were only of the size of hemp-seed. The third pig, which was killed on the 23rd of August, was uniformly set, throughout all parts of the body, with cysticerci of various degrees of growth and development. I undertook the examination of a weighed piece of flesh, and found 133 Cysticerci cellulosæ in four and a half drachms of it. If we calculate from this quantity the number of cysticerci which would have existed in one stone of pork, we obtain the great number of 88,000 individuals in this weight. A fourth pig of the same litter, to which no tæniæ had been administered, exlibited no traces of the cysticerci on dissection.

EXPERIMENTS OF FEEDING WITH CYSTICERCUS CELLULOSA.

In order to discover from which kind of tape-worm the Cysticercus cellulosa was produced, Von Siebold instituted the following experiments:-1st, a young dog was fed on the 22nd of May with forty-four cysticerci; on the 24th, fourteen more were given him, and on the following day, thirty-five. Before the worms were given they were taken out of their cysts. The dog was killed on the 3rd of July, which was thirty-nine days after the last feeding, and fortytwo days after the first. Only four tape-worms of two inches in length were found in the dog's small intestine. From their appearance they were evidently the product of the cysticerci which the dog had swallowed. 2nd, Having procured two cysticerci from a human brain, which when put into water thirty-six hours after the death of the subject, still moved, I would not, few as they were, allow the opportunity to pass of making an experiment of feeding with them. The young dog fed upon them, however, when killed, showed not the slightest trace of tape-worm or scolex. 3rd, On the 18th of June a young poodle swallowed forty-two cysticerci from the pig, deprived of their cysts. The examination of this dog on the 4th of August, fifty-one days after feeding, showed eight tape-worms of different lengths. The smallest individual measured $1 \frac{1}{4}$ inch, a few others measured $5 \frac{1}{2}$ to 171 inches, a larger individual was $25 \frac{1}{4}$ inches long, whilst the three largest had attained the length of 51 inches. Notwithstanding the length which the worms had attained, and the great number 
of their joints, Von Siebold could discover no perfectly developed eggs in any of the latter. 4th, To a young pug dog thirty cysticerci without cysts were administered on the 11th of July, and forty-five on the 17th. On the 21st of July the dog was killed. On inspecting the small intestines forty-eight scolices were found, of which the shortest measured one line, and the longest six. All bore the characteristic scar on the posterior extremitics. The smallest individuals consisted of nothing else than the head and neck of the Cysticercus cellulosa. The remaining and somewhat longer individuals had a transversely wrinkled body, which as yet bore no traces of joints. 5th, On the 8th of August, a young setter was fed with forty-five cysticerci, which were still in the cysts and inclosed flesh. On the 21st of August this dog was likewise killed. In his small intestines a few tape-worms were found in course of development, of $\frac{3}{4}$ of an inch in length.

From the recorded experiments, it is evident, first, that if tape-worms, either the Tænia solium or Tænia serrata, be administered to pigs, they will produce within them the cysticerci ; and second, if the cysticercus be given to dogs, it will develop in their intestines into a tape-worm. The old doctrine of spontaneous generation, caused by the accumulation of filth and other causes, which the advocates of this theory have from time to time brought forward, and particularly regarding measles in pigs, entirely falls to the ground; and as fresh light is thrown upon the important subject of parasitic existence, I feel confident that not only will it be proved that many intestinal worms commence life as hydatids, but that other parasites of a microscopic character are produced by a metamorphosis from some still smaller creature, which the microscope has as yet failed to detect.

VON GIEBOLD'S REMARKS ON THE EXPERIMENTS OF FEEDING WITH CYSTICERCI, AND TIIE SIMILARITY OF THE TENIA SOLIUM AND TANIA SERRATA.

"I must here remark that the dogs I made use of for the second, fourth, and fifth experiments, were troubled with the distemper, a thing of common occurrence amongst young dogs, and that the disease had probably had an injurious iffect upon the development of the tape-worms. Notwithstanding these experiments of feeding the dogs with Cysticercus cellulosa afforded no such completely favourable results as the foregoing series, they nevertheless went far enough to prove that the Cysticercus cellulosa may also, in the intestine of the dog, become developed into a tænia.

"The few tænia which were obtained from these cysticerci were, moreover, a source of great perplexity to me; for when ] attempted to define the species to which they belonged, I was doubtful whether to consider them as appertaining to the Tænia serrata or to the Tænia solium. The head and perfectly developed joints accorded with either species, only the neck was longer and more slender than that of Tænia serrata, so that I was inclined to regard them as Tænia solium. Oring to the resemblance of these tape-worms, Tænia serrata and solium, to one another, I was induced to submit the specimens of 'Trenia solium in my collection to a more Bearching examination, and to compare them with the examples of the 'Trnia serrata taken out of the dogs. 'To my no small astonishment I found individuals amongst tania which had bcen taken from the human subject, that were not to be distinguished from Tænia serrata. They had the short broad joints, with transversely wrinkled integument and undulating posterior edge, just like 'I'ænia serrata; the head, too, was formed exactly like tlat of the latter, though the neck was mort elongatcd. Besides these, there were a few fceble individuals amongst them which fully corresponded with some of the tapeworms produced from Cysticercus fusiformis; and the eggs of the Tænia solium were not distinguishable from those of the Tænia serrata, so that I was forced to conclude that Tænia solium and Trenia serrata were identical. In order to obtain a still clearer insight into the matter, I further compared the heads, with their apparatus of hooks, of Cysticercus fusiformis, longicollis, and cellulosa with one another, and in these also I could find no difference.

"With regard to the length of the neck, and the circumference and contour of the joints, though there are, as I have already partly shown, discoverable differences, they are not sufficiently marked to rank as distinctive characters of two species of tape-worms, and I must therefore maintain that Tænia solium and Tænia serrata belong to one and the same species; that they are the extreme forms of a single species, connected by a series of transitional forms."

In the year 1857, Mr. Rainey presented the Royal Society of London with a paper on the structure and development of the Cysticercus cellulosa, in which he proved that this hydatid's presence in the muscular tissue of pigs constituted the "measled pork" of the London markets, and which, owing to its importance, is transcribed below.

\section{THE DEVELOPMENT OF THE CYSTICERCUS CELLULOSA.}

"The earliest indication of this species of cysticercus which admits of certain recognition as a form of cystic entozoon, is the presence of a collection of reniform corpuscles of about 1-2666th of an inch in length, and 1-\$000th in breadth, mixed with very minute, highly refractive molecules, of different sizes, in the substance of a primary fasciculus of a muscular tibre, or between its sarcolemma and the sarcous elements.

"Though such a collection of corpuscles has a moderately definite shape, being somewhat fusiform, yet it has not a complete investment. It soon, however, acquires a very distinct membranous covering, which is first apparent at its middle, and afterwards at its extremities. Its dimensions in this stage of formation may be about 1-150th of an inch in length, and 1-1500th in breadth, but these are by no means regular. The external investment at first appears as a bright line of homogeneous substance, best defined on the side next the sarcous matter. It soon, however, increases in thickness, and afterwards becomes converted into short fibres, which increase in size and distinctness as the animaleule grows 
larger. These fibres are peculiar; there is nothing that $I$ am acquainted with analogous to them. They have not the sharp and well defined outline of true cilia, vor are they pointed like setæ, or curled like cirri. They have somewhat the nature of white fibrous tissue, their distinctness being impaired by acetic acid. They are of different lengths in the same entozoon, and generally longer, though not thicker, in the large than in the small ones. Their length averages about 1-2100th of an inch.

"The most remarkable circumstance connected with them is the great uniformity of their arrangement in different cysticerci. They cover the whole of the onter surface of the membrane, and on opposite sides of the same entozoon their form, size, and direction are similar, so that the two halves taken longitudinally are in this respect symmetrical. If the direction of these fibres be examined about midway between the two extremities of one of these animalcules, they will be seen to project from the surface at right angles with the axis of its body; but if traced each way from this point, they will be observed gradually to incline to this axis at an angle which keeps diminishing as they approach the two extremities, so that the fibres nearest the two ends almost coincide in their direction with that of the axis, and thus correspond in their situation to the barbs situated on each side of an extremity of an ordinary feather.

"As the first position of these animals is in the very substance of a primary muscular fasciculus, it is obvious that the mechanical action of this apparatus will be to aid their longitudinal development whilst new cells are in progress in their interior. For it is scarcely possible that the muscular fibrillæ by which they are surrounded can, when in action, fail by their friction to urge the two extremities onwards in opposite directions, whilst at the same time the fibres by which these entozoa are corered, are in consequence of their direction preventing the separated ends from regaining their former position; and thus the two ends beings always carried in opposite directions, without the possibility of a counter movement, a general elongation must ensue. This apparatus also, by splitting up the primary fasciculi, will serve a locomotive purpose, and thus enable these animals to reach the cellular intervals between the muscular fibres, where their further development will be completed. That such is the effect of the fibres in question is evident on a careful inspection of some of the fasciculi in which these animalcules are contained, in which a separation of the fibrilla can be seen to have been produced by the pointed ends of the entozoon; these fibrillæ having been obviously turned out of their original course, and some directed to one side, and some to the other. This explanation receives confirmation from the fact of these cysticerci, which are developed in the muscular parietes of the heart, being of a different shape from those formed elsewhere, although the structure in all other respects is precisely the same. These cysticerci, in the first or vermicular stage of their development, are very short and thick, and of an oval shape. Their locomotive fibres, though perfectly demonstrable, are very short, and in meny instances imperfect.

"After these cysticerci have reached the spaces between the muscular fibres, their subsequent development is the same as in other situations, and the perfect animals formed in the heart cannot be distinguished from those formed in other muscles. I may also add, that while in the vermicular stage, the cysticerci developed in the short muscular fibres of the tongue are of a shape resembling very much those of the heart.

"The investing membrane, which has just been described as covered with cilia, is entirely filled with corpuscles, all of one kind, remarkably characteristic, and differing only according to their states of development. The perfect cells are best seen in the middle of an entozoon, but their mode of formation, and the subsequent changes which they undergo, must be examined in those parts which are increasing most rapidly, as in the growing ends of an animalcule.

"The first appearance indicative of an increase in the length of an animalcule is a thinning of the investing membrane, and a separation or partial detachment of the cilia-like fibres of the growing end. Next, a clear space, of the form of the part which is about to be added, is perceptible a little in advance of the extremity, apparently the result of a very fine membranous protrusion. This contains numerous dark molecules of different forms and sizes, mixed with granules more or less perfectly spherical : the most perfect of these globular bodies are those which are nearest to the perfectly formed part of the animalcule. These corpuscles, when completely formed, have a bright oily-looking aspect, and a diameter of about 1-5000th of an inch.

"These corpuscles have the appearance of being formed by the coalescence of molecules which had existed in the clear space before any corpuscles were apparent, by which they are afterwards replaced. After a growing end has become thus filled with these globular bodies the terminal membrane becomes more and more distinct, and the cilia-like fibres are afterwards added, which are generally neither so regularly disposed, nor so distinct, as on other parts of the entozoon. Next, these corpuscles lose their spherical form and become flattened; and lastly, they assume their characteristic elliptical or reniform figure before mentioned, which they retain as long as the entozoon remains in its primary muscular fasciculus. This shape, however, is not essential to those corpuscles, but merely results from the rounded form of the masses into which they are grouped together, each corpuscle, by its convexity, forming a segment of the circular outline of its respective group. These corpuscles contain very fine dark granules, so variously disposed in different ones as to present a variety of appearances, such as circular or oval spaces which might be taken for nuclei or nucleoli. These collections of corpuscles make up nearly the whole of an animalcule, and they frequently give to it a lobulated, and sometimes an obscurely annulose, appearance.

"The entozoa, as loug as they remain in the primary fasciculi, retain all those characteristics which have so far 
been described; but these characteristics gradually disappear after they have broken away from the cavity of the sarcolemma, and gained access to the spaces between the muscular tibres. In this situation they gradually lose their former membranous clothing, studded with cilia-like fibres, which can occasionally be seen partially deprived of its corpuscular contents, though sufficiently perfect to admit of demonstration. The reniform corpuscles, before aggregated together in circular groups, now gradually lose their distinctness of outline, and imperfectly coalesce into confused, ill-defined masses, having an oily aspect; so that if, in this state, one of these vermicules be crushed under the microscope, amorphous, oily, and granular matter will be seen to have escaped from it, similar to that contained in the ventral part of the adult animal. Here, too, the restraint to the lateral growth of these entozoa being very much diminished, their breadth increases rapidly, and they present globular projections, extending out very irregularly from their sides, giving them an irregular figure. These projections gradually take on the form of those which were described on the ventral part of the perfect entozoon. The largest of the entozoa which I have seen in this stage is about 1-12th of an inch in length and $1-40$ th in breadth.

"The next facts requiring special notice are those connected with that stage of development which takes place after the animalcule has become surrounded by an adventitious cyst. The first indication of the formation of such a cyst is, the turgescency of the capillaries, or some of the smaller vessels in the vicinity of one or more entozoa. Granular bodies, exudation-corpuscles, and fibres of different shapes, next make their appearance. These at first only partially obscure the entozoon, but afterwards completely conceal it. When the cyst is first formed the animalcule can, by a good light and careful examination, be obscurely seen within it, and by dissection under the microscope it can be dislodged.

"The interior of the cyst being smaller than the animalcule contained therein, it naturally follows that during its growth one portion must be folded over another. By this means it is adapted to the fine locality in which it is lodged during the period of its development. Hence the ventral portions of all cysticerci are, when first taken from their cysts, very much plicated; but t\},ese plicæ disappear after the ventral sac has become distended with the fluid brought into contact with its surface.

"Up to this point of the development of the cysticercus, it is a simple cyst, growing by the assimilation of fluid imbibed equally by every part of its surface, no one part differing sensibly in its structure from another. No portion of this surface presents any indication of incipient hooklets or suckers. There is nothing on its surface, or in its interior, analogous to the structure of an ovum; nor is there any other anatomical character which would raise its organization above that of a simple acephalocyst. However, this so exactly resembles in its structure that of the ventral portion of the cysticercus, that it is impossible to doubt their identity of character. Its size, too, is not much beneath that stage where the sucker and hooklets first begin to present obscure indications of the part they are about to occupy.

"The first indication of the addition of the neck, with the suckers and hooklets, to the ventral part of a cysticercus, it the appearance about its centre of a slightly raised body, depressed in the middle, with longitudinal folds proceeding from each side of it towards the poles of the ventral cyst, appearing as if at this part the parietes of the latter had been drawn inwards. On two sides of this hollow there are dark transverse lines, rather more distinct on one side than the other, indicating the commencement of the transverse rugæ of the neck, mentioned in the description of this part of the perfect animal, in which the laminated carthy bodies are contained. About the central part of the cervical projection there is an ill-defined oval space, having a granular appearance, and containing some minute spherical particles of a dark colour, consisting apparently of a highly refractive material. In this condition of the entozoon there is nothing in this space which has the shightest resemblance to the parts which are there about to be developed, namely, the hooklets, suckers, and earthy concretions; and it is only by the comparison of these obscure appearances with the other specimens, in which the development of the hooklets is a little more adranced, that their true signification can be learned.

"From the facts that have just been mentioned, the hooklets of the animalcule in question do not appear to be formed by cell development; for by the most careful examination of these organs, both recent and after the application of acids, I have not been able to distinguish anything that can be looked upon as a cell or cell-nucleus, calculated to give the idea of their being developed from previously existing cells, or in dependence on cells; but, on the contrars, all the various forms which they present, dnring the process of their formation, simply indicate the coalescence of very minute spherules of a homogeneous material, exceeding the number of a complete set of hooklets, into small globular masses, and these again into larger pieces, and so on successively until recognizable portions of hooklets come into view, which, coalescing, build up, as it rere, an entire organ.

"It is worthy of remark that, if these structures had bcen produced directly from the metamorphosis of previously existing cells, the circumstances connected with their formation would have been the most favourable for observing both the original cells and the changes which they pass through; indeed, so much so that it is almost impossible that they could lave escaped notice. First, because these parts are of such a size and degree of transparency as to admit of examination with the highest powers of the microscope, without the necessity of disarranging them or disturbing their position by manipulation. Secondly, because the material of which they are composed is so dissimilar in appearance to that forming the adjacent tissue, and so characteristic, that it cannot be confounded with the structures in their immediate vicinity. Thirdly, because at one view, in s farourable 
specimen, hooklets can be seen in every stage of their formation, from the first grouping together of the masses of formative particles, to the blending of them into perfect organs. And lastly, because it is not as if a mere thread of tissue were formed amongst other threads, slightly differing in appearance, as fibres of elastic tissue, for instance, in a mass of connective tissue, but the objects referred to are perfect organs, which possess an arrangement of parts connected logether with order and remarkable regularity; so that, under such circumstances, if these organs had heen preceded by nncleated cells, and the cells had been transformed into hooklets, neither these cells in their primitive state, nor in their several stages of transformation, could have escaped detection.

"The parts next to be noticed are the suckers. Indications of these are visible as soon as the hooklets. They appear as four circular spaces, presenting a granular aspect about the size of perfectly-formed suckers. The two sets of fibres next make their appearance, the radiating and circular, which have not at first the sharp outline which they afterwards acquire, but still appear obscurely granular. As the tissue of these organs possesses nothing characteristic, like that of the parts just described, the progressive changes which they undergo, during the different periods of their formation, can be but imperfectly distingnished, $a^{\lambda}$ hence no further description of them will be necessary.

"It has been observed, in the two sets of organs above aescribed, that their size does not increase materially after being once formed. Exactly the reverse is the case in reference to the part called the neck, and the quantity, though not the size of the laminated bodies, which increase in number as the cavity of the latter increases in size. These bodies appear as soon as the hooklets and suckers, and they are as large when first formed as afterwards; but there are indications of the transverse wrinkles of the neck before either hooklets or snckers can be distinguished. The neck afterwards continues to grow, so that its relative length, in respect to the ventral portion, is some indication of the age of a cysticercus.

"It is probable that this part does not arrive at its full size until after it has been protruded, which I have never seen to be the case in any animalcules occurring in or between the muscular fibres, and which perhaps is not effected until the entozoa quit their confined locality between the mnscular fibres, and gain access to the free surface of a mucous membrane, there, as physiologists generally believe, to be further developed into a higher form of entozoon."

The ancients were in the habit of adopting a varied nomenclature for diseases whose origin was somewhat obscure, and particularly those where a suspicion existed that they were of a parasitic nature: for instance, measles in pigs sometimes received the name of "leprosy," and when it assumed an epizootic type it was designated "murrain," as appears from the fact that the symptoms detailed as characteristic of the one and the other are identical; and the treatment recommended for "measles," leprosy, and murrain, is not very dissimilar. Youat, in describing the symptoms and treatment of leprosy, writes- "In the onset, all that is remarkable is a certain marked stupidity or obstinacy in the animal, a state of languor and apparent general debility, an evident thickening of the skin, a slight adhesion of bristles, a tendency in the hair to fall off. In its successive progress this disease attacks the animal economy more or less profoundly, without the functions appearing otherwise troubled. There is ulceration of the cellular tissue, and the animal does not appear to be generally and seriously ill. Far from losing his appetite, he is occasionally voracious. Me does not appear to suffer in his lungs, his breath is not embarrassed, nor is his voice loarser than usual. Such, at least, may be observed when the vesicles are not numerous. It is when they increase in quantity that they begin to affect the health of the patient. He then becomes indifferent to everything, moves about slowly, totters as he walks, his eyes are dull, the buccal membrane is pale, and sometimes strewed with violet spots. Strength begins to abandon the patient, he can no longer sustain bimself on his legs, the posterior part of the trunk becomes paralysed, and the body exhales an unpleasant smell. This is a very obstinate disease, probably from its having usually taken hold of the system before it is suspected, and numerous have been the medicaments recommended for it. Antimony, sulphur, small and repeated doses of Epsom salts, and general bleeding, seem to se attended with success, and these are aided by a strict attention to diet and cleanliness." Numerous have been the opinions advanced relative to the predisposing causes of measles. 3̈ome authors attribute it to the inclemency of the weather, insufficient food, and damp localities; and support their views by asserting that the disease is always more prevalent among swine when turned into woods and forests, than when lodged in piggeries where a judicious system of dietary is adopted. Others attribute the disease to bad water-containing compounds injurious to health-and to improper food. These opinions, as will be apparent from the remarks made regarding the cysticercus, did not tend to throw much light upon the origin of measles. But the assertion that animals feeding in forests, \&c., are more prone than others to the disease, and that bad water and improper food are causes of it, demands some consideration; for no doubt, indirectly, the food obtained in these locations furnished the media wherein the tape-worm (the breeder of the cysticercus) existed. For instance, the Tænia solium existing in the excrement of man, or the Tænia serrats in that of the dog, might become deposited in the forest land, and be devoured by the greedy pig, which might thus impregnate itself with the cysticercus. Again, trough fcod, consisting of blood and the entrails of other animals, might contain segments of the tape-worm, which, eaten by swine, would be sure to produce the disease.

The only rational treatment for this affection, where existing, consists in the destruction and removal of the cysticercns from the muscular tissue of the pig; but to effect this, no medicine has been as yet discovered. Our endeavonr, 
Q 2

a

20 

therefore, should be to prevent its occurrence by feeding our pigs upon aliment which cannot, by any possibility, contain the segments of tape-worms. If no tænia existed, no cysticerci could be bred; therefore, by reducing the supply of the former, we should be diminishing the means for the diffusion of the latter. It is a fact wortly of notice, that mations which are prohibited from eating pork are seldom affected with tapeworm; and Tacitus states he considered that the Jews were forbidden to eat pork because the flesh of the hog was liable to become leprous. Doubtless the communities which obey this law are to a great extent exempt from the attack of tapeworm. The flesh of the hog affected with measles is soft, Habby, and almost tasteless; and whatever anthors may say to the contrary, is totally unfit for human food. As before stated, thorough cooking destroys the life of the parasite; but some portion or portions of the flesh may escape the action of the fire to the extent necessary to destroy the eysticercus. Under any circumstances measly flesh should be burnt, and not given to any animal. In man, soup made from it has produced romiting and diarrhœea, and other evil consequences which it is needless here to detail. Suffice it to say, measly pork, containing living cysticerci, if eaten, will produce tapeworms. If not thoroughly cooked, it will, in like manner, cause the development of tæniæ; and the flesh infested with cysticerci, even if thoroughly cooked, is otherwise unwholesome, and totally unfit for the food of man or of any other animal.

QUINSY OR STRANGLES, MALIGNANT SORE THROAT OF THE PIG.

According to ancient authorities, disease of the glands in the region of the throat was in their time very prevalent among swine. H. D'Arboval gives a long account of this affection, which lie designates by the names Poil piqué, maladie piquante or soie, and regards as the result of cutaneous irritation, which, sympathizing with some internal ailment induced by too stimulating food, hot or ill-ventilated sties, and damp litter, determines this local disease of the glands. Others believe that miasmatic influences produce it, and that it rages as an epizootic. The discase consists of a swelling, extending around the throat and down the line of the trachea; great thirst, dullness, loss of appetite, accompanied with pain, and general symptoms of fever prevail. As the malady increases in intensity, laborious breathing, swelling of the tongue, and difficulty in swallowing supervene, and often the patient dies of suffocation. Sometimes the skin is raised in hard swellings along the sides of the neck and trachea, and at times between the fore legs. The treatment consists in giving an emetic, as-

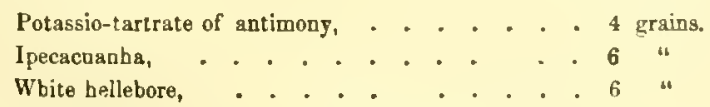

If the animal will drink or eat a little, Gamgee recommends that a purgative powder, consisting of two or three drachms of castor oil seeds, should be given. $A$ blister or hot rugs applied to the throat also assists the treatment.

In carbuncular quinsy the tonsil on one side of the neck is affected; the bristles in the skin of that part stand out erect, and if pulled cause great pain. The post morten appearances give evidence of acute inflammation of the laryns and pharyns, and of the tonsil on the affected side. As the disease is of a contagious nature, it is necessary to separate the healthy swine from those affectcd, and to keep the latter scrupulously clean, as the spreading of the malady is sand to be favoured by dirty sties and neglect of hygicnic measures. Cold water with nitre in it should be placed before the patients, in order that they may drink it at their pleasure, and if constipation prevails, drachm doses of aloes can be administered.

The diseased tissues, moreover, must be removed with the knife or actual cautery, and afterwards the system must be supported by stimulants and food easy of digestion, as oatmeal gruel, \&c.

\section{CALCUlOUS CONCRETIONS OCCURRfNG IN THE OX, SHEEP,} AND PIG.

The word calculus (derived from the Latin calx, "lime") is a term used to designate certain concretions occurning in the abdominal viscera of nearly every living animal; they may be divided, first, into calculi found in the alimentary canal: secondly, into urinary calculi, or those met with in the urmary organs; and thirdly, into casual calculi, which include those found in various glands of the body, \&c. Alimentary calculi are of two kinds: those which occur in the stomach, and called stomachical; and those which exist in the intestines, denominated intestinal.

\section{STOMACHICAL CALCULI.}

Globular masses of hair, called hair-balls, are commonly met met with in the stomach of the ox. They are of different forms, and vary in weight from a few ounces to seven or eight pounds. Their composition also varies; sometimes they consist solely of hair matted together with mucus. This is the case when they are found in the abomasum; the animal whilst licking itself takes the hair from its skin into its stomach, through the medium of its mouth. Sometimes these hair-balls contain a nucleus or centre, consisting of a small piece of wood, stone, or iron, such as a nail, around which the hair aggregates. Other concretions are met with in the rumen and reticulum, which are generally composed of a mixture of food and earthy matter and hair.

"When simple food," says Youatt, "mingles with the hair, the ball seems to be formed by a succession of concentric layers, and in the centre a bit of nail or stone, or if the beasts have access to running water, a piece of shell often constitutes the nucleus." 'l'he existence of these concretions in the stomachs of cattle seldom affects their health. Some authors assert that lean cattle are more subject to them thau those that are well nurtured; but my experience tells me, 
that they are as constantly met with among fat stock as others: in fact, their presence in cattle which during the process of fattening have " done well," has never becn detected until after death, and it is therefore evident that in the stomachs of ruminants they seldom produce injurious results.

\section{INTESTINAL UALCULI.}

These are of rare occurrence among cattle. Youatt informs us that they are very seldom, but sometimes, found in the large intestines. "They are not of great size, for the food passes too rapidly over the smooth surface of these portions of the digestive canal. There are no symptoms by which their presence can be recognized, nor is there any evidence of their being a cause of disease; although it is not improbable that the presence of these bodies, and the irritation produced by them, may in some instances be the cause of colic, strangulation. and other serious affections."

\section{URINART CALCULI.}

Urinary calculi are of three kinds, viz., those found in the kidneys, called renal; those met with in the bladder, or vesical; and those of the urethra, denominated urethral calculi.

The kidneys, as the reader knows, secrete the urine, which by means of two ducts called ureters is conveyed into the bladder, and thence finds its way into the urethra. In these positions, as stated, calculi occur, arising, it may be, from an altered or vitiated secretion of urine, or from deranged functional vigour 'Renal and vesical concretions are of common occurrence among herbivorous animals; they usually consist of carbonate of lime, mixed with a small quantity of carbonate of magnesia and a considerable portion of anımal matter. "Traces of phosphate, oxalate, and sulphate of lime, with various saline ingredients of the urine, may often be detected." Carbonate of lime concretions from the ox are seldom of large size. Those from the kidney rarely exceed an inch in length, while those in the bladder are usually about the size of peas. The latter generally occur in great number, often amounting to several hundreds. They are small rounded globules, usually smooth and polished on their surface, but occasionally tuberculated, resembling mulberry concretions. Whether occurring in the bladder or in the kidney, they are generally remarkable as presenting a pearly, metallic exterior. When broken they readily separate into thin concentric layers. The tuberculated calculi, on the contrary, are exceedingly hard, and do not separate into layers when broken.

The calculi met with in the bladder of the hog differ little in their cliemical character from those found in the urinary organs of the Herbivora. They vary in size from "a pea to a hen's egg." Their exterior is granular or tuberculated. of liwe.
'They are extremely hard, and when sawn through exhibit a compact laminated structure, with the appearance of indistinct lines radiating from the centre. Urethral calculi commonly occur among cattle and sheep, and their existence is usually attended with great discomfort to the animals affected. Several cases are recorded in which ruptured bladder has resulted from their presence. Two oxen who fell away in condition, and were otherwise unwell, were killed some years ago in Norfolk, when at a post mortem examination the cause was discovered. "In the urethra several calculi, varying in size from a bean to a pin's head, were found." This obstruction in the urethra prevented the free escape of urine; the bladder, in consequence, became persistently distended, until its walls grew thin and weakened, which ultimately gave way (by rupture) to the pressure produced by the presence of an inordinate quantity of urine.

\section{CALCULI IN THE URETERS.}

Of these Youatt gives the following description:-— There can be no doubt that many calculi descend from the cavity or pelvis of the kidney into the bladder, yet there is but one case on record of it. The case is relatcd by $\mathrm{H}$. d'Arboval. Gattoin sent to the Society of Agriculture a history of the sickness and examination of a cow, in the left ureter of which many calculi were found, that had produced corsiderable dilatation of the canal. They were of a brilliant metallic brown colour; they were polished and heavy." In cases of this nature Chorbert recommends cutting through the rectum and ureter, and extracting the stone.

\section{Casual calculi.}

Biliary calculi are found in the gall-bladder of oxen, and are chiefly composed of the colouring matter of the bile. In the catalogue of calculi at the museum of the Royal College of Surgeons we find the following description of biliary calculi:-_"These concretions have been known for a very considerable time, probably long before biliary calculi had been discovered in the human subject. They are of a rich, reddish brown colour. They are exceedingly light and friable, and readily separate into concentric layers. 'They vary in size from that of a pea to that of a hen's egg, and are usually of an ovoid figure; but when two or more calculi are con. tained in the gall-bladder they often present a very regular cubic or tetrahedric figure. These calculi always possess a musky odour, which appears to be peculiar to the concretions of the ox." "lhe chemical composition of biliary calculi, according to Andral, consists of five concretions--yellow colouring matter, resin, cholesterine, picromel, and phosphate 


\section{N D E X.}

Nore. - This Index has been arranged in sections, each named in accordance with the various divisions of the work itself: a system which will greatly facilitate reference to any particular subject.

\section{VARIETIES AND MANAGEMENT OF THE HORSE.}

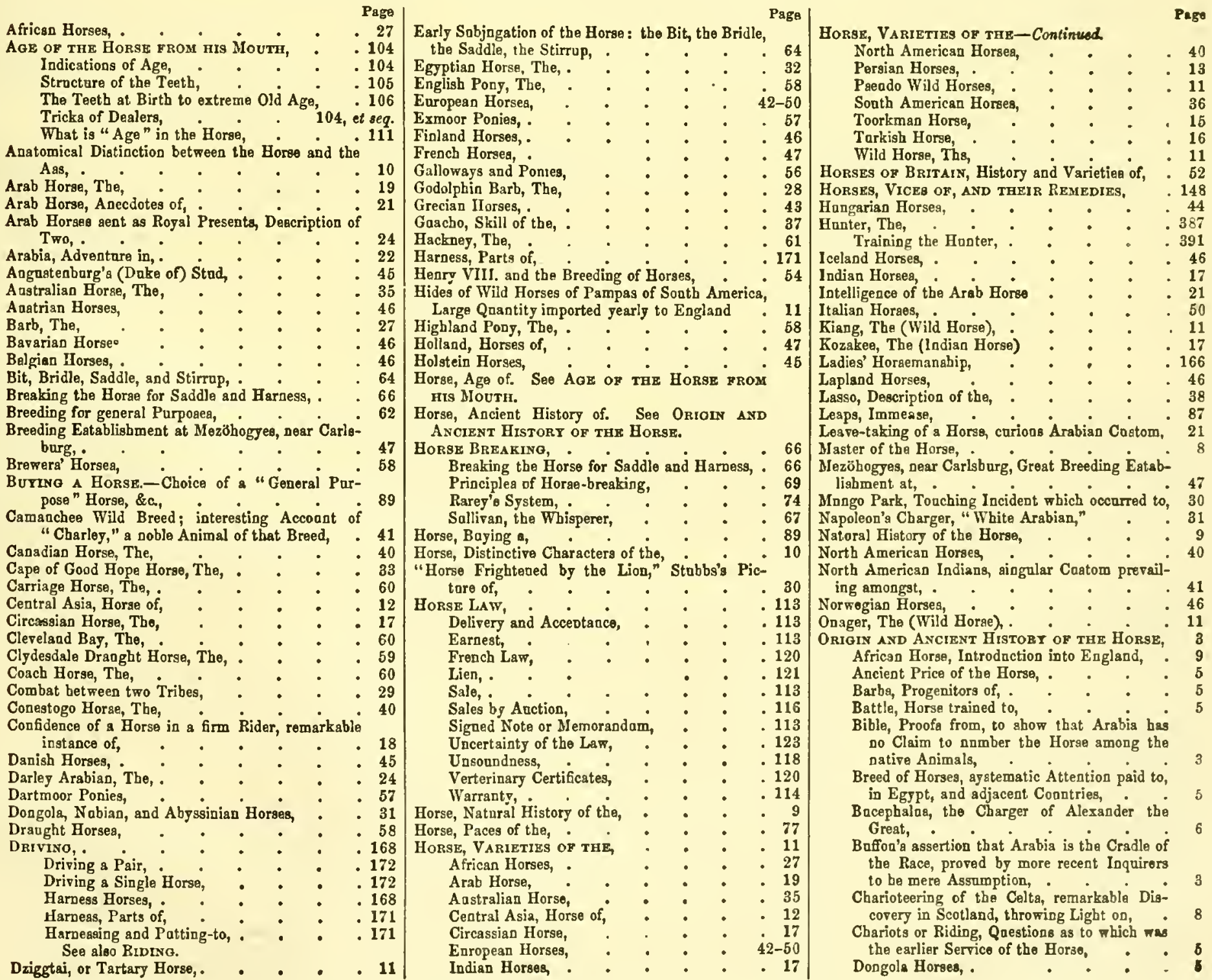


Equestrisn Warfare in Britain, Mode of, as practised in the centory before Chriet,

Grecian Horses,

Hastinge, Victory of, in great meaature to be ascribed to Cavalry,

Horse, Mare, and Colt, Fixed Standards of Valoe with many of the Asiatic Nations,

Horsemen of the Ancient World, The most celebrated,

Horses made Prizes of in the Field, Practice to hamstring them,

Joline Cxsar the frot to ordain Horses as a Spectacle to fight with Wild Balls, and to kill them,

Koran, Kindness and Forbearance towards Animals inculcated by the

Naster of the Horse,

Bythologic Fables of the Ancients, prominent Feature formed by the Horse in,

Nationa in which, at the earliest Periods, the Horse wse noed in War and in the Arte of Peace,

Number and Value of Horses now in Great Britain, .

Origialal Conntry of the Horse,

Ostrich, Horse employed in the Chase of

Plonghing, First Use of the Horse in, by the Anglo-Saroos

Ponies of Great Britain,

Price paid by Seathis the Thracian for the Steed which he rode during the Retreat of the Ten Thousand,

Sonrce from which Solomon derived his Snpplies,

Sabjugation of the Horse,

Soperstitious Veneration entertained by the Sarong for the Horse,

"Thonder," The true rendering of the Term in Job's poetical Picture of the War Horse,

Trade for Horses established with Africa by Solomon,

\section{Page \\ 8}

Value of the Horee in the Time of Alfred the Great,

Pace at which the imported Anstralien Race-horse cas travel,

8 Paces of the Horse, . . . . Perilons Feat performed at the Cape of Good

5 Peraian Horse, The,

5 Petroffsi (Baron), and bis Stad, Polish Horses,

4 Ponies of Great Britain,

Portuguese Horses,

Prussian Horses,

7 RaCe Honse, The,

Breaking and Training,

9 Breeding, 8 Races, Winners of the Great.

Ridina,

6 Mouting and Diemonnting,

Reins, Jlansgement of,

Riding to Heunds,
Saddle, Bridle, and Stirraps, Proper Position of, 156

Seat on Horsebaek.

Ladies' Horsemsnship, and Chooeing a Lady'o

Horse, alio Drirrisa.

Russian Horses,. • • . . . 43

8 Sale of the Roysl Stod at Death of William IV. . 25

Shetland Pooy, The.

South American Horses,

5 Spanish Horaee, .

StaBle, ThE,

Construction,

Draining,

Lighting,

Temperature,

Ventilation,

Harness Room,

Hnnting Stables, and the Loore Boz,

129
Modern Stable Fittings,

StARLE MANAOKMENT, . . 131

Clesning, : $. \quad \cdot \quad: \quad 143$

Clipping and Singeing, : . $\quad .137$

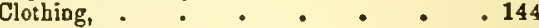

Conditioning, . . . . 145

Exercise, : . . . . . . 141

Feeding, . . . . . . .137

Groom, The, . . . . . 134

"Helper," The, . . . . . . 134

"Litter" . . 136

Racking aod Dressing,: : : : : $\quad$ : 135

"Stable Boye" . . . . . . 134

"Strapper" The.

Stables of the King of Denmark, . . . 45

Swedish Horses, . .

Swimming of Horses in South America, • . 39

Tattoo, or Native Indian Pony, • 17

Teeth, Age of the Horse from. See Aor or THE

Horse from ha Mouth.

Toorkee, The (Indian Horse),

Toorkman Horse, The,

Treatuent of a Horse on a Journer, : 173

Care of the Legs and Feet, . . . . 176

Cutting, . $\quad: 175$

General Mledical Hints, . $\quad 176$

Stambling, . . . . . 174

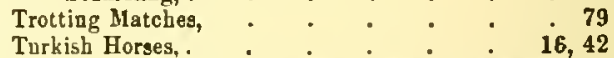

Varieties of the Horse. Sea Horse, Varietres

50
124

124 Varieties of Horse日 of Britsin.$\quad 52$

129 WeIsh Ponies, $: 52$

Welsh Ponies,
Wild Horses,

Wild Horses, Horse of the Pampas of Sonth America, $\quad$ - 11

- 126 Wiid Horses of the Steppes near the banks of the

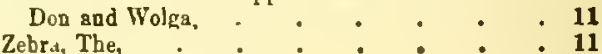

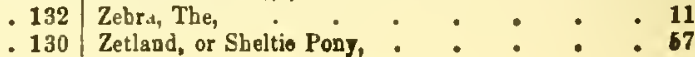

\section{THE STRUCTURE AND ANATOMY OF THE HORSE.}

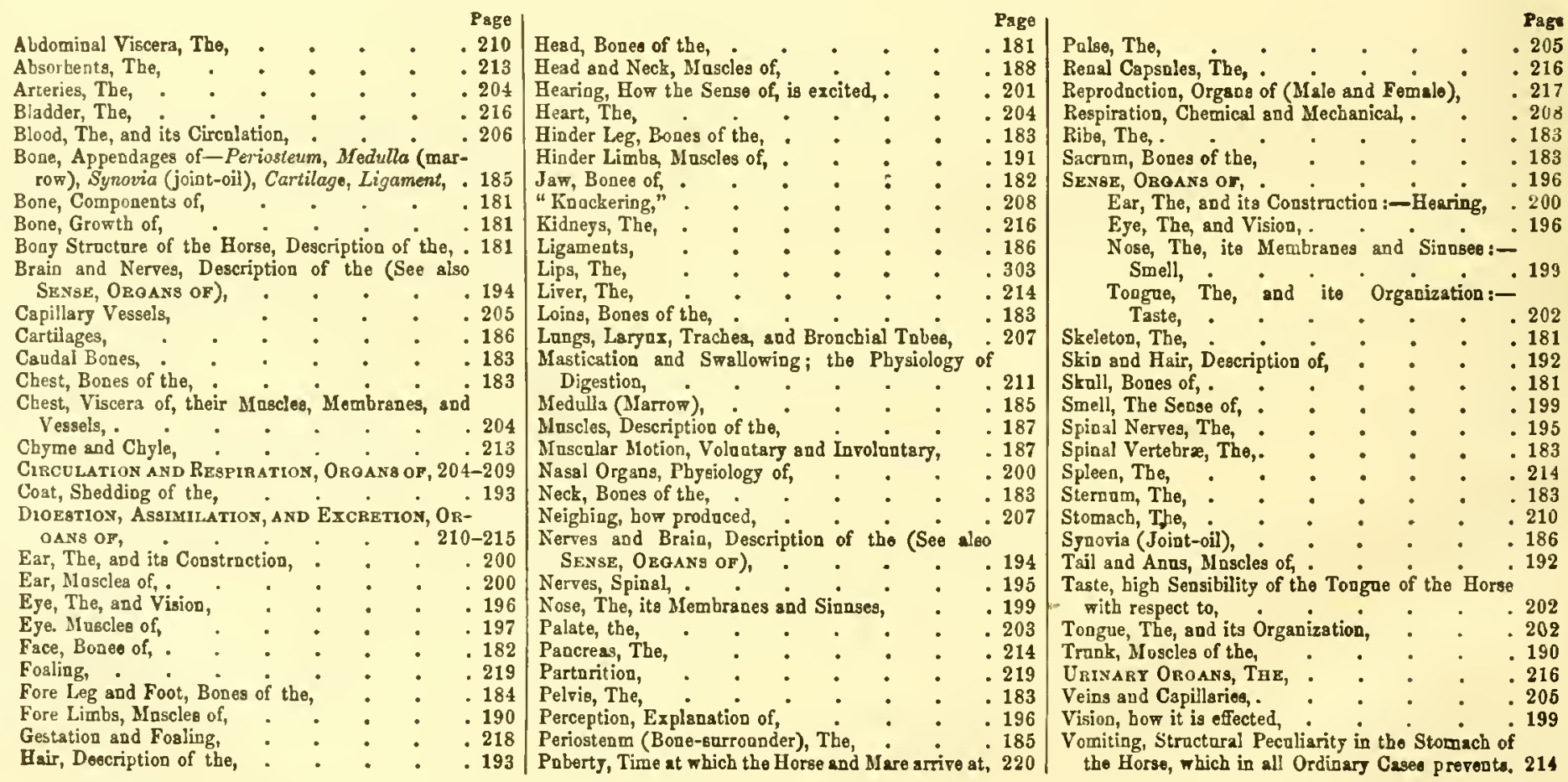




\section{THE PRACTICE OF VETERINARY MEDICINE.}

Abscess, A ppearance of,

Abscesa in the Brain,

Abscess, Purulent, and its Treatment,

Alscess, Serons, and its Treatment,

Adhesion, Explanation of

Air Passaoes, Diseases of the,

Amaurosis (Gntts Serena),

Anæmia, .

Anchylosis (Stiff and Bent $\dot{J}_{\text {oint), }}$

Ascites,

Back-sinew, Rupture of the,

Bandaging and Poolticing, .

Barmacles, The,

Biliary Calcali,

$\mathrm{Bl}_{3}$ dder, Diseases of,

Bleeding and tbe lustruments osed therein.

Operations, Instrumest8, \&

Blistering,

Bots, Worms, and Parasitic Animsls, Symptoms

and Trestment thereof,

Bowels, Inflammation, Intus 306

Brain, Skull, and Nerves, Diseases axd

INJURIES OF,

$272-278$

Breaking-down (Roptnre of Snspensory Ligsment), $3 \pm 1$

Broken Wind, and ite Treatment . 288

Bronchitis, and its Treatment, 283

Bronchocele, and its Treatment, : $\quad . \quad$. $\quad .290$

Bronchotomy; the Operation described, . $\quad$. 310

Casting the Horse. Sea Opkrations, IkstruMENTS, \&C.

Castration, beat Penud for, and Description of the Operation,

Cataract, and its Treatment, . . . . 280

Catarrh, Congh, Common Cold, Sore Throat, and

the Treatment thereof

$\begin{array}{ll}\text { the Treatment thereof, } & .287 \\ \text { Chloroform, Advantags of, in severe Operations, } & .360 \\ \text { Cboking, } & .297\end{array}$

Cicatrization, Explanation of,

Colic, Flatnlent,

Colic, Spasmodic, its Symptoms and Treatment, $\quad 302$

Congestion, Sanguineons and Seroos, • . . 296

Corns, and their Treatment,

Costiveness,

Crib-biting and Wind-sucking,

Crown Scab and Rat Tuils,

Corb,

Cyetitis (Inflammation of the Bladder),

Deposition, wbat it includes,

Disbetes, and its Trestment,

Diaphragm, Spasm and Rupture of,

Diarrbœa, its Canses and Treatment,

Diseases and their Treatment, Arrangement of,

Diseases, Specific. S88 Sprcifio Disearks of

THE HORSE.

Docking and Nicking,

Dropsy,

Dyaectery (Molten Greese)

Embryotomy, Observations on

Enteritis, and its Treatmeut,

EYE, Diseases of,

Farcy, and its Treatment,

Farcy, Water, and its Treatment

Feet, Lamenesseg, \&c., of the. Ses Fore Leos ANd FeET, siso Hock, Hixd Leos AND FeET.

Fetlocks and Pssterns, Injuries, \&c., of the. See

Fore Lros and Fent; also Hock, Hind Legs AND FEET.

Fever, its Causes and Treatment. See Speciric Diseases of THE Horse.

Firing,

Flezor Tendon, Division of the,

Flexor Tendon, Strain of the,

Fore Leos and Feet, Lamenesses, Diseases, AND INJURIES OF THE,

Tho Arm and Elbor,

The Feet,

The Kaee,

The Leg,

The Pasterns and Fetlocks,

The Shoulder.

3

333

$\mathbf{3 3 6}$

338
Galla, Sitfasta, and Warbleg,

Gastritis, and Chronic Gastritis,

Glanders and Farcy, and their Treatment, 261-279

Glondera, Communication of, to the Human Subject,

Glands, Disorders of the,

Granulation, Erplanation of,

Grease, and ite Treatment, .

Grogginess, Knockling, \&c., .

Gutta Serena (Glass Eye),

Halter-cast,

Harbess Gallg,

Heart, Pericardium and Blood Vesseli,

Diseases of THE. . . . 292-296

Hæmsturia (Bloody Ürine), and its Treatment, $\quad 320$

Hepatitis (Intammation of the Liver), and its

Treatment,

Hernis,

Hidebound,

Hobblee for Casting the Horse

Hock, Hind Leas and Feet, Lamenisser, Dis-

EASES, AND INJURIES OF THE,

Ancbylusis (Stiff and Bent Joint),

Dislocation of the Patella

Fracture of the Patella,

Hanncb and Stifle, Description of

Strain of the "Ronnd-bone,"

Strain or Injury of the Ligamente of the Stille,

or Patella, and its Treatment,

The Hind Feet.

The Hind Lege, Pasterns, and Fetlock-joint, 353

The Hock, . . . . . . . 351

Horse, Casting the. See Operations, InstuuMENTS, \&c,

Horse Jizdicines and Remedies, Doses, Forarula, and Preparations,

Horse, Slinging tbe,

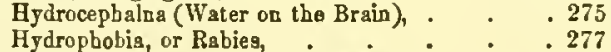

Hydrothorax (Water on the Chest), . . . . 287

Indigestion, its ordinary Sest, Symptoms, and

Treatment, Scirbos, Hepatization, Ossification,

Explanation of the Terms, . .

Inflammation, its Canses, Terminatione, and Treatment

$253-257$

Influenza, its Symptome snd Treatment,
Instrnoents, Operations, \&c. See Opensions, INSTRUMENTs, \&c.

256 Integtines, Calculi, \&c., in, . . . . . 314

319 Jtcb, \&c., . • . . . . . 328

291 Janndice, or "Yellows," its Symptoms and Trest-

ment,
idneye, Abscess, Softening, Induration, and En-

largement of the,

Kidneys, Inflammation of the (Nephritis), its Cange日,

Symptoms, and Treatment,

Lice,

Laminitis,

Lampas,

Larve in the Skin,

Legs, Diseases, \&c., of ths. See Fore Legs ard Feet; also Hock, Hixd Leos and Feet.

encorrhra (Wbites),

Litbotomy, Case illustrating the Operation

LTEE, DISEASES AND INJURIES OF THE,

Locked Jaw (Tetanus), its Symptoms and Treatment.

Mlalignant Epidemic, and its Treatment,

Mallenders and Sallenders,

l'a oge, \&c.

366
340

342 Mortification, Explanstion of,

338 Month and Teeth, Injuries to

339 Nasa! Gleet,

341 Nasal Polypus,

386 Navicular-joint Disesse,
Pago

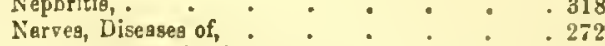

Necrotomy, and the Mode of performing the Operation,

Nicking and Docking,

Nosology, Systema of rejected

Obstetrics, Observations on,

(Stricture, Cbokiog),

Oferation, IxgtruMENT, \&C: Barnacles, Tbe,

Bleeding, and Instroments nsed thereir

Blistering, .

Eronchotomy,

Casting the Horse,

Chloroform,

Firing

Flezor Tendon Divi

Hobbles, The, - . * . 358

Lithotomy, . . . . . 321

Nearotomy, and the Mlode of performing the Operation, affs

Nicking and Docking, . . . . . . 3f,

Esophagotomy, . . . . . . 298

Periosteotom $y_{1}$. • • • . 36

Ponlticing and Bandaging, . . 369

Rowels and Setons, . . . 363

Side Lines, Single and Double, : : 359

Slinging tbe Horse, . . . . . 359

Tracheotomy, . 36 -

Travis, The, . . . 359

Twitch, The, . $\quad . \quad$. $\quad . \quad 360$

Ophthalmia, Simple and Specific, and the Treatmeut

Palate, \&c, Diseases of the, 280

Paralysis, and its Treatment, . . . 275

Pasterns and Fetlocks, Diseaseo, \&c., of the see Fole Leos and Feet; also Hock, Hind Legs AND FEET.

Patella, Dislocation and Fracture of the, . . 350

Pericardin m, Diseases of the, . . 293

Periosteotomy, for the Reduction of Splints and Ringbone, - interives, Diseases

INJURIES OF THE, $310-314$

Pharynx, Dicorders of the, : . . . 282

Phlebitis, its Symptams and Treatment, . . 294

Phrenitis (Irflammation of the Brain), Staggers, . 273

Phymosis and Paraphymosis, . . . . 323

Pletbora and Anæmia, . . . . 295

Plecritis (Pleurisy), and its Trestment, . . 284

Pnenmonia, (Inflammation of the Lungs), its 6 fmptoms and Trestment.

Ponlticing and Bandaging. . 369

Prurigo, \&c., - . . $\quad 328$

Patrid Ferer, and its Treatment, . . 253

338 Quittor, and its Treatment, . . . . 345

342 Rabies, or Hydrophobia, . . . 277

281 "Red Colic" . . . . 310

30 Reprodectre Oroass, Diseases and Isjeries OF THE, . . 323-328

Resolution, Signification of, - . . . 255

24 Ringbone, .

330 Ricgworm, and its Treatment, . 329

321 Roaring, and its Treatment, . . . . 288

Rowels and Setods, . . . . . . 363

Sard-crack, \&c.

275 Shoeino, aNd the Vartocs forms of

253 SHOEs,

Shoulder, Lamenesses, \&c, of the 2 . 336

Side Lines, Single and Donble, . . 359

Sitfasts, Warbles, and Galls, - $\quad 331$

Skin, Diseases and INJUEIES OF THE, • 328-335

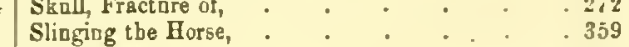

Sore Throat, . . . . . . . 287

Spasms, . . . . . .. .278

Spario,

SFecific Diseases of THR Horse:

Ferer, its Causes and Treatment

Glanders and Farcy,

Infemmation, Canses and rarions Resules of $268^{\circ}$ 


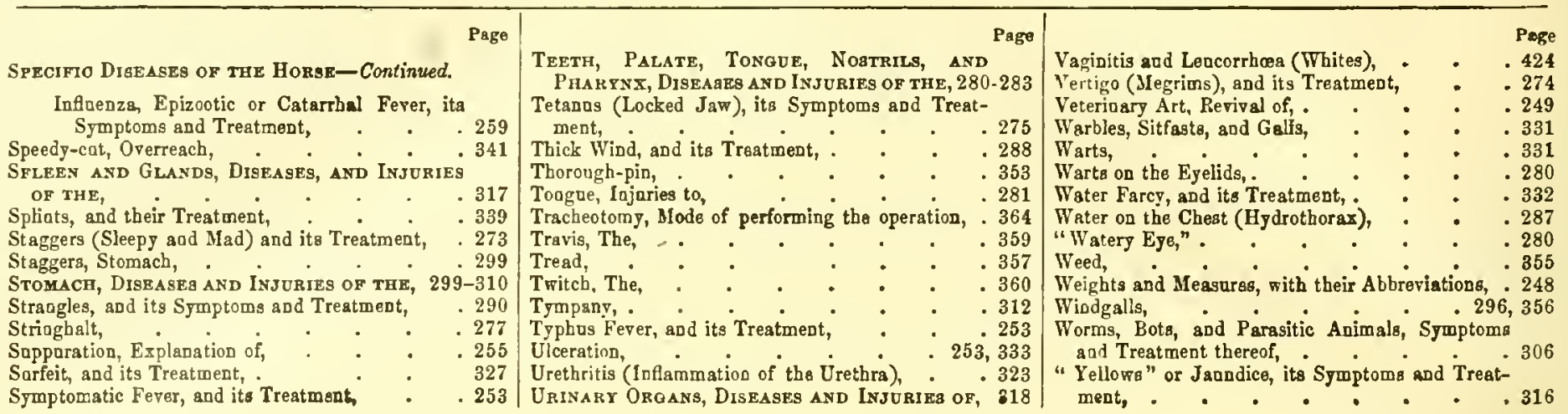

\section{MANAGEMENT OF CATTLE, SHEEP, ETC.}

\section{CATTLE, THEIR MANAGEMENT IN DAIRY, FIELD, AND STALL.}

Age of Cow, Indications of,

Alderney, Points of Merit in an,

Apoplexy, Parturieat,

Ayrshire Com, Mlilking Capsbilities of,

Bag or Udder, The,

Breeding Purposes, Selection of Cows for

Breeds, Description of the Varion日,

" Chanel Inlapd

$$
\text { English, }
$$

Hereford,

Irish,

Scotch,

Welsh,.

Breeda of Cattle and their Mrita,

Buying Cattle,

Calf, The,

Fattening of,

Food for,

Great Care required first Fortnight

Reariog of,

Treatmeat of

Cattle, Breeds of, and their MIerits,

Alderney,

Arrshire Cuw,

Channel Islands,

Cottar's Cow,

Dairy Cow,

Dairymag's Cow,

Darbam,

Eaglish Breeds,

Flemish Cow,

Gentleman's Cow,

Hereford,

Kerry,

Kerry Cow,

London Cow

Loughoras,

Normandy Cow,

Pembrokes,

Scotch,

Shorthorn Bull,

Shorthorns,

Soffolk Dun,

Welsh,

Cattle Raisiog,

Cost of earrying Store,

Fattening in the Field, Sheds,
Stall,

Food, Feeding,

Channel Islaod Breeds,

Cottar's Cow,
Cow, Age of,

" Care in Drying her of Mlilk,

" Constitation of the,
Page

. 411

- 404

.417

. 401

406

.405

. 401

404
.402

402

.401

. 401

. 401

. 401

407

. 420

422

. 421

422

.422

.421

. 401

.404

.408

.404
.410

417

.407

.402

. 402

. 408

. 404

.402
.411

411
.402

.408

.403

.408

.410

.401

.415

. 402

.404

. 410

.428

.429

- 431

.432

.404

. 408

.410

. 419

. 419
Cow, Poor $1190 \%$

Purchasing a.

"Selection of, for Breeding porposes,

"What constitutes good qualities of,

Corr aud Calf, Prize,

Cowshed Draiaage,

Cravens,

Dairy, The,

Butter Worker,

Cleanliness necessary,

Coastruction,

Creamer,

Herd Recorder, The,

Refrigerator

Separator,

Dairy Cow, Disposiog of the,

$$
\text { Food for, }
$$

True Specimes of,

Deatition of the $\mathrm{Ox}$.

Drainage of the Cowshed, .

Fatteniag in the Stall,

Feeding, Stall,

Food for Dairy Cows,

Food, Manore prodaced by Varieties of

Food-preparing Mlacbinery,

Gestation,

Frights or Bad Smella to be aroided,

Nutritious Food aecessary, .

Pore Water essential.

Quiet Field best :-

Spring Water to be avoiaed,

Treatmest duriag,

Glands, Good Constitution of,

Grazing,

Heifers, Choosing,

Defects to he guarded againat,

Points in Purchasing,

Where to boy,

Horns, Means of determining Age,

Machiaery for prepariog Food, .

Mammary Glands,

Maaure produced by Varieties of Food,

IIilk, Coastitueat Elements of,

"Veins,

Milking Cоwв, .

Kindness required in,

Tigns of Good,

$0 x$, Deatitiou of the,

Parturition,

$$
\text { Treatment during, }
$$

Shorthorn Cow, "Point of an aged Cow,

Suffolk Don,

Table ban, 404 shire Cow,

Teeth, Jieas of determiniog Ag,, · • . 411

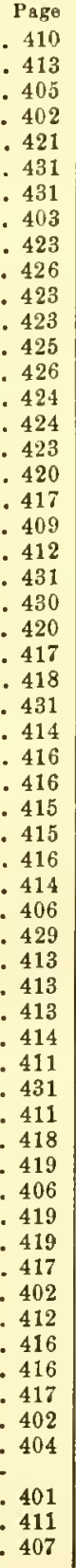

Udder, The,

Ventilation of the Cowshed,

Wrinkes oo Horas indicative of Age, . $\quad: 411$

PASTURE GRASSES AND FORAGE PLANTS.

Agrostis alba,

dispar,

" vulgaris,

Aira cespitosa,

Alopecaras pratensis

Anuual Lleadow Grasb,

Aathoxanthum odoratum,

A thyllis rolneraria,

Arrhenatherum avenaceum,

Aveas elatior,

Bent Grass, Fine,

Black Grass, Seed of the,

Broad Clover, .

Brome Grass, Schrœder's,

Bromus arrensis,

" erectos,

" inermis,

" mollis, Seed of,

$$
\text { prateosis, }
$$

secolinus, Seed of

Broom Rape, Lesser and Greater,

Bull Snout,

Canary Grass,

Clovers, the Alsike,

Common Yellow,

Jaarl or Cowgrass,

Red,

White or Dotch,

Compositions of the most Important Grasses, $\quad: 471$

\begin{tabular}{ll} 
Cow-grass, Single cot, $: \cdot: \quad: \quad: 463$ \\
\hline
\end{tabular}

Creeping Beat,

Crested Dogtail

Crimsoa Clover,

Cascuta trifolii,

Cynosorus cristatus,

Dactylis glomerats

Dodder, Clover,

Dogstail, Crested,

Dutch Clover,

Ergot and Ergotism

Fescues,

Festuca bromoides,

calamaria,

elatior,

ersets,
. 447

448

. 448

- 445

. 460

. 443

- 46

- 443

.444

- 448

- 443

- 462

.446
.444

- $44 \varepsilon$

- $44 \varepsilon$

- 448

445

. 445

- 441

. 437

.441

. 462

. 465

. 463

.462

. 451

- 446

. 468

. 441

- 446

. 448

.441

. 446

. 464

439

449

.453

. 460

449

451

. 445 
INDEX.

Featuca heterophylla,

loliacea,
ovina tenuifolia,
pratensis, .
rubra,
sciuroidea, .

Fiorin or Creeping Bant

Forage Plants,

Furze,

Galega officinalis,

Glyceria aquatica,

Goat'a Rue,

Gorse, Whin, or Furze

Grasses, The,

Chemical Aralysia of,

Green Bristle Grasa,

Guinea Grass,

Hair Grass, Soft,

"Wary Monatain,

Hassock or Tufted,

Hassoek Grass,

Haymaking, Some Pointa in,

Herd Grass,

Holcus arenaceps,

" lanatus,

Indian Corn,

Loliam italienm,

" perenne,

Maize or Indian Corn,

Meadow Fescues-Tall Meadow,

Meadow,

Squirrel Tailed, .

Yorkshire Fox,

Meadow Fostail,

Neadow Grasses, Flat-ntemmed,

Reflexed,

Water,

Wood,

Wood Reed,

Meadow Soft Grass,

Medicago lupulina,

Medicago sativa,

Melica cœrulea,

Melic Grasa, Blae,

Millet.

Molinia corulea

M1nstard, .

Oat Grass, Yellow or Golden,

" Tall,

Onobrychis sativa

Ornithorpus sativa

Orobanche elatior,

ox-eyed Daisy,.

Panicum jumentorum, miliaceam, viride,

Perennial Grass, Seed of

Phalaris arundinacea,

Phleum pratense,

Poa aquatica,

" annua,

" compressa,

"distans,

"L nemoralis,

"pratensis,

" sylvatica,

" trivialis,
Prickly Comfre

Reed Canary Grase

Rough-stalked Meadow Grasa,

Rye, Cornmon,

Rye-grass, Italiaa, Pereanial,

Sainfoin, Common,

Secale cereale,

Seed Adulteration Act

"Sale of Impure,

"To jndge,

Serradella,

Setaria viridis,

Sheeps Fescues, Hard, Fine-leared,

Red,
Sinapis, . .0000

Sinapis,

468

Smooth-stalked Mfaadow Graar, .

. 459

Soft Brome Grasa, Seed of

Sorgham halapenae,

" fulgare,

Spike of Rye-grass with the Spurs,

44.5

. 470

470

Spiked Meadow Grass,

Sugar Corn or Sugar Grase,

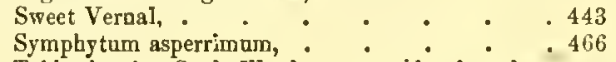

Table showing Seeds Weeda are capaole of prodac-

ing in one Season, .

Tare, Common,

Timothy Grass,

Trifolium hybridum,

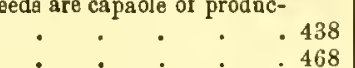

468

- 468

.471

.461

. 472

.445

. 445

.445

. 472

. 448

443
.453

453
.470

.453

.454

.465

. 470

.451
.452

.452
.453

453
.453

. 442

.460

.461
.460

- 459

.453

-453
.465

.465

- 456

. 456

.461
.456

.456
.468

.444

. 443

469
-467

.467
.$\quad 441$

.441

.437

.470

- 461

. 461

.452

461

. 457

.460

.460

.460
.461

459
.459

. 459

460
.458

458
.466

. 461

458
.464

.464
.453

- 45

.469

- 469 lncisors and Molars ai veŕtuns Stages,

. 439 Dipping, Receipts for.

437 "Trough fe.

470 Docking Sheep,

467 Ear Mlarks,

461 Ewe Mliiking,

449 Ewes and Lambs, Management of,

450 Ewes, Autumn,

.451 " Winter,
Fat Lambs, Rearing Early,

Feeding Sheep, Implements ased in, .

.521

Food, and Feeding of Sheep

. 490

497

497

- 497

492

497

496
493

497

497

497

.493

493

493

.497
.538

537

. 510

. 513

. 511

. 513

.515

.508

.528

. 522

. 505

. 507

- 512

521
.498

529

. 530

.530

.513

Keel Jlark,

Marking,

Pool washing,

Scoring Numerals,

517
523

518

Tab washing,

517

516

526

528

525

526
528

48 :

490

537 


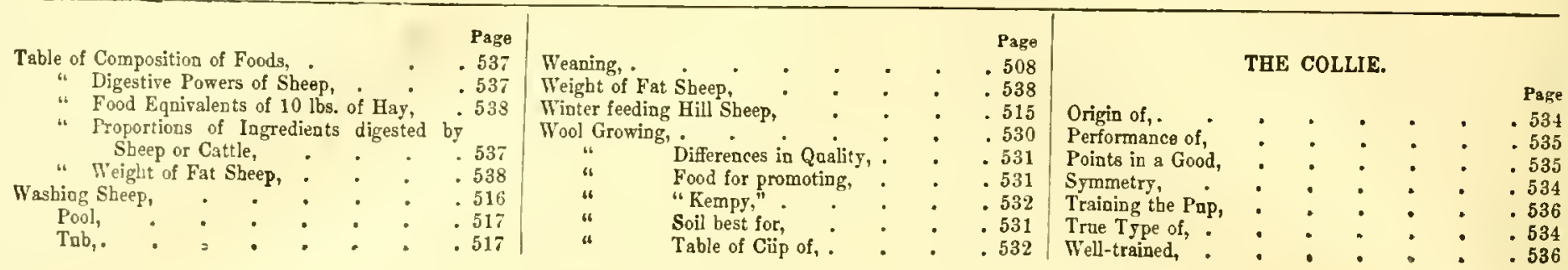

\section{DISEASES OF CATTLE, SHEEP, AND PIGS.}

\section{DISEASES OF CATTLE.}

Abortion,

$$
\text { Treatment, }
$$

After-birth, The,

Age of the Ox as indicated by his Teeth,

Ansmia,

Angle-berries,

Anthrar,

Bite of Venomous Reptiles,

Black I.eg,

$$
\begin{aligned}
& \text { Quarter, } \\
& \text { Treatment, }
\end{aligned}
$$

Black Water,

Blown,

Brain, Inflammation of the,

Bull-barnt,

Calculi, Casaal,

"Intestiual,

in the Ureters,

Stomacbical,

Calres, Costiveness of

Diarrbca or Dysentery,

Diseases incidental to Young,

Hoose,

How to extract when the Calf presents itself in a Wrong Position,

Method of Treating the Naval Striag after extraction of,

Cattle Plague, The,

Colic,

Cnncretions, Calculat a,

Cow-pos,

Diarrioes

Epizootic Cold,

Eprosthotonos,

Fellon,

Fover Joint,

“Puerperal,

"Splenie,

Fog Sickness,

$$
\text { Treatment, }
$$

Food, Prehension of, .

Foot and Moutl. Disease, Treatment,

Font, The Foul in the,

Fordel, Boand,

Gripes,

Hove,

Inflammation,

Influenza,

Intestinal Calcnli,

Jaundice, .

Joint Fellon,

Joints, Strains of the,

"Woands of the,

Kidneys, Inflammation of tb Liver, Inflammation of the, Locked Jaw,

Langs, Inflammation of the,

Iange,
16

- 16

- 18

59,64

3
-20

20
$-\quad 13$

25

10

11

14

- 10

21

-21
- 96
- 96

96

95

24

24

23

24

17

23

26

15
95
20

20

4
23

4

16

16

14

14

59

8

23

14

15

1
4

96

6
19

22
22

12 Age of the Sheep as indicated by ber Teeth,

22 Clearage in the Upper Lip,

5 Diarhoea,

Dental

Placenta, Retention of the,

Pletbora,

Post-mortem Appearances,

Preventive Measures, .

Trestment,

earosthotonos,

Poisons,

Prolapsus ateri,

Puerperal Fever,

Red Water,

eumatism,

Symptoms,

Rinderpest,

Post-mortem Appearances,

Treatment,

$$
\text { in Odessa, }
$$

Rapidity of Repair in Diseased Tissnes,

Slinking,

Treatment,

Calcali,

$$
\text { Treatment, }
$$

Teeth, The,

Development of the,

Eruption of Temporary,

Formation of the Hard Tissnes,

Tooth Stractare,

Udder, Inflammation of the,

$$
\text { Treatment }
$$

Ureters, Calculi in the,

Vertigo,

Treatment,

Yoliows, The,

\section{DISEASES OF SHEEP.}

Page

16 Eye, Treatment, Page

Fly, The, on Sheep.

Foot Ilalt, The,

Foot Rot,

Giddy,

- 10

- 18

Lambing Season, The,

Lambs, Diseases of Young,

Treatment,

Lice and Ticks

Maggots on Sheep,

Ovina rariola,

Treatment

Rot, The, .

Treatment,

Scab, The,

Scour, The

Sheep-dipping Mixtures,

Directions for asing

Small Pox in Sbeep.

History of ita Extension,

History of the Treatment,

Inocalation,

Mode of Inoculating, .

Origin of,

Peport of the Wiltshire Matual Association, 56

Selection and Preservation of Variolons Lymph, 52

Sore Head,

Sturdy in Sbeep, -

Ticks,

Turasick,

20

- 20

- 60

- 61

- 62

- 64

- 60

- 22

- 18

- 19

- 96

- 14

- 20

- 21

- 22

Parents, Choice of,

Parturition,

Piggeries, Construction of, Troagbs, Doable, • $\cdot{ }^{\circ} \cdot 75$ Yards,

DISEASES OF PJGS.

Age of the Pig as indicated by his Teeth, . . 71 Apoplexy,

Diseases incident to,

Feeding and Fattening,

Food for Pigs, .

Starch Jlannfactories,

rin 77

77

89

73

74

Quinsy,

Rearing,

Sow and their Sacklings, Treatment of

Strangles, . . . . . . 95 




- 
$f$

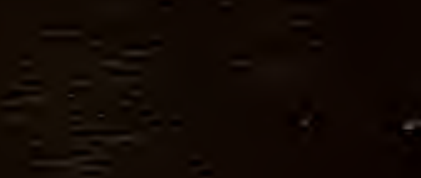

1

$=$$$
\text { 픈 }
$$$$
\text { E. }
$$

5 